ISSN 1809-3647 (print)
ISSN 1983-2605 (online)

$\mathbf{I P} \rightleftharpoons \mathbf{B}$

Pesq. flor. bras., Colombo, v. 39, e201902043, Special issue, 768 p., 2019

\section{Editor-Chief}

Patrícia Póvoa de Mattos

Embrapa Florestas, Colombo, PR, Brazil

\section{Co-editors}

Alvaro Figueredo dos Santos

Embrapa Florestas, Colombo, PR, Brazil

Annete Bonnet

Embrapa Florestas, Colombo, PR, Brazil

Carolin Córdova Sáez

Universidad de Concepcion, Concepción, Chile

Cristiane Fioravante Reis

Embrapa Florestas, Colombo, PR, Brazil

Daniel Burckhardt

Naturhistorisches Museum, Switzerland

Eugenio Alfredo Sanfuentes von Stowasser

Universidad de Concepción, Centro de Biotecnología, Concepción, Chile

Francides Gomes da Silva Júnior

Universidade de São Paulo, Campus Luiz de Queiroz, Piracicaba, SP, Brazil

Hugo Enrique Fassola

Instituto Nacional de Tecnología Agropecuaria Estación Experimental Agropecuaria Montecarlo (INTA-EEA Montecarlo), Misiones, Argentina

Guilherme Schnell e Schuhli

Embrapa Florestas, Colombo, PR, Brazil

Jose Elidney Pinto Junior

Embrapa Florestas, Colombo, PR, Brazil

Krisle da Silva

Embrapa Florestas,Colombo, PR, Brazil

Marcelo Francia Arco-Verde

Embrapa Florestas, Colombo, PR, Brazil

Marilice Cordeiro Garrastazu

Embrapa Florestas, Colombo, PR, Brazil

Peter Michael Spathelf

University for Sustainable Development Eberswalde (FH), Eberswalde, Germany

Valderês Aparecida de Sousa

Embrapa Florestas, Colombo, PR, Brazil

\section{Associate Editors}

Afonso Figueiredo Filho

Universidade Estadual do Centro-Oeste, Departamento de Engenharia Florestal, Irati, PR, Brazil

Aloisio Xavier

Universidade Federal de Viçosa, Departamento de Engenharia Florestal, Viçosa, MG, Brazil

Eduardo Mansur

International Tropical Timber Organization (ITTO), Yokohama, Japan

Gledson Vigiano Bianconi

Instituto Federal do Paraná, Campus Pinhais, Brazil
Heinrich Spiecker

University of Freiburg, Freiburg, Germany

John Parrotta

US Forest Service, Research \& Development, Virginia, United States

Ivan Tomaselli

STCP Engenharia de Projetos Ltda, Curitiba, PR, Brazil

Jorge Alberto Gazel Yared

Universidade Federal Rural da Amazônia, Belém, PA, Brazil

José Aníbal Palavecino

Universidad Nacional de Misiones, Eldorado, Misiones, Argentina

José Rente Nascimento

International Consultant, United States

Laercio Couto

Centro Brasileiro Para Conservação da Natureza e Desenvolvimento Sustentável (CBCN), Viçosa, MG, Brazil

\section{Leif Nutto}

Albert-Ludwigs-Universität Freiburg, Instituto Para Utilização da Madeira e das Ciências, Freiburg, Germany

\section{Manoel Malheiros Tourinho}

Universidade Federal Rural da Amazônia, Instituto Socioambiental e dos Recursos Hídricos - ISARH, Belém, PA, Brazil

Marcus Vinicio Neves d'Oliveira

Embrapa Acre, Rio Branco, AC, Brazil

Pablo Christian Cruz Johnson

Centro de Investigación de Estudios de Recursos Naturales, Santiago, Chile

Ricardo Cesar Larrobla

Consultor independente, Maldonado, Uruguay

Sebastião do Amaral Machado

Universidade Federal do Paraná, Curitiba, PR, Brazil

Versides Sebastião de Moraes e Silva

Universidade Federal de Mato Grosso, Faculdade de Engenharia Florestal, Cuiabá, MT, Brazil

\section{Secretaria}

Elisabete Marques Oaida

Embrapa Floresta, Colombo, Brazil

\section{Editoração}

Cristina Mosol

Curitiba, Brazil

\section{Normalização Bibligráfica}

Francisca Rasche

Embrapa Floresta, Colombo, Brazil 


\section{csc Chair}

Jerry Vanclay

Southern Cross University, Australia

\section{CSC Members}

Pil Sun Park

Division 1

Seoul National University, South Korea

Santiago González-Martínez

Division 2

French National Institute for Agricultural Research-INRA, France

Woodam Chung

Division 3

Oregon State University, USA

Donald Hodges

Division 4

University of Tennessee, USA

Pekka Saranpää

Division 5

Natural Resources Institute Finland / Luonnonvarakeskus-Luke, Finland

Cecil Konijnendijk

Division 6

University of British Columbia, Canada

Eckehard Brockerhoff

Division 7

Scion Crown Research Institute-CRI, New Zealand

Alexia Stokes

Division 8

French National Institute for Agricultural Research-INRA, France

Sandra Luque

Division 8

National Research Institute of Science and Technology for Environment and Agriculture-IRSTEA, France

Daniela Kleinschmit

Division 9

University of Freiburg, Germany

Björn Hånell

Vice-President Divisions

Swedish University of Agricultural Sciences, Sweden

John Parrotta

Vice-President Task Forces, Special Programmes, Projects and IUFRO-LED Initiatives

US Forest Service, USA

Dolores Pavlovic

Student Representative

International Forestry Students Association

Joseph Cobbinah

Africa Representative

University of Ghana, Africa

Manuel Guariguata

Latin America Representative

Center for International Forestry Research-CIFOR, Peru

Patrícia Povoa de Mattos

COC Representative

Embrapa Florestas, Brazil
The abstracts in this Special Issue are the sole responsibility of their authors. The statements and opinions they contain, as well as mentions of any machinery, equipment, products, or techniques, do not constitute endorsement by the Organizing Committee or the institutions involved in the 25th IUFRO World Congress. The editors and event organizers are not responsible for spelling, grammar errors, content, in these abstracts, or for any inaccuracies or ambiguity in the identification or affiliation of their authors.
Pesquisa florestal brasileira $=$ Brazilian journal of forestry research. - v. 39, e 201902043, Special issue (2019) -

Colombo : Embrapa Florestas, 2019.

Continuous publishing since 2018-

Published online: <http://www.cnpf.embrapa.br/pfb/>. Special issue: Abstracts of the XXV IUFRO World Congress: Forest Research and Cooperation for Sustainable Development.

ISSN 1809-3647 (print)

ISSN 1983-2605 (online)

1. Forest - Journal - Brazil. 2. Forestry research. 3. Sustainable development. I. Embrapa Florestas.

CDD 634.905

Francisca Rasche CRB 9-1204 
Pesquisa Florestal Brasileira /Brazilian Journal of Forestry Research

\title{
Forest Research and Cooperation
} for Sustainable Development

\section{IUFRO World Congress, 29 sept - 5 October 2019, \\ Curitiba, PR, Brazil}

\author{
Abstracts
}



It is with great satisfaction that Brazil is hosting the 25th edition of the IUFRO World Congress. This year's theme, "Forest Research and Cooperation for Sustainable Development," is very fitting now that the issues of production, preservation, environmental services, and their influences on a global scale have moved beyond purely technical debates in closed academic or business circles to become part of everyday life for urban as well as rural dwellers. In this sense, holding an event like the IUFRO World Congress in a country like Brazil, which has its forest DNA rooted in its large-scale diversity and the productive capacity of its planted forests, is very timely.

We are even prouder knowing that this is only the second time this event is taking place in the Southern Hemisphere, and the first time in Latin America. Participants will have an opportunity to exchange knowledge with researchers and professionals from over 120 countries on a wide range of forest-related topics. It will also be a chance for us to show off our Country, which so many people have heard about. However, only a few have had the chance to experience Brazil's unique characteristics and striking regional diversity.

This Special Edition of the Brazilian Journal of Forestry Research is a collection of approximately 2.700 abstracts. Each is one piece of a puzzle of questions and challenges faced by scientists in different social or regional conditions combined with a myriad of solutions. Coincident findings should support policymaking. Conflicting results or approaches should arise curiosity and trigger the search for consensus. We hope all together they pave the way to new products, new approaches, and new ways of looking at our future.

Colombo, August 2019

\section{Sergio Gaiad}

\section{Deputy Head of Research and Development}

Embrapa Florestas 



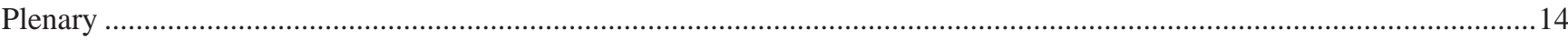

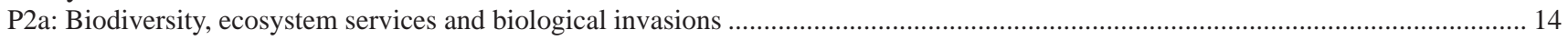

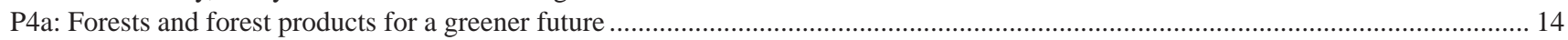

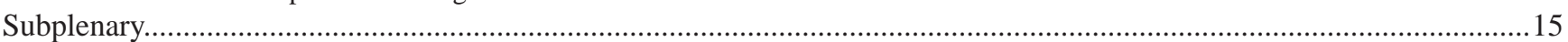

A6a: Women and forests: promoting gender equality connecting research, public policies and forest management in the tropics.......... 15

A9a: Political ecology and integrated landscape approaches: complementarity or unhappy marriage? ................................................ 15

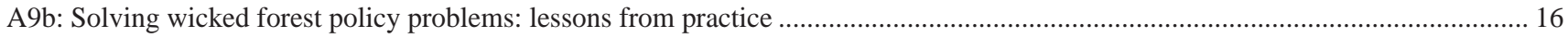

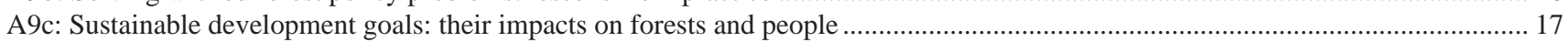

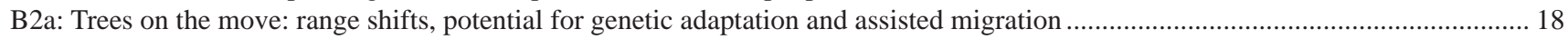

B4a: Climate smart forestry or how to integrate adaptation, mitigation and sustainable forest management ...................................... 19

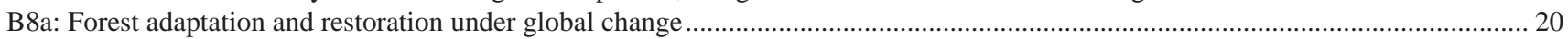

C1a: Managing forest ecosystem resilience and biological and social diversity for future forest products............................................ 21

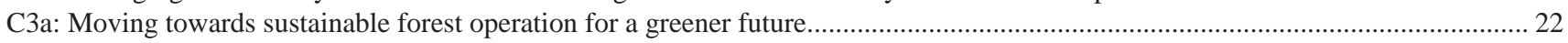

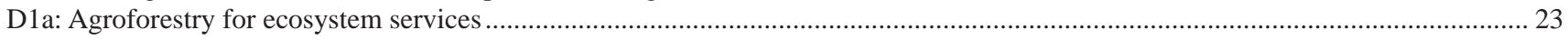

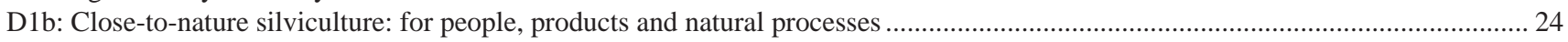

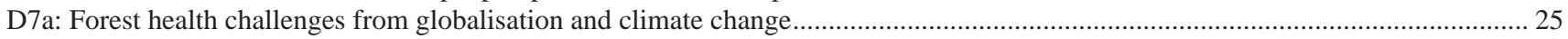

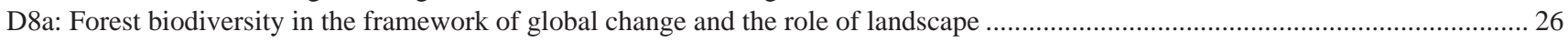

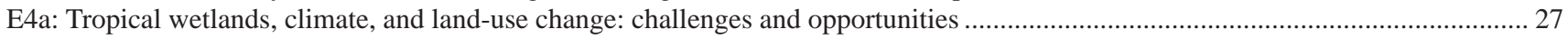

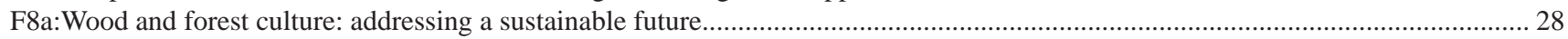

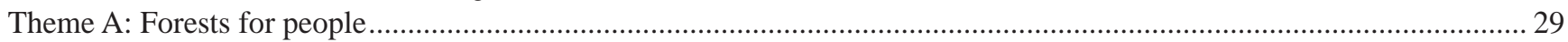

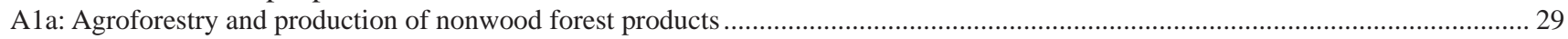

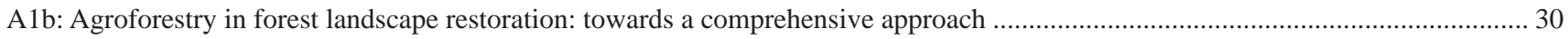

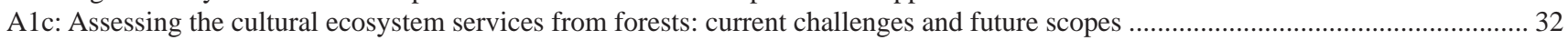

A1d: Fostering effective agroecological and agroforestry practices for sustainable transformation and food resilience .......................... 34

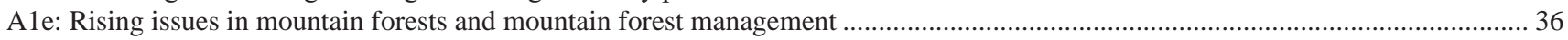

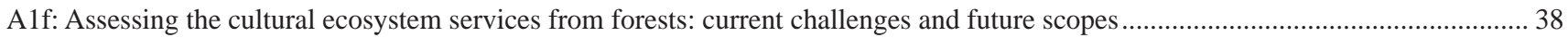

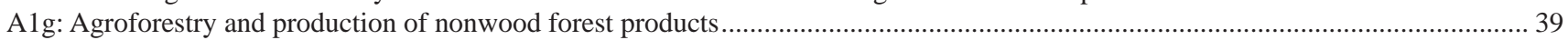

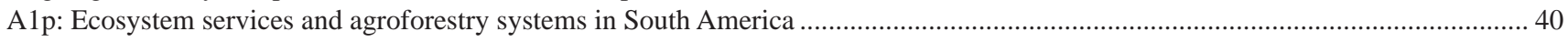

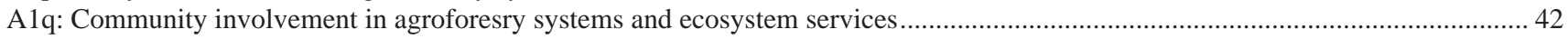

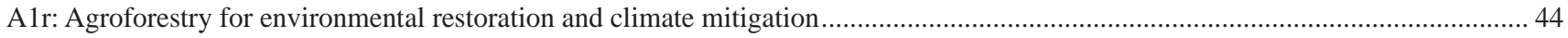

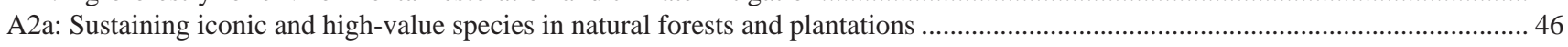

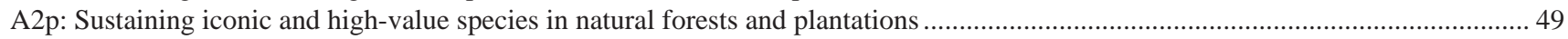

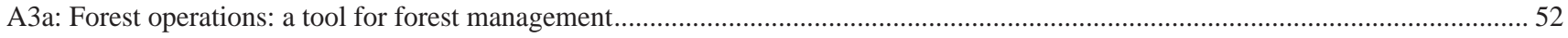

A3b: The implementation of economics, forest policy, forest law and governance in Latin America forestry ..................................... 54

A3p: The implementation of economics, forest policy, forest law and governance in Latin America forestry …................................... 56

A3q: The implementation of economics, forest policy, forest law and governance in Latin America forestry ...................................... 58

A4a: Artificial Intelligence, machine learning and knowledge sharing: combining old and new skills to improve decision-making

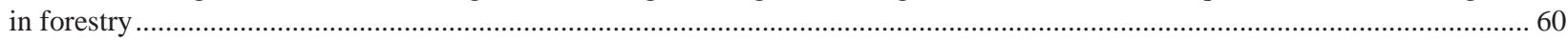

A4b: Forests without borders: multi-national forest inventory cooperation and harmonisation to enhance sustainable development ...... 61

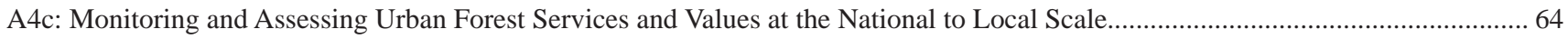

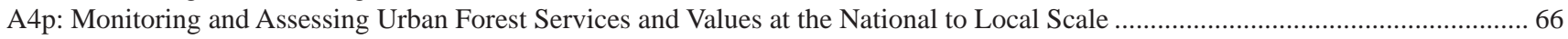

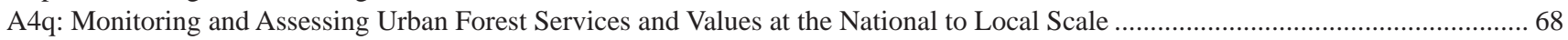

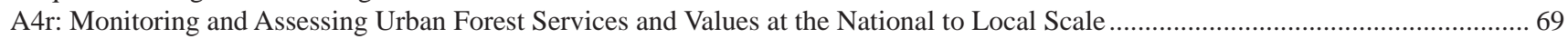

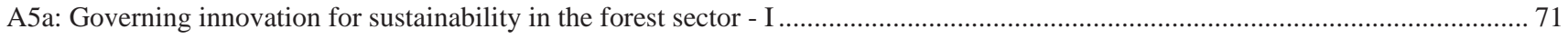

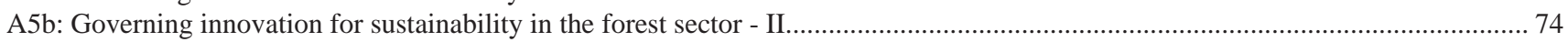

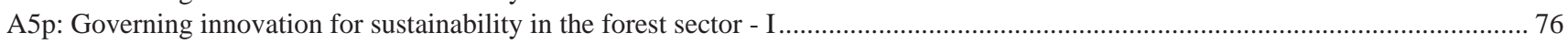

A6b: Balancing environmental, productive and social needs to meet sustainable goals in the forest industry: experiences

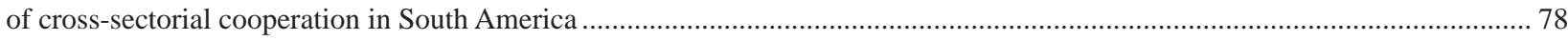

A6c: Challenges to sustainable forest management to enhance traditional communities and smallholders' livelihoods in the Amazon basin..... Commin

A6d: Community and family forest management in Latin America: guaranteeing rights and citizenship with sustainability ................. 82

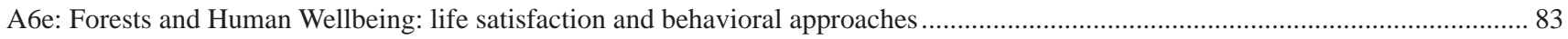

A6f: Gender, forestry and rural communities: shaping power and agencies in an era of globalisation ............................................... 85

A6g: Indigenous and traditional peoples and their forests: knowledge, management and governance towards sustainable development goals.

A6h: Pathways towards sustainable resource use from African Sudanian and Zambezian woodlands: resolving conflicting points of view.....

A6i: Social and economic benefits in protected areas: partnerships and concessions for local development...................................... 92 
A6j: Strengthening community and smallholder forestry for SDGs and other Forest-Related Goals ................................................ 94

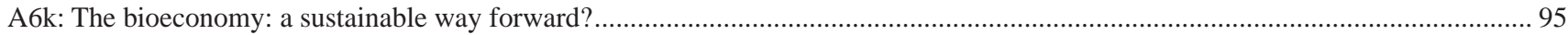

A6l: Indigenous and traditional peoples and their forests: knowledge, management and governance towards sustainable

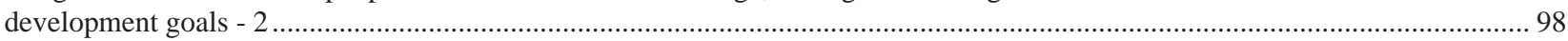

A6m: Women and Forests: promoting gender equality connecting research, public policies and forest management in the tropics...... 100

A6p: Women and Forests: promoting gender equality connecting research, public policies and forest management in the tropics....... 102

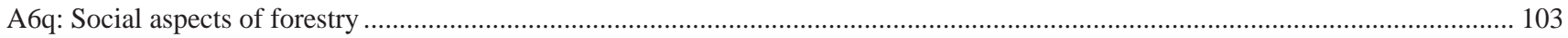

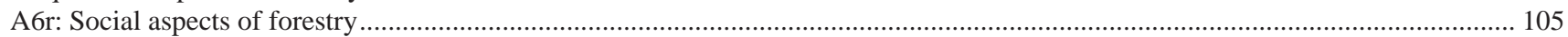

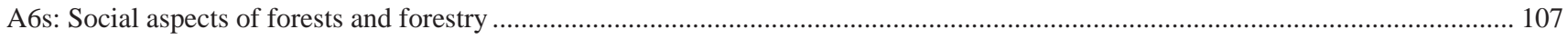

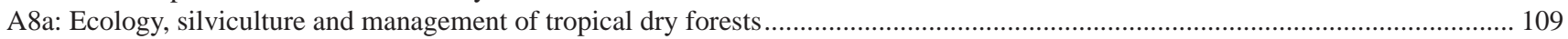

A8b: Forecasting the effects of land-use on wildlife communities and conflict at human-wildlife interface ..........................................112

A9d: Committed and held accountable? Exploring accountability relations of state, business and civil society organisations

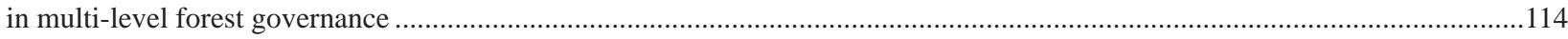

A9e: Forestry in transition? Forest policies in changing societies. Part 1: Europe …....................................................................116

A9f: Governing farm-forest interfaces: lessons from practice and methodological advances to improve policy..................................118

A9g: Innovative forest laws and environmental legislation for enhanced forest ecosystem services in local communities ................... 120

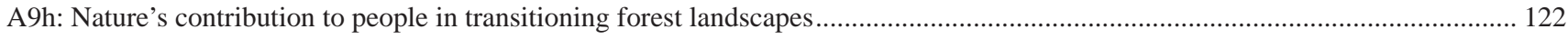

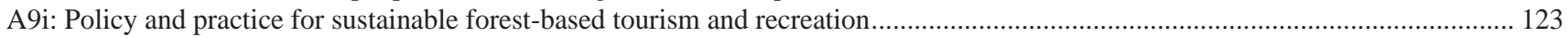

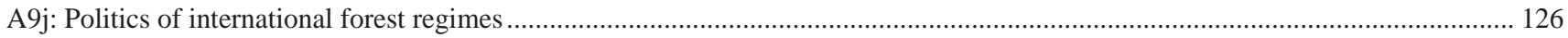

A9k: Status and current developments in South-South cooperation in forestry .......................................................................... 128

A9l: Sustainable development goals: their impacts on Forests and People ................................................................................... 129

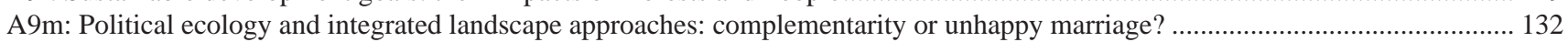

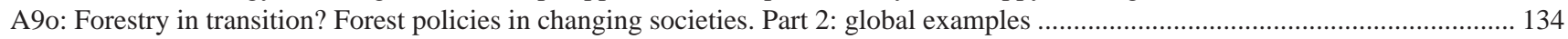

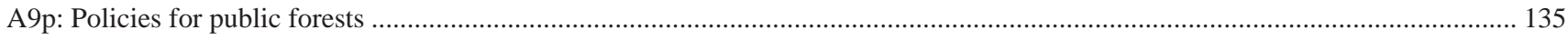

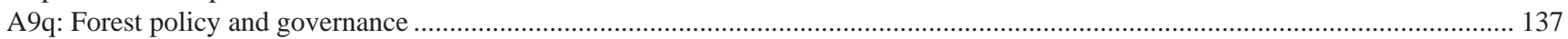

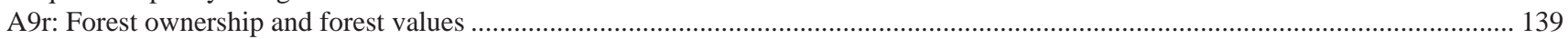

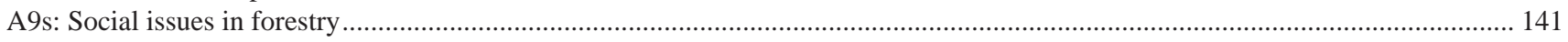

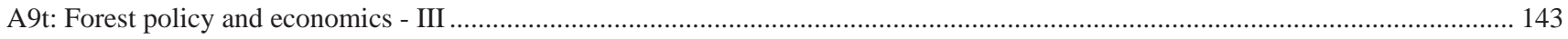

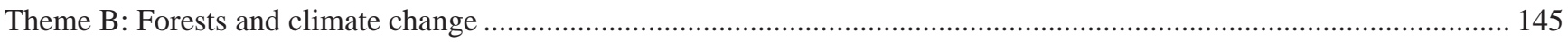

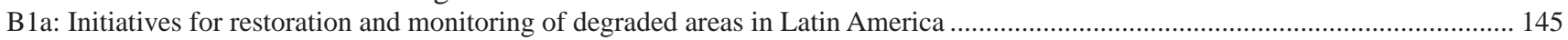

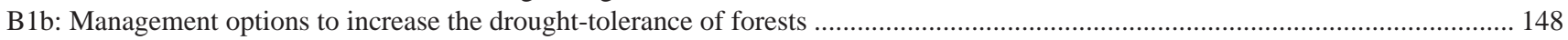

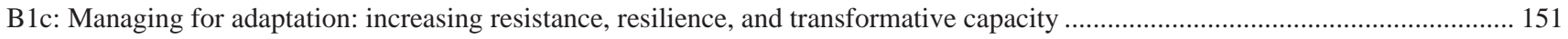

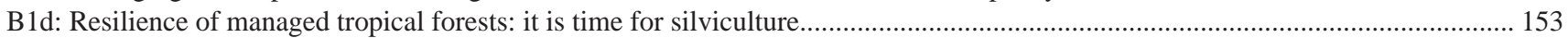

B1e: Trees on the move: seed sourcing, germination, genetic adaptation and assisted migration in a changing climate....................... 156

B1f: Silviculture and management of tropical natural forests in Amazon region: rescuing classic solutions to attend new demands -

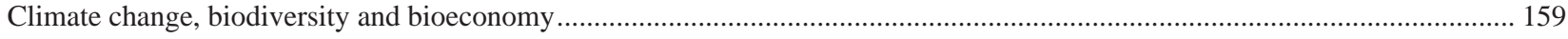

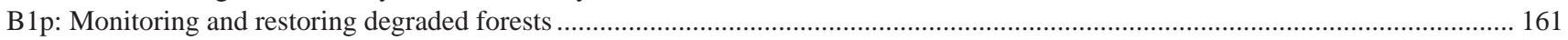

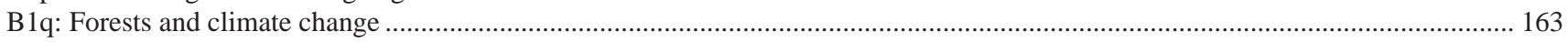

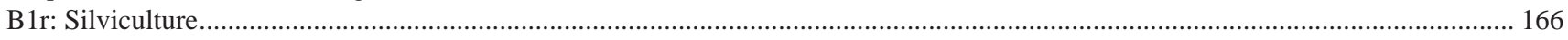

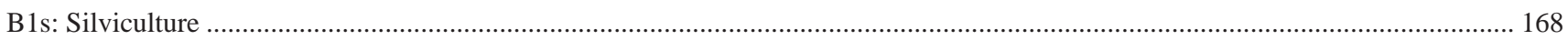

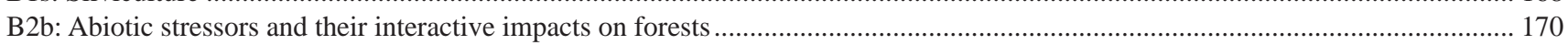

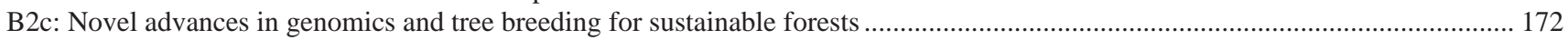

B2d: Wood and tree-ring studies of forest adaptation to climate change; implications for wood production....................................... 175

B2f: Wood and tree-ring studies of forest adaptation to climate change; implications for wood production - 1................................ 177

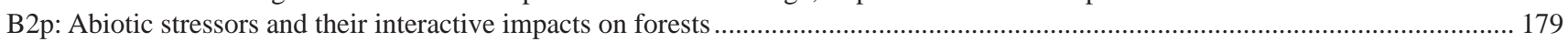

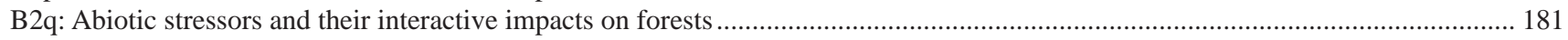

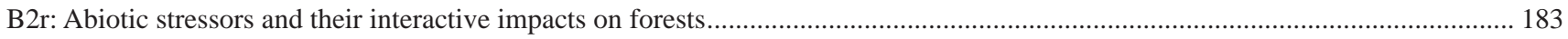

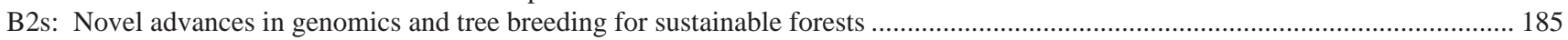

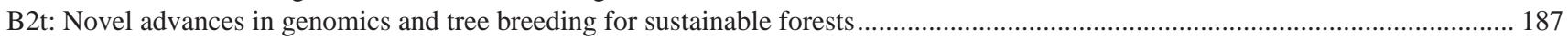

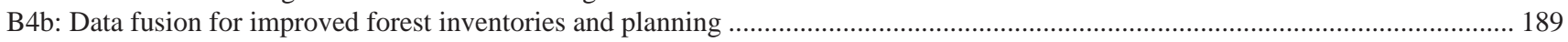

B4c: Estimation of status and change in forest carbon pools based on inventory data: going beyond tree carbon …........................... 191

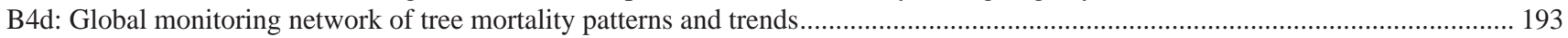

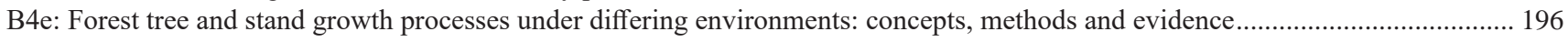

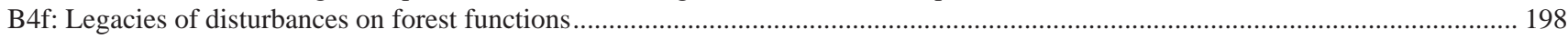

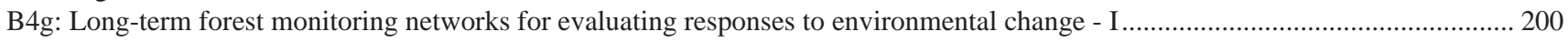

B4h: Novel remote sensing approaches to quantify carbon stocks, structure and functional diversity of forests - 1 …....................... 204

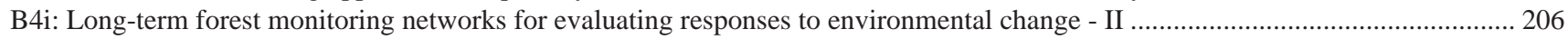

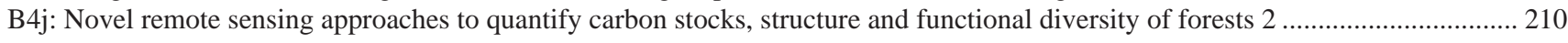

B4k: Novel remote sensing approaches to quantify carbon stocks, structure and functional diversity of forests 3 ............................. 212 
B4l: Climate smart forestry or how to integrate adaptation, mitigation and sustainable forest management ...................................... 214

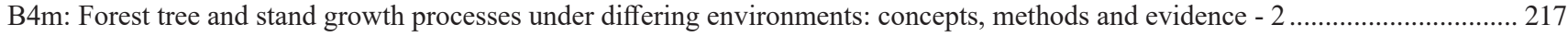

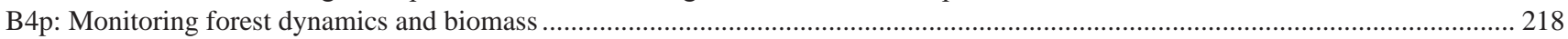

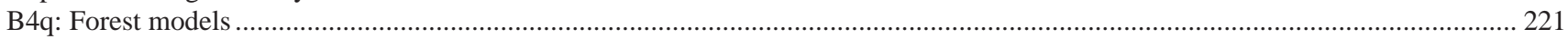

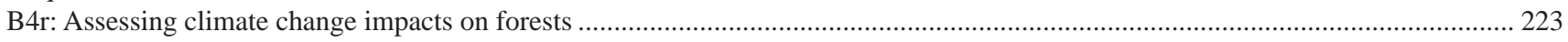

B4s: Climate smart forestry or how to integrate adaptation, mitigation and sustainable forest management..................................... 224

B4t: Estimation of status and change in forest carbon pools based on inventory data: going beyond tree carbon ................................ 2226

B4u: Estimation of status and change in forest carbon pools based on inventory data: going beyond tree carbon ............................... 228

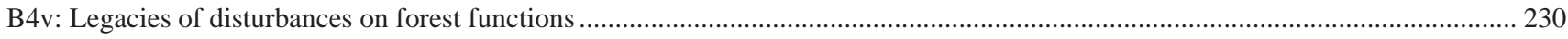

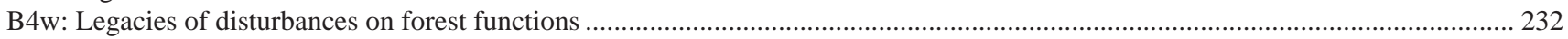

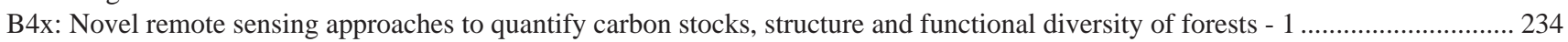

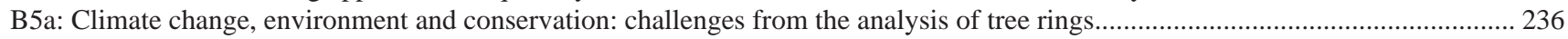

B5b: Innovative wood protection and durability strategies to mitigate climate change in the tropics and warm temperate climes........ 239

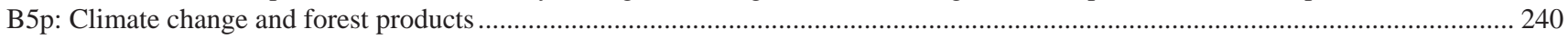

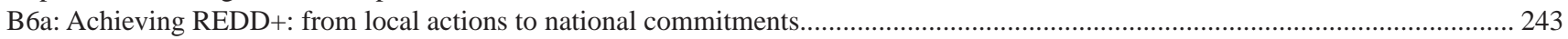

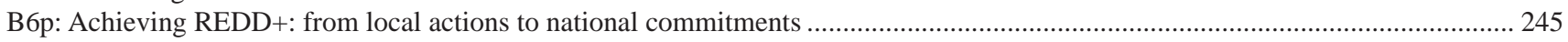

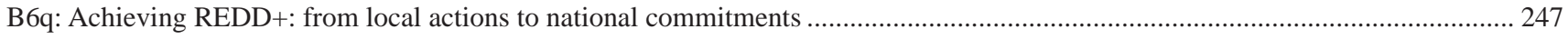

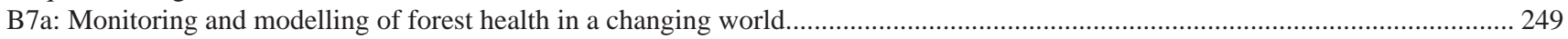

B7b: Physiological and biogeochemical response of forest ecosystems to climate change and air pollution ..................................... 251

B7p: Physiological and biogeochemical response of forest ecosystems to climate change and air pollution ................................... 253

B7q: Physiological and biogeochemical response of forest ecosystems to climate change and air pollution ..................................... 255

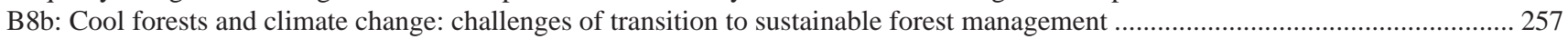

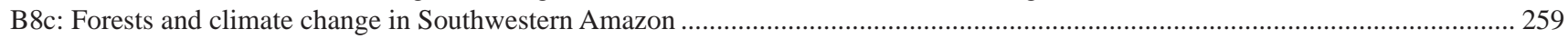

B8d: Response of forest ecosystems to climate change: learning from experimental manipulations and natural gradients ................... 262

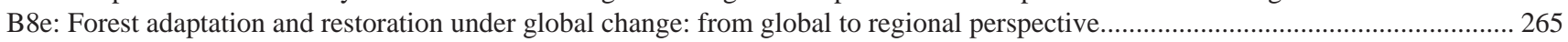

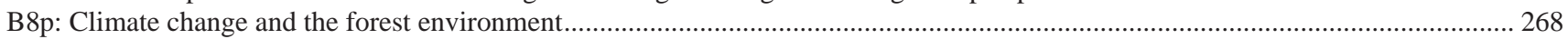

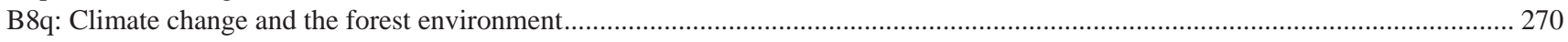

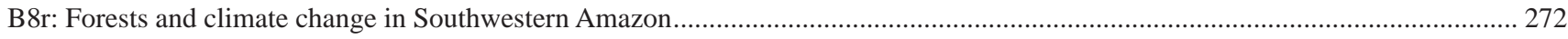

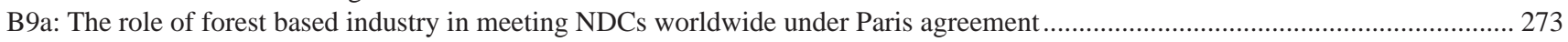

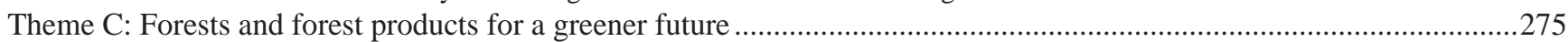

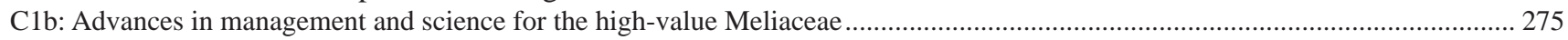

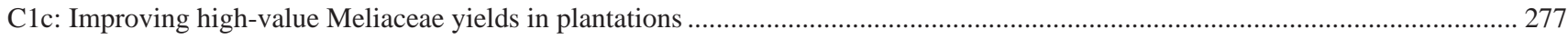

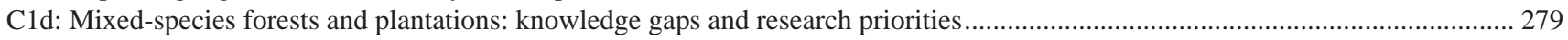

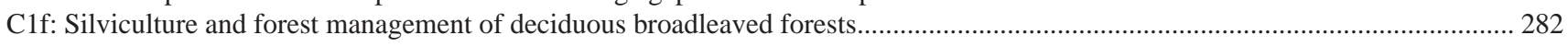

C1g: Silvopastoral systems: contributions to livestock and to the sustainable development objective ............................................... 284

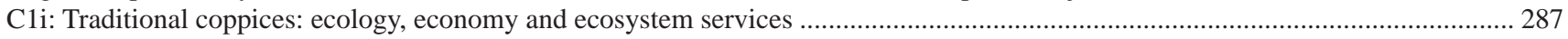

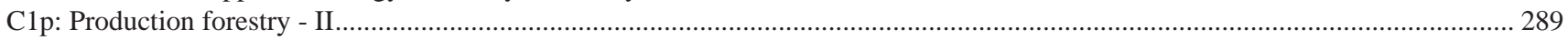

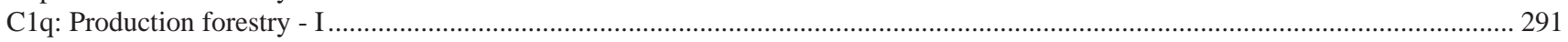

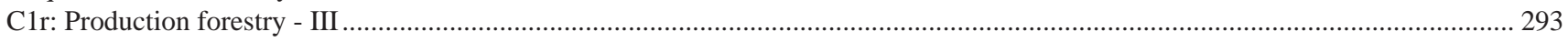

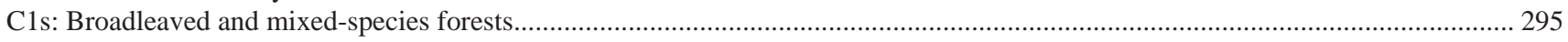

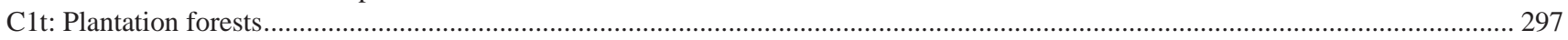

C1u: Mixed-species forests and plantations: knowledge gaps and research priorities .................................................................. 299

C1v: Mixed-species forests and plantations: knowledge gaps and research priorities................................................................ 301

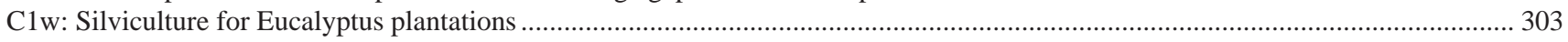

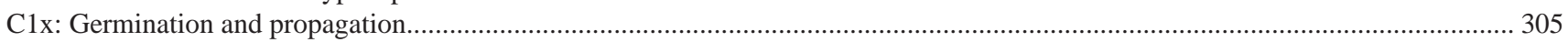

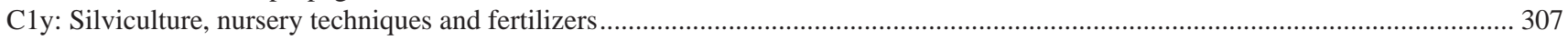

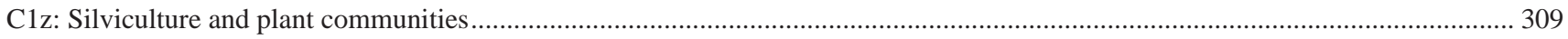

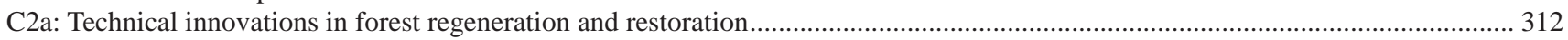

C2b: Tolerance of Eucalyptus clones to abiotic and biotic stresses: building the foundation for the future plantations ......................... 313

C2c: Towards sustainable development of the global teak Sector in a changing world................................................................. 316

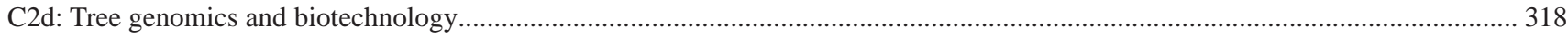

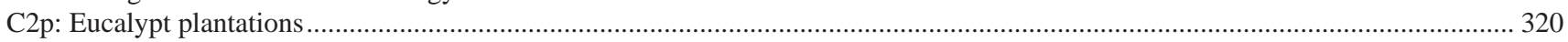

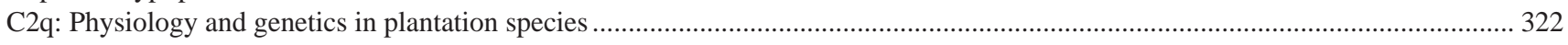

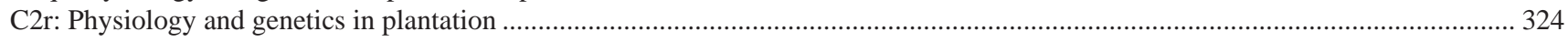

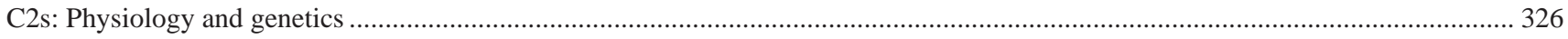

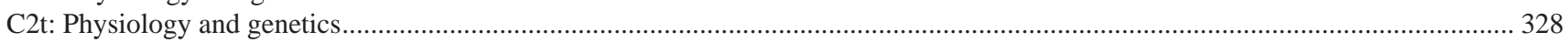

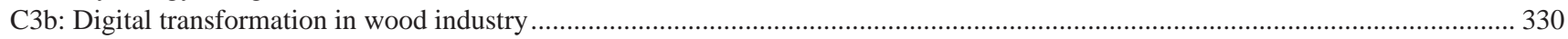

C3c: Forest operations engineering and management innovations for the future ................................................................... 332

C3d: Global green supply chains as a driver for sustainable forest management in the tropics ........................................................ 334 
C3e: Precision Forestry.

C3f: Promoting the environmental, social and economic benefits by monitoring the performance of forest machines: new approaches in precision forest operations

C3g: The forest and fire operations nexus: syntheses and perspectives on integrating fire risk management with forest engineering and management.....

$\mathrm{C} 3 \mathrm{~h}:$ The role of forest ergonomics in sustainable forest management in tropical regions.............................................................. 342

C3i: LPF/SFB - IAWA panel siscussion: new methods and applications of tropical timber identification to promote legal loggin ........ 344

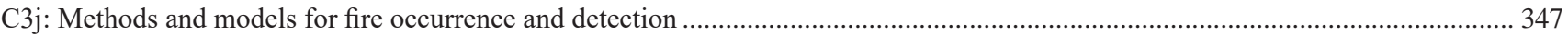

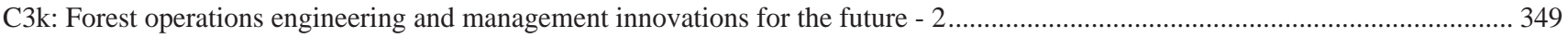

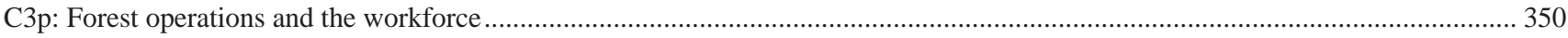

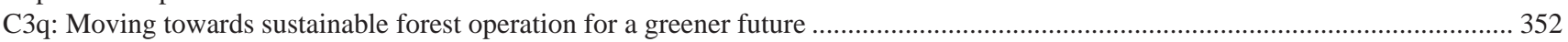

C3r: LPF/SFB - IAWA panel discussion: new methods and applications of tropical timber identification to promote legal logging

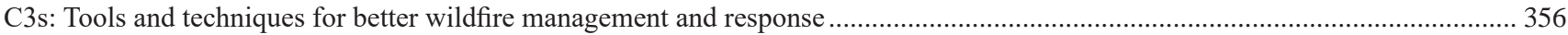

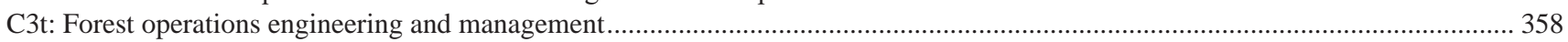

C4a: Advancements in digital technologies for dendrometry and qualitative indicators of forests .................................................. 360

C4b: Advances in remote sensing of vegetation: sensors, methodologies and applications ............................................................ 361

C4c: Benchmarking in forestry: challenges and solutions for establishing benchmarking systems ................................................. 363

C4d: Crown structure and dynamics as cause and effect in modelling tree growth, form, and wood quality..................................... 365

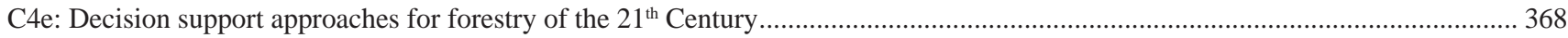

C4f: Forest assessment, modelling and management for nonwood forest products....................................................................... 370

C4g: Forest inventory and modeling: past successes, current challenges and future prospects ......................................................... 372

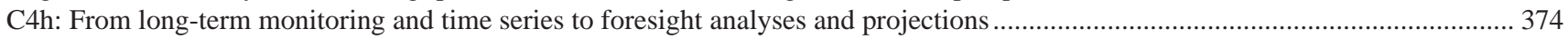

C4i: Innovative Applications of Unmanned Aerial Vehicles (UAVs) in forest science and management........................................... 376

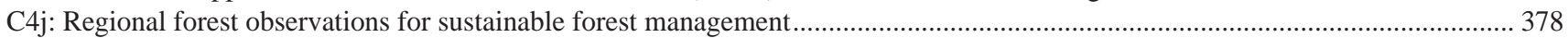

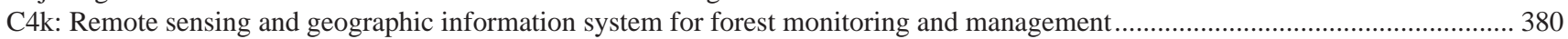

C4l: Forest inventory and modeling: past successes, current challenges and future prospects - 2 ......................................................382

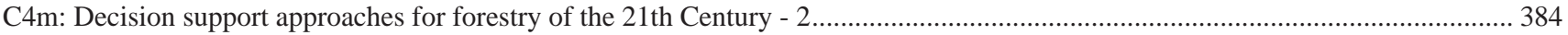

C4n: Innovative applications of Unmanned Aerial Vehicles (UAVs) in forest science and management - 2 .................................... 387

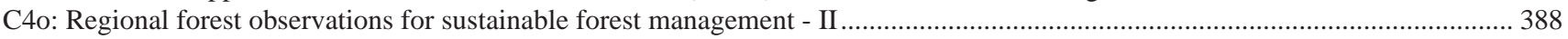

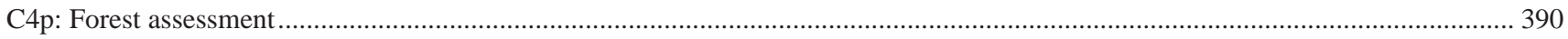

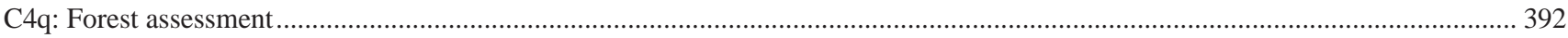

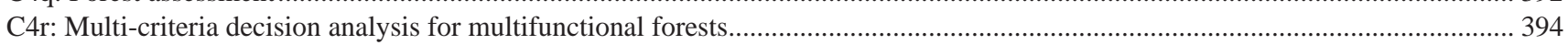

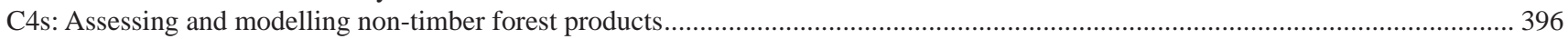

C4t: Forest inventory and modeling: past successes, current challenges and future prospects ........................................................ 398

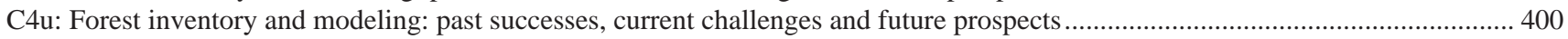

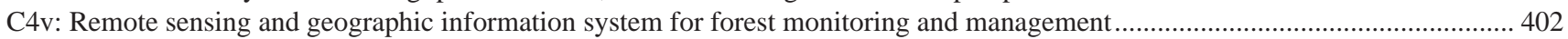

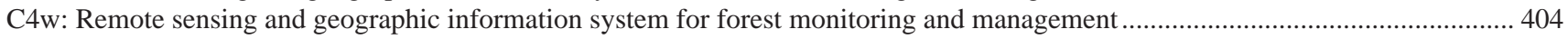

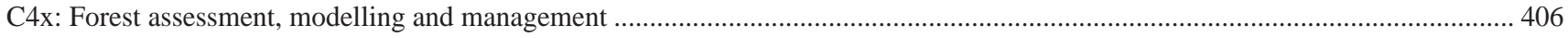

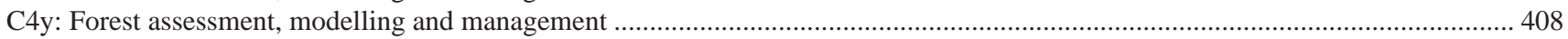

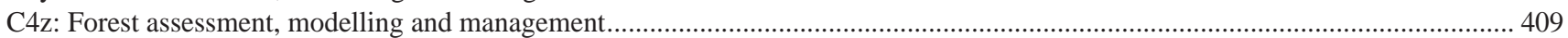

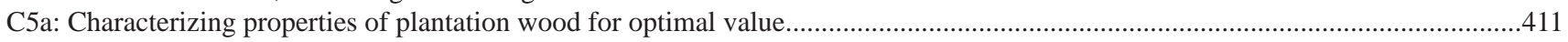

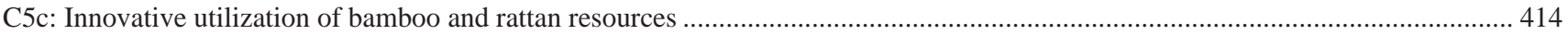

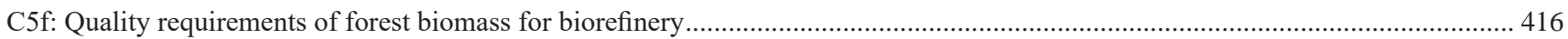

C5g: Quantifying and forecasting market specific forest products in the forestry wood chain......................................................... 418

C5h: Research and industrial use of wood bio-based (formaldehyde free) adhesives: raw material and introduction to the

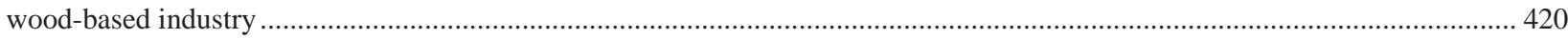

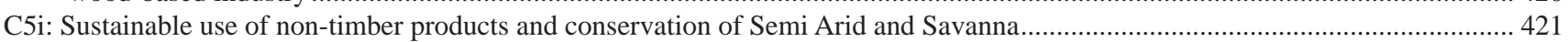

C5j: The use of forest and mill residues for advanced bioenergy/biofuels production .................................................................... 423

C5p: Characterizing properties of plantation wood for optimal value …....................................................................................... 425

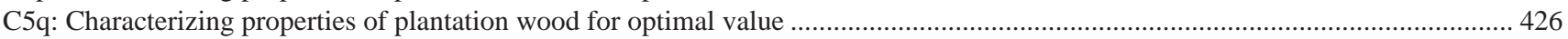

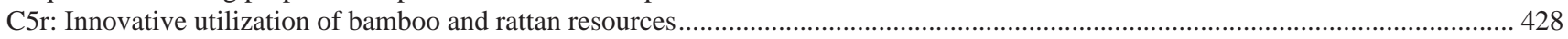

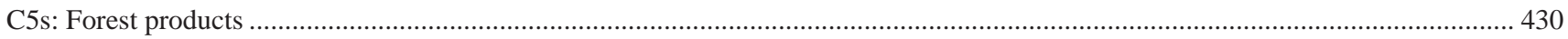

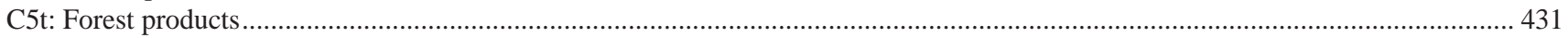

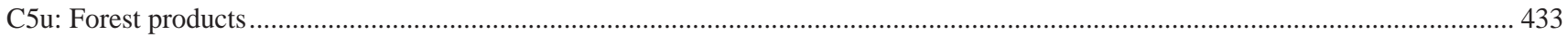

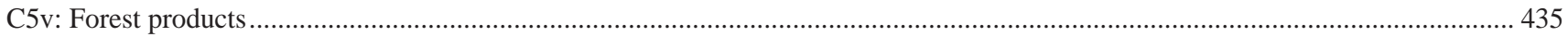

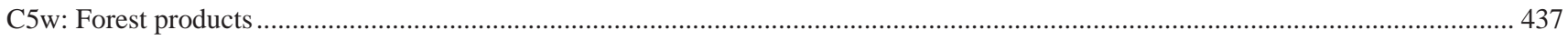

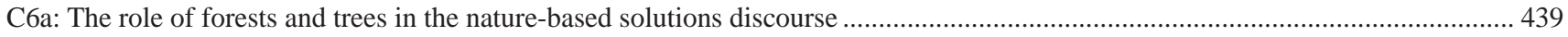

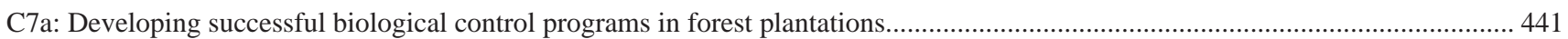


C7b: Needle and shoot diseases of pine.

C7c: Sustainable biomass for a greener future

C7d: Will active restoration of Secondary and Degraded Forests (SDFs) help to address sustainably the gap between wood demand and supply?...

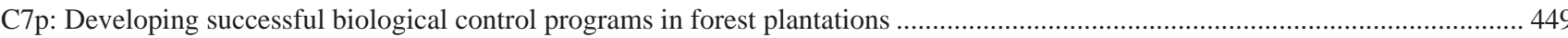

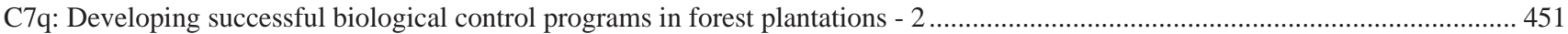

C7r: Developing successful biological control programs in forest plantations - 3

C7s: Will active restoration of Secondary and Degraded Forests (SDFs) help to address sustainably the gap between wood demand and supply?

C8a: Intensification within limits: increasing productivity without compromising ecosystem services............................................ 456

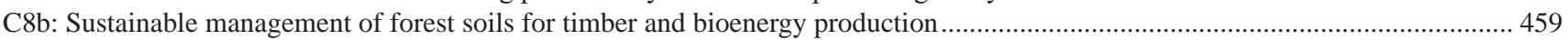

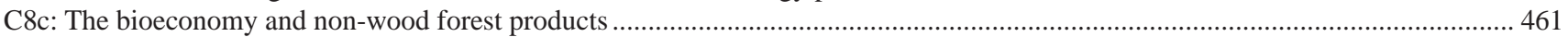

C8d: Intensification within limits: increasing productivity without compromising ecosystem services ............................................. 463

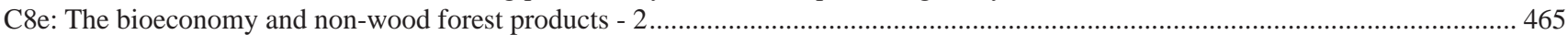

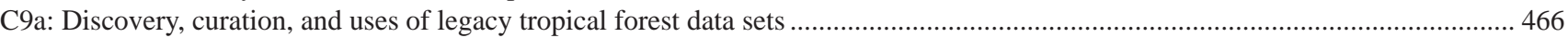

C9b: Planted forests for a Greener Future and achieving Sustainable Development Goals (SDGs) ...................................................468

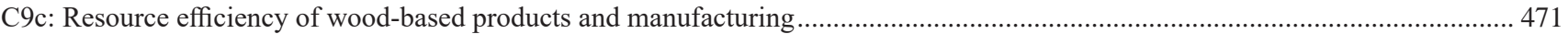

C9d: Societal perceptions, new products, markets, and business models of the circular forest bioeconomy ……................................. 473

C9e: Traditional, emerging and new forest products in a bioeconomy: advances and applications in modelling the market potentials and sectoral impacts ......

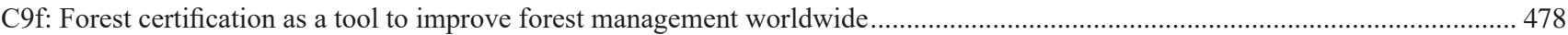

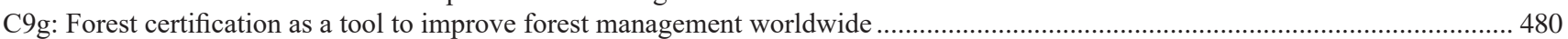

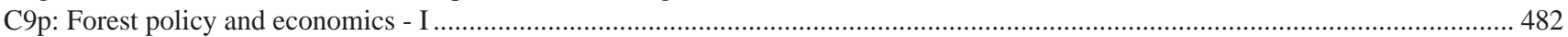

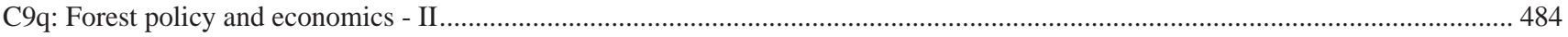

Theme D: Biodiversity, ecosystem services and biological invasions ..................................................................486

D1c: Disturbance, ecosystem memory, risk and forest management in a changing socio-ecological environment' ............................. 486

D1d: Employing plantations to restore native forests using successional forest management systems ............................................... 489

D1e: Forest landscape restoration for climate change mitigation and adaptation: integrating research into policy ............................. 491

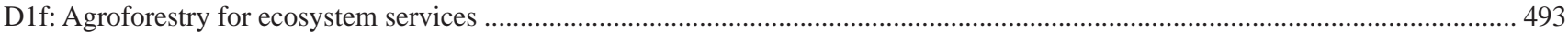

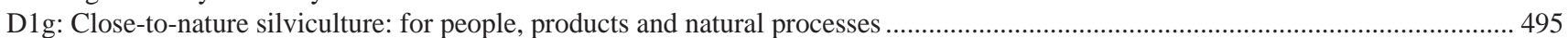

D1p: Disturbance, ecosystem memory, risk and forest management in a changing socio-ecological environment' ............................ 497

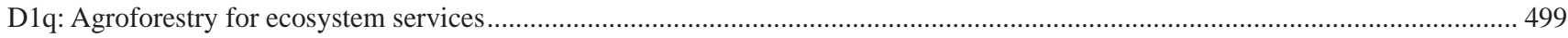

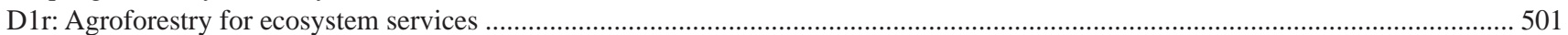

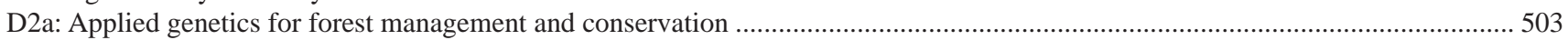

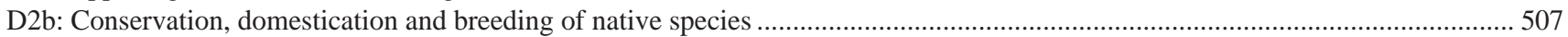

D2c: Conservation, sustainable management and development of forest genetic resources across their ranges: regional

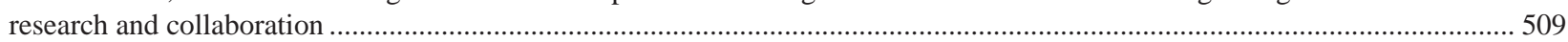

D2d: Genetics, management and conservation of Cerrado forest species: their challenges and achievements....................................511

D2f: Integrating tree resistance development with deeper understanding of local and long-distance movement of pest

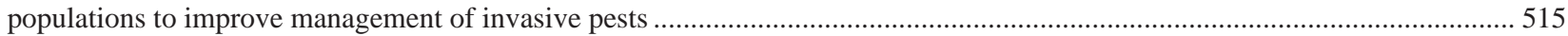

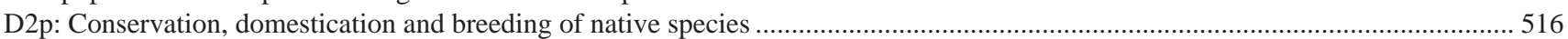

D2q: Conservation, domestication and breeding of native species ............................................................................................. 518

D2r: Conservation, sustainable management and development of forest genetic resources across their ranges: regional

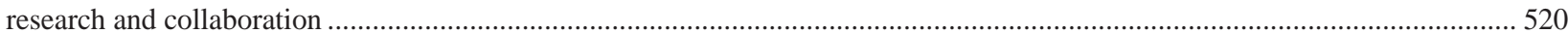

D4a: Cloud computing and remote sensing to understand 30-year dynamics of Brazilian forests .................................................... 522

D4b: Technological innovations for native forest management in different Brazilian biomes ......................................................... 525

D4c: Valuation Issues for wood and nonwood forest products to balance biodiversity and ecosystem services in managed forests...... 528

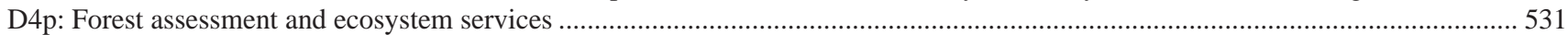

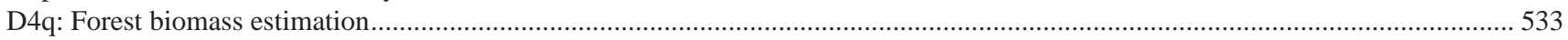

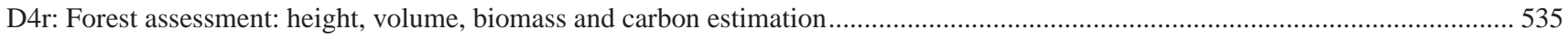

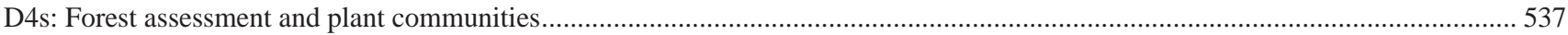

D5a: Improving forest management certification: integrating ecosystem services with forest assessments....................................... 538

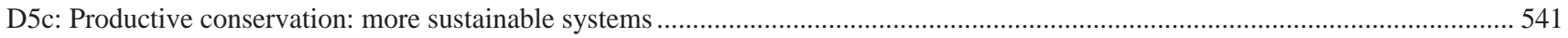

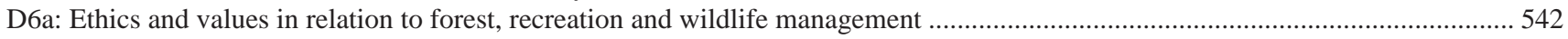

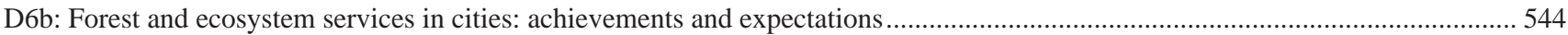

D6c: Forest health defenders: empowering citizens to protect forests through research contributions .............................................. 547

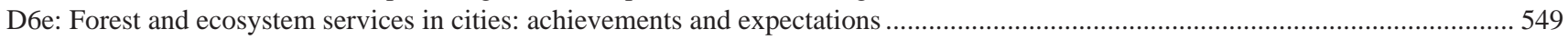

D6p: Forest and ecosystem services in cities: achievements and expectations ......................................................................... 552

D6q: Forest and ecosystem services in cities: achievements and expectations .............................................................................. 554 
D7b: Biodiversity, biotic interactions and threats to forest ecosystem services associated with tree reproductive

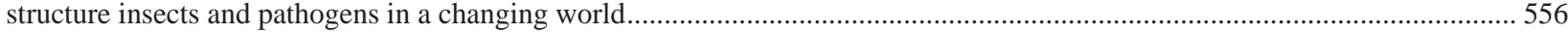

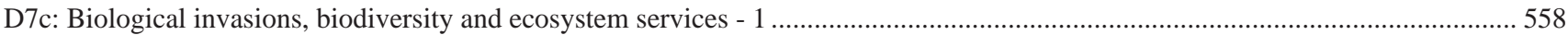

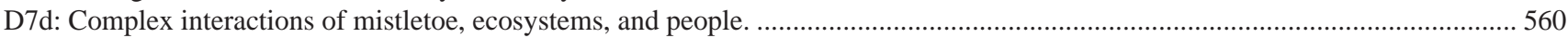

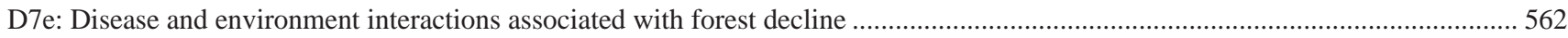

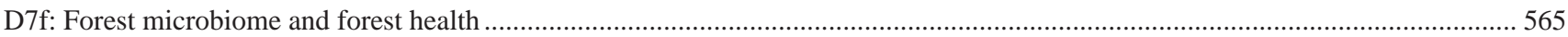

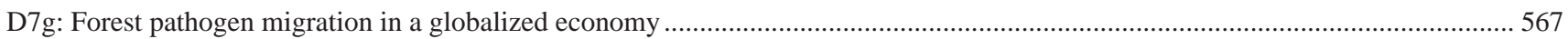

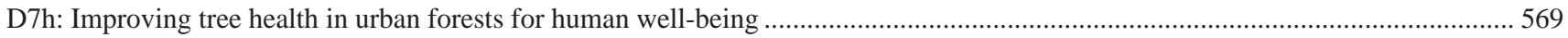

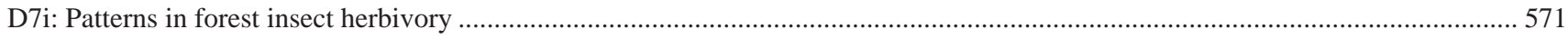

D7j: Phytophthoras as emergent forest threats in the human-wildland interface. ......................................................................... 573

D7k: Pine pitch canker: strategies for management of Fusarium circinatum in greenhouses and forests (PINESTRENGTH)............. 575

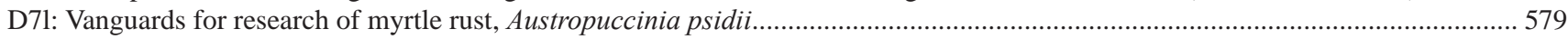

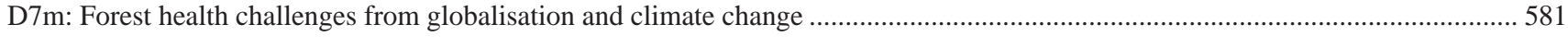

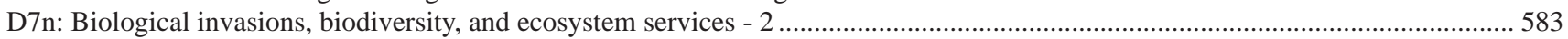

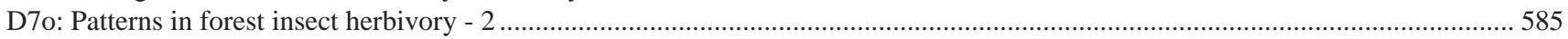

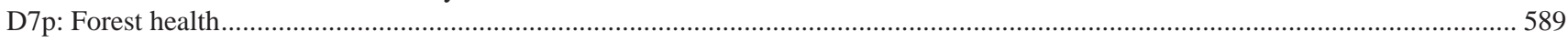

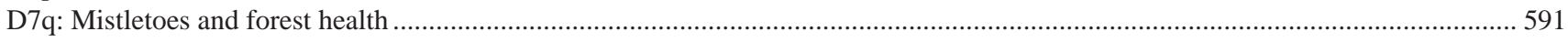

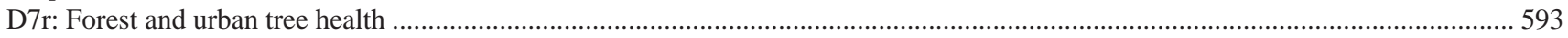

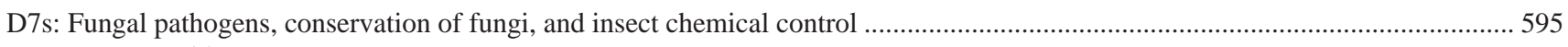

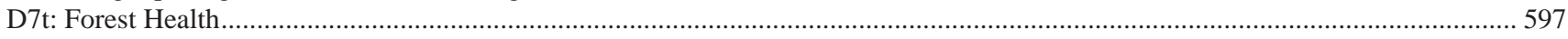

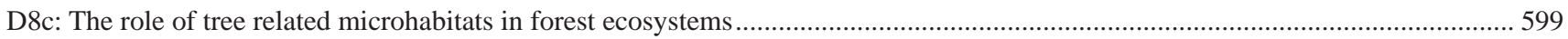

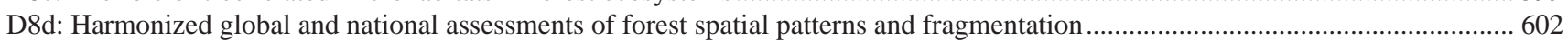

D8e: Improving conservation targets for forest biodiversity: towards operational solutions from remote sensing technology .............. 604

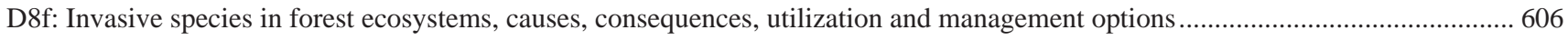

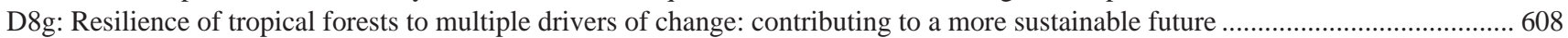

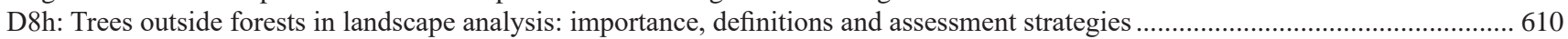

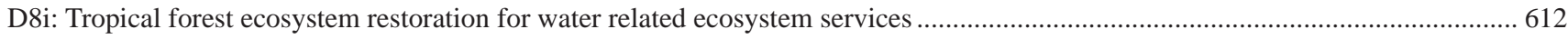

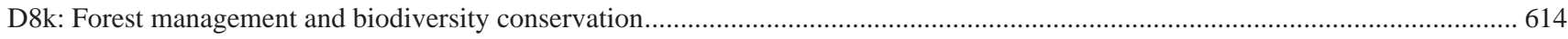

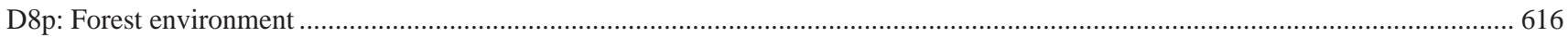

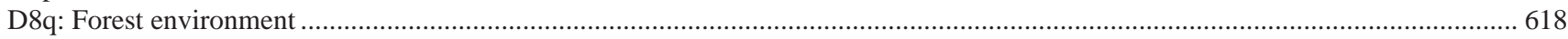

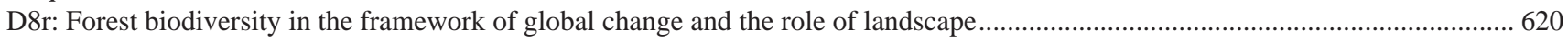

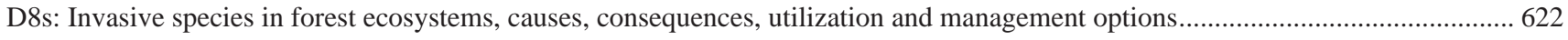

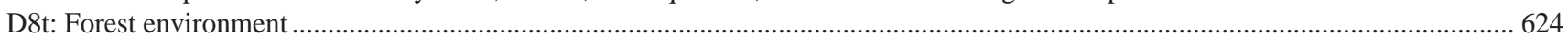

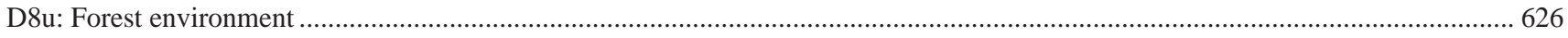

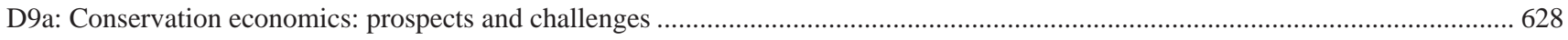

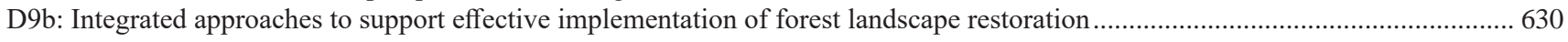

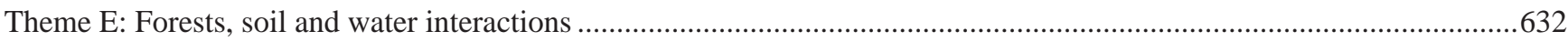

E1a: An integrated approach for African forest landscape management: Water, Energy and Food (WEF) nexus................................. 632

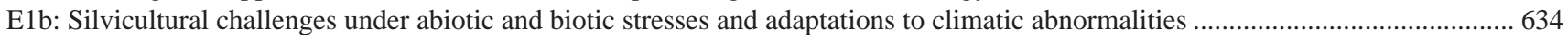

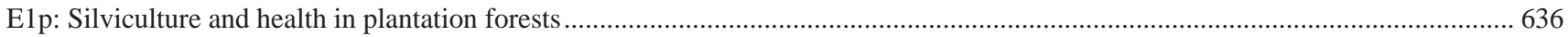

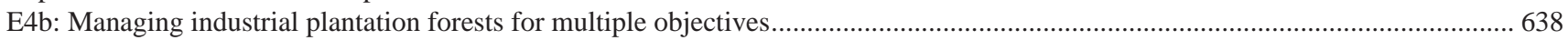

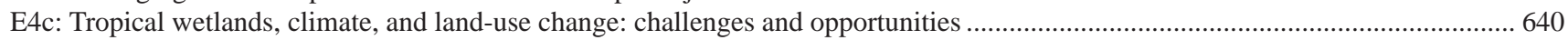

E8a: Forest management practices and the responses of soil carbon, water, nutrients and their interactions...................................... 643

E8b: Hydrological and biological responses of aquatic ecosystems to contemporary forest practices around the world ...................... 645

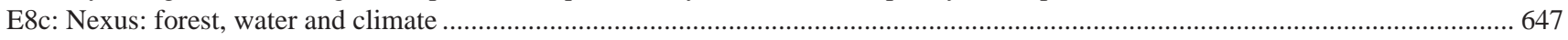

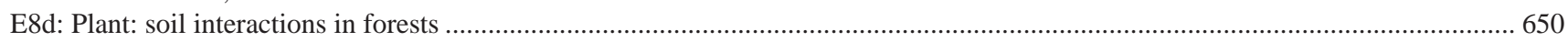

E8f: Current understanding and future challenges for forest research after the two nuclear accidents of Chernobyl

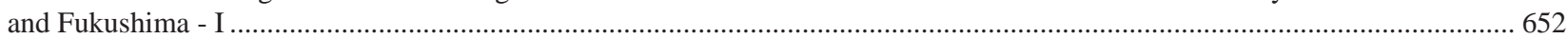

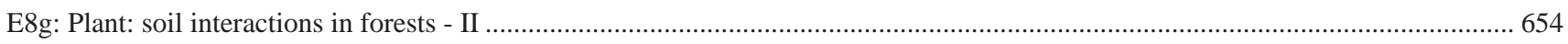

E8h: Current understanding and future challenges for forest research after the two nuclear accidents of Chernobyl

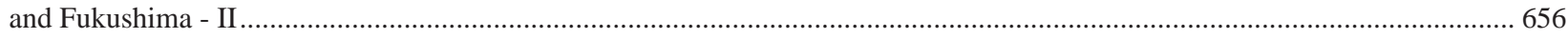

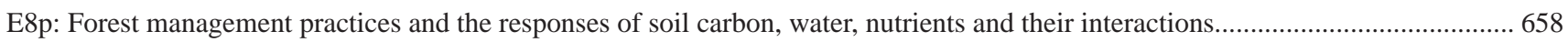

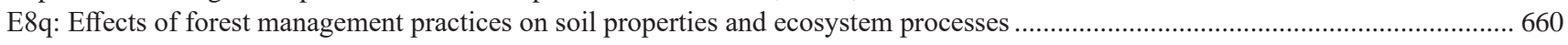

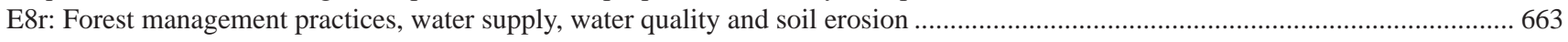

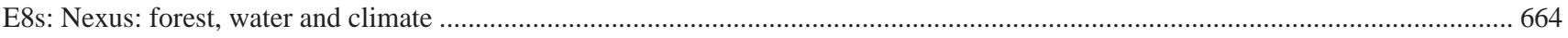

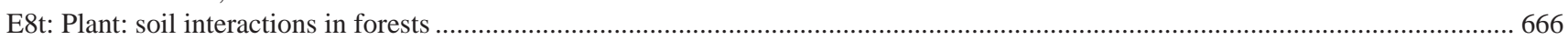

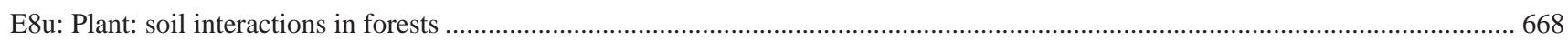

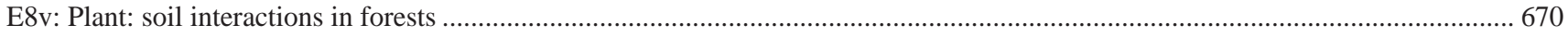

E8w: Current understanding and future challenges for forest research after the two nuclear accidents of Chernobyl and Fukushima .. 671 


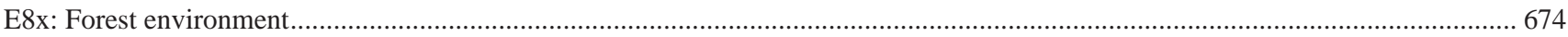

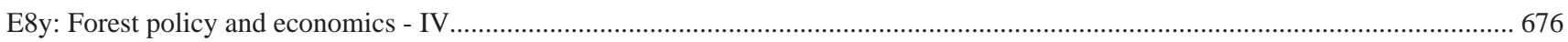

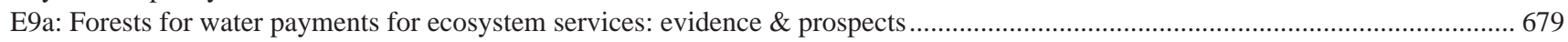

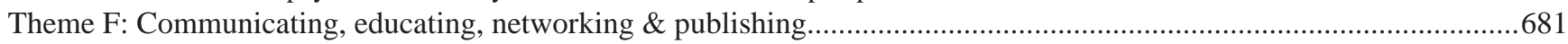

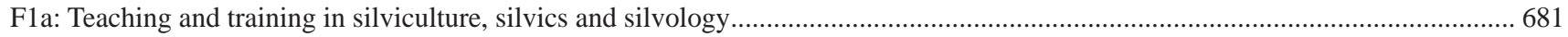

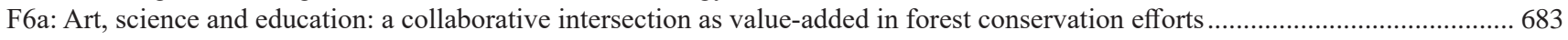

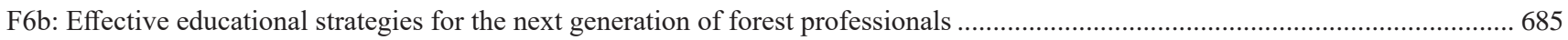

F6c: How to teach forest sciences in the future: challenges and opportunities of changing ecological, socio-economic, and

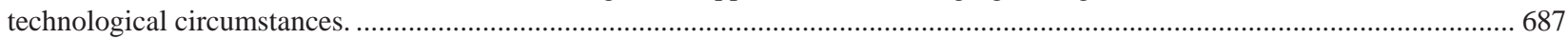

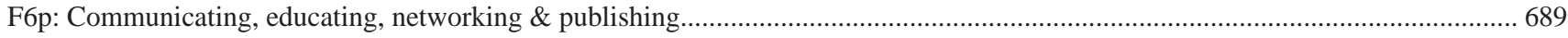

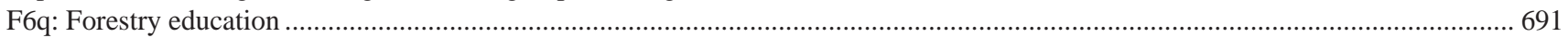

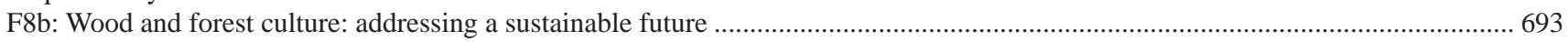

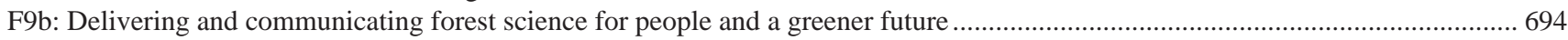

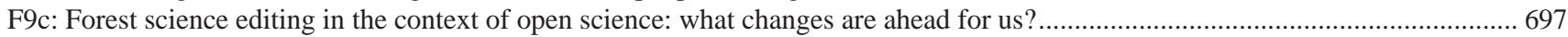

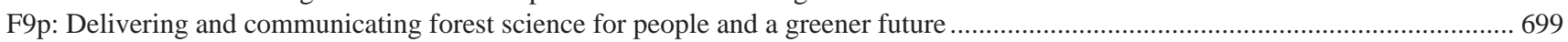

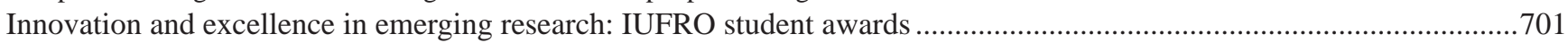

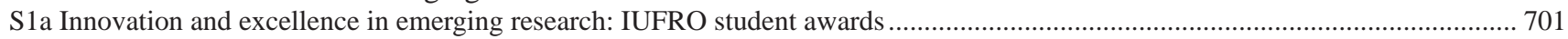

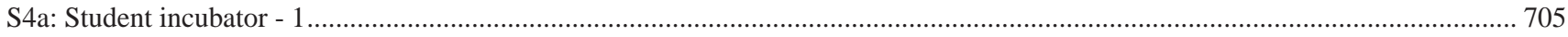

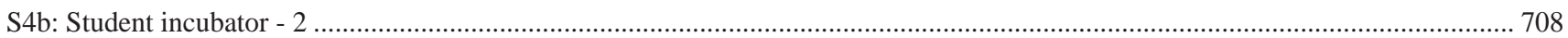

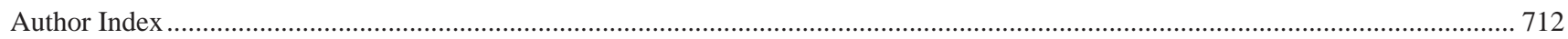




\section{Voice of the mother trees}

Suzanne Simard ${ }^{1}$

${ }^{1}$ University of British Columbia (suzanne.simard@ubc.ca)

In three decades of studying interspecific relationships in the forests of Canada, we have discovered that trees not only compete with each other, but also connect, communicate and cooperate through belowground mycorrhizal fungal networks. The largest trees are hubs of the networks, where they link with other trees and plants. The big trees convey resources such as carbon, nitrogen and water, and these are transmitted down source-sink gradients to smaller trees, resulting in a redistribution of matter and information throughout the forest. The big hub trees also facilitate the regeneration of new seedlings, particularly their own offspring, enhancing their survival and growth, and we have therefore taken to calling the hubs, "mother trees". When the mother trees become sick or damaged, they transmit even more resources to the surrounding individuals, as well as defense information that enhances the recipient's resistance to the disturbance. Deciphering such communications will take considerable more research, but it is clear that mother trees have a voice and what they have to say is crucial to forest resilience. In working with the Aboriginal people of British Columbia, we have learned that these discoveries resonate with traditional ecological knowledge. Based on this knowledge, and in collaboration with indigenous people, academics, government and the forest industry, we launched "The Mother Tree Project" in the Douglas-fir forests of British Columbia in 2015. This rigorous experiment, where we are testing how best to retain mother trees during harvesting so the forest remains resilient as climate changes, is designed as a hub for a century of collaborative research. It includes nine replicated forests that cover the climatic envelope of interior Douglas-fir, across which we are comparing five patterns of mother tree retention, from clearcutting to partial retention to no-harvest controls. The mother tree retention treatments have been planted with a wide range of species as well as local and migrated genotypes of Douglas fir, creating diverse mixes of regenerating trees that should enhance resource uptake and decrease risk of catastrophic mortality. We are measuring how these practices are affecting key ecological structures and functions, including species diversity, carbon storage, and forest regeneration. This presentation tells the story of the origins of The Mother Tree Project, provides early results, lays out a vision for globalization of the project, and gives information on how to get involved.

\section{P4a: FORESTS AND FOREST PRODUCTS FOR A GREENER FUTURE}

\section{Forests and forest products for a greener future}

Vincent Gitz ${ }^{1}$

${ }^{1}$ GCIAR Research Program on Forests, Trees and Agroforestry, Bogor, Indonesia (v.gitz@cgiar.org)

The strong scientific consensus on the need for more forests and trees, mainly for environmental reasons, especially to mitigate climate change, is broadly recognized by policy makers. It has led to numerous political commitments. As part of the Green Economy discourse there is also a growing political support for bio-energy and for substituting non-renewable, energy intensive, materials by wood products (and other comparable products like bamboo and rattan) that are both renewable and stock carbon. However, results on the ground are more mixed. One of the reasons being that economic development is a main driver of deforestation, and that the amounts of public money to be committed for forest conservation and forest restoration do not compare to short time economic benefits of alternative activities. One illustration of this is the recent debate on the potential for tree planting (Lewis et al. and rebuttals) between a biophysical approach and those recalling economic realities. This leads to the following questions, that the presentation will aim to articulate and address: How can more wood products be the way to more -rather than less- trees and forests? And which wood products and from which forests, given the social, environmental and economic performance of the associated production and transformation systems? Which "wood value webs" to prioritize and to optimize, given multiple objectives, differing characteristics of diverse silviculture/ plantation/ forest management types and their related objectives, as well as other development constraints, such as land-use, the time to grow wood and to develop the industrial infrastructure? And how will it work, especially considering that forest economies are very different in developed and developing countries? What would be the economic, trade and markets, financial, institutional, regulatory and legal conditions for it to happen?

\section{Forests and forest products for a greener future}

Francisco Razzolini ${ }^{1}$

${ }^{1}$ Klabin SA, São Paulo, Brazil (fcrazzolini@klabin.com.br)

There is a rising concern and global awareness related to climate changes, global warming, water and food scarcity, excess emissions and pollution all over - air, land and water. There is increasing scientific evidence that a significant proportion of the fossil resources need to stay underground if the world has to reach its climate goals. Bio-based products are of a huge importance for climate change mitigation, GHG emissions and sequestration. While the energy sector can be extensively decarbonized, the chemical sector and plastic industry depend heavily on carbon, and with this, there's a great opportunity for renewable carbon to reduce the GHG impact. Currently, the only important source for renewable carbon is biomass. Klabin, Brazil's largest packaging paper and paper packaging producer, has been focusing the development challenges for new bio-based, renewable, circular and compostable products. A corporate research, development and innovation (R\&D+I) structure, including a brand new Technology Center, was established. Five technology routs being explored - forest, pulp, paper, environmental and new technologies based on planted forests. New applications and products from forest based materials, through technology, will enable Klabin enhance its products as well as explore new business opportunities. This is one of the most important steps in the company's history aiming to improve sustainability. There is still a lot to do to scale up the basic research into industrial scale and many questions to answer. The presentation will address some opportunities and developments for multiple uses of the forest and trees into sustainable products. 


\title{
A6a: WOMEN AND FORESTS: PROMOTING GENDER EQUALITY CONNECTING RESEARCH, PUBLIC POLICIES AND FOREST MANAGEMENT IN THE TROPICS
}

\author{
The feminine space in forest management in the Amazon, Amapá case study \\ Ana Margarida Castro Euler ${ }^{1}$ \\ ${ }^{1}$ Embrapa Amapá, Macapá, Brasil (ana.euler@embrapa.br)
}

Amapá is a sui generis state located in Eastern Brazilian Amazon, with low historical deforestation rate and where 73\% of its territory is under protected areas. It is the only one women wages are, on average, higher than men in the public sector. Also it is the only Brazilian Amazon state that has an Institute of Forests (IEF) with a function of forestry extension, protected areas management, forest concessions and environmental services. From 2011 to 2014 , for the first time a female forest engineer headed the IEF. During this period, the state government had less than $20 \%$ of executive positions held by women. Challenges at the IEF ranged from the scarcity of budget resources to high demand in a region where forests occupy $80 \%$ of the territory. Remarkable outcomes were achieved such as the State Register of Public Forests, the 1st State Forest Program, and the 1st Forest Concession bidding notice. The launch of the Pro-extrativism programme, which assisted more than 1,500 families of agroextractivists, quilombolas, indigenous and riverine communities; and the weekly radio program "Vozes da Floresta", a forum for the dissemination of information on market, forestry policies and projects. A major difficulty came up in the relationship with timber companies, run by men with patriarchal culture and retrograde practices. Confronting conflicts related to corruption associated with the public land tenure, and a tense relationship with the Legislative Assembly, whose the majority of representatives, advocate interests unrelated to the traditional communities and the protection of the environment.

\section{Gender equality in forestry education in a Kenyan University}

Jane Kiragu ${ }^{1}$

${ }^{1}$ University of Eldoret, Eldoret, Kenya (wambuikirash@gmail.com)

Women play a major role in the establishment and management of forests in the world and especially in the developing world, and Kenya in particular. Women are found in large numbers working in the tree nurseries and during tree planting in the field, but their numbers reduce drastically in the management positions. About $90 \%$ of the rural households use fuelwood for their cooking, heating and lighting. Fuelwood collection is done mainly by women and girls in the forest at a fee, while boys are left to play or look after cattle in the field. A lot of time is spent which can be reduced if both men and women can be encouraged to plant trees in their farms. In Kenya, this has not been easy due to land tenure, tree tenure, government policies, land sizes, the long term state of the crop and culture problems. To promote forests, more women should be in policy making positions both in the forestry sector and in politics where most decisions are made. Women should be encouraged to vie for those positions whenever advertised and given a level ground with their male counterparts. The government has put the $2 / 3$ gender rule in the constitution, but its implementation is yet to be realized. More research should be done on why fewer women are found in forest related sectors and how this can be changed.

\section{Women in forest governance policy: analysis and empirical studies from Latin America and Asia}

\section{Purabi Bose}

${ }^{1}$ Landing Together, Mumbai, India (purabibose@gmail.com)

A search for the words women and gender in the Draft National Forest Policy, 2018 - which governs the formulation of all laws and schemes related to forestry returns zero results. While terms like wood, economic or timber appear all over the 10-page draft policy released by the Indian government in March. Likewise, the policies on forest in Latin America's Colombia shows the challenge of integrating women's active role in collective forest governance, particularly in agro-forestry. This paper makes a comparative analysis between Latin America and Asia in understanding the role of women in forest policy. The two countries Mexico and Colombia from Latin America while India and Indonesia from Asia will be used as empirical case study. The study uses primary and secondary data to show how recent forest policies impact women from rural and indigenous areas. The findings indicate that forest policy rarely uses the words 'women' or 'gender' to ensure women's active role in forest governance. The first challenge is to overcome the challenge is for the environment ministry to acknowledge that the draft policy fails to discuss gender integration and women's issues in the management of forests, trees, agroforestry and afforestation. The next step will have to be to open up the dialogue for social and gender inclusion, and to ensure that environmental defenders, including women, are protected through India's forest policy. With these measures in place, this paper indicates a chance of saving India's forests and the communities who depend on them.

A9a: POLITICAL ECOLOGY AND INTEGRATED LANDSCAPE APPROACHES: COMPLEMENTARITY OR UNHAPPY MARRIAGE?

\section{Context, power and equity in territorial planning multi-stakeholder commissions: a comparative analysis of two very different Brazilian States}

Jazmin Gonzales Tovar ${ }^{1,2}$, Grenville Barnes ${ }^{1}$, Anne Larson ${ }^{2}$

${ }^{1}$ University of Florida, Gainesville, USA; ${ }^{2}$ Center for International Forestry Research, Bogor, Indonesia (jazmin.gonzalest@gmail.com; gbarnes@ufl.edu; a.larson@cgiar.org)

"Ecological-Economic Zoning" (ZEE) was regulated in Brazil as a territory planning tool aimed to organize the sustainable use of land and natural resources, through multi-stakeholder forums (MSFs) and other participation mechanisms. MSFs have gained global popularity as an innovative institutional reform in the governance of land use and forests. In territorial planning, the idea is to bring together diverse actors to advance "good governance" and "sustainable development" (e.g. Nolte et al. 2017). However, both territorial planning and MSFs constitute a double-edged sword: advancing certain goals, strengthening certain land use rights and benefiting certain actors can come at the expense of others. They can either challenge power asymmetries or merely reproduce them (e.g. Kohlepp 2002). Based on 10 months of research, we comparatively analyze the multi-stakeholder commissions created for the ZEE of Acre and Mato 
Grosso, two Amazonian Brazilian States with very different characteristics and history. We delve into the influence of the national and regional context, and how power is exerted, distributed and shared between actors. We capture perceptions and collect empirical evidence from q-methodology and differentiated questionnaires. We reveal that land use planning MSFs have better chances to promote equitable power relations when they emerge from - and are nourished by - an historical context that embraces local movements, culture, identity and differences, rather than from technocratic top-down processes. Our ultimate goal is to offer a critical analysis and shed light on how to improve the equity of MSFs in decision-making around land use, forests and local people's wellbeing.

\section{Linking landscape governance and system change in Global commodity markets}

Pablo Pacheco ${ }^{1}$

${ }^{1}$ WWF, Washington, DC, USA (pablo.pacheco@wwf.org)

There is growing consensus on the potential of integrated landscape governance approaches to achieve landscape sustainability. These views emphasize socio-environmental dynamics, yet fail to acknowledge wider sustainability challenges in the global supply chains shaping landscapes’ performance. Major sustainability challenges in landscapes in transition, are the pressures originated on Global sourcing of food, energy and materials, linked to disparate financial and corporate interests. Efforts to support sustainable landscapes through both corporate commitments to zero deforestation and governments' regulatory frameworks aimed at sustainable land use, face several barriers. Main are: 1) legacy issues associated with specific pathways of landscape development, where greater progress is likely to be achieved where stronger local economies have developed but there is likely little forest left; 2) leakage, since deforestation tends to move to poorly governed landscapes where greater short-term interests for capturing economic rents persist; and 3) legitimacy, since solutions often tend to reinforce asymmetric power relations in the landscapes, while excluding low performing farmers. More structural solutions to deforestation and forest degradation are needed by linking wider system change interventions of corporate actors in the supply chains, and state policies across landscapes undergoing different stages of social and economic development and resource use. This paper, by looking at the specific cases of Brazil and Indonesia, argues in favor of wider corporate engagement in 'nature-based solutions' across landscapes (moving beyond zero deforestation only) and 'hybrid governance mechanisms' for dealing with legacy and leakage across landscapes, and power disparities and competing values in each specific landscape.

\section{A9b: SOLVING WICKED FOREST POLICY PROBLEMS: LESSONS FROM PRACTICE}

\section{Integrating diverse knowledge systems to address complex forest policy challenges: insights from large-scale genomics research}

Shannon Hagerman ${ }^{1}$, Robert Kozak', Guillaume Peterson ${ }^{2}$, Richard Hamelin ${ }^{1}$, Sally Aitken ${ }^{1}$

${ }^{1}$ University of British Columbia, Faculty of Forestry, Vancouver, Canada; ${ }^{2}$ University of British Columbia, Vancouver, Canada (shannon.hagerman@ubc.ca; rob.kozak@ubc.ca; guillaume.peterson@ubc.ca; richard.hamelin@ubc.ca; sally.aitken@ubc.ca)

The integration of diverse forms of knowledge is widely acknowledged as essential for addressing complex environmental forest policy challenges. While forest research spans multiple disciplines, the integration of knowledge in an interdisciplinary manner is often lacking. Recognizing that meaningful integration continues to be elusive, some funding agencies have tried to address this by explicitly incorporating a requirement for integrating natural and social science insights. One such program, the GE3LS program within Genome Canada, was developed to encourage integration across disciplines and, specifically, to consider the ethical, environmental, economic, legal and social issues involved in genomics research. Here, we draw from our collective experience across two large-scale interdisciplinary forest research projects (AdapTree and CoAdapTree) addressing genetic and reforestation choices for new climates, to evaluate opportunities and challenges of integration in applied research practice. We explore three examples of integration and ask: what is integrated, who integrates, at what stage of the research process, and what does/should integration achieve? Our inquiry is based on the premise that a common barrier to productive integration is an often-unquestioned assumption that the meaning and purpose of "integration" is known and shared across research teams and affected stakeholders. We identify success factors and persistent dilemmas by distinguishing between issues of "knowledge architecture" (e.g. relating to epistemological differences, including between western scientific and indigenous knowledge systems) on the one hand, and "project architecture" (e.g. relating to communication, trust, institutional incentives) on the other.

\section{The Brazilian show-case for prevention and control of deforestation in the Amazon: PPCDAM's roots andresults}

Mayte Benicio Rizek ${ }^{1}$, Anne Larson ${ }^{2}$, Juan Pablo Sarmiento ${ }^{2}$

${ }^{1}$ Universidae Federal do Rio de Janeiro, Rio de Janeiro, Brasil; ' ${ }^{2}$ Center for International Forestry Research (CIFOR), Lima, Peru (mayte.cifor@gmail.com; a.larson@cgiar.org; j.sarmiento@cgiar.org)

During the first Worker's Party mandate (2003-2006), tackling deforestation took a central place in the presidential agenda and Brazil came up with the Action Plan for the Prevention and Control of Deforestation in the Legal Amazon (PPCDAM). Through an interministerial working group of 13 federal agencies led by the Chief of Staff Office, each institution proposed strategic actions leading to a more than $50 \%$ decrease in deforestation rates from 2004 to 2008 . This research analyzes the PPCDAM political roots and approaches considering the perceptions across three conveners and eighteen mid-level bureaucrats who worked or still works on PPCDAM agenda representing environmental interests, such as protection-and-conservation goals, as well as the production interests, including traditional uses, mining and rural development interests. It all supplemented by seven non-participant relevant stakeholders interviews and research on official documents and third-party evaluations. Part of CIFOR's mixed-method global research into multi-stakeholder forums, the results show that when the federal government gave political weight and budget prioritization, PPCDAM changed Brazil's approach to deforestation. It happened by organizing multi-institutional command-and-control actions supported by remote sensing techniques, promoting access to public services as compensation for the economic impacts after command-and-control actions, and by raising awareness that land-use planning can optimize resources, including the creation of protected areas in deforestation hot-spots. However, local governments were not enough engaged, although many actions focused on their territorial performance. Thus, PPCDAM was unable to change the local economic matrix, and illegal deforesters shifted their patterns to subvert control by remote sensing.

\section{Explaining variation in deforestation in Uganda: the role of forest sector decentralization, protected areas, and institutions}

\section{Michaela Foster ${ }^{1}$}

${ }^{1}$ Yale University, New Haven, USA (michaela.foster@yale.edu)

Decentralization has been pushed as an effective strategy for forest governance. Policy makers across the globe have implemented decentralization reforms with the aims of improving environmental conditions and rural livelihoods. Many studies have assessed the impacts of decentralization across countries 
and in case studies, presenting mixed evidence of the effectiveness of reforms. Fewer studies, however, have examined how decentralization influences the effectiveness of other existing conservation interventions, such as protected areas. In this study, I use a mixed methods approach to assess the impact of forest sector decentralization on forest cover change within protected areas in Uganda since 2000 and to investigate how forest management institutions emerging from the reform have operated to influence subnational forest outcomes. The decentralization process in Uganda devolved forest management under the jurisdiction of three managing authorities: Uganda Wildlife Authority, National Forest Authority, and District Forest Services, allowing for comparisons of deforestation outcomes on plots under the management of each authority over time. This study traces how the unique institutional arrangements of each managing authority, including agency mandates, capacities, and management rules, changed following the reform, and have, in turn, shaped forest management and led to heterogeneous effects across protected areas. Findings from this study point to the institutional conditions that appear to be conducive to effective governance and conservation and can be used to draw lessons about the opportunities and constraints emerging from decentralization in the governance of protected areas.

\section{Governing wicked problems across boundaries: the case of wildfire governance in the Western US}

Benjamin Gray ${ }^{1}$, Daniel Williams ${ }^{2,3}$, Carina Wyborn ${ }^{1}$, Laurie Yung ${ }^{1}$

${ }^{1}$ University of Montana, Missoula, USA; ${ }^{2}$ USDA Forest Service Rocky Mountain Research Station, Fort Collins, USA; ${ }^{3}$ Luc Hoffmann Institute Gland

Switzerland (benjamin.gray@umontana.edu; drwilliams@fs.fed.us; cwyborn@wwfint.org; laurie.yung@umontana.edu)

Mitigating wildfire risk is a particularly wicked socio-ecological problem. Climate change, on-going development in the wildland-urban interface, and other factors have made wildfires in the Western US increasingly problematic. Due to the patchwork of private land ownership and local, state, and federal government jurisdictions in the West, no single authority can direct or mandate wildfire risk mitigation efforts at the landscape scale. Effective mitigation of wildfire risk, therefore, requires cross-institution coordination and collective action in the form of wildfire governance. Governance refers to the ways that heterogeneous networks of individuals and institutions, both public and private, manage their shared interests through formal and informal norms and rules. This project uses interviews with fire and forest management professionals to examine the institutional tools, work arrangements, and cultures that enable or constrain the shared governance of fire risk across ownership and jurisdictional boundaries in two large landscapes in the western US. We find that, compared to the persistent ross jurisdictional challenges of fire suppression among a small number of formal organizations, fire risk mitigation remains an especially wicked problem due to different concepts of forest health and management, the desires of private citizens, the cost of certain mitigation interventions, and the unique missions of the many government agencies involved in managing forests and wildfires. However, actors in each of the examined landscapes are building their capacity to mitigate wildfire risk through partnerships that span agencies and ownerships and that serve the needs of their unique stakeholders.

\section{A9c: SUSTAINABLE DEVELOPMENT GOALS: THEIR IMPACTS ON FORESTS AND PEOPLE}

\section{Sustainable development goals: their impacts on forests and people}

Pia Katila ${ }^{1}$, Carol J. Pierce Colfer, ${ }^{2,3}$, Wil de Jong ${ }^{4}$, Glenn Galloway, Pablo Pacheco ${ }^{2,6}$, Georg Winkel ${ }^{7}$

${ }^{1}$ Natural Resources Institute Finland, Helsinki, Finland; ${ }^{2}$ CIFOR, Bogor, Indonesia, ${ }^{3}$ Cornell University, Ithaca, USA; ${ }^{4}$ Kyoto University, Kyoto, Japan;

${ }^{5}$ University of Florida, Gainesville, USA; ${ }^{6}$ WWF, Washington, USA; ${ }^{7}$ European Forest Institute, Bonn, Germany (pia.katila@luke.fi; c.colfer@cgiar.com; dejongwil@gmail.com; ggalloway@latam.ufl.edu; p.pacheco@cgiar.org;georg.winkel@efi.int)

The presentation is an introduction to the session. It introduces the new IUFRO WFSE book Sustainable development goals: Their impacts on forests and people and the process for developing this book. The potential contributions of forests to achieving the SDGs were explored before the SDGs were formally adopted and have since been further discussed. Little attention, however, has been focused on possible and likely impacts that efforts undertaken to advance towards the 17 SDGs will have on forests and forest-related livelihoods/human wellbeing, and how these impacts, in turn, will contribute or undermine the contributions of forests to climate change (mitigation and adaptation) and development. The book provides a systematic, transdisciplinary, scientific assessment of potential and anticipated impacts of efforts to achieve the SDGs on forests and related socio-economic systems and forest-related development. It discusses the contextual conditions that influence how SDGs are implemented and prioritized, and how these conditions and the SDG implementation influence impacts on forests and related socio-economic systems. Furthermore it considers the important interconnections and interlinkages among the SDGs and potential or anticipated tradeoffs and synergies among the SDGs from the perspective of forests and related socio-economic systems, and sheds light on how the implementation of the SDGs may transform existing forest-related development scenarios, and affect the roles of forests in sustainable development in the future.

\section{Multi pathway impacts of the SDGs on forests and people}

Wilhelmus de Jong ${ }^{1}$, Pia Katila ${ }^{2}$, Carol J. Pierce Colfer ${ }^{3}$, Glenn Galloway ${ }^{4}$, Georg Winkel ${ }^{5}$, Pablo Pacheco ${ }^{6}$

${ }^{1}$ Kyoto University, Kyoto, Japan; ${ }^{2}$ Natural Resource Institute Finland, Helsinki, Finland; ${ }^{3}$ CIFOR, Ithaca, USA; ${ }^{4}$ University of Florida, Gainesville, USA; ${ }^{5}$ European Forestry Institute, Bonn, Germany; ${ }^{6}$ WWF, Washington, USA (dejongwil@gmail.com; pia.katila@luke.fi; c.colfer@cgiar.org; ggalloway@latam. ufl.edu; georg.winkel@efi.int; pablo.pacheco@wwf.org)

Forestry experts have pointed out the potential contribution of forests to achieving the SDGs. A fundamental question that needs addressing is how Agenda 2030 will likely affect forests and forests' capacities to contribute the multiple goods and services demanded by people whose livelihoods and well-being depend on forests and by society at large. We present the Synthesis and Findings chapter of the IUFRO-WFSE volume Sustainable development goals: Their impacts on forests and people. Many SDGs relate to their own policy domain and can be expected to have impacts on forests and people similar to the sectors that they relate to. The impacts of SDGs implementation are influenced at international, national, sub-national to a forest landscape scale, and multiple sets of factors influence SDG priority setting and implementation at every scale. The impact pathways of SDGs on forests and people are complex because of these factors shaping implementation, but also because of complex interactions when multiple SDGs are implemented simultaneously. It is possible to identify opportunities for synergies to achieve more desired outcomes, or to recognize and address unavoidable trade-offs. The recognition of positive and negative impacts of SDG implementation, but also of synergies and trade-offs allow for alternative implementation choices. The important contribution of the volume is to identify contextual factors and conditions that influence effective SDG implementation, recognize opportunities for synergies and trade-offs and identify alternative courses of action for enhanced SDG implementation outcomes and more positive impacts for forests and people. 


\title{
The SDGs and their impacts on forest and people: conclusions from a collaborative global book project
}

Georg Winkel

${ }^{1}$ European Forest Institute, Bonn, Germany (georg.winkel@efi.int)

The SDGs describe a globally set agenda for sustainable development. They are, consequently, of critical importance for the world's forests and people that depend on them either directly or indirectly This presentation summarizes the conclusions chapter of the IUFRO-WFSE volume Sustainable development goals: their impacts on forest and people, which has be written jointly by the editors and supported by the work of a huge set of authors of the entire volume. It, first, takes a step back and reflects in the very nature of the SDGs as being a conglomerate of objectives and approaches rooted in distinct sectoral policies, creating synergies and conflicts amongst them. Subsequently, the talk elaborates on the immense, but context-dependent distinct role that forest play for sustainable development, and vice versa the potentially very different effects the SDGs might have for forests and people. Issue such as critical context factors, distinct forest related development pathways, the necessity to accept related different trajectories for forest-related development, including the need to deal with trade-offs, and the possibility of universal principles for sustainable development are discussed. The talk concludes with assessing both possible "development potentials" of the SDG concept itself in view of forest related development, and perspectives for future research.

\section{SDG's impacts on forests: discussion on perspectives to deepen our current understanding}

\author{
Pablo Pacheco ${ }^{1}$ \\ ${ }^{1}$ WWF, Washington, DC, USA (pablo.pacheco@wwf.org)
}

This presentation offers critical reflections on the IUFRO WFSE book Sustainable development goals: their impacts on forests and people. This book argues that SDGs implementation will impact on forests and forest-related livelihoods, thus contributing to or undermining the role of forests in climate and development, depending on context-specific factors. This work provides important foundations to understand the role and impacts of the sustainable development agenda on forests with potential to catalyse future political and societal action. Nonetheless, to improve current understanding of the impacts of SDG implementation on forests, there is need to 1) advance our conceptualizations of place, as influenced by different pathways of societal development and natural resources use, to better foresee the likely impacts on forests associated with SDGs implementation under different types of local- or national-specific contexts; 2) embrace a system change perspective to understand the outcomes and trade-offs on forests and the forest-people nexus resulting from the simultaneous implementation of the SDGs, establishing synergistic and antagonistic interactions among them; and 3) conduct wider examinations on what would be the future threats on and opportunities for forests under wider agendas of food security, sustainable energy development, economic growth, and climate change mitigation, in a future in which it likely won't be possible to achieve all of them, and trade-offs are unavoidable. Adopting these lenses may contribute to visualizing the most effective pathways to SDG implementation that could preserve forest ecosystem services while contributing to enhancing people's livelihoods and low-carbon development options in different contexts.

\section{B2a: TREES ON THE MOVE: RANGE SHIFTS, POTENTIAL FOR GENETIC ADAPTATION AND} ASSISTED MIGRATION

\section{Conifer ecotypic variation for traits related to light quality and photosynthesis \\ María Rosario Garcia Gil ${ }^{1}$; ; Sonali Ranade ${ }^{1}$ \\ ${ }^{1} S L U$, Umea, Sweden (m.rosario.garcia@slu.se; sonali.ranade@slu.se)}

It is a well-accepted fact that conifer breeding programs need to account for the climate change. An increase in temperature in the north of about three degrees in the next 100 years has been predicted in Scandinavia. Warmer temperatures in the north can be seen as an opportunity to assist migration (transfer) of southern genotypes to the north in order to gain on growth and biomass production; however, this interpretation only takes into account tree growth. Considering that response to the environment is governed at the canopy level where light sensing, and photosynthesis are regulated, understanding the genetic basis of adaptation to the local light conditions (i.e., light quality and intensity, and day length) is key in the design of assisted migration programs to ensure the expected gain. Our phenotypic and transcriptomic (RNAseq) results support ecotypic variation in conifer seedling growth in response to the light quality in conifers and in needle anatomy and chemical composition that can be related to the phenomena of local adaptation.

\section{Negative selection and polygenic adaptation in maritime pine}

Marina de Miguel ${ }^{1}$, Isabel Rodríguez-Quilón ${ }^{2}$, Agathe Hurel ${ }^{1}$, Juan-Pablo Jaramillo-Correa ${ }^{3}$, Myriam Heuertz ${ }^{1}$, Delphine Grivet ${ }^{2}$, Giovanni Vendramin ${ }^{4}$, Christophe Plomion ${ }^{1}$, Ricardo Alia ${ }^{2}$, Andrew Eckert ${ }^{5}$, Santiago Gonzalez-Martinez ${ }^{1}$

${ }^{1}$ BIOGECO, INRA, Univ. Bordeaux, Cestas, France; ${ }^{2}$ Department of Forest Ecology and Genetics, Forest Research Centre, INIA, Madrid, Spain; ${ }^{3}$ Department of Evolutionary Ecology, Institute of Ecology, Universidad Nacional Autónoma de México, Mexico City, Mexico; ${ }^{4}$ Institute of Biosciences and Bioresources, Division of Florence, National Research Council, Sesto Fiorentino , Italy; ${ }^{5}$ Department of Biology, Virginia Commonwealth University, Richmond,USA (demiguel.marina@gmail.com; irodriguezquilon@gmail.com; agathe.hurel@inra.fr; jaramillo@ecologia.unam.mx; heuertzm@gmail.com; delphine.grivet@gmail.com; giovanni.vendramin@ibbr.cnr.it; christophe.plomion@inra.fr; alia@inia.es; aeckert2@vcu.edu; santiago.gonzalez-martinez@inra.fr)

Understanding the genetic basis of adaptive phenotypes is crucial to implement conservation and breeding programs in forest trees. Results from standard association and QTL mapping studies illustratethat many fitness-related traits are polygenic. Recent evolutionary frameworks, moreover, have identified soft sweeps involving a large number of loci as the dominant signature of natural selection. These soft sweeps are difficult to detect by traditional methods. Here, we investigate the underlying genetic architecture of fitness-related traits for maritime pine (Pinus pinaster Aiton) to assess importance of polygenic adaptation to shaping range-wide patterns of phenotypic and genetic variation for this iconic tree species. Using a multi-environment clonal common garden comprising rangewide populations, we assessed phenotypic variation for multiple fitness-related traits and genotyped 6,100 SNPs in all clones. Genetic control was moderate for height and phenology (mean $\left.\mathrm{H}^{2}=0.15\right)$ and smaller (mean $\mathrm{H}^{2}=0.05$ ), but still significant, for survival, needle morphology, and pathogen susceptibilities. Among-population genetic differentiation for adaptive traits $\left(\mathrm{Q}^{\mathrm{ST}}\right)$ was about 2.5 -fold that for molecular markers ( $\left.\mathrm{F}^{\mathrm{ST}}\right)$, suggesting local adaptation. We performed genome-wide joint analysis of all SNPs in association with the evaluated phenotypes and calculated their level of polygenicity. Initial results highlight varying levels of polygenicity across phenotypic trait and growing environment (Mediterranean vs Atlantic). We also provide evidence of negative selection as a relevant factor explaining polygenicity. Polygenic approaches, such as those commonly used in human evolution studies, will thus significantly improve our understanding of the genetic basis of adaptation in forest trees and their expected genetic responses to environmental change. 


\section{Does local adaptation to drought need to be considered in assisted gene flow strategies for Douglas-fir reforestation?}

Rafael Candido Ribeiro ${ }^{1}$, Christine Chourmouzis ${ }^{1}$, Pia Smets ${ }^{1}$, Alex Girard ${ }^{1}$, Dragana Vidakovic ${ }^{1}$, Brandon Lind ${ }^{1}$, Sam Yeaman ${ }^{2}$, Sally Aitken ${ }^{1}$ ${ }^{1}$ Department of Forest and Conservation Sciences, University of British Columbia, Vancouver, Canada; ${ }^{2}$ Department of Biological Sciences, University of Calgary,Calgary,Canada (rafael.ribeiro@ubc.ca; christine.chourmouzis@gmail.com; pia.smets@ubc.ca; algirard205@hotmail.com; dragana.vidakovic@ubc.ca; brandon.lind@ubc.ca; samuel.yeaman@ucalgary.ca; sally.aitken@ubc.ca)

Drought is a major concern in forest management and conservation around the world as it can directly or indirectly hinder tree growth and increase tree mortality, affecting ecological processes and ecosystem services. With climate change, droughts are expected to increase in frequency and intensity. Douglasfir (Pseudotsuga menziesii) is an important species in North America, both ecologically and economically. In order to investigate how tolerance of summer drought varies among populations and varieties (coastal var. menziesii and interior var. glauca), we established a greenhouse common-garden experiment with seedlings from 87 different provenances spanning $\sim 16^{\circ}$ latitude, $\sim 14^{\circ}$ longitude, and $\sim 1700 \mathrm{~m}$ elevation. The experiment had a split-plot design with a drought treatment gradually reducing soil water content, and a control treatment maintaining field capacity. Chlorophyll fluorescence (Fv/Fm), visual damage and height were assessed five times in 160 days. Drought reduced the photosynthetic performance of seedlings, which negatively affected growth in both varieties, but the rate of response differed among provenances. There were significant differences in drought hardiness between varieties for all traits. However, within varieties, most of the variation observed was within provenances, suggesting local adaptation to drought is weak within var. glaucaand even weaker for var. menziesii. Targeted exome capture and sequencing of DNA pools from each population are underway to detect candidate genes associated with the observed patterns in drought tolerance and other climate-related traits. Results from this study, which is part of the CoAdapTree Project, will be used to inform assisted gene flow strategies for reforestation.

\section{Identifying adapted seed sources for major European tree species under climate change}

Debojyoti Chakraborty ${ }^{1}$, Jan-Peter George ${ }^{1}$, Julian Gaviria ${ }^{2}$, Jan Kowalczyk ${ }^{3}$, László Nagy $^{4}$, Lea Henning $^{5}$, Marcin Klisz $^{3}$, Valerie Poupon ${ }^{6}$, Silvio Schueler ${ }^{1}$ ${ }^{1}$ Austrian Research Centre for Forests, Vienna, Austria; ${ }^{2}$ The Bavarian Office for Forestry Seed and Plant Breeding, Teisendorf, Germany; ${ }^{3}$ Forest Research institute, Warsaw, Poland; ${ }^{4}$ Forest Research Institute, Sopron, Hungary; 5 Johann Heinrich von Thünen Institute Federal Research Institute for Rural Areas, Forestry and Fisheries, Eberswalde, Germany; ${ }^{6}$ Czech University of Life Sciences, Prague, Czech Republic (debojyoti.chakraborty@bfw.gv.at; jan-peter.george@bfw.gv.at; julian.gaviria@asp.bayern.de; j.kowalczyk@ibles.waw.pl; lnagy@erti.hu; lea.henning@thuenen.de; m.klisz@ibles.waw.pl; poupon@fld.czu.cz; silvio.schueler@bfw.gv.at)

Adaptive forest management aims at reducing vulnerability and enhancing the resilience of forest ecosystems in order to preserve the capacity of forests to provide multiple ecosystem services also under climate change. Adaptive management also includes a better utilization of the intrinsic genetic variation within tree species to identify adapted seed sources for planting under future conditions, following assisted migration and assisted gene flow approaches. Traditionally, seed material for plantations are identified based on the concept of "local is best" whereby local seed sources are considered to be optimally adapted to the regions where they grow. Here, we introduce a new harmonized dataset of in total 545 provenance trials of seven economically and ecologically important tree species of Europe. These data are the basis for Universal Response Functions (URFs) that combine both climate and genetic effects to model the phenotypic variation in functional traits. The URFs helped to identify the major drivers of phenotypic variation in functional traits and were used a basis for reforestation tool guiding seed deployment and the identification of adapted planting materials for future climate conditions.

\section{B4a: CLIMATE SMART FORESTRY OR HOW TO INTEGRATE ADAPTATION, MITIGATION} AND SUSTAINABLE FOREST MANA GEMENT

\section{Uncertainty of carbon economy in forestry}

Rasoul Yousefpour ${ }^{1}$, Andrey Augustynczik ${ }^{1}$

${ }^{1}$ Albert-Ludwigs-University of Freiburg, Freiburg, Germany (rasoul.yousefpour@ife.uni-freiburg.de;andrey.lessa@ife.uni-freiburg.de)

Forest growth predictions are used to build expectations about future economic performance of management decisions. Most of the predictions and consequently expectations are based on emperical knowledge, assuming a steady state in climate and a deterministic forest growth approach. However, climate may change to a different degree in the comming decades causing a dynamic and uncertain forest growth and carbon budget. The uncertainty of modeling systems' parameters and climate state propagates over time to the final decision about carbon economy and optimal management solutions. Here we quantify this untertanty using Bayesian inference to predict the growth of European beech (Fagus Sylvatica) in central european conditions as an example. The results show a strong influence of models parameters uncertainty on the final decisions about timber based and carbon economy. To deal with deep uncertainty, a robust decison-making approach has been applied to find solutions with minimum regret or maximum value at risk regarding all scenarios. Moreover, we applied the concept for realizing European Climaet Smart Forestry. We conclude that communicating uncertainty is a fundamental issue for forestry economics under changing climate conditions. The key message for designing global forest governance policy in the uncertain times of climate chnage will be the neccessity to take into acount both the uncertainty of demand side, i.e. socio-economic dvelopments and regional population needs for forest ecosystem services such as wood, but also the uncertainty of supply side and the inherent ecological uncertainties in predicting the forests growth, resonses, and climatic conditions.

\section{Climate-effective reduced-impact logging (RIL-C) can nearly halve emissions from selective logging and meet one tenth of nationally determined contributions from tropical countries}

Rosa Goodman ${ }^{1}$, Peter Ellis ${ }^{2}$, Trisha Gopalakrishna ${ }^{2}$, Matias Harman ${ }^{3}$, Anand Roopsind ${ }^{4}$, Bronson Griscom ${ }^{2}$, Peter Umunay $^{5}$, Joey Zalman $^{6}$, Eddie Ellis $^{7}$, Karen $\mathrm{Mo}^{8}$, Francis Putz ${ }^{9}$

${ }^{1}$ Swedish University of Agricultural Sciences, Umea, Sweden; ${ }^{2}$ The Nature Conservancy, Arlington, USA; ${ }^{3}$ World Wildlife Fund, Lima, Peru; ${ }^{4}$ Boise State University, Boise, USA; ${ }^{5}$ Yale School of Forestry and Environmental Studies, New Haven, USA; ${ }^{6}$ Foundation for Forest Management and Production Control, Paramaribo, Suriname; ${ }^{7}$ Centro de Investigaciones Tropicales Universidad Veracruzana, Morelos, Mexico; ${ }^{8}$ World Wildlife Fund, Washington, USA; ${ }^{9}$ Universityof Florida, Gainesville,USA(rosa.goodman@slu.se; pellis@tnc.org; trisha.gopalakrishna@tnc.org; matiasharman@gmail.com; aroopsind@gmail.com; bgriscom@tnc.org; peter.umunay@yale.edu; joeyzalman92@gmail.com; ellis_eddie@yahoo.com; karen.mo@wwfus.org;fep@ufl. edu)

Selective logging is responsible for over half the emissions from forest degradation in the tropics. We assessed carbon emissions from felling, skidding, and hauling in 61 forest management units across seven tropical countries to establish baseline emissions from selective logging and estimate potential emissions 
reductions through 'climate-effective reduced-impact logging' (RIL-C). Emissions per Mg carbon in extracted timber (termed 'carbon impact factor'; CIF) varied greatly both within and between countries-from 2.3 to 20.0. Within the studied geographies, CIF typically decreased with increasing logging intensity, but we found the opposite trend between countries. In general, Latin American countries had the lowest harvest intensities and lowest CIFs, and African countries had intermediate harvest intensities and the highest CIFs. The majority of logging emissions (59\%) came from felling (felled tree residuals and collateral damage), but emissions from the countries with the highest CIFs were dominated by roads. Scaling-up, we estimated that tropical selective logging emitted $831 \mathrm{Tg} \mathrm{CO}_{2}$ in 2015 - 6\% of all greenhouse gas emissions from tropical countries. We propose a target CIF of 2.3 through RIL-C implementation. Such changes include improved bucking to increase timber recovery and reduce wood waste, building narrower haul roads, and using lower impact skidding equipment, as well as improving employee retention. If our target were achieved, timber supplies could be maintained while emissions from logging operations are reduced by $44 \%$ (365 $\mathrm{Tg} \mathrm{CO}$ year-1). On average,11\% of nationally determined contributions by tropical countries to the Paris Climate Agreement could be met through RIL-C implementation.

\section{Integrating climate change adaptation and mitigation objectives in British Columbia's forests}

Guillaume Peterson St-Laurent ${ }^{1,2}$, George Hoberg ${ }^{3}$, Bruno Locatelli ${ }^{4}$, Shannon Hagerman ${ }^{1}$

${ }^{1}$ Faculty of Forestry, University of British Columbia, Vancouver, Canada; ${ }^{2}$ Pacific Institute for Climate Solutions, Victoria, Canada; ${ }^{3}$ School of Public Policy and Global Affairs, University of British Columbia, Vancouver, Canada; ${ }^{4}$ Centre de Coopération In (peterson.guil@gmail.com; george.hoberg@ubc.ca;

bruno.locatelli@cirad.fr; shannon.hagerman@ubc.ca)

Climate change mitigation and adaptation objectives have usually been treated separately in policies and interventions addressing climate change in the forests. However, increasing efforts have been directed towards the joint consideration of adaptation and mitigation objectives during the design of forest management interventions and policy. Not only are both climate objectives often compatible, but they also sometimes display synergies so that their combined effect is greater than the sum of their effects if implemented separately. Despite this potential, very few integrative initiatives have been attempted in practice. We use the case of the Canadian province of British Columbia (BC) to better understand the relationship between climate change adaptation and mitigation policy in the forests. Drawing on the review of existing forest management policy and a survey and semi-structured interviews with BC government officials, we address two major research objectives: (1) To what extent do current climate and non-climate BC forest management policies effectively integrate adaptation and mitigation objectives? (2) What challenges and opportunities are associated with the joint consideration of both objectives when developing forest management interventions and policy? Our results highlight the potential positive and/or negative ecological (e.g., ecosystem resilience, biodiversity), economic (e.g., cost or profitability) and social (e.g., effect on livelihood) outcomes of considering both adaptation and mitigation objectives together during the design of forest management interventions. We also provide policy insights into when and how to consider mitigation and adaptation together and to successfully mainstream both objectives into climate and non-climate forest management policies.

\section{Mitigating climate change through Climate-Smart Forestry}

Hans Verkerk ${ }^{1}$, Pekka Leskinen ${ }^{1}$, Marc Palahi $^{1}$, Mariana Hassegawa ${ }^{1}$

${ }^{1}$ European Forest Institute, Joensuu, Finland (hans.verkerk@efi.int; pekka.leskinen@efi.int; marc.palahi@efi.int; mariana.hassegawa@efi.int)

To achieve the objective of the Paris Climate Agreement, a significant reduction in $\mathrm{CO}_{2}$ emissions is needed, as well as increased removals by carbon sinks. Forests play an important role in the discussion how to meet this objective. Storing carbon in forest ecosystems provides mainly benefits during the next few decades, but such a strategy is not free of risks. Many existing climate impact studies suggest an increasing risk from natural disturbances and accumulating more biomass in forests in high risk conditions may exacerbate the impact of future natural disturbances. A long-term, successful mitigation strategy must therefore consider adequate adaptation measures to ensure the resilience of forest resources in the future. A mitigation strategy that only emphasizes storing carbon in forest ecosystems also disregards the urgent need to decarbonize the global economy. In this presentation, we argue that a regionally-tailored ClimateSmart Forestry approach is needed to (a) increase the total forest area and avoid deforestation, (b) connect mitigation with adaption measures to enhance the resilience of global forest resources, and (c) produce wood-based products that store carbon and substitute emission-intensive fossil and non-renewable products and materials. We provide examples of measures related to each of the three issues. The challenge for forest management will be to find the right balance between short and long-term goals as well as between the need for wood production and other important ecosystem services. Such optimal balance may vary from country to country and region to region.

\section{B8a: FOREST ADAPTATION AND RESTORATION UNDER GLOBAL CHANGE}

\section{Implementing forest landscape restoration under the Bonn Challenge}

John Stanturf 1 iD; Michael Kleine ${ }^{2}$, Stephanie Mansourian ${ }^{3}$, Palle Madsen ${ }^{4}$, Promode Kant ${ }^{5}$, Janice Burns ${ }^{2}$ ${ }^{1}$ Estonian University of Life Sciences, Tartu, Estonia; ${ }^{2}$ IUFRO, Vienna, Austria; ${ }^{3}$ University of Geneva, Geneva, Switzerland; ${ }^{4}$ InNovaSilva, Vejle, Denmark; 5Institute of Green Economy,Delhi, India (drdirt48@gmail.com; kleine@iufro.org; smansourian@infomaniak.ch;pallemadsen47@gmail.com; promode. kant@gmail.com; burns@iufro.org)

The Bonn Challenge sets a goal for societies globally to restore 350 million hectares of forested landscapes by 2030. The Bonn Challenge is not a new commitment but rather a practical means of realizing many existing international commitments. Underlying the Bonn Challenge is forest landscape restoration (FLR), which aims to restore ecological integrity at the same time as improving human well-being through multi-functional landscapes. Translating the high level of political enthusiasm into real accomplishments requires a long-term commitment. Successful FLR is based on the premise that healthy landscapes provide a diversity of long-term benefits that can only be sustainably managed by and for local populations. Past experience with broad-scale restoration has shown the importance of defining and reconciling multiple objectives, a process that begins with well-defined goals and proceeds through implementation, monitoring, and adaptive management. FLR recognizes the need for local and adaptive options and avoids the "one size fits all" model. The emphasis on restoring mosaic landscapes requires integration of various land uses such as forestry (including timber plantations), agroforestry, agriculture, wildlife; biodiversity conservation; and infrastructure (roads and settlements). Although FLR favors historic fidelity, native species, and strongly advises against converting even degraded native forests to exotic plantations, the challenges imposed by climate change may in some circumstances also require adaptation to novel conditions. Implementing FLR requires detailed planning for what will be done, where, when, by whom, and at what cost. Included in the planning should be long-term monitoring and data archiving as well as on-going sustainable management. 


\title{
Policies to engage the private sector in forest restoration in South East Asia
}

Rodney Keenan ${ }^{1}$

${ }^{1}$ University of Melbourne, Melbourne, Australia (rkeenan@unimelb.edu.au)

Forest landscape restoration aims to restore landscape function through a mix of forest conservation, reforestation and productive uses of trees in conjunction with other land uses. There is an estimated 110 million hectares of degraded forest lands in South East Asia, 60 percent of the total forest area, and widespread recognition of the need to restore ecological function to these forest landscapes. This could sequester carbon, conserve biodiversity, improve water quality and provide spiritual and cultural benefits. However, there are differing views on the processes, actors and desirable end points for restoration goals. While many of the technical aspects of forest restoration are well understood, institutional, regulatory and policy issues are key challenges for implementing restoration. Constraints include lack of devolution, lack of clarity on tenure and lack of participation by communities and the private sector. Using forest transition theory as a basis for analysis, this paper describes new approaches to overcoming the policy and financial challenges of forest restoration in this region. Analysis included governance issues, property, tenure and access rights, and strengthening capacity of public organisations. A key focus was policies for integrated investment models that engage the private sector and markets and that empower rural people and small landholders to become more engaged in sustainable forest management and restoration.

\author{
Adaptive Forest Management (AFM) and its role for adapting forests to climate change \\ Andreas Bolte 1 iD; Peter Spathelf ${ }^{2}$, Magnus Löf $f^{3}$, Palle Madsen ${ }^{4}$, Klaus Puettmann 5 \\ ${ }^{1}$ Thünen Institute of Forest Ecosystems, Eberswalde, Germany; ${ }^{2}$ University of Sustainable Development, Eberswalde, Germany; ${ }^{3}$ Swedish University of \\ Agricultural Sciences, Alnarp, Sweden; ${ }^{4}$ InNovaSilva, Vejle, Denmark; ${ }^{5}$ Oregon State University, Corvallis, Uni (andreas.bolte@thuenen.de; \\ peter.spathelf@hnee.de; magnus.lof@slu.se; pallemadsen47@gmail.com; klaus.puettmann@oregonstate.edu)
}

Adaptive forest management (AFM) is a dynamic and future-oriented concept to maintain and further develop forest functions and the associated variety of ecosystem services consistent with respective management goals. To accomplish these goals, AFM needs a frequent or even continuous effect monitoring of both growing conditions and management practices in order to modify or adjust management to changing environmental and societal conditions. Since climate change has been considered as the major driver of the variation of growth, in particular of survival conditions, the dynamic and flexible concept of AFM also has come into the focus for adapting forests to changing climatic conditions. The core principle of AFM is improving management by learning of its outcomes. A core element is a frequent feedback loop that adjusts management to changing forest ecosystem status or structure and varying goals. This loop is meant to be flexible in time, but typical loop frequency may vary between five and 20 years. Based on this, we suggest to define AFM as a process of frequently monitoring and adjusting three components: (1) biophysical conditions ("what?"), (2) management goals ("what for/why?"), and (3) management techniques ("how?"). Based on this approach, we evaluate examples of AFM application in boreal and temperate zones with regard to their effectiveness for increasing forest resistance and resilience to more extreme weather events driven by climate change. Finally, we discuss best practice strategies for different regions and draw conclusions for a future optimized AFM.

\section{Exploring adaptive capacity in forest ecosystems}

Klaus Puettmann ${ }^{1}$

${ }^{1}$ Oregon State University, Corvallis, USA (klaus.puettmann@oregonstate.edu)

In the last years, themes around adaptability have emerged as a major research agenda related to global change. Adaptive capacity has been proposed as the component of the IPCC's vulnerability framework that is "most amendable to influence". As such, adaptive capacity is of great interest to forest managers. The presentation provides conceptual insights into adaptive capacity of forest ecosystems to make the concept more "operational" to researchers and managers. First, adaptive capacity of ecosystems is placed within the larger context of the socio-ecological system. Next, I discuss how ecological adaptation strategies can vary as a function of uncertainty, by ecosystem characteristics, and by organizational levels. Finally, I provide examples, how information obtained in studies of ecosystem stability can be used to develop management strategies that increase adaptive capacity of forest ecosystems.

C1a: MANAGING FOREST ECOSYSTEM RESILIENCE AND BIOLOGICALAND SOCIAL
DIVERSITY FOR FUTURE FOREST PRODUCTS

\section{Computer vision technology for improving forest operations sustainability}

Woodam Chung ${ }^{1}$, Lucas Wells ${ }^{1}$

${ }^{1}$ Oregon State University, Corvallis, USA (woodam.chung@oregonstate.edu; lucas.wells@oregonstate.edu)

Forest harvesting is an essential part of sustainable forest management that deals with the provision of forest goods and services. A recently developed concept of sustainable forest operations by Marchi et al. (2018) calls for a paradigm shift from conventional productivity and cost-driven forest operations toward a balance of operational performance across economic, environmental and social sustainability. In this presentation, we introduce computer vision technology as a new tool that supports sustainable forest operations. It has potential to facilitate implementation of complex, ecology-based silvicultural prescriptions, improve both the working environment of humans and efficiency of forest operations, and maximize utilization, quality and value of wood products. Specifically, we introduce a purpose-built camera system for forest harvesting machines for detecting and measuring individual trees in real-time. The computer vision algorithms developed for this system can estimate angle, distance, diameter at breast height and stem taper for trees while producing an accurate stem map of the stand. This individual stem information can be coupled with a silvicultural prescription to provide equipment operators with cut/leave decision aids enabling the implementation of individual tree-level treatments. The stem taper information coupled with optimal bucking can maximize value of wood products and minimize waste. Real-time stem mapping of residual trees can ensure treatment compliance for quality control of forest operations. The paradigm shift from conventional forest operations toward sustainability requires extensive modifications to current practices in all stages of forestry. Computer vision is one of the promising technologies that can help realize such a transition. 


\title{
Future forest products and sustainability
}

Pekka Saranpää ${ }^{1}$

${ }^{1}$ Natural Resources Institute Finland (Luke), Helsinki, Finland (pekka.saranpaa@luke.fi)

The challenge of research related to forest resources and forest products is related to rapid increase of human population and growing demand of materials and products. The potential for irreversible changes in our environment and far reaching consequences increases. Indicators of environmental stress include the loss of biodiversity, increasing greenhouse gas emissions, increasing deforestation and shortages of fuel-wood in many parts of the world. Norway spruce and Silver birch are important tree species in Nordic forestry and their bark contains valuable compounds. However, the bark is mainly used for energy production. Part of this important side product is possible to use to improve properties of wood and fibre based products and thus, promote the cascading use of them. For example, birch bark contains suberin which could be used to create hydrophobic and antimicrobial surfaces. These are a few examples of the diversity of the future products based on forest biomass. Cellulose based textile fibres are under development and lignin is intensively studied to replace fossil raw materials in various products. The diversity of future forest products and the impact of both environmental, economic, cultural and social sustainability on utilisation of forest biomass will be discussed.

\section{Dipterocarps protected by Jering local wisdom in Jering Menduyung Nature Recreational Park, Bangka Island, Indonesia}

Eddy Nurtjahya ${ }^{1}$ iD; Akrima Risyda ${ }^{1}$, Cindy Ika Putri ${ }^{1}$, Lastri Dwi Saputri ${ }^{1}$,Lanita Sakila ${ }^{1}$, Tiwi Mandasari ${ }^{1}$, Tuning Wiji Jepari ${ }^{1}$

${ }^{1}$ Universitas Bangka Belitung, Sungailiat, Indonesia (eddy_nurtjahya@yahoo.com; akrima.risyda@gmail.com; cindyikaputri03@gmail.com;

lastridwi78@gmail.com; lanitasakila01@gmail.com; tiwi.mandasari97@gmail.com; tuningwjr97@gmail.com)

Apart of the oil palm plantation expansion, the Jering Menduyung Nature Recreational Park has relatively diverse plants. The 3,538 ha park is located at the north west of Bangka Island, Indonesia. The minimum species-area curve was 0.82 ha which is just below Dalil conservation forest that is 1.2 ha, but it is much higher than measurements of several secondary forests in the Island that are $0.2 \mathrm{ha}$. The plot is inhabited by more than 50 plant species. Of 22 tree species, there are 40 individual poles with the average diameter of $15.3 \mathrm{~cm}$, and 64 individual trees with the average diameter of $48.9 \mathrm{~cm}$. The density of Dipterocarpus grandiflorus (Blanco) Blanco or kruing, is 20.7 individual/ha with the diameter ranges of $12.1-212.7 \mathrm{~cm}$ or with the average diameter of $69.0 \mathrm{~cm}$. The relatively intact park is supported by the local wisdom of Jering tribe, one of indigenous tribes in the island. People has regulated in cutting trees especially in the cape. The conservation agency designates the park as one of the kruing propagules sources in the province. The growing oil palm plantation and the less adoption of local wisdom among the youth is a challenge to forest conservation in the province where tin mining activities have been the economic driver for decades. More socialization from the conservation agency and the involvement of university students in raising environmental awareness is important to be done.

\section{C3a: MOVING TOWARDS SUSTAINABLE FOREST OPERATION FOR A GREENER FUTURE}

\section{An overview of forest operations in Europe within the concept of Sustainable Forest Operations (SFO)}

Andrea Laschi ${ }^{1}$, Tomas Nordfjell ${ }^{2}$, Piotr Mederski ${ }^{3}$, Enrico Marchi ${ }^{1}$

${ }^{1}$ Università di Firenze, Firenze, Italy; ${ }^{2}$ Sveriges lantbruksuniversitet, Umeå, Sweden; ${ }^{3}$ Uniwersytet Przyrodniczy w Poznaniu, Poznan, Poland (andrea.laschi@unifi.it; tomas.nordfjell@slu.se; piotr.mederski@up.poznan.pl; enrico.marchi@unifi.it)

The importance of the concepts 'Sustainability' and 'Sustainable Development' has increased in recent years in order to meet the changing needs of society. The forest sector and research activities should support sustainability to enhance all the benefits from the various functions of forests and the ecosystem. Forest operations play a key role in forest management and wood production, thus leading to an important role in the sustainability of the forest sector. In recent years, within the IUFRO Task Force on Climate Change and Forest Health, the new paradigm of 'Sustainable Forest Operations - SFO' has been developed in order to change the approach to wood harvesting. The aim of this contribution is to give an overview of forest operation issues in Europe, considering the main relations between forest management, wood production, environment and society in the light of the SFO paradigm. Wood production is strategic worldwide, but it cannot compromise the efficiency of forests, increase environmental impact or affect social and economic issues. In this context, Europe with its 1015 million hectares of forest is an important geographic area. However, many different social, economic and environmental conditions exist on this continent, from north to south and east to west. Moreover, in most European countries, forests play important roles beyond wood production, for example, hydro-geological protection, recreation, pollutant protection, as well as social and cultural services. For these reasons, forest operations have to guarantee environmental protection and enhance the ecosystem functions related to forests while at the same time respecting social needs.

\section{The "Sustainable Forest Operations" concept: an overview of forest operations in Africa}

\author{
Andrew McEwan ${ }^{1}$, Michal Brink ${ }^{2}$,Elisha Ngulube ${ }^{3}$ \\ ${ }^{1}$ Nelson Mandela University, George, South Africa; ${ }^{2}$ University of Pretoria, Pretoria, South Africa; ${ }^{3}$ Mzuzu University, Mzuzu, Malawi \\ (andrew@loggingon.net; michal@cmogroup.net; esn12003@yahoo.co.uk)
}

Forest operations in Africa have been associated with unsustainable harvest levels and operations. The deforestation of Africa's tropical forests has been well documented. Simultaneously, the operations used to log the forests have focussed on the minimisation of costs with little regard to other societal values such as safety and environmental concerns. The exceptions to this include some of the well managed plantations that occur in South Africa and on a smaller scale in certain other African countries. Globally, the concepts of "Sustainability" and "Sustainable Development" have recently received increasing attention to ensure that forest management is practised in a way that meets societal values. Even considering the geographic variability of forests and their uses, African countries have begun to realise the importance of managing their forests according to more modern sustainability principles. This is primarily driven by the need to preserve the few remaining tropical forests, the need to ensure that current operations do not jeopardise future growth potential, the need to carry out operations in a way that reflect the more modern principle of "Sustainable Forest Operations - SFO", the requirements of investors of new plantations or forest operations, and the requirements of markets, often outside the boundaries of the African continent. The aim of this contribution is to give an overview about forest operation issues in Africa, considering the main relations between forest management, wood production, environment and society in the light of the SFO paradigm. 
Environmental impact of forest operations - silviculture and harvesting - in Uruguay: an evaluation program

Alejandro Olivera Farias ${ }^{1}$, Carlos Perdomo ${ }^{1}$

${ }^{1}$ Centro Universitario de Tacuarembo, Universidad de la Republica, Tacuarembo, Uruguay (alejandro.olivera@cut.edu.uy; cperdomo@fagro.edu.uy)

Fast growing Eucalyptus and Pinus plantations in Uruguay have increased in the last decades, rising from less than 100,000 hectares in 1990 to $1,100,000$ in 2015. A process of mechanization of forest operations have accompanied this growth in both, area and wood availability. Forest mechanization brings advantages for large-scale operations, such as, increase productivity, reduce costs, and improve health and safety conditions. However, it also increases the environmental impact. The use of heavy machinery, affects the soil causing compaction (direct impact), and erosion (indirect impact); while, the consumption of fossil fuels by machines contributes to the green house effect. The mechanization of forest operations in Uruguay has some decades, however, there is no scientific studies quantifying its environmental impact. We propose a research program aiming to quantify the impact of forest operations in Uruguay in the sequence Harvesting - Plantation; comparing two harvesting systems and two technologies for planting. These impacts are, soil compaction and erosion, energy balance, and carbon balance. Moreover, we plan to evaluate the costs of the treatments, to obtain an integral evaluation of the alternatives; i.e. environmental and financial indicators. The program would quantify the changes in the first four years; however, we plan to maintain plots during a rotation. The knowledge generated from this program, could be used for companies and police makers in a series of manners: to weight the evaluation of technologies for harvesting and Silviculture according their environmental impact; to establish benefits or taxes to promote the adoption of different technologies.

\title{
An overview of forest operations in the United States within the concept of Sustainable Forest Operations (SFO) \\ Dalia Abbas ${ }^{1}$, Enrico Marchi ${ }^{2}$ \\ ${ }^{1}$ American University, Washington, USA; 2 Università degli Studi Di Firenze, Florence, Italy (daliaabbas@yahoo.com; enrico.marchi@unifi.it)
}

In 2018, March et al. 2018 developed a study that outlines the modern interpretation of sustainable forest operations (SFO) and their practices. The study was highlighted in the July 2018 IUFRO Spotlight \#60 - Creating a virtuous circle in forest operations. The study intended to complement existing studies by integrating environmental, economic, ergonomics, quality and people and society aspects. These aspects are concerned with the forests operations supply chain. The purpose of this study is to test the relevance of the SFO study in the United States and identify issues related to its applicability. It develops an understanding of the potential for, or lack thereof, of applying the SFO framework.

\section{D1a: AGROFORESTRY FOR ECOSYSTEM SERVICES}

\section{Agroforestry for ecosystem service enhancements across U.S. landscapes: science status and a path forward}

\author{
Susan Stein ${ }^{1}$, Gary Bentrup ${ }^{2}$ \\ ${ }^{1}$ USDA National Agroforestry Center, Washington, D.C., USA; 2USDA National Agroforestry Center, Lincoln, NE, USA (susan.stein@usda.gov; \\ gary.bentrup@usda.gov)
}

There is rising interest among U.S. farmers, ranchers and forest owners, as well as public and private entities, in the use of agroforestry to enhance ecosystem service values of working lands in the United States. Science-based data and information is critical to informing policies and programs that support agroforestry, in addition to decisions by landowners regarding agroforestry adoption. What information do we have and what more is needed? This presentation will review the state of science on agroforestry ecosystem service benefits in the United States, based on a recent assessment by the United States Department of Agriculture Forest Service, National Agroforestry Center[1] [file://C\%3A/Users/sstein/Documents/My\%20Documents/Presentations/IUFRO/IUFRO\%20 D1A\%20session\%20description.docx\#_ftn1]. It will also highlight additional research needed to better-inform landowner decisions on agroforestry adoption, as well as decisions by national and regional entities on the integration of agroforestry into sustainable land management programs. The presentation will highlight the role of agroforestry in carbon sequestration, air and water quality, soil enrichment, and biodiversity conservation, with a special focus on the delivery of these services under a changing climate. [1] [file:///C\%3A/Users/sstein/Documents/My\%20Documents/Presentations/IUFRO/IUFRO\%20D1A\%20 session\%20description.docx\#_ftnref1] Schoeneberger, Michele M.; Bentrup, Gary; Patel-Weynand, Toral, eds. 2017. Agroforestry: Enhancing resiliency in U.S. agricultural landscapes under changing conditions. Gen. Tech. Report WO-96. Washington, DC: U.S. Department of Agriculture, Forest Service.

\section{Biodiversity conservation in silvopastoral systems in Colombia}

Julian Chara ${ }^{1}$, Enrique Murgueitio ${ }^{1}$, Carolina Giraldo

${ }^{1}$ CIPAV, Cali, Colombia (julian@fun.cipav.org.co; enriquem@fun.cipav.org.co; carolina@fun.cipav.org.co)

Among agroforestry systems, those that purposely combine fodder plants, such as grasses and leguminous herbs, with shrubs and trees for animal nutrition, timber production and other uses are known as silvopastoral systems (SPS). In addition to the improved animal production, the presence of shrubs and trees in these arrangements have demonstrated effects on biodiversity by creating more complex habitats for wild animals and plants, harboring a richer soil biota and increasing connectivity between forest fragments. In farmed landscapes, SPS provide food and cover for birds and other organisms, serving as wildlife corridors where unique species assemblages can be found. The introduction of the tree component has also demonstrated effects on the physical, chemical and microbiological properties of the soil since they provide more layers of vegetation capable of transforming solar energy into biomass that is, in part, deposited on the soil in the form of leaves, branches, fruits, legumes and exudates that have positive effects on soil properties and carbon sequestration. In a study in Colombia, the areas with SPS were found to have three times as many bird species as pasture areas without trees and complemented forest fragments in the conservation of birds by providing temporary habitats for forest-dependent species. Population and richness of dung beetles and ants was also increased when compared to tree-less pastures. Due to these characteristics, SPS are an important alternative for the development of sustainable livestock production systems with generation of timber and fruits and the provision of important environmental services for the society. 


\section{Natural capital accounting: a useful framework for valuing agroforestry plantings?}

Zara Marais $^{1,2}$, Mark Hunt ${ }^{1,2}$, Thomas Baker ${ }^{1,2}$, Anthony O' Grady $^{3}$

${ }^{1}$ University of Tasmania, Hobart, Australia; ${ }^{2}$ ARC Training Centre for Forest Value Hobart Australia; ${ }^{3}$ National Research Collections Australia Land and

Water,Hobart,Australia (zara.marais@utas.edu.au; m.hunt@utas.edu.au; thomas.baker@utas.edu.au; anthony.o'grady@csiro.au)

One way of approaching the challenge of sustainable production in agriculture is to expand the use of ecosystem services to increase productivity and in doing so reduce or replace external inputs. Agroforestry systems have received some recognition, notably from FAO, for their capacity to enhance the provision of a range of beneficial ecosystem services. However, few studies have attempted to quantify these services or to account for trade-offs and additive interactions between them. Natural capital accounting (NCA) provides information on stocks and flows of natural resources and services in physical or monetary terms. This may provide a useful mechanism for assessing the economic value of the trees and shrubs that comprise agroforestry plantings, based on the ecosystem service inflows that they provide to agriculture. NCA has been widely applied at national and regional scales. However, this project explores the challenges, limitations, and potential opportunities associated with applying NCA to agroforestry at the farm scale. Our findings suggest that NCA may indeed be a useful framework for quantifying and comparing the value of various types of agroforestry plantings, based on the ecosystem services that they provide at the farm scale. Use of NCA as a tool in this context presents opportunities to better understand.

\section{D1b: CLOSE-TO-NATURE SILVICULTURE: FOR PEOPLE, PRODUCTS AND NATURAL} PROCESSES

\section{Close-to-nature silviculture: an introduction}

Jens Peter Skovsgaard ${ }^{1}$ (D; Khosro Sagheb-Talebi ${ }^{2}$

${ }^{1}$ Swedish University of Agricultural Sciences, Alnarp, Sweden; ${ }^{2}$ Ministry of Jahad-e Szandegi, Agricultural Research and Education Organization, Research Institute of Forests and Rangelands, Tehran, Islamic Republic of Iran (jps@slu.se; saghebtalebi@rifr-ac.ir)

Most forestry objectives claim to maintain the forest to benefit people, to produce various goods and products (again, to benefit people) and to rely on, conserve or even improve natural forest processes. Moreover, essentially all of these subscribe to the paradigm of sustainability. One such approach is called close-tonature silviculture. Occurring in various disguises, close-to-nature silviculture dates back to the introduction of planned forestry and was developed based on more-or-less scientific arguments originating mainly in Central Europe. For example, even-aged clearcutting was, and is still, viewed as an opposite to close-to-nature silviculture which, in turn, relies mainly on continuous cover forestry principles, often accompanied by large variation in species and age class composition. Following two centuries of alternating fashion waves in silviculture, the concept of close-to-nature silviculture has become established and is now being applied, often in locally adapted variations, in many forest types across the world. Although close-to-nature silviculture is well-established and is generally accepted as a management paradigm in most of Europe, we believe that scientifically-based modifications are needed to successfully implement this concept in other regions and for other forest types. Moreover, there is a need to clarify and further develop a consistent and logical terminology. What do we talk about when we refer to close-to-nature silviculture? Do we speak a common language in silviculture or do we need an interpreter?

\section{Silviculture and management in uneven-aged temperate forests}

\section{Hubert Hasenauer ${ }^{1}$}

${ }^{1}$ University of Natural Resources and Life Sciences, Vienna, Austria (hubert.hasenauer@boku.ac.at)

Uneven-aged or selection systems are implemented for a variety of reasons, one of which is their apparent sustainability. This sustainability is assumed to be achieved through a relative steady state of structure and function over time as compared with even-aged systems. As a result, uneven-aged systems are often considered as 'close-to-nature', 'diversity-oriented' etc. The sustainability of stand management regimes is important as stands are the land unit for implementation in forestry. Even-aged stands differ in stand characteristics over a rotation, while uneven-aged or multi-aged stands seem to be relatively consistent in their stand variation and without a beginning or end point in the cutting cycle. In this presentation we give an historical overview from a central European perspective, assess the term "close to nature" in the context of uneven-aged forestry, and provide threeexamples (i) for the soil dynamics of unevenaged versus even aged forests, (ii) harvesting models within uneven aged forests, and (iii) the forest management implications if uneven-aged silvicultural management systems are applied at an enterprise level.

\section{Close-to-nature silviculture in Asia: geospatial technology facilitates its practical application \\ Toshiaki Owari ${ }^{1}$ iD ; Pil Sun Park ${ }^{2}$ \\ ${ }^{1}$ The University of Tokyo, Tokyo, Japan; ${ }^{2}$ Seoul National University, Seoul, Republic of Korea (owari@uf.a.u-tokyo.ac.jp; pspark@snu.ac.kr)}

Close-to-nature silviculture is a type of silvicultural approach, in which the intrinsic processes of forest ecosystems are regarded as highly important. Partial cutting with natural regeneration is typically used, so that the stability and diversity of stand structure can be maintained. It is increasingly gaining attention worldwide as an effective method for sustainable forest management and enables to harmonize the use of renewable natural resources with the conservation of multiple ecological functions. Close-to-nature silviculture has been applied uniquely in each country and region, because forest ecosystems are locally inherent in nature. Following a brief historical overview, we present the current trends and major developments of close to-nature silviculture in Asia. Our presentation mainly focuses on the potential of geospatial technology for facilitating close-tonature forest management practices. Emerging technologies such as light detection and ranging (LiDAR) and unmanned aerial vehicle (UAV) photogrammetry can be utilized to characterize forest canopy structure and vegetation type and to estimate stand volume and carbon stock over uneven-aged mixed forests managed under close-to-nature principles. It is possible to pinpoint the location of tree individuals and canopy gaps using such technologies, and the information can be used to develop spatially explicit, individual-based models for predicting long-term stand dynamics, to identify the sites with poor natural regeneration for restoration planning, and to manage high-value tree species on a single-tree basis. As a unique application of geospatial technology in Asia, we present close-to-nature silviculture practices at the University of Tokyo Hokkaido Forest, Northern Japan. 


\section{Close-to-nature silviculture from a tropial viewpoint}

Sven Günter ${ }^{1}$

${ }^{1}$ Thünen Institute of International Forestry and Forest Economics, Hamburg, Germany (sven.guenter@thuenen.de)

Historically, silviculture in the tropics was mainly targeting the production of high-value timber in natural forests for centuries. Degradation and deforestation are still ongoing in the tropics endangering hotspots of biodiversity and livelihoods of poor people. Additional pressure is attributed to climate change. Today, tropical forests have to fulfill increasing demands for various ecosystem services from different stakeholders ranging from provisioning services and fuel wood for poverty alleviation, conservation of biodiversity, control of water fluxes and soil fertility to climate change mitigation. Consequently, this implies the development of multipurpose forestry strategies in addition to sustainable timber production. How can close-to nature silviculture in natural forests deal with invasive species, changing disturbances regimes, e.g. hurricanes or fires which finally could lead to novel forest ecosystems with unknown consequences for resilience? Species-specific and site-specific management plans are not yet business as usual in tropical forests. While remaining old-growth forests are increasingly facing a balancing act between sustainable use and conservation strategies, the focus is shifting to reforestation and landscape restoration. Bonn Challenge, and AFR-100 are prominent examples for this trend setting new priorities on the silvicultural agenda: from management of seed sources over provision of suitable planting material to the identification of optimum species-mixtures for plantations. Although the trend towards reforestation and restoration might be too slow to reduce pressure from remaining natural forests, it might be ambitious to develop the necessary silvicultural tools in a short time at a large scale, and thus enabling multifunctional close-to nature-forests for the future.

\section{D7a: FOREST HEALTH CHALLENGES FROM GLOBALISATION AND CLIMATE CHANGE}

\section{Invasive insects in plantation forests in South America: ecological patterns and management challenges}

Juan Corley ${ }^{1,2}$, Maria Victoria Lantschner ${ }^{1}$, Jose Maria Villacide ${ }^{1}$

${ }^{1}$ IFAB (INTA Bariloche/CONICET), Bariloche, Argentina; ${ }^{2}$ Departamento de Ecologia, Universidad Nacional del Comahue, Bariloche, Argentina

(elmallin@gmail.com; vlantschner@gmail.com; josevillacide@gmail.com)

In the last decades, growing international trade and tourism have significantly increased the rate at which non-native species reach new ecosystems. Plantation forests systems in South America are especially exposed to alien insects, partly because forestry is dominated by pines and eucalypts which have been introduced to produce timber and pulp, based, among other things, on the benefits related to the lack of native herbivores (i.e., the "natural enemy release hypothesis"). As noted worldwide, where the invasion by non-indigenous forest insects is also rising, often strong negative economic and ecologic impacts on the invaded ecosystems are reported. Remarkably, the most damaging non-native forest insects found in plantation forestry are common to large parts of South America and also to other regions of the Southern Hemisphere. This could suggest common traits among invasive species and between the invaded systems that may allow us to identify broad ecological patterns behind invasion success. By focusing on several case studies of established alien insects feeding on pines and eucalypts in South America, I look into likely ecological patterns and explore how these affect the main strategies for the management of both, the species already present and, to prevent the establishment of new forest pests.

\section{Oxidative stress effects on the Brazilian Atlantic Forest}

Marisa Domingos ${ }^{1}$, Marisia P. Esposito ${ }^{1}$, Solange E. Brandão ${ }^{1}$, Francine F. Fernandes ${ }^{1}$, Marcela R.G. S. Engela ${ }^{1}$, Ricardo K. Nakazato ${ }^{1}$, Giovanna Boccuzzi ${ }^{1}$, Douglas D. Santos ${ }^{1}$, Milton A. G. Pereira ${ }^{1}$, Mirian C. S. Rinaldi ${ }^{1}$, Marcia I. M. S. Lopes ${ }^{1}$, Patricia Bulbovas ${ }^{2}$, Claudia M. Furlan ${ }^{3}$,

Poliana Cardoso-Gustavson ${ }^{4}$

${ }^{1}$ Instituto de Botânica, São Paulo, Brasil; ; ${ }^{2}$ niversidade de Guarulhos, Guarulhos, Brasil;; ${ }^{3}$ Universidade de São Paulo, São Paulo, Brazil; ${ }^{4}$ Oxiteno S/A, Mauá,Brasil(mmingos@superig.com.br; biompe@gmail.com; solangeeu35@gmail.com; fran_fernandess@hotmail.com; marcelaengela@gmail.com; ricardo.nakazato@outlook.com; giovanna.boccuzzi@gmail.com; dougdourados@gmail.com; milton.augustogp@gmail.com; mrinaldi@ibot.sp.gov.br; mimlopes2001@yahoo.com.br;pbulbovas@hotmail.com; furlancm@ib.usp.br; cardoso.poliana@gmail.com)

The tolerance potential against the oxidative injury in forest species affected by environmental stressors depends on how efficiently they keep their pro-oxidant/ antioxidant balance. Great variations in plant tolerance are expected, highlighting the high relevance of measuring chemical, anatomical, physiological and biochemical leaf trait indicators of oxidative effects in species with similar functions in the forest. The use of the functional approach has been very useful in the Brazilian Atlantic Forest because its high plant diversity. We have been focused our studies on forest remnants in SE Brazil, the most developed region in the country, aiming at determining the tolerance potential of pioneer and non-pioneer tree species against multiple oxidative environmental stressors. The studies were carried out in Atlantic Forest remnants, which differ in physiognomy, species composition, climatic characteristics and air pollution exposure (e.g. NO2, $\mathrm{O}_{3}$ and particulate material). Leaves of the most abundant tree species in each forest were collected during wet and dry periods, for analyses of concentrations of soluble nitrogen, trace elements and polycyclic aromatic hydrocarbons, anatomical traits and levels of non-enzymatic and enzymatic antioxidants and oxidative injury indicators. Pioneer species accumulated proportionally more $\mathrm{N}-\mathrm{NH} 4$ than $\mathrm{N}-\mathrm{NO}_{3}$ compared to non-pioneer trees, and higher contents of trace elements were observed in non-pioneer trees. The pioneer tree species generally displayed anatomical and biochemical leaf traits that indicate their higher potential tolerance against oxidative environmental stressors than non-pioneer species. In conclusion, the pioneer species have better conditions to acclimate to the oxidative stress imposed by environmental conditions.

\section{Converging threats to ash (Fraxinus): is an invasional meltdown imminent?}

Michelle Cleary', Pierluigi Bonello' ${ }^{2}$ Patrick Sherwood ${ }^{1}$, David Showalter ${ }^{3}$, Yuri Baranchikov ${ }^{4}$

${ }^{1}$ Swedish University of Agricultual Sciences, Alnarp, Sweden; ${ }^{2}$ The Ohio State University, Columbus, USA; ${ }^{3}$ University of Minnesota, Greater Minneapolis-St. Paul Area, USA; ${ }^{4}$ Sukachev Institute of Forest FRC KSC, Siberian Branch Russian Academy of Sciences, Krasnoyarsk, Russian Federation

(michelle.cleary@slu.se; bonello.2@osu.edu; patrick.sherwood@slu.se; showa028@umn.edu; baranchikov_yuri@yahoo.com)

The global decline of ash (Fraxinus) can be linked to two invasive alien species: the ascomycete fungus Hymenoscyphus fraxineus and the emerald ash borer (EAB; Agrilus planipennis, Coleoptera: Buprestidae), both of which are native to Asia. In Europe, the spread and intensification of $H$. fraxineus has caused large-scale decline in European ash (Fraxinus excelsior) which is now Red-listed. In North America, devastation to ash populations by EAB has caused nine North American Fraxinus species to become Red-listed; six of those are considered 'on the brink of (functional) extinction'. In European temperate broadleaved forests where $F$. excelsior is a keystone species, the loss of ash is likely to cause wider community impacts to many other obligate or highly-associated 
organisms, and cause cascading effects in these ecosystems. Luckily, ash shows high genetic variation in resistance. Efforts at breeding for resistance against H. fraxineus are currently underway, however, such efforts are variable in scale among countries, and with their level of committed resources. Recent research shows huge promise in rapid resistance breeding coupled with advanced phenotyping methods, and gives hope that European ash will rise from the ashes of devastation. More pressing though is the imminent invasion of EAB, now occupying the European part of Russia and Lugansk District of Ukraine, and on the fringe of invading the rest of Europe - invoking the fear of a pseudo-invasional meltdown which may prove to be highly devastating. The European preparedness for these converging threats and futuristic outlook for ash must rely on regional/global cooperation, science-based knowledge and intervention, and coordinated investments in solutions.

D8a: FOREST BIODIVERSITY IN THE FRAMEWORK OF GLOBAL CHANGE AND THE ROLE OF LANDSCAPE

\section{Forest conservation, building local capacity and enhancing livelihoods: the potential for synergies through agroforestry}

Maria J. Santos ${ }^{1}$, Rosalien Jezeer ${ }^{2,3}$, Sergio Galaz-Segura ${ }^{2}$, Pita Verweij ${ }^{2}$

${ }^{1}$ University Research Priority Program in Global Change and Biodiversity and Department of Geography, University of Zurich, Zurich, Switzerland;

${ }^{2}$ University of Utrecht, Copernicus Institute for Sustainable Development, Utrecht, Netherlands; ${ }^{3}$ Tropenbos, Wageningen, Netherlands

(maria.j.santos@geo.uzh.ch; rosalien.jezeer@tropenbos.org; sgalaz@protonmail.com; p.a.verweij@uu.nl)

Agroforestry has been widely proposed as a solution for small holders and communities to overcome common pool management dilemmas to maintain and prevent the decline of their common resources. However, such management actions might conflict with required outcomes for forest conservation. Here we question the extent to which can forest conservation, building local capacity and enhancing livelihoods can be synergistic through agroforestry practices. We propose that achieving such goals requires a scaling process similar to that through which innovations are accepted to scale. When properly using livelihood capitals will be enhanced and allow for reaching the desired scaling and synergies between forest conservation and livelihoods achieved. We test this hypothesis in two contrasting agroforestry cases, in avocado farms in Mexico and coffee plantations in Peru, to assess the extent to which livelihood capitals change with a given intervention (interventions aimed at forest conservation or enhancing biodiversity and other ecological processes). We find that (i) in the case of Mexico, the intervention only increased natural capital, and (ii) in the case of Peru, the intervention increased both natural and social capital. These cases illustrate how interventions to build local capacity to implement agroforestry systems may produce counter-intuitive outcomes, and that we need to better understand how and whether the livelihood capitals can indeed be useful to provide the necessary scaling effects and prevent trade-offs between conservation and livelihoods.

\section{Do ecoparks support multifunctional forests and high biodiversity?}

Anne-Maarit Hekkala 1 iD, Paulina Bergmark ${ }^{1}$, Johan Svensson ${ }^{1}$, Joakim Hjältén ${ }^{1}$

${ }^{1}$ Swedish University of Agricultural Sciences, Umeå,Sweden (anne.maarit.hekkala@slu.se; paulina.bergmark@slu.se; johan.svensson@slu.se; joakim.hjalten@slu.se)

The Fennoscandian forests are extremely efficiently managed, and since the industrialized forest management begun in 1950's, the forested land cover and forest productivity has significantly increased. This economically positive development has however led to simplified forest structure and loss of biodiversity within the boreal forests of Fennoscandia. Today the forest management aims to secure multifunctional forests that provide a wide variety of ecosystem services, high wood production, good possibilities for human recreation (hunting, camping, berry picking) and maintain high biodiversity. The largest forest owner in Sweden and Europe has established 37 so called ecoparks across Sweden to maintain all above functions of forests in the landscape scale. These landscapes of 860 to 14000 ha in size are managed by using a combination of restoration, conservation and silviculture. At the same time, most forested landscapes are managed by "business as usual" (BAU), including rotation times of ca. 80 years, and thinning operations 2-3 times within the rotation time, assuring good timber and biomass production but with negative effects on biodiversity. This study aims to assess the short-term efficiency of ecoparks to maintain higher biodiversity in comparison to landscapes that are managed by BAU. To start with, we investigate the biodiversity of deadwood-dependent beetles and hymenopterans in the ecoparks and in the nearby BAU-landscapes, and discuss the further plans of the project to quantify the effects of sustainable landscape management on biodiversity.

\section{Biodiversity responses to local and landscape-level forest structures and dynamics in Northern European forests}

Olav Skarpaas ${ }^{1,2}$, Anne Sverdrup-Thygeson ${ }^{3}$, Siri Lie Olsen ${ }^{2}$

${ }^{1}$ University of Oslo, Oslo,Norway; ${ }^{2}$ IINA, Oslo,Norway; ${ }^{3}$ NMBU, As, Norway (olav.skarpaas@nhm.uio.no; anne.sverdrup-thygeson@nmbu.no; siri.lie.olsen@nina.no)

Balancing forest management across multiple objectives including biodiversity and conservation requires frameworks for tradeoff assessments. While simple metrics for tradeoff analyses exist for e.g. forest products and climate regulation, biodiversity metrics need further development, especially with respect to spatial scales and dynamics. I present and integrate results from a selection of studies in northern forest landscapes considering various metrics of biodiversity and ecosystem service tradeoffs. The studies are based partly on systematic monitoring (e.g. forest inventories and biodiversity monitoring), and partly on remote sensing and publicly available citizen science data (e.g. GBIF). Results from these studies suggest that both the spatial context, at local and landscape scales, and the temporal dynamics matter. For instance, the occurrence and distribution of veteran oaks, local biodiversity hotspots for insects, fungi and epiphytes, is shaped both by the fundamental climatic and edaphic oak niche as well as logging patterns and other anthropogenic factors affecting the long-term persistence and quality of oak trees and their surroundings. Similarly, the occurrence and abundance of fungi, lichens and plants in forests are partly related to landscape structure and partly forest age, at local and landscape scales. While individual species show different responses to the various ecological and anthropogenic drivers, common responses can be seen within taxonomic/functional groups. In sum, this suggests that biodiversity metrics may be developed on the basis of appropriate species assemblages and that local and landscape-level spatial patterns, as well as temporal dynamics should be taken into consideration in ecosystem service tradeoff assessments. 


\author{
Managing biodiversity across the landscape: an approach developed for the Tasmanian forest practices system \\ Anne Chuter ${ }^{1}$, Amy Koch ${ }^{1}$, Sarah Munks ${ }^{1}$ \\ ${ }^{1}$ Forest Practices Authority, Hobart, Australia (anne.chuter@fpa.tas.gov.au; amy.koch@fpa.tas.gov.au; sarah.munks@fpa.tas.gov.au)
}

In Tasmania, forest biodiversity conservation is achieved through maintenance of a permanent native forest estate, the reserve system, and through applying management prescriptions in wood production forests, conducted in accordance with the forest practices system. Management prescription in wood production areas have traditionally been planned and applied at the local scale on a case-by-case basis. However, this approach is not always an effective or efficient way to manage the biodiversity values, or to take account of social and economic considerations. For example, wide-ranging species may benefit from a landscape-scale approach to habitat management, and this approach may also be more cost effective for the land manager.

E4a: TROPICAL WETLANDS, CLIMATE, AND LAND-USE CHANGE: CHALLENGES AND OPPORTUNITIES

\author{
New research results on the extent and the nature of degradation of peatlands in Northwestern South America \\ Louis Verchot ${ }^{1}$, Kristell Hergoualc' $h^{2}$, Mayesse da Silva ${ }^{1}$, Rosa Maria Roman-Cuesta ${ }^{3}$ \\ ${ }^{1}$ CIAT, Cali, Colombia; ${ }^{2}$ CIFOR, Lima, Peru; ${ }^{3}$ CIFOR, Nairobi, Kenya (l.verchot@criar.org; k.hergoualch@cgiar.org; m.a.dasilva@cgiar.org; \\ r.roman-cuesta@cgiar.org)
}

Tropical peatland maps have been developed using national data and from surveys undertaken by the International Peat Society. Much of the underlying primary data is untraceable and uncertainty information is often unavailable. Thus, a fresh approach was warranted. We used an expert system model to develop a new map of tropical and subtropical peatlands that shows that tropical and subtropical peatlands are more widespread in South America than on any other continent, with extensive areas in Brazil, Colombia, Peru and Venezuela. The massive scale, isolation and unavailability of most tropical South Latin American peatlands has protected them from large-scale human degradation, keeping them out of the interest of the international community, in contrast to the heavily disturbed Southeast Asian peatlands. New climatic stresses, such as increased droughts and fire frequencies could, undo their forgotten status. Our fieldwork looked at peatlands in 2 biomes: the Peruvian Amazon and the Colombian Savannas. In a 350,000 ha area in Ucayali and Maranon River basins we found that 73 percent were degraded. Much of the degradation was associated with unsustainable harvesting of the fruits of Mauritia flexuosa. This degradation is characterized by a loss of palm density and vegetation carbon stocks. In the Colombian Savannas, the existence of peat soils has not been reported previously. We report new estimates for the extent of peat soils in the "flooded" savannas and we extrapolate field measurements to estimate the carbon stock for the region. This exercise validates and refines the results of pan tropical peatland map.

\title{
The national wetland strategy in Peru / La estrategia nacional de humedales del Perú
}

José Álvarez ${ }^{1}$, Walter Huamani ${ }^{1}$

${ }^{1}$ MINAM, Lima, Peru (jalvarez@minam.gob.pe; whuamani@minam.gob.pe)

Los humedales son ecosistemas vitales para la humanidad, dado que albergan una gran biodiversidad y proveen de importantes servicios ecosistémicos, que van desde el abastecimiento de agua dulce, alimentos y otros insumos para el desarrollo local hasta la regulación de crecidas y recarga de aguas subterráneas, así como la mitigación del cambio climático. En reconocimiento a ello, el Perú adhirió a la Convención de Ramsar en 1991 y actualizó su Estrategia Nacional de Humedales en el 2015. Esta estrategia busca promover la conservación y el uso sostenible de los humedales a través de la prevención, reducción y mitigación de la degradación de estos ecosistemas, garantizando la provisión de servicios ecosistémicos y medios de subsistencia vitales para muchos pueblos indígenas y poblaciones locales. El Perú está implementando su estrategia nacional, habiendo realizado acciones importantes, como la conformación de su Comité Nacional de Humedales y la gestión de sus sitios Ramsar, asimismo, está avanzando en los lineamientos generales para el inventario nacional de humedales; en este caso, realizó en el 2012 una estimación cartográfica de la extensión de humedales, obteniéndose como resultado un área de 7953191 ha. considerando lagos, lagunas y cochas, bofedales, aguajales y pantanos amazónicos. Esta presentación brindará a nivel general información acerca de los avances, logros y desafíos en la implementación de la estrategia nacional de humedales del país.

\section{Tropical Andean mountain peatlands are more extensive, carbon dense, and vulnerable to global change than previously recognized}

Erik Lilleskov ${ }^{1}$, Rodney Chimner ${ }^{2}$, John Hribljan ${ }^{2,3}$,Esteban Suarez ${ }^{4}$, Laura Bourgeau-Chavez ${ }^{5}$, Sarah Grelik ${ }^{5}$

${ }^{1}$ USDA Forest Service, Northern Research Station, Houghton, USA; ${ }^{2}$ Michigan Technological University, Houghton, USA; ${ }^{3}$ Colorado State University, Fort Collins, USA; ${ }^{4}$ Universidad San Francisco de Quito, Quito, Ecuador; ${ }^{5}$ Michigan Tech Resarch Institute, Ann Arbor, USA (elilleskov@fs.fed.us; rchimner@mtu.edu; jahriblj@rams.colostate.edu; esuarez@usfq.edu.ec; lchavez@mtu.edu; slendres@mtu.edu)

Until recently, tropical peatlands in general, and especially tropical mountain peatlands, were largely ignored by the international scientific community. Mapping in particular focused on lowland peat swamp forests, completely overlooking mountain peatlands. Our ongoing mapping efforts are revealing much more extensive areas of peatland in the tropical Andean páramo and jalca than previously recognized, representing over $20 \%$ of mapped páramo in Ecuador, and about 5\% of mapped jalca in Peru. Despite their low-stature vegetation, these peatlands are some of the most carbon-dense ecosystems in the world, harboring on average $>1800 \mathrm{Mg} \mathrm{C} \mathrm{ha}^{-1}$, several times higher than tropical rainforests. Formed since the end of the last glaciation, they also support high long-term carbon accumulation rates. These rates are especially high in the younger peatlands at higher elevations, declining in older peatlands near the lower elevation limits of the páramo, and are expected to decline further in response to global warming. Mountain peatlands are critical to the livelihoods of millions of people, providing pasture, farmland, and clean water for many Andean cities. They are often ditched for agriculture, and sometimes overgrazed or otherwise damaged by sheep or cattle. These activities can shift these peatlands from net sinks for atmospheric $\mathrm{CO}_{2}$ to sources. Additionally, intensive cattle disturbance can drive high emissions of methane, a potent greenhouse gas. Currently efforts are underway to improve our understanding of the distribution, carbon storage, and vulnerabilities of mountain peatland ecosystems, and to integrate this understanding in efforts supporting local sustainable livelihoods. 


\section{Ecological, social, economic and cultural aspects of the third largest tropical peatland region: the Peruvian Pastaza Marañon Basin}

Jhon del Aguila Pasquel ${ }^{1}$, Euridice Honorio Coronado ${ }^{1}$, Ximena Tagle Casapia ${ }^{1}$, Luis Freitas Alvarado ${ }^{1}$, Gerardo Flores Llampazo ${ }^{1}$, Manolo Martín Brañas ${ }^{1}$, Dennis del Castillo Torres ${ }^{1}$, Timothy Baker ${ }^{2}$, Ian Lawson ${ }^{3}$, Katherine Roucoux ${ }^{3}$

${ }^{1}$ Instituto de Investigaciones de la Amazonia Peruana (IIAP), Iquitos, Peru; ${ }^{2}$ University of Leeds, Leeds, United Kingdom; ${ }^{3}$ University of Saint Andrews,

SaintAndrews, United Kingdom (jhonpasquel@gmail.com; eurihc@yahoo.com; xtagle@iiap.org.pe; lfreitas@iiap.org.pe; gerardo.rfl@gmail.com;

manolomartinb@gmail.com; ddelcastillo@iiap.org.pe; t.r.baker@leeds.ac.uk; itl2@st-andrews.ac.uk; khr@st-andrews.ac.uk)

The vastest peatland complex in South America, the Pastaza-Marañon Basin (PMB), is dominated by palm swamp forests characterized by native Mauritia flexuosa palm trees. Our research group in the Peruvian Amazon Research Institute (IIAP) has been studying the PMB ecosystems under an interdisciplinary approach and our aim is explain the relevance of these ecosystems for local people livelihood and for mitigation of climate change. Our up-to-date map of PMB (stock: 3.14 Pg C) was used as a baseline for an on-going program of payments for ecosystem services. We manage a network of 17 permanent vegetation plots within PMB with the aim to understand the long-term dynamics of vegetation, structure, and carbon balance and hydrology of the PMB. We are studying the drivers of peat accumulation in a short term basis: organic matter inputs, organic matter decomposition, water table changes and weather conditions. We also quantified the methane emissions released from PMB peat surface and found the emissions are $\sim 120 \mathrm{mg}$ m- 2 day-1 under natural conditions. We have promoted sustainable harvest techniques of $M$. flexuosa fruits (e.g. usage of climbing equipment) in PMB. Likewise, we are working with the Peruvian Service of Protected Areas to generate tools to estimate the production of $M$. flexuosa fruits (e.g. forest inventories and UAV analysis). We have re-validated the traditional knowledge about the relationship between an Urarina native community and the usage of peatland resources within PMB. Our interdisciplinary research is making the importance of peatlands gain more visibility for stakeholders and decision makers.

\section{Managing and understanding wetlands in Colombia}

Brigitte Baptiste ${ }^{1}$

${ }^{1}$ Instituto Alexander von Humboldt, Bogotá, Colombia (brigittebaptiste@humboldt.org.co)

For natural hydrological regimen and extreme events like El Niño and La Niña, wetlands play a role in water regulation among others services. Then is necessary has an integral understanding of this ecosystems, so that in Colombia, the Humboldt Institute in partnership with other institutions has been developing many research in wetlands, from a national scale to a local scale, support in three blocks: institutional information, the scientific community, and dialogue of knowledge. The results of these works included the first "Identification Wetlands Map of Colombia Inland Territory" using official information available at 1:100.000 of soils, geomorphology, and associated wetland vegetation coverage, as well as radar satellite images. The cartography processes identified 30.781.149 hectares of wetlands (26.99\% of the national inland area). This characteristic implies that many organisms and the human must be adapted for the availability of water, for this reason, we can call our country like "Colombia an amphibian territory". In a regional scale in La Mojana, located in a lower land of Magdalena and Cauca Rivers, many works are framed in a restoration of wetlands behind 3 years of flooding after La Niña 2010-2011, where 700 ha of wetlands were restored into a participatory process, this work had an important collaboration of local communities of fishers and farmers, who through their relation whit a complex system of swamps give us the tools for understanding the functionality of wetlands and we returned nature based solutions for the improvement of their life quality and the health of the wetlands.

\section{F8a:WOOD AND FOREST CULTURE: ADDRESSING A SUSTAINABLE FUTURE}

\section{The cultural importance of nontimber forest products in the United States}

James Chamberlain ${ }^{1}$, Michelle Baumflek ${ }^{2}$, Frank Lake

${ }^{1}$ US Forest Service, Blacksburg, USA; ${ }^{2}$ US Forest Service, Asheville, USA; ${ }^{3}$ US Forest Service, Orleans, USA (jchamberlain@fs.fed.us; michelle.baumflek@usda.gov; franklake@usda.gov)

Many nontimber forest products (NTFPs) have deep and significant cultural meaning for people around the world. In the United States (US), NTFPs contribute notablyto the traditions, livelihoods, food sovereignty and well-being of indigenous peoples and minority communities, as well as immigrant and settler social groups. Presenting findings from a recent national assessment of NTFPs in the US under changing climates, the authors discuss cultural importance of NTFPs for indigenous and nonindigenous peoples of the United States. They explore traditional and local ecological knowledge related to the harvest, preparation and distribution of plants and fungi, and report on the crucial need for access to NTFPs for sustaining cultural identity and practices. Drawing on regional case studies from the Pacific Northwest and Southeast US, this presentation also examines the potential impacts of climate variability on cultural uses of specific NTFPs. Key knowledge gaps where research can contribute to a sustainable future for cultural practices around NTFP harvest and utilization are identified.

\section{Social and cultural dimensions of sustainable forest management}

\section{Elisabeth Johann}

${ }^{1}$ Austrian Forest Association, St. Margareten, Austria (elisabet.johann@aon.at)

Social and cultural dimensions of sustainable forest management are reflected in landscapes, historical sites and buildings, in artistic and linguistic knowledge, in traditional forest management practices, and in the use of wood and non-wood goods and forest services. The forest is the indispensable prerequisite for the cultural development of society. However, behaviour and attitude of humans in dealing with forests have been characterized both in the past as today by a contrast between exploiting destruction and careful use. Thus, the role of social and cultural aspects of sustainable forest management, including the role of traditional knowledge in the overall goal of sustainable development, is becoming increasingly important throughout the world. The paper deals with the interactions between forest and humans, especially in the context of diverse social and economic frame conditions. The aim of the study is to examine how in the past the society has reconciled its increasing demand for wood with the maintenance of the forest area. It examines the manifold ways in which the forest has been used, how these multiple uses related to the social and economic power structures, and how the population has dealt with the threat of natural hazards and climate change. The study looks at the early advanced knowledge and techniques that have been developed in order to ensure the preservation of the locally available forest resources. 


\title{
Acoustics features of ten kinds of small ethnic wood musical instruments
}

Ping Yang ${ }^{1}$

${ }^{1}$ Kumamoto University, Kumamoto, Japan (yangping@educ.kumamoto-u.ac.jp)

Wood musical instruments are good educational components in elementary schools not only for kids to enjoy wood characteristics in auditory but also to understand easily the reason why there are so many wood musical instruments relating to their cultural and religious background. This study conducted the experiments for measuring the acoustic features from ten kinds of small ethnic wood musical instruments. They were divided in four groups of idiophones, membranophones, chordophones and aerophones, including Bolivian matraka, Brazilian caxixi, Tanzanian kalimba, West African talking drum, Egyptian barrel drum, Angolian cuica, Indian manduka and gopichand, Ethiopian lyre, as well as Nigerian shawm. Their acoustic data were collected within a recording studio fully surrounded by the walls in three-dimensional wedge structures to insure the sound energy traveling away from the source with almost none reflected back, which is called as anechoic chamber. An integral sound level meter (NL-05) made by Rion Ltd. was used. All musical signal was detected by an AUDIO Capture(UA-30) made by EDIROL Ltd. Their acoustic features such as sound pressure and frequency were analyzed respectively in real time by using DSSF (Ver.5.1.X.X) software installed in a computer. Such ethnic wood musical instruments made from different wood species, with various interesting shapes and diverse acoustics features played a great role in stimulating the strong curiosity of elementary school kids and opening their mind to the diversity of wood culture worldwide.

\section{THEME A: FORESTS FOR PEOPLE}

A1a: AGROFORESTRY AND PRODUCTION OF NONWOOD FOREST PRODUCTS

\author{
Systemic vision in planning and managing agroforestry systems / Visão sistêmica utilizada no planejamento e gestão dos sistemas \\ agroflorestais \\ Martin Ewert ${ }^{1}$, Marcelo Francia Arco-Verde ${ }^{2}$,Viviane Helena Palma ${ }^{3}$, Daniele Cristine da Silva Kazama \\ ${ }^{1}$ Universidade Federal de Santa Catarina, Florianópolis, Brasil; ${ }^{2}$ Embrapa Florestas, Colombo, Brazil; ${ }^{3}$ Universidade Federal do Paraná, Curitiba, Brasil \\ (nitram.ewert@gmail.com; marcelo.arco-verde@embrapa.br; viviane-palma@outlook.com; danielekazama@yahoo.com.br)
}

A fim de contribuir com o desenvolvimento dos Sistemas Agroflorestais (SAFs), a pesquisa tomou como base um estudo de caso realizado no Assentamento Contestado, localizado no município da Lapa, Paraná. O objetivo foi apontar fatores que podem melhorar o desempenho dos SAFs por meio de uma visão sistêmica de gestão das unidades produtivas. A matriz metodológica ocorreu em diversas reuniões e envolveu diferentes atores sociais na avaliação do processo de implantação e ajustes do sistema. Nesse período foi acompanhado o cotidiano de 5 famílias de agricultores agroecológicos associados a Cooperativa Terra Livre que desenvolvem SAFs desde 2011. Os resultados apontam que o enfoque sistêmico aliado a gestão e planejamento estratégico pode contribuir para criar projetos eficientes, produtivos e rentáveis. Para tanto, é preciso realizar análise financeira do projeto com visão de curto, médio e longo prazos; planejamento estratégico com objetivos e metas bem definidos; planejamento da demanda da mão de obra, insumos e possibilidade de mecanização; diversidade, interação, espaçamento e escolha das espécies de acordo com suas funções e conexões; logística, mercado e comercialização; meio físico e condições edafoclimáticas; experiência, habilidade e vocação do agricultor; fatores sociais e culturais; capacitação periódica e criar relação de confiança com o agricultor. Conclui-se que a visão sistêmica é fundamental pois considera múltiplas perspectivas, relações, variáveis sendo possível conhecer todo o sistema, cada parte ou interação. Além disso, integra de forma interdisciplinar os diferentes conhecimentos tradicionais, técnicos e científicos ao valorizar práticas e falas de cada indivíduo no processo da construção de soluções satisfatórias.

\section{Assessing the economic feasibility of Noni (Morinda citrifolia) production model to increase income for Forest Villages in Laos \\ Bohwi Lee ${ }^{\text {(D) }}$ Se bin Kim ${ }^{1}$ (D; Hakjun Rhee ${ }^{1}$ (D; Joon-Woo Lee ${ }^{1}$, Sangjin Lee ${ }^{1}$ \\ 1Department of Environment and Forest Resources, Chungnam National University, Deajeon, Republic of Korea (bohwi00@gmail.com; sbkim@cnu.ac.kr; hakjun.rhee@gmail.com;jwlee@cnu.ac.kr; sangjin78@cnu.ac.kr)}

This study developed and applied an agroforestry product model to a local forest village, Nongboua in Laos, and analyzed its economic feasibility to increase income for villagers who earned most of income from rice production. Possible strategies were considered to increase the village revenue, and Noni was chosen as the short-term agroforestry product due to its high price and demands from tourists. A total of 1,100 Noni seedlings were planted in one hectare at $3 \mathrm{~m}$ by $3 \mathrm{~m}$ spacing. Noni fruits from the village can be sold to Noni product companies at a price of $\$ 0.29 / \mathrm{kg}$. For an economic feasibility analysis, a project period of 20 years was assumed and three scenarios were simulated by seedling survival rate and purchase price of Noni fruits. This study used conservative seedling survival rates to consider potential risks such as inexperienced management and, tree disease; Scenario 1 used survival rates of $50 \%$, $60 \%$, and $70 \%$ with the current purchase price for the first, second, and third year and after; scenario 2 used, $10 \%$ less, $(40 \%, 50 \%$, and $60 \%$ ); and scenario 3 used, $10 \%$ less with purchase price of $\$ 0.26 / \mathrm{kg}, 10 \%$ less than the current price. All three scenarios resulted in economically-feasible IRRs: $24.81 \%, 19.02 \%$, and $16.30 \%$ with a discounting rate of $10 \%$. The B/C ratios of three scenarios were $1.71,1.47$, and 1.31 . The study found that the plantation and management of an alternative agroforestry product, such as Noni, could improve current low-income structures of local forest villages in Laos.

Underutilized species of the walnut-fruit forests of Southern Kyrgyzstan: use by local households, contribution to livelihoods, and influencing factors

Will Fulwider ${ }^{1}$, Dietrich Darr ${ }^{1}$

${ }^{1}$ Rhein-Waal University of Applied Sciences, Kleve, Germany (wmfulwider@gmail.com; dietrich.darr@hochschule-rhein-waal.de)

Much of the literature surrounding the use of the walnut-fruit forests of Southern Kyrgyzstan, a global biodiversity hotspot, has centered on the economically important Juglans regia, however the usage of the forests'various other fruit, nut, and medicinal species has received little attention. This article assesses current usage of these underutilized species. To do so, a household survey was conducted $(\mathrm{n}=307)$ across 7 villages representing a gradient of forest proximity, climate, and wealth. Furthermore, 78 qualitative in-depth interviews were conducted with selected households and key informants on decision-making criteria driving the collection, processing, and consumption vs. commercialization decision for the 8 most important species. Species use was determined by market pressures and household perception of the health benefits of the species. The economic contribution of underutilized species to annual income (1.8\%) while small 
compared to employment (43\%) and walnut collection (27\%), is significant in its timing aspect, providing an influx of cash after the winter months or acting as a coping strategy between harvests. Household value addition was highly dependent on the stability of other sources of income. Factors constraining the use of these species included access to the forest through tenure and proximity, available labor, nearness to local markets, and household age and length of time in the village. While wealthier households exhibiting a diverse array of income sources are best positioned to take advantage of the opportunities presented by these underutilized species, they are less dependent on these species to act as a coping strategy.

\section{Assessment of potential socioeconomic impact of introducing multipurpose trees and agroforestry systems in rural communities of KwaZulu-Natal in South Africa}

Sihle Pokwana ${ }^{1,2}$, Ratsodo Phillip Tshidzumba ${ }^{1}$, Paxie Wanangwa Chirwa ${ }^{1}$

${ }^{1}$ University of Pretoria, Pretoria, South Africa; ${ }^{2}$ Fort Cox Agriculture and Forestry Training Institute Middledrift South Africa (sihlepoks@gmail.com; phillipmgf@yahoo.com; paxie.chirwa@up.ac.za)

In South Africa, forests benefit rural people in various ways, such as providing various agroforestry systems possibilities and non-timber forest products amongst others. The objective of this study was to identify the potential socio-economic impact of introducing trees and agroforestry in rural areas of KwaZulu-Natal, South Africa. The study was conducted in three purposefully selected communities, which include Mkhoba, Ngubelanga and Kwabase situated in Harding-Weza region. Using the mixed method approach, quantitative data was collected through a means of structured questionnaire, while focus group discussion was also used to collect qualitative data from key members of the communities. The descriptive statistical analysis, including frequencies and Chi-square test of independence to understanding the relationship between respondents knowledge on the benefits of agroforestry in improving the livelihood of the rural communities. Findings revealed that, the household respondents highly accrued non-timber products such medicinal plants, fruits and fodder for their livestock from forests. On the other hand, the results showed that majority of household respondents ranging from $40 \%$ to $72.1 \%$ were not familiar with agroforestry practice. In the contrary, majority showed interests in planting trees in their homesteads (90.6\% to $100 \%$ ). The introduction of multipurpose trees in these communities has clear potential to improve the household's socio-economic status. However, it would be significant to consider a much-coordinated approach between government and forestry industry stakeholders in order for effective rolling out of impactful agroforestry systems in rural communities of South Africa.

\section{Financial evaluation of Amazonian monocultures conversion to agroforestry systems in Guaviare (Colombia)}

Carlos William Rodriguez Contreras ${ }^{1}$, Angie Alexandra Vargas Solano ${ }^{1}$, Liz Villarraga ${ }^{1}$

${ }^{1}$ Universidad Distrital Francisco José de Caldas, Bogota, Colombia (cwrodriguezc@gmail.com; angie.roglis@gmail.com; lizv@udistrital.edu.co)

In the framework of post-conflict in Colombia, the agroforestry systems (SAF) are an alternative to optimize the land use and improve the economic income of their owners. In Guaviare (Colombia), the Producers’ Association for Economic Change of Guaviare (ASOPROCEGUA), is dedicated to the change of illicit activities by the agricultural exploitation and produces pulps of Amazonian fruits in monoculture systems and in some cases in agroforestry. In this study, the financial viability in the conversion of monocultures to agroforestry systems implemented in the farms of ASOPROCEGUA was evaluated, in order to compare the profitability in both systems and be a source of information for farmers who are interested in maximizing their income and benefits with the conversion of monocultures to SAF. For this, semi-structured interviews are developed, based on a systematic sampling with replacement in 20 production farms. Additionally, an analysis of the environmental services provided by the SAF is done. Finally, it was found that the SAFs are more profitable and sustainable in the long term compared to the monocultures, since a product of commercialization is obtained in a short time and also in a period of 20 years a profit is generated by the forest component as well as the environmental services obtained thanks to the change in the productive systems.

\section{A study on community collaboration forest management system of National Forest in Indonesia: its contribution to local economy and environment}

Chiharu Maeda ${ }^{1}$ Ikuo Ota ${ }^{2}$

${ }^{1}$ Kagoshima University, Kagoshima, Japan; ${ }^{2}$ University of the Ryukyus, Okinawa, Japan (chiharu.maeda.21@gmail.com; ikuota@agr.u-ryukyu.ac.jp)

Since 2001, the Indonesian State Forest Company (Perum Perhutani) has cooperated with local community groups for managing National Forests in Java Island. This management program is known as the Community Collaboration Forest Management System (Pengelolaan Hutan Bersama Masyarakat, PHBM). The authors investigated the impacts of the PHBM on local peoples' income, using a case of the Sukabumi Forest District, West Java. Interview surveys were conducted for the staffs of Perum Perhutani and local households participating in PHBM. PHBM in this area divided into two programs: Agroforestry program and resin tapping program. Before 2000, local people occupied the national forest area for illegal cultivation. The PHBM was introduced to Sukabumi in 2007 and local farmers have been allowed to grow agricultural crops on teak (Tectona grandis) plantation sites for the first two years. The average income from crop production including upland rice and some beans was Rp 37 million (US\$ 2,600) for year 2013. The Resin tapping program was introduced since 2008 at the pine (Pinus merkusii) plantation sites. Perum Perhutani has hired landless farmers and unemployed local people from surrounding communities as resin collectors. The average income of collectors from resin was Rp 9.3 million (US\$ 660) for year 2015, accounting for 70\% of their total household income. Forests in Sukabumi has been successfully covered with planted teak and pine, and forest resources are gradually growing. The authors conclude that PHBM has contributed to the local peoples' income and environment on the denuded land.

\section{A1b: AGROFORESTRY IN FOREST LANDSCAPE RESTORATION: TOWARDS A COMPREHENSIVE APPROACH}

Social technologies and sustainability's reach into public policies: integrated systems involving crops, livestock, and Forests / Tecnologias sociais e o alcance da sustentabilidade em políticas públicas: o exemplo de ILPS e SAFS

Edson Leite ${ }^{1,2}$, Ana Maria Junqueira ${ }^{3}$

${ }^{1}$ Embrapa, Brasilia, Brazil; ${ }^{2}$ Ministério da Agricultura, Pecuária e Abastecimento, Brasilia Brazil; ${ }^{3}$ Universidade de Brasília, Brasília, Brazil (edson.leite@agricultura.gov.br; anamaria@unb.br)

A Integração Lavoura-Pecuária-Floresta (ILPF) é uma estratégia de produção sustentável que integra atividades agrícolas, pecuárias e/ou florestais realizadas na mesma área, em cultivo consorciado, em sucessão ou rotacionado, e busca efeitos sinérgicos entre os componentes do agroecossistema. Os Sistemas 
Agroflorestais (SAFs) são descritos como sistemas de uso e ocupação do solo em que plantas lenhosas perenes são manejadas em associação com plantas herbáceas, arbustivas, arbóreas, culturas agrícolas e forrageiras, em uma mesma unidade de manejo, de acordo com arranjo espacial e temporal, com alta diversidade de espécies e interações desses componentes. A ILPF e os SAFs contribuem para recuperação de áreas degradadas, manutenção e reconstituição da cobertura florestal, promoção e geração de emprego e renda, adoção de boas práticas agropecuárias (BPA), melhoria das condições sociais, adequação da unidade produtiva à legislação ambiental e valorização de serviços ambientais oferecidos pelos agroecossistemas, tais como: a) conservação dos recursos hídricos e edáficos; b) abrigo para os agentes polinizadores e de controle natural de insetos-pragas e doenças; c) fixação de carbono e nitrogênio; d) redução da emissão de gases de efeito estufa; e) reciclagem de nutrientes; f) biorremediação do solo, ou seja processo nos quais organismos vivos, normalmente plantas ou microrganismos, são utilizados tecnologicamente; e g) manutenção e uso sustentável da biodiversidade A estratégia de ILPF e os Sistemas Agroflorestais contemplam quatro modalidades de sistemas, assim caracterizados: Integração Lavoura-Pecuária (Agropastoril), Pecuária-Floresta (Silvipastoril), LavouraFloresta (Silviagrícola) e Lavoura-Pecuária-Floresta (Agrossilvipastoril). Neste trabalho mostra-se como uma política pública bem-sucedida, o Plano ABC, vem dando excelentes resultados.

\section{Agroforestry systems to remediate degraded areas / Sistemas agroflorestais para recuperação de áreas degradadas}

Viviane Helena Palma ${ }^{1}$, Marcelo Francia Arco-Verde ${ }^{2}$, Martin Ewert ${ }^{3}$

${ }^{1}$ Universidade Federal do Paraná, Curitiba, Brazil; ${ }^{2}$ Embrapa Florestas, Colombo, Brazil; ${ }^{3}$ Universidade Federal de Santa Catarina, Florianópolis, Brazil (viviane-palma@outlook.com; marcelo.arco-verde@embrapa.br;nitram.ewert@gmail.com)

Os Sistemas Agroflorestais (SAFs) têm figurado como estratégia capaz de mitigar efeitos da fragmentação florestal, uma ameaça latente em todo o mundo, e ainda unir temáticas ambiental, social e econômica. Resultados expressivos em termos de recuperação de ambientes degradados, conectividade de fragmentos florestais, melhoria de solo e qualidade de água, além de resgate do cultivo de espécies nativas e gêneros alimentícios diversos, têm sido cada vez mais observados e valorizados. No que tange à segurança financeira frente às oscilações de mercado, se bem planejado, o sistema garante resiliência, pois há diversidade de produtos comercializáveis ao longo do ano e durante muitos anos. No Brasil, pesquisa em desenvolvimento com agricultores familiares no estado do Paraná, evidencia que SAFs têm acelerado a recuperação de áreas com histórico de degradação por pastoreio e monocultivos extensivos. A recuperação se dá principalmente por meio de conservação e maior deposição de matéria orgânica sobre o solo, aumento da ciclagem de nutrientes e diversificação da paisagem. Nos casos de maior êxito, além dos benefícios ambientais supracitados, muitos destes agricultores têm garantido aporte financeiro constante. Outro efeito advindo da maior segurança financeira tem sido percebido pela permanência ou mesmo pelo retorno de jovens ao ambiente rural, por vislumbrarem ali uma perspectiva de futuro, garantindo a diminuição do êxodo rural. Portanto, observa-se que um dos principais desafios à maior difusão e adoção dos SAFs ainda é o planejamento, pois quando adequado aos seus atores, este tipo de sistema produtivo integrado pode recuperar ambientes, mudar vidas, fortalecer e diversificar mercados.

\section{Sustainable land management for improved livelihoods and environmental sustainability: the role of agroforestry}

Daniel A. Ofori ${ }^{1}$, Kouame Christophe ${ }^{2}$, Jeremias Mowo ${ }^{3}$, Jamnadass Ramni ${ }^{3}$, Stephen Akpalu ${ }^{1}$, Lars Graudal ${ }^{3}$ ${ }^{1}$ CSIR-Forestry Research Institute of Ghana, Kumasi, Ghana; ${ }^{2}$ World Agroforestry Centre, Abidjan, Côte d'Ivoire; ${ }^{3}$ World Agroforestry Centre, Nairobi, Kenya; (dofori@csir-forig.org.gh; c.kouame@cgiar.org;.j.mowo@cgiar.org;r.jamnadass@cgiar.org; sakpalu2@gmail.com; graudal@cgiar.org)

A healthy viable multifunctional landscape has the capability of supporting sustainable agricultural productivity, providing agroforestry and forest products (timber, fuel wood, fruits, medicine, fertilizer, gum etc.) for the sustenance of mankind while providing other environmental services. However these products are increasingly becoming unavailable due tode clining soil fertility, climatic extremes, and high costs of inputs. Identifying low-cost, sustainable ways to attain food security and sustainable environment for millions of smallholder farmers in Sub Saharan Africa (SSA) remains a major developmental challenge. The poor performance of the agricultural sector in SSA therefore calls for innovative approaches for sustainable land management and sustainable agricultural productivity. Agroforestry offers an opportunity to meet this challenge. The paper reviews the major challenges confronting the drylands of Western, Eastern and Southern Africa regions with case studies from these regions showing the potential of agroforestry / evergreen agriculture in support of sustainable land management and increased agricultural productivity. This evidence has encouraged development of evergreen agriculture for improved food security, livelihoods and environmental sustainability.

\section{Agroforestry for livelihood revitalization in degraded peat ecosystems as integral part of peat restoration in Indonesia}

Endri Martini ${ }^{1}$, Subekti Rahayu ${ }^{1}$, Sonya Dewi ${ }^{1}$

${ }^{1}$ world Agroforestry Centre, Bogor, Indonesia; (e.martini@cgiar.org; s.rahayu@cgiar.org; s.dewi@cgiar.org)

Peatland ecosystems in Indonesia have undergone major degradation phases. The impacts of the degradation on increased GHG emission, biodiversity loss, high fire risk, and soaring economic and social costs have been understood. Government of Indonesia has committed to restore degraded peat ecosystems throughout Indonesia with three approaches: rewetting, revegetation, revitalization. Considering the rural communities living within peatland ecosystems, whose livelihoods depend on land-based agricultural activities, the rewetting and revegetation for reforestation potentially reduce their options for livelihoods. Species diversification in agroforestry is expected to enhance options to revitalize livelihoods as well as restore the ecosystems in degraded peatland. However, the success stories are limited due to: (i) less options of economic species that can be productive in water logged areas; (ii) agroforestry technologies for rewetted peat are not widely developed; (iii) limited knowledge exchange on agroforestry technologies between stakeholders. Competing land use options and low government support to market agroforestry products from peatlands also make agroforestry options not interesting. This study in Central Kalimantan and South Sumatra revealed issues at farm level such as the potential species list, agroforestry technologies (including land clearing without burning), and farmers' awareness and interests in maintaining their peat sustainably through agroforestry practices. At landscape level, zonation of peat hydrological unit is important in prioritizing the agroforestry management types. Agroforestry options for livelihood revitalization can be designed by identifying the enabling factors such as market availability, local policies and government support across gradients of peat depths.

Project Cacau Floresta: restoring landscapes and people through biodiverse agroforestry systems in the Brazilian Amazon region / Projeto Cacau Floresta: restaurando paisagens e pessoas via sistemas agroflorestais biodiversos na Amazônia Brasileira

Rodrigo Mauro Freire ${ }^{1}$, Thais Ferreira Maier ${ }^{1}$, Edenise Garcia ${ }^{2}$

${ }^{1}$ the Nature Conservancy, Belem, Brazil; ${ }^{2}$ the Nature Conservancy, Brasilia, Brazil (rfreire@tnc.org; tferreira@tnc.org; egarcia@tnc.org)

Os sistemas agroflorestais (SAFs) com espécies nativas em pequenas propriedades rurais podem ser uma solução para o combate ao desmatamento e promoção do reflorestamento econômico na Amazônia. Em 2013 a The Nature Conservancy iniciou o Projeto Cacau Floresta visando à restauração de pastagens degradadas 
por meio de SAFs baseados no cacaueiro (Theobroma cacao) em São Félix do Xingu e Tucumã, no sudeste do Estado do Pará. Agricultores familiares foram incluídos de forma participativa no projeto, sendo que atualmente o projeto conta com 130 propriedades, 500 hectares de novos plantios de cacau em SAFs e 70 diagnósticos ambientais realizados para os imóveis rurais que possuem o cadastro ambiental rural (CAR). São produzidos, além do cacau, espécies como mandioca (Manihot esculenta), milho (Zea mays), banana (Musa sp.), açaí (Euterpe oleracea), mogno (Swietenia macrophylla), copaíba (Copaifera spp.), andiroba (Carapa guianensis), taperebá (Spondias mombin), jatobá (Hymenaea courbaril), bacuri (Platonia insignis), castanheira (Bertholletia excelsa Bonpl.), entre outras nativas amazônicas. O projeto vem atuando nos seguintes domínios: produção rural (assistência técnica, garantia de acesso a insumos); socioeconômico (fortalecimento de mulheres, jovens e lideranças locais); organização socioprodutiva (fortalecimento de cooperativas, associações e casa familiar rural; organização de produção e oferta de sementes e mudas florestais) e ambiental (treinamentos em restauração, estabelecimento de acordos de desmatamento zero). Este estudo de caso apresenta uma promissora oportunidade de dinamização da economia local via fomento da cacauicultura em SAFs e restauração florestal, contribuindo para a conservação da biodiversidade e mitigação das mudanças climáticas numa importante fronteira de desenvolvimento da Amazônia.

Growth and production of Schizolobium parahyba var. amazonicum Huber Ex (Ducke) Barneby as a function of soil management in an agroforestry system / Crescimento e produção de Schizolobium parahyba var. amazonicum (Huber Ex Ducke) Barneby em função do manejo do solo em sistema agroflorestal

Agust Sales ${ }^{1}$, Sílvio Nolasco de Oliveira Neto ${ }^{1}$, Haroldo Nogueira de Paiva ${ }^{1}$, Helio Garcia Leite ${ }^{1}$, Marco Antonio Siviero ${ }^{2}$, Sabrina Benmuyal Vieira ${ }^{3}$ ${ }^{1}$ Universidade Federal de Viçosa, Viçosa, Brazil; ${ }^{2}$ Grupo Arboris, Dom Eliseu, Brazil; ${ }^{3}$ Universidade Federal do Pará, Belém, Brasil (agustsales@hotmail.com; snolasco@ufv.br; hnpaiva@ufv.br; hgleite@gmail.com; m.g@masiviero.com.br; sabrina.benmuyal@grupoarboris.com.br)

Em sistemas agroflorestais práticas de manejo do solo podem ampliar a capacidade de produção. Avaliou-se o crescimento e produção de paricá (Schizolobium parahyba) em sistema agroflorestal com práticas de manejo do solo, em Ulianópolis, Pará, Brasil. Implantou-se o paricá no espaçamento 5 x 2 m, consorciado com soja (Glycine max), no primeiro ano, e milho (Zea mays) no segundo. Avaliou-se os tratamentos T1 = subsolagem, adubação de base, adubação de cobertura, inoculação, consórcio com soja/milho; nos T2, T3, T4 e T5 aplicou-se as mesmas práticas do T1, exceto subsolagem (T2), adubação de base (T3), adubação de cobertura (T4) e inoculação (T5); sendo o T6 a testemunha sem práticas de manejo do solo. Avaliou-se o diâmetro a 1,3 m de altura (dap), a altura total (ht) e a sobrevivência (\%) das árvores aos 8, 22 e 36 meses de idade. Aos 36 meses, ajustou-se modelos para estimativas de crescimento e volume de madeira para 48 e 60 meses. Maiores sobrevivências ocorreram em T2, T3 e T4. O crescimento em dap, ht e volume no período com soja/milho foi superior em T2 e T6. Em idades futuras, o dap e volume apresentaram tendências superiores em T6 e recuperação em T1 e T5. Maiores sobrevivências ocorreram em T2, T3 e T4, provavelmente diante maior competição entre plantas que comprometeram o crescimento em dap e volume. Tendências de maior crescimento e produção na ausência de consórcio indicam que a competição exerceu maior influência que práticas de manejo do solo, diante boa fertilidade do solo.

\title{
A1c: ASSESSING THE CULTURAL ECOSYSTEM SERVICES FROM FORESTS: CURRENT
} CHALLENGES AND FUTURE SCOPES

\section{Accounting for cultural ecosystem services: a case of recreation services in Finland}

\author{
Tuija Sievänen ${ }^{1}$, Tuija Lankia ${ }^{1}$, Marjo Neuvonen ${ }^{1}$, Eija Pouta ${ }^{1}$ \\ ${ }^{1}$ natural Resources Institute Finland,Helsinki,Finland(tuija.sievanen@luke.fi; tuija.lankia@luke.fi;marjo.neuvonen@luke.fi; eija.pouta@luke.fi)
}

Ecosystem accounting is a coherent framework for integrating measures of ecosystems and the flows of services from ecosystems with measures of economic and other human activity. Ecosystem accounting complements, and builds on the accounting for environmental assets as described in the System of EnvironmentalEconomic Accounting (SEEA) Central Framework. In this study of cultural ecosystem service accounting, the aim was to make a pilot assessment of naturebased recreation in Finland. This presentation describes the methods and data sets used in analyses of indicators, and thoughts of advantages and shortcomings and identification of the gaps in data and methods as the main outcome. We offer a framework for methodology and needed assets, which are suitable to be processed for the accounting system of cultural ecosystem services. The account includes an estimate of the annual volume of recreational visits to nature areas, and an estimate of the value in monetary terms of the recreational use of nature areas and natural resources. We present pilot calculations for accounting. We illustrate how the nationwide data collection that provides the estimate of number of recreational visits in nature areas is a solid base for physical measures, and also for monetary values of the recreational visits. The assessment for the supply of recreational resources is based on land use categoriesand on data set of public recreation services (LIPAS -Geographic database for sport facilities for Finland). We discuss what improvements of data collection are needed for a functional cultural ecosystem service accounting in Finland.

Replanting life: perceptions of the benefits from forest restoration in resocializing inmates / Replantando vida: percepção dos beneficios da restauração florestal na ressocialização de presidiários

Alan Henrique Marques de Abreu ${ }^{1}$, Elton Luis da Silva Abel ${ }^{1}$, Alcione Duarte Ferreira ${ }^{1}$, Jorge Makhlouta Alonso ${ }^{1}$ Companhia Estadual de Águas e Esgotos - CEDAE, Nova Iguaçu, Brasil; ${ }^{2}$ Universidade Federal Rural do Rio de Janeiro, Seropédica, Brasil (alan.abreu@) cedae.com.br; elton@cedae.com.br;alcione@cedae.com.br;j_makh@hotmail.com)

Ambientes penitenciários são frequentemente sombrios, caóticos, superlotados, e insalubres físico e mentalmente. O trabalho na restauração florestal como forma laborativa, produtiva e terápica, aproxima os presidiários da natureza, oferece alívio de ambientes sociais tão duros e promove interação com meio ambiente. Um dos poucos exemplos no Brasil é o Programa Replantando Vida, desenvolvido no Rio de Janeiro pela Companhia Estadual de Águas e Esgotos (CEDAE), que oferece à presidiários capacitação profissional e trabalho em atividades de coleta de sementes, produção de mudas e restauração florestal. Nosso objetivo foi analisar a percepção dos presidiários sobre como as atividades da cadeia produtiva da restauração florestal podem contribuir no processo de ressocialização. Foi aplicado um questionário estruturado à 35 apenados da Colônia Penal Agrícola de Magé que participam do Programa. Os presidiários que participaram da pesquisa possuem em média 35 anos de idade, 80\% não terminaram o ensino médio e estão em média a 7 meses no Programa. Os entrevistados declararam que os principais motivos para procurarem o Programa, são a remissão de pena (83\%), seguido da oportunidade de aprendizado e capacitação $(63 \%)$, valorização dos familiares e amigos (51\%), além da remuneração (43\%). O aumento do senso de responsabilidade foi o beneficio mais percebido pelos apenados (66\%). O interesse em buscar mais capacitação (48\%), melhoria no relacionamento com a família (40\%), melhor perspectiva futura (37\%), aumento da auto estima (37\%) e valorização como ser humano (29\%), foram outros benefícios citados. O trabalho com restauração promoveu mudanças significativas na percepção de vida dos presidiários. 


\section{Landscape context matters: socio-ecological drivers of woodland recreation}

Chloe Bellamy ${ }^{1}$ D, Rebecca Spake ${ }^{2}$, Mark Atkinson $^{3}$, David Edwards ${ }^{1}$, Kevin Watts $^{3}$, Felix Eigenbrod ${ }^{1}$

${ }^{1}$ forest Research, Edinburgh, United Kingdom; ${ }^{2}$ southampton University, Southampton, United Kingdom; ${ }^{3}$ forest Research, Farnham, United Kingdom; (chloe. bellamy@forestresearch.gov.uk; r.spake@soton.ac.uk; mark.atkinson@forestresearch.gov.uk; '1avid.edwards@forestresearch.gov.uk;

kevin.watts@forestresearch.gov.uk; f.eigenbrod@soton.ac.uk)

There is increasing evidence for the mental and physical health benefits of spending time in woodlands and the wider natural environment, but information on how to manage our landscapes to enhance these cultural ecosystem services is lacking. To develop cost-effective strategies for improving woodland recreation we need a better understanding of where particular management actions will be most successful and why. We applied a statistical framework developed under the SCALEFORES project to identify the factors determining demand for, and supply of, recreation in 15,000 ha- ${ }^{-1}$ National Forest Inventory plots across Great Britain. This comprehensive field survey measures various biophysical and human characteristics of a woodland plot, including its composition, structure, management, condition and social use. These local attributes were integrated with data on the surrounding social and environmental landscape at multiple scales; machine learning was used to identify drivers and their scales of effect. Importantly, by incorporating interactions between variables measured at different scales we were able to investigate how the influence of local features varied according to the landscape context. We demonstrate the usefulness of this spatiallyexplicit approach for informing the management and restoration of Britain's highly fragmented, sparsely wooded landscape to support social use and highlight its transferability to other regions, environmental contexts and land management challenges.

\section{Assessing social values of urban forest as a key component for urban planning}

Sandra Rodriguez-Pineros ${ }^{1}$, Nelson Aguilar-Palma ${ }^{1}$, Rosalia Sánchez-Basualdo ${ }^{1}$, Leonor Cortés-Palacio ${ }^{1}$

${ }^{1}$ Universidad AutonomaDe Chihuahua, Chihuahua, Mexico (sandra_osu@yahoo.com; naguilar@uach.mx; rbasualdo@uach.mx; lcortes@uach.mx)

Urban forests provide several benefits to urban dwellers; they enhance city aesthetics, provide shadow, reduce the amount of greenhouse gases in the air by sequestering carbon dioxide, and help to reduce the amount of energy needed to heat and cool buildings. To understand the effects of climate change to the cities and to develop policies for adaptation it is important to know how stakeholders value the ecosystem services provide by the urban forests. Therefore, urban planning should be based on an integrated approach in which direct and indirect users participate. This study uses Q methodology to assess social values of a forest located in the city of Chihuahua, Mexico, a city that is characterized for being very vulnerable to the effects of climate change due to its geographical location. Seven groups of different stakeholders have been identified, direct users (runners and sport groups), municipal authorities (parks and recreation, municipal maintenance, ecology, library, health department, and planning), vendors, neighborhoods, and non-government organization located inside the park. From the groups of stakeholders thirty individuals were selected to sort a Q-sample of 25 statements that were carefully developed using the quasi-naturalistic approach. At this moment we are collecting the Q-sorts for further analysis, we expect to find two or three factors that reveal how stakeholders value the forest, we also expect to find areas of agreement and disagreement about that valuation. This information is useful for urban planners to develop forestation strategies in the already known hot spots of the city.

Assessing the links among cultural services, future scenarios, and the wellbeing of different cultural groups: an example from Northwestern Australia

Milena Kiatkoski Kim ${ }^{l, 2}$, David Pannell ${ }^{1}$, Ken Wallace ${ }^{1}$, Jorge Alvarez Romero ${ }^{3}$, Oliver Knight ${ }^{4}$

${ }^{1}$ Centre for Environmental Economics and Policy, School of Agriculture and the Environment, University of Western Australia, Perth, Australia; ${ }^{2}$ National Environmental Sciences Programme, Northern Australia Environmental Resources Hub, Canberra Australia; ${ }^{3}$ ARC Centre of Excellence for Coral Reef

Studies, James Cook University, Townsville, Australia; 4Aboriginal Interpreting WA Aboriginal Corporation, Fremantle, Australia(milena.kim@uwa.edu.au; david.pannell@uwa.edu.au; ken.wallace@uwa.edu.au; jorge.alvarezromero@jcu.edu.au; oknight21@yahoo.com)

Changes in ecosystem services can affect people's wellbeing. Our project uses participatory scenario planning to explore how future environmental changes in the Kimberley region in northwest Australia may affect the wellbeing of different stakeholder groups. The project has two stages: first, future scenarios were developed by a team ( $\sim 35$ people) representing Aboriginal organizations, government, industry and environmental groups. The resulting four spatially-explicit scenarios include 30-year changes in water and land-use, species habitat, and economic indicators. Second, stakeholders were asked to predict the impacts of each scenario on their wellbeing in comparison with their current situation. The cultural benefits of natural forests in the study area included access to: knowledge that comes from nature and special natural places; recreational satisfaction; and spiritual fulfillment. The assessment method uses a classification of wellbeing factors that was translated to work across different cultural groups. In this presentation we show how the method allows for the identification of win-win and win-lose situations associated with future environmental changes between multiple stakeholder groups, and how it could be adapted to different social and environmental contexts.

\section{Public preference for mixed forests: the results of a transdisciplinary research project on ecosystem services in Germany}

Iulia Milena Almeida Yakouchenkova ${ }^{1}$, Somidh Saha ${ }^{1}$, Christine Rösch ${ }^{1}$

${ }^{1}$ Karlsruhe Institute of Technology (KIT), Karlsruhe, Germany (iulia.yakouchenkova@kit.edu; somidh.saha@kit.edu; christine.roesch@kit.edu)

Mixed forests are known for their higher resilience to climate change impacts such as storms and droughts and superior biodiversity compared to monospecific forests. The supporting (e.g. biodiversity), regulating (e.g. carbon sequestration) and provisioning (e.g. wood production) ecosystem services are well investigated. For cultural ecosystem services such as recreation, tourism and aesthetic experience, however, only few studies are available in Europe. No insights at all exist about the perceptions of stakeholder and citizens for the famous Black Forest Region in South West Germany. In order to close that knowledge gap, a survey was carried out to analyze the views of stakeholder and citizens located in this region on ecosystem services of mixed forests with silver fir and European beech compared to monospecific forests with beech only. Our findings show that people believe that mixed forests provide better regulating, supporting and cultural ecosystem services than monospecific forests. Respondents' perceptions that in mixed forests more large and old trees can be found have a big impact on this rating and the feelings of pleasantness. The only drawback is seen by constraints in provisioning services, which are regarded to be better provided by monospecific forests. These results are surprising since spruces and firs are characteristic for the Black Forest. It can be explained by the change in attitude and behavior of citizens towards the use of the Black Forest. Our insights support the development of politic strategies to increase the share of mixed forests for a higher resilience and public acceptance. 


\title{
Nature's characteristics and benefits influence Latinos environmental responsibility
}

Jose J Sanchez ${ }^{1}$, Netasha Pizano ${ }^{2}$, Anthony Higgins ${ }^{3}$, David Flores ${ }^{4}$

${ }^{1}$ usda Forest Service, Riverside, Usa; ${ }^{2}$ california State University, Fullerton, Fullerton, Usa; ${ }^{3}$ california State Polytechnic University, Pomona, Usa; ${ }^{4}$ usda

Forest Service,Fort Collins, Usa (jsanchez@fs.fed.us; npizano@csu.fullerton.edu; anthonyhiggins@fs.fed.us; davidflores@fs.fed.us)

While Latinos are the second largest group in the United States contributing to the protection of natural resources, little research has considered Latinos' perspectives on environmental protection. Through quantitative and qualitative analyses, this study aimed to determine Latinos' views on environmental responsibility and the factors that influence such perspectives. Participants were individuals engaged in organized outdoor recreation facilitated by a Latino-led organization. A structural equation model was used to identify potential benefits that recreating in natural settings had on participants' levels of environmental responsibility. Quantitative results indicated that leisurely benefits significantly impacted the perspectives of Latinos. Moreover, personal advancement, such as the gaining of education or inspiration, was negatively related to Latinos reported levels of environmental responsibility. Through qualitative analysis, participants identified additional factors that influenced their levels of responsibility, such as personal health and well-being. Results suggest that Latinos' sense of environmental responsibility may be fostered through recreation that promotes connection and is free from demands. Such results may assist agencies and organizations that seek to build and influence Latinos' conservation practices and beliefs.

\section{A1d: FOSTERING EFFECTIVE AGROECOLOGICAL AND AGROFORESTRY PRACTICES FOR SUSTAINABLE TRANSFORMATION AND FOOD RESILIENCE}

\section{Fostering effective agroecology and agroforestry for sustainable transformation}

Erin Nelson ${ }^{1}$

${ }^{1}$ University of Guelph, Guelph, Canada (enelson@uoguelph.ca)

Agroforestry and agroecology are increasingly being recognized as having significant potential for contributing to sustainable development, climate change adaptation and mitigation, and food security. This panel brings together researchers and practitioners working in Brazil, Costa Rica, Mexico, Cuba, and Honduras, to share knowledge and identify common themes related to supporting and improving agroecological and agroforestry practices as a means to ensure community resilience through food security, encourage sustainable production in the face of transformation, and foster intergenerational knowledge sharing. All panel members are currently involved in participatory research and outreach with small-scale farmers and are co-producing transdisciplinary knowledge to ensure policies and practices incorporate local knowledge and realities. Panel members will discuss their current research and a moderated discussion will emphasize common challenges and innovative solutions at the local level, while encouraging audience participation. The goal of the panel is to launch a global north-south knowledge sharing network that will build capacity for farmers to transform their agroecosystems into sites that maximize production of socioecological services.

\section{Supporting sustainable communities through erva-mate agroforestry systems \\ Evelyn Nimmo ${ }^{1}$ (D) \\ ${ }^{1}$ Universidade Estadual de Ponta Grossa, Ponta Grossa, Brasil (ernimmo@gmail.com)}

In Southern Brazil, traditional agroforestry systems, which include the cultivation of erva-mate (a tea commonly consumed in Southern Latin America), are being threatened by increased pressure on farmers to deforest their lands and move toward monocrop systems. As a result, rates of deforestation in the region have risen dramatically and small-holder farmers are facing issues related to food security, poverty, and loss of traditional knowledge. Our team is working with local community members, government institutions and NGOs to document these traditional life-ways and develop networks of knowledge to support local community members in sharing knowledge about food heritage and culture and supporting sustainable practices that ensure the continuation of traditional food procurement practices and natural forest ecosystems.

\section{The tree species Cordia collococca (L.) and its potential for agroforestry systems in Cuba}

\author{
Maria Teresa Martinez ${ }^{1}$, Mariol Morejon Garcia ${ }^{1}$, Angel Leyva ${ }^{2}$ \\ ${ }^{1}$ University of Pinar Del Rio, Pinar Del Rio, Cuba; ${ }^{2}$ Instituto Nacional de Ciencias Agricolas, San Jose de Las Lajas, Cuba (aleyva@inca.edu.cu; \\ morejongarciamariol@gmail.com; luleyva@yahoo.es)
}

The tree species Cordia collococca (L.), known by the common name ateje, was described in 1953 as a plant of economic interest for Cuba. During the first half of the $20^{\text {th }}$ Century, it was used extensively by campesino communities in the province of Pinar del Rio, primarily for the nutritional value of its fruit for fowl and pig feed. As Cuban farmers gained increased access to imported animal feed, the plant was gradually forgotten. As a result, its current presence in agroecosystems is scarce. In 2013, an in-depth ethnobotanical study of the atejewas begun, and the research found the species to have more than 20 useful properties. It was also found to have a high level of resilience to adverse impacts of a changing climate. Some of its other useful properties include: high growth levels; nutritional value of its fruit; functions as a sanctuary for wild fauna; maintains high quantities of organic material in its leaves. Phytochemical analyses of the tree fruits found high levels of reductive compounds, free amino acids, carotenoids, and flavonoids, of high value for industry. Laboratory testing also found an abundance of reductive sugars and protein in its fruits. Introducing the species to agroecosystems was found to have multiple economic benefits. The research has allowed us to establish as yet unpublished benefits of this species, which have been (and will be) explored through a process of strategic introduction of the trees into local agroecosystems in Pinar del Rio, without reducing land cover dedicated to other crops.

\section{Organic and agroecological orange production: technology diffusion to organized small-scale producers in Veracruz, Mexico}

\section{Laura Gomez}

${ }^{1}$ Universidad Autonoma Chapingo, Chapingo, Mexico (gomezlaura@yahoo.com)

Oranges are the most important fruit crop in Mexico, occupying 335, 336 hectares, from which 4.6 million tons are harvested annually, primarily in the state of Veracruz (SIAP, 2017). The majority of the orange production in Veracruz is conventional, using pesticides (primarily Glyphosate), which represents a series of threats to sustainability, fruit quality, and the health of the fruit producers and consumers (Plengue, et. al., 2007). Twelve years ago, one orange farm began 
to introduce agroecological practices, innovating various processes, and managing to yield three times more than the average for conventional producers in the region. At the same time, prices for the crop were at least double the conventional price, and costs of production were $22 \%$ less. Since 2014 , this "mother farm" has served as a base for sharing the technologies used with organized small-scale producers from cooperatives in 10 municipailities. The techniques used include compost, rock flours, reproduction of locally-sourced beneficial microorganisms, mineral washes (e.g ash, lime sulphur), legumes as cover crops, agrohomeophathy, pruning, diversification of non-crop species, living barriers, and farm diversification (e.g. coconut, avocado, noni, other citrus). The Centre for Interdisciplinary Research for Rural Development (CIIDRI) at the Chapingo Autonomous University is leading this process, with a participatory action research methodology that favours knowledge exchange amongst different actors and the development of human resources in the university as well as technicians in the region.

\section{Food systems in Canada's Northwest territories}

Andrew Spring ${ }^{1}$

${ }^{1}$ wilfrid Laurier University, Waterloo, Canada (aspring@wlu.ca)

Food systems in Canada's Northwest Territories (NWT) rely on the availability of traditional foods that are harvested, hunted or gathered from the boreal forest. The health of the people is linked to the health of the land, water and forest ecosystem. Climate change is having profound impacts on northern ecosystems and is impacting availability of and access to traditional food sources. For many communities where food insecurity is already an issue, these impacts can further threaten food systems, health and well-being. Many communities, such as Kakisa, NWT, are turning to local food production, or small-scale agriculture, as a way to address these issues and provide fresh, healthy food and avoids the high cost and environmental impacts of purchased food in these remote communities. As climate change continues to impact the NWT, there are opportunities for local food production, as temperature warms and ecosystems shift. It is therefore important to ensure that agriculture is developed in a way that meets the needs of local residents, is culturally relevant, and contributes to the resilience of the boreal forest. Food systems in the NWT already align closely with principles of agroecology, therefore sharing knowledge, research and experiences with partners that practice agroecology can inform how communities such as Kakisa move forward with agriculture in both practice and policy.

\section{Tree-dominated landholdings ensure food and nutritional security}

Kamal Melvani ${ }^{1,2}$

${ }^{1}$ Neo Synthesis Research Centre, Polgasowita, Sri Lanka; ${ }^{2}$ Charles Darwin University, Darwin, Australia (neosynth@sltnet.lk)

Food and nutritional security are serious issues in Sri Lanka where assessments mainly focus on per capita availability of staple foods and individual crop yields. Alternately, tree-dominated landholdings covering $22 \%$ of Sri Lanka's land area ensure continuous access to and availability of nutritious food through time and assure livelihood stability. To test this hypothesis, food and nutritional security provided by tree-dominated landholdings were assessed across wet and dry seasons of the reference year and 100 years. Floristic inventories were undertaken in 85 landholdings across the Intermediate zone. Crops harvested in the reference year were classified into Very Short-(vegetables, leafy vegetables, cereals, pulses), Short-(root, herb), Long- (fruit, spice trees) and Very Longterm (fuelwood, timber trees) categories based on times of first return. Crop utilities, nutrient values and phenologies were retrieved from literature. Farmers cultivated various crops for food, fuelwood, timber and income, and most were from the Long-term category. Households were nutritionally secure because $75 \%$ of crops provided food with the full complement of macronutrients, while Long- and Very Short-term crops were especially micronutrient-rich. Households were food secure because diverse crop phenologies ensured the availability and access to food and income through wet and dry seasons of the reference year and continuously for 100 years. Consistent revenue lent stability to households and provided purchasing power to buy food when cultivation failed. Crop diverse, tree-dominated landholdings in Sri Lanka provide livelihood stability and alleviate food and nutritional insecurity. They have similar potential in other food and nutrition insecure countries.

\section{Agroforestry adoption as a systems concept: a review}

Dagninet Amare ${ }^{1}$, Jurgen Pretzsch ${ }^{2}$, Dietrich Darr ${ }^{3}$

${ }^{1}$ Amhara Regional Agricultural Research Institute, Bahir Dar, Ethiopia; ${ }^{2} T U$ Dresden, Tharandt, Germany; ${ }^{3}$ Rhine Waal University of Applied Sciences, Kleve, Germany(dagnnet@gmail.com; pretzsch@forst.tu-dresden.de;dietrich.darr@hochschule-rhein-waal.de)

Adoption of innovations is central to improved livelihoods of smallholders and agricultural modernization. Nevertheless, the best suit leading to optimum adoption rates remains blurred amidst several decades of research and development work. The paper employs both qualitative and meta-analysis to summarize the theoretical and empirical studies conducted in the past three decades in agroforestry adoption practice and research. Literature from innovation, social networks, diffusion, and adoption of agricultural innovations are explored to systematically analyze the main outputs of adoption studies. The gaps and progress are then discussed with benchmarks from previous research need recommendations and recent theoretical and analytical propositions. Overall, 23 variables have been often used in 34 econometric models spanning 24 studies to examine the intensity and adoption of different agroforestry innovations. Qualitative and descriptive analysis, however, provided better explanations by exploring additional perspectives away from the overriding socioeconomic variables in econometric models. While risk and uncertainty have been loosely explored by insufficiently defined proxy variables, profitability has not been part of the analysis of agroforestry adoption studies. There is a need to fine-tune the visualization of the adoption concept and adjust analytical defaults to get robust recommendations from agroforestry adoption studies to inform policy and action as well as for designing optimal agroforestry extension interventions.

\section{India's right to food act: human rights for tribal communities' forest food}

Purabi Bose $e^{1}$

${ }^{1}$ Landing Together, Mumbai, India (purabibose@gmail.com)

India's National Food Security Act, 2013 marks a historic shift from a welfare-based to a rights-based approach to food security. The importance of 'wild' food gathered from landscapes like forests, water, mountains, grasslands - or lack thereof - for food and nutrition security of indigenous peoples and pastoralists remains underexposed. This evidence-based paper examines forest-based food cultures vis-à-vis the Act's subsidized food grains. This paper proposes a 'right to forest food' governance framework to analyse the data. Primary data was collected from 12 distinct indigenous communities living in tribal India. This study result shows that agri-food and not forest food is promoted by the Act's public distribution system, which is ill suited to ensure indigenous peoples' food security. The paper highlight implications of 'cultural acceptability' and Aadhar - identity card regulations in the human right to food. 


\section{Global analysis of the share of steep slope in forest land}

Mikael Lundbäck', Carola Häggström ${ }^{1}$, Tomas Nordfjell ${ }^{1}$

${ }^{1}$ Swedish University of Agricultural Sciences, Umeå, Sweden (mikael.lundback@slu.se; carola.haggstrom@slu.se; tomas.nordfjell@slu.se)

There are many different ways of harvesting and extracting roundwood around the world. While analyzing why certain harvesting methods are dominant in certain countries in a bigger context, it became apparent that there are no available statistics of the share of steep slope in forest land that are comparable between countries. At the same time steep slopes have traditionally been a limitation for the cut-to-length harvesting method with rubber wheeled harvester and forwarder, so it was considered as an important variable to control in the larger analysis. A Geographic Information System (GIS) analysis was performed in the open source QGIS software, version 3.2. The core of the analysis is a digital elevation model (DEM) and to cover all 29 studied countries in this case four different DEM:s was used, most commonly with resolution 90 meters. To convert the DEM data from elevation to slope a built in tool in QGIS was used. All pixel values $<20^{\circ}$ was set to zero and the rest to one. A raster dataset of land cover was used in combination with the DEM:s to mask away all land other than forest land. The rasters of "slope" and "forest" were combined in the QGIS raster calculator and the resulting raster consisted of forest land with slope $>20^{\circ}$. When that figure was related to the total forest land a percentage was extracted and demonstrated for all countries in a figure. This result can be used as base facts in many contexts where countries are compared.

\section{Forest operations in mountainous areas: a challenging question}

Raffaele Cavalli ${ }^{1}$ (D); Omar Mologni ${ }^{1}$ (D)

${ }^{1}$ Dept. TESAF - University of Padova, Legnaro, Italy (raffaele.cavalli@unipd.it; omar.mologni@hotmail.it)

Mountainous forests are crucial sources of wood, especially in an increasingly urbanized world, where the global timber trade is expanding rapidly and around the world the forest industry is facing challenges in accessing wood fibre on steep terrain.Steeper slopes require alternate harvesting systems such as cable yarding, helicopter, and hand falling but these options are more expensive and much more hazardous relative to mechanized ground-based harvesting operations. New machines available today equipped with specialized undercarriages and carriers or with assisted traction devices have been shown to safely access and operate on terrain up to 70-80\% slope.With the exponential development of technology, an integrated approach must be developed for conducting productive, injury-free and environmental friendly mechanical harvesting operations on steep slopes.Considering productivity, safety and environmental impacts, two technologies for logging operation in steep terrain forests (i.e. cable logging and ground-based assisted forwarding) will be compared adopting simplified multi criteria analitical procedure. A number of factors, both quantitative and qualitative, will be taken into consideration in order to assess the level of competition between the two technologies and to define the proper field of application. The results will be useful to evaluate the efficiency of the technologies, in the broad sense of the term, and to consider which will be the improvements needed to increase the safety of work and to fit the environmental constraints.

\section{Comparison of erosion potential between manual and cable-assisted mechanized felling on steep slopes: a case study in Southern Oregon, USA}

Brett Morrissette ${ }^{1}$, Woodam Chung ${ }^{1}$, Kevin Bladon ${ }^{1}$, Ben Leshchinsky ${ }^{1}$, Jeffery Hatten ${ }^{1}$, Joh Sessions ${ }^{1}$

${ }^{1}$ Oregon State University, Corvallis,USA (brett.morrissette@oregonstate.edu; woodam.chung@oregonstate.edu; kevin.bladon@oregonstate.edu; ben.leshchinsky@oregonstate.edu;jeff.hatten@oregonstate.edu;john.sessions@oregonstate.edu)

Cable-assisted logging systems are a relatively new technology being used on steep slopes in the Pacific Northwest, USA. We will present preliminary results from a study comparing traditional manual timber harvesting practices with a cable-assisted, mechanized timber cutting system. Approximately 2 hectares of the 18 hectare harvest unit were manually using a chain saw, and the remaining area was harvested mechanically by a cable-assisted feller-buncher. Timber in both areas was then extracted using the same cable logging system. After cable logging, in late fall 2018, we installed erosion fences in (a) skyline corridors in cableassisted machine felling areas, (b) skyline corridors in manual felling areas, and (c) cable-assisted machine tracks. Our objectives are to quantify differences in soil erosion and sediment transport between harvest types. We installed 4 pairs of soil moisture probe clusters (10, 20, 30, 40, and 50 cm depth) along machine tracks and minimally disturbed ground in the cable-assisted timber harvesting area to quantify soil water content. We will present preliminary results of overwintering and partial summer erosion, sediment delivery, and soil moisture impacts from the two forest harvesting treatments. To facilitate interpretation of the erosion data, we are also collecting data on post-yarding ground based LIDAR, precipitation intensity and total, and pre- and post-treatment bulk density, soil strength (penetrometer), soil water content, and saturated hydraulic conductivity. This study is expected to provide insights into the relative impacts of steep slope cable-assisted harvesting operations on runoff and erosion compared to the traditional manual timber felling and cable-logging.

\section{Utilization potential of unused broadleaved tree stands harvested with simple rigging cable systems on mountainous area}

Yasushi Suzuki (D) Tetsuhiko Yoshimura ${ }^{2}$

${ }^{1}$ Kochi University, Nankoku, Japan; ${ }^{2}$ Shimane University, Matsue, Japan (ysuzuki@kochi-u.ac.jp; t_yoshimura@life.shimane-u.ac.jp)

How treat unused broadleaved tree stands have been one of major issues in Japanese forestry sector. Such stands provided fuel woods and non-timber commodity products before modern industrialization. No treatment over some decades degraded the stands, hence it has been said to have fostered oak mortality diseases and invasion of bamboo forests. Recent ecological research achievements have proved that appropriate treatment, i.e., thinning and regeneration cutting, recover such forests to be in ecologically sound condition. However low log price has been an obstacle to conduct such treatment because its cost exceeds income from the harvest in most cases, especially in mountainous area. Recent forest machine development and enhanced technique of forest road construction have improved operational efficiency and cost reduction for harvesting man-made forests, mainly consisted of cedar, cypress, and pine. Application of these developments over the treatments of the unused broadleaved tree stands is one possible answer. The authors have been researched on cable systems with simple rigging methods and found that they especially suitable for small scale harvesting operations combined with appropriate forest road networks. The present study assesses utilization potential of unused broadleaved tree stands on mountainous area by three aspects: 1. resource management, i.e., species and size distribution, 2. operational efficiency and cost of harvesting simple rigging cable systems, and 3. effect of treatment, i.e., harvesting, on remaining stands. 


\section{The challenge of sustaining the integrity of forest soils in mountain regions}

Klaus Katzensteiner ${ }^{1}$

${ }^{1}$ University of Natural Resources and Life Sciences (BOKU), Vienna, Austria (klaus.katzensteiner@boku.ac.at)

The sustainable provision of ecosystem services of mountain forests closely depends on the integrity of soils. As soil formation is a slow process, from a human perspective, soils are a non-renewable resource. In many regions, in particular of the Global South, the integrity of mountain forests soils is under threat. The expansion of agriculture by smallholder farmers into steep slopes enhances soil erosion; unregulated cattle grazing causes soil compaction; intensive biomass extraction leads to nutrient depletion and a decrease of humus content of the soil. Moreover, recent climatic changes alter the carbon and nutrient turnover in soil and change the disturbance regime, again causing feedback on soil conditions. On the other hand, financial incentives from offset strategies for greenhouse gas emissions offer chances for improved forest management. Measures for sustainable management and ecosystem restoration have to take into account both, the changing ecological site conditions as well as specific societal demands and economic situations. Communities in Nepal and in the Ethiopian highlands, where carbon offset projects with a strong focus on sustainable management of forest resources have been initiated are our 'living labs'. In the pilot projects, land users are participating at all stages: from research to planning and implementation of measures. It can be demonstrated, that participation is a successful strategy for establishing a certain tree cover: enclosures on erosion prone slopes, selected, afforested and protected by the community as well as on farm trees provide extra resources, thus reducing the pressure on the natural forest.

\section{Tree mortality and recruitment in a high mountain coniferous stand on Mt. Jiri, Korea}

Pil Sun Park ${ }^{1}$ Jong Bin Jung ${ }^{1}$, Hyun Jung Kim², Ahreum Han ${ }^{3}$

${ }^{1}$ Seoul National University, Seoul, Republic of Korea; ${ }^{2}$ Baekdu-daegan National Arboretum, Bonghwa, Republic of Korea; ${ }^{3}$ National Institute of Ecology, Seocheon,Republic of Korea (pspark@snu.ac.kr;jb1373@snu.ac.kr; sophie.kim@bdna.or.kr; subalpine@nie.re.kr)

The decline of high mountain coniferous forests has been reported worldwide since $20^{\text {th }}$ century. Global warming and unexpected weather events were suspected to be the major cause of the decline and became one of the important disturbance factors in mountain forests. Diverse disturbances occur on high mountains depending on the region. Windthrow and landslide can result in tree mortality by a discrete event, while drought stress works as a chronic disturbance, resulting in gradual degradation of forests. Individual tree mortality and recruitment were monitored in a Korean fir (Abies koreana) old growth stand in 4-year intervals for 12 years. Most species showed fluctuation of mortality, however, the mortality of Korean fir and Korean birth (Betula costata) continued to increase, showing the highest mortality among tree species in the study area. The density decrease was $18 \%$ for Korean fir and $73 \%$ for Korean birch from 2005 to 2017. About $1 / 3$ of dead Korean fir had DBH larger than $20 \mathrm{~cm}$. The ratio of seedling recruitment to tree mortality of Korean fir and Korean birch was about 0.1 and 0, respectively. Most species with seedling recruitment were subtree or shrub species except Korean fir and Acer pseudosieboldianum. The stand experienced typhoon almost every year and three to four windthrow events occurred during the study period. Unusual temperature increase in early spring also occurred recently.

\section{The legacy of Pre-Columbian fire on the pine-oak forests of Upland Guatemala}

William Harvey ${ }^{1,2}$, Sandra Nogue ${ }^{3}$, Nathan Stansell $^{4}$, Gillian Petrokofsky ${ }^{1}$, Byron Steinman ${ }^{5}$, Katherine Willis ${ }^{1}$

${ }^{1}$ University of Oxford, Oxford, United Kingdom; ${ }^{2}$ St Edmund Hall Oxford United Kingdom; ${ }^{3}$ University of Southampton, Southampton, United Kingdom;

${ }^{4}$ Northern Illinois University, de Kalb, USA; ${ }^{5}$ University of Minnesota Duluth, Duluth, USA (william.harvey@seh.ox.ac.uk; s.nogue-bosch@soton.ac.uk; nstansell@niu.edu; gillian.petrokofsky@zoo.ox.ac.uk; bsteinma@d.umn.edu; kathy.willis@zoo.ox.ac.uk)

Mountain tropical forests of the Southern Maya Area (Pacific Chiapas and Guatemala, El Salvador and Northern Honduras) predominantly comprise pine and oak formations, which form intricate mosaics and complex successional interactions following large-scale fire. These forests have been transformed by the peoples of the Maya civilization through practices of horticulture, agriculture and architectural developments over thousands of years. In this study we identify: (i) the natural baseline vegetation of the region: (ii) when human impact and agrarian practices began in the Maya uplands; and (iii) what impacts the Maya had on forest structure, composition, and successional regeneration. Past vegetation, anthropogenic use of fire, and faunal abundance were reconstructed using proxy analysis of fossil pollen, macroscopic charcoal, microscopic charcoal, and dung fungal spores (Sporormiella). Three phases of forest succession were identified over the past 6,000 years broadly pertaining to the well-defined archaeological periods of (i) the Archaic (10,000-2000 B.C.); (ii) Pre-Classic (2000 B.C. - 100 A.D.); and (iii) Terminal Pre-Classic (100-250 A.D.), Classic (250-950 A.D.), and Post-Classic (950-1522A.D.). Persistent high intensity burning during the Late-PreClassic to Classic Period resulted in a compositional change of forest structure c.150 B.C. from oak (Quercus) dominated forests to pine (Pinus) dominated forests. We present the earliest evidence for agriculture within the Southern Maya Area through presence of peppers (Capsicum) from 3850B.C. and the rise of maize cultivation (Zea mays) from 970 B.C. The legacy of Pre-Columbian anthropogenically driven fire in these mountain tropical forests demonstrates the resilience and thresholds for fire driven succession.

\section{Assessing ecosystem services from mountain forests}

Himlal Baral ${ }^{1}$

${ }^{1}$ Center for International Forestry Research, Bogor, Indonesia (h.baral@cgiar.org)

Mountain forest ecosystems provide a wide range of direct and indirect contributions to the people who live in the mountains and surrounding areas. Occupying steep slopes at high elevation, these ecosystems provide services such as stabilizing slopes, regulating hydrological cycles, maintaining rich biodiversity and supporting the livelihoods of those who are diverse in culture but vulnerable to poverty and food security. To manage these services sustainably, their diverse values must be recognized, assessed and valued. To support this assessment, this paper 1) reviews several tools for assessing the sociocultural, economic and ecological values of mountain forest ecosystem services, 2) demonstrates case studies of tool applications from several countries namely, Bhutan, India, Indonesia, Iran and Nepal, and 3) discusses assessment challenges that should be considered in the application of these tools. Several challenges exist for the assessment of mountain forest ecosystem services and these must be reflected in assessment design. These challenges include the complexity of defining and classifying ecosystem services; limited availability of data on ecosystem services; uncertainties associated with climate change; complex relationships among services including trade-offs and synergies; and limitation of assessments to build successful payments for ecosystem services. 


\title{
A1f: ASSESSING THE CULTURAL ECOSYSTEM SERVICES FROM FORESTS: CURRENT CHALLENGES AND FUTURE SCOPES
}

\author{
Non-timber forest product as cultural ecosystem services: a case study from the Western Ukraine \\ Nataliya Stryamets ${ }^{1}$, Giulia Mattalia ${ }^{1}$, Renata Sõukand ${ }^{1}$ \\ ${ }^{1}$ Ca'Foscari University of Venice,Venice, Italy (natastr@gmail.com; juliamattalia@gmail.com; renata.soukand@unive.it)
}

Forests provide a diversity of tangible and intangible benefits for sustaining local rural livelihoods. The analysis of the intangible benefits provided by forest landscapes have been highlighted as significant research question recently. Within the framework of intimate human-nature interaction, the aim of our research was to analyze the role of non-timber forest products (NTFPs) as cultural ecosystem services for rural residents in the Carpathian Mountains and Roztochya, Western Ukraine. We conducted seventy-two in-depth semi-structured interviews with local rural residents during summer 2018 to understand the role of forest resources as cultural ecosystem services, focusing on spiritual uses of different plant and mushroom taxa. Despite the severe restrictions of performing religious rituals for over fifty years (1939-1991), we found a richness of used rituals and NTFPs. Our results show the celebration of ten religious feasts among Christians in the region, in which 40 wild plant (most important Salix sp., Acorus calamus, Armoracia rusticana) and 12 mushroom taxa (most important Boletus sp., Leccinum sp.) were employed as ritual food and as ornamental decorations. We discuss the need to maintain cultural use of NTFPs, especially in Western Ukraine. We conclude that the role of NTFPs as cultural ecosystem services for local livelihoods is crucial. Moreover, cultural values and human-nature interactions are irreplaceable and secure the preservation of cultural heritage.This project has received funding from the ERC (grant agreement No 714874 [https://cordis.europa.eu/project/rcn/208447_en.html]).

The LandsCare system: a tool to add value to cultural ecosystem services / Sistema LandsCare: ferramenta para a valorização dos serviços ecossistêmicos culturais

Michele Benetti Leite ${ }^{1}$, Pablo Martínez de Anguita ${ }^{2,3}$

${ }^{1}$ LandsCare, Santa Maria, RS, Brasil; ${ }^{2}$ Universidade Rey Juan Carlos, Madri, Spain; ${ }^{3}$ LandsCare Madri Spain

(micheleleit@gmail.com; pablo.martinezdeanguita@gmail.com)

É cada vez maior a pressão sobre os ecossistemas, especialmente os florestais, muitas vezes por falta de alternativas sustentáveis que superem o custo de oportunidade da terra. É preciso encontrar mecanismos pelos quais a sociedade que se beneficia da riqueza natural possa contribuir à sua conservação, apoiando seus proprietários. Uma das alternativas mais utilizadas para fomentar a conservação são os esquemas de pagamento por serviços ecossistêmicos (PSE), que pretendem captar e reverter parte dos benefícios que a conservação do patrimônio natural e cultural geram à sociedade. Entretanto, os projetos são normalmente com foco em carbono ou recursos hídricos, e os serviços culturais são negligenciados. No caso, os PSE por serviços culturais florestais, são sistemas que tentam capturar o valor intangível destes serviços (e que não possuem mercado), para assim compensar aos responsáveis pela sua conservação. Por isso o aplicativo LandsCare surge como uma proposta inovadora de interpretação da paisagem com foco nos serviços ecossistêmicos de beleza cênica (incluindo os culturais) e de biodiversidade, buscando dar visibilidade ao território, agregando valor à paisagem, aos seus valores culturais e a quem torna isso possível. LandsCare é uma ferramenta prática pois auxilia na valoração desses serviços através do método de valoração contingente que está inserido nele, pois cada usuário destina, de forma pessoal, um valor ao micropagamento, que é destinado diretamente ao provedor dos serviços. O usuário do aplicativo tem informação georreferenciada sobre natureza, cultura, trilhas, onde comer e hospedar-se, produtos típicos e guias locais na zona em que se aplica LandsCare.

\section{Forests, people and biodiversity: Chiles national integrated monitoring of forest ecosystems}

Sabine Müller-Using ${ }^{1}$, Carlos Bahamodez ${ }^{1}$, Jaime Valdes ${ }^{2}$

${ }^{1}$ INFOR, Valdivia, Chile; ${ }^{2} F A O$, Santiago,Chile (smuller@infor.cl; cbahamon@infor.cl; jaime.valdes@fao.org)

Chilehostsan extraordinary diversity of ecosystemsas its natural forests cover 13.6 million ha and possess almost one-third of the world's few remaining large tracts of relatively undisturbed temperate forest; $70 \%$ of these forests are private and were regulated since 2008 by a "Native Forest Law". The government of Chile has developed relevant instruments to monitor these forest ecosystems, namely the Vegetation Cadaster and the National Forest Inventory (NFI), which have led toimproved policies and practices stopping overall deforestation. However, two major concerns remain. One is the continuous degradation of forests (an estimated 58,04 ha/year according to the national reference level of forest emissions). The second issue is the increasing demand of wood biomass to cover household heating demand, which imply a threat to the forest ecosystem integrity. For adequate monitoring, Chile created the "Integrated national Monitoring System on Forest Ecosystems" in support of policies and Sustainable Forest Management practices incorporating REDD+ and biodiversity conservation. It was built upon a holistic model considering a wide range of socioeconomic and biodiversity variables. The system includes the permanent participation of the society concerned, ensuring a governance model for monitoring at scales from the local to the national.For its implementation, it was necessary to create an inter-institutional coordination and management structure and to free data for its use by national and local policy and regulation formulators. First results show the usefulness of this system to initiate landscape restoration processes with a territory focus in three geographically very different áreas.

The Paraná pine (araucária) and the cultural landscape in the colonial center of Paraná, Brazil / A araucária e a paisagem cultural em núcleo colonial paranaense

Janice Bernardo ${ }^{1}$, Marcelo Langer ${ }^{1}$, Luciane Regina Meira Bastos Camargo ${ }^{2}$, Camila Sanchotene ${ }^{1}$, Viviane Gariba ${ }^{3}$,Marcio Pereira da Rocha ${ }^{1}$ ${ }^{1}$ Eng.Florestal Universidade Federal do Paraná, Curitiba, Brasil; ${ }^{2}$ Faculdade Estácio Curitiba, Curitiba, Brasil; ${ }^{3}$ SESI Curitiba, Curitiba, Brasil (janicebs@gmail.com; malanger04@yahoo.es; lucianebastos.psi@gmail.com; camilasanchotene@gmail.com; viviane.gariba@gmail.com; mprocha01@ gmail.com)

No final do século XIX imensas florestas da Mata Atlântica, ricas da espécie Araucaria angustifolia, cobriam o Estado do Paraná. Na colônia Murici, fundada em 1878, localizada em São José dos Pinhais, a araucária foi a primeira fonte de renda, era picada e vendida como lenha em Curitiba, foi também utilizada para construir pontes, carroças e as casas. Troncos inteiros eram encaixados nas extremidades e constituíam as paredes das "casas de troncos", o trabalho era comunitário e artesanal. Prevaleceu a instalação dos imigrantes poloneses que trouxeram consigo o conhecimento das técnicas agrícolas e das técnicas construtivas, o saber fazerda carpintaria e de outras tradições do país de origem. A madeira obteve importância econômica e social, o pinheiro e o pinhão constituíram os elementos simbólicos do espírito Paranista alcançando importância artística e cultural. O objetivo do estudo é avaliar a relação da floresta de araucária com a paisagem cultural da Colônia Murici. A 
metodologia consiste na aplicação de questionários usando a Avaliação Social do Ciclo de Vida (ACV-S) que define os principais grupos de interesse e as subcategorias de impacto social, entre eles os residentes da colônia e descendentes dos imigrantes, os religiosos, os gestores e os turistas. Busca desse modo analisar o reconhecimento dos valores ambientais e culturais locais. Visa compreender a relação homem natureza e os valores que as sustentam, a fim de viabilizar a motivação responsável da sociedade na promoção da qualidade de vida e das ações de preservação do patrimônio natural, material e imaterial da região.

\section{Alternative management models for addressing emerging demand on forest-based cultural services: a case-study in Northern Italy \\ Giulia Corradini ${ }^{1}$, Mauro Masiero ${ }^{1}$, Davide Pettenella ${ }^{1}$, Ilaria Doimo ${ }^{1}$, Paola Gatto ${ }^{1}$ \\ ${ }_{1}^{1}$ University of Padova, Padova, Italy (giulia.corradini@unipd.it; mauro.masiero@unipd.it; davide.pettenella@unipd.it; ilaria.doimo@phd.unipd.it; paola. gatto@unipd.it)}

Scientists and practitioners are paying growing attention to forest-based cultural ecosystem services (ES), including Forest Care Initiatives (FCIs). FCIs are organized initiatives supporting active and passive interaction with forests, aiming at increasing human health, wellbeing and quality of life. The use of forests for cultural, recreational and therapeutic uses may represent an opportunity for valuing forest resources and supporting development in marginalized areas. However, this requires new management solutions as well as tailored planning and forest management models (FMMs). The paper analyses the case of the Lowland Forest Association (AFP), a network of forests located in Northern Italy, close to densely populated and touristic sites along the Adriatic Sea. Within the European Union Horizon 2020 project ALTERFOR, current FMMs and stakeholder's ES needs/priorities have been identified via field surveys, meetings and interviews. Data have been then analysed, discussed with experts and modeled to set alternative FMMs and to assess the basket of ES associated to them.It has emerged that cultural ES, including FCIs, are paramount for local stakeholders, however FMMs for promoting them are not limited to technical aspects, rather they shall include mechanisms to enhance governance of forest resources. Alternative FMMs -including group forest management solutions, new investment mechanisms to attract investors, ad hoc initiatives, etc. -shall combine silvicultural choices and arrangements to favor cooperation among different actors. Results from the AFP case study may provide useful insights to inform future policies and inspire research activities on management choices for the provision of forest-based ES.

\section{Tourism in the forested landscape close to urban areas: Parco Regionale dei Castelli Romani case study}

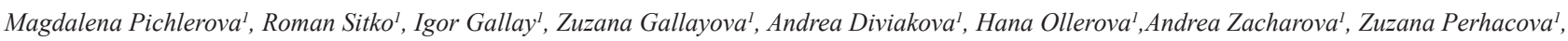
Adela Wiezikova ${ }^{1}$

${ }^{1}$ Technical University in Zvolen, Zvolen, Slovakia(magi1.pichler@gmail.com; sitko@tuzvo.sk; gallay@tuzvo.sk; zgallayova@gmail.com; andreadiviakova@gmail.com; hana.ollerova@tuzvo.sk; andrea.m.zacharova@gmail.com; zperhacova@gmail.com; a.wiezikova@gmail.com)

Different forms of tourism with properly secured infrastructure can encourage the arrival of tourists to the region together with an economic benefit. Planning is essential to minimize any impact of human activities and to support the functioning of natural processes. Recently the demand for products and services relating more to health and well-being are on rise, especially in forested areas. This is also supported by results of the public survey we carried out in Italy in 2017. It can be stated that forests for people represent especially the source of relaxation and clean air, rather than the source of wood. Our poster represents the case study focused on development of soft (health) tourism in forested landscape close to Roma. Our study area lies within the Parco Regionale dei Castelli Romani and belongs to the Colli Albani volcanic complex. The dominant nature feature of the area is lake Nemi. We focused our attention on its basic natural environment characteristics as well as local features (e.g. exposure of mostly used public areas and trails to direct sunlight). Important input data is on vegetation and quantification of its direct and indirect benefits, as well as determination of possible risks (e.g. allergenic plants, etc.). Introduced is also the Trail assessment decision check-list for measures proposal, to help various subjects to evaluate trails condition. Further, we created land cover and land use characteristics and classification with the use of a very high resolution satellite images, supplemented by assessment of vegetation change over the year 2017.

Economic valuation of remaining carob trees through direct and indirect benefits to conserve the biocultural landscape, a foundation for quality of life / Valoración económica del relicto de algarrobos, por beneficiarios directos e indirectos para la conservación del paisaje biocultural, fundamento del vivir bien

Huascar Camacho ${ }^{1}$

${ }^{1}$ Universidad Mayor de San Simón, Cochabamba, Plurinational State of Bolivia (huascachoo@hotmail.com)

En la comunidad de Tiataco, municipio de Arbieto, Cochabamba, Bolivia, existe un relicto de 12 hectáreas de algarrobos centenarios que por muchísimos años estuvo haciendo solo presencia paisajística, sin que la comunidad y sus habitantes puedan aprovechar de la diversidad de los servicios ambientales que brinda el bosque. Para demostrar el potencial integral del relicto, se desarrollaron junto a los comunarios, actividades teórico prácticas, que permitieron identificar su valor socio-económico, cultural e histórico. Se aplicó la metodología de valoración contingente con formato binario, entre beneficiarios directos (familias de la comunidad), e indirectos (residentes en la ciudad de Cochabamba, $35 \mathrm{~km}$ de Tiataco) obteniendo como resultado, la disposición a pagar por los beneficiarios directos 58,42 Bs/año (8.39 USD/año) y de 105.288 Bs/año (15.12 USD/año) por los indirectos (tipos de cambio septiembre 2018, B.C.B.: 1 \$US =6,96 Bs). Con los resultados de la valoración económica, se implementaron acciones de conservación y manejo silvicultural, como de recuperación de saberes bioculturales que promueven y dinamizan relaciones de equilibrio y armonía entre el hombre y la naturaleza, junto con la creación de modelos de desarrollo económico local. La recuperación de saberes locales desde el ámbito social y antropológico, permitió implementar actividades de Jornadas turísticas, socio, culturales pedagógicas que recuperan los ritos, costumbres y tradiciones de la cosmovisión andina, practicadas en el Aya Markay quilla (noviembre, mes de retribución con los difuntos) como son La Wallunk’a nativa y el Mast’aku, manifestaciones vivas referentes a la Vida y la Muerte.

\section{A1g: AGROFORESTRY AND PRODUCTION OF NONWOOD FOREST PRODUCTS}

\section{Incorporation of non-timber forest products in forest plantation: case study on the growth and yield performance of NTFPS in modified Taungya System}

Rita Baaba Abekah ${ }^{1}$, Regina Yeboah ${ }^{1}$

${ }^{1}$ Resource Management Support Centre, Kumasi, Ghana (ritabaabaabekah@yahoo.com; oforiattaregina@yahoo.co.uk)

The Forestry Commission of Ghana has adopted forest plantations as a strategy to ensure landscape restoration, enhance environmental quality and develop a sustainable resource base to satisfy future timber demands. Modified Taungya System (MTS) is a co-management system between the Forestry Commission and smallholder farmers that allows inter-cropping of timber and food crops. Practitioners and farmers observed decline in NTFPs from the wild which in recent 
times have become a threatening to source of livelihood that often contributes significantly to household incomes. NTFPs were introduced in MTS to engage farmers to protect the forest from wildfire and decrease theft incidences. However, farmers had to leave these lands because their crops were not doing well during canopy closure. Grains of paradise amongst others were found to do well under shade but the best silvicultural practice to apply is indefinite. This study was undertaking to research and determine the best condition (spacing, \% of shade, height and yield) suitable for Grain of Paradise cultivation. Primary data was used to gather information. The results show that growth of the Grains of Paradise can grow and yield under both stands (Teak and Cedrela). However, GoP under Teak stand with planting distance of $4 \mathrm{X} 4$ and shade cover $84 \%-86 \%$ was found as the suitable condition for GoP productions in terms of growth and yield. Recommended that the Production of GoP should be introduced to other MTS farmers and interested farmers throughout the country as an alternative livelihood.

\title{
Bamboo agroforestry in East China: models and their socioeconomic importance
}

\author{
Xiaoniu Xu ${ }^{1}$, Qin Wang ${ }^{1}$, Jingjing Wang ${ }^{1}$ \\ ${ }^{1}$ Anhui Agricultural University, Hefei, China (xnxu6162@163.com; qlsforest@ahau.edu.cn; forest6211@sina.com)
}

Bamboo is an extremely versatile plant capable of providing ecological, economic and livelihood security to the people. However, there are limited available data to verify the suitability of the system. In this study, an investigation was conducted in eastern China to analyse the potential socioeconomic and environmental benefits of Moso bamboo (Phyllostachys pubescens) based agroforestryand accentuate implications on sustainable rural development in the region.Bamboo forests are a typical forest type in Southern China, representing an area of 6.16 million hectares, and more than 70\% of the bamboo forests consist of Moso bamboo. Bamboos play a major role in the livelihood of rural people and rural industry. Results from the investigation showed that there are five models which outmatch most tree species the ability to provide versatility of use. These models include bamboo-tea model, bamboo-medicinal plant model, bamboo-edible fungi model, bamboo-poultry model, and bamboo-tree mixed forest. With comparison to the mono-bamboo system, the economic benefits increased 1 to 4 times for these models. The benefit-cost ratios varied from 2.19 to 3.52. The maximum income in Moso bamboo - Bletilla striata (precious Chinese medicine) model reached US\$ $2.32 \times 104 / \mathrm{ha} / \mathrm{yr}$. In addition, soil organic carbon, and available nitrogen and phosphorus increased in the intercropping systems. Therefore, bamboo-based agroforestry systems are expected to open new income streams by diversifying agroecosystems and offering multiple economic benefits, which can contribute to rural poverty reduction and improved livelihoods in the hilly area.

\section{Effect of light and nutrient availability and planting methods on the productivity of Adenophora divaricata and Heracleum moellendorffii}

Byung Bae Park ${ }^{1,2}$, Woo Bin Youn ${ }^{1}$, Aung Aung ${ }^{1}$, Si Ho Han ${ }^{1}$, Huong Thi Thuy Dao ${ }^{1}$, Jeong Min Seo ${ }^{1}$, Ser-Oddamba Byambadorj ${ }^{1}$, Se Bin Kim ${ }^{1}$

${ }^{1}$ Department of Environment and Forest Resources, Chungnam National University, Daejeon, Republic of Korea; ${ }^{2}$ Korean Society of Forest Sicence Seoul, Republic of Korea(bbpark@cnu.ac.kr; younwoobin95@gmail.com; aungaung1361986@gmail.com; bupleurumhan@cnu.ac.kr; thuyhuong.150495@gmail.com;jmseo3@naver.com; seroddamba@gmail.com; sbkim@cnu.ac.kr)

In the agroforestry system, woody plants can affect the quantity and quality of produced herbaceous vegetation. So, the relationship between woody plants and herbaceous vegetation is important. To implement successful agroforestry system, it will be necessary to know the characteristics of plants in the microclimate. For this, we studied the effects of artificial shade and fertilizer on productivity of plants. For this research, Heracleum moellendorffii (H) and Adenophora divaricata (A) was used. We set the three treatments: shade, fertilization and planting method. For shade treatment, 0\%, 35\% and 55\% shading nets were installed in consideration of different light availability in natural forests. As for fertilization, N, P, K 20-20-20 fertilizer was used. And for planting method, single and mixed planting methods were used with 2 species with the idea of inter and intra-specific relationship in nature. And we replicated them three times. As a result, productivity of $\mathrm{H}$ was higher in the $35 \%$ shading and fertilization treatment and that of A was higher in the $0 \%$ shading and non-fertilization treatment than other treatments. Also, when two different species were planted together, it was found that the competition effect was significant, which greatly influenced the growth of other species. Therefore, the success of agroforestry systems depends on the selection and management of appropriate shade tolerant herbaceous species for optimal productivity and sustainability. So, further studies with each factor would help to clarify the relative importance of each factor as limiting factors of yield in agroforestry systems.

Progress and results of agroforestry in Chile: connecting agriculture to the forests / Desarrollo y resultados de la agroforestería en Chile: conectando la agricultura con los bosques

Alvaro Sotomayor ${ }^{1}$, Alejandro Lucero ${ }^{1}$, Jaime Salinas ${ }^{1}$, Arnoldo Villarroel ${ }^{1}$, Bernardo Acuña ${ }^{1}$

${ }^{1}$ instituto Forestal,Coyhaique,Chile(asotomay@infor.cl; alucero@infor.cl; jsalinas@infor.cl; arnoldo.villarroel@infor.cl; bacuna@infor.cl)

En Chile durante su colonización, y hasta inicios del siglo XX, existieron Políticas de Estado para eliminar bosques, utilizando sistema de cortas y quemas, para utilizar estos terrenos en actividades agrícolas y ganaderas. Esta política originó que el $49,1 \%$ de los suelos se encuentren erosionados, equivalente a 36,8 millones de hectáreas. Los principales factores responsables de esta erosión ha sido la acción humana. Para paliar lo anterior han existido políticas de forestación con fines industriales desde la década del 70, y programas de recuperación de suelos degradados. En Chile se ha estudiado durante los últimos 20 años un modelo de desarrollo agroforestal alternativo al forestal tradicional con fines industriales, con el objetivo de entregar alternativas a los pequeños productores agrícolas, fomentándose la introducción de especies leñosas en los campos considerando su identidad cultural, sistema productivo, y recuperación de suelos. Con esta forma de reintroducción de especies leñosas bajo sistemas agroforestales, se han verificado disminución de procesos erosivos de hasta $1.700 \%$ en terrenos con prácticas para cultivos agrícolas tradicionales; reducción del viento hasta un $200 \%$ por el establecimiento de árboles en sistemas silvopastorales, originando a su vez un aumento de la producción pratense; uso de cortinas cortavientos aumentando la productividad pratense y cultivos agrícolas hasta 41\%. Esta forma de reintroducir árboles en los campos, bajo ordenación agroforestal, ha tenido mejor aceptación en pequeños y medianos propietarios que plantaciones industriales, donde un 93,1\% de estos prefieren establecer árboles en un arreglo agroforestal, versus $27,5 \%$ que mostraron disposición a forestar con plantaciones tradicionales

A1p: ECOSYSTEM SERVICES AND AGROFORESTRY SYSTEMS IN SOUTH AMERICA

Application of legislation and public policies related to ecosystem services in the Lujan River basin of Argentina, and connections to levels of perception and educational education / La aplicación de normativa y políticas públicas sobre servicios ecosistémicos en la cuenca del Río Luján, Argentina, y su interrelación con los niveles de percepción y de educación ambiental

Clara Minaverry ${ }^{1}$, Mariano Ferro ${ }^{2}$

${ }^{1}$ CONICET, INEDES, Luján, Argentina; ${ }^{2}$ Universidad de Buenos Aires, Facultad de Derecho, Buenos Aires, Argentina (clara.minaverry@gmail.com; cminaverry@mail.unlu.edu.ar)

Pesq. flor. bras., Colombo, v. 39, e201902043, Special issue, p. 1-768, 2019 
La Cuenca del Río Luján es el sistema hídrico más importante de la Región Metropolitana del Gran Buenos Aires (Argentina), posee una superficie total de 2940 km y una longitud de $450 \mathrm{~km}$. Se encuentra dentro de la región pampeana, en la subregión de la pampa ondulada y se caracteriza por la ausencia de árboles, la existencia del pastizal como fisonomía predominante. El régimen hídrico abundante de esta área es ideal para el cultivo de cereales, mientras los suaves valles formados por ríos, arroyos y arroyuelos son indispensables para el ganado. En las áreas rurales, las transformaciones antrópicas han modificado este paisaje original por el de agrosistemas. Dada la relevancia estratégica que posee este ámbito territorial, el objetivo principal de este trabajo es exponer los principales lineamientos de la normativa y de las políticas públicas ambientales vinculadas con la protección de los servicios ecosistémicos en la Cuenca del Río Luján en la Provincia de Buenos Aires, en Argentina, y relevar los niveles de percepción ambiental de la población. La metodología consistirá en realizar un análisis de documentos públicos a través de la aplicación de la hermenéutica jurídica, y también un relevamiento de la percepción ambiental de la población mediante la confección, realización y procesamiento de los resultados brindados por encuestas.

Integrated governance of forests on the Northern Coast of São Paulo, Brazil: the role of the Fazenda and Caçandoca Quilombola communities in protecting ecosystem services / Governança integrada de florestas na região do litoral norte do estado de São Paulo, Brasil: o lugar das comunidades quilombolas da Fazenda e Caçandoca na proteção dos serviços de ecossistema

Gerson de Freitas Junior ${ }^{1,2}$, Maria de Fátima Pereira Alves ${ }^{1,2}$, Paula Cristina de Oliveira Castro ${ }^{3}$

${ }^{I}$ Universidade Aberta de Portugal - UAb, Lisboa, Portugal; ${ }^{2}$ Centro para Ecologia Funcional - CEF Science for People \& the Planet, Coimbra, Portugal; ${ }^{3}$ Universidade de Coimbra - UC, Coimbra,Portugal (gerson.freitas.junior@gmail.com; fatimaa@uab.pt; pcastro@ci.uc.pt)

O processo histórico de criação de um modelo de proteção ambiental na forma de Unidades de Conservação (UCs) no Brasil se desenvolveu sobre um contexto de profundo conflito socioambiental. Criaram-se áreas de proteção em locais habitados por comunidades tradicionais (indígenas, caboclos, sitiantes, seringueiros, caiçaras e, especificamente, quilombolas), de modo que essas populações que organizaram seus territórios, sua cultura e seu modo de vida e construíram os espaços que habitam historicamente, constituindo-os em florestas culturais (e em florestas de memória), tiveram sua mobilidade e sua realização social restringidas pelas diretrizes das UCs. Marginalizadas em relação ao processo de criação das UCs pelos órgãos do poder público e ambientais, essas populações tradicionais resistem, se organizam e buscam garantir seus direitos, como o reconhecimento de sua ancestralidade (em oposição à ideia de terra nullius). Objetiva-se verificar, em abordagem indutivo-comparativa, como as comunidades da Fazenda e da Caçandoca se relacionam com a natureza do ponto de vista da sustentabilidade, contribuem para a proteção dos serviços de ecossistema e desenvolvem sistemas de participação cidadã. Em pesquisa qualiquantitativa recorrendo a entrevistas, pretende-se construir tipologias de governança e níveis de participação destas comunidades.

Financial viability of agroforestry systems using cacao to restore degraded pastures in Southeastern Pará, Brazil / Viabilidade financeira de sistema agroflorestal com cacaueiro para restauração de pastagens degradadas no Sudeste do Pará

Thais Ferreira Maier', Rodrigo Mauro Freire ${ }^{1}$

${ }^{1}$ The Nature Conservancy, Belem, Brazil (tferreira@tnc.org; rfreire@tnc.org)

Os sistemas agroflorestais com cacaueiro (Theobroma cacao) têm se apresentado como uma solução para o reflorestamento econômico e social no sudeste do Pará. A The Nature Conservancy vem trabalhando no Projeto Cacau floresta, nos municípios de São Félix do Xingu e Tucumã, utilizando estes sistemas para restauração de pastagens degradadas, gerando renda e aumentando a segurança alimentar dos pequenos produtores. O objetivo deste trabalho foi realizar uma análise financeira de um SAF com cacaueiro e frutíferas para produção de polpas, na região de São Félix do Xingu, PA. A composição das receitas foi calculada a partir da comercialização das amêndoas de cacau, banana (Musa sp.), inhame (Dioscorea spp. L.), jiló (Solanum aethiopicum) e polpas de cacau e goiaba (Psidium guajava). Na composição dos custos foi considerada toda mão de obra necessária para implantação, manejo e beneficiamento dos produtos, bem como insumos, equipamentos e infraestrutura utilizados na produção. Como resultados, o modelo se mostrou viável financeiramente a uma taxa de $5,5 \%$ ao ano, apresentando taxa interna de retorno (TIR) de 22,04\%, valor presente líquido (VPL) de R\$ 43.457,96, relação benefício/custo de 1,7 e payback descontado de 9 anos, em um horizonte de 20 anos de análise. O cacau foi o elemento que mais contribuiu com a geração de renda, sendo complementado pela produção de polpas, seguido da produção de banana. É fundamental encontrar soluções para geração de renda nos primeiros anos do sistema, para que o payback possa diminuir e aumentar a viabilidade financeira ao pequeno agricultor.

Beyond income: motivations for family farmers to incorporate greater diversity of native trees in agroforestry systems in Eastern Amazonia / Para além da renda: motivações para agricultores familiares incorporarem maior diversidade de árvores nativas em sistemas agroflorestais ( $S A F S$ ) na Amazônia Oriental

Mário Oliveira Neto ${ }^{1}$, Livia Navegantes-Alves ${ }^{1}$

${ }^{1}$ Universidade Federal do Pará, Belém, Brasil (marioneto.eng@hotmail.com; lnavegantes@gmail.com)

Agricultores familiares amazônicos praticam a recuperação florestal de variadas formas, destacando-se os Sistemas Agroflorestais (SAFs) pela intensidade da ação antrópica. Esses sistemas podem apresentar diferentes graus de biodiversidade, conforme a decisão do agricultor. O presente estudo objetiva analisar as motivações dos agricultores familiares para incorporar uma maior diversidade de árvores nativas nos SAFs, no município de Tomé Açu, estado do Pará. Este município foi escolhido por ter um histórico de práticas agroflorestais ao longo de 30 anos, onde foram aplicadas entrevistas semiestruturadas e observação direta com 17 agricultores familiares praticantes de SAFs. As espécies agrícolas e perenes (Piper nigrum, Theobroma cacao, Theobroma grandiflorum, Euterpe oleracea) sãopredominantes nos SAFs analisados, pois, segundo os agricultores, são elas que sustentam as despesas da família. As espécies arbóreas têm como função primordial o sombreamento, tanto para fins produtivos das espécies agrícolas, quanto para o conforto microclimático.Além de geração de renda e qualidade de vida, aspectos morais, religiosos e preocupações sociais, especialmente com as gerações futuras e com os vizinhos, foram referenciados como motivos centrais para integração de maior diversidade arbórea. Três fatores sobressaíram como impulsos para incorporar árvores nativas nos SAFs: mercado e incentivo estatal, e conhecimento das espécies. Em síntese, os agricultores familiares destacaram variadas motivações para incorporação de maior diversidade de árvores nos SAFs, a função das espécies e os impulsos internos e externos também devem ser considerados para compreensão e estímulo à diversificação.

Diversity of agroforestry systems in the State of Bahia, Brazil / Diversidad de los sistemas agroforestales en el estado de Bahia, Brasil

Rozimar de Pereira ${ }^{1}$, Gabriel Andrade ${ }^{1}$, Thaine Silva ${ }^{1}$, Silvanne Santos ${ }^{1}$

${ }^{1}$ Universidade Federal Rural de Pernambuco, Cruzdas Almas, Brasil (rozimarcp@gmail.com; andradegabrieel@gmail.com; silvathai28@gmail.com;

analise.silvane@yahoo.com.br)

Pesq. flor. bras., Colombo, v. 39, e201902043, Special issue, p. 1-768, 2019 
Los sistemas agroforestales (SAFs) son un sistema de uso de la tierra con la introducción o retención deliberada de árboles en asociación con otros cultivos perennes o anuales y/ o animales, presentando mutuo beneficio resultante de las interacciones ecológicas y económicas. Así se constituyen en una alternativa para aliar la estabilidad del ecosistema con miras a la eficiencia y optimización de recursos naturales en la producción de forma integrada y sostenida. El objetivo de este trabajo fue evaluar la diversidad de especies arbóreas de los SAFs en los municipios Recôncavo de Bahía - Brasil. Se utilizaron enfoques participativa y multidisciplinario, herramientas del DRP y Diagnóstico Rural Rápido. Los SAF se definieron en 4 tipos. Los datos fueron analizados por la estadística descriptiva y análisis de factores por el índice de similitud. En los SAFs se observó la ocurrencia de especies frutales, madereras, medicinales y ornamentales en las propiedades estudiadas (30), con 98 diferentes especies encontradas, distribuidas en 35 familias botánicas. Las familias Fabaceae y Myrtaceae fueron las más representativas en número de especies. Los modelos SAF1, SAF2, SAF3 y SAF4 presentaron índices de diversidad Shannon (H ') de 3,155; 3172; 3135; 2,843 y la equidad ( ' ') 0,906; 0,928; 0,957; 0,949, respectivamente. En cuanto 32,8\% de las especies muestreadas son pioneras, el $24,5 \%$ secundarias iniciales, el 39,9\% secundarias tardías y el 2,8\% sin caracterización. El Sistema Agroforestal es de gran relevancia para los remanentes de Mata Atlántica en Bahía, ya que presentan una significativa biodiversidad local.

\title{
Food security and income from traditional African oils
}

Anne Mette Lykke (D; Imael Henri Nestor Bassolé2, Amadé Ouédraogo ${ }^{2}$, Elie Antoine Padonou ${ }^{3}$, Amadou Malé Kouyaté ${ }^{4}$ ${ }^{1}$ Aarhus University, Silkeborg, Denmark; ${ }^{2}$ University of Ouaga I, Ouagadougou, Burkina Faso; ${ }^{3}$ National University of Agriculture, Ketou, Benin; ${ }^{4}$ Institute of RuralEconomy, Sikasso,Mali(aml@bios.au.dk; ismael.bassole@gmail.com; amadeouedraogo@gmail.com; padonouelie@gmail.com; amadoumkouyate@) yahoo.fr)

Food oil of good quality is important for health, food security and income. Women in rural Africa traditionally extract oil from seeds of numerous native trees, but the potentials are far from fully realized. During two projects, QUALITREE and TREEFOOD, we investigated ethnobotanical knowledge in Mali and Burkina Faso, analyzed physiochemical properties of over 30 native oil trees and made a literature review of native tree oils from West Africa. Local knowledge about oil production is often confined to local areas or specific ethnic groups. Screening of oils from native species revealed very good potentials for ameliorated use, production, sale and export. Examples of highly interesting oil species are Adansonia digitata, Afzelia africana, Balanites aegyptiaca, Carapa procera, Lannea kerstingii, Lophira lanceolata and Pentadesma butyracea. Few species (mainly Elaeis guineensis and Vitellaria paradoxa) are highly investigated and used, despite the fact that there is clearly an extraordinary potential for improving health, food security and economic development in poor communities via diversified, increased and improved oil production. Marketing interests of oil includes both local and international markets. However, in many cases tree planting or nature protection in collaboration with local communities are needed to ensure sufficient and continuous oil supplies. Such activities have a potential to improve local biodiversity and give opportunities for carbon certification and sale.

\section{Influence of the tree component in the animal production in an integrated crop livstock system in an environmental protection area in the Brazilian Subtropic}

\author{
Silvano Kruchelski ${ }^{1}$, Thales Baggio ${ }^{1}$, Breno Campos $^{1}$, Anibal de Moraes ${ }^{1}$ \\ ${ }^{1}$ Universidade Federal do Paraná,Curitiba,Brasil (silvanokr65@gmail.com; baggio.thales@gmail.com;brenomcamposs@gmail.com; anibaldemoraes@) \\ gmail.com)
}

This study aimed to compare animal daily gain of beef cattle in four arrangements of Integrated Crop-Livestock Systems. The experiment was carried out at

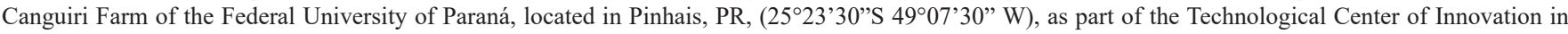
Agriculture protocol. The protocol is located in an Environmental Protection Area with 1400 mm average of total annual rainfall, $12.5^{\circ} \mathrm{C}$ and $22.5^{\circ} \mathrm{C}$ of mean minimum and maximum temperature, respectively. The design was a randomized block with three repetitions and four treatments, livestock system (LS), silvopastoral system (SS), livestock and crop system (LC) and livestock - crop with tree system (LCT). Plot size was about 1.5 hectares for each experimental unit. The tree species in the SS and LCT systems was Eucalyptus benthamii spacing $14.0 \mathrm{~m}$ between tree rows, and $2.0 \mathrm{~m}$ within the tree row. The average tree height was $13.65 \mathrm{~m}$. The grazing method was continuous stocking with variable stocking rate, to the "put and take" technique. A group of 36 animals (testers) was used on the study. Three animals testers (Angus breed) was taken for each treatment. The experiment was conducted from Jun/2017 to March/2018. The comparison of the mean variables evaluated between LS, SS, LC and LCT was performed by the Tukey test. Daily weight gain was evaluated weighing testers each 28 days during ten months. The daily weight gain did not present significant difference for treatments $(\mathrm{LS}=0.82 \mathrm{~kg} ; \mathrm{SS}=0.77 \mathrm{~kg} ; \mathrm{LC}=0.86 \mathrm{~kg} ; \mathrm{LCT}=$ $0.84 \mathrm{~kg})$.

\section{A1q: COMMUNITY INVOLVEMENT IN AGROFORESRY SYSTEMS AND ECOSYSTEM} SERVICES

\section{Towards productive landscapes: trade-offs in tree-cover and income across a matrix of smallholder agricultural land-use systems}

Syed Rahman ${ }^{1}$

${ }^{1}$ Center for International Forestry Research (CIFOR), Bogor, Indonesia (sumonsociology@yahoo.com)

One of the main causes of tropical forest loss is conversion to agriculture, which is constantly increasing as a dominant land cover in the tropics. The loss of forests greatly affects biodiversity and ecosystem services. This paper assesses the economic return from increasing tree cover in agricultural landscapes in two tropical locations, West Java, Indonesia and Eastern Bangladesh. Agroforestry systems are com-pared with subsistence seasonal food-crop-based agricultural systems. Data were collected through rapid rural appraisal, field observation, focus groups and semi-structured interviews of farm households. The inclusion of agroforestry tree crops in seasonal agriculture improved the systems' overall economic performance (net present value), even when it reduced understorey crop production. However, seasonal agriculture has higher income per unit of land area used for crop cultivation compared with the tree establishment and development phase of agroforestry farms. Thus, there is a trade-off between short-term loss of agricultural income and longer-term economic gain from planting trees in farmland. For resource-poor farmers to implement this change, institutional support is needed to improve their knowledge and skills with this unfamiliar form of land management, sufficient capital for the initial investment,and an increase in the security of land tenure. 
Empowering farmers in India through sandalwood cultivation \& economic development impact in Rural India

K. T. Chandrashekar ${ }^{1}$, Malleshachari Lingachar ${ }^{1}$

${ }^{1}$ Sandalwood Society of India, Bangalore, India (ktchandrashekar2@gmail.com; mallesh@itrads.com)

Indian Sandalwood is considered as the richest forest species and it was declared as Royal Tree in India. Santalum album $L$. is considered as a premium class which is commercially known as East Indian Sandal wood. Indian Sandalwood is highly prized due to its fragrant wood, oil, which is used as a fixative in world class perfumes, aromatherapy, various pharmaceutical preparations and cosmetics. The oil has an important role in indigenous system of medicinal properties. Every part of the tree is exploitable; sapwood also finds utilization in carving and turnery. Demand of sandalwood is in the tune of 20,000 Metric tons and oil demand estimated at 1000 tons in the international markets. Different agro forestry models introduced are helping farmers realizing higher yield. With other forest species as host plants, the whole eco system of sandalwood clusters is helping in improved soil carbon. This fertile land is becoming useful in growing many high return inter crops. Developed value added products in sandalwood as part of improving farmers revenue. In addition to farmers getting very high economic value, introduction of value added products in sandalwood is helping government in huge revenues. In the next few years, India will see its economic independence by way of empowering rural India. This paper discusses the various agro forestry models introduced, steps taken to improve soil fertility, value added products introduction \& yield growth.

\title{
Involvement of Tribal Community in cultivation of Cinnamomum malabatrum (Burm. F.Bl) and Persea macarantha (Nees Kosterm) trees across Western Ghats of India asbinding material for Agarbhati (incense) industry
}

\author{
K. T. Chandrashekar ${ }^{1}$, Malleshachari Lingachar ${ }^{1}$ \\ ${ }^{1}$ Sandalwood Society of India, Bangalore, India (ktchandrashekar2@gmail.com; mallesh@itrads.com)
}

Burning of incense is a century's old tradition in the religious rites, rituals, and customs of all communities in Asian countries. In India, incense is more commonly known as agarbathi. It is also used as air freshener, disinfectant and masking agent. Indian incense industry is one of the most vibrant cottage industries that employees up to 2 million people who are mostly under privileged in the country. Incense export industry has grown at a CAGR of $15 \%$ and is expected to grow exponentially and reach USD 3.5 B (AIAMA) in the next five years. The industry today has scarcity of forest based raw materials like jigat (binding material). The expansion of agarbathi industry has inflated the demand for jigat. These trees are grown in Western Ghats of India where the population of tribal community is highest. These trees have been over exploited and are unable to regenerate themselves as they are unscientifically debarked. It is estimated that approximately 20,000 ha. of captive plantation is required in the next ten years. Cultivation of these trees in different clusters is done in select areas and plans are already drawn for further expansion. In this paper, selection, cultivation of high bark yielding and adhesive property of trees is discussed. This paper also presents structured plans to enrich the livelihood of tribal community by involving them closely in raising the large scale plantation.

\section{Forests for people seen in a national forest inventory (NFI) perspective: experiences and results of measuring cultural ecosystem} services in Denmark

\author{
Frank Søndergaard Jensen ${ }^{1}$ (D) Thomas Nord-Larsen ${ }^{1}$, Vivian Kvist Johannsen ${ }^{1}$ \\ ${ }^{1}$ University of Copenhagen,Frederiksberg,Denmark(fsj@ign.ku.dk; tnl@ign.ku.dk; vkj@ign.ku.dk)
}

A number of international processes aim to monitor the forest status, which includes cultural values and services like forest recreation - the question is what role National Forest Inventories (NFIs) can play in this context. The Danish NFI is a continuous sample-based inventory with partial re-placement of sample plots based on a 2 × $2 \mathrm{~km}$ grid. A number of recreational indicators is registered as part of the NFI measurement procedures, including: access (forest roads, formal and informal paths), camping (formal campsites, evidence of camping and camp fires), infrastructure (hunting facilities and other visitor facilities) and abuse (littering, vandalism). Danish forests are easily accessible as a total of $70 \%$ of the sample clusters were accessible by forest roads or paths. The recreational activity is visible in the forest. On $46 \%$ of the clusters, the NFI teams found evidence of camping, camp fires, hunting facilities or other visitor facilities (forest playgrounds, picnic tables etc). The downside to the widespread activity is that litter was found on $20 \%$ of the clusters.It is revealed that NFIs relatively simply and cost efficient can be expanded to include a number of recreational/social indicators which generally is not available otherwise. The measurements is a valuable contribution to sustainable knowledge-based management and policy decisions, and may serve as a baseline for monitoring the trend in parts of both the supply and demand of forest recreation - as well as the downside of the activity such as littering or vandalism.

\section{Portuguese regional agroforestry innovation network from the AFINET Project: SWOT analysis after two years of establishment \\ Joana Paulo ${ }^{\bullet}$; Raquel Almeida ${ }^{1}$, João Palma ${ }^{1}$, Ana Tomás ${ }^{1}$, Margarida Tomé ${ }^{1}$ \\ ${ }^{1}$ Instituto Superior de Agronomia,Lisboa,Portugal (joanaap@isa.ulisboa.pt; rpalmeida@isa.ulisboa.p; joaopalma@isa.ulisboa.pt; anaraqueltomas@gmail.com; magatome@isa.ulisboa.pt)}

The AFINET project acts in nine European countries aiming at taking up available research results on agroforestry into agricultural practice. Portugal is one of those countries. One of the main tools developed by the project is the creation, at each participating country, of Regional Agroforestry Innovation Networks (RAIN). A SWOT analysis exercise was carried out in order to analyze current results of the RAIN actions. The results show: Strengths - current interest on Agroforestry; - large impact of the available communication channels, in particular social media; - relationship to the EURAF member's community; - high number of agroforestry systems and practices referred by stakeholders; - awareness of relationships constraints between different stakeholder types; Weaknesses - small impact at the national policy level; - practical constrains to increase the implementation of activities covering a broader geographical distribution area; - lack of expertise regarding all of the referred topics, demanding a significant increase of time to tackle them; Opportunities using the RAIN as the network for future projects related to the Agroforestry topic; - increase communication of scientific knowledge from science to practice; - establishment of new experimental and demonstration trials in collaboration to farmers; - basis for the creation of a national Agroforestry association; Threats - lack of funding for RAIN activities sustainability after 2019; - large scope of subjects approached by the RAIN members, that increase the demand of funding for future activity; - concentration of efforts in already well established and recognized agroforestry systems in Portugal; - lack of institutional awareness to the agroforestry concept. 
Urbanisation and implications on norms, taboos and customs in forest governance of Miombo woodlands and implications on forest governance among peri-urban and rural communities

\author{
Felix Kalaba \\ ${ }^{1}$ Copperbelt University, School of Natural Resources, Kitwe, Zambia (kanungwe@gmail.com)
}

Migration of people in new areas has the potential to change existing norms and customs regulating human-forest interactions. The study aimed at understanding how different cultural institutional settings shape access, use and governance of forest resources. This study was conducted in the Miombo woodlands of Zambia's Copperbelt region. Data was collected using a multiple methods approach combining household interviews with 244 households, focus group discussions and key informant interviews. Findings show that traditional rules regarding harvesting of forest products are prominent in rural settings as opposed to peri-urban areas. Local institutions affect the prevalence of norms and customs that inform resource utilization and management. Communities in peri-urban areas do not engage in protecting forests for any environmental or cultural services. The lack of traditional institutions and diversity of ethnic tribes has led to erosion of cultural norms and practices that regulate forest use. In customary lands, traditional rules on forest use and management exist. Forested areas are important for providing cultural services and norms, taboos and folkways exist that regulate harvesting of products such as barks for medicinal purposes. Traditional governance of forest resources is more likely to provide sustainable management due to adherence to cultural norms, and proximity to decision making structures. Urbanization has the capacity to change local institutional arrangements undermining and eroding customary systems due to diversity of tribes around urban centres. Management of woodlands around urban areas requires deliberate measures to strengthen local authority and promote locally appropriate management actions and plans.

\title{
Developing regenerative agroforestry designs to foster gender-responsive forest restoration in the Brazilian Amazon
}

\author{
Mariana Oliveira ${ }^{1}$, Paula Costa ${ }^{2}$, Valter Ziantoni ${ }^{2}$ \\ ${ }^{1}$ WRI Brasil,São Paulo,Brasil; ${ }^{2}$ PRETATERRA, São Paulo,Brasil (moliveira@wri.org; paula.costa.agroforestry@gmail.com; ziantoni.valter@gmail.com)
}

Project entitled Restoration Compatible with Gender Equality and Climate Change, aims to enhance efforts on the link between low-carbon agriculture techniques, forest restoration and sustainable landscape management in Juruti, PA, Brazil. With an HDI of 0.592, the region depends on agro-extractivism and subsistence agriculture based on slash-and-burn cassava cultivation. Fallow reduced from 20 to 2 years, constant growing population, and the increase of wildfires make mandatory creation of new agriculture regenerative models to thrive under climate change conditions. The study aimed to develop participative agroforestry designs as an alternative for slash and burn in the region; prototyping and implementing modular replicable agroforestry units in a successional decision-making logic. During 2018, data collection and pairwise sessions were conducted in 25 communities (157 farmers). The analysis used selected principles, criteria, and indicators. Final adjustments were made merging local ecological knowledge, empirical information and scientific data. Result was a co-created elastic regenerative design, maximizing biomass production and high-value fruit indigenous trees within the system. Estimative annual yield per hectare for cassava is 12 ton; fruits, 24.4 tons and dry biomass, over 3.53 tons, after 4 years, according to farmers' preferences, system can migrate to (1) agrosilvipasture, (2) perennial fruit orchard or (3) biodiverse NTFP forest. Implementation has already started in Nov-2018. With the presented design its expected to drastically improve food resilience while imputing new cash crops and creating an elastic and highly acceptable low-carbon model for amazon cassava-based agriculture, building a new productive paradigm which is sustainable, resilient and long-lasting.

A1r: AGROFORESTRY FOR ENVIRONMENTAL RESTORATION AND CLIMATE MITIGATION

\section{The commercialization of Adansonia digitata L. In Malawi: from emergency food to high value market products?}

Chifundo Chopi-Msadala ${ }^{1,2}$, Chimuleke Munthali ${ }^{1}, K_{\text {Kathrin Meinhold }}^{2}$, Dietrich Darr ${ }^{2}$

${ }^{1}$ Mzuzu University, Mzuzu, Malawi; ${ }^{2}$ Rhine-Waal University, Kleve, Germany (chifundochopi@gmail.com; chimuleke.munthali@gmail.com;

kathrin.meinhold@hochschule-rhein-waal.de; dietrich.darr@hochschule-rhein-waal.de)

The baobab tree (Adansonia digitata L.)is common in semi-arid sub-Saharan Africa and an important source of Non Wood Forest Products (NWFP). Its fruits contain high amounts of vitamin C, E, calcium and dietary fiber. Other parts of the tree are traditionally used for human consumption, particularly during lean seasons. In line with increasing demand for natural, healthy and nutritious food products in domestic and international markets, the baobab has great potential to address human nutrition and improve rural livelihoods if commercialized properly. In Malawi, where demand for baobab has substantially increased within the last decade, the baobab fruits are being commercialized by both formal and informal processing enterprises to produce fruit juice, cosmetics, ice-lollies and sweets for various rural and urban consumer segments. Yet, information about the sociodemographic background and quality preferences of baobab consumers is scanty. Therefore, a consumer study of 179 juice consumers was conducted in formal and informal retail markets. Qualitative and quantitative data was analyzed by means of cluster analysis and cross tabulation. Results suggest that consumers of baobab and fruit juices in major supermarkets are mostly females between 21 to 40 years old, mainly hold a bachelor's degree and belong to the middle income group. Consumers mostly preferred imported fruit juices over baobab juice due to packaging quality and sweetness. The study concludes that domestic baobab processors should invest in product innovation and process improvements, and quality standards need to be enforced which encourage the positioning of baobab products in higher value segments.

\section{Tree shade control for farming inside Tan Phu Protection Forest of Vietnam: the conflict or new farming technique}

Trang Bui Thi Thu ${ }^{1}$, Linh Nguyen Thuy $M^{2}$

${ }^{1}$ Vietnam National University of Forestry Southern Campus, Dong Nai, Vietnam; ${ }^{2}$ Vietnamese Academy of Forest Sciences, Ha noi, Vietnam

(trang.bui3282@gmail.com; linh.ntm@rcfee.org.vn)

Agroforestry systems not only play an important technique to minimize negative impacts on biodiversity, human livelihoods, well-being in conservation work, but also create the conflict between conservation and development objectives. In some agroforestry systems in Tan Phu Protection Forest of Vietnam, in order to facilitate coffee and peppercorn production, local people tend to release Dipterocarpaceae tree shade by branch cutting all. This practice is not forbidden in law but has been leading to negative impacts on long-term conservation work: reducing on forest tree foliage, branch production and increment annual stem diameter. Paying farmer to protect forest is minimal in comparison with benefits from their crops, thus it's hard to encourage them cultivating crops without pruning forest trees. This paper aims to provide the view of gaps in relevant policies and how to building on mutually beneficial relationships among farmers and authorities in Tan Phu. The systematic reviews on forestry policies and relevant journal articles are implemented to access the influences of these policies 
and law to farmer livelihoods and conservation conflicts. Some studies on specific land-use management and optimal tree shade methods in agroforestry systems are further discussed. The results expect to seek the optimal shade tree density and shade cover for agroforestry systems. And the suggestion to recommend legal and institutional frameworks in agroforestry sector and the options for policy action to support the development of not only improving conservation outcomes, but also respecting and protecting the rights of local people in the use and management of forests.

\section{Interventions for agroforestry and species restoration in Novel Forests of Puerto Rico: enrichment planting success before and after Hurricane María}

Génesis Túa Ayala ${ }^{1}$, Oscar Abelleira Martínez ${ }^{1}$

${ }^{1}$ Universidad de Puerto Rico, Mayaguez,Puerto Rico (genesis.tua@upr.edu; oscarj.abelleira@upr.edu)

Much of Puerto Rico is covered by novel forests growing on lands previously used for intensive agriculture, resulting in extreme soil degradation and dominance of introduced tree species. Social-ecological vulnerabilities to extreme events call for interventions to support provision of goods and biodiversity conservation in abundant and idle novel forests. We report on year-one of an experiment to test the suitability of novel forests for agroforestry and species restoration interventions in Puerto Rico, as affected by Hurricane María on September, 2017. We established enrichment plantings of sun (avocado, breadfruit), shade (cacao, coffee) and native (jácana, jagua) fruit tree species to test for effects of dominant canopy tree species traits upon planted tree species growth and survival. Beginning on August, 2017, we planted six individuals of each species on each of 30 sites of which roughly half were dominated by nitrogen-fixing tree species. Ten and 20 sites were planted before and within six months after the event, respectively. We observed high survival rates (80\%) of all species across all sites, including those planted before the Hurricane. Planted tree growth was boosted at sites were the Hurricane caused canopy opening or flooding. Results are too preliminary to indicate relationships between planted tree species growth, survival and dominant species traits, yet show the capacity of novel forests for successful establishment of agricultural and extirpated species, protecting plantings from extreme events. Long-term results will aid communities and institutions couple Puerto Rico’s forests with provision of goods, biodiversity conservation and resilience to extreme events.

\section{Agroforestry in Southern Africa - new pathways of innovative land use systems under a changing climate (ASAP)}

Rafael Bohn Reckziegel ${ }^{1}$ D; Lars Borrass ${ }^{2}$, Steve Carr ${ }^{3}$, Paxie Chirwa ${ }^{4}$, Roger Funk ${ }^{5}$, Sibylle K. Hassler ${ }^{6}$, Jörg Helmschrot ${ }^{7}$, Hans-Peter Kahle ${ }^{1}$ (D), Friederike Lang ${ }^{8}$, Rebekka Maier ${ }^{8}$, Mirko Maelicke ${ }^{6}$, Christopher Morhart ${ }^{1}$ (D) Nicholas P. Ndlovu ${ }^{2}$, Betserai I. Nyoka ${ }^{9}$, Thomas Seifert ${ }^{\prime 0}$, Jonathan P. Sheppard ${ }^{10}$; Stephen Syampungani ${ }^{11}$, Ben du Toit ${ }^{12}$, Maik Veste ${ }^{13}$

${ }^{1}$ Chair of Forest Growth, University of Freiburg, Freiburg im Breisgau, Germany; ${ }^{2}$ Chair of Forest and Environmental Policy, University of Freiburg, Freiburg im Breisgau, Germany; ${ }^{3}$ Economic Botany Programme, National Botanical Research Institute, Windhoek, Namibia; ${ }^{4}$ Department of Plant and Soil Sciences, University of Pretoria, Pretoria, South Africa; ${ }^{5}$ Institute of Soil Landscape Research, Leibniz Centre for Agricultural Landscape Research, Müncheberg, Germany; ${ }^{6}$ Institute for Water and River Basin Management, Karlsruhe Institute of Technology, Karlsruhe, Germany; ${ }^{7}$ Southern African Science Service Centre for Climate Change and Adaptive Land Management (SASSCAL), Windhoek, Namibia, ${ }^{8}$ Chair of Soil Ecology, University of Freiburg, Freiburg im Breisgau, Germany; ${ }^{9}$ World Agroforestry Centre, ICRAF-Southern Africa Node, Chitedze Research Station, Lilongwe, Malawi; ${ }^{10}$ Scientes Mondium UG, Altomünster, Germany; ${ }^{11}$ Department of Plant and Environmental Sciences, The Copperbelt University, Kitwe, Zambia; ${ }^{12}$ Department of Forest and Wood Science, Stellenbosch University, Stellenbosch, South Africa; ${ }^{13}$ Centrum for Energy Technology Brandenburg e.V. (CEBra), Cottbus, Germany (rafael.bohn.reckziegel@iww.uni-freiburg.de; lars.borrass@ifp.uni-freiburg.de; steve.carr@mawf.gov.na; paxie.chirwa@up.ac.za; rfunk@zalf.de; sibylle.hassler@kit.edu; joerg.helmschrot@sasscal.org; hans-peter.kahle@iww.uni-freiburg.de; friederike.lang@bodenkunde.uni-freiburg.de; rebekka.maier@bodenkunde.uni-freiburg.de; mirko.maelicke@kit.edu; christopher.morhart@iww.uni-freiburg.de; pyndlovu86@gmail.com, b.nyoka@cgiar.org; t.seifert@scimond.com; jonathan.sheppard@iww.uni-freiburg.de; ssyampungani@yahoo.com; ben@sun.ac.za; maik.veste@icloud.com)

Climate change is already a measurable reality generating significant social, economic and environmental challenges, impacting sustainable development around the globe. The African continent is most vulnerable to the forecasted change in global climate, Southern Africa in particular will face severe challenges within the upcoming decades. Innovative, flexible and improved land use systems are expected to be part of the adaptive solution, mitigating the effects of a changing climate and positively influencing agriculture and food security under altered conditions. The BMBF funded research project 'Agroforestry in Southern Africa - new Pathways of innovative land use systems under a changing climate' (acronym ASAP; grant number: 0LL1803) incorporating partners from South Africa, Namibia, Mozambique, Malawi and Zambia alongside researchers from Germany, targets the employment of agroforestry systems (AFS), as an appropriate response to climate change.ASAP aims at investigating ecosystem services as well as socio-economic and environmental benefits of AFS in the southern Africa region. The chosen transdisciplinary approach to investigate the biophysical environment and ecosystem services in conjunction with socio-economic aspects of AFS will help develop a better understanding of a range of possible solutions using AFS for varied agro-climatic zones and landscape scales. The exploration of human-environment interactions within AFS is a major focus with the intention of facilitating a sustainable improvement to rural livelihood utilising AFS. Project outputs will be disseminated to practitioners and researchers through local facilitators in the framework of workshops, lectures and practical guidance in order to establish a paradigm shift.

\section{Tree-based conflict management mechanisms among small land holders in agroforestry systems of Kenya}

Pauline Bala ${ }^{1}$, Abdalla Kisiwa ${ }^{2}$, Samson Okoth ${ }^{3}$, Robert Nyambati ${ }^{4}$, Joyce Okumu ${ }^{2}$, Joshua Cheboiwo ${ }^{4}$

${ }^{1}$ Kenya Forestry Research Institute -RVERP, Turbo, Kenya; ${ }^{2}$ Kenya Forestry Research Institurte -RVERP, Londiani, Kenya; ${ }^{3}$ Kenya Forestry Research Institute LVBERP, Maseno, Kenya; ${ }^{4}$ Kenya Forestry Research Institute, Nairobi, Kenya; (paulineballa@gmail.com; abdulkyz@yahoo.com; mcojijosamsa@gmail.com;nyambatir@yahoo.com;joyce.okumu@gmail.com;jkchemangare@yahoo.com)

Afforestation programs for adaptation to climate change is challenged by competing land uses. Such conflicts arise whenever there is divergent, incompatible use; access and management of the land resources. Agroforestry is considered an option to reconcile such competition. However, practicing agroforestry on small land holdings remain a challenge due to negative ecological and social impacts of most preferred tree species. Such negative impacts lead to conflict among neighbouring land users and in most instances slow down afforestation efforts. Mechanisms for management of such conflict are not documented. This study intends to explore conflicts arising from tree-planting on farm among different land users, identify the local conflict management mechanism adopted by them and to evaluate effectiveness of the mechanisms adopted. Structured and semi structured interviews were conducted in Kisii County, Kenya. Content analysis was done. Reduction of crop by poorly configured trees on farm and poor choice of tree species were the main sources of tree-based conflicts. Planting $\mathrm{f}$ such tree species was mainly driven by the high economic value attached to such trees of negative ecological impact like Eucalyptus coupled with small land holdings. Only $36 \%$ of the respondents employed co-operative methods of voluntary negotiations such as shared tree ownership, appropriate silvicultural 
management and compensation. Some 20\% of the respondent adopted third party intervention mechanisms such as Mediation, Adjudication and Arbitration while $10 \%$ used avoidance methods. Voluntary negotiations promoted good relations but imposed some cost on livelihood strategies. When involuntary and non-cooperative methods were employed, some land uses were displaced.

Factors affecting the willingness of households to apply HCG technology in black fungus cultivation: an investigation in the forest area of Heilongjiang Province, China

Hongge Zhu', Shilei Hu ${ }^{1}$, Yue Ren ${ }^{1}$, Yukun Cao ${ }^{1}$, Xiangyue Liu ${ }^{1}$

${ }^{1}$ Northeast Forest University, Harbin, China (honggebill@163.com; yiruodongchuan@163.com; ren13199442303@163.com; cyklk@163.com; 1335759586@qq.com)

Hanging-bag cultivation in greenhouses (HCG) of black fungi is a new technology that is being promoted in state-owned forest regions in China. It significantly improves the efficiency of black fungus cultivation; alleviates forested land resource shortages; promotes the smooth transition towards an ecological economy in state-owned forest regions; and promotes the sustainable development of forested areas. However, the effective promotion and application of HCG technology largely depends on the acceptance and willingness of households, who are the final recipients of the promotion of this technology, to engage with it. This empirical study investigated the factors affecting the willingness of households to use HCG technology in the forest area of Heilongjiang Province, using the technology acceptance model (TAM) framework and the partial least squares (PLS) method. The study found that the perceived usefulness (PU) had a significantly positive effect on the willingness to accept the technology. The perceived ease of use (PEOU) affected the willingness to use the HCG technology via the perceived usefulness (PU). Facilitating conditions (FC) not only directly affected the PEOU, but also indirectly affected the PU via the PEOU. The results of the study should provide useful insight into the promotion and application of new forestry technologies.

\section{Neem tree agroforestry practices for degraded soil recovery in tropical areas}

Paul Luzuriaga ${ }^{1,2}$, Monica Gonzalez ${ }^{1}$, Cesar Moreira ${ }^{2}$

${ }^{1}$ TeamUp Initiative, Guayaquil, Ecuador; ${ }^{2 E S P O L ~ G u a y a q u i l ~ E c u a d o r(l u z u r i a g a m p @ g m a i l . c o m ; ~ m g o n z a b u r @ g m a i l . c o m ; ~ c e m o r e i r @ e s p o l . e d u . e c) ~}$

Since 2007 several plots of Neem tree (Azadirachta indica) and Neem tree plus agroforestry techniques have been tried in the Santa Elena province, a coastal region in Ecuador.The area where the trials took place had eroded soils, highly mineralized because of intensive fertilizer usage and dry weather with precipitations below $300 \mathrm{~mm}$ per year. Vegetation as scarce mostly as small bushes characteristic in dry tropical forests. Also, previous owner and local people have tried to produce short term crops with unsuccessful results. The study started by finding endemic species capable to survive in dry weather. Saman, Guayacan and Neem tree were found in the region. Propagation techniques were applied to these species under low irrigation conditions. Neem tree seemed successful with almost 57\% survival while others presented 19\% for Saman and 33\% for Guayacan. After a 7 years adaptation process, Neem tree propagation achieved $73 \%$ survival as seedlings, and $64 \%$ after planted in the field.Plots developed with agroforestry practices produced micro-climates capable of retaining air humidity and contribute to pasture growth. Cattle was introduced at the fourth year of forestry management. Cattle management started at 0.5 heads per hectare and stabilized at 2 heads per hectare at the tenth year. Other byproducts were obtained with proper forest management, as dry leaves for infusions, bark powder as mild bactericide, Neem seed extract as organic pesticide, and Neem seeds residue as cattle feedstock.

Agroforestry systems in the Atlantic Forest: assessment and proposals for a diagnosis and propositions in the SPVS environmental preserve in the coastal plain of Paraná, Brazil / Sistemas agroflorestais na Mata Atlântica: diagnóstico e proposições em reserva ambiental da SPVS na planície litorânea paranaense

Stefanie Vieira de Albuquerque ${ }^{1}$, Rodrigo Condé Alves ${ }^{1}$, Ivan Crespo Silva ${ }^{1}$, Alessandro Camargo Angelo ${ }^{1}$

${ }^{1}$ Universidade Federaldo Paraná, Curitiba,Brasil (stefanievieira28@gmail.com; rconde@gmail.com; ivancrespo@ufpr.br; alessandrocangelo@gmail.com)

O presente trabalho foi realizado na planície litorânea do Paraná dentro das reservas ambientais da ONG Sociedade de Pesquisa em Vida Selvagem e Educação Ambiental - SPVS. Esta região possui grande importância ambiental, histórica e econômica para o estado do Paraná. A biodiversidade da Mata Atlântica nesta região em conjunto com a Serra do Mar forma uma das maiores reservas de riquezas naturais de fauna e flora no mundo. A SPVS é uma ONG que atua através de diversos projetos conservacionistas em prol da biodiversidade. Dentre esses projetos, a instituição constituiu três reservas naturais na região: Reserva Papagaiode-cara-roxa, Reserva Natural das águas e Reserva Guaricica que totalizam 18.722,07 hectares de áreas protegidas. Um dos maiores desafios e prioridades destas áreas é captação de recursos para garantir a sustentabilidade econômica e a relação de desenvolvimento com a população local. Diante deste contexto, os Sistemas Agroflorestais podem ser uma solução. Foram diagnosticados potenciais e desafios locais que orientaram a proposta de futuras ações de implantação de Sistemas agroflorestais nas reservas com base em pesquisas de campo, aplicação de questionários e revisão de literatura. Os diagnósticos aplicados apresentaram resultados positivos em relação a aceitação dos sistemas agroflorestais por parte da instituição e funcionários. Foram apresentadas 24 espécies que cumprem com funções especificas no sistema, focando principalmente frutíferas nativas com potencial de beneficiamento e comércio. E por fim, foi apresentado um arranjo das espécies em forma de croqui agroflorestal.

A2a: SUSTAINING ICONIC AND HIGH-VALUE SPECIES IN NATURAL FORESTS AND PLANTATIONS

Interaction of conservation of genetic resources with forest management for mahogany and Spanish cedar in the Yucatan Peninsula, Mexico

Sheila Ward iD $^{\text {I }}$

${ }^{1}$ Mahogany for the Future, Inc., San Juan, Puerto Rico (mahoganyforthefuture@gmail.com)

Various trials and gene banks have been implemented for ex situ conservation of the genetic resources of the high-value species mahogany (Swietenia macrophylla) and Spanish cedar (Cedrela odorata) in the Yucatan Peninsula of Mexico. But these trials can be subject to loss from fire, human interference, hurricanes, or disease. Such was the experience with a set of trials established in community forests (ejidos) in 1996 to 1998. In situ conservation of designated seed trees in community forest reserves might be a more practical solution. Stands can be replicated in different ejidos, reducing overall vulnerability to 
loss.Mexican forest policy encourages ex situ and in situ conservation of forest genetic resources. But work remains to be done for sufficient protection of populations and genetic resources of species under harvest for their long term sustainability. This presentation reviews long term viability and results for various ex situ trials and seed banks for mahogany and Spanish cedar in the Yucatan, especially for the 1996-1998 trials in Quintana Roo. Of two trials of mahogany and two trials of cedar established on community and private lands, only one remain of each. The remaining trials are being converted to seed orchards in Spring 2020. Also considered is the current status of in situ seed stands for these species, and the relative usefulness of ex situ and in situ strategies for maintaining genetic resources. In addition, current harvest policy and possible modifications for better maintenance of populations and genetic variation are considered.

\title{
Management of natural regeneration of Araucaria angustifolia in small farms in Southern Brazil: an alternative for the conservation of the species
}

\author{
Denise Jeton Cardoso ${ }^{1}$, Maria Augusta Doetzer Rosot ${ }^{1}$ (D); Marilice Cordeiro Garrastazún ${ }^{1}$ (D) André Eduardo Biscaia de Lacerda ${ }^{1}$, \\ Yeda Maria Malheiros de Oliveira 1 (D) \\ ${ }^{1}$ Embrapa Florestas, Colombo,Brasil (denise.cardoso@embrapa.br; augusta.rosot@embrapa.br; marilice.garrastazu@embrapa.br; \\ andre.biscaia@embrapa.br; yeda.oliveira@embrapa.br)
}

Araucaria angustifolia (Bert.) O. Kuntze occurs naturally in south and Southeastern Brazil. It has cultural and ecological significance as its seeds are traditionally consumed by local communities and are an important source of food for wildlife. It also has multiple potential uses for timber, paper, and the food industry. Its exploitation is forbidden by law and it is currently listed as critically endangered. Because of legal limitations, regrowth of araucaria trees is seen by landowners as problematic, thus inducing seedling removal. One way to promote its conservation is taking advantage of traditional agroforestry productive systems such as caívas and faxinais that integrate animal husbandry, erva-mate (Ilex paraguariensis), and other crop production in forested areas. Under these conditions, araucaria regeneration is abundant and can be managed for productive and conservation goals. We analyzed two examples of such agroforestry systems and confirmed the potential for maintaining high levels of forest diversity, income generation through livestock and erva-mate production, combined with important regeneration of araucaria. In one area we observed a predominance of Araucaria (48\%) along with 46 other species, and Araucaria plants were distributed in various DBH classes. In the second property, we observed that Araucaria abundance corresponds to around 13\% of the forest with a higher representation in larger DBH classes (up to 86\%) while maintaining a diversity of 44 tree species. Overall, despite its economic potential, the species continues to be a poorly understood resource with limited interest in establishing plantations and maintaining natural stands.

\section{From disaster to opportunity: examining the effects of hurricanes Irma and Maria on mahoganies in Puerto Rico and U.S. Virgin Islands, related policy responses, and potential for enhancing long-term sustainability}

Kathleen Mcginley ${ }^{1}$, Sheila Ward $^{2}$

${ }^{1}$ U.S. Forest Service, International Institute of Tropical Forestry, Rio Piedras, Puerto Rico; ${ }^{2}$ Mahogany for the Future, Inc., San Juan, Puerto Rico (kmcginley@fs.fed.us; mahoganyforthefuture@gmail.com)

In September 2017, two major hurricanes - Irma and Maria - passed through the Caribbean, resulting in significant loss of life, impacts on local economies, and effects on natural resources. Large areas of forest were nearly to completely defoliated and countless trees were uprooted, snapped, or damaged in natural to urban settings. Tree damage and death occurred throughout the islands, including high-value species, such as big-leaf, small-leaf, and hybrid mahoganies. These species are not native to Puerto Rico or the U.S. Virgin Islands, but have become naturalized with extensive planting since they were first introduced in 1790 . Although significant volumes of hurricane-downed mahoganies and other timber species were collected in debris removals as part of the response and recovery efforts in Puerto Rico and the U.S. Virgin Islands, very limited volumes were salvaged for timber and other products, due in large part to limited industrial capacity for wood transformation as well as limited foresight or policy coherence on disturbance-downed wood. The local economic loss has been estimated at millions of dollars. We examine the effects of the 2017 hurricanes on planted and naturalized mahoganies in Puerto Rico and the U.S. Virgin Islands and the related short and long term management and policy responses. We discuss the implications for the sustainable management and use of these high value species, in the context of islands searching for solutions that increase resilience and decrease dependence on imports, including wood products, and which face a likely future of more severe and frequent storms and hurricanes.

\section{Araucaria angustifolia breeding program at Embrapa Florestas}

Valderês Aparecida de Sousa ${ }^{1}$, Ananda Virginia de Aguiar ${ }^{1}$, Miguel Luiz Menezes de Freitas ${ }^{2}$, Alexandre Sebbenn ${ }^{2}$, Jarbas Yukio Shimizu ${ }^{3}$ ${ }^{1}$ Embrapa Florestas, Colombo, Brasil; ${ }^{2}$ Instituto Florestal de São Paulo, São Paulo, Brasil; ${ }^{3}$ Autonomous, Curitiba, Brasil (valderes.sousa@embrapa.br; ananda.aguiar@embrapa.br; miguellmfreitas@yahoo.com.br; alexandresebbenn@yahoo.com.br; shimizujy@gmail.com)

Araucaria angustifolia (Bert.) O. Ktze is a native species from Brazil which plays as important social and economic role, especially in the southernmost region of the country. Currently it is threatened on extinction, and consequently its remnants cannot be exploited. Conservation by use is one feasible way to conserve this tree through plantations ensuring adequate variability. However, the seed supply with high physiological and genetic quality to this plantation is a major problem which could be overcome through breeding programs. Embrapa Florestas (CNPF), together with Instituto Florestal de São Paulo (IF-SP) started a breeding program nearly 40 years ago as provenance/progenies tests, covering a wide natural area. As Araucaria occurs in an over a wide geographical region, southern and Southeastern Brazil, differences between them must be considered in breeding and conservation programs. The introduced tests were submitted to a thinning of $50 \%$ intensity. From recombining of the remaining trees seeds a second generation provenance/progeny tests were established in CuritibanosSC, Ponta Grossa-PR, Caçador-SC, and Monte Belo do Sul-SC. Consequently, a higher productivity gain is expected in relation to the current seed sources. Moreover a participatory improvement is being considered aiming to promote the increasing of variability and the development and use of adapted germplasm to specific conditions. For this purpose a cooperative araucaria breeding project is been implemented among Embrapa Florestas and partners aiming to develop genetically improved seeds and clones of araucaria, based on a wider genetic base to ensure the potential for genetic improvement for consecutive generations.

\section{Threatened by conservation: addressing policy gaps for the maintenance of high-density Brazil nut tree clumps}

Paulo Marcelo Paiva ${ }^{1}$

${ }^{1}$ Embrapa Amapá, Macapá, Brasil (paulo.paiva@embrapa.br)

Considered a cornerstone species in Amazonian forest conservation strategies, the Brazil nut enjoys a unique status. It is immune to cutting and most of its distribution is under some category of protected area. Nonetheless, both nut-gatherers and researchers consistently report insufficient natural regeneration 
levels and the population decline of high-density stands, including at strict nature reserves. The initial hypothesis of seed overharvesting lacks consensus as later studies identified the scarcity of canopy gaps at mature forests as the main cause for the recruitment failure of this gap-loving species. This observation supports the anthropogenic origin hypothesis and is consistent with the abundant recruitment observed in traditional swiddens, where the regeneration density increases with the number of cultivation cycles. This is due to a number of factors, including the scatterhoarder habit of the natural disperser, gap-clearance frequency, species' resistance to fire and remarkable re-sprouting capability. Nut-gatherers intuitively understand the role of swiddens for the maintenance and expansion of high-density Brazil nut stands, and many voluntarily protect their spontaneously enriched fallows from further cultivation cycles. Surprisingly, the very conservation policies end up hindering such traditional management practices. For example, when forbidding nut-gatherers/swidden-farmers from clearing new plots of forest in exchange for those fallows they chose to protect. Expensive, labor-intensive and unpopular recommendations like enrichment planting are puny alternatives for what the ubiquitous swiddens can do, provided revised policies allow them to. Failing that, densities of senescent Brazil nut stands will continue to decrease until hardly justifying the "sustainable alternative to deforestation" discourse.

\section{Morphometry of Araucaria angustifolia at different altitudes in Southern Brazil applied in the identification of critical growth points Pollyni Ricken ${ }^{1}$ (D) André Felipe Hess ${ }^{2}$, Patrícia Póvoa de Mattos ${ }^{3}$ (D) Nelson Yoshihiro Nakajima ${ }^{1}$, Roberto Tuyoshi Hosokawa ${ }^{1}$ ${ }^{1}$ Universidade Federal do Paraná, Curitiba, Brasil; ${ }^{2}$ Universidade do Estado de Santa Catarina, Lages, Brasil; ${ }^{3}$ Embrapa Florestas, Colombo, Brasil (pollyni7@hotmail.com; andre.hess@udesc.br; patricia.mattos@embrapa.br;nelson.nakajima@ufpr.br; roberto.hosokawa@pq.cnpq.br)}

The aim of this study was to use morphometric characteristics of Araucaria angustifolia, as basis to elaborate management plans. Data was collected in three sites of Santa Catarina State: S1 (altitude of 1,350 m), S2 (1,150 m) and S3 (950 m). Random sampling and Bitterlich method were applied using 2 as basal area factor. We sampled 247 individuals (77 at S1, 93 at S2 and 77 at S3). The degree of indexes association was examined by Pearson correlation coefficient. S2 was constituted by larger trees, indicating better growth conditions. S3 presented the highest density of trees (403 trees.ha-1), while at S1 and S2 there were 362 and 188 trees.ha ${ }^{-1}$, respectively. At S3 most trees had a crown proportion greater than 50\% and crown formal smaller than 1, reflecting trees with narrower and longer crowns. The height/diameter ratio was similar among sites (0.4 to 0.5). Diameter correlation with slenderness ratiowas negative and bigger than $70 \%$. In all sites diameter at $1.30 \mathrm{~m}$ from ground level (DBH) showed positive relation with crown diameter, indicating that as trees increase in DBH, crown diameters also increase. The removal of competing trees becomes essential to increase growth rate by increasing space and light incidence. Morphometric indexes can be used to support sustainable forest management plans, allowing the identification of critical points related to the trees development pattern.

Adapting the Prodan method for sampling species associated with Araucaria angustifolia (Bertol.) Kuntze /Adaptação do uso do método de Prodan para amostragem de espécies associadas a Araucaria angustifolia (Bertol.) Kuntze

Joelmir Augustinho Mazon ${ }^{1,2}$, Richeliel Albert Rodrigues Silva ${ }^{1,3}$, Luciano Farinha Watzlawick ${ }^{1}$

${ }^{1}$ Universidade Estadual do Centro Oeste, Guarapuava, Brasil; ${ }^{2}$ Faculdade Guairacá Guarapuava Brasil; ${ }^{3}$ Universidade Federal do Rio Grande do Norte

Natal,Brasil (joelmir23@hotmail.com; richelielufrn@gmail.com; farinha@unicentro.br)

Este trabalho objetivou a adaptação do método de amostragem de área variável de Prodan para o estudo de espécies de porte arbóreo que ocorrem com maior frequência próximas à Araucária (Araucaria angustifolia), considerando estas como espécies associadas desta espécie. Para tanto, percorreram-se cinco transectos equidistantes paralelamente em 100 metros, totalizando 1.830 metros de caminhamento em um fragmento de Floresta Ombrófila Mista de 22 hectares no Parque Natural Municipal das Araucárias, em Guarapuava, PR. A aplicação do método consistiu na demarcação de indivíduos de Araucária ao longo de cada transecto,utilizando-os como ponto central para a unidade amostral e a cada destes, determinou-se o raio das seis árvores mais próximas, as quais foram identificadas taxonomicamente e classificadas quanto à sua frequência absoluta. Foram mensurados 55 indivíduos de Araucária ao longo de todos os transectos, cujo os diâmetros variaram em média 71,5 $\pm 26,8 \mathrm{~cm}$, contemplando uma área total amostrada de 0,54 hectares e um total 38 espécies encontradas. As espécies mais frequentemente identificadas consideradas como associadas da Araucária foram: Campomanesia xanthocarpa O. Berg, que ocorreu próxima de 51\% das Araucárias observadas, Casearia decandra Jacq. (34,5\%), Gymnanthes klotzschiana Müll. Arg. (30,1\%), Araucaria angustifolia e Cinnamodendron dinisii Schwanke (27,3\%), Allophylus edulis (A. St- Hil., Cambess e A. Juss.) Radlk (20\%) e Matayba elaeagnoides Radlk. (18,2\%). A adaptação do método de Prodan mostra-se uma ferramenta útil para o entendimento da ecologia e fitossociologia da Araucaria angustifolia, podendo ser utilizada para projetos de manejo e conservação desta espécie icônica e tão ameaçada no Brasil devido a sua importância econômica.

Genetic analysis of growth curves of individual trees and country-wide provenances of Araucaria angustifolia shows huge potential for enhanced domestication, breeding and conservation of this iconic Brazilian conifer

Rafael Tassinari Resende ${ }^{1}$, Pedro Tanno ${ }^{2}$, Orzenil Bonfim Silva-Junior ${ }^{3}$, Ananda Virginia de Aguiar ${ }^{4}$, Valderês Aparecida de Sousa ${ }^{4}$, Alexandre Sebbenn ${ }^{5,6}$, Dario Grattapaglia ${ }^{3,7}$

${ }^{1}$ Universidade Federal de Goiás, Goiânia, Brasil; ${ }^{2}$ Universidade de Brasília, Brasillia, Brasil; ${ }^{3}$ Embrapa Recursos Genéticos e Biotecnologia, Brasília, Brasil; ${ }^{4}$ Embrapa Florestas, Colombo, Brasil; ${ }^{5}$ Instituto Florestal de São Paulo, São Paulo, Brasil; ${ }^{6}$ Universidade Estadual Paulista "Júlio de Mesquita Filho”, Ilha Solteira, Brasil; ${ }^{7}$ Universidade Católica de Brasília, Brasilia, Brasil (rafael.tassinari@gmail.com; tanno.pedro@gmail.com; orzenil.silva@embrapa.br; ananda.aguiar@embrapa.br; valderes.sousa@embrapa.br; alexandresebbenn@yahoo.com.br;dario.grattapaglia@embrapa.br)

Understanding the growth behavior of forest tree species is important for early selection, and to understand ecological patterns, predict future biomass and adaptive tree fitness. We investigated the genetic variation for growth traits of Araucaria angustifolia in a trial involving 122 families from 15 provenances from three Brazilian regions. Measurements at ages 7, 24, 32, 33 and 35 were used to adjust continuous growth curves based on nonlinear mixed-effect models for all 2,158 trees, providing estimates for unmeasured ages in the 7-35 interval. Estimated values closely matched observed ones and a reduction of the coefficient of residual variation was observed in the estimated data, possibly due to removal of random error in observed measurements, making the estimated curves more reliable to predict growth patterns. Genetic variation within provenances was greater than between, with a trend of increasing heritabilities over time for most provenances. Growth curves show that trees invest first in DBH and later in height, and even at age 35 A. angustifolia does not show biomass growth stagnation. Provenances with great potential for breeding and genetic conservation were identified with variable adaptation to support global climate and landscape change. The data clearly indicate potential for early selection at age 7-10 with $85 \%$ accuracy of selection at age 35 , and possibility of shortening rotation age to $15-20$ years by selecting the best individuals and families. These results underscore the huge potential of expanding investments in breeding and plantation forestry of A. angustifolia with a concomitant enhancement of conservation efforts. 
Growth of different progeny of Araucaria angustifolia (Bertol.) O. Kuntze in Southwestern Paraná, Brazil / Crescimento de diferentes progênies de Araucaria angustifolia (Bertol.) O. Kuntze no Sudoeste do Estado do Paraná

Marcos Eduardo da Silva Santos ${ }^{1}$, Emanoele Cristina Weiss ${ }^{1}$, Wellington Mateus Ribeiro Dzindzik ${ }^{1}$, Michel Anderson Masiero ${ }^{1}$, Eleandro José Brun ${ }^{1}$ (D

${ }^{1}$ Universidade Tecnológica Federal do Paraná, Dois Vizinhos, Brasil (marcoseduardoferraz12@gmail.com; weissemanoele@gmail.com;

wellingtondzindzik@alunos.utfpr.edu.br; masiero@alunos.utfpr.edu.br; eleandrobrun.utfpr@gmail.com)

Araucaria angustifolia é considerada uma espécie ameaçada de extinção, devido à exploração indiscriminada e erosão genética historicamente ocorrida. Existe uma grande necessidade de pesquisas e melhoramento da espécie visando conservação e uso sustentável da mesma. Neste trabalho, avaliou-se o desempenho silvicultural de diferentes progênies de A. angustifolia, em experimento emdelineamento inteiramente casualizado (DIC), implantadas em julho/2016, em 30 tratamentos (progênies) oriundas de Santa Catarina (15) e Paraná (15), com três repetições de cinco mudas cada. Este trabalho apresenta os resultados do inventário realizados aos dois anos de idade, para as variáveis: Diâmetro do colo (D); Altura (H) e Vigor (V), as quais foram submetidas a análise de variância e teste de médias de Tukey a 5\% no programa SISVAR v; 5.6. Houve diferença significativa entre as progênies para H e D, onde a maior média para H foi na progênie 957PR $(1,54 \mathrm{~m})$ diferindo significativamente de algumas progênies como a 958PR (0,18 m) que obteve a menor altura. No D, o maior valor ocorreu na progênie 963PR $(4,2 \mathrm{~cm})$ e a menor foi a 954PR $(0,35 \mathrm{~cm})$. Quanto ao vigor $(\mathrm{V}), 96,6 \%$ apresentam o vigor médio, 2,2\% baixo e 1,2\% alto, mostrando que as plantas ainda estão em processo de adaptação. Ocorreram diferenças significativa entre o crescimento das araucárias, onde as progênies do Paraná (PR) apresentam-se melhor adaptadas que as de Santa Catarina (SC), principalmente as progênies 963PR e 957PR que obtiveram as melhores médias e vigor superior.

\section{Roads with Araucarias: payment for ecosystem services project for small-scale rural producers}

Edilson Batista de Oliveira ${ }^{1}$

${ }^{1}$ Embrapa Florestas, Colombo, Brasil (edilson.oliveira@embrapa.br)

Araucaria angustifolia is the symbolic tree species of Southern Brazil. However, its extensive exploitation over several decades to meet domestic and export market demands for lumber, as well as the expansion of agriculture, has resulted in a significant reduction in the species' population and its inclusion on the Brazilian list of threatened species. Through Payment for Ecosystem Services, the Roads with Araucarias Project encourages the planting of $A$. angustifolia along roadways and property lines on small-scale family farms. Rural producers plant A. angustifolia trees on their properties and are remunerated by private companies who use the trees as compensation for greenhouse gas emissions and to promote other ecosystem services, such as roadway landscaping, environmental protection, preservation of the $A$. angustifolia species, environmental education, production of $A$. angustifolia pine nuts (pinhões), benefits for fauna, and shade for cattle. The project also seeks to increase the population size of $A$. angustifolia. Each producer receives R\$ 1,000 (approximately US\$ 300 ) annually for every 200 trees that he/she plants and maintains along roadways. The project began in 2011 and includes 70 properties in the municipalities of Lapa, Fazenda Rio Grande, and Irati, Paraná, and Caçador, Santa Catarina. In the four municipalities, 20,000 trees have been planted. However, the most positive result is the dissemination of the technique to other rural property owners, particularly those that are not small-scale farmers. Producers have voluntarily adopted the practice of planting $A$. angustifolia along property lines because of the advantages these trees offer, including improved aesthetics.

\section{Overcoming constraints for incorporating valuable-timber native species in the mesoamerican humid lowlands: recent research findings on Roseodendron donnell-smithii}

Boris Mendez-Paiz

${ }^{1}$ University San Carlos de Guatemala, Agriculture and Environmental Research Institute, Guatemala, Guatemala (bmpaiz@yahoo.com)

High diversity of tree species is a remarkable feature of humid tropical lowland landscapes; land conversion, forest degradation and overexploitation of wood are reducing populations of native valuable timber producer species. Cultivation of such species is a highly desirable goal in different forestry and agroforestry plantations; however, that is hampered by the scarcity of knowledge on their ecological requirements and feasible silvicultural treatments. This paper describes recent research on the ecology and silviculture of Roseodendron donnell-smithii, a valuable timber producer, native of the humid lowlands of Mesoamerica. Species remnant populations are restricted to agroforestry plantations in Guatemala, mostly on Coffee and Silvopastoral Systems due to its value for shade, ornamental and valuable cabinet-timber. Failure of monoculture plantations established in a variety of sites throughout Guatemala with government incentives during the last two decades, raised awareness on needed knowledge of the auto-ecology of the species as the foundation for proper silviculture. Species recent research addressed site requirements, genetic variability and conservation, timber yield potential and stand productivity in mixed stands with other timber species and some permanent agricultural crops as an alternative to monoculture. Research findings for Roseodendron donnell-smithii are demonstrating that successful cultivation of valuable tropical native species is feasible for multiple purposes including productive, conservation and restoration, as long as species ecological knowledge support appropriate design and management practices. Long-term research and collaborative efforts among different stakeholders at national and international levels is essential to enhance innovation for increasing the use of such species.

A2p: SUSTAINING ICONIC AND HIGH-VALUE SPECIES IN NATURAL FORESTS AND PLANTATIONS

Effects of the microclimate of different forest community type on the distribution of endangered fern, Mankyua jejuense in Jeju Island in South Korea

Younghan You ${ }^{1}$, Euijoo Kim ${ }^{1}$, Eungpil Lee ${ }^{1}$, Seungyeon Lee ${ }^{1}$, Yongsik Hong ${ }^{1}$, Hyunmo Jung ${ }^{2}$

${ }^{1}$ Kongju National University, Kongju, Republic of Korea; ${ }^{2}$ National Inistitute of Ecology, Seochon, Republic of Korea (youeco21@kongju.ac.kr; euijoo@kongju.ac.kr; lyp2279@kongju.ac.kr; ecolee21@kongju.ac.kr; hongfin@smail.kongju.ac.kr; eimple01@nie.re.kr)

Endangered plant, Mankyua jejuense (fern), which is distributed only in Jeju Island in South Korea, is one of the smallest one in the world. This species appears to be habitats called Gotjawzl where the geology and soil of the basaltic plain are scarcely developed, and temporary seasonal wetlands are often formed by summer heavy rains. In particular, in terms of climate zone, the potential natural vegetation in this area is evergreen broad-leaved forest, but there is almost no Mankyua jejuense in this area. Instead, it is distributed mainly in the floor of the deciduous forest, which can be said to be the disclimax forest type of this area. In this study, we monitored and analyzed the microclimate of weather, light and soil factors in two different forests type of Jeju Island. Through this study, we tried to clarify the difference of the microclimatic conditions of the two forests type and attempt to interpret the influence of such microclimate factors on 
Mankyua jejuense. As a result, the number of inundation frequency and soil water content were higher in Castanopsis sieboldii community (evergreen) than that of Ulmus parvifolia community (deciduous), and the inundation level and light intensity were opposite. The average monthly light intensity was higher in Castanopsis sieboldii community (evergreen) than of Ulmus parvifolia community (deciduous). In conclusion, Mankyua jejuenseis weak against flooding and low light intensity. These microenvironmental characteristics are thought to be derived from two different life forms of woody plant communities in the upper layer.This funded by project of the Korea Research Foundation (No. NRF-2018R1D1A1B07050269) Korea government (Ministry of Education)

Initial mortality in clones of Ilex paraguariensis A. St. -Hil (erva-mate) in plantations in Southwestern Paraná, Brazil / Mortalidade inicial de clones de Ilex paraguariensis A.St. -Hil (erva-mate) em plantio na região sudoeste do Paraná

Gabriel Michalichen ${ }^{1}$, Henrique Ribeiro ${ }^{1}$, Débora Kreczkiuski ${ }^{1}$, Marjorie Eliza Maia Reis ${ }^{1}$, Eduardo Pimentel Araldi ${ }^{2}$, Eleandro José Brun ${ }^{1}$ (D) Ivar Wendling ${ }^{3}$ (D)

${ }^{1}$ Universidade Tecnológica Federal do Paraná, Dois Vizinhos, Brasil; ; ${ }^{2}$ Colégio Estadual Leonardo da Vinci, Dois Vizinhos, Brazil; ${ }^{3}$ Embrapa Florestas, Colombo,Brasil(gabrielmichalichen@gmail.com; henrique-ribeiro-chap@hotmail.com; debora-kreczkiuski@hotmail.com; marjorieeliza99@hotmail.com; edwardomarrola@gmail.com; eleandrobrun.utfpr@gmail.com; ivar.wendling@embrapa.br)

A erva-mate é uma espécie florestal de grande importância não madeireira, tanto economicamente como culturalmente, por ser produtora da matéria prima do chimarrão e de uma série de outros produtos alimentares, cosméticos e medicinais. Estudos estão em andamento com 8 diferentes clones diferenciados em função de características relacionadas a qualidade dos produtos potenciais, em parceria com a Embrapa Florestas. Os mesmos foram plantadas em 4 blocos com 5 mudas de cada clone por bloco, em espaçamento de $1,50 \mathrm{~m}$ x 1,50 m, com preparo mecanizado do solo (escarificação) e covas manuais de $20 \mathrm{~cm}$ de profundidade, com o uso de hidro gel e sombreamento por tabuas do lado oeste, em plantio realizado em Agosto de 2018. Tratos culturais de controle de invasoras e formigas cortadeiras vem sendo realizado rotineiramente. Avaliou-se, visualmente, a mortalidade das mudas clonais aos 90 dias após o plantio, onde o clone 3 apresentou porcentagem (\%) de mortalidade igual a 0\%, clone 12 igual a 5\%, clone 81 igual a 5\%, clone 82 igual a $5 \%$, clone 1 igual a $15 \%$, clone 101 igual a 15\%, clone 83 igual a 30\% e clone 84 igual a 35\%. Ocorreram grandes diferenças no índice de mortalidade, que variou de 0\% (clone 3) a 35\% (clone 84), mostrando que o nível de estresse ambiental decorrente da adaptação inicial a área de campo é diferente entre os clones, os quais se comportam de forma variada em sua reação ao clima local.

Spacing patterns for Araucaria angustifolia (Bertol.) Kuntze in two management systems for Mixed Ombrophile Forest / Padrão espacial da Araucaria angustifolia (Bertol.) Kuntze em dois sistemas de manejo na Floresta Ombrófila Mista

Luciano Farinha Watzlawick ${ }^{1}$, Richeliel Silva ${ }^{1}$, Joelmir Mazon ${ }^{1}$

${ }^{1}$ Universidade Estadualdo Centro Oeste, Guarapuava,Brazil; (farinha@unicentro.br; richeliel@yahoo.com.br; joelmir23@hotmail.com)

Araucaria angustifolia é um espécie pertencente à família Araucariaceae, nativa do Brasil e em risco de extinção. Objetivou-se neste estudo analisar o padrão espacial da espécie em dois fragmentos de Floresta Ombrófila Mista, sendo o primeiro sob sistema silvipastoril e o segundo uma floresta em processo de sucessão secundária. A amostragem foi realizada em duas parcelas de 1,2 hectares, na propriedade particular Edelweiss, no município de Turvo, Paraná. Para isso, foram registradas as coordenadas (x,y) de cada ponto, com objetivo de testar a hipótese de completa aleatoriedade espacial (hipótese nula), por meio da função K de Ripley, na forma univariada, sendo avaliado o padrão espacial de todos os indivíduos da espécie, como também a distribuição em duas classes diamétricas ( 5 a $20 \mathrm{~cm}$ e igual ou superior a $20 \mathrm{~cm}$ ), no programa SpPack 1.38. A espécie apresentou distribuição espacial agregada nas áreas de floresta em sucessão secundária e silvipastoril, indicando que as sementes foram dispersas próximas à planta mãe. Em relação aos indivíduos das classes diamétricas de 5 a $10 \mathrm{~cm}$ nas duas áreas, o padrão observado também foi agregado. Nas classes superiores a $20 \mathrm{~cm}$, o padrão verificado nas duas áreas foi aleatório. $\mathrm{O}$ referido padrão é esperado para as classes com maiores diâmetros, devido à baixa competição e mortalidade, estabelecendo-se assim, os indivíduos mais resistentes. Pode-se concluir que a $A$. angustifolia apresenta o mesmo padrão espacial nos dois sistemas de manejo. Diante disso, os resultados obtidos podem auxiliar no manejo da espécie, contribuindo para sua conservação.

\section{Effects of multi-stem, stand density on cone and timber production of Pinus koraiensis in a cone production circle}

Hailong Shen ${ }^{1}$, Nguyen Thanh Tuan ${ }^{2}$

${ }^{1}$ Northeast Forestry University, Harbin, China; ${ }^{2}$ Vietnam National University of Forestry, Southern Campus, Dong Nai, Vietnam (shenhl-cf@nefu.edu.cn; tuanvfu2@gmail.com)

Korean pine is an excellent timber and nutritious seed production tree species natively distributed in Northeast China and adjacent areas. Recently, its edible nut production has become a most important issue to the local economic development. During the growth and development of Pinus koraiensis, very popular multi-stem phenomenon and stand density has great influence on its timber and seed production. Therefore, four different stand density treatments in a 40-yearold Korean pine plantation were set and an investigation were conducted in a stand with artificial top-pruning 16 years ago to study the effects of multi-stem and stand density on cone production and tree growth in one fruiting circle. The results shown that (1) there was significant positive correlations between natural multi-stem of Pinus koraiensis trees and plantation density; both natural multi-stem and top-pruning derived multi-stem were favorable to increase of timber production and cone production of Korean pine in tree level and stand level as well; (2) Korean pine plantations in about 40-year-old at 600-750 trees $\times \mathrm{hm}^{-2}$ and multi-stem occurring position above 8-10 m were favorable to high-quality bole timber production and yield and quality promotion of cones and seeds as well; (3) Double stem trees should be taken as the main cultivation ones because this tree types was the majority in stand, distributed uniformly, had much more contribution to cone production, had better bole production than that of non-multi-stemmed and single-multi stemmed types, and had weak competition and small ecological resource occupancy than that of multiple multi-stemmed type.

Diameter growth of Retrophyllum rospigliosii in the Colombian Andes / Crecimiento diamétrico de Retrophyllum rospigliosii en los Andes Colombianos

Jorge Ramirez $^{l}$ (D); Alejandro Gomez ${ }^{2}$, Adriana Marin ${ }^{3}$, Jorge Ignacio Del Valle ${ }^{2}$

${ }^{1}$ Universidad del Cauca, Popayan, Colombia; ${ }^{2}$ Universidad Nacional de Colombia, Medellin, Colombia; ${ }^{3}$ Smurfit Kappa Cartón de Colombia, Cali, Colombia(j.ramirez@unicauca.edu.co; agomezch@unal.edu.co; adriana.marin@smurfitkappa.com.co; jidvalle@unal.edu.co)

Las plantaciones tropicales con especies nativas se plantean como alternativa al uso de especies exóticas debido a su aceptación en términos ecológicos y sociales. El pino colombiano (Retrophyllum rospigliosii) se ha sugerido para la reforestación comercial debido a sus posibles usos para aserrío y pulpa de fibra larga. En plantaciones de $R$. rospigliosii de 20 años en cuatro sitios contrastantes de los Andes colombianos modelamos el crecimiento del diámetro (D) 
en función de la edad (t) con la ecuación diferencial de tasas de crecimiento relativizadas de von Bertalanffy mediante modelos mixtos no lineales. Ajustamos un modelo multinivel Bayesiano con dos grupos anidados, sitio e individuo, obteniendo un R-cuadrado Bayesiano de 99 \% y cumpliendo los supuestos de la regresión. Nuestros resultados sugieren que esta especie creció hasta $\mathrm{D} \approx 30 \mathrm{~cm}$ en $\mathrm{t} \approx 18$ años; luego el crecimiento fue casi nulo. El crecimiento medio anual de $1.6 \mathrm{~cm}$ año-1, se maximizó rápidamente en $\mathrm{t}=1.2$ años cuando $\mathrm{D}=1.7 \mathrm{~cm}$. En contraste, otra conífera comúnmente plantada, Pinus patula en sitios medios y densidades comparables alcanza en Colombia $\mathrm{D}=45 \mathrm{~cm}$ en $\mathrm{t}=20$ años, y continúa creciendo a altas tasas. $R$. rospigliosii no parece una alternativa atractiva para la producción maderera. Se sugiere su preservación en condiciones naturales, su empleo en restauración y en reconstrucciones climáticas dada su longevidad y la existencia de anillos de crecimiento anuales.

\title{
Experiments with mahogany plantations (Swietenia macrophylla King) in integrated forest-livestock and agroforestry systems in the Western Amazon / Experiências com o plantio de mogno (Swietenia macrophylla King) em SAF e ILPF, na Amazônia Ocidental
}

\author{
Silas Garcia Aquino de Sousa ${ }^{1}$, Elisa V. Wandelli ${ }^{1}$, João Carlos Matos ${ }^{2}$ \\ ${ }^{1}$ Embrapa Amazônia Ocidental, Manaus, Brasil; '2Gardeners Consulting, Manaus, Brasil (silas.garcia@embrapa.br; elisa.wandelli@embrapa.br; \\ joaomatosconsult@gmail.com)
}

Na Amazônia, plantio de Swietenia macrophylla em escala comercial enfrenta grande desafio. Objetivou-se neste trabalho sistematizar experiências com o plantio de mogno, ao longo de 26 anos de pesquisa agroflorestal, na Região Metropolitana de Manaus-AM (RMM). O plantio mais antigo foi realizado em jan/1993, na Estação Experimental da Embrapa (2 $\left.2^{\circ} 51^{\prime} 13^{\prime \prime}-60^{\circ} 02^{\prime} 95^{\prime \prime}\right)$. Os mogno foram plantados conjuntamente com Inga edulis e distribuídos em três sítios (1,5 ha), em três condições de plantio e uma testemunha, uma em SAF-multiextratificado, consociado com Theobroma gradiflorum, entre outros nove componentes e duas em ILPF-agrosilvipastoril 1 (altos insumos) e 2 (baixos insumos), consorciado com Schizolobium amazônico, pastagem e culturas agrícolas, totalizando 66 mognos/tratamento. Aos 26 anos do plantio, verificou-se no sítio 2 e iLPF 1 indivíduos com maiores DAP (média 48,50 cm), maiores alturas, comercial (média 10,0 m) e altura total (media 19,0 m) e sobrevivência de 75\%. No SAF-multiextratificado verificou-se maior índice de mortalidade (95\%). Ensaios em outros sítios na RMM, os resultados foram semelhantes. O plantio em ILPF apresentou melhor resultado em DAP, altura e sobrevivência, por causa da adubação periódica com o plantio de Zea mays e renovação da pastagem. O plantio sombreado dentro de capoeira ou em agroecossistemas já estabelecidos apresentam severo ataque de Hypsipyla grandella. Entretanto, deixar a capoeira ou o ingá crescer junto com o mogno é uma alternativa de menor ataque de $\mathrm{H}$ grandella. $\mathrm{O}$ mogno é uma espécie exigente em solos férteis e apresenta melhor desempenho em ILPF.

\section{Araucaria angustifolia pollen handling and germination}

Valderês Aparecida de Sousa ${ }^{1}$, Giovana Guimarães ${ }^{2}$, Dayane Tomigian ${ }^{1}$, Ananda Virginia de Aguiar ${ }^{1}$

${ }^{1}$ Embrapa Florestas, Colombo, Brasil; ${ }^{2}$ Universidade Federal do Paraná, Curitiba, Brasil (valderes.sousa@embrapa.br; ggiovanaguima@gmail.com; dayane.tomigian@gmail.com; ananda.aguiar@embrapa.br)

Conservation of Ombrophilous Mixed Forest tree species in Brazil is imperative. Araucaria angustifolia (Bert.) O. Ktze is an important tree species over exploited and threatened on extinction. Ex situ conservation through pollen storage, under suitable conditions, could be an alternative to keep male diversity. However an adequate pollen handling methods must be developed specifically. There are critical steps like collection, drying, storage, as well viability estimation. Our goal with Araucaria pollen in long term is to keep pollen at deep freezing temperatures as long as possible and evaluate it with appropriate methodology. Here we will introduce results of pollen germination submitted to different freeze drying levels, and culture media regarding medium composition. Germination trials were conducted in randomized complete block design and four replications for treatment. Freeze drying for 15 and 30 minutes; one hour; two hours and four hours has been considered. Germination was leading on a culture medium with agar (0.8\%), sucrose (10 \%) and Brewbaker and Kwack (1963) solution for 72 and 96 hours. From these results it was concluded that germination was low both for 72 and for 96 periods affecting conclusions about treatments even with sucrose addition. As a longer period of germination is not possible, due to the contamination, other variables must be considered, as the increase of the rehydration period before germination, among others, to optimize protocols of pollen germination.On the other hand, the use of specific stain could be also useful to estimate the viability of Araucaria pollen in the future.

\section{Benefits from the use and practice of non-timber forest products in Amazonia / Beneficios do uso e costume de PFNM da Amazônia}

Maria Isabel Araújo ${ }^{1}$, Silas Garcia Aquino de Sousa ${ }^{2}$ Evandro de Morais Ramos ${ }^{1}$

${ }^{1}$ Universidade Federal da Amazônia, PPGSCA, Manaus, Brasil;; 2Embrapa Amazônia Ocidental, Manaus, Brasil; (miar@terra.com.br; silas.garcia@embrapa.br; evandro.ramos@ufam.edu.br.)

Os produtos florestais não madeireiros (PFNM) em grande número são utilizados como: alimentícios, aromáticos, artesanais, industriais, medicinais, ornamentais, além disso, configura-se como uma alternativa de renda aos agricultores familiares da região. Objetiva o presente identificar os PFNM, ofertados e demandados nas feiras regional da Agência de Desenvolvimento Sustentável do Amazonas (ADS/AM), em Manaus/AM. Quanto ao método de investigação, utilizou-se a pesquisa-ação, cujo lócusda pesquisa compreendeu as feiras semanais da ADS/AM, localizadas na Associação dos sargentos do exército (ASA), Associação dos sargentos da aeronáutica (Cassam), pátio do Comando da Policia Militar, pátio do Shopping Sumaúma Park, coletados no $2^{\circ}$ semestre de 2017. Verificou-se a oferta de uma grande diversidade de produtos e derivados de plantas da floresta e agroflorestal, Estes produtos são bastante demandados pelas populações do campo e da cidade, sendo utilizados como alimento, na medicina popular, cosméticos e demais usos. Observou-se a oferta com registro de 60 espécies, distribuídas em 18 famílias botânica. Destaque para: Carapa guianensis, Protium heptaphyllum, Myrciaria dubia, Bertholletia excelsa, Lecythis pisonis, Copaifera officinalis, Dipteryx odorata, Pourouma cecropiifolia, Byrsonima crassifolia, Conepia bracteosa, Oenocarpus bataua, Astrocaryum aculeatum, Endopleura uchi, Hymenaea courbaril, Calycobulus ferrugineus, Parahancornia fasciculata. A comercialização destes produtos nas feiras regionais permite que a população da cidade tenha acesso facilitado destes produtos e derivados, seja na forma in natura ou beneficiados. Conclui-se que, a utilização racional dos PFNM, além de manter a floresta em pé, transforma este grande potencial da biodiversidade Amazônica em vários benéficos tanto às populações do campo como da cidade. 


\section{A3a: FOREST OPERATIONS: A TOOL FOR FOREST MANAGEMENT}

\section{Assessing the cost and risks of owning and operating used machines}

Dalia Abbas ${ }^{1}$, Fulvio Di Fulvio², Enrico Marchi ${ }^{3}$, Raffaele Spinilli ${ }^{4}$, Mike Schmidt $^{5}$, Ted Bilek ${ }^{6}$, Han-Sup Han ${ }^{7}$

${ }^{1}$ American University, Washington, DC, USA; ${ }^{2} I I A S A$, Vienna, Austria; ${ }^{3}$ UNIFI, Florence, Italy; ${ }^{4} I V A L S A$, San Michele all'Adige TN, Italy; ${ }^{5}$ Self, Moline,

USA; ${ }^{6}$ Forest Service, Madison, WI, USA; ${ }^{7}$ Northern Arizona University, Flagstaff, USA(daliaabbas@yahoo.com; difulvi@iiasa.ac.at;

enrico.marchi@unifi.it; spinelli@ivalsa.cnrit; schmidtjamesm@johndeere.com; tbilek@fs.fed.us; han-sup.han@nau.edu)

The market for used forestry machines is growing. Standard machine costing methods do not account for already depreciated or used machines in a manner that reflects operations run by small-sized firms. This is because the assumptions made for new machines are not very descriptive of the actual conditions of the operations on the ground using used machines - no one size fits all. As a result, these methods alienate this segment of the logging community, because they are not very relevant to what they paid for the machine, nor the actual performance on the ground. To address this issue, this presentation is based on an expertbased understanding developed to integrate operational-economic-market factors in costing used machines. The intent is to help used machine operators more realistically value the cost of their operations in relation to the machines used and their production.

\section{Forest operations for ecosystem services}

Yeon-Su Kim ${ }^{1}$, Han-Sup Han ${ }^{1}$

${ }^{1}$ Northern Arizona University, Flagstaff, USA; ${ }^{1}$ Northern Arizona University, Flagstaff, USA (ysk@nau.edu; han-sup.han@nau.edu)

Forest operations have been traditionally understood as a means of timber harvesting, which is just one of various ecosystem services that forests provide for human well-being. Today, forest operations are an integral part of ecological restoration efforts, which aim to enhance synergic delivery of various ecosystem services, such as healthy watershed and biodiversity, as well as resilience under changing climate. We will present a case of forest restoration activities in American Southwest where overabundant small-diameter trees create high risk of unnatural, mega-fires. Necessary restoration treatments to remove smalldiameter trees face challenges due to high costs of harvesting and transportation and low values associated with small-diameter logs and biomass materials. Lack of forest products industry in the region, which makes it difficult to market those materials, is a key barrier to implementing a large-scale forest restoration program. We will present the ongoing efforts to develop innovative forest operations and utilization strategies for promoting forest restoration treatments and assess their impacts on various ecosystem services. This presentation will provide an opportunity for participants to share their own experiences dealing with the challenges that they face and promote the discussions on applying forest operations to maximize the synergic effects of ecosystem services delivery.

\section{Full economic valuation and the case for unprofitable forest operations}

Nathaniel Anderson ${ }^{1}$, Robert Campbell ${ }^{2}$

${ }^{1}$ United States Forest Service, Missoula, USA; ${ }^{2}$ University of Montana, Missoula, USA (nathaniel.m.anderson@usda.gov; robert ${ }^{3}$.campbell@umconnect.umt. edu)

As described by Marchi et al. (2018), economic sustainability is one of the five pillars of Sustainable Forest Operations (SFO). Historically, the emphasis of operations has been on extracting timber and other market products from a forest, and economic sustainability has been closely tied to profitability. By minimizing unit costs and maximizing productivity and product value, efficient operations ensure that revenues exceed costs. Emissions and site impacts are assumed to be negative, but manageable. Nonmarket ecosystem goods and services are assumed to be byproducts of effective, profitable forest operations. In the public forests of the western United States, this paradigm has been smashed by landscape-scale tree mortality and poor forest health associated with wildfire, insects and disease. Revenues from the low grade and low value products flowing from fuel treatments, salvage harvests, and forest restoration can be far exceeded by the cost of operations. Net positive environmental effects and enhanced ecosystem services are frequently the implicit justification for unprofitable operations, but these benefits are rarely measured at the project scale, and are seldom the focus of engineering optimization in practice. This paper presents a new methodology to more fully integrate the valuation of non-market benefits into the cost and productivity measures of forest operations. Examples from wildfire fuel treatment and beetle kill salvage are presented to illustrate the importance of explicitly accounting for the non-market costs and benefits of such treatments. This has direct implications for decision making in the SFO framework, especially when operations would otherwise be considered unprofitable.

\section{Planning tools for best practice management of threatened species under the Tasmanian Forest Practices System}

Dydee Mann ${ }^{1}$, Sarah Munks ${ }^{1}$

${ }^{1}$ Forest Practices Authority, Hobart, Australia; ${ }^{1}$ Forest Practices Authority, Hobart, Australia (dydee.mann@fpa.tas.gov.au; sarah.munks@fpa.tas.gov.au)

Australia's island state of Tasmania has around 700 threatened flora and fauna species, many of which are found in wood production areas. Tasmania's "clean, green image" relies on well managed forests where native flora and fauna persist. Under current legislation and policy, potential impacts on these threatened fauna species and their habitat must be considered in all planning for forestry activities. Research into flora and fauna species life history, habitat preferences, distribution and threats feeds into a series of planning tools to support decision-making on the appropriate ways to manage each species under different silvicultural systems. Statewide species range boundary maps and specific habitat descriptions are developed, which help forest planners to recognise areas of the state that require more or less intense species management. Species-specific management recommendations are developed to mitigate the impact of forestry activities and delivered in an online tool, then translated by forest planners into on-ground instructions for forest contractors. Management recommendations are designed to be applied at multiple spatial scales, from coupe-level to the broader landscape, and are reviewed whenever new research findings are released. Importantly, implementation and effectiveness monitoring are carried out to support a continually adaptive management approach. This combination of planning tools, science-based management recommendations and regular review contributes to the success of biodiversity management under the Tasmanian Forest Practices System. 
Evaluating the exposure of chainsaw operators to wood dust in felling operations

Abdullah Emin Akay ${ }^{1}$,Ebru Bilici², Dalia Abbas ${ }^{3}$, Inanç Taş ${ }^{1}$

${ }^{1}$ Bursa Technical University, Bursa, Turkey; ${ }^{2}$ Giresun University, Giresun, Turkey; ${ }^{3}$ American University, Department of Environmental Sciences, Washington,

D.C.,USA(abdullah.akay@btu.edu.tr; ebru.bilici@giresun.edu.tr; daliaabbas@yahoo.com; inanc.tas@btu.edu.tr)

The motorized handheld chainsaw is widely used in felling, delimbing, and bucking tasks during forest harvesting operations. The chainsaw operators usually use chainsaw during most of the work hours which potentially leads to various health risks exposures caused by noise, wood dust, exhaust gas, and vibrations. Wood dust particles, in particular, in ambient air may cause occupational lung diseases due to the collection of dust particles on the lung tissues. These particles are divided into two major groups including big particles (PM10) between 2.5 and 10 micrometers in diameter and small or fine particles (PM $\left.{ }^{2.5}\right) 2.5$ micrometers or less in diameter. In this study, wood dust particles exposed by a chainsaw operator were measured during a felling operation. In the field, wood dusts with various sizes (0.3, 0.5, 1.0, 2.5, 5.0, 10.0 micrometers) were sampled using Extech VPC300; particulate matter measurement device. After analyzing the particle sizes, it was found that the percentages of particulate matter sizes sampled were $60.71 \%, 29.29 \%, 6.99 \%$, $2.80 \%, 0.16 \%$, and $0.04 \%$, respectively. The results indicate that most of the wood dust $(99.80 \%)$ that resulted from the chainsaw operations were categorized as fine particles (PM $\left.{ }^{2.5}\right)$. Based on the analsis using Pearson correlation coefficient, it was found that there was a statistically significant $(\mathrm{p}=001)$ positive correlation between the tree diameter and the amount of wood dust. The results suggest that chainsaw operators are under the risk of fine wood dust exposure, therefore, they should use appropriate personal protection equipment during felling operations.

\section{Short-term effects of forest road construction on bird, mammal, and plant communities: a case study on Forest Road in Minjujisan, Korea \\ Seung-Woo Han ${ }^{1}$, Joon-Woo Lee², Hyoun-Sook Kim², Hakjun Rhee'(10 \\ ${ }^{1}$ Korea Institute of Environment Ecology, Daejeon, Republic of Korea; ${ }^{2}$ Chungnam National University, Daejeon, Republic of Korea (hanus2000@naver.com; jwlee@cnu.ac.kr;woangsister@hanmail.net; hakjun.rhee@gmail.com)}

Forest road is essential for forest management, but it might cause changes in forest ecosystem. This study investigated the short-term effects of forest road construction on bird, mammal, and plant communities by monitoring a newly-built forest road in Minjujisan, Korea before, during, and after the construction from 2012 to 2015 until the monitoring was interrupted by logging operations. From this period the number of bird species decreased from 34 to 24, but the number of bird individuals slightly increased. The major dominant species and species evenness did not change significantly, but species diversity and richness decreased. The bird community in canopy layer was observed frequently, because large tree canopies were well-connected even after the construction. The inhabited birds, especially summer migratory and resident birds, were affected by road construction in summer, and returned after the construction. Mammals used the forest road more frequently than the control area inside forest according to sensor camera analysis. Large mammals such as wild boar, Korea water deer, and roe deer mainly used the forest road as a passage at night. Therefore, the road use in daytime had no major effects on the movement of nocturnal mammals. The number of species and the growth rates of shrubs and herbs increased after the construction, because it opened the canopy, increased light intensity, and brought herbaceous seeds around the forest road. This study found that the forest road construction disturbed the inhabited bird community, but it might have positive impacts on mammal movement and plant growth.

\section{Comparison of productivity, costs, and effect on the forest soil by four forest harvesting systems in small-scale woodland}

Oscar Bustos ${ }^{1}$, Carlos Mena ${ }^{1}$

${ }^{1}$ Universidad de Talca, Talca, Chile (obustos@utalca.cl; cmena@utalca.cl)

A comparison of the productivity, costs and effects on the forest soil expressed in percentage of compaction, when applying four harvesting systems for wood extraction from the forest of small landowners was studied. The systems used in the yarding were a forwarder with harvester, and skidder, a farm tractor, and a bulldozer using chainsaws for felling activities. A statistical design was applied in blocks completely at random, considering the different treatments with its respective replicate assigned to each block. A continuous time and motion techniques in which running times were recorded and the number of stems and volume yarded were determined and recorded for each machines per cycle. Soil compaction was measured on samples in trafficked and untrafficked areas in two general places: skid trail and in the harvested areas.The finding showed a greater productivity in terms of cubic meters per productive machine hour $\left(11.45 \mathrm{~m}^{3} / \mathrm{PMH}\right)$, it was reached by the forwarder system, which also caused the smaller effect of compaction on the forest soil $\left(0.86 \mathrm{~g} / \mathrm{cm}^{3}\right)$ and its production cost per unit were lowest value among the four harvesting systems $\left(10.03 \$ / \mathrm{m}^{3}\right)$. On the other hand, the system bulldozer caused the greater compaction on the soil $\left(0.97 \mathrm{~g} / \mathrm{cm}^{3}\right)$, with a low productivity $\left(4.64 \mathrm{~m}^{3} / \mathrm{PMH}\right)$ and production cost $\left(14.10 \$ / \mathrm{m}^{3}\right)$, similar to the skidder and farm tractor systems. The results have a strong implication on the selection of machineries for the planning of the small-scale woodland, as well as, aspect related to sustainability management and conservation of forest soils.

\section{Reducing hazardous fuels with simple biochar kilns}

Darren Mcavoy ${ }^{1}$

${ }^{1}$ Utah State University, Logan, USA (darren.mcavoy@usu.edu)

The Utah Biomass Resources Group (UBRG) introduced simple biochar kilns to Utah in 2017 to reduce hazardous fuels and produce a valuable product. We have conducted seven workshops in Utah to date, educating more than 200 people, and have reduced hazardous fuels by approximately 20 semi-truck loads in the state. More recently, the UBRG received a Public Lands Initiative Grant to scale up this simple approach, from boxes that measure 1.5 meters across, to kilns that can be more than six meters across. Parallel efforts are ongoing in Oregon, Nevada, and North Dakota using a variety of kiln designs that depend on repurposed local materials; several of these approaches will be introduced in this presentation.Advantages of this approach over more high tech machines include significantly reduced cost, increased accessibility, and considerably less cost in feedstock preparation by avoiding the expense and energy necessary for chipping and/or grinding feedstock material. We have safely deployed these kilns in close proximity to heavy fuels loads, urban infrastructure, homes, and ecologically sensitive locations such as within Stream Management Zones.The workshops included a diverse audience of forest landowners and managers; wildland fuels specialists, arborists, gardeners, and city managers. Evaluation results op indicate that $80 \%$ of the participants were interested in biochar production for its soil amendment properties while $49 \%$ of the audience was interested in biochar production as a hazardous fuels disposal method; these results indicate that some were interested in both. 


\title{
A3b: THE IMPLEMENTATION OF ECONOMICS, FOREST POLICY, FOREST LAW AND GOVERNANCE IN LATIN AMERICA FORESTRY
}

\section{Forest policy and governance in Uruguay: progress and challenges / Política y gobernanza forestal en Uruguay: avances y desafios}

Virginia Morales Olmos $^{1}$, Amalia Stuhldreher ${ }^{1}$

1Universidad de la República,Tacuarembó,Uruguay(vmolmos@gmail.com; astuhldreher@hotmail.com)

Uruguay desarrolló su sector forestal en el marco de una regulación específica que tuvo su origen en la Ley Forestal 15.939 de 1988. Sucesivos decretos han regulado la misma y realizado algunas modificaciones. La mencionada Ley Forestal fue aprobada por unanimidad del Parlamento y, a pesar de la alternancia de los tres partidos políticos mayoritarios en el poder, la política fue mantenida. A 30 años de aprobada la Ley Forestal el país se enfrenta al desafío del desarrollo de un sector industrial diversificado, el cual no se ha materializado. El objetivo de este trabajo es analizar la situación actual de la gobernanza en el sector forestal uruguayo y sus implicancias en términos de su desarrollo. El concepto de gobernanza ha tenido una evolución desde sus orígenes relacionados con la economía institucional (inicios del siglo XX) y también con la escuela de la regulación (década del '70) hasta hoy, donde se lo utiliza en perspectiva multinivel desde lo global, regional, nacional hasta lo subnacional y local, analizando los procesos de desarrollo en su multidimensionalidad. El concepto incluye asimismo relaciones más amplias de aquellas propias del formato político tradicional de gobierno, abarcando vínculos con actores de la sociedad civil y sector privado. En la última década, el gobierno nacional ha realizado diversos esfuerzos para contribuir al desarrollo del sector, en particular, implementado programas. Los resultados han sido dispares: en algunos casos aislados se ha fortalecido la gobernanza y en otros se observa que no existe una coordinación para generar procesos acumulativos.

\author{
Willingness to pay for forest conservation in ecuador: results from a nationwide contingent valuation survey in a combined \\ "referendum” - “consequential open-ended” design \\ Fernando Gordillo ${ }^{1}$; Peter Elsasser ${ }^{1}$, Sven Günter ${ }^{1}$ \\ ${ }^{1}$ Thuenen Institute of International Forestry and Forest Economics, Hamburg-Bergedorf, Germany (fernando.gordillo@thuenen.de; \\ peter.elsasser@thuenen.de; sven.guenter@thuenen.de)
}

Deforestation is a threatening pan-tropical problem. Net deforestation in Ecuador amounts to approximately $500 \mathrm{~km}^{2}$ per year for 2008-2014. It represents not only an environmental problem but also a threat to social welfare. As social welfare depends on individual preferences, we examined households' preferences and willingness-to-pay (WTP) for a proposed forest conservation program aiming to avoid deforestation in Ecuador. Our study presents results from a nationwide contingent valuation survey conducted in a geographically stratified random sample of 976 households across the three main geographical regions of Ecuador as well as urban and rural areas. About $98 \%$ of surveyed households consider the proposed program worth supporting. For forest conservation, the monthly mean WTP per household lies between $\$ 6.28$ (dichotomous choice) - \$3.17 (open-ended) depending on the method of analysis indicating a solid potential for supporting incentive-based conservation programs. Households also expressed their preferences by regions and types of forests but our results are inconclusive in this regard. Methodologically, our study sheds some new light on the causes for the well-known discrepancy between dichotomous-choice and open-ended WTP estimates. Our results may help improving social welfare by incorporating households' preferences into the design of forest conservation programs. Currently realized payments for the Socio Bosque program are based on sound social support which opens doors to discuss amplifying the financial scope of the program by examining the role that households could play in funding forest conservation programs. Our WTP estimates provide aggregate information that could support the design of forest policy instruments.

\section{Multicriterion optimizaton of livestock and timber production in Uruguay}

Adriana Bussoni ${ }^{1}$, Valentin Picasso ${ }^{2}$, Frederick Cubbage ${ }^{3}$, Jorge Alvarez ${ }^{1}$

${ }^{1}$ Departamento de Ciencias Sociales, Facultad de Agronomía, Universidad de la Republica, Montevideo, Uruguay; ${ }^{2}$ Agronomy Department, University of Wisconsin, Madison, USA; ${ }^{3}$ Department of Forestry and Environmental Resources, North Carolina State University, Raleigh, USA (abussoni@fagro.edu.uy; picassorisso@wisc.edu; cubbage@gw.ncsu.edu; jalvarez@fagro.edu.uy)

The integration of the livestock and timber value chain in Uruguay presents great challenges, including assessing the degree of complementarity and competitiveness in their production, their economic and environmental sustainability, including carbon balance of the system. Despite the fact that demand for wood in Uruguay has grown steadily in the last decade, planted forests still cover a very low proportion of land owned by livestock producers. One problem is the lack of economic valuation of the trade-offs between both activities, and an inadequate ranking of the goals to be achieved. Based on a survey of livestock producers with some afforestation on their farms, preferential weights, hierarchies and productive, economic and environmental targets were established, which are applied using a lexicographic goal programming model. Lexicographic models define a solution subset on which values that conserve or exceed the objectives of the next hierarchy must be based. The results indicate that better livestock economic returns and income stability are achieved when livestock profitability is established as the first priority level, and forest profitability and minimization of income deviations as a second priority level. However, an added environmental carbon goal cannot be met, due to the fact that the pre-established livestock activity cannot be reduced. In spite of this, joint production models can be obtained that improve the environmental goals by establishing another order of priority. This would be possible only if economic or market incentives were applied to achieve the environmental carbon goal as well as livestock production.

\footnotetext{
Wood yields in native forests and their effects on land opportunity cost for the Arenal-Huetar Norte Conservation area in Costa Rica / Rentabilidad del aprovechamiento maderable en bosque natural y su efecto en el costo de oportunidad de la tierra, para el área de Conservación Arenal - Huetar Norte, Costa Rica

Christian Zúñiga-Méndez"1, Sebastián Ugalde-Alfaro², Víctor Meza-Picado ${ }^{3}$,Jhonny Méndez-Gamboa ${ }^{4}$

${ }^{1}$ Universidad Nacional de Costa Rica, Heredia, Costa Rica; ${ }^{2}$ Oficina Nacional Forestal (ONF), Heredia, Costa Rica; ${ }^{3}$ Instituto de Investigación y Servicios Forestales (INISEFOR-UNA), Heredia, Costa Rica; ${ }^{4}$ Comisión para el Desarrollo Forestal de San Carlos (CODEFORSA), Ciudad Quesada, Costa Rica (czunigamendez@gmail.com; sugalde@oficinaforestalcr.org; victor.meza.picado@una.cr;jmendez@codeforsa.org)
}

Esta investigación evaluó la rentabilidad del modelo actual de aprovechamiento maderable en bosque natural y su costo de oportunidad por usos alternativos del suelo, dentro del Área de Conservación Arenal-Huetar Norte, Costa Rica. Se utilizaron 24 sitios con plan de manejo aprobado y ejecutado durante el 2010-2013, 
con ello se generaron tres estructuras de costos según el área efectiva de manejo; donde se encontró que la planificación y la formalización del permiso abarcan el 80\% de los costos para acceder de forma legal al recurso. Así mismo, la rentabilidad se abordó a través de un modelo microeconómico que utiliza el valor del bosque como indicador, obteniéndose beneficios netos entre $\$ 346,41 \mathrm{ha}^{-1}$ y $\$ 910,13 \mathrm{ha}^{-1}$; que no lograron superar el precio del bosque en el mercado (\$3 503,85 $\mathrm{ha}^{-1}$ ). Con los datos de costo de oportunidad se generó un mapa regional, que señala a los bosques del sur como los más vulnerables a presiones económicas por usos del suelo. Se concluye que, aunque las rentas son positivas, el aprovechamiento de madera no se puede considerar rentable, ya que no logra superar ni igualar el precio del bosque en el mercado; sumado a ello, existen limitaciones por gobernanza que encarecen aún más la actividad, y altas presiones económicas de los usos alternativos. Esta dinámica hace que el aprovechamiento maderable en bosque se restrinja a lugares cada vez más alejados del mercado, y a unidades de manejo superiores a 50 ha; desplazando al pequeño productor.

\section{The probability of default on BNDES funding programs for plantations in legal reserve areas: a case study of Paraiba Valley

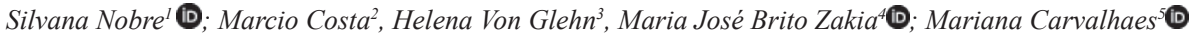 \\ ${ }^{1}$ UPM - Universidad Politécnica de Madrid - ETSI de Montes, Forestal y del Medio Natural, Madrid, Spain; ${ }^{2}$ BNDES -Nacional Bank of Development, Department of Environment, Brasilia, Brazil; ${ }^{3}$ SMA SP - The Secretariat for the Environment of the State of São Paulo, São Paulo, Brazil; ${ }^{4} I P E F-F o r e s t r y$ Science and Research Institute - Silviculture of Native Species Program, Piracicaba, Brazil; ${ }^{5}$ Embrapa, Secretaria de Inovação e Negócios, Campinas, Brasil (silvana.rnobre@gmail.com; mmc@bndes.gov.br; hcarrascosa@sp.gov.br; zeze.zakia@uol.com.br; mariana.carvalhaes@embrapa.br)}

São Paulo has a legal reserve deficit of 1.7 million hectares that should be regularized by planting native species with economic purposes, especially in underutilized forestry vocation areas. São Paulo State Secretariat of Environment (SMA-SP) identified the Paraiba Valley, as a priority for a multifunctional forest hub due to its relevance for the biodiversity and water conservation, and the low land-use conflicts expectation. SMA-SP led research to create technical recommendation packages for plantations that might adapt to the soil and climatic conditions. Those packages were embedded in open-to-public IT (information technology) tools to support plantation projects. We used the contents of those IT tools to evaluate the BNDES funding programs that might be used to finance legal reserve plantations. This work presents the probability of the default to the BNDES funding conditions applied to the recommendation packages. We used the Monte Carlo simulation methodology to calculate optimistic and pessimistic scenarios for Savana and Atlantic Forest biomes in the context the timber, tropical fruits and pellets industrial hub chains. We evaluated Climate Fund, ABC (Low Carbon Agriculture), and Pronaf (Family Agriculture) funding programs. Results are presented as probabilities of installments non-payment considering revenues from the restoration project. The probabilities vary according to the terms and composition of interest rates; from $2 \%$ to $50 \%$. The risk classification that comprises the interest rates is the variable that most influences the default rates. Consequently, if the forest hub is considered a meaningful market risk reduction, the funding programs would have non-significative default rates.

\section{Making forest concessions work for the SDGs and climate change mitigation in Latin America}

Thais Linhares Juvenal ${ }^{1}$, Baastian Louman', Marco Otarola ${ }^{3}$, Marcus Alves $^{4}$, Cesar Sabogal ${ }^{3}$, Fernando Carrera ${ }^{3}$, Marco Boscolo $^{1}$ ${ }^{1}$ FAO, ROMA, Italy; ${ }^{2}$ Tropenbos International, Wageningen, Netherlands; ${ }^{3}$ CATIE, Turrialba, Costa Rica; ${ }^{4}$ Servico Florestal Brasileiro, Brasilia, Brasil (thais.linharesjuvenal@fao.org; blouman59@gmail.com; marco.otarola@catie.ac.cr; marcus.alves@florestal.gov.br; sabogalcesar10@gmail.com; fcarrera@catie.ac.cr; marco.boscolo@fao.org)

Latin America's 910 million hectares of natural forests have an average carbon content of 119 tonnes per hectare (t/ha) and hosts 40 million forest dependent peoples. Conserving and sustainably managing these forests, therefore, must be a global priority, not only for achieving the Sustainable Development Goal (SDG) 15 - life on land, but also for achieving all other SDGs. About 45 percent of the Latin American natural forest estate is reserved for wood production or has not been assigned a specific use. At least 18.5 million hectares of production forests are managed through forest concessions. This article will build on recent evidence collected in Brazil, Guatemala and Peru to argue that forest concessions, i.e. the allocation of management and utilizing rights of public production forests to non-state agents (private sector, communities, civil society organizations) through contracts establishing clear rights and responsibilities, can be an effective policy instrument to improve forest governance and advance sustainable forest management. Organized around four main sessions, the article will: i) build on the Voluntary Guidelines for forest concessions in the tropics (FAO \& EFI 2018) to discuss conditions whereby concessions can be effective policy instruments; ii) assess environmental (deforestation, forest degradation) and socioeconomic indicators (income, employment, access to social services) of forest concessions in Latin America; iii) discuss opportunities and barriers to realize the effectiveness of forest concessions; and iv) present conclusions and recommendations to policy makers on the use of forest concession regimes, as well as the links with developmental and climate change objectives.

\section{Restoration through agroforestry in Brazil: deciphering the forest code to inform policies and practices}

Andrew Miccolis ${ }^{1}$

${ }^{1}$ ICRAF, World Agroforestry Centre, Brasilia, Brasil (a.miccolis@cgiar.org)

The new Brazilian Forest Code includes key provisions allowing farmers to perform mandatory restoration of privately-owned protected areas through Agroforestry Systems (AFS), provided they maintain basic ecological functions. The state governments are still in the process of regulating, however, under what conditions this can be done, generating enormous uncertainty among farmers, extension and enforcement agents. This case study discusses how ICRAF and partners have fed into the formulation of policies on agroforestry for ecological restoration so as to fulfill environmental and social functions on Permanent Preservation Areas and Legal Reserves through two examples of pioneering state-level restoration policies in the states of Federal District and Minas Gerais developed through multi-stakeholder and evidence-based policymaking processes. In the Federal District, a multi-stakeholder alliance drafted a policy allowing and encouraging different restoration approaches, including agroforestry systems, to restore these protected areas. A series of indicators and guidelines has brought the focus of restoration to the long-term impacts rather than short-term results, methods adopted, or number of trees planted. In the State of Minas Gerais, a similarly participatory led to the drafting of guidelines for establishing and managing agroforestry-based restoration that tackle some of the key gaps in the national forest law: species selection, systems composition and management practices, including inputs, mechanization, and intensive pruning. Both cases point clearly to paths forward for other states in the process of regulating agroforestry and restoration in Brazil, shedding light on systems and management practices required to achieve ambitious restoration targets. 
Analysis of dynamics in production, commerce, and public policies in the Chilean and Costa Rican forest sectors and their impact on competitiveness / Análisis de la dinámica productiva, comercial y de políticas públicas del sector forestal de Chile y Costa Rica y su impacto en la competitividad

Natalia María Chacón Cid ${ }^{1}$

${ }^{1}$ Universidad Nacional, Heredia, Costa Rica (ncid2213@gmail.com)

El sector forestal muestra serias deficiencias en términos de competitividad sectorial, pero las alianzas con otros sectores productivos son en la actualidad la alternativa para lograr mejoras sustanciales. Las características de las actividades económicas que a él se vinculan muestran opciones para implementar las estrategias regionales y mitigar la variabilidad climática, potenciando el uso de la madera como medio para la captura de carbono y la adaptación de economías verdes (PNUD 2018).Por otra parte, en el sector forestal las tendencias mundiales de comercio de productos de madera responden a un modelo de mercado más consciente de la realidad ambiental y con impactos diferenciados en los grupos generacionales. Actualmente hay quienes buscan alternativas sostenibles o una mayor utilidad y funcionalidad en un mismo producto, por lo que generar bienes mediante procesos de sostenibilidad y que propicien satisfacción por el consumo se vuelven aspectos clave, indispensables para el comercio de productos de madera con miras a la exportación. Los antecedentes sobre las perspectivas del sector forestal en América Latina muestran grandes esfuerzos por afianzar los flujos de comercio de los productos forestales y a su vez generar un mayor aporte a la balanza comercial de cada nación. La información a presentar evidencia los principales factores productivos, de mercado y las políticas públicas que han impactado la dinámica forestal de Costa Rica y Chile, así como el panorama regional en el cual estas dos Naciones han desarrollado la cadena de valor de productos forestales, como una oportunidad para el desarrollo humano.

\section{A3p: THE IMPLEMENTATION OF ECONOMICS, FOREST POLICY, FOREST LAW AND} GOVERNANCE IN LATIN AMERICA FORESTRY

\section{Informal markets of forest products: characterization and methods for its analysis}

Sergio Molina-Murillo ${ }^{1}$ iD; Manuel Guariguata ${ }^{2}$

${ }^{1}$ Universidad Nacional (UNA), Heredia, Costa Rica; ${ }^{2}$ CIFOR, Lima, Peru (sergiomolina@una.ac.cr; m.guariguata@cgiar.org)

The informal sector is an important source of income for millions of families. It has been estimated that about 60 \% of the employed population worldwide are in the informal sector; and specifically, the employment of the informal forestry sector triples the formal one. Multiple countries are taking measures to improve family access to forest resources through sectoral policies, particularly in Latin America. Although there is also pressure through international financing (e.g., REDD+) or trade (e.g., FLEGT) mechanisms, the fact is that there are still no safe and adequate options for those communities that actively participate in informal markets. Understanding adequately the structures and operations of informal markets is a requirement to support and plan the management and conservation of forest resources, as well as to promote the development of local businesses and families involved in them. In this sense, it is not enough to know which species are commercialized and at what prices or in what quantities; it is equally important to know who participates in the — commonly complex commercial chains, how they are organized and how they evolve. This information is not easily accessible and tends to be of low priority for institutions that collect statistical information. The objective of this review was to explore the role of informal markets in the forestry sector, and explain some of the methods used in their research, citing its main advantages and limitations.

Looking beyond the leaves and understanding the roots: motivations and concerns of farmers planting trees for commercial purposes in Brazil

Manuela Czinar ${ }^{1}$, Rocio A. Diaz-Chavez ${ }^{1}$

${ }_{1}^{1}$ mperial College London, London, United Kingdom (m.czinar@imperial.ac.uk; r.diaz-chavez@imperial.ac.uk)

The Brazilian government has launched in December 2018 its National Plan for Planted Forests setting the goal of increasing the area by 2 million hectares by 2030. In order to understand Brazilian farmers' motivations to plant trees for commercial purposes, a questionnaire was applied to 65 farmers between October 2017 and July 2018. Results show that most of the farmers started planting trees because the prices were attractive by the time of planting. Also, many farmers pointed out that the lack of labour was an important factor in deciding to switch from labour-intensive crops and livestock to forestry. A high number of farmers revealed the possibility of not continuing planting trees for commercial purposes, which could pose a risk to the success of the National Plan. On the other hand, responses indicated that certified farmers are less likely to switch to other crops, suggesting that one less studied impact of certification is the persistence of land use decisions. Other important results were that farmers with less education and income are more likely to be part of associations. However, they do not receive technical support to the same extent than more educated and richer farmers do. This shows that many associations are not providing technical support to their members. In conclusion, by providing more technical support to farmers, the Brazilian government could enhance sustainability practices and expand the adoption of certifications which could help to detain farmers to switching from planted trees to other crops.

\section{Understanding the determinants of technical assistance to support public policy towards planted forests in Brazil}

Manuela Czinar ${ }^{1}$, Rocio A. Diaz-Chavez ${ }^{1}$

${ }_{1}^{1}$ Imperial College London,London,United Kingdom (m.czinar@imperial.ac.uk; r.diaz-chavez@imperial.ac.uk)

The Brazilian government has launched in December 2018 its National Plan for Planted Forests. The plan consists of various goals, being one of them the expansion of knowledge transfer, training and technical assistance. This presentation focuses on the determinants of technical assistance by analysing data from the Brazilian Census of Agriculture. Data indicated that $78 \%$ of farmers in the country do not receive any technical assistance. In order to understand better the variables that determine technical assistance, a logistic model was built using the microdata of the 2006 Brazilian Census of Agriculture. It showed that the probability of farmers in the first quintile of income to receive technical assistance is $88 \%$ lower than farmers in the fifth quintile of income. The level of education was the variable with the highest odds: the odds of a farmer with any bachelor's degree to receive technical assistance is 3,128 times that of a farmer without formal education, proving that the farmers with less education have much lower probability of receiving technical assistance. The State in Brazil where the farm is located is not significant for determining technical assistance. Regarding farmers that plant trees for commercial purposes, they are $25 \%$ more likely to receive technical assistance than other farmers. By understanding how the coverage of technical assistance differs among the various types of farmers, the Brazilian government can work together with public agencies and the private sector to expand the technical assistance coverage and reach the respective goal set in the National Plan. 


\section{Comparing the Brazilian forest concessions model and the FAO voluntary guidelines}

Rayssa Yuki Murakami Lima ${ }^{1}$, Claudia Azevedo-Ramos ${ }^{1}$

${ }^{1}$ Universidade Federal do Pará, Belém, Brasil (rayssa.yuki@gmail.com; claudia.azevedoramos@gmail.com)

Forest concessions in public areas have been used as an instrument to regulate the management of forest resources while protecting the rights of local populations and conserving biodiversity. Nevertheless, international experiences have shown several issues of the forest concession system worldwide. In 2018, the Food and Agriculture Organization (FAO) proposed 8 principles and 39 guidelines to reach the intended scenario for forest concessions in accordance with the UN's 2030 Agenda for Sustainable Development. In this study, we compared the 18 years of Brazilian experience in federal forest concessions with the legal forecast and/or implantation of FAO guidelines by the Brazilian system. As a measure of compliance with FAO guidelines, we uselegal framework, concession processes, participation mechanisms and transparency. Each guideline was evaluated in a color system indicating satisfactory, unsatisfactory or non-attendant service. Results indicated compliance with $69 \%$ of the guideline. As positive points: transparent forest governance; independent forest audits; social control; indicator system. Among the negatives: intersectoral relationship in the governamental sphere; conflict resolution mechanisms; social inclusion; post contract management; operational complexity; competition with illegal timber; and lack of a specific forest credit system.It is concluded that the Brazilian system adheres to the guidelines of FAO in its majority, but there is still room for improvement, some suggested in this study.

A survey of springs and forest coverage in the municipality of Caxambu, State of Minas Gerais, Brazil, as a strategy for guiding municipal conservation policies / Levantamento das nascentes e área de cobertura florestal do município de Caxambu - MG, Brasil, como estratégia para orientar politicas de conservação municipais

Rodrigo Condé Alves ${ }^{1}$, Yohanna Cunha De Mello ${ }^{2}$, Ciro Duarte de Paula ${ }^{3}$, Alexandre França Tetto ${ }^{1}$

${ }^{1}$ Universidade Federal do Paraná, Curitiba, Brasil, ${ }^{2}$ Escola Superior de Agricultura "Luiz de Queiroz", Universidade de São Paulo, Piracicaba, Brasil;

${ }^{3}$ NeoflorestaServiços Ecossistemicos, DoisVizinhos,Brasil (rconde@gmail.com; yoohmello@gmail.com; ciro.floresta@gmail.com; tetto@ufpr.br)

A cidade de Caxambu-MG, Brasil, concentra o maior número de fontes de água mineral carbogasosas no mundo, tendo grande importância turística e cultural. O objetivo deste estudo foi analisar a situação da cobertura florestal das nascentes do município. As áreas florestais foram delimitadas por varredura visual na escala 1:10.000 por meio de imagens de satélite nosoftware ArcGIS com 0,5 m de resolução, datadas de 2016 e 2017. O mapeamento considerou os fragmentos inseridos e contíguos ao limite do munícipio. As nascentes foram determinadas a partir da base de dados do IDE-SISEMA/MG. A área de estudo possui 280 fragmentos que foram classificados como muito grandes ( $>100 \mathrm{ha})$, grandes (50-100 ha), médios (10-50 ha) e pequenos ( $<5-0,5$ ha). O tamanho do fragmento florestal está diretamente ligado a qualidade e perenidade dos serviços ambientais que a área pode prover, incluindo proteção hídrica e fluxo gênico. Observou-se que das 300 nascentes identificadas 163 não possuem cobertura florestal e das 137 inseridas em áreas florestadas, 37,4\% estão inseridas em fragmentos pequenos ou muito pequenos, $22,6 \%$ em fragmentos médios e 40,0\% em fragmentos grandes ou muito grandes, o que revela a importância das maiores áreas florestais na conservação dos mananciais de água. Políticas públicas municipais, criação de unidades de conservação, assim como diálogo com produtores rurais, podem ser alternativas a proteção dos fragmentos e recuperação do déficit florestal existente, embora sejam necessários estudos futuros para verificação in loco da existência das nascentes identificadas e definição das melhores estratégias para restauração das áreas irregulares.

\section{The technological disaster of the Fundão dam and the (in)experience in the economic valuation of environmental damage in Brazil}

Mauro Magliano ${ }^{1}$, Humberto Angelo ${ }^{1}$

${ }^{1}$ Universidade de Brasília, Brasília, Brasil (mauromagliano@hotmail.com; humb@unb.br)

Critical events such as the disruption of the Fundão tailings dam, considered the biggest technological disaster in Brazil and the biggest of its category in the world, test the responsiveness of organizations in charge of protecting the environment. In the process of assign liability for damage, lawsuits initially proposed were replaced by settlements negotiated between companies, state agencies and the Public Prosecution Service, which previously have stipulated amounts for mitigation actions and environmental compensation. The economic valuation of environmental damage, despite being a tool capable of assisting in the quantification of environmental compensation, has not yet been adequately used in the initiatives to hold the Fundão dam case accountable. Preliminary diagnoses of the disaster have not sufficiently detailed the estimated economic values for environmental and socioeconomic repair, nor have they distinguished between the repairable damage and the irreparable ones that must be compensated. Due to the lack of clear definition of who is responsible for the economic valuation of environmental damage, Brazilian environmental protection institutions have not developed standardized procedures for this purpose, except in an incipient, experimental or particular way for certain types of damage. The implementation of civil liability settlements based on inaccurate diagnoses and values can compromise their effectiveness and perpetuate, without compensation, the damage to Brazilian environmental heritage.

\section{Smallholder land clearing behavior and Forest Code enforcement perceptions in the Brazilian Amazon}

Stella Schons ${ }^{1}$, Eirivelthon Lima', Gregory Amacher ${ }^{1}$, Frank Merry ${ }^{3}$

${ }^{1}$ Virginia Tech, Blacksburg, USA; ${ }^{2}$ Inter-American Development Bank, Washington, USA; ${ }^{3}$ Conservation Strategy Fund, Washington DC, USA

(szschons@vt.edu; elima@iadb.org; gamacher@vt.edu; frank@conservation-strategy.org)

Small landholder contribution to Amazon deforestation in Brazil has been persistent even after government actions have allowed a steep reduction in the overall annual deforestation area since 2004. We investigate land clearing and the incentives to comply versus not to comply with environmental legislation within the context of the Forest Code in Brazil through a dynamic land clearing model that takes into account smallholder perceptions of the risk of being caught violating the legislation. This model is empirically tested through an endogenous switching regression method applied to data collected from 1,108 households sampled in 2003 and 542 households sampled in 2013/14 in the Transamazon-BR163 region. We show smallholder compliance and noncompliance preferences lead to a selection problem that must be addressed in any land clearing behavior examination. We find greater marginalization, longer land tenure and transitions to cattle grazing, but not agricultural rents, to be major contributors to forest clearance and incentives not to comply with the Forest Code. We also find that higher probability of carrying out forest management leads to lower land clearing behavior and does not contribute to a household's decision to switch from the compliant into the non-compliant group. Our results suggest that the perceived costs of violating the Forest Code are not high enough to surpass the cost of transitioning into more efficient production systems, considering that intensification of smallholder production systems have been prescribed as a solution to reduce deforestation within this group of landholders. 
Assessing the effectiveness of forest closures using the National Forest Inventory, forest management plan records, and reforestation statistics in Nicaragua, Central America / Evaluación de la efectividad de la veda forestal utilizando el Inventario Nacional Forestal, los registros de planes de manejo de bosque y las estadísticas de reforestación en Nicaragua, Centroamérica

Guillermo Navarro ${ }^{1,3}$, Nestor Sagüi ${ }^{2,3}$, Bryan Finegan ${ }^{3}$, Juan Zamora ${ }^{3}$, Sergio Vílchez ${ }^{3}$

${ }^{1}$ FAO, Panamá, Panama; ${ }^{2}$ Naturaleza para la Vida, Asunción, Paraguay; ${ }^{3}$ CATIE, Turrialba, Costa Rica (gnavarrom@gmail.com; nestor.sagui@naturalezavida.org; bfinegan@catie.ac.cr; juancarlos.zamora@catie.ac.cr; svilchez@catie.ac.cr)

La investigación analizó el estado de conservación de cuatro especies forestales vedadas por la Ley No; 585 del 2006 en Nicaragua: caoba (Swietenia macrophylla King y Swietenia humilis), cedro (Cedrela odorata Linnaeus) y pochote (Pachira quinata) en los paisajes de distribución natural de las mismas. En cada paisaje se determinaron los impactos de la ley de veda en la dinámica de distribución, regeneración y cultivo en bosques naturales, bosques bajo Manejo Forestal Sostenible (MFS) y sistemas agroforestales (SAF). Se analizó la estructura de las poblaciones de cada especie y su distribución actual y cambios potenciales utilizando software MaxEnt. Se determinó la distribución y estructura de las poblaciones empleando análisis estadístico comparativo con el software INFOST. Los analisis se realizaron a partir delos inventarios forestales nacionales del Instituto Nacional Forestal (INAFOR). Para tal caso, se utilizaron dos periodos de comparación: 2008 y 2015. Adicionalmente, se analizaron las bases de datos disponibles de plantaciones forestales establecidas durante el periodo y los planes de aprovechamiento forestal de fincas forestales a nviel nacional.Los resultados se presentan en 11 hallazgos científicos que apuntan a la poca efectividad de la veda forestal como instrumento de política para recuperar y conservar las poblaciones de las cuatro especies vedadas. Particularmente, se identificó que en el largo plazo existe el riesgo de pérdida y degradación de las poblaciones de las especies. Con base en los hallazgos se formularon recomendaciones para revisar y ajustar los lineamientos, estrategias y prácticas de manejo y conservación contempladas en la Ley de veda forestal.

Contributing to forest accounting: valuation of standing wood assets / Contribución a la contabilidad forestal: valuación del activo madera en pie

Fabiana Ines Molina

${ }^{1}$ FCE-UNC, Córdoba, Argentina (fabimolina@gmail.com)

En el presente trabajo se analizará la problemática de valuación de la madera en pie, en especial sobre la consideración de los cambios de los activos forestales en la contabilidad de la empresa, para objetivos internos y externos. Se iniciará la presentación con una reseña histórica y actual de diversas metodologías propuestas y las vigentes para la valuación de los activos forestales: Se orientará el análisis tomando como base la información de la literatura europea de IUFRO, en especial de la literatura alemana de los autores Günter Karisch, Hans A. Jöbstl y otros, la literatura americana W. David Klemperer, y autores latinoamericanos como Dr Berger Ricardo y Joao Batista Padilla Junior. Estos desde un punto de vista de la contabilidad interna. Luego se analizará las metodologías propuestas por las normas contables internacionales vigentes NIC 41, Brasil, Argentina, Chile. También se citará la práctica contable de valuación de empresas del país en especial con domicilio de explotación en Misiones, con exposición de problemáticas que se detectan al efecto. Se llegara al final a una conclusión sobre la mejor propuesta en función de los riesgos inherentes que puedan llevar al uso inadecuado de esta información.

Forest policy related to non-timber forest products in Chile / Política forestal en torno al rubro de los productos forestales no madereros (PFNM) en Chile

Gerardo Valdebenito Rebolledo ${ }^{1,2}$

${ }^{1}$ Instituto Forestal, Santiago, Chile; ${ }^{2}$ Universidad Mayor Santiago Chile (gvaldebe@infor.cl)

La valoración económica social, ambiental y patrimonial de los PFNM generados por los ecosistemas boscosos es creciente en el mundo. Chile por su geografía y recursos forestales posee ventajas comparativas en este rubro, reflejado en un creciente mercado nacional e internacional, con exportaciones anuales de 90 MMUS\$ y un consumo interno de 370 MM US\$, lo cual contrasta con problemas de sostenibilidad en lo social y ambiental. En este contexto, el Consejo de Política Forestal, organismo con visión de Estado responsable de proponer políticas publicas sectoriales, desarrolló el proceso de planificación, diseño e implementación de programas y acciones público/privadas que permitan en el mediano y largo plazo ampliar significativamente en extensión, calidad y sustentabilidad el rubro de los PFNM en Chile, respetando tradiciones, conocimiento y cultura de los habitantes rurales y pueblos originarios. Utilizando metodologías de levantamiento y sistematización de información de fuentes primarias y secundarias, asegurando una amplia participación y representatividad de actores del rubro de los PFNM, fue posible construir una agenda de política pública que contiene tres ejes estratégicos: productividad y crecimiento económico, equidad e inclusión social, y protección y restauración del patrimonio forestal. Los resultados se materializan en más de 60 acciones de corto, mediano y largo plazo, que hoy se implementan en Chile, las cuales, entre otras, buscan generar bienes públicos, mejorar la asociatividad, agregar valor, fortalecer las organizaciones locales, disminuir brechas, mejorar las condiciones laborales, desarrollar normas de manejo y cosecha sustentable en los bosques y valorar y respetar el conocimiento empírico y ancestral.

Characteristics of companies providing forestry services in Paraguay / Caracterización de empresas prestadoras de servicios forestales en el Paraguay

Pablo Enrique Espínola Ferreira', Maria Laura Quevedo Fernandez¹, William Tomaz Folmann ${ }^{2}$

${ }^{1}$ Universidad Nacional de Asuncion, Asuncion, Paraguay; ${ }^{2}$ Independiente, Asuncion, Paraguay (pabloespinola744@gmail.com; marialauraquevedo@gmail.com; wfolmann@gmail.com)

Se ha identificado que la mayor parte de las plantaciones forestales en el país son planificadas, implementadas, mantenidas y cosechadas por medio de prestadores de servicios, es por eso que mediante el presente trabajo se ha buscado caracterizar a los mismos mediante la aplicación de un cuestionario; se ha caracterizado a 3 empresas que prestan servicios de consultoría, 7 que prestan servicios de plantaciones y manejo, así como 3 empresas que realizan cosecha y transporte, todas ellas distribuidas en los departamentos de Alto Paraná, Canindeyú, Caaguazú e Itapuá. Los principales servicios de consultoría prestados por las empresas entrevistadas son los de asesoramientos de plantaciones con costos medios de 297US\$ por visita de campo. y adecuación ambiental de la propiedad con un costo medio de 847US\$ por proyecto, en tanto el servicio silvicultura y manejo se da por paquetes que pueden incluir limpieza previa del 
terreno, preparación de suelo, canalización, caminos, control de hormigas, análisis de suelo, plantación, reposición, riego, fertilización, encalado, control de malezas, poda, raleo; se han identificado 11 posibles paquetes y sus costos varían entre 508 a $1.525 \mathrm{USS} / \mathrm{ha}$, mientras que los costos de cosecha van desde 11 a 21,5USS/ton, que puede incluir destronque, desrama, troceo, carga, descarga, desalijo y chipeado; los costos de trasporte van de 11 a 15 US\$ En el servicio de consultoría el principal factor crítico identificado fue la disponibilidad de mano de obra calificada, en el servicio de silvicultura la competencia desleal y en el servicio de cosecha y transporte la condición de los caminos.

Situation and perspectives on forest policy and forest governance in post-conflict in Colombia / Situación y perspectivas de politica forestal y gobernanza forestal en el contexto del postconflicto en Colombia

José Miguel Orozco ${ }^{1}$

${ }^{1}$ Universidad Distrital, Bogotá, Colombia (josemiguelorozco@gmail.com)

Entre los años 2015 y 2017 la deforestación en Colombia se incrementó en 77\%, pasando de 124.035 a 219.973 hectáreas. Las proyecciones preliminares indican que durante 2018 la pérdida bosques continuó a niveles aún mayores, con una estimación de 270.000 hectáreas de área deforestada, equivalente a un aumento del $117 \%$. Lo anterior confirma los peores temores de expertos que, basados en experiencias internacionales de situaciones similares, advirtieron que de no tomarse las medidas apropiadas por parte de las entidades responsables, habría un alto riesgo de un fuerte incremento de la deforestación en la etapa de posconflicto, luego de suscritos los Acuerdos de Paz entre el Gobierno de Colombia y la guerrilla de las FARC. Si bien este es un fenómeno complejo originado por múltiples causas y agentes, que no es responsabilidad exclusiva del "sector ambiental", obliga a una reflexión sobre los enfoques y logros de la gestión forestal durante la era del Sistema Nacional Ambiental -SINA- (1993-2019), ya que en este periodo han desaparecido alrededor de 6 millones de hectáreas de bosques y, por otra parte, de acuerdo al Segundo Reporte Bienal de Colombia ante la CMNUCC, el 44\% de las emisiones de GEI generadas en el país entre 1990 y 2014, se debió a la deforestación y a la mala gestión de los bosques.Para revertir esta situación se propone hacer de la gobernanza forestal el fundamento para orientar una profunda transformación en aspectos estructurales de la gestión: política forestal, ley forestal, administración forestal, participación de actores e incentivos.

The forest sector in Nicaragua in the face of sociopolitical crisis: key reflections for the future / El sector forestal en Nicaragua ante la crisis sociopolítica: Reflexiones claves para el futuro

Ivania Cornejo ${ }^{l}$ iD

${ }^{1}$ Instituto Interdisciplinario de Ciencias Naturales, Universidad Centroamericana (UCA), Managua, Nicaragua (acornejo@uca.edu.ni)

Nicaragua enfrenta una crisis sociopolítica que estalló en Abril de 2018 afectando a múltiples sectores del país. Previamente la actividad forestal y el manejo sostenible de los bosques y sus recursos representaban ya un reto en Nicaragua principalmente debido a una débil gobernanza. La situación sociopolítica actual afecta al sector forestal pero puede representar la oportunidad para su resurgimiento en un país donde a pesar de que la vocación de los suelos se cuenta hasta en $40 \%$ para uso forestal, éste solo representa 1\% del PIB. Haciendo uso de cuestionarios, entrevistas a profundidad y fuentes secundarias así como herramientas de pensamiento sistémico para análisis de la información, este estudio presentará: (a) un panorama de la situación del sector forestal a través de la mirada de actores clave (sector pequeña y mediana empresa, empresas high-end, reservas privadas, comunidades indígenas en áreas protegidas, plantaciones forestales, ONGs) y (b) recomendaciones para un futuro escenario postcrisis. Impactos reportados como las continuas invasiones en tierras comunitarias indígenas y reservas privadas, suspensión de actividades de investigación, cierre de proyectos de cooperación internacional y mermada capacidad institucional, derivan en mayores costos de oportunidad y posible aumento de vulnerabilidad de los bosques, biodiversidad y comunidades asociadasante eventos naturales o amenazas antropogénicas. En el escenario postcrisis nuevas formas de gobernanza basadas en la ciencia y modelos participativos,y recuperación de confianza entre los diferentes actores serán necesarios para un nuevo consenso social que permita hacer del sector forestal un pilar del desarrollo de un país en reconstrucción.

Challenges of governing native forests in South American countries (Brazil and Chile) / Desafios de la Gobernanza de los Bosques Nativos en dos países de America del Sur (Brasil y Chile)

Liviam Elizabeth Cordeiro-Beduschil iD ; Cristina Adamsi ${ }^{1}$; René Reyes ${ }^{2}$

${ }^{1}$ Universidade de São Paulo (PROCAM-IEE/USP); Instituto Forestal(INFOR),Valdivia, Chile liviamcordeiro@gmail.com; cadams@usp.br; rene.reyes@ infor.cl)

En las últimas décadas, nuevas formas de gobernanza forestal se han establecido en América del Sur para promover el manejo sostenible de los bosques nativos, a partir de la interacción de diferentes actores sociales. El presente artículo presenta el resultado de una investigación doctoral sobre el modelo de gobernanza forestal en Brasil y en Chile entre 1990-2015. El objetivo de la investigación fue analizar la evolución de la política forestal, los límites y el alcance de las estrategias adoptadas para disuadir sobre la deforestación y la degradación de los bosques nativos. A partir de las corrientes teóricas que contribuyen al análisis de la gobernanza forestal, se analizó el marco institucional competente al manejo de los bosques de cada país y el espacio multi-actores que se establece con base en sus intereses, recursos y poder de decisión sobre los bosques. El estudio se basó en métodos de investigación cualitativa, a partir de la recopilación de datos secundarios y entrevistas con actores involucrados en la implementación de las leyes forestales vigentes, como la Ley de Bosques Nativos (en Chile) y la Ley de Gestión de Bosques Públicos (en Brasil). Los resultados del estudio apuntan al reducido alcance en la implementación de estas políticas y a la necesidad de fortalecer las capacidades de los distintos actores para redefinir el modelo forestal a partir de nuevas institucionalidades que promuevan efectivamente la gestión sostenible de los bosques nativos con base en el desarrollo territorial y comunitário.

\section{Assessment of multi-purpose forests in Paraguay / Diagnostico de plantaciones con fines multipropositos en el Paraguay}

Rodrigo Antonio Burgos Garcete ${ }^{1}$, Elias Jose Roman Lozantos ${ }^{1}$, Maria Laura Quevedo Fernandez ${ }^{1}$, William Tomaz Folmann ${ }^{2}$

${ }^{1}$ Universidad Nacional de Asuncion, Asuncion, Paraguay; ${ }^{2}$ Investigador independiente, Asuncion, Paraguay (yoyiburgos@hotmail.es; eliasroman194@gmail.com; marialauraquevedo@gmail.com;wfolmann@gmail.com)

Con el objetivo de diagnosticar las plantaciones con fines multipropósitos fue aplicado un cuestionario a 3 empresas y realizado inventario forestal en 2 de ellas. Fueron identificados 8 materiales, entre los que se destacan el I144 plantado en todas las empresas. La habilitación del área para la plantación es realizada en mayor parte con fuego, en cuanto que la preparación de terreno todas las empresas realizan con rastra pesada, estas pudiendo ser combinadas con rastra liviana, con subsolado, taipeado y canalización. Los principales los meses de preparación de terreno son de febrero a abril y agosto a setiembre, y los principales meses de plantación de marzo a mayo y setiembre a noviembre, realizada de forma manual con 780 a $1.333 p l / h a$. El control de hormigas es realizado con fipronil y todas realizan fertilización; en el control de malezas se destacan los métodos químico y manual en la línea de plantación, y mecanico 
y quimico en la entrelínea. Se realizan entre 7 a 8 podas con alturas máxima entre 9 a 11 m y 2 raleos selectivos o mixtos entre los 3 a 7 años. La cosecha es semimecánica y se destacan como productos la leña y rollos. Con respecto al crecimiento se destaca el I144 en la empresa A con 33,72m³/ha/año. Con relación a la estimación de la viabilidad económica, se puede observar que todas las empresas son viables económicamente. El factor crítico identificado por todas las empresas fue "la falta de normativas que incentiven el uso de plantaciones"

\section{A4a: ARTIFICIAL INTELLIGENCE, MACHINE LEARNING AND KNOWLEDGE SHARING: COMBINING OLD AND NEW SKILLS TO IMPROVE DECISION-MAKING IN FORESTRY}

\section{A study on immersion 3D visualization system to promote decision-making of forest management}

Huaiqing Zhang ${ }^{1}$, Yongliang Li $^{1}$, Tingdong Yang ${ }^{1}$, Xinjian Tan ${ }^{2}$

${ }^{1}$ Institute of Forest Resource Information Techniques Chinese Academy of Forestry, Beijing, China; (huaiqingzhang@aliyun.com; lyl@ifrit.ac.cn; yangtd@ifrit.ac.cn; bjtan@caf.ac.cn)

Using three-dimensional visualization technology, combining with tree diversity simulation, forest structure and growth interaction models and forest management process models, an immersion virtual forest environment was constructed on the basis of forest resources investigation in Huangfengqiao forest farm, Central South of China. Firstly, a parametric tree modeling based on morphological structure parameters and dynamic self-adjustment was developed using dynamic IFS fractal algorithm, which realized rapid parameterized modeling of different types of tree morphological structure. Secondly, an adaptive three-dimensional visualization simulation method of forest structure based on intelligent model agent and dynamic parameters was established, and a forest growth model was constructed by combination with the environmental factors and the distribution parameters of forest structure, which realized the visual simulation of forest growth dynamics under different structure and environment conditions. Furthermore, a self-defined model simulation method of forest management measures is constructed, which broke through the difficulties of interactive models of forest structure, growth and management. Finally, using the inventory data and plots data from the forest farm, an immersion virtual forest environment was developed with Unity 3D software environment, which ran on VR platform with 320-degree cylindrical structure comprised of tiled stereo-capable displays, tracking system and multi-surround envrionment. The system provided an ultra-high resolution 2D \& 3D visualization systems combined with forest ecosystem models with multi-perception interaction mode and knowledge decision model were proposed to realize immersion three-dimensional feasibility of forest resources status, change, forestry production and management activities, which provided new skills to improve prediction analysis and decision-making in forestry.

X-Stock: a smartphone app for inventory and management of secondary Nothofagus forests / X-Stock Una aplicación smartphone de apoyo al inventario y manejo de renovales de Nothofagus

Marjorie Martin ${ }^{1}$, Sabine Müller-Using ${ }^{1}$, Bernardo Pilquinao ${ }^{1}$, Carlos Bahamondez ${ }^{1}$, Jose Bava ${ }^{2}$, Gabriel Loguercio ${ }^{2}$

${ }^{1}$ Instituto Forestal, Valdivia, Chile; ${ }^{2}$ Centro de Investigación y Extensión Forestal Andino Patagónico, Esquel, Argentina; (mmartin@infor.cl; smuller@infor.cl; bpilquinao@infor.cl; cbahamon@infor.cl;jbava@ciefap.org.ar;.gloguercio@ciefap.org.ar)

El Instituto Forestal ha venido promoviendo el uso de Diagramas de Manejo de Densidad y la Cartilla de Descripción narrativa para el manejo de renovales de Nothofagus. Principalmente Roble-Raulí-Coihue (Nothofagus obliqua, $N$. alpina, $N$. dombeyi) y para renovales de Lenga ( $N$. pumilio), bajo condiciones relativamente homogéneas y coetáneas. Las herramientas propuestas permiten determinar la relación entre tamaño, densidad, competencia, ocupación del sitio y auto raleo. Por otra parte, la "Cartilla de Descripción Narrativa" recoge desde el terreno los aspectos como calidad, sanidad y vigor, entre otros, logrando una mejor caracterización del rodal o bosquete y la pertinencia de las futuras intervenciones. Así la definición de un rodal meta y planificación de raleos se pueden enmarcar dentro de los límites de un manejo sustentable, para aproximarse a su valor potencial, sin comprometer su sustentabilidad. Para facilitar el uso en terreno de estas herramientas de apoyo a la toma de decisiones, se desarrolló la aplicación para Smartphone Xstock, que permite utilizar el teléfono como medio de captura de parcelas de inventario y calcular los parámetros que los diagramas necesitan como datos de entrada incluyendo los aspectos cualitativos, para enviar la información vía email cuando la señal de red esté disponible.

\section{Extraction of phenological features using deep convolutional neural networks and random forest models using MODIS EVI time series}

Esteban Roitberg ${ }^{1}$, Verónica Barraza ${ }^{1}$, Francisco Grings ${ }^{1}$, Mercedes Salvia ${ }^{1}$

${ }^{1}$ IAFE - UBA - CONICET, Buenos Aires, Argentina (estebanroitberg@gmail.com; vdbarraza@gmail.com; verderis@gmail.com; mercedessalvia@gmail.com)

Understanding the spatiotemporal dynamics of phenology is critical for forest monitoring and management. In South America, much of the effort in these studies with remote sensing data has been concentrated on tropical rainforests (i.e. Amazonas), while subtropical formations (xerophytic Chaco forests) have been given less attention, although they account for a large fraction of South American forests.In this study, we exploit the 18-year long MODIS EVI data to study time series similarity measures, and to use them to develop a methodology to classify areas with similar phenology over the Chaco Forest in Argentina. The idea to develop a phenology-based classification is not new; several models have been developed to estimate phenology metrics from NDVI time series, from simple linear smoothing methods to more complicated spectral methods (i.e. TIMESAT). Nowadays, machine learning algorithms provide a powerful tool to develop classifiers, even on data sets with poor signal-to-noise ratios or characterized by a high dimensionality. Since we opted for a supervised training approach, we defined six pilot areas inside every major ecosystem, homogeneous in terms of phenology (as seen by MODIS EVI). From each area we extracted EVI time series and used them to train classifiers based on Deep Convolutional Neural Networks and Random Forest. Then, we used these models to classify the whole study area. In this way, we obtained several annual maps of phenologically-similar areas, in which is it possible to study its spatiotemporal dynamics and it is also possible to recognize the anthropogenic impact, mainly related to deforestation.

\section{Comparison of SFM methods on automatic counting of trees in a Brazilian Atlantic Forest restoration area}

Rafael Albuquerque ${ }^{1}$, Manuel Ferreira ${ }^{2}$,Vanessa Girão ${ }^{3}$, Cintia Balieiro ${ }^{3}$, Hendrik Mansur ${ }^{3}, J_{o}$ ão Costa ${ }^{2}$, Mauricio Branco $^{4}$, Carlos Grohmann ${ }^{1}$ ${ }^{1}$ Universidade de São Paulo, Instituto de Energia e Ambiente, São Paulo, Brazsl; ${ }^{2}$ Instituto de Estudos Socioambientais da Universidade Federal de Goiás, Goiânia, Brasil; ${ }^{3}$ The Nature Conservancy Brasil, São Paulo, Brasil; ${ }^{4}$ Instituto Terra de Preservação Ambiental, Miguel Pereira, Brasil (r.w.albuquerque@gmail.com; mferreira.geo@gmail.com; vgirao@tnc.org; cbalieiro@tnc.org; hmansur@tnc.org;joaovsc17@gmail.com; mauricio@itpa.org.br;guano@usp.br)

One of the important parameters measured on areas under Forest Restoration (FR) is the number of trees that are present on the site. Such an important parameter is conventionally obtained by a manual counting process in field works, which takes a significant amount of time and, consequently, increases the project's 
costs. Remote Sensing technologies, such as data collected by Unmanned Aerial Vehicles (UAV), provide a panoramic and georeferenced view of whole areas of interest and bring possibilities of automatic data mining processes, such as the automatic counting of trees and therefore reducing FR costs. Two of the most popular Structure from Motion (SfM) software used to process UAV data are Photoscan and Pix4D Mapper. As these software use different SfM methods, they generate slightly different outputs and a possible influence on automatic tree count accuracy should be evaluated. This work aims to compare Photoscan and Pix4D accuracy results on automatic tree counting of a FR area. The automatic tree count was based on watershed algorithm and each identified tree was represented by a coordinate on its highest crown point. Visually, both platforms deliver similar products. But Photoscan presented a better performance than Pix 4D, as their general accuracies were equal to 0.938 and 0.105 , respectively, suggesting that Photoscan is more adequate to FR monitoring. Although Pix $4 \mathrm{D}$, an effective and high quality software, presented poor results, future works should evaluate if high slope conditions, as was found in the study area, influence on the software's automatic tree counting results.

A4b: FORESTS WITHOUT BORDERS: MULTI-NATIONAL FOREST INVENTORY COOPERATION AND HARMONISATION TO ENHANCE SUSTAINABLE DEVELOPMENT

\section{Toward a harmonized regional forest inventory: a need for sustainability in South America}

Carlos Bahamondez ${ }^{1}$, Marjorie Martin ${ }^{1}$, Yasna Rojas Ponce ${ }^{1}$, Rodrigo Sagardia ${ }^{1}$

${ }^{1}$ Instituto Forestal, Valdivia, Chile; (cbahamon@infor.cl; mmartin@infor.cl; yrojas@infor.cl; rsagardia@infor.cl)

Countries which accounts forest resources in South America faces the needs of reporting to the national and international community about the state and condition of their forest periodically. Up to date, countries in the region have made important efforts in planning and implementing national forest inventory initiatives in cooperation with FAO and others relevant institutions. However, countries share similarities, like common biomes, irrespective of national borders, but have differences in species compositions, growing stock, forest structure, industrial and market development and yield, issues that are reflected in their definitions, measurements and methods applied in the national forest inventory. Harmonizing these topics on already existing national forest inventories or standardizing those in new initiatives in the region, will provide a common ground to secure a comprehensive and comparable indicators related to sustainability in the region, will provide a solid framework for policy makers and will produce a consistent and transparent trend on biodiversity, carbon and sustainability indicators.

\section{Challenges and opportunities for the harmonization of national forest inventories in the Amazon Region}

Joberto Freitas ${ }^{1}$, Doadi Brena ${ }^{2}$, Sarah Crabbe ${ }^{3}$, Elvira Gómez Rivero ${ }^{4}$

${ }^{1}$ Serviço Florestal Brasileiro, Brasilia, Brasil; ${ }^{2}$ FAO/SFB, Nova Prata, Brazil; ${ }^{3}$ SBB, Paramaribo, Suriname; ${ }^{4}$ SERFOR, Lima, Peru

(joberto.freitas@florestal.gov.br; dabrena@gmail.com; sarah_crabbe@yahoo.com; egomez@serfor.gob.pe)

The extent of forests in the Amazon region was approximately 544 million ha in 2015, of which 21\% was assigned to forest production. Most of the eight amazon countries have advanced in the implementation of their national forest inventories (IFN) in the last decade, with the common purpose of producing appropriate information supporting the sustainable management of their forests. Despite similar forest characteristics among countries, since they belong to the same biome, their national forest inventories have different methodologies making the comparison of the acquired results difficult. Within the creation of a common agenda for national forest inventories, that started in 2017 by several Latin American countries, the Amazonian countries prioritized starting a harmonization process focusing on variables related to the estimates of growing stocks of volume and biomass. However, in order to improve the results of this process, it was also identified that a preliminar requirement is to study and compare terminologies and definitions applied in each country, especially related to the forest definition, the forest area estimates, the vegetation classification and the nomenclature of tree species and species groups. The challenges for harmonization are mainly related to the complexity of the forests, especially due to the large number of tree species and their diversity in shape and size. On the other hand, the harmonization of NFIs is certainly an opportunity to improve forest information at a regional level and to promote sustainable forest management.

\section{The North American forest database: successes and challenges in continental-scale forest inventory harmonization into a relational database}

Sonja Oswalt 1 , Graham Stinson'2, Sergio Armando Villela Gaytan ${ }^{3}$, Rubi Angelica Cuenca Lara ${ }^{3}$, Pat Miles ${ }^{4}$, Alex Song ${ }^{2}$, Carlos Isaias Godinez Valdivia ${ }^{3}$, Carina Edith Delgado Caballero ${ }^{3}$, Brad Smith ${ }^{5}$, Joseph Kapron ${ }^{6}$, Juan Carlos Leyva Reyes ${ }^{3}$, Carmen Lourdes Meneses Tovar ${ }^{3}$, Mayra Ramirez Salgado ${ }^{3}$ ${ }^{1}$ USDA Forest Service, Knoxville, USA; ${ }^{2}$ Natural Resources Canada, Victoria, Canada; ${ }^{3}$ Comision Nacional Forestal, Guadalajara, Mexico; ${ }^{4}$ USDA Forest Service, Minneapolis/St. Paul, USA; ${ }^{5}$ USDA Forest Service, Retired, Washington, DC, USA; ${ }^{6}$ Natural Resources Canada, Retired, Ontario, Canada (soswalt@fs.fed.us; graham.stinson@canada.ca; svillela@conafor.gob.mx; rcuenca@conafor.gob.mx; pmiles@fs.fed.us; alex.song@canada.ca; cgodinez@conafor.gob.mx)

Forest Inventory is a fundamental requirement of forest science and policy. Canada, the United States, and Mexico have a legacy of working together on inventory related topics, particularly those in ecological zones that cross political boundaries. Through the North American Forest Commission Inventory and Monitoring working group, the United States, Canada, and Mexico have integrated common forest inventory attributes into an online, user-accessible North American database to provide a borderless assessment of North American ecosystems using a common map developed in conjunction with the Commission for Environmental Cooperation. The first phase of the project is complete and products include a searchable database and an informational ArcGIS Online Storymap, as well as an information brochure and journal publication. Phase two, currently underway, focuses on the expansion of included variables and the addition of a second time step for trend analysis. Here we discuss the successes accomplished in this cross-border effort, as well as the challenges inherent in a project of this magnitude.

\section{The European National Forest Inventory Network ENFIN: achievements, lessons learned and challenges}

Klemens Schadauer ${ }^{1}$

${ }^{1}$ Austrian Research Centre for Forests, Vienna, Austria (klemens.schadauer@bfw.gv.at)

The European National forest Inventory network enfin has been working for more than 15 years on the harmonisation of the nfis. The main driver for its foundation was a lack of comparability of results caused by the variety of national approaches. the 17 member institutions in 2003 where inspired by the idea 
of harmonisation in a bottom up process and thus developed basic concepts for the harmonisation of nfis on different levels. Actually enfin has 32 member organisations from 29 countries. so far, the network was successful in developing more than 100 detailed and commonly agreed "reference definitions" based on existing international definitions and a thorough screening of national solutions. ENFIN developed and applied so called "bridging functions" to overcome the gap between national and international approaches. the work also included basics for the harmonisation of modelling approaches. all the work was carried out within 24 international projects and is described in more than 40 publications including 4 books. The main challenges for the future work include the harmonised estimation of changes, the demanding development of remote sensing techniques and a common data policy.

\section{FAO's initiatives and lessons learned on forestry information harmonization}

Carla Ramirez-Zea ${ }^{1}$, David Morales-Hidalgo ${ }^{2}$, Rebecca Tavani ${ }^{1}$, Anne Branthomme ${ }^{3}$, Monica Garzuglia ${ }^{3}$, Leticia Piña ${ }^{3}$, Anssi Pekkarinen ${ }^{3}$ ${ }^{1}$ Food and Agriculture Organization of the United Nations, San Jose, Costa Rica; ${ }^{2}$ Food and Agriculture Organization of the United Nations, Panama, Panama; ${ }^{3}$ Food and Agriculture Organization of the United Nations, Rome, Italy (carla.ramirez@fao.org; david.morales@fao.org; rebecca.tavani@fao.org; anne.branthomme@fao.org; monica.garzuglia@fao.org; leticia.pina@fao.org; anssi.pekkarinen@fao.org)

Harmonization of forest-related definitions is a key process for clear understanding of what we are measuring and reporting, as well as to compare data between countries in order to facilitate decisions and agreements at national, regional and global level. Harmonization allows for both temporal and geographical comparability without differences being attributed to subjective definitions. FAO, through the Global Forest Resources Assessments (FRA) is spear-heading such harmonization efforts. Since 1946, each assessment contributed to the improvement of forest-related definitions. Strong efforts have been made to harmonize and streamline reporting with other international forest-related processes within the framework of the Collaborative Partnership on Forest (CPF). The development of the Collaborative Forest Resources Questionnaire (CFRQ), further simplified and harmonized forest-related reporting and allowed joint collection and analysis of forest data. In parallel to these developments, FAO initiated the National Forest Monitoring and Assessment Program (NFMA) in 2000 with the objective of supporting developing countries to enhance the quality of information through designing and implementing continuous National Forest Inventories (NFI). Further promoting the need for well-defined harmonized definitions for REDD+ reporting requirements which call for a comprehensive National Forest Monitoring System (NFMS), which include NFI data amongst other data sets. This document presents a historical analysis of global harmonization efforts, good practices, lessons learned and their influence on the implementation of the NFMS that FAO has supported in developing countries over the years, with the objective of facilitate the production of transparent, reliable, complete and coherent information.

\section{Harmonisation of the estimation of forest available for wood supply in Europe}

Iciar Alberdi ${ }^{1}$, Thomas Riedel ${ }^{2}$, Sussan Bender ${ }^{2}$, Benoit Pesty $^{3}$, Nickola Stoyanov ${ }^{4}$, Vivian Kvist ${ }^{5}$, Thomas Nord-Larsen ${ }^{5}$, Laszlo Kolosz $^{16}$, Kristaps Makovskis ${ }^{7}$, Andrius Kuliesis ${ }^{8}$, Gintaras Kulbokas ${ }^{8}$, Jan Oldenburger ${ }^{9}$, Andrzej Talarczyk ${ }^{10}$, Marko Kovac ${ }^{11}$, Mitja Skudnik ${ }^{11}$, Michal Bosela ${ }^{12}$, Andrea Camia ${ }^{13}$, Sebastian Schnel $^{12}$, Isabel Cañellas ${ }^{1}$, Francisco C Rego $^{14}$, Christoph Fischer ${ }^{15}$, Sarah Mubareka ${ }^{13}$, Laura H Mateo ${ }^{1}$, Tomas Pikula ${ }^{16}$, Monica Notarangelo ${ }^{17}$, Leonia Nunes $^{14}$, Benoit Pesty ${ }^{18}$, John J Redmond ${ }^{19}$, Maria Rizzo ${ }^{17}$, Vladimir Seben ${ }^{12}$, Arnor Snorrason ${ }^{20}$, Bjarki Thor Kjartansson ${ }^{20}$, Stein Tomter ${ }^{21}$, Silvia Guerrero ${ }^{1}$, Olivier Bouriaud ${ }^{22}$, Alexandra Freudenschuss ${ }^{23}$, Jonas Fridman ${ }^{24}$, Patrizia Gasparini ${ }^{17}$, Thomas Gschwantner ${ }^{23}$, Milos Kucera ${ }^{25}$, Adrian Lanz ${ }^{15}$, Gheorghe Marin $^{26}$, Valerio Avitabile ${ }^{13}$

${ }^{1} I N I A$, Madrid, Spain; ${ }^{2}$ Thünen , Eberswalde, Germany; ${ }^{3} I G N$, Nogent-sur-Vernisson, France; ${ }^{4}$ University of Forestry, Bulgaria, Sofia, Bulgaria; ${ }^{5}$ UCPH, Copenhaguen, Denmark; ${ }^{6}$ Nebih, Budapest, Hungary; ${ }^{7}$ Silava, Riga, Latvia; ${ }^{8}$ State Forest Service, Kaunas, Lithuania; ${ }^{9}$ Probos, Wageningen, Netherlands; ${ }^{10}$ Bureau for Forest Management and Geodesy, Warsow, Poland; ${ }^{11}$ Slovenian Forestry Institute, Ljubljana, Slovenia; ${ }^{22}$ National Forest Centre, Zvolen, Slovakia; ${ }^{13}$ JRC, Ispra, Italy; ${ }^{14}$ ISA, Lisbon, Portugal; ${ }^{15}$ WSL, Birmensdorf, Switzerland; ${ }^{16}$ FMI Brandys nad Labem, Brandys nad Labem, Czech Republic; ${ }^{17}$ CREA, Trento, Italy; ${ }^{18}$ IGN, Nogent-sur-Vernisson, France; ${ }^{19}$ Department of Agriculture, Food and the Marine, Dublin, Ireland; ${ }^{20}$ Icelandic Forest Research, Reykjavik, Iceland; ${ }^{21}$ Norwegian Forest and Landscape Institute, As, Norway; ${ }^{22}$ National Research and Development Institute in Forestry '”Marin, Voluntari, Romania; ${ }^{23}$ BFW, Vienna, Austria; ${ }^{24}$ SLU, Umea, Sweden; ${ }^{25}$ FMI Brandys nad Labem, Brandys nad Labem, Czech Republic; ${ }^{26}$ Forest Research and Management Institute, Bucharest, Romania (alberdi.iciar@inia.es; thomas.riedel@thuenen.de; susann.klatt@thuenen.de; benoit.pesty@ign.fr; stoyanovnick@abv.bg;vkj@ign.ku.dk; tnl@ign.ku.dk; kolozsl@nebih.gov.hu; kristaps.makovskis@silava.lv; andrius.kuliesis@amvmt.lt; Gintaras.Kulbokas@amvmt.lt;jan.oldenburger@probos.nl; andrzej.talarczyk@zarzad.buligl.pl; marko.kovac@gozdis.si;mitja.skudnik@gozdis.si; bosela@nlcsk.org;Andrea.CAMIA@ec.europa.eu; Sebastian.Schnell@thuenen.de; canellas@inia.es; frego@isa.utl.pt; christoph.fischer@wsl.ch; Sarah.MUBAREKA@ec.europa.eu; lauhmateo@gmail.com; pikula.tomas@uhul.cz; monica.notarangelo@crea.gov.it; Inunes@isa.ulisboa.pt; Benoit.Pesty@ign.fr; JohnJ.Redmond@agriculture.gov.ie; maria.rizzo@crea.gov.it; seben@nlcsk.org; arnor@skogur.is; bjarki@skogur.is; stein.tomter@nibio.no; guerrero.garcia.silvia@gmail.com; obouriaud@gmail.com; alexandra.freudenschuss@bfw.gv.at; Jonas.Fridman@slu.se; patrizia.gasparini@crea.gov.it; thomas.gschwantner@bfw.gv.at; kucera.milos@uhul.cz; Adrian.lanz@wsl.ch;ghmarin@roifn.ro; Valerio.AVITABILE@ec.europa.eu.)

Wood is currently the main source of financial revenue from forests and its demand is rapidly growing in Europe. It is important to determine whether forest is available or not for wood supply (FAWS and FNAWS) in order to develop forestry related policies with regard to the maintenance and enhancement of forest resources and their contribution to global carbon cycles. The importance of reporting on FAWS and FNAWS is reflected in the agreed criteria and indicators for sustainable forest management assembled in the State of Europe's Forests and indirectly in the Goals of the UN 2030 Agenda for Sustainable Development. Based on the information provided by the National Forest inventories from 21 European countries, this study aims to quantify the areas of FAWS and FNAWS as well as aboveground dry matter biomass according to national definitions and common reference definitions, and to determine the restrictions and thresholds considered at country level to classify forest into FAWS and FNAWS. Preliminary results indicates that FAWS represents between 80-95\% of forest area and AGB in nearly all of the studied countries. A nested restriction list was elaborated, identifying the restrictions considered for the national estimates and those included in the references definition. In Europe, economic and environmental restrictions are the main factors associated with FNAWS, of which profitability, slope and accessibility as economic and protected areas as environmental restrictions are the most frequently considered types of restrictions determining the forests availability for wood supply.

\section{NFI plot based analysis of forest structure in the mountain forests of the Alps}

Adrian Lanz ${ }^{1}$, Radim Adolt ${ }^{2}$, Christoph Bauerhansl ${ }^{3}$, Jiri Fejfar ${ }^{2}$, Christoph Fischer ${ }^{1}$, Antonio Floris ${ }^{4}$, Patrizia Gasparini $^{4}$, Christian Ginzler ${ }^{1}$, David Hladnik ${ }^{5,6}$, Ivo Kohn ${ }^{2}$, François Morneau ${ }^{7}$, Benoît Pesty ${ }^{7}$, Thomas Riedel ${ }^{8}$, Maria Rizzo ${ }^{4}$, Klemens Schadauer ${ }^{3}$, Mitja Skudnik ${ }^{9}$, Wolfgang Stöger ${ }^{10}$, Stéphanie Wurpillot ${ }^{7}$

${ }^{1}$ Swiss Federal Institute for Forest, Snow and Landscape Research WSL, Birmensdorf, Switzerland; ${ }^{2}$ Forest Management Institute UHUL, Brandýs nad Labem, Czech Republic; ${ }^{3}$ Federal Research and Training Centre for Forests, Natural Hazards and Landscape (BFW), Vienna, Austria; ${ }^{4}$ Council for Agricultural Research and Economics CREA, Trento, Italy; ${ }^{5}$ University of Ljubljana (UL), Ljubljana, Slovenia; ${ }^{6}$ Slovenia and Slovenian Forestry Institute 
(SFI) Ljubljana Slovenia; ${ }^{7}$ Institut National de l'Information Géographique et Forestière (IGN), Nogent-sur-Vernisson, France; ${ }^{8}$ Thünen Institute of Forest Ecosystems (TI), Eberswalde, Germany; ${ }^{9}$ Slovenian Forestry Institute (SFI), Ljubljana, Slovenia; ${ }^{10}$ Bayerische Landesanstalt für Wald und Forstwirtschaft (LWF),Freising,Germany(adrian.lanz@wsl.ch; adolt.radim@uhul.cz; christoph.bauerhansl@bfw.gv.at; fejfar.jiri@uhul.cz; christoph.fischer@wsl.ch; antonio.floris@crea.gov.it; patrizia.gasparini@crea.gov.it; christian.ginzler@wsl.ch;david.hladnik@bf.uni-lj.si; kohn.ivo@uhul.cz; francois.morneau@ign.fr; benoit.pesty@ign.fr; thomas.riedel@thuenen.de; maria.rizzo@crea.gov.it; klemens.schadauer@bfw.gv.at; mitja.skudnik@gozdis.si;wolfgang.stoeger@lwf.bayern.de; stephanie.wurpillot@ign.fr)

Large parts of the Alpine forest are forest protecting people, settlements and transport routes andindustrial installations against natural disasters such as landslides, avalanches, rock avalanches and rock fall. Insufficient utilisation of wood and management causes an imbalanced age structure inforests and compromises the protection against natural hazards. Reliable informaiton on the structure of these forests which are also under considerable use as recreational space and represent valuable landscape elements in a touristic region is of high priority and a precondition for a balanced and efficient management of the functions carried by these forests. In this multi-national forest inventory cooperation, we demonstrate the analysis of the forest structure based on NFI field plots with associated harmonised target variables. At the estimation stage, the NFI plots from Austria, Germany, France, Italy, Slovenia and Switzerland are combined with remote sensing auxiliary data from different sources. Model-assisted GREG regressione stimators which optionally borrow strength from outside the estimation region are applied. The analysis software is implemented as a PostgreSQL extension which was assembled within the Horizon 2020 Diabolo project. The system is both genric and flexible: in the handling NFI plot data sampled accordign to various designs, in the integration of auxiliary data, in the selection of estimators and in the defintion of arbitrary trans-national sub-regions of interest. The analysis of forest structures across the Alpine space provides a common information basis for an improved management of the mountain forest in the Alps.

\section{NFIs of Europe towards future: visions and challenges}

${\text { Annika Susanna Kangas }{ }^{1} \text { iD, Kari T. Korhonen }}$ iD, Minna Räty ${ }^{2}$ iD, Tuula Packalen ${ }^{l}$ iD

${ }^{1}$ Luke, Joensuu,Finland; 2Luke, Helsinki,Finland (annika.kangas@luke.fi; kari.t.korhonen@luke.fi; minna.raty@luke.fi; tuula.packalen@luke.fi)

We outline the current challenges of NFIs in the continental and global level assessments. These challenges come from the variation between national NFI designs, measurements and models. While harmonization is necessary to make meaningful comparisons between the countries, there is a tradeoff in the harmonization between introducing additional uncertainty and losing useful information. For instance, harmonization may require using data from other countries in modelling and predicting some required information. This, in turn may introduce bias in the national level results. Harmonization may also require discarding some nationally important data from the harmonized results, for instance when nationally important forest types are combined to broader level classes. An approach of harmonization maximizing the used information content of the national NFIs and minimizing the added uncertainty is therefore required. Especially, the possibility of introducing national or regional level bias in the process of harmonization needs to be addressed. This introduces methodological challenges into the forest resources estimation that can possibly be solved using either hybrid or model-based estimation. These approaches may also be used for calculating accuracy in the continental or global level assessments which are currently lacking.

\section{Synthesis on bioeconomy monitoring systems in the EU Member States: indicators for monitoring the progress of bioeconomy}

Markus Lier ${ }^{1}$, Martti Aarne ${ }^{2}$, Leena Kärkkäinen ${ }^{1}$, Kari T. Korhonen ${ }^{1}$, Anja Yli-Viikari ${ }^{3}$, Tuula Packalen ${ }^{1}$

${ }^{1}$ Natural Resources Institute Finland (Luke), Joensuu, Finland; ${ }^{2}$ Natural Resources Institute Finland (Luke), Helsinki, Finland; ${ }^{3}$ Natural Resources Institute Finland (Luke),Jokioinen,Finland (markus.lier@luke.fi; martti.aarne@luke.fi;leena.karkkainen@luke.fi; kari.t.korhonen@luke.fi;

anja.yli-viikari@luke.fi; tuula.packalen@luke.fi)

The urgent need to shift our economy towards a more sustainable, resource-efficient bioeconomy based on renewable resources has been recognized widely by the EU Member States (EU MS). Because the main drivers for the transition towards a bioeconomy often strongly vary from EU MS to EU MS depending on the country-specific economic and ecological settings, legal framework, and social demands, also the national or regional bioeconomy strategies vary in their goals and measures. Consequently, proxies and indicators used to measure the development of a national bioeconomy or the success of a bioeconomy strategy depend on the national goals, and are therefore often not applicable in any other country. Nevertheless, synchronizing the national bioeconomy monitoring activities is necessary to ensure comparability of the results of the national monitoring systems. We identified and compared the different approaches within the EU MS to monitor the progress in a country's bioeconomy. An integrated part was the participatory approach of the project, by direct involvement of ministries and research organizations responsible for developing, assessing and monitoring national bioeconomy strategies. This allowed us to identify- existing national bioeconomy strategies,- industries and activities that are included in the bioeconomy sector at national level,- already existing and desired bioeconomy key indicators and their respective data availability. The identified bioeconomy indicators important and feasible at the national context can contribute to the further discussions when setting the frame for the development of a common EU bioeconomy monitoring system.

\section{The importance of forests for people in the Cerrado: evidences from the Brazilian National Forest Inventory}

Raquel Leao', David Fagner de Souza e Lira ${ }^{1}$, Claudia Rosa ${ }^{1}$, Joberto Freitas ${ }^{1}$

${ }^{1}$ Serviço Florestal Brasileiro, Brasilia, Brasil (raquel.leao@florestal.gov.br; liradfs@gmail.com; claudia.rosa@florestal.gov.br;

joberto.freitas@florestal.gov.br)

The Brazilian National Forest Inventory (NFI-BR), currently under implementation in 22 states and in the Federal District, has collected biophysical and socio-environmental data based on a systematic cluster sampling with samples distributed every $20 \mathrm{~km}$ on a regular grid. Biophysical data include information on forest condition. Socio-environmental data provide information on how people use and perceive the forest resources surrounding them. The NFI-BR methodology provides interviews with four people within a radius of $2 \mathrm{~km}$ from the cluster's central point. To better understand the importance of the forests to the people living in the Cerrado biome, the categories assessed were (i) the use of forest products and (ii) environmental services. Results were gathered from 10,007 interviews in the states of Goiás, Mato Grosso, Mato Grosso do Sul, Tocantins, Bahia, Piauí, Maranhão and Distrito Federal. For 31.99\% of the respondents, the use of forest products contributed to the family income, higher in the northern states of the biome $(21.95-65.34 \%)$. The results indicate that the predominant use of wood are as firewood $(42.77 \%)$ and stakes $(37.26 \%)$. The most used non-wood forest products were fruits (46.10\%) and barks (33.34\%). The NFI-BR's socio-environmental survey results is an important tool to identify productive chains to be strengthened, improve Cerrado's products trade, as well as to identify forest management research priorities. In addition, the results could support the formulation of forest management public policies in a local based approach. 
Ecuador's National Forest Assessment: a new cycle of implementation / Evaluación nacional forestal (ENF) del Ecuador. hacia un nuevo ciclo de implementación

Jessica Coronel ${ }^{1}$, Leonardo Ayala ${ }^{1}$, Miguel Chinchero ${ }^{1}$, Ximena Herrera ${ }^{1}$, Juan Iglesias ${ }^{1}$, Digner Jiménez ${ }^{1}$, Carlos Morales ${ }^{1}$, Daniel Segura ${ }^{1}$

${ }^{1}$ Ministerio del Ambiente del Ecuador, Quito, Ecuador (jessica.coronel@ambiente.gob.ec; leonardo.ayala@ambiente.gob.ec;

miguel.chinchero@ambiente.gob.ec; ximena.herrera@ambiente.gob.ec;juan.iglesias@ambiente.gob.ec; digner.jimenez@ambiente.gob.ec;

carlos.morales@ambiente.gob.ec; daniel.segura@ambiente.gob.ec)

En el periodo 2009 - 2014 el Ecuador desarrolló su primera Evaluación Nacional Forestal (ENF) como una iniciativa liderada por el Ministerio de Ambiente del Ecuador (MAE), con el acompañamiento técnico de la FAO. Este instrumento multipropósito se creó con la finalidad de i) proporcionar datos para la toma de decisiones y desarrollo de políticas para el manejo forestal sostenible (MFS), ii) responder a los requerimientos de información forestal en el contexto climático y, iii) promover periodicidad para el monitoreo a largo plazo. Luego de esta primera experiencia del Ecuador en materia de evaluaciones nacionales forestales (ENF1), el país a partir del 2017 se encuentra en un proceso de tránsito hacia un segundo periodo de evaluación (ENF2), continuando con el desafío de recoger información para fortalecer la gestión forestal en el país, considerando las lecciones aprendidas del periodo inicial e insertándose en la actualidad dentro del Sistema Nacional de Monitoreo de Bosques del Ecuador del MAE. La ENF2 hoy en día, recoge todos los aprendizajes de la ENF1, tomando en cuenta desde las nuevas necesidades institucionales, hasta mejoras en el marco de muestreo y el diseño metodológico, manteniendo la estratificación forestal original, perfeccionando el registro florístico e incorporando ajustes en la captura de datos y otras variables de vinculación con el monitoreo forestal satelital. Este nuevo ciclo de trabajo busca evaluar con mayor precisión el potencial productivo de los bosques, sin dejar de determinar existencias carbono en sus distintos almacenes y la diversidad forestal de los bosques del Ecuador, entre otros.

A4c: MONITORING AND ASSESSING URBAN FOREST SERVICES AND VALUES AT THE NATIONAL TO LOCAL SCALE

\section{National forest inventory for assessment of urban trees in India \\ Vindhya Prasad Tewari ${ }^{1}$, Prakash Lakhchaura ${ }^{2}$,Hirendra Tripathi ${ }^{2}$, Rajesh Kumar ${ }^{3}$ \\ ${ }^{1}$ Himalayan Forest Research Institute, Shimla, India; ${ }^{2}$ Forest Survey of India, Dehradun, India; ${ }^{3}$ National Sample Survey Office, Dehradun, India \\ (vptewari@yahoo.com; prakash293@gmail.com; tripathi_hk@rediffmail.com; rajsus1@rediffmail.com)}

In India, National Forest Inventory also includes inventory of urban trees since 2002 on a two-year cycle by stratifying the country into 14 physiographic zones. The sampling frame for the selection of sampling unit in urban areas is obtained from National Sample Survey office who has prepared sampling frames for each urban area of the country. The surveys in urban areas are carried out by dividing all the urban centers of a district into Urban Frame Survey (UFS) blocks which are of varying sizes. The UFS blocks have well defined boundaries and are formed on the basis of population or number of households and cover the whole area within the geographical boundary of towns including vacant lands. For estimating tree wealth, species name, dbh, crown width etc. are recorded on each tree falling in the selected UFS block.The total tree wealth for a selected district is estimated using value of corresponding parameter from the selected UFS blocks. On the basis of tree wealth of sampled districts, the tree wealth in each physiographic zone is estimated. Aggregation of tree wealth of all the physiographic zones leads to tree wealth estimate of the country. The present estimate is based on 7360 UFS blocks falling in 180 sampled districts across the country which were inventoried during the period spanning from 2010 to 2016 . The total urban tree cover of the country has been estimated to be 14,147 sq km, which constitutes $17.14 \%$ percent of the country's urban area.

\section{National U.S. urban forest inventories and monitoring}

David Nowak ${ }^{1}$, Mark Majewsky ${ }^{2}$, Tonya Lister ${ }^{3}$

${ }^{1}$ USDA Forest Service, Syracuse, USA; '2USDA Forest Service, Tofte, USA; ${ }^{3}$ USDA Forest Service, Newtown Square, USA (dnowak@fs.fed.us; mmajewsky@fs.fed.us; tlister01@fs.fed.us)

The United States Forest Service has been inventorying and monitoring urban forests since the 1990s. These urban forest assessments evaluate and monitor the entire urban forest population, as well as assess their associated ecosystem services and values. The program initially started with developing methods to assess individual city' urban forests, which led to the development of the free urban forest assessment modeling tool suite known as i-Tree (www.itreetools.org [http:// www.itreetools.org]). This tool suite can be used globally to inventory and monitor urban forests, as well as assess ecosystem services and values. In addition to i-Tree, the U.S. Forest Service implemented a national urban forest inventory (FIA) program in 2014 (https:/www.nrs.fs.fed.us/fia/urban/ [https://www.nrs. fs.fed.us/fia/urban/]), with a goal to monitor urban forests in the 100 most populated cities, as well as the 68 million acres of urban land nationwide. To date, over 35 cities are being monitored annually. This presentation will discuss the development of the U.S. national urban forest inventory program, the integration of i-Tree within the current urban FIA program, and methods and outputs of both programs. These U.S. based methods and tools can help facilitate the development of urban forest monitoring programs in other nations. Expanded urban forest inventories and monitoring will lead to a better understanding of this important resource and how it is changing, as well as improve forest management to sustain environmental quality and human health in cities across the world.

\section{Chapultepec: old urban park in Mexico City but new information. pioneering the quantification-valorization of environmental services using the i-Tree Eco version adapted to Mexico}

Hector M. Benavides-Meza

1INIFAP, Mexico, Mexico(hmb27@yahoo.com.mx)

Chapultepec Forest has been a strategic place for Mexico City for more than seven centuries. In the beginning as potable water source and game preserve for the Aztec emperors. After the Spanish conquest, Chapultepec was declared property of the city (1530) and remained up to the XIX Century as the source of water and the country residence of viceroys, presidents and emperors at Chapultepec Castle. The periurban forest role changed in the early XX Century to an urban park, when the outskirts of the city and the new ways of transportation reached the forest. Urban forestry researchers have studied the benefits-environmental services provided by the urban forest and the important contributions that supplied to city dwellers and the urban environment. Nowadays i-Tree Eco allows the quantification of those environmental services as well as its economic value. Recently this software was adapted for more than 30 Mexican cities where more than $60 \%$ of the population lives. Updated tree inventory data from Chapultepec was run in the adapted version and for the first time the environmental services and the economic value of these benefits was determined for any urban green space in Mexico; 21,902 trees were inventoried and the results are presented for 
every zone/subzone. The most important environmental services provided by the tree cover of Chapultepec was the carbon reservoir (6,216 Mg) and the capture of air pollutants (9.8 Mg/year), however this environmental service showed the highest economic value of all of them (around \$475,000.00 USD/year).

\title{
Urban forests in Latin America: opportunities and challenges
}

\author{
Tahia Devisscher ${ }^{1}$, Cynnamon Dobbs ${ }^{2}$, Francisco Escobedo ${ }^{3}$, Ferreira da Silva Filho Demóstenes ${ }^{4}$, Mariana Baptista ${ }^{5}$, Mónica Nuria Navarro $^{1}$, \\ Camilo Ordóñez Barona ${ }^{6}$, Luis A Orozco Aguilar ${ }^{6}$ \\ ${ }^{1}$ University of British Columbia, Melbourne, Canada $;{ }^{2}$ Universidad Mayor, Santiago, Chile; ${ }^{3}$ Universidad del Rosario, Bogota, Colombia $;{ }^{4}$ Universidade \\ de São Paulo, São Paulo, Brasil; ${ }^{5}$ RMIT University, Melbourne, Australia; ${ }^{6}$ The University of Melbourne, Melbourne, Australia (tahia.devisscher@ubc. \\ ca; cdobbsbr@gmail.com; franciscoj.escobedo@urosario.edu.co; desilvafilho@gmail.com; marianadbaptista@gmail.com; nuriamnavarropl@gmail.com; \\ camilo.ordonez@unimelb.edu.au; lorozco@student.unimelb.edu.au)
}

Urban forests in Latin America \& the Caribbean (LAC) face several challenges, including socio-economic inequities, scarce resources for management and planning, increased exposure to climate extremes, and new demands for participatory governance processes. Although research on urban forests has expanded in the last 30 years in the US, Canada, Europe, and Australia, it is unclear what this research looks like in LAC, and where it is going. LAC is one of the most urbanized, socially inequitable, and climate-vulnerable regions in the world, and despite the potential of urban forests for alleviating many of these problems, there are no regional-scale assessments on how urban forests contribute to sustainability and resilience in the region. We address this gap by providing a baseline understanding of urban forestry and its potential in LAC. We systematically reviewed the scientific literature on urban forests in LAC, including 182 scientific articles from 13 countries, published from 1970 to 2018 (inclusive) in English, Spanish, and Portuguese. Based on this empirical scientific evidence, and online survey data collected from a wide range of practitioners and researchers working on urban forests in the region, we provide a map of urban forest research, strategies, and practice in Latin America. This presentation will assess current discourses, research directions and needs, capacities, barriers, and opportunities in urban forestry in the region. We discuss these findings in the context of global trends in urban forest research, planning, and management in relation to nature-based solutions and ecosystem services.

\section{Urban greenery variations in 31 main cities and their association with climatic, socio-economic status, and forest attributes: inter- and intra-city comparison}

Xingyuan He ${ }^{1,2}$, Lu Xiao ${ }^{1}$, Wenjie Wang ${ }^{1,3}$

${ }^{1}$ Northeast Institute of Geography and Agroecology, Chinese Academy of Science, Changchun, China; ${ }^{2}$ Institute of Applied Ecology, Chinese Academy of Sciences Shenyang China; ${ }^{3}$ Northeast Forestry University Harbin China (hexingyuan@iga.ac.cn ; xiaolu@iga.ac.cn; wangwenjie@iga.ac.cn)

Urban greenery from street-view image provide new tool for evaluating urban green spaces, their utilization in evaluation at national scale and local scale are scarce. Here, we assess urban greenery, quantified by green view index, variations in 31 provincial capital cities in China, and ask two questions 1) How does urban greenery vary, and 2) how do climatic, socio-economic status, and forest attributes drivers contribute to this variation? We found that Hefei, Chengdu and Chongqing had the best urban greenery, while Shijiazhuang and Lhasa had the poorest greenness on average. Greenery variations, as manifested by standard deviation of total measured data, was lowest in Lhasa and Urumqi, while the largest variations were found in Nanjing. These urban greenery pattern on average was mainly controlled by climatic condition, rather than socio-economic status. The lower sunshine hours, higher MAP and RH, together with higher income and GDP usually accompanied with highest peak greenery. However, we failed to find that higher social development accompanying deduction in intra-city greenery variations, indicating a risk that economic development in China has possibly resulted in even larger inequality of greenery distribution in urban region. By using Changchun as an example, greenery variation in a city and possible reason were also studied, and we found that the urban greenery was mainly driven by green space total area, landscape shape index, and tree diameter at breast height (DBH). Our data in this paper provide a new basis for urban greenspace management from the street scape both in one-city or multiple city level.

Scale issues in remote sensing-based tree cover assessment along the rural-urban gradient of Bengaluru, India: comparing four sensors from $30 \mathrm{~m}$ to $30 \mathrm{~cm}$ spatial resolution

Nils Nölke ${ }^{1}$, Md. Abdullah Al Mahmud ${ }^{1}$, Christoph Kleinn ${ }^{1}$

${ }^{1}$ University of Goettingen, Dept. of Forest Inventory and Remote Sensing, Faculty of Forest Sciences and Forest Ecology, Goettingen, Germany

(nils.noelke@forst.uni-goettingen.de;m.mahmud@stud.uni-goettingen.de; ckleinn@gwdg.de)

In fast developing megacities, the rapid rate of urbanization is leading frequently to drastic changes in tree cover which may follow different patterns along the rural-urban gradient. Monitoring of changes in tree cover may be desired for an assessment of potential ecological functions of these trees. Remote-sensing time series are among the very few data sources that allow such monitoring in an efficient manner. However, estimating tree cover in more or less densely built-up areas is a notorious challenge per se - and sensors of different spatial resolutions may perform differently. This study researches into the question of how sensors of different spatial resolution "see" tree cover of different composition and configuration along a rural-urban gradient. Our study area was the very fast-developing megacity of Bengaluru, India. WorldView-3 imagery of $30 \mathrm{~cm}$ resolution served to measure true tree cover on 330 1-hectare square sample plots laid out systematically over a $5 \mathrm{~km}$ x $50 \mathrm{~km}$ transect extending from the city center to the more rural outskirts. The results illustrate that sensors of different resolution of $30 \mathrm{~m}$ (Landsat 8), $10 \mathrm{~m}$ (Sentinel-2A) and $5 \mathrm{~m}$ (RapidEye) determine tree cover differently- where all 3 sensors underestimate the true tree cover along the rural-urban gradient. This underestimation may also have to do with the overestimation of impervious surface as reported for Landsat. The results of our study are relevant for unbiased and compatible estimation of tree cover in built-up environments and point to the need for suitable calibration approaches.

\section{The pattern of tree species composition changes along the urban-rural gradient in the Indian megacity of Bengaluru}

Baragur Neelappa Divakara ${ }^{1}$, Chitradurga Umesh Nikhitha ${ }^{1}$, Nils Nölke², Vindhya Prasad Tewari ${ }^{3}$, Christoph Kleinn ${ }^{2}$

${ }^{1}$ Institute of Wood Science and Technology, Bengaluru, India; ${ }^{2}$ Georg-August-University, Goettingen, Germany; ${ }^{3}$ Himalayan Forest Research Institute, Shimla,India(bndsira@gmail.com; thoshitha.cu@gmail.com; nils.noelke@forst.uni-goettingen.de; tewarivp@gmail.com; ckleinn@gwdg.de)

Urban expansion and the corresponding growth in the industrial and economic sector due to construction activities, infrastructure expansion and population inflow has a major impact on biodiversity and ecosystems at various scales. Our study was to elucidate the details of tree composition, density and diversity along the urban-rural gradient in two research transects in the Northern and Southern parts of Bengaluru. Twenty-three and twenty-five plots of 1 ha each were surveyed within the Northern and Southern transects respectively with aid of World View - 3 imagery $(0.30 \mathrm{~cm})$. A total of 93 and 83 tree species were observed 
in the northern and southern transact respectively. Diversity indices such as Shannon index, Simpson index, Pielou's evenness and Margalef's richness served to analyse how tree species diversity changes along the gradient. Our analysis revealed that tree species are about evenly distributed over all three domain categories for both the Northern and the Southern transect. The diversity index was about constant for the urban domain and the curve decreases as moved towards the transition and rural domain showing less species diversity and dominant species in comparison with urban domain for northern plots, whereas for southern plots no significant trend in the curve were observed as they varied from plot to plot, but decreased towards the transition and rural domain. The overall comparison of northern and southern plots indicated that, the northern plots were more diverse in terms of species richness and total number of trees surveyed i.e 1128 and 1080 trees respectively.

\section{Regulating services from forest tree species in urban park, Bangkok, Thailand}

Areerut Yarnvudhi ${ }^{1}$, Nisa Leksungnoen ${ }^{1}$

${ }^{1}$ Kasetsart University, Bangkok, Thailand; (psdaryv@ku.ac.th; ffornsl@ku.ac.th)

Bangkok has been urbanized with rapid growth of population and expected to become one of the world's megacities by 2030 with a population over 10 million. The overpopulation causes an inadequate basic infrastructure and health problem from the pollutions for people.Bangkok has green space only 13 m ${ }^{2}$ per capita which is less than what United Nations (UN) recommends ( $30 \mathrm{~m}^{2}$ per capita); therefore, increase green area in Bangkok is necessarily urgent task. Consequently, Chulalongkorn University Centenary Park was established in central Bangkok. The park is aimed to serve for societies' activities, economic, aesthetic, flood defenses and communities' health. This study was focused on regulating services of urban forest in this park emphasizing on air pollution tolerant index (APTI) and air and soil temperature reduction.Trees in the park consist of 19 species from 17 genera and 10 families with both deciduous (9) and evergreen (10) species. Most species were intermediate tolerance to air pollution regarding to the APTI approximately 11 - 13 . Trees in the park could reduce air temperature between 0.60 - 2; 53 oC while the soil temperature was cooler than the concrete pavementby $9.75-11.35$ oC. Species selection is one the most important processes for ecosystem services. We recommended that the species with thicker leaf and high relative water content tolerate more pollution. Hairy and light-color leaves would reflect more radiation than darker leaves while dense canopy with high leaf area can reduce more air and soil temperature.

\section{A4p: MONITORING AND ASSESSING URBAN FOREST SERVICES AND VALUES AT THE} NATIONAL TO LOCAL SCALE

\section{Urban carbon budget for Seoul's community forest landscapes}

Hyun-Kil Jo ${ }^{1}$

${ }^{1}$ Department of Ecological Landscape Architecture Design, Kangwon National University, Chuncheon, Republic of Korea (jhk@kangwon.ac.kr)

Urban forests play an important role in supplying carbon offset and other ecological services in urban landscapes. This study quantified the role of community forest landscapes in urban carbon budget for Seoul, the capital of the Republic of Korea. Urban community forests are here defined as the forests except parks within urban area delimited by zoning regulations. Storage and annual fixation of carbon by the community forests were estimated applying carbon indicators for trees and soils per unit area by forest type and age class. Their carbon offset services were quantified reflecting carbon emissions from energy consumption. Total area of the community forests accounted for about $22 \%$ of total study city area. Carbon storage in trees and soils of the community forests was approximately $2,090 \mathrm{kt}$, and their annual carbon fixation was $116.8 \mathrm{kt}$. Of all forest types and age classes, broad leaved forests of age class IV (31-40 years) showed the greatest carbon input due to higher carbon estimates per unit area and larger total area. The community forest landscapes annually offset total carbon emissions from residential electricity consumption by $7.3 \%$, and their carbon storage was equivalent to 1.3 times of the carbon emissions. Desirable planning and management strategies should be explored to improve the role for the community forests to contribute to urban carbon budget.This study was carried out with the support of the 'R\&D Program for Forest Science Technology (Project No; 2017043B10-1919-BB01)' provided by Korea Forest Service (Korea Forestry Promotion Institute).

\section{Services of particulate matter reduction by urban parks in Seoul}

Hyun-Kil Jo ${ }^{1}$, Hye-Mi Park

${ }^{1}$ Department of Ecological Landscape Architecture Design, Kangwon National University, Chuncheon, Republic of Korea (jhk@kangwon.ac.kr; phm2071@ gmail.com)

Increasing concentration of fine particulate matter (PM), which negatively affects human health, is a serious environmental concern in the world. The purpose of this study was to quantify PM $^{2.5}$ reduction services by urban parks in Seoul, the capital of the Republic of Korea and to suggest desirable planting strategies to improve the services. A total of 38 parks was sampled applying a stratified random sampling method, and then all the trees planted in each park were fieldsurveyed including species, stem diameter, and crown volume. These survey data and a dry deposition model were used to estimate annual PM ${ }^{2.5}$ reduction by park trees. Tree cover averaged about $50.9 \%$ in study parks. Trees with stem diameter at breast height of less than 30 cm accounted for $81.3 \%$ of all the trees. Annual $\mathrm{PM}^{2.5}$ reduction per unit area by the trees was approximately $23.1 \mathrm{~kg} / \mathrm{ha} / \mathrm{yr}$, and total $\mathrm{PM}^{2.5}$ reduction of the entire park area in the study city was $102.6 \mathrm{t} / \mathrm{yr}$ Total annual $\mathrm{PM}^{2.5}$ emissions from human activities were about 2,580 t/yr in the study city. Seoul's urban parks annually offset the PM ${ }^{2.5}$ emissions by $4.0 \%$. To enhance $\mathrm{PM}^{2.5}$ reduction services, suggested are minimization of extensive grass area, full planting in available growing spaces, and multi-layered and multiaged tree planting. This study could be useful in sharing the role of urban parks regarding PM ${ }^{2.5}$ deposition. This study was carried out with the support of the 'R\&D Program for Forest Science Technology (Project No; 2017043B10-1919-BB01)' provided by Korea Forest Service (Korea Forestry Promotion Institute).

\section{Uptake of air pollutants by street trees in Seoul}

Hyun-Kil Jo', Jin-Young Kim²

${ }^{1}$ Department of Ecological Landscape Architecture Design, Kangwon National University, Chuncheon, Republic of Korea; ${ }^{2}$ Department of Landscape Architecture, Graduate School, Kangwon National University, Chuncheon, Republic of Korea (jhk@kangwon.ac.kr; jykim84@kangwon.ac.kr)

This study quantified uptake of SO2, NO2, and $\mathrm{O} 3$ by street trees in Seoul, the capital of the Republic of Korea and explored suitable planting and management strategies to enhance the uptake. A stratified sampling method was applied to select 50 plots and street trees within each plot were field-surveyed to analyze horizontal and vertical planting structures.Annual uptake ofthe air pollutants was estimated using quantitative models derived from deposition velocity by 
pollutant and leaf area by tree species and size. Mean tree density and cover were 5.8 trees/100 $\mathrm{m}^{2}$ and $12.1 \%$, respectively. Trees with stem diameter at breast height of less than $30 \mathrm{~cm}$ accounted for $66.3 \%$ of all the trees. Annual uptake per unit area ofthe air pollutants by the trees averaged $2.1 \mathrm{~kg} / \mathrm{ha} / \mathrm{yr}$ for SO2, $7.0 \mathrm{~kg} / \mathrm{ha} / \mathrm{yr}$ for NO2, and $5.1 \mathrm{~kg} / \mathrm{ha} / \mathrm{yr}$ for O3. Total annual uptake of each air pollutant for the entire street area in the study city was about $18 \mathrm{t} / \mathrm{yr}$ for SO2, $59 \mathrm{t} /$ yr for $\mathrm{NO} 2$, and $43 \mathrm{t}$ /yr for O3. Seoul's street trees annually offset total SOx and NOx emissions from vehicles by approximately $89.1 \%$ and $0.2 \%$, respectively. To improve the offset benefits, suggested are multi-layered and multi-aged tree planting, securing ground and space for normal tree growth, and avoiding excessive tree pruning. Study results could be useful in globally sharing air purification services of street trees and desirable planting techniques. This study was carried out with the support of the 'R\&D Program for Forest Science Technology (Project No; 2017043B10-1919-BB01)' provided by Korea Forest Service (Korea Forestry Promotion Institute).

\section{Microclimatic simulation in urban heat island area in Natal, RN, Brazil}

Joaquim Custódio Coutinho', Flávio Henrique Mendes², Amanda Brito da Silva ${ }^{1}$, Wesley Brito da Silva

${ }^{1}$ Universidade Federal do Rio Grande do Norte, Natal, Brasil; ${ }^{2}$ Universidade de São Paulo, Escola Superior de Agricultura "Luiz de Queiroz", Piracicaba, Brasil(joaquimcustodiocoutinho@gmail.com; friquemendes@usp.br; amandab_silva12@hotmail.com; wesleybrito.natal@hotmail.com)

The urban heat island is a common problem of large urban centers. As a consequence, it entails higher energy costs due to uncomfortable environments. The objective of this research was to analyze the thermal behavior of a densely urbanized area in Natal/RN/Brazil (city with almost one million inhabitants) and, from this, to identify critical locations regarding air temperature. We used the ENVI-met version 3.1 to perform the microclimatic simulation of an area of 51.8 ha. The software requires two input files: (i) modeling of the area, containing buildings, vegetation and soil and (ii) microclimatic variables, with air temperature $\left(27.24{ }^{\circ} \mathrm{C}\right)$, relative air humidity $(76 \%)$, wind direction $\left(138{ }^{\circ} \mathrm{SE}\right)$, wind speed $\left(4.4 \mathrm{~m} \mathrm{~s}^{-1}\right)$ and specific humidity $\left(5.7 \mathrm{~g}\right.$ water kg ar $\left.{ }^{-1}\right)$, with data from the Meteorological Stations of Aeroporto de Natal and the Parque das Dunas, representing a typical summer day (January/2016 - 9:00 p.m., to ensure neutral atmosphere conditions). To obtain stable results, the simulation was done in the cloud and took 104 uninterrupted hours. The results showed that the hottest hour of the day was at 1:00 p.m., with a difference of up to $2{ }^{\circ} \mathrm{C}$ within the simulated cutout, with the highest temperatures in places with little or no vegetation. Thus, these areas should be considered as priorities for planning and urban afforestation actions, considering the benefits of vegetation in the amortization of the heat island effect, by promoting better conditions of thermal comfort for the population.

\section{Comparison of two urban heat islands in the center of Natal, RN, Brazil}

Joaquim Custódio Coutinho ${ }^{1}$, Flávio Henrique Mendes ${ }^{2}$, Amanda Brito da Silva ${ }^{1}$, Wesley Brito da Silva

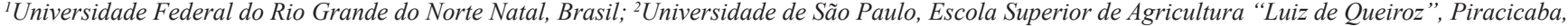
Brasil(joaquimcustodiocoutinho@gmail.com; friquemendes@usp.br; amandab_silva12@hotmail.com; wesleybrito.natal@hotmail.com)

The phenomenon of the heat island is understood by a climatic event occurring in urban centers, expressing a higher temperature when compared to the areas of its surroundings. The objective of this research was to analyze and compare the air temperature for two areas in the urban center of Natal/ RN/ Brazil, where the urban heat island occurs. For this, we used the ENVI-met version 3.1 program to perform the microclimatic simulation, one in the East Zone and the other in the North Zone. The program requires two input files: (i) modeling of the area, containing buildings, vegetation and soil and (ii) microclimatic variables, with air temperature $\left(27.24^{\circ} \mathrm{C}\right)$, relative humidity $(76 \%)$, wind direction (138 $\left.{ }^{\circ} \mathrm{SE}\right)$, wind speed $\left(4.4 \mathrm{~m} \mathrm{~s} \mathrm{~s}^{-1}\right)$ and specific humidity $\left(5.7 \mathrm{~g}\right.$ water $\left.\mathrm{kg} \mathrm{ar}^{-1}\right)$, with data from the Meteorological Stations of Natal Airport and the Parque das Dunes, representing a typical summer day (January / 2016 - 21 h). The simulation of the East and North Zone clipping was done in the cloud and took 104 and 160 consecutive hours, respectively, with the highest air temperature values in both regions at 1:00 p.m. The difference in air temperature was the same for the two heat islands. However, the Northern Zone presents more points with maximum temperatures when compared with the other urban area studied. Thus, the Northern Zone demonstrates a priority in the increase of afforestation in public roads, parks and squares to soften the effect of the urban heat islands.

\section{Urban green areas and real estate prices in Curitiba, Brazil}

Alessandro Panasolo ${ }^{1}$, Franklin Galvão ${ }^{1}$, Hermes Yukio Higachi ${ }^{2}$, Edilson Batista de Oliveira ${ }^{3}$, Fernando Campos de Oliveira ${ }^{4}$, Carlos Augusto Wroblewski ${ }^{1}$, Tatiana Gadda ${ }^{5}$, Camila Fossa Balbinot ${ }^{6}$

${ }^{1}$ Universidade Federal do Paraná, Curitiba, Brasil; ${ }^{2}$ Universidade Estadual de Ponta Grossa, Ponta Grossa, Brasil; ${ }^{3}$ Embrapa Florestas, Colombo, Brasil; ${ }^{4}$ Fundação Boticário, Curitiba, Brasil; ${ }^{5}$ Universidade Tecnológica Federal do Paraná, Curitiba, Brasil; ${ }^{6}$ Instituto Capital Natural, Curitiba, Brasil (apanasolo@gmail.com;fgalvao@ufpr.br; hhigachi@uepg.br; edilson.oliveira@embrapa.br;fercampos@gmail.com; carloswroblewski@ufpr.br; tatianagadda@utfpr.edu.br; camilabalbinot@gmail.com)

This research aims to evaluate the impact of urban green areas in the prices of apartments and houses in the city of Curitiba, PR, and to propose a methodology for valuation of ecosystem services generated by urban green areas. The study was based on econometric techniques and Theory of prices provides pleasure, applied in 43 urban green areas, with three units: Private Reserve of the Municipal Natural Municipal Airumã; Teresa Urban Ecological Station; and, refinery President Getúlio Vargas (Repar). Were obtained information about the structural characteristics of 2,832 2,500 apartments and houses. Presented results of exploratory spatial data Analysis (ESDA) and the parameter estimates of the regression models and provides pleasure (theory of prices provides pleasure). The results revealed that these areas contribute to the formation of the final price of the property. Thus, it is concluded that the farther a property located in the commercial and Service Center (CBD) lower your selling price, at the same time that the proximity of the property of green urban areas contributes to the increase in the price of a square meter of housing. However, the real estate valuation should not be interpreted in a linear fashion, as well as, it must be considered that the effects of public and private green areas on the price of residential properties are not homogeneous and stationary along the urban space, and may generate different spatial clusters of real estate prices: high-high and low-bass.

\section{Thermal comfort in the different types of urban forest of Curitiba, Paraná, Brazil \\ Angeline Martini $^{\text {iD ; Daniela Biondi }{ }^{2} \text {, Antonio Carlos Batista }}{ }^{2}$, Jennifer Viezzer ${ }^{2}$}

${ }^{1}$ Universidade Federal Viçosa, Viçosa, Brasil; ${ }^{2}$ Universidade Federal do Paraná, Curitiba, Brasil (martini@ufv.br; dbiondi@ufpr.br; batistaufpr@ufpr.br; jeviezzer@yahoo.com.br)

The presence of urban forest is fundamental for the quality of life in the cities due to its numerous benefits, among which the thermal comfort stands out. Determining how to better plan the cities' vegetation to promote thermal improvement becomes critical in the face of climate change. Thus, the aim of this 
research was to analyze the thermal comfort provided by the different typologies of urban forest present in the city of Curitiba. For this, three distinct areas were selected for each type of urban forest (forest fragments, old green area, new green area, street trees, and isolated trees). The variables temperature $\left({ }^{\circ} \mathrm{C}\right)$ and air relative humidity (\%) were collected every minute, with a Hobo ${ }^{\circledR}$ model data logger, installed in meteorological mini-shelters for 48 hours during summer. These variables were used to calculate the Human Discomfort Index (HDI). The results showed an average HDI lower for the forest fragments and higher for the isolated trees, with maximum values of 75.8 and 84.9 , respectively. In all typologies, the "comfortable" class was predominant for the most part, which proves the benefit provided by the urban forest. The isolated trees presented "discomfort" to the heat only in $8.4 \%$ of the analyzed time, and the street trees in $3.5 \%$. For the other typologies, values of discomfort were observed on lower than $0.5 \%$ of the time. Therefore, all typologies of urban forest contribute to thermal comfort, with the greatest benefits provided by fragments of forest remains.

\title{
Cooling potential of the vegetation in urban squares on their immediate surroundings in Curitiba, Paraná, Brazil \\ Angeline Martini $^{1}$; Daniela Biondi ${ }^{2}$, Antonio Carlos Batista ${ }^{2}$, Jennifer Viezzer ${ }^{2}$ \\ ${ }^{1}$ Universidade Federal Viçosa, Viçosa, Brasil; ${ }^{2}$ Universidade Federal do Paraná, Curitiba,Brasil (martini@ufv.br;dbiondi@ufpr.br; batistaufpr@ufpr.br; jeviezzer@yahoo.com.br)
}

The adoption of green areas has been proposed to improve the climatic conditions of cities, making it essential to understand the climatic effect provided by the different compositions of the urban forest. Forest fragments in cities have significant cooling potential. However, these areas are increasingly scarce, making the creation of urban squares with trees in practice more promising. The present study aimed to analyze the air temperature and the cooling potential of the vegetation present in urban squares on their immediate surroundings, comparing their effect with the ones provided by forest fragments in the city of Curitiba. For this, three squares and three forest fragments located in the central portion of the city were selected. Meteorological data was collected using two Kestrel ${ }^{\circledR}$ markings, simultaneously inside the area of interest (urban square or forest fragment) and on a mobile transect through an adjacent street, during summer. On average, the air temperature was $2.4^{\circ} \mathrm{C}$ lower in the urban squares than in the transect, and $4.2{ }^{\circ} \mathrm{C}$ lower in the forest fragments. Up to $100 \mathrm{~m}$ away, the urban squares contributed to reduce $0.6^{\circ} \mathrm{C}$ in their surroundings, while the forest fragments contributed to $0.7^{\circ} \mathrm{C}$. The radius of influence of the urban squares on their surroundings reaches approximately $150 \mathrm{~m}$ and the forest fragments, $250 \mathrm{~m}$. Thus, even though forest fragments presented a greater effect, we believe that urban squares with trees contribute to the microclimatic improvement of the city, being an efficient alternative for the cooling of their immediate surroundings.

\section{A4q: MONITORING AND ASSESSING URBAN FOREST SERVICES AND VALUES AT THE NATIONAL TO LOCAL SCALE \\ Effects of wind on trees / Ação do vento em árvores \\ Raquel Amaral ${ }^{1}$, Takashi Yojo ${ }^{1}$, Reinaldo Lima ${ }^{1}$, Ana Paula Silva ${ }^{1}$, Gilder Nader ${ }^{1}$, Paulo Jabardo ${ }^{1}$ \\ ${ }^{1}$ Instituto de Pesquisas Tecnológicas do Estado de São Paulo, São Paulo,Brasil(raquel@ipt.br; yojos@ipt.br; reinaldol@ipt.br; apaula@ipt.br; gnader@ipt.br; pjabardo@ipt.br)}

A chegada do verão traz também um aumento no número de queda de árvores, causando problemas na circulação de veículos, prejuízos materiais e, o mais grave, riscos de acidentes para a população. Para determinar o risco de queda, utiliza-se um modelo probabilístico e dinâmico que considera parâmetros como: altura total da árvore, diâmetro à altura do peito, porcentagem de deterioração interna e densidade aparente do lenho. Além disso, simula a ruptura da árvore em 12 diferentes velocidades de vento, indicando a probabilidade de rompimento no colo (transição da raiz com o tronco). Devido à variação do coeficiente de arrasto em função da velocidade do vento nas árvores, foram desenvolvidos ensaios com galhos de eucalipto (Eucalyptus sp., Myrtaceae) em túnel de vento para determinação destas variações. A partir desses resultados e do comportamento das árvores sob a ação do vento, foi desenvolvida uma metodologia genérica de modelagem numérica de copas de árvores por meio de um modelo de interferência de esteiras para extrapolar os dados de um galho para a árvore inteira. Os resultados obtidos, a partir dos ensaios de galhos de eucalipto, servirão para diminuir as incertezas da análise de risco de queda das árvores na condição urbana e nos plantios homogêneos de eucalipto.

Restoring species using analog forestry techniques in the Gran Parque Metropolitano de La Habana, Cuba / Restauración de especies mediante las técnicas de Forestería Análoga en el Gran Parque Metropolitano de La Habana, Cuba

\author{
Ana María Peñalver Jaime ${ }^{1}$, Wilmer Toirac Arguelle ${ }^{1}$, Orlidia Hechavarría Kindelán ${ }^{1}$ \\ ${ }^{1}$ Instituto de Investigaciones Agro-Forestales, La Habana,Cuba (anamarianalverp@gmail.com; wilmer@forestales.co.cu; orlidia@forestales.co.cu)
}

El estudio se realizó en el Gran Parque Metropolitano de La Habana perteneciente al municipio Plaza en la provincia Habana en el periodo de febrero - marzo de 2017,empleando las técnicas de Forestería Análoga (FA) se realizó un análisis de la estructura y composición de la vegetación del área. Cumpliendo con los 12 principios que rigen la FA se realizó la valoración ecológica en el área la cual contiene una clave numérica de 1-8 y comprende diferentes indicadores tales como: perfil del suelo, densidad aparente, macro-fauna del suelo, componente vegetal e indicadores de productividad. Además, se plasmó la fórmula fisionómica de la vegetación para obtener una representación en símbolo de la estructura y composición del sitio;, se elaboró una tabla de datos de las especies existente y se realiza una propuesta de especies a utilizar en la restauración con objetivo de crear un ambiente recreativo. Para este fin se tuvo en cuenta el tipo de suelo, y las exigencias de cada especie.

\section{Computer machine learning to evaluate the safety condition of urban forest}

\section{Luís Miguel Ferreira Martins ${ }^{1,2}$, Hélder Sousa ${ }^{1}$, Tânia Gabirro ${ }^{1}$}

${ }^{1}$ Universidade de Trás-os-Montes e Alto Douro, Vila Real, Portugal; ${ }^{2}$ Centre for the Research and Technology of Agro-Environmental and Biological Sciences,Vila Real,Portugal (lmartins@utad.pt; hfps@utad.pt; taniagabirro@gmail.com)

Phytosanitary assessment and tree inventory are important tools to help the management and organization of all activities in order to improve the Urban Forests quality and safety. In Porto city (Portugal), the urban trees, namely in the urban parks, were evaluated in the period of 2016-2017. In the urban parks of Palácio de Cristal, Mata da Pasteleira, Parque da Cidade, Parque Oriental, Quinta do Covelo and Parque de São Roque a total of 24.380 trees were evaluated, considering 42 attributes for each tree (12 quantitative attributes and 30 qualitative attributes). By using those attributes a machine learning (ML) methodology was performed in order to recognize the best variables to explain the health condition evaluated by Visual Tree Assessment (VTA). The ML methods are based 
on learning data representations, as opposed to task-specific algorithms. In this study were used supervised, semi-supervised and unsupervised data. First the supervised data was performed using a ML algorithm for a universe of 1600 trees. The model can quantify if the biotic or abiotic injuries in trunk, or principal branches are based in quantified variables. The model can also explain the most important variables related to the safety conditions as well as, recognize the differences between injurie dimensions, and the relation between the tree height and the trunk diameter. By using the ML, first tested in a high amount of data, is also possible to predict the risk conditions and reduce the subjectivity of VTA method.

\section{Biotic integrity in urban forests in Southeast Brazil}

Vanessa Peixoto Giacon ${ }^{1}$, Ana Paola Di Toro ${ }^{1}$, Eliana Cardoso-Leite ${ }^{1}$

${ }^{1}$ Universidade Federal de São Carlos, Sorocaba,Brasil (vanessapeixotogiacon@gmail.com; anapaolagomes@hotmail.com; cardosoleite@yahoo.com.br)

In southeastern Brazil, forests have been undergoing fragmentation and degradation, causing genetic problems in their populations local extinction processes and reduction of ecosystem services. Thus, it is urgent to monitor the quality of the remaining urban forests, that is, how much they bear with pressure and still manage to maintain their biotic integrity. The objective of this study was to analyze the biotic integrity of forest fragments in the municipality of Boituva (SP), Southeastern of Brazil, and discuss the results comparing them with area size and soil use in the environment. It was used a Biotic Integrity Index (IBB) that is composed of 11 indicators (littler, grass, dead trees, exotic wood, vines, gaps, vascular epiphytes, later species in canopy and in understory, height and diameter of trees) that were applied in 12 areas. The value of IBB can vary from 11 to 55 points. It was observed that the IBB recorded ranged from 31 to 43.5 , with $25 \%$ of the studied areas showing good integrity and 75\% showing regular integrity. The areas with good IBB were the largest (from 75 to 98 there), and most areas with regular IBB were the smallest (from 10 to 62 ha), however a large area (91 ha) also had regular IBB. Most of the areas with urban surroundings presented regular integrity, but one of them presented good integrity, showing that even in urbanized areas the forests can maintain their biotic integrity, and consequently must be conserved to maintain the ecosystem services.

\section{Assessing hurricane impacts on ecosystem services for urban forests in Louisiana, USA}

Kamran Abdollahi ${ }^{1}$, Zhu Hua Ning ${ }^{2}$

${ }^{1} S U$ Agricultural Research \& Extension Center, Baton Rouge, USA; ${ }^{2}$ SU Agricultural Research and Extension Center , Baton Rouge, USA (kamran_abdollahi@subr.edu; zhu_ning@subr.edu)

Hurricane Gustav was the second most destructive hurricane of the 2008 Atlantic hurricane season. In Baton Rouge, Louisiana the wind damage from Gustav was the worst of any storm in memory. Thousands of urban forest trees were uprooted and snapped in half by Gustav's fierce winds. A post hurricane analysis of the Baton Rouge's urban forest ecosystem was conducted using i-Tree Eco software application and based on the Urban Forest Effects Model (UFORE). The analysis revealed that this area has about 1,036,175 trees with tree canopies that cover $44.6 \%$ percent of the city. The analysis reveals a significant tree canopy reduction. The city has more than 45 tree species. Trees currently store about 2 million tons of carbon per year with an associated estimated value of \$ 41 million per year. In addition, these trees remove about 178,354 tons of $\mathrm{CO}_{2}$ per year with an associated estimated value of $\$ 1.1$ million per year. Baton Rouge’s trees are estimated to reduce annual residential energy costs by $\$ 8.0$ million annually and reduce air pollution (ozone, particulate matter, sulfur dioxide, and nitrogen dioxide) by 860 tons per year with an associated estimated value of $\$ 6.2$ million per year. The structural value of the trees is estimated at $\$ 6.2$ billion. With the increase in climate variability, increased frequency and intensity of storms, and urbanization pressure, more trees need to be planted and maintained to sustain the current level of structural values and ecological services.

Generating a database for forestry management in $\mathbf{6}$ community organizations of Cochabamba, Bolivia / Generación de una base de datos para el manejo silvicultural en 6 otb's del Municipio de Cochabamba - Bolivia

Alvaro Rico $^{1}$, Ana Alvarez ${ }^{1}$ Edwars Sanzetenea ${ }^{1}$

${ }^{1}$ Universidad Mayor de San Simon, Cochabamba, Plurinational State of Bolivia (alvarorico.bolivia@gmail.com; ${ }^{131503}$ anita.aa@gmail.com; e.sanzetenea@ gmail.com)

El Municipio del Cercado en Cochabamba-Bolivia está rodeado de cerros lo que ocasiona que el área urbana este en continuo riesgo ambiental y social debido al rápido crecimiento demográfico, la expansión urbana sin planificación, el cambio continuo de uso del suelo y la expansión de la frontera agrícola. Esto ha ocasionado la reducción en la calidad y cantidad de árboles en el área urbana, el incremento en la temperatura ambiente y la reducción de la calidad de vida de sus habitantes. Sin embargo y a pesar de estos problemas, el Gobierno del Municipio del Cercado no cuenta con una base de datos del arbolado urbano que le permita contar con información real y actualizada para realizar una planificación del espacio urbano y periurbano, así como la confección de políticas y normativa ambiental que contribuya a preservar el arbolado urbano y mejorar la calidad de vida de sus habitantes. El presente estudio es una prueba piloto del desarrollo de una base de datos que contribuye a la realización de mejores prácticas silviculturales y la toma de decisiones técnicas, económicas, sociales y ambientales en 6 Organizaciones Territoriales de Base del distrito 12 y el perímetro de la Laguna Alalay a través del uso de la geomatica con la generación de mapas multitematicos y el monitoreo del arbolado urbano.

\section{A4r: MONITORING AND ASSESSING URBAN FOREST SERVICES AND VALUES AT THE NATIONAL TO LOCAL SCALE \\ An evaluation of long-term management efforts for five historic urban forests in the mid-Atlantic Region of the United States \\ Robert Loeb ${ }^{1}$ iD \\ ${ }^{1}$ Pennsylvania State University,DuBois, Pennsylvania, USA (rxl5@psu.edu)}

Urban forests provide a variety of services to cities including historical resources. Five sites in the Mid-Atlantic Region of the United States are historic urban forests: Central Park, New York, New York; Fairmont Park, Philadelphia, Pennsylvania; Glenmont - Edison National Historic Park, West Orange, New Jersey; Sagamore Hill National Historic Site, Oyster Bay, New York; and Vanderbilt Mansion National Historic Site, Hyde Park, New York. The landscape designs of all five forests follow the naturalistic landscape design principles of the father of American landscape design - Andrew Jackson Downing. Rehabilitation is the guiding principle for conservation of the forest landscape which involves maintaining and replacing trees planted and present during the time period of historic significance. This evaluation of long-term management efforts is based on reinventory of the forests and comparison to maps of a past inventory of the historic 
urban forests. The comparisons of inventories revealed several common patterns of long-term forest changes. The management efforts resulted in extensive non-native tree replacement, sometimes with cuttings from rare specimens being taken to grow the replacement trees. Recent volunteer growth was aggressively removed and dying recent plantings not reflective of the historic context were not replaced. A common problem with trees planted for visual screening is the trees grew far taller and larger than originally intended, especially in the cases of coniferous species. Large size native species predating the historic period, were common outside of the forest core and have not been replaced at rates found for non-native species.

\section{Sustainability indicators for conservations units located in urban concentrations}

Guilherme Silva ${ }^{1}$, Bruna Branchi ${ }^{1}$

${ }^{1}$ Pontificia Universidade Católica de Campinas, Campinas, Brasil (guilherme.silva632@gmail.com; bruna.branchi@puc-campinas.edu.br)

Anthropogenic pressure on the environment and a massive increase in the use of resources during urbanization are two of the most representative and active forces in the $21^{\text {st }}$ century. Although there are m any social and environmental problems in the cities, we must know that the process of urban growth is a constant and that its greatest leap has not yet occurred. Therefore, more pressure on the environment must be expected. The need for establishing [\#_msocom_3] protected areas rises as one of the most controversial measures in the conservation context. Protection through land acquisition laws and processes does not ensure the preservation of the habitat, however they represent a starting point for the conservation of the environment. Despite the vision of untouched environment held by some sectors of society, these areas are not protected spaces unrelated to the human being. Their goods and services can satisfy diverse needs of the society, including those related to the productive processes. In view of the presented scenario, this study aims to develop indicators that can evaluate the degree of sustainability of protected areas located in urban concentrations. Forests management plans, academic studies published in article and books since 2000 proposing and applying such kind of instruments in Brazil were selected and analyzed. By comparing their methodology, it will be possible to identify strengths and weaknesses and, consequently, propose indicators for protected areas in urban concentrations.

Social participation and environmental policy: cases in urban watersheds within the greater Buenos Aires metropolitan area / Participación social y política ambiental: estudio de casos de las cuencas urbanas de la región metropolitana del gran Buenos Aires

Mariano Ferro ${ }^{1,2}$ iD; Clara Minaverry ${ }^{1,3,4,5}$ iD

${ }^{1}$ Universidad de Buenos Aires (UBA), Buenos Aires, Argentina; ${ }^{2}$ CONICET Buenos Aires Argentina; ${ }^{3}$ Universidad Nacional de Luján (UNLu), Luján,

Argentina; ${ }^{4}$ CONICET Luján Argentina; ${ }^{5}$ INEDES Luján Argentina (marianodamianferro@gmail.com; clara.minaverry@gmail.com)

Este trabajo trata sobre la relación entre ciudadanía y política pública ambiental en las cuencas metropolitanas del Gran Buenos Aires desde la perspectiva de la sociología ambiental y de la sociología jurídica. El foco de la indagación se centra en analizar la incidencia de la participación social en la política pública ambiental. Se evalúan los progresos y obstáculos respecto de dos enfoques complementarios y fundamentales para la implementación del paradigma ambiental en el área de estudio: la Gestión Integral de los Recursos Hídricos y el enfoque ecosistémico. Se presentan una serie de hallazgos de investigación empírica del análisis comparado de los conflictos ambientales en las tres principales cuencas urbanas del Gran Buenos Aires: Matanza-Riachuelo; del Río Reconquista y del Río Luján. El abordaje diacrónico ha permitido detectar que la incidencia del activismo ambiental en la institucionalización del paradigma ambiental en el área de estudio se dio como resultado de ciertas condiciones facilitadoras para la incorporación de los temas ambientales a la agenda pública, como resultado de un proceso de selección del riesgo, a mediados de la década de 2000. Que la modificación que dicho contexto, en la década de 2010, ha comportado una situación desfavorable para la implementación de una gobernanza sustentable del agua en ecosistemas, en nuestro caso de estudio, debido a la inercia de los obstáculos jurídico-institucionales. La metodología utilizada es principalmente cualitativa. Los métodos aplicados son el método de caso (Stake, 2010; Yin, 2009) en combinación con el método narrativo de tópico (Mertens, 2005).

Dynamics of urban forestry in the central area of Imperatriz, MA, Brazil / Dinâmica da arborização urbana da zona central da cidade de Imperatriz, MA, Brasil

Juliana Andrade Pereira ${ }^{1}$, Jaqueline Macedo Gomes $^{1}$, Dalton Henrique Angelo ${ }^{2}$

${ }^{1}$ Universidade Estadual da Região Tocantina do Maranhão, Imperatriz, Brasil; ${ }^{2}$ STCP Engenharia de Projetos Ltda, Curitiba, Brasil

(juliana_andradep@hotmail.com; jaquelinemacedogomes@hotmail.com; daltonambiente@gmail.com)

A arborização sem planejamento ocorre devido a carência de informações técnicas que podem ser obtidas através de inventários que indicarão a necessidade de poda, plantio, tratamentos fitossanitários, remoção de indivíduos. Neste contexto, o objetivo da pesquisa foi caracterizar a arborização urbana de Imperatriz MA, fornecendo subsídios para elaboração do plano de arborização da cidade. O estudo foi realizado na Zona Central de Imperatriz ( $05^{\circ} 31^{\prime} 59,8^{\prime \prime}$ ' S; 47²9'11,2”' W) dividida em 86 quadras, compreendendo uma área de 92,87 ha. Foram medidos todos os indivíduos com altura $\geq 1,5 \mathrm{~m}$ nos anos de 2016 e 2018. Analisaramse a fitossociologia, estrutura horizontal, distribuição diamétrica, ingresso e mortalidade. Registraram-se 700 indivíduos de 20 famílias botânicas e 46 espécies,

representando 69,57\% exóticas, não recomendadas para arborização e 30,43\% nativas. Licania tomentosa e Azadirachta indica totalizam 49\% da abundância do povoamento e os maiores IVI, 20,25\% e 13,26\%, respectivamente. Mangifera indica apresentou maior dominância. A distribuição diamétrica é unimodal, característica de povoamentos jovens e equiâneos. Não houve diferença significativa ( $p>0,05)$ entre as distribuições de 2016 e 2018 . A mortalidade correspondeu a $27,08 \%$ e o ingresso foi $19,55 \%$, observando a substituição ou remoção de alguns indivíduos. L. tomentosa teve maior mortalidade (23,90\%), seguido pelo Ficus benjamina (11,71\%) e $A$. indica (9,76\%). A. indica possui maior ingresso (41,22\%), seguido por L. tomentosa (12,84 \%). A. indica é preferida na arborização devido seu rápido crescimento e rusticidade, porém não é recomendada, por ser exótica e promover a morte de polinizadores devido suas propriedades bioinseticida e alelopática (UEMASUL, FAPEMA).

\section{Climate-regulation services from riparian preservation areas of Curitiba, PR, Brazil}

Jennifer Viezzer ${ }^{1}$, Daniela Biondi ${ }^{1}$, Angeline Martini ${ }^{2}$

${ }^{1}$ Universidade Federal do Paraná, Curitiba, Brasil; ${ }^{2}$ Universidade Federal de Viçosa, Viçosa,Brasil (jen.viezzer@gmail.com; dbiondi@ufpr.br; martini.angeline@gmail.com)

Riparian preservation areas (RPA) are established by The Brazilian Native Vegetation Protection Law (n; 12.651/2012) to ensure the provision of ecosystem services, mainly in relation to water resources. However, these forests generate multiple benefits to people besides water protection. Thus, here we discuss the importance of Curitiba's forests on RPA to climate regulation. For this, we used the RPA mapping made by the Brazilian Foundation for Sustainable 
Development (FBDS), and the results of previous studies about the cooling effect of vegetal cover. The climate regulation provided by the RPA in Curitiba was calculated relating data of the amount of well-conserved forests on RPA in the city $\left(28,232,089.85 \mathrm{~m}^{2}-44.8 \%\right.$ of total RPA) with the decrease in average temperature generated by vegetation cover $\left(-1{ }^{\circ} \mathrm{C}\right.$ for each $\left.3,381,384.00 \mathrm{~m}^{2}\right)$. We found that the conserved forests on RPA are responsible for reducing $4.055{ }^{\circ} \mathrm{C}$ in Curitiba, which means that, without it, the temperature of the city today would be approximately $4{ }^{\circ} \mathrm{C}$ higher. This result is significant for a city with $1,751,907$ inhabitants, 1,412,917 car fleet, $69.0811 \%$ built area and 100\% urbanized. If Curitiba maintained the current land use and land cover (LULC) standards, forest restoration on the remaining $55.2 \%$ of degraded RPA would contribute to further reduce $4.984{ }^{\circ} \mathrm{C}$. However, with LULC and climate changes scenarios, the effect of RPA restoration on climate regulation may differ, making it necessary to monitor its benefits through time. The results demonstrate the importance of RPA conservation and restoration for climate regulation in Curitiba.

\section{Urban forest spatial indices of Curitiba, PR, Brasil}

Mayssa Grise ${ }^{1}$, Daniela Biondi ${ }^{1}$, Hideo Araki ${ }^{1}$

${ }^{1}$ Universidade Federal do Paraná, Curitiba, Brasil (mayssamonteiro@gmail.com; dbiondi@ufpr.br; haraki@ufpr.br)

The urban space quality has been estimate by spatial vegetation indices. This study aims to determine and quantify the spatial indices of Curitiba-Paraná-Brazil urban forest (UF) through techniques of high spatial resolution remote sensing, to generate information for the land use planning. To identify the UF (public and private) were used GeoEye-1 images, which were applied enhancement techniques for decision tree classification. Were measured four spatial indices: total UF, private UF, public UF and UF in public green areas. Curitiba showed a high spatial index of total UF with $108.35 \mathrm{~m}^{2} /$ inhabitant, however this should be considered with caution as it includes all vegetation (public and private) present in the city. Spatial indices representing the UF that is available for direct use by the population were $22.28 \mathrm{~m}^{2} /$ inhabitant public UF (street's trees, urban green protected areas and water bodies) and only $8.01 \mathrm{~m}^{2} /$ inhabitant UF in urban green protected areas (woods, parks, squares and public gardens). It was found that the amount of UF covered area by the administrative regions of the city is inversely proportional to its population density.

University/corporate partnerships to preserve urban green space / Parceria entre universidade e empresa para conservação de área verde urbana

Marianna Araujo ${ }^{1}$, Helijone Rosa ${ }^{1}$, Tomas Domingues ${ }^{1}$

${ }^{1}$ Faculdade de Filosofia, Ciências e Letras de Ribeirão Preto, Ribeirão Preto, Brasil (marianna.araujo@usp.br; helijone.rosa@usp.br; tomas@ffclrp.usp.br)

O Centro de Estudo e Extensão Florestal da USP de Ribeirão Preto (CEEFLORUSP) possui um convênio com a Empresa Vila do Ipê Empreendimentos Ltda., com o intuito de desenvolver pesquisas e promover a conservação da reserva legal da empresa, constituída por um fragmento estacional Semidecidual de 20 ha da Mata de Santa Tereza, localizado no perímetro urbano de Ribeirão Preto, SP, e adjacente à Estação Ecológica de Ribeirão Preto. Desde 2005 várias pesquisas sobre estrutura arbórea, influência e manejo das lianas foram realizadas na reserva. No ano de 2014 grande parte da mata sofreu incêndio que destruiu mais de 25 ha. O presente trabalho visa implementar uma metodologia de análise comparativa permanente entre a estrutura arbórea da área intacta com a que foi queimada. Com base nas informações de coordenadas de GPS e bússola de visada, serão estabelecidas 32 parcelas de $20 \mathrm{~m}$ x $10 \mathrm{~m}$ dispostas em sequência, sendo 16 parcelas em cada área estudada. O critério de inclusão será DAP $>10 \mathrm{~cm}$. Os indivíduos serão identificados com placas de metal numeradas e os dados coletados. Na monografia de Bruno Brazíl (2005) os resultados obtidos mostraram que a reserva apresenta valores baixos para a maioria dos parâmetros fitossociológicos analisados, quando comparados com outros fragmentos semelhantes. Com o estudo atual, pretendemos encontrar valores diferentes dos de Brazíl, visto que as metodologias usadas são diferentes e pelo fragmento ter sofrido queimada. A importância desse estudo consiste na elaboração de um monitoramento permanente mais preciso, na identificação do estágio de recuperação natural que a mata se encontra e promover sua conservação.

\section{Urban forest study in northeast China, new advances and conclusions}

Wenjie Wang ${ }^{1,2}$, Panli Tian', Xingyuan He ${ }^{1,3}$

${ }^{1}$ Northeast Institute of Geography and Agroecology, Chinese academy of sciences, Changchun, China; ${ }^{2}$ Northeast Forestry University, Harbin, China;

${ }^{3}$ Shenyang Institute of Applied Ecology, Chinese academy of sciences, Chinese academy of sciences, Shenyang, China (wangwenjie@iga.ac.cn;

863100147@qq.com; hexingyuan@iga.ac.cn)

Urban forests are important for urban environments, and clarification of their ecological functions are vital for their management. We have studied the urban forest carbon sink, microclimate regulation, biodiversity conservation and soil properties in Northeast China. We found the following conclusion; 1)urban forest could function as carbon sink, and urbanization could result in the accumulation of soil carbon in forests; 2) urban forest could shade the environment, and down-regulate air and soil temperature, humidify air in the semi-arid cities; 3)urban forest is also a biodiversity conservation place for different trees and also birds; 4)various soil nutrient are determined and some place had the risk of soil alkalinization; 5) by using ring-road development and urban settlement history, the urbanization effect on various urban forest parameters could be clarified. The data in this paper provide basis for urban forest development and management in China.

\section{A5a: GOVERNING INNOVATION FOR SUSTAINABILITY IN THE FOREST SECTOR - I}

\section{Fitting in a local context: local community initiatives in managing and harvesting community forests in Southern Highlands, Tanzania}

Numan Amanzi ${ }^{1}$

${ }^{1}$ Tanzania Forestry Research Institute, Morogoro, United Republic of Tanzania (numansaidi@gmail.com)

In Tanzania, a Forest Management Plan (FMP) is a pre-requisite of transferring power of managing forest to local communities. The FMP entails de jure forest management prescriptions that require local communities to comply with. These include a prescribed burning, restriction of grazing, and harvesting levels of forest products. Undertaking the prescribed activities are costly and some requires a procedural form of knowledge of which the majority of local communities do not possess. This study, therefore, investigate how local community modify the management prescriptions in order to fit in their local context. The study was conducted in four villages owning and managing community forest in Southern Highlands, Tanzania. Primary data were collected through field observations, indepth interviews with community and forest committee members, and a review of documents on the management plan implementation. The findings show that forest committees were deliberately allow grazing in the community forests as a means of earning incomes to cover management costs, reducing fuel load and thus reducing forest fires intensity and addressing a challenge of grazing land scarcity facing villagers. In addition, committee members did not use the inventory 
results to estimate annual allowable cuts as were considered to be not reflecting actual forest condition, instead, they estimated the harvest level of fuelwood based on their practical experiences. In most cases, harvesting levels they estimated were relatively lower as compared to one based on forest inventory. The findings suggest that the practical experience of the local community should also be considered for sustainability of forests.

\section{Forest conservation using market driven mechanisms in Russia}

Andrey Ptichnikov ${ }^{1}$ iD

${ }^{1}$ Institute of Geography, Russian academy of sciences, Moscow, Russian Federation (aptichnikov@igras.ru)

The Strategic Plan for Conservation and Sustainable Use of Biodiversity of the Convention on Biodiversity, the Aichi Biodiversity Targets for the period 2011 2020 , envisage the conservation, by 2020 , of at least $17 \%$ of terrestrial ecosystems, especially areas of high importance for biodiversity and ecosystem services. The main mechanisms for forest conservation in Russia are protected natural areas (PNAs). However, within the protected areas only about 7\% of the country forests is protected. About $16 \%$ of the forests is located in protective forests, however, the economic management regimes of many categories of protective forests are not in line with the Aichi targets. In recent years, voluntary forest certification in the Forest Stewardship Council scheme has become increasingly important. FSC standards enforce forest companies to maintain high conservation values in forests (HCVF). Around 46 million hectares of FSC certified forests in Russia, of which about 5-6 million hectares of HCVF received additional protection as part of certification. The most important category of HCVF are intact forest landscapes (IFL). As part of the certification, more than 1 million hectares of these priority conservation objects are voluntarily excluded from logging by companies. For 35 certified forest users in the North-West Federal District of Russia, the share of voluntarily maintained HCVF in the lease is comparable to the relative share of protected areas in this region. FSC certification is becoming increasingly important for establishment of an internationally recognized system of forest protection in Russia. Supported by the Institute of Geography RAS state assignment 0148-2019-0006.

\section{Social innovation for sustainable rural communities: overcoming institutional challenges in Serbia}

Ivana Zivojinovic ${ }^{1}$, Karl Hogl ${ }^{2}$, Gerhard Weiss' ${ }^{1}$, Alice Ludvig ${ }^{1}$

${ }^{1}$ Institute of Forest, Environment and Natural Resource Policy, University of Natural Resources and Life Sciences, Vienna (BOKU) and European Forest

Institute, Forest Policy Research Network, Vienna, Austria; ${ }^{2}$ Institute of Forest, Environment and Natural (ivana.zivojinovic@boku.ac.at;

karl.hogl@boku.ac.at; gerhard.weiss@boku.ac.at; alice.ludvig@boku.ac.at)

Today's world society is facing a number of longstanding challenges, such as poverty, famine, inequalities, environmental challenges, and migration, which call for new and creative responses that stimulate change and are often lacking in traditional governmental approaches. Social innovations are such responses that can offer social-ecological and economic solutions to mitigate social problems by introducing new practices. They are highly relevant for rural communities for reducing social inequalities and disproportionate resource use, and fostering sustainable development. Understanding the role of social innovation is especially complicated in unstable institutional environments, e.g. in developing, post-war, or countries in transition. This paper, firstly, traces institutional voids related to social innovation in Serbia, such as a relatively poor legitimacy and enforcement of the rule of law, and institutions that fail to address societal needs. Secondly, it analyses ten cases of social innovations in rural areas, related also to forestry sector, based on in-depth interviews and document analysis. The analysis contributes to the understanding of factors that facilitate and constrain social innovations, but also efforts of social innovators to overcome institutional voids. Our results show that some types of social innovation are more likely to fill in institutional gaps and to create social values while others are oriented to secure economic benefits. Furthermore, the need for context-specific structures that enable and foster social innovations is emphasised, including improved legal frameworks (e.g. forestry and rural development related policies), favourable tax regulations and innovative financial mechanisms, which allow implementing social innovations in rural communities.

\section{Assessment of factors affecting participation of community beneficiaries in forest-based land reform public-private partnership models in South Africa}

Ratsodo Phillip Tshidzumba ${ }^{1,2}$, Paxie Wanangwa Chirwa ${ }^{1}$, Folaranmi Dapo Babalola ${ }^{1,3}$

${ }^{1}$ University of Pretoria, Pretoria, South Africa; ${ }^{2}$ Fort Cox Agriculture and Fort Training Institute, Middledrift, South Africa, ${ }^{3}$ University of Ilorin, Ilorin,

Nigeria(phillipmgf@yahoo.com; paxie.chirwa@up.ac.za; folababs2000@gmail.com)

The sustainability of agriculture and forestry production on land subjected to land restitution has been of concern for both government and the private sector in South Africa. The objective of this study was to assess factors that facilitated or hindered participation of the community beneficiaries in forest-based land reform publicprivate partnership models. The generic structured questionnaire was administered to 140 and 175 randomly selected household beneficiaries in Amabomvini and Cata, respectively. The Amabomvini community managed their claimed land through a Trust's registered contracting company, while the Cata community managed their land themselves under the leadership of the Community Property Association (CPA). The results of the study found that there was a significant relationship with both the level of awareness $(\chi 2=27.026 ; \mathrm{df}=3 ; \mathrm{p}<0.01)$ and participation $(\chi 2=97.278 ; \mathrm{df}=1 ; \mathrm{p}<0.01)$ in the respective partnership arrangements adopted by the community beneficiaries. Some of the factors found to have contributed to low participation in the partnership initiative by household respondents included a lack of transparency, commitment of trustees, lack of technical skills, conflicts over land use priorities amongst beneficiaries, and barriers to markets. Furthermore, research to understand land management priorities desirable to community beneficiaries of land restitution need to be prioritized. Thus, government's role in influencing the participation of the community beneficiaries through provision of necessary governance, technical and financial post-settlement support is critical for the successful management and sustainability of the inclusive project under forest-based land reform public-private partnerships.

\section{Community forest associations: is it far-fetched in Kenyan forestry management and forest conservation}

Roxventa Ongugo ${ }^{1}$, Benjamin Owuor ${ }^{2}$

${ }^{1}$ Kenya Forestry Research Institute (KEFRI), Nairobi, Kenya; ${ }^{2}$ ACAL, Nairobi, Kenya (rongugo@gmail.com; benjaminowuor@gmail.com)

Community Forest Associations (CFAs) are local based organizations bringing together forest users aim of ensuring sustainable forest utilization. They are formed on the basis of members' proximity to and interest in forest resources contributing to their livelihoods. Under the Kenya's Forest Acts (2005 and 2016), community involvement in management of public forests is provided for through formation of CFAs. In Kenya currently there are about 100 CFAs across the country (Ongugo et al., 2007). While the role CFAs is to participate in public forest management, they have further expanded this to include conflict management, fundraising, and negotiation. Despite their formation, forests have continued to be degraded. Timber harvesting, charcoal production and forest encroachment have increased. Studies conducted by Scientists from KEFRI (Ongugo R. A. et al., 2016 Unpublished) to evaluate the effectiveness of the 
CFAs in forest conservation showed that even though CFAs are considered good institutions that give communities a sense of ownership and governance; the communities feel that the full effect and benefits have so far not been felt in the forestry sector. It further shows that forest governance even though devolved through PFM, CFAs are not involved in decision making. As a result, members of the CFAs still feel that they have been left out of decision making structures that affect livelihoods and forestry sector. Therefore, the purpose for which the CFAs were formed still remains a far-fetched dream in Kenya's forestry sector.

\section{Enhancing scientific and social research in landscapes globally through model forests}

Leonardo Durán ${ }^{1}$, Richard Verbisky ${ }^{2}$, Roger Villalobos ${ }^{3}$, Fernando Carrera $^{3}$

${ }^{1}$ Universidad Mayor, Santiago, Chile; ${ }^{2}$ Natural Resources, Toronto, Canada; ${ }^{3}$ CATIE, Turrialba, Costa Rica (leonardo.duran@umayor.cl;

richard.verbisky@canada.ca; rvillalo@catie.ac.cr;fcarrera@catie.ac.cr)

Society has been tackling the concept of managing forests sustainably for many years. In 1992, Canada launched the Model Forest concept internationally as a concrete example of sustainable forest management in practice. By design, Model Forests are inclusive, transparent partnerships with a voluntary governance structure providing a mechanism for long-term engagement in research, programming, and capacity building at a landscape scale. As one of the earth's most widespread ecosystems and as a renewable resource providing a wide range of benefits to society, forests have been at the centre of many recent policy discussions. National and international commitments such as UNFCCC, Convention on Biological Diversity, Sustainable Development Goals, Bonn Challenge, Initiative 20 × 20 and others have signalled a shift towards multi-sectoral and balanced approaches to sustainable development, which include functions and services such as recreation, health and well-being, biological diversity, local livelihoods, equality, climate change mitigation-adaptation. This further supports the understanding that processes in support of sustainable development must include healthy, broad-based partnerships that combine the interests, mandates, and objectives of diverse stakeholders. In this paper, key foundations of sustainable forest management are reviewed, including the balancing of economic and environmental objectives, the concept of landscape management, the role of science and technology, and public participation in decision-making. To examine the practical implications of these concepts, over 600 publications associated with Model Forests as platforms for demand driven research are drawn upon to highlight the benefit and contributions made to integrated natural resource management, knowledge sharing and strengthening local governance.

Creating shared value through group certification for small producers and forestry companies in Argentina / Creando valor compartido a través de la certificación en grupo de pequeños productores y empresas forestales en Argentina

Carolina Isabel Llavallol ${ }^{1}$, Florencia Chavat ${ }^{2}$, Roberta Amaral de Andrade ${ }^{3}$

${ }^{1}$ Secretaría de Agroindustria de la Nación Argentina, Buenos Aires, Argentina; ${ }^{2}$ CERFOAR - PEFC Argentina, Buenos Aires, Argentina; ${ }^{3}$ Secretaría de Agroindustria de la Nación Argentina, Ciudad Autónoma de Buenos Aires, Argentina (cllavallol@magyp.gob.ar; fchavat@cerfoar.org.ar;

betinha.amaral@gmail.com)

La aplicación de la sostenibilidad en la producción ha evolucionado rápidamente desde la superposición de conceptos estancos que tratan por separado lo económico, lo ambiental y lo social - aún vigente en la estructura de ciertas organizaciones -, al de un concepto que se inserta directamente como eje del negocio, tal como expresa el "Valor Compartido" desarrollado por Porter (2011). La certificación forestal es una herramienta que representa la posibilidad de demostrar esta integración en sus procesos productivos para los productores e industriales, lo que se traduce en nuevas oportunidades de mercado, agregando valor al negocio. Como contracara, en un mercado cada vez más competitivo puede convertirse en un factor de exclusión. En Argentina, debido a la falta de recursos económicos y técnicos, los pequeños productores y empresas son los que tienen mayores dificultades para alcanzar los niveles de legalidad y sostenibilidad exigidos en la certificación. Al reducir los costos individuales del proceso y proporcionar escala a la comercialización, la certificación en grupo puede ser una alternativa para esos actores. Sin embargo, muchas veces no están dispuestos o no pueden asumir los compromisos de largo plazo requeridos para la certificación, lo que puede ser solucionado a través de una estrategia de alianza entre proveedores y empresas del "downstream" forestal, para promover el desarrollo mutuo de manera sostenida. En este trabajo mostraremos cómo la certificación forestal en grupo puede crear valor compartido, contribuyendo a los logros individuales y del conjunto e integrándose estrategias de gobernanza para el sector forestal.

Social organization and governance in integrating sustainable use of timber and non-timber forest products, a case study in Mexico I Organización social y gobernanza en la integración del aprovechamiento sustentable de productos forestales maderables y no maderables, estudio de caso en México

Diana Lorena Sánchez Vidaña ${ }^{1}$ iD; Esteban Valtierra Pacheco 0 (iD)

${ }^{1}$ Colegio de Postgraduados, Texcoco, Mexico (sanchez.diana@colpos.mx; evaltier@colpos.mx)

Los bosques son ecosistemas de importancia ambiental, social y económica para la humanidad. México ha sido privilegiado por sus recursos forestales, gran parte de su territorio (71\%) alberga vegetación forestal con potencial para generar progreso en comunidades y ejidos, sin embargo, presentan problemas debido a la mala gestión de estos recursos como: sobreexplotación, contaminación, pérdida de biodiversidad, degradación, y en las últimas décadas, deforestación, aunado a lo anterior, se suman pérdidas de empleos por falta de competitividad del sector en un contexto de mercado globalizado. En México, existen cadenas forestales que están emergiendo como empresas exitosas que se organizan y crean instrumentos para gestionar y conservar sus bosques, administrarlos y con ello generar empleos e ingresos en sus comunidades. El propósito de este estudio fue analizar los procesos e instituciones de gobernanza comunitaria en la integración de la cadena de valor maderable y en el aprovechamiento de recursos forestales no maderables en un ejido de la Sierra Norte de Puebla, México. La investigación se realizó a través de entrevistas semiestructuradas dirigidas a actores clave, encuestas estructuradas a trabajadores de la industria forestal y observación directa de las fases productivas. Los resultados muestran que los procesos e instituciones de gobernanza comunal implementados por el ejido han contribuido al manejo sustentable del capital natural y establecido las bases para el desarrollo de sus capitales: social, humano, físico y tecnológico, además de fortalecer su integración a redes de apoyo estatales, nacionales e internacionales. 


\author{
Determining the collaborative potential in Oregon's forest products industry: a method to foster cross-sector collaboration \\ Jose E. Guerrero ${ }^{1,2}$, Eric Hansen ${ }^{1}$ \\ ${ }^{1}$ Department of Wood Science and Engineering, College of Forestry, Oregon State University, Corvallis, USA; ${ }^{2}$ Grupo Argos S.A., Medellin, Colombia \\ (jose.guerrero@oregonstate.edu; eric.hansen@oregonstate.edu)
}

Current global challenges faced by society such as population growth, consumers demand for greener products, and climate change are altering the operational environment of the forest sector. Forest companies are transforming their business through bio-innovations to create value, enhance competitiveness, and replace human dependence on fossil-based products. However, questions remain regarding how can forest companies identify and develop new innovations, capitalize on the business opportunities presented, and achieve a successful transition to the bioeconomy? Research and strategies around the bioeconomy have emphasized cross-sector collaboration as a means for achieving a successful transition via creating new forest-based products. This study aims to assess the potential of Oregon's forest companies to collaborate with companies from other sectors, as well as explore barriers to implementing collaboration with other industries. Personal interviews with top executive members (CEOs, VPs, etc.) of large, Oregon-based companies will be conducted to develop an understanding of their approach to collaboration. An adaptation of the collaborative learning approach, a theory-based framework proposed by Daniels and Walker (2001), will be used to determine company's collaborative potential. Results will help to identify weaknesses, barriers, and feasibility to collaborate across sectors, and provide knowledge-driven recommendations for improving collaborative potential in forest products companies.

\title{
A social-ecological-technical analysis framework for forest ecosystem services governance innovations
}

Carsten Mann ${ }^{1}$, Stefan Sorge ${ }^{1}$

${ }^{1}$ Eberswalde University for Sustainable Development, Eberswalde, Germany (carsten.mann@hnee.de; stefan.sorge@hnee.de)

European forests provide a variety of ecosystem services. Due to the public goods character of many forest ecosystem services, the appearance of externalities, imperfect property rights and insufficient knowledge and information, markets often fail to efficiently allocate natural resources. Ensuring the sustainable provision of the range of forest ecosystem services requires new and unconventional approaches in forest management, business, and in the policies and interventions that govern these. In this talk, we present the conceptual foundation and first empirical application of an analysis framework for explaining the emergence, development of spread of successful governance innovations for the provision of forest ecosystem services (FES). The framework builds on the idea of complex and interlinked social-ecological-technical-forestry-innovation systems in the context of the H2020 InnoForESt Innovation Action. Studying six governance innovations, payment schemes for ecosystem services (PES) and network approaches, the objective is to gain a solid understanding of what has influenced the governance innovations emergence and development, and what needs to be changed for innovation upgrading and/or upscaling. A wide range of stakeholders are included in the analysis following a multi-actor approach for knowledge co-creation. Through the analysis, interdependencies are revealed and adjustment possibilities of crucial influencing factors are conjointly elaborated for road mapping strategies, depending on the vision and ideas of participating actors. In addition it is shown how the analysis results are integrated with other project findings elaborating on forestry innovation system conditions on EU level, down to local stakeholder visions and interactions.

\section{Conditional incentives: What governance lessons for the design of innovative environmental mechanisms?}

Sven Wunder ${ }^{1,2}$

${ }^{1}$ European Forest Institute, Barcelona, Spain; ${ }^{2}$ Center for International Forestry Research Lima Peru (swunder@cgiarorg)

In recent decades, a greater societal scrutiny of public spending for 'value for money' criteria has also penetrated the forestry and environmental sectors, thus promoting the use of performance-based instruments. Payments for Environmental Services (PES), 'green' production certification, reduced emissions from deforestation and forest degradation (REDD+), and ecological fiscal transfers (EFT) are all examples of 'payments by results', i.e. environmental incentives based on a quid-pro-quo, contractual principle: you only pay for what you get. In what contexts do such instruments provide an adequate governance framework for effective and cost-efficient environmental management between an environmental principal (e.g. a government) and agents (e.g. landowners)? We review meta-studies and systematic reviews related to these four instruments. Our results point to a number of conditions for these instruments to work adequately. For instance, the performance proxy has to be closely correlated to the underlying broader environmental service, and needs to be unambiguously measurable, with a well-defined environmental baseline or standard. Upfront investments for agents need to be either small or externally subsidized. Risks need to be carefully distributed between the two parties for incentive compatibility; agents usually need to be relatively well in control of the outcomes. Transactions costs of monitoring and verifying compliance need to remain manageable. Finally, the principal needs politically to be able to sanction incompliance, by effectively withholding payments independent of spending pressures. These observations provide some lessons for prospectively using the conditionality principle vis-à-vis other innovative mechanisms, e.g. in managing product markets and value chains.

\section{Policy implications for social innovation in forestry}

Alice Ludvig ${ }^{1,2}$, Gerhard Weiss ${ }^{1,2}$, Ivana Zivojinovic ${ }^{1,2}$

${ }^{1}$ University of Natural Resources and Life Sciences Vienna, BOKU, Vienna, Austria; ${ }^{2}$ EFI Research Network, Vienna, Austria

(alice.ludvig@boku.ac.at; gerhard.weiss@boku.ac.at; ivana.zivojinovic@boku.ac.at)

Over the last decade, the term Social Innovation (SI) has received increasing attention to address complex global social problems and to add collective values. The forest sector has many potentials for fostering employment, community development and for preventing land flight. It thus appears to be a promising field to investigate modes of SI in terms of collective action and collective benefits through both private and public-private collaborative efforts. One of the main advocates of the concept has formulated briefly that social innovation can be seen as 'new ideas that address unmet social needs - and that work' (Mulgan et al., 2007, p; 2). The paper focuses on examples for new "social practices" that have ultimately become institutionalized and asks the question of how new actors constellations and organizational innovations in forestry have led to innovative business solutions. Methodologically we examine this question with example of qualitative in-depth case studies in different European and Mediterranean countries and study how policies have impacted in fostering these innovations. In conclusion the paper derives the main factors for supportive policy and governance implications and provides an outlook for future governance of SI. 


\section{Social innovation: forest owners and their willingness to cooperate}

Matthias Sonnhoff ${ }^{1}$, Andy Selter ${ }^{1}$

${ }^{1}$ University of Freiburg, Freiburg i.Br., Germany (matthias.sonnhoff@ifp.uni-freiburg.de; andy.selter@ifp.uni-freiburg.de)

Germany is characterized by a large number of small-scale forest owners. Since more than 50 years they have decide to cooperate in forest owner associations or in community forests to overcome the predominant fragmentation of ownership. Forest owners cooperate to meet the demands of markets, society and environmental influences by a continuous development. Therefore, it is necessary, that innovation takes place. In this context cooperation between forest owners can be defined as social innovation. Forest owner associations are based on this social innovation. The social innovation itself is based on a transfer of knowledge and depended on the context. It is unclear, which factors are adjuvant or obstructive for social innovation. Consequently, we aim to identify the factors that lead to social innovation in the context of forest owner associations. Therefore, the actor-centered institutionalism approach is used, to highlight the abilities and the environmental influences that influence actors and their willingness to cooperate. We have made 25 qualitative interviews with managers of forest owner associations and a quantitative survey directed to 160 forest owner associations in Baden-Wuerttemberg. Preliminary results indicate that forest owners cooperate, if several factors are fulfilled and considered. Especially social needs of forest owners in the context of protecting the independence of their property and the institutional context have to be considered. Furthermore, social demands have also an influence and regulations, organizational structures and natural events are relevant, if social innovation takes place.

\section{Mapping governance of innovations in forest ecosystem service provision}

Eeva Primmer ${ }^{1}$

${ }^{1}$ Finnish Environment Institute, Helsinki, Finland (eeva.primmer@ymparisto.fi)

Scientific and policy interest in ecosystem service provision has consolidated in two major streams: in mapping the spatial distribution of ecosystem service provision and in new income generation mechanisms. In these endeavors, forests represent a key area of practical experimentation, rigorous empirical analysis and prospected application. The two streams of knowledge production have remained surprisingly segregated. The deficient understanding of the spatial distribution of governance mechanisms and the ways in which they match ecosystem service provision is particularly aggravated relative to innovations. Enriching the spatial ecosystem service supply and demand analyses that overlay ecosystem types and recreational use or willingness to pay, this study combines biophysical and institutional analysis to map innovation governance. The talk reports results from a European mapping of forest ecosystem services - representing supply - and forest strategies addressing the same ecosystem services and promoting innovations - representing institutional demand. The hypothesis is that strategies promote innovations for governing such ecosystem services that are either rather scarce or abundant, reflecting the different societal motivations for steering the use of forest. Scarcity would drive policies promoting ecosystem resilience and sustainability of use, while abundance would drive policies boosting market creation, specialization and competitive advantage. The initial document analysis identifying ecosystem services, rights and responsibilities, innovations and governance mechanisms, was carried out in 2018. The completed biophysical and institutional mapping of European forest ecosystem services will allow the evaluation of the role of strategies in the institutional landscape and the ways in which such medium-term policy documents can support innovation.

\section{Devolving community forest commons to smaller, sub-communal user groups: Is it worth the efforts?}

Yiwen Zhang ${ }^{1}$, Shashi Kant ${ }^{1}$

${ }^{1}$ Faculty of Forestry, University of Toronto,Toronto, Canada (yww.zhang@mail.utoronto.ca; shashi.kant@utoronto.ca)

Existing research has extensively explored various approaches to enhancing community forest management; however, little research has discussed the feasibility of devolving forests from community-level organizations to smaller, sub-communal user groups (DCFS). Based on a comparative case study of two communities devolving forests from the administrative village to villagers' groups in Western Fujian, China, we explore the effects of DCFS in forest communities specializing in commercial timber production. This study shows that by providing farmers with more forest rights, DFCS increases farmers' representation in managing community forests and makes farmers share more timber revenue. However, the increase in farmers' representation may not necessarily increase the long-run efficiency of timber production. Compared to communal organizations, smaller, sub-communal user groups, which tend to have less capital, technology and leadership, may fail to form collective actions of developing value-added timber production and making long-run investments, which impedes the sustainability of timber revenue generation. Market risks and social changes may also threaten the efficacy of DCFS and bring challenges to commercial timber production of forest communities. Despite these potential problems, sub-communal user groups may develop appropriate institutions to address the problems after DFCS. This research not only presents a new innovative toolkit of enhancing community forest management but also provides insights into certain significant but often neglected issues in managing the commons, such as the correlation between group size and farmers' representation, and trade-off between farmers' representation and the economic sustainability of community timber production.

\section{Science fiction or cutting edge science: How might factory grown wood influence land management?}

Jamie Barbour ${ }^{1}$, Robert Deal ${ }^{1}$

${ }^{1} U D S A$ Forest Service, Portland, USA (roy.barbour@usda.gov; robert.deal@usda.gov)

Advances in cellular biology have made commercial scale fabrication of plant and animal products a real possibility. The most advanced efforts are with commercial meat production and once this technology is perfected it seems likely that it will also be applied to other cellular materials. At the 2017 IUFRO Division 5 Congress this topic was discussed during brainstorming sessions for the IUFRO Task Force on Foresight for the Forest Sector. Much of the discussion was about the potential to create designer wood products with high value and quality. The question of how large scale fabrication of wood might influence options for land use. If experience gained from the shift of wood production from natural forests to plantation forestry serves as an example, the impact on land management could be substantial by removing an important incentive for keeping forests in forests rather than converting them to agriculture or some other more highly developed use. This could have implications for sustainability of wildlife habitat, recreation, and other ecosystem services. This presentation will explore both the opportunities offered by commercial scale fabrication of wood and the challenges such a technology might present in maintaining other benefits derived from both natural and managed forests. 
Characteristics of community housing built in the Western Amazonian city of Pimenta Bueno, Rondônia, Brazil, within the wooden public housing program / Caracterização de habitações sociais edificadas no município de Pimenta Bueno, estado de Rondônia, Amazônia Ocidental, Brasil, a partir do projeto habitação popular em madeira

Maria de Fátima de Brito Lima ${ }^{1,2}$, Cecília Manavella ${ }^{1}$, Divino Eterno Teixeira ${ }^{1}$, Álvaro Nogueira de Souza ${ }^{2}$, Peter Wimmer $^{1}$, Júlio Eustáquio de Melo ${ }^{2}$ ${ }^{1}$ Serviço Florestal Brasileiro, Brasilia, Brasil; ${ }^{2}$ Universidade de Brasilia, Brasília, Brasil (fatima.lima@florestal.gov.br; cecilia.manavella@florestal.gov.br; divino.teixeira@florestal.gov.br; ansouza@unb.br;peterwimmer@florestal.gov.br;alej@unb.br)

Devido ao grande déficit habitacional brasileiro que atinge especialmente às populações de baixa renda, foram edificadas diversas habitações sociais com madeiras oriundas de apreensões promovidas e doadas pelo Instituto Brasileiro de Meio Ambiente e dos Recursos Naturais Renováveis entre os anos de 2002 e 2003, no Município de Pimenta Bueno, Estado de Rondônia, na Amazônia Ocidental, a partir do projeto "Habitação Popular em Madeira", desenvolvido pelo Laboratório de Produtos Florestais - LPF, em parceria com a Universidade de Brasília - UnB. Tais moradias foram destinadas a famílias residentes na periferia e em risco de habitabilidade social. O objetivo desse trabalho foi analisar as condições atuais das moradias anteriormente construídas, sob os aspectos de reformas efetivadas, manutenções feitas pelas famílias, resistência do material madeira às intempéries do tempo e conservação geral dos imóveis. Os resultados encontrados, a partir da aplicação às famílias beneficiadas, de questionários socioeconômicos e de habitabilidade, apontaram para que aquelas que tiveram alguma ascensão social através da educação dos descendentes e melhoria da renda familiar promoveram reformas visando ampliação e manutenção dos imóveis, estando aqueles bastante conservados. As famílias que se mantiveram sem nenhuma ascensão social ou que os descendentes não buscaram educação ou melhoria da renda familiar não efetivaram qualquer manutenção ou reforma das moradias e o estado geral de conservação observado se mostrou bastante precário, incluindo risco de desabamento.

Expanding cultivation of peach palm (Bactris gasipaes) in Northwestern Paraná State, Brazil / A expansão do cultivo da pupunheira na região noroeste do Paraná

Edison Eiti Mikami ${ }^{1}$, Sidney Aurelio Valeriano Ramos ${ }^{1}$

${ }^{1}$ Emater-PR, Cianorte,_Brasil (eite@hotmail.com; sidney_valeriano@yahoo.com.br)

Os primeiros plantios foram iniciados na década de 1990 em diversos municípios do noroeste paranaense em pequenas áreas como plantios experimentais e posteriormente houve algumas iniciativas de plantios maiores, porem sem resultados promissores. A partir de pesquisas experimentais do IAPAR, Embrapa, UEM e do Instituto Emater-PR, houve a validação de alguns resultados que permitiram mapear áreas e regiões aptas ao seu cultivo no Paraná e aplicar as tecnologias geradas. $\mathrm{O}$ aumento das áreas de cultivo da pupunheira deve ser atribuído a implantação de algumas agroindústrias e a versatilidade no aproveitamento de sua matéria prima, sendo amplamente utilizada na forma in natura. O modelo de produção adotado na região noroeste do Paraná é diferente das técnicas utilizadas nas regiões litorâneas de São Paulo, Paraná e Santa Catarina, caracterizando-se pelo sistema de adensamento e emprego de mecanização agrícola nas áreas de cultivo. Os principais fatores que restringem a expansão da pupunha são o número pequeno de agroindústrias, os custos de implantação, assistência técnica, necessidade de irrigação e crédito.

Tax and environmental control of native timber products: the use of digital technologies / Controle tributário e ambiental de produtos madeireiros nativos: o uso de tecnologias digitais

Daniel Teixeira ${ }^{1}$ iD; Felipe Vieira ${ }^{2}$, Italo Veras ${ }^{3}$, José Bandeira ${ }^{3}$, Lucian Stoenica $^{3}$, Marcello Rangel $^{3}$, Alexandre Brasil ${ }^{3}$, Ariel Andrade Al $^{3}$ ${ }^{1}$ Universidade de Brasília, Brasília, Brasil; ${ }^{2}$ Gestão de Ativos Ambientais e Florestais, Brasília, Brasil; ${ }^{3}$ Instituto Avaliação, Brasília, Brasil (dnmoura@gmail.com; stockfv@gmail.com; italoverasedu@gmail.com; claudio@avaliacao.org.br; lutisto@gmail.com; marcellorangel@gmail.com; brasil@avaliacao.org.br; arielandrade@yahoo.com)

A participação das florestas nativas na produção primária florestal brasileira tem sido gradualmente reduzida em função de diversos problemas estruturais no setor, com destaque para: a pesada burocracia envolvida na gestão e controle das atividades florestais, levando o empreendedor para a informalidade, e; a fragilidade dos sistemas de fiscalização envolvidos no controle do desmatamento ilegal. A literatura mostra que esses problemas persistem, apesar de haverem normas, ações integradas de combate ao desmatamento ilegal, de constrangimento de mercados consumidores e de promoção ao manejo florestal. As tecnologias da era digital, baseadas em dados, computação e automação se credenciam como uma forma de aperfeiçoar a burocracia e controle da informalidade e ilegalidade da madeira. Assim, as atividades humanas e processos envolvidos na fiscalização seriam criados e recriados com base em volume de dados em escalas antes inexistentes. Portanto, o objetivo do presente estudo foi avaliar, do ponto de vista legal, as potencialidades dos sistemas de controle tributário e ambiental da madeira nativa em absorver as tecnologias digitais. Para isso, realizou-se o levantamento da legislação que rege os sistemas de controle da madeira e distribuiu-se os instrumentos em matrizes analíticas. Os resultados mostraram que a legislação atual já permite que diferentes instituições públicas e privadas possam compartilhar dados não sigilosos. Porém, as normas ainda não expressam as reais possibilidades de incorporação de tecnologias digitais já utilizadas em outros setores da economia, como o de medicamentos controlados.

Rural communities producing wood shingles: an alternative source of income for small forest producers in community and family forest management / Produção de telhas de madeira (cavacos) por comunidades rurais da Amazônia: uma alternativa de renda para o pequeno produtor florestal no manejo florestal comunitário e familiar

Ana Luiza Violato Espada ${ }^{1}$ iD; Junia Ruggiero ${ }^{2}$, Iran Pires ${ }^{3}$, Benedito Pacatuba ${ }^{3}$, Paulo Bittencourt ${ }^{3}$, Marco Lentini $^{4}$, Ana Luiza Violato Espada ${ }^{3,5}$ ${ }^{1}$ Instituto Floresta Tropical, Gainesville, FL, Brasil; ${ }^{2}$ Instituto de Manejo e Certificação Florestal e Agrícola, Piracicaba, Brasil; ${ }^{3}$ Instituto Floresta Tropical, Belém, Brasil; ${ }^{4} \mathrm{WWF}$, Brasilia, Brasil; ${ }^{5}$ University of Florida, Gainesville, FL, USA (violatoespada@ufl.edu; junia@imaflora.org; iran@ift.org.br; iran@ift.org.br; paulo@ift.org.br; mwlentini@gmail.com; violatoespada@ufl.edu)

Cavacos são telhas de madeira produzidas com técnicas desenvolvidas de forma empírica durante muitas gerações e que ocorrem de forma manual e em pequena intensidade. Paradoxalmente, apesar das vantagens e do baixo custo em comparação às telhas de barro e de fibrocimento, os cavacos raramente são usados. O estudo realizado pelo Instituto Floresta Tropical apresenta as vantagens do uso do cavaco, de forma a resgatá-lo como uma boa opção para a construção civil rural e para a geração de renda, clamando a atenção das agências licenciadoras para a necessidade de regulamentações específicas que simplifiquem o 
acesso aos produtos florestais originados tradicionalmente no mercado formal. Apresenta uma análise de viabilidade econômica, de forma a comparar os custos associados à produção e ao uso do cavaco em comparação às telhas de barro e de fibrocimento. Os dados foram coletados no Centro de Manejo Florestal Roberto Bauch, Paragominas. Foram utilizadas duas árvores de Holopyxidium jarana. As coletas de dados ocorreram em duas etapas. Em 2009, foram selecionados aleatoriamente 30 cavacos para a mensuração de seu comprimento, largura e espessura. Em 2011, foram sorteados $20 \%$ da produção diária e foram medidos produtividade no trabalho e consumo de combustíveis e de materiais. A produção e uso do cavaco apresenta vantagens em relação a produtos alternativos para a cobertura de casas e estruturas rurais, além de ser uma opção de renda interessante para pequenos produtores rurais. Entretanto, tal prática tem sido lentamente abandonada por diferentes razões, e buscamos através deste resumo resgatar o seu uso.

Critiques of the Brazilian national policy on forest biofuels (Project of Law 1291/15) / Comentários críticos sobre a politica nacional de biocombustíveis florestais (PL $n^{0} 1291 / 15$ )

Rafaela Prosdocini Parmeggiani ${ }^{1}$, Luiz César Ribas ${ }^{1}$

${ }^{1}$ Universidade Estadual Paulista “Júlio de Mesquita Filho”, Botucatu, Brasil (rafaela.prosdocini@gmail.com; luiz.c.ribas@unesp.br)

A Política Nacional de Biocombustíveis Florestais (PNBF) trata dos combustíveis sólidos, líquidos ou gasosos oriundos da biomassa florestal (lenha e carvão vegetal). Seu objetivo é de ampliar a participação na matriz energética brasileira e o cultivo de florestas plantadas com potencial energético para a produção sustentável de biocombustíveis. Sua implantação dependerá da análise (no qual o custo de oportunidade da terra será uma das variáveis) das alternativas de uso, ocupação e alteração antrópica das áreas rurais (produção alimentar e agropecuária, cana-de-açúcar, soja, carne, reforma agrária e proteção ambiental). Para uma decisão pelos biocombustíveis florestais, os instrumentos (incentivos fiscais, linhas de crédito rural e apoio ao cooperativismo, sequestro de carbono com uma alternativa de pagamento por serviços ambientais, reposição florestal, plantio energético em áreas rurais consolidadas mediante a não destoca da área, etc.) de política florestal, alimentar, agrária, ambiental e energética, devem ser sopesados. Diversos dispositivos da PNBF, portanto, estão justapostos à outras legislações e políticas públicas de cunho nacional e internacional (nova Lei Florestal, Política Nacional do Meio Ambiente, Política Nacional de Florestas Plantadas, dentre outras). A questão da "fiscalização" sempre tem sido o nó górdio de políticas de base florestal, mesmo que se propondo, aqui, mecanismos como o Sistema Nacional de Informações sobre Florestas com Potencial Energético e respectivo banco de dados. O PL 1291-15, inclusive dada a Contribuição de Intervenção no Domínio Econômico, ainda terá que passar por diversas comissões do Congresso Nacional, demandando um acompanhamento mais acurado de seu processo de aprovação, regulamentação e implementação.

\section{The use of participatory approach at the introduction of modern forest harvesting operations with an emphasis on soil protection:} project "Links4Soils"

Jurij Begušn ${ }^{1}$ Aleš Poljanec ${ }^{1}$

${ }^{1}$ Slovenia Forest Service, Ljubljana, Slovenia (jurij.begus@zgs.si; ales.poljanec@zgs.si)

Introducing novelties is always accompanied with a certain extent of resistance that can be overcome only by dialogue. Due to close to nature oriented forestry and ecological conditions in Slovenia, modern forest harvesting operations (FHO) have not been always accepted positively. The attitude among different stakeholders towards FHO has been and still is diverse. To overcome differences in attitude and find appropriate solutions, participatory process, consisted of several workshops (WS), has been introduced in 2002 and repeated several times (2010 and 2018). Such uniform approach enabled us to get a systematic view on participants' attitude towards the use of FHO over the last two decades. Results shows that soil damages caused by FHO are one of the most important issues. Thus, several activities for better integration of soil protection in forest harvesting operations were performed within the Links4Soils project, co-financed by the European Union as part of the Alpine Space Program. Maps showing risks of harvesting operations for soil degradation based on existing soil data were prepared and guidelines for forest operations were upgraded. Important part of the activities was WS (2018) on soil protection for forest experts and practitioners, organized as continuation of participatory process. The results of different activities will be presented and applicability of approaches and methods used will be further discussed.

Pinus elliottii Engelm. Resin: a non-timber forest product providing environmental, social, and economic benefits in the coastal grassland region of Rio Grande do Sul, Brazil / Resina de Pinus elliottii Engelm.: produto florestal não madeireiro promovendo beneficios ambientais, sociais e econômicos nos campos litorâneos do Rio Grande do Sul

Samara Lazarotto ${ }^{1}$, Rafaelo Balbinot ${ }^{1}$, Maria Inez Azevedo Velho ${ }^{2}$

${ }^{1}$ Universidade Federal de Santa Maria, Campus Frederico Westphalen, Frederico Westphalen, Brasil; ${ }^{2}$ Âmbar Florestal, São José do Norte, Brasil (samara. fk@hotmail.com; rafaelo.balbinot@gmail.com; mivelho@ambarflorestal.com.br)

A extração da resina de árvores é uma técnica antiga e que vem sendo atualizada ao longo do tempo. Atualmente a resina do Pinus elliottii Engelm. é retirada de uma maneira mais efetiva e com ferramentas que facilitam o processo. A área de estudo compreende quatro fazendas pertencentes a empresa Florestadora Palmares - Flopal localizadas em Santa Vitória do Palmar, RS, que em um sistema de parceria são resinadas pela Âmbar Florestal. O objetivo deste trabalho é analisar a importância da resinagem para os colaboradores e obter dados socioambientais. A metodologia se resume a entrevistas realizadas por meio de um questionário formulado pelos autores. Foram entrevistados $87 \%$ do total de colaboradores da Âmbar Florestal, entre esses a maioria (87,7\%) são homens, contudo a representatividade feminina vem aumentando nas atividades a campo. Aproximadamente $63,4 \%$ dos entrevistados tem filhos que na sua maior parte são crianças de 10 a 15 anos de idade, faixa etária onde cuidados com educação, escola, saúde e alimentação são essenciais e representam custos para os responsáveis. O maior número dos entrevistados (66,6\%) vivem em residências com até 4 indivíduos onde a única fonte de renda provém da resinagem de Pinus. A partir destes resultados constatamos a importância da resinagem diretamente na vida do colaborador e indiretamente nas vidas da sua família e na sociedade como um todo. 


\title{
A6b: BALANCING ENVIRONMENTAL, PRODUCTIVE AND SOCIAL NEEDS TO MEET SUSTAINABLE GOALS IN THE FOREST INDUSTRY: EXPERIENCES OF CROSS-SECTORIAL COOPERATION IN SOUTH AMERICA
}

\author{
Development of a forest sustainable/balance model based on plantations. Perspective of MPC, a private forest company in Chile \\ Francisco Rodriguez ${ }^{1}$ \\ ${ }^{1}$ CMPC Celulosa, Los Angeles, Chile (francisco.rodriguez@cmpc.cl)
}

The evolution of this issue within the forest companies in Chile has been very important since the early 90s. The situation of CMPC, although particular, is not far from what has happened in the Chilean forestry sector during the last 30 years. Created in 1920, CMPC is a company whose mission is to produce and market solid wood products, cellulose, paper and tissue products made from plantations. It currently operates in 8 countries in Latin America, providing almost 18.000 direct jobs, with annual sales above 6 billion dollars. It is only in 1991 that CMPC draws up its first Forest Environmental Policy; 8 years later, started a "Good Neighborhood Plan", oriented mainly to ensure its operational continuity through the establishment of agreements with communities neighboring its operations. These initiatives were finally taken to a higher stage driven by Forest Management Certifications. CERTFOR / PEFC in 2004 and FSC in 2012, unleash a very strong change in the work of CMPC and the entire Chilean forestry sector. Market itself mandates the monitoring of principles and criteria, based on its 3 pillars: economic, social and environmental. As a new link to the aforementioned, multiparty work initiatives have been added including the views of NGOs, local communities, companies and governmental bodies to carry out balanced restoration actions at a landscape level, and to develop their shared governance.

Experiences with conservation and sustainable forest production in Paraguay / Experiencias de conservación y producción forestal sostenibles en Paraguay

Laura Rodriguez ${ }^{1}$

${ }^{1}$ Fundación Moisés Bertoni, Asunción, Paraguay (mrodriguez@mbertoni.org.py)

Con el desarrollo y la expansión de la actividad agropecuaria, especialmente desde mediados del siglo 20, los bosques en Paraguay han disminuido de manera drástica. El Bosque Atlántico de Alto Paraná sólo mantiene el 13\% de su superficie original (WWF 2017) y actualmente el bosque chaqueño está experimentando el mismo proceso. Siendo un país que basa su economía en los commodities y teniendo un territorio casi en su totalidad apto para la producción, es necesario rescatar experiencias exitosas de producción forestal sostenible que puedan ser replicadas y que ayuden a disminuir el impacto no sólo sobre los bosques, sino sobre otros ecosistemas como el cerrado o los humedales, por lo que esta presentación busca, por un lado, dar un breve análisis sobre el marco legal forestal y ambiental, acerca de las oportunidades que ofrece, y por otro, exponer algunas experiencias de conservación y de producción forestal sostenibles. Las experiencias son desarrolladas en gran parte bajo alianzas entre el sector privado, el sector público, las ONGs y la academia. Las mismas desarrollan distintas estrategias como el desarrollo turístico en áreas protegidas, el manejo de bosque nativo y plantaciones forestales, las dos últimas realizadas bajo diversas certificaciones internacionales. Con estas experiencias, se cuenta hoy con 82.733 ha protegidas bajo la figura de Reservas Naturales Privadas. Asimismo, trabajos con pequeños productores y comunidades indígenas, buscando fortalecer corredores de conectividad a través de la puesta en valor de sus bosques, enriqueciéndolos con yerba mate, logrando la protección de unas 300 ha de bosque.

\section{Environmental, social and economic impacts of forest plantations in Chile}

Hans Grosse ${ }^{1}$

${ }^{1}$ Instituto Forestal, Santiago, Chile (hgrosse@infor.cl)

For decades, Chile's native forest in the Central and Southern mountain areas where exploited to use the biomass for melting metals of a young mining industry and cleared by fires for giving space to agriculture and livestock, impoverished rural population due reduced soil productivity. Significant environmental, social and economic changes by recovering about 2.5 million ha was the result of a national incentivized afforestation program with well adapted pioneer species. Planted areas stopped erosion and material flow to watersheds was reduced and catastrophic floods regulated. Chile's forests contribute about $60 \%$ of the country's carbon capture with a significant contribution from plantations. Forest harvest has been concentrated during the last 50 years in planted forests, allowing native forests biomass and biodiversity to recover, being Chile one of the two countries in Latin America where forest cover does not decrease. Taxes payment, considering the complete forest production chain, recovers annually more than the 800 million US\$ the state has invested during 40 years in afforestation incentives. During the same period of time, private investment close to US \$ 20 billion, are currently allowing exports that exceed US \$ 6,000 million yearly. Depressed rural communities 40 years ago, have been able to equal their development to those of suitable agriculture and fishing conditions after afforestation. Increasing forestry activity has a positive impact on employment, to sustain economically at least $9 \%$ of Chiles population.

\section{Historical analyses of landscape changes with emphasis on forestry in Mesopotamia, Argentina}

Victoria E. Espinoza-Mendoza ${ }^{I, 2}$, Gustavo Adolfo Zuleta ${ }^{1}$

${ }^{1}$ DECA - CEBBAD, Universidad Maimonides, Buenos Aires, Argentina; ${ }^{2}$ CONICET, Buenos Aires, Argentina (espinoza.victoria@maimonides.edu; zuleta.gustavo@maimonides.edu)

Commercial tree plantations in Argentina are increasing since 1999, usually motivated by public policies and market forces. The Mesopotamia region currently harbors 79\% of plantations. By reconstructing the history of land cover in this region, including analyses of transitions, it is possible to understand the landscape changes. In this research we focus on forestry in Mesopotamia which has a history of timber trade dating to the 1900s. Diverse regulations and policies facilitated a significant growth of the sector, such as government subsidies that encouraged the establishment of paper and cellulose companies. The national policies involve two major goals: (a) the promotion of industrial forestry and (b) the creation of new areas of commercial plantations. The processes are based on commercial industry represented by fast-growing exotic species such as Eucalyptus and Pinus. Under this context, we did spatial analyses and reviewed historical data derived from scientific literature. We found that (1) the total planted area in Mesopotamia has increased $4000 \%$, from 27.000 ha in 1900 to 1.100.000 ha in 2018, (2) commercial plantation have been concentrated on soils with high suitability and replacing natural forests or grasslands, (3) only one company includes native tree species in its commercial program, and (4) exists a displacement in forestry demands among the three provinces of the region. Besides, we found that (5) the forest transition model can predict some landscape changes in Misiones, whereas in Corrientes and Entre Ríos land uses can be explained by a multiple transition approach. 


\section{Factors associated with forest degradation on an Amazonian logging frontier area in Southwestern Pará, Brazil}

Danilo Avancini Rodrigues ${ }^{1}$, Maria Isabel Sobral Escada ${ }^{1}$

${ }^{1}$ National Institute for Space Research, São José dos Campos, Brasil (danilo.avancini@gmail.com; isabel.escada@inpe.br)

Forest degradation is a long-term process that reduces forest's biodiversity and impoverishes the ecosystems. Understanding the factors that generates and intensifies forest degradation, and its consequences, allows directing public policies to prevent this process. This study performed a spatial regression analysis between forest degradation intensity (dependent variable), environmental, political and economic variables in Novo Progresso (PA), a logging frontier expansion area in the Amazon Forest, from 2009 to 2011. The independent variables were related to fire occurrence, deforestation, conservation units, indigenous lands, logging poles and roads. The relationship between the dependent and independent variables ( $\mathrm{R}^{2}$ and $\mathrm{p}$-value) was individually tested, and the variables with the highest relationship were included in the regression model. Then, the variables with multicollinearity were excluded from the model with the stepwise backward technique. It was used the Moran test to detect spatial dependency on the data. Spatial dependency was detected with statistical significance (I = 0,2434; $\mathrm{p}$-valor $=0$ e $\mathrm{z}$-score $=9,91$ ), justifying the use of a spatial regression model. The Lagrange Multiplier test pointed out Spatial Lag Model as the best model adjusted to the data. The variables area of deforestation and total edge area explained $40 \%\left(\mathrm{R}^{2}\right.$-adj: 0,4092) of the forest degradation intensity, indicating that fragmented forest and the forest areas closest to deforested areas are more likely to suffer higher degradation. For further studies, the $\mathrm{R}^{2}$ of the model can be raised by adding variables related to pasture expansion, forest management, colonization projects and updating the roads data yearly.

\section{Are government incentives effective for avoided deforestation in the tropical Andean forest?}

Pablo Cuenca ${ }^{1}$, Juan Robalino ${ }^{2,3}$, Rodrigo Arriagada ${ }^{4,5,6}$, Cristian Echeverría ${ }^{6,7}$

${ }^{1}$ Laboratorio de Cambio Global, Universidad Regional Amazónica Ikiam, Tena, Ecuador; ${ }^{2}$ School of Economics, Universidad de Costa Rica, San José, Costa Rica; ${ }^{3}$ Centro Agronómico Tropical de Investigación y Enseñanza (CATIE), Turrialba, Costa Rica; ${ }^{4}$ Department of Ecosystems and Environment, Pontificia Universidad Católica de Chile, Santiago, Chile; ${ }^{5}$ Center for Applied Ecology and Sustainability (CAPES), Santiago, Chile; ${ }^{6}$ Millennium Nucleus Center for the Socioeconomic Impact of Environmental Policies (CESIEP), Santiago, Chile; 7 Laboratorio de Ecología de Paisaje, Facultad de Ciencias Forestales, Universidad de Concepción, Concepción, Chile(pablo.cuenca@ikiam.edu.ec; juan.robalino@ucr.ac.cr; rarriagadac@uc.cl; cristian.echeverria@udec.cl)

In order to ensure the provision of goods and services from forests, many governments have promoted less-traditional conservation initiatives such as programs of payments for ecosystem services called, more broadly, direct payments for conservation. The Socio Bosque Program (SBP) is a governmental program in Ecuador that directly provides economic incentives to rural families and local and indigenous communities who have voluntarily agreed to comply with some conservation activities. An impact evaluation method (matching) was used to assess the impact of the SBP between 2008 and 2014 . This study revealed that on average, the SBP reduced deforestation by $1.5 \%$ in those forests that received the SBP's direct payment. These forests would have been deforested if the SBP had not been implemented. Assessment of the impact of the SBP on individual and collective contracts, using the matching method, revealed that 3.4\% and roughly $1 \%$ of the forest would have been deforested in the absence of the program, respectively. In other words, the protected area in the collective SBP was $1,247,500$ ha and, if the SBP had not been implemented, an area of 11,227 ha would have been lost between 2008 and 2014 . The 165,700 ha protected by the individual SBP, it was estimated that 5,733 ha were not deforested due to the implementation of the conservation program. The conclusions are robust, even given potential hidden biases. The present study demonstrated that the SBP serves to mitigate the effects of climate change, especially with those contracts that are intended for individual owners.

\section{Cross-sectorial experiences to meet environmental goals in forestry plantations of Mesopotamia, Argentina}

Gustavo Adolfo Zuleta ${ }^{1}$, Agustín Guiscafré ${ }^{1}$, Victoria E. Espinoza-Mendoza ${ }^{1}$

${ }^{1}$ DECA-CEBBAD. Universidad Maimonides, Buenos Aires, Argentina (zuleta.gustavo@maimonides.edu; guiscafre.agustin@maimonides.edu; espinoza.victoria@maimonides.edu)

Despite early warnings during the '60s, degradation of natural resources is still a relevant concern worldwide. In 2019, conservation, restoration and sustainable use are still relevant goals to improve ecological conditions but not enough. In Argentina, the forestry sector is increasingly expanding the area planted with commercial trees, but also implementing environmental measures motivated by public policies, eco-demanding customers, and a strong cross-sectorial interaction. The later driver is based on the influence of scientists, consultants, and managers from a wide range of institutions (universities, CONICET, INTA, National Parks Administration, NGOs, environmental firms). As a result, inter-institutional networks were generated, for example a participatory wildlife monitoring program. However, most actions are voluntary and limited to the site or local scale, within the ownership boundaries. To fulfill effective sustainability, regional and multi-scale actions are needed, such as: (1) contribute to establish natural protected areas to preserve at least $17 \%$ of each ecoregion historical area (or major ecosystem types), (2) avoid commercial plantations in zones with high conservation values (e.g. riparian habitats, wetlands), (3) minimize new forestry in ecosystems with low legal protection (e.g. grasslands that represent unique habitats for species threatened to extinction, particularly birds), (4) restore or facilitate connectivity at multiple scales, and (5) estimate (and reduce) cumulative and synergic impacts. These measures require forest companies accept that their social and environmental responsibilities are beyond the limits of their properties. In fact, this is also valid for the agriculture and livestock sectors of Mesopotamia.

\section{A6c: CHALLENGES TO SUSTAINABLE FOREST MANAGEMENT TO ENHANCE TRADITIONAL COMMUNITIES AND SMALLHOLDERS'LIVELIHOODS IN THE AMAZON} BASIN

\section{Do conservation strategies influence households' land clearing decisions in the Peruvian Amazon? Insights from the Nanay basin \\ Javier Montoya ${ }^{1}$, Aoife Bennet ${ }^{2}$ \\ ${ }^{1}$ Australian National University, Canberra, Australia; ${ }^{2}$ University of Oxford, Oxford, United Kingdom (jmontoya.iq@gmail.com; aoife.bennett@gmail.com)}

We combine remote sensing data and household surveys to determine the drivers of land clearing decision making of riverine villagers settled in Protected Areas (PAs) and those not settled in PAs in the Nanay Basin in the Peruvian Amazon. Using empirical data, we ran reduced econometric models both for villages connected to the PAs, and those unconnected to them to determine whether land-clearing decision making was related to PAs. We found that in villages not influenced by PAs, households' land clearing decisions are motivated by market opportunities; meanwhile, in the villages influenced by the PAs (and their 
respective conservation projects and initiatives), off-farm incomes, derived mainly from households' participation in Integrated Conservation and Development Projects (ICDP), has resulted in $23 \%$ less land clearance overall, with only a marginal difference in land cleared for farm extension. This finding suggests that ICDP interventions have an important inhibitory effect on households' cleared land expansion when they provide high economic returns to village participants. In light of our results, we discuss the limitations to current conservation strategies in the area, and we suggest policy elements that should be in place to strengthen them as soon as possible and going forward. This is critical right now, considering the governments explicit intention for infrastructure development in the region, which will intensify already existing drivers of land clearing, further threatening the socio-environmental integrity of the watershed and nullifying the positive impacts of the ICDP strategies.

\section{From exploitation to management: a review of the context, life history and potential pathways to sustain and increase Brazil nut production}

Karen Kainer ${ }^{1}$, Lúcia Helena de Oliveira Wadt ${ }^{2}$, Christina Staudhammer ${ }^{3}$

${ }^{1}$ University of Florida, Gainesville, USA; ${ }^{2}$ Embrapa Rondônia, Porto Velho, Brasil; ${ }^{3}$ University of Alabama, Tuscaloosa, USA (kkainer@ufl.edu;

lucia.wadt@embrapa.br; cstaudhammer@ua.edu)

Brazil nut (Bertholletia excelsa) has emerged as a cornerstone species of the Amazonian extractive economy, coinciding with creation of Brazilian extractive reserves. This alternative land use model attempts to balance biodiversity conservation with rural development. Traditional forest residents are assigned legal responsibility to co-manage these reserves and their resources, including Brazil nut, precipitating a shift from general nut exploitation to more conscious, intensive species management. Drawing heavily on our 25 plus years of research in the Brazilian state of Acre and surrounding tri-border region, we ask: (1) Are Brazil nut harvests sustainable in terms of fruit production patterns and resilience to nut (seed) collection? (2) In what ways might production be augmented and nut quality enhanced? We highlight that scientific evidence and local knowledge indicate that restrictions on current levels of nut harvests are not necessary to sustain populations of $B$. excelsa and its key seed disperser, Dasyprocta spp. Rather than concentrating on the fate of most seeds produced, the more pressing risk to $B$. excelsa populations is survival of existing large trees. Ample knowledge indicates possible futures to increase productivity by protecting and improving tree conditions: Cutting lianas from host tree crowns dramatically improves productivity; enrichment plantings and tending new recruits, particularly in abandoned agricultural fallows, is an extremely promising way to grow Brazil nut-rich forests. Nut quality and the Brazil nut market also have improved dramatically. Working together, researchers, local communities and progressive industries can promote understanding, sustainable use and conservation of standing Amazonian.

\section{Açaí as a driving force of rural development in the communities of the Amazon river estuary}

Ana Margarida Euler ${ }^{1}$, Silas Mochiutti ${ }^{1}$, Carlos Ramos ${ }^{2}$

${ }^{1}$ Embrapa Amapá, Macapá, Brasil; '2Estuário Consultorias Socioambientais, Belém, Brasil (ana.euler@embrapa.br; silas.mochiutti@embrapa.br; pantojaramos@gmail.com)

The estuary of the Amazon River comprises the area with influence of the tides, where the Marajó archipelago is located with its many islands inhabited by traditional communities that live from agroextrativism. This region has one of the lowest Human Development Index (0.489) in Brazil and 87.28\% of the population is vulnerable to poverty. In this context, the açaí (Euterpe oleracea Mart.) emerges as a product from the local biodiversity with immense importance in food security, having become the driving force for the Marajó socioeconomic development. Participatory research conducted in 2018, in the municipality of Afuá (Pará), with 135 families of Ilha do Meio Agroextractivist Settlement Project, showed that the açaí constitutes on average 94.5\% of the families’ income, with an annual revenue of about six thousand US dollars per family. However, $83 \%$ of the interviewed families do not have the habit of saving and at the end of the harvest season they are deprived of resources. On the other hand, the açaí economy has generated an improvement in the families' quality of life and consumption patterns. It has also changed their eating habits and the way they use the forest. As a main conclusion, the study points out the need to discuss new market strategies for the diversification of production in order to use other fruits, seeds and oils. Improvement of the financial planning knowhow of the community, by encouraging the habit of saving and creation of community funds is essential to improve the current vulnerability of these populations.

Traditional communities of the Xingu River accessing the timber market: challenges, risks, and opportunity / Comunidades tradicionais no Rio Xingú acessando o mercado madeireiro: desafio, risco e chance

Maximilian K. A. Steinbrenner ${ }^{1}$, Iran Paz Pires ${ }^{2}$

${ }^{1}$ Embrapa Amazonia Ocidental,Belém,Brasil; 2Instituto Floresta Tropical, Belém,Brasil (max.steinbrenner@gmail.com;iran@ift.org.br)

O presente artigo relata as experiências com a produção de madeira em tora de seis comunidades na Reserva Extrativista Verde para Sempre, no Rio Xingú, no estado do Pará. Empreendimentos florestais organizados por comunidades rurais com o intento de produzir para os mercados representam um novo ator no setor madeireiro que ainda não aparece em escala, mas tem um potencial importante, já que essas comunidades habitam em $60 \%$ das florestas públicas, numa área de 132 milhões de hectares (SFB 2009). Nos casos aqui relatados os comunitários recebem treinamento e capacitação do Instituto Floresta Tropical (IFT), apoiado pela Climate and Land Use Alliance. Adicionalmente, no âmbito do Projeto Bom Manejo, financiado pela Organização Internacional de Madeira Tropical (ITTO) a EMBRAPA Amazônia Oriental e o IFT desenvolvem junto às comunidades uma metodologia de monitoramento de critérios e indicadores técnicos, ambientais, sociais e econômicos do manejo florestal. Esse método deve servir como uma ferramenta de gestão para as comunidades e funciona com a introdução de ferramentas de manejo florestal sustentável desenvolvidas pelo Projeto Bom Manejo na sua primeira fase. Os primeiros resultados do referido monitoramento técnico-ambiental revelaram a vocação das comunidades para o manejo florestal que atende suas tradições. O desempenho produtivo se mostrou promissor e as análises preliminares indicam que os projetos de manejo são rentáveis. Os desafios para assegurar a sustentabilidade dos empreendimentos encontram-se na logística da colheita, na gestão do Plano de Manejo, nas negociações de serviços contratados e das condições de venda e o cumprimento dos contratos.

\section{Management and governance of the use of timber resources by local populations in a floodplain area in Central Amazonia, Brazil /} Gestão e governança do uso de recursos madeireiros por populações locais em uma área de várzea na Amazônia Central, Brasil

Caetano Franco ${ }^{1}$, Ana Jéssica Silva de Oliveira ${ }^{1,2}$, Zeneide Damião Silva ${ }^{1,2}$, Viviane da Silva Marcos ${ }^{1}$, Claudio Roberto Anholetto Junior ${ }^{1,3}$

${ }^{1}$ Instituto de Desenvolvimento Sustentável Mamirauá, Tefé, Brasil; ${ }^{2}$ Universidade Estadual do Amazonas, Tefé, Brasil; ${ }^{3}$ Universidade de São Paulo,

Piracicaba,Brasil (caetano@mamiraua.org.br; ana_jeka@hotmail.com; zeneide.silva@mamirauá.org.br; viviane.marcos@mamiraua.org.br; claudio@mamiraua.org.br) 
Na Amazônia, grupos humanos fazem uso direto dos recursos naturais para a reprodução social. Recursos madeireiros são usados para diversas finalidades (embarcações e infraestruturas comunitárias). Populações que habitam áreas de várzea seguem o ritmo da variação do nível d’agua, estão sujeitos às alagações anuais. Este ciclo define as variações nos padrões de renda, disponibilidade de recursos naturais e condições de saúde. A legislação ambiental permite que estas pessoas explorem os recursos naturais existentes para manutenção. A Reserva de Desenvolvimento Sustentável Mamirauá (RDSM) abrange 1.124.000 hectares. Este trabalho discute a prática da gestão e governança dos recursos madeireiros pelas comunidades tradicionais residentes da RDSM através de um monitoramento realizado há mais de duas décadas. No período analisado, foram explorados 10,3 mil $\mathrm{m}^{3}$ de madeira não manejada para usos de subsistência dos moradores da RDSM. O Assacú (38,2\% - Hura crepitans L.) e o Louro Inamuí (21,4\% - Ocotea cymbarum Kunth) foram as espécies mais exploradas. A Jacareúba (8,02\% - Calophyllum lucidum Benth.) e o Cedro (2,27\% - Cedrela odorata L.) estão entre as espécies mais exploradas e são protegidas por acordo local desde a década de 1990. A Castenheira (1,68\% - Bertholletia excelsa Bonpl.) se encontra nesta lista e é protegida por legislação federal. O monitoramento prove resultados que são parâmetros para o planejamento de uso dos recursos naturais pelos usuários e tomadores de decisões, bem como para a gestão adaptativa e a governança dos mesmos e da área protegida. Isso garante a conservação de espécies biológica e economicamente importantes para a manutenção da floresta e conhecimento tradicional de seus povos usuários.

\title{
Logging in protected areas in Amazonia: communities that flourish can inform those that struggle \\ Ana Luiza Violato Espada ${ }^{1,2}$ iD : Natalie Cooper ${ }^{1}$,Eduardo Bongiolo ${ }^{1}$, Karen Kainer ${ }^{1}$, Lúcia Helena de Oliveira Wadt ${ }^{3}$ \\ ${ }^{1}$ University of Florida, Gainesville, USA; ${ }^{2}$ Instituto Floresta Tropical, Belém, Brasil; ${ }^{3}$ Embrapa Rondônia, Porto Velho, Brasil (violatoespada@ufl.edu; natalieacooper@ufl.edu; eduardosbongiolo@gmail.com; kkainer@ufl.edu; lucia.wadt@embrapa.br)
}

Timber extraction for commercial use has been introduced as a strategy for tropical forest management and conservation. Despite the achievements championed, forest management in the Amazon region has faced a spectrum of challenges, to which forest livelihoods and management stability within protected areas such as extractive reserves are precariously sensitive. However, regional cases of community forestry paired with institutional alliances have emerged with hopeful lessons for the future of forest communities. Communities from three extractive reserves in the states of Pará and Amazonas are thriving since initiating timber management projects, each structured around distinct local needs and visions of community forest management with technical and governance support from government and non-governmental organizations. In contrast, communities in an extractive reserve in the state of Acre are struggling with timber management. To exchange experiences and facilitate a critical link between stakeholder groups (government, universities, researchers and community members) positioned to strengthen community-based forest management, a group of students, faculty, and alumni from University of Florida (UF) and Brazilian partners conducted an information exchange workshop in Acre in June 2017. Key community members and others who have worked to incrementally build community forest management in these Eastern Amazonian reserves shared their experiences with those in Acre positioned to strengthen timber-based community forestry. Based on a social learning framework, we will present lessons learned from different community-based perspectives and experiences as related to forestry operations, financial limitations, partnerships, and collective action that improve community-based timber management, conservation, and development in the tropics.

Organizational arrangements for managing community enterprises in implementing sustainable forest management plans in the Amazon region / Arranjos organizacionais para a gestão de empreendimentos comunitários na implementação de plano de manejo florestal sustentável na Amazônia

Katiuscia Miranda ${ }^{1,2}$, Manuel Amaral Neto ${ }^{1}$, Romier Sousa ${ }^{2}$, Roberta Coelho ${ }^{2}$

${ }^{1}$ Instituto Internacional de Educação do Brasil, Belém, Brasil; ' Instituto Federal de Educação, Ciência e Tecnologia do Pará, Campus Castanhal, Castanhal, Brasil(glaukat2001@gmail.com; manuel@iieb.org.br; romier.sousa.ifpa@gmail.com; roberta.fatimacoelho@gmail.com)

O uso comum de recursos naturais configura uma marcante característica das "populações tradicionais" na Amazônia, reconhecidas legalmente como "povos e comunidades tradicionais". Estes grupos sociais desenvolvem capacidades organizativas para a gestão de seus recursos florestais com base em suas identidades culturais, adaptados aos ecossistemas em que vivem. Exercem atividades produtivas em várias modalidades fundiárias, sejam em unidades de conservação de uso sustentável, ou assentamentos da reforma agrária. A importância dessa produção tem se configurado cada vez mais estratégica para o abastecimento do mercado. No caso da madeira, o volume oriundo de áreas comunitárias pode chegar a 1/3 de todo volume produzido na Amazônia.Para dar conta desse desafio, as comunidades têm se organizado em associações e cooperativas para fazer a implementação de planos de manejo florestais comunitários (PMFS). Contudo, estabelecer na Amazônia empreendimentos florestais organizados por agroextrativistas que residem em florestas públicas é um desafio. Principalmente, se forem levadas em conta fatores como logística, a baixa escolaridade dos diretores, a complexidade do marco regulatório para a gestão de PMFS, etc. Nesse caso, torna-se central construir estratégias participativas e transparentes para gestão dos empreendimentos. Este trabalho analisa arranjos organizacionais na Reserva Extrativista Verde para Sempre pautados em ações de avaliação e planejamento contínuo e ferramentas simplificadas de sistemas de gestão nos campos da organização, produção e comercialização. Como resultado tem-se obtido um maior empoderamento dos atores sociais envolvidos na gestão e aumento da maturidade organizacional garantindo maior autonomia e rapidez na tomada de decisão dos empreendimentos comunitários na Unidade de Conservação.

\section{Challenges to the policy of supporting plant extractivism by traditional populations in Brazil / Desafios da politica de apoio ao} extrativismo vegetal praticado por populações tradicionais no Brasil

\author{
Mauro Pires ${ }^{1}$ \\ ${ }^{1}$ ICMbio, Brasilia, Brasil (mauro.pires27@gmail.com)
}

O objetivo é refletir sobre desafios, limites e lições das políticas brasileiras do período 1998 a 2018 direcionadas a povos e comunidades tradicionais que encontram no extrativismo vegetal, aliado a outras atividades econômicas, a base de seu bem-viver e de sua identidade. Essas políticas ancoram-se no reconhecimento do papel que os segmentos tradicionais cumprem na conservação ambiental. O trabalho discute as principais políticas, com especial destaque para o programa Bolsa Verde (2011-2018) e o Plano Nacional de Fortalecimento das Comunidades Extrativistas e Ribeirinhas (PLANAFE), instituído recentemente para atender o conjunto das demandas desses segmentos tradicionais. Com especial interesse, o trabalho debate os limites que dificultam a ampliação do escopo, escala e número de beneficiários. Observa que, quando prevalece política econômica de restrição de gastos públicos, maiores são as barreiras enfrentadas por políticas direcionadas aos extrativistas. Constata outros fatores igualmente desafiantes: dificuldade de obtenção de informações para a avaliação do impacto e a necessidade de formação dos servidores públicos para lidar com esses segmentos. Por outro lado, da análise da trajetória das políticas sobressaem lições, principalmente quanto a governança, participação social e tecnologia social, que podem orientar tanto o redesenho na esfera federal quanto ao engajamento de outras esferas governamentais. Conclui apontando que a continuidade das políticas que priorizam segmentos extrativistas depende essencialmente da capacidade de reinvenção de instrumentos e, sobretudo, da formação de alianças com outros setores da sociedade, do ministério público, dos meios de comunicação e mesmo de parceiros internacionais. 


\title{
Democratizing biodiversity monitoring in acto member countries: collective inputs on the development of a low-cost monitoring tool
} for Amazonian production forests

Catherine Gamba-Trimino ${ }^{1}$, Anders Lindhe ${ }^{2}$, Vicente Guadalupe ${ }^{1}$, Otavio Marangoni ${ }^{1}$, Iran Pires ${ }^{3}$, Ana Violato $^{4}$, Mariane Nardi $^{5}$

${ }^{1}$ Organizacion del Tratado de Cooperacion Amazonica, Brasilia, Brasil; ${ }^{2}$ HCV Resource Network, Oxford, United Kingdom; ${ }^{3}$ Instituto Floresta Tropical,

Belem, Brasil; ${ }^{4}$ University of Florida, Gainesville, USA; ${ }^{5}$ Universidade Federal do Amapá, Amapá, Brasil (catherinetrimino@gmail.com; anders@

hcvnetwork.org; vicente.guadalupe@otca.org.br; otavio.marangoni@otca.org.br;iran@ift.org.br; anaviolatoespada@gmail.com;

marianenardi@gmail.com)

One of the principles of adaptive management is to frequently read the environment in order to introduce management changes accordingly. Thus, the ITTO/ IUCN Guidelines for biodiversity conservation in tropical production forests (2009) recommend the development of low-cost monitoring programs serving the needs of forest managers, making information on failures and achievements widely available. In the framework of the ITTO/CBD/ACTO International courses in biodiversity conservation through ecologically responsible management of Amazonian production forests, recently implemented in Brazil, Peru and Guyana, a collective exercise on the development of a monitoring tool was proposed to participants and regional training centers. Utilizing the HCVNForest Integrity Assessment (FIA) tool, which uses habitats as proxies for biodiversity, and that has not yet been adapted to the Region, as a canvas, around 80 forestry professionals and managers working in different sectors at ACTO member countries provided technical and multi-actor input into this endeavor. Most participants agreed on the importance to make of biodiversity monitoring a participatory exercise, highlighting the benefits for local communities empowerment and to set up feasible conservation goals at the forest management unit scale. Suggestions on adding variables such as soil type, canopy height and forest health indicator species were made and, particularly for forestry operators, the opportunity to look at forest habitats, "rather than just measuring", and to apply local knowledge was highly appreciated. Some resistance was also encountered, which demonstrates the need to work harder in the diffusion of simpler and more cost-efficient biodiversity monitoring tools, such as FIA.

\section{A6d: COMMUNITY AND FAMILY FOREST MANAGEMENT IN LATIN AMERICA:} GUARANTEEING RIGHTS AND CITIZENSHIP WITH SUSTAINABILITY

Public policies and environmental justice: progress and challenges in community-based forest management in the amazon lowlands / Políticas públicas e justiça ambiental: avanços e desafios do manejo florestal comunitário nas várzeas amazônicas

\begin{abstract}
Luciano Regis Cardoso ${ }^{1}$,Emanuelle Raiol Pinto ${ }^{1}$ iD; Elenice Assis do Nascimento ${ }^{1}$, Davila Suellen Souza Correa ${ }^{1}$, Claudio Roberto Anholetto Juniorr, ${ }^{1,2}$ ${ }^{1}$ Instituto de Desenvolvimento Sustentável Mamiraua, Tefé, Brasil; ${ }^{2}$ Universidade de São Paulo, Piracicaba, Brasil (luciano.cardoso@mamiraua.org.br; emanuelle@mamiraua.org.br; elenice@mamiraua.org.br; davila@mamiraua.org.br; claudio@mamiraua.org.br)
\end{abstract}

As provisões de serviços ecossistêmicos da floresta aos povos indígenas e comunidades locais na Amazônia são regidas pela sazonalidade hídrica, clima equatorial e alta diversidade biológica, cultural e étnica, gerando relações materiais e cosmológicas únicas. Compondo mais recentemente esta gama de relações, o mercado e o Estado produzem novas dinâmicas monetárias e burocráticas, conduzindo estas pessoas à economia e política ocidentais. O Instituto de Desenvolvimento Sustentável Mamirauá contribuiu na coprodução de conhecimentos entre cientistas, técnicos e populações locais no estado do Amazonas, Brasil, para o manejo sustentável dos recursos naturais com vistas aos direitos humanos, corroborando para que relações mais justas sejam estabelecidas. Esse é o caso do Manejo Florestal Comunitário (MFC), que através de pesquisas científicas e práticas experimentais vêm contribuindo para o fortalecimento dessa atividade econômica na várzea amazônica. Avanços como a promulgação da Instrução Normativa 09/2010/SDS foram essenciais para a adequação da atividade à realidade de áreas alagadas sazonalmente, definindo intensidade, diâmetros e ciclo de corte específicos e diferenciados. Porém, outros desafios obstaculizam o fortalecimento do MFC, como a competição com a madeira ilegal, a instabilidade da cadeia produtiva, a complexa burocracia distante da realidade dos povos indígenas e comunidades locais e os vazios de conhecimento, tanto os técnicos relacionados à ecologia florestal quanto os de caráter social, que avaliam e explicitam as respostas ao bem-estar. Impulsado pelos desafios, o Instituto Mamirauá em seus 20 anos, reafirma sua convicção, estimulando as pesquisas nos manejos madeireiros e não-madeireiros como possibilidades de justiça ambiental com as populações da Amazônia.

Timber-producing forests and biodiversity: environmentally responsible forest management within the focus of the ITTO/IUCN guidelines in the Amazon region / Florestas produtoras de madeira e biodiversidade: manejo florestal ecologicamente responsável sob o enfoque das diretrizes ITTO/IUCN na região amazônica

Otavio Marangoni Souza ${ }^{1}$,Erilene Lima Silva², Vicente Guadalupe

${ }^{1}$ Organização Tratado de Cooperação Amazônica, Brasília, Brasil; ${ }^{2}$ Gikitaya Socioambiente, Rio Branco, Brasil (otavioflorestal@gmail.com; erillima@yahoo.com.br; vicente.guadalupe@otca.org.br)

A melhoria das práticas e técnicas florestais, com base na incorporação de aspectos teóricos e práticos da conservação da biodiversidade nas diferentes etapas do manejo florestal, pode gerar mudanças positivas nos níveis de biodiversidade e, consequentemente, nos meios de subsistência das comunidades e famílias dependentes de florestas, assim como favorecer a manutenção e melhoria dos benefícios oferecidos à sociedade pelos serviços ecossistêmicos. Nesse sentido, foram criadas as Diretrizes IUCN/ITTO, constando de 11 princípios e 46 diretrizes voltados à florestas tropicais de produção, que abordam desde a soberania da sociedade, compromissos internacionais, políticos, educação, manejo florestal, conservação da biodiversidade, entre outros aspectos. A partir destas diretrizes, realizou-se uma análise dos oito países membros da OTCA: Bolívia, Brasil, Colômbia, Equador, Guiana, Peru, Suriname e Venezuela, em duas etapas: a primeira focada na avaliação quantitativa do grau de implementação das diretrizes e a segunda etapa, a qualitativa, composta pelo detalhamento da informação por diretriz e princípio pré-estabelecidos. A análise demonstrou que a média geral de atendimento às diretrizes foi de 2,65, considerado de regular a bom. Com estes resultados pode-se, de maneira abrangente, fornecer informações atualizadas e oficiais relacionadas à conservação de florestas e biodiversidade no âmbito do manejo florestal ecologicamente responsável da região amazônica dos oito países-membros da OTCA, testar a utilidade prática das diretrizes, identificar obstáculos que possam limitar sua aplicação e gerar insumos suficientes para ampliar e diversificar a análise e recomendações para o manejo florestal ecologicamente responsável e conservação da biodiversidade em florestas produtoras de madeira na Amazônia. 
Challenges related to the concept of intact forest landscapes (PFI) for developing community-based FSC forest management certification in the Brazilian Amazon / Desafios do conceito de paisagens florestais intactas (PFI) para o desenvolvimento do manejo florestal comunitário certificado FSC na Amazônia brasileira

Nathalia Ribeiro ${ }^{1}$, Junia Ruggiero ${ }^{1}$, Marco Lentini ${ }^{1}$, Vinícius de Faria ${ }^{1}$, Leonardo Sobral ${ }^{1}$, Edson Vidal ${ }^{2}$

${ }^{1}$ Imaflora, Instituto de Manejo e Certificação Florestal e Agrícola, Piracicaba, Brasil; ${ }^{2}$ Universidade de São Paulo, Piracicaba, Brasil

(nathalia@imaflora.org; junia@imaflora.org; mwlentini@gmail.com; vinicius@imaflora.org;leonardo@imaflora.org; edson.vidal@usp.br)

Segundo Instituto BVRio, atualmente há 118 Planos de Manejos Florestais Sustentáveis (PMFS) comunitários operando na Amazônia, sendo que cinco possuem certificação FSC. O Manejo Florestal de Impacto Reduzido (MF-EIR) realizado na Amazônia é uma alternativa para valorização da floresta em pé, utilizando técnicas especiais para que árvores criteriosamente selecionadas sejam retiradas (volumetria máxima de $30 \mathrm{~m}^{3}$ ha ${ }^{-1}$ ), com ciclo de corte que pode variar de 25 a 35 anos. Segundo ICMBio, o manejo florestal comunitário é uma estratégia efetiva de conservação ambiental, otimizando gestão compartilhada da floresta com populações tradicionais beneficiárias de áreas protegidas e possibilitando benefícios diretos e indiretos. A revisão da norma de manejo florestal FSC incluiu o conceito de Paisagens Florestais Intactas (PFI): grandes ecossistemas florestais ou não florestais minimamente influenciados por atividades humanas. A conservação de PFI é um mecanismo robusto para manter a integridade ecológica desses ecossistemas. Entretanto, segundo o conceito incluído no FSC, atualmente $80 \%$ de áreas de PFI de comunidades certificadas FSC não podem ser manejadas, mesmo utilizando técnicas previstas no MF-EIR. Os PMFS comunitários em RESEX, FLONA e RDS são o futuro para o desenvolvimento do manejo florestal comunitário, o qual também está intrinsecamente relacionado com a missão do FSC. Dessa forma, foi analisada a dominialidade de PFI do Brasil nos anos 2000, 2013 e 2016 e avaliado como o conceito de PFI pode influenciar o desenvolvimento de PMFS comunitários certificados FSC no Brasil. A maior porção de PFI está em terras indígenas e há PFI em PMFS comunitários certificados e não certificados.

SWOT analysis of the Pae Bacuri I agroextractivist venture in the lowlands of Maranhão, Brazil / Análise SWOT do projeto agroextrativista - Pae Bacuri I na baixada Maranhense

Vera Maria Gouveia ${ }^{1}$, Joao Flavio Bomfim Gomes ${ }^{1}$, Anida Claudia Dominici Soares ${ }^{2}$, Hulda Rocha e Silva ${ }^{2}$, Tatiana Ribeiro de Santana ${ }^{2}$

${ }^{1}$ Embrapa Cocais, São Luís, Brasil; ${ }^{2}$ Incra,SãoLuís,Brasil(vera.gouveia@embrapa.br; joaoflavio.gomes@embrapa.br; anida.soares@sls.incra.gov.br;

hulda.silva@sls.incra.gov.br; tatiana.santana@sls.incra.gov.br)

O babaçu representa um expressivo recurso do extrativismo vegetal e a atividade é essencial para as quebradeiras de coco, populações rurais e indústria. Geralmente, a posse da terra não é dos extrativistas cujo acesso é realizado por meio de parcerias com os latifundiários tanto na produção agrícola como na forma de comercialização das amêndoas. Face a essa conjuntura o presente estudo teve por objetivo estudar o Projeto Agroextrativista - PAE Bacuri I cuja comunidade sobrevive do extrativismo e da pesca. Localizado no município de Cajari pertencente ao Hot Spot do extrativismo babaçu no Maranhão, o assentamento está inserido na região da Baixada Maranhense, uma complexa interface de ecossistemas do bioma Amazônia e do Nordeste brasileiro rica em biodiversidade aquática e terrestre. Foi produzido um relatório com a análise SWOT, do inglês, ou FOFA, do português, para o cruzamento das Forças (Strenghts), Fraquezas (Weaknesses), Oportunidades (Opportunities) e Ameaças Threats para o gerenciamento sustentável das atividades de uso e ocupação do solo no assentamento. Destaca-se como forças o Cadastro Ambiental Rural com a vegetação nativa que se encontra bem conservada atendendo a legislação florestal e possibilitando atender nichos de mercado para produtos florestais e produção agroecológica. Entre as ameaças identificadas encontram-se a pesca predatória no lago, a caça e o desmatamento de palmeiras de babaçu utilizadas pelas mulheres que vivem no assentamento. Essas ameaças são decorrentes das fraquezas dos assentados como a falta de fiscalização ambiental, acesso a tecnologias produtivas sustentáveis e a falta de organização e articulação para gestão produtiva do assentamento.

Factors in deciding whether to grow trees on subsistence farms in Costa Rica / Factores de decisión que influyen en la adopción del cultivo de árboles en fincas de subsistencia, Costa Rica

Monserrat Romero Mora ${ }^{1}$, Victor Meza Picado ${ }^{1}$

${ }^{1}$ Instituto de Investigación y Servicios Forestales, Universidad Nacional, INISEFOR-UNA, Heredia, Costa Rica (mariamonse01@gmail.com;

victor.meza.picado@una.cr)

La creciente segmentación de tierras propicia un incremento en el número de fincas pequeñas dedicadas en su mayoría a la producción de subsistencia, esto aunado al retroceso de la producción forestal, mostrado en las tasas de reforestación y del manejo de bosques de la última década, reafirman la premisa de una necesaria transición forestal. A lo que distintas organizaciones han respondido con la generación de proyectos en conjunto con comunidades o productores, sin embargo, no han logrado hacer que permanezcan en el tiempo, ya que al retirarse las organizaciones se da un repetitivo abandono de las actividades forestales. Lo que sugiere que la elaboración de los proyectos y el fomento del cultivo de árboles han sido poco eficientes y evidencia el asistencialismo en su planteamiento, alejándose de la realidad sociocultural y económica de los productores. Por lo tanto, el estudio presenta como alternativa, para enfrentar la tendencia negativa, encausar esfuerzos hacia comprender los factores que influyen en la toma de decisiones del productor, basados en un censo aplicado a 80 fincas de subsistencia ubicadas en dos sitios de Sarapiquí de Heredia, cuyo formulario busca entender los factores vinculados al principal sistema productivo. Mostrando en los resultados preferencias ligadas a actividades tradicionales, facilidad de producción y comercialización, lo que involucra factores como costumbres, rentabilidad, capacidad de venta, entre otros. La aplicación de estos resultados en el ajuste de proyectos forestales mejorara la aceptación de la actividad, aumentando la adopción del cultivo arbóreo y contribuyendo al bienestar de los pequeños productores.

A6e: FORESTS AND HUMAN WELLBEING: LIFE SATISFACTION AND BEHAVIORAL APPROACHES

\section{Planning for green infrastructure in Europe: linking ecosystem services, landscape preferences and human wellbeing}

Marine Elbakidze ${ }^{1}$,Lucas Dawson ${ }^{2}$, Mykhailo Grodzynskyi ${ }^{3}$, Diana Surova ${ }^{4}$

${ }^{1}$ Swedish University of Agricultural Sceinces, Skinnskatteberg, Sweden; ${ }^{2}$ Stockholm University, Stockholm, Sweden; ${ }^{3}$ Taras Shevchenko National University of Kyiv, Kyiv, Ukraine; ${ }^{4}$ Universidade de Évora,Evora, Portugal (marine.elbakidze@slu.se; lucas.dawson@natgeo.su.se; mgrodz@ukr.net; dj@uevora.pt)

Green infrastructure (GI) policy encourages the spatial planning of natural and semi-natural areas that deliver biodiversity conservation and a wide range of ecosystem services (ES) important to human well-being. Much of the current literature relies on expert-led, top-down processes to investigate connections 
between landscapes and ES. Little is known regarding the preferences of residents, and how they correlate land covers with the delivery of ES important for their well-being. The aim of this study is to identify and locate such land cover types as GI hubs and hotspots that provide multiple ES important for human well-being in different contexts. First, we surveyed 1600 urban and rural residents to identify ES important for personal well-being and the land covers that deliver multiple ES in four European countries - Sweden, Latvia, Belarus, and Russia. Second, to support the inclusion of GI in spatial planning we identified and located spatial concentrations of individual land covers providing multiple ES (GI hubs) and significant clusters of such land covers (GI hotspots). The majority of urban and rural respondents associated their well-being with lakes, old-growth forests, wooded-pastures, mature pine forests and rural farmsteads. There were significant differences in appreciation of GI hubs among different groups of respondents that depended on their education level, gender and urban-rural context. At least three land management strategies are needed to sustain GI hubs: maintenance of the composition, structure and function of natural ecosystems; support for traditional agroforestry and villages as social-ecological systems; and diversification of the current intensive forest management approach.

\section{What do we know about forest health benefits in Europe?}

Liisa Tyrväinen' ${ }^{1}$, Nicole Bauer², Liz O'Brien ${ }^{3}$

${ }^{1}$ Natural Resources Institute Finland, Helsinki, Finland; ${ }^{2}$ Swiss Federal Institute for Forest, Snow and Landscape Reseach, Birmensdorf, Switzerland; ${ }^{3}$ Forest Research,Farnham, United Kingdom(liisa.tyrvainen@luke.fi;nicole.bauer@wsl.ch; liz.o’brien@forestry.gsi.gov.uk)

Health enhancing qualities of forests are a result of multiple benefits such as noise abatement, pollution control and scenic environment that reinforce each other. Key pathways to deliver health benefits are enhanced microclimatic conditions, stress recovery, enhanced social ties/integration, physical activity and strengthened human immune function. This presentation synthesizes knowledge regarding impacts of forests on human health and well-being in Europe with a focus on behavioral aspects. The review was conducted as a part of pan-European expert cooperation Forests Europe serving reformulation of forest policies. The analysis is based on literature reviews and meta-analyses as well as individual peer reviewed studies. There is rather strong evidence that forest visits have positive effects on restoration and psychological wellbeing. Increased evidence also exist that forest visits contribute to beneficial changes in human cardiovascular physiology. The amount of correlational studies analyzing long-term and the curative effect of forests are limited. More studies regarding long-term health benefits and dose-response relationship are needed. Furthermore, information regarding the effect of different type and size of forests as well as effects of their management on health benefits is limited. More scientific evidence is also needed about individual differences in nature exposure. The majority of studies report that forest areas are positively associated with social benefits, but note that the benefits may not be experienced equally by all social groups. The presentation also presents policy implications and recommendations that can strengthen the potential role of forests in health promotion and the preventative aspects of ill-health in Europe.

\section{Spatial behaviour in urban woodlands: mapping pathways and recreational activities using public participation GIS}

Tina Gerstenberg ${ }^{1}$ (D); Christoph Baumeister ${ }^{1}$, Ulrich Schraml ${ }^{1}$, Tobias Plieninger ${ }^{2}$

${ }^{1}$ Forest Research Institute of Baden-Württemberg, Freiburg, Germany; ${ }^{2}$ University of Göttingen, Göttingen, Germany (tina.gerstenberg@web.de; baumeister@alumni.ubc.ca; ulrich.schraml@forst.bwl.de; plieninger@uni-goettingen.de)

An increasing number of scientific papers describe and explain the connections between natural landscape features and hotspots of cultural ecosystem services, values, and preferences. The results help environmental planning and decision making with prioritising and balancing management objectives. However, there is a lack of knowledge on associations between physical landscape attributes that characterise used routes and activities of outdoor recreationists (e.g., cycling, dog walking, jogging, walking). In order to address this knowledge gap, we applied Public Participation GIS (PPGIS) to assess spatial behaviour, i.e., way usage, in urban woodlands of city dwellers from three densely populated regions in Germany's Southwest. Respondents also stated their activities for mapped routes, sociodemographic backgrounds, and perceived cultural ecosystem services. In order to characterise each mapped route according to physical landscape features, we used a $50 \mathrm{~m}$ buffer around each route and measured area sizes (in $\mathrm{m}^{2}$ ) of landcover classes represented within this buffer, e.g., water bodies, broadleaved, coniferous and mixed species dominated stands, meadows, and human-made infrastructure. Data on these features were derived from OpenStreetMap, inventory maps, high resolution LiDAR satellite imagery, and forest function maps of the provinces' forestry administration. For data analysis, we use the Line Density tool in ArcGIS and linear mixed effects models. We present linkages between visitor intensities and mapped routes' characteristics. If applied in urban forest management, this knowledge may contribute to visitor-centred planning and decision-making as well as development of visitor guidance concepts for urban woodlands.

\section{Form over function? Aesthetic drivers of forest management}

Jakob Derks ${ }^{1}$

${ }^{1}$ European Forest Institute, Bonn, Germany (jakob.derks@efi.int)

Conflicts on forest-related issues are often dichotomised using the same two categories: forestry and nature conservation. Members of these two groups are often perceived as the two main antagonistic factions that set the tone of the debate. This categorical perception often tends to simplify the debate and answers to our innate instinct to classify the environment in which we live. One group uses economic data to back up its viewpoint, the other one fences with biodiversity. These arguments can often be described as a rationalisation of the debate. Indeed, with the same assertion different viewpoints can be defended. It is clear that economic predictions depend on so many variables, many of which are uncertain, that it is hard to produce reliable models for any given case. Similarly, when basing management choices on biodiversity criteria, the choice of the target species is inherently (partly) arbitrary. Every day, forest managers have to make decisions based on incomplete information and unknown future events. How do they do this? A large and often overlooked factor in decision-making relates to emotional choices. Research shows that management choices often relate to the personal history and reference point of the manager and society, and that rational argumentations are interlinked with aesthetic preferences.

\section{Pro-social preferences of first nations people of Ontario, Canada}

Shashi Kant ${ }^{1}$, Ilan Vertinsky ${ }^{2}$

${ }^{1}$ University of Toronto, Toronto, Canada; ${ }^{2}$ University of British Columbia,Vancouver, Canada (shashi.kant@utoronto.ca; ilan.vertinsky@ubc.ca)

The characterization of individuals as "rational agents" as a core assumption has resulted in flawed policies. Pro-social preferences towards unknown others in a community is an important determinant of its social capital which influences community development. We develop and test a utility model that captures more fully and accurately the heterogeneity of motives that guide individuals when encountering situations where they are offered the opportunity to display unconditional pro-social preferences to unknown others. We conducted field experiments in a First Nation of Canada using modified Dictators Games (DG) 
designed to test the proposed model. Results highlighted strong relationships among expressed motives, social norms and identities, and revealed allocations. The First Nation's culture was manifested by a pattern of more generous giving to elders and women. The provision to dictators of gender or age clues about second players' identities was found to: a) increase average giving; b) shift self-regarding to other-regarding preferences; and c) enable more nuanced allocation decisions. These findings have important implications for forest and other land use policies and management practices.

\section{Bushmeat consumption in Rubi-Tele Hunting domain, DRC}

Sagesse Nziavake ${ }^{1}$, Mampeta Wabasa ${ }^{1}$, Amundala Drazo $^{1}$, Sabongo Yangayobo ${ }^{1}$, Nathalie Van Vliet ${ }^{2}$

${ }^{1}$ University of Kisangani, Kisangani, Congo, Republic of the Democratic; ${ }^{2}$ CIFOR, Guiyane, France (sagessenziavake@gmail.com; salomonmampeta@gmail.com; nicaise.amundala@gmail.com; sabongo_prosper@yahoo.fr; vanvlietnathalie@yahoo.com)

African rural communities rely on gathering, hunting and fishing activities for their livelihoods. Wildlife, a renewable biological resource which available quantity is directly linked to previous harvests, contributes to the diet of rural people. Household consumption occupies a prominent place among the major economic aggregates. In DRC, the consumption of wild animals, "bush meat", constitutes in rural forest areas, the main and essential source of protein, given the unfavorable pastoral environment and the under-development of agriculture. Thus this study seeks to determine the supply way of the local communities of the Rubi-Tele Hunting Domain (RTHD). To achieve this goal, we will conduct household surveys through a questionnaire, in 4 localities of the RTHD: Ngbete, Bobonge, Sukisa and Mabanga. Data processing will be performed using R and Excel software. The way local communities of the RTHD are supplied in bushmeat will be determined, as well as the dependency and the species most consumed by local communities will be highlighted. Also, the causes of decline in bushmeat supply in the RTHD will be discussed, as well as the reasons for ineffectiveness of wildlife regulation within these local communities will be determined. As result of these expected findings, strategies for sustainable management of bushmeat in RTHD will be identified.

Method for pricing forest concessions in the Brazilian Amazon: signs of poverty traps in the forest sector / Método de precificação das concessões florestais na Amazônia brasileira: as evidências de armadilhas de pobreza no setor florestal

Daniel Teixeira ${ }^{1}$ iD

${ }^{1}$ Universidade de Brasilia, Brasilia, Brasil (dnmoura@gmail.com)

A política florestal tem por objetivo prover a combinação de benefícios ambientais, sociais e econômicos que maximize o bem-estar da sociedade de maneira contínua e sustentável no longo prazo. Entre os instrumentos de política disponíveis, as concessões florestais são amplamente utilizadas quando o Estado é detentor de grandes extensões de florestas. Acredita-se que as concessões têm potencial de fomentar o desenvolvimento econômico das regiões em que estão localizadas mediante o manejo florestal sustentável. Contudo, há indícios de que as concessões de florestas nativas têm sido alocadas de maneira ineficiente devido à forma como os preços dos contratos são estabelecidos. Portanto, o objetivo do estudo foi apontar as evidências de como a metodologia de precificação das concessões florestais contribui para o surgimento, nos estados detentores de florestas nativas, de ciclos viciosos de subdesenvolvimento persistente, denominados "armadilha de pobreza". Nesse sentido, foi verificado que os critérios de reajuste dos valores a serem pagos pelos concessionários, baseados no IPCA, gerando um descompasso entre os preços pagos pelos mercados de produtos florestais e o preço das concessões. Considerando os usos alternativos da terra, como a pecuária e a agricultura, o manejo florestal se torna inviável financeiramente, restringindo os investimentos florestais e, consequentemente, o aumento da produtividade do trabalho.

\section{The school basin in Jaguariaiva, State of Paraná, Brazil / Bacia escola de Jaguariaíva, PR}

Marilu Mazurechen ${ }^{1}$, Samantha Nazaré de Paiva ${ }^{1}$, Gilmar Henrique de Oliveira ${ }^{1}$, Rogerio Salamuni ${ }^{1}$, Uilson Paiva ${ }^{1}$, Carolina Bozzeti Rodrigues ${ }^{2}$, Maria José Brito Zakia ${ }^{3}$

${ }^{1}$ Klabin, Telêmaco Borba, Brasil; ${ }^{2} I P F$, Jaguariaíva, Brasil; ${ }^{3}$ Prática Assessoria Socioambiental, Piracicaba, Brasil (mmazurechen@klabin.com.br; snpaiva@klabin.com.br; gilmar.olivveira@klabin.com.br; rogerio.salamuni@klabin.com.br;upaiva@klabin.com.br;cabreuva@gmail.com; zeze.zaquia@uol.com.br)

O abastecimento público do município de Jaguariaíva, PR, é realizado por meio de captações de água em três fontes, sendo uma delas a microbacia hidrográfica Três Bocas, de propriedade da Klabin S/A. A área da microbacia abrange 489 ha, dos quais 287 ha são destinados às florestas plantadas e 119 ha destinados à conservação (vegetação nativa em diferentes estágios de conservação). A localização e as características da microbacia Três Bocas são ideais para a realização do monitoramento hidrológico do PROMAB/IPEF, ao mesmo tempo que reúne condições excepcionais para a implantação do projeto Bacia Escola, levando em conta a proximidade com a cidade e a presença de instituições de ensino, além da atuação da empresa de saneamento do município (SAMAE). O projeto Bacia Escola, inspirado em um trabalho desenvolvido pelo Serviço Geológico Brasileiro no Rio Catu, BA, tem sido uma oportunidade de se gerar conhecimento compartilhado, visto que o conhecimento das relações floresta - água tem ficado restrito a poucos setores. A bacia escola como área de estudo e vivência para diferentes públicos, em especial aos alunos do Ensino Fundamental (com a elaboração de material paradidático e trilhas interpretativas), bem como escolas técnicas e universidades, é uma contribuição para a democratização do conhecimento aliado à geração de valor compartilhado, que é um dos objetivos de empresas na busca pela sustentabilidade.

A6f: GENDER, FORESTRY AND RURAL COMMUNITIES: SHAPING POWER AND AGENCIES
IN AN ERA OF GLOBALISATION

\section{Same-same but different: gendering forest ownership in Sweden}

Elias Andersson ${ }^{1}$, Sabina Bergstén ${ }^{2}$, Carina Keskitalo ${ }^{2}$

${ }^{1}$ Swedish Univeristy of Agricultural Sciences, Umeå,Sweden; ${ }^{2}$ Umeå University, Umeå, Sweden (elias.andersson@slu.se; sabina.bergsten@umu.se; arina.keskitalo@umu.se)

As a major feature of the Swedish rural landscape, forests have been shown in studies to reflect pronounced differences and inequalities between women and men with regard to ownership. Employing a more in-depth approach, this study examines how gender construct private forest owners' experiences, perceptions and practices associated with their forests and forest ownership. The gendering, through articulations and meaning making, of forest ownership and its structuring of value and agency is thematically analysed through semi-structured interviews with 25 female and 26 male owners with forest properties located in the South or in the North of Sweden. The findings show a gendering of forest management behaviour and activities, formed by a set of historical and socialisation processes and practices. They suggest a dichotomised understanding of how gender is constructed, whereby specific bodies (male/female) were linked with specific spaces 
(forest/household), tasks (manual forest labour/domestic labour), characteristics (strong/caring), and perspectives (economic/ecological). These dichotomies correlate to male forest owners being associated with having more power and more knowledge of forests. Forest values and attitudes connected with values other than production forestry were attributed more to female owners, thereby mirroring the gendering process of doing 'different' as a means of 'othering', but also when perceived as positive and innovative as a way of resisting and negotiating the current gendering of forest ownership and the forestry discourse of production-oriented forestry.

\section{Gender and the inheritance of traditional forest-related knowledge in minority regions in Guizhou Province, China}

Juanwen Yuan ${ }^{1}$

${ }^{1}$ University of Finance and Economics, Guiyang, ${ }^{550025}$, China (yuanjuanwen@qq.com)

Women and men play different roles in the inheritance of traditional forest-related knowledge, meanwhile the roles are also changing because of urbanization and rural revitalization in China. However, this research has not attracted much attention by the researchers. This paper aims at understanding the inheritance of traditional forest-related knowledge from gender perspective. The research will employ both qualitative and quantitative to conduct the research in minority regions in Guizhou province in China. The research finds that traditional forest-related knowledge is rich in minority areas in Guizhou. women are more involved in the inheritance activities relating to time-consuming, while men are more involved in those relating to higher technologies. Men are migrating to cities while women are main labours in the forest management in last three decades. Women are learning more knowledges which are traditionally dominated by men. In recent years, government is promoting rural revitalization and eco-tourism is very popular. Forest plays more important roles. Meanwhile more men are back to the village. The inheritance methods are also changing because of innovative ways are introduced into the village by the in-migrants. Both men and women are important actors and agencies in inheriting traditional forest-related knowledge which promotes sustainable forest management.

\section{Too male, too pale, too stale: dilemmas of public engagement in sustainable forest management in Canada}

Maureen G. Reed ${ }^{1}$, Jim Robson ${ }^{1}$, John Parkins ${ }^{2}$, A John Sinclair ${ }^{3}$, Solange Nadeau ${ }^{4}$, Amanda Lindgren ${ }^{1}$

${ }^{1}$ University of Saskatchewan, Saskatoon, Canada; ${ }^{2}$ University of Alberta, Edmonton, Canada; ${ }^{3}$ University of Manitoba, Winnipeg, Canada; ${ }^{4}$ Canadian Forest Service,Quebec,Canada(mgr774@mail.usask.ca; james.robson@usask.ca;jparkins@ualberta.ca; john.sinclair@umanitoba.ca; solange.nadeau@canada. ca; amanda.lindgren@usask.ca)

Engaging the public is now a key element of sustainable forest management (SFM). In Canada, "society's responsibility" is one of 6 criteria for SFM, defined through these indicators: Aboriginal and treaty rights; Aboriginal land use and forest-based ecological knowledge; forest community well-being and resilience; fair and effective decision making; informed decision making. The forest advisory committee (FAC) has become the dominant mechanism, located in rural areas, and sponsored either by provincial agencies or forest companies. In 2004 and in 2016, we conducted national surveys of FACs to understand committee demographics, mandates, values, representation, learning outcomes, satisfaction, and effectiveness. Here, we address two questions: (1) How has the representation of people and values on public advisory committees changed since 2004? (2) Are public advisory committees contributing to fair, effective, and informed decision making about sustainable forest management? Our findings from both surveys show that FACs remain dominated by a white, male and aging rural population. This demographic was well satisfied with the achievements of their FACs. Those who are under-represented, in particular, women and Indigenous peoples, were the least satisfied that decision-making was fair and effective. Our findings point to dilemmas of effective and fair SFM governance processes. Given their relative ineffectiveness in representing the Canadian public, if these committees are disbanded, what kind of public oversight might replace them? If committees are maintained, how can they be reformed? We explore options for governance that might allow for more effective engagement of local peoples and more effective practices of SFM.

\section{Gender dynamics in forestry development: experiences from farm forestry in the Kenyan Coast}

Leila Ndalilo ${ }^{1,2}$

${ }^{1}$ Kenya Forestry Research Institute, Malindi, Kenya; ${ }^{2}$ Egerton University, Nakuru, Kenya (leylilo@yahoo.com)

Women are disadvantaged by insecure access and property rights to forest, tree and land resources. Discrimination and male bias in land ownership and service provisions like credit and technology and exclusion from policy formulation and decision making at the household, community and national levels have exacerbated the problem. A study was conducted to assess gender participation in farm forestry and the existing mechanisms of benefit sharing amongst tree farmers in the coast region of Kenya. The survey covered Kwale, Kilifi and Lamu Counties, the main tree growing counties in the coast region. Household questionnaires, expert interviews and focus group discussions were conducted to collect data. The study established that women realize only a fraction of the benefits from tree farming and tend to be involved in decision making only when forest and tree resources are already degraded. Moreover, cultural barriers and women's lack of formal education, employment and personal networks inhibits their ability to influence resource allocation and benefit sharing. The study established that gender inclusivity can significantly improve sustainable forest management, and the overall welfare and social protection of families, communities and national economies. There is need to mainstream gender equality at all levels of forestry in order to achieve broader social and economic goals, including the Sustainable Development Goals.

\section{Uncovering the hidden complexities of agency in the rural network of female forest owners}

Katri Hamunen ${ }^{1}$, Hanna Kumela ${ }^{2}$, Jukka Tikkanen ${ }^{3}$, Teppo Hujala ${ }^{3}$

${ }^{1}$ Natural Resources Institute Finland (Luke), Joensuu, Finland; ${ }^{2}$ Natural Resources Institute Finland (Luke), Mikkeli, Finland; ${ }^{3}$ University of Eastern Finland, Joensuu,Finland (katri.hamunen@luke.fi; hanna.kumela@luke.fi; jukka.tikkanen@uef.fi; teppo.hujala@uef.fi)

Forestry has predominantly been a masculine sphere, providing easy environments for males and more challenging positions for females. Recognition of female forest owners has led to special events and new activity forms targeted for women forest owners both in the USA and in the Nordic Countries. However, responding to the females' suppressed situation with institutionalized tools and technocratic practices carries the risk that females lose the opportunity for political transformation and stay reproducing gendered practices in a niche that the masculine social system has given for them. Therefore, the new task is to enable and reinforce such empowering "doing gender" practices that support female forest owners' agency and escape from the niches. This study analyzed a rural network of female forest owners in Finland $(n=15)$, data comprising individual and group interviews as well as researcher's observations and participants' feedback from ten forestry learning meetings. The analysis sought a deeper understanding of the owners’ perceptions and behaviors as forest owners in general 
and in their peer-learning network. The theory-driven qualitative analysis was done with NVivo software employing researcher triangulation. Cognitive, emotional, and motivational difficulties in taking responsibility on forestry decisions were observed. Self-efficacy was often assessed in relation to men. This kind of mirroring was not present in the women-only meetings where they felt less shy to discuss and were not afraid of ignorance. Seeing other female owners' forestry results was empowering. Thus, an appreciating discourse space and a sense of belonging to an actor community fostered female owners' agency.

\title{
Rural communities, forestry and women
}

Peter Edwards', Deanna Grant-Smith², Robyn Maves ${ }^{2}$

${ }^{1}$ Manaaki Whenua Landcare Research, Wellington, New Zealand; '2Queensland University of Technology, Brisbane, Australia

(peter.edwards@scionresearch.com; deanna.grantsmith@qut.edu.au; robyn.mayes@qut.edu.au)

Although forestry has traditionally been constructed as a masculine rural activity, women are participating in increasing numbers and the impact of forestry on women's lives is widely recognised. There is growing interest in gender, forestry and the survival of rural communities in Latin America and Oceania. In these contexts a number of observations have been made around the influence of forestry and gender on the survival of rural communities. Namely, that forestry, on a 30-year harvesting cycle (as compared to other industries), reduces economic opportunities, driving down the population in rural communities and negatively impacting employment opportunities for women (i.e., as teachers in schools and nurses in hospitals) which leads to further depopulation. While in developing countries, this could contribute to the feminisation of poverty, women in developed countries have the ability and capacity to move to larger centres, where employment and services are available. As forestry becomes increasingly important globally for climate mitigation, maintenance of or increasing biodiversity, and sustainability in general, there are likely to be increasing gendered issues emerging from the expansion of forests and forestry. With much of the expansion of forests in Europe, North America, OECD members and high-income countries, we examine the place/role of women in rural communities affected by increasing or decreasing investment in forestry at the local and/or regional level.

\section{A6g: INDIGENOUS AND TRADITIONAL PEOPLES AND THEIR FORESTS: KNOWLEDGE, MANAGEMENT AND GOVERNANCE TOWARDS SUSTAINABLE DEVELOPMENT GOALS}

\section{Ethnobotanical assessment of plant species used medicinally / Diagnóstico etnobotánico de uso de especies vegetales como medicinales Misleidy Gato Hernández ${ }^{1}$, Osvaldo Celestino Lupupo Calderín², Magyuri Avila Martinez ${ }^{1}$, Hector Barrero Medel ${ }^{1}$ ${ }^{1}$ Universidad de Pinar del Río Hermanos Saiz Montes de Oca, Pinar del Río, Cuba; ${ }^{2}$ Universidad de Pinar del Río Hermanos Saiz Montes de Oca, Sagua la grande,Cuba(sheena@upr.edu.cu; avilam@upr.edu.cu; hbarrero@upr.edu.cu)}

El siguiente es un estudio etnobotánico fue realizado en diferentes comunidades de la provincia Pinar del Río, con el objetivo de determinar las relaciones etnobotánicas de especies vegetales empleadas en el área de investigación, mediante el conocimiento de los pobladores de las comunidades. En el estudio etnobotánico se recopiló la información de las especies de interés medicinal y el material se identificó por taxones considerando: nombres científicos, nombres comunes, familia, género, especie, autor, endemismo, amenaza, formaciones vegetales, formas de la población de obtener el conocimiento, parte de las plantas que usan, propiedades curativas (atribuidas y comprobadas), preparación y posología utilizada por las comunidades. Se determinó la frecuencia de uso de las especies seleccionadas con el fin de determinarle el valor de uso a cada una de ellas. En esta se mostró que existe una relación entre el género de los encuestados y el conocimiento que tienen estos sobre especies de interés medicinal, existe una gran relación entre los grupos etarios y el conocimiento en cuanto a la diferencia de géneros. Se demostró la pérdida del conocimiento en estas poblaciones. De las especies identificadas en el área de estudio; son de consistencia leñosa el (31\%); mientras que el restante (69\%) son herbáceas, de estas especies las partes más usadas son las hojas. Se realizó un análisis de todos los padecimientos tratados por las plantas en la localidad y la cantidad de especies que se usan para cada uno de ellos.

\section{Shift in the use of forest and consequences on traditional ecological knowledge among hutsuls in the Carpathians, Western Ukraine Giulia Mattalia $^{1}$ iD; Nataliya Stryamets ${ }^{1}$, Renata Soukand ${ }^{1}$ \\ ${ }^{1}$ University of Venice Ca'Foscari,Venezia,Italy (juliamattalia@gmail.com; nataliya.stryamets@unive.it; renata.soukand@unive.it)}

In the Carpathian Mountains, lives of local dwellers and forests are deeply interweaved. This is especially evident for minority groups such as the Hutsuls, a population living in the Carpathian Mountains. For many centuries, Hutsuls had been working in forest-related activities. However, the economic crises occurred at the end of the XX century caused a sudden abandonment of these forestry activities. This led to a strong emigration and urbanization, but also to an overexploitation of local natural resources. In this study, we aimed at discussing how this economic and social phenomenon affected the knowledge related to use of provisioning ecosystem services among Ukrainian Hutsuls. Specifically, we studied the use of wild taxa gathered in the forest to address the consequences of such a social and economic shift on traditional ecological knowledge (TEK) and local ecological practices (LEP). In summer 2018, we gathered 45 in-depth, semi-structured interviews among Hutsuls regarding the current and past uses of mushroom and plant taxa collected in the forest. We found that TEK and LEP are undergoing a process of erosion due to several factors including traditional livestock breeding abandonment, loss of unintentional contact with natural resources and the commoditization and specialization to few taxa such as Vaccinium myrtillus and Boletus edulis, which are economically valuable. We discuss that this may lead to severe loss of diversity of the local ecological resources used, which would affect negatively the sustainability and resilience of the local community in case of severe food shortage. (ERC grantagreement 714874 [https://cordis.europa.eu/project/ rcn/208447_en.html]).

\section{Role of Mijikenda sacred forests in biodiversity conservation and livelihood improvement: the case of the Kenyan Coast}

\author{
Leila Ndalilo ${ }^{1,2}$, Chemuku Wekesa ${ }^{3}$ \\ ${ }^{1}$ Kenya Forestry Research Institute, Malindi, Kenya; ${ }^{2}$ Egerton University, Nakuru, Kenya; ${ }^{3}$ Kenya Forestry Research Institute, Taita Taveta, Kenya \\ (leylilo@yahoo.com; chemukukefri@gmail.com)
}

Kayaforests, located in Kenya's coastal landscape, are sacred forests of the Mijikenda people. These forests have been preserved since the 16th century as sacred places where prayers, rituals and sacrifices take place. Protection of the Kayasis deeply entrenched in traditional Mijikenda culture and their integrity and sanctity have been safeguarded by a council of Kayaelders who employ a system of taboos and traditional rules to protect the forests. A study was conducted to assess the role of kaya forests in biodiversity conservation and livelihood improvement among the Mijikenda community in the 
Kenyan coast. The study was conducted in Kilifi and Kwale counties of Kenya and the target communities were the Giriama, Chonyi, Rabai, Digo and Duruma sub-tribes of the Mijikenda community. Household questionnaires, focus group discussion and key informant interviews were used to collect data. The study revealed that Kaya forests are facing threats from rapidly changing socioeconomic and ecological conditions leading to a decline in their pristineness. Decline in cultural values attributed to modernity was mentioned by $40 \%$ of the respondents as a leading contributor to degradation of the forests. Despite the numerous threats faced by kaya forests, they continue to conserve biodiversity and provide an array of goods and services needed for improving human well-being and livelihood systems, with about $60 \%$ of the communities dependent on them for their livelihoods. There is need to protect traditional knowledge and strengthen traditional governance systems which underpin the conservation of Kaya forests for enhanced conservation and socio-economic benefits.

\section{Diversity of local knowledge and use of wild food plants in communities around five biodiversity hotspots in Zimbabwe}

Lizzie Mujuru ${ }^{1}$, Luke Jimu ${ }^{1}$, Admore Mureva ${ }^{1}$, Justice Muvengwi ${ }^{1}$, Anthony Mapaura ${ }^{2}$, Innocent Nyakudya ${ }^{1}$

${ }^{1}$ Bindura University of Science Education, Bindura, Zimbabwe; ${ }^{2}$ National Herbarium and Botanic Gardens, Harare, Zimbabwe (lzzmjr2009@gmail.com; jimaldino@yahoo.com; admury@gmail.com;justicemuvengwi@gmail.com; amapaura@gmail.com; pupunege@yahoo.com)

This study documented the use of wild food plants in areas around five biodiversity hot spots in Zimbabwe. Data was collected using semi-structured interviews and focus group discussions in representative communities. Direct matrix ranking, pairwise ranking, and priority ranking methods were used to analyse data. A total of 89 wild food plants were used by communities in the five hotspot areas. Trees constituted $65 \%$, shrubs (11\%), tubers/herbs constituted (12\%), lianas/ climbers ( $8 \%$ ) and succulents (4\%). Fruits were the most used parts (52\%) followed by leaves (28\%), and others (roots/rhizomes/tubers, sap and fibres) (20\%). The fruits are mostly consumed raw (96\%) whilst others are processed into juices (4\%), mostly collected by women and children, but the participation of men was also evident. According to pairwise ranking analysis, fruits of Adansonia digitata, Vangueria infausta, Uapacca kirkiana, Berchemia discolour/zeyheri, Vitex doniana and the leaves of $A$. digitata were the most preferred plant species because of their taste and availability. However, some fruits such as Vitex spp. and U. kirkiana were known to have side effects of causing constipation and diahorrea respectively if consumed in excess. Cultural/Traditional knowledge plays an important role in the value of a species in a particular area and the associated conservation activities of the wild food plants. Biodiversity conservation activities and value addition could help as solution for the conservation and sustainable use of wild food plants in the biodiversity hotspots. Furthermore, more studies are needed to determine medicinal applications of the woodland species around hotspot areas.

Rural communities' local knowledge of forest resources utilization for their livelihoods: a case study in the Katha District, Myanmar

Zar Chi Hlaing ${ }^{1}$, Osamu Saito ${ }^{2}$

${ }^{1}$ Forest Research Institute, Nay Pyi Taw, Myanmar; ${ }^{2}$ United Nations University Institute for the Advanced Study of Sustainabiltity (UNU-IAS), Tokyo, Japan (zarchihlaing08@gmail.com; saito@unu.edu)

Although the application of local knowledge has received increasing attention and became an important role in environmental conservation, the successes, and challenges encountered in the application of local knowledge in managing and governing natural resources. This case study aimed to examine rural communities' applying local knowledge practices related to forest resources for their livelihoods and to understand the role of local knowledge in forest resources management. Data collection was conducted through the face-to-face household interview from 218 households and focus group discussions in four rural communities in the Katha District. The study documented four different types of local knowledge practices such as taboos, custom, norms and other local knowledge related to livelihood activities, and they are acquired and transmitted through family custom, social networks and oral communication including learning from elder people. The results showed that a significantly lower proportion of applying local knowledge when compared to the awareness in each studied community. Household characteristics like length of stay, HHH's age and livestock varieties were found as the influence variables on the awareness and application of local knowledge, and average $85 \%$ of local communities showed their agreement on the application of local knowledge. Communities' applying knowledge practices are supporting the forest resources conservation activities directly, and helping to address contemporary livelihood (socio-economic) and environmental conditions. But the vice versa effects like beneficial and detrimental, of local knowledge practices, are observed as one of the attention factors when local knowledge is utilized in forest resource management and livelihood improvement activities.

Chañar (Geoffroea decorticans (Gill. ex Hook. et Arn.)): forest heritage and a traditional food from the Atacama region of Chile / Chañar (Geoffroea decorticans (Gill. ex Hook. et Arn.)): un patrimonio forestal, agroalimentario y ancestral de la región de Atacama, Chile

Sandra Gacitúa ${ }^{1}$, Marlene González ${ }^{2}$, Jaime Montenegro ${ }^{1}$, Jose Hernandez ${ }^{1}$, Carmen Varela ${ }^{3}$, Ricardo Muñoz ${ }^{4}$

${ }^{1}$ Instituto Forestal, la Serena, Chile, Chile; ${ }^{2}$ Instituto Forestal, Santiago, Chile; ${ }^{3}$ Consultor Privado, Concepcion, Chile; ${ }^{4}$ Universidad de La Serena, La

Serena,Chile (sgacitua@infor.cl; marlene.gonzalez@infor.cl; jmontengro@infor.cl; jhernandez@infor.cl; varcarmen@gmail.com;

ricardo.munoz.cisternas@gmail.com)

Chañar (Geoffroea decorticans Gill. ex Hook. et Arn.) es un árbol de la familia Fabaceae que crece en la Región de Atacama, Chile, y en países limítrofes. Produce frutos que han sido fuente de alimento ancestral, constituyendo un importante patrimonio alimentario y cultural, pero de uso y conocimiento restringido. Este fruto tiene un alto potencial nutracéutico aportado por polifenoles y actividad antioxidante, características que favorecen la promoción de su consumo. El estudio se centró en rescatar el conocimiento ancestral y valorar el patrimonio alimentario del fruto y arrope de chañar, con el fin de evidenciar su consumo a través del arrope de chañar como un producto con características especiales para consumidores que buscan lo natural y orgánico, manteniendo y destacando su connotación étnica y ancestral. Para el rescate del conocimiento ancestral referido al uso y proceso productivo se usaron procedimientos metodológicos que se enmarcan en estrategias y técnicas cualitativas, las que fueron aplicadas y trabajadas con comunidades Collas de la comuna de Copiapó. Para la valoración nutricional se determinaron los componentes proximales, antioxidantes y flavonoides de frutos de chañar, específicamente del mesocarpio (pulpa s/cáscara) y su semilla (s/carozo), colectados de diferentes sectores. Los resultados confirman la alta presencia de carbohidratos, flavonoides y antioxidantes, lo que, unido a lo citado en literatura, posiciona los frutos y arrope de chañar como un importante producto, no solamente dirigido al consumo de alimentos en mercados nichos sino también en el ámbito de la medicina popular (producto etnofarmacéutico), mercado que será abordado por la comunidad. 


\author{
Threats to indigenous beliefs in protection of sacred forests in Southwest Nigeria \\ Folaranmi Dapo Babalola ${ }^{1,2}$ iD \\ ${ }^{1}$ Forest Resources Management, University of Ilorin, Ilorin, Nigeria; ${ }^{2}$ University of Pretoria, Pretoria, South Africa (babalola.fd@unilorin.edu.ng)
}

Sacred forests play a central role in the cultural and livelihoods of indigenous people. Despite the vital roles of sacred forests, declines in the areas of the forests have been reported. The consequence of this is that many indigenous knowledge systems built over the years toward protection of the endemic forest diversity are being abandoned due to civilization and pressing land demands. The study investigated the indigenous beliefs used in conserving sacred forests as well as the challenges facing the beliefs. The respondents include people living adjacent to Igbo Igunnko (meaning Igunnukosacred forest) and Igbo Oro (Orosacred forest) located in Ogun State, Southwest Nigeria. The forests form part of the history upon which the surrounding villages were established. Among the taboos supporting existence of the sacred forests, prohibition of fishing in Oso'ro River (that links the two sacred forests) is the most effective. At the local scale, factors such as demand for farmlands, firewood collection and poaching constitute threat to the sacred forests. However, emerging issues such as infiltration of factors like modern civilization, western cultural diffusion and foreign religion are contributing to the neglect of cultural beliefs that are in support of the sacred forests. There is need for proper demarcation of the boundary of sacred forest for protection against pressing land uses and over exploitation. Also, the current traditional knowledge and beliefs in support of sacred forest should be properly institutionalized and strengthened.

\title{
Conditional cash transfers to indigenous societies and the long-term impacts on Amazonian deforestation: a case study of Bolsa Família Program to the Kĩsêdjê indigenous people
}

Priscila dos Reis Cunha ${ }^{1}$, Camilo Rodrigues Neto $^{1}$, Carla Morsello ${ }^{1}$

${ }^{1}$ Universidade de São Paulo, São Paulo,Brasil (priscila.cunha@usp.br; camilorneto@gmail.com; cmorsello@gmail.com)

Indigenous territories correspond to $\sim 23 \%$ of the Brazilian Amazon, which implies they are essential for the fate of forest conservation. Evidence indicates the traditional natural resources use by Amazonian indigenous societies produces low environmental impacts. However, increased access to the market economy is likely to raise negative environmental impacts produced by these groups. Currently, Conditional Cash Transfers (CCTs) affect indigenous societies worldwide and increase their exposure to the market economy. Even so, few studies investigate their long-term impact on natural resources and, when they do, depart from models which assume people's decisions on time use follow the principles of Rational Choice Theory. Yet, unlike proposed by the Rational Choice Theory, evidence suggests that people do not think about time fungibly, but tend to mentally divide time in different accounts (e.g., "work" and "non-work"), such as expected by the Mental Accounting model. Changing people's decisions rules might lead to different predictions of CCT long-term impacts, because the time dedicated likely affects the expected size of the crop area and, consequently, deforestation. Therefore, we investigated in this study the CCTs effects on the area deforested for agriculture, and if/how the adoption of alternative decision theories (Rational Choice and Mental Accounting) changes the predictions. To do that, we investigated CCTs from the Bolsa Família Program to the Kĩsêdjê indigenous people, through an agent-based model, described using the ODD + D protocol and parameterized with empirical data obtained through a survey based on interviews, time allocation, weigh day and farm area measurement.

Forest holdings, food security, and ways of life in native communities in loreto and Madre de Dios, Peru / Tenencia forestal, seguridad alimentaria y medios de vida en comunidades nativas de loreto y Madre de Dios, Perú

Zoila Cruz-Burga 1 iD; María de los Ángeles La Torre-Cuadros ${ }^{1,2}$ iD; Iliana Monterroso ${ }^{3}$; Anne M Larson ${ }^{3}$

${ }^{1}$ Grupo Sistemas Socioecológicos y Servicios Ecosistémicos, Facultad de Ciencias Forestales, Universidad Nacional Agraria La Molina, Av. La Universidad S/N Lima 12, Peru; ${ }^{2}$ Facultad de Ciencias Ambientales, Universidad Cientifica del Sur, Av. Panamericana Sur km 19, Villa, Lima 42, Peru; ${ }^{3}$ Center for International Forestry Research, Av.La Molina 1895, Lima 12,Peru(zcruz@lamolina.edu.pe; mlatorrec@ucientifica.edu.pe; i.monterroso@cgiar.org; a.larson@cgiar.org)

En Perú, durante los últimos 40 años, se han titulado más de 1300 comunidades nativas en la Amazonía peruana. Sin embargo, quedan desafíos importantes para cerrar la brecha en la formalización de las áreas reclamadas aún por los pueblos indígenas. Según la Asociación Interétnica para el Desarrollo de la Amazonía Peruana, AIDESEP existen reclamos sobre 20 millones de hectáreas de tierra y bosque. Este trabajo analiza los impactos de la formalización de derechos colectivos a la tierra y el bosque (titulada y no titulada) en relación a los cambios en la seguridad alimentaria y medios de vida en 22 comunidades de la Amazonia en dos regiones, Loreto y Madre Dios. A partir del análisis de datos cuantitativos (1006 encuestas intrahogar) y cualitativos (44 grupos focales y 52 entrevistas en profundidad) se encontró que existe una tendencia a que las comunidades tituladas tengan menos problemas para satisfacer las necesidades alimentarias en la familia que las no tituladas a un $90 \%$ de confianza y se encontró que la comunidades no tituladas nativas tienen menores patrimonios agropecuarios que las comunidades no tituladas campesinas con relación a los medios de vida. Estos resultados demuestran que el reconocimiento de derecho colectivo sobre tierras forestales y la seguridad de tenencia contribuyen a la diversificación y mejora de los medios de vida de las comunidades nativas en la Amazonia peruana.

\section{How can traditional knowledge for managing forests be legally ensured by government? Collecting Styrax benzoin tap and conflicts of land tenure in customary forest in North Sumatra, Indonesia}

Kazuhiro Harada ${ }^{1}$, Wiyono Putro ${ }^{2}$, Yumi Sakata ${ }^{1}$

${ }^{1}$ Graduate School of Bioagricultural Sciences, Nagoya University, Nagoya, Japan; ${ }^{2}$ Faculty of vocational school, Gadjah Mada University, Yogyakarta, Indonesia(harada@agr.nagoya-u.ac.jp; wiyono.putro@gmail.com; ta72483@yahoo.co.jp)

Collecting Styrax benzoin tree tap in customary forest is a sustainable way of life inherited for generations in North Sumatra. Customary forest has had traditionally individual land holdings, in which collecting tree tap is a significant means of livelihood. The government partially entitled a pulp company to the concession to cut the trees and plant first growing trees as Eucalyptus, which evoked conflicts between local people and the company. This study investigates; 1) how local people may collect the tap, 2) how much money they can earn from the activity, 3) how conflicts evoked between the two parties and been solved with new government forest law. Household survey and interviews with local people and NGOs revealed that local people had approximately 1 ha of customary forest and collected tree tap mainly twice a year, which is their daily subsistence and main income source. While customary forest traditionally owned by them have been partially deprived by the government with the juridical land classification, the forest environment changed badly, induced the reduction of the amount of the production and jeopardized the traditional property right of local people. The 
situations has been changing after the issue of new forest law in 2015, in which customary forest was recognized to have communities' property right, separated from state forest. The customary forest in North Sumatra has been in the process of being recognized as property forests after intensive negotiations and discussions between local people and central/local governments under the support of local NGOs.

The role of international law in the protection of traditional forest-related knowledge (TFRK) of Amazonian indigenous peoples Siu Lang Carrillo Yap ${ }^{1}$

${ }^{1}$ Göttingen University, Göttingen, Germany (siulang.muchik@gmail.com)

The growing value of forest resources has produced an increasing regulation of the use of forest resources in the national States of the Amazonian region. The new generation of forest norms has established a standardized system for the utilization of forest resources based on two main aspects: the elaboration of forest management plans for ordering the extraction of forest resources, and the granting of forest licences by the State's authorities before the implementation of the forest management plans. While this system has improved control over the extraction of forest resources in concessions and private lands, it has produced a number of conflicts in indigenous lands. One of the claims of indigenous peoples is that there are increasing barriers for the application of TFRK in their lands because the current forest norms consider neither their knowledge, nor their customary law, nor their values. Then, national norms are in disagreement with the customary law of indigenous peoples, when it comes to regulating the use of TFRK. This situation implies the breach of international agreements which order the protection, promotion and further development of traditional knowledge. In view of this problem, this research identifies the gaps and opportunities of three international agreements, namely CBD, UNDRIP and the ICH Conventionfor the protection of the TFRK of Amazonian indigenous peoples, considering the national legal frameworks of Bolivia, Brazil, Ecuador and Peru.[1] [\#_ftn1] [1] [\#_ftnref1] The four countries account for approximately $80 \%$ of the Amazonian region.

A6h: PATHWAYS TOWARDS SUSTAINABLE RESOURCE USE FROM AFRICAN SUDANIAN AND ZAMBEZIAN WOODLANDS: RESOLVING CONFLICTING POINTS OF VIEW

\section{Effectiveness of woodland management to meet local need in fuelwood in Sudanian zone}

Eméline Sêssi Pélagie Assede ${ }^{1}$ iD; Fortuné a. Azihou ${ }^{2}$, Sayuni b. Mariki ${ }^{3}$, Samadori S. H. Biaou ${ }^{1}$, Coert j. Geldenhuys ${ }^{4}$, Paxie w. Chirwa $^{4}$, Brice Sinsin $^{2}$ ${ }^{1}$ Faculty of Agronomy, University of Parakou, Parakou, Benin; ${ }^{2}$ Faculté of Agronomy Science, University of Abomey-Calavi, Abomey-Calavi, Benin; ${ }^{3}$ Sokoine University of Agriculture, Morogoro, United Republic of Tanzania; ${ }^{4}$ University of Pretoria, South Africa(assedeemeline@gmail.com; fazihou@gmail.com; zion ${ }^{2000} t z @ g m a i l . c o m ;$ hbiaou@gmail.com; cgelden@mweb.co.za; paxie.chirwa@up.ac.za; bsinsin@gmail.com)

Woodlands in Sudanian zone are under different management regimes, including total protection to controlled use. However, the intensity of tree harvesting mainly for fuel wood does not meet local need and thereby threats the biodiversity. This study implemented in Sudanian zone of Benin aims to access the effectiveness of Sudanian woodlands to meet local population needs in term of biomass productivity. Three vegetation units of about $80 \mathrm{~m}$ x $80 \mathrm{~m}$ each were identified, representing the three development stages of the study area. Three random blocks (repetition) of $20 \mathrm{~m}$ x $20 \mathrm{~m}$ each were demarcated per unit in homogeneous stands. Blocks were divided into four treatment plots of $10 \mathrm{~m} \times 10 \mathrm{~m}$ each. Treatments were randomly allocated and consisted in i) no thinning and no pruning, ii) 30\% thinning and pruning, iii) $60 \%$ thinning and pruning iv) $100 \%$ thinning. Tree growth in height of individual $\geq 1 \mathrm{~m}$ were measured every 6 months between 2015 and 2016 . The need of local population for fuelwood was estimated at $9,515,850.22$ $\mathrm{kg}$ biomass/year. The influence of thinning and pruning on biomass production was positive. The best biomass production (3,018,736.25 $\mathrm{kg} / \mathrm{year}) \mathrm{was}$ obtained with $30 \%$ thinning and pruning. A long term experimentation ( $\geq 10$ years) is crucial to confirm these results.

Disturbance impacts on the composition and diversity of the Baikiaea-Guibourtia-Pterocarpus woodlands of North-western Zimbabwe Angella Chichinyel, ${ }^{1,2}$ Coert $J$ Geldenhuys ${ }^{2}$, Paxie W Chirwa ${ }^{2}$

${ }^{1}$ National University of Science and Technology, Bulawayo, Zimbabwe; ${ }^{2}$ University of Pretoria, Pretoria, South Africa (angiechichinye@gmail.com; cgelden@mweb.co.za; paxie.chirwa@up.ac.za)

Variation in floristic composition of recovering Baikiaea-Guibourtia-Pterocarpus woodlands was studied in four different development stages and utilization systems in Gwaai and Tsholotsho areas in north-western Zimbabwe; 150 nested concentric circular plots were sampled. Diameter at breast height (DBH) and tree height were recorded by species for all trees with $\mathrm{DBH} \geq 15 \mathrm{~cm}$ and $5.0-14.9 \mathrm{~cm}$ trees were measured in a $30 \mathrm{~m}$ radius concentric plot $(0.283$ ha) and $11.3 \mathrm{~m}$ radius concentric plot ( $0.04 \mathrm{ha}$ ) respectively. Stems $<5 \mathrm{~cm}$ DBH were counted in an inner sub-plot of $5.65 \mathrm{~m}(0.01$ ha) radius. Tree data (stems $\geq 5 \mathrm{~cm}$ $\mathrm{DBH}$ ) and regeneration data (stems $<5 \mathrm{~cm}$ DBH), were used separately to run TWINSPAN ((Two-way Indicator Species Analysis) classifications. Importance values were calculated for all tree species per community. Shannon Weiner diversity indices were tested for differences using the One-Way ANOVA in SPSS Version 21. Detrended Correspondence Analysis (DCA) in the CANOCO ordination programme was used to determine the extent of variation amongst the identified communities. The classification identified 12 tree and 13 regeneration communities. Baikiaea plurijuga was the most important tree in all tree and most regeneration communities. P. angolensis showed low importance in most communities, except for communities from undisturbed sites and abandoned fields (mostly young trees). Species diversity differed significantly $(\mathrm{p}<0.05)$ amongst tree communities. The DCA ordination showed little variation amongst the tree communities with a cumulative contribution of $22.6 \%$ and $26.1 \%$ for regeneration communities, suggesting that disturbance is the main driver of changes in species composition among other factors.

\section{Assessing dependence and pressure on forest resources in Limpopo National Park (Mozambique): the case of Mopane woodlands}

Vilela de Sousa ${ }^{1}$, Cristiano Pires ${ }^{1}$, Coert J. Geldenhuys ${ }^{2}$, Albano Figueiredo ${ }^{3}$

${ }^{1}$ Universidade Pedagogica, Campus de Lhanguene Faculdade de Ciencias Naturais e Matematica - Biologia, Maputo, Mozambique; ${ }^{2}$ Forestwood, Pretoria, South Africa; ${ }^{3}$ University of Coimbra, Coimbra, Portugal (vilelasousa2@gmail.com; cristo.pires@gmail.com; cgelden@mweb.co.za; geofiguc@gmail.com)

This study forms part of a larger study in mono-specific Mopane woodlands (dominated by Colophospermum mopane) within the Zambezian Region, conducted in the Limpopo National Park, Mozambique. The aims are to correlate the dependence of local communities for mopane woodland resources with the composition and structure of mopane woodland, as a basis for sustainable use management and conservation of Mopane woodland. The dependence of communities on Mopane woodlands was estimated through a survey to qualify and quantify the main sources of income, dominant 
housing type, and shape, type and attributes of building materials, seasonality of resource collecting, the replacement rate of materials used in types of infrastructure. A current Mopane woodland status was assessed trough forest inventory within 2 land use and land cover systems (woodland with tree harvesting, woodland in recovery stages after abandoned crop cultivation and people resettlement) compared with intact woodland structure and composition. Plots were sampled in each land use zone to collect information on Mopane stand development stage, type of disturbance, recovery period, and stem diameter and height, by species. Preliminary results show that construction materials and firewood contribute to community income although leads the reasons to disturbance of Mopane woodland with tree harvesting, that influencing the structure and composition. The outcome of this study will indicate what are the human impacts on Mopane woodlands sustainable resource use, and how this could be improved through guided sustainable uses.

\title{
Zambezian woodlands: matching resource use needs of people with the ecology of these woodlands to sustain their biodiversity, productivity and resource use products, values and services
}

\author{
Coert J Geldenhuys ${ }^{1}$ \\ ${ }^{1}$ Department of Plant and Soil Sciences, University of Pretoria, Pretoria, South Africa (cgelden@mweb.co.za)
}

Zambezian dry, deciduous woodlands cover 11 countries in southern Africa, where millions of rural people rely mostly on subsistence use of products and services obtained from them. Miombo woodland (largest area), Undifferentiated woodland and Mopane woodland are the main woodland types. Most of their tree species developed unique underground rootstocks to survive browsing by fire, wildlife and people, and are strongly light-demanding for good regeneration, mainly vegetative regrowth. The main causes of their perceived degradation/deforestation are cultivation of crops and harvesting poles and fuelwood by rural societies. Current policies of agriculture, woodland timber concessions, plantation forestry, biodiversity conservation, REDD+ strategies and rural development are not aligned with the woodland ecology; generally following a protectionist approach of protecting mature tree stands, and maintaining minimum stem diameter cutting limits. Slash-and-burn traditional agriculture and charcoal production are condemned; plantation forestry is considered a viable alternative for wood production. Recent studies in all three systems showed that slash-and-burn agriculture and charcoal production provide for fast recovery of plant diversity and productivity through vegetative regrowth from the rootstocks, and maintain the diverse woodland use value. An integrated, multiple-use approach based on selective stem thinning in stand development stages, branch pruning of retained good trees, and group-felling of mature stands, is promoted. It will maintain the supply in fuelwood and poles, maintain plant diversity, improve woodland condition and productivity, increase carbon stocks and sequestration rates; all to the direct benefit of rural small-scale farmers; in sharp contrast to the moribund old-growth stands in protected areas.

\section{Drivers of change in Sudanian woodlands and potential management strategies for a sustainable use}

\author{
Samadori Sorotori Honoré Biaou ${ }^{1,2}$, Sêssi Pélagie Eméline Assédél, , Jesugnon Fifamè Murielle Féty Tonouéwa², Shegoun Eudes Idjigbérou ${ }^{2,3}$, \\ Armand Kuyema Natta, \\ ${ }^{1}$ Faculté d'Agronomie, Université de Parakou, Parakou, Benin; ${ }^{2}$ Laboratoire d'Ecologie, de Botanique et de Biologie Végétale (LEB), Université de Parakou, \\ Parakou, Benin; ${ }^{3}$ Communauté Forestière du Moyen Ouémé(CoForMO), Tchaourou,Benin (hbiaou@gmail.com; assedeemeline@gmail.com; \\ tonouewam@gmail.com; shegouneudes@gmail.com; armand.natta@gmail.com)
}

Sudanian woodlands belong mostly to the Isoberlinia woodland type, which is typical of Africa northern hemisphere and forms a large and almost continuous strip extending from Mali to Uganda. In this study, we discuss the importance, drivers of change, and potential management strategies of Sudanian woodlands. Woodlands structure and species composition are strongly influenced by disturbances such as fire, grazing regimes and tree removal. The underlying mechanisms are complex and include a multitude of resource gradients (e.g. soil or climate driven stress) which potentially interact with or modify the importance of the disturbances. Woodland is also the most abundant vegetation type having significant woody cover in the Sudanian region. As such, a great number of people depend on them for their livelihoods, including for food, medicine,fuel wood, charcoal, construction and furniture woods, and cash income. An increasing pressure on woodlands should be expected in the future due to the depletion of traditional timber "hard wood" species and increased demand for "soft wood" tree species such as Isoberlinia spp. The dangers that would result from the destruction of Sudanian woodlands include the extension of savannas, an increase in fire damages, the denudation and drying up of soils, the reduced wood production and loss of tree species diversity. With regards to these threats, relevant management strategies, accounting for local needs, could ensure a sustainable use of woodlands.

\section{Socio-economic contributions of chainsaw milling enterprise to rural development in Ogun State, Nigeria}

Ismail Azeez ${ }^{1}$, Akeem Abibu ${ }^{1}$

${ }^{1}$ Department of Social \& Environmental Forestry, University of Ibadan, Ibadan, Nigeria (ismail.azeez@mail.ui.edu.ng; besomeoneinlife@gmail.com)

Despite the prevalence and increasing activities of Chainsaw milling (CSM), its unapproachable nature tends to limit study on its economic and livelihood implications, which could serve as basis for policy review on the enterprise. This study reports the contributions of CSM to socio-economic development in the cities of Ago-iwoye and Isara Remo, Ogun state, Nigeria. Data were obtained from community residents using simple random sampling procedure through questionnaire administration. Results were subjected to descriptive and Chi-square test statistics at $\alpha 0.05$. The study was based on responses from $61.5 \%$ male respondents with age distribution cutting across those less than 20 years to those above 50 years. Chain sawmilling enterprise was positively associatedwith employment (81.7\%), women participation (76.7\%), coordinated activities (74.2\%) and poverty reduction (85.8\%) in the study area. Also, cohesion between associations, designation of key responsibilities to women and revenue generation for the community are open opportunities that will significantly complement the socio economic contributions of the enterprise. However, age and occupation of practitioners have the most significant effects on the enterprise while CSM operations was confirmed as negatively impacting the study area environment Meanwhile, the negative impacts on agricultural production could be abated by ensuring that farmers get their due compensation to crop damage. The study also explicates the prospects of CSM enterprise in the study area provided learning the art of chainsaw machine handling is enforced before issuance of permit for CSM operation. 


\title{
A6i: SOCIAL AND ECONOMIC BENEFITS IN PROTECTED AREAS: PARTNERSHIPS AND CONCESSIONS FOR LOCAL DEVELOPMENT
}

\section{Community engagement in tourism concessions in parks}

Lucas Milani Rodrigues ${ }^{1}$, Moema Pauline Barão Septanil ${ }^{1}$, Camila G. de Oliveira Rodrigues ${ }^{2}$, Teresa Cristina Magro Lindenkamp ${ }^{3}$, Victor Eduardo Lima Ranieri $^{1}$

${ }^{1}$ Universidade de São Paulo, São Carlos, Brasil; ${ }^{2}$ Universidade Federal de Rio de Janeiro, Rio de Janeiro, Brasil; ${ }^{3}$ Universidade de São Paulo, Piracicaba, Brasil(rodrigues.milani@gmail.com; moema@usp.br; camirural@gmail.com; teresa.magro@usp.br; victor.ranieri@gmail.com)

Twelve parks within the State of São Paulo, Brazil, ruled by its government, had theconcession of their tourism services approved by State Law $n^{\circ} 16.260 / 2016$. In a previous publication, we verified that Consultative Councils (CC) of those Parks did not conduct a substantive discussion prior to the approval of the Law. In this work, through documentary analysis of meeting and public hearing minutes, the community involvement in discussions about the concession in Jaraguá State Park (PEJ) was analyzed. It was found that the indigenous community living in PEJ was informed about the concession only after the approval of the law, and there was no previous discussion in the village about new possibilities of tourism arrangements. The analysis of meeting minutes shows that the indigenous community of Jaraguá objected the new proposal, participated in a public hearing after the approval of the law in the Legislative Assembly of São Paulo State and brought to the public its dissatisfaction with regard to the new law. It can be concluded that the top-down approach adopted, without prior discussion with the community directly affected by the change, was rejected by local residents, resulting in potential future conflict in the development of activities under concession.

\section{Impact of state forest concession revenues on municipalities of the Eastern Amazon}

\author{
Jime Rodrigues Ribeiro ${ }^{1}$, Iranilda Silva Moraes ${ }^{1}$, Claudia Azevedo-Ramos ${ }^{1}$ \\ ${ }^{1}$ Núcleo de Altos Estudos Amazonicos, Universidade Federaldo Pará,Belém, Brasil (engenheirajime@gmail.com; iranilda.ideflor@gmail.com; \\ claudia.azevedoramos@gmail.com)
}

The forest concession is one of the main instruments for public forest management in Brazil. However, the effective social benefits of Amazon forest concessions still raise concerns. In 2011, Pará state had its first state concession contracts signed on 151 thousand hectares of native forests in the region of the Glebas Mamuru-Arapiuns, comprising three municipalities (Aveiro, Juruti and Santarém) in northwest of the state. In order to evaluate the forest concession revenue transferred to these municipalities and its use, this study analyzed financial reports from the state environmental agency and the municipalities. By 2016 , the State Fund for Forest Development - Fundeflor - transferred approximately R 3.2 million royalties to the three municipalities: 15.4\% (R\$ 507,169.63) for Aveiro, 35.1\% ( R\$ 1,156,865.28) for Juruti and 49.5\% (R\$ 1,629,427.04) for Santarém. The financial reports of Aveiro reported that the 2014 and 2015's economic resources were applied in infrastructure and purchase of supplies. Santarém reports revealed that most of the 2014 to 2016 resources were spent on travels, staff, supplies and equipment. Juriti did not present a report. The use of these resources in activities unrelated to those predicted in forest policies (or the lack of accountability) reveals the need for greater monitoring of the distribution state forest concession revenues in order to increase local benefits.

The impact of forest concessions on deforestation in protected areas of Brazilian Amazonia / Concessões florestais afetam dinâmica de desmatamento nas áreas protegidas na Amazônia brasileira

Roberto Palmieri ${ }^{1,2}$, Vinicius Faria ${ }^{2}$, Felipe Cerignoni ${ }^{2}$, Mateus Batistella ${ }^{1,3}$

${ }^{1}$ Universidade Estadual de Campinas, Piracicaba, Brasil; ${ }^{2}$ Imaflora, Piracicaba, Brasil; ${ }^{3}$ Embrapa Informática Agropecuária, Campinas, Brasil (palmieri@imaflora.org; vinicius@imaflora.org;felipe@imaflora.org;mateus.batistella@embrapa.br)

Cerca de dois milhões de hectares de Áreas Protegidas (APs) na Amazônia brasileira foram concedidas para manejo florestal por empresas privadas. Alguns atores envolvidos com as concessões apontam preocupações quanto ao interesse econômico das empresas sobreporem-se aos interesses públicos de proteção ambiental. Esse estudo contribui para avaliar o impacto das concessões florestais no desmatamento. Foi utilizada a série histórica dos dados sobre desmatamento do PRODES/INPE de 2000 a 2016. Também foram realizadas entrevistas com atores relacionados às concessões. Optou-se por considerar as APs com assinatura de contrato da concessão até 2014. Cada AP foi comparada com duas APs similares em tamanho, formato, fitofisionomia e declividade, porém sem concessões florestais (grupo controle). As cinco APs concedidas analisadas tiveram menores taxas de desmatamento em comparação com as APs similares interpretados estatisticamente ao nível de 5\% de significância evidenciando a contribuição das concessões florestais para manutenção da cobertura florestal. Isso pode estar relacionado ao fato das empresas que se instalam em uma UC terem inibido invasores e atividades predatórias na área protegida devido à corresponsabilidade contratual sobre essas áreas e pelo seu interesse em manter o estoque de madeira para posterior manejo pela própria empresa já que são contratos de 40 anos. Continuar monitorando essas APs por mais tempo, assim como incluir outras APs concedidas mais recentemente, evidenciarão as interferências das concessões na atividade madeireira local. Efeitos inesperados, tal como o aumento da pressão de desmatamento para áreas próximas também devem ser avaliados para o entendimento sobre as mudanças nas paisagens.

Planning concessions for support services related to visiting Brazilian Federal Conservation Units, 1998-2018 / Ações de planejamento de concessões dos serviços de apoio à visitação em unidades de conservação federais brasileiras entre 1998 e 2018

Moema Pauline Barão Septanil ${ }^{1}$ iD; Victor Ranieri ${ }^{1}$

${ }^{1}$ Universidade de São Paulo, São Carlos,Brasil (moema@usp.br; vranieri@sc.usp.br)

Concessões dos serviços de apoio à visitação em áreas protegidas têm sido defendidas como uma forma de aprimorar o uso público e contribuir para um aumento dos recursos financeiros arrecadados. Países como Brasil, Estados Unidos, Canadá, África do Sul, Nova Zelândia, entre outros, têm experiências de concessão em áreas protegidas e estudos apontam uma tendência de ampliação dessa prática. Neste contexto, o presente estudo buscou identificar as ações de planejamento das concessões em Unidades de Conservação (UCs) federais brasileiras desde 1998. Para isso, foram buscados dados sobre Leis, Decretos, Instruções Normativas, Editais, Políticas, Planos, Programas, Estratégias, e notícias e publicações do Ministério do Meio Ambiente e do Instituto Chico Mendes de Conservação da Biodiversidade sobre o tema, onde foram identificadas 25 ações. Destas, seis ocorreram entre 1998 e 2002, todas sobre concessões no Parque Nacional do Iguaçu, nenhuma entre 2003 e 2009, e nove entre 2010 e 2017. Para 2018, dez ações foram identificadas relacionadas à assinatura de dois contratos e à elaboração de dez projetos. Percebe-se que houve aumento nos esforços de planejamento durante o período analisado, entretanto as informações identificadas não permitem compreender como este planejamento foi ou 
está sendo realizado. Não foram encontradas Políticas ou Planos sobre o tema. Há menção sobre um Programa a partir de 2017, porém não há esclarecimentos a cerca de seus objetivos, metas e cronogramas de execução, e sobre uma Estratégia em 2018, onde apenas são apresentadas as UCs onde os projetos de concessão estão sendo desenvolvidos e quais os serviços concessionados.

\section{Private conservation in indonesia: Is it possible? A comparative study from Bukit Barisan Selatan National Park, Indonesia and Kruger National Park, South Africa}

Adi Gangga ${ }^{1}$, Jeni Pareira ${ }^{2}$, Matthew Leggett ${ }^{2}$

${ }^{1}$ University of Florida, Gainesville, USA; ${ }^{2}$ Wildlife Conservation Society (WCS), Bogor, Indonesia (gangga.gangga@gmail.com; jpareira@wcs.org; mleggett@wcs.org)

Prioritization of economic growth and development goals at the national level contributes to the long-standing natural resources management conflict between humanwildlife and human-human at the local level. As part of a global issue, conflict in national park management has always been an obstacle in the protected areas system in Indonesia. Recognizing the importance of a bottom-up approach, privately managed conservation area as the devolvement of management role has been acknowledged and encouraged for effective and sustainable forest management. This literature review was designed to evaluate how private conservation has been implemented in Indonesia. Bukit Barisan Selatan National Park (BBSNP), home for three flagship wildlife species - Panthera tigris sumatrensis, Elephas maximus sumatranus, and Dicerorhinus sumatrensis, provides substantial materials for forest-dependent communities living in and around the Park. With high interest in utilizing the Park for multi-purpose at multi-level, engaging private sectors including individual(s) and group(s) to collaborate in the Park management can be a strategic approach. Learning from existing initiatives in Indonesia and other countries such as South Africa, a success story is feasible to create only with the consideration of the needs of the Park. Legal regulations, bureaucracy, and stakeholders' commitment are the key factors in the implementation of private conservation yet remain challenging. By understanding its specific context and addressing potential challenges, private conservation could work successfully to mitigate the trade-offs between conservation and development.

\section{An analysis of hut and shelter management in mountain national parks of Japan Alps}

Taiichi Ito ${ }^{1}$, Shoma Jingu ${ }^{1}$

${ }^{1}$ University of Tsukuba, Tsukuba, Japan (ito.taiichi.ft@u.tsukuba.ac.jp; jinguu.shoma.xa@alumni.tsukuba.ac.jp)

Japan's national park system started in the 1930's, and the roles of concession was stipulated in the national parks law of 1931. However, the concessionaire has not developed in Japan's national parks because the park authorities did not own any lands in the park, and because the mountain huts and trail to them were already developed before park designation by local entrepreneurs. The increasing demand for outdoor recreation after the Second World War brought over-use problems in the national parks of Japan Alps since the park authorities could not regulate the number of huts and their guest capacities. The private hut managers increased the hut numbers and their capacities by incorporating personal business to accommodate more trekkers in the northern Japan Alps, while in the less-popular southern Japan Alps, local government installed shelters along the trails systematically intervals and then asked local hiking club or forestry companies to manage them. Now, Japan's population is rapidly aging and decreasing especially in rural areas. To cope with reduction of local staff and of guests, the hut-managing companies recruited urban or foreign staff and then attracted group tours including foreign visitors. In the southern part, hut managing companies supplied shuttle bus to and from the trail-heads to bring more guests. In both areas, the quality of food and other service has improved, and the environmental impacts reduced. However, the resulting rise of accommodation fee kept less affluent trekkers away from huts and mountains. This is a dilemma common to ecotourism.

\section{Forest conservation and socio-economic benefits through community forest concessions: evidence from the Maya Biosphere Reserve in Petén, Guatemala}

Dietmar Stoian ${ }^{1}$, Aldo Rodas ${ }^{2}$, Iliana Monterroso ${ }^{3}$

${ }^{1}$ World Agroforestry Centre (ICRAF), Montpellier, France; ${ }^{2}$ Ministry of Agriculture and Livestock, Petén, Guatemala; ${ }^{3}$ CIFOR, Guatemala City, Guatemala (d.stoian@cgiar.org; aldorodasc@gmail.com; i.monterroso@cgiar.org)

With an extension of 2.1 million ha, the Maya Biosphere Reserve (MBR) in Petén, Guatemala is the largest protected area in Central America. To reconcile forest conservation and socio-economic development, community forest concessions were created in its Multiple Use Zone (MUZ) in the late 1990s and early 2000s. Operated by a community forest enterprise (CFE), and with a cycle of 25 years, the concessions grant usufruct rights to local communities on an area of about 400,000 ha. Currently, nine concessions are active, while the contracts of two concessions were cancelled and the management plan of another suspended. Our study of the 12 CFEs and associated member households $(n=292)$ shows that the community concessions have largely been successful, both in terms of forest conservation and socio-economic development. Between 2000 and 2013, deforestation rates in the nine active concessions were negligible $(0.1 \%$ p.a.), as opposed to the core $(1.0 \%$ p.a.) and buffer zone $(5.5 \%)$ of the MBR. In terms of socio-economic development, we found asset building both in the CFEs and their member households. At enterprise level, forest revenues have been reinvested in physical infrastructure, machinery and equipment for higher value adding; and business management skills have improved, as has working capital and degree of indebtedness. At household level, forest income has allowed to enhance nutrition, education and health, and to invest in vehicles, home appliances, and livestock. The findings support the communities' claim for concession renewal, which is due over the next years, and have broader implications for natural resource governance.

\section{An environmental multipurpose project at Soforestal, Tuluá-Colombia}

Fernando Velez Escobar ${ }^{1}$

${ }^{1}$ Independent professional, Medellin, Colombia (fernando.velez52@gmail.com)

A pine plantation forest project was stablished at the Central Mountain region in 1980s, altitude range 1.500-3.050 m.a.s.l., lower-montane and montane moist and wet Holdridge's life zones, steep terrain, whole area of 5.811 ha, conserving 1.984 hectares of natural forest and 3.282 hectares of pine plantation. Due to difficult accessibility and financial constrain, now there are 808 hectares of pine plantation left, and 2.474 hectares of wild vegetation succession or pine natural regeneration. A multipurpose environmental proposal is therefore presented, giving a regional example of forest conservation with economic social options: Water capture, regulation and quality control of about 100 million $\mathrm{m}^{3} / \mathrm{year}$, usefull for human consumption, and water supply to coffee and sugar cane farmlands. Ecological tourism, education, environmental culture programs, for about 12.000 potential visitors per year, will be possible with the establishment 
of 20 local rural families as hostels and guides. Biodiversity conservation: equivalent natural reserves declare about 350 animal and 725 flora species. This will help to contrast neighbor's land use of cattle grasslands and intensive bare land crops. Pine plantation stumpage volume of $310.000 \mathrm{~m}^{3}$, that is possible to harvest at a rate of $20.000 \mathrm{~m}^{3}$ round wood per year, to industrialize it locally, and then replant the area, alto gether for labor offer to 62 rural workers. After a forest management program for 16 years it will then offer a sustainable wood production of $8.000 \mathrm{~m}^{3} /$ year. Existing carbon retention is closed to a 1,8 million $\mathrm{CO}_{2}$-eq, and carbon caption to $18.000 \mathrm{CO}_{2}$-eq ton/year.

A6J: STRENGTHENING COMIUNITY AND SMALLHOLDER FORESTRY FOR SDGS AND
OTHER FOREST-RELATED GOALS

\section{Assessing the status of community-based forestry at national levels and building a framework for a global comparison}

Andrew Taber ${ }^{1}$, Jean-Claude Nguinguiri ${ }^{1}$, Safia Aggarwal ${ }^{1}$, Didier Habimana ${ }^{1}$

${ }^{1}$ UN Food and Agriculture Organization, Rome, Italy(andrew.taber@fao.org; jean-claude.nguinguiri@fao.org; safia.aggarwal@fao.org; didier.habimana@fao.org)

The extent of the world's forest estate under community-based forestry (CBF) regimes, including both collaborative and smallholder forestry, and related tenure transformations is growing. Evidence indicates that transfer of forest management rights to communities can improve the sustainable use and resilience of forest resources, social and economic conditions of impoverished rural populations, and prospects for attaining various SDG targets. Potential beneficiaries are 100 's of millions of forest people, including many indigenous communities, and the large proportion of the world's population that depend on forest products and ecosystems services. However, standardized tools are lacking to undertake national-level assessments of the extent and effectiveness of CBF regimes. Understanding the factors contributing to the success and failure of different CBF regimes is crucial to ensure that they fulfill their promise in securing forest resources while delivering a wide range of environmental, social and economic benefits. This talk builds on a process to develop a standardized CBF assessment framework facilitated by FAO. We will present results of the application of a draft framework in 15 countries in Latin America, Asia and Africa. The impacts of different CBF regimes will be reviewed along with requirements to ensure their environmental, social and economic effectiveness. Building on lessons learned, we will launch framework tools for national assessments of $\mathrm{CBF}$ and forest tenure with the goal of improving effectiveness at country levels, and to inform comprehensive Global comparisons.

\section{Smallholder forestry and Sustainable Development Goals: from knowledge gaps to Global collaborative research}

Markku Kanninen ${ }^{1,2}$, Maarit Kallio ${ }^{1,2}$

${ }^{1}$ University of Helsinki, Viikki Tropical Resources Institute (VITRI), Helsinki, Finland; '2University of Helsinki, Helsinki Institute of Sustainability Science, Helsinki, Finland (markku.kanninen@helsinki.fi; maarit.kallio@helsinki.fi)

Trees in farms managed by smallholders in diverse systems (e.g. tree stands, agroforestry systems, home gardens, living fences, managed secondary forests) are becoming increasingly important in increasing need for sustainably produced food, fodder and wood. Trees grown by smallholder-managed systems can contribute towards many of the Sustainable Development Goals by providing vital ecosystem services and by supporting smallholder livelihoods. To set up realistic expectations of such a win-win approach, and to design meaningfully measures to support smallholders in their tree growing initiatives, it is necessary to generate a more comprehensive understanding on the real scale and impacts of trees planted or managed by smallholders in the tropics and subtropics. Furthermore, there is a lack of recognition, understanding and data on the enabling environment of such incentives, such as on markets, logistics, risks and opportunities enhancing or preventing smallholder tree growing from becoming an attractive livelihood option. This paper addresses the above-mentioned challenges and assesses current state of knowledge, knowledge gaps, and bottlenecks. It also examines opportunities for filling the above-mentioned research gaps e.g. through collaborative multidisciplinary research efforts.

\section{Forest: the important support to end poverty}

Choiriatun Nur Annisa ${ }^{1}$

${ }^{1}$ Independent Forestry Consultant, Jakarta, Indonesia (c.nur.annisa@gmail.com)

Approximately 820 million people in tropics live in and around forests and 40\% of them are living below US\$1.25/day (FAO, 2018; Chomitz et al., 2007). Up to one-fifth of the world's population get direct and indirect forest benefits with approximately $9 \%$ of the rural populations are lifted above the extreme poverty level with resources from forest (World Bank Group, 2016). Thus, forest is potentially significant to alleviate global poverty. Understanding the underlining cause of poverty in forest communities is important to formulate suitable approaches to eliminate it. Lack of necessary major capitals is one of the reasons (Sachs, 2005). Forest is usually remote that often found in rural areas with minimum facilities. Most of the forest areas are also publicly owned (UNFF, 2011). People are landless and most likely have no access to finance mechanism, therefore they are "forced' to "live on common property resources" (Dasgupta, 1993). Forest is not the panacea, but rather it is an important support. Ending extreme poverty is our common agenda that is stated in SDGs. Forests can be the intersection to achieve multiple goals that leads to reducing poverty. There are at least three priorities to make forests worth contributing to eradicate poverty (particularly for forests communities): (i) Open the Access and Management to Community - Accelerating sustainable and inclusive economic growth; (ii) Capacity Building - Investing in people to build human capital; and (iii) Improve Forest Governance - Fostering resilience to global shocks and threats.

\section{Assessing and communicating benefit sharing best practices to achieve sustainable land management at the jurisdictional scale \\ Lauren Cooper ${ }^{1}$, Emily Huff ${ }^{1}$, Dietmar Stoian ${ }^{2}$ \\ ${ }^{1}$ Michigan State University Department of Forestry, East Lansing, USA; ${ }^{2}$ World Agroforestry Centre, Montpellier Area, France (ltcooper@msu.edu; ehuff@msu.edu; d.stoian@cgiar.org)}

Benefits are an important incentive for actors who would otherwise not reduce greenhouse emissions, namely by way of deforestation. However, sharing schemes must be transparent, legitimate, and fair; especially challenging because payments are often based on avoided actions rather than tied to specific goods. Earlier approaches focused on financial returns, but new thinking encompasses a broader set of 'monetary' and 'non-monetary' benefits, including tenure reform, local climate regulation, and community resilience. There is precedent for programming at various jurisdictional (geo-political boundary) levels, and multi-year efforts at different scales have highlighted both the great potential for this type of approach, as well as associated challenges. However, there is a 
gap in understanding best practices for benefit sharing at the jurisdictional scale, which is reflected in the limited guidance for jurisdictions to develop such plans. This study aims to address this gap by assessing, compiling, and communicating best practices across the spectrum of data currently available in multiple programs, supplemented with a case study approach in two focal countries (Peru and Indonesia) using sound scientific methods including semi-structured interviews, surveys, strengths weakness opportunities and threats (SWOT) analysis, Q-sorting, and statistical analysis. To reduce conflation between familiarity with common practices and the identification of best practices, the study undertook a specific data collection and analysis approach; these findings are used to highlight knowledge transfer opportunities. Further analysis assessed how information was deployed and closes with recommendations to increase uptake of the best practices idenitifed.

\section{External factors contributing to customary forest formation and recognition in Jambi, Indonesia}

Yumi Sakata ${ }^{1}$, Kazuhiro Harada ${ }^{1}$

${ }^{1}$ Nagoya University, Nagoya, Japan (sakata.yumi@e.mbox.nagoya-u.ac.jp; harada@agr.nagoya-u.ac.jp)

Customary forests (CFs) have been managed by local/indigenous people for a long time. While CFs had been included in state forests, the status of CFs was changed by the constitutional court decision No 35/2012, which ruled that CFs are excluded from state forests. A ministerial regulation was stipulated as an enforcement regulation of CFs in 2015 and recognition of each CF by the central government started; 34 CF units covering 23,000 ha have already been recognized by the central government by the end of 2018. Out of 34 cases, 20 cases are located in Jambi Province, even though Indonesia has 34 provinces. Then this study investigated why formulation and recognition of CFs have proceeded in Jambi. Establishment of Kerinci Seblat National Park (KSNP) in 1990s was a start of recognition process of CFs in Jambi. During a project for KSNP, World Wildlife Fund (WWF) found existence of CFs on borders of the KSNP and asked local governments to recognize them to secure rights of local people. In 2000s, forest area in Jambi began to be under development pressure of timber production, palm oil plantation and mining, which triggered claims of CF rights by local people. There are also some CFs which were formulated by top-down approach by means of dissemination by a forest management unit (KPH). Cases in Jambi shows that CF recognition is important for forest conservation and security of local life, however, continuity of management of CFs certified by policy-based top-down is still questioned.

\section{Evaluation of involvement of local stakeholders in sustainable management of state forest reserve under concession in Kwara State, Nigeria}

Folaranmi Dapo Babalola ${ }^{1,2}$ iD

${ }^{1}$ Forest Resources Management, University of Ilorin, Ilorin, Nigeria; ${ }^{2}$ University of Pretoria Pretoria South Africa (babalola.fd@unilorin.edu.ng)

In implementing Sustainable Forest Management, there has been shift from sole ownership of forests to participatory forest management. Odun Forest Reserve (OFR) is located in Kwara State, Nigeria. It comprises about 203 ha plantations of Tectona grandis and Gmelina arborea established through Taungya System. The plantation was established by a private investor in 1976, but later transferred to the state forestry Department and then gazette into forest reserve. Currently, exploitation in the reserve is based on concessions through payment of levy to the state forestry department. The reserve has provided employment for about 43.8\% households in the adjoining community. However, only $18.8 \%$ of the interviewed rural dwellers have paid levies to collect products from the reserve, while $26.3 \%$ and $26.3 \%$ have collected firewood and leaves respectively for free in the reserve. Majority (95.0\%) of the rural dwellers did not participate in the management of the reserve with education significantly $(\mathrm{t}=2.736, \mathrm{p}=$ value $=0.008)$ contributing to this. Timber contractors working in the reserve carry out pruning and coppice management, while only $35.0 \%$ participated in voluntary fire control. Less than half ( $45.0 \%)$ of the contractors have been invited by the state forestry department in decision making process on the reserve. Other than revenue generation from exploitation in the reserve, participation of the stakeholders in management of the reserve from the contractors and rural dwellers is inadequate. There is therefore, the need for proper engagement of the stakeholders to facilitate sustainable management of the reserve.

Contributions by forest concessions in Guatemala toward fulfilling Sustainable Development Goals / Contribución de las concesiones forestales en Guatemala al cumplimiento de los Objetivos de Desarrollo Sostenible

Fernando Carrera ${ }^{1}$, Aldo Rodas ${ }^{2}$

${ }^{1}$ CATIE, Turrialba, Costa Rica; ${ }^{2}$ MAGA, Petén, Guatemala(fcarrera@catie.ac.cr; aldorodasc@gmail.com)

Las concesiones forestales en Guatemala fueron otorgadas como estrategia, por parte del Consejo Nacional de Áreas Protegidas (CONAP), para frenar el avance de la deforestación en la Zona de Uso Múltiple de la Reserva de la Biosfera Maya (RBM). Se trata de cerca de medio millón de hectáreas otorgadas a grupos comunitarios organizados e industriales de la madera donde uno de los requisitos para su funcionamiento era la obligatoriedad de obtener la certificación forestal del FSC a mas tardar el tercer año de adjudicada la concesión y mantenerla vigente durante todo el periodo del contrato estipulado en 25 años prorrogables. El estudio se fundamenta en una evaluación realizada bajo la metodología de FAO, enmarcada en las Directrices Voluntarias para el Manejo de Bosques Públicos de Producción, el análisis de informes de auditorías de certificación y de varios estudios científicos y socioeconómicos realizados al proceso concesionario. Los resultados revelan que el proceso de manejo forestal en las concesiones en Guatemala no solo logró frenar el avance de la deforestación, en contraste con lo sucedido en las áreas protegidas aledañas, sino que además están contribuyendo a cumplir con varias de las Metas de los Objetivos de Desarrollo Sostenible (ODS).

\section{A6k: THE BIOECONOMY: A SUSTAINABLE WAY FORWARD?}

\section{The SDGS, bioeconomy and forests: a nexus for Global sustainability?}

Peter Edwards ${ }^{1}$, Helga Pülzl ${ }^{2,3}$

${ }^{1}$ Manaaki Whenua Landcare Research, Wellington, New Zealand; ${ }^{2}$ University of Natural Resources and Life Sciences, Vienna, Austria; ${ }^{3}$ European Forest Institute,Vienna,Austria (edwardsp@landcareresearch.co.nz; helga.puelzl@boku.ac.at)

Nearly $1 / 3$ of global land area is currently forested. Due to the upcoming "bioeconomy paradigm" the transition of current economies to one where materials, chemicals, and energy are derived directly from renewable (forest) resources or based on biotechnological processes may result in more intensified use and/ or expansion of forest areas. The bioeconomy is also framed as a transformative way to achieve a low waste/carbon bio-based economy. Many bioeconomy policies however display technocratic or efficiency-oriented approaches, where the idea of sustainable development is narrowed. The globally agreed Sustainable 
Development Goals (SDGs) encourage global transformation to sustainable use \& management of resources along 17 goals including ending poverty, hunger \& climate change, encouraging wellbeing, clean water, energy, gender equality \& economic growth, with forests specifically addressed in goal 15 . SDGs promote a shift to integrating economic and social development with environmental sustainability, providing a holistic view of sustainable development. The ambition is to overcome disconnected approaches \& silo thinking. Applying a nexus approach and integration theory to bioeconomy policies \& SDGs the paper aims to understand how both are connected \& (not) governed in a way to achieve societal transition. Based on an analysis of bioeconomy strategies and SDG polices in forested and low-cover forest countries we aim to determine the ways in which the bioeconomy and SDGs are (dis)connected, and thus the role of forests in contributing to the SDGs plays out.

\section{Roadmap to competitive circular bioeconomy: from challenges to solutions and strategy}

Janni Kunttu ${ }^{1}$, Diana Tuomasjukka ${ }^{1}$, Jo Van Brusselen ${ }^{1}$, Hans Verkerk ${ }^{1}$, Michael den Herder ${ }^{1}$, Mercedes Rois ${ }^{1}$, Pekka Leskinen ${ }^{1}$, Cleo Orfanidou ${ }^{1}$, Yitagesu Tekle ${ }^{1}$, Xiaoqian Chen ${ }^{1}$

${ }^{1}$ European Forest Institute, Joensuu, Finland (janni.kunttu@efi.int; diana.tuomasjukka@efi.int; jo.vanbrusselen@efi.int; hans.verkerk@efi.int; michael.denherder@efi.int; mercedes.rois@efi.int; pekka.leskinen@efi.int; cleo.orfanidou@efi.int; yitagesu.tekle@efi.int; xiaoqian.chen@efi.int)

Circular bioeconomy is a wide concept based on goods and services from renewable, agriculture and forest, or aquatic bio-based resources, aiming to keep the materials in use through re-use and recycling for as long as possible. Despite the massive research and innovation creation around the topic, there are still many knowledge gaps to overcome, such as barriers in cascade use or new business creation. One reason for this is, that the findings often lack information of how to implement the changes in practice, and what are the synergies between those changes. Also, they often do not reach the real actors. We aim at developing a detailed roadmap to strengthen circular bioeconomy in Nordic regions. We will i) create a network model on the circular bioeconomy key influence factors to overcome the barriers, and ii) utilize research and other stakeholder partners including Nordic research institutes and circular bioeconomy actors to develop a step-wise strategy to realize the actions needed. This is carried out in a KETSO workshop, which is also the first step towards change, as we directly transfer knowledge to the key audience. The 'roadmap to competitive Nordic circular bioeconomy' will be an actual example of the outcome of this participative strategy creation method, which connects knowledge and the key audience. In our presentation we will also discuss how to apply this method to other regions and purposes.

\section{Assessing the sustainability of the German bioeconomy - the primary timber footprint \\ Vincent Egenolf ${ }^{1}$, Stefan Bringezu ${ }^{1}$ \\ ${ }^{1}$ University of Kassel, Kassel, Germany (vincent.egenolf@usf.uni-kassel.de; bringezu@uni-kassel.de)}

The increased use of biogenic resources is linked to expectations of "green" economic growth, innovation spurts through biotechnology, development options for rural areas and an increasingly regenerative resource base that is also climate-neutral. However, since several years the signs for unintentional and unwanted side effects are increasing. A comprehensive framework for the evaluation of the sustainability of the bioeconomy based on the three pillars of sustainability concept was developed. A special focus is set to the intersection area of the pillars where the particularly important integrative key objectives "food security, sustainable consumption, production and infrastructures" and their assigned indicators apply. The scale of the consumption of natural resources and GHG emissions determines the bundle of environmental impacts caused by human activities at national and foreign territory. The use of footprint indicators (agricultural land, primary timber, water, material and climate) is a viable tool to quantify the resource and climate impact of the German production and consumption system and to highlight the share the bioeconomy has. We calculated the primary timber footprint of the German bioeconomy. However, the quantification of a resource footprint does not allow statements about the change in sustainability performance. It is necessary to put the respective footprint in relation to orientation values in a meaningful reference system (global, regional, local). One example is the comparison to net the annual increment of forest biomass at national and global level to calculate the self-sufficiency rate and global supply rate.

Policy narratives regarding the growth of wooden multi-story construction (WMC) and sustainability transformation in the society: the case of Finland

Heini Vihemäki ${ }^{1,2}$, Ritva Toivonen ${ }^{1,2}$, Anne Toppinen ${ }^{2,3}$

${ }^{1}$ Department of Forest Sciences, University of Helsinki, Helsinki, Finland; ${ }^{2}$ Helsinki Institute of Sustainability Science, Helsinki, Finland; ${ }^{3}$ Department of Forest Sciences, University of Helsinki, Helsinki, Finland (heini.vihemaki@helsinki.fi; ritva.toivonen@helsinki.fi; anne.toppinen@helsinki.fi)

Wooden Multi-story Construction (WMC) is often considered as a way to promote socio-economic transformation, and shifting toward sustainable bioeconomy or low-carbon economy. The goal to increase industrial wood construction has thus gained much political support and public interest, but the market share of WMC has increased only slowly. This paper addresses the dynamics of policy efforts to transform the construction sector towards increased WMC in urban contexts, using Finland as a case. We approach the topic by exploring narratives of national level policy-makers and other key actors involved in the policy processes, and in shaping related agendas. The actors' conceptualizations of the WMC and its relationship with socio-economic transformations, including policies to support such transformation, were explored using a discursive approach. Sixteen thematic interviews of policy-makers, business and third sector actors were conducted in 2018, and complemented with analysis of policy programs and participatory observation. In the analysis, four partly competing, partly over-lapping policy narratives regarding WMC and socio-economic change were identified, including (1) a shift toward bioeconomy, (2) sustainable and low-carbon development, and (3) (forest and wood) industry development. The preferred policy solutions varied from bottom-up to top-down approaches, whereas the forth narrative was generally critical about the agenda to promote wood in construction, seeing it as "unsustainable". The results highlight the diversity of actors and interests involved in the policy debates at the nexus of bioeconomy and sustainable development. The findings indicate need for well-coordinated efforts to effectively support the growth of WMC.

\section{A plantation boom and structural change: the impact of the Indonesian palm oil expansion on manufacturing firm TFP}

Nicolas Koch ${ }^{1}$, Sebastian Kraus ${ }^{1}$, Sabine Fuss ${ }^{1}$

${ }^{1}$ MCC,Berlin, Germany (koch@mcc-berlin.net; kraus@mcc-berlin.net; fuss@mcc-berlin.net)

For many tropical countries, the prospect of advancing a bio-economy has been attractive from the perspective of economic development. Brazil's bio-economy is already thriving and Indonesia has experienced a palm oil boom that has turned it into the biggest producer of the commodity. However, while the palm oil expansion has reduced poverty, it has also led to deforestation, so it stands to question whether this is a sustainable way forward. This paper investigates whether the palm oil boom has also created positive spillovers on the industrial sector empirically. We combine digitized archive data on district-level oil palm area and 
remote-sensed and crowdsourced maps on palm oil plantations with all available waves of the Indonesian manufacturing census in an instrumented long-difference and difference-in-differences design to estimate local firm-level Total Factor Productivity. A land suitability instrument is derived from a global spatially explicit model on crop-specific soil and climatic conditions.

\section{Beyond bioproducts production: enhancing bioeconomic value from forests}

Karen Bayne ${ }^{1}$, Robert Radics ${ }^{1}$, Carel Bezuidenhout ${ }^{2}$, Peter Edwards ${ }^{3}$

${ }^{1}$ Scion, Christchurch, New Zealand; ${ }^{2}$ Toi Ohomai, Tauranga, New Zealand; ${ }^{3}$ Scion, Wellington, New Zealand (karen.bayne@scionresearch.com; robert.radics@scionresearch.com; carel.bezuidenhout@toiohomai.ac.nz; edwardsp@landcareresearch.co.nz)

Increased recognition of the need to reduce dependence on non-renewables has seen a renewed interest in bio-based products and their markets. Globally, New Zealand has a strength in natural biological resources, particularly in agriculture, and forestry, and more latterly, growth in horticulture and marine production. Despite this strong resource base and supporting infrastructure, New Zealand remains largely in pathway 'lock-in' around intensive production, low-value production and an innovation system that supports the existing food and fibre-based sectors. Allowing niches to break into the mainstream through infrastructural and institutional remodelling remains challenging. New Zealand forest business is somewhat restricted from taking full advantage of the innovative opportunities due to difficulty in attracting finance, and a lack of government policy. Drivers for change in the traditional forestry products model, or even in enhanced wood production, is largely economic. To fully embrace the opportunities provided by a 'newer' bioeconomic model, New Zealand will need a different model of diversification, innovation, and marketing, rather than reliance only on enhanced technology, and refinement of current processing pathways. We examine the drivers for enhancing the 'new' bioeconomy in New Zealand, both at the niche and regime levels, and provide examples and evidence for mechanisms to build additional value through leveraging forest-based products’ services, bi-products, credence attributes and brand story.

\section{Enabling a sustainable bioeconomy through wood value chains}

Pierre Bouillon ${ }^{1}$, Thais Linhares Juvenal ${ }^{1}$, Anastasiia Kraskovska ${ }^{1}$

${ }^{1}$ FAO, Roma, Italy (pierre.bouillon@fao.org; thais.linharesjuvenal@fao.org; anastasiia.kraskovska@fao.org)

Food, agriculture, wood-based industries and forestry are the biggest components of bioeconomy. A first assessment by the European Union (EU/JRC) in 2016 showed that EU bioeconomyrepresented 4\% of EU value-added. While representing only 0,8\% of value added to total economy, the wood-based industries and forestry represented $19 \%$ of EU bioeconomyand $15 \%$ of EU bioeconomyjobs. Based on global evidence, this article will : i) lay down the current status of wood value chains contributions to the bioeconomy, from the forest to the mills and end markets, establishing the link with the Sustainable Development Goals and climate change objectives; ii) discuss their high suitability to circularity and cascading; iii) assess the barriers and opportunities for enhancing wood value chains' contributions to sustainable bioeconomy; and iv) outline some policy recommendations to enhance such contributions.

\section{Existing National C\&I Systems used for monitoring of forest-based bioeconomy related SDGs in selected Countries}

Markus Lier ${ }^{1}$, Stefanie Linser ${ }^{2}$

${ }^{1}$ Natural Resources Institute Finland, Joensuu, Finland; ${ }^{2}$ EFI Forest Policy Network and University of Natural Resources and Life Sciences, Vienna (BOKU), Vienna,Austria (markus.lier@luke.fi; stefanie.linser@efi.int)

A circular and sustainable bioeconomy is the pathway to achieve the UN Sustainable Development Goals (SDGs) by 2030. The forest-based bioeconomy contributes particularly to a number of SDGs. Our interest is focusing on how these SDGs are taken into account in the formulation of a national bioeconomy strategy and how the indicator-based progress monitoring could be improved. Our study focuses on 10 countries which have already elaborated national bioecomony indicator sets within their bioeconomy strategies. As these countries are from all over the world, the sets have different country-specific-socioeconomic, ecologic and cultural settings. We analyse if and how forest-based SDG targets are taken into account in the formulation of the national bioeconomy strategy, and compare and analyse the different national indicators used to monitor the progress of forest-related SDGs and of the bioeconomy. Our material and methods are based on literature study, qualitative analysis and a questionnaire sent to the ministries responsible for national bioeconomy strategies. Against this background, we compare if the different national bioeconomy indicators used are similar to the respective intergovernmental forest-related regional or international C\&I for SFM sets and derive recommendations for the further development of the national SFM and bioeconomy indicators.

\section{Measuring the value of forests in a green economy}

Alicja Kacprzak

${ }^{1}$ UNECE/FAO Forestry and Timber Section, Genève, Switzerland (alicja.kacprzak@un.org)

Forests are of essential importance in the transition to a green economy and to the implementation of the 2030 Agenda for Sustainable Development. However, assigning a value to forests as natural capital and the environmental and social services provided by forests, which could help assess the role of forests in this transition, remains a major challenge. This paper presents green economy related definitions and concepts, as well as internationally developed assessment methods for measuring the progress in transition to a green economy, green growth and sustainable development as well as natural capital and ecosystem services valuation methodologies. It also takes stock of assessment systems, including criteria and indicators, developed by the forest sector to measure sustainable forest management (SFM). Itanalyses the complementarity of present forest sector valuation systems with approaches developed by other sectors in the context of the green economy. The paper explores alignment of forest sector measuring approaches of SFM to those being used in wider economy contexts and explains how they could be adapted to measure progress of the forest sector towards a green economy. Building on the Rovaniemi Action Plan for the Forest sector in a Green Economy, it proposes a new specific approach on how the forest sector's contribution to a green economy could be measured. Among others, the following approaches have been taken into account in the analysis: OECD Green Growth Indicators, UNEP Green Economy Progress Index, natural capital accounting approaches and Sustainable Forest Management Criteria and Indicators (Forest Europe and Montréal Process). 


\section{Corporates-communites economic relations: creating a dialogue between indigenous people and the forest industry in Canada}

Helin Dura ${ }^{1}$, Jean-Michel Beaudoin ${ }^{1}$, Thierry Rodon ${ }^{1}$

${ }^{1}$ UniversitéLaval,Québec, Canada (helin-subhi.dura.1@ulaval.ca; jean-michel.beaudoin@sbf.ulaval.ca; thierry.rodon@pol.ulaval.ca)

Creating a fair share of the benefits from forest-based development between the industry and the Indigenous communities is an important concern in Canada and many other countries. This can be done by building Corporate-Community economic relations (CCER). A strategy based on corporate-community economic relations has several advantages: socio-economic improvement, fairer participation in benefit sharing, availability of workforce while simultaneously reducing operating costs. Yet, CCER face a range of challenges: unfair power sharing, difference between the partners' visions, and communications gap between what the community needs and what the industry wants. However, available information on this topic is scarce and outdated. We use a qualitative approach and a comparative case study method to address the following question: How to design a Corporate-Community economic relations model between Indigenous communities and the forest industry to better address and target the needs and goals of both parties? We identified a based model that take into account decisionmaking and management processes that fit Indigenous culture and expectations, strategies for recruiting and retaining Indigenous employees and adaptive learning approaches where partnership members share a common understanding and engage in the cocreation of knowledge and practices. Our study provide information to develop better-adapted interventions to help Indigenous communities and the forest industry to work together more effectively in improving the quality and reliability of their mutual relations.

\section{Challenges to environmental management in indigenous lands / Desafios à gestão ambiental em terras indigenas}

Elke Costanti ${ }^{1}$, Jorge Nogueira ${ }^{1}$, Cloude de Souza Correia ${ }^{2}$

${ }^{1}$ UnB, Brasilia, Brasil; '2Instituto Internacional de Educaçãodo Brasil,Brasilia, Brasil (e.costanti@terra.com.br; jmn0702@unb.br; cloude@iieb.org.br)

O papel fundamental dos povos indígenas em gerir e preservas as florestas tem sido reconhecido em estudos recentes que mostram a relação positiva entre a regularização de terras indígenas e o menor desmatamento na floresta Amazônica brasileira. Atualmente, há cerca de 1.180 .000 km² de terras indígenas estabelecidas no Brasil, equivalentes a 14\% do território nacional, e 24\% da região Amazônica brasileira. Realizar uma eficiente gestão ambiental e territorial dessas terras é fundamental para o desenvolvimento sustentável do País. A Política Nacional de Gestão Ambiental e Territorial (PNGATI), lançada em junho de 2012, estabeleceu os planos de gestão ambiental e territorial como a principal ferramenta de gestão das terras indígenas. Essa política inclui ainda a questão do uso sustentável, do monitoramento e proteção, e das alternativas econômicas de desenvolvimento para os povos indígenas. O artigo irá mostrar experiências exitosas de gestão territorial e de produção sustentável das terras indígenas, bem como os principais desafios e obstáculos para a comercialização e valorização de seus produtos. Ademais, mostrará uma análise custo-benefício econômica e social que aponta serem os custos de proteção ambiental muito menores do que os custos de recuperação. Mostra também que os benefícios para a sociedade como um todo derivados dos serviços ecossistêmicos são maiores do que os advindos da exploração de seus recursos naturais "business-as-usual”, opção que leva a benefícios privados mas, apesar do efeito distributivo dos tributos para a sociedade, consome capital natural, com diminuição do bem-estar futuro.

\section{Forest land for oil palm plantations? A case about indigenous peoples in Northeast India}

Purabi Bose ${ }^{1}$

${ }^{1}$ Landing Together, Mumbai, India (purabibose@gmail.com)

Mizoram state of Northeast India is referred to as 'Bamboo Queen' for its largest bamboo forest. It is becoming famous for country's first commercial oil palm plantations. The state's $90 \%$ of the population are diverse ethnic minority tribes otherwise identified as indigenous peoples, traditionally practicing or shifting cultivation. In 2011, Mizoram implemented New Land Use Policy (NLUP) to formalize forestland titles that has been till date decentralized and managed by traditional laws. How the centralized NLUP brings change by replacing shifting cultivation in customary forest through settled farming is examined here. The paper analyzes the NLUP using empirical data collected from focus group discussions and interviews of diverse stakeholders, including indigenous peoples of two districts: Kolasib, and Lai Autonomous District Council of Lawngtlai. The study result indicates even after the NLUP the bamboo forests are allocated for shifting cultivation. These abandoned forestlands are then promoted by the Agriculture Department for palm oil plantations. Gender dynamics is observed wherein women's roles become 'submissive' in settled cultivation of oil palm as compared to their contribution in shifting cultivation. Private palm oil companies do not collect fruits from farmers living away from motorable roads, which pushes men to do daily-wage labour work, and women to do artisanal palm oil extraction at home. The key recommendations for implementing the NLUP are (a) introduce the RSPO sustainable certificate, (b) acknowledges indigenous system of land-use for conservation and gender equity, and (c) prioritizing household land titling as well community land tenure.

\section{Combining environmental policy with indigenous rights and knowledge: a practical perspective to forest conservation in Acre, Brazil}

Ane Schjolden ${ }^{1}$

${ }^{1}$ Rainforest Foundation Norway, Oslo, Norway (ane@rainforest.no)

The Brazilian state of Acre has collaborated with local communities to find workable forest management strategies, with an aim to safeguard the Amazon rainforest's ecosystem services and simultaneously secure forest peoples' rights and livelihoods. This resulted in various "florestania" policies, shaped by and adapted to the history, culture and identity of the different local and indigenous communities involved. To assess how the interaction between policy and practice has influenced the situation for forest dependent peoples, Rainforest Foundation Norway undertook case studies with interviews on experiences and management strategies in two different indigenous territories, that of the Ashaninka of the Amônia river and the Huni Kuin territory Colônia 27. In both cases, the recognition of territorial rights over a fixed area has been essential for the investment in both environmental qualities and the improvement of livelihoods. Further, the usefulness of government policies really depends on the continuous participation and involvement of the local communities. Letting traditional knowledge and culture form the basis for e.g. management plans, has increased identity, pride and sense of community, and spurred an increased interest in the passing on of traditional culture. Food security has been improved both by changing management practices and by supporting the advantageous participation in local and regional markets. While many of the policies have rendered success, there is need for greater coordination between the different policy instruments and better law enforcement, particularly to improve the security situation in this border region with Peru, plagued by illegal logging and drug trafficking. 
Forest governance and indigenous peoples: the case of prior consultation of forest policy in Peru

Cristina Miranda ${ }^{1}$

${ }^{1}$ PUCP, Lima, Peru (cristinamirandabeas@gmail.com)

In Latin America, a region that is half tropical forests, has a third of freshwater reserves, the quarter of the world's potentially arable land, and indigenous peoples who represent $8 \%$ of the South American population, social changes are intimately related to the governance processes of natural resources. In 2015, 185 people died from extractive conflicts in the world, two-thirds were Latin American and about half were indigenous. From this perspective, this research analyzes the political and technical changes that characterized the process of a Peruvian forest policy that was submitted to prior consultation of indigenous peoples during the years 2014 and 2015, this happened as a result of one of the most serious socio-environmental conflicts in the country in Peru, "Baguazo", which caused the death of 33 people. Indigenous peoples occupy almost 30\% of the extension of Peruvian forests that represent $56 \%$ of the territory. The indigenous demanded the right to use the forest resources and their territorial rights, therefore the Peruvian State was forced to establish spaces for dialogue and agreement. This process generated structural changes in the governance of natural resources that in this research is called Relational Capacity, composed of four elements: relationship and articulation of actors, formal and informal rules of the game, provision of human and financial resources and leadership. The consensus reached between public and private actors, as well as the development of the relational capacity, generated changes in the decision making on forest resources and the design of policies on Peruvian forests.

Social and environmental governance in extractive reserves: a strategy for collective management of conservation units in the Amazon region / Governança socioambiental em reservas extrativistas: uma estratégia para a gestão coletiva de unidades de conservação na Amazônia

Ana Carolina Vieira ${ }^{1}$, Ana Luiza Violato Espada ${ }^{1,2}$ (D) Elias Serejo ${ }^{1}$

${ }^{1}$ Instituto Floresta Tropical, Belém, Brasil; 2University of Florida, Gainesville,USA (carolina@ift.org.br; violatoespada@ufl.edu; elias@ift.org.br)

Com a implementação das Unidades de Conservação de Uso Sustentável, criadas para conciliar a conservação da natureza ao uso sustentável dos recursos naturais por populações que tradicionalmente residem nesses territórios, houve uma mudança no paradigma da natureza intocada. A partir de então, a gestão seria compartilhada e, governo, comunidades locais e sociedade civil organizada passaram a dividir direitos e responsabilidades sobre o uso do território e recursos naturais associados. A gestão compartilhada é um reconhecimento político do protagonismo social na conservação da biodiversidade, e para isso é necessário um olhar que integre indicadores sociais vinculados às estratégias de uso e conservação da natureza. Desde 2012, o Instituto Floresta Tropical (IFT) tem atuado com o fomento ao manejo florestal comunitário em seis reservas extrativistas da Amazônia. Na perspectiva de gerar indicadores sociais e operacionais para a governança socioambiental nesses territórios, o IFT tem monitorado, por meio de observação participante e entrevistas individuais, como as comunidades e seus parceiros têm atuado de forma coletiva, considerando a ação colaborativa para a conservação e melhoria da qualidade de vida. A participação de diferentes atores dos três setores: órgãos públicos, empresas privadas e organizações da sociedade civil é chave para que se estabeleçam relações que promovam: a criação de um ambiente de parceria interinstitucional capaz de definir acordos, negociar interesses e definir estratégias; o diálogo constante entre os parceiros; a transparência de informações e interesses entre os parceiros; a construção coletiva das estratégias; um ambiente favorável à resolução de conflitos e flexibilização de interesses.

\section{Respect, on whose terms? Collaborating with Asheninka and Yine Peoples in the Peruvian Amazon \\ Andrea M Vásquez Fernández ${ }^{1,2,3}$, María Shuñaqui Sangama ${ }^{4}$, Raúl Sebastián Lizardo ${ }^{5}$, Miriam Pérez Pinedo ${ }^{6}$ \\ ${ }^{1}$ UBC, Vancouver, Canada; ${ }^{2}$ PUCP, Lima, Peru; ${ }^{3}$ Unión Regional de los Pueblos Indigenas de la Amazonía de la Provincia de Atalaya, Atalaya, Peru; \\ ${ }^{4}$ Asheninka, Atalaya, Peru; ${ }^{5}$ Yine, Atalaya, Peru; ${ }^{6}$ Federación de Mujeres Indígenas de la Provincia de Atalaya, Atalaya, Peru \\ (ecomundo.andrea@gmail.com)}

Amazonian Indigenous Peoples have said they are disrespected. Their accounts of exploitation and violent dispossession of their territories at the hands of outsiders include the rubber boom in the $19^{\text {th }}$ century and current contexts in which oil, gas, minerals, and timber exploitations occur. In these contexts, the rhetoric of "development" is used to push the agendas and values of the outsider proponents of resource exploitation practices over the Indigenous Peoples' own desired futures. National and international policies encourage "mutual respect" as the most important practice to have a peaceful coexistence in culturally diverse scenarios. However, can this respect really be "mutual" if Amazonian Indigenous sets of subjectivities, sensitivities, and practices of what they translate from their own languages into the colonial/imperial language as "respect" are either not known and/or neglected by outsiders' praxis? German philosopher Immanuel Kant continues to be the main reference for definitions of respect in the world. Asheninka and Yine Peoples argue that their conceptions and practices of "respect" exceed those articulated in hegemonic spheres. How do Asheninka and Yine perspectives of "respect" inform and transform hegemonic conceptions and practices of "mutual respect" when the latter is heavily based on euro-western perspectives of respect? The purpose of our research is to build from Asheninka and Yine perspectives an "intercultural respect" model instead of "mutual respect" with the Peruvian central government in the context of industrial "natural resource" extraction. This project was initiated at the invitation of Indigenous community members, and uses decolonizing and Indigenous approaches.

\section{Building trust during collaborative natural resource governance}

Ngaio Hotte ${ }^{1}$, Stephen Wyatt ${ }^{2}$, Robert Kozak ${ }^{1}$

${ }^{1}$ University of British Columbia, Vancouver, Canada; ${ }^{2}$ Université de Moncton, Edmundston, Canada (ngaio.hotte@alumni.ubc.ca; stephen.wyatt@umoncton.ca; rob.kozak@ubc.ca)

In Canada, an estimated 490 bilateral and trilateral agreements have been established between Indigenous organizations and governments and provinces regarding lands, resources and economic development. This reflects a broader global trend toward implementation of collaborative natural resource governance to resolve conflicts, generate social and ecological benefits and increase implementation of decisions. Several studies have identified the importance of trust in the context of collaborative natural resource governance. Lack of trust between collaborators, and the absence of processes for building trust, are barriers to collaboration and natural resource governance outcomes, including those related to sustainable development. Insights into how trust is created during collaborative natural resource governance have the potential to improve processes and outcomes. This research tested a theoretical framework for building trust in the context of collaborative natural resource governance in Canada using a survey of representatives from Indigenous, federal and provincial governments. The theoretical framework focused on three types of influences on trust that are identified in the literature: individual 
influences, interpersonal influences and institutional influences. Institutional influences are further divided into institutional characteristics and trust in institutions. Research results identify the relative weight of each of these influences on collaborators' decisions to trust others, as well as the degree to which these variables interact and contribute to mutually beneficial solutions. Results of this research can be used to inform the establishment of collaborative governance protocols based on trust that are more conducive to successful and sustainable outcomes.

Leveraging conflict and cooperation: indigenous strategies to achieve both transformational and incremental change in governing Quebec's forest lands

Stephen Wyatt ${ }^{1}$, Martin Hébert ${ }^{2}$, Jean-Francois Fortier ${ }^{2}$

${ }^{1}$ Université de Mocton, Edmundston, Canada; ${ }^{2}$ UniversitéLaval, Quebec, Canada (stephen.wyatt@umoncton.ca; martin.hebert@ant.ulaval.ca;

jean-francois.fortier.1@ulaval.ca)

First Nations in Quebec, Canada, like most Indigenous peoples elsewhere around the world, find themselves on the margins of governance arrangements for forests on their traditional lands. While Indigenous rights are increasingly recognized, Indigenous peoples typically face considerable barriers in transforming these rights into meaningful governance arrangements, improved access to forestlands, and an equitable share of the economic benefits of forestry. Governments and the private sector are proposing collaborative mechanisms to incrementally develop forestry opportunities for Indigenous peoples, but some groups consider that such proposals remain insufficient. This disconnect creates situations in which conflict or opposition come to be seen as necessary means to achieve significant transformational change. This study presents a longitudinal analysis of the experiences of the Atikamekw Nehirowisiwok, Huron-Wendat and Mi'gmaq nations in Quebec, Canada over more than thirty years. Examining the numerous and diverse processes used by each nation to expand their engagement in forestland management, we sought to determine if these represented a broader strategy. All three nations made use of both conflictual processes (road blockades and legal actions) and collaborative arrangements (round tables, consultations, business partnerships, etc.), sometimes sequentially, but also simultaneously. Considering the history of different processes and the connections between these, we conclude that each nation has develop a distinct strategy to use different opportunities to change an existing situation, and then to build upon this change through collaboration with other actors. Accordingly, First Nations should be seen as strategic actors who seek to enhance their roles in forest management.

A6m: WOMEN AND FORESTS: PROMOTING GENDER EQUALITY CONNECTING RESEARCH, PUBLIC POLICIES AND FOREST MANAGEMENT IN THE TROPICS

The challenges of female extractivist leadership in constructing public policies for community forest management in the Amazon / $O s$ desafios de uma liderança feminina extrativista na construção de políticas públicas para o manejo florestal comunitário na Amazônia

Maria Margarida da Silva

${ }^{1}$ Cooperativa Mista do Rio Arimum, Porto de Moz, Brasil (margarida.florestal@gmail.com)

A história do manejo florestal comunitário na Amazônia brasileira é uma história de luta pelo direito a terra, pelo reconhecimento dos territórios de uso comum, e por políticas de promoção do uso dos recursos naturais. Há 30 anos Chico Mendes, um dos principais líderes do movimento extrativista, foi assassinado por defender a floresta e os direitos das populações tradicionais. Desde então, 27 milhões de hectares de florestas comunitárias foram destinadas em diferentes categorias (RESEX, PAE, RDS, PDS, PAF). A gestão destas áreas é compartilhada entre governo e organizações sociais. E é neste contexto que apresentamos a experiência e lições aprendidas de uma liderança feminina da Resex Verde para Sempre (Pará). Agroextrativista, mãe de três filhos, militante do movimento de mulheres, da juventude e sindical. Como Presidente da Associação Comunitária do Rio Arimum aprovou o $1^{\circ}$ plano de manejo florestal comunitário em Unidade de Conservação no Brasil. Teve atuação decisiva na proposição das políticas estadual e nacional de manejo florestal comunitário. Em 2014 participou da criação da Cooperativa Mista do rio Arimum que implementa sete planos de manejo florestal. Atualmente trabalha na formação de novas lideranças. Por suas realizações, em 2017 foi vencedora do Prêmio Wangari Maathai. Acredita que a mulher é capaz de fazer gestão florestal em todas as etapas desta cadeia produtiva, desde o inventário, exploração, romaneio, comercialização. Sendo o principal desafio promover o acesso a um modelo diferenciado de educação para os jovens extrativistas, desde o ensino básico ao superior, com foco no uso da floresta.

Women and forests: progress and challenges in recognizing the role of women in forest governance in the Amazon region / Mulheres $e$ floresta: avanços e desafios para o reconhecimento do papel das mulheres na governança florestal na Amazônia

Ana Luiza Violato Espada ${ }^{1,2}$ (D); Ana Carolina Vieira ${ }^{2}$

${ }^{1}$ University of Florida, Gainesville, USA; ${ }^{2}$ Instituto Floresta Tropical, Belém, Brasil (violatoespada@ufl.edu; carolina@ift.org.br)

São nos ambientes rurais que as desigualdades de gênero ficam ainda mais evidentes nas relações familiares e comunitárias. Por exemplo, o manejo florestal foi, por muitos anos, visto como uma atividade masculina e machista, tanto entre produtores florestais familiares, como profissionais da engenharia florestal. Esse cenário vem mudando, comunidades tradicionais e seus parceiros estão se empenhando para estimular o envolvimento das mulheres na tomada de decisão referentes às melhorias das cadeias de valor de produtos florestais. Desde 2012, o Instituto Floresta Tropical (IFT) tem atuado com o fomento ao manejo florestal comunitário em seis reservas extrativistas da Amazônia. Na perspectiva de aumentar a participação das mulheres, o IFT tem monitorado, por meio de observação participante e entrevistas individuais, como as comunidades estão incorporando conceitos de participação de gênero nas atividades produtivas locais. Participação assume, pelo menos, três dimensões: acesso à informação e preparação em pé de igualdade para a tomada de decisão que reflete na vida da família e da comunidade; direito de ser ouvida nos encontros e momentos chave de tomada de decisão; boa vontade dos demais participantes em ouvir, discutir e deliberar as e alternativas propostas pelas mulheres. As funções executadas pelas mulheres refletem diretamente na qualidade e entrega da produção ao comprador. As mulheres estão envolvidas desde a preparação para a colheita ao beneficiamento dos produtos florestais. Mas é preciso se esforçar ainda mais. É evidente que a mulher tem papel importante nas atividades produtivas, mas é o homem que ainda aparece como o protagonista. 
Model forests: regions in search for equity and gender equality / Bosques Modelo: territorios en búsqueda de la equidad e igualdad de género

Maria Ximena Campos Bustos ${ }^{1}$, Fernando Carrera², Richard Verbisky ${ }^{3}$

${ }^{1}$ Red Latinoamericana de Bosques Modelo, Jamundí, Colombia; ${ }^{2}$ Centro Agronómico Tropical de Investigación y Enseñanza, Turrialba, Costa Rica; ${ }^{3}$ Servicio ForestalCanadiense,Ottawa,Canada(maria.campos@catie.ac.cr; fcarrera@catie.ac.cr; richard.verbisky@canada.ca)

La Red Latinoamericana de Bosques Modelo (RLABM) promueve un modelo de gestión territorial que se centra en las alianzas de las personas con una visión común hacia el desarrollo sostenible, sin embargo, se ha identificado que en los principios y en los criterios de evaluación de un Bosque Modelo no se plantea claramente la equidad e igualdad de género, siendo éste un eje transversal necesario para lograr realmente el desarrollo sostenible. Por lo anterior, la gerencia de la RLABM, abordó la elaboración de una propuesta de estrategia de equidad e igualdad de género adaptada al contexto de los Bosques Modelo. La propuesta fue elaborada bajo una metodología participativa que involucró al equipo gerencial de la RLABM, a organizaciones y personas aliadas y a representantes de los Bosques Modelo. La propuesta se validó de manera presencial en el Bosque Modelo de Pichanaki y se presentó en la reunión anual del 2017 del directorio de la RLABM. Se espera que la estrategia desarrollada contribuya a institucionalizar o transversalizar el enfoque de género en la RLABM y en cada uno de los Bosques Modelo, con el propósito de examinar las implicaciones de las acciones emprendidas para los hombres y mujeres, y hacer que todas las necesidades, intereses y experiencias de mujeres y hombres sean parte integral del diseño, ejecución, monitoreo y evaluación de políticas, programas y proyectos.

\section{The perception of female forest engineering students about gender devaluation in the profession}

Ana Caroline Oliveira da Silva ${ }^{1}$ (D) Andressa Ribeiro ${ }^{1}$

${ }^{1}$ Universidade Federal do Piauí, Bom Jesus, Brasil (anacarol.ctbj@gmail.com; andressa.florestal@ufpi.edu.br)

The struggle for gender equality has intensified in recent decades, highlighting the academic, science and technology fields. Historically these areas have been predominantly occupied by men, but the number of women in courses such as engineering have increased in the past years. The objective of this work was to evaluate the perception of female students of the forestry engineering course of the Federal University of Piauí about gender devaluation in the profession. For this a survey with 12 questions was answered by 35 students. The course has a total of 254 students, being $41 \%$ women. The results showed that $65.7 \%$ have been discouraged by someone to become a forester, $54.3 \%$ felt devalued regarding to the profession by colleagues and/or professors and $48.6 \%$ witnessed one of these situations with other women. A total of $51.4 \%$ felt less capable than their male counterparts, being the feeling of insecurity, sense of devaluation, constant criticism and manual labor regarded as work for men the principal reasons cited; $17.1 \%$ of the students believe that this devaluation occurs equally in other institutions, while $14.3 \%$ believe that it manifests with more force locally. To change this scenario, the suggestion of engagement of women in groups to discuss their role in the space they are occupying, by discussion circles for example, are fundamental to break this paradigm.

\section{The presence of women in the Brazilian forestry sector / A presença das mulheres no setor florestal brasileiro \\ Fernanda Rodrigues ${ }^{1}$, Maria Harumi Yoshioka ${ }^{1}$, Patricia Nazario ${ }^{1}$, Vitor Afonso Hoeflich ${ }^{2}$ (D) \\ ${ }^{1}$ Rede Mulher Florestal, Curitiba, Brasil; ${ }^{2}$ Universidade Federal do Paraná, Curitiba, Brasil (fe.rodrigues.1412@gmail.com; mhyoshioka@gmail.com; pattyinpa78@gmail.com; vitor.ufpr@gmail.com)}

O setor florestal brasileiro tem grande relevância para a economia nacional. Em 2017, contribuiu com cerca de 6\% do PIB e foi responsável por 91\% de toda a madeira produzida para fins industriais. As mulheres já são a maior parte da população brasileira representando $51 \%$ desta conforme demonstrado no último censo em 2010, todavia o País não tem estatísticas precisas sobre a participação das mulheres no setor florestal. De acordo com a Organização Internacional do Trabalho os últimos vinte anos foram positivos para a situação das mulheres no mundo do trabalho e da igualdade de gênero na sociedade. O levantamento deste estudo abrangeu formados do curso de Engenharia Florestal da Universidade Federal do Paraná entre 1964 e 2016 apresentando que nos primeiros anos da criação deste curso no Brasil, praticamente homens se formaram engenheiros. Esta realidade vem gradualmente se modificando. Apenas em 2004 houve um número maior de mulheres do que homens formados(as) na UFPR neste curso. Em 2017, dentre as pessoas empregadas na área florestal no Brasil considerando o setor de plantações e florestas nativas das empresas certificadas pelo FSC, as mulheres representavam em média $8 \%$. Apesar de existir uma tendência apresentada pela maior participação no número de mulheres formadas em engenharia florestal, no campo as mulheres ainda têm baixa representatividade na força de trabalho. Espera-se que, a partir da implementação da Agenda 2030 da ONU no setor florestal, se alcance o ODS 5 quer almeja alcançar a igualdade de gênero e empoderar todas as meninas e mulheres.

Building partnerships and strengthening social capital in community forest management: the case of the Tapajós National forest in the Amazon region of Brazil / Construindo parcerias e fortalecendo capital social no manejo florestal comunitário: o caso da Flona do Tapajós, Amazônia

Ana Luiza Violato Espada ${ }^{1,2,3}$ (D; Mário Vasconcellos Sobrinho

${ }^{1}$ University of Florida, Gainesville, USA; ${ }^{2}$ Instituto Floresta Tropical Belém Brasil; ${ }^{3}$ Universidade Federal do Pará, Belém, Brasil (violatoespada@ufl.edu; mariovasc@ufpa.br)

Parceria pode ser importante estratégia para a implementação e o aprimoramento de atividades produtivas sustentáveis em florestas públicas da Amazônia. Em Unidades de Conservação de Uso Sustentável, o manejo florestal comunitário é prática que pode gerar benefícios socioeconômicos, tais como trabalho e renda, além de promover a conservação ambiental. O objetivo do artigo é compreender como as parcerias, enquanto instrumento da governança ambiental, podem contribuir para a promoção de atividades sustentáveis e para o desenvolvimento local. Os conceitos teóricos que fundamentam a discussão são da governança ambiental e capital social, ao considerá-los processos construtivos que envolvem diferentes atores atuando de forma sinérgica para a promoção da melhoria da qualidade de vida e uso sustentável dos recursos naturais. Estudou-se o caso de uma cooperativa comunitária que executa manejo florestal na Floresta Nacional do Tapajós, oeste paraense. Os resultados revelam que o manejo florestal comunitário nessa floresta pública foi implementado e aprimorado a partir de uma rede de parceiros envolvendo comunidades tradicionais, governo, sociedade civil organizada e setor privado. Essa rede de parceiros contribui para a formatação da gestão coletiva dos recursos florestais, a qual se mostra eficiente e qualificada, ao permitir a geração de trabalho, renda e aperfeiçoamento técnico e profissionalizante dos moradores da floresta. Atualmente, o modelo de gestão do manejo florestal na Floresta Nacional do Tapajós é referência nacional e internacional, sendo fruto da atuação de diversos parceiros que promovem, cada um com sua expertise, as bases para o desenvolvimento local e sustentável do oeste do Pará, Amazônia. 


\section{The more the merrier? The perspectives of female college student leaders on gender aspects in the forest sector}

Pipiet Larasatie ${ }^{1,2}$, Taylor Barnett ${ }^{1}$, Eric Hansen ${ }^{1}$

${ }^{1}$ Oregon State University, Corvallis, USA; ${ }^{2}$ PDP, Jakarta, Indonesia (larasatp@oregonstate.edu; barnettt@oregonstate.edu; eric.hansen@oregonstate.edu)

Continuous efforts to increase gender diversity result in some good news such as more women in education, paid employment, and top management positions. However, women still suffer greater economic exclusion with an average of 15-20 percent less earnings than men. This study utilizes interviews to explore the perspectives of female college student leaders on gender aspects in the forest sector. Our respondents are 28 female student leaders in the top four forestry universities in the world based on The Center for World University Rankings: Swedish University of Agricultural Sciences, Oregon State University, University of British Columbia, and University of Helsinki. The research questions are (1) What are perceptions of female college student leaders on the current situation with respect to gender diversity in forest sector education? (2) What motivates female students to enter forest sector education and industry? (3) In what ways do gender stereotypes and expectations influence the experiences of being a collegiate forest student organization leader? and (4) In what ways do female college student leaders think the forest sector education and industry could be made more attractive to young females?

\section{Forests for people}

Joyce Ofori Kwafo ${ }^{1}$

${ }^{1}$ Forestry Commission, Accra, Ghana (afuakwafo2000@yahoo.com)

Forests play an important role in the lives of people and how people can ensure their sustainable use. "Forests are for people and people are for forests". Forests are sources of income for people through the collection and sale of non-timber forest products (NTFPs), the Modified Taungya System (MTS), which is a system of intercropping foodstuff with trees until such a time that the trees form canopy, then the foodstuffs are harvested and the trees are allowed to grow. People get income from forests through the hunting and selling of "bushmeat". Timber sales on the local market and export markets and tourists visitations to wildlife protected areas and national parks for nature based - tourism, creates income for people. Community Resource Management Areas (CREMAs) concept where indigenous people are trained and engaged in forest management provides alternative sources of livelihoods to communities while improving their well - being. The National Forestry Development Plan birthed the Youth in Afforestation Programme which has engaged over 70,000 youth to plant trees on degraded forest areas.

The role of women in extraction pracaxi nut oil in the Limão do Curuá community of the Bailique Archipelago, Amapá in the Brazilian Amazon / O protagonismo feminino na exploração de óleo de Pracaxi da Comunidade do Limão do Curuá, Arquipélago do Bailique, Amapá, Amazônia, Brasil

Ana Cláudia Lira-Guedes ${ }^{1}$ iD : Ranielly Coutinho Barbosa ${ }^{2}$, Isabelly Ribeiro Guabiraba ${ }^{3}$, Ana Margarida Castro Euler ${ }^{1}$ iD

${ }^{1}$ Embrapa Amapá, Macapá, Brasil; ${ }^{2}$ Projeto Bem Diverso, Macapá, Brasil; ${ }^{3}$ Universidade do Estado do Amapá, Macapá, Brasil

(ana-lira.guedes@embrapa.br; raniellycb@gmail.com; isabellyguabiraba@gmail.com; ana.euler@embrapa.br)

Algumas atividades de uso da biodiversidade na Amazônia são culturalmente desenvolvidas por mulheres, como a extração artesanal de óleos de sementes florestais. Essa cultura está relacionada ao conhecimento tradicional sobre o uso de plantas medicinais, principalmente por parteiras e/ou benzedeiras. A comunidade do Limão do Curuá - Ilha que compõem o Arquipélago do Bailique, costa leste do Amapá - vem ganhando destaque, no Estado, nos últimos anos, devido à extração artesanal de óleo de sementes de pracaxi (Pentaclethra macroloba (Wild.) Kuntze), realizada por, aproximadamente, 70 mulheres. Esse óleo é um produto fitoterápico conhecido localmente por seu poder antiofídico e de cicatrização, e vem recebendo notoriedade nas indústrias de fármacos e cosméticos. As mulheres do Limão do Curuá, têm adaptado métodos para a extração do óleo, não cozinhando as sementes e usando um triturador e uma prensa artesanal de madeira. Com essas adaptações, as extratoras conseguem produzir grande quantidade de óleo (em média, meia tonelada em 2017 e uma tonelada em 2018 ), com boa qualidade (odor agradável). No entanto, ainda é necessária a adoção de boas práticas, desde a coleta até o envasamento do óleo, para aumentar a qualidade do produto. Também é urgente a organização dessas mulheres para que tenham maior alcance de mercado e poder de negociação. É notório que essa atividade tem potencial de crescimento e pode se consolidar, como um dos principais empreendedorismos femininos do Arquipélago do Bailique, potencializando a economia da biodiversidade da Amazônia.

Constructing an integrated approach to gender in a restoration project using agroforestry systems in Southeastern Pará, Brazil / Construção de abordagem integrada de gênero em projeto de restauração com sistemas agroflorestais no Sudeste do Pará

Thais Ferreira Maier ${ }^{1}$, Edenise Garcia ${ }^{1}$, Rodrigo Mauro Freire ${ }^{1}$

${ }^{1}$ The Nature Conservancy, Belem, Brasil (tferreira@tnc.org; egarcia@tnc.org; rfreire@tnc.org)

O Projeto Cacau Floresta, conduzido pela The Nature Conservancy, tem como objetivo a promoção da restauração de pastagens degradadas por meio de sistemas agroflorestais com base no cacau (Theobroma cacao) junto a pequenos agricultores, no sudeste do Pará. Atualmente, o projeto tem focado numa abordagem integrada de gênero para aumentar a eficiência das ações, a sustentabilidade e a equidade do mesmo. Iniciado em 2013, o projeto conta com 130 propriedades e tem atraído cada vez mais mulheres agricultoras, que demonstram aptidão e interesse por temas ligados à produção, segurança alimentar, gestão financeira da propriedade e beneficiamento de produtos agroflorestais. Em recentes oficinas sobre a gestão financeira da propriedade, as mulheres representaram $44 \%$ dos participantes. Outras oficinas sobre biodiversificação da produção, transição agroecológica e beneficiamento de produtos agroflorestais estão previstas. Também serão realizadas oficinas participativas para diagnóstico de oportunidades e desafios do maior protagonismo feminino, bem como coleta e análise de dados desagregados sobre esta temática. A desagregação constitui basicamente na separação de dados de mulheres e homens, tais como participantes do projeto, uso de mão de obra, participação em treinamentos, tipos de tarefa que executam, entre outros. Desta forma, é possível obter análises diferenciadas, com maior riqueza de informações em relação ao gênero e apoiar numa melhor gestão em termos de promoção da equidade de gênero. Trata-se de uma perspectiva pioneira para a restauração que tem por objetivo empoderar as mulheres e melhorar suas habilidades para gerenciar as propriedades rurais. 
Beekeeping and community honey production: a project to develop strategies for conservation of natural ecosystems in the Juan de Mena district of Paraguay through a comprehensive approach / Apicultura y meliponicultura comunitaria - Proyecto para el desarrollo de estrategias para la conservación de ecosistemas naturales en el Distrito de Juan de Mena, Paraguay a partir de un enfoque integral

Samara Lazarotto ${ }^{1}$, Carolina Blanca Alvarez Fretes², Carmen Monges ${ }^{2}$, Fabiana Maria Benitez Popoff ${ }^{2}$

${ }^{1}$ Universidade Federal de Santa Maria, Campus Frederico Westphalen, Frederico Westphalen, Brasil; ${ }^{2}$ Universidad Nacional de Asunción, Carrera de Ingienería Forestal, San Lorenzo, Paraguay(samara.fk@hotmail.com; alvarezfretes10@gmail.com; aracelymonges@gmail.com;

fabibenitez0927@gmail.com)

La polinización es uno de los procesos más importantes para la manutención de la biodiversidad de ecosistemas naturales terrestres y las abejas son una de las principales responsables de este proceso, ya que se encargan de la dispersión de polen. Las mismas visitan las flores en busca de néctar y polen que más tarde convertirán en miel, su principal alimento. Este proyecto busca instalar un modelo de producción orgánica de miel con abejas nativas y comerciales, y de esta manera promover la ecología integral con un enfoque ecosistémico. Por medio del empoderamiento de un grupo de mujeres, asentadas en una localidad rural del distrito de Juan de Mena, Paraguay. De manera a mejorar sus ingresos económicos y contribuir a la conservación de la biodiversidad de flora y fauna. La metodología a emplear para el desarrollo de este proyecto se dividirá en 3 etapas: $1^{\text {a }}$ Aplicación de herramientas de diagnóstico rural participativo con enfoque de género, que permita un intercambio horizontal de saberes con miras a que las mujeres se sienten aptas para discutir y construir su propia visión y capacitación; $2^{\text {a }}$ Realización de cursos y talleres sobre apicultura y meliponicultura; $3^{\text {a }}$. Desarrollo, gestión y puesta en marcha de una propuesta de empresa comunitaria de productos obtenidos de la apicultura y meliponicultura. Al final del proyecto esperamos que el grupo de mujeres se apropien y desarrollen de manera integral las actividades de producción y comercialización de miel con propósitos a la conservación de la biodiversidad de flora y fauna local.

Productive social inclusion of rural women through sustainable forest management of natural resources in the Amazon region / Inclusão sócio produtiva das mulheres rurais por meio do manejo florestal sustentável dos recursos naturais na Amazônia

Katiuscia Miranda ${ }^{1,2}$, Manuel Amaral Neto ${ }^{1}$, Marcos Silva ${ }^{1}$, Waldileia Amaral ${ }^{1}$

${ }^{1}$ Instituto Internacional de Educação do Brasil, Belém, Brasil; ${ }^{2}$ Instituto Federal de Educação, Ciência e Tecnologia do Pará, Campus Castanhal, Castanhal, Brasil(glaukat2001@gmail.com;manuel@iieb.org.br;marcos@iieb.org.br;walamaral2013@gmail.com)

A Amazônia brasileira se estende por uma área de aproximadamente cinco milhões de km², possuindo aproximadamente 63\% de sua extensão coberta por florestas nativas. A mesorregião do Marajó, localizada no estado do Pará, congrega parte deste potencial florestal com destaque para a região de Portel com uma área territorial de 25.384,960 km² e uma população de 57.205 habitantes.Em que pese sua importância estratégica para o desenvolvimento da região por conta de seu potencial social, produtivo e ambiental, o Território Marajoara vem sofrendo grande pressão por conta da exploração ilegal de madeira e pela desordem na exploração dos seus recursos naturais e a disputa pelo território. Buscando superar esses desafios, nos últimos anos, o município de Portel tem sido foco de ações governamentais e da sociedade civil com o objetivo de promover a produção sustentável, o qual tem se dado, principalmente pelo enfrentamento feito pelas comunidades extrativistas contra a exploração predatória da madeira e seus impactos sobre o meio ambiente e a vida das comunidades. Os resultados aqui apresentam a experiência de constituição de uma cozinha agroextrativista na comunidade de Santo Ezequiel Moreno, em Portel, onde ações solidárias e de inclusão sócio produtiva sustentável das famílias agroextrativistas são protagonizadas por um grupo de mulheres, que buscam estratégias para potencializar a diversidade da produção e o acesso à mercados mais justos e solidários. Atualmente, a cozinha agroextrativista fornece aproximadamente $80 \%$ da merenda escolar na comunidade com uma variedade grande de produtos da culinária regional, garantindo segurança e soberania alimentar à comunidade.

A6q: SOCIAL ASPECTS OF FORESTRY

\section{Impact of forest concessions on local jobs in Central Amazon}

Jime Rodrigues Ribeiro', Claudia Azevedo-Ramos ${ }^{1}$, Ricardo Bruno Nascimento dos Santos ${ }^{2}$

${ }^{1}$ Núcleo de Altos Estudos Amazônicos, Universidade Federal do Pará, Belém, Brasil; ' 2 Departmento de Economia, Universidade Federal do Pará, Belém,

Brasil(engenheirajime@gmail.com; claudia.azevedoramos@gmail.com; ricardobns@gmail.com)

In the humid tropics, forest concessions have become the main mechanism for accessing public forest resources. In Brazil, the forest concession was established in 2006 and had as one of its assumptions the generation of local jobs. In order to assess whether this impact has been effective around the first Brazilian forest concessions established in a National Forest in 2010, the municipality of Itapuã do Oeste in Rondônia state was used as a case study. The impact of the public policy on jobs was verified through the Synthetic Control technique between the period 2002-2015. The impact on forestry jobs start in 2014, four years after the beginning of forest operations. This fact may be related to the emergence of new concession areas in Rondônia, contractual changes through federal resolution and compliance with local workers' qualification requirements by concessionaires. Itapuã do Oeste benefited from an increase in forestry jobs by concentrating timber processing from local and neighboring forest concessions. It can be concluded that local development in the Amazon region may be benefited from forestry if the planning of forest concessions combines jobs in forest and industry. This would need the support of broader and integrated national and state policies than those under the responsibilities of the environmental agencies that manage the concessions today.

\section{Local initiatives for strengthening community forest management in Jigme Dorji National Park in Bhutan}

Kazuhiro Harada', Sonam Phuntsho², Om Katel ${ }^{2}$

${ }^{1}$ Graduate School of Bioagricultural Sciences, Nagoya University, Nagoya, Japan; ${ }^{2}$ College of Natural Resources, Royal University of Bhutan, Lobesa, Bhutan (harada@agr.nagoya-u.ac.jp; som ${ }^{\text {s09 }}$ inso@gmail.com; om@cnr.edu.bt)

Community forestry (CF) has been recent forest management trend in Bhutan. CF was firstly introduced in 1979 by National Royal Decree and became popular in 1990s. The purpose of CF is to put management initiative of state forests to local people, some parts of which used to be customarily managed. This study tries to investigate how local people have management initiatives of CF under the supports of national park authorities in Jigme Dorji National Park. The village which acquired CF prepared 10 year forest management plan under the guidance of the national park authority, and based on it, CF members in the village voluntarily managed forests. In the management plan, usage of all resources including building materials and fuelwoods was only allowed for village members and strictly managed to keep sustainability. In case of fuelwood, for example, members were permitted to cut one or two pieces of trees and take them from $\mathrm{CF}$ once a year. Members and park officers inspected the site together and checked the trees preferred by members, and then the officers stamped on the trees 
decided to cut. After the process, members paid royalties to the CF committee and cut down the trees within a certain period of time. Strict forest management by CF members and the park authority made it possible to prevent invasion of outsiders in CF as well as to achieve both forest conservation and local utilization in a good balance, realizing SDGs targets.

\section{Three perspectives to assess and foster sustainable wood: global, landscape, value chain}

Vincent Gitz ${ }^{1}$, Alexandre Meybeck ${ }^{2}$

${ }^{1}$ CIFOR, Bogor, Indonesia; ${ }^{2}$ CIFOR, Rome, Italy (v.gitz@cgiar.org; a.meybeck@cgiar.org)

Wood is, by definition, a sustainable material: it is renewable and biodegradable. It has, however, to be produced at least at the same rate as it is consumed, while accounting for competing demands on land, and for all environmental, economic and social potential benefits and trade-offs. This presentation aims to provide a framework for the sustainable development of wood production and consumption along three perspectives: global, landscape and value chain. From a global perspective, wood is to be considered as a renewable material to be compared to other materials. It invites to analyze its use to growth time ratio, how it can be recycled and its final use for energy production, with corresponding contributions to climate change mitigation through carbon sequestration and substitution to other materials. At landscape level, sustainable forest management calls for an integrated landscape approach, taking into account, along with wood production, all potential impacts on natural resources and human well-being, including remote effects. Value chains can enhance the sustainability of wood by improving resource efficiency, reducing waste, facilitating the use of less valued species and parts as well as recycling and final use for energy production. It is along value chains that are distributed economic and social benefits and that sustainable consumption and production can be linked. Such a framework is effective to assess the sustainability of wood in all its dimensions while facilitating the consideration of synergies and trade-offs in order to design appropriate institutions and policies to enhance bioeconomy and sustainable development.

\section{Fuels, food and forests: fathoming bioeconomy's 3 Fs}

Valny Giacomelli Sobrinho ${ }^{1}$ Eva Cudlinová ${ }^{2}$

${ }^{1}$ Universidade Federal de Santa Maria, Santa Maria, Brasil; ${ }^{2}$ University of South Bohemia, Ceské Budejovice, Czech Republic (giacomelliv@yahoo.com.br; evacu@ef.jcu.cz)

Within the strategy of substituting renewable energy inputs for fossil fuels to curb greenhouse gases, bioeconomy stands out as an option to reduce the harmful effects from these emissions. Bioeconomy from this perspective is seen as a sustainable solution for global problems, yet we suppose it cannot be considered as self-evidently sustainable. The emissions reduction effect will only take place if neither does biofuel production spread over forestland, thereby causing deforestation, nor does it displace food production to areas previously covered with forests. Bioeconomy, and particularly biofuel, production is related to food and forest outputs, where the relationship between biofuel development and tropical deforestation is a complex problem in terms of biodiversity and carbon sequestration. Although its 3F-grounded (fuels, food and forests) decarbonization thrust resembles the 3R-based (reduce, reuse and recycle) dematerialization one in waste management, the reduction of fossil fuels, the reuse and recycle of food and forest wastes claimed by the bioeconomy strategy stumble on two opposite stances. Biofuels are said to be grown on degraded agricultural and pastureland, not driving deforestation. But the practice of their expansion causing the threatening of standing forests, either directly, through land-grabbing and deforestation, or indirectly, by displacing farmland onto forestland. This paper seeks to estimate how strong the connection among deforestation, biofuel (sugarcane ethanol) and food production in Brazil is. Brazil case was chosen because of the institutional framework set down in the 1970s (e.g. Proalcool) for producing biofuels, which turned the country into the second world's largest producer.

\section{Impacts of earthquake on community forest and livelihoods: perspectives from the community forest user group members of Sindupalchok District, Nepal}

Sudha Adhikari ${ }^{1}$, Kazuhiro Harada ${ }^{1}$, Yumi Sakata ${ }^{1}$

${ }^{1}$ Nagoya University, Nagoya,Japan (adsudha21@gmail.com; harada@agr.nagoya-u.ac.jp; sakata.yumi@e.mbox.nagoya-u.ac.jp)

Community forests are the crucial component of farming systems and people's livelihood in rural middle-hills of Nepal, as they depend upon forest for fuelwood, fodder, and leaf litter for their daily needs. Almost two and half years have passed since the massive earthquake of April 2015 and the forest-dependent communities in hilly Nepal are still in the process of the recovery phase. The study aims to assess the community forest users group's perception on community forest products supply and local environmental condition as well as their livelihood capitals. In addition to open-ended interviews with 68 earthquake-affected households; extensive visits to the study area, key informants interviews and focus group discussions were carried out. The study showed that the community forest user group perception towards community forest products supply was decreased, the local environmental condition was degraded and livelihood capitals were negatively affected. Out-migration, inflow of remittance, manpower shortage and reduced dependency on forest were also observed leading to the risk of passive participation in community forestry. The recovery activities carried out by community forest user group members were based on traditional knowledge, skills and practices. Policies should thus be implemented to support livelihood options which are sustainable such as agriculture and livestock in rural hilly areas of Nepal with new technologies and access to productive resources. There is a need to strengthen local institutional policy and mechanism to provide the communities with knowledge, skills and practices for smoother and effective post-disaster recovery.

\section{Politics of transition in the New Zealand bioeconomy}

Peter Edwards ${ }^{1}$, Anita Wreford ${ }^{2}$, Karen Bayne ${ }^{3}$, Alan Renwick ${ }^{2}$

${ }^{1}$ Manaaki Whenua Landcare Research, Wellington, New Zealand; ${ }^{2}$ Lincoln University, Lincoln, New Zealand; ${ }^{3}$ Scion, Christchurch, New Zealand;

(edwardsp@landcareresearch.co.nz; anita.wreford@lincoln.ac.nz; karen.bayne@scionresearch.com; alan.renwick@lincoln.ac.nz)

New Zealand is currently struggling to transition/transform from an 'old' bioeconomy based on the provision of food and fibre to a 'new' bioeconomy. The underpinning economic and political foundations remain largely the same - using market forces to maintain or add value, increasing capital accumulation for businesses. Because the free-market foundations remain unchanged, the vision of the 'new' bioeconomy is not heavily or directly promoted or adopted by the government or overtly political forces, but are solidly entrenched in sectorally-based industry bodies. Without a coherent national strategy and a foundation maintaining capital accumulation, there is limited opportunity to link the bioeconomy to achieving the Sustainable Development Goals (SDGs) in New Zealand. The pervasive neoliberal philosophies are an indication of the political (and economic) forces at play in New Zealand with respect to the bioeconomy, and appear conflict with social and environmental targets in the SDGs. The potential turn to a bioeconomy through more intense utilisation of natural resources using biotech and other bioprocessing is not necessarily an answer to environmental and social sustainability issues. A central question we examine is what 
economic and political practices or changes are necessary to develop a nexus approach to the bioeconomy and SDG attainment? We examine the bioeconomy in New Zealand in the context of its underlying neoliberal economic and political environment, and potential conflict between changing land uses, and social and environmental outcomes in New Zealand.

\section{Tropical forests and people in the Asia-Pacific Region}

John Herbohn ${ }^{1}$, Jack Baynes ${ }^{1}$, Nestor Gregorio ${ }^{1}$, Liz Ota ${ }^{1}$, Kurt von Kleist ${ }^{1}$, Kanchana Wiset ${ }^{1}$

1'University of the Sunshine Coast, Sippy Downs, Qld, Australia(jherbohn@usc.edu.au; jbaynes@usc.edu.au; ngregori@usc.edu.au; lizmsota@gmail.com; kurtvk3@gmail.com; kanchana.wiset@gmail.com)

Despite the recent economic growth of countries in the Asia-Pacific region, poverty rates are still high in rural areas, especially in areas with dense forests (Sunderlin et al; 2008). The degradation and loss of these tropical forests are a threat to the more than 450 million people for whom forests are essential to their livelihoods (RECOFT, 2013). The Tropical Forests and People Research Centre (TFAP), of the University of the Sunshine Coast in Australia, undertakes research and development in south-east Asia and in the the Asia-Pacific Region. The purpose of this research is to ascertain how to establish, restore or manage forests while improving the lives and livelihoods of local communities. For instance, in Papua New Guinea, our focus has been to assist farmers to grow seedlings and establish woodlots for firewood and timber. These woodlots may also be used as a shade crop for cacao. Research into the sustainable harvesting of native forest is continuing. In the Philippines, a pilot watershed rehabilitation project with local communities has demonstrated how social preparation is critically important for engaging and motivating community members. This project has also identified several challenges for watershed rehabilitation and forest and landscape restoration, including: lack of institutional support, limited human capital, high vulnerability to natural disasters, high discount rates of rural people, among others. The poster brings a synthesis of major findings of over 18 years of forest-related research in the Asia-Pacific Region by TFAP members and the implications for practice.

\section{Gender and NTFPs: case study in Putao District, Kachin State of Myanmar}

\section{Ei Ei Swe Hlaing ${ }^{1}$, Zar Chi Hlaing ${ }^{1}$, Chan Nyein Kyaw ${ }^{1}$, Thaung Naing Oo ${ }^{1}$}

1Forest Department, Naypyitaw, Myanmar (eieiswehlaing@gmail.com; zarchihlaing08@gmail.com;channyeinkyaw.cnk1990@gmail.com; tnoo71@gmail.com)

This study examines gender differentials in collecting, processing and marketing of non-timber forest products (NTFPs) in Putao District which is a home to three major ethnic groups: Lisu, Shan and Yawan. The specific objectives are to identify the NTFPs extracted from natural forests and to assess the resource availability. Field-based quantitative and qualitative data collections were carried out in June, October and December 2018. Data were obtained from seasonal market survey, focus group discussions and face to face interview with 36 women and 50 men. Respondents were selected by using snowball sampling method. Participatory assessment of the identified NTFPs and scientific inventory of Rattan (15 circle shape sample plots of $78.5 \mathrm{~m}^{2}$ were randomly selected in the natural forests where women collect Rattan) were conducted to estimate the distribution area of resources. A total of (56) species of NTFPs used by the local people were documented including edible plant products (32 species) collected by men and women for food source; medicinal products (18 species) and non-edible plant products (6 species) collected and processed by men for livelihood. Study shows that NTFPs provide not only production function but also buffer function in times of scarcity of staple food and social function. It is found that unsustainable harvesting and insecure marketing were the major constraints for sustainable utilization of the products. We suggest supportive policy for secure marketing and sustainable management of NTFPs for income generation and livelihood improvement of forest-dependent communities.

\section{A6r: SOCIAL ASPECTS OF FORESTRY}

\section{The wood-resource-balance as monitoring tool to estimate wood-processing-residues in Brazil \\ Emilin Joma da Silva ${ }^{1}$ iD; Udo Mantau ${ }^{2}$ iD \\ ${ }^{1}$ University Hamburg, Hamburg, Germany; ${ }^{2} I N F R O$, Informationssysteme für Rohstoffe, Hamburg, Germany (emilin.joma.da.silva@uni-hamburg.de; udo.mantau@iufro.eu)}

Resource monitoring tools supports the development of public polices aiming the achievement of circular economy. The forestry sector integrates the bioeconomy, hence the recommendation to periodically monitor forest production and further wood consumption to assure its sustainability. The wood-resource-balance (WRB) developed by Mantau (2009) consist of a method to record information related to wood consumption. Furthermore, it takes into account the recycling potential of wood-processing-residues (WPR). According to the Brazilian Forest Service (SFB), in 2017 around 85\% of the wood consumption in Brazil had been supplied by planted forest. Therefore, the Brazilian WRB calculation consulted official statistics and carried out a primary survey exclusively related to planted forest round wood. The selected enterprises informed besides wood production and consumption, the amount and type of occurred residues. The potential WPR volume was estimated to be greater than 70.0 million cubic meter of round wood. In 2017, the majority of wood secondary resources were utilized for energy purposes. However, WPR were also demanded for material uses at panel factories, pulp mills, livestock, gardening and for wood-plastic-composites (WPC) production. Knowledge about WPR availability helps to promote recycling and the cascade use of secondary resources. Integrated inventories about forest production and wood consumption are essential to satisfy the need for wood and add value on WPR, as well as to develop knowledge about recycling potential of secondary resources.

Contributions from a public forestry incentive program to developing a biomass energy production chain in Dois Vizinhos, Paraná, Brazil / Contribuição de um programa de fomento florestal público para o desenvolvimento da cadeia produtiva de energia de biomassa no município de Dois Vizinhos, Paraná, Brasil

Anathan Bichel ${ }^{1}$, Eleandro José Brun ${ }^{2}$

${ }^{1}$ Engenheiro Florestal, Londrina, Brasil; ${ }^{2}$ Universidade Tecnológica Federal do Paraná, Campus Dois Vizinhos, Dois Vizinhos, Brasil (anathan_sulina@hotmail.com; eleandrobrun.utfpr@gmail.com)

Para suprir a falta de madeira para fins energéticos e a pressão de uso irracional sobre as florestas nativas, sistemas de desenvolvimento socioeconômicos sustentáveis, como programas de incentivo aos plantios florestais vêm ganhando força, tanto no setor público como privado. O fomento florestal é um instrumento estratégico que promove a integração dos produtores rurais à cadeia produtiva e lhes proporciona vantagens ambientais, sociais e econômicas. Desta forma, objetivou-se com o presente trabalho avaliar a contribuição de um programa de incentivo ao plantio de Eucalyptus spp. para o abastecimento da cadeia produtiva de energia no 
município de Dois Vizinhos, Paraná. O trabalho foi elaborado por meio do banco de dados dos projetos: "Metodologia de monitoramento do programa de fomento ao plantio de eucalipto do município de Dois Vizinhos: ferramenta de gestão florestal municipal" e "Demandas e oportunidades de mercado para o setor florestal/ madeireiro de Dois Vizinhos, PR", ambos realizados pela Universidade Tecnológica Federal do Paraná (UTFPR), Campus Dois Vizinhos e apoiados por outras instituições. Os resultados mostram que a maioria dos plantios florestais provenientes do incentivo são para o segmento de energia. A visão dos participantes do programa sobre o uso do eucalipto apresenta diversos elementos positivos, entre os quais, a contribuição das áreas plantadas em benefícios socioeconômicos e ambientais, autoabastecimento e segurança energética, perspectivas para um equilíbrio nos mercados consumidores da região, principalmente no segmento de biomassa energética.

National forests: an essential organizational chart for staffing / Florestas nacionais: organograma de pessoal, fundamental na estruturação.

Trajano Gracia Neto ${ }^{1}$

${ }^{1}$ MMA/ICMBio, Fernandes Pinheiro, Brasil (trajanogracianeto@gmail.com)

As florestas nacionais fazem parte no Brasil do Sistema Nacional de Unidades de Conservação da Natureza (SNUC), classificadas na condição de uso sustentável, contando com precursores como o Instituto Nacional do Pinho (INP) nas décadas de 40 até a de 60, o IBDF nas décadas de 60 até a de 80 e agora inseridas no Instituto Chico Mendes de Conservação da Biodiversidade (ICMBio), na Diretoria de Criação e Gestão de Unidades de Conservação (DIMAN). Essas unidades de conservação encontram-se com seus quadros de pessoal extremamente defasados em relação a um quadro de pessoal básico e mínimo, ainda agravados pela falta de diversificação de atribuições, principalmente no tocante a formação acadêmica para os setores básicos técnicos e científicos. Essas limitações implica em não ter condições de resolutividade em vários campos de ação da gestão, monitoramento e proteção da biodiversidade com isso deixando essas áreas protegidas em parte de cumprir com seus objetivos. Como alternativa para solucionar esse cenário de carência estrutural apresento a implementação de um quadro de pessoal permanente e básico com enfoque pluritemático, ou seja, multidisciplinar e integrando áreas de conhecimentos próximas e afins. A setorização de pessoal pelas principais áreas de conhecimentos aplicados em recursos naturais proporcionam seguridade e resolutividade, complementada.

The observatory for community and family forest management: a strategy for inter-institutional connection with civil society to promote public forest policies in the Amazon region / Observatório do manejo florestal comunitário e familiar: estratégia de articulação interinstitucional da sociedade civil para promoção de politicas públicas florestais na Amazonia

Manuel Amaral Neto ${ }^{1}$, Katiuscia Miranda ${ }^{1,2}$, Milton Kanashiro ${ }^{3}$

${ }^{1}$ Instituto Internacional de Educação do Brasil, Belém, Brasil; ${ }^{2}$ Instituto Federal de Educação, Ciência e Tecnologia do Pará, Campus Castanhal, Castanhal, Brasil; ${ }^{3}$ Embrapa Amazônia Oriental,Belém,Brasil (manuel@iieb.org.br; glaukat2001@gmail.com; milton.kanashiro@gmail.com)

As florestas públicas comunitárias no Brasil representam grande potencial de dimensões social e econômica no país. Essas florestas comunitárias tem demonstrado eficácia em resistir às pressões do desmatamento no Brasil. Estes territórios ocupam, aproximadamente, 136 milhões de hectares envolvendo um contingente de mais de dois milhões de pessoas, compostas por povos e comunidades tradicionais, agricultores familiares e assentados da reforma agrária (SFB, 2010). Por conta disso, constituem-se territórios estratégicos nas negociações internacionais celebradas pelo governo brasileiro relacionadas à manutenção do clima. Contudo, as florestas comunitárias no Brasil são alvo de pressão de setores da indústria florestal para exploração ilegal e predatória. Visando articular o engajamento de atores sociais e promover o Manejo Florestal Comunitário e Familiar (MFCF) por meio de políticas e implementação de planos que viabilize a produção sustentável das florestas, geração de renda e defesa de seus territórios surge, em 2017, o Observatório do MFCF. O Observatório é uma articulação interinstitucional composta por 32 instituições, entre organizações associações comunitárias, ONGs e entidades de ensino e pesquisa voltada para a produção de conhecimento aplicado com atuação sociopolítica em torno de uma agenda comum de fortalecimento comunitário na implementação de planos de manejo, proteção ao território, sistemas de produção sustentáveis e agroecológicos, a inclusão e fortalecimento de mulheres e jovens, em ações de advocacy que reforcem a influência em formulação e acesso a políticas públicas por parte das organizações comunitárias. Trata-se de uma iniciativa inovadora de grande potencial para o protagonismo da sociedade civil na agenda florestal.

Governance of forest resources in communities within the Verde para Sempre Extractivist Reserve / Governança de recursos florestais em comunidades da RESEX Verde para Sempre

Marlon Costa de Menezes ${ }^{1}$, Suzana Ligoski Zeferino ${ }^{1}$, Natally Celestino Gama1, Saymon Roberto Pontes da Fonseca ${ }^{2}$, César Augusto Tenório de Lima ${ }^{1}$ Universidade Federal do Pará, Altamira, Brasil; ${ }^{2}$ Comitê de Desenvolvimento Sustentável de Porto de Moz-CDS, Porto de Moz, Brasil; ${ }^{3}$ Universidade Federal Ruralda Amazônia, Paragominas, Brasil (marlon@ufpa.br; suzanaligosk@gmail.com; natallygama28@gmail.com; saymonpontes21@gmail.com; cesar.tenorio@ufra.edu.br)

A Reserva Extrativista Verde para Sempre criada em 8 de novembro de 2004 para assegurar a proteção da população extrativista e a conservação dos recursos naturais, vem fomentando a utilização da madeira através do Manejo Florestal Comunitário (MFC). Essa pesquisa tem como objetivo demonstrar a importância do fortalecimento do MFC em comunidades da RESEX Verde para Sempre, possibilitando a melhoria da governança local. Está localizada entre os rios Xingu e Amazonas, município de Porto de Moz-PA, com 1.288.717,00 hectares. Atualmente 6 comunidades extraem madeira orientadas pelas diretrizes do MFC, sendo precursora a comunidade Arimum, em 2007 através do IBAMA e em 2016 as comunidades Arimum, Por ti meu Deus, Paraíso, Ynumbi, Itapéua e Espírito Santo via ICMBio. Os principais resultados de um conjunto de ações implementadas são apoio interinstitucional através do Comitê de Desenvolvimento Sustentável de Porto de Moz (CDS), da Universidade Federal do Pará (UFPA), do Serviço Florestal Brasileiro (SFB), do Instituto Internacional de Educação do Brasil (IEB) e do Instituto Floresta Tropical (IFT), fortalecimento das associações comunitárias e criação de cooperativas para a gestão florestal, regularização da produção madeireira e incremento da renda das famílias nas comunidades Arimum, Por ti meu Deus, Paraíso, Ynumbi, Itapéua e Espírito Santo com receitas anuais de R\$ 642.485,34, R\$ 141.129,42, R\$ 255.053,67, R \$ 207.384,01, R\$ 408.407,78 e R\$ 323.006,00, respectivamente. A criação da RESEX trouxe segurança jurídica para os extrativistas utilizarem seus recursos florestais, regularizando sua produção através da formalização de planos de manejo, conservando a floresta e gerando renda para as famílias.

Pesq. flor. bras., Colombo, v. 39, e201902043, Special issue, p. 1-768, 2019 
Challenges in selling palm hearts from management of açai palm groves in Federal Conservation Units / Desafios para a comercialização do palmito oriundo de manejo de açaizais em Unidades de Conservação Federais

Simone Rabelo

${ }^{1}$ ICMBio, Breves, Brasil (simone.rabelo@icmbio.gov.br)

A Ilha do Marajó/PA, apesar de possuir uma elevada biodiversidade, é uma das áreas mais pobres no Brasil, nessa perspectiva as Unidades de Conservação (UCs) possuem papel fundamental na mudança desse cenário. Como a ilha é conhecida pela sua abundância em açaizais nativos, o ICMBio, desde a criação das Reservas Extrativistas, vem trabalhando, em parceria com a Emater/PA, o manejo de açaizais, especialmente porque o manejo é visto como principal substituto à exploração madeireira ilegal. Mas, apesar dessa atividade ser fortemente incentivada pelo ICMBio, ainda há alguns desafios a serem superados. Atualmente, os extrativistas que possuem áreas de manejo de açaizal dentro de UCs federais enfrentam uma legislação pesada no que tange à burocracia e viabilidade econômica, que impossibilita a comercialização do palmito. Apesar de haver uma legislação no Pará que simplifica e libera de onerações o comércio de palmito, IN9/2013 da Sema/PA, esta não é válida para os extrativistas de UCs federais. Então, todos os extrativistas que hoje trabalham de forma legalizada, veem-se obrigados a transformar o palmito em adubo, ração ou alimento próprio. O ICMBio, na tentativa de minimizar os trâmites burocráticos em apoio aos extrativistas, publicou a IN16/2011, no entanto ainda deixou algumas questões não resolvidas, especialmente, no caso em questão, o documento não isenta o extrativista da emissão do DOF, à exemplo da IN9/2013 da Sema/PA. Portanto, o aproveitamento financeiro da etapa de desbaste/limpeza do açaizal, executado no processo de manejo, é juridicamente impraticável pelos extrativistas de UCs federais marajoaras.

Similarities and differences between the Environmental Reserve Quota (CRA) and tradable permits: potential for the new instrument and recommendations / Semelhanças e diferenças entre a Cota de Reserva Ambiental (CRA) e as Licenças Negociáveis: potencialidades do novo instrumento e recomendações

Maria Luiza Almeida Luz ${ }^{1}$

${ }^{1}$ Universidade de Brasilia, Brasília, Brasil (marialuizaluz@gmail.com)

Em fevereiro de 2018, o Supremo Tribunal Federal tornou constitucional a compensação ambiental por Cotas de Reserva Ambiental (CRA) como prevista no Novo Código Florestal. Apesar da constitucionalidade da compensação, quando da votação do instrumento, o STF alterou o texto, acrescentando que a área cadastrada para compensação ambiental deve guardar relação de "identidade ecológica" com a ARL desmatada. Assim, estabeleceu-se um cenário de insegurança jurídica, porque faltam definições do que se entenderá por "identidade ecológica", que não é um termo reconhecido pelo direito ou pela comunidade científica brasileiros. Esse estudo teve dois objetivos: levantar semelhanças e diferenças das CRAs com as licenças negociáveis, instrumento econômico consolidado, e analisar a relevância do conceito de "identidade ecológica" para os objetivos de implementação das CRAs. Os resultados corroboram que a CRA tem potencial, mas ainda carece de melhor regulamentação, principalmente para sanar as inseguranças jurídicas relacionadas a situações de adicionalidade de proteção e cancelamento e reversibilidade de áreas adicionais de ARL após o vencimento da CRA. Quanto à utilização do termo "identidade ecológica", rigorosamente, seria necessário avaliar os benefícios, custos e resultados ambientais que seriam alcançados ao se adotar diferentes abordagens de classificação de áreas equivalentes para a compensação ambiental. Considerando escassez de recursos e tempo como fatores limitantes, fica a recomendação da adoção do conceito de "equivalência ecológica" para áreas de compensação ambiental, em especial às CRAs. Isso porque esse já é um conceito consolidado na esfera jurídica e científica e, portanto, retira a insegurança jurídica trazida pelo termo "identidade ecológica".

\section{A6s: SOCIALASPECTS OF FORESTS AND FORESTRY}

Deployment of integrated silvopasture systems in rural properties near Cianorte, in Northwestern Paraná state, Brazil / Implantação de Sistemas de Integração Lavoura, Pecuária e Florestas (SIPAS) em propriedades rurais da Região de Cianorte, noroeste do Estado do Paraná

Sidney Aurelio Valeriano Ramos ${ }^{1}$

${ }^{1}$ Emater-PR, Cianorte, Brasil (sidney_valeriano@yahoo.com.br)

A Região de Cianorte juntamente a Paranavaí e Umuarama compreendem a Região Noroeste do Estado do Paraná. De acordo com os dados de 2013 do Departamento de Economia Rural (DERAL), $50 \%$ da receita da região provêm da agricultura, sendo $49 \%$ da pecuária e $1 \%$ das florestas plantadas. Utilizando-se do modelo agrícola existente, a implantação de sistemas de integração lavoura pecuária e florestas (SIPAS) tem o propósito de assegurar benefícios econômicos ao produtor de gado de corte e de leite além benefícios ambientais a região, associados ao bem-estar animal por meio do conforto térmico. A sensibilização do produtor para adesão ao SIPAS se dará por meio de visitas técnicas a propriedade e repasse das experiências de sucesso e das dificuldades encontradas, por meio dos dias de campo e reuniões técnicas com depoimento dos produtores já adeptos do SIPAS. Os resultados esperados dizem respeito a ampliação da renda da propriedade sem aumentar o volume das atividades já existentes; produção de madeira de qualidade a baixo custo; impactar positivamente a sucessão familiar; agregação de valor ao produto por meio do marketing ambiental; estreitamento do vínculo entre pesquisa e extensão rural, atuação desde a produção das mudas até o manejo dos resíduos industriais.

\section{Years of National Park Management: determining best practices for moderninternational application}

\section{Kalifi Ferretti-Gallon ${ }^{1}$, Guangyu Wang ${ }^{1}$}

${ }^{1}$ The University of British Columbia, Vancouver, Canada (kalififg@mail.ubc.ca; guangyu.wang@ubc.ca)

National park systems worldwide are changing. For over a century, national parks have played a critical role in ensuring the protection of natural landscapes worldwide. Parks have functioned to protect the world's biodiversity, conserve carbon stocks, and ensure food security to local communities. The introduction of an applied national park framework to countries rich in biodiversity but without a current system, therefore, is crucial. The concept of what a national park is and how it should be managed has been in development since the late 19th century. In 1872, the world's first national park, Yellowstone National Park, was established as a recreational area, in the United States. Within the decade, similar systems were adopted in Australia, Canada, and New Zealand. While all four countries have unique experiences specific to their distinct landscapes and species allocation, they share a wealth of knowledge on how to effectively introduce and sustain a long-term national park system. With over 100 years of experience in national park management each, Australia, Canada, New Zealand, and the United States can offer invaluable lessons on lessons learned and best practices. This project seeks to review the evolution of park development in all four countries, synthesize available expert opinion, and establish guidelines on how to best introduce and effectively manage national parks. This will greatly benefit countries in emerging economies, lacking relevant expertise. 
Strategic planning for the Latin American Model Forest Network (RLABM), 2018-2022 / Planificación estratégica de la RLABM para el periodo 2018-2022

Maria Ximena Campos Bustos ${ }^{1}$, Fernando Carrera ${ }^{2,3}$, Roger Villalobos Soto ${ }^{2,3}$

${ }^{1}$ Red Latinoamericana de Bosques Modelo, Jamundi, Colombia; ${ }^{2}$ Red Latinoamericana de Bosques Modelo, Turrialba, Costa Rica; ${ }^{3}$ Centro Agronómico

Tropical de Investigación y Enseñanza, Turrialba, Costa Rica (maria.campos@catie.ac.cr; fcarrera@catie.ac.cr; rvillalo@catie.ac.cr)

La Red Latinoamericana de Bosques Modelo (RLABM) se define como una alianza voluntaria entre los Bosques Modelo de Latinoamérica, respaldados por representaciones gubernamentales de cada país miembro, organizaciones internacionales de investigación, de cooperación y organizaciones privadas. Los Bosques Modelo se pueden definir comoplataformas neutras para la gobernanza participativa que agrupan un amplio rango de organizaciones y personas que se asocian voluntariamente y trabajan conjuntamente hacia una visión común para la gestión sostenible de sus recursos naturales. La Planificación Estratégica de la RLABM define los principales ejes temáticos reconocidos por los diversos miembros de la organización para su crecimiento y consolidación en el mediano y largo plazo. El proceso de Planificación Estratégica de la RLABM para el periodo 2018-2022 se realizó de forma participativa y constó de 4 pasos fundamentales: la identificacióny establecimiento de la plataforma de participación, elanálisis de situación, una planificación preliminar y una planificación final. Como resultado se definieron tres tipos de objetivos estratégicos: para los Bosques Modelo, para el equipo de Gerencia y para las instituciones socias, reconociendo como principales ejes temáticos la implementación de buenas prácticasde conservación y producción,la equidad e igualdad de género y la comunicación interna y externa de la organización.

\section{Evaluation of plantation establishment and livelihood improvement scheme as method for raising frest plantations in Kenya}

Joram Kagombe ${ }^{1}$, Mercelyne Khalumba ${ }^{2}$

${ }^{1}$ Kenya Forestry Research Institute, Nairobi, Kenya; ${ }^{2}$ Kenya Forest Service, Nairobi, Kenya (jokagombe@gmail.com; khalumbamercelyne@yahoo.com)

Plantation establishment has incorporated communities and had changed over time from shamba system, Non resident cultivation and presently plantation establishment and livelihood improvement scheme (PELIS). Success of PELIS varies from region to region. The case study evaluated PELIS in Mau, Eastern, Nairobi, North Rift and Central highlands conservancies. A socioeconomic survey was conducted followed by visit to the site. Total area under PELIS in Kenya was 18,932.63 ha distributed in six forest conservancies. The overall seedling survival rate was $67 \%$ with Nairobi leading with $78 \%$ followed by Central Highlands conservancy with $74 \%$ and North Rift with $65 \%$. Main cause of low survival was poor seedling quality. Most farmers (91\%) got their household food requirements from crops grown in PELIS plots and this contributed to household food security. The PELIS rules were abused by 55\% and 33\% of the respondents in Bahati and Dundori respectively. Most farmers (70\%) paid rent for the first year but this reduced to $10 \%$ in the third year. The level of satisfaction with PELIS depended on how community members were involved, plot allocation methods and methods in place for solving conflicts. Results suggest that PELIS is suitable practice in which both the Kenya Forest Service and the farmers benefits. For the farmers, the food crop yields and financial earnings realized are sufficient to attract their participation. Therefore the PELIS qualifies to be sustained. KFS PELIS rules need some adjustment, especially on type of food crops, plot allocation, and collection of revenue.

Mapping communities: putting the concept of impacted parties into practice / Mapeamento de Comunidades: operacionalização do conceito de partes afetadas

Uilson Paiva ${ }^{1}$, Pricilla Soltovski ${ }^{1}$, Andreia Pimentel ${ }^{1}$, Neri Pires de Lima Filho ${ }^{1}$, Darlon Orlamunder de Souza ${ }^{1}$, Marciano Souza de Oliveira Silva ${ }^{1}$, Clewerson Scheraiber', Maria José Brito Zakia ${ }^{2}$

${ }^{1}$ Klabin, Telêmaco Borba, Brasil; '2Prática Assessoria Socioaambiental, Guararema,Brasil (upaiva@klabin.com.br; psoltovski@klabin.com.br; anpimentel@klabin.com.br;nfilho@klabin.com.br; dosouza@klabin.com.br; marciano.silva@klabin.com.br; cscheraiber@klabin.com.br; zeze.zakia@uol.com.br)

A matriz de aspectos e impactos sociais é um instrumento para balizar a tomada de decisão em uma empresa, visando minimizar os impactos que podem ser causados por suas operações. Na Klabin S/A, a construção da matriz envolveu diretamente cerca de 250 funcionários e consultas à sociedade. Para minimizar impactos das operações florestais evoluindo de uma ação corretiva para atuação mais proativa, todas as comunidades foram mapeadas e classificadas conforme os critérios: a) Casas Isoladas I: até 10 casas - menos de 30 pessoas; b) Núcleo II: 10 a 20 casas - de 30 a 50 pessoas; c) Vila III: 20 a 100 casas - mais de 50 e até 300 pessoas; d) Distrito IV: mais de 100 casas - mais de 300 e até 3000; As rotas (estradas) foram classificadas de acordo com o fluxo e intensidade de tráfego, também quanto à duração da operação (permanente/temporária). O impacto mais percebido está relacionado ao transporte de madeira, em função da poeira gerada. Com base no monitoramento das informações, foram direcionadas ações de mitigação, como: mudança de itinerário, utilização de caminhões pipas; alteração de posição do escapamento de veículos, revestimento das estradas. São atendidos sete dos 17 ODSs da ONU : 8. Trabalho descente e crescimento econômico; 9. Indústria, inovação e infraestrutura; 11. Cidades e comunidades sustentáveis; 12. Consumo e produção responsáveis; 13 . Ação contra a mudança global do clima; 15. Vida terrestre; 17. Parcerias e meios de implementação.

Determining tourist load capacity on the cascata trail in Desengano State Park, Rio de Janeiro, Brazil / Determinação da capacidade de carga turística na trilha da cascata do Parque Estadual do Desengano, Rio de Janeiro

Thamires de Souza Carvalho ${ }^{1}$, Marcello Pinto de Almeida ${ }^{1}$, Gumercindo Souza Lima ${ }^{1}$, Angeline Martini

${ }^{1}$ Universidade Federal de Viçosa,Viçosa,Brasil (dsc.thamires@gmail.com; marcello.efl@gmail.com; gumercindo.ufv@gmail.com; martini.angeline@gmail.com)

O uso público nas áreas naturais protegidas, se mal conduzido, pode representar uma ameaça para a proteção dos recursos naturais existentes. Dessa maneira, uma boa estratégia é a implantação de um sistema de monitoramento e gestão dos impactos da visitação. Considerando a importância da conservação e proteção da natureza e o desenvolvimento do ecoturismo no Parque Estadual do Desengano, o presente trabalho buscou determinar a capacidade de carga turística de uma das trilhas mais visitadas, a Trilha da Cascata, utilizando-se a metodologia proposta por Cifuentes. Tal método leva em consideração fatores biológicos, físicos e a qualidade da experiência da visitação para estimar a quantidade máxima diária de visitantes que uma determinada área pode receber sem apresentar danos ao meio ambiente. A capacidade de carga física (CCF) estimada foi de 14.067 visitantes por dia. A capacidade de carga real (CCR) encontrada foi de 9.969 visitantes por dia, sendo obtida a partir da CCF depois de submetida a fatores de correção. Por sua vez, a capacidade de carga efetiva (CCE) calculada, que considera além dos fatores de correção a capacidade de manejo (CM), foi de 6.879 visitantes por dia. A CCF sofreu uma redução de $29 \%$ após aplicação dos fatores de correção selecionados para este trabalho, enquanto a CCR foi reduzida em 31\% em função da CM estimada para o parque. Os resultados obtidos permitiram determinar que a capacidade de carga trística para a Trilha da Cascata é de 6.879 visitantes por dia. 


\title{
Social forests: planning sustainable properties / Matas Sociais: planejando propriedades sustentáveis
}

Uilson Paiva ${ }^{1}$, Sabrina Bicca ${ }^{1}$, Marcos Alexandre Danieli ${ }^{2}$, Emilio Ribas $^{2}$, Joel Franzim Junior $^{3}$, Rosana Silva $^{3}$, Suelen Pavanelo $^{3}$, Giovana Baggio ${ }^{4}$, Paulo Santana $^{4}$ ${ }^{1}$ Klabin, Telêmaco Borba, Brasil; ; ${ }^{2}$ premavi, Atalanta, Brasil; ; ${ }^{3}$ Sebrae, Londrina, Brasil; ; ${ }^{4}$ TNC, São Paulo, Brasil (upaiva@klabin.com.br;

sfbicca@klabin.com.br; marcos@apremavi.org.br; emilio@apremavi.org.br; jfranzim@pr.sebrae.com.br; rosilva@pr.sebrae.com.br; susilva@pr.sebrae.com.br; gbaggio@tnc.org; psantana@tnc.org)

Com o objetivo de estimular a economia local em uma das regiões mais pobres do Paraná, bem como valorizar o trabalho e o protagonismo dos pequenos e médios produtores rurais, aliando desenvolvimento sustentável à preservação da biodiversidade, a Klabin S/A promove, desde 2015, o programa "Matas Sociais". A iniciativa incentiva a agricultura familiar e auxilia pequenos produtores rurais dos municípios de Ortigueira, Imbaú e Telêmaco Borba em todas as etapas de produção. Em três anos de trabalho, 334 produtores rurais receberam assistência técnica, tiveram acesso a novas tecnologias e mercados, receberam capacitações, participaram de rodadas de negócios e oficinas para novas alternativas de cultivos agrícolas. Os benefícios do programa também se refletem na reconstituição da floresta, de sua função ecológica e dos serviços ambientais associados. Exemplos são os mais de 60 hectares de áreas de preservação permanente restaurados, 17 nascentes protegidas e mais de 136 mil mudas plantadas. Além disso, foi realizado o Cadastramento Ambiental Rural (CAR) de 690 propriedades em Imbaú e 1.888 em Ortigueira. O programa contribui ainda no atendimento de 11 das 17 Metas do Milênio, os ODSs da ONU: 1. Erradicação da pobreza; 2. Fome zero e agricultura sustentável; 6. Água potável e saneamento; 8. Trabalho descente e crescimento econômico; 10. Redução das desigualdades; 11. Cidades e comunidades sustentáveis; 12. Consumo e produção responsáveis; 13. Ação contra a mudança global do clima; 14. Vida na água; 15. Vida terrestre; 17. Parcerias e meios de implementação;

\section{Benefit distribution among smallholders in large-scale forestry projects: the case of Camellia in China}

\author{
Jia Li ${ }^{1}$, Bettina Bluemling ${ }^{2}$, Zuomin Wen \\ ${ }^{1}$ Nanjing Forestry University, Nanjing, China; ${ }^{2}$ The University of Queensland, Queensland, Australia (lijiashy@hotmail.com; b.bluemling@uq.edu.au; \\ zmwen@njfu.edu.cn)
}

While internationally, large-scale forestry projects have gained importance for local livelihoods, and the implementation of such projects faces various obstacles. Hereby, the equity of benefit distribution is generally considered vital to support a balanced socio-economic development in poor rural areas and guarantee long-term project success. China presents an especially interesting case of smallholder forestry. Camellia is a typical Chinese perennial oilproducing wood species, providing non-wood products in sub-tropical areas. Using two cases of (inter)national camellia plantation projects, this research analyzes the distribution of benefits under different so-called forestry project implementation regimes. Empirical research was undertaken in thirty villages in two counties of Jiangxi province, China, applying a survey among over 308 smallholders in 2010, and semi-structured stakeholder interviews in 2010 and 2017. Results show that five implementation regimes of Camellia plantations can be distinguished, i.e. individual, partnership, collective-individual, collective, company, each having their own specifics of project access and benefit distribution among smallholders. Collective-individual, collective, and company forest implementation regimes perform better in terms of program access and equal benefit distribution than individual and partnership regimes. But also for the former three regimes, village leaders and companies may seize substantial project benefit reducing the benefits to and marginal smallholders. Finally, some individual and partnership are still continuing the program. Company and collective-individual are searching for new management schemes and technology to solve the problems in the program. These conclusions are policy relevant as in formulating (inter)national forestry projects the local implementation regimes need to be taken into account.

\section{A8a: ECOLOGY, SILVICULTURE AND MANA GEMENT OF TROPICAL DRY FORESTS}

\section{Ecology and silviculture of dry forests in the tropics: where we are and where we go}

Sven Günter ${ }^{1}$, Carlos Ivan Espinosa Iñiguez ${ }^{2}$, Mehdi Pourhasemi ${ }^{3}$

${ }^{1}$ Thünen Institut, Hamburg, Germany; ${ }^{2}$ Universidad Particular de Loja, Loja, Ecuador; ${ }^{3}$ Research Institute of Forest and Rangelands, Teheran, Islamic Republic ofIran (sven.guenter@thuenen.de; ciespinosa@utpl.edu.ec; pourhashemi@rifr-ac.ir)

Seasonally dry forests are heavily threatened by human disturbances and climate change. They are particularly affected by fuel wood extraction, exploitation of high value timber species, browsing, and conversion into agricultural land. Additionally they are heavily threatened by fires, with an increasing trend due to climate change. In this presentation we aim to give an introduction to the state of the art of research on dry forest silviculture and management in the tropics. A central issue is to identify ecological research gaps which are of importance for improving the potential for sustainable use. Further on, we discuss future challenges for science and practice which are rooted in the ongoing trends of deforestation, degradation and climate change. Emphasis is set on contributing to the development of management systems and silvicultural tools for sustainable provision of multiple ecosystem services, including fuel wood, timber, biodiversity conservation, and control of soil and water fluxes. By means of a short participatory exercise we invite the audience and participants of the session to identify needs for future research as well as strengths and research foci of the participants. This can be the basis to reinitiate the IUFRO working group "Ecology, silviculture and management of tropical dry forests". You are cordially invited to join the group.

\section{Sustainable Caatinga forest management in NE Brazil: state of the art}

Frans Pareyn ${ }^{1}$, Enrique Riegelhaupt ${ }^{1}$

${ }^{1}$ Associação Plantasdo Nordeste, APNE, Recife,Brasil (franspar@rocketmail.com; riegelya@yahoo.com)

Caatinga native forest was used since Portuguese colonization for cattle raising and extraction of wood and non-wood forest products. From 1980, wood fuel demand for domestic and industrial use rose sharply. The first research plots on caatinga management were installed in the 80 's. The Caatinga forest Management Network was established in 2003: about 185 permanent plots were monitored every 3 years, in more than 85 ha. The network includes seven federal universities, federal and state research organizations and is coordinated by APNE (Associação Plantas do Nordeste), which carried out additional research on commercially managed forests. This study presents some of the main results and conclusions obtained from the experimental areas and commercial stands. Tree diversity is very much site-dependent and it can increase after the forest is cut. After 10-15 years of harvested, no differences are found between clear cut and diverse selective cuttings. Forest growth after harvest follows similar patterns at each site, whichever the cutting regime. Variability between sites and plots can be very high but growth patterns along time are very similar in different plots. Growth rates are mainly defined by 
rainfall and can be efficiently predicted by growth equations based on mean annual rainfall as independent variable. The soil properties have almost no effect on the growth after harvest. These results should be urgently considered in forest management regulations and should guide all involved stakeholders (foresters, land owners, environmental agencies and researchers).

\section{Understanding regeneration mechanisms of the Southern African Savannah: the pathway towards developing sustainable Silvicultural systems for the Zambezian woodlands}

Annie Namuuya Sikanwe ${ }^{1}$, Stephen Syampungani ${ }^{1}$

${ }^{1}$ The Copperbelt University, Kitwe, Zambia (anniesikanwe@gmail.com; ssyampungani@yahoo.com)

Most African savannas tree species are capable of regenerating both sexually and asexually. However, specific studies on regeneration mechanisms of species of woodland savannas are limited yet integrating the knowledge of regeneration mechanisms of the woodland savannas is a pre-requisite for developing appropriate silvicultural management regimes for this woodland ecosystem. We therefore examined the different regeneration mechanisms of the Miombo woodland tree species in the Zambian forest reserve of Mwekera on Copperbelt Province by excavating the ground and assessing the aerial and basal sprouts within 66 plots along transects of different ages of charcoal abandoned sites. The results show that coppices/sprouts were predominant (77\%) compared to true seedling (22.9\%). Among the 63 species studied 41 were observed to regenerate through coppicing while others regenerated from both seed and root suckering. Twenty-nine species among which were of the genera Brachystegia, Albizia and Julbernardia were observed to regenerate from both seeds and root suckering. Brachystegia species, Julbernardia paniculata and Diospyros kirkii were observed to develop from all the regeneration mechanisms. Significant difference in terms of the influence of regeneration mechanisms on shoot collar diameter and height development were observed with coppicing (p <0.001) and true seedlings $(\mathrm{p}<0.01)$. The variation in regeneration mechanisms and associated influence on shoot development has a direct implication on developing a suitable silvicultural system for Miombo woodlands. Management of Miombo woodland would require a strategy that considers the regeneration mechanisms of major species if we are to sustain the woodlands.

\section{Drivers of land use change: effects on forest structure in Miombo woodlands and implications for sustainable forest management}

Christina Jany ${ }^{1}$, Jobst Michael Schroeder ${ }^{1}$, Davison Gumbo ${ }^{2}$, Moses Kazungu' ${ }^{1}$, Tiza Mfuni ${ }^{2}$, Sven Günter ${ }^{1}$

${ }^{1}$ Thuenen Institute for International Forestry and Forest Economics, Hamburg, Germany; ${ }^{2}$ Center for International Forestry Research (CIFOR), Lusaka, Zambia(christina.jany@thuenen.de; jobst.schroeder@thuenen.de; d.gumbo@cgiar.org;moses.kazungu@thuenen.de; t.mfuni@cgiar.org; sven.guenter@thuenen.de)

In Sub-Saharan Africa, dependency on forests and woodlands is high as people use these as sources for timber and non-timber products for a multiplicity of daily needs and as assets. One of the most important types are the Miombo woodlands. In Zambia, they make up about $80 \%$ of the volume of the growing stock. Although studies have attempted to assess the extent and causes of deforestation and forest degradation of the Miombo woodlands, much is still unknown or lacks sufficient data. In our study, we analyse forest structural data, tree species' composition and the regeneration potential on basis of 144 plots in 12 landscapes throughout Zambia, comparing old-growth forests with post extraction and swidden-fallow forests under different use regimes. The inventory data are compared with forest use patterns of the inhabitants living in or near the respective forests on basis of 100 household interviews for each landscape. Emphasis is on tree species with high local demand, including Pterocarpus chrysothrix, a tree species, which faces extinction in Zambia. The results of this study will enable us to draw conclusions on current use trends on the assessed landscapes and to develop recommendations for sustainable forest management strategies in the Miombo woodlands and tropical dry forests in general.

Sustainable forest management plans as a tool for sustainable use of the Caatinga: past, present and future / Planos de manejo florestal sustentável como ferramenta de uso sustentável da Caatinga: passado, presente e futuro

Frans Pareyn ${ }^{1}$, Enrique Riegelhaupt ${ }^{1}$, José Luiz Vieira ${ }^{1}$, Mário Marques ${ }^{1}$, Elcida Araújo ${ }^{I, 2}$

${ }^{1}$ Associação Plantas do Nordeste, APNE, Recife, Brasil; ${ }^{2}$ Universidade Federal Rural de Pernambuco, Recife, Brasil (franspar@rocketmail.com; riegelya@ yahoo.com;jlvieira@gmail.com; mariowm@gmail.com; elcida.araujo@ufrpe.br)

A implementação do manejo florestal da caatinga teve início na década de 80 , visando principalmente atender a demanda de biomassa energética. O seu instrumento principal consiste em um Plano de Manejo Florestal Sustentado (PMFS) que contém o inventário florestal e as propostas técnicas de intervenção, licenciado pelos órgãos ambientais. Desde 2005, a APNE vem construindo um banco de dados sobre os PMFS para monitorar a dinâmica do manejo na caatinga. Este estudo objetiva apresentar as principais tendências dessa dinâmica nos últimos 15 anos e as perspectivas futuras. Embora o número total de PMFS tem aumentado, nos últimos três anos observa-se uma queda significativa e preocupante dos PMFS ativos (50\% do total). A distribuição dos PMFS concentra-se no Ceará; 40\% dos PMFS são pequenos ( $<250$ ha) e $5 \%$ são grandes $(>2.000$ ha). Os PMFS pequenos, embora muitos, contribuem pouco para o volume anual autorizado; 15\% dos PMFS ocorrem em projetos de assentamento. Atualmente, 59\% dos PMFS tem até cinco talhões explorados e apenas 18 dos 473 planos ativos tem mais de oito talhões explorados. O ciclo de corte adotado nos PMFS é definido em função da normativa existente e não baseado em critério técnico. A lenha é o principal produto do manejo oferecendo apenas 0,4 milhões de tMS/ano de uma demanda industrial crescente (atualmente 6,5 milhões de tMS/ano). Perante a necessidade de evitar emissões de Gases de Efeito Estufa, é fundamental identificar os problemas que desestimulam o manejo para reverter o cenário de decadência do manejo na região. (Financiamento CNPq-441310/2017-6).

\section{The role of fire in regeneration of a Colombian tropical dry forest}

Angela Parrado-Rosselli ${ }^{1}$, Anghy Gutiérrez-Rincón ${ }^{1}$, Alejandro Hernandez Cobos ${ }^{1}$

${ }^{1}$ Facultad del Medio ambiente y Recursos Naturales, Universidad Distrital Francisco José de Caldas, Bogotá, Colombia (aparrador@udistrital.edu.co; anghyforestal@gmail.com; jalhercobos@gmail.com)

In fire-influenced ecosystems some plant species have the ability to germinate and establish after a fire; however, their proportion varies between sites. Currently, there is a debate on the influence of fire in Colombian tropical dry forests (TDF) and if the vegetation has the capacity to regenerate after fire. In that way, in a TDF of the Upper Magdalena River Valley in Colombia, we characterized natural regeneration following a fire and the effect of heat shock on seed germination of dominant legume trees. All seedlings and saplings of woody species were recorded 1.5 years after a fire in $752 \times 2 \mathrm{~m}$ plots installed in burned and unburned sites. Additionally, we exposed seeds of five dominant legume species to nine experimental heat shock treatments (i.e; $80{ }^{\circ} \mathrm{C}$, $100{ }^{\circ} \mathrm{C}$ and $140{ }^{\circ} \mathrm{C}$ for 1,3 and 5 minutes). Seeds were then incubated in an acclimatized germination chamber. Regarding natural regeneration following fire, species richness was lower in 
burned sites, but the number of individuals was higher than in unburned areas. Casearia corymbosa, Machaerium capote and Astronium graveolens were highly abundant in the burned plots, while poorly represented in the unburned ones. Regarding legumes, Chloroleucon mangense and Enterolobium cyclocarpum showed heat-tolerant germination while Pseudosamanea guachapele was heat stimulated. In contrast Albizia niopoides and Piptadenia sp were heat sensitive. Our findings indicate that some tropical dry forest species have fire-tolerant traits that should be considered in restoration programs in light of future and more frequent forest fires due to climate change.

Priority areas for conserving biodiversity and ecosystem services in dry tropical forests in the Upper Magdalena river basin (Colombia) / Áreas prioritarias de conservación de la biodiversidad y los servicios ecosistémicos del bosque tropical seco en la cuenca alta del río Magdalena (Colombia)

Luz Piedad Romero-Duque ${ }^{1}$ iD : María Fernanda Batista Morales ${ }^{1}$, Jessica Alejandra Vargas González ${ }^{1}$, Patricia Balvanera Levy ${ }^{2}$, Víctor Jaramillo Luque ${ }^{1}$ Universidad de Ciencias Aplicadas y Ambientales, Bogotá, Colombia; ${ }^{2}$ Instituto de Investigación en Ecosistemas y Sustentabilidad, Morelia, Mexico (luz.romero@udca.edu.co; mfbatistam@gmail.com; alejavargas@gmail.com; pbalvanera@cieco.unam.mx; luque@cieco.unam.mx)

Uno de los aspectos más importantes para tener en cuenta en el ordenamiento territorial es la conservación de bienes y servicios ecosistémicos. Esto se puede hacer mediante la identificación de áreas prioritarias. Estas áreas surgen cuando están en riesgo o son vulnerables a cambios que disminuyen su capacidad para proveer el servicio o actividad considerada. El área de distribución del Bosque tropical seco (BsT) de la cuenca alta del río Magdalena en Colombia ha disminuido un $87 \%$ y se encuentra amenazado por proyectos viales. Para identificar áreas prioritarias de conservación de este ecosistema 1) caracterizamos la diversidad y estructura de 12 parches de bosque, 2) establecimos la variación espacial de la diversidad, su magnitud y estado de conservación e 3) identificamos la variación espacial de servicios de regulación climática, retención de agua y prevención de la erosión. La diversidad, estado de conservación y prestación de servicios ecosistémicos del BsT son mayores en los departamentos de Tolima y Cundinamarca. La superposición la información espacial indica que el 20\% de los $2018 \mathrm{~km}^{2}$ de BsT son de alta prioridad de conservación y se distribuyen en su mayoría en Tolima (407.6 km²) y Cundinamarca (142.9 km²), mientras que en el Huila se presenta baja prioridad de conservación. Por ello, en Tolima y Cundinamarca el ordenamiento debe apuntar a la conservación y, en Huila debe apuntar a la restauración y la recuperación de este ecosistema. Esto teniendo en cuenta la tenencia de la tierra, la accesibilidad y las presiones o amenazas.

Ecological vulnerability of Anacardium excelsum caused by climate variability in areas of dry tropical forest in the Magdalena Valley, Tolima, Colombia / Vulnerabilidad ecológica de Anacardium excelsum causada por la variabilidad climática en áreas del bosque seco tropical, valle del Magdalena, departamento del Tolima. Colombia

Luis Alfredo Lozano Botache ${ }^{1}$, Omar Aubrelio Melo Cruz ${ }^{1}$, Miguel Ángel Quimbayo Cardona

${ }^{1}$ Universidad del Tolima,Ibagué,Colombia(llozano@ut.edu.co; omelo@ut.edu.co; miguelq@ut.edu.co)

En el bs-T del departamento del Tolima, la demanda del maderable Anacardium excelsum ha conllevado a su disminución poblacional. Un estudio previo determina que su distribución poblacional es aleatoria y que se requieren 80 años para conseguir dimensiones de corta comercial. Este hecho se suma al cambio de uso de áreas de bosques hacia la ganadería y la agricultura, y al riesgo por variación climática. Para evaluar la vulnerabilidad ecológica de la especie ante la variación climática, se tomaron tres sitios de muestreo al norte del Tolima, con mediciones semestrales de crecimiento diamétrico y la homogeneización de mediciones climáticas de 52 estaciones meteorológicas en torno y con influencia en el área de estudio. Con ello, por modelo determinístico, se contrasta el crecimiento diamétrico de $A$. excelsum versus los extremos de temperatura y lluvia causados por el fenómeno del niño, durante los últimos ocho años. Se estiman rangos de tolerancia climática y plasticidad para adecuarse a las nuevas condiciones ambientales y la capacidad para mantener su población en su área de distribución del bs-T. Los resultados son evidencia científica que aporta a las decisiones de la gestión de los recursos naturales en el departamento del Tolima. Esta investigación será modelo para estimaciones similares en otras especies forestales.

\section{The role of stem traits in Cordia alliodora survival after a fire in a Colombian tropical dry forest}

Angela Parrado-Rosselli ${ }^{1}$, Laura Carolina Segura ${ }^{1}$

${ }^{1}$ Facultad del Medio Ambiente y Recursos Naturales, Universidad Distrital Francisco José de Caldas, Bogotá, Colombia (aparrador@udistrital.edu.co, lauraseguratriana@gmail.com)

Plant species exhibit fire resistance and tolerance traits in fire prone ecosystems that allow them to survive or to generate new individuals after a fire. For instance, bark thickness protects trees and epicormic buds from fire, while stem height may allow apical buds to escape being scorched after a fire. Currently, there is a debate on the influence of fire in Colombian tropical dry forests (TDF) and if the vegetation has the capacity to regenerate after fire. Therefore, we evaluated whether bark thickness, stem height and diameter of Cordia alliodora (Boraginaceae), a representative tree species of these forests, was associated with stem survival and resprouting. In that way, 149 Cordia alliodora individuals were sampled, after a fire, in a Tropical Dry forest in the Upper Magdalena Valley Colombia. The number and type (epicormic or basal) of resprouts per individual, bark thickness, tree height and DBH were recorded for all individuals in a 2 ha plot. Results showed that most trees (66\%) survived after the fire. Stem survival was positively correlated to stem height and bark thickness. Epicormic resprouting was more common than basal resprouting, and was positively associated to height and bark thickness. Stem diameter was not a strong predictor of stem survival or resprouting. Our results suggest that Cordia alliodora and has both fire resistance and tolerance traits, as the species avoids fire-death by a combination of stem-height and bark thickness, as well as most of the surviving individuals exhibited either (or both) epicormic or basal resprouting after fire.

\section{Changes in soil hydraulic properties, soil moisture and water balance in Acacia senegal plantations of varying age in Sudan}

Wafa Abaker ${ }^{1}$, Frank Berninger ${ }^{2}$, Mike Starr

${ }^{1}$ University of Khartoum, Khartoum, Sudan; ${ }^{2}$ University of Eastern Finland, Kuopio, Finland; ${ }^{3}$ University of Helsinki, Helsinki, Finland

(wafaadam59@yahoo.com; frank.berninger@uef.fi; mike.starr@helsinki.fi)

We investigated the effects of Acacia senegal trees on soil moisture (SM) and hydraulic properties in relation to plantation age (7 to 24 years) in two semi-arid sites in Sudan. Adjacent grasslands at the two sites were used for comparison. Profiles of SM contents were measured for two years (2011-2012) using Time Domain Reflectometry (TDR). Daily water balances of the plantations and grasslands were computed using a simple water balance model and temperature and rainfall data nearby meteorological station. The TDR SM data was used for model calibration purposes. Hortonian runoff was calculated using the SCS runoff curve number $(\mathrm{CN})$ method and evapotranspiration calculated using Jensen-Haise global radiation reference crop evapotranspiration, seasonal crop coefficients 
derived from MODIS NDVI values, and a soil water availability index. Soil hydraulic parameter values were derived using pedotransfer functions based on measured soil texture and soil organic carbon (SOC) contents. Measured SM contents in the plantations were lower than in the grasslands, but increased with plantation age, reflecting a similar trend in SOC contents and related plant available water holding capacities. Annual runoff was lower from the plantations because of increased infiltration, while evapotranspiration was higher which resulted in reduced drainage and lower SM contents, as shown by measurements. Greater SM contents in the grasslands were attributed to the lower evapotranspiration and resulted in the greater drainage fluxes compared to the plantations. The study highlighted the need for more empirical studies on the effect of trees on the water balance of savanna woodlands in Africa.

\title{
A8b: FORECASTING THE EFFECTS OF LAND-USE ON WILDLIFE COMIUNITIES AND
} CONFLICT AT HUMAN-WILDLIFE INTERFACE

\section{Stable isotope niche segregation and overlap amongst rare antelope and other sympatric bulk grazers from a West African Savanna \\ Chabi Djagoun ${ }^{1}$, Nicole Wrage-Mönnig ${ }^{2}$ \\ ${ }^{1}$ Laboratory of Applied Ecology/University of Abomey Calavi, Calavi, Benin; ${ }^{2}$ Grassland and Fodder Sciences, Agricultural and Environmental Faculty, University of Rostock, Rostock, Germany(dchabi@gmail.com;nicole.wrage-moennig@uni-rostock.de)}

Understanding the mechanisms of species coexistence within local assemblages can play a crucial role in conservation of a species. There is little understanding of how large mammalian bovid species from West Africa partition diet resources, and to what extent the rare antelope and other sympatric bulk grazers can cope with this co-existing system. Using teeth stable isotopic composition data we studied an assemblage of three sympatric grazers (topi, hartebeest and roan) with different population density. We find little evidence for diet niche overlap between rare antelope with bulk grazing species. The sizes of the dietary isotopic space was higher in hartebeest $\left(1.30 \pm 1.14 \% 0^{2}\right)$ and roan $\left(1.86 \pm 0.88 \% 0^{2}\right)$ compared to topi $\left(0.26 \pm 0.19 \% 0^{2}\right)$ with a significant variation at individual scale. This high variation of isotopic niche at individual level in hartebeest and roan species revealed that within species variation of stable isotope ratios explained the isotopic niche breadth of the study species better than between-species variation. The isotopically partitioning of dietary niches at individual scale may facilitate coexisting in rare and high density ungulate community.

\section{The "Bird Detectives” environmental education program / O programa de educação ambiental "Detetives de Aves"}

Lilly Briggs ${ }^{1}$

${ }^{1}$ Cornell Lab of Ornithology, Ithaca, USA(lpb29@cornell.edu)

Detetives de Aves é um programa de educação ambiental que foi criado pelo Laboratório de Ornitologia da Universidade de Cornell, que pretende ampliar os conhecimentos das crianças sobre ciência e meio ambiente através das aves. Ele também busca desenvolver a capacidade de os estudantes participaremem ciência cidadã, observando aves e inserindo os dados no site do eBird (www.ebird.org [http://www.ebird.org/]). Nesta oficina, os participantes vão obter experiência com o uso do programa, e como podem engajar seus estudantes na ciência cidadã do eBird para poderem apoiar os esforços de conservação.

\section{Forest structure modulates the response of wildlife to human recreation}

Veronika Braunisch ${ }^{1,2}$, Coppes Joy ${ }^{1}$, Rudi Suchant ${ }^{1}$, Ursula Nopp-Mayr ${ }^{3}$

${ }^{1}$ Forest Research Institute of Baden-Wuerttemberg, Freiburg, Germany; ${ }^{2}$ University of Bern, Bern, Switzerland; ${ }^{3}$ University of Life Sciences and Natural Ressources,Vienna,Austria (veronika.braunisch@iee.unibe.ch; joy.coppes@forst.bwl.de; rudi.suchant@forst.bwl.de; ursula.nopp-mayr@boku.ac.at)

Outdoor recreation activities in forest ecosystems are growing in popularity, causing increasing pressure on wildlife. There are various ways in which wildlife reacts to recreation activities, ranging from behavioural to physiological responses, with regional variation in response-intensity within the same species. We tested whether negative effects of human recreation on wildlife are modulated or even mitigated by habitat suitability, i.e. forest structures providing food and cover. Based on radio-telemetry and a systematic, plot-based survey of species presence and forest structure over 13 years in 13 study regions across central Europe, we studied how recreation infrastructure and habitat suitability interact and affect local habitat use and population densities of an endangered model species: the Western Capercaillie (Tetrao urogallus). Radio-telemetry revealed the species avoidance of recreation infrastructure with seasonal differences in avoidance-distances. Moreover, avoidance was stronger under poor habitat conditions, while it was mediated by high habitat suitability. Population densities varied greatly between study years and regions and were mainly determined by habitat suitability. However - independently of habitat conditions - densities dropped markedly when more than $50 \%$ of the area was influenced by human recreation. Our results indicate that negative effects of recreation activities can to some extent be mitigated by forest management measures improving habitat suitability; however this has limits because it only affects local habitat use but not regional population densities. For the latter, we stress the importance of recreation-free areas in human-dominated landscapes which act as refuges for wildlife.

\section{Sustainable collection of Bertholletia excelsa: coexistence between humans and dispersers}

\author{
Lúcia Helena de Oliveira Wadt ${ }^{1}$, Camila Lima Faustino ${ }^{2}$, Christina L. Staudhammer ${ }^{3}$, Karen A. Kainer $^{4}$, Joziane Silva Evangelista ${ }^{5}$ \\ ${ }^{1}$ Embrapa Rondônia, Porto Velho, Brasil; ${ }^{2}$ Instituto Federal de Educação, Ciência e Tecnologia do Acre, Tarauaca, Brasil; ${ }^{3}$ Universidade do Alabama, \\ Departamento de Ciências Biologicas, Tuscaloosa, USA; ${ }^{4}$ Universidade da Florida, Escola de Recursos Florestais e Conservação, Gainesville, USA; \\ ${ }^{5}$ Universidade Federaldo Acre,RioBranco,Brasil(lucia.wadt@embrapa.br; camila.faustino@ifac.edu.br; cstaudhammer@ua.edu; kkainer@ufl.edu; \\ joziane.gestorambiental@gmail.com)
}

We tracked whole fruits of Bertholletia excelsa during primary (fruitfall) and secondary mammalian fruit dispersal. Dasyprocta spp. is particularly important for $B$. excelsa, because it is the main disperser and often buries $B$. excelsa seeds, facilitating seed germination and early seedling establishment. We asked: (1) Given a short and synchronous fruiting period, what patterns of primary and secondary fruit dispersal emerge? (2) Do rainfall and local vegetation affect dispersal? We monitored date of fruitfall and condition of individual fruits from 20 trees over a 20 ha area, sequentially visiting each study tree on average every 3-4 days. As expected, primary dispersal was fairly synchronous over 3-month period. While 6855 observed fruits were falling, scatterhoarders were removing some to outside tree crown projection (4.1\%) and opening a much smaller proportion (0.5\%) under mother trees. Approximately $1 / 4$ fruit opening or removal occurred within 5 days of fruitfall. More fruits were opened or removed when subcanopy vegetation had higher bamboo density or lower densities of saplings and trees. While humans directly compete with native dispersers/predators for $B$. excelsa's seeds, our results revealed that prior to human collection in mid-January, $94 \%$ 
of fruits had fallen, and mammal dispersers had already accessed (moved beyond the canopy, consumed or buried) 197 fruits (2.9\%) or approximately xx seeds. Considering our dispersalfindings, cumulative research and collective understanding of the Bertholletia-Dasyprocta-Homo sapiens interactions, we conclude that Brazil nut harvests boost rural incomes and in our study site, likely do not threaten Brazil nut recruitment or maintenance of agouti populations.

\section{Consultations between forestry and reindeer husbandry in Sweden: history, status and possibilities for a land-use partnership and an inclusive co-management process}

Ulrika Roos ${ }^{1}$

${ }^{1}$ Department of Forest Resource Management, Umea, Sweden (ulrika.roos@slu.se)

Functioning coexistence between different land users is usually a central part of sustainable resource management. In Northern Sweden, forestry and reindeer husbandry are the two major land use practices that overlap spatially. Thus, sustainable forestry is greater than the sum of its parts and requires implements for coexistence. To facilitate the coexistence, consultations between forest land owners and reindeer herders has been carried out since 1954. However, long lasting conflicts indicate that that the consultation procedures have not been satisfactory and also that the purport of the consultations is unclear to the participants. Drawing on Arnsteins (1969) ladder of participation and Wandéns (1997) classification of different conflicting goals, this paper address the concept of consultation and participation in relation to how it has been carried out in this particular context. Relevant literature will be reviewed, together with an in-depth analysis of the process based on protocols from consultations and notes from meetings of the Central Advisory Group for Reindeer Husbandry and Forestry, as well as observations during ongoing consultations. Identified problems and opportunities will be used towards an improved and more inclusive co-management process.

\section{Changes in conservation values in modified forest: Does human involvement affect its land use pattern and wildlife presence?}

Shoma Jingu ${ }^{1}$, Keisuke Sakata ${ }^{2}$, Taiichi Ito ${ }^{2}$

${ }^{1}$ Division of Appropriate Technology and Sciences for Sustainable Development, Graduate School of Life and Environmental Sciences, University of Tsukuba, Tsukuba, Japan; ${ }^{2}$ Faculty of Life and Environmental Sciences, University of Tsukuba, Tsukuba, Japan(s1730263@s.tsukuba.ac.jp;

sakata.keisuke.gn@u.tsukuba.ac.jp; ito.taiichi.ft@u.tsukuba.ac.jp)

Conservation of biodiversity is an important issue not only in protected areas but also in secondary natural environments which have been modified by many years of human use. One typical example in japan is a "satoyama" forest. Satoyama is considered symbolic of human-nature coexistence as it is a forest based on traditional, sustainable use of natural resources. The government is putting its efforts in conserving the satoyama which is decreasing in coverage. However, it is questioned whether conservation of present state satoyama can play a similar role of traditional human-nature coexistence. Here we show the historical change of satoyama through satoyama-related land use and wildlife presence. In Tsukuba city, located $50 \mathrm{~km}$ North East of Tokyo, we found that many satoyama remnants have undergone various changes in its land use and have equally affected wildlife presence. Some areas have changed far enough to question the human-nature coexistence conservation value of satoyama. Although largely changed satoyama may retain wildlife conservation value through provision of habitats, we found changes in observed wildlife. While we agree that human-modified forests are important for conservation, change in usage patterns result in varied environmental outcomes. This study provides an example that traditional human-nature coexistence should not necessarily be the primary conservation value in secondary natural environments which are subject to change in human involvement.

\section{Community forestry and crop raiding: understating feedback effect of community-based forest policy in Nepal}

Rajesh Bista

${ }^{1}$ University of North Carolina at Chapel Hill, Carrboro, USA (raaj@live.unc.edu)

Community forestry (CF) in Nepal has improved forest condition significantly and has become a key source of rural livelihood. As a result, Nepal's forest cover increased from $37 \%$ in 1986 to $45 \%$ at the present. Approximately 30\% of Nepal's forest is under community management. However, there is no empirical study that assessed impacts of wildlife on crops/livestock with increase in forest cover and improvement of habitat quality because of CF. We adopted the coupled natural-human systems framework to examine the feedbacks to the human from natural systems. We carried out a survey with 215 households in 2018 across seven CF in the Kavrepalanchok, Nepal. We found that crop-raiding is one of the main reasons for agriculture-land abandonment. Study shows that $16 \%$ of cropland abandonment were solely caused by crop-raiding by wildlife; $39.9 \%$ of cultivated land-parcels have suffered damage from wildlife (monkey, wildboar, porcupine), though the intensity is different among communities. More than $88 \%$ of the farmers perceived that the increase in forest stock in $\mathrm{CF}$ is the major reason behind increasing incidences of crop-raiding. Farmers from higher caste suffered most as they have comparatively higher amount of land holdings. Though Nepal government has formulated Wildlife Damage Relief Guideline 2069, none of the farmers have claimed for compensation for the crop-damage due to lengthy beaurocratic procedure. Moreover, monkey is not included within the government relief scheme. These findings suggest addressing these issues from policy level as well as recommends introducing wildlife conflict management measures in operational plan of CF.

\section{Human-primate conflict in Brazilian pine plantations: linking production and conservation through research}

Sandra Bos Mikich ${ }^{1}$, Dieter Liebsch², Edilson Batista de Oliveira ${ }^{1}$, José Mauro Magalhães Avila Paz Moreira ${ }^{1}$

${ }^{1}$ Embrapa Florestas, Colombo, Brasil; ${ }^{2}$ Dieter Liebsch Consultoria Ambiental, Curitiba,Brasil (sandra.mikich@embrapa.br; dieterliebsch@yahoo.com.br; edilson.oliveira@embrapa.br; jose-mauro.moreira@embrapa.br)

Capuchin monkeys (Sapajus nigritus) saw part of their native habitat replaced by other land uses as pine plantations in South Brazil. With the gradual reduction in food (mainly fruit and insects) supply, they have included pine sap in their diets giving rise to a conflict with the wood industry. Our multidisciplinary team have been studying this sensitive issue since 2003 as the impact on production is significant but capuchins are native protected species and provide important ecological services. One of the outcomes of this research is that, contrary to everybody's expectations, we have found that capuchin populations are quite low, preventing any direct management. Additionally, we have established procedures, variables and parameters to evaluate capuchins' damage translated into a computer tool that allow us to forecast impacts on production. We have also classified subtropical and tropical pine species based on the preference of this primate. As a result, depending on the degree of damage we might indicate the management of the pine stand, the replacement of Pinus taeda (preferred species) by P. patula (avoided species) and/or native forest enrichment using fruit species that are important in the capuchin's diet based in local long-term studies. This way we expect to reconcile wood pulp/timber production and conservation. 


\section{Understanding the livestock depredations pattern by sympathetic carnivores in tropical deciduous forest of Western India}

Randeep Singh ${ }^{1}$

${ }^{1}$ Amity University, Noida, India (rsingh18@amity.edu)

We investigated the influence of environmental and socio-ecological factors on livestock depredation by carnivores in pastoral villages conflicts pattern in pastoral villages adjacent to Ranthambhore Tiger Reserve (RTR), Rajasthan, India a protected area situated in tropical dry deciducious forest and characterized and examined the causes of conflicts. Both leopards (Panthera pardus) and tiger (Panthera tigris) are sympatric and involved in depredation and responsible for $81 \%$, and $19 \%$, of attacks on livestock, respectively. Examination of cattle kills indicate that leopards killed a significantly greater proportion of smaller livestock (e.g., goats and calves), whereas tigers killed a significantly greater proportion of larger livestock (e.g., cows and bulls). The livestock depredation was $44 \%$ in summer and $56 \%$ in winter by both felids. Of the depredation on livestock by leopard was majority (81\%) were goats, sheep, and calves (72\%) and where as $28 \%$ cow and bull. Information-theoretic evaluation of models found that leopard kills livestock inside villages during night time, while tiger kills livestock outside villages. Even leopard attack caused the greatest overall financial loss to villagers, which negatively affected local tolerance towards carnivores. To improve both large carnivore and local livelihood prospects, conservation and development projects should be trailed as conflict mitigation strategies.

\section{A9d: COMMITTED AND HELD ACCOUNTABLE? EXPLORING ACCOUNTABILITY RELATIONS OF STATE, BUSINESS AND CIVIL SOCIETY ORGANISATIONS IN MULTI-LEVEL FOREST GOVERNANCE}

\section{The politics of designing accountability in REDD+ benefit sharing}

Grace Wong ${ }^{1}$, Maria Brockhaus ${ }^{2,3}$, Moira Moeliono ${ }^{4}$, Thu Thuy Pham ${ }^{4}$

${ }^{1}$ Stockholm University, Stockholm, Sweden; ${ }^{2}$ University of Helsinki, Helsinki, Finland; ${ }^{3}$ Helsinki Institute of Sustainability Science, Helsinki, Finland; ${ }^{4}$ Center for International Forestry Research, Bogor, Indonesia (grace.wong@su.se; maria.brockhaus@helsinki.fi; m.moeliono@cgiar.org; t.pham@cgiar.org)

Benefit sharing mechanisms (BSMs) related to forest exploitation and conservation has long been an area of contestation. Conflicts have arisen over perceived injustices in how and what benefits and burdens are allocated between the State, private or non-governmental entities and forest communities (Myers and Muhajir 2015), around inclusion and exclusion in decision-making processes, and in the inadequacies of benefits relative to burdens (Luttrell et al; 2017). These conflicts are often exacerbated by a lack of accountability and transparency in the design and implementation of benefit sharing mechanisms, and can lead to risks of elite capture, perceived inequity and illegitimacy of the policy process, and dis-incentivizing behavior to reduce deforestation (Loft et al; 2016). Accountability would have to include an assessment of the interests and biases of state, private sector, international and non-governmental institutions (Kramarz and Park 2016) in the design of BSMs, which would determine what to account for and to whom. In this paper, we focus on the relational aspect of accountability: who are held accountable to those who have the right to hold to account (Biermann and Gupta 2011). We draw on data from a global comparative study to assess the stances of different groups on who should benefit from REDD + , how these influence the design of REDD+ BSMs and hence, identify what REDD+ is accountable for and to whom. We draw on environmental governance practices ranging from safeguards, grievance mechanisms, anti-corruption mechanisms and transnational legal instruments to identify potential accountability structures for design of REDD+ BSMs

Certification in the Brazilian palm oil production chain: A case of socioenvironmental responsibility? / Certificação na cadeia produtiva de óleo de palma no Brasil: Um caso de responsabilidade socioambiental?

Susane Ferreira ${ }^{1}$, Claudia Azevedo-Ramos ${ }^{1}$

${ }^{1}$ Universidade Federal do Pará, Belém, Brasil (susane_cristini@hotmail.com; claudia.azevedoramos@gmail.com)

Empresas de óleo de palma (dendê) têm procurado a certificação por exigências mercadológicas. Dentre os vários disponíveis está o da "Round Table on Sustainable Palm Oil" - RSPO, que dita os padrões do óleo de palma sustentável. No Brasil, o grupo Agropalma é um dos maiores produtores de óleo de palma e, portanto, tem grande visibilidade. Este estudo revisou os compromissos de sustentabilidade declarados pela Agropalma, sua inserção no sistema de certificações e comparou com os estudos recentes que avaliam seu desempenho socioambiental. A Agropalma tem declarado compromisso com o desmatamento zero e a conservação de florestas nativas. Tem, ainda, demostrado interesse na melhoria de seu desempenho, comprovado pela conquista de 12 selos de qualidade e certificação de acordo com os padrões RSPO. No entanto, vários estudos criticam sua responsabilidade socioambiental atribuindo ao grupo empresarial a subordinação dos agricultores familiares à empresa, êxodo rural, ameaças ao sistema de produção local, pressão sobre a mata secundária, tratamento inadequado dos resíduos agroindustriais, com econtaminação de rios, e preservação inadequada do capital natural e de seus serviços ecossistêmicos. Embora a Agropalma tenha demonstrado ações em direção a uma produção mais sustentável, ainda há criticas quanto ao seu desempenho. Conclui-se que a sustentabilidade na produção do óleo de palma ainda depende de um aperfeiçoamento na interação empresa- órgãos certificadores- pesquisas para garantir um progresso continuo nos padrões exigidos e na sua conformidade.

Transparency and accountability in monitoring national scheme on payment for forest environmental services-lessons learnt from Vietnam

Thuy Pham Thu', Tien Nguyen Dinh ${ }^{1}$, Long Hoang Tuan ${ }^{1}$, Chi Dao Thi Linh ${ }^{1}$, Thang Le Manh ${ }^{2}$

${ }^{1}$ Center for International Forestry Research, Hanoi, Vietnam; ${ }^{2}$ Son La forest protection and development fund, Son La, Vietnam (t.pham@cgiar.org; ndtien.up@gmail.com; bberviet@gmail.com; chi.daolinh161194@gmail.com; thanglnsl@gmail.com)

Payment for forest environmental services (PFES) is seen by Vietnamese policymakers as one of breakthroughs in forestry sector. PFES is run and managed by state agencies but there is alack of rigorous and scientific assessment on actual impacts of PFES on environment and local livelihood. Moreover, legal framework on monitoring and evaluation of PFES in Vietnam is still at infant stage. Public and private sector who have paid PFES fee through water and electricity bills have raised concern on transparency and accountability of the schemes in the absence of no available data on effectiveness of PFES schemes. This paper investigates enabling and hindering conditions for transparency and accountability in monitoring and implementing PFES policy in Vietnam as well as draw out lessons learnt for improved forest governance.We found that PFES has enhanced transparency and accountability in forest monitoring as it creates additional funding and independent agencies to verifying government forest inventory results. However, transparency and accountability of government reporting on PFES results are impeded by political interests and political missions of governmental agencies to only report 
on program positive outcomes, conflicts of interests and unclear responsibilities amongst government agencies, elite capture in natural resources and information, and the lack of political space given to local communities and non-state actors to take part in monitoring and evaluation process. Our paper suggests that enhancing transparency and accountability in monitoring and implementing PFES requires not only application of advanced technology but also to address underlying politics of numbers.

Lessons from land management platforms: model forests in Latin America / Lecciones aprendidas de las plataformas de gestión territorial: caso de los bosques modelo de Latinoamérica

Fernando Carrera ${ }^{1}$, Roger Villalobos ${ }^{1}$, Leonardo Duran ${ }^{2}$, Claudia Rojas ${ }^{1}$

${ }^{1}$ CATIE, Turrialba, Costa Rica; ${ }^{2}$ Universidad Mayor, Santiago de Chile, Chile (fcarrera@catie.ac.cr; rvillalo@catie.ac.cr; leonardo.duran@umayor.cl;

claudia.rojas@catie.ac.cr)

Los Bosques Modelo son plataformas de gobernanza para la gestión territorial que vienen operando en Latinoamérica desde hace dos décadas. Estas plataformas están enlazadas a través de la Red Latinoamericana de Bosques Modelo (RLABM) que reúne a 33 territorios de incidenciaen 14 países y el apoyo de organizaciones internacionales como FAO, CUSO, CIFOR, CIAT y CATIE. La RLABM es parte de la Red Internacional de Bosques Modelo (RIBM) que aglutina a más de 70 plataformasen 30 países a nivel global. La investigación sintetiza las principales lecciones aprendidas de estos procesos de gestión territorial en Latinoamérica, mismos que son reconocidos como un espacio que favorece la articulación de actores del ámbito público, privado y de la sociedad civil para responder a las oportunidades y desafíos del desarrollo sostenible en un territorio de interés común. Estas lecciones fueron obtenidas con base en entrevistas, revisión de documentación y visitas de campo. Entre los aprendizajes se destacanla necesidad de involucrar a los gobiernos locales e instituciones académicas en la gestión de estas plataformas; la conveniencia de que organizaciones locales asuman con mayor peso el liderazgo; la importancia de contar con personal y un mínimo de recursos físicos y financieros; el peligro que representan los cambios en la políticas gubernamentales en la continuidad del proceso; la conveniencia de contar con planes estratégicos participativos; lo determinante del liderazgo social, el compromiso de los socios y la identidad territorial. Se resalta que el establecimiento de alianzas estratégicas desde la acción favorece la sostenibilidad de la gobernanza.

\section{Interests and conflicts in forest management: Who possess power in Slovakian forest governance?}

Yvonne Brodrechtova ${ }^{1}$, Róbert Sedmák' ${ }^{1}$ Ján Bahýl ${ }^{1}$, Michal Bošel'a ${ }^{1}$, Ján Ján Tuček ${ }^{1}$

${ }^{1}$ Technical University in Zvolen, Zvolen, Slovakia (yvonne.brodrechtova@tuzvo.sk; robert.sedmak@tuzvo.sk; jan.bahyl@tuzvo.sk; michal.bosela@tuzvo.sk; jan.tucek@tuzvo.sk)

The actor landscape in Slovakian forestry has become more diverse since the early 1990s due to the transition from planned to market economy. This has led to various conflicts among actors concerning forest management and its output: ecosystem services (ES). Who are the relevant actors and what power resources they possess to act in forest management today? Based on the actor-centered power approach the actors' interests in ES and power to drive forest management were assessed based on the ability of actors to apply the mechanisms of coercion, incentives, and dominant information. The results of 38 in-person interviews and participatory observations revealed that both actors both inside and outside of the forestry arena drive forest management in Slovakia. However, governmental actors in forestry, environment (with various interests in ESs) and agriculture are still the most powerful and have the highest impact on forest management. Moreover, the governmental actors are often influenced by businesses rather than politics. The power is increasingly being taken by businesses, which either formally (e.g., associations, (environmental) non-governmental organizations) or informally (e.g., media, lobbying) influence forest politics. In contrast to actors representing the environment via various non-governmental organizations that exercise medium power in the forest arena, the actors in forestry represented via various associations have a rather low impact. As a result, forest management research should focus more to power resources and relations of actors acting on forest management. If not, powerful actors driving forest management may use conflicts for their benefit and avert balanced ES trade-off.

\section{Puzzle pieces or poker chips? How citizens use multistakeholder forums to hold government and NGOs accountable}

Anne Larson ${ }^{1}$, Juan Pablo Sarmiento Barletti ${ }^{1}$

${ }^{1}$ CIFOR, Lima, Peru (a.larson@cgiar.org; j.sarmiento@cgiar.org)

Greater coordination and collaboration among actors - particularly across governance levels and sectors - is one of the main strategies proposed to support the achievement of climate goals regarding land and forest use. Such strategies have recently been referred to as landscape approaches, multistakeholder initiatives or jurisdictional approaches, but they emerge from a history of similar efforts at participatory processes, integrated conservation and development initiatives or co-management arrangements. To what extent have these past experiences informed current efforts at collaboration? How are new initiatives addressing power relations and inequity in order to assure legitimacy and accountability in processes and outcomes? This paper is based on the comparative analysis of 14 multistakeholder forums (MSFs) established to conserve forests and/or improve land use, primarily in subnational jurisdictions. We focus on four countries - Brazil, Peru, Indonesia and Ethiopia - and specifically on forums that bring together subnational (and sometimes national) government, NGOs, grassroots organizations and private sector stakeholders in a specific geographical location. Data were collected through 30 to 40 structured, in-depth interviews for each MSF, with organizers, participants and non-participants, as well as with key informants who have knowledge and firsthand experience on the context of forest management in each region. In four cases, focus groups were conducted with rural communities. This article analyzes approaches to addressing power differences and inequities across the MSFs and, specifically, the obstacles and opportunities for actors from marginalized groups (indigenous people, peasants, women) to voice their concerns and to influence the forums' agenda and outcomes. 


\section{Evolution of Estonian forest policy during and after transition}

Paavo Kaimre ${ }^{1}$

${ }^{1}$ Estonian University of Life Sciences, Tartu, Estonia (paavo.kaimre@emu.ee)

The presentation covers the most important forest policy decisions in Estonia during and after transition period. Forest policy is observed in interaction with country's development and general economic policy. Forestry related legislation has played a major role in the policy implementation. Consequently, remarkable number of changes and completely new versions of Forest Act have been passed by the Parliament. For example, one of the main goals of the 1993 Forest Act was to create a basis for private forest ownership; Forest Act passed in 1998 focused on the reform of public forest management; changes in legislation in the 21 st century are mostly related to the principles and rules of forest management. Another very important document influencing the whole forest sector is the Estonian Forestry Development Program. The first national program was approved by the Parliament in 2002, the second in 2011, and the preparations for the third one were started in 2018. The most important goals and measures listed in the development programs have been shortly analysed. The policy formulation process has been changed remarkably within decades, from the decisions made by public administration to the open debate and participation of stakeholders. At present, the public interest and expectations on forestry are higher than ever, therefore the involvement of interest groups and scientific expertise into the policy making is crucial.

\section{Good-bye to command-and-control in forest governance? A critical analysis of two countries after socio-economic transition}

Ekaterina Makrickiene ${ }^{1}$, Vilis Brukas ${ }^{2}$, Yvonne Brodrechtova ${ }^{3}$, Gintautas Mozgeris ${ }^{1}$, Róbert Sedmák ${ }^{3}$, Jaroslav Šálka ${ }^{3}$

${ }^{1}$ Vytautas Magnus University, Kaunas, Lithuania; ${ }^{2}$ Swedish University of Agricultural Sciences, Alnarp, Sweden; ${ }^{3}$ Technical University in Zvolen, Zvolen, Slovakia(ekaterina.makrickiene@asu.lt; vilis.brukas@slu.se; yvonne.brodrechtova@tuzvo.sk; gintautas.mozgeris@asu.lt; robert.sedmak@tuzvo.sk; jaroslav.salka@tuzvo.sk)

Sharing similar socialistic past and almost three decades of transition from planned to market economy, Lithuania and Slovakia had to cope with the legacy of command-and-control approach in forest governance and management. Our study is aimed to theorise on criteria suitable to judge the degree to which forestry in a given country is steered by command-and-control as opposed to the more adaptive forms of governance and to apply the devised analytical framework for the selected case countries. The analysis involves five criteria, four of which - efficiency, equity, transparency and participation - stem from the framework of good governance. The fifth criterion - adaptiveness - corresponds to the concept of adaptive governance. The analysis was based on desktop research, expert opinions and stakeholder interviews. Both countries perform rather well in transparency, not least in terms of comprehensive data on forest resources. The performance for all other criteria is poor: economic efficiency is low, forest owners lack decision freedom and face injustice, wide public participation is weak, and the adaptive capacity of forest management low. This leads to the conclusion that, despite the economic and societal transition, the command-and-control forest governance is still in full effect in Lithuania and Slovakia. There is a long way to go towards more adaptive governance characterised by flatter hierarchies, lighter regulative load and bigger decision freedom.

\section{Is there a transition towards participatory forest governance in Ukraine?}

Maria Nijnik ${ }^{1}$, Simo Sarkki ${ }^{2}$, Mariana Melnykovych ${ }^{3}$, Ivana Zivojinovic ${ }^{4}$

${ }^{1}$ James Hutton Institute, Aberdeen, United Kingdom; ${ }^{2}$ University of Oulu, Oulu, Finland; ${ }^{3}$ Ukrainian National Forestry University, Lviv, Ukraine; ${ }^{4} B O K U$,

Vienna,Austria (maria.nijnik@hutton.ac.uk; simo.sarkki@oulu.fi;mariana.melnykovych@ukr.net; ivana.zivojinovic@boku.ac.at)

Is there a transition in forest governance in Ukraine? What are the pathways to change? How do people see the future? What are the dominant public attitudes concerning the transition? What policies can be designed and operationalised using socially innovative tools, strategies and adaptive management practices? We conducted a national level survey on forest governance, and complemented the use of participatory methods with the application of Q-methodology on public attitudes towards forestry-in-transition. We analyzed the results by discourse analysis and inductive content analysis. The findings indicate that deliberative governance systems can enhance collective agreement on: (i) how to achieve desirable trade-offs between non-marketed and provisioning ecosystem services and (ii) which strategies, policy instruments and management tools to use to promote sustainable forestry. Results suggest that participatory decision-making processes and collaborative networks, involving scientists and other relevant stakeholders can assist in the development of a better understanding of the drivers and pathways of change, and demonstrate how these drivers may affect the forestry sector and local communities, residing in wooded areas. The findings indicate that tuning ofparticipatory processes is often insufficient to achieve transition from authoritative state to democratic and participatory forest governance. This is due to institutional inertia and unwillingness to decentralize decision-making power.Our results offer some useful insights into innovative responses to addressing the challengesfaced by the sector and forest-dependent communities, specifically through the promotion ofsocial innovationand linked novel governancemechanisms. Acknowledgement:The project on Social Innovation in Marginalised Rural Areas (SIMRA) is supported by the European Commission (GA 677622).

\section{Professional forest manager - as an instrument for sustainable forest management in private forests}

Zuzana Sarvašová ${ }^{1}$, Vilém Jarský, Jaroslav Šálka ${ }^{3}$, Zuzana Dobšinská3, Milan Sarvaš ${ }^{4}$

${ }^{1}$ Department of Forest Policy, Economics and Forest Management, National Forest Centre - Forest Research Institute , Zvolen, Slovakia; ${ }^{2}$ Department of Forestry and Wood Economics, Faculty of Forestry and Wood Sciences, Czech University of Life Sciences Prague, Praha, Czech Republic; ${ }^{3}$ Department of Forest Economics and Management, Faculty of Forestry, Technical University in Zvolen, Zvolen, Slovakia; ${ }^{4}$ National Forest Centre - Institute for Forest Consultancy and Education,Zvolen,Slovakia(zuzana.sarvasova@nlcsk.org;jarsky@fld.czu.cz; salka@tuzvo.sk; dobsinska@tuzvo.sk; sarvas@nlcsk.org)

Sustainable forest management as a key approach in European forestry is ensured by several policy instruments. This presentation compares findings of implementation of the institute called Professional Forest Managers (PFM) that is applied in the forest law in the Czech Republic and Slovakia. The main role of the PFM is to organize and direct forestry management. Because PFM's rights and obligations are directly determined by forest act, it can be stated that PFM can be considered as a tool of the state forest policy. Surveys among private forest owners as well as interviews with PFM confirm the necessity to have such kind of professional advice. On the other hand, our results have shown that in many cases, especially in the case of small or fragmented private property, the PFM does not fulfil its function adequately. There are gaps in communication, lack of finances, different attitudes of forest owners and PFM etc. Nearly 30 years 
of newly implemented PFM in private forests after the restitution processes, call for changes based on an evaluation research studies. Presented findings are based on the evaluation of data received in frame of national projects NAZV QK1820041 in the Czech Republic and project APVV IMPEVALES in Slovakia.

\section{Tools for professional forest management in central and Southeast Europe}

\section{Vilém Jarský, Zuzana Sarvašová2, Marcel Riedl ${ }^{1}$, Michal Hrib ${ }^{1}$, Martin Flora ${ }^{1}$, Jiři Oliva ${ }^{1}$, Luděk Šišák ${ }^{1}$}

${ }^{1}$ Czech University of Life Sciences Prague, Prague, Czech Republic; ' ${ }^{2}$ Department of Forestry and Wood Economics, Faculty of Forestry and Wood Sciences, Czech University of Life Sciences Prague, Praha, Czech Republic; ${ }^{3}$ Department of Forest Economics and Management, Faculty of Forestry, Technical University in Zvolen, Zvolen, Slovakia; ${ }^{4}$ National Forest Centre - Institute for Forest Consultancy and Education, Zvolen, Slovakia (jarsky@fld.czu.cz; sarvasova@nlcsk.org; riedl@fld.czu.cz; hrib@fld.czu.cz; flora@phpartners.cz; oliva@fld.czu.cz; sisak@fld.czu.cz)

The aim of this presentation is to describe the tools how the sustainable forest management is secure in selected Central (CZ, SK, PL, HU, AT) and Southeastern European counties (SI, RO, BIH, HR, SRB, MN). We are focusing on the analysis of the role of so called Professional Forest Manager (PFM) which is described in several countries as a person with forestry education and praxis who helps forest owners to manage their property. Methodically the data for the analysis were obtained in two ways. The first way was the text analysis of national forestry legislation (forest act). The second approach was based on common terms of reference filled by national experts due to lack of available English texts of forest acts. The results of the analysis of the legislation show that in the Czech Republic, Slovakia, and Hungary there it is obligation of the forest owner to have (or follow the opinion according to) a PFM and its duties and competences are very similar. On the other hand, other countries are using different approaches, e.g. state forest administration, experts from state forests, extension service or contracts with private associations to ensure professional forest management in private forests. Presented findings are basedon the evaluation of data received in frame of national projects NAZVQK1820041in the Czech Republic and project APVV IMPEVALES in Slovakia.

\section{Forest ownership changes in ECE region and policy responses}

Ivana Zivojinovic ${ }^{1,2}$, Gun Lidestav ${ }^{3}$, Gerhard Weiss ${ }^{1,2}$

${ }^{1}$ Institute of Forest, Environment and Natural Resource Policy, University of Natural Resources and Life Sciences, Vienna, Austria; ${ }^{2}$ European Forest Institute, Forest Policy Research Network, Vienna, Austria; ${ }^{3}$ Swedish University of Agricultural Sciences, Department of Forest Resource Management, Umeå, Sweden (ivana.zivojinovic@boku.ac.at; gun.lidestav@slu.se; gerhard.weiss@boku.ac.at)

Multiple changes in forest ownership structures have been observed worldwide, e.g. emergence of new ownership types, denationalisation and restitution of state forests, fragmentation and urbanisation of private forest ownership. Forest policies are often struggling to respond adequately. In our paper we assess these forest ownership changes and their drivers inthe ECE region during the last 25 years, by conducting atwo-stage expert assessment of the changes in each country, mapping geographical patterns, and discussing policy implications. The analysis shows that the share of the main ownership categories (public/private) remained fairly stable in the ECE region, however, significant qualitative changes deserve attention. The main change has been the restitution of forestland to private owners intransition countries in central and southeast Europe.Change in the owners' motivations, lifestyle and attitudes is the second important trend, particular in Western and Northern Europe.

\section{Forestry in transition or in opposition? Muddling through the societal transformations}

Vilis Brukas ${ }^{1}$

${ }^{1}$ Swedish University of Agricultural Sciences, Alnarp,Sweden (vilis.brukas@slu.se)

Societies in the Baltic, Central and Eastern European region underwent radical transformations in early 1990s, the pace of social changes is increasing in any country across the globe. How do such changes affect the forestry subsystem is a crucial question, however, forest policy scholarship struggles with providing reasonable answers. Different studies examine selected bits and pieces, often without attempting a more holistic understanding of the intricate relationships between society and forestry. Based on critical analyses of forest governance, this presentation attempts to shed light on these inherently complex developments. What kind of societal developments have been most crucial in framing the arena of change for forestry? What professional ideological core has been at odds with these external catalysts? How did the social change affect the policy landscape in terms of actors' constellations and power? These and other questions will be addressed, illustrated by examples from so-called countries in transition. Rather pretending value-neutral objectivity, the author will not be shy off providing an evaluative touch, sharing his own views on (mis)achievements in forest governance.

\section{Tropical forest and likely futures: an analysis of different pathways to reach sustainable economic growth in Indonesia}

Esther Boere ${ }^{1}$, Aline Mosnier ${ }^{1}$, Andree Ekadinata ${ }^{2}$, Ping Yowargana ${ }^{1}$, Adrian Dwiputra ${ }^{2}$, Betha Lusiana ${ }^{2}$, Fulvio Di Fulvio ${ }^{1}$, Pekka Lauri ${ }^{1}$, Dmitry Schepaschenko ${ }^{1}$, Juraj Balkovic ${ }^{1}$, Hugo Valin ${ }^{1}$, Florian Kraxner ${ }^{1}$

${ }^{1}$ International Institute for Applied Systems Analysis, Laxenburg, Austria; ${ }^{2} I C R A F$, Bogor, Indonesia (boere@iiasa.ac.at; mosnier@iiasa.ac.at; a.ekadinata@cgiar.org; yowargan@iiasa.ac.at; a.dwiputra@cgiar.org; b.lusiana@cgiar.org; difulvi@iiasa.ac.at; lauri@iiasa.ac.at; schepd@iiasa.ac.at; balkovic@iiasa.ac.at; valin@iiasa.ac.at; kraxner@iiasa.ac.at)

The role of competing land uses in the decline of Indonesia's natural forest cover has been extensively discussed. Commitments to reduce GHG emissions by $26 \%$ by 2020, together with a moratorium on clearing of primary forests and peatlands helped strengthen the countries' environmental goals. Simultaneously, Indonesia experiences significant economic growth based on natural resources and growing demand for some of its key products. Future impacts of these economic pressures on forest cover and the environment remain largely unknown. This study presents a spatially-explicit assessment of Indonesia's agriculture and forestry-sector trajectories, and how various policies can influence them, until 2050. GLOBIOM-Indonesia, a recursive-dynamic economic model tailored to Indonesia, is used to assess the impact of agricultural intensification, natural forest and peatland conservation, restoration of degraded forests and rewetting of peatlands as distinctive future scenarios. Our results show that, under full enforcement, policy interventions aimed at conservation and restoration can save 33 to $36 \%$ of total forest cover losses and $36 \%$ of annual GHG emissions from the AFOLU sector by 2050 . If combined with intensified agricultural management practices, this leads to an increase of $30 \%$ in area and $55 \%$ in production of rice and corn, but a decrease of $46 \%$ in area and $14 \%$ in production of the more forestcompeting oil palm. Furthermore, results show that intensifying agricultural practices without promoting forest conservation or restoration leads to a slight increase in deforestation due to the increased competitiveness of Indonesia compared to other world regions, highlighting the need for inclusive policy-making. 


\section{Effective inclusion of family farmers in the forest sector of Peru requires a multi-sectoral approach}

Valentina Robiglio ${ }^{1}$

${ }^{1}$ World Agroforestry Centre, Lima, Peru (v.robiglio@cgiar.org)

This paper seeks to identify the key ingredients of the transition towards agroforestry and sustainable land management (including small-scale forestry) by farmers living at the tropical forest-agriculture interface. It takes the case of Agroforestry Concessions (AC) in Peru, a promising legal mechanism in the last national Forest Law, that seeks to slow down deforestation in public forest land by formalising land and tree rights of encroaching smallholders, enabling their inclusion in the forest sector. The concession consists of a 40 years contract that commits the farmers to avoid deforestation and manage land sustainably. First, we map the multiple sectorial policies and institutional arrangements that regulate smallholders' land trees and production systems at the forest margin. Then we assess the coherence of their articulation in light of the challenges to comply with AC requirements and to manage or market forest products. We do so by analyzing data from a study of livelihoods and land and trees resources management by 120 potential beneficiaries of the Agroforestry Concession in 8 communities at the forest margin, complemented by focus group work on local governance and land cover and use dynamics, and on local actors' perceptions of risks and opportunities related to AC. We conclude that AC successful implementation depends on household level factors (such as farm size and composition), on the performance of the agricultural component of the farm, in particular on productivity, and ultimately on a set of complementary incentives, regulations and institutional arrangements from different sectors, besides, of course, the forestry one.

\section{Jurisdictional approach of farm-forest interfaces in Paragominas, PA: a municipal strategy to guarantee agricultural sustainable intensification and forest conservation in Amazonian landscapes}

René Poccard-Chapuis ${ }^{1,2}$, Marie-Gabrielle Piketty ${ }^{1,3}$, Jaqueline Peçanha ${ }^{4}$, Isabel Drigo ${ }^{5}$, Mario Oliveira Gomes ${ }^{2}$, Pablo Pacheco $^{6}$ ${ }^{1}$ CIRAD, Montpellier, France; ${ }^{2}$ Embrapa Oriental, Paragominas, Brasil; ${ }^{3}$ Pontifica Universidad Javeriana, Bogota, Colombia; ${ }^{4}$ Paragominas Municipal Government, Paragominas, Brasil; ${ }^{5}$ Instituto de Manejo e Certificação Florestal e Agrícola, Piracicaba, Brasil; ${ }^{6}$ WWF, Washington, USA (renepoccard@gmail.com; marie-gabrielle.piketty@cirad.fr; jaquelineadvambiental@gmail.com; isabel.drigo@gmail.com; mario.gomes@embrapa.br; pablo.pacheco@wwf.org)

In the Brazilian Amazon, since the last ten years, federal policies and value chains private commitments have been successful in reducing deforestation. However, the Amazonian landscapes are facing remaining challenges at the farm-forest interfaces such as halting forest degradation, restoring degraded lands, intensify and diversify land uses. Innovative local governance mechanisms are needed. This contribution will present a jurisdictional initiative in the Municipality of Paragominas (19342 $\mathrm{km}^{2}$ ), the first green municipality of the Brazilian Amazon. A geographic information system (GIS) has been developed, combining several data such as soils texture, slope, hydrographic and transport networks, land uses, forest cover including several level of degradation. It allowed to identify, for the whole municipality, land suitability for agricultural intensification and diversification, forest conservation and restoration and to support participative forwardlooking scenarios. A municipal plan to reorganize land and forest uses has then been elaborated. Such plan allow to preserve or restore 9000 km² of forests and to reforest $3500 \mathrm{~km}^{2}$ of land strategic for the production of ecosystems services. More $3500 \mathrm{~km}^{2}$ of degraded forest could be converted into productive agricultural systems and $4200 \mathrm{~km}^{2}$ of productive deforested areas could be intensified. Conversely to the classical opposition between production and conservation, this win-win strategy allows to build efficient landscapes and engage public and private actors. More, the GIS allows to monitor a large set of indicators that can be verified by third parties, such as certifying bodies, to transparently attest to the municipality's progress towards sustainability beyond the end of deforestation.

Turning words into actions: analyzing forest interventions and their effects on land use and welfare in rural settlements in Acre and Northwestern Mato Grosso, Brazil / Transformando palavras em ações: analisando intervenções florestais e seus efeitos no uso do solo e bem-estar em assentamentos rurais no Acre e noroeste do Mato Grosso, Brasil

Mayte Benicio Rizek ${ }^{1}$, Amy E. Duchelle ${ }^{2}$, Peter H. May

${ }^{1}$ Universidade Federal do Rio de Janeiro, Rio de Janeiro, Brasil; ${ }^{2}$ Center For International Forestry Research (CIFOR), Bogor, Indonesia; ${ }^{3}$ Universidade Federal Rural do Rio de Janeiro, Rio de Janeiro, Brasil (mayte.cifor@gmail.com; a.duchelle@cgiar.org; peterhmay@gmail.com)

Os estados amazônicos comportam 81\% da área destinada para a reforma agrária no Brasil. Se estes assentamentos rurais teriam potencial de formar bolsões de baixa concentração de terra e gestão sustentável dos recursos florestais, a realidade aponta um contexto de desigualdade, informalidade e invisibilidade, levando ao fracasso, migração e a reconcentração da terra em sistemas de agropecuária extensiva com alto impacto ambiental e baixa rentabilidade. Para reverter a trajetória de desmatamento em assentamentos rurais o Brasil tem contado com apoio financeiro internacional para a implementação de intervenções florestais, definidas por iniciativas introduzidas ou apoiadas por entidade não comunitária que busca influenciar direta ou indiretamente a maneira como comunidades gerenciam suas florestas. Parte de um estudo comparativo global do CIFOR, este estudo identificaintervenções florestaise avalia seus efeitos no uso do solo e bem-estar com dados empíricosidênticos coletados em assentamentos com delineamento antes/depois e com/sem intervenção florestal. Os resultados indicam que as intervenções do Acre melhoraram o bem-estar familiar, mas não foram capazes de conter o desmatamento. Já nos assentamentos do Mato Grosso observou-se uma redução do desmatamento, aparentemente sem afetar o bem-estar familiar. Em todos os casos o desmatamento está associado com a área de floresta, apontando um custo de oportunidade com relação ao potencial de desenvolvimento de base florestal. Ou seja, mesmo para um País tropical relativamente capaz, como é o caso brasileiro no período estudado, o desenvolvimento de base florestal enfrenta desafios para se estabelecer como o uso do solo mais atraente, especialmente no contexto dos assentamentos rurais.

\section{Cerrado Biome: agricultural production and territorial dimension of environmental preservation areas registered in the Brazilian rural environmental registry}

Gisele Freitas Vilela ${ }^{1}$, André R. Farias ${ }^{1}$, Fernando A. de Pádua Paim ${ }^{1}$, Gustavo Spadotti A. Castro ${ }^{1}$, Osvaldo Tadatomo Oshiro ${ }^{1}$, Carlos A. de Carvalho ${ }^{1}$ 1Embrapa Territorial,Campinas,Brasil (gisele.vilela@embrapa.br; andre.farias@embrapa.br; fernando.paim@embrapa.br; gustavo.castro@embrapa.br; osvaldo.oshiro@embrapa.br; carlos-alberto.carvalho@embrapa.br)

In this study we analyzed the territorial occupation of the Brazilian Cerrado biome considering the areas within rural properties that are dedicated to environmental preservation - such as Permanent Preservation Areas (APP), Legal Reserves (RL), and additional vegetation areas -, ADPs, and areas occupied with agriculture, 
production, and the gross value of the main agricultural products (soybean, maize, cotton, coffee, sugarcane, citrus and beans). With the aim of making the physical boundary of the Cerrado biome compatible with the country's political-administrative structure, all microregions featuring at least $25 \%$ of Cerrado areas within their coverage were considered, which amounted to a total of 234.9 million hectares under 132 microregions and 1,394 municipalities. This Cerrado clipping encompasses 1,047,898 rural properties registered under SICAR (in January 2019), amounting to a total of 166 million hectares or $70.7 \%$ of the total Cerrado area. These rural properties preserve 66.9 million hectares of ADPs and $40.2 \%$ of their land, which accounts for $28.4 \%$ of the Cerrado study area. The gross value of the selected agricultural products - soybean, maize and cotton - accounts for more than $50 \%$ of the total produced in Brazil. The agricultural production in this territory, when compared against the country's total production is: soybean (55\%), maize (58\%) and cotton (98\%). The areas planted with soybean, maize and cotton cover 28.7 million hectares. In this study we verified that the implementation of the Brazilian Forest Code is ensuring the preservation of $1 / 4$ of the Cerrado biome in this very important agribusiness region.

\section{A multi-faceted approach to overcoming obstacles to the uptake of sustainable agricultural practices - outcomes of the low carbon agriculture project}

Luis Tadeu Assad ${ }^{1}$, Gracie Verde Selva ${ }^{1}$

${ }^{1}$ Instituto Brasileiro de Desenvolvimento e Sustentabilidade, Brasilia,Brasil (assadmar@iabs.org.br; t-gracie@iabs.org.br)

Reducing carbon emissions from the agricultural sector is a key component of Brazil's national climate strategy. Low-carbon agricultural practices include many forest-centric activities including forest restoration and management. The implementation of low-carbon agricultural technologies by small and medium sized land holders faces many barriers including insufficient knowledge of available technologies, access to technical support and a lack of incentives for farmers to invest the necessary time and energy. The low-carbon agriculture project was implemented with the aim of promoting sustainable rural development in the Brazilian Amazon and Atlantic Forest biomes. It reached over 3000 small and medium sized private land-holders, supporting the implementation of sustainable agricultural practices such as integrated crop-livestock-forestry systems. The Project, the result of technical cooperation between the British Government, the Ministry of Agriculture and the Inter-American Development Bank and executed by IABS, utilised a three-prong approach. First the project provided access to information, through demonstration units, field days and the distribution of educational and technical materials. Second it offered rural producers a financial incentive for the implementation of one or more of four low-carbon agricultural practices promoted by the Project, prioritizing those with a forest component. Third the project provided training opportunities to local technical assistance agents that supported land-owners throughout implementation. This presentation will explore some of the results of the project in promoting sustainable rural development. It offers insights on how to combine governance interventions at national, state and local levels to achieve environmental and socio-economic development goals at the farm-forest interface.

\section{Relationship between farmers and the forest within Machadinho D'Oeste/RO's settlement project: using fauna as a bioindicator}

Angelo Mansur Mendes ${ }^{1}$, José Roberto Miranda ${ }^{1}$, José Paulo Franzin ${ }^{1}$, Bruno Scarazatti ${ }^{1}$, Fernando Antonio de Pádua Paim ${ }^{1}$, Jaudete Daltio ${ }^{1}$,

Gisele Freitas Vilela ${ }^{1}$

${ }^{1}$ Embrapa Territorial, Campinas, Brasil (angelo.mansur@embrapa.br; jose-roberto.miranda@embrapa.br; jose.franzin@embrapa.br; bruno.scarazatti@embrapa.br;fernando.paim@embrapa.br; jaudete.daltio@embrapa.br; gisele.vilela@embrapa.br)

Monitoring farms in a settlement project in Amazônia for a period of 100 years is an initiative that produces a series of data on soil use and occupation dynamics by small farmers. These data enable producing sustainability indicators, which offer elements for understanding the consequences of the articulations among local strategies and public policies which aim to strengthen small farming in Amazônia. The aim of this study was to analyze the data collected in the survey carried out in 2018, 36 years after the settlement of the farmers in PA Machadinho D’Oeste-RO, using fauna as an ecological indicator. The survey was carried out in 414 lots. Their farmers were interviewed regarding their visual perception of the fauna: frequency of spotting (often; regularly; occasionally; once; and never); predation (animal attacks on crops or livestock); accidents (harmful effects on health); and consumption (fishing and hunting). The data collected enabled analyzing the distance between the forests and the lots, and also separating the forest's indirect effects through the fauna as positive (food security) or negative (accidents and predation).

\section{Quality management of agroforestry products focusing on cultivated mountain ginseng}

Tae Hoon Kim ${ }^{1}$, Mi Sun Park ${ }^{1}$ iD

${ }^{1}$ Seoul National University, Pyeongchang, Republic of Korea (switch-thkim@snu.ac.kr; mpark@snu.ac.kr)

Forest farming is the most common type of agroforestry in the Republic of Korea. Agroforestry products are recognized as cleaner products comparing with other agricultural products in the Korean market. Accompanied with positive market perception, demand on agroforestry products is expected to increase. This paper focused on cultivated mountain ginseng as a non-timber forest product. It aims to scrutinize the current status of producing cultivated mountain ginseng and policies for improving production of cultivated mountain ginseng in the Republic of Korea. Policy instruments for supporting production of cultivated mountain ginseng were analyzed. Policy instruments include regulatory, economic, informational, organizational and planning instruments. In particular, traceability scheme of cultivated mountain ginseng as an innovative policy instrument was introduced. This study indicates combination of multiple policy instruments for supporting cultivated mountain ginseng producers and consumers in the Republic of Korea. Base on the research results, this research suggests policy recommendation to reduce institutional barriers and facilitate agroforestry activities in the Republic of Korea.

Facilitating women's participation to improve management of the forest farm interface: participatory lessons from Northern Ghana and Southern Burkina Faso

Peter Cronkleton ${ }^{1}$

${ }^{1}$ CIFOR, Lima, Peru (p.cronkleton@cgiar.org)

In the Sahelian landscapes of Southern Burkina Faso and Northern Ghana, the integration of agriculture, forestry, and livestock within the natural resource management systems used by smallholder households makes it difficult to separate agricultural land use from forest and tree use. Women play integral roles in these systems, particularly in the management of trees. However, customary systems of land and tree tenure differentially constrain women's access to resources, while national policies do not acknowledge or support their roles as resource managers. In such context, multi-stakeholder dialogues could be an effective strategy for assisting policy makers to better understand these complex production systems. However ensuring that such fora include the perspective of both male and female managers is crucial and creating conditions in which women can share their resource management knowledge and experience is 
central to guaranteeing the inclusion of their concerns. This paper analyzes efforts to use participatory methods in two multi-village landscapes to facilitate women's engagement, give voice to their priorities, and frame debate around topics important for their livelihoods. It builds on fieldwork conducted by CIFOR, ICRAF and Tree Aid as part of the West Africa Forest Farm Interface Project (WAFFI) funded by IFAD. The WAFFI team used participatory approaches to facilitate smallholder involvement in the definition, analysis and evaluation of management issues. As a result of these activities, women's groups catalyzed dialogue on conflict of use problems related to shea (Vitellaria paradoxa), unintended consequences of conservation boundaries and resource degradation due to uncontrolled bushfires.

\title{
Governing non-timber forest products in the Congo Basin farm-forest interface
}

Verina Ingram ${ }^{1}$, Donald Midoko Iponga ${ }^{2}$, Abdon Awono ${ }^{3}$, Christian Yobo Mikolo ${ }^{2}$, Denis Sonwa ${ }^{3}$

${ }^{1}$ Wageningen UR, Wageningen, Netherlands; ${ }^{2}$ IRET, Libreville, Gabon; ${ }^{3}$ CIFOR, Yaounde, Cameroon(verina.ingram@wur.nl; dmiponga@gmail.com; a.awono@cgiar.org;jaggermike2012@gmail.com;d.sonwa@cgiar.org)

In the Congo Basin, farms and forests are governed by separate regimes. This paper provides insights into the practices in which the transition from farm to forest (farm, agro forestry mosaics, fallows, farm forests, agro forestry mosaics, enriched forests) is governed in different cultural, economic and geographic contexts. The resulting fragmentation in governance regimes affects both access to forests, land and resources, and access to markets for products originating from these systems. The practices of both smallholders and larger landowners within this farm-forest interface are often bricolages to meet the demands of state, voluntary market and customary governance arrangements. This paper provides evidence and recommendations for how farm-forest interfaces in the Congo Basin can be governed such that multi-use practices are accommodated and result in positive sustainable, people centred outcomes.

\section{A9g: INNOVATIVE FOREST LAWS AND ENVIRONMENTAL LEGISLATION FOR ENHANCED} FOREST ECOSYSTEM SERVICES IN LOCAL COMMUNITIES

\section{Land and forest of Amazonian indigenous peoples: Why should they have ownership rights over both?}

\author{
Siu Lang Carrillo Yap \\ ${ }^{1}$ Göttingen University, Göttingen, Germany (siulang.muchik@gmail.com)
}

This research explores the level of recognition of the rights of Amazonian indigenous peoples to their land and forest and identifies the key aspects that must be considered for the strengthening of their rights, including a common regulation of their property rights over land and forest. The scope of the research is limited to four countries, which cover around $80 \%$ of the Amazonian region, namely Bolivia, Brazil, Ecuador and Peru. In this research, firstly, the overall conditions of the relationship between national States and indigenous peoples are discussed. Here, the status of indigenous peoples in constitutions and national laws is explored; their status influences their capacity to acquire and to manage their lands and forest resources. Secondly, the land rights of indigenous peoples are analyzed, considering two levels of control over land: property rights and indigenous territorial units. In this part, three models for recognizing the land rights of indigenous peoples are identified. Thirdly, the rights of indigenous peoples over their forest resources are examined. In this part, the types of recognized rights of indigenous peoples as holders of the titularity over the forest resources are analyzed, considering the attributions provided by these rights. Finally, the key elements that should be considered for reinforcing the land and forest rights of Amazonian indigenous peoples are reflected upon, considering land and forest rights as one unit (a right to the territory) and applying findings of natural sciences and property law theory.

\section{Forestland in Eeyou-Istchee: exploration of a far-reaching case of indigenous co-governance in Quebec, Canada}

Francois-Xavier Cyr', Stephen Wyatt ${ }^{2}$,Martin Hebert ${ }^{1}$

${ }^{1}$ Université Laval, Quebec, Canada; ${ }^{2}$ Université de Moncton, Edmundston, Canada; (francois-xavier.cyr.1@ulaval.ca; stephen.wyatt@umoncton.ca; martin. hebert@ant.ulaval.ca)

Forest governance arrangements for Indigenous peoples often include legal framing through treaties and/or land rights and shared institutions or management arrangements. In Canada, the 1975 James Bay and Northern Quebec Agreement (JBNQA) marked the first of a series of "modern" treaties and first attempts at creating mechanisms and institutions that would provide the James Bay Crees with increased power and responsibility over their territory of Eeyou-Istchee. A subsequent agreement in 2002, the "Paix des Braves" lead to the creation of the Cree-Quebec Forestry Board (CQFB) by which the Cree and the government of Quebec collaborate to oversee the co-governance of forest resources of Eeyou-Istchee. This presentation examines the history and functioning of the CQFB, and its efforts to balance the aspirations of the James Bay Cree in asserting their sovereignty over their traditional lands and those of the Quebec government in maintaining ultimate authority and in promoting industrial development of natural resources. In particular, we consider the governance processes that are used at different levels, as well as the monitoring instruments that are used to determine the effectiveness of forest management efforts in maintaining the Cree way of life and on promoting closer relations between Indigenous and non-indigenous inhabitants of the land.

\section{Analysing Zambia's community-based forest's legal framework and its potential to improve forest management and livelihoods}

\section{Felix Kalaba}

${ }^{1}$ School of Natural Resources, Copperbelt University, P.O Box ${ }^{21692}$, Kitwe, Zambia (kanungwe@gmail.com)

This study examined Zambia's community forestry regime using the FAO's analytical framework for the assessment of extent and effectiveness of community based forestry (CBF) regimes and identify areas of improvement to ensure sustainable forest management for food. The methodology included policy analysis and key informant interviews which followed a combination of purposive and snowball sampling. Policy documents analysed included Zambia Forest Policy of 2014, Forest Act of 2015, Wildlife Act of 2015. This was followed by in-depth interviews with key experts which included government officials at district level responsible for Forestry, wildlife, planning and agriculture.Findings show institutionalisation of CBF in the legal framework. There is recognition of the rights of forest communities for all the analysed CBF types. Enjoyment of rights is outlined in the policy and legal framework though hindered by factors such as access to markets, lack of recognition of gender and marginalised members of communities. Access to justice in case of disputes is through formal dispute resolution processes which has challenges of human and financial resources. The legal framework however lack provisions and specific strategies addressing gender in recognition of rights.Subsidiary laws lack provisions and specific strategies for addressing historical and cultural gender disparities. The law is further silent on compensation of forest owners when rights are revoked under community forest or JFM regimes. There is need for recognition of rights and deliberate promotion and recognition of women in CBF regimes if sustainable management of forests and livelihood improvement are to be achieved. 
Forest access, rights, and benefits: exploring the role of community forests as an innovative tenure regime for protecting ecosystem services in the US

Kathleen McGinley ${ }^{1}$, Frederick Cubbage ${ }^{2}$, Gregory Frey ${ }^{3}$, Meredith Hovis $^{2}$, Megan Lupek ${ }^{2}$, Han Xue ${ }^{3}$

${ }^{1}$ U.S. Forest Service, International Institute of Tropical Forestry, Rio Piedras, Puerto Rico; ${ }^{2}$ North Carolina State University, Dept. of Forestry and

Environmental Resources, Raleigh,_USA; ${ }^{3}$ U.S. Forest Service, Southern Research Station, Raleigh, USA(kmcginley@fs.fed.us; fred_cubbage@ncsu.edu;

gregoryefrey@fs.fed.us; mehovis@ncsu.edu; mlupek@ncsu.edu; xue.han@usda.gov)

Forests in the United States of America (U.S.) support livelihoods, protect environmental quality, and provide social benefits. However, their modest market returns and provision of nonmarket goods and services that often go uncompensated place them at some risk of over-exploitation and loss to other land uses with greater market values. A promising renewed approach to redress the imbalances between social forest benefits and limited market returns are 'community forests' that permit forest tenure rights holders to cooperatively identify and develop forest resource benefits; achieve economies of scale; capture increased market and nonmarket returns; contribute to rural economic development; and enhance forest retention and management.Community forests in the U.S. occur on tribal forest lands, federal forest lands under stewardship contracts to community-based organizations, and lands held in trust for communities by local government or non-profit entities, among other models. However, there is limited empirical data on the status, trends, characteristics, or outcomes of these forests. Through mixed methods research, we take stock of the broadening range and extent of community forests in the U.S. to qualify and quantify their legal designations, tenure regimes, governance mechanisms, management practices, and outcomes and to evaluate the associated contexts, enabling factors, and limiting conditions. The results shed light on the state of community forestry in the U.S. and the characteristics and conditions that lead to enhanced forest retention, ecosystem services provision, environmental protection, profitability, and community well-being and resilience.

\section{Legal aspects of providing forest ecosystem services: case of the Slovak land associations}

Rastislav Sulek ${ }^{1}$, Jan Lichy ${ }^{1}$, Martina Kasubova ${ }^{1}$

${ }^{1}$ Technical University in Zvolen, Zvolen, Slovakia (sulek@tuzvo.sk; jan.lichy@tuzvo.sk; kasubova.martina@gmail.com)

The provision of forest ecosystem services is closely interlinked with the specific impacts of forest resource management that are determined by the internal business circumstances as well as by the external restrictions. While the internal conditions are determined by the economic efficiency of forest enterprises, the external restrictions are governed, except for the nature conditions, by the regulative state measures, characteristics of business environment, and principles accepted by the whole society. Land associations belong to the important legal type of the Slovak forest enterprises - they manage almost $30 \%$ of forest land. Still, their legal regime is somehow specific in comparison with the other legal types of forest enterprises. The provision of forest ecosystem services by land associations is thus affected by a number of factors - the most important ones are specific property rights in land associations, interests of forest landowners, legal restrictions, social and environmental interests and preferences of the society. The anticipated contribution of the paper is, based on the analysis of legal factors that affect the provision of ecosystem services under specific conditions of land associations in Slovakia, to model the most important legal aspects of the optimal provision of forest ecosystem services in common forests.

\section{Role of spatial development planning towards sustainable forest management}

Lìga Mengele-Stillere ${ }^{1}$

${ }^{1}$ State Forest Service, Riga, Latvia (ligamenstill@inbox.lv)

Interests how to use forest land vary from economic ones till social and environmental interests where people want to use forest for recreational purposes or protect forest nature values. Question is: How to balance all different interests of land use and who should do it? State through legislative procedures has to form the system pf spatial development planning and local authorities have to realize this process. Spatial development planning results are foundation for further land use realization. Spatial development planning legal regulation has strong impact on balancing different interests in forest sector. Planning documents adopted as a result of spatial planning must be like agreements between representatives of several interests. Legal acts guarantees rights - access to information, public participation in decision - making and access to justice in environmental matters. These Environmental procedural rights has to be used actively by NGOs representing several interests in land (and forest as well) use and protection starting from the beginning of the spatial planning process, but not after land owner starts tree harvesting in his ownership. Ability of local governments to find the right balance of several interests in some cases is not satisfactory, that can be illustrated with some Constitutional Court cases in Latvia.

Rural environmental register in Espirito Santo, Brazil: more than $\mathbf{3}$ million hectares registered so far / Cadastro ambiental rural no Espírito Santo: mais de 3 milhões de hectares já cadastrados

Livia Almeida ${ }^{1}$, Fabrício Zanzarini ${ }^{1}$, Michel Simon ${ }^{1}$

${ }^{1} I D A F$, Vitória, Brasil (livia.almeida@idaf.es.gov.br; fabricio.zanzarini@idaf.es.gov.br; michel.simon@idaf.es.gov.br)

O Cadastro Ambiental Rural (CAR) foi instituído por meio do novo Código Florestal Brasileiro, (Lei 12.651/2012) e o Espírito Santo foi um dos primeiros estados a regulamentá-lo, já em 2013. Após seis anos de implementação do CAR no estado, é possível afirmar que a ferramenta confere um diagnóstico detalhado das áreas rurais do estado, por meio do qual é possível obter informações sobre o uso do solo de cada propriedade rural, com o mapeamento das áreas de vegetação nativa, Áreas de Preservação Permanente (APPs) e a demarcação das áreas de reserva legal, especialmente. De acordo com estimativas do Instituto de Defesa Agropecuária e Florestal do Espírito Santo (Idaf), órgão gestor do CAR no estado, o Espírito Santo possui cerca de 133 mil propriedades rurais e os números registrados até o início de 2019 mostram que mais de 84 mil imóveis já estão inscritos, sendo mais de 64 mil já validados. Extrapolando para área, são mais de três milhões de hectares cadastrados, correspondendo a 73\% da área rural do estado. A partir dos dados declarados no CAR, até o momento foram mapeados mais de 638 mil hectares de florestas preservadas, o que equivale a $20 \%$ da área cadastrada. Desse total, cerca de 360 mil hectares foram demarcados como reserva legal e outros 67 mil estão em APPs. Em paralelo, foram demarcados 78 mil hectares de reserva legal e 86 mil hectares de APPs que deverão ser recuperados para adequação ambiental dos imóveis, por meio do Programa de Regularização Ambiental (PRA). 


\title{
New Brazilian Forest Code, PSE programmes and deforestation: What are the links?
}

Leidimari Neves do Prado ${ }^{1}$

${ }^{1}$ Institut National de la Recherche Agronomique, Nancy, France (leidimari.neves-do-prado@inra.fr)

Since the reformulation of Brazil's Forest Code (BFC - law 12.651/2012) in 2012 the Brazilian government made a move towards more stringent environmental conservation and announced that landowners in disconformity with this law would be punished (e.g. fines and additional barriers to obtain bank loans). This announcement had great impact on the landowners' perception of the importance to comply with the law. In parallel, the Brazilian government set up, in 2012, at the Pipiripau River Basin (Federal District) the Water Producer Programme (WPP): the foremost example of PES schemes in Brasil. WPP deviates largely from other predominant approaches: Contract signatories are subsidized of all implementation costs, such as restoration of Areas of Permanent Protection (APP) and Legal Reserves (RL), two important environmental obligations demanded by the BFC to all Brazilian landowners. Those landowners who do not sign the contract must regularize the property in a 20-year period starting from 2012, with at least $10 \%$ of the total area rehabilitated every two years. All these aspects are great challenges for producers because they cost not just effort but also money and time. This paper studies the links between BFC, WPP and deforestation in the Cerrado biome. Our results show that deforestation is strongly correlated with law-incentives for agricultural expansion. The reformulation of BFC with a special focus on PES programmes was an important tool to reduce deforestation and increase the restoration area and the recovery of all deforested areas will be reached long before 2032, the expected date by BFC.

\section{A9h: NATURE'S CONTRIBUTION TO PEOPLE IN TRANSITIONING FOREST LANDSCAPES}

\section{The encroachment of ecosystem services into forest restoration discourses}

Wilhelmus de Jong ${ }^{1}$

${ }^{1}$ Kyoto University, Kyoto, Japan (dejongwil@gmail.com)

Forest restoration refers to conscious efforts that are being made to bring back forest where it has disappeared or restore the condition of degraded forests. The last three decades or so, have seen a tremendous global commitment in target areas of forest land where forests is to be restored. The multiple global or regional forest restoration targets reflect an expanding interest and commitment in forest restoration practice, advocacy and discourses. The current surge in restoration efforts, analysis and debates can be originated somewhere in the early 1990s. Over the period of the last two to three decades the forest restoration discourse and debates have shifted. Two terms have been competing in the related academic and non- academic literature, rehabilitation and restoration. The latter term has now taken over in the global forest restoration discourse. This reflects a progressive dominance of forest restoration advocates who emphasize ecological services of restored forests, in addition to providing provisional ecosystem services to society, which are functions emphasized by a forest rehabilitation camp. The paper will analyze the changes in discourses related to forest restoration in general, and in particular how ecosystem services explicitly or implicitly have appeared in those shifting forest restoration discourses. The paper is based on research of a relevant number of academic papers, advocacy pieces as well as written materials produced by several key actors with interest and commitments related for forest restoration.

\section{A system dynamics framework for policy impact on forest ecosystem services}

\author{
So-Hee Park ${ }^{1}$, Youn Yeo-Chang ${ }^{1}$, Nathaniel Anderson ${ }^{2}$
}

${ }^{1}$ Seoul National University, Seoul, Republic of Korea; ${ }^{2}$ United States Forest Service, Missoula, USA(dannysohui@snu.ac.kr; youn@snu.ac.kr; nathaniel.m.anderson@usda.gov)

Ecosystem services-based decision-making has advantages in that it can provide policy alternatives to have a balanced supply and distribution of ecosystem services value. To support the ecosystem services-based decision-making, research should be conducted to understand the process and structure of ecosystem services from forest ecosystem, evaluate supply and value of ecosystem services, as well as impacts of policy and management system on ecosystem services. This study aims to develop a system dynamics framework in the form of causal loop diagrams in order to determine relationship between forest ecosystem services and management system including policy. First, this study develops causal loop diagrams for forest ecosystem services considering synergies and tradeoffs among various types of ecosystem services to assess supply and value of ecosystem services. How four types of forest ecosystem services (provisioning services of timber and non-timber forest products, regulation services of water storage, soil erosion prevention, and carbon absorption, supporting services of species diversity, and cultural services of recreation and scenery) are linking with forest ecosystem characteristics (e.g. as forest area, growing stock, soil characteristic and depth, forest road system, etc.) in the causal loop diagrams is explored in this study.Second, policy-ES integrated model is developed by grafting policy factors onto a causal loop diagrams of forest ecosystem services in order to determine impacts of policy and management system on ecosystem services.This framework might contribute to evaluate effectiveness of forest management on ecosystem services and develop optimization strategies for the provision of ecosystem services.

\section{Effects of farmer income and roads on forest transition}

Xiaodi Zhao ${ }^{1,2}$, Lingchao Li ${ }^{2}$, Lingchao $\mathrm{Li}^{2}$

${ }^{1}$ Chinese Academy of Forestry, Beijing, China; ${ }^{2}$ Beijing Forestry University, Beijing, China (edison19890918@126.com; lowrychen@sina.com; 847317773@qq.com)

Objective To study the impact of farmers'income and roads on forest transition and provide reference for promoting the coordinated development of regional socio-economy and forest ecology. Method based on the remote sensing images and socio-economic statistics of 32 sample counties in Fujian province from 2000 to 2016, this paper studies the impact of farmer income and roads on forest transition under different resource endowments by quantile regression method, explores the influence of interaction between farmers' income and road conditions on forest cover changes and analyze the moderating effect of roads on farmers' income. Results 1) Farmer per capita income has a significant effect on the growth of forest area, and in counties with moderate forest resources endowment, per capita income has a greater effect on forest transition, while in counties with rich or relatively low forest resources endowment, per capita income has a smaller effect; 2) Road density has a significant negative impact on forest area, the higher the forest resources endowment, the greater the negative effect of road density on forest transition; 3) The concurrent of low rural road density and high farmer income are more conducive to promoting forest transition.Other things being equal, the lower the density of rural roads, the greater the comprehensive impact of farmer income on forest transition. Conclusion Income growth of farmers is an important factor to promote forest transition in Fujian, and road facilities will have a negative effect on forest transition. Under different forest resources endowment conditions, income and road shave different effects on forest resources, and road density has a negative moderating effect on income. 


\section{The power of actors behind the change of relationship between human beings and Asian elephants: a case study of Xishuangbanna}

Pei Zhang ${ }^{1}$, Jiacheng Zhao

${ }^{1}$ Renmin University of China, Beijing, China (zhangpei9511@163.com; zhaojiacheng@ruc.edu.cn)

With the development of Chinese society, the relationship between the humanity and wildlife has undergone profound changes, of which the relationship between people and the Asian elephant is the epitome. This paper hope to reveal the power of actors hidden in the transformation of the relationship. Taking Actor-centered power theory as the analysis framework, this paper analyzes three important periods of relationship between human and Asian elephant based on the case of Xishuangbanna. The first is the attack period, with the implementation of policy of developing Xishuangbanna as a turning point. The government and the immigrates opened up the land together, which squeezed the habitat of Asian elephants. The second is the Transition period, with the establishment of a Tropical Rainforest Reserve as a turning point. The government turned to nature conservation which was based on Asian elephant, while the community, as a powerful actor, continued to develop natural resources under the encouragement of the market element. The third is the defense period, with the prohibition of reclamation as a turning point. The government which gained powerful status through compulsory, incentive and informational means prevented the community continuing land reclamation and the relationship between people and Asian elephants reversed. In conclusion, the relationship between humans and Asian elephants has been deeply embedded in social networks where the power game of actors happens. From this perspective, in the critical period of China's construction of ecological civilization, this paper hopes to bring inspiration for the further studies of nature conservation.

\section{Conservation and recovery participatory of forest in the Mixteca Geopark, Oaxaca, Mexico}

J. Antonio Hernández-Aguilar ${ }^{1}$, Elvira Durán ${ }^{1}$

${ }^{1}$ CIIDIR Oaxaca -Instituto Politécnico Nacional, Santa Cruz Xoxocotlán, Oaxaca, Mexico (antonio.hernandez.aguilar@gmail.com; eduran3@hotmail.com)

In contrast to deforestation, the trends of forest recovery have been still insufficiently studied, particularly when they are impulse by social involvement. Before the current century, Mexico was a high deforestation rate, one extreme case was in the indigenous Mixteca region in Oaxaca State, consider with the highest soil erosion and forest degradation in the world. Because of the impressive landscape degradation, UNESCO gave it in 2016 the recognition of "Geopark". With this study, we analyze the forest recovery in the Mixteca Geopark and the role of local people in conducting the tendencies. Field trips and satellite images classification were made to identify the status of the forest remnants and the cover recovery. In addition, five workshops were organized and semi-structured and informal interviews with leaders and inhabitants documented social processes and local actions that have helped forest recovery. It found $120 \%$ (495 ha) of pine-oak forest increase during the period 1990-2018, and a growth of 35\% (317 ha) of secondary forest (pine). The recovery result of collective reforestation activities since 1995, based on local initiatives with supported for governmental programs. Besides reforestation activities, regulations to prohibited free logging and grazing for more than two decades allow the forest natural recovery. We concluded that the people from Mixteca Geopark intentionally stop and begin to reverse deforestation, though collective action and communal rules. The Geopark status started to promote social learning about the severe degradation of the territory and the importance of forests for soil protection, carbon capture and water recharge.

\section{Local people participation in climate change related projects: its impacts to social capital and livelihoods}

Roswin B. Valenzuela ${ }^{1}$, YOUN Yeo-Chang ${ }^{1}$, Mi Sun Park

${ }^{1}$ Seoul National University, Seoul, Republic of Korea (roswinbobisvalenzuela@gmail.com; youn@snu.ac.kr; mpark@snu.ac.kr)

Climate change is a global problem caused by the cumulative actions of multi-level actors; therefore, solving the climate change problem requires collective action. Networks have been created to establish cooperation and collaboration between multi-level stakeholders, this facilitates the exchange of knowledge and strengthens the cooperation between the stakeholders. Cooperation is not only significant for the actions against climate change, but it also contributes to the local communities by increasing their social capital through their involvement in climate change mitigation projects. Through the increase of the connections and relationships of the local communities with other stakeholders, their assets also increase, which are important in accumulating more capitals and in gaining economic profits. This study focuses on the impacts of local community participation in climate change related projects to the level of social capital. Moreover, the study analyses the impacts of the changes in the level of social capital to the local communities' access to resources and services, and to the flow of information in the community; these two variables are essential in improving the livelihoods of the local communities. The improvement of the livelihood of the local communities is critical in the natural resource conservation since it can reduce the pressure to resource dependency, especially to the poor people with no other means of acquiring resources for their needs, subsistence, and livelihood. The study will be done in the Province of Quezon, Philippines. Household interviews and key informant interviews will be conducted for the data gathering.

A9i: POLICY AND PRACTICE FOR SUSTAINABLE FOREST-BASED TOURISM AND RECREATION

\section{Forests, nature-based tourism trends and the drivers behind}

Peter Fredman ${ }^{1}$, Jan Vidar Haukeland ${ }^{1}$, Liisa Tyrväinen ${ }^{2}$, Dominik Siegrist ${ }^{3}$, Kreg Lindberg ${ }^{4}$

${ }^{1}$ Norwegian University of Life Sciences, As, Norway; ${ }^{2}$ Natural Resources Institute Finland, Helsinki, Finland; ${ }^{3}$ Hochschule für Technik, Rapperswil,

Switzerland; ${ }^{4}$ Oregon State University, Bend,USA(peter.fredman@nmbu.no; jan.vidar.haukeland@nmbu.no; liisa.tyrvainen@luke.fi;

dominik.siegrist@hsr.ch; kreg.lindberg@osucascades.edu)

Forests are an important resource for the delivery of tourism and recreation services in many parts of the world. Recreation in the outdoors have potential to improve quality of life and nature-based tourism to support regional development outside the urban districts. Recent trends in the tourism and recreation sectors show evidence of increased diversification and globalization, driven by social, technological, economic, environmental and political factors. To understand these dynamics better, this presentation reports findings from a Delphi-study including 70 experts in Norway, Sweden, Finland, Central Europe and Western United States. The Delphi method is a structured communication technique organized in several iterations where respondents get controlled feedback for each repetition and the researcher is looking for convergence in the distribution of opinions. The first iteration had an open-ended format asking questions about the most significant trends, associated drivers, challenges and opportunities. The following two iterations operated with closed-ended questions, measuring the significance of the trends identified. The study is part of the BIOTOUR project, a Norwegian multi-disciplinary research project with the overall hypothesis that an integrated perspective of the nature-based tourism sector will provide a basis for both innovative products and a more sustainable development. The presentation will discuss the study results in the light of policies and practices to manage tourism and recreation for a more sustainable use of forests and other natural resources for the benefits of people. 


\section{Using the extension service to increase the capacity for ecotourism development in Florida, USA}

Taylor Stein ${ }^{1}$, Shane Feyers ${ }^{1}$, Katherine Nelson ${ }^{1}$, Kotryna Klizentyte ${ }^{1}$

${ }^{1}$ University of Florida, Gainesville,USA (tstein@ufl.edu; sfeyers@ufl.edu; knelson407@ufl.edu; kklizentyte@ufl.edu)

Florida is one of the most popular tourism destinations in the USA, but as an ecotourism destination, it is relative unknown. Facing unprecedented growth in new residents and tourism arrivals, Florida has the potential to use ecotourism as an industry to promote sustainable development, while contributing to the improvement of local economies and quality of life. The Florida Extension Service, which has traditionally been associated with agricultural education, has the capacity to help Florida tourism businesses, policy makers, and land management agencies use ecotourism as a development strategy, but research is needed to understand Extension's role to aid in ecotourism development. Researchers conducted six nominal group interviews, two surveys of nature-based tourism providers, and individual interviews with tourism professionals to understand how the Extension Service can best assist in Florida's ecotourism development. Results show stakeholders believe the Extension Service must take on a leadership role, as well as, an educational role to help Florida's counties implement ecotourism. Specifically, many Florida counties are working to develop sustainable tourism enterprises, but they are not integrating nature into their tourism planning. Extension professionals have the ability to not only educate diverse stakeholders on successful nature-based tourism planning, but they also have the capacity to form innovative and valuable partnerships between stakeholders, which previously did not exist. This presentation will discuss how diverse stakeholders believe the Extension Service can help Florida counties achieve specific ecotourism outcomes and the methods to achieve those outcomes.

\section{Creating markets for forests amenities in nature-based tourism context: case of Ruka-Kuusamo Finland}

Liisa Tyrväinen ${ }^{1}$ Erkki Mäntymaa ${ }^{2}$, Artti Juutinen ${ }^{2}$, Mikko Kurttila $^{3}$

${ }^{1}$ Natural Resources Institute Finland, Helsinki, Finland; ${ }^{2}$ Natural Resources Institute Finland, Oulu, Finland; ${ }^{3}$ Natural Resources Institute Finland, Joensuu, Finland(liisa.tyrvainen@luke.fi; erkki.mantymaa@luke.fi; artti.juutinen@luke.fi;mikko.kurttila@luke.fi)

Nature-based tourism is an important and growing economic sector in Europe that builds on attractive nature environments, experiences and activities. In many European countries, and in particular in the north,intensified wood production with shortened rotation cycles and large size of management units negatively affect the scenic and environmental qualities of forests and decrease locally their suitability for tourism. Therefore, new policy instruments, such as Payments of Ecosystem Services (PES), are needed to secure and enhance the quality of forest landscapes. These instruments could engage private forest owners and nature-based tourism companies (NBTs) to cooperate in enhancing production of forest amenities. This presentation sums up research results and experiences regarding development of landscape and recreation value trading model in Ruka-Kuusamo region, Finland, where both commercial forestry and nature-based tourism are important. Research results show that tourists' are willing to contributing to funding of landscape and biodiversity protection during their stay. Moreover, landowners are relatively willing to participate in suggested payment scheme if reasonable compensation is paid and, have increased interest if both landscape and biodiversity will be protected. In contrast, local tourism entrepreneurs' are less interested in funding production of forest amenities, although they see forest landscapes important for their business. Therefore, awareness raising, improved communication of benefits of environmental investments are needed. The key actors include forest owners, authorities and managers as well as nature-based tourism companies, planners and managers. The presentation discusses also ongoing collaborative deliberation, co-design and communication processes involving multiple stakeholders striving for implementation of the mechanism.

\section{Igniting the Science of Outdoor Recreation (ISOR): introducing a research strategy developed through a National assessment and multi-stakeholder process}

Anna Miller ${ }^{\text {ID, Steven Selin }}{ }^{2}$, Lee Cerveny ${ }^{1}$, Monika Derrien $^{1}$

${ }^{1}$ USDA Forest Service, Seattle,USA; '2West Virginia University,Morgantown,USA (annamiller@fs.fed.us; sselin@wvu.edu; lcerveny@fs.fed.us; mderrien@fs.fed.us)

Enhancing sustainable recreation opportunities has emerged as a priority for protected area and public land managers globally. In many regions, management and research capacity to support recreation decision-making has diminished over the past two decades, while visitation to public lands has increased. Updated conceptual frameworks and management tools are needed to guide agency decision-makers. This presentation reports on outcomes of the interagency "Igniting the Science of Outdoor Recreation" (ISOR) collaborative in the United States. The mission of ISOR is to generate new energy and focus, resulting in outdoor recreation research that addresses pressing land management challenges. This effort has produced a Research Strategy, which synthesizes management challenges and identifies areas of research to address them. The Research Strategywas developed over 18 months and involved dozens of outdoor recreation professionals, including resource managers, researchers, and practitioners from multiple agencies. A series of events including two workshops and an international needs assessment were conducted, resulting in ideas that were synthesized by interdisciplinary writing teams to produce the final document. This presentation will introduce the final Research Strategy document. The document covers nine Research Focus Areas (RFAs) including: Integrative Outdoor Recreation Planning, Transforming Organizational Culture, Outdoor Recreation Drivers, Visitor Monitoring, Health Benefits, Fostering Nature Connections, Enhancing Heritage and Shared Stewardship, Sustainable Tourism, and Ecological Interactions. Cross-cutting themes synthesized from the RFAs include systems thinking, integration, and resilience. We will present strategies identified to implement the Research Strategy and implications of this document for the international management of public lands.

\section{Local community's perceptions of sport fishing in the Amazon}

Yasmin Cristina Hess ${ }^{1}$, Teresa Cristina Magro Lindenkamp ${ }^{1}$, Carlos Gabriel Koury ${ }^{2}$

${ }^{1}$ Universidade de São Paulo, Piracicaba, Brasil; '2IDESAM-Instituto de Conservação e Desenvolvimento Sustentável da Amazônia, Manaus, Brasil (yasmin.hess@usp.br; teresa.magro@usp.br; carlosgabriel@idesam.org.br)

Tourism in the Uatumã Sustainable Development Reserve (RDS) is an activity with potential for social inclusion, income generation, community empowerment and natural resource preservation. According to the Management Plan, $30 \%$ of the residents consider that tourism causes damages and complain about the difficulty of catching fish after tourism and sport fishing activities. In this context, we developed a protocol to monitor the impact of the sport fishing and its relationship with the traditional community in the Uatumã RDS. We work with the perceptions of community members regarding a series of indicators identified through interviews. Regarding boat traffic, boat speeding and dead fish the opinion of the interviewed was less negative when they had a relation with sport fishing. Residents with a direct relation to sport fishing considered these indicators less impacting than those who do not work with sport fishing. Surprisingly, residents with no relation with tourism don't criticize the presence of oil in the water. Most likely because they don't perceive the pollution. Among the parameters evaluated, the change in watercolor was the most negatively assessed indicator by the residents. In general, the indicator evaluation shows that sport 
fishing has little effect on the inhabitants of the Reserve. The RDSU has the potential to carry out sport fishing activities and bring benefits to the community, but we emphasize that this research shows only the perception of the residents. More study is necessary related to the impacts of sweet water life.

\section{Determination of carrying capacity for Quezon protected landscape's ecotourism attractions}

Gerald Eduarte ${ }^{1}$, Rogelio II Andrada ${ }^{1}$

${ }^{1}$ Unversity of the Philippines Los Banos, Los Banos, Philippines (gteduarte@up.edu.ph; rtandrada@up.edu.ph)

Protected areas are becoming extremely important ecotourism destinations. These areas are at risk from uninformed and uncontrolled visitors which can cause pollution (air, noise, water, etc.) and alteration of the natural ecosystem processes. An effective ecotourism planning and management approach should consider and define an optimum threshold level for the use of ecotourism attractions while maintaining a sound biophysical and social environment. Although carrying capacity is important in regulating visitor influx, the application and practice of this concept is not being observed in Malabayabas forest, Pinagbanderahan trail and peak, which are ecotourism attractions of Quezon protected landscape in Atimonan, Quezon Province. This study focuses on the carrying capacity standards of these ecotourism attractions with considerations of site-specific factors. The physical, biological/ecological, social and economic conditions of the site were assessed. Data concerning demographics and visitation characteristics were collected through a survey, administered in August to December 2015. The results demonstrated that the actual number of visitors in these ecotourism attractions is currently lower than the calculated carrying capacity. In reality, there is still a risk for congestion and overcrowding particularly during high visitation. Therefore, a responsive visitor management program should be developed.

\section{Nature-based tourism governance in addressing paradigm shifting challenges in managing protected areas of Bangladesh \\ Md. Wasiul Islam ${ }^{1}$ (D) Md Nazmus Sadath ${ }^{1}$ \\ ${ }^{1}$ Forestry and Wood Technology Discipline, Khulna University, Khulna, Bangladesh (wasiulislam7@yahoo.com; mnsadath@yahoo.com)}

Currently, most of the protected areas of Bangladesh are undergoing a transition period between traditional management approach to collaborative management (co-management) approach to ensure a better management system basically through shared governance system. However, such paradigm shifting in protected area management approach is not that smooth as anticipated earlier. Various types of socio-economic, environmental and institutional challenges are impeding this paradigm shifting. This qualitative study has explored how nature-based tourism governance system under co-management approach can influence these challenges. Nature-based tourism has been implementing in these protected areas as one of the eco-friendly enterprises and alternative income generating opportunities under this bottom-up approach. Such tourism governance system is facilitating multi-stakeholder participation, transparency, accountability, social learning, decentralization of power and local empowerment, and following rules of laws in these protected areas which ultimately contributes to reduce abovementioned various challenges and motivating local stakeholders to support and promote co-management approach as an alternative protected area management approach. Nature-based tourism is treated as the sole revenue generating enterprise in these protected areas which is not only generating revenues for different stakeholders but also facilitating significantly to improve environmental awareness and education which ultimately promoting protected area management and conservation. Additionally, it is accelerating to address various issues of traditional management approach particularly through improving collaboration among various stakeholders, decision-making process, resource leveraging, institutional arrangement, lesson and learning opportunity, and so on. Adaptive co-management is an advanced, dynamic, and innovative governance approach can further improve the overall governance system of these protected areas.

\section{Challenges and potentials of ecotourism practices: a case study of Sinharaja rainforest in Sri Lanka \\ Manjula Karunaratne ${ }^{1}$ (D) Indi Akurugoda \\ ${ }^{1}$ University of Ruhuna, Matara,Sri Lanka (mlankanath@gmail.com; ndiakuru@gmail.com)}

Tourism is one of the major income sources of Sri Lanka. The government, therefore, has given the top priority to tourism sector development. However, government approaches are not effective and efficient to promote some of the newer, significant and diverse tourism concepts such as ecotourism and forestbased tourism. When these tourism concepts being applied in forest peripheries, several mismatches and malpractices occur. This study mainly focuses on why the concept of ecotourism does not contribute towards benefitting development and conservation initiatives. The study identifies challenges and potentials of ecotourism practices in the Sinharaja rainforest in Sri Lanka. The Sinharaja rainforest is a UNESCO world heritage site which is famous among local and foreign tourists throughout the year. This research used the semi-structured interview method to collect primary data from villagers live in the Sinharaja forest periphery, the forest officials and local and foreign tourists who visit Sinharaja rainforest. Secondary data were collected using books, journals, reports and websites. According to research findings, although the authorities have identified and introduced certain tourism practices in Sinharaja under the name of ecotourism, such practices do not embody at least the basics of such tourism concept. The authorities do not have the knowledge to identify or promote ecotourism and therefore, their activities have led to certain discouragements of tourism promotion. Making communities and officials aware of ecotourism practices in Sinharaja has a potential to benefit people in the area and contribute in sustainable forest conservation and management.

\section{Birds and shutterbugs: how nature photography is driving local conservation efforts in the Eastern Himalaya \\ Deepa Basnet ${ }^{1}$ D; Yang Jianmei ${ }^{2}$, Yi Shaoliang ${ }^{1}$ \\ ${ }^{1}$ International Centre for Integrated Mountain Development (ICIMOD), Kathmandu, Nepal; ${ }^{2}$ Southwest Forestry University, Kunming, China (deepa.basnet@icimod.org; yangjm21@qq.com;yi.shaoliang@icimod.org)}

The Eastern Himalaya encompasses several Important Bird Areas (IBA), with high species diversity and endemism. Avifaunal diversity is not only ecologically important but also provides cultural and recreational services. Due to rich bird diversity, the area has gained popularity among birdwatchers/ photographers, researchers, and nature lovers. The villagers of Hanlong, southeast of Gaoligongshan National Nature Reserve (GNNR) are engaged in bird photography tourism by developing hides, establishing feeding and watering spots, and providing infrastructure to cater to the needs of photographers who seek convenient and less strenuous ways to photograph birds. As tourist numbers increased, the number of ponds grew from 6 in 2013 to over 100 in 2018 . Using a mixedmethodology [(eg: household interviews (50), focused group discussions (3), web survey of visitors (90), and expert opinions of ornithologists and conservation experts (6)], assessment of this newly-adopted bird photography tourism was carried out. It also included a review of documents from local government and protected area management departments. References to published and un-published documents from various sources including journals, institutions, travel magazines, national park offices, planning documents etc. were collected and analyzed based on the structured literature review of more than 60 publications in 2017 \& 2018 to understand the historical and policy contexts of the study area. The publications were collected using search engine Google Scholar. Bird photography tourism is a major source of income for Hanlong engaging about $86 \%$ of local people; $50 \%$ percent of households earned about 2,900 USD, 
16\% earned 2,900-5,800 USD, and 10\% earned 5,800-8,700 USD from homestays, ponds and hides, transportation services, and as guides. Birdphotography tourism has benefited women by improving their knowledge of birds, enhancing their visitor management and hospitality skills, and exposure to new viewpoints gained from interactions with tourists. The growth of tourism has encouraged biodiversity conservation. Local dependence on forest resources has decreased exponentially and local perceptions of forest use and ecosystem services has changed. In terms of perceived benefits, $100 \%$ of respondents valued the regulating services, $21 \%$ provisioning services, and $88 \%$ cultural services; $64 \%$ of visitors to Hanlong are attracted through online and social media marketing, and referrals on social media. In the case of Hanlong it has led to spontaneous protective actions and change in local perceptions of ecosystem services. It is also an effective way to enhance public awareness and knowledge of biodiversity.

A9j: POLITICS OF INTERNATIONAL FOREST REGIMES

Governing forests as global commons for achieving sustainable development goals: a review of policy design and effectiveness of the international forest regime complex

Metodi Sotirov ${ }^{1}$, Benno Pokorny ${ }^{1}$, Daniela Kleinschmit ${ }^{1}$, Peter Kanowski ${ }^{2}$

${ }^{1}$ University of Freiburg, Freiburg, Germany; ${ }^{2}$ Australian National University, Canberra, Australia

(metodi.sotirov@ifp.uni-freiburg.de; benno.pokorny@waldbau.uni-freiburg.de; daniela.kleinschmit@ifp.uni-freiburg.de; peter.kanowski@anu.edu.au)

This paper reviews the International Forest Governance (IFG) and analyses their impacts on tackling deforestation, forest degradation, biodiversity loss, climate change while achieving sustainable forest management. Based on international relations and the "governance triangle" literatures, six basic types are derived that the IFG elements are clustered into: (1) multilateral intergovernmental treaties (ITAA, UNFCCC, CBD, failed forest convention), (2) non-legally binding multilateral agreements (IAF), (3) transnational hybrid governance regimes (FLEGT/timber legality regime), (4) public-private-partnerships (e.g., REDD+ initiatives), (5) non-state market driven governance (FSC/PEFC), and (6) private sector partnerships (deforestation free initiatives). In addition, forest adverse governance arrangements outside the forest sector (e.g., agriculture, bioenergy, mining) are assessed. All processes are reviewed and compared in terms of their governance approaches. This refers to analysis of the involved state and non-state actors including their positions, mind-sets and coalitions, as well as their specific policy aims, tools, management concepts, monitoring and control mechanisms, and main pathways of influence. Thereby, important challenges in the design and implementation as well as in the coordination, integration and coherence of all these governance elements are identified. Last, but not least, the paper synthesizes (i.) the analysis of policies, governance processes and other actions affecting the drivers and global contributions of forests with an (ii.) the assessment of the existing, probable and needed functions of forests as global commons in order to (iii.) offer a critical reflection about the need and possibilities for transformative changes to secure the global commons function and sustainable development of forests.

\section{Comparing forest policies of regional regimes: the cases of ACTO and Mercosur}

\section{Sarah Lilian Burns ${ }^{1}$, Lukas Giessen ${ }^{2}$}

${ }^{1}$ LISEA - FCAyF - UNLP, La Plata, Argentina; ${ }^{2}$ European Forest Institute, Bonn, Germany (salibu@agro.unlp.edu.ar; lukas.giessen@efi.int)

Forests as an issue in world politics are governed by global and regional regimes. Political analyses have mainly focused on international forest governance by global forest-related regimes, e.g. on sustainable forest management. In addition to these global forest-related regimes a number of studies acknowledge the relevance of regional forest-related regimes in the form of "regional organisations, institutions, instruments, processes, initiatives and networks". So far such studies, however, do not provide for detailed empirical analyses. According to previous studies regional forest regimes differ in their institutional design regarding the way in which they address forests as issues,ranging from forest-focused regimes with forests as the main issue to forest-relevant regimes, which do not address forests formally and explicitly, but have empirical relevance for forests on the ground. The potential of regional forest regimes and their policies with weak or no formal link to forests, but with a potentially immense influence on forests has only rarely been analyzed. By applying an interest-based, actor-centered, and bureaucracy-oriented approach our study aimed to analyze two regional regimes from South America, the Amazon Cooperation Treaty Organization and the Mercosur with differences in the focus on forests as issue, acknowledging the key role state bureaucracies play in the design of international regimes and their policies. Qualitative content analysis of key policy documents was used on regime design and on the individual forest policies developed within both selected regimes. Our results show that despite a weak forest focus, forest-relevant regimes, like Mercosur, can develop strong forest policies.

\section{Comparing forest policies of regional regimes: formality, sectors, and hegemony as drivers?}

Pradip Kumar Sarker ${ }^{1,2}$, Lukas Giessen ${ }^{1}$

${ }^{1}$ European Forest Institute, Bonn, Germany; 2Goettingen University, Goettingen, Germany (protikswa@gmail.com; lukas.giessen@efi.int)

In the absence of a comprehensive forest regime at the global level, a number of forest-focused but also forest-relevant initiatives, processes, and institutions have proliferated at regional scales around the globe and by different sectors. Over time, a number of such regional regimes developed policies for addressing forests in multiple ways. This paper aims at comparing the forest policies of selected regional regimes, trying to identify key factors determining whether these policies are strong or weak. We use a fuzzy set Qualitative Comparative Analysis (QCA) methodology as well as deep empirical insights into a number of regional regimes for this comparison. The results provide indications on whether sectoral, forest-focused regimes produce weaker forest policies than general regimes on e.g. economic integration. Likewise, the influence of the degree of regime formality (i.e. informal vs. formal treaty/convention regimes) on regime policies will be presented. Lastly, the influence of hegemonic regional powers on the regimes' forest policies will be revealed. The study concludes with indications of factors and combinations thereof, which lead to rather strong or weak forest policies of a wide array of regional regimes.

Comparing the effects of international regimes in unitary and federal systems: insights from plantation forest development in Argentina and Uruguay

Julian Daniel Mijailoff ${ }^{1,2}$, Sarah Lilian Burns², Lukas Giessen ${ }^{3}$

${ }^{1}$ CONICET, La Plata, Argentina; ${ }^{2}$ LISEA, Facultad de Ciencias Agrarias y Forestales, Universidad Nacional de La Plata, La Plata, Argentina; ${ }^{3}$ European

ForestInstitute,Göttingen,Germany(julymihail@hotmail.com; sarahlilburns@gmail.com; lukas.giessen@efi.int)

Plantation forests are rapidly expanding, concentrating mainly in the southern hemisphere where they are becoming one of the main land use changes. In South America, this expansion has been promoted by international actors, with the aim of creating a pulp production cluster. Previous studies have described the 
influence of the international forest regime (IFR) in the definition of national policies that promote plantation forests. However, recent studies suggest that it is the domestic setting with their competing actors, which determines the influence the IFR at the domestic level. It is then expected that the way the IFR influences the domestic level will vary between federal and unitary countries. Hence, the aim of our study was to analyse how the influence of the IFR differs in federal and unitary systems. In order to do so, the cases of Argentina (federal country) and Uruguay (unitary country) were selected as two neighbouring countries from the global south with similar ecological conditions for the establishment of plantation forests. Process tracing of the development of the plantation forest sector in both countries was carried out using extensive data from expert interviews and document analysis. The results shed light on why the unitary system was able to fruitfully utilize the IFR in support of plantation forestry, whereas the federal system displayed severe constraints in this regard. The paper concludes that despite cross-sectoral competition among different land uses, the domestic multi-level setting is a decisive factor in enabling or constraining effects of the IFR in national contexts.

\section{The two faces of international forest governance: customising international regimes through domestic politics}

Lukas Giessen ${ }^{1}$

${ }^{1}$ European Forest Institute (EFI), Bonn, Germany (lukas.giessen@efi.int)

A large number of international, i.e. global, regional and bi-lateral governance regimes and initiatives tackle forests at international levels. On the one hand, they strive for making a meaningful addition to the existing set of international governance arrangements. On the other, they aim to achieve political and biophysical impacts in national settings. For the latter, international forest governance regimes and initiatives crucially depend on domestic partners, who in turn utilize and customize international processes according to their interests. This customization of international governance initiatives in multiple domestic contexts lends those initiatives two faces - an international as well as a domestic one. Using theories and methods from public policy and international relations, and based on multiple empirical insights from around the globe, this paper illustrates how international forest governance initiatives and regimes are being customized by powerful actors in domestic settings. Cases include bi-lateral forest development policy in Bangladesh, forest-related World Bank interventions in Argentina, EU Biodiversity policy in Poland, as well as forest-related palm oil politics in Indonesia. The paper concludes with methodological and empirical questions and directions for future research into the effects of internationalization and international governance concerning forests.

\section{International forest policy: an example for output convergence? \\ Helga Pülzl ${ }^{1}$ iD; Catherine Ohler ${ }^{1}$ \\ ${ }^{1}$ University of Natural Resources and Life Sciences, Vienna (BOKU),Vienna, Austria (helga.puelzl@boku.ac.at; catherinelohler@gmail.com)}

Presently, international forest policy is occurring within an intricate governance arrangement viewed by as complex, including many actors and forums as well as agreements conventions, and policy documents. One major critique is that it is ineffective, lacking the ability to adequately solve the global forest-relevant problems of today. Institutional fragmentation and fragmentation of objectives are most often understood the cause of ineffectiveness. Since those have already been widely explored, the paper is focused on the fragmentation of addressed issue areas and regime outputs. Furthermore, the study also aims to determine in what subject or issue areas the fragmentation and overlaps can be found. This is to determine if it is highly fragmented or it does in fact exhibit levels of coherence and synthesis. The goal is to explore how the regime is fragmented through the use of content analysis using MAXQDA. The results reveal that the regime contains instances of both overlap and fragmentation. Overall, there is substantial overlap when considering the many different topics addressed. Additionally, while there may be institutional fragmentation and fragmentation of objectives there was considerably less fragmentation of outputs. Despite the existence of many overlapping forest-relevant subject areas, there is till substantial room for strengthening existing synergies and fostering new relationships from these overlaps through the use of various coordination efforts. Consequently, the ultimate goal of improving the effectiveness of the IFRC can be reached through the use of coordination mechanism that promote the enhancement of synergies amongst regime elements.

\section{The future of global forest governance: a transdisciplinary Delphi study \\ Begemann Anna ${ }^{1}$, Lukas Giessen ${ }^{1}$, Georg Winkel ${ }^{1}$ \\ ${ }^{1}$ European Forest Institute, Bonn, Germany (anna.begemann@efi.int; lukas.giessen@efi.ing; georg.winkel@efi.int)}

Since the early 1990ies, a large number of state- as well as private sector-driven global forest governance initiatives emerged, many of which achieved only modest implementation impacts. This way many lessons could be learnt. However, the trends of deforestation and forest degradation in the tropics could not be reversed. Hence, being somewhat at the crossroads, taking stock of the lessons learned as well as looking into the anticipated future pathways and options of global forest governance is an important enterprise. Against this background, this study aims to 1) assess major challenges and lessons learnt for Global forest governance initiatives and to 2) identify possible pathways for the future of global forest governance. In order to achieve this, the European Forest Institute's Bonn office carried out a Delphi assessment based on a high-level panel of 38 experts from international governmental and non-governmental organizations, public administrations, and academia. The Delphi method consisted of three consecutive steps: 1 . expert interviews among panellists, 2 . an online survey, 3. a joint workshop, whereby the results were reflected back and validated by the expert panel. The paper will showcase selected results of the study including the experts' perceptions on important challenges in and effects of global forest governance, the most and least promising initiatives, the most and least important actors and possible future pathways of Global forest governance, including salient but unexplored research topics. In addition, it will highlight options for action for the future of Global forest governance.

\section{Are international forest regimes being formed on social media?A review and a case study}

Ida Wallin ${ }^{1}$

${ }^{1}$ University of Freiburg, Freiburg, Germany (ida.wallin@ifp.uni-freiburg.de)

International forest regimes involve the reconciliation of dissimilar values, beliefs and ideas held by the various stakeholder groups that participate in the decision-making process. Regimes are thus influenced by the different policy ideas, narratives and frames held by the stakeholders. Today forest-related policy ideas, narratives and frames are frequently occurring and debated on social media platforms. Here, individuals and organizations alike shape and reshape their own and others' ideas concerning the future of forests. The potential of social media content to influence the development of international forest regimes is yet to be explored and researchers need to take a closer look into these activities. Social media is arguably the most dynamic, largest and richest source of information about human behavior. Activities on social media platforms contribute to the co-production of knowledge, norms and public opinions for all aspects of society and forests are no exception. Actors, both individuals and organizations, battle for control over ideas by framing and connecting statements to their preferred 
narratives. For example, each tweet is a microblog and a story-line, carrying meaning directed to decision-makers. This presentation reviews current knowledge about international forest-related debates on social media platforms and discuss the potential for improving our understanding of international forest governance development through studying social media. It covers a literature review and a case study of Twitter debates concerning forest-related issues in Europe and the EU.

\section{Coalitions, collaborations and conspiracies: dynamics of REDD+ and Global forest politics}

Maria Brockhaus ${ }^{1,2}$, Grace Wong ${ }^{3}$, Cecilia Lutrell ${ }^{4}$, Moira Moelinono ${ }^{4}$, Thu Thuy Pham ${ }^{5}$

${ }^{1}$ University of Helsinki, Helsinki, Finland; ${ }^{2}$ Helsus, Helsinki, Finland; ${ }^{3}$ Stockholm Resilience Centre, University of Stockholm, Stockholm, Sweden; ${ }^{4}$ CIFOR, Bogor,Indonesia; ${ }^{5}$ CIFOR, Hanoi,Vietnam (maria.brockhaus@helsinki.fi; grace.wong@su.se; cecilia.luttrell@gmail.com; m.moeliono@cgiar.org; t.pham@cgiar.org)

In 2005, RED(D+) emerged as a climate mitigation strategy to reduce emissions from deforestation and forest degradation in the tropics under the UNFCCC. Despite a number of contestations, a wide range of diverse actors were able to unite under the canopy of REDD+ objectives of halting deforestation while providing for development and delivering other co-benefits. The contestations remain however and include fundamental questioning of the instruments and measures to realise these objectives, such as the concept of a forest carbon market and offsetting, which raises global climate justice concerns. Within REDD+ target countries, indigenous rights organisations put forward equity concerns of REDD+ being used to justify a recentralisation of forest resources rather than devolution of rights and tenure for local forest stewards. Effectiveness and cost-efficiency of a REDD + mechanism was also questioned by researchers, civil society, business and state actors with regards to leakage and permanence, and the untackled political economy of deforestation. Voices within the long-standing international forest regimes criticised REDD+ for taking away financial resources and global attention from established approaches to the governance (and management) of forests and forest land in the global South. Building on a global comparative dataset of national REDD+ policy networks, and participatory observations and interview material from UNFF meetings, UNFCCC COPs, SBSTAs, IUFRO conferences and other international meetings since 2007, we explore the coalitions of adversaries and advocates of REDD+, and discuss how politics and the underlying beliefs, interests, and discourses affect objectives to reduce emissions from deforestation and forest degradation.

\section{The private in the public of international forest regimes}

\section{Daniela Kleinschmit ${ }^{1}$}

${ }^{1}$ University of Freiburg, Freiburg, Germany (daniela.kleinschmit@ifp.uni-freiburg.de)

The role of private actors in international regimes has been investigated for a long time resulting in different conclusions, ranging from "hollowing out the state" to "governance in the shadow of hierarchy" depending on the perspective taken and the process analysed. A comprehensive analysis about the role of private actors is missing so far and the specific situation of international relations in the area of forest policy with its long-term relationship between traditional actors is hardly acknowledged. This presentation starts out from the understanding of public and private in the way it is regarded by western modernity, demarcating the "public" domain of state power from the private domain of market and civil society. Concentrating on at the first glance intergovernmental processes within the international forest regime this presentation aims to unlock the role of private actors in negotiations and standard setting. Building on the theory of network governance and the concept of legitimacy three main research questions are addressed: (i) how far are private actors formally and informally involved in forest centred and related intergovernmental processes, (ii) whether private actors have influenced the process and (iii) the involvement is perceived as legitimating the process. Theoretically, the presentation builds on a network governance perspective adding the concept of legitimacy. Findings resulting from a comprehensive analysis of international governance literature and additional analysis of policy documents will close the gap of so far only isolated and scattered results of private actors involvement in international forest regimes.

\section{A9k: STATUS AND CURRENT DEVELOPMENTS IN SOUTH-SOUTH COOPERATION IN} FORESTRY

\section{Status and current developments in South-South cooperation (SSC) in forestry}

Stephan A. Pietsch ${ }^{1,2}$

${ }^{1} I I A S A$, Laxenburg, Austria; ${ }^{2} B O K U$,Vienna, Austria (pietsch@iiasa.ac.at)

In 1978 the UN-Conference on Technical Cooperation among Developing Countries in Buenos Aires acknowledged South-South Cooperation (SSC) as significant tool of development and poverty reduction. The similarity in problems and challenges logically suggests the exchange and transfer of successful solutions. Since the First South Summit, held in Havana in 2000, the evolution and agenda of South-South cooperation (SSC) made progress at technical, scientific, institutional and policy levels and delivers a significant contribution to sustainable development. This presentation will give an overview of past achievements and current developments of SSC activities within the forestry sector.

\section{Options for inner-African South-South cooperation}

Coert J Geldenhuys ${ }^{1}$

${ }^{1}$ Plant \& Soil Sciences, University of Pretoria, Pretoria, South Africa (cgelden@mweb.co.za)

Africa has vast tropical moist forests and seasonally dry, deciduous woodlands. These resources of timber, non-timber and non-wood forest products are used globally, mostly for economic development elsewhere. Forest policies seem to be imposed onto governments across the continent, mostly from elsewhere, via FAO, seemingly without or very little consideration for the ecology of the different systems, nor for the needs of the rural societies living within these resource areas. Conflicts exist between policies for forestry, agriculture, conservation and rural development towards sustainable development. Some regulations are enforced with reference to local and regional timber concessionaires, but ignored when multinational groups or companies export large timber volumes, often of trees of small sizes. There is no care for proper silvicultural management of the remaining resources. Some ideas will be presented with examples from the different management conflicts. 


\section{Forestry training, education and research in the Congo basin}

Damase P. Khasa', Claude Kachaka ${ }^{2,3}$, Stephan A. Pietsch ${ }^{3}$

${ }^{1}$ Université Laval, Quebec, Canada; ${ }^{2}$ RIFFEAC, Yaounde, Cameroon; ${ }^{3}$ University of Kinshasa, Kinshasa, Democratic Republic of the Congo, ${ }^{3}$ IIASA, Vienna, Austria(damase.khasa@sbf.ulaval.ca; kachaka_sudi@yahoo.com; pietsch@iiasa.ac.at)

The Congo basin is the world's second largest tropical forest after the Amazon basin. This region is undergoing rapid socioeconomic development coincident with problems such as rapid population growth, poverty and hunger, and accelerating rates of natural resource exploitation, often involving powerful foreign interests, political and social tensions, and weak governance of institutions. The success of economic development and green growth efforts often hinges on the ability to strengthen human and institutional capacity, e.g., by promoting education, training, research and building institutional capacity. In this paper, we aim to present the work undertaken since the early 1970s by the Faculty of Forestry, Geography and Geomatics of Université Laval (the oldest French-language university in North America) and its partners, more specifically the Network of Environmental and Forest Training Institutions in Central Africa (RIFFEAC), in capacity building to promote the conservation and sustainable management of tropical forests in Congo Basin's natural resources, in accordance with the Revised Convergence Plan of the Central African Forest Commission (COMIFAC) (2015-2025). Ex-post-analysis of different training projects was conducted for looking at their strengths, weaknesses, opportunities, and challenges (SWOC). The analysis took into account different aspects including the funding in higher education and research, the development of curricula, the training of highly qualified personnel both at university and technical levels, and job opportunities.

\section{Lessons learned from the EU FLEGT process to spur the Chinese "Global Green Supply Chain" (GGSC) initiative offering opportunities for China-Africa cooperation}

Ralph Ridder ${ }^{1}$

${ }^{1}$ Consultant for the GIZ Forest Policy Facility in Beijing, China., Geneva, Switzerland (ralph.ridder@bluewin.ch)

Assessing the results of the ongoing FLEGT process can provide valuable input to the newly created GGSC initiative by Chinese wood importing/wood processing industry. China-Africa south-south cooperation strengthening GGSC in reaching its targets of sustainable wood production and sustainable supply can contribute to improving forest governance in African wood exporting countries as well as helping EU wood product imports to comply with EUTR.

A9l: SUSTAINABLE DEVELOPMENT GOALS: THEIR IMPACTS ON FORESTS AND PEOPLE

Sustainable Development Goal \#1 and forests: implications of expanding social protection, securing tenure, and building resilience to environmental shocks

Kathleen Lawlor ${ }^{1}$, Stibniati Atmadja ${ }^{2}$,Liwei Lin ${ }^{3}$, Karnjana Songwathana ${ }^{4}$,Erin Sills ${ }^{3}$

${ }^{1}$ University of North Carolina at Asheville, Asheville, USA; ${ }^{2}$ CIFOR, Addis Ababa, Ethiopia; ${ }^{3} N C$ State University, Raleigh, USA; ${ }^{4}$ Bangkok University,

Bangkok,Thailand (klawlor@unca.edu; s.atmadja@cgiar.org; livia1020@gmail.com;karnjana.s@bu.ac.th; sills@ncsu.edu)

Sustainable Development Goal (SDG) \#1 seeks to "end poverty in all its forms everywhere." The effects on forests will depend on how poverty alleviation is approached. SDG\#1 calls for reducing poverty specifically by ensuring that the poor are covered by social protection systems; by securing the poor's rights to economic resources, access to basic services, and property ownership; and by building their resilience to economic, social and environmental shocks. The empirical literature shows that social protection in the form of cash transfers and more secure property rights - especially for community land - can be conducive to forest conservation, given the right context and conditionalities. As demonstrated by programs for reforestation of hillsides in China and mangroves in many other countries, policies designed to reduce vulnerability can promote ecosystem-based adaptation, including expansion of forest cover. This is consistent with the scientific evidence that forests are both a mainstay of rural livelihoods and a buffer and source of natural insurance. However, there is relatively little evidence that this scientific knowledge is actually shaping poverty alleviation and national development strategies. To the extent that those strategies continue to be based on infrastructure and agricultural development, they are likely to remain in conflict with the conservation and sustainable management of forests.

\section{Achieving Sustainable Development Goals on food security and nutrition: the impacts on forests and livelihoods}

Terence Sunderland ${ }^{1,2}$

${ }^{1}$ University of British Columbia, Vancouver, Canada; ${ }^{2}$ Centre for International Forestry Research, Bogor, Indonesia (terry.sunderland@ubc.ca)

As the human population continues to grow, so does pressure to increase food production. Agriculture now dominates the Global landscape and more food is being produced than ever before. Yet, our population is characterized by alarming rates of obesity and malnourishment. Concomitantly, much of the agricultural expansion related to achieving Global food security is at the expense of forest ecosystems, critical for biodiversity and the provision of ecosystem services. SDG 2: Zero Hunger seeks to "End hunger, achieve food security and nutrition and promote sustainable agriculture". In this chapter we explore the potential impacts of achieving SDG 2 on forests and forest dependent people. We focus on five of the targets (2.1-2.5) under SDG 2 which are closely entwined with forests and forest related livelihoods. We discuss how the current food system polarises food production and forest conservation, when in fact, they should, and can be harmonised. Paying special attention to the role of maintaining genetic diversity (Target 2.5) and investing in small-scale food producers (Target 2.3 ) in sustainable food systems (Target 2.4) to reduce hunger and malnutrition (Targets 2.1 and 2.2). We close with observations on the potential tradeoffs and synergies between SDG 2 and the other SDGs, emphasizing the need for integrated land use management.

\section{Impacts of addressing Sustainable Development Goal 3 health and Wellbeing on forests and forest people}

Rosemary McFarlane ${ }^{1}$, John Barry ${ }^{2}$, Guéladio Cissé ${ }^{3}$, Maya Gislason ${ }^{4}$, Marta Gruca $^{5}$, Kerryn Higgs $^{6}$, Pierre Horwitz $^{7}$, Giang Huu Nguyen $^{7}$, Jane O 'Sullivan $^{8}$, Subashis Sahu ${ }^{9}$, Colin Butler ${ }^{I 0}$

${ }^{1}$ University of Canberra, Canberra, Australia; ${ }^{2}$ University of Belfast, Belfast, United Kingdom; ${ }^{3}$ Swiss Tropical and Public Health Institute, Basel, Switzerland; ${ }^{4}$ Simon Fraser University, Burnaby, Canada; ${ }^{5}$ FAO, Rome, Israel; ${ }^{6}$ University of Tasmania, Hobart, Australia; ${ }^{7}$ Edith Cowan University, Perth, Australia; ${ }^{8}$ University of Queensland, Brisbane, Australia; ${ }^{9}$ University of Kalyani, Kalyani, India; ${ }^{10}$ Australian National University, Canberra, Australia(romcfarlane@gmail.com; j.barry@qub.ac.uk; gueladio.cisse@unibas.ch; maya_gislason@sfu.ca; marta.gruca@fao.org;kerryn999@gmail.com; p.horwitz@ecu.edu.au; huugiangkn@gmail.com;j.osullivan@uq.edu.au; skcsahu@yahoo.co.in;0colin.butler1955@gmail.com) 
The achievement of the third Sustainable Development Goal (SDG3), Health and Wellbeing for All, depends on many other SDGs but there are also potential conflicts and trade-offs. We have examined SDG3 targets and identified the contexts in which positive outcomes for both forests and people can be met. We stress the importance of forests to global health and wellbeing as well as for Indigenous and local populations. In contrast, short-term economic and human health gains from further forest conversion (e.g. deforestation for food production) will create direct and indirect health risks for humans, as well as for other biota. Controlling indiscriminate burning and clearing of forests can reduce significant harm to health and wellbeing, via improved quality of water, soil, air (a transnational issue), by reducing exposure to some infectious diseases, through preservation of traditional (and future) medicines, and by supporting other forest resources and services, including climate regulation. Many infectious diseases are associated with forest disturbance and intrusions and some may be prevented or modified through forest management. Universal access to sexual and reproductive health-care services, including for family planning, is a critical SDG3 target to decrease demographic pressures on forests at local, regional and global scales, and to enhance wellbeing. Greater exposure to green space, including the 'urban forest', is likely to have many benefits for mental, social and physical health for the increasingly urban global population. More broadly, forests play important roles in enriching cultural and religious wellbeing.

\section{“The golden thread": Sustainable Development Goal 4 education for all, and forests}

Peter Kanowski ${ }^{1}$, Dollie Yao ${ }^{1}$, Stephen Wyatt ${ }^{2}$

${ }^{1}$ Australian National University, Canberra, Australia; ${ }^{2}$ Université de Moncton, Moncton, Canada (peter.kanowski@anu.edu.au; dollie.yao@anu.edu.au; stephen.wyatt@umoncton.ca)

Education has been characterised as "the golden thread that runs through all 17 Sustainable Development Goals (SDGs)". This paper explores the relationships between SDG4, "Ensure inclusive and equitable quality education and promote lifelong learning opportunities for all", and forests and their benefits and services. SDG4 focuses on broadening the depth and breadth of education; it expands the scope of 'education' beyond the traditional focus of formal schooling environment and years, to a lifelong process spanning a range of non-formal and informal settings; and emphasises quality of access to education, particularly for girls and women and marginalised groups. We draw on literature exploring "pro-environment" behaviour to consider how progress towards SDG4 might impact on forests, forest ecosystem services, and forest-related livelihoods. We introduce the concept of "pro-forest" behaviour to describe those elements of pro-environment behaviour related to forests. We suggest that encouraging and enabling pro-forest behaviour is the basis of the relationship between SDG4 and forests. Inclusive education that builds and reinforces understanding and knowledge of forests, and that helps individuals and communities feel or stay connected to forests, will foster and sustain pro-forest behaviours. Progress towards SDG4 will benefit forests if education; Informs, encourages and enables 'pro-forest' behaviour; Respects, nurtures and enables Indigenous and traditional knowledge; Promotes forest-related Education for Sustainability and Environment in each of formal, non-formal and informal settings; Strengthens forest-related professional and technical and vocational education and training, and capacity development; Capitalises on the power of both established and new media.

\section{Taking SDG 5 seriously}

Seema Arora-Jonsson ${ }^{1}$, Shruti Agarwal ${ }^{2}$, Carol J. Pierce Colfer ${ }^{3,4}$, Stephanie Keene ${ }^{5}$, Priya Kurian ${ }^{6}$, Anne Larson $^{3}$

${ }^{1}$ Swedish University of Agricultural Sciences, Umå, Sweden; ${ }^{2}$ Center for Science and Environment, New Delhi, India; ${ }^{3}$ CIFOR, Bogor, Indonesia; ${ }^{4}$ Cornell University Ithaca USA; ${ }^{5}$ Rights and Resources Initiative, Washington, USA; ${ }^{6}$ University of Waikato, Hamilton, New Zealand (seema.arora.jonsson@slu.se; shruti_agarwal@cseindia.org; cjpcolfer@gmail.com; skeene@rightsandresources.org; priya.kurian@waikato.ac.nz; a.larson@cgiar.org)

Taking SDG 5 seriously brings to the fore issues usually taken for granted in forest debates - people, their relationships to one another and to the forests, which together determine forest outcomes. We first analyze the forest context for SDG 5; second, we consider the impacts of taking SDG 5 and its targets seriously on forests and people's livelihoods. Overall, little progress has been made in implementing these targets within the forestry sector. We will need a fundamental change in approaches to forests and the environment---one that incorporates systemic and contextual factors as well as the people's relations outside of forestry (e.G., Health, violence, unpaid care work, both in and outside the forest). Closer attention to SDG 5 can highlight the invisible labor and relations so crucial to good forest management and help to develop democratic and sustainable strategies so key to sustainable forest relations and of benefit to forest peoples. Politically we need to transform unequal relationships, to challenge privilege based on sex, class, ethnicity or caste and to destabilize inequitable micro and macro-economic structures (based on notions of private property, commodification, etc.). Iufro has an important role to play in this context in questioning its own business as usual and also in undertaking gender research and analysis of forestry policies and programs to better understand gender dynamics. The welfare and dignity that achieving SDG 5 would bring to forest peoples and livelihoods is essential to ensuring better managed and sustainable forests.

\section{Decent work and economic growth: potential impacts of SDG 8 on forests and forest-dependent livelihoods}

Dietmar Stoian ${ }^{1}$, Iliana Monterroso ${ }^{2}$, Dean Current ${ }^{3}$

${ }^{1}$ World Agroforestry Centre (ICRAF), Montpellier, France; ${ }^{2}$ CIFOR, Guatemala City, Guatemala, ${ }^{3}$ University of Minnesota, St. Paul, USA

(d.stoian@cgiar.org; i.monterroso@cgiar.org; curre002@umn.edu)

This paper assesses the potential impact of Sustainable Development Goal (SDG) 8 on forests and forest-dependent people. The concepts of decent work and economic growth are put in the context of predominant development theories and paradigms (modernization, economic growth, basic needs, sustainable development) which shape the agendas of governments, private sector, civil society, and investors. These stakeholders pursue different goals and interests, with uneven prioritization of SDG 8 targets and mixed impacts on forests and livelihoods. Significant trade-offs are expected for countries where growth strategies and policies focus on sectors competing with forestry for space and resources, such as agriculture, energy, and mining. In these cases, the decoupling of economic growth from environmental degradation will be a major challenge. At global level, trade-offs are anticipated as the combined effects of such policies and strategies contribute to climate change. A potential for synergies between SDG 8 and forests exists where growth is explicitly sought for in the forest sector, focusing on tree plantations, timber and NTFPs from natural forests, eco-tourism, and environmental service payments. Advancing decent work in the forest sector requires addressing issues related to gender, ethnicity, mobility associated with forest-based operations, and labor safety. Improvements in the enabling environment can help minimize trade-offs and maximize synergies by reconciling government policies and private sustainability standards (e.g. zero deforestation, sustainable palm oil and cocoa), formalizing community stewardship of tropical forests, addressing informality prevalent in forest product value chains, and providing incentives for youth to become involved in forest-based economic activities. 


\section{Anticipating the potential impacts of Sustainable Development Goal 9 on forests and forest-based livelihoods}

Maria Fernanda Tomaselli ${ }^{1}$, Joleen Timko', Robert Kozak ${ }^{1}$

${ }^{1}$ University of British Columbia, Vancouver, Canada (fernanda.tomaselli@ubc.ca; joleen.timko@ubc.ca; rob.kozak@ubc.ca)

Sustainable Development Goal (SDG) 9 is centered on three main pillars - industry, infrastructure and innovation. With eight targets and twelve indicators, SDG 9 will have multiple impacts on forests, forest-based livelihoods and forest-based economies. This presentation highlights some of the potential implications of SDG 9, as currently written, on forests and forest-dependent people. Drawing on a comprehensive literature review, we will elucidate possible interactions, synergies, and trade-offs that could be at play as SDG 9 is implemented. For example, major trade-offs will exist between SDG 9 and SDG 15, especially if economic expansion and increasing planetary impacts remain coupled. More specifically, target 9.1 and its corresponding indicators (road, infrastructure and transportation expansion) risk irreversible and widespread forest degradation and deforestation; thus, the short and long-term environmental and social costs of this goal need to be better assessed. The impacts on forests and livelihoods of other targets (e.g. small-scale industry expansion [Target 9.3]; access to information and communications technology [Target 9.c]) will largely depend on how they are implemented. We conclude our presentation with a call for reforming SDG 9 to promote and support alternative socioeconomic models that are not based on indefinite economic growth, nor reliant on the ongoing expansion of infrastructure, and in which, the maintenance of ecosystem services and forests would be seen as essential building blocks of a green and sustainable economy.

\section{Impacts of the urban Sustainable Development Goal 11 on forests and people}

Tahia Devisscher ${ }^{1}$, Cecil Konijnendijk ${ }^{1}$, Lorien Nesbitt ${ }^{1}$, Jennifer Lenhart ${ }^{2}$, Fabio Salbitano $^{3}$, Zhaohua Cindy Cheng ${ }^{1}$, Shuaib Lwasa ${ }^{4}$, Matilda van den Bosch ${ }^{1}$ ${ }^{1}$ University of British Columbia, Vancouver, Canada; ${ }^{2}$ Worldwide Fund for Nature, Santiago, Chile; ${ }^{3}$ Università di Firenze, Florence, Italy; ${ }^{4}$ Makerere University,Kampala,Uganda (tahia.devisscher@ubc.ca; cecil.konijnendijk@ubc.ca; lorien.nesbitt@ubc.ca; jennifer.lenhart@wwf.se;

fabio.salbitano@unifi.it; zhaohua.cheng@ubc.ca; lwasa_s@caes.mak.ac.ug; matilda.vandenbosch@ubc.ca)

Addressing this century's urban challenges greatly depends on how cities prioritise resources and urban planning strategies over the next decade. In 2015, a global effort to address urban challenges was endorsed by 193 countries as part of the United Nations 2030 Agenda for Sustainable Development and its Sustainable Development Goal 11 (SDG11) to "make cities and human settlements inclusive, safe, resilient and sustainable". By endorsing a stand-alone goal on cities, the international community recognized urbanisation as a transformative force for innovation and sustainable development. We provide an analysis of SDG11 implementation taking into consideration global monitoring of SDG11 impacts, and different local priorities linked to distinct urbanisation patterns. We focus particularly on the effects on forests and forest-based livelihoods, and propose a framework to assess synergies and trade-offs between SDG11 and other SDGs accounting for diverse city types. As part of global SDG11 implementation, we found that countries tend to prioritise access to adequate housing and sustainable transport with interlinkages to health, education, and employment. Few countries enforce policies to ensure safe, green and accessible public places and the protection of cultural and natural heritage in and around cities, despite the manifold benefits urban forests can bring. Little attention is given to building strategic social and environmental links between urban and rural areas. A more integrated approach to urban-rural territorial planning could have a positive impact on forests and forest-based livelihoods by diversifying and improving access to ecosystem services and socio-economic benefits generated by forests.

\section{Are peace and justice good for forests? An analysis of SDG 16 and its implications for forests and people}

Constance McDermott ${ }^{1}$, Seema Arora-Jonsson ${ }^{2}$, Rebecca Asare $^{3}$, Wil de Jong ${ }^{4}$, Mark Hirons $^{1}$, Kaysara Khatun $^{1}$, Mary Menton ${ }^{5}$, Fiona Nunan $^{6}$, Mahesh Poudyal ${ }^{7}$, Abidah Setyowati ${ }^{8}$, Emmanuel Acheampong ${ }^{9}$

${ }^{1}$ University of Oxford, Oxford, United Kingdom; ${ }^{2}$ Swedish University of Agricultural Sciences, Uppsala, Sweden; ${ }^{3}$ The Nature Conservation Research Centre (NCRC), Accra, Ghana; ${ }^{4}$ Kyoto University, Kyoto, Japan; ${ }^{5}$ University of Sussex, Sussex, United Kingdom; ${ }^{6}$ Birmingham, UK, United Kingdom; ${ }^{7}$ University of Leeds, Leeds, United Kingdom; ${ }^{8}$ Australian National University, Canberra, Australia; ${ }^{9}$ Kwame Nkrumah University of Science and Technology, Kumasi, Ghanaconstance.mcdermott@ouce.ox.ac.uk; seema.arora.jonsson@slu.se; rebeccaashleyasare@yahoo.com; dejongwil@gmail.com; mark.hirons@ouce.ox.ac. uk; kaysara.khatun@ouce.ox.ac.uk; mcsmenton@gmail.com; f.s.nunan@bham.ac.uk; mahesh.poudyal@celp.org.uk; abidah.setyowati@anu.edu.au; ekachie.ekachie@gmail.com)

This chapter assesses the implications of implementing UN SDG 16 - "Peace, Justice and Strong Institutions", for both forests and people. Despite the widespread appeal of "peace" and "justice" as international goals, the intense debates preceding agreement on SDG 16 highlight the power dynamics underlying its interpretation and implementation. Our analysis focuses in particular on three thematic areas: 1) peace and the reduction of armed conflict, 2) the rule of law, accountability and transparency, and access to justice and 3) inclusiveness and participation. Regarding peace and conflict, existing literature reveals highly variable outcomes: conflict may either curtail agricultural expansion into forest frontiers and/or drive illicit crop production, and foster migration in or out of forested areas; while peace is often accompanied by state-supported mining and expansion of commercial crops. More generally, national laws governing forests and land use in many countries favor political elite, large-scale industry actors and international trade. Hence if SDG implementation emphasizes strengthening state institutions, the rule of law and transparency linked with international trade, it is likely to reinforce existing inequalities, unless it is counter-balanced with legal reforms that strengthen local rights to land and resources. While there has been much recent progress in expanding forest areas under "community-based" or "participatory" forest management, in many cases this has been tightly controlled by the state, contributing to local administrative burdens without significantly redistributing power and benefits. In sum, the impacts of implementing SDG 16 on forests and people depend on socio-political priorities and power dynamics.

\section{SDG17 and sustainable forest management: strengthening the means of implementation and revitalising the global partnership for sustainable development}

David Humphreys ${ }^{1}$, Benjamin Singer ${ }^{2}$, Kathleen McGinley $^{3}$, Roy Smith $^{4}$, Jessica Budds ${ }^{5}$, Monica Gabay ${ }^{6}$, Shonil Bhagwat ${ }^{1}$, Wil de Jong ${ }^{7}$, Newing Helen $^{8}$, Charlotte Cross ${ }^{9}$, Poshendra Satyal

${ }^{1}$ Open University, Milton Kenyes, United Kingdom; ${ }^{2}$ United Nations Forum on Forests, New York, USA; ${ }^{3}$ International Institute of Tropical Forestry, Raleigh NC, USA; ${ }^{4}$ Nottingham Trent University, Nottingham, United Kingdom; ${ }^{5}$ University of East Anglia, Norwich, , Norwich, United Kingdom; ${ }^{6}$ Escuela de Politica y Gobierno, Buenos Aires, Argentina; ${ }^{7}$ Kyoto University, Kyoto, Japan; ${ }^{8}$ University of Oxford, Oxford, United Kingdom; ${ }^{9}$ Open University, Milton Kenyes, United States Minor, Outlying Islands (david.humphreys@open.ac.uk; benjamin.singer@gmail.com; kmcginley@fs.fed.us; roy.smith@ntu.ac.uk; j.budds@uea.ac.uk; monagabay@yahoo.com; shonil.bhagwat@open.ac.uk; dejongwil@cseas.kyoto-u.ac.jp; h.s.newing@gmail.com;

charlotte.cross@open.ac.uk; p.satyal@uea.ac.uk)

This paper examines how actions in support of SDG17 can promote sustainable forest management. Statistical evidence is provided to show that funding for forests from both ODA and other sources is trending upwards since 2000, providing reason for cautious optimism. While finance for REDD + is in decline, private sector 
investment remains important. The idea of impact investment, which aims to solve pressing environmental and social problems, may make a significant contribution to the sustainability agenda. The paper argues that the policy of zero net deforestation (ZND) is leading to the creation of some important partnerships, some of which include the financial sector, that aim to ensure deforestation-free commodity supply chains of key agricultural commodities. However, tensions remain between some SDGs and not all sustainable development finance promotes the conservation of forests. The target of increasing funding for agricultural production to contribute to SDG2 (zero hunger) often incentivises the conversion of forests to agricultural land and livestock. In several countries international forest-related ODA is dwarfed by domestic subsidies to agricultural production. This provides a structural incentive for the conversion of forests to agricultural land, in particular of the four forest risk commodities. Realising forest-related sustainable development thus depends on policy coherence between the forests sector and forest-related SDGs, and the complex conflicts and synergies between them. However, partnerships for sustainable development exist within a neoliberal global economic order in which there are net financial flows from the global South to the global North that often negate financial flows for sustainable development.

\section{Health, gender, equity, and justice: potential synergies among SDGs}

Carol J. Pierce Colfer ${ }^{1,2}$, Rosemary A. McFarlane ${ }^{3}$, Richard Dudley ${ }^{4}$, Seema Arora-Jonsson ${ }^{5}$, Bimbika Sijapati Basnett ${ }^{1}$, Constance McDermott ${ }^{6}$ ${ }^{1}$ CIFOR, Bogor, Indonesia; ${ }^{2}$ Cornell University Ithaca USA; ${ }^{3}$ University of Canberra, Canberra, Australia; ${ }^{4}$ Indonesia; ${ }^{5}$ Svedish University of Agricultural Sciences, Umeå, Sweden; ${ }^{6}$ University of Oxford, Oxford, United Kingdom (cjpcolfer@gmail.com; romcfarlane@gmail.com; rgdudley@gmail.com; seema.arora.jonsson@slu.se; bimbika@gmail.com; constance.mcdermott@ouce.ox.ac.uk)

Building on several chapters of the IUFRO WFSE project's newly published book, Sustainable Development Goals: Their Impacts on Forests and People, this presentation focuses on the following people-oriented SDGs, SDG 3 (health), SDG 5 (gender), SDG 10 (equity), and SDG 16 (justice). The book considers the potential and likely impacts of the implementation of each of the SDGs on forests and people. The findings from across the globe show an evident lack of attention to these people-oriented SDGs, which if implemented with care, represent a combination that has the potential to work in a transformative manner for both people and for forests. The presentation examines some of the potential synergies among these SDGs and identifies some of the shortcomings in current implementation efforts. Particular attention is devoted to 1) the potential to stimulate and support constructive efforts of the female half of the global population (including traditional knowledge, creativity, energy, and motivation); 2) how to activate currently marginalized groups (certain ethnic groups, lower castes, those financially strapped, LGBTQ individuals, etc.); 3) the synergies between progress in establishing greater global justice (between the 'rich' and the 'poor' and among groups within each broad category) with clear impacts on and roles for marginalized groups; and 4) the positive contributions to forests and peoples of improved health for forest populations.

\section{A9m: POLITICAL ECOLOGY AND INTEGRATED LANDSCAPE APPROACHES: COMPLEMENTARITY OR UNHAPPY MARRIAGE?}

\section{Political ecology and integrated landscape approaches: complementarity or unhappy marriage?}

Mirjam Ros-Tonen ${ }^{1,2}$, Bas Arts ${ }^{3,4}$, Terry Sunderland 5

${ }^{1}$ University of Amsterdam, Amsterdam, Netherlands; ${ }^{2}$ PBL Netherlands Environmental Assessment Agency, The Hague, Netherlands; ${ }^{3}$ Wageningen University, Wageningen, Netherlands; ${ }^{4}$ Centre for International International Forestry Research, Bogor, Indonesia; ${ }^{5}$ University of British Columbia, Vancouver, BC, Canada(m.a.f.ros-tonen@uva.nl; bas.arts@wur.nl; terry.sunderland@ubc.ca)

Forests play a rapidly changing role in the livelihoods of rural people as they find themselves increasingly embedded in multifunctional landscapes, where tradeoffs exist between competing land uses. Integrated landscape approaches (ILAs) are gaining ground to negotiate such trade-offs. Although power imbalances are increasingly acknowledged as a challenge to achieving negotiated outcomes in ILAs, the politics of negotiated landscape governance still remain underexposed in the literature. Based on a review of literature, this paper aims to explore whether and how synergy can be created between two seemingly contradictory approaches towards global challenges affecting landscapes, such as deforestation, biodiversity loss, climate change and food security. Whereas ILAs are based on a rather naïve assumption that landscape actors are on the same page in their determination to address these challenges, critical approaches such as political ecology take power imbalances and unequal access to natural resources as a starting point to analyze landscape dynamics. In this paper, we argue that both approaches are needed for integrated and inclusive landscape governance. Political ecology and critical studies more broadly provide insights into the politics and framing of human-nature interactions as well as the diverging interests, power imbalances and inequalities in resource access and decision-making at landscape level. We explore how these insights can be made functional to the operationalization of ILAs, thus contributing to both theory building and the operationalization of integrated landscape governance.

\section{Implementing landscape conservation from above: donor funding, conservation politics and local struggles over land in Machemba village, Tanzania}

Numan Amanzi

${ }^{1}$ Tanzania Forestry Research Institute, Morogoro, United Republic of Tanzania (numansaidi@gmail.com)

Current conservation emphasizes territorial expansion beyond traditional protected areas to safeguard boundless spaces for wildlife and bring more forests under the reserved estate. Territorial expansion in Tanzania is pursued through Wildlife Management Area (WMA), and through community-based forest management. These two approaches are pursued by different institutions who compete over authority to claim and set aside village land as a WMA or as a village land forest reserve. This competition is shaped by changing priorities of international donor financing for conservation and shifting institutional landscapes and political priorities in the Tanzanian government. In this paper we trace the struggles of a village in navigating this complex and changing legal and institutional landscape to maintain authority over village land. The village is facing pressures from different conservation actors to set aside parts of it for forest or wildlife management. The struggles we document are indicative of a complex politics of conservation and the significant challenges this presents to rural communities that happen to be situated in areas targeted in the name of environmental conservation. While policy makers and conservation practitioners are envisioning a world of largescale area-based interventions to achieve globally tracked targets, the reality of doing this work on the ground defies the notion of community-based, consensusoriented, participatory, and apolitical spaces where global ideas can be simply and smoothly implemented locally. 
Exceptional bureaucratic rivalry and policy competitions in mangrove forests: explanations from the Sundarbans, Bangladesh

Faisal Abedin Khan ${ }^{1}$, Lukas Giessen ${ }^{2}$

${ }^{1}$ Georg August University of Göttingen, Göttingen, Germany; ${ }^{2}$ European Forest Institute, Bonn, Germany(fkhan@uni-goettingen.de; lukas.giessen@efi.int)

Bearing diversified natural resources, the Sundarbans Mangrove Forests (SMF) considered a thrust area of ecological as well as economic importance of which a number of public bureaucracies of Bangladesh are given due attention for managing its resources. The aim of this study is to analyse the high degrees of competing policy conflicts of different bureaucracies prevailed for Sundarbans management practised on both formal and informal approach. Empirically, all policies and practices pursued by multiple administrations in Sundarbans are scrutinised. As an empirical method, the content analyses of various acts, rules, policy documents, missions, mandates and development initiatives of relevant ministries and public agencies were carried out and to distinguish the activities linked with informal interest present practices were critically analysed. The study observes that being the officially responsible administration for the Sundarbans, Bangladesh Forest Department possess 'control and command' approach towards managing SMF. The position of Forest Department is empowered by the existing laws and rules though observed approach has been threatened due to multi-bureaucracies' involvement in different sectors of Sundarbans for due reasons. Other bureaucracies became influential with their institutional capacities in respective sectors resulting exceptional high degree of bureaucratic competition among relevant bureaucracies. Forest bureaucracy is currently facing challenges of technical capacities, financial resources and institutional arrangements addressing effective management of Sundarbans. Administrative structures for complex landscapes, such as mangrove forests, pose real challenge to common bureaucratic structures which recommends in this study to establish an Integrated Mangrove Authority for the Sundarbans.

\title{
Participatory spatial scenario building in a mixed cocoa-oil palm area in the Eastern Region of Ghana as a way towards inclusive governance of mosaic landscapes
}

Kwabena Asubonteng ${ }^{1,2}$, Mirjam Ros-Tonen ${ }^{1}$, Isa Baud ${ }^{1}$, Karin Pfeffer $^{3}$

${ }^{1}$ University of Amsterdam, Amsterdam, Netherlands; ${ }^{2}$ United Nations University Institute for Natural Resources in Africa, Accra, Ghana; ${ }^{3}$ University of

Twente,Enschede, Netherlands(k.o.asubonteng@uva.nl; m.a.f.ros-tonen@uva.nl; i.s.a.baud@uva.nl; k.pfeffer@utwente.nl)

Compositionally complex and multifunctional landscapes provide multiple ecosystem services relevant for rural livelihoods. Due to a growing population, climate change and the expansion of agricultural commodities, the future of mosaic landscapes is of scientific and societal concern. In the debate on mosaic landscapes, remarkably few scholars consider the views of farmers and other landscape dwellers. Political ecology makes local people’s landscape knowledge and aspirations transparent, thus contributing to inclusive landscape governance. Employing participatory spatial scenario development with actors in a mixed cocoa-oil palm area in Ghana's Eastern Region, this study generates insights into farmers' perceived changes, desired future landscapes and the actions considered necessary to achieve them. Results show that landscape actors are aware of the state of the landscape and changes that have occurred, with the participatory scenario maps coming close to actual landscape composition and spatial configuration. Contrary to assumptions underlying many studies in the sparing-sharing debate, farmers' desired landscape is largely similar to the current situation, characterized by increasing homogenization due to expanding areas of commodity crops, as oil palm and cocoa represent the major source of stable income. Farmers however acknowledge drawbacks such as decreasing foodcrop land, reduced availability of provisioning ecosystem services such as non-timber forest products, and declining presence of shade trees, and consider forest conservation and tree planting important. These findings challenge the prevailing assumption that small-scale farmers in the tropics prefer mosaic landscapes, implying that inclusive landscape governance should be based on a critical analysis of farmers' knowledge and views.

Spatial analysis to support rural development in settlements in Maranhão, Brazil / Análise espacial como subsídio ao desenvolvimento rural em assentamentos do Maranhão

Vera Maria Gouveia ${ }^{1}$, Hulda Rocha e Silva ${ }^{2}$, Anida Claudia Dominici Soares², Tatiana Ribeiro de Santana ${ }^{2}$

${ }^{1}$ Embrapa Cocais, São Luís, Brasil, 2Incra, São Luís, Brasil (vera.gouveia@embrapa.br; hulda.silva@sls.incra.gov.br; anida.soares@sls.incra.gov.br; tatiana.santana@sls.incra.gov.br)

A maioria dos municípios no Maranhão possui base econômica nas atividades extrativistas, agropecuárias e em serviços essenciais, e envolve comunidades tradicionais e o agronegócio. O babaçu representa um expressivo recurso do extrativismo vegetal e a atividade é essencial para as quebradeiras de coco, populações rurais e indústria. Porém, a posse da terra, em geral, não é dos extrativistas cujo acesso é realizado por meio de parcerias com os latifundiários tanto na produção agrícola como na forma de comercialização das amêndoas. Apesar de sua grande área territorial o Maranhão detém uns dos mais baixos números de proprietários rurais revelando grande concentração de terra, porém, também é o $2^{\circ}$ estado brasileiro com mais assentamentos. O presente estudo teve por objetivo realizar a Análise Hot Spot do extrativismo babaçu e das atividades agropecuárias no Maranhão e identificar a localização de assentamentos nas modalidades Projeto de Assentamento - PA, Projeto Agroextrativista - PAE e Projeto de Desenvolvimento Sustentável - PDS. Utilizou-se a ferramenta "Hotspot Analysis" disponível no software Arc GIS, pela criação de um banco de dados geográfico com a base cartográfica digital Malha Municipal Digital do Zoneamento do Estado do Maranhão, dados do Sistema IBGE/SIDRA e dados cartográficos e informações de assentamentos do Incra. Os mapas produzidos com os hot spots e com os assentamentos constitui uma abordagem espacial para identificar cenários de conflito e uma ferramenta para subsidiar políticas públicas em nível da paisagem para a proposição de projetos de desenvolvimento rural visando a manutenção de florestas e serviços ambientais.

\section{Characterizing the space-time patterns of deforestation and land use intensification within the cattle supply sheds from meatpackers} with zero-deforestation commitments in the Brazilian Amazon

\author{
Amintas Brandao Junior ${ }^{1}$, Lisa Rausch ${ }^{1}$, Holly Gibbs ${ }^{1}$, Jacob Munger ${ }^{1}$, Matthew Christie ${ }^{1}$ \\ ${ }^{1}$ University of Wisconsin-Madison, Madison,USA(abrandao@wisc.edu; llrausch@wisc.edu; hkgibbs@wisc.edu; munger@wisc.edu; mjchristie@wisc.edu)
}

Supply chain agreements launched by governmental agencies and NGOs have been pushing meatpacking companies to reduce deforestation associated with cattle raised in the Brazilian Amazon. One current challenge is the lack of precise information on the cattle supply sheds and the patterns of land use associated with the agreements. In this study, we combined cattle movement data, properties boundaries, and roads network, to identify the cattle supply sheds of direct and indirect suppliers from meatpackers located in the states of Mato Grosso, Pará, and Rondônia for the period 2013 to 2017. Next, we documented the spacetime patterns of deforestation and land intensification within each supply shed, from slaughterhouses that sign and did not sign the agreements. Our results have shown that most of the cattle transactions from the plants that signed the agreements, were from ranchers near to the plants and with little recent deforestation. However, cattle farms with deforestation can travel farther to reach plants that do not monitor their suppliers or send cattle to farms without deforestation for non-slaughtering purposes, which could be an indication of laundering. Finally, we found that land was more intensified within the supply sheds from plants that 
signed the agreements. We demonstrate the importance of the cattle agreements by highlighting the extent to which non-compliant producers can go to avoid conforming to deforestation-free production, given the opportunity.

\title{
A90: FORESTRY IN TRANSITION? FOREST POLICIES IN CHANGING SOCIETIES. PART 2:
} GLOBAL EXAMPLES

\section{Implementing forest devolution in a rapidly changing society: a case from China}

Yiwen Zhang ${ }^{1}$, Shashi Kant ${ }^{1}$, Hexing Long ${ }^{2}$, Jinlong Liu ${ }^{3}$

${ }^{1}$ Faculty of Forestry, University of Toronto, Toronto, Canada; ${ }^{2}$ School of Economics, Minzu University of China, Beijing, China; ${ }^{3}$ School of Agricultural Economics and Rural Development, Renmin University of China, Beijing, China (yww.zhang@mail.utoronto.ca; shashi.kant@utoronto.ca;

longhx1986@163.com; liujinlong_jl@hotmail.com)

Researchers often emphasize the significance of devolving sufficient forest rights to farmers; however, the question remains whether farmers living in a rapidly changing society can successfully manage forests even if they obtain sufficient rights. This case study focuses on a community that conducted two forest devolution reforms in different periods. These two forest devolution reforms, despite their similar contents and goals, caused totally different outcomes. Based on the process tracing method, we explore why these two devolution reforms have different efficacy by unraveling the interactions between forest devolution and the dramatic socio-economic changes of the community. We find that although the second forest devolution reform tried to duplicate the success of the first one, it neglected the socio-economic changes including income increase, outmigration, livelihood diversification, market changes and the decreasing importance of forests, thereby failing to stimulate farmers' enthusiasm about managing forests and exposing farmers to high market risks instead. Therefore, although farmers obtained substantial forest rights in the second reform, they failed to successfully self-organize to manage forests. We argue that before implementing forest devolution we need to determine whether the local socio-economic context facilitates the self-organization of managing forests and a dynamic perspective is needed to make policies compatible with rapid socio-economic changes.

\section{Towards better information on the costs and benefits of forest and landscape restoration projects in the Sahel Region}

Daowei Zhang ${ }^{1}$

${ }^{1}$ FAO , Rome, Italy (daowei.zhang@fao.org)

Some 160 million hectares of degraded lands need to be restored in the Sahel region, but only few attempts have been made to assess the costs and benefits of these restoration efforts. FAO has teamed up with other institutions to fill this gap by establishing a methodological framework for cost-benefit analysis and by conducting a pilot study of restoration projects in the region. Preliminary results show that the cost of restoration activities starts at about USD 300 per hectare and rises along with more sophisticated interventions and on more difficult sites. Furthermore, the tangible benefits for local residents are rather limited, but adding the benefits of other ecosystem services would make these projects have a much higher benefit-cost ratio. The results of this study would be available in the summer of 2019 and be ready to be presented at IUFRO 2019.

\section{Re-examining of Japanese yield regulation system by recent forest growth information}

Keisuke Toyama ${ }^{1}$

${ }^{1}$ The University of Tokyo Chiba Forest, Kamogawa, Japan (toyama@uf.a.u-tokyo.ac.jp)

In Japan, woodland owners or their agents can formulate a five-year plan named "Collective Forest Management Plan" (CFMP) and submit it to the local government, which allows them to obtain subsidies for silvicultural operations. However, each CFMP must fulfill some numerical constraints, one of which is the allowable cutting volume restriction defined by a formula similar to the Austrian formula. Although this public rule can theoretically constrain the unregulated intensive clearcutting, it seems to disturb CFMP submission in actuality and lead to the low rate of CFMP-covering area. This allowable cutting volume is calculated from the stand age and site index of each stand recorded in the public forest registries which cover the whole Japanese private forests. However, recent forest data from such as LiDAR and NFI have revealed the inaccuracy of the existing stand volume estimation model. For the sustainability of forestry and forest resource, effective yield regulation for Japanese public system is examined, considering the shift of the allowable cutting volume of Japanese CFMP system followed by additional precise forest information.

\section{When shall forests become beautiful in Kenya! The dilemma of reconciling stakeholder interests and values}

\author{
Musingo Tito E. Mbuvi ${ }^{1}$, Paul O. Ongugo ${ }^{1}$, Eric T. Nahama ${ }^{2}$, Leila Ndalilo ${ }^{1}$ \\ ${ }^{1}$ Kenya Forestry Research Institute, Nairobi, Kenya; ${ }^{2}$ Kenya Forest Service, Nairobi, Kenya(mtembuvi@gmail.com; apulongugo@live.com; \\ e_nahama@yahoo.com; leylilo@yahoo.com)
}

Forests in Kenya are sources of timber, firewood, grazing; and are niches for conserving biodiversity. The last three decades have witnessed a transition of forest governance from community to joint management under different governance regimes. A review of forest management documents, Discussion with Focus Groups and Key Informant revealed that: this transformation has not changed the way communities perceive forests "as a resource to support their survival". It showed that: high poverty levels are prevalent in forest adjacent communities' forests contribute to rural and urban household energy and livelihoods needs with urban forests providing both aesthetic and basic needs to the communities differentially across the well-being status. The well-off communities perceive forests as beautiful and should be preserved for aesthetic value. The provision of alternative products and services have not replaced the needs or changed less-off members value system. This poses a dilemma to the stakeholders as increasingly the country is getting urbanized and the poor are not reducing proportionately. Experts opine that by 2030 over $90 \%$ of the forests in the country will be under joint management. The country will witness forests neighbouring large urban centre being managed through coexistence with stakeholders contributing on their own volition to ensure provision of environmental services. We are moving to a time when urbanized communities will be using the slogan, "The forests are very beautiful, let us go to the forest to enjoy and relax". This move calls for a schematic engagement with stakeholders and policy makers’ to support the transformation. 


\section{Key factors in the enabling environment for smallholder tree growing}

Anne Arvola ${ }^{1}$, Maria Brockhaus ${ }^{1}$, Maarit Kallio $^{2,3}$, Thu Thuy Pham ${ }^{4}$

${ }^{1}$ University of Helsinki, Helsinki, Finland; ${ }^{2}$ University of Helsinki, Viikki Tropical Resources Institute (VITRI), Helsinki, Finland; ${ }^{3}$ University of Helsinki,

Helsinki Institute of Sustainability Science, Helsinki, Finland; ${ }^{4}$ CIFOR, Hanoi, Vietnam (anne.arvola@helsinki.fi; maria.brockhaus@helsinki.fi;

maarit.kallio@helsinki.fi;.t.pham@cgiar.org)

Attempts to encourage smallholder tree growing with policies and incentives have had variable outcomes and earlier research and theories have identified various important factors in the enabling environment and in promotional policies. Success of policies and incentives depends on the socioeconomic context where they are applied, the overall political and market environment, the perseverance of policies, and relevancy of incentives to target the actual hindrances for tree growing. A systematic analysis was carried out to complement previous qualitative research, and to clarify which factor combinations produce increased smallholder tree growing in developing country contexts. We applied two-step Qualitative Comparative Analysis (QCA) to identify necessary and sufficient factors in the enabling environment over time between 1990-2015 in Indonesian Java, Kalimantan \& Sumatra, Lao PDR, Tanzania, Uganda and Vietnam. Material was collected through field research (smallholder and key informant interviews) in Tanzania and Lao PDR, and literature review. Strong tenure rights and demand were always necessary and sometimes even sufficient alone to trigger commercial tree growing. Well-functioning wood markets or strong knowledge base combined with direct incentives played their role as sufficient conditions in many cases and increased the pace of tree growing area expansion. Indirect incentives we insignificant in our case countries as an enabling factor. A key message to policy-makers is that governments are in a central role firstly, in ensuring tenure rights, and secondly as knowledge-service and incentive providers as they may be needed to set up sufficient enabling environment for smallholder tree growing to take-off.

\section{Socioeconomic predictors of willingness to participate in forest support programs in the miombo areas of Zambia}

Moses Kazungu ${ }^{1,2}$, Eliza Zhunusova ${ }^{1}$, Gillian Kabwe ${ }^{3}$, Davison Gumbo ${ }^{4}$, Sven Günter ${ }^{1,2}$

${ }^{1}$ Thünen Institute of International Forestry and Forestry Economics, Hamburg, Germany; ${ }^{2}$ Technical University of Munich, Germany, TUM School of Life Sciences Weihenstephan, Department of Ecology and Ecosystem Sciences, Chair of Silviculture, Munich, Germany; ${ }^{3}$ School of Natural Resources, Copperbelt University, Kitwe, Zambia; ${ }^{4}$ Center for International Forestry Research, Lusaka, Zambia (moses.kazungu@thuenen.de; eliza.zhunusova@thuenen.de; gkabwe@yahoo.co.uk;d.gumbo@cgiar.org;sven.guenter@thuenen.de)

Background: Zambia has a large population of its people living in rural areas and depending on forests for livelihoods. Despite high deforestation of about 250 000 to 300000 ha/year, Zambia has about $66 \%$ of its land covered by the forests of which $45 \%$ is Miombo woodlands. Forest management in Zambia aims to strengthen participation in the utilisation of forest resources. Most forest programs, however, are often designed without taking into account the features of households that could influence participation. Ultimately this has resulted in a lack of understanding of the socioeconomic behaviours that determine households' willingness to participate in forest programs. Methods: We present preliminary findings from a cross-sectional study using data from 412 households interviewed in the Miombo areas. We introduced an instrumental variable approach to address endogeneity between latent participation and willingness to participate, and parameters estimated using two-stage least square. Predictors of willingness to participate were identified using a binary logistic regression with backward stepwise regression. Results: The factors that were significantly associated with willingness to participate in forest programs were: head of household educational level $(\mathrm{OR}=3.31)$ and access to credit $(\mathrm{OR}=2.17)$. The following negatively affected households' willingness to participate: access to roads $(\mathrm{OR}=$ $0.64)$, loss of forest cover $(\mathrm{OR}=0.19)$, increasing age $(\mathrm{OR}=0.98)$, ethnic grouping $(\mathrm{OR}=0.61)$, and self-employment $(\mathrm{OR}=1.00)$. Discussion: Findings are in agreement with most studies; higher educational levels, and access to credit, significantly influences willingness to participate in forest programs. Interventions such as REDD+ should target increasing community-wide access to education and credit facilities.

\section{A9p: POLICIES FOR PUBLIC FORESTS}

\section{Araucaria angustifolia (Bertol.) Kuntze conservation and health: legal and ecosystemic bases}

Alvaro Boson de Castro Faria ${ }^{1}$

${ }^{1}$ Brasilian University of Technology, Dois Vizinhos, Brasil (alvarob@utfpr.edu.br)

Forest health and protection have not yet been considered in the environmental assessment procedures and in the conservation policies of the Atlantic Forest. The book "Araucarias Conservation and Health: legal and ecosystemic foundations" (Conservação e Saúde das Araucárias: fundamentos legais e ecossistêmicos), presents the Brazilian legislation applied to the subject, arguing the possibility of managing with exceptional criteria, this threatened species. It proposes a classification-based system on mature trees and ways to monitor their wellness. The Decline Syndrome process is described, with a simple protocol for the diagnosis of trees at an advanced stage of development. The term Phytosanitary Management is conceptualized, justifying it for the exploitation of the Legal Reserves of the Atlantic Forest in private lands, under the Clean Development Mechanism scheme. This book integrates Environmental Legislation and Ethics, together with Forest Protection, proposing to be a reference for researchers from several areas of knowledge, as well as for people who defend the conservation of Brazilian pine. The work establishes a protocol for the diagnosis of trees, necessary for conservation within the framework of the National Plan of Action, mandatory by law due to the Convention on Biological Diversity (CBD). Universities, teachers, environmental analysts, public managers and others who believe in the term Conservation in situ with the sustainable use of specially protected forests, would be interested in this reading.

\section{Forest concession and territorial planning: governance and conflict resolution in the Eastern Amazon}

Jime Rodrigues Ribeiro ${ }^{1}$, Iranilda Silva Moraes ${ }^{1}$, Claudia Azevedo-Ramos ${ }^{1}$

${ }^{1}$ Núcleo de Altos Estudos Amazônicos, Universidade Federaldo Pará, Belém, Brasil (engenheirajime@gmail.com; ira_geo4@yahoo.com.br;

claudia.azevedoramos@gmail.com)

Forest concession is a public forest governance policy predominant in tropical countries. In the Brazilian Amazon, this instrument was applied since 2008 under the main premise of increasing governance in remote areas being an alternative for the development of a forest-based economy and curbing illegal deforestation. Since 2011, the concessions of the Glebas Mamuru-Arapiuns in Pará state have been implemented as a forest governance tool to promote territorial planning in a former undesignated public forestland with a history of local conflicts. This study aimed to understand how these state forest concessions mayhave contributed to spatial planning and a more effective governance of these areas before the beginning of forest operations. Secondary data and legal framework that focused on the discussions of the first concessions under state management were used to review the historical process. After 12 months of discussions involving 37 
groups with different positions, the state strategy using a participatory process has resulted in advances on the governance of 1-million hectares of state public forests through land titling, destination for community use, creation of conservation units and forest concession, decreasing local conflicts. However, indigenous territories are still under dispute. Overall, the participatory process may be considered a successful case study of territorial planning and conflict resolution having forest concession as a starting point.

Forms of regularizing legal reserves: the preference of rural producers / Formas de regularização do déficit de reserva legal: a preferência declarada dos produtores rurais

Rayane Pacheco ${ }^{1}$, Raoni Rajão

${ }^{1}$ Universidade Federal de Minas Gerais, Belo Horizonte, Brasil; ${ }^{2}$ Universidade Federal de Minas Gerais, Laboratório de Gestão de Serviços Ambientais, Belo Horizonte, Brasil (enayar.costa@hotmail.com; rajão@ufmg.br)

O Código Florestal (Lei 12.651/2012), que regulamenta a proteção da vegetação nativa, estabelece alternativas de regularização do déficit de Reserva Legal (RL) aos proprietários ou possuidores de imóveis rurais, sendo: recomposição, regeneração natural e/ou compensação da RL. Apesar das opções existentes, a efetiva regularização é uma realidade distante e pouco se sabe sobre as prováveis escolhas dos produtores rurais. Este estudo analisou qual alternativa de regularização os produtores que reconhecem possuir déficit de RL nos estados do Pará e Mato Grosso $(\mathrm{n}=21.523)$ pretendem adotar. Utilizou-se de estatística descritiva e modelo logístico multinomial ajustado no R a partir do questionário preenchido junto com o envio do CAR (2017). Os resultados revelam que cerca de $46 \%$ dos produtores declararam que pretendem compensar a RL, 38\% almejam permitir a regeneração natural e 16\% recompor a RL. Existe maior possibilidade de a compensação ser adotada pelos agricultores, especialmente os mais jovens, os que possuem grandes imóveis (> 15 MF) e título de propriedade, ao passo que a recuperação tem maior probabilidade de ser realizada pelos pecuaristas mais velhos, os que possuem pequenos e médios imóveis e documento de posse. Conclui-se que, para os dados analisados, a compensação se mostrou a alternativa com maior demanda provável. Isso pode estar ligado à resistência dos produtores em recuperar a área consolidada, ao custo de oportunidade e ao risco de investimentos em uma restauração que pode não funcionar. Logo, as descobertas aqui apresentadas são pontos de partida nas explorações sobre os mecanismos de regularização de RL.

Assessing the impacts of visitation in Desengano State Park, Rio de Janeiro, Brazil / Avaliação dos impactos da visitação no Parque Estadual do Desengano, Rio de Janeiro

Thamires de Souza Carvalho ${ }^{1}$, Marcello Pinto de Almeida ${ }^{1}$, Gumercindo Souza Lima ${ }^{1}$, Angeline Martini ${ }^{1}$

${ }^{1}$ UniversidadeFederaldeViçosa,Viçosa,Brasil(dsc.thamires@gmail.com;marcello.efl@gmail.com;gumercindo.ufv@gmail.com;martini.angeline@gmail.com)

O uso público nas áreas naturais protegidas, quando bem manejado, traz inúmeros benefícios, como a proteção e a conservação da natureza advindos da conscientização ambiental. Dessa maneira, é de extrema importância conhecer os impactos que a visitação pode causar e, assim, evitá-los, controlá-los ou minimizá-los, permitindo a atividade turística sustentável sob o ponto vista ambiental e econômico. Considerando a importância estratégica do Parque Estadual do Desengano na conservação dos ambientes regionais e no desenvolvimento do ecoturismo, cada vez mais estimulado na região, o presente trabalho buscou avaliar seu potencial de uso público por meio de uma análise de intensidade dos impactos da visitação, utilizando-se para tal a metodologia do Checklist. Tal metodologia propõe identificar e enumerar os impactos a partir de uma avaliação ambiental preliminar dos meios físico, biótico e socioeconômico, realizada por especialistas. Dentre os impactos ambientais observados na Trilha da Pedra do Desengano, uma das trilhas mais visitadas de todo o parque, estão: atalhos e bifurcações, vegetação de borda danificada e depredação do ecossistema. Os resultados obtidos permitem inferir que o impacto referente à depredação do ecossistema caracterizou-se principalmente pela coleta ilegal de material biológico e mineral. Os impactos relacionados aos atalhos e bifurcações e à vegetação de borda danificada foram observados com maior frequência no terço final da trilha, que coincide, majoritariamente, com os trechos mais íngremes. Visando mitigar esses impactos sugere-se que o investimento em sinalização de trilhas e em educação ambiental seja ampliado.

\section{Seeds for implementing the Brazilian forest code and Paris agreement: an example of collaboration between the Ashaninka indigenous people and public institutions in Southwestern Amazonia}

Andrea Alechandre ${ }^{1}$, Marilene Bento ${ }^{1}$, Brenda Melo ${ }^{1}$, Cleverson Carvalho ${ }^{2}$, Lucia Hall ${ }^{3}$, Elaine Lopes ${ }^{1}$, Foster Brown $^{4}$, Eliane Yawanawa ${ }^{5}$, Francisco Piyako ${ }^{6}$ ${ }^{1}$ Universidade Federal do Acre, Rio Branco, Brasil; ' ${ }^{2}$ Universidade Federal do Acre, Programa de Pós-Graduação de Ciências Florestais, Rio Branco, Brasil; ${ }^{3}$ Cooperativa de Trabalho do Acre, Rio Branco, Brasil; ${ }^{4}$ Woods Hole Research Center , Universidade Federal do Acre, Rio Branco, Brasil; ${ }^{5}$ Associação Ashaninka do Rio Amônia-Apiwtxa, Rio Branco, Brasil; ${ }^{6}$ Associação Ashaninka do Rio Amônia-Apiwtxa, Marechal Thaumaturgo, Brasil (andreaalechandre@gmail.com; marilenepz@yahoo.com.br; brendameloeng@gmail.com; cleversoncarvalho92@gmail.com; luciahall02@gmail.com; lopes.elaine7@gmail.com;fbrown@uol.com.br; sanayawa41@hotmail.com; francisco.piyako@hotmail.com)

Brazil committed in the Paris Agreement to recover and restore 12 million hectares by 2030. This, along with Brazil’s Forest Code requirements, has created an enormous demand for certified tree seeds. The Ashaninka people of the Indigenous Territory Kampa of the Amônea River in Acre State, have their economy based on extraction of non-timber forest products, hunting and handicrafts production. In order to increase the supply of sustainable products, the process of legalization of the sale of native forest seeds was started in 2015 with technical support from the Zoobotanical Park of the Federal University of Acre-UFAC and financial contribution of the Amazon Fund / BNDES and of Sema-BID / AC. The indigenous institutions, such as the Apiwtxa Association and Ayôpare Cooperative, are responsible for managing and marketing the seeds. There are currently three Seed Collection Areas covering 550 hectares, with 840 seedlings distributed in 29 species. The period of greatest seed production runs from June to September, the period of lower rainfall in the region. The fruits / seeds collected in the indigenous area will be transported to the Seed Distribution Center, located at the headquarters of the municipality of Marechal Thaumaturgo, where they will be made available for commercialization. Certification will be done by the Acre-Lasfac / UFAC Seed Analysis Laboratory, which will carry out the analyzes and determine the quality of the commercialized seeds, thus meeting both the demand of reforestation companies and farmers who need to comply with minimum forest cover regulations.

Integrated activities to promote environmental regularization policy with social and productive improvements for family farmers in the Amazon Biome / Ações integradas para promover a política de regularização ambiental com a melhoria sócioprodutiva de agricultores familiares no bioma Amazônia

Michelliny Bentes ${ }^{1}$, Joanne Regis da Costa ${ }^{2}$, Ladislau Skorupa ${ }^{3}$, Aldecy José Moraes ${ }^{1}$, Everaldo Almeida ${ }^{1}$, Vera Maria Gouveia ${ }^{1}$ Embrapa Amazônia Oriental, Belém, Brasil; ${ }^{2}$ Embrapa Amazônia Ocidental, Manaus, Brasil; ${ }^{3}$ Embrapa Territorial, Campinas, Brasil; ${ }^{4}$ Embrapa Cocais, SãoLuís,Brasil (michelliny.bentes@embrapa.br; joanne.regis@embrapa.br; ladislau.skorupa@embrapa.br; aldecy.moraes@embrapa.br; everaldo.almeida@embrapa.br;vera.gouveia@embrapa.br)

Pesq. flor. bras., Colombo, v. 39, e201902043, Special issue, p. 1-768, 2019 
O Código Florestal Brasileiro (CFB), ou novo Código Florestal, renovou em anos recentes algumas obrigações aos proprietários rurais, quanto à recomposição das Áreas de Reserva Legal, considerando os limites de exploração econômica dentro da propriedade, dando reforço também à importância da manutenção de Áreas de Preservação Permanente, enquanto espaços vitais de proteção biológica dos seres e organismos vivos, e dos recursos hídricos. No que se refere ao segmento produtivo familiar na Amazônia, o entendimento de aplicação dessas normativas, com alto grau de formalidade, têm promovido mais irregularidade e desmotivação, que seu próprio cumprimento. Como desafio e proposta de intervenção dessa realidade, o Projeto Inovaflora, que integra o Projeto Integrado da Amazônia (Fundo Amazônia), estabeleceu a articulação territorial com agricultores familiares, suas representações, e parceiros institucionais atuantes nos segmentos produtivo e ambiental no bioma Amazônia, e a integração de ferramentas e métodos de monitoramento e de avaliação da adoção e dos impactos, para promover a validação e o incentivo de alternativas produtivas associando florestas e culturas agroalimentares, em favorecimento ao fortalecimento de cadeias produtivas locais e aumento da participação nos programas estaduais de regularização ambiental nos territórios afetados pelo desmatamento. Estão sendo realizadas ações periódicas nos territórios, com processos de mediação e intercâmbio de informações e conhecimentos, para a conexão com experiências e saberes da agricultura familiar, e o conhecimento gerado pela pesquisa no campo da recomposição e restauração florestal, visando ampliar a inclusão socioambiental e econômica de agricultores familiares e reduzir a pressão sobre a floresta primária no bioma.

\section{Pilot forest hub Paraiba valley (SP): incentive to multifunctional native species plantations for timber and non-timber products, and ecosystem services}

Helena Carrascosa von Glehn ${ }^{1}$, Maria José Brito Zakia 2 (D); Silvana Nobre ${ }^{3}$ (D)

${ }^{1}$ Secretaria de Infraestrutura e Meio Ambiente do Estado de São Paulo, São Paulo, Brasil; 2 Instituto de Pesquisas e Estudos Florestais, Programa Silviculture of Native Species, Piracicaba, Brasil; ; ${ }^{3}$ Universidad Politécnica de Madrid, ETSI de Montes, Forestal y del Medio Natural, Madrid, Spain

(hcarrascosa@sp.gov.br; zeze.zakia@uol.com.br; silvana.rnobre@gmail.com)

The Brazilian Forest Law designates 20\% of all rural properties in São Paulo to be considered legal reserve (LR), which means the area, besides economic use, should provide ecosystem services such as soil conservation, water spring protection, and biodiversity preservation. Most of the properties in São Paulo do not have enough vegetation to fulfill this regulation. The LR might be subject to sustainable management; however, reforestation with native species is not conventional in Brazil due to the lack of silvicultural information and market uncertainties. The Secretariat for the Environment of the State of São Paulo (SMA-SP) led the working toward the large-scale forest plantations that fulfill ecological and economic purposes, which is crucial for the adhesion of farmers. We identified the native species to make it feasible. Furthermore, the need for structuring the chains (wood and non-timber products) became evident, guiding to a regional hub including forest production, industrial processing, and marketing. The Paraiba Valley was chosen due to its biophysical characteristics, good infrastructure, proximity to mattering markets and sources of water supply, and the underutilized degraded agricultural areas. Economic evaluations using the usual indicators revealed promising results; accordingly, the investment thesis is under development. The governance structure is being built supported by highly qualified professionals, and the active participation of local organizations, reinforcing the expectations of success. The objective of this paper is to present the status of the project, lessons learned during the process, and which actions are being taken to ensure the success of the program.

\section{National register of public forests: 10 years of experience in Brazil}

Gustavo Oliveira ${ }^{1}$, Leandro Biondo ${ }^{1}$, Janaina Rocha ${ }^{1}$, Bernardo Trovão ${ }^{1}$, Rejane Mendes ${ }^{1}$

${ }^{1}$ Serviço Florestal Brasilia, Brasilia, Brasil (gustavo.oliveira@florestal.gov.br; leandro.biondo@florestal.gov.br; janaina.rocha@florestal.gov.br; bernardo.trovao@florestal.gov.br; rejane.mendes@florestal.gov.br)

The National Register of Public Forests - CNFP is a Brazilian forestry management planning instrument. By collecting geo-referenced data on Brazilian public forests, it contributes to the strategic view of the conservation and sustainable use of forest and environmental assets, as well as the unification of destination information and the protection of these forests. This paper describes the ten years of implementation and reports the evolution of the registration and identification of these public forests. For the execution of the Union's Public Forests Map, we worked with: Survey of federal public land information (National Indian Foundation / FUNAI, Chico Mendes Conservation Institute / ICMBio and Ministry of Environment / MMA, National Institute of Colonization and Agrarian Reform / INCRA and Ministry of Defense / MD); Survey of existing forest cover in March 2006 (Public Forest Management Law, No; 11.284 / 2006); and, Crossing the qualitative information of these public forests through satellite images. Initially, in 2007, there were 193 million hectares registered and, in the 2017 update, there are already 311.6 million hectares registered (equivalent to $36.6 \%$ of the national territory). Of the total number of registered areas, $21 \%$ are Non-Targeted Public Forests (29 million federal hectares and 47 million state hectares), the remainder being divided among the categories of Community Use (50\%), Biodiversity Protection (35\%), Military use (1\%), among others (including 1.5 million hectares allocated to the 26 sustainable forest management units under concession under both the federal 17 (1.02 million hectares) and the 9 state ones (477 thousand hectares).

A9q: FOREST POLICY AND GOVERNANCE

\section{Brazilian forest code and forest connectivity among rural properties in the Amazon \\ Pedro Luis Trejo Moreno ${ }^{1,2}$ (D), Claudia Azevedo-Ramos ${ }^{1}$ \\ ${ }^{1}$ Universidade Federal do Pará, Belém, Brasil; ${ }^{2}$ Universidad de Los Andes Mérida Venezuela, Republic of Bolivarian (trejopedro21@gmail.com; claudia.azevedoramos@gmail.com)}

Tropical countries have developed different legal frameworks for the protection of their forests. In Brazil, the Legal Reserve - LR (a forested area within rural properties) and the Permanent Protection Areas - PPA (a riparian protection zone) were established by the Brazilian Forest Code (BFC) to ensure the conservation of natural resources. The National System of Rural Environmental Cadaster (SICAR) organizes the compulsory georeferenced registration of LR and PPA of private properties as the first step for the environmental regularization. In theory, LR and PPA may also work as important ecological corridors among forest patches depending on their spatial location. A connectivity analysis of forest fragments among properties may help to understand whether the environmental goals of BFC are being achieved. We tested this assumption using the agrarian municipality of Tomé-Açu (5.150 km² and 1994 properties) in the Amazon as a case study. Small properties (66.3\%) dominate the landscape in number while big properties occupy $76.6 \%$ of the area. We calculated the Integral Index of Connectivity (IIC) using deforestation and SICAR data with the software Conefor 2.6. The IIC ranges from 0 to 1 (the best scenario). The results showed an IIC of 0.150 , which means a high forest fragmentation, complicated by $11.1 \%$ of overlaps among LR. The assurance of environmental benefits from the BFC may depend on a better spatial design and restoration of LR and PPA. In this sense, the environmental public agencies may have an important role in the Environmental Regularization Program and its monitoring. 
Compensation for affecting the biotic environment, developing environmental easements as an economic instrument to restore forest cover / Compensaciones por afectación al medio biótico desarrollando servidumbres ambientales como instrumento económico de gestión para recuperar cubiertas forestales

Jaime Alberto Moreno Gutiérrez ${ }^{1}$

${ }^{1}$ Universidad Distrital Francisco José de Caldas, Bogotá D.C., Colombia (jamemoreno@gmail.com)

Instrumentos como el de los Pagos por Servicios Ambientales - PSA, se convierten en instrumentos perversos para la conservación de ecosistemas forestales de no mediar un pago, en tanto que las estrategias corrientes de compra de predios para la conservación ecosistemas estratégicos existentes en ellas desencadenan desplazamiento poblacional, el presente estudio plantea desde lo teórico conceptual y la viabilidad operativa en Colombia como alternativa de alta eficacia, un mecanismo de pagos por SERVIDUMBRES AMBIENTALES, como estrategia alternativa para la implementación de compensaciones por afectación al medio biótico, derivadas del uso y aprovechamiento forestal; se plantea la conceptualización alterna a las servidumbres ecológicas para recuperación de servicios ecosistémicos en áreas donde se han perdido, esto desde el enfoque del costo de oportunidad, a partir del excedente del productor, calculado a partir del diferencial entre valor de explotación productiva de áreas con importancia ecosistémica en coberturas forestales susceptibles de ser recuperadas, restauradas o conservadas, y los costos que se enfrentan para generar dicha producción, financiándose con obligaciones de compensación emanadas de permisos.

\section{Communication as a tool of forest policy to harmonise the needs of society and the forestry sector}

Marcel Riedl ${ }^{1}$, Vilém Jarský ${ }^{1}$, Roman Dudik ${ }^{1}$, Jaroslav Śálka ${ }^{2}$, Jiři Oliva ${ }^{1}$, Petra Palátová ${ }^{1}$

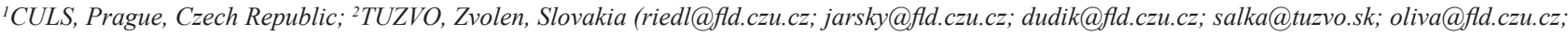
palatovap@fld.czu.cz)

Global changes taking place both in nature and in society create new challenges for the forest policy. The basic prerequisite for their solution is effective communication both within the forestry sector and with the public. The presentation deals with the analytical process of creating an effective communication strategy as a tool for the long-term harmonisation of the needs of society and forestry using procedures based on detailed research on public lifestyle and media behaviour. Within the forestry sector, the effectiveness of the strategy based on a one-stage and two-stage communication model communicating scientific knowledge and expertise to small forest owners and the impact of this strategy on the cognitive, affective and conative attitudes of small forest owners and the possibilities of their greater activation are analysed. The presentation is complemented by a number of actual results from market research as well as demonstrating the implementation of a specific communication campaign including its media evaluation.

\section{Deciding the future of forest ownership: opportunities and challenges of forest services and forest governance}

Gun Lidestav ${ }^{1}$, Elias Andersson ${ }^{1}$, Anne Matilainen ${ }^{2}$, Merja Lähdesmäki $^{2}$

${ }^{1}$ Swedish University of Agricultural Sciences, Umeå, Sweden; ${ }^{2}$ Ruralia Institute, Helsinki University, Seinäjoki, Finland (gun.lidestav@slu.se;

elias.andersson@slu.se; anne.matilainen@helsinki.fi; merja.lahdesmaki@helsinki.fi)

Over the last decade, the increasing heterogeneity of private non-industrial forest ownership has been studied and discussed in research. Although the acknowledgment of diversity in characteristics and objectives of forest owners, the outcome in terms of diversity in forest management practice is seldom observed. Further, research on forest-related service market is very limited, but a traditional production-oriented logic seems to dominate. In the emerging circular bio-economy discourse, the role of forest owners in the value chain is often overlooked. Drawing upon a review study of Finnish and Swedish literature, this paper explores the conceptualization of non-industrial forest ownership and their decision-making, and the potential implications for policies and service provision. The results illustrates that the forest owner related factors impact on decision making at strategic, tactic and operational decision making levels, while resource and operational environment related impact mostly on certain types of tactical and operational decisions. The dominant traditional production-oriented logic and related categorization/segmentation results in limitations in the conceptions of subjectivity and agency in forest ownership. This limited understanding of the various subject positions contribute to the exclusion of individuals and the closing of space and actions. Further, it suggest restrictions in the effectiveness and legitimacy of forest governance. The implications of this will be discussed both from the perspective of research, the development of support and service to endorse the heterogeneity and specific forms of agency within forest ownership.

\section{Multi-level and multi-stakeholder governance of non-timber forest products? Cases from Ukraine and the Russian Federation}

Nataliya Stryamets ${ }^{1}$, Marine Elbakidze ${ }^{2}$

${ }^{1}$ Ca'Foscari University of Venice, Venice, Italy; ${ }^{2}$ Swedish University of Agricultural Science, Skinnskatteberg, Sweden (natastr@gmail.com; marine.elbakidze@slu.se)

Governance for non-timber forest products (NTFPs) is about rules, decision-making processes and institutional arrangements that govern production systems from access to the resources, its use and to markets. Compared to other forest products, there are only few studies on governance of NTFPs in European postsocialistic countries transitioning from planned to market economy. The aim of this study is to compare institutional and governance arrangements related to NTFPs using case studies in the Russian Federation and Ukraine. Both countries have a legacy of top-down forest government, state owned forests, and a rural population with a long history dependent on plant and animal-based NTFPs. To understand institutional frameworks and governance arrangements that deal with different aspects of NTFPs production systems we analysed legal documents dealing with NTFPs in each country and conducted 48 expert interviews with representatives of stakeholders from public, private and civil sectors that were involved in governance of NTFPs. Governance systems of plant- and animalbased NTFPs in both countries were complex, including institutions at multiple levels. In Russia and Ukraine national level institutions and public organisations at multiple levels are supposed to ensure the sustainable use of NTFPs by defining and controlling their extraction. Global institutions influenced NTFPs governance only in the Russian case study, where forest certification facilitated stakeholders from civil sector to develop instruments that are used by local communities to protect their customary rights to secure access to NTFPs. Decentralization, stakeholder involvement and dialog are instruments to encourage multi-stakeholder multi-level governance of plant- and animal-based NTFPs. 
Testing the effects of legislation on deforestation rates in conservation units within the Legal Amazon

Felipe Cozim Melges ${ }^{1}$,Hugo de Boer ${ }^{2}$, Maria J. Santos ${ }^{3}$

${ }^{1}$ German Centre for Integrative Biodiversity Research (iDiv) Halle-Jena-Leipzig, Leipzig, Germany; ${ }^{2}$ Copernicus Institute of Sustainable Development, Utrecht, Netherlands; ${ }^{3}$ University Research Priority Program in Global Change and Biodiversity and and Department of Geography, Zurich, Switzerland (fc57ruqa@studserv.uni-leipzig.de; h.j.deboer@uu.nl; maria.dossantos@geo.uzh.ch)

Deforestation and destruction of natural ecosystems represent a serious threat to biodiversity and environmentally provided services. The Legal Amazon territory in Brazil is such a case, containing the largest continuous tropical forest on earth, which accounts for a large fraction of the global carbon budget, water cycle and biodiversity. The Amazon deforestation is a multi layered, complex issue involving multiple actors. Establishment of conservation units, implementation of focused legislation and adoption of deforestation programmes are considered important tools in conserving forests and biodiversity. Specifically, Federal Laws 9.985/00; 11.284/06 and 12.651/12 are designed to prevent further deforestation and harmonize economic development. Here we evaluate whether Federal Law 11.284/06 and 12.651/12, and the 2008 deforestation programmes decreased deforestation rates within conservation units in the Legal Amazon. We analyzed legislation on annual basis and found no significant change; however, we did find a significant change in deforestation rates after the compilation of operations and programs of 2008. Further, when we analyzed deforestation over a reasonable period for the effect of legislation, we found significant changes for Federal Law 11.284/06 resulting in a decrease in mean deforestation rates of 0.73 and 0.02 in absolute $\left(\mathrm{km}^{2}\right)$ and relative terms (\%) respectively. Federal Law $12.651 / 12$ showed no significant change, despite increase in mean absolute deforestation $\left(+0.11 \mathrm{~km}^{2}\right)$ and decrease in mean relative deforestation (-0.04\%). These results imply that both focused legislation and deforestation programmes contribute to reduce deforestation, conserve forest and biodiversity. However, the effects of the implementation of new legislation are not immediately clear.

\title{
The complexity of managing native forests through participation by local actors / La complejidad de la gestión del bosque natural por la participial de actores locales \\ Jaime Alberto Moreno Gutiérrez ${ }^{1,2}$ \\ ${ }^{1}$ Universidad Distrital Francisco José de Caldas, Bogotá, D.C., Colombia; ${ }^{2}$ Multiversidad Mundo Real Edgar Morin Mexico D.C. Mexico (jamemoreno@ gmail.com)
}

La evolución y desarrollo de la humanidad históricamente ha estado signada por su relacionamiento con el bosque, inicialmente como proveedor de frutos y leña, que se convirtió en un determinante para intervenir el medio, hasta sostener relaciones complejas como soporte y regulación de la vida misma de la humanidad a través de los servicios ecosistémicos que provee. Esta investigación permite identificar la evolución conceptual que el hombre ha tenido del bosque, desde consideraciones netamente extractivistas por explotación hasta su tratamiento holístico por múltiples servicios ecosistémicos propios de su dinámica, bases para la consecución del desarrollo sostenible tanto de las comunidades que tiene un contacto directo con él, como de la sociedad que requiere de muchos de sus servicios para satisfacer necesidades básicas. La percepción conceptual ha evolucionado de objeto de explotación, considerado como recurso, a requerimientos de gestión multinivel para alcanzar un manejo hacia la provisión de medios para la consecución del bienestar, para su perpetuación como recurso natural renovable; así se hace necesario evolucionar de una consideración de simple factor de producción, cerniéndose entre el libre acceso y derechos de propiedad, hacia la definición de un conjunto de condicionantes o principios de arreglo institucional de relacionamiento, que se definen resultado de la presente investigación, en pro de prospectar la gestión del bosque como recurso de uso común en el siglo XXI, para hacer una efectiva gobernanza forestal.

\section{A9r: FOREST OWNERSHIP AND FOREST VALUES}

\section{Estimation of the asset value of lands reserved for environmental preservation in Brazil}

\author{
Rogério Resende Martins Ferreira ${ }^{1}$, Daniela Tatiane de Souza ${ }^{1}$, Gustavo Spadotti Amaral Castro ${ }^{1}$, Evaristo Eduardo de Miranda ${ }^{1}$ \\ ${ }^{1}$ Embrapa Territorial, Campinas, Brasil (rogerio.ferreira@embrapa.br; daniela.souza@embrapa.br; gustavo.castro@embrapa.br; \\ evaristo.miranda@embrapa.br)
}

The territorial and economic dimension of the areas devoted by farms to preserve native vegetation was not known in Brazil until the Forestry Code was promulgated (Law 12,651/2012). By law, rural properties should maintain areas with native vegetation cover in various categories (Legal Reserve, Permanent Preservation Areas, Surplus Vegetation, etc.). Created by the Forestry Code, the Rural Environmental Registry (CAR) is a mandatory electronic registry for all rural producers that became a relevant tool for agricultural and socio-environmental planning. The aim of this study was to quantify the property asset value of each hectare of legal reserve and permanent preservation areas in Brazil should they be sold for current market prices. Based on the price of land published by FNP Consultoria \& Negócio for the year 2017, it is possible to assess by activity group (grain, rice, semi-arid shrubland, coffee, sugar cane, savannah, Amazon rainforest, transition forest, planted forests, fruit farming, Atlantic rainforest, horticulture, pasture, miscellaneous production) the average and full values of municipal land. With data from the CAR regarding the territorial area of the 218 million hectares of areas devoted to preserving native vegetation in Brazilian rural properties, produced by Embrapa Territorial, reserved areas were calculated by municipality, micro-region, and state. The results were then multiplied by the respective full land values (FNP, 2017). The national total shows that Brazilian farmers and cattle ranchers own land assets reserved for the benefit of the environment in excess of 3.1 trillion reais.

\section{Costs of opportunity and potential for the generation of jobs, taxes, and food in mandatory environmental reserves of Brazilian rural properties}

Daniela Tatiane de Souza ${ }^{1}$, Rogério Resende Martins Ferreira ${ }^{1}$, Gustavo Spadotti Amaral Castro ${ }^{1}$, Evaristo Eduardo de Miranda ${ }^{1}$ ${ }^{1}$ Embrapa Territorial, Campinas, Brasil (daniela.souza@embrapa.br; rogerio.ferreira@embrapa.br; gustavo.castro@embrapa.br; evaristo.miranda@embrapa.br)

The assessment of costs of opportunity is one way to estimate the wealth that was renounced with the legal obligation to keep areas with productive potential as environmental reserves in Brazil. Knowing the costs of opportunity is relevant in order to estimate the economic value of ecosystem services, providing environmental information to agents, aiming to underline the role of farmers in the preservation of nature and its impact in society, in socioeconomic terms as well as in terms of food production. The goal was to calculate the costs of opportunity, generation of jobs, taxes, and food in mandatory environmental reserve areas in Brazil. To calculate the cost of opportunity, we considered the main crop in the municipality under assessment, as well as corn, which has a more widespread territorial distribution. For the number of jobs to be generated, we used the average direct jobs in the corn sector. Tax generation was calculated 
based on Funrural (Law 13,606/2018). Information about environmental reserves was extracted from the Rural Environmental Registry (2018) and organized by staff from Embrapa Territorial. Taking into consideration the main crop in each municipality, the 97.9 million hectares of mandatory environmental reserves in Brazil have a cost of opportunity of 309.8 billion reais. Taking into consideration corn for all municipalities, the value is 246.5 billion reais. Annually, more than 419.8 million tons of corn could be produced, an amount that could feed approximately 1.68 billion people, generate 4.9 million direct jobs, and collect 4.6 billion reais in taxes (Funrural).

\section{Forgotten forests in the Brazilian Amazon: policy and territorial planning}

Claudia Azevedo-Ramos ${ }^{1}$, Paulo Moutinho ${ }^{2}$

${ }^{1}$ Núcleo de Altos Estudos Amazônicos, Universidade Federal do Pará, Belém, Brasil; ${ }^{2}$ Instituto de Pesquisa Ambiental da Amazônia, Brasília, Brasil (claudia.azevedoramos@gmail.com; moutinho@ipam.org.br)

The Brazilian Amazon had ca; 65.4 million hectares of undesignated public forestlands in 017. This massive block of forests is not under some category of use or effective supervision by a designated public agency, increasing the risk of continued land grabbing and predatory use. We estimated that ca; $25 \%$ of Amazon annual deforestation occurred in these forestlands between 2015-2018, responding for 200 million tons of $\mathrm{CO}_{2}$ emissions. Under the current scenario of deforestation growth in the region, the immediate allocation of undesignated forestlands to production, conservation or social use by the government would reduce the availability of unsupervised public land, increase forest protection and, therefore, decrease deforestation and carbon emissions. The careful designation planning and landscape design may contribute to form a mosaic of different categories of forest protection that may optimize the maintaining of ecosystem services in large extensions of forests, mitigating the effect of climate changing and its consequences. Doing so, Brazil will also increase governance of its large share of the Amazon forest.

\section{Assessing indigenous people's perception and preference for ecosystem services: case study of Omo Biosphere Reserve, Nigeria \\ Opeyemi Adeyemi ${ }^{1,4}$, Paxie Chirwa ${ }^{2}$, Folaranmi Dapo Babalola ${ }^{2,5}$, Pasicha Chaikaew ${ }^{3}$ \\ ${ }^{1}$ Federal University of Technology, Akure, Nigeria; ${ }^{2}$ University of Pretoria, Pretoria, South Africa; ${ }^{3}$ Chulalongkorn University, Bangkok, Thailand; ${ }^{4}$ University of Pretoria Pretoria South Africa; ${ }^{5}$ University of Ilorin, Ilorin, Nigeria (adeyemiadetunjiopeyemi@gmail.com; paxie.chirwa@up.ac.za; folababs2000@gmail.com; pasicha.c@chula.ac.th)}

Biosphere reserves are designated to harmonize the relationships between humans and their environment in order to mitigate biodiversity loss which underpins ecosystem services and environmental sustainability. However, previous studies have shown an increasing decline in the availability of ecosystem services over the past few decades due to unsustainable use and management of forest resources. Though an urgent intervention program is needed for sustainable ecosystem services provision for the local communities, the translation of indigenous people's perception of ecosystem services into actionable strategies is still lacking. This study aims to understand local people's perception of ecosystem services that are of priority for their basic needs. Such understanding will help in focusing intervention programs to conserve the ecosystem services while conserving forest resources. To achieve this, empirical data will be collected using a face-to-face questionnaire survey. The questionnaire will be designed to collect information relating to socioeconomic, demographic, identification of ecosystem services, perception about ecosystem services in terms of importance and preferences, accessibility to ecosystem services, and willingness to conserve ecosystem services. Frequencies and multinomial logistic regression will be used to determine which ecosystem services are perceived as important and likely to be utilized in Omo Biosphere Reserve and other similar landscape. This study will help to understand direct users' preferences which will facilitate policy-makers to respond to stakeholders' priorities and better orient management of forest resources. Such orientation can help to improve indigenous peoples' livelihood while contributing to the Global Sustainable Development Goals

\section{How to choose a suitable family forest cooperative organization for local small-scale private forestry in China: a successful experience from Yongan county}

Hesheng Xiee ${ }^{1}$, Youjun He ${ }^{1}$, Dengju Wang ${ }^{1}$

${ }^{1}$ Research Institute of Forestry Policy and Information, Chinese Academy of Forestry, Beijing, China (791555389@qq.com; hyjun163@163.com; wdengju@163.com)

Since the Chinese Collective Forest Tenure Reform (CCFTR), three typical Family Forest Cooperative Organizations (FFCOs)in the form of Forestry Professional Cooperatives (FPC), Family Stock-Cooperative Forest Farm (FSCFF) and Forestry Association(FA) have been successfully established and operated at most of local villages. Based on the sample data of 143 FFCOs and thevillages where they locate in in Yongan, a successful demonstration county of CCFTR, we make a model by Multiple Logistic Regression and Stepwise Regression through using R software. Results show thatthe model with the smallestAkaike Inf. Crit.(AIC) of 67.06 is selected, and influencing factors such as local race category, forest resource category, law condition, land scale served by FFCOs, number of the Party member, distance to town or market, proportion of migrant worker and forest land scale managed by family are significant at $1 \%$ probability level. It is concluded that, compared with FA, FPC and FSCFF, especially FPC with good policy conditions, are chose with big probability by local, and more suitable for local SHE race villages, or local with timber or bamboo forest, or smaller land scale served by FFCOs, or smaller forest land scale managed by family, or more Party members, or long distance to town, or more proportion of migrant workers. Finally, we suggest that the successful experience of demonstration county should be actively summarize , and appropriate FFCOs should beselected and popularized for other small-scale family forestry according to local actual conditions such as forest resource conditions, village social conditions, and policy environment.

\section{Economic optimization of landscape restoration in Latin America}

Rene Zamora Cristales ${ }^{1}$

${ }^{1}$ World Resources Insitute, Washington DC, USA; ${ }^{1}$ Oregon State University Corvallis, Oregon USA (rene.zamora@wri.org)

Landscape Restoration in Latin America is becoming an increasable feasible strategy to mitigate and adapt to climate change effects. Restoration includes interventions such as reforestation, agroforestry, and silvopastures. Many governments in the region have committed to restoring about 50 million hectares to the Bonn Challenge, Initiative 20x20 and the New York Declaration on Forest. However, challenges remain about where, when, and how to implement restoration activities in the landscape. In this study, we developed a multi-objective multi-criteria spatial optimization model to identify, rank and prioritize different restoration opportunities based on their contribution to multiple objectives. The model optimizes spatial resource allocation to priority areas to restore forest connectivity, improve carbon stocks and protect water resources. We have applied the model in two countries, Guatemala and Colombia to estimate the 
most cost-effective restoration strategies that can be implemented in the landscape to achieve the objectives of mitigation and adaptation to climate change. In Guatemala, the analysis focused on how and where to allocate forest incentives (direct payments to landowners) to restore degraded land. In Colombia, the analysis focused on identifying areas to improve connectivity through productive restoration strategies between two nature reserves. In both countries, the model provides decision support to identify where and how to restore key areas in the landscape. We applied a combination of Mixed-integer programming, simulated annealing heuristics, and spatial analysis to develop the model as a toolbox in ArcGIS. Results from the model are being used by governments to implement better strategic planning of landscape restoration.

\title{
Spatial distribution of forest ownership as a result of the restitution process
}

\author{
Jan Wild ${ }^{1}$, Vilém Jarský1 \\ ${ }^{1}$ Czech University of Life Sciences Prague, Prague, Czech Republic (wild@fzp.czu.cz; jarsky@fld.czu.cz)
}

Forest ownership structure in post communistic countries, including the Czech Republic, strongly changed after the end of communistic era. Restitution of nationalized forestland to the former private owners and further demographic and legal processes affect mainly the size of forestland parcels and the distance between the forestland and place of residence of its owner. The size and especially the distances may strongly influence in which way the forest is managed. Within the project NAZV QK1820041 we have analyzed distances of more than 1.4 million of forest parcels and place of residence of their ca 300,000 individual private owners (18\% of the forestland in the country). Anonymized data were provided by Czech Office for Surveying, Mapping and Cadaster and analyzed using ArcGIS 10.5 and R statistical software. Here we present the basic explorative analyses of spatial relationship between forest parcels and their private owners. We found that shorter distances prevail. Local owners possess ca $74 \%$ of total forest land owned by private owners. Average distance from owner residence to his/her forest is $23.8 \mathrm{~km}\left(5^{\text {th }}\right.$ percentile $=0,4 \mathrm{~km}$; $95^{\text {th }}$ percentile $\left.=119 \mathrm{~km} ; \mathrm{sd}=48.2 \mathrm{~km}\right)$. Most of owners $(81 \%)$ also live outside larger cities (> 40,000 inhabitant) and possess almost $80 \%$ of forest land owned by private owners. Spatial data also allow us visualize distribution of ownership structure and thus further support the understanding of this phenomena. The real ownership structure and its spatial distribution is essential for proper targeting of forest policy.

\section{Calculating environmental damage to deforested rain forests in the Amazon region of Pará / Valoração dos danos ambientais em} Florestas Ombrófilas desmatadas na Amazônia paraense

Cyro José Matavelli ${ }^{1,2}$

${ }^{1}$ Policia Federal, Setor Técnico-Cientifico, Florianópolis, Brasil; ${ }^{2}$ Universidade Federal de Santa Catarina, Florianópolis, Brasil (cjmatave@yahoo.com.br)

Nas últimas décadas, em razão da intensificação da expansão agropecuária, o desmatamento avança na região Amazônica. No Estado do Pará, a especulação e grilagem de terras, a criação de assentamentos rurais e a pavimentação de rodovias, contribuem para uma migração espontânea e desordenada, em busca de novos recursos naturais. Nesse contexto, a ocorrência de crimes ambientais é frequente e a sua materialização pode ser determinada através de perícias ambientais. No entanto, não basta somente materializar o dano, também se deve valorá-lo através de metodologias que cumpram algumas exigências, tais como praticidade, rápida execução, baixo custo e plausibilidade da aceitação na esfera judicial. O presente estudo tem por objetivos estimar o volume de madeira comercial explorado em florestas no Estado do Pará, por meio de dados de inventários florestais e de sensoriamento remoto, a fim de utilizá-lo como principal componente do valor de uso direto. A área de estudo situa-se em uma faixa de $50 \mathrm{~km}$ de cada lado ao longo do trecho paraense da BR-163, perfazendo 6,2 milhões de hectares, grande parte inserida em Unidades de Conservação, Terras Indígenas e Áreas Militares. A área desmatada através de corte raso até o ano de 2015 foi estimada em 1,2 milhões de hectares. O VUD, baseado nos componentes valor da madeira comercial e custos da recuperação, em 481 mil hectares, perfaz um total de 9 bilhões de reais. Espera-se uma maior eficiência na elaboração de Laudos na Amazônia, com o dano materializado e valorado, auxiliando na persecução penal e civil.

\section{A9s: SOCIAL ISSUES IN FORESTRY}

\section{How the "tourism-based country promotion policy" effects Japanese nature-based tourism}

Nobuhiko Tanaka ${ }^{1}$

${ }^{1}$ Tokai University, Tokyo, Japan (tanaka_nobuhiko@tokai-u.jp)

To change from a less-developed country in terms of its "Tourism industry," particularly inbound tourism and regional revitalization aspects, Japan has commenced with the "Tourism-based Country Promotion Policy" as of the beginning of 21st century. For instance, the Japanese government started the "Visit Japan Campaign" in 2003, enacted the "Tourism-based Country Promotion Basic Act" in 2007, founded Japan Tourism Agency in 2008, and established "Our Vision to Support the Future of Japan Through Tourism" in 2016. According to this vision, Japanese nature-based tourism policies have also been dramatically changed during this decade. This vision uses the following three viewpoints: 1 . Tourist resource issues, 2 . Tourism industry issues, 3 . Tourist convenience issues. The first one is closely related to forest nature-based tourism. And this vision also advocated the 10 significant reforms necessary to make Japan a "Tourism Advanced Country." "The reform of national parks" and "the reform of landscape" are included among these 10 reforms for Japanese tourism promotion. To undertake these reforms effectively, the Japanese Ministry of the Environment started the "Project to Fully Enjoy National Parks." The Japanese Forestry Agency also started policies for forest recreation and tourism in the National Forest. This study summarizes the recent political situation vis-à-vis Tourism policy making, and discuss the ideal state of Japanese nature-based tourism policy in the near future.

\section{Synchronizing the sustainable development goals into forestry, a case study of Austria}

Reneema Hazarika ${ }^{1,2}$, Robert Jand ${ }^{2}$

${ }^{1}$ Institute of Geography, University of Hamburg, Hamburg, Germany; ${ }^{2}$ Austrian Research Centre for Forests, Vienna, Austria

(reneema.hazarika@studium.uni-hamburg.de; robert.jandl@bfw.gv.at)

Since its inception, there has been much conceptual progress on the linkages of the Sustainable Development Goals (SDGs) and their targets in a comprehensive way. While this conceptualization is an essential first step, action must now move towards translating such concepts into concrete results. One such important inter-linkage is between forestry and the Goal-15 (life on land). Global change factors such as climate change are likely to challenge the ambitions of development laid down in these goals. Such challenges are predicted to be intense in countries with mountain forests such as Austria where effects of climate 
change have already started to manifest. Therefore evaluating the forestry sector within Europe with the sustainable management of Austrian forests in focus can be interesting. We reviewed the linkages and tradeoffs between the SDGs and the principles of sustainability in the Austrian forestry sector. In addition, we compiled the perceptions of Austrian opinion leaders on such linkages and tradeoffs. We found strong linkages between SDG-15 and Austrian forestry sector. The opinion leaders perceive the SDGs as well-placed but broad and at times lacking clarity. The 15-year tenure of the SDGs was perceived to be inadequate to match the temporal scale of forest's development which spans across decades. Apparently, the success of the SDGs will depend upon coordination, governance and most importantly awareness among all stakeholders. Therefore in addition to "leaving no one behind" the development goals must evidently provide incentives for benefitting everybody.

\section{Forest law and environmental legislation for enhanced ecosystem services in Serbia}

Nataša Tomić-Petrović ${ }^{1}$, Mirjana Stevanov ${ }^{2}$

${ }^{1}$ University of Belgrade, Belgrade, Serbia; ${ }^{2}$ University of Novi Sad, Institute of lowland forestry and environment, Novi Sad, Serbia

(atlantic@orion.rs; mzavodj@gwdg.de)

Key challenges of European integrations are in environmental protection. In Serbia since 2007 the Ombudsman has received almost 500 complaints regarding the violation of rights in the field of environment. It shows that citizens do not recognize these problems enough, but that they are also afraid to report them. In our capital Belgrade the first Ministerial Conference "Innovative decisions against pollution in the South and South-East Europe" was held in December 2018. There were representatives from 20 countries of the Southern and South-Eastern Europe and the final document called "Common regional vision of the innovative solutions for decrease of pollution in the South and South-East Europe“ was adopted. Serbia is forested $27 \%$, what is very good, but we have a problem in Vojvodina, where only $6-7 \%$ of the territory is covered with forests. Unfortunately problems with soil erosion and flood are causing huge damage to all areas of life in Serbia. It is necessary to harmonize our positive regulations in Serbia with regulations in the European Union refering to the cutting of forests, but also the control of import and export of wood and wood products. In Serbia, the current issue is trade of illegally-cut trees for fuel. After the amendments to the Law on Forests ("Official Gazette of the Republic of Serbia“, no; 89/15) except market inspectors, now foresters, i.e. forestry inspectors and technicians, are allowed to intervene if they find out that someone traded illegally with felled wood, even if they were from his private forests.

Accountability issues in centrally-led forest governance: addressing climate and development challenges through enabling local communities in Sri Lanka

Indi Akurugoda ${ }^{1}$ iD; Manjula Karunaratne ${ }^{1}$

${ }^{1}$ University of Ruhuna, Matara,SriLanka (indiakuru@gmail.com; mlankanath@gmail.com)

As a developing country where government policies have the top priority on large scale infrastructure development projects using deforested lands, Sri Lanka faces extreme impacts of climate change. The export-oriented plantation economy introduced by the British colonial rulers contributed to forest land clearance prior to independence in 1948. After independence, new major development projects have added further strains on deforestation. The 2019 Long-Term Climate Risk Index has listed Sri Lanka as the second most affected country by extreme weather events. According to the UN-REDD programme in 2017, Sri Lanka's forests, which currently cover 29.7 percent of the total land area can make a significant contribution to both adaptation and mitigation of climate change impacts. Sri Lanka's forest governance is centrally-led. Although there are a number of central government authorities such as the Ministry of Wildlife, Forest Department, Department of Wildlife Conservation and the Central Environmental Authority, which are accountable for forest governance and wildlife conservation, there are several policy fragmentations and accountability clashes. Based on Sinharaja and Kanneliya rainforests, this research explores why the centrally-led forest governance is less accountable for addressing climate and development challenges, and how to enable local communities to address such challenges. Using the data gathered by interviewing forest and wildlife officials, this research identifies the gaps in centrally-led forest governance. The paper observes the potential of enabling local communities in protecting forests from degradation and deforestation and facing climate and development challenges.

\section{Transformative change to a sustainable use of firewood in southern Chile, a wicked problem}

Gustavo Torres

${ }^{1}$ Programa de Doctorado de Ciencias Sociales en Estudios Territoriales, Universidad de Los Lagos, Osorno, Chile (gustavo.torres@ulagos.cl)

In southern Chile there are socio-metabolic needs to use energy for heating in the residential sector during several months of the year. This demand has historically been met with firewood or dendroenergy, with the current consumption of 450,000 $\mathrm{m}^{3} / \mathrm{year}$ in the Province of Osorno, which is obtained mainly from the native forest, where rural producers face problems of poverty and depletion of forests. Firewood is traded in a mostly informal market, where there is no regulation of its quality. Due to this and an inappropriate combustion, there are episodes of high air pollution and health problems in the population. Recently the Government is facing the situation through policy measures restricting the use of wet firewood, however it has not been possible to meet the proposed goals. Thus, the sustainability of the use of firewood is a wicked problem and to address it, the present study proposes a systemic and interdisciplinary approach defining it as a Socio-Ecological System (SES). As an initial result, a proposal for a general analytical framework for the SES of firewood will be shown. Using it, the available information is synthesized to determine the key interactions between the natural system and the social system, emphasizing the main socio-ecological traps that must be addressed to visualize the possibilities for a transformative change towards a sustainable use of firewood in the Province of Osorno. The present study is part of the author's doctoral thesis. The contributions of the Projects FIC BIP 30233422-0 and FONDECYT 1181282 are gratefully acknowledged.

\section{Actionable knowledge for wicked problems: co-production in the USDA Forest Service Rocky Mountain Research Station}

Daniel Williams ${ }^{1}$, Evora Glenn ${ }^{2,3}$, Carina Wyborn ${ }^{2}$, Laurie Yung ${ }^{2}$

${ }^{1}$ USDA Forest Service Rocky Mountain Research Station, Fort Collins, USA; ${ }^{2}$ University of Montana, Missoula, USA; ${ }^{3}$ Luc Hoffmann Institute, Gland, Switzerland(drwilliams@fs.fed.us; evora.glenn@umontana.edu; cwyborn@wwfint.org; laurie.yung@umontana.edu)

The mission of the Rocky Mountain Research Station (RMRS) is to support public and private landowners with best available science to inform land management decisions. Those decisions, however, have become increasingly wicked, complex, and interdisciplinary. To address growing demands for actionable science RMRS is engaging land managers, local communities, and other stakeholders in the co-production of science and science products. Knowledge co-production emphasizes collaboration between researchers and stakeholders to jointly define challenges, identify knowledge gaps, and determine actions to address them. These approaches focus on creating durable, iterative collaborative processes that facilitate co-developing and learning 
together. Co-production seeks to build reciprocal connections between knowledge (scientific, local, experiential, traditional etc.) and decision-making (in policy and practice) to achieve outcomes that are collectively agreed on by those engaged in the process. This presentation describes recent projects involving RMRS in science-management collaborations that incorporate principles of co-production, and examines the ways that RMRS institutional structures and cultures impact the process and outcomes of co-production in these projects. The projects studied include seven research projects covering a variety of landscapes and management problems. In each case, researchers work with managers and other stakeholders to collaboratively describe the multiple dimensions of resource challenges and identify solutions that can address these many dimensions effectively. We will highlight lessons learned from these projects, particularly with respect to the strategies that can be employed by science and management agencies to support co-production processes to realize their aspirations for change.

Integrated management of trophic interactions: moose, red deer and sustainable forest management in Sweden, Belarus and Republic of Moldova

Vitalie Gulca ${ }^{1}$, Per Angelstam ${ }^{2}$, Robert Deal ${ }^{3}$

${ }^{1}$ State Agricultural University of Moldova, Department of Forestry and Public Gardens, Chisinau, Republic of Moldova; ${ }^{2}$ Swedish University of Agricultural Sciences, School for Forest Management, Skinnskatteberg, Sweden, ${ }^{3}$ USDA Forest Service, Pacific Northwest Research Station, Portland, USA (vitalie. gulca@gmail.com; per.angelstam@slu.se; rdeal@fs.fed.us)

Sustainable forest management includes the integration of biophysical, economic and social considerations and the management of many important ecosystem services for forest landowners. Damages to tree regeneration caused by browsing large herbivores depend on their density and the amount of food available under different forest landscape management systems. Within the hemiboreal and temperate ecoregions different countries provide different socialecological and governance contexts and thus opportunity for comparative studies regarding the trade-offs among different variables. Currently, wildlife law is being reformed in Sweden, Belarus and Republic of Moldova. In Sweden moose browsing hampers regeneration of Scots pine for wood production and deciduous tree species for biodiversity conservation. Complex governance makes regulation difficult. In Belarus moose hunting is a significant ecosystem service delivered by forests, which can be steered top-down by development and change of hunting and forests. Decision to increase the number of red deer populations for hunting revenue in Republic of Moldova may compromise another strategic national task, to increase forest area. First, based on interviews we assessed stakeholders' perceived ecosystem services linked to moose, red deer and forests. Second, we assessed the carrying capacity for moose and red deer in case study landscapes in these three countries. The big difference in moose and red deer density and harvest between the countries was linked to different carrying capacities. Finally, we propose innovative wildlife law focused on integration of the interactions between wild herbivore populations, sustainable forest management and local communities.

\section{Hiking as a certified ecosystem service tool to promote healthy life style (HLS) and to increase forestland value}

Vitalie Gulca ${ }^{1}$, Marion Karmann², Robert Deal ${ }^{3}$, Lu Wenming ${ }^{4}$

${ }^{1}$ State Agricultural University of Moldova, Chisinau, Republic of Moldova; ${ }^{2}$ FSC International, FSC Global Development GmbH, Bonn, Germany; ${ }^{3}$ USDA Forest Service, Pacific Northwest Research Station, Portland, USA; ${ }^{4}$ Chinese Academy of Forestry, Beijing, China (vitalie.gulca@gmail.com; m.karmann@ fsc.org; rdeal@fs.fed.us; luwenmingcaf@126.com)

The most unique and effective recovery, scientists say today is healing in the forest. The scientific report of Japanese scientists in 2011 officially confirmed that "forest baths" are not just fun. Having visited once in a forest "clinic", a person develops resistance to all diseases, relieves stress and overcomes chronic fatigue, lowers blood pressure, sugar in the blood and depression, increases concentration and memory, increases self-esteem, develops an independent view of the world, in which its modern civilization drives. Similar results were demonstrated by the latest research conducted in Sweden, England, Canada, the USA. They were attended by 8,500 people and as a result the scientists came to the conclusion: the connection of man with nature gives him a sense of happiness. The goal of the paper in that context is to develop a hiking as a labelled product of emerging markets for ecosystem services (ES) for assessing and communicating the environmental and social performance of forest operations and HLS. Article has an objective to develop a policy for family hiking routes. We hypothesize that hiking present new opportunities for forest landowners and managers, with increasing international recognition of the importance of ES markets and national values. To realize our paper, we have analyzed the health as a system, confronted health and forest legislations, studied the hiking as a process in organizing periodically hiking tours in Republic of Moldova.

A9t: FOREST POLICY AND ECONOMICS - III

\section{A prospectus of leading and lagging indicators for forest restoration in the Philippines}

Liz Ota ${ }^{1}$, John Herbohn ${ }^{1}$, Nestor Gregorio ${ }^{1}$, Arturo Pasa ${ }^{2}$, Dennis Peque 2 , Jennifer Firn ${ }^{3}$

${ }^{1}$ University of the Sunshine Coast, Sippy Downs, Australia; ${ }^{2}$ Visayas State University, Baybay, Leyte, Philippines; ${ }^{3}$ Queensland University of Technology,

Brisbane,Australia(lizmsota@gmail.com; jherbohn@usc.edu.au;ngregori@usc.edu.au; arturo.pasa@vsu.edu.ph;dppeque@vsu.edu.ph;

jennifer:firn@qut.edu.au)

We aim at proposing a prospectus of leading and lagging indicators for forest restoration in the Philippines. While leading indicators point to the likelihood of an outcome, lagging indicators represent realised outcomes of a process. Current forest restoration approaches are focused on much more than just reintroducing trees to the landscape. They acknowledge that a landscape comprises multiple stakeholders who pursue different objectives in a multi-governance structure, and are aimed at providing environmental benefits while improving human well-being. Therefore simple measures of effort (e.g. number of seedlings or area planted) or of short-term outcomes (e.g. tree growth and survival rates) are not enough to assess forest restoration, and several lagging indicators are needed across time and scales. However, forest restoration is a long-term process and some impacts can only be observed years or even decades after its commencement. Leading indicators that suggest our current actions will likely result in the desired outcomes can assist to guide interventions.

\section{Harmonizing trans-boundary wildlife management to improve ecological connectivity of chamois and Alpine ibex}

Aleš Poljanec ${ }^{1}$, Andrej Arih ${ }^{2}$, Stefano Santi ${ }^{3}$, Chris Walzer ${ }^{4}$

${ }^{1}$ Slovenia Forest Service, Ljubljana, Slovenia; ${ }^{2}$ Triglav National Park, Bled, Slovenia; ${ }^{3}$ Prealpi Giulie Nature Park, Resia, Italy; ${ }^{4}$ University of Veterinary Medicine Vienna; Research Institute of Wildlife Ecology,Vienna,Austria (ales.poljanec@zgs.si; andrej.arih@tnp.gov.si; stefano.santi@parcoprealpigiulie.it; chris.walzer@vetmeduni.ac.at) 
The behaviour and habitat use of animals can be strongly affected by hunting methods and wildlife management strategies. Lack of consistency in wildlife management between regions can cause problems for population connectivity for some species, particularly for those with large home ranges. Thus, to facilitate the goals of ecological connectivity, ALPBIONET2030 aims to improve wildlife management of chamois (Rupicapra rupicapra) and Alpine ibex (Capra ibex) in cross-border area of the Julian Alps (289.660 ha). A participatory process, consisted of several expert meetings and workshops was used to discuss possibilities for reconciling land use conflicts and to set up the long-term vision for conservation, protection and sustainable management of both species and their habitats. The process targeted stakeholders from the Alpine regions, including representatives from wildlife management, hunting, park management, forest management, and other interested area residents. The results of the participatory process and applicability of approaches and methods for improving ecological connectivity of wildlife species in cross-border areas will be presented and further discussed. The research is financed by the ALPBIONET2030 project and co-financed by the European Union as part of the Alpine Space Program.

Towards a theory of change to enable forest people to build prosperity while delivering Global benefits for adaptation, mitigation, biodiversity, ecosystem services and cultural heritage

Andrew Taber ${ }^{1}$, Jose DiazDiaz ${ }^{1}$, Marta Gruca ${ }^{1}$, Safia Aggarwal ${ }^{1}$, Jeremie Mbairamadji ${ }^{1}$

${ }^{1}$ UN Food and Agriculture Organization,Rome, Italy(andrew.taber@fao.org; jose.diazdiaz@fao.org; marta.gruca@fao.org; safia.aggarwal@fao.org;

jeremie.mbairamadji@fao.org)

Forest communities, often indigenous peoples, face high levels of poverty and social, economic and political marginalization in many parts of the world. Yet they inhabit biologically diverse landscapes that provide a wide range of ecosystems services at greater scales, including for bolstering resilience in response to climate change. They also harbor rich cultural heritage and traditional knowledge; and produce a variety of wood and non-wood forest products, as well as services such as ecotourism that contribute to local, national and international economies. Research has documented their contributions. However, full recognition is lacking of the existing and potential role of forest communities, under the right conditions, for securing a wide range of environmental goods and services of vital importance to forests and global sustainability while improving their lives and livelihoods. In this poster, we review impediments for forest peoples to realize their potential, and present a theory of change based on the implementation of a holistic and integrated policy and practice framework. This includes strengthening recognition of rights, particularly for forest lands and resources, culturally and gender sensitive economic empowerment and education, and mechanisms to incentivize and sustain their contributions to global environmental goods and services.

\section{Addressing policy-makers in stakeholder communication: LIFEGENMON project case study}

Tjaša Baloh ${ }^{1}$, Boris Rantaša ${ }^{2}$, Katja Sonnenschein ${ }^{1}$, Veronika Vodlan ${ }^{3}$, Marjana Westergren ${ }^{1}$, Fotios Kiourtsis $^{4}$, Xrysi Sarvani $^{4}$, Ermioni Malliarou ${ }^{5}$, Mark Walter ${ }^{6}$, Nikitas Fragiskakis ${ }^{4}$, Andrej Breznikar ${ }^{2}$, Hojka Kraigher ${ }^{1}$

${ }^{1}$ Slovenian Forestry Institute, Ljubljana, Slovenia; ${ }^{2}$ Slovenia Forest Service, Ljubljana, Slovenia; ${ }^{3}$ Center for Information service, co-operation and development of NGOs, Ljubljana, Slovenia; ${ }^{4}$ The Decentralized Administration of Macedonia - Thrace, Thessaloniki, Greece; ${ }^{5}$ Aristotle University of Thessaloniki, Thessaloniki, Greece; 'Bavarian Office for Forest Seeding and Planting, Teisendorf, Germany (tjasa.baloh@gozdis.si; boris.rantasa@zgs.si; katja.sonnenschein@gozdis.si; veronika.vodlan@cnvos.si)

One of the LIFEGENMON project aims is to raise awareness of the importance of genetic diversity of forests for their survival and the importance of implementation of policies that promote such diversity. The obstacles to achieve policy implementation is often unclear communication due to technical language, lack of understanding of the policy-making process and consequently, unrealistic expectations on the side of scientists and a lack of knowledge and understanding of the problem on the side of policy makers. The other obstacle is difficulty to reach all interest groups in policy-making arena. To address the problem of the gap in knowledge between scientists and policy makers, the case study delves into the forms of communication that would successfully warn policy makers and other stakeholders about problems and guide them toward solutions in an innovative way. Moreover, it tries to recognize the moments of opportunity and possibilities to effectively act on them. To address the problem of stakeholders' participation in decision-making processes, the case study focuses on observing activities carried out within the LIFEGENMON project to reach policy-makers and analyses results in terms of their expected and achieved impact. The study provides recommendations in response to specific problems identified. The presentation contributes to the aims and means of the project LIFEGENMON (LIFE13 ENV/SI/000148) for European forest genetic monitoring system, co-financed by the Ministry for the environment and spatial planning RS, and in Slovenia by the Ministry for agriculture, forestry and food and the Slovenian Forestry Institute.

\section{Community forest management and ecosystem conservation in the Vicos Recuayhuanca microbasin, Ancash, Peru}

Aurea Erica Castro Aponte ${ }^{1,2}$

${ }^{1}$ Pontificia Universidad Católica del Perú, Lima, Peru; ${ }^{2}$ Forest Stewardship Council (FSC), Lima, Peru (ericaforestales@gmail.com)

During the last years communities around the world are playing a more central role in the management of local forest and ecosystem conservation. In the Andes communities have a long tradition in managing the forest based on a particular worldview. This research contributes to the understanding of the management and conservations strategies of local forest by the community of Vicus. The research aimed to shed light on the engineering and social practices, and on the strategies of organizational management at community level. The methodology applied is qualitative. Peasants, public agency officers and local NGOs representatives were interviewed. The research concludes that social practices such as solidarity, reciprocity, collectiveness and equity are key to manage the forest sustainably by the Vicus community and the those practices condition the organizational structure, power relationship and collaboration schemes in the community. The research identifies that the efforts of the Vicus community are not backed by the Peruvian state agencies and most of local NGOs, as a result the community social practices are being eroded and conflicts enhanced. Finally, the research suggests a model of sustainable forest management at community level worldwide based on the Vicus community case and the monitoring of organizational and cultural aspects beside of ecological ones for a sustainable community forest management.

\section{Understanding expert disagreements and finding common ground: the case of forest policy research and advocacy in India}

Vanya Bisht ${ }^{1}$

${ }^{1}$ School for the Future of Innovation in Society, Arizona State University, Tempe, USA (vbisht2@asu.edu)

A crucial forest policy problem in many developing countries is the challenge of effectively managing forest resources to meet the competing social, ecological and economic goals of the countries. On one hand there is a need to safeguard the rights of traditional forest dwelling communities to access and manage their 
resources, and on the other hand the need to utilize those resources for meeting industrial demands for the national economy, while maintaining ecological and climatic stability. Solutions or policy recommendations to the above problem coming from experts or policy advisers in different academic disciplines tend to diverge or disagree with one another over critical issues. This often results in a stalemate and impedes major policy decisions. This research investigates the multiplicity of policy recommendations offered by researchers, thinkers and practitioners in the context of forest governance in India. Academic and nonacademic writings (in the form of journal publications, and articles in newspaper and magazines) giving recommendations on forest policies have been analysed to understand how the framing of the problem and approaches to solutions vary across academic and professional silos. This study explores the possibilities of places where commonalities can be found among the policy approaches suggested by different groups. The results are useful in facilitating interdisciplinary collaborations in policy research, overcoming policy stalemates and solving complex forest policy problems in India as well as other countries.

\section{Flora, population structure and conservation management plan of natural monument coastal tree Koelreuteria paniculata community in South Korea}

YoungHan You ${ }^{1}$, Kyu-Tae Cho ${ }^{1,2}$, SeungYeon Lee ${ }^{1}$,EungPill Lee ${ }^{1}$, YongSik Hong ${ }^{1}$, Euijoo Kim ${ }^{1}$

${ }^{1}$ Kongju National University, Kongju, Republic of Korea; ${ }^{2}$ Kongju National University, Kongju, Republic of Korea (youeco21@kongju.ac.kr;

rbxo38@kongju.ac.kr; ecolee21@kongju.ac.kr;lyp2279@kongju.ac.kr; hongfin@kongju.ac.kr; euijoo@kongju.ac.kr)

This study was conducted to investigate the external factors and problems that inhibit the sustainability ofNatural Monument Coastal Tree Koelreuteria paniculata Communities in two local area (the natural monument No; 138 and No; 428) and to establish an effective conservation management plan for these forests. The field investigation surveyed the flora, tree counting, growth status, succession status, surrounding facilities and management status in three times (Spring, Summer, Autumn) in 2016. A total of 133 taxa (60 families, 109 genera, 115 species, 11 varieties, 4 forms, 3 subspecies) appeared in the tree communities of Taean County. A total of 253 trees were 2-8 m high with growth performance. There were seedling and sapling plants due to seed germination evenly throughout the growing area, but they were decreasing due to weed cutting activity. A total of 86 taxa (46 families, 76 genera, 76 species, 10 varieties) appeared in the tree communities of Wando Island. A total of 600 trees were 2-17 m high with growth performance. There were many seedling and sapling plants due to seed germination in edge and open area of the forest. In order to conserve these plant communities, management measures should be prepared such as strengthening regular management in protected areas, improving methods of removing weeds in lower layer, regular monitoring for population dynamics, and strengthening local residents' participation in preventing artificial damage.

\section{Costs of threatened species conservation: evidence from Australia}

Ram Pandit ${ }^{1}$, Asha Gunawardena ${ }^{1}$, Stephen Garnett ${ }^{2}$, David Pannell ${ }^{1}$, James Brasill-Boast ${ }^{3}$, Kerstin Zander ${ }^{2}$

${ }^{1}$ University of Western Australia, Perth, Australia; ${ }^{2}$ Charles Darwin University, Darwin, Australia; ${ }^{3}$ Office of Environment \& Heritage, New South Wases, Sydney,Australia(ram.pandit@uwa.edu.au; asha.gunawardena@uwa.edu.au; stephen.garnett@cdu.edu.au; david.pannell@uwa.edu.au;

james.brazillboast@environment.nsw.gov.au; kerstin.zander@cdu.edu.au)

Species conservation decisions are inherently complex, require careful analysis of different types of information and are also made with resource constraints. Both globally and locally, there are more species to conserve with limited budget. Incorporating economics into conservation planning right from the beginning of developing recovery plans to implementing and evaluating their success is vital. This study aims to examine conservation of threatened species planning in Australia using recovery actions level costs data from a large- scale systematic database of New South Wales. It also explores the determinants of actual expenditure of recovery actions and reporting gaps in current practice to improve systematic conservation planning of threatened species in Australia.

\section{THEME B: FORESTS AND CLIMATE CHANGE}

\section{B1a: INITIATIVES FOR RESTORATION AND MONITORING OF DEGRADED AREAS IN LATIN AMERICA}

\section{Monitoring and transparency of restoration in Latin America: a landscape sustainability index \\ Rene Zamora Cristales ${ }^{1,2}$ \\ ${ }^{1}$ World Resources Institute, Washington DC, USA; ${ }^{2}$ Oregon State University Corvallis, Oregon, USA (rene.zamora@wri.org)}

Monitoring the impacts of restoration activities in the landscape as a system is particularly difficult and it poses some challenges to identifying strategic areas within the landscape that can signal an effect in the overall sustainability. In this study, we developed a cost-effective Landscape Sustainability Index (LSI) to measure the sustainability of the landscape due to restoration against baseline conditions. The LSI is intended to demonstrate correlation (positive or negative) between the restoration activities that are being implemented and the impacts stated in the national restoration plans of countries in Latin America. The LSI is composed of cost-effective social, environmental and economic qualitative and quantitative indicators and uses information available in most of the countries. For social aspects, we developed a governance indicator to measure the level of coordination and organization of the communities living in a landscape. For environmental aspects, we develop indicators for carbon, water quality, water quantity, and soil carbon. To assess the economics, an indicator of employment generated by restoration activities was introduced. The index was implemented in a pilot landscape in El Salvador, Apaneca/ El Imposible /Barra de Santiago where restoration activities have been carried out since 2012. Results show that the sustainability of this landscape has increased since 2011. THE LSI estimated a positive correlation between restoration interventions and carbon stocks, water quality, and connectivity since 2011. The index is the first of its kind to provide a holistic method to monitor impacts of restoration in Landscapes in Latin America.

\section{Initiative 20 x 20: The rise of a movement to support landscape restoration in Latin America}

Rene Zamora Cristales ${ }^{1}$

${ }^{1}$ World Resources Institute, Washington DC, USA (rene.zamora@wri.org)

Initiative 20x20 is a country-led effort to bring under restoration 20 million hectares of degraded land by 2020 . This country-led platform is the largest regional movement supporting the Bonn Challenge effort of restoring 150 million hectares worldwide. Currently, 17 countries have pledged more than 50 million 
hectares to restore. In addition to that private sector partners have earmarked 2 billion USD to invest in productive restoration across the region. Also, technical assistance is provided to the countries, through more than 30 technical partners that are helping the countries with capacity development and research to achieve their restoration targets. Countries are developing on plans and strategies to support restoration ambitions with special achieve their restoration targets. Countries are developing on plans and strategies to support restoration ambitions with special priority on rehabilitating the functionality of the land to improve livelihoods, biodiversity and provide sustainable financial resources to landowners. Private partners, financial institutions and technical partners are working together to unlock private investments in lands restoration using different mechanisms. These mechanisms include the deployment of a partial risk mitigation guarantee, the structuring of an investment readiness fund to prepare potential restoration projects to be investment ready and the use of highly valuable forest species (from commercial and biodiversity point of view) as collateral to allow landowners to access to credits. The landscape restoration activities under the initiative aim to restore degraded land functionality to increase social wellbeing while improving environmental conditions and generating financial and economic benefits. Strategies may include but not limited to agroforestry, tree plantations, silvopasture systems or silvicultural management of degraded and secondary forests.

\section{The alliance for restoration in the Amazon and the importance of scaling up forest landscape restoration as a nature based solution for societal challenges}

Miguel Moraes ${ }^{1}$, Catarina Jakovac ${ }^{2}$, Danielle Celentano ${ }^{3}$, Marcos Tito $^{4}$, Marlúcia Martins ${ }^{5}$, Rodrigo Freire ${ }^{6}$, Rodrigo Junqueira ${ }^{7}$, Rodrigo Medeiros $^{8}$, Sâmia Nunes ${ }^{9}$

${ }^{1}$ Conservation International, Rio de Janeiro, Brasil; ${ }^{2}$ Centro de Ciências da Conservação e Sustentabilie, Rio de Janeiro, Brasil; ${ }^{3}$ Universidade Estadual do Maranhão, São Luiz, Brasil; ${ }^{4}$ União Internacional para a Conservação da Natureza, Brasília, Brasil;; ${ }^{5}$ Museu Goeldi, Belém, Brasil; ${ }^{6}$ The Nature Conservancy, Belém, Brasil; ${ }^{7}$ Instituto Socioambiental, Brasília, Brasil; ${ }^{8}$ Conservation International, Rio de Janeiro, Brasil; ${ }^{9}$ Vale Environment Technology, Belém,Brasil(mdmoraes@conservation.org; c.jakovac@iis-rio.org; danicelentano@yahoo.com.br; marcos.rugnitz@iucn.org; marlucia@museu-goeldi.br; rfreire@tnc.org; rodrigojunqueira@socioambiental.org; rmedeiros@conservation.org; samiasnunes@gmail.com)

Large-scale forest landscape restoration in the Amazon is an agenda of human development, environmental sustainability and agricultural productivity. It represents a virtuous change in the paradigm of economic development in the Amazon, since it generates jobs and income, integrates different productive and social sectors, values its biological and cultural diversity, avoids deforestation and prevents against violence in land disputes. In the Amazon, the forest is synonym for water, wealth, abundance and prosperity. Defining territorial priorities and identifying areas where restoration maximizes ecological, social and economic benefits are fundamental to scale-up forest landscape restoration. Furthermore, the implementation of public policies for large-scale restoration in the Amazon depends on regulation and compliance with environmental legislation, at national and subnational level. Public and private investments in research, development, innovation and human capital are also needed. However, the capacity to articulate all sectors of society is probably one of the greatest challenges ahead of us. The Alliance for Restoration in the Amazon is working to bring key stakeholders together to promote, qualify and expand the scale of Forest Landscape Restoration in the Amazon. The Alliance is an inter-institutional and multi-sectoral articulation, established in 2017, which believes that by restoring forests in the Amazon, land use efficiency will be increased, and ecosystem services provision will be enhanced, strengthening local economies and promoting well-being. Therefore, working groups have been established to define technical priorities, promote advocacy, and raise awareness of the importance of Forest Landscape Restoration for the Amazon, Brazil and the Planet.

Restoration opportunities in Colombia: the multispecies and multiscale approache to territory management in Colombia / Oportunidades de restauración en Colombia: el enfoque multiespecies y multiescala para la gestión del territorio en Colombia

Paola Isaacs ${ }^{1}$,Wilson Ramírez ${ }^{1}$, Vivian Ochoa ${ }^{1}$,Wilmer Marin ${ }^{1}$, Mauricio Aguilar $^{1}$, Angelica Diaz ${ }^{1}$,Talia Waldron ${ }^{1}$, Julián Díaz-Timoté2

${ }^{1}$ Instituto Humboldt, Bogotá, Colombia; ${ }^{2}$ Universidad Distrital Francisco José de Caldas, Bogotá, Colombia (ecologa@gmail.com;

wramirez@humboldt.org.co; vochoa@humboldt.org.co;wmarin@humboldt.org.co; maguilar@humboldt.org.co; adiaz@humboldt.org.co;

twaldron@humboldt.org.co; jjuliandiazt@hotmail.com)

El reto de contribuir a la restauración del $15 \%$ de la superficie del mundo, requiere esfuerzo interdisciplinario a escala de paisaje. Colombia se comprometió a millón de hectáreas, con una tasa actual de 200.000 ha deforestadas en especial en zonas de posconflicto, lo cual requiere de abordajes ambiciosos. Se realizó una propuesta desde lo social, económico y biótico para definir oportunidades de restauración del paisaje. Se desarrollaron modelos de conectividad para grandes felinos, como base para definir prioridades de restauración, preservación y uso mediante modelos de servicios ecosistémicos (carbono, alimento, polinización, oferta y regulación hídrica, control de erosión y de remoción en masa) y aptitud de uso de la tierra para la gestión del riesgo a escala 1:100.000. Se analizaron modos de vida de las comunidades y evaluación económica de sus formas de producción versus reconversión productiva. De acuerdo a la zonificación multicriterio propuesta, se realizan modelos de finca, en áreas priorizadas para restaurar corredores. Se implementaron propuestas de productividad para el bienestar y la producción, y restauración en áreas erosionadas y corredores riparios, con producción adaptada para disminuir el conflicto felino actual. Se zonificaron 360.000 ha de paisajes funcionales con enfoque socioecológico que puede ser monitoreada al corto y largo plazo y que permite incrementar la productividad del campesino para detener las tasas de deforestación y optimizar el uso de la tierra dentro de áreas que son corredores importantes para la fauna.

\section{An approach to restore functionality and productive capacity of degraded native forests in South-Central Chile}

Gerardo Vergara-Asenjo ${ }^{1}$, Bastienne Schlegel ${ }^{1}$, Christian Little

${ }^{1}$ Instituto Forestal,Valdivia, Chile (gevergara@gmail.com; bschlegel@infor.cl; clittle@infor.cl)

Forest degradation has been identified as one of the most significant anthropic forces affecting forestsin Chile and constitutes one of the most important challenges in achieving sustainable management in nativeforests. Nevertheless, clarity and consensus on the meaning of degradation has been a constraint for the development of management plans and restoration practices in the country. This presentation explores the results of a research program at the Instituto Forestal (INFOR) that works on restoration of degraded native forests. Here we focus in three main topics: A conceptual approach to forest degradation. Using an operational approach, we present the theoretical aspects of forest degradation based on elements of forest dynamics, resilience and the national regulatory framework. Here we distinguish between process and state of forest degradation, which are linked to anthropic actions affecting key ecological processes and induce an arrested succession. The approach was discussed with local stakeholders (wood local associations, NGOs, research centers) which enriched the proposal. Exploring indicators and thresholds. To identify the indicators and thresholds of forest degradation, the gradients of past anthropic interventions in the Los Rios Region in southern Chile were explored. The results provide key information to identify arrested succession, as well as to categorize other anthropic impacts on forests. Implications for decision making. We discuss the implications of applying this approach on native forests in the country. Aspects such as national laws, management plans and the costs of restoring the functionality and productivity of native forests in the medium and long-term are considered in the analysis. 


\section{Standard for planning and executing restoration processes with a forestry landscape approach}

Elizabeth Bustos ${ }^{1}$, Roger Villalobos ${ }^{1}$, Fernando Carrera $^{1}$, Diego Delgado $^{1}$

${ }^{1}$ CATIE, Turrialba, Costa Rica (elizabeth.bustos@catie.ac.cr; rvillalo@catie.ac.cr; fcarrera@catie.ac.cr; ddelgado@catie.ac.cr)

Although the restoration of landscapes is a concept used more and more frequently in the literature and is mentioned in international discussions and commitments, there are still many doubts about how to organize and execute forest landscape restoration processes. Model forests are cross-sectoral social platforms of governance for large forest landscapes, in which there are diverse agricultural, forestry, urban or industrial land uses; various forms of tenure, social groups, interests and values. The partners of the Ibero-American Model Forest Network have been promoting, or wish to promote, restoration processes with a landscape approach in their areas of influence. That is why, from the analysis of processes and the discussion with managers of 4 Model forests, in Peru, Colombia and Costa Rica, a standard was developed to guide the development of productive restoration of forest landscapes. This standard consist of five principles. The first one refers to the ordering of the restoration actions themselves, the second to the political and institutional conditions that are required, the third to the conditions of local governance, the fourth to the availability of financial resources and market conditions, the fifth to the structures required for the process to be adaptive, including ongoing monitoring and evaluation. These principles are divided into 19 criteria and 51 possible indicators, which must be adapted to each particular situation.

\section{Effect of the application of sewage sludge on the foliary contents of $\mathrm{B}, \mathrm{Cu}, \mathrm{Fe}, \mathrm{Mn}$ and $\mathrm{Zn}$ in native species of the Atlantic Forest}

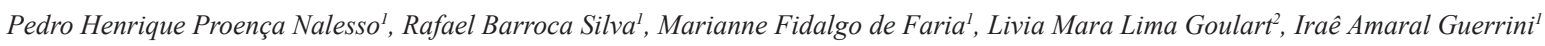
${ }^{1}$ Universidade Estadual Paulista “Júlio de Mesquita Filho”, Botucatu, Brasil; '2IFRR, Novo Paraíso, Brasil (pedronalesso@hotmail.com; rafael.barroca@outlook.com; marianneffaria@hotmail.com; liviamlgoulart@yahoo.com.br; irae.guerrini@unesp.br)

Sewage sludge is a source rich in organic matter and nutrients, being an alternative for the recovery of degraded areas. The objective of this study was to evaluate the effect of sewage sludge on the micronutrient foliar content of native Atlantic Forest species after 10 years of application of the residue. The experiment was set up in 2005 on the farm Entre-Rios,in the region of Itatinga-SP, Brazil. The experimental area was divided into 32 plots where 9 native species were planted. The experimental design was randomized blocks with four replications, considering the five increasing doses of sludge $\left(2.5 ; 5 ; 10 ; 15\right.$ and $20 \mathrm{t}$ ha $\left.{ }^{-1}\right)$ with supplementation of K; mineral fertilization; dose of K used as supplementation and control, totaling 8 treatments. In 2015 , leaves of three species (aroeirapimenteira, canafístula and copaíba) were harvested, for subsequent evaluation of the micronutrient content. The data were submitted to analysis of variance and the means were compared by the Tukey test at $5 \%$. It was observed a significant effect of the sewage sludge on the foliary contents of B, Fe, Mn and Zn for aroeira-pimenteira, $\mathrm{Cu}, \mathrm{Fe}$ and $\mathrm{Zn}$ for canafístula and Fe and $\mathrm{Zn}$ for copaíba. The highest mean values of leaf contents for micronutrients were found in the highest doses of sludge and in mineral fertilization. In general, the doses of sewage sludge provided higher leaf contents of B, Cu, Fe, Mn and Zn for the species studied in relation to mineral fertilization.

Priority areas for forest restoration after Geographic Information Systems in Paraguay's San Rafael National Park Reserve / Áreas prioritarias para restauración forestal desde los Sistemas de Información Geográfica en la Reserva para Parque Nacional San Rafael, Paraguay

Fabiana Miranda ${ }^{1}$, Stella Mary Amarilla ${ }^{1}$, Janet Villalba ${ }^{1}$, Lourdes González $^{1}$

${ }^{1}$ Universidad Nacional de Asunción, San Lorenzo,Paraguay(fabianamgaray@gmail.com; stella.amarilla@agr.una.py; janetvv@gmail.com; lourdesgspy@ gmail.com)

Debido a la necesidad de estudios referidos al tema de la degradación y restauración de ecosistemas en Paraguay; se ha considerado importante evaluar áreas prioritarias para la restauración forestal en la Reserva para Parque San Rafael (RPSR) reconocida tanto por su importancia para la conservación, como por sus procesos de degradación históricos, siendo este tema el objetivo general de la investigación. La RPSR ubicada entre los departamentos de Itapúa y Caazapá es considerada un remanente boscoso representativo de la ecorregión Bosque Atlántico del Alto Paraná. La metodología se basó en la priorización espacial de criterios relacionados a la restauración de bosques a través de Sistemas de Información Geográfica. Se utilizaron imágenes satelitales Sentinel 2-A, cartografías temáticas y herramientas ArcGis 10.3 y QGIS 2.18. Se aplicó una evaluación multicriterio, con la cual se combinaron 14 capas de información para obtener el mapa final de áreas prioritarias para acciones de restauración forestal. Los resultados indican que la categoría máxima prioridadde restauración representa el 7,03\% y la categoría alta prioridadel 17,86\%, ambas ubicadas en la zona Oeste del área protegida. Esta investigación buscó facilitar información para futuros proyectos de restauración forestal y otras acciones de manejo y conservación, oportunamente enmarcados en la declaración de la Década de las Naciones Unidas para la restauración de los ecosistemas (2021-2030).

\section{Structural heterogeneity and tree species mixing as basis of climate smart forest management}

Hans Pretzsch ${ }^{1}$

${ }^{1}$ Chair for Forest Growth and Yield Science, Center of Life and Food Sciences Weihenstephan, Technical University of Munich, Freising, Germany (hans.pretzsch@lrz.tum.de)

Firstly, this talk will give an overview of the species' interactions and growth reactions in mixed-species stands under chronic and acute drought. In the second part, the species-specific mixing reactions on drought are traced from the stand to the species, tree and organ level. A focus will be on drought stress effects on the growth, partitioning between the trees of different species and sizes in a stand. Thirdly, the mixing reactions on drought are analyzed in dependence on site conditions and stand structure. Fourth, we show how the results can be applied to design drought tolerant mixed-species stands. Fifth, the next steps for research and implementation will be discussed: Mixed-species experiments along environmental gradients, experiments with water retention for a better understanding of species stress behaviour in intra- and inter-specific environments, process-based models for scenario analyses, and guidelines for the design of drought tolerant forest stands. The results are based on the EU funded projects REFORM (Mixed species forest management. Lowering risk, increasing resilience \# 2816ERA02S) and COST CLIMO (Climate-Smart Forestry in Mountain Regions \# CA 15226). 
Applying post-forest-fire restoration techniques to erosion control: the case of CONAF, Chile / Aplicación de técnicas de restauracion post-incendios forestales para el control de la erosión - experiencias dee CONAF Chile

Samuel Francke ${ }^{1}$

${ }^{1}$ Corporacion Nacional Forestal, CONAF, Santiago, Chile (samuel.francke@conaf.cl)

Uno de los principales efectos de los incendios forestales resulta en impactar en los procesos de erosión de suelos al destruir la vegetación, la hojarasca del suelo e incluso inducir a procesos de calcinación , los procesos de laterización e hidrofobia en el suelo mineral, dependiendo de su intensidad afectando la textura, estructura, materia orgánica y alteración de las relaciones hídrico-edáfico. El fuego afecta el perfil del suelo, sus propiedades físicas, químicas y biológicas, en síntesis, se destruye la función de protección y estabilidad del suelo, favoreciendo los procesos de erosión y sedimentación. Las tasas de erosión pueden variar en promedio de 10 a 30 ton/ha/año, dependiendo de factores como la topografía la erosividad, la erodabilidad y la práctica de conservación de suelo y aguas, entre otros factores. La idea del proyecto emana de la temporada 2017/2018, donde se afectaron 518.448 ha en Chile, el segundo mega incendio forestal de chile del siglo y calificado por expertos de la UE, como de sexta generación. Se detenta como conaf diversas y valiosas experiencias de restauración hidrológica forestal de cuencas hidrográficas post incendios forestales en Chile. Se describen 20 prácticas y técnicas más comunes de rehabilitación suelos y cuencas hidrográficas post incendios forestales, se clasifican y ordenan de acuerdo a su funcionalidad a nivel de suelo y de su aplicación a nivel de la cuenca hidrográfica: regulación de flujos hídricos, de regulación de flujos hídricos de cauces, de estabilización de laderas mediante siembras (con hidro-mulch) y de retención de erosión y sedimentos.

\section{Selected $\mathrm{C}$ fluxes in Nothofagus forests under different levels of degradation in the the Andes and Coastal Mountain Ranges of Southwestern South America}

Francis Dube ${ }^{1}$, Neal Stolpe ${ }^{1}$, Carlos Valenzuela ${ }^{1}$

${ }^{1}$ University of Concepción, Concepción, Chile (fdube@udec.cl; nstolpe@udec.cl; cvalen@udec.cl)

This study was undertaken to measure certain carbon (C) fluxes in Nothofagus forests with different levels of degradation (degraded-DEF, partly-degraded-PDF and undisturbed-UNF forests). Litter decomposition was determined using the litterbag method. Leached soil solution was collected with tension lysimeters at $80 \mathrm{~cm}$ depth, and soil respiration evaluated in situ with the soda lime technique for $\mathrm{CO}_{2}$ absorption. Soil samples were taken at 0-5, 5-20 and 20-40 cm depths. In the Andes Mountains, rates of litter decomposition were lower in UNF and higher in DEF (21.8 and $14.1 \%$ remaining residue weight after 30 months, respectively), while in the Coastal Mountains, these values were 22.6 and $13.9 \%$, respectively. On the other hand, total soil respiration was greater in UNF than DEF (0.37 vs; 0.32 g CO $\mathrm{h}-1 \mathrm{~m}-2$, respectively) in the Andes, and $0.44 \mathrm{vs} ; 0.36 \mathrm{~g} \mathrm{CO}$ h- $1 \mathrm{~m}-2$, respectively, in the Coast. Regarding soil microbial respiration at 0-5 cm depth, a significant difference was only observed in the Coastal Mountains, with 2.44 and $3.71 \mathrm{~cm}^{3} \mathrm{CO}_{2} \mathrm{~h}-1100 \mathrm{~g}$ dry soil-1 in DEF and UNF, respectively. Despite not obtaining significant differences in the $\mathrm{NO}_{3}$ - and $\mathrm{NH} 4+$ contents in soil leachates, a trend of higher content was found in the undisturbed soils. The overall soil organic carbon $(\mathrm{SOC})$ and $\mathrm{N}$ contents at $0-40 \mathrm{~cm}$ depth decreased significantly in the order $\mathrm{UNF}>\mathrm{PDF}>\mathrm{DEF}$. The presence of greater plant coverage and number of species in undisturbed forests favored the productivity of the ecosystem, conserving nutrients and sequestering more carbon in the vegetation and soil.

\section{Evaluation of two tropical wet forest restoration practices through assisted secondary succession in Costa Rica \\ Ana María Sierra ${ }^{1}$, Roger Villalobos ${ }^{1}$, Diego Delgado ${ }^{1}$, Christian Herrera ${ }^{1}$, Milena Gutiérrez ${ }^{2}$ \\ ${ }^{1}$ CATIE, Turrialba, Costa Rica; ${ }^{2}$ SINAC, Liberia, Costa Rica (ana.sierra@catie.ac.cr; rvillalo@catie.ac.cr; ddelgado@catie.ac.cr; \\ christian.herrera@catie.ac.cr;mgutierrez@acguanacaste.ac.cr)}

The performance of two assisted restoration practices of humid tropical forests, aged between 18 and 22 years, was analyzed in the Rincon Cacao Biological Corridor, Costa Rica, consisting of the plantation (1999-2000) of the exotic species Gmelina arborea, as nurse tree, and islands of plantation of native species. The previous condition was degraded grasslands for livestock; 31 plots of 0.04 ha and 62 of 0.0025 ha were established, where the structure and species composition of each treatment was evaluated, compared to two nearby secondary forests of passive restoration of 23 and 30 years of age. Each individual was identified within the categories of 2.5 to $4.9 \mathrm{~cm} \mathrm{DBH}$ and more than $5 \mathrm{~cm} \mathrm{DBH}$, ecological guilds were assigned for most species. The treatment with greater degree of development was that of Gmelina as a nurse species, although its diversity of species was lower than that of the reference forests, which are older. The secondary forest of more than 30 years was the one with the greatest diversity of species. There were no significant differences in the diversity indices evaluated. The most abundant ecological guild in all treatments was that of durable heliophyte species. It was found that both the melina, as a nurse species, and the cultivated islands, help accelerate the regeneration of the secondary forest in these conditions, the recovery of its structure and the presence of their original species. Gmelina seems to disappear as the forest matures, but this must be verified.

\section{B1b: MANAGEMENT OPTIONS TO INCREASE THE DROUGHT-TOLERANCE OF FORESTS}

\section{Forest growth resilience to drought: tree diversity takes centre stage}

Rita Sousa-Silva ${ }^{1,2}$, Kris Verheyen $^{3}$, Bart Muys ${ }^{2}$

${ }^{1} U Q A M$, Montreal, Canada; ${ }^{2} K U$ Leuven, Leuven, Belgium; ${ }^{3} U G e n t$, Gent, Belgium (anarita.silva@kuleuven.be; kris.verheyen@ugent.be; bart.muys@kuleuven.be)

Recent research linking forests to changes in climate - including increased temperatures and changes in rainfall patterns, with more frequent, prolonged and intense episodes of drought as a consequence - has revealed increases in tree mortality rates and die-off events in forests worldwide. The higher resistance and resilience of mixed forests has been proposed as a strategic approach for managing forests, particularly under stress conditions. Complementarity among species for resource use may lead to reduced competition and increased facilitation, resulting in higher growth rates and higher resilience to drought. In this study, we investigated how the growth and resilience to drought of Fagus sylvatica, Quercus petraea, and Quercus robur relate to tree diversity, across three distinct drought events, and whether declining growth was correlated with increased defoliation. We monitored over 1.900 individual trees across 90 long-term forest vitality monitoring plots between 1990 and 2016. Trees growing in mixtures were more resilient to drought compared to those growing in monocultures, and recovery after drought was also faster and more pronounced in mixtures than in monocultures. Additionally, we found a tendency towards lower resilience to drought in defoliated trees. Our results demonstrate a clear link between more frequent droughts and a reduction in forest productivity, associated with longer recovery times. Even in environments that are not normally considered water-limited, mixed-species stands presented a greater resilience to drought, which adds further evidence to the overall positive impact of diversity on forest productivity under the anticipated warmer and drier conditions. 
Tree neighbourhood diversity increases community productivity and growth stability under contrasting climatic regimes

Florian Schnabel ${ }^{1,2}$ (D); Julia Schwarz ${ }^{1}$ (D); Adrian Dănescu ${ }^{3}$ (D); Andreas Fichtner ${ }^{4}$ (D); Charles Nock ${ }^{5}$ (D); Jürgen Bauhus ${ }^{1}$ (D); Catherine Potvin ${ }^{6}$ ${ }^{1}$ Chair of Silviculture, Faculty of Environment and Natural Resources, Freiburg University, Freiburg, Germany; ${ }^{2}$ German Centre for Integrative Biodiversity Research (iDiv) Halle-Jena-Leipzig, Leipzig, Germany; ${ }^{3}$ Thünen Institute of Forest Ecosystems, Eberswalde, Germany; ${ }^{4}$ Institute of Ecology, Leuphana University of Lüneburg, Lüneburg, Germany; ${ }^{5}$ Geobotany, Faculty of Biology, University of Freiburg, Freiburg, Germany; ${ }^{6}$ Department of Biology, McGill University, Montreal, Canada(florian.schnabel@idiv.de; julia.schwarz@waldbau.uni-freiburg.de; adrian.danescu@thuenen.de; fichtner@leuphana.de; charles.nock@gmail.com; juergen.bauhus@waldbau.uni-freiburg.de; catherine.potvin@mcgill.ca)

There is increasing evidence that mixed-species forests can provide multiple ecosystem services at a higher level than their monospecific counterparts. Here, we provide insights into the temporal development of diversity-productivity (DPRs) and diversity-stability relationships (DSRs) in the oldest tree diversity experiment in the tropics, 'Sardinilla' in Panama (established in 2001). We used annually resolved inventory data of tree diameters and heights from 22 plots with a species richness gradient comprising monocultures, two-, three-, and five-species mixtures of native tree species. Combining tree neighbourhood- and community-level analyses, we tested the effects of two diversity components, species diversity and structural diversity, on productivity and stability. Over time, we found a mean overyielding (higher productivity in mixtures compared to monocultures) of about $25-30 \%$ in the two- and three-species mixtures and the highest overyielding at 50\% in the five-species mixtures. Tree neighbourhood diversity enhanced community productivity but the effect of species diversity was stronger and increased over time, while the effect of structural diversity declined. The temporal stability of community productivity increased with increasing species diversity driven by two principal processes: species asynchrony and overyielding. Along with increased stability, the benefits of mixing on productivity were highest during a strong El Niño phenomenon, characterized by low precipitation. This suggests a higher resistance of the examined mixtures to droughts. These results provide new insights into mixing effects in diverse, tropical plantations and highlight the importance of analyses of temporal dynamics for our understanding of the complex relationships between diversity, productivity and stability.

\section{The role of species asynchrony in the stability of forest productivity}

Miren del Rio ${ }^{1,2}$, Hans Pretzsch ${ }^{3}$, Marta Vergarechea ${ }^{1,3}$

${ }^{1}$ INIA-Instituto Nacional de Investigación y Tecnología Agraria y Alimentaria, Madrid, Spain; ${ }^{2}$ Sustainable Forest Management Research Institute, Palencia, Spain; ${ }^{3} T U M$-Technical University of Munich, Freising, Germany (delrio@inia.es; h.pretzsch@lrz.tum.de; vergarechea.marta@inia.es)

Diversifying stand composition is considered one of the management options to adapt forests to climate change, since higher species diversity is frequently linked to a greater stability of ecosystems (resistance, resilience, and temporal stability). Mixed-species stands had been found to increase the temporal stability of productivity in comparison to monospecific stands, although there are still few studies, whereas the effects of species-mixing on resistance and resilience to extreme drought events seem to vary with species composition and site conditions. One of the mechanisms identified as a possible cause of the greater stability in mixed stands is species asynchrony in responses to climate conditions, which can influence on both temporal stability and resistance and resilience to severe droughts. In this presentation we first review the main concepts of species synchrony/asynchrony and its effects on stability in mixed stands, with special emphasis on temporal stability of productivity. Then, we show some examples of intra- and inter-specific synchrony/asynchrony analysis for stands with different species compositions along environmental gradients in Europe (mixtures of two and three species), and of how inter-specific asynchrony is related to temporal stability of productivity. Finally, we discuss the results of the shown and relevance of further synchrony analysis for forest vulnerability to climate change and the implications for adapting forest management to future climate conditions. The results are based on the Sumforest ERA-net project REFORM(PCIN2017-026) and COST CLIMO (Climate-Smart Forestry in Mountain Regions \# CA 15226

\section{How does magnitude and timing of forest density reduction influence drought resilience in a Norway Spruce - Silver fir mixed forest in Central Europe?}

Juan Carlos Zamora ${ }^{1}$, Rasoul Yousefpour ${ }^{1}$,Harald Bugmann' ${ }^{2}$ Peter Weisberg, Alessandra Bottero ${ }^{4}$, Maxime Cailleret $^{5}$, Marc Hanewinkel ${ }^{1}$ ${ }^{1}$ Chair of Forestry Economics and Forest Planning, University of Freiburg, Freiburg, Germany; ${ }^{2}$ Chair of Forest Ecology, ETH Zürich, Zürich, Switzerland; ${ }^{3}$ Department of Natural Resources and Environmental Science, University of Nevada, Reno, USA; ${ }^{4}$ Swiss Federal Research Institute WSL, Birmensdorf, Switzerland; ${ }^{5} L$ 'Institut national de recherche en sciences et technologies pour l'environnement et l'agriculture, Aix-en-Provence, France (juan.zamora@ife.uni-freiburg.de; rasoul.yousefpour@ife.uni-freiburg.de; harald.bugmann@env.ethz.ch; pweisberg@cabnr.unr.edu; alessandra.bottero@wsl.ch; maxime.cailleret@irstea.fr; marc.hanewinkel@ife.uni-freiburg.de)

Climate change scenarios forecasting increased occurrence of extreme drought events will require innovative ways of managing stand density to increase the adaptive capacity of forest ecosystems. Needed is an improved understanding of the interactions between drought and competition among forest trees for critical limiting resources, leading to quantitative, predictive models that relate stand density to drought-related tree mortality. We address this question with an adaptive approach, combining thinning experiments (field data) and historical resilience responses to natural and managed conditions (dendrochronological data) in a climate-sensitive forest gap model. The effect of the proposed strategies is tested in a gradient of site conditions of Norway spruce (Picea abies) Silver fir (Abies alba) mixed forests in Central Europe. We hypothesize that (1) intensive reductions on large DBH-classes, in short time intervals will have bigger impacts, and (2) sites with high tree density need more intensive reductions. This methodology allows the forest manager to plan for short periods $(\leq 10$ years), and make the necessary changes in the strategy for a longer period ( $>10$ years) by monitoring forest state. Economic and ecological evaluation methods are proposed to evaluate the performance of the solutions selected for the approach. Results from this study will contribute to the risk assessment, economic evaluation and development of optimized management strategies to adapt Norway spruce and silver fir forests to extreme drought events.

\section{Ecological and economic feasibility of adaptation strategies for Beech Forest to climate change}

Dominik Sperlich ${ }^{1}$, Marc Hanewinkel ${ }^{1}$, Rasoul Yousefpour ${ }^{1}$

${ }^{1}$ Albert-Ludwigs University, Freiburg, Germany(dominik.sperlich@ife.uni-freiburg.de; marc.hanewinkel@ife.uni-freiburg.de; rasoul.yousefpour@ife.unifreiburg.de)

Increasing drought events and decreasing precipitation trends challenge the ecological, economic and socio-economic services and functions of forests in many regions of the world. To increase the resilience of managed forest, conversion of monocultures into mixed stands are among the most prominent adaptation strategies. Potential species for the establishment of mixed forests have not only to be evaluated against their present but also future suitability with changed climate conditions. We aimed to evaluate the ecological but also economic feasibility of potential species admixtures for Fagus sylvatica (L.) in the Black Forest - naturally one of the most dominant tree species of central and Western Europe. We identified Quercus spp. for submontane and Silver fir (Abies alba) for 
mountainous sites to potentially reduce the drought impacts on forest growth via hydraulic redistribution of soil water. We then quantified growth, productivity and economic value of a European beech stand with/without climate change scenarios and with/without species admixtures. The more profitable silver fir compensated the higher establishment costs when admixed at a stand age of 60 or earlier. Climate change reduced the total cumulative growth of beech between $15-35 \%$ depending on the scenario with an economic loss of 15-33\% in net present value (NPV). Site-adapted admixture dampened the climate change effects on beech growth and reduced the economic losses. We stress that, beside the ecological and silvicultural feasibility of potential species mixtures, the economic implications have to be thoroughly assessed to provide a valid basis for investment decisions in forest conversion strategies.

\title{
Relative importance of climate, thinning and light use efficiency on drought vulnerability of Norway spruce and Silver fir in Central European Mixed Forests
}

Alessandra Bottero ${ }^{1}$, David I. Forrester ${ }^{1,4}$, Maxime Cailleret ${ }^{2}$, Ulrich Kohnle ${ }^{3}$, Arun K. Bose ${ }^{1}$, Jürgen Bauhus ${ }^{4}$, Harald Bugmann ${ }^{5}$, Matthias Cuntz ${ }^{6}$, Arthur Gessler ${ }^{1}$, Lö̈c Gillerot ${ }^{5}$, Marc Hanewinkel $^{7}$, Mathieu Lévesque $^{5}$, Julien Sainte-Marie 6 , Julia Schwarz ${ }^{4}$, Rasoul Yousepfour ${ }^{7}$, Juan Carlos Zamora ${ }^{7}$, Andreas Rigling ${ }^{1}$

${ }^{1}$ Swiss Federal Research Institute WSL, Birmensdorf, Switzerland; ${ }^{2} I R S T E A$ Aix-en-Provence, Aix-en-Provence, France; ${ }^{3}$ Forest Research Institute of BadenWürttemberg FVA, Freiburg, Germany; ${ }^{4}$ Chair of Silviculture, University of Freiburg, Freiburg, Germany; ${ }^{5}$ Chair of Forest Ecology, ETH Zürich, Zürich, Switzerland; ${ }^{6} I N R A$, Université de Lorraine, AgroParisTech, UMR Silva, Nancy, France; ${ }^{7}$ Chair of Forestry Economics and Forest Planning, University of Freiburg,Freiburg, Germany(alessandra.bottero@wsl.ch; david.forrester@wsl.ch; maxime.cailleret@wsl.ch; ulrich.kohnle@forst.bwl.de; arun.bose@wsl.ch; juergen.bauhus@waldbau.uni-freiburg.de; harald.bugmann@env.ethz.ch; matthias.cuntz@inra.fr; arthur.gessler@wsl.ch; loic.gillerot@usys.ethz.ch; marc.hanewinkel@ife.uni-freiburg.de; mathieu.levesque@usys.ethz.ch; julien.sainte-marie@inra.fr; julia.schwarz@waldbau.uni-freiburg.de; rasoul.yousefpour@ife.uni-freiburg.de; juan.zamora@ife.uni-freiburg.de; andreas.rigling@wsl.ch)

Drought intensity and frequency are expected to increase in Central Europe, posing unprecedented challenges to forest managers, who are searching for adaptive strategies that minimize drought impacts on forests. Maintaining low stand densities and high structural diversity are advocated for moderating droughtinduced tree growth reduction. However, few studies have investigated which processes most strongly influence tree drought vulnerability. We investigated the contribution of management, light use efficiency and climate on the drought response of silver fir and Norway spruce in mixed stands in Southwestern Germany. We used inventory and tree-ring data from six long-term irregular group shelterwood experiments, located along a precipitation gradient. Tree growth response to drought was expressed as indices of resistance, resilience and recovery. Silver fir was more resilient to summer drought than Norway spruce, but had a lower resistance to spring drought. Species, light use efficiency and species interactions had the strongest impact on tree growth response to drought at tree-level, while stand basal area, mean stand diameter, years since first and last intervention, and drought year were important predictors for stand-level resistance, resilience and recovery. Economically valuable species like Norway spruce might decline in the absence of adaptation measures that use thinning to obtain stand structures that can support retained trees during droughts. Our study provides quantitative information on the processes influencing the drought response of two important tree species, and provides a basis for the development of adaptive management strategies that consider not only punctual responses to drought, but also their driving processes.

\section{Drought events and shrub encroachment reduce the functioning and resilience of water-limited ecosystems}

Maria C. Caldeira ${ }^{1}$, Raquel Lobo-do-Vale ${ }^{1}$, Xavier Lecomte ${ }^{1}$, Teresa S. David ${ }^{2}$, Minguel N. Bugalho ${ }^{3}$, Christiane Werner ${ }^{4}$

${ }^{1}$ Centro de Estudos Florestais, Instituto Superior de Agronomia, Universidade de Lisboa, Lisboa, Portugal; ${ }^{2}$ Instituto Nacional de Investigação Agrária e Veterinária I.P., Oeiras, Portugal; ${ }^{3}$ CEABN-Inbio,Instituto Superior de Agronomia, Lisboa, Portugal; ${ }^{4}$ Institute of Ecosystem Physiology, University Freiburg, Freiburg,Germany(mcaldeira@isa.ulisboa.pt; raquelvale@isa.ulisboa.pt; xlecomte@isa.ulisboa.pt; teresa.david@iniav.pt; migbugalho@isa.ulisboa.pt; c.werner@cep.uni-freiburg.de)

Extreme droughts and shrub encroachment are major drivers of global change that can critically affect tree and ecosystem functioning and resilience. Namely, the increase in tree mortality observed worldwide has been related to overall higher frequency and severity of droughts and locally to factors such as competition with other plant species. Shrub encroachment, i.e, the increase in density and biomass of shrubs, is increasing in many regions worldwide, including the Mediterranean region. Shrub encroachment can aggravate the effects of drought and decrease tree resistance to water stress. Nevertheless, little is known about how these drivers may interact and affect ecosystem functioning and resilience. In a 6 year (2011-2017) manipulative shrub removal experiment in a Mediterranean oak woodland, we measured sapflow and pre-dawn leaf water potential of trees and shrubs and soil water content in six plots of $25 \mathrm{x} 25 \mathrm{~m}$, where we combined shrub encroachment and shrub removal treatments. We show that the combination of native shrub encroachment (Cistus ladanifer L.) and drought events reduced ecosystem transpiration and the resilience of the key-stone cork-oak tree species (Quercus suber L.). Ecosystem transpiration was dominated by the water use of the shrub, which further increased the droughts. Tree transpiration in shrub encroached plots declined more than in plots cleared from shrubs Our results imply that in Mediterranean-type of climate shrub encroachment by water spending species coupled with the projected recurrent extreme droughts will cause critical drought tolerance thresholds of trees to be overcome, thus increasing the probability of tree mortality.

\section{The potential of liming to improve drought tolerance of Norway spruce (Picea abies)}

\author{
Jürgen Bauhus ${ }^{1}$ (D) Joerg Kunz ${ }^{1}$, Peter Hartmann ${ }^{2}$, Lelde Jansone ${ }^{2}$, Heike Puhlmann ${ }^{2}$, Klaus von Wilpert ${ }^{2}$, Martin Kohler $^{1}$ \\ ${ }^{1}$ University of Freiburg, Freiburg, Germany; ${ }^{2}$ Forest Research Institute of Baden-Wuerttemberg, Freiburg, Germany \\ (juergen.bauhus@waldbau.uni-freiburg.de; joerg.kunz@waldbau.uni-freiburg.de; peter.hartmann@forst.bwl.de;lelde.jansone@forst.bwl.de; \\ heike.puhlmann@forst.bwl.de; klaus.von-wilpert@online.de; martin.kohler@waldbau.uni-freiburg.de)
}

In response to wide-spread decline in forest vitality associated with acid rain in the 1980s, liming of forest soils has been implemented in many parts of Germany. Liming may increase vitality and depth of fine-root systems and hence improve the drought tolerance of species such as Picea abies, which occurs mostly on acidic forest soils. However, the influence of repeated liming on drought tolerance of trees was never studied. Here we compared the resistance, recovery and resilience of radial growth in $P$. abies in relation to drought in limed and control stands and assessed how the dosage and interval between lime applications and drought years influence radial growth responses. We analyzed radial growth of 198 trees from limed and control treatments at six experimental sites in South-West Germany. Using generalized linear models we assessed the influence of drought intensity, site, and period since first liming on the drought tolerance of Norway spruce. Regardless of drought intensity, there was no general increase in drought resistance of $P$. abies in response to liming. However, recovery and resilience of radial growth after severe drought events were better in Norway spruce trees from limed treatments. This indicates a shorter stress period for trees growing on limed soil which may reduce their susceptibility to secondary, drought-related pests and pathogens. Based on the small magnitude 
of the effect, liming is not recommended for the sole purpose to increase drought tolerance. Where liming is carried out to mitigate soil acidification, it does not decrease drought tolerance.

\title{
B1c: MANAGING FOR ADAPTATION: INCREASING RESISTANCE, RESILIENCE, AND
} TRANSFORMATIVE CAPACITY

\author{
The precautionary principle as a framework for resilience in forest planning and practices \\ Philip Burton ${ }^{1}$ \\ ${ }^{1}$ University of Northern British Columbia, Terrace, Canada (phil.burton@unbc.ca)
}

The "precautionary principle" has been incorporated in dozens of international environmental agreements since 1987, including Agenda 21 and the Rio Declaration stemming from the 1992 Earth Summit. The principle essentially urges that decisions regarding industrial activities and development proposals should err on the side of caution with respect to potential environmental or human impacts where scientific uncertainty exists. Many processes affecting public forestlands are subject to variability, with increasing uncertainty due to a changing climate and altered disturbance regimes. Nominally managed under a mandate of multiple use, decisions regarding timber harvesting and silviculture on public lands clearly have impacts on forest values ranging from biodiversity and carbon sequestration to hydrology and meaningful employment. Yet many forest policies and practices continue to rely on historical norms, optimistic assumptions and modelling approaches optimized for timber production. Precautionary approaches that could be applied in British Columbia, Canada, are explored, including better estimation of the likelihood of losses due to fire and insects in timber supply projections, and basing vegetation management (brushing) decisions on thresholds for crop tree survival rather than trying to achieve maximum crop tree growth. Analogous to the trade-off between high-risk stock investments and low-risk bond purchases, some profit potential needs to be foregone in exchange for greater certainty and the persistence of multiple forest values. Worst-case scenarios do not necessarily need to be followed, but precautionary decision making can do much to keep future options open and thereby promote the resilience of forests, forest workers, and forest-dependent communities.

\section{Adapting to climate change through silvicultural opportunities to address natural disturbances}

\author{
Mike Cruickshank ${ }^{1}$, Rona Sturrock ${ }^{2}$,Elisa Becker ${ }^{1}$, Katherine Bleiker $^{1}$, Bogdanski Bryan $^{1}$, Isabel Leal ${ }^{1}$ \\ ${ }^{1}$ Natural Resources Canada Canadian Forest Service Canadian Wood Fibre Centre, Victoria, BC, Canada; ${ }^{2}$ Retired, Natural Resources Canada Canadian \\ Forest Service,Victoria,BC,Canada(mike.cruickshank@canada.ca; ronasturrock250@gmail.com; elisa.becker@canada.ca; katherine.bleiker@canada.ca; \\ bryan.bogdanski@canada.ca; isabel.leal@canada.ca)
}

Climate is a key driver of forest distribution, productivity, and disturbance regimes that limit growth and survival of forest species. These limits increase with the frequency and size of climate fluctuations acting on ecological functions affecting the health and productivity of forests. Adaptation strategies at the forest level are complex, and there are a limited number of options available for large areas that forests cover. Silviculture is one strategy that can alter the conditions in forests, including, but not limited to, planting adapted trees, altering tree density and age, changing species composition, and removal of inciting stress conditions mainly affecting insects and disease. Genetic variation within a population can be used to identify trees for planting that cope with heritable multiple biotic and abiotic adaptation to common stressors. Many of these are unknown. Douglas-fir half-siblings are used as an example of the frequency and size of genetic adaptations to insect, drought, and two root diseases agents. Resistance versus tolerance response mechanisms to stress are examined for trade-offs with each other and between stress agents. Also, an example of site preparation using sanitation of root disease inoculum prior to planting to increase carbon, stand productivity, and economic payback as a companion strategy to genetic adaptation. Both strategies are compatible and applied at the reforestation stage, and are discussed in terms of how they can affect trees under stress.

\section{Increasing adaptive capacity of Urban Forests}

\author{
Linda Nagel ${ }^{1}$, Chris Looney ${ }^{1}$, Courtney Peterson ${ }^{1,2}$, Leslie Brandt ${ }^{2,3}$, Maria Janowiak ${ }^{2,4}$, Christopher Swanston ${ }^{2,4}$, James Guldin ${ }^{5}$ \\ ${ }^{1}$ Colorado State University, Fort Collins, CO, USA; ${ }^{2}$ Northern Institute of Applied Climate Science Houghton, MI, USA; ${ }^{3}$ USDA Forest Service, St. Paul, MN, \\ USA; ${ }^{4}$ USDA Forest Service, Houghton, MI, USA; ${ }^{5}$ USDA Forest Service, Hot Springs, AR, USA (linda.nagel@colostate.edu; chris.looney@colostate.edu; \\ courtney.peterson@colostate.edu; lbrandt@fs.fed.us; mjanowiak02@fs.fed.us; cswanston@fs.fed.us; jguldin@fs.fed.us)
}

With over half of the world's population living in urban areas, forest managers must learn to implement climate-adaptive strategies in urban forests to ensure the continued provision of benefits to people living in urban communities as the climate changes. Three common adaptive silviculture options discussed in the context of climate change are: (1) resistance - maintaining relatively unchanged conditions over time; (2) resilience - allowing some change in current conditions, but encouraging an eventual return to reference conditions; and (3) transition - actively facilitating change to encourage adaptive responses. However, there is a lack of on-the-ground forest research to indicate what adaptation measures might be effective in preparing local forest ecosystems to deal with climate change, which can create challenges in translating these concepts into management decisions specific for individual forests that vary in structure, composition, function, and local management contexts. The Adaptive Silviculture for Climate Change (ASCC) project translates these adaptation concepts into on-the-ground, operational-scale research through a network of replicated sites testing ecosystem-specific climate change treatments across this gradient of adaptive approaches. The ASCC Network has established partnerships to begin applying silviculture options aimed at enhancing the adaptive capacity of urban forest ecosystems to the environmental, social, and economic implications of climate change. This includes designing adaptation and mitigation strategies thatenhance carbon storage and other ecosystem services, promote urban forest health, protect high-value urban trees, and create resilience to invasive species, whileincorporating a more explicit social dimension through local community education and engagement.

\section{Why foresters do not adapt their forests to climate change while they know its impacts? The project "Adaptation measures to climate change by foresters" in France}

Julie Thomas ${ }^{1,2}$, Annabelle $\mathrm{Amm}^{3}$

${ }^{1}$ Institut National de la Recherche Agronomique, Nancy, France; ${ }^{2}$ Centre National de la propriété forestière, Paris, France; ${ }^{3}$ GIP ECOFOR, Paris, France (julie.thomas@inra.fr; annabelle.amm@gip-ecofor.org)

Forests are threatened by climate change: increase of major events involve large landscape changes such as distribution range of tree species. Since the early century, several research projects about climate change forest impacts and their perception by foresters have been implemented in France. They show the need 
to implement measures to adapt forests to climate change. All is knowledge necessary for forest managers. Many efforts are needed, particularly in terms of communication, to remove obstacles to the implementation of these measures without forgetting technical and financial aspects. In this context, the aim of our paper is thus to understand the reasons of the non-implementation of adaptative measures. For this purpose, we conducted surveys among forest owners and forest managers about their silvicultural practices in France and their links with climate change. Our study aims to enhance a better understanding of the perception of climate change of forest owners and forest managers, the actions implemented and their constraints to adapt their forests. It will help forest managers to be more informed about the different adaptation measures before taking decisions, and forest owners will be more supported during their adaptation process. The presentation focus on none industrial private forest owners who own $75 \%$ of French forest.

\section{Exploring the knowledge dynamics associated with forest management for climate change in South Africa}

Chidiebere Ofoegbu ${ }^{1}$, Chinwe Ifejika-Speranza ${ }^{2}$

${ }^{1}$ Africa Climate and Development Initiative, University of Cape Town, Cape Town, South Africa; ${ }^{2}$ University of Bern Bern Switzerland

(ofoegbu.c@gmail.com; chinwe.ifejika.speranza@giub.unibe.ch)

Forests are critical for the global climate policy agenda with respect to actions for climate change adaptation and mitigation. Many people also depend on forests for their livelihoods. Although the forest industry in South Africa contributes about $2 \%$ to the national GDP, it provides direct and indirect employment to between 200,000 and 260,000 people and is a significant component of South Africa's national climate change response policy. Though information on adapting forest management practices to climate change is increasingly being generated, the adoption is very poor. Issues often mentioned in the literature with respect to this challenge include mismatch of generated knowledge with users context, poor feedback between knowledge users and producers/brokers, and poor relation ties between organizations operating in the generation and brokering of climate knowledge. This study will use the lens of the knowledge system to undertake a network analysis of the organizations working in the intersection of climate change and forest management. The aim is to understand how climate information flows among these stakeholders, and tease out the barriers and enablers of climate knowledge flow and adoption in forest management. Key informant interviews and questionnaire survey will be used to collect data. Data analysis will focus on the identification of barriers and enablers of climate knowledge flow and uptake in forest management. Insights from this study will inform future interventions aimed at improving or implementing actions for forest-based climate change interventions.

Soil and water conservation as a mechanism for adapting to climate change and impacts on the Maule River Watershed in Chile / Conservación de suelos y aguas como mecanismo de adaptación al cambio climático e impactos en la Cuenca Hidrográfica del Río Maule Chile

Samuel Francke ${ }^{1}$, Celso Carnieletto ${ }^{1}$, Luis Carrasco $^{1}$

${ }^{1}$ Conaf, Santiago, Chile (samuel.francke@conaf.cl; celso.carnieletto@conaf.cl; luis.carrasco@conaf.cl)

Los impactos del cambio climático en la Cuenca Hidrográfica del Rio Maule se expresan enl aumento de la temperatura promedio máxima $+0,6^{\circ} \mathrm{C}$ en los últimos 14 años sobre el promedio mundial (Universidad de Talca, 2017), reducción de las precipitaciones del orden 30\% (periodo 1973-2013, ODEPA 2013) y una merma de caudales al 2025 del 16,3 \% (DGA, 2011), como efectos hidro-meteorológicos directos. La sequía y escasez del recursos hídricos afecta la calidad de vida de los pequeños y medianos agricultores/silvicultores. Con alta probabilidad los incendios forestales 2016/ 2017, donde se afectaron del orden de 280.106 ha, constituye la evidencia empírica de un cambio climático antrópico. Se implementan y evalúan medidas adaptativas de conservación de suelos y aguas tales como subsolado con camellón y zanja de infiltración, asociadas a la forestación de plantaciones de Pinus radiata en 17 propiedades. En cada predio se muestrean variables dasometricas y edafo-hidricas. Se realiza 320 parcelas de muestreo para un análisis comparativo de plantaciones con edades similares con y sin tratamientos de obras de conservación de suelos y aguas. Los resultados del estudio indican que la aplicación de medidas adaptativas al cambio climático como obras de conservación de suelos y aguas, inciden en el rendimiento hidrológico forestal a nivel de la microcuenca hidrográfica y se expresan favorablemente en la productividad del sitio forestal. De esta forma, se obtiene un manejo forestal sostenible y un manejo hidrológico forestal en plantaciones forestales en Pinus radiata, en función de la cuenca hidrográfica. "Los bosques en función delas cuencas".

\section{Connecting across borders: an approach to building forest resilience across Western North America}

Kristen Waring ${ }^{1}$, Linda Nagel ${ }^{2}$, Christian Wehenkel ${ }^{3}$, Che Elkin ${ }^{4}$

${ }^{1}$ Northern Arizona University, Flagstaff, USA; ${ }^{2}$ Colorado State University, Fort Collins, USA; ${ }^{3}$ Universidad Juarez del Estado de Durango, Durango, Mexico; ${ }^{4}$ University of Northern British Columbia, Prince George, Canada (kristen.waring@nau.edu; linda.nagel@colostate.edu; wehenkel@ujed.mx; che.elkin@unbc.ca)

Temperate coniferous forests of western North America extend from South-Central Mexico north into boreal Canada. Some tree species span across Mexico, the United States and Canada, while other species are located primarily in one country. However, climate change may induce northward shifts in species distributions, with the extent and relative dominance of species shifting across borders. Unpredictable shifts are also likely to occur, with forest disturbances likely exacerbated by climate change. Western temperate forests are particularly vulnerable to climate-sensitive disturbances such as drought, wildfire, insects and diseases, which are often not constrained by national boundaries. Under such uncertainty, forest managers need access to emerging research along with guidance on decision-making surrounding best practices. All three countries have developed frameworks to aid managers in designing and implementing future silvicultural treatments for climate change adaptation. However, only one program in the United States (Adaptive Silviculture for Climate Change, ASCC) includes a direct pathway and assistance in developing specific prescriptions for local ecosystems within a nationwide network of sites that share experimental goals and objectives through a robust experimental design. Other frameworks provide specific management recommendations but leave the interpretation and implementation to local managers. Given the ecological, economic and social connectivity across Western North American forests, a collaborative, international network is critical to managing our collective forests now and into the future. This presentation will describe our new effort to assess and synthesize how well existing forest treatments fit these frameworks in each country, and explore expanding the ASCC network internationally. 


\title{
Achieving multifunctional forest management through three-level structured silvicultural regimes: a review of case studies and pilot
} demonstration progress in China

Yuanchang Lu ${ }^{1}$, Xianzhao Liu ${ }^{1}$, Yangsheng Xie ${ }^{1}$, Xiangdong Lei ${ }^{1}$

${ }^{1}$ Chinese Academy of Forestry, Beijing, China (ylu@ifrit.ac.cn; xieys@ifrit.ac.cn; xieys@ifrit.ac.cn; xieys@ifrit.ac.cn)

Multifunctional forest management (MFFM) has been the new trend in forestry development in China and the world in the $21^{\text {st }}$ century. It is an innovative model which actively strengthens and develops the many forest services and provides social, economic, environmental and ecological benefits for sustainable human development. The fundamental objective of forest management is to establish and maintain the stability and resilience of the forest ecosystem to maximize its viability, productivity and service functions. In this review the concept, scientific principles, technical processes and methodology for experimental verification of the silvicultural regimes (SRs) of MFFM are described. In addition, the paper addresses a three-level structured silvicultural technical system (STS) and Chinese MFFM development system which, based on the principle of using natural and artificial forces synergistically, integrates function/condition constrains, full growth/management cycle and standardized description of measures and elements of the final target. By monitoring, comparing and analyzing data from operational and reference plots of applying this STS as a national basis for forest management were compared. These results show that the objectives of MFFM models are being achieved and the new STS with three-level SR has a positive impact on the development of multifunctional forestry in China.

\section{Risk and governance dilemmas associated with assisted migration in the forest sector of British Columbia, Canada}

Ricardo Pelai ${ }^{1}$, Shannon Hagerman ${ }^{1}$, Robert Kozak ${ }^{1}$

${ }^{1}$ University of British Columbia, Vancouver, Canada (ricardo.pelai@alumni.ubc.ca; shannon.hagerman@ubc.ca; rob.kozak@ubc.ca)

The assisted migration (AM) of trees is increasingly being proposed as a means of adapting forest management to climate change impacts. While there is a proliferation of natural science research to inform the implementation of AM, social science research in this domain remains relatively sparse. We use the case of the Canadian province of British Columbia (where AM policy is currently in development) to examine the human behavioral (e.g. perceived risks), and governance (e.g. participation in decision-making and the use of different forms of knowledge) dimensions of this emerging policy option. Based on 30 in-depth, semi-structured interviews with key government officials and forest industry professionals involved with AM, we find an overall optimistic view of AM. However, we identify three emergent dilemmas: i) narrow conceptions of the types of evidence that is required in decision-making (mostly biophysical), ii) uneven input from different stakeholder and rights holders, and iii) prevailing views that knowledge flows in a linear fashion at the science-policy interface. These findings demonstrate the contributions that social sciences (produced at multiple scales and from different worldviews) can make to decision-making for the implementation of assisted migration.

\section{B1d: RESILIENCE OF MANAGED TROPICAL FORESTS: IT IS TIME FOR SILVICULTURE}

\author{
Disturbance intensity determines recovery of multiple functions after a first logging cycle in the Brazilian Amazon \\ Angela Luciana de Avila ${ }^{1}$, Ademir Roberto Ruschel ${ }^{2}$, José Natalino Macedo Silva ${ }^{3}$, Lucas Mazzei ${ }^{2}$, João Olegário Pereira de Carvalho ${ }^{3}$, Jürgen Bauhus ${ }^{4}$ \\ ${ }^{1}$ Forest Research Institute Baden-Württemberg, Freiburg im Breisgau, Germany; ${ }^{2}$ Embrapa Amazonia Oriental, Belém, Brasil; ${ }^{3}$ Universidade Federal Rural \\ da Amazônia, Belém, Brasil; ${ }^{4}$ Chair of Silviculture, Faculty of Environment and Natural Resources, University of Freiburg, Freiburg im Breisgau, Germany \\ (angela.avila@forst.bwl.de; ademir.ruschel@embrapa.br; silvanatalino734@gmail.com; lucas.mazzei@embrapa.br; olegario.carvalho@gmail.com; \\ juergen.bauhus@waldbau.uni-freiburg.de)
}

Sustainable forest management is based on the assumption that forest ecosystems are resilient to silvicultural interventions so that their ecosystem functions can recover between felling cycles and thus be maintained in the long term. However, our understanding of responses to silvicultural interventions and factors driving tropical forest resilience is rather limited. Here, we investigated how management intensity and post-logging (remaining) biological legacies (basal area and species diversity) affect the resilience of important forest attributes and functions related to biodiversity conservation, carbon sequestration and timber provision within 30 years following initial logging. We analysed data from a unique long-term experiment located in the Tapajós National Forest, Pará, Brazil, where trees $\geq 5 \mathrm{~cm}$ DBH were measured on 8 occasions in 41 permanent sample plots including unlogged forest. Management intensities comprised logging (1982) with associated damage and follow-up thinning (1993-1994). An important finding was that the recovery of tree species composition, aboveground biomass and timber stocks was impaired when basal area was reduced by more than $20 \%$ relative to pre-logging stocks. In contrast to our expectations, remaining basal area and diversity had no effect, but management intensity determined the recovery of multiple functions over the first logging cycle. Thus, when managing for ecosystem resilience within current felling cycles, our findings indicate that management intensity will directly affect the recovery capacity and subsequent ability of continuous provision of goods and services in these managed tropical forests of the Eastern Amazon.

\section{The main challenges of sustainable forest management in the Amazon: why sustainable forest management in the Amazon should be reinforced? \\ Plinio Sist ${ }^{\text {D }}$; Lucas Mazzei ${ }^{2}$, Camille Piponiot ${ }^{1}$, Bruno Herault ${ }^{1}$, Geraldine Derroire ${ }^{3}$, Euridice Honorio ${ }^{4}$, Milton Kanashiro ${ }^{2}$, Marcus d'Oliveira $^{5}$, Marielos Peña-Claros ${ }^{6}$, Ken Rodney ${ }^{7}$, Verginia Wortel ${ }^{8}$, Alexander Shenkin ${ }^{9}$ \\ ${ }^{1}$ Cirad-Forests \& Societies, Montpellier, France; ${ }^{2}$ Embrapa Amazonia Oriental, Belém, Brasil; ${ }^{3}$ Cirad-Ecofog, Kourou, French-Guiana; ${ }^{4} I I A P$, Iquitos, Peru; ${ }^{5}$ Embrapa Acre, Rio Branco, Brasil; ${ }^{6}$ Wageningen University, Wageningen, Netherlands; ${ }^{7}$ Iwokrama, Iwokra, Guyana; ${ }^{8}$ CELOS, Paramaribo, Suriname; 90xford,London,United Kingdom(sist@cirad.fr; lucas.mazzei@embrapa.br; camille.piponiot@gmail.com; bruno.herault@cirad.fr; geraldine.derroire@cirad.fr; eurihc@yahoo.com; milton.kanashiro@embrapa.br; marcus.oliveira@cirad.fr; marielos.penaclaros@wur.nl; krodney@iwokrama.org; rubia_w@yahoo.com; ashenkin@ufl.edu)}

Since the last 50 years, tropical natural forests have been intensively logged in the tropics to supply the increasing demand of tropical timber. Unplanned logging operations caused forest degradation leading to their conversion due to the loss of their commercial value. Today, natural forests remain a major source of timber and tropical production forests worldwide are estimated to cover around 400 million ha. Studies carried out on the long term impact of logging on timber yield showed that at best about only $50 \%$ of the timber volume extracted during the first harvest will be available for the subsequent cycles. We estimated the potential of natural production of the Amazonian forest to supply the future wood demand using more than 200 permanent plots for monitoring the long term response after logging of the TmFO network. Our results clearly show that natural forests alone will not be able to supply the increasing demand of tropical timber in the region and that significant efforts in forest restoration through plantations as well as intensive silvicultural practices such as enrichment planting in gaps and liberation, must 
be initiated immediately. Although natural forests will not be able to supply alone the timber market demand, they will play a major role in environmental services (including biodiversity protection and conservation, climate change mitigation rather than solely for timber provision while they will continue to provide necessary income to forest communities that depend on the forests for their livelihoods.

\title{
Population management of Juniperus procera tree from Ethiopia
}

Mindaye Teshome Legese ${ }^{1,2}$ (D) Tesfaye Bekele ${ }^{1}$, Patrícia Póvoa de Mattos ${ }^{3}$; Aline Canetti (D); Evaldo Muñoz Braz $^{3}$ (D) Carlos Moreira Miquelino Eleto Torres ${ }^{2}$ ${ }^{1}$ Ethiopian Environment and Forestry Research Institute, P. O. Box ${ }^{30708}$ code ${ }^{1000}$, Addis Ababa, Ethiopia; ${ }^{2}$ Universidade Federal de Viçosa, Departamento de Engenharia Florestal, Viçosa, Brasil; ${ }^{3}$ Embrapa Florestas, Colombo, Brasil; ${ }^{4}$ Universidade Federal do Paraná, Departamento de Engenharia Florestal, Curitiba,Brasil(mindayet@gmail.com; tebean77@yahoo.com; patricia.mattos@embrapa.br; alinecanetti@gmail.com; evaldo.braz@embrapa.br; carlos.eleto@ufv.br.)

In this study we evaluated the sustainability of Juniperus procera timber management from two important dry afromontane forests (Chilimo and Wofwasha) in Central Ethiopia. A total of 141 major sample plots were established. We used dendrochrological techniques and stand class projection model. The cutting cycle simulated was 30-year. Due to the higher population disturbance in Chilimo forest three scenarios were simulated: disturbance ceased; remain at the same intensity and increased by 25\%. For Wofwasha forest we only considered the current situation. For both forests the diameter limit was simulated varying between 50 and $60 \mathrm{~cm}$, seeking the optimal harvestable diameter and ensure a more sustainable structure. In Chilimo forest it would be possible to produce $0.76 \mathrm{~m}^{3} \mathrm{ha}^{-1}$ year- 1 , stabilizing after 5 cutting cycles. The continuity of undue exploitation in the forest following the same pattern will lead to a reduction in $37 \%$ of timber volume production. And increasing the exploitation by $25 \%$ will lead to a $76 \%$ reduction, potentially destroying the capacity of the forest to recover, and it was considered unsustainable. In Wofwasha forest simulations resulted in $0.63 \mathrm{~m}^{3}$ ha $^{-1}$ year- 1 of timber production. The simulations also showed that population structures of both forests become similar after the sixth cycle, suggesting that these forests have the same forest formation. The differences today appear to be due to the disturbance level or interventions by local communities and history of logging in each forest.

\section{Implications of silvicultural interventions for sustainable forest management: case study of Bobiri Forest in Ghana}

Ernest Foli

${ }^{1}$ Forestry Research Institute of Ghana, Kumasi, Ghana (efoli@hotmail.com)

Silvicultural interventions are necessary for regulating tropical forest growth and productivity. This paper describes experiments carried out in Bobiri forest in Ghana through the tropical shelterwood system (TSS), post-exploitation system (PES) and the girth limit selection system (GLS) to simplify the forest structure and species composition to enhance productivity. Stand basal area was reduced from about $30 \mathrm{~m}^{2} \mathrm{ha}^{-1}$ to 12 - $15 \mathrm{~m}^{2}$ ha-1 . After 40 years data on height, diameter and species were collected for all trees with $\mathrm{DBH}>10 \mathrm{~cm}$ from six one-hectare plots in each treatment. The results showed that the forest was capable of recovery in terms of structure, species diversity, and productivity to the pre-intervention state. There was no significant difference between treated and unlogged forest $(\mathrm{c} 2=26.3 ; \mathrm{df}=21 ; \mathrm{P}=0.196)$. However, stand density was higher in the silviculturally-treated stands relative to unlogged forest $(\mathrm{F}=7.62 ; \mathrm{df}=3$; $\mathrm{P}=0.002$ ). A total of 176 tree species were recorded in 38 families; the 10 most common species between treatments accounted for $>50 \%$ of the species, but $<46 \%$ in unlogged forest, with no significant shifts in species composition. The treated stands attained structural and compositional attributes similar to unlogged forest after 40 years, but commercial basal area was higher in the treated forest. In conclusion, silvicultural interventions (including harvesting) can improve both commercial productivity and species composition, depending on intensity and frequency of interventions.

Population dynamics of Mezilaurus duckei van der Werff (Lauraceae) in a managed forest in the Eastern Amazon region / Dinâmica da população de Mezilaurus duckei van der Werff(Lauraceae) em uma floresta manejada na Amazônia Oriental

Jaqueline Macedo Gomes ${ }^{1}$, João Olegário Pereira de Carvalho ${ }^{2}$, Ademir Roberto Ruschel ${ }^{3}$, Nisângela Severino Lopes Costa

${ }^{1}$ Universidade Estadual da Região Tocantina do Maranhão, Imperatriz, Brasil; ${ }^{2}$ Universidade Federal Rural da Amazônia, Capitão Poço, Brasil; ${ }^{3}$ Embrapa AmazôniaOriental,Belém,Brasil(jaquelinemacedogomes@hotmail.com; olegario.carvalho@gmail.com; ademir.ruschel@embrapa.br;

nisangela.lopes@hotmail.com)

Estudos ecológicos são primordiais para avaliar a sustentabilidade do manejo florestal, pois indicam o estado de conservação das espécies exploradas. Com a finalidade de inferir sobre a conservação da população de Mezilaurus duckei, avaliou-se a sua dinâmica no período de 33 anos após a exploração. A pesquisa foi realizada na Área Experimental km 67, na Floresta Nacional do Tapajós ( $02^{\circ}$ 53’ 03,09” S; 54 55’ 30,10” W). Os dados são provenientes de inventário contínuo realizado em 36 parcelas permanentes (50 x 50 m) instaladas em 1981 em 64 ha que foram explorados em 1979 . Foram medidas as árvores com DAP $\geq 5 \mathrm{~cm}$ em 9 ocasiões no período 1981-2012. Analisou-se a abundância, dominância, distribuição diamétrica, taxas de ingresso e mortalidade. A abundância (1,1 indivíduo ha-1 em 1981) aumentou 10\% em 31 anos e a dominância (0,051 m² ha-1) aumentou 39\%. Não houve mortalidade no período, mas houve ingresso de 10\%. Por isso, em relação à distribuição diamétrica houve acúmulo de indivíduos no período avaliado, sendo 54,5\% na classe DAP < 25 cm, 36,4\% na classe DAP $25-45 \mathrm{~cm}$ e $9,1 \%$ na classe DAP $\geq 45 \mathrm{~cm}$. Comparando as distribuições diamétricas de 1981 e 2012 , observa-se claramente a passagem de indivíduos das classes inferiores para as superiores. $M$. duckei aumentou gradativamente seu estoque na área explorada, demonstrando que pode se recuperar e garantir futuras colheitas de madeira. Recomenda-se a aplicação de tratamentos silviculturais na área para estimular o recrutamento, crescimento e evitar a sua extinção local. (Embrapa, CNPq, UEMASUL).

\section{The influence of initial stand structure on plant community composition and diversity in eucalypt forest}

\author{
Anu Singh ${ }^{1}$, Craig Nitschke ${ }^{1}$, Patrick Baker ${ }^{1}$, Sabine kasel ${ }^{1}$ \\ ${ }^{1}$ University of Melbourne, Melbourne,Australia(anu6@student.unimelb.edu.au; craign@unimelb.edu.au; patrick.baker@unimelb.edu.au; \\ skasel@unimelb.edu.au)
}

Effective forest management and conservation require knowledge of the structure and composition of forest stands and how they change over time. Disturbances are important drivers of these forest stand dynamics, providing opportunities for recruitment, shifts in relative dominance of species, and changes in the trajectory of stand development especially in Southeastern Australia. The type of disturbance, its intensity, and any interactions with previous disturbances all influence how individual species respond and will shape the post-disturbance development patterns. Forest structure has a substantial influence on plant community composition. The structure of vegetation plays a vital role in shaping biodiversity. The recruitment of target species in managed forests following harvesting is a crucial objective of sustainable 
forest management. The success or failure of managed forests in Southeastern Australia is dependent on the density of Eucalyptus stems after stand establishment. We studied the influence of density on the diversity of the understorey species and found that light has a bigger impact on the species composition of the forest rather than the density of the species.

\section{Intact forest landscapes: how to conciliate forest management and conservation efforts under FSC certification in Brazilian Amazon}

Edson Vidal ${ }^{1}$, Nathalia Ribeiro $^{2}$, Isabel Garcia-Drigo ${ }^{2}$, Marco Lentini $^{3}$, Leonardo Sobral ${ }^{2}$

${ }^{1}$ Escola Superior de Agricultura "Luiz de Queiroz”, Universidade de São Paulo Piracicaba, Brasil; '2Instituto de Manejo e Certificação Florestal e Agrícola, Piracicaba,Brasil; ${ }^{3}$ WWF Brasil, Sao Paulo,Brasil(edson.vidal@usp.br; nathalia@imaflora.org; isabel@imaflora.org; marcolentini@wwf.org.br; leonardo@imaflora.org)

Maintenance of large natural forest landscapes is paramount to protect biodiversity, but also to reduce carbon emissions from deforestation and forest degradation. Intact Forest Landscapes (IFLs) are defined as unbroken portions of natural ecosystems within the current global forest extent, showing no signs of significant human activity, and vast enough to effectively maintain biodiversity. In 2015, the Forest Stewardship Council (FSC) has introduced the concept of IFLs in the new Principle, Criteria and Generic Indicators for certification. Hence, certified forest managers have to identify the IFL portion in their forest management units to design and apply specific management strategies. The present study analyzed spatial data to enlighten the scale and territorial domains where IFLs are found in Brazilian Amazon. We also demonstrate the proportion of IFLs within certified Forest Management Units (FMU). In addition to these analyses, we performed a survey to reveal the challenges to manage IFLs portions from FSC certificate holders and experts perspective. Results showed a significant proportion of IFLs within certified forests in federal or state forest concessions more than in private lands. The primary challenge is how to develop the IFL portions while maintaining its values and ensuring protection. While the market for ecosystem services and non-timber forest products are uncertain, a more stringent Reduced Impact Logging (RIL) model is defended as one of the best management strategies to conciliate sustainable forest management and conservation within IFL areas.

\section{Development of dipterocarp rainforests after timber harvesting challenge the current slow recovery paradigm}

Jan Falck ${ }^{1}$, Daniel Lussetti ${ }^{1}$, Petter Axelsson ${ }^{2}$, David Alloysius ${ }^{3}$, Ulrik Ilstedt ${ }^{1}$ iD

${ }^{1}$ Swedish University of Agricultural Sciences, Dept. of Forest Ecology and Management, Umea, Sweden; ${ }^{2}$ Forest Ecology and Management, Umea, Sweden; ${ }^{3}$ Yayasan Sabah,Tawau, Malaysia (jan.falck@slu.se; daniel.lusetti@slu.se; petter.axelsson@slu.se; david.alloysius@gmail.com; ulrik.ilstedt@slu.se)

Timber harvesting in tropical rainforests is under debate partly because of the natural recovery of stand structures are believed too slow to provide a sustainable provision of timber, and maintenance of biodiversity and carbon storage potential. We present a long-term study of selective logging in a virgin tropical rain forest in Sabah, North Borneo, Malaysia, starting in 1992 and re-measured every second year up to 2017; 25 years after logging operation, forest plots harvested with supervised logging and climber cutting (SLC) - which aim to minimize damage to the residual stand have improved stand recovery compared to the conventional practices, and restored the number of trees with DBH $10 \mathrm{~cm}$ and above, the number of harvestable trees (DBH $60 \mathrm{~cm}$ and above), as well as the number of germlings, seedlings and saplings, to a level almost equivalent to the mean numbers of trees in virgin control plots. The growth rate of dipterocarp species in SLC was $5 \mathrm{~m}^{3} \mathrm{ha}^{-1} \mathrm{yr}-1$ and in 2017, the number of species recorded in all diameter classes was nearly the same as in control plots. In general, recovery was faster than expected after such logging operation, which usually kill or damage many trees for every tree logged. Our results stress the need for wider evaluation of economic and carbon potential of managed dipterocarp forests. Comparisons with other land use options should consider improved logging methods and the possibility of faster above ground volume and carbon recovery.

\section{Economic and environmental potential benefits of charcoal production from logging residues in sustainable forest management in the Brazilian Amazon}

Camila Thiemy Dias Numazawa ${ }^{1}$,Dmitry Schepaschenko ${ }^{2}$, Andrey Krasovskii ${ }^{2}$, Stephan A. Pietsch ${ }^{2}$

${ }^{1}$ Universidade de São Paulo, São Paulo, Brasil; ${ }^{2}$ International Institute for Applied Systems Analysis, Laxenburg, Austria (numazawacamila@gmail.com;

schepd@iiasa.ac.at; krasov@iiasa.ac.at; pietsch@iiasa.ac.at)

Under sustainable forest management principles, primary data from 13 forest plots located in the western Brazilian Amazon were adopted to calibrate and estimate projected net primary productivity (NPP) and the net measure of ecosystem exchange (NEE) using the complex BioGeo Chemistry model (BGC-MAN) approach. The purpose of this study was to show the potential economic and environmental benefits associated with charcoal co-production from part of the logging residues (LR). The analysis was done for five scenarios: the legal reserves (reference scenario), one cutting cycle over the whole period, three timber rotation periods of 30-year, and the last two scenarios complemented with collecting part of the woody LR $\geq 10 \mathrm{~cm}$ for charcoal production. For each case, we simulated the NPP and the NEE over a time-horizon of 120 years. Results indicated an economic gain for charcoal production using woody LR ( $\approx 77 \%$ of total LR) which could reach $\approx 46 \%$ of the total stem value. Additionally, we found that in scenarios where LR were harvested the biomass recovered faster. The benefits would not only consist of the generation of new income and promoting new jobs, but also lead to increased NPP and NEE by removing part of the LR to assist the forest regrowth. The Brazilian Forest Code strategy could focus on maximizing the economic gain to ensure exploitation viability while implementing the reduction of logging intensity necessary for full forest recovery within cutting cycles. This could be associated with carbon credit incentives.

\section{Floristic analysis to subsidize forest management planning in the Amazon Forest region \\ Mariana Oliveira 1 (D), Marilice Cordeiro Garrastazu ${ }^{2}$ (D), Evaldo Muñoz Braz ${ }^{2}$ (D), Patricia Póvoa de Mattos ${ }^{2}$ (D), Nelson Carlos Rosot ${ }^{1}$ (D) ${ }^{1}$ Universidade Federal do Paraná, Curitiba, Brasil; ${ }^{2}$ Embrapa Florestas, Colombo, Brasil (marianaferraz.floresta@gmail.com; marilice.garrastazu@embrapa.br; evaldo.braz@embrapa.br; patricia.mattos@embrapa.br;ncrosot@ufpr.br)}

The objective of this study was to characterize the horizontal structure of a primary Amazon Forest, with emphasis on three commercial species, using conventional methods and Geographic Information System. The study area consists of an approved management plan, in Santa Carmem, MT, Sinop Microregion, with 1,024 ha, where all trees with a diameter of $1.30 \mathrm{~m}(\mathrm{DBH}) \geq 30 \mathrm{~cm}$ were measured. We calculated densities, frequencies and absolute and relative dominances, as well as the importance and coverage value indexes, using 1 ha plots. Kernel Density and Dispersion Analysis AT species level were obtained with ArcGIS. Among the 36 species observed, Qualea spp. presented the highest values for all analyzed parameters. Goupia glabra and Dipteryx odorata were, respectively, the fourth and sixth in importance index value. The area was classified as low diversity by Shannon Index. It was observed a higher concentration of individuals in commercial diametric classes (DBH $50 \mathrm{~cm}$ ), concluding that the area presents potential to be sustainably managed. The estimates obtained by spatial analysis 
for both density and dispersion were similar to those observed in the conventional estimatives, however, as the first method considers the geographic coordinates of each tree, it is suggested that it is more accurate than the second, that estimatives are generated at plot level.

B1e: TREES ON THE MOVE: SEED SOURCING, GERMINATION, GENETIC ADAPTATION AND ASSISTED MIGRATION IN A CHANGING CLIMATE

\title{
Origin, genetic variation and genetic change of non-native forest trees in their introduced range \\ Charalambos Neophytou ${ }^{1}$ (D), Marcela van Loo ${ }^{l, 2}$ (D), Elisabeth Pötzelsberger ${ }^{1}$ (D), Hubert Hasenauer ${ }^{1}$ (D) \\ ${ }^{1}$ Institute of Silviculture, Department of Forest and Soil Sciences, University of Natural Resources and Applied Sciences (BOKU), Peter-Jordan Str; 82, 1190, Vienna, Austria, Vienna, Austria; ${ }^{2}$ Department of Botany and Biodiversity Research, Faculty of Life Life Sciences, University of Vienna, Rennweg 14, 1030, Vienna,Austria(charalambos.neophytou@boku.ac.at; marcela.van.loo@univie.ac.at; elisabeth.poetzelsberger@boku.ac.at; hubert.hasenauer@boku.ac.at)
}

Non-native tree species play an important role in European forestry which may even increase in future due to climate change. Environmental adaptation depends on genetic variation and this is true for non-native species, too. Here, we explore the origin, genetic variation and genetic change over time, observed in the introduced range of such species. First, we focus on Douglas-fir (Pseudotsuga menziesii), a species with a prominent position in Central European forestry. Marker based genetic analysis indicated that a relatively small part of the native range served as seed source for most of 67 European Douglas-fir study stands spread across Germany and Austria. Moreover, a comparison between adult trees and natural regeneration revealed a significant reduction of genetic diversity in the younger generation. Second, we examine the outcome of genetic analysis in populations of tree of heaven (Ailanthus altissima), a species with an invasive character. Whereas results from chloroplast DNA markers do not suggest multiple origins, we observed a significant population genetic structure at nuclear microsatellites in our study area in Eastern Austria. We attribute this pattern to repeated founder effects. Third, we present current results on the origin and genetic variation of Northern red oak (Quercus rubra) in introduced European populations. We conclude that drift is a major factor shaping the genetic variation in the introduced range. Since introduced populations constitute an important seed source, special caution should be exercised when establishing seed stands and seed orchards, but also during seed harvesting, in order to avoid genetic erosion.

Assisted migration of Araucaria araucana in Chile to safeguard genetic diversity of populations in the face of climate change / Migración asistida de la Araucaria araucana, en Chile, para salvaguardar la diversidad genética de sus poblaciones ante la presión del Cambio Climático

Roberto Ipinza ${ }^{1}$, Jorge Gonzalez², Braulio Gutierrez ${ }^{2}$, Hernan Soto ${ }^{2}$, Marcos Barrientos ${ }^{1}$, Maria Paz Molina $^{2}$, Andres Bello ${ }^{3}$, Patricio Rojas $^{4}$ Sabine Muller-Using ${ }^{4,5}$, Fernando Santibañez ${ }^{6,7}$, Juan Andres Celhay ${ }^{8}$, Dante Corti ${ }^{1}$, Richard Velasquez ${ }^{5}$

${ }^{1}$ Instituto Forestal, Valdivia, Chile; ${ }^{2}$ Instituto Forestal, BioBio, Chile; ${ }^{3}$ Consultor, Concepcion, Chile; ${ }^{4}$ Instituto Forestal, Santiago, Chile; ${ }^{5}$ SIMEF, Valdivia, Chile; ${ }^{6}$ Universidad de Chile, Santiago, Chile; ${ }^{7} I N F O D E P$ Santiago Chile ${ }^{8}$ CMPC, Los Angeles, Chile (roberto.ipinza@infor.cl; jgonzalez@infor.cl; bgutierr@infor.cl; hsoto@infor.cl; mbarrientos@infor.cl; mmolina@infor.cl; beduan13@hotmail.com; patricio.rojas@infor.cl; smuller@infor.cl; fersantiba@gmail.com; juan.celhay@cmpc.cl; dcorti@infor.cl; richard.velasquez@simef.cl)

La Araucaria araucana (Molina) K. Koch (Araucaria) es una especie emblemática del bosque nativo chileno, se distribuye en la costa y en la cordillera de los Andes (desde los $37^{\circ} 30^{\prime}$ a los $40^{\circ} 03^{\prime}$ S). La Araucaria está asociada a prácticas ancestrales y alimentación del pueblo pehuenche, declarada monumento natural, protegida por la convención CITES y constituye un patrimonio nacional que contribuye a la belleza escénica del paisaje en las regiones de La Araucanía, Biobío y Los Ríos. La Araucaria está catalogada como una especie vulnerable y recientemente las poblaciones costeras han sido declaradas en vías de extinción en el actual escenario de cambio climático. El estrés integral del cambio climático, actúa como un factor de predisposición que disminuye la vitalidad y es luego atacada por innumerables poblaciones de microorganismos e insectos, lo que finalmente se expresa en un Daño Foliar de la Araucaria (DFA). Este fenómeno está amenazando su adaptación, su potencial evolutivo y por ende su supervivencia. Por esta razón, se realizó el rescate genético en toda el área de distribución a través de la técnica conocida como "Migración Asistida", donde se colecto semilla de 418 madres, se viverizaron y luego se plantan las familias, estructuradas como ensayos de progenies y procedencias, en lugares donde las proyecciones de cambio climático en los próximos 50 años le dan más posibilidades de supervivencia a la especie. Por otro lado, estas nuevas poblaciones podrán generar germoplasma para recuperar áreas afectadas por el DFA.

\section{Stability of species and provenance performance following translocation into diverse restoration communities}

\author{
Nicolò Camarretta ${ }^{1}$ (D), Peter A. Harrison ${ }^{1}$, Tanya G. Bailey ${ }^{1,2}$, Neil Davidson ${ }^{2}$, Arko Lucieer ${ }^{3}$, Mark Hunt $^{1}$, Brad M. Potts ${ }^{1}$ \\ ${ }^{1}$ University of Tasmania and ARC Training Centre for Forest Value, Hobart, Australia; ${ }^{2}$ Greening Australia, Hobart, Australia; ${ }^{3}$ University of Tasmania, \\ Hobart,Australia(nicolo.camarretta@utas.edu.au; p.a.harrison@utas.edu.au; tanya.bailey@utas.edu.au; ndavidson@greeningaustralia.org.au; \\ arko.lucieer@utas.edu.au; mark.hunt@utas.edu.au;b.m.potts@utas.edu.au)
}

Assisted migration is increasingly integrated into conservation and restoration strategies. For long-lived species such as trees, future climate models are being used to guide translocation decisions to develop resilient plantings better adapted to future climates. In restoration, this involves strategies such as climateadjusted provenancing, aimed at enriching local plantings with seed genetically adapted to future climates predicted for the planting site. However, translocation decisions rarely consider the extent to which biotic interactions modify performance. This is particularly important as species and provenance translocations are not made in isolation but embedded in diverse and even novel communities. We here examined how species and provenance performance are affected by community composition using two focal eucalypt species planted under six community treatments, in a degraded agricultural landscape in Tasmania, Australia. These community treatments differed in the species planted as immediate neighbour to the focal plant, and co-plantings comprised of same species, same genus or one of three different genera.Six years after planting, there were significant differences between the focal eucalypt species and among their provenances for measured performance traits, while their interactions with community treatments were not significant. Provenance differences in both species were mainly due to non-local provenances experiencing greater insects and frost damage and having higher mortality than the local provenances. Home-site altitude predicted provenance performance, and the extent to which up-slope translocations impacted provenance performance differed between focal species, regardless of the community composition. 
The importance of genetic variation and phenotypic plasticity for climate adaptation in Pinus sylvestris: conclusions from a continentwide study in Europe

José Alberto Ramirez-Valiente ${ }^{1}$ (D, Aida Solé ${ }^{1}$,Raquel Benavides ${ }^{2}$, Sandra Cervantes-Arango ${ }^{3}$, Darius Danusevicius ${ }^{4}$, Katrin Heer $^{5}$, Eduardo Notivol ${ }^{6}$, Lars Opgenoorth ${ }^{5}$, Tanja Pyhäjärvi ${ }^{3}$,Outi Savolainen ${ }^{3}$, Juan José Robledo-Arnuncio ${ }^{1}$

${ }^{1}$ Instituto Nacional de Investigación y Tecnología Agraria y Alimentaria, Madrid, Spain; ${ }^{2}$ Museo Nacional de Ciencias Naturales, Consejo Superior de Investigaciones Cientificas, Madrid, Spain; ${ }^{3}$ University of Oulu, Oulu, Finland; ${ }^{4}$ Aleksandras Stulginskis University, Linkuva, Lithuania; ${ }^{5}$ Philipps University

Marburg, Marburg, Germany; ${ }^{6}$ Centro de Investigación y Tecnología Agroalimentaria de Aragón, Zaragoza, Spain (josealberto.ramirezvaliente@gmail. com; aidasome@gmail.com; rbenavidescalvo@gmail.com; sandra.cervantesarango@oulu.fi;darius.danusevicius@asu.lt; katrin.heer@uni-marburg.de; enotivol@cita-aragon.es; opgenoorth@uni-marburg.de; tanja.pyhajarvi@oulu.fi; outi.savolainen@oulu.fi;jjrobledo@gmail.com)

Given the ongoing rapid climate change, the ability of species to respond to novel and changing environmental conditions is critical for long-term survival of populations. In forest trees, common gardens, reciprocal transplants and provenance trials have been widely used to assess the genetic composition and potential response to climate variation. However, such studies largely focus on juvenile or adult traits with little consideration on the early stages of development, which are crucial for niche regeneration. In this study, we explored the adaptive divergence and phenotypic plasticity in early fitness traits in Pinus sylvestris and examined the potential evolutionary response to the predicted future conditions of climate. We conducted a continent-wide series of experiments where 24.000 seeds from eighteen populations were established in common garden along a latitudinal gradient in Europe. In addition, geographically-closed populations with contrasting climates were included to evaluate the role of adaptation at small spatial scales. We monitored germination, survival, growth, phenology and ontogenic development over two years. Our results showed that populations largely differed in all studied traits and fitness components. Phenotypic differences were also observed between populations separated by a few hundred meters but with different altitudes. Interestingly, maternal families within populations exhibited a variation comparable with differences among long-distance populations. High plasticity to local environment was also found. Overall, our study suggests that climate has exerted strong selective pressures on Pinus sylvestris, driving the genetic differentiation of populations in traits important for fitness during the first stages of seedling development.

\section{Production and quality of Caatinga dry forest seeds in a changing climate}

Barbara França Dantas ${ }^{1}$, Gilmara Moreira de Oliveira ${ }^{2}$, Samara Elizabeth Vieira Gomes ${ }^{3}$

${ }^{1}$ Embrapa Semiárido, Petrolina, Brasil; ${ }^{2}$ Universidade de Feira de Santana, Feira de Santanta, Brasil; ${ }^{3}$ Universidade do Estado da Bahia, Juazeiro, Brasil

(barbara.dantas@embrapa.br;gilmara_5@hotmail.com; samaraelizabethvg@yahoo.com.br)

The Caatinga dry forest has been experiencing, since 2010, the most severe drought ever recorded in the region, which has led to tree mortality, lack of seed production and/or quality and lower recruitment of seedlings. We aimed to correlate climate variations specifically, precipitation and temperature and seed quality of two important Caatinga species, Anadenanthera colubrina (Vell.) Brenan (Leguminosae - Mimosoideae) and Myracrodruon urundeuva Allemão(Anacardiaceae), in different harvest years from 2012 to 2018. Seeds were collected directly from mother-plants in a partially human-degraded Caatinga area. Anadenanthera colubrina seeds were sorted as small $(\varnothing \leq 1 \mathrm{~cm})$ and large $(\varnothing 1 \mathrm{~cm})$. Seeds of both species of each harvest and/or classification were weighed and germinated for physiological quality evaluation. The climatic data were obtained by nearby agrometeorological stations. With $A$. colubrina seed size evaluation of four consecutive years and the mean, minimum and maximum annual precipitation and temperature, it was possible to observe that the variation in seed size in the lots may be related to the low precipitation and the high temperatures. Seeds of M. urundeuva showed improved germination percentage when produced in years with more rain. Physiological quality of seeds of both species were affected not only by rainfall volume but also by high temperatures. Thus, one can predict poor seed production and quality in a future climate at the Caatinga region, for which is predicted temperature increase of $4.5^{\circ} \mathrm{C}$ and $30 \%$ decrease in rainfall volume by 2100 .

\section{Genetic variation and evolutionary potential in a natural beech population}

Marjana Westergren ${ }^{1}$, Marko Bajc ${ }^{1}$, Rok Damjanic ${ }^{1}$, Domen Finzgar ${ }^{2}$, Barbara Fussi ${ }^{3}$, Filippos A. Aravanopoulos ${ }^{4}$, Hojka Kraigher $^{1}$, Santiago C. González-Martínez ${ }^{5}$

${ }^{1}$ Slovenian Forestry Institute, Ljubljana, Slovenia; ${ }^{2}$ University of Edinburgh, Edinburgh, United Kingdom; ${ }^{3}$ Bavarian Office for Forest Seeding and Planting, Teisendorf, Germany; ${ }^{4}$ Aristotle University of Thessaloniki, Thessaloniki, Greece; ${ }^{5}$ BIOGECO, INRA, Bordeaux, France (marjana.westergren@gozdis.si; marko.bajc@gozdis.si; rok.damjanic@gozdis.si;.finzgar@sms.ed.ac.uk; barbara.fussi@asp.bayern.de; aravanop@for.auth.gr; hojka.kraigher@gozdis.si; santiago.gonzalez-martinez@inra.fr)

Local survival of natural populations of forest trees relies on standing genetic variation and their capacity for adaptation to changing environments. Selection gradients, heritability, evolvability and selection response was studied in a natural population of European beech (Fagus sylvatica) in Slovenia. Adult trees (250), saplings (200) and 400 seeds obtained from 20 mother trees, were genotyped with 16 nuSSRs. Adaptive traits related to growth and phenology were assessed for all adult trees. Effective reproductive success, a fitness proxy, was estimated via parentage analysis. Log-linear models were used to compute female and male selection gradients correlating adaptive traits with fitness. Heritability was estimated using mixed models based on pedigrees reconstructed using nuSSRs. The study revealed skewed effective reproductive success, with few parents contributing to successful regeneration, and significant selection gradients. Strong directional selection was found for growth, with bigger trees having more offspring; also, trees with earlier phenology had higher reproductive output; finally, both early and late trees in terms of bud burst mothered less offspring. Heritability was low (albeit significant) for all traits except leaf senescence. Low phenotypic variance for phenological traits and moderate selection gradients resulted in low responses to selection, but that could be larger under increased selection pressure, as suggested by high evolvability for flowering and fruiting phenology $(\sim 20 \%)$. In conclusion, our study suggests some capacity of populations of forest trees to adapt locally; however, pace and intensity of climate change will determine whether such evolutionary responses will suffice for unassisted population survival. 
Genetic variation and phenotypic plasticity in early fitness traits across the range of a Mediterranean conifer: implications in a changing climate

Aida Solè ${ }^{1,2}$, Agathe Hurel ${ }^{3}$, Juan José Robledo-Arnuncio ${ }^{1}$, Santiago C. González-Martínez ${ }^{3}$, Eduardo Notivol ${ }^{4}$, Giovanni G. Vendramin ${ }^{5}$, Andrea Piotti ${ }^{5}$, Jose Alberto Ramirez-Valiente ${ }^{1}$

${ }^{1} I N I A-C I F O R$, MADRID, Spain; ${ }^{2} U R J C$, MADRID, Spain; ${ }^{3}$ Institut National de la Recherche Agronomique, BORDEAUX, France; ${ }^{4}$ CITA, Zaragoza, Spain; ${ }^{5}$ CNR-IBBR,FIRENZE, Italy (aidasome@gmail.com; agathe.hurel@inra.fr; jjrobledo@gmail.com; santiago.gonzalez-martinez@inra.fr; enotivol@aragon.es; giovanni.vendramin@ibbr.cnr.it; andrea.piotti@gmail.com; josealberto.ramirezvaliente@gmail.com)

Both standing levels of genetic variation and the potential for adaptive plastic responses are crucial to forecast the susceptibility of forest tree species to climate change and manage its impacts. Environmental heterogeneity across species' ranges produces differential selective pressures, resulting in intra-specific genetic variation and potential population-specific responses to climate change. Early seedling traits are subject to particularly strong selective pressures and, as determinants of the regeneration niche, may have a disproportionate contribution to future species' distributions. We present here an international field trial to elucidate patterns of intra-specific genetic variation at early fitness traits in Mediterranean Pinus pinaster, in the framework of the H 2020 European project GenTree. Seeds from 14 provenances were collected across the species range and sown at two sites with contrasting climates. Germination, developmental stage, growth and survival were monitored periodically. Results show significant among-population genetic variation in early fitness traits and in their plasticity, which were correlated with climatic and geographic variables of the site of origin of the seeds. There were evidences of local adaptive differentiation even over small spatial scales, in the cases of nearby populations growing over steep environmental gradients. The experiment results will help decision making for adaptive forest management and conservation, by improving our understanding of population-specific climate-change threats to early recruitment and therefore to population persistence.

\title{
Germination response to heat shocks in five legume species from Colombian tropical dry forests
}

\author{
Alejandro Hernandez Cobos $^{1}$, Angela Parrado-Rosselli ${ }^{1}$ \\ ${ }^{1}$ Universidad Distrital Francisco José de Caldas, Bogotá, Colombia (jalhercobos@gmail.com; aparrado-rosselli@lycos.com)
}

Fire regimes of tropical dry forests of Colombia are not well known and there is still a debate if fire has been a frequent natural disturbance. Consequently, whether plant species of this ecosystem have specialized fire-response traits, such as heat-stimulated germination is also poorly understood. As germination of several legumes in fire-dominated ecosystems is stimulated by fire and heat shocks, the objective of this research was to evaluate, for five legume species common to the tropical dry forests of the Upper Magdalena River Valley in Colombia, the effect of heat shock on seed germination. We exposed 810 seeds per species to nine experimental heat shock treatments (i.e; $80^{\circ} \mathrm{C}, 100^{\circ} \mathrm{C}$ and $140{ }^{\circ} \mathrm{C}$ for 1,3 and 5 minutes). We then incubated the seeds in an acclimatized germination chamber. Seeds were also classified into seed size classes (i.e. small, medium and large) in order to test if germination response was correlated with seed size. Results showed that germination of all seed species was stimulated by heat; however, germination percentages of Albizia niopoides, Pseudosamanea guachapele and Piptadenia sp were higher under less-intense heat treatments. In contrast, Enterolobium cyclocarpum and Chloroleucon manguense exhibited a better germination response under high temperatures $\left(100\right.$ and $140{ }^{\circ} \mathrm{C}$ for 3 and 5 minutes). Seed size did not correlate with germination response. Our findings indicate that some tropical dry forest legumes might have an adaptive advantage to forest fires, which are expected to become more frequent and intense even in nonfire-prone environments due to climate change.

\section{Effect of fertilization on stone pine (Pinus pinea L.) growth and cone yield in a young plantation located in a non-native habitat}

Verónica Loewe-Muñoz ${ }^{1}$, Claudia Delard ${ }^{1}$, Rodrigo Del Río ${ }^{1}$, Mónica Balzarini ${ }^{2}$

${ }^{1} I N F O R$, Santiago, Chile; ${ }^{2}$ Universidad Nacionalde Córdoba,Córdoba,Argentina (vloewe@infor.cl; cdelard@infor.cl; rdelrio@infor.cl; mbalzari@gmail.com)

Stone pine is a species of economic interest for its nutritious and highly demanded pine nuts. Despite this traditional use, cones are harvested mostly from natural forests; advances in techniques for its cultivation as a fruit tree have been limited. Fruit development is characterized by a long cycle (3.5 years), with one-, two- and three-year-old cones occurring simultaneously on the trees; this phenomenon makes the evaluation of management practices even more challenging than in other perennial crops. The objective of this work was to monitor the effect of fertilization on growth and fruiting over time. A fertilization trial with two treatments (fertilized and non-fertilized), was set up in a previously thinned and pruned 16-year-old stone pine plantation in central Chile. In spring 2009, trees of fertilized treatment were treated with macro- and micronutrients. All 3-year-old cones in each tree were harvested, weighed and counted annually for 10 years (2009-2018), diameter (DBH and crown) and height were repeatedly measured. Nine years after fertilization, significant differences were found for DBH and crown diameter growth, with a $32.3 \%$ and $20.8 \%$ higher annual growth, respectively, in fertilized trees. Significant effects of fertilization on fruiting were evident five years after application, and continued up to the end of the study, leading to cone yields up to 2.6 times higher than in non-fertilized trees. Fertilization also affected cone weight positively. Fertilization was a useful cultural practice to enhance stone pine fruiting and growth. Results suggest the convenience of repeating fertilization to enhance cone production and weight.

\section{Assessing biodiversity change in the last 70 years by eDNA metabarcoding and pollen analyses of ice core from Adamello glacier, Italian Alps}

Cristiano Vernesi ${ }^{1}$, Alexis Marchesini ${ }^{1}$, Matteo Girardi ${ }^{1}$, Antonella Cristofori $^{1}$, Valter Maggi ${ }^{2}$, Camilla Wellstein ${ }^{3}$, Nicola Alessi ${ }^{4}$, Stefan Zerbe ${ }^{3}$, Daniela Festi ${ }^{3}$, Klaus Oeggl ${ }^{4}$

${ }^{1}$ Fondazione Edmund Mach, San Michele all'Adige, Italy; ${ }^{2}$ Università Milano Bicocca, Milano, Italy; ${ }^{3}$ Libera Università Bolzano, Bolzano, Italy; ${ }^{4}$ University of Innsbruck,Innsbruck, Austria (cristiano.vernesi@fmach.it; alexis.marchesini@fmach.it; matteo.girardi@fmach.it; antonella.cristofori@fmach.it; valter.maggi@unimib.it; camilla.wellstein@unibz.it;nicola.alessi@unibz.it; stefan.zerbe@unibz.it; daniela.festi@unibz.it; klaus.oeggl@uibk.ac)

Forest ecosystems in mountain areas like the European Alps are particularly affected by climate and land use changes. Modern genetic technologies (e.g. NGS metabarcoding) are fostering new opportunities for extending biodiversity monitoring to the ecosystem level. Using a $45 \mathrm{~m}$ ice core extracted from the Adamello glacier (Alps, Italy) as biological archive, we propose a new approach for studying how taxonomic and functional diversity has changed through time. Taking advantage of the relatively precise ice core stratigraphy we can assume that our ice core covers the last about 70 years. This is the time period where in this area climate and land use changes dramatically impacted mountain areas, with glacier retreat as the most iconic event. By dividing the ice core in different layers, each approximately corresponding to one year, we aim at identifying the occurrence of major plant taxa in the last 70 years. From each layer environmental DNA (eDNA) is extracted and analysed using three different barcode markers: trnL, matK and rbcL. This eDNA metabarcoding analysis has been coupled with pollen 
morphological investigation. Taxonomic assignment is accomplished by comparing the retrieved DNA sequences to a custom-made reference database and by morphological identification of pollen grains contained in each layer. eDNA metabarcoding and morphological investigation give complementary taxonomic information, able to reveal the overall floristic composition of the glacier catchment area across time. Results are discussed in light of methodological challenges (e.g. contamination) and biodiversity data gained by additional sources such as remote sensing data, vegetation surveys and maps.

\section{Measures for "genetic protection of forests" need implementation, recording and monitoring}

Hojka Kraigher', Paraskevi Alizoti ${ }^{2}$, Marjana Westergren

${ }^{1}$ Slovenian Forestry Institute, Ljubljana, Slovenia; ${ }^{2}$ Aristotle University of Thessaloniki, Thessaloniki, Greece (hojka.kraigher@gozdis.si; alizotp@for.auth.gr; marjana.westergren@gozdis.si)

Silviculture can have profound effects on gene flow and selection processes, thus affecting the adaptability of future forests to the changing environment The measures for the 'genetic protection of forests' to the environmental changes are mainly focusing on supporting and securing their adaptive potential to uncertain futures through, among others, adaptive thinning and cutting, support to and selection of diverse tree species composition, support to and accelerated enhancement of genetic diversity. This last can be achieved through combining natural regeneration with assisted migration and enrichment planting; that could be of particular interestin the case of highly diverse natural environments, where both climate change modelling, as well as forest reproductive material (FRM) translocation studies, are failing to provide accurate and reliable results. Hence an in situ long-term FRM inventorying system needs to be developed, based on: the choice of a high number of (predominantly native) tree and shrub species with different roles and interactions in the forest ecosystems, the choice of appropriate non-autochthonous provenances that could contribute to the genetic diversity enhancement and acceleration of selection processes, a well designed planning of enrichment planting, and long-term recording of all tending measures applied on stands established based on the strategy above, so that the initial forest reproductive material establishment success could be disentangled from the effect of silvicultural practices. However, all these measures need to be supported also by the long term monitoring of genetic diversity changes, as it is currently being developed in the implementation EU project LIFEGENMON, contributing to EUFORGEN.

B1f: SILVICULTURE AND MANAGEMENT OF TROPICAL NATURAL FORESTS IN AMAZON
REGION: RESCUING CLASSIC SOLUTIONS TO ATTEND NEW DEMANDS - CLIMATE
CHANGE, BIODIVERSITY AND BIOECONOMY

\section{Opportunities for carbon emissions reduction from selective logging in Suriname}

Zalman Joey ${ }^{1}$, Peter W. Ellis ${ }^{2}$, Sarah Crabbe ${ }^{3}$, Anand Roopsind ${ }^{4}$

${ }^{1}$ Stichting voor Bosbeheer en Bostoezicht, Paramaribo, Suriname; ${ }^{2}$ The Nature Conservancy, Arlington, USA; ${ }^{3}$ Stichting voor Bosbeheer en Bostoezicht, Paramaribo,Suriname; ${ }^{4}$ Boise State University, Idaho,USA (joeyzalman92@gmail.com; pellis@tnc.org; sarah_crabbe@yahoo.com; aroopsind@gmail.com)

Improved forest management is a cost-effect intervention to reduce carbon emissions and mitigate climate change. Emissions reductions from the forestry sector are especially important in countries such as Suriname, a high forest cover low deforestation country, where large areas are allocated for logging. In this study we quantify carbon emissions from selective logging from three forest management systems applied in Suriname: (1) conventional timber harvests, which does not require pre-harvest inventories or planning of skid trails and roads prior to timber harvests; (2) controlled timber harvests, that requires forest management plans that include pre-harvest inventories and skid trail planning and; (3) controlled timber harvests that are Forest Stewardship Council (FSC) certified. Our carbon accounting method tracks emissions associated with the extracted log, unextracted portions of the felled tree, felling damage, as well as deforestation caused by logging infrastructure. Carbon emissions were highest from conventional timber harvests ( $3.23 \mathrm{mg} \mathrm{C} / \mathrm{m}^{3}$ ), $40 \%$ lower in controlled harvests $\left(1.96 \mathrm{mg} \mathrm{C} / \mathrm{m}^{3}\right)$, and lowest in FSC certified timber harvests $\left(1.82 \mathrm{mg} \mathrm{C} / \mathrm{m}^{3}\right)$. The majority of carbon emissions were from the unextracted sections of felled trees $\left(0.63-0.77 \mathrm{mg} C / \mathrm{m}^{3}\right)$, followed by felling damage (0.41-0.70 $\left.\mathrm{mg} \mathrm{C} / \mathrm{m}^{3}\right)$. Based on the current scale of timber production under conventional timber harvests in Suriname, we estimate emissions from the forestry sector could be reduced annually by 0.39 million $\mathrm{Mg} \mathrm{C}$ (37.1\% of current forestry emissions) by switching to the controlled timber harvest system.

\section{Forest degradation and restoration of carbon stocks in lowlands landscapes}

\section{Paul Eguiguren ${ }^{1,2}$, Sven Günter ${ }^{l, 2}$}

${ }^{1}$ Technical University of Munich, TUM School of Life Sciences Weihenstephan, Munich, Germany; ${ }^{2}$ Thünen Institute of International Forestry and Forest Economics, Hamburg, Germany (paul.eguiguren@thuenen.de; sven.guenter@thuenen.de)

Latin America's tropical forests contain 49\% of thetotal biomass carbon in the tropics, influencing the global carbon cycle. Despite this, are heavilyimpacted by anthropogenic activities, such as timber extraction and forest conversion. We analyzed total carbon stocks (aboveground biomass, dead organic matter and soil carbon) in five lowland ecosystems (old growth forest-OGF, logged forest-LF, successional forest-SF, agroforestry systems-AF and plantations-PL), in order to generateinputs to reduce forest degradation and promote landscapes restoration. As logging is an important driver of degradation we evaluated the impact of this activity on OGF. In addition, we assessed different restoration strategies (active-passive) for carbon recovery. We used astratified random sampling design to establish 156 plots of $1600 \mathrm{~m} 2$ between Esmeraldas and the Amazon Region in Ecuador. Analysis of variance using general mixed models was conducted. We found that OGF accumulate between $237 \mathrm{mg} \mathrm{C} \cdot \mathrm{ha}^{-1}$ in Amazonia and $206 \mathrm{mg} \mathrm{C} \cdot \mathrm{ha}^{-1}$ in Esmeraldas. LF present up to $25 \%$ of degradation in terms of carbon contents when they are contrasted with OGF. Regarding to restoration strategies, SF (between 12 to 30 years) can store among 143 and $153 \mathrm{mg} \mathrm{C}^{-h^{-1}}$. In the long term, SF is an adequate alternative for carbon recovery, since they store almost $69 \%$ of a mature forest at a low cost. Meanwhile, AF can store around $42 \%$ and PL 54\% in contrast with the OGF. Although AF and PL only represent half of the OGF carbon, these restoration strategies are important not only to maintain carbon stocks but for climate change mitigation and local livelihoods. 


\section{Disentangling the drivers of fruit production in a long-lived tropical tree: What drives Brazil nut (Bertholletia excelsa) production?}

Christina Staudhammer ${ }^{1}$, Karen Kainer ${ }^{2}$, Thiago da Cunha ${ }^{3}$, Lúcia Helena de Oliveira Wadt ${ }^{4}$

${ }^{1}$ University of Alabama, Tuscaloosa, Alabama, USA; ${ }^{2}$ University of Florida, Gainesville, Florida, USA; ${ }^{3}$ Universidade Federal do Acre, Rio Branco, AC,

Brasil; ${ }^{4}$ Embrapa Rondônia, PortoVelho,Brasil(cstaudhammer@ua.edu; kkainer@ufl.edu; etsfor@yahoo.com; lucia.wadt@embrapa.br)

Brazil nut is an important non-timber forest product (NTFP), and widely recognized as the cornerstone species of the Amazonian extractive economy. It is the only commercial nut collected almost entirely from natural populations in mature forest; however, fruiting varies both among trees and among years, with 8-10\% of mature trees not producing any fruit in a given year. Despite this observed variability, and its important links to Amazonian forest conservation, few studies have quantified the factors explaining long-term Brazil nut fruit production variation. Our objective is to address knowledge gaps in explaining production variation over time, while providing insights to the larger ecological question of fruit production variation and its causes. We utilized long-term data collected in two extractive reserves in Acre, Brazil, which have similar climate but differ in soil characteristics and land use legacies, to address hypotheses about the role of site- and tree-level characteristics, as well as climate, in fruit production. We found that fruit production was significantly higher for trees growing at higher elevations in both sites. The site with a longer, more intense history of management and extractivism had significantly higher fruit production, and was less affected by other tree-level characteristics and climate. In the poorer site, production was significantly lower with greater vegetative competition, as well as higher dry season temperatures and vapor pressure deficit. These results indicate that long-term observation is important to adequately quantify the response of this and other NTFP species to future climate and development pressures.

\section{Evaluation of Swidden fallow potential to increase landscape-level Brazil nut (Bertholletia excelsa) productivity in the Western Amazon}

Eduardo Bongiolo ${ }^{1}$, Karen Kainer ${ }^{1}$, Wendell Cropper ${ }^{1}$, Christina Staudhammer ${ }^{2}$, Lúcia Helena de Oliveira Wadt ${ }^{3}$

${ }^{1}$ University of Florida, Gainesville, USA; ' ${ }^{2}$ niversity of Alabama, Tuscaloosa, USA; ${ }^{3}$ Embrapa Rondônia, Porto Velho, Brasil

(eduardosbongiolo@gmail.com; kkainer@ufl.edu; wcropper@ufl.edu; cstaudhammer@ua.edu; lucia.wadt@embrapa.br)

Brazil nut (Bertholletia excelsa Bonpl.) is considered the 'cornerstone non-timber species of Amazonian conservation'. Nuts (or seeds) of this massive tree are harvested by local people living in and near old growth forests, supporting local livelihoods and regional economies. Secondary forests, however, particularly plots previously used for agriculture (swidden fallows), present better $B$. excelsa seedling and sapling recruitment than mature forest. This study examines the extent to which forest residents could increase nut productivity by allowing their fallows to grow into Brazil nut rich forests. We conducted $B$. excelsa inventories in the Brazilian state of Acre in abandoned swidden fallows. We also conducted interviews to determine landowner perspectives on fallow potential for increasing nut production. An individual-based model estimated growth, survivorship and production from the 250 inventoried trees in 18 fallows of varying sizes (from 0.41 to 4.18 ha) and different regrowth stages (12 to 60 years old). Model predictions showed that after 10 years, $2.4 \%$ of existing trees will be productive, with an average of $68.6 \pm 21.5$ fruits per reproductively mature tree in the four fallows that most quickly yielded productive trees. By the final projected time interval (40 years), all fallows were predicted to produce fruits with cumulative production averaging $1475 \pm 359$ fruits ha-1, suggesting an increase in landowner income of US\$55.1 \pm 13.4 per hectare of fallow. Our model likely underpredicts $B$. excelsa growth and nut production, considering that swidden fallows provide better resource availability than the forest-derived datasets used to construct model equations.

Predicting clearing sizes in floodplain areas under forest management: a case study in the Mamirauá Sustainable Development Reserve, Amazonas, Brazil / Predição do tamanho de clareira em área de várzea sob regime de manejo florestal: estudo de caso na Reserva de Desenvolvimento Sustentável Mamirauá, Amazonas

Márcio Lima de Abreu ${ }^{1}$, Celso Paulo de Azevedo ${ }^{2}$, Claudio Roberto Anholetto Junior ${ }^{3,4}$ (D) Emilio Manabu Higashikawa ${ }^{5}$; Kátia Emídio ${ }^{2}$ ${ }^{1}$ Universidade Federal do Amazonas, Manaus, Brasil; ${ }^{2}$ Embrapa Amazonia Ocidental, Manaus, Brasil; ${ }^{3}$ Universidade de São Paulo, Piracicaba, Brasil; ${ }^{4}$ Instituto de Desenvolvimento Sustentável Mamirauá, Tefé, Brasil; ${ }^{5}$ Centro de Estudos Integrados da Biodiversidade Amazônica, Manaus, Brasil (mwmarcio82@hotmail.com; celso.azevedo@embrapa.br; claudio@mamiraua.org.br; emilio.higashikawa@gmail.com; katia.emidio@embrapa.br)

O objetivo do estudo foi desenvolver modelos matemáticos capazes de relacionar o tamanho das áreas de clareiras de espécies florestais exploradas com dados dendrométricos e características morfométricas de copa, gerando parâmetros para planejamento de exploração e estimativas de área impactada aperfeiçoados. Este estudo foi conduzido em áreas de manejo florestal da Reserva de Desenvolvimento Sustentável Mamirauá, estado do Amazonas. Os inventários florestais foram realizados pelas associações comunitárias que desenvolvem as atividades em suas respectivas áreas de manejo florestal, entre janeiro e fevereiro nos anos de 2012 a 2014. Os dados morfométricos da copa foram coletados em janeiro de 2018 e analisados por meio da análise de variância, coeficiente de correlação de Pearson e análise de regressão linear múltipla. A exploração sob regime de manejo florestal ocasionou a abertura de $89,76 \%$ de clareiras de categoria pequena. Os testes mostraram diferença significativa entre as clareiras de espécies exploradas, sendo que a espécie Açacú (Hura crepitans) apresentou os maiores valores, com área de clareira de 341,88 $\left(\mathrm{m}^{2}\right) \pm 99,09\left(\mathrm{~m}^{2}\right)$. As variáveis diâmetro a altura do peito (DAP) e volume (V) apresentaram forte correlação com áreas de clareira, DAP $(r=0,85)$ e volume $(r=0,697)$, indicando que as áreas de clareiras $\left(\mathrm{m}^{2}\right)$ aumentam proporcionalmente a estes parâmetros. A equação CL $=-626,5439+6,6645 \cdot \mathrm{DAP}-127,3025 \cdot \mathrm{G}+69,295 \cdot \mathrm{IS}-1,9302 \cdot \mathrm{IEV}+292,765 \cdot \mathrm{IA}-4,3849$.VSH foi a que apresentou os melhores valores de R2Ajust (0,9358), de Cp mallows (7,000), AIC $(238,38)$ e Syx\% $(19,7)$, permitindo indicar para predição de área de clareira a equação CL = -134,5395 + 2,8028.DAP + 13,266.IS.

\section{Aspects of agroforestry and agroextractivist production in the Amazonian Hinterlands / Aspectos da produção agrosilvicultural e} agroextrativista na Hinterlândia Amazônica

Maria Isabel Araújo ${ }^{1}$, Silas Garcia Aquino de Sousa ${ }^{2}$,Evandro de Morais Ramos ${ }^{1}$, Márcio A. O. de Menezes ${ }^{3}$

${ }^{1}$ Universidade Federal do Amazonas, PPGSCA, Manaus, Brasil; ${ }^{2}$ Embrapa Amazonia Ocidental, Manaus, Brasil; ${ }^{3}$ Universidade Federal do Amazonas,

PPGCASA, Manaus, Brasil (miar@terra.com.br; silas.garcia@embrapa.br; evandro.ramos@ufam.edu.br.; mzmarcio@yahoo.com)

Sob a auto-gestão dos agricultores familiares, a produção agrosilvicultural e agroextrativista na hinterlândia amazônica apresenta resultados eloquentes sob a ótica da oferta de produtos regionais e a preocupação e o respeito ao meio ambiente. Objetiva-se neste trabalho, discutir os aspectos da produção agrosilvicultural e agroextrativista pela agricultura familiar, ofertados nas feiras regionais do Amazonas. Utilizou-se a abordagem do método pesquisa-ação etnográfica, com visita de campo na Comunidade São Francisco de Assis e feira de produtos regionais, do município de Rio Preto da Eva/AM. A comunidade reune 15 agricultores familiares que manejam diferentes sistemas de produção, combinando plantios agricolas e espécies florestais, manejo de produtos florestais madeireiros (PFM) e não madeireiros (PFNM) voltados para o mercado local e o consumo da família. Os resultados demonstraram a utilização de boas práticas do manejo da floresta e do solo, com base nos princípios do desenvolvimento rural sustentável. Com referência as ofertas de produtos da agrosilvicultura destacam-se as frutíferas regionais: Theobroma grandiflorum, Annona muricata, Spondias mombin, Bactris gasipaes, dentre outras frutíferas; os PFNM: Euterpe oleracea; E. precatoria, 
Myrciaria dubia, Bertholletia excelsa, Caryocar villosum, Astrocaryum aculeatum, dentre outras espécies; bem como, uma variedade de espécies hortícolas, flores, raízes, plantas alimentícias não convencionais (PANC) e medicinais. Conclui-se que agricultores familiares da hinterlândia amazônica ofertam grande variedade de produtos da agrosilvicultura e do manejo florestal, combinando benefícios das dimensões sociais, culturais, econômicas e ambientais, com base nos princípios da sustentabilidade.

Natural regeneration of commercial species in areas subjected to multiple-cycle forestry systems in Central Amazonia / Regeneração natural de espécies comerciais em áreas submetidas ao sistema silvicultural policíclico na Amazônia Central

Alexsandro da Silva Silveira ${ }^{1}$, Celso Paulo de Azevedo ${ }^{1,2}$, Cíntia Rodrigues de Souza ${ }^{2}$

${ }^{1}$ Universidade Federal do Amazonas, Programa de Pós-Graduação em Ciências Florestais e Ambientais, Manaus, Brasil; ${ }^{2}$ Embrapa Amazônia Ocidental, Manaus,Brasil(alexsandro.cheff@gmail.com; celso.azevedo@embrapa.br; cintia.souza@embrapa.br)

Para que o manejo florestal seja considerado sustentável é necessário que haja a renovação de quotas, das espécies exploradas comercialmente, em vários aspectos em um determinado período de tempo preestabelecido. Neste sentido destaca-se a importância de buscar compreender como funciona a renovação de quotas e a dinâmica, do principal alicerce do manejo florestal em regime sustentado, a regeneração natural. O objetivo deste estudo foi avaliar os efeitos de curto e médio prazos do sistema silvicultural policíclico, na dinâmica e no estoque da regeneração natural $(5 \mathrm{~cm} \leq \mathrm{DAP}<15 \mathrm{~cm})$ do povoamento total e as espécies comerciais/ potenciais, considerando três UPAs da Mil Madeiras Preciosas em Itacoatiara/AM, em 820 subparcelas de 100 m² $^{2}$ pertencentes a 41 parcelas permanentes de 1 hectare. Calculou-se as taxas de ingresso e mortalidade, estoque (DAP, G, V, N e S), e IPAs. Avaliou-se, também, o nível de recomposição da floresta utilizando variáveis categóricas. Observou-se efeito positivo da exploração para espécies, DAP, N, G e V. O povoamento total apresenta balanço dinâmico positivo e o comercial/potencial ainda é negativo. Os IPAs decrescem com o tempo. O teste de Scott-Knott agrupou as espécies em três grupos considerando o IPADAP. A classe de floresta mostrou que o povoamento está em construção. Considerando o período de 17 anos, conclui-se que a regeneração natural recuperou ao estado antes da intervenção, no entanto, é necessário cuidado uma vez que o balanço dinâmico das espécies comerciais/potenciais é negativo.

Biometry of Bertholletia excelsa Bonpl. seeds in two regions in the state of Amazonas, Brazil / Biometria de sementes de Bertholletia excelsa Bonpl. em duas regiões produtoras no estado do Amazonas

Ana Lorena da Silva Aguiar 1 , Kátia Emídio da Silva², Thais Carla Vieira Alves ${ }^{3}$

${ }^{1}$ Universidade Nilton Lins, Manaus, Brasil,; ${ }^{2}$ Embrapa Amazônia Ocidental, Manaus, Brasil; ${ }^{3}$ Universidade Federal do Amazonas, Manaus, Brasil (aguiarz. ana@gmail.com;katia.emidio@embrapa.br; thais.vieira.alves@hotmail.com)

A castanheira (Bertholletia excelsa) é uma das árvores símbolo da Amazônia por sua importância no contexto social, econômico e ecológico para a região. Sua semente, também chamada de castanha, é um produto florestal não madeireiro-PFNM de relevante importância para famílias de agroextrativistas, que têm neste produto uma fonte de renda complementar. Este estudo objetivou contribuir com informações sobre a biometria de sementes da castanheira, avaliando-a em dois segmentos da cadeia produtiva (produtor e intermediário). Desta forma, avaliou-se o comprimento, largura e espessura, de sementes oriundas de amostras adquiridas na Reserva de Desenvolvimento Sustentável (RDS) Piagaçu-Purus - Anori/AM e na Comunidade Lago das Pedras Reserva Extrativista (RESEX) do Rio Unini - Barcelos, AM. Três representantes de cada segmento foram amostrados, onde sete latas de 20 litros de sementes in natura de cada representante foram amostradas, sendo que de cada lata foram obtidas 10 sementes, as quais foram utilizadas nos estudos biométricos. Os resultados indicaram que há maior variabilidade entre o segmento de produtores dentro de cada localidade, onde as variáveis que apresentaram diferenças significativas foram comprimento $(\mathrm{p}$-value $=1.472 \mathrm{e}-07)$, largura $(\mathrm{p}$-value $=0.0119)$ e espessura $(\mathrm{p}$-value $=1.409 \mathrm{e}-05)$ na RESEX Unini e comprimento $(\mathrm{p}$-value $=0.04212)$ e largura $(\mathrm{p}$-value $=0.00031)$ na RDS Piagaçu Purus, quando comparados aos intermediários que apresentaramapenas diferença significativa na espessura $(\mathrm{p}$ value $=0.0066)$ na RESEX Unini. Quando se comparou de forma global o tamanho das sementes entre as duas áreas, estas não mostraram variações significativas nos valores médios das variáveis estudadas, apesar das áreas estarem localizadas em regiões muito distantes entre si.

B1p: MONITORING AND RESTORING DEGRADED FORESTS

The Matas Legais program: integrating sustainability on rural properties and expanding areas of native vegetation / Programa Matas Legais: integrando a sustentabilidade nas propriedades rurais e ampliando as áreas de vegetação nativas

Maurício Batista Reis ${ }^{1}$, Samantha Nazaré de Paiva², Gabriela Sanches Dolenc ${ }^{2}$, Ana Cristina André2

${ }^{1}$ Apremavi, Telêmaco Borba, Brasil; ${ }^{2}$ Klabin, Telêmaco Borba,Brasil(mauricio@apremavi.org.br; snpaiva@klabin.com.br; gabrielasdolenc@gmail.com, ana.andre@klabin.com.br

O Programa Matas Legais, uma parceria entre a Associação de Preservação do Meio Ambiente e da Vida - Apremavi e Klabin, implementa ações de desenvolvimento sustentável tendo como base o planejamento de propriedades e paisagens dos pequenos produtores localizados na área de atuação da empresa. As metodologias de restauração das áreas de preservação permanente e reservas legais são: o plantio de mudas nativas em áreas com pouca ou sem resiliência e a regeneração natural quando há fragmentos florestais próximos às áreas degradadas. Em 13 anos de parceria estão sendo atendidas 998 propriedades. Já foram restaurados 380 hectares com plantio de mudas nativas, 1.390 hectares em processo de regeneração natural e doadas cerca de 1,4 milhões de mudas nativas. Este trabalho tem o objetivo de apresentar como as ações do Projeto, mesmo que atuando em uma propriedade de cada vez, impactam positivamente o desenvolvimento de uma região, criando conectividade entre os fragmentos nativos ao passar do tempo. Um dos estudos de casos mostra a evolução de imóveis localizados no bairro José Lacerda, Reserva - PR. As ações do Projeto iniciaram em 2013 em 07 propriedades, identificando 101,71 ha degradados. Em cinco anos de atuação a área foi convertida para 80,56 ha que estão em processo de restauração com plantio de 23.880 mudas nativas e 21,15 ha em processo de regeneração natural. Nesses imóveis foram identificadas 136 nascentes sendo que 37 escoam para bacia hidrográfica do Rio Ivaí e 99 para a bacia do Rio Tibagi. 
Analyzing ecological processes in projects to remediate degraded areas within the Matas Legais program / Análise dos processos ecológicos nos projetos de recuperação de áreas degradadas dentro do Programa Matas Legais

Maurício Batista Reis ${ }^{1}$, Samantha Nazaré de Paiva², Gabriela Sanches Dolenc ${ }^{2}$, Ana Cristina André2

${ }^{1}$ Apremavi, Telêmaco Borba, Brasil; ${ }^{2}$ Klabin, Telêmaco Borba, Brasil ((mauricio@apremavi.org.br; snpaiva@klabin.com.br; gabrielasdolenc@gmail.com; ana.andre@klabin.com.br)

O Programa Matas Legais, uma parceria entre a Associação de Preservação do Meio Ambiente e da Vida - Apremavi e Klabin, implementa ações de desenvolvimento sustentável como: recuperação com plantio de mudas nativas ou regeneração natural de áreas de preservação permanente e reservas legais, sistemas agroflorestais, enriquecimento ecológico de florestas secundárias e agricultura orgânica em propriedades de pequenos produtores localizados na área de atuação da empresa. O programa iniciou em 2005 em Santa Catarina e em 2008 foi ampliado para o Paraná. Em 13 anos de parceria estão sendo atendidas 998 propriedades. Já foram restaurados 380 hectares com plantio de mudas nativas, 1.390 hectares em processo de regeneração natural e doadas cerca de 1,4 milhões de mudas nativas. O objetivo deste trabalho é apresentar os resultados de uma análise dos projetos de restauração realizada em 232 dos projetos do programa. A avaliação dos projetos foi feita de forma qualitativa e quantitativa onde os resultados indicam a qualidade e quantidade de mudas plantadas que sobreviveram, bem como na qualidade e quantidade de plântulas regenerantes no local. Para avaliar a evolução dos processos ecológicos, nos projetos de recuperação de áreas degradadas, foram adotados quatro critérios, que compreendem a mortalidade da mudas plantadas, a chance de sucesso para que essas mudas sobrevivam ao longo do tempo, a quantidade de regenerantes na área de plantio e o sucesso da regeneração natural. Além da análise de todas as propriedades foi feita uma comparação entre proprietários certificados e não certificados FSC.

Arthropod fauna in the leaf litter: improvement monitoring techniques for ecological restoration, knowledge on biodiversity and ecosystem services in the Serra do Itajai National Park, Brazil / Artropodofauna de serapilheira: utilização no aperfeiçoamento de técnicas de monitoramento da restauração ecológica, conhecimento da biodiversidade e serviços ecossistêmicos do Parque Nacional da Serra do Itajaí, Brasil

Taise Cristina Plattau Arenhardt ${ }^{1,2}$, Guilherme Alan Klunk ${ }^{2}$, Joice Adriana Rezini ${ }^{2}$, Marcelo Diniz Vitorino ${ }^{2}$

${ }^{1}$ Universidade Federal de Viçosa, Viçosa, Brasil; ${ }^{2}$ Fundação Fundação Universidade Regional de Blumenau, Blumenau, Brasil

(taise.arenhardt@hotmail.com; guilhermeklunk@hotmail.com; joice_rezini@hotmail.com; dinizvitorino@gmail.com)

Artrópodes de serapilheira representam grande porção da biodiversidade e podem ter aplicação no monitoramento de iniciativas de restauração ecológica. Assim, o objetivo deste trabalho foi avaliar a influência de técnicas de restauração e o potencial de aplicação de famílias da Classe Collembola e Insecta e espécies da família Formicidae (Hymenoptera) como indicadores da restauração ecológica no Parque Nacional da Serra do Itajaí (PNSI). As coletas foram realizadas com uso de armadilhas pitfall e funil de Berlese-Tüllgren, entre agosto/2014 e agosto/2015. Para análise de dados foram utilizados parâmetros de abundância, riqueza, diversidade, composição, similaridade, grupos funcionais e também a estrutura vegetacional. Foram coletados 128.957 artrópodes, sendo $80,25 \%$ de Collembola e 19,75\% de Insecta. A riqueza total de Formicidae foi de 102 espécies, sendo que destas, 37 foram exclusivas em floresta nativa. Os potenciais grupos bioindicadores foram as famílias Ptiliidae (Coleoptera), Cicadellidae e Cercopidae (Hemiptera) e espécies Pheidole sarcina, Hypoponera spp., Solenopsis sp., Linepithema sp. e Camponotus rufipes (Formicidae). As famílias mais representativas de Collembola foram Entomobryidae, Paronellidae, Isotomidae, Dicyrtomidae, Katiannidae e Neanuridae, sendo este o primeiro levantamento deste grupo no PNSI. Os resultados demonstram que as famílias e espécies de Insecta respondem de forma diferenciada aos processos de restauração e de que isso está fortemente associado à cobertura vegetal. A utilização conjunta de parâmetros ecológicos da comunidade de artrópodes mostrou-se eficiente para a aplicação no monitoramento das técnicas de restauração ecológica. Além disso, o levantamento dos artrópodes servirá de base para avaliação do retorno de serviços ecossistêmicos nas áreas no PNSI.

Ecological restoration in a brazilian Atlantic Forest hotspot - Project Restaurar / Restauração ecológica em um hotspot de Mata Atlântica brasileira - Projeto Restaurar

Marcelo Diniz Vitorino ${ }^{1}$, Eduardo Adenesky Filho ${ }^{1}$, Taise Cristina Plattau Arenhardt ${ }^{1,2}$

${ }^{1}$ Fundação Universidade Regional de Blumenau, Blumenau, Brasil; ${ }^{2}$ Universidade Federal de Viçosa, Viçosa, Brasil (dinizvitorino@gmail.com; eduardo_florestal@hotmail.com; taise.arenhardt@hotmail.com)

A Floresta Tropical Atlântica brasileira é um hotspot de maior biodiversidade do mundo, detêm elevada diversidade de espécies endêmicas e ameaçadas. Iniciativas para a restauração e conservação desse bioma estão distribuídos pelo país. Entretanto, poucas ações são implementadas em unidades de conservação. O Parque Nacional da Serra do Itajaí (SC), abrange cerca de 57 mil hectares de Floresta Atlântica. Em 2013, um projeto de restauração ecológica (Restaurar) foi implantado para recuperar 300 ha de 1.500 ha, de áreas degradadas com pastagens abandonadas, no interior do parque. Primeiramente foi realizado o diagnóstico abiótico do ambiente e posteriormente, foram amostrados diferentes grupos de fauna (insetos, aves, répteis, anuros, mamíferos) e caracterizado a vegetação por meio do estudo fitossociológico, método de parcelas (20 parcelas - $400 \mathrm{~m}^{2}$ cada). A descrição vegetal foi utilizada como referência para futuras comparações, marcação de árvores matrizes produtoras de sementes (2.500 árvores marcadas) e subsidiar os plantios. Após o diagnóstico, três técnicas de nucleação (poleiros artificiais, transferência de serapilheira e instalação de rugosidade do solo) foram selecionadas e implementadas isoladamente e em associação com mudas produzidas no viveiro (germoplasma autóctone), totalizando 51 ha. A semeadura direta foi implantada em 60 ha e o plantio de mudas em 123 ha, utilizando módulos circulares adaptados de Anderson, em uma densidade de 1.100 mudas/ha. A seleção das espécies para o plantio foi orientada pelo valor de importância e grupos ecológicos, resultantes do estudo fitossociológico. Monitoramentos estão sendo efetuados para descrever a trajetória da restauração, e subsidiar projetos de restauração para o bioma.

Effect of temperature on germination of Poincianella pluviosa (sibipiruna) seeds / Efeito da variação da temperatura na germinação de sementes de Poincianella pluviosa (sibipiruna)

Dayane Lopes Pinto ${ }^{1}$, Ana Cláudia Nogueira Silva ${ }^{1}$, Gumercindo Souza Lima ${ }^{1}$, Lydiane Lúcia de Sousa Bastos ${ }^{1}$

${ }^{1}$ Universidade Federal de Viçosa,Viçosa,Brasil (dayanelopesp@gmail.com; anasilvanogueira@yahoo.com.br; gslima@ufv.br; lydilucia@gmail.com)

A intensificação da restauração florestal e da arborização urbana vem resultando no aumento da demanda por sementes e mudas de espécies arbóreas nativas. A Poincianella pluviosa var. peltophoroides (Benth.) L.P. Queiroz, popularmente conhecida como Sibipiruna, é uma espécie da família Fabaceae que se distribui pela maioria dos biomas brasileiros. Considerando a importância da temperatura na germinação, o objetivo deste trabalho foi estudar o efeito desse fator na germinação de sementes de $P$. pluviosa afim de definir a temperatura ideal de germinação da espécie. Foi realizada a avaliação da protusão da raiz primária sob quatro temperaturas constantes $\left(25,30,35\right.$ e $\left.40^{\circ} \mathrm{C}\right)$ em laboratório, com cinco repetições de 20 sementes cada, durante 10 dias. A temperatura de $25^{\circ} \mathrm{C}$ resultou 
em uma maior germinação em menor tempo (média de 7,4 dias), comparada a de $30^{\circ} \mathrm{C}$. A temperatura de $35^{\circ} \mathrm{C}$ não apresentou germinação e a de $40{ }^{\circ} \mathrm{C}$ foi letal, revelando que esta espécie é sensível à mudança térmica em até cinco graus centígrados da sua temperatura ideal. A temperatura ótima para germinação da espécie é, portanto, $25^{\circ} \mathrm{C}$. Variações na temperatura podem diminuir o poder germinativo da $P$. pluviosa ou até impossibilitar sua germinação, o que torna esta espécie sensível às mudanças climáticas previstas em cenários mais drásticos para o futuro.

Planning optimized ecological restoration using drones in the Piraí do Sul National Forest, Paraná, Brazil / Planejamento da restauração ecológica otimizado pelo uso de VANT na Floresta Nacional de Piraí do Sul, PR

Patricia Portela Feldmann ${ }^{1}$, Marlon Prestes ${ }^{1}$, Leonardo Gomes Glir², Carolina Mesquita ${ }^{2}$, Maria Vitória Yamada Müller ${ }^{1}$, Alessandra Xavier de Oliveira ${ }^{1}$ ${ }^{1}$ Instituto de Pesquisa em Vida Selvagem e Educação Ambiental, Curitiba, Brasil;; ${ }^{2}$ Notus Topografia, Curitiba, Brasil (patricia.feldmann@spvs.org.br; sig@spvs.org.br; leonardo@notustopografia.com.br; carolina@notustopografia.com.br; vitoria.consultoria@spvs.org.br; alessandra.xavier@spvs.org.br)

Este trabalho apresenta o estudo de caso realizado na Floresta Nacional de Piraí do Sul (FLONA) - PR, elaborado no contexto do Projeto Conexão Araucária em curso pela SPVS, financiado pelo BNDES. A FLONA tem 150 hectares (ha) e está inserida no bioma Mata Atlântica. O projeto tem como proposta iniciar o processo de restauração ecológica em 36 ha de áreas que antes eram recobertas por reflorestamento de pinus. Para agilizar o planejamento da restauração e obter um refinamento do diagnóstico ambiental foi realizado um sobrevoo com veículo aéreo não tripulado (VANT) multirotor (drone), que forneceu informações com precisão geográfica, imagens de alta resolução e planialtimetria da área. As cinco Zonas de Restauração definidas no Plano de Manejo da FLONA, foram subdivididas em polígonos de acordo com a sua heterogeneidade física e ecológica. A visita de campo e o mapeamento oferecido pelo DRONE possibilitaram identificar as técnicas de restauração mais adequadas para cada situação. Os dados permitiram a análise da paisagem e dos solos, como: proximidade de remanescentes de florestas nativas, existência de fluxo de água, regeneração natural, erosão, exposição e compactação do solo, deficiência hídrica, e declividade. O mapa gerado otimizou tempo e recursos para a restauração, e o modelo digital de elevação propiciou o monitoramento do crescimento e altura da vegetação com menor esforço de campo.

Intensity and cutting cycle of a population of Protium altsonii Sandwith (breu vermelho) in the upper Capim River region of Paragominas, Pará, Brazil / Intensidade e ciclo de corte de uma população de Protium altsonii sandwith (breu vermelho) na região do alto Rio Capim, Paragominas, Pará

Kenia Brito' ${ }^{1}$ Fabricio Gomes ${ }^{2}$, Esther Castro², Lucas Mazzei ${ }^{3}$

${ }^{1}$ Universidade de Brasília, Brasília , Brasil; ${ }^{2}$ Universidade Estadual da Região Tocantina do Maranhão, Imperatriz, Brasil; ${ }^{3}$ Embrapa Amazônia Oriental, Belém,Brasil (keniaribeiro_@hotmail.com; freisflorestal@gmail.com; ebandeiradecastro@gmail.com; lucas.mazzei@embrapa.br)

As espécies arbóreas comercias mais exploradas na Amazônia necessitam ter suas populações estudadas em termos dinâmicos pois os incrementos diamétricos e os ciclos ótimos de corte variam por espécie e por sítio. O objetivo deste trabalho foi estimar uma intensidade e um ciclo de corte para uma população de Protium altsonii Sandwith em uma área de 100 ha na Fazenda Rio Capim. Os dados foram obtidos em 18 parcelas permanentes de 100 x $100 \mathrm{~m}$, que foram medidas em oito ocasiões (2004, antes da exploração, e 2005, 2006, 2008, 2010, 2012, 2014 e 2016 após exploração), considerando os indivíduos com DAP (diâmetro a 1,30 $\mathrm{m}$ do solo) $\geq 20 \mathrm{~cm}$. Foi calculado o incremento em volume no período considerado (após exploração) e transformado em valor percentual (IPAv\%), intensidade e o ciclo de corte com base na teoria de crescimentos relativos anuais volumétricos seguindo a regra dos juros compostos, considerando os indivíduos com DAP $\geq 55 \mathrm{~cm}$. A intensidade de corte obtida para população de árvores comerciais vivas de $P$. altsonii com DAP $\geq$ DMC, foi de $23,9 \mathrm{~m}^{3} \mathrm{ou} 1,3 \mathrm{~m}^{3}$.ha- 1 , a partir de uma taxa de crescimento volumétrico de 14,1 \% a.a. e ciclo de corte de 35 anos. Observou-se na área de estudo que, uma exploração considerando uma taxa de corte de até 99\% do volume disponível, permite a produção madeireira continuada da espécie no ciclo de corte de 35 anos. Assim, para uma produção sustentada da espécie é necessário considerar a intensidade de corte mediante o volume comercial disponível.

Case study: reparatory activities in a brownfield area of Ribeirão Santo Antônio do Grama in Minas Gerais, Brazil / Estudo de caso: ações reparatórias em um trecho antropizado do Ribeirão Santo Antônio do Grama em Minas Gerais

Elizabeth Neire da Silva ${ }^{1}$, Rogério Vasconcellos Pinto ${ }^{2}$, Gabriel Vargas Mendonça ${ }^{2}$, Vanessa Pataro Maffia ${ }^{1}$, Luana Oliveira Caló ${ }^{1}$

${ }^{1}$ Agroflor Engenharia e Meio Ambiente, Viçosa, Brasil; ${ }^{2}$ Anglo American, Belo Horizonte, Brasil (elizabeth@agroflor.com.br;

rogerio.vasconcellos@angloamerican.com; gabriel.mendonca@angloamerican.com; vanessa.maffia@agroflor.com.br; luana.calo@agroflor.com.br)

Em função de dois vazamentos de um mineroduto em Santo Antônio do Grama, foram propostas ações de estabilização e recuperação de áreas de preservação permanente (APPs) do ribeirão, como forma e medidas mitigatórias e compensatórias. As ações de recuperação contemplam proprietários rurais e abrangem aproximadamente $8 \mathrm{~km}$ de calha do ribeirão. Todas proposições foram fundamentadas na Lei Federal $\mathrm{n}^{\circ}$ 12.651/12 para definição da largura das APPs que variam de acordo com a extensão em módulos fiscais, que resulta em faixas estreitas e isoladas em uma matriz de campos antrópicos. Utilizando-se dessa premissa, utilizou-se métodos diversos e diferentes do convencional, propostos especificamente para a área de estudo, e testando métodos alternativos com a priorização de higrófilas, heliófilas, pioneiras e ruderais, especialmente não arbóreas, com predomínio de herbáceas e arbustivas. Primeiramente, fez a remoção de todo minério do leito e margens do rio. Posteriormente, utilizou-se resgate, transplantio e reintrodução de flora, semeio manual de nativas e plantio de mudas para recobrimento das bordas, calha e APP's. O término das atividades ocorreu em janeiro de 2019, quando iniciaram-se as atividades de monitoramento das áreas que irão durar pelo menos 30 meses e gerarão novos dados científicos. Os resultados já alcançados demonstram que a área apresentará no futuro qualidade ambiental superior ao cenário antes do ocorrido.

\section{B1q: FORESTS AND CLIMATE CHANGE}

Proposed governance for landscape recovery in two regions in Chile / Una propuesta de gobernanza para la restauración de paisajes en dos regiones de Chile

Roger Villalobos ${ }^{1}$, Natalia Ruiz-Guevara ${ }^{1}$, Leonardo Duran Gárate ${ }^{2}$

${ }^{1}$ Centro Agronómico Tropical de Investigación y Enseñanza, Turrialba, Costa Rica; ${ }^{2}$ Universidad Mayor de Chile, Santiago de Chile, Chile (rvillalo@catie.ac.cr; natalia.ruiz@catie.ac.cr; leonardo.duran@umayor.cl)

La ocurrencia de los megaincendios forestales del periodo 2016-2017, que afectó más de 500 mil hectáreas, se concentró en las regiones de O’Higgins y del Maule. Para abordar el desafío de la restauración a escala de paisaje, el Ministerio de Medio Ambiente solicitó elaborar una propuesta de gobernanza, que oriente a 
actores clave de nivel regional y nacional para su articulación, bajo una visión integrada. Para construir las bases de la propuesta se realizaron entrevistas, revisión bibliográfica y talleres para el diagnóstico de las bases técnicas, organizativas, de conocimiento y experiencias relacionadas a restauración en ambas regiones; así como un análisis institucional y de lecciones aprendidas de otros contextos. Como resultado, se propuso la conformación de estructuras descentralizadas para la participación, aprendizaje y toma de decisiones en las escalas local, regional y nacional, que trabajen de manera colaborativa en cuatro ejes centrales: coordinación, participación y promoción, gestión del conocimiento y fortalecimiento de capacidades, y financiamiento. En en torno a estos ejes se propuso estrategias para la puesta en marcha de las estructuras y acciones para la implementación, tales como la identificación de territorios prioritarios para la restauración, la definición de roles y funciones, la toma de acuerdos y compromisos de acción por parte de actores clave, y el diseño conjunto de indicadores para el monitoreo. La estructura se vinculará con el Comité Nacional de Restauración con el objetivo de replicar en otras regiones los procesos de participación integrada, para abordar las necesidades de restauración bajo una visión nacional.

\author{
Survival and growth of Brazil-nut (Bertholletia excelsa Humb. \& Bonp.) seedlings in tree-fall gaps and forest understory \\ Jorge Santiago Garate Quispe ${ }^{1,2}$ (D), Rosel Quispe-Herrera ${ }^{2}$, Percy Zevallos-Pollito ${ }^{1}$ \\ ${ }^{1}$ Departamento Académico de Ingeniería Forestal, Universidad Nacional Amazónica de Madre de Dios, Puerto Maldonado, Madre de Dios, Peru; ${ }^{2} H e r b a r i o$ \\ Alwyn Gentry, Universidad Nacional Amazónica de Madre de Dios Puerto Maldonado Peru; ${ }^{3}$ Departamento Académico (jgarate@unamad.edu.pe; \\ roquihe@yahoo.es; pazpolli@yahoo.com.br)
}

This study aimed to evaluate the influence of canopy openness on survival and growth of Bertholletia excelsa seedlings, through experimental plantings in tree-fall gaps and forest understory in Madre de Dios, Perú. Sixty-four seedlings were planted within the experimental design, with eight repetitions each with four seedlings in two treatments of canopy openness. Basal diameter, height, and incidences of mortality and regrowth of seedlings were evaluated for twelve months. The survivorship, the annual increase in height and diameter were significantly higher in gaps than in the understory $(\mathrm{P}$-value $<0.05)$. The regression analysis showed a direct and highly significant relationship between canopy openness and diameter increment $\left(\mathrm{r}^{2}=0.61\right)$ and between canopy openness and height increment $\left(\mathrm{r}^{2}=0.34\right)$. We recommend the use of Brazil-nut seedlings in enrichment planting of forests in Madre de Dios, using large gaps and guarantee high growth rates.

\title{
Aboveground biomass quantification and tree-level prediction models for the Brazilian Subtropical Atlantic Forest \\ Heitor Felippe Uller ${ }^{1}$, Laio Zimermann Oliveira ${ }^{1}$, Aline Renata Klitzke ${ }^{1}$, Jackson Roberto Eleotério ${ }^{1}$, Alfredo Celso Fantini ${ }^{2}$, Alexander Christian Vibrans ${ }^{1}$ ${ }^{1}$ Fundação Universidade Regional de Blumenau, Blumenau, Brasil; ' 2 Universidade Federal de Santa Catarina, Florianópolis, Brasil (heitor.ullerfflorestal@gmail.com; laiozoliveira@gmail.com; klitzkealine@gmail.com; eleoterio@furb.br; alfredo.fantini@ufsc.br;acv@furb.br)
}

Forests are the largest biological reservoir of biomass and carbon on the planet. This turns them into the main tool to neutralize the $\mathrm{CO}_{2}$ emitted by human activities. Despite such importance, the uncertainties associated with biomass estimates in forests, especially in (sub)tropical forests, are enormous. Facing this scenario, the objectives of this study were: (i) to quantify through destructive sampling the aboveground biomass (AGB) of 105 trees of 47 species occurring in a secondary subtropical evergreen rainforest in Brazil; (ii) to investigate the AGB distribution in different tree compartments; and (iii) to fit tree-level models to improve biomass estimates for the referred forest type. The results revealed that most of the AGB was stored in the compartmentsstem and large branches (diameter $\geq 5 \mathrm{~cm}$ ). There was an increase in the proportion of biomass-in relation to the total treeAGB( $\mathrm{kg}$ ) - allocated in the large branches as tree diameter at breast height (DBH) increased; this pattern was not observed for the compartmentsstem, thin branches (diameter $<5 \mathrm{~cm}$ ), andleaves. The compartments thin branches andleaves represented between $5.4 \%$ and $17.0 \%$ and $1.3 \%$ and $2.9 \%$ of the total tree AGB, respectively. From the 10 fitted biomass models, the linearized power models yielded the smallest errors. The best performance model, which returned a mean bias of $1.7 \%$, may be written as AGB $=\exp (-8.9807$ $+2.1642 \cdot \ln (\mathrm{DBH})+0.5072 \cdot \ln (\mathrm{h})+0.9999 \cdot \ln (\rho \mathrm{bas})) ;$ Baskerville's factor $=1.0175$.

\section{Replanting Lives: convicts helping to restore forests / Replantando Vida: presidiários contribuindo para a restauração florestal}

Alan Henrique Marques de Abreu ${ }^{1,2}$, Elton Luis da Silva Abel ${ }^{1,2}$, Paulo Sérgio dos Santos Leles ${ }^{2}$, Alcione Duarte Ferreira ${ }^{1}$, Jorge Makhlouta Alonso ${ }^{2}$ ${ }^{1}$ Companhia Estadual de Águas e Esgotos, Rio de Janeiro, Brasil; ${ }^{2}$ Universidade Federal Rural do Rio de Janeiro, Seropédica, Brasil (alan.abreu@cedae.com.br; elton@cedae.com.br; pleles@ufrrj.br; alcione@cedae.com.br;j_makh@hotmail.com)

O Programa Socioambiental Replantando Vida, desenvolvido no Rio de Janeiro, pela Companhia Estadual de Águas e Esgotos (CEDAE), emprega presidiários em atividades da cadeia produtiva da restauração florestal, com oportunidade de trabalho digno, capacitação profissional e geração de renda, sendo uma alternativa interessante de integrar a necessidade de proteção de mananciais hídricos com a necessidade de promover a ressocialização de apenados, em uma relação ganha-ganha, com reflexos sociais, econômicos e ambientais. Os apenados atuam desde a coleta de sementes, produção de mudas, até o plantio e manutenção dos reflorestamentos. O objetivo deste trabalho é apresentar o modelo de fomento a restauração florestal, desenvolvido pelo Programa. A CEDAE emprega atualmente 439 apenados, em diferentes frentes de trabalho e um quarto desta mão de obra é utilizada na área ambiental. Os apenados recebem capacitação profissional, salário mínimo nacional, auxílio transporte e alimentação, além do direito garantido por lei de remissão de um dia de pena a cada três dias trabalhados. O Programa possui sete viveiros florestais estruturados, com capacidade instalada de 1,8 milhão de mudas ano-1. Parte das mudas produzidas nos viveiros florestais são plantadas em projetos de recuperação de nascentes e matas ciliares pelos próprios apenados, e o restante é disponibilizado gratuitamente para projetos voluntários de restauração florestal em todo o estado do Rio de Janeiro. De 2015 a 2018, o programa já disponibilizou 518.000 mudas florestais para projetos de restauração florestal, em 47 municípios do estado, desenvolvidos por instituições públicas, privadas, organizações sociais, pessoas físicas e produtores rurais.

\section{Analysis of ecological resilience and resistance in temperate forest systems in central Mexico / Análisis de resiliencia y resistencia socioecológica en sistemas forestales templados del centro de México \\ Lesly Elizabeth Solis Mendoza ${ }^{1}$ D, Leopoldo Galicia Sarmiento ${ }^{1}$ \\ ${ }^{1}$ Instituto de Geografia, Universidad Nacional Autónoma de México, Ciudad de México, Mexico (l.solis@ciencias.unam.mx; lgalicia@igg.unam.mx)}

Los ecosistemas forestales templados se enfrentan al aprovechamiento intensivo-extensivo, baja cobertura de áreas forestales de conservación, políticas de intensificación de extracción de madera y bajo capital social, comprometiendo su resistencia y resiliencia. El aprovechamiento sostenible de la producción forestal es imprescindible para asegurar la resiliencia sociecológica que permita conservar sus funciones, capacidad autorganizativa, de aprendizaje y de adaptación al cambio bajo las nuevas presiones antropogénicas. El objetivo de este trabajo fue comparar la resiliencia sociecológica de dos sistemas de manejo 
forestal (un sistema intensivo y otro semi-intensivo) a través de indicadores de resiliencia en bosques templados del centro de México. Se construyó un modelo socioecológico teórico y se definieron indicadores de resiliencia sociecológica. Los indicadores de capacidad de resiliencia fueron biomasa arbórea, fertilidad, diversidad e ingreso de las familias productoras. Los indicadores de autoorganización fueron afiliación a organizaciones productoras, nivel de dependencia económica en la producción, rendimientos e ingreso familiar anual. La habilidad de construir capacidades para el aprendizaje y resiliencia se evaluó a partir de la disposición de los ejidatarios hacia la transición de un aprovechamiento forestal multipropósito. Los resultados muestran que en ambos sistemas de manejo la biomasa arbórea se recupera, pero en el método intensivo las tasas de fertilidad se reducen drásticamente en cada ciclo. Por otro lado, en el sistema de aprovechamiento intensivo la capacidad autorganizativa y diversificación de aprovechamiento en recursos forestales fueron mayores. Finalmente, el sistema de aprovechamiento intensivo resulta tener una mayor resiliencia social y menor resiliencia ecológica con relación al sistema semi-intensivo.

\section{Volume equations for Southern Amazonas, Brazil / Equações de volume para região Sul do Estado do Amazonas \\ Érico Trevisan ${ }^{1}$, Alberto Pinto ${ }^{1}$, Joaquim Santos 2 , Adriano Lima ${ }^{2}$, Niro Higuchi' ${ }^{2}$, Victor Andrade ${ }^{3}$ \\ ${ }^{1}$ Universidade Federal do Amazonas, Manaus, Brasil; ${ }^{2}$ Instituto Nacional de Pesquisa da Amazônia, Manaus, Brasil; ${ }^{3}$ Universidade Estadual do Centro- Oeste,Irati,Brasil(ericotrevisan@hotmail.com; albertocarlos@ufam.edu.br; joca@inpa.gov.br; adrianolmf@gmail.com; higuchi.niro@gmail.com; victorhugofandrade@gmail.com)}

A exploração madeireira em regime de manejo florestal sustentável tem sido fundamental no desempenho econômico da região. Para utilizar os produtos da floresta, por lei, é necessário Plano de Manejo Florestal Sustentável - PMFS com informações técnicas e específicas com dimensionamento volumétrico do local. Atualmente, o volume comercial é calculado por equação com o uso do fator de forma 0,7 proposto por Heinsdijk (1963), beneficiando o mercado de madeira ilegal por meio da homologação de créditos virtuais no Sistema Nacional de Controle da Origem dos Produtos Florestais - SINAFLOR. Portando, foram testados seis modelos de regressão, sendo três de simples e três com dupla entrada, visando selecionar a equação que melhor representa o volume de madeira comercial das árvores em pé numa área de manejo florestal licenciada no município de Novo Aripuanã-AM. Foram geradas 6 equações de volume com base nos modelos selecionados, utilizando dados da cubagem rigorosa de 323 árvores de espécies comerciais com diâmetros acima de 0,5 metros. Adotando os critérios estatísticos, Syx(\%), R²ajustado, Incerteza(\%), Critério de Informação de Akaike (AIC), elencados no ranking de seleção sugerido por Bartoszeck (2000) e validação pela estatística do Qui-quadrado $\left(X^{2}\right)$, foi possível afirmar que a equação $V=0,8643 * 0,0007 * D^{2} P^{2}\left(R^{2}\right.$ aj. $\left.=0,82\right)$ gerada pelo modelo de Kopezky e Gehrhardt apresentou melhor resultado com simples entrada e a equação $\mathrm{V}=7,3035+(-0,1045 * \mathrm{DAP})+0,0004 * \mathrm{DAP}{ }^{2}+0,0145 *(\mathrm{DAP} * \mathrm{Hc})+$ $0,0000 *\left(\mathrm{DAP}^{2 *} \mathrm{H}\right)+(-0,7813 * \mathrm{Hc})\left(\mathrm{R}^{2} \mathrm{aj} .=0,88\right)$ gerada com base no modelo de Meyer apresentou melhor ajuste dentre os modelos com dupla entrada.

\section{Assessment of cashew production potentials and ComCashew contributions for restoring the productive capacity of degraded lands and forests in Sierra Leone}

Mintah Agyarko', Abraham Conteh², Mohamed Salifou Issaka', Rita Weidinger ${ }^{1}$, Medgar Brown $^{3}$

${ }^{1}$ GIZ, Accra, Ghana; ${ }^{2}$ Ministry of Agriculture and Forestry, Freetown, Sierra Leone; ${ }^{3}$ Balmed Holdings Ltd, Freetown, Sierra Leone (agyarko.mintah@giz.de; abratu2006@gmail.com; issaka.salifou@giz.de; rita.weidinger@giz.de; med@balmedholdings.com)

Sierra Leone is a post-conflict and post-Ebola country in West Africa. Large scale land degradation caused by unsustainable use of forest resources and mining practices have resulted in low productivity of agricultural lands. With a low requirement of inputs, Cashew is a crop for smallholders and also a tree crop for soil conservation, restauration of degraded lands and climate change mitigation. After having built a basis for the cashew sector in the five African project countries, ComCashew aims now to consolidate its achievements and scale up its interventions to other countries. To get started in Sierra Leone, the project conducted a baseline study in 2017 to assess the potential of cashew cultivation as a crop for restoring the degraded lands and forests. Data from 231 households in 10 districts have been collected to determine the extent to which farmers are involved in cashew production, their production and selling practices and also to understand the knowledge gaps for future intervention strategies. The findings show that $22 \%$ of the responded households have been growing cashew for more than 10 years, whiles $75 \%$ have been growing it for less than 5 years. Only $9 \%$ of the households have had some training on cashew whilst $60 \%$ of them have a yield of no more than $100 \mathrm{~kg} / \mathrm{ha}$. Planting degraded, deforested and new lands with improved planting materials, agroforestry, capacity building and access to market are key intervention areas for the project activities. Project interventions will concern a total of 30,000 farmers.

Small islands with big ideas: systems using traditional resources and resistance to climate change in the South Pacific / Islas pequeñas con ideas valiosas: sistemas del uso de los recursos consuetudinarios y la resiliencia al cambio climático en el Pacifico Sur

Dan Orcherton

${ }^{1}$ UNSCH, Pichari (Cuzco), Peru (orchertonandsudario@gmail.com)

Comprender la resiliencia de los sistemas socios ecológicos al cambio climático es uno de los asuntos más cruciales del mundo en la actualidad. Revisamos el estado de los sistemas de conocimiento en cuanto a resiliencia y adaptación, y destacamos las necesidades críticas de investigación para abordar las áreas interrelacionadas de: (1) Experiencia local y observaciones de cambio con respecto al clima, historia de vida ciclos y procesos ecológicos; (2) Instituciones y prácticas consuetudinarias de gestión de recursos (es decir, con agroforestales y el entorno marino costero); y (3) los roles de los líderes, las instituciones sociales y las redes sociales en el contexto de la perturbación y el cambio. Se llegó a la conclusión de que estos sistemas de conocimiento pueden aportar observaciones de alta resolución, datos de referencia y conocimientos sobre prácticas que mejoran la resiliencia y la capacidad de adaptación en sistemas terrestres y marinos integrados. Los enfoques basados en la participación comunitaria) pueden complementar y establecer modelos climáticos fundamentales y dirigir las medidas de gestión, investigación y adaptación de recursos culturalmente apropiados. Aunque la mayoría de las islas del Pacífico son geográficamente pequeñas, sus sistemas de conocimiento incluyen valiosa información sobre los ciclos estacionales, los procesos ecológicos y la gestión de la diversidad biocultural que son relevantes a gran escala para comprender la resiliencia y la adaptabilidad a los efectos socio-ecológicos del cambio climático. 


\title{
Major bottlenecks for the restoration of natural forests in Chile
}

\author{
Jan R. Bannister ${ }^{1}$, Rodrigo Vargas-Gaete ${ }^{2}$,Juan F. Ovalle ${ }^{3}$, Manuel Acevedo $^{1}$, Andrés Fuentes-Ramírez ${ }^{2}$, Pablo J. Donoso $^{4}$, Alvaro Promis $^{3}$, \\ Cecilia Smith-Ramirez ${ }^{4,5,6}$ \\ ${ }^{1}$ Instituto Forestal, Castro, Chile; ${ }^{2}$ Universidad de La Frontera, Temuco, Chile; ${ }^{3}$ Universidad de Chile, Santiago, Chile; ${ }^{4}$ Universidad Austral de Chile, \\ Valdivia, Chile; ${ }^{5}$ Universidad de Los Lagoss, Osorno, Chile; ${ }^{6}$ Instituto de Ecología y Biodiversidad, Santiago, Chile (jbannister@infor.cl; \\ rodrigo.vargas@ufrontera.cl; juan.ovalle@uchile.cl; macevedo@infor.cl; andres.fuentes@ufrontera.cl; pdonoso@uach.cl; alvaro.promis@gmail.com; \\ ceciliasmithramirez@gmail.com)
}

International agreements combined with the recent Chilean Forestry Policy (2015-2035) represent a challenge and an opportunity for forest landscape restoration (FLR) in Chile. Nevertheless, restoring over 500,000 ha using mainly native species seems like a daunting task by 2035. Here, we discuss the three major bottlenecks that currently constrain the restoration efforts of forest ecosystems in Chile. First, Chile urgently needs a national strategic plan for FLR, which should take into account mid- and long-term goals. There is also a need to prioritize resource allocation for an efficient use, promoting the creation of economic subsidies for restoration that consider different types of forest ecosystems. Second, there is a great need for better nursery protocols in plant production as well as to strengthen educational programs for professional and technical training, given the lack of high-quality personnel in Chilean nurseries. This would help increase the currently limited national plant supply, improving quality and increasing the diversity of native species suitable for forest restoration. Lastly, taking advantage of novel eco-technological tools and promoting innovative plantation design would help to overcome the usually deficient results in the establishment phase, leading to higher survival rates and promoting better performance of native species. Beyond current experiments that are relatively efficient on a small spatial scale, the practice of forest restoration needs to become massive and successful at a landscape scale. More and better applied research is crucial for improving the impact of FLR, so that Chile can achieve its forest restoration challenge in the next decade.

\section{Effects of tending on the species and functional diversity of woody plants in a secondary tropical lowland rain forest}

\author{
Yi Ding ${ }^{1}$, Runguo Zang ${ }^{1}$ \\ ${ }^{1}$ Institute of Forest Ecology, Environment and Protection, Chinese Academy of Forestry, Beijing, China (dingyi@caf.ac.cn; zangrung@caf.ac.cn)
}

The function and productivity of secondary forests are relatively low compared with old growth forests. Therefore, it may prove important to enhance the recovery rate and related ecosystem services of these forests through forest tending practices. Here, we explored the effects of tending measures on species and functional diversity of woody plants in a secondary tropical lowland rain forest in Bawangling forest region on Hainan Island. We logged trees which hindered the growth of the target species in 30 plots $(50 \mathrm{~m} \times 50 \mathrm{~m})$. The result showed that stem density in overstory $(\mathrm{dbh} \geq 5 \mathrm{~cm})$ and understory $(1 \mathrm{~cm} \leq \mathrm{dbh}<5 \mathrm{~cm})$ reduced by $24.9 \%$ and $59.9 \%$, and the basal area decreased by $13.1 \%$ and $54.9 \%$ after tending. The stem size distribution structure was not significantly changed after tending. Both the community species compositions in overstory and understory did not significantly change. Species diversity of overstory trees did not change significantly, but the effect of tending on understory trees was more significant. The specific leaf area, leaf dry matter content, leaf nitrogen content and leaf potassium content significantly decreased, but woody density and the maximum potential height significantly increased. Leaf chlorophyll content, leaf phosphorus content did not change significantly after tending. Functional richness decreased significantly, and functional evenness and functional divergence significantly increased, while functional dispersion did not change significantly after tending. Our results point to the various ways in which tending can change the trajectory of a secondary forest as it succeeds towards an old growth forest.

\section{Pattems and influencing factors for natural regeneration of Sorbus pohuashanensis in Eastern forest region of Northeast China}

Ling Yang ${ }^{1}$, Hailong Shen ${ }^{1}$

${ }^{1}$ State Key Laboratory of Tree Genetics and Breeding, School of Forestry, Northeast Forestry University, Harbin, China (yangling082477@yahoo.com; shenhl-cf@nefu.edu.cn)

Mountain ash (Sorbus pohuashanensis) is an endemic accompanying broad-leaved species in boreal coniferous forest and mountain dark coniferous forest distributed in single-scattered or contagious patterns in the Northeast and north China. As an important non-timber tree species, mountain ash has been overdeveloped recently and its population declined or even disappeared in some areas. We investigated the wild seedlings establishment, seed natural dispersal, soil seed bank and seedling emergence for the purpose of understanding the natural regeneration characteristics of this species and its influencing factors. We conclude that habitats have certain effect on seedlings establishment types of mountain ash, and human disturbance could significantly reduce the establishment ratio of root sprouts. Adequate seedling bank was not a limiting factor of mountain ash natural regeneration, but the transfer rate from diameter class II to diameter class III was very lower and was the key limit factor for mountain ash natural regeneration. The temporal and spatial pattern of soil seed bank had significant effect on mountain ash natural regeneration. Temperature may be a limiting factor for mountain ash natural regeneration. Soil moisture and burial depth were the crucial factor in mountain ash natural regeneration. Insects and birds were the main predators for fruits on tree crown layer. The intensive predation of fruit and seeds decreased seed resources and limited natural regeneration of mountain ash. But the predation promoted the dispersal of seeds ofmountain ash that favorite the natural regeneration and extension of population of mountain ash.

\section{Ecological and social barriers to successful restoration of mangrove forests under a community-based management regime}

Daniel Schoenig ${ }^{1}$, Manon Davies ${ }^{2}$

${ }^{1}$ Centre for Forest Research, Université du Québec à Montréal, Montréal, Canada; ${ }^{2}$ Schutzwaldverein e.V., Radolfzell, Germany

(schonig.daniel@courrier.uqam.ca; manondavies@rocketmail.com)

A major part of the mangrove forests in the Gulf of Guayaquil (Ecuador) was converted to shrimp aquaculture throughout the 20th century. The remaining forests are crucial for supporting the livelihoods of local communities, coastal protection and carbon sequestration. What are the decisive ecological and social barriers that restoration efforts have to overcome to restore mangrove forests and their ecosystem services? How relevant are social barriers compared to ecological ones? To investigate these questions we analyzed restoration trajectories within a community-managed area that is part of the Ramsar site "Don Goyo". We traced natural regeneration and institutional change over a five-year period by integrating forest inventories and regeneration assessments of nine abandoned shrimp ponds with interviews of key stakeholders. Contrary to our expectations, ecological barriers could be easily identified and overcome. In eight of the nine ponds, established natural regeneration far exceeded a minimum density of 1500 trees per hectare. Ecological barriers also were regarded as 
less important by local stakeholders. Rather, safe access to restored areas, a functioning management council including all communities of the area, adaptive institutions within the communities, and education efforts appeared to be most relevant to restore mangrove ecosystem services. Our analysis thus emphasizes that these social factors must explicitly be accounted for as they may be decisive for success of restoration efforts, especially in a community-based management context and under low-input conditions. In addition, we consider the most influential factors within our study also potential targets for efforts to enhance resilience and adaptive capacity.

\section{Rooting of Apuleia leiocarpa (Vogel) J. F. Macbr. minicuttings}

Deborah Barroso ${ }^{1}$, David Siqueira ${ }^{1}$, Giovanna Carvalho ${ }^{1}$

${ }^{1}$ Universidade Estadual do Norte Fluminense Darcy Ribeiro, Campos dos Goytacazes, Brasil (deborah@uenf.br; pessanhasdavid@hotmail.com; giovannacampos85@yahoo.com.br)

The Apuleia leiocarpa is a brazilian Atlantic Forest species valued for its timber and medicinal uses. There is a growing seedlings demand for reforestation, environmental adequacy of rural properties in accordance with laws, and to commercial purposes. This study aimed to evaluate the $A$. leiocarpa minicuttings rooting aiming the vegetative propagation. Sprouts of mini-stumps produced by seeds were collected for mini-cuttings production. Minicuttings of the apical and intermediate segment of these sprouts were made. The work was carried out in completely randomized design with 10 plots per treatment, composed of 15 minicutting each. After staking in $280 \mathrm{~cm}^{3}$ polyethylene tubes, the minicuttings were taken into the nebulization chamber and at 40 days they were evaluated for survival, percentage and quality rooting, and then transferred to greenhouse. At 165 days after staking the seedlings were evaluated for survival, base diameter, height, leaf area and rooting, using WinRhizo software. There was a greater survival of intermediate minicuttings in relation to the apical ones, both in the expedition of the rooting sector (58 and $85 \%$, for apical minicuttings and intermediate ones, respectively), and in the final evaluation of the seedlings (13\% apical mini-cuttings and $42 \%$ intermediate). There was no difference in the rooting percentage between the propagules in the nebulization chamber, reaching on average $49 \%$. However, the intermediate minicuttings had a higher number of roots. At the end of the cycle, the mean height was higher in the clonal seedlings originated from intermediate minicutting $(21 \mathrm{~cm})$

\section{Rooting of Paratecoma peroba (Record) Kuhlm. and Amburana cearensis (Allemão) A. C. Sm. minicuttings}

\section{Deborah Barroso ${ }^{1}$, David Siqueira ${ }^{1}$, Giovanna Carvalho ${ }^{1}$, José Gabriel Silva ${ }^{1}$}

${ }^{1}$ Universidade Estadual do Norte Fluminense Darcy Ribeiro, Campos dos Goytacazes,Brasil (deborah@uenf.br; pessanhasdavid@hotmail.com; giovannacampos85@yahoo.com.br; jgabrielshs@gmail.com)

The minicutting can be an alternative for species of difficult access, irregularity in seed production, and a short shelf life when stored, limiting supply of seedlings. The aim of this work was to establish an optimal time in a nebulization chamber for rhizogenesis in juvenile Paratecoma peroba and Amburana cearensis minicuttings. The staking was carried out in polypropylene tubes $\left(120 \mathrm{~cm}^{3}\right)$, with commercial forest substrate. After staking of 192 minicuttings of A. cearensis (96 apical and 96 basal) and 70 minicuttings of $P$. peroba, the tubes were taken to the nebulization chamber with sprays of 30 seconds, every 15 minutes. At 30 days the rooting evaluation was started, and 10 live minicuttings were taken at random. The procedure was repeated every 10 days, up to 70 days after staking. Rooting (\%) and total length of roots per clonal seedlings were evaluated. The $A$. cearensis began rooting at 40 days after staking, with a higher rooting of apical minicuttings. Up to 70 days, $60 \%$ rooting was observed in apical minicuttings and $30 \%$ in basal, with an average length of $27.7 \mathrm{~cm}$ and 14.45 $\mathrm{cm}$, respectively. The $P$. peroba presented calluses in $90 \%$ of the minicuttings and $80 \%$ of rooting, which starts from 40 days after the staking. The adventitious roots of the $P$. peroba reached $24 \mathrm{~cm}$ of total length per seedling. Both species can be removed from the nebulization chamber from 50 days after staking, and studies are necessary to increase the rooting percentage of the basal minicuttings of $A$. cearensis.

\section{Innovative systems for large-scale environmental governance in agrarian reform settlements in Brazil: the Radis-Project Plataform}

Iris Roitman ${ }^{1}$, Tamiel Khan Baiocchi Jacobson ${ }^{1}$, Rômulo José da Costa Ribeiro ${ }^{1}$, Nivea Jorgia Silva Marcondes ${ }^{1}$, Luciana Silva Estevam ${ }^{1}$, Raimundo Fagner Vansconcelos ${ }^{1}$, Carla Silva Souza ${ }^{1}$, Paula Daniella Prado Ramos ${ }^{1}$, José Tito Lima Neto ${ }^{1}$, Reinaldo José de Miranda Filho ${ }^{1}$, Mário Lucio de Avila ${ }^{1}$

${ }^{1}$ Radis Project, Faculdade Unb Planaltina (FUP), Universidade de Brasília, Planaltina,Brasil (irisroitman01@gmail.com; tamiel@unb.br; rjcribeiro@unb.br; marcondes.nivea@gmail.com; luestevam@hotmail.com; raimundofagner83@gmail.com; carlassousa.css@gmail.com; dannyprado8@gmail.com; ljostito@gmail.com; rjmiranda@unb.br; unbavila@gmail.com)

In Brazil, there are 9,373 Agrarian Reform Rural Settlements (ARRS), comprising more than 87 million ha. Many of them have deforestation liabilities. The National Institute for Colonization and Agrarian Reform (Incra) is responsible for the environmental regularization of settlements in which farmers haven't obtained land tenure yet. The challenge for such large-scale environmental governance requires innovative solutions for big data collection and management. Therfore, the Radis Project, a partnership between Incra and the University of Brasilia, developed a platform to collect and integrate environmental and social data toward the environmental regulation (including the rural environmental registry) and sustainable development of ARRS in the state of Mato Grosso. The platform, developed with Open Data Kit, allows the collection of social, economic and environmental field data (text, numbers, media, geodata), with cloudbased storage, and its integration with satellite and other GIS-based data. We also developed a user-friendly platform to include restoration dynamics data in those areas, according to monitoring indicators (eg. morphotypes tree density, and tree cover) defined by state law. The system allowed the environmental assessment of 12,105 rural family units from 101 ARRS (991,843 ha) in 28 municipalities. Besides social and economic data, we identified native vegetation and consolidated areas (deforested areas in which restoration is not mandatory) and deforested areas in which restoration is mandatory. The platform proved effective for large-scale environmental monitoring and governance and research purposes and, thus, has been extended nationwide to other ten states.

\section{Deforestation and carbon dynamics between 2008 and 2016 and potential for ecosystems services in 55 agrarian reform settlements in Southeastern Amazon, Mato Grosso, Brazil}

Iris Roitman ${ }^{1}$, Rômulo José da Costa Ribeiro ${ }^{1}$, Tamiel Khan Baiocchi Jacobson ${ }^{1}$, Luciana Silva Estevam ${ }^{1}$, Nivea Jorgia Silva Marcondes ${ }^{1}$, Reinaldo José de Miranda Filho ${ }^{1}$, Mário Lúcio de Ávila

${ }^{1}$ Radis Project, Faculdade Unb Planaltina, Universidade de Brasilia, Planaltina, Brasil (irisroitman01@gmail.com; rjcribeiro@unb.br; tamiel@unb.br; luestevam@hotmail.com; marcondes.nivea@gmail.com; rjmiranda@unb.br; unbavila@gmail.com)

In the Amazon region, $80 \%$ of rural properties should be preserved as Legal Reserves. However, in small properties, restoration is not mandatory in areas deforested before July 2008. We evaluated deforestation and carbon (C) dynamics in 55 agrarian reform settlements in 23 municipalities of Mato Grosso, Brazil, between 2008 
and 2016. We used Sentinel images and field campaigns to determine settlements' perimeters and land-use changes. Carbon emissions were calculated using the Radam-IBGE CCSIVAN vegetation map (1:250,000) and carbon reference values from the FREL-Amazonia. The 55 settlements comprise $689,614.70$ ha of which $0.68 \%$ is made up of water bodies and rocky outcrops and 33,70 \% is covered with native vegetation, which represents $35 \mathrm{Tg}$ of C. Total deforestation was $454,133.93$ ha (66.30\%), corresponding to $68.07 \mathrm{Tg}$ of C. However, most of which (77.69\%) was deforested before June 2008 (352,825.34 ha, 52.43 Tgof C). Deforestation and associated carbon-emission rates between 2008 and 2016 were 12,663.57 ha $\mathrm{y}^{-1}$ and $1.96 \mathrm{Tg}^{-1}$. Most of the deforested areas comprise pastures with low productivity rates. Besides, competition with large-scale agribusiness farming is difficult. Although restoration of areas deforested before July 2008 is not mandatory, it can provide revenue from carbon credits, environmental reserve quotas, forest management and agroforestry. Besides small-scale livestock and farming, restoration efforts may provide ecosystem services, additional income and, thus, improve the livelihood of farmers.

\section{B1s: SILVICULTURE}

\section{Rehabilitation of mined-out and waste-dump areas using pre-selected forest tree species in Bagacay, Hinabangan, Samar, Philippines}

Angelito Exconde ${ }^{1}$, Albert Piñon ${ }^{1}$, Alan Castillo ${ }^{1}$, Analyn Pasagdan ${ }^{1}$, Maria Theresa de Alday ${ }^{1}$

${ }^{1}$ Ecosystems Research and Development Bureau, Department of Environment and Natural Resources, Los Baños, Laguna, Philippines

(erdb.excondelito@gmail.com; alpinon@yahoo.com; alan.castillo@usq.edu.au; arpasagdan@gmail.com; mtvdealday@gmail.com)

The destructive method of harnessing the mineral resources of Bagacay, Hinabangan in Western Samar, Philippines from 1956 to 1992 left tons of mine tailings containing toxic heavy metals that pollutes the water ways and surrounding landscapes. With the aim of rehabilitating the area using various tree species, ascertain the most suitable soil amelioration, and identify the best-performing tree species in terms of growth and survival, the study investigates the phytoremediation capacity of pre-selected trees in rehabilitating the mined-out and waste dump site. In 2009, the experiment was established using split-plot in Randomized Complete Block Design replicated three times with six soil amendments (main plot) and four pre-selected tree species (Pterocarpus indicus Willd., Acacia auriculiformis A. Cunn. Ex Benth, Acacia mangium Willd. and Gymnostoma rumphiana L. A. S. Johnson) for sub-plot. A total of 900 seedlings were planted in holes measuring $0.125 \mathrm{~m}^{3}$ at $3 \mathrm{~m} \mathrm{x} 3 \mathrm{~m}$ spacing with replanting for mortality applied only within a year after planting. Measurements of height, diameter and percent survival were undertaken in 2010, 2011, 2013 and 2016. After a year, growth and percent survival of trees treated with forest soil + chicken dung + lime were found significantly different compared to control (forest soil), but not in 2011, 2013 and 2016. In 2011, P. indicus performed best in terms of growth and percent survival, while A. mangium outperformed the other species in 2013. Finally, A. auriculiformis stand out after seven years.

\section{Mixing Silver fir (Abies alba) and European beech (Fagus sylvatica) leads to faster and more complete growth recovery following drought}

Julia Schwarz ${ }^{1}$, Jürgen Bauhus ${ }^{1}$

${ }^{1}$ Chair of Silviculture, University of Freiburg, Freiburg, Germany (julia.schwarz@waldbau.uni-freiburg.de; juergen.bauhus@waldbau.uni-freiburg.de)

In Europe, replacing drought-sensitive monocultures of spruce (Picea abies) with mixtures of European beech (Fagus sylvatica) and Silver fir (Abies alba) promises to be an effective forest management strategy as the latter two are expected to be more drought tolerant compared to spruce. This study investigates the influence of mixing Beech and Fir on the tree response to extreme drought stress using neighbourhood-analyses. We derived basal area increment (BAI) series from increment cores of 160 trees from 3 sites in south-western Germany and from 1 site in Croatia. In addition, for all trees, we determined the carbon isotope composition $(\delta 13 \mathrm{C})$ of latewood in a wet and dry year. At most sites, fir trees growing in mixed neighbourhoods exhibited higher BAI compared to firs from monospecific neighbourhoods while growth of beech trees was less affected by neighbourhood composition. Results of mixed models suggest that mixing benefits depend on tree size and neighbourhood density but not on species identity: Mixing improved growth of large trees from both species irrespective of neighbourhood density while for smaller trees benefits of mixing appeared only in trees from denser neighbourhoods. For either species, there was no benefit of mixing for growth resistance during the 2003-drought. Yet, trees in mixed neighbourhoods exhibited a smaller increase of $\delta 13 \mathrm{C}$ in the dry compared to the wet year as trees in monospecific neighbourhoods indicating complementary water-use of these 2 species under drought. Trees from both species showed higher growth recovery and resilience following drought in mixed compared to monospecific neighbourhoods.

\section{Effect of stump height on sprouting capacity of native tree species from Northeast Brazil}

Antonio Carlos Ferraz Filho ${ }^{1}$, Andressa Ribeiro ${ }^{1}$, Rodolfo Molinário de Souza ${ }^{1}$, Helionai Pereira da Silva ${ }^{1}$, Lucas de Souza Silva ${ }^{1}$, Lailla Sabrina Queiroz Nazareno ${ }^{1}$

${ }^{1}$ Universidade Federal do Piaui, Bom Jesus, Brasil(acferrazfilho@ufpi.edu.br; andressa.florestal@ufpi.edu.br; molinariodesouza@gmail.com; helionai_2012@hotmail.com; lucas045furtado@gmail.com; sabrinaaqueiroz@hotmail.com)

Wood extraction from native forests in Brazil is responsible for ${ }^{15} \%$ of the total industrial wood produced in the country. However, great care must be taken to ensure that managed areas are adequately restored. Stump height is an important variable to achieve this, since higher stumps might facilitate sprouting, but leave larger quantities of wood in the field. The objective of this study is to determine the impact of the stump height $\left({ }^{10}\right.$, ${ }^{20}$ and $\left.{ }^{30} \mathrm{~cm}\right)$ on the sprouting capacity of native tree species. The study area is located in Cristino Castro, Piauí, and is a transition vegetation between savannah (cerrado) and dry forest (caatinga); ${ }^{9}$ sample plots $\left({ }^{10} \mathrm{~m} \mathrm{x}{ }^{10} \mathrm{~m}\right.$ ) were clear cut (January ${ }^{2017}$ ) installing ${ }^{3}$ stump height treatments $\left(\mathrm{T}^{10}, \mathrm{~T}^{20}\right.$, $\mathrm{T}^{30}$ ). The plots were installed in a forest managed for fire wood production, clear-cutting followed by restoration through coppicing. Six months after cutting, all stumps were evaluated for the following traits: presence, number and height of the sprouts. Leaf area index (LAI) was measured in each plot using an AccuPAR LP- ${ }^{80}$ ceptometer. The results showed that stump height did not affect the percentage of sprouted stumps $\left({ }^{83} .9 \%\right)$, height of the dominant sprout $\left({ }^{111} .{ }^{4} \mathrm{~cm}\right)$ or LAI $\left({ }^{1} .{ }^{2} \mathrm{~m}^{2} / \mathrm{m}^{2}\right)$. The only statistically different variable was number of sprouts per stump, being double for $\mathrm{T}^{10}\left({ }^{24} \cdot{ }^{5}\right.$ sprouts/stump) than for the other two treatments ( ${ }^{12} .{ }^{3}$ sprouts/stump). These results are preliminary, additional plots are being implemented and will be monitored during a complete harvest cycle ( ${ }^{15}$ years). Acknowledgements: TAESA, Gurguéia Manejo Florestal. 


\section{$\mathrm{CO}_{2}$ removal by forest restoration in Amazon}

Carlos Sanquetta ${ }^{1}$, Alexis Bastos ${ }^{2}$, Mateus Sanquetta ${ }^{1}$, Marcelo Ferronato ${ }^{3}$, Ana Corte ${ }^{1}$

${ }^{1}$ Universidade Federal do Paraná, Curitiba, Brasil; ${ }^{2}$ Centro de Estudos Rioterra, Porto Velho, Brasil; ${ }^{3}$ ECOPORÉ, Rolim de Moura, Brasil

(carlossanquetta@gmail.com; alexis@rioterra.org.br; mateus.sanquetta@gmail.com; marcelo@ecopore.org.br; anapaulacorte@gmail.com)

Deforestation rates in the Amazon remain alarming, implying high levels of emission of greenhouse gases (GHG) into the atmosphere. Rondônia is one of the Brazilian states with the highest rates of deforestation in the country. Forest restoration is a concrete action to recover its biodiversity and ecological functions, as well as to mitigate GHG emissions, especially in protection zones and legal forest reserve as defined by law. $\mathrm{CO}_{2}$ removal of mixed young stands with native species implanted in family farms, aged between 5 and 7 years, was quantified. A forest inventory was carried out by establishing 40 permanent plots and the biomasses of 40 sample trees were determined by the destructive direct method. Laboratory analyzes of plant tissues were carried out. The total dry biomass was estimated at $65.77 \mathrm{t}$.ha ${ }^{-1}$, which has the following order of partitioning: stems $>$ branches $>$ roots foliage $>$ miscellaneous. The carbon stock stored in the stands was calculated at 29.60 t.ha $^{-1}$, which corresponds to $16 \%$ of the average stock of mature natural forest in the region. Carbon dioxide removal was estimated at $108.52 \mathrm{t} \mathrm{CO}_{2}$ eq.ha ${ }^{-1}$, which corresponds to the annual rate $16.99 \mathrm{t} \mathrm{CO}_{2}$ eq.ha- ${ }^{-1}$.year-1. It was concluded that, in spite of being young, these restoration stands store large amounts of carbon and promote GHG mitigation and help in recovering forest cover affected by deforestation. In addition to this role, the restoration stands in question play an important role in the recovery of biodiversity in this tropical region highly affected by the human perturbation.

\section{Forest regeneration challenges in a changing climate}

Alaba Emmanuel Gbadamosi ${ }^{1}$

${ }^{1}$ Adekunle Ajasin University, Department of Forestry \& Wildlife Management,, Akungba-Akoko, Nigeria (alaba.gbadamosi@aaua.edu.ng)

Extreme conditions of cold or heat are known to exclude trees. Fluctuating temperatures and unpredictable rainfall regimes which are hallmarks of changing climatic conditions, on the long run, will alter the composition of plants on the earth' surface. Forest helps to mitigate these unpleasant consequences when grown and managed sustainably. Forest trees are raised vegetatively or from seeds which engender variability. Seeds are propagules which carry genetic information from one generation to the other but these are impacted by inherent challenges of dormancy-a natural time clock, which is presently aggravated by unfavourable environmental conditions which promote irregular fruiting patterns. Dormancy of seeds is a major problem in artificial and natural regeneration process. Anthropogenic activities of unregulated forest conversions, uncontrolled exploitation and incessant fire outbreaks, and the economics matrix which precludes biological and ecological considerations have combined to limit the natural regeneration process of forest. Therefore, in order to combat the consequences of a changing climate on natural regeneration of forest trees especially in the tropics where forest are mainly revenue generating units; conservation and domestication of useful species, reinforcement of forest reserve boundaries, novel dormancy breaking mechanism, enrichment plantings of tree species with complex dormancy mechanism, seeding of forest floors and knowledge-driven storage system of recalcitrant seeds must be a priority in the new-look management of forest estate and resources. Conclusively, reforestation and afforestation projects must be re-initiated, re-invigorated and encouraged with adequate funding by governments, local and international agencies to arrest the diminishing forest estates.

\section{Quantifying growth response of trees to drought: a critique of the Lloret-concept and recommendations for future studies}

Julia Schwarz' Jörg Kunz', Martin Kohler ${ }^{1}$, Florian Schnabel ${ }^{2}$, Valentina Vitali ${ }^{3}$, Jürgen Bauhus ${ }^{1}$

${ }^{1}$ Chair of Silviculture/University of Freiburg, Freiburg, Germany; ${ }^{2}$ German Centre for Integrative Biodiversity Research (iDiv), Leipzig, Germany;

${ }^{3}$ Universitédu Québec à Montréal (UQAM), Montréal, Canada (julia.schwarz@waldbau.uni-freiburg.de; joerg.kunz@waldbau.uni-freiburg.de; martin.kohler@waldbau.uni-freiburg.de; florian.schnabel@idiv.de; valentina.vitali89@gmail.com; juergen.bauhus@waldbau.uni-freiburg.de)

The components of tree resilience, as originally proposed by Lloret et al. in 2011, have been widely applied to assess the drought tolerance of (radial) growth of trees for different purposes. The majority of studies calculated indices of resistance, recovery, and resilience to quantify the potential of silvicultural management, i.e. thinning or mixing of tree species, to improve drought tolerance. In other cases, they were used to compare the drought tolerance of trees of different species, populations, age, or dimension. Despite its wide application, the current concept exhibits some major drawbacks and limitations, which may lead to spurious results or misinterpretations of observed patterns. In this study, we, therefore identify and discuss several shortcomings of the Lloret-indices based on re-analyses of different datasets. In addition, we present a new approach that allows synthesizing the entire drought-related growth deviation of trees while considering the growth level of a given tree. In addition, we give recommendations for future studies that employ the Lloret concept concerning 1) the type of input data to be used (raw ring-widths, basal area increment, or standardized growth series), 2) objective selection procedures for the number of years included in pre- and post-drought periods and 3) cases where one should refrain from calculating indices of recovery. Finally, we propose that future studies should aim at relating short-term responses of trees to drought (i.e., the resilience indices) to the temporal stability of tree growth.

\section{Non-timber forest products and climate change adaptation by forest adjacent communities in selected forests in Kenya}

Roxventa Ongugo ${ }^{1}$, Jonah Kipsat ${ }^{1}$

${ }^{1}$ KEFRI, Nairobi, Kenya (rongugo@gmail.com; jonahkipsat@gmail.com)

Non-timber forest products (NTFPs) are products other than timber, extracted from the forest for the human use (Wiersum, 2003). The most commonly used NTFPs are medicinal plants, wild vegetables, fuelwood, and edible fruits.In this study, NTFPs were both direct benefits like food and healthcare and indirect benefits like biodiversity and ecotourism. The poor depend on economic activities sensitive to the climate; eg, agricultural and forestry activities that depend on local climate conditions; a change in those conditions could directly impact productivity levels and diminish livelihoods. Majority of the forest dependents have reduced opportunity to cope with the adversities of climate change due to low capabilities, poverty, weak institutional mechanisms and lack of access to resources (Brooks et al., 2005). Therefore, the main objective of the study was toassess the role of NTFPs to forest dependent communities as a strategy to cope/ adapt with the impacts of climate change. The study was conducted among communities in the selected forests. Questionnaires were the main methods of data collection. Tentative results showed that communities identified different NTFPS of importance to them. Majority of them also perceived changes in climate pattern due to increased temperatures and unpredictable rainfalls. The respondents admitted to use of NTFPs for subsistence and source of income as a climate change coping strategy. The study concluded that NTFPs still play a safety role in assisting communities cope withthe current climate change. 
Carbon sequestration associated with alternative strategies for the reforestation of degraded areas: an analysis of analog forests, plantation forests, and degraded pastures

\author{
Raul Ramos ${ }^{1}$, David MacFarlane ${ }^{2}$, Lauren Cooper ${ }^{2}$ \\ ${ }^{1}$ Escuela Superior Politécnica de Chimborazo, Riobamba, Ecuador; ${ }^{2}$ Michigan State University Department of Forestry, East Lansing, USA \\ (raulramos@gmail.com; macfar24@msu.edu; ltcooper@msu.edu)
}

In European countries and the United States, the ability of 'analog' forestry - a unique silvicultural approach which undertakes restoration of degraded land by focusing on high biodiversity and resiliency, but avoids agrochemicals and fossil fuels - to provide an alternative land restoration and carbon sequestration technique has been demonstrated. However, there has been little analysis comparing the potential for above- and below-ground carbon sequestration and storage in analog forests, monoculture forest plantations, and degraded pastures. Taking place in degraded farmland in the Cumaná, Ecuador, this study estimated the storage potential of organic soil carbon up to 1 meter in depth and in aboveground biomass in the three types of land use listed above. The study used a randomized split-plot design and evaluated the following variables: apparent density and organic carbon of the soil, diameter at breast height (DBH) and total height of the trees, and biomass estimated by use of allometric equations. The study found that analog and plantation forests stored higher quantities of total carbon (178 and $141 \mathrm{t} \mathrm{ha}^{-1}$, respectively) compared to degraded pasture (124 t ha $\mathrm{t}^{-1}$. These findings show that the analog forest system presents a high potential for intentional carbon sequestration. Furthermore, this approach generates other ecosystem products and services that provide economic resources for producers and communities. With planning, the analog forestry approach could be utilized in a transformative reforestation strategy for restoration of degraded areas at the farm and landscape levels to deliver high-impact carbon storage and human development benefits.

\title{
B2b: ABIOTIC STRESSORS AND THEIR INTERACTIVE IMPACTS ON FORESTS
}

\section{Population dynamics of endophytic fungi in monsoon forests of Cape York Peninsula, Northern Australia: water stress and biogeographical host affinities}

\author{
Jed Calvert ${ }^{1}$, Alistair McTaggart ${ }^{1}$, Lilia Costa Carvalhais $^{1}$, Paul Dennis ${ }^{1}$, Andre Drenth ${ }^{1}$, Roger Shivas ${ }^{1}$ \\ 1University of Queensland,Brisbane,Australia(j.calvert@uq.net.au; a.mctaggart@uq.edu.au; l.carvalhais@uq.edu.au; p.dennis@uq.edu.au; \\ a.drenth@uq.edu.au; r.shivas@uq.edu.au)
}

Fungal endophytes play important ecological roles in relation to their host plants, including promotion of plant growth, inhibition of plant pathogens and drought tolerance, which are all characteristics that have potential far-reaching applicability in the forestry sphere. However, the way in which massively diverse endophyte communities across the major terrestrial plant lineages respond to seasonal water stress is a question that has not yet been examined in tropical endophytes using culture-independent methods. The lowland rainforests of the Iron Range in north-eastern Australia experience extreme seasonal fluctuations in water availability due to the monsoon cycle. The aims of this study are to (a) establish how fungal endophyte diversity and community composition differ during the dry and wet seasons in the monsoon tropics, and (b) whether endophytes of host plants that evolved on the Sunda and Sahul continental plates exhibit differing community-level patterns of fungal colonisation. This information has the potential to direct agriculture-focused bioprospecting efforts to isolate beneficial fungal endophytes from the Australian tropics, and to clarify the degree to which land plants have developed divergent microbiomes over deep evolutionary time. We used high-throughput internal transcribed spacer (ITS) sequence analysis to compare the fungal endophyte communities in leaves and stems of plants in Cape York Peninsula sampled from wet and dry seasons. Twelve plant taxa were evaluated, including representative members of angiosperms, monocots, magnoliids and bryophytes.

\section{Change of gas exchange characteristics and chlorophyll fluorescence of three dominant tree species during the vegetation season in European hemi-boreal zone, Lithuania}

Vitas Marozas ${ }^{1}$, Ainis Pivoras ${ }^{1}$, Algirdas Augustaitis ${ }^{1}$

${ }^{1}$ Vytautas Magnus University, Kaunas,Lithuania (vitas.marozas@vdu.lt; ainis.pivoras@vdu.lt; algirdas.augustaitis@vdu.lt)

Current climate scenarios predict rising air temperature along with increasing frequency and intensity of summer drought in the Central and Eastern Europe. Severe drought episodes affect physiological processes in trees such as transpiration, photosynthesis and carbon allocation. Understanding gas exchange between plants and the atmosphere is important in woody plant research. The aim of this study was to evaluate differences in gas exchange characteristics and chlorophyll fluorescence of tree species prevailing in Lithuania (Scots pine, Norway spruce and Silver birch and their physiological response to water stress. The study was conducted in Aukstaitija integrated monitoring station, Lithuania. Gas exchange parameters and chlorophyll fluorescence was measured during the vegetation season of 2016-2018. Meteorological parameters were obtained from the monitoring station. Under moderate drought conditions all investigated tree species demonstrated reduced photosynthetic rates, lower stomatal conduction transpiration rates, water use efficiency, instantaneous carboxylation efficiency. During moderate drought, intercellular $\mathrm{CO}_{2}$ concentration of Norway spruce was higher and this species demonstrated the highest decrease in instantaneous carboxylation efficiency. No significant changes of maximal chlorophyll fluorescence (Fv/Fm) among species were detected during different weather periods. The investigated tree species reacted differently to weather conditions. The study confirmed the sensitivity of Norway spruce to drought conditions. The Silver birch was the least sensitive to temperature and humidity conditions variation. The Scots pine demonstrated the highest tolerance to different weather conditions.

\section{Waterlogging affected the production, mortality and longevity of fine roots in Scots pine saplings}

Tapani Repo ${ }^{1}$, Timo Domisch ${ }^{1}$, Jouni Kilpeläinen ${ }^{1}$, Sirpa Piirainen ${ }^{1}$, Ji Qian ${ }^{1,2}$, Marja Roitto $^{1}$, Ai-fang Wang $^{1,2}$, Leena Finér ${ }^{1}$, Samuli Launiainen ${ }^{3}$, Tarja Lehto $^{4}$ ${ }^{1}$ Natural Resources Institute Finland, Joensuu, Finland; ${ }^{2}$ Agricultural University of Hebei Baoding China; ${ }^{3}$ Natural Resources Institute Finland, Helsinki, Finland; ${ }^{4}$ University of Eastern Finland, Joensuu, Finland (tapani.repo@luke.fi; timo.domisch@luke.fi; jouni.kilpelainen@luke.fi; sirpa.piirainen@luke.fi; qianji167@163.com; mroitto@saunalahti.fi;wangaifang82@126.com; leena.finer@luke.fi; samuli.launiainen@luke.fi; tarja.lehto@luke.fi)

Excess soil water limits tree growth especially on peatlands but also on fine-textured mineral soils. Predictions for global change effects include increasing flooding events which may worsen the situation. Elevated water table impairs root functioning through oxygen deficiency but the implications for fine root dynamics are known poorly. We studied the effects of waterlogging (WL) on the phenology, longevity and mortality of short (1st order) and long (1st order) roots of Scots pine (Pinus sylvestris L.) saplings in two controlled laboratory experiments. Tree roots were monitored by minirhizotron imaging and their responses 
were compared with the aboveground physiology and growth. In the first experiment, five-week WL starting at the time of cessation of shoot elongation killed most of the saplings. Trunk sap flow decreased within a few days after WL onset. Short root mortality started to increase and root production and photosynthesis to decrease after three weeks of WL. Waterlogging decreased fine root longevity. In the second experiment, three weeks of WL in the beginning of growing season affected both roots and shoots. Interrupted WL alternating at one week intervals decreased root longevity more than continuous WL, whereas shoot elongation was affected more by continuous WL. In conclusion, elevated water table changed the fine root dynamics of Scots pine. Changing soil water table by changes in distributions of rainfall events may affect carbon cycle of trees through roots in boreal forest ecosystems more than previously envisaged.

\section{Drought reduces carbon storage and soil respiration: results from throughfall exclusion experiment in moso bamboo stand in Southeast China}

Benzhi Zhou', Xiaogai Ge ${ }^{1}$, Yonghui Cao ${ }^{1}$, Qian $\mathrm{Li}^{+}$

${ }^{1}$ Research Institute of Subtropical Forestry, Chinese Academy of Forestry, Hangzhou, China (benzhi_zhou@126.com; gexiaogai2006@163.com;

fjcyh77@sina.com; sxczliqian@163.com)

Drought can severely affects alteration of carbon sink-source relationships through impacts on carbon storage and carbon emission in forest ecosystems. Onsite field experiment is very rare on drought effect on forest carbon cycle, especially in subtropical forest ecosystems. In this study, we imposed drought to a moso bamboo stand by excluding throughfall to the forest floor beginning in July 2012, and measured biomass carbon, soil carbon, and soil respiration during specific period over the drought duration. Bamboo shoot number, new culm number, and their height and diameter at breast height were significantly lower in throughfall exclusion (TE) plots than in control (CK) plots, with decrease of 64.6, 70.8, 10.6 and 11.3\%,respectively. Annual carbon sequestration for TE plots was 58.1\% lower than that for CK plots. Soil carbon storage in the $0-60-\mathrm{cm}$ layer in CK and TE plots decreased by 3.7 and $12.2 \%$, respectively, during the 10-month experiment period. Drought led to $\sim 10 \%$ decrease for ecosystem carbon storage in moso bamboo stand. On the other hands, drought caused a significant decline $(\sim 25 \%)$ in annual soil respiration rate and $\mathrm{CO}_{2}$ emission $(\sim 26 \%)$, with the significant difference occurring in growing seasons. Drought does not change the exponential relationship between soil respiration and temperature, but decreases the temperature sensitivity, and the correlation coefficient between soil respiration and temperature/moisture. Our findings should provide a better understanding of carbon sequestration potential and determination of how future climate change may impact carbon budgets.

\section{Toward the definition of epidemiologically-based stomatal-flux critical levels for forest protection against ozone: the MOTTLES approach}

Elena Paoletti ${ }^{1}$,Ovidiu Badea ${ }^{2}$,Elisa Carrari ${ }^{1}$, Laurence Dalstein-Richier ${ }^{3}$, Alessandra de Marco ${ }^{4}$, Silvano Fares ${ }^{5}$, Ionel Popa ${ }^{2}$, Pierre Sicard ${ }^{6}$, Yasutomo Hoshika

${ }^{1}$ CNR, Sesto Fiorentino, Italy; ${ }^{2} I N C D S$, Bucharest, Romania; ${ }^{3}$ GIEFS, Nice, France; ${ }^{4}$ ENEA, Casaccia, Italy; ${ }^{5}$ CREA, Arezzo, Italy; ${ }^{6}$ ARGANS, Sophie Antipolis,France(elena.paoletti@cnrit; badea63@yahoo.com; elisa.carrari@ipsp.cnr.it; ldalstein-richier@departement06.fr;

alessandra.demarco@enea.it; silvano.fares@crea.gov.it; popaicas@gmail.com;psicard@argans.eu; yasutomo.hoshika@cnr.it)

European directives for the protection of vegetation from phytotoxic ozone $\left(\mathrm{O}_{3}\right)$ are based on atmospheric exposure (AOT40) while $\mathrm{O}_{3}$ effects on forests depend on gas uptake through stomata (stomatal flux). MOTTLES is a LIFE project establishing a permanent network of forest sites based on active $\mathrm{O}_{3}$ monitoring, in order to define new standards based on stomatal flux, i.e. PODY (Phytotoxic Ozone Dose above a threshold Y of uptake). Based on the first year of MOTTLES data, we describe the typical monitoring station, together with measure protocols and index calculation methods. AOT40 and PODY are then compared and correlated with plant-response indicators (radial growth, crown defoliation, leaf visible injury). For 2017, the average AOT40 calculated according with the European Directive was almost twice the EC legislative standard of 5,000 ppb h. The metrics calculated by EC protocols (EC Directive, ICP-Vegetation) resulted well correlated to those calculated from the real duration of the growing season (MOTTLES method) and are thus representative of the actual exposure/ flux. AOT40 showed an opposite trend compared to PODY, hence it cannot be recommended as an optimal metric for forest protection. Visible foliar injury was the best plant-response indicator of tree responses to $\mathrm{O}_{3}$ under field conditions and more easily detected at the forest edge than inside the forest. These results help the set-up of further long-term forest monitoring networks for $\mathrm{O}_{3}$ assessment. This is recommended in Europe where stomatal $\mathrm{O}_{3}$ fluxes shall now be monitored in different habitats according with the new National Emission Ceiling directive.

\section{Interactive effects of climate and land-use on tree diversity in three ecological zones of Ghana}

Reginald Tang Guuroh ${ }^{1,2}$, Gloria K. Adeyiga ${ }^{1}$

${ }^{1}$ Council for Scientific and Industrial Research, Forestry Research Institute of Ghana, Kumasi, Ghana; ${ }^{2}$ University of Cologne, Range Ecology and Range Management Group, Botanical Institute Cologne, Germany (rguuroh@gmail.com; gloriaadeyiga@gmail.com)

Ecosystem health and functioning is closely related to plant diversity. Plant diversity is interactively driven by biotic and abiotic environmental factors. The importance of these drivers for tree diversity is still poorly understood particularly within the context of ongoing global changes. This knowledge gap affects ecosystem management and services provision. The study uses a combined gradient approach with area comprising a gradient of climatic aridity from the forestsavannah transition zone to the sudanian savannah of Ghana, in combination with local gradients of soil and land-use (distinguishing between protected areas with and without fire). Using species richness and Shannon diversity index as response variables, linear mixed-effect models and model selection were applied to test the links between environmental variables and diversity. In total, 180 species were recorded. Highest species richness was recorded in the forest-savannah transition (123), while the guinea and sudan savannah had 50 and 41 species respectively. In the drier savannah zones, species richness was highest in protected areas without fire followed by communal areas while protected areas with fire had the lowest species richness. In the wetter forest-savannah transition zone, species richness was highest in protected areas without fire followed by protected areas with fire and then communal areas. We found that climate and land-use were more important than soil for tree diversity. Precipitation was the most important driver of species richness and Shannon diversity index (> 50\% explained variance). These results are useful for land managers and can be used as a guide for management and conservation planning. 


\author{
Analysis of wind effect on trees in riparian areas \\ Oscar Bustos ${ }^{1}$, Carlos Mena ${ }^{1}$ \\ ${ }^{1}$ Universidad de Talca, Talca, China (obustos@utalca.cl; cmena@utalca.cl)
}

The natural fall of trees in riparian areas is an important source of coarse woody debris for mountain streams, improving fish habitat and influencing stream morphology. This research presents the results of a physical and probabilistic model to estimate the probability of a tree falling into the stream including the effects of tree lean and wind direction of conifers near a stream in a stand in the Maule's Coast Range, Chile. Two hundred trees were measured in this study area. A systematic sampling method was applied in each stream. The sample plots were defined as a rectangle of $20 \mathrm{~m} \times 50 \mathrm{~m}$ located each $30 \mathrm{~m}$ on both sides of the stream. The total area sampled was $3 \mathrm{ha}$. In every sample plot all trees were measured. Results of this study indicate that tree lean is not a major factor with respect to influencing tree blowdown for the range of tree lean data collected from coniferous trees along streams in the study area.

\title{
Sensitivity of stomatal conductance to soil moisture: implications for tropospheric ozone
}

Alessandra de Marco $^{1}$, Alessandro Anav ${ }^{1}$, Elena Paoletti ${ }^{2}$

${ }^{1}$ ENEA, Rome, Italy; ${ }^{2}$ CNR, Sesto Fiorentino, Italy (alessandra.demarco@enea.it; alessandro.anav@enea.it; elena.paoletti@cnr.it)

Plants remove a large amount of atmospheric compounds from the lower troposphere through stomata; however the role of water availability was often neglected in atmospheric chemistry modelling studies as well as in integrated risk assessments.The aim of this study is to evaluate the effect of soil water limitation on stomatal conductance and assess resulting changes in atmospheric chemistry testing various hypotheses of water uptake by plants in the rooting zone; following the main assumption that roots maximize water uptake,we improve the dry deposition scheme within the chemistry transport model CHIMERE. Results highlight how dry deposition significantly declines when soil moisture is used to regulate the stomatal opening, mainly in the semi-arid environments: over Europe the amount of ozone removed by dry deposition in one year without considering any soil water limitation to stomatal conductance is about 8.5 $\mathrm{TgO}_{3}$, while using a dynamic layer that ensures plants to maximize the water uptake from soil, we found a reduction of $10 \%$ in the amount of ozone removed by dry deposition $\left(\sim 7.7 \mathrm{TgO}_{3}\right)$. Despite dry deposition occurs from top of canopy to ground level, it affects concentration of gases remaining into the lower atmosphere with a significant impact on ozone concentration (up to $4 \mathrm{ppb}$ ) extending from surface to upper troposphere (up to $650 \mathrm{hPa}$ ). Our results shed light on the importance of improving parameterizations of processes occurring at plant level (i.e. from the soil to the canopy) as they have significant implications on concentration of gases in the lower troposphere.

B2c: NOVEL ADVANCES IN GENOMICS AND TREE BREEDING FOR SUSTAINABLE FORESTS

\section{The status of forest trees breeding in Sweden and realized genetic gain in Norway spruce breeding program}

Mateusz Liziniewicz ${ }^{1}$, Mats Berlin ${ }^{2}$, Bo Karlsson ${ }^{1}$, Andreas Helmersson ${ }^{1}$

${ }^{1}$ Skogforsk,Ekebo,Sweden; ${ }^{2}$ Skogforsk, Uppsala,Sweden(mateusz.liziniewicz@skogforsk.se; mats.berlin@skogforsk.se; bo.karlsson@skogforsk.se; andreas.helmersson@skogforsk.se)

The forest tree breeding has started in Sweden in 1950's. The species of interest have been Norway spruce (Picea abies), Scots pine (Pinus sylvestris), lodgepole pine (Pinus contorta) and silver birch (Betula pendula). The breeding aim for all species is to combine intensive breeding, gene conservation and preparedness for future climate change. The test strategy is based on multiple breeding populations formed from tested plus-trees selected in wild populations. The breeding cycle is repeated generation by generation and expected genetic gain in growth is estimated to be between $10 \%$ and $15 \%$ per generation. The deployment into operational forestry is mainly by mass propagation in seed-orchards. Soon, seed orchards from tested material will start to produce seeds with expected gain of $25 \%$ in areal production. The realized gain trails have been established for Norway spruce in southern and central Sweden to demonstrate effects of ongoing breeding program. The planted genetical material, ranged from unimproved local seedlings up to the best clones from breeding front. The results showed that the differences between material matched the predictions and increased with an increase in breeding level. Moreover, an early height measurement gave reliable estimations of genetic gain in areal production in the time of first commercial thinning. Finally, it was shown that planting clonal bulk is a reasonable to spread the production risk as there is a great clonal variation for areal growth.

\section{Genomic selection for half-sib family using exome capture as genotyping platform in Norway spruce}

Linghua Zhou ${ }^{1}$, Zhiqiang Chen ${ }^{1}$, John Baison ${ }^{1}$, Bo Karlsson ${ }^{2}$, Sven-Olof Lundqvist ${ }^{3}$, Maria Rosario Garcia-Gil ${ }^{1}$, Harry $^{\text {Wi,4 }}$ ${ }^{1}$ Swedish University of Agriculture Science, Umeå, Sweden; ${ }^{2}$ Skogforsk, Ekebo, Sweden; ${ }^{3} I I C$, Stockholm, Sweden; ${ }^{4}$ National Research Collections Australia NRCA, Canberra,Australia (linghua.zhou@slu.se; zhiqiang.chen@slu.se; john.baison@slu.se; bo.karlsson@skogforsk.se; svenolof.lundqvist@indic.se; m.rosario.garcia@slu.se; harry.wu@slu.se)

Genomic selection (GS) is considered a promising approach to accelerate tree breeding and enhance genetic gain. We investigated the predictive ability of GS based on 484 progeny trees from 62 half-sib families in Norway spruce (Picea abies (L.) Karst.) for density, modulus of elasticity and microfibril angle (MFA) scored with SilviScan technology and two indirect methods, Hitmann (a proxy to MFA) and Pylodin (a proxy to density). GS predictive ability (PA) was comparable with that based on pedigree-based selection. PA assessment for each cambial age and calendar age showed the possibility to train the GS model at an early stage. In this study, we also tested PA based on different ratio between the training and validation sets and different statistical models. Different statistical models have no significant impact on the estimated PAs. Taking into account the cost of wood property assessment, the two indirect methods could be considered a cost-efficient alternative for the implementation of GS for solid wood properties into operational breeding.

Advances in genetic improvement in three Acacia species in Cuba / Avances en el mejoramiento genético en tres especies del género Acacia en Cuba

Sandra Herrera Soler ${ }^{1}$, Arnaldo Fabian Álvarez Brito ${ }^{1}$

${ }^{1}$ Instituto de Investigaciones Agro-Forestales, La Habana, Cuba (sherreras1992@gmail.com; archie@forestales.co.cu)

Los programas de mejoramiento genético en las especies forestales son esenciales para elevar rendimientos de productos madereros y no madereros, así como la tolerancia a factores bióticos y abióticos adversos. Sobre este último aspecto los registros climáticos disponibles indican que la pluviosidad media de Cuba 
ha disminuido $200 \mathrm{~mm}$ en los últimos 50 años y los escenarios climáticos evidencian que tal tendencia aumentará, extendiéndose de oriente a occidente, por lo que disponer de material de elevados rendimientos de madera y tolerante a la sequía constituye un objetivo central del programa forestal al 2030. El objetivo de este trabajo es analizar los avances del mejoramiento genético con el género Acacia: A. mangium, A. auriculiformis y el híbrido interespecífico, basado en el total de áreas dedicadas a las plantaciones, los experimentos establecidos y las investigaciones realizadas. Desde principios de los años 90 hasta el 2000 fueron establecidos siete experimentos con ambas especies parentales, en los que se desarrollaron ocho investigaciones sobre su introducción en Cuba, una relacionada con la introducción de procedencias y otra con la obtención del híbrido interespecífico. La superficie destinada para las especies del género Acacia incrementó en seis años, hasta fines de 2016, en $65 \%$, mostrando su relevancia en el sector productivo. El análisis de esos resultados condujo a la elaboración del programa de mejoramiento genético a seguir para cumplir los objetivos de obtención de semilla híbrida para la producción de madera en rollo y tolerante a la sequía.

\section{Breeding for resistance to Teratosphaeria nubilosa on Eucalyptus globulus}

Gustavo Balmelli ${ }^{1}$ (D), Sofia Simeto ${ }^{1}$, Alicia Castillo ${ }^{2}$, Pilar Gasparri ${ }^{1}$, Danilo Cabrera ${ }^{3}$, Ignacio Aguilar ${ }^{3}$, Marianella Quezada ${ }^{3}$, Cecilia da Silva ${ }^{4}$, Facundo Giorello

${ }^{1}$ Programa Nacional de Investigación en Producción Forestal, Instituto Nacional de Investigación Agropecuaria, Tacuarembó, Uruguay; ${ }^{2}$ Unidad de Biotecnología, INIA, Montevideo, Uruguay; ${ }^{3}$ Programa Nacional de Investigación en Producción Frutícola, Instituto Nacional de Investigación Agropecuaria, Montevideo, Uruguay; ${ }^{4}$ PDU Biología Vegetal del Noreste, Centro Universitario de Tacuarembó, Universidad de la República, Montevideo, Uruguay(gbalmelli@inia.org.uy; ssimeto@inia.org.uy; acastillo@inia.org.uy; pgasparri@inia.org.uy; dcabrera@inia.org.uy; iaguilar@inia.org.uy; mquezada@inia.org.uy; cecilia.dasilva@cut.edu.uy; fagire@gmail.com)

The devastating damage caused by Teratosphaeria nubilosa in plantations of Eucalyptus globulus is forcing the replacement of this species in Uruguay. As there is no local availability of resistant genotypes, INIA reoriented its Tree Breeding Plan to the specific aim of developing clones with good performance against this disease. Genetic variation in disease resistance (\% defoliation) and precocity of phase change (\% of adult foliage) at 14 and 21 months of age was analyzed in five progeny tests (comprising 87 full-sib families) naturally infected by T. nubilosa in Southeastern Uruguay. The narrow-sense individual tree heritability for disease severity was low or moderate (0.05 at 14 months and 0.15 at 21 months) and was moderate to high (0.21 at 14 months and 0.38 at 21 months) for precocity of phase change. The genotype $\mathrm{x}$ environment interaction for disease severity and precocity of phase change was moderate at 14 months (Type B rg = 0.56 and 0.67 , respectively) and low at 21 months (Type B $\mathrm{rg}=0.90$ and 0.86 , respectively). Based on these parameters, the main selection criterion currently used, both in the selection of parents for controlled pollination and candidates for cloning, is the proportion of adult foliage at 21 months. Currently, the capture and multiplication of clones is underway, both from intraspecific crosses and from interspecific crosses with E. grandis, and the incorporation of Genomic Selection is in process through the development and validation of selection models for the characteristics of interest.

\section{Applications of nuclear technologies in conservation and forest genetic improvement under a climate change scenario}

Patricio Rojas ${ }^{1}$, Paulina Aguirre ${ }^{2}$, Oscar Duran ${ }^{2}$, Adriana Nario ${ }^{2}$, Ethel Velasquez ${ }^{2}$, Daniel Villegas ${ }^{2}$, Jorge Gonzalez ${ }^{1}$ ${ }^{1} I N F O R, S A N T I A G O$,Chile; ${ }^{2 C C H E N, S A N T I A G O, C h i l e(p a r o j a s @ i n f o r . c l ; p a u l i n a . a g u i r r e @ c c h e n . c l ; ~ o s c a r . d u r a n @ c c h e n . c l ; ~ a d r i a n a . n a r i o @ c c h e n . c l ; ~}$ ethel.velasquez@cchen.cl; eldanivillegas@gmail.com;jgonzalez@infor.cl)

Chilean forestry sector represents $2.1 \%$ of GDP and is the third industrial sector for export (US \$ 5,271 million), after copper mining and agricultural and food sector. The forest area of native forest is 13.4 million hectares and plantations (Pinus, Eucalyptus, others) reaches 2.4 million hectares. Recent research shows that climate change is altering the distribution of forest species, growth rates, susceptibility to insects and fungi, causing mortality of trees (Araucaria araucana) because of decrease in rainfall and increase in temperatures in last decade. Application of gamma rays in agricultural crops has generated enormous economic benefits and better living standards in the world, however there are few global experiences of application of in forest species. There is a challenge to generate new genotypes that does not exist in nature through mutagenesis to reforest with more adapted species to climate change, like more drought tolerant and resistant to pests and diseases. Chile has nuclear reactors (CCHEN) and advanced tree improvement programs (INFOR) for propagation of trees by seeds, clones and micro propagation. However, for the selection of short-term valuable M1 mutants equipment for assisted selection by molecular markers (DNA) will be required. In the first phase dosimetry in sublethal doses will be determined to improve germination on Peumus boldus and rooting of Eucalyptus nitens and hybrids clones. In later stage, protocols will be developed for genotypic screening based in Next-Generation Sequencing (NGS) for mutations targeted discovery species and Genome-Wide Association Study (GWAS) in species where genetic information is lacking.

\section{Genetics, epigenetics and metabolomics of taxus baccata for the selection of antineoplastic taxol/taxane-producing plant material in Greece}

Filippos Aravanopoulos ${ }^{1}$, Evangelia Avramidou ${ }^{1}$, Aliki Xanthopoulou ${ }^{1}$, Eleftheria Dalmaris

1AAristotle University,Thessaloniki, Greece(aravanop@for.auth.gr; aevaggelia@yahoo.com; aliki.xanthopoulou@gmail.com; edalmaris@gmail.com)

The demand for taxol a promising cancer chemotherapeutic agent exceeds supply, hence expanding its potential sources to the European yew species Taxus baccata. Natural marginal populations, especially at the xerothermic edge where stresses are more frequent and profound, may possess particular gene complexes reflected in the quantitative and qualitative profile of European yew taxol. We study the distribution and magnitude of genetic and non-genetic sources of variation in taxol content marginal south-eastern natural populations of T. baccata in Greece. The goals of this study are: to develop taxol plantations that would contribute to the supply of an important antineoplastic agent, to increase the quantity and quality of produced taxol by applying methods of classical and molecular breeding, and to provide genetic conservation guidelines for natural populations. Demographic data were recorded and needlesfrom genetically isolated natural populations (30 trees per population) were collected for genetic (SSRs; 14 primers), epigenetic (MSAP; EcoRIrare cutter, HpaII andMspI frequent cutters) and metabolomic (LC-MS/MSMRM; taxol, taxanes, alkaloids, phenolic profile) analyses. Preliminary data demonstrate that height, diameter and volume index distribution curves in the natural populations are not generally normal, while effective population sizes are generally low (Ne $<30$ ). Results are examined against the available literature for T. baccata, T. brevifolia and T. canadensis. To the best of our knowledge, this is the first study using Greek populations and the first study that combines genetic, epigenetic and metabolomic analyses in Taxus worldwide. This work is funded by project NSRF5004922/ TAXOL-GR 


\section{Genomic prediction of complex traits: genomics and quantitative genetics converge to innovate Eucalyptus breeding in Brazil}

Dario Grattapaglia ${ }^{1,2}$, Rafael Resende ${ }^{1,3}$, Barbara Müller ${ }^{4}$, Bruno Lima $^{5}$, Biyue Tan $^{6}$, Elizabete Takahashi ${ }^{7}$, Regiane Estopa $^{8}$, Carla Garcia ${ }^{9}$, Leonardo Rosse $^{10}$, Orzenil Silva-Junior ${ }^{1}$

${ }^{1}$ Embrapa Recursos Genéticos e Biotecnologia, Brasília, Brasil; ${ }^{2}$ Universidade Católica de Brasília Brasília Brasil; ${ }^{3}$ Universidade Federal de Goiás Goiania Brasil; ${ }^{4}$ University of Florida, Gainesville, USA; ${ }^{5}$ Fibria Celulose, Jacarei, Brasil;; ${ }^{6}$ Stora Enso AB, Nacka, Sweden; ${ }^{7}$ Cenibra Celulose, Ipatinga, Brasil;

${ }^{8}$ Klabin S.A., Telemaco Borba, Brasil; ${ }^{9}$ Veracel Celulose S.A., Eunápolis, Brasil; ${ }^{10}$ Eldorado Brasil Celulose, Três Lagoas, Brasil

(dario.grattapaglia@embrapa.br; rafael.tassinari@gmail.com; mullerbsf@gmail.com; bruno.lima@fibria.com.br; biyue.tan@storaenso.com;

elizabete.takahashi@cenibra.com.br; restopa@klabin.com.br; carla.garcia@veracel.com.br; leonardo.rosse@eldoradobrasil.com.br;

orzenil.silva@embrapa.br)

Genetically improved seeds or clonal stocks have been successfully delivered by systematic tree breeding, but several challenges remain. Long life cycles, late flowering, poor juvenile-mature correlations and changes in market demands and climate, frequently make the progress of tree breeding slow and uncertain. Following the largely fruitless attempts to develop MAS (Marker Assisted Selection) for forest trees, based on the unrealistic concept of dissecting a complex trait in its individual components, the convergence of high-throughput genomics and quantitative genetics has established the paradigm of genomic prediction of breeding values as a way to accelerate breeding of complex traits. Additionally, the adoption of realized genomic relationships, provide innovations in breeding approaches and genetic parameters' estimation by accounting for the random Mendelian segregation in pedigrees. Using the Eucalyptus genome sequence we developed a breeder-friendly and cost-effective SNP genotyping "chip" that provides high-density genotyping for eucalypts. Using this platform in several breeding programs in Brazil, we have shown that genomic selection (GS) matches the accuracy of phenotypic selection for growth and wood traits, nevertheless enhancing the rate of genetic gain by increasing selection intensity, radically reducing generation interval and improving the accuracy of breeding values. Yet, predictive abilities are impacted by GxE interaction and driven mainly by relatedness, such that population-specific predictive models are necessary. We are on the brink of adopting GS in operational eucalypt breeding in Brazil. Strategic and logistics aspects for the adoption of GS are now the challenges to fully integrate this new breeding technology into routine tree improvement.

\section{The Eucalyptus SNP array initiative: second-generation SNP arrays for low-cost operational genomic selection and very high-density} genotyping for advanced genomic and breeding applications

Orzenil Silva-Junior ${ }^{1}$, Rafael Tassinari², Dario Grattapaglia ${ }^{1}$

${ }^{1}$ Embrapa Recursos Genéticos e Biotecnologia, Brasília, Brasil; ${ }^{2}$ Universidade Federal de Goiás, Goiânia, Brasil (orzenil.silva@embrapa.br; rafael.tassinari@gmail.com; dario.grattapaglia@embrapa.br)

Following the development and worldwide adoption of the Eucalyptus EuCHIP60K SNP, we have now advanced a new initiative to build second-generation SNP arrays. The objective of the ESAI (Eucalyptus SNP Arrays Initiative) was to provide an improved performance 65k SNP genotyping array with wider applicability and significantly lower cost for operational genomic selection and a very high-density (HD) array with 500,000 to 1,000,000 SNPs for advanced genomic investigation and breeding applications. The new arrays were developed on the Axiom myDesign technology platform and provide a larger number of SNPs than the previous chip. A total of 1.3 million SNPs with coordinates to Eucalyptus grandis genome sequence assembly v2.0 were screened bioinformatically, including previously validated SNPs and a large set of newly discovered ones from new sequencing data for Eucalyptus species of subgenus Symphyomyrtus and genus Corymbia. This screening was carried out with 960 samples, including germplasm sources of 18 Eucalyptus and 3 Corymbia species contributed by the 17 ESAI participating organizations, allowing selection of an optimized set of SNPs. The newly developed ESAI65K SNP array includes a set of $\sim 10,000$ SNP for Corymbia, a set of cpDNA SNPs for inferring maternal lineages and a set of SNPs making the previous SNP chip data fully portable to this new one. The ESAIHD array with $>500,000$ SNPs was used to genotype parents of breeding populations, subsequently allowing SNP imputation to high-density for offspring individuals genotyped with the ESAI65K to improve accuracy and longevity of prediction models along generations of genomic selection.

\section{Cooperative research effort for the production of pine solid wood and resin in Brazil}

Ananda Virginia de Aguiar ${ }^{1}$, Jarbas Y. Shimizu ${ }^{2}$, Edilson Batista Oliveira ${ }^{1}$, Valderês Aparecida Sousa ${ }^{1}$, Carlos Mendes ${ }^{3}$, Gilson Geronasso ${ }^{4}$, Mauro Murara Junior $^{5}$ ${ }^{1}$ Embrapa Florestas, Colombo, Brasil; ${ }^{2}$ Autonomo, Curitiba, Brasil;; ${ }^{3}$ Associação Paranaense de Empresas de Base Florestal, Curitiba, Brasil; ${ }^{4}$ Empresa Remasa,Bituruna, Brasil; ${ }^{5}$ Associação Catarinense de Empresas Florestais, Lages, Brasil (ananda.aguiar@embrapa.br; shimizujy@gmail.com; edilson.oliveira@embrapa.br; valderes.sousa@embrapa.br; carlosmendes@apreflorestas.com.br; gilson@remasa.com.br;mauro.murara@acr.org.br)

Companies working with pines in the solid wood and resin segments in Brazil highlight scientific developments in the areas of gene conservation, genetic improvement and silviculture as basic priorities. However, the required long term research activities in forestry are costly and companies usually face budgetary and structural limitations. High investments are necessary and routine activities are complex, involving procurement of genetic material, specialized personnel, laboratory facilities and establishment and maintenance of both short- and long-term field experiments. In a quest to reduce costs and optimize efficiency in the implementation of research with support from Embrapa Florestas, forest companies associated with APRE (Associação Paranaense de Empresas de Base Florestal) and ACR (Associação Catarinense de Empresas Florestais) set up PCMP (Projeto Cooperativo de Melhoramento de Pinus), a cooperative project for the improvement of pines, and Funpinus (Fundo Cooperativo para Melhoramento de Pinus), a cooperative fund for the improvement of pines. Funpinus provides the administrative structure and financial organization for the implementation of PCMP. The cooperative currently has ten associated companies (resin and solid wood production) from the states of Santa Catarina, São Paulo, and Paraná. The objective of PCMP is to focus efforts on the development of improved pine genetic material, including interspecific hybrids to meet growing demands for high-quality raw material and higher productive efficiency. The PCMP began operations in 2017, with the basic premise to offer an addition to the work developed by individual companies, so that independence and autonomy of each participant company's particular work is honored. 
B2d: WOOD AND TREE-RING STUDIES OF FOREST ADAPTATION TO CLIMATE CHANGE; IMPLICATIONS FOR WOOD PRODUCTION

\section{Functional role of Eucalyptus wood in terms of drought resistance traits: trends at interspecific and intraspecific levels}

María Elena Fernández ${ }^{1}$ (D), Antonio José Barotto ${ }^{2}$, Alejandro Martínez-Meier ${ }^{3}$,Javier E. Gyenge ${ }^{1}$, Têtè S. Barigah ${ }^{4}$, Adriana Quiñones Martorello ${ }^{5}$, Natalia Tesón ${ }^{6}$, Esther Merlo, Guillermina Dalla Salda ${ }^{3}$, Silvia Monteoliva ${ }^{8}$

${ }^{1}$ CONICET- INTA Tandil, Tandil, Argentina; ${ }^{2}$ FCAyF.Universidad Nacional de La Plata, La Plata, Argentina; ${ }^{3} I N T A$ EEA Bariloche, Bariloche, Argentina; ${ }^{4}$ Institut National de la Recherche Agronomique, Clermont Ferrand, France; ${ }^{5}$ CONICET- FCA UNMdP, Balcarce, Argentina; ${ }^{6} I N T A$ EEA Concordia, Concordia, Argentina; ${ }^{7}$ Madera Plus SL, Ourense, Spain; ${ }^{8}$ CONICET-FCAyF UNLP, La Plata, Argentina (mefernandez1973@gmail.com; josecuervo86@gmail.com; martinezmeier.a@inta.gob.ar; gyenge_javier@inta.gob.ar; tete-severien.barigah@inra.fr; adriana.silvia.quinones@gmail.com, teson.natalia@inta.gob.ar; maderaplus@maderaplus.es; dallasalda.guillermina@inta.gob.ar; smonteoliva@yahoo.com.ar)

Multispecies surveys have showed that there is a weak but significant tradeoff between xylem efficiency and safety in woody species, and that there are no species occupying the space with high efficiency and high safety. Large vessels and tracheids result in high vulnerability to xylem cavitation (VC) due to tension. Moreover, relationships between xylem structure and function are studied mostly at the interspecific level, with few studies considering the relationships at the intraspecific level, particularly in angiosperms. Recent studies in Quercus species, finding opposite trends in wood anatomy-function relationships considering the interspecies and the intraspecific levels, raises the question about the value of multispecies studies to shed light over what is adaptive within a given species. Eucalyptus species share with Quercus a xylem anatomy composed by solitary vessels surrounded and connected to imperforate tracheary cells and parenchyma, a type of wood anatomy which is poorly understood in functional terms. Contrary to results in that genus, our results in four Eucalyptus species revealed that the trends observed between vessel size (mean and distribution) and VC are similar at the interspecific and intraspecific (E. globulus) levels. No tradeoff was observed between xylem efficiency and safety: the largest the vessels, the lower the VC. The amount of cells around different size-vessels could be involved in this phenomenon. Trends observed in this important forestry genus challenge what we already know about xylem anatomy and function, and may help to widen our vision about the role of wood in adaptation to drought stress.

\section{Wood anatomical traits reveal water constraints on black spruce xylem formation in the Boreal ecosystem}

Paulina Puchi ${ }^{1}$, Daniele Castagneri ${ }^{2}$, Sergio Rossi ${ }^{3}$, Marco Carrer ${ }^{1}$

${ }^{1}$ Università degli Studi di Padova, Padova, Italy; ${ }^{2}$ Swiss Federal Research Institute, Birmensdorf, Switzerland; ${ }^{3}$ Université du Québec à Chicoutimi,

Chicoutimi,Canada (paulinafernanda.puchigonzalez@phd.unipd.it; daniele.castagneri@unipd.it; sergio_rossi@uqac.ca; marco.carrer@unipd.it)

One of the most evident effects of the rapid warming occurring recently in cold and high-latitude forests is the lengthening of the growing season, with the concurrent extension of the period of wood formation. In addition, the increase of evapotranspiration demand is starting to induce drought-stress conditions. By selecting the same black spruce (Picea mariana) trees (20 trees in 4 sites along a latitudinal gradient in Quebec, Canada) where xylogenesis analyses were performed in the last years, we investigatedlong-term series of wood anatomical traits and compare them to previous short-term findings. Time series of wood anatomical traits were correlated to chronologies of daily temperature, VPD and precipitation during the period 1936-2010. In all sites, tracheid area correlated negatively with June-September temperature and VPD, and positively with precipitation. Meanwhile, cell-wall thickness and the number of cells per ring in the northernmost site were positively affected by spring and summer temperature. While previous monitoring studies evidenced temperature as the key climate variable influencing the timing of xylogenesis phases, our results show that water availability plays a central role in shaping xylem cell features in boreal black spruce. This stresses the importance of an integrate approach to better understand the relationships between wood formation and climate variability at both intra-annual and long (decadal) time scales. This approach will hopefully reduce the uncertainties and skewed interpretations of models on how boreal forest will perform in the future.

\section{Impact of drought on Eucalyptus wood chemistry by near infrared hyperspectral imaging}

Gilles Chaix ${ }^{1,2}$, Mariana Pires Franco ${ }^{2}$, Roger Chambi Legoas ${ }^{2}$, Nathalie Gorretta $^{3}$, Celio Pasquini ${ }^{4}$, Cristiane Vidal ${ }^{4}$, Jean-Michel Roger ${ }^{3}$, Mario Tomazello-Filho ${ }^{2}$

${ }^{1}$ Cirad, Montpellier Cedex, France; ${ }^{2}$ Escola Superior de Agricultura “Luiz de Queiroz”, Universidade de São Paulo, Piracicaba, Brasil; ${ }^{3} I R S T E A$, Montpellier, France; ${ }^{4}$ Universidade Estadualde Campinas, Campinas,Brasil gilles.chaix@cirad.fr; ma.pires@hotmail.com; rogerchl86@hotmail.com; nathalie.gorretta@irstea.com; pasquini@iqm.unicamp.br; cristiane.vidal@iqm.unicamp.br;jean-michel.roger@irstea.fr; mtomazel@usp.br)

The aim is to study tree development submitted to different water and mineral constraints. The objective is to correlate spatial distribution of wood chemistry with wood density, secondary growth. We sampled wood discs from 54 trees in rainfall exclusion design with Eucalyptus grandis at Esalq-USP, Itatinga Station, brazil. We felled the 5 years old trees growing under different water availability. For each disk, we acquired an image with a near infrared (nir) hyperspectral camera (hsi, specim, pixel size $625 \times 625 \mu \mathrm{m}$ ). The challenge here was to transfer our previous nir calibrations for total extractives built with a benchtop spectrometer (vector, bruker) to a hsi camera by using standard sample set measured on the two devices. An efficient model were built for the his camera with a prediction error of $10.3 \%$ compared to the prediction error of $11.6 \%$ for our previous calibration with benchtop spectrometer. Then, based on spectra from his image, we predicted extractive contents and built images. These allow us to compare their spatial distributions according to the growth conditions. In the absence or absence of fertilization, trees with higher water stress showed a higher heterogeneous distribution, from pith to bark, for the total extractive contents and a higher average mean value. In perspective, these data will allow us to study and refine the knowledge on cambium activity according to climatic variations by crossing variability of the chemical properties, x-ray micro-density and anatomy of wood, and diameter growth rate measured by electronic dendrometers.

\section{Spatial variation of wood density for Eucalyptus grandis by near infrared hyperspectral imaging combined with X-ray analysis}

Roger Chambi-Legoas ${ }^{1}$ (D, Mario Tomazello-Filho², Nathalie Gorretta ${ }^{3}$, Celio Pasquini ${ }^{4}$, Cristiane Vidal ${ }^{4}$, Jean-Michel Roger ${ }^{3}$, Gilles Chaix ${ }^{5,6}$ ${ }^{1}$ Escola Superior de Agricultura Luiz de Queiroz, Universidade de São Paulo, Departamento de Ciencias Florestais, Montpellier, Brazil; 2 Escola Superior de Agricultura Luiz de Queiroz, Universidade de São Paulo, Departamento de Ciências Florestais, Piracicaba, Brasil; ${ }^{3}$ IRSTEA, UMR ITAP, Montpellier, France; ${ }^{4}$ UNICAMP, Department of Analytical Chemistry, Campinas, Brasil ${ }^{5}$ CIRAD, UMR AGAP, Univ Montpellier, INRA, Montpellier SupAgro, Montpellier, France; ${ }^{6}$ Escola Superior de Agricultura Luiz de Queiroz, Universidade de São Paulo, Departamento de Ciências Florestais, Piracicaba, Brasil (rogerchl@usp.br; mtomazel@usp.br; gilles.chaix@cirad.fr; gilles.chaix@cirad.fr; cristiane.vidal@iqm.unicamp.br; gilles.chaix@cirad.fr; gilles.chaix@cirad.fr) 
Most near-infrared spectroscopy (NIRS) studies for wood density use multiple spectral acquisitions taken manually at several points from pith to bark. Recently the use of near-infrared hyperspectral imaging (NIR- HSI) has shown good performance in predictions of wood properties, allowing build high spatial resolution predictive images. The combined use of NIR-HSI and X-ray microdensity imaging (X-ray MDI) could be more practical for evaluation of spatial variation of wood density. The aim was to develop a wood density calibration model for NIR-HSI ( $625 \mu \mathrm{m}$ pixel size) from X-ray MDI ( $30 \mu \mathrm{m}$ pixel size) and evaluate the spatial variation of wood density along stem cross-section in Eucalyptus grandis trees. Wood discs were collected from 18 trees of 6 years old, submitted to two different water availability, located in São Paulo, Brazil. The challenge here was to match the pixels of X-ray MDI to pixels of NIR-HSI (in 2 mm width radial region) to transfer accurate values of wood density to each pixel of NIR-HSI. The $\mathrm{R}^{2}$ of the model was 0.72 , while the root mean squared error was and $4.8 \times$ $10^{-2} \mathrm{~g} \mathrm{~cm}^{-3}$ for the validation group. The prediction model allows comparing their spatial distributions according to the growth conditions. Trees with higher water stress showed higher wood density. Treatments showed a similar spatial variation of wood density, increasing from pith to bark. In perspective, these data will allow evaluating the spatial distribution of wood density inter and intra-tree rings in relation to meteorological variability.

\title{
A novel approach to understanding the formation of tree rings in tropical species by analyzing traces of elements
}

\author{
Daigard Ricardo Ortega Rodriguez ${ }^{1}$, Luiz Santini ${ }^{1}$, Hudson Carvalho ${ }^{2}$, Mario Tomazello-Filho ${ }^{1}$ \\ ${ }^{1}$ Escola Superior de Agricultura “Luiz de Queiroz”, Universidade de São Paulo, Piracicaba, Brasil; '2Universidade de São Paulo, CENA, Piracicaba, Brasil \\ (dai.ricardo.or@gmail.com; luizsantini82@gmail.com; hudson@cena.usp.br; mtomazel@usp.br)
}

After the initial division of the cambium and tree-ring formation, derivative cells are subject to cell expansion and secondary wall deposition. In this process, different chemical elements are allocated and translocated as part of tree metabolism and physiology. Both anatomical and chemical events, vary among the xylem cells according to their transport or storage functions. Here we analyze the anatomical and chemical pattern at the intra and inter ring level of two tropical species extensively used for dendrochronological studies, Cedrella fisilis and Hymenaea coubaril. The samples were them cut transversely (1.5 mm, thickness) with a parallel double circular saw for chemical analysis by X-ray fluorescence. And the rest of wood samples were used to prepare histological slides to evaluate the microscopic anatomical structure. Simultaneous multielemental and anatomical evaluation for each species-wood sample at different positions (five rings close to pith, in the sapwood and heartwood transition and close to bark) were performed. Elements such as Ca and K stood out in both samples. The highest $\mathrm{K}$ presence are observed in the developing xylem (rings close to the bark). While the highest Ca presence were found near to the pith. Furthermore, both elements were observed related to parenquimatic tissue. Elements content differences were observed between the rings of sapwood and heartwood. Altogether, this work shows interesting clues to understand the tree-physiology based on element traces related to their anatomical structures.

\section{A simple and new method for enhance tree-ring visualization using fluorescence}

Milena Godoy-Veiga ${ }^{1}$, Paula Alecio ${ }^{1}$, Gregório Ceccantini ${ }^{1}$, Marcos Buckeridge $^{1}$, Giuliano Locosselli ${ }^{1}$

${ }^{1}$ Universidade de São Paulo, Institute of Biosciences, São Paulo,Brasil(milena.gveiga@gmail.com; pcalecio@gmail.com; gregorio@usp.br; msbuckeridge@gmail.com; locosselli@yahoo.com.br)

Tropical forests harbor about 50.000 tree species, out of which only few hundreds are used for dendrochronological purposes. One of the reasons is because only few species are known to produce annual tree rings. The other reason is the proportional diversity of wood anatomy that may result in less than clear tree-ring boundaries. In order to improve tree-ring visualization we evaluated the suitability of using fluorescence to enhance the contrast among wood cells. We tested three sets of fluorescence filters: GFP (green fluorescent protein), RFP (red fluorescent protein) and UV and compared with visualization under natural light. Overall, fluorescence enhanced the contrast among fibres, parenchyma and vessels on different tree species improving tree-ring visualization. For a few species tree-ring boundaries were highlighted by the presence of fibrous zones, by the presence of parenchyma bands, by presence of early-wood large vessels and/or narrow late-wood vessels, or by highlighting the content of secretory canals. For species known to have clear tree ring boundaries, fluorescence may aid visualization of false tree-rings. We also found this technique suitable for qualitative and quantitative wood anatomy studies. Therefore, tropical dendrochronologists may find this method useful for tree-ring counting, cross-dating and to expand the available set of species suitable for tree-ring investigations.

\section{Geographical patterns and drivers of regeneration and growth dynamics of Quercus variabilis}

Gao Wen-Qiang ${ }^{1}$, Lei Xiang-Dong ${ }^{1}$

${ }^{1}$ Institute of Forest Resource Information Techniques, Chinese Academy of Forestry, Key Laboratory of Forest Management and Growth Modelling, State Forestry and Grassland Administration, Beijing, China (gwq9975@ifrit.ac.cn; xdlei@ifrit.ac.cn)

Impending climate warming is expected to influence plant regeneration, growth and distribution ranges. However, synchronous comparisons of regeneration and growth dynamics associated with biotic factors across latitudinal, longitudinal and altitudinal gradients at a single species'level have received little attention. In the present study, we investigated regeneration (seedling and sapling) and growth variations (radial and height growth) of Quercus variabilis along latitudinal, longitudinal and altitudinal gradients; meanwhile, the effects of environmental factors (climate, soil and stand conditions) on regeneration and growth across the three geographical gradients were ranked and apportioned using linear mixed-effects models. Our results indicated that the regeneration of Chinese cork oak decreased from middle to the range limit, the radial growth of ringwood and latewood increased with latitude, and latewood and height growth decreased with longitude; furthermore, the growth sensitivity to climate were less in the southern and eastern populations than the northern and western. When pooling all sites'data, we found that climate variables were not solely decisive factors to drive the geographic variations in the regeneration and growth of $Q$. variabilis, stand conditions (stand density and total basal area) and soil properties ( $\mathrm{pH}, \mathrm{Ca}, \mathrm{Mg}, \mathrm{N}$ and N/P) also played important roles in shaping large geographical patterns of the oak regeneration and growth. 


\begin{abstract}
The relationships between functional, adaptive, and technological characteristics of cypress wood from the Cordillera / Relaciones entre caracteres funcionales, adaptativos y tecnológicos de la madera en ciprés de la cordillera

Anne-Sophie Sergent ${ }^{1,2}$, Gonzalo Caballe ${ }^{2}$, Guillermina Dalla-Salda ${ }^{2}$, Juan Pablo Diez ${ }^{2}$, María Elena Fernández ${ }^{3,4}$, Nicolas Martin-StPaul ${ }^{5}$, Philippe Rozenberg ${ }^{6}$, Oscar Santaclara ${ }^{7}$, Santiago Agustin Varela ${ }^{2}$, Alejandro Martinez-Meier ${ }^{2}$

${ }^{1}$ CONICET, Consejo Nacional de Investigaciones Cientificas y Técnicas, Bariloche, Argentina; ${ }^{2}$ INTA, Instituto Nacional de Tecnología Agropecuaria, Grupo de Ecología Forestal - LEEMA, EEA Bariloche, Bariloche, Argentina; ${ }^{3}$ INTA, Instituto Nacional de Tecnología Agropecuaria, Grupo de Ecología Forestal - LEEMA, EEA Bariloche, , Bariloche, Argentina; ${ }^{4}$ INTA, Instituto Nacional de Tecnología Agropecuaria, Grupo de Ecología Forestal, AER Tandil Tandil Argentina; ${ }^{5} I N R A$, UR ${ }^{629}$ Ecologie des Forêts Méditerranéennes (URFM), Avignon, France; ${ }^{6} I N R A$, UMR0588 Biologie Intégrée Pour la Valorisation de la Diversité des Arbres et de la Forêt (Biofora), Orléans, France; ${ }^{7}$ Madera Plus, Ourense, Spain (ansosergent@gmail.com; caballe.gonzalo@inta.gob.ar; dallasalda.guillermina@inta.gob.ar;diez.juan@inta.gob.ar;ecologiaforestal@yahoo.com.ar;nicolas.martin@inra.fr;philippe.rozenberg@inra.fr; oscar.santaclara@gmail.com; varela.santiago@inta.gob.ar; martinezmeier.a@inta.gob.ar)
\end{abstract}

Eventos de mortalidad han sido registrados en los bosques de ciprés de la cordillera (Austrocedrus chilensis), una conífera endémica cuya distribución abarca un marcado gradiente ambiental. Estudios recientes asocian los eventos de mortalidad a decaimientos previo del crecimiento, coincidiendo con eventos extremos de calor y sequía, los cuales son cada vez más recurrentes en el marco del cambio climático. Dado los múltiples procesos biológicos en los cuales la madera se encuentra involucrada, ciertas propiedades determinantes de la calidad de la madera para usos sólidos, pueden ser utilizadas para estudiar el potencial de adaptación de los árboles a eventos de estrés abióticos. El presente estudio propone un abordaje interdisciplinario del análisis conjunto de las propiedades físicas, mecánicas, hidráulicas y de la dinámica de formación de la madera, a lo largo del área de distribución natural de la especie. Perfiles de microdensidad permitieron establecer diferencias significativas de crecimiento y densidad entre árboles vivos y muertos. El estudio de los mecanismos de respuesta a la sequía permitió relacionar los ajustes funcionales con las condiciones ecológicas. El estudio de la dinámica de la formación de la madera, mediante el empleo de dendrómetros, permitió determinar como el clima afecta el crecimiento. Métodos sónicos permitieron determinar la aptitud tecnológica de la madera para usos estructurales. El análisis conjunto de los resultados permitirá determinar la existencia de un compromiso entre las propiedades físicas y función biológica, que condicione la producción de madera y el potencial de adaptación al estrés abiótico en el marco del cambio climático.

\title{
Shoots length growth dynamics and dendroclimatology of dwarf shrubs in treeline of Eastern Carpathians
}

Ionel Popa ${ }^{1}$, Anca Semeniuc ${ }^{1}$, Mihai Balabasciuc ${ }^{1}$

${ }^{1}$ National Institute for Reseach and Development in Forestry Marin Dracea, Campulung Moldovenesc, Romania(popaicas@gmail.com; semeniuc.anca@yahoo.ro; mihaibalabasciuc@yahoo.ro)

High altitude mountain ecosystems are ones of the most vulnerable and sensitive to climate change effects. In high mountain ecosystems, the trees and dwarf shrubs growth is assume to be limited by temperature, and most scientists expect a significant increase of growth due to recent and future warming. The main aim of this study is to fill the gaps on data and knowledge about the response of dwarf shrubs growth (tree ring and shoots length) to climate from ecotone of Carpathians region. To highlight the shoots length growth dynamics and dendroclimatic patterns, six dwarf shrubs species and two slope aspects (sunny and shade) in two high altitude location from Eastern Carpathians (Romania) where analysed and monitorized weekly in 2018 and 2019 , during the growing season. The results reveal a differentiation at species and slope aspects level in the dynamics of the growth processes in shoots length and phenophases. A 5-10-day delay was observed between the shaded slopes compared to the sunny ones on the dynamics of the shoot length growth phenology. The length of the shoot length growing season varies from species to species, ranging from 60 to 90 days. Generally, the maximum length is observed on the sunny slope $70-90$ days, and the minimum on the shaded 60-70 days. The general dendroclimatic pattern of climate-growth (radial growth and shoots length) relationship is characterised by a positive and significant influence of the summer temperature, but species specific.

Analysis of growth rings in Bulnesia sarmientoi Lorentz ex Griseb in its climate gradient in Argentina / Análisis de anillos de crecimiento de Bulnesia sarmientoi Lorentz ex Griseb, en su gradiente climático en Argentina.

Vanina Chifarelli ${ }^{1}$, Maria Senilliani ${ }^{1}$, Natalia Bonel ${ }^{2}$, Erwin Bartel ${ }^{1}$, Juana Moglia ${ }^{1}$, Ana Gimenez ${ }^{1}$

${ }^{1}$ Universidad Nacional de Santiago del Estero, Santiago del Estero, Argentina; ${ }^{2}$ Servicio Meteorológico Nacional, Buenos Aires, Argentina (vaninachifarelli@yahoo.com.ar; senilliani@yahoo.com.ar;nataliabonel@gmail.com; matiasbartel@yahoo.com.ar; vimog@unse.edu.ar; amig@unse.edu.ar)

Esta investigación busca determinar el crecimiento de la especie y si hay diferencia entre sitios donde se distribuye, ya que la especie Bulnesia sarmientoi Lorentz ex Griseb. (Zigophyllaceae) presenta un área de distribución restringida en la región norte de Argentina. Esta especie está incluida en el apéndice II Convención Internacional de Tráfico de Especies Amenazadas de Fauna y Flora Silvestres, incluye especies que, aunque no se encuentran necesariamente en peligro de extinción están amenazadas. El trabajo pretende determinar el crecimiento en función de la edad, la evolución del incremento radial (IR), estimar el incremento medio (IMA) y anual (IA), con la finalidad luego de establecer la relación entre los espesores de anillos por sitio. El estudio se realizó en tres provincias Formosa (Las Lomitas e Ingeniero Juárez), Salta (Rivadavia) y Chaco (las Hacheras), abarcando un amplio gradiente climático. Se estudiaron 35 individuos, de posición sociológica dominantes, buen estado sanitario. La marcación y medición de anillos se efectuó con el programa Image-Pro-Plus. Los datos se analizaron con el software estadístico INFOSTAT. El espesor promedio de anillos determinado fue 3.03 mm. El incremento medio anual en Las Hacheras y Las Lomitas es mayor que en los demás sitios.

\section{Ecological adaptations of endemic trees from two biodiverse hotspots of India}

Deepa Bisht ${ }^{1}$, Sangeeta Gupta

${ }^{1}$ Forest Research Institute, Dehradun, India (deejyala@gmail.com; sangeeta.fri@gmail.com)

The variations in climatic conditions of India has made it one of the most biodiverse regions in the world with four biodiversity hotspots viz. The Eastern Himalayas, Indo-Burma, Western Ghats \& Sri Lanka and Sundaland. These biogeographical regions are well-known for high level of endemism and have 
cultural, socio-economic and ecological roles. Several sacred groves are also documented in these areas. They provide various ecosystem services and serve as life supporting system of native communities. The present study was carried out to elucidate the adaptive responses of trees in two tropical hotspots of India: Western Ghats and North-Eeastern region (Indo-Burma). The wood microstructure of selected endemic trees was examined as per the IAWA terminology. The study reflected variations and similarities in wood microstructure, especially, vessel characters for the successful establishment of different taxa. Values of hydraulic conductivity based on vessel dimensions reflected the efficiency of water transport while values of mesomorphy and vulnerability indices represented the ecological adaptations of different trees. The study further depicted that the adaptation was governed by water transport efficiency and drought resistance or hydraulic safety supported by the negative relationship between vessel diameter and vessel frequency.

\section{Radial growth response to climate change of populations of Pinus halepensis Mill., Pinus pinea L. and Pinus canariensis C.Sm. ex DC in the Collserola Natural Park (Barcelona)}

Jorge Santiago Garate Quispe ${ }^{1,2}$ (D) Cristina Valeriano ${ }^{2}$, Emilia Gutiérrez ${ }^{2}$

${ }^{1}$ Departamento Académico de Ingeniería Forestal, Universidad Nacional Amazónica de Madre de Dios-UNAMAD, Av. Jorge Chavez 1160, 17001 Puerto

Maldonado, Peru; ${ }^{2}$ Dept. Biologia Evolutiva, Ecologia i Ciències Ambientals, Universitat de Barcelona, Av. Diagonal 643, 08028 Barcelona, Spain

(jgarate@unamad.edu.pe; cristinavaleriano@ub.edu; emgutierrez@ub.edu)

Increasing temperatures, hotter and more frequent droughts and climate variability in western Mediterranean Basin are causing tree dieback episodes, high mortality rates and reduction in tree recruitment in southeastern Spain. The forests of two of the most drought resistant Mediterranean species, Pinus halepensis and Pinus pinea, do show forest die-off. The aim of this study was to evaluate tree growth trends of $P$. halepensis, $P$. pinea and Pinus canariensis populations in the Natural Park of Collserola (Barcelona) located in the Northeast of Spain. We also analyze the effect of climate on radial growth of these species and the trend and proportions of the late-wood and early-wood growth. The results show that only $P$. canariensis increased its basal area, while $P$. pinea and $P$. halepensis show a significant growth decrease since 1970. In all tree species, precipitation showed a positive effect while the effect of temperatures is mainly negative; growth was limited by water stress early in spring and summer due to the lack of available water because of the joint effect of temperature and precipitation. All the three species show an increasing trend the latewood proportion, but it was not significant, although $P$. pinea showed a change in the trend of this ratio since 1950 affected by rising temperatures. Our results suggest that $P$. canariensis has got adapted to the Mediterranean climate and shows higher annual growth rates in basal area increment (BAI, cm2/year) and its response to climate is similar to $P$. pinea and $P$. halepensis in Collserola.

Formation of growth rings, radial increment, and the relationship between growth and climate: assessing two potential species used in projects to restore the Atlantic Forest / Formação dos anéis de crescimento, incremento radial e relação crescimento-clima: avaliando duas espécies potenciais usadas em projetos de restauração da Mata Atlântica

Rafael P. Albuquerque ${ }^{1}$, Arno F. N. Brandes ${ }^{2}$, Claudio S. Lisi ${ }^{3}$, Luiz Fernando Duarte de Moraes ${ }^{4}$ Claudia Franca Barros $^{1}$

${ }^{1}$ Instituto de Pesquisas Jardim Botânico do Rio de Janeiro, Rio de Janeiro, Brasil; ${ }^{2}$ Universidade Federal Fluminense, Niterói, Brasil; ${ }^{3}$ Universidade Federal de Sergipe, Aracaju, Brasil; ㄹmbrapaAgrobiologia, Seropédica, Brasil (albuquerque.perpetuo@gmail.com; arnofritz@id.uff.br; clcslisi@gmail.com;

luiz.moraes@embrapa.br; claudiafrancabarros@gmail.com)

Avaliar projetos de restauração de áreas degradadas é um passo importante na conservação de biomas ameaçados como a Mata Atlântica. Através da dendrocronologia é possível investigar as dinâmicas de crescimento de espécies usadas em plantios de restauração e indicar espécies potenciais para estudos posteriores. O objetivo do presente trabalho foi estudar a formação dos anéis de crescimento, as tendências de crescimento radial e a relação crescimento-clima de Pseudobombax grandiflorum (Cav.) A. Robyns and Citharexylum myrianthum Cham. em remanescentes de Mata Atlântica e plantios para restauração na Rebio de Poço das Antas, Rio de Janeiro, Brasil. Para entender a periodicidade de formação dos anéis de crescimento, foram realizados experimentos de lesão no câmbio vascular e análises microscópicas diretas do câmbio e dos tecidos adjacentes. A largura dos anéis de crescimento foram usadas para investigar o incremento radial das espécies e para construir cronologias. Foi observado que o crescimento radial de ambas as espécies ocorre durante as estações chuvosas e de transição, passando por um período de dormência cambial na estação seca. A relação entre crescimento radial e chuva foi reforçada ao observar que as cronologias da largura dos anéis de crescimento possuem correlação positiva com a precipitação, no entanto, as espécies respondem a precipitação em períodos diferentes do ano. As taxas e tendências de crescimento foram semelhantes nos plantios e nos remanescentes florestais, mostrando que a situação de plantio não afeta o crescimento potencial das espécies. Esse dado reforça o sucesso da restauração ecológica desenvolvida na Rebio de Poço das Antas.

\section{Impacts of edge effects on the growth of an emergent tree species in a tropical forest fragment}

Milena Godoy-Veiga ${ }^{1}$, Gregório Ceccantini ${ }^{1}$, Philipp Pitsch ${ }^{2}$, Stefan Krottenthaler ${ }^{2}$, Dieter Anhuf ${ }^{2}$, Giuliano Locosselli ${ }^{1}$

${ }^{1}$ Universidade de São Paulo, Institute of Biosciences, São Paulo, Brasil; ${ }^{2}$ University of Passau, Department of Physical Geography, Passau, Germany (milena.gveiga@gmail.com; gregorio@usp.br; philipp.pitsch@uni-passau.de; gruenermann@googlemail.com; dieter.anhuf@uni-passau.de; locosselli@yahoo.com.br)

Climate change and deforestation are affecting trees worldwide. Intensive deforestation in tropical regions is raising fragmentation to alarming levels, leading to losses of forest area. Abiotic and biotic changes on forest edge areas alter the development of the remaining trees. We aimed to evaluate the effects of forest fragmentation on the growth of the emergent tree species Aspidosperma polyneuron (Apocynaceae) at forest edge and interior in the endangered Brazilian Atlantic Forest. We sampled increment cores of each tree along with their current levels of liana infestation and data about tree and surrounding canopy heights. We used tree-ring analyses to estimate age and growth rate of trees. Both sampled trees and surrounding canopy were taller at the forest interior than at the edge. Nonetheless, trees DBH and age were similar between forest interior and edge. Trees at forest interior display lifetime growth trends common to shade-tolerant species, with a peak of growth rate at 120 years. Such growth trends are shared by all trees before fragmentation. However, growth rates are constantly slow for all diameter classes after fragmentation. The dominance of lianas at forest edge prevents trees from experiencing the expected growth releases during life, probably by keeping the leaves of $A$. polyneuron under conditions similar to the forest understory. Therefore, the management of lianas at the forest edge is an effective procedure to promote the growth of emergent trees, guarantying their role on forests structure, carbon storage, and ecosystem functioning 


\section{Centenarian Brazilian pines may enter into decline due to climate change effect}

Alvaro Boson de Castro Faria ${ }^{1}$, Fagner Goes Conceição ${ }^{1}$, Solon Jonas Longhi ${ }^{1}$

${ }^{1}$ Universidade Tecnológica Federal do Paraná,DoisVizinhos, Brasil (alvarob@utfpr.edu.br; fagnerconceicao@utfpr.edu.br; longhi.solon@gmail.com)

Forest health needs to be considered in the in situ conservation strategies for Araucaria angustifolia, and climate changes anomalies may be influencing droughtinduced tree mortality in the mature trees, with low recovery power. We present a phytosanitary assessment for a native forest in Palmas (State of Paraná), with centenarian trees, for future comparisons over the dead ones. It was verified the behavior of meteorological variables between 2008 and 2018 . The data series were organized by ANOVA and by average tests. A Grouping Analysis was performed, using the Euclidean distance as a similarity pattern, obtaining the groups. A Principal Component Analysis was performed to order the variables. The changes reported here were for the winter months, where in southern Brazil, rainfall is mainly caused by the interaction between the polar air masses, with the continental masses conditioned to ENSO events. The changes were cyclical and standards were verified. Air heat and dryness needs long-term monitoring for climatic warming statement, but, it was verified that overconcentrated rainfall in short periods may have influenced the devitalization and conditioned trees to wilt by dryness, due to hydraulic failure, which would increase mortality in the long term. There are indications that 2009 and 2015 winters were stressful to the Brazilian pine, due to the irregular distribution of the rains and the droughts periods. Still, that a next prolonged drought could be verified until the winter of 2021.

\section{Is climate change adaptation in alpine mountain forests constrained by forest seed production and its climatic triggers?}

Katharina Lapin ${ }^{1}$, Martin Braun ${ }^{2}$, Peter Schwarzbauer ${ }^{2,3}$, Theo Koller $^{3}$, Franziska Hesser $^{3}$, Christoph Dobeš ${ }^{1}$, Silvio Schueler ${ }^{1}$

${ }^{1}$ Federal Research and Training Centre for Forests, Natural Hazards and Landscape, Vienna, Austria, ${ }^{2}$ Institute of Marketing \& Innovation, Department of Economics and Social Sciences, University of Natural Resources and Life Sciences, Vienna, Austria; ${ }^{3}$ Team for Market Analysis and Innovation Research, Wood K plus - Kompetenzzentrum HolzGmbH,Linz,Austria(katharina.lapin@bfw.gv.at; martin.braun@boku.ac.at; peter.schwarzbauer@boku.ac.at; theo.koller@boku.ac.at; franziska.hesser@boku.ac.at; christoph.dobes@bfw.gv.at; silvio.schueler@bfw.gv.at)

Climate change $(\mathrm{CC})$ will considerably alter environmental conditions like temperature and precipitation patterns affecting Central European tree species, especially in alpine regions. To reduce CC-related risks for forests, the planting of different tree species and provenances better adapted to the expected climate has been suggested. However, the amount of seeds produced by temperate tree species varies between years and depends on numerous factors including site and weather conditions during and preceding the year of seed maturation. This study aims to identify the most important climate factors affecting variable seed production in order to estimate the need for forest plantations of key tree species in Austria under different adaptation strategies. Historical data on mast seeding and seed harvest from 1960 to 2016 were collected and analyzed for the currently main tree species. The main climatic conditions and regimes affecting their reproductive features were determined and the occurrence of mast fruiting in each species clustered and mapped at the district level to allow the application of predictive models for all Austrian regions. The results show that the climatic variables affecting masting vary between species and geographical areas and that elevation likewise influences seed production. A heterogeneous distribution of mast fruiting clusters was found for all key tree species. Forest seed producers and forest nurseries are key stakeholders for the implementation of adaptation measures to reliably meet forest seed \& seedling demand. Results of this study can support the development of a transnational CC adaptation management strategy in Austria and Central Europe.

\section{Responses of photosynthesis and component processes to temperature: are Mediterranean trees fit for climate change?}

Dominik Sperlich ${ }^{1}$, Chaoting Chang ${ }^{2}, J_{\text {osep Penuelas }}^{3}$, Santi Sabaté, Juan Carlos Zamora

${ }^{1}$ Albert-Ludwig University, Freiburg, Germany; ${ }^{2}$ CREAF, Barcelona, Spain; ${ }^{3}$ CSIC, Global Ecology Unit CREAF-CSIC-UAB, Cerdanyola del Valles, Spain;

${ }^{4}$ University of Barcelona, Barcelona, Spain; ${ }^{5}$ University of Freiburg, Freiburg, Germany (dominik.sperlich@ife.uni-freiburg.de; r91625045@gmail.com; josep.penuelas@uab.cat; santi.sabate@ub.edu; juan.zamora@ife.uni-freiburg.de)

Global warming is raising concerns about the acclimatory capacity of trees and forests, especially in Mediterranean-type ecosystems. The sensitivity of photosynthesis to temperature is a key uncertainty for projecting the magnitude of terrestrial feedbacks on future climate change. While boreal, temperate and tropical species have been comparatively well investigated less attention has been paid to the Mediterranean trees. We quantified seasonal changes in the responses of net photosynthesis (Anet), stomatal conductance (gs), mesophyllic conductance (gm), and electron-transport rate (Jcf) and investigated their sensitivity to drought and thermal stress in sunlit and shaded leaves of Quercus ilex, Q. pubescens, Pinus halepensis, and Arbutus unedo. All four species showed a remarkably dynamic acclimation of Topt characterised by high thermal tolerance. Seasonal changes in Topt were consistent in all four species, whereas the shape of the response curves was highly species-specific. Surprisingly, severe drought decreased Topt (similar to winter) accompanied by narrower response curves above all in $P$. halepensis, reducing the optimal range for photosynthesis to the cooler morning/evening periods. In contrast, less strict stomatal control under severe drought led to leaf shedding in $Q$. ilex and $Q$. pubescens and additionally branch dieback in $A$. unedo. Water availability was thus a key factor, in addition to growth temperature to explain acclimation of photosynthetic responses to temperature. More frequent and severe drought periods as predicted by climate change may disrupt the acclimatory capacity of Mediterranean trees, which could lead to reduced growth and, for some species such as $A$. unedo, increased mortality risk.

\section{Climate, genetic variability and natural distribution of yerba mate in Southern Brazil}

Elenice Fritzsons ${ }^{1}$, Marcos Silveira Wrege ${ }^{1}$, Márcia Toffani Simão Soares ${ }^{1}$, Ananda Virgínia de Aguiar ${ }^{1}$, Valderês Aparecida de Sousa ${ }^{1}$ ${ }^{1}$ Embrapa Florestas, Colombo,Brasil(elenice.fritzsons@embrapa.br;marcos.wrege@embrapa.br; marcia.toffani@embrapa.br; ananda.aguiar@embrapa.br; valderes.sousa@embrapa.br)

It is believed that very little of the genetic variability of yerba mate (Ilex paraguariensis S. T. Hill) is being explored in breeding programs and in commercial plantations. It is also believed that climate affects the phenotype of plants and models the genetic variation among populations. The aim of this work was to determine differences between specific climates where yerba mate naturally occurs in southern Brazil. A database of 195 natural occurrences of mate (one of the largest databases of yerba mate in Brazil) was set up. These data was applied to multivariate analysis, georeferencing and modelling. As a result, four climatic groups had being obtained using eleven climatic parameters in addition to altitude. Although these groups feature spatial geographic contiguity, it has being found that yerba mate occurs in several lithologic substrates, in different ecosystems (Mixed Ombrophylous Forest, Ombrophylous Dense Montana Forest, Deciduous and Semidecidual Seasonal Forest), and in Atlantic Forest biome and in Pampa biome. Such a distribution indicates great adaptive plasticity of 
yerba mate, greater than those of Araucaria, a symbol species of the Mixed Ombrophilous Forest. The group located in the most temperate climate of Brazil was isolated from the others. This isolated group can be verified in genetic studies that aim to know whether the populations are also genetically different. The output of this study may be used to support further improvement in breeding and conservation of species programs, currently and future use, considering the climatic changes and the anthropic pressures.

\title{
Tree-ring and response to climate variability and carbon sequestration using dendrochronology in the Sahelian Agroforestry of Niger
}

Moussa Massaoudou ${ }^{1}$, Larwanou Mahamane

${ }^{1}$ National institute for Agricultural Research, Maradi, Niger; ${ }^{2}$ International Crops Research Institute for the Semi-Arid Tropics (ICRISAT), Niamey, Niger

(mmassaoudou13@gmail.com; larwanou,mahamane (icrisat-ne))

Agroforestry Parklands are the predominant agro-ecosystems in West Africa where Prosopis africana and Faidherbia albida are some of key species for rural population. While these trees are resistant to external stress, their growth and regeneration depend strongly on local conditions. Meanwhile, characterizing tree response to climate variability and carbon sequestration is limited in the Sahelian Agroforestry Parklands. This study was carried out in two agroforestry parklands in the South Central Niger and purports at characterizing the response to climate variability and carbon sequestration of $P$. africana and $F$. albida trees using modern dendrochronology methods. The methodological approach consisted of sampling discs using standard dendrochronology techniques, LINTAB 6 system for ring width measurements, COFFECHA and ASTAN for respectively crossdating and standardization of chronological series. There was no significant difference in mean ring-width between the two tree species $(\mathrm{P} \geq 0.05)$. However the dynamic of cambial growth varied with tree age for both species indicating strong influence of environmental factors. P. africana $(\mathrm{r} 1=0.50)$ expresses more dependence on annual rainfall than $F$. albida $(\mathrm{r} 2=0.63)$. There was a significant difference in carbon sequestration between the two species $(\mathrm{P} \leq 0.05)$. These results can guide policy makers in the choice of adapted species to climate variability and other anthropogenic pressures in the Sahelian belt of Niger.

\section{Estimating the impact of climate change on Brazil's planted forests sector}

Marluce Scarabello ${ }^{1,2}$, Aline Soterroni ${ }^{1,3}$, Marcia Zilli $^{1}$, Hugo Valin $^{3}$, Aline Mosnier ${ }^{3}$, Florian Kraxner ${ }^{3}$, Fernando Ramos ${ }^{1}$

${ }^{1}$ Instituto Nacional de Pesquisas Espaciais, São José dos Campos, Brasil; ${ }^{2}$ Instituto de Pesquisa Economica Aplicada, Brasília, Brasil; ${ }^{3}$ International Institutefor Applied Systems Analysis,Vienna, Austria(mascarabello@gmail.com; soterr@iiasa.ac.at; marciatz@gmail.com; valin@iiasa.ac.at; mosnier@iiasa.ac.at; kraxner@iiasa.ac.at; fernando.ramos@inpe.br)

Brazil has 9.85 million hectares of planted forests, grown mainly in the South and Southeast regions. These forests have species of the genera Eucalyptus and Pinus, which represent 93\% of the total. In 2017, 139.83 million cubic meters of log wood for paper, cellulose and other purposes were produced, with a production value of several billions of US dollars. However, projected advances of the planted forests sector in Brazil can be directly impacted by climate change and resulting biophysical effects. Here, we quantify these impacts using GLOBIOM-Brazil, a global bottom-up partial equilibrium model of competition for land use between agriculture, forestry, and bioenergy sectors, which includes various refinements reflecting Brazil's specificities. It computes consumption and trade for 30 regions of the world; and production and land use at a $50 \mathrm{~km}$ grid resolution in Brazil and $250 \mathrm{~km}$ in other regions for the most important crops, wood, and animal products. Land use change depends on the feedback between agricultural demand and biophysical and regulatory constraints on land. Climate change impacts are incorporated in the model by climate shocks on future crop, grass and biomass productivities as projected by Global Gridded Crop Growth Models simulated for five Global Climate Models (HadGEM-ES, MIROC-ESM-CHEM, IPSL-CM5A-LR, GFDL-ESM2M, NorESM1-M) and two climate change scenarios (RCP 2.6 and RCP 8.5). Simulations through the year 2050 indicate a slight decrease of the biomass of planted forests in all Brazilian biomes but the Pampa, where the conditions for planted forests are projected to improve.

\section{Dry of Brazil nut trees at Resex Cajari: new evidence that climate anomalies are affecting Amazonian biodiversity}

\author{
Marcelino Guedes ${ }^{1}$ (D), Dayane Pastana ${ }^{2}$ Érica Modena ${ }^{3}$ \\ ${ }^{1}$ Embrapa Amapá, Macapá, Brasil; ${ }^{2}$ Embrapa Amapá, CNPq, fellowship of scientific initiation, Macapá, Brasil; ${ }^{3}$ CAPES/FAPEAP, fellowship of post \\ doctoral, Macapá, Brasil (marcelino.guedes@embrapa.br; dayanepastanaa@gmail.com; erimodena@yahoo.com.br)
}

The Brazil nut (Bertholletia excelsa Bonp.) is among the largest trees in the Amazon. It has big canopy area, and is a deciduous species, indicating high water dependence. In order to investigate Brazil nut trees dry, after strong " 2015 el nino", we evaluated occurrence and possible explanations of this drought, and relationships with climatic anomalies and nut production. We conduct semi-structured interviews with agroextractivists, and we analyzed leaves and soil near at 15 trees, with and without symptoms of dry. In the years 2015/2016, was registered the strongest El Niño in the Amazon, with an increase of more than 2 ${ }^{\circ} \mathrm{C}$ in the average temperature, reduction of precipitation and prolongation of the dry period. Probably, the water deficit and temperature stress caused the dry (burn) of the leaves and thin branches of the higher Brazil nut trees, observed in the Santa Rosa region, Resex Cajari-Amapá, Eastern Amazonia. The same did not occur in the young trees, in other species and in other regions. There was a drastic fall in fruit production in 2017, and negative correlation of the production with positive anomalies in the Pacific temperature, demonstrating that this species has sensitivity to climate change. Brazil nut trees can recover and sprout new leaves, but the next harvest is it impaired. The nutritional variables did not present significant relationships with trees dry. The hypothesis raised is that this may be related with hydraulic conductance problems, when occurs cavitation and loss of water molecules adhesion, after physiological stress in large trees.

\section{For the assessment of ozone and climate change impacts on southern European forests: MITIMPACT PROJECT}

Yasutomo Hoshika ${ }^{1}$, Alessandra De Marco ${ }^{2}$, Pierre Sicard ${ }^{3}$, Elisa Carrari ${ }^{1}$, Elena Paoletti ${ }^{1}$

${ }^{1}$ CNR, Sesto Fiorentino (FI), Italy; ${ }^{2}$ ENEA, Roma, Italy; ${ }^{3}$ ARGANS, Biot,France (yasutomo.hoshika@cnr.it; alessandra.demarco@enea.it;

psicard@argans.eu; eli.carrari@gmail.com; elena.paoletti@cnr.it)

Climate change and air pollution are two significant stressors affecting forest health and vitality of European forests. Mediterranean area has been identified as one of the most prominent "Hot-Spots" in future climate change projections and is seriously affected by air pollution, in particular ozone ( $\left.\mathrm{O}_{3}\right)$. The MITIMPACT ALCOTRA project aims to quantify ozone impacts on forest test sites distributed in South East France and Northwest Italy, by evaluating ecosystem health and ecosystem services. The project area can be considered as a case study for the assessment of global change impacts in Mediterranean forests. This innovative aspect of the project can be useful to provide cost-effective measures for forest management in preparation to future climate conditions. Here we will introduce a new monitoring station to measure in real time $\mathrm{O}_{3}$ concentrations together with meteorological parameters in MITIMPACT project. Based on the data obtained here, calculated several $\mathrm{O}_{3}$ indices, especieally the effective dose of $\mathrm{O}_{3}$ entering into the stomata so called phytotoxic ozone dose with a threshold Y (PODy), will be shown. We will discuss new appropriate thresholds to protect Mediterranean forest against the negative effect of $\mathrm{O}_{3}$ for future climate change. 


\section{Derivation of flux-based critical levels for European forest protection against ozone}

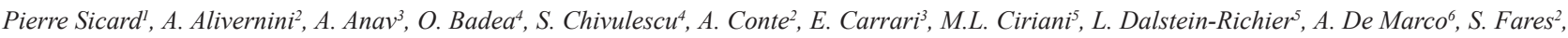
G. Fasano ${ }^{3}$, A. Giovannelli ${ }^{3}$, M. Lazzara ${ }^{3}$, S. Leca ${ }^{4}$, A. Materassi ${ }^{3}$, V. Moretti ${ }^{2}$, D. Pitar-Silaghi ${ }^{4}$, I I. Popa ${ }^{4}$, F. Sabatini ${ }^{3}$, L. Salvati ${ }^{2}$, T. Sorgi ${ }^{2}$, Y. Hoshika ${ }^{3}$, Elena Paoletti ${ }^{3}$

${ }^{1}$ ARGANS, Biot, France; ${ }^{2}$ Forestry Research Centre, CREA-FL, Arezzo, Italy; ${ }^{3}$ Consiglio Nazionale delle Ricerche, Sesto Fiorentino, Italy; ${ }^{4}$ National Institute for Research and Development in Forestry Marin Dracea, Voluntari, Romania; GIEFS, Nice, France; ${ }^{6}$ ENEA, Rome, Italy (psicard@argans.eu; alessandro. anav@ipsp.cnrit; badea63@yahoo.com; eli.carrari@gmail.com; legiefs@aol.com; legiefs@aol.com; alessandra.demarco@enea.it; silvano.fares@crea.gov. it; giovannelli@ivalsa.cnrit; stefan.leca@icas.ro; a.materassi@ibimet.cnr.it; valerio.moretti@crea.gov.it; diana.silaghi@icas.ro; popaicas@gmail.com; f.sabatini@ibimet.cnr.it; tiziano.sorgi@crea.gov.it; hoshika0803@gmail.com; elena.paoletti@cnr.it)

Unique in the world, the project MOTTLES takes place in the main European areas at highest and medium risk of ozone injury, relative to human well-being and vegetation impacts, i.e. Southern and Central Europe and combines field epidemiology with plant-responses to ozone. A standard for forest protection is considered biologically relevant when it translates into real-world forest impacts. For this reason, epidemiological investigations where large-scale biological responses (e.g radial growth, crown defoliation and visible foliar ozone injury) are compared with ambient data in the field provide useful information for establishing the best standards and thresholds for forest protection from ozone. Ozone effects on vegetation depend on the air concentrations but also on the ozoneuptake through the stomata, i.e. phytotoxic ozone dose above a threshold Y of uptake (PODY). With the effort of implementing permanent new-generation monitoring stations across Europe, capable to return continuous hourly ozone concentrations with meteorological and environmental parameters in real-time, PODY is estimated and correlated to measured forest-response indicators to develop flux-based critical levels (CLef) for forest protection against ozone. Based on real-world flux-effect relationships, derivation of suitable species-specific epidemiologically-based ozone critical levels for European tree species represents a considerable progress in the development of methods for quantifying ozone effects on vegetation at the regional scale. This work was carried out with the contribution of the LIFE financial instrument of the European Union (LIFE15 ENV/IT/000183) in the framework of the MOTTLES project "Monitoring ozone injury for setting new critical levels".

\section{Seasonal growth of a clonal Eucalyptus plantation in soil fertilized with class b sewage sludge}

Cassio Hamilton Abreu-Junior ${ }^{1}$ D, Paulo Henrique Silveira Cardoso ${ }^{1}$, Thays da Silva Mandu ${ }^{1}$, Anibal Deboni Neto ${ }^{1}$, Antonio Leite Florentino 2 (D) Rhayra da Silva Paiva Branco ${ }^{1}$, Marcelo Gomes de Oliveira, Thomas Gamper Feitoza ${ }^{1}$, Clayton Alcarde Alvares ${ }^{3}$, José Luiz Stape

${ }^{1}$ Universidade de São Paulo, Centro de Energia Nuclear na Agricultura, Piracicaba, Brasil;; ${ }^{2}$ Universidade de São Paulo, Piracicaba, Brasil; ${ }^{3}$ Suzano Papel eCelulose,Itapetininga,Brasil(cahabreu@cena.usp.br; paulohscardoso@usp.br; thaysmandu@usp.br; anibaldeboni@gmail.com; antonio.florentino@usp. br; rhayra.branco@usp.br; magoliveira102@hotmail.com; thomasfeitoza@gmail.com; calcarde@suzano.com.br; stape@suzano.com.br)

The objective of this work was to evaluate seasonality of trees growth of a Eucalyptus plantation fertilized with sewage sludge (SS) and K, complemented or not with P and/or B, and their respective response to meteorological variables. Therefore, in February 2015, a randomized block experiment was set up using clones of Eucalyptus (SP5727), with ten treatments and four replications, in a commercial area with water restriction (Cwa, Köppen scale) and low soil fertility of the company Suzano Papel e Celulose S.A. The treatments were two levels of mineral fertilization, seven treatments with SS and K, supplemented or not with $\mathrm{P}$ and/or B, and one control. From 23 to 35 months after planting, a biweekly monitoring was carried out, using dendrometer bands, in five trees per plot. The treatments with application of 50\%LE+86\%P-B+K, 100\%LE+66\%P-B+K, $100 \%$ LE+66\% $\mathrm{P}+\mathrm{B}+\mathrm{K}, 150 \% \mathrm{LE}-\mathrm{P}-\mathrm{B}+\mathrm{K}$ and the highest level of mineral fertilization presented a volume of wood $\left(139 \mathrm{~m}^{3} \mathrm{ha}^{-1}\right)$ higher than the control $\left(125 \mathrm{~m}^{3} \mathrm{ha}^{-1}\right)$. There was a smaller increase of transversal area in the period of low rainfall (July to October), with a high growth rate in October, after precipitation of $50 \mathrm{~mm}$. The variables minimum temperature and potential evapotranspiration were the ones that most influenced the increment of the cross-sectional area, positively and negatively, respectively. The precipitation, although significant, showed low growth influence. There were no differences due to climatic variables between treatments. The fertilization of Eucalyptus with sewage sludge promoted growth equivalent to the application of mineral fertilizer for high productivity.

\section{Intra-annual radial growth patterns of four species of Larix decidua and Abies alba in relation to water limitations}

Adriana Lestianska ${ }^{1}$, Peter Fleischer Junior ${ }^{1}$, Peter Fleischer ${ }^{1}$, Katarina Strelcova ${ }^{1}$, Katarina $18^{1}$

${ }^{1}$ Technical University in Zvolen,Faculty of Forestry,Zvolen, Slovakia (adriana.lestianska@tuzvo.sk; p.flesischerjr@gmail.com; p.fleischersr@gamial.com; katarina.strelcova@tuzvo.sk; katarina.merganicova@tuzvo.sk)

Climate change is expected to increase the frequency and intensity of droughts and heatwaves in Europe, leading to effects on forest growth. This study aims at increasing the understanding on species-specific effects of climate factors on radial growth, which is necessary to assess the responses of tree radial growth to anticipated climate changes. We monitored radial growth response to climate fluctuation of four mature coniferous species (Larix decidua and Abies alba) located ataltitudes from $290 \mathrm{~m}$ a.s.l. to $377 \mathrm{~m}$ a.s.l., Zvolen valley, Central Slovakia. Based on continuous monitoring of stem radial variation of coniferous species using dendrometers within the growing season, daily changes in stem radial variation $(\Delta \mathrm{R})$ and extracted water deficit $(\Delta \mathrm{W})$, maximum daily shrinkage (MDS) and radial growth were extracted. Diurnal cycles were divided into the three phases of contraction, expansion and stem radius increment. We used Morlet wavelet analysis to assess the differences in cyclic radial stem variations between coniferous species. Stem radial variation and extracted variables $(\Delta \mathrm{W})$ were compared among coniferous species and the influences of environmental variables were evaluated by applying correlation analysis and moving correlation analysis (MCA). L. decidua showed more pronounced variability in seasonal course of stem radius variations than A. alba. 


\title{
Biochemical responses to stresses water and light in Cecropia pachystachya Trécul. and Myroxylon peruiferum L.F. used for Tropical forest restoration
}

\author{
Marcela Aparecida de Moraes ${ }^{1}$ (D), Daniele Ribeiro Contin ${ }^{1}$, Eduardo Habermann ${ }^{1}$, Mario Luiz Teixeira de Moraes ${ }^{2}$, Carlos Alberto Martinez ${ }^{1}$ \\ ${ }^{1}$ Universidade de São Paulo, Ribeirão Preto, Brasil; ; Universidade Estadual Paulista "Júlio de Mesquita Filho", Ilha Solteira, Brasil \\ (marcela.apmoraes@gmail.com; danibyo@gmail.com; eduardohabermann@gmail.com; mario.moraes@unesp.br; carlosamh@ffclrp.usp.br)
}

In the tropics, plants are exposed to various abiotic stress conditions and suffer mainly from photoinhibition by high levels of solar radiation, compromising their survival. In the present study, the biochemical characterization was done in two native tree species used in forest restoration projects, one pioneer (Cecropia pachystachya) and one late succession (Myroxylon peruiferum), submitted to two light conditions (full sun and shade) and two water conditions (irrigated and progressive water deficit). Subsequently, plants grown under shade conditions were transferred to sun simulating the opening of a clearing to induce light stress. The concentrations of photosynthetic pigments, carotenoids and enzymatic activity of superoxide dismutase, catalase, ascorbate peroxidase and lipid peroxidation were determined. In all species there was a greater decrease in total chlorophyll content in the sun condition, and water stress accelerated the degradation of this pigment. In rehydration the species didn't present photosynthetic pigment contents similar to the control, suggesting that there wasn't complete biochemical restoration. The highest enzymatic activity was observed in $C$. pachystachya, indicating greater efficiency in the biochemical defense system. On the other hand, $M$. peruiferum presented greater lipid peroxidation, mainly under light stress, indicating the occurrence of oxidative damages. Therefore, independent of the successional classification of the species, these present greater damages when there is a clearing opening in the forest, than to a long period of drought. Thus, the present study contributed to a better understanding of the defense mechanisms of the species the photoinhibition, from the biochemical evaluations under abiotic stresses.

Interactions between urban tree-based biogenic volatile organic compounds (BVOCs) emissions and $\mathrm{O}_{3}$

Jong Kyu Lee ${ }^{1}$, Su Young Woo ${ }^{1}$, Myeongja Kwak', Ji Eun Kim ${ }^{1}$, Sang Hee Park ${ }^{1}$, Han Dong Kim ${ }^{1}$, Yea Ji Lim ${ }^{1}$

${ }^{1}$ University of Seoul, Seoul,Republic of Korea (gpl90@naver.com; wsy@uos.ac.kr; 016na8349@hanmail.net; amarg@naver.com;

parksanghee0930@gmail.com; blasterkhd92@gmail.com; oxlll@naver.com)

Volatile organic compounds (VOCs) has become a big issue, and urban trees can play critical roles in reducing air pollution including gas-phase VOCs by means of the absorption. But plants also may emit a considerable amount of biogenic volatile organic compounds (BVOCs) into the air. BVOCs can contribute to ozone $\left(\mathrm{O}_{3}\right)$ and second organic aerosol (SOA) formation. Air pollution, such as $\mathrm{O}_{3}, \mathrm{SO}_{2}$ and NOx, may induce or decrease BVOCs emissions by affecting metabolism of plants in different ways. Interaction between BVOCs and air pollution is a key factor of characteristics of the atmospheric environment. This research aimed to study BVOCs emission on five major urban trees (Pinus densiflora, Ginkgo biloba, Taxus cuspidata, Prunus yedoensis and Zelkova serrata) under elevated ${ }_{3}$ (100 ppb), which is one of the most serious air pollutants. The experiment was conducted by using $\mathrm{O}_{3}{ }^{-}$controlled phytotron chamber. Many BVOCs, including isoprene, $\alpha$-pinene, $\beta$-pinene and limonene, are investigated; $100 \mathrm{ppb}$ of $\mathrm{O}_{3}$ induced change of BVOCs, either increasing or decreasing emission. With $100 \mathrm{ppb}$ $\mathrm{O}_{3}$ for 6 weeks, the content of $\alpha$-pinene from Pinus densiflora and Ginkgo biloba was significantly increased compared to control chamber ( 10 ppb of $\left.\mathrm{O}_{3}\right)$. The emission of other BVOCs under $100 \mathrm{ppb}$ of $\mathrm{O}_{3}$ presented significant difference compared to $10 \mathrm{ppb}$. Also, the change of BVOCs emission under elevated $\mathrm{O}_{3}$ was also depending on species. Acknowledgment: This research was supported by Basic Science Research Program through the National Research Foundation of Korea (NRF) funded by the Ministry of Education (No; 2018R1D1A1A02044683).

\section{Artificial night lighting causes photosynthetic downregulation and incomplete stomatal closure in Liriodendron tulipifera L.}

Myeongja Kwak', Jongkyu Lee ${ }^{1}$, Yeaji Lim ${ }^{1}$, Handong Kim¹, Sanghee Park ${ }^{1}$, Suyoung Woo ${ }^{1}$, Saenggeul Back ${ }^{2}$

${ }^{1}$ University of Seoul, Seoul, Republic of Korea; ${ }^{2}$ Baekdudaegan National Arboretum, Bonghwa-gun, Republic of Korea (016na8349@hanmail.net; gpl90@naver.com; oxll²@naver.com; blasterkhd92@gmail.com; parksanghee0930@gmail.com; wsy@uos.ac.kr; bsg1175@bdna.or.kr)

Light pollution generated by artificial night lighting can alter natural light patterns and have a negative impact on living organisms, including plants. This study determined the impact of artificial night lighting on yellow-poplar (Liriodendron tulipifera L.) seedlings using artificial street lighting (high-pressure sodium lamp). Seedlings were exposed to either natural night lighting (control) or artificial night lighting (treatment) with a photoperiod of $13 \mathrm{~h}$ day/11 h night over two years. Yellow-poplar seedlings were evaluated for their nighttime light response strategies, including photosynthetic light harvesting relative to daytime gas exchange parameters, nighttime stomatal opening, photosystem II photochemistry, and photosynthetic function. Yellow-poplar seedlings exposed to artificial night lighting showed functional dynamics in their photosynthetic capacity, including night lighting inhibition of photosynthesis, reduced photochemical efficiency of photosystem II, and increased stomatal limitation, especially at the highest level of artificial night lighting. Furthermore, nighttime stomatal opening was frequently observed in yellow-poplar leaves grown under artificial night lighting. Results of this study advance our understanding of the interrelationship between photosynthetic downregulation and incomplete nighttime stomatal closure, via modification of photoperiod perception by circadian dysfunction. This research was supported by Basic Science Research Program through the National Research Foundation of Korea (NRF) funded by the Ministry of Education ( No 2012R1A1A2005498).

\section{Bioindicators to evaluate the impact of industrial plants on urban settlement: a case study in Southern}

Giuseppe Colangelo ${ }^{1}$, Giovanni Sanesi ${ }^{1}$

${ }^{1}$ University of Bari, Bari, Italy (giuseppe.colangelo@uniba.it; giovanni.sanesi@uniba.it)

Atmospheric pollution of industrial areas near to urban centre play a crucial role in contamination and degradation of the urban health and safety. This study analysed the chemical composition of tree rings and lichens to investigate: 1 . ranging impact of pollutant according to the distance from pollutant sources; 2. spatial and temporal variability of pollutants in relation with the sprawling and transformation of industrial activities; 3 . potential use of bioindicators as passive samplers in monitoring of the urban environment. The study area consists of an industrial area with different pollutants sources (steel factory, oil refinery) close to the city centre of Taranto (Italy). The city is mentioned among the Italian national sites with documented contamination and associated potential health impacts (National Priority Contaminated Sites-NPCSs). Field data collection was performed in a 36 km circular buffer with 8 concentric areas assuming the industrial site as the centre of the study area. Were sampled 42 sites collecting tree corers and lichens. All samples were analysed to detect trace element index (Cr, Be, As, Cd, Pb, Hg, Sn, Ni, V, and Zn). The initial hypothesis focused on the spatial variation of the impact of the pollutants on such bioindicators according to the proximity of the industrial plants. Moreover, chemical patterns were detected to assess the suitability of results in reflecting the variations of industrial activities over time. Results show that the analysis is a suitable methodology to investigate past and recent diffusion of pollutants and to support the management of such areas. 


\author{
Evaluation of real options: strategy in the allocation of resources for planting of Ochroma pyramidale \\ Rafaele Almeida Munis $^{1}$ (D), Ricardo Hideaki Miyajima 1 (D), Gislaine Cristina Batistela 2 (D, Douglas Henrique da Fé $\left(\mathbb{D}\right.$, Danilo Simões $^{1}$ (D)

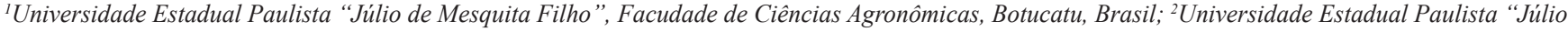 \\ de Mesquita Filho”, Campus de Itapeva, Itapeva, Brasil(rafaele.munis@gmail.com; richidetoshimiyajima@hotmail.com; gislaine.batistela@unesp.br; \\ douglas.fe@unesp.br; danilo.simoes@unesp.br)
}

The real options approach makes it possible to integrate the uncertainties and management flexibilities of investment projects into real assets, that is, it allows explicit calculation of the value of strategic decisions that can be contemplated during the life of the project, which does not occur with the traditional form calculation of net present value. The objective of this study was to evaluate a forest investment project for the Ochroma pyramidale planting in the Center-West region of the State of São Paulo, to quantify the strategic value based on a binomial pricing model. The project aims to plant Ochroma pyramidale established in an area of five hectares, spaced $3 \mathrm{~m}^{2} \times 1.5 \mathrm{~m}^{2}$, which required an CAPEX of USD40,521.92. The cash flow was projected for a five-year horizon, discounted through the capital asset pricing model (CAPM). The underlying asset was modeled using a binomial tree, and the behavior of the asset value was described by the multiplicative values of increase and decrease. Consequently, the relevant options (American Call) were the deferral and expansion, that is, from the focal date the forest producer can wait two years to realize the investment until uncertainties are resolved and the project becomes feasible and, in the fourth year of the useful life the planted area can be expanded by 30\%. The results revealed that by integrating the option value of USD43,151.13 to the capital budget, an expanded (strategic) NPV of USD46,155.13.

\author{
Effects of soil nitrogen $(\mathrm{N})$ deficiency on photosynthetic $\mathrm{N}$-use efficiency in $\mathrm{N}$-fixing and non-N-fixing tree seedlings in subtropical \\ China \\ Zuomin Shi ${ }^{1}$, Ruimei Cheng ${ }^{1}$ \\ ${ }^{1}$ Institute of Forest Ecology, Environment and Protection, CAF, Beijing, China (shizm@caf.ac.cn; chengrm@caf.ac.cn)
}

Soil nitrogen $(\mathrm{N})$ deficiencies can affect the photosynthetic N-use efficiency (PNUE), mesophyll conductance (gm), and leaf $\mathrm{N}$ allocation in many plant species. However, there is a lack of information about how these physiological characteristics in N-fixing trees could be affected by soil $\mathrm{N}$ deficiency and the difference in adaptations to $\mathrm{N}$ deficiency between $\mathrm{N}$-fixing and non-N-fixing trees. In this study, we choose seedlings of two N-fixing (Dalbergia odorifera and Erythrophleum fordii) and two non-N-fixing trees (Castanopsis hystrix and Betula alnoides) as study objects, and we conducted a pot experiment with three levels of soil $\mathrm{N}$ treatments (high nitrogen, $\mathrm{HN}$; medium nitrogen, MN; and low nitrogen, LN). Our results showed that soil N deficiency significantly decreased the leaf $\mathrm{N}$ concentration and photosynthesis ability of thetwonon-N-fixing trees, but it had less influence on these indices in the two $\mathrm{N}$-fixing trees. The LN treatment had lower gm in $D$. odorifera and lower leaf $\mathrm{N}$ allocated to Rubisco (PR), leaf $\mathrm{N}$ allocated to bioenergetics (PB), and gm in $B$. alnoides, eventually resulting in low PNUE values. D. odorifera, B. alnoides, and C. hystrix seedling leaves had improved leaf $\mathrm{N}$ allocated to the cell wall (PCW) and (or) the leaf mass per area (LMA) to adapt to a low-N soil environment. Our findings suggested that the $D$. odorifera and $E$. fordii seedlings could grow well in N-deficient soil and adding $\mathrm{N}$ may increase the growth rates of $B$. alnoides and $C$. hystrix seedlings and promote the growth of artificial forests.

\title{
Geographic clines in genetic diversity and variation in adaptive traits of two major pine species, Pinus densiflora and Pinus thunbergii, in Japan
}

Masakazu G. Iwaizumi ${ }^{1}$,Yoshiaki Tsuda 2 , Yoshihiko Tsumura ${ }^{2}$, Makoto Takahashi', Tomonori Hirao ${ }^{4}$, Atsushi Watanabe

${ }^{1}$ Kansai Regional Breeding Office, Forest Tree Breeding Center (FTBC), Forestry and Forest Products Research Institute (FFPRI), Forest Research and Management Organization (FRMO), Katsuta, Japan; ${ }^{2}$ Faculty of Life and Environmental Sciences, University of Tsukuba, Tsukuba, Japan; ${ }^{3}$ Genetic Resources Department, FTBC, FFPRI, FRMO, Hitachi, Japan; ${ }^{4}$ Forest Bio-research Center, FFPRI, FRMO, Hitachi, Japan; ${ }^{5}$ Department of Forest Environmental Science, Faculty of Agriculture, Kyushu University, Fukuoka, Japan (ganchan@ffpri.affrc.go.jp; tsuda.yoshiaki.ge@u.tsukuba.ac.jp; tsumura.yoshihiko.ke@u.tsukuba.ac.jp; makotot@ffpri.affrc.go.jp; hiratomo@ffpri.affrc.go.jp; nabeatsu@agr.kyushu-u.ac.jp)

Pinus densiflora (Japanese red pine) and $P$. thunbergii (Japanese black pine) are two major economically and ecologically important pine species in Japan. Because of serious population size reduction throughout Japan due to the extensive damages from pine wilt disease, appropriate design for conserving and managing their regional genetic resources is essential. In the present study, geographic patterns of genetic diversity of 62 P. densiflora natural populations (in total of 1,883 trees) and 49 P. thunbergii old planted populations (2,755 trees) were examined using nuclear microsatellite markers. As adaptive traits, geographic variations in cone characteristics were also investigated for 28 and 24 genotyped populations, respectively. We found that allelic diversity was significantly lower in northeastern populations for both species. Structure analyses revealed a clinal genetic structure from southwestern to northeastern populations. For $P$. densiflora, the northeastern cluster showed the highest $\mathrm{F}$ value; whereas, for $P$. thunbergii, some populations showed quite a different local proportion of cluster memberships from nearby populations. These results indicated species-specific backgrounds; genetic drift through recent population expansion in northeastern Japan suggested by anthropological and paleoecological studies ( $P$. densiflora) and historical seed pool transfer to develop coastal forest against land erosion (P. thunbergii). We also found that cone size (length, width) of trees was significantly larger in northern populations for both species. Results obtained in these variations would provide fundamental information for designing nematode-resistant breeding zones and also for evaluating adaptive genetic variations against climate changes in future studies.

Estimating the biomass of Guadua weberbaueri inside and on the edge of forests in the Western Brazilian Amazon / Estimativa de biomassa e anatomia de Guadua weberbaueri no Interior e Borda de Floresta na Amazônia Ocidental Brasileira

Berenice Silva $^{1}$ D, Yasmin Rodrigues ${ }^{1}$, Sebastião Santos ${ }^{1}$, Vitor Andrade ${ }^{1}$, Moisés Lobão ${ }^{1}$

${ }^{1}$ Universidade Federal do Acre, Rio Branco,Brasil (bereniceka@gmail.com; iasmimalves.ro2011@gmail.com; kennonsantos@gmail.com; vitorjg.andrade@gmail.com; moiseslobao6@gmail.com)

A floresta Amazônica, no estado do Acre, Brasil, se destaca como uma região rica em diversidade de espécies de bambus lenhosos, visto que 38\% da composição florística dessa região é constituída por bambuzais. A cultura do bambu, embora milenar, tem sua utilização e pesquisas em sua maioria restritas aos países orientais, sendo, portanto, interessante que haja o fomento de projetos de estudo para as espécies de bambu nativos da Amazônia tendo em vista a sua 
versatilidade. Neste trabalho, foram avaliados dados biométricos de Guadua weberbaueri (popularmente conhecido como taboca) que se desenvolveu em borda de floresta (ambiente antropizado) e no interior da floresta. Valores de DAP (diâmetro na altura do peito) foram usados para calcular a biomassa de acordo com modelos específicos para a espécie e região. Observou-se que os tabocais que cresceram na borda obtiveram menores valores de biomassa em comparação aos tabocais crescendo no interior da floresta, observando-se uma média de $1,76 \mathrm{~kg} \mathrm{vs;} 4,59 \mathrm{~kg}$ por indivíduo, respectivamente, o que mostra um efeito negativo do estresse abiótico causado por diversos fatores antrópicos característicos da borda da floresta (desmatamento, danos mecânicos, efeitos do vento etc). Além dos dados biométricos, este trabalho irá correlacionar a biomassa com as características anatômicas dos colmos e raízes de bambu de forma a entender como esses fatores de estresse abiótico interferem na anatomia do bambu.

\section{Flowering phenology and pollen characteristics of Quercus species growing in Korea}

Myeongja Kwak', Jongkyu Lee ${ }^{1}$, Handong Kim ${ }^{1}$, Yeaji Lim ${ }^{1}$, Sanghee Park ${ }^{1}$, Suyoung Woo

${ }^{1}$ University of Seoul, Seoul, Republic of Korea(016na8349@hanmail.net; gpl90@naver.com; blasterkhd92@gmail.com; oxll2l@naver.com; arksanghee0930@gmail.com;wsy@uos.ac.kr)

Recently, the incidence of major allergic diseases has increased by the conversion of coniferous forests to deciduous broad-leaved forest in Korea. Oaks such as Quercus serrata, Q. acutissima, and Q. mongolica, which are typical broad-leaved species of Korea, are allergen-inducing pollen species. Furthermore, identification of the dynamics between the flowering time and pollen dispersal under elevated $\mathrm{CO}_{2}$ is very important in the establishment of health monitoring system. The present study aimed to assess bud development stages and pollen dispersal of $Q$. acutissima according to elevated $\mathrm{CO}_{2}$. The pollen dispersal and production of oak species can be predicted by the interaction between temperature and other climatic factors as well as the complexity of overlapping plant seasonality. The pollen production increased in $Q$. acutissima grown under elevated $\mathrm{CO}_{2}$ compared with the atmospheric $\mathrm{CO}_{2}$. The pollen dispersal of $Q$. serrata tends to be different depending on the climatic factors, and the climate change due to the increase of $\mathrm{CO}_{2}$ concentration is expected to increase the air pollen dispersal. Climate change and global warming are the main cause of plant phenology, but these phenological patterns can also affect by other factors including precipitation and $\mathrm{CO}_{2}$ concentration. Plant phenological patterns are an important biomarker of ongoing ecosystem changes and can provide a general idea that future climate change can be a key driver of biodiversity changes. This research was supported by Basic Science Research Program through the National Research Foundation of Korea (NRF) funded by the Ministry of Education (No; 2018R1D1A1A02044683).

\section{Effects of potassium/sodium fertilization and water availability on wood properties of Eucalyptus grandis trees \\ Roger Chambi-Legoas ${ }^{1}$ (D), Gilles Chaix ${ }^{I, 2}$, Mario Tomazello-Filho ${ }^{1}$ \\ ${ }^{1}$ Escola Superior de Agricultura “Luiz de Queiroz”, Universidade de São Paulo, Piracicaba, Brasil; ${ }^{2}$ CIRAD, UMR AGAP, Montpellier, France (rogerchl@usp.br; gilles.chaix@cirad.fr; mtomazel@usp.br)}

In Brazil, most Eucalyptus plantations are located in regions experiencing periods of water shortage where fertilizers such as potassium (K) are intensively used to achieve high productivity. Recently, sodium $(\mathrm{Na})$ has also been considered a potential nutrient. As well as tree growth, wood properties are also an important factor to consider in order to measure the impacts of silvicultural practices and water deficit on forest productivity, since they are determinants for quality and yield of pulp and paper. In a split-plot experimental design with 4-year-old Eucalyptus grandis trees, located in São Paulo State, Brazil, we evaluate the effects of K and Na supply compared with a control treatment, under two water supply regimes (37\% throughfall reduction versus no throughfall reduction) on stem volume, heartwood proportion, basic density, fiber, and vessel properties. K and Na fertilization increased stem volume 2.7 and 1.9 fold, respectively, with a nonsignificant effect of $37 \%$ throughfall reduction. Na fertilization was more detrimental to wood properties that K fertilization, affecting heartwood proportion, basic density, and fiber wall thickness. K fertilization affected only heartwood proportion and basic density. The $37 \%$ throughfall reduction only affected wood basic density, increasing it. Effects of fertilization treatments did not change regardless changes in water supply.Despite the detrimental effects of fertilizers (stronger with Na supply) in wood properties there is a large beneficial effect on stem volume (stronger with K supply), even under a water availability reduction, that would be compensates the loss of wood quality for pulp and paper production.

\section{Urban and industrial air pollution effects on a native specie of Atlantic Rainforest}

Daniel Rodrigues da Silva ${ }^{1}$, Luzimar Campos da Silva ${ }^{1}$, Silvia Ribeiro de Souza ${ }^{2}$, Larisse de Freitas Silva ${ }^{3}$

${ }^{1}$ Plant Anatomy Laboratory, Department of Plant Biology, Federal University of Viçosa, Viçosa, Brasil; ${ }^{2}$ Ecology and Physiology Research Center, Botanical Institute, São Paulo, Brasil; ${ }^{3}$ Federal University of Recôncavo da Bahia, Center for Agricultural, Env (silvabiodaniel@yahoo.com.br;

luzimarcampos@yahoo.com.br; souzasrd@gmail.com; larisse_bio@yahoo.com.br)

The large Brazilian urban centers are located in the Atlantic Rainforest domain, an important global biome, and urban air pollution contributes to forest decline. In the Ipatinga's city, Minas Gerais - Brazil, exist a steel mill and a circulating fleet of vehicles responsible for atmospheric pollutants emissions that contribute to the reduction of environmental quality. The objective was to evaluate the urban and industrial air pollution effects of Ipatinga in Joannesia princeps Vell. (Euphorbiaceae), a native Atlantic Rainforest specie. For this, we analyzed the visual foliar damages and the anatomical and micromorphological effects in extrafloral nectaries (EFNs) of this species. During 126 days, J. princeps seedlings wereexposed in stand systemsat Bom Retiro, Cariru, Cidade Nobre and Veneza points in the Ipatinga's city. The leaf symptomatology was evaluated monthly. For the anatomical analysis, EFNs were collected and processed for analysis in light microscopy and scanning electron microscopy. At Bom Retiro and Cariru points, the highest concentrations of NO, NOX, SO2, O3, benzene and naphthalene were recorded. The highest concentrations of hydrocarbon pollutants were recorded in the Cidade Nobre and Veneza points. In plants exposed at the Cariru point, more visual damage was observed. Regarding the anatomical and micromorphological damages in the EFNs, tissue necrosis,wound healing formation and cell hyperplasia, intense superficial damage such as epidermal rupture, fungal colonization, disarrangement and trichome fall were observed. Thus, our data suggest that the urban air pollution of Ipatinga's citypromotes changes in the morphology and micromorphology of native plant species.

\section{Mangrove species of Rhizophora apiculata BL. and Avicennia alba BL. in responses to the changes in sediment condition impacted by processes of deposition and erosion in coastal areas, Vietnam}

Linh Nguyen Thuy My ${ }^{1,2}$, Pil Sun Park ${ }^{2}$

${ }^{1}$ Vietnamese Academy of Forest Sciences, Hanoi, Vietnam; ${ }^{2}$ Seoul National University, Seoul, Republic of Korea (linh.ntm@rcfee.org.vn; pspark@snu.ac.kr)

Mangroveforests are one ofimportant estuarine ecosystems, controllingthe formulation, stabilization and development of coastal muddy banks. Mangroves species are naturally adaptive to normal disturbances butsensitive to stressors. Rhizophora apiculata BL. and Avicennia alba BL. are the most abundance mangrove species distributed in the South areas of Vietnam. Unbalance in the deposition and erosion processes within this area have been strongly affecting 
mangrove lost. Two species were hypothesized to respond differently corresponding with soil condition variations between contrasting sites of deposition anderosion. Relative abundance, regenerative status and root morphology were analyzed in correlations with changes in elevation and sediment properties of soil salinity, acidic, porosity, organic matter and water content. Avicennia alba BL. and Rhizophora apiculata BL. remained the dominance from seedlings to matures in deposition and erosion area, respectively. To be better adaptation to soil condition variation, higher number of primary stilt roots and root spread distance of Rhizophora apiculata BL. were detected in erosive substrate. Pneumatophores of Avicennia alba BL., however, showed lower values of root density, length and coverage, associated with the weak adaptation in erosion area. Our results suggested that the restoration of mangrove forests should use appropriate species that are adapted to erosion and deposition processes in coastal areas.

B2s: NOVEL ADVANCES IN GENOMICS AND TREE BREEDING FOR SUSTAINABLE FORESTS

\section{Early selection efficiency for growth in two half-sib population of Eucalyptus grandis Hill ex. Maiden}

Paola Molina ${ }^{1,2}$, Jorge Franco ${ }^{3}$, Ariel Castro ${ }^{4}$

${ }^{1}$ Lumin, Tacuarembó, Uruguay; ${ }^{2}$ Centro Universitario de Tacuarembó, Universidad de la República Tacuarembó Uruguay; ${ }^{3}$ Departamento de Biometría, Estadística y Computación, Facultad de Agronomía, Universidad de la República, Paysandú, Uruguay; ${ }^{4}$ Departamento de Producción Vegetal, Facultad de Agronomia, Universidad de la República, Paysandú,Uruguay (paolamleon@gmail.com; jfranco@fagro.edu.uy; vontruch@fagro.edu.uy)

Reducing the time in each cycle on breeding programs is one strategy to increase genetic gains. The objective of the study was to estimate the efficiency of early selection in Eucalyptus grandis Hill ex Maiden half-sib families selected prior to year 5 based on diameter at breast height (DBH), total height (HT) and cylindrical volume (VOL) in a solid wood genetic improvement program. Progeny trials, grouped in two populations according to the seed source (Population 1 and Population 2), were planted in 2009 in the departments of Tacuarembó and Cerro Largo, Uruguay, with randomized complete block design (BCA) and single tree plot (STP). Genotype by environment interaction was identified in Population 2 for DAP and VOL. Mean heritability increased as they approached year 5 , DAP 0.21 to 0.36 , HT 0.42 to 0.54 and VOL 0.20 to 0.36 . Age-age genetic correlations were high $(>0.70)$ from year 3 . DAP was the variable that presented the highest genetic correlation with VOL $(>0.60)$ from year 3 . The selection efficiency (E) was higher in years 3 and 4 . The genetic parameters, the percentages of G/year and the E for DAP, HT and VOL showed similar behaviors within each trial and variations between trials which indicate the potential for early selection prior to year 5 in populations of $E$. grandis and shorten the time of the material evaluation phase to reduce the cycle of improvement.

\section{Variety testing and selection of the intersectional poplar hybrids for industrial plantation forests in the Central Chenrozem region of Russia \\ Tsarev Vadim Anatol'evich ${ }^{1}$ \\ ${ }^{1}$ All-Russian Research Institute of Forest Genetics, Breeding and Biotechnology, Voronezh, Russian Federation (vad.tsareff@yandex.ru)}

The urgency of the problem of variety testing and hybridization of poplars is due to the need to develop and select the most productive and sustainable hybrids of fast-growing tree species in order to create plantations which cover the ever-growing shortage of wood in the densely populated but low-forest South-Eastern part of the European territory of Russia. The objectives of research were to summarize the results of long-term variety testing of the intersectional hybrids obtained from controlled crosses of balsamic poplars with black and black poplars with balsamic ones and to select the best of them. The object of research was the testing site (populetum) on the area of 4 ha made in 1974 on Typical Chernozem soil by stem cuttings with arrangement place $5 \times 4 \mathrm{~m}$ in Semiluki situated in Voronezh region; 13 clones of intersectional poplar hybrids were introduced into the test. The results of 40 -year studies of their survival, height and diameter growth, trunk volume and wood stock dynamics have been allowed identifying the most promising poplars' intersectional hybrids proposed in the assortment for the creation of the most fast-growing and sustainable forest and shelter belt plantations in the region. By the age of quantitative timber maturity of intersectional poplar hybrids (i.e; 25 years) their survival was $83-100 \%$, the wood stock $-462-641 \mathrm{~m}^{3} / \mathrm{ha}$ and the average increment $-18.5-25.6 \mathrm{~m} / \mathrm{ha} / \mathrm{yr}$. Further by the age of 40 their productivity and sustainability also remained quite high (survival 63-96\%, wood stock $-417-764 \mathrm{~m}^{3} / \mathrm{ha}$ and average increment $-10.45-19.1 \mathrm{~m} / \mathrm{ha} / \mathrm{yr}$ )

Genetic variation for growth traits in progenies of Eucalyptus pellita F. Muell / Variação genética para caracteres de crescimento em progênies de Eucalyptus pellita F. Muell

Darlin Gonzalez Zaruma1, Jose Carlos de Oliveira ${ }^{2}$, Jory Alvarado Chamba ${ }^{3}$, Ney Quezada Cabrera ${ }^{3}$, Henrry Cuenca Suing ${ }^{3}$, Daniele Fernanda Zulian ${ }^{2}$, Maiara Ribeiro Cornacini ${ }^{1}$, Paulo Henrique Müller da Silva4, Mario Luiz Teixeira de Moraes ${ }^{2}$

${ }^{1}$ Universidade Estadual Paulista "Júlio de Mesquita Filho", Botucatu, Brasil; ${ }^{2}$ Universidade Estadual Paulista "Júlio de Mesquita Filho", Ilha Solteira, Brasil; ${ }^{3}$ Universidad Nacional de Loja, Loja, Ecuador; ${ }^{4}$ Instituto de Pesquisas e Estudos Florestais, Pir (dgzaruma@gmail.com; ze0897@gmail.com; yory. andres1993@gmail.com; quezadaney@gmail.com; henrrycuenca93@gmail.com; danizullian@gmail.com; maiaracornacini@gmail.com; paulohenrique@ipef.br; teixeira@agr.feis.unesp.br)

Eucalyptus pellita é uma espécie arbórea que possui atributos silviculturais promissoras que a tornam atraente para o estabelecimento de plantações, contudo, a melhor compreensão do controle genético do crescimento é necessária para apoiar os esforços de melhoramento genético. Nesse sentido, o objetivo do estudo foi avaliar a variação genética para caracteres silviculturais, em um teste de progênies. O teste foi instalado em maio de 2016, na Fazenda de Ensino, Pesquisa e Extensão (FEPE/Unesp), em Selvíria-MS. O delineamento experimental foi de blocos casualizados, com uma planta por parcela, 20 repetições, no espaçamento de 3,0 $\mathrm{m} \times 1,5 \mathrm{~m}$. Foram utilizados 206 tratamentos (progênies). Aos dois anos de idade foi avaliado: altura total (ALT) diâmetro a altura do peito (DAP) e sobrevivência (SOB). As estimativas de componentes de variância e parâmetros genéticos foram obtidas pelo método da máxima verossimilhança restrita e melhor predição linear não viciada (REML/BLUP). Os indivíduos apresentaram boa adaptação ao local com 77\% de SOB e a média para ALT e DAP foi de 8,14 $\mathrm{m}$ e $6,35 \mathrm{~cm}$, respectivamente. Foram detectadas diferenças significativas a $1 \%$ de significância na análise de deviance (LRT). O coeficiente de herdabilidade, em nível de média de progênies, foi de 0,77 (ALT) e 0,64 (DAP) resultando em acurácia elevada. O coeficiente de variação genética, em nível de progênies, foi de 13,8\% (ALT) e 10,7\% (DAP). Assim, a presença de variação genética e a acurácia encontradas, para os caráteres nas progênies, indicam boas perspectivas de ganho na seleção nessa população de E. pellita. 
Genotype characteristics of Eucalyptus benthamii in developing clonal cultivars / Caracterização de genótipo de Eucalyptus benthamii no desenvolvimento de cultivar clonal

Paulo Eduardo Telles dos Santos ${ }^{1}$, Estefano Paludzyszyn Filho', Washington Luiz E. Magalhães ${ }^{1}$

${ }^{1}$ Embrapa Florestas, Colombo,Brasil (paulo.telles@embrapa.br; estefano.filho@embrapa.br; washington.magalhaes@embrapa.br)

A formação de plantações florestais com eucaliptos em regiões propensas a fortes geadas, comuns no Sul do Brasil, ainda está grandemente vinculada à utilização de sementes de um reduzido número de espécies, havendo pouca disponibilidade de clones comerciais. Nesse contexto, E. benthamii é particularmente estratégica para a obtenção de madeira, principalmente para atender finalidades energéticas e utilização na forma roliça. A matriz denominada "brs 203 " foi selecionada em um amplo teste de progênies instalado em 2007 na localidade de Candói, PR, Brasil (25³6’S; 5204’O; 870m), sendo os parentais originários de Kedumba Valley, NSW, Austrália (3349’S; $150^{\circ} 23^{\prime} \mathrm{E} ; 140 \mathrm{~m}$ ). A alta taxa de crescimento e o elevado padrão silvicultural foram os critérios iniciais de seleção. Os valores encontrados para diversos caracteres avaliados aos 9 anos de idade foram os seguintes: DAP 48,7 cm; altura total 33,7 m; altura comercial 29,5 m; volume de tronco com casca 2,60 $\mathrm{m}^{3}$; volume de tronco sem casca 2,14 $\mathrm{m}^{3}$; porcentagem de casca $17,8 \%$; densidade básica $537 \mathrm{~kg} / \mathrm{m}^{3}$; teor de cinzas $0,28 \%$; teor de extrativos 2,20\%; teor de lignina Klason 24,25\%; teor de lignina solúvel em ácido 1,89\%; teor de holocelulose 71,38\%. Um dos aspectos de destaque desse genótipo é o fato de estar demonstrando em viveiro resultados iniciais bastante favoráveis quanto à formação de raízes a partir de estacas, fundamental para se ter sucesso na estratégia de desenvolvimento de clones comerciais. Muito embora haja necessidade, na sequência dos trabalhos, de se realizar inúmeros testes adicionais de campo comprobatórios de desempenho e qualidade, as perspectivas são promissoras.

\section{Genetic parameters in seed characters of Stryphnodendron pulcherrimum under different temperature levels}

Ivinne Nara Lobato dos Santos ${ }^{1}$, Maria Teresa Gomes Lopes ${ }^{1}$, Mágno Sávio Ferreira Valente ${ }^{1}$, Manuel de Jesus Vieira Lima Junior ${ }^{1}$ Universidade Federaldos Amazonas, Manaus, Brasil (ivinne.lobato@gmail.com; mtglopes@hotmail.com; magnosavio@yahoo.com.br; mjlimajunior@gmail.com)

The Stryphnodendronpulcherrimum(Fabaceae)is Amazonian tree species also found inAtlantic Forest, Guianas, Venezuela and Colombia. It has a potential for urban afforestation use, reforestation, ecological recovery of degraded areas and extraction of tannin. However, genetic and physiologic traits of its seeds are poorly studied. This work aimed to estimate genetic parameters in $S$. pulcherrimum seeds under different temperatures of germination, proposing superior matrices in seedlings production and subsidize strategies for domestication as well as to genetic enhancement of this specie. Seeds of 21 matrices of the species were collected in Apuí, Amazonas. Thedesignwascompletelyrandomized, withfourreplicatesof 25 seedspermatrices. Thegerminationtestswereconductedattemperaturesof 25 , 30 and $35^{\circ} \mathrm{C}$. Whereas genetic parameters, selection gain for germination percentage, mean germination time, synchronization and germination rate indexes were subjected to analysis of variance (ANOVA) in order to examine the difference among matrices or warming level. The genetic variability and high values of heritability and selective accuracy (> 69\%) for all germination traits suggest that the phenotypic value can provide a reliable measure for selection of superior genotypes. The highest percentage of germination was obtained in the environment of $25^{\circ} \mathrm{C}(92 \%)$ with decreasing of twinned seeds and mean germination time with increasing temperature. Progenies 11, 14 and 15 presented good germination characteristics for all analyzed environments.

\section{Biometric parameters in seed characters of Stryphnodendron pulcherrimum}

Ivinne Nara Lobato dos Santos ${ }^{1}$, Maria Teresa Gomes Lopes ${ }^{1}$, Mágno Sávio Ferreira Valente ${ }^{1}$, Manuel de Jesus Vieira Lima Junior ${ }^{1}$ ${ }^{1}$ Universidade Federal do Amazonas, Manaus, Brasil (ivinne.lobato@gmail.com; mtglopes@hotmail.com; magnosavio@yahoo.com.br; mjlimajunior@gmail.com)

The species Stryphnodendron pulcherrimum is a Fabacea. In Brazil it grows in the Amazon region and in the south of Bahia and has importance for the recovery of degraded areas, however, it is difficult to obtain seedlings. The objectives of this work were to estimate biometric parameters of seeds of $21 S$. pulcherrimum matrices located in Apuí, AM, in order to the selection of those that present the characteristics desirable for future generations. The matrices were selected according to their phenotypic characteristics as plant productivity and sanity. For each matrix, 30 seeds were randomly selected and measured weight, length, width and thickness of each seed. All statistical analyzes were performed using the Genes program. Progenies of $S$. pulcherrimum presented significant genetic variability for all high-heritability $(>87 \%$ ) traits, as well as mean values for the wet weight of $0.061 \mathrm{~g}$ (ranged from 0.046 to 0.081 g), length of $7.11 \mathrm{~mm}$ (ranged from 6.47 to $7.78 \mathrm{~mm}$ ), width of $4.47 \mathrm{~mm}$ (ranged from 3.82 to 5.18 ) and thickness of 2.96 (ranged from 2.68 to 3.24 mm). The repeatability coefficient presented median values, except thickness that assumed low values. The coefficients of determination were higher than $80 \%$, demonstrating that the evaluation of the characteristics can be performed with high reliability. The results show that with only 14 seeds it is possible to evaluate the characteristics with good accuracy in the selection of superior genetic material.

\section{From phloem to xylem: a metabolomic overview of wood formation in hybrid aspen}

Ilara Budzinski ${ }^{1}$, Ilka Abreu ${ }^{1}$, Thomas Moritz ${ }^{1}$

${ }^{1}$ Swedish University of Agricultural Sciences, Umea,Sweden (ilara.frasson.budzinski@slu.se; ilka.abreu@slu.se; thomas.moritz@slu.se)

Wood (secondary xylem) is a valuable resource for the generation of renewable energy and it isan important feedstock for fiber, pulp and cellulose production. The process of wood formation is strongly affected by environmental conditions such as water, nutrient and light availability. Despite the importance of secondary growth to trees, the metabolic profile underlying wood formation still poorly understood. Here, we present a metabolomics approach (GC-TOF-MS and LC-QTOF-MS) performed to identify both (a) the metabolic distribution from phloem towards wood-forming tissues, (b) key metabolites with specific roles during wood formation. To this purpose, hybrid aspen (Populus tremula $\mathrm{x} P$. tremuloides) trees were cultivated under greenhouse conditions and supplied four different levels of nitrogen, to obtain trees with different secondary growth. The stems from four-month-old trees were cryo-sectioned (20 $\mu \mathrm{m})$ in: bark, inner bark, phloem, expanding phloem, cambium, expanding xylem, xylem, mature xylem and pith. Trees treated with high nitrogen concentration showed higher diameter, height and biomass, compared to the others treatments. By multivariate analysis, we could discriminate tissues and treatments. A gradient of metabolites belonging to different chemical classes (sugars, amino acids, phenolics) was identified along the differentiated wood tissue and towards phloem. The results obtained here represent the metabolic overview of secondary growth and highlighted the powerful combination of cryosectioning and metabolomics analysis in forestry research. 


\section{The variation of genotypes in natural forest populations: an important variable to precision silviculture}

João Antonio Pereira Fowler ${ }^{1}$

${ }^{1}$ Embrapa Florestas, Colombo, Brasil (joao-antonio.fowler@embrapa.br)

The term precision silviculture can mean the selection of individuals of a species in a natural population with characteristics suitable for a particular purpose of use. As each individual of the population occupies a specific site, in addition to the soil variables, it is fundamental to genotype characterization to identify genotype environment interactions. To access of DNA of each individuals, we adapted a method of extraction of the genomic DNA of this samples. An improved protocol for the isolation of DNA from sapwood of Astronium fraxinifolium Schott, Cariniana legalis (Mart.) Kuntze, Pterocarpus rohrii Vahl, Handroanthus serratifolius (Vahl) S.Grose, Astronium graveolens Jacq., Cedrela odorata L., Lecythis pisonis Cambess., Manilkara salzmanii (A.DC.) H.J.Lam., Handroanthus riodocencis (A.H.Gentry) S.O.Grose, native species of Mixed Ombrophilous Forest is described. The isolated DNA is suitable for RAPD and SSR for DNA analysis. Different DNA protocols were examined to determine which might yield DNA from sapwwood of the studied species. The protocols tested were Cationic hexadecyl trimethyl ammonium bromide (CTAB), CTAB modified, and the commercial kits Quiagen ${ }^{\circledR}$ - DNeasy Plant Mini Kit, MoBio ${ }^{\circledR}$, Noren Biotek ${ }^{\circledR}$ and Himedia ${ }^{\circledR}$. None of these protocols produced yielded DNA suitable purity for RAPD analysis. We established a new procedure involving CTAB protocol varying the incubation time and the concentration of proteinase $\mathrm{K}$, denominated CTAB modified. The recovery of DNA with an average yield of 20 and $100 \mu \mathrm{L}$ of sapwood samples, using protocol CTAB modified.

\section{Evaluation of growth traits as selection indicators for Phyllostachys pubescens seedlings in radiation-induced breeding programs}

Zhihua $\mathrm{Cao}^{1}$, Zhongneng $W u^{1}$, Hongfei Zhao ${ }^{2}$

${ }^{1}$ Anhui Academy of Forestry, Hefei, China; '2hejiang Shuren University,Hangzhou, China(308457017@qq.com; 312412679@qq.com; 971660891@qq.com)

Deriving novel germplasm of the bamboo Phyllostachys pubescens from tradition approaches to plant breeding is problematic, due to its indeterminate growth, however radiation-induced breeding represents a potential solution. Here, seeds of $P$. pubescens were radiation-treated with 60 Co $\gamma$-ray irradiation, from which 16 superior seedlings were screened and planted in an experiment from 2011 to 2017 and found variation in the traits among the phenotypes within and across years, and principal components analysis showed that growth of the phenotypes was more accurately described using a combination of growth traits, rather than a single trait. Using our trait analysis, we found that growth in a phenotype derived from seed irradiated with 10 Gy of60 Co $\gamma$-ray irradiation was superior; these results supported a previous study of growth of this phenotype in an afforestation experiment. This study provides a feasible method and foundation for the selection and screening of superior P. pubescens genotypes in radiation-induced breeding programs.

\section{Ecology and evolution of a tree species challenged by dual threats}

Kristen Waring ${ }^{1}$, Sam Cushman ${ }^{2}$, Andrew Eckert $^{3}$, Lluvia Flores-Renteria ${ }^{4}$, Richard Sniezko $^{5}$, Christopher Still ${ }^{6}$, Christian Wehenkel $^{7}$, Amy Whipple ${ }^{1}$, Michael Wing ${ }^{6}$, Justin Bagley, Ethan Bucholz ${ }^{1}$, Socorro Gonzalez-Elizondo ${ }^{8}$, Jessica Hartsell ${ }^{1}$, Cory Garms ${ }^{6}$, Evan Heck ${ }^{5}$, Jeremy Johnson ${ }^{1,5}$, Erin Landguth ${ }^{9}$, Alejandro Leal-Saenz ${ }^{7}$, Mitra Menon ${ }^{3}$,Ehren Moler ${ }^{1}$, Gerald Page ${ }^{6}$, John Shaw ${ }^{l 0}$, Andrew Shirk ${ }^{11}$, Jared Swenson ${ }^{1}$ ${ }^{1}$ Northern Arizona University, Flagstaff, USA; ${ }^{2}$ USDA Forest Service, Flagstaff, USA; ${ }^{3}$ Virginia Commonwealth University, Richmond, USA; ${ }^{4}$ San Diego State University, San Diego, USA; ${ }^{5}$ USDA Forest Service, Cottage Grove, USA; ${ }^{6}$ Oregon State University, Corvallis, USA; ${ }^{7}$ Universidad Juarez del Estado de Durango, Durango, Mexico; ${ }^{8}$ Instituto Politecnico Nacional, Durango, Mexico; ${ }^{9}$ University of Montana, Missoula, USA; ${ }^{10}$ USDA Forest Service, Ogden, USA; ${ }^{11}$ University of Washington, Seattle,USA (kristen.waring@nau.edu; scushman@fs.fed.us; aeckert2@vcu.edu; lfloresrenteria@sdsu.edu; rsniezko@fs.fed.us; chris.still@oregonstate.edu; wehenkel@ujed.mx; amy.whipple@nau.edu; michael.wing@oregonstate.edu; centrarchidae@gmail.com; eb692@nau.edu; herbario_ciidir@yahoo.com.mx; jad495@nau.edu; cory.garms@oregonstate.edu; eheck@fs.fed.us; jeremy.johnson@nau.edu;

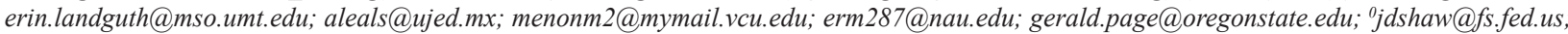
ashirk@uw.edu;jks383@nau.edu)

We are studying the ecological and evolutionary processes affecting the geographical distribution of southwestern white pine (SWWP; Pinus strobiformis), an important tree species of the Southwestern USA and Mexico. Southwestern white pine viability is threatened by changing climate and an invasive tree disease, white pine blister rust (caused by the fungal pathogen, Cronartium ribicola). Rapid climate change is negatively affecting SWWP by increasing heat and drought stress, and thus challenging its ability to adapt. White pine blister rust causes extensive tree decline and mortality, including in SWWP. The dual threats of climate change and invasive species make forecasting future tree distributions at continental scales an urgent challenge. The goal of our project is to determine how gene movement among populations, adaptation to disease and drought, heritable changes beyond DNA mutations, and a changing environment interact to govern the success of SWWP. We are utilizing and developing tools to help forecast and manage the future of the species, including those from genomics, common gardens, tree disease resistance testing, engineering and technology innovation to measure drought tolerance and physiological response. Results will be synthesized and included in cutting-edge landscape genomics models to meet our overarching goal. We will present our framework and current project status, including results. Completed products include development of landscape genomic models, a species distribution model incorporating climate change, and adaptive trait, phenotype plasticity and genomic variation analyses. Continuing work incorporates these aspects in addition to transgenerational plasticity research and a genome-wide association study.

\section{Artificial neural networks for predicting the genetic value of Eucalyptus progenies}

William Medeiros ${ }^{1}$, Silvelise Pupin², Diego Torres-Dini 3,4, Bruno Ettore Pavan², Antônio Sérgio Ferraudo², Mario Luiz Teixeira de Moraes², Rinaldo Cesar de Paula ${ }^{1}$

${ }^{1}$ Universidade Estadual Paulista “Júlio de Mesquita Filho”, Faculdade de Ciências Agrárias e Veterinárias, Departamento de Produção Vegetal, Jaboticabal, Brasil; ' ${ }^{2}$ niversidade Estadual Paulista "Júlio de Mesquita Filho”, Faculdade de Engenharia, Departamento de Fitotecnia, Tecnologia de Alimentos e Sócio Economia, Ilha Solteira, Brasil; 'Investigador Adjunto, Instituto Nacional de Investigación Agropecuaria (INIA) Programa Nacional de Producción Forestal, Estación Experimental INIA Tacuarembó, Tacuarembó, Uruguay; "Universidade Estadual Paulista "Júlio de Mesquita Filho", Faculdade de Agronomia, Ilha Solteira, Brasil, " Professor Assistente Doutor no Departamento de Ciências Exatas. Universidade Estadual Paulista "Júlio de Mesquita Filho”, Faculdade de Ciências Agrárias e Veterinárias, Jaboticabal, Brasil (will.medeirossilva@gmail.com; silvelise.pupin@gmail.com; dtorres@inia.org.uy; pavan@agr.feis.unesp.br; ferraudo@fcav.unesp.br; teixeira@agr.feis.unesp.br; rcpaula@fcav.unesp.br) 
The main goal of researchers in genetic breeding programs is to select superior genotypes and recommend varieties through effective selection methods. Thus, the objective of this study was to evaluate the performance of Artificial Neural Networks (ANN) in predicting genetic values for progeny selection of Eucalyptus sp. For the training of ANN, 64 experiments were simulated that varied among means (5, 10, 15 and 20), heritability (10, 20,30 and 40\%) and coefficient of variation (10, 20, 30 and 40\%). For validation of ANN, data from a progeny test of Eucalyptus camaldulensis was used. The genetic values of both the simulated and progeny data were obtained by the REML / BLUP procedure. The ANN used was a multiple layer type with three inputs (phenotype value, block means, and progeny mean), a hidden layer containing four neurons and one exit layer. The algorithm used was backpropagation. The correlation between genetic values predicted by the BLUP methodology and those obtained by ANN was $99 \%$ in the training phase and $91 \%$ in the validation stage. The good performance of ANN in the validation stage reflected in the correlation of the ordering of individuals (92\%) and families (99\%) of E. camaldulensis by the two methods. Thus, multiple layer ANN showed good performance in predicting genetic values in progeny tests of Eucalyptus sp. for DBH which are promising tools for selection of progenies in forest breeding programs.

\section{A genotyping array of 3,400 Single Nucleotide Polymorphisms (SNPs) advances the genetic analysis of the iconic tree Araucaria angustifolia, showing that the natural populations are more differentiated than previously reported}

Pedro Tanno ${ }^{1}$, Orzenil Silva-Junior ${ }^{2}$, Lucileide Resende ${ }^{2}$, Valderês Aparecida de Sousa ${ }^{3}$, Dario Grattapaglia ${ }^{2,4}$

${ }^{1}$ Universidade de Brasília, Brasilia, Brasil; ${ }^{2}$ Embrapa Recursos Genéticos e Biotecnologia, Brasília, Brasil; ${ }^{3}$ Embrapa Florestas, Colombo, Brasil;

${ }^{4}$ Universidade Católica de Brasilia,Brasillia,Brasil(tanno.pedro@gmail.com; orzenil.silva@embrapa.br; vilelar@gmail.com; valderes.sousa@embrapa.br; dario.grattapaglia@embrapa.br)

We have developed a genotyping "chip" for the iconic and endangered Araucaria angustifolia tree containing 3,400 SNPs, discovered from RNAseq and RAD-sequencing data. Of these, 1,643 were polymorphic in a sample of 192 individuals from a provenance/progeny collection involving 15 populations from Brazil (SP, MG, PR and SC). These same 192 individuals were genotyped with 30 microsatellites (SSR). Analysis of the population genetic structure with SSR and SNPs revealed substantial differences in the magnitude of population differentiation: Fst was 0.13 with SSR and 0.28 with an equivalent number of SNPs. This pattern was maintained with different estimators (Gst, Gst', Dst) or Rst for microsatellites. Using all 1,643 SNPs covering the entire spectrum of allelic frequencies Fst was slightly higher (0.31). These results corroborate the recognized fact that the multiallelism of SSR restricts the maximum Fst value even in the absence of gene flow, and allele homoplasy tends to overestimate gene flow and homogeneity among populations resulting in largely underestimated population differentiation. Conversely, although bi-allelic and less informative individually, SNPs have a considerably lower mutation rate and a negligible mutation reversal rate, providing robust, accurate, genome-wide estimates of genetic differentiation. These results raise important questions about the validity of the low levels of genetic differentiation between natural populations typically reported for Araucaria based on microsatellites. An underestimated Fst has critical repercussions on inferences of genetic structure and gene flow and, more importantly, on strategic decisions about the conservation of natural populations and enrichment of germplasm banks of this ecologically keystone tree.

Determining genotype-environment interactions for precedents and progeny of $\boldsymbol{E}$. nitens established in $\mathbf{3}$ trials in 2 growth areas for this species in Chile at 4 years of age / Determinación interacción genotipo-ambiente para procedencias y progenies de E. nitens establecidas en 3 ensayosen 2 zonas de crecimiento para la especie en Chile a los 4 años de edad

Maria Paz Molina ${ }^{1}$, Roberto Ipinza ${ }^{2}$

${ }^{1}$ Instituto Forestal de Chile, Bio Bio, Chile; ${ }^{2}$ Instituto Forestal de Chile, Valdivia, Chile (mmolina@infor.cl; robertoipinza@infor.cl)

Eucalyptus nitens Deane \& Maidenoriginaria del sudeste australiano y de alto interés para el sector forestal chileno, dada su resistencia al frio y a plagas y enfermedades forestales. Actualmente hay aproximadamente 255.000 hectáreas en Chile, establecidas en su gran mayoría para la producción de pulpa. Es la especie forestal de mayor tasa de crecimiento, alcanzando hasta $400 \mathrm{~m}^{3} /$ ha a los 8 años. Dados los efectos del cambio climático en Chile, se analiza la interacción genotipo-ambiente con el fin de optimizar el uso del material genético en distintas zonas de alta productividad para la especie. De modo de conocer la interacción genotipo - ambiente entre pares de ensayos se determinó la correlación tipo B, la cual era significativa entre los pares de ensayo. Luego para profundizar la interacción Sitio-Familia se seleccionó un grupo de 30 progenies para cada ensayo siendo las de mayor Ganancia Genética para la variable D2H. Posteriormente se verificó que todas estas familias estuvieran representadas en cada uno de los ensayos, encontrándose un subgrupo de 21 familias que cumplían con esta condición. Mediante gráficos se comparó el comportamiento de las familias en cada uno de los ensayos. En las variables analizadas hay una fuerte interacción de sitios sobre las familias y gráficamente se visualiza la no coincidencia de las mejores familias para los tres ensayos e incluso, se detecta que familias que son de mejor desempeño en un ensayo tienen el desempeño menor en otro.

Estimated genetic gains in bolaina blanca (Guazuma crinita) in forest plantations within Peruvian Amazonia / Estimación de la ganancia genética esperada de bolaina blanca (Guazuma crinita) en plantaciones forestales de la Amazonía Peruana

Guillermo Eduardo Gorbitz Dupuy ${ }^{1}$, Lino Rios ${ }^{1}$, Victor Cornejo ${ }^{2}$

${ }^{1}$ DIPTERYX SAC, Pucallpa, Peru; ${ }^{2}$ Restaura Peru S.A.C., Lima, Peru (guillermo@dipteryx.org; lino@dipteryx.org; victorcornejobadillo@gmail.com)

Bolaina blanca (Guazuma crinita) es la especie forestal maderable más plantada en la Amazonía baja del Perú, además, su madera es la principal fuente de ingresos para cientos de pequeños agricultores. Sin embargo, la productividad de G. crinita se mantiene aún muy por debajo de su potencial. El trabajo de investigación tuvo como objetivo estimar la ganancia genética esperada de árboles plus seleccionados para su introducción en un programa de mejoramiento genético forestal. Siguiendo la metodología propuesta por Vallejos et al. (2010), se seleccionaron 36 árboles plus según caracteres de volumen comercial y calidad de las cuatro primeras trozas. La superioridad de estos árboles plus fue validada luego de la evaluación fenotípica de cada árbol en relación a sus cuatro mejores vecinos en un radio inmediato de $15 \mathrm{~m}$. Posteriormente, los árboles plus fueron clasificados en dos listas, la lista A para el árbol que presenta superioridad en volumen comercial y calidad de troza, y la lista B para aquellos árboles que presenta sólo superioridad en uno de los dos caracteres. La ganancia genética esperada, entendida como el producto del diferencial de selección del árbol plus por un valor esperable de heredabilidad en el sentido amplio (H2), para el total de árboles candidatos se estimó en 14.94\% y 3.99\% de ganancia para los caracteres de volumen comercial y calidad de troza respectivamente, mientras que si solo se toma la lista A, la ganancia genética sería de 20.05\% para volumen comercial y 6.20\% para calidad de troza. 
Dendrochronological study of Brosmium utile (Kunth) Oken from Timbiquí, Cauca, Colombia / Estudio dendrocronológico de Brosimum utile (Kunth) Oken procedente de Timbiqui, Cauca, Colombia

Claudia Parada ${ }^{1}$, Cesar Polanco Tapia ${ }^{1}$, Mario Tommasiello ${ }^{2}$

${ }^{1}$ Universidad Distrital Francisco Jose de Caldas, Bogotá D. C., Colombia; ${ }^{2}$ Universidade de São Paulo, São Paulo, Brasil (cmparada.r@gmail.com; cpolanco@udistrital.edu.co; mtomazel@usp.br)

Brosimum utile es una especie con una amplia distribución sobre zonas tropicales, posee alto potencial maderable y altas tasas de aprovechamiento y movilización sobre el territorio colombiano, de acuerdo al IDEAM, el pacífico Colombiano movilizó $364.227 \mathrm{~m}^{3}$ en el periodo 2008-2010. Esta especie es comercializada de forma importante en el distrito de Buenaventura, Valle del Cauca. Con el ánimo de aportar elementos de manejo silvicultural al bosque natural desde las técnicas dendrocronológicas, que propendan por el aprovechamiento sostenible de la especie, fueron muestreados en Buenaventura, diez discos de madera usando trozas basales con diámetros de entre 394 y 881 mm y 3000 mm de longitud. Estas trozas tradicionalmente son utilizadas para la obtención de chapas para fabricación de plywood. La procedencia del material fue Timbiquí, Cauca. Una vez el material llegó al equilibrio en la ciudad de Bogotá, D.C. las trozas fueron preparadas en la superficie, se visualizaron y marcaron los anillos de crecimiento verificando las fluctuaciones del crecimiento. Con la ayuda de técnicas de cofechado y el análisis de valores de densitometría con rayos X, realizados en La ESALQ-USP, Brasil. Se realizó la construcción de las cronologías y su correlación con la intensidad de la precipitación, en una serie de 44 años. Se identificaron señales ambientales incitadoras del cambium. Adicionalmente, se obtuvo el crecimiento medio anual y corriente anual, permitiendo el cálculo del diámetro mínimo de corta ajustado, que podrá contribuir al aprovechamiento adecuado de la especie y al manejo forestal sostenible en esta región del país.

B4b: DATA FUSION FOR IMPROVED FOREST INVENTORIES AND PLANNING

\title{
Double calibration estimation of forest wood volume for exploiting Airborne Laser Scanning and satellite auxiliary variables
}

Piermaria Corona ${ }^{1}$, Sara Franceschi ${ }^{2}$, Gherardo Chirici ${ }^{3}$, Francesca Giannetti $^{4}$, Lorenzo Fattorini ${ }^{4}$

${ }^{1}$ CREA Research Centre for Forestry and Wood, Arezzo, Italy; ${ }^{2}$ University of Calabria, Rende, Italy; ${ }^{3}$ University of Florence, Firenze, Italy; ${ }^{4}$ University of

Siena,Siena,Italy (piermaria.corona@unitus.it; sara.franceschi@unical.it; herardo.chirici@unifi.it; francesca.giannetti@unifi.it; lorenzo.fattorini@unisi.it)

Under-coverage is present in many forest surveys when only a portion of the forested area is surveyed but the estimation of the total of a forest attribute for the whole area is the target. Under frequent circumstances Airborne Laser Scanning (ALS) information is available for the surveyed portion and satellite information is available for the whole area. In these cases, two-stage least-squares or hierarchical model-based estimation are usually adopted to estimate totals for the whole area. The purpose of this paper is to propose an alternative, completely design-based estimation strategy based on a two-step calibration. The first calibration exploits auxiliary variable arising from ALS metrics to improve the precision of the crude design-based estimation of the total over the sampled portion. The second calibration exploits the set of auxiliary variables arising from satellite information to expand the total estimate achieved for the sampled portion to the total estimate over the whole area. The two calibrations are unified in a double-calibration estimator. Mean and variance of the estimator are derived up to the first order of approximation. Conditions ensuring approximate unbiasedness are derived and discussed. The strategy is empirically checked by a simulation study performed on an artificial forest. A large-scale case study is considered to assess the total wood volume and basal area in a forested land of Central Italy.

\section{Estimates of biomass that use the global ecosystem dynamics investigation lidar mission waveform Data}

Paul Patterson ${ }^{1}$, Sean Healey ${ }^{2}$, Göran Ståhl ${ }^{3}$, Svetlana Saarela ${ }^{3}$, Sören Holm ${ }^{3}$, Ralph Dubayah ${ }^{4}$, Laura Duncanson ${ }^{4}$, Steven Hancock ${ }^{4}$, John Armston $^{4}$, Jim Kellner ${ }^{5}$, Hans-Erik Andersen ${ }^{6}$, Warren Cohen ${ }^{7}$, Zhiqiang Yang ${ }^{2}$

${ }^{1}$ United States Forest Service, Fort Collins, USA; ${ }^{2}$ United States Forest Service, Ogden, USA; ${ }^{3}$ Swedish University of Agricultural Sciences, Umeå, Sweden; ${ }^{4}$ University of Maryland, College Park, USA; ${ }^{5}$ Brown University, Providence, USA; ${ }^{6}$ United States Forest Service, Seattle, USA; ${ }^{7}$ United States Forest Service, Corvallis,USA(paul.l.patterson@usda.gov; seanhealey@fs.fed.us; goran.stahl@slu.se; svetlana.saarela@slu.se; soren.holm@gronstenen.se;dubayah@ umd.edu; lduncans@umd.edu; hancock@umd.edu; armston@umd.edu; jamesrrkellner@brown.edu; andersen@fs.fed.us; warren.cohen@oregonstate.edu; zhiqiangyang@fs.fed.us)

In December 2018 the NASA GEDI (Global Ecosystem Dynamics Investigation) mission installed a full-waveform lidar instrument on the International Space Station for the purpose of measuring global forest structure. The waveforms are collected in "footprints" that are spatially discontinuous; the waveform data is expected to be strongly correlated with aboveground forest biomass (AGB). Using simulated GEDI waveforms models have been constructed for the footprints by plant functional types within the six continental regions. The estimates for the discontinuous footprint level AGB will be combined to estimate the AGB within geographical regions, e.g., $1 \mathrm{~km}$ grid cell, administrative unit, national park, etc. using a hybrid estimator. The precision of the hybrid estimator depends on both the sample strategy and the model uncertainty. Using a diverse set of global sites a simulation study was conducted to empirically assess the statistical properties of hybrid estimator and the proposed variance estimator for $1 \mathrm{~km}$ gird cells using the plant functional type within continental regional footprint models. The results show the performance in terms density of the GEDI overpasses. It is possible to decompose the variance estimator into model and sample components. The relative contributions to the variance and variance estimator are assessed.

\section{An imputation/copula approach for fusing and analyzing multiple, large datasets in forestry}

\author{
John Kershaw ${ }^{1}$, Ting-Ru Yang ${ }^{1}$, Yung-Han Hsu' ${ }^{1}$ Elizabeth McGarrigle ${ }^{2}$ \\ ${ }^{1}$ University of New Brunswick, Fredericton, Canada; ${ }^{2}$ Nova Scotia Department of Natural Resources, Truro, Canada (kershaw@unb.ca; tyang1@unb.ca; \\ yhsu@unb.ca; emcgarrigle@gmail.com)
}

Big data analytics are rapidly becoming the norm in many disciplines in forest resource evaluation and modeling. While these machine learning algorithms are very good at shifting through large datasets and building robust predictions for the "here and now," they have very limited capabilities of predicting the "then and there." We propose an alternative approach to data fusion and big data analytics that applies an iterative cycle of multiple imputation and copula sampling to develop predictions. The multiple imputation step narrows the range of data used to model or predict a given observation through a nearest neighbor selection process. Empirical or distribution-based copulas are derived from the set of nearest neighbors, and copula sampling is used to develop a probability distribution of predictions. Because of the iterative process of imputation and copula sampling, the model can be run multiple times and uncertainties directly assessed. Applications to stand and tree modeling and LiDAR analyses are presented. Implications of bandwidth selection (number of nearest neighbors) and sample sizes (number of copula samples) are explored. 
Towards a global standard of digital forest representation and monitoring. How airborne and terrestrial LIDAR combined with artificial intelligence and blockchain technology will change traditional forest inventory concepts

\author{
Guenther Bronner ${ }^{1}$, Mathias Schardt ${ }^{2}$ \\ ${ }^{1}$ Umweltdata,Vienna, Austria; ${ }^{2}$ Hoanneum Research, Graz,Austria (g.bronner@umweltdata.at; mathias.schardt@joanneum.at)
}

LIDAR is the most dynamic segment in the development of forest assessment. In Styria 1Mio hectares forest resources have been mapped using only 2000 well distributed sample plots. Swiss Neuchatel has already time series of single-tree segmentation. Umweltdata has several years experience in designing 2-phase inventories based on aerial laserscanning and traditional terrestrial fieldwork where the number of sample plots was reduced by factor 4 while maintaining statistical accuracy. As enhancement an intermediate layer with stripes of high density aerial LIDAR point-clouds is added. This new dataset allows 3D-segmentation of trees, determining basal and tree top coordinates and the distance to competing trees. Despite this surplus of information, the fieldwork assessment effort is again significantly reduced. Regarding fieldwork we now introduce a new concept of terrestrial LIDAR. Mounting a small LIDAR sensor on a slowly moving eccentric arm, occlusion of trees far from sample plot centre can be avoided; in one single scan more than 99\% of the basal area is recorded. The future implementation of blockchain technology on different stages of data recording and data processing will generate certified snapshots of the forest, which could be a basis for an international trade with $\mathrm{CO}_{2}$ certificates based on cryptocurrency. Deep learning algorithms will enhance single tree forest growth modelling sensitive to climate change. All proposed methods work within existing NFI designs and allow wall-to-wall interpolation of NFI-results being ready for Forest Management Planning. The presentation will include results from operational and research projects as well as concepts for future developments.

\title{
Interrelation and interchangeability of Sentinel-2 and Landsat 8 data for burnt areas mapping
}

Maria Prodromou ${ }^{1}$, Miltw Miltiadou ${ }^{1}$, Diofantos Hadjimitsis ${ }^{1}$

${ }^{1}$ Cyprus University of Technology,Limassol, Cyprus (ml.prodromou@gmail.com; milto_miltiadou@hotmail.com; diofantosh@gmail.com)

Forest monitoring has benefited from the technological advancement and the increased availability of open remotely sensed data. Issues like cloud covered areas and the desired of increased temporal resolution has been solved by combining Sentinel-2 and Landsat-8 data. This research exploits whether these two datasets are interrelated and whether they can be used interchangeably for burnt area mapping, since fires destroy vegetation and chlorophyll, affect soil moisture and lead to the creation of leave bare areas. Two study areas in Cyprus were selected: Solea and Ora-Vavatsinia, which were burnt in June 2016 and July 2017 respectively. Solea contains pine forests, plantains, shrubs and Mediterranean vegetation, while Ora contains wild vegetation, pines and olive trees. This study explores the relationship between three spectral indices (Normalized Difference Vegetation Index NDVI, the Normalized Burn Ratio NBR and the Burn Area Index BAI) derived from Sentinel 2 and Landsat-8 OLI imagery. The Pearson correlation for NBR index was 0.89 and 0.91 , for NDVI was 0.85 and 0.89 and for BAI was 0.76 and 0.80 for the Ora and Solea areas. Furthermore, the deviation between the estimated burnt area using the different datasets was less than $0.6 \%$. It is therefore shown that the two datasets can be used interchangeably for burnt area mapping and the most interrelated index is the NBR, while BAI was the least correlated.

\section{Estimating wood quality in standing timber with the fusion of point cloud - based forest inventory data and saw mill measurements}

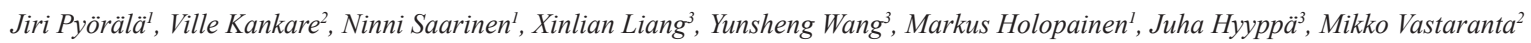
${ }^{1}$ University of Helsinki, Helsinki, Finland; ${ }^{2}$ University of Eastern Finland, Joensuu, Finland; ${ }^{3}$ Finnish Geospatial Institute, Masala, Finland; ${ }^{3}$ Finnish GeospatialInstitute, Masala,Finland (jiri.pyorala@helsinki.fi; ville.kankare@uef.fi; inni.saarinen@helsinki.fi; xinlian.liang@nls.fi; yunsheng.wang@nls.fi; markus.holopainen@helsinki.fi; juha.coelasr@gmail.com; mikko.vastaranta@uef.fi)

Changes in climate and silviculture are altering forest growth globally, including adverse effects to wood properties that may limit timber usage as long-term carbon storage. Forest industries could better adapt to these challenges if wood quality was more precisely accounted for in wood procurement planning. Because wood properties are a consequence of tree's adaptation to the environment by regulating wood formation, the tree phenology, e.g. stem geometry and branching reflect wood quality. In this study, we studied the wood quality of Scots pine (Pinus sylvestris L.) in Southern Finland. We recorded geometrical tree attributes using terrestrial laser scanning (TLS) and compared them firstly with wood quality measured at sawmill by means of X-ray scanning for 180 trees, and secondly with upper canopy features delineated from airborne laser scanning (ALS) data for a separate set of ca; 300 trees. Ultimately, we used the ALS and TLS data to produce tree lists with detailed stem and branching attributes for harvestable forest stands, and estimated the tree-specific wood quality using the TLS and sawmill data. We will evaluate the accuracy of our tree lists by comparing the predicted wood quality against stand-specific sawmill measurements of over 2000 trees harvested from six Scots pine forest stands within the same geographic region. We aim at assessing the potential gains of pre-harvest wood quality estimation that utilized existing sawmill databases and point cloud based - forest inventory data and the implications to the sustainability of industrial wood procurement in the future.

\section{Using heterogeneity indices to adjust basal area: leaf area index relationship in managed coniferous stands}

Alex Appiah Mensah ${ }^{1}$, Svetlana Saarela ${ }^{1}$,Hans Petersson ${ }^{1}$, Emma Holmström², Martin Goude ${ }^{2}$

${ }^{1}$ Swedish University of Agricultural Sciences, Umea, Sweden; ${ }^{2}$ Swedish University of Agricultural Sciences, Alnarp, Sweden (alex.appiah.mensah@slu.se; svetlana.saarela@slu.se; hans.petersson@slu.se; emma.holmstrom@slu.se; martin.goude@slu.se)

The structure of contemporary managed forests are complex which can be described with indices of heterogeneity. To apply theoretical growth functions on managed forests, adjustments are required, especially for leaf area index (LAI) which is a key biophysical variable in process-based growth models. The performance of canopy LAI in modelling the basal area (BA) of managed boreal forests dominated by Norway spruce (Picea abies (L). Karst) and Scots pine (Pinus sylvestris L.) was investigated by heterogeneity analysis. The heterogeneity was studied in two parts: (a) ground-based stand structural heterogeneity (SSH) described by coefficient of tree diameter variation, tree social status and height-diameter ratio, and (b) spectral heterogeneity (SPH) by vegetation and textural indices developed from Sentinel-2. Species-specific final (with heterogeneity metrics) and base (without heterogeneity metrics) models were fitted for BA-LAI relationships by nonlinear least squares regression functions. For both species, BA-LAI final models (FMs) accounting for heterogeneity resulted in larger explained variance (RMSE, $\mathrm{m}^{2} \mathrm{ha}^{-1}$ ) than the base models (BMs). Compared with the BMs, FMs with SSH reduced the variance by 55\% in Norway spruce $(\mathrm{RMSE}=3.330$, relative-RMSE $=15.398 \%$ ) and 43\% in Scots pine $(\mathrm{RMSE}=3.701$, relative-RMSE $=17.377 \%)$. The fit between BA-LAI with SPH also showed an improvement in the RMSEs for Norway spruce and Scots pine over the BMs, suggesting the potential use of Sentinel-2 in future growth models. The study concludes that when extrapolating theoretical growth functions to managed forests, there is a need to calibrate the models with the forest structural heterogeneity. 


\title{
Experiences from stand level applications of data assimilation based on combinations of remotely sensed and field data
}

Håkan Olsson ${ }^{1}$, Anton Grafström ${ }^{1}$, Nils Lindgren ${ }^{1}$, Kenneth Nyström ${ }^{1}$, Mattias Nyström ${ }^{1}$, Göran Ståhl

${ }^{1}$ Swedish University of Agricultural Sciences, Umeå, Sweden (hakan.olsson@slu.se; anton.grafstrom@slu.se; nils.lindgren@slu.se; kenneth.nystrom@slu.se; mattias.nystrom@slu.se; goran.stahl@slu.se)

Data assimilation has found widespread application in fields such as meteorology and robotics. The basic idea is to use data from multiple time points for improving the accuracy of estimates of current state of a system. The baseline alternative would be to utilize only data from the last time point. Through data assimilation all sources of data are, ideally, used in a way so that best possible estimates are obtained by combining the different sources, considering their uncertainties. Since 2012 studies on data assimilation for improving stand level estimates of characteristics such as growing stock volume, biomass, and mean height have been carried out at the Swedish University of Agricultural Sciences (SLU), by combining multiple sources of remotely sensed data with field reference data. During this presentation the experiences from these studies will be summarized. Some important findings and conclusions are that (i) data assimilation offers great potential to utilize all new sources of remotely sensed data that are becoming available today, (ii) theoretical studies point at substantial improvements in the precision of estimators of stand level characteristics, (iii) several practical obstacles are faced when data assimilation is applied in practice implying that, (iv) the gain in precision obtained in practice is typically modest compared to what theoretical studies suggest. However, in addition to slightly improving the precision of estimators, data assimilation systems provide benefits in terms of identifying stands where changes have occurred and through growth updates based on remotely sensed data.

B4c: ESTIMATION OF STATUS AND CHANGE IN FOREST CARBON POOLS BASED ON INVENTORY DATA: GOING BEYOND TREE CARBON

\section{The carbon mitigation potential of European forests}

Hubert Hasenauer', Adam Moreno², Mathias Neumann ${ }^{1}$, Frits Mohren ${ }^{3}$

${ }^{1}$ University of Natural Resources and Life Sciences, Vienna, Austria; ${ }^{2}$ California Air Resource Board, Sacramento, USA; ${ }^{3}$ Wageningen University,

Wageningen,Netherlands (hubert.hasenauer@boku.ac.at; adam.moreno@arb.ca.gov;mathias@neumann@boku.ac.at; frits.mohren@wur.nl)

European forests, covering one third of the land surface in Europe, have recentlysequestered more than 700 million tones $\mathrm{CO}_{2}$ every year. Biomass functions in combination with forest inventory data allow estimating the carbon stocks of European forests. In this study we collate consistent information on coarse and fine roots, above-ground litterfall and above ground biomass. A gap-filled map based on harmonized forest inventory data from 13 countries is applied to produce pan European gridded datasets derived from a single methodology to inform researchers, policy makers and conservationists on the state of forest structures would improve our ability to study forests independent of political boundaries and along various gradients. Although National Forest Inventory (NFI) data provide information on the characteristics of forests, including carbon content, volume, height, and age, such spatial data is not available across Europe. We produced a pan European map for each of the four key variables on a $0.133^{\circ}$ grid representing the time period $2000-2010$. The results of the study are that European forests exhibit an annual average carbon uptake of $577 \mathrm{gC} / \mathrm{m}^{2} / \mathrm{year}$, which can be considered of the average carbon sequestration potential.

\section{Forest inventories in a systems approach to understanding the carbon cycling of forest ecosystems}

\author{
Anatoly Shvidenko ${ }^{1,2}$, Dmitry Schepaschenko ${ }^{1,3}$, Florian Kraxner ${ }^{1}$ \\ ${ }^{1}$ International Institute for Applied Systems Analysis, Laxenburg, Austria; ${ }^{2}$ Institute of Forest SB RAS, Krasnoyarsk, Russian Federation; ${ }^{3}$ Forestry Faculty, \\ Bauman State Technical University, Mytischi,Russian Federation (shvidenk@iiasa.ac.at; schepd@iiasa.ac.at; kraxner@iiasa.ac.at)
}

System theory considers full and verified account (FCA) of carbon budget of forests as underspecified (fuzzy) system. The major methodological consequence of this is understanding that any method of the FCA (i.e., landscape-ecosystem approach as aggregation of different inventories, eddy covariance, inverse modelling, diverse models, "direct" estimates of FCA components by remote sensing) used individually is not able to assess structural uncertainty, thus the calculated uncertainties of FCA (e.g. Net Ecosystem Carbon Budget, NECB) are inevitable incomplete. Elimination of this requires complimentary use of all available methods of FCA with following mutual constraints of both results and uncertainties. National forest inventories (NFI) present unique information for such an approach, although a number of unresolved questions exist, including 1) incomplete identity of basic definitions used by forest inventories and other sources; 2) incompatible classifications; 3) lack of spatially distributed models of structure of forest ecosystems, especially for assessing forest parameters unobservable by remote sensing; 4) unsatisfactory quantification of other than trees ecosystems' components etc. Much more complicated problems arise in countries which have no operational NFI yet. The presentation considers problems, challenges and opportunities for Russian forests (above $20 \%$ of the world forests) which inherited the previous soviet system of forest inventory, but political, social and economic changes of the last decades have led to a dramatic decline of forest inventory. Use of official inventory data results in a significant ( $>2$ times) bias of the forest NECB. We present a system of updating forest inventory information and its use in FCA.

\section{Assessment of the amount of fine woody debris}

Jan Merganic ${ }^{1}$,Katarina Merganicova ${ }^{2}$, Martin Mokros $^{2}$, Zuzana Allmanova ${ }^{1}$, Michal Ferencik ${ }^{1}$, Maria Vlckova $^{1}$, Vladimir Jusko ${ }^{1}$

${ }^{1}$ Technical University Zvolen, Faculty of Forestry, Zvolen, Slovakia; ${ }^{2}$ Czech University of Life Sciences Prague, Prague, Czech Republic (j.merganic@forim. sk; k.merganicova@forim.sk; martin.mokros@gmail.com; zuzana.allmanova@gmail.com; ferencik@tuzvo.sk; maria.vlckova@tuzvo.sk; jusko@tuzvo.sk)

Deadwood material is an important component of forest ecosystems. Within national forest inventories monitoring of its amount and spatial distribution started in many countries only recently. Moreover, frequently only coarse woody debris is accounted for, while fine deadwood is often omitted although it can make a substantial proportion of carbon stock in woody debris. Here we evaluate several different inventory methods of downed fine deadwood applied to five windthrown areas of the Forest School Enterprise of the Technical University Zvolen, Slovakia. For the inventory of fine woody debris on these disturbed areas we applied a randomised systematic sampling design. In total, 536 quadratic sampling plots, each $1 \mathrm{~m}^{2}$, were established in the field in the year 2018 . The situation on the ground of the plots was documented with the photos taken using Panasonic DMC-FZ1000 camera. The relative cover of fine deadwood was first visually estimated, after which the lengths and the mid-diameters of individual pieces of fine woody debris within the sample plot were measured and recorded. 
The photographs of the 124 randomly selected plots were transformed to orthophotos with Agisoft Photoscan Professional software. On the orthophotos, the relative cover of fine woody debris was visually estimated on the computer screen. Then, fine deadwood pieces were measured by operators in QGIS software. The comparison of the outputs of all applied methods revealed that the measurements of the amount of fine woody debris on the ortophotos had a systematic negative bias.

\title{
Quantification of tree stems and soil carbon stocks in Omo Biosphere Reserve, Nigeria
}

Oladele F. Falade ${ }^{1}$, Rosemary E. Ubaekwe

${ }^{1}$ Department of Forest Production and Products, University of Ibadan, Ibadan, Nigeria (faladedele@yahoo.com; rosemary.ubaekwe@gmail.com)

Omo Biosphere Reserves (OBR) contributes to mitigation of climate change through provision of carbon sinks. Tree stems and soil are major carbon stocks in (OBR). There is partition and transfer of carbon among the components of stocks. However, rate of carbon transfer between stocks is hindered because knowledge on carbon distribution among components is limited. Therefore, this study quantified carbon stocks of Omo Biosphere Reserve. Twenty ( $30 \mathrm{~m} x$ $30 \mathrm{~m}$ ) plots were randomly demarcated within OBR. The reserve was stratified into close and open canopy structures. Fourteen and six plots were demarcated in close and open canopy structures, respectively. Tree stems with diameter-at-breast-height $\geq 10 \mathrm{~cm}$ were identified and enumerated. The diameter-at-breastheight and merchantable height were measured for carbon estimation. Profile pits were dug at the centre of plots and soil core samples were collected to 100 $\mathrm{cm}$ depth with $20 \mathrm{~cm}$ interval. Soil core samples were oven dried at $1050 \mathrm{C}$ to constant weight and $100 \mathrm{~g}$ of soil sample was sieved into five aggregate sizes (> $2,2-1,1-0.5,0.5-0.05,<0.05 \mathrm{~mm})$ and carbon contents were determined. Data collected were analyzed using descriptive statistics. The carbon stocks of aboveground and below-ground stem were $140.56 \mathrm{mg} / \mathrm{ha}$ and $28.11 \mathrm{mg} / \mathrm{ha}$ and $30.79 \mathrm{mg} / \mathrm{ha}$ and $6.15 \mathrm{mg} / \mathrm{ha}$ in close and open canopy structure, respectively. Ceiba pentandra and Terminalia superba contributed highest carbon stock density in close and open canopy structure, respectively. Aggregate $(<0.05 \mathrm{~mm})$ contributed highest proportion to soil carbon at all depths in both canopy structures. The conservation of soil carbon stock and regeneration of Ceiba pentandra should be encouraged in Omo Biosphere Reserve.

\section{The estimation and modelling of carbon stocks from harvested wood products in New Zealand}

\author{
Anne Wekesa ${ }^{1}$, Bruce Manley ${ }^{1}$, David Evison ${ }^{1}$ \\ ${ }^{1}$ University of Canterbury, Christchurch,New Zealand (anne.wekesa@pg.canterbury.ac.nz; bruce.manley@canterbury.ac.nz; david.evison@canterbury.
} ac.nz)

End use categories such as buildings, furniture, pallets and paper are the main stores of carbon in the harvested wood products (HWP) pool. Nonetheless, information on the actual carbon stocks, the contribution of the different semi-finished wood products to these carbon stocks and the duration of carbon storage for these products is little known and understood and not explored in relation to New Zealand. This information is very important as it allows for robust estimates of carbon stored in this pool to be reported. In this research, a survey is being carried out of wood processing companies across New Zealand, namely, sawmills, plywood, veneer, laminated veneer lumber (LVL), cross laminated timber (CLT), pulp and paper, paper board, newsprint, furniture and pallet manufacturers. The aim is to collect information on the material flow of roundwood logs to the end use products. Roundwood flow data is being collected using a country specific approach. It tracks wood flow from log grades that are harvested and processed domestically. In addition, the information on conversion efficiencies, waste flows during the manufacturing process and the service lives of the end use products will also be gathered in order to improve carbon stock estimates from HWP in New Zealand.

\section{$\mathrm{CO}_{2}$ dynamics from harvested wood products in Brazil during 1900-2016}

Carlos Sanquetta ${ }^{1}$, Margarida Tomé2, Ana Dias ${ }^{3}$, Greyce Maas ${ }^{1}$, Felipe Sanquetta ${ }^{1}$

${ }^{1}$ Universidade Federal do Paraná, Curitiba, Brasil; ${ }^{2}$ University of Lisbon, Lisbon, Portugal; ' 3 niversity of Aveiro, Aveiro, Portugal (carlossanquetta@gmail. com; magatome@isa.ulisboa.pt; acdias@ua.pt; greyce.maas@gmail.com; felipe_sanquetta@hotmail.com)

How relevant is the role of carbon dioxide $\left(\mathrm{CO}_{2}\right)$ from harvested wood products (HWP) for the Brazilian greenhouse gas (GHG) emission balance? We evaluated the $\mathrm{C}$ stocks and $\mathrm{CO}_{2}$ emissions and removals in the HWP in Brazil in the period 1900-2016 using three IPCC methodological approaches: stock-change, production, and stock change of domestic origin. Data from the FAOSTAT system on the production, import and export of semi-finished products (sawn wood, wood panels and paper) were analyzed, considering afforestation/reforestation (A/R), forest management (FM) and deforestation (D) activities. Two scenarios to evaluate the effect of HWP from D were evaluated. The stock of C in HWP in 2016 reached $252 \mathrm{Mt} \mathrm{C}$, by the stock-change approach, that was considered the most complete to report HWP. Contributions on C storage historically were higher in lumber, but wood panels and paper have recently outperformed it. The A/R

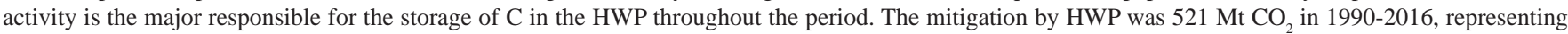
$1.1 \%$ of the country's GHG emissions in that period. It was concluded that Brazil has become a major producer and consumer of wood and the HWP are allies for a positive $\mathrm{C}$ balance and fulfillment of the commitments assumed by the country regarding climate change.

\section{Estimating potential carbon storage of domestic harvested wood products in Republic of Korea}

Eun-Kyung Jang ${ }^{1}$, Youn Yeo-Chang ${ }^{1}$

${ }^{1}$ Seoul National University, Seoul, Republic of Korea (mentaka1209@gmail.com; youn@snu.ac.kr)

Korea Forest Services has set the plan to increase HWP carbon pool to increase quantities of domestic harvest wood and sawn wood production. However, if the use of domestic wood resources has an unsustainable way, the policy effect of increasing the amount of carbon stored in the HWP carbon pool will not be high, no matter how much the volume is increased. In this context, this study aims to identify major material flow of primary products including sawnwood, plywood, wooden-based panel, woodchip etc. and its flow into industries including construction, civil engineering (temporal structural materials), transfortation and household of domestic harvested wood products, to evaluate of carbon storage efficiency in Korea using Material Flow Analysis (MFA) and estimate potential carbon reduction of policy scenario (a. increasing production of sawnwood, b. increasing production of panel and c. increasing recycling rate). As a result, Korea has a small amount of sawn wood production as a lumber for building construction, but a lot of domestic wood flows to wood chips used as paper and board materials. From a point of carbon view, it shows low efficiency as a HWP carbon storage, using wood resources for period of 30 years. Policy scenario to encourage long-term use of wood products may increase the using time and efficiency of HWP carbon pool in Korea. This study can provide information for decision making in establishing and implementing policies to increase carbon stocks in HWP and the utilization efficiency of wood resources. 


\section{Carbon storage in harvested wood products for a selected number of countries worldwide, based on FAO country data}

Frits Mohren ${ }^{1}$, Ashley Steel ${ }^{2}$, Federico Alice ${ }^{3}$

${ }^{1}$ Forest Ecology and Forest Management Group, Wageningen University and Research, Wageningen, Netherlands; ${ }^{2}$ Forestry Department, Food and Agricultural Organization (FAO), Rome, Italy; ${ }^{3}$ School of Environmental Sciences, Universidad Nacional de Costa Rica ( (frits.mohren@wur.nl; ashley.steel@fao.org;federico.alice@wur.nl)

Forests make a strong contribution to meeting the Sustainable Development Goals (FAO’s The State of the World's Forests, 2018), and are of paramount importance in storing carbon and mitigating $\mathrm{CO}_{2}$ emissions. We estimate the climate change mitigation potential of carbon storage in harvested wood products. Our estimates, based on Tier 1 methods from the IPCC Guidelines, use FAO country statistics and a first order decay model with default half-lives. We focus on the development of estimates of carbon storage in harvested wood products for developing countries and incorporate uncertainties in default assumptions about half-lives and carbon content. Overall carbon storage in harvested wood products is compared with carbon storage in forest ecosystems. For select countries, trends in carbon storage in harvested wood products are compared to trends in related phenomena, e.g., greenhouse gas emissions, change in forest area, and gross domestic product (GDP). We also discuss carbon storage accounting related to forests more generally, including carbon losses from managed lands and the effects of forest management on overall carbon storage. B4d: GLOBAL MONITORING NETWORK OF TREE MORTALITY PATTERNS AND TRENDS

\section{Global monitoring network of tree mortality patterns and trends: a new IUFRO task force}

Henrik Hartmann ${ }^{1}$, Aster Gebrekirstos ${ }^{2}$, Nadine Ruehr $^{3}$, Tanja Sanders ${ }^{4}$, Bernhard Schuldt ${ }^{5}$

${ }^{1}$ Max-Planck Institute for Biogeochemistry, Jena, Germany; ${ }^{2}$ World Agroforestry Center, Nairobi, Kenya; ${ }^{3}$ Karlsruhe Institute for Technology, GarmischPatenkirchen, Germany; ${ }^{4}$ Thuenen Institute of Forest Ecosystems, Eberswalde, Germany; ${ }^{5}$ University Wuerzburg, Wuerzburg, Germany (hhart@bgc-jena.mpg.de; a.gebrekirstos@cgiar.org;nadine.ruehr@kit.edu; tanja.sanders@thuenen.de; bernhard.schuldt@uni-wuerzburg.de)

Forests cover about 31\% of the Earth's land surface and the sustainable provision of resources and ecological services from forests, such as carbon storage, hosting biodiversity, and climate regulation ensures human welfare. Yet, recent observations in temperate, boreal, and tropical forests indicate that this sustainable provision may be threatened by increasing tree mortality and forest decline from environmental change. There currently is, however, no global assessment of forest condition that could validate a global general trend in climate change-induced forest decline. Given the importance of global forests for biogeochemical cycles and human welfare there is an urgent need to understand forest responses to changing climate and to predict future forest conditions. Assessments of forest condition at the global scale are challenging. Although recent remote sensing products can identify large-scale changes in forest cover, the spatial resolution is often to coarse to detect climate change-induced tree mortality. Field observations from forest inventories or research plot networks can detect individual tree mortality but are often not openly accessible and spread across different ownerships. The new IUFRO Task Force 'Global monitoring network of tree mortality patterns and trends’ aims to overcome these limitations by facilitating sharing of knowledge and data and promoting international collaborations between different disciplines concerned with forest assessment, tree physiology and ecological modelling. Here we present how this task force was created, its goals and objectives and discuss future activities. We encourage anyone who is interested in making progress in assessments of global forest conditions to join our initiative.

\section{Mortality trends of old-growth trees and forests under global change stresses: Global monitoring needs and opportunities}

Craig Allen ${ }^{1}$

${ }^{1}$ US Geological Survey, Los Alamos, USA (craig_allen@usgs.gov)

Many tree species and forest landscapes globally are noticeably adjusting in diverse (sometimes contrasting) ways to changing temperature and precipitation climate conditions, particularly including warming temperatures and changing precipitation patterns. Significant theoretical and empirical evidence indicates that larger (and thus often older) trees and forest stands may be disproportionately vulnerable to increased growth stress and mortality under hotter drought conditions. The responses of the world's largest, oldest trees and forests to global change are of particular interest, given that such ancient trees and forests are valued as: a) disproportionately large carbon sinks; b) among the most biodiverse and rare terrestrial ecosystems; c) irreplaceable archives of ecological history; and d) venerated for spiritual and cultural reasons. Development of improved global forest monitoring capabilities is vital to broadly interpret spatially and temporally contrasting observations of forest responses to emerging climate changes, and to foster integrated multidisciplinary understanding of climateinduced tree mortality and forest die-off. This presentation addresses global forest monitoring needs and opportunities, with a particular emphasis on the needs and opportunities associated with determining the broad-scale status and trends of the world's remaining large ancient trees and old-growth forests.

\section{Long-term, large-scale harmonized monitoring to detect changes in forest health and mortality: the ICP Forests experience}

Marco Ferretti ${ }^{1}$

${ }^{1}$ Swiss Federal Research Institute WSL, Birmensdorf, Switzerland (marco.ferretti@wsl.ch)

Concern generated from observation of poor forest condition and tree death in some parts of central Europe prompted the set-up of international forest monitoring initiatives in Europe in the 1980s. The similarity with today's concern on tree mortality makes it interesting to look at the development of forest health monitoring (FHM) in Europe over the past decades. International FHM in Europe is carried out within the International Co-operative Programme on Assessment and Monitoring Air Pollution Effects on Forests (ICP Forests) under the auspices of the UN ECE Convention on Long-Range Transboundary Air Pollution (CLRTAP). Today ICP Forests monitors forest health on ca; 5000 plots on a 16 x16 km grid (Level I), and on ca; 600 plots purposively selected (Level II). FHM is carried out annually since the 1980s, and consists of a visual inspection of sample trees carried out according to SOP and QA/QC. At the beginning FHM concentrated on defoliation, discoloration and most obvious categories of damaging agents. Now it includes many attributes related to foliage, branches and stem, and attempt to identify causes of damage (when present). Subsequent changes in attributes/scoring system, however, caused some noise in the dataseries. Long-term mortality assessment, in particular, was constrained by several factors, including the difficult separation between removals (management) and actual mortality. Here I will provide an overview of the ICP Forests, its FHM methods, achievements, advantages and disadvantages, as well as possible contribution to a global assessment of tree mortality. 


\title{
A nation-wide analysis of tree mortality under climate change: forest loss and its causes in Israel 1948-2017
}

Tamir Klein ${ }^{1}$

${ }^{1}$ Weizmann Institute of Science, Rehovot, Israel (tamir.klein@weizmann.ac.il)

Is tree mortality increasing? Are recent mortality events related to climate change? Which tree species are the most affected? Many case studies have been published in the last decade, but the necessary large-scale and long-term knowledge is still missing. Here we combined data from forest surveys and satellite imagery, to create the first spatial tree mortality history at the national scale. Israel is a small country with only $7 \%$ forest cover, but its large environmental diversity and mosaic of many, small, forest areas makes it a good 'miniature model' for the task. Tree mortality events have been increasing significantly since 1991 and correlated well with drought. Among mortality events, $24 \%$ of the loss was directly related to drought, and $58 \%$ to fire, with $69 \%$ of fires occurring over a drought background. Conifers were disproportionally more affected than native broadleaved trees. This is the first national-scale study of tree mortality dynamics, and it confirms the suspected increase in this phenomenon in recent decades, and the dominant role of drought. Our study opens a way to a better, multi-source monitoring future for forest management and ensuring forest sustainability under climate change.

\section{One century of forest monitoring data in Switzerland reveals species - and site - specific trends of climate-induced tree mortality}

Sophia Etzold ${ }^{1}$,Kasia Ziemińska ${ }^{1}$, Brigitte Rohner ${ }^{1}$, Alessandra Bottero ${ }^{1}$, Arun K Bose ${ }^{1}$, Nadine Ruehr ${ }^{2}$, Andreas Zingg ${ }^{1}$, Andreas Rigling ${ }^{1}$ ${ }^{1}$ WSL Swiss Federal Research Institute, Birmensdorf, Switzerland; 'Institute of Meteorology and Climate Research IMK, Garmish-Partenkirchen, Germany (sophia.etzold@wsl.ch; kasia.zieminska@wsl.ch; brigitte.rohner@wsl.ch; alessandra.bottero@wsl.ch; arun.bose@wsl.ch; nadine.ruehr@kit.edu; andreas.zingg@wsl.ch; andreas.rigling@wsl.ch)

Climate-induced tree mortality became a global phenomenon during the last century and is expected to further increase in many regions. However, our current understanding of forest mortality trends is limited by the short time span of majority of studies, small number of species or narrow geographical ranges. Here, we present an overview of mortality trends of five common European tree species (Norway spruce, Scots pine, silver fir, European beech, and oak), using a unique data set of monitoring records from 127 unmanaged forest stands across broad climatic gradients in Switzerland, covering a time span of over one century (1898-2013). Species-specific annual mortality rates did not consistently increase over the entire study period nor the last decades, except for pine forests at lower altitudes, which exhibited a clear increase of mortality since the 1960s. Mixed effects models revealed that gradual changes in stand parameters (stand basal area and stand age) had the strongest impact on mortality rates, further modulated by climate, especially during the last decades. However, climate had highly variable effects on tree mortality rates, depending on the species, abiotic and biotic factors, and stand and site conditions. We complement these results with a synthesis of several case studies, conducted at species' range edges such as the upper tree line or at very dry hot-spots, where mortality trends are clearly visible. Overall, our findings highlight the complexity of forest dynamic processes such as long-term, gradual changes of forest structure, demography and species composition, which together with climate determine mortality rates.

\section{Towards a realistic representation of disturbance events in Global vegetation models}

Thomas Pugh ${ }^{1,2}$, Nezha Acil $^{1}$, Mats Lindeskog ${ }^{3}$, Benjamin Poulter $^{4}$, Rupert Seidl ${ }^{5}$, Cornelius Senf 5

${ }^{1}$ School of Geography, Earth and Environmental Sciences, University of Birmingham, Birmingham, United Kingdom; ${ }^{2}$ Birmingham Institute of Forest

Research, University of Birmingham, Birmingham, United Kingdom; ${ }^{3}$ Department of Physical Geography and Ecosystem Science, Lund University, Lund, Sweden; ${ }^{4}$ Biospheric Sciences Laboratory, NASA Goddard Space Flight Center, Greenbelt, USA; ${ }^{5}$ Institute for Silviculture, University of Natural Resources andLife Sciences (BOKU),Vienna,Austria(t.a.m.pugh@bham.ac.uk;nxa807@student.bham.ac.uk; mats.lindeskog@nateko.lu.se; benjamin.poulter@nasa.gov;rupert.seidl@boku.ac.at; cornelius.senf@geo.hu-berlin.de)

Stand-replacing disturbances, including those from fire, wind-throw, bark beetles and harvest, are a cornerstone of forest dynamics, defining the age structure of forests across the landscape, with significant implications for carbon fluxes and species composition. Their extent, frequency and type are believed to have changed substantially over the last few centuries and are expected to further change over the next century. In order to realistically capture the effects of standreplacing disturbances, dynamic global vegetation models (DGVMs) need to move beyond the current paradigm of representing all natural disturbances as fire, by explicitly representing the effects of multiple disturbance types on forest age structure. This, however, requires a range of observation-based constraints to effectively implement. Here, we will present recent efforts drawing on space-based and ground-based observations to improve the representation of these disturbance events within a DGVM. Using a model-data fusion approach with satellite forest loss products, we will show an estimate of the total contribution of all large-scale disturbance types to recent forest dynamics. We will compare this with the results of forest inventory-based approaches to determining stand age and assess what this implies about disturbance size and the equilibrium of forests with respect to current disturbance regimes. Finally, we will present work implementing relationships of disturbance frequency as a function of forest composition and climate variability from protected forest areas into a DGVM. We will conclude by highlighting key knowledge and data gaps which constrain further progress on this topic.

\section{Characterising and quantifying forest disturbance patches using Global satellite-derived data}

\author{
Nezha Acil ${ }^{1,2}$, Thomas A. M. Pugh ${ }^{1,2}$, Jonathan P. Sadler ${ }^{1,2}$ \\ ${ }^{1}$ School of Geography, Earth and Environmental Sciences, University of Birmingham, Birmingham, United Kingdom; ${ }^{2}$ Birmingham Institute of Forest \\ Research, University of Birmingham Birmingham,United Kingdom (nxa807@student.bham.ac.uk; t.a.m.pugh@bham.ac.uk; j.p.sadler@bham.ac.uk)
}

Earth Observation imagery has permitted major advances in the detection and quantification of forest loss across the globe. However, discerning what agents caused these losses and understanding how the disturbance regimes vary over time and space remain challenging. Based on global geospatial data products for the period 2001-2018, this study seeks to (i) identify the disturbance agents causing tree cover loss at the stand scale through a process of patch analysis and classification, and (ii) comparatively assess how the frequency and severity of different disturbance agents vary across the globe. Using the 30-m resolution Global Forest Change dataset, the structural patterns of forest loss patches were explored and quantified inter-annually across biomes. Derived patch-level landscape indices will be combined with putative explanatory data to establish process links and attribute likely agents. The global distribution of standreplacing disturbances over the period studied will be used to examine linkages between occurrence rates and environmental factors. The results will contribute to enhanced disturbance representation within a dynamic Global vegetation model, leading to better constrained simulations of forest structure and function, particularly with regard to carbon cycling. 


\section{Large scale assessment of forest attribute dynamics in Southern Brazil}

Alexander Christian Vibrans ${ }^{1}$, André Luís de Gasper ${ }^{1}$, Laio Zimermann Oliveira ${ }^{1}$, Débora Vanessa Lingner ${ }^{1}$

${ }^{1}$ Fundação Universidade Regionalde Blumenau,Blumenau,Brasil(acv@furb.br; algasper@furb.br; laiozoliveira@gmail.com;deboravanessa.ef@gmail.com)

Tropical secondary forests play important roles as carbon sink, stepping stone for biodiversity conservation, provider of ecosystem services and multiple forest products. Notwithstanding, uncertainties about increment and biomass/carbon accumulation, as well as legal restrictions are still hindering innovative practices of sustainable use within Brazilian Atlantic Forest Biome. Reliable data on secondary forest dynamics may contribute to overcome traditional paradigms and subsidize public forest land use policies. We discuss methodologic aspects of large-scale continuous tree plot measuring and present results of a systematically designed, spatially unbiased statewide forest and floristic inventory (IFFSC). We analyzed data from 418 field plots, with sample area of $4,000 \mathrm{~m}^{2}$ each, covering the entire territory of Santa Catarina state $\left(95,000 \mathrm{~km}^{2}\right)$, in Southern Brazil, measured at two occasions with mean interstice of 7.1 years (2007-2011 and 2014-2019). We present overall and forest type mean annual change rates of tree (DBH $>10 \mathrm{~cm}$ ) recruitment and mortality (human induced and natural), of gain and loss of basal area, stem volume and biomass, as also regeneration $(\mathrm{DBH}<10 \mathrm{~cm}$, height $>1,30 \mathrm{~cm})$ dynamics. Annual tree mortality is about $2.5 \%$, while recruitment is about 3,6\%; in a similar way basal area gain (3,6\%) is greater than loss $(2,2 \%)$. Stem volume and biomass changes present the same trend, unfolded by species and species groups. Species composition is significantly changing, with decrease of pioneer/early secondary and increase of shade-tolerant species, regarding both tree density and basal area level. Our data-sets are open for data-sharing and integrated with Global Forest Diversity Initiative (GFBI) and sPlot (iDIV) data-bases.

\section{On modelling individual-based tree mortality: dealing with unequal period lengths and hierarchical effects \\ Christian Salas-Eljatib ${ }^{l}$ (D, Aaaron Weiskittel ${ }^{2}$, Joaquin Riquelme ${ }^{1}$ \\ ${ }^{1}$ Universidad Mayor, Santiago, Chile; ${ }^{2}$ University of Maine, Orono,USA (cseljatib@gmail.com; aaron.weiskittel@maine.edu; joaquin.riquelme@umayor.cl)}

Tree mortality is a critical ecological phenomenon shaping forest ecosystem dynamics, structure, and composition, and its effects are of global relevance due to its relationship with forest conditions and environmental changes. Both density-dependent and environmental factors strongly influence tree mortality, but there are challenges associated with individual-based mortality data, particularly observations with uneven measurements intervals. In this analysis, we develop and examine several individual-based mortality modelling strategies that simultaneously account for unequal period lengths and the hierarchical structure of the data in long-term, permanent plot data from the mixed Nothofagus forests in southern Chile. These strategies depend on: the data structure to be used (traditional or all multiple combinations of the time series), the functional form (logit and Gompit), and the period length adjustments (annualized, covariate, and exposure). Our findings indicated that the Gompit functional form outperforms the traditional logit link function. In addition, considering the period length as an exposure in the generalized linear mixed-effects model offered better goodness-of-fit than the other examined period length adjustments. Using all the possible combinations of the dynamic data did not improve the prediction capabilities of the model variants, but important differences were found in the statistical inferences of the fitted modes. Our results highlighted that understanding tree mortality strongly relies on a suitable model being able to both capture and assign the sources of variation to the corresponding variables, which was best accomplished using a multi-level binary Gompit-exposure modelling framework.

\section{Effects of extreme storms in the Portuguese forest: assessment of damages and development of a storm catalogue}

Teresa de Jesus Fidalgo Fonseca ${ }^{1,2}$, Stéphanie Lopes Ribeiro ${ }^{1}$, Irene Pereira Cascarejo ${ }^{3}$, Ana Paula Alves Neves ${ }^{2}$, Margarida da Conceição Rasteiro Magano Lopes Rodrigues Liberato ${ }^{1,4}$

${ }^{1}$ Universidade de Trás-os-Montes e Alto Douro, Vila Real, Portugal; ${ }^{2}$ Centro de Estudos Florestais, Universidade de Lisboa, Lisboa, Portugal; ${ }^{3}$ Instituto da Conservação da Natureza e das Florestas, IP., Porto, Portugal; ${ }^{4}$ Instituto Dom Luiz, Universidade de Universidade de Lisboa, Lisboa, Portugal (tfonseca@utad.pt; ribeiro.stephanie.lopes@gmail.com; irene.cascarejo@icnf.pt; ana.neves@icnf.pt; mlr@utad.pt)

Extreme storms are an important abiotic disturbance factor with a negative impact in forest systems across the world. Disturbances strongly affect the forest resources, their dynamics and have a negative impact on forest carbon budget. In Europe's forests, more than 130 storms causing notable damage to forests were identified since 1950 (FORESTORMS database). Forest damages are likely to increase further in the frequency and in the damages in coming decades due to more extreme weather conditions associated with the effects of climate change. Moreover, storms are predicted to affect wider areas and penetrate further east across Europe (Gardiner et al; 2010). The information on the storm damages is not equally balanced across European countries, with a paucity of information available for countries of the Mediterranean area being reported. In Portugal, partially due to the historical importance of wildfires, little prominence has been given to data collection of the storm's damages in the forests. Known exceptions refer to the cyclone of 1941 and to the Gong depression in 2013 . This communication aims to present information gathered under the umbrella of WEx-Atlantic project and to share the results achieved so far, on the preparation of a catalogue of storms and forest wind damage for Portugal. The catalogue, by providing appropriate and up-to-date information will help to understand storm risk and to promote adequate national strategies. Moreover, the results of the research can be integrated into the monitoring of damage studies that are being promoted across Europe, enhancing post-storm coordination between countries.

\section{Climate-induced forest mortality in the Pacific islands: What do we really know?}

Hans Juergen Boehmer ${ }^{1}$, Stephen Galvin ${ }^{1}$

${ }^{1}$ University of the South Pacific, Suva,Fiji (neobiota@web.de; stephen.galvin@usp.ac.fj)

In 1991, Allan N. D. Auclair submitted a report to the US Environmental Protection Agency that discussed the widespread forest dieback of the 1970s and 1980s in the Pacific Rim in the context of extreme climatic fluctuations. Auclair's work was based on over 20 years of intense and complex research on the causes of forest dieback in Hawaii and other islands across the Pacific, carried out by multiple research groups, in particular on the effects of pathogens, nutrient limitations, and potential climatic triggers like droughts and other extreme events. After careful consideration of all available knowledge he concluded that region-wide, persistent episodes of forest dieback are incited by extreme moisture stresses. Ironically, perception of this spectacular phenomenon and related ground-breaking research vanished while the awareness of climate change and its potential impact on the World's forests started to grow, rapidly becoming a major focus of forest mortality-related research in recent years. In this paper, we reinforce memory of the World's first complex discussion on the natural causes of forest dieback as a showcase for the complexity of forest mortality research, and try to summarize what science has added to our knowledge on the links between tree mortality, forest dynamics and climate change in the Pacific islands in the meantime. 


\section{Monitoring urban forest mortality and change globally}

David Nowak ${ }^{1}$

${ }^{1}$ USDA Forest Service, Syracuse, USA (dnowak@fs.fed.us)

Urban forests provide numerous benefits to society, but face numerous threats due to development, insects and diseases, climate change and other environmental pressures. To better manage this important resource, it is essential to inventory and monitor changes in forest composition and value through time. To this end, a free suite of forest assessment and monitoring tools have been developed that can be applied in cities across the world. These tools provide an easy and standardized means to monitor tree cover change using Google images and establish permanent plots to monitor urban forest change and mortality. This presentation will discuss these monitoring protocols and tools. In addition, it will present results on: a) urban forest change and mortality in Syracuse, NY and Baltimore, MD, and b) recent urban tree and impervious cover change globally using random paired-point analysis of Google aerial images. These monitoring protocols can be used globally to assess forest mortality and change.

\section{An assessment of tree health in Brazil / Diagnóstico sobre a sanidade das árvores do Brasil}

David Fagner de Souza e Lira1, Raquel Leao ${ }^{1}$, Doádi Antônio Brena ${ }^{1}$, Claudia Maria Mello Rosa ${ }^{1}$, Joberto Veloso de Freitas ${ }^{1}$ ${ }^{1}$ Serviço Florestal Brasileiro,Brasilia, Brasil (liradfs@gmail.com; raquel.leao@florestal.gov.br; dabrena@gmail.com; claudia.rosa@florestal.gov.br; joberto.freitas@florestal.gov.br)

As florestas estão suscetíveis à influência de fatores que podem ser causados por eventos naturais, influenciados pelo clima, por pragas e doenças ou ainda por ações do homem, como o uso de fogo. A influência desses fatores pode levar a alterações na composição, estrutura e funções das florestas, afetando sua saúde e vitalidade. De acordo com o processo de amostragem do Inventário Florestal Nacional do Brasil (IFN-BR) para a coleta de dados em campo seguindo grade nacional de pontos amostrais equidistantes 20 x 20 km entre si estabelecida pelo Serviço Florestal Brasileiro, uma enorme gama de informações é coletada. As variáveis coletadas foram classificadas de forma a facilitar o seu entendimento, como por exemplo, as biofísicas, que no caso de inventários florestais correspondem às informações mais diretamente ligadas aos recursos florestais e por isso são consideradas de fundamental importância nos levantamentos de campo. Dados sobre árvores sadias, árvores mortas, com podridões, com cupins e com ocos foram registrados e analisados em 21 estados mais o distrito federal até o início de 2019 nos levantamentos do IFN-BRem 650.181 indivíduos. Os resultados da análise conjunta dos dados demonstram que aproximadamente $53 \%$ dos indivíduos foram classificados em estágio sadio, $30 \%$ estão classificados em estágio inicial e $16 \%$ em estado avançado de deterioração ou são indivíduos mortos em pé. Pode-se dizer que é de extrema importância a continuidade do IFN-BR utilizando-o como ferramenta efetiva de classificação de padrões qualitativos e quantitativos sobre as florestas do Brasil.

B4e: FOREST TREE AND STAND GROWTH PROCESSES UNDER DIFFERING ENVIRONMENTS: CONCEPTS, METHODS AND EVIDENCE

\section{Transport and distribution characteristics of photoassimilates of Pinus massoniana seedlings}

Wenfa Xiao ${ }^{1}$, Xiuxiu Deng ${ }^{1}$, Lixiong Zeng ${ }^{1}$, Lei Lei ${ }^{1}$, Zheng Shi ${ }^{1}$

${ }^{1}$ Research Institute of Forest Ecology, Environment and Protection, Chinese Academy of Forestry, State Forestry Administration Key Laboratory of Forest Ecology and Environment,Beijing, China (xiaowenf@caf.ac.cn; dengxxiu@163.com; zlxcaf@163.com; lei19860123@163.com; sz481@126.com)

Exploring the transport and distribution of photoassimilates in Pinus massoniana would deepen our understanding of its productivity formation. The 1.5-year-old P. massoniana seedlings were feeding with pulse-chased $13 \mathrm{C}$ labeling for $4 \mathrm{~h}$, and different organs were collected at $0,2,5,17,24,72,120,168,216$ and 360 $\mathrm{h}$ after labeling to analyze $13 \mathrm{C}$ levels, to investigate the transport and distribution of recent photoassimilates in the seedlings; meanwhile, total carbon and nonstructural carbohydrate were determined in various organs. The amount of photoassimilates transport from source to sink gradually decreased until completing. Concretely, after the end of marked time within 0-24 hours, the value of recently photoassimilates transport was the most, within 24-216 hours the transport decreased gradually, and was completed after 216 hours, and more than 59\% of photoassimilates completed transport to sink organs within 0-24 hours; After the photoassimilates completed transport, the distribution of recently photoassimilates was ordered as 1-year leaves $>$ current-year leaves $>$ roots $>$ stem $>1$-year branches $>$ current-year branches, same as the distribution of the biomass. The sink activity was ordered as current-year leaves $>$ current-year branches $>1$ year leaves> roots $>1$-year branches>stem. The distribution of total carbon and NSC accumulation in various organs was in accordance with the distribution of recently photoassimilates. The photoassimilates transport rate of $P$. massoniana seedlings was greater than $0.1 \mathrm{~m} / \mathrm{h}$. More than $59 \%$ photoassimilates was exported to each sink organ within $0-24 \mathrm{~h}$. The accumulation of photoassimilates in various organs was mostly functional organs. This distribution pattern is conducive to the growth of $P$. massoniana in the seedling stage.

\section{Changes in biomass allocation in Eucalyptus rootstock induced by forest rotation}

Humberto Eufrade-Junior ${ }^{1}$, Carla Brito ${ }^{1}$, Renan Mangialardo ${ }^{1}$, Julio Horta ${ }^{2}, J_{\text {José Marcos Freitas }}^{3}$, Saulo Guerra ${ }^{1}$

${ }^{1}$ Universidade Estadual Paulista "Júlio de Mesquita Filho”, Universidade de São Paulo, Botucatu, Brasil; ${ }^{2}$ Ambar Energia , São Paulo, Brasil; ${ }^{3}$ Florena, Negocios Florestais Eireli, Uberlândia,Brasil(hdjejunior@gmail.com; cmbunesp@gmail.com; rsmangialardo@gmail.com; julio.horta@ambarenergia.com. br;josemarcos@florenaflorestal.com.br; saulo.guerra@unesp.br)

Studies about trees root growth have gained importance, moreover due to the recent climate change. The seek for a sustainable forest conditions to require deepening the knowledge of belowground biomass dynamic. This work had as objective to identify patterns of biomass allocation in eucalypt rootstock induced by forest rotation. Thus, four Eucalyptus clones were managed in first and second rotation at Midwest region of Brazil. Rootstock Eucalyptus biomass (5.7 to 13.1 years old) were removed from the underground with a front wheel loader and was cut with a chainsaw into three different fractions: stump (above-ground biomass); root crown (below-ground biomass) and; coarse and fines roots (below-ground biomass). The fractions were weighted and the dry biomass was obtained after analyzing the moisture content of the material in the laboratory. Results showed that rootstock biomass varied of 30.4 to 105.3 kg per tree and the crown root is the most representative fraction (67.3\%) of the Eucalyptus rootstock followed by fines and coarse roots (25.8\%) and stump (6.9\%). It was observed for all clones a higher biomass allocation in crown root compared to the others fractions which can be related with maturity of tree, either for support above-ground structure or nutritional reserve accumulation. 


\section{The contribution of fine roots to net primary production in temperate broadleaved and coniferous forests}

Ji Young An ${ }^{1,2}$, Akira Osawa ${ }^{2}$, Byung Bae Park ${ }^{1,3}$, Si Ho Han ${ }^{1}$, Woo Bin Youn ${ }^{1}$, Jeong Min Seo ${ }^{1}$

${ }^{1}$ Chungnam National University, Republic of Korea Daejeon; ${ }^{2}$ Kyoto University, Kyoto, Japan; ${ }^{3}$ Korean Society of Forest Science, Seoul, Republic of Korea

(ajy2656@cnu.ac.kr; aosawa@kais.kyoto-u.ac.jp; bbpark@cnu.ac.kr; bupleurumhan@cnu.ac.kr; dbsdnqls95@naver.com; jmseo3@naver.com)

Net primary production (NPP) is one of the key indices describing carbon fixation capacity of terrestrial ecosystems. Estimates of forest NPP is of importance to understand carbon and nutrient cycling because forest ecosystems are major carbon sink on land. One of essential parts of NPP is assimilated carbon and nutrients translocated to belowground for growing fine roots which take a role of acquiring soil resources such as water and nutrients. However, there is still no consensus on how fine roots contribute to forest NPP in terms of quantitative assessment. In this study, we investigated patterns and quantities of fine roots in relation to forest NPP estimation in temperate broadleaved and coniferous forests of Korea and Japan. We used sequential soil core and ingrowth core methods to estimate fine root biomass and production, and the flat-bed scanner method was used to investigate seasonal dynamics of fine roots. Annual fine root production ranged from 93 to $1342 \mathrm{~g} \mathrm{~m}^{-2}$ across 13 stands, accounting for 10-44\% of NPP. The estimates of fine root production by sequential cores were higher than that by ingrowth cores. Relatively high fine root production in spring was observed in broadleaved forests where Quercus serrata dominates. Fine root production was positively correlated with NPP, suggesting that high belowground carbon allocation in forests leading to high productivity. Further, we will review the literature regarding the relationship between fine roots and forest productivity for better understanding of the contribution of fine roots to carbon and nutrient dynamics in ecosystem processes.

\section{A two-year defoliation experiment in Pinus radiata grafts: does the lower canopy matter?}

Mireia Gomez Gallego ${ }^{1}$, Nari Williams ${ }^{1}$, Sebastian Leuzinger ${ }^{2}$, Peter Scott ${ }^{1}$, Martin Bader ${ }^{2}$

${ }^{1}$ Scion. New Zealand Forest Research Institute, Rotorua, New Zealand; 2 Institute for Applied Ecology New Zealand, School of Sciences, Auckland University of Technology, Auckland, New Zealand (mireia.gomez@scionresearch.com;

nari.williams@scionresearch.com; sebastian.leuzinger@aut.ac.nz; peter.scott@scionresearch.com; martin.bader@aut.ac.nz)

Biotic and abiotic stressors can lead to different defoliation patterns within trees. Foliar pathogens of conifers commonly prefer older needles and infection frequently progresses from the bottom canopy to the top. During mild defoliation episodes, only old foliage in the lower canopy is affected, which represents a defoliation pattern that has received little attention in past research. A two-year artificial defoliation experiment was performed using 2-year-old Pinus radiata grafts to investigate the effects of lower-canopy defoliation on carbon assimilation and allocation. Sixty-two grafts received the following treatments in consecutive years: Control-Control, Control-Defoliated, Defoliated-Control and Defoliated-Defoliated. Stomatal conductance, A/Ci curves, diameter, height, biomass and non-structural carbohydrate concentrations in needles, stems, and roots were measured before and after each treatment. No upregulation of photosynthesis was observed in response to defoliation. Root: shoot ratio and leaf mass were not affected by any treatment, suggesting prioritization of canopy regrowth following defoliation. In genotype B, defoliation appeared to impose carbon shortage and also reduced sugar storage in roots, while in genotype A, neither growth nor storage was altered. Root carbon storage in genotype B recovered over the second growing season. Our results suggest genotype-specific defoliation tolerance in P. radiata. In genotype A, the contribution of the lower canopy to the whole-tree carbon uptake appears to be negligible presumably conferring resilience to foliar pathogens affecting the crown base. Redundancy of lower-canopy foliage in terms of carbon assimilation is shown, raising a fundamental question on the role of the lower canopy in plants' carbon budget.

\section{Functional responses of Gmelina arborea Roxb seedlings, bring under to contrasting light environments in tropical dry forest areas in Colombia}

Omar Melo ${ }^{1}$, Carolina Betancourt ${ }^{1}$

${ }^{1}$ Universidad Del Tolima, Ibagué, Colombia (omelo@ut.edu.co; acbetancourtoro@ut.edu.co)

The research was conducted in areas of tropical dry forest in Colombia and shows the behavior of the relative growth rate (RGR), functional and morphological components in $G$. arborea seedlings, bring under to different lighting conditions. The evaluation period was 120 days. The lighting conditions were expressed as the relative proportion of the Photosynthetically Active Radiation (PAR), established in umbracles within the nursery. The illumination values correspond to 40, 60 and $100 \%$. The total biomass and its components of stem, root, leaves and leaf area were generated from the seedling harvest and the determination of its dry weights for six evaluation periods (0,15, 30, 60, 90 and 120 days). A foliar analysis was carried out and the contents of nitrogen, total proteins and total phenols were evaluated. The growth components evaluated were net assimilation rate, specific leaf area and shoot/root ratio. The results showed that seedlings that grow in environments with light restrictions have higher RGR than those that grow at full exposure, for which the seedlings adjust their morphological and physiological characters in these environments. The results show a high plasticity in the populations of the species that prioritize the distribution of its biomass and its functionality according to the lighting conditions of the growing environment. These results contribute to the optimization of agroforestry systems and pure plantations, to maximize their conditions of competition or adaptation.

\section{Ideotype competition dynamics in clonal Pinus taeda stands with contrasting crown attributes}

Timothy Martin ${ }^{1}$, Tania Quesada ${ }^{1}$, Gary Peter ${ }^{1}$, Jason Vogel ${ }^{1}$, Salvador Gezan ${ }^{1}$, Eric Jokela

${ }^{1}$ University of Florida School of Forest Resources and Conservation, Gainesville,USA (tamartin@ufl.edu; tquesada@ufl.edu; gfpeter@ufl.edu; jvogel@ufl. edu; sgezan@ufl.edu; ejokela@ufl.edu)

Competition is central to forest stand structure and function. Competition has been conceptualized as ideotypes, conceptual models which hypothesize suites of traits which may contribute to varying competitive dynamics among genotypes. We examined competition from an ideotype perspective in a Pinus taeda clonal block plot experiment planted in 2010 in Gainesville, Florida. The design was a split-plot randomized complete block with treatment factors of planting density (741 trees/ha vs; 1483 trees/ha) and genetic type (three clones), with three replicates. Plot size ranged from 0.05 to 0.16 ha, depending on treatment. The three clones in the experiment differ in crown architecture, with one clone having significantly narrower crowns than the other two clones. By the second year of stand development onward, a significant $(\mathrm{P}<0.05)$ spacing x clone interaction manifested for several variables $(\mathrm{DBH}$, height, individual tree stem volume, stand-level stem volume). This interaction was due almost entirely to the differential response of the narrow-crowned clone to spacing. At age 7 at 741 trees/ha, the narrow-crowned clone had similar mean height, DBH, and individual tree stem volume to other clones. However, at 1483 trees/ha, the narrow-crowned clone showed a smaller decrease in DBH and stem volume (5\% decrease vs; $19 \%$ decrease in other clone) and increased height (increase of about $1 \mathrm{~m}$ vs. no increase in other clones), resulting in rank changes among the clones depending on competitive environment/spacing. We will report on the results of an allometric harvest designed to elucidate the mechanism of the differential responses. 


\section{How can tree rings help to detect past forest disturbances and understand their legacy?}

Paolo Cherubini ${ }^{1,2}$, Andreas Rigling ${ }^{1}$

${ }^{1}$ WSL Swiss Federal Research Institute, Birmensdorf, Switzerland; ${ }^{2}$ University of British Columbia, Vancouver BC, Canada (paolo.cherubini@wsl.ch; andreas.rigling@wsl.ch)

Tree rings have a tremendous power for reconstructing environmental conditions. In temperate climates, cambial activity of trees stops during the cold season and annual tree rings are formed. Tree rings have been widely used for reconstructing past climate, and can be used as indicators of the environmental (not only climatic) conditions in which trees have been growing, because their characteristics depend on the environmental conditions in which they grew. Within a forest stand, tree rings can provide information about the occurrence and impact of past disturbances such asinsect infestation, fungal disease, wildfire, snow avalanche, windstorm or drought and frost. Reading tree rings in a proper way, tree and stand age can be determined with annual resolution. Past tree-growth trends, and abrupt decreases or releases after suppression can be identified, and information on the spatiotemporal occurrence of past disturbances (natural and anthropogenical), and their impact on tree growth, can be inferred for periods of time for which there are no historical records. It is more difficult to use tree rings to assess forest stand biomass. Some attempts have been made, but almost all the studies have been subject to some form of sampling bias. Using tree rings as indicators of tree biomass accumulation through time is possible but a sampling design that deals with all these issues adequately has yet to be developed, and represents a major challenge for dendroecology.

\section{Management of bark beetle outbreaks: a carbon perspective}

Laura Dobor ${ }^{1}$, Tomáš Hlásny ${ }^{1}$, Soňa Zimová1, Werner Rammer ${ }^{2}$, Rupert Seidl ${ }^{2}$

${ }^{1}$ Czech University of Life Sciences, Faculty of Forestry and Wood Sciences, Prague, Czech Republic; ${ }^{2}$ University of Natural Resources and Life Sciences, Department of Forest-and Soil Sciences, Vienna, Austria(dobor.laura@gmail.com; hlasny@nlcsk.org; zimova.sona@seznam.cz;werner.rammer@boku.ac.at; rupert.seidl@boku.ac.at)

Bark beetle outbreaks have recently disturbed substantial amounts of timber worldwide and triggered diverse management responses. These have ranged from the absence of active intervention to unprecedented intensities of salvage and sanitation logging, beetle trapping and insecticides application. Some responses included modified silviculture regimes, which aimed to reduce the share of vulnerable overmature stands or host trees. Synergistic impacts of bark beetle disturbance and subsequent management responses on ecosystem functioning, however, remain insufficiently understood. We used the forest landscape and disturbance model iLand to explore the effects of management efforts to prevent or suppress outbreaks of the European spruce bark beetlein a forest landscape in central Europe. We described the implementation of bark beetle disturbances in the iLand modelling framework and used simulations to disentangle the impacts of disturbance and management on forest carbon. We investigated trade-offs between excessive carbon removal by sanitation logging and premature harvesting of host trees, and the potentially positive effects of these measures via reducing outbreak risks. The overall effect of sanitation logging on landscape carbon was negative, though aboveground carbon benefited from reduced bark beetle disturbance. Long-term outbreak prevention, however, increased forest vulnerability to wind, and had an overall negative impact on forest carbon. A reduced rotation period reduced both bark beetle and wind disturbance; however, the amount of carbon in the landscape decreased sharply. We showed how ecosystem models can quantify a cascade of processes triggered by bark beetles and their management, and thus help better understand their impacts on ecosystem functioning.

Effects of forest fires on the fluxes of carbon dioxide $\left(\mathrm{CO}_{2}\right)$, methane $\left(\mathrm{CH}_{4}\right)$, and nitrous oxide $\left(\mathrm{N}_{2} \mathrm{O}\right)$ in permafrost and non-permafrost soils of Boreal Forests

Chris Ribeiro-Kumara ${ }^{1}$ (D), Kajar Köster ${ }^{1}$, Frank Berninger ${ }^{2}$, Jukka Pumpanen ${ }^{3}$, Egle Köster ${ }^{1}$

${ }^{1}$ University of Helsinki, Helsinki, Finland; ${ }^{2}$ University of Eastern Finland, Joensuu, Finland; ${ }^{3}$ University of Eastern Finland, Kuopio, Finland

(christine.ribeiro@helsinki.fi; kajar.koster@helsinki.fi; frank.berninger@uef.fi; jukka.pumpanen@uef.fi; egle.koster@helsinki.fi)

Approximately half of the carbon entering the boreal forest ecosystem through photosynthesis is allocated belowground, where it can be stored for millennia. This reservoir is notably significant in boreal peatlands and areas of permafrost. Boreal soils may act as source and sink of greenhouse gases (GHGs) (e.g., $\mathrm{CO}_{2}, \mathrm{CH}_{4}$, and N2O), with the net balance resulting from a multitude of dynamic processes. Fire disturbance is an integral part of boreal forests and impacts GHG fluxes and emission rates. However, studies comprising fluxes of $\mathrm{CH}_{4}$ and $\mathrm{N} 2 \mathrm{O}$ are still scarce for boreal soils, especially when combined with post-fire succession. Our study introduces a network of fire chronosequences throughout boreal forests, including study sites in permafrost areas (Canada and Siberia) and in non-permafrost areas (Finland and Estonia), where we investigate GHG fluxes using a closed chamber system. The chamber is equipped with a diffusiontype $\mathrm{CO}_{2}$ probe that measures soil respiration instantaneously. The $\mathrm{CH}_{4}$ and $\mathrm{N} 2 \mathrm{O}$ fluxes are sampled simultaneously from the chamber headspace and further analysed via gas chromatography. We found that in permafrost and non-permafrost areas, soil was a source for $\mathrm{CO}_{2}$ and a sink for $\mathrm{CH}_{4}$. $\mathrm{CO}_{2}$ emissions were lowest in the first years after fire, stabilizing around 60 years after fire. In Finland, the highest $\mathrm{CH}_{4}$ uptake occurred a few years after fire, whereas in Canada it happened a few decades after fire. We could not identify a consistent pattern in $\mathrm{N} 2 \mathrm{O}$ flux among our study areas.

\section{Is it possible to affect browsing pressure, food availability, and visitation rates of Alces alces with fire? A comparative study between wildfire and prescribed burning in the Swedish Boreal Forest}

Emelie Fredriksson ${ }^{1}$, Märtha Wallgren ${ }^{2}$, Therese Löfroth ${ }^{1}$

${ }^{1}$ Swedish University of Agricultural Sciences, Umeå, Sweden; ${ }^{2}$ Skogforsk, Uppsala, Sweden (emelie.fredriksson@slu.se; martha.wallgren@skogforsk.se; therese.lofroth@slu.se)

Land use conflicts between maximizing forest production, conservation and maintaining ecosystem services is an urgent challenge for sustainable forest management today. In the boreal forest, fire is a fundamental natural disturbance that has been replaced by timber harvest in Fennoscandia. These changes have had negative impacts on biodiversity, however, prescribed burn for restoration purposes is currently being implemented to counteract the reduction of natural fire disturbance. Another important disturbance is herbivory where large ungulates play a central role. Studies of the interactions between fire and herbivory in the boreal forest ecosystems of Fennoscandia are almost absent. The aim of this project is to quantify the long-term effects of forest fire and 
browsing by moose (Alces alces), as well as the possible interaction between the two disturbances, on food availability, tree damage, and moose habitat use. We sampled three large wildfires and five prescribed burns 12 years post-fire. There were higher visitation rates (based on pellet counts) in the wildfire areas compared with the unburnt controls, however, the pattern was not significant for the prescribed burns. Possible due to the lower intensity of the fire in the prescribed burns, the effects on food availability and browsing damage differs both from the control and the wildfire areas with wildfire areas having both the highest food availability and browsing damage. These results are important to better understand the differences between prescribed burns and wildfires and their interaction with herbivory so that negative impacts of browsing can be reduced in managed stands.

\section{Projecting future aboveground biomass and productivity of managed Eastern Canadian mixedwood Boreal Forest in response to climate change}

Eliana Molina ${ }^{1}$, Osvaldo Valeria ${ }^{1}$, Louis de Grandpre ${ }^{2}$, Jorge Ramirez ${ }^{3}$, Dominic Cyr ${ }^{4}$, Yan Boulanger ${ }^{2}$

${ }^{1}$ Forest Reserach Institute, UQAT, Rouyn-Noranda, Canada; ${ }^{2}$ Natural Resources Canada, Canadian Forest Service, Sainte-Foy, Canada; ${ }^{3}$ Faculty of Agrarian Science, University of Cauca, Popayan, Colombia; ${ }^{4}$ Environment and Climate Change Canada, Pollutant Inventories and Reporting Division, Motreal,Canada(ecmolinag@gmail.com; osvaldo.valeria@uqat.ca; louis.degrandpre@canada.ca; j.ramirez@unicauca.edu.ca; dominic.cyr@canada.ca; yan.boulanger@canada.ca)

Eastern Canadian Boreal Forests are modulated by wildfires and forest management. To evaluate forest dynamics under possible interactions among fire and timber harvest in a future climate warming scenario (RCP 2.6, RCP 4.5 and RCP 8.5) we simulated with LANDIS II the dynamic of the $78000 \mathrm{~km}^{2}$ of boreal forests. Forest management intensity was modeled considering changes in total harvested area $(0.5 \%, 1 \%$, and $2 \%)$ and the age that conifers and hardwoods can be harvested (5030, 7050, and 9070). The model projections showed that both forest management intensity and climatic scenarios explained most of the variability in aboveground biomass, productivity (ANPP), and forest composition. Forest management was the most important factor in the southern forests because there were more stands with the age and composition required by each harvesting prescription to deal with the annual prescription. On the contrary, in the northern forests, there was a mixed effect of climate change and forest management because many of the areas suitable for harvesting were previously burned limiting the forests available for harvesting. Although an increase in burned area due to climate change is expected, the intensification of forest management seems to be the most important driver of the increase of hardwoods and mixed stands and the decrease of conifers stands, as well as the decrease of the aboveground biomass and ANPP on the landscape. These results suggest that timber supply would be at risk in the Eastern Canadian, therefore, some strategies should be applied to adapt forest management to climate change.

\section{Linking ecosystem and disturbance simulation models for enhancing the resilience of Alpine protection forests}

Peter Antkowiak ${ }^{1}$, Rasoul Yousefpour ${ }^{1}$, Peter Bebi ${ }^{2}$, Perry Bartelt ${ }^{2}$, Adrian Ringenbach ${ }^{2}$, Werner Rammer ${ }^{3}$, Manfred J. Lexer ${ }^{3}$, Marc Hanewinkel ${ }^{1}$ ${ }^{1}$ Chair of Forestry Economics and Forest Planning, University of Freiburg, Freiburg, Germany; ${ }^{2}$ WSL Institute for Snow and Avalanche Research SLF, Davos, Switzerland; ${ }^{3}$ Institute of Silviculture, Department of Forest- and Soil Scinences, University of Natural Resources and Life Sciences (BOKU), Vienna, Austria(peter.antkowiak@ife.uni-freiburg.de; rasoul.yousefpour@ife.uni-freiburg.de; bebi@slf.ch; bartelt@slf.ch; adrian.ringenbach@slf.ch; werner. rammer@boku.ac.at;mj.lexer@boku.ac.at;marc.hanewinkel@ife.uni-freiburg.de)

Alpine forests fulfill an important protective function against gravitational hazards such as landslides, avalanches or rockfall. At the same time they are subject to a variety of disturbances such as storms or insect outbreaks. As disturbances are expected to increase with climate change, forest resilience will be increasingly important for maintaining sufficient levels of protection. We study how an altered disturbance regime would affect the provision of protection ecosystem servicesinalpine forests in the future and whether it is possible and economically beneficial to increase forest resilience by targeted management measures.To disentangle the dynamic interaction of forest growth, disturbance events and management measures in alpine forests, we simulate future forest development in two valleys in Switzerland that are highly exposed to gravitational natural hazards. We use the hybrid forest simulator PICUS for simulating climate effects, storms and biotic disturbances. For simulating rockfall and avalanche impacts, we couple PICUS with the the RAMMS mass movement simulation software.An intermediate software layer schedules management actions and disturbance events and feedsthe effects of gravitational mass movementsback into the main forestsimulation. We quantify management costs, timber revenues and the value of disaster risk reduction resulting from different management scenarios to develop management strategies that are optimally adapted to future disturbance regimes and stakeholder preferences in the case study areas. For encouraging forest owners to invest into resilience-enhancing measures, we develop and test an approach to integrate protection forest management with the current system of financial property insurance.

\section{Identifying areas of stable habitat in dynamic landscapes: implications for the management and conservation of forests \\ Craig Nitschke ${ }^{1}$, Raphael Trouve ${ }^{1}$,Lindy Lumsden ${ }^{2}$,Lauren Bennett ${ }^{3}$, Melissa Fedrigo ${ }^{1}$, Andrew Robinson ${ }^{4}$, Patrick Baker ${ }^{1}$ \\ ${ }^{1}$ The University of Melbourne, Richmond, Australia; ${ }^{2}$ Arthur Rylah Institute for Environmental Research, Heidelberg, Australia; ${ }^{3}$ The University of \\ Melbourne, Creswick, Australia; ${ }^{4}$ The University of Melbourne, Parkville, Australia (craign@unimelb.edu.au; raphael.trouve@unimelb.edu.au; \\ lindy.lumsden@delwp.vic.gov.au; ltb@unimelb.edu.au; mel.fed@gmail.com; apro@unimelb.edu.au; patrick.baker@unimelb.edu.au)}

Effective conservation planning for species that require multiple structural features depends on vegetation models that can capture the dynamics of each habitat element across both spatial and temporal scales. Incorporating these dynamics at landscape scales is essential to identifying areas of habitat that will be stable over time in response to disturbances, management, and climate change. Using a critically endangered species, the Leadbeater's possum (LBP; Gymnobelideus leadbeateri McCoy) as a case study, we explored the effects of a range of management and climate scenarios upon the structure and availability of habitat within a 280,000 ha landscape in southeast Australia. We used a spatially explicit landscape-simulation model, LANDIS-II, linked to habitat suitability and patch modelling, to identify areas of temporal stability or transience in habitat for LBP. Using boosted regression trees and general additive modelling we explored the impact of resource availability, wildfire, forest management, and climate change on LBP habitat with the goal of understanding the importance of these factors on future habitat availability. Wildfire was the main factor determining all habitat components for LBP, both alone and in interaction with climate change and forest management. We identified stable habitat patches that will likely persist under future conditions, and that might be prioritised for conservation. We highlight how the current reserve network could be augmented to improve the future conservation status of LBP. Our approach provides conservation planners with a spatially and temporally explicit framework for incorporating the key dynamic processes that are typically omitted in conservation planning. 


\section{Burning for biodiversity? Decadal effects of wildfire on saproxylic communities in Northern Boreal Forest with a long history of fire suppression}

Therese Löfroth ${ }^{1}$, Emelie Fredriksson ${ }^{1}$, Isak Vahlström ${ }^{1}$, Roger Pettersson ${ }^{1}$

${ }^{1}$ SLU,Umeå,Sweden (therese.lofroth@slu.se; emelie.fredriksson@slu.se; isak.vahlstrom@gmail.com; roger.b.pettersson@slu.se)

Wildfire is an important disturbance in Boreal ecosystems, restarting succession and creating habitat for species dependent on fire for their survival. In Fennoscandia, efficient fire suppression during the last century has almost eradicated fire from the forest landscape, resulting in population declines for several species. However, active reintroduction of fire as an ecological restoration tool has been introduced the last decades and climate change has increased the frequency of wildfires. It is still unclear how these prescribed fires differ from wildfires and how species are affected by fire in landscapes with a long history of fire suppression. We studied the ecological decadal (>10 years) effects of wildfire and prescribed burnings on biodiversity of invertebrates and wood decay fungi. The study focused around three large wildfires in Northern Sweden that burnt the same year and are located in landscapes with different management intensity. Prescribed burnings and unburned stands were included as comparison. We show that fire impact the biodiversity of wood living beetles and fungi for more than a decade. The turnover of beetles was fast the first few years after fire and differences in assemblage composition still remained after 12 years. Wood decay fungi communities shifted towards generalist species favoured by early successional habitat after fire but several rare species occurred only in burned areas. The abundance of microarthropods was also affected with significantly lower densities of both mites and springtails in burned areas 12 years after fire. Thus, fire is an important ecological restoration tool in boreal landscapes.

\section{Sustainable forest management: a simulation case-study on fire resilience}

Susana Barreiro ${ }^{1,2}$, João Rua ${ }^{1}$, Akli Benali ${ }^{1}$, Margarida Tomé

${ }^{1}$ Universidade de Lisboa, Instituto Superior de Agronomia, Centro de Estudos Florestais, Lisboa, Portugal; ${ }^{2}$ Forest Ecology and Forest Management Group, Wageningen University and Research,Wageningen, Netherlands (smb@isa.ulisboa.pt; jcprua@isa.ulisboa.pt; aklibenali@gmail.com;

magatome@isa.ulisboa.pt)

The supply of forest products and services depends on forest area, forest productivity and on a set of management choices. StandsSIM.md, a management driven forest simulator, was used in a practical exercise aiming to assess the impact of different management scenarios on wood supply and profitability of eucalypt plantations. A small parish in the center of Portugal, struck by a large wildfire in 2017, was selected as the case-study area. The objective was to show local forest owners that by reducing forest degradation and improving management eucalypt plantations could become more productive, economically viable and eventually more fire-resilient. Before the fire, around $90 \%$ of the parish was forested mainly with eucalypt (52\%). Local stakeholders were deeply engaged in identifying and characterizing the forest management approaches (FMAs) defining five main forest owner types. Simulation scenarios were defined by assigning different shares of forest area to the five owner types/FMAs. A business-as-usual (BAU) scenario and three additional scenarios (S0, S1, S2) reflecting a reduction in forest area (for creating a fuel-break network) combined with increasing levels of management intensification were created. Estimates of eucalypt standing volume and of net present value were obtained for the parish running StandsSIM.md simulator under the four scenarios for a period of 36 years considering an interest rate of $4 \%$. Preliminary results indicated that despite reducing forest area, for creating the fuel-breaks, standing volume increased from the BAU towards the S2 scenario, proving that implementing sustainable forest management makes a difference.

\section{B4g: LONG-TERM FOREST MONITORING NETWORKS FOR EVALUATING RESPONSES TO ENVIRONMENTAL CHANGE - I}

\section{Responses of forest ecosystems in Europe to decreasing nitrogen deposition}

Andreas Schmitz ${ }^{1,2}$, Tanja G.M. Sanders ${ }^{1}$, Andreas Bolte ${ }^{1}$, Filippo Bussotti ${ }^{3}$, Thomas Dirnböck ${ }^{4}$, Jim Johnson ${ }^{5}$, Josep Peñuelas ${ }^{6,7}$, Martina Pollastrini ${ }^{3}$, Anne-Katrin Prescher ${ }^{1}$, Jordi Sardans ${ }^{6,7}$, Arne Verstraeten ${ }^{8}$, Wim de Vries ${ }^{9}$

${ }^{1}$ Thünen Institute of Forest Ecosystems, Eberswalde, Germany; ${ }^{2}$ University of Göttingen, Göttingen, Germany; ${ }^{3}$ University of Florence, Firenze, Italy; ${ }^{4}$ Environment Agency Austria, Vienna, Austria; ${ }^{5}$ University College Dublin, Dublin, Ireland; ${ }^{6}$ Consejo Superior de Investigaciones Cientificas, Barcelona, Spain; ${ }^{7}$ Centre de Recerca Ecològica i Aplicacions Forestals, Barcelona, Spain; ${ }^{8}$ Research Institute for Nature and Forest, Geraardsbergen, Belgium; ${ }^{9}$ Wageningen University and Research,Wageningen,Netherlands (andreas.schmitz@thuenen.de; tanja.sanders@thuenen.de; andreas.bolte@thuenen.de; filippo.bussotti@unifi.it; thomas.dirnboeck@umweltbundesamt.at;jim.johnson@ucd.ie; josep.penuelas@uab.cat; martina.pollastrini@unifi.it; anne.prescher@thuenen.de; j.sardans@creaf.uab.cat; arne.verstraeten@inbo.be; wim.devries@wur.nl)

Elevated nitrogen $(\mathrm{N})$ deposition can cause substantial changes in forest ecosystems. In Europe, $\mathrm{N}$ deposition increased for several decades until it peaked around 1990. Since then, moderate decreases in N deposition have been observed especially in Central and Western Europe where deposition levels are highest. We reviewed observational studies on the responses of forest ecosystems in Europe to the decrease in $\mathrm{N}$ deposition. We focused on five indicators, i.e. soil acidification and eutrophication, understory vegetation, tree nutrition (foliage concentrations), tree vitality and tree growth. We found a limited decrease in soil solution nitrate concentrations and a potential reaction in foliar $\mathrm{N}$ concentrations but no broad-scale responses in understory vegetation, tree growth, or vitality. Results from experimental studies supported the observation of a greater sensitivity of soil solution and foliar element concentrations to changes in $\mathrm{N}$ supply. Despite the decline in $\mathrm{N}$ deposition in the last 30 years, deposition rates are still high compared to pre-industrial levels in most parts of Europe and future decreases are expected to be small. We hypothesize that the past and future decline in $\mathrm{N}$ deposition alone is unlikely to reverse the effects of $\mathrm{N}$ saturation in Europe's forests. Instead, the reaction of soil $\mathrm{N}$ pools to climate change and forest management might be decisive for forest ecosystem $\mathrm{N}$ cycling in the future.

\section{Environmental and host filtering of ectomycorrhizal fungi at large scales}

Sietse van der Linde ${ }^{1,2,3}$, Laura M Suz ${ }^{2}$, David Orme ${ }^{3}$, Filipa Cox ${ }^{4}$, Henning Andreae ${ }^{5}$, Endla Asi ${ }^{6}$, Bonnie Atkinson $^{2,3}$, Sue Benham $^{1}$, Christopher Carroll ${ }^{3}$, Nathalie Cools ${ }^{7}$, Bruno de Vos ${ }^{7}$, Hans-Peter Dietrich ${ }^{8}$, Johannes Eichhorn ${ }^{9}$, Joachim Gehrmann ${ }^{10}$, Tine Grebenc ${ }^{11}$, Hyun S. Gweon ${ }^{12,13}$, Karin Hansen ${ }^{14}$, Frank Jacob ${ }^{15}$, Ferdinand Kristöfel ${ }^{16}$, Pawet Lech ${ }^{17}$, Miklós Manninger ${ }^{18}$, Jan Martin ${ }^{19}$, Henning Meesenburg ${ }^{9}$, Päivi Merilä ${ }^{20}$, Manuel Nicolas ${ }^{21}$, Pavel Pavlenda ${ }^{22}$, Pasi Rautio ${ }^{23}$, Marcus Schaub ${ }^{24}$, Hans-Werner Schröck ${ }^{25}$, Walter Seidling ${ }^{26}$, Vit Srámek ${ }^{27}$, Anne Thimonier ${ }^{24}$, Iben Margrete Thomsen ${ }^{28}$, Hugues Titeux ${ }^{29}$, Elena Vanguelova ${ }^{1}$, Arne Verstraeten ${ }^{7}$, Lars Vesterdal ${ }^{28}$, Peter Waldner ${ }^{24}$, Sture Wijk ${ }^{30}$, Yuxin Zhang ${ }^{3}$, Daniel Žlindra ${ }^{11}$, Martin Bidartondo ${ }^{2,3}$ ${ }^{1}$ Forest Research, Farnham, United Kingdom; ${ }^{2} R B G$ Kew, London, United Kingdom; ${ }^{3}$ Imperial College London, London, United Kingdom; ${ }^{4}$ University of Manchester, Manchester, United Kingdom; ${ }^{5}$ Public Enterprise Sachsenforst, Pirna, Germany; ${ }^{6}$ Estonian Environment Agency, Tallinn, Estonia; ${ }^{7}$ Nature and 
Forest Research Institute, Geraadsbergen, Belgium; ${ }^{8}$ Bavarian State Forestry Institute, Freising, Germany; ${ }^{9}$ Northwest German Forest Research Institute, Göttingen, Germany; ${ }^{10}$ Landesamt für Natur Umwelt und Verbraucherschutz Nordrhein-Westfalen, Recklinghausen, Germany; ${ }^{11}$ Slovenian Forestry Institute, Ljubjana, Slovenia; ${ }^{12}$ University of Reading, Reading, United Kingdom; ${ }^{13}$ Centre for Ecology \& Hydrology, Wallingford, United Kingdom; ${ }^{14}$ IVL Swedish Environmental Research Institute, Stockholm, Sweden; ${ }^{15}$ Staatsbetrieb Sachsenforst, Pirna, Germany; ${ }^{16}$ Federal Research and Training Centre for Forests, Wien, Austria; ${ }^{17}$ Forest Research Institute, Sękocin Stary, Poland; ${ }^{18}$ NARIC Forest Research Institute, Sárvár, Hungary; ${ }^{19}$ Landesforstanstalt M-V BT: FVI, Schwerin, Germany; ${ }^{20}$ Natural Resources Institute Finland, Oulu, Finland; ${ }^{21}$ Office National des Forêts, Fontainebleau, France; ${ }^{22}$ National Forest Centre, Zvolen, Slovakia; ${ }^{23}$ Natural Resources Institute Finland, Rovaniemi, Finland; ${ }^{24}$ WSL Swiss Federal Institute for Forest, Snow and Landscape Research, Birmensdorf, Switzerland; ${ }^{25}$ Forschungsanstalt für Waldökologie und Forstwirtschaft, Trippstadt, Germany; ${ }^{26}$ Thünen Institute of Forest Ecosystems, Eberswalde, Germany; ${ }^{27}$ Forestry and Game Management Research Institute, Jiloviště, Czech Republic; ${ }^{28}$ University of Copenhagen, Copenhagen, Denmark, ${ }^{29}$ University of Louvain, Louvain-la-Neuve, Belgium; ${ }^{30}$ Swedish Forest Agency, Jönköping, Sweden (sietse.vanderlinde@forestresearch.gov.uk; l.martinez-suz@kew.org;d.orme@imperial.ac.uk; filipa.cox@manchester.ac.uk; henning.andreae@smul.sachsen.de; endla.asi@envir.ee; bonnieatkinson11@gmail.com; sue.benham@forestry.gov.uk; christophertcarroll@btinternet.com; nathalie.cools@inbo.be; bruno.devos@inbo.be; hans-peter.dietrich@lwf.bayern.de; johannes.eichhorn@nw-fva.de; joachim.gehrmann@lanuv.nrw.de; tine.grebenc@gozdis.si; xc917132@reading.ac.uk; karin.hansen@naturvardsverket.se; frank.jacob@smul.sachsen.de; ferdinand.kristoefel@bfw.gv.at; p.lech@ibles.waw.pl; manningerm@erti.hu; jan.martin@lfoa-mv.de; henning.meesenburg@nw-fva.de; paivi.merila@luke.fi; manuel.nicolas@onf.fr; pavlenda@nlcsk.org; pasi.rautio@luke.fi; marcus.schaub@wsl.ch; hans-werner.schroeck@wald-rlp.de; walter.seidling@thuenen.de; sramek@vulhm.cz; anne.thimonier@wsl.ch; imt@ign.ku.dk; hugues.titeux@uclouvain.be; elena.vanguelova@forestry.gov.uk; arne.verstraeten@inbo.be; lv@ign.ku.dk; peter.waldner@wsl.ch; sture.wijk@skogsstyrelsen.se; yuxin.zhang15@imperial.ac.uk; daniel.zlindra@gozdis.si;m.bidartondo@imperial.ac.uk)

Understanding the large-scale diversity and distribution of soil organisms that drive biogeochemical processes and responses to environmental change remains a contentious field of study; there is a generally acknowledged lack of consistent drivers of diversity and abundance at large spatial scales. Here we investigate ectomycorrhizal fungi at unprecedented scale and resolution across European forests to test for key biotic and abiotic environmental predictors, identify dominant responses and thresholds across complex gradients of environmental variables, and investigate whether there is plasticity in traits.Across Europewe sampled 137 level II plotsof ICP Forests; one of the most extensive biomonitoring networks on Earth in which the effects of pollution and changes in forest soil quality have been closely monitored.We show the effect of 38 host, environment, climate and geographical variables on ectomycorrhizal diversity, and define thresholds of community change for key variables. We quantify host specificity and reveal plasticity in functional traits involved in soil foraging across gradients. We conclude that environmental and host factors explain most of the variation in ectomycorrhizal diversity, that the environmental thresholds used as major ecosystem assessment tools need adjustment and that the importance of belowground specificity and plasticity has previously been underappreciated.

\section{Ozone concentrations and foliar symptoms on European forests}

Marcus Schaub ${ }^{1,2}$ (D, Maxime Cailleret ${ }^{1,2}$, Elena Gottardini ${ }^{3,4}$, , Matthias Häni ${ }^{1,2}$, Marco Ferretti $^{1,2}$

${ }^{1}$ Swiss Federal Research Institute WSL, Birmensdorf, Switzerland; ${ }^{2}$ Swiss ForestLab, Birmensdorf, Switzerland; ${ }^{3}$ Research and Innovation Centre,

Fondazione Edmund Mach (FEM), San Michele all'Adige, Italy; ${ }^{4} I R S T E A$ Aix-en-Provence, France (marcus.schaub@wsl.ch; maxime.cailleret@irstea.fr; elena.gottardini@fmach.it; matthias.haeni@wsl.ch;marco.ferretti@wsl.ch)

Specific visible foliar symptoms have been widely used to detect the impact of tropospheric ozone $\left(\mathrm{O}_{3}\right)$ on vegetation. Here, April-September $\mathrm{O}_{3}$ concentrations and $\mathrm{O}_{3}$-induced visible foliar symptoms have been assessed across Europe in 2002-2016 according to ICP Forests standardized methods. This activity provided bi-weekly mean $\mathrm{O}_{3}$ concentrations from over 18,000 passive samplers on 206 plots in 15 countries and over 29,000 symptom records from 285 woody plant species on 169 plots, in 19 countries. Data were evaluated for the period 2005-2016, excluding a calibration phase during the initial three years of the monitoring program. A linear-mixed-effects modeling approach was applied to analyze the temporal trends in $\mathrm{O}_{3}$ concentrations and symptoms and their inter-correlation while accounting for the heterogeneity and incompleteness of the datasets. We also used re-sampling procedures (focus on different subsets, bootstrap, and jackknife) to test for the robustness of our results. The long-term mean $\mathrm{O}_{3}$ concentrations in the growing season (April-September) showed an increasing trend from north to south in forests across Europe. The highest concentrations occurred in Italy, southern Switzerland, the Czech Republic, Slovakia, Romania and Greece. Trend analysis reveals a slight but significant decrease in growing season (April-September) $\mathrm{O}_{3}$ concentrations. There were no clear spatial or temporal trends in mean $\mathrm{O}_{3}$ symptoms, but we found differences among biogeographical regions using the EEA stratification. These first results demonstrate the potential of the survey on visible foliar symptoms to detect the possible impact of ozone on European vegetation.

\section{The role of pollen in forest throughfall biochemistry}

Arne Verstraeten ${ }^{1}$, Elena Gottardini ${ }^{2}$, Nicolas Bruffaerts ${ }^{3}$, Bruno de Vos ${ }^{1}$, Elena Vanguelova ${ }^{4}$, Fabiana Cristofolini ${ }^{2}$, Sue Benham ${ }^{4}$, Pasi Rautio ${ }^{5}$, Liisa Ukonmaanaho ${ }^{5}$, Päivi Merilä ${ }^{5}$, Annika Saarto ${ }^{6}$, Peter Waldner ${ }^{7}$, Marijke Hendrickx ${ }^{3}$, Gerrit Genouw ${ }^{1}$, Peter Roskams ${ }^{1}$, Nathalie Cools ${ }^{1}$, Johan Neirynck ${ }^{1}$, Arthur de Haeck ${ }^{1}$, Yvan de Bodt ${ }^{1}$, Anita Nussbaumer ${ }^{7}$, Mathias Neumann ${ }^{8}$, Nicholas Clarke ${ }^{9}$, Volkmar Timmermann ${ }^{9}$, Karin Hansen ${ }^{10}$, Hans-Peter Dietrich ${ }^{11}$, Manuel Nicolas ${ }^{12}$, Maria Schmitt ${ }^{7}$, Anne Thimonier ${ }^{7}$, Katrin Meusburger $^{7}$, Silvio Schüler ${ }^{8}$, Anna Kowalska ${ }^{13}$, Idalia Kasprzyk ${ }^{14}$, Katarzyna Borycka ${ }^{14}$, Lukasz Grewling ${ }^{15}$, Joanna Święta-Musznicka ${ }^{16}$, Matgorzata Latałowa ${ }^{16}$, Marcelina Zimny ${ }^{16}$, Matgorzata Malkiewicz ${ }^{17}$, Lars Vesterdal ${ }^{18}$, Iben Margrete Thomsen ${ }^{18}$, Miklós Manninger ${ }^{19}$, Hugues Titeux ${ }^{20}$

${ }^{1}$ Research Institute for Nature and Forest (INBO), Brussels, Belgium; ${ }^{2}$ Department of Biodiversity and Molecular Ecology, Research and Innovation Centre, Fondazione Edmund Mach (FEM), San Michele all'Adige, Italy; ${ }^{3}$ Sciensano, Mycology \& Aerobiology, Brussels, Belgium; ${ }^{4}$ Centre for Ecosystem, Society and Biosecurity, Forest Research, Alice Holt Lodge, Surrey, United Kingdom; ${ }^{5}$ Luke, Natural Resources Institute Finland, Helsinki, Finland; ${ }^{6}$ Aerobiology, Biodiversity Unit, University of Turku, Turku, Finland; ${ }^{7}$ Swiss Federal Institute on Forest, Snow and Landscape (WSL), Birmensdorf, Switzerland; ${ }^{8}$ Institute of Silviculture, University of Natural Resources and Life Sciences, Vienna, Austria; ${ }^{9}$ Norwegian Institute of Bioeconomy Research (NIBIO), As, Norway; ${ }^{10}$ Swedish Environmental Protection Agency, Stockholm, Sweden; ${ }^{11}$ Bavarian State Institute of Forestry, Freising, Germany; ${ }^{12}$ Office National des Forêts, Fontainebleau, France; ${ }^{13}$ Forest Research Institute, Raszyn, Poland; ${ }^{14}$ University of Rzeszów, Rzeszów, Poland; ${ }^{15}$ Adam Mickiewicz University, Poznan, Poland; ${ }^{16}$ University of Gdánsk, Gdánsk, Poland; ${ }^{17}$ University of Wroclaw, Wroclaw, Poland; ${ }^{18}$ University of Copenhagen, Copenhagen, Denmark; ${ }^{19}$ NARIC Forest Research Institute, Sárvár, Hungary; ${ }^{20}$ Université catholique de Louvain, Louvain-la-Neuve, Belgium (arne.verstraeten@inbo.be; elena.gottardini@fmach.it; nicolas.bruffaerts@sciensano.be; bruno.devos@inbo.be; elena.vanguelova@forestry.gsi.gov.uk; fabiana.cristofolini@fmach.it; sue.benham@forestry.gsi.gov.uk; pasi.rautio@luke.fi; liisa.ukonmaanaho@luke.fi;paivi.merila@luke.fi; annika.saarto@utu.fi;peter.waldner@wsl.ch; marijke.hendrickx@sciensano.be; gerrit.genouw@inbo.be; peter.roskams@inbo.be;nathalie.cools@inbo.be; johan.neirynck@inbo.be; arthur.dehaeck@inbo.be; yvan.debodt@inbo.be; anita.nussbaumer@wsl.ch; mathias.neumann@boku.ac.at; nicholas.clarke@nibio.no; volkmar.timmermann@nibio.no; karin.hansen@naturvardsverket.se; hans-peter.dietrich@lwf.bayern.de; manuel.nicolas@onf.fr; maria.schmitt@wsl.ch; 
anne.thimonier@wsl.ch; katrin.meusburger@wsl.ch; silvio.schueler@bfw.gv.at; a.kowalska@ibles.waw.pl; idalia@univ.rzeszow.pl; kborycka@ur.edu.pl; grewling@amu.edu.pl; joanna.swieta-musznicka@biol.ug.edu.pl; malgorzata.latalowa@biol.ug.edu.pl; marcelina.zimny@biol.ug.edu.pl; malgorzata.malkiewicz@uwr.edu.pl; lv@ign.ku.dk; imt@ign.ku.dk; manningerm@erti.hu; hugues.titeux@uclouvain.be)

Pollen from wind-pollinated forest trees, beside by dry gravitational settling, is washed out from the atmosphere by precipitation, but little is known about the effects of this pollen on throughfall biochemistry. We analysed long-term data from five UNECE ICP Forests intensive monitoring (Level II) plots in Flanders, Belgium, and nearby pollen monitoring stations. Preliminary results indicate a positive relationship between airborne pollen concentrations and both throughfall dissolved organic carbon (DOC) flux in May and biomass of fruiting/seeds in the same year. The complete opposite happens with throughfall nitrate $\left(\mathrm{NO}_{3}-\right.$ ) flux in May that is reduced in mast years, particularly in deciduous trees. Dissolution experiments using commercially available birch (Betula pendula L.) pollen in a $50 \mathrm{mg} / \mathrm{L} \mathrm{NO}_{3}$ - solution showed that pollen can remove $\mathrm{NO}_{3}$ - and release DOC, nitrite, potassium, calcium, magnesium, sulphate and phosphate in throughfall samples. Pollen from wind-pollinated forest trees clearly is an important in-canopy source of nutrients during spring, which should be considered in the quality control of analytical results of for example throughfall measurements and in the calculation of nutrient budgets. The observed effects are further examined in ongoing studies at larger spatial scale using long-term data from ICP Forests Level II plots and pollen monitoring stations in 13 European countries, and throughfall samples and pollen collected in precipitation, from a subset of plots sampled during spring 2018.

\section{Supersites for superior forest science: integrated research on ecosystem-level climate change and air pollution responses}

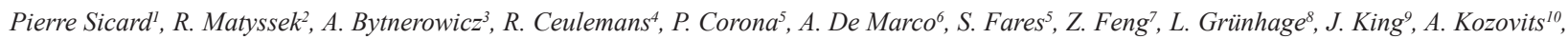
D. Le Thiec ${ }^{11}$, R. Lindroth ${ }^{12}$, T. Mikkelsen ${ }^{13}$, K. Pregitzer ${ }^{14}$, H. Rennenberg ${ }^{15}$, C. Reyer ${ }^{16}$, G. Scarascia--Mugnozza ${ }^{17}$, J-P. Tuovinen ${ }^{18}$, G. Wieser ${ }^{19}$, Elena Paoletti $^{20}$

${ }^{1}$ ARGANS, Biot, France; ${ }^{2}$ Technischen Universität München, Freising, Germany; ${ }^{3}$ Forest Service, Riverside, USA; ${ }^{4}$ University Antwerp, Antwerp, Belgium; ${ }^{5}$ CREA-FL, Arezzo, Italy; ${ }^{6}$ ENEA, Rome, Italy; ${ }^{7} \mathrm{CAS}$, Beijing, China; ${ }^{8}$ Justus-Liebig University, Giessen, Germany; ${ }^{9}$ North Carolina State University, Raleigh, USA; ${ }^{10}$ Ouro Preto University, Ouro Preto, Brasil; ${ }^{11}$ UMR INRA, Nancy, France; ${ }^{12}$ University of Wisconsin-Madison, Wisconsin, USA; ${ }^{13}$ Technical University Roskilde, Roskilde, Denmark; ${ }^{14}$ University of Idaho, Moscow, USA; ${ }^{15}$ University Freiburg, Freiburg, Germany; ${ }^{16}$ Potsdam Institute for Climate Impact Research, Potsdam, Germany; ${ }^{17}$ University Tuscia, Viterbo, Italy; ${ }^{18}$ Finnish Meteorological Institute, Helsinki, Finland; ${ }^{19}$ UIBK, Innsbruck, Austria; ${ }^{20}$ CNR, Sesto Fiorentino,Italy(psicard@argans.eu; matyssek@wzw.tum.de; abytnerowicz@fs.fed.us; reinhart.ceulemans@uantwerpen.be; piermaria.corona@entecra.it; alessandra.demarco@enea.it; silvano.fares@entecra.it; zhzhfeng201@hotmail.com; ludger.gruenhage@bot.bio.uni-giessen.de; john_king@ncsu.edu; kozovits@iceb.ufop.br; lethiec@nancy.inra.fr; richard.lindroth@wisc.edu; temi@kt.dtu.dk; kpregitzer@uidaho.edu; heinz.rennenberg@ctp.uni-freiburg.de; reyer@pik-potsdam.de; gscaras@unitus.it; juha-pekka.tuovinen@fmi.fi;gerhard.wieser@uibk.ac.at; elena.paoletti@cnr.it)

Forest ecosystems are subject worldwide to anthropogenic impacts, directly through land-usechanges, and indirectly via the atmosphere, e.g. through elevated $\mathrm{CO}_{2}$, warming and drought, soil acidification, dry and wet depositions (e.g. nitrogen, particulate matter) or precursor emissions of tropospheric ozone. After decades oftranscontinental forest ecosystem research, few questions are still open and gaps in our understanding identified. For example, what is the influence of the increase of the tree growing seasons, and what is the inhibitory potential of ozone stress on forests? Does warming increases carbon storage, in particular in cool climates, besides promoting risks for drought? Research aims to establish mechanistic understanding of inter-related feedbacks between climate change, air pollution and forest ecosystem responses. To overcome these issues, a concept, i.e. supersites for forest research, was developed and proposed within the COST Action FP0903 and the Task Force IUFRO on Climate Change and Forest Health. The forest supersites are global operational platforms to be established by networking and upgrading of existing highly-equipped sites. The apparent novelties are interlinked i) by clarifying climate change - air pollution - forest ecosystem interactions, ii) by cross-linking experimenting - monitoring - modelling at same sites, and iii) by operating studies across key forest sites worldwide under a long-term perspective.

\section{The COST Action CLIMO: a network on climate-smart forestry in mountain regions to face environmental threats in a changing climate}

Roberto Tognetti ${ }^{1,2}$ D, Pietro Panzacchi ${ }^{1,3}$, Cost Action Climo ${ }^{1}$

${ }^{1}$ Università del Molise, Campobasso, Italy; ${ }^{2}$ Fondazione Edmund Mach, San Michele all'Adige, Italy; ${ }^{3}$ Università di Bolzano, Bolzano, Italy

(tognetti@unimol.it; pietro.panzacchi@gmail.com; climo@unimol.it)

Mitigation goals fixed by the Paris Agreement cannot be met without a significant contribution from forests (sequestration lever) and increasing use of biomaterials and bioenergy (substitution lever). Natural climate solutions (conservation, restoration, improved land management) may provide cost-effective climate mitigation to stabilize warming to below $2{ }^{\circ} \mathrm{C}$. Terrestrial GPP is the largest global $\mathrm{CO}_{2}$ flux, and carbon stored in forest land represents $60 \%$ of total carbon stock contained in terrestrial carbon pools. The central role of forests in the carbon cycle can be enhanced through climate-smart forest management. Nevertheless, climate benefits from carbon sequestration through forest management can also be offset by concurrent management-induced changes in surface albedo, land-surface roughness, emissions of BVOCs, transpiration and sensible heat flux. Therefore, the role of forest management in the coming decades should focus on the adaptation of the forest cover to future climate and disturbances (drought spells, forest fires, heath waves, pest outbreaks, wind storms), moving forward climate mitigation objectives. The capacity to forecast the thresholds of irreversible transformation of forest ecosystems needs geographically distributed research infrastructures and long-term observation programs designed to monitor climate change, better understand its impacts, and evaluate possible mitigation and adaptation strategies. The COST Action CLIMO aims to identify a coordinated network of climate-smart forests for challenging ecological change throughout European mountain ranges. Variety of European mountains and local circumstances is an opportunity to test the resilience of forest systems to climate change and the role of forestry in the climate targets, in systems at climate risk.

\section{The CzeCOS ecosystem stations network}

Manuel Acosta ${ }^{1}$, Marian Pavelka ${ }^{1}$,Eva Dařenová ${ }^{1}$, Jíri Dušek $^{1}$, George Jocher ${ }^{1}$, Ina Kyselova ${ }^{1}$, Natalia Kowalska ${ }^{1}$, Lenka Foltynová ${ }^{1}$, Ladislav Šigut ${ }^{1}$, Caleb Mensah', Dalibor Janoušs, Michal V. Marek ${ }^{1}$, Pavel Cudlín ${ }^{1}$

${ }^{1}$ Global Change Research Institute, CAS,Brno,Czech Republic (acosta.m@czechglobe.cz; pavelka.m@czechglobe.cz;darenova.e@czechglobe.cz; dusek.j@czechglobe.cz; jocher.g@czechglobe.cz; kyselova.i@czechglobe.cz; kowalska.n@czechglobe.cz; foltynova.l@czechglobe.cz; sigut.l@czechglobe.cz; mensah.c@czechglobe.cz; janous.d@czechglobe.cz; marek.mv@czechglobe.cz; cudlin.p@czechglobe.cz)

The Global Change Research Institute of the Czech Academy of Sciences (CzechGlobe) have established a well-equipped network of ecosystem stations, with modern instrumentation for eco-physiological, plant physiological and micrometeorological studies, and estimation of GHG emissions. The research 
infrastructure CzeCOS is included in the national roadmap of major research infrastructures. The network covers the main terrestrial ecosystems of the Czech Republic (coniferous forests, deciduous forest, mixed floodplain forest, grassland, wetland and cropland).The floodplain forest have been influenced by anthropological impact of water management the last decades. The 40-aged coniferous forest is located in high latitude, typical for Central European coniferous forest, while, the 110-aged coniferous forest is located at low latitude (influenced by drought period). The wetland station is located in UNESCO Man and Biosphere reservation. The deciduous forest is managed even-aged European mature beech stand with tree species composition close to natural. Further two ecosystems are part of the typical managed ecosystem, grassland (mowed one per year) and cropland (intensively used). Three stations of the network are proposed as ICOS stations. The network enables detailed research to be conducted on topics such as: the carbon balance of different ecosystems, energy balance closure, the impact of current climate conditions on production and ecosystem disturbances during extreme weather conditions (drought, floods, winter storms, etc). In the poster we show specific results from the sites and outline the importance of the regional/national network for improving our knowledge about the exchange of matter and energy fluxes at different ecosystems.

\section{Optimising observation networks for the early detection and unequivocal attribution of environmental effects on European forests \\ Virginie Moreaux ${ }^{1,2}$, Dario Papale ${ }^{3,4}$, Bert Gielen $^{4,5}$, Denis Loustau ${ }^{6}$ \\ ${ }^{1} I N R A$, UMR ISPA, Villenave d'Ornon, France; ${ }^{2} U M R$ IGE, Grenoble, France; ${ }^{3}$ University of Tuscia, Viterbo, Italy; ${ }^{4} I C O S$ Ecosystem Thematic Centre, Viterbo, Italy; ${ }^{5}$ University of Antwerpen, Antwerpen, Belgium; ${ }^{6}$ ICOS Ecosystem Thematic Centre, Antwerpen, Belgium (virginie.moreaux@inra.fr; \\ darpap@unitus.it; bert.gielen@uantwerpen.be; denis.loustau@inra.fr)}

The world forests are being observed and monitored by inventory and observatory systems organised mainly at country level and deployed across a wealth of temporal and spatial resolutions, making it difficult to coordinate and to interoperate the data collected. We demonstrate why the standardisation and coordination of such in situ monitoring networks such as ICOS are a prerequisite to detect the effects of environmental changes on forests and disentangle their causal chain. The ICOS network is monitoring the greenhouse gas fluxes, carbon, energy and water balances and phenology on the long term (20 years) at an hourly resolution with a high level of standardisation. We projected across Europe three different climate and pollution scenarios and estimated their impacts on forests functioning using both models and literature analysis. In parallel, the performances in terms of accuracy, standardisation and precision of $\mathrm{t}$ the ICOS ecosystem network have been evaluated. Afterwards, we related the projected impacts of changing environmental forcings to the sensitivity and metrological performances of the station network. We show how the station network of ICOS in combination with companion forest networks (ICP Forests, ANAEE-RI, eLTER-RI) can be optimised to detect and attribute the effects of ozone and nitrogen deposition, temperature increase, $\mathrm{CO}_{2}$ concentration and diffuse radiation on forests: which variables are most meaningful, how precise and accurate should they be measured, which observations should be added and where and how much stations is requested to detect expected changes and identify their driver(s).

\section{Forest ecosystems biodiversity assessment and inventory based on ICP-Forests grid of sample plots}

Alexander Alekseev ${ }^{1}$, Iurii Belenkii ${ }^{1}$

${ }^{1}$ Saint-Petersburg State Forest Technical University, Saint-Petersburg, Russian Federation(a_s_alekseev@mail.ru; rector@spbftu.ru)

Regular grid of permanent sample plots (PSP) of ICP-Forests monitoring system was used for forest ecosystems biodiversity assessments and inventory. The supplementary features were added to the PSP structure to conduct biological diversity census: eight sample plots $1 \mathrm{x} 1 \mathrm{~m}$ for geo-botanical description; two sample plots of $5 \times 5 \mathrm{~m}$ each for description of the PSP's undergrowth; one 25 x $25 \mathrm{~m}$ plot for coarse woody debris estimations; four soil inventory pits. The total number of PSP amounted to 248 . General statistical indicators of $\alpha$-diversity characterizing forest land cover diversity were calculated. $\beta$ - diversity of forest ecosystems as well as $\gamma$-diversity also was studied on the base of information collected on the same regular grid of sample plots. It appears that sample plots distribution by species diversity gradation is well described by the standard curve of normal distribution for the entire Karelian Isthmus forest (determination coefficient of the curve being 95.2\%) as well as for each type of forest. Hence, the criterion (standard) of biodiversity for forest ecosystems can be defined as the mean value of alpha diversity for each forest type group $-\mathrm{m}$; and the standard deviation $-\sigma$, as a tool for assessing deviations from the standard biodiversity. Indication of man-made effects on forest ecosystems using occurrence of species of 5 different phyto-ecological groups was done; 5 phyto-ecological groups of species were distinguished: forest, bogged forest, forest-meadow, meadow, weed and ruderal. Estimated non-forest species presence (meadow, weed and ruderal) was used as indicators of the man-made effect on forest ecosystem.

\section{Methodological issues and outputs of the REINFFORCE network: a unique transnational infrastructure of tree species arboreta for the adaptation of planted forests to future climate}

Christophe Orazio ${ }^{1}$, Hernan Serrano-León ${ }^{1}$

'European Forest Institute, Cestas, France (christophe.orazio@efi.int; hernan.serrano@efi.int)

Predicting the future responses of productive forests and choosing the best-adapted regeneration material to climate change requires transnational infrastructures that provide evidence-based knowledge of the response of multiple tree species under a wide range of climatic conditions. This is why REINFFORCE was established as a unique network of demonstration sites to test the field performance and adaptation of 32 tree species from all over the world, including currently established and alternative productive species/provenances. The network made of 38 arboreta with common genetic material distributed along the European Atlantic arc (latitudes $37^{\circ}$ to $58^{\circ} \mathrm{N}$ ). This latitudinal gradient, covering a large diversity of climate and soil conditions, allows assessing the response of 120,000 tested trees from 176 provenances to current and anticipated future climatic conditions outside their current distribution range. We present methodological issues for the establishment, maintenance and coordination of the transnational network between the multiple partners, based on the common protocols and consolidated database for long-term monitoring and knowledge sharing. The latest outputs in methodological innovation include a harmonized field protocol for phenology assessment, height measurements with drone technology, and the use of the arboreta network as sentinels for emerging pests and diseases.The successful experience of the REINFFORCE network provides a strategic research platform for transnational cooperation and creates synergies with other research initiatives on forest adaptation to climate change. The latest research findings provides evidences and decision support for multiple forest stakeholders to increase the adaptation of the planted forests facing future climate uncertainty. 


\title{
Relationship between forest ecosystems capacity to provide regulating ecosystem services and their structural and biodiversity
} attributes in Romanian forest LTER sites

\author{
Diana Pitar ${ }^{1}$, Stefan Leca ${ }^{1}$, Carmen Iacoban ${ }^{1}$, Marius Curca ${ }^{1}$, Ovidiu Badea ${ }^{1,2}$ \\ ${ }^{1}$ National Institute for Research and Development in Forestry "Marin Dracea", Voluntari, Romania; " "Transilvania" University, Brasov, Romania \\ (diana.silaghi@icas.ro; stefan.leca@icas.ro; carmeniacoban@ymail.com; c.marius83@yahoo.com; badea63@yahoo.com)
}

Forests provide a wide range of ecosystem services (ES), including timber production, local climate air quality and water regulation, carbon storage, and many cultural services associated with recreational activities and nature experience. Traditionally, forest management has targeted only few of these benefits, particularly timber production. In forest protected areas, where wood logging is forbidden, regulating and cultural ES are the main benefits provided by forests. In order to investigate forest ecosystems capacity to provide regulating ES, particularly air quality regulation, through nitrogen and sulphur retention, we studied the relationship between dry deposition of $\mathrm{N}_{-} \mathrm{NO}_{4}, \mathrm{~N}_{-} \mathrm{NH}_{3}$ and $\mathrm{S}-\mathrm{SO}_{4}$ fluxes and different forests attributes (forest type, number of trees per hectare - $\mathrm{N}$, mean height - Hm, mean DBH, mean defoliation - def_med, Shannon diversity index of the tree layer - H') in 11 plots placed in 2 Romanian forest LTER sites (Retezat and Bucegi-Piatra Craiului). Our results show that only sulphur retention is significantly different $(F(2,94)=5.9$, $p<0.05)$ in different forest types (coniferous, broadleaves and mixed); $12.9 \%$ of the N-NH4 variation in Bucegi-Piatra Craiului LTER site is explained by N (8.6\%) and H' (4.3\%). N , mean $\mathrm{DBH}$ and $\mathrm{H}$ ' explain $9.5 \%$ and $31 \%$ of the $\mathrm{N}-\mathrm{NO}_{3}$ variation in all plots and coniferous stands, respectively. Regarding S-SO, $30 \%$ of its variation is explained by H' in mixed forests, $23.1 \%$ by N, Hm, mean DBH and def_med in coniferous stands and $14.2 \%$ by N and H' in Bucegi - Piatra Craiului LTER site. Additional forest attributes and environmental and climatic factors will be further tested.

\section{Long-Term monitoring to study the structure and function of Venezuelan tropical forests: a summary of findings and the future ahead}

Emilio Vilanova ${ }^{1,2}$, Hirma Ramirez-Angulo², Armando Torres-Lezama ${ }^{2}$, Gerardo Aymard ${ }^{3}$, Luis Gámez ${ }^{4}$, Cristabel Durán ${ }^{5}$, Lionel Hernández $^{6}$,

Rafael Herrera ${ }^{7,8}$, van der Heijden Geerjte ${ }^{9}$, Oliver Phillips ${ }^{10}$, Gregory Ettl ${ }^{1}$

${ }^{1}$ School of Environmental and Forest Sciences, University of Washington, Seattle, USA; ${ }^{2}$ Instituto de Investigaciones para el Desarrollo Forestal, Universidad de Los Andes Merida, Venezuela, Republic of Bolivarian; ${ }^{3}$ Universidad Experimental de los Llanos Ezequiel Zamora, Guanare, Venezuela, Republic of Bolivarian; ${ }^{4}$ Escuela de Ingeniería Forestal, Universidad de Los Andes, Merida, Venezuela, Republic of Bolivarian; ${ }^{5}$ University of Freiburg, Freiburg, Germany; ${ }^{6}$ Universidad Nacional Experimental de Guayana, Ciudad Bolivar, Venezuela, Republic of Bolivarian; ${ }^{7}$ Centro de Ecología, Instituto Venezolano de Investigaciones Cientificas, Caracas, Venezuela, Republic of Bolivarian; ${ }^{8}$ Department of Geography and Regional Research, Geoecology, University of Vienna, Vienna, Austria; ${ }^{9}$ School of Geography, University of Nottingham, Nottingham, United Kingdom; ${ }^{10}$ School of Geography, University of Leeds, Leeds, UnitedKingdom(vilanova@uw.edu; rhirma@gmail.com; torres@ula.ve; cuyuni24@hotmail.com; lgamez@ula.ve; cristabelduran@gmx.de; lionelher@yahoo.com; potoy1@hotmail.com; geertje.vanderheijden@nottingham.ac.uk; o.phillips@leeds.ac.uk; ettl@uw.edu)

Permanent plots continuously measured through time are unique windows to advance forest monitoring systems from local to global scales. A team of researchers initially led by Jean Pierre Veillon and others thereafter, established in the 1960s, and late afterwards, a systematic Venezuelan forests plot monitoring network, with some of these plots being the longest running sites in Latin America and the tropics. The purpose of this study is to offer a summary of the main findings of more than three decades of research and discuss the still unlocked potential that these sites hold in terms of their value to understand the effects of climate change in tropical forests. Through this network we now know that Guiana Shield Forests are the most productive and carbon-rich systems, while the seasonal forests of the Western Plains region are characterized by a much faster dynamic with higher rates of tree mortality. Available water and length of dry season are fundamental factors driving the process of carbon accumulation and turnover. Overall, forests in wet, low elevation sites and with slow turnover stored the greatest amounts of biomass. Although faster stand dynamics are closely associated with lower carbon storage, stem-level turnover rates and woody productivity did not show any correlation, indicating that stem dynamics and carbon dynamics are largely decoupled from one another. We also highlight the risks and threats posed by the current economic and political crisis and propose a set of ideas to protect and expand this network.

B4h: NOVEL REMOTE SENSING APPROACHES TO QUANTIFY CARBON STOCKS, STRUCTURE AND FUNCTIONAL DIVERSITY OF FORESTS - 1

\author{
Automatic assessment of crown projection area on single trees and stand-level, based on terrestrial laser-scanning data \\ Tim Ritter 1 (D), Arne Nothdurft ${ }^{1}$ (D) \\ ${ }^{1}$ University of Natural Resources and Life Sciences, Vienna (BOKU),Vienna, Austria (tim.ritter@boku.ac.at; arne.nothdurft@boku.ac.at)
}

Assessing Crown projection area (CPA) is crucial for estimating inter-tree competition and tree biomass volume. An approach to the fully automated assessment of CPA, using a multi-layer seeded region growing algorithm and high-resolution 3D point cloud data is presented. Data were collected via multi-scan TLS in a 4.08 ha mixed-species stand with high vertical structure, located in Lower-Austria. The new approach is tested against independently repeated manual CPA-measurements by different observers that serve as the reference. The inter-observer bias of the manual CPA-measurements is quantified, and allometric models are used to predict CPA from diameter at breast height (DBH) measurements. These predictions are then compared to the TLS-based estimates on the single tree- and stand-level. It is shown, that for single trees, there is a remarkable inter-observer bias of manual CPA measurements. The deviation between CPA measurements derived from TLS data and manual measurements is on par with the deviations between manual measurements by different observers. The inter-observer bias of the manual measurements propagates into the allometric models, resulting in a high uncertainty of the derived estimates at tree-level. At the stand level, TLS measurements reveal the high influence of crown morphology on the CPA, which only can be taken into account by the TLS measurements and not by the allometric models.

\section{Assessing legacy effects of wildfires on tree crown structure of fire-tolerant eucalypts using airborne lidar data}

Yogendra Karna ${ }^{1}$, Mihai Tanase ${ }^{2}$, Trent Penman ${ }^{1}$, Cristina Aponte ${ }^{2}$, Lauren Bennett ${ }^{1}$

${ }^{1}$ School of Ecosystem and Forest Sciences, The University of Melbourne, Creswick, Australia; ${ }^{2}$ School of Ecosystem and Forest Sciences, The University of Melbourne,Richmond,Australia(ykarna@student.unimelb.edu.au; mtanase@unimelb.edu.au; trent.penman@unimelb.edu.au; caponte@unimelb.edu.au; ltb@unimelb.edu.au)

Fire-tolerant eucalypt forests of South-Eastern Australia are assumed to fully recover from even the most intense fires but surprisingly very few studies have assessed that recovery. Accurate assessment of horizontal and vertical attributes of tree crowns after fire is essential to understand the fire's legacy effects on tree 
growth and on forest structure. This study quantitatively assessed individual tree crowns nearly a decade after a 2009 wildfire that burnt extensive areas of temperate eucalypt forests. We used airborne lidar data validated with field measurements to estimate multiple individual tree crown metrics in 12 to 13 plots ( 0.05 ha) per each of four wildfire severities (unburnt, low, moderate, high). Linear mixed-effects models indicated persistent effects of both moderate- and high-severity wildfire on tree crown architecture. Trees at high-severity sites in two size classes $(20-50 \mathrm{~cm},>50 \mathrm{~cm}$ diameter) had significantly less crown projection area and live crown width than those at unburnt and low-severity sites. Significant differences in lidar-based metrics (crown cover, evenness, leaf area density profiles) indicated that tree crowns at moderate- and high-severity sites were comparatively narrow and more evenly distributed down the tree stem. These conical-shaped crowns contrasted sharply with the rounded crowns of trees at unburnt and low-severity sites. Our data provide clear evidence that moderate- and high-severity wildfire can modify the structure of fire-tolerant eucalypts' tree for nearly a decade after the wildfire. The implications of these legacy effects on, for example, tree productivity and the accuracy of biomass allometric equations warrants further study.

\title{
Optimization of TLS based forest inventories
}

\author{
Christoph Gollob ${ }^{1}$ (D); Tim Ritter ${ }^{1}$ (D); Arne Nothdurft (D) \\ ${ }^{1}$ University of Natural Resources and Life Science, Vienna (BOKU); Department of Forest- and Soil Sciences; Institute of Forest Growth, Vienna, Austria \\ (christoph.gollob@boku.ac.at; tim.ritter@boku.ac.at; arne.nothdurft@boku.ac.at)
}

In contrast to traditional inventories, modern terrestrial laser scanning (TLS) systems are available, which became likewise easy-to-handle in survey practice. However, before TLS systems can substitute traditional measurement instruments, computer algorithms have to be developed so that the novel laser-based technology is able to fulfill very basic tasks, prominently the automatic detection of tree positions and the measurement of tree diameters. In this talk, a multi stage density-based clustering approach is presented for the automatic mapping of tree positions, and a subsequently applied algorithm is shown for the automatic measurement of tree diameters. The algorithms were tested in different settings with respect to the number and the spatial alignment of scanner positions under manifold forest conditions, covering different age classes and mixture scenarios and representing a broad gradient of structural complexity. If circular sample plots were applied with a fixed truncation distance of $20 \mathrm{~m}$, the tree mapping algorithm showed a detection rate of $89.3 \%$ with seven scanner positions (hexagon vertices plus center coordinates) and achieves a detection rate of $78.2 \%$ with four scanner positions aligned in a triangle plus center. Detection rates were significantly increased with smaller truncation distances. Thus, with a truncation distance of $10 \mathrm{~m}$ the hexagon setting yielded a detection rate of $92 \%$ and the triangle $90.4 \%$. Other alignments of scanner positions were also tested, but proved to be either unfavorable or too labor intensive. The commission rates were on average less than $5 \%$. The algorithms were successfully tested by means of an international benchmark dataset.

\section{A simple approach for bioregional assessment of forest structure types using airborne laser scanning}

Syed Adnan ${ }^{1,2}$, Matti Maltamo ${ }^{1}$, David A. Coomes ${ }^{3}$, Antonio García-Abril ${ }^{4}$, Yadvinder Malhi ${ }^{5}$, José Antonio Manzanera ${ }^{4}$, Nathalie Butt ${ }^{5,6}$, Mike Morecroft ${ }^{7}$, Rubén Valbuena ${ }^{8}$

${ }^{1}$ University of Eastern Finland, School of Forest Sciences. PO Box 111., 80100 Joensuu, Finland; ${ }^{2}$ National University of Sciences and Technology, Institute of Geographical Information Systems 44000 Islamabad, Pakistan; ${ }^{3}$ University of Cambridge, Department of Plant Sciences. Forest Ecology and Conservation, CB2 3EA Cambridge, United Kingdom; ${ }^{4}$ Universidad Politecnica de Madrid, College of Forestry and Natural Environment, Research Group SILVANET, 28040 Madrid, Spain; ${ }^{5}$ University of Oxford, School of Geography and the Environment. Environmental Change Institute, OX1 3QY Oxford, United Kingdom; ${ }^{6}$ The University of Queensland, School of Biological Sciences, 4072 Queensland, Australia; ${ }^{7}$ Natural England, SO23 7BT Winchester, United Kingdom; ${ }^{8}$ Bangor University. School of Natural Sciences, LL572DG Gwynedd, United Kingdom (adnan@uef.fi; matti.maltamo@uef.fi; dac18@cam.ac.uk; antonio.garcia.abril@upm.es; yadvinder.malhi@ouce.ox.ac.uk; joseantonio.manzanera@upm.es; n.butt@uq.edu.au; mike.morecroft@naturalengland.org.uk;r.valbuena@bangor.ac.uk)

Forest structural types (FSTs) assessment is important for a sustainable forest management. We used field and airborne laser scanning (ALS) data from Boreal, Mediterranean and Atlantic biogeographical regions and developed a simple methodology for FSTs identification. Four forest structural variables - quadratic mean diameter (QMD), Gini coefficient (GC), basal area larger than mean (BALM) and density of stems (N) - were calculated from forest inventory data. Hierarchal clustering analysis (HCA) was applied using these four structural variables and potential clusters (FSTs) were determined in the coniferous and deciduous forests. Then, the empirical threshold values for discriminating those clusters were extracted using classification and regression tree analysis (CART). Single storey FSTs, multilayered FSTs and exponentially decreasing size distributions (reversed J) were separated by lower, medium and high values of GC and BALM, respectively, and these two were found to be the most important variables in the identification of FSTs. We also identified young/mature and sparse/dense subtypes within each of these main FST groups using QMD and N. Furthermore, similar structural predictors derived from ALS - maximum height (Max), L-coefficient of variation (Lcv), L-skewness (Lskew), and percentage of penetration (Cover), - were used in the nearest neighbour method to predict the FSTs. The overall accuracy achieved in the deciduous forest $(0.87)$ was higher than the coniferous forest $(0.72)$. Our methodology proves that ALS data is useful for structural heterogeneity assessment of forests and paves the way toward transnational assessments of forest structure across bioregions.

\section{Integrating mobile laser scanner system and unmanned aerial vehicle to measure tree characteristics}

\author{
Chi-Hua Chang', Chaur-Tzuhn Chen', Jan-Chang Chen ${ }^{2}$ \\ ${ }^{1}$ Institute of Tropical Agriculture and International Cooperation, Pingtung, Taiwan; 2Department of Forestry, Pingtung, Taiwan (harry199180116@gmail.com; \\ cct@mail.npust.edu.tw; zzzjohn@mail.npust.edu.tw)
}

Forest resource inventories corresponded with models according to the purpose of survey equipment and management. With the advancement of science and technology, manual survey mode can be changed into a survey mode of high technology equipment. In this paper, the practical operation is used to explore the application of Handheld Mobile Laser Scanning (HMLS) and Unmanned Aerial Vehicle (UAV) in forest resource inventories. Further, we use Terrestrial Laser Scanning (TLS) as the valid data to compare the accuracy. With advantage of handheld mobile laser scanners (HMLS) and UAV, we discuss with estimating limitations and potentials of forest plot surveys. Using TLS data as ground true data, we combine the HMLS point cloud and UAV point cloud data to estimate the tree height of 43 trees. As One-way ANOVA results displayed, the tree height results between HMLS $(11.8 \pm 2.1 \mathrm{~m})$ and TLS (15.9 $\pm 3.2 \mathrm{~m})$ has significant differences $(\mathrm{P}<0.01)$, but after we combined the UAV point cloud and HMLS point cloud, the results shows no differences $(\mathrm{P}>0.05)$ with combined point cloud data $(16.7 \pm 3.7 \mathrm{~m})$ and TLS $(15.9 \pm 3.2 \mathrm{~m})$ point cloud data. For the TLS method, it has much more limitations for our investigation in Taiwan including time consuming and few conveniences. Combined point cloud data has more flexible procedure with high accuracy instead of time-consuming TLS method. 


\section{Mapping of forest carbon stocks and their changes using LiDAR data, high-spatial-resolution satellite data and time-series Landsat} data for REDD+ implimentation

Yasumasa Hirata ${ }^{1}$, Hideki Saito ${ }^{1}$, Chivin Leng ${ }^{2}$, Sophyra Sar ${ }^{2}$

${ }^{1}$ Forestry and Forest Products Research Institute, Tsukuba, Japan; ${ }^{2}$ Ministry of Environment, Phnom Penh, Cambodia (hirat09@affrc.go.jp;

rslsaito@affrc.go.jp; lengchivin@gmail.com; sophyra.sar@gmail.com)

Developing countries that intend to implement the United Nations REDD-plus framework and obtain economic incentives are required to estimate changes in forest carbon stocks based on the IPCC guidelines. In this study, we developed a method to support REDD-plus implementation by estimating tropical forest aboveground biomass (AGB) by combining airborne LiDAR with high-spatial-resolution (HSR) satellite data, and by mapping forest carbon stocks and their changes at a sub-national level using time-series Landsat data. The results of AGB estimation from airborne LiDAR and HSR satellite data were used as training data for classification of forest carbon stock classes of Landsat data. We used a two-step method to estimate AGB and map it in a tropical environment in Cambodia. First, we created a multiple-regression model to estimate AGB from the LiDAR data and plotted field-surveyed AGB values against AGB values predicted by the LiDAR-based model, and calculated reflectance values in each band of the satellite data for the analyzed objects. Then, we created a multipleregression model using AGB predicted by the LiDAR-based model as the dependent variable and the mean and standard deviation of the reflectance values in each band of the satellite data as the explanatory variables. Then, we conducted object-based classification of forest carbon stocks for time-series Landsat data using AGB derived from high-resolution satellite data as training data. Our results suggest that this approach can provide the forest carbon stock map required to support REDD-plus.

\section{Using multispectral terrestrial lidar for early detection of tree decline: from leaf water content to fine structural details}

Samuli Junttila ${ }^{1}$, Markus Holopainen ${ }^{1}$, Mikko Vastaranta ${ }^{2}$, Riikka Linnakoski ${ }^{3}$, Päivi Lyytikäinen-Saarenmaa ${ }^{1}$, Juha Hyyppä ${ }^{4}$

${ }^{1}$ University of Helsinki, Helsinki, Finland; ' ${ }^{2}$ niversity of Eastern Finland, Joensuu, Finland; ${ }^{3}$ Natural Resources Institute Finland, Helsinki, Finland;

${ }^{4}$ Finnish Geodetic Institute FGI, Kirkkonummi, Finland(samuli.junttila@helsinki.fi; markus.holopainen@helsinki.fi; mikko.vastaranta@uef.fi;

riikka.linnakoski@luke.fi; paivi.lyytikainen-saarenmaa@helsinki.fi; juha.coelasr@gmail.com)

Climate change is causing novel stress to forests that is difficult to predict. Information on forest health has been identified as one of the key information gaps in evaluating the effects of climate change. The mapping of small-scale forest disturbance events is largely based on visual observations which is time-consuming and prone to error especially in the early stages of tree decline. Thus, new methods for objective estimation of tree decline are required. Multispectral lidar can provide highly detailed measurements of tree structure and reflectance simultaneously enabling novel approaches for the detection of tree stress. Over the last four years, we have developed a novel remote sensing method for detecting and evaluating tree decline using multispectral terrestrial lidar. The developed methods are based on utilizing lidar intensity data and the sensitivity of the used wavelengths to varying leaf water content (LWC). Thus, we have also investigated the relationship between LWC and various disturbance symptoms in different environments to determine the optimal LWC metrics for detecting tree stress. We found that multispectral lidar can detect and assess tree decline of single trees with high accuracy in our test forest that was infested by Ips typographus (L.) and its fungal symbionts. The developed methods showed potential in discriminating between healthy and stressed trees already in the early stages of tree decline when the foliage did not show visual symptoms. Therefore, the methods could provide new means for objective assessment of early tree decline allowing improved estimation, prediction and mitigation of forest damages.

\section{Integration of Landsat and simulated spaceborne GEDI LiDAR data to estimate time since disturbance at the forest stand level}

Nuria Sanchez-Lopez ${ }^{1}$, Luigi Boschetti ${ }^{1}$, Andrew Hudak ${ }^{2}$

${ }^{1}$ University of Idaho, Department of Natural Resources and Society, College of Natural Resources, Moscow (Idaho), USA; ${ }^{2}$ Forest Service, U.S. Department of Agriculture, Rocky Mountain Research Station, Forestry Sciences Laboratory, Moscow (Idaho), USA (nsanchezlopez@uidaho.edu; luigi@uidaho.edu; ahudak@fs.fed.us)

Maps of stand-level forest disturbance history (Time Since Disturbance, TSD) are fundamental for modeling forest ecosystem processes. Recent research shows that airborne LiDAR data analysis can reconstruct the long-term (>100 years) disturbance history of a forest; this is a significantly longer time frame than what can be observed with the established methods of change detection with optical data. However, the use of airborne LiDAR is limited by its high cost compared to satellite data. These limitations could largely overcome by NASA's spaceborne LiDAR Global Ecosystem Dynamics Investigations (GEDI) instrument, launched in December 2018. The sampling configuration of GEDI (footprints separated by $600 \mathrm{~m}$ across-track and $60 \mathrm{~m}$ along-track) imposes, however, some challenges for continuous spatial analysis compared to the common discrete-return airborne LiDAR. We propose an object-oriented data fusion methodology where Landsat data are used to identify forest stands, and GEDI waveforms are used to estimate TSD. The methodology involves three main steps: (1) forest stand delineation using object-based techniques of image segmentation on Landsat derived data; (2) estimation of TSD at the GEDI footprint level using random forest analysis; (3) estimation of TSD at the stand level, by combining TSD estimated at the GEDI footprint locations with the forest stand map. The methodology is demonstrated on a 52,000 ha study area located in the Nez-Perce Clearwater National Forest (Idaho, USA), where reference maps of TSD are available for accuracy assessment. The results indicate that the GEDI-Landsat fusion has the potential of estimating TSD with accuracy comparable to airborne LiDAR data.

B4i: LONG-TERM FOREST MONITORING NETWORKS FOR EVALUATING RESPONSES TO ENVIRONMENTAL CHANGE - II

\section{EANET monitoring in forest area under changing atmospheric environments}

Hiroyuki Sase ${ }^{1}$,Wilfredo Carandang ${ }^{2}$, Naoyuki Yamashita $^{3}$, Elizabeth Philip $^{4}$, Junko Shindo $^{5}$,Tatsuyoshi Saito ${ }^{6}$, Masayuki Morohashi ${ }^{1}$, Masaaki Takahashi $^{1}$, Masamichi Takahashi ${ }^{3}$, Tsuyoshi Ohizumi ${ }^{1}$

${ }^{1}$ Asia Center for Air Pollution Research, Niigata, Japan; ${ }^{2}$ University of the Philippines Los Baños, Los Baños, Philippines; ${ }^{3}$ Forestry and Forest Products Research Institute, Tsukuba, Japan; ${ }^{4}$ Forest Research Institute Malaysia, Selangor Darul Ehsan, Malaysia; ${ }^{5}$ Yamanashi University, Kofu, Japan; ${ }^{6}$ Niigata Prefectural Institute of Public Health and Environmental Sciences, Niigata, Japan (sase@acap.asia; wmcarandang@up.edu.ph;nyamashita@ffpri.affrc.go.jp; philip@frim.gov.my; jshindoh@yamanashi.ac.jp; /tsaitoª@gmail.com; morohashi@acap.asia; mtakahashi@acap.asia; masamichi_takahashi@hotmail.com; tohizumi@acap.asia) 
Acid Deposition Monitoring Network in East Asia (EANET) was established as a regional cooperative initiative in 1998 and started its regular-phase activities in 2001. Currently, thirteen countries in Northeast Asia and Southeast Asia participate in the network. In the case of EANET, not only monitoring on atmospheric deposition in 62 sites but also monitoring on ecosystem components in forest area, including soil, vegetation, and inland water, have been carried out in the same network. Although the number of the regular monitoring sites is not many in forest area, 31 forest plots, 19 lakes/rivers, and 2 forest catchments, the observational data have been accumulated for more than 15 years in many of sites. According to the Third Periodic Report of State of Acid Deposition in East Asia (PRSAD3) published by EANET in 2016, no clear trend was found in soil chemical properties and forest growth rates in most of the sites, while a few sites on inland water showed acidification. However, the updated data suggested recovery from acidification, which might reflect reduction of atmospheric deposition. The long-term data since the 1980s also showed that biogeochemical processes in a forest catchment in Japan sensitively responded to changing atmospheric deposition and climate. Application of isotopic analysis to the existing monitoring samples showed new views on possible mechanisms. Acknowledgements: The authors thank all the surveyors on EANET and Japanese national monitoring, the current/previous ACAP colleagues for their data compilation, and the scientists contributed to the isotopic analysis.

\title{
The Tropical managed Forests Observatory: a research network addressing the future of tropical logged forests \\ Plinio Sist ${ }^{1}$ (D) \\ ${ }^{1}$ Cirad-Forests \& Societies, Montpellier, France (sist@cirad.fr)
}

While attention to logging in the tropics has been increasing, studies on the long-term effects of silviculture on forest dynamics and ecology remain scare and spatially limited. Indeed, most of our knowledge on tropical forests arise from studies carried out in undisturbed tropical forests. This bias is problematic given that logged and disturbed tropical forests are covering now a larger area than the so-called primary forests. The Tropical managed Forests Observatory (TmFO), a new network of permanent sample plots in logged forests, aims to fill this gap by providing unprecedented opportunities to examine long-term data on the resilience of logged tropical forests at regional and global scales TmFO currently includes 24 experimental sites distributed across three tropical regions, with a total of 536 permanent plots and about 1200 ha of forest inventories. In this paper we will present the main results generated by the network on the impact of logging on Carbon and timber recovery, as well as biodiversity changes in the Amazon basin and South East Asia.

Long-term growth records of Cryptomeria japonica plantations at the University of Tokyo Forests, Japan: towards a network of experimental plots in East Asia

Toshiaki Owari ${ }^{1}$ D, Keisuke Toyama ${ }^{1}$, Satoshi N. Suzuki ${ }^{1}$, Takuya Hiroshima ${ }^{1}$, Seiji Ishibashi ${ }^{1}$

${ }^{1}$ The University of Tokyo,Tokyo,Japan (owari@uf.a.u-tokyo.ac.jp; oyama@uf.a.u-tokyo.ac.jp; s-suzuki@uf.a.u-tokyo.ac.jp; hiroshim@uf.a.u-tokyo.ac.jp;

bashi@uf.a.u-tokyo.ac.jp)

Long-term experimental plots can provide reliable and consistent tree growth data as a quantitative basis for sustainable forest management. The Europe-wide network of long-term experimental plots is currently used for quantifying and characterizing changes in forest stand growth dynamics, while Asian-wide networks of long-term experimental plots especially for plantations are still limited. Cryptomeria japonica D. Don is one of the important plantation species in East Asia including Japan, Taiwan, and South Korea. C. japonica plantations cover ca; ${ }^{4} \cdot{ }^{4}$ million ha, comprising about ${ }^{44 \%}$ of total plantations of Japan. It is an important plantation species covering about ${ }^{41,000}$ ha, equivalent to ${ }^{14} .7 \%$ of the total plantation area of Taiwan. C. japonica was widely planted in the ${ }^{1920} \mathrm{~s}$ throughout the southern regions of South Korea. It is desirable to promote international collaborative research focusing on long-term $C$. japonica growth. We are aiming to create an extensive network of long-term experimental plots for $C$. japonica plantations with counterpart universities in East Asia. In Japan, the University of Tokyo Forests has established experimental forest plots in $C$. japonica plantations since the early ${ }^{20}$ th century. Long-term growth records on these plots are valuable to model forest growth and yield, to quantify the effects of silvicultural interventions (e.g., thinning), and to assess the ability to sequester carbon. We present the site and plot information, summary of long-term growth records, and previous studies in the oldest experimental forest plots at the University of Tokyo Chiba Forest (UTCBF) and Chichibu Forest (UTCF).

\section{Popa (Peld do Oeste do Pará) Lter: reconciling long-term ecological research and communities in central Amazonia to understand effects of environmental changes in biodiversity}

\author{
Leandro Lacerda Giacomin ${ }^{1}$, Amanda Mortati ${ }^{1}$, Rodrigo Fadini ${ }^{1}$, Thais Almeida ${ }^{1}$, Thiago André $e^{1}$, Susan Aragón ${ }^{1}$, Quêzia Guerreiro ${ }^{1}$, Daniela Pauletto ${ }^{1}$, \\ Maria Jociléia Silva', Jorge Porto ${ }^{3}$,William Magnusson ${ }^{4}$, Albertina Lima ${ }^{4}$ \\ ${ }^{1}$ Universidade Federal do Oeste do Pará, Santarém, Brasil; ${ }^{2}$ Instituto Chico Mendes de Conservação da Biodiversidade, Santarém, Brasil; ${ }^{3}$ Instituto \\ Nacional de Pesquisas da Amazônia, Santarém, Brasil; ${ }^{4}$ Instituto Nacional de Pesquisas da Amazônia, Manaus, Brasil(giacomin.leandro@gmail.com, \\ amortati@gmail.com; rfadini@gmail.com; blotiella@gmail.com; hiagojcandre@gmail.com; saragongeo@yahoo.com; queziamoura@hotmail.com; \\ danielapauletto@hotmail.com; leia.icmbio@gmail.com;jirporto@gmail.com; bill@inpa.gov.br; lima
}

The Amazon poses as containing the world's largest continuum of tropical rain forest and its rich biodiversity has captured the attention of scientists for centuries. Although it is mostly known for its astonishing forests, the domain is in fact a complex mosaic of formations and ecosystems, including savannah-like formations. This complexity is for sure associated with its rich biodiversity, but how these ecosystems interact is poorly known, as is its biota itself. Nevertheless, as population grows, large areas of the domain are rapidly transformed, especially in Brazil, being mostly converted to agricultural areas. This "against-the-odds" situation brought the idea of a long-term ecological research (LTER) in a populated area and involving the communities to light. The POPA LTER aims to monitor biodiversity along a continuum of forest and savannah-like formations in the lower Tapajós river basing close to Santarém, PA, Brazil, in protected areas of sustainable use. We maintain 64 permanent plots (RAPELD model) in pristine and disturbed formations, far and close to riverine communities, seeking a bigger picture of the natural and humaninduced dynamics of the areas monitored. The riverine population is encouraged to participate in the research, seeking scientific literacy and awareness of how changes in land use can impact the availability of natural resources. Also, part of the plots structure is dedicated to fostering a scientific tourism to be maintained by the community, while short-term courses are offered, as a pilot idea of knowledge transfer and promoting conservation through a community-based ecological tourism. 


\title{
Main sources of uncertainty in large-scale assessments of ozone effects on forest growth
}

\author{
Maxime Cailleret ${ }^{1,2}$, Matthias Haeni ${ }^{1}$, Marco Ferretti ${ }^{1}$, Leonie Schoenbeck ${ }^{1}$, David Simpson ${ }^{3,4}$, Marcus Schaub $^{1}$
}

${ }^{1}$ WSL, Birmensdorf, Switzerland; ${ }^{2}$ IRSTEA, Aix-en-Provence, France; ${ }^{3}$ Norwegian Meteorological Institute, Oslo, Norway; ${ }^{4}$ Chalmers University of Technology Gothenburg, Sweden(maxime.cailleret@irstea.fr; matthias.haeni@wsl.ch; marco.ferretti@wsl.ch; leonie.schoenbeck@wsl.ch;davids@met.no; marcus.schaub@wsl.ch)

Tropospheric ozone $\left(\mathrm{O}_{3}\right)$ has large impacts on plant metabolism and functions at the individual tree level. However, due to the presence of several compensatory and acclimation mechanisms, and to interactions between ozone and other environmental stressors, its long-term impacts on forest functions and dynamics at larger spatial scales is controversial (see Cailleret et al; 2018). This study aims at accurately quantifying ozone impacts on tree- and stand-scale growth across Europe and their uncertainties related to the type and quality of the data source used. Wecombined measured data from different national and international longterm monitoring networks (ICP Forests, LWF, Sanasilva, Swiss NFI) with modeled data (Meteotest, EMEP, ECMWF). We considered several ozone metrics such as mean ozone concentration, AOT40 and POD1 (based on the physiological process-based $\mathrm{DO}_{3} \mathrm{SE}$ model; Emberson et al; 2000), and applied multiple statistical and re-sampling techniques to consider confounding abiotic and biotic environmental factors and for the heterogeneity in sample characteristics, respectively. We found a large uncertainty in the estimation of ozone metrics with a strong variability across sites, and that the quality of the vegetation data tends to matter more than for the meteorological variables. The estimated relationships between ozone and tree- or stand-scale growth strongly depend on the sample characteristics (e.g., size and temporal coverage of the sampling) and on the data source used (e.g., modeled vs. measured ozone concentration data). Our study provides new methodological insights into the data required to improve large-scale assessments of ozone impacts on forest ecosystems.

\section{Long-term ecosystem research infrastructure for carbon, water and nitrogen (LTER-CWN)}

Eugenio Diaz-Pines ${ }^{1}$, Michael Bahn², Thomas Dirnböck ${ }^{3}$, Michael Englisch ${ }^{4}$, Stephan Glatzel ${ }^{5}$, Barbara Kitzler ${ }^{4}$, Sophie Zechmeister-Boltenstern ${ }^{1}$ ${ }^{1}$ Institute of Soil Research, University of Natural Resources and Life Sciences, Vienna, Austria; ' ${ }^{2}$ epartment of Ecology, University of Innsbruck, Innsbruck, Austria; ${ }^{3}$ Environment Agency Austria, Vienna, Austria; ${ }^{4}$ Institute of Forest Ecology and Soils, Austrian Research Centre for Forests, Vienna, Austria; ${ }^{5}$ Geoecology, Department of Geography and Regional Research, University of Vienna, Vienna, Austria (eugenio.diaz-pines@boku.ac.at; michael.bahn@uibk.ac.at; thomas.dirnboeck@umweltbundesamt.at; michael.englisch@bfw.gv.at; stephan.glatzel@univie.ac.at; barbara.kitzler@bfw.gv.at; sophie.zechmeister@boku.ac.at)

Long-term, coordinated monitoring networks are an extremely useful tool contributing to the better understanding of ecosystems and their response to changes in environmental conditions. Here, we present the LTER-CWN Infrastructure Network which is currently being implemented on sites belonging to the LTER-Austria network, covering major ecosystem types (forests, grasslands and wetlands). One focal point of the network is the investigation of climate extreme events and their impacts on ecosystem processes. Specifically, we aim at 1) monitoring major ecosystem processes across our sites with a top quality, comparable standard; 2) providing a research platform for ecological experiments; 3) obtaining a novel understanding of the mechanisms underlying the ecosystem responses and 4) integrating the research sites and data in the international research arena. For this purpose, harmonized instrumentation is being installed for measuring fluxes of carbon (net ecosystem exchange, ecosystem primary productivity, soil respiration, soil methane fluxes), water (water vapour, solutes in soil- and streamwater) and nitrogen (soil nitrogen, nitrous oxide emissions). Next to continuous monitoring across the sites, a mobile platform is being established involving novel isotope-laser based analyses to increase our understanding of the in-situ activities of soil microorganisms and their link to greenhouse gas fluxes. Overall, our network comprises outstanding long-term ecosystem research sites with existing long-term data, an extensive record of research studies, and a comprehensive research infrastructure

\section{ICP Forests: long-term monitoring of the effects of anthropogenic and natural stressors on forest ecosystems under the UNECE Air Convention}

Alexa Michel ${ }^{1}$, Anne-Katrin Prescher ${ }^{1}$, Andreas Schmitz ${ }^{1}$, Inken Krüger ${ }^{1}$, Till Kirchner ${ }^{1}$, Manuel Nicolas ${ }^{2}$, Marco Ferretti ${ }^{3}$

${ }^{1}$ Thünen Institute of Forest Ecosystems, Eberswalde, Germany; ${ }^{2}$ Office National des Forêts, Fontainebleau, France; ${ }^{3}$ Swiss Federal Research Institute WSL, Birmensdorf,Switzerland (alexa.michel@thuenen.de; anne.prescher@thuenen.de; andreas.schmitz@thuenen.de; inken.krueger@thuenen.de; till.kirchner@thuenen.de; manuel.nicolas@onf.fr; marco.ferretti@wsl.ch)

The International Co-operative Programme on Assessment and Monitoring of Air Pollution Effects on Forests (ICP Forests) was established within the UNECE Air Convention in 1985 in response to wide public and political concern about the extensive forest damage observed in central Europe and North America which had been attributed to increasing air pollution and acidic deposition. Since then, ICP Forests has developed into a multifunctional long-term forest monitoring programme across the UNECE region with 42 member countries participating and produces scientific data and knowledge not only on the impact of air pollution but also on the effects of climate change and other stressors on forest ecosystems. ICP Forests works at two levels: (i) the systematic, large-scale monitoring network (Level I) provides annual data on forest condition, (ii) the intensive forest monitoring network (Level II) consists of permanent, highly-equipped plots to foster integrative studies on cause-effect relationships based on consistent long-term data series. All in all, ICP Forests collects data on ambient air quality; biodiversity and ground vegetation; crown condition and damage causes; deposition; foliage and litterfall; forest growth; meteorology, phenology and LAI; soil and soil solution. An outstanding feature of the ICP Forests monitoring programme is its high degree of standardization of data collection and quality assurance in each survey and across all member states. An overview of the ICP Forests programme and its data infrastructure, a summary of results from over 30 years of forest monitoring, latest activities as well as future challenges will be presented.

\section{Existing long-term monitoring networks in Romanian forests}

Ovidiu Badea ${ }^{1,2}$, Ionel Popa ${ }^{1}$,Stefan Leca ${ }^{1}$, Diana Pitar ${ }^{1}$, Ecaterina Apostol $^{1}$, Serban Chivulescu ${ }^{1}$

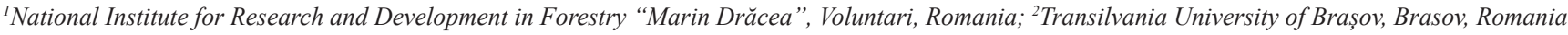
(obadea@icas.ro; popaicas@gmail.com; stefan.leca@icas.ro; diana.silaghi@icas.ro; cathyches@yahoo.com; serban.chivulescu@icas.ro)

In order to meet the ever-increasing needs for scientific knowledge progress about injury symptoms on forests the quality of different stressors (biotic, abiotic, pollution, fire etc.), and climate change effects on trees and forest ecosystems status and biodiversity in most European countries, several forest long-term monitoring networks have been designed and located in the forests of Romania. The first such networks (1990-1992) were created consistent with the objectives of the ICP Forests. Level I (16 x $16 \mathrm{~km}-254$ plots) and the Level II monitoring plots (12 plots). To identify and monitor the phytotoxic effects of ozone and others potential pollutants $\left(\mathrm{NO}_{2}, \mathrm{SO}_{2} \mathrm{NOX}\right.$, and NH3) and biodiversity in the Carpathian Mountains, in 1997, the Carpathians countries in partnership with 
the USDA-Forest Service had placed a monitoring network consisting of 26 sites, 6 of which in the Romanian Carpathians. This network has contributed to initiate the International Long-Term Ecological Research (ILTER) with three Romanian sites (Retezat, Bucegi-Piatra Craiului and Rodna), and subsequently in the LTER-Europe. Furthermore, dendrochronological high potential of Romanian forest ecosystems, have been correlated with a lack of integration of Romanian research at the international level, were decisive factors in elaborating a network of dendrochronological series for the Romanian Carpathians which is integrated in European and international networks. These networks provide an integrated scientific framework, aiming for advancement in complex research projects at national and international levels, specifically relying on supporting productive capacity of socio-ecological systems in the context of climate change and air pollution effects.

\title{
Decrease of nutrients in main trees species indicated by long term monitoring across Czech and Slovak forests within the ICP Forests network \\ Radek Novotný1 ${ }^{\text {D, Danica Krupová2 }}$, Vit Šrámek ${ }^{1}$, Pavel Pavlenda ${ }^{2}$ \\ ${ }^{1}$ Forestry and Game Management Research Institute, Jiloviště, Czech Republic; ${ }^{2} N F C$, Forest Research Institute, Zvolen, Slovakia (novotny@vulhm.cz; krupova@nlcsk.org; sramek@vulhm.cz; pavlenda@nlcsk.org)
}

The contribution evaluates the nutritional status and development of the main tree species in Central European countries - Czechia and Slovakia. Foliar nutrition data from ICP Forests monitoring network in both countries are analysed. The longest time series cover more than 20 years (1995-2017 in Czechia; 19952013 in Slovakia). Seven coniferous (Norway spruce and Scotch pine) and six broadleaves (European beech and Turkey oak) intensively monitored plots are evaluated. Data shows a significant decrease of main nutrients concentration, mainly $\mathrm{P}$ and $\mathrm{K}$. Concentration of $\mathrm{P}$ is on roughly half of plots near or below the deficiency limit $\left(1.2{\mathrm{~g} . \mathrm{kg}^{-1}}^{-1}\right.$, concentration of $\mathrm{K}$ has dropped by 10 to 50 percent, especially in stands of broadleaves during the evaluated period. Temporal trends for $\mathrm{P}$ and $\mathrm{K}$ have been significantly decreasing on one third of evaluated coniferous plots and similar situation has occurred on broadleaves plots. Both countries differ in $\mathrm{Mg}$ trends in spruce stands - there is a decrease of $\mathrm{Mg}$ concentration in needles in Slovakia compared with Czech coniferous plots. On the other hand, in beech leaves there is a decrease of $\mathrm{Mg}$ in both countries, although only in Czechia is the trend significant. In general observed changes in nutrition level document stable or slightly increasing $\mathrm{N}$ concentration and decreasing tendency of phosphorus and base cations. This situation lead to nutrient imbalance, especially considering $\mathrm{N}$ and $\mathrm{P}$ ratio. Potential nutritional disorder represents a threat for forest vitality, especially in connection with drought or other abiotic or biotic risk factors.

\section{Analysis and modelling of the wood density variability of the French forest species for the assessment of the forest biomass under climatic change}

\author{
Jean-Michel Leban ${ }^{1}$, Baptiste Kerfriden ${ }^{1}$, Jean-Daniel Bontemps ${ }^{2}$ \\ ${ }^{1}$ Institut National de la Recherche Agronomique, Champenoux, France; ${ }^{2} I G N$, Nancy, France (jean-michel.leban@inra.fr; baptiste.kerfriden@inra.fr; \\ jean-daniel.bontemps@ign.fr)
}

There is an increasing demand on the monitoring of the forest resources, on forests statistics, and on projections of future forest resource availability especially in terms of biomass (Leban \& Bontemps, 2016). We developed a new method to enrich the forest information produced by the French National French Inventory by the measurement of the wood density. This technological innovation permits the fast and reliable measurement of the wood density on unprepared increments cores collected in the forests by the NFI staff. The cores are passed through a medical Xray scanner. Since 2015, about thirty thousand cores were sampled each year. At the end of this project, in November 2019 we will have a novel data base with wood density measurements on more than one hundred thousand increment cores. We will present several preliminary results that illustrate the different ways to enrich forest information, e.g. (i) the reassessment of the total standing biomass for the main forest species and (ii) the wood density models that can be used for the simulation of the forest biomass changes at the national level for different climatic hypothesis. We will present and discuss the perspective for the analysis and the sharing of this new data base that combines at the national scale level wood density and the usual forest inventory measurements such as DBH, height, age etc. Such data base pave the avenue for a better understanding of the biomass production along different climatic and trophic gradients.

\section{Towards a better integration between National Forest Inventories and Forest Condition Monitoring - a Swiss contribution. \\ Marco Ferretti ${ }^{1}$, Arthur Gessler ${ }^{1}$,Urs-Beat Brändli ${ }^{1}$, Esther Thürig ${ }^{1}$, Lorenzo Fattorini ${ }^{2}$, Adrian Lanz ${ }^{1}$ \\ ${ }^{1}$ Swiss Federal Research Institute WSL, Birmensdorf, Switzerland; 2University of Siena, Siena, Italy (marco.ferretti@wsl.ch; arthur.gessler@wsl.ch; urs-beat.braendli@wsl.ch; esther.thuerig@wsl.ch;lorenzo.fattorini@unisi.it; adrian.lanz@wsl.ch)}

European forests are being monitored by means of National Forest Inventories (NFI) installed on a national basis, and the Forest Condition Monitoring (FCM), installed under the UNECE ICP Forests. FCM is further subdivided into a large-scale survey on forest health (Level I), and intensive monitoring seeking to identify relationships between stressors and forest condition (Level II). In general, NFIs, Level I and Level II occur on different networks of plots. NFIs are based on probabilistic sample surveys (p-surveys) designed at national level; Level I is also frequently based on p-based surveys, in many cases located apart from NFIs; and Level II is a series of purposively selected case studies, with no formal link to a defined statistical population. The question is therefore how to make better use of these networks, in a way that results from individual ones can be integrated for a better understanding of status and changes of forest resources, and their response to environmental changes. While a better integration between NFIs and Level I is relatively straightforward, here we present an attempt to use Level II data to improve the estimation process of the NFI in Switzerland. We concentrated on key NFI target variables measured also at Level II sites, e.g. basal area, volume and biomass increment. We investigated (i) significant predictors of increment on the basis of measurements at the Level II sites; and (ii) whether those predictors can be used as auxiliary variables in the model-assisted, design-based estimation framework of the Swiss NFI. 


\author{
Temporal-spatial changes of wetlands in the Tarim Populus Euphratica National Nature Reserve over the past 24 years \\ Yiming Feng ${ }^{1}$, Xiaoming Cao ${ }^{1}$ \\ ${ }^{1}$ Institute of Desertification Studies, Chinese Academy of Forestry,CAF, Beijing, China (fengym@caf.ac.cn; caoxm@caf.ac.cn)
}

The landscape information of wetland in the Tarim Populus Euphratica National Nature Reserve (abbreviated as the Reserve, the same as below) was extracted under the support of GIS and RS technology by using the remote sensing images obtained in 1992, 1999 and 2016, and meanwhile the temporal-spatial change characteristics of wetland was analyzed before and after the ecological water conveyance. It was found that the wetland area in the Reserve showed a trend of decreasing first and increasing later. The wetland area was deceased by 16.8\% during 1992-1999 (namely before ecological water conveyance), while that was increased by $6.9 \%$ during 1999-2016 (namely after ecological water conveyance), indicating that the ecological water conveyance had positive effects on the ecological restoration and protection of wetland. During 1993-1999, the different wetlands showed a large change in the dynamic degree, and the disturbance of humans was intensified. After 17 years of ecological water conveyance, the change in the dynamic degree value of wetland slowed down, and the rapid degradation of wetland was effectively inhibited, but the restoration process was slow. The ecological water conveyance increased wetland area indeed, but which was mainly conducted along the main stream of the Tarim River, and the increased area was derived from the temporary watersheds such as permanent rivers. There was no significant increase in the swamp area with real ecological benefits. So, the increased wetland area only exerted the limited function of wetland ecosystem, and the strategy of the ecological water conveyance was not very reasonable.

\title{
Monitoring forest carbon gain and loss, and isolation of protected areas: implications to the carbon benefits of protection
}

Belachew Gizachew Zeleke ${ }^{1}$, Svein Solberg ${ }^{1}$, Stefano Puliti ${ }^{1}$

${ }^{1}$ Norwegian Institute of Bioeconomy Research, As, Norway (belachew.gizachew@nibio.no; svien.solberg@nibio.no; stefano.puliti@nibio.no)

Protected Areas (PAs) may offer great potential for carbon conservation in the context of climate change mitigation. Two Digital Elevation Model (DEM) datasets for the period 2000-2012 were used to develop a wall-to-wall map of forest carbon gain and loss for the entire Uganda. Drawing on the map, this study (1) quantified forest carbon gain and loss within 713 PAs and external buffer zones of $0.5-10 \mathrm{~km}$ surrounding each PA, and (2) evaluated the effectiveness of PAs and management regimes and detect the prevalence of local leakage in terms of forest carbon, and thus isolation of PAs in the general landscape. The net annual forest carbon gain in PAs of Uganda was $0.22 \pm 1.36$ t/ha, but a significant proportion (63\%) of the PAs exhibited a net carbon loss. Further, carbon gain and loss varied significantly among management categories. About $37 \%$ of the PAs were "effective", i.e., gained or at least maintained forest carbon during the period. Nevertheless, carbon losses in buffer zones of effective PAs significantly contrast with carbon gains inside of the PAs, providing strong evidence of leakage. This suggests that PAs were being threatened by deforestation and forest degradation, and thus face a significant isolation and fragmentation. For forested countries that will aim to benefit from carbon conservation through protected area management from international policies such as REDD+, there is an urgent need to look into their PA management, and design protection strategies that account for the surrounding landscapes and communities outside of the PAs.

\section{Tropical forest and land cover monitoring using optical and SAR data}

Manuela Hirschmugl, Mathias Schardt ${ }^{1}$, Carina Sobe ${ }^{1}$, Janik Deutscher ${ }^{1}$

${ }^{1}$ Joanneum Research Forschungsgesellschaft mbH, Graz, Austria (manuela.hirschmugl@joanneum.at;

mathias.schardt@joanneum.at; carina.sobe@joanneum.at; janik.deutscher@joanneum.at)

Tropical forest monitoring is currently in a transition phase from (i) annual mapping updates to automated, near real-time applications that rely on full time-series analysis and (ii) from single sensor applications to multi-sensor monitoring systems. The research aim of the Horizon2020 project EOMonDIS is to assess the benefit of a joint use of high resolution optical and SAR time series data for cost-efficient and accurate tropical forest monitoring, specifically for REDD+ applications. We compare different methods for data combination: first, a Random Forest classification based on a combination of pre-processed SAR and optical data, and second, a result-based fusion of separate optical and SAR classification results using Bayesian combination. The final products are high resolution forest and land use maps as well as deforestation and forest disturbance maps. We present the classification results for four diverse forest monitoring test sites in Africa and Latin America that cover both humid and dry tropical forests. The accuracies of the results vary strongly among test sites and products. We analyze the influencing factors in order to better understand existing inter-dependencies. For areas with frequent cloud cover and for large deforestation plots, SAR data gives a significant added value in terms of detection timeliness and classification accuracy. However, the added value of SAR data in the processing chain for small changes (forest degradation) is only marginal. We found the use of SAR time series data in combination with a mono-temporal optical image can compensate for a full time series of optical data.

\section{Use of SfM-constructed 3D models to estimate biomass of buttressed trees in the central Amazon}

Tatsuya Otani ${ }^{1}$, Rempei Suwa ${ }^{2}$, Shinta Ohashi ${ }^{3}$, Adriano Lima ${ }^{4}$

${ }^{1}$ FFPRI, Kochi, Japan; ${ }^{2} J$ RCAS, Tsukuba, Japan; ${ }^{3}$ FFPRI, Tsukuba, Japan; ${ }^{4} I N P A$, Manaus, Brasil (tatsuyao@affrc.go.jp; swrmp@affrc.go.jp; shinta0084@affrc.go.jp; adriano@inpa.gov.br)

Safe and accurate measurement of stem diameter of large buttressed trees is challenging. New simple methods are required to accurately estimate tropical forest biomass to support REDD+ efforts. In the present study, we developed computations employing dimensionally-accurate $3 \mathrm{D}$ models created using structure from motion (SfM) to convert perimeter measurements of convex hull of a buttressed trunk to cross-sectional area at breast height; 3D models of 26 buttressed trunks in the central Amazon were constructed using free software, such as Regard3D, MeshLab, Meshmixer, and FreeCAD. Perimeter measurements of 3D model trunks were compared to field-measured values at a given height, and the results indicated that the free software created good $3 \mathrm{D}$ models. Regression analysis confirmed that the cross-sectional area of a buttressed trunk was estimated from $3 \mathrm{D}$ model perimeter of a convex hull; $\ln \left(\right.$ Area $\left.{ }_{13}\right)=-2.697+1.370$ $\ln \left(\right.$ Perimeter $\left._{1.3}\right)$, where Area ${ }_{1.3}$ is the cross-sectional area $\left(\mathrm{m}^{2}\right)$ and Perimeter ${ }_{1.3}$ is the perimeter of a convex hull $(\mathrm{m})$ at the standard breast height of $1.3 \mathrm{~m}\left(\mathrm{R}^{2}=\right.$ $\left.0.835, \mathrm{~F}_{1,24}=127.4, \mathrm{p}=4.39 \mathrm{e}^{-11}\right)$. Further, we showed that Area $_{1.3}$ was estimated from the perimeter of a convex hull at $0.3 \mathrm{~m}$ height; $\ln \left(\right.$ Area $\left._{1.3}\right)=-3.538+1.433$ $\ln \left(\right.$ Perimeter $\left._{0.3}\right),\left(\mathrm{R}^{2}=0.696, \mathrm{~F}_{1,24}=58.5, \mathrm{p}=6.95 \mathrm{e}^{-8}\right)$, demonstrating that Area ${ }^{1} .^{3}$ could also be estimated from buttressed tree stumps; 3D models combined with our computational equations provide a cost-effective and simplified method that can be used to calculate species-specific parameters and for estimating lost biomass in logged forests. 
Comparison of estimation results of aboveground biomass using different allometric equations in a lowland Dipterocarp forest, Peninsular Malaysia

Tamotsu Sato ${ }^{1}$, Kaoru Niiyama ${ }^{1}$, Tsutomu Yagihashi ${ }^{1}$, Zamah Shari Nur Hajar ${ }^{2}$, Ripin Azizi ${ }^{3}$

${ }^{1}$ Forestry and Forest Product Research Institute, Tsukuba, Japan; ${ }^{2}$ Forest Research Institute Malaysia, Selangor Darul Ehsan, Malaysia; ${ }^{3}$ Advanced Forest

Resources,SelangorDarulEhsan, Malaysia (satoo@affrc.go.jp; niiya@affrc.go.jp; yagihasi@affrc.go.jp; hajar@frim.gov.my; azizi_ripin@yahoo.com)

Accurate forest carbon stock estimation is indispensable to implement a REDD+ project. To date, many allometric equations have been developed to estimate aboveground biomass (AGB) around the tropical forests. In this study, we compared estimation results of AGB between locally developed equation (Kato et al; 1978) and general equation developed by Chave et al. (2005) using a tree census data from 6-ha plot in lowland Dipterocarp forest, Peninsular Malaysia. To use the general equation, we had also calculated species specific wood densities for each tree species in the plot. The results of applying the locally developed equation, without wood density parameter, showed relatively low value (ca; 8\%) than those of the general equation. Some heavy hardwood tree species (e.g. Dipterocarpus crinitus and Koompassia malaccensis) were causing differences in estimation results. On the other hand, many light hardwood tree species (e.g. Melicope glabra and Endospermum diadenum) had emerged and dominated within secondary patch where clear cutting had conducted in the early 1970s, and showed overestimated values by the locally developed equation due to lack of wood density data. Our results imply that selection of ineligible allometric equation could lead to inaccurate AGB estimation in secondary forests. Moreover, tree species identification is also important to evaluate forest carbon stocks on a regional scale using combination of remote sensing data and ground-based inventory.

\section{Modelling the spatial variation in above ground carbon stocks in Zimbabwe's dry indigenous forests}

Richard Muchena ${ }^{1}$

${ }^{1}$ Zimbabwe Forestry Commission, Bulawayo, Zimbabwe (richymuchena@gmail.com)

The above ground carbon pool in Zimbabwe's dry indigenous forests is often unknown and under-estimated. This is often as a result of limited resources to carry out large scale forest inventories. Moreover, most work on the estimation of forest carbon stocks have mainly focused on tropical rainforests. In that regard this study sought to close that gap by modelling the relationship between in-situ field based Above Ground-Biomass measurements and satellite data. To achieve this objective, satellite reflectance values of Bands 3, 4 and 8, the Difference Vegetation Index (DVI), Ratio Vegetation Index (RVI), Normalized Difference Vegetation Index (NDVI) and the Soil Adjusted Vegetation Index (SAVI) were computed from Sentinel satellite data of June 2018. Correlation and regression analysis were then used to relate field based carbon measurements and remotely sensed parameters. Results showed that NDVIhad the most significant positive relationship with field based carbon measurements $\left(\mathrm{r}^{2}=0.72 ; \mathrm{p}<0.05\right)$ thus it can be used as a proxy for carbon estimation in Zimbabwe's dry indigenous forests. These findings underscore the potential and significance of remote sensing data in particular Sentinel in understanding and quantifying carbon stocks in Zimbabwe's dry indigenous forests.

\section{First mission - towards a global harmonised in-situ data repository for forest biomass datasets validation}

Dmitry Schepaschenko ${ }^{1,2}$ D, Jérôme Chave ${ }^{3}$, Oliver L. Phillips ${ }^{4}$, Stuart J. Davies ${ }^{5}$, Simon L. Lewis ${ }^{4,6}$, Plinio Sist ${ }^{7}$, Maxime Réjou-Méchain ${ }^{8}$, Christoph Perger ${ }^{1}$, Klaus Scipal ${ }^{9}$

${ }^{1}$ International Institute for Applied Systems Analysis (IIASA), Laxenburg, Austria; ${ }^{2}$ Forestry Faculty, Bauman Moscow State Technical University, Mytischi, Russian Federation; ${ }^{3}$ Laboratoire Evolution et Diversité Biologique CNRS, Université Paul Sabatier, Toulouse, France; ${ }^{4}$ School of Geography, University of Leeds, Leeds, United Kingdom; ${ }^{5}$ Center for Tropical Forest Science, Smithsonian Tropical Research Institute, Panama City, Panama; ${ }^{6}$ University College London, London, United Kingdom; ${ }^{7}$ CIRAD, Montpellier, France; ${ }^{8} A M A P$, IRD, CNRS, CIRAD, INRA, University Montpellier, Montpellier, France, ${ }^{9}$ European Space Agency,ESTEC, Noordwijk, Netherlands (schepd@iiasa.ac.at; jerome.chave@univ-tlse3.fr; o.phillips@leeds.ac.uk; daviess@si.edu; s.l.lewis@leeds.ac.uk; plinio.sist@cirad.fr; maxime.rejou@gmail.com; perger@iiasa.ac.at; klaus.scipal@esa.int)

Global measurements of forest height, biomass are urgently needed as essential climate and ecosystem variables, but can benefit from greater co-operation between remote sensing (RS) and forest ecological communities. The Forest Observation System - FOS (https://forest-observation-system.net/ [https://forestobservation-system.net/]) is an international cooperation to establish a global in-situ forest biomass database to support earth observation and to encourage investment in relevant field-based observations and science. FOS aims to link the RS community with ecologists who measure forest biomass and estimating biodiversity in the field. The FOS aims to overcome data sharing issues and introduce a standard biomass data flow from tree-level measurement to the plot-level aggregation served in the most suitable form for the RS. Ecologists benefit from the FOS with improved access to global biomass information, data standards, gap identification and potentially improved funding opportunities to address the known gaps and deficiencies in the data. FOS closely collaborate with the CTFS-ForestGEO, the ForestPlots.net (incl. RAINFOR, AfriTRON and T-FORCES), AusCover, TmFO and the IIASA network. FOS is an open initiative with other networks and teams most welcome to join. The online database provides open access for forest plot location, canopy height and above-ground biomass. Plot size is 0.25ha or larger. Comparison of plot biomass data with available global and regional maps (incl. Kindermann et al., 2013; Thurner et al., 2013; Saatchi et al., 2011; Baccini et al., 2012; Avitabile et al., 2016; Hu et al., 2016; Santoro et al., 2018) shows wide range of uncertainties associated with biomass estimation.

\section{Understanding the disturbance dynamics of forests using time-series remote sensing}

Simon Jones ${ }^{1}$, Mariela Soto-Berelov ${ }^{1}$, Samuel Hislop ${ }^{1}$, Trung Nguyen ${ }^{1}$, Jenna Guffogg ${ }^{1}$, Shirley Famelli ${ }^{1}$, Andrew Haywood ${ }^{2}$ ${ }^{1}$ RMIT University, Melbourne, Australia; 2European Forestry Institute, Barcelona, Spain (simon.jones@rmit.edu.au; mariela.soto-berelov@rmit.edu.au; samuel hislop@rmit.edu.au; trung.nguyen3@rmit.edu.au; jenna.guffogg@rmit.edu.au; shirley.famelli@rmit.edu.au; andrew.haywood@efi.int)

Time series remote sensing can be used to map trends and changes in forests over time. This research utilises long time series Landsat imagery to map and examine disturbance events, and subsequent recovery, over 8.2 million hectares of sclerophyll forest in SE Australia. All available Landsat TM imagery (19882017) for southern hemisphere summer months was used to create annual composites of six vegetation indices (using LandsatLinkR) across 19 WRS Landsat tiles. The spectral trajectory of each index was extracted on a per pixel basis over the 30-year period, and used to characterise the disturbance-recovery dynamics of forests. A reference dataset consisting of 8,000 training pixels and 786 permanent plots were then created to attribute disturbance events using a multiple lines of evidence approach. This was then used to prime a set classifiers (Random Forest) and map disturbance and recovery by severity/completeness of recovery and agent of change: logging (clear fell and selective logging), fire (wildfire and prescribed burning), low severity disturbance including pests, flooding, drought and 
disease. Results, which achieved an $87 \%$ overall accuracy, clearly show annualised abrupt disturbance events such as logging and wildfire, as well as gradual changes such as drought and disease. About a quarter of the study area forests were impacted by medium or high severity fires during the three-decade study with a trend towards recovery times getting shorter in recent years (from a mean of 15 years to 12 years) across a range of biomes.

\section{Tropical rainforest above ground biomass and carbon stock estimation for upper and lower canopies using terrestrial laser scanner and canopy height model from UAV imagery in Ayer-Hitam, Malaysia}

Yuvenal Mtui ${ }^{1}$, Yousif Hussin ${ }^{1}$, Henk Kloosternam ${ }^{1}$, Mohd Hasmadi Ismail ${ }^{2}$

${ }^{1}$ ITC, University of Twente, Enchede, Netherlands, ' 2 University Putra Malaysia, Serdang, Selangor, Malaysia (y.p.mtui@student.utwente.nl; y.a.hussin@utwente.nl; e.h.kloosterman@utwente.nl; mhasmadi@upm.edu.my)

To control the impact of climate change, REDD+ program and its MRV mechanism have been established under UNFCCC. There is a need for an accurate method to assess the complex multi-layered tropical rain-forest parameters for estimating above-ground biomass (AGB)/carbon stock. The emergent of Unmanned Aerial Vehicle (UAV) and Terrestrial Laser Scanner (TLS) technologies operate from air and ground respectively can provide accurate information of upper and lower canopy layers at a reasonable accuracy for monitoring of carbon stock. However, both sensors are associated with limitation of foliage coverage in the complex multi-layer tropical forest which can underestimate AGB estimation when used separately. This study aimed at establishing a reasonably accurate method for the assessment of tropical rainforest AGB/carbon estimation for REDD+ and its MRV system by complimenting UAV imagery and TLS data. The upper canopy tree height was derived from UAV imagery using SfM method, while the lower canopy height was measured using TLS. The DBH derived from TLS point clouds were used for the AGB of both upper and lower canopies.The derived AGB from the upper (using UAV data) and lower (using TLS data) canopies were combined. The accuracy of the estimated forest AGB/carbon stock on plot base using the developed method when compared to reference method achieved an $\mathrm{R}^{2}$ of 0.98 and RMSE of $536.25 \mathrm{~kg}$ per plot (6.23\%) for 30 plots. Also, a t-test shows no statistical significance difference between the AGB/carbon estimated by the two methods.

\section{B4k: NOVEL REMOTE SENSING APPROACHES TO QUANTIFY CARBON STOCKS, STRUCTURE AND FUNCTIONAL DIVERSITY OF FORESTS 3}

\section{Comparison of regression techniques for LiDAR-derived aboveground biomass estimation in the Amazon}

Catherine Almeida ${ }^{1}$, Lênio Galvão ${ }^{1}$, Luiz Eduardo Aragão ${ }^{1}$, Jean Ometto ${ }^{1}$, Aline Jacon ${ }^{1}$, Francisca Pereira ${ }^{1}$, Luciane Sato ${ }^{1}$

${ }^{1}$ Instituto Nacional de Pesquisas Espaciais, São Josédos Campos, Brasil (cathe.torres@gmail.com; lenio.galvao@inpe.br; luiz.aragao@inpe.br; jean.ometto@inpe.br; alinejacon@hotmail.com; franrspereira@gmail.com; lucianesato@gmail.com)

Light Detection And Ranging (LiDAR) is an active remote sensor that has been successfully applied for characterizing canopy structure, especially to estimate aboveground biomass (AGB).Parametric models, mainly the linear regressionwith stepwise feature selection (LMstep), are the most common approaches used for estimating AGB. However, non-parametric machine learning techniques, such as Support Vector Regression (SVR),Stochastic Gradient Boosting (SGB), and Random Forest (RF), can better address complex relationships between biomass and remote sensing variables. Therefore, it is desirable to assess the performance of different regression strategies. This study aims to compare eight regression techniques for LiDAR-based AGB estimation: LMstep, Linear Models with Regularization (LMR), Partial Least Squares (PLS), K-Nearest Neighbor (KNN), SVR, RF, SGB, and Cubist. For this purpose, 34 LiDAR metrics were regressed against AGB from 147 inventory plots across the Brazilian Amazon Biome. Models performance were evaluated by the average Root Mean Squared Error (RMSE) and R2 from a 5-fold cross-validation strategy with 10 repetitions. The Kruskal-Wallis test was used to evaluate statistical differences among models. Results showed that LMstep presented the highest RMSE (68.85 Mg.ha-1) and lowest R2 (0.66), while SVR had the lowest RMSE (65.23 Mg.ha ${ }^{-1}$ ) and highest R2 (0.69). However, the differences in performance of the models were not statistically significant. Thus, we confirmed the results of previous studies that showed that simple approaches, such as linear regression models, performed just as well as advanced machine learning methods for estimating AGB based on LiDAR data.

\section{Selection of hyperspectral variables for aboveground biomass estimation in the Brazilian Amazon}

Catherine Almeida ${ }^{1}$, Lênio Galvão ${ }^{1}$, Luiz Eduardo Aragão ${ }^{1}$, Jean Ometto ${ }^{1}$, Aline Jacon ${ }^{1}$, Francisca Pereira ${ }^{1}$, Luciane Sato ${ }^{1}$

${ }^{1}$ Instituto Nacional de Pesquisas Espaciais, São Josédos Campos, Brasil (cathe.torres@gmail.com; lenio.galvao@inpe.br; luiz.aragao@inpe.br; jean.ometto@inpe.br; alinejacon@hotmail.com; franrspereira@gmail.com; lucianesato@gmail.com)

Due to the limited coverage of field Above Ground Biomass (AGB), remote sensing becomes an alternative formonitoring carbon stocks at the landscape scale. However, the most commonly used sensors have limited spectral resolution. Hyperspectral imaging (HSI) provides high-resolution information, although its high data dimensionality becomes a challenge for modeling.In this context, selection of suitable variables is a critical step for estimating AGB from HSI data. Support Vector Regression coupled with the Recursive Feature Elimination approach (SVR-RFE) can produce parsimonious models from a reduced subset of features. We applied the SVR-RFE in a 5-fold cross-validation strategy with 5 repetitions to determine which hyperspectral variables were most effective to estimate AGB. We used field AGB from 147 inventory plots across the Brazilian Amazon and 64 plot-level HSI metrics, including 14 reflectance bands, 30 vegetation indices, continuum-removal absorption features at five wavelengths $(495,670,980,1200$, and $2100 \mathrm{~nm}$ ), and endmember fractions (green vegetation, shade, and nonphotosynthetic vegetation/soil) from Spectral Mixture Analysis. The SVR-RFE explained 67\% of the AGB variation, by selecting eight HSI variables. The three most effective variables came from theshortwave infraredregion (width and depth of the 2100-nm absorption band and the NDNI index), related to canopy moisture and lignin-cellulose-nitrogen absorption bands. Four metrics were retrieved from the water absorption band centered at $980 \mathrm{~nm}$ (depth, asymmetry, and the indices PWI and LWVI1). The width of the band placed at $495 \mathrm{~nm}$ was also selected. SVR-RFE proved to be an efficient technique for estimating AGB from HSI data. 
Correlation between distribution of emergent trees in the Brazilian Amazon and biomass maps / Correlação entre distribuição das árvores emergentes na Amazônia Brasileira e mapas de biomassa

Alline Zagnoli Villela Motta ${ }^{1}$, Cristiano Rodrigues Reis' ${ }^{2}$, Luiz Carlos Estraviz Rodriguez ${ }^{2}$, Eric Bastos Gorgens ${ }^{1}$

${ }^{1}$ Universidade Federal dos Vales do Jequitinhonha e Mucuri, Diamantina, Brasil; ' Escola Superior de Agricultura "Luiz de Queiroz", Universidade de São

Paulo,SãoPaulo,Brasil (allinezvm@gmail.com; crreis28@gmail.com; lcer@usp.br; e.gorgens@gmail.com)

Quantificar a biomassa e o carbono do bioma amazônia é um desafio que vem sendo trabalhado por diversos pesquisadores. De acordo com a literatura, os mapas existentes de biomassa disponíveis para a região possuem diferenças significativas. Ainda que, o estoque de carbono estimado pelas metodologias apresentem um padrão espacial coerente, a incerteza associada aos valores encontrados são elevados. Pensando em tecnologias que possam contribuir na redução dessas incertezas, o escaneamento a laser aerotransportado (ALS, Airborne Laser Scanning) tem ganhado destaque. Para contribuir com as iniciativas de quantificação dos estoques de biomassa da Amazônia, o Projeto Monitoramento Ambiental da Amazônia, apoiado com recursos do Fundo Amazônia, realizou o levantamento de mais de 800 transectos distribuídos aleatoriamente na região. As nuvens de pontos obtidos pelo levantamento ALS foram filtradas e normalizadas. As árvores emergentes foram localizadas utilizando um algoritmo de busca por máximos locais com janela fixa. Cada máximo local identificado representou uma árvore emergente. O centróide do transecto foi associado ao valor médio da altura obtida com base no modelo digital de altura de dossel das 3750 árvores mais altas (10 árvores por hectare). Os valores obtidos para cada transecto serão correlacionados com os valores de biomassa estimados pelos diferentes mapas de biomassa disponíveis. Espera-se apresentar o grau de aderência dos atuais mapas de biomassa aos valores de altura obtidos das árvores emergentes.

\title{
Assessing the association between surfaces derived from LiDAR cloud in an Amazon Tropical Forest
}

\author{
Eric Gorgens ${ }^{1}$, Cristiano Reis ${ }^{2}$, Mariana Andrade ${ }^{3}$, Luiz Carlos Rodriguez ${ }^{2}$ \\ ${ }^{1}$ Universidade Federal dos Vales do Jequitinhonha e Mucuri, Diamantina, Brasil; ${ }^{2}$ Universidade de São Paulo, Piracicaba, Brasil; ${ }^{3}$ European Forestry \\ Erasmus Mundus, Joensuu, Finland; (e.gorgens@gmail.com; cristiano.reis@usp.br; mandrade0305@gmail.com; lcer@usp.br)
}

Association is a general relationship implicating that one variable brings information about another. Currently, a large number of layers of information can be extracted from an airborne laser scanning (ALS) cloud. Directly from the LiDAR cloud, three main surfaces were usually created: the digital terrain model (DTM), the canopy height model (CHM) and the relative density model (RDM). Especially from DTM and CHM, many other layers can be derived. From those surfaces, many other surfaces can be extracted, adding information from different aspects of the study area. From DTM, we analyzed 4 layers related to hydrologic information, 2 related to operational restrictions, and 1 related to topographic information. From the CHM, one extra layer was derived bringing information about the vegetation. Any new layer was created from the RDM. To investigate the association between those layers we used the hierarchical clustering based on the Euclidean distance and Ward's minimum variance criterion for grouping. We suggest that five groups can capture the most important information to planning. The representatives of each group were: DTM, slope model (SLM), CHP, RDM, and topographic wetness model (TWM). Usually, the hierarchical cluster grouped layers from similar parent surface, or a parental surface and its subproduct. The exception was the group formed by RDM and vertical distance to the drainage. SLM and TWN are both derived from the DTM, but they were not grouped together, either with the DTM. This indicates that those layers are adding different information that holding by DTM.

\section{Detecting forest management impacts over the canopy}

Cristiano Rodrigues Reis ${ }^{1}$, Luiz Carlos Estraviz Rodriguez ${ }^{1}$, Eric Bastos Gorgens ${ }^{2}$

${ }^{1}$ Universidade de São Paulo, Piracicaba, Brasil; ${ }^{2}$ Universidade Federal dos Vales do Jequitinhonha e Mucuri, Diamantina, Brasil (cristiano.reis@usp.br; lcer@usp.br; eric.gorgens@ufvjm.edu.br)

Selective logging comprises on harvesting a few trees of interest in large forested areas without compromise the ecosystem function. Remote sensing has already been applied for monitoring deforestation. However, most of the traditional techniques are not able to deal properly with degradation. Usually, degradation occurred in the layers below the canopy, which is a limitation for monitoring using aerial or satellite images. LiDAR sensors coupled in aircraft was able to provide information about forest vertical structure for large areas, including the understory layer. Modeling the vertical profile of the understory using airborne laser scanning through probability density functions identified the impact of selective logging activities over the forest structure. Overall, the values for scale and shape Weibull coefficients decrease in stands where roads and skid trails were opened, damaging the forest canopy. The curve format for the distribution of Weibull coefficients revealed different patterns for recently exploited and not exploited areas. Clustering the scale coefficients allowed us to classify the study area in low, medium-low, medium-high and high impacted areas. Recently managed areas showed a proportion of high impacted areas. Instead, conservation areas presented much more areas classified as low impact. These results showed that the impact classification by the scale coefficient clearly matched selective logging activities incidence. Further, our results showed that modeling understory profile through Weibull function can be used to monitor the effects of forest management under dense vegetation for large areas.

Comparing dendrometric variables obtained from conventional forest inventory and from land-platform LiDAR / Comparação entre variáveis dendrométricas obtidas pelo inventário florestal convencional e pelo sistema LiDAR de plataforma terrestre

Lucas Timo ${ }^{1}$, Aguida Viana ${ }^{1}$, Carlos Torres ${ }^{1}$, Cibele Amaral ${ }^{1}$, Elpidio Fernandes ${ }^{1}$, Felipe Santana

${ }^{1}$ Universidade Federalde Viçosa,Viçosa,Brasil(lucas.timo@ufv.br; aguida.viana@ufv.br; carlos.eleto@yahoo.com.br; cibeleha@gmail.com; elpidio@ufv.br; fcsantana90@gmail.com)

A utilização dos sistemas de varredura a laser (LiDAR - Light Detection and Ranging) tem se tornado uma prática recorrente e eficaz no que diz respeito à análise das variáveis dendrométricas em um inventário florestal. Desta forma, objetivou-se comparar as estimativas de variáveis dendrométrias coletadas por meio do inventário florestal convencional e com o auxílio de um laserscanner terrestre (TLS - Terrestrial Laser Scanning) em um fragmento de Floresta Estacional Semidecidual. A coleta dos dados foi realizada em 30 indivíduos arbóreos de 9 espécies distintas presentes em uma parcela permanente do fragmento. Desses, coletaram-se o CAP (circunferência a altura do peito) $(\mathrm{cm})$ e altura total $(\mathrm{m})$ com o auxílio de uma fita métrica e um hipsômetro Vertex, para avaliar o método de inventário florestal convencional. Para a estimação utilizando o TLS, o equipamento foi posicionado em 12 pontos diferentes dentro da parcela. A nuvem de pontos obtida foi processada nos softwares Riscan-Pro e 3D Forest, no qual foi coletado o DAP e altura total dos indivíduos. A espécie Trichilia pallida foi a que apresentou menor diferença para DAP médio, $0.14 \mathrm{~cm}( \pm 0.10)$. Já a espécie Rollinia laurifolia, apresentou a maior diferença, $1.34 \mathrm{~cm}$ ( \pm 0.95$)$. Para altura total média, a espécie que se destacou foi Siparuna guianiensis, com diferença igual a $0.28 \mathrm{~m}( \pm 0.20)$. A espécie Albizia polycephala obteve a maior diferença, $-7.18 \mathrm{~m}( \pm 5.08)$. Os valores encontrados demonstram que o uso do LiDAR obtém resultados significativos para o DAP, entretanto, as alturas totais demonstraram uma tendência a superestimação. 
Obtaining information to subsidize annual production units definition in forest management plans through the combination of ground plots, LiDAR data and satellite images

\author{
Marcus d'Oliveira ${ }^{1}$,Evandro Figueiredo ${ }^{1}$, Daniel Papa ${ }^{1}$, Nara Pantoja ${ }^{2}$ \\ ${ }^{1}$ Embrapa Acre, Rio Branco,Brasil; ${ }^{2}$ MMA, Brasilia,Brasil (marcus.oliveira@embrapa.br; evandro.figueiredo@embrapa.br; daniel.papa@embrapa.br; \\ narapantoja@gmail.com)
}

The objective of this work was to optimize the design of the Annual Production Units (APU) in forest management plans, through the combination of field and remote sensing data. The study was carried out in the Antimary State Forest (ASF) located in Acre State, Southwestern Brazilian Amazon. As this area already have a forest management plan our study was limited to the identification of the UPA forest structure and relief. A high resolution biomass map was elaborated trough the upscaling of biomass models from ground plots (permanent sample plots) to LiDAR data and from LiDAR to Landsat-OLI and ALOSPALSAR images. To the identification of the, watersheds, restrict access areas (RAA) and permanent preservation areas (PPA) a digital terrain model (DTM) was elaborated through the use of ground information (GPS), LiDAR and ALOS-PALSAR images. The biomass map was used to the forest stratification in three forest typologies, used to identify the forest areas timber production potential. For each APU we determine: i. the APP and watershed areas and location; ii. restricted access; areas iii. forest stratums and dried above ground biomass stocks. The APU shape, size and distribution must be defined in a way to promote similar annual costs and timber production, minimizing environmental damages. This procedure can be used as a method to define APU in forest management plans in the Amazon.

\title{
An overview on the use of active and passive remote sensors to estimate carbon stocks, structure and diversity in forests \\ Luiz Carlos Estraviz Rodriguez ${ }^{1}$, Thaís Hudari Abib ${ }^{1}$, Juliana Vicentini ${ }^{1}$ \\ ${ }^{1}$ Escola Superior de Agricultura “Luizde Queiroz”, Universidade de São Paulo, Piracicaba, Brasil (lcer@usp.br; thais.abib@usp.br; ju_vicentini@yahoo.com.br)
}

Remote sensing techniques used to quantify forest biomass or to assess the structural diversity of forests have become ubiquitous. Based on a collection of scientific papers published over the last twenty years, we categorize the use of active and/or passive remote sensors to provide some sort of estimate about forest biomass and forest structural diversity. The method used to categorize these historical contributions consists on classifying the estimate according to the type of sensor used to collect data (for instance, optical, radar, lidar, multispectral, hyperspectral etc.); the type of platform used to fasten the sensor (fixed, mobile, terrestrial, aerial, orbital etc.); the scale of the estimate (local, regional, global), the methodological approach and type of algorithms used to process the estimates (empirical, model based etc.); the type of estimate (biomass allocation, carbon stock, etc.) and allocation (total, above or bellow ground, per vegetation type etc.). The assessment tries to identify the set of essential questions and hypothesis proposed by the many authors and the seminal contributions and technological breakthroughs observed in the period. The review presents a table with some open questions still not sufficiently explored that might offer interesting opportunities for researchers. The fast pace evolution of new technologies and data analysis make projections difficult, but we prospectively comment on some new approaches that will make the future monitoring of our forests very promising.

\section{B4I: CLIMATE SMART FORESTRY OR HOW TO INTEGRATE ADAPTATION, MITIGATION AND SUSTAINABLE FOREST MANAGEMENT

\author{
Varying effects of tree composition, diversity and structure on the microclimate of European forests \\ Radim Matula ${ }^{1,2}$, Martin Svátek ${ }^{2}$, Roman Gebauer ${ }^{2}$, Roman Plichta ${ }^{2}$ \\ ${ }^{1}$ Czech University of Life Sciences, Prague, Czech Republic; ${ }^{2}$ Mendel University in Brno, Brno, Czech Republic (radimmatula@gmail.com; \\ msvatek@centrum.cz;gebo@email.cz;plichta.roman@gmail.com)
}

Due to climate change, European forests face rising temperatures and increasing severity and frequency of droughts. However, forests itself may potentially buffer a great part of the negative climate-change effects. These buffering effects likely depend on forest structure, composition and diversity, which in most European forests can be manipulated by forest management to support these climate-change mitigation functions. Here, we present results of the project in which we measured soil moisture, temperature and air temperature in 200 research plots with varying species composition and species mixtures spanning from boreal to Mediterranean forests.The most pronounced difference was found between coniferous and broadleaved trees species, which, in comparison with conifers, had greater summer maximum and winter minimum air and soil temperatures but conserved better soil moisture, especially in late summer and the autumn. Mixed stands had an intermediate microclimate. Increasing tree density reduced temperature extremes but decreases soil moisture. These results suggest that by varying tree composition and structure, foresters may influence forest microclimate but the species that mediate temperature extremes may be different from species the best conserve soil moisture. The great microclimate variation observed in our study also indicates that the typical use of one climate dataset from the nearest climatic station (usually located outside forest) for all study site may be inaccurate. This also means that the quantification of the effects of droughts for forest on the small and medium spatial scale may be significantly biased without local data.

\section{Consistent carbon equivalents for pricing the warming power of surface albedo according to its social cost}

Jussi Lintunen ${ }^{1}$, Aapo Rautiainen ${ }^{1}$

${ }^{1}$ Natural Resources Institute Finland, Helsinki, Finland (jussi.lintunen@luke.fi; aapo.rautiainen@luke.fi)

Optimizing forest management for timber and climate benefits means choosing a management schedule that jointly maximizes the net present value of both ecosystem services. Forests affect the climate through various channels. Here, we focus on carbon storage and surface albedo which tend to force the climate in opposite directions. The accumulation of biomass in boreal coniferous forests increases carbon storage (cooling effect) but also reduces Earth's surface albedo (warming effect). Taking carbon and albedo optimally into account in forest management requires pricing them according to their social value. Management choices are affected by the assigned prices, as well as the strength of the climatic impacts caused through these channels. The socially optimal price for $\mathrm{CO}_{2}$ is the Social Cost of Carbon (SCC). Albedo can be priced in two ways: directly, based on the transient warming power of a given surface and the Social Cost of Forcing (SCF), or indirectly, by converting its warming impact into carbon equivalents and then applying the carbon price. Potential inconsistencies between the methods lead to different albedo prices and affect inferences made about optimal forest management. We present a consistent way to calculate carbon equivalents and compare it with a common but inconsistent method. We show that the latter method can (coincidentally) produce roughly correct albedo prices but is sensitive to arbitrary parameter choices and is unable to capture temporal changes in the albedo-to-carbon price ratio. Our results improve the transparency of comparisons between studies in which different albedo pricing methods are applied. 


\section{Economic and environmental impacts of European conservation and bioenergy forest management strategies}

Alexander Moiseyev ${ }^{1}$, Birger Solberg ${ }^{1}$, Annikki Mäkelä², Sanna Härkönen ${ }^{2}$

${ }^{1}$ Norwegian University of Life Sciences, As, Norway; ${ }^{2}$ University of Helsinki, Helsinki, Finland (alexander.moiseyev@nmbu.no; birger.solberg@nmbu.no; annikki.makela@helsinki.fi; sanharko@gmail.com)

Forest conservation and use of wood for energy can be alternative forest management strategies to mitigate climate change. The global partial equilibrium forest sector model and the FORMIT forest simulation model are applied together to study the market impacts of the Business as Usual (BAU) and two alternative forest management scenarios - Maximum Bioenergy and Biodiversity scenarios. The Biodiversity scenario is similar to BAU on the demand side, but differs on the biomass supply side as it assumes $20 \%$ of the EU forest growing stock is set aside in 2010, longer rotation periods, selection of species better adapted for climate change and no logging residues removals in the EU region. The Bioenergy scenario differs by higher energy wood demand in Europe and globally, and on the wood supply side by shorter rotation periods, selection of the faster growing species and high share of residues removals. The quantified results show that the Bioenergy scenario will substantially increase EU forest owner's gross income from selling wood, forest industries gross sales and value added, and in addition substantial energy substitution effect will benefit climate change mitigation. The Biodiversity scenario will benefit climate adaptation and biodiversity conservation policies in Europe, but will negatively affect EU forest owner's gross income from timber sales and forest industries gross sales, value added and employment. However, neither the reduced growing stock in forests under the Bioenergy scenario nor the increased harvest leakage under Biodiversity scenario give clear benefits for climate change mitigation policy.

\section{Adapting current forest management for multiple ecosystem services to climate change in the Austrian Alps}

Florian Irauschek ${ }^{1}$, Werner Rammer ${ }^{1}$, Manfred J. Lexer ${ }^{1}$

${ }^{1}$ University of Natural Resources and Life Sciences, Vienna, Austria (florian.irauschek@boku.ac.at; werner.rammer@boku.ac.at; mj.lexer@boku.ac.at)

Traditional forest planning tools focus on sustainable timber yield by utilizing classical volume-based indicators. Services beyond timber provision are not explicitly included and largely depend on the knowledge and experience of local foresters. State-of-the-art forest simulation models can predict multiple ecosystem services and impacts of changing climates to inform forest planning processes. However, so far just a few applications at sufficient operational detail levels are available. In this contribution we assess the multifunctionality of the currently practiced management regime for a management unit of 4500 hectare in an Alpine valley in Austria. We initialize the simulation model PICUSv1.5 with data from standard inventory and remote sensing sources. Forest management routines are prescribed at compartment level and disturbances are included via submodules for spruce bark beetle, windthrow and browsing by ungulates. Ecosystem service indicators are evaluated using tree-level model output in a spatially explicit landscape. First we assessed multifunctionality and resilience of the current management strategy for a period of 90 years under 5 climate scenarios. Subsequently we designed a targeted management alternative including altered species composition, retention trees and sanitary concepts. Results show interacting effects of management, forest dynamics and disturbance regimes driven by temperature, precipitation and disturbance events. Particularly storm damages disrupted ecosystem service provisioning. Impacts of less intensive climate change were partly compensated by increasing growth rates. Adaptive management moderated negative effects and caused positive impacts for some ecosystem services. Results showed the potential of landscape scale ecosystem service analysis and its integration in long term management planning.

\section{Agroforestry systems and soil remineralizers: effects on $\mathrm{CO}_{2}$ capture / Sistemas agroflorestais e remineralizadores de solos: efeitos na} captura de $\mathrm{CO}_{2}$

Gustavo Soares ${ }^{1}$, Suzi Theodoro ${ }^{1}$

${ }^{1}$ Universidade de Brasilia, Brasília,Brasil (suzihuff@hotmail.com; suzitheodoro@unb.br)

Os Sistemas Agroflorestais (SAFs) são uma opção viável para garantir a produção de alimentos de forma sustentável. O uso de remineralizadores de solo (derivados de rochas moídas) aplicados ao solo amplia a oferta de nutrientes e facilita o desenvolvimento das espécies vegetais inseridas nesses Sistemaa. Este trabalho tem como objetivo demonstrar que o uso de remineralizadores assegura o crescimento das espécies vegetais e potencializa a captura de $\mathrm{CO}_{2}$. Partiu-se da hipótese de que ao se combinar o uso de insumos minerais em sistemas biodiversos está se favorecendo o crescimento das espécies vegetais, o que resulta em maior captura e retenção de $\mathrm{CO}_{2}$. A pesquisa comparou as práticas de manejo e o uso (ou não) dos remineralizadores em quatro SAFs (localizados no Distrito Federal) e de que forma eles contribuíram para a melhoria físico-química do solo e para o incremento na retenção de $\mathrm{CO}_{2}$, averiguado por meio do crescimento de indivíduos arbóreos previamente selecionados e acompanhados durante um ano. Os dados obtidos nas diferentes fases da pesquisa foram tabulados e submetidos a análises não-paramétrica "ANOVA on Ranks". Adicionalmente, uma análise multivariada (sem atribuição de pesos ou limites para os parâmetros) foi realizada para os parâmetros que apresentaram diferenças significativas isoladamente. As médias foram comparadas entre si pelo teste "Tukey on Ranks". Os resultados mostraram que as áreas onde os remineralizadores foram inseridos apresentaram níveis de fertilidade superiores aquela área sem o acréscimo desse insumo, o que possivelmente influenciou no desenvolvimento das espécies analisadas e no potencial de captura de $\mathrm{CO}_{2}$

\section{Estimating the climate services value for forest management: the case of drought for maritime Pine plantations in South-West France}

Sylvain Caurla ${ }^{1}$, Antonello Lobianco ${ }^{2}$

${ }^{1}$ Institut National de la Recherche Agronomique, Nancy, France; ${ }^{2}$ AgroParisTech, Nancy, France (sylvain.caurla@inra.fr; antonello.lobianco@agroparistech.fr)

In Western Europe, climate changes are likely to come with increasing risk of droughts and heat waves during summer. For forest ecosystems, a drought may result both in an increase of trees mortality and a reduction of tree growth. These impacts are delayed in time, which makes it possible to adjust forest management practices and, in particular, to harvest the impacted stand prematurely and replant a new stand if it is economically profitable to do so. We define here the Climate Services (CS) as the information which supports forest owners in their decision to harvest prematurely or not after a drought. Our paper aims at developing a method to estimate the economic value of these CS in the case of a maritime Pine stand in South-West of France. Using a comparison of Land Expected Values over an infinite period of forest rotations, our analysis suggests that the Climate Services Value (CSV) is highly dependent on three characteristics: (1) the age of the forest facing the drought; (2) the intensity of the drought both in terms of mortality and growth impacts; and (3) the value of discount rate used. Overall, for a $2 \%$ discount rate, for a young stand (below 15-20 years old), CSV is rather low and ranges from 0 to 50 €/ha depending on the intensity of the drought. However for a mature stand, CSV increases rapidly, up to a maximum the year before the optimal harvest date. In this latter case, for intense droughts, CSV reach 4,900 €/ha. 


\title{
Empirical evidences on the potential adaptive performance of alternative species under current and future climate: first results of the
} REINFFORCE arboreta network

\author{
António Henrique Correia ${ }^{1}$, Christophe Orazio², Hernán Serrano-León ${ }^{2}$, Maria Helena Almeida ${ }^{1}$ \\ ${ }^{1}$ CEF, Intituto Superior de Agronomia, Universidade de Lisboa, Lisboa, Portugal; ${ }^{2}$ European Federation for Immunogenetics, Bordeaux, France \\ (ahcorreia@isa.ulisboa.pt; christophe.orazio@efi.int; hernan.serrano@efi.int; nica@isa.ulisboa.pt)
}

The forestry sector is strongly dependent on a very limited number of tree species whose long-term performance is increasingly threaten by climate change impacts. In order to sustain their productivity and mitigation capacity, the adaptation potential of our productive forests needs to be increased by diversifying the number of available species with better-adapted provenances. It is therefore crucial to provide forest owners and managers with empirical evidences on the potential performance of alternative species/provenances under a future climate. However, most of the current available information is originated from models that do not account for species/provenance plasticity, nor climatic conditions outside their current distribution. With the aim of reducing the uncertainty in the selection of adapted material, the REINFFORCE arboreta network was established along the European Atlantic arc (between latitudes $37^{\circ}$-58 $8^{\circ} \mathrm{N}$ ) to test current and alternative species/provenances under contemporary and future climates. We present the field performance results of 33 different tree species under the wide gradient of climatic conditions covered by the 38 innovative network sites. We identified the climate drivers which better explain growth and survival performance, and the best and worst performing species under different climatic conditions. We also present a risk analysis for predicted performance for RCP 4.5 and 8.5 climate change scenarios. Our results will improve the knowledge about the site - climate matching of alternative planting species and the prediction of its behaviour in response to future climate, providing evidences for recommended plantation material with real adaptive capacity to climate change.

\section{Forestry policies and practices for climate adaptation and mitigation in China}

Youjun $\mathrm{He}^{1}$, Ye Bing ${ }^{1}$

${ }^{1}$ Chinese Academy of Forestry, Beijing, China (hyjun163@163.com; yb70@caf.ac.cn)

In recent decades, changes in climate have caused impacts on natural and human systems on all continents and across the oceans. Mitigation and adaptation are complementary strategies for reducing and managing the risks of climate change. Forestry has multiple benefits which is the best and economic way for adaptation and mitigation to climate change in the future. In the past decades, China has always regarded forestry as a strategic choice to deal with climate change, and has implemented a series of major measures, which have made important contributions to the adaptation and mitigation of climate change. Intended Nationally Determined Contributions on forestry in China stated that by 2030 is to increase the forest stock volume by around 4.5 billion cubic meters on the 2005 level. In this paper, the forestry Policies and practices on climate change in China were summarized, the achievements and problems were analyzed, and the opportunities and challenges for forestry to cope with climate change were discussed, forestry carbon project and markets in China was also introduced. Finally, priorities for forestry response to climate change in the future were proposed, which include how to increase forestry carbon sink by large-scale territory greening activities and improve forest management, reduce forestry carbon emission by resources management and forest degradation prevention, strengthen wetland and grassland protection, develop green and prosperous industries, strengthen carbon accounting and monitoring, promote forestry carbon sink trading and enhance international cooperation.

\section{Contribution of indigenous knowledge by local communities to forest management and climate change mitigation and adaptation: case study of Offinso Municipality in Ghana}

\author{
Margaret Sraku-Lartey ${ }^{1}$ Ernest Foli ${ }^{1}$ \\ ${ }^{1}$ CSIR-Forestry Research Institute of Ghana, Kumasi, Ghana (msrakulartey@gmail.com; efoli@hotmail.com)
}

Goal 13 of the Sustainable Development Goals (SDG) stipulates that all countries should take urgent action to combat climate change and reduce its impact because it is considered to be a significant threat that faces mankind in this century. Climate change impacts all sectors of the global economy, but Africa is one of the most vulnerable continents. It is therefore important to develop and implement policies to help curb the effects of climate change. These policies must be based on local people's perception and knowledge of climate change, the adaptation strategies they adopt, and the perceived barriers to adaptation. The main objective of this study was to assess the contribution of indigenous knowledge to climate change adaptation strategies by local people in the Offinso District of Ghana, and to determine management protocols needed to document the knowledge. A mixed methods approach was used to collect primary data on local people's perception and knowledge on climate change from five communities in the Offinso Municipality. The results indicated that local people in the study area perceive climate change in terms of low rainfall, high temperatures and prolonged drought, indicators that are in consonance with scientific literature. Managing, processing and storing this indigenous knowledge on climate change will contribute greatly to policy guidance on forest management and climate change mitigation efforts in Ghana. It is recommended that indigenous knowledge should be documented and backed with scientific information to contribute meaningfully to policy on climate change mitigation and adaptation in Ghana.

The epistemology of models in relation to the border between science and policy: public policies for land use and occupation in mitigating and adapting to climate change in Minas Gerais, Brazil / A epistemologia dos modelos na relação de fronteira entre ciência e política: políticas públicas de uso-ocupação do solo em face à mitigação e adaptação às mudanças climáticas em $M G$

Maxwel Ferreira da Silva ${ }^{1,2}$

${ }^{1}$ Centro Federal de Educação Tecnológica de Minas Gerais, Belo Horizonte, Brasil; '2Escola de Engenharia da Universidade Federal de Minas Gerais, Belo Horizonte,Brasil (max.wel.ferreira@hotmail.com)

Esta proposta de discussão gira em torno da utilização de cenários de referência, ou simulações computacionais que incorporam os efeitos das mudanças climáticas globais (MCG), para a avaliação dos impactos climatológicos sobre o território do Estado de Minas Gerais e, na perspectiva regional de mitigação e adaptação às MCG, como instrumentos para a elaboração e prática de políticas públicas de uso e ocupação do solo na produtividade agrícola, levando-se em conta os efeitos das MCG sobre as áreas de lavoura, pasto e floresta. Nossa perspectiva é de que tais modelos ou cenários apenas se tornam instrumentos efetivos para políticas públicas quando ressignificados no espaço de fronteira em que ciência, política e sociedade precisam se articular para a produção de sentidos, de acordos e de um comum horizonte de expectativa. A partir de uma abordagem epistemológica dos modelos e da produção discursiva que se realiza sobre eles, buscamos analisar como uma simulação pode se transformar num norteamento para as ações e práticas governamentais e quais os limites de sua performatividade. Em outros termos, como poderia ser possível inserir a produção científica na arena social e política, levando-se em conta a competição entre os imperativos de ordem econômica, social e ambiental e, é claro, os diferentes jogos de linguagem que permeiam esse espaço. Esperamos explicitar, por vias 
teóricas, que existe um real problema de teoria e prática no que diz respeito aos modelos ambientais (enfoque aos que se ocupam do uso do solo) que se configura como um problema de ordem política.

B4m: FOREST TREE AND STAND GROWTH PROCESSES UNDER DIFFERING ENVIRONMENTS: CONCEPTS, METHODS AND EVIDENCE - 2

Spatial fine root distribution in pure and mixed stands of European beech, Norway spruce, and Douglas-fir under different site conditions

Amani Saul Lwila ${ }^{1}$, Christian Ammer ${ }^{1}$, Martina Mund ${ }^{1}$

${ }^{1}$ Burckhardt-Institut - Georg-August-Universität Göttingen, Göttingen,Germany (amani.lwila@uni-goettingen.de; christian.ammer@forst.uni-goettingen.de; martina.mund@forst.uni-goettingen.de)

Inter and intraspecific competition play an important role on below ground functional traits and resulting ecosystem functioning. Root biomass production is not the only determinant for below ground success but also rapid vertical and horizontal roots capability to explore the additional soil space along the limited resources. We investigated the impact of inter-intraspecific competition on spatial fine root distribution, and how the effects differ with site conditions and species identity. By pulling together the effect of site condition and different in competitions effects on ecosystem functioning, helped us to understand the existing complementarity between the species in water usage as strategies to reduce drought water stress. We studied the spatial fine root distribution in four quintets comprising in total 20 mature stands aged over 60 years of pure beech, pure spruce, pure Douglas-fir, mixed beech-spruce, and mixed beech-Douglas fir in Northwestern Germany. We considered the site quality by analyzing site nutrient and intra-and interannual variation in weather conditions, and soil moisture our findings show that, beech and douglas-fir have high plasticity by changing with site conditions and competition while spruce shows to be more conservative in changing, e.g. the mixed stands of Douglas-fir and beech shows higher interspecific root diversity, specific root lengths and biomass of fine root than pure stands and mixed stands of spruce and beech, this difference was more pronounced with changes in site quality. Our finding will help to understand the below ground complex interaction in responses to species identity, site quality and inter and intraspecific competition.

\section{Multi-layered scots pine forests in boreal Sweden result from mass regeneration and size stratification}

Lars Lundqvist ${ }^{1}$, Martin Ahlström ${ }^{1}$, Petter Axelsson ${ }^{2}$, Tommy Mörling ${ }^{1}$, Erik Valinger $^{1}$

${ }^{1}$ Dept of forest ecology and management, SLU, Umeå, Sweden; ${ }^{2}$ Dept of wildlife, fish and environmental studies, SLU, Umeå, Sweden

(lars.lundqvist@slu.se; martin.a.ahlstrom@slu.se; petter.axelsson@slu.se; tommy.morling@slu.se; rrik.valinger@slu.se)

Understanding historic development of multi-layered Scots pine (Pinus sylvestris L.) stands and how they became multi-layered is essential for assessing the feasibility of other management practices than rotation-forestry and clear cutting. To address this we measured trees (DBH $\geq 4 \mathrm{~cm})$ and saplings (height $>0.5$ $\mathrm{m} \mathrm{DBH}<4 \mathrm{~cm}$ ) and used increment cores from 244 sample trees to reconstruct stand structure development, ingrowth and basal area increment in four multilayered Scots pine stands in Sweden. Three of the four stands had age distributions that were dominated by one or two 20 year age classes, suggesting that the irregular diameter distributions displayed in 2013 had developed from more homogeneous distributions. Analyses of the historical ingrowth of Scots pine into the tree layer suggested that the multi-layered structure was created by mass regeneration followed by size stratification caused by differences in growth rates within even-aged cohorts of regeneration. Large basal area reductions in the past resulted in abundant regeneration and ingrowth of Scots pine. When the overstory increased in basal area over time, there was a growth differentiation among the saplings and small trees, gradually creating a multi-layered stand structure as some of the trees grew into the larger size classes while others remained in the smaller size classes. When the stands reached a basal area of $13-14 \mathrm{~m}^{2} \mathrm{ha}{ }^{-1}$ the ingrowth of saplings past $1.3 \mathrm{~m}$ height essentially stopped but the size stratification among the small trees continued, further enhancing the multi-layered structure.

\section{Estimating aboveground net biomass change in tropical and subtropical forests: refinement of IPCC default values using forest plot} data

Daniela Requena Suarez ${ }^{1}$ (D), Danaë M. A. Rozendaal ${ }^{1,2,3}$, Veronique De Sy $^{1}$ (D) Oliver L. Phillips ${ }^{4}$ (D) Esteban Alvarez-Dávila ${ }^{5,6}$ (D)

Kristina Anderson-Teixeira ${ }^{7,}$ (D); Alejandro Araujo-Murakami ${ }^{9}$, Luzmila Arroyo ${ }^{10}$, Timothy R. Baker ${ }^{4}$, Frans Bongers ${ }^{11}$, Roel J. W. Brienen ${ }^{4}$ (D) ;

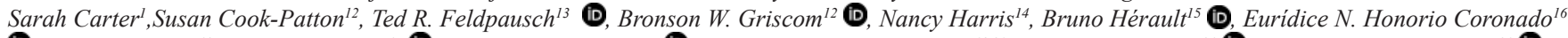
(D), Sara M. Leavitt ${ }^{12}$, Simon L. Lewis ${ }^{4,17}$ (D), Beatriz S. Marimom ${ }^{18}$ (D), Abel Monteagudo Mendoza ${ }^{19,20}$, Justin Kassi N'dja ${ }^{21}$ (D), Anny Estelle N'Guessan ${ }^{21}$ (D), Lourens Poorter ${ }^{11}$ (D) Lan Qie ${ }^{22}$, Ervan Rutishauser ${ }^{23}$ (D) Plinio Sist $t^{15}$ (D), Bonaventure Sonké $e^{24}$, Martin J. P. Sullivan ${ }^{4}$ (D), Emilio Vilanova ${ }^{25,26}$ (D) Maria M. H. Wang ${ }^{27}$, Christopher Martius ${ }^{28}$ (D), Martin Herold ${ }^{1}$ (D)

${ }^{1}$ Laboratory of Geo-Information Science and Remote Sensing, Wageningen University and Research, Wageningen, Netherlands; ${ }^{2}$ Plant Production Systems Group, Wageningen University and Research Wageningen Netherlands, ${ }^{3}$ Centre for Crop Systems Analysis, Wageningen University and Research, Wageningen, Netherlands; ${ }^{4}$ School of Geography, University of Leeds, Leeds, United Kingdom; ${ }^{5}$ Escuela de Ciencias agricolas, pecuarias y ambientales, Universidad Nacional Abierta y a Distancia, Bogotá, Colombia; ${ }^{6}$ Fundación ConVida, Medellín, Colombia; ${ }^{7}$ Conservation Ecology Center, Smithsonian Conservation Biology Institute, Virginia, USA; ${ }^{8}$ Center for Tropical Forest Science-Forest Global Earth Observatory, Smithsonian Tropical Research Institute, Panama, Panama; ${ }^{9}$ Museo de Historia Natural Noel Kempff Mercado, Universidad Autónoma Gabriel René Moreno, Santa Cruz, , Plurinational State of Bolivia; ${ }^{10}$ Universidad Autónoma Gabriel René Moreno, Santa Cruz, Plurinational State of Bolivia; ${ }^{11}$ Forest Ecology and Forest Management, Wageningen University and Research, Wageningen, Netherlands; ${ }^{12}$ The Nature Conservancy, Arlington, USA; ${ }^{13}$ Geography, College of Life and Environmental Sciences, University of Exeter, Exeter, United Kingdom; ${ }^{14}$ World Resources Institute, Washington DC, USA; ${ }^{15}$ Cirad, UR Forests \& Societies, University of Montpellier, Montpellier, France; ${ }^{16}$ Instituto de Investigaciones de la Amazonia Peruana, Iquitos, Peru; ${ }^{17}$ Department of Geography, University College London, London, United Kingdom; ${ }^{18}$ Universidade do Estado de Mato Grosso, Campus de Nova Xavantina, Nova Xavantina, Brasil; ${ }^{19}$ Jardín Botánico de Missouri, Oxapampa, Peru; ${ }^{20}$ Universidad Nacional de San Antonio Abad del Cusco, Cusco, Peru; ${ }^{21}$ Université Félix Houphouet-Boigny, UFR Biosciences, Laboratoire de Botanique, Abidjan, Côte d'Ivoire; ${ }^{22}$ School of Life Sciences, University of Lincoln, Lincoln, United Kingdom, ${ }^{23}$ Smithsonian Tropical Research Institute, Panama, Panama; ${ }^{24}$ Plant Systematic and Ecology Laboratory, University of Yaoundé, Yaoundé, Cameroon; ${ }^{25}$ Universidad de Los Andes, Mérida, Venezuela, Republic of Bolivarian; ${ }^{26}$ School of Environmental and Forest Sciences, University of Washington, Seattle, USA; ${ }^{27}$ Department of Animal \& Plant Sciences, University of Sheffield, Sheffield, United Kingdom, ${ }^{28}$ Center for International Forestry Research (CIFOR), Bogor, Indonesia (daniela.requenasuarez@wur.nl;danae.rozendaal@wur.nl;veronique.desy@wur.nl; o.phillips@leeds.ac.uk; esalvarez3000@gmail.com; 
esalvarez3000@gmail.com; teixeirak@si.edu; araujomurakami@hotmail.com; luzmilaarroyo@hotmail.com; t.r.baker@leeds.ac.uk; frans.bongers@wur.nl; r.brienen@leeds.ac.uk; sarah.carter@wur.nl; susan.cook-patton@tnc.org; t.rfeldpausch@exeter.ac.uk; bgriscom@tnc.org; nharris@wri.org; bruno.herault@cirad.fr; eurihc@yahoo.com; sara.leavitt@tnc.org; s.l.lewis@leeds.ac.uk; biamarimon@unemat.br; amonteagudomendoza@gmail.

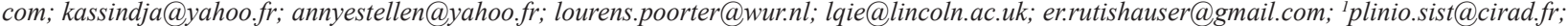
bonaventuresonke@ens.cm; m.j.sullivan@leeds.ac.uk; vilanova@uw.edu; mariawang1990@gmail.com; c.martius@cgiar.org; martin.herold@wur.nl)

As countries advance in greenhouse gas (GHG) accounting for climate change mitigation, consistent estimates of aboveground biomass (AGB) net change are needed for the tropics and subtropics. Countries with limited forest monitoring capabilities rely on 2006 IPCC default AGB net change values, which are averages per ecological zone, per continent. These previous defaults come from single studies, provide no uncertainty indications, and aggregate old secondary forests and old-growth forests. In this study, we update these default values using forest plot data. In comparison with previous estimates, new values include data published from 2006 onwards, are derived from multiple sites per global ecological zone, provide measures of variation, and divide forests $>20$ years old into older secondary forests and old-growth forests. We compiled 176 AGB chronosequences in secondary forests and AGB net change rates from 536 permanent plots in old-growth and managed or logged forests. In this dataset, across all continents and ecozones, AGB net change rates in younger secondary forests ( $\leq 20$ years) are higher than rates in older secondary ( $>20$ years and $\leq 100$ years) forests and managed or logged forests, which in turn are higher than rates in old-growth forests (>100 years). Data availability is highest for North and South America, followed by Asia then Africa. We provide a rigorous and traceable refinement of the IPCC 2006 AGB net change default rates, identify which areas in the tropics and subtropics require more research on AGB change, and reflect on possibilities for improvement as more data becomes available.

\section{The significance of temporal and spatial variation in forest growth for climate change impact modelling}

Hans-Peter Kahle 1 (D), Chaofang Yue

${ }^{1}$ Chair of Forest Growth, Institute of Forest Sciences, Albert-Ludwigs-University Freiburg, Freiburg, Germany; ${ }^{2}$ Forest Research Station Baden-Württemberg, Freiburg, Germany (hans-peter.kahle@iww.uni-freiburg.de; chaofang.yue@forst.bwl.de)

The factors that control forest growth vary across spatial and temporal scales. Modificative adaptation allows trees to cope with short-term fluctuations and long-term trends in environmental conditions that occur during their lifetime, as well as enables species growing on diverse sites to adjust to spatial environmental heterogeneity. Whereas it is difficult to determine to which extent such changes in growth response are genetically determined or the result of phenotypic plasticity, it is evident, that individuals with a greater adaptive plasticity will be more likely to survive under environmental change. Models predicting climate change impacts on forest growth often draw upon the space-for-time substitution (SFTS) approach, thus relying on the assumption that the growth response across spatial environmental gradients is analogue to the dynamic growth response over time. Forest inventory-based models typically rely on the SFTS approach. In contrast, longitudinal studies combining time series of forest growth with forest growth variation across space are scarce. In this presentation, we revisit application of the SFTS approach to predict forest production under climate change in light of longitudinal growth data. Based on measurement data from long-term forest research plots we found that site index changes of Norway spruce across spatial climatic gradients largely differ from dynamic changes in site index under climate change. Thus, application of SFTS would produce largely misleading results. Finally, an updated concept is provided to assess the potentials and limitations of the SFTS approach in a systematic way.

\section{Do increasing respiratory costs explain the decline with age in forest growth rate?}

\section{P.W. West ${ }^{1}$ iD}

${ }^{1}$ Forest Research Centre, Southern Cross University, Lismore, NSW 2480, Australia (pwest@nor.com.au)

Once forests have achieved a full canopy, their growth rate declines progressively with age. This work analysed a global data set with estimates from a wide range of forest types, aged 20-795 yr, of their annual photosynthetic production (gross primary production, GPP) and subsequent biomass production (net primary production, NPP). Both GPP and NPP increased with increasing mean annual temperature and precipitation. GPP was then unaffected by forest age whilst NPP declined progressively with age, meaning that autotrophic respiration increased with age. It has been proposed that GPP should decline in response to increasing water stress in leaves as water is raised to greater heights as trees grow taller with age. However, trees may make substantial plastic adjustment in morphology and anatomy of newly developing leaves, xylem and fine roots to compensate for this stress and maintain GPP with age. This work suggests NPP declines with age as respiratory costs increase progressively in, any or all of, the construction and maintenance of more complex tissues, the maintenance of increasing amounts of live tissue within the sapwood of stems and coarse roots, the conversion of sapwood to heartwood, the increasing distance of phloem transport, increased turnover rates of fine roots, maintaining alive competitively unsuccessful small trees or supporting very tall trees that are unable to compensate fully for increased water stress in their canopies.

\section{B4p: MONITORING FOREST DYNAMICS AND BIOMASS}

Forest and biomass dynamics in the Andean forests of Southern Ecuador / Dinâmica florestal e biomassa nas florestas andinas do Sul do Equador

Celso Yaguana ${ }^{1}$, Deicy Lozano ${ }^{1}$, Ney Quezada², Jhoana Muñoz ${ }^{2}$, Giselda Durigan ${ }^{3}$

${ }^{1}$ Universidade Estadual Paulista "Júlio de Mesquita Filho", Botucatu, Brasil; ${ }^{2}$ Universidad Nacional de Loja, Loja, Ecuador; ${ }^{3}$ Instituto Florestal do Estado deSão Paulo,Assis,Brasil (anibalya09@gmail.com; caroladeicylo@hotmail.com; quezadaney@gmail.com; joana.munoz@unl.edu.ec; giselda.durigan@gmail.com)

As florestas montanhosas andinas são consideradas prioridade global de conservação, especialmente pela elevada biodiversidade e grau de endemismo. No entanto, são ecossistemas fortemente ameaçados por perturbações antrópicas, mas ainda pouco estudados e mal compreendidos. O objetivo deste estudo foi caracterizar a dinâmica da floresta em parcela permanente com área de 1 hectare, na Reserva Natural Tapichalaca, localizada na cordilheira do sudeste dos Andes equatorianos, para quantificar seu papel no armazenamento e, possivelmente, como sumidouro de carbono. Realizamos a amostragem da comunidade arbórea com diâmetro mínimo de 10 cm, em duas ocasiões (2008 e 2018), utilizando o método padronizado pela Rede Amazônica de Inventários Florestais - RAINFOR. A biomassa foi estimada pela equação alométrica para florestas úmidas tropicais de Chave et al. (2005). A biomassa aérea registrada em 2018 foi de 255,63 $\mathrm{Mg} \mathrm{ha}^{-1}$, correspondendo a um estoque de carbono aproximado de $128 \mathrm{Mg}^{-1}$. A taxa anual de mortalidade $(1,99 \%)$ foi similar à taxa anual de recrutamento (1,57\%). O incremento diamétrico médio anual foi de 1,94 mm, valores similares aos observados na Amazônia brasileira (1.4-2 mm por ano). A dinâmica da biomassa correspondeu a um incremento de 26,62 $\mathrm{Mg} \mathrm{ha}^{-1} \mathrm{em} \mathrm{dez}$ anos, com aumento de 2,82 $\mathrm{m}^{2} \mathrm{ha}^{-1}$ na área basal. A floresta estudada, portanto, 
apresentou balanço positivo de biomassa no período 2008-2018, exercendo o papel de sumidouro de carbono e, assim, contribuindo para mitigação dos efeitos das mudanças climáticas globais.

Tree community dynamics over ten years in an Andean forest in Southern Ecuador / Dinâmica da comunidade arbórea ao longo de dez anos em uma Floresta Andina do sul do Equador

Celso Yaguana ${ }^{1}$, Deicy Lozano ${ }^{1}$, Ney Quezada', Jhoana Muñoz², Giselda Durigan ${ }^{3}$

${ }^{1}$ Universidade Estadual Paulista "Júlio de Mesquita Filho", Botucatu, Brasil; ${ }^{2}$ Universidad Nacional de Loja, Loja, Ecuador; ${ }^{3}$ Instituto Florestal do Estado deSãoPaulo,Assis,Brasil(anibalya09@gmail.com; caroladeicylo@hotmail.com; quezadaney@gmail.com; joana.munoz@unl.edu.ec; giselda.durigan@gmail.com)

As florestas montanhosas dos Andes tropicais, incluídas entre os hotspots globais para conservação da biodiversidade, são pouco conhecidas em sua estrutura, composição e mudanças temporais. Em parcela permanente de 01 ha na Reserva Natural de Tapichalaca, cordilheira oriental do sul do Equador, amostramos a comunidade arbórea (DAP $\geq 10 \mathrm{~cm}$ ) em duas ocasiões (2008 e 2018), com o objetivo de compreender as mudanças na comunidade nesse período. Em 10 anos, constatamos mudança na composição florística do dossel, com a perda de 5 espécies (morte) e o ingresso de 6 espécies (recrutamento), de modo que o nível de riqueza permaneceu praticamente constante (74 espécies em 2008 e 80 espécies em 2018). Por outro lado, as mudanças ocorridas na abundância relativa das espécies resultaram em aumento do índice de diversidade de Shannon de 3,81 para 3,90, especialmente porque espécies dominantes na comunidade, como Nectandra laurel Klotzsch ex Nees e Hieronyma asperifolia Pax \& K. Hoffm. sofreram redução populacional de 12,8\% e 12,3\%, respectivamente. Algumas espécies apresentaram incremento em área basal, destacando-se Ficus insipida Willd. (5,98 m²ha-1), Nectandra laurel Ness. (1,99 m²ha-1) e Guarea kunthiana A. Juss. $\left(1,81 \mathrm{~m}^{2} \mathrm{ha} \mathrm{a}^{-1}\right)$, sendo que os maiores incrementos diamétricos foram observados na classe entre 23 a $36 \mathrm{~cm}$. As mudanças observadas podem ser consideradas positivas do ponto de vista da conservação, uma vez que houve ligeiro aumento de diversidade, devido ao aumento da equabilidade no trecho amostrado da floresta.

Periodic increment in seed-based plantations of Khaya ivorensis A. Chev. in Bonfinópolis, Goiás, Brazil Incremento periódico em um plantio seminal de Khaya ivorensis A.Chev. no municipio de Bonfinópolis, GO

Marco Antônio Marcelino Bahia ${ }^{1}$, Matheus Zampetrik Caetano ${ }^{1}$, Sybelle Barreira ${ }^{1}$

${ }^{1}$ Universidade Federal de Goiás, Goiânia, Brasil (eng.marcobahia@gmail.com; matheuszampetrik@gmail.com; sybelle.barreira@gmail.com)

A resistência apresentada pela Khaya ivorensis contra a Broca-do-ponteiro (Hypsipyla grandella), e a sua adaptabilidade ao clima brasileiro são motivos pelos quais os plantios florestais de mognos exóticos têm sido amplamente recomendados. Objetivando aumentar o conhecimento a respeito do crescimento e desenvolvimento da espécie na região, esse estudo tem por objetivo apresentar o incremento em diâmetro a 1,3 m (DAP) e altura total de um plantio seminal de mogno africano referente ao período de março a setembro de 2018. O plantio está localizado no município de Bonfinópolis-GO e tem idade de 6 anos. O clima da região segundo a classificação de Kopen é Aw, sendo que o período de avaliação coincidiu com o período seco do ano. O DAP foi obtido através da medição com a suta, e a altura estimada com o uso de um clinômetro digital. Na primeira medição realizada em março de 2018 as árvores apresentaram uma média de 11,1 cm de DAP e 8,4 m de altura, já em setembro as médias subiram para 12,4 cm e 8,6 m respectivamente. Dessa forma, o incremento periódico para os meses de março a setembro de 2018 foi de 1,3cm para o DAP e 0,2 m para a altura. O baixo incremento em ambas variáveis pode ser explicado pela alta densidade do plantio e pelo período da amostragem. A expectativa é que o incremento periódico para os meses complementares do ano seja consideravelmente maior, e que após os primeiros desbastes a média dos incrementos também se eleve.

Aerial woody biomass in savanna and forest formations in the Cerrado biome associated with cambissols in the Rio Vermelho Watershed in Goiás, Brazil / Biomassa aérea lenhosa em formações savânica e florestal de Cerrado associadas a Cambissolos na Bacia Hidrográfica do Rio Vermelho, GO

Sabrina Miranda ${ }^{1}$, Plauto De-Carvalho ${ }^{1}$, Cássio Cezare ${ }^{2}$, Weuler Vasconcelos ${ }^{3}$, Laerte Ferreira ${ }^{2}$

${ }^{1}$ Universidade Estadual de Goiás, Palmeiras de Goiás, Brasil; ${ }^{1}$ Universidade Estadual de Goiás, Palmeiras de Goiás, Brasil; ${ }^{2}$ Universidade Federal de Goiás, Goiânia, Brasil; ${ }^{3}$ Universidade Federal do Tocantins, Gurupi, Brasil (sabrinac.miranda@gmail.com; plauto.decarvalho@gmail.com; cassio_cezare@hotmail.com; weulervasconcelos@hotmail.com; lapig.ufg@gmail.com)

Este trabalho analisou a contribuição de remanescentes de vegetação nativa de Cerrado, em áreas de Reserva Legal (RL), em termos de estoque de carbono na biomassa aérea da vegetação lenhosa (BAVL). Foram amostrados cerrado típico (formação savânica) na base da Serra Dourada e cerradão (formação florestal) em Itapirapuã, GO, ambos na Bacia Hidrográfica do Rio Vermelho sobre Cambissolos (textura franco-arenosa com cascalho). Em cada área foram instaladas 10 parcelas $\left(1.000 \mathrm{~m}^{2}\right.$ cada) e amostrados os indivíduos com diâmetro da base $\geq 5 \mathrm{~cm}$. Nas estimativas foram utilizadas equações alométricas específicas. O cerrado típico apresentou densidade de 879 ind/ha, com BAVL e estoque de carbono 15,83 Mg/ha e 7,44 Mg/ha. A densidade total no cerradão foi 1.699 ind/ha. Para os indivíduos com DAP $\geq 5 \mathrm{~cm}$ o valor foi $1.259 \mathrm{ind} / \mathrm{haestes} \mathrm{somam} 157,30 \mathrm{Mg} / \mathrm{ha}$ de BAVL e estoque de carbono 73,93 Mg/ha. O cerrado típico é constituído por indivíduos de pequeno porte, altura entre 2,0 e 5,9 m (81,1\% do total), que contribuem com 64,6\% da BAVL. Apenas dois indivíduos apresentaram altura $\geq 10$ m. No cerradão a maioria dos indivíduos possuem altura entre 4,0 e 7,9 m (70\% do total) estes somam 36,3\% da BAVL. Em contrapartida 65 indivíduos apresentaram altura $\geq 10 \mathrm{~m}$ que representam $42,4 \%$ da BAVL. As formações estudadas são estruturalmente distintas, o cerradão é mais denso e com indivíduos mais altos. Estes resultados destacam a importância das áreas de RL além da conservação da biodiversidade, são também relevantes para armazenamento de carbono e emissões evitadas.

Frost risk zoning at the local scale to optimize Eucalyptus plantations / Zoneamento de risco de geadas em escala local para otimização de plantios de eucalipto

Alexandre Simões Lorenzon ${ }^{1}$, Cibele Hummel do Amaral', Rosane Barbosa Lopes Cavalcante ${ }^{2}$, Gustavo Eduardo Marcatti ${ }^{3}$, Nero Lemos Martins de Castro ${ }^{1}$, Rafael Tassinari Resende ${ }^{1}$, Lucas Arthur de Almeida Telles ${ }^{1}$, Brener de Almeida Oliveira ${ }^{1}$, Rodrigo Vieira Leite

${ }^{1}$ Universidade Federal de Viçosa, Viçosa, Brasil; ${ }^{2}$ CMPC Celulose Rio Grandense, Guaíba, Brasil; ${ }^{3}$ Universidade Federal de São João del-Rei, Sete Lagoas, Brasil, ${ }^{1}$ Universidade Federal de Viçosa, Viçosa,Brasil (alexandre.lorenzon@ufv.br; chamaral@ufv.br; rosanecavalcante@gmail.com;

gustavomarcatti@ufsj.edu.br; nerolmcastro@gmail.com; rafael.tassinari@gmail.com; lucasarthur36@gmail.com; b.oliveiraef@gmail.com; r.vieiraleite@gmail.com)

Nas últimas décadas, os eventos de geada afetaram consideravelmente as atividades florestais, causando enormes prejuízos para o setor. A frequência e a intensidade das geadas têm alta variabilidade temporal e espacial e podem ser causadas por diversos fatores ambientais. Em escala local, as geadas ocorrem com 
maior frequência nas partes mais baixas do terreno. Diante disso, este trabalho objetiva realizar o zoneamento da probabilidade do risco de geada em plantios florestais de eucalipto na região sul do Brasil. O classificador utilizado para predizer a ocorrência de geada foi o Random Forest. O algoritmo foi treinado a partir de dados históricos de ocorrência de geada. Parte destes dados (30\%) foram separados e utilizados para a validação do modelo. As variáveis preditoras do modelo foram: longitude, latitude, altitude, altitude relativa, distância euclidiana da hidrografia e orientação do relevo. Todo o processo foi realizado nos softwares R e ArcGIS. As variáveis mais importantes para o modelo foram a longitude e a altitude relativa. A longitude reflete o efeito da continentalidade. Já a altitude relativa reflete os efeitos locais de cada unidade de manejo, sugerindo que as regiões mais baixas do terreno possuem maior probabilidade de ocorrência de geada. O resultado da validação gerou uma exatidão global de $91 \%$. O modelo permitiu determinar a aptidão climática para as unidades de manejo. Desta forma, os clones mais produtivos, porém sem resistência a geadas, poderão ser implantados de forma otimizada em áreas de baixo risco de ocorrência desse evento climático.

Linear models for predicting tree biomass in an area of Atlantic Forest undergoing ecological restoration / Modelos lineares para predição de biomassa arbórea em área de Mata Atlântica em processo de restauração ecológica

Susane Rasera ${ }^{1}$, Flávio Gandara ${ }^{1}$, Edgar Vismara ${ }^{2}$

Escola Superior de Agricultura "Luiz de Queiroz", Universidade de São Paulo; ${ }^{2}$ Universidade Tecnológica Federal do Paraná, ITFPR/DV Campus Dois Vizinhos,DoisVizinhos,Brasil (susanerasera@yahoo.com;fgandara@usp.br; edgarvismara@gmail.com)

Frente às mudanças climáticas, foi estabelecido via Acordo de Paris o compromisso brasileiro em reduzir as emissões de gases do efeito estufa em $37 \%$ até 2025 e $43 \%$ até 2030 . Sendo a restauração de 12 milhões de hectares de florestas uma das formas apresentadas para atingir essas metas, entender o real potencial das florestas plantadas em sequestrar carbono, obtido via quantificação da biomassa, torna-se de grande importância e oportunidade. O objetivo do trabalho foi desenvolver modelos de predição de biomassa do estrato arbóreo para uma área restaurada com 12 anos de idade, localizada na Estação Experimental de Ciências Florestais de Anhembi (ESALQ/USP). Para desenvolvimento das equações foi realizado o abate de 100 indivíduos arbóreos das 20 espécies presentes na área. Todas as árvores foram divididas e pesadas separadamente em quatro compartimentos: raízes, tronco, galhos grossos e copa. De cada compartimento foram retiradas amostras para determinação do teor de umidade e densidade básica dos discos. Foram desenvolvidas quatro equações para predição de biomassa: Biomassa total acima do solo (Btas), Biomassa de tronco (Btr), Biomassa de copa (Bcp) e Biomassa de raiz (Brz). Para ajuste dos modelos foram testadas duas equações lineares, comumente utilizadas no meio florestal para cálculo de volume, e variações dessas equações com a inclusão de cinco variáveis preditoras: DAP, Altura, Altura do tronco, Comprimento de Copa e Densidade básica da madeira do tronco. As melhores equações incluíram pelo menos o DAP e densidade básica da madeira, sendo esta essencial para melhoria nos critérios de seleção de modelos.

Diversity and dynamics of the tree community in four natural forests in southeastern Brazil / Diversidade e dinâmica da comunidade arbórea em quatro florestas naturais do Sudeste do Brasil

Natalia Ivanauskas ${ }^{1}$, Renato Lima ${ }^{2}$, Debora Rother ${ }^{3}$, Juliana Vendrami ${ }^{2}$, Jefferson Polizel ${ }^{4}$, Geraldo Franco ${ }^{1}$, Vinicius Souza ${ }^{4}$, Alexandre Oliveira ${ }^{2}$, Ricardo Rodrigues $^{4}$

${ }^{1}$ Instituto Florestal, São Paulo, Brasil; ${ }^{2}$ Universidade de São Paulo, São Paulo, Brasil; ${ }^{3}$ Universidade Estadual de Campinas, Campinas, Brasil;

${ }^{4}$ Universidade de São Paulo,Piracicaba,Brasil (nivanaus@yahoo.com.br; raflima@usp.br; deborarother@gmail.com; juliana.lv@gmail.com;

jlpolize@usp.br;gadcfranco@gmail.com;vcsouza@usp.br; adalardo@usp.br;rrresalq@usp.br)

Na região Sudeste do Brasil existem poucas áreas extensas de florestas naturais, grande parte protegidas em unidades de conservação, mas imersas numa paisagem bastante modificada pela ação humana. O conhecimento da composição, estrutura e dinâmica dessas florestas é essencial para o entendimento dos padrões e processos relacionados à resiliência dessas comunidades, consideradas ecossistemas de referência para a restauração de áreas degradadas no entorno. No Estado de São Paulo, numa estreita faixa latitudinal (entre 22 e $25^{\circ}$ S) a partir do litoral e em direção ao interior do continente, encontram-se quatro formações florestais distintas: Floresta Ombrófila Densa de Terras Baixas (floresta alta de restinga), Floresta Ombrófila Densa Submontana (floresta atlântica de encosta), Floresta Estacional Semidecidual Montana (floresta de planalto) e Savana Florestada (cerradão). Em cada fitofisionomia foi instalada uma parcela de 320 x 320 m (10,24 ha), na qual foi realizado o mapeamento pedológico ultradetalhado. Todas as árvores com circunferência na altura do peito (CAP a 1,30 m) maior ou igual a $15 \mathrm{~cm}$ foram mapeadas e tiveram o seu perímetro registrado periodicamente (censos de 2002, 2005, 2011, 2018), para cálculo posterior de descritores demográficos (taxas de mortalidade e recrutamento, tempo de estabilidade e rotatividade). Listas florísticas e guias de identificação foram produzidos para cada fitofisionomia, a fim de facilitar o reconhecimento das espécies no campo. Ao término da última avaliação, as quatro parcelas totalizavam cerca de 61.000 indivíduos e 487 espécies, figurando entre um dos inventários mais extensos já realizados em São Paulo, e, para algumas dessas formações, no Brasil.

Factors associated with uncertainties in estimating biomass stocks in native Atlantic Forest / Fatores associados às incertezas nas estimativas de estoque de biomassa em floresta nativa da Mata Atlântica

Eduardo Gusson ${ }^{1}$ Edgar Vismara ${ }^{2}$

${ }^{1}$ Biodendro Consultoria Florestal Ltda, Piracicaba, Brasil; ${ }^{2}$ Universidade Tecnológica Federal do Paraná, Dois Vizinhos, Brasil (eduardogusson@gmail. com; edgarvismara@utfpr.edu.br)

O estudo analisa alguns fatores relacionados aos erros de predição e de estimação de estoque de biomassa em floresta nativa da Mata Atlântica, localizada no município de Registro-SP. Para isso, inicialmente avaliou-se o ajuste de equações de predição de biomassa a partir de dados de uma amostra estratificada contendo 80 árvores de 10 espécies distintas, considerando diferentes combinações de preditores, incluindo diâmetro, altura total e informação relativa à densidade da madeira. Juntamente com outras equações disponíveis em literatura, verificou-se o desempenho de aplicação desses, utilizando-as na predição da biomassa de um conjunto de 146 árvores presentes em nove parcelas destrutivas instaladas em diferentes estágios sucessionais da floresta. Posteriormente estas foram aplicadas aos dados de inventário florestal previamente realizado na área do estudo com o objetivo de se verificar as discrepâncias nas estimativas e incertezas associadas às quantificações de biomassa devido ao uso das diferentes equações de predição. O estudo confirma a natureza empírica dessas equações, expondo alguns fatores relacionados à sua construção e ajuste que podem gerar vieses preditivos, atentando também para a necessidade de previa avaliação do desempenho de predição das equações antes de sua aplicação e, em especial, das ajustadas com amostras de outras florestas. Por fim, o estudo demonstra as discrepâncias nas estimativas de estoques de biomassa em florestas nativas devido ao uso de diferentes modelos de predição. 


\title{
Modeling stand-level mortality of mongolian oak (Quercus mongolica) using stand, climate, and site type based on mixed effect model and zero-inflated model methods
}

\author{
Chunming $L i^{1}$ \\ ${ }^{1}$ Chinese Academy of Forestry, Beijing, China (lichunm@ifrit.ac.cn)
}

Accurate prediction of mortality is an important component of forest growth yield systems, yet mortality remains one of the least understood components of the system. The permanent sample plot was established across the natural range of mongolian oak in the JiLin province in 1995. The main objective of this study was to develop models for predicting stand-level mortality of mongolian oak natural forest using stand characteristics, climate and site type variables. Models were constructed using a two-step modeling strategy. In the first step, a model predicting the probability of tree death occurring in a stand over a measurement period was developed based on bernoulli distribution and logistic function; in the second step, a function that estimates the reduction in tree number was fitted, and the function including the Poisson, negative binomial (NB), and generalized Poisson (GP). Also considered are zero-inflated and hurdle modifications of these basic models. Data used in modelling are from nested samples, with the highest level referred to as plots. Each plot contains many trees with repeated measurements. Analyses performed on stand-level mortality data has recently begun to account for the structured nature and non-independence by using generalized linear mixed-effects models. Performance of all the approaches was compared using leave-one-cluster-out cross-validation. When climate and site type variables, the generalized linear mixed-effects models and the ZINB model were used in the model simultaneously, the prediction approach performed the best.

\author{
Aboveground biomass and expansion factors of a riparian forest in the Brazilian Savanna \\ Luanna Elis Guimarães ${ }^{1}$, Gabriel Mendes Santana ${ }^{2}$, Indiara Nunes Mesquita Ferreira ${ }^{1}$, Fernanda Gomes Ferreira ${ }^{1}$, Joberto Veloso de Freitas ${ }^{3}$, Iris Roitman ${ }^{4}$, \\ Fábio Venturoli ${ }^{5}$ \\ ${ }^{1}$ Programa de Pós Graduação em Agronomia, Produção Vegetal, Universidade Federal de Goiás, Goiânia, Brasil; '²Programa de Pós Graduação em \\ Engenharia Florestal, Universidade Federal do Paraná, Curitiba, Brasil; ${ }^{3}$ Serviço Florestal Brasileiro, Brasília, Brasil; ${ }^{4}$ Radis Project, Faculdade UnB \\ Planaltina, Universidade de Brasília, Brasilia, Brasil; ${ }^{5}$ Universidade Federal de Goiás, Goiânia, Brasil (luanna.meioambiente@gmail.com; \\ gabrielmendes_santana@hotmail.com; indiaranunes22@gmail.com; gomesfernanda@hotmail.com; joberto.freitas@florestal.gov.br; \\ irisroitman01@gmail.com; fabioventuroli@gmail.com)
}

We estimated biomass for different aboveground compartments of a riparian forest in Niquelândia, Goiás, Brazil, and determined expansion factors for necromass, litter, herbaceous layer, tree poles and undergrowth. The tree sample comprised $20(10 \mathrm{x} 10 \mathrm{~m})$ plots of trees with diameter at breast height $(\mathrm{dbh}) \geq 5 \mathrm{~cm}$, distributed in four transects (five plots per transect). In each transect, plots were equidistant (50 m apart). For each plot, we sampled the following compartments in five $(1 \times 1 \mathrm{~m})$ subplots: tree poles $(\mathrm{dbh}<5 \mathrm{~cm}$ and height $(\mathrm{h}) \geq 1.5 \mathrm{~m})$, undergrowth (trees, shrubs and herbs with $\mathrm{h}<1.5 \mathrm{~m})$, necromass, and litter. The herbaceous layer sample consisted of one $(0.4 \times 0.6 \mathrm{~m})$ subplot per plot. Tree biomass was estimated with the equation: $\ln (\mathrm{AGB})=$ $-10.4398+2.1183 * \ln (\mathrm{dbh})+0.8339 * \ln (\mathrm{h})$, where $\mathrm{AGB}$, dbh and $\mathrm{h}$ are in $\mathrm{Mg}, \mathrm{cm}$, and $\mathrm{m}$, respectively. Dry weight of all other compartments was determined in the laboratory. Tree aboveground biomass was $92.74 \mathrm{Mg} \mathrm{ha}^{-1}\left( \pm 36.93 \mathrm{Mg} \mathrm{ha}^{-1}\right)$, necromass was $1.2292 \mathrm{Mg} \mathrm{ha}^{-1}\left( \pm 0.3063 \mathrm{Mg}^{-1}\right)$, litter biomass $2.5675 \mathrm{Mg}^{-1}$ $\left( \pm 0.2365 \mathrm{Mg} \mathrm{ha}^{-1}\right)$, herbaceous layer biomass was $0.3996 \mathrm{Mg} \mathrm{ha}^{-1}\left( \pm 0.2288 \mathrm{Mg} \mathrm{ha}^{-1}\right)$, tree-pole biomass was $0.4600 \mathrm{Mg} \mathrm{ha}^{-1}\left( \pm 0.1761 \mathrm{Mg}^{-1}\right)$, undergrowth biomass was $0.2230 \mathrm{Mg} \mathrm{ha}^{-1}\left( \pm 0.0925 \mathrm{Mg} \mathrm{ha}^{-1}\right)$. Necromass, litter, herbaceous layer, tree-pole, and undergrowth biomass comprised $0.33 \%, 0.26 \%, 0.25 \%$, $0.19 \%$, and $0.10 \%$ of tree aboveground biomass, respectively.

\section{Retrieving diameters from trees using increment cores: a need for shelterbelt trees in Saskatchewan, Canada}

Rafaella Mayrinck ${ }^{1}$, Colin Laroque ${ }^{1}$

${ }^{1}$ University of Saskatchewan, Saskatoon, Canada(rcm786@mail.usask.ca; cpl585@mail.usask.ca)

Tons of carbon have been locked in shelterbelt trees in Saskatchewan. However, it is hard to quantify their carbon stocks, since data on tree growth is lacking due to no standard inventories ever having been made on shelterbelt trees. A carbon tax was recently implemented in Canada, but before the carbon sequestration conducted by these trees can receive a monetary value, shelterbelt tree carbon balance needs to be precisely quantified on a site specific basis through time. To do so, information on past tree attributes are needed, such as the change in tree diameter from year-to-year. The goal of this study was to retrieve information on tree diameter using increment cores by testing three methods: A) using the average growth from two increment cores subtracted by the last diameter; B) using the average growth from three increment cores subtracted by the last diameter; C) using a Steiner ellipse formula to calculate diameter from the increment cores. An analysis of variance was done and contrasts were applied. The methods differ significantly from each other and the best method was the number two, since it yielded the smallest error and standard deviation.

\section{Allometric equations for Pinus leiophylla and Pinus pringlei in Sao Paulo}

\section{Rafaella Mayrinck ${ }^{1}$,Vinicius Roque ${ }^{2}$, Anani Zanini ${ }^{3}$}

${ }^{1}$ University of Saskatchewan, Saskatoon, Canada, ${ }^{2}$ Resinas Brasil, Itapeva, Brasil; ${ }^{3}$ Escola Superior de Agricultura "Luiz de Queiroz”, Universidade de São Paulo,Piracicaba,Brasil(rcm786@mail.usask.ca; vinicius.gontijo@resinasbrasil.com.br; ananizanini@hotmail.com)

Forest inventories are expensive and time demanding. Hence, having accurate allometric equations to estimate difficult-to-measure variables is helpful, especially for species that are not commercially established such as Pinus leiophylla and Pinus pringlei. These species, although native of Central America, have not had their commercial potential and commercial capacity fully exploited in Brazil. This study's goal is to fit volume equations for these species, and to present stand attribute values for two-level spacing plantations owned by Resinas Brasil in Guarei, São Paulo. Models were evaluated for fit by the adjusted coefficient of determination, mean square error, and residual plots. The best model for estimating volume was the Logaritmized Spurr for both species. The mean form factor for all species was 0.53. The mean annual increment ranged from 9.6 to $17.4 \mathrm{~m}^{3} \mathrm{ha} \mathrm{p}^{-1}$ (Pinus leiophylla at $3 \times 3$ and $3 \times 1.5$, respectively), which is very good, considering that the trees have no genetic improvement and or fertilization level, further enforcing the silvicultural potential for these species. 


\section{Towards a global network of tree-ring based information on tree mortality}

Maxime Cailleret ${ }^{1,2}$, Christof Bigler ${ }^{3}$, Harald Bugmann ${ }^{3}$, Vasilis Dakos $^{4}$, Lucia de Soto $^{5,6}$, Arthur Gessler $^{2}$, Steven Jansen ${ }^{7}$, Elisabeth Robert ${ }^{8}$, Jordi Martínez-Viilalta ${ }^{8,9}$

${ }^{1}$ IRSTEA, Aix-en-Provence, France; ${ }^{2}$ WSL, Birmensdorf, Switzerland; ${ }^{3}$ ETH Zürich, Zürich, Switzerland; ${ }^{4} I S E M$, CNRS, Montpellier, France; ${ }^{5}$ EEZA-CSIC, Almeria, Spain; ${ }^{6}$ University of Coimbra, Coimbra, Portugal; ${ }^{7}$ Ulm University, Ulm, Germany; ${ }^{8}$ CREAF, Cerdanyola del Vallès, Spain; ${ }^{9}$ Universitat Autonoma de Barcelona, Cerdanyola del Vallès,Spain (maxime.cailleret@irstea.fr; christof.bigler@env.ethz.ch; harald.bugmann@env.ethz.ch; vasilis.dakos@umontpellier.fr; luciadesoto@gmail.com; arthur.gessler@wsl.ch; steven.jansen@uni-ulm.de; e.robert@creaf.uab.cat; jordi.martinez.vilalta@uab.cat)

Tree mortality is a key driver of forest dynamics and its occurrence is projected to increase in the future due to climate change. Despite our better understanding of carbon and water dynamics associated with mortality, our ability to predict individual tree mortality is still limited. Most studies thus far have focused on saplings and on few stress factors only such as drought. Consequently, their outputs are not necessarily valid for the multifactorial and long-term processes that usually occur in old-growth forests. Instead, focusing on the temporal changes in tree-ring properties is pertinent as tree-ring data are available for numerous individuals, sites, and species, and for almost the entire life span of a tree at an annual resolution. In this presentation, we will show how tree rings can be used as an indicator of individual tree mortality, and contribute to our understanding of the physiological and ecological drivers of the actual mortality process. Based on a pan-continental tree ring-width database from sites where both dead and living trees were sampled (more than 8000 trees from 198 sites; 36 species), we will show that growth patterns (growth rate, trend, resilience to extreme events, inter-annual variability, lag $^{-1}$ temporal autocorrelation, and synchrony) differ between trees that died and those that survived a given mortality event. On a subset of sites, we will also highlight the value of combining ring-based $\delta 13 \mathrm{C}$ and $\delta 180$ information to indicate the various physiological pathways that may occur prior to drought-induced mortality.

\section{Top-down tree growth modelling: a case study for silver fir at its Southernmost European distribution limit}

Pasquale Antonio Marziliano ${ }^{1}$, Roberto Tognetti ${ }^{2}$, Fabio Lombardi ${ }^{1}$

${ }^{1}$ Mediterranean University of Reggio Calabria, Department of Agraria, Reggio Calabria, Italy; ${ }^{2}$ University of Molise, Campobasso, Italy (pasquale. marziliano@unirc.it; tognetti@unimol.it; fabio.lombardi@unirc.it)

Global climate change will modify forest productivity. As a consequence, the analysis of forest growth and yield during the transition period of climate change is essential for supporting forest management activities in relation to the most widespread forest tree species. In Europe, silver-fir forests are one of the most important sources of timber and $\mathrm{CO}_{2}$ storage. The sustainable management of these stands requires adequate growth models. In this contest, we here present the fundamentals of a top-down growth model for silver-fir forests occurring in Italy at their southernmost European distribution limit. Top-down modelling begins when bottom-up process modelling ends. In the top-down approaches, the most common predictable parameters are the standing volume, aboveground biomass and basal area; they are usually disaggregated into size-classes, but also into individual-tree information. The basic element of the proposed model is the stand basal area growth equation. Stand age, current stand basal area and site index are considered as predictors. If the current diameter at breast height distribution is also known, a second function estimates the size-class distribution of the overall stand growth, projecting the dbh distribution to the end of the considered growth period. The parameter estimated by the model were significant, describing most of the variations of the basal area growth. No systematic bias for all the observed age classes and diameter classes were observed. The proposed prototype predicts the tree growth at least as accurately as the empirical equations, and this prediction can be easily based on the available forest inventory data.

\section{Performance of Douglas-fir provenances on the crossroads of Central and Southeast Europe - growth, historical aspect, contemporary silviculture and adaptation possibilities}

Martina Dodan ${ }^{1}$,Sanja Peric ${ }^{1}$

${ }^{1}$ Croatian Forest Research Institute, Jastrebarsko, Croatia (martinat@sumins.hr; sanjap@sumins.hr)

Douglas-fir is a species of increased importance in reforestation activities in Europe due to its higher potential for coping with predicting climate change in respect to declining Norway spruce. It has become important non native tree species in European forests. Provenance selection is essential for climate change adaptation of newly planted forests, both including afforestation and reforestation activities. In this respect, we stress the importance of long-term studies concerning introduced tree species since those are expensive and sensitive to ever changing managerial decisions. We discuss advantages and disadvantages of the use of 26 Douglas-fir provenances in continental and coastal area placed on the crossroads of Central and Southeast Europe (case studies from Croatia), both from historical aspect and contemporary silvicultural aspect. Study provides review on the research activities, which include 26 Douglas-fir provenances tested in the last 60 years. The intent of this review is to provide a synthesis of what is known about Douglas-fir provenances on the study area, to facilitate decision making on which provenance to use in afforestation and forest restoration programs. It tracks the performance of different provenances, providing insight into provenances with best and lowest survival and wood production. Review includes management and legislative legacy as well as state of the art of contemporary silvicuture. Since present legislative restrictions may omit the successful use of this tree species in Southeast Europe, special consideration is given to forest and nature conservation acts.

\section{Litter and soil organic carbon stocks under different land uses in Bangladesh}

Md. Akhter Hossain ${ }^{1,2}$, Mondal Falgoonee Kumar ${ }^{1}$, Kristofer Johnson ${ }^{1}$, Matieu Henry $^{1}$, Rashed Jalal ${ }^{1}$, Rajib Mahamud ${ }^{1}$

${ }^{1}$ Food and Agriculture Organization of the United Nations, Dhaka, Bangladesh; ${ }^{2}$ Institute of Forestry and Environmental Sciences, University of Chittagong, Chittagong,Bangladesh(akhter.hossain@cu.ac.bd; falgoonee_kumar@hotmail.com; kristofer.johnson@fao.org; matieu.henry@fao.org;

rashed.jalal@fao.org; rajib.mahamud@fao.org)

Estimation of litter and soil organic carbon is crucial for improving sustainable forest management and understanding the global carbon cycle affected by deforestation, forest degradation, and land-use changes. This research aims to quantify C stored in the litter and mineral soils of major land cover classes of Bangladesh. Soil and litter samples were collected inside nested plots of 0.57 ha each. The stratified random sampling method was followed for laying the plots across the country. According to the national land cover classification system, the survey identified 25 land cover classes taking account of the locations of soil sampling points. Results indicate that total soil organic carbon up to $30 \mathrm{~cm}$ is about 1120 times greater than the litter carbon. The litter carbon ranged from 0.001 (Herb Dominated Area) to 0.448 (Plain Land Forest (Sal Forest)) $\mathrm{Mg} \mathrm{C} \mathrm{ha}^{-1}$ whereas soil organic carbon ranged from 14.3 (Sand) to 153.6 (Bamboo forest) $\mathrm{Mg} \mathrm{C} \mathrm{ha-1}$ up to $30 \mathrm{~cm}$ soil depth. The highest soil and litter carbon density were found in the natural forests and plantations respectively, especially bamboo 
forest and forest plantations, and they are lowest in built-up areas. In terms of total soil organic carbon, cultivated areas have the highest carbon stocks followed by rural settlements and hill forests. The study also explored the importance of these pools for supporting biomass and tree diversity. The results are relevant for understanding greenhouse gas emissions and the role of soils in the country's ecosystems.

\section{B4r: ASSESSING CLIMATE CHANGE IMPACTS ON FORESTS}

\section{High-resolution bias corrected EURO-CORDEX climate data for historical and future periods for Europe}

Debojyoti Chakraborty ${ }^{1}$, Laura Dobor ${ }^{2}$, Lea Henning ${ }^{3}$, Tomáš Hlásny², Silvio Schueler ${ }^{1}$

${ }^{1}$ Austrian Research Centre for Forests, Vienna, Austria; ${ }^{2}$ Czech University of Life Sciences Prague, Prague, Czech Republic; ${ }^{3} J o h a n n$ Heinrich von Thünen Institute Federal Research Institute for Rural Areas, Forestry and Fisheries, Eberswalde, Germany (debojyoti.chakraborty@bfw.gv.at; doborlaura@gmail.com; lea.henning@thuenen.de; tomas.hlasny@gmail.com; silvio.schueler@bfw.gv.at)

Climate projections are in immediate demand by scientists, governments and nongovernmental organizations. In climate-sensitive sectors such as forestry and agriculture, the biological relevance of the climate data is of equal importance as its resolution and accuracy. In the last decades, continental scale high-resolution climate projections have become globally available. Majority of these climate surfaces are empirically downscaled directly from Global climate models. Downscaling is a general concept that embraces various methods for increasing spatial resolution and reduces some of the biases in order to improve the usability of climate scenarios. Two major approaches to downscaling climate data are, statistical and dynamic. For robust predictions, a dynamic approach is often recommended because it is based on the dynamical and physical processes that govern the weather and thus the climate. EURO-CORDEX is an initiative of the World Climate Research Program for coordinating dynamic regional downscaling of the global climate projections from the CMIP5 (Coupled Model Intercomparison Project Phase 5. We used five bias-corrected regional climate model (RCM) projections of daily temperature and precipitation from the EURO-CORDEX database and downscaled them from $10 \mathrm{~km}$ resolution to $1 \mathrm{~km}$ with the delta-algorithm of spatial downscaling. Using this approach we calculated 83 biologically relevant climate variables for both historic periods (mean of 1961-90) and future periods (2041-2060, 2061-2080, 2081-2100) under RCP4.5 and RCP8.5 scenarios. An evaluation with independent data from approximately 3000 weather stations across Europe showed promising results with high correlations between observed and predicted data. The dataset is available for free public use.

\section{Growth rate and carbon storage in South African plantation forests for the period July 2001 to June 2017 \\ Iain $\operatorname{Kerr}^{1,2}$ (D), Oswald Olembong ${ }^{2}$ \\ ${ }^{1}$ University of KwaZulu-Natal, Durban, South Africa; ${ }^{2}$ The Paper Manufacturers Association of South Africa, Johannesburg, South Africa (kerr@ukzn.ac.za; oswald.alembong@gmail.com)}

Measuring the carbon stored by forests is an obligation of signatories to The United Nations Framework Convention on Climate Change (UNFCCC) and Kyoto Protocol. South Africa is a signatory to the Paris Agreement and is required to submit a national greenhouse gas inventory to the UNFCCC biennially. Storing carbon in fast-growing forests is a climate change mitigation option for South Africa. We developed a model to determine the amount of carbon sequestered in the living biomass of plantation forests in South Africa. These forests are managed to produce either industrial roundwood or pulpwood. The model was used to determine carbon stocks for the years 2001 to 2017 using publically available data. The model was re-run using average yield tables for the new Eucalypt hybrids reported as "other gum" and updated yield tables for softwood species. This resulted in an increase in estimated carbon stocks of 46.6 and $4.3 \%$ for hardwoods and softwoods respectively. Although the area under plantations is decreasing temporally, the stocks are relatively constant taking into account the growth rates of new hybrids. Local demand for roundwood is being met from local resources as a result. The model requires further refinement and discrepancies in the various government forest inventory reports need to be investigated. Collection of data by the government requires more detail including the extent of the area planted to new hybrids and number of survey forms not returned versus the number of registered growers and extent of the area permitted for afforestation.

\section{Plurifor: transnational plans for the management of forest risks}

Sarah Yoga ${ }^{1}$, Christophe Orazio ${ }^{1}$, Eduard Mauri ${ }^{1}$

${ }^{1}$ European Forest Institute, Cestas, France (sarah.yoga@efi.int; christophe.orazio@efi.int; eduard.mauri@efi.int)

Forest ecosystems play an important role in South West Europe. They occupy more than $30 \%$ of the land area in France, Spain, and Portugal. These ecosystems are subject to increasing multiple biotic (e.g. insects and fungi) and abiotic (e.g. storms, fires) hazards. Although European forests are managed at a local level, forest damages often have effects beyond administrative borders. PLURIFOR is a three-year project that aimed to facilitate cross-border collaboration in South-west Europe and to improve local or transnational risk management plans for forest areas susceptible to forest hazards. The project focused on five biotic (eucalyptus weevil, pinewood nematode, chestnut gall wasp, pine pitch canker, emerging pests, and diseases) and three abiotic (storm, wildfire, soil degradation) hazards currently prevailing in southwestern forests. Research institutes, universities, forest-related organisations, and governments at local, regional and national levels exchanged their expertise through survey questionnaires and during technical workshops to build innovative risk tools and up to date risk management plans. Field inventory and laboratory analyses were conducted to test new methodologies for forest risk prevention. Remote sensing tools (lidar, UAV) were also used to characterize tree mortality. Altogether, PLURIFOR contributed to the development of 27 risk management tools and 13 risk management plans. A panel of forest risk management experts has been implemented to ensure an on-going collaboration on forest hazards at a European level.

\section{Phenologically contrasting silver fir (Abies alba Mill.) groups and belowground root-associated fungal communities in Slovenia}

Tina Unuk ${ }^{1,2}$, Tijana Martinovičn ${ }^{1}$,Domen Finžgar ${ }^{1}$, Rok Damjanic ${ }^{1}$, Nataša Šibanc ${ }^{1}$, Tine Grebenc ${ }^{1}$, Hojka Kraigher ${ }^{1}$

${ }^{1}$ Slovenian Forestry Institute, Ljubljana, Slovenia; ${ }^{2}$ Institute of Microbiology of the CAS, Prague, Czech Republic (tina.unuk@gozdis.si; tijana.martinovic@gozdis.si; domen.finzgar@gozdis.si; rok.damjanic@gozdis.si; natasa.sibanc@gozdis.si; tine.grebenc@gozdis.si; hojka.kraigher@gozdis.si)

Leaf phenology is one of the most important characteristics for tree growth and survival and tend to be crucial in controlling ecosystem processes. In forest ecosystems, tree roots are colonized by various ecto- or endo-mycorrhizal and endophytic fungi, which impact plant growth and vigour, as drives nutrient mobilization processes of their host plants. Linking plant phenological characteristics with belowground ectomycorrhiza community composition was rarely questioned, thus we aimed to (1) analyse fungal communities of four phenologically distinct groups of silver fir trees, by using Ilumina MiSeq platform, and to (2) link analysed communities and community differences with phenological characteristics of sampled groups. Based on phenological data of silver fir 
trees (project LIFEGENMON), individual trees with extreme phenologies were combined into two phenologically contrasting groups, and further separated based on silver fir tree age. Changes in fungal community composition were evaluated with PerMANOVA on Bray-Curtis distances, meanwhile for aplha diversity estimation Shannon-Wiener and Simpson indexes were used. Significant differences in beta diversity and mean alpha diversity were confirmed for overall community of ectomycorrhizal root-associated fungi of young silver fir trees, but not also for ectomycorrhizal community of adult silver fir trees. Meanwhile for non-ectomycorrhizal root-associated fungi only significant differences in beta diversity were observed. At genus level root-associated fungal genera abundances differed significantly between early and late flushing young and adult silver fir trees. The presentation contributes to the aims and means of the project LIFEGENMON (LIFE13 ENV/SI/000148).

\section{Growth response of the main Carpathian forest tree species to climate extremes between 1997 and 2017}

Zuzana Sitková1, Jozef Pajtik ${ }^{1}$, Roman Sitko ${ }^{2}$, Katarina Merganičová ${ }^{2,3}$, Pavel Pavlenda ${ }^{1}$, Ján Merganič ${ }^{2}$, Peter Fleischer ${ }^{2}$

${ }^{1}$ National Forest Centre, Forest Research Institute, Zvolen, Slovakia; ${ }^{2}$ Technical University in Zvolen, Faculty of Forestry, Zvolen, Slovakia; ${ }^{3}$ Czech University of Life Sciences Prague, Faculty of Forestry and Wood Sciences,Prague, Czech Republic (sitkova@nlcsk.org; pajtik@nlcsk.org; sitko@tuzvo.sk; k.merganicova@forim.sk; pavlenda@nlcsk.org;merganic@tuzvo.sk; p.fleischerjr@gmail.com)

Recent knowledge indicates that climate-induced changes affect productivity of temperate forests in Central Europe. Systematic measurements conducted within the framework of the unique forest monitoring networks enable an evaluation of tree responses to unprecedented long-term environmental changes at a large spatial scale. The primary objective of this study is to analyse recent growth changes in key tree species of the West Carpathians in relation to climate extremes. We focused on economically most significant forest tree species in Central Europe: European beech (Fagus sylvatica L.), Norway spruce (Picea abies L. Karst.), Sessile oak (Quercus petraea Liebl.) and Downy oak (Quercus pubescens Willd.). Growth analysis is based on 20 years of periodic measurements of a large number of individual trees growing on eight ICP-Forests plots (Level II) distributed across Slovakia at an altitudinal range from $225 \mathrm{~m}$ to $1,250 \mathrm{~m}$ a.s.l. In the study, we analysed annual increments of the following growth parameters: diameter at breast height, tree height, tree volume and tree basal area. The series of bioclimatological indicators and various climate indices quantifying particularly drought and extreme air temperatures were derived from the data of meteorological stations situated in the surrounding of the research plots for individual years between 1997 and 2017 . Key questions answered by this contribution are: Do tree species exhibit recent climate-driven growth changes? How do species growth reactions to climate extremes differ? Which environmental indicators affecting tree growth were most significant? How does the changing climate affect the inter-annual variability in forest productivity of study sites?

\section{Use of the normalized difference vegetation index to estimate biomass and carbon stocks of restored areas in the Atlantic Forest}

Eduardo Gusson ${ }^{1}$, Edgar de Souza Vismara ${ }^{2}$,Frederico Tomas de Souza e Miranda ${ }^{1}$, Paulo Guilherme Molin ${ }^{3}$

${ }^{1}$ Biodendro Consultoria Florestal Ltda, Piracicaba, Brasil; ${ }^{2}$ Universidade Tecnológica Federal do Paraná, Dois Vizinhos, Brasil; ${ }^{3}$ Universidade de São

Carlos,Buri,Brasil (eduardogusson@gmail.com; edgarvismara@utfpr.edu.br; fredtsmiranda@gmail.com; pgmolin@gmail.com)

This study aims to evaluate the applicability of the vegetation index NDVI to assist in inventory of biomass stocks in natural forests. For this, we used the information obtained in the study of case project, entitled "Forest Restoration and Carbon Credits AES Tietê S/A". Different sampling procedures commonly used in forest inventories were applied, looking to compare them in terms of accuracy and conservativeness of the estimates of biomass and carbon. The vegetation index NDVI show good correlation with the measured biomass in the field inventory plots. As result, this index can be applied as support decision tool to define the strata in the stratified random sampling as well as a predictor variable of the regression estimator in the double sampling procedure. This latter procedure was able to minimize the uncertainty of estimates, using a reduced sampling effort. It makes the approach very interesting in the context of biomass and carbon surveys applied to natural and restored Atlantic forests. It is because those studies are often applied in large areas, where the field works are time consuming and very expensive.

Growth of pau-marfim (Balfourodendron ridelianum) for introduction into urban forestry programs in Brazil / Crescimento de Paumarfim (Balfourodendron ridelianum) para fins de introdução em planos de arborização em áreas urbanas no Brasil

Isis Manzano ${ }^{1}$, Flavia Brun ${ }^{1}$

${ }^{1}$ Universidade Tecnológica Federal do Paraná, Dois Vizinhos, Brasil (manzano@alunos.utfpr.edu.br; flaviagbrun@gmail.com)

O objetivo do presente estudo foi avaliar o desenvolvimento do Pau-marfim (Balfourodendron ridelianum) em área urbana, a fim de avaliar seu potencial para a utilização em arborização viária. Estudaram-se quarto indivíduos, implantados em 2013 no campus da UTFPR Dois Vizinhos. As mudas, quando implantadas, apresentavam altura média (Ht) 1,65 m e diâmetro médio (DAP) 0,71 cm, plantados em covas formato bacia (1,5 m x 0,6 m), recebendo adubação orgânica (5 L de cama de aviário) e química (300 g de NPK 06-30-06 incorporados ao solo da cova+150 g da mesma fórmula, como cobertura, em coveta lateral, aos 12 meses de idade), em área livre de $1 \mathrm{~m}^{2}$. Foram mensuradas $\mathrm{Ht}$ (m) com o uso do hipsômetro Vertex IV, Diâmetro a altura do peito (DAP cm), obtido pela medição da circunferência à altura do peito (CAP) com fita métrica e cálculo do DAP pela relação CAP/ $\pi$ e a Área de Copa (m²), calculada com base na medição de 4 raios equidistantes a partir do tronco até a extensão dos galhos. Os resultados encontrados estão de acordo com o previsto na literatura científica sobre o tema, com um incremento médio em Ht de $1,7 \mathrm{~m} / \mathrm{ano}$, DAP de 2,8 cm/ano e área de copa de 5,1 m²/ano, sendo assim, os resultados encontrados nesse estudo foram satisfatórios ao se tratar de árvores nativas com 6 anos de idade, expostas e submetidas ao estresse cotidiano urbano, de acordo com os resultados encontrados, o Pau-marfim mostra-se como espécie potencial para a utilização na arborização urbana devido ao seu bom desenvolvimento no ambiente urbano.

B4s: CLIMATE SMART FORESTRY OR HOW TO INTEGRATE ADAPTATION, MITIGATION AND SUSTAINABLE FOREST MANAGEMENT

\section{Modeling changes in the distribution of agro-climatological zones of Kenya for incorporation of area-specific mitigation and adaptation measures in integrated land use plans and forest management at Sub-county level}

Richard Muita ${ }^{1}$, Phesto Osano ${ }^{2}$, Mercy Gichora $^{2}$, Kasina Muo ${ }^{3}$

${ }^{1}$ KenyaMeteorologicalDepartment, InstituteForMeteorologicalTrainingandResearch, Nairobi, Kenya; ${ }^{2}$ KenyaForestry ResearchInstitute, Nairobi, Kenya, ${ }^{3}$ Kenya AgriculturalandLivestockResearchOrganization,Nairobi,Kenya(muita.richard@gmail.com; phesto@kefri.org;mgichora@kefri.org;muo.kasina@kalro.org)

Kenya's seven agroclimatic zones were first published in 1983 and upscaled to 12 homogenous climatic zones in 2000 . As climate change became more evident over time, a need was identified to once again review and update the distribution of existing climatic zones at a finer scale for use in Sub-counties, the lowest 
administrative units of the country. For the study, daily rainfall from 300 locations for the period 1960 to 2015 and daily temperature from 30 locations for the period 1974 to 2015 were obtained from the Kenya Meteorological Department. Combined approaches to missing data-imputation were used. TheStatistical Downscaling Modelwas applied to reconstruct the daily data sets using NCEP predictors whilesatellite- derived values obtained from NOAA were used to calibrate the observed station records for improved accuracy on estimating the missing observations. A Generalized Additive Model (GAM) in R environment was applied to derive the relationships and trends of rainfall and temperature over the period and to testthe capability of GAM to predict the spatial distribution of the historical climatic data across all the Sub-counties in Kenya.This model is expected to become a valuable tool for operational forecasters and decision makers in the natural resource-based economic sector of Kenya. It can generate more accurate and area-specific climatic information and provide information required by policy makers to initiate effective adaptation and mitigation measures against impacts of climate change. It has application in County integrated land use planning and management of forests and agriculture, among other sectors.

\section{Harvesting of old-growth Boreal Forest decrease soil carbon stock}

Jenny Dahl', Tomas Lundmark ${ }^{1}$

${ }^{1}$ Swedish University of Agricultural Sciences, Umeå,Sweden (jenny.dahl@slu.se; tomas.lundmark@slu.se)

The Boreal Forest is a vast region, consisting of diverse ecosystem types with different carbon dynamics and vulnerability to climate change, exposed to various intensities of forest management. There are large uncertainties among scientists on the contribution of boreal forest management to climate change mitigation, and disagreements among stakeholders whether bio-economy or conservation is the winning concept. The most appropriate mitigation actions will be decided by current forest conditions and climate change impacts, socio-economic state and regional policy for mitigation actions. Therefore, mitigation strategies need to be adapted to regional conditions to meet objectives regarding carbon as well as other forest management objectives. This study focus on the effects on soil carbon in old-growth boreal forests in northern Sweden after a first regeneration cut. This was done by empirically quantifying soil carbon stock in the humus layer and down to $20 \mathrm{~cm}$ in the mineral soil at 14 paired sites of adjacent old-growth and younger stands. The younger stands had been established after clear cutting of old-growth forests similar to the one at the adjacent site 15-55 years ago. Results indicate a reduction of soil carbon after a final harvest. This temporary or permanent carbon debt needs to be considered when assessing the climate benefit of turning old growth forests into managed forests.

Changes in the rate of shrub coverage in native forests within the Mesopotamian Espinal Region of Argentina: using remote sensing for analysis / Evolucion del nivel arbustización en bosques nativos del espinal mesopotamico: utilización de sensores remotos para su análisis

Julian Alberto Sabattini ${ }^{1}$, Rafael Alberto Sabattini ${ }^{1}$, Florencia Alicia Urteaga Omar ${ }^{1}$, Juan Carlos Cian ${ }^{2}$, Ivan Alberto Sabattini $^{3}$, Victor Manuel Dopazzo ${ }^{4}$ ${ }^{1}$ Universidad Nacional de Entre Ríos, E3100XAD, Argentina; ${ }^{2}$ Profesional Independiente, E3134, Argentina; ${ }^{3}$ Profesional Independiente, E3100FIL, Argentina; ${ }^{4}$ Las Taperitas S.A. - Area Natural ProtegidaEl Carayá,E3100XAD,Argentina (juliansabattini@hotmail.com; rsabatti@outlook.com; fuomar@yahoo.com.ar;juancarloscian@hotmail.com;ivanagro@live.com.ar; elcaraya@williner.com.ar)

Monitorear la evolución de los cambios ocurridos sobre los recursos naturales es una prioridad a nivel mundial. Los modelos de cambio y cobertura de la tierra, y su facilidad en la predicción, son una herramienta potente de análisis espacial. El objetivo del trabajo consistió en determinar y explicar los cambios sobre el nivel de arbustización en bosques nativos del Espinal Mesopotámico, con la finalidad de predecir el nivel degradación y ajustar la carga animal. El estudio se realizó en el Área Natural Protegida "El Carayá" ubicada en Entre Ríos (Argentina). El estado del bosque nativo se determinó en los años 2012 y 2018 , a través puntos georreferenciados con GPS. Se cuantificó el nivel de arbustización en cinco clases, y utilizaron dos imágenes satelitales Landsat. El modelo Markov fue utilizado para determinar las predicciones. El 36\% (3.775 ha) del "El Carayá" se mantuvo estable en relación con el nivel de arbustización durante el período evaluado. El porcentaje restante, presentó cambios notables debido a la dinámica sucesional característica de estos ecosistemas. En el año 2027 se espera que la superficie sin cambios sea del 33\%. La dinámica sucesional en la cobertura de arbustivas propia de los bosques nativos, estuvo influenciada por la variación estacional del clima, la intervención antrópica a través de la limpieza química y la implementación de un sistema de pastoreo rotativo intensivo. Este trabajo permitió definir y ajustar la capacidad de carga de los diferentes ambientes teniendo en cuenta los potenciales cambios sobre la arbustización de los bosques nativos.

\section{Calculations of socio-economic efficiency of environmental forestry measures including reforestation activities considering climate change and forests disasters in the Czech Republic}

Ludek Sisak ${ }^{1}$,Vilem Jarsky ${ }^{1}$, Roman Dudik ${ }^{1}$, Roman Sloup $^{1}$, Marcel Ried $^{1}$

${ }^{1}$ Czech University ofLife Sciences Prague,Prague, Czech Republic (sisak@fld.czu.cz;jarsky@fld.czu.cz;dudik@fld.czu.cz; sloup@fld.czu.cz; riedl@fld.czu.cz)

The first experimental socio-economic efficiency evaluation of environmental forestry operations in the landscape under the Rural Development Programme (RDP) in the Czech Republic is presented. The efficiency evaluation is based on environmental operations costs provided by the Ministry of Agriculture for all the Czech Republic in years 2015-2017, considering the future socio-economic improvements of the respective environmental landscape ecosystem services'socio-economic values (both market and non-market) expressed by their differences. The socio-economic efficiency represents a relationship between public financial inputs into the forestry environmental measures on one hand, and enhancement of respective landscape ecosystems services'socio-economic values on the other hand. The main landscape ecosystems such as forestland, grassland, arable land, and solid soil cover were included, and valued by the methodology created by the research team, and certified in the Czech Republic in 2018. The following main services were included: production service (both market and non-market), game management and hunting, hydrological services, soil protection services, air protection - $\mathrm{CO}_{2}$ sequestration services, healthhygienic (recreational services), cultural-educational services (based on nature-protection service closely related to biodiversity, important in educational, scientific and institutional points of view). The results show that the selected forestry measures within the RDP significantly improve the given landscape services'socio-economic values within the Czech Republic and that all measures'value benefits are higher than the public funds invested.

Dicyandiamide as an alternative for mitigating nitrous oxide emissions from nitrogen fertilizer used on eucalyptus / $U s o$ da dicianodiamida como alternativa para a mitigação da emissão de óxido nitroso proveniente da adubação nitrogenada do eucalipto

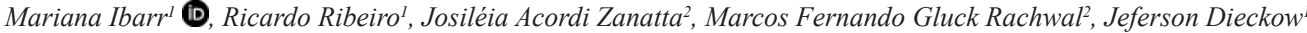

${ }^{1}$ Universidade Federal do Paraná, Curitiba, Brasil; 2Embrapa Florestas, Colombo, Brasil (marianaibarr@gmail.com; kico_ribeiro@hotmail.com; josileia. zanatta@embrapa.br;marcos.rachwal@embrapa.br;jefersondieckow@ufpr.br)

$\mathrm{O}$ uso de inibidor de nitrificação (IN) concomitantemente à adubação nitrogenada constitui uma alternativa para a mitigação da emissão de óxido nitroso ( $\mathrm{N}_{2} \mathrm{O}$ ) do solo. O objetivo do estudo foi avaliar o potencial do IN dicianodiamida (DCD) em reduzir a emissão de $\mathrm{N}_{2} \mathrm{O}$ do solo proveniente da adubação nitrogenada do 
eucalipto. O experimento foi conduzido em povoamento de Eucalyptus urograndis cultivado em Latossolo Vermelho argiloso. Os tratamentos foram: controle (C), ureia (U) e ureia com DCD (U-DCD), aplicados 10 e 120 dias após plantio (DAP), correspondendo à adubação de base (13 kg N ha-1) e cobertura $(33$ kg N ha-1), respectivamente. O fluxo de $\mathrm{N}_{2} \mathrm{O}$ foi avaliado durante 247 dias pelo método da câmara estática fechada. O fluxo de $\mathrm{N}_{2} \mathrm{O}$ do solo variou de $1,5 \mathrm{a} 1030,8 \mu \mathrm{g} \mathrm{N} \mathrm{m}{ }^{-2} \mathrm{~h}^{-1}$, com picos concentrados entre 15 e $65 \mathrm{DAP}$, seguidos de valores basais até o final do período de avaliação. A emissão acumulada $(\mathrm{EA})$ de $\mathrm{N}_{2} \mathrm{O}$ do solo do tratamento C, U e U-DCD foi de 2,93, 5,53 e 3,29 $\mathrm{kg} \mathrm{N} \mathrm{ha}^{-1}$, respectivamente. No entanto, embora a U apresente EA duas vezes maior que o controle e que a U-DCD tenha reduzido a emissão de $\mathrm{N}_{2} \mathrm{O}$ do solo fertilizado com U em 40,5\%, os tratamentos não apresentaram diferença significativa entre si, possivelmente devido ao elevado coeficiente de variação entre as repetições (3). Neste sentido, conclui-se que o inibidor de nitrificação dicianodiamida não foi eficiente em reduzir a emissão de $\mathrm{N}_{2} \mathrm{O}$ do solo nas condições edafoclimáticas deste estudo.

Nitrous oxide emissions in an area of mixed eucalyptus and acacia plantations in Northern Mato Grosso, Brazil / Emissões de óxido nitroso em área de plantio misto de eucalipto e acácia no norte Mato-grossense

Júlia Graziela da Silveira ${ }^{1}$, Renato de Aragão Ribeiro Rodrigues², Maurel Behling ${ }^{3}$, Diego Camargo ${ }^{4}$, Leticia Helena Campos de Souza ${ }^{5}$,

Jacqueline Jesus Nogueira da Silva ${ }^{6}$, Natassia Magalhães Armacolo ${ }^{7}$, Antonio de Arruda Tsukamoto Filho ${ }^{5}$

${ }^{1}$ Universidade Federal de Viçosa, Viçosa, Brasil; ${ }^{2}$ Embrapa Solos, Rio de Janeiro, Brasil;; ${ }^{3}$ Embrapa Agrossilvipastoril, Sinop, Brasil; ${ }^{4}$ Universidade Federal de Mato Grosso, Sinop, Brasil, ${ }^{5}$ Universidade Federal de Mato Grosso, Cuiabá, Brasil; ${ }^{6}$ Universidade Federal Fluminense, Niterói, Brasil; ${ }^{7}$ Universidade Estadualde Londrina, Londrina, Brasil (juliagrazielasilveira@gmail.com; renato.rodrigues@embrapa.br; maurel.behling@embrapa.br; camargo.die@gmail.com; leticiahelena_cs@hotmail.com; jacqueufmt@gmail.com;nmarmacolo@gmail.com; tsukamoto@ufmt.br)

O eucalipto é a espécie florestal mais plantada no Brasil e para explorar seu máximo potencial produtivo, é necessária a reposição de nutrientes, sobretudo nitrogênio (N), principal fonte de emissão de óxido nitroso (N2O). Plantios mistos de eucalipto com leguminosas arbóreas fixadoras de nitrogênio, surge como uma alternativa sustentável de fornecer $\mathrm{N}$ e reduzir as emissões de N2O. O objetivo do estudo foi avaliar o efeito do plantio misto de Eucalyptus urograndis (E. urophylla x E. grandis) e Acacia mangium na redução das emissões de N2O. Foi realizado na Embrapa Agrossilvipastoril, Sinop-MT e foram avaliados cinco tratamentos: monocultivo de eucalipto com fertilização nitrogenada $(E+N)$, sendo aplicado $190 \mathrm{~kg}$ ha-1 de ureia; monocultivo de eucalipto sem fertilização nitrogenada (E); monocultivo de acácia (A); plantio misto com 67\% eucalipto e 33\% acácia (67E:33A); plantio misto com 50\% eucalipto e 50\% acácia (50E:50A).O delineamento experimental foi blocos casualizados, com três repetições. As coletas foram realizadas em 2016 e 2017, em período de seca e chuva. Foram instaladas câmaras estáticas para coleta de gases e as amostras foram analisadas por cromatografo gasoso. No período seco, os maiores valores de emissões de $\mathrm{N} 2 \mathrm{O}$ foram $5,44 \mu \mathrm{g} \mathrm{N} \mathrm{m}-2$ h-1, não apresentando diferença significativa entre os tratamentos. No período de chuva, a emissão foi superior à seca e os maiores valores foram no E+N, com emissões de 189,49 $\mu \mathrm{g} \mathrm{N} \mathrm{m-2} \mathrm{h-1,} \mathrm{sendo} \mathrm{superior} \mathrm{aos} \mathrm{demais} \mathrm{tratamentos.} \mathrm{Plantio} \mathrm{misto} \mathrm{de} \mathrm{eucalipto} \mathrm{com} \mathrm{acácia} \mathrm{tem}$ potencial de mitigação de emissões de N2O, comparado a monocultivos fertilizados com N.

\section{B4t: ESTIMATION OF STATUS AND CHANGE IN FOREST CARBON POOLS BASED ON} INVENTORY DATA: GOING BEYOND TREE CARBON

\section{Combretum-Terminalia vegetation accumulates more carbon stocks in the soil than the biomass along the elevation ranges of dryland ecosystem in Southern Ethiopia}

Musse Tesfaye ${ }^{1}$, Mesele Negash ${ }^{2}$

${ }^{1}$ Ethiopian Environment and Forest Research Institute, Addis Abeba, Ethiopia; ${ }^{2}$ Wondo Genet College of Forestry and Natural Resources, Hawassa University, Hawassa, Ethiopia (mussetesfaye36@gmail.com; kelemuamesele@yahoo.com)

Dryland ecosystems including Combretum-Terminalia vegetation cover a wider area in the tropics. These resources are believed to greatly contribute to climate change mitigation in dryland ecosystems. Therefore, the objective of this study was to investigate biomass and soil carbon stocks of Combretum-Terminalia vegetation along the elevation ranges. A total of 60 nested sample plots of $20 \mathrm{~m} \times 20 \mathrm{~m}$ were laid systematically along lower, middle and higher elevation ranges, representing 20 plots for each elevation. Within each nested sample plot of woody species, litter and soil samples (0-15, 15-30 cm layers) were collected. The total carbon stocks (biomass plus soil) significantly $(\mathrm{p}<0.05)$ differed among the three studied elevation ranges. The biomass carbon stocks were significantly different between middle and higher elevations but both of them significantly $(\mathrm{p}<0.05)$ differed from lower elevation, and also showed a decreasing trend from lower to higher elevations. However, inconsistence trends were observed for organic carbon and litter along the elevation ranges. It was concluded that the woodland ecosystem has a potential to accumulate higher carbon stocks in the soil than the biomass and significantly vary along elevations.

\section{Quantification of soil organic and inorganic carbon stocks in Gambari Forest Reserve, Nigeria}

Oladele F. Falade ${ }^{1}$, Ayobami A. Adeagbo ${ }^{1}$

${ }^{1}$ Department of Forest Production and Products, University of Ibadan, Ibadan, Nigeria (faladedele@yahoo.com; aydeagbo@yahoo.com)

Soil carbon is the largest carbon pool in the terrestrial biosphere and contains organic carbon and inorganic carbon components. Inorganic carbon has not been considered in estimation of soil carbon stock. Assessment of both carbon components is required to understand the effects of land use on soil carbon stock. Therefore, this study was conducted to quantify organic and inorganic carbon among soil aggregates of selected land use types in Gambari Forest Reserve. Four (30m x 30m) plots were randomly demarcated on each land use; Natural Forest, Plantation Forest and Cultivated Land. Soil core samples were collected to depths of $0-15,15-30$ and 30-45cm in the sub-plots of $8 \mathrm{~m}$ x $8 \mathrm{~m}$ established at four corners and centre of each plot. Soil core samples were oven dried at $1050 \mathrm{C}$ to constant weight and $100 \mathrm{~g}$ of soil sample was sieved into five aggregate sizes $(>2,2-1,1-0.5,0.5-0.05,<0.05 \mathrm{~mm})$ and total carbon content was determined by Loss-in-Ignition method at 5000C for 4 hours. Walkley Black mehod was used to determine soil organic carbon and inorganic carbon was computed from each aggregate fractions. Data collected were analyzed using descriptive statistics. Aggregates $>2.0$ mm had the highest total carbon content at three depths in Plantation Forest and Cultivated Land while $1.0 \mathrm{~mm}$ had the highest carbon content at three depth in Natural Forest. Soil organic and inorganic carbon decreased with increase in soil depths in the three land use type. Land use and aggregates determined the distribution pattern of soil organic and inorganic carbon. 


\section{Soil organic carbon stock under poplar based plantation in relation to tree age and soil depth}

Gurveen Aroral, Rajesh Kaushal

${ }^{I}$ Indian Council of Forestry Research and Education, Dehradun, India; ${ }^{2}$ Indian Institute of Soil and Water Conservation, Dehradun, India

(gargi_one@yahoo.com; kaushalrajsh1@rediffmail.com)

Poplar based agroforestry system improves aggregation of soil through huge amounts of organic matter in the form of leaf biomass. The extent of improvement however is largely governed by the age of the poplar trees and the soil type. Keeping above in view, a study was conducted in "Tarai"region of Central Himalayas to quantify the soil carbon stock along age series "Populus deltoides" plantation at different soil depth. Soil samples were collected from 1 to 11 years from 3 depths i.e. $0-30 \mathrm{~cm}, 31-60 \mathrm{~cm}$ and $61-90 \mathrm{~cm}$ respectively. The results showed that organic carbon per cent increased significantly with age ranging from $1.59-2.20 \mathrm{in} 0-30 \mathrm{~cm}$, $1.39-1.43$ in $31-60 \mathrm{~cm}$ and $1.25-1.31$ in $61-90 \mathrm{~cm}$ depth. Similar trend was observed in bulk density varying from $1.27-1.34,1.38-1.44 \mathrm{and} 1.47-1.52 \mathrm{~g} / \mathrm{cm}^{3} \mathrm{in} 0-30 \mathrm{~cm}$, $31-60 \mathrm{~cm}$ and $61-90 \mathrm{~cm}$ respectively. Both the factors decreased with increasing soil depth. Soil carbon stock also increased significantly with increasing tree age and showed reverse trend with soil depth at 5 per cent probability level. Soil carbon stock in different ages of plantations varied from 63.9 to $83.8 \mathrm{Mg} / \mathrm{ha}$ at $0-30 \mathrm{~cm}$ depth, 57.5 to $60.1 \mathrm{Mg} / \mathrm{ha}$ at $30-60 \mathrm{~cm}$ depth, and 55.5 to $59.7 \mathrm{Mg} /$ ha at $60-90 \mathrm{~cm}$ depth. The carbon sequestration rate of the soil varied from 1.18 to $1.81 \mathrm{Mg}$ / ha/yr from 7 to 11 years. Based on the study, it can be recommended that poplar based plantation helps in retention of soil organic matter.

\section{Forest ecosystem carbon fluxes after stand-replacing disturbance}

Sille Rebane ${ }^{1}$, Kalev Jõgiste ${ }^{1}$, Andres Kiviste ${ }^{I}$, John Stanturf ${ }^{1}$, Marek Metslaid ${ }^{1,2}$

${ }^{1}$ Estonian University of Life Science, Tartu, Estonia; ${ }^{2}$ Norwegian Institute of Bioeconomy Research, As, Norway(rebane.sille@gmail.com; kalev.jogiste@emu.ee; andres.kiviste@emu.ee; drdirt@gmail.com; marek.metslaid@emu.ee)

A large area of Estonian hemiboreal forest is recovering from clear-cut harvesting and reflecting carbon $(\mathrm{C})$ balance with the stand. Net ecosystem total $\mathrm{CO}_{2}$ exchange (NEE) was measured by eddy covariance (EC) technique between two different stages of stand development. The one study site, which is divided into two stands are located in south-east Estonia, Europe. Growing trees and the harvest stands is moderated into a $\mathrm{C}$ source immediately after harvesting. Stands which already were 6 and 8 years old, were acting as a light $C$ sinks. They had similar patterns of carbon exchange and results showed clear correlation between $\mathrm{C}$ fluxes and ecosystem responses to environmental conditions. Eddy fluxes were based on high quality data being most accurate and reliable. Mean summertime (May-September) measured NEE for 2014 was $-1.4281 \mu \mathrm{mol} \mathrm{m}^{-2} \mathrm{~s}^{-1}$. Seasonally, NEE peaked in July with $-96.793 \mu \mathrm{mol} \mathrm{m} \mathrm{m}^{-2} \mathrm{~s}^{-1}$. In June, August and September was the highest $-78.110,-96.618$ and -73.785 , respectively. However measured mean $\mathrm{CO}_{2}$ concentration was 343 ppm and mean temperature was 15 degrees. Weather conditions played a key role in the rapid rise in NEE results. NEE result was driven primarily by early-growing-season temperature and length. Meteorological data confirm ecosystem depends on climate variability and water vapor. Results indicates strong relationship between carbon fluxes, stand age and climate conditions.

\section{Investigating wood density as a proxy for biomass production of economically relevant tree species in the temperate zone of China}

Lars Sprengel', Sandra-Maria Hipler', Wu Shuirong ${ }^{2}$, Heinrich Spiecker ${ }^{l}$

${ }^{1}$ University of Freiburg, Freiburg, Germany; ${ }^{2}$ Chinese Academy of Forestry, Beijing, China (lars.sprengel@iww.uni-freiburg.de; sandra.hipler@iww.uni-freiburg.de; shuirongwu@126.com; instww@iww.uni-freiburg.de)

Recent trends in climate change and future predictions of increasing carbon emissions and rising temperature have drawn a general focus towards the topic of carbon storage and the enlargement of carbon sinks. However, some forest ecosystems and tree species have not been investigated in terms of their biomass production and the closely linked carbon storage potential in much detail. Here, we investigate biomass production of Larix gmelinii (Rupr.) Kuzen, Pinus tabulaeformis Carr. and Quercus mongolica Fisch. ex Ledeb. in the temperate zone of China by analyzing gravimetric wood density as a proxy. As gravimetric wood density varies within a tree we use high-frequency densitometry on radial cuts of stem discs to analyze the inter-annual density variations at $1.3 \mathrm{~m}$ and $10 \mathrm{~m}$ stem height, respectively, by applying linear mixed-effects models and pairwise comparisons of estimated marginal means. Results show an overall lower gravimetric wood density for $P$. tabulaeformis compared to L. gmelinii and $Q$. mongolica. For all three tree species mean annual gravimetric density develops in a curvy-linear pattern and decreases to lower values than the initial values after leveling off at different cambial ages. Results will help to quantify stored carbon in the aboveground merchantable timber compartment of the investigated tree species and during different developmental stages of a tree.

\section{Quantification of the effect of agriculture on forest carbon stock: case study of a Nigerian Forest Reserve}

Temitope Elizabeth Ogana ${ }^{I}$, Friday Nwabueze Ogana

IUniversity of Ibadan, Ibadan, Nigeria (topeadeniyi2005@gmail.com; fn.ogana@ui.edu.ng)

The competition for land between forest and agriculture has been a long-time issue. The tropical forest has been greatly reducing due to agricultural activities. There are few studies on the quantification of forest carbon loss stock caused by encroaching agricultural activities. Therefore, this study compared the biomass in the areas encroached by farming activities and forested areas; and also analyze the forest cover change in Cross River South Forest Reserve, Nigeria. Data were obtained through forest inventory and satellite imageries. Eight sample plots of 0.25 ha were used (plots were laid in the forested and the encroached parts of the reserve). Established allometric equation was used to estimate the biomass. Satellite images from Landsat between 2002 and 2017 were used for the forest cover change. The results showed thatthere is a significant difference in the mean aboveground carbon density of the forested part (108.6571 tC/ha) and the encroached part (44.1567 tC/ha) of the reserve. The forest cover change of Forest Reserve showed that about 6,750 ha was deforested within the period with an annual rate of forest cover loss of $0.54 \%$. It was concluded that thefarming activities have negatively impacted the quantity of carbon stock of the Forest Reserve.

\section{Forest management certification for sustainable negative emissions}

Florian Kraxner ${ }^{l}$, Dmitry Schepaschenko ${ }^{l, 2}$, Piera Patrizio ${ }^{l}$, Sylvain Leduc ${ }^{l}$, Sabine Fuss ${ }^{1,3}$, Linda See ${ }^{l}$, Ping Yowargana ${ }^{l}$, Bintang Yuwono ${ }^{l}$, Kasparas Spokas, Anders Lunnan', Anatoly Shvidenko ${ }^{1}$

${ }^{I}$ International Institute for Applied Systems Analysis, Laxenburg, Austria; ${ }^{2}$ Bauman Moscow State Technical University, Mytischi, Moscow, Russian Federation; ${ }^{3}$ Mercator Research Institute on Global Commons and Climate Change, Berlin, Germany; ${ }^{4}$ Princeton, University, Princeton, USA; ${ }^{5}$ Norwegian University of Life Sciences, As, Norway (kraxner@iiasa.ac.at; schepd@iiasa.ac.at; patrizip@iiasa.ac.at; leduc@iiasa.ac.at; fuss@mcc-berlin.net; see@iiasa.ac.at; yowargan@iiasa.ac.at; yuwono@iiasa.ac.at; kspokas@princeton.edu; anders.lunnan@nmbu.no; shvidenk@iiasa.ac.at) 
Land-based negative emission technologies (NETs), in particular bioenergy with carbon capture and storage (BECCS), are often criticized by science and policy with respect to their land demand and potentially negative environmental effects. However, the ambitious climate mitigation targets under the Paris Agreement and with some of the most relevant SDGs might become unattainable without NETs, says the latest IPCC special report on 1.5 deg C. This study presents a new methodology for identifying sustainable forest biomass feedstock for BECCS applications. A new global forest certification map at one-kilometer resolution (Geo-Wiki) together with a biophysical forest model (G4M) and an engineering model (BeWhere) to optimize the feedstock supply chain are applied to map a realizable and sustainable potential for BECCS in the US. It is shown that BECCS potentials strongly vary under different sustainability scenarios developed for the US. Rather conservative assumptions with respect to biomass availability indicate that BECCS potentials are reduced by up to two thirds if strict sustainability criteria are being applied. However, the study also reveals that sustainable feedstock supply chains for BECCS can be developed with the help of this new integrated approach. Furthermore, forest certification appears to be an appropriate tool for identifying sustainable bioenergy feedstock - i.e. for the generation of negative emissions for climate mitigation. Certifying multiple ecosystem services including energy provision and carbon sequestration seems to be a promising way forward for present and future certification schemes. Finally, a near-term ramping up of bioenergy systems with highest sustainability safeguards is strongly recommended.

\title{
Blue carbon and biodiversity within Suriname's mangrove forests using a multipurpose NFI
}

Gianni Wip ${ }^{1}$, Verginia Wortel ${ }^{2}$, Gunovaino Marjanom ${ }^{3}$, Jasper Feyen ${ }^{1}$, Sarah Crabbe ${ }^{1}$, Joey Zalman ${ }^{1}$, Dorothy Traag ${ }^{3}$, Gwen Landburg ${ }^{4}$ ${ }^{1}$ Foundation for Forest Management and Production Control, Paramaribo, Suriname; ${ }^{2}$ Center for Agricultural Research and Development Suriname, Paramaribo, Suriname; ${ }^{3}$ The National Herbarium of Suriname, Paramaribo, Suriname; ${ }^{4}$ National Zoological Collection Suriname, Paramaribo, Suriname (gianniw@sbb.sr;wortelv@gmail.com; gunovaino.marjanom@gmail.com; jasperfeyen@hotmail.com; crabbes@sbb.sr; zalmanj@sbb.sr; dorothy.traag@uvs.edu; gwendolyn.landburg@uvs.edu)

Mangrove forests provide important ecosystem services as habitat, feeding, aery grounds for fish, molluscs, crustaceans, as well as coastline protection. The biomass, dead organic material and the soil are significant sinks of blue carbon (Mcleod, E; 2011) and represent an important economic resource pool for adjacent communities. These mangrove forests are currently threatened by urban and rural development.. While we are well aware of its importance, insufficient statistically sound data is available on the extent of the mangrove forests, the blue carbon and the biodiversity it fosters. To better inform policy makers, Suriname has initiated its efforts towards a National Forest Inventory (NFI) within the mangrove forest in a collaborative process between governmental and academic institutions. The methodology implemented can be easily harmonized with the NFI-methodology used in its neighbouring country Brazil. Data is collected on the blue carbon stored in mangrove forests, but also on its floristic and fauna biodiversity. The NFI is a component of the National Forest Monitoring System (NFMS) developed within the framework of REDD+ and thus provides data for reporting to the UNFCCC, but also to the Convention of Biological Diversity (CBD) and the Forest Resource Assessment (FRA). According to the previous mangrove plot data collected in Suriname, a carbon stock of $57.93 \mathrm{Mg} /$ ha was found, but the inclusion of soil organic carbon in this study and a more extensive sampling intensity could prove that the carbon storage potential of mangroves is much higher, supporting the case for intensifying mangrove forest conservation efforts.

\section{B4u: ESTIMATION OF STATUS AND CHANGE IN FOREST CARBON POOLS BASED ON} INVENTORY DATA: GOING BEYOND TREE CARBON

Detecting and evaluating degraded forests by combining remote sensors and data and information from the Chilean national forest inventory / Detección y evaluación de bosques degradados mediante la combinación de sensores remotos y datos e información del inventario forestal nacional en Chile

\author{
Carlos Bahamondez ${ }^{1}$, Yasna Rojas Ponce ${ }^{1}$, Rodrigo Sagardia ${ }^{1}$, Marjorie Martin ${ }^{1}$, Müller-Using Sabine ${ }^{1}$ \\ ${ }^{1}$ Instituto Forestal,Valdivia, Chile (cbhamon@infor.cl; yrojas@infor.cl; rsagardia@infor.cl; mmartin@infor.cl; smuller@infor.cl)
}

Los bosques degradados en Chile constituyen la principal causa de pérdida del potencial de remoción de carbono desde la atmósfera. Avanzar en la detección de estos bosques permite determinar en qué áreas concentrar los esfuerzos en el marco de REDD+ y mejorar el rol mitigador de los bosques. En este contexto, INFOR ha desarrollado una metodología espacialmente explícita para la detección de bosques degradados, que permite evaluar en el tiempo las pérdidas y ganancias de carbono en un período de evaluación. Esta metodología se ha utilizado para establecer el nivel de referencia de emisiones forestales/nivel de referencia forestal de los bosques templados de Chile. La metodologíaconsiste en la combinación de material satelital Landsat con unidades de muestreo generadas por el Inventario Forestal Nacional de INFOR. Se recurre a herramientas biométricas respecto del bosque, que permiten establecer los valores umbrales que determinan en forma operacional, cuando un rodal está en estado de degradación, y necesita de recuperación activa. S utilizan los diagramas de densidad de los bosques que establecen la relación de número de árboles y área basal por hectárea. Los resultados muestran para el período 2001-2010 una superficie total de degradación de 461.231 hectáreas con emisiones anuales de 4,9 millones de toneladas de $\mathrm{CO}_{2}$ e y de 677.669 hectáreas que se recuperaron con una absorción neta anual de 9,1 millones de toneladas de $\mathrm{CO}_{2}$. La metodología ha demostrado resultados aceptables y es suficientemente flexible para ser parte relevante de un sistema medición, reporte y verificación en el contexto de REDD+.

Influence of methodologies for forest restoration in fine-root carbon stocks / Influência de metodologias de restauração florestal no estoque de carbono da raiz fina

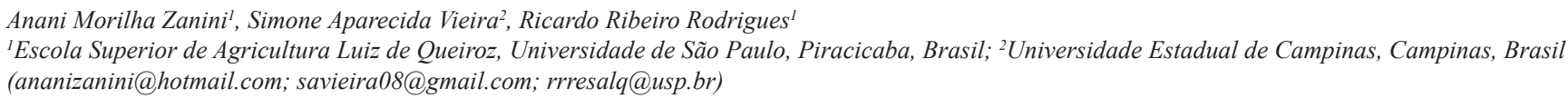

Estimativas de biomassa são importantes nos estudos de mudanças climáticas, sendo as raízes finas potenciais fontes de carbono. Assim, o objetivo do trabalho foi quantificar o estoque de carbono da raiz fina de áreas com diferentes metodologias de restauração florestal. O presente estudo foi realizado no município de Itu, SP, em parcelas de 30 x 30 m (900 m²) distribuídas de forma sistemáticas na área, sendo elas: restauração passiva (apenas isolamento da área dos fatores de perturbação), restauração assistida (condução da regeneração natural, adensamento e enriquecimento de espécies), restauração ativa (plantio total escalonado), pasto limpo em uso e fragmento nativo remanescente de floresta estacional semidecidual. Para coleta, foram utilizados 2 pontos sorteados por parcela. Em cada ponto, foram retiradas porções de solo correspondentes às profundidades de 0-10,10-20 e 20-30 cm. Para a quantificação da biomassa foi utilizado a metodologia do ponto-a-ponto, que consiste em remover concomitantemente das três profundidades de solo, todas as raízes com diâmetro igual ou menor a 
2 mm em 4 intervalos de tempo de 2 minutos, para ajuste de uma curva de tendência logarítmica que estima a produção total. Posteriormente as raízes foram submetidas a análise de teor de carbono. A partir de ANOVA e teste de Tukey, observamos que entre os tratamentos a estocagem no fragmento e nas áreas com maior quantidade de gramíneas foi superior, e que entre profundidade cerca de $58 \%$ foi estocado na primeira camada. Podendo concluir que a produção de raízes finas é um indicador de conservação, principalmente do solo.

\section{Quantification of carbon and diversity at the Atlantic Rainforest in the South central region of the State of São Paulo, Brazil}

Deicy Carolina Lozano Sivisaca ${ }^{1}$, Jaqueline Pinheiro da Silva ${ }^{1}$, Celso Anibal Yaguana Puglla ${ }^{1}$, Felipe Góes de Moraes ${ }^{1}$, Renata Cristina Batista Fonseca ${ }^{1}$, Maria Tereza Umbelino', Carlos Alexandre Costa Crusciol, Iraê Amaral Guerrini ${ }^{1}$

${ }^{1}$ Escola Superior de Agricultura Luiz de Queiroz, Universidade de São Paulo, Botucatu, Brasil; ${ }^{2}$ Brasil Mata Viva Program, Goiânia, Brasil (caroladeicylo@hotmail.com; jaqueline.pinheiros@hotmail.com; anibalya@hotmail.com;felipe.goes.de.moraes@gmail.com; rfonseca@fca.unesp.br; maria.tereza@brasilmataviva.com.br; carlos.crusciol@unesp.br;irae.guerrini@unesp.br)

The aims of this work were to estimate the total accumulation of elemental carbon (Celem) and equivalent $\left(\mathrm{CO}_{2}\right)$, and the species diversity in three physiognomies of the Atlantic Rainforest: Semideciduous Seasonal Forest (SSF), Riparian Forest (RF) and "Cerradão" (CE). All five carbon sinks proposed by the IPCC were measured: tree biomass ( $\mathrm{DBH} \geq 5 \mathrm{~cm}$ ), dead wood, root biomass, litter and soil (every $20 \mathrm{~cm}$ up to $1 \mathrm{~m}$ depth). An analysis of variance (ANOVA) was performed to compare Celem and $\mathrm{CO}_{2}$ accumulation in the vegetations and the diversity index of Shannon ( $\left.\mathrm{H}^{\prime}\right)$ was calculated. ANOVA indicated that Celem and $\mathrm{CO}_{2}$ in the Riparian Forest and Cerradão present a significant difference. Celem average in RF was $385.89 \pm 50.59 \mathrm{Mg} \mathrm{ha}^{-1}$, in SSF it was $350.97 \pm 27.71 \mathrm{Mg}^{-1}$ and $212.79 \pm 39.19 \mathrm{Mg} \mathrm{ha}^{-1}$ in CE. The $\mathrm{CO}_{2}$ average reached $1416.22 \pm 185.67 \mathrm{Mg} \mathrm{ha}^{-1}$ in RF, in SSF it ranked $1288.07 \pm 101.69 \mathrm{Mg}^{-1}$ and $780.95 \pm 143.82 \mathrm{Mg}^{-1}$ $\mathrm{ha}^{-1}$ in CE. In all three physiognomies the Celem and $\mathrm{CO}_{2}$ distribution in the sinks was on average $40 \%$ in trees, $52 \%$ in the soil, $5 \%$ in roots, $1 \%$ in the litter and $2 \%$ in dead wood. The species diversity was the like in the three vegetation formations: RF $\left(\mathrm{H}^{\prime}=3.42\right), \mathrm{SSF}\left(\mathrm{H}^{\prime}=3.66\right)$ and $\mathrm{CE}\left(\mathrm{H}^{\prime}=3.70\right)$. Forests can have different amounts of carbon and equal species diversity, and therefore, carbon and diversity require explicit considerations in environmental policies.

\section{Carbon storage potential of selected mangrove Forests in Padre Burgos, Quezon, Philippines}

\section{Lourdes Breva}

${ }^{1}$ Ecosystems Research and Development Bureau-Department of Environment and Natural Resources, Los Baños, Philippines (alcala_breva99@yahoo.com)

One of the most-talked about issues of global concerns today is climate change. Tropical forests play an important role in the climate change as sources and sink of carbon. Thus, mangrove forests have significant role in mitigating the climate change problem. The study aimed to measure the amount of accumulated biomass in a mangrove forest; determine the amount of carbon storage in the above-ground biomass and belowground of the area; and assess the potential contribution of mangrove forest to the mitigation of climate change. Results of the study showed that the mangrove area has a mean biomass carbon density of $189.53 \mathrm{Mg} / \mathrm{ha}$ where the entire amount is contributed only by tree biomass. Soil however, accounted to $51.92 \mathrm{Mg} / \mathrm{ha}$ of carbon density. Total carbon density of the area including aboveground (tree) biomass and belowground (soil) has amounted to $241.45 \mathrm{Mg} / \mathrm{ha}$. Highest amounted was accounted by the aboveground which is 78 percent and the remaining 22 percent was in belowground.Using the results obtained in this study, Philippine mangrove forest can store $28 \mathrm{M}$ tons of carbon. This implies that mangrove can offer a great potential carbon sink.

\section{Field-based performance of macropropagated and seedlings of Narra (Pterocarpus indicus willd.) in the experimental plantation, Digos, Davao del Sur, Philippines}

Lourdes Breva ${ }^{1}$, Ma. Lourdes Reyes ${ }^{1}$, Marilou Avanzado ${ }^{1}$

${ }^{1}$ Ecosystem Research and Development Bureau, Los Baños, Philippines (alcala_breva99@yahoo.com; ludcreyes@yahoo.com; malu_rene@yahoo.com)

In the absence of quality seeds for massive and restoration of degraded forest lands, the use of vegetative parts of plant like stem as planting material, is a feasible alternative. However, there are reports indicating the morphological differences between cuttings and seedlings, hence, gauging the extent of how such differences could affect the growth and performance in the field. This study compares the growth (height and diameter) and survival of the macropropagated and seedlings of Narra (Pterocarpus indicus Willd.) in the established field trail plantation in Davao Region of Mindanao. Three hundred seedling materials were evaluated. After 2 years, survival in the stock-type trials was $96 \%$ for rooted cuttings, and $98 \%$ for seedlings. Mean diameter and height ratios revealed that rooted cuttings are better than seedlings with $14.42 \mathrm{~mm}$ and $121.51 \mathrm{~cm} ; 13.98 \mathrm{~mm}$ and $119.81 \mathrm{~cm}$, respectively. Despite the differences of cloned and seedling results, differences in size and relative growth rates had no significant differences between treatments.

\section{Woody plant waste in a commercially managed plantation and undisturbed forest in Central Amazonia / Necromassa lenhosa em floresta sob manejo comercial e floresta não perturbada na Amazônia Central \\ Filipe Campos de Freitas ${ }^{1}$, Celso Paulo de Azevedo $o^{2,3}$, Cíntia Rodrigues de Souza ${ }^{2}$, Natalino Calegario ${ }^{4}$ \\ ${ }^{1}$ Universidade Federal de Lavras, Programa de Pós-Graduação, Lavras, Brasil; ${ }^{2}$ Embrapa Amazônia Ocidental, Manaus, Brasil; ${ }^{3}$ Universidade Estadual do Amazonas, Manaus, Brasil; ${ }^{4}$ Universidade Federal de Lavras, Lavras, Brasil (felipecamposdefreitas@hotmail.com; celso.azevedo@embrapa.br; cintia.souza@embrapa.br; calegari@dcf.ufla.br)}

O estoque de necromassa em florestas tropicais tem mostrado grande relevância à dinâmica de carbono, não quantificá-lo pode gerar uma subestimativa de até $45 \%$ do carbono disponível nesses ecossistemas. O objetivo deste estudo foi avaliar o estoque de necromassa em duas florestas na Amazônia Central, uma sob manejo florestal comercial, outra sem distúrbios antrópicos. A coleta de dados foi realizada nos municípios de Itacoatiara e Rio Preto da Eva, estado do Amazonas, Brasil. Coletou-se dados de árvores mortas em pé e troncos caídos com diâmetro mínimo de $10 \mathrm{~cm}$. Foram feitas estimativas de volume, massa e carbono para a necromassa medida em campo e a estimativa de carbono em indivíduos mortos identificados em inventário florestal contínuo. Na floresta manejada observou-se volume médio de 72,46 \pm 10,93 $\mathrm{m}^{3} \mathrm{ha}^{-1}$, massa de 66,19 \pm 9,56 $\mathrm{Mg}^{3} \mathrm{ha}^{-1}$ e 32,09 \pm 4,64 $\mathrm{Mg}^{3} \mathrm{ha}^{-1}$ de carbono. A floresta não manejada apresentou volume médio de 44,41 $\pm 16,19 \mathrm{~m}^{3}$ ha- ${ }^{-1}$, massa igual a 40,80 $\pm 11,17 \mathrm{Mg}^{3}$ ha $^{-1}$ e 20,67 $\pm 8,20 \mathrm{Mg}^{3} \mathrm{ha}^{-1}$ para o carbono. Não houve diferença estatística significativa entre as médias das duas áreas. Não foi observada diferença entre as estimativas de carbono feitas com a taxa de mortalidade e as obtidas em campo. A exploração florestal proporcionou maior estoque de necromassa. Por outro lado, a intensidade de exploração não exerceu influência significativa. Considerando apenas troncos caídos e árvores mortas em pé, a taxa de mortalidade é suficiente para gerar estimativas do estoque de necromassa. 


\section{Carbon dynamics in a seasonal semideciduous forest in Brazil / Dinâmica de carbono em floresta estacional semidecidual no Brasil}

Samuel José Silva Soares da Rocha1, Carlos Moreira Miquelino Eleto Torres ${ }^{1}$, Ivaldo da Silva Tavares Júnior', Paulo Henrique Villanova ${ }^{1}$, Bruno Leão Said Schettini ${ }^{1}$, Rodrigo Vieira Leite ${ }^{1}$

1Universidade Federal de Viçosa,Viçosa,Brasil(samueljoserocha@gmail.com; cmmet23@gmail.com; ivaldojr8@hotmail.com; villa.floresta09@gmail.com; blsschettini@gmail.com; r.vieiraleite@gmail.com)

Entender a dinâmica do estoque de carbono em florestas secundárias da Mata Atlântica fornece subsídios para projetos de gestão que visem a conservação e recuperação dos serviços ecossistêmicos nesses ambientes Desta forma, objetivou-se avaliar o estoque e a dinâmica de carbono no fuste, por 22 anos, de uma Floresta Estacional Semidecidual, em Viçosa, MG, Brasil. O estudo foi realizado em um fragmento de Mata Atlântica, com 17 ha. Os dados de 10 parcelas permanentes, com 0,1 ha (20 x 50 m) cada, foram utilizados. Nos anos de monitoramento (1994, 1997, 2000, 2004, 2008, 2010 , 2013 e 2016), todos os indivíduos com DAP (Diâmetro à Altura do Peito; à 1,3 $\mathrm{m}$ do solo) maior ou igual $5,0 \mathrm{~cm}$ foram inventariados e identificados.Para verificar diferenças estatísticas entre as estimativas dos anos aplicou-se o teste " $\mathrm{t}$ " pareado. O incremento periódico foi calculado com dos dados de crescimento, mortalidade e ingresso. Em relação ao estoque de carbono, observou-se uma tendência de acréscimo com o passar dos anos, de 50,36 Mg ha-1, em 1994, para 75,87 Mg ha-1, em 2016, um aumento de 25,51 Mg ha-1. Não foram observadas diferenças significativas pelo teste $\mathrm{t}$ "pareado" para os períodos de 2000-2004 (p-valor $=0,2155)$, 2008-2010 (p-valor = 0,8491) e 2013-2016 (p-valor = 0,4945). O incremento periódico líquido anual em carbono para a comunidade foi de1,16 $\mathrm{Mg}^{-1} \mathrm{ano}^{-1}$. O fragmento avaliado apresenta um alto potencial de estocagem de carbono e contribui efetivamente para remoção do carbono atmosférico e consequente mitigação dos impactos no clima.

\section{Carbon stocks in planted foret in Brazil / Estoque de carbono de florestas plantadas no Brasil}

Josileia Acordi Zanatta ${ }^{1}$, Marcos Fernando Gluck Rachwal ${ }^{1}$, Wilson Anderson Holler ${ }^{1}$, Bruno Bordron ${ }^{1}$, Luiz Marcelo Rossi ${ }^{1}$, Rosana Clara Victoria Higa ${ }^{1}$ ${ }^{1}$ Embrapa Florestas, Colombo,Brasil (josileia.zanatta@embrapa.br; marcos.rachwal@embrapa.br; wilson.holler@embrapa.br; bruno.bordron@gmail.com; marcelo.rossi@embrapa.br; rosana.higa@embrapa.br)

A estimativa do carbono (C) contido nas florestas plantadas é feita com base na produtividade média nacional, que não reflete as variações devido ao clima, solo e material genético. O objetivo deste estudo foi estimar o estoque de $\mathrm{C}$ das florestas plantadas no Brasil seguindo procedimentos do IPCC, e produtividades regionalizadas por tipo climático, para 2017. A produção de eucalipto foi identificada em 9 tipos climáticos, sendo as maiores áreas no Aw (31\%), Cfa (22\%), Cwa (12\%), Cfb (10\%), Am (10\%) e Cwb (7\%). O pinus está presente no clima Cfb predominantemente (81\%), enquanto acácia negra fica restrita ao Cfa. Baseado em levantamento bibliográfico foi identificado a produtividade de biomassa da parte aérea, do sistema radicular e da necromassa para cada região climática. Para o eucalipto o incremento médio anual de C (IncRef) variou de 5,9 t C /ha/ano no clima Am até 16,1 t C /ha/ano no clima Cfb. O pinus teve IncRef de 7,3 e 5,6 t C /ha/ano para os climas Cfa e Cfb, respectivamente. Na acácia negra, o IncRef foi de 6,5 t C /ha/ano. A razão parte aérea raiz foi estimada em 0,21 para pinus e eucalipto e 0,12 para acácia negra. O fator de expansão para necromassa foi de $14 \%$ para pinus e $13 \%$ para eucalipto e acácia. O estoque de C total do reflorestamento no Brasil em 2017 foi de 508 milhões de toneladas de C, dos quais eucalipto respondeu por $76 \%$, pinus por $23 \%$ e acácia negra $1 \%$.

\section{B4v: LEGACIES OF DISTURBANCES ON FOREST FUNCTIONS}

Dynamics of pioneer tree species in dense ombrophilous forests affected by fire in western Pará, in the Amazon region of Brazil / Dinâmica de espécies arbóreas pioneiras em floresta ombrófila densa atingida por fogo no oeste do estado do Pará, Amazônia, Brasil

Dárlison Fernandes Carvalho de Andrade ${ }^{1,1}$, João Ricardo Vasconcellos Gama ${ }^{1}$, Ademir Roberto Ruschel ${ }^{3}$ ${ }^{1}$ Universidade Federal do Oeste do Pará, Santarém, Brasil; ${ }^{2}$ Instituto Chico Mendes de Conservação da Biodiversidade - ICMBio Santarém Brasil; ${ }^{3}$ EmbrapaAmazonia Oriental,Belém,Brasil (darlisonicmbio@gmail.com;jrvgama@gmail.com; ademir.ruschel@embrapa.br)

Os incêndios em florestas úmidas na Amazônia têm potencial para alterar taxas de recrutamento e mortalidade de árvores, composição florística e aumentar a densidade de espécies pioneiras. Neste estudo, a dinâmica de recrutamento de espécies arbóreas pioneiras foi monitorada, por meio de dados de inventário em 12 parcelas permanentes de 0,25 hectares, ao longo de 29 anos (1983 - 2012), sendo 5 (cinco) parcelas atingidas por incêndio (T1-fogo), em 1997, e 7 (sete) parcelas controle (T0-semfogo), em área de floresta ombrófila densa, sem histórico de distúrbios antrópicos, na Floresta Nacional do Tapajós. O estudo buscou responder: qual o efeito do fogo no aumento das taxas de recrutamento de espécies pioneiras em uma floresta ombrófila densa na Amazônia Central? Para isto calculamos o tamanho da população de espécies arbóreas pioneiras em períodos anterior (1983-1995) e posterior ao fogo (1995-2012), analisamos as mudanças nas taxas de recrutamento ao longo do tempo e avaliamos quais espécies se beneficiaram com o ambiente pós-fogo. Antes do fogo, as taxas de recrutamento para as pioneiras variaram entre 0,31 árvores ha ${ }^{-1}$ ano $^{-1}$ (1987-1989) a 0,94 árvores ha-1 ano ${ }^{-1}$ (1983-1987) e, após o fogo aumentou para 6,05 árvores ha ano $^{-1}$ (1995-2008) e 5,11 árvores ha ${ }^{-1}$ ano $^{-1}$ (2008 e 2012). Em T0-fogo, a maior taxa de recrutamento registrada para as pioneiras foi de 1,33 árvores ha-1 ano ${ }^{-1}$ (1987 e 1989). As condições pós-fogo da floresta foram favoráveis ao aumento das taxas de recrutamento de espécies pioneiras, principalmente Cecropia sciadophylla e Aparasthmium cordatum que se destacaram no ambiente pós-fogo.

\section{Changed land-use and increased deer browsing reduce the oak regeneration niche at a landscape-scale}

Linda Petersson ${ }^{1}$, Per Milberg ${ }^{2}$, Johan Bergstedt ${ }^{2}$, Jonas Dahlgren ${ }^{3}$, Annika Felton ${ }^{1}$, Frank Götmark $^{4}$, Carl Salk ${ }^{1}$, Magnus Löf $^{1}$ ${ }^{1}$ Swedish University of Agricultural Sciences, Alnarp, Sweden; ${ }^{2}$ Linköping University, Linköping, Sweden; ${ }^{3}$ Swedish University of Agricultural Sciences, Umeå, Sweden; ${ }^{4}$ University of Gothenburg, Gothenburg,Sweden (linda.petersson@slu.se; per.milberg@liu.se; johan.bergstedt@gmail.com; jonas.dahlgren@slu.se; annika.felton@slu.se; frank.gotmark@bioenv.gu.se; carlsalk@gmail.com; magnus.lof@slu.se)

Rapidly changing land-use and disturbance regimes may reduce tree regeneration niches and thereby affect the forest ecosystem services. However, it is difficult to disentangle complex effects influencing regeneration processes on long-lived tree species at large scales. We use Swedish National Forest Inventory data (1953-2015) combined with ungulate hunting data (1960-2015) to reveal experimentally-intractable processes impeding oak (Quercus spp.) regeneration in southern Sweden. Oak-dominated ecosystems are widespread in northern temperate regions, where they provide multiple ecosystem services and harbor biodiversity. Our study reveals that during the six decades, oak tree numbers increased continuously, while natural oak regeneration declined steeply after the early 1980s. We connect this decline to denser and darker forests, combined with an overabundance of deer. Land-use changes during the six decades (e.g. abandonment of forest grazing and large-scale introduction of forest management oriented towards high volume production) led to continuously denser forests and thereby reduced the oak regeneration niche. Moreover, the negative effect of changed game management was evident. This was particularly clear from a 
natural experiment on Gotland, a large island that lacked wild ungulates until roe deer were introduced in the late $20^{\text {th }}$ century, resulting in a steep decline of oak regeneration on the island. Active management that resemble previous disturbance regimes and restore forest habitats with more light and less browsing pressure therefore seem essential. The latter includes developing strategies that manage both ungulate populations and their available food across landscapes.

\section{Mapping burned forest recovery using time-series satellite images}

Xianlin Qin ${ }^{1,2}$, Xiaotong Li ${ }^{1}$, Qian Liu ${ }^{1}$, Guifen Sun ${ }^{1}$, Shuchao Liu ${ }^{1}$

${ }^{1}$ Institute of Forest Resources Information Technique, Chinese Academy of Forestry, Beijing, China; ${ }^{2}$ Forestry Remote Sensing and Information Technology Laboratory of State ForestryAdministration, Beijing, China (noaags@ifrit.ac.cn; girl19950388@qq.com;olivia250864095@163.com; sunguifen12@163.com;83453418@qq.com)

To satisfy the monitoring technology needs for the long-term effect on forest growth and restoration by forest fires, the burned forest area formed in May 6,1987 in the Great Xing'an Mountain of China has been selected as the experimental area. Based on the selected time-series of Landsat TM/ETM+ images, the stand regrowth index (SRI) and the relative regrowth index (RRI) have been used to study annual changes of vegetation regeneration in different disturbance intensity during 30 years after the fire. The SRI showed that the vegetation could recover to the pre-fire vegetation state in the third year after the fire for the light burned area, 6 years for the moderate burned area, and 14 years for the severe fire area. However, according to the RRI, it took 8 years to restore to the same state as the post-fire normal vegetation for the light burned area, 13 years for the moderate burned area, and 14 years for the severe fire area.

\section{Ecological modelling of hawk moths (Insecta: Lepidoptera) of kerala part of Western ghats using climatic variables}

Sheik Mohammed Shamsudeen ${ }^{1}$,Wah Wah Linn ${ }^{2}$

${ }^{1}$ Sir Syed College, Kannur University, Taliparamba, Kannur-670142, Kannur, India; ${ }^{2}$ Forest Protection Sub Section, Forest Reserach Institute, Yezin, Nay Pyi Taw, Myanmar(rsmshamsudeen@gmail.com; wahwahlinn48@gmail.com)

Like butterflies being so diverse and ecologically important, Hawk Moths are affected by disturbances to their habitat and climatic change. The moths which are being conspicuous insects like butterflies and dragonflies are therefore particularly valuable in monitoring ecological changes and serve to warn us of today's deteriorating environment. They have a significant and beneficial role as the pollinators. Distribution range and status of Sphingidae are often a prerequisite information for developing appropriate conservation strategies. However, most often several surveys failed to collect such data largely because of time, financial, labour and in accessible terrain conditions. Considering these facts, we predicted the geographic distribution of Ecologically important Hawk Moths Kerala part of Western Ghats using ecological niche modelling paradigm (Maxent algorithm) with a set of eco-geographical variables (Bioclimatic and topographic variables). The geo-coordinates of occurrence localities of the Sphingidae were recorded during the long term study on Lepidoptera in the Southern Western Ghats. The result revealed that high probability sites were found in the low and mid elevation forests of Kerala. Among the eco-geographical variables, MODIS Tree cover had the highest gain when used in isolation, which therefore appears to have the most useful information by itself. The environmental variable that decreases the gain the most, when it is omitted, is altitude, which therefore appears to have the most information that isn't present in the other variables. Hence, conservation of low and mid elevations forest patches is required for the long term conservation of Hawk Moths in Kerala part of Western Ghats.

\section{Recover of boreal forest functions after fire and clear-cutting}

Frank Berninger ${ }^{1}$, Narasinha Shurpali ${ }^{2}$, Ville Kasurien ${ }^{2}$, Marjo Palviainen $^{3}$, Kajar Köster $^{3}$, Xuan Zhou $^{3}$, Heidi Aaltonen $^{3}$, Anatoly Prokushkin $^{4}$, Jukka Pumpanen ${ }^{2}$

${ }^{1}$ University of Eastern Finland, Joensuu, Finland; ${ }^{2}$ University of Eastern Finland, Kuopio, Finland; ${ }^{3}$ University of Helsinki, Helsinki, Finland; ${ }^{4}$ Sukachev Forest Institute, Krasnoyarsk, Russian Federation (frank.berninger@uef.fi;narasinha.shurpali@uef.fi; ville.kasurinen@helsinki.fi; marjo.palviainen@helsinki.fi; kajar.köster@helsinki.fi; xuan.zhou@helsinki.fi; heidi.m.aaltonen@helsinki.fi;prokushkin@ksc.krasn.ru; jukka.pumpanen@uef.fi)

Fire has been the dominant disturbance in boreal forests. However, larger and larger boreal areas are regenerated by clearcutting. Clearcutting and fire differ since fire removes a large part of the organic layer and the ground vegetation. However, clearcutting removes tree stems and often also tree foliage. Here we use various published data sources to compare carbon and nitrogen balances of boreal forests over several decades after disturbance. The results indicate that carbon stocks of southern more productive ecosystems recover more rapidly from disturbances and that the carbon stocks of older stands in these are higher than in northern less productive forests. Stands, after a stand-replacing fire, recover less rapidly than stands after clearcutting. Fire, also, leads to a substantial reduction of nitrogen stocks which has to be replaced gradually over time. It was not easy to estimate the recovery of soil carbon stocks after the disturbance since there was quite a lot of scatter in the data. Besides, we analysed patterns in vascular diversity as well as wood volume for fire chronosequences only. Diversity was highest in middle-aged stands. Wood volume started to decrease in northernmost stands due to paludification.

Influences of agricultural and forestry land uses on the microclimate of natural forests / Influencia de los usos del suelo pecuarios y forestales sobre el microclima de bosques naturales

Maria Constanza Meza Elizalde ${ }^{1,2}$, Dolors Armenteras Pascual ${ }^{3}$

${ }^{1}$ Maestría en Manejo, Uso y Conservación del Bosque. Universidad Distrital Francisco José de Caldas., Bogotá, Colombia; ${ }^{2}$ Grupo de Investigación en Ecologia del Paisaje y Modelación de Ecosistemas. Universidad Nacional de Colombia. Bogotá Colombia; ${ }^{3}$ Universidad Nacional de Colombia, Bogotá, Colombia(mmezae@unal.edu.co; darmenterasp@unal.edu.co)

Los bordes generan cambios en la humedad de los bosques que influyen en las respuestas de las especies. Para evaluar esta influencia en fragmentos amazónicos colombianos, se cuantificó el alcance y magnitud de la pérdida de humedad desde bordes de pastos y plantaciones de caucho hacia el interior del bosque, a partir de análisis multitemporales y multiescalares de los cambios en la estructura del paisaje, variables climáticas, la vegetación y la desecación del dosel en el periodo 1989-2016. Se emplearon imágenes satelitales, transectos de vegetación y sensores de temperatura y humedad atmosférica. Se evidenció una expansión de las áreas de pastos y una reducción del 56,34\% de las áreas de bosque, los índices NDMI y SIWSI reflejan pérdidas de humedad y aumento del estrés hídrico de la vegetación que se extienden hacia el interior de los relictos boscosos. La respuesta de la humedad difiere según la cobertura adyacente, las plantaciones de caucho proporcionan un buffer que mantiene la humedad del bosque, mientras que hay una pérdida significativa de la humedad cuando los bosques limitan con pastos, en las zonas de mayor estrés hídrico hay menor diversidad y dominan especies forestales características de ambientes perturbados. Los resultados encontrados señalan que para aumentar la tolerancia a la sequía de los bosques se deben considerar los contrastes entre la matriz y los relictos, y definir estrategias orientadas a la reducción de bordes abruptos y el impulso de usos de la tierra que proporcionen condiciones para la protección del microclima de los bosques. 
Academic contribution to formulating policies on the topic of forest fires and forest governance / Aporte de la academia a la formulación de politicas en torno al tema de incendios forestales y gobernanza forestal

Maria Constanza Meza Elizalde ${ }^{1}$, Tania Marisol Gonzalez ${ }^{1}$, Dolors Armenteras Pascual ${ }^{1}$

${ }^{1}$ Grupo de Investigación en Ecología del Paisaje y Modelación de Ecosistemas, Universidad Nacional de Colombia, Bogotá, Colombia

(mmezae@unal.edu.co; tmgonzalezd@unal.edu.co; darmenterasp@unal.edu.co)

Los incendios de la vegetación han sido un proceso ecológico natural presente en los trópicos, influyendo en la estructura del paisaje, en la composición de especies y en la diversidad biológica. Sin embargo, también han estado presentes como una perturbación antropogénica en prácticas de gestión del suelo y son un motor de degradación de los bosques. Considerando la dinámica de los incendios forestales en Colombia y los efectos negativos que tienen sobre los bosques, se propone cerrar las brechas entre la ciencia y la política, respaldando con las investigaciones realizadas la formulación de legislación que atienda la problemática de Incendios Forestales y Degradación de Bosques por esta causa. Se recopiló la investigación científica de más de 10 años en incendios forestales, se realizó la revisión documental de la propuesta normativa para identificar los vacíos en torno al tema en la legislación nacional, se realizaron talleres con diferentes actores (parques nacionales, entes territoriales, autoridades ambientales, empresas forestales, acueductos comunitarios, tomadores de decisiones y comunidades) para identificar su percepción sobre el tema, se crearon espacios de coordinación para aunar esfuerzos y visibilizar el tema en lo instrumentos de planificación territorial, y se diseñaron estrategias de comunicación incluyentes. Con la información cuantitativa y cualitativa recopilada, se ha respaldado la formulación de política pública de forma conjunta con el Congreso de la República, se han establecido acuerdos de voluntades entre diferentes actores y se ha aterrizado el tema a instrumentos de planeación como los Planes de Ordenación de Cuencas Hidrográficas.

Carbon capture in Andean forests within private nature reserves in Zapatoca (Santander, Colombia) / Captura de carbono en bosques andinos de dos reservas naturales de la sociedad civil en Zapatoca (Santander, Colombia)

Carolina Serna ${ }^{1}$, Jaime Polanía

${ }^{1}$ Universidad Nacional de Colombia sede Medellín, Medellín, Colombia (csernac@unal.edu.co; jhpolaniav@unal.edu.co)

El carbono capturado por un bosque es crucial para estimar sus servicios ecosistémicos. Este estudio estimó la biomasa aérea y el carbono almacenado en dos reservas naturales de la sociedad civil (en adelante RNSC), en Zapatoca (Santander, Colombia). Una de ellas (RNSC-PF) fue creada hace aproximadamente 10 años, y otra (RNSC-MM) hace cinco y comparten zona de vida bh-PM. En los predios de las RNSC se desarrollaron previamente tala indiscriminada y ganadería extensiva, pero aún conservan relictos de Quercus humboldtii ('roble'), amenazados. También cuentan con otras formas de sucesión vegetal y especies emblemáticas (e.g. Ceroxylon quindiuense y Tremarctos ornatus). El protocolo IDEAM permitió estimar C capturado y biomasa a partir del diámetro de individuos DAP $\geq 10 \mathrm{~cm}$ en 58 parcelas permanentes de $400 \mathrm{~m}^{2}$, así como en subparcelas de $25 \mathrm{~m}^{2}$ (allí se midieron los individuos $5 \leq \mathrm{DAP}<10$ $\mathrm{cm})$. Hubo diferencias entre parcelas más conservadas y aquellas en recuperación. RNSC-PF presentó mayor acumulación de C (64,67 mg/ha en promedio, versus RNSC-MM: 44,64 mg/ha); así como máximos y mínimos (v.gr. bosque denso: 224,70 mg/ha y vegetación secundaria: 0,92 mg/ha). Comparativamente, bosques secundarios de otras cordilleras andinas colombianas capturaron en promedio 20,9 mg/ha (en Antioquia), y bosques de 'roble' 197,8 mg/ha (en Huila), equivalente al bosque denso de Zapatoca. El C fijado por ecosistemas forestales puede mitigar efectos del cambio climático y, por lo tanto, confirma la importancia de formas alternativas de áreas protegidas.

\section{B4w: LEGACIES OF DISTURBANCES ON FOREST FUNCTIONS}

\section{Complex disturbance histories in seasonal tropical forests from western Thailand: evidence and implications}

Patrick Baker ${ }^{1}$, Sarayudh Bunyavejchewin ${ }^{2,3}$

${ }^{1}$ University of Melbourne, Richmond, Australia; ${ }^{2}$ Department of Forest Biology, Faculty of Forestry, Kasetsart University, Bangkok, Thailand; ${ }^{3}$ Department of National Parks, Wildlife, and Plant Conservation,_Bangkok,Thailand (patrick.baker@unimelb.edu.au; sarayudh_b@yahoo.com)

The legacy of disturbance on tropical forest functioning is poorly understood due to the lack of annual growth rings in most tropical tree species. Recent advances in tree-ring research in seasonal tropical forests have begun to address this issue. Here we describe the historical legacy of disturbance in an area of Thailand's Western Forest Complex based on dendrochronology and long-term, large-scale forest dynamics plots. Over the past 200 years these forests have been impacted by disturbances that vary in intensity, spatial scale, and return interval. We found that evergreen and deciduous forest types within the broader landscape mosaic had all experienced complex disturbance histories, with landscape-scale disturbances impacting all forests and forest types at the decadal to centennial scale, and more stochastic, small-scale disturbances impacting different forest types at the annual to decadal scale. Extreme climate events, particularly ENSO-driven droughts, appear to drive landscape-scale fires, which generate a synchronous pulse of treefall gaps across hundreds of square kilometres. Interactions between regional climate variability, disturbances, and reproductive phenology may lead to a wide range of potential stand development trajectories in these forested landscapes complicating strategies for restoration and management.

\section{Increasing end-user participation in the management of forest risk through integrated open-access tools}

Barry Gardiner ${ }^{1}$, Christophe Orazio ${ }^{1}$, Sarah Yoga ${ }^{1}$, Tommaso Locatelli ${ }^{2}$, Duncan Heathfield ${ }^{3}$

${ }^{1}$ EFI Planted Forests Facility, Cestas, France; ${ }^{2}$ Forest Research, Roslin, United Kingdom; ${ }^{3}$ World in a Box Finland OY, Karkkila, Finland

(barry.gardiner@efi.int; christophe.orazio@efi.int; sarah.yoga@efi.int; tom.locatelli@forestry.gsi.gov.uk; duncan.heathfield@worldinabox.eu)

In order to develop resilient forests it is necessary to understand the factors affecting the level of risk from different hazards. In add ition it is critical to know how these risks change with management choices and with the changing climate in order to develop adaptive management strategies. In this paper we discuss the creation of an open-access system for calculating the risk of wind damage to forests. The system combines the predictions of the Forest GALES wind risk model and the industry standard airflow model WAsP within the open-access QGIS software. The combined system allows calculation of wind risk within a forested landscape and the impacts of tree growth and forest management choices. Because the models are incorporated within GIS software the models can be integrated with standard forest management plans and environmental data sets, such as LiDAR measurements of tree and terrain heights, in order to calculate the level of risk at all scales from individual trees to the landscape. To make the system useful and applicable within the forestry sector a series of workshops has been organised in south-west France, the Spanish Basque country and Scotland to train foresters and forest owners in the software and to receive feedback on how it can be improved. In addition, there has been close liaison with the regional authorities in these regions in the incorporation of the software in the forest risk management process as part of regional crisis management plans. 


\section{The assessment of forest disturbance and vulnerability from 2000-2015 year in Kao Ping River Basin of Taiwan}

Ya-Li Huang ${ }^{1}$, Chaur-Tzuhn Chen ${ }^{1}$, Jan-Chang Chen ${ }^{1}$

${ }^{1}$ Forestry department, National Pingtung University of Science and Technology, Pingtung, Taiwan (goodrinoa93@gmail.com; goodrinoa93@gmail.com; goodrinoa93@gmail.com)

Taiwan is located on the Pacific seismic belt where the geological structure is more complex, and cause frequent landslides, debris flows and other sediment disasters. Chishan and Lennon river working circle lays in the national forest land of Kaoping river basin, and was greatly damaged by 2009 Morakot typhoon, thus, the understanding of land cover change before and after typhoon were important tasks in watershed management. In this study, the variation of forest disturbance index (DI) from 2000-2015 was obtained through Tasseled Cap Transformation. Moreover, estimating the distribution of environmental vulnerability through Principal Components Analysis, reduces the number of environmental variables and determines the weight of principal components. The results shows that Landslides has indeed disturbed Chishan and Lennon river working circle. The Integrated of Disturbance Index (IDI) of Chishan were 2.128, 2.751 and 2.670, respectively, which represents that some areas were damaged by Morakot typhoon were partially recovered after 2015. There were no significant change in the annual IDI of Lennon river working circle; however, differences between each DI level of sample plot was found. The environment vulnerability in Chishan and Lennon River were classified as heavy and extreme level of environmental vulnerability accounts for $38 \%$ and $31 \%$ of the area, mostly are located in relatively high altitude and steep terrain, where vegetation renewal and restoration is unlikely to happen. Facing extreme climate challenges, the forest watershed management must be based on the principle of ecological management and forest structure, in order to maintain the balance of the ecosystem.

\section{The Weakest Link: assessing vulnerabilities, risks, and tree adaptive capacity of temperate forests to global changes}

Rita Sousa-Silva ${ }^{1}$, Frédérik Doyon ${ }^{2}$, Philippe Nolet ${ }^{2}$

${ }^{1}$ UQAM, Montreal, Canada; ${ }^{2}$ ISFORT, Ripon,Canada (anarita.silva@kuleuven.be; frederik.doyon@uqo.ca; philippe.nolet@uqo.ca)

Forests are shaped by disturbances - for better or worse. Disturbances can be analysed individually, but it is their interactions that are likely to lead to megadisturbances regimes - such as hotter droughts and more extensive and severe wildfires - challenging the main objectives of forest management, which are to provide ecosystem services sustainably to society and to restore or maintain its resilience. Applying resilience concepts in forest management is especially relevant in a context of climate variability because the stochastic nature of disturbances often makes them difficult to predict. The resistance of a forest to disturbance depends largely on the species composition of the canopy trees that currently dominate the forest; yet its adaptive capacity may reside primarily in future canopy replacement by trees of the same or other species. Therefore, we focused on (i) the effect of disturbances on a subset of biological characteristics (e.g., dispersal, shade tolerance) of 30 tree species of temperate forests; and (ii) their tolerance to a wide range of disturbances (e.g., drought, insects) for both the overstory and regeneration strata. While recognizing that ecosystem collapse will likely manifest itself differently depending on landscape context, we provide a systematic approach that can be applied to any forest to evaluate the risk of collapsing, as a result of loss of ecosystem resistance and resilience. We argue that, given the complexities and uncertainties related to increasingly frequent and severe disturbances, management should aim at increasing diversity thus keeping more options open for the future if conditions or responses change.

\section{Changes in land use and ground coverage from 1985 to 2017 in the production of sediments in the Taquari River Basin / Variação das} mudanças no uso e cobertura da terra entre 1985 e 2017 na produção de sedimentos da Bacia do Rio Taquari

Rafael Mingoti ${ }^{1}$, Isabelle Caroline Ribeiro Sais ${ }^{2}$, Carlos Roberto Padovani ${ }^{3}$, Marcia Divina Oliveira ${ }^{3}$, Debora Fernandes Calheiros ${ }^{3}$ ${ }^{1}$ Embrapa Territorial, Campinas, Brasil; ; ${ }^{2}$ Universidade Estadual de Campinas, Campinas, SP, Brasil; ${ }^{3}$ Embrapa Pantanal, Corumbá, Brasil (rafael.mingoti@embrapa.br; isabellersais@gmail.com; carlos.padovani@embrapa.br;marcia.divina@embrapa.br;debora.calheiros@embrapa.br)

O objetivo desse trabalho é comparar o efeito da alteração do uso e cobertura da terra, entre os anos de 1985 e 2017, na produção de sedimentos da sub-bacia do Rio Taquari. Essa bacia possui área de drenagem de 26.924 km² e está localizada na Bacia do Alto Paraguai, na região do Planalto do Pantanal brasileiro. Foram utilizados mapeamentos de uso e cobertura da terra, elaborados com imagens do satélite Landsat, por meio dos quais verificou-se a supressão de $48,4 \%$ na vegetação nativa no período analisado, sendo substituída predominantemente por pastagem. Em 1985 a cobertura vegetal nativa ocupava 18.000 km² da área da sub-bacia e em 2017 passou a ocupar $9.280 \mathrm{~km}^{2}$. A estimativa da produção de sedimentos foi realizada por meio do modelo hidrológico SWAT, aplicativo ArcGIS, mapa pedológico, dados de atributos de solos e de uso da terra e dados meteorológicos diários. Verificou-se que as alterações de uso e cobertura da terra promoveram aumento médio de 30,5\% na produção de sedimentos, sendo que em algumas microbacias o aumento na produção de sedimentos foi de $157 \%$. As regiões em que a mudança no uso e ocupação acarretou maior aumento na produção de sedimentos estão localizadas nos municípios de Alcinópolis/MS, Camapuã/MS, São Gabriel do Oeste/MS, Figueirão/MS, Coxim/MS e Alto Araguaia/MS. Os resultados gerados poderão subsidiar os diferentes órgãos públicos na tomada de decisão para o planejamento de ações prioritárias de conservação do solo.

\section{Economic value of ecosystem service losses due to disturbances in Western United States forests}

Jose J. Sanchez ${ }^{1}$, Lorie Srivastava ${ }^{2}$, Raymundo Marcos-Martinez ${ }^{3}$

${ }^{1}$ USDA Forest Service, Pacific Southwest Research Station, Riverside, USA; ${ }^{2}$ University of California, Davis, Davis, USA; ${ }^{3}$ National Research Collections AustraliaCanberra,Australia (jsanchez@fs.fed.us; lsrivastava@ucdavis.edu; raymundo.marcosmartinez@csiro.au)

The increasing severity and frequency of environmental climate-driven forest disturbances challenge the sustainable management and protection of forests in the United States (U.S.), and the benefits they provide to individuals and communities. Between 1985 and 2015, about 9 million acres of U.S. forest land was disturbed annually across the country. In the western U.S., wildfires, droughts, timber harvesting, and bark beetle outbreaks are the main drivers of tree mortality, loss of recreation opportunities, and water quantity. An understanding of the environmental and socioeconomic consequences of forest disturbances could improve the management and protection of public lands. This study provides monetised estimates of forest disturbances for two key areas of value: recreation and carbon storage. We estimate the monetary value of these ecosystem services and how they are affected by fire, drought or disease due to climate change. We employ benefit function transfer to estimate the economic value of forest ecosystem services - both market and non-market values. This information may improve stakeholders' understanding of how heterogeneous forests disturbances affect economic and environmental processes at different temporal and spatial scales. The results could also inform the design of spatially targeted forest conservation, pest control, or fire suppression strategies to generate greater benefits to society. 


\section{Prioritization of forest patches for conservation through geotechnologies}

Ana Paola Di Toro ${ }^{1}$, Roberta Valente ${ }^{1}$, Eliana Cardoso-Leite ${ }^{1}$

${ }^{1}$ Universidade Federal de São Carlos, Sorocaba,Brasil (anapaolagomes@hotmail.com; roavalen@ufscar.br; cardosoleite@yahoo.com.br)

Forest patches in rural and urban landscapes have been the main responsible for their biodiversity maintenance. Despite of that, they are suffering constant both cropland and urbanization pressure. So, aiming at the forest conservation, strategies of environmental planning are needed, which should be supported by the knowledge of forest patches dynamic. In this context, the we aimed to show the Patches Prioritization Index (IPP) application for biodiversity conservation planning, at the municipality of Boituva - São Paulo, Brazil. Firstly, we identified the forest remnants (bigger than 5 ha), that represents either Atlantic forest and Cerrado type, basing in the remote sensing image ( $5 \mathrm{~m}$ resolution) and, using a supervised classification (MaxLike algorithm). The Normalized Difference Vegetation Index (NDVI) was calculated to separate the forest types. Basing in the Atlantic forest patches map, we calculated the IPP value, that is composed by the metrics "AREA", "SHAPE" and "CONNECTIVITY", including weights, which reflect their importance to forest conservation.It were mapped 155 fragments of native vegetation, occupying $9.62 \%$ of the area of the municipality. All of themwere classified into three priority classes (high - 9,03\%, medium - 82,6\% and low - 8,38\%) for biodiversity conservation. We concluded that IPP is accurate to determine priority forest remnants for biodiversity conservation, due to the techniques and metrics used, which were precise to support environmental planning with focus on biodiversity conservation, and these data can be used by decision markers in landscape management.

\section{B4X: NOVEL REMOTE SENSING APPROACHES TO QUANTIFY CARBON STOCKS,} STRUCTURE AND FUNCTIONAL DIVERSITY OF FORESTS - 1

\section{Evaluation of persian oak forests die-back using Spot 6}

Mohammadreza Negahdarsaber ${ }^{1}$, Mehrdad Zarafshar ${ }^{1}$

${ }^{1}$ Agricultural Research,Education and Extension Organization (AREEO) Research institute of forest and range land - Forest Department, Shiraz, Iran, Islamic Republic of (sabersiamak@gmail.com; mehrdadzarafshar@gmail.com)

Iranian oak has been affected by oak canopy level dieback in recent years. This phenomenon has led to damage a vast part of the oak forests in the Zagros arena. As to the suitable temporal and special resolution of the recent satellite images, it seems promising to detect the forest dieback by remote sensing. The spatial capabilities of Spot 6 images with pan and spectral resolution of 1.5 and $5 \mathrm{~m}$, respectively in detecting the drying of oak trees was investigated. The forest area was located on Kuhmareh district of Shiraz in Fars province. The results showed that by using standard deviation values, the NDVI value of each tree base can be estimated for the stocks with more than $30 \%$ of dieback using the obtained equation as $y=19.96(x-0.04)-0.21$ with an $R^{2}=79$. Monitoring forest areas to understand the decline or recovery of trees will be of great help to the forest management community. Therefore, using the results of this study can be a proof to compare the current situation with future periods.

\section{Mapping of potential carbon storage in kalimantan (Indonesia) forests, using the high carbon stock approach (HCSA) criteria by airborne LiDAR}

Olivier Matte ${ }^{1}$

${ }^{1}$ Université Laval, Québec, Canada (olivier.matte.5@ulaval.ca)

Forests in Southeast Asia are under heavy pressure from extensive land-use activities, including oil palm plantations. The desire to protect and manage habitats with high carbon storage potential has increased the need for preserving the unique ecosystems of local forests. To preserve tropical forest ecosystems from agricultural expansion, a methodology for classifying forests with high carbon storage potential, known as the High Carbon Stock Approach (HCSA) was developed. Our research objective is to evaluate the efficiency of using airborne LiDAR for HCSA classification. To do this, we will examine the above-ground biomass using the equation developed by Asner (2018) and Jucker (2017), established in the Sabah territory, as well as LiDAR metrics such as canopy height, canopy cover, and the forest basal area. LiDAR metrics of forest structure will also be used to try to differentiate HCS classes. LiDAR data and field surveys were collected from the Jet Propulsion Laboratory (JPL - NASA). The area of interest for this study covers part of the Kalimantan territory (Indonesian part of Borneo). The data collected has been part of the ongoing Carbon Monitoring System (CMS) project. The results will develop a forest classification methodology based on the airborne LiDAR HCS approach within Southeast Asian forests.

Testing four models to estimate eucalyptus volumes using airborne LIDAR / Teste de quatro modelos para estimativa de volume de eucalipto utilizando LiDAR aerotransportado

Rodrigo Leite ${ }^{1}$, Cibele Amaral ${ }^{1}$, Hélio Leite ${ }^{1}$, Renata Macedo ${ }^{1}$, Brener Oliveira1, Lucas Arthur de Almeida Telles ${ }^{1}$, Antonilmar Silva ${ }^{2}$

${ }^{1}$ Universidade Federal de Viçosa, Viçosa, Brasil; ${ }^{2}$ Cenibra - Celulose Nipo-brasileira S.A, Belo Oriente, Brasil (r.vieiraleite@gmail.com; cibeleha@gmail.com; hgleite@gmail.com; renata.macedoufv@gmail.com; b.oliveiraef@gmail.com; lucasarthur36@gmail.com; antonilmarsilva@cenibra.com.br)

Sensores LiDAR aerotransportados podem ser utilizados para estimativas de densidade, altura, biomassa e volume de florestas, com exatidão similar a métodos convencionais com a vantagem de possibilitar a espacialização dos dados. Uma das abordagens mais comuns para se obter essas estimativas é a partir da relação entre as métricas LiDAR (estatísticas referentes às nuvens de pontos) e a variável dendrométrica de interesse. Esse estudo teve por objetivo estimar o volume de um plantio de eucalipto a partir de métricas geradas de dados LiDAR. Para isso, utilizou-se dados de 17 talhões de eucalipto somando aproximadamente 470 ha. Para cada talhão foram calculados: volume, através de dados de inventário, e 93 métricas, utilizando uma nuvem de pontos gerada a partir de LiDAR aerotransportado. O número de métricas a serem utilizadas nos modelos foi reduzido a cinco, utilizando o método Recursive Feature Elimination. Quatro modelos foram testados: Random Forest (RF), Máquina de Suporte de Vetor (MSV), Cubist e Linear. Utilizouse como variável de entrada as métricas e volume como variável de saída. Os dados foram separados em $70 \%$ para ajuste e $30 \%$ para validação dos modelos e foram avaliados utilizando as estatísticas R² e RMSE. Os valores de $\mathrm{R}^{2}$ e RMSE dos modelos variaram entre 0,82 a 0,97 e 21,2 a 69,75 m³/ha, respectivamente. Os resultados mostram um bom desempenho dos algoritmos testados para estimativa de volume, utilizando cinco métricas LiDAR. Futuros estudos podem ser feitos variando-se o número de métricas para verificar o desempenho dos modelos. 


\section{Use of low-density LiDAR to characterize structural attributes of restored areas in the Atlantic Forest}

Frederico Tomas de Souza e Miranda ${ }^{1}$, Girlei Costa Cunha ${ }^{1}$, Susane Rasera ${ }^{2}$,Eduardo Gusson ${ }^{1}$, Flávio Bertin Gandara Mendes ${ }^{2}$, Raquel Aparecida Passaretti ${ }^{3}$ ${ }^{1}$ Biodendro Forest Consulting, Piracicaba, Brasil; ${ }^{2}$ Luiz de Queiroz College of Agriculture, Piracicaba, Brasil; ${ }^{3}$ AES Tietê, Bauru, Brasil (fredtsmiranda@gmail.com;girlei.cunha@gmail.com; susanerasera@yahoo.com;eduardogusson@gmail.com;fgandara@usp.br;raquel.passaretti@aes.com)

Restored areas monitoring is a current subject of study due to the growing demand for large scale degraded ecosystems restoration. Remote sensing has been used for evaluating restored areas, and among new geotechnologies, the Light Detection and Ranging (LiDAR) has a wide advantage by enabling a three-dimensional analysis of forest structure. However, the high cost of scanning, mainly when there are high densities of points per square meter, limits a more detailed study of plant structure. Through the metrics extracted from the low-density points LiDAR $\left(3 \mathrm{pts} / \mathrm{m}^{2}\right)$, our first aim was to estimate the biomass ( $\mathrm{t} / \mathrm{ha}$ ) of an experimental restored area at 10 years, with different spatial arrangements $(3 \times 1 \mathrm{~m}$ and $3 \times 2 \mathrm{~m})$, managements (usual and maximum) and species proportions of pioneers and non-pioneers. We also aimed to try to discriminate the plots with different spatial arrangements and proportions of ecological groups using the metrics extracted from the LiDAR. The results showed that the number of returns up to the average height, the percentiles of return between $25 \%$ and $99 \%$, and the canopy relief ratio, obtained larger correlations with the biomass per plot, all with $\mathrm{R}^{2}$ above 0.75 , especially the average height $\left(\mathrm{R}^{2}=0.81 ; \mathrm{p}\right.$-value $\left.<0.001\right)$. We were able to discriminate the plots with the $3 \times 1 \mathrm{~m}$ arrangement from the $3 \times 2 \mathrm{~m}$ using the return percentiles between $20 \%$ and $35 \%$. The $3 \times 2 \mathrm{~m}$ plots had more returns in the lower parts of the vertical stratum and smaller biomass. In conclusion, low-density points clouds were able to characterize important restored areas vegetation attributes.

\section{Resilient future forests development platform}

Palle Madsen ${ }^{1}$, John Stanturf ${ }^{2}$, Ahto Kangur ${ }^{2}$, Marek Metslai ${ }^{2}$

${ }^{1}$ InNovaSilva,Vejle, Denmark; ${ }^{2}$ Estonian Univ. of Life Sciences, Tartu,Estonia (pallemadsen47@gmail.com; drdirt48@gmail.com; ahto.kangur@emu.ee; marek.metslaid@emu.ee)

Forest growth isthe main driver of climate change mitigation; additional mitigation will be proportional to the area managed and restored into highlyproductive forests. The Sustainable Intensification Principle has become an important driver of climate change mitigation. The intensively managed and highly-productive planted forests component of the global forest resource and as part of FLR efforts can contribute to the implementation of this principle, which may be applied to other land-uses as well, including agriculture, agroforestry, horticulture and nature conservation. Such mosaic forests can serve a range of important functions and ecosystem services in addition to carbon sequestration. To validate this approach, field experiments and modeling are needed to provide evidence for managers and decision makers. Field experiments generate experimental data to develop, document, demonstrate and support implementation of new or alternative cost-efficient silvicultural and restoration methods that result in high CC-mitigation capacity of the forests. Installation and management of long-term field experiments, however, is constantly under pressure because they are seen as expensive science infrastructure to establish and maintain. Nevertheless, new and rapidly developing technology based on remote sensing and terrestrial LiDAR offer lower cost measurement and inventory methods that may pave the road for a new generation of field experiments. We explore the content and structure of a global scientific platform for shared data to provide site-adapted and goal-oriented solutions for adaptive silvicultural practices for sustainable forest management and restoration and globally.

Use of LANDSAT 8 satellite imagery to apply vegetation indexes in characterizing vegetation cover in the Raimundo Irineu Serra environmental preservation area, 2013-2018 / Utilização de imagens do Satélite LANDSAT 8 para aplicação dos índices de vegetação na caracterização da cobertura vegetal da APA Raimundo Irineu Serra no período de 2013 à 2018

Julio Roberto da Rocha Almeida ${ }^{1}$, Karla da Silva Rocha

${ }^{1}$ Universidade Federal do Acre, Rio Branco,Brasil (julio.151094@gmail.com; rocha.karla3@gmail.com)

A demanda por estudos e metodologias que quantifiquem o estoque de $\mathrm{CO}_{2}$ em ambientes florestais vem crescendo exponencialmente nas últimas décadas, tanto em florestas plantadas quanto em florestas tropicais. Neste sentido, o presente trabalho teve como objetivo contribuir com esta literatura no sentido de avaliar os índices de vegetação (NDVI, PRI e $\mathrm{CO}_{2}$ Flux), visando caracterizar a cobertura vegetal, assim como estimar relações de sequestro e estoque de carbono em uma área de proteção ambiental no município de Rio Branco, AC, dentro de um período de 5 anos (2013 - 2018). Para as análises, foram utilizadas duas cenas do sensor OLI do satélite Landsat 8, a escolha das cenas tiveram como critério o período de menor cobertura de nuvens, para o processamento das imagens foram utilizados os softwares Envi 4.5 e Arcgis 10.6, onde foi realizada a correção atmosférica nas duas cenas. Os resultados encontrados apresentaram pouca diferença em relação ao estoque de carbono na APA para as duas datas em estudo, de modo a ser possível concluir que a APA vem contribuindo para a manutenção e equilíbrio do ecossistema em estudo.

Spatio-temporal evaluation of forest cover and relationship with socioeconomic data in landscapes of the Caatinga biome in the Sertão region of Pernambuco, Brazil / Avaliação espaço-temporal da cobertura florestal e a relação com dados socioeconômicos em paisagens do Bioma Caatinga no sertão de Pernambuco

Emanuel Araújo da Silva ${ }^{1}$,Elisiane Alba ${ }^{2}$, José Jorge Monteiro Júnior ${ }^{1}$, João Pedro Mesquita Souza Santos ${ }^{1}$, Gabriela Salami ${ }^{1}$, Mayara Maria de Lima Pessoa ${ }^{1}$, Rinaldo Luiz Caraciolo Ferreira ${ }^{1}$

${ }^{1}$ Universidade Federal Rural de Pernambuco, Recife, Brasil; ' 2 Universidade Federal de Santa Maria, Santa Maria, Brasil (emanuel.ufrpe@gmail.com; elisianealba@gmail.com; josejorgemonteirojunior@gmail.com; joao_mesquita01@outlook.com; gabriela.salami@ufersa.edu.br;mayapessoa@gmail.com; rinaldo.ferreira@ufrpe.br)

Modelos de simulação espacial visam auxiliar o entendimento dos mecanismos causais e processos de desenvolvimento de sistemas ambientais, e assim determinar como eles evoluem frente diferentes cenários traduzindo em quadros socioeconômicos, políticos e ambientais. Esse estudo objetivou uma avaliação espaço-temporal da degradação de paisagens do bioma Caatinga, no sertão do Estado de Pernambuco, BR, por meio de imagens provenientes do sensor OLI do satélite LANDSAT-8, correlacionando com dados socioeconômicos da região, esta que sofre com a supressão de vegetação nativa devido ao mercado energético e das atividades agropecuárias e silvipastoris. Foi realizado o mosaico com as imagens adquiridas para obtenção do recobrimento total da área e criadas novas classes temáticas que correspondessem ao cruzamento das classes de uso e cobertura da terra do período estudado, obtendo assim um mapa de dinâmica da cobertura florestal e as seguintes classes: cobertura florestal consolidada, cobertura florestal regenerante, supressão da cobertura florestal e outros usos. Portanto, após avaliação, foi constatado que as variáveis provenientes do cruzamento do mapa temático com os dados socioeconômicos influenciaram 
na alteração da cobertura vegetal da região. As classes temáticas regeneração e manutenção apresentaram a maior quantidade de áreas quando os fatores PIB, IDH e índice populacional estiveram altos. Constatou-se também que a densidade de caprinos é inversamente proporcional a quantidade de áreas regeneradas. A classe desmatamento se torna mais presente em áreas menos populosas e com o PIB e IDH considerados baixos, bem como em regiões onde a densidade de caprinos e bovinos é considerada alta.

Identifying heat islands in a dry forest in the Sertão region of Pernambuco, Brazil / Identificação de ilhas de calor em Floresta Seca no Sertão de Pernambuco

Emanuel Araújo da Silva ${ }^{1}$, Fernanda Vanilly de Lira Paulo ${ }^{1}$, Carolina Rovira Pereira Fernandes ${ }^{1}$, José Jorge Monteiro Júnior ${ }^{1}$, Gabriela Salami ${ }^{1}$, Elisiane Alba ${ }^{2}$, Mayara Maria de Lima Pessoa ${ }^{1}$, Rinaldo Luiz Caraciolo Ferreira ${ }^{1}$

${ }^{1}$ Universidade Federal Rural de Pernambuco, Recife, Brasil; ${ }^{2}$ Universidade Federal de Santa Maria, Santa Maria, Brasil (emanuel.ufrpe@gmail.com; fernandavanilly@hotmail.com; fernandes.rovira@gmail.com; josejorgemonteirojunior@gmail.com; gabriela.salami@ufersa.edu.br;

elisianealba@gmail.com; mayapessoa@gmail.com; rinaldo.ferreira@ufrpe.br)

O objetivo do estudo foi relacionar o uso da terra com o aumento da temperatura em áreas da Caatinga no sertão Pernambucano por meio de imagens do satélite LANDSAT-8 sensor TIRS e OLI, com resolução de $30 \mathrm{~m}$ em dezembro de 2017. Foi elaborado o mapa de uso e ocupação do solo desta região classificadas em: água, solo exposto, agropecuária e floresta. Utilizou-se o algoritmo da Máxima Verossimilhança e o ajuste atmosférico pela radiância no topo da atmosfera e o delineamento de classificação do solo foi realizado por meio de software a partir do coeficiente NDVI dos usos em questão. Calculou-se assim a emissividade do ambiente, temperatura de brilho e superfície. Para verificar a correlação realizou-se um cruzamento entre o Mapa de Temperatura e de Uso do Solo. A área de estudo apresentou 1.742.828,22 ha, os municípios de Floresta e Ibimirim apresentaram maior presença de muito solo exposto e consequentemente as áreas com maior elevação de temperatura; em contrapartida, os municípios com maior área de floresta são os municípios de maior altitude ao leste: Buíque e Arcoverde. As áreas de agropecuária apresentaram temperatura moderada causada pela constante irrigação existente em algumas culturas e também à similaridade de emitância na agropecuária e Caatinga de baixo porte, que, por ser uma floresta, mantém a temperatura. É possível perceber que as ilhas de calor se formam, principalmente, em áreas de solo exposto e longe de grandes cursos d'água; refletindo a importância da vegetação da Caatinga para a manutenção das temperaturas.

\section{B5a: CLIMATE CHANGE, ENVIRONMENT AND CONSERVATION: CHALLENGES FROM THE ANALYSIS OF TREE RINGS}

\section{Effects of competitions on the relationships between tree-ring width and climate}

Biing Guan ${ }^{1}$, Bo-Yin Chen ${ }^{1}$

${ }^{1}$ National Taiwan University, Taipei, Taiwan (btguan@ntu.edu.tw; b04613026@ntu.edu.tw)

One of the goals of dendrochronology is to clarify the effects of interactions between tree growth and environmental conditions across space and time, e.g. the influences of competition and climate. The main objective of this study is to understand the differences in climate signal expressions among trees grew under different initial spacings in a sugi (Cryptomeria japonica) plantation in central Taiwan. This study used ensemble empirical mode decomposition to develop chronologies. Correlations were calculated between the detrended tree-ring width chronologies and local monthly climatic records, including the monthly average of daily maximum temperature, the monthly average of daily mean temperature, the monthly average of daily minimum temperature, and monthly precipitation amount. Results showed that the high-frequency variations of sugi ring widths, regardless of the initial spacings, were negatively correlated with temperature, especially the temperature from the previous summer to early current winter. Except for trees grew in the narrowest initial spacing, high-frequency variations of sugi ring widths were also negatively correlated with the amount of precipitation of the previous growing season in general. Trees grew in the wider initial spacings showed stronger relationships with the local climatic factors. Only ring widths after the initial 15 to 20 years of growth had significant correlations with large-scale atmospheric-ocean circulations. In summary, sugi trees in the study area were more sensitive to local climatic variations when they grew under a weaker competition situation.

\section{Photometric method for tree rings determination}

Sergij Striamets ${ }^{1}$, Nataliya Stryamets ${ }^{2}$

${ }^{1}$ Lviv Politechnic National University, Lviv, Ukraine; ${ }^{2}$ Ca'Foscari University of Venice, Venice, Italy (sergijstr@gmail.com; natastr@gmail.com)

The tree rings determination is crucial for the climate change research. The photometric method of the determination of the tree rings growth on the cross-cut are proposed in this study. This method helps determinate the year trees growth on the photos of the trees cross-cut using the software. Precise determination of tree age and annual growth is done by developed and patented software by counting annual rings and measuring the distance between adjacent annual rings on the trees crosscut photos. Aim of our study was to develop and patent the photometric method and analyse the pros and cos of developed software to determinate and calculate automatically the tree rings from the tree crosscut' photo. This method was patented, based on a patent the computer software was developed and tested. The pros and cons of the method and software were demonstrated. The advantages of this method are that automatic measurement of annual tree rings and are improving the accuracy, avoiding in the process of measuring the human factor influence, speed of the research and the software provides for the applicability of the linear filtering image slices, which allows to eliminate random noise in the image. The disadvantages of the method is need of places the scale ruler on the trees crosscut before taking photo. We discussed the importance of development and improvement of this method and software in order to get more precise results for tree rings determination.

\section{Climate sensitivity of tropical tree growth: a global meta-analysis based on tree rings \\ Peter Groenendijk ${ }^{1}$ (D), Valerie Trouet ${ }^{2}$, Flurin Babst ${ }^{3,4}$ (D), Pieter A. Zuidema ${ }^{5}$ (D)}

${ }^{1}$ Department of Plant Biology, Institute of Biology, University of Campinas - UNICAMP, Campinas, Brasil; ${ }^{2}$ Laboratory of Tree-Ring Research, University of Arizona, Tucson, USA; ${ }^{3}$ Swiss Federal Research Institute for Forest, Snow and Landscape Research (WSL), Birmensdorf, Switzerland; ${ }^{4}$ Department of Ecology, W. Szafer Institute of Botany, Polish Academy of Sciences Krakow Poland; ${ }^{5}$ Forest Ecology and Forest Management Group, Wageningen University, Wageningen,Netherlands (peterg@unicamp.br; trouet@email.arizona.edu; flurinbabst@gmail.com; pieter.zuidema@wur.nl)

Tropical forests are crucial components of the global carbon cycle. Yet, we poorly understand climatic drivers of tropical tree growth and their responses to climatic shifts. Tree-ring based global analyses of climate sensitivity typically exclude tropical regions due to a perceived lack of data. Here, we help filling 
this knowledge gap with a meta-analysis of published tropical tree-ring width chronologies. We compiled $>400$ tropical chronologies from various climate zones across the tropics between $30^{\circ} \mathrm{N}-30^{\circ} \mathrm{S}$. We explore i) the main climatic drivers of tropical tree growth and their clustering, ii) how tropical tree-growth variability and climate sensitivity change along temperature and precipitation gradients, and iii) how common are autocorrelation and lag effects of previousyear climate on tree growth. The main drivers of tropical tree growth are mean annual precipitation (MAP) and temperature (MAT) and we identified several climate-response clusters. The strength of the growth-precipitation correlation, the inter-series correlations and growth variability decrease with increasing MAP, but MAP does not affect autocorrelation. The strength of the growth-temperature correlation increases with increasing elevation (i.e., decreasing MAT). Increasing MAT leads to lower inter-series correlations and autocorrelation, while leading to increased growth variability. We discuss how the strength of MAP and MAT as drivers of tree-growth variability changes across tropical climate zones. We show that tree-ring studies have a strong potential to improve our understanding of global tropical forest climate-growth patterns. Our results can be used to benchmark global vegetation modelling and to understand responses of tropical tree species to climate change.

\title{
Intensifying the development of tropical tree-ring research using multi proxy measurements across temporal and spatial scales \\ Aster Gebrekirstos ${ }^{1}$, Mulugeta Mokria ${ }^{1}$, Abrham Abiyu ${ }^{2}$, Achim Braeuning ${ }^{3}$ \\ ${ }^{1}$ World Agroforestry Centre, Nairobi, Kenya; ${ }^{2}$ World Agroforestry Centre, Addis Ababa, Ethiopia; ${ }^{3}$ Institute of Geography, University Erlangen-Nuremberg, Erlangen,Germany (a.gebrekirstos@cgiar.org;m.mokria@cgiar.org; abrham.abiyu@gmail.com; achim.braeuning@fau.de)
}

Global climate change is modifying the patterns of rainfall variability and the composition of vegetation, with many consequences on the use and management of trees and forests. Recent advances in tropical dendrochronolgy shows a high number of tree species form datable annual tree rings and may reach multi century age. Tree-ring based climate reconstructions provided potentials to fill the severe lack of instrumental climate data, to understand the drivers and impact of climate, their interactions and impacts in the tropics. In turn, the gap on fundamental knowledge concerning how tropical species grow in response to climate variability, and therefore how they might react to future climatic change is substantial and can be addressed using tree-ring based data and novel quantitative wood anatomy measurements. This presentation will be highlighting on the prospects and applications of dendrochronological techniques in the tropics. We will present results from case studies in East and West Africa and South America using multi proxy measurements (ring width, carbon and oxygen isotopes, and wood anatomical techniques) to exemplify reconstructions of climate variability, trends and atmospheric circulation patterns and long-term impacts of climate variations at the species and landscape levels and their implications in forest restoration and management. In addition, we will discuss on the need to advance dendrochronology research and the development of tree-ring based networks, especially in Africa, where large scale tree ring based data is still lacking compared to other continents.

\section{Recent advances in isotope dendroclimatology at Forestry and Forest Products Research Institute/FFPRI, Tsukuba, Japan}

Akira Kagawa ${ }^{1}$

${ }^{1}$ Wood Anatomy and Quality Laboratory, Forestry and Forest Products Research Institute, Tsukuba, Japan (akagawa@ffpri.affrc.go.jp)

This talk reviews advances of isotope dendroclimatological research at FFPRI. Recent methodological breakthroughs in both tree-ring core sampling and cellulose extraction enabled rapid development of tree-ring oxygen isotope network in Japan, which currently dates back to 4500 yBP. In order to facilitate production of tree-ring isotope data, we have made breakthroughs in the two bottle-neck processes, i.e. core sampling and cellulose extraction. Firstly, we developed a light-weight rechargeable increment borer (Kagawa \& Fujiwara 2018, Journal of Wood Science, www.smartborer.com [http://www.smartborer. com]) to facilitate collection of increment cores. Secondly, we have developed new method for rapidly processing tree-ring samples to cellulose, which makes the extraction process 10-100 times more efficient compared to the conventional methods (Kagawa et al; 2015, Chemical Geology). These methodological breakthroughs expanded the application of stable isotope analysis to various fields in Forestry research, such as estimating the geographic origins of wood for detecting illegally-sourced wood (Kagawa \& Leavitt 2010, Journal of Wood Science), detecting "invisible oxygen isotope rings" of trees from Amazon (Ohashi et al 2016, Oecologia), visualizing the effects of the 2011 Tsunami on the pacific coast in Japan via tree-ring carbon isotopes of pines (Kubota et al 2017, Ecological Research), and the effects of mass fruiting on tree-ring carbon isotopes of beech (Han et al; 2016, Tree Physiology). Application of tree-ring oxygen isotopes, are currently spreading across various fields of forestry research in Japan and future applications of tree-ring isotopes into the new frontier, such as into tropical dendroclimatology, is expected.

\section{The responses of dominant tree species to climate warming at the treeline on the eastern edge of the Tibetan Plateau}

\author{
Mingming Guo ${ }^{1}$, Yuandong Zhang ${ }^{2}$ \\ ${ }^{1}$ International Centre for Bamboo and Rattan, Beijing, China; ${ }^{2 C}$ Chinese Academy of Forestry, Beijing, China(736011705@qq.com; zyd@caf.ac.cn)
}

Tree growth at boreal/alpine treelines is generally expected to be stimulated by climate warming. However, tree growth has been shown to have changed insignificantly or reduced in numerous studies. Tree response to climate warming also varies among species in the same eco-region. The Tibetan Plateau has experienced rapid warming in the past several decades. It remains unknown how the dominant species in this regionhave responded to this warming, which is expected to significantly influence treeline dynamics. We obtained 288 tree cores from fir (Abies faxoniana and Abies squamata) and spruce (Picea purpurea and Picea baifouriana) at six treeline sites on the eastern edge of the Tibetan Plateau to detect their growth trends and climate responses. The results showed thatthe growth of fir did not change significantly at any site, whereas spruce growth increased, especially at the Songpan and Luhuo sites. The strong negative temperature or positive moisture controls of April on fir growth indicated spring drought stress. The radial growth of spruce was positively related to June and July temperature; at the Songpan and Luhuo sites, it was also positively related to the temperature from February to April . The results indicatethat both pregrowing season temperature and growing season temperature accelerate spruce growth, whereas pre-growing season temperature causes drought stress to fir The tree species composition at the alpine treeline on the eastern edge of the Tibetan Plateau will change as warming continues.

\section{Influence of climate change on tree ring characteristics of Cunninghamia lanceolata provenances in South Subtropical China \\ Aiguo Duan ${ }^{1}$, Anming Zhu', Jianguo Zhang ${ }^{1}$, Xiongqing Zhang ${ }^{1}$ \\ ${ }^{1}$ Research Institute of Forestry, Beijing,China (duanag@163.com; 844239445@qq.com; zhangjg@caf.ac.cn; xqzhang85@caf.ac.cn)}

To select the provenances adaptive to future's climate change. The different responses of tree ring width of fifty-two provenances to climate were studied by the method of dendroclimatology. It indicated that the response of the whole tree ring width, early wood width and late wood width to mean annual temperature was obvious, the maximum correlation coefficients are $-0.515,-0.590$ and -0.491 respectively. The response of the whole tree ring width, early wood width and 
late wood width to the maximum annual temperature was also obvious, and the maximum correlation coefficients are $-0.482,-0.624$ and -0.499 respectively. In recent years, there is an increasing trend of mean annual temperature of test plot, which will be unfavorable to tree growth to a certain extent. It will be an effective way to solve this problem to select appropriate provenances which are not sensitive to the mean or maximum annual temperature and have relatively high growth. The provenances from Jianghua in Hunan Province, Bobai and Ziyuan in Guangxi Province may be the adaptable provenances for the afforestation at Liuzhou in Guangxi Province .

\section{Wildfire regime shifts and fire feedbacks in Andean Araucaria forests: climate and anthropogenic influences}

Mauro Gonzalez ${ }^{1,2}$, Jason Sibold ${ }^{3}$, Ariel Muñoz ${ }^{4}$, Ana Abarzúa ${ }^{1}$, Timothy Assal ${ }^{5}$

${ }^{1}$ Universidad Austral de Chile, Valdivia, Chile; ${ }^{2}$ Center for Climate and Resilience Research, Santiago, Chile; ${ }^{3}$ Colorado State University, Fort Collins, USA; ${ }^{4}$ Pontificia Universidad Católica De Valparaíso, Valparaíso, Chile; ${ }^{5}$ U.S. Geological Survey, Fort (maurogonzalez@uach.cl; jason.sibold@colostate.edu; ariel.munoz@pucv.cl; anaabarzua@uach.cl; assalt@usgs.gov)

Wildfire activity of many forests around the world has increased as a consequence of climate change, increasing the likelihood that recently burned areas will reburn in a subsequent fire. In this study we examine the fire history of Araucaria forests, fire-climate relationships, and the causes and consequences of the recent increased wildfire activity. Fire is the most important disturbance influencing the Andean Araucaria - Nothofagus forested landscape. Across the Andean distribution, these forests have been shaped by a mixed-severity fire regime, including low-severity surface fires to stand-replacing fires. Over the last $\sim 500$ years, climate variability and changes in land-use practices have had a strong influence on the fire regime. The Euro-Chilean settlers (1883-1960) significantly increased fire activity compared to the Modern Fire Exclusion period (1961-2005) and the Native American period (pre-1882). Even though human land use plays a central role in shaping multi-decadal trends in fire activity, the occurrence of wildfire is still strongly controlled by weather. Specifically, regional-scale drought drives fire occurrence and large fire events. Since 2000 fire activity has increased in Araucaria forests. During the summer 2001-2002 a significant area of Andean Araucaria forests burned at different severities, which provided differential opportunities for tree seedling and understory species recruitment. In 2015 a subsequent severe fire reburned c. $>60 \%$ of area that burned in 2001-2002. Using long-term monitoring plots, we examine the vegetation response following two high severity fires in a relatively short time period, and evaluate the likely increased susceptibility of the post-fire vegetation to subsequent fires.

\section{Amazon trees exposed to edge effects are more susceptible to Atlantic Ocean warming and Intertropical Convergence Zone North displacement from 1980}

Alci Albiero-Júnior ${ }^{1}$, Alejandro Venegas-González ${ }^{2}$, Fidel Alejandro Roig ${ }^{3}$, José Luís Campana Camargo ${ }^{4}$, Mario Tomazello-Filho ${ }^{1}$

${ }^{1}$ Escola Superior de Agricultura “Luiz de Queiroz”, Universidade de São Paulo, Departamento de Ciências Florestais, Piracicaba, Brasil; ${ }^{2}$ Escuela de Ingeniería Forestal, Facultad de Ciencias, Universidad Mayor, Santiago, Chile; ${ }^{3}$ Laboratorio de Dendrocronología e Historia Ambiental, IANIGLA, CCT CONICET, Mendoza, Argentina; ${ }^{4}$ Biological Dynamics of Forest Fragment Project (BDFFP), Manaus, Brasil (mtomazel@usp.br; avenegasgon@gmail.com; froig@mendoza-conicet.gob.ar; zeluiscamargo@gmail.com; mtomazel@usp.br)

Recent researches observed an Atlantic Ocean temperature increase since 1980, probably influenced by anthropic actions, inducing rainfall intensification mainly during the rainy season and slight reductions during the dry period in the Amazon. Here we demonstrate through a dendrochronological approach using non-destructive samples of Scleronema micranthum growth rings located in Terra Firme forest at the Biological Dynamics of Forest Fragments Project in the Brazilian central Amazon and spatial correlations, using the data available from the Climate Explorer Website, how trees, exposed and not exposed to edge effects are influenced by these changes previously (1941 to 1982) and after the forest fragmentation (1983 to 2013 ) in three moments: previously the dry period (March to June) during the dry period (July to October) and after the dry period (November to February). Through the spatial correlations, we can verify the strong action of the Atlantic sea surface temperature in the growth dynamics of the trees, and we highlight here the space-time transition of the influence of the South Atlantic sea surface temperature before the forest fragmentation and the North Atlantic sea surface temperature after fragmentation, and proved that trees growth dynamics responded to the Intertropical Convergence Zone displacement to the north, due to the increase in Atlantic sea surface temperature from 1980, mainly during the dry period. Consequently, if we consider the future scenarios of global warming, significant increases in sea surface temperature will modify rainfall patterns in the Amazon, influencing the performance of trees, especially in fragmented forest as edge areas.

\section{Linking climate and wood properties with the use of carbon and oxygen stable isotopes as proxies}

Mariana Hassegawa ${ }^{1}$, Lisa Wingate ${ }^{2}$, Alexis Achim ${ }^{1}$

${ }^{1}$ Laval University, Quebec, Canada; ${ }^{2}$ French National Institute for Agricultural Research, Bordeaux, France (mariana.hassegawa@sbf.ulaval.ca; lisa.wingate@bordeaux.inra.fr; alexis.achim@sbf.ulaval.ca)

Black spruce (Picea mariana), one of the main tree species in the North American boreal forests, has great economic importance in Canada. To improve the resilience of the boreal forest and ensure the future supply of high-quality wood, it is critical to understand the factors that affect wood formation. The difference in temporal resolution between climate variables and annual growth data, as well as the high collinearity between climate variables, can contribute to the low predictive power of current models relating climatic conditions to tree growth or wood properties. One solution for linking climate events and wood formation is to use high-resolution assessments of $\delta 13 \mathrm{C}$ cellulose (ratio of carbon-13 and carbon-12 isotopes in $\alpha$-cellulose) and $\delta 18 \mathrm{O}$ cellulose (ratio of oxygen-18 to oxygen-16 isotopes in $\alpha$-cellulose) as indicator variables for environmental factors. This work aimed to study the effects of climate on wood density of black spruce, using $\delta 13 \mathrm{C}$ cellulose and $\delta 180$ cellulose as proxies. Our results suggested that higher water availability during wood formation was related to lower values for $\delta 13 \mathrm{C}$ cellulose, a behavior identified through the standardized precipitation-evapotranspiration index. Good correlations were observed between $\delta 180$ cellulose and climate variables. The average temperature during the growing season and the total amount of rain in July were responsible for about $70 \%$ of the variation in $\delta 180$ cellulose. These results may contribute to the improvement of predictions of the boreal forest's growth and ability to act as a carbon sink in a changing climate. 


\section{From fungal detoxification systems to wood durability}

Eric Gelhaye ${ }^{1}$, Melanie Rouhier ${ }^{2}$, Rodnay Sormani ${ }^{2}$, Thomas Perrot ${ }^{2}$

${ }^{1}$ Institut National de la Recherche Agronomique, Nancy, France; ${ }^{2}$ Université de Lorraine, Nancy, France (eric.gelhaye@univ-lorraine.fr;

melanie.morel@univ-lorraine.fr; rodnay.sormani@univ-lorraine.fr; thomas.perrot@univ-lorraine.fr)

Organisms and in particular static (no-motile) organisms have to be adapted to their environment to cope with biotic and abiotic stresses. In the case of wooddecaying fungi, these latter have developed an efficient detoxification system with expended multigenic families, such as cytochrome P450 monooxygenases and glutathione transferases (GSTs), involved in the catabolism/detoxification of wood extractives. Concerning GSTs, their activity or even their expression are widely used to evaluate physiological and environmental stress of diverse organisms. In this context, we postulated that fungal GSTs could be used as tools to identify wood extracts that possess interesting biological properties and could also give some clues on the ecological traits of the corresponding trees. We have therefore developed biochemical tests quantifying the interactions between fungal GSTs and wood extracts from subtropical and temperate forests. The obtained results that validate the initial hypothesis and demonstrate a correlation between these interactions and the natural durability of the tested woods as well as the growth strategy (heliophilic/sciaphilic continuum) of the considered species, will be discussed. Related articles: - Deroy et al.(2015) The GSTome Reflects the Chemical Environment of White-Rot Fungi. PLOS ONE. DOI: 10.1371/journal.pone.0137083 - Schwartz et al. (2018) Molecular recognition of wood polyphenols by phase II detoxification enzymes of the white rot Trametes versicolor. Scientific reports. DOI: 10.1038/s41598-018-26601-3 - Perrot et al., (2018) Fungal glutathione transferases as tools to explore the chemical diversity of Amazonian wood extractives. ACS sustainable chemistry and engineering. DOI: 10.1021/acssuschemeng.8b02636.

Exemplary kempas hardwood protection with two proprietary microemulsion termiticides based on permethrin and cypermethrin against Coptotermes termite attack under tropical aboveground indoor and weathered conditions

Daouia Messaoudi ${ }^{1}$, Andrew H. H. Wong ${ }^{2}$, Carlson A. D. Tawi ${ }^{2}$, Nebil Bourguiba ${ }^{3}$, Olivier Fahy ${ }^{3}$

${ }^{1}$ Adkalis, Blanquefort, France; ${ }^{2}$ Universiti Malaysia Sarawak, Kota Samarahan, Malaysia; ${ }^{3}$ Adkalis, Blanquefort, France (daouia.messaoudi@berkem.com, awong.unimas@gmail.com; carlson.tawi@gmail.com;nebil.bourguiba@berkem.com; olivierfahy@berkem.com)

Patented proprietary SARPECO ${ }^{\circledR}$ and AXIL ${ }^{\circledR}$ environmentally acceptable microemulsion wood-protecting chemicals are water-based wood preservatives approved for dipping and pressure treatment providing 25 years of termite protection for solid wood and wood-based products in Europe and for more than 10 years in Indonesia. Field trials conducted in Malaysia confirmed the efficacy of SARPECO ${ }^{\circledR}$ and AXIL ${ }^{\circledR}$ solutions at three product concentrations on short dip-treated kempas (Koompassia malaccensis) heartwood, a major hardwood species used in Malaysian wood construction, against the Southeast Asian subterranean termite Coptotermes curvignathus exposed to aboveground H2 (indoor, non-wetting conditions) hazard class targeting termites compared to CCA-treated kempas and radiata pine (Pinus radiata) sapwood. Prior to the $\mathrm{H} 2$ hazard class termite field test exposure, treated wood blocks were conditioned to either a non-leaching volatilization (H2 hazard class weathered wood) or to a leaching with volatilization (aboveground H3 hazard class weathered wood) as well as non-leaching/non-volatilization and leaching/non-volatilization reference treatments. After 6 months field exposure, untreated kempas was severely (AWPA termite ratings: 0, mean mass loss: 97.4\%) or moderately attacked (mean ratings: 7.7, mean mass loss: 17.5\%), while none of the leached-volatilized (H3 hazard class) or non-leached-volatilized (H2 hazard class) test blocks treated with SARPECO ${ }^{\circledR}$ and AXIL ${ }^{\circledR}$ at both target retentions were regarded as attacked (mean ratings: 9.7-10, negligible mean mass loss) at low applied termiticide concentrations, leached or non-leached wood, volatilized or non-volatilized wood treatments. Concluding, due to their unique compositions, both patented formulations conferred excellent protection against Coptotermes curvignathus, at far lower termiticide concentrations where conventional agro-insecticides will fail, for tropical aboveground indoor-outdoor wood construction.

\section{Tropical indoor wood floorings and outdoor deckings are in dire need of wood protection}

Andrew H. H. Wong ${ }^{1}$, Malcolm Farmer ${ }^{2}$

${ }^{1}$ Universiti Malaysia Sarawak, Kota Samarahan, Malaysia; ${ }^{2}$ Koppers Performance Chemicals, Manila, Philippines (awong.unimas@gmail.com, farmerm@koppers.eu)

In many tropical regions indoor timber floorings and sometimes outdoor deckings have become popular features of buildings and parks, which when installed without naturally durable woods, are readily predisposed to the biological hazards of termites and rot fungi that are destructive to wood materials. Such premature failure of unprotected structural materials incurs considerable monetary losses as well as carbon loss from wood biodeterioration that is detrimental to climate change mitigation plans. Brief illustrations of wood being climate-friendly material, that wood must be treated in the tropics, variable natural durability of Malaysian woods, their tropical wood degraders, options for biocidal and non-biocidal wood protection strategies of wood floorings and deckings, and case studies of biocidal wood protection of tropical woods in aboveground conditions, are presented.

\section{Evaluation of furfural/urea complexes to improve properties of commercial birch wood (Betula sp.)}

Davood Efhamisisi ${ }^{1}$, Marie-France Thevenon ${ }^{2,3}$, Marzieh Sharifat ${ }^{1}$, Asghar Taromian $^{1}$, Mehdi Jonoobi $^{1}$

${ }^{1}$ Department of Wood and Paper Sciences and Technology, Faculty of Natural Resources, University of Tehran, Tehran, Islamic Republic of Iran; ${ }^{2}$ Wood Preservation Laboratory, CIRAD, UR BIOWooEB, Montpellier, France; ${ }^{3}$ BIOWooEB, Univ. Montpellier, CIRAD Mont (efhami@ut.ac.ir :

marie-france.thevenon@cirad.fr; marzieh.sharifat@ut.ac.ir;asghar.taromian@ut.ac.ir;mehdi.jonoobi@ut.ac.ir)

Due to recent national forestry policy banning logging from the Northern parts of the country, Iranian wood industry must mostly rely on wood importation. Birch (Betula sp.) from Russia is a commonly imported wood, but has a low durability and therefore must be protected for long-term uses. Protection systems based on wood impregnation with different monomers and their conversion to un-leachable reacted polymers were developed to create new wooden products with improved properties. Furan compounds such as Furfuryl Alcohol (FA) can be commercially used for wood modification. Wood is impregnated with FA, which is converted to polyFA by heating. Furfural is, in fact, the primary raw material in the production of FA, and is extensively manufactured in Iran from residues of sugar cane. Furfural can not be easily polymerized alone like FA; however it is an aldehyde able to react with urea to make polymer network. In this study, the possibility of creating furfural/urea polymer along with acidic catalyzer (maleic anhydride) was evaluated for the improvement of physico-mechanical properties, as well as the durability of birch wood. 


\section{Valorization of pyrolysis by-products from sugar cane bagasse for the protection of biomaterials}

Febrina Dellarose Boer ${ }^{1,2}$, Marie France Thevenon ${ }^{1,2}$, Jean-Michel Commandré ${ }^{1,2}$, Mériem Fournier ${ }^{3}$

${ }^{1}$ CIRAD, UR BIOWooEB, Montpellier, France; ${ }^{2}$ BIOWooEB, Univ. Montpellier, CIRAD Montpellier France; ${ }^{3}$ LERFOB, AgroParisTech, INRA, Nancy, France (febrina.boer@cirad.fr; marie-france.thevenon@cirad.fr; jean-michel.commandre@cirad.fr; meriem.fournier@agroparistech.fr)

This research focused on the "Energy valorization of lignocellulosic products and their by-products for the protection of bio-materials", is dedicated to the valorization of the sugar cane bagasse from Réunion Island (Oversea territory, France), a region where the sugar industry plays an important role in the agricultural sector. The objectives of this research were to: (i) characterize the biochar and the bio-oil according to the pyrolysis process parameter and the biomass used, and to (ii) evaluate the potential of said bio-oil as wood preservatives. Pyrolysis of bagasse was conducted using an experimental set up of fixed bed reactor. Various temperatures $\left(\mathrm{T}=400^{\circ} \mathrm{C}, 500{ }^{\circ} \mathrm{C}\right)$ and holding time th $(30$ and 60 minutes $)$, and a heating rate of $10{ }^{\circ} \mathrm{C} / \mathrm{minutes}$ were applied. Pyrolysis products, consisting of biochar and bio-oil, were recovered for further analysis. The biochars were characterized for their proximate and ultimate analysis for energy valorization. For evaluating the antifungal efficacy of the recovered bio-oil, we conducted fungal growth inhibition tests against two types of wood-decaying fungi: Coriolus versicolor (white-rot) and Coniophora puteana (brown-rot) on Petri dishes, as well as decay tests on treated wood samples.

\section{Engineered Wood Products (EWPs) in mass timber construction and their durability}

Tripti Singh

${ }^{1}$ Scion, Rotorua, New Zealand (tripti.singh@scionresearch.com)

With proven improved performance in fire and seismic characteristic, the projected market potential for softwood Engineered Wood Products such as CLT (Cross Laminated Timber) and LVL (Laminated Veneer Lumber) for multi-story buildings are very positive. However, potential prolonged rain leakage or moisture exposure during construction and in-service could pose considerable concern for its durability and reputation. This research was conducted to assess the decay resistance of LVL, OSB (Oriented Strand Board) and CLT produced from radiata pine in an accelerated trial. This testing method is used in establishing the effectiveness of wood products in framing subject to intermittent wetting. The results showed untreated OSB and CLT were very susceptible to decay. In comparison, LVL was less susceptible. Testing conducted on CLT using surface application of boron preservative prevented decay. Further work is needed to understand the full extent of moisture ingress in wooden panels during construction and service of the multistory buildings and improving the durability of panel products.

\section{Improvement of the dimensional stability and weathering resistency of wood treated with an hydrorepelent product for exterior use}

Claudia Ibañez $z^{1}$ Damian Ghersovic ${ }^{2}$

${ }^{1}$ Universidad dela Republica, Tacuarembo,Uruguay; ${ }^{2}$ INTI, Buenos Aires, Argentina (cmibanes@gmail.com;damianghe@hotmail.com)

Wood is a common construction material used in all environments. However its sensibility to abiotic agents, in particular its dimentional inestability limit its durability and decrease its properties. In In this work, the efficiency of a parafine-emulsion-based product as a wood protector was tested for its use on both interiors and exteriors- mainly decks and utility poles. Eucalyptus grandis and Pinus taeda sapwood were treated with the Bethel method at two retention levels, and later compared with untreated wood. The dimensional stability of the treated samples was studied through determining the swelling percentage and the water repellency level. Test samples were also exposed to accelerated weathering processes of 100 and 300 h, and later analized by FTIR and SEM microscopy. Results showed a significative improvement of the dimensional stability of treated wood when compared to untreated samples. Despite the weathering process slightly affected the surface of the wood, the product is suitable for exterior use.

\section{Protection of wood from fungi and termite with liquefied wood polyols}

Anil Kumar ${ }^{1}$, Asieleavio John ${ }^{1}$, TaraSingh Mehra ${ }^{1}$, B.N. Hazarika ${ }^{1}$

${ }^{1}$ College of Horticulture and Forestry, Central Agricultural University,Pasighat, Arunachal Pradesh, India, Pasighat, India (anil19wst@gmail.com; asieleavio@gmail.com;mehra_chf@hotmail.com;chfdeanpsg@gmail.com)

Liquefaction of wood is one of the promising approaches to utilize woody waste wherein wood meal is converted into chemically active liquid with the help of a liquefying agent like polyhydric alcohols, phenol, cresol, etc. The potential of liquefied wood as a wood preservative has not been studied. In this study, wood meal was liquefied in phenol, glycerol and polyethylene glycol as the liquefying media and the efficacy of liquefied wood was tested as a wood preservative against termite and fungi.Wood samples were impregnated with liquefied wood diluted with methanol and were subjected to accelerated termite graveyard test and fungal resistance test. The level of impregnation of liquefied wood in wood was estimated by determining the weight percent gain. In the graveyard test, samples were periodically observed for 18 months. Samples treated with phenol-assisted liquefied wood exhibited promising results both in visual observation and percentage weight loss as compare to initial condition and untreated control samples. The percentage weight loss of phenolated wood treated wood sample was ranging from only $5-20 \%$ of its initial weight; whereas treatment with glycerol and PEG based liquefied wood did not exhibit any improved resistance against termite as compared to the untreated samples. The treated samples were also exposed to fungus for 16 weeks. The fungicidal traits of phenolated wood showed higher antifungal efficacy against both white rot and brown rot of wood whereas liquefied wood in glycerol and polyethylene glycol shows insignificant effects on growth of fungus and was similar to control samples.

\section{B5p: CLIMATE CHANGE AND FOREST PRODUCTS}

\section{The contributions of rate and duration of stem radial increment to annual increments of Picea meyeri in a sub-alpine habitat, North- Central China}

Yuan Jiang ${ }^{1}$, Mingchang Wang

${ }^{1}$ Beijing Normal University, Faculty of Geographical Science, School of Natural Resources, Beijing, China (jiangy@bnu.edu.cn; wmch123@yeah.net)

Stem radial increment rate and duration are the most important parameters in determining the width of annual tree rings. To identify the contributions of rate and duration to annual radial increments and their relationships with environmental factors, we analyzed intra-annual stem increments of five Picea meyeri trees 
in a sub-alpine habitat of North-Central China over 7 years (2008-2015, except for the year 2012) with point dendrometers in this study. The results showed the following. (1) We estimated that approximately $53 \%$ of the variability in the annual radial increments is attributable to the rate of radial increment and approximately $47 \%$ to its duration. (2) The contribution of cessation time to the annual increments was more than three times that of the initiation time. (3) The initiation of radial increment was primarily controlled by soil temperature and warmer soil temperature could advance the initiation time. The cessation and rate of radial increment were mainly influenced by thermal and light-related environmental factors. During growing seasons, low temperatures and insufficient light caused by many rainy and cloudy days at the high altitudes of the Luya Mountains may result in earlier cessations and lower rates of radial increment. Overall, our results may have further applications in modeling the responses of tree stem growth to climate change in a sub-alpine habitat of North-Central China.

\section{Dendrochronology applied to urban afforestation management}

Cláudia Fontana ${ }^{1,2}$ (i)

${ }^{1}$ Instituto Federal Catarinense, Luzerna, Brasil; ${ }^{2}$ Claretino, Blumenau, Brasil (claudiafontanabio@gmail.com)

Trees in urban area present their own responses to environmental pressures when compared to those in native forests. Monitoring these trees is essential for urban planning and security. Jacaranda mimosifolia D. Don is an exotic species in Brazil but widely used in urban afforestation. Tree falls of this species in urban area have been related to fungal infection. In this work, a dendrochronological study of a wood disc of J. mimosifolia that fell in an urban square (Joaçaba, Santa Catarina state) was carried out. The tree was flowering and apparently healthy. A disk with a diameter of $58 \mathrm{~cm}$ was collected one meter above the ground. It was polished (sands from 80 to 2000 grains) and five radii were dated, photographed with a reference scale and the growth rings measured in image software. Dating was checked in Cofecha and dendrochronological parameters were generated in Arstan. The estimated age was 37 years, and the correlation between the radii was $r=0.563$ and the sensitivity of 0.255 (Cofecha), with $\mathrm{rbar}=0.451$ (standard chronology). The average width-rings was $7.96 \mathrm{~mm}(0.74$ to $16.89 \mathrm{~mm}$ ) Areas with rot caused by fungi and routes caused by termites were observed. One hypothesis is that the fungal infection occurred for some injury between the tree's 17 and 20 ages (years 1998 to 2001) facilitating insects entry. The rot compromised about 2/3 of the disk, causing tree weakening and probably its fall.

\section{Dendroecology and wood anatomy of a rare species Dinizia jueirana-facao (Fabaceae), "Tabuleiros"Atlantic Forest, Brazil Cláudia Fontana $^{1}$ (D, Luiz Santini-Junior ${ }^{2}$ (D), Caroline Américo da Silva ${ }^{2}$ (D), Juliano Morales Oliveira 3 (D), Mario Tomazello-Filho ${ }^{2}$ (D), Paulo Cesar Botosso $0^{4}$ (D) \\ ${ }^{1}$ Instituto Federal Catarinense, Luzerna, Brasil; ' 2 Escola Superior de Agricultura “Luiz de Queiroz”, Universidade de São Paulo, Piracicaba, Brasil; ${ }^{3}$ Unisinos, São Leopoldo, Brasil; ${ }^{4}$ Embrapa Florestas, Colombo, Brasil (claudiafontanabio@gmail.com ; luizsantini82@gmail.com; caroline.americo.silva@usp.br; julianooliveira@unisinos.br)}

The great diversity of tree species present in the tropics results from the high quantity of rare species. Therefore, understanding their ecology is critical to the conservation of these complex tropical ecosystems. Dendrochronology can retrieve valuable information from tree rings analysis. We characterize the wood anatomy of Dinizia jueirana-facao, a rare tree species recently described, occurring only in semi-deciduous Atlantic rain forest in Espírito Santo State, Southeastern Brazil. Preliminary results of dendrochronological studies are also presented. For microscopic analysis of growth-ring boundaries and dendrochronology, we prepared samples of five adult trees by standard techniques in each area. Dinizia jueirana-facao has growth rings visible to the naked eye, but sometimes with difficulty, demarcated by thin marginal parenchyma bands. It shows fiber wall thickness variation sometimes resulting in distinct tangential fiber zones in the latewood. Confluent parenchyma bands are especially frequent sometimes masking the tree-ring boundaries. Despite difficulties in some samples, we crossdating five trees ( 10 rays). The correlations within the trees were 0.40 up to 0.80 , among trees of $r=0.538, \mathrm{rbar}=0.277, \mathrm{EPS}=0.81$ and mean sensitivity of 0.551 . Although preliminary, the results obtained so far demonstrate the dendrochronological potential of the species can already be verified. The high synchronicity and sensitivity of the growth rings in the investigated population shows that this rare tree species is affected by recurrent variations in the environment. After completing crossdating, we will test the chronology with local and global climate data.

\section{Dendroanatomy of Copaifera pubiflora and the prospect of oleoresin production}

Patricia da Costa ${ }^{1}$ (D) Mateus Natan Lee Cardoso ${ }^{2}$, Tomaz Longhi-Santos ${ }^{2}$ iD; Renata Cristina Bovi ${ }^{3}$ ${ }^{1}$ Embrapa Roraima, Boa Vista, Brasil; ' ${ }^{2}$ niversidade Federal do Paraná, Curitiba, Brasil; ${ }^{3}$ Universidade Estadual Paulista “Júlio de Mesquita Filho”, Instituto de Geociências e Ciências Exatas, Rio Claro,Brasil (patricia.da-costa@embrapa.br; zoso2622@gmail.com; longhi@ufpr.br; bovirc@gmail.com)

Copaifera pubiflora Benth. (Fabaceae) is a medium-sized tree species recorded in Brazil, only in Roraima state, on river Branco Savannas, where it is observed in forest islands and gallery forests. It can also be found in small patches of tropical rainforests at its Southern boundary, in a transition area between the savanna formation and tropical rainforests. The word copaíba comes from the Tupi "kupa "iwa" and means "tank tree", referring to the fact that the species produces and stores an oleoresin in its trunks. This oil is collected solely from native forests, mainly in Amazon. In spite a large number of studies conducted on copaiba oleoresin chemical composition and pharmacological activities, aiming the definition of potential applications, there are still gaps in species ecological aspects that must be filled to define its productive potential, contributing to the establishment of management plans and practices. In this work, preliminarily, we used a dendroecological approach to characterize $C$. pubiflora's growth rings and its annual formation from non-destructive samples collected in two phyto-ecological units, in Roraima. With ring dating and data synchronization, we hope to quantify the secretory structures occurrence and density in $C$. pubiflora's timber over time, relating them to oleoresin production (liters) and trees functional and structural attributes (age, diameter at breast height, total height, commercial height, crown area), from a dendroanatomic analysis. Funding: This work was supported by Embrapa through Kamukaia III Project - "Appreciation of non-timber forest products in the Amazon" [grant number SEG 12.13.07.007.00.00].

\section{Prediction of tree-ring widths using climate data time-series modeling approach}

Dejan Stojanovic ${ }^{1}$, Milena Kresoja ${ }^{2}$, Tom Levanič³, Bratislav Matovic ${ }^{1}$, Vladimir Djurdjevic ${ }^{4}$, Sasa Orlovic ${ }^{1,5}$, Srdjan Stojnic ${ }^{1}$, Mirjana Stevanov ${ }^{1,6}$ ${ }^{1}$ University of Novi Sad, Institute of lowland forestry and environment, Novi Sad, Serbia; ${ }^{2}$ University of Novi Sad, Faculty of Sciences, Department of Mathematics and Informatics, Novi Sad, Serbia; ${ }^{3}$ Slovenian Forestry Institute, Ljubljana, Slovenia; ${ }^{4}$ University of Belgrade, Faculty of Physics, Institute of Meteorology, Belgrade, Serbia; ${ }^{5}$ University of Novi Sad, Faculty of Agriculture, Novi Sad, Serbia; ${ }^{6}$ University of Goettingen, Faculty of forest sciences and forest ecology, Chair of forest and nature conservation policy Goettingen Germany (dejan.stojanovic@uns.ac.rs; milena.kresoja@dmi.uns.ac.rs; tom.levanic@gozdis.si; bratislav.matovic@gmail.com;vdj@ff.bg.ac.rs; sasao@uns.ac.rs; srdjan.stojnic@uns.ac.rs; mzavodj@gwdg.de)

Dendrochronology is a scientific discipline that performs dating of historical events allowing better understandig of environmental processes and human induced changes including past weather, forest fires, landslides, insect outbreaks, etc. Tree-rings, central paradigm of Dendrochronology, may be well used also 
for climate-growth studies. Impact of extreme climate events on forests in Europe are well documented (forests mortality, frequency of forest fires, intensive and frequent pest attacks, etc.). Numerous climate impact studies were published regarding potential forest survival and growth in the 21st century. What was missing are prediction regarding near future. We analyzed tree-ring data from oak trees from southeast Europe together with temperature and precipitation data from CARPATCLIM database using time-series model. Autoregressive Integrated Moving Average Model joined with mean temperature and precipitation for the period April-August was used. Model parameters were obtained for the period 1961-2000 and then tested on the last 10 years of climate data (20\% of sample, period 2001-2010). Calculated mean absolute error and mean square error between modeled and measured data were below 5\%. Devoloped modeling approach may provide firm base for near real-time prediction of tree-ring widths and consequentally forest growth and their response to exteme weather events.

\section{Dendroecology applied to the sustainability of Hevea spruceana management in central Amazon \\ Claudio Roberto Anholetto Junior ${ }^{1,2}$ iD, Mario Tomazello-Filho ${ }^{2}$ (D) \\ ${ }^{1}$ Mamirauá Institute for Sustainable Development, Tefé, Brasil; 2Universidade de São Paulo,Piracicaba, Brasil (anholettojr@usp.br; mtomazel@usp.br)}

Among the Amazon forest environments, the várzea stands out because it occupies a large part of the territory. They are floodplains with high productivity that occur along white water rivers with high concentration of nutrients and sediments. The effects of climate change in Amazon are mainly felt in the influence on the hydrological cycle, with recent and recurring events of climate extremes, and várzea is known as one of the most vulnerable environments to these events. In order to verify the effect of the climate change over growth dynamics of tree species in the Amazonian floodplain, samples of Hevea spruceana trees secondary xylem were obtained for tree rings analisys. Permanent plots were installed in the Mamirauá Sustainable Development Reserve, in Amazonas state, in areas that were later submitted to community forest management, and 20 trees were sampled from there. From the macro/microscopic anatomical analysis we verified the formation of growth limits by thickening of secondary cell walls. The delimitation of the annual rings allowed the definition of the diametric increment pattern, followed by the date synchronization between the samples and time series of growth rings. The correlation between the growth series presented values of $r=$ 480 , notably influenced by the presence of false growth rings throughout the series. The sensitivity of the master series was $r=425$. The analysis of the growth series will allow the definition of the minimum cutting diameter and cutting cycle to which species should be submitted, contributing to the sustainability of the activity.

\section{Dendrogeomorphological approach to evaluate soil degradation process in the tropics}

Renata Cristina Bovi ${ }^{1}$, Marcelo Pablo Chartier ${ }^{2}$,Fidel Alejandro Roig ${ }^{3}$, Mario Tomazello-Filho ID $_{\text {Miguel Cooper }}^{5}$

${ }^{1}$ Universidade Estadual Paulista "Júlio de Mesquita Filho", Instituto de Geociências e Ciências Exatas, Rio Claro, Brasil;; ${ }^{2}$ Instituto de Investigaciones Biológicas y Tecnológicas, Centro de Ecología y Recursos Naturales Renovables, Córdoba, Argentina; ${ }^{3}$ Instituto Argentino de Nivología, Glaciología y Ciencias Ambientales, Mendoza, Argentina; ${ }^{4}$ Univeridade de São Paulo, Departamento de Ciências Florestais, Piracicaba, Brasil; ${ }^{5}$ Universidade de São Paulo, Departamento de Solos e Nutrição de Plantas, Piracicaba, Brasil (bovirc@gmail.com; mpchartier@gmail.com; froig@mendoza-conicet.gob.ar; mtomazel@usp.br; mcooper@usp.br)

Soil erosion is a degradation process that has caused significant impacts in the environment and does not glimpse changes in the 21 st century, especially in developing countries in the tropics and subtropics. The basis of the dendrogeomorphology method is the determination of the influence of geomorphological processes that affect the tree spcies healthy growth, verified by changes in the growth patterns and tree-rings anatomical features. In this study, we describe the anatomical responses and changes in the pattern of root growth subject to the natural exposure by erosive processes of a Brazil native hardwood species (Esenbeckia leiocarpa, Rutaceae), to estimate the first year of root exposure. Changes in the growth and anatomy of the tree-ring after the root exposure was identified, such as changes in eccentricity index, tree-ring width, vessel frequency and scars, which enabled dating the first year of root exposure. Based on the dates of exposure of each root, we reconstructed the dynamics of the erosive process and inferred the soil loss rate. The present study represents one of the firsts applications of the dendrogeomorphology in a tropical climate arboreal species once almost all studies were carried out in temperate species. This analysis allowed quantifying and evaluate the erosive process dynamics of complex systems in tropical regions, in a time and space form, and to infer soil erosion rates. The results can be relevant to warn about the dangers of soil loss in forests and agricultural areas that sustain large economies in the neotropics.

Measuring growth rings in cedar trees (Cedrela odorata L.) from the Tapajós National Forest in Pará, Brazil using X-ray absorptiometry for environmental studies / Caracterização dos anéis de crescimento das árvores de cedro (Cedrela odorata l.), da Flona, Tapajós, PA, Brasil, pela densitometria de raios $x$ para estudos ambientais

Ariele Martinelli Bondioli ${ }^{1}$,Luciana Karla Valéria dos Santos Souza ${ }^{1}$, Bruna Hornink ${ }^{1}$, Daigard Ricardo Ortega Rodriguez ${ }^{1}$, Mario Tomazello-Filho ${ }^{1}$ Escola Superior de Agricultura "Luiz de Queiroz", Universidade de São Paulo Piracicaba, Brasil (ariele.bondioli@usp.br; lucianasousaufopa@gmail.com; bruna.hornink@usp.br;dai.ricardo.or@gmail.com;mtomazel@usp.br)

No Brasil, os estudos dendroclimatológicos têm significativa e estratégica importância na floresta tropical da Amazônia, a qual colabora com o regime de chuva do país e vem sofrendo contínuo desmatamento. Assim, este projeto tem o objetivo, no contexto de mudanças do clima, de caracterização da microdensidade dos anéis de crescimento do lenho das árvores de Cedrela odorata, a fim de subsidiar estudos climatológicos. Foram coletadas 15 discos do lenho da base de árvores de Cedrela odorata na Floresta Nacional do Tapajós, Belterraém, PA. Foi utilizado um raio por amostra. As amostras foram polidas e um raio por disco cortado obtido na uma secção transversal para análise por microdensitometria de raios X. Verifica-se, através do perfil de densidade, que a espécie delimita seus anéis por parênquima marginal, podendo apresentar anéis falsos ou descontínuos. Os anéis de crescimento apresentam densidade aparente de $0,377 \mathrm{~g} / \mathrm{cm}^{3}$ no cerne e no alburno de $0,434 \mathrm{~g} / \mathrm{cm}^{3}$. Na região do lenho inicial, a densidade média é de $0,311 \mathrm{~g} / \mathrm{cm}^{3}$ e no lenho tardio, $0,403 \mathrm{~g} / \mathrm{cm}^{3}$. Em anéis estreitos, a densidade é de $0,308 \mathrm{~g} / \mathrm{cm}^{3}$, no lenho inicial e $0,398 \mathrm{~g} / \mathrm{cm}^{3}$, no lenho tardio, ocorrendo redução aproximada de $8 \%$ e de $1 \%$ respectivamente. Esses resultados auxiliarão na determinação acurada dos anéis de crescimento para a construção do incremento anual e dos perfis de microdensidade dos anéis de crescimento da espécie, para estudos dendroclimatológicos. 


\title{
Growth response to extreme drought of endemic Mediterranean forests in central Chile
}

Alejandro Venegas-González¹, Tania Gipoulou', Ariel Muñoz², Isabella Aguilera²

${ }^{1}$ Universidad Mayor, Santiago, Chile; ${ }^{2}$ Pontificia Universidad Católica de Valparaíso,Valparaíso, Chile (alejandro.venegas@umayor.cl;

taniagipoulou@gmail.com; ariel.munoz@pucv.cl; isabella.aguilera@pucv.cl)

The forest ecosystems of central Chile $\left(30^{\circ}-35^{\circ} \mathrm{S}\right)$ are the only Mediterranean forests in South America. These forests contain a high diversity of endemic plants, so they have been declared a biodiversity hotspot, that is, a biogeographic area of great biological richness with need of conservation. The increase in drought conditions experienced in central Chile during the last century has been little studied, mainly the extremes droughts. For this reason, it is essential to study the influence of climate change and extreme drought on the forest dynamics of the two most important forest-types in central Chile, sclerophyllous forests (evergreen trees, <1000 m a.s.l.) in valleys and hillsides; and Nothofagus forests (deciduous trees, >1000 m a.s.l.) on the mountain peaks of central Chile. Here, we use a dendroecological approach to asses the resistance, resilience and recovery of sclerophyllous and Nothofagus forest to exceptional droughts in 1968 and 1998. We selected five chronologies per forest type in a latitudinal gradient $\left(32^{\circ}-34^{\circ} \mathrm{S}\right)$. Preliminary results showed that southern populations (sites with higher rainfall) are more resistant to drought than northern sites, but they have lower recover. Relative resilience to drought increased with dry sites but decreased with increasing winter precipitation in southern sites. Similar results have found in forests from Western Mediterranean basin. The results will provide valuable information to understand the ecological resilience of the Mediterranean ecosystems of South America, and thus be useful for future conservation and restoration programs for the effects of climate change.

\section{B6a: ACHIEVING REDD+: FROM LOCAL ACTIONS TO NATIONAL COMMITMENTS}

\section{Saying no to ITMO: implications for REDD+ finance from Indonesia's rejection of internationally transferred mitigation outcomes \\ Ellyn Kathalina Damayanti, (D, Andi Fadly Yahya², Nicholas John Berry ${ }^{3}$ (D) \\ ${ }^{1}$ Faculty of Forestry, Bogor Agricultural University, Bogor, Indonesia; ${ }^{2}$ Rafflesia Research Network, Bogor, Indonesia; ${ }^{3}$ The Landscapes and Livelihoods \\ Group,Edinburgh, United Kingdom (ellynk.damayanti@gmail.com; andifyahya@gmail.com; nick@landscapesandlivelihoods.com)}

Indonesia was one of the first countries to finalize its National REDD+ strategy and has made good progress with other REDD+ instruments development. The Funding Instruments for REDD+ have only recently been clarified, however, and the implications of Indonesia's decisions in UNFCCC negotiations are not yet fully understood. In 2016, Indonesia ratified the Paris Agreement, but excluded Article 6 that allow voluntary international transfers of mitigation outcomes (ITMO). Indonesia intends to use all emission reductions achieved within the country, including those from REDD+, to the targets in its Nationally Determined Contribution (NDC), reducing the potential for REDD+ projects and sub-national programs to directly access international finance for emission reductions. This research aims to clarify the current state of REDD+ funding instrument development in Indonesia and identify the funding opportunities can now be accessed by the REDD+ proponents. The study highlights that through the funding instrument system being developed, REDD+ proponents must be registered in a National Registry System. Emission reductions achieved within Performance Measurement Areas delineated by the Ministry of Environment and Forestry, may receive funding for implementing REDD+ activities and result-based payments through the Environment Fund Management Agency. This Agency will manage funds from various sources for restoration of environmental destruction and pollution, including REDD+. Indonesia's decision on Article 6 of the Paris Agreement therefore affects proponents who have been engaging international cooperation and transfer of mitigation outcomes, who must now comply with this decision and adjust any cooperation agreements to exclude ITMO by 31 December 2019.

\section{Identifying entry points among competing forest conservation and land development priorities in subnational implementation of REDD+ in Indonesia's agricultural frontiers}

\author{
Anna Sanders ${ }^{1}$, Rebecca Ford ${ }^{1}$, Rodney Keenan ${ }^{1}$, Anne Larson ${ }^{2}$ \\ ${ }^{1}$ University of Melbourne, Parkville, Australia; ${ }^{2}$ Center for International Forestry Research, Lima, Peru (annaps@student.unimelb.edu.au; \\ fordr@unimelb.edu.au; rkeenan@unimelb.edu.au; a.larson@cgiar.org)
}

Limitations of top-down approaches are often identified in the design and implementation of international forest conservation and climate change objectives. Reducing Emissions from Degradation and Forest Degradation (REDD+) is a prominent environmental scheme focusing in carbon-rich forested landscapes in developing countries. This research addresses gaps in understanding of subnational implementation of REDD+ relating to competing forest conservation and land development priorities in resource frontiers. The case study in the southern peatlands of Central Kalimantan province in Indonesia, an agricultural resource frontier, combined an ethnographic approach with document analysis. The findings are based on approximately 10 months of field research conducted at time intervals between 2013 and 2015. Features of actor-network theory (ANT) were used to explore negotiations over land relating to large REDD+ projects, forest conservation, such as national parks, and large-scale land development, principally commercial oil palm concessions. The concept of an entry point was identified to describe how different actors, including oil palm and REDD+ investors, entered the existing systems of forest and land allocation in contested legal arrangements, and how interactions among land use changes affect local villagers. This concept is relevant to approaches to forest conservation and environmental governance to identify impediments to achieving global objectives and provide space for local inputs into planning processes at higher levels. It is also relevant to land development in resource frontiers generally, where there is a need to identify strategic, political entry points to target environmental reform.

\section{Jurisdictional REDD+ in Brazil: transnational pathways of influence and domestic strategies of policy entrepreneurship in subnational policy processes}

Carolina Gueiros ${ }^{1}$

${ }^{1}$ University of Oxford, Oxford, United Kingdom (carolina.gueiros@ouce.ox.ac.uk)

As part of the world's efforts to combat climate change, many tropical states and provinces are developing subnational 'jurisdictional' REDD+ policy programs that seek to transform the way forests and related sectors are governed. While these initiatives are largely 'bottom-up', they are also guided and supported through the rules, norms, funding, and assistance provided by a wide array of multilateral and bilateral initiatives. Whether REDD+ efforts will be able to deliver transformative change in environmental governance or reproduce the policy status quo remains an outstanding question. More research is needed to understand whether and how domestic policy actors may harness the transnational pathways of influence opened by REDD+. This paper examines the pursuit of subnational jurisdictional REDD+ in Brazil. While debates have been ongoing at the federal level, three states in the Brazilian Amazon have developed state-level REDD+ policies. This paper seeks to understand progress made by the Brazilian states of Amazonas, Acre, and Mato Grosso in enacting subnational 
jurisdictional policies. Through exploring the interplay between the transnational pathways of influence generated by REDD+ and strategies of domestic policy entrepreneurship in each state, this paper draws on 50 interviews with key policy makers in Brazil, documental analysis, and participant-observation to processtrace how domestic policy actors in those states have harnessed or not the pathways of influence provided by the transnational REDD + movement. This paper aims to generate important lessons about the pursuit of REDD+ within a federal system, and about the cross-scale dynamics of policy innovation more broadly.

\section{Designing the market for environmental reserve quotas: property-level analysis of environmental compliance strategies in Mato Grosso, Brazil}

Ruben Lubowskil,2, Breno Pietracci $i^{1}$, Diego Herrera ${ }^{1}$, Gabriela Leslie ${ }^{1}$

${ }^{1}$ Environmental Defense Fund, New York, USA; ${ }^{2}$ School of International and Public Affairs, Columbia Univerisity, New York, USA (rlubowski@edf.org; bpietracci@edf.org; dherrera@edf.org; gleslie@edf.org)

The 2012 Brazilian Forest Code establishes native vegetation preservation requirements within private rural properties. It introduced a marketable instrument, Environmental Reserve Quotas (Cota de Reserva Ambiental; CRA) that enables landowners to compensate for deficits by paying for the conservation of surplus forest areas on other properties. The recent promulgation of federal regulations for CRAs in December 2018 can be a major opportunity for landowners to monetize environmental assets and reduce costs of Forest Code compliance, but impacts hinge critically on appropriate market designs. We provide a microeconomic analysis of the economic and environmental impacts of alternative potential designs for the CRA market using a novel property-level database for the leading agricultural state of Mato Grosso where private properties have to bring to compliance a deficit of 8.7 million hectares. Using econometricallyderived estimates of opportunity costs of avoided deforestation, property data on native vegetation surpluses and deficits, and land values and reforestation cost information, we build supply and demand curves for CRAs for each property and model alternative market equilibria. A large potential supply of CRAs with zero opportunity costs can drive the market equilibrium price to zero, while the price is about 500 reais/hectare/year with supply only from medium-large properties with native vegetation surplus. We evaluate alternatives to restrict supply, interactions with potential carbon and other ecosystem service incentives programs, role of penalties for noncompliance, and transaction costs, and show that a well-designed market can drive important environmental benefits and costs savings.

\section{Evaluating the impacts of different types of REDD+ interventions on forests and people}

Amy Duchelle ${ }^{1}$,Astrid Bos ${ }^{2}$, Claudio de Sassi ${ }^{1,3}$,Erin Sills ${ }^{1,4}$, Mella Komalasari $^{1}$, Sven Wunder ${ }^{5}$

${ }^{1}$ Center for International Forestry Research (CIFOR), Bogor Barat, Indonesia; ${ }^{2}$ Wageningen University, Wageningen, Netherlands; ${ }^{3}$ Swiss Federal Office for the Environment, Bern, Switzerland; ${ }^{4}$ North Carolina State University, Raleigh, USA; ${ }^{5}$ European Forest Institute (EFI), Barcelona, Spain (a.duchelle@cgiar. org; astrid.bos@wur.nl; cdesassi@gmail.com; sills@ncsu.edu;m.komalasari@cgiar.org;s.wunder@cgiar.org)

Since its inception over ten years ago, REDD+ (Reducing Emissions from Deforestation and forest Degradation plus enhancing carbon stocks) has been piloted through more than 300 subnational initiatives across the tropics. Initiative implementers are applying REDD+ intervention packages that in customized ways combine disincentives (e.g. restrictions on forest access or conversion) and incentives (conditional or non-conditional) to allegedly achieve better protection of forests. Through CIFOR's Global Comparative Study on REDD+,we evaluated the forest conservation and community well-being impacts of 22 subnational REDD+ initiatives in Brazil, Peru, Cameroon, Tanzania, Indonesia and Vietnam. We combined socioeconomic surveys in 150 communities and nearly 4,000 households (including control groups) in 2010-2012 (pre-intervention) and 2013-2014 (post-intervention), with an analysis of Global Forest Change data (2000-2015), to assess how different interventions affected changes in income, assets, perceived well-being and forest cover at the community level. We found a reduction in forest cover loss at half of the REDD+ sites, with better conservation outcomes in places where there was higher treatment intensity of disincentives. Both intervention types had neutral impacts on income and assets, but higher exposure to disincentives led to decreases in overall perceived wellbeing, except when balanced out by incentives. Although disincentives may be an effective REDD+ instrument for conserving forests, other measures are clearly needed to safeguard and enhance community well-being.This critically needed empirical evidence on REDD+ performance on the groundis relevant to policy makers and practitioners interested in developing REDD+ strategies that can provide both conservation and livelihood benefits.

Can REDD+ provide local as well as global forest benefits? A process and impact evaluation of the Katingan Mentaya Project, Central Kalimantan, Indonesia

Vivi Selviana ${ }^{1}$, Stibniati Atmadja ${ }^{2}$, Erin Sills ${ }^{1}$

${ }^{1}$ North Carolina State University, Raleigh,USA; ${ }^{2}$ Center for International Forestry Research, Addis Ababa, Ethiopia (vselvia@ncsu.edu; s.atmadja@cgiar.org; sills@ncsu.edu)

The traditional rural population of Indonesia is highly dependent on forests for their livelihoods, including both products and services for both market and subsistence. Thus, their livelihoods are threatened by economic development activities that lead to deforestation. In this context, REDD+ can potentially be a win-win for local and global populations, protecting livelihoods while it mitigates climate change. However, there is significant controversy over whether REDD + can achieve this potential. The controversy partly reflects highly varied understandings about what REDD + really is and how it will be implemented on the ground. To shed light on this debate, we present a detailed explanation of how one REDD+ project has been implemented and counterfactual-based evidence on its livelihood impacts. The Katingan Mentaya Project was launched in 2009 and issued its first carbon credits in 2017. To accomplish this, it implemented a bundle of interventions, which we categorize as restrictions on forest access and/or conversion, forest enhancement, non-conditional livelihood enhancements, conditional livelihood enhancement, environmental education, and tenure clarification. Based on detailed income data collected at three points in time (2011, 2014, and 2018) in communities both inside and outside the intervention area, we estimate a difference-in-difference model in a matched sample to test the effects of these interventions on household income from the forest.

\section{Evaluating the impacts of integrated conservation as a REDD+ strategy in Mato Grosso (Brazilian Amazon)}

Adriana Molina Garzon ${ }^{1}$, Amy E. Duchelle ${ }^{2}$, Sven Wunder ${ }^{2,3}$

${ }^{1}$ University of Colorado at Boulder, Boulder, USA; ${ }^{2}$ Center for International Forestry Research (CIFOR), Bogor, Indonesia; ${ }^{3}$ European Forest Institute (EFI), Barcelona,Spain (adriana.molinagarzon@colorado.edu; a.duchelle@cgiar.org; s.wunder@cgiarorg)

For decades, integrated conservation and development projects (ICDP) have attempted to simultaneously reduce deforestation and improve livelihoods, by creating alternative employment options, introducing land-sparing agricultural technologies, and reducing rural poverty. ICDP-like strategies also prove to 
be at the core of many subnational REDD+ programmes to mitigate climate change. Here we examine one such programme, implemented in northwestern Mato Grosso, in the so-called Arc of Deforestation of the Brazilian Amazon. Interventions have aimed to improve agricultural productivity and livelihoods of beneficiary communities, without establishing direct conditions of conservation outcomes in exchange (non-performance-based incentives). Based on beforeafter control-intervention (BACI) surveys of 240 households (53\% intervention, $47 \%$ control group), we first identify household-level drivers of forest clearing, and then examine early conservation impacts after four years of programme implementation. Our preliminary findings stress the importance of male adult labour for households' self-reported forest clearing: female-dominated and elderly households clear significantly less forest, as do more educated households that likely have higher opportunity costs of labour. In principle, the ICDP focus on household use of labour thus the main goal would be to redirect male adult labour into more sustainable activities. Nevertheless, the intervention has so far not mitigated forest clearing: the difference-in-difference (DID) impacts between intervention and control groups are insignificant, both for the entire programme as for selected subcomponents: either its conservation impacts need more time to pan out, or the ICDP approach was locally inadequate, compared for instance to performance-based alternative forms of intervention.

\title{
Evaluating the forest conservation impacts of local REDD+ initiatives: insights from Madre de Dios, Peru \\ Javier Montoya ${ }^{1,3}$, Sven Wunder ${ }^{2,3}$, Amy Duchelle \\ ${ }^{1}$ Australian National University, Canberra, Australia; ${ }^{2}$ European Forest Institute (EFI), Barcelona, Spain; ${ }^{3}$ Center for International Forestry Research (CIFOR),Bogor, Indonesia (jmontoya.iq@gmail.com; s.wunder@cgiar.org; a.duchelle@cgiar.org)
}

Initiatives to Reduce Emissions from Deforestation and forest Degradation and enhance carbon stocks (REDD+) have been implemented tropics-wide over the last decade, yet so far surprisingly little is known about their forest conservation impacts. REDD+ policy mixes are often highly complex, combining incentives, forest law enforcement, and investments in productive alternatives, which also makes their attributive impact evaluation methodologically challenging. Here we analyze one such REDD+ initiative, involving Brazil nut concessionaries in the Peruvian Amazon (Department of Madre de Dios), close to Peru's trinational border with Bolivia and Brazil. This initiative is emblematic in that it seeks to conserve a portion of the largest remaining tract of Brazil nut rich-forests through private funds. Combining longitudinal data from remote sensing (2000-2018) and surveys with 240 households from 2010, 2014, and 2018, we evaluate the project's impacts vis-à-vis the intended goal of mitigating forest degradation and conversion. To do so, we use a before-after control-intervention (BACI) approach, combined with matching techniques and multivariate regressions, so as to minimize any participation selection bias. As for results, we find that forest conservation impacts so far have been curtailed by low treatment intensities, caused particularly by interrupted funding and consequent project delays. This highlights the importance of REDD+ financial sustainability. We discuss the relevance of our findings for national policies that seek to mitigate Peru's forestbased emissions, such as the Programa Bosques that is currently being upscaled from its pilot stage.

\section{B6p: ACHIEVING REDD+: FROM LOCAL ACTIONS TO NATIONAL COMMITMENTS}

\section{Quantifying emissions and their uncertainties in a forest transition landscape: the case of the Southern Cameroon forest plateau}

\author{
Johannes Pirker ${ }^{1,2}$, Aline Mosnier ${ }^{1,3}$, Tatiana Nana ${ }^{4}$, Matthias Dees $^{5,6}$, Achille Momo $^{4}$, René Siwe \\ ${ }^{1}$ International Institute for Applied Systems Analysis, Laxenburg, Austria; ${ }^{2}$ KU Leuven, Catholic University of Leuven, Leuven, Belgium; ${ }^{3}$ Sustainable \\ Development Solutions Network, Paris, France; ${ }^{4}$ Technical REDD+ Secretariat, Ministry of the Environment, Yaoundé, Cameroon; ${ }^{5}$ University of Freiburg, \\ Freiburg, Germany; ${ }^{6}$ UNIQUE forestry and land use GmbH, Freiburg, Germany; ${ }^{7}$ US Forest Service, Brazzaville, Congo (pirker@iiasa.ac.at; \\ mosnier@iiasa.ac.at; andytatiana@gmail.com; matthias.dees@t-online.de; machibe2003@yahoo.fr; rene.siwe@gmail.com)
}

Cameroon is a HFLD country characterized by high remaining forest cover and relatively low but steadily rising deforestation rates (i.e. $>50 \%$ forest cover and a deforestation rate $<0.22 \%$ per year). The driving forces of forest conversion are expected to even accelerate in the next decades due to population growth, infrastructure development and agriculture expansion. These factors have to be taken into account when predicting future forest loss and resulting emissions for the establishment of forest reference (emission) levels. However, the consideration of these likely future developments contributes an additional degree of uncertainty to the overall uncertainty of future GHG emission estimates. Greenhouse gas accountings should follow the TCCCA principles (Data underlying any emissions reporting need to be Transparent, Complete, Consistent, Comparable and Accurate according to the UNFCCC), which many countries often find difficult to live up to in their national GHG reportings, specifically when addressing projections into the future. The objective of this paper is to introduce a new and flexible methodology in us in Cameroon to account for likely future development trajectories in projections of greenhouse while also quantifying the sources of uncertainty underlying these calculations. Accounting for the future demand for agricultural commodities, the approach takes quantitative account of emerging mega-trends in Cameroon such as population growth and urbanization; both are considered to have substantial impact on land use in the country. Furthermore, the contribution will place specific focus on quantifying the uncertainty associated with the calculation of emissions, in particular when accounting for likely future development trajectories.

\section{The contribution of the Austrian forest-based sector to climate change mitigation with regard to climate change impacts and adaptation measures in Austrian forests}

Martin Braun ${ }^{1}$, Peter Schwarzbauer ${ }^{1,2}$, Franziska Hesser ${ }^{2}$, Thomas Ledermann ${ }^{3}$, Thomas Gschwantner ${ }^{3}$, Georg Kindermann ${ }^{3}$, Klemens Schadauer $^{3}$, Robert Jandl ${ }^{3}$, Alice Ludvig, Gerhard Weiss ${ }^{4}$, David Fritz, Werner Pölz ${ }^{5}$, Carmen Schmid ${ }^{5}$, Peter Weiss ${ }^{5}$

${ }^{1}$ Institute of Marketing \& Innovation, Dept. of Economics and Social Sciences, University of Natural Resources and Life Sciences, Vienna, Austria; ${ }^{2}$ Team for Market Analysis and Innovation Research, Wood K plus - Kompetenzzentrum Holz GmbH, Linz, Austria; ${ }^{3}$ Federal Research and Training Centre for Forests, Natural Hazards and Landscape, Vienna, Austria; ${ }^{4}$ Institute of Forest, Environmental, and Natural Resource Policy, Dept. of Economics and Social Sciences, University of Natural Resources and Life Sciences, Vienna, Austria; ${ }^{5}$ Environment Agency Austria, Vienna, Austria (martin.braun@boku.ac.at; peter.schwarzbauer@boku.ac.at; franziska.hesser@wood-kplus.at; thomas.ledermann@bfw.gv.at; thomas.gschwantner@bfw.gv.at; georg.kindermann@bfw. gv.at; klemens.schadauer@bfw.gv.at; robert.jandl@bfw.gv.at; alice.ludvig@boku.ac.at; gerhard.weiss@boku.ac.at; david.fritz@umweltbundesamt.at; werner. poelz@umweltbundesamt.at; carmen.schmid@umweltbundesamt.at; peter.weiss@umweltbundesamt.at)

Forests and harvested wood products (HWP) can significantly contribute to meet nationally determined contributions (NDC) arising from the Paris Agreement. The global forest-based sector (FBS) and its contribution to climate change mitigation is not only affected by climate change impacts and expected forest adaptation measures affecting harvest rates and wood delivery but is also facing structural changes through global shifts in production centres and changes in production and consumption patterns. The presented project analysed mid- to long-term developments in the Austrian wood-based value chain using a partial equilibrium dynamic forest sector model for different climate change impacts and related adaptation measures in the forests including six scenarios: - two 
business-as-usual scenarios (for RCP 4.5 and 8.5), a scenario assuming tree species shift through adaptive management, a catastrophe scenario with rising impacts from storm, bark beetle infestation, and dry spells, a scenario implementing a reduction of the rotation period and a scenario aiming at the increase of the growing stock in forests. Simulations were conducted for the time period 2010-2150 including long-term forecasts for economic framework conditions until 2050 and assumptions for constant market conditions after 2050. Results help contribute to the understanding of carbon dynamics through a cascade of models comprising forest management, harvested wood products and life cycle assessments (considering material \& energy substitution). Identification of critical factors helps to assess the potential contribution of the FBS to NDC. Furthermore, associated impacts on forest product markets as well as interdependencies within the FBS can be identified.

\title{
Forestry sector engagement in climate change action: the role of public and private sector in Zimbabwe
}

Lizzie Mujuru ${ }^{1}$ (D), Vincent Oeba ${ }^{2}$, Mahamane Larwanou ${ }^{2}$

${ }^{1}$ Bindura University of Science Education, Bindura, Zimbabwe; '2African Forest Forum (AFF), Nairobi, Kenya (lzzmjr2009@gmail.com; v.oeba@cgiar.org; m.larwanou@cgiar.org)

Forests and forest products industries are a source of economic growth and employment in both developed and developing nations. A study was done to examine the role of Zimbabwean forestry sector in responding to climate change with the aim of generating knowledge to facilitate development of public-private sector partnerships. Questionnaires and face to face interviews were used to collect data from public, private and non-governmental organisations (NGOs) working in forestry. Results suggest that there was some response to climate change by public and private forest organizations and NGOs. There was however, realization of climate change and some effort to change management practices (e.g. using planting gel and species selection) although, there was uncertainty about how to adapt. Level of adaptation was low and somehow difficult to measure among key actors as existing adaptive actions were not normally documented as climate change actions. Climate change related actions were mostly limited to ways of reducing emissions in industrial operations. Forestry activities were not really focused on addressing climate change but on survival given national economic crisis. All private sector actors were not involved and had no plans for marketing and trade in forest carbon but efforts were made by NGOs to make communities aware of climate change. Main challenges to forest productivity included the poor national economy, wild fires and invasion of forests by illegal settlers. More work is needed to encourage forestry sector to focus on climate change mitigation and adaptation and promote resilience.

\section{Carbon sequestration as a new objective in fast growing plantations' tactical management}

Carlos Romero ${ }^{1}$, Luis Diaz-Baltero ${ }^{1}$

${ }^{1}$ Universidad Politécnica de Madrid, Madrid, Spain (inv.florestal@gmail.com; carlos.romero@upm.es; luis.diaz.balteiro@upm.es)

Forest plantations can play an important role in the $\mathrm{CO}_{2}$ removals considering this new ecosystem service in the forest management planning issues. This goal might contribute to the mitigation of climate change, considering the reduction of the greenhouse gases emissions from the harvesting operations and transportation in spatially explicit tactical planning problems. This research aims to integrate the carbon balance as a new objective for solving a tactical forest planning integrating other production criteria by resorting to multiple criteria decision making tools. The case study corresponds to an industrial forest company located in Brazil. The results reveal the marked difficulty in obtaining from an economic and forestry viewpoint good harvest schedules compatible with high levels of carbon captured.

\section{A large-scale restoration strategy for small landowners in Brazil}

\author{
Aline Soterroni ${ }^{1,2}$, Fernando Ramos ${ }^{1}$, Marluce Scarabello ${ }^{1}$, Hugo Valin ${ }^{2}$, Aline Mosnier ${ }^{2}$, Vagna Pereira ${ }^{3}$, Marcia Zilli ${ }^{1}$, Wanderson Costa ${ }^{1}$, Pedro Andrade , $^{1}$ \\ Marina Pena ${ }^{4}$, Heloisa Ruivo ${ }^{1}$, Rolf Simões ${ }^{1}$, Alexandre Carvalho ${ }^{4}$, Gilberto Câmara ${ }^{1}$, Michael Obersteiner ${ }^{2}$ \\ ${ }^{1}$ Instituto Nacional de Pesquisas Espaciais, São José dos Campos, Brasil; ${ }^{2}$ International Institute for Applied Systems Analysis, Laxenburg, Austria; \\ ${ }^{3}$ Universidade Federal de Viçosa, Viçosa, Brasil; ${ }^{4}$ Instituto de Pesquisa Econômica Aplicada, Brasilia, Brasil; ${ }^{5}$ UN Environment World Conservation \\ Monitoring Centre, Cambridge,United Kingdom (soterr@iiasa.ac.at; fernando.ramos@inpe.br; mascarabello@gmail.com; valin@iiasa.ac.at; \\ mosnier@iiasa.ac.at;vagna.jp@gmail.com; marciatz@gmail.com; wcosta.comp@gmail.com; pedro.andrade@inpe.br;marina.pena@ipea.gov.br; \\ helo_mr@hotmail.com; rolfsimoes@gmail.com; alexandre.ywata@ipea.gov.br; gilberto.camara@inpe.br; oberstei@iiasa.ac.at; pirker@iiasa.ac.at; \\ havlikpt@iiasa.ac.at; val.kapos@unep-wcmc.org;will.simonson@unep-wcmc.org;shena.garciarangel@unep-wcmc.org;kraxner@iiasa.ac.at)
}

Brazil's new Forest Code grants amnesty of environmental debts for small landowners that illegally cleared their forests before 22 July 2008 . Based on the Rural Environmental Registry (Portuguese acronym: CAR) from December 2016, this exemption applies to 19 million deforested hectares across country, mainly located in Atlantic Forest and Amazon biomes. We investigated the implications of this amnesty for the potential for forest restoration and associated changes to land use and emissions using the global economic partial equilibrium model GLOBIOM-Brazil. We modeled scenarios on the future enforcement of the Forest Code and its restoration requirements, with and without the small farms amnesty, and found that the area of forest restoration ranged from 12 to 31 million hectares. The different scenarios investigated included different governance in relation to the degree of control of illegal deforestation and compliance with forest restoration obligations. We estimated future negative emissions from each of these scenarios along with positive emissions from land use conversions. We assess the potential for emissions reduction of forest restoration within the land for which amnesty was granted, as well as the trade-offs with the production sector. Our results emphasize the need to design large-scale restoration policies or incentives for small landowners that could be key to enabling Brazil to fulfill its Nationally Determined Contributions of emissions reductions under the Paris Agreement.

\section{Assessment of per capita $\mathrm{CO}_{2}$ emission from households' fuel wood consumption in and around the forest areas of Bangladesh}

Md Nazmus Sadath ${ }^{1,2}$, Md Wasiul Islam ${ }^{1}$

${ }^{1}$ Forestry and Wood Technology Discipline, Khulna University, Khulna, Bangladesh; ${ }^{2}$ Georg August University, Goettingen Forest and Nature Conservation Policy and Forest History, Georg-August University, Goettingen, Germany(mnsadath@yahoo.com; wasiulislam7@yahoo.com)

Forest emission reference level determination is first step in successful implementation of UN- REDD program. Fuel-wood is the most important energy source for rural households in and around the forest areas of Bangladesh, hence fuel-wood consumption is one of the major contributor to the $\mathrm{CO}_{2}$ emission source, which needs to be accounted. However, very little to no study has been done in Bangladesh to estimate $\mathrm{CO}_{2}$ emission from household fuel-wood consumption. This research has been conducted to determine the per-capita household $\mathrm{CO}_{2}$ emission from fuel-wood consumption in and around the forest areas of Bangladesh. Household survey using a semi-structured questionnaire was the applied method for data collection; 500 households were surveyed in five 
differ regions; Southwest zone near the Sundarbans forest, Southeast zone near the hill forest, Northeast zone near hill and swamp forest of Sylhet, Northwest zone near Birol Sal forest and Central zone near Inland Sal forest. The study reveals that the average per capita household carbon emission from fuel-wood consumption is 9.923 tons $\mathrm{CO}_{2}$ per year however the amount varies on the household size and household income. Out of these amount 4.45 ton $\mathrm{CO}_{2}$ per capita household emission is coming from natural forest sources and 5.47 ton $\mathrm{CO}_{2}$ per capita household emission is coming from non-forest sources like home garden and plantations. The study also indicate a possible increasing trends of $\mathrm{CO}_{2}$ emission from household fuel-wood consumption and hence an alternative renewable energy source is warranted for reduction of carbon emission from forest sources.

\section{The potential of tree-based management systems in optimizing the outcomes of REDD+ strategies}

Caroline Souza ${ }^{1}$

${ }^{1}$ Instituto de Pesquisas Tecnológicas, São Paulo,Brasil (casouza@uol.com.br)

This study highlights the potential of commercial tree-based management systems in optimizing the outcomes of REDD+ strategies. Five smallholder treebased management systems were compared regarding both GHG emissions reductions and generation of environmental and socio-economic co-benefits. The systems analyzed were: oil palm plantation, rubber plantation, rubber agroforestry and forest plantation for pulp wood and natural forest management for wood fuel production. A questionnaire with key questions on environmental and socioeconomic aspects of the system was used in semi-structured interviews with 70 producers. The performance of each system considered three indexes: carbon benefit index (I-carbon), environmental conservation benefit index (I-env) and local quality of life benefit index (I-qual life). The average of the three indexes generated the REDD + index (I-REDD) - representing the potential of the system in contributing to REDD+ strategies. The best performance for I-REDD $(0,8114)$ was achieved by natural forest management for wood fuel production, followed by rubber agroforestry $(0,6167)$, rubber plantation $(0,5204)$, oil palm plantation $(0,4054)$ and forest plantation for pulpwood $(0,2758)$. The final classification on each system's potential in contributing to REDD+ strategies was as follows: very high for natural forest management for wood fuel production; high for rubber agroforestry; medium for both rubber plantation and oil palm plantation; low for forest plantation for pulpwood. The methodology proposed can help decisionmakers to design REDD+ strategies considering the potential of tree-based management systems to complement conservation activities in composing the strategy.

\section{Forest governance challenges and opportunities in Bangladesh: institutionalization of co-management as the local level solution under UN-REDD regime}

Md Nazmus Sadath ${ }^{1,2}$, Abdus Subhan Mollick', Md Wasiul Islam ${ }^{1}$

${ }^{1}$ Forestry and Wood Technology Discipline, Khulna University, Khulna, Bangladesh; ${ }^{2}$ Forest and Nature Conservation Policy and Forest History, Gerog August University, Goettingen, Germany(mnsadath@yahoo.com; amsubhan@hotmail.com; wasiulislam7@yahoo.com)

For successful implementation of UN-REDD+ program, good forest governance and equity-based benefit sharing is imperative, which is the challenge in Bangladesh forest sector. The newly adopted Co-management of forest resources has been perceived as the solution for the forest governance issue particularly in light of UN-REDD+ Bangladesh National Program. Despite the establishment of legal and institutional frameworks for developing a meaningful authority of local people, Co-management in Bangladesh has been facing many governance challenges. Therefore meaningful involvement of multilevel stakeholders in forest governance needs to be evaluated. A quantitative and qualitative research method has been applied to investigate a forest governance framework for evaluating the Co-management of forest resources in Bangladesh. A category based content analysis of relevant policy documents and 80 key personal in-depth interview were applied to obtain the data for analysis. A proposed modified framework for evaluation of good governance in terms of participation, transparency, accountability and capacity are adopted. Analysis of data revealed the institutional and legal arrangement of co-management program can provide the local level institution for REDD+ program implementation in Bangladesh. Analysis also indicate that participation received the highest score (3.90/5) followed by capacity (3.70/5), transparency in decision-making (2.42/5) and accountability has the lowest score (2.3/5). Initiation of UN-REDD+ program enhanced the capacity of the stakeholders and forest administration in terms of forest governance. Findings indicate that poor governance still exists in Co-management program but emergence of REDD+ initiative has provided opportunities for achieving good forest governance.

\section{B6q: ACHIEVING REDD+: FROM LOCAL ACTIONS TO NATIONAL COMMITMENTS}

\section{Generating green energy and reducing greenhouse gas emissions / Geração energia verde e redução de emissões de GEE}

Fábio de Paula ${ }^{1}$

${ }^{1}$ Eldorado Brasil Celulose SA, Três Lagoas, Brasil (fabio.paula@eldoradobrasil.com.br)

A Eldorado Brasil já nasceu comprometida com as práticas responsáveis, realizando as atividades de forma ambientalmente adequado, socialmente benéfico e economicamente viável. O que reforça esta diretriz são as certificações que conquistamos: FSC ${ }^{\circledR}$ e CERFLOR, que atestam o emprego das melhores práticas de manejo florestal e o compromisso da Companhia no cumprimento do Código Florestal e legislações pertinentes. A fábrica é autossuficiente em energia renovável e ainda disponibiliza mais de $45 \mathrm{MW} / \mathrm{h}$ de sua geração para o sistema elétrico nacional, contribuindo com ganhos de eficiência no setor elétrico. Também, estamos em fase de construção uma UTE - Usina Termoelétrica, que terá capacidade para produzir 50 MW/h a partir de 2021, cuja matéria prima é a biomassa vinda do aproveitamento de tocos e galhos da produção florestal de eucalipto, fazendo um maior aproveitamento da árvore. A companhia possui diversos programas e estudos que visam reduzir e gerenciar as emissões de GEE para atmosfera. Desde 2013 a empresa faz parte do Programa Brasileiro GHG Protocol, programa que possui método mais usado mundialmente pelas empresas e governos para a realização de inventários de GEE - Gases de Efeito Estufa. Para monitorar cerca de $30 \%$ das áreas destinadas à conservação ambiental e mais de 230 mil hectares de reflorestamento, a Eldorado utiliza sistema de monitoramento com câmeras de última geração e com qualidade de imagem em Full HD que captam ocorrências de focos de incêndios em tempo real. Esta tecnologia possibilitou redução de $70 \%$ dos incêndios florestais reduzindo assim as emissões involuntárias de GEE, demonstrando o compromisso com a conservação das florestas e a qualidade do ar. Nossas florestas em contante crescimento, sequestram o $\mathrm{CO}_{2}$ da atmosfera, acumulando um estoque atual de carbono suficiente para neutralizar mais de 11 anos de todas nossas operações. Na industria, substituímos a matriz energética de uma das nossas três principais fontes de emissões na fabrica, substituindo no forno de cal o óleo combustível por gás natural, além disso a eficiência operacional da fabrica é de $96 \%$, isso permite operarmos em média $30 \%$ abaixo dos limites legisláveis de emissões atmosféricas, contribuindo assim para a redução dos gases de efeito estufa, contribuindo assim para a melhoria da qualidade do ar e da vida. 


\title{
Locking carbon in wooden school furniture - a case study of Haryana State, India
}

Subhash Chander ${ }^{1}$, Vivek Saxena ${ }^{1}$, Amarinder Kaur ${ }^{2}$

${ }^{1}$ Haryana Forest Development Corporation, Gurugram, India; ${ }^{2}$ Haryana Forest Development Corporation, Panchkula, India (syadavhfs02@gmail.com;

viveksax1@gmail.com; md@hfdc.gov.in)

Locking carbon in wooden furniture has been discussed at many platforms in relation to one of strategy under climate change adaptation and mitigation. The wooden furniture in schools can play an important role in locking carbon. The dual desks and furniture used in schools were mainly of iron or plastic in past. But a big initiative was taken by State Government to use wooden dual desks or furniture for government schools to be supplied by State Forest Department or State Forest Development Corporation. Forest Department or State Forest Development Corporation used to do logging activities in the state. The harvested forest produce used to be auctioned to contractors. The contractors used to utilize some of the lesser timber value species for fuelwood after sawing on their saw mills. A big initiative was taken and school furniture of wood was supplied in government schools during 2015-16 and 2016-17 from furniture workshops of the Forest Department and State Forest Development Corporation. The various types furniture supplied and estimated carbon locked in the school furniture will be discussed in the paper and will be presented during the Congress.

\section{Application of REDD+ scheme for blue carbon ecosystem management: potentials and challenges}

\author{
Ryo Kohsaka ${ }^{1}$ (D), Yuta Uchiyama ${ }^{1}$ ID, Kaoru Kakinuma ${ }^{2}$,Jay Mar D. Quevedo ${ }^{3}$, Kevin Muhamad Lukman ${ }^{3}$ \\ ${ }^{1}$ Graduate School of Environmental Studies, Nagoya University, Nagoya, Japan; ${ }^{2}$ Asian Demographic Research Institute, Shanghai University, Shanghai, \\ China; ${ }^{3}$ Graduate School of Environmental Studies,Tohoku University, Sendai, Japan (yutanu4@gmail.com; yutanu4@yahoo.co.jp; \\ k.kakinuma0214@gmail.com; quevedojaymar@gmail.com;kevin.muhamad.lukman@gmail.com)
}

Sustainable management of blue carbon ecosystems is an urgent task especially in the so called "coral triangle area" as emerging frontier for REDD+ related discussions. Blue carbon ecosystems provide multi ecosystem services from their main components including (mangroves, seagrass meadows and salt marshes). They are gaining salience as globally major carbon stocks. Despite its great potentials to enhance the local and global sustainability, blue carbon ecosystems have serious challenges in their managements to acknowledge their multi services. Particularly, implementation of schemes of benefit sharing including REDD+ for their sustainable managements involve issues related to their monitoring and evaluation methods and collaboration of stakeholders including consensus building among them. For example, accurate assessment of carbon stock in blue carbon ecosystem is remained as a challenging task. The remote sensing technic applied for terrestrial forests to identify their carbon stocks cannot be used, because the carbon stocks of blue carbon ecosystem mainly exist underground and simple correlation between the carbon stocks of the aboveground parts of the ecosystem and those of the underground parts is not methodologically solved. Furthermore, the managements of blue carbon ecosystems require collaboration of various stakeholders, and the industrial sectors related to the managements from local and comprehensive perspectives, because of the geographical location of blue carbon ecosystems located in between marine and terrestrial areas.

Socio-economic monitoring in the La Amistad community within the REDD+ Paraguay forest conservation project, Alto Paraná Atlantic Forest component (BAAPA) / Monitoreo socioeconómico en la comunidad La Amistad en el marco del Proyecto de Conservación de Bosques del Paraguay REDD+ componente Bosque Atlántico del Alto Paraná (BAAPA)

Carmen Monges ${ }^{1}$, Elizabeth Monges ${ }^{1}$, Cecilia Pizzurno ${ }^{2}$

${ }^{1}$ Universidad Nacional de Asunción, Asunción, Paraguay; ${ }^{2}$ Guyra Paraguay, Asunción, Paraguay(aracelymonges@gmail.com; lizamonges@gmail.com; ccipizzu2@gmail.com)

El proyecto de Conservación de Bosques del Paraguay en su componente REDD+ BAAPA, busca fortalecer las capacidades y los medios de vida a los beneficiarios de la comunidad La Amistad, integrada por pequeños productores agrícolas que se asentaron dentro de los límites de la reserva para Parque Nacional San Rafael en el distrito de Alto Vera, Departamento de Itapúa, Paraguay. Es la primera experiencia exitosa de mercado voluntario de carbono en Paraguay con certificación internacional bajo los estándares de Verifield Carbon Standard (VCS) y Climate, Community and Biodiversity Standards (CCB). Las actividades establecidas por el proyecto incluyen; el pago por servicios ambientales correspondiente a un ingreso fijo anual de 170USD por superficie de bosque comprometida con REDD+ servicios de extensión, apoyo técnico para la gestión sostenible de sus bosques y el mejoramiento de su producción agrícola. El objetivo general del trabajo fue monitorear los capitales de la comunidad mediante el análisis de indicadores socioeconómicos, la cuantificación de la evolución de los mismos desde el inicio del proyecto hasta el año 2015 y la identificación de los impactos sociales netos, la recolección de datos se realizó mediante una encuesta. Se observó que el contexto de vulnerabilidad está dado por la debilidad en la gestión y organización de la comunidad así como también en la infraestructura vial limitada que impide el acceso a mercados y otros servicios. El aislamiento territorial y la falta de oportunidades de desarrollo generan una mayor tendencia a utilizar el capital natural para la generación de ingresos económicos.

History and current panorama of payment for environmental services in the state of São Paulo: a potential vision for Brazil / Histórico e panorama atual do Pagamento de Serviços Ambientais no Estado de São Paulo: uma visão prospectiva para o Brasil

Luiz César Ribas ${ }^{1}$, Rafaela Prosdocini Parmeggiani ${ }^{1}$, Miguel Ángel Sarmiento ${ }^{2}$

${ }^{1}$ Universidade Estadual Paulista “Júlio de Mesquita Filho”, Botucatu, Brasil; ' ${ }^{2}$ niversidade Nacional de Santiago del Estero, Santiago del Estero, Argentina (luiz.c.ribas@unesp.br; rafaela.prosdocini@gmail.com;migui@unse.edu.ar)

Pagamento de Serviços Ambientais (PSA) é um instrumento de política florestal que remunera, pecuniariamente ou não, prestadores de serviços ecossistêmicos que propiciem suporte para atividades econômicas. Serviços ecossistêmicos (de provisão, suporte, regulação e culturais) são benefícios que as pessoas obtêm dos ecossistemas. Serviços ambientais são os serviços ecossistêmicos obtidos por iniciativas antrópicas que impactam positivamente os ecossistemas. O PSA é um instrumento econômico, mas integra-se também aos de comando e controle, de mercado e voluntários. Em São Paulo, o PSA está originariamente atrelado à Convenção-Quadro das Nações Unidas sobre Mudança do Clima (UNFCC-Rio 92), à Lei n; 12.187/2009 (Política Nacional sobre Mudança do Clima), à Lei n; 13.798/2009 (Política Estadual de Mudanças Climáticas) e ao Decreto n; 55.947/2010 (regulamento paulista). O PSA paulista tem origem na mitigação das mudanças climáticas globais e no Programa de Remanescentes Florestais, sendo pautado na restauração da vegetação nativa e no reflorestamento visando a absorção e fixação de carbono e na biodiversidade. À estratégia paulista (e mesmo nacional) do PSA devem ser fortemente agregados, conforme previsão legal, mecanismos financeiros de liquidez para antecipar o retorno dos investimentos para plantio de essências florestais nativas com potencial de exploração econômica. Para tanto, deve-se também consolidar: i) exploração de produtos madeireiros e não madeireiros; ii) exploração econômica de florestas nativas implantadas; iii) SAF's e sistemas de iLPF, e; iv) manejo de culturas e plantações florestais que favoreçam o desenvolvimento de vegetação nativa em subbosque, sem prejuízo da colheita da produção ou do corte da floresta plantada. 


\section{Forestry potential, under the REDD + mechanism in Tocantins State, threatened by agricultural and livestock expansion}

Yara Ferreira ${ }^{1}$, Jacqueline Gerage Marques ${ }^{1}$, Luciana S. Soler ${ }^{1}$, Jean Pierre Ometto ${ }^{1}$

1nstituto de Pesquisas Espaciais, SãoJosé dos Campos, Brasil(ycf1690@hotmail.com; jacqueline.marques@inpe.br; lusoler@gmail.com;

jean.ometto@inpe.br)

Cerrado conservation is essential to the maintenance a number of species and ecosystem services (ESS), as it holds 30\% of national biodiversity. Considering REDD+ mechanisms facilitate forest conservation and prevent climate change, these mechanisms contribute to the maintenance of ESS. The Tocantins state is into nowadays area of expansion agriculture and livestock in Brazil, however, the total of production is not completely destinate to population consumption. The objective of this work was to relate areas with potential for REDD + and their use for the generation of calory for human consumption through agricultural production. Based on SICAR data of limits of properties and land use/cover of MapBiomas we performed spatial analyses to retrieve relationships between agricultural and forested areas. Agricultural Census data (IBGE) will allow the estimation of available calory from regional agricultural production. The analysis resulted in approximately 484,16 Mha of forested areas prone for REDD+ at the property level in Tocantins. Despite agricultural expansion in the Cerrado it's based on high technological improvements, part of this production is not consumed directly by the population, where almost $20 \%$ of soybean production goes to national livestock feeding linked to increasing meat consumption by population. That is food habits of Brazilian population is also contributing to land pressure over forests, but not improving nutrients intake. So REDD+ mechanisms policies must be considered together with more sustainable food education habits.

\section{B7a: MONITORING AND MODELLING OF FOREST HEALTH IN A CHANGING WORLD}

\section{How accurate are the predictions made by ecological modelling? A case study of the eucalypt pest Glycaspis brimblecombei (Hemiptera) around the world \\ Dalva Queiroz ${ }^{1}$ (D, Marilice Cordeiro Garrastazu ${ }^{1}$ (D), Marcos Silveira Wrege ${ }^{1}$ (D), Daniel Burckhardt ${ }^{2}$ (D) \\ ${ }^{1}$ Embrapa Florestas, Colombo, Brasil; ; ${ }^{2}$ aturhistorisches Museum Basel, Basel, Switzerland (dalva.queiroz@embrapa.br; marilice.garrastazu@embrapa.br; marcos.wrege@embrapa.brdaniel.burckhardt@unibas.ch)}

The red gum lerp psyllid Glycaspis brimblecombei Moore (Psylloidea: Aphalaridae), originating from Southeast Australia, is a major pest in eucalypt plantations around the world. In a study published in 2012 the potential distribution was estimated using ecological modelling based on the occurrence of the species in Australia, the Americas (eight countries), Mauritius, Italy, Portugal and Spain. The study predicted that temperate areas are more favourable for the occurrence of Glycaspis brimblecombei than tropical ones. Since the publication of the study, the red gum lerp psyllid spread all around the Mediterranean Basin (Africa: three countries; Asia: two countries; Europe: five countries) and invaded southern Africa (four countries). The envelope score model that seemed very pessimistic at the time turned out to be quite realistic. According to the canonical analysis, the pest $G$. brimblecombei is very plastic, adapting easily to newly colonised areas. We conclude that ecological modelling provides reliable predictions and, hence, is a useful tool for managing eucalypt plantations.

\section{Ecological niche modeling of Araucaria angustifolia}

Giulliana Baggio Bernardinis ${ }^{1}$, Victor Pereira Zwiener ${ }^{2}$, Fernanda Thiesen Brum ${ }^{1}$, Marcos Bergmann Carlucci ${ }^{1}$

${ }^{1}$ Universidade Federal do Paraná, Curitiba, Brasil; ${ }^{2}$ Universidade Federal do Paraná, Palotina, Brasil (giulli_bag@hotmail.com; vzwiener@gmail.com; ftbrum@gmail.com; marcos.carlucci@gmail.com)

Ecological niche modeling (ENM) has been used to estimate current, past, and future geographic distributions, based on the correlation of observed species occurrences and environmental variables. Such estimates can be used in ecology to predict geographic changes in species occurrences, and give support to decisions towards conservation of biodiversity. Species of the genus Araucaria are mostly endemic and restricted to areas with temperate climate. In Brazil Araucaria angustifolia is the only representative of the genus, with great ecological importance in the Atlantic forest, characterinzing an entire forest ecosystem. Currently the species is in danger of extinction, yet only few attempts have been made to estimate potential effects climate change to its distribution. In this study we aim to assess spatio-temporal changes in the distribution of Araucaria angustifolia with regard to current, past and future climatic scenarios. We obtained occurrences and climatic layers for different scenarios on digital databases and used Maxent to calibrate models and project to different scenarios. Our results indicate that the overall trend for future climate change scenarios is retraction of the geographic distribution, however the intensity of changes depends on the future scenario. The species may experience expansion to some areas, indicating the variability of local responses. Conservation and restoration actions need to consider potential effects of climate change for effective use of limited resources, ENM has been shown to give support to decision making with regard to estimating geographical distribution of endemic and endangered species such as Araucaria angustifolia.

\section{Do ozone and drought change the parameters of photosynthesis-stomatal model? The analysis by the optimal stomatal conductance model}

Yasutomo Hoshika ${ }^{1}$ Elena Paoletti ${ }^{1}$

${ }^{1}$ CNR, Sesto Fiorentino (FI), Italy (yasutomo.hoshika@cnr.it; elena.paoletti@cnr.it)

The exchange of gases, as well as water vapor, between interior of leaves and the atmosphere are regulated by stomatal pores, termed stomatal conductance (gs). Semi-empirical photosynthesis-stomatal models (e.g., Ball-Woodrow-Berry model) are widely used in many land-surface schemes in climate model. These model need two important parameters, 1) the slope of the conductance-photosynthesis relationship, 2) the y-intercept of this relationship (gmin, minimum conductance). In Mediterranean region, trees are often suffered from ozone (O3) and drought stress in summer. Both O3 and drought are known to affect gs. Therefore we investigated whether $\mathrm{O} 3$ would change the parameters of the photosynthesis-stomatal model in Mediterranean trees (Phillyrea angustifolia, Quercus ilex, Q. pubescens, Q. robur) grown under O3 FACE (Free-Air Controlled Exposure) experiment. To discuss the effect of O3 on gs, we applied the optimal photosynthesis-stomatal model involving water, $\mathrm{CO}_{2}$ and $\mathrm{O} 3$ flux using gas exchange data. This analytical model was proposed based on the optimization theory of gs for maximizing carbon gain while minimizing accompanying water loss and O3 influx.The optimization theory suggests that O3induced stomatal closure in early summer may reduce $\mathrm{O} 3$ influx, and allow maximum photosynthetic capacity to be reached. However, in late summer, the theory did not explain the effects of $\mathrm{O} 3$ on gsin $Q$. robur, showing an increase of gmin under elevated O3. This may relate to the loss of closing response of stomata by $\mathrm{O} 3$ (i.e., stomatal sluggishness). 


\title{
Climate change and air pollution effects on forest ecosystems status in representative Romanian Level II monitoring plots
}

Ovidiu Badea ${ }^{1,2}$, Ionel Popa ${ }^{1}$, Diana Pitar ${ }^{1}$, Stefan Leca ${ }^{1}$, Ecaterina Apostol $^{1}$, Albert Ciceu $^{1}$, Serban Chivulescu ${ }^{1}$

${ }^{1}$ National Institute for Research and Development in Forestry "Marin Drăcea”, Voluntari, Romania; '2Transilvania University of Brașov, Brasov, Romania

(obadea@icas.ro; popaicas@gmail.com; diana.silaghi@icas.ro; stefan.leca@icas.ro; cathyches@yahoo.com; albert.ciceu@yahoo.ro;

serban.chivulescu@icas.ro)

This research refers to monitoring and evaluation of forests ecosystems status in four representative Level II monitoring sites under air pollution and climate change effects. During the last period 2011-2017, trees from these plots have been slightly affected by excessive drought, high temperatures or air pollution. The pedunculate oak registered the lowest mean crown defoliation percentage in Stefanesti - stejar plot, ranging between 5.4\% (2011) and 10.9\% (2016). Sessile oak and beech proved to be more sensitive to stress factors, the highest mean crown defoliation percentage being registered in 2014 (20\%). For spruce the health status maintained relatively constant due to optimal site condition from Predeal - molid plot. The years 2014 and 2016 proved to be the most stressful ones being characterized by high temperatures and low precipitations. Volume growth of forests is correlated with mean defoliation percentage recording decreasing values while crown defoliation increase, also the influence of climate change on growth season was emphasized. Phytotoxic pollutants $\left(\mathrm{O}_{3}\right.$, NO2, NH3) recorded low concentrations. In Ştefăneşti-stejar site, ozone recorded the lowest values of the studied plots. At mean levels ( $>40$ ppb), in Predeal-molid site, ozone positively correlates $(\mathrm{r}=0.43)$ with mean defoliation percentage, indicating a possible negative effect on forests health status. Although NO2 and NH3 concentrations show a positive/negative correlation with crown mean defoliation percentage $(r=-0.25 ; r=0.49)$, they have no real influence on forest health status. Positive values of net throughfall, especially for Sulphur anions, show the important filtering role of the forest ecosystems

Tree and microclimate measurements using low-cost automated devices: the reliable approach for quantifying climate effects on woody vegetation across ecosystems

Radim Matula ${ }^{1,2}$, Josef Urban ${ }^{2,3}$, Roman Gebauer ${ }^{2}$, Roman Plichta ${ }^{2}$, Martin Svátek $^{2}$

${ }^{1}$ Czech University of Life Sciences, Prague, Czech Republic; ${ }^{2}$ Mendel University in Brno, Brno, Czech Republic; ${ }^{3}$ Siberian Federal University, Krasnoyarsk, RussianFederation(radimmatula@gmail.com; josef.urban@email.cz; gebo@email.cz; plichta.roman@gmail.com; msvatek@centrum.cz)

Alteration of climate patterns under climate change affects productivity and stability of forests. However, current data on tree growth have too low precision and remeasurement frequency for a mechanistic understanding of how trees respond to climate variation and particularly drought. In addition, available climate and soil moisture data usually do not represent local microclimate of the study sites because they come either from climate stations located outside forest or from climate databases, which have a low spatial resolution. To tackle these issues, we developed low-cost but high precision and resistant automatic point dendrometers that continuously measure tree diameter changes. In combination with inexpensive automatic microclimate dataloggers they represent a powerful tool for measuring tree responses to climate on a very fine scale. These devices have been used in ecophysiology for a long time, but their high costs have limited their use to a low number of trees and sites, not allowing for broader ecological inference. By testing these devices in various forest ecosystems, we demonstrated, that they provide high precision and directly comparable data on diurnal and daily tree diameter changes, on soil moisture, soil and air temperature from boreal to tropical forests. Due to low-cost, they can be used on a great number of trees and sites even within a limited budget. The low-cost automatic dendrometers in combination with microclimate dataloggers are a reliable and cost-effective way to quantify climate effects on tree vitality, growth and carbon allocation across forest ecosystems.

\section{Simulating the response of mixed broadleaved forests to changes in climate conditions: disentangling the relative importance of} various abiotic factors

Louis de Wergifosse ${ }^{1}$, Frédéric André1, Nicolas Beudez ${ }^{2}$, François de Coligny², Hugues Goosse', Mathieu Jonard ${ }^{1}$

${ }^{1}$ UCLouvain, Louvain-la-Neuve, Belgium; IInstitut National de la Recherche Agronomique, Montpellier, France(louis.dewergifosse@uclouvain.be;

frederic.andre@uclouvain.be; nicolas.beudez@inra.fr; francois.decoligny@inra.fr; hugues.goosse@uclouvain.be; mathieu.jonard@uclouvain.be)

Forests will face in the future unprecedented climatic conditions that are expected to impact them in various and sometimes opposite ways. The fertilizing effect of rising atmospheric $\mathrm{CO}_{2}$ concentrations and nitrogen deposits added to the lengthening of the vegetation period due to warmer temperatures are likely to increase forest productivity. These effects could be offset or even reversed by the increase of drought frequency and severity that trigger stomatal closure and can even lead to tree death. Due to the complex interactions between these factors, their spatial variability and the uniqueness of their combinations, the future forest response to climate change cannot be deducted only from observational studies or environmental manipulation experiments. Here, we use HETEROFOR, an individual and mechanistic tree growth model recently developed and evaluated to simulate the gross primary production of diverse mixed broadleaved forest according to different climatic scenarios. Among the model outputs, a drought index accounting for both the length and the magnitude of the stand hydric deficit is calculated. First, these simulations are conducted with atmospheric $\mathrm{CO}_{2}$ concentration values maintained constant, then with those from the IPCC scenarios. The results of these simulations are finally used to assess the impact of the various abiotic stressors and their interactions on forest productivity. In a second step, a second set of simulations is launched to assess the impact of the soil properties and of the stand composition, structure and density on tree growth by interchanging soil and forest structures subjected or not to different thinning intensity.

\section{HETEROFOR: an individual-based and spatially-explicit model for exploring the response of structurally-complex forests to} uncertain future conditions

\author{
Mathieu Jonard ${ }^{1}$, Frédéric André1, Nicolas Beudez ${ }^{2}$, François de Coligny', Louis de Wergifosse ${ }^{1}$, Quentin Ponette ${ }^{1}$, Caroline Vincke ${ }^{1}$ \\ ${ }^{1}$ Université catholique de Louvain, Louvain-la-Neuve, Belgium; ${ }^{2}$ Institut National de la Recherche Agronomique, Montpellier, France; ${ }^{3}$ CIRAD, Montpellier, \\ France(mathieu.jonard@uclouvain.be; frederic.andre@uclouvain.be; nicolas.beudez@inra.fr; coligny@cirad.fr; louis.dewergifosse@uclouvain.be; \\ quentin.ponette@uclouvain.be; caroline.vincke@uclouvain.be)
}

Given the multiple abiotic and biotic stressors resulting from the global changes, management systems and practices must be adapted in order to maintain and reinforce the resilience of the forests. Among others, the transformation of monocultures into uneven-aged and mixed stands is an avenue to improve forest resilience. To explore the forest response to these new silvicultural practices and to the changing environment, one needs models combining a process-based approach with a detailed spatial organisation, which is very rare. We therefore decided to develop our own model (HETEROFOR) according to a spatiallyexplicit approach describing individual tree growth based on resource sharing (light, water and nutrients). HETEROFOR was progressively elaborated through the integration of various modules (light interception, phenology, water cycling, photosynthesis and respiration, carbon allocation, mineral nutrition and nutrient 
cycling) within the modelling plateform CAPSIS devoted to tree growth and stand dynamics. The advantage of using such a collaborative platform is to use a common development environment, model execution system, user-interface and visualization tools and to share data structures, objects, methods and libraries. The objectives of this presentation are to describe the functioning of HETEROFOR, to show its ability to estimate resource availability and to reconstruct tree growth in mixed oak and beech stands in Wallonia (Belgium). The growth dynamics in these stands was simulated according to four climate scenarios of IPCC to illustrate how the model can be used to predict climate change impacts on forest ecosystems.

\section{Impact of climate change and land use and land cover change on forest biodiversity \\ Saroj Panthi ${ }^{1}$ \\ ${ }^{1}$ Ministry of Industry, Tourism, Forest, and Environment, Pokhara, Nepal (mountsaroj@gmail.com)}

Impact of environmental change may affect the biodiversity. Due to lack of scientific information about effect of future environmental change on biodiversity, long-term conservation plans can be incomplete and inaccurate. Here, we identified the impact of climate change and land use and land cover change on red panda based on red panda occurrence data and environmental variables: climatic, topographic and anthropogenic variables. The model suggested that the future suitable habitat for red pandas in Nepal will be increased by $6.5 \%$ under the future climate change scenario. However, the suitable habitat will be reduced by $0.5 \%$ due to the combined effects of future climate change and land use and land cover changes. The study recommends that conservationists should pay more attention to the land use planning in the future in order to mitigate the potential economic impact on red panda as well as other endangered species.

B7b: PHYSIOLOGICAL AND BIOGEOCHEMICAL RESPONSE OF FOREST ECOSYSTEMS TO
CLIMATE CHANGE AND AIR POLLUTION

\section{Dynamics of sulfur in forest ecosystems under changing atmospheric environment in Japan and Thailand}

Hiroyuki Sase ${ }^{1}$, Naoyuki Yamashita ${ }^{2}$, Tatsuyoshi Saito ${ }^{3}$, Bopit Kietvuttinon $^{4}$, Hathairatana Garivait $^{5}$, Masayuki Morohashi $^{1}$, Masaaki Takahashi $^{1}$, Yayoi Inomata ${ }^{6}$, Makoto Nakata ${ }^{7}, K_{a z u h i d e ~ M a t s u d a}{ }^{3}$, Tsuyoshi Ohizumi ${ }^{1}$

${ }^{1}$ Asia Center for Air Pollution Research, Niigata, Japan; ${ }^{2}$ Forestry and Forest Products Research Institute, Tsukuba, Japan; ${ }^{3}$ Niigata Prefectural Institute of Public Health and Environmental Sciences, Niigata, Japan; ${ }^{4}$ Royal Forest Department, Bangkok, Thailand; ${ }^{5}$ Environmental Research and Training Centre, Pathumthani, Thailand; ' Kanazawa University, Kanazawa, Japan; ${ }^{7}$ Niigata University, Niigata, Japan; ${ }^{8}$ Tokyo University of Agricultural and Technology, Fuchu,Japan(sase@acap.asia; nyamashita@ffpri.affrc.go.jp; tsaitooa@gmail.com; bopit7827@gmail.com; hathairatana@gmail.com; morohashi@acap. asia; mtakahashi@acap.asia; yinomata@se.kanazawa-u.ac.jp; nakata@agr.niigata-u.ac.jp; kmatsuda@cc.tuat.ac.jp; tohizumi@acap.asia)

Atmospheric environment in Northeast Asia and Southeast Asia is dynamically changing. In particular, gaseous air pollutants, such as SO and NOX, which were largely emitted from developing countries in the 1990s/2000s, have started declining recently. Since effects of these air pollutants may remain for a while even after reduction of the emissions, their dynamics in forest ecosystems should carefully be investigated. In particular, SO42- is retained in the soil-plant system and its retention/release processes may be changed with air pollution and climate. In this study, monitoring on atmospheric deposition and stream water (SW) chemistry has been conducted in forested catchments in different climatic zones, namely in Kajikawa site (KJK) under the humid subtropical climate in Japan since 2002 and in Sakaerat site (SKT) under the tropical savanna climate in Thailand since 2005. In both countries, atmospheric S deposition has been declining, reflecting national and/or regional $\mathrm{SO}_{2}$ emission trends. The $\mathrm{SO} 42$ - concentration in $\mathrm{SW}$ declined with increase in $\mathrm{pH}$ and alkalinity in $\mathrm{KJK}$, however it increased with decline of $\mathrm{pH}$ in SKT. The different climatic conditions appear to cause the different reactions. Reactions of forested catchments to declining $\mathrm{S}$ deposition should carefully be monitored in the region, where atmospheric environment is dynamically changing. The possible mechanisms in both sites will be discussed with sulfur isotopic data in the presentation.

\section{Measuring and mapping the effectiveness of the European air quality directive in reducing $\mathbf{N}$ and $\mathbf{S}$ deposition at the ecosystem level \\ Cristina Branquinho ${ }^{1}$, Helena Cristina Serrano ${ }^{1}$, Maria Alexandra Oliveira ${ }^{1}$, Pedro Pinho ${ }^{1}$ \\ ${ }^{1}$ Centre for Ecology, Evolution and Environmental Changes (cE ${ }^{3}$ c), Faculdade de Ciências, Universidade de Lisboa, Lisboa, Portugal (cmbranquinho@fc.ul. pt; hcserrano@fc.ul.pt; alexandra.oliv@gmail.com; paplopes@fc.ul.pt)}

To protect human health and the environment, the 2001 EU Air Quality Directive imposed national emission ceilings for atmospheric pollutants (Directive 2001/81/EC), including the reduction of sulfur (S) and nitrogen (N) emissions, by 2010. The evaluation of the results of this emission reduction at the ecosystem level has not been thoroughly done. Our aim was to measure and map the consequences of the emission's reduction at the ecosystem level. This was done in a region with multiple industrial activities using ecological indicators, comparing data at the onset of the Directive implementation (2002) and nine years after (2011). The reduction of S emissions was a success at the ecosystem level, emphasizing that most S deposited to the ecosystem had an industrial origin. Overall, the ecosystem within the region experienced a reduction of S deposition (up to -72\%), coincident with reductions of SO2 in emissions (-76\%) and air concentration (ca. -59\%). However, for $\mathrm{N}$ that was not the case. Although a reduction of emissions was achieved for industrial facilities (ca. -37\%), for NO2 and $\mathrm{NO}_{3}-$, ca. -24\% reduction was noticed, but on the other hand, there was a 47\% increase in NH3. The results highlight the critical importance of going beyond emissions and air concentrations to verify the success of the implementation of the air quality directive. $\mathrm{N}$ pollution remains a challenge for air quality mainly because deposition to ecosystems did not reflect those reductions. Acknowledgements: NitroPortugal EU H2020 research and innovation programme, n.69233 and "Towards INMS", implemented by UN Environment.

\section{$\mathrm{N}$ and $\mathrm{S}$ deposition across Europe and the impact on tree nutrition}

Anne-Katrin Prescher ${ }^{1}$, Andreas Schmitz ${ }^{1}$, Inken Krüger ${ }^{1}$, Tanja Sanders ${ }^{1}$, Alexa Michel ${ }^{1}$ Pasi Rautio $^{2}$ ${ }^{1}$ Thünen Institute of Forest Ecosystems, Eberswalde, Germany; ${ }^{2}$ Natural Resources Institute Finland (Luke), Helsinki, Finland (anne.prescher@thuenen.de; andreas.schmitz@thuenen.de; inken.krueger@thuenen.de; tanja.sanders@thuenen.de; alexa.michel@thuenen.de; pasi.rautio@luke.fi)

Anthropogenic emissions of nitrogen and sulphur are affecting tree nutrition and nutrient cycling of forest ecosystems across Europe. While nitrogen deposition is still on a high level, the legacy of historic sulphur inputs still takes effect on forest soils. Here we use the extensive data provided by the monitoring framework of UNECE/ICP Forests (International Co-operative Programme on Assessment and Monitoring of Air Pollution Effects on Forests). Across Europe and beyond, this programme is monitoring deposition, foliar concentrations and other variables in forest ecosystems. This study reports on trends in nitrogen 
and sulphur deposition and the influence on foliar nitrogen, phosphorus and sulphur concentrations in European beech (Fagus sylvatica), Norway spruce (Picea abies) and Scots pine (Pinus sylvestris) in Europe. The measurements in nitrogen and sulphur deposition over the period 2000 - 2015 revealed reductions, however, most ICP Forests plots are still at risk of eutrophication effects since nitrogen deposition levels are above critical values. Variable trends in foliar nitrogen, phosphorus and sulphur concentration were found depending on tree species and location. Similarly, the comparison of foliar nitrogen and phosphorus concentrations between the periods 2000 - 2005 and 2010 - 2015 indicated heterogeneous developments following the critical ranges for foliar element ratios defined in the literature. It was found that depending on site conditions and tree species, deposition can have an increasing or decreasing effect on foliar nutrient concentrations. Thus, reductions in air pollution can have diverse implications for tree nutrition status.

\title{
Interactive effects of ozone, nitrogen deposition and climate in terrestrial ecosystems of Spanish mountain areas
}

Rocio Alonso ${ }^{1}$, Ignacio González-Fernández ${ }^{1}$, Héctor García-Gómez ${ }^{1}$, Raquel Ruiz-Checa ${ }^{1}$, Susana Elvira ${ }^{1}$, Isaura Rábago ${ }^{1}$, Javier Sanz ${ }^{1}$, Victoria Bermejo ${ }^{1}$ ${ }^{1}$ Ecotoxicology of Air Pollution, CIEMAT, Madrid, Spain(rocio.alonso@ciemat.es; ignacio.gonzalez@ciemat.es; hector.garcia@externos.ciemat.es; r.ruizcheca@gmail.com; susana.elvira@ciemat.es; isaura.rabago@ciemat.es; j.sanz@ciemat.es; victoria.bermejo@ciemat.es)

The Mediterranean Basin is one of the Biodiversity Hotspots for conservation priorities. Particularly, the Mediterranean mountains concentrate some of the most valuable areas, due to the high biodiversity and to the provision of many environmental, cultural and economic services. Many of these areas have been recognized and protected under different conservation plans. While conservation plans can implement management strategies to reduce the impact of human activities, those ecosystems can still be affected by air quality and climate change. Tropospheric ozone $\left(\mathrm{O}_{3}\right)$ and atmospheric nitrogen (N) deposition are two of the main air pollutants affecting natural and semi-natural ecosystems of the Mediterranean Basin. Unfortunately, most of the air quality networks do not include monitoring stations at high elevation. Ozone, atmospheric $\mathrm{N}$ deposition and meteorology have been monitored at different elevations in the Guadarrama mountain range (Madrid, Spain) from 500 up to 2200 m.a.s.l. for several years. At some plots, soil water content data are also available. New flux-based $\mathrm{O}_{3}$ critical levels proposed for the protection of the Mediterranean vegetation and new methodologies for estimating $\mathrm{N}$ deposition in water-limited environments have been used for risk assessment of effects of air pollution in different ecosystems along the elevation gradient. Air pollutants, meteorological variables and plant physiological activity data of different plant communities will be presented. Possible interactions between $\mathrm{O}_{3}, \mathrm{~N}$ deposition and soil water availability on plant physiology, growth and stomatal uptake of air pollutants will be discussed.

\author{
The influence of water and nutrition on productivity of Pinus taeda / Influência dos fatores hídricos e nutricionais na produtividade do \\ Pinus taeda \\ Isabel Deliberali ${ }^{1}$, Mauro Valdir Schumacher ${ }^{2}$, James Stahl ${ }^{3}$, Marco Aurélio Figura ${ }^{3}$, Rodrigo Toledo Coutinho ${ }^{4}$, Reinaldo Hoinacki da Costa ${ }^{5}$, \\ Rildo Moreira e Moreira ${ }^{6}$ \\ ${ }^{1}$ Instituto de Pesquisas e Estudos Florestais, Piracicaba, Brasil; ${ }^{2}$ Universidade Federal de Santa Maria, Santa Maria, Brasil; ${ }^{3}$ Klabin S.A., Telêmaco Borba, \\ Brasil; ${ }^{4}$ Arauco do Brasil, Curitiba, Brasil;; ${ }^{5} J u l i a n a$ Florestal Ltda, Caçador, Brasil; ${ }^{6}$ Escola Supe (isabel@ipef.br; mauro.schumacher@ufsm.br; \\ jstahl@klabin.com.br; mafigura@klabin.com.br;rcoutinho@arauco.com.br; reinaldo@frameport.com.br; rmoreira@usp.br)
}

O Pinus taeda é a espécie florestal de maior expressão econômica plantada no sul do Brasil e possui uma das maiores produtividades do mundo. Entretanto, devido ao seu bom crescimento (média nacional de $31 \mathrm{~m}^{3} \mathrm{ha}^{-1}$ ano $^{-1}$ ) até mesmo em solos de baixa fertilidade e ausência de sintomas visuais de deficiência nutricional, não é comum realizarem-se fertilizações nos plantios comerciais. Além do fator nutricional, a disponibilidade de água e luz é essencial para produção e madeira. Dessa forma, este estudo buscou avaliar o efeito hídrico (irrigação ou redução de 30\% da chuva) e nutricional (duas fertilizações de cobertura com 1 e 9 anos de idade) no crescimento do Pinus taeda em Itatinga-SP e Telêmaco Borba-PR, até os 11 anos de idade, em Latossolos Vermelhos de textura média. Em Itatinga, o incremento médio anual em volume (IMA) do tratamento irrigado (1,5 x ETP) foi 7\% maior que o controle (sem irrigação e sem fertilização), passando de 21,2 para 22,6 $\mathrm{m}^{3}$ ha $^{-1}$ ano ${ }^{-1}$ e quando combinado com a fertilização, o aumento foi de $14 \%$. Já em Telêmaco Borba-PR, região com excedente hídrico o ano todo, a redução de $30 \%$ da chuva não diminuiu o crescimento das árvores, porém a fertilização aumentou a produtividade em $28 \%$ (de 26,5 para $33,8 \mathrm{~m}^{3} \mathrm{ha}^{-1}$ ano-1). Portanto, em Telêmaco Borba o fator nutricional se mostrou limitante ao crescimento do $P$. taeda, enquanto em Itatinga o fator hídrico teve maior resposta. Esses resultados de manipulação hídrica são importantes no desenvolvimento de modelos processuais que simulam mudanças climáticas.

\section{Soil respiration under elevated $\mathrm{CO}_{2}$ at a temperate mature forest}

Angeliki Kourmouli, ${ }^{1,2}$, Liz Hamilton ${ }^{3}$, Rebecca Bartlett ${ }^{1}$, Iain Hartley ${ }^{4}$, Zongbo Shi ${ }^{1}$

${ }^{1}$ University of Birmingham, Birmingham, United Kingdom; ${ }^{2}$ Birmingham's Institute of Forest Research, Birmingham, United Kingdom; ${ }^{3}$ University of Gloucestershire, Cheltenham, United Kingdom; ${ }^{4}$ University of Exeter, Exeter, United Kingdom (axk661@bham.ac.uk; Ihamilton3@glos.ac.uk; r.bartlett@ bham.ac.uk; i.hartley@exeter.ac.uk; z.shi@bham.ac.uk)

Forest ecosystems are of high importance in the global carbon cycle since they currently stock $861 \pm 66$ Pg C, and represent one of the most important carbon sinks, absorbing approximately $2.4 \pm 0.4 \mathrm{PgCy}^{-1} 1$. With the atmospheric $\mathrm{CO}_{2}$ continuously rising, forests might be able to uptake more carbon. Hence, trees may invest more carbon in their belowground systems to increase their access to soil nutrients, prompting a soil respiration (Rs) increase. However, there is limited understanding of how nutrient dynamics interact with Rs under elevated $\mathrm{CO}_{2}$. Thus, Rs regulates significantly the carbon dynamics, and even small changes may may impact significantly atmospheric $\mathrm{CO}_{2}$ and global climate. This study assesses the impact of elevated $\mathrm{CO}_{2}$ on soil respiration at the BIFoR FACE research facility. BIFoR FACE is a second generation FACE experiment, and is the first, globally, set in a mature, temperate woodland. The site comprises of control and elevated $\mathrm{CO}_{2}$ rings, with $\mathrm{CO}_{2}$ concentrations matching the 2050 atmospheric $\mathrm{CO}_{2}$ scenario. Experimental blocks were established in every ring,in order to investigate the contribution of heterotrophic and autotropic respiration 2. Measurements were made continuously since December 2016. Results from 20162018 show higher soil respiration in $\mathrm{eCO}_{2}$ rings, post fumigation. Further analysis on the heterotrophic respiration data will help us identify the mechanisms of this increase. 
Carbon flux from decomposing wood and its dependency on temperature, wood $\mathrm{N}_{2}$ fixation rate, moisture and fungal composition in a Norway spruce forest

Katja Rinne-Garmston ${ }^{1}$, Krista Peltoniemi ${ }^{1}$, Janet Chen ${ }^{1}$, Mikko Peltoniemi ${ }^{1}$, Hannu Fritze ${ }^{1}$, Raisa Mäkipää ${ }^{1}$

${ }^{1}$ Natural Resources Institute Finland, Helsinki,Finland (katja.rinne-garmston@luke.fi; krista.peltoniemi@luke.fi; janetchen613@gmail.com;

mikko.peltoniemi@luke.fi; hannu.fritze@luke.fi; raisa.makipaa@luke.fi)

Globally 40-70 Pg of C are stored in coarse woody debris on forest floor. Climate change may reduce the function of this stock as a $\mathrm{C}$ sink in the future due to increasing temperature. However, current knowledge on the drivers of wood decomposition is inadequate for detailed predictions. To define the factors that control wood respiration rate of Norway spruce and to produce a model that adequately describes the decomposition process of this species as a function of time, we used an unprecedentedly diverse analytical approach, which included measurements of e.g. respiration, fungal community sequencing and $\mathrm{N}_{2}$ fixation rate. Our results suggest that climate change will accelerate $\mathrm{C}$ flux from deadwood in boreal conditions, due to the observed strong temperature dependency of deadwood respiration. At the research site, the annual C flux from deadwood would increase by $27 \%$ with the projected climate warming. The second most important control on respiration rate was the stage of wood decomposition.. Wood decomposition process was best described by a Sigmoidal model, where after 116 years of wood decomposition mass loss of 95\% was reached. Our results on deadwood decomposition are important for C budget calculations in ecosystem and climate change models. We observed for the first time that the temperature dependency of $\mathrm{N}_{2}$ fixation, which has a major role at providing $\mathrm{N}$ for wood-inhabiting fungi, was not constant but varied between wood density classes due to source supply and wood quality. This has significant consequences on projecting $\mathrm{N}_{2}$ fixation rates for deadwood in changing climate.

\section{Wood degradation by white rot basidiomycetes and production of simple phenolic compounds}

Nicola La Porta ${ }^{1,2}$ (D) Stefania Di Lella ${ }^{1,2,3}$, Tognetti Roberto ${ }^{2,4}$ Fabio Lombardi ${ }^{5}$, Tiziana Nardin ${ }^{6}$, Roberto Larcher $^{6}$

${ }^{1}$ IASMA Research and Innovation Centre, Fondazione Edmund Mach, Via E. Mach 1, 38010 San Michele all'Adige (Trento), Italy; ${ }^{2}$ The EFI Project Centre on Mountain Forests (MOUNTFOR) Trento Italy; ${ }^{3}$ Department of Biosciences and Territory, University of Molise Contrada Fonte Lappone, 86090 Pesche Italy; ${ }^{4}$ Department of Agricultural, Environmental and Food Sciences, University of Molise, Via Francesco De Sanctis, 86100 Campobasso, Italy; ${ }^{5}$ Department of Agraria, Mediterranean University of Reggio Calabria, Feo di Vito, 89123 Reggio Calabria, Italy; ${ }^{6}$ IASMA Technology Transfer Centre, Fondazione Edmund Mach, Via E. Mach 1, 38010 San Michele all'Adige(Trento), Italy(nicola.laporta@fmach.it; dilella.stefania@gmail.com; zognetti@unimol.it; fabio.lombardi@unirc.it; tiziana.nardin@fmach.it; roberto.larcher@fmach.it)

White rot fungi degrade and mineralize lignin through secretion of strong oxidative ligninolytic enzymes, preventing accumulation of deadwood organic matter. Due to the specific structures, different lignolytic enzymes has different mechanism in lignin degradation/oxidation, producing many natural secondary metabolites, including phenolic compounds (PC). PC in soil may regulate nutrient cycling in forest ecosystems by controllingthe pool and form of nutrients available for trees. This work explores the PC produced at different times by nine main decay fungal species, belonging to Heterobasidion and Armillaria genera, before and after their inoculation and growthon silver fir (Abies alba Mill.) sawdust, as axenic culture system, under controlled conditions. A total of 81 samples (three replicates for each fungal species and other three replicates kept as a control) were analysed usinghigh-performance liquid chromatography coupled to a hybrid quadrupole-orbitrap mass spectrometer.EighteenPC, includingsimple phenols, alkylphenyl alcohols, hydroxybenzoketones, hydroxycinnamaldehydes, hydroxybenzaldehydes, hydroxyphenylacetic acids, hydroxycinnamic acids, hydroxybenzoic acids and hydroxycoumarins were detected. In particular, coniferyl alcohol, ferulic acid, p-coumaric acid, acetovanillone, vanillic acid, etc. showed a decreasing trend during degradation process, by contrast an accumulation trend was observed for protocatechuic acid, syringic acid and scopoletin. These results suggesteddifferent strategies of silver fir lignin degradation by selected fungal species. PCA revealed a good differentiation between PC and the activity of nine fungal species along the three times of silver fir sawdust degradation. The nine fungal species have different climate requirements which imply different PC production under different global warming scenarios.

\section{B7p: PHYSIOLOGICAL AND BIOGEOCHEMICAL RESPONSE OF FOREST ECOSYSTEMS TO CLIMATE CHANGE AND AIR POLLUTION \\ The effect of elevated carbon dioxide on leaf-level physiology in a mature temperate woodland

\author{
Anna Gardner ${ }^{l, 2}$, Jeremy Pritchard ${ }^{l, 2}$, Rob Mackenzie ${ }^{l, 2}$ \\ ${ }^{1}$ University of Birmingham, Birmingham, United Kingdom; ${ }^{2}$ Birmingham Institute of Forest Research, Birmingham, United Kingdom \\ (axg042@student.bham.ac.uk; j.pritchard@bham.ac.uk; a.r.mackenzie@bham.ac.uk)
}

Anthropogenic carbon dioxide $\left(\mathrm{CO}_{2}\right)$ is the main greenhouse gas driving change in the Earth's climate. Rising $\mathrm{CO}_{2}$ is expected to stimulate photosynthesis, but limited studies have been conducted on mature or temperate forests. It is uncertain how mature temperate forest ecosystems may respond to the future $\mathrm{CO}_{2}$ emissions and what interacting environmental factors may influence this. This experiment has been conducted at the Birmingham Institute of Forest Research Free Air Carbon Enrichment Experiment (BIFoR-FACE). BIFoR-FACE is set in a mature oak (Quercus robur L.) woodland and provides additional CO ${ }_{2}$, to 30 $\mathrm{m}$ diameter experimental plots, to simulate the future atmospheric conditions in 50 years' time $(+150 \mathrm{ppm})$. Instantaneous gas exchange measurements have been conducted in the second year of $\mathrm{CO}_{2}$ fumigation (2018) in the upper canopy of $Q$. robur trees, from bud burst (June) to leaf fall (October). This study used a paired plot design $(\mathrm{n}=3)$ of elevated $\mathrm{CO}_{2}\left(\mathrm{eCO}_{2}\right)(550 \mathrm{ppm})$ and ambient control plots $\left(\mathrm{aCO}_{2}\right)(400 \mathrm{ppm})$. Measurements were taken using a Li-6800 portable photosynthesis machine (LICOR) to calculate leaf-level rates of photosynthesis (A), stomatal conductance (gsw) and intrinsic water use efficiency (iWUE) across the growing season. The results suggest an average of $+24 \%$ increase in photosynthesis, seasonally variable decrease in gsw and increase in iWUE under $\mathrm{eCO}_{2}$ conditions. The effect of $\mathrm{eCO}_{2}$ varied depending on the prevailing seasonal and diurnal fluctuations in environmental variables, such as light and water availability. This data will help understand, and contribute, to the accurate modelling of canopy physiological responses to eCO for mature temperate forest ecosystems. 


\title{
Projected global tropospheric ozone impacts on vegetation under different emission and climate scenarios
}

Pierre Sicard ${ }^{1}$, Alessandro Anav'2, Alessandra De Marco $^{3}$, Elena Paoletti ${ }^{2}$

${ }^{1}$ ARGANS, Biot, France; ${ }^{2}$ Consiglio Nazionale delle Ricerche, Sesto Fiorentino, Italy; ${ }^{3} E N E A$, Rome, Italy (psicard@argans.eu; alessandro.anav@ipsp.cnr.it; alessandra.demarco@enea.it; elena.paoletti@cnr.it)

The impact of ground-level ozone on vegetation is largely under-investigated at global scale despite worldwide large areas are exposed to high surface ozone levels and concentrations are expected to increase in the next future. To explore future potential impacts of ozoneon vegetation, we compared historical and projected ozone concentrations simulated by six global atmospheric chemistry transport models on the basis of three representative concentration pathways emission scenarios (i.e. RCP 2.6, 4.5, 8.5). To assess changes in the potential ozone threat to vegetation, we used the AOT40 metric. Results point out a significant overrun of AOT40 in comparison with the recommendations of UNECE for the protection of vegetation. In fact, many areas of the northern hemisphere show that AOT40-based critical levels will be exceeded by a factor of at least 10 under RCP 8.5. Changes in surface ozone by 2100 range from about + 4-5 ppb worldwide in RCP 8.5 scenario to reductions of about 2-10 ppb in the RCP 2.6 scenario. The risk of ozone injury for vegetation decreased by $61 \%$ and 47\% under RCP 2.6 and RCP 4.5, respectively and increased by 70\% under RCP 8.5. Key biodiversity areas in South and North Asia, Central Africa and Northern America were identified as being at risk from high ozoneconcentrations. To better evaluate the regional exposure of ecosystems to ozone pollution, we recommend the use of improved chemistry-climate modelling system, fully coupled with dynamic vegetation models. We thank the project MOTTLES "Monitoring ozone injury for setting new critical levels" (LIFE15 ENV/IT/000183) for financial support.

\section{Nutritional availability changes ozone risk-assessment for poplars: results by the Ozone FACE study}

Yasutomo Hoshika ${ }^{1}$, Lu Zhang $^{2}$, Elisa Carrari ${ }^{1}$, Lorenzo Cotrozzi $^{3}$, Elisa Pellegrini ${ }^{3}$, Ovidiu Badea ${ }^{4}$, Elena Paoletti $^{1}$

${ }^{1}$ CNR, Sesto Fiorentino (FI), Italy; ${ }^{2}$ Northeast Agricultural University, Harbin, China; ${ }^{3}$ University of Pisa, Pisa, Italy; ${ }^{4}$ INCDS, Bucarest, Romania

(yasutomo.hoshika@cnr.it; caszhanglu@hotmail.com; eli.carrari@gmail.com; lorenzo.cotrozzi@for.unipi.it; elisa.pellegrini@unipi.it; obadea@icas.ro; elena.paoletti@cnrit)

Assessing ozone (O3) risk to vegetation is crucial for informing policy making. The availability of nitrogen (N) and phosphorus (P) could influence photosynthesis and growth. However, our knowledge of plant responses to $\mathrm{O} 3$ under various nutritional conditions is still limited. In this study, a sensitive poplar clone (Oxford) was subject to two $\mathrm{N}$ levels (N0, $0 \mathrm{~kg} \mathrm{~N} \mathrm{ha}^{-1}$; N80, $80 \mathrm{~kg} \mathrm{~N} \mathrm{ha}^{-1}$ ), three P levels (P0, $0 \mathrm{~kg} \mathrm{P} \mathrm{ha}^{-1}$; P40, 40 kg P ha-1; P80, 80 kg P ha ${ }^{-1}$ ) and three levels of O3 exposure (ambient concentration, AA; 1.5 $\times$ AA; $2.0 \times \mathrm{AA}$ ) for a whole growing season in an O3 free air controlled exposure (FACE) facilityin Florence, Italy $\left(43^{\circ} 48^{\prime} 59^{\prime} \mathrm{N}, 11^{\circ} 12^{\prime} 01\right.$ ” E, $55 \mathrm{~m}$ a.s.1.), which is the first O3 FACE facility in Mediterranean Europe. Ozone-induced biomass decline was greater at high N supply, while P alleviated such biomass losses, but not under high $\mathrm{N}$ supply. Ozone-induced loss of net photosynthetic rate was mitigated by $\mathrm{N}$ in medium O3 exposure $(1.5 \times$ AA). However, such a mitigation effect was not observed in the higher O3 level $(2.0 \times$ AA). Nitrogen addition exacerbated O3-induced increase of dark respiration rate suggesting an increased respiratory carbon loss in the presence of $\mathrm{O} 3$ and $\mathrm{N}$. This may result in a further reduction of the net carbon gain for poplars exposed to O3.

\section{Leaf micromorphological traits of trees for improvement of urban air quality: air pollution abatement potential}

\author{
Myeongja Kwak', Jongkyu Lee ${ }^{1}$, Sanghee Park ${ }^{1}$,Handong Kim ${ }^{1}$, Yeaji Lim ${ }^{1}$, Suyoung Woo ${ }^{1}$ \\ ${ }^{1}$ University of Seoul, Seoul, Republic of Korea1016na8349@hanmail.net; gpl90@naver.com; parksanghee0930@gmail.com; blasterkhd92@gmail.com; \\ oxlll@naver.com;wsy@uos.ac.kr)
}

Plants have functional advantages for reducing ambient air pollution including particulate matter (PM) on human health in urban areas, and this is one of the recognized ecosystem services of urban vegetation. Especially, trees within urban life zones are considered to be one of the key elements to mitigate and reform atmospheric environmental issues, however, in fact that it does not take into account tree potential in urban policy and strategy. Tree species efficiency for capturing PM is influenced by plant ecophysiology and environmental factors including altitude, wind direction, precipitation, and seasons. Leaf micromorphology (e.g., groove, trichomes, and wax crystals) showed a strong correlation for trapping and retention of PM rather than macromorphology in the broadleaved tree species, thus serving as effective indicators for evaluating PM adsorption. Coniferous pine needles had a higher efficiency of potential PM retention after rainfall than broadleaved species. Regarding needle traits of an evergreen, conifers may be effective for PM reduction, especially during winter and early spring than other seasons. Urban tree diversity with different phenologies can maximize the trapping effects of PM by a prolonged leaf expansion period for urban areas in temperate climates. Because of the limited open space for green infrastructure planning in urban areas, it is necessary to study various planting techniques that maximize the adsorption and absorption of PM. This research was supported by Basic Science Research Program through the National Research Foundation of Korea (NRF) funded by the Ministry of Education ( $\mathrm{N}^{\circ}$ 2018R1A6A3A11050628).

\section{Effects of elevated Ozone $\left(\mathrm{O}_{3}\right)$ on photosynthetic apparatus of Chionanthus retusus}

\author{
Sanghee Park ${ }^{1}$, Sungeun Yoon ${ }^{1}$, Myeongja Kwak ${ }^{1}$, Jongkyu Lee ${ }^{1}$, Jieun Kim ${ }^{1}$, Yeaji Lim ${ }^{1}$, Handong Kim ${ }^{1}$, Suyoung Woo ${ }^{1}$ \\ ${ }^{1}$ University of Seoul, Seoul, Republic of Korea (parksanghee0930@gmail.com; sanghui4629@naver.com; 016na8349@hanmail.net; gpl90@naver.com; \\ quhweii@gmail.com; oxll²l@naver.com; blasterkhd92@gmail.com;wsy@uos.ac.kr)
}

Increasing ground-level O3 concentrations is one of the main environmental issues in forest ecosystems. This study was conducted to examine the potential non-stomatal limitations induced by elevated $\mathrm{O} 3$ on photosynthesis of leaves in Chionanthus retusus which is native species in East Asia. Two years old seedlings of $C$. retusus were exposed to elevated $\mathrm{O} 3$ concentration (100 nmol mol-1, $8 \mathrm{~h}$ d-1) in growth chamber. To investigate the effect of elevated ozone on the photosynthetic apparatus of $C$. retusus, net photosynthetic rate and the curves of photosynthesis rate (A) against intercellular CO ${ }_{2}$ concentration (Ci) were investigated after 6 weeks exposure to O3. The maximum rate of carboxylation by RuBisCO (Ribulose-1,5-bisphosphate carboxylase/oxygenase) (Vcmax), the maximum rate of photosynthetic electron transport based on NADPH requirement (Jmax) and the rate of triose-phosphate use (Tp) were calculated by analyzing the A/Ci curves. While Tp had no significant difference between two groups, Vcmax and Jmax of treatment group were decreased $42 \%$ and $24 \%$, respectively, compared to the control. Also, there was significant difference in net photosynthetic rate between two groups. O3 exposure had a negative impact on nonstomatal responses; reduction in the activity of RuBisCO and rate of photosynthetic electron transport chain and it induced decrease of carbon assimilation capacity of $C$. retusus. This research was supported by Basic Science Research Program through the National Research Foundation of Korea (NRF) funded by the Ministry of Education (No 2018R1D1A1A02044683). 


\title{
Multiple environmental stresses, future climate and germination of Caatinga endemic Cenostigma sp. seeds
}

Barbara França Dantas ${ }^{1}$, Samara Elizabeth Vieira Gomes², Janete Rodrigues Matias ${ }^{3}$

${ }^{1}$ Embrapa Semiárido, Petrolina, Brasil; ; ${ }^{2}$ niversidade do Estado da Bahia, Juazeiro, Brasil; ${ }^{3}$ Universidade Federal Rural do Semi-Arido, Mossoró, Brasil

(barbara.dantas@embrapa.br; samaraelizabethvg@yahoo.com.br; janete07@hotmail.com)

The Caatinga is predicted to be the most vulnerable Brazilian biome in a future climate scenario of global warming and decreased rainfall. Climate projections for the region in 2100 indicate significantly hotter conditions and a decrease of almost $50 \%$ in rainfall, thus worsening the water deficit in the region. Cenostigma pyramidale (Tul.) Gagnon \& G.P. Lewis and C. microphyllum (Mart. ex G. Don) E. Gagnon \& G. P. Lewis are endemic Fabaceae from the Brazilian Caatinga. The objective of this study was to evaluate the influence of combined environmental stresses (temperature $\mathrm{x}$ water restriction or temperature $\mathrm{x}$ salinity) on the germination of seeds of C. pyramidale and C. microphyllum. Seeds were germinated at constant temperatures between 10 to $40^{\circ} \mathrm{C}$ combined with osmotic potentials from 0 to -1.0 MPa (in polyethylene glycol 6000 or NaCl solutions). Germination data were then analysed using thermal, hydro and halo time models, and future germination responses projected according to climate change scenarios predicted by IPCC (International Panel for Climate Change) and PBMC (Brazilian Panel for Climate Change). The germination thermal thresholds ranged from 5 to $55^{\circ} \mathrm{C}$. The germination base osmotic threshold (using polyethylene glycol or $\mathrm{NaCl}$ ) were decreased in higher temperatures. According to the predictions for future climate (RCP 8.5), the reduced rainfall volime and increased temperature by 2100 will directly affect seed germination and seedling development of C. pyramidale and C. microphyllum.

\section{Stomatal uptake to improve air pollution mitigation in urban tree species}

Myeongja Kwak', Jongkyu Lee ${ }^{1}$, Suyoung Woo ${ }^{1}$, Sanghee Park ${ }^{1}$, Yeaji Lim ${ }^{1}$, Handong Kim ${ }^{1}$

${ }^{1}$ University of Seoul, Seoul, Republic of Korea(16na8349@hanmail.net; gpl90@naver.com; wsy@uos.ac.kr; parksanghee0930@gmail.com, oxll²l@naver.com; blasterkhd92@gmail.com)

Urban forests interact directly with air pollution abatement, local microclimate changes, pollen dispersal, and volatile organic compounds (VOCs) emissions. Therefore, it is necessary to understand the interactions of trees and air pollutants to improve air quality. The aim of the present study was to investigate the stomatal uptake, photosynthetic carbon assimilation, and stomatal physiological control in major tree species response to urban air pollution such as ozone $\left(\mathrm{O}_{3}\right)$ and sulfur dioxide (SO2). Trees exposed to air pollution generally showed excellent ability to absorb $\mathrm{O}_{3}$ and $\mathrm{SO} 2$ due to their abilities to improve air pollution tolerance through the positive regulation of stomatal movement. Among the main tree species used in this study, it is resistant to atmospheric pollutants $\left(\mathrm{O}_{3}\right.$ and SO2) by maintaining photosynthetic ability and stomatal conductance in treatment compared to control, even though it has high ability to absorb air pollutants. This research was supported by Basic Science Research Program through the National Research Foundation of Korea (NRF) funded by the Ministry of Education (No; 2018R1D1A1A02044683).

\section{B7q: PHYSIOLOGICAL AND BIOGEOCHEMICAL RESPONSE OF FOREST ECOSYSTEMS TO CLIMATE CHANGE AND AIR POLLUTION}

\author{
Nitrogen $\left(\mathrm{NO}_{3}^{-}\right)$input from rainfall in Eucalyptus saligna plantations / Input de nitrogênio $\left(\mathrm{NO}_{3}^{-}\right)$via precipitação pluviométrica em \\ plantação de Eucalyptus saligna \\ Grasiele Dick', Mauro Valdir Schumacher ${ }^{1}$, Monique Pimentel Lagemann ${ }^{1}$, Claudinei Garlet ${ }^{1}$ \\ ${ }^{1}$ Universidade Federal de Santa Maria, Santa Maria,Brasil (grasidick@hotmail.com; mauro.schumacher@ufsm.br; moniquelagemann@gmail.com; \\ claudineigarlet@gmail.com)
}

A precipitação pluviométrica é uma importante via de aporte dos nutrientes em plantações florestais. Por meio da água que incide sobre as árvores, lava o dossel e escoa pelo tronco, muitos nutrientes são carreados até o solo, ou são absorvidos diretamente pelas folhas. Neste estudo avaliamos a entrada de nitrogênio via precipitação pluviométrica incidente e precipitação interna em uma plantação de Eucalyptus saligna, cultivada na região central do bioma Pampa, Rio Grande do Sul, Brasil. O monitoramento ocorreu durante o ano de 2012, onde o volume de precipitação médio foi de 1.224,7 mm. Através da precipitação pluviométrica houve a entrada de $2,25 \mathrm{~kg} \mathrm{ha}^{-1}$ ano $^{-1}$ de nitrogênio $\left(\mathrm{NO}_{3}^{-}\right)$e, após a água passar pelo dossel, a quantidade foi de 3,98 $\mathrm{kg} \mathrm{ha}^{-1}$ ano-1. Ou seja, com a lavagem das copas das árvores houve aumento de 76,8\% na quantidade de nitrogênio depositada no interior da plantação. Considerando este valor anual, para um ciclo de corte das árvores após sete anos de cultivo, a precipitação interna representa mais de $25 \mathrm{~kg} \mathrm{ha}^{-1}$ nitrogênio ( $\mathrm{NO}_{3}{ }^{-}$). Visando a redução de impactos ambientais decorrentes da contaminação hídrica e edáfica, causada pelo excesso de nitrogênio, além de economia de recursos financeiros, esta quantidade deverá ser reduzida da aplicação via fertilizante mineral. O nitrato é preferencialmente absorvido pelas árvores e, este estudo evidencia a importante contribuição da precipitação pluviométrica na nutrição florestal. Ressaltamos que, além do fornecimento deste elemento às plantações florestais, também há possibilidade de redução de custos e impactos ambientais.

\section{Adaptation of Agro-IBIS model for Eucalyptus carbon budget estimation at regional level - a case study in São Paulo State, Brazil \\ Michel Anderson Almeida Colmanetti ${ }^{1}$, Santiago Vianna Cuadra ${ }^{2}$, Ahmed Attia $^{1}$, Yann Nouvellon ${ }^{3,4,5}$, Joannès Guillemot ${ }^{3,4,5}$, Otávio Campoe ${ }^{6,7}$, Osvaldo Cabral ${ }^{8}$, Jean-Paul Laclau ${ }^{3,4,6}$, Marcelo Galdos ${ }^{9}$, Rubens Augusto Camargo Lamparelli ${ }^{1}$, Jair Bortolucci ${ }^{1}$, Bruno Pereira ${ }^{1}$, Guerric le Maire ${ }^{1,3,4}$ ${ }^{1}$ Universidade de Campinas, Campinas, Brasil; ${ }^{2}$ Embrapa Cima Temperado, Campinas, Brasil; ${ }^{3}$ CIRAD, UMR Eco\&Sols, Montpellier, France; ${ }^{4}$ Eco\&Sols, Univ Montpellier, CIRAD, INRA, IRD, Montpellier, France; 'Escola Superior de Agricultura "Luiz de Queiroz", Universidade de São Paulo, Piracicaba, Brasil; " Universidade Estadual Paulista "Júlio de Mesquita Filho”, Botucatu, Brasil; " Universidade Federal de Santa Catarina, Curitibanos Brasil; ${ }^{8}$ Embrapa Meio Ambiente, Jaguariúna, Brasil; ${ }^{9}$ Institute for Climate and Atmospheric Science, School of Earth and Environment, University of Leeds, Leeds, United Kingdom(michelcolmanetti@gmail.com; santiago.cuadra@embrapa.br; ahmedatia80@gmail.com; yann.nouvellon@cirad.fr; joannes.guillemot@cirad.fr; otavio.campoe@ufsc.br; osvaldo.cabral@embrapa.br;jean-paul.laclau@cirad.fr;mvgaldos@gmail.com; lamparel@unicamp.br; jairbortolucci@hotmail.com; zehwallace@gmail.com; guerric.le_maire@cirad.fr)}

Highly productive fast-growing Eucalyptus plantations cover more than 5 million hectares in Brazil and exhibit very dynamic carbon fluxes throughout their 6-7 year rotations. These plantations quickly shift from $\mathrm{C}$ sources at the beginning of the rotation to large $\mathrm{C}$ sinks until harvest. In order to get a model simulating carbon pool and fluxes for both Eucalyptus plantations and other crops, we integrated several sub-models of the Eucalyptus-dedicated Generic Decomposition And Yield Model (G'DAY) into the large scale and multi-cover model Agro-IBIS (Integrated Biosphere Simulator). The G'DAY model was 
previously parametrized and validated using large experimental datasets obtained in commercial eucalypt plantations in the state of São Paulo. Implementing an Eucalyptus plantation cover type within AgroIBIS, which had no Plant Functional Type dedicated to fast-growing forest plantations, required important changes in the carbon allocation turnover sub-models. This study included three phases: (1) the computational modification of AgroIBIS; (2) the model parametrization, calibration and validation using data fromintensively monitored sites or inventories datasets; and (3) model application at regional scaleusing sets of parameters which were considered to be constant in space and/or time based on data from the local experiments, and other sets of parameters which could vary spatially. Carbon fluxes of Eucalyptus plantations were simulated at the regional scale, and their inter-annual and spatial variabilities were analysed. Such spatial and multiannual quantification of carbon fluxesat large scalesbrings a better understanding of these forest ecosystems on global carbon cycling, which is a prerequisite to support policy decisions.

\title{
Shoot water potential of saxaul trees Haloxylon ammodendron (C.A.Mey.) Bunge from two distinctive populations of Mongolia \\ Enkhchimeg Tsedensodnom ${ }^{1,2}$, Batkhuu Nyam-Osor ${ }^{2}$ \\ ${ }^{1}$ Institute of Geography and Geoecology, Mongolian Academy of Sciences, Ulaanbaatar, Mongolia; ${ }^{2}$ Laboratory of Forest Genetics and Ecophysiology, Department of Environment and Forest Engineering, National University of Mongolia, Ulaanbaatar, Mongolia (enkhii_smile@yahoo.com, nbatkhuu@gmail.com)
}

Haloxylon ammodendron (C.A. Mey) Bunge, Amaranthacaeae (saxaul) is grows in the desert and semi-desert regions of Mongolia forming southern Saxaul forests. This species is of great ecological and economic importance, not only because it can survive in harsh environmental conditions but also because it can reduce wind erosion and sand movement. The objectives of this study were to determine the water potential of assimilation shoot of Saxaul trees of natural stands.This study was conducted in the two distinctive population differing geographical location, vegetation and climate condition. The BZ population, Bayanzag $\left(103^{\circ} 42^{\prime} \mathrm{E}, 44^{\circ} 05^{\prime} \mathrm{N}, 1,100 \mathrm{~m}\right.$, asl) is situated in the southern part of Mongolia, Umnugobi province and DU poluation, Dulaan uul ( $44^{\circ} 12^{\prime} \mathrm{N}, 110^{\circ} 01^{\prime} \mathrm{E}$, 700-1,000 m, asl) is located in the southeastern part of Mongolia, Dornogobi province. Shoot water potential were measured using a Pressure Chamber (Model 1505DPMS Instrument Company, U.S.A.) following the method of Scholander. The assimilation shoot water potential was measured in trees differing in their age classes, mature tree $(200 \leq \mathrm{cm})$, young tree $(80-200 \mathrm{~cm})$ and juvenile $(\leq 80 \mathrm{~cm})$ according to their stem height classes. Generally, trees BZ population trend to have higher water potential at predawn, while DU population had higher in midday. According to measurement of water potential the young and juvenile trees are more subjected water stress than that of mature trees, which shows their adaptation performance in drought conditions.

\section{Nitrogen and sulfur deposition by rainfall and throughfall in Pinus taeda L. in Southern Brazil}

Mauro Valdir Schumacher ${ }^{1}$, Grasiele Dick ${ }^{1}$

${ }^{1}$ Universidade Federal de Santa Maria, Santa Maria,Brasil (mauro.schumacher@ufsm.br; grasidick@hotmail.com)

Soil fertility in areas planted with Pinus taeda is closely associated with nutrient input by atmospheric deposition, mainly with rainfall and throughfall. The objective of the present study is to quantify the input of nitrogen- $\mathrm{NO}_{3}^{-}$and sulfur- $\mathrm{SO}_{4}^{2-}$ in Pinus taeda stand, in Cambará do Sul, Southern Brazil. For the quantification and sampling of water from rainfall, three funnels surrounded by a bird ring were installed. In order to evaluate the throughfall, nine funnels were installed. Sampling was biweekly for a period of four years. After the samples were filtered and analyzed for $\mathrm{N}_{-} \mathrm{NO}_{3}^{-}$and $\mathrm{S}_{-} \mathrm{SO}_{4}{ }^{2-}$. The average total annual rainfall and throughfall was $2081.5 \mathrm{~mm}$ and $1280 \mathrm{~mm}$, respectively. Rainfall added $2.70 \mathrm{~kg} \mathrm{ha}^{-1}$ year $^{-1}$ and $4.97 \mathrm{~kg} \mathrm{ha}^{-1}$ year ${ }^{-1}$ of N$^{-\mathrm{NO}_{3}{ }^{-} \text {and S-SO }}{ }_{4}^{2-}$, respectively.

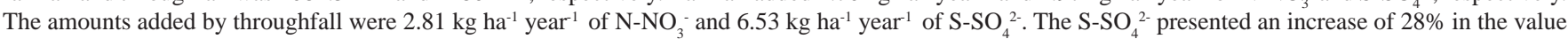
of its quantity, after the interaction with the canopy of the trees.

\section{Nitrogen return to soil by litterfall in Semidecidual Seasonal Forest and Pinus taeda L.}

Mauro Valdir Schumacher ${ }^{1}$, Grasiele Dick ${ }^{1}$, Monique Lagemann $^{1}$, Claudinei Garlet ${ }^{1}$

${ }^{1}$ Universidade Federal de Santa Maria, Santa Maria,Brasil (mauro.schumacher@ufsm.br; grasidick@hotmail.com; moniquelagemann@gmail.com; claudineigarlet@gmail.com)

The dynamics of litter and nutrients is essential to maintaining the productive capacity of native forests and commercial plantations with tree species. The objective of the present study is to characterize the return of total nitrogen, via litterfall, in a semideciduous seasonal forest and a Pinus taeda stands, in Quedas do Iguaçu, Paraná, Brazil. In each ecosystem three plots of $21 \mathrm{~m}$ x $20 \mathrm{~m}$ were demarcated, in which four traps with $1 \mathrm{~m}^{2}$ of area were systematically distributed to quantify the litterfall. The amount of litterfall in native forest and pinus stands is 7.76 and $7.15 \mathrm{mg} \mathrm{ha}^{-1}$ year $^{-1}$, respectively. In the native forest the amount of $\mathrm{N}$ was $147.19 \mathrm{~kg} \mathrm{ha}^{-1}$ year $^{-1}$, about $191.3 \%$ higher than the value found in pinus, which presents $50.53 \mathrm{~kg} \mathrm{ha}^{-1}$ year ${ }^{-1}$. This difference in the values obtained is explained by the presence of legume species in the native forest, which by symbiosis with bacteria of the genus Rhizobium, can fix the atmospheric nitrogen and increase the values of this element in its biomass. Litterfall is the most important source of nitrogen return to the soil.

\section{Using process-based modelling to better understand the impact of mineral (N, P, K) cycles and climate change on stand growth and resource-use in Eucalypt plantations}

\author{
Ivan Cornut ${ }^{1}$, Nicolas Delpierre ${ }^{1}$, Otávio Campoe ${ }^{2,3}$, Joannès Guillemot ${ }^{4,5,6}$, Jean-Paul Laclau ${ }^{4,5}$, Louis Mareschal ${ }^{4,5}$, Yann Nouvellon ${ }^{4,5}$, José-Luiz Stape ${ }^{2,7}$, \\ Guerric le Maire M,5, $^{4}$ \\ ${ }^{1}$ Ecologie Systématique Evolution, Université Paris-Sud, CNRS, AgroParisTech, Université Paris-Saclay, Orsay, France; ${ }^{2}$ Universidade Estadual Paulista \\ “Júlio de Mesquita Filho", Botucatu, Brasil; ${ }^{3}$ Universidade Federal de Santa Catarina, Curitibanos, Brasil; ${ }^{4}$ UMR Eco\&Sols, CIRAD, Montpellier, France; \\ ${ }^{5}$ Eco\&Sols, Univ Montpellier, CIRAD, INRA, IRD, Montpellier, France; ' ${ }^{6}$ scola Superior de Agricultura "Luiz de Queiroz”, Universidade de São Paulo, \\ Piracicaba Brasil; ' ${ }^{7}$ Suzano Pulp and Paper, Suzano, Brasil; ${ }^{8}$ Universidade Estadual de Campinas, Campinas, Brasil (ivan.cornut@u-psud.fr; nicolas. \\ delpierre@u-psud.fr; otavio.campoe@ufsc.br; joannes.guillemot@cirad.fr; laclau@cirad.fr; louis.mareschal@cirad.fr;yann.nouvellon@cirad.fr; \\ stape@suzano.com.br; guerric.le_maire@cirad.fr)
}

In addition to wood production services, forest ecosystems play an important role in the mitigation of anthropogenic climate change. However the role of forests as future $\mathrm{C}$ sinks is being discussed since there is increasing evidence of a progressive shift from carbon-limited growth to nutrient-limited growth as demonstrated in FACE experiments. The development of mechanistic models, including the main nutrient balance and their relationship with the carbon and water balances, is necessary to evaluate the future response of forests to climate change. In this contribution, we present the first joint evaluation of a coupled C-water-N-P-K model on a large number of biogeochemical measurements collected in fast-growing eucalyptus plantations in Brazil along entire rotations, including trials with variable levels of fertilisation and water availability. We have first adapted the CASTANEA ecophysiological model, primarily designed for 
temperate and boreal forests, to the simulation of carbon and water fluxes in tropical Eucalypt. Then, the N, P, K fluxes and stocks within the plant were modelled based on process from the literature and calibrated on specific measurements, including the interaction between nutrient content of organs and carbon and water related processes. The final objective is to quantify the relative importance of single nutrients and water limitation on stand growth and carbon productivity, and evaluate the impact of climate change on these different cycles through a change in mean temperature, $\mathrm{CO}_{2}$ concentration and precipitation regime.

Monitoring populations of Picea mexicana Martínez and conservation activities in Mexico / Monitoreo de poblaciones de Picea mexicana Martínez y acciones de conservación en México

Celestino Flores-López ${ }^{1}$, Loreto Edelmira Chaparro-Gómez ${ }^{1}$, Salvador Valencia-Manzo', Adrián Hernández-Ramos ${ }^{2}$

${ }^{1}$ Universidad Autónoma Agraria Antonio Narro, Saltillo, Mexico; ${ }^{2}$ Instituto Nacional de Investigaciones Forestales, Agricolas y Pecuarias, Saltillo, Mexico (cele64@gmail.com; edel_188@hotmail.com; svalenciam2016@gmail.com; hernandez.adrian@inifap.gob.mx)

Picea mexicana es una especie de clima subalpino con distribución natural superior a los $2800 \mathrm{~m}$ de altitud, endémica, en riesgo y sensible al cambio climático del Norte de México. Se evaluaron sitios permanentes en las tres únicas poblaciones conocidas: La Marta, Nuevo León, El Coahuilón, Coahuila y El Mohinora, Chihuahua. Durante el periodo 2006-2018 se realizaron dos inventarios, se desarrolló una tabla de proyección de volumen, se evaluaron indicadores reproductivos de conos, semillas y germinación. Las especies dominantes en las poblaciones son Pseudotsuga menziesii, Pinus rudis, Abies vejari, Abies duranguensis y Picea mexicana, ésta última sobresale de las especies asociadas en incremento en volumen anual con un rango de 0.5 a 3.4 m³/ha, sin embargo, del 49 al $85 \%$ del arbolado no hay cambio de categoría diamétrica, concentrándose la mortalidad en la población el Coahuilón para las especies Picea mexicana y Pinus rudis. El coeficiente plántulas/árboles en las poblaciones menor de 6es bajo con respecto a las especies del género Picea. La baja eficiencia en la producción de semillas y los tamaños de la semilla reflejan valores mayores de 0.7 en índice de endogamia, con mayor efecto en las poblaciones El Mohinora y El Coahuilón. La sequía crítica de un año con presencia de incendios ha sido la causa principal de mortalidad. Las acciones de los ejidatarios y particulares, así como el desarrollo de proyectos de investigación paralelos y de servicios ambientales en apoyo a estas áreas de conservación de montaña, favorecen la conservación in situ.

\title{
The Potential of Sentinel-2 Images to detect damage levels on Pinus taeda stands caused by Sapajus nigritus Kerr (1972)
}

\author{
Carla Talita Pertille ${ }^{1}$, Marcos Benedito Schimalski ${ }^{1}$, Veraldo Liesenberg
}

${ }^{1}$ Universidade do Estado de Santa Catarina,Lagea,Brasil (carla_pertille@hotmail.com; marcos.schimalski@udesc.br; veraldo.liesenberg@udesc.br)

This study aimed to apply both regression and classification methods using Sentinel-2/MSI images to detect damage levels occurred in Pinus taeda stands caused by Sapajus nigritus (monkey). The forest stands are located in Bocaina do Sul (Santa Catarina State). Three images were selected encompassing different attack periods. We selected images before (May/2017), during (November/2017) and after attacks (April/2018). A total of 46 field plots were verified in the field where tree individuals were classified according to the damage intensity: i) no damage, ii) moderate, iii) severe, and iv) dead. In order to estimate the damage level per plot, spectral reflectance, principal component analysis (PCA), and vegetation indices (VI) were selected as regressor variables for the development of regression models using Stepwise, Support Vector Machine (SVM) and Random Forest (RF) approaches. The best model selection was based on the regression model fit statistics. The most robust indexes were MCARI, NDI45 and NDVIRR, which estimated for the classes a percentage of attack of $S$. nigritus per plot with adjusted $\mathrm{R}^{2}$ of $0.8042,0.4603,0.8815$ and 0.9766 ; Syx of 13.49, 61.42, 15.11 and 8.69 (\% 0.045 ha-1) and RMSE of 1.95, 4.49, 2.11 and 0.32 (\% 0.045 ha-1), respectively. It was possible to estimate and to identify areas attacked by this species highlighting the Stepwise model, followed afterward by SVM and RF. However, it is still recommended to evaluate digital images of high and ultra-high spatial resolution sensors in order to corroborate with the proposed methodology.

\section{B8b: COOL FORESTS AND CLIMATE CHANGE: CHALLENGES OF TRANSITION TO SUSTAINABLE FOREST MANAGEMENT}

\section{Cool Forests - an introduction}

Florian Kraxner $^{1}$, Anatoly Shvidenko ${ }^{1}$, Dmitry Schepaschenko ${ }^{1}$, Charlotte Kottusch ${ }^{1}$, Anni Reissell ${ }^{1}$, Gerald Steindlegger ${ }^{2}$ ${ }^{1}$ International Institute for Applied Systems Analysis, Laxenburg, Austria; ${ }^{2}$ Steindlegger ISS - Integrated Sustainability Solutions, Oberneukirchen, Austria (kraxner@iiasa.ac.at; shvidenk@iiasa.ac.at; schepd@iiasa.ac.at; kottusch@iiasa.ac.at; reissell@iiasa.ac.at; gerald@steindlegger-iss.com)

Forests developed in regions of cold climate over thousands of years. These "Cool Forests", located in boreal and mountain areas, make up more than one third of the global forest extent. They are found from the circumpolar belt in the northern hemisphere to high-elevation zones in temperate, mid-latitude and tropical zones. Cool Forests show many similarities throughout the boreal and high mountain ecozones - especially with respect to species composition, growth patterns, and response to climate exposure. They are tremendously important for carbon storage, together forming the single largest carbon pool of all terrestrial ecosystems. Cool Forests are partially underlined by permafrost soils and deliver much of the world's harvested wood products including timber, pulp, and paper. Furthermore, they are home to unique landscapes and biological diversity, providing ecosystems that are crucial for the livelihoods of millions of people. Yet, the impacts of current social, economic, environmental, climatic and technological changes on cool Forests remain uncertain. As climate is changing and temperatures rise, the permafrost is thawing, resulting in significant release of greenhouse gases which further accelerate climate change. Permafrost thawing in mountain and boreal ecozones has already caused soil collapses, landslides, rock falls, and mudflows. Rising temperatures are linked to an increase in the frequency and severity of natural disturbances such as wildfire, insect outbreaks, and wind storms and thus present a growing threat to people and nature, the bioeconomy and the climate. This presentation provides an introduction to cool Forests and why they are in danger.

\section{The potential contributions of the forest sector to climate change mitigation and negative emissions}

Werner Kurz ${ }^{1}$, Carolyn Smyth ${ }^{1}$

${ }^{1}$ Natural Resources Canada,Victoria, Canada (werner.kurz@canada.ca; carolyn.smyth@canada.ca)

The goals of the Paris Agreement cannot be reached without the support of forests and the forest sector as active carbon sinks that contribute towards net negative emissions. The design of climate effective mitigation strategies must take a systems perspective that takes into consideration the changes in emissions and removals in forest carbon stocks, in harvested wood products (HWP) carbon stocks, and in other sectors where wood products substitute for other emissionintensive materials and fossil fuels. Moreover, all mitigation options have to be assessed relative to a business as usual baseline. New spatially-explicit analyses of forest sector mitigation options in Canada demonstrate the need for regionally-differentiated strategies to climate change mitigation. Cost-effective 
opportunities exist through changes in forest management, HWP use and substitution benefits. However, the impacts of climate change and the resulting increases in emissions from drought, insects and fires further complicate the analyses. Adaptation strategies need to be designed that also meet mitigation objectives. For example, post-disturbance salvage logging and fuel reduction treatments to reduce the risk of fires provide opportunities to access biomass that can provide feedstock for engineered long-lived timber products or renewable energy sources such a second-generation liquid transportation fuels. Results from ongoing analyses will be presented.

\title{
Opportunity and challenges for transition of Northern Eurasian cool forests to sustainable forest management
}

Anatoly Shvidenko ${ }^{1,2}$, Florian Kraxner ${ }^{1}$, Dmitry Schepaschenko ${ }^{1,3}$

${ }^{1}$ International Institute for Applied Systems Analysis, Laxenburg, Austria; ${ }^{2}$ Institute of Forest SB RAS, Krasnoyarsk, Russian Federation; ${ }^{3}$ Bauman Moscow State Technical University, Mytischi,RussianFederation (shvidenk@iiasa.ac.at; kraxner@iiasa.ac.at; schepd@iiasa.ac.at)

The Northern Eurasian (NE) cool forests (boreal Russia and mountains of the NE Mid-Latitude ecotone) comprise about one-fourth of the global forest area. Specific features of the NE cool forest and landscapes predestine their extremely high exposure, vulnerability and risks under new climates. The most critical climate change on the planet are expected in continental NE, and some IPCC Scenarios (e.g. RCP6.5/8.5) suppose cool forests as a tipping element. A particular threat to global climate mitigation efforts is generated by thawing permafrost. Decreasing vitality, vulnerability and productivity of forests are expected also in the mid-latitude ecotone. The forests and wetlands of the NE require specific societal, scientific and managerial attention. This presentation considers needs, possibilities, opportunities and challenges of transition to adaptive risk-resilient sustainable forest management (ASFM) in NE. We analyze specifics, points of departure, challenges and strategies of transition to ASFM. A key challenge is assessing future resilience of forest ecosystems, biophysical and economic valuation of all ecosystem services, and quantifying tradeoffs between services. The capacity of transition to ASFM differs substantially over NE. We analyze specifics and commonalities over NE to assess potential, opportunities and challenges of ASFM and identify problems which require both national and global efforts (e.g. slowdown of permafrost thaw). There is no single strategy, which would allow reaching all goals of ASFM. High uncertainty of climatic predictions and lack of knowledge on behavior of boreal and high-elevation forests under new environments require integrated observing systems, new science and technologies realized within regional ASFM programs.

\section{Role, technology, policy of forest resources for the NDC (Nationally Determined Contributions) of the Republic of Korea}

Woo-Kyun Lee ${ }^{1}$, Boyoung Ham ${ }^{1}$, Cholho Song ${ }^{1}$, Eunbeen Park', Chul-Hee Lim ${ }^{1}$, Halim Lee ${ }^{1}$, YoungJin Ko ${ }^{1}$

${ }^{1}$ Korea University, Seoul, Republic of Korea(leewk@korea.ac.kr; tomboy04@gmail.com; cholhosong@gmail.com; heyevvin@gmail.com; limpossibe@korea.ac.kr; halimlee91@gmail.com;ko871004@gmail.com)

The Republic of Korea (RoK) decided to include carbon absorption from forest resources in the Nationally Determined Contributions (NDC) from 2020. About two-thirds of Korean land is covered by forest, and it is reported that about 47 million ton $\mathrm{CO}_{2}$ can be absorbed per year by forest. This will be included in the NDC that will be submitted by the Republic of Korea.However, the Korean forest is getting older over time and intensive forest management for carbon storage can also face some difficulties in relation to land cover conflicts and environmental issues. It is also predicted that the $\mathrm{CO}_{2}$ absorption will decrease from 47 to 22 million tons by the year 2030. Securing determined amount of carbon storage and absorption in forest can play an important role in ensuring NDC's soundness. Forest biomass and carbon should be estimated through the analysis of forest activity data and the usage of carbon accounting system. In addition, these two factors should be integrated into forest growth models which can predict future carbon stock under a forest management regime. National Forest Inventory (NFI) system should be well operated for having confidential national forest carbon database. Land cover/use change monitoring is also essential for monitoring national carbon budget in relation to LULUCF (Land Use, Land-Use Change and Forestry) mechanism and MRV (Measurement, Reporting and Verification) system. In this presentation, role, technology and policy of forest resources for the NDC of the RoK will be introduced and some future prospects will be suggested.

\section{Forecast of State of Ukraine's forests under climate change conditions}

\author{
Ivan Lakyda ${ }^{1}$,Anatoly Shvidenko ${ }^{2}$, Roman Vasylyshyn ${ }^{1}$, Petro Lakyda ${ }^{1}$, Anatolii Karpuk ${ }^{1}$, Maryna Lakyda ${ }^{1}$ \\ ${ }^{1}$ National University of Life and Environmental Sciences of Ukraine, Kyiv, Ukraine; ${ }^{2}$ International Institute for Applied Systems Analysis, Laxenburg, Austria \\ (ivan.lakyda@nubip.edu.ua; shvidenk@iiasa.ac.at; vasylyshyn@nubip.edu.ua; lakyda@nubip.edu.ua; karpuk@nubip.edu.ua; maryna.lakyda@gmail.com)
}

A precondition for correct forest management planning for mid- and long-term time horizons is accounting for influence of factors of the changing world. This directly influences not only such questions as selecting tree species composition, rotation ages etc., but also is extremely important for correct assessment of forests' ecosystems services, which are deemed to have an increasing importance in current and future economy. When done correctly, forecast of forests' future state with provisions for dynamics of environmental factors can support national and global decision- and policy-making processes in the frame of risk-resilient forest management. This abstract presents research results on first detailed forecast of state of Ukraine's forests under climate change. To enable reaching the research goal, an original methodological approach was applied incorporating the data of stand-level forest management planning (biometric description of stands and their geospatial location), climatology-based forecasts of suitability of certain environmental conditions (climate humidity, continentality and cryoclimate) for the major forest-forming tree species of Ukraine, and the updated information support basis of forestry (systematized numerous models widely applied in forest sector). The forecast results are available as a spatially explicit stand-level biometric information for certain time points in future. The results of our research create preconditions for forecasting growth, productivity and ecosystems services of Ukraine's forests under climate change, and the methodological approach can be used for further scenario analysis accounting for wide combinations of different environmental factors. Also, this research can serve as a platform for international multidisciplinary scientific collaboration in the mid-latitude ecotone.

\section{Projection of fire regimes in Russian forests: the FLAM approach}

\author{
Andrey Krasovskii ${ }^{1}$, Anatoly Shvidenko ${ }^{1}$, Dmitry Schepaschenko ${ }^{1}$, Nikolay Khabarov ${ }^{1}$, Florian Kraxner ${ }^{1}$ \\ ${ }^{1}$ Ecosystems Services and Management Program, International Institute for Applied Systems Analysis, Laxenburg, Austria (krasov@iiasa.ac.at; \\ shvidenk@iiasa.ac.at; schepd@iiasa.ac.at; khabarov@iiasa.ac.at; kraxner@iiasa.ac.at)
}

Over 2000-2015, wildfire enveloped of about 10 million hectares in Russia annually, mainly in the boreal zone with carbon emissions above 130 Tg $\mathrm{C} \mathrm{yr}^{-1}$. Half of this area is presented by closed forests, and almost two-third - by forest land. Climatic projections, particularly for the harsh IPCC 
Scenarios (RCP6.5 or RCP8.5), suggest substantial increase of fire risk in Russian forests during the $21^{\text {st }}$ century that puts serious problem on planning the adaptation policies in the Russian forest sector. In this study, we apply wilFire cLimate impacts and Adaptation Model (FLAM) to project future fire regimes in Russia. FLAM estimates burned areas under different suppression activities and allow assessing impacts of fire on the carbon cycle. FLAM is a mechanistic model operating at a daily time step on the grid cell of 0.25 arc degree, the same spatio-temporal resolution as in the Global Fire Emissions Database v4.1s (GFED). By applying historical climate data, we calibrated FLAM against observed burned areas from GFED for the period 2000-2016. Calibration of the spatial suppression efficiency took into account seasonality and other specific features of wildfires in Russia. Fire ignition was estimated based on population density maps and assessment of natural sources such as lightning. FLAM projections of burned areas and expected fire emissions by major land classes are presented for $4 \mathrm{RCP}$ scenarios. The results obtained are used for discussion of appropriate mitigation options to minimize impact of future fires on Russian forest ecosystems and the Earth climate system.

\title{
Assessment of the impact of alternative forest management models on cool forests in Europe
}

\author{
Mykola Gusti ${ }^{1}$, Anu Korosuo ${ }^{1}$, Fulvio Di Fulvio ${ }^{1}$, Pekka Lauri ${ }^{1}$, Nicklas Forsell ${ }^{1}$ \\ ${ }^{1}$ International Institute for Applied Systems Analysis, Laxenburg, Austria (gusti@iiasa.ac.at; korosuo@iiasa.ac.at; difulvi@iiasa.ac.at; lauri@iiasa.ac.at; \\ forsell@iiasa.ac.at)
}

Boreal and mountainous forests are highly vulnerable to climate change and the potential changes in forest use. These forests provide a number of ecosystem services important for the environment and people living in and around them (e.g., wood for material and energy, soil protection, regulation of water flow, biodiversity, recreation). Increasing biomass demand, rising population and climate change will challenge the current state of the cool forests and their future ability of providing ecosystem services. Alternative forest management models (AFMM) may be needed to adapt the forests to these challenges. We provide a modelling study of the impact of AFMMs in different EU regions. These potential AFMMs are being developed in ALTERFOR project in a close collaboration with different stakeholders, and with a focus on learning from the experiences from other countries. From the AFMMs suitable for each EU region, a selection of "robust" ones are being implemented in a large-scale modelling framework. A combination of Global Biosphere Management Model (GLOBIOM) and Global Forest Model (G4M) are applied in the study. GLOBIOM is used to assess competition for land use between agriculture, bioenergy, and forestry, while G4M provides detailed representation of forest stand dynamics as a response to forest management aimed at satisfying wood demand and mitigation policies. The results are expected to point out the most relevant AFMMs under the different socioeconomic scenarios, with a specific focus on assessing changes in carbon dynamics, sustainable potentials for forest harvest and residue extraction, employment etc.

\section{From 1990 to 2050: retrospective and projection of carbon budget of Russian forests}

Dmitrii Zamolodchikov ${ }^{1}$ (D) Wassily Grabowsky ${ }^{1}$, Olga Chestnykh

${ }^{1}$ Center for Forest Ecology and Productivity of the Russian Academy of Sciences (CEPF RAS), Moscow, Russian Federation (dzamolod@mail.ru; wgrabo@mail.ru; ochestn@mail.ru)

Earlier we developed the system of carbon balance inventory in forestry of Russia, called Regional Evaluation of Carbon Budget of Forests (RECBF). Evaluations given here refer to the forested lands of the Russian Forest Fund, the area of which increased from 758.7 to 785.6 million hectares from 1988 to 2015. Carbon sink to the forests of Russia was minimal in 1988 ( $80.3 \pm 65.1 \mathrm{Mt} \mathrm{C} /$ year). Since the first half of the1990s, there was an increase in the carbon sink to $239.4 \pm 57.7 \mathrm{Mt}$ C/year in 2008. This increase was explained by a significant reduction of the timber harvesting in connection with socioeconomic reforms in Russia. After reaching the maximum value in 2008, the carbon sink was gradually decreased to $206.1 \pm 58.9$ Mt C/year in 2015 . This reduction was by $44.5 \%$ due to increased losses in logging operations, by $21.5 \%$ due to increase of forest fires and by $34.5 \%$ due to a decrease in absorption. The modeling tool RECBF-M was recently developed, based on concept of forest transitions models. If the level of all disturbances including felling and forest fires will not change in future, the Russian forests still decrease carbon sink till 176.5 Mt C/year in 2020, 122.6 in 2030, 86.7 in 2040, 60.8 Mt C/year in 2050. The projected decrease is explained by changes of forest age structure. The massive forest management activates are necessary to maintain carbon sink to Russian forests, from which most effective are regulation of rotation time and forest fire protection.

\section{B8c: FORESTS AND CLIMATE CHANGE IN SOUTHWESTERN AMAZON}

Vulnerability to extreme climate events in the Southwestern Amazon region: a case study of the trinational area of the Acre River Basin in the MAP region comprising Madre de Dios, Peru, Acre, Brazil, and Pando, Bolivia / Vulnerabilidade aos eventos extremos climáticos no Sudoeste da Amazônia: um estudo de caso da área trinacional da bacia do Rio Acre, na região MAP (Madre de Dios-PE, AcreBR e Pando-BO)

Foster Brown ${ }^{1,2}$ (D, Vera Reis-Brown ${ }^{3}$,Elsa Mendoza ${ }^{4}$, Hugo Fuentes ${ }^{5}$, Jiang Torres ${ }^{6}$, Wilson Palomino ${ }^{7}$, Fronika de Wit ${ }^{8}$, Sonaira Silva ${ }^{9}$, Juan Fernando Reyes ${ }^{10}$, Ronald Gomringer ${ }^{11}$

${ }^{1}$ Woods Hole Research Center, Massachusetts, USA; ${ }^{2}$ Universidade Federal do Acre, Rio Branco, Brasil; ${ }^{3}$ Secretaria de Estado de Meio Ambiente do Acre, Rio Branco, Brasil; ${ }^{4}$ Earth Innovation Institute, Rio Branco, Brasil; ${ }^{5}$ Herencia, Cobija, Plurinational State of Bolivia; ${ }^{6}$ Setor de Meio Ambiente e Manejo de Recursos Naturais do Departamento Regional de Madre de Dios, Madre de Dios, Peru; ${ }^{7}$ Universidad Nacional San Antonio Abad del Cusco, Cusco, Peru; ${ }^{8}$ Secretaria Municipal de Meio Ambiente de Rio Branco, Rio Branco, Brasil; ${ }^{9}$ Universidade Federal do Acre, Cruzeiro do Sul, Brasil; ${ }^{10}$ Herencia, Cobija, Plurinational State of Bolivia; ${ }^{11}$ Instituto de Pesquisa de la Amazonía, Iquitos, Peru(fbrown@uol.com.br, vlreis.reis21@gmail.com; elsa_mendoza@uol.com.br; hleeoos@gmail.com; jliaot@hotmail.com; wilsonsurip@hotmail.com; fronikadewit@gmail.com; sonairasilva@gmail.com; jfr@herencia.org.bo; ronaldcorvera@gmail.com)

O sudoeste da Amazônia enfrenta inúmeros desafios para a utilização sustentável dos recursos naturais na medida em que experimenta rápido crescimento populacional e econômico, expandindo setores de agricultura, transporte e energia, associados aos impactos de extremos climáticos frequentes e severos. A parte trinacional da bacia do Rio Acre, situada na fronteira do Peru, Brasil e Bolívia, nas áreas contíguas do Departamento de Madre de Dios, PE, do Estado do Acre-BR e do Departamento de Pando-BO ou da Região MAP, incorpora grande parte desses desafios. Nesse contexto de transição, a Região Amazônica em geral e a bacia do Rio Acre, em particular, se deparam com a necessidade de adaptação às alterações dos contextos sociais e ambientais, em especial aqueles associados às mudanças climáticas. Com o objetivo de abordar a vulnerabilidade da bacia aos eventos extremos climáticos, realizou-se a análise integrada da vulnerabilidade da floresta e dos recursos hídricos, utilizando como referência o Programa Global Water Partnership (Wouters, 2013). Aplicou-se o método do QCCE (2011) para vincular conhecimento científico e local a ações relevantes para a política na Região MAP. As variáveis e elementos climáticos ligados a 
floresta e recursos hídricos foram classificados por prioridade ou severidade, a partir dos quais construiu-se uma matriz de risco usando as três prioridades mais altas. Um esquema de classificação ordinal, usando matrizes, permitiu priorizar os riscos e a vulnerabilidade, indicando que as secas prolongadas, os incêndios florestais associados e as inundações são os três riscos prioritários na região.

Project Forest Health: participatory training for community forest monitoring / Projeto saúde das florestas: capacitação participativa para o monitoramento florestal comunitário

Sabina Ribeiro ${ }^{1}$ (D) Fernando Schmidt ${ }^{1}$ (D) Foster Brown ${ }^{2}$ (D); Galia Selaya ${ }^{3}$ (D); Stephen Perz ${ }^{4}$, Richarlly Silva ${ }^{5}$

${ }^{1}$ Universidade Federal do Acre, Rio Branco, Brasil; ${ }^{2}$ Woods Hole Research Center, Falmouth, USA; ${ }^{3}$ Herencia, Cobija, Plurinational State of Bolivia;

${ }^{4}$ University of Florida, Gainesville,USA; Instituto Federal do Acre, Cruzeiro do Sul, Brasil (sabina.ufac@gmail.com; schmidt.fa@gmail.com;

fbrown@uol.com.br;gselaya@outlook.com; sperz@ufl.edu; rcosta.bio@gmail.com

O desmatamento na Amazônia contribui para o aumento das secas na região e intensifica o efeito das mudanças ambientais. O pagamento por serviços ambientais, aliado ao aumento da consciência ambiental, podem contribuir para frear o desmatamento na região. Nesse sentido, o projeto Saúde das Florestas objetiva aumentar a capacidade de comunidades extrativistas em compreender a dinâmica das suas florestas e realizar o manejo sustentável de suas áreas. As comunidades extrativistas abrangidas pelo projeto fazem parte da Reserva Extrativista Chico Mendes, no estado do Acre, Brasil. Os comunitários participantes das capacitações abrangeram jovens lideranças das regiões de Xapuri e Assis Brasil. As capacitações foram realizadas de forma voluntária e participativa por meio de oito oficinas que abrangeram temas ligados a orientação em campo, ecologia florestal e taxonomia botânica, protocolo de instalação e remedição de parcelas permanentes (RAINFOR), estabelecimento de uma parcela permanente e análise de dados em planilha eletrônica. O conhecimento adquirido nessas capacitações foi multiplicado para outros comunitários por meio de duas oficinas de disseminação, nas quais os jovens capacitados organizaram e conduziram a multiplicação do conhecimento sobre o monitoramento florestal. Ademais, atendendo as sugestões dos comunitários participantes, foi implementado um segundo projeto em que o tema saúde das florestas é trabalhado através de dinâmicas complementares ao conteúdo do ensino fundamental e médio de escolas rurais do estado Acre. Embora iniciativas como essas enfrentam diversas barreiras, elas são fundamentais para promover a reflexão dos comunitários sobre o impacto de suas atividades na saúde das florestas.

Regulatory and financial mechanisms for environmental conservation, sustainable development, and remuneration for results at REDD+ in Acre, Brazil / Marco regulatório e mecanismos financeiros para conservação ambiental, desenvolvimento sustentável e remuneração de resultados de REDD+ no Acre

Ricardo Assis Mello ${ }^{1}$, Sarah Hutchinson ${ }^{2}$, Moacyr Araújo Silva ${ }^{3}$

${ }^{1}$ WWF Brasil, Brasilia, Brasil; ${ }^{2}$ WWF UK, London, United Kingdom; ${ }^{3}$ WWF Brasil, Rio Branco, Brasil (ricardomello@wwf.org.br; shutchison@wwf.org.uk; moacyr@wwf.org.br)

O objetivo desta apresentação é compartilhar experiências do Programa Jurisdicional ISA Carbono do Estado do Acre, que tem focos na remuneração por resultados de REDD+ e na repartição de benefícios por meio de subprogramas que apoiam provedores de serviços ambientais relacionados com o carbono florestal no Estado do Acre. Além do marco legal regulatório básico, o painel traz uma contextualização do Sistema de Incentivos aos Serviços Ambientais (SISA) e da contribuição do WWF no seu desenvolvimento enquanto mecanismo de diversificação produtiva e de direcionar fluxos financeiros em suporte às cadeias produtivas de base florestal e baixas emissões. O estudo também aborda avanços, lições e desafios que permanecem para a consolidação do SISA Acre e para o desenvolvimento de outros programas de incentivos ambientais considerando elementos como, por exemplo, sociobiodiversidade e água. A implementação do SISA, juntamente com outras políticas estruturantes da economia de base florestal, contribuíram até 2018 para aumentar o volume de investimentos no Estado e reduzir taxas de desmatamento. O grau de conservação ambiental do Estado ( $87 \%$ do seu território total com cobertura florestal mantida), o estoque de capital natural e o potencial de retorno econômico e financeiro das cadeias produtivas de baixo carbono são vantagens comparativas do Acre nos mercados voluntários e regulados de carbono. Tendo em vista as parcerias do Acre com outras iniciativas de REDD+ jurisdicional, espera-se que esta iniciativa seja útil para atores sociais e governantes de outras jurisdições, bem como para investidores e outros interessados em mecanismos financeiros de REDD+.

\section{Education as a sine qua non for strengthening integrated watershed management for extreme climate events in the Madre de Dios- Peru, Acre-Brazil, and Pando-Bolivia (MAP) Region of Southwestern Amazonia}

Irving Brown ${ }^{1,2}$, Guillermo Rioja-Ballivián ${ }^{3}$, Marta Torres $^{4}$, Ednilza Rocha ${ }^{5}$, Cristina Boaventura ${ }^{1}$, Juan Fernando Reyes ${ }^{6}$, Carmen Acho ${ }^{7}$, Elaine Lopes ${ }^{1}$, Mercedes Perales ${ }^{8,9}$, Nazaré Macêdo $^{1}$, Cesar Ascorra ${ }^{3}$, Marilia Carmo ${ }^{1}$, Andrea Alechandre ${ }^{1}$, Quéren Luna ${ }^{1}$, George Santos ${ }^{10}$

${ }^{1}$ Universidade Federal do Acre, Rio Branco, Brasil; ${ }^{2}$ Woods Hole Research Center Falmouth USA; ${ }^{3}$ Projecto Ecominda, Cobija, Plurinational State of Bolivia; ${ }^{4}$ Centro de Inovación Cientifica Amazonica, Puerto Maldonado, Peru; ${ }^{5}$ Secretaria Estadual de Educação e Esportes do Acre, Rio Branco, Brasil; ${ }^{6}$ Herencia, Cobija, Plurinational State of Bolivia; ${ }^{7}$ Centro de Inovación Cientifica Amazonica, Puerto Maldonado, Peru; ${ }^{8}$ Senamhi, Inapari, Peru; ${ }^{9}$ Comite de Gestion del Parque Nacional de Alto Purus Inapari Peru; ${ }^{10}$ Defesa Civil Municipal, Rio Branco,Brasil(fbrown@uol.com.br; guillermorioja@gmail.com; torresmi@wfu.edu; nilzadoce@gmail.com;wcris7@gmail.com;jfr@herencia.org.bo; achocj@wfu.edu; lopes.elaine7@gmail.com;

leomeche@hotmail.com;mncmaced@gmail.com; ascorrcf@wfu.edu; mariliaangelac@gmail.com; andreaalechandre@gmail.com; querenluna@gmail.com; georgeacre@gmail.com)

The global trends of tropical deforestation, biotic impoverishment, climate perturbation, and demands for forest-related products and ecosystem services are sobering. Proposals to alter these trends must include societal rethinking of world views and values that have promoted these trends. In this context, education has a critical role to play, particularly in preparing the decision-making capacity of current and future generations. While Sustainable Development Goals do mention education, many publications on forest and water management focus almost exclusively on stakeholders and decision-makers without considering the formation or transformation of their worldviews. To help this societal rethinking we initiated in 2017 a trinational educational effort to promote stewardship of watersheds, using as a theme "Taking care of the Earth's water, starting in the MAP Region." It is part of a program to increase resilience to extreme climate events which have increasingly affected Southwestern Amazonia. One objective was to prepare teachers to apply concepts such as the role of forests as transpiration pumps, river basin dynamics, and extreme climate events to integrated river basin management in their classes. An effective educational device both for formal and informal education was role-playing where participants took on the role of mayors or Civil Defense Coordinators of municipalities suffering extreme climate events. While education is an essential and underutilized tool to alter on-going trends both in the MAP Region and globally, it is not a panacea and needs to be integrated into comprehensive programs to make sustainable development a reality in the $21^{\text {st }}$ Century. 
Forests and climate change in the Southwestern Amazon region: supporting training for forestry engineers, research, and graduate study / Florestas e mudanças climáticas no sudoeste da amazônia: subsídios para formação de engenheiros florestais, pesquisa e pósgraduação

Marco Amaro $^{1}$ (D) Margarida Lima de Carvalho ${ }^{1}$

${ }^{1}$ Universidade Federal do Acre Rio Branco,Brasil (marcoantonioamaro@hotmail.com; margaridalimacarvalho@hotmail.com)

Floresta e clima são duas dimensões fundamentais à vida. Cuidar dessas dimensões é cuidar de nós mesmos. As mudanças climáticas que vivenciamos têm se revelado preocupante para a preservação da floresta. A Amazônia deve ser vista não apenas como produtora de bens e serviços naturais, mas também como produtora de riqueza humana através do processo produtivo, por ser um espaço habitado. Sem ciência e tecnologia não haverá solução plausível. Neste sentido a UFAC entende que é necessário focar nestas questões em suas pesquisa e consequentemente na pós-graduação, bem como que estejam contempladas na formação de engenheiros florestais. Espera-se dos cursos de graduação profissionais que contribuam com o desenvolvimento, assim como para o aperfeiçoamento da qualidade de vida da sociedade. No Acre existem o curso de Engenharia Florestal no campus Cruzeiro do Sul e Rio Branco da UFAC, cujos projetos pedagógicos serão adequados aos avanços e mudanças, conteplando estas questões no processo de formação dos alunos. Estes ajustes serão feitos visando definir as opções de caminhos e prioridades na formação. O foco será as habilidades e competências, objetivando o engajamento do aluno como protagonista do processo de ensino aprendizagem. É de fundamental importância que os professores superem o pensamento compartimentado e o conhecimento fragmentado, uma vez que este não consegue mais atender a formação necessária para a compreensão e análise dos acontecimentos e até mesmo para o mercado de trabalho. A prática pedagógica requer a integração, visando superar a fragmentação do saber, em busca da sua totalidade.

\author{
Woody biomass in bamboo forests in the Southwestern Amazon region / Biomassa lenhosa em floresta com bambu no Sudoeste da \\ Amazônia \\ Égon Lima 1 (D); Sabina Ribeiro ${ }^{1}$ (D; Angélica Santos ${ }^{1}$ (D); Richarlly Silva ${ }^{2}$ ( \\ ${ }^{1}$ Universidade Federal do Acre, Rio Branco, Brasil; ${ }^{2}$ Instituto Federal de Educação, Ciência e Tecnologia do Acre, Cruzeiro do Sul, Brasil \\ (egon.fabricio@hotmail.com; sabina.ufac@gmail.com; angelicams.ali@gmail.com; rcosta.bio@gmail.com)
}

A floresta Amazônica tem papel importante no ciclo de carbono global, com a biomassa florestal representando um expressivo reservatório de carbono. Essa biomassa poderá variar conforme a tipologia florestal, o que tem motivado pesquisas em diferentes regiões da Amazônia. No sudoeste da Amazônia, o bambu predomina em $165.000 \mathrm{~km}^{2}$ de floresta e isso pode afetar a capacidade de estoque de biomassa na região. Nesse estudo avaliamos a influência do bambu no estoque de biomassa lenhosa acima do solo em quatro parcelas permanentes da RAINFOR, monitoradas durante o período de 2000 a 2016, no estado do Acre, no sudoeste da Amazônia. A biomassa acima do solo foi calculada usando-se uma equação alométrica (Chave et al., 2014). Em média, encontramos 254,3 Mg ha ${ }^{-1}$ de biomassa lenhosa estocada por parcela, valor que está de acordo com o estoque de biomassa obtido por outro estudo na região (250-320 Mg ha-1). Por meio de uma ANOVA, identificamos que quanto maior a densidade de bambu, menor é a quantidade de biomassa lenhosa acima do solo estocada na parcela (F3,16= 542,16; p <0,01 ), e que as parcelas com menor densidade de bambu têm, em média, 204 Mg ha-1a mais de biomassa estocada. Esses resultados demonstram que o estoque de biomassa e carbono florestal é afetado pelo bambu, e que programas de REED+ deveriam considerar a influência do bambu no processo de contabilização do estoque de biomassa e carbono na região do sudoeste da Amazônia.

Forests and climate change in the Southwestern Amazon region: a productive arrangement for community-managed wood from the Chico Mendes Extractivist Reserve / Florestas e mudanças climáticas no sudoeste da amazônia: arranjo produtivo para madeira manejada comunitária da Resex Chico Mendes

Moacyr Araújo Silva ${ }^{1}$
${ }^{1}$ WWF Brasil, Rio Branco,Brasil (moacyr@wwf.org.br)

O WWF Brasil apoia e incentiva a mais de 20 anos diversas iniciativas de manejo florestal comunitário, de certificação florestal FSC e de organização/ fortalecimento de cadeias de valor da socibiodiversidade na Ecorregião Sudoeste da Amazônia. A apresentação levada ao painel B8c busca uma abordagem focada nos trabalhos do arranjo produtivo da madeira comunitária, trazendo lições aprendidas, resultados sistematizados, aspectos promissores e desafios para governos, comunidades, pesquisadores e ONGs socioambientais e indigenistas apoiadoras das comunidades tradicionais daquela região. No tocante ao arranjo produtivo da madeira, a parcerias institucionais em curso permitiram à Cooperativa dos Produtores Florestais Comunitários (Cooperfloresta) estar atuando a quase 15 anos na articulação de 210 famílias de extrativistas da Resex Chico Mendes e de Projetos de Assentamentos Agroextrativistas do entorno desta UC. Neste arranjo produtivo atua também a UFAC, conduzindo capacitações e pesquisas de monitoramento do crescimento florestal e dos aspectos socioeconomicos da atividade. Em parceria com a Cooperfloresta o ICMBio o WWF Brasil tem avaliado a fauna silvestre presente nas áreas do plano de manejo florestal da Resex. O manejo em 2018/19 envolveu e beneficiou diretamente um total de 80 famílias agroextrativistas, que através da dedicação de 15 a 20 dias por ano nas atividades de campo, reuniões e treinamentos relativos às práticas do manejo florestal madeireiro, alcançaram valores médios de repartição de benefícios de $\mathrm{R} \$$ 4.500,00, que tem garantido interesse de outros produtores para ingressar no grupo/Cooperativa e, no geral tem sido uma boa alternativa de complementação da renda familiar para atuais cooperados.

Volumetric yield coefficient for timber species obtained from a small sawmill in Rio Branco, Acre, Brazil / Coeficiente de rendimento volumétrico para espécies madeireiras, obtido em uma serraria de pequeno porte no município de Rio Branco, Acre

Adeilson Veiga ${ }^{1}$, Marco Amaro ${ }^{1}$ iD

1Universidade Federal do Acre, Rio Branco,Brasil (nascimentoadeilson18@gmail.com; marcoantonioamaro@hotmail.com)

A fixação de um valor de Coeficiente de Rendimento Volumétrico-CRV em 35\% na Resolução n; 474/2016, do Conselho Nacional do Meio Ambiente CONAMA, é controverso porque o rendimento madeireiro em serra fita é variável, uma vez que inúmeros fatores podem interferir em algum momento do processo de desdobro, gerando valores de CRV inferiores ou superiores ao estabelecido na legislação. Como base no exposto o objetivo deste trabalho foi determinar o CRV de espécies madeireiras do Acre, bem como as circunstâncias que influenciaram o rendimento. O estudo ocorreu em uma serraria situada no município de Rio Branco, AC. Foram amostradas 80 toras, divididas entre as espécies Manilkara bidentata (A.DC.) A.Chev, Couratari guianensis Aubl., Zanthoxylum amapaense Albuq. P.G. Waterman, Brosimum alicastrum Sw. subsp. Bolivarense pittier C. C. Berg, Agonandra brasiliensis Miers ex Benth, Cassia Sp., Bouchenavia Sp. Eichler e Ficus glabra Vell. Para o cálculo do volume total, volume serrado e determinação do rendimento utilizou-se os métodos previsto na Resolução. O CRV médio para todas espécies foi de $36,25 \%$, em serra fita, valor que está dentro dos limites estabelecidos pela legislação, uma vez 
que atende a probabilidade de $95 \%$ de confiança e erro máximo de $10 \%$ do valor médio. Dentre os fatores que influenciaram no rendimento, os mais importantes foram a qualidade das toras, maquinário e a baixa qualificação de mão de obra, além da diferença entre o comprimento da tora e a maior peça desdobrada para todas espécies, que representou a perda em $6,14 \%$ do volume de total.

Potential impacts on vegetation structure from severe drought in the southwestern Amazon region / Possiveis impactos na estrutura da vegetação frente aos eventos de secas severas no Sudoeste da Amazônia

Richarlly Silva 1 (D); Sabina Ribeiro ${ }^{2}$ (D); Angélica Santos ${ }^{2}$ (D) Égon Lima ${ }^{2}$ (D)

${ }^{1}$ Instituto Federal de Educação, Ciência e Tecnologia do Acre, Cruzeiro do Sul, Brasil; '²Universidade Federal do Acre, Rio Branco, Brasil (rcosta.bio@) gmail.com; sabina.ufac@gmail.com; angelicams.ali@gmail.com; egon.fabricio@hotmail.com)

Os efeitos negativos das mudanças no clima sobre a vegetação arbórea têm sido avaliados ao longo dos anos em diferentes regiões da Amazônia. Estudos de dinâmica da vegetação arbórea podem colaborar para a avaliação da possível perda ou substituição de espécies estruturalmente dominantes durante eventos de secas severas. Neste sentido, nosso objetivo foi investigar possíveis respostas das espécies arbóreas aos eventos de secas severas (2005 e 2010) considerando mudanças na representatividade estrutural, com base no valor de cobertura de cada espécie. Os dados utilizados neste estudo são de quatro parcelas permanentes (RAINFOR) na região sudoeste da Amazônia, estado do Acre. Cada parcela utilizada foi monitorada por aproximadamente 16 anos (2000 a 2016). Assim, realizamos o cálculo de valor de cobertura utilizando informações do diâmetro de 3595 indivíduos de 527 espécies. Os resultados encontrados para valor de cobertura mostraram que entre oito e dez (variação entre parcelas) espécies representam $50 \%$ do valor de cobertura total da parcela e as 50 espécies com maiores valores de cobertura representam em média 83,88\% (SD $\pm 2,57)$ da cobertura total, demonstrando alta dominância na estocagem de carbono. Porém, não foi encontrada diferença significativa nos valores de cobertura entre anos secos e não secos, indicando que os efeitos estruturais da seca não devem ser refletidos a curto prazo. Dada a resposta estrutural retardada das florestas em resposta às secas severas, este tipo de abordagem deve ser realizada em maiores escalas, o que pode revelar respostas regionais da estrutura vegetal em função de secas severas.

\section{B8d: RESPONSE OF FOREST ECOSYSTEMS TO CLIMATE CHANGE: LEARNING FROMI} EXPERIMENTAL MANIPULATIONS AND NATURAL GRADIENTS

\section{Testing the sensitivity of humid temperate forests to drought: results from a superimposed experimental manipulation and severe natural drought in New Hampshire, U.S.A.}

Heidi Asbjornsen ${ }^{1}$, Cameron McIntire², Matthew Vadeboncoeur ${ }^{1}$, Carter Berry ${ }^{3}$, Adam Coble ${ }^{4}$, Katie Jennings ${ }^{1}$

${ }^{1}$ University of New Hampshire, Durham, USA; ${ }^{2}$ University of New Mexico, Albuquerque, USA; ${ }^{3}$ Chapman University, Orange, USA; ${ }^{4}$ Oregon Department of Forestry,Corvallis, USA heidi.asbjornsen@unh.edu; cameron.d.mcintire@gmail.com; matthew.vadeboncoeur@unh.edu; zcberry@gmail.com;

coble.adam@gmail.com; katie.jennings22@gmail.com)

The Northeastern U.S. is expected to become both wetter and drier, yet the response of the region's moisture-adapted forests to drought is limited. We conducted a throughfall exclusion experiment in a mature New Hampshire forest, coinciding with the severe 2016 drought. Physiological and growth measurements were collected in two species with contrasting drought strategies: Quercus rubra (anisohydric) and Pinus strobus (isohydric). As expected, P. strobus exhibited greater growth reduction (51\%) in response to drought compared to Q. rubra (22\%); however, Q. rubra showed continued growth declines (35\%) the following year while $P$. strobus'growth modestly increased (control) or remained stable (treatment). Sensitivity to drought, indicated by the relationship between sapflow and soil volumetric water content (VWC), was greater for $P$. strobus than, $Q$. rubra (R2 $=42$ vs; 22, respectively). While both species reduced sapflow during drought, the effect size between drought and control trees was much greater for $Q$. rubra. Both speciesnearly ceased transpiring during peak drought (VWC $=8 \%$ ), and exhibited a similar threshold when sapflow declined sharply (14\%). These findings suggest that despite much higher resistance to drought, $Q$. rubra experienced greater post-drought legacy effects and longer recovery times. The greater effect size on $Q$. rubra's sapflow may indicate that physiological thresholds were reached, whereby its anisohydric strategy (and low safety margins) may have prevented it from avoiding catastrophic hydraulic failure. Current work focuses on unraveling the underlying mechanisms of how differing adaptive strategies and growth phenologies contribute to drought response in these humid temperate forests.

\section{Natural and simulated ice storms, droughts, soil freezing and soil warming shed light on response and recovery of Northern Hardwood Forests to extreme weather}

Lindsey Rustad ${ }^{1}$, Pamela Templer ${ }^{2}$, Heidi Asbjornsen ${ }^{3}$, John L. Campbell ${ }^{1}$, Matthew Vadeboncoueur $^{3}$, Charles Driscoll', Timothy Fahey ${ }^{5}$, Robert Fahey ${ }^{6}$, Peter Groffman ${ }^{7}$ Paul Schaberg, Andrew Reinmann ${ }^{9}$, Katie Jennings ${ }^{3}$

${ }^{1}$ USDA Forest Service, Durham, NH, USA; ${ }^{2}$ Boston University, Boston, MA, USA $;{ }^{3}$ University of New Hampshire, Durham, NH, USA; ${ }^{4}$ Syracuse University, Syracuse, NY, USA; ${ }^{5}$ Cornell University, Ithaca, NY, USA; ${ }^{6}$ University of Connecticut, Storrs, CT, USA; ${ }^{7}$ Cary Institute of Ecosystem Studies, Millbrook, NY, USA; ${ }^{8}$ USDA Forest Service, Burlington, VT, USA; ${ }^{9}$ Hunter College, New York, NY, USA (lindsey.rustad@usda.gov; ptempler@bu.edu;

heidi.asbjornsen@unh.edu; jlcampbell@fs.fed.us; matthew.vadeboncoueur@unh.edu; ctdrisco@syracuse.edu; tjf5@cornell.edu; robert.fahey@uconn.edu; groffmanp@caryinstitute.org; paul.schaberg@usda.gov; andrew.reinmann@asrc.cuny.edu; katie.jennings@unh.edu)

A feature of a changing climate is the increase in the frequency and severity of extreme weather events. Although less is known about the impacts of these events on forested ecosystems, a consensus is emerging that they may have an equal or greater impact on forest biogeochemistry, stand structure and species composition than the more gradual, chronic changes in mean temperature and precipitation that are typically associated with climate change. In the northeastern United States, increased intensity of ice storms, increased occurrence of short- and mid-term droughts and increased frequency and depth of soil frost are among the anticipated types of extreme weather events associated with a changing climate. At the Hubbard Brook Experimental Forest, we combine ad hoc retrospective studies of how these types of events have impacted the biogeochemistry of forests and surface waters in the past with a new suite of experimental studies to better tease apart cause-and-effect relationships between these above and belowground extreme disturbances on the biogeochemistry of forests of today. 
Early results from a temperate deciduous forest free-air carbon dioxide $\left(\mathrm{CO}_{2}\right)$ enrichment facility: seasons $0,1,2(\& 3)$ of 10

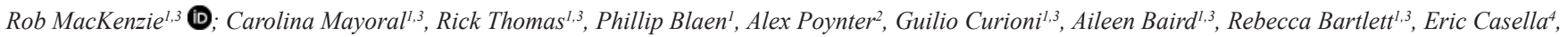
Kristine Crous ${ }^{5,6}$, Liam Crowley $^{1,3}$, Rosemary Dyson ${ }^{1,3}$, David Ellsworth ${ }^{5,6}$, Anna Gardner 1,3, Elizabeth Hamilton ${ }^{7}$, Anna Harper ${ }^{8}$, Kris Hart ${ }^{1,3}$, Iain Hartley $^{8}$, Scott Hayward ${ }^{1,3}$, Deborah Hemming ${ }^{9}$, Iain Johnston ${ }^{1,3}$, Alan Jones ${ }^{10}$, Angeliki Kourmouli ${ }^{1,3}$, Stefan Krause ${ }^{1,3}$, Keith Lewin ${ }^{11}$, Neil Loader ${ }^{12}$, Kadmiel Maseyk ${ }^{13}$, Robin May ${ }^{1,3}$, Lina Mercado ${ }^{8}$, Francis Pope ${ }^{1,3}$, Iain Colin Prentice ${ }^{14}$, Jeremy Pritchard ${ }^{1,3}$, Susan Quick ${ }^{1,3}$, Zongo Shi ${ }^{1,3}$, Stephen Sitch ${ }^{8}$, Michael Tausz ${ }^{1,3}$, Sami Ullah $^{1}$, Peter Wynn ${ }^{15}$, Calre Ziegler ${ }^{1,3}$

${ }^{1}$ Birmingham Institute of Forest Research (BIFoR), Birmingham, United Kingdom; ${ }^{2}$ University Of Cumbria, Cumbria, United Kingdom; ${ }^{3}$ University of Birmingham, Birmingham, United Kingdom; ${ }^{4}$ Forest Research, Farnham, United Kingdom; ${ }^{5}$ Hawkesbury Institute of the Environment, Sydney, Australia; ${ }^{6}$ University Of Western Sydney, Sydney, Australia; ${ }^{7}$ University of Gloucester, Gloucester, United Kingdom; ${ }^{8}$ University of Exeter, Exeter, United Kingdom; ${ }^{9}$ Met Office, Exeter, United Kingdom; ${ }^{10}$ Earthwatch, Oxford, United Kingdom; ${ }^{11}$ Brookhaven National Laboratory, New York, USA; ${ }^{12}$ Swansea University, Swansea, United Kingdom; ${ }^{13}$ Open University, Milton Keynes, United Kingdom; ${ }^{14}$ Imperial College London, London, United Kingdom; ${ }^{15}$ Lancaster University,Lancaster,United Kingdom(a.rmackenzie@bham.ac.uk; c.mayoral@bham.ac.uk; r.thomas@bham.ac.uk; p.j.blaen@bham.ac.uk; alexander.poynter@cumbria.ac.uk; g.curioni@bham.ac.uk;abb324@student.bham.ac.uk;r.bartlett@bham.ac.uk; eric.casella@forestry.gsi.gov.uk; k.crous@uws.edu.au; lxc661@student.bham.ac.uk; r.j.dyson@bham.ac.uk; d.ellsworth@uws.edu.au; axg042@student.bham.ac.uk; Ihamilton3@glos.ac.uk; a.harper@exeter.ac.uk; k.m.hart@bham.ac.uk; i.hartley@exeterac.uk; s.a.hayward@bham.ac.uk; debbie.hemming@metoffice.gov.uk; i.johnston.1@bham.ac.uk; ajones@earthwatch.org.uk; axk661@student.bham.ac.uk; s.krause@bham.ac.uk; ${ }^{\circ}$ lewin@bnl.gov; ${ }^{1}$.j.j.loader@swansea.ac.uk; kadmiel.maseyk@open.ac.uk;r.c.may@bham.ac.uk; l.mercado@exeter.ac.uk;.pope@bham.ac.uk; c.prentice@imperial.ac.uk; j.pritchard@bham.ac.uk; seq616@student.bham.ac.uk; z.shi@bham.ac.uk; s.a.sitch@exeter.ac.uk;m.tausz@bham.ac.uk; s.ullah@bham.ac.uk; p.wynn@lancaster.ac.uk; cxz551@student.bham.ac.uk)

Land carbon sink is calculated to be the most important carbon cycle feedback to 21st century climate change, yet forecasts are highly uncertain and Earthsystem models of the process contain significant 'known unknowns'. Nutritional constraints and environmental stress may limit the land sink, especially mature forests (a dominant part of this sink). This would mean that current model climate projections - dependent upon an accurate assessment of the carbon cycle - are overly optimistic because scenarios, such as those used to inform the Paris-Katowice agreement, rely on a continuing strong sink. Experimental data underpinning current projections are from '1st generation' Free Air $\mathrm{CO}_{2}$ Enrichment (FACE) experiments on young, vigorously growing, recently planted trees. Ample evidence exists that mature forests behave differently, especially in critical aspects of water/nutrient cycling, intraspecific competition, stress responses and resilience. Birmingham Institute of Forest Research (BIFoR) FACE is set in UK broadleaf forest dominated by 160 -year-old and $25 \mathrm{~m}$ tall oak interspersed with sycamore, hazel, hawthorn and holly. $\mathrm{CO}_{2}$-enrichment, scheduled to run until 2026, commenced in spring 2017 and has performed to very high engineering standards. The whole canopy volume of three replicate 30 m-diameter ( 0.07 ha) plots is immersed in air containing 150 ppm $\mathrm{CO}_{2}$ above ambient. We report an overview of results from 2017-2019 growing seasons of eCO $\mathrm{e}_{2}$ combined with baseline (2015 - March 2017) pre-treatment measurements. We find speciesdependent increased carbon assimilation, increased fine root production, and prompt responses in water and nutrient cycling with which we begin to evaluate year-ahead predictions using the Joint UK Land Environment Simulator.

\section{More to a tree than diameter at breast height: how tree form varies with environmental variables}

Robert Schneider ${ }^{1}$, Tommy Simard ${ }^{1}$

${ }^{1}$ Universitédu Québec à Rimouski,Rimouski, Canada (robert_schneider@uqar.ca; tommy.simard@uqar.ca)

Studies on the effects of global changes on tree or forest productivity often use diameter at breast height increments. However, trees change their vertical growth distribution along the bole with both shifts in biotic and abiotic factors. It has been long known that stem taper increases with site richness, crown size and less competition. Biomechanics have been used to explain these changes, where trees will change their stem form in order to support their crown. Using a unique database of more than 9000 stem analysis across a large climatic gradient from the temperate to the boreal forest, recent studies have however shown that tree taper will also change with climatic variables, with these shifts having been related to certain functional traits of the trees. More precisely, the yearly bole increment changes with both climatic and wind variables. Vapour pressure deficit and precipitations seem to play a key role. Wind also shifts the growth distribution along the stem. The effects of wind and climate on stem taper however have been reported to have the same importance in the Canadian boreal forest. Thus both biomechanical and physiological constraints must be taken into account in understanding stem form, and this has to be accounted for when looking at large scale changes in forest productivity, in order to not introduce biases.

\section{Effects of repeated drying-wetting cycles on the forest soil greenhouse gas emissions. A manipulation study}

Eugenio Diaz-Pines ${ }^{1}$, Sonja Leitner ${ }^{2}$, Sophie Zechmeister-Boltenstern ${ }^{1}$

${ }^{1}$ Institute of Soil Research, University of Natural Resources and Life Sciences, Vienna, Austria; ${ }^{2}$ Mazingira Center, International Livestock Research Institute, Nairobi,Kenya (eugenio.diaz-pines@boku.ac.at; s.leitner@cgiar.org; sophie.zechmeister@boku.ac.at)

Climate change forecasts shifts in precipitation patterns, involving both longer dry spells and more frequent heavy rainfall events. As a consequence, the intensity and frequency of the so-called drying-wetting cycles will increase in the future, with unknown overall consequences on soil biogeochemical processes. Here, we present results from a precipitation manipulation experiment in a beech forest in Austria. Two intensities of drying-wetting cycles during the vegetation period were simulated (moderate and severe stress, involving different rainfall exclusion length and amount of rainfall during rewetting) with rain-out shelters from 2013 to 2015, followed by a "recovery" year without manipulation in 2016. Soil-atmosphere exchange of $\mathrm{CO}_{2}$, CH4 and N2O were monitored automatically with sub-daily resolution. Soil microbial parameters and nutrient dynamics were also investigated. Our results show a decrease in the production of $\mathrm{CO}_{2}$ and $\mathrm{N} 2 \mathrm{O}$ in the soil during drought periods which was not compensated by the rainfall-triggered pulse events. Thus, soil $\mathrm{CO}_{2}$ and $\mathrm{N} 2 \mathrm{O}$ efflux decreased by roughly 30 and $55 \%$, respectively, in the severe stress treatment. Soil $\mathrm{CO}_{2}$ effluxes returned to reference levels when manipulation was discontinued. Methane uptake was enhanced during drought probably due to higher $\mathrm{CH} 4$ diffusivity. However, a legacy effect suggests some adaptation of the microbial community. Highly dynamic responses after rewetting in GHG turnover and $\mathrm{N}$ cycling strongly call for high temporal $(<$ daily) measurements. Overall, differences between environmental control and moderate stress treatments were absent or very modest, suggesting that, in order to see effects of extreme weather events, extreme manipulations are required. 


\section{Changing Environments in Northern Peatlands: the SPRUCE Experiment}

Randy Kolka ${ }^{1}$, Paul Hanson ${ }^{2}$

${ }^{1}$ USDA Forest Service Northern Research Station, Grand Rapids, MN, USA; '2Oak Ridge National Laboratory, Oak Ridge, TN, USA (kolka003@umn.edu; hansonpj@ornl.gove)

The Spruce and Peatland Responses Under Changing Environments experiment, or SPRUCE, is an ambitious ecosystem-level experiment that is testing the response of high-carbon northern peatland ecosystems to increased temperatures and elevated carbon dioxide. The experiment is being conducted in a black spruce peatland in northern Minnesota, USA, at the USDA Forest Service's Marcell Experimental Forest (MEF). SPRUCE is supported by the US Department of Energy and is a collaboration between Oak Ridge National Lab, the USDA Forest Service and numerous other scientists from across the globe. Northern peatlands are an ecosystem considered especially vulnerable to climate change, and anticipated to be near their tipping point with respect to their carbon balance, especially at the southern margin of their range at MEF. Responses to warming and interactions with increased atmospheric CO ${ }_{2}$ concentration are anticipated to have important feedbacks on the atmosphere and climate. The manipulation is evaluating the response of the existing communities to a range of warming levels from ambient to $+9^{\circ} \mathrm{C}$, with and without elevated $\mathrm{CO}_{2}$, provided via large, open-top chambers. Belowground heating began in 2014 , aboveground heating in 2015, and elevated $\mathrm{CO}_{2}$ treatments commenced in June 2016. We anticipate running the experiment for 10 years. I will give an overview of SPRUCE and some initial results, including pre-treatment characterization of the peatland and some early findings following the establishment of the treatments.

\section{Throughfall exclusion in New Zealand native forest - effects of drought on Agathis australis}

Cate Macinnis- $\mathrm{Ng}^{1}$, Benjamin Cranston ${ }^{1}$

${ }^{1}$ University of Auckland, Auckland, New Zealand (c.macinnis-ng@auckland.ac.nz; benjamin.cranston@auckland.ac.nz)

Global analysis indicates that large trees and those from mesic environments are most vulnerable to drought impacts. New Zealand kauri (Agathis australis) is amongst the largest and longest-lived trees in the world. Kauri are endemic to the north of the north island of Aotearoa, a region that is predicted to become hotter and drier under future climates. We have developed a tree-centred throughfall exclusion experimental design to simulate drought for large trees. Our sample trees are instrumented with sap flow sensors, point dendrometers, and soil moisture probes. We are also conducting periodic canopy sampling of leaf gas exchange, water potential and tissue water content to explore how trees respond as the drought develops. We have found that $A$. australis has some adaptations for drought survival including access to deep water stores and loss of leaves in a drought-deciduous response. Ongoing measurements will help us identify the limits of drought avoidance and tolerance in these iconic trees.

\section{Can we assist the migration of cloud forest trees?}

Tarin Toledo-Aceves ${ }^{1}$ (D) Fabiola López-Barrera ${ }^{1}$, Vinicio Sosa ${ }^{1}$, María de los Angeles García-Hernández ${ }^{1}$

${ }^{1}$ Instituto de Ecología A. C., Xalapa,Veracruz, Mexico (tarin.toledo@inecol.mx; fabiola.lopez@inecol.mx; vinicio.sosa@inecol.mx; mag_10f@yahoo.com.mx)

In response to increased temperatures caused by global climate change, shifts and retractions have been reported in the distribution range of cloud forest tree species. Evaluating the establishment of introduced saplings along an elevation gradient offers an opportunity to assess the capacity of species to respond to the observed or predicted effects of climate change, the influence of environmental factors on early establishment and the potential response of species to assisted migration at higher elevations as a mitigatory management strategy. We evaluated early establishment in 13 shade tolerant cloud forest tree species in enrichment plantings in nine forests subjected to traditional selective logging, along an elevation gradient (1250-2517 m a.s.l.) in southern Mexico. In each site, 30 saplings were planted and their survival and relative growth rate (RGR) recorded, along with the environmental factors temperature, canopy cover and humidity. After three years 10 species displayed high survival (> 80\%). Survival increased at lower temperature in four species and with canopy cover in five species. RGR increased with elevation, followed by a decrease at the highest plots in nine species. RGR decreased with canopy cover in five species. Humidity had no effect on sapling performance. Our results indicate that most of the species have a high probability of sapling survival under canopy cover, even beyond the limits of their reported range of elevation distribution. This study supports the potential of assisted migration of cloud forest tree species with narrow distributions, as a climate change mitigation strategy.

\section{Experimental warming reduced topsoil carbon content and increased soil bacterial diversity in a subtropical planted forest}

Hui Wang ${ }^{1}$, Shirong Liu ${ }^{1}$, Andreas Schindlbacher ${ }^{2}$, Jingxin Wang ${ }^{3}$, Zuomin Shi ${ }^{1}$, Angang Ming ${ }^{4}$, Lihua Lu ${ }^{4}$, Daoxiong Cai $^{4}$

${ }^{1}$ Institute of Forest Ecology, Environment and Protection, Chinese Academy of Forestry, Beijing, China; ${ }^{2}$ Department of Forest Ecology, Federal Research and Training Centre for Forests, Natural Hazards and Landscape-BFW, Vienna, Austria; ${ }^{3}$ Division of Forestry and Natural Resources, West Virginia University, Morgantown, USA; ${ }^{4}$ Experimental Center of Tropical Forestry, Chinese Academy of Forestry, Pingxiang, China (wanghui@caf.ac.cn; liusr@caf.ac.cn;andreas.schindlbacher@bfw.gv.at;jxwang@wvu.edu;shizm@caf.ac.cn;mingangang0111@163.com;kjc8526136@163.com;rlzxcdx@126.com)

The potential effects of global warming on the soil carbon (C) dynamics of subtropical forests are still uncertain. To assess the effects of warming on soil $\mathrm{C}$ and tree roots, combined soil warming (infrared heaters, $+1.5^{\circ} \mathrm{C}$ soil temperature) and trenching experiments were conducted in a subtropical Castanopsis hystrix plantation. Topsoil C content was reassessed after five years of warming, and the effects on soil organic carbon (SOC) quality and microbial diversity were analyzed. Compared with corresponding controls, the topsoil $(0-10 \mathrm{~cm})$ SOC content was significantly lower in un-trenched warmed soil (-13.6\%) as well as in trenched warmed soil $(-15.4 \%)$. However, the range of SOC content after five years of warming was similar to that observed after two years of warming $(-14.6 \%,-19.2 \%)$, indicating that the warming effect on SOC content leveled off during the latter three years. In trenched plots, warming significantly decreased the carbohydrate $\mathrm{C}$ as well as the ratio of carbohydrate $\mathrm{C}$ to $\mathrm{N}$-alkyl/methoxyl $\mathrm{C}$ ratio, suggesting that labile $\mathrm{C}$ was preferentially decomposed. In un-trenched plots, SOC quality was unaffected, indicating a compensatory input of labile root $\mathrm{C}$. Bacterial $\alpha$-diversity increased under warming, whereas no significant warming effects on fungal community diversity were observed. Both the SOC content and the proportion of soil carbohydrate $\mathrm{C}$ were negatively correlated with soil bacterial $\alpha$-diversity, suggesting that the abundance of more recalcitrant SOC increased soil microbial diversity. Overall, soil warming resulted in a reduction in SOC in the first two years, and then SOC content was sustained. 


\section{Physiological performance of temperate seedlings in a FACE experimental forest}

Carolina Mayoral ${ }^{1,2}$, A. Rob Mackenzie ${ }^{l, 2}$, Michael Tausz $^{3}$

${ }^{1}$ Birmingham Institute of Forest Research, Birmingham, United Kingdom; ${ }^{2}$ University of Birmingham, Birmingham, United Kingdom; ${ }^{3} \mathrm{CQUniversity,} \mathrm{Cairns,}$ Australia(c.mayoral@bham.ac.uk; a.r.mackenzie@bham.ac.uk;m.tausz@cqu.edu.au)

In a changing climate, understanding the behaviour of tree species subjected to elevated $\mathrm{CO}_{2}$ is crucial to predicting the future of forest ecosystems. We selected the five most representative tree species coexisting in a mature, unmanaged, oak-dominated, FACE forest to assess their performance during one growing season. We measured leaf-level physiological traits on naturally regenerated seedlings coming from seeds that were developed under elevated atmospheric $\mathrm{CO}_{2}$. We also introduced self-irrigated, nursery-sourced, potted seedlings from the same five species into the treatment and control patches in order to have an estimation of the physiological baseline of these species under somewhat more controlled conditions and elevated $\mathrm{CO}_{2}$. A Non-linear model was fitted to each set of measurements from each seedling to describe the temperature effect on photosynthetic capacity. More than one hundred and fifty combinations of ecologically meaningful parameters (Amax at saturating light and Topt) were obtained. Under field water capacity (potted seedlings), the five species showed similar photosynthetic capacity to each other and under both treatments. However, natural Quercus robur, Crataegus monogyna and Ilex aquifolium seedlings exhibited higher maximum photosynthetic capacity (Amax) under elevated $\mathrm{CO}_{2}$, suggesting a positive effect of increasing $\mathrm{CO}_{2}$ on $\mathrm{Amax}$ with decreasing soil moisture. We did not find differences in the optimum temperature to maximize photosynthetic capacity, excepting for naturally regenerated Acer pseudoplatanus seedlings. Under the forecasted scenario of increasing $\mathrm{CO}_{2}$, our preliminary results suggest a competitive advantage at the regeneration stage of species able to maximise photosynthetic capacity with elevated $\mathrm{CO}_{2}$ under drier conditions over the other species.

B8e: FOREST ADAPTATION AND RESTORATION UNDER GLOBAL CHANGE: FROM GLOBAL
TO REGIONAL PERSPECTIVE

\section{Results of a global online survey on forest adaptation and restoration}

Markus Höhl ${ }^{1,2}$, John Stanturf ${ }^{3}$, Peter Spathelf ${ }^{4}$, Michael Kleine ${ }^{5}$, Peter Elsasser ${ }^{6}$, Andreas Bolte ${ }^{1}$

${ }^{1}$ Thuenen Institute of Forest Ecosystems, Eberswalde, Germany; ${ }^{2}$ Graduate School Forest and Agricultural Sciences, University of Göttingen, Göttingen, Germany; ${ }^{3}$ Estonian University of Life Sciences, Tartu, Estonia; ${ }^{4}$ Eberswalde University for Sustainable Development, Eberswalde, Germany; ${ }^{5}$ IUFRO, Vienna, Austria; ${ }^{6}$ Thuenen Institute of International Forestry and Forest Economics, Hamburg, Germany (markus.hoehl@thuenen.de; drdirt48@gmail.com; peter.spathelf@hnee.de; kleine@iufro.org; peter.elsasser@thuenen.de; andreas.bolte@thuenen.de)

Adaptive Forest Management and Forest Landscape Restoration are major challenges for forest management in times of global change and there is a need for information regarding the implementation of such measures. We present results from a global online survey on real-world examples of forest adaptation and restoration. The survey gathers information on the location, environmental conditions, management regimes, involved actors, targets, silvicultural measures and success factors for the respective forest adaptation and restoration projects. The survey audience can be classified as forestry experts. We examine the possibility to combine forest restoration and -adaptation and present results regarding targets, species selection (native vs. non-native), and forest management as reported by the survey participants. We further identify success factors derived from the survey information. Almost half of the reported projects pursue an approach that combines forest restoration and adaptation. Forest adaptation is associated with very high human development (HDI < 0.8$)$ in contrast to forest restoration which is associated with low human development ( $\mathrm{HDI}<0.55)$. Native tree species are often preferred. Silvicultural interventions targeting existing stands (e.g. changing species composition, thinning etc.) are associated with adaptation whereas measures related to stand establishment are associated with restoration. Adaptation measures are likely to play a role in the future management of restored forests. Capacities in silviculture and the production of seedlings of native species should be assessed and developed to reach restoration goals. Restoration goals and objectives need to be clearly defined in a participatory process and monitored using criteria and indicators.

\section{Do we have sufficient data and information for a knowledge based adaptation of forest management to climate change?}

Pavel Cudlin ${ }^{1}$, Harald Vacik ${ }^{2}$, Nicola La Porta ${ }^{3,4}$, Filip Lysak', Michal Marek ${ }^{5}$

${ }^{1}$ Global Change Research Institute, Ceske Budejovice, Czech Republic; ${ }^{2}$ Institute of Silviculture BOKU, Wien, Austria; ${ }^{3}$ IASMA Research and Innovation Centre, Fondazione Edmund Mach, San Michele all'Adige, Italy; ${ }^{4}$ The EFI Project Centre on Mountain Forests (MOUNTFOR), Trento, Italy; ${ }^{5}$ Global Change ResearchInstitute,Brno, Czech Republic (cudlin.p@czechglobe.cz; harald.vacik@boku.ac.at; nicola.laporta@fmach.it; filip.lysak@tiscali.cz; marek.m@czechglobe.cz)

Scientifically based data on the relationship of forest ecosystem functioning, forest stand naturalness and biodiversity status are urgently needed for a better understanding of the effects of forest management adaptation strategies under climate change. The contribution will summarize information on i) natural processes in forest ecosystems; ii) natural disturbance history, iii) differences between ecosystem processes during grow stage and mature stage and iv) the sustainability of forest management compared to the natural forest ecosystem processes. A framework of indicators will be proposed to quantify the key elements of natural processes (succession), the forest biodiversity status (genetic, species, ecosystem and landscape level) and the effects of sustainable forest management. The framework will allow to answer questions with regard to quantitative and qualitative aspects of forest management and maintaining forest ecosystem functioning (e.g. genetic pools, energetic-material fluxes, including soil nutrient level, water regime and forest microclimate and the incremental risks of natural forest disturbance, including resilience processes in disturbed forests). In addition, the possibility of comparison the primary (with an emphasis on improving soil properties) and secondary forest succession (similarity of clear cutting with natural disturbance) will be discussed. The findings will be exemplified by case studies from different forest ecosystems in Europe.

\section{From commitment to commitment? Translating multiple FLR targets}

Stephanie Mansourian ${ }^{1,3}$, John Stanturf ${ }^{2}$

${ }^{1}$ Mansourian.org, Gingins, Switzerland; ${ }^{2}$ Estonian University of Life Sciences, Tartu, Estonia; ${ }^{3}$ University of Geneva, Geneva, Switzerland (smansourian@infomaniak.ch; drdirt48@gmail.com)

Restoration, and forest landscape restoration (FLR) in particular, has become a widely used tool to reverse forest loss and degradation. Several countries have identified restoration opportunities via the restoration opportunities assessment methodology (ROAM) and have also committed to restore vast areas under the Bonn Challenge on FLR. For a selection of the countries with publicly-accessible ROAM reports we explore, analyse and compare their commitments under the 
three main (Rio) environmental conventions (UNCCD, UNFCCC and CBD). Our aim is to compare and contrast these commitments and intended restoration interventions. We also seek to understand the extent to which commitments under the Bonn Challenge, areas and methods identified under ROAM and commitments under the three Rio conventions are realistic and what they might entail in practice in terms of their social, economic and ecological consequences.

\section{Landscape restoration for sustainable forests in Europe: navigating multi-scale governance and management dynamics in diverse contexts}

Lucas Dawson ${ }^{1}$, Marine Elbakidze $e^{2}$

${ }^{1}$ Stockholm University, Stockholm, Sweden; ${ }^{2}$ Swedish University of Agricultural Sciences, Skinnskatteberg, Sweden (lucas.dawson@natgeo.su.se; marine.elbakidze@slu.se)

Conventional intensification of forestry has dramatically reduced biodiversity and threatens the sustainable provision of ecosystem services important for human wellbeing. Landscape restoration is an important strategy for improving the functionality, resilience, and long-term productivity of forests. National and transnational institutions - e.g. the Bonn Challenge and the New York declaration - are recognised as important drivers of restoration. However, complex system dynamics make it difficult to evaluate the effectiveness of policy interventions, and little is known about how landscape restoration initiatives are influenced by the governance contexts in which they are situated. Adaptive management (AM), whilst frequently suggested as essential for the sustainable management of natural resources, is an emergent phenomenon and is thus strongly shaped by surrounding governance constraints. We used a qualitative complex systems approach to explore the causal dynamics of forest landscape restoration in the context of global drivers of forest degradation. Against this backdrop, we then examined a number of successful landscape restoration case studies at different scales and in different governance contexts in Europe. We found five processes that are key to restoration outcomes, viz. planning, garnering stakeholder support, adequacy of inputs, implementation, and knowledge management. Whilst aspects of AM emerged in all cases, the degree to which surrounding governance contexts proved conducive to AM varied. Major constraints relate to formal and informal institutional contexts, regulatory flexibility and funding. Key strategies identified relate to management of positive feedback loops concerning stakeholder perceptions, risk mitigation, learning cycles, and knowledge sharing practices.

\section{Seeds without borders: a transnational approach to adapt European forests to climate change}

Silvio Schüler ${ }^{1}$, Debojyoti Chakraborty ${ }^{1}$, Andreas Bolte ${ }^{2}$, Christina Bouissou ${ }^{1}$, Dagmar Bedranova ${ }^{3}$, Ivana Tomášková ${ }^{4}, J_{a n}$ Stejskal ${ }^{4}$, Julian Gaviria ${ }^{5}$, Jan Kowalczyk ${ }^{6}$, László Nagy ${ }^{7}$, Lea Henning ${ }^{8}$, Marcin Klisz ${ }^{6}$, Milan Lstibưrek, Monika Kanzian ${ }^{4}$, Reneema Hazarika ${ }^{1}$, Roman Longauer ${ }^{3}$,

Stefan Schoerghuber ${ }^{9}$, Valerie Poupon ${ }^{4}$, Jan-Peter George ${ }^{1}$

${ }^{1}$ Federal Research and Training Centre for Forests, Natural Hazards and Landscape, Vienna, Austria; ${ }^{2} J o h a n n$ Heinrich von Thünen Institute, Federal Research Institute for Rural Areas, Forestry and Fisheries, Eberswalde, Germany; ${ }^{3}$ National Forest Centre, Zvolen, Slovakia; ${ }^{4}$ Czech University of Life Sciences , Prague, Czech Republic; ${ }^{5}$ Bavarian Office for Forest Seeding and Planting, Teisendorf, Germany; ${ }^{6}$ Forest Research Institute, Warswaw, Poland; ${ }^{7}$ National Agricultural Research and Innovation Centre, Sárvár, Hungary; ${ }^{8}$ Johann Heinrich von Thünen Institute, Federal Research Institute for Rural Areas, Forestry and Fisheries, Eberswalde, Germany; ${ }^{9}$ Austrian Federal Forests, Purkersdorf, Austria (silvio.schueler@bfw.gv.at; debojyoti.chakraborty@bfw.gv.at; andreas.bolte@thuenen.de;christina.bouissou@bfw.gv.at; bednarova@nlcsk.org; tomaskova@fld.czu.cz; stejskalj@fld.czu.cz; julian.gaviria@asp.bayern.de; j.kowalczyk@ibles.waw.pl; lnagy@erti.hu; lea.henning@thuenen.de; m.klisz@ibles.waw.pl; lstiburek@fld.czu.cz; monika.kanzian@bundesforste.at; reneema.hazarika@bfw.gv.at; longauer@nlcsk.org; stefan.schoerghuber@bundesforste.at; poupon@fld.czu.cz; jan-peter.george@bfw.gv.at)

Forest trees exhibit manifold local adaptations to the climate of their local habitat guaranteeing optimal growth and survival under stable environmental conditions. Climate is predicted to change at a significantly faster pace than the natural migration and adaptation capacity of trees, thus disrupting the link between climate and local adaptations. Planting alternative tree species and utilizing the tree species' intrinsic adaptive capacity are considered to be the most promising adaptation strategy. In Europe, the utilization of forest reproductive material is regulated by European and National legislation which define National Regions of Provenance. These Regions differs among countries and do neither reflect climate conditions nor climate change. However, climate change may render the local seed sources maladapted, while optimum seed sources may be the ones located outside of these defined regions. Therefore a transnational approach is required to integrate the link between local adaptation and climate change into reforestation policies. In the cooperation project SUSTREE, we develop transnational delineation models for forest seed transfer and genetic conservation based on species distribution models and trait-based intraspecific climate response functions. These models are being connected to registers of forest reproductive material as basis for decision support tools such as a Smartphone App and WEB-GIS which shall guide the selection of adapted planting materials under climate change. We recommend that legislation governing reforestation and seed transfer should be based on range-wide local adaptations of trees to assist management of genetic resources under climate change.

\section{Global Forest Landscape Restoration: opportunities, benefits, and challenges for Canada in the context of cumulative effects}

Nicolas Mansuy ${ }^{1}$

${ }^{1}$ Canadian forest service, Edmonton, Canada (nicolas.mansuy@canada.ca)

Global Forest Landscape Restoration (GFLR) offers an unprecedented opportunity to restore degraded lands into functional and working landscapes that deliver co-benefits to multiple stakeholders. Recent efforts by non-governmental organizations have been launched with the goal of achieving large-scale restoration targets. Over 20 countries and regional initiatives have already committed to restore close to 150 million hectares of degraded land and are seeking ways to integrate restoration strategies into a sustainable forest management and conservation agenda. However, the path towards achieving these goals is unmapped due to the challenges of navigating poorly understood ecological, socio-economic and governance impediments and the complexity of integrating multiple benefits and stakeholders. We put in perspective the opportunities and challenges for Canada to be an active player in respect to these international initiatives by addressing multidisciplinary knowledge gaps and issues: What are the international organizations and landscape-scale restoration programs; what are the principles of a GFLR approach; Are they relevant for the Canadian context; What are the tools and strategies available to move from target to implementation, and what key policies are needed to facilitate restoration at large scale. Sustainable forest management practices in Canada could be valued to support international commitments. However, recurrent large-scale anthropogenic disturbances cumulated with natural disturbances may challenge effective restoration in Canada. Policies driven by multi-stakeholder decision-making may also be needed to move towards a national framework supported by a multidisciplinary research agenda. 


\section{Forest landscape restoration initiatives and opportunities in India as an effective strategy to combat climate change}

Vindhya Prasad Tewari ${ }^{1}$, Suresh Gairola ${ }^{2}$

${ }^{1}$ Himalayan Forest Research Institute, Shimla, India; ${ }^{2}$ Indian Council of Forestry Research and Education, Dehradun, India (vptewari@yahoo.com; scgairola@hotmail.com)

Protecting forests from degradation, deforestation and fragmentation, and tree-based landscape restoration are globally recognized as cost-effective solutions for combating climate change. India's Nationally Determined Contribution to the Paris Agreement commits to sequester additional 2.5 to 3 billion tons CO equivalent by 2030 through increased forest and tree cover and this ties in with the Bonn Challenge commitment to restore 21 mha of deforested and degraded lands by 2030 as well as the SDGs. This commitment can only be achieved if existing forests are protected and improved and tree cover is extended by 25 to $30 \mathrm{~m}$ ha. Forest Restoration works in India need to tackle three questions: Where can forest and tree cover be protected and increased, and how much carbon sequestration this will result in? Which tree-based interventions have been implemented in different states and who are the principal actors who have implemented these projects?, What necessary enabling conditions need to be in place and what risks addressed to ensure achievement of protection and restoration goals? Here, we present how India can achieve the NDC and Bonn Challenge through forest protection and landscape restoration. Information about the areas suitable for protection, wide-scale restoration, and mosaic restoration have been presented and potential for increase in forest and tree cover and the associated carbon sequestration that can be achieved has been discussed. This will support planning for landscape restoration through the past and on-going initiatives which identifies different types of interventions implemented in different states by various implementing actors.

\section{Adaptation trial with exotic species in Iran and Denmark considering climate change}

Khosro Sagheb Talebi ${ }^{1}$, Palle Madsen ${ }^{2}$, Bahram Naseri ${ }^{3}$, Ole Kim Hansen ${ }^{4}$, Farhad Asadi ${ }^{5}$, Shirzad Mohammadnejad Kiasari ${ }^{5}$, Mohammad Vatanparast $^{4}$, Assadollah Karimidoost ${ }^{6}$, Karim Maghsudloo ${ }^{6}$, Baba Khanjani Shiraz $^{7}$

${ }^{1}$ Agricultural Research, Education and Extension Organization, Research Institute of Forests and Rangelands (RIFR), Tehran, Islamic Republic of Iran; ${ }^{2}$ InNovaSilva, Vejle, Denmark; ${ }^{3}$ Seed Center of Caspian Forests, Amol, Islamic Republic of Iran; ${ }^{4}$ University of Copenhagen, Copenhagen, Denmark; ${ }^{5}$ Agricultural Research, Education and Extension Organization, Research Center of Agriculture and Natural Resources, Mazandaran province, Sari, Islamic Republic of Iran; ' ${ }^{6}$ Agricultural Research, Education and Extension Organization, Research Center of Agriculture and Natural Resources, Golestan Province, Gorgan, Islamic Republic of Iran; ${ }^{7}$ Agricultural Research, Education and Extension Organization, Research Center of Agriculture and Natural Resources, Gilan Province, Pilambara, Islamic Republic of Iran (saghebtalebi@rifr-ac.ir; pallemadsen47@gmail.com; bnasery@gmail.com; okh@ign. ku.dk; farhadasadi14@yahoo.com; ms.mohammadnezhadk@gmail.com;mov@ign.ku.dk; karimidoost@yahoo.com; karimmaghsudloo@yahoo.com; babasarak1964@gmail.com)

Caspian forests cover 1.8 million hectares of the north facing slopes of the Elburz Mountains on the South coasts of the Caspian Sea. These forests include a range of broad-leaved species, which are the same species or same genera as important European trees including beech, oak, maple, hornbeam, ash, and lime. These ancient forests date back to early Pleistocene and were not affected strongly by glaciations; thus they can be considered as refugial area. Relative to European forests, the Caspian forest has higher species diversity as well as greater genetic diversity within species. As climate change challenges cause increasing concern for maintaining future forest functions and ecosystem services for the next generations, we are gradually realizing how much we need robust forests and tree species with a great capacity for adaptation to new conditions. Therefore, we are testing the reaction, survival, growth and adaptation of some of the most important Euro-Asian species and provenances under very different climatic conditions. For this purpose, we have selected a total of ten species; five species of the Caspian forests including oriental beech, chestnut-leaved oak, velvet maple, common ash and Caucasian alder and five species from southern latitudes of Europe including sessile oak, pedunculate oak, Norway maple, sycamore maple and small-leaved lime. Seedlings are planted in long-term field trials in northern Iran and Denmark. The outcome of the project will be a unique research infrastructure that provides the basis for future and long-term research in forest and tree species adaptation capacity to climate change.

\section{How is European forestry prepared to face the intensifying outbreaks of bark beetles?}

Tomáš Hlásny ${ }^{1}$, Rupert Seidl ${ }^{2}$,Kenneth Raffa ${ }^{3}$, Jorg Müller ${ }^{4}$, Clair Montagne-Huck ${ }^{5}$, Andrew Liebhold ${ }^{1}$, Hua Qin ${ }^{6}$, Mart-Jan Schelhaas ${ }^{7,8}$, Paal Krokene ${ }^{9}$, Miroslav Svoboda ${ }^{1}$ Heli Viiri ${ }^{10}$

${ }^{1}$ Czech University of Life Sciences, Faculty of Forestry and Wood Sciences, Prague, Czech Republic; ${ }^{2}$ University of Natural Resources and Life Sciences, Department of Forest- and Soil Sciences, Vienna, Austria; ${ }^{3}$ University of Wisconsin, Madison, Department of Entomology, Madison, USA; ${ }^{4}$ uliusMaximilians-University Würzburg, Field Station Fabrikschleichach, Department of Animal Ecology and Tropical Biology, Würzburg, Germany; ${ }^{5}$ Université de Lorraine, Université de Strasbourg, AgroParisTech, CNRS, INRA, BETA, Strasbourg, France; ${ }^{6}$ University of Missouri-Columbia, Division of Applied Social Sciences, Columbia, USA; ${ }^{7}$ Wageningen Environmental Research, Wageningen, Netherlands; ${ }^{8}$ Wageningen University and Research Wageningen Netherlands; ${ }^{9}$ Norwegian Institute of Bioeconomy Research, Division of Biotechnology and Plant Health, Høgskoleveien, Norway; ${ }^{10}$ Natural Resource Institute,Helsinki,Finland (tomas.hlasny@gmail.com; rupert.seidl@boku.ac.at; kfraffa@wisc.edu; joerg.mueller@uni-wuerzburg.de; claire.montagne-huck@inra.fr; aliebhold@gmail.com; qinh@missouri.edu; martjan.schelhaas@wur.nl; paal.krokene@nibio.no; svobodam@fld.czu.cz; heli.viiri@luke.fi)

Bark beetle outbreaks have intensified in recent years and expanded to new parts of Europe, Siberia, Canada and USA. These outbreaks have affected regional economies but also precipitated often contradictory reactions among forest professionals, ecologists and other stakeholders in their attitudes toward forest protection. Climate change will further facilitate bark beetle survival and development and thus add further challenges to forest management. In response to these challenges, European governments requested that the European Forest Institute (EFI) undertake a study on the current understanding of bark beetle outbreaks and options to address them in the future. This study was conducted by an international team of scientists from Europe and the USA, and will be published as an EFI "Science to Policy" report. The study emphasized that management objectives must be clearly defined before the advantages or disadvantages of various mitigation options can be weighed. The study showed that in much of Europe outbreak management overly relies on risk reduction through extensive sanitation logging and beetle trapping. This is not adequately combined with management fostering forest resilience, and may likely result in increased forest vulnerability to other disturbances. A stand-scale oriented management approach dominates, while the importance of landscape configuration in controlling bark beetle spread is not sufficiently considered. The study proposed recommendations on how to improve the overall preparedness of the European forestry to face intensifying bark beetle outbreaks. Finally, it pointed out areas where heightened outbreak management might interfere with other management objectives, such as biodiversity maintenance and carbon accumulation. 


\section{Potentials and risks of selected introduced forest tree species in the Central European forestry}

Vilém Podrázský1

${ }^{1}$ Czech University of Life Sciences, Prague, Czech Republic (podrazsky@fld.czu.cz)

Forestry is periodically focusing at silviculture of introduced tree species, which is connected with problems related to native species usually. At present, many species, including Norway spruce, European ash, alder and others show serious problems concerning stability and vitality of their stands, as a consequence of climatic change and connected abiotic and biotic harmful factors activation. Partial solution of these problems can be represented by more intense use of nonnative tree species. In the conditions of the Czech Republic, the main species used in the forestry are: black locust (Robinia pseudacacia L.), exotic spruces (Picea spp.), Douglas-fir (Pseudotsuga menziesii /Mirb./ Franco), American red oak (Quercus rubra L.), grand fir (Abies grandis/Dougl. ex D.Don/ Lindl), and black walnut (Juglans nigra L). Other introduced species are of minor economic importance. Aim of the presented study is the documenting of the original and summary review results concerning these species in the Czech forestry, and dissemination of knowledge on their functions in the Central Europe. The results focused on the comparison of their production capacity comparing to relevant native species, and especially the presentation of original and unique data evaluating their environmental effects - benefits and risks -are presented. Douglas-fir represents the most productive species with high-quality timber, with less unfavorable site effects comparing to Norway spruce. Exotic spruces finished the preparatory functions in the air polluted areas, reconstruction of the stands is urgent. Other species can be used in strictly defined conditions with high production gain and minimized environmental risks.

\section{B8p: CLIMATE CHANGE AND THE FOREST ENVIRONMENT}

\section{Forest adaptation to climate change - is non-management an option?}

Robert Jandl $l^{1}$, Peter Spathelf ${ }^{2}$, Andreas Bolte ${ }^{3}$, Cindy Prescott ${ }^{4}$

${ }^{1}$ Bundesforschungszentrum für Wald, Vienna, Austria; ${ }^{2} H N E$ Eberswalde, Eberswalde, Germany; ${ }^{3}$ Thünen Institute, Eberswalde, Germany; ${ }^{4}$ University of British Columbia,Vancouver, Canada (robert.jandl@bfw.gv.at; peter.spathelf@hnee.de; andreas.bolte@thuenen.de; cindy.prescott@ubc.ca)

Climate change is posing a considerable challenge to foresters. The intensity of required adaptive measures and the relevance of old-growth forests as benchmark for managed forests are debated. Forest managers need to make decisions on stand treatment that are based on climatological and biological parameters with high uncertainties. We provided the conceptual basis for adaptive forest management and provide a number of case studies that reflect the options and limitations of ways of coping with climate change. The examples are derived from the experience of the authors. We conclude that only few forest types are either not strongly affected by climate change or do not require immediate adaptations of forest management. Many productive forests have stand properties that are decisively shaped by past management decisions, such as tree species composition, age distribution, rotation period, and stand structure. Maintaining these properties under the influence of climate change requires continuous and even increasing efforts of forest managers.

Forest pathways for sustainable development - emergent trends and good practice for forest and landscape restoration from the grassroots

Kenichi Shono ${ }^{1}$, Yelena Finegold ${ }^{1}$, Benjamin Caldwell ${ }^{1}$, Faustine Zoveda ${ }^{1}$

${ }^{1}$ Food and Agriculture Organization of the United Nations, Rome, Italy (kenichi.shono@fao.org; yelena.finegold@fao.org; benjamin.caldwell@fao.org; faustine.zoveda@fao.org)

Climate change is viewed by the Food and Agriculture Organization of the United Nations (FAO) as a key risk to its mission and to the 2030 agenda for sustainable development. FAO sees forests and trees as key elements of the response to that climate risk. Forests make vital contributions to both people and the planet, bolstering livelihoods, providing clean air and water, conserving biodiversity and mitigating climate change. Effective forest management strengthens resilience and adaptive capacities to climate-related natural disasters, contributes to climate mitigation by sequestering and storing carbon, and reduces emissions from deforestation and forest degradation, which is the second-leading cause of climate change after burning fossil fuels. Recent studies have demonstrated the potential of forest and landscape restoration to contribute to climate change mitigation. This potential is reinforced by political pledges like the Bonn Challenge, the UN decade on ecosystem restoration, and the African Forest Landscape Restoration Initiative (AFR100). To realize this potential and translate political will into results, practitioners need realistic, cost-effective approaches to implement restoration. Based on global work on forestry and food security, we present several proven, scalable approaches involving assisted natural regeneration and direct seeding that can be part of the effort to realize forest and landscape restoration's potential worldwide. We conclude by identifying some gaps that require assistance from researchers to address and with key messages for practitioners and policy-makers.

\section{Resprouts mortality of Schima superba following a severe ice storm in early 2008 in Southern China: a six-year study}

Yonghui Cao ${ }^{1}$, Benzhi Zhou ${ }^{1}$

${ }^{1}$ Research Institute of Subtropical Forestry, Chinese Academy of Forestry,_Hangzhou, China(fjcyh77@sina.com; benzhi_zhou@126.com)

Resprouting by woody plants has received little attention in undisturbed subtropical forest. From mid-January to mid-February 2008, an unexpected severe ice storm occurred in Southern China. We surveyed the damage and resprouts of all tree individuals with a minimum basal diameter of $4 \mathrm{~cm}$ for $6 \mathrm{consecutive}$ years, to assess the importance of resprouting for forest dynamics. The decapitation and leaning tree types had the largest mean number of sprouts in the first year, while the uprooted tree in the second year and then all declined with increasing year. At the sixth years after the disaster (in 2013), that of three types of Schima superba all declined to a minimum and stable level, only with about $13.28 \%$ to $23.42 \%$ of that of the disaster year. The new sprouts germinated in each year after disaster for different damaged types of individual had an increasing mortality rate with increasing time, and the sprouts survival rate was much lower over the 5 years recovery for new sprouts germinated in current year after disaster. The new sprouts germinated in current year had a higher mortality rate until the third year and rose to $87.39 \%( \pm 3.28 \%)$ and $96.27 \%( \pm 7.47 \%)$ in the sixth year for three damaged types. The new sprouts germinated in current year had a more exuberant vitality, and about $15 \%$ of that for decapitation trees could survive 6 years, while that for uprooted and leaning trees survived for 6 years was about $3.48 \%-3.73 \%$, and that could survive 5 years was about $10 \%$. 


\section{$\mathrm{N}_{2} \mathrm{O}$ and $\mathrm{CH}_{4}$ fluxes of forested floodplains in the Danube National Park, Austria}

Andreas Schindlbacher ${ }^{1}$, Erwin Moldaschl ${ }^{1}$, Kerstin Michel ${ }^{1}$, Barbara Kitzler ${ }^{1}$

${ }^{1}$ Federal Research and Training Centre for Forests - BFW, Vienna, Austria (andreas.schindlbacher@bfw.gv.at; erwin.mol21@gmail.com;

kerstin.michel@bfw.gv.at; barbara.kitzler@bfw.gv.at)

Favorable hydrological properties combined with periodic input of organic matter and nutrients after flooding dispose floodplain forests as potential "hot spots" of carbon $(\mathrm{C})$ and nitrogen $(\mathrm{N})$ cycling. Environmental conditions could also be favorable for the production of nitrous oxide $\left(\mathrm{N}_{2} \mathrm{O}\right)$ and methane $\left(\mathrm{CH}_{4}\right)$. We measured soil $\mathrm{N}_{2} \mathrm{O}$ and $\mathrm{CH}_{4}$ fluxes at 18 sites in the Danube National Park ( 10.000 ha), spanning natural gradients from frequently to less frequently flooded forest. Intensive monitoring sites were additionally equipped with auto-chambers to measure soil GHG fluxes in daily resolution. Stem $\mathrm{N}_{2} \mathrm{O}$ and $\mathrm{CH}_{4}$ fluxes were measured at the intensive sites as well. Against our expectations, soils acted primarily as $\mathrm{CH}_{4}$ sinks. Though we observed $\mathrm{CH}_{4}$ emissions shortly after flooding, the soil at the frequently flooded sites still showed average $\mathrm{CH}_{4}$ uptake of $18 \mu \mathrm{g} \mathrm{CH}_{4}-\mathrm{C} \mathrm{m}^{-2} \mathrm{~h}^{-1} \mathrm{during}$ the first $18 \mathrm{month}$ of our study. Less frequently flooded sites showed soil $\mathrm{CH}_{4}$ uptake of on average $54 \mu \mathrm{g} \mathrm{CH}_{4}-\mathrm{C} \mathrm{m}^{-2} \mathrm{~h}^{-1}$. Nitrous oxide was mostly emitted from soil and fluxes increased shortly after flooding events. Highest soil $\mathrm{N}_{2} \mathrm{O}$ emissions $\left(>70 \mu \mathrm{g} \mathrm{N} \mathrm{N}_{2}-\mathrm{N} \mathrm{m}^{-2} \mathrm{~h}^{-1}\right)$ were, however, measured independently of flooding during freeze-thaw periods in late spring. Tree stems fluxes differed among tree species (poplar, ash) and among stem sampling heights. Poplar showed sharply declining $\mathrm{CH}_{4}$ and $\mathrm{N}_{2} \mathrm{O}$ emissions with increasing stem measurement height. Ash showed opposite trends with regard to $\mathrm{CH}_{4}$ and no distinctive pattern with regard to $\mathrm{N}_{2} \mathrm{O}$. Generally, stems mostly emitted $\mathrm{CH}_{4}$ and $\mathrm{N}_{2} \mathrm{O}$, but emissions were very low.

\section{Strategic genetic resources from Uruguay, the Southern limit of the Atlantic forest, on the current scenario of climate change}

Diego Torres-Dini ${ }^{1,2}$, Andres Gonzalez ${ }^{3}$, Joaquin Garrido ${ }^{4}$, Cecilia da Silva ${ }^{5}$, Wanderley dos Santos ${ }^{6}$, Danilla Cristina Lemos ${ }^{2}$, Diana Castillo $^{7}$, Janaina Rodrigues da Silva ${ }^{2}$, Mario Teixeira de Moraes ${ }^{2}$, Miguel Luiz Menezes Freitas ${ }^{6}$, Valderês Aparecida de Souza ${ }^{8}$, Alexandre Magno Sebbenn ${ }^{6}$, Ananda Virginia de Aguiar ${ }^{8}$

${ }^{1}$ Instituto Nacional de Investigación Agropecuaria (INIA) Programa Nacional de Producción Forestal, Estación Experimental INIA Tacuarembó. Ruta 5 km 386, Tacuarembó, Uruguay; ${ }^{2}$ Universidade Estadual Paulista “Júlio de Mesquita Filho”, Ilha Solteira, Brasil; ${ }^{3}$ Museo de Historia Natural Montevideo, Montevideo, Uruguay; ${ }^{4}$ Dirección General Forestal (MGAP), Toledo, Uruguay; ${ }^{5}$ Centro Universitario de Tacuarembó (CUT), Tacuarembó Ruta 5 km 386., Tacuarembó, Uruguay; ${ }^{6}$ Instituto Florestal do Estado de São Paulo, Secretaria Meio Ambiente do Estado de São Paulo, São Paulo, Brasil; ${ }^{7}$ Guangxi University, College of Forestry, Nanning, China; ${ }^{8}$ Embrapa Florestas, Colombo, Brasil dtorres@inia.org.uy; andres260390@gmail.com; jgarrido@mgap.gub.uy; dasilvacece@gmail.com; wanderley.dossantos@hotmail.com;danillacls@yahoo.com.br;dianacastillodiaz@outlook.com; janainars_t@hotmail.com; teixeira@agr.feis.unesp.br; miguellmfreitas@yahoo.com.br; valderes.sousa@embrapa.br; alexandresebbenn@yahoo.com.br; ananda.aguiar@embrapa.br)

The Atlantic Rainforest is a Neotropical plant formation, traditionally present in Brazil, Paraguay, and Argentina. In Brazil, it followed the country coastal zone, from Rio Grande do Norte to Rio Grande do Sul, reaching inland the Province of Misiones in North-Eastern Argentina, and east of Paraguay. It is a threatened tropical forest and its surface has been fragmented discontinuously due to intensive deforestation of the biome, mainly in the twentieth century. It still holds one of the greatest biodiversities on the planet. It covered important stretches of mountain ranges and escarpments of the Brazilian plateau and was the extension of the Amazon rainforest. It was the second largest tropical forest in expansion in South America. The largest area continues as original surviving forest, the best preserved of this ecosystem is in the Argentine province of Misiones. However, Uruguay has small remnants of Atlantic forest that make it the final limit of the southern distribution. The edaphoclimatic conditions of Uruguay are different from those in the rest of this biome. It has four distinct seasons with contrasting temperatures. The low relief soil does not represent a physical barrier for the winds, making the changes of weather very variable. The aim of this work is to describe five genetic resources species of this biome, its potential for reforestation and productivity in the current scenario of climate change. These are Parapiptadenia rigida, Ilex paraguariensis, Myrcianthes pungens, Eugenia invlolucrata, and Cordia americana. We propose Conservation in situ, improvement and international germplasm interchange.

\section{Estimation of carbon fluxes from the decomposition of coarse woody debris in Pinus koraiensis stands in the Russian Far East}

Aleksandr Ivanov ${ }^{1}$, Martin Braun ${ }^{2}$, Dmitrii Zamolodchikov ${ }^{3}$,Stanislav Loshakov ${ }^{1}$, Daniil Kosinov ${ }^{1}$

${ }^{1}$ Primorskaya State Academy of Agriculture, Ussuriisk, Russian Federation; ${ }^{2}$ University of Natural Resources and Life Sciences, Vienna, Austria; ${ }^{3}$ Center for Forest Ecology and Productivity of the Russian Academy of Sciences (CEPF RAS), Moscow, Russian Fede (aleksandrgg86@mail.ru; martin.braun@boku.ac.at; dzamolod@mail.ru; dokgonzo@ya.ru; kosinovdaniil69@gmail.com)

Forests play an important role in global carbon cycles by accumulating carbon in biomass as well as through photosynthesis and respiration. An accurate assessment is complicated because of variations in carbon fluxes for different decomposition stages of wood. The carbon stored in coarse woody debris (CWD) belongs to anthropogenically heavily affected carbon pools in forests available for wood supply (FAWS). The CWD pool in the forest is regulated by natural processes such as mortality and decomposition as well as the activities of the local population such as the use as easily accessible fuelwood. Furthermore, forest fires have a significant impact on CWD stocks. CWD stocks in Pinus koraiensis dominated forest stands were investigated in the Primorsky Krai territory of Russia including Bikin national park (no logging) with a CWD stock of $104-119$ m/ha, and in an Ussuriisk-based forest stand of FAWS with a CWD stock of $10-59 \mathrm{~m}^{3} / \mathrm{ha}$. The deadwood basic density for Pinus was determined at five consecutive decomposition stages as $0.30,0.26,0.20,0.16$, and $0.10 \mathrm{~g} / \mathrm{cm}^{3}$. For the different decomposition stages carbon emissions were measured for the CWD surface throughout 2015-2017 with annual emissions ranging from 0.06 to $0.59 \mathrm{t} \mathrm{C} /$ ha for the stands investigated. CWD decomposition amounts to $2-7 \%$ of total destructive carbon flux. Comprehensive data on CWD differentiated by decomposition stage is useful not only for the refinement of carbon budgets in Primorsky Krai but also for soil scientists, mycologists, forest scientists and biodiversity assessments.

\section{Climate gas emissions from forestry - silvicultural measures about models for allocation}

Johann K. Ncess' ${ }^{1}$, Anders Q. Nyrud ${ }^{1}$, Lars G. F. Tellnes ${ }^{2}$

${ }^{1}$ Norwegian University of Life Sciences, Ass, Oman; ${ }^{2}$ Ostfold Research, Fredrikstad, Norway (johann.kristian.nass@nmbu.no; anders.qvale.nyrud@nmbu.no; lars@ostfoldforskning.no)

The Norwegian forest industry is increasingly being requested for environmental documentation, typically environmental product declarations (epds). Currently, the environmental documentation is based on aggregated quantities for industrial roundwood and fiber. This implies that wood products in general do not reflect wood species (spurce or pine). It is therefore important to calculate emissions from products from specific wood species. Climate gas emissions from Norwegian forestry 
activities was previously estimated with 2010 as reference year. Hence, the data used for allocation of wood products can be developed further with respect to different products and with respect to year the data are collected from. The study investigates five relevant scenarios: i) estimations based on data from single years, ii) estimations based on calculated averages, iii) estimates based on data from when measures actually took place, iv) sensitivity analysis on effects of fertilization, and v) estimates based on regional data. Climate gas emissions are within the interval 10,6 til 18,9 gwp $/ \mathrm{m}^{3}$. Harvesting, transport to roadside and fertilzation were the measures with the larges impact on emissions. In general, sawlogs from pine had the largest yearly variation in emissions. Furthermore, there is also substantial differences between emissions from aggregated products (i.e. estimated for both pine and spruce) and estimated emissions from specific tree species. The results indicate that results from the five scenarios differ by up to $30 \%$ for single products.

\section{Achieving India's forestry sector NDC: adapting to the changing climate is the key \\ Promode Kant ${ }^{1}$ \\ ${ }^{1}$ Institute of Green Economy, Gurgaon, India (promode.kant@gmail.com)}

Under the Paris Agreement India has promised a Nationally Determined Contribution of 2.5 to 3 billion tons of additional $\mathrm{CO}_{2}$ sequestration by 2030 . This translates roughly into Forest Landscape Restoration over 26 Mha but in the three years since the Agreement almost no progress could be made. This is because the policy approach has been largely to reach the target by bringing $33 \%$ of country's geographic area under forest and tree cover from the current level of 24.39\% but very little lands are actually available for allowing it to happen. This paper proposes that the NDC targets can only be achieved by enhancing the Net Primary Productivity of all types of forests in India from their currently abysmally low levels by enhancing soil moisture retention, replacement of weeds by ecologically appropriate species, reducing their vulnerability to pests and diseases through the use of innovative silvicultural tools, and drastically reducing the incidences of wildfires. Since these adverse conditions have worsened in the recent decades largely due to the changing climate a very large scale and comprehensive transformational approach to adaptation that would involve the active, and income enhancing, participation of a large number of local population is proposed. The expected high levels of investments in adaptation to the changing climate under the Paris Agreement would make it financially feasible.

\section{B8a: CLIMATE CHANGE AND THE FOREST ENVIRONMENT}

\section{Substitution effects of wood-based products in climate change mitigation}

Hans Verkerk ${ }^{1}$, Pekka Leskinen ${ }^{1}$, Giuseppe Cardellini ${ }^{2}$,Elias Hurmekoski ${ }^{1}$, Roger Sathre ${ }^{3}$, Jyri Seppälä4, Carolyn Smyth ${ }^{5}$, Mariana Hassegawa ${ }^{1}$ ${ }^{1}$ European Forest Institute, Joensuu, Finland; ${ }^{2}$ Technical University of Munich, Munich, Germany; ${ }^{3}$ Institute for Transformative Technologies, Berkeley, USA; ${ }^{4}$ Finnish Environment Institute, Helsinki, Finland; ${ }^{5}$ Natural Resources Canada, Vancouver, Canada (hans.verkerk@efi.int; pekka.leskinen@efi.int; cardellini@hfm.tum.de; elias.hurmekoski@gmail.com; roger@transformativetechnologies.org; jyri.seppala@ymparisto.fi; carolyn.smyth@canada.ca; mariana.hassegawa@efi.int)

Forests store carbon in biomass and soil and when harvested, part of the carbon is stored in wood products. These products may substitute functionally similar products made from more emission-intensive materials. We reviewed the existing literature to update and improve the understanding of the climate effects of substituting wood products. We conducted a systematic review covering over 50 studies and yielding over 400 substitution factors. Most studies focused on North America and the Nordic countries in Europe with only few studies from other regions. Most of the substitution factors related to construction materials, and substantially fewer substitution factors were available for other product types (furniture, packaging, and textiles) and even fewer for paper and chemicals. Overall, the reviewed studies suggest an average substitution effect of $1.2 \mathrm{~kg} \mathrm{C} / \mathrm{kg} \mathrm{C}$, which means that per kilogram of wood products that substitute non-wood products, there occurs an average emission reduction of $2.2 \mathrm{~kg} \mathrm{CO}$. However, the substitution effects vary significantly, depending on the wood and non-wood products considered and the assumptions applied to estimate emissions. We conclude that the use of wood products is generally associated with lower fossil and process-based emissions, compared to non-wood products. However, substitution factors as such are not sufficient to guide policy-making. The fundamental aim should be to minimize emissions, through forest management activities, long-term storage of $C$ in wood products and substituting emission-intensive materials. Resource-efficiency and minimizing material waste for both wood and non-wood based products should be simultaneous policy targets for climate change mitigation.

\section{Environmental heterogeneity of Araucaria angustifolia populations in Central-South region of Brazil: a preliminary analysis}

Itamar Antonio Bognola ${ }^{1}$ (D) Márcia Toffani Simão Soares ${ }^{1}$, João Bosco Vasconcellos Gomes ${ }^{1}$, Marcos Silveira Wrege ${ }^{1}$, Elenice Fritzsons ${ }^{1}$, Valderês Aparecida Sousa ${ }^{1}$, Ananda Virginia Aguiar ${ }^{1}$, Letícia Penno de Sousa ${ }^{1}$, Patricia Póvoa de Mattos ${ }^{1}$; Maria de Fátima Silva Matos ${ }^{2}$, Andressa Godinho Scarante ${ }^{2}$, Hugo Barbosa Bognola ${ }^{2}$, Gustavo Crizel Gomes ${ }^{3}$

${ }^{1}$ Embrapa Florestas, Colombo, Brasil; ${ }^{1}$ Embrapa Clima Temperado, Pelotas, Brasil; ${ }^{2}$ Pontificia Universidade Católica do Paraná, Curitiba, Brasil; ${ }^{3}$ Universidade Federal de Pelotas, Pelotas,Brasil (itamar.bognola@embrapa.br; marcia.toffani@embrapa.br; joao.bv.gomes@embrapa.br; marcos.wrege@embrapa.br; elenice.fritzsons@embrapa.br; valderes.sousa@embrapa.br; ananda.aguiar@embrapa.br;leticia.penno@embrapa.br; patricia.mattos@embrapa.br; fatimamatosg9@gmail.com; andressa.scarante@hotmail.com; hbbog@yahoo.com.br; crizelgomes@gmail.com)

Araucaria angustifolia (Bert.) O. Kuntze (Araucariaceae) is a subtropical rain forest tree that has social and economic importance due its wood quality and eatable seeds. To increase the knowledge about its genetic variability and its probable relationship with the physical environment, we are performing the edaphic, landscape and climatic characterization of natural populations occurring in a wide region including the latitudinal limits of Brazilian territory. From October 2015 to August 2016, we selected A. angustifolia trees from natural populations representing four Brazilian States. In those places, individuals were sampled, georeferenced (latitude, longitude, altitude), the relief was characterized and the soil were classified according to Brazilian Soil Classification System. Descriptive and cluster analysis, with field information, allowed the preliminary evaluation of these environments. As for edaphic aspect, the main classes of soil observed are Latosols (Oxisols), Cambisols (Inceptsols), Neosols (Entisols) and Nitosols (Alfisols). The southernmost sampled populations of Brazil (Pelotas region, Rio Grande do Sul State) are distinct from others by their lower altitude, around two hundred and ninety meters, and prevalence of shallow soil. Environments with the greatest contrast to this condition were located in the south of Minas Gerais State, with populations established over two thousand meters of altitude. Populations surviving in stressful environments are very important for conservation purpose, as result of local adaptation driving by extreme conditions. The attributes analyzed compose an information plan that will help to project the present and future occupation of these populations based on the IPCC scenarios. 
Tree species managed as fodder shrubs: a strategy to balance the sown plant density and the stocking rate for silvopastoral systems in dry areas

Nelson Pérez Almario ${ }^{1}$, Jairo Mora Delgado², Dagoberto Criollo Cruz ${ }^{3}$, Christian Carvajal Bazurto ${ }^{1}$, Sonia Ospina ${ }^{4}$, Eliana Medina Rios ${ }^{2}$

${ }^{1}$ Agrosavia, Espinal, Colombia; ${ }^{2}$ Universidad del Tolima, Ibagué, Colombia; ${ }^{3}$ Agrosavia, Florencia, Colombia; ${ }^{4}$ Agrosavia, Palmira, Colombia

(nperez@agrosavia.co;jrmora@ut.edu.co; dcriollo@agrosavia.co; ccarvajal@agrosavia.co; sospina@agrosavia.co; lizeth1301@hotmail.com)

In order to quantify productivity and forage quality in silvopastoral systems the species Albizia niopoides, Cordia alba, Gliricidia sepium, Guazuma ulmifolia, Leucaena leucocephala, Moringa oleifera, Senna spectabilis and Tithonia diversifolia were evaluated in El Espinal (C. I Nataima, Agrosavia). The growth form of the tree plant was modified by pruning at $0.8 \mathrm{~m}$ (height) and time intervals between harvests (30-45-60 days). In a randomized complete block design, plots with 270 individual plants per species were sown in three rows, and water or nutrients were not added. The species T. diversifolia, $C$. alba and S. spectabilis had the higher forage averages for 30 days harvest period with 145, 139 and 160g-1DM respectively, however these species presented had high mortality under this harvest's interval. On 45 days harvest period, the survival and the forage production improved for the species. The highest production respectively was presented by C. alba 450g-1DM, S. spectabilis 395g-1DM and T. diversifolia 330g-1DM. On 60 days harvest period the highest production was for S. spectabilis 643g-1DM and C. alba 612g-1DM. At this interval, some branches were mainly a woody resource and sometimes unattractive for ruminant's consumption. On the other hand, L. leucocephala and M. oleifera presented the lowest forage biomass production per plant $<160$ g-1DM and the higher protein content. This evaluation allows to recommend managing these tree species in silvopastoral systems at $0,8 \mathrm{~m}$ and harvest intervals of 45 days. Under these recommendations these tree species decrease mortality and improve adaptation to climate seasonality during the establishment of silvopastoral systems in dry zones.

\title{
Reproductive phenology of Eutepe edulis Mart. in an altitudinal gradient at the Altantic Forest
}

\author{
Andressa Tres ${ }^{1}$, Franciane Pajewski ${ }^{1}$, Alexandre França Tetto ${ }^{1}$, Jaçanan Eloisa de Freitas Milani ${ }^{2}$, Bruna Kovalsyki ${ }^{1}$ \\ ${ }^{1}$ Universidade Federal do Paraná, Curitiba, Brasil; ${ }^{2}$ Universidade do Estado de Santa Catarina, Lages, Brasil (tres.andressa@gmail.com; \\ franpajewski@yahoo.com.br; tetto@ufpr.br;jacanan.milani@gmail.com; kovalsyki.b@gmail.com)
}

Euterpe edulis is considered a key species in the Atlantic Forest and is currently classified as vulnerable at a Brazilian list of threatened species, due to illegal extraction. In order to provide information for future projects of conservation, the present study characterized $E$. edulis reproductive phenology in four altitudes $(30,100,200$ and $400 \mathrm{~m})$ in Salto Morato Natural Reserve - Guaraqueçaba, PR. In each altitude, five individuals were monthly monitored from March/2017 to February/2018. The intensity of phenophases was registered following the methodology proposed by Fournier. Flowering started at the lowest altitude (in September) and lasted for four months with a peak in November. At $200 \mathrm{~m}$, flowering was present only in November. Immature fruits were present in the lowest altitude from December until February (with a peak in January) and, at $200 \mathrm{~m}$, it only occurred in March. Green fruits were observed in three altitudes: at $30 \mathrm{~m}$, it started in February and lasted for three months; at 100 m, it started with one month of delay (in March) and lasted for four months; at $200 \mathrm{~m}$, this phenophase initiated with two months of delay (in April) and lasted also for three months. Mature fruits also presented differences as they initiated at different altitudes: it started in February at $30 \mathrm{~m}$; in June at $100 \mathrm{~m}$ and in May at $200 \mathrm{~m}$. There are differences in reproductive phenology of $E$. edulis throughout the gradient, which can be explained by differences in microclimate.

\section{Characteristic of phytodiversity and plants communities in a climate transition area in Burkina Faso (West Africa)}

Assan Gnoumou ${ }^{1}$, Adjima Thiombiano ${ }^{1}$

${ }^{1}$ University of Ouaga I Pr Joseph Ki-Zerbo, Ouagadougou, Burkina Faso (agnoumou@gmail.com; adjma_thiombiano@yahoo.fr)

The diversities of plants and ecosystems are sensitive to climate and soils variations, however climate is fast deteriorating at large scale. Therefore, botanical and ecological studies are necessary in climate transition area for phytodiversity monitoring, then to prevent species extinction. In this particular case, we carefully chosen Comoé-Léraba protected area. After inventories, based on the recent plants species listed in Burkina Faso, this protected area provides in proportion $26.12 \%$. The importance of Guineo-Congolian species (113) proved that the Comoé-Léraba flora belongs to the Sudano-Guinean transition sector. It also accounts the highest number of exclusive species (118) in the country. Furthermore, in related to each ecosystem, 11 plants communities' have been clearly defined, according the phytosociological statements (DCA). Among these communities four news taxa were determined based on previous studies in the same phytogeographical zones. Then their direct ordination (CCA) with soil's (physical and chemical) parameters, shows that plants communities' distribution is governed mainly by water regulation on the ground and also its texture. Comoé-Léraba is located at the most humid zone of the country, but due to climate warming, exclusive species and rare plants communities which have been discovered, could move away from the country. Consequently, this protected area required closely attention.

\section{Energy potentials of mountain forests of Eastern European Mid-latitude ecotone as the basis for adaptive forest management under climate change}

Roman Vasylyshyn ${ }^{1}$, Ivan Lakyda ${ }^{1}$, Andrii Bilous ${ }^{1}$, Vasyl Holian ${ }^{2}$

${ }^{1}$ National University of Life and Environmental Sciences of Ukraine, Kyiv, Ukraine; ${ }^{2}$ Lutsk National Technical University, Lutsk, Ukraine

(vasylyshyn@nubip.edu.ua; ivan.lakyda@nubip.edu.ua; bilous@nubip.edu.ua; golian_v@ukr.net)

Forests act as important components of ecosystems in mountainous areas, where forest management should balance environmental protection and socio-economic development of local communities. Being a part of Eastern European Mid-latitude ecotone, mountain forests of the Ukrainian Carpathians represent a resource-rich forest management hotspot in a developing country. Given the low efficiency of energy use in Ukraine and growing energy demands, forests can and should play an important role as a renewable energy source in the near and far-off prospects. Theoretical and methodological background for quantitative assessment of energy potential of woody biomass in mountain forests shall be based on provisions of sustainable forest management and reflect the balance of the three structural components of sustainable development - environmental safety, economic development, and social interests. Considering certain environmental, economic and social constraints on energy use of wood biomass in mountain forests, we propose to distinguish five types of energy potential: theoretically possible, technically accessible, environmentally safe, economically profitable and socially conditioned. Having implemented the abovementioned principles and approaches, we have assessed energy potentials of wood biomass for Carpathian Mountains region: theoretically possible - 49.4 PJ; technically accessible - 35.2 PJ; environmentally safe - 25.4 PJ; economically profitable - 22.9 PJ and socially conditioned - 20.3 PJ. The last-mentioned type of energy potential expressed in volume of timber means that over 2.2 million cubic meters of wood could be used for bioenergy purposes. The proposed research results can serve as a component of an information system aimed at implementation of adaptive forest management in the Carpathian region. 


\title{
Interspecific and intraspecific variability of functional traits in two tree species in three ecological scales influenced by the Tatacoa desert,
} Colombia

Nelson Pérez Almario ${ }^{1}$, Jairo Mora Delgado ${ }^{2}$, Dagoberto Criollo Cruz ${ }^{3}$, Christian Carvajal Bazurto ${ }^{1}$, Oscar Orjuela ${ }^{1}$, Eliana Medina Rios $^{2}$

${ }^{1}$ Agrosavia, Espinal, Colombia; ${ }^{2}$ Universidad del Tolima, Ibagué, Colombia; ${ }^{3}$ Agrosavia, Florencia, Colombia (nperez@agrosavia.co; jrmora@ut.edu.co; dcriollo@agrosavia.co; ccarvajal@agrosavia.co; oorjuela@agrosavia.co; lizeth1301@hotmail.com)

The dry tropical region of Colombia has periods of 145 to 220 days / year without rainfall. In addition, the average temperature of $29{ }^{\circ} \mathrm{C}$, relative humidity between 56 and 65\%, poorly distributed precipitation, however, fall 1272 to $1400 \mathrm{~mm}$ / year and evaporates more than the precipitation received. These variables would be directing the behavior of the plants towards different forms of response, since a plant hardly maintains its leaf tissues alive, when periods of drought are long. Using mixed linear models with varcomp statistical function in two key functional features, specific leaf area (SLA) y Wood density (WD) of species (Cordia alba y Guazuma ulmifolia) found in paddocks at three ecological scales (species, tree and show). Interspecific variability of traits (50.34 - 79.08\%) e intraspecífic Árbol (28.18-17\%) and simple (41\% para SLA) respectively. Comparisons for SLA and WD, shows that features trees in paddocks with significant differences(P-valor=0,0001. R2=0,77). SLA values in C. alba varies between $(17,19+0,7$ to 17,49 + 0,57 mm2 mg-1) y G. ulmifolia $(12,71+0,57$ to13,83+0,57 mm2mg-1), showing stability. The WD for $C$. alba varía between $(0,45+0,02$ to $0,53+0,01 \mathrm{mg} \mathrm{mm}-3)$ y G. ulmifolia entre $(0,44+0,02$ to $0,53+0,01 \mathrm{mg} \mathrm{mm}-3)$, being this variable, indicator of adaptation of species to water stress. The high interspecific variability (50-79\%), it follows patterns reached in other studies, while intraspecific variability (tree-show), present important varability. Results indicate that intraspecific variability (tree-show) are dominated by interspecific variation (species), but that there is an intra-specific variability in trees and foliar structures that can not be ignored.

\section{Forest amount affects crops productivity in Brazilian agricultural frontier}

Ludmila Rattis ${ }^{1,2}$, Paulo Brando ${ }^{2,3}$, Marcia Macedo ${ }^{2,4}$, Michael Coe $^{1}$

${ }^{1}$ Woods Hole Research Center, Passos, Brasil; ${ }^{2}$ Instituto de Pesquisa Ambiental da Amazônia, Brasilia, Brasil; ${ }^{3}$ Woods Hole Research Center, Brasilia, Brasil; ${ }^{4}$ Woods Hole Research Center,Falmouth,USA (ludmilarattis@gmail.com; pbrando@whrc.org; mmacedo@whrc.org; mtcoe@whrc.org)

The relationship between climate and the agricultural system is well known and described in the literature. However, with the increase in the frequency of occurrence of extreme climatic events - such as prolonged and successive droughts, torrential rains, high daytime, and nighttime temperatures - the agricultural production system has become even more unstable. Given the humanity dependence on increasing agricultural production, here we hypothesized that agriculture is moving to areas less suitable to grow crops and even the consolidated fields could become less suitable in the future. We also tested if different landscape compositions would change the relationship between crop productivity and the weather. Especifically, we 1) quantified the relationship between climate and first and second crops across the Brazilian agricultural frontier; 2) characterized climatically the areas where agriculture is expanding to in recent years; 3) quantified agricultural de-intensification, 4) compared the past and future climatic conditions of agricultural fields; and 5) quantified the relationship between forest amount and crop yield productivity of the second crop. In hotter and drier years, production, productivity, and planted area were lower in the second crop. Agricultural climate space has already changed. At the same time, agriculture expanded into hotter regions, although into places with more precipitation during the wet season. In regions with lower forest cover, the forest plays a positive role in the productivity of the first and second harvests. The crop production stability in the Brazilian agricultural frontier may depend on the standing forest.

\section{B8r: FORESTS AND CLIMATE CHANGE IN SOUTHWESTERN AMAZON}

Estimated stocks of volume, biomass, and carbon in vegetation with $\mathrm{DBH} \geq 20 \mathrm{~cm}$ from the riparian forest along the Acre River in Brasiléia, Acre, Brazil / Estimativa do estoque de volume, biomassa e carbono em vegetação de mata ciliar ao longo do Rio Acre, com DAP $\geq$ $20 \mathrm{~cm}$, em Brasiléia, $A C$

\author{
Reyneiberg da Silva Araújo ${ }^{1}$, Marco Amaro ${ }^{1}$ iD; Ecio Rodrigues Silva ${ }^{1}$, Alana Chocorosqui Fernandes ${ }^{2}$ \\ ${ }^{1}$ Universidade Federal do Acre, Rio Branco, Brasil; '2Instituto Federal do Acre, Rio Branco, Brasil (reyneiberg@hotmail.com, \\ marcoantonioamaro@hotmail.com; ecio@ufac.br; alanacfernandes@yahoo.com.br)
}

Este estudo teve como objetivo quantificar o estoque de volume, biomassa e carbono na mata ciliar do Rio Acre em Brasiléia, AC, considerando a vegetação com DAP $\geq 20 \mathrm{~cm}$, para subsidiar futuros estudos de valorização da floresta, e ainda conseguir evidenciar a importância da conservação de florestas nativas para redução das emissões de gases na atmosfera. O Inventário Florestal do projeto Ciliar Só-rio foi realizado utilizando unidades amostrais com dois estágios (conglomerados) para coleta dos dados, com emprego de técnicas de amostragem aleatória estratificada pela faixa marginal do Rio Acre por município. Dentre os municípios que são cortados pelo Rio Acre, o escolhido para realização deste estudo foi Brasiléia, no qual foram instaladas quatro parcelas primarias. Dentro destas foram mensuradas quatro parcelas secundárias cada uma com: 10 m x 250 m, somando 1 ha. Para o cálculo de volume e biomassa utilizou-se equações baseadas no modelo Schumacher e Hall. O estoque de biomassa para demais compartimentos (folhas, frutos, flores e raízes) foi obtido através de percentuais encontrados em trabalhos realizados na Amazônia. Para estimar os estoques de carbono considerou-se 50\% da biomassa seca. O volume médio de madeira para o compartimento fuste por ha, para DAP $\geq 20 \mathrm{~cm}$, foi estimado em $61,07 \mathrm{~m}^{3}$. O estoque de biomassa seca e carbono foram de $117,80 \mathrm{t}$ ha ${ }^{-1} \mathrm{e} 58,90 \mathrm{t}$ ha ${ }^{-1}$ respectivamente. Esses valores são inferiores aos encontrados em alguns estudos, para a mata ciliar do município de Porto Acre.

Biomass and carbon stocks in the vegetation within the Seringal Nova Esperança Ecological Area, in Epitaciolândia, Acre, Brazil / Estoque de biomassa e carbono na vegetação da Arie Seringal Nova Esperança, Epitaciolândia, AC

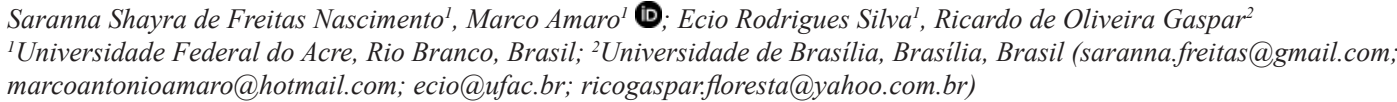

Este estudo objetivou estimar o estoque de biomassa e carbono na vegetação da Área de Relevante Interesse EcológicoARIE Seringal Nova Esperança, em Epitaciolândia, AC, para subsidiar estudos que evidenciem a importância da conservação de florestas nativas, para redução das emissões de gases na atmosfera. Para estimar a biomassa na vegetação com DAP $\geq 5$ cm utilizou-se os dados de um inventário florestal realizado em 30 parcelas de 10 x $100 \mathrm{~m}$. Estimou-se a biomassa do fuste utilizando-se equações baseadas em literatura e a da copa pelo uso de fator. Para estimar a biomassa na vegetação com DAP $<5$ cm foram instaladas 18 parcelas secundárias de 5 x 5 m, para 
pesar toda a vegetação encontrada, para determinação do peso úmido. Foram pesadas amostras deste material, para determinação do peso úmido, as quais foram levadas para laboratório para determinação do peso seco (biomassa). Com a obtenção do peso seco das amostras, a biomassa das parcelas foi estimada. Os estoques de biomassa para folhas, frutos, flores, raízes e serrapilheira foram obtidos através de percentuais encontrados em literatura. A biomassa seca foi convertida em carbono, utilizando o valor de 50\% recomendado pelo Serviço Florestal Brasileiro. O teor de umidade médio obtido para a copa foi de 68,70\% e para o fuste 50,5\%. A biomassa seca total média, abaixo e acima do solo, foi estimada em 400,92 t ha-1 ${ }^{-1}$, sendo 2,71 na vegetação com DAP < 5 cm; o carbono foi estimado em 200,84 t/ha ${ }^{-1}$, sendo 1,36 na vegetação com DAP $<5 \mathrm{~cm}$. Valores superiores a maioria de outros estudos realizados no Acre.

Assemblies of ants indicating the type of land use in the Southwestern Brazilian Amazon region / Assembleias de formigas como indicadoras do tipo do uso do solo no Sudoeste da Amazônia brasileira

Francisco Matheus da Silva Sales ${ }^{1,2,3}$, Fernando Schmidt ${ }^{1,2,3,4}$

${ }^{1}$ Laboratório de Ecologia de Insetos, Rio Branco, Brasil; ${ }^{2}$ Centro de Ciências Biológicas e da Natureza, Rio Branco, Brasil; ${ }^{3}$ Universidade Federal do Acre, Rio Branco, Brasil; ${ }^{4}$ Programa de Pós-graduação em Ecologia e Manejo de Recursos Naturais, Rio Branco,Brasil (matheussalles07@gmail.com; schmidt.fa@gmail.com)

A implementação de pastagens é apontada como uma das principais formas de mudança do uso do solo no Sudoeste da Amazônia Brasileira. Considerando a dificuldade de se avaliar a resposta de toda a biodiversidade aos diferentes tipos de impactos antrópicos, tem sido proposto o uso de bioindicadores, grupos de organismos que são facilmente amostrados e que reagem de forma previsível as perturbações antrópicas, como por exemplo as formigas. Assim, temos como objetivos fornecer parâmetros para o uso das assembleias de formigas como bioindicadoras do uso do solo no Sudoeste da Amazônia brasileira. As assembleias de formigas foram caracterizadas em termos de número e composição de espécies. As coletas de formigas foram feitas em três pontos de um fragmento florestal e em três pastagens do seu entorno. Em cada local de coleta, estabelecemos um transecto de $200 \mathrm{~m}$ com um ponto amostral a cada $20 \mathrm{~m}$. Cada ponto amostral foi constituído de oito armadilhas de queda sendo quatro epigéicas e quatro hipogéicas. $\mathrm{O}$ habitat de floresta acumulou mais espécies de formigas para ambos os estratos. Houve diferença na composição de espécies entre floresta e pasto nos dois estratos. A transformação de áreas de floresta em pastagem impacta as assembleias de formigas, reduzindo a riqueza de espécies e alterando a composição de espécies. Além disso, a identificação das espécies associadas a cada tipo de ambiente é útil para se aferir o estado de conservação/recuperação de um ambiente com base nos parâmetros observados das assembleias de formigas.

B9a: THE ROLE OF FOREST BASED INDUSTRY IN MEETING NDCS WORLDWIDE UNDER PARIS AGREEMENT

\section{New generation plantations, a carbon dioxide reduction technology}

Luis Neves Silva

${ }^{1}$ WWF Brasil, Vila Nova Santo André, Portugal (lnsilva@wwfint.org)

The planet has warmed by $1^{\circ} \mathrm{C}$ since the industrial revolution, and staying within $1.5^{\circ} \mathrm{C}$ will require action at an unprecedented pace and scale. One part of the solution is removing significant quantities of carbon dioxide from the atmosphere. This is where planting trees comes in. For the last 10 years, the New Generation Plantations (NGP) platform has developed a concept that works, demonstrating how tree plantations can be established and managed in ways that benefit nature and climate while contributing to sustainable development. Research indicates that plantations can provide a variety of ecosystem services beyond simply supplying timber. If expanding plantations follows the NGP concept, trees planted in the right way and in the right places can make a major contribution to reducing carbon dioxide levels. In the Atlantic forest biome, where the NGP Participants manage more than 2 million hectares of land, around half of this area is planted with eucalyptus in former degraded grazing land, while the rest is set aside for conservation. Increasing production in these intensively managed areas frees up land for conservation and forest restoration, while increasing carbon storage. As technology continues to develop, almost everything derived from fossil fuels today could come from trees in the future. The variety of plastics that can now be made from bio-based sources is growing all the time. By providing a reliable, renewable and climate-positive source of fibre, plantations can contribute to reducing emissions and supporting the transition to a sustainable biobased economy.

\section{Robust projection of carbon stored in harvested wood products for establishing a national forest reference level under the European Union's contribution to the Paris Agreement}

Niclas Scott Bentsen ${ }^{1}$, Vivian Kvist Johannsen ${ }^{1}$

${ }^{1}$ University of Copenhagen, Department of Geosciences and Natural Resource Management, Frederiksberg C,Denmark(nb@ign.ku.dk; vkj@ign.ku.dk)

With the 2030 climate and energy framework the European Union (EU) has committed itself to reduce GHG emissions by 2030 at least $40 \%$ relative to 1990. The commitment forms the EU's contribution (NDC) to the Paris Agreement. For the first time the land sector is considered to achieving the reduction targets. Since the land sector, particularly forests, is characterized by long time perspectives, it is essential to ensure transparent and coherent accounting and reporting for the sector. For documentation and accounting of the forest sector's contribution, each Member State shall develop a National Forestry Accounting Plan and a Forest Reference Level including Harvested Wood Products to project expected greenhouse gas emissions from the forest sector.

\section{Modeling the use of wood to strengthen its socio-economic and environmental impacts}

\section{Martin Moravčík ${ }^{1}$, Miroslav Kovalčík ${ }^{1}$, Hubert Paluš², Ján Parobek ${ }^{2}$}

${ }^{1}$ National Forest Centre, Zvolen, Slovakia; ${ }^{2}$ Technical University,Zvolen, Slovakia(moravcik@nlcsk.org;kovalcik@nlcsk.org; palus@tuzvo.sk; parobek@tuzvo.sk)

This paper builds on the preliminary results of the ongoing research project aimed at the use of wood as a renewable raw material, the main objective of which is to create an optimal model of wood use in Slovakia. Sustainable production, adequate financial appreciation and increasing social and environmental benefits of timber production are important goals of the forestry sector. One of the options for ensuring better appreciation of felled timber is to increase the production of more valuable assortments. This paper aims at the comparison of actual volume and value structure of raw wood assortments supplies produced by forestry with the possible available structure of assortments. To carry out the above-mentioned analyses these data sources were used: the summary forest management plans, the mathematical and statistical methods of forest national inventory and the sectoral forest market information system. Based on the analysis of and 
discussion on the factors affecting wood flows a variant models as alternatives to the current wood flows were developed with the aim to achieve (i) the optimal value utilisation of available raw wood assortments structure, (ii) increased domestic level of wood consumption, and (iii) the improved carbon balance of wood use through the changes in the portfolio of wood products. The difference between the carbon volumes stored in harvested wood products within the mentioned variants were quantified so that they could be assessed from the viewpoint of the best protection of atmosphere from disproportionate $\mathrm{CO}_{2}$ growth. The carbon balances were calculated using the IPCC procedures.

\section{The role of forest based industry in meetings NDCs worldwide under Paris Agreement}

Nathalia Granato Loures ${ }^{1}$

${ }^{1}$ Indústria Brasileira de Árvores, São Paulo,Brasil (n.granato@iba.org)

The Paris Agreement has been ratified by 179 Parties, which have compromised to National Determined Contributions to be performed in the next decade. Governments, industries and consumers have a huge responsibility in helping meeting the goals and moving towards a new low carbon economy. This session aims to emphasize the significant role played by the forest sector in removing and stocking carbon, besides providing renewable and recyclable raw materials, products and ecosystem services. The event also aims to demonstrate how innovation in technology and management can help forestry adapt in a condition of a growing global demand for forest based products and a climate change environment. Additionally, reinforce the potential of forest based industry in adaptation by investing in research, developing and innovation and adoption of best practices that allow rational use and conservation of natural resources. Cases from Brazil and from other regions that are engaged in the New Generation Plantations Platform will be portrayed as examples of governance, engagement in policy making and management that have helped their respective regions to get closer to implementing the assumed NDC.

\section{Vision 2030-2050: the future of the forests and agriculture in Brazil / Visão 2030-2050: o futuro das florestas e da agricultura no Brasil}

Luana Oliveira ${ }^{1}$, Laura Lamonica ${ }^{1}$, André Guimarães ${ }^{1,2}$

${ }^{1}$ Coalizão Brasil Clima, Florestas e Agricultura, São Paulo, Brasil; ${ }^{1}$ Instituto de Pesquisa Ambiental da Amazônia, Brasília, Brasil

(assistente@coalizaobrasil.org; admin@coalizaobrasil.org; admin@coalizaobrasil.org)

O Brasil possui um território extenso e diversificado, agropecuária forte e competitiva, capital natural extraordinário e elevada biodiversidade e serviços ecossistêmicos. O país é um grande produtor de alimentos e, portanto, corresponsável pela segurança alimentar do planeta. Ao mesmo tempo, possui a maior floresta tropical do mundo e, por isso, é também corresponsável pela segurança hídrica e climática da humanidade. Nos últimos 40 anos, o país se tornou uma potência agrícola. Passou de importador de alimento a terceiro no ranking dos exportadores de produtos agrícolas, segundo a FAO. Esse salto foi possível graças a uma poderosa combinação entre o que foi garantido pela natureza - fertilidade dos solos, disponibilidade de água, condições climáticas, polinizadores e biocontroladores de pragas e doenças - e os ganhos em produtividade resultantes dos investimentos em pesquisa e inovação. No entanto, ainda somos o sétimo maior emissor de gases de efeito estufa do planeta, com grande parte dessas emissões decorrentes direta e indiretamente das atividades relacionadas à produção agropecuária, especialmente o desmatamento. Na visão da Coalizão Brasil Clima, Florestas e Agricultura, é possível não apenas enfrentar e mitigar os impactos das mudanças climáticas, mas transformar a crise climática em oportunidade para o desenvolvimento do país, a partir do uso harmônico, inclusivo e sustentável da sua terra. Não cabe mais considerar a produção florestal e agropecuária em dissonância com a conservação ambiental. Precisamos adotar práticas produtivas que reduzam emissões e a restauração em larga escala de áreas críticas para a provisão de serviços e produtos a partir da natureza.

\section{Comparison of Life Cycle Analysis (LCA) models for biochemical second-generation (2G) ethanol production from forest residues}

Nariê Rinke Dias de Souza ${ }^{1}$, Bruno Colling Klein ${ }^{1}$, Mateus Ferreira Chagas ${ }^{1}$, Otavio Cavalett ${ }^{1}$, Antonio Bonomi ${ }^{1}$

${ }^{1}$ Laboratório Nacional de Biorrenováveis, Centro Nacional de Pesquisa em Energia e Materiais, Campinas, Brasil (narie.souza@ctbe.cnpem.br; bruno.klein@ctbe.cnpem.br; mateus.chagas@ctbe.cnpem.br; otavio.cavalett@bioetanol.org.br; antonio.bonomi@ctbe.cnpem.br)

Bioenergy plays an important role in the decarbonization of the transportation sector and the reduction of fossil fuel dependence worldwide. Second-generation (2G) ethanol is considered an advanced biofuel and has gained prominence due to its potential to reduce greenhouse gas emissions (GHG), which can be quantitatively determined through a Life Cycle Analysis (LCA) methodology. The scope of this study is the comparison and harmonization of 2G ethanol production from forest residues considering three LCA models: GHGenius (Canada), GREET (USA) and VSB (Brazil). In this context, it was possible to identify the main differences and commonalities in methodological structures, calculation procedures and assumptions of each LCA model. In general, there are differences in the inputs data and, also, in the methodological choices. Some of these differences are justified by the particularities of each model, while others can be harmonized. For instance, the location of feedstock production and industrial process are specific for each model and, therefore, variable results are expected in terms of GHG emissions per MJ of 2G ethanol. To demonstrate the possibility of obtaining homogeneous results, the three models were harmonized. For that, default data and parameters (e.g. agricultural and industrial inputs, emission factors and allocation procedure) for the production of 2G ethanol from forest residues were retrieved from the VSB database and entered on the other models. With this approach, it was possible to identify the main differences and to reach similar impacts from different LCA models considering the same production system.

\section{The effects of REDD+ on deforestation and well-being: a panel study in the Brazilian TransAmazon}

Caue Carrilho', Carla Morsello ${ }^{2}$

${ }^{1}$ PROCAM/USP, São Paulo,Brasil; 2PROCAM-EACH/USP, São Paulo, Brasil (cauecarrilho@gmail.com; morsello@usp.br)

The REDD+ mechanism was designed to achieve multiple objectives, such as reducing emissions from deforestation and forest degradation and increasing carbon stocks, alongside co-benefits such as reducing poverty and improving the well-being of local inhabitants. Although there are few robust evaluations of REDD+ outcomes, those existing suggest weak effects. However, the discouraging results could be a consequence of the short time-span (i.e., $\sim 3$ y.o.) of the evidence evaluated, leaving the question of whether REDD+ work open. This study, therefore, aims to assess the effects of REDD+ interventions on household deforestation (area cleared) and subjective/local perceived well-being over an 8-year time span. To do that, we evaluated a REDD+ initiative in the Brazilian Transamazon Highway region, which combines Payments for Environmental Services and Integrated Conservation and Development Projects (i.e., incentives for low impact activities). Data comes from a panel-based survey design based on interviews of 127 households (treatment: 52; control: 75) on two years (2010, 2019). Analyses will rely on a BACI (i.e., before-after-control-intervention) quasi-experimental design, with pre- and post-intervention data. Effects will be estimated through the difference-in-differences method, matching treatment and control households in characteristics that affect their probability of receiving the treatment (e.g., property area, total income). We believe this information will help us to understand whether REDD+ is achieving the intended results, but also if longer time-spans translate into more expressive effects than those currently observed. 


\title{
Local adaptation in natural populations of Toona ciliata is driven by precipitation and temperature
}

Jun Liu $^{1}$

${ }^{1}$ Chinese Academy of Forestry, Hangzhou, China (ywliu2005@163.com)

Environmental factors are strong drivers of local adaptation in forest tree species. Toona ciliata, an endangered tree species endemic to China, is widely distributed across Eastern and Southwestern China. We studied the adaptive variation and genetic structure of T. ciliata, using 8 genomic microsatellite markers and 17 EST-SSR markers across 9 populations from Yunnan-Kweichow Plateau and Eastern China. High genetic diversity and significant genetic differentiation were revealed in populations of $T$. ciliata. Patterns of population structure were apparent using a Bayesian clustering program, STRUCTURE, which identified four distinct clusters. We identified four outlier loci that were potentially under selection using multinomial-Dirichlet and hierarchic simulation models. A Mantel test indicated that geographic and climatic factors have jointly affected the genetic structure of $T$. ciliata in the study area. Based on redundancy analysis (RDA), climatic variables are more strongly associated with variation than are geographic variables. Eight alleles from outlier loci were potentially adaptive, being correlated with either precipitation or temperature variables. This shows that the climatic variables including precipitation and temperature are drivers of local adaptation in populations of T. ciliata.

Using the logistic model in improvement for propagation by minicuttings in Toona ciliata M. Roemer var. australis / Uso do modelo logístico no melhoramento para propagação por miniestaquia em Toona ciliata M. Roemer var. australis

\author{
Eduardo de Castro Stehling ${ }^{1}$; Sebastião Carlos da Silva Rosado ${ }^{2}$, Erika Steinmetz Vilela ${ }^{3}$ \\ ${ }^{1}$ Fuste Consultoria Florestal, Campo Belo, Brasil; ${ }^{2}$ Universidade Federal de Lavras, Lavras, Brasil; ${ }^{3}$ Bela Vista Florestal, Campo Belo, Brasil \\ (fusteconsultoria@gmail.com; scrosado@dcf.ufla.br; erika@belavistaflorestal.com.br)
}

Com o objetivo de identificar genótipos mais produtivos para a propagação vegetativa de cultivares de cedro australiano, foram avaliadas brotações de minicepas de 73 famílias provenientes de 14 origens da Austrália. O experimento foi instalado na Bela Vista Florestal em Campo Belo, Minas Gerais, no segundo semestre de 2007. A pesquisa fez parte do programa de melhoramento e desenvolvimento de cultivares da empresa. O delineamento foi de blocos ao acaso, com 3 repetições e 8 plantas por parcela. Inicialmente houve a clonagem das mudas seminais originando às minicepas. Após o plantio das minicepas, as miniestacas coletadas foram estaqueadas por 226 dias, sendo individualmente identificadas. Após o enraizamento, obteve-se o número de miniestacas por minicepa e de miniestacas enraizadas produzidas no período, acompanhando o enraizamento de cada miniestaca coletada. Os dados obtidos foram submetidos à uma regressão logística no software S-Plus e as estimativas dos parâmetros genéticos do modelo logístico de cada variável estudada via metodologia REML/BLUP. Os resultados foram obtidos selecionando os indivíduos de maior valor genético aditivo para as variáveis miniestacas enraizadas e miniestacas com e sem a associação da variável enraizamento. Verificou-se grande variabilidade para os parâmetros $\alpha$, $\beta$ e E, para as diferentes variáveis. O melhor critério de seleção conjunta obtido foi usando os parâmetros $\alpha+\beta$ e $\alpha+\beta+\gamma$. Foi observada grande variabilidade genética dentro e entre famílias. O uso do modelo logístico foi eficiente na seleção de genótipos superiores de cedro australiano, proporcionando propagaçãoem escala comercial para a cultivares obtidos.

\section{Assessing the anticipated response of tree growth and resilience to drought of candidates of an Australian red cedar population for assisted migration to Brazil}

\author{
Sebastião C Rosado ${ }^{1}$,Eduardo de Castro Stehling ${ }^{2}$, Luiz M Takarada ${ }^{1}$, Lucas R Rosado ${ }^{1}$, Ana C. Caxito Araújo ${ }^{1}$ \\ ${ }^{1}$ Universidade Federal de Lavras, Lavras,Brasil; ${ }^{2}$ Fuste Consultoria, Campo Belo, MG, Brasil (scrosado@dcf.ufla.br; fusteconsultoria@gmail.com; \\ takarada@hotmail.com; lucasrosado@yahoo.com.br; anacaxitoengflor@hotmail.com)
}

Recurrent droughts are a threat to the cellular homeostasis of plants and can significantly affect the functioning of forests. Under drought trees tend to use their defense mechanisms to evade or diminish the stress load. One such mechanism consists of storage and use of non-structural carbohydrates (NSC), which are energy reservoirs for use in growth or the maintenance of tree integrity. We conjectured that in the growth rings there are "marks of the past" that reveal the trees' capacities for growth and resilience to droughts that have occurred during their lives and that these marks can be revealed by the levels of NSCs stored in the external ring (in formation) and the internal ones. The growth rings of two trees from each of 16 provenances from eastern coastal Australia (ranging from latitude $12^{\circ} 33^{\prime} \mathrm{S}$ - Pascoe River- QLD to $34^{\circ} 38^{\prime} \mathrm{S}$ - Kangaroo Valley - NSW) at age 10 years and planted in Campo Belo (Minas Gerais, Brazil) were evaluated, along with their basal area and stocked NSCs. The significant variations in the annual increments of basal areas and patterns of inter-ring variation of CNE contents in the 16 provenances allowed us to identify and select, by transfer models, origins of seed with higher productivity and drought resilience. With these results an appropriate program for assisted migration of Australian Red Cedar populations is proposed, taking into consideration precipitation of the areas of origin and destination sites in Brazil.

\section{Simulation study of Leaf Litter on natural seedling regeneration in Toona ciliata var. pubescens}

Lu Zhang ${ }^{1}$, Xiaoyan Guo ${ }^{1}$, Shenggui Yuan ${ }^{1}$, Qiangqiang Cheng ${ }^{1}$

${ }^{1}$ Jiangxi Agricultural University, Nanchang, China (zhlu856@163.com; guoxiaoyan1970@126.com; 1686524177@qq.com; 271374945@qq.com)

The mechanism of litter on seedling formation limitation of $T$. ciliata var. pubescens was discussed. The results showed that the effect of litter on seed germination and seedling establishment varies because of its different position and thickness. Litter thickness $\geq 2 \mathrm{~cm}$ has a significant negative effect on seedling regeneration of $T$. ciliata var. pubescens. Leaching liquor of forest litter, fallen leaves and decomposed fallen leaves of $T$. ciliata var. pubescens. have allelopathic effects on seed germination and seedling growth. The allelopathic effect is concentration dependent. It showed inhibitory effect on seed germination. Low concentration ( $10 \mathrm{~g} \cdot \mathrm{L}-1$ leaching solution of the decaying leaves and the humus (decomposed for 3 months) had a promoting effect on seedling growth. Forest litter $\geq 38 \mathrm{~g} \bullet \mathrm{L}-1$, fallen leaves $\geq 10 \mathrm{~g} \bullet \mathrm{L}-1$, decaying leaves $1000 \mathrm{~g} \cdot \mathrm{L}-1$ all had inhibitory effect on seedling root growth. Alcohols, phenols and ketonesin in water extracts of fallen leaves may be allelopathic constituents. Derivatives of benzoic acid may be the main allelochemicals in the humus. The weak polar components of leaching solution of the decaying leaves is mainly sterols, fatty acids and their esters. Leaf litter of $T$. ciliata var. pubescens in decomposition 
process had inhibitory effect on seed germination and seedling early growth. The litter amount $\geq 30 \mathrm{~g} /$ Basin has a significant negative impact on seedling early growth, mainly affecting the growth of roots. But with the continuous decomposition of litter and the growth of seedlings, the inhibition of leaf litter was relieved and changed to promote the growth of seedlings.

\section{Genetic diversity of Chukrasia spp}

Chong $\mathrm{Wu}^{1,2}$, Chonglu Zhong ${ }^{1}$, Khongsak Pinyopusarerk ${ }^{3}$

${ }^{1}$ Research Institute of Tropical Forestry, Chinese Academy of Forestry, Guangzhou, China; ${ }^{2}$ Shandong Institute of Pomology, Shandong Academy of Agricultural Science, Tai'an, China; ${ }^{3}$ National Research Collections Australia National Research Collections Aust(wuchongge@163.com; zclritf@126.com, khongsak.pinyopusarerk@csiro.au)

There are different views as to whether the genus Chukrasia (Meliaceae) consists of one species, C. tabularis, or two species C. tabularis and C. velutina. Despite a clear pattern of variation in many morphological characteristics such as leaves and bark, some authors regard the latter merely an ecotype of the former in seasonal forest. In the present study, ISSR markers were used to determine the genetic diversity and population structure among 23 Chukrasia subpopulations from across the natural range in Asia. Molecular analysis clearly differentiated two distinct groups of subpopulations, corresponding to the putative species, as well as well-defined subpopulations corresponding to geographic regions within the two groups. The molecular results are in concordance with morphological differentiation and corresponded to the two recognized taxa. The study has demonstrated that ISSR markers can be used to characterize the genetic diversity and genetic relationships among Chukrasia populations from within their natural range. We have shown that Chukrasia populations are strongly structured. Firstly, the populations can be apportioned to the two highly distinct groups consistent with morphological characterization for $C$. tabularis and $C$. velutina. Secondly, there are strong affinities among populations within countries. The present study suggests that the current taxonomic classification of the genus Chukrasia should be reviewed. The results also have implications in the design of conservation strategies of biodiversity: it is probable that gene conservation stands for the two main taxonomic groups should be managed separately.

Effect of planting density on biocide plants in different agroforestry arrangements involving Swietenia macrophylla and Theobroma cacao to control Hypsipyla grandella Zéller / Efecto de la densidad de siembra de plantas biocidas en diferentes arreglos agroforestales con Swietenia macrophylla y Theobroma cacao para el control de Hypsipyla grandella Zéller

Héctor Guerra-Arévalo ${ }^{1}$, Diego Celis Espinoza ${ }^{2}$, Ana Lucia Milagros Vásquez Vela ${ }^{3}$, Luís Alberto Arévalo López ${ }^{1}$, Wilson Franciso Guerra Arévalo ${ }^{1}$ Enrique Arévalo-Gardini ${ }^{3}$, Carlos Abanto-Rodriguez ${ }^{1}$

${ }^{1}$ Instituto de Investigaciones de la Amazonia Peruana, San Martin, Peru; ${ }^{2}$ Universidad Nacional de San Martin-Tarapoto, San Martin, Peru; ${ }^{3}$ Instituto de Cultivos Tropicales,San Martin,Peru(hguerra@iiap.org.pe; mgdiego159@gmail.com; analuciava.2012@gmail.com; larevalol@iiap.org.pe;

wguerra@iiap.org.pe; enriquearevaloga@gmail.com;cabanto@iiap.org.pe)

Con el objetivo de evaluar el efecto de la densidad de siembra de plantas de Azadirachta indica - AI y Jatropha curcas - JC en diferentes arreglos agroforestales con Swietenia macrophylla - SM con Theobroma cacao - TC para el control de Hypsipyla grandella, fue ejecutado un DBCA, con 03 bloques, 05 tratamientos conformados por la asociación agroforestal con 2 plantas biocidas y 2 densidades de siembra, siendo T1: SM + TC (testigo); T2: SM + TC + AI (1 x 3 m); T3: SM + TC + AI (1 x 1 m); T4: SM + TC + JC (1 x 3 m); y T5: SM + TC + JC (1 x 1 m). Se emplearon mallas con $80 \%$ de sombra usado para revestir los tratamientos y asegurar la infestación de la plaga (10 pares de insectos hembras y machos). El análisis de varianza para las variables evaluadas infestación de la plaga (\%), número de infestaciones $\left(\mathrm{n}^{\circ}\right)$ y sobrevivencia de larvas $(\%)$ fueron altamente significativas $(\mathrm{p} \leq 0.001)$. Las comparaciones de medias Tukey indican que los tratamientos 3 y 5 fueron similares estadísticamente $(\mathrm{p} \leq 0.05)$ reduciendo las infestaciones en $0.95 \%$ y $2.86 \%$ respectivamente en comparación con $\mathrm{T} 4=13.33 \%, \mathrm{~T} 2=16.67 \%$ y T1 $=46.67 \%$. Se concluye, que a mayor densidad de siembra de plantas biocidas se reduce significativamente ( $\leq 0.05)$ el porcentaje de infestación de $H$. grandella en las plantas de $S$. macrophylla. Dado que en los primeros años el umbral de daño causado por la plaga (H. grandella) es perjudicial para su desarrollo, es importante considerar estos resultados para reducir la afectación de la plaga y asegurar la sostenibilidad en el manejo de la especie.

\section{Preference of Hypsipyla grandella Zeller (Lepidoptera: Pyralidae) for Cedrela odorata L. vs. Swietenia macrophylla King and relation to host growth in Colombia}

\section{John Alexander Pulgarín Díaz ${ }^{1}$ (D); Verónica Cañas Mesa ${ }^{2}$ (D); Ángela María Arcila Cardona ${ }^{3}$ (D)}

${ }^{1}$ Corporación Colombiana de Investigación Agropecuaria - AGROSAVIA. Centro de Investigación El Nus - Vereda Ica, Corregimiento San José del Nus, San Roque, Antioquia, Colombia; ${ }^{2}$ Universidade Federal de Viçosa, Viçosa, Brasil; ${ }^{3}$ Corporación Colombiana de In (jpulgarin@agrosavia.co; vcanasm@unal.edu.co; aarcila@agrosavia.co)

Hypsipyla grandella, the mahogany shoot borer, attacks up to $100 \%$ of Cedrela odorata and Swietenia macrophylla individuals in forest plantations, what prevents its cultivation. Preference for one of the species has been reported in different ways and strength. Hypsipyla grandella preference for the mentioned hosts and their growth was evaluated in three Cedrela odorata and four Swietenia macrophylla permanent plots of 36 individuals each. Plots were established in October 2013 and assessed until 4.9 years old, with a total of 15 evaluations. Survival was 98.6\% in Swietenia macrophylla and 94.1\% in Cedrela odorata. Host preference was not detected considering the complete data pool (proportion of attacked trees: Cedrela odorata 16.6\%, Swietenia macrophylla 17.5\%), but preference for $S$. macrophylla was found in three evaluations and for $C$. odorata in one. The proportion of attacked individuals changed over time in each host and maximum attack peaks coincided between hosts. Mean annual increment (MAI) in height (H) and in diameter at breast height (DBH) decreased in time for both hosts. In the period 2.3-4.9 yrs, a significant monotonic relationship (Spearman rs) between the proportion of attacked individuals of Cedrela odorata and $\mathrm{H}(-0.81)$ and DBH (-0.83) was found, and between the proportion of attacked individuals of Swietenia macrophylla and IMA-DBH (-0.78). Switches in preference could be due to host phenological changes and related to environmental changes. Such preferences could generate intraspecific differences and effects on growth, survival, and reproduction of offspring. The proportion of attacked individuals affects negatively the growth of both hosts. 


\section{Morphometric variability of Hypsipyla grandella Zeller (Lepidoptera: Pyralidae) in two hosts (Swietenia macrophylla King and Cedrela odorata L.)}

Verónica Cañas Mesa ${ }^{1}$ (D); John Alexander Pulgarín Díaz ${ }^{2}$; Edna Judith Márquez ${ }^{3}$

${ }^{1}$ Universidade Federal de Viçosa, Viçosa, Brasil; ${ }^{2}$ Corporación Colombiana de Investigación Agropecuaria, Centro de Investigación El Nus - Vereda Ica, Corregimiento San José del Nus, San Roque, Antioquia, Colombia; ${ }^{3}$ Universidad Nacional de Colombia, Medellin, Colombia(vcanasm@unal.edu.co; jpulgarin@agrosavia.co; ejmarque@unal.edu.co)

Hypsipyla grandella, the mahogany shoot borer, affects considerably plantations of different Meliaceae species, being the main limitation for its establishment. Hypsipyla grandella has been documented with greater preference for Cedrela odorata vs. Swietenia macrophylla, on some occasions, which could generate intraspecific variations on wing size and shape. We studied the effect of those two hosts on $\mathrm{H}$. grandella phenotypic variation. Larvae were collected in adjacent plantations of each host, in a humid tropical forest (Antioquia, Colombia) and raised in the respective host seedlings. Geometric morphometrics tools were used with 63 right-anterior wings based on 13 landmarks. Wings were larger in individuals collected in Cedrela odorata, some occasions the preferred host. Sexual shape dimorphism was significant in terms of direction (even removing allometric effects); therefore only same-sex individuals were compared between hosts. There were no differences in the wing shape by sexes when comparing between hosts but allometric effects were present. Removing the allometric effect and comparing males between hosts shape differences were found, indicating that the larval food source influences wing shape in males but not in females. When comparing each sex between hosts (i.e. males of Cedrela odorata vs males in Swietenia macrophylla), there were no differences in magnitude and direction of plastic responses, even removing allometric effects. This is the first work showing sexual shape dimorphism and that hosts influence phenotypic changes in Hypsipyla grandella wings.

\section{C1c: IMPROVING HIGH-VALUE MELIACEAE YIELDS IN PLANTATIONS}

\section{Thinning effects on plantation grown African mahogany}

Antonio Carlos Ferraz Filho ${ }^{1}$, Andressa Ribeiro ${ }^{1}$, Raphael Valle Cruz ${ }^{2}$

${ }^{1}$ Universidade Federal do Piaui, Bom Jesus, Brasil; '2KhayaWoods Group, Belo Horizonte, Brasil (acferrazfilho@ufpi.edu.br; andressa.florestal@ufpi.edu.br; raphacruz@yahoo.com.br)

Thinning is the partial removal of trees from a stand, with the objective of reducing completion and increase the growth of the remaining trees. The objective of this work is to describe how thinning affects the growth of Khaya sp. plantations located in Nova Porteirinha, Minas Gerais, Brazil. The stands belong to Khaya Woods Group, were installed with 6 x 4 m spacing and thinned around age 8. Seven permanent sample plots were analyzed, using two measurements before (2015 and 2016) and two after (2017 and 2018) thinning in 2017. One plot was unthinned and used as a control. We evaluated the effect of thinning in stand (mean annual increment in volume per hectare, MAIv) and tree level (mean annual diameter growth, id) characteristics. The mean stand characteristics at the time of thinning were: $\mathrm{dbh}=20.2 \mathrm{~cm}$; height $=17.7 \mathrm{~m}$; basal area $=14.1 \mathrm{~m}^{2} / \mathrm{ha}$; volume $=127 \mathrm{~m}^{3} / \mathrm{ha}$; trees per hectare $($ tph $)=408 \mathrm{~N} / \mathrm{ha}$. Thinning was carried out from below, removing $17 \mathrm{~m}^{3} / \mathrm{ha}$ (15\% reduction) and $91.1 \mathrm{tph}(22.6 \%$ reduction). The unthinned plot presented higher MAIvone year after thinning $\left(22.5 \mathrm{~m}^{3} /\right.$ ha.year) than the thinned plots $\left(12.6 \mathrm{~m}^{3} / \mathrm{ha}\right.$.year), due to the larger number of tph. Contrary to the stand variable, id of unthinned trees averaged 1.15 ; 1.67 and $0.68 \mathrm{~cm} /$ year for plots one year before, one year after thinning and unthinned, respectively. Id increased by $88 \%$ one year after thinning, and decreased $57 \%$ in the unthinned plot. We found that plots with id lower than $1.2 \mathrm{~cm} /$ year one year before thinning were able to better increase the post thinning growth rate, with one case increasing the idby $250 \%$.

\section{Seed source variation for growth and stem-form characteristics of Khaya senagalensis and its improvement program in Sri Lanka}

Bandara K. M. A. ${ }^{1}$, Arnold R. J. ${ }^{2}$

${ }^{1}$ Forest Department, Nuwara Eliya, Sri Lanka; ${ }^{2}$ China Eucalypt Research Centre, Zhanjiang, China (abandara15@hotmail.com; rogerarnold@y 9 mail.com)

Khaya senagalensis is an important commercial plantation tree species in Sri Lanka. Genetic improvement of this species was initiated with the establishment of two large provenance trials in the country's intermediate rainfall zone in 2008. These trials included 3 Sri Lankan land race and 21 natural stand sources from sub-Saharan Africa. Both trials were assessed for height and survival at 2 years of age and then diameter at breast height, total height, merchantable height, axis persistence and stem-form traits at age 6 years. For each individual tree, the standardized value of merchantable volume and straightness were used to calculate a merchantable value index (MerVal). Coefficients of variation were calculated for economically important traits to enable to assess the within seed source phenotypic variability. Significant differences were found between seed sources for all traits at both sites. Significant differences were also found among seed sources in the one trial that had remained unthinned for within seed source variability. The best seed sources (based on Merval)at the site that was unthinned included two from Burkina Faso, one from Senegal and one from Sri Lanka; while for the other site that was selectively thinned at age 5 years included two from Senegal, one from Burkina Faso and one from Mali. The selected seed sources can be used for immediate seed requirements for the Sri Lankan plantation program, while greater benefit will be achieved through plus tree selection within this breeding population, and associated clonal seed orchard development.

Possibilities and limitations for production of mahogany wood (Swietenia and Khaya) in mixed and multiple-age-class stands within successional agroforests in southern Bahia, Brazil / Possibilidades e limitações para a produção de madeiras de mogno (Khaya e Swietenia) em stands mistos e inequiâneos de agroflorestas sucessionais no sul da Bahia (Brasil)

Gilberto Terra1, Felipe Martini Santos ${ }^{2}$, Guilherme Chaer ${ }^{3}$

${ }^{1}$ Sucupira Agroflorestas, Valença, Brasil; ${ }^{2}$ Universidade Federal Rural do Rio de Janeiro, Seropédica, Brasil; ${ }^{3}$ Embrapa Agrobiologia, Seropédica, Brasil (gilbertoterra@gmail.com; martinisantos@gmail.com;gmchaer@gmail.com)

A produção de madeira de mognos na fazenda Sucupira (Valença - BA, Brasil) é realizada em agroflorestas sucessionais e do tipo "Cabruca", associada à produção de frutas, especiarias e outras madeiras nativas. O stand inicial de madeireiras é misto e inequiâneo, composto por pelo menos 5 espécies de 3 diferentes rotações. Após a realização de plantios experimentais com 8 espécies de Meliaceae, foram selecionadas duas espécies de Khayas $(K$. ivorensis e $K$. anthotheca) e o mogno amazônico (Swietenia macrophylla) para compor a primeira e a segunda rotações, respectivamente. As diferenças ecofisiológicas e silviculturais entre as duas espécies de Khaya e entre estas e o mogno amazônico são utilizadas para ocupar com mais eficiência os diferentes ambientes das agroflorestas. Em geral, sob as mesmas condições, S. macrophylla tem desempenho produtivo inferior às Khayas e é mais vulnerável ao ataque da broca do 
ponteiro (Hypsipyla grandella). O mogno com maior incremento volumétrico é $K$. anthotheca, seguido de $K$. ivorensis e S. macrophylla. A melhor forma de fuste é observada em $K$. ivorensis, seja sob sombreamento (ca; 50\% de sombra) ou a sol pleno. O ataque da Hypsipyla grandella foi registrado em 3 espécies de Khaya, tanto em tecidos vegetativos quanto nos frutos. Em alguns talhões há mais de $50 \%$ das plantas de Khaya ivorensis e $K$. anthotheca atacadas pela broca. Evidências de campo apontam para a possibilidade de haver uma relação entre oferta de nitrogênio no solo e susceptibilidade ao ataque de Hypsipyla grandella em K. ivorensis, K. anthotheca e S. macrophylla.

\section{The present and future of Khaya in Brazil}

Andressa Ribeiro ${ }^{1}$, Antonio Carlos Ferraz Filho ${ }^{1}$

${ }^{1}$ Universidade Federal do Piauí, Bom Jesus, Brasil (andressa.florestal@ufpi.edu.br; acferrazfilho@ufpi.edu.br)

The wood of the genus Khaya is commercialized since the end of the 20th century. In Brazil its cultivation is recent, the oldest individuals located in the state of Pará are about to become 40-years-old. The objective of this work is to characterize the management of African mahogany, elucidating the growth and market possibilities in the country. It is estimated that a total of 38,000 hectares are planted with the main species of the genus (K. grandifolia, K. senegalensis, $K$. ivorensis and $K$. anthotheca) concentrated in the Southeast region. In general the plantations are implanted using wide spacings (ranging from $4 \times 4$ to $12 \mathrm{x} 12 \mathrm{~m}$, commonly around $36 \mathrm{~m} 2$ per plant), with intensified silvicultural treatments and in some places with irrigation system (rainfall $<1000 \mathrm{~mm}$ ). We monitor plantations located in the states of Minas Gerais, Goiás, Sergipe, Mato Grosso and Pará. These plantations have ages ranging from 2 to 15 years, with an average diameter of 4 to $49 \mathrm{~cm}$ and an average height of 3 to $26 \mathrm{~m}$. Some plantations have begun the first thinning ( 8 to 12 years of age) and the wood was successfully commercialized. The insertion of African mahogany wood of Brazilian origin in the timber market is expected to be a success. Producers associations (such as the ABPMA) are an important tool for the feasibility of the enterprise, as they promote sustainability of the production cycle, guaranteeing the supply of material that meets markets demand, strengthening the individual producers in negotiation processes and visibility of the wood.

State of the art in genetic improvement of Australian cedar (Toona ciliata M. Roemer var. australis) for cultivation in the bioclimatic conditions of Brazil / Estado da arte do melhoramento genético do cedro australiano (Toona ciliata M. Roemer Var. australis) para cultivo em condições bioclimáticas brasileiras

Sebastião C Rosado ${ }^{1}$, Eduardo de Castro Stehling ${ }^{2}$, Lucas R Rosado ${ }^{1}$

${ }^{1}$ Federal University of Lavras, Lavras, Brasil; ${ }^{2}$ Fuste Consultoria, Campo Belo - MG, Brasil (scrosado@dcf.ufla.br; fusteconsultoria@gmail.com; lucasrosado@yahoo.com.br)

O cedro australiano é uma meliaceae exótica que, quando cultivada no Brasil, se destaca por três razões básicas: estar em áreas de escape de sua broca dos ponteiros, a Hypsipyla robusta; ser resistente à broca dos cedros brasileiro e mogno, a Hypsipyla grandella e pela produção de toras de alta qualidade a partir de fustes com crescimento monopodial e com forte dominância apical, que conferem alto rendimento no processamento primário da madeira. Entretanto, os cultivos realizados no passado apresentaram baixa produtividade em decorrência, principalmente, do uso materiais de propagação de baixa qualidade e de origem genética desconhecida. Hoje, a solução desses problemas está acontecendo, principalmente,pela implantação de um programa de melhoramento genético específico para as condições brasileiras e fundamentado na migração assistida de 16 origens de sementes da costa leste da Austrália, com ocorrência natural entre as latitudes de $12^{\circ} 33^{\prime}$ 'S (Pascoe River - QLD) e 34³8'S (Kangaroo Valley - NSW). As estimativas dos parâmetros genéticos e a predição dos valores genotípicos conduzidos em níveis de indivíduos dentro progênies e dentro de procedências permitiram selecionar genótipos promissores para o melhoramento que, em etapas posteriores, foram incluídos em testes clonais e cultivados experimental em escala reduzida. Esse trabalho permitiu a seleção de clones para cultivo em várias regiões do Brasil e apresentam uma produtividade média superior a $30 \mathrm{~m}^{3}$.ha.ano. Adicionalmente foram selecionadas duas árvores por origem perfazendo um total de 32 genitores que, por cruzamentos controlados, possibilitarão a constituição das gerações avançadas de melhoramento.

Biografting in Meliaceae and its role in controlling Hypsipyla grandella Zéller / Bioinjertación en meliáceas y su papel en el control de Hypsipyla grandella Zéller

Wilson Francisco Guerra Arevalo ${ }^{1}$, Hector Guerra Arevalo ${ }^{2}$, Carlos Abanto-Rodriguez ${ }^{1}$

${ }^{1}$ Instituto de investigaciones de la amazonia peruana, Pucallpa, Peru; ${ }^{2}$ Instituto de investigaciones de la amazonia peruana, Tarapoto, Peru (wguerra@iiap.org.pe; hguerra@iiap.org.pe; cabanto@iiap.org.pe)

La bioinjertación es una herramienta muy valiosa para mejoramiento genético de especies agroforestales, ayuda a controlar la presencia de plagas, debido a las propiedades fotoquímicas trasferidas desde los patrones hacia los injertos. En meliáceas existen especies como el nim (Azadirachta indica) que no es atacado por Hypsipyla grandella y puede utilizarse como patrón para injertos de cedro (Cedrela odorata) y caoba (Swietenia macrophylla) susceptibles al ataque de la plaga. El presente trabajo pretende estudiar el efecto compatible de especies meliáceas (Nim, cedro y caoba) en el prendimiento y ataque de Hypsipyla grandella en condiciones controladas. El experimento fue establecido bajo DCA, con 03 repeticiones, 06 tratamientos y 10 plantas como unidad experimental. Los tratamientos fueron constituidos por 06 combinaciones de diferentes relaciones de patrones/injertos tal como sigue: T1: nim/cedro; T2: nim/caoba; T3: cedro/ caoba; T4: caoba/cedro; T5: cedro/nim y T6: caoba/nim; con técnica "púa central". Las variables evaluadas: prendimiento (\%), número de chupones, número de foliolos por injerto, y longitud del brote. Los resultados indican que los tratamientos influyeron significativamente ( $\mathrm{p} \leq 0.05)$ en el porcentaje de prendimiento de plantas injertadas. Las pruebas de medias Tukey reflejaron que el tratamiento T2 presentó un alto porcentaje de prendimiento ( $90 \%$ ), seguidamente el tratamiento T4 con 73.3\%, alto, comparado a otros tratamientos. Se concluye que, para obtener un alto porcentaje de prendimiento emplear patrones de nim e injertos de caoba, ya que son altamente compatibles, además mejoraron positivamente la resistencia de la planta reduciendo el ataque de $H$. grandella.

Dasymetric modeling of Khaya nyasica Stapf ex Baker $f$ in plantations: a corporate case study for conservation in Cienaga de Zapata / Modelación dasométrica de Khaya nyasica Stapf ex Baker fen plantaciones: caso de estudio Empresa para la Conservación de la Ciénaga de Zapata

Héctor Barrero medel ${ }^{1}$, Giraldo Cirilo Fagundo Abreu², Germán Padilla Torres ${ }^{1}$

${ }^{1}$ Univeridad de Pinar del Rio, Pinar del Río, Cuba; ${ }^{2}$ Empresa para la Conservación de la Ciénaga de Zapata, Jaguey Grande, Cuba (hbarrero@upr.edu.cu; silvicultura@eficz.co.cu; odelyn@upr.edu.cu)

Este trabajo tuvo como objetivo definir modelos dasométricos para K. nyasica en las Unidades Silvícolas “ Jagüey Grande y Calimete" de la Empresa para la Conservación de la Ciénaga de Zapata de la provincia Matanzas. Para el estudio se establecieron parcelas rectangulares de $1000 \mathrm{~m}^{2}$ ubicadas al azar en diferentes edades de cada rodal, siendo 101 temporales y 5 permanentes; para la modelación estadística se empleó el procedimiento de Redes Neuronales Artificiales 
(RNAs) así como la regresión lineal, en correspondencia con la tendencia que siguieron las variables dasométricas. Resultando un sistema de curvas de índices de sitio para los valores 12, 16, 20, 24, 28 y $32 \mathrm{~m}$ a la edad de 22 años determinadas por el valor de la altura dominante, una función de probabilidad de densidad de Weibull que garantiza la predicción de la distribución por clases diamétricas en función de las variables dasométricas diámetro medio y edad, un turno de corta de 25-30 años de edad, así como la demostración del empleo de RNA como una herramienta estadística eficiente en la modelación forestal.

Symptoms of nutritional deficiency in mahogany plants (Swietenia macrophylla King) under controlled conditions / Sintomatología en plantas de caoba (Swietenia macrophylla King) expresada por deficiencia nutricional en condiciones controladas

Héctor Guerra-Arévalo ${ }^{1}$, Rubi Salas Guerra², Ana Lucia Milagros Vásquez Vela ${ }^{3}$, Alfredo Rodriguez Delfin ${ }^{4}$, Luís Alberto Arévalo López ${ }^{1}$, Wilson Francisco Guerra Arévalo ${ }^{5}$, Oscar Oswaldo Loli Figueroa ${ }^{4}$, Carlos Abanto-Rodriguez ${ }^{5}$

${ }^{1}$ Instituto de Investigaciones de la Amazonia Peruana, San Martin, Peru; ${ }^{2}$ Universidad Nacional de la Amazonia Peruana, Iquitos, Peru; ${ }^{3}$ Instituto de Cultivos Tropicales, San Martin, Peru; ${ }^{4}$ Universidad Nacional Agraria La Molina, Lima, Peru; ${ }^{5}$ Instituto de Investigaciones de la Amazonia Peruana, Ucayali,Peru(hguerra@iiap.org.pe; rusague_18@outlook.com; analuciava.2012@gmail.com; delfin@lamolina.edu.pe; larevalol@iiap.org.pe; wguerra@iiap.org.pe; ololi@lamolina.edu.pe; ololi@lamolina.edu.pe)

Swietenia macrophylla King es una especie maderable de alto valor comercial, que presenta problemas en condiciones de vivero y campo debido a la deficiencia nutricional y sanidad; por ello, el objetivo fue evaluar la sintomatología expresada de Swietenia macrophylla por la deficiencia de un elemento faltante de macro y micro-elementos en condiciones controladas, desarrollado bajo un DCA, con 4 repeticiones, 13 tratamientos (N, P, K, Ca, Mg, S, Fe, Mn, B, Mo, Zn, Cu y un control) y 8 plantas por unidad experimental. Las evaluaciones fueron: [1] síntomas basados en el color de la hoja, [2] forma y estado de las hojas, y [3] tallos y puntos de crecimiento. La ausencia de Fe y N influyeron $(\mathrm{p} \leq 0.05)$ sobre todas las variables sintomatológicas, siendo esencial para el desarrollo y sanidad de las plantas. La ausencia de N, K, Ca, Mg, S, Fe, Mn, B y Mo mostraron síntomas cloróticos en las hojas, asimismo, la ausencia de P, K, Ca, Mg, S, Fe, Mn, B y Mo influyeron $(\mathrm{p} \leq 0.05)$ en la presencia de puntos de crecimiento. La ausencia de N presentó un crecimiento muy lento comparativamente. En conclusión la ausencia de Fe y N fueron los elementos más esencial en el crecimiento y desarrollo de las plantas de $S$. macrophylla, esto se logró evidenciar al observar la clorosis en las hojas, menor desarrollo en el diámetro y altura total de las plantas, muerte de los tejidos meristemáticos secundarios y malformación del tallo.

C1d: MIXED-SPECIES FORESTS AND PLANTATIONS: KNOWLEDGE GAPS AND RESEARCH
PRIORITIES

\section{Mixed-species forest stands: from understanding to design}

Hans Pretzsch ${ }^{1}$

${ }^{1}$ Chair for Forest Growth and Yield Science, Center of Life and Food Sciences Weihenstephan, Technical University of Munich, Freising, Germany (hans. pretzsch@lrz.tum.de)

Firstly, this talk will give an overview of the species interactions and growth reactions in mixed-species stands. Species mixing may result in an overyielding of $20-30 \%$ and provide more stabilized growth compared to mono-specific stands. The mixing reactions can be traced from the stand to the tree and organ level, and reveal results primarily from complementarity and facilitation caused by species specific functional traits. The second part of the presentation will deal with the design of forest stands based on functional traits, utilizing models, which integrate existing knowledge on process and structures into forest systems. Exemplary scenario analyses for the transformation of monocultures to mixed species forest stands and management diagrams for mixed stands will be introduced. Their development requires stand simulation models, which consider the functional ecology of tree species. Thirdly, the next steps for research and implementation will be discussed: Mixed-species experiments for a better understanding of species behaviour in inter-specific environments, models for scenario analyses, and guidelines for complex forest stands. The results are based on the EU funded projects REFORM (Mixed species forest management. Lowering risk, increasing resilience \# 2816ERA02S) and COST CLIMO (Climate-Smart Forestry in Mountain Regions \# CA 15226)

\section{Assessing competition in multi-species stands \\ Jerry Vanclay ${ }^{1}$ \\ ${ }^{1}$ Southern Cross University, Lismore NSW, Australia (jerry.vanclay@scu.edu.au)}

There are few guidelines for the design of mixtures or ways to make efficient prognoses of their performance. Many studies examine pairwise mixtures, but few publications deal with rich mixtures. Nonetheless, insights from pairwise experiments offer useful insights. This presentation examines a planting of 16 diverse species, replicated in 25 randomized blocks. The trial was established in 1991, and has been measured regularly for 25 years, during which time competition and mortality trends have become evident. Hegyi indices were computed for each tree for each measurement interval. In addition to the conventional Hegyi index summing all competitors, partial indices were computed for each species group. Analyses reveal a wide spectrum of competition responses that correlate roughly with the successional status of species (i.e., light-demanding versus shade-tolerant). These trends emerge more clearly in pairwise analyses, and range from facilitation to strong competitors, and the observed trends of all 16 species align with independent prior observations of successional status. This correlation suggests the possibility to calibrate species interactions from empirical trials, and the ability to predict responses without trials for species of known silvics. This trial of 16 species indicates a spectrum of species interaction responses, and suggests that the spectrum is closely aligned with the successional status of the species. If this alignment is confirmed for other species and other trials, it would suggest a way to calibrate species interactions for simulation models, and to predict responses of species with known silvics but for which no trials are available for analysis.

\section{Mode of competition in mixed versus pure stands: does it change over time and environmental conditions?}

Andrés Bravo-Oviedo ${ }^{1,2}$, Miren del Río ${ }^{3,4}$, Hans Pretzsch ${ }^{5}$

${ }^{1}$ MNCN-CSIC, Department of Biogeography and Global Change, Madrid, Spain; ${ }^{2}$ Sustainable Forest Management Research Institute - IUFOR, Palencia, Spain; ${ }^{3}$ INIA-CIFOR, Madrid, Spain; ${ }^{4}$ Sustainable Forest Management Research Institute - iuFOR, Madrid, Spain; ${ }^{5}$ Chair of Forest Growth and Yield Science, Technische Universität München, Munich, Germany(bravo@mncn.csic.es; delrio@inia.es; hans.pretzsch@lrz.tu-muenchen.de)

Mixed forests are considered more productive, resilient and resistance to perturbations than monospecific stands. Mechanisms explaining this outperformance are usually related to complementary use of resources over time. However, the identification of the type of competition for resources in mixed versus pure 
stands remain rather limited. Competition for resources can be proportional to the size trees (symmetric competition) or more than proportional (asymmetric competition). It is hypothesized that in dry and nutrient-limited conditions competition is symmetric whereas in milder situations competition is asymmetric. In this presentation we investigate the mode of competition (asymmetry versus symmetry) in mixed versus pure stands of European beech and Scots pine. Data from a transect of triplets of both species across Europe was used. A triplet is a set of three plots representing two pure stands and one mixed stand of the corresponding species. Mixing effects, i.e. if the mode of competition of species growing in mixtures differs from that found in pure stands, and modifications of the mode of competition due to changing environmental conditions are assessed using size-growth relationships. Our hypothesis is that symmetric competition is dominant in dry years whereas the strength of the competition is modulated by mixing effects. First results indicated that the mode of competition is sitespecific with divergent mixing effects across Europe.

\section{Complementarity in mixed stands of Norway spruce (Picea abies L. Karst) and European Larch (Larix decidua Mill.): the contribution of stand characteristics}

Hubert Sterba ${ }^{1}$ (D; Gerald Dirnberger ${ }^{1}$ (D; Tim Ritter $^{1}$ (D)

${ }^{1}$ University of Natural Resources and Life Sciences, Vienna, Austria (hubert.sterba@boku.ac.at; gerald.dirnberger@boku.ac.at; tim.ritter@boku.ac.at)

Interactions between complementarity and stand and site characteristics have been found in many investigations. However, mixed stands of Norway spruce and European larch are among the least-investigated mixture types. Twelve plots, sized between 0.25 ha and 1.6 ha, were established within stands of varying age and proportion of European larch and Norway spruce, at altitudes between approximately 880 and $1330 \mathrm{~m}$ above sea level located in the northern part of the eastern intermediate Alps in Austria. Tree coordinates, diameter at breast height, tree height, crown height, and crown projection area were measured for all trees within the plots. All trees were cored at breast height, and from a sub-sample of about 200 felled trees, equations for leaf area and for the five-year volume increment were developed. We found a clear interaction between age and the volume increment of a species per its fraction of the stand area (growth efficiency). In mixed young stands, the growth efficiency of both species was less than the reference from the pure stands, while in the older stands especially spruce had a much higher growth efficiency in the mixed stands. Furthermore, we found that the Clark Evans index (i) explained more variance than the species proportion and (ii) revealed an additional influence of stand density on the complementarity of the species.

\section{Fine-root soil exploration and exploitation in mixed and monospecific forest stands across Europe}

Janna Wambsganss' ${ }^{1}$, Friderike Beyer ${ }^{1}$, Gregoire Freschet ${ }^{2}$, Michael Scherer-Lorenzen ${ }^{3}$, Jürgen Bauhus ${ }^{1}$

${ }^{1}$ Chair of Silviculture, University of Freiburg, Freiburg, Germany; ${ }^{2}$ Centre d'Ecologie Fonctionnelle et Evolutive, Montpellier, France; ${ }^{3}$ Institute of Geobotany, University of Freiburg, Freiburg, Germany (janna.wambsganss@waldbau.uni-freiburg.de; friderike.beyer@waldbau.uni-freiburg.de; gregoire.freschet@cefe.cnrs.fr; michael.scherer@biologie.uni-freiburg.de; juergen.bauhus@waldbau.uni-freiburg.de)

Mixed-species forests have often been shown to enhance above-ground ecosystem properties and functions. Despite the significance of fine roots for tree and ecosystem functioning, the role of tree species diversity for below-ground functions driven by fine roots such as nutrient exploitation remains largely unknown. Therefore, the objective of this study was to assess the effect of tree species diversity on fine-root soil exploration and exploitation for 13 different tree species along an environmental gradient at four study sites in Finland, Poland, Romania and Italy. We hypothesized that: (1) owing to niche differentiation among species, the overall exploration and exploitation of soil volume by fine roots would be higher in mixed species stands than in monospecific stands; (2) such complementarity effects would be greater at sites with less favorable environmental conditions such as soil water availability and nutrient status. Soil cores were taken at the level of tree neighborhoods in mature tree species mixtures consisting of three tree species and corresponding monospecific stands in four major European forest types. Morphological, architectural and chemical fine-root traits were measured, in addition to total fine-root biomass. Roots were sorted by species and a functional classification approach was applied to distinguish absorptive from transport fine roots by root order. Initial results show effects of different tree species diversity levels on the measured fine-root traits. If corroborated by further analyses, such changes in fine-root traits related to soil exploration and exploitation could indicate enhanced resource uptake in mixtures and thereby positive effects on overall ecosystem functioning.

\section{Did belowground $\mathbf{N}$ transfer in mixed plantations of Acacia mangium and Eucalyptus meet the Stress Gradient Hypothesis?}

Ivanka Rosada de Oliveira ${ }^{1}$ (D, Ranieri Ribeiro Paula ${ }^{2}$, Bruno Bordron ${ }^{3}$, Alexandre Vicente Ferraz ${ }^{4}$, José Leonardo Moraes Gonçalves ${ }^{1}$, Iraê Amaral Guerrini ${ }^{5}$, Agnès Robin ${ }^{1,6}$, Jean-Pierre Bouillet ${ }^{1,6}$

${ }^{1}$ Escola Superior de Agricultura "Luiz de Queiroz", Universidade de São Paulo Piracicaba, Brasil;; ${ }^{2}$ Universidade Federal do Espírito Santo, Jerônimo Monteiro, Brasil; ${ }^{3}$ Embrapa Florestas, Colombo, Brasil; ${ }^{4}$ Instituto de Pesquisas e Estudos Florestais, Piracicaba, Brasil; ${ }^{5}$ Universidade Estadual Paulista Júlio de Mesquita Filho, Botucatu, Brasil ; ${ }^{6}$ CIRAD, Montpellier,France(ivanka.ivi@gmail.com, ranierirpaula@gmail.com; bruno.bordron@gmail.com; alexandre@ipef.br; jlmgonca@usp.br; iguerrini@fca.unesp.br; agnes.robin@cirad.fr; jean-pierre.bouillet@cirad.fr)

Belowground interactions in mixed forest plantations remain poorly understood as that of short-term nitrogen (N) transfer from $\mathrm{N}$-fixing trees to non-N-fixing trees (Non-NFT) depending on nutrient availability. We investigated if this facilitation process met the Stress Gradient Hypothesis, which predicts that under stressful environmental conditions competition decreases and facilitation increases. A $15 \mathrm{~N}$ pulse-labelling study was conducted in a five-year-old mixture of 50\% Eucalyptus grandis x E. urophylla and 50\% Acacia mangium with the hypothesis of higher $\mathrm{N}$ transfer from acacia when no fertilization was applied. A complete randomized block design was set up with three replicates of fertilized and non-fertilized mixture. In each treatment of each block, a labeled solution of potassium nitrate (98 atom\% 15N-NO3) was injected into the stem of an Acacia tree with the same basal area as the average of the stand. The $\mathrm{x}$ (15N) was monitored over two months in each labeled acacia and four neighboring eucalypts. For both species, young leaves and fine roots were sampled at 7, 14 and 30 days after injection. After 60 days, the $\mathrm{x}(15 \mathrm{~N})$ was determined in the wood, bark, branches, total foliage and fine rootsof the 6 labeled acacias and 12 eucalypts trees. The preliminary results showed that complete absorption of the labeled solution occurred between 28 and 60 days after labeling depending on Acacia trees and treatments. The dynamics in the proportion of Eucalyptus $\mathrm{N}$ derived from transfer will give insights into how this process may promote $\mathrm{N}$ nutrition of non-NFTs growing in unfertile tropical soils. 


\section{Tree diversity and fertilization effects on above- and belowground biomass productivity: outcomes from a young tree experiment}

Dai Saito ${ }^{1}$,Friderike Beyer ${ }^{1}$, Grégoire T. Freschet ${ }^{2}$, Charles Nock ${ }^{3}$, Michael Scherer-Lorenzen ${ }^{4}$, Jürgen Bauhus ${ }^{1}$

${ }^{1}$ Chair of Silviculture, Faculty of Environment and Natural Resources, University of Freiburg, Freiburg, Germany; ${ }^{2}$ Centre d'Ecologie Fonctionnelle et Evolutive, UMR ${ }^{5175}$ (CNRS - Université de Montpellier - Université Paul-Valéry Montpellier - EPHE), Montpellier, France; ${ }^{3}$ Department of Renewable Resources , Faculty of Agricultural, Life and Environmental Sciences, University of Alberta, Edmonton, Canada; ${ }^{4}$ Geobotany, Faculty of Biology, University of Freiburg,Freiburg, Germany (niyagisenndai@gmail.com; friderike.beyer@waldbau.uni-freiburg.de; gregoire.freschet@cefe.cnrs.fr; nock@ualberta.ca; michael.scherer@biologie.uni-freiburg.de; juergen.bauhus@waldbau.uni-freiburg.de)

There is substantial evidence that species diverse forests are more productive than monocultures. Selection and complementary effects have been proposed as the main drivers for overyielding; the former may be more predominant than the latter in early-successional communities. However, to date, the linkages between above- and belowground responses to species diversity has rarely been addressed. Additionally, little is known about how the diversity-productivity relationship changes along abiotic gradients, although declining diversity effects on productivity with increasing nutrient availability are often assumed. Moreover, despite recent calls for more mechanistic studies linking traits with ecosystem functions, few studies addressed root traits and belowground functions. Here we present results from a young tree diversity experiment established in 2013 in Freiburg, Germany. Tree seedlings of six European species representing a wide range of functional diversity were planted at high density with combinations of one, two and four species, in order to decouple species richness and functional diversity of communities. We also manipulated nutrient availability, using non-fertilized controls as well as a fertilization treatment with both $\mathrm{N}$ and P. For each community, we calculated aboveground stem and fine-root biomass and functional traits. This studyexplores the following hypotheses: 1) tree diversity in young tree communities promotes above- and belowground productivity mainly through the selection effect; 2) fertilization reduces belowground, but improves aboveground complementarity; 3) certain functional traits determine overyielding to a large degree, and in particular, traits of dominant species are important since the selection effect outweighs the complementary effect.

\section{Silviculture with native tree species - markets, viability and competitiveness}

Alan Batista ${ }^{1}$, Miguel Calmon ${ }^{1}$, Daniel Piotto ${ }^{2}$, Samir Rolim ${ }^{3}$

${ }^{1}$ WRI, São Paulo, Brasil; ${ }^{2}$ Universidade Federal do Sul da Bahia, Ilhéus, Brasil; ${ }^{3}$ Amplo Engenharia, Belo Horizonte, Brasil (alan.batista@wri.org; miguel.calmon@wri.org; daniel.piotto@ufsb.edu.br;sgrolim@gmail.com)

In the global capital markets there is a risk and return history of over 100 years for various asset classes and publicly traded companies. Although native species have existed for thousands of years, and some good comercial experience with them, there is no track record of this asset class from a capital market perspective. Thus, the present study had the objective to evaluate the tropical wood market in Brazil and worldwide; the viability of native species forestry through case studies already in place; and the main lever of competitiveness: investments and benefits of an R\&D platform with native tree species from Brazil. The discounted cash flow method was used over a period of 30 years. The key metrics used to compare asset returns were internal rate of return, and net present value. Assets valued in this study were: mixed species plantation (native from Atlantic Forest biome); mixed species plantation (exotic and native), monoculture plantation wit native species (Amazon Biome); and with exotic species (Eucalyptus), the latter is considered the benchmark for the study. Lumber prices in both the domestic and foreign markets had a significant real appreciation, ranging from $0.6 \%$ per year to $3.5 \%$ per year in the period analyzed between 1997 and 2017 . Risk adjusted returns from mixed species plantation are higher than mainstream assets such as our benchmark Eucalyptus plantation. Investments in R\&D in promising native tree species can increase IRR more than $5 \%$ and is the most promising upside potential for native tree species.

\section{Management strategies to increase stand structural and tree species diversity and enhance ecosystem services in coastal rainforests of Alaska}

Robert Deal ${ }^{1}$, Ewa Orlikowska², Paul Hennon ${ }^{3}$

${ }^{1}$ USDA Forest Service, PNW Research Station, Portland, USA; ${ }^{2}$ Swedish University of Agricultural Sciences, Skinnskatteberg, Sweden; ${ }^{3}$ USDA Forest Service, PNW Research Station,Juneau,USA (rdeal@fs.fed.us; ewa.orlikowska@slu.se; nootkatin@gmail.com)

There is worldwide interest in managing forests to improve biodiversity, enhance ecosystem services and assure long-term sustainability of forest resources. Coastal rainforests of southeast Alaska have relatively simple tree species composition but complex structures with high diversity of tree ages, sizes and forest canopy levels, and an abundant understory plant community. Clearcutting has greatly altered these forest ecosystems with significant decreases in structural diversity of forest stands and greatly reduced biodiversity. Well-planned silvicultural systems containing a mixture of broadleaf-conifer species have potential to enhance stand diversity and provide other important ecosystem services earlier than typical even-aged conifer plantations. This paper synthesizes information on management options in older forests that have never been actively managed, and in younger forests to increase diversity of stand structures and their associated effects on biodiversity. Light to moderate levels of partial cutting in old-growth forests can maintain the original diversity of overstory stand structures and understory plant communities.In younger forests that develop after clearcutting, mixed red alder-conifer stands provide more heterogeneous structures and significantly higher understory biomass than in pure conifer forests. Research has shown that red alder clearly benefits understory plants, and provides forage for deer and small mammals. A combination of light partial cutting in older forests along with inclusion of red alder in conifer-dominated forests could provide the greatest amount of diversity and maintain the complex stand structures that are an important component of these forest ecosystems.

\section{Productivity-diversity relationships in mixed-hardwood plantations}

Madeline Montague ${ }^{1}$, Kliffi Blackstone ${ }^{1}$, Lorenzo Cotrozzi ${ }^{1}$, Nate Ibarluzea ${ }^{1}$,Elizabeth LaRue ${ }^{1}$, Taylor Nelson ${ }^{1}$, Franklin Wagner ${ }^{1}$, John Couture ${ }^{1}$; Brady Hardiman ${ }^{1}$, Gordon McNickle ${ }^{1}$, Douglass Jacobs ${ }^{1}$

1Purdue University,West Lafayette,USA (montague@purdue.edu; kliffi.blackstone@gmail.com; lcotrozz@purdue.edu; nibarluz@purdue.edu; elarue@ purdue.edu; tmnelson@purdue.edu; wagnerf@purdue.edu; couture@purdue.edu; hardimanb@purdue.edu; gmcnickle@purdue.edu; djacobs@purdue.edu)

The diversity of trees in hardwood forests has conservation and social value, fosters wildlife resources, and generally reduces the risk of pest and disease incidence. Ecologists have shown that productivity and species diversity are positively correlated, but the mechanistic causes of the productivity-diversity correlation remain unresolved in forest trees. Therefore, although we know that mixed-species plantations can be more productive than monocultures, it is currently not possible to predict the number and types of species that should be planted to maximize timber production and other desired attributes. We investigate the productivity-diversity relationship using a 12-year-old experiment of fine hardwoods planted in varying species mixtures and densities. American chestnut (Castanea dentata (Marsh.) Borkh.), northern red oak (Quercus rubra L.) and black cherry (Prunus serotina Ehrh.) were planted as monocultures 
and polycultures at $1 \times 1 \mathrm{~m}, 2 \times 2 \mathrm{~m}$, and $3 \times 3 \mathrm{~m}$ spacings in a split-split plot design to assess the effects of species selection, diversity, and competition on productivity. Above and below-ground productivity and an inclusive suite of functional traits were measured in pursuit of a mechanistic understanding of the productivity-diversity relationship. We measured physiological, morphological, chemical, and structural functional traits; for example, canopy structural metrics linked to light interception and above-ground productivity were calculated using Terrestrial LiDAR data. This study addresses the paucity of knowledge on below-ground dynamics in mixed-species plantations, as root growth and root-soil interactions have implications for carbon cycling and competition for water and nutrients. Results are synthesized to generate management advice and identify future research priorities.

\section{Risk resilient management in mixed forests: insights from an European triplet-transects approach}

Miren del Río ${ }^{1}$, Hans Pretzsch ${ }^{2}$, Hervé Jactel ${ }^{3}$, Anna Barbati ${ }^{4}$, Felipe Bravo $^{5}$, Magnus Löf ${ }^{6}$, Arne Nothdurf', Quentine Ponette ${ }^{8}$, Xavier Morin $^{9}$, Aris Jansons ${ }^{10}$, Gediminas Brazaitis ${ }^{11}$, Andreas Brunner ${ }^{12}$, Maciej Pach ${ }^{13}$

${ }^{1}$ INIA- Instituto Nacional de Investigación y Tecnología Agraria y Alimentaria , Madrid, Spain; ${ }^{2}$ TUM- Technical University of Munich , Freising, Germany; ${ }^{3}$ INRA-Institut National de la Recherche Agronomique, CESTAS, France; ${ }^{4}$ UNITUS- University of Tuscia, Viterbo, Italy; ${ }^{5}$ UVa- University of Valladolid, Palencia, Spain; ${ }^{6} S L U$-Swedish University of Agricultural Sciences, Alnarp, Sweden; ${ }^{7} B O K U$ - University of Natural Resources and Life Sciences, Vienna, Austria; ${ }^{8}$ UCL- Université catholique de Louvain, Louvain-la-Neuve, Belgium, ${ }^{9} \mathrm{CNRS}$ - Centre National de la Recheche Scientifique, Montpellier, France,

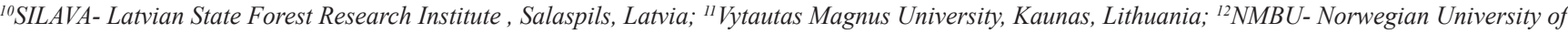
Life Sciences, As, Norway; ${ }^{13}$ AUK- University of Agriculture in Krakow,Krakow, Poland (delrio@inia.es; hans.pretzsch@lrz.tu-muenchen.de; herve.jactel@inra.fr; barbati.sisfor@unitus.it; fbravo@pvs.uva.es; magnus.lof@slu.se; arne.nothdurft@boku.ac.at; quentin.ponette@uclouvain.be; xavier.morin@cefe.cnrs.fr; aris.jansons@silava.lv; gediminas.brazaitis@asu.lt; andreas.brunner@nmbu.no; rlpach@cyf-kr.edu.pl)

Promoting mixed forests is a strategic element for adapting forest management to climate change. Higher tree species diversity is expected to provide higher productivity, higher temporal stability, lower risk of biotic and abiotic disturbances, and a more diverse portfolio of ecosystem services. There is considerable evidence that tree species interactions vary with species traits, environmental conditions, age, and stand density. However, there is presently not enough knowledge to generalize the patterns of these variations to provide a scientific-based theory. This information is crucial for developing climate resilient forest management regimes for mixed forests that reduce the natural, social and economic impacts of climate change on forests and their services. In this presentation we show our research approach to answer this need based on thinned and unthinned triplets along environmental gradients and forest models. Three triplettransects (88 triplets, 264 plots) of Scots pine admixed with species with different functional traits (Picea abies, Fagus sylvatica and Quercus petraea) and relevant in European forestry were established along Europe (one triplet includes one mixed plot and two monospecific plots of the component species). Data collected in triplets includes: dendrometric variables, tree growth series, crown damages, soil characteristics, and some variables related to five ecosystem services. This empirical information is finally combined with simulations from forest modelsto integrate results and for scenario analysis at large temporal and spatial scales. Then we illustrate the strength of the approach by presenting some examples of the results of mixing effects on productivity, stability, and provision of ecosystem systems.

\section{Resistance of mixed forests to insect herbivory in the context of climate change}

Hervé Jactel ${ }^{1}$, Charlotte Poeydebat ${ }^{1}$, Xavier Morin ${ }^{2}$, Bastien Castagneyrol ${ }^{1}$

${ }^{1}$ Institut National de la Recherche Agronomique, Cestas, France; ${ }^{2}$ Centre National de la Recherche Scientifique, Montpellier, France (herve.jactel@inra.fr, charlotte.poeydebat@inra.fr; xavier.morin@cefe.cnrs.fr; bastien.castagneyrol@inra.fr)

Forests are likely to experience more stressful conditions in the future because of climate change. Mixed forests are expected to be more resistant to specific hazards. However little is known about resistance of mixed-species forests to multiple hazards and particularly to synergistic or cascading effects of biotic and abiotic perturbations. Here we used two experimental platforms to investigate the effect of mixing tree species on associational resistance to pest damage in contrasting climatic contexts. In one experiment, we compared the level of leaf herbivory in a paired comparison of pure and mixed stands at different latitudes and elevations. In the second, manipulative experiment, we compared tree damage by insects in paired comparisons of pure and mixed stands grown in irrigated vs. drought stressed blocks. The patterns of associational resistance (or susceptibility) were often context dependent, as demonstrated by significant interactions between tree diversity and climatic factors on leaf herbivory. We propose mechanisms to interpret those patterns, which are based on change in tree apparency and leaf quality. Our findings provide new insights into the understanding of mixed forest resistance to multiple stresses and pave the way for the design of mixed species plantations better able to cope with climate change.

\section{C1f: SILVICULTURE AND FOREST MANAGEMENT OF DECIDUOUS BROADLEAVED} FORESTS

\section{Managing regeneration potential to sustain oak forests in North America}

Daniel Dey ${ }^{1}$

${ }^{1}$ US Forest Service, Columbia, USA (ddey@fs.fed.us)

Today in North America, there is a well-accepted recognition of oak regeneration failure and the widespread loss of oak forests. Similar observations are being reported around the world. Regeneration potential of a species is the probability that the species will be competitive through regeneration and stand development to prevail in the mature stand. It is the summation of a species regeneration potential from all modes of reproduction, including current seed, seed bank, new seedlings that establish after a regeneration disturbance, advance reproduction, and vegetative reproduction from stump sprouting, root sprouting and layering. Regeneration potential has been quantified for some oak species. Large, competitive oak advance reproduction and stump sprouts are essential to sustain oak forests. Regeneration potential is influenced by initial floristics, site quality, competing vegetation, herbivores, and level of management. Oak regeneration potential in modern forests is commonly too low to sustain oak stocking at current levels. Recommendations are given for silvicultural prescriptions designed to increase oak regeneration potential to sustain oak forests. 


\title{
A review of research-based methods for managing deer herbivory of hardwood regeneration
}

Caleb Redick ${ }^{1}$, Douglass Jacobs ${ }^{1}$

1Purdue University,WestLafayette,USA (credick@purdue.edu; djacobs@purdue.edu)

Pervasive ungulate herbivory poses a major obstacle to forest regeneration in many regions. Various deer species threaten to shift existing forest composition in North America and Europe as they preferentially browse oaks and other high value hardwoods. Herbivory thereby presents a challenge to foresters who want to maintain oak dominated forests. Herbivory also impedes successful afforestation of abandoned agricultural or mined lands. Population control can be difficult to implement, and even small populations of deer can have negative effects. Methods other than hunting to manage deer browse are required until populations are reduced on a regional level. Forest landowners and managers attempting hardwood forestation have come up with many creative solutions to deal with wildlife damage, ranging from fences and shelters, to repellents. Many empirical studies on browse management methods have been published in the scientific literature and results can be generalized. Fences are effective, yet require maintenance. Shelters, though expensive, have been shown to be effective in increasing growth and survival in many cases and promote seedling growth to free-to-grow status. Repellents are a common alternative to physical barriers, but their usefulness is short-lived so reapplication is necessary. In addition, there is much variability in effectiveness depending on the repellent type and local deer population. Systemic repellents have been tested, but success is sporadic and depends upon uptake of the chemical. This literature review catalogs research on browse management methods in the presence of high deer populations and compares the effectiveness of such methods.

\section{Potential of prescribed fire as a management tool for natural oak regeneration in temperate Europe}

Linda Petersson ${ }^{1}$, Daniel Dey², Annika Felton ${ }^{1}$, Emile Gardiner ${ }^{3}$, Magnus Löf $^{1}$

${ }^{1}$ Swedish University of Agricultural Sciences, Alnarp, Sweden; ${ }^{2}$ USDA Forest Service, Columbia, USA; ${ }^{3}$ USDA Forest Service, Stoneville, USA

(linda.petersson@slu.se; ddey@fs.fed.us; annika.felton@slu.se; emile.gardiner@usda.gov;magnus.lof@slu.se)

Oak-dominated forests provide ecosystem services and harbor biodiversity. However, rapidly changing land-use and disturbance regimes have reduced suitable regeneration niches and unsuccessful natural oak regeneration have caused concern in Europe and North America for over a century. In eastern North America, a fire-oak hypothesis has been developed which attributes some oak regeneration problems to effective fire suppression. Prescribed burns are used to regenerate oak-dominated ecosystems, often combined with thinning to increase light and control competing vegetation. In temperate Europe the role of fire is not clear, but fire suppression is widespread. Our study investigates if the fire-oak hypothesis can be applied to European temperate oaks $(Q$. robur and $Q$. petraea). A field experiment combining effects of light (high-low), browsing (fence-no fence), and fire (burn-no burn) in a complete block design was established in 2016 at five oak-dominated forests in Sweden. We recorded survival and growth of 2357 naturally regenerated oak seedlings. Two growing season following burn treatment, oak seedling survival ranged from $52 \%$ in low-light*no-fence*burn-treatment to $96 \%$ in high-light*fence*no burn-treatment. For all burn treatments, $93 \%$ of surviving oaks had re-sprouted. This is the first field study to investigate use of a low-intensity prescribed fire as a management tool in European temperate oak forests. The initial results are positive in that we demonstrate the high sprouting capacity of naturally established oak seedlings that experienced a low-intensity prescribed fire. Our results also highlight the importance of investigating combined effects of multiple factors, continued research will further explore these interactive effects.

\section{The status quo and scope for future development of oak forestry in China}

\author{
Xiuling Guan ${ }^{1}$, Wenhui Zhang ${ }^{1}$ \\ ${ }^{1}$ Chinese Soceity of Forestry, Beijing, China; ${ }^{1}$ North West Agriculture and Forestry University, Yangling, China \\ (guanxiuling@sina.com; 839951676@qq.com)
}

China boasts rich diversity of oak species (Quercus spp.) with a wide distribution. According to the 8th forest resources inventory of China, the total area of oak is 16.10 million ha, accounting for $13.7 \%$ of natural forests. Importance of oaks will be going to increase because China is prioritizing mixed forests of native species than monoculture of exotic species to increase resilience of forests. Oaks have been underestimated in China for long, often being used as fuel wood, whereas its economic, ecological and cultural values have been ignored. Since 2015, the CSF has initiated promotion of oak forestry and industry in China. In last three years, apart from involving oak experts from abroad, the CSF has also facilitated the management of secondary forests of oak in over 10 provinces in northern China. The Oak Division of the CSF and China Innovation Alliance of Oak were established in 2018. At present, oak industry is attracting increasing attention from forest departments at different levels, stepping on the path of industry-education-research and coordinated development under the guidance of the CSF. In this presentation, I will present a comprehensive picture of current oak forestry in China and future potentials.

\section{Regeneration and conservation of oaks in Western Himalayan forest of Uttarakhand, India}

Manisha Thapliyal ${ }^{1}$, Namitha N.K. ${ }^{1}$, Pravin Rawat ${ }^{1}$

${ }^{1}$ Forest Research Institute, Dehradun, India (manishathapliyal98@gmail.com; namithafri@gmail.com; pravinrawat15@gmail.com)

Oak forests are one of the oldest vegetation types of the Himalayan region and a climax community. They have great social and ecological relevance in the Western Himalayan region providing many important ecosystem services like retention and enriching soil, sustaining the hydrological regime of hills. Oaks are also highly valued economically in the region as they are closely linked with hill agriculture and sustenance as an important source of fodder for livestock, litter for compost, fire wood and timber. Owing to the intense anthropogenic pressure, recurrent forest fires and poor acorn production at times, regenerative capacity of oaks is declining in the Himalayan region. The regeneration of Quercus leucotrichophora and Q. semecarpifolia was studied in Kedarnath Forest Division, of Uttarakhand state. In Q. semecarpifolia forests, there are large number of old trees but establishment of sapling and low girth class trees was hampered due to poor acorn production, disturbances like grazing, trampling, etc. In case of $Q$. leucotrichophora poor regeneration was observed due to poor acorn setting, weevil attack, acorn predation, browsing damage to seedlings, lopping, forest fire, etc. Natural regeneration of both the species was poor both in disturbed and undisturbed forests in the study area. Existing Oak forests need to be conserved through active involvement of the community in protection and planting of oak, restricting anthropogenic activities and also planting of other fodder species by the Forest department and Self Help Groups to reduce the people's dependence on oak. 


\section{The impact of admixing rich litter tree species on the vitality and growth of pedunculate oak forests}

Ellen Desie', Leon van den Berg' ${ }^{2}$,Bart Nyssen², Maaike Weijters ${ }^{3}$, Arnold van den Burg', Gert-Jan van Duinen ${ }^{5}$, Jan den Ouden ${ }^{6}$, Karen Vancampenhout ${ }^{7}$, Bart Muys ${ }^{1}$

${ }^{1}$ KU Leuven, Leuven, Belgium; ${ }^{2}$ Bosgroep Zuid Nederland, Heeze, Netherlands; ${ }^{3}$ B-Ware, Nijmegen, Netherlands; ${ }^{4}$ Stichting BioSFeer, Otterlo, Netherlands; ${ }^{5}$ Bargerveen, Nijmegen, Netherlands; ${ }^{6}$ Wageningen University, Wageningen, Netherlands; ${ }^{7}$ KU Leuven Campus Geel, Geel, Belgium

(ellen.desie@kuleuven.be; l.vandenberg@bosgroepzuid.nl; b.nyssen@bosgroepzuid.nl; m.weijters@b-ware.eu; bsp@upcmail.nl; g.vanduinen@science.ru.nl; jan.denouden@wur.nl; karen.vancampenhout@kuleuven.be; bart.muys@kuleuven.be)

Due to the combined effects of land use changes since the Neolithic and more recent atmospheric deposition, many West-European forests are located on degraded and acidified soils. The adverse effects of soil acidity are far reaching, and have resulted in hampered ecosystem functioning and lower delivery of ecosystem services. Forest management, by altering the overstory tree species composition, can accelerate or counteract soil acidification through the quantity and quality of litter input. The admixture of tree species with nutrient rich litter is hypothesized to be a successful soil restoration intervention improving forest vitality, productivity and resilience. The positive impact of rich litter on the soil nutrient status and belowground ecosystem functioning has already been evidenced in common gardens of monocultures. Given the increasing relevance of mixed forests in a context of climate change adaptation, we aimed to evaluate whether the rich litter effect is substantial enough to also improve the soil nutrient status in mixed forest stands and, moreover, whether it can improve aboveground ecosystem functioning. We studied the effect of admixture of black cherry (Prunus serotina) in pedunculate oak (Quercus robur) stands on the belowground ecosystem functioning and on the vitality of oak trees. This was done by pairwise comparison of individual oaks in black cherry neighbourhoods with oaks in monospecific neighbourhoods located over Belgium, The Netherlands and Germany. Results of this study allow to better understand the underlying mechanisms of rich litter admixture and make more applied recommendations for forest management.

\section{Ecology and management of young Hungarian oak (Quercus frainetto Ten.) stands in the south of Romania}

Valeriu-Norocel Nicolescu ${ }^{1}$,Valentina Aga ${ }^{1}$,Ecaterina-Maria Chirteș ${ }^{1}$,Adrian-Vasile Chirteș ${ }^{1}$,Alexandru-Sorin Stainbok ${ }^{1}$, Adina-Elena Nicola ${ }^{1}$, Cătălin

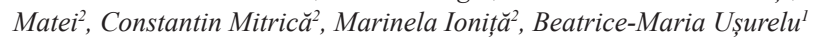

${ }^{1}$ Faculty of Silviculture and Forest Engineering, Transylvania University of Brasov, Brasov, Romania; ${ }^{2}$ Olt County Branch, National Forest Administration Romsilva, Slatina,Romania (nvnicolescu@unitbv.ro; aga.valentina@yahoo.com; ecaterinachirtes@gmail.com;

adrianchr56@gmail.com; stainbokalexandru@gmail.com; adinaelena7@yahoo.com; office@slatina.rosilva.ro; slatina@slatina.rosilva.ro; marinelavalentina93@gmail.com; usurelubeatricemaria@gmail.com)

Hungarian oak (Quercus frainetto Ten.) is one of the six oaks in Romania, where it covers ca; 130,000 ha. The species is found chiefly in the south and west of the country, where its occurrence is mostly soil-controlled, as being especially adapted to heavy acidic soils. In the South of Romania (Seaca-Optășani Forest, the largest block of Hungarian oak in the entire native range, ca; 1,560 ha), the species grows under difficult site conditions: local climate specific to a forest steppe zone (mean annual temperature $10.8^{\circ} \mathrm{C}$; mean annual precipitation $559.8 \mathrm{~mm}$; mean annual evapotranspiration 685 mm; mean aridity index 26.9 ), with heavy soils (Vertisols, developed on loess, marl and clay). Since 1890’s, Hungarian oak is managed as high forest, regenerated by seed following the application of group shelterwood cuttings. The resulting young stands are monospecific, highly stocked, with tall and slender trees, and show a high level of mortality (up to $60 \%$ of number of trees at 10-15 years of age). Cleaning-respacing interventions - first when mean dbh is ca; $5 \mathrm{~cm}$, second when it reaches $8-9 \mathrm{~cm}-$, carried out in two adjacent Hungarian oak sub-compartments in 2018, have improved the vertical structure and quality of residual stands by performing interventions across the canopy (but mostly from below) and eliminating dead, dying, bent-over, wounded trees, as well as those individuals competing strongly with potential final crop trees, selected based on the vigor-quality-distribution criteria.

\section{Pre-commercial thinning in naturally regenerated stands of European beech (Fagus sylvatica L.): effects of thinning pattern, stand density and pruning on tree growth and stem quality}

Ditlev Otto Juel Reventlow ${ }^{1}$, Thomas Nord-Larsen ${ }^{1}$, Jens Peter Skovsgaard ${ }^{2}$

${ }^{1}$ Department of Geosciences and Natural Resource Management, University of Copenhagen, Frederiksberg C, Denmark; ${ }^{2}$ Southern Swedish Forest Research Centre, Swedish University of Agricultural Sciences, Alnarp,Sweden (dire@ign.ku.dk; tnl@ign.ku.dk; jps@slu.se)

Pre-commercial thinning in naturally regenerated stands of European beech is often expensive and must be justified by improved development of the remaining crop. Based on a field experiment established in two 14-year-old naturally regenerated beech stands in Denmark, we investigated some effects of pre-commercial thinning and pruning on future crop tree growth and stem quality. The treatments included (1) no thinning, (2) moderate to heavy strip thinning, with or without subsequent selective thinning, and (3) extremely heavy strip thinning in two perpendicular directions (checkerboard thinning), with or without subsequent selective thinning and with or without pruning. The resulting residual stand densities ranged from 105 to only 200 ha $^{-1}$. Treatment effects were evaluated at age 32 on one potential future crop tree for every $100 \mathrm{~m}^{2}$. Total crop tree height was reduced by checkerboard thinning. Stem diameter increased with decreasing stand density but was reduced by pruning. The lower live branch was positioned lower with heavy strip thinning and with checkerboard thinning without pruning. Forks were more frequent and at a lower position in checkerboard thinning. Stem tilt and stem straightness were unaffected by thinning. However, pruned trees tilted less and had straighter stems. Extremely heavy thinning increased the formation of epicormic branches, but these did not reemerge after pruning. In summary, moderate to heavy pre-commercial thinning had no effect on stem quality, while extremely heavy thinning without pruning resulted in unacceptably low stem quality. No-thinning resulted in acceptable growth and stem quality of the crop trees and remains an alternative.

C1g: SILVOPASTORAL SYSTEMS: CONTRIBUTIONS TO LIVESTOCK AND TO THE SUSTAINABLE DEVELOPMENT OBJECTIVE

Effect of plantation spacing in production of wood and forage and economic outcomes in Eucalyptus globulus in Eastern Uruguay I Efecto del marco de plantación en la producción de madera y forraje y su resultado economico en Eucalyptus globulus en el Este de Uruguay

Mariana Boscana ${ }^{1}$, Adriana Bussoni ${ }^{1}$, Oscar Bentacur ${ }^{2}$, Eduardo Llanos ${ }^{1}$, Fabián Varela ${ }^{1}$

${ }^{1}$ Universidad de la República, Montevideo,Uruguay; ${ }^{2}$ Universidad de la República, Paysandú, Uruguay (mboscana@fagro.edu.uy; abussoni@fagro.edu.uy; obent@fagro.edu.uy; edullan20@gmail.com; fabianv.uy@gmail.com) 
Los sistemas silvopastoriles constituyen una modalidad con potencial de expansión en Uruguay. El trabajo tuvo como objetivo evaluar la producción de madera, forraje y su resultado económico en dos marcos de plantación en Eucalyptus globulus en el Este del Uruguay: 3,5 x 2,7 m (SPC, 1.258 árb/ha) y (2 x 2) + 8 m (SSFC, 1.000 árb/ha). En cada sistema se relevaron: diámetro a la altura del pecho (DAP), Altura total (Ht) y sobrevivencia de los árboles a los 36, 41, 45, 51 y 68 meses de edad. Cada 60 días se midió producción de forraje; finalmente se estimó los indicadores de Valor Actual Neto (VAN) y Tasa interna de retorno (TIR). Los resultados indican que el marco de plantación no tuvo efecto significativo $(\mathrm{p}>0,05)$ sobre los valores individuales para DAP y Ht. El sistema SPC resultó en $83,7 \mathrm{~m}^{3} / \mathrm{ha}( \pm 3,60)$ a los 68 meses mientras que el SSFC fue de $62,7 \mathrm{~m}^{3} / \mathrm{ha}( \pm 3,60)$. La producción media estacional de forraje fue $42 \%$ mayor para el sistema SSFC en relación al SPC $(587,5 \mathrm{~kg}$ Ms/ha $( \pm 39,1))$. Considerando tanto la producción de madera como ganado bajo dosel, a los 12 años de edad de cosecha, el sistema SPC resultó en una VAN de 930 U\$S/ha y una TIR de 12,1\%, mientras que el sistema SSFC fue de 955 U\$S/ha y 13,4\% respectivamente, a los 13 años de edad de cosecha . Los resultados aportan información para la toma de decisiones y la elección del marco de plantación.

\section{SisILPF: software for forest component management in integrated crop-livestock-forest (ICLF) systems}

Edilson Batista de Oliveira ${ }^{1}$

${ }^{1}$ Embrapa Florestas, Colombo, Brasil (edilson.oliveira@embrapa.br)

The SisILPF software suite is built for Pinus (caribaea, elliottii, taeda), Eucalyptus (grandis, urograndis, dunnii, saligna), Toona ciliata, Khaya ivorensis, and Tectona grandis. The software supports management, economic analysis, and planning of the forest component of integrated crop-livestock-forest (ICLF) systems for decision-making related to when, how, and how much to thin, and when to conduct the final harvest. Users can: test for different climate and soil conditions; simulate all tree component management options of ICLFs; forecast present and future production; conduct economic analyses; and decide on the best alternatives to manage their plantation. Built using the Delphi programming language, each software generates prognosis charts and graphs for growth and yield of trees in the ICLF, based on inventory data. The software suite indicates how much wood will be produced at any age and tests any management regime that one wishes to apply. Users can also calculate the carbon (Methane and $\mathrm{CO}_{2}$ equiv.) stored by the trees and generate tables of wood assortment by industrial use classes such as lamination, sawmill, and fuel, according to log diameters and lengths identified by the user. SisILPFs enables the simulation of several thinning regimes, generating an assortment table for each. The software is available for download on the Embrapa Florestas website (www.embrapa. br/florestas).

\section{Improvement of caívas in Southern Brazil: “milk and meat of the forest” with sustainability}

Ana Lúcia Hanisch ${ }^{1}$, Raquel R. B. Negrelle ${ }^{2}$, Ligia C. A. Pinotti ${ }^{2}$

${ }^{1}$ Epagri, Canoinhas, Brasil; ${ }^{2}$ Universidade Federal do Paraná, Curitiba, Brasil (analucia@epagri.sc.gov.br; negrelle@ufpr.br; ligiapinotti@outlook.com)

The use of native forest remnants for animal production occurs in various parts of the world. These traditional silvopastoral systems contribute to the conservation of these remnants. Valuing them through productive techniques accepted by sustainable livestock is a way to build strategies that combine environmental conservation with the generation of sustainable animal products, such as "milk or meat from the forest." In the South of Brazil, the caíva are traditional systems that have existed for more than a century, where the animals are raised loose in areas of remnants of the Araucarian Forest. The introduction of the Axonopus catharinensis grass, with the adoption of the rational grazing and split fertilization in coverage, was evaluated in caívas. One of the sustainability indicators evaluated was forest regeneration. After two years of use, there was no effect of pasture management on the regeneration component. A total of 49 tree species characteristic of the Araucarian Forest were found. In general, the increase in pasture productivity showed a low correlation with the species richness ( -0.20$)$ and the density (-0.24) of the forest regeneration, indicating that the intensification of pasture use did not negatively interfere in these variables. The richness and density of tree regeneration in the caívas confirmed the relevant contribution of this traditional silvopastoral system to the provision of ecosystem services such as the conservation of the vegetal biodiversity of the Araucarian Forest, despite the anthropic use and the presence of the animals for almost a century.

\section{Reducing competition in crop-livestock-forest integrated system by thinning Eucalyptus trees}

José Ricardo Macedo Pezzopane ${ }^{1}$, Willian Lucas Bonani ${ }^{2}$, Eduardo Lopez Fernandes da Rocha ${ }^{3}$, Alberto Carlos de Campos Bernardi ${ }^{1}$, Patricia Perondi Anchão de Oliveira ${ }^{1}$, André de Faria Pedroso ${ }^{1}$

${ }^{1}$ Embrapa Pecuaria Sudeste, São Carlos, Brasil; ${ }^{2}$ Universidade de Araraquara, Araraquara, Brasil; ${ }^{3}$ Unicep, São Carlos, Brasil (jose.pezzopane@embrapa.br; willian_bonani@hotmail.com; lopezrocha19@gmail.com; alberto.bernardi@embrapa.br; patricia.achao-oliveira@embrapa.br;andre.pedroso@embrapa.br)

This study aimed to evaluate the effects of eucalyptus trees thinning on yield and nutritive value of corn for silage and palisadegrass in a crop-livestock-forest integrated system. Assessments of plant variables, as well as of photosynthetically active radiation (PAR) incidence and soil moisture were performed between October 2016 and March 2018 in São Carlos, SP, in a crop-livestock-forest and, for comparison, in a crop-livestock system. In the crop-livestock-forest system, eucalyptus trees (Eucalyptus urograndis clone GG100) were planted in April 2011, in single rows, with a 15 x $2 \mathrm{~m}$ spacing. In 2016, trees were thinned and the spacing changed to $15 \times 4 \mathrm{~m}$. In this system, the assessments were performed in four equidistant positions in relation to the eucalyptus rows. Corn was sown first, and palisadegrass was sown after corn harvest. PAR transmission during the corn cycle and the pasture cycles was $65.3 \%$ and $60 \%$, respectively. Soil moisture was lower at the 50 to $100 \mathrm{~cm}$ depth layer near the tree line than at the other positions, during the dry period. Corn yields were similar between systems with an average of $13.6 \mathrm{mg}$ of dry matter ha- ${ }^{-1}$. Corn silage produced in the crop-livestock-forest system presented higher percentage of grain (41.4 and $42.1 \%$ ) than that produced in the crop-livestock system $(35.6 \%)$. No differences in forage yield were observed. Crude protein of corn for silage and palisadegrass was higher in the crop-livestock-forest than in the crop-livestock system. Such results indicate that tree thinning was favorable for production in the crop-livestock-forest system.

\section{Establishment of sustainable agrosilvopastoral systems from degraded soils in the dry Colombian Caribbean}

Luis Fernando Chavez ${ }^{1,3}$, Sonia Ospina ${ }^{1}$, Kenica Yulith Mendoza ${ }^{2}$, Adelina Caballero ${ }^{3}$, Darwin Fabian Lombo ${ }^{3}$

${ }^{1}$ Corporacion Colombiana de Investigacion Agropecuaria (Agrosavia), Palmira, Colombia; ${ }^{2}$ El Cerrejon, La Guajira, Colombia; ${ }^{3}$ Corporacion Colombiana de Investigacion Agropecuaria (Agrosavia),Agustin Codazzi,Colombia (lchavez@agrosavia.co; sospina@agrosavia.co; kenica.yulith@gmail.com; acaballerol@agrosavia.co;dlombo@agrosavia.co)

The objective was to identify options for the sustainable use of natural resources and to enhance the productivity with agricultural and livestock systems. The research was developed with small-scale farmers in regions with arid and semi-arid conditions of La Guajira (2012) and Cesar (2014), which main activity is cattle raising. Clayey soils predominate with nearly level to gently slopes degraded by burning, monoculture, and overgrazing. The methodology approach 
was participatory with qualitative and quantitative variables for monitoring soil and people begin to identify the benefits represented by a sustainable use. This was done by conformation of local researchers committees and the installation of farm field experiments. The methodology resulted in the improvement of productivity and sustainability of farming practices, which in turn has contributed to improve food security. After six years, more than 70 hectares of degraded soils have been recovered and agrosilvopastoral systems (ASPS) have been established incorporating the native woody species: Acacia farnesiana, Prosopis juliflora, Cordia alba y Guazuma ulmifolia, and Panicum máximum cv Mombasa sp. associated with the production of more than 50 tons of food (black beans, watermelons, buttercup squash and corn) that provide food security and increase the productivity of the land through the improvement of the soil. The assessment demonstrates that there is widespread recognition and value of importance from farmers and technicians towards ASPS that include the native woody species. Farmers recognize their contribution to the support of animals in the most critical times and to the provision of services.

\section{Determination of financial risk in agroforestry system susing Monte Carlo method}

Maisa Isabela Rodrigues ${ }^{1}$, Bruno Souza ${ }^{1}$, Álvaro Nogueira de Souza ${ }^{1}$, Maisa Santos Joaquim ${ }^{1}$, Patrícia Aparecida de Souza ${ }^{2}$, Juliana Baldan Costa Neves Araújo ${ }^{1}$ Universidade de Brasília, Brasília, Brasil; ${ }^{2}$ Universidade Federal de São João Del Rei, Sete Lagoas, Brasil (maisaisabela@hotmail.com;

brunosouza@gmail.com; alvarosouza14@gmail.com; maisaunb@gmail.com; patriciasouza@gmail.com; juliana.bcneves@gmail.com)

This work dealt with the determination of the financial risk in a silvopasture system implemented in the Northern region of the State of Minas Gerais. Five genetic materials were used with the intention to select the best one for the plantation in large scale. There were used traditional methods of analysis (NPV, EPB, IRR) of the investments with the discount tax of $8 \%$ p.a. to calculate the profit in a database obtained in a property in the North of the State of Minas Gerais. The analysis with the traditional methods of financial viability of projects yielded a Net Present Value (NPV) of R\$2,906.90/ha for the most significant clone. The method Monte Carlo was used for the determination of the risk and the comparison of the values of the deterministic methods. To the values of a historical series of prices of wood and calf was applied GIRP (General Index of Retail Prices) as a deflator. The results showed that the NPV with an application of a CMM has a value of $\mathrm{R} \$ 6,342.95 /$ ha with more the $80 \%$ of probability of occurrence. Compared with the original activity of the property, the cattle raising, the Silvopasture System offers more investments returning conditions.

Prognoses for growth and timber production and economic assessment of Pinus taeda in monoculture and in integrated silvopasture systems / Prognose do crescimento e da produção madeireira e avaliação econômica de Pinus taeda em monocultivo e em ILPF

Caroline Cruz de Mello ${ }^{1}$ Edilson Batista de Oliveira ${ }^{2}$

${ }^{1}$ Universidade Federal do Paraná, Curitiba, Brasil; ${ }^{2}$ Embrapa Florestas, Colombo, Brasil (carol.mello@ufpr.br; edilson.oliveira@embrapa.br)

Este trabalho teve por objetivos estimar o crescimento e produção madeireira e avaliar a rentabilidade econômica de Pinus taeda em monocultivo e em sistema de integração lavoura-pecuária-floresta (ILPF). Foram simulados sete regimes de manejo por meio de softwares desenvolvidos pela Embrapa Florestas. Os regimes foram divididos em dois experimentos: o primeiro com quatro tratamentos (R1, R2, R3, R4) em ILPF delineados com espaçamento 3,0 m x 2,0 m e distância de $14 \mathrm{~m}$ entre os renques, diferenciando-se entre si pelo número de fileiras no renque (fileiras simples, dupla, tripla e quádrupla); e o segundo com três tratamentos (R5, R6, R7) em monocultivo com 1667 árvores por hectare. R1, R2, R3 e R4 tiveram corte final projetado para 20 anos, com desbaste seletivo de $50 \%$ da população aos 10 anos. R5 teve desbaste seletivo de $40 \%$ da população aos 10 e 15 anos, com corte final aos 20 anos. R6 teve desbaste seletivo de $50 \%$ da população aos 12 anos e corte final aos 20 anos. O tratamento R7 foi projetado sem desbastes e com corte final aos 16 anos.Em nossa simulação, as árvores propiciaram retorno econômico nos sete tratamentos avaliados, indicando que, além de diversificar a produção, a inserção da árvore na propriedade rural pode ser considerada uma atrativa fonte de renda. Com esses tratamentos,mostramos que os softwares para manejo e análise econômica de florestas podem auxiliar produtores na tomada de decisão para a implantação do componente florestal em suas propriedades.

Assessment and seasonal production of herbaceous forage biomass and correlation between environmental variables and basal area / Avaliação e produção estacional de biomassa herbácea forrageira e correlação entre variáveis ambientais e área basal

Talyta Mytsuy Zanardini Galeski Sens ${ }^{1}$, Sebastião Brasil Campos Lustosa ${ }^{1}$, Luciano Farinha Watzlawick ${ }^{1}$, Iris Cristina Bertolini ${ }^{1}$, Ana Paula Vantroba ${ }^{1}$ ${ }^{1}$ Universidade Estadual do Centro-Oeste, Guarapuava,Brasil (talytagaleski@hotmail.com; slustosa@unicentro.br;farinha@unicentro.br;

iris_cristinabertolini@hotmail.com; paulavantroba@hotmail.com)

Este estudo foi realizado em duas áreas sob formação florestal Floresta Ombrófila Mista, no município de Turvo-PR, uma área de floresta secundária e uma área de sistema silvipastoril natural, tendo como objetivo quantificar a produção estacional de biomassa herbácea forrageira e inferir as diferenças entre as áreas em função do seu manejo. A coleta de biomassa e componente botânico seguiu a metodologia Botanal, a área basal arbórea foi obtida por meio da dinâmica florestal. Foram avaliadas as variáveis ambientais:insolação, precipitação, radiação solar, temperatura máxima, média, mínima e umidade relativa. A maior produção de matéria seca ocorreu na área silvipastoril, no outono, com média de 265,44 kg MS.ha-1 , na área de floresta secundária não houve estação de maior produção, com menor média na primavera, 35,33 kg MS.ha-1 ${ }^{-1}$ Panicum sp. apresentou a maior produção de biomassa, no outono no sistema silvipastoril e verão na floresta secundária. A porcentagem de solo descoberto não apresentou diferença significativa entre as estações no sistema silvipastoril, na área de floresta secundária a menor porcentagem foi no inverno 48,90\% e a maior na primavera 65,39\%. A análise composta por variáveis ambientais, biomassa e área basal, resultou uma correlação alta negativa entre biomassa da área silvipastoril e temperatura máxima, apresentando ainda correlação significativa entre biomassa do inverno na floresta secundária e área basal. O gênero Panicum sp. é predominante na produção de biomassa de ambas as áreas, está presente em todas as estações do ano. Temperatura máxima e biomassa do sistema silvipastoril apresentam uma relação inversamente proporcional.

Double and simple entry equations for estimating the volume of trees established in integrated silvopasture systems / Equações de dupla e simples entrada para estimação do volume de árvores estabelecidas em sistemas silvipastoris

Marcelo Müller ${ }^{1}$, Alexandre Brighenti ${ }^{1}$, Carlos Martins ${ }^{1}$

${ }^{1}$ Embrapa Gado de Leite, Juiz de Fora,Brasil (marcelo.muller@embrapa.br; alexandre.brighenti@embrapa.br; carlos.eugenio@embrapa.br)

O objetivo deste trabalho foi avaliar a precisão e a acurácia de equações de simples entrada para estimação do volume individual de árvores de eucalipto estabelecidas em sistemas silvipastoris. Foram ajustados sete modelos volumétricos, sendo quatro de simples e quatro de dupla entrada, para dois clones de eucalipto (GG 100 e I 144) plantados em dois diferentes espaçamentos (15 x 3 e 15 + (3 x 2)) e um híbrido de Eucalyptus grandis x Eucalyptus urophylla propagado por sementes, também em dois espaçamentos (15 + (3 x 2) e 15 + (3 x 2,5)). A partir dos valores das variáveis Ht, Dap e Vt obtidas através do método de cubagem proposto por Smalian, foram ajustadas as equações volumétricas de simples e dupla entrada para cada material. Os modelos foram ajustados pelo 
método dos mínimos quadrados não lineares via o algoritmo de Gauss-Newton, e a seleção do melhor modelo para cada estrato foi baseada em três critérios: Índice de Furnival (IF), coeficiente de determinação ajustado ( $\left.\mathrm{R}^{2} \mathrm{aj}\right)$ e análise gráfica dos resíduos. De forma geral, os modelos de dupla entrada apresentaram resultados mais satisfatórios para todos os casos, com destaque para os modelos de Spurr logaritimizado e Schumacher \& Hall logaritmizado. Entretanto, os modelos de simples entrada demonstraram estatísticas muito próximas daquelas observadas para os modelos de dupla entrada, com destaque para os modelos de Husch e Brenac. Neste sentido, o uso de equações de simples entrada pode ser recomendado, principalmente no caso de pequenos produtores, como forma de tornar a aferição da sua produção menos onerosa.

\section{C1i: TRADITIONAL COPPICES: ECOLOGY, ECONOMY AND ECOSYSTEM SERVICES}

\section{Early growth and development of black locust (Robinia pseudoacacia L.) in root sucker-regenerated stands in the Northwest of Romania}

Valeriu-Norocel Nicolescu ${ }^{1}$, Cornelia Hernea ${ }^{2}$, Nicolae Iacob ${ }^{1,3}$, Beatrice-Maria Usurelu ${ }^{1}$

${ }^{1}$ Transylvania University of Brasov, Faculty of Silviculture and Forest Engineering, Brasov, Romania; ${ }^{2}$ Faculty of Horticulture and Forestry, Banat's University of Agricultural Sciences and Veterinary Medicine, Timisoara, Romania; ${ }^{3}$ Săcueni Forest District, Bihor County Branch, National Forest

Administration-Romsilva, Sacueni, Romania(nvnicolescu@unitbv.ro; corneliahernea@yahoo.com; sacueni@oradea.rosilva.ro; usurelubeatricemaria@gmail.com)

In the Northwest of Romania, a region with a warm (mean annual temperature $10.30{ }^{\circ} \mathrm{C}$ ) and quite dry climate (mean annual precipitation $573.3 \mathrm{~mm}$ ), forest vegetation covers about $12 \%$ of the total area of continental sand dunes part of Carei - Valea lui Mihai Plain, with black locust (Robinia pseudoacacia L.) as the main tree species covering ca; 3,000 ha (over $80 \%$ of all forestland). Since its introduction in the area, black locust has been treated as low coppice, usually on a rotation of 20-30 years. In these stands the most commonly used rejuvenation method is by root suckers as black locust develops horizontal, shallow and widespreading roots which can extend to $15-20 \mathrm{~m}$ from the parent tree. The paper outlines the main results of a research and demonstration project on regeneration and early growth of black locust in the NW of Romania started in 2016. It was carried out in two young and pure black locust stands, naturally regenerated by root suckers following simple coppice cuts and removal of stumps. The initial growth of young black locust individuals was quick in both height and diameter Consequently, the newly established stands have closed the canopy within two years regardless the initial stocking or basal area, resulting in effective sand dune stabilization and control of wind erosion.

\section{Resilience and dynamics of the landscape in the oak forests of the Galicia Eastern mountains (Northwest of the Iberian Peninsula)}

Díaz-Maroto Ignacio J. ${ }^{1}$

${ }^{1}$ University of Santiago de Compostela,Lugo, Spain (ignacio.diazmaroto@usc.es)

The landscape dynamics of the eastern Galician mountains is mostly effect of human intervention during centuries ago. Our research has studied the resilience and changes - environmental, socioeconomic and historical changes - in this region. The objective is to suggest a set of silvicultural actions for the conservation and improvement of the landscape of these lands. The study focused on the progression of the natural broadleaved forests, intensively exploited since ancestral times. These forests were transformed to agricultural land, exploited for the naval, metallurgical and railway industries, joined with Church possessions, suffered forest fires, and were replaced by fast growing species, mainly coniferous and, today Eucalyptus nitens Shining Gum. All of these actions have led to a reduction of the occupied area by them. Now, broadleaved forests cover small and generally sloped sites, remaining where the soil features often avoid other land use, however their natural regeneration is very limited by human activities. These sites have a much modified landscape, but with a slow transformation where the biodiversity conservation, the hunting phenomenon and the cultural or environmental tourism have a high importance. Their current situation raises the problem of their socioeconomic reconversion. From a positive standpoint, the area covered by these forests has recently increased, and there is a greater awareness of the importance of their conservation given the recognition as habitats of interest to the European Union, being part of the NATURA 2000 Network.

\section{Influence of plantation stand structure change by thinning operation}

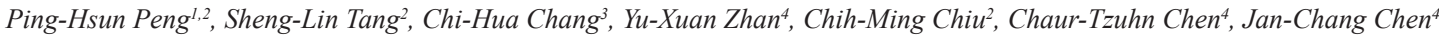
${ }^{1}$ Graduate Institute of Bioresources, Pingtung, Taiwan; ${ }^{2}$ Taiwan Forestry Research Institute, Taipei, Taiwan; ${ }^{3}$ Institute of Tropical Agriculture and International Cooperation, Pingtung, Taiwan; ${ }^{4}$ Department of Forestry, Pingtung, Taiwan(a22312793@gmail.com; a23112793@gmail.com; harry199180116@gmail.com; b10312050@gmail.com;a23112793@gmail.com; cct@mail.npust.edu.tw; zzzjohn@mail.npust.edu.tw)

Taiwan Kagome Co., Ltd has implemented understory thinning operation in their Swietenia macropnylla plantation since 2011. Thinning rates set from 25\% to $45 \%$. In this study, we investigate the juvenile trees, which from 14 to 20 years. We use Three Parameter Weibull Probability Distribution, conducted from Maximum Likelihood Method to simulate the diameter distribution before thinning and after. As results, the Dn values of K-S test are all lower than threshold value (D0.05). The estimation results by Weibull Probability Distribution of different age trees demonstrate well, validate with $100 \%$. It means this method is effective to display diameter distribution with different age plantations. With parameter of Weibull, a value, which is annual increasing of thinning plots shows from 0.81 to 0.93 , all higher than Control plots (0.26). The b values represent three stages, which are before thinning, after thinning and six years after thinning. Operation method contains four groups, which are 1,760 trees/ha (Group A, b value $=13.5,13.5,14.5), 1,200$ trees/ha $($ Group B, b value $=12.9,10.0,12.2)$, $1,000$ trees/ha (Group C, b value $=9.9,10.7,9.1)$, and 800 trees/ha (Group D, b value $=13.6,12.3,14.7)$. The $b$ value become lower as the distribution curve become smaller in Group A, B and D. After six years, diameter distribution goes bigger as tree age goes on. However, Group C has opposite results. The reason we found that lots of trees were dead because of pest and diseases hazards.

\section{Challenges and options for future coppice management in Europe. Lessons from the pan-European COST Action EuroCoppice}

Gero Becker ${ }^{1}$, Alicia Unrau ${ }^{1}$, Valeriu-Norocel Nicolescu ${ }^{2}$

${ }^{1}$ University of Freiburg, chair of forest utilization, Freiburg im Breisgau, Germany; ${ }^{2}$ University of Brasov, Faculty of Silviculture and Forest Engineering, Brasov,Romania (gero.becker@fob.uni-freiburg.de; lisch_unrau@hotmail.com; nvnicolescu@unitbv.ro)

Coppicing takes advantage of the natural ability of certain tree species to regenerate vegetatively after cutting, releasing fast growing stool sprouts or root suckers. Various forms of coppice management systems have been established worldwide, supplying wood and NWFP to rural societies and local economies. With industrialization and the increased use of fossil fuels many European coppice forests have been converted to high forests or abandoned, but over 20 million 
ha, representing over $10 \%$ of the forest cover are still showing characteristic features of coppice. The renaissance of wood as renewable resource for energy and bioeconomy, but also concerns about climate change and the loss of biodiversity results in a new interest in this flexible and adaptive, cost-effective sustainable management concept. In a four year project of international cooperation, researchers and experts from $35 \mathrm{EU}$ and neighboring countries collected data and scientific and practical knowledge about all aspects of coppice forests. Their major findings and conclusions and the proposed strategies to preserve and develop further coppice forest management are presented.

\title{
Restoration of traditional coppicing positively influences biodiversity: evidence from the Czech Republic
}

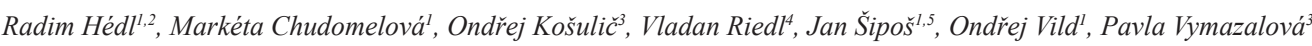

${ }^{1}$ Institute of Botany, Czech Academy of Sciences, Brno, Czech Republic; ${ }^{2}$ Department of Botany, Palacky University in Olomouc, Olomouc, Czech Republic; ${ }^{3}$ Department of Forest Protection and Wildlife Management, Faculty of Forestry and Wood Technology, Mendel University in Brno, Brno, Czech Republic; ${ }^{4}$ Nature Conservation Agency of the Czech Republic, Brno, Czech Republic; ${ }^{5}$ Department of Zoology, Fisheries, Hydrobiology and Apiculture, Faculty of AgriSciences, Mendel University in Brno,Brno, Czech Republic (radim.hedl@ibot.cas.cz; marketa.chudomelova@ibot.cas.cz; ondra.kosulic@seznam.cz; vladan.riedl@nature.cz; jsipos@seznam.cz; ondrej.vild@gmail.com; vymazalova.pavla@gmail.com)

Traditional coppicing was a very widespread forest management form in the European lowlands. In the area of today's Czech Republic, it was practiced from prehistory to the mid-20th century, frequently comprising $80-90 \%$ of forest management in individual estates. The abandonment of coppicing was a gradual process resulting from a transition to high forest management. Various groups of organisms adapted to coppicing vanished as coppicing management was abandoned. Current efforts of nature conservation and some foresters aim at restoring traditional coppicing and biodiversity linked to it. We briefly illustrate the changes in plant communities between the 1950s and 2000s reflecting the period of coppicing abandonment. Shady and nutrient-richer closed-canopy forests support only impoverished communities; many species vanished completely. Light- and warm-demanding species were most significantly influenced by the abandonment of coppicing. Monitoring focused on the effects of coppicing restoration (2008-present), specifically on the biodiversity of vascular plants and invertebrates. Results showed that species richness of vascular plants reacted with a quick increase in the first years after canopy opening. This change is much more pronounced than any fluctuation during time if no management action was taken. Species richness and abundance of spider communities were enhanced immediately after coppice restoration; functional diversity peaked in intensively restored stands. However, the longevity of induced biodiversity changes depends on the continuation of coppicing management. We conclude that coppicing restoration had a fast and strong effect on biodiversity. It may present a suitable way of biodiversity restoration in European lowland forests.

\section{Biomass allocation and carbon potential of beech (Fagus spp) coppice forests in Eastern Macedonia}

Christian Aeschlimann ${ }^{1}$, Marija Sterjovska ${ }^{2}$, Patrick Schwab ${ }^{1}$

${ }^{1}$ Bern University of Applied Science, Bern, Switzerland; ${ }^{2}$ St. Cyril and Methodius University, Skopje, Macedonia, Republic of the former Yugoslav (christian.aeschli@gmail.com; marija'sterjovska@gmail.com; patrickschwab20@hotmail.com)

In Macedonia, the great majority of rural people depend on firewood and coppice forests play an essential role in their livelihood strategies. Sustainable coppice forest management can also play an important role as carbon sinks and in adaptive management to climate change. This study aims at analysing the carbon stock potential of beech coppice forests in Eastern Macedonia. Eleven trees were harvested in mountainous Eastern Macedonia, their trunks were excavated and their complete biomass was measured and analysed, both above and below ground.The main research questions included (i) the relation between aboveground- and belowground biomass of beech coppice trees in different age; (ii) the comparison of beech high stem- and coppice forests with regard to biomass stockage and allocation; and (iii) the overall carbon stock potential of beech coppice forests in Eastern Macedonia. The data analysis showed that the rate between above and below ground biomass in beech coppice forests is higher by trend to the one in high stem beech forests and is about $25-27 \%$. With a rotation time of 50 years the average total biomass of 116 t/ha is $60-70 \%$ lower than the one in high stem forests located in similar sites. This study provides results, which can be used as instruments for measurements of carbon potential in southern Balkan beech coppice forests. A conclusion, however, can only be made after further forest inventories in order to improve data basis.

\section{Adaptive forestry in Slovakia: in search of alternative forest management models}

\author{
Róbert Sedmák ${ }^{1}$, Yvonne Brodrechtova ${ }^{1}$, Ján Bahýl', Michal Bošel'a', Ján Tuček ${ }^{1}$ \\ ${ }^{1}$ Technical University in Zvolen,Zvolen, Slovakia(robert.sedmak@tuzvo.sk; yvonne.brodrechtova@tuzvo.sk; jan.bahyl@tuzvo.sk; michal.bosela@tuzvo.sk; \\ jan.tucek@tuzvo.sk)
}

Forestry today has to provide robust approaches to forest management when confronted with $21^{\text {st }}$ century challenges. As the current forest management models (FMMs) in Slovakia face uncertainties including command-and-control governance inherited from the past, two alternative FMMs tackling a wide spectrum of ecosystem services (ES) were proposed: model of mixed management concepts and model of flexible aged forests. While the first model focuses on sustainable multifunctional management in partly uneven-aged mixed stands, the second alternative emphasizes sustainable timber provision in even-aged mixed stands (e.g. flexibility of rotation and regeneration periods). The FMMs were simulated for ten decades considering ES provisioning under the influence of climate change, demands for nature protection, changes in forest ownership structure, and various forest owner types. The preliminary simulation results exposed very small differences among current and altered management in comparison to today's situation (both management concepts do not considerably increase the overall multi-criterial utility of the considered ES). Climate had more impact due to differences in final multi-criterial utilities. Changes in nature protection and forest ownership structures had a markedly smaller impact on the provisioning of ES in the tested time span. Finally, on large areas within a longer time period there was an interaction equalizing synergies and negative exchanges in provisioning (trade-offs) among ES. This leads to the conclusion that if alternative FMMs based on more adaptive governance lead to similar outcome then the complicated, heavy regulative command-and-control governance with limited decision freedom could be rationalized to better cope with $21^{\text {st }}$ century challenges. 
Forage yield of Congo grass (Urochloa ruziziensis) in silvopasture systems with Khaya ivorensis Chev. / Produtividade da forrageira Urochloa ruziziensis em sistema silvipastoril com Khaya ivorensis Chev.

Filipe Gonçalves de Sousa ${ }^{1}$, Francine Neves Calil ${ }^{1}$, Sybelle Barreira ${ }^{1}$

${ }^{1}$ Universidade Federal de Goiás, Goiânia, Brasil (filipesousa.fhf@gmail.com; fncalil@gmail.com; sybelle.barreira@gmail.com)

Os sistemas silvipastoris são sistemas que visam o melhor aproveitamento da terra por meio do consórcio entre o componente arbóreo e animal, intensificando o uso da terra, potencializando os efeitos complementares da interação entre os componentes, como o sombreamento das árvores na criação pecuária e aumentando a renda do produtor, sem comprometer de forma excessiva o meio ambiente. A Khaya ivorensis Chev., conhecida popularmente como mogno-africano, possui uso múltiplo e alto valor comercial agregado, além de possuir alta adaptação ao clima do Brasil e crescimento rápido comparado a espécies com madeiras de densidade semelhante. O objetivo deste trabalho foi avaliar a produtividade da forrageira Urochloa ruziziensis entre renques de sistema silvipastoril consorciado com $K$. ivorensis Chev. O estudo foi realizado em um sistema silvipastoril com mogno-africano plantado em linhas triplas e com distância entre renques de $26 \mathrm{~m}$, onde se encontra implantada a forrageira $U$. ruziziensis. Foram coletadas, com auxílio de gabarito $50 \mathrm{x} 50 \mathrm{~cm}\left(0,25 \mathrm{~m}{ }^{2}\right)$, amostras da forrageira nas distâncias 1, 7, 13, 19 e 25 m, considerando a linha mais externa das árvores como referência. A produtividade média da forrageira foi de 517,91 kg/ha, sendo que os valores obtidos para cada distância dentro dos renques foram de 455,44; 492,90; 616,80; 600,57 e 423,86 kg/ha, respectivamente. Há um aumento na produtividade do material vegetal quando o ponto da amostragem está localizado mais ao centro do renque, evidenciando o papel fundamental da radiação solar para o crescimento das forrageiras.

Parkia multijuga Benth: a new option for reforestation and remediation of degraded areas in the Amazon region / Parkia multijuga Benth: uma nova opção para reflorestamento e recuperação de áreas degradadas na Amazônia

Osmar José de Aguiar ${ }^{1}$, Nayanna de Nazaré Brito Freitas ${ }^{1}$, Gleiciane de Meireles Batista

${ }^{1}$ Universidade do Estado do Pará,Belém,Brasil (o.aguiarromeiro@gmail.com; nayyyfreitas@hotmail.com; gleicianemeirelesbatista@gmail.com)

Desde o meados do século XX ocorre o desmatamento na Amazônia, intensificado pelos processos de urbanização e industrialização, atualmente, agravado pelas extrações ilegais, muitas vezes estimulados por política de ocupação da região. Em função da grande importância que a floresta Amazônia tem para a humanidade, estudos são desenvolvidos na região, desde da década de 50 pela SUDAM e o INPA, sobre silvicultura de espécie nativas, visando a recuperação de áreas degradadas. Por apresentar rápido crescimento e proteção do solo, a Parkia multijuga Benth., é utilizada para a recuperação de áreas de florestas secundárias e solo degradado na região. Assim, o presente trabalho tem como objetivo apresentar a parkia como uma nova opção para reflorestamento e recuperação de áreas degradadas na Amazônia, em função do potencial silvicultural apresentado. O material utilizado para o estudo foi proveniente de um plantio misto de paricá com parkia aos 5 anos, localizado no município de Ipixuna do Pará - PA. Em uma parcela amostral com 7 linhas contendo 30 árvores cada, foram mensurados os DAP de 206 árvores, sendo ao acaso 20 árvores de cada espécie para a determinação do potencial silvicultural por meio do IMA. Resultou que, os valores da espécie parkia foram de 32,83 $\mathrm{m}^{3} /$ ha.ano e paricá de $31,23 \mathrm{~m}^{3} /$ ha.ano, desta forma, verificou-se que não houve diferença significativa estatisticamente. Portanto, a parkia torna-se uma nova opção para ser utilizada em plantio comercial e recuperação de áreas degradadas no estado do Pará.

\section{Impact of natural shade on the thermal comfort of animals in pastures of Mato Grosso do Sul, Brazil / Influência do sombreamento} natural no conforto térmico animal em pastagens do Mato Grosso do Sul

Fabiana Villa Alves ${ }^{1}$, Genilson Fernando da Costa ${ }^{2}$, Ariadne Pegoraro Mastelaro 3 , Pedro Nelson Cesar do Amaral', Geovani Ferreira Alves ${ }^{4}$, Valdemir Antonio Laura ${ }^{1}$, Roberto Giolo de Almeida ${ }^{1}$

${ }^{1}$ Embrapa Gado de Corte, Campo Grande, Brasil; ${ }^{2}$ Universidade Estadual de Mato Grosso do Sul, Aquidauana, Brasil; ${ }^{3}$ Universidade Federal do Paraná, Curitiba, Brasil; ${ }^{4}$ Universidade Federal do Mato Grosso do Sul, Campo Grande, Brasil (fabiana.alves@embrapa.br; genilson.fernando@yahoo.com.br; aripmvet@gmail.com; plnelson.@uems.br; geovani.alves@ufms.br; valdemir.laura@embrapa.br; roberto.giolo@embrapa.br)

Uma das práticas mais eficientes para diminuir os efeitos indesejáveis do estresse térmico em animais à pasto, nos trópicos, é a implantação de árvores. Em experimento realizado de junho a agosto de 2018, na Fazenda Boa Aguada (URT Carne Carbono Neutro, da Embrapa Gado de Corte), em Ribas do Rio Pardo, Mato Grosso do Sul, foram avaliados três índices de conforto térmico (ITU, ITGU e CTR) na pastagem em monocultivo (PM), e em dois sistemas silvipastoris (28 x $2 \mathrm{~m}$ - S1 e 28 x $2+(3+3 \mathrm{~m})$ - S2), com diferentes arranjos de E. urograndis (altura média de $15 \mathrm{~m}$ ). As mensurações ocorreram ao sol (nos três sistemas) e à sombra (sistemas silvipastoris), em três dias consecutivos, as 13h00 (GMT - 4:00). O ITU e ITGU ao sol foram maiores na pastagem em monocultivo (85 e 89), em comparação aos S1 e S2 (ITU 82 e ITGU 85 em ambos os sistemas). À sombra, o ITU foi ligeiramente menor no S1 (79) em relação ao S2 (80), sendo que o ITGU foi igual em ambos os sistemas (80). A CTR ao sol também apresentou maiores valores para PM (634 W.m-2), em comparação ao S1 e S2 (587 e

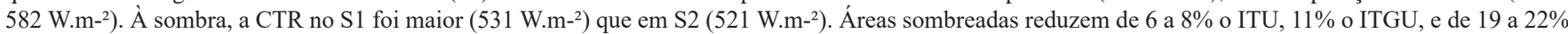
a CTR, segundo o arranjo de árvores implantado, com prováveis benefícios ao bem-estar animal.

Global temperature and humidity index in integration systems in the Cerrado / Índice de Temperatura Globo e Umidade em Sistemas de Integração no Cerrado

Ariadne Pegoraro Mastelaro ${ }^{1}$, Fabiana Villa Alves' ${ }^{2}$ Geovani Ferreira Alves ${ }^{3}$, Roberto Giolo de Almeida ${ }^{2}$, Valdemir Antônio Laura ${ }^{2}$, Maity Zopollatto ${ }^{1}$ ${ }^{1}$ Universidade Federal do Paraná, Curitiba, Brasil; ${ }^{2}$ Embrapa Gado de Corte, Campo Grande, Brasil; ${ }^{3}$ Universidade Federal do Mato Grosso do Sul, Campo Grande,Brasil(aripmvet@gmail.com; fabiana.alves@embrapa.br; gfalves@hotmail.it; roberto.giolo@embrapa.br; valdemirlaura@embrapa.br; maity@ufpr.br)

A alta incidência de radiação solar é considerada um dos problemas que mais influencia a produção animal em pastagens na faixa intertropical do globo terrestre. Práticas de manejo como a inserção de árvores, com vistas à oferta de sombra, são essenciais ao bem-estar animal nestas regiões. Em experimento realizado na fazenda Boa Aguada, em Ribas do Rio Pardo (MS), em outubro de 2018, objetivou-se verificar os benefícios aportados pela as árvores em arranjos ordenados, do tipo silvipastoril. Para tal, calculou-se o índice de temperatura de globo negro e umidade (ITGU) em 2 sistemas produtivos, implantados em 2016: pastagem monocultivo (PM) e silvipastoril 28 x $2 \mathrm{~m}$ (SP), com E. urograndis (altura média de $17 \mathrm{~m}$ ). Para tal, foram mensuradas as temperaturas de globo negro (Tgn, ${ }^{\circ} \mathrm{C}$ ) e ponto de orvalho $\left(\mathrm{Tpo},{ }^{\circ} \mathrm{C}\right)$, com termohigrômetro digital, no ponto central do piquete (a), em ambos os sistemas, e à $2 \mathrm{~m}$ das árvores no SP (b), por 24 horas, durante 31 dias, com duas repetições por ponto. O delineamento experimental foi em blocos casualizados, com médias comparadas pelo teste de Tukey (5\%). 
O ITGU médio foi diferente $(\mathrm{P} \leq 0,05)$ entre os sistemas e ao longo do dia. Os maiores valores de ITGU (94) foram encontrados no PM, ás $12 \mathrm{~h} 00$. No mesmo horário, o ITGU no SP foi de 86. Na média, o ITGU foi significativamente maior no PM (a) quando comparado ao SP (78 x 77 (a) e 76 (b)). Os dados obtidos ressaltam a importância da sombra, para os animais, nos horários mais quentes do dia.

\author{
Analyzing complete stem growth of Matayba elaeagnoides Radlk in a fragment of regenerating seasonal semideciduous forest / Análise \\ de tronco completa de crescimento de Matayba elaeagnoides Radlk em fragmento de floresta estacional semidecidual em regeneração \\ Girlaine Glenda Simplicio Brito ${ }^{1}$, Davidson da Silva Novaes ${ }^{1}$, Veridiana Padoin Weber ${ }^{1}$ \\ ${ }^{1}$ Universidade Tecnológica Federal do Paraná, Dois Vizinhos, Brasil (girlaine@alunos.utfpr.edu.br; davidsonnovaes@alunos.utfpr.edu.br; \\ veridianapadoin@utfpr.edu.br)
}

A dendrocronologia é a técnica que melhor permite interpretar e avaliar o crescimento de uma árvore, e observar possíveis relações com fatores ambientais de forma rápida e confiável. A pesquisa foi desenvolvida na Universidade Tecnológica Federal do Paraná, Campus Dois Vizinhos, na área da UNEPE (Unidade de Pesquisa e Extensão) Trilha Ecológica que é um fragmento de Floresta Estacional Semidecidual em Regeneração. A espécie estudada foi a Matayba elaeagnoides Radlk, cujas amostras foram obtidas através do projeto: Alternativas de manejo florestal para reestruturação e obtenção de produtos madeireiros de interesse econômico de um remanescente florestal no sudoeste do Paraná. Os dados foram obtidos mediante análise do tronco completa através do software Image Pro Plus. Foram calculados o Incremento Corrente Anual (ICA) em diâmetro e o Incremento Médio Anual (IMA) em diâmetro de acordo com o modelo ajustado de Chapman-Richards. De acordo com a contagem dos anéis a árvore possui 45 anos de idade. O ICA e IMA se encontram na idade 29, essa é a idade em que o ICA passa a decair e fica abaixo do IMA até a idade final. O IMA passa a estabilizar na idade 29. A espécie é tolerante a sombra e é enquadrada como secundária inicial, secundária tardia e Climax. O ponto de intersecção entre IMA e ICA mostra o melhor momento para o corte da árvore estudada ou momento de desbaste para manter o incremento.

Using the modified Liocourt method for managing native forests in Southwestern Paraná, Brazil / Uso do método de Liocourt modificado para o manejo de floresta nativa no sudoeste do Paraná

Mauricio Gorenstein ${ }^{1}$ (D; Elisabete Vuaden ${ }^{1}$, Veridiana Weber ${ }^{1}$, Edgar Vismara $^{1}$, Claudio Thomas ${ }^{1}$, Amanda Silva ${ }^{1}$

${ }^{1}$ Universidade Tecnológica Federaldo Paraná,Dois Vizinhos, Brasil (mauriciorg@utfpr.edu.br; elisabetev@utfpr.edu.br; veridianapadoin@utfpr.edu.br; edgarvismara@utfpr.edu.br; claudiothomas@utfpr.edu.br;amanda.1994@alunos.utfpr.edu.br)

O trabalho visa desenvolver uma metodologia baseada no Quociente de Liocourt médio atual da estrutura diamétrica para calcular o corte da floresta. A pesquisa foi realizada em um remanescente florestal na UTFPR-DV. Os dados foram coletados em três parcelas de $2400 \mathrm{~m}^{2}$, considerando todas as árvores com circunferência à altura do peito (cap) maior que $15 \mathrm{~cm}$. A metodologia consistiu em calcular um quociente de Liocourt atual (q) e um quociente médio (qmédio) obtido pela média aritmética dos quocientes calculados para cada classe diamétrica multiplicado pelo número de árvores presentes em cada classe, pela seguinte fórmula: [(q - qmédio)/q]*N. Os valores de q variaram de 1,2 a 9,2 e o qmédio nas parcelas 1,2 e 3 foram q1 =2,9, q2 =2, q3 $=6,9$, respectivamente. Os maiores valores de q foram obtidos nas menores classes diamétricas, o que demonstra alta regeneração de um número limitado de espécies remanescentes, prejudicando a diversidade ecológica do povoamento. Assim, para que a floresta fique balanceada após o corte, somente as árvores abaixo de $34 \mathrm{~cm}$ de diâmetro à altura do peito deverão ser retiradas. Nas parcelas 1 e 3, 91\% dos indivíduos a serem desbastados estão concentrados na primeira classe diamétrica e na parcela 2, $81 \%$ das árvores. A porcentagem de árvores desbastadas será: 9,73\%, 20,73\%, 24,19\% nas parcelas 1, 2 e 3, respectivamente. A utilização do método de Liocourt modificado se justifica para aumentar a diversidade de espécies com a retirada da regeneração de indivíduos que dominam o estrato nas primeiras classes diamétricas, garantindo a perpetuidade da floresta.

Physiological dormancy in five shrub species of Rubiaceae native to Brazil / Dormência fisiológica em cinco espécies arbustivas de Rubiaceae da flora nativa brasileira

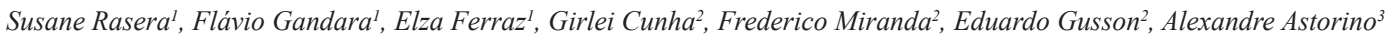 \\ ${ }^{1}$ Escola Superior de Agricultura "Luiz de Queiroz", Piracicaba, Brasil; ${ }^{2}$ Biodendro Consultoria Florestal, Piracicaba, Brasil; ${ }^{3}$ AES Brasil, Bauru, Brasil \\ (susanerasera@yahoo.com; fgandara@usp.br; elzamferrazz@gmail.com; girlei.cunha@gmail.com; fredtsmiranda@gmail.com; \\ eduardogusson@gmail.com; alexandre.astorino@aes.com)
}

Espécies não arbóreas representam aproximadamente dois terços das espécies de plantas da floresta tropical, além de serem fonte de alimento para diversos animais e contribuírem para a formação de nichos ecológicos específicos dentro do sistema florestal. Tendo em vista a baixa regeneração natural desse componente em áreas restauradas, torna-se necessária a introdução dessas espécies em áreas em restauração. Existindo uma grande lacuna de informações sobre essas espécies e sendo a germinação de sementes uma das etapas fundamentais para permitir a introdução delas em campo, o objetivo desse trabalho foi testar o efeito da quebra de dormência na germinação de cinco espécies arbustivas pertencentes à família Rubiaceae: Psychotria warmingii, Psychotria deflexa, Psychotria anceps, Palicourea cf. croceoides e Margaritopsis cf. schuechiana. O estudo foi desenvolvido no Laboratório de Ecologia Vegetal e Agroecologia da ESALQ/USP. Primeiramente, foi testada a possibilidade de dormência tegumentar, usando-se como tratamentos: $\mathrm{H}_{2} \mathrm{SO}_{4} 98 \%$ (1, 5, 10 e 15 minutos); $\mathrm{H}_{2} \mathrm{O} 80{ }^{\circ} \mathrm{C}(1,5,10$ e 15 minutos) e imersão em água $(8,12,24$ e 48 horas). Como não houve resposta germinativa aos tratamentos, foi testada a possibilidade de dormência fisiológica, com o uso de Ácido Giberélico (GA3) por 24 horas em diferentes concentrações: i) GA3 100 ppm (exceto para Margaritopsis cf. schuechiana); ii) GA3 250 ppm; iii) GA3 500 ppm; iv) GA3 750 ppm; e v) Testemunha. Todas as espécies responderam ao uso do Ácido Giberélico, sendo as maiores taxas de germinação obtidas para concentrações de 500 e 750 ppm, evidenciando a dormência fisiológica existente nessas espécies.

Economic radius as an instrument for guiding adoption of sustainable forest management in the Amazon region: a case study in Acre, Brazil / Raio econômico como um instrumento para orientar a adoção do manejo florestal sustentável na Amazônia: um estudo de caso no estado do Acre

Zenobio Abel Gouvêa Perelli da Gama e Silva ${ }^{1}$, Karine Silva ${ }^{1}$

${ }^{1}$ Universidade Federal do Acre, Rio Branco, Brasil (zenobio.siva@gmail.com; karinemilene26@gmail.com)

Este estudo aborda a produção racional de madeira na Amazônia brasileira. Seu objetivo foi identificar a distância econômica limite entre uma floresta, sob regime de manejo florestal sustentável (MFS), e o pátio de uma firma madeireira, e assim colaborar na formulação de políticas que fomentem o uso racional dos recursos florestais-madeireiros regionais. Para tal, adotou-se, como área de estudo, as florestas localizadas no estado do Acre. Os dados usados nessa pesquisa 
foram obtidos em entrevistas com os proprietários de serrarias que atuavam, nesse estado, no período 2008-2010. Os conceitos adotados para quantificar o raio econômico para atividade florestal-madeireira nessa região, foram: 1) renda líquida, na venda da madeira serrada, para diferentes distâncias entre uma floresta manejada e o pátio da serraria e 2) valor esperado da terra (VET), válido para uma terra destinada à produção florestal manejada. A partir dos resultados gerados, conclui-se que: 1) considerando-se os custos de uma serraria com a produção e comercialização de madeira serrada e o preço de venda dessa mercadoria, tem-se que o raio econômico, para essa atividade florestal-madeireira, no Acre, é de $282 \mathrm{~km}$ e 2) uma comparação do preço médio da terra florestal, na região, com o VET obtido indica que só é viável, economicamente, um empresário manejar e explorar uma floresta, e vender a madeira em tora, posto no pátio da serraria, e esse processo lhe render uma taxa de juros de $6 \%$ ao ano, se a distância dessa floresta até a firma madeireira for, no máximo, igual a $125 \mathrm{~km}$.

C1q: PRODUCTION FORESTRY - I

Estimating the microfibrillar angle using fiber biometrics and physical properties of African mahogany wood / Estimativa do angulo microfibrilar por biometria das fibras e propriedades fisicas da madeira de mogno africano

Sofia Maria Rocha ${ }^{1}$, João Gabriel Missia ${ }^{1}$, Graziela Vidaurre ${ }^{1}$, Ramon Oliveira ${ }^{1}$, Alexa Melo ${ }^{1}$, Daniela Minini ${ }^{1}$, Maria Naruna Félix ${ }^{1}$

${ }^{1}$ Universidade Federal do Espirito Santo,Jerônimo Monteiro,Brasil (sofiamaria.r@hotmail.com; j.gabrielmissia@hotmail.com; grazividaurre@gmail.com; oliveira.r.eim@gmail.com; alexabmelo@hotmail.com; daniminini16@gmail.com; narunafelix@gmail.com)

O ângulo microfibrilar (AMF) da parede celular influencia a estabilidade dimensional e as propriedades mecânicas, e sua estimativa permite compreender o comportamento da madeira de $K$. ivorensis e $K$. senegalensis no beneficiamento e como produto. A mensuração do AMF pela microscopia de luz polarizada, é onerosa, demorada e dependente da perícia do observador[SM1], por isso, teve-se por objetivo estimar o AMF por outras propriedades da madeira [SM2] , de mais fácil determinação. Foram colhidas 3 árvores por espécie, em parcela experimental (espaçamento de 3 x 2 m) da Reserva Natural Vale, Linhares - ES, Brasil. De discos do DAP, determinou-se a biometria das fibras (dimensões e índices) e dos vasos (dimensões e número), as contrações lineares e volumétrica e o fator anisotrópico. Pelo método exhaustive search, que determina a melhor combinação de variáveis independentes para estimar a dependente, selecionouse equações que melhor estimaram o AMF por outras propriedades da madeira[SM3] . A variação do AMF da K. ivorensis foi 82\% explicada em modelo de 5 variáveis, espessura de parede + índice de esbeltez + índice de Runkel + densidade básica + contração longitudinal, com erro de 5\%. O AMF da K. senegalensis foi apenas $18 \%$ explicado por modelo de 4 variáveis, comprimento das fibras + índice de esbeltez + coeficiente de flexibilidade + espessura de parede, com erro de 10,1[SM4] \%. O AMFda K. ivorensis pode ser estimado por outras propriedades de determinação mais simples. Para a K. senegalensis, o AMF não expressou relação clara com as propriedades da madeira.

\section{Volumetric estimates for forest concession areas in the Amazon Forest}

Mateus Sanquetta ${ }^{1}$, Ana Paula Dalla Corte ${ }^{1}$, Vinicius Cysneiros ${ }^{1}$, Carlos Sanquetta ${ }^{1}$, Luciane Schmidt ${ }^{1}$

${ }^{1}$ Universidade Federaldo Parana, Curitiba,Brasil(mateus.sanquetta@gmail.com; anapaulacorte@gmail.com; vccysneiros.florestal@gmail.com; carlossanquetta@gmail.com; lunaimekeschmidt@gmail.com)

Forest concession consist in an important mechanism to reduce deforestation rates and develop social and economically the Amazonian region. Estimating the commercial volume and better planning the use of resources are essential for concessionaires. This study aimed to evaluate different approaches to estimate the commercial tree volume of under concession species in the National Forest of Jamari, located in the state of Rondônia, Northern Brazil. Regression models of simple and double inputs were fitted and then compared with form factor (average value of 0.7). The Schumacher and Hall model showed the best estimates. The inclusion of random effects related to stand (plot) and specie provided major gain in accuracy and bias. This study serve as a technical subsidy for concessionaires of public forests, adopting more reliable approaches to estimate the commercial volume of tropical species.

Controlling larvae of Hypsipyla grandella Zéller with biocide extracts / Control de larvas de Hypsipyla grandella Zéller con extractos biocidas

Héctor Guerra-Arévalo ${ }^{1}$, Fernando Flores Fasanando ${ }^{2}$, Agustin Cerna Mendoza ${ }^{2}$, Ana Lucia Milagros Vásquez Vela ${ }^{3}$, Enrique Arévalo-Gardini ${ }^{3}$ Wilson Francisco Guerra Arévalo ${ }^{4}$, Carlos Abanto-Rodriguez ${ }^{1}$

${ }^{1}$ Instituto de Investigaciones de la Amazonia Peruana, San Martin, Peru; ${ }^{2}$ Universidad Nacional de San Martin-Tarapoto, San Martin, Peru; ${ }^{3}$ Instituto de Cultivos Tropicales, San Martin, Peru; ${ }^{4}$ Instituto de Investigaciones de la Amazonia Peruana, Ucayali, Peru (hyuerra@iiap.org.pe; floresfer1996@gmail.com; agucerna@hotmail.com; analuciava.2012@gmail.com; enriquearevaloga@gmail.com; wguerra@iiap.org.pe; cabanto@iiap.org.pe)

En Perú existen una alta diversidad de especies biocidas nativas e introducidas con potencial insecticida para el control de plagas y enfermedades en sistemas productivos, siendo así, el objetivo de este trabajo fue evaluar el efecto de dosificaciones de extractos biocidas (Ruta graveolens-RG.; Azadirachta indicaAI; Simarouba amara-SA; Tagetes erecta-TE) en el control de larvas de Hypsipyla grandella Zéller. El experimento fue conducido mediante un Diseño Completamente al Azar (DCA), en esquema de parcelas subdivididas, con 5 tratamientos, 3 repeticiones y 10 discos foliares de Swietenia macrophylla por unidad experimental. Las parcelas fueron constituidas por 5 concentraciones (T1: 0\%; T2: 10\%; T3: 20\%; T4: 30\%; y T5: 40\%) para cada extracto biocida y las sub-parcelas fueron constituidas por 4 tiempos de evaluación (6h, $12 \mathrm{~h}, 18 \mathrm{~h}$ y $24 \mathrm{~h}$ ) durante el día. Las variables evaluadas fueron: consumo del disco foliares-CDF (\%), incremento de consumo foliar-ICF (\%), mortandad - ML (\%) y actividad larval-AL (\%). Los extractos que ocasionaron los mejores efectos significativos $(\mathrm{p} \leq 0.05)$ fueron RG y SA con $48.67 \%$ y $49.14 \%$ respectivamente de consumo foliar, $13.3 \%$ y $10 \%$ de larvas muertas y menor actividad larval. De este modo, las concentraciones menores fueron menos eficientes en el control de larvas. Se concluye que, los extractos de RG y SA, actuaron como insecticida en el control de larvas de $H$. grandella y la mayor mortalidad de larvas ocurrió en las altas concentraciones de la mayoría de los extractos. 
Characteristics of integrated silvopasture systems utilizing eucalyptus in Paraguay / Caracterización de sistemas silvopastoriles con eucalipto en el Paraguay

María Alexandra Perrone González ${ }^{1}$, Tobias Marcelo Ybañez Roman ${ }^{1}$, Maria Laura Quevedo Fernandez ${ }^{1}$, William Tomaz Folmann ${ }^{1}$

${ }^{1}$ Universidad Nacional de Asuncion, Asuncion, Paraguay; Independiente, Asuncion, Paraguay (alexandraperroneg@gmail.com;

tobias.ybanhez@gmail.com; marialauraquevedo@gmail.com;.wfolmann@gmail.com)

Con el objetivo de caracterizar los sistemas silvopastoriles (SSP) con Eucalipto en el Paraguay, se realizó a 7 empresas la aplicación de un cuestionario contemplando aspectos de identificación, técnico, económicos y factores críticos. Además, se ha estimado el crecimiento de plantaciones bajo SSP mediante la instalación y medición de 134 parcelas permanentes en 3 empresas. La preparación de terreno generalmente es realizada con rastra pesa en todos los casos en combinaciones que varían con rastra liviana, subsolado, taipeado y en $71 \%$ de los casos son realizadas con canalizaciones. Entre los principales meses de preparación de terreno se destacan enero a abril y julio a noviembre. La plantación es realizada de forma manual principalmente entre los meses de abril a mayo y octubre a noviembre. El control de hormiga es realizado con Fipronil. Todas las empresas realizan fertilización y $71 \%$ encalado, en cuanto que el control de malezas realizado en la línea de plantación es principalmente químico combinado con manual. Son realizadas de 4 a 10 podas hasta los 11 a 15 metros y 2 raleos selectivo o mixto con cosecha mecanizada y semimecanizada. El inventario evidencio que los mejores valores correspondieron al I144 con $32 \mathrm{~m}^{3} / \mathrm{ha} / \mathrm{año}$, en cuanto a la estimación de la viabilidad económica la empresa 7 resulto con los indicadores mayormente viables con un VAN de 1.254US\$/ha, una TIR de 19\%, una RB/C de 1,48 y un VPE de 165U\$/ha/año. Como principal factor critico se destaca "Falta de referencia de precios de mercado de productos forestales".

Using greenhouses, substrates, and rooting agents to root cuttings of Guazuma crinita Martius / Uso de invernaderos, sustratos y aditivos enraizantes en el enraizamiento de miniestacas de Guazuma crinita Martius

Wilson Francisco Guerra Arevalo ${ }^{1}$, Yanisse Basauri Torres ${ }^{2}$, Carlos Abanto-Rodriguez ${ }^{1}$, Guillermo Eduardo Gorbitz Dupuy ${ }^{3}$, Dennis del Castillo Torres ${ }^{1}$, Hector Guerra Arevalo 1

${ }^{1}$ Instituto de investigaciones de la Amazonía Peruana, Pucallpa, Peru; ${ }^{2}$ University of Eastern Finland, Kuopio, Finland; ${ }^{3}$ DIPTERYX SAC, Pucallpa, Peru

La falta de métodos adecuados para producir plantas de G. crinita en vivero, viene siendo la principal desventaja para garantizar el éxito de las plantaciones forestales, por tanto, técnicas de propagación deben ser utilizadas. Así, el objetivo en este trabajo fue determinar el mejor invernadero, sustrato y aditivo enraizante para la producción de plantas mediante el enraizamiento de miniestacas de Guazuma crinita M. Para ello fue utilizado material apical de 5.0 cm de longitud, $4.0 \mathrm{~mm}$ de diámetro y 2/3 de área foliar $\left(20-30 \mathrm{~cm}^{2}\right)$, provenientes de brotes sanos y vigorosos de plantas de bolaina. Después de 20 días, fue determinado entre 93.3 y 100\% de enraizamiento, $100 \%$ de sobrevivencia y 100\% de brotes en las miniestacas ubicadas en los invernaderos policarbonato y malla raschel ${ }^{\circledR}$ asociados con los sustratos y aditivos arena fina-sanix ${ }^{\circledR}$ y jiffy ${ }^{\circledR}$-rapid root ${ }^{\circledR}$. También fue determinado 18.9 raíces en la combinación de

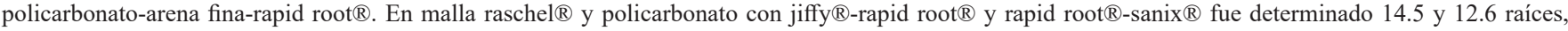
respectivamente. En condiciones de policarbonato-arena fina fue constatado $46,1 \mathrm{~cm}$ y en jiffy ${ }^{\circledR}$ con malla raschel ${ }^{\circledR}$ y policarbonato las raíces presentaron 41.4 y $35.3 \mathrm{~cm}$ de longitud, respectivamente. Los invernaderos construidos de policarbonato y de malla raschel ${ }^{\circledR}$ asociados con los sustratos arena fina y jiffy ${ }^{\circledR}$ más los aditivos enraizantes rapid $\operatorname{root}{ }^{\circledR}$ y sanix ${ }^{\circledR}$ fueron las mejores condiciones para el enraizamiento de miniestacas de Guazuma crinita M.

Production and diameter classes of eucalyptus wood in two spatial arrangements within an integrated crop-livestock-forest system / Produção e sortimento de madeira de eucalipto em dois arranjos espaciais, em sistema agrossilvipastoril

Maria Tereza Angeletti Nunes ${ }^{1}$, Silvio Nolasco de Oliveira Neto ${ }^{1}$, Simone Silva ${ }^{1}$, Amana de Magalhães Matos Obolari ${ }^{1}$, Ricardo Fernandes Pena ${ }^{1}$, Bruno Leão Said Schettini ${ }^{1}$

${ }^{1}$ Universidade Federal de Viçosa, Viçosa,Brasil (mtangeletti@hotmail.com; snolasco@ufv.br; simone.silva.ufv@gmail.com; amanaobolari@gmail.com; ricardopena.mg@gmail.com; blsschettini@gmail.com)

O aumento da produção em equilíbrio com a qualidade ambiental é um dos grandes desafios no cenário agrícola atual. A adoção de sistemas agroflorestais é uma das alternativas potenciais para lidar com essa questão, logo, pesquisas sobre esse tema tornam-se fundamentais. Sendo assim, o objetivo desse trabalho é avaliar a possível influência da variação de espaçamento na produção e sortimento de madeira de eucalipto em um sistema agrossilvipastoril aos 7 anos de idade. O sistema em questão foi implantado em dezembro de 2007 com milho (Zea mays) e espécies forrageiras (Brachiaria sp.), combinados com dois arranjos de espécies arbóreas constituídos por eucalipto (Eucalyptus grandis x E. urophylla - clone 3336) em monocultivo e em plantio misto com Acácia (Acacia mangium), em espaçamento 12 × 2 m. Quatro anos após a implantação realizou-se o desbaste da acácia, condicionando o eucalipto aos espaçamentos 12 x 2 m e 12 x 4 m. Após realização de um inventário seguido da cubagem de três árvores representativas para cada classe de diâmetro, foram avaliados modelos para estimativas do volume e análise de sortimento. A variação do espaçamento não influenciou o crescimento em altura das árvores, mas favoreceu o crescimento em diâmetro. O espaçamento 12 × $2 \mathrm{~m}$ apresentou maior produção volumétrica por unidade de área apesar de o 12 x 4 m apresentar maiores diâmetros. O modelo de Dermaerschalk (1972) foi utilizado para análise de sortimento e indicou, para os dois espaçamentos, a destinação conjunta para serraria e lenha.

\section{Assessing the state of the art in research and development of agroforestry systems in Colombia/ Evaluación del estado del arte de la investigación y desarrollo en sistemas agroforestales en Colombia}

Paula Alejandra Alba Martínez ${ }^{1}$, María Fernanda Riaño Peláez

${ }^{1}$ Forestal Ingeniería, Bogotá, Colombia (pau.alba.m@gmail.com; mfrianop@gmail.com)

El propósito de la investigación es identificar hasta donde se ha avanzado en las temáticas agroforestales del país por medio de la crítica y el uso de publicaciones de manera ordenada, precisa y analitica. El conocimiento del estado del arte, la seriedad en términos de publicación, justificación con datos de respaldo, aceptación, entre otros; y la rigurosidad de la investigación en los sistemas agroforestales no lo hacemos únicamente con la finalidad de hacer investigación. La importancia de esta revisión resulta en brindar una herramienta básica para avanzar en la práctica; abre las puertas a la inspiración y difusión de nuevas ideas, poniendo sobre la mesa las contradicciones en los conocimientos actuales. Este proyecto posibilita la evaluación de las prácticas vigentes y formulación de recomendaciones. 


\section{Temporal variation in species composition, diversity and regeneration status along altitudinal gradient and slope: the case of Chilimo Dryafromontane forest, Central Highlands of Ethiopia}

Mehari A Tesfaye ${ }^{1}$, Oliver Gardi ${ }^{2}$, Tesfaye Bekele ${ }^{1}$, Jurgen Blaser ${ }^{2}$

${ }^{1}$ EEFRI, Addis Ababa,Ethiopia; ${ }^{2 H A F L-B E R N, B e r n, S w i t z e r l a n d ~(m e h a r i a l e b a c h e w 25 @ g m a i l . c o m ; ~ o l i v e r . g a r d i @ b f h . c h ; ~ t e b e a n 77 @ y a h o o . c o m ; ~}$ juergen.blaser@bfh.ch)

The aim of this study was to investigate temporal variation in species composition, diversity and regeneration status of Chilimo dry afromontane forest, Central Highlands of Ethiopia. A total of 35, 20 m x 20 m permanent squared sampled plots were established. Two times inventory in 2012 and 2017 were conducted. Three subplots, $5 \mathrm{~m}$ x $5 \mathrm{~m}$ and $1 \mathrm{~m}^{2}$ were laid out inside main plots for saplings, shrubs and seedlings data collection. However, biometric and stump data were collected in the main plots. Spp composition, diversity, IVI and regeneration data were analyzed using appropriate formulas. Data analysis and graphics were performed using R software. A total of 31 Spp of trees and shrubs, representing 25 families were recorded, 20 (64.52\%) were trees and 11 (35.48 \%) were shrubs. The 5 most dominant tree Spp were: Juniperus procera, Podocarpus falcatus, Olea europea, Olinia rochetiana and Allophyllus abyssinicus. Growth and regeneration were significantly varied among the Spp, altitudinal gradient, forest patch and slope. The mean annual increment was ranged from 4.223 to $0.228 \mathrm{~m}^{3} \mathrm{ha}^{-1} \mathrm{yr}^{-1}$ and the basal area increment was ranged from 0.85 to $0.020 \mathrm{~m}^{2} \mathrm{ha}^{-1} \mathrm{yr}^{-1}$. Ten Spphad fair, 5 poor and 14 no regeneration.

\section{Chronological change and resilience of oak forests in areas occupied by autochthonous broadleaf forests of the Northwestern Iberian}

Díaz-Maroto Ignacio J. ${ }^{1}$

${ }^{1}$ University of Santiago de Compostela,Lugo, Spain (ignacio.diazmaroto@usc.es)

The present ecosystems are the consequence of a mixture of anthropogenic involvement and vegetation dynamics in the last glacial-interglacial cycle, and their progression can be describe by different methods (dendrochronology, isotope dating, palynology,...). In the Northwest Iberian there is confirmation of the presence of Quercus species since the Cretaceous and their diversification in the Tertiary. The decline of broadleaved forests began in prehistoric period and coincided with the increase of human activity and the establishment of crops and pasture. The expansion of agriculture and cattle breeding began between 4000-5000 years BC. Other causes were the expansion of the naval industry, extraction of wood and firewood for domestic/industrial use and forest fires.All the actions have caused a diminution in the area occupied by woodlands until the middle of the $19^{\text {th }}$ century, without make any management action to allow the natural regeneration. The forests were either not managed at all or were subjected to inappropriate silviculture, such as pollarding and felling of the best trees. In the second half of the century there was an increase in the area occupied by broadleaved species. This grow was due to the abandonment of certain activities such as the use of firewood, agriculture and extensive pasture, and the reduction in the shipbuilding. Much of smallholder farms have recently disappeared, and have been replaced by protection forests, reforestation with fast growing species and unproductive land. As a result, in the last decades, there has been an important increase in the area occupied by natural forests.

\section{Growth and sustainable management of Cedrela fissilis Vell. in the Atlantic Forest in Southern Brazil}

Rafael Schmitz ${ }^{1,2}$, Luciano Farinha Watzlawick ${ }^{3}$, Patricia Póvoa de Mattos ${ }^{4}$ (D; Evaldo Muñoz Braz ${ }^{4}$ (D)

${ }^{1}$ Universidade Federal do Paraná, Curitiba, Brasil; ${ }^{2}$ Instituto Federal de Santa Catarina, Florianópolis, Brasil; ${ }^{3}$ Universidade Estadual do Centro-Oeste, Irati,Brasil; ${ }^{4}$ Embrapa Florestas, Colombo,Brasil (schmitz.efl@hotmail.com; farinha@unicentro.br; patricia.mattos@embrapa.br; evaldo.braz@embrapa.br)

This study aimed to determine the annual diameter increment and the time passage between diameter classes of Cedrela fissilis Vell. in a remnant of the Deciduous forest in the Atlantic Forest biome, near the border between Brazil and Argentina. We also aimed to adjust diameter growth models according to age, to develop the basis of management and conservation plans. The assessment was in traversal tracks in $41.9 \mathrm{~h}$. All $C$. fissilis trees were sampled for dendrochronological analysis, using increment cores. We found 126 trees with diameter varying between 11 and $82 \mathrm{~cm}$. The maximum mean increment was $0.62 \mathrm{~cm} \mathrm{yr}^{-1}(170$ years old with $\mathrm{DBH}=81.9 \mathrm{~cm})$ and the minimum $0.29 \mathrm{~cm} \mathrm{yr}^{-1}$. Schumacher growth model presented better adjustment to the species growth pattern. It was observed that the optimum moment for interventions, considering the increment in diameter, occur, in the class of $25 \mathrm{~cm}$ of DBH, in cutting cycle of 21 years. This would allow the maintenance of the population under sustainable management system in the studied forest remnant.

\section{Phytosociological structure on edaphic aspects of an Atlantic Forest fragment in Southern Brazil}

Rafael Schmitz ${ }^{1,2}$, Luciano Farinha Watzlawick ${ }^{3}$, Patricia Povoa Mattos ${ }^{4}$; Evaldo Muñoz Braz ${ }^{4}$ (D)

${ }^{1}$ Universidade Federal do Paraná, Curitiba, Brasil; ${ }^{2}$ Instituto Federal de Santa Catarina, Florianópolis, Brasil; ${ }^{3}$ Universidade Estadual do Centro-Oeste, Irati,Brasil; ${ }^{4}$ Embrapa Florestas, Colombo,Brasil (schmitz.efl@hotmail.com; farinha@unicentro.br; patricia.mattos@embrapa.br; evaldo.braz@embrapa.br)

In this work an analysis of the floristic, phytosociological and soil characteristics aspects was carried out in a remnant of Decidual Seasonal Forest in the extreme west region of Santa Catarina, Southern Brazil. We aimed to provide information for the understanding of biogeographic patterns and to add subsidies to the determination of priority areas for sustainable management in fragmented forest formations; The study area presented 41.9 ha of Deciduous Seasonal Forest in the Atlantic Forest Biome near the border between Brazil and Argentina. The surveys were carried out in 30 circular sample units with a variable area. All trees with circumference at $1.30 \mathrm{~m}$ from the soil $\geq 10 \mathrm{~cm}$ were identified. Soil samples were collected for chemical and physical analysis. There were 94 tree species, distributed in 33 families. From those, 33 species are considered important for timber production (representing 14 families). The families Lauraceae, Meliaceae, Myrtaceae, Rutaceae and Papilonodaceae represented 52.1\% of the total species identified. The Shanon Diversity Index was 3.96 and three subareas were differentiated by soil and species frequency in the forest remnant. Organic matter, phosphorus, $\mathrm{pH}$, calcium and clay basically defined the subareas. These results, in the exploratory context of the Atlantic Forest biome, indicate that the remnant still presents high diversity and also of timber tree species, therefore, the forest resources could be sustainably managed for use or conservation. 


\section{Growth and forage yield of tropical grasses in silvopastoral systems in Brazil}

Valéria Santos ${ }^{1}$, Roberto Almeida ${ }^{2}$,Valdemir Laura ${ }^{2}$, Fabiana Alves $^{2}$

${ }^{1}$ Escola Superior de Agricultura “Luiz de Queiroz”, Universidade de São Paulo Piracicaba, SP, Brasil; '2Embrapa Gado de Corte, Campo Grande, Brasil (valeria.corvala@usp.br; roberto.giolo@embrapa.br; valdemir.laura@embrapa.br;fabiana.alves@embrapa.br)

The interest in the knowledge of the establishment of grasses under shading increased, aiming to provide subsidies for the successful implantation of silvopastoral systems. In this study, we analyzed tiller growth and forage production of Brachiaria brizantha (cultivars BRS-Paiaguás, BRS-Piatã and Marandu) and Panicum maximum (cultivars Massai and BRS-Tamani) in silvopastoral systems, at Campo Grande, MS, Brazil.The experiment was arranged in randomized complete block design, with strip plots and two replications. The plots were implanted in March 2016, among the Eucalyptus urograndis adult tree rows, with an average height of $28 \mathrm{~m}$, in $22 \times 2 \mathrm{~m}$ arrangement. The tiller count (tiller. $\mathrm{m}^{-2}$ ) was performed every 30 days at five equidistant points (A, B, C, D and E) between rows of eucalyptus and one point at full sun (F).To determine forage yield, three cuts (at 60 day intervals), at the height of $10 \mathrm{~cm}$ of soil residue, were performed. The points presented different solar transmittances: $\mathrm{F}=100 \%, \mathrm{~A}=85 \%, \mathrm{~B}=87 \%, \mathrm{C}=77 \%, \mathrm{D}=25 \%$ and $\mathrm{E}=15 \%$. The shading points presented a reduction of $74 \%$ in tiller population compared to the sun. The biomass production of Brachiaria cultivars (1,466 kg.ha-1 DM) was higher than that of Panicum cultivars (980 kg.ha- ${ }^{-1} \mathrm{DM}$ ), with no differences in the same species. In general, the grasses showed biomass reduction decreasing from point A to $\mathrm{E}$ (36 to $67 \%$ ). The cultivars of Brachiaria brizantha are more suitable for implantation in silvopastoral systems with adult trees, as an establishment strategy in fall-winter (off-season).

\section{Cattle productivity and carbon stock in silvopastoral systems with Cratylia argentea in the Colombian Dry Caribbean}

Jose Edwin Mojica ${ }^{1}$, Milton Rivera Rojas ${ }^{1}$, Darwin Fabian Lombo ${ }^{1}$, Juan Ricardo Zambrano ${ }^{1}$, Jaime Andres Arias Rojas ${ }^{1}$, Sonia Ospina Hernadez ${ }^{2}$ ${ }^{1}$ Agrosavia, Agustin Cosazzi Cesar, Colombia; ${ }^{2}$ Agrosavia, Palmira Valledel Cauca, Colombia (jmojica@agrosavia.co; mrivera@agrosavia.co;dlombo@ agrosavia.co;jzambrano@agrosavia.co; jarias@agrosavia.co; sospina@agrosavia.co)

Dual-purpose cattle systems in department of Cesar are based on grazing of grasses. Milk yield total solids, fat and protein content for cows Zebu x Swiss brown at mid lactation stage were evaluated for silvopastoral systems with Eucalyptus camaldulensis and Cratylia argentea cv Veranera associated with Brachiaria hybrid Mulato II (T1), Bothriochloa pertusa (T2), Brachiaria brizantha cv. Toledo (T3) and Megathyrsus maximus cv. Tanzania (T4).The initial establishing density of tree was 500 units per hectare with harvest projection for fencing post at six years and final plot density of 300 trees. A simple crossover design was used to analyse the variables. The saleable milk yield was higher $(\mathrm{P}<0,05)$ in $\mathrm{T} 1(6,0 \mathrm{1} / \mathrm{v} / \mathrm{d})$ in comparison to the other associations. The treatment did not affect $(\mathrm{P}>0,05)$ the milk quality variables. The total timber volume of E. camaldulensis was 56,2 when considering $17,1 \mathrm{~m}$ and $13,9 \mathrm{~cm}$ as total height and diameter at breast height, respectively. For carbon stock aerial biomass, the reserve was estimated as 11,65 tC/ha with fixation rates of1,94 tC/ha/yr. The association Mulato II - Cratylia - E. camaldulensis was identified as a silvopastoril system that increase the saleable yield of milk compared with the predominant open grass (Bothriochloa pertusa) in the Colombian dry Caribbean region, that has shown a milk production of 3,9 $\mathrm{l} / \mathrm{v} / \mathrm{d}$ at the midterm of the lactating curve for dual-purpose cows. This system also represents an opportunity to contribute to mitigation from carbonfixation rates of1,94 tC/ha/yr at the cattle production system and farm level.

\section{Paspalum umbrosum: a posible option C4 grass for silvopastoral systems in subtropical zones.}

Jaime Gonzalez-Talice ${ }^{1}$, Jean Fedrigo ${ }^{2}$, Adriana Bussoni ${ }^{1}$, Gonzalo Amarillo ${ }^{1}$, Javier Frigerio ${ }^{1}$, Eugenia Cabrera ${ }^{1}$, Pablo Speranza ${ }^{1}$ ${ }^{1}$ Universidad de la Republica, Montevideo, Uruguay; ${ }^{2}$ Universidad de la Republica, Cerro Largo, Uruguay (jaimetalice@yahoo.com; jkfedrigo@gmail.com, abussoni@gmail.com; yayo.amarillo@hotmail.com;jfrigerio.smc@gmail.com; euyi.17@hotmail.com;pablosperanza@gmail.com)

Silvopastoral Systems is a sustainable production alternative. The success of these systems is based on the interaction among its components. The use of forage species tolerant to understory conditions is crucial to keep a positive balance. Instead, keeping within the structure of the C4 and C3 pastures components gives them more resilience, productivity and proliferation of weeds. In winter of 2018, a trial was established to determine the response of three species of de Paspalum ( $P$. dilatatum, $P$. notatum y P. umbrosum) in three understories conditions under an old plantation of $E$. dunnii; 16 plants of each were placed thrice in plots located on the stand's boundary; $10 \mathrm{~m}$ inside and outside it. The yield by plant was determined from the October 1 to the November 16 , leaf water potential ( $\Psi \mathrm{L}$ ) and leaf temperature. There was interaction between specie and condition. $P$. dilatatum produced more than the double of dry weight than $P$. umbrosum in the exterior condition, meanwhile the last is $20 \%$ superior in the internal. Simultaneously, $P$. dilatatum showed $\Psi$ L de -1.9 Mpa in the external, while $P$. notatum and $P$. umbrosum reached -2.9 y $-3.1 \mathrm{Mpa}$, respectively. However, there were no differences between species in the internal, with a mean of $-2 \mathrm{Mpa}$. Leaf temperature was superior to $30^{\circ} \mathrm{C}$ outside the stand and less than $23^{\circ} \mathrm{C}$ on the boundary and inside. $P$. umbrosum presents a good perspective to be used as a C4 forage for silvopastoral. Its tolerance may be associated to water relation at high radiation.

\section{Morphometry of Peltophorum dubium in a silvopasture system in Southwestern Paraná, Brazil / Morfometria de Peltophorum dubium (Canafistula) em sistema silvipastoril no Sudoeste do Paraná \\ Marjorie Reis ${ }^{1}$, Debora Kreczkiuski ${ }^{1}$, Gabriel Michalichen ${ }^{1}$, Eleandro José Brun ${ }^{1}$ \\ ${ }^{1}$ Universidade Tecnológica Federal do Paraná, Dois Vizinhos, Brasil; ${ }^{1}$ Universidade Tecnológica Federal do Paraná, Programa de Pós-graduação em Agroecossistemas, Dois Vizinhos,Brasil (marjorieeliza99@hotmail.com; debora-kreczkiuski@hotmail.com; gabrielmichalichen@gmail.com; eleandrobrun.utfpr@gmail.com)}

Canafistula é nativa do Brasil, secundária inicial, de ocorrência em Floresta Estacional Decidual e Semidecidual, usada na arborização urbana e rural, pelo ótimo sombreamento. É estudada em sistemas silvipastoris, pela influência da sua área de copa na luminosidade do sub-bosque e a altura de copa no período ideal para introdução de animais no sistema. Avaliaram-se estas variáveis em um experimento de sistema silvipastoril no Sudoeste do Paraná-Brasil (Universidade Tecnológica Federal do Paraná, Dois Vizinhos), implantado em quatro linhas duplas (repetições), espaçadas 10 metros entre elas e 2 m x 1,5 m na linha/ entrelinha de cada linha dupla. Em um inventário florestal, em junho/2018, quatro anos após o plantio, foram obtidas as variáveis deste estudo. Área de copa média foi de $4,1 \mathrm{~m}^{2}$ árvore (CV\% 92,0), considerada suficiente para abrigar um animal de pequeno até de grande porte. A altura de copa teve valor médio de 2,4 m (CV\% 23,6), ainda abaixo da altura adequada para inserção de animais de grande porte, que é de pelo menos 3 metros. Contudo, as árvores possuem 6,8 cm de DAP, variável apropriada ao emprego de animais no sistema, onde o mínimo estabelecido é $6 \mathrm{~cm}$. E, para melhor eficiência, faz-se a adoção de cercas eletrificadas para impedir o contato direto dos animais com as árvores. A canafístula, aos 4 anos, já pode abrigar animais de pequeno porte, porém necessita aumentar sua altura de copa para evitar danos por animais de grande porte, caso sejam soltos sem uso de cerca elétrica curcundando os renques. 


\section{Release cutting for cost-effective restoration of temperate broadleaved forests}

Magnus Löf ${ }^{1}$, Björn Nordén ${ }^{2}$, Per Kristian Rørstad ${ }^{3}$

${ }^{1}$ Swedish University of Agricultural Sciences, Alnarp, Sweden; ${ }^{2}$ The Norwegian Institute for Nature Research, Oslo, Norway; ${ }^{3}$ Norwegian University of Life Sciences, Oslo,Norway(magnus.lof@slu.se; bjorn.norden@nina.no; per.kristian.rorstad@nmbu.no)

Expansion of agriculture has during the last millennium led to a steep decline of temperate broadleaved forest in Europe. This biome is of outstanding importance for biodiversity, and presently covers only a small fraction of its former distribution area. However, the total area and standing volume of temperate deciduous trees are now increasing and mainly due to re-colonization of trees on abandoned (marginal) agricultural land. These relatively recent forests may or may not have a natural species composition, and management approaches may need to be applied to restore biodiversity and ecosystem services. For example, a semiopen canopy following release cuttings may favour flowering plants, pollination, the regeneration of less shade adapted shrubs and trees, and simultaneously increase the recreation value of such forests. The potential for economy and biodiversity however need to be evaluated. We used data from national forest inventories and from 26 field experiments in Norway and Sweden. We found that there are large areas potentially available for this kind of restoration, and that the biomass harvested following the release cutting many times may cover the costs for this operation. Moreover, there are probably many positive effects on biodiversity although additional studies are needed.

\section{Cultivation Improvement of Dalbergia odorifera in Southern China}

Xiaojin Liu ${ }^{1}$, Daping X u $^{1}$, Zhiyi Cui ${ }^{1}$

${ }^{1}$ Research Institute of Tropical Forestry, Chinese Academy of Forestry, Guangzhou, China (xjliu@caf.ac.cn; gzfsrd@163.com; cuizhiyi2012@126.com)

Dalbergia odorifera T. Chen (Leguminosae) is a semi-deciduous tree species endemic to Hainan province in Southern China. It is renowned for its fragrant heartwood which shows widely applications in furniture manufacturing, crafting and traditional Chinese medicines. Plus trees were selected through provenance \& family trials, and the corresponding cultivation media was optimized for clone propagation of plus trees. The most suitable seedling age for plantation establishment was 2 3 years old at the height of $1 \sim 1.5 \mathrm{~m}$. In this case, weed control and fertilization were very useful for early growth, stem shape and plantation development. As young trees usually have large amount of flowers and fruits when they are more than 2 years old, fertilizer or phytohormone application can alter the growth of reproductive and vegetative. Foliar application of gibberellins can promote the vegetative growth of 10-year old $D$. odorifera significantly, while phosphorus and potassium application was helpful for reproductive growth. Heartwood formation of young $D$. odorifara can be induced through many approaches under field condition, such as pruning, transplanting, fertilization, water and acid stresses, plant growth regulates etc. Ethylene and $\mathrm{H} 2 \mathrm{O} 2$ played important roles in the process of heartwood formation, and may be used as an indicator for heartwood formation. Keep the plantation soil dry for a long period can induce heartwood formation, and stem injection of ethrel can also promote young trees to form fragrant heartwood. The rotation period can be reduced by $1 / 3$, and corresponding economic values can be increased by $30 \%$ approximately through the above technique improvement.

\section{Effects of organic and inorganic fertilizer in different methods on growth and nutrient responses of three economic tree species in South Korea}

Byung Bae Park ${ }^{1,2}$, Huong Thi Thuy Dao ${ }^{1}$, Don Koo Lee ${ }^{1,3}$, Jeong Min Seo ${ }^{1}$, Aung Aung ${ }^{1}$, Woo Bin Youn ${ }^{1}$, Si Ho Han ${ }^{1}$ ${ }^{1}$ Department of Environment and Forest Resources, Chungnam National University, Daejeon, Republic of Korea; ${ }^{2}$ Korean Society of Forest Science, Seoul, Republic of Korea; ${ }^{3}$ Park Chung Hee School of Policy and Saemaul, Gyeongsan, Republic of Korea (bbpark@cnu.ac.kr; thuyhuong.150495@gmail.com; leedk@snu.ac.kr;jmseo3@naver.com; aungaung1361986@gmail.com;dbsdnqls95@naver.com; bupleurumhan@cnu.ac.kr)

Applications of fertilizer are needed to improve soil fertility and to increase crop yields in the short term. The effects of organic composts vs. inorganic fertilizer amounts on plant responses have been widely observed, but application of these fertilizers in different positions in soil has rarely tested in forestry sector. We used $767 \mathrm{~g} /$ pot vermicompost (VC) and $84 \mathrm{~g} /$ pot solid compound fertilizer (SCF) with three economic tree species: Betula platyphylla, Chamaecyparis obtusa, and Larix kaempferi in our study. Seven fertilization methods were applied in greenhouse at Chungnam National University, Republic of Korea as follows: no fertilization as control, VC surface fertilization (VCs), VC circular fertilization (VCc), mixed VC with soil (VCm), bottom application VC (VCb), surface application of SCF at 4-spots (SCFs), and bottom application of SCF (SCFb) with 9 replications. Results showed significant effects of treatments on each species. Most of results showed the highest growth of B. platyphylla, C. obtusa in the SCFs treatment. RCD and height growth of L. kaempferi were affected by both VCc and SCFs. VC treatments can improve belowground biomass for all three species. Meanwhile, aboveground biomass was shown the highest with treatment of SCFs. Quality index followed the same trend with RCD and height growth. Generally, VCc in L. kaempferi and SCFs in the other species with the longest vectors identified the most responsive treatments. Our results suggested that SCFs is the best for those three economic species and VCc could be good for L. kaempferi.

\section{Ecological trends of evergreen and deciduous oaks of India}

Prachi Gupta ${ }^{1}$, Sangeeta Gupta ${ }^{1}$

${ }^{1}$ Forest Research Institute,Dehradun, India (prachi.gpta@gmail.com; sangeeta.fri@gmail.com)

The economically and ecologically important genus Quercus (oaks) dominates in the Northern Hemisphere, from tropical and temperate forests to dry thorn scrub and semi-desert. In India, different species of evergreen and deciduous oaks dominate the temperate broad-leaf forests in the Eastern and Western Himalayas. The Eastern Himalayas have high temperature and high rainfall as compared to Western Himalayas. The local inhabitants of the hills rely on oaks for direct provisioning services. Oak forests play important ecological roles such as mutualistic interactions with fungi and epiphytes, cycling of nutrients, sustenance of wildlife and maintaining biodiversity. However, huge dependency of humans on oaks and changes in climatic conditions have adversely affected oak forests. This has resulted in replacement of oaks by pines which can grow in nutrient-poor soils. Considering the economic and ecological significance of oaks, the present study is an attempt to understand the ecological trends of Indian oaks based on wood microstructure. The wood anatomical characteristics of sixteen species of Indian Quercus were examined in accordance with terminology given by the International Association of Wood Anatomists. The study revealed that the deciduous oaks are ring-porous and evergreen oaks are diffuse porous. Interestingly, based on cluster analysis of quantitative wood anatomical characters, our study revealed that the microstructure of Indian oaks is largely governed by different environmental conditions of Eastern and Western Himalayas. Ecological adaptability of different species to mesic conditions was well reflected by values of mesomorphy and vulnerability indices. 


\section{Wood quality and assortment determination through non-destructive acoustic analysis: a case study in chestnut coppices in Aspromonte National Park (Southern Italy)}

Diego Russo ${ }^{1}$, Pasquale Antonio Marziliano ${ }^{1}$, Giorgio Macri ${ }^{1}$, Giuseppe Zimbalatti ${ }^{1}$, Fabio Lombardi ${ }^{1}$

${ }^{1}$ Mediterranian University of Reggio Calabria, Reggio Calabria, Italy (diego.russo@unirc.it; pasquale.marziliano@unirc.it; giorgio.macri@unirc.it; gzimbalatti@unirc.it;fabio.lombardi@unirc.it)

Chestnut is one of the most important species for timber production in Italy, even if the related woody supply chain is not able to enhance enough the market value of the woody assortments. The internal production is negatively conditioned by the market demands, mainly due to the absence of enough information on the wood quality. The acoustic technologies applied to predict the mechanical properties of timber are well-established practices in forest research. In this context, experimental trials have been applied in the "Aspromonte National Park" (Southern Italy) to identify and verify the wood quality in the early stages of chestnut growth and among their cutting cycle of 18-20 years. Specifically, in a chestnut coppices characterized by an homogeneous stand density and a good site index, we aimed to evaluate the biological response to the applied silviculture, analysing the dendrometric parameters and estimating the wood quality in the first years of growth and at different ages, taking also into account the wood assortments and amounts available. The study was focused on three experimental areas characterized by different slopes. The results showed similarities on the wood quality, even if significant differences among the average annual increment parameters for hectare were observed. This study then provided relevant results useful to support the wood supply chain of the chestnut through information on the quality of woody products.

\section{Management of African economic trees for new research, the review of Entandrophragma genus (Meliaceae)}

Emmanuel Kasongo Yakusu ${ }^{1,2,3}$, Nils Bourland ${ }^{2}$, Dominique Louppe ${ }^{4}$, Wannes Hubau ${ }^{2}$, Jan Van Den Bulcke ${ }^{1}$, Joris Van Acker ${ }^{1}$, Hans Beeckman ${ }^{2}$ ${ }^{1}$ Ghent University, Ghent, Belgium, ${ }^{2}$ Royal Museum of Central Africa, Tervuren, Belgium, ${ }^{3}$ University of Kisangani Kisangani Congo, Republic of the Democratic; ${ }^{4}$ Centre de coopération Internationale en Recherche Agronomique pour le Développement, Montpellie (emmanuel.kasongoyakusu@ugent.be; nils.bourland@aigx.be; dominique.louppe@cirad.fr; wannes.hubau@africamuseum.be; jan.vandenbulcke@ugent.be; joris.vanacker@ugent.be; hans.beeckman@africamuseum.be)

Entandrophragma genus includes exclusively African species (10 to 12), five of which are on the IUCN Red List. Characterized by a taxonomic evolution that has resulted in an important synonymy of species names (36-37) and insufficient ecological knowledge, it is the richest in valuable species exploited as timber in Africa. This important exploitation is likely to compromise their durability in the absence of sustainable management. Our study is mainly based on scientific data (e.g., publications), economic data (production and export statistics) and legal data (laws and regulations); on management plans and inventory reports. The heavy industrial exploitation as artisanal does not always proceed in the respect of a validated management plan, nor of the duration of the rotations which would make it possible to reach a rate of reconstitution likely to perpetuate the resource which these species represent. Their sustainable management requires the development and respect of management measures to make their exploitation sustainable in the long term. This exploitation must be based on an adequate management of natural stands and on reforestation as well as on conservation measures. The research to be developed must focus on their growth rate (eg, in the face of climate change), the analysis of stable rings and isotopes, the evaluation of their stocks (production, biomass, carbon), their spatial distribution and molecular phylogeny, the improvement of their natural regeneration, their reproduction, phenology and anatomy, as well as the reinforcement of other relevant lines of research to guarantee the durability of these forest species.

\section{Functional trait plasticity as an empirical basis to improve our understanding about the productivity and functioning of mixed-species stands}

Hernán Serrano-León ${ }^{1}$, David Forrester ${ }^{2}$, Michael Scherer-Lorenzen ${ }^{3}$, Charles Nock ${ }^{4}$

${ }^{1}$ European Forest Institute, Cestas, France; ${ }^{2}$ Swiss Federal Institute for Forest, Snow and Landscape Research, Birmensdorf, Switzerland; ${ }^{3}$ University of

Freiburg, Freiburg, Germany; ${ }^{4}$ University of Alberta,Edmonton, Canada(hernan.serrano@efi.int; david.forrester@wsl.ch;

michael.scherer@biologie.uni-freiburg.de; charles.nock@gmail.com)

In order to promote mixed forests, forest managers need to be provided with empirical evidence of how tree species mixing improves forest productivity and resilience. However, there is still a limited understanding about how intra-specific variability influences tree species interactions and their role in regulating forest ecosystems. Interactions between different species may cause plastic adjustments in the phenotype expression of functional traits related to tree resource-use efficiency, which in turn alters ecosystem productivity. We examined the effects of tree species mixtures on leaf trait plasticity in a case study at the BIOTREE diversity experiment. We analyzed the intra-specific variability of leaf functional traits (specific leaf area, nitrogen content) in monocultures and mixed stands of three important species in Central Europe (Fagus sylvatica, Quercus petraea, Picea abies). Results showed a significant effect of the species mixture on the trait distributions, indicating that intra-specific variability of key leaf traits was already influenced at young development stages by inter-specific interactions in mixed stands. Further research findings on the links between leaf trait plasticity and tree species interactions will provide a basis for the parameterization of process-based forest growth models, improving the prediction of growth dynamics and functioning in mixed forests. This will help to identify the most efficient tree mixtures for sustainable forest management in order to increase the forest managers' acceptance for mixed forests.

\section{The Classification of forest types for ecological forest management in the deciduous and mixed forests of South Korea}

Young Keun Lee 1 , Sang Tae Lee ${ }^{1}$, Sang Hoon Chung ${ }^{1}$, Joo Han Sung ${ }^{1}$, Yong Sik Hong ${ }^{2}$, Young Han You ${ }^{2}$

${ }^{1}$ Forest Technology and Management Research Center, National Institute of Forest Science, Pocheon-si, Republic of Korea; ${ }^{2}$ Department of Biology. Kongju NationalUniversity, Gongju, Republic of Korea(yghanna@korea.kr; ist9953@korea.kr; chsh80@korea.kr; jhs033@korea.kr; hongfin@smail.kongju.ac.kr; youeco21@kongju.ac.kr)

South Korea is classed as having a temperate climate with four distinct seasons and belongs to the vegetative zone of the temperate deciduous forests. According to the forestry statistics in 2016, the area of deciduous forest is 2,029,000 ha (33.4\%) and the area of natural mixed forests is $1,706,000$ ha (28.1\%). In order to classify the forest types with similar ecological attributes, the NFI (National Forest Inventory) vegetative data for 2,814 sampling points were used. The forest types were grouped by TWINSPAN (Two-way Indicator Species Analysis) according to the importance value of tree species in the upper layer. The correlation between forest types and environmental factors was analyzed by CCA (Canonical Correspondence Analysis). The sampling points were classified into ten forest types such as Quercus mongolica - Tilia amurensis forest, $Q$. variabilis - Q. serrata forest, Pinus densiflora - Q. variabilis forest, etc. The species composition, stand structure and growth characteristic of each forest type are described to establish the foundation of ecological forest management. The correlation between 
forest types and environmental factors showed that the elevation, slope, and annual average temperature were identified as the main influencing factors. Since the main forest types were classified according to the distribution ratio of the oak, the quality grade of standing trees was evaluated by considering the utilization of wood. The evaluation factors of the grade were the bending of stem, branch, stem damage and other defects. The results were as follows: $Q$. acutissima $>Q$. variabilis $>Q$. serrata $>Q$. aliena $>Q$. mongolica $>Q$. dentata.

\title{
C1t: PLANTATION FORESTS
}

\section{Early growth of planted Norway spruce and Scots pine after site preparation in Sweden}

Oscar Nilsson ${ }^{1}$, Karin Hjelm² ${ }^{2}$ (D) Urban Nilsson ${ }^{1}$

${ }^{1}$ Swedish University of Agricultural Sciences - SLU, Southern Swedish Forest Research Centre, Alnarp, Sweden; ${ }^{2}$ Forestry Research Institute of Sweden, Ekebo,Sweden(oscar.nilsson@slu.se; karin.hjelm@skogforsk.se; urban.nilsson@slu.se)

Norway spruce (Picea abies (L.) H. Karst) and Scots pine (Pinus sylvestris L.) have different site preferences, but silvicultural recommendations for their regeneration at planting (including site preparation) are often the same. Thus, there is a clear need for greater understanding of species-specific interactions between site preparation and site properties. To meet this need, the species' growth and survival have been monitored at both fertile and poor sites in Northern and Southern Sweden. At each of these sites, effects of three types of site preparation - removed humus (RH), deep soil cultivation (DSC) and control (C, no site preparation) - were compared. Results show that Scots pine grew more rapidly initially than Norway spruce, and DSC site preparation promoted growth of both species. However, on poor sites there was a delay in growth responses. In addition, removal of organic material in the RH treatment caused a sustained growth check of Norway spruce, but not for Scots pine. This study confirms that it is beneficial to use site preparation as it increases survival of both species and may increase growth. However, site preparation methods that reduce the amount of organic material in the planting spots should be avoided for Norway spruce.

\section{Tree planting spatial arrangements and eucalypt clones interaction in southern Brazil: effect on growth}

\author{
Filipe V. P. Cacau ${ }^{1}$, Geraldo G. Reis ${ }^{1}$ (D; Maria G. F. Reis ${ }^{1}$, Thales G. V. Martins ${ }^{1}$, Jônio P. Caliman ${ }^{1}$, Catia C. Silva ${ }^{1}$ \\ ${ }^{1}$ Universidade Federal de Viçosa, Departamento de Engenharia Florestal,Viçosa, Brasil (filipecacau@gmail.com; greisufv@gmail.com; mgfreis@ufv.br; \\ thales.eng.florestal@gmail.com; jpcaliman@gmail.com; catiasilvaflorestal@gmail.com)
}

Eucalypt stands in Brazil are, usually, highly productive and have been exploited at short rotations ( $\leq 7$ years) as a result of the genotype selection for specific sites and the use of appropriate silvicultural techniques. The present study aimed at the selection of genotypes and spatial arrangements to obtain high productivity in plantations in the Brazilian Southern region. Hybrid clones of Eucalyptus urophylla x E. grandis (A, B) and E. urophylla x E. globulus (C, D) were planted in the arrangements 3.75 × $2.40 \mathrm{~m} ; 6.0$ × $1.5 \mathrm{~m}$ and 4.0 × $3.0 \mathrm{~m}$. The stand variables were estimated by Gompertz model. The total height (Ht) and diameter $(\mathrm{dbh})$ were measured annually up to 88 months. The $\mathrm{Ht}$ and dbh were the highest $(\mathrm{p} \leq 0.05)$ for clone B in the arrangement $4.00 \times 3.00 \mathrm{~m}$. The reduction of the distance between trees in the planting line $(6.00 \times 1.50 \mathrm{~m})$, leading to increasing rectangularity, resulted in smaller dbh in relation to the $3.75 \times 2.40 \mathrm{~m}$, both with $9 \mathrm{~m} 2$ per plant and, the individual volume was the largest in the $4.0 \times 3.0 \mathrm{~m}$, for all clones. Clone B showed the highest yield in the arrangement 3.75 x $2.40 \mathrm{~m}$ and, presented the largest annual mean increase at tree harvesting age. The regulatory rotation at 5, 6 and 7 years should be adopted. The results allow inferring that the tree planting arrangements with greater rectangularity should be avoided because they result in lower productivity and diameter growth. Wider spacings are more adequate to produce logs of larger diameter.

\section{Identification of planting habitats and wood demand regions for Micropholis venulosa (Mart. \& E. ex Miq.) and Simarouba amara Aubl. in Minas Gerais, Brazil}

Thales G. V. Martins ${ }^{1}$, Geraldo G. Reis ${ }^{1}$ iD Maria G. F. Reis ${ }^{1}$, Jônio P. Caliman ${ }^{1}$, Filipe V. P. Cacau ${ }^{1}$, Heitor E. F. C. M. Filpi ${ }^{1}$

${ }^{1}$ Universidade Federal de Viçosa, Departamento de Engenharia Florestal, Viçosa, Brasil; ${ }^{1}$ Universidade Federal de Viçosa, Departamento de Engenharia Florestal,Viçosa,Brasil (thales.eng.florestal@gmail.com; greisufv@gmail.com,mgfreis@ufv.br; jpcaliman@gmail.com; filipecacau@gmail.com; heitor. filpi@gmail.com)

The native wood species plantations are an alternative for supplying high quality wood demand of the Brazilian industries. Planting habitats and wood demand regions were identified for the state of Minas Gerais (MG), for M. venulosa and S. amara, largely used in the timber industry of that state (95,152 and 22,587 $\mathrm{m}^{3}$ of wood consumed in the last 11 years, respectively). The MaxEnt model was used for the environmental zoning, based on matching mainly climatic variables constraints and requirements of the natural occurrence sites with the planting sites. The wood demanding zoning was performed with the clustering algorithm (ArcGIS), using the Brazilian consumption records by species (DOF System - Document of Origin of the Wood). The total area suitable for planting was $208,820 \mathrm{~km} 2$ for $M$. venulosa and 158,254 $\mathrm{km} 2$ for $S$. amara. The models showed high precision (AUC $\geq 0.80$ ). The variables temperature seasonality and warmer month maximum temperature were the most important ones to match species origin to planting sites. Three wood demand zones for these species were identified (R2 $\geq 0.90$ ) for Minas Gerais. The high demand zones included the microregions of Montes Claros (North MG) for M. venulosa, and Belo Horizonte (Centre MG), Juiz de Fora and Ubá (East MG) for S. amara. By planting these species in suitable habitats, near the industries based on indigenous wood species, implies in greater conservation of the species in their natural occurrence region and strengthening of the economy in the consumer centers (Supported by CAPES, CNPq, FAPEMIG and UFV).

\section{Management units for pine in lands of the western Santa Catarina State, Brazil: development and application of methodology}

João Bosco Vasconcellos Gomes ${ }^{1}$, Itamar Antonio Bognola ${ }^{1}$,Lorena Stolle ${ }^{2}$, Paulo Eduardo Telles dos Santos ${ }^{1}$, Shizuo Maeda ${ }^{1}$, Lorenzo Teixeira de Melo Silva ${ }^{3}$, Antonio Francisco Jurado Bellote ${ }^{1}$, Guilherme de Castro Andrade ${ }^{1}$

${ }^{1}$ Embrapa Florestas, Colombo, Brasil; ${ }^{2}$ Universidade Federal do, Chapadão do Sul, Brasil; ${ }^{3} F \& W$ Forestry, Porto Alegre, Brasil (joao.bv.gomes@embrapa.br; itamar.bognola@embrapa.br; lorenastolle@yahoo.com.br; paulo.telles@embrapa.br; shizuo.maeda@embrapa.br; lorenzotms@hotmail.com; antonio.bellote@embrapa.br; guilherme.andrade@embrapa.br)

This study was carried out in order to develop and implement (in pilot area of 457.7 ha) an enhanced methodology for establishing management units for pine tree plantations, in lands of the west of Santa Catarina associated to the effusive rock spill of the Serra Geral Formation. The regional pine production system disregards the hypothesis of response to the nutrient deficiency improvement (DN). The methodology preferably requires semi-detailed soil mapping 
and secondary local climate information. Each polygon of the soil map was associated with a database, which allowed the definition of the land limitation degrees (DN, water deficiency, oxygen deficiency, erosion susceptibility and management impediments) for the pine cultivation. The management units classes of pine cultivation were defined by a set of criteria, considering the different land limitation degrees achieved for each land polygon (from soil map). The most important land limitation degree for pine growth in the pilot area was the management impediments, due to limitations of the soil depth, terrain slope and rocky fragments. The following quantitative data from the management units were obtained in the pilot area: 111.6 ha of Lowly suitable (24.8\% of the area); 282.0 ha Upper marginal (62.6\% of the area); and 57.2 ha Lower marginal (12.7\% of the area).

\title{
Biodegradable containers in the production of Pinus maximinoi seedlings.
}

Leticia Miranda ${ }^{1}$, Fabricio Antônio Biernaski ${ }^{1}$, James Stahl ${ }^{1}$

${ }^{1}$ Klabin S/A, Telêmaco Borba,Brasil (lemiranda@klabin.com.br;fbiernaski@klabin.com.br; jstahl@klabin.com.br)

Pinus maximinoi is an important and promising species in Brazilian forestry. This species has a sensitivity to physical impediments during its root system formation, requiring adjustments in its silviculture management. Biodegradable containers, specifically the paperpot system have been an alternative for seedlings production. However, the paper degradation range may affect the survival of the seedlings after planting, causing impediments to roots expansion. Therefore, the objective of this work was to evaluate five commercial papers with different degradation times in the production of $P$. maximinoi seedlings. Five types of paperpots were tested, three of them of Ellepot ${ }^{\circledR}$ brand, with durability times: (T1) +12 months, (T2) 8-12 months, (T3) 4-6 months, one of Plantpaper ${ }^{\circledR}$ (T4) brand, and one of BCC $®$ brand (T5), both without specification of durability. At 135 and 210 days of nursery, the quality of the seedlings and the level of the papers degradation was evaluated, using a percentages scale with four levels. At 210 days, the seedlings were planted in the field for future evaluations. The degradation levels were statistically different at $1 \%$ of significance in both evaluation periods. The T5 reached $100 \%$ degradation at 210 days, while the T4 paper showed no signs of degradation at the same period. T3 was the most promising paper, with an average of 54 and $75 \%$ degradation at 135 and 210 days respectively. The other two papers had 54\% of degradation average at the end of the seedling production cycle.

\section{The determinants of optimal leaf area in eucalypt plantations}

\author{
Rose Brinkhoff (D, Mark Hovenden ${ }^{1}$ (D), Mark Hunt ${ }^{1}$ (D) \\ ${ }^{1}$ School of Natural Sciences and ARC Training Centre for Forest Value, University of Tasmania, Sandy Bay, Australia (roseb2@utas.edu.au, \\ mark.hovenden@utas.edu.au,mark.hunt@utas.edu.au)
}

It is well understood that stand leaf area index (LAI) is extremely responsive to fertiliser application in Australian temperate Eucalyptus plantations. At energylimited but nonwater-limited sites a high LAI is beneficial for maximising productivity and there is limited evidence to suggest that some of the leaf area may operate below the light compensation point and act primarily as a nutrient store. Conversely, on seasonally water limited sites, a high LAI has the potential for negative consequences for rotation-length plantation growth. The dynamics of these relationships, particularly the role that fertiliser application plays, are not yet well understood, and thus constitute an impediment to developing accurate, informed management prescriptions. In our study a range of fertiliser experiments in Eucalyptus nitens and E. globulus plantations were established along a temperature and precipitation gradient in southern Australia. We explored the relationship between nitrogen and phosphorus fertiliser treatments and stand LAI, the vertical distribution of leaf area and the longevity of $\mathrm{N}$ and $\mathrm{P}$ stored in leaves. We also explored differences in photosynthesis and respiration as a function of light, temperature and nutritional status. The outcomes of this research will include robust assessments of how the costs and benefits to plantation production of an increase in LAI are related to climatic conditions. This will facilitate the development of fertiliser prescriptions better tailored to local climatic conditions and assist with our understanding of how plantation nutrition may explain part of the inter-rotation productivity decline that has been observed at some water-limited sites across the estate.

Shade area and microclimate under the canopy of Cerrado trees in silvopasture systems / Área de sombra e microclima sob a copa de árvores do Cerrado para sistemas silvipastoris

Diego' Fonseca', Silvia Pereira' ${ }^{2}$,Valdemir Laura ${ }^{1,2}, 3$, Ariadne Mastelaro ${ }^{4}$, Fabiana Alves $^{3}, 4$, Roberto Almeida $^{3}$

${ }^{1}$ Universidade Federal de Mato Grosso do Sul, Campo Grande, Brasil; ${ }^{2}$ Universidade Anhanguera , Campo Grande, Brasil; ${ }^{3}$ Embrapa Gado de Corte,

Campo Grande, Brasil; ${ }^{4}$ Universidade Federal do Paraná, Curitiba, Brasil (diegorezendes1@gmail.com; silviarahe@gmail.com;

valdemir.laura@embrapa.br; aripmvet@gmail.com; fabiana.alves@embrapa.br; roberto.giolo@embrapa.br)

Em dezembro de 2015 implantamos um arboreto com 13 espécies arbóreas nativas do Cerrado (24 mudas de cada espécie) em uma área de aproximadamente 1,0 ha, na Embrapa Gado de Corte, Campo Grande - MS. Medimos a temperatura, a umidade relativa do ar e a radiação solar sob a copa de quatro indivíduos de oito espécies e a pleno sol, entre maio e junho de 2018. A partir dos dados coletados, calculamos os Índices de Temperatura e Umidade (ITU) e determinamos a porcentagem de bloqueio de radiação solar sob a copa das árvores. Adicionalmente determinamos a área projetada de copa às $12 \mathrm{~h} 00$ em junho de 2018 com base das dimensões das árvores e o ângulo de elevação do sol. Comparamos as dimensões das árvores e área de sombra entre as espécies, e o índice de temperatura e umidade (ITU) entre espécies e ao longo das horas do dia, através da Análise da Variância (ANOVA) e teste Tukey a 5\%. Pterogyne nitens e Peltophorum dubium, apresentaram maiores dimensões e maiores áreas de sombra projetada, dois anos e meio após plantio. Não houve diferenças (p > 0,05) entre as espécies e a pleno sol para ITU; diferindo apenas ao longo do dia $(\mathrm{p}<0,05)$, com menores valores ao final da tarde. Em relação a porcentagem de bloqueio de radiação, $P$. nitens está entre as espécies com maior bloqueio enquanto $P$. dubium de menor bloqueio de radiação. Com base nessas características $P$. dubium e $P$. nitens são as espécies de maior potencial para uso em sistemas silvipastoris.

Survival of Eucalyptus spp. clones in different spacing arrangements in the semiarid region of Pernambuco, Brazil / Sobrevivência de clones de Eucalyptus spp. em diferentes espaçamentos com condições climáticas extremas no semiárido pernambucano

Rinaldo Luiz Caraciolo Ferreira ${ }^{1}$, José Antônio Aleixo da Silva ${ }^{1}$, José Wesley Lima Silva ${ }^{1}$, Marilia Regina Costa Castro ${ }^{2}$

${ }^{1}$ Universidade Federal Rural de Pernambuco, Recife, Brasil; ${ }^{2}$ Instituto de Educação, Ciência e Tecnologia de Pernambuco, Recife, Brasil

(rinaldo.ferreira@ufrpe.br; jaaleixo@uol.com.br;wesleylima_l6silva@hotmail.com; mariliarcastro@uol.com)

O Polo Gesseiro do Araripe, situado no semiárido pernambucano, é uma região bastante afetada pelas mudanças climáticas e grande consumidor da vegetação nativa com fins energéticos para indústria do gesso. Florestas de eucaliptos foram implantadas na região para atender a alta demanda energética da indústria gesseira, responsáveis por 95\% da produção nacional. Desta forma, objetivou-se com esta pesquisa avaliar a sobrevivência de clones de Eucalyptus spp. em diferentes espaçamentos em condições de seca extrema. Os dados foram provenientes de um experimento inteiramente aleatório com três clones de Eucalyptus 
em cinco espaçamentos na idade de 8 anos. O experimento foi desenvolvido na Estação Experimental do Instituto Agronômico de Pernambuco (IPA) em Araripina que apresenta uma temperatura média anual de $25^{\circ} \mathrm{C}$ e precipitação média anual é de aproximadamente $750 \mathrm{~mm}$, com concentração de $70 \%$ entre os meses de dezembro a março. Durante o período experimental a precipitação média anual foi $529.4 \mathrm{~mm}$, concentrada nos meses de janeiro a abril, o que configura uma mudança temporal severa e faz dessa década uma das mais secas da história. A taxa de sobrevivência média do experimento foi de $90 \%$, constatando-se diferenças significativas entre os clones, sendo o C11 no espaçamento $3 \mathrm{~m}$ x $3 \mathrm{~m}$ o que apresentou maior taxa de sobrevivência $98.40 \%$. Pelo teste de ScottKnott $(\mathrm{p}<0.05)$ os tratamentos foram divididos em três grupos sendo o espaçamento $2 \mathrm{~m}$ x $1 \mathrm{~m}$ o que apresentou as menores taxas de sobrevivência. Mesmo em condições climáticas severas os clones de eucaliptos conseguem se desenvolver e apresentam baixo índice de mortalidade.

\section{C1u: MIXED-SPECIES FORESTS AND PLANTATIONS: KNOWLEDGE GAPS AND RESEARCH} PRIORITIES

\section{Mixed settlements of eucalyptus and acacia in transition area between Brazilian Savana (Cerrado) and Amazon Forest biomes}

Diego Camargo ${ }^{1}$, Maurel Behling' ${ }^{2}$, Jean-Pierre Daniel Bouillet ${ }^{3}$, Ivanka Rosada de Oliveira ${ }^{4}$, José Leonardo de Moraes Gonçalves ${ }^{4}$, Murilo Campos Pereira $^{1}$ ${ }^{1}$ Universidade Federal do Mato Grosso, Sinop, Brasil; ${ }^{2}$ Embrapa Agrossilvipastoril, Sinop, Brasil; ${ }^{3}$ CIRAD, Piracicaba, Brasil; ${ }^{4}$ Escola Superior de Agricultura "Luiz de Queiroz", Universidade de São Paulo, Piracicaba, Brasil (camargo.die@gmail.com; maurel.behling@embrapa.br; jean-pierre.bouillet@cirad.fr; ivanka.ivi@gmail.com; jlmgonca@usp.br; murilo_camposcol@hotmail.com)

The adoption of mixed planting with eucalyptus and legume tree espcie - able to fix nitrogen, is a sustainable alternative to provide nitrogen to the eucalyptus. Our objective was to evaluate if the mixed planting of eucalyptus and acacia yields basal area equivalent to homogeneous eucalyptus planting. The treatments evaluated were: Eucalyptus (E, clone I144 - E. urophylla x E. grandis) with and without nitrogen fertilization (0A: 100E + N e 0A: 100E-N), acacia (A, Acacia mangium) (100A: 0E), acacia and eucalypt ratio 1:2 (33A: 67E) and 1:1 (50A: 50E). Randomized blocks design (RBD) was used, with four replicates and plot with $1,296 \mathrm{~m}^{2}\left(12 \times 12\right.$ trees) and $576 \mathrm{~m}^{2}$ of useful area (double surround, with spacing $\left.3 \times 3 \mathrm{~m}\right)$. The trees were measured at three years of age by circumference at brest height $(\mathrm{CBH})$ and basal area $\left(\mathrm{BA}, \mathrm{m}^{2} \mathrm{ha}^{-1}\right)$. BA was different among treatments $(\mathrm{p}<0.000)$, the higher was in homogeneous acacia planting $\left(14.5 \mathrm{~m}^{2}\right.$ $\left.\mathrm{ha}^{-1}\right)$. The mixed planting was no different from the eucalyptus homogeneous fertilized with $\mathrm{N}(\mathrm{p}>0.35$, in both acacia represented $60 \%$ and $84 \%$ of the BA for 1:2 and 1:1 ratio between eucalyptus and acacia. The interspecific competition was positive for acacia and negative for eucalyptus.

Developing founding forest species in a disturbed area within the city of Rio Branco, Acre, Brazil, after three decades of age / Desenvolvimento de essências florestais plantadas em uma área alterada na cidade de Rio Branco-Acre após três décadas de idade

Harley Araújo da Silva , Veronica Telma da Rocha Passos ${ }^{1}$, Thiago Augusto da Cunha ${ }^{2}$

${ }^{1}$ Universidade Federal do Acre, Parque Zoobotânico, Rio Branco, Brasil; ${ }^{2}$ Universidade Federal do Acre, Centro de Ciências Biológicas e da Natureza, Rio Branco,Brasil(harleyaraujo@ufac.br; veronica.passos@ufac.br; etsfor@yahoo.com)

Poucas são as experiências de plantios florestais na Amazônia com idade avançada e que reúnam grande número de espécies arbóreas, como é o caso do Experimento Arboreto, localizado no Parque Zoobotânico da Universidade Federal do Acre. Nesse caso, em duas áreas de 1,38 ha cada, foram plantados indivíduos de 138 espécies diferentes no espaçamento de 2,5 m x 2,5 m, sendo a roçagem e coroamento os únicos tratamentos silviculturais aplicados. Buscando saber o estado atual das espécies, trinta e cinco anos após o plantio foi realizado o censo dos indivíduos plantados, bem como mensuração de variáveis dendrométricas como o diâmetro à altura do peito (DAP) e a altura total (Ht). Das espécies plantadas, 59 apresentam indivíduos vivos merecendo destaque a palmeira Syagrus sancona e Handroanthus serratifolius por apresentarem sobrevivência acima de 75\%. Espécies como Annona montana, Aspidosperma vargasii, Ceiba samauma, Couepia bracteosa, Dalbergia inundata, Hymenaea courbaril, Hymenaea parvifolia e Simira rubescens apresentaram taxas regulares de sobrevivência, variando entre 50\% e $69 \%$. Essências comumente usadas pelo mercado madeireiro como Aspidosperma vargasii, Cedrela odorata, Dipteryx odorata, Hymenaea courbaril e Hymenaea parvifolia se destacaram perante as demais por apresentarem médias de DAP com valores variando entre $26 \mathrm{~cm}$ e $31 \mathrm{~cm}$, e Ht entre $17 \mathrm{~m}$ e $19 \mathrm{~m}$. A importância desse trabalho reside na necessidade de, passados 35 anos do plantio, se determinar quais espécies melhor se adaptaram em uma área onde foram aplicados os tratos silviculturais mais básicos ao pleno desenvolvimento das mudas.

\section{Integrating the intra- and inter-species-groups competition effects into an individual diameter at breast height growth model for mixed-species forests in Mexico}

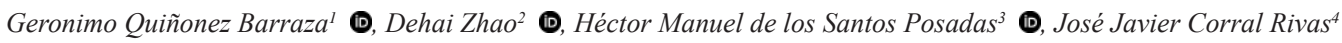
${ }^{1}$ Campo Experimental Valle del Guadiana, Instituto Nacional de Investigaciones Forestales Agrícolas y Pecuarias, Durango, DGO, Mexico; ${ }^{2}$ Warnell School of Forestry and Natural Resources, University of Georgia, Athens, GA, USA; ${ }^{3}$ Postgrado en Ciencias Forest (quinonez.geronimo@inifap.gob.mx, dzhao@warnell.uga.edu,hmsantos@colpos.mx,jcorral@ujed.mx)

The forest management-planning in Northwest of Durango, Mexico involve mixed-species stands and the selection method is normally applied for uneven-aged stands in such forests. An individual distance-dependent model without age was used to evaluated the diameter at breast height (dbh) growth and neighborhood effects for four species groups in mixed-species stands. The dataset considers 44 stem-mapped re-measurement plots and twenty-two species were grouped as: Pinus (seven species), other conifers (three species), other broadleaves (four species) and Quercus (eight species). Four methods were used to select neighboring trees, 12 distance-dependent competition indices were computed, and the con-group and hetero-group neighborhood effect were carried out for species groups. The dbh growth model was fitted separately under the assumptions of no-competition effect (without competition term), equivalent and nonequivalent neighborhood effects. The dbh growth models under the assumption of nonequivalent neighborhood effect outperformed the models under the assumptions of equivalent neighborhood effect and without competition effect. The intra-species-group competition negatively affect the diameter growth for all species groups, except for the Quercus group. In all cases, the fitted age-independent dbh growth models showed a good of fit to the stem-mapped plots data with adjusted coefficient of determination values larger than 0.97 and root mean square error values smaller than $1.33 \mathrm{~cm}$. The growth models can be used to predict the dbh growth for the species groups in mixed-species forests. 
Growth of native Cerrado tree species with potential for use in foresting pasture / Crescimento de árvores nativas de Cerrado com potencial de uso na arborização de pastagens

Diego Fonseca ${ }^{1}$, Silvia Pereira ${ }^{1}$, Valdemir Laura ${ }^{1,2,3}$, Camila Miranda $^{1}$, Ariadne Mastelaro $^{4}$, Fabiana Alves $^{3,4}$, Roberto Almeida ${ }^{3}$

${ }^{1}$ Universidade Federal de Mato Grosso do Sul, Campo Grande, Brasil,; ${ }^{2}$ Universidade Anhanguera, Campo Grande, Brasil; ${ }^{3}$ Embrapa Gado de Corte, Campo Grande, Brasil; ${ }^{4}$ Universidade Federal do Paraná,Curitiba, Brasil (diegorezendes1@gmail.com; silviarahe@gmail.com; valdemirlaura@embrapa.br; camilaoliveiramiranda20@gmail.com; aripmvet@gmail.com; fabiana.alves@embrapa.br; roberto.giolo@embrapa.br)

Em sua maioria, as espécies arbóreas utilizadas em sistemas silivipastoris no Brasil são exóticas, principalmente pela ausência de estudos que investiguem o potencial de uso de espécies nativas brasileiras. Deste modo, o objetivo deste estudo foi avaliar o crescimento de 13 espécies arbóreas do Cerrado, notadamente com potencial de uso em sistemas silvipastoris. Em dezembro de 2015 foi implantado um arboreto com 13 espécies nativas do Cerrado, em uma área de aproximadamente 1,0 ha, na Embrapa Gado de Corte, Campo Grande - MS. As espécies foram selecionadas com base no potencial de uso e disponibilidade de mudas nos viveiros da região. O delineamento foi inteiramente casualizado, com 24 mudas de cada espécie, no qual foram mensurados crescimento em altura e diâmetro à altura do solo, em dezembro dos anos 2016, 2017 e 2018. A fim de comparar as diferenças de crescimento entre as espécies, foi aplicado o teste Scott-Knott para agrupamento das médias com nível de significância de 5\%. Ao final do primeiro ano, quatro grupos de espécies foram formados, enquanto que nos segundo e terceiro ano, formaram-se cinco grupos. Guazuma ulmifolia e Peltophorum dubium foram as espécies com maior crescimento em altura e diâmetro, enquanto Dipteryx alata e Hymenaea stigonocarpa foram as espécies de menor altura. H. stigonocarpa foi a espécie que apresentou menor diâmetro nos anos avaliados. Com base nos achados deste experimento, ressalta-se a importância da escolha correta do componente arbóreo em sistemas silvipastoris para o total alcance dos objetivos pré-definidos.

Ecological restoration: evaluating models and site factors in areas degraded after agricultural and livestock use in Medellín-Antioquia, Colombia / Restauración ecológica: evaluación de modelos y factores de sitio en zonas degradadas por uso agropecuario en MedellínAntioquia (Colombia)

Diana Carolina Becerra Merchan ${ }^{1}$, Cristobal Ordoñez Alonso ${ }^{2}$, Felipe Bravo Oviedo ${ }^{2}$, Luis Fernando Osorio Velez ${ }^{1}$, Juan Carlos Salazar Uribe ${ }^{1}$ ${ }^{1}$ Universidad Nacional de Colombia, Medellín, Colombia; ${ }^{2}$ Universidad de Valladolid, Valladolid, Spain (dcbecerr@unal.edu.co; a_cristo@pvs.uva.es; fbravo@pvs.uva.es; lfosoriv@unal.edu.co; jcsalaza@unal.edu.co)

El área rural del municipio de Medellín (Colombia), se ha caracterizado por un acelerado proceso de praderización y uso intensivo del suelo, dosminuyendo los remanentes de bosque nativo en la ciudad. Para mitigar y compensar los efectos negativos, se viene implementado el proyecto "Mas Bosques Para Medellín", con el que se pretende aumentar la cobertura boscosa mediante reforestación mixta de especies nativas propias del Bosque Húmedo premontano (Bh-PM) y bosque húmedo montano bajo (Bh-MB). Estos ensayos se monitorearon mediante el establecimiento de parcelas permanentes, evaluando variables dendrométricas (diámetro a la base del cuello, diámetro a la altura de pecho (DAP) y altura total), y de mortalidad, desde el año 2010 hasta el año 2016. Generalmente, variables como la mortalidad se evalúan como el número de individuos muertos, sin tomar en consideración las dinámicas asociadas a través del tiempo. Para determinar los factores que inciden en la mortalidad de los árboles plantados, se realizaron curvas de supervivencia mediante el uso de estimadores de Kaplan-Meier y factores de riesgo por medio de la regresión de Cox, empleando como factores de sitio, el tipo de cobertura anterior a la plantación, suelos, precipitación y altura sobre el nivel del mar, y se estimaron modelos de sitio para las especies Montanoa cuadrangularis, Croton magdalenensis, Citharexylum subflavescens, Chamaessena colombiana, Retrophyllum rospigliosii, Quercus humboldtii, Cedrela montana, Alnus acuminata, Tecoma stans y Calophyllum brasiliense. Estos resultados se pueden emplear como base para el desarrollo de nuevas plantaciones mixtas en zonas tropicales de Bh-PM y Bh-MB.

Stocks of leaf litter in a mixed eucalyptus and acacia plantation / Estoque de serapilheira em área de plantio misto de eucalipto e acácia

Júlia Graziela da Silveira1 , Renato de Aragão Ribeiro Rodrigues ${ }^{2}$, Maurel Behling ${ }^{3}$, Diego Camargo ${ }^{4}$, Leticia Helena Campos de Souza ${ }^{5}$,

Natassia Magalhães Armacolo ${ }^{6}$, Jacqueline Jesus Nogueira da Silva ${ }^{7}$, Antonio de Arruda Tsukamoto Filho ${ }^{5}$

${ }^{1}$ Universidade Federal de Viçosa, Viçosa, Brasil; ${ }^{2}$ Embrapa Solos, Rio de Janeiro, Brasil; ${ }^{3}$ Embrapa Agrossilvipastoril, Sinop, Brasil; ${ }^{4}$ Universidade Federal de Mato Grosso, Sinop, Brasil; ${ }^{5}$ Universidade Federal de Mato Grosso, Cuiabá, Brasil; ${ }^{6}$ Universidade Estadual de Londrina, Londrina, Brasil; ${ }^{7}$ Universidade Federal Fluminense, Niterói, Brasil (juliagrazielasilveira@gmail.com; renato.rodrigues@embrapa.br; maurel.behling@embrapa.br; camargo.die@gmail.com; leticiahelena_cs@hotmail.com; nmarmacolo@gmail.com; jacqueufmt@gmail.com; tsukamoto@ufmt.br)

Plantios mistos de eucalipto com espécies fixadoras de nitrogênio podem aumentar o aporte de serapilheira, favorecendo a ciclagem de nutrientes e sendo fonte de matéria orgânica. O objetivo do trabalho foi quantificar o estoque de serapilheira em monocultivos e plantios mistos de Eucalyptus urograndis ( E. urophylla x E. grandis) e Acacia mangium, após 29 meses de plantio. Foi desenvolvido na Embrapa Agrossilvipastoril (Sinop, MT), com cinco tratamentos: monocultivo de eucalipto com fertilização nitrogenada $(\mathrm{E}+\mathrm{N})$; monocultivo de eucalipto sem fertilização nitrogenada (E-N); monocultivo de acácia (A); plantio misto com $67 \%$ eucalipto e $33 \%$ acácia (67E+33A); plantio misto com 50\% eucalipto e 50\% acácia (50E+50A). O delineamento experimental foi em blocos casualizados, com três repetições. Amostras de serapilheira foram coletados com gabarito 0,5 x 0,5 m no ano de 2017. O estoque médio de serapilheira foi 5,38 $\mathrm{Mg}$ ha ${ }^{-1}$ no $\mathrm{E}+\mathrm{N}$, 4,89 mg ha-1 no E - N, 6,31 $\mathrm{Mg} \mathrm{ha}^{-1}$ na A, 5,17 $\mathrm{Mg} \mathrm{ha}^{-1}$ no 67E + 33A (2,18 $\mathrm{Mg}^{-1}{ }^{-1}$ de E e 2,99 Mg ha-1 de A) e 5,48 Mg ha-1 no 50E + 50A (1,97 Mg ha $^{-1}$ de E e 3,51 Mg ha-1 de A). A serapilheira diferiu estatisticamente nos contrastes E + N vs. E-misto, E - N vs. E-misto, A vs. A-misto e A vs. E d/50E + 50A. Mesmo os plantios mistos não promovendo aumento na deposição de serapilheira, foi observado a contribuição da acácia em 58 e $61 \%$ nos tratamentos de $67 \mathrm{E}$ + 33A e 50E + 50A respectivamente, para produção de serapilheira, evidenciando a importância dessa espécie para o aumento da quantidade de material vegetal depositado sobre o solo.

\section{Mixed forest stands in Europe: can we spot them from high-resolution satellite remote sensing?}

Loredana Oreti ${ }^{1}$, Francesca Giannetti ${ }^{2}$, Anna Barbati ${ }^{1}$

${ }^{1}$ Università degli Studi della Tuscia, Viterbo, Italy; ${ }^{2}$ Università degli Studidi Firenze, Firenze, Italy (loredanaoreti@unitus.it; francesca.giannetti@unifi.it; barbati.sisfor@unitus.it)

In forest inventories stands dominated by one tree species are classified as monospecific stands even if containing several forest species, if these contribute less than $10-20 \%$ to canopy cover or stand density. Official statistics provided by the State of Europe forests report that about two-thirds of the European forests contain from two up to six (or more) forest tree species. But mixed forest stands, where two or more tree species contribute each to more than 10-20\% to canopy cover/stand density, might indeed not be sampled with sufficient intensity by traditional forest inventories, compared to monocultures, especially in forest 
landscapes where the average stand condition is relatively species poor. This limits the set up of replicated experiments, at single or several sites, to analyse in real-world conditions e.g. the effect of mixing of two (or more) tree species on forest ecosystem properties and services. Designing such experiments would greatly benefit from high resolution maps of monospecific vs mixed stands. Today, Sentinel 2 multispectral satellite imagery allows to cover large areas over a short period of time, with a relatively high spatial resolution $(10-20 \mathrm{~m})$. The aim of this contribution is to offer an exploratory analysis of the capabilities offered by Sentinel 2 and Random Forest classifier, for the detection and mapping of widespread mixed forest stand types in Europe, based on a case study characterized by different admixtures of coniferous and broadleaved tree species.

Using hydrogel in germination and seedling establishment of white ipê (Tabebuia roseo-alba (Ridl.) Sand.) / Uso de hidrogel na germinação de sementes e estabelecimento de plântulas de Ipê branco (Tabebuia roseo-alba (Ridl.) Sand.)

Juliano Miranda de Oliveira ${ }^{1}$, Anderson Marcos de Souza

${ }^{1}$ Universidade de Brasilia, Brasillia,Brasil (julianooliveira.engflorestal@gmail.com; andermsouza@yahoo.com.br)

O ipê-branco (Tabebuia roseo-alba (Ridl.) Sand.) é uma espécie bastante utilizada em reflorestamentos mistos destinados à recomposição de áreas degradadas e de preservação permanente. O objetivo do trabalho foi avaliar o uso de hidrogel na germinação e no desenvolvimento das plântulas de sementes de ipê branco. As sementes foram submetidas aos tratamentos: com hidrogel: 0,5 g/l, 1,0 g/l, 1,5 g/l, 2,0 g/l, e sem hidrogel. Foram realizados as avaliações de: Número de sementes germinadas (NSG); número de folhas (NF); comprimento da parte aérea (CPA); número de raízes (NR); peso fresco (PF); peso seco (PS) e número de sementes não germinadas duras (NSNGD). O delineamento adotado foi o inteiramente casualizado, com quatro repetições e a média dos dados obtidos foram submetidos a análise de variância utilizando o software estatístico SISVAR e foram discriminadas pelo teste de tukey ao nível de 5\% de probabilidade. As variáveis NR, PF e PS apresentaram os maiores valores de coeficiente de variação $(23,30$ a 42,96\%). As demais variáveis apresentaram valores de coeficiente de variação entre 13,04 e 15,02\%. Conforme a análise de variância, verificou se que para a maioria das varáveis avaliadas a incorporação de hidrogel no substrato não apresentou resultados significativos. A dosagem de $1,5 \mathrm{~g} / 1$ pode ser indicada nos estudos de germinação e estabelecimento de plântulas de Tabebuia roseoalba (Ridl.) Sand. por terem apresentado valores que favoreceram a germinação assim como o estabelecimento de plântulas com melhores médias de padrões morfológicos.

C1v: MIXED-SPECIES FORESTS AND PLANTATIONS: KNOWLEDGE GAPS AND RESEARCH
PRIORITIES

\section{Admixture of rich-litter species as a management concept boosting forest resilience}

Bart Muys $^{1}$, Ellen Desie ${ }^{1}$, Bart Nyssen ${ }^{1,2}$, Karen Vancampenhout ${ }^{1}$

${ }^{1}$ KU Leuven, Leuven, Belgium; ${ }^{2}$ Bosgroep Zuid-Nederland Heeze Netherlands (bart.muys@kuleuven.be; ellen.desie@kuleuven.be; bart.nyssen@kuleuven.be; karen.vancampenhout@kuleuven.be)

Many forests Europe-wide are growing on nutrient-imbalanced acid soils, and are often composed of monocultures of adapted tree species that further amplify this oligotrophic regime. But study of palynological records and relict forests suggests that even on the poorest sands a rich, more productive alternative stable state, dominated by rich-litter tree species exists. From an evolutionary point of view, rich-litter is a more recent functional trait supporting fast nutrient turnover, earthworm bioturbation and mull humus. Research in common gardens has shown the potential of rich-litter species to maintain or restore resilient mesotrophic systems. But restoration is not straightforward: oligotrophic system interactions induce and maintain conditions that are hostile for rich-litter species. But restoration is hampered by the conditions of the oligotrophic system, which are hostile for rich-litter species. Successful large-scale restoration therefore implies deeper understanding of the factors underlying the attractor behavior of the oligotrophic system, which may be soil type and context dependent. As a result, integrated soil restoration combines actions supporting the introduction of rich-litter species, e.g. fertilization with rock dust, inoculation of earthworms, or introduction of accompanying shrub and herb species. This perspective paves the way for large-scale admixture of rich-litter species, from the fundamental research on litter decomposition and soil effects of mixtures, over the conceptual framework of rich-litter species and alternative stable states in forest soils, to the first results of restoration management experiments. It concludes with some considerations on the validity of this new concept in other continents.

\section{Are mixtures a good option to reduce drought-induced risk of forest decline? Carbon accounting and economic approach \\ Sandrine Brèteau-Amores ${ }^{1}$ (D), Mathieu Fortin ${ }^{2}$, Pablo Andrés-Domenech ${ }^{3}$, Nathalie Bréda 4 \\ ${ }^{1}$ Institut National de la Recherche Agronomique - BETA, Nancy, France; ${ }^{2}$ Canadian Forest Service, Ottawa, Canada; ${ }^{3}$ AgroParisTech - BETA, Nancy, France, ${ }^{4}$ Institut National de la Recherche Agronomique - SILVA, Nancy, France (sandrine.breteau-amores@inra.fr,mathieu.fortin@agroparistech.fr; pablo.andres-domenech@agroparistech.fr; nathalie.breda@inra.fr)}

Drought is the principal source of stress limiting forest health and it causes financial losses for forest owners and amenity losses for society. The major part of the forested area in the Grand-Est region (France) is dominated by beech, which is predicted to decline in the future due to repeated drought events driven by climate change. Beech forests need to adapt and mixture is known to decrease drought risk. In this context, the objective of the paper was to compare, from an economical perspective, different forest adaptation strategies aiming at reducing drought-induced risk of decline. For this purpose, we studied two types of mixture that we analysed separately and jointly: mixture of beech with oak and age mixture (i.e. from an even-aged to an uneven-aged forest), which is rarely considered as an adaptation strategy. We also considered two types of loss (financial, and in terms of carbon sequestration) under different recurrences of drought, that are a consequence of climate change. We combined a forest growth simulator (MATHILDE) with a traditional forest economic approach (Fautsmann's LEV and Hartman's LEV). The maximisation of the two LEV criteria made it possible to identify the best adaptation strategies in economic terms. We also developed the carbon approach considering different accounting methods (from the market value to the social cost of carbon). The results are discussed taking into account the trade-offs between the financial balance and the carbon balance, and the underlying question of the additivity (or not) of the two adaptation strategies. 


\section{How richness of tree species affects stand volume and stability in Hemiboreal Forest of Lithuania?}

Gediminas Brazaitis ${ }^{1}$ (D), Ramūnas Mažètis ${ }^{1}$, Hans Pretzsch ${ }^{2}$, Miren del Rio ${ }^{3}$, Gintaras Kulbokas ${ }^{4}$, Remigijus Žalkauskas ${ }^{1}$

${ }^{1}$ Institute of Forest Biology and Silviculture Vytautas Magnus university, Kaunas, Lithuania; ${ }^{2}$ Chair for Forest Growth and Yield Science, Technical University of Munich, Freising, Germany; ${ }^{3}$ Department of Silviculture and Forest Management, INIA, Forest Research Centre INIA-CIFOR Forest Research Centre, Madrid, Spain; ${ }^{4}$ Institute of Environment and Ecology Vytautas Magnus university, Kaunas, Lithuania (gediminas.brazaitis@asu.lt, r.mazetis@mmu.lt; hans.pretzsch@lrz.tum.de; delrio@inia.es; g.kulbokas@amvmt.lt; remigijus.zalkauskas@vdu.lt)

This study analyses the effects of tree species richness on stand stability and volume in Hemiboreal Forest in Southwest Lithuania $\left(54^{\circ} 22^{\prime}-54^{\circ} 38^{\prime} \mathrm{N}, 22^{\circ} 47^{\prime}-\right.$ $23^{\circ} 49^{\prime} \mathrm{E}$ ). Field surveys were conducted in 586 systematically dispersed circular plots ( $500 \mathrm{~m}^{2}$ in size). We recorded tree species, tree condition and tree volume in each plot. In total, we recorded 15 tree species with plots containing between 1-10 tree species. However, most plots contained 3-7 tree species. Results show, survival rates of Betula pendula, Betula pubescens, Carpinus betulus, Alnus glutnosa and Quercus robur were better in stands with higher species richness. In contrast, Fraxinus excelsior, Populus tremula, and Picea abies showed a slight survival increase in stand with lower tree species richness. Finally, Ulmus minor, Tilia cordata and Salix caprea showed highly reduced survival in stands with high richness. In all stands $<60$ years of age, tree survival decreased as stand age increased. However, in stands 60-120 years, survival was negatively dependent on tree species richness. The survival of trees in stands containing 3-7 species was stable among the oldest stands (130-160 years). Total stand volume,containing up to 6 species, showed increased stand volume, reaching peak stand volume at age 100-120. However, for all stands between 90-110 years there were no effects on stand volume. In young stands species, richness had a positive effect on stand volume, but in stands $>110$ years was a negative relationship between stand volume and species richness. Thus, species richness does effect stand volume and tree survival.

\section{Structure of old-growth mixed broad-leaved stands in the Caspian Forests}

Khosro Sagheb Talebi ${ }^{1}$, Pejman Parhizkar ${ }^{1}$, Majid Hassani ${ }^{1}$, Assadollah Karimidoost ${ }^{1}$, Karim Maghsudloo ${ }^{1}$, Hossein Ghorbani ${ }^{1}$ ${ }^{1}$ Agricultural Research, Education and Extension Organization, Research Institute of Forests and Rangelands (RIFR), Tehran, Islamic Republic of Iran (saghebtalebi@rifr-ac.ir; parhizkar@rifr-ac.ir; hassani@rifr-ac.ir; karimidoost@yahoo.com; karimmaghsudloo@yahoo.com; ghorbani_32@yahoo.com)

Caspian mountainous temperate deciduous forests containing diverse broad-leaved species are located in the south of the Caspian Sea. These ancient forests date back to the early Pleistocene and were not affected strongly by glaciations. Our research aims to study the diversity of tree species, vertical and horizontal structure as well as the regeneration process within the mixed stands. For this purpose, we selected 9 sample plots, each 1 ha within an intact stand with no silvicultural interventions. All trees with diameter at breast height (dbh) larger than $7.5 \mathrm{~cm}$ were assessed, and dbh, height and coordination of trees were measured. Results showed a multi-aged stand containing 12 woody species with stem number between 308 and 560 trees ha ${ }^{-1}$. The proportion of common hornbeam (64.6\%) was higher than large-leaved lime (18.6\%) followed by chestnut-leaved oak (5.4\%). The frequency of other companion species, including Cappadocian maple, velvet maple, wild cherry, wild service, field maple, elm, ash, Persian ironwood and common medlar was $11.4 \%$. The largest measured trees were lime and oak with a dbh of $225 \mathrm{~cm}$ and $165 \mathrm{~cm}$, respectively. Forming the upper storey, oak and lime were the tallest trees and other species accupy the middle and lower stories. Lack of oak regeneration is noteworthy which could be the main challenge for the future of the stand. While the spatial pattern of oak showed a random pattern, that of lime and maple showed clump pattern. Results could be applied for management of natural forests as well as in planted mixed forests.

\section{Management alternatives of spontaneously regenerated mixed stands of Birch and Norway spruce in Sweden.}

Felicia Lidman ${ }^{1}$, Emma Holmström², Tomas Lundmark ${ }^{1}$, Nils fahlvik ${ }^{3}$

${ }^{1}$ Swedish university of Agricultural Sciences, Umeå, Sweden; ${ }^{2}$ Swedish university of Agricultural Sciences, Alnarp, Sweden; ${ }^{3}$ Skogforsk, Ekebo, Sweden (felicia.lidman@slu.se; emma.holmstrom@slu.se; tomas.lundmark@slu.se; nils.fahlvik@skogforsk.se)

More than 75\% of clearcuts in Sweden are regenerated by planting coniferous tree species followed by subsequent pre-commercial thinnings to secure growth on the main crop trees. However, areas on clearcuts without active regeneration methods, tend to be spontaneously forested with a mixture of naturally regenerated Birch (Betula pendula Roth and Betula pubescens Ehrh.) and Norway spruce (Pices abies (L.) Karst.) The aim of this study is to compare the alternatives and effect of first thinning and extraction of forest fuel on stand development and future tree species composition, in areas with low investment regeneration. A long term experiment with a randomized block design was established 2007 (22 years after clearcutting) on two naturally regenerated sites, on the east-central coast of Sweden. Treatments included thinning of forest fuel leaving (1) 1300 stems ha $^{-1}$ of Norway spruce, (2) 1200 stems ha-1 of birch, (3) a tree-wise mixture with 1200 stems ha $^{-1}$ of birch and 1300 stems ha-1 of Norway spruce and (4) an unthinned control. A second thinning was made 2016 in treatment (2) and (3), to favor the main crop trees. Treatment (1) created a stand suitable for a longer rotation period, (2) for a medium length rotation period, (3) for two harvests of crop trees during a longer rotation period and (4) for a short rotation period. All treatments had different levels of forest fuel outtake and management intensity. These results can be used to optimize the different silvicultural practices strategically towards the goal of the forest owner.

\section{Wild pear tree and wild service tree pure and mixed plantations for high-quality timber production}

Verónica Loewe-Muñoz ${ }^{1}$, Rodrigo Del Río ${ }^{1}$, Claudia Delard ${ }^{1}$, Mónica Balzarini ${ }^{2}$

${ }^{1}$ INFOR, Santiago, Chile; '2Universidad Nacionalde Córdoba, Córdoba,Argentina (vloewe@infor.cl; rdelrio@infor.cl; cdelard@infor.cl; vloewe@infor.cl)

Wild service (Sorbus torminalis) and wild pear (Pyrus pyraster) are sporadic species with highly priced timber for noble uses (cabinet-making, musical instruments). However, adequate management is necessary to obtain valuable logs. Pure and mixed plantations of both species were compared to explore the benefits of species associations on productivity and timber quality. Growth, straightness and survival were measured during 12 years. Besides both monocultures, five mixtures were tested: T1: Pyrus pyraster + Sorbus torminalis; T2: mixture incorporating one arboreal N-fixing companion (T1 + Italian alder (Alnus cordata)); and three associations including shrub nurse species (T3: T1 + hazelnut (Corylus avellana), T4: T1 + dwarf elderberry (Sambucus ebulus) (and T5: $\mathrm{T} 1$ + black elderberry (Sambucus nigra)). Wild pear in T2 presented the highest height $(10.7 \mathrm{~m})$, with statistical differences from the monoculture (7.2 $\mathrm{m})$. The monoculture presented $47 \%$ of straight trees, whereas the association including Sambucus ebulusshowed a higher proportion of straight trees (57\%). Wild pear survival was high in all associations ( $80 \%)$, except for T1 $(60 \%)$. Wild service also presented the highest height $(8.9 \mathrm{~m})$ in $\mathrm{T} 2$, with significant differences from the monoculture $(5.8 \mathrm{~m})$; the same effect was recorded for DBH $(10.0 \mathrm{vs} 6.5 \mathrm{~cm})$. The monoculture presented $38 \%$ of straight trees, and T1 $50 \%$. The highest wild service tree survival occurred in T2 (67\%), being 58\% in monoculture. Both species are suitable for being planted for quality timber production, with higher growth in associations including Italian alder than in monoculture. Some companion species favored wild pear and wild service tree growth, vigor and survival. 


\section{Light use efficiency in pure and mixed Eucalyptus and Acacia mangium plantations with different stocking densities}

Ivanka Rosada de Oliveira ${ }^{1}$ @ , Guerric le Maire ${ }^{2,3}$, Jean-Paul Laclau ${ }^{3,4}$, Carolina Braga Brandani ${ }^{5}$, José Leonardo de Moraes Gonçalves ${ }^{1}$, Joannès Guillemot ${ }^{1,3}$, Iraê Amaral Guerrini ${ }^{4}$, Jean-Pierre Bouillet ${ }^{1,3}$

${ }^{1}$ Escola Superior de Agricultura "Luiz de Queiroz", Universidade de São Paulo Piracicaba, Brasil; ${ }^{2}$ Universidade Estadual deCampinas, Campinas, Brasil; ${ }^{3}$ CIRAD Eco\&Soils, Montpellier, France; ${ }^{4}$ Universidade Estadual Paulista "Júlio de Mesquita Filho”, Botucatu, Brasil; " University of Florida, Florida, USA (ivanka.ivi@gmail.com,guerric.le_maire@cirad.fr; jean-paul.laclau@cirad.fr; carolbrandani@yahoo.com.br; jlmgonca@usp.br; joannes.guillemot@cirad. fr; iraeguerrini@gmail.com; jean-pierre.bouillet@cirad.fr)

Competition for light in mixed-species plantations is a main limiting factor for tree growth. Understanding the light absorption and light use efficiency for each species at different planting densities and spatial arrangement of trees is essential for improving these plantations management. The study was conducted in Itatinga-SP, Brazil. A complete randomized block design was set up with 4 blocks and 10 treatments per block with pure and mixed plantations of Eucalyptus grandis (E) and Acacia mangium (A), a $\mathrm{N}_{2}$-fixing species (NFS). The treatments were composed with different planting densities $(6 \mathrm{~m} \times 3 \mathrm{~m}, 3 \mathrm{~m} \times 3 \mathrm{~m}$ and $3 \mathrm{~m}$ x $2 \mathrm{~m}$ ) and arrangements (100\% A, 100\% E, 50\% A and 50\% E, 33\% A and 67\% E) between species. Tree growth and biomass were monitored at 38, 45 and 52 months after planting. The absorbed photosynthetically activeradiation (APAR) for each tree was simulated with the MAESTRA model. The leaf area of each tree, leaf angle distributions and leaf area density was estimated in situ to parameterize the model. Hemispherical photos were taken over the same period of time (every 2 months) and used to test MAESTRA simulations and validate the light interception simulations. Computed Light Use Efficiency (LUE) for trunk wood production was estimated as the ratio of the wood growth and the MAESTRA simulated APAR, showing contrasted patterns of LUE for each treatment. The results will give insights to choose the best design, decreasing light competition and improving the association between eucalyptus and NFS, for a more sustainable management of pure and mixed forest plantations.

Rehabilitating evergreen forests through supplementary planting of native wood species in Pumillahue, Chile / Rehabilitación de bosques siempreverdes mediante plantación suplementaria de especies madereras nativas en Pumillahue, Chile

Roberto Ipinza ${ }^{1}$, Braulio Gutierrez ${ }^{2}$, Jorge Gonzalez ${ }^{2}$, Maria Paz Molina ${ }^{2}$, Patricio Rojas ${ }^{1}$, Carlos Magni ${ }^{3}$, Jose Cabello ${ }^{4}$, Celso Navarro ${ }^{5}$, Dante Corti ${ }^{1}$, German Clasing ${ }^{6}$, Luis Riquelme ${ }^{6}$

${ }^{1}$ Instituto Forestal, Valdivia, Chile; ${ }^{2}$ Instituto Forestal, Biobio, Chile; ${ }^{3}$ Universidad de Chile, Santiago, Chile; ${ }^{4}$ Corporacion Nacional Forestal, Santiago, Chile; ${ }^{5}$ Universidad Catolica de Temuco,Temuco, Chile; ${ }^{6}$ Consultor, Valdivia, Chile (roberto.ipinza@infor.cl; bgutierr@infor.cl; jgonzalez@infor.cl; mmolina@infor.cl; patricio.rojas@infor.cl; crmagni@uchile.cl; jose.cabello@conaf.cl; cnavarro@uct.cl; dcorti@infor.cl; germanclasing@gmail.com; roman.riquelme751@gmail.com)

Las áreas cosechadas de bosque siempreverde son profusa y rápidamente invadidas por Chusquea quila, inhibiendo el desarrollo de la regeneración y dinámica del bosque. El quilantal resultante varía de $1 \frac{1}{2}$ a algunas decenas de ha. La importancia económica para sus propietarios, amerita su rehabilitación mediante plantación mixta de especies nativas de valor maderero, para recuperar la biodiversidad, minimizar endogamia y acercar este nuevo bosque al ecosistema de referencia. De acuerdo a un inventario florístico y al interés del propietario, en el predio Pumillahue se seleccionó las especies madereras roble, ulmo, tepa, lingue y olivillo, y como especie de relleno raulí, estas se clasificaron según su ecología en pioneras o finales. Para colectar semillas que minimicen la endogamia y garanticen la adaptación local, se establecieron rutas semilleras con una distancia mínima de 30 a 50 m entre árboles de igual especie, bajo ellos se instalaron mallas para colectar sus semillas, luego se viverizó manteniendo la identificación de cada madre para evaluar posteriormente su desempeño según su estructura familiar. Se plantó endiseño de parcelas al azar en tres bloques o quilantal. Se probó 6 tratamientos de estructura factorial 3 x 2, tres niveles de espaciamiento $(3 \times 5,3 \times 3$ y $3 \times 2 \mathrm{~m})$ y dos proporciones entre especies pioneras/finales (50/50 y 67/33). La plantación es en líneas de biodiversidad. La supervivencia y altura se evaluó en dos mediciones. La supervivencia fue cercana al $100 \%$ y las especies pioneras ulmo y roble presentaron los mayores incrementos en altura. La heredabilidad también alta y significativa.

C1w: SILVICULTURE FOR EUCALYPTUS PLANTATIONS

Quality control for forestry in cultivating eucalyptus in the state of São Paulo, Brazil / Controle da qualidade das atividades silviculturais na cultura do eucalipto no estado de São Paulo, Brasil

Diana Carolina Vasquez Castro ${ }^{1,2}$ (D, Thiago Romanelli', Marcos Milan ${ }^{2}$

${ }^{1}$ Grupo de Investigación Navarra Ambiental, Facultad de Ingenierias, Fundación Universitaria Navarra - Univarra, Neiva, Colombia; ${ }^{2}$ Universidade de São Paulo,Piracicaba,Brasil(carito1986@hotmail.com; romanelli@usp.br;macmilan@usp.br)

O setor florestal tem grande importância econômica na formação do PIB do Brasil e o reflorestamento contribui para a redução do desmatamento das florestas nativas. A demanda crescente pela cultura do eucalipto exige do setor florestal a busca pela competitividade, e essa competitividade está associada à produtividade. A produção do eucalipto é uma atividade complexa que envolve inúmeras operações e atender às exigências da planta em cada operação é um dos requisitos para se obter uma boa produtividade da cultura. Para tanto, padrões que atendam às necessidades das plantas devem ser estabelecidos e mantidos constantes ao longo dos processos de instalação, condução e colheita da cultura. Com isso, o objetivo da pesquisa foi avaliar se operações de preparo do solo e de plantio estão sendo realizadas dentro dos padrões estipulados. A metodologia empregada foi o controle estatístico do processo. O trabalho foi realizado em dois locais, localizados nos municípios de Itirapina e Agudos no estado de São Paulo no Brasil em áreas com preparo do solo convencional e preparo do solo reduzido utilizando o implemento savanah. Os resultados mostram que embora as profundidades de subsolagem atendem ao especificado, o processo não está sob controle. Já para o plantio, o processo está sob controle nas áreas avaliadas.

\section{Change in height-diameter relationship with age for six clones of eucalyptus under different spacing}

Silvio Henrique Menezes Gomes ${ }^{1}$, João Luís Ferreira Batista ${ }^{1}$, Kálita Luis Soares ${ }^{1}$, Luciana Duque Silva ${ }^{1}$ ${ }^{1}$ Escola Superior de Agricultura "Luiz de Queiroz", Universidade de São Paulo, Piracicaba, Brasil (silviogomes@usp.br; batista.jlf@usp.br; kalitasoares@usp.br; lucianaduques@usp.br)

Height-diameter relationship is a basic attribute of forest stands that changes with age and can be affected by silvicultural practices such as genetic material and planting spacing. In this paper, we studied the change height-diameter relationship of trees of six eucalyptus clones planted in three different planting spacing and remeasured along seven ages. Planting spacing was transformed to planting stand density. Three basic models were applied to the height-diameter 
relationship in each specific condition of clone, age and planting spacing: the simple linear model, simple linear in logarithmic scale and exponential model. For each eucalyptus clone, the basic model parameters (intercept and slope) were taken as linear functions of age and planting spacing and eight effect models were fitted: 1) null model, don't change with age and spacing; 2) full model, change as function of age, spacing and interaction age-spacing; 3) age effect model, only; 4) spacing effect model, only; 5) age-interaction model, change with age and interaction; 6) spacing-interaction model, change with spacing and interaction; 7) age and spacing model, change with age and spacing, but no interaction; and 8) interaction model, only with the interaction. Models were fitted and their performance were compared using Akaike Information Criterion (AIC). In five of the six clones, the exponential age-interaction model performed best, while in one clone the exponential age-spacing model was best. Generally, the full model was a second best option, showing that, along with age, silvicultural practices have important effect on shaping height-diameter relationships in eucalyptus plantation forests.

\section{Biometric parameters of Eucalyptus after pure and composted sewage sludge application}

Iraê Amaral Guerrini ${ }^{1}$, Camila Rocha Pergentino da Silva ${ }^{1}$, Luciane Cristina Lazzarin ${ }^{1}$, Sérgio Augusto Rodrigues ${ }^{1}$, Caroline Moura D’Andréa Mateus ${ }^{1}$, Roberto Lyra Villas Boas ${ }^{1}$

${ }^{1}$ Universidade Estadual Paulista “Júlio de Mesquita Filho”, Faculdade de Ciências Agronômicas, Brasil (irae.guerrini@unesp.br;

camilapergentino@hotmail.com; lucianelazzarin@unc.br; sergio.rodrigues@unesp.br; caroline_mateus@hotmail.com;roberto.lyra@unesp.br)

Because of the prohibitions of using pure sewage sludge (PSL) in forest plantations in Brazil, this work had the objective of identifying the dose of composted sewage sludge (CSL) that proposes the best development of Eucalyptus. The experiment was conducted in plastic greenhouse and was composed of 48 vessels containing 50L of dystrophic medium texture. It is a factorial experiment 2 x 5 (pure and composted sewage sludge x dose 20, 30, 40 and 50 mg ha-1), in addition to absolute control and mineral fertilization, with four repetitions per treatment. The parameters evaluated were: index of green color (IGC), measured monthly during six months, dry mass (DM) and leaf area (LA), evaluated in the end of the experiment. After six months, the dose of $40 \mathrm{Mg}^{-1} \mathrm{of}^{-1} \mathrm{CSL}$ promoted the highest value of IGC, whereas the dose of $50 \mathrm{mg} \mathrm{ha}^{-1}$ of CSL promoted the highest LA of plants. The doses of 40 and $50 \mathrm{mg} \mathrm{ha}^{-1}$ of CSL of both sludges promoted the highest production of biomass in each part of plants (leaf, branch, trunk and root). The highest production of total DM occurred in the dose of $50 \mathrm{mg}^{-1} \mathrm{of}^{-1}$ CSL (868.95g/plant), similar to MS produced by the dose of $40 \mathrm{mg} \mathrm{ha}^{-1}$ of PSL (852,08g/plant). In relation to mineral fertilization, the gains with fertilization of

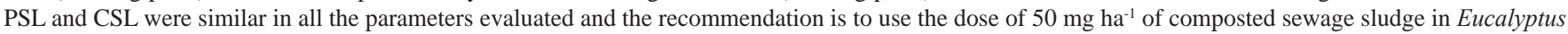
plantations.

The effect of a curtain of Eucalyptus dunnii in reducing wind speed in Flores, Uruguay / Efecto de una cortina de Eucalyptus dunnii en la reducción de la velocidad del viento en el Departamento de Flores, Uruguay

Carolina Munka ${ }^{1}$, Juan Pablo Chiara ${ }^{1}$, Celmira Saravia ${ }^{2}$, Adriana Bussoni $^{3}$, Marcelo Rachetti ${ }^{4}$

${ }^{1}$ Universidad de la República, Facultad de Agronomía, Departamento de Sistemas Ambientales, Montevideo, Uruguay; ${ }^{2}$ Universidad de la República, Facultad de Agronomía, Departamento de Sistemas Ambientales, Salto, Uruguay; ${ }^{3}$ Universidad de la República, Facul (macamunka@gmail.com; jp@fagro.edu.uy; tsara@unorte.edu.uy; abussoni@gmail.com; chelorachetti@yahoo.com.ar)

Existe escasa evidencia nacional sobre los efectos de forestaciones para servicio a la ganadería, a pesar de ser el principal motivo para incorporar montes en la producción ganadera. Este trabajo describe el efecto del abrigo de una forestación en un predio ganadero del sur de Uruguay. El estudio se realizó en una cortina semipermeable de Eucalyptus dunnii (3,5 m × 2 m) de 9 años, y $20 \mathrm{~m}$ de altura media. Entre julio y setiembre de 2018 se midió la velocidad del viento $(\mathrm{m} / \mathrm{s})$ en cuatro puntos sobre una transecta perpendicular a la orientación de la cortina (NE a SO): un punto a barlovento (SE) a una distancia horizontal a la cortina de $80 \mathrm{~m}$ y otros tres puntos a sotavento (NO), área protegida por la cortina de árboles, a distancias de $40 \mathrm{~m}, 80 \mathrm{~m}$ y $160 \mathrm{~m}$. A sotavento (NO), el viento del sureste, generalmente frío, se redujo en promedio (\% \pm desvío estándar), en: $57 \pm 18,7,82 \pm 14,6$ y $48 \pm 22,2$, a una distancia de 2, 4 y 8 veces la altura de la cortina, respectivamente. La mayor reducción se dio a una distancia de 4 veces la altura de la cortina. En todos los casos se observó una disminución del viento, condicionante para mejorar el confort animal por reducción del estrés térmico por frío, que conlleva a una potencial mejora productiva del ganado. Se debe profundizar el estudio de la interacción del árbol con las variables que más inciden en el confort animal.

Development and quality of Eucalyptus grandis x Eucalyptus urophylla seedlings under different covering materials / Desenvolvimento e qualidade de mudas de Eucalyptus grandis $x$ Eucalyptus urophylla sob diferentes coberturas de canteiros

Jhuan Lucas Melo Maciel ${ }^{1}$, Jheyson Jerzel Valdivia Gómez ${ }^{1}$, Andrew Kim Lopes Ferraz ${ }^{1}$, Magali Ribeiro da Silva ${ }^{1}$

${ }^{1}$ Universidade Estadual Paulista “Júlio de Mesquita Filho”, Botucatu,Brasil (jhuanlucas@outlook.com; jheyson540@gmail.com; andrewkim.lf@gmail.com; magaliribeiro@fca.unesp.br)

Filmes plásticos podem alterar os microambientes e, consequentemente, a qualidade das mudas florestais, havendo a necessidade de compreender a dinâmica planta-substrato-água-atmosfera por meio das variáveis de crescimento e fisiológicas das mudas. O objetivo deste trabalho foi avaliar como os microambientes afetam a fisiologia de mudas clonais do híbrido Eucalyptus grandis x Eucalyptus urophylla. Os microambientes testados foram: canteiros suspensos a pleno sol sem cobertura plástica; minitúnel com cobertura de filme plástico difusor de 150 mícron; e minitúnel com cobertura de filme plástico azul. Cada tratamento continha 4 repetições de 32 mudas. As variáveis analisadas ao final do ciclo de produção, 90 dias após a estaquia, foram altura, diâmetro do colo, massa seca aérea (MSA), radicular e total, índice de qualidade de Dickson (IQD), número de folhas, área foliar, transpiração e índice SPAD. Aos 90 DAE, altura e diâmetro do colo das mudas foram maiores quando produzidas em minitúnel independente do filme plástico. A MSA foi maior nas mudas do minitúnel com filme plástico difusor e a pleno sol. Embora neste último as mudas tenham sido menores em altura, elas tiveram maior número de folhas, sendo estas mais espessas, o que levou a uma mesma MSA. Não houve diferença significativa entre os microambientes para as variáveis massa seca radicular e total, área foliar e IQD. O Índice SPAD foi maior nas mudas a pleno sol. A transpiração foi menor nas mudas produzidas a pleno sol, indicando maior rusticidade nestas plantas.

Microenvironmental influence on production of Eucalyptus grandis Hill ex Maiden x Eucalyptus urophylla S. T. Blake seedlings / Microambientes influenciam a produção de mudas de Eucalyptus grandis Hill ex Maiden x Eucalyptus urophylla S. T. Blake

Jhuan Lucas Melo Maciel ${ }^{1}$ (D, Jheyson Jerzel Valdivia Gómez ${ }^{1}$, Andrew Kim Lopes Ferraz ${ }^{1}$, Magali Ribeiro da Silva ${ }^{1}$ ${ }^{1}$ Universidade Estadual Paulista “Júlio de MesquitaFilho”, Botucatu,Brazil (jhuanlucas@outlook.com; jheyson540@gmail.com; andrewkim.lf@gmail.com; magaliribeiro@fca.unesp.br)

Filmes plásticos proporcionam ambientes favoráveis para o desenvolvimento de mudas florestais aumentando qualidade e produtividade, onde a criação de microambientes adequadas no interior dos ambientes protegidos pode ser obtida pela combinação de diferentes materiais de cobertura. O objetivo deste trabalho 
foi quantificar a influência do microambiente sobre variáveis de crescimento em mudas clonais de Eucalyptus grandis x Eucalyptus urophylla (E. urograndis) em fase de viveiro. A pesquisa foi composta por dois experimentos (clone IPB02 e IPB13) em delineamento experimental inteiramente casualizado com três tratamentos (microambientes): canteiros suspensos a pleno sol sem cobertura plástica; minitúnel com cobertura de filme plástico difusor de 150 mícron; minitúnel com cobertura de filme plástico azul. As variáveis morfofisiológicas analisadas no final do ciclo de produção, 90 dias após a estaquia, foram altura, diâmetro do colo, números de folhas, área foliar e transpiração. Aos 90 DAE, a altura média das mudas foi maior quando produzidas em minitúnel com os filmes plásticos azul e difusor, para os dois clones. Minitúnel com filme plástico azul promoveu maior diâmetro das mudas de IPB 2. Não houve diferença significativa entre os diferentes microambientes para as variáveis número de folhas e área foliar das mudas do clone IPB02. Para as mudas do clone IPB13, tanto a área foliar quanto o número de folhas das mudas foram maiores a pleno sol. Os microambientes, proporcionados pelas diferentes coberturas, influenciaram diferentemente os clones de Eucalyptus urograndis. As mudas do clone IPB13 apresentaram maior rusticidade quando produzidas a pleno sol.

Collecting trays versus traditional trays in the production of Eucalyptus grandis Hill ex Maiden $\mathbf{x}$ Eucalyptus urophylla S. T. Blake seedlings / Bandejas coletoras x bandejas tradicionais na produção de mudas de Eucalyptus grandis Hill ex Maiden x Eucalyptus urophylla S. T. Blake

Jheyson Jerzel Valdivia Gómez ${ }^{1}$, Jhuan Lucas Melo Maciel', Magali Ribeiro da SIlva ${ }^{1}$

${ }^{1}$ Universidade Estadual Paulista “Júlio de Mesquita Filho”,Botucatu,Brasil(jheyson540@gmail.com;jhuanlucas@outlook.com; magaliribeiro@fca.unesp.br)

Existe no mercado uma nova bandeja que coleta e direciona a água de irrigação para o tubete, reduzindo as perdas causadas pelos espaços vazios e, portanto, influenciando o manejo hídrico e consequentemente o uso da água no viveiro. O objetivo deste trabalho foi avaliar como bandejas e lâminas de irrigação interagem no desenvolvimento de mudas de Eucalyptus urophylla $\mathrm{x}$ E. grandis (E. urograndis) e qual lâmina mais adequada para cada bandeja. O delineamento experimental foi o inteiramente casualizado em esquema fatorial 2 x 4, totalizando 8 tratamentos com 4 repetições de 32 mudas, sendo os tratamentos compostos de dois tipos de bandejas, bandeja tradicional (BT) e bandeja coletora (BC) e quatro lâminas de irrigação diárias de 8, 11, 14 e 17 mm. As variáveis analisadas ao final do ciclo de produção, 80 dias após estaqueamento (DAE), foram: altura, diâmetro do colo e índice SPAD. Aos 80 DAE, a altura das mudas foram maiores quando utilizadas as BC (média de 26,0 cm). Para diâmetro do colo houve interação entre os fatores, sendo que nas mudas produzidas com menores lâminas (8 e $11 \mathrm{~mm}$ ) os maiores diâmetros foram das mudas que estavam na BC, mas nas lâminas maiores (14 e $17 \mathrm{~mm}$ ) não houve diferença entre as bandejas. O Índice SPAD foi menor nas mudas provenientes da lâmina $17 \mathrm{~mm}$. Considerando as variáveis analisadas e o uso racional da água conclui-se que as lâminas de 8 mm e 14 mm são os indicados quando se usam a BC e BT, respectivamente.

Enhancing genetic deployment strategies using an understanding of clonal sensitivity to differences in soil proprieties for Eucalytus hybrids in Indonesia

Jonggi P. Simanungkalit ${ }^{1}$, Paul Anthony Clegg ${ }^{1}$, Adventris Hutagaol ${ }^{1}$, Jeremy Brawner ${ }^{2}$, Jupiter Muro Abad ${ }^{1}$

${ }^{1}$ Toba Pulp Lestari, Porsea, Indonesia; ${ }^{2}$ USC, Queensland, Australia (jonggi_simanungkalit@tobapulp.com; paul_clegg@tobapulp.com;

adventris_hutagaol@tobapulp.com; jbrawner@usc.edu.au; jupiter_abad@tobapulp.com)

Eucalyptus clones that are adapted to high-elevation climates in North Sumatra have been developed for cellulose production over the past 23 years. Hybrids among E. grandis, E. pellita and E. urophylla were evaluated across the diverse soils in the region using a trial network that replicated clones in large-plots across many sites to provide estimates of productivity. To clarify what soil properties caused clones to perform differently than expected, productivity estimates from 28 trials were paired with 975 soil samples that were assessed for 32 chemical and physical properties. In areas where the local climate is very similar, the volcanic soils and topography encompass a wide range of chemical and physical properties that are associated with significant changes in tree growth. In addition to environmentally induced changes in productivity, major changes in productivity are evident when different clones are planted; data from the clonal trials indicate there is a clear genetic signal (Heritability $(\mathrm{H} 2)=0.40 \pm 0.06$ ). Nevertheless, significant changes in clonal rankings across the different sites were evident (Among-site genetic correlation $(\mathrm{rg})=0.61 \pm 0.07)$. These clone by site interactions were associated with the underlying soil properties in order to identify individuals that were sensitive to differences in soil properties. It is hoped that targeting clones to sites similar to those where they have performed better than expected will lead to improved productivity as well as reduce abiotic stress and sensitivity to pathogens.

C1x: GERMINATION AND PROPAGATION

\title{
Effects of substrates on germination and growth of Moringa oleifera Lam, Acacia mellifera and Zizyphus mauritiana seedlings
}

\author{
Antoine Sambou ${ }^{1}$ \\ ${ }^{1}$ Assane Seck University of Ziguinchor, Ziguinchor, Senegal (tonysambouegos@yahoo.fr)
}

This study focuses on Moringa oleifera Lam, Acacia mellifera and Zizyphus mauritiana Lam which constitute a significant source of food and economic value for the populations of Casamance. In addition to a germination test, a follow-up of seedlings on different substrates was carried out in the nursery, in order to determine the effect of substrates on growth parameters (number of leaves, height, diameter and biomass). The substrates used were three potting mixtures of forest soil of Faidherbia albida (FSFA), Elaeis guineensis (FSEG) and Anacardium occidentale (FSAO) with sand with the following proportion: 1/3 sand $+2 / 3$ forest soil). Based on species, the germination rate was higher for A. mellifera (84\%) followed by M. oleifera (55\%) and Z. mauritiana (50\%). The germination rate was more important in FSFA and FSEG than in FSAO. For growth parameters, there was a significant effect $(\mathrm{P}<0.05)$ of substrate type on height, diameter, number of leaves and root biomass. In term of growth parameters, the seedling performed better in FSFA and FSEG than in FSAO. The species effect was also significant $(\mathrm{P}<0.05)$ with higher root biomass and diameter found in $M$. oleifera and height and number of leaves in A. mellifera. The most important total biomass was found in FSFA followed by FSEG. Comparing the fraction of biomass according the part of the seedling, the stem and branch had the higher fraction of biomass for A. mellifera (43\%) and M. oleifera (38\%) and the leaves for Z. mauritiana (46\%). Better results were recorded in FSFA and FSEG substrates. 


\title{
Germination of Aristida riparia Trin: a native Cerrado grass species / Germinação de Aristida riparia Trin: gramínea nativa do Cerrado
}

Brenda Barbara Araujo Ribeiro ${ }^{1}$, Thiago Sampaio Teles ${ }^{1}$, Sybelle Barreira ${ }^{1}$

${ }^{1}$ Universidade Federal de Goiás, Goiania, Brazil (brendabarbara33@gmail.com; thiagosampateles@gmail.com; sybelle.barreira@gmail.com)

A maneira segura de conhecer a qualidade de um lote de sementes é através da análise física e fisiológica, objetivando cumprir a legislação o MAPA organizou as Regras de Análise de Sementes - RAS, que descreve protocolos para análise de sementes. Desta forma o objetivo deste trabalho foi validar o protocolo de germinação da RAS e testar diferentes substratos para germinação de sementes de Aristida riparia Trin. As sementes foram coletadas no ano de 2017 e transportadas para o Laboratório Reprodução de Espécies Florestais para limpeza e triagem. Os testes de germinação iniciaram-se em 2018 e foi realizado com 4 repetições de 25 sementes. Como substratos foram utilizados rolo de papel com duas folhas de papel germitest (RP) e papel mata borrão (SP). Na condução dos testes foram utilizados solução à $0,2 \%$ de $\mathrm{KNO}_{3}(1)$ e $6 \mathrm{ml} \mathrm{de} \mathrm{H}_{2} \mathrm{O}(2)$ deionizada totalizando-se 4 tratamentos. Os testes foram conduzidos com luz fluorescente branca e controle da temperatura de $30^{\circ} \mathrm{C}$ e fotoperíodo de 12 horas. Os dados obtidos foram submetidos a análise de variância, empregando-se o teste de Tukey a 5\% de probabilidade. A taxa de germinação apresentou foi de 10\% SP1, 7\% RP1, 17\% SP2 e 12\% RP2. O tratamento sobre papel a 6 ml de água deionizada difere significativamente dos demais. Este resultado demonstra que as sementes de Aristida riparia Trin tiveram maior taxa de germinação em água deionizada, sugerindo que o disposto na RAS pode não ser válido para esta espécie.

\section{Assessing germination of Tibouchina granulosa Cogn seeds collected during different periods / Avaliação da germinação de sementes de Tibouchina granulosa Cogn coletadas em diferentes periodos}

Álvaro de Oliveira Moreira ${ }^{1}$, Thiago Augusto Sampaio Teles ${ }^{1}$, Sybelle Barreira ${ }^{1}$

${ }^{1}$ Universidade Federal de Goiás, Goiania,Brasil (alvaroom96@gmail.com; thiagosampateles@gmail.com; sybelle.barreira@gmail.com)

Tibouchina granulosa Cogn., planta da família Melastomataceae, popularmente conhecida como Quaresmeira, é uma espécie nativa brasileira amplamente utilizada para fins ornamentais e para recuperação de áreas degradadas. Todavia, o tamanho reduzido de suas sementes e o baixo grau de germinação são empecilhos para a propagação sexuada da espécie, dificultando a produção comercial da mesma. Neste sentido, o presente trabalho objetivou estudar a taxa de germinação de sementes de quaresmeira e a melhor época de colheita. O material vegetal foi obtido de uma planta matriz localizada no Campus II da UFG, Goiânia-GO. Durante os meses de abril e maio de 2018 foram coletadas amostras de frutos, sendo uma coleta por semana, totalizando 9 coletas. Os frutos foram conduzidos ao Laboratório de Reprodução de Espécies florestais (REFLOR) para ser efetuado o teste de germinação. O teste de cada coleta foi composto por 4 repetições de 25 sementes, sendo estas acondicionadas em gerbox com auxilio de pinças, sobre papel autoclavado afim de se evitar contaminações por agentes biológicos. As gerbox foram colocadas em estufa de germinação, com temperatura constante de $30^{\circ} \mathrm{C}$, sendo estas avaliadas semanalmente. A germinação foi avaliada pela porcentagem de plântulas normais, sendo a protrusão da radícula o indicador de germinação. Não houve germinação até a primeira quinzena de maio, e, a maior porcentagem de germinação foi obtida entre a sétima e oitava semana de avaliação, com 39\% das sementes de quaresmeira consideradas germinadas.

Variation in soil organic matter in an irrigated plantation of Toona ciliata M. Roemer var. australis / Variação da matéria orgânica do solo em plantio irrigado de Toona ciliata M. Roemer var. australis

Eduardo de Castro Stehling ${ }^{1}$ (D, Eduardo Aparecido Ribeiro ${ }^{2}$, Sebastião Carlos da Silva Rosado ${ }^{3}$, Erika Steinmetz Vilela ${ }^{4}$

${ }^{1}$ Fuste Consultoria Florestal, Campo Belo, Brasil; ${ }^{2}$ Natureza Reflorestamento, Belo Horizonte, Brasil; ${ }^{3}$ Universidade Federal de Lavras, Lavras, Brasil; ${ }^{4}$ Bela Vista Florestal, Campo Belo, Brasil (fusteconsultoria@gmail.com, eduardoribeiro.natureza@yahoo.com; scrosado@dcf.ufla.br; erika@belavistaflorestal.com.br)

O cedro australiano é uma espécie caducifólia de rápido crescimento. Com o objetivo de acompanhar a influência dos tratos culturais e do comportamento caducifólio na variação da matéria orgânica do solo (M. O.), foram realizadas análises nos diferentes talhões, na profundidade de 0-20 cm entre agosto/2014 e junho/2018 em 6 diferentes momentos. O plantio irrigado por gotejamento pertence a Natureza Reflorestamento consistindo em uma área de 130 ha situados no distrito de Santana da Caatinga, João Pinheiro, MG. O solo possui textura franco-arenosa (8\% silte, 18\% argila e 74\% areia). Após limpeza e preparo, o plantio foi realizado em maio de 2016. Não foram utilizadas outras fontes de matéria orgânica. Entre agosto e novembro de 2016, as linhas de plantio foram consorciadas com melancia e abóboras capotiá e sergipana. Foram realizadas 2 podas anuais após a implantação, totalizando 6, com a maior intensidade em 2018. Os resultados médios da M.O. obtidos em dag/kg, foram respectivamente: ago/2014 (área bruta, 0,4); out/2014 (pós-gradagem, 1,24); jun/2016 (antesconsórcio, 1,05); set/2017 (pós-consórcio, 1,02); jun/2018 (pós-queda de folhas e desrama, 1,54). Não foi observada variação da M. O. após a erradicação das abóboras e melancias. O incremento médio de M. $O$. no período foi de $1,1 \mathrm{dag} / \mathrm{kg}$ (aumento de $275 \%$ ). O aumento da M. $O$. deveu-se aos tratos culturais requeridos pela cultura (controle de mato-competição e desrama) com grande contribuição da queda de folhas devido ao comportamento caducifólio da espécie. Ocorreu um aumento da fertilidade do solo após a implantação da cultura considerando o parâmetro matéria orgânica.

Height of complete bark girdling in Ilex paraguariensis to produce epicormic shoots / Alturas de anelamento completo em Ilex paraguariensis para produção de brotações epicórmicas

\author{
Bruno Nascimento ${ }^{1}$, Alexandra Cristina Schatz Sá1, Marcio Carlos Navroski ${ }^{1}$ D, Mariane de Oliveira Pereira ${ }^{1}$ \\ ${ }^{1}$ Universidade do Estado de Santa Catarina, Lages, Brasil (b.nascimento_92@hotmail.com; alexandra.schatz.sa@gmail.com; marcio.navroski@udesc.br; \\ maripereira.florestal@gmail.com)
}

O uso de brotações epicórmicas em espécies florestais é de grande importância para o sucesso de sua propagação vegetativa. Este fato está relacionado com a idade ontogenética do material, pois quanto mais próximo da base da planta forem obtidas as brotações, maior vigor e possibilidade de enraizamento. O objetivo deste trabalho foi testar alturas de anelamento completo em genótipos de Ilex paraguariensis para produção de brotações epicórmicas. Foram selecionadas plantas nativas da espécie, sombreadas e fenotipicamente semelhantes, sendo aneladas em três diferentes alturas do solo (30, 60 e 90 cm), no município de Urupema - SC em agosto de 2016. A altura foi obtida com uma trena milimétrica e o anelamento efetuado com um facão, removendo-se somente a casca externa, não afetando o lenho, com aproximadamente $5 \mathrm{~cm}$ de largura. Com 210 dias avaliou-se: genótipos com brotações (\%), número médio de brotos formados e comprimento médio de brotos ( $\mathrm{cm})$. A maior média de genótipos com brotações foi obtida para o anelamento a $90 \mathrm{~cm}$ (53\%), enquanto os demais tratamentos apresentaram a mesma média (27\%). Consequentemente, o número médio de brotos também foi maior para este tratamento (1,6), seguido por 60 $\mathrm{cm}(0,5)$ e $30 \mathrm{~cm}(0,3 \mathrm{~cm})$. A mesma ordem decrescente foi constatada para o comprimento médio de brotos $(1,6 \mathrm{~cm} ; 0,9 \mathrm{~cm}$ e $0,4 \mathrm{~cm})$. A maior brotação obtida aos $90 \mathrm{~cm}$ pode ter sido ocasionada pelo maior acúmulo de gemas dormentes nesta região. Ressalta-se que quanto mais altas forem produzidas as brotações epicórmicas, mais ontogeneticamente maduro é o material vegetal. 
Effects of biofertilizers on survival and development of native seedlings used in pasture restoration in San Félix, Colombia / Efectos de biofertilizantes en la supervivencia y desarrollo de plántulas nativas en restauración de potreros en San Félix, Colombia

Mateo Molina López ${ }^{1}$, Jaime Polania ${ }^{1}$, Jessica López López ${ }^{1}$, Carolina Serna ${ }^{1}$

${ }^{1}$ Universidad Nacional de Colombia Sede Medellín, Medellín,Colombia (mmolinal@unal.edu.co; jhpolaniav@unal.edu.co; jplopezl@unal.edu.co; csernac@unal.edu.co)

La biofertilización y la asociación con microorganismos permiten a las plantas mejorar la captación de nutrientes y desarrollar sus raíces, lo cual constituye una herramienta importante para sobrevivir procesos de reforestación y restauración ecológica. Además, los menores costos de mantenimiento contribuyen al éxito de estos proyectos. Un experimento de biofertilización en un predio con historial de uso ganadero en el altiplano occidental del Valle de Aburrá (Medellín, Colombia), incluyó Psidium guajava, Tecoma stans y Citharexylum subflavescens, elegidas por su rápido crecimiento y carácter heliófilo. Se utilizaron como biofertilizantes bacterias de los géneros Azospirillum y Trichoderma y, además, dos cubiertas para evitar el crecimiento de arvenses. El diseño fue en bloques aleatorios con cuatro tratamientos (i. control, sin tratamiento; ii. biofertilizante; iii. biofertilizante + cubierta de cartón; y iv. biofertilizante + cubierta de Arachis pintoi) y cuatro repeticiones; 64 individuos en total. Se midieron tasas de supervivencia/mortalidad, crecimiento y ancho de copa durante los siguientes seis meses. La supervivencia superó resultados de otro proyecto de mayor escala en Santander (Colombia: 85\%) y, aunque no hubo diferencias significativas entre los tratamientos, las mayores alturas fueron alcanzadas por $C$. subflavescens. Todas las especies presentaron una tendencia general, mientras que el ancho de copa fue variable. Las diferencias entre tratamientos se atribuyen a la heterogeneidad espacial, la corta duración, dificultades del monitoreo y cuidado. La diferencia en supervivencia con Santander pudo derivar de condiciones distintas de clima, suelo, especies, y un mayor número de repeticiones.

\section{Brightness in mini-cuttings of Sequoia sempervirens (D. Dom.) Endl. / Luminosidade na miniestaquia de Sequoia Sempervirens (D. Dom.) Endl. \\ Liliane Schicora ${ }^{1}$, Marcio Carlos Navroski ${ }^{1}$ @ , Mariane de Oliveira Pereira $^{1}$, Tamara Rosa Gerber ${ }^{1}$ \\ ${ }^{1}$ Universidade do Estado de Santa Catarina, Lages, Brasil (lilianeschicora@yahoo.com.br; marcio.navroski@udesc.br; maripereira.florestal@gmail.com; tamygerber@hotmail.com)}

A busca pela introdução de novas espécies florestais no Brasil é crescente e a valorização daquelas consideradas de madeira nobre inquestionável, podendo assim destacar-se Sequoia sempervirens. A produção de mudas da espécie por sementes possui vários empecilhos que dificultam sua propagação, sendo a miniestaquia uma alternativa viável. Objetivou-se comparar a produção e enraizamento de miniestacas de Sequoia sempervirens em diferentes condições de luz no minijardim clonal. O experimento foi desenvolvido em casa de vegetação, utilizando-se um clone (A228). Foi empregado o delineamento inteiramente casualizado com 15 repetições por tratamento, sendo cada repetição constituída de um vaso (uma minicepa). Os três tratamentos constaram de diferentes níveis de luminosidade, sendo: T1 - controle (sem sombreamento), T2 - minicepas com camada simples de sombrite (33\% de sombreamento) e T3 - minicepas com camada dupla de sombrite (66\% de sombreamento). Após 60 dias da aplicação dos tratamentos foi realizada avaliação de produção de miniestacas, sendo estas coletadas e postas para enraizar em estufim. Posteriormente (95 dias) realizou-se avaliação de sobrevivência (\%), enraizamento (\%) e número de raízes emitidas por miniestaca. A produção de miniestacas não apresentou diferença entre os tratamentos de luz, sendo a média de miniestacas por minicepa de 7,0. Não houve diferença entre os tratamentos na sobrevivência das miniestacas (100\%) e também no número de raízes (média de 5,0). Quanto ao enraizamento das miniestacas, T3 foi superior $16 \%$ em relação ao tratamento controle, apresentando 93,7\% de enraizamento. Apesar de não incrementar a produção de miniestacas, o sombreamento das minicepas eleva o enraizamento.

\section{Fertilizing in clonal minihedges of Sequoia sempervirens (D. Dom.) Endl. / Adubação em minijardim clonal de Sequoia sempervirens (D.} Dom.) Endl.

Marcio Carlos Navroski ${ }^{1}$ ๑, Luis Fernando Chaves Duarte ${ }^{1}$, Mariane de Oliveira Pereira ${ }^{1}$, Pedro Henrique Tavares da Fonseca

${ }^{1}$ Universidade do Estado de Santa Catarina, Lages,SC,Brasil(marcio.navroski@udesc.br; luisfchavesdt@gmail.com; maripereira.florestal@gmail.com; pedrohentavares@hotmail.com)

A adubação em minijardim clonal é indispensável em função da necessidade de uma nutrição adequada para a produção de miniestacas a partir de minicepas. Dessa forma, objetivou-se verificar a produção de miniestacas em função de diferentes tratamentos de adubação no minijardim clonal em vasos de Sequoia sempervirens. O minijardim clonal é formado por vasos (5 L), preenchidos com substrato comercial a base de casca de pinus e cobertura de vermiculita. Após o plantio nos vasos as mudas foram conduzidas com podas durante dois meses até o início do experimento. O delineamento utilizado foi inteiramente casualizado (DIC), com 5 repetições de uma minicepa cada. Testou-se quatro clones (A116, A117, A138 e A200) e quatro adubações, compostas por dois adubos administrados via diluição em água - fertilizante para fertirrigação (19-19-19) 1 g L-1 e fertilizante organomineral (8-6-7) 10 ml L-11 1 L de solução por vaso) - e dois adubos adicionados aos vasos - fertilizante de liberação controlada (15-9-12) $10 \mathrm{~g}$ por vaso e fertilizante de liberação imediata (5-20-20) $5 \mathrm{~g}$ por vaso. A aplicação ocorreu quinzenalmente durante dois meses, momento em que foi realizada a coleta e contagem de miniestacas por minicepa. O fertilizante de liberação controlada apresentou a maior produção de miniestacas por minicepa em todos os clones (média de 31,5), seguido pelo fertilizante de liberação imediata (22,2). O fertilizante para fertirrigação apresentou menor média $(10,5)$. Em relação aos clones, A200 foi superior em relação aos demais $(29,2)$. Recomenda-se o uso do fertilizante de liberação controlada na adubação de minicepas de sequoia.

\section{C1y: SILVICULTURE, NURSERY TECHNIQUES AND FERTILIZERS}

\section{Recognizing a non-industrial method as an alternative for germinating Juglans neotropica Diels / Reconocimiento del método artesanal} como alternativa para la germinación de Juglans neotropica Diels

Yair Villanueva ${ }^{1}$ (D), Diego Rincon ${ }^{1}$

${ }^{1}$ Universidad Distrital Francisco José de Caldas, Bogotá, Colombia (yair_villanueva@yahoo.com,drinconprieto@gmail.com)

Las semillas de Juglans neotropica en relación con su testa, se caracterizan por ser muy duras y gruesas, impidiendo la disponibilidad de agua para el embrión y facilitando la latencia por lapsos de tiempo muy prolongados; considerando así su importancia en el estudio de tratamientos que disminuyan su tiempo de emergencia. Se desarrollaron dos métodos con el fin de disminuir el tiempo en la germinación de esta especie, procediendo a tapar las semillas con una bolsa negra durante el día y retirándola en la noche, la escarificación mediante la ruptura de la testa con una prensa, y el testigo sin tratamiento alguno. Controlando 
variables de riego y suelo, se valoró porcentajes de germinación en cada tratamiento, donde sus resultados indicaron la mayor cantidad de semillas de Juglans neotropica germinadas en el método artesanal, teniendo en cuenta las diferencias significativas encontradas entre los testigos y las semillas del método artesanal.

Feasibility of composting sewage sludge from a treatment plant in Balneário Camboriú, Santa Catarina, Brazil for use as fertilizer I Análise da viabilidade da compostagem do lodo de esgoto da Estação de Tratamento de Esgoto de Balneário Camboriú, SC, para fins de adubação

Carla Claudino ${ }^{1}$, Tania Pedrelli ${ }^{2}$, Caio Rebouças ${ }^{2}$, Pedro Cardoso ${ }^{1}$

${ }^{1}$ Universidade do Vale do Itajai, Itajai, Brasil; ${ }^{2}$ Empresa Municipal de Água e Saneamento, Balneário Camboriú, Brasil (carlaclaudino@yahoo.com; tania.p@emasa.com.br; caio.cardinali@emasa.com.br; pedrocardoso1056@gmail.com)

O lodo de esgoto possuí elevada quantidade de matéria orgânica e nutrientes, de forma que, após receber tratamento adequado pode ser considerado um adubo. Logo, o presente estudo teve como objetivo efetuar e analisar o processo de compostagem como alternativa para o tratamento do lodo de esgoto da ETE - Nova Esperança, localizada no município de Balneário Camboriú - SC, para fins de adubação. Realizou-se a análise da composição física, química e biológica do lodo desidratado da ETE de amostras coletadas nos meses de abril a agosto de 2018, teste do tratamento do lodo desidratado com processo de compostagem com areação natural em formato de pilha, bem como avaliação da viabilidade da utilização do composto como adubo por meio da comparação das propriedades analisadas com o que estabelece as diretrizes do MAPA. Como resultado obteve-se que há alteração nas características físico-químicas e biológicas entre o lodo desidratado e composto final, que para se atingir a fase termófila, a pilha de compostagem do lodo da ETE - Nova Esperança precisa ser realizada com volume mínimo de $3,45 \mathrm{~m}^{3}$, atingindo com esse volume temperatura média de $53^{\circ} \mathrm{C}$ em menos de um mês após o início do processo, bem como que o setor de paisagismo do município de Balneário Camboriú configura fonte insuficiente de material estruturante para compostagem de $100 \%$ do lodo de esgoto gerado na ETE - Nova Esperança. Por fim, o composto final foi classificado como adequado para utilização como adubo de forma a diminuir o passivo ambiental da ETE Nova Esperança.

Corn and soy productivity in integrated agroforestry and direct planting systems using organic or mineral fertilizers / Produtividade de milho e soja em sistemas ILPF e PD com adubação orgânica ou mineral

Paulo Hentz ${ }^{1}$ (D, Juliano Coruli Correa ${ }^{2}$, José Juscelino de Oliveira ${ }^{1}$, Luciane Cristina Lazzarin ${ }^{3}$, Gauana de Abreu Clamer ${ }^{1}$ (D

${ }^{1}$ Instituto Federal Catarinense Campus Concórdia, Concórdia, SC, Brasil; ${ }^{2}$ Embrapa Suínos e Aves, Concórdia, SC, Brasil; ${ }^{3}$ Universidade do Contestado, Concórdia,SC,Brasil (paulo.hentz@ifc.edu.br, juliano.correa@embrapa.br; jose.oliveira@ifc.edu.br; lucianelazzarin@unc.br; gauanadeabreu01@gmail.com

A geração de fertilizantes orgânicos provenientes dos sistemas produtivos de suínos e aves no sul do Brasil traz a responsabilidade de utilizá-los na agricultura de acordo com recomendações técnicas para que não sejam encarados como potencial poluidor do ambiente e sim como fertilizantes aptos ao aumento da produtividade. A sua utilização em sistema de produção integrado pode resultar em ganhos econômicos e ambientais. O objetivo do trabalho foi avaliar a resposta da adubação com cama de aves (CA), dejeto de suínos (DS) e fertilizantes minerais (M) em relação à produtividade de milho e soja nas safras 2015/16 e 2016/2017 em sistema de produção integração lavoura-pecuária-floresta (ILPF) e sistema plantio direto (PD). O experimento foi conduzido no município de Concórdia-SC, onde o delineamento experimental foi blocos casualizados, com 3 repetições, em fatorial 2 x 4, sendo dois tipos de sistemas de produção (ILPF e PD) em interação com três tipos de fertilizantes DS, CA, M e o controle (sem adubação). A produtividade de milho apresentou diferenças em razão do sistema de produção, onde o PD foi superior ao iLPF, provavelmente em função do efeito de sombreamento do componente arbóreo sobre a cultura. A produtividade da cultura da soja demonstrou superioridade dos tratamentos CA e DS quando comparado com o mineral no PD em relação ao iLPF.

\section{Influence of liming on growth of Cedrela odorata L. seedlings and attack by Hypsipyla grandella Zeller (Lepidoptera: Pyralidae)}

John Alexander Pulgarín Díaz ${ }^{1}$ (D), Lucas Esteban Cano Gallego ${ }^{2}$, Ángela María Arcila Cardona ${ }^{3}$ (D)

${ }^{1}$ Corporación Colombiana de Investigación Agropecuaria, Centro de Investigación El Nus, Vereda Ica, Corregimiento San José del Nus, San Roque, Antioquia, Colombia; ${ }^{2}$ Agrosavia, Bogotá, Colombia; ${ }^{3}$ Corporación Colombiana de Investigación Agropecuaria, Centro (jpulgarin@agrosavia.co, lcanog@agrosavia.co; aarcila@agrosavia.co)

Cedrela odorata is one of the most important neotropical forest species; its commercial plantation is limited by $H$. grandella attacks. Inverse relation of available calcium concentration for $C$. odorata in the soil and $H$. grandella attacks had been reported; moreover, its height growth had been correlated with available phosphate concentration. The effect of adding dolomitic limestone (CaCO3 57.8\% and MgCO3 36.7\%) on the height-growth, aerial-biomass and attack by $H$.

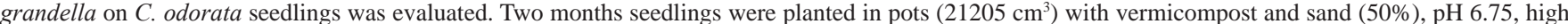
saturation of calcium, magnesium and potassium. Treatments were 0 (T1), 200 (T2), 300 (T3) and 400 gm (T4) of dolomitic limestone. The seedlings were exposed to full sunlight for four months. Survival was $99.9 \%$ in all treatments. Height growth was positively influenced by liming, T3 showed the higher mean height $(93.9 \mathrm{~cm})$. Shoot-dry-weight was also affected by treatments, being T4 the one with the higher mean weight (59.96 g). T2 had the highest proportion of dry mass (38.9\%). There was no difference in the number of attacks by $H$. grandella between treatments; however, the fact that the seedlings had a better growth, possibly due to a better nutrition, will help them reach commercial height in less time, reducing exposure to damage by $H$. grandella. Improving soil nutritional properties should be part of an integrated pest management scheme, although plants with better nutrition could improve the development of $H$. grandella larvae.

\section{Cariniana pyriformis Miers growth in two light environments in Antioquia, Colombia}

John Alexander Pulgarín Díaz ${ }^{1}$ (D), lucas Esteban Cano gallego ${ }^{2}$. Juan Pablo Gil Restrepo ${ }^{2}$

${ }^{1}$ Corporación Colombiana de Investigación Agropecuaria, Centro de Investigación El Nus, Vereda Ica, Corregimiento San José del Nus, San Roque, Antioquia, Colombia; ${ }^{2}$ Agrosavia,Bogota, Colombia (jpulgarin@agrosavia.co,lcanog@agrosavia.co;jpgil@agrosavia.co)

Cariniana pyriformis is a valuable species in South America wood market. It is harvested in the natural forest, in spite of being in critical danger of extinction. There is a substantial lack of information about the growth of Neotropical forest species, which constitutes the first steps to develop the forestry sector. Growth in height $(\mathrm{H})$ and diameter at breast height $(\mathrm{DBH})$ of Cariniana pyriformis were compared in two light environments and related to temperature, precipitation, evapotranspiration and relative humidity. In October 2013, three plots were established with 109 individuals at full-sunlight, and six with 59 individuals with 35- 43\% shade, in a Neotropical humid forest; 15 dasometric evaluations were done, until 5.17 years old. Survival was $81 \%$ in full-sunlight and $89.8 \%$ in partial-sunlight. From 0.5 - 1.42 years old, full-sunlight individuals showed a greater mean annual increment (MAI) in H (1.58) than the ones in shade (1.35) 
(pairwise comparisons). In the period of 1.42 - 5.17 years no differences were detected; nor were differences in MAI-DBH in pairwise comparisons in the 1.42 - 5.17 years period. At 5.17 years no differences in mean $\mathrm{H}$ between systems $(7.1 \mathrm{~m}$ in full sunlight and $6.97 \mathrm{~m}$ shade) were found; but DBH was greater in full sunlight $(8.46 \mathrm{~cm})$ than in shade $(6.03 \mathrm{~cm})$. Relation between climate variables and MAI were not detected. Insects damage were only present until 2.31 years in partial shading in 64 individuals. This is the first work assessing the initial growth of Cariniana pyriformis in plantations, providing information for future plantations.

Ecological contribution of the Siempre Verde Forest in the Guangras community within Sangay National Park, Ecuador / Contribucion a la ecología del bosque siempre verde de la comunidad de guangras en el parque nacional sangay ecuador

Daniel Adrián Vistín Guamantaqui ${ }^{1}$ D, Héctor Barrero Medel $^{2}$

${ }^{1}$ Escuela Superior Politécnica de Chimborazo, Ríobamba, Ecuador; ${ }^{2}$ Universidad de Pinar del Río, Pinar del Río, Cuba(daniel.vistin@espoch.edu.ec, hbarrero@upr.edu.cu)

Este trabajo tuvo como objetivo determinar el efecto de las varaibles ambientales edáficas y dasométricas sobre el bosque siempre verde de la comunidad de Guangras en la Parroquia Achupallas, Ecuador a partir de conocer su estado de estructura y composición actual. Se establecieron 4 transeptos de $3600 \mathrm{~m}^{2}$ cada uno, dos en la parte baja y dos en la parte alta del área, distribuidos al azar, se realizó un estudio floristico, determinandose la diversidad, el Indice de valor de importancia ecológica (IVIE), el volumen por especie y un Analisis de Correpondencia Canónica (CCA) para analizar el efecto de la variables ambientales sobre la vegetación. Como resultados. Se registran un total de 18 especies arbóreas pertenecientes a 15 familias y 15 géneros siendo las más representativas las familias Cunoniaceae, Asteraceae y Myrtaceae, las especies de mayor IVIE resultaron Miconia sp, Aegiphila sp y Weinmannia mariquitae así como la inexistenciade un gradiente al resultar un CCA con inercia igual a 0.3564 donde las variables de mayor peso son las del suelo específicamente la pedregosidad, la textura y la fisiografía.

\section{Aniba perutilis Hemsley and Pachira quinata (Jacq.) W.S. Alverson initial growth in a tropical humid forest in Antioquia, Colombia \\ John Alexander Pulgarín Díaz ${ }^{1}$ (D, Lucas Esteban Cano Gallego², Juan Pablo Gil Restrepo ${ }^{2}$ \\ ${ }^{1}$ Corporación Colombiana de Investigación Agropecuaria, Centro de Investigación El Nus, Vereda Ica, Corregimiento San José del Nus, San Roque, Antioquia, Colombia; ${ }^{2}$ Corporación Colombiana de Investigación Agropecuaria, Bogotá, Colombia (jpulgarin@agrosavia.co,lcanog@agrosavia.co; jpgil@agrosavia.co)}

Aniba perutilis and Pachira quinata are valuable species in South America wood market. These species are harvested in the natural forest, taking their populations to high-degree of degradation. Information about their initial growth and interaction with environmental conditions are scarce and are essential for planning purposes. We correlated the growth in total height $(\mathrm{H})$ and diameter at breast height (DBH) of Aniba perutilis and Pachira quinata with climate variables. In October 2013, three plots were established with 73 individuals of Aniba perutilis, and three plots with 107 individuals of Pachira quinata at full sunlight in an abandoned grassland for cattle; 15 dasometric evaluations were done until 5.17 years old. Monthly average temperature, relative humidity, precipitation, and evapotranspiration were registered; $16.5 \%$ of individuals of $A$. perutilis survived. At 5.17 years mean annual increment (MAI) in H and MAI-DBH were 0.44 $\mathrm{m}$ and $0.35 \mathrm{~cm}$, respectively. MAI-H correlated negatively with temperature, precipitation and evapotranspiration, and positively with relative humidity. All individuals of $P$. quinata survived. At 5.17 years MAI-H and MAI-DBH were $0.92 \mathrm{~m}$ and $1.41 \mathrm{~cm}$, respectively. MAI-H correlated negatively with temperature and evapotranspiration, and positively with relative humidity; MAI-DBH correlated negatively with temperature and relative humidity, and positively with precipitation and evapotranspiration. In all assessments, $37.4 \%$ of the P. quinata individuals were leafless. Insect attacks were not significant in P. quinata, but A. perutilis presented 73 attacks in the 5 years of evaluation. This is the first assessment of the initial growth of Aniba perutilis and Pachira quinata providing information for future plantations.

Assessing restriction resulting from container volume on growth and allocation of resources in Cerrado tree species / Avaliação da restrição do volume do recipiente de cultivo no crescimento e alocação de recursos em espécies arbóreas de Cerrado

Caroline Stritar ${ }^{1}$, Valdemir Laura', Silvia Pereira ${ }^{3}$, Fabiana Alves $^{2}$, Roberto Almeida

${ }^{1}$ Universidade Federal do Mato Grosso do Sul, Campo Grande, MS, Brasil; ${ }^{2}$ Embrapa Gado de Corte, Campo Grande, Brasil; ${ }^{3}$ Universidade Anhanguera, Campo Grande, MS, Brasil (carolramires.silva@gmail.com; valdemir.laura@embrapa.br; silviarahe@gmail.com; fabiana.alves@embrapa.br;

roberto.giolo@embrapa.br)

O tipo e volume do recipiente utilizado no cultivo de mudas tem um efeito significativo na distribuição de recursos entre raiz e parte aérea, causando prejuízo significativo no desempenho das mudas. O objetivo foi avaliar o efeito do volume do recipiente de cultivo em três espécies florestais nativas no crescimento em altura e na alocação de recursos entre raízes e partes aéreas. O experimento foi conduzido em casa de vegetação, na Embrapa Gado de Corte em Campo Grande, MS, entre abril a outubro de 2018. As espécies utilizadas foram Anadenanthera peregrina var. falcata (Benth.) Altschul, Hymenaea stigonocarpa Mart. ex Hayne e Myracrodruon urundeuva Allemão. Após a germinação das sementes, as mudas foram cultivadas em recipientes de $110 \mathrm{~cm}^{3}$ (tubetinho), $290 \mathrm{~cm}^{3}$ (tubetão) e $7000 \mathrm{~cm}^{3}$ (citropote). O crescimento das mudas foi monitorado individualmente por 120 dias, através da medida da altura da parte aérea (cm). Ao final do experimento foram registradas as seguintes medidas: massa seca da raiz, massa seca da parte aérea, fração de massa na raiz e massa seca da planta. As diferenças em altura da parte aérea entre os tratamentos foram significativas apenas em A. peregrina e $M$. urundeuva. A massa seca da raiz também diferiu significativamente apenas em A. peregrina e $M$. urundeuva, recipientes de maior volume apresentaram valores maiores. A alocação de recursos para as raízes em A. peregrina e $M$. urundeuva foi negativamente relacionado com o tamanho da planta, já em $H$. stigonocarpa a relação com o tamanho da planta foi positiva.

\section{C1z: SILVICULTURE AND PLANT COMMUNITIES}

\section{Population distribution and structure of Afzelia species in Southwestern Nigeria}

Adejoke Akinyele ${ }^{1}$, Akintunde Solomon ${ }^{1}$

${ }^{1}$ University of Ibadan, Ibadan, Nigeria (akinyelejo@yahoo.co.uk; solomonakintunde32@gmail.com)

Investigation was conducted to assess the population distribution and structure of Afzelia species in Southwestern Nigeria..The study areas are Omo Biosphere Reserve, Gambari Forest Reserve and Akure Forest Reserve. Data were collected in 125 plots of $2500 \mathrm{~m}^{2}$ on diameter at breast (DBH $\left.\geq 10 \mathrm{~cm}\right)$, total height and bole height of Afzelia species. Tree variables such as Blackman and Green indices, basal area, average diameter, height of Lorey and density were calculated and 
interpreted. Density $(0.06)$, diameter $(0.01 \mathrm{~cm})$, basal surface area $(0.01 \mathrm{chm})$, Lorey height $(0.07 \mathrm{~m})$ and Green index $(0.03)$ were significant across locations while medium basal surface area $(0.01 \mathrm{~cm} 2)$ and Blackman index $(0.01)$ were not. Density $(0.23)$, stand/hectare and stand diameter $(\mathrm{cm})(0.01)$ were significant for regeneration status while basal surface area $(\mathrm{cm} 2)(0.00)$ was not significant for saplings. Diameter/hectare $(0.01)$ and basal surface area $(\mathrm{cm} 2)(0.23)$ were significant for seedlings while stand density/hectare (0.01) was not. Shannon index (1.54), Simpson index (0.82), and Shannon Maximum diversity index (2.89) in Akure Forest Reserve was highest while Gambari Forest Reserve had the least ( 0.80 and 0.45 , respectively). Gambari Forest Reserve had the highest value for species evenness (0.28). The high diversity recorded from Akure Forest Reserve could be because of the management of the reserve under Forestry Research Institute of Nigeria (FRIN) which provided more security against illegal activities.

\title{
Tree community reassembly after selective and clear-cut logging in an Afro-tropical rainforest
}

\author{
Arthur Arnold Owiny ${ }^{l, 2}$ \\ ${ }^{1}$ Uganda Christian University, Mukono, Uganda; ${ }^{2}$ Makerere University Biological Field Station, Kampala, Uganda (owinyiarthur@yahoo.com)
}

Understanding the process of community reassembly is crucial for the conservation of biodiversity and rehabilitation of degraded forest ecosystems. This study tested whether tree communities in logged forests follow an equilibrium (deterministic) or nonequilibrium (stochastic) model of succession. We assessed reassembly of tree communities in different size classes along a successional gradient consisting of nine differently aged successional forests, namely, four regenerating former clear-cuts (9 to _x005F 19 years), three selectively logged (42_x005F to 43 years) and two primary forests (PFs) in Kibale National Park, Uganda. The results show that the forests are converging and undergoing reassembly towards primary forest. The species composition of seedlings, saplings and poles declined in similarity to the PF with age but that of mature trees in the different successional stages increased towards the PFs. These differences in tree species composition among the different size classes might be due to dominance of some particular species. Recovery of tree species density, diversity and dominance in all the size classes showed directional patterns as predicted by the deterministic model of succession. Compared to other variables, tree species density and diversity in selectively logged forests recovered relatively faster and was equivalent to or higher than that of PFs at 43 years. The results of the present study indicate that community reassembly in smaller sized trees followed a stochastic model of succession. However, as trees matured, they conform to the deterministic model of succession. Disturbance had variable long-term effects on tree community structure, highlighting need of management and conservation priorities.

\section{Pandanus spp.: A minor forest produce of cultural and economic significance in Southeast Asia}

Wan Rasidah Kadir ${ }^{1}$, Siti Fadzueri Radzali ${ }^{2}$, Ahmad Kamal Ariffin ${ }^{2}$

${ }^{1}$ Forest Research Institute Malaysia, Selangor, Malaysia; ${ }^{2}$ South East Johore Development Authority, Johor, Malaysia (rashidah@frim.gov.my; sitifazueri@kejora.gov.my; kamal@kejora.gov.my)

Pandanus spp., having over 750 species, are integral part of rural and indigenous peoples' cultures. The species spread well over wetlands and coastal shores, has its own genus in Pandanales order and Pandanaceae family. Endemic to the tropics and subtropics, Pandanaceae are monocot and flowering plants. Species most sought after by the locals are Pandanus amaryllifolius for food preparation and P. atrocarpus for weaving and handicrafts. Village weavers are dwindling in numbers and this traditional knowledge will soon disappear without effective steps to promote the industry. Random survey carried out in Peninsular Malaysia showed that only one out of five premises still in operation. This is alarming thus a program to revive the industry was initiated. Recent finding revealed that Pandanus spp. are also exploited for medicinal and health food, as well as filler for fibreboard. Apart from their important resource for downstream, these species are integral in the daily lives of aborigines in their rituals. The Mah Meri tribes in Carey Island is one example. The species are fast declining partly due to shrinking interest by young generation, slow replanting effort, land use change and urbanization. A number of Pandanus species are known to be under threat as reported in the IUCN Red List Categories and Criteria 2015. This paper highlighted current effort undertaken to replant selected Pandanus species aimed at securing raw material for downstream product development particularly weaving industry. As Pandanus leaves are reputed to having strong fibre strand, product development could be extended to fibreboard production.

\section{Effect of irrigation and fertilization on the growth and physiological characteristics of Populus sibirica at the afforestation site in dry- steppe of Mongolia}

Byambadorj Ser-Oddamba ${ }^{1}$, Park Byung Bae ${ }^{2}$, Sainbuyan Zoljargal ${ }^{1}$, Nyam-Osor Batkhuu ${ }^{1}$

${ }^{1}$ National University of Mongolia, Ulaanbaatar, Mongolia; ${ }^{2}$ Chungnam National University, Daejeon, Republic of Korea (seroddamba@gmail.com; bbpark@cnu.ac.kr; szoljargal13@gmail.com;nbatkhuu@gmail.com)

We have conducted comparative analysis of growth and physiological performances of planted Poplar (Populus sibirica Tausch) trees in dry-steppe of Mongolia with the objectives of 1) to determine effects of irrigation and fertilizer on the growth of trees; 2)to evaluate the physiological responses of planted trees on different irrigation and fertilization treatments.Two-year-old seedlings were planted in 2011 at four different irrigations (ambient, ambient $+42 \mathrm{~mm} /$ tree ${ }^{-1}$, ambient $+84 \mathrm{~mm} /$ tree $^{-1}$, ambient $+182 \mathrm{~mm} /$ tree $\left.^{-1}\right)$ and two fertilizer NPK (16:12:10); sheep manure (COMP) treatments and seven years of monitoring results on revealed that all measured variables (root collar diameter, height, survival rate, stomata number and their aperture, leaf water potential and leaf biomass) were significantly differed among treatments. Excellent growth performance was observed in trees grown at ambient $+81 /$ hour tree-1 and fertilized with NPK, respectively. Mean survival rate was $96.4 \%$ and the lowest was observed in ambient treatment with $12.5 \%$. Diurnal measurement of leaf water potential revealed that trees were stressed by water deficit between 12:00 - 14:00 with lowest water potential in irrigation treatment ambient $+84 \mathrm{~mm} /$ tree-1 (-3.3 $\pm 0.06 \mathrm{MPa})$. Poplar trees grown in ambient treatment were more stressed by water deficit and could not recovered its required water even at predawn. Stomata aperture (open, half-closed, closed stomata) of trees tend to have more closed stomata in ambient treatment and trees in ambient $+182 \mathrm{~mm} /$ tree- 1 treatment showed high fluctuation of stomata aperture such as opening at predawn and closed at noon. Consideration of ecologically and physiologically important genetic variation within species is important which could be integrated intospecies selection strategies for successful ecological restoration. 


\section{Post-planting survival of Anadenanthera colubrina (Vell.) Brenan var. cebil [Griseb.] Altschul inoculated with mycorrhizal fungi under nitrogen and potassium fertilization in the Brazilian Pantanal}

Márcia Toffani Simão Soares ${ }^{1}$, Gustavo Ribas Curcio ${ }^{1}$, Fernando Antônio Fernandes ${ }^{2}$, Sérgio Gaiad ${ }^{1}$, Shizuo Maeda ${ }^{1}$, Alexander Silva de Resende ${ }^{3}$, Marcos Silveira Wrege ${ }^{1}$, Gustavo Ibarreche Menezes ${ }^{4}$

${ }^{1}$ Embrapa Florestas, Colombo, Brasil; ${ }^{2}$ Embrapa Pantanal, Corumbá, Brasil; ${ }^{3}$ Embrapa Agrobiologia, Seropédica, Brasil; ${ }^{4}$ Guará Ambiental, Corumbá, Brasil(marcia.toffani@embrapa.br; gustavo.curcio@embrapa.br;fernando.fernandes@embrapa.br; sergio.gaiad@embrapa.br;

shizuo.maeda@embrapa.br; alexander.resende@embrapa.br; marcos.wrege@embrapa.br; guarambiente@gmail.com)

The objective of this work was to compare the post-planting survival of Anadenanthera colubrina (Vell.) Brenan var. [Griseb.] Altschul inoculated with mycorrhizal fungi (MF) under nitrogen plus potassium fertilization in Brazilian Pantanal. The experimental area is located in the sub-region of Nhecolândia, in a physiognomy called "cordilheira", where there was almost complete suppression of tree vegetation, with few individuals remaining. The experimental design was randomized blocks with subdivided plots and three replicates.The main treatments consisted in seedlings planted (March 2015) in 6 m² (3 x 2 m) space, submitted or not to MF (Glomus clarum and Gigaspora margarita) inoculation. The secondary treatments received at the planting pit, respectively, $15 \mathrm{~g}+5 \mathrm{~g}$ (A), $30 \mathrm{~g}+10 \mathrm{~g}$ (B) and $30 \mathrm{~g}+15 \mathrm{~g}$ (C) of ammonium sulphate and potassium chloride. At two months after planting, there was no effect of MF inoculation on survival and regrowth of seedlings. However, the survival were higher in the plots located in the inferior position of the "cordilheira", closer to the watercourse, and under a lower dose of nitrogen plus potassium fertilization $(\mathrm{p}<0.01)$. The results obtained suggested that, in Pantanal Wetland conditions, it is extremely recommended the monitoring and adaptation of soil fertility management in function of soil water supply, to reduce the environmental vulnerability related with the typical hydric and climatic fluctuations of this region.

\section{Modelling diametric distribution of Brachystegia spiciformis Benth. in Miombo forest, Mozambique}

Celio Jossefa ${ }^{1}$, Helder Juliao ${ }^{1}$, Arnaldo Uetela ${ }^{1}$

${ }^{1}$ Instituto Superior Politecnico de Manica, Chimoio, Mozambique (celiovasconcelos22@yahoo.com.br; juliaohelder@gmail.com; autela@gmail.com)

The identification and estimation of quantitative characteristics of tree species are considered as the initial requirement for forest planning. Therefore, it was intended with this work, to select among Weibulll, Gamma, Beta, Sb Johnson, Normal and Log-normal, provide the most appropriate to describe the diametric distribution Brachystegia spiciformis Benth. The quality adjustment produced by the methods of probability distribution was measured by the nonparametric adhrence index Kolmogorov-Smirnov a 5\% level of probability. The results indicated that there are more trees on the smaller diameter class than in larger diameter class. The functions of Weibull and Gamma, were selected to describe the diameter distribution of Brachystegia spiciformis Benth.

Genetic variability for juvenile characteristics pf progeny of Apuleia leiocarpa Vog. Macbride / Variabilidade genética para caracteres juvenis de progênies de Apuleia leiocarpa Vog. Macbride

Queli Cristina Lovatel ${ }^{1}$, Marcio Carlos Navroski ${ }^{1}$ (D, Tamara Rosa Gerber ${ }^{1}$, Mariane de Oliveira Pereira ${ }^{1}$, Franciele Sombrio ${ }^{1}$, Luciana Magda de Oliveira ${ }^{1}$, Ligiane Lissandrina Ongaratto ${ }^{1}$

${ }^{1}$ Universidade do Estado de Santa Catarina,Lages,Brasil(queli.lovatel@edu.udesc.br; marcio.navroski@udesc.br,tamygerber@hotmail.com; maripereira.florestal@gmail.com; fran_sombrio@hotmail.com; luciana.oliveira@udesc.br; ligiane.ongaratto@edu.udesc.br)

Os estudos de variabilidade genética em populações de espécies nativas servem de subsídio para a busca de progênies com alto desempenho, que podem ser utilizadas para restauração florestal ou em estudos para plantios comerciais. Com este foco, o objetivo do trabalho é verificar a existência de variabilidade genética para caracteres juvenis em 13 progênies de Apuleia leiocarpa. As matrizes foram marcadas em área de Floresta Estacional Decidual no Sul do Brasil, destinadas à coleta de sementes. Realizou-se a biometria (comprimento e largura) em um lote de 100 sementes de cada matriz. A semeadura foi efetuada em blocos acaso com 13 tratamentos (progênies), 17 plantas por parcela linear e oito repetições. Coletou-se informações sobre o índice de velocidade de germinação e taxa de germinação (\%). A análise dos dados foi realizada por análise de variância (ANOVA) com o auxílio do software estatístico SELEGEN (modelo 82). Os resultados apontam que a maior taxa de germinação foi de 92,6\% para a matriz AL 09 e menor taxa de 33\% para a matriz AL 37. Para a biometria de sementes, houve diferença significativa entre as matrizes pela ANOVA $(\mathrm{p}<0,05)$, sendo que a matriz AL 09 obteve as menores médias de comprimento e largura, não interferindo na taxa de germinação. Para análise genética, a herdabilidade individual no sentido restrito foi alta, com valor de 1,40 ( $\pm 0,58)$ para a variável comprimento de sementes e 3,04 $( \pm 0,86)$ para a variável largura, sendo características com alto potencial de herdabilidade.

\section{Leaf litter decompostion and nutrient content of selected agroforestry tree species}

Adejoke Akinyele ${ }^{1}$, Ugonma Donald-Amaechi ${ }^{1}$

${ }^{1}$ University of Ibadan, Ibadan, Nigeria (akinyelejo@yahoo.co.uk; u.longman81@gmail.com)

Litter decomposition and nutrient release are major sources of nutrient return into the soil. Investigation was carried out on leaf litter decomposition and nutrient content of three agroforestry species - Annona muricata L., Senna siamea (Lam.) and Cola nitida (Vent.). Oven-dry leaf litters of each species was put in 144 litterbags of $23 \mathrm{~g}$ each. These were divided into two sets with a set placed on soil surface (SSP) and the other, soil incorporated (SIP) mode of leaf litter decomposition giving a 3 x 2 factorial in RCBD. Initial nutrient content (INC), decay constant and half-lives (weeks) were determined. Decomposition rates, nitrogen release pattern (NRP), total organic carbon (TOC) and litter quality were measured fortnightly for 24 weeks after litter placement (WALP). Data collected were subjected to descriptive statistics and ANOVA at $\mathrm{p}<0.05$. The INC was significantly different among the species. N concentration decreased from $C$. nitida $<$ A. muricata $<$ S. siamea. P was significantly higher in S. siamea $(0.38 \%)$ than $C$. nitida $(0.22 \%)$ and $A$. muricata $(0.32 \%)$. In SSP, decay constant and half-lives for A. muricata and S. siamea (0.004) (24.8) were significantly higher than C. nitida (0.005) (19.8) while $C$. nitida and $S$. siamea (0.002) (49.5) were significantly higher than A. muricata (0.003) (33.0) in SIP. Results on decomposition rates, NRP, TOC and litter quality are shown in the figures. These species could be effective in soil nutrient addition in an agroforestry system. 


\section{Slash and burn agriculture as silvicultural treatment to regenerate Swietenia macrophylla King}

Patricia Negreros-Castillo ${ }^{1}$ (D, Imelda Martínez-Salazar ${ }^{2}$, Claudia Alvarez Aquino $^{3}$, Angélica Navarro Martínez $^{4}$, Carl W Mize $^{5}$

${ }^{1}$ Academia Nacional de Ciencias Forestales, Ciudad de México, Mexico; ${ }^{2}$ Investigador Independiente, Chetumal, Mexico; ${ }^{3}$ Universidad Veracruzana, Xalapa, Mexico; ${ }^{4}$ Colegio de la Frontera Sur, Chetumal, Mexico; ${ }^{5}$ Iowa State University, Ames, USA(patri_nc@yahoo.com,ims_puma@hotmail.com;

aaclaudia@yahoo.com; manavaster@gmail.com; carlmize@gmail.com)

Swietenia macrophylla King (mahogany) is the most important tree species commercially in tropical America. It is so important that it could be considered a 'financial' keystone species because its absence increases the likelihood of conversion of a forest to another, more profitable land use. Slash and Burn Agriculture (SBA) has been used in the Maya region of the Yucatan peninsula, Mexico for more than 3,000 years, and it is the most spatially distributed disturbance in the region. Abandoned SBA fields seem to create suitable regeneration conditions for mahogany; in fact, mahogany populations in the Yucatan Peninsula exhibit strong spatial correlations with abandoned SBA fields. This research reports on direct seeding of mahogany in three slash and burn fields in Betania, Quintana Roo, Mexico during the last cropping year. In each field 121 planting sites were located in a 0.25 ha plot, and five seeds were sown at each planting site. Soil color and shading of each planting site were noted. Height, diameter and indications of damage by Hypsipyla grandella of all sprouted seeds were recorded at $2,11,23,38,45$, and 58 months after sowing. Five years later $63 \%$ of seedlings had died, leaving $7.4 \%$ of the planting sites occupied by a seedling. Seedling height varied from 0.3 to $8 \mathrm{~m}$ after 58 months. Remarkably, none of 212 seedlings showed indications of damage by $H$. grandella.

\section{From past to future: approaches to protect seeded acorns against consumption by granivorous rodents}

Adrian Villalobos ${ }^{1}$, Mattias Engman ${ }^{1}$, Magnus Löf ${ }^{1}$

${ }^{1}$ Swedish University of Agricultural Sciences, Alnarp, Sweden (adrian.villalobos@slu.se; mattias.engman@slu.se; magnus.lof@slu.se)

As one of the oldest methods for forest restoration, direct seeding has the potential to improve the cost-efficiency of oak restoration programs around Europe. However, acorn consumption by granivorous rodents such as the bank vole (Myodes glareolus) and the wood mouse (Apodemus sylvaticus) is one of the major drawbacks for the implementation of this low-cost method. Through the years several techniques have been developed in order to protect acorns from consumption. These techniques are classified into chemical, ecological, physical and site preparation approaches. The goal of these methods is to reduce the consumption of acorns, without impairing germination and seedling performance. But at the same time operation costs may increase and therefore reduce the benefits of direct seeding when compared to planting. Therefore, here we present the advantages and disadvantages of the different methods developed for acorn protection. We show the results of our current state of the artfield and laboratory projects usingvolatile organic compounds from feces, urine or fur of rodent predators such as the stoat (Mustela erminea), American mink (Neovision vision), and the red fox (Vulpes vulpes) to deter acorn consumption from rodents. Additionally we used acorn based volatile compounds to camouflage seeded acorns. Finally, we aim to review the best available methods and the potential upcoming technologies for acorn protection in direct seeding.

\section{Subirrigation wffects on larch seedling growth, root morphology, and media chemistry}

Fangfang Wan ${ }^{1}$, Amy Ross-Davis ${ }^{2}$,Wenhui Shi ${ }^{3}$, Christopher Weston ${ }^{4}$, Xiehai Song ${ }^{1}$, Xiaochao Chang ${ }^{1}$, Anthony Davis ${ }^{2}$, Yong Liu ${ }^{1}$, Fei Teng $^{1}$ ${ }^{1}$ Beijing Forestry University, Beijing, China; ${ }^{2}$ Oregon State University, Corvallis, USA; ${ }^{3}$ Zhejiang A\&F University, Zhejiang, China; ${ }^{4}$ the University of Melbourne,Creswick, Australia (wanfangfang1991@163.com; rossdava@oregonstate.edu; shiwenhui2008@163.com; weston@unimelb.edu.au; sxiehai@163.com; changxiaochao@bjfu.edu.cn; anthony.davis@oregonstate.edu; lyong@bjfu.edu.cn; tengf7@chinaunicom.cn)

Subirrigation (SI) is regarded as an environmentally-responsible method of delivering water and fertilizer to nursery-grown plants. But a potential higher salt concentration in the upper layers of growing media under SI may inhibit root growth and result in decreased plant quality, few studies have focused on how root morphology is altered by SI. This study assessed the growth response of larch seedlings when subjected to three rates of fertilization and grown using SI or overhead irrigation (OI) for one nursery season. Associated changes between rhizosphere electrical conductivity (EC) and root morphology of different root size classes were analyzed. Results show that (1) SI and OI seedlingshadsimilar height, root-collar diameter, and root volume. However, (2) compared to OI-seedlings, SI-seedlings had less root mass, length, and surface area but greater average root diameter (ARD). (3) Morphological differences were evident primarily in root diameter size classes I - III $(\mathrm{D} \leq 1.0 \mathrm{~mm}$ ). (4) Fertilizer rate influenced root length and surface area up to 130 days after sowing. (5) As the growing season progressed, SI-media had significantly higher EC compared to OI-media and EC increased with increasing fertilizer rate under SI but not under OI. These results indicate that SI can produce larch seedlings of similar height and root collar diameter (RCD) compared to OI, but root systems are smaller overall with fewer small-diameter roots, which may be related to high EC levels in SI-media. Therefore, the EC in the media should be monitored and adjusted by reducing fertilizer rates under SI.

\section{Interactive effects of seedling stock size and vegetation management treatments on Douglas-fir plantation productivity after 10 growing seasons}

Maxwell Wightman ${ }^{1}$, Carlos Gonzalez-Benecke ${ }^{1}$, Eric Dinger ${ }^{1}$

1Oregon State University, Corvallis,USA (maxwell.wightman@oregonstate.edu; carlos.gonzalez@oregonstate.edu; ericd@rfpco.com)

Forest vegetation management (FVM) treatments and seedling stock type selection are important considerations in any reforestation project. The growth and survival of Douglas-fir seedlings has been shown to benefit from FVM, but the interactive effects of stock size and FVM are less well understood. This study tested the combined effects of three FVM regimes and three containerized stock sizes on Douglas-fir growth over ten years. Stock types included stryo-8, stryo-15, and styro-60 seedlings creating large differences in seedling size at the time of planting. FVM treatments included a no action control, a pre-planting herbicide treatment followed by a spring release during the first growing season, and a pre-planting herbicide treatment followed by a spring release during the first and second growing seasons. Plots that received an herbicide application had lower competing vegetation cover and higher stand volume than the no action control after ten growing seasons. The herbicide treatments applied in this study also had a long-term effect of the cover of shrubs, especially Gaultheria shallon, and shrub cover was well correlated with stand growth. Styro- 60 seedlings were also larger than styro- 8 seedlings after ten growing seasons but did not differ from the styro- 15 seedlings. At age 10 years, the only significant stock type by FVM interactive effect was the styro- 60 seedlings growing under the no action control treatment having a higher mortality rate than all other treatment combinations. 
Pre-planting root system as a quality parameter for forest species seedlings / Sistema radicular pivotante pré plantio - como parâmetro de qualidade das mudas de espécies florestais

Osmar José de Aguiar ${ }^{1}$, Jaqueline Sousa Almeida ${ }^{1}$

${ }^{1}$ Universidade do Estado do Pará, Belém, Brasil (o.aguiarromeiro@gmail.com; jaqueline almeida23@hotmail.com)

Apesar das altas produtividades e competitividades das florestas plantadas no Brasil, problemas fisiológicos e de fitossanidades ocorrem com frequência na região Norte. Como forma de justificar esses problemas, levantou-se a seguinte hipótese: "Mudas florestais com meristema apical radicular danificado, serão mais susceptíveis ao estresse, principalmente, nos períodos de déficit hídrico". Sabendo-se que, com a retirada dessas células, a raiz pivotante se atrofia, e a eficiência na busca de umidade no solo, torna-se reduzida, como consequência a baixa resistência natural, aumentando a susceptibilidade à pragas e doenças Na avaliação do desenvolvimento comparativo da parte aérea com a raiz, das mudas de Khaya ivorensis A. Chev., e Genipa americana L., semeadas em sacos plásticos de $17 \mathrm{~cm} \mathrm{x} 27 \mathrm{~cm}$, no viveiro em São Francisco do Pará. Selecionou-se mudas com $5 \mathrm{~cm}, 10 \mathrm{~cm}$ e $15 \mathrm{~cm}$ de altura da parte aérea, com dez repetições cada. Foi observado uma correlação direta, entre o comprimento da parte aérea e raiz, quando a parte aérea atinge altura de 10 cm, a raiz atinge o fundo do saco, o que induzirá ao enovelamento da pivotante ou se ultrapassar, será danificada, na remoção do saco no canteiro. Deste modo, parâmetros de qualidades como: idade, parte aérea e a relação da sua massa seca com a da radicular,podem não serem suficientes para garantir obom desenvolvimento das mudas nos plantios. Espera-se que no final dessa pesquisa, poder desenvolver um novo sistema de produção de muda, onde a integridade das raízes pivotantes seja considerado como parâmetro de qualidade.

\title{
Detecting seedling physiology with a Near Infrared (NIR) Consumer digital camera
}

Francesca Giannetti ${ }^{1}$, Sabrina Raddi ${ }^{1}$,Sofia Martini ${ }^{1}$, Alberto Maltoni ${ }^{1}$, Andrea Tani ${ }^{1}$, Gherardo Chirici ${ }^{1}$, Barbara Mariotti ${ }^{1}$ (D ${ }^{1}$ Universitàdi Firenze,Firenze, Italy (francesca.giannetti@unifi.it; sabrina.raddi@unifi.it; sofia.martini@unifi.it; alberto.maltoni@unifi.it; andrea.tani@unifi.it; gherardo.chirici@unifi.it; barbara.mariotti@unifi.it)

The development of new methods to monitor plantation physiological status is a key point to strengthen the success of forest restoration projects in a climate change context. An innovative forefront role can be played by NIR Consumer digital cameras. This technology, considered by remote-sensing communities as a cost-effective forest monitoring method over large area, can provide highly detailed data also at single plant scale. Our study aimed to test the possibility of monitoring seedlings physiology by NIR camera images (i.e. CANON S110 NIR) and their derived vegetation indices with the leaf physiological measurements by spectrometer and fluorimeter (i.e. USB-2000 Ocean Optics and PAM-2000 Walz). The final objective was to evaluate if in future NIR camera can be a reliable tool to assess seedling physiology both in nursery and after transplanting.In 2018, two parallel experiments were carried out on seedlings coming from the same nursery stock grown in 2017 in Central Italy: six different combinations of three Quercus species grown in two substrates (peat and coconut fiber), and three different fertilizations (nursery standard, P-enriched, K-enriched). We concurrently monitored seedlings both during a water test under controlled conditions (three water regimes) at leaf and plant scale, and at plantation scale by an Unmanned Aerial Vehicle. The first results revealed a good correlation between spectrometer and NIR camera bands, with the advantage for NIR camera of collecting information on images that cover one or several entire leaves and, potentially, the whole plant in comparison with the on-time punctual data obtained by spectrometer.

\section{Restoring native forests in Brazil with direct seeding / Restaurando florestas nativas no Brasil com semeadura direta}

Eduardo Campos Filho ${ }^{1}$, Guilherme Carmo ${ }^{2}$, Heber Alves $^{2}$, Lara Costa $^{2}$, Juliano Nascimento ${ }^{3}$, Rodrigo Junqueira ${ }^{4}$

${ }^{1}$ Instituto Socioambiental, São Paulo, Brasil; ${ }^{2}$ Instituto Socioambiental, Canarana, Brasil; ${ }^{3}$ Instituto Socioambiental, Eldorado, Brasil; ${ }^{4}$ Instituto

Socioambiental,Brasilia,Brasil(eduardomalta@socioambiental.org; guilhermepompiano@socioambiental.org; heber@socioambiental.org;

lara@socioambiental.org; juliano@socioambiental.org; rodrigojunqueira@socioambiental.org)

A semeadura direta de muvuca de sementes tem sido utilizada e aperfeiçoada desde 2006 no Xingu, pelo ISA - Instituto Socioambiental e parceiros, onde tem sido considerada uma forma ágil, barata e eficaz de restauração florestal, com aspectos que dialogam com as habilidades dos proprietários rurais e, consequentemente, com a restauração em larga escala: flexibilidade técnica para a implantação, desde a mecanização até o plantio manual, melhor desenvolvimento de raízes e resistência a secas, densidade dos grupos ecológicos e distribuição espacial mais semelhante a capoeiras naturais e rápida cobertura do solo. O método é recente no Brasil, embora seja utilizado há décadas em outros países. Serão apresentadas técnicas e resultados de semeaduras diretas de muvuca monitoradas em MT, SP, BA e ES nos biomas Amazônia, Cerrado e Mata Atlântica. Os cuidados desde a escolha de espécies, coleta, beneficiamento e armazenamento das sementes, preparo do solo, plantio, monitoramento e manejo, incluindo uso ou não de herbicidas serão abordados. Serão discutidas questões sobre a cadeia produtiva para a semeadura direta, custos, resultados ecológicos e sociais, gargalos e principais lacunas para o aprimoramento do método. A estruturação de uma cadeia regional de produção de sementes, que seja capaz de atender à demanda da semeadura direta e de produzir os benefícios sociais, econômicos e de biodiversidade almejados pelos diferentes atores envolvidos, depende da governança sobre a produção de sementes e sobre a demanda por sementes nativas decorrentes das áreas a restaurar a cada ano.

\section{C2b: TOLERANCE OF EUCALYPTUS CLONES TO ABIOTIC AND BIOTIC STRESSES:} BUILDING THE FOUNDATION FOR THE FUTURE PLANTATIONS

\section{ENVIROTYPING in forest tree breeding: exploitation of genotype by environment interaction to avoid misallocation of genotypes in field deployment}

\author{
Rafael Tassinari Resende ${ }^{1,2}$, Orzenil Bonfim Silva-Junior ${ }^{2}$, Dario Grattapaglia ${ }^{2,3}$ \\ ${ }^{1}$ Universidade Federal de Goiás, Goiânia, Brasil; ${ }^{2}$ Embrapa Recursos Genéticos e Biotecnologia, Brasília, Brasil; ${ }^{3}$ Universidade Católica de Brasília, \\ Brasilia,Brasil(rafael.tassinari@gmail.com; orzenil.silva@embrapa.br; dario.grattapaglia@embrapa.br)
}

We present GIS-GE, which is a strategy for exploiting $\mathrm{G}$ x E interaction aimed at maximizing genetic gain, allowing for recommending genotypes in a geospatial way. In our approach, a land area represents an envirome from which genetic traits of organisms, develop. An envirome is a set of envirotypes from the expression of all the environmental factors in that area that interact with the genetic makeup of the organisms resulting in rank differences based on estimates of breeding value. Here, we used GIS-GE on simulated data to develop maps of 100 envirotypes and estimate their effects simultaneously from a limited number of phenotypic records for a trait gathered from genotypes in field deployments. In the simulation, a square land area is a geoprocessing 
environment of 10,000 pixels, wherein 50 breeding trials of the same genotypes (i.e. eucalyptus clones) are randomly allocated. We used 100 non-related genotypes expressing a low heritability quantitative trait that mimics yield. GIS-GE uses spatial interpolation to environmental data, referring either to climatic and landscape variables, to define Environmental Indexes (EI) by their relationship to the phenotypic data, totaling 1 million of envirotypic markers (100 envirotypes * 10,000 pixels). For this envirome, we used advanced genetic modeling to estimate the EI effects across the whole set of pixels. We show that GIS-GE presents advantages in breeding, including matching of genotypes to their most appropriate sites; definition of breeding areas of highest genetic correlation to genotypes; and indication of the locations that maximize the capture of lost phenotypic heritability in trials.

\section{Full-rotation carbon, water and energy fluxes in a tropical eucalypt plantation}

Yann Nouvellon ${ }^{1}$, José-Luiz Stape ${ }^{2,3}$, Guerric le Maire ${ }^{1,4}$, Jean-Marc Bonnefond ${ }^{5}$, Joannès Guillemot ${ }^{1,6}$, Mathias Christina ${ }^{1}$, Jean-Pierre Bouillet ${ }^{1,6}$, Otávio Campoe $^{3,7}$, Jean-Paul Laclau ${ }^{1,3}$

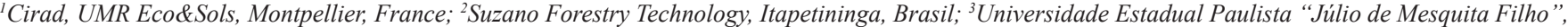
Botucatu, Brasil; ${ }^{4}$ Universidade Estadual de Campinas, NIPE, Campinas, Brasil; ${ }^{5}$ Institut National de (yann.nouvellon@cirad.fr; stape@suzano.com.br; guerric.le_maire@cirad.fr; bonnefon@bordeaux.inra.fr; joannes.guillemot@cirad.fr; mathias.christina@inra.fr; jean-pierre.bouillet@cirad.fr; otavio.campoe@ufsc.br; jean-paul.laclau@cirad.fr)

Eucalyptus plantations in Brazil are among the most productive forests of the world, reaching mean annual increments of about $50 \mathrm{~m}^{3}$ ha $\mathrm{yr}^{-1} \mathrm{yver}^{-1}$ short $(6$ - 7 yrs) rotations. We continuously monitored water vapor, $\mathrm{CO}_{2}$ and energy flux through the eddy-covariance method over a 9 year-period in southeastern Brazil. Tree growth, Leaf Area Index (LAI), water table depth, and soil water content (SWC) down to $10 \mathrm{~m}$ depth were also monitored. Rooting depth and vertical fine root distribution were assessed at various ages. Mean annual evapotranspiration (AET; $1383 \mathrm{~mm} \mathrm{yr}^{-1}$ ) represented 90\% of the annual precipitations (P; 1539 mm $\mathrm{yr}^{-1}$ ). AET reached maximum values (1598 $\mathrm{mm} \mathrm{yr}^{-1}$ ) about 2-3 years after planting (a.p) when LAI peaked and when deep rooting (about $15 \mathrm{~m}$ deep 2.5 yrs a.p) provided access to the large amount of water stored in deep soil layers during the first months after clear-cutting and replanting. Most (88\%) of the available energy (3852 $\mathrm{MJ} \mathrm{yr}^{-1}$ ) was partitioned to the evaporation process (latent heat fluxes), with very low sensible heat fluxes over the rotation, except after harvesting and replanting when LAI was low, and later in the rotation during dry events. Deep drainage after harvest of the first stand allowed the water table to rise from -18 to $-12 \mathrm{~m}$ over the first 2 years after replanting. Both measurements of SWC and model simulations showed that deep water storage and subsequent uptake played a major role in supporting the very high wood production and dampening seasonal droughts.

\section{Light use efficiency and productivity of 16 genotypes of Eucalyptus along a 6-year rotation in Brazil}

Guerric le Maire ${ }^{1,2}$, Joannès Guillemot ${ }^{1,3}$, Otávio Campoe ${ }^{4,5}$, José-Luiz Stape $^{5,6}$, Jean-Paul Laclau ${ }^{1}$, Yann Nouvellon ${ }^{1}$

${ }^{1}$ CIRAD, Montpellier, France; ' ${ }^{2}$ niversidade Estadual de Campinas, Campinas Brasil; ${ }^{3}$ Escola Superior de Agricultura "Luiz de Queiroz", Universidade de São Paulo, Piracicaba, Brasil; " Universidade Federal de Santa Catarina, Curitibanos, Brasil; " Universidade Estadual Paulista "Júlio de Mesquita Filho", BotucatuBrasil; ${ }^{6}$ Suzano Pulp and Paper,Suzano,Brasil(guerric.le_maire@cirad.fr; joannes.guillemot@cirad.fr; otavio.campoe@ufsc.br; t ape@suzano.com.br; laclau@cirad.fr; yann.nouvellon@cirad.fr)

Forest stemwood productivity depends on the amount of absorbed light and on the Light Use Efficiency (LUE), i.e. the amount of stemwood produced per amount of absorbed light. Other growth limiting factors than absorbed light are for instance water and nutrients, carbohydrates allocation processes, and management practices. In fertilized eucalyptus plantations in Brazil, a shift in the main factor limiting growth is expected, from light at the beginning of the rotation (not limited by water because soil has been recharged during the interval between rotation) to other factors such as water in the subsequent years. Changes of allocation patterns and foliar traits also occur along the rotation. These trends may differ between genotypes. These hypotheses were tested along a 6-year rotation, with 16 contrasted genotypes planted in 10 randomized repetitions in São Paulo Region, Brazil. Absorbed light was estimated using the MAESTRA 3D model precisely parameterized at tree scale for each plot. Stand growth was computed based on allometric relationships calibrated on regular destructive biomass measurements. Results at stand scale showed that 1 ) LUE increased with stand age for all genotypes, from 0.15 to 0.70 g dry $_{\text {matte }}$ r/MJ on average; 2) light was the main limiting factor during the first year of growth ( $\mathrm{R}^{2}$ between 0.5 and 0.95 ). Subsequently, the variability of wood production explained by light was variable among genotypes $\left(\mathrm{R}^{2}\right.$ of 0.25 on average; 3$)$ The effect of genotype on stemwood production remains high and significant along the rotation. These results and their implications for plantation management are discussed.

\section{Unraveling drivers of growth dominance and its impact on stand growth of Eucalyptus plantations across Brazil}

\section{Alvaro A. V. Soares ${ }^{1}$, Otávio Campoe ${ }^{2}$, Rafaela Carneiro ${ }^{3}$, David I. Forrester ${ }^{4}$}

${ }^{1}$ Universidade Federal de Uberlandia, Monte Carmelo, Brasil; ${ }^{2}$ Universidade Federal de Lavras, Lavras, Brasil; ${ }^{3}$ Instituto de Pesquisas e Estudos Florestais, Piracicaba, Brasil; ${ }^{4}$ Swiss Federal Institute for Forest, Snow and Landscape Research-WSL, Birmensdo(alvaroavsoares@gmail.com; otavio.campoe@gmail.com; rafaela@ipef.br; david.forrester@wsl.ch)

Growth dominance (GD) occurs when trees grow disproportionally to their size compared to other trees. High growth dominance indicates that stand growth is concentrated in larger trees, leading to further increase in size heterogeneity in stand structure. Growth dominance increases have been associated with lower productivity in tree monocultures, especially in monoclonal stands such as the eucalypt plantations in Brazil. Understanding how GD develops for different eucalypt genotypes and the effects of site and age are fundamental to understand the link between stand structure and productivity. We used data from the TECHS-IPEF cooperative research program, a continental experimental platform, in which different genotypes were planted in sites ranging from north Brazil to Uruguay. We chose four contrasting sites regarding soil water deficit, in which 18 genotypes were planted in monoclonal plots at $3 \mathrm{~m} \times 3 \mathrm{~m}$ spacing (genotype differed among sites). Two adjacent plots were established for each genotype, one treated with $30 \%$ throughfall exclusion. We investigated whether there was difference in the development of GD among genotypes; whether water stress (represented by the contrasting sites and by throughfall exclusion within site) affects GD; and whether GD is associated with decreasing plot volume increment. We found significant differences in GD, as well as in its development throughout time, among genotypes. GD increased with age and tended to be lower with slowest development for the drier sites as well as for the throughfall exclusion plots. After other factors were accounted for, increasing GD was associated with decreasing plot volume increment. 


\section{Variation in basic wood density of Eucalyptus clones in tropical regions of Brazil}

Maria Almeida1, Sofia Rocha ${ }^{1}$, Graziela Vidaurre ${ }^{1}$, Rafaela Carneiro ${ }^{2}$, Otávio Campoe ${ }^{3}$

${ }^{1}$ Universidade Federal do Espirito Santo, Jerônimo Monteiro, Brasil; ${ }^{2}$ Instituo de Pesquisas e Estudos Florestais, Piracicaba, Brasil; ${ }^{3}$ Universidade Federal de SantaCatarina,Curitibanos,Brasil (narunafelix@gmail.com; sofiamaria.r@hotmail.com; grazividaurre@gmail.com; rafaela@ipef.br; otavio.campoe@ufsc.br)

Wood density is considered one of the main attributes of wood quality. Edaphoclimatic differences are commonly used for selection of species and planting sites, with wood density being influenced differently by meteorological variables. The aim was to assess the variation of wood density in eucalyptus clones planted in tropical regions of Brazil by the correlation of density with meteorological variables. Eucalyptus clones (R9 - E. urophyla, B2 - E. urophyla x E. grandis, H8 and D4 - E. grandis x E. urophyla) were analyzed at 4 years, in 10 sites distributed in wide climatic variation of the TECHS-IPEF Cooperative Research Program. Three trees from each site were sampled and the basic wood density (BD) was determined. For each clone, BD was correlated with mean annual increment (MAI), temperature (T), precipitation (P), soil water deficit (SWD) and maximum vapor pressure deficit (VPD). Only clone B2 showed significant correlations between BD and T, SWD, VPD and MAI. In the others, density didn't correlate with any variable, which may be associated to low BD variation coefficient between sites (10\%) or indicating a nonlinear relationship. In humid sites (Arapoti/Telêmaco), clones showed same densities values, ranging from 0.37 to 0.42 $\mathrm{g} \mathrm{cm-1}$. The same behavior was observed in the site with greatest SWD (Bocaiúva), however with densities ranging from 0.49 to $0.55 \mathrm{~g} \mathrm{~cm}-1$, while in sub humid sites, similar values of SWD was associated with different densities means. In general, the effects of meteorological variables in BD are more evident in extreme situations related to high or lower SWD.

\section{Development of dynamic dominant height equations with parameters refined by water availability in clonal eucalypt stands in Brazil}

Henrique Scolforo ${ }^{1}$, Cristian Montes ${ }^{2}$, John Paul McTague ${ }^{2}$, Otávio Campoe ${ }^{1}$, José Stape $^{1}$

${ }^{1}$ Suzano, Limeira, Brasil; ; 2 University of Georgia, Athens, USA; ${ }^{1}$ Federal University of Santa Catarina, Curitibanos, Brasil (hscolforo@suzano.com.br; crmontes@uga.edu; forestbiometrician@yahoo.com; tavio.campoe@gmail.com; stape@suzano.com.br)

Growth models refined by environmental variables are capable of updating forest inventories and recomputing site quality in clonal eucalypt stands. However, there is a lack of studies quantifying the uncertainty associated with modeling mean response as well as the bias involved in the dominant height estimation. A modeling approach that accounts for the impact of water availability in the projection of dominant height, as well as in the projection uncertainty, is desired. This study aims to calibrate the best dominant height projection curve to be applied for a variety of clones in Brazil. Two approaches are compared: 1) the data assimilation approach, as implemented by a Kalman-Filter; 2) the difference approach, as implemented by the algebraic difference approach combined to mixed modeling. The first approach separates observation error from process error, which quantifies the impact of climate variation on dominant height growth and provides a measure of the uncertainty in the height projection. The second approach assumes estimation error as process error only and is commonly applied to assess site quality in Brazil. The dataset is part of the Cooperative Research Program TECHS-IPEF and originates from remeasurements of 16 sites across a climatic gradient in Brazil. At each site, the same eleven eucalypt clones were planted in single plots. We propose a new dominant height curve that possesses the ability to make long-term projections with better and sounder biological behavior for eucalypt stands.

\section{Use of process-based models for sustainable intensification of Eucalyptus plantations by yield gap analysis}

Elvis Felipe Elli ${ }^{1}$, Paulo Cesar Sentelhas ${ }^{1}$, Cleverson Henrique de Freitas ${ }^{1}$, Rafaela Carneiro ${ }^{2}$, Clayton Alcarde Alvares ${ }^{2}$

${ }^{1}$ Escola Superior de Agricultura "Luiz de Queiroz" - Universidade de São Paulo, Piracicaba, Brasil; ${ }^{2}$ Instituto de Pesquisas e Estudos Florestais, Piracicaba,Brasil (elvisfelipeelli@usp.br; pcsentel.esalq@usp.br; sonhfreitas@gmail.com; rafaela@ipef.br; caalvares@yahoo.com.br)

Eucalyptus growth is conditioned by climate, genetics, soil conditions, incidence of pests and diseases and forest management. From this, a huge temporal and spatial variability of Eucalyptus yield is observed, leading to yield gaps. Identifying yield gaps may be a valuable opportunity for increasing Eucalyptus yield in a sustainable way and improve forest planning and management. This study aimed to assess the Eucalyptus yield gaps using a multimodel approach from differentproducing locations in Brazil and to identify the main causes and the possible mitigation strategies. Potential and attainable yields were assessed by three process-based models properly calibrated and evaluated. Actual yields were obtained from 30 producing locations in Brazil from the TECHSProject. The yield gap at all locations in Midwest and Northeast regions were predominantly caused by water deficit. In Southeast and North regions, the water deficit was the main cause of yield gaps in 87 and 67\% of the locations, respectively. In Southern Brazil, the management was the main cause of yield gap at all locations. Aswater deficit represented the main cause of Eucalyptus yield gaps in Brazil, the possible strategies to surpass that is the use of genotypes more tolerant to water deficit, to use more open planting spacing, and adoption of soil practices that could improve water infiltration and roots deep growth. Yield gaps by management may be mitigated by adequate fertilizer management, better control of the genotype x environment interaction, use of high-quality seedlings, forest protection (weeds, pests and diseases), control of forest fires and increasing resiliency to windstorms and waterlogging events.

\section{Gauging the effects of climate variability for improved planning and management of Eucalyptus plantations: a process-based modelling application}

Elvis Felipe Elli ${ }^{1}$, Neil Huth ${ }^{2}$, Paulo Cesar Sentelhas ${ }^{1}$, Rafaela Carneiro ${ }^{3}$, Clayton Alcarde Alvares ${ }^{3}$

${ }^{1}$ Escola Superior de Agricultura "Luiz de Queiroz" - Universidade de São Paulo, Piracicaba, Brasil; ${ }^{2}$ National Research Collections Australia Toowoomba, Australia; ${ }^{3}$ Instituto de Pesquisas e Estudos Florestais, Piracicaba, Brasil (elvisfelipeelli@usp.br; neil.huth@csiro.au; pcsentel.esalq@usp.br; rafaela@ipef.br; caalvares@yahoo.com.br)

Process-based simulations for assessing environmental and management effects on Eucalyptus yield may be a valuable decision support toolin the pursuit of appropriate forest planning and management. This study aimed to gauge the effects of climate variability on Eucalyptus yield in different producing regions of Brazil using a process-based modelling approach.The APSIM Next Generation Eucalyptus model was properly calibrated and then was used to perform the long-term assessments. Thirty-one simulations ofstem biomass production for a seven-year rotation were performed using weather data from 1980 to 2017 . This was reproduced for eight Brazilian locations with contrasting climates and soil conditions: Rio Verde, GO (07-CCO), Inhambupe, BA (8-COP), São Gabriel, RS (18-CMS), Peixe, TO (19-GMR), Mogi Guaçu, SP (20-IPB), Telêmaco Borba, PR (22-KLT), Coração de Jesus, MG (26-PLA) and Urbano Santos, MA (29-SUZ). The mean annual volume increment at 7 years-old (MAI) and its coefficient of variation (CV), growth modifiers by water deficit and temperature were evaluated. The long-term simulations identified the spatial and temporal climate variability in Brazil. The average MAI were 48.6, 45.7, 60.8, 39.4, 63.6, 69.8, 36.0 and $37.6 \mathrm{~m}^{3}$ ha $^{-1}$ year ${ }^{-1}$ for 7-CCO, 8-COP, 18-CMS, 19-GMR, 20-IPB, 22-KLT and 29-SUZ, respectively. The CV ranged from 2.9\% (19-GMR) to 
$14.7 \%$ (08-COP). Higher MAI found at locations 22-KLT and 20-IPB are justified by lower effects of both water and temperature deficits. Climate variability assessments have been demonstrated to be effective in identifying climatic risk in Eucalyptus plantations and may be used for improved planning, breeding strategies, management and decision-making on the forest sector.

\section{Productivity of Eucalyptus in Brazil and Uruguay: exploring the genetic $x$ environment interaction}

Otávio Campoe ${ }^{1}$, Rafaela Carneiro ${ }^{2}$, Dan Binkley ${ }^{3}$, Antonio Fardin $^{4}$, Aurélio Aguiar $^{5}$, Carlos Afonso $^{6}$, Cláudio Silva ${ }^{7}$, Clayton Alcarde Alvares ${ }^{8}$, Elias Araujo $^{9}$, Fernando Leite ${ }^{10}$, Francisco Gomes ${ }^{11}$, Gabriela Bassa ${ }^{12}$, Gabriela Moreira ${ }^{13}$, Gustavo Friederichs ${ }^{14}$, Helton Lourenço ${ }^{15}$, James Stahl ${ }^{16}$, Raul Chaves ${ }^{17}$, Jose Stape $^{8}$, Manoel Silva ${ }^{18}$, Marcus Masson ${ }^{19}$, Paulo Leite Leite ${ }^{20}$, Ricardo Buzzo ${ }^{21}$, Ricardo Paim ${ }^{22}$, Roosevelt Almado ${ }^{23}$, Rodolfo Costa ${ }^{24}$, Rodrigo Coutinho ${ }^{25}$, Sandro Conceição Conceição ${ }^{26}$, Sharlles Dias ${ }^{27}$, Ubirajara Oliveira ${ }^{28}$, Viviane Nogueira ${ }^{29}$

${ }^{1}$ Universidade Federal de Lavras, Lavras, Brasil; ${ }^{2}$ Instituto de Pesquisas e Estudos Florestais, Piracicaba, Brasil; ${ }^{3}$ Northern Arizona University, Fort Collins, USA; ${ }^{4}$ ngloAmerican Brasil, Niquelandia, Brasil; ${ }^{5}$ Fibria, Jacarei, Brasil; ${ }^{6}$ Plantar, Coração de Jesus, Brasil; ${ }^{7}$ Montes del Plata, Conchilhas, Uruguay; ${ }^{8}$ Suzano, Itapetininga, Brasil; ${ }^{9} \mathrm{CMPC}$, Guaiba, Brasil; ${ }^{10}$ Cenibra, Belo Oriente, Brasil; ${ }^{11}$ Gerdau, Três Marias, Brasil; ${ }^{12}$ Arborgen, Campinas, Brasil; ${ }^{13}$ International Paper, Mogi Guaçu, Brasil; ${ }^{14}$ Lwarcel, Lençóis Paulista, Brasil; ${ }^{15}$ Veracel, Eunápolis, Brasil; ${ }^{16}$ Klabin, Telêmaco Borba, Brasil; ${ }^{17}$ Duratex, Botucatu, Brasil; ${ }^{8}$ Suzano, Itapetininga, Brasil; ${ }^{18} \mathrm{FCB}$, Chapadão do Sul, Brasil; ${ }^{19}$ Bahia Specialty Cellulose, Camaçari, Brasil; ${ }^{20}$ GMR, Peixe, Brasil; ${ }^{21}$ Forestal Oriental, Paysandu, Brasil; ${ }^{22}$ WestRock, Três Barras, Brasil; ${ }^{23}$ ArcelorMittal, Bom Despacho, Brasil; ${ }^{24}$ Vallourec, Sete Lagoas, Brasil; ${ }^{25}$ Arauco, Curitiba, Brasil; ${ }^{26}$ Florestal Itaquari, Gurupi, Brasil; ${ }^{27}$ Eldorado, Três Lagoas, Brasil; ${ }^{28}$ Comigo, Rio Verde, Brasil; ${ }^{29}$ Jari, Monte Dourado, Brasil (otavio.campoe@gmail.com; rafaela@ipef.br;dan.binkley@colostate.edu)

Understanding the interaction between genetic and environment is crucial to reduce risks of reduced productivity and high mortality in regions with low supply of resources, and also provide opportunities to increase Eucalyptus productivity. The TECHS-IPEF project (Tolerance of Eucalyptus Clones to Hydric, Thermal and Biotic Stresses), was develop to explore the ecophysiological processes controlling productivity of Eucalyptus. The experimental network with 36 sites was installed in 2012, covering a wide range of latitudes, from $1^{\circ} \mathrm{S}$ to $33^{\circ} \mathrm{S}$ in Brazil and Uruguay, across a strong climatic gradient (temperature (T): 12 to $35^{\circ} \mathrm{C}$; precipitation (P): 700 to $2300 \mathrm{~mm} \mathrm{yr}^{-1}$ ). To intensify soil water deficit (SWD), and explore impacts of climate change, at each site, throughfall exclusion systems removed 33\% of the water since planting. At each site 11 different Eucalyptus clones were planted. The most productive sites, near the tropic of Capricorn, $(\mathrm{P}>$ $1200 \mathrm{~mm}$, evenly distributed) reached mean annual increment (MAI, age of 6 years) of approximately $65 \mathrm{~m}^{3} \mathrm{ha}^{-1}$ year-1. Conversely, regions with intense SWD (> 500mm for more than 5 months) showed MAI of approximately $20 \mathrm{~m}^{3} \mathrm{ha}^{-1}$ year ${ }^{-1}$. Differences of productivity among clones within site reached $100 \%$. The effect of rainfall reduction on productivity was positively correlated with SWD (R2 $=0.33, p=0.01)$. Ecophysiological studies related to carbon allocation, water use, fine root dynamics, and stomatal behaviour provided explanations for tolerance to stresses for some clones, and high productivity for others. The dataset is completed, and will be used to parameterization of process-based models and zoning of Eucalyptus.

\section{Diseases of eucalypts in China}

ShuaiFei Chen ${ }^{1}$, Michael J. Wingfield ${ }^{2}$

${ }^{1}$ China Eucalypt Research Centre (CERC), Chinese Academy of Forestry (CAF), ZhanJiang, China; ${ }^{2}$ Forestry and Agricultural Biotechnology Institute (FABI), University of Pretoria, Pretoria, South Africa (cerccsf@126.com; mike.wingfield@fabi.up.ac.za)

Eucalypt plantations cover approximately 4.5 million ha in China, constituting $6.5 \%$ of the plantation area in the country. Numerous disease problems have emerged in these plantations during the course of the last two decades. These include leaf blight/spot caused by species of Teratosphaeriaceae, Mycosphaerellaceae, Calonectria and Quambalaria, seedling stem/leaf rot caused by Botrytis cinerea and Calonectria spp., stem canker/wilt caused by species of Botryosphaeriaceae, Cryphonectriaceae, Ceratocystis and Teratosphaeria, and bacterial wilt associated with infection Ralstonia pseudosolanacearum. Glasshouse and field trials have been conducted to test the relative pathogenicity of these fungi on plantation-grown eucalypt genotypes. Results have revealed that there are significant differences in the susceptibility amongst eucalypt genotypes and showing that breeding and selection of disease resistant planting stock can be achieved in the future. Results of studies have also shown that the species and genetic diversity of some of these pathogens is high, suggesting that they are native to China. More extensive research is required to better understand the geographic distribution, genetic diversity and biology of eucalypt pathogens in China and thus to reduce the negative impact on an important and growing industry.

\section{C2c: TOWARDS SUSTAINABLE DEVELOPMENT OF THE GLOBAL TEAK SECTOR IN A} CHANGING WORLD

\section{Enhancing conservation and sustainable management of teak forests and the legality of wood supply in the Greater Mekong Sub-region}

Tetra Yanuariadi ${ }^{1}$

International Tropical Timber Organization (ITTO), Yokohama, Japan (tetra@itto.int)

Natural teak forest area has reduced substantially in all native teak growing countries mainly due to over exploitation, agriculture expansion, and shifting cultivation. Old-growth high-quality teak stands have declined significantly for many years. There is a risk of losing their diversity of genetic traits and wood characteristics. ITTO is implementing a project aimed at assisting governments, local communities and smallholders to enhance natural teak forest management, production and marketing to facilitate the establishment of legal and sustainable wood supply chains while improving national economy and local communities' livelihood in the Greater Mekong Sub-region. The project will also provide an opportunity to build-up sustainable forest management capacities which pursue livelihood improvement and ecological significance in all countries of the Greater Mekong Sub-region (GMS). The following outputs will contribute to meet the objective of the project: 1) The conservation of teak genetic resources, sustainable management and use of natural teak forests and market accesses of teak from legal sources have been improved; 2) Community-based and smallholders teak forest management and agroforestry systems have been strengthened with improved legal and sustainable supply chains; and 3) Regional and international collaboration, information sharing and knowledge management, networking, policy development and outreach on the sustainable management of teak forests, including sustainable use of teak genetic resources have been strengthened. The project comprises interventions at regional, national, and community levels. It promotes policy adjustments at regional and national level, building up trained human resources, implementing joined research programs, and generating and sharing new information and knowledge. 


\title{
Improving structural diversity of teak monocultures and economic implications
}

Anja Nölte ${ }^{1}$, Henrik Meilby ${ }^{2}$, Rasoul Yousefpour ${ }^{1}$

${ }^{1}$ Chair of Forestry Economics and Forest Planning, University of Freiburg, Freiburg, Germany; ${ }^{2}$ Department of Food and Resource Economics, University of Copenhagen, Copenhagen,Denmark (anja.noelte@ife.uni-freiburg.de; heme@ifro.ku.dk; rasoul.yousefpour@ife.uni-freiburg.de)

High timber prices and increasing demand made Tectona grandis (teak) cultivation attractive to many private investment companies especially in tropical Latin America. While timber production and economic return are usually the main objectives in teak plantation forestry, there is globally a growing interest in sustainable forest management, i.e. managing for a system that is resilient to changing environmental conditions and contributes to biodiversity and other ecological benefits from degraded lands and to socio-economic development. We addressed the sustainable management of teak plantations by applying a threefold strategy: First, we simulated teak growth affected by future climate scenarios under low input management in Costa Rica by calibrating a processbased forest growth model (3PG). Second, we used the model to simulate management strategies that enhance carbon storage in biomass and evaluated them with regard to their economic performance, including revenues from payment for ecosystem services (PES). Third, we simulated a management approach of group harvesting, which was hypothesized to increase structural heterogeneity (Gini coefficient) and canopy continuity, thus contributing to habitat provision and biodiversity conservation. The latter may further increase forest resilience and provides a more regular income. We further discuss other important management actions and open research questions to realize a true ecological economy of teak plantations.

\section{Growth performance and physical properties of 15 year old TEAK clones from Kerala, India}

Thulasidas P $K^{1}$, Hrideek T K $K^{2}$, Sabu Saji ${ }^{1}$

${ }^{1}$ Wood Science \& Technology Division, Kerala Forest Research Institute, Peechi - ${ }^{680653}$, Kerala, India; ${ }^{2}$ Tree Breeding \& Genetics Dept, Kerala Forest ResearchInstitute, Peechi -680653, Kerala, India (pktdas@gmail.com; drhrideek@gmail.com; sabusajiks777@gmail.com)

Teak clonal forestry is considered to be a rapidly expanding true-to true type massive multiplication method expected to produce higher yield with uniform quality timber in shortest possible time. In this context, an evaluation of teak clonal plantations established by KFRI in the year 2000 was undertaken in a locality in Kerala, India. The performance of ten clones, namely T1, T3, T4, T5, T6 and T10 originated from its parent plus trees of teak (Nilambur), T11 and T16 (Konni), T24 and T46 (Ariyankavu) were studied for the dbh, ring width, physical properties like wood colour, density and heartwood/sapwood percentage. The clones were planted at a spacing of $5 \times 5 \mathrm{~m}$. Nilambur clones $(\mathrm{T} 1, \mathrm{~T} 3, \mathrm{~T} 4 \& \mathrm{~T} 10)$ showed significant difference $(\mathrm{P} \leq 0.05)$ in terms of DBH, ring width, heartwood percentage and density than Konni and Ariyankavu clones. The density of clone T11 and T16 are significantly less $\left(0.55 \mathrm{~g} / \mathrm{cm}^{3}\right)$ when compared to Nilambur $\left(0.630 \mathrm{~g} / \mathrm{cm}^{3}\right)$ because of higher earlywood percent with thin walled fibres. Tree height and sapwood percentage was found to be insignificant $(\mathrm{P} \geq 0.05)$ among all the clones studied. At 15 years, Nilambur clones attained maturity with respect to density $\left(0.630 \mathrm{~g} / \mathrm{cm}^{3}\right)$ and growth performance was found to be superior in terms of higher DBH and heartwood percentage. The wood colour as studied by CIE L*a* $\mathrm{b}^{*}$ system showed no significant colour difference $(\mathrm{dE})$ between the clones. However, the redness index $\left(\mathrm{a}^{*}\right)$ of clone T1, T16 and T46 are distinctly different $(\mathrm{P} \leq 0.5)$ than other clones.

\section{Growth performance of 18 years old Teak of different planting stocks}

\author{
Zar Chi Hlaing ${ }^{1}$
}

${ }^{1}$ Forest Research Institute, Nay Pyi Taw, Myanmar (zarchihlaing08@gmail.com)

The growth of a tree is dependent on a complex series of interactions between genetics and environmental factors, and also planting methods. For the successful establishment of a plantation, the economically effective means should be explored, as teak plantation is being established in Myanmar especially for commercial purposes including forest rehabilitation purposes. This study was conducted in the 18 years old Teak plantation that was established in the compartment No. (9) of Ngalaik Reserved Forest managed by Forest Research Institute. This teak plantation was established with the stored stump, fresh stump and potted seedlings in 2000. As a preliminary step, in 2002, the stored stumps planting was significantly better in height growth as compared to those of fresh stumps and seedling plantings, nonetheless, survival percentages among them were not significant. Now, we conduct this follow-up study to explore the growth performance of this 18 years old teak plantation of different planting stocks. We expect this study's finding will be supported the useful and applicable information for the commercial plantation programme to raising environmentally friendly and economically successful teak plantations.

\section{Development of sustainable livelihoods for forest fringe communities from Teak plantations in Ghana}

Valerie Fumey Nassah ${ }^{1}$, Hugh Brown ${ }^{2}$, Alexander Asare ${ }^{1}$

${ }^{1}$ ForestryCommission, Kumasi, Ghana; ${ }^{2}$ ForestryCommission, Accra, Ghana(valfn2003@yahoo.co.uk; hughbrown03@hotmail.com; abasare99@yahoo.com)

The adoption of massive forest plantations initiatives to promote the rehabilitation and restoration of degraded landscapes has been emphasized as one of the main strategic objectives of the 2012 Forest and Wildlife Policy of Ghana. In addition to the policy Ghana participated in Kigali 2016 Ministers roundtable conference and agreed, signed and is committed to convert two million hectares of degraded and deforested lands under landscape restoration initiative and is o committed to the AFR100 for Africa which is a regional implementation platform for the Bonn Challenge. Ghana s two million hectare target is based on the national goals and targets agreed in the National plantation strategy 2016 to 2040 to establish and manage 625,000 ha of forest plantations and 100,000 ha enrichment planting and 3.75 million hectares of agricultural landscapes, by year 2040 through the application of best practice principles. Approximately $80 \%$ of forest plantations are Teak based on multiple benefits received by government agencies, communities, farmers and private developers. This paper highlights the sustainable livelihood opportunities generated by forest plantations of teak from 2002 to date under the National Forest Plantation Development Programme as well as the Community Forestry Management Project which was implemented by the government of Ghana with support from African development Bank. Successes and challenges of the livelihood initiatives generated and benefits received will be discussed.

\section{Technological characterization of Tectona grandis sawing wood waste and considerations of its potential uses}

Marina Coelho ${ }^{1}$, Caio Almeida ${ }^{1}$, Francides Silva Júnior ${ }^{1}$, Geraldo Bortoletto Júnior ${ }^{1}$, Vanderlei Benedetti ${ }^{1}$

${ }^{1}$ Universidadede São Paulo,Piracicaba,Brasil (marina.ulian@usp.br; caio.cfalmeida@usp.br; fjr@usp.br; gbjunior@usp.br;vabenedetti@gmail.com)

The objective of this study was to evaluate the technological characteristics of 14-year-old Tectona grandis (Teak) wood, aiming the multiple use of its sawing waste. For that, it was used Tectona grandis slabs, obtained on the primary sawing of its wood logs. The technological wood analysis realized were: wood 
chemical (total extractives and lignin contents), wood physical (basic density) and calorific value as higher heating value. Teak wood presented average total extractives content of $9.5 \%$, average lignin content of $37.5 \%$, wood basic density of $0.538 \mathrm{~g} / \mathrm{cm}^{3}$ and higher heating value of $4753 \mathrm{kcal} / \mathrm{kg}$. From the wood technological characterization, some challenges for its multiple use were observed: the high extractive content can negatively affect wood glued products, particleboard panels and pulp production. On the other hand, the high extractives content can provide natural protection to wood degrading agents, which favors its use in outdoor environment, such as floors, boards and furniture. Another potential is the refining of teak extractives for use in the chemical industry. Due to the high values observed of lignin content, basic wood density and calorific content, it is suggested the use of Tectona grandis slab for energetic purposes, especially because the results observed are near to species traditionally used for coal, briquette and pallets, such as Eucalyptus, Acacia and Mimosa spp. The results of this study allows to conclude that the Tectona grandis wood slabs presents considerable potential for energetic and outdoor environment uses, but its application for pulp and panels need further studies to be endorsed.

\section{Strategies and practices to manage teak plantations in south China}

Zaizhi Zhou ${ }^{1}$, Xiyang Wang ${ }^{1}$, Guang Yang ${ }^{1}$, Guihua Huang ${ }^{1}$

${ }^{1}$ Research Institute of Tropical Forestry,CAF, Guangzhou, China (zzzhou@caf.ac.cn; teakpro@qq.com; yangguang200510@126.com; hghmhx@163.com)

Motivated by attractive marketing and financial return, some private companies and individuals have invested in teak plantations by using superior clones since 1980s. Strategies and practices to manage these plantations in a sustainable way are urgently needed for forest products. In recent years, high priority and attention have also been given to the tree increment and quality through using rational operational regimes by Chinese forestry authorities. Pilot demonstration sites for younger teak plantations are being established in Guizhou, Yunnan, Fujian, Guangxi and Guangdong Province by the support of technique and demonstration project of teak, issued by State Key Research and Development Plan from 2017 to 2020. The objective of the paper is to provide some strategies and methods in the area of establishing high-yielding and fast-growing teak plantations by an intensive way, and available fertilizing, pruning and thinning regimes for promoting growth and straight stem with less knots. Some intercropping operations were also practiced in teak plantations for livelihood enhancement. Meanwhile the relationship between teak clone growth, wood properties and planting sites are also focused on.

\section{TEAKNET towards the Development of Teak Sector}

Sreelakshmy $M P^{1}$, Thulasidas $P K^{1}$

${ }^{1}$ TEAKNET, Kerala Forest Research Institute,Peechi,India (secretariat@teaknet.org; coordintaor@teaknet.org)

Food and Agricultural Organization of the United Nations with an aim to bring together the stakeholders of teak worldwide, constituted a network named TEAKNET (International Teak Information Network) in 1995. The Kerala Forest Research Institute, Peechi, India hosts the Secretariat of the network and is actively functioning at its current location since 2007. The vital focus of this network is to share information on the needs of the global teak sector. The major stakeholders of this network is teak growers, traders, researchers apart from policy makers among others. Each category requires different information or support and TEAKNET circulates all authentic information through its wide network. By linking the various international institutions, the network acts like a virtual research and development organization for the species. Scientific data on seed handling techniques, clonal propagation, tissue culture, silvicultural practices, timber quality, marketing information and anything related to teak is available from this network. The information exchange of this network reached to the public through its website, quarterly online newsletter, conferences \& training programmes and expertise sharing invitations. The network collaborates with international organizations like FAO, IUFRO, ITTO and formulates action plans for the sustainable management and development of the global teak sector and improve the livelihood support by promoting smallholder teak farming. The network is successfully functioning with wider participation and members who are concerned with the conservation, management and utilization of teak.

C2d: TREE GENOMICS AND BIOTECHNOLOGY

\section{Draft genome assembly of the tropical tree Bertholletia excelsa using long-read sequence data}

Laís Rossetto F. de Barros ${ }^{1}$, Lúcia Helena de Oliveira Wadt ${ }^{2}$,Mateus Mondin ${ }^{3}$, Georgios Pappas Junior. ${ }^{4}$, Rodrigo Theodoro Rocha ${ }^{4}$, Marilia de Castro Rodrigues Pappas ${ }^{5}$, Renato Kenji Kimura ${ }^{1}$, Karina Martins ${ }^{1}$

${ }^{1}$ Universidade Federal de São Carlos, Programa de Pós-Graduação em Biotecnologia e Monitoramento Ambiental, Sorocaba, Brasil; ${ }^{2}$ Embrapa Rondônia, Porto Velho, Brasil; ' ${ }^{3}$ Universidade de São Paulo, Escola Superior de Agricultura Luiz de Queiroz, Departamento de Genética, Piracicaba, Brasil; ${ }^{4}$ Universidade de Brasilia, Brasília, Brasil; ${ }^{5}$ Embrapa Recursos Genéticos e Biotecnologia, Brasilia, Brasil; ${ }^{1}$ Universidade Federal de São Carlos, Departamentode Biologia, Sorocaba,Brasil laisrossetto015@gmail.com; lucia.wadt@embrapa.br; mmondin@usp.br; gpappas@unb.br; theodorobiotec@gmail.com; marilia.pappas@embrapa.br; renato-kimura@ufscar.br;karimartins@yahoo.com)

The availability of reference genomes has revolutionized the study of biology, allowing major advances in understanding the relationship between genotype and phenotype. The reference genome is the backbone of numerous lines of research that utilize genomic resources. However, the quantity and availability of well annotated reference genomes are still limited, especially for forest species. Bertholletia excelsa Bonpl. (Lecythidaceae), popularly known as Amazon nut or Brazil nut, is an economically and ecologically important tropical tree widely distributed throughout most of the Amazon forest. To advance landscape genomics, phylogeography, functional genomics, and breeding programs across the Brazilian Amazon using genome-wide markers, we aimed to advance the development of genomic resources for $B$. excels $a$ by assembling and annotating a reference genome. Genome size was estimated by flow cytometry in $930-940$ Mbp. Long-read SMRT PacBio sequencing resulted in a coverage of $\sim 100 \times$ and an average read length of $12.5 \mathrm{~kb}$. We used Quast to compare the efficiency of two assemblers, Falcon and Miniasm, which were run with different settings. We compare results of N50 and discuss the best strategy for $B$. excelsa considering its high heterozygosity. Funding: São Paulo Research Foundation (Grant FAPESP 2017/06102-0)

\section{Reference genome of yellowhorn Xanthoceras sorbifolium: a wood oil tree in China}

Quanxin Bi ${ }^{1}$, Yang Zhao ${ }^{1}$, Xiaojuan Liu ${ }^{1}$, Haiyan Yu ${ }^{1}$, Libing Wang ${ }^{1}$

${ }^{1}$ State Key Laboratory of Tree Genetics and Breeding, Research Institute of Forestry, Chinese Academy of Forestry, Beijing, China (biquanxin@caf.ac.cn; 15736874202@163.com; liuxiaojuan@caf.ac.cn; yuhaiyan@caf.ac.cn; wlibing@caf.ac.cn)

Yellowhorn (Xanthoceras sorbifolium) was a woody oil species, which belongs to the Sapindaceae family and the monotypic genus Xanthoceras. As an endemicand economic species in Northern China, it was widely used for conserving soil and water due to the capacity to survive in arid, saline, alkaline land 
and in extreme temperature even below $-40{ }^{\circ} \mathrm{C}$. The oil content of its seed kernel could be as high as $67 \%$, of which $85 \%$ - $93 \%$ is unsaturated fatty acid, including $37.1 \%$ - $46.2 \%$ linoleic acid and $28.6 \%$ - 37.1\% oleic acid, which are essential fatty acids in diets. Recently, yellowhorn as one of the major woody oil plant species has drawn government and people's attention again for the shortage of vegetable oil resources in China. Notably, an essential nutrient for brain growth and maintenance - nervonic acid, which is rarely contained in plants, reached nearly 3.04\% in the seed oil of yellowhorn. In this study,We generated 15 pseudomolecules of the yellowhorn chromosomes, on which 97.04\% of scaffolds anchored, using Illmina HiSeq, Pacifc Biosciences and Hi-C technologies. The final genome assembly of yellowhorn is $504.2 \mathrm{Mb}$ with a contig N50 size of $1.04 \mathrm{Mb}$ and a scaffold N50 size of $32.17 \mathrm{Mb}$. Genome annotation revealed that $68.67 \%$ of the yellowhorn genome is composed of repetitive elements. Gene modeling has predicted 24,672 protein-coding genes.The high-quality yellowhorn genome and conduct the annotation and genomic structures, evolution and the data provide a rich resource of genetic information for developing these resources and understanding the special space of Xanthoceras and Sapindaceae in plant evolution.

\title{
Genome-wide analysis of laccase genes in moso bamboo highlights PeLAC10 involved in lignin biosynthesis and in response to abiotic stresses
}

Zhimin Gao ${ }^{1}$, Lichao Li $i^{1}$, Sining Wang ${ }^{1}$, Hao Xu ${ }^{1}$, Xueping $L i^{1}$

${ }^{1}$ Institute of Gene Science for Bamboo and Rattan Resources, International Center for Bamboo and Rattan, Beijing, China (gaozhimin@icbr.ac.cn; lilichao1991@126.com; wangsining@icbr.ac.cn; xuhao@icbr.ac.cn; lixueping@icbr.ac.cn)

Laccases (LACs) have multifunction involved in the processes of cell elongation, lignification ands tress response in plants. However, the laccases in bamboo are still not well characterized. A total of 23 laccase proteins were identified in moso bamboo (Phyllostachys edulis) which were clustered into four groups. The diversity of gene structures and expression patterns of PeLACs suggested that their regulation and function should be spatiotemporal and complicated. It was predicted that 18 of the 23 PeLACs were identified as the targets of ped-miR397. The put ative ped-miR397-binding site in the coding region of PeLAC10 was further confirmed by RLM-5' RACE, indicating that PeLAC10 was regulated by ped-miR397 after transcription. With the shoot height increasing, the expression abundance of PeLAC10 increased and reached the maximum in $15 \mathrm{~cm}$ shoots, while that of ped-miR397 was relative lower and showed the minimum in $15 \mathrm{~cm}$ shoots. PeLAC10 was up-regulated obviously under the treatments of $\mathrm{ABA}\left(100 \mu \mathrm{mol} \cdot \mathrm{L}^{-1}\right)$ and $\mathrm{NaCl}\left(400 \mathrm{mmol} \cdot \mathrm{L}^{-1}\right)$, and it was down-regulated under the treatment of GA3 $\left(100 \mu \mathrm{mol} \cdot \mathrm{L}^{-1}\right)$. The transgenic Arabidopsis plants over-expressing PeLAC10 became smaller and their petiole were shorter than those of Col-0. However, they had a stronger capacity in resistance to drought and phenolic acids besides higher lignin content. These results indicated the complex expression regulation and functional diversity of PeLACs. Overexpression of PeLAC10 was helpful to increase the content of lignin in transgenic Arabidopsis and improve the adaptability to drought and phenolic acid stresses.

\section{Integrated mRNA, microRNA transcriptome and degradome analyses provide insights into stamen development in moso bamboo (Phyllostachys edulis)}

\author{
Jian $\mathrm{Gao}^{1}$ \\ ${ }^{1}$ Internatioanl Centre for Bamboo and Rattan,Beijing, China (gaojianicbr@163.com)
}

Moso bamboo is a large and woody bamboo of great economic and ecological value, a typical clonal plant and simultaneously flowers happened at the end of very long vegetative growth phases, followed by the death of large areas of them. Long-term clonal reproduction led to the decline of bamboo forests, however, the setting rate of moso bamboo is very low, which largely affects the regeneration of bamboo forest. The floral organs, especially stamens, are essential for sexual reproduction of flowering plants. However, abortion mechanism of moso bamboo is unknown till now. Transcriptomic, small RNA and degradome analyses to characterize miRNA-mediated pathways of moso bamboo stamens were studied; 16 conserved miRNAs were specific highly expressed, including miRNA159 and miRNA166. In situ hybridization showed that miRNA159 might play an important role in the regulation of stamen development while expression levels of its targets PheMYB98 and PheMYB42 were hard to detect. Furthermore, overexpression of Phe-PremiR159 could cause anther dehisce failure, and the mature pollens could not be dispersed and further reduce fertility. Semi-thin section result showed that anther endothelial layer of PhePremiR159 overexpressing lines weren't detected in secondary thickening, resulting in lack of the force required for opening. The expression levels of MYB26, NST1, NST2 related to anther dehiscence in overexpression lines were significantly verified, indicating the Phe-miR159 might regulate these genes associated with secondary thickening through negative regulation of AtMYB33, thus affect the anther dehiscence. Together, this study provides a foundation for further investigations of the RNA-mediated silencing mechanism in stamens of moso bamboo.

\section{The Salix SmSPR1 involved in light-regulated directional cell expansion by modulating microtubule elongation}

Rao Guodong ${ }^{1}$, Liu Xiaoxia ${ }^{1}$

${ }^{1}$ Research Institute of Forestry, Chinese Academy of Forestry, Beijing, China (rgd@caf.ac.cn; shiyoo01@163.com)

Light signaling and cortical microtubule (MT) arrays are generally recognized to be important for anisotropic growth of plant cells. Microtubule associated proteins (MAPs) function as regulators that mediate plant cell expansion or elongation by altering arrangements of MT arrays. However, little is known about molecular mechanism of MAPs are affected by light to regulate cell expansion or elongation. Here, we found the microtubule associate protein SPR1 was involved in light-regulated directional cell expansion by modulating microtubule elongation in Salix matsudana. Overexpression of SmSRP1 in Arabidopsis result in right-handed helical orientation of hypocotyls in dark-grown etiolated seedling, while phenotype of transgenic plants was indistinguishable from those of wild type plants in the condition of light. Characterization of the transgenic plants phenotypes showed reduced anisotropic growth and left-handed helical MT arrays in etiolated hypocotyl cells. Protein interaction assays revealed that SPR1, CSN5A (subunits of COP9 signalosome, an negative regulator of photomorphogenesis), and ELONGATED HYPOCOTYL 5 (HY5, transcription factor, function in promote photomorphogenesis) were interacted to each other. Phenotype of Arabidopsis AtSPR1 overexpressing transgenic lines were similar to that of SmSPR1 overexpressing transgenic plants, and overexpression of Salix SmSPR1 can rescue the spr1 mutant phenotype, indicating a generality function of SPR1 in plants. Taken together, our study reveals that the Salix SPR1, $\mathrm{COP}$, and HY5 may form different protein complex to regulate MT arrays arrangement and anisotropic growth of cells in the condition of light and dark. 


\author{
Transcriptional regulation of cell cycle genes during the temperature-modulated larch tree dormancy release and reactivation \\ Wan-Feng Li $i^{1}$ (D, Yanhui Kang ${ }^{1}$, Yao Zhang ${ }^{1}$, Li-Wang $Q i^{1}$ \\ ${ }^{1}$ State Key Laboratory of Tree Genetics and Breeding, Key Laboratory of Tree Breeding and Cultivation, National Forestry and Grassland Administration, \\ Research Institute of Forestry, Chinese Academy of Forestr, Beijing, China (liwf@caf.ac.cn, kk15110057556@126.com; 243165265@qq.com; lwqi@caf.ac.cn)
}

Dormancy release and reactivation of temperate-zone trees in spring involve the temperature-modulated expression of cell cycle genes. However, information on the detailed regulatory mechanism is limited. Here, we compared the transcriptome of stems of active and dormant larch trees, emphasizing the expression patterns of cell cycle genes and transcription factors, their relationships and responses to temperatures. The results showed that 12 cell cycle genes and 31 transcription factor, belonging to 17 families, were highly expressed in active stage, indicating regulatory relationships might exist between them. Bioinformatics analysis of the promoter sequences of 12 cell cycle genes suggested that they might be regulated by the transcription factors from 10 families. Altogether, 16 transcription factors from 7 families co-expressed with 12 cell cycle genes, and 73 regulations were predicted; while yeast one-hybrid assay showed that three regulations occurred between three transcription factors and two cell cycle genes. Last we measured their expression patterns during dormancy release and reactivation induced by temperatures naturally or artificially, and found that they almost had the same expression patterns, indicating that these regulatory modules functioned in the temperature-modulated dormancy release and reactivation of temperate-zone trees. These findings provide new insights into the links between the temperature signals and the expression of cell cycle regulators, helping to understand the temperature control of tree growth and development in the context of climate change.

\title{
Genetic background hidden by methylation in hickory (Carya cathayensis) --- a view based on the construction of genetic and epigenetic linkage maps
}

Ang Dong ${ }^{1}$, Xuli Zhu ${ }^{2}$, Wenchong Chen ${ }^{1}$, Yanyao Tang ${ }^{1}$, Ning Jia ${ }^{1}$, Yanru Zeng ${ }^{1}$, Huwei Yuan ${ }^{1}$, Bingsong Zheng ${ }^{1}$, Rongling Wu ${ }^{3}$

${ }^{1}$ The State Key Laboratory of Subtropical Silviculture, Zhejiang A\&F University, Hangzhou, China; ${ }^{2}$ Center for Computational Biology, Beijing Forestry University, Beijing, China; ${ }^{3}$ Center for Statistical Genetics, Pennsylvania State University, Hershey, US (fantasys05227@gmail.com; 349082942@qq.com; 506396307@qq.com; 790930248@qq.com;981183096@qq.com;yrzeng@zafu.edu.cn; yuanhuwei86@163.com; bszheng@zafu.edu.cn; rwu@phs.psu.edu)

Recent studies have suggested epigenetic mechanism, one of which is DNA methylation, is involved in heterosis and apomixis in plant species. Hickory (Carya cathayensis), a woody nut species quite different from its relative pecan ( $C$. illinoensis), has so far had no cultivar developed, presented a low DNA polymorphism by conventional molecular markers although propagated by seeding, but shown heterosis, apomixis and imprinted quantitative trait loci (iQTLs). To figure out the DNA mythylation status in hickory, we analyzed the cytosine methylation pattern of two mapping populations resulting from reciprocal crosses between a hickory tree and a pecan cultivar "Mahan"using MSAP (methylation-sensitive amplified polymorphism) markers. With the locus information from MSAP, both non-methylation loci (NML) or methylation sensitive loci (MSL), and that from other molecular markers such as RAPD, ISSR and SRAP markers on the same mapping populations, we constructed a genetic and an epigenetic maps in hickory. Our results show that the epigenetic map (7742.3 cM) was doubled as compared with the genetic map (3580.2 cM) either in terms of the total length of linkage groups or in terms of the number of molecular markers. In addition, makers from MSAP, either NML or MSL, accounted for a large percentage of the total markers used and MSAP markers were often clustered in each of linkage groups. The results reveal that the hickory genome is highly methylated and DNA methylation might play an important role in this species, which has survived from global cooling in the late Tertiary.

C2p: EUCALYPT PLANTATIONS

\section{Density and stomatal dimensions of contrasting Eucalyptus clones of across a climatic gradient}

Tatiani Maria Pech ${ }^{1}$, Otávio Campoe Caf, Rafala Carneiro $^{3}$, Paulo Cesar Poeta Fermino Júnior ${ }^{2}$

${ }^{1}$ Universidade do Estado de Santa Catarina, Lages, Brasil; ${ }^{2}$ Universidade Federal de Santa Catarina, Curitibanos, Brasil; ${ }^{3}$ Instituto de Pesquisas e Estudos

Florestais, Piracicaba,Brasil (tatianimariapech@gmail.com; otavio.campoe@gmail.com; rafaela@ipef.br; paulo.fermino@ufsc.br)

The species of the Eucalyptus genus are widely used in forest plantations, representing economic importance for Brazil. However, little is known about the physiological processes that control their growth, and how these processes are governed by genetic and climatic factors. Therefore, the objective of this study is to characterize the density and dimensions of the stomata of different species of the Eucalyptus genus, and to evaluate the plasticity of these variables across a strong climatic gradient in Brazil. The experimental sites are part of the TECHS-IPEF Cooperative Research Program, located in SC, PR, SP, MG (from latitude $17^{\circ}$ to $27^{\circ}$ South). The clones evaluated are pure or hybrid of the following species: E. urophylla, E. grandis, E. camaldulensis, E. saligna, E. benthamii, E. dunnii. Histological blades of abaxial and adaxial leaf surfaces were prepared from leaves of three trees of each clone at each site, and the images analyzed in an optical microscope. The study is under development, and the studied clones have not been evaluated yet at all sites. However, previous results show that the clones differ in the occurrence of stomata in the leaf sides. Among the six clones, three showed stomata at both sides of the leaves, and the other three clones only on the abaxial side. The stomatal density is also different among clones, ranging from approximately 200 to 500 stomata per mm-2. The stomatal characteristics are important to understand the physiological response of the trees and how they may be related to the adaptation of these clones to different climates.

\section{Coppice potential of 16 different species of Eucalyptus after an eight-year rotation.}

Marina Sbardella ${ }^{1}$, Otávio Campoe ${ }^{1}$, Joannès Guillemot ${ }^{2,3}$, Guerric Le Maire ${ }^{2,4}$

${ }^{1}$ Universidade Estadual Paulista “Júlio de Mesquita Filho”, Faculdade de Ciências Agrônomicas, Botucatu, Brasil; ' ${ }^{2}$ CIRAD , Montpellier, Brasil; ${ }^{2}$ Escola Superior de Agricultura "Luiz de Queiroz”, Universidade de São Paulo, Piracicaba, Brasil; “4niversidade E (marina.sba@hotmail.com; otavio.campoe@gmail.com; joannes.guillemot@cirad.fr; guerric.le_maire@cirad.fr)

The adoption of coppice is a commonly used management in different regions of Brazil for plantations of Eucalyptus, which requires less investments. However, there are variations in the ability of each genotype to emit sprouts, and higher yields can be obtained by changing the genetic material. The objective of this study was to evaluate the coppice potential of 16 Eucalyptus genotypes of different species, (14 clonal and 2 seed origin). The experiment is located in the area of the EUCFLUX-IPEF Cooperative Research Program, in the state of São Paulo, Brazil. The following variables were evaluated at 100 days after harvest of an eight-year rotation of the 16 genotypes: number of shoots per stump, total height, and basal diameter of the three main shoots. Twelve genetic materials showed one or two shoots per stump, and the three clones, with higher development in height and diameter, showed 3 or more shoots per stump. The best shoots of the best clones presented total height of approximately $1 \mathrm{~m}$ and average base diameter of $8 \mathrm{~cm}$. The genotypes with the highest number of shoots also presented 
better development in height and basal diameter. The 3 less developed genotypes presented mean basal diameter of less than $3 \mathrm{~cm}$ and average height of $40 \mathrm{~cm}$ for the three main shoots. The results show the clone/species coppice potential, which is important to move forward with coppicing techniques. Future studies will be conducted to evaluate the productivity physiology of these genetic materials.

Changes in biomass production after windstorms in Eucalyptus grandis $\mathbf{x}$ Eucalyptus urophylla hybrids / Alterações na produção de biomassa de híbridos de Eucalyptus grandis $x$ Eucalyptus urophylla danificados por vendavais

Marco Aurélio Figura ${ }^{1}$ D, Regiane Abjaud Estopa ${ }^{1}$, Mariane Bueno de Camargo ${ }^{1}$, James Stahl ${ }^{1}$

${ }^{1}$ Klabin SA, Telemaco Borba,PR,Brasil(mafigura@klabin.com.br, restopa@klabin.com.br; maricamargo@klabin.com.br; jstahl@klabin.com.br)

As florestas plantadas do gênero Eucalyptus estão expostas à ação dos fatores abióticos do ambiente, que muitas vezes as causam danos e geram reduções em sua produtividade. Nos últimos anos tem-se intensificado as observações de danos por vendavais em plantios clonais de Eucalyptus, principalmente em idades mais jovens, preocupando a silvicultura nacional. O presente estudo buscou quantificar as perdas médias na produção de árvores de 7 anos de idade decorrentes de danos anteriores por vento na idade de 2 anos. Foram selecionados 3 talhões de híbridos de E. grandis x E. urophylla que apresentassem árvores normais (retas e sem danos) próximas a árvores danificadas pelo vento e que permaneceram vivas até a idade final, tipicamente arqueadas e com a presença de brotações ao longo do fuste. Quantificou-se, para cada talhão, um número de 4 árvores médias arqueadas pelo vento e 2 árvores médias normais, medindo-se sua biomassa recém abatida do fuste, separando-a nos sortimentos de celulose (acima de $8 \mathrm{~cm}$ de diâmetro com casca), resíduo (entre 2 e $8 \mathrm{~cm}$ com casca) e total (somatório dos anteriores). A biomassa média, respectivamente para os sortimentos de celulose, resíduo e total, foi de 411,19 e $430 \mathrm{~kg} /$ árvore para as árvores normais e de 193, 61 e 254 kg/árvore para as árvores arqueadas. Isto corresponde a uma diminuição de 53\% na madeira antes destinada a celulose e um aumento de $231 \%$ na quantidade de resíduo gerada, ocasionada pelas brotações ao longo dos fustes arqueados. A biomassa fresca total foi reduzida em $41 \%$.

\title{
Changes in heartwood/sapwood ratio in Eucalyptus urophylla due to soil water deficit
}

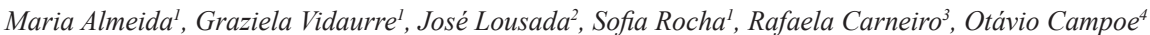

${ }^{1}$ Universidade Federal do Espirito Santo, Jerônimo Monteiro, Brasil; ${ }^{2}$ Universidade de Trás os Montes e Alto Douro, Vila Real, Portugal; ${ }^{3}$ Instituo de Pesquisas e Estudos Florestais, Piracicaba, Brasil; ${ }^{4}$ Universidade Federal de Santa Catarina, Curitibanos, (narunafelix@gmail.com, grazividaurre@gmail.com; jlousada@utad.pt; sofiamaria.r@hotmail.com; rafaela@ipef.br; otavio.campoe@ufsc.br)

Different heartwood/sapwood proportions affect wood use and quality. With forest plantation expansion, clones tend to decrease their ideal phenotypic expression due to the occupation of areas with different edaphoclimatic conditions from locations they were developed. The aim of the study was to compare the heartwood/sapwood ratio (C/A) of eucalyptus wood in contrasting soil water deficit conditions (SWD) across Brazil latitudinal gradient. One wood disc at DBH was sampled from seven Eucalyptus urophylla trees at age of 6 years for C/A quantification at 10 sites of the TECHS-IPEF Cooperative Research Program. Heartwood delimitation was visual, by the color difference. The discs were scanned and total heartwood area values were obtained by image analysis system. The sites were separated into 3 groups. Those with the highest latitudes, Botucatu/SP and Buri/SP (SWD: 106 mm year-1) presented the highest C/A values, 2.3 and 1.8, respectively. The sites Estrela do Sul/MG, Guanhães/MG, Rio Verde/GO and Três Lagoas/MS, located at medium latitudes, formed the second group with means of C/A: 1.1 and SWD of $367 \mathrm{~mm}$ year-1. The group with the lowest C/A mean (0.6) belonged to sites of the highest values of SWD (534 mm year ${ }^{-1}$ ) and lower latitudes, Peixe/TO, Urbano Santos/MA and Eunápolis/BA, and also Belo Oriente/MG. The C/A ration decreased with the increase of the SWD and decrease of the latitude, demonstrating that SWD conditions the response of tree to heartwood production.

\section{Growth and distribution of fine roots in clonal Eucalyptus plantations under contrasting climate}

\author{
Josiana Basílio', Otávio Campoe ${ }^{2}$, Rafaela Carneiro ${ }^{3}$, Túlio Queiroz ${ }^{1}$, James Stahl ${ }^{4}$, Marco Aurélio Figura ${ }^{4}$, Rodolfo Costa ${ }^{5}$ \\ ${ }^{1}$ Universidade Estadual Paulista "Júlio de Mesquita Filho", Botucatu-SP, Brasil; ${ }^{2}$ Universidade Federal de Santa Catarina, Curitibanos, Brasil; ${ }^{3}$ Instituto \\ de Pesquisas e Estudos Florestais, Piracicaba,Brasil; (josianajussara@gmail.com; otavio.campoe@gmail.com; rafaela@ipef.br; tulio-bq@hotmail.com; \\ jstahl@klabin.com.br; mafigura@klabin.com.br; rodolfo.costa@vallourec.com)
}

The main function of fine roots is to provide water and nutrients, therefore, understanding their growth in depth, and distribution over the soil layers is crucial to understand soil water dynamics and nutrients uptake by forest plantations. The objective of this study is to quantify biomass of fine roots $(\leq 2 \mathrm{~mm})$ in different species of Eucalyptus on contracting climatic conditions. Fine roots were sampled at the age of 3 years, on four genotypes (E. urophylla, E. urophylla x $E$. grandis, E. grandis $\mathrm{x}$ E. camaldulensis and E. urophylla $\mathrm{x}$ E. brassiana) at two sites (Bocaiúva-MG and Telêmaco Borba-PR) of the TECHS-IPEF Cooperative Research Program, with deep Oxisols and mean annual precipitation of 850 and $1750 \mathrm{~mm}$, respectively. On the drier site, fine roots were shallower, with the distribution of their biomass on the top 3 meters ranging from 58 to $91 \%$ among clones. The wetter site showed deeper fine roots with the distribution of their biomass on the top 3 meters ranging from 60 to $82 \%$. On both sites, the hybrid E. urophylla $\mathrm{x}$ E. grandis showed the shallower fine roots, contrasting with $E$. grandis $\times$ E. camaldulensis and E. urophylla x E. brassiana, that showed similarly deeper roots. Studies currently under development are focusing on understanding the relations among fine roots, aboveground growth, wood production, soil water use at different soil layers, and tolerance capacity of these clones to water stress.

\section{Optimal temperatures for growth of contrasting Eucalyptus species in Brazil}

Túlio Queiroz ${ }^{1}$, Otávio Campoe ${ }^{1,2}$, Clayton Alcarde Alvares ${ }^{3}$, Rafaela Carneiro ${ }^{4}$, James Stahl ${ }^{5}$, Gabriela Moreira ${ }^{6}$, Marco Aurélio Figura ${ }^{5}$, Helton Lourenço ${ }^{7}$, Helder Andrade ${ }^{8}$, Cristian Montes ${ }^{9}$

${ }^{1}$ Universidade Estadual Paulista “Júlio de Mesquita Filho”, Botucatu, Brasil; ' ${ }^{2}$ Universidade Federal de Santa Catarina, Curitibanos, Brasil; ${ }^{3}$ Suzano, Imperatriz, Brasil; ${ }^{4}$ Instituto de Pesquisas e Estudos Florestais, Piracicaba,Brasil; 5 Klabin, Telêmaco B (tulio-bq@hotmail.com; otavio.campoe@gmail.com; calcarde@suzano.com.br; rafaela@ipef.br; jstahl@klabin.com.br;gabriela.moreira@ipaper.com; mafigura@klabin.com.br;

helton.lourenco@veracel.com.br; helder.andrade@vallourec.com; crmontes@uga.edu)

The genetic improvement of eucalyptus has evolved in the development of genotypes, but we still need more information on the genotype-environment interaction. Understanding the interactions between forest plantation and climate is mandatory for predicting the impacts of climate change on terrestrial ecosystems, and assessing the adaptation and vulnerability of tree species. In this context, potential genotypes were planted at 6 experimental sites, from the South to North of Brazil. We measured the CBH every 15 to 30 days of 9 genotypes ( 6 trees per genotype) planted in 3 x 3 m spacing, from 2012 to 2018 . Finally, two destructive samplings were performed in the middle and at the end of the rotation (2014 and 2018, respectively). Meteorological data of each site was used 
to assess the optimal growth temperature. Our results show that optimum temperature for growth depends on the species. The three most planted genotypes in

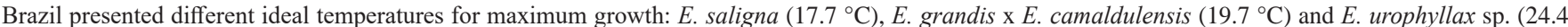
${ }^{\circ} \mathrm{C}$ ). Minimum temperatures, ranging from $11.7-13.8^{\circ} \mathrm{C}$, and maximum from $31.6-32.6^{\circ} \mathrm{C}$ were responsible for initiating or stop growth. Understanding the dynamics of tree growth and the relationship with climate is useful to predict productivity in new expanding regions with no previous information, to improve growth predicting models, and to perform zoning of genotypes of Eucalyptus.

\section{Spacing effects on volume of Eucalyptus plantations across a climatic gradient in Brazil and Uruguay}

Rafaela Pereira Naves ${ }^{1}$, Rafaela Carneiro ${ }^{2}$, Renata Aparecida Serio Abranches Junqueira ${ }^{3}$, Otávio Campoe 4

${ }^{1}$ Escola Superior de Agricultura "Luiz de Queiroz”, Universidade de São Paulo, Piracicaba, Brasil; ${ }^{2}$ Instituto de Pesquisas e Estudos Florestais, Piracicaba, Brasil; ${ }^{3}$ Floragro, Itatinga, Brasil; ${ }^{4}$ Universidade Federal de Santa Catarina, Curitibanos, Brasil (rafaelapnaves@gmail.com; rafaela@ipef.br; renatabranches@yahoo.com.br; otavio.campoe@gmail.com)

The productivity of commercial forest plantations depends on several variables such as age, genetic material, biotic and abiotic conditions. There are interactions among those variables, e.g., the drier the environment, the higher the competition for water, thereby the area per tree must be larger, without compromise stand level production. The cooperative research program TECHS (Tolerance of Eucalyptus clonal to Hydric, Thermal and Biotic Stresses) of the Forestry Science and Research Institute (IPEF) aims to study the biotic and abiotic stresses that affect the productivity of different Eucalyptus clones. Our goal in this study is to determine which Eucalyptus materials are more efficient for which region in which spacing. We evaluated 34 sites in a wide climatic gradient from northern Brazil to Uruguay (latitudes ranging from $3^{\circ}$ to $33^{\circ}$ South). In each site, on average, 11 clones were tested in permanent plots where the spacing was increasing from $0.75 \mathrm{~m}^{2}$ to $24 \mathrm{~m}^{2}$. We evaluated the mean volume per tree and the mean volume per hectare according to the spacing at the end of the rotation (approximately 7 years). The preliminary results indicated that in general, plastic clones had a better performance, although in some extreme conditions site-specific clones performed better. The volume per hectare was greater in smaller spacings but in most cases, the production was unfeasible, due to the high mortality or small dimension of the trees in high stocking. These results contributed to understand how the future productivities will be in relation to the management and climate.

Characteristics of waste from colonies of Atta colombica (Hymenoptera: used in dry forest restoration processes / Caracterizacion del residuo proveniente de colonias de atta colombica (Hymenoptera: Formicidae) utilizado en el proceso de restauracion en bosque seco

Alexandra Fonseca Vargas $^{1}$, Miguel Eugenio Cadena Romero ${ }^{1}$

${ }^{1}$ Universidad Distrital Francisco Jose de Caldas, Bogota, Colombia (ing.alexandraf@gmail.com; cademielro@hotmail.com)

En el área de compensación del Embalse El Quimbo en el Departamento del Huila Colombia, se utiliza el material residual proveniente de las colonias de hormiga arriera Atta colombica en el proceso de restauración, como sustrato en vivero y aporte de materia orgánica. Se caracterizó químicamente el desecho, para la evaluación estructural (mineralización) y composición mineral en sus estados residuales reportados en los montículos "in situ", en tres diferentes coberturas naturales: Bosque (BQ), Herbazal Abierto (HA) y Arbusto Denso (AD), así mismo evaluar la influencia de tres profundidades del montículo (superior, medio e inferior), en época seca y húmeda, la forma de bloqueo correspondió a tres intervalos de tiempo durante el día (Mañana, Mediodia y Tarde). Las variables de respuesta se analizaron mediante un Análisis de Varianza Combinado, para un diseño de Bloques Completos al Azar con arreglo factorial $2 \mathrm{x}$ 3 en serie de experimentos. La relación C:N osciló entre 3.90 y 12.00, mostrando que el valor inferior se obtiene en la interacción de la Época Seca (ES) con Herbazal Abierto (HA) y a la Profundidad Inferior (PI). Así mismo, en la interacción existente de ES x HA x PI, los elementos P (11.29 ppm), Ca (5.43\% M.S.), Mg (0.89 \%M.S.), B (84.57 ppm) y Cu (17.77 ppm), mostraron sus mayores concentraciones. El K presentó su mayor concentración de $1.90 \%$ M.S para la Época Húmeda en un HA y Profundidad Superior, también en Época Seca se presentó la misma concentración, pero en AD y a la misma profundidad

\section{C2q: PHYSIOLOGY AND GENETICS IN PLANTATION SPECIES}

\section{RNA interference supression of DOF transcription factor from Populus tremula x Populus alba}

Laudiane Zanella ${ }^{1}$, Juliana Degenhardt-Goldbach ${ }^{2}$, Isabel Gerhardt ${ }^{3}$, João Carlos Bespalhok Filho ${ }^{1}$

${ }^{1}$ Universidade Federal do Paraná, Curitiba, Brasil; ${ }^{2}$ Embrapa Florestas, Colombo, Brasil; ; Embrapa Informática Agropecuária, Campinas, Brasil (laudianezanella@hotmail.com; juliana.degenhardt@embrapa.br; isabel.gerhardt@embrapa.br;joao.bespa@gmail.com)

From the total biomass produced by plants, $70 \%$ is represented by cell wall, in which carbon is mainly accumulated in the secondary wall. Therefore, the understanding of the mechanisms that regulate cell wall synthesis and its modification through genetic engineering may lead to the increase of lignocellulosic biomass. Among several functions already attributed to the proteins of the Dof transcription factors, its relation with cell wall formation is one of the most studied. However, the mechanisms involved in this process are not fully elucidated. Populus is the most used model plant for studies with forest species, including functional genomics. The objective of this work was to silence one gene of the Dof family by RNAi in plants of Populus tremula $\mathrm{x} P$. alba, and investigate its function, aiming at the future production of Eucalyptus and Pinus plants with higher biomass production. For this, a silencing vector was constructed with specific primers of a Dof family gene from Populus. To obtain the transgenic plants via Agrobacterium tumefaciens, root segments were used as initial explants. Fifteen events were obtained, and in twelve the Dof expression was suppressed at different levels, according to qPCR analyzes. Of these, on five the expression was highly suppressed, indicating that the gene was successfully silenced. In morphological evaluations after 90 days the events did not present phenotypic differences in relation to non transformed plants. Physiological and histochemical analyzes are underway to evaluate lignin and cellulose contents and structural changes in transformed plants.

\section{Cloning optimization of gene encoding trypsin inhibitor in Falcataria molucana Miq.}

Ulfah J Siregar ${ }^{1,2}$, Auraga Dewantoro ${ }^{1}$, Nofri Yanti ${ }^{1}$

${ }^{1}$ BogorAgriculturalUniversity,Bogor,Indonesia; ${ }^{2}$ SEAMEOBIOTROP,Bogor,Indonesia(siregaruj@gmail.com;auragadewanto@yahoo.com;nofriy17@gmail.com)

Sengon (Falcataria moluccana Miq.) is a multifunctional and fast growing tree species which has a high economic value. However, the increasing trend of sengon plantation has caused a pest outbreak, especially Xystrocera festiva stem borer. Boktor larvae have trypsin enzyme in their gut to hydrolyse stem of sengon. Some sengon resistant accessions showed inhibitory activity of trypsin enzyme, which are important aspect for sengon tree improvement program. The objectives of this research are to optimize preparation of cloning method for the construction of genomic library, especially trypsin inhibitor (TI) gene. This 
research used shotgun cloning and specific gene cloning method to establish genomic library. The genomic library was successfully constructed using pGEM-T Easy vector in $E$. coli bacteria strain DH5 $\alpha$, generating about 9 colonies by shotgun cloning method and sequences of sengon TI genes were obtained with sizes ranging from 107 to $308 \mathrm{bp}$. The sequences of the colonies had high similarity from nuclear, chloroplast and mitochondrial genomes of various tree species and TI sequences were similar to Tamarindus indica, Glycine max, Populus trichocarpa and Populus nigra, however those TI sequences had low E values.

\section{Studying ecophysiological patterns to improve the management of high-productivity Eucalypt plantations: the EUCFLUX project}

Joannès Guillemot ${ }^{1,2}$, Guerric le Maire ${ }^{1,3}$, Clayton Alcarde Alvares ${ }^{4}$, Jarbas Borges ${ }^{5}$, Raul Chaves ${ }^{5}$, Marco Aurélio Figura ${ }^{6}$, Guilherme Luiz de Jesus ${ }^{7}$, Fernando Leite, Rodolfo Araujo Loos ${ }^{8}$, Gabriela Moreira ${ }^{9}$, Vinicius Silva ${ }^{10}$, James Stahl ${ }^{6}$, Jean-Paul Laclau ${ }^{1,11}$, Yann Nouvellon ${ }^{I}$, Jose Luiz Stape ${ }^{4,11}$, Otávio Campoe ${ }^{1,12}$

${ }^{I}$ Cirad, UMR Eco\&Sols, Montpellier, France; ${ }^{2}$ Escola Superior de Agricultura Luiz de Queiroz, Universidade de São Paulo, Piracicaba, Brasil; ${ }^{3}$ Universidade Estadual de Campinas , NIPE Campinas Brasil; ${ }^{4}$ Suzano Forestry Technology, Itapetininga, Brasil; ${ }^{5}$ Duratex Forest Technology, Agudos, Brasil; ${ }^{6}$ Klabin Forest Research, Telêmaco Borba, Brasil; ${ }^{7}$ Cenibra, SP, Brasil; ${ }^{8}$ Fibria Technology Center, Aracruz, Brasil; ${ }^{9}$ International Paper, SP, Brasil, ${ }^{10}$ Eldorado Brasil Celulose, Tres Lagoas, Brasil; " 1 Universidade Estadual Paulista "Júlio de Mesquita Filho", Botucatu Brasil; ${ }^{12}$ Universidade Federal de SantaCatarina,Curitibanos,_Brasil (joannes.guillemot@cirad.fr; guerric.le_maire@cirad.fr; calcarde@suzano.com.br; jarbas.borges@duratex.com.br; raul.chaves@duratex.com.br; mafigura@klabin.com.br; guilherme.jesus@cenibra.com.br;fernando.leite@cenibra.com.br; raloos@fibria.com.br; gabriela.moreira@ipaper.com; vinicius.silva@eldoradobrasil.com.br; jstahl@klabin.com.br; jean-paul.laclau@cirad.fr; yann.nouvellon@cirad.fr; stape@suzano.com.br; otavio.campoe@ufsc.br)

Global climatic changes may deeply affect the functioning of Eucalyptus plantations. It is therefore crucial to gain knowledge on the drivers of Eucalyptus productivity, carbon $(\mathrm{C})$ allocation and resource-use efficiency in order to ensure a sustained productivity. These data are key to improve the productivity of Eucalyptus plantations and reduce their impacts on natural resources towards sustainable management. Building on the innovative results obtained in its first phase (2007-2017), the second phase of the EUCFLUX project, initiated in 2018, aims to enhance our knowledge on eucalypt plantations functioning at various spatiotemporal scales. The EUCFLUX study site is located on a commercial clonal plantation of ca 260 ha in Southern Brazil. The project will specifically 1) quantify the fluxes of energy, $\mathrm{C}$ and water along a complete rotation using the Eddy Covariance technique, girth inventories, litter and $\mathrm{C}$ content surveys and flux chambers; and assess the effects of forest plantations on soil water availability down to $10 \mathrm{~m}$ and water table 2) use high-resolution dendrometers and anatomical analyses to study the determinism of growth 3) combine field data, high resolution remote sensing and modelling to upscale our knowledge of eucalypt functioning from site to regional scales and 4) compare the functional responses of more than 16 eucalypt genotypes (clonal and seed-origin) in a common-environment field trial, in order to evaluate the generality of the results obtained on the main clone, but also to evaluate how different are the functional responses of coppice and planted eucalypt trees.

\section{JERFs regulate intracellular $\mathrm{K}+/ \mathrm{Na}+$ balance in Populus alba $\times P$. berolinensis under salt stress}

Changjun Ding ${ }^{l, 2}$, Weixi Zhang ${ }^{l, 2}$, Dan Li ${ }^{1,2}$, Qinjun Huang ${ }^{1,2}$, Xiaohua Su ${ }^{1,2}$

${ }^{I}$ State Key Laboratory of Tree Genetics and Breeding, Research Institute of Forestry, Chinese Academy of Forestry, Beijing, China; ${ }^{2}$ Key Laboratory of Tree Breeding and Cultivation of State Forestry Administration, Research Institute of Forestry, Chinese Academy of Forestry Beijing China

(changjund@126.com; weixizhang@126.com; changjund@126.com; huangqj@caf.ac.cn;suxh@caf.ac.cn)

Maintaining $\mathrm{K}+/ \mathrm{Na}+$ balance in the cytoplasm is important for metabolism as well as salt resistance in plants. In this study, we monitored the growth (height and diameter) of Populus alba $\times$ P. berolinensis genotypes 9\# and transgene 9\# (ABJ01)carrying the JERF gene over 4 years. Expression of NHX1 and $\mathrm{SOS} 1$ whichencode $\mathrm{Na}+/ \mathrm{H}+$ antiporters in the vacuole and plasma membranes were measured in leaves. Ion flux of $\mathrm{Na}+, \mathrm{K}+$ and $\mathrm{H}+$ were measured in the root tip of seedlings stressed by $100 \mathrm{mM} \mathrm{NaCl}$ for 7 days, 15 days and 30 days. The results showed that transgenic genotype (ABJ01) grew faster than 9\#, and ABJ01 displayed higher NHX1 and SOS1 expression in leaves than 9\#. Root ion flux measurement revealed a higher Na+ efflux and $\mathrm{H}+$ influx in ABJ01 than in 9\#, but $\mathrm{K}+$ efflux was lower in ABJ01. The results suggest that salt stress induces NHX1 and SOS1 to a greater extent in the ABJ01 genotype, which up-regulate the $\mathrm{Na}+/ \mathrm{H}+$ antiporter to better maintain $\mathrm{K}+/ \mathrm{Na}+$ balance in the cytoplasm of this more salt resistant variety.

\section{Morphological dissection and cellular and transcriptome characterizations of bamboo pith cavity formation reveal a pivotal role of genes related to programmed cell death}

Lin Guo ${ }^{l}$, Xuepeng Sun ${ }^{2}$,Zhongru Li ${ }^{l}$, Yujun Wang ${ }^{l}$, Zhangjun Fei ${ }^{2}$, Chen Jiao ${ }^{2}$, Jianyuan Feng ${ }^{l}$, Dingfan Cui ${ }^{l}$, Xingyu Feng ${ }^{l}$, Yulong Ding ${ }^{l}$, Chunxia Zhang ${ }^{l}$, Qiang $\mathrm{Wei}^{1}$ (D)

${ }^{I}$ Nanjing Forestry University, Nanjing, China; ${ }^{2}$ Cornell University,Ithaca,USA (guolin0915@nifu.edu.cn; xs57@cornell.edu; 840826495@qq.com; 171474787@qq.com; zf25@cornell.edu; cj334@cornell.edu; 274505453@qq.com;1152319726@qq.com; 921824407@qq.com; ylding@vip.163.com; 550445950@qq.com; weiqiang@njfu.edu.cn)

Pith cavity formation is critical for bamboo to overcome the bending force during fast growth, but the molecular mechanism is largely unknown. Multiple approaches were employed to study the biology of pith cavity formation, including anatomical dissection, mathematical modeling, and transcriptome profiling. We found that the corruption of pith tissue occurred sequentially and asymmetrically from the top-center of the internode down to the bottom, which might be caused by the combined effects of asymmetrical radial and axial tensile forces during shoot-wall cell elongation and spiral growth of bamboo internode Programmed pith cell death manifested by TUNEL positive nuclei, DNA cleavage and degraded organelles, which was regulated by ethylene and calcium signaling pathway, ROS burst, cell wall modification, proteolysis, and nutrient recycle genes finally might be responsible for pith tissue corruption of Pseudosasa japonica. Although similar physiological changings and transcriptome profiles were found in other randomly selected bamboo species, different forming speed of pith cavity, which might be caused by different pith cells across the internode that negatively correlate with culm diameter was discovered. These findings provided a systematical view on the formation of the bamboo pith cavity and revealed that PCD plays an important role in the bamboo pith cavity formation.

\section{Douglas-fir seedlings in the Pacific Northwest: the genetics of drought adaptation}

Erda Celer ${ }^{l}$

${ }^{1}$ Republic of Turkey Ministry of Agriculture and Forestry General Directorate of Forestry, Ankara, Turkey (celererda@gmail.com)

Douglas-fir (Pseudotsuga menziesii) is a widely distributed, ecologically important, and commercially valuable tree species in North America. However, climate change is expected to adversely impact Douglas-fir trees, and assisted migration may become necessary to lessen the effects of climate change. Because 
drought stress is one of the projected effects of climate change in the western U.S., it is increasingly important to include drought adaptation traits in breeding programs and in reforestation decisions. In this study, I addressed the following objectives: (1) obtain baseline measurements and climate data to help in the analysis and interpretation of future measurements in the Drought Hardiness Study; (2) characterize the quantitative genetics of drought adaptation traits; and (3) determine whether drought adaptation traits are associated with the climatic origin of Douglas-fir seedlings. To achieve these objectives, data were collected from about 10,000 Douglas-fir seedlings from 429 families from western Oregon and Washington that were planted at two sites (Sprague and Lost Creek) in southern Oregon. Measured variables, which I refer to as drought adaptation traits, included height, second flushing, spring bud flush, damage (foliage, stems, and leaders), and survival. I will discuss the design and results of a study that help increase the understanding about the importance of climatic-driven genetic differences for drought adaptation traits in Douglas-fir. The results of this study will provide useful information for understanding drought, enhancing breeding programs, and potentially adjusting forest management to climate change impacts.

\title{
C2r: PHYSIOLOGY AND GENETICS IN PLANTATION
}

\section{The growing importance of Eucalyptus in forest plantations in Chile / Creciente importancia de eucaliptos en plantaciones forestales} chilenas

Santiago Barros ${ }^{I}$, Roberto Ipinza ${ }^{1}$, Maria Paz Molina ${ }^{1}$, Braulio Gutiérrez ${ }^{l}$, Patricio Rojas ${ }^{1}$, Juan Carlos Pinilla

IInstitutoForestal,Santiago,Chile (sbarros@infor.cl; ripinza@infor.cl; mmolina@infor.cl; bgutier@infor.cl; parojas@infor.cl; jpinilla@infor.cl)

Planted forests in Chile cover 2.4 MMha; 1,4 Pinus radiata, 0,59 Eucalyptus globulus, 0,27 Eucalyptus nitens and 0,16 other species, including other Eucalypts like E. camaldulensis, E. cladocalyx, E. delegatensis, E. regnans, E. sideroxylon and E. viminalis. Pinus radiata was the main species since the middle of the past century, Eucalypt species were gradually included later. Today eucalypts cover over than $860 \mathrm{Mha}$, important resource for forest companies and medium and small forest owners. Chilean Forestry Institute (INFOR) has developed research on Eucalypts since the 60s, introducing and breeding Eucalypt species, developing plantation establishment and management techniques, and starting a genetic improvement programme with main focus on E. globulus an E. nitens and in collaboration with companies and owner associations. Objectives are improving growth, drought or frost tolerance, pulp yield in short turns and solid wood yield in longer turns. Under the climate change scenario challenges seem to be others. Chile's central part, where planted forests are located, face changes like lower medium rainfalls and higher medium temperatures. Changes will involve new threats to planted forests; water scarcity and pest damages, problems that require appropriated genetic material; new species and hybrids. Hybrids and their silviculture, appears as an appropriate way in facing the challenges. INFOR has experience on species introduction and genetic improvement and on hybrids development and management. For instance, E. tereticornis $\mathrm{x} E$. globulus, as drought tolerant material, and E. nitens x E. globulus, as frost tolerant material and tolerance to pests.

\section{Kraft pulp production from Tectona grandis sawing wood waste}

\author{
Marina Coelho ${ }^{I}$, Eduardo Almeida ${ }^{I}$, Caio Almeida ${ }^{I}$, Francides Silva Júnior ${ }^{l}$, Vanderlei Benedetti ${ }^{l}$ \\ 'UniversidadedeSãoPaulo,Piracicaba,Brasil(marina.ulian@usp.br;eduardoleitedealmeida@usp.br;caio.cfalmeida@usp.br;fjr@usp.br;vabenedetti@gmail.com)
}

This work aimed to verify the potential use of 14-year-old Tectona grandis slab wood for kraft pulp production. Tectona grandis wood chips were classified in thickness from 4 to $6 \mathrm{~mm}$ and dried outdoors to be used in the kraft pulp productions. The pulping processes were carried out in rotative digester, with 8 individual reactors, which made it possible to obtain delignification curves by applying distinct alkali charges in each reactor, varying from 20 to $27 \%$ ( $\mathrm{NaOH}$ based); $30 \%$ of sulphidity and 4:1 liquor-to-wood ratio were used. The heating and cooking times were 60 and 240 minutes, respectively, and the maximum temperature applied was $154^{\circ} \mathrm{C}$. The parameters of bulk yield, screened yield, reject content, kappa number and residual alkali charge were analyzed and, later, mathematical models were adjusted by means simple regression in order to estimate the parameters necessary to produce pulp with kappa number 28 . The adjusted mathematical models indicated that, to produce pulp with kappa number 28 from Tectona grandis wood, it is required alkali charge of $25.5 \%$, resulting in screened yield of $46.4 \%$ and residual alkali charge of $23.5 \%$. In conclusion, this preliminary study indicated that it is possible to produce pulp from Tectona grandis slab wood. It is highlighted that there is room to optimize the pulping parameters, especially with regards to higher yields, lower kappa number and residual alkali charge.

Genetic variation for heights in progeny of Eucalyptus tereticornis in Selvíria, Brazil / Variação genética para altura em progênies de Eucalyptus tereticornis em Selviria, Brasil

Daniele Fernanda Zulian ${ }^{l}$, Darlin Ulises González Zaruma², Murilo da Serra Silval, Francieli Alves Caldeira Saul ${ }^{1}$, José Cambuim ${ }^{l}$, Paulo Henrique Müller da Silva ${ }^{3}$, Mario Luiz Teixeira de Moraes ${ }^{1}$, Ananda Virginia Aguiar ${ }^{4}$

${ }^{1}$ Universidade Estadual Paulista "Júlio de Mesquita Filho", Faculdade de Engenharia de Ilha Solteira, Ilha Solteira, Brasil; ${ }^{2}$ Universidade Estadual Paulista "Júlio de Mesquita Filho”, Faculdade de Ciências Agronômicas, Botucatu, Brasil; ${ }^{3}$ Instituto de Pesqu(danizullian@gmail.com; dgzaruma@gmail. com; mserrasilva@yahoo.com.br; francieli_eng.ambiental@yahoo.com.br; josecambuim@yahoo.com.br; paulohenrique@ipef.br; mario.moraes@unesp.br; ananda.aguiar@embrapa.br)

O Eucalyptus tereticornis é uma espécie promissora para regiões tropicais e/ou com déficit hídrico, a espécie apresenta rápido crescimento e madeira apropriada para fins energéticos. Foi avaliado a variabilidade genética em dois testes de progênies de polinização aberta de E. tereticornis, instalados na região do Bolsão Sul-mato-grossense - Brasil. Os testes foram instalados em setembro de 2017, na Fazenda de Ensino, Pesquisa e Extensão (FEPE/Unesp), em Selvíria - MS. Em cada teste, foram utilizadas 87 progênies do Programa Cooperativo de Melhoramento Florestal do IPEF. O delineamento experimental foi em blocos casualizados, uma planta por parcela, com 18 e 6 repetições para o teste 1 e 2, respectivamente. Aos 12 meses de idade foram obtidos dados de sobrevivência e altura, os parâmetros genéticos foram obtidos pelo método da máxima verossimilhança restrita e melhor predição linear não viciada (REML/BLUP). A sobrevivência foi alta em ambos os testes $(>80,0 \%)$, caracterizando uma boa adaptação da espécie na região. Nos dois testes foram obtidas diferenças significativas entre progênies em nível de $1 \%$ de probabilidade pelo teste de qui-quadrado. O coeficiente de herdabilidade em nível de média de progênies foram de 0,62 para o teste 1 e 0,28 para o teste 2 . O coeficiente de variação genética em nível de progênies foram de $8,8 \%$ e $8,4 \%$ para os testes 1 e 2 , respectivamente. A interação entre os testes $(0,095)$ não foi significativa pelo teste de qui-quadrado. Os testes apresentam variação genética para o caráter altura na avaliação precoce. 


\title{
Is it possible to produce forest nursery stock to face droughty periods after transplanting?
}

Barbara Mariotti ${ }^{1}$ (D), Sofia Martini ${ }^{1}$, Sabrina Raddi ${ }^{1}$, Alberto Maltoni ${ }^{1}$, Francesca Ugolini ${ }^{2}$, Juan Oliet ${ }^{3}$, Douglass F. Jacobs ${ }^{4}$, Andrea Tani ${ }^{1}$ ${ }^{1}$ Università di Firenze, Firenze, Italy; ${ }^{2}$ Consiglio Nazionale delle Ricerche, Firenze, Italy; ${ }^{3}$ Universidad Politécnica de Madrid, Madrid, Spain; ${ }^{2}$ Purdue University,West Lafayette,USA (barbara.mariotti@unifi.it, sofia.martini@unifi.it; sabrina.raddi@unifi.it; alberto.maltoni@unifi.it; f.ugolini@ibimet.it; juan.oliet@upm.es; djacobs@purdue.edu; andrea.tani@unifi.it)

Nursery stock with higher tolerance to water stress conditions during the season following transplanting could increase field performance when subjected to seasonally conditions (i.e. Mediterranean climate). This could contribute to the success of forest restoration also in relation to the consequences of climate change. We specifically addressed: (a) the effects of two substrates and three fertilization rates on morphological (root and shoot system) and physiological traits (fluorescence and spectroscopy) after nursery cultivation in three Quercus species (18 combinations); (b) the morphological and physiological response of each nursery stock combination to hydric stress test in greenhouse and in the field after transplant. In $2017, Q$. ilex, $Q$. pubescens, $Q$. robur seedlings were grown in peat and coir (a renewable, sustainable resource). In addition to the nursery-standard fertilization, two other fertilization treatments were tested (enriched in K and in P). In 2018, two parallel performance trials were carried out: a hydric-stress test in controlled conditions (comparing three regimes) and a field planting (central Italy). At the end of nursery cultivation, greater growth, both in shoot and root biomass, was observed in peat-K treatment in all species, followed by the other fertilization treatments within peat substrate. Seedlings in coir showed a general lower development despite a higher shoot/root ratio. Combinations responded differently to the hydric stress test, with generally higher survival and performance for seedlings grown in coir. Results were combined with data collected in the field providing useful information to identify the most promising stock of each species to overcome 'transplant shock' .

\section{In vitro cultivation of Ilex paraguariensis A. St. Hil seeds}

\author{
Maria Cecilia Mireski ${ }^{1}$ (D, Elisa Vieira² (D), Antônio Carlos Nogueira ${ }^{1}$ \\ ${ }^{1}$ Universidade Federal do Paraná, Curitiba, Brasil; ${ }^{2}$ Embrapa Florestas, Colombo, Brasil (mariacecilia.agro@gmail.com, elisa.vieira@embrapa.br, \\ acnogueira.ufpr@gmail.com)
}

Ilex paraguariensis seeds are involved in a wood endocarp and the embryos are immature in the ripe fruits. As a consequence the germination is low even after months of adequate conditions. In vitro cultivation in medium supplemented with growth regulators is an alternative for obtaining seedlings from seeds with poor germination. The aim of this work was evaluate the effect of diferent growth regulators in yerba mate seeds cultivated in culture medium. The medium Murashige e Skoog 1/4 was used and supplemented with 3\% sucrose, 0.6\% phytagel, $4 \mathrm{ml} \mathrm{L}^{-1}$ cercobin; $8 \mathrm{ml} \mathrm{L}^{-1}$ ampicillin and 16 ml L $\mathrm{L}^{-1}$ chloramphenicol.

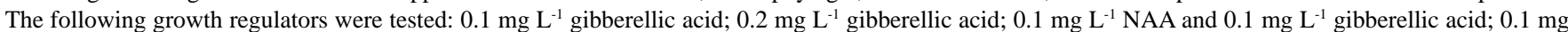
$\mathrm{L}^{-1}$ NAA. For each treatment 60 tubes were used containing one seed cut longitudinally and disinfested with $70 \%$ alcohol; $0.5 \%$ bleach and ultrapure water. The tubes were incubated at $27 \pm$ Celsius degrees with light during 14 hours during 60 days. MS medium supplemented with 0.1 mg $^{-1} \mathrm{NAA}$ and 0.1 mg L ${ }^{-1}$ gibberellic acid was efficient with $7 \%$ of germination. Nonetheless it was not possible obtain normal seedlings once only the hypocotyl developed radicules with atrophy. New studies are necessary to improve the technic for yerba-mate seed propagation.

\section{Genetic variation among half-sib families of Tectona grandis L.f. in Colombia}

Ana M. López ${ }^{1}$, Alonso Barrios ${ }^{1}$, Luis F. Llanos ${ }^{1}$

${ }^{1}$ Universidad del Tolima,Ibagué, Colombia (amlopeza@ut.edu.co; abarriost@ut.edu.co; lflanosm@ut.edu.co)

Teak is a high interest commercial tree species, mainly for its outstanding physical and mechanical wood properties, growth rates and adaptability to different site conditions. Superior genetic stocks of teak are required to contribute to the maximization of production in increasingly short periods of time. A study was carried out to evaluate the genetic variation of growth and tree quality traits among 40 half-sib families from 4 provenances from the Atlantic Coast of Colombia. Traits were measured in a 4-year-old progeny test established with a single-tree-plot arrangement in the interior valleys of the country. Variance components were determined using restricted maximum likelihood to calculate narrow-sense heritabilities and genetic gains considering different selection indices. Genetic correlations among traits were computed using multivariate analysis of variance. Additionally, a ranking of families according to total wood volume per hectare was developed. The analysis showed that all the families had a higher survival rate ranging $73-100 \%$. The genetic gains by selecting $30 \%$ of the best families were estimated in2.93, 4.83, 11.97, 6.53, 4.26 and 14.42\%for diameter, stem volume, total volume per hectare, crown projection area, branch insertion angle and number of basal sprouts, respectively. Total wood volume per hectare showed signifcant positive genetic correlations with diameter (rg $=0.72$ ), stem volume (rg $=0.69)$, crown projection area $(\mathrm{rg}=0.66)$ and stem straightness $(\mathrm{rg}=0.31)$ and a negative correlation with branch diameter $(\mathrm{rg}=-0.21)$. The study identified that the best families proceed from municipalities of Canalete and San Antero, Córdoba.

\section{How does water availability and drought sensitivity impact water use and water use efficiency in three fast growing Eucalyptus plantations?}

Robert Hubbard ${ }^{1}$, Otávio Campoe ${ }^{2}$, Rafaela Carneiro ${ }^{3}$, Marco Aurélio Figura ${ }^{4}$, Gabriela Moreira ${ }^{5}$, Dan Binkley ${ }^{6}$

${ }^{1}$ USDA Forest Service, Fort Collins, CO, USA; ${ }^{2}$ Federal University of Santa Catarina, Santa Catarina, Brasil; ${ }^{3}$ Instituto de Pesquisas e Estudos Florestais, Piracicaba, Brasil; ${ }^{4}$ Klabine, Telemarco Borba, Brasil; ${ }^{5}$ International Paper, Mogi Guacu,Brasil; ${ }^{6} U n$ (rhubbard@fs.fed.us; otavio.campoe@gmail.com; rafaela@ipef.br; marco.figura@klabine.br; gabriela.moreira@internationalpaper.br;dan@cn.colostate.edu)

As climate change continues to drive changes in temperature and precipitation, understanding the trade-offs between wood growth and water use is becoming increasingly important. While a large number of studies have focused on resource use efficiency of stands, less attention has been directed to individual trees. Furthermore, we lack a detailed understanding of how clonal selection and environment impact tree water use in Eucalyptus plantations. Our previous work showed that larger, dominant trees had higher rates of wood growth, water use and water use efficiency (WUE) than smaller trees and this pattern persisted with increased water supply in irrigated plots. Here, we expand on this work and examine total water use and WUE for a drought sensitive and drought tolerant Eucalyptus clone growing at three climatically different sites within the TECHS research platform in Brazil. At each site, we measured WUE for each clone in control and rainfall reduction treatments. We are testing three hypotheses; 1) water use increases with precipitation inputs and is higher in drought sensitive clones, 2) larger trees use more water and have higher WUE than smaller trees and; 3) this pattern with tree size persists across all treatments and sites regardless of drought sensitivity of the clone. Preliminary data indicates mean annual increment (MAI) was higher in control versus rainfall reduction treatments and dominant trees grew faster than dominated trees. Final results for our hypothesis tests will be available in June 2019 when data analyses are completed. 


\section{Reforestation after disturbances in planted Norway spruce stands - influence of silvicultural techniques on seedlings field performance}

Martina Dodan ${ }^{2}$, Sanja Peric ${ }^{2}$

${ }^{2}$ Croatian Forest Research Institute, Jastrebarsko, Croatia (martinat@sumins.hr; sanjap@sumins.hr)

Reforestation after forest decline can be difficult. Selection of silvicultural techniques used during reforestation is crucial for good reforestation outcome, also lowering costs of labour and reproductive material used. Climate change will add to complexity of silvicultural interventions. Present and predicted disturbance regime points to the increase of areas for reforestation in Europe, thus creating the need for update of knowledge on regeneration methods and seedling types used. Newly gained knowledge acts as a background for national forestry and nursery programmes. Study examines area after bark beetles attack and wind throw in planted Norway spruce stand after it was reforestated by seeding and planting of European beech and Silver fir at European beech and Silver fir dominated forest area (placed on the crossroads of Central and Southeast Europe). Analysed data track seedlings field performance (height, basal diameter, quality indices and height increment) during three consecutive years (2010-2013) and again eight year after canopy loss (2017). In addition, we discuss the issues of different silvicultural interventions (direct seeding, planting of different type of seedlings, intensities of canopy loss, site preparation techniques) during reforestation of area after disturbances in hilly and mountain areas. Review includes management and legislative legacy as well as state of the art of contemporary silvicuture related to reforestation practices of Southeast Europe, with Croatia as a case study.

\section{C2s: PHYSIOLOGY AND GENETICS}

\section{Morphological, environmental and genetic attributes of wolf trees' morphological types in Scots pine (Pinus sylvestris L.) \\ Ekaterina Makrickiene ${ }^{1}$, Gediminas Brazaitis ${ }^{1}$, Darius Danusevičius ${ }^{1}$ \\ ${ }^{1}$ Vytautas Magnus University, Kaunas,Lithuania (ekaterina.makrickiene@asu.lt; gediminas.brazaitis@asu.lt; darius.danusevicius@asu.lt)}

Wolf trees are super-dominant trees with wide crowns and thick branches. Usually such trees are undesired in the stand due to their odd morphological characteristics; however, such trees can be valuable as habitat, biomass source or for genetic conservation. In our study we approved the existence of two wolf trees' morphological types in Scots pine (Pinus sylvestris L.). With the use of environmental and progeny analysis, dendrochronological and genetic methods we assessed the wolf trees in Scots pine from several points of view. This allowed us to find out the differences both between the regular trees and wolf trees and between the two wolf trees" morphological types. Both morphological types were genetically different from the regular Scots pine trees, what resulted in significant differences between the two wolf tree morphological types and the regular trees in their responses to soil fertility and mezorelief. Comparing the annual increments of wolf trees and regular trees, we could observe faster growth of the wolf trees up to the age of 35 years. Sensitivity to the climatic factors strongly depended on the wolf tree morphological type. The second morphological type exhibited a stronger response to precipitation, while the control trees and the first wolf tree morphological type had stronger responses to temperature. Progeny analysis showed that as early as the first year of growth, the wolf tree progenies had longer branches and a higher branch number, while the progenies of the regular trees had bigger height increment.

\section{Research of morphologic features of up to 10-year-old pedunculate oak (Quercus robur l.) in the provenance test in Žepče, Bosnia and Herzegovina}

Mirzeta Memišević ${ }^{1}$, Dalibor Ballian ${ }^{1,2}$, Hojka Kraigher $^{2}$

${ }^{1}$ Forest Faculty University of Sarajevo, Sarajevo, Bosnia and Herzegovina; ${ }^{2}$ Slovenian Forest Institute, 1000 Ljubljana, Slovenia (mirzeta.mh@sfsa.unsa.ba; balliandalibor9@gmail.com; hojka.kraigher@gozdis.si)

Even though remaining populations of pedunculate oak in Bosnia and Herzegovina are small and scattered, their specific genetic structure makes them significant for preserving varieties of pedunculate oak (Quercus robur L.) in Bosnia and Herzegovina and Europe. This was the reason for establishing Bosnia and Herzegovina pedunculate oak provenance test in Žepče in 2009. The test material was used in this research. The test includes 28 provenances. The aim of the research is to use morphologic features of height and root collar diameter of plants to determine variability of the remaining pedunculate oak populations in Bosnia and Herzegovina. Average height of one-year-old plants (2009) in all provenances amounts to $36.41 \mathrm{~cm}$, and average root collar diameter to $5.66 \mathrm{~mm}$, while average height of ten-year-old plants reaches $260.0 \mathrm{~cm}$, and average root collar diameter amounts to $67.7 \mathrm{~mm}$. Jelah provenance stood out from the beginning with the above average height of its plants - 30\% above total average of all provenances and $25 \%$ bigger average root collar diameter compared to total average size in other provenances. After the plants were eight years old, the lowest average height was recorded in Visoko Muhašinovići provenance - $20 \%$ lower height compared to total average, $24 \%$ smaller diameter in comparison with the total average. The variance analysis has shown statistically significant differences between populations in all tested features, which has been confirmed by Duncan test.

\section{Phenology of Pentaclethra macroloba (Willd.) Kuntze (Fabaceae): hyperdominant tree of the Amazonian estuary}

Adelson Rocha Dantas ${ }^{1}$, Maria Teresa Fernandez Piedade ${ }^{1}$, Marcelino Carneiro Guedes ${ }^{2}$, Ana Claudia Lira-Guedes ${ }^{2}$

${ }^{1}$ Instituto Nacional de Pesquisas da Amazônia, Manaus, Brasil; ${ }^{2}$ Programa de Pós-Graduação em Ecologia, Manaus, Brasil; ${ }^{2}$ Embrapa, Macapá, Brasil (adelson.dantas@yahoo.com.br;maua.manaus@gmail.com; marcelino.guedes@embrapa.br; ana-lira.guedes@embrapa.br)

Pentaclethra macroloba (pracaxizeiro) is a hyperdominant species of the Amazon estuary floodplain. The oil extracted from its seeds has medicinal properties. The effect of the polymodal flood cycle on the phenology of tree, including the pracaxizeiro, from Amazonian estuary is little known. The hypothesis that the flood pulse is the main factor that directs the phenological processes of the pracaxizeiro was tested. Reproductive and vegetative phenophases of 30 pracaxizeiro were monitored fortnight from September/2017 to September/2018, in the Environmental Protection Area of Fazendinha, Macapá, Brazil. Phenophases were correlated with maximum temperature $\left({ }^{\circ} \mathrm{C}\right)$, precipitation $(\mathrm{mm})$ and flood level $(\mathrm{cm})$, using the Spearman correlation. There was positive correlation with temperature between flower buds $(\mathrm{rs}=0.57)$ and flowers in anthesis $(\mathrm{rs}=0.63)$, already with precipitation $($ buds: $\mathrm{rs}=$ -0.50 , anthesis: $r s=-0.53$ ) and floods (buds: $r s=-0.65$, anthesis: $r s=-0.69)$ correlations were negative. The correlation was positive between immature fruit with temperature $(\mathrm{rs}=0.73)$ and negative with precipitation $(\mathrm{rs}=-0.64)$ and flood $(\mathrm{rs}=-0.57)$. Fruit ripening (rainfall: $\mathrm{rs}=0.38$, flood: $\mathrm{rs}=0.50)$ and $\mathrm{seed}$ dispersal (rainfall: $\mathrm{rs}=0.76$, flood: $\mathrm{rs}=0.81$ ) occur in the rainy season and peak flood Amazon river. Leaf production and fall have low correlation with the abiotic variables tested. Flourish in the dry season prevents loss of floral resources due to torrential rains of the Amazon and maximizes pollination by insects. The flood pulse, together with precipitation, acts as a trigger in fruit ripening and seed dispersal. 


\title{
Difference in leaf $\delta 15 \mathrm{~N}$ among tree species with different type of microbial symbiosis in subtropical, warm-temperate and cool- temperate forests
}

\author{
Shin Ugawa ${ }^{1}$, Yoshiyuki Inagaki², Karibu Fukuzawa ${ }^{3}$, Keisuke Koba ${ }^{4}$, Ryunosuke Tateno ${ }^{5}$,Erik Hobbie 6 \\ ${ }^{1}$ Faculty of Agriculture, Kagoshima University, Kagoshima, Japan; ${ }^{2}$ Shikoku Research Center, Forestry and Forest Products Research Institute, Kochi, Japan; \\ ${ }^{3}$ Field Science Center for Northern Biosphere, Hokkaido University, Sapporo, Japan; ${ }^{4}$ Center for Ecolo (ushin@agri.kagoshima-u.ac.jp; \\ yinagaki@affrc.go.jp; caribu@fsc.hokudai.ac.jp; keikoba@ecology.kyoto-u.ac.jp; rtateno@kais.kyoto-u.ac.jp; erik.hobbie@unh.edu)
}

Nutrient acquisition strategies of tree species determine their competitive ability under different nutrient regimes. The process for absorbing soil nitrogen ( $\mathrm{N}$ ) can be estimated by the $\mathrm{N}$ stable isotope ratio of leaves $(15 \mathrm{~N}: 14 \mathrm{~N}$, expressed as $\delta 15 \mathrm{~N})$, which is determined by different $\mathrm{N}$ sources and isotope fractionation in the absorption process. In this study, we examined leaf $\delta 15 \mathrm{~N}$ of 23 tree species which grew in four forests of the subtropical, warm-temperate and cool temperate zones to understand the absorption process of tree species with different types of microbial symbiosis, i.e., ectomycorrhizal (ECM), arbuscular mycorrhizal (AM) and root nodule bacteria (RNB). In contrast to global patterns, where ECM plants averaged $1 \%$ lower than AM plants, leaf $\delta 15 \mathrm{~N}$ of tree species forming ECM symbioses averaged 1.7\% higher than those forming AM symbioses. Plants with N-fixing symbioses were $0.9 \%$ higher than plants with ECM symbioses. However, genus-level variability within AM plants was greater than variability among other plant symbioses. The leaf $\delta 15 \mathrm{~N}$ of these species may be influenced more strongly by the $\mathrm{N}$ form acquired or the depth of $\mathrm{N}$ acquisition than by $15 \mathrm{~N}$ fractionation by ECM fungi. The leaf $\delta 15 \mathrm{~N}$ of tree species associated with RNB was closer to zero than other species, but negative. We thus suggest that leaf $\delta 15 \mathrm{~N}$ of tree species with RNB was determined mainly by nitrogen fixation although it may reflect the isotope fractionation by RNB.

\section{Studies on salt-tolerence of Halophyte Nitraria L.}

Xiuyan Yang ${ }^{1}$, Huanyong Li $^{1}$, Xiaoqian Tang ${ }^{1}$, Ping Huang ${ }^{1}$

${ }^{1}$ Chinese Academy of Frestry, Beijing, China (sueyxy@126.com; huanyong0913@sina.com; txqcaf@163.com; huangping@caf.ac.cn)

Genus Nitraria (about 12 species) are tertiary relict and widespread from Africa, Asia, Europe and Australia. Some 5 species as the primary constructive species distribute in deserts region in northwest of China. As typical halophytes, Nitraria have remarkable salt tolerance. In this report, some of our research results were showed: (1) The uptake and accumulation of $\mathrm{Na}^{+}$and $\mathrm{Cl}^{-}$in roots, stems and leaves tended to increase in $N$. tangutorum with the $\mathrm{NaCl}$ stress with the $\mathrm{K}^{+}$ uptake enhanced and the $\mathrm{Ca}^{2+}$ uptake decreased. The abilities of ion selective absorption-transportation of $N$. tangutorum were important for maintaining ion homeostasis in leaves under salt stress. (2) $\mathrm{Na}^{+}$efflux in $N$. sibirica seedlings increased due to increased plasma membrane $\mathrm{H}^{+}$-ATPase and $\mathrm{Na}^{+} / \mathrm{H}^{+}$antiporter activity under salt stress. High $\mathrm{H}^{+}$pump activity restricts the $\mathrm{Na}^{+}$influx through NSCC sandlimits $\mathrm{K}+$ leakage through outward-rectifying $\mathrm{K}+$ channels and NSCCs. (3) Under $\mathrm{NaCl}$ concentration of $8 \%$ for 40 days, the contents of photosynthetic pigments trended to decrease in N. Sibirica and N. tangutorum. The Pn of $N$. tangutorum was lower and N. sibirica was higher than that of the control when the PAR reached about $1000 \mu \mathrm{mol}^{\circ} \mathrm{m}^{-2} \bullet \mathrm{s}^{-1}$. The activities of Rubisco, PEPC, Ciand Gs decreased in N. tangutorum leaves, while Ls increased. The PEPC activity of $N$. sibirica leaves decreased but Rubisco activity, Ciand Gs increased. The $\delta 13 \mathrm{C}$ value increased in 2 species under the $\mathrm{NaCl}$ stress. Salt stress led to the decrease of Rd and LCP for 2 species.

\section{Willow breeding for diversified and sustainable applications in Argentina}

\section{Teresa Cerrillo ${ }^{1}$, Sabrina Loval ${ }^{1}$,Edgardo Casaubón ${ }^{1}$,Esteban Thomas ${ }^{2}$, Jorgelina Grande $^{3}$, Silvia Monteoliva ${ }^{4}$}

${ }^{1}$ INTA, Campana, Argentina; ${ }^{2}$ INTA, Allen, Argentina; ${ }^{2}$ Papel Prensa SA, San Pedro, Argentina; ${ }^{4}$ CONICET, La Plata, Argentina; ${ }^{5}$ Universidad de La Plata, La Plata,Argentina (cerrillo.teresa@inta.gob.ar; loval.sabrina@inta.gob.ar; casaubon.edgardo@inta.gob.ar; thomas.esteban@inta.gob.ar;

jgrande@papelprensa-sp.com.ar; monteoliva@yahoo.com.ar)

Willow plantations (Salix spp) in Argentina are located mainly in Delta of Paraná River and, in a smaller scale, in Northern Patagonia. The old stands are planted with traditional clones, which have low volumetric yield and limited wood quality for paper and sawing industries. In a global context characterized by climate change and by new needs of society and markets, it is essential to improve and adapt clonal availability. Considering these premises, INTA is developing a breeding program. First, more focused on the improvement to achieve clones with high wood production performance; later, the program has been adding objectives that also include other applications (wood and non-wood products). INTA's breeding program, through hybridizations and selection in sequential phases, focuses on obtaining fast growing genotypes, adapted to environmental conditions and suitable for diversified applications. In recent years, seven clones (originated in Salix matsudana x Salix alba; Salix matsudana x Salix nigra, and from open pollination on Salix alba, Salix matsudana and Salix nigra) have been released. They show an average volume $45 \%$ better than the average of the oldest commercial clones and are suitable for sawing and elaboration of paper pulp for newspapers. The five clones selected for pulp-paper showed good standards also for packing paper. In addition, other seven experimental clones are promising for these integrated applications, including biomass production, silvopastoral systems and experiences in quarries gravel restoration and phytoremediation.

\section{Breeding and clonal selection for basket-making, a strategic activity for smallholders}

Teresa Cerrillo ${ }^{1}$, Sabrina Loval ${ }^{1}$, Mauro Fernández ${ }^{2}$, Victorio Dieta ${ }^{2}$

${ }^{1} I N T A$, Campana, Argentina; ${ }^{1} I N T A$, Campana, Argentina; ${ }^{2} I N T A$, Tigre, Argentina; ${ }^{2} I N T A$, Tigre, Argentina (cerrillo.teresa@inta.gob.ar; loval.sabrina@inta.gob.ar;fernandez.mauro@inta.gob.ar;dieta.victorio@inta.gob.ar)

Some species of shrubby willows (Salix spp) have suitable for basket-making, after applying specific treatment techniques and industrialization methods. In Argentina, these plantations are located in the central-east of the country, with excellent soil and climatic conditions for willow growth. Shrub willows cultivation for basket-making take its biggest expansion in Delta del Paraná between 1930 and 1950 and today represents a strategic activity for smallholders. This small-scale activity provides a sustainable tool to improve the life quality of the families settled in this wetland region. With the aim to obtain a broader and improved offer of clones, INTA is developing a classical breeding program since 2012, by means of controlled crossings and sequential selection phases. After a first selection in 2015, over a seedling bank (originally composed of 200 individuals), 20 pre-selected genotypes were established in a clonal bank and measured between 2016 and 2018. Total plant height, morphological and phenologycal variables and diseases susceptibility were registered. After that, network of trials was established in six experimental field plots to evaluate the response in different site conditions. Final evaluations showed a group of seven pre-selected genotypes with higher growth and outstanding performance in the other variables, including aptitude to elaborate baskets. These genotypes belong to intraspecific crossings of: Salix viminalis and interspecific: Salix viminalis x Salix caprea. It's expected that these preselected clones will be able to provide, in the short term, a new tool to improve the human well-being and social equity of these smallholders in the territory. 


\section{Population structure of Pentaclethra macroloba (Willd.) Kuntze in high and low floodplains of the Amazonian estuary}

Adelson Rocha Dantas ${ }^{1}$, Maria Teresa Fernandez Piedade ${ }^{1}$, Marcelino Carneiro Guedes ${ }^{2}$, Ana Claudia Lira-Guedes ${ }^{2}$

${ }^{1}$ Instituto Nacional de Pesquisas da Amazônia, Manaus, Brasil; ' 2 Programa de Pós-Graduação em Ecologia, Manaus, Brasil; '2Embrapa Amapá, Macapá,

Brasil(adelson.dantas@yahoo.com.br; maua.manaus@gmail.com; marcelino.guedes@embrapa.br; ana-lira.guedes@embrapa.br)

The flood cycle of floodplain forests and topographic variations are important factors of diversification and morphological and ecophysiological adaptations of the plant community. Pentaclethra macroloba is a hyperdominant species adapted to flood variations. The objective of this study was to characterize the $P$. macroloba population structure between environments with high topography, flooded only during the rainy season and peak flood of the river, (high várzea-HV) and low topography with daily flood (low várzea-LV). The study was carried in the Mazagão Experimental Field, Brazil. Four plots of 1 ha were installed in each environment. All individuals with $\mathrm{DBH} \geq 5 \mathrm{~cm}$ were measured and georeferenced. ANOVA test, $0.05 \%$ probability, was applied to verify the structural differences between two environments. The HV had higher population density (51.2 individuals.ha-1) compared to the LV (36.7 individuals.ha-1), although without significance. Basal area was higher in the HV $\left(10.42 \mathrm{~m}^{2}\right)$ in comparison with LV $\left(5.90 \mathrm{~m}^{2}\right)$, with significant difference $(\mathrm{F}=7.13$, $\mathrm{p}=0.00795)$. The maximum DAP of HV was $67 \mathrm{~cm}$ with mean of $24 \mathrm{~cm}$. The LV presented maximum DBH of $42 \mathrm{~cm}$ with mean of $21 \mathrm{~cm}$, showing structural difference between the two environments $(F=6.22, p=0.0131)$. The aggregation index showed high aggregation in the $L V(R=0.89)$ than in the HV ( $R=0.79)$, differing significantly between the two environments $(\mathrm{F}=11.31, \mathrm{p}=0.0008)$. Frequency and time of flooding are ecological drives that structure the population of pracaxizeiro causing morphological and ecophysiological adaptations to the individual.

\section{C2t: PHYSIOLOGY AND GENETICS}

\section{Environmental interactions and marker assisted selection in a changing world}

Luciano Medina-Macedo ${ }^{\text {(D), Jacqueline Grima Pettenati }}$ (D), Ana Clara Oliveira Ferraz Barbosa ${ }^{2}$ (D), Juliana Vitoria Messias Bittencourt (D), Ludmila Ferreira Bandeira ${ }^{4}$ (D), Alexandre Siqueira Guedes Coelho ${ }^{4}$ (D)

${ }^{1}$ LRSV - Laboratoire de Recherche en Sciences Végétales, Toulouse, France; ${ }^{2}$ Instituto Florestal Goiano, Urutai, Brasil; ${ }^{3}$ Universidade Tecnológica Federal do Paraná, Ponta Grossa, Brasil; ${ }^{4}$ Universidade Federal de Goiás, Goiânia, Brasil (medina.ppgebb@gmail.com; grima@lrsv.ups-tlse.fr; bioaco@gmail. com; julianavitoria@utfpr.edu.br; ludmilafb@gmail.com; asgcoelho@gmail.com)

There is evidence that climatic changes can influence genetic interactions among traits as well as the genetic variance themselves. Genetic correlations can shift when populations encounter different environmental conditions, reflecting the fact that genes influencing a trait in one environment may not be important in a different one. Thus, is necessary to understand the forces driving the adaptive ability of forest species. Starting from 300 SSR primers, one hundred without segregation distortion were select to build a genetic map to QTL mapping in a double-hybrid Eucalyptus progeny composed by 200 individuals (select hybrid among E. dunnii and E. grandis x E. globulus). Genetic data, as well as growth and wood properties assessed by NIRS, were gathered in Brazil at field trials located in Minas Gerais and Rio Grande do Sul provinces. An integrated genetic map with 11 linkage groups was built, covering approximately $90 \%$ of Eucalyptus genome in a total length of $1420 \mathrm{cM}$. Applying $99 \%$ confidence, a total of seven QTL were associated to growth (diameter, height and to volume), in addition to another twelve QTL related to wood properties (three to density; four to cellulose yielding; three to lignin content; and two QTL to relation siringil/ guaiacil). Among these QTL, one QTL related to lignin content and another to cellulose content displayed interactions among environments. These results allow the adoption of breeding strategies as Marker Assisted Selection, taking into account the alleles according to the location and ensuring operational solutions to better adapt forests to climate changes.

Genetic variability among genotypes of paricá (Schizolobium parahyba var. amazonicum) with regard to initial growth in Sinop, Mato Grosso, Brazil / Variabilidade genética entre genótipos de paricá (Schizolobium parahyba var. amazonicum) quanto ao crescimento inicial em Sinop - Mato Grosso

Aisy Botega Baldoni ${ }^{1}$, Flávio Dessaune Tardin ${ }^{1}$, Andreia Alves Botin ${ }^{2}$, Jairo Alex de Barros Marques ${ }^{3}$, Fábio Linsbinski de Oliveira ${ }^{3}$, Adailthon Jourdan Rodrigues Silva ${ }^{3}$, Bruno Spiering ${ }^{3}$, Denise Caragnato Parisotto ${ }^{4}$, Leonarda Grillo Neves ${ }^{4}$

${ }^{1}$ Embrapa Agrossilvipastoril, Sinop, Brasil,; ${ }^{2}$ Universidade Federal do Mato Grosso, Cuiabá, Brasil; ${ }^{4}$ Universidade do Estado de Mato Grosso , Cáceres, Brasil(aisy.baldoni@embrapa.br; flavio.tardin@embrapa.br; andreia.botin@yahoo.com.br;jairo_alex@hotmail.com; fabiolinsbinski@hotmail.com; adailthonrodrigues@gmail.com; bruno_spiering@hotmail.com; dcparisotto@gmail.com; leonardaneves@unemat.br)

O paricá (Schizolobium parahyba var. amazonicum) é uma espécie nativa da Amazônia, de rápido crescimento e vem ganhando espaço no cenário nacional dentre as culturas florestais plantadas. Para um plantio bem-sucedido são necessárias plantas de boa qualidade e que apresentem desenvolvimento uniforme. O melhoramento genético pode contribuir para a seleção de genótipos superiores, que manifestem as características desejáveis para a cadeia produtiva, estimulando o plantio. Neste contexto, o objetivo foi avaliar a existência de variabilidade genética entre 58 genótipos e possibilidade de seleção de matrizes superiores, por meio da avaliação do crescimento inicial médio de suas progênies. Para tanto, as progênies foram plantadas na área experimental da Embrapa Agrossilvipastoril, no município de Sinop-MT, num delineamento experimental de blocos casualizados, com 4 repetições e 5 plantas por parcela, nas quais foram mensurados o diâmetro do coleto $(\mathrm{mm})$, altura $(\mathrm{m})$ e número de folhas, 6 meses após o plantio. Os dados coletados foram submetidos a análise de variância, considerando, para cada parcela, a média das cinco plantas. Posteriormente, foi obtida a matriz de distâncias entre genótipos proposta por Mahalanobis e agrupamento dos genótipos pelo método de otimização de Tocher. Os resultados da análise de variância demonstraram diferenças significativas entre genótipos $(\mathrm{P}<0,05)$ para todas as características avaliadas. Pela matriz de distâncias, os genótipos 12 e 42 foram os mais similares e os genótipos 44 e 50 os mais divergentes. Nove grupos de médias foram formados pelo método de Tocher, demonstrando variabilidade genética e possibilidade de seleção de matrizes promissoras para a região.

\section{Simulating environmental changes to evaluate the frost resilience of Eucalyptus clones}

Luciano Medina-Macedo ${ }^{1}$ (D, Jacqueline Grima Pettenati ${ }^{1}$ (D, Francisco de Assis Bibeiro ${ }^{2}$, Juliana Vitoria Messias Bittencourt ${ }^{3}$ (D, Rosana Clara Victoria Higa $a^{4}$, Antonio Rioyei Higa ${ }^{5}$

${ }^{1}$ Laboratoire de Recherche en Sciences Végétales, LRSV, Toulouse, France; ${ }^{2}$ Ciliar Mudas, Conchal, Brasil; ${ }^{3}$ Universidade Tecnologica Federal do Paraná, Ponta Grossa, Brasil; ; ${ }^{4}$ mbrapa Florestas, Colombo, Brasil; ${ }^{5}$ Universidade Federal do Paraná, Curitiba, Brasil (medina.ppgebb@gmail.com, grima@lrsv.ups-tlse.fr,francisco@ciliarmudas.com.br; julianavitoria@utfpr.edu.br, rosana.higa@embrapa.br; higa@ufpr.br)

The evolving climate is a significant driver of change, reducing forest health and productivity. In spite the Brazilian Forestry be the worldwide leader on Eucalyptus cellulose production and yield, this sector had strong economic losses with low-temperature events at every 20 years since the 1970 s. To guarantee 
the sustainability of forest production systems under rapid climate change, this study aims to evaluate selected clones to frost survival using chambers with controlled environmental conditions, simulating the Brazilian frost events. The frost damage was estimated to one hundred Eucalyptus clones through evaluation of leaves hurt. Before the frozen, the seedlings were acclimated during 24 hours without, to later be submitted to artificial frozen, where the local temperature decreases as of $-1{ }^{\circ} \mathrm{C}$ unto $-5^{\circ} \mathrm{C}$. The results pointed $E$. grandis as the most susceptible species, followed by hybrids and clones from $E$. viminalis, E. dunnii and E. banjensis. At $-5{ }^{\circ} \mathrm{C}$ only clones from $E$. dunnii and E. banjensis species were resistant. Moreover, at $-1{ }^{\circ} \mathrm{C}$ nine hybrids were better than $E$. viminalis clones. The ANOVA claims the existence of high genetic structure related to low-temperature resilience, with heritability around $50 \%$ and an environmental coefficient near to $14 \%$. The average frost resilience of fifteen best-scored clones was $25 \%$ higher than other ones. Therefore, the controlled environmental chambers are useful to evaluate the resilience of forest species to environmental changes scenarios, allowing the adoption of operational solutions to prepare the forest-based sector to the climatic changes.

Analysis of substrates for transplanting native seedling species cultivated in vitro / Análise de substratos para transplantio de mudas nativas cultivadas in vitro

Fabio Silva ${ }^{1}$, Giovani Silva ${ }^{1}$, Nadine Desene ${ }^{1}$, Natasha Lima $^{1}$, Bruno Castilho $^{1}$, Berenice Silval iD

${ }^{1}$ Universidade Federal do Acre, Rio Branco,Brasil (italofabio2011@gmail.com; silva.sgiovani@gmail.com;nadinezuncke@gmail.com; natashalimadas16@) gmail.com; bruno-rnc@hotmail.com; bereniceka@gmail.com)

Dentre os métodos de conservação de florestas nativas, a estratégia ex situ tem sido utilizada de forma complementar às estratégias in situ e on farm, auxiliando na minimização das potenciais perdas de diversidade genética causadas pelos impactos do desmatamento e das mudanças climáticas. Um dos métodos de conservação ex situ é a micropropagação que visa a produção de grandes quantidades de mudas a partir de uma única célula ou tecido vegetal. Para integrar pesquisa e ensino, no presente trabalho, alunos da disciplina de biotecnologia florestal realizaram um experimento de propagação de mudas a partir de plantas nativas da flora brasileira cultivadas in vitro: Euterpe precatoria (açaí-solteiro); Ananas comosus (abacaxizeiro) e Guadua chacoensis (bambu). Após a micropropagação, foram testados dois tipos de substratos para a avaliação da sensibilidade/tolerância ao transplantio: 1) substrato comercial (uma mistura 1:1 de casca de coco e húmus de minhoca) e 2) solo argiloso. Copos de plástico transparentes de $300 \mathrm{~mL}$ foram preenchidos com os diferentes substratos sendo realizadas duas repetições por tratamento. O substrato e o solo foram encharcados com água $(25-50 \mathrm{~mL})$ para o transplantio e estes foram cobertos com o mesmo tipo de copo transparente para simular o ambiente in vitro facilitando a aclimatação das mudas. Após 6 dias, foram observados o índice de pegamento que resultou em $100 \%$ constatando-se que não houve diferença entre os substratos.

\section{Effect of diffent methods of pretreatment for dormancy breaking for higher germination of Leucaena leucacephala Seeds}

Stephen Ndung' $u^{1}$, Nancy Mugo ${ }^{2}$

${ }^{1}$ Kenya Forestry Research Institute, Nairobi, Kenya; ${ }^{2}$ Egerton University, Nakuru, Kenya (stephenmn06@gmail.com; nancymugo65@gmail.com)

The main objective of this study was to determine the effect of different seed dormancy breaking methods and best exposure time regime of leucaena leucocephala seeds for mass multiplication. Tree seeds of Leucaena leucocephala were sourced from Kenya Forestry Seed Centre stored and subjected to different pretreatment methods ranging from soaking in sulphic acid at different concentration and time, soaking in hot water at different temperature and time, soaking in cold time and service scarification. Higher germination of $96 \%$ was shown by seeds soaked in hot water at $1000{ }^{\circ} \mathrm{C}$ for 24 hours followed by those soaked at $100 \%$ concentrated sulphic acid for $3 \mathrm{hrs}$, scarification and cold water in that order for 15 days. Germination percentage declined with increase of both sulphic acid concentration and soaking time at different constant concentration ranging from $50 \%$ to $100 \%$. Equally germination percentage declined with decrease of both water temperature and soaking time at different constant temperature ranging from $1000{ }^{\circ} \mathrm{C}$ to $500{ }^{\circ} \mathrm{C}$. The results obtained will be applied in mass germination for mass seedlings production with inform germination at shorter period for increased fodder production.

Effect of indolebutyric acid in treating cuttings of Bambusa vulgaris Schrad. ex J.C.Wendl. / Efeitos do ácido indolbutírico no tratamento de Estacas de Bambusa vulgaris Schrad. Ex J.C.Wendl.

Adalberto Novaes ${ }^{1}$, Débora Benedito ${ }^{1}$, Kemele Coelho ${ }^{1}$, Carlos Sanquetta ${ }^{2}$

${ }^{1}$ Universidade Estadual do Sudoeste da Bahia, Vitória da Conquista, Brasil; ${ }^{2}$ Universidade Federal do Paraná, Curitiba, Brasil (adalberto.brito@globo.com; debora_defensor@outlook.com; kemelecristina@hotmail.com;carlos_sanquetta@hotmail.com)

A presente pesquisa objetivou-se avaliar os efeitos do Ácido Indolbutírico (AIB) em diferentes concentrações na emissão de brotações, comprimento de ramos e enraizamento de estacas de Bambusa vulgaris Schrad. ex J.C.Wendl. O experimento foi conduzido em casa de vegetação na Universidade Estadual do Sudoeste da Bahia-UESB, no município de Vitória da Conquista-BA, Brasil. Para a instalação do experimento, as estacas foram imersas por 10 segundos em solução com ácido indolbutírico (AIB), diluído com hidróxido de sódio em quatro concentrações (0, 1.000, 2.000, e 3.000 mg. $\left.\mathrm{L}^{-1}\right)$ correspondentes aos quatro tratamentos. Usou-se quatro repetições e 10 estacas em cada amostra. As estacas, após tratadas com as respectivas soluções, foram transplantadas para tubetes com capacidade volumétrica de $288 \mathrm{~cm}^{3}$, já preenchidos com o substrato e na posição vertical com o nó basal na profundidade de 5,0 cm. Avaliou-se: a) número de brotações; b) número e comprimento de ramos; c) área foliar; e d) número de raízes. Entre as concentrações de AIB, os efeitos foram similares para número e comprimento de ramos, todavia, para as demais variáveis o AIB usado na concentração $1000 \mathrm{mg}$. $\mathrm{L}^{-1}$ exerceu efeitos positivos, destacando-se o aumento do número de raízes quatro vezes maior, quando comparado com a concentração Controle, demonstrando portanto, a sua eficiência no enraizamento de estacas dessa espécie.

\section{Beyond restoration success: searching for long term economical sustainability of successional biodiversity-rich agroforestry at the tropical Atlantic rainforest dominion, Brazil}

Carlos Eduardo Sicole Seoane 1 , Luis Claudio Maranhao Froufe, Ocimar Bim², Ronivaldo Moura ${ }^{3}$, Artur Lima ${ }^{3}$, Marcelo Francia Arco-Verde 1 , Evaldo Muñoz Braz', Antônio Nascim Kalil Filho', Raul cezar ${ }^{4}$, Sebastian Rech ${ }^{5}$, Pedro Rossi ${ }^{4}$, Jaqueline Cremonese ${ }^{4}$, Pietro Graff

${ }^{1}$ Embrapa Florestas, Colombo, Brasil; ${ }^{2}$ Instituto Florestal de São Paulo, Registro, Brasil; ${ }^{3}$ Cooperafloresta, Barra do Turvo, Brasil; ${ }^{1}$ Embrapa Florestas, Colombo, Brasil; ${ }^{4}$ Universidade Federal do Paraná, Curitiba, Brasil; ${ }^{5}$ Pontificia Universidade Católica (eduardo.seoane@embrapa.br; luis.froufe@ embrapa.br; ocimarbim@gmail.com; lima.adalton@gmail.com; lima.adalton@gmail.com; marcelo.arco-verde@embrapa.br; evaldo.braz@embrapa.br; antonio.kalil@embrapa.br; raulmatiascezar@yahho.com.br; sebjpv@gmail.com; rossipedrop@gmail.com;jaque.tila@gmail.com;pietrograff77@gmail.com)

On going and past researches demonstrates the positive environmental and social changes brought by agroforest practices adoption and maintenance by peasants at the tropical Atlantic rainforest dominion of the vale do Ribeira region, Brazil. During the succession process at agroflorestas plots, short-lived species are 
gradually replaced by long-lived species, aiming to provide continuous food production and to ultimately become a multilayer food production forest system. But one noticeable fact is that once the agroforest plots reaches a forest structure, they do not yield enough marketable products and are cut down or abandoned. This is due to the lack of adequate planning for the latter phases of succession, which is a consequence of planning emphasis on diversity richness and ecological niche filling paradigms. One other aspect on question is that the labor necessary to execute the ongoing management plan is much greater than the labor that the peasants are able or willing to spend. There are some possible alternatives to generate income from the later succession phases of agroforestry, such as agroecoturism structuring, simplification of agroforest design and a shift to productive chains and market analysis paradigms. Our research efforts aims to find and implement mature agroforest planning and management based on focal species that yield an already market consolidated and valuable product, have a relatively low labor demand and establishes viable populations with no need of further reintroduction. Many of the peasants are reluctant to accept the necessary paradigm change, but there are others that are joining us on this effort.

\section{Chemical changes in a series of consecutive rhizome of Gigantochloa scortechinii in relation with hydraulic conductance}

Hazandy Abdul Hamid ${ }^{1,2}$, Johar Mohamed ${ }^{1}$, Ahmad Ainuddin Nuruddin ${ }^{1}$

${ }^{1}$ Institute of Tropical Forestry and Forest Products, Serdang, Malaysia; ${ }^{2}$ Faculty of Forestry, Serdang, Malaysia (hazandy@upm.edu.my; joe5587_forr@yahoo.com; ainuddin@upm.edu.my)

The aim of this study was to 1) determine the variation of chemical attributes among study sites, 2) define the chemical attributes changes during maturation period of rhizome, and 3) investigate is there any relationship of chemical attributes with hydraulic conductance (Kbg). Bamboo rhizome is important as for storage, translocation and reproduction system. This translocation function is hypothesized to significantly affect by the chemical attributes changes during maturation period of rhizome. Therefore there is an interest to investigate the variation of chemical attributes in a consecutivebamboo rhizome ages. The destructive sampling method was conducted using selective random sampling method on four consecutive rhizomes from healthy Gigantochloa scortechinii clumps. Sampling was conducted at two natural forests and one secondary forest (planted). The chemical attributes were examined according to TAPPI standard method except for the holocellulose. Results indicate that the ash content (AC), alcohol-acetone soluble (AAS) and holocellulose (HC) were significant different $(\mathrm{p}<0.01)$ among study sites. Furthermore, AC, hot water soluble (HWS), AAS, lignin (L), and HC were found significantly different ( $\mathrm{p}<0.01)$ with a strong relationship $(\mathrm{r}=-0.823,0.688,0.986,0.945,0.510$ respectively) with rhizome age. The AC showed a significant $(\mathrm{p}<0.01)$ positive relationship $(\mathrm{r}=0.747)$ with $\mathrm{Kbg}$ which depicted that the decreasing of AC in increasing of rhizome age resulted to decreasing of Kbg, but, HWS, AAS, L, and HC showed a significant $(\mathrm{p}<0.01)$ negative relationship $(\mathrm{r}=-0.706,-0.914,-0.857,-0.567$ respectively) with Kbg which depicted that the increasing of those chemical attributes in increasing of rhizome age resulted to decreasing of Kbg.

C3b: DIGITAL TRANSFORMATION IN WOOD INDUSTRY

\section{X-ray determination of moisture content in wood biofuel assortments for bioenergy plant process control}

Henning Horn ${ }^{1}$, Janka Dibdiakova², Nils Lindström ${ }^{3}$

${ }^{1}$ Norwegian Institute of Wood Technology, Oslo, Norway; ${ }^{2}$ Norwegian Institute of Bioeconomy Research (NIBIO), As, Norway; ${ }^{3}$ Mantex AB, Kista, Sweden (henning.horn@treteknisk.no; janka.dibdiakova@nibio.no;nils.lindstrom@mantex.se)

An X-ray measurement method for simultaneous determination of moisture- and ash content, and heating value has been demonstrated at a Norwegian sawmill on a mixture of spruce bark and dry chips. The method is based on combining X-ray transmission imaging and X-ray fluorescence spectroscopy. Bark is normally used to fuel the heat production within the sawmill together with varied portions of chips and/or sawdust. In our study, we use a mix of wet bark and dry chips to increase the overall net heating value of the mix to ensure a stable combustion process. As the biofuel material is usually stored outside without any cover, the moisture content will vary with weather conditions throughout the year. Efficient utilization of the biofuel material to achieve a stable combustion process requires rapid determination of the biofuel moisture content, which is the single most important process parameter of the feed-in material. The method performance has previously been demonstrated with good agreement on other biofuel assortments, but is in this study calibrated for a new mixture of biomass material. The volume of measured samples was approximately 3 litres, with a total analysis time of one minute per sample. By using rapid and accurate X-ray determination of the moisture content, the project aimed to improve the combustion process to ensure more efficient energy use, lower flue gas emissions, and lower maintenance costs at the selected biomass combustion plant. The obtained results from the X-ray measurements showed a good agreement compared to the reference method.

\section{Clear image acquisition: moving board tracking for surface defects identification}

Xiao Wang ${ }^{1}$, Yucehng Zhou ${ }^{1}$

${ }^{1}$ Research Institute of Wood Industry, Chinese Academy of Forestry, Beijing, China (wx_dykm@126.com; zhouyc@caf.ac.cn)

Surface quality testing which helps to eliminate the products that contain surface defects is important in wood-based panel production to guarantee the resource efficiency. However, in most industries, such step still depended on manual inspection which is proven to be not efficient enough. In this study, a computer vision based testing system was proposed. To remove the image blur caused by fast moving of the boards on production line, the system used a cam mechanism to drive the camera moving along with the board during exposure time. To examine the tracking performance of the system, the experiment was carried out based on a laboratory scale platform. The result showed that, in each motion period of the cam, the camera velocity would reach board velocity for a certain time which could be used for shooting. Meanwhile, the board could be tracked at any velocity by controlling the cam rotation. The increase in uniform motion angle of the cam would increase the time used for exposure as well as the stability of the mechanism. The images were collected on-line at different board velocities, and it was shown that the board in image was clear while surroundings contained some blurs. Moreover, the blurring length of the image was calculated. It was found that the blurring length was limited to 3 pixels at velocity ranging from 200 to $800 \mathrm{~mm} / \mathrm{s}$, which made the image quality high enough for defects identification. 


\title{
An agent-based model of wood markets
}

Oliver Thees ${ }^{1}$, Stefan Holm ${ }^{1}$, Lorenz Hilty ${ }^{2}$

${ }^{1}$ Swiss Federal Institute for Forest, Snow and Landscape Research WSL, Birmensdorf, Switzerland; ${ }^{2}$ University of Zurich, Zürich, Switzerland

(oliver.thees@wsl.ch; stefan.hom@wsl.ch; hilty@ifi.uzh.ch)

We present an agent-based model of wood markets. The model covers softwood and hardwood markets for sawlogs, energy wood, and industrial wood. Our study region is a mountainous area in Switzerland. The wood markets in this study region are characterized by many small-scale wood suppliers, and a mix of private and public-owned forests. The model was developed to investigate the availability of wood in the study region under different market conditions. We defined several scenarios that are relevant to policy makers and analyzed them with a focus on the two most important assortments of wood in the study region, namely, sawlogs softwood and energy wood made from softwood. The development of the prices and amounts sold in the scenarios are compared to a businessas-usual scenario. The scenarios were designed to investigate i) the influence of intermediaries, ii) the influence of the profit-orientation of forest owners, iii) the influence of the exchange rate, and iv) the consequences of set-asides in the study region. The presented model has a large potential to support the planning of policy measures as it allows capturing emergent phenomena, and thereby facilitates identifying potential consequences of policy measures planned prior to their implementation. This was demonstrated by discussing the scenario findings with respect to Switzerland's forestry policy objective of increasing the harvested amount of wood to the sustainable potential. We showed that a higher profit-orientation of forest owners would be beneficial for this objective, but also revealed potential conflicts of different economic goals.

\section{Decision support system for the assemble of floorboard top layers}

\author{
Matthias Kaltenbrunner ${ }^{1}$, Maria Anna Huka ${ }^{1}$, Manfred Gronalt ${ }^{1}$ \\ ${ }^{1}$ University of Natural Resources and Life Sciences, Vienna,Vienna,Austria (matthias.kaltenbrunner@boku.ac.at; maria.huka@boku.ac.at; \\ manfred.gronalt@boku.ac.at)
}

The goal of the study is to develop a decision support system for assembling the top layer of floorboards in the parquet industry. The top layer of a floorboard, which has standardized dimensions, is constructed with lamellas of different lengths and grades that are aligned in three lanes. The used grades and the arrangement of the lamellas define the quality of the produced floorboard. This leads to a huge number of possible placement patterns that have to be considered in production planning. Hence, we use a MIP model embedded in the decision support system to optimize the production planning. In detail, the total production costs are minimized, considering the available raw material, the needed amount of different qualities of demanded top layers, and a minimal production quantity per product. First, we present an approach to reduce the number of patterns without constraining the feasible region and second, we investigate numerical experiments where different pattern selection strategies are used. Third, we showcase the decision support system which brings the research to a daily use in the industry. With this talk we want to display how optimization algorithms and tools can improve processes in the wood industry, their development and integration from the problem description to daily use, and their contribution to an ongoing digital transformation.

\section{Performance measurement of industrialized housebuilding on-site activities: a qualitative study to identify improvement potential through digitalization}

\author{
Wolfgang Grenzfurtner ${ }^{1}$, Manfred Gronalt ${ }^{1}$ \\ ${ }_{1}^{1}$ University of Natural Resources and Life Science Vienna, Vienna, Austria (wolfgang.grenzfurtner@boku.ac.at; manfred.gronalt@boku.ac.at)
}

Industrialized housebuilding (IHB) companies prefabricate wall-, ceiling- and roof elements or modules from forest-based products in plants and assemble them on-site. To collect and analyze data from on-site processes is currently a challenge, as common methods do not provide accurate statements to interventions effects, are not reliable enough or are too cost- or time consuming for periodical performance management. In order to develop an improved performance management for an IHB on-site context and to enable a continual improvement of construction processes and building systems this research aims (1) to investigate current IHB performance measurement and (2) to analyse the needs for improving performance assessment for various production strategies. In this context a pivotal role is given to improvement potentials through the usage of digitalisation concepts. Qualitative interviews with IHB companies from Central Europe are conducted and specific cases are selected to collect insights from various IHB companies' strategies. Further, prevailing concepts for improving IHB performance measurement are developed. Research reveal the need for performance management systems (PMS) to better cope with present real on-site processes and for supporting their controlling. Improvement potentials are identified in the translation of a company's business strategy to critical performance variables for on-site work. A further finding is the need for application scenarios for digital technologies collecting and analysing on-site data. As a results of this work new PMS will be developed according to IHB companies' needs. These may then better support decision in the construction processes and improve overall wood building systems’ competitiveness.

\section{Industry 4.0 concepts for the wood industry's digital transformation: three steps to forestry $\mathbf{4 . 0}$}

Jürgen Rossmann; Michael Schluse ${ }^{1}$, Thomas Gerritzen ${ }^{1}$, Frank Heinze ${ }^{1}$, Martin Hoppen ${ }^{2}$, Oliver Stern ${ }^{1}$

RWTH Aachen University, Aachen, Germany; ${ }^{1}$ RWTH Aachen University, Aachen, Germany; ${ }^{1}$ RIF Institute for Research and Transfer e.V., Dortmund, Germany; ${ }^{2}$ WWH Aachen University, Aachen, Germany(rossmann@mmi.rwth-aachen.de; schluse@mmi.rwth-aachen.de; thomas.gerritzen@rt.rif-ev.de; frank.heinze@rt.rif-ev.de; hoppen@mmi.rwth-aachen.de; oliver.stern@rt.rif-ev.de)

Digital transformation is revolutionizing the world and is taking production to a new age. The cornerstone of digital transformation is the real-time availability of all relevant information - in an Internet of Things, Services and Persons (IoTSP). New technologies provide more accurate data of forests than ever before and smart devices are facilitating the daily business. However, due to the heterogeneity of the wood industry, its great number of players with often conflicting objectives, and its decentral structures and processes, the generated data is not used efficiently yet. The new "Center of Excellence for Forestry 4.0 " focuses on three major tasks to help the wood industry with digital transformation. (1) Support research and industry to jointly develop concepts and standards to be documented in a "Forestry 4.0 Implementation Strategy". Like a guideline, this strategy comprises recommendations and hints for the practical implementation of Forestry 4.0. (2) Support the implementation of new technologies by providing knowledge and training programs, provide support for research and implementation projects, and connect interested stakeholders from the industry. (3) Provide so-called Smart Forest Labs as real and virtual environments to develop, test, evaluate and demonstrate new Forestry 4.0 compliant components, systems and processes. The center of excellence provides relevant reference implementations of connected and interactive assets, e.g., digitized forest stands, a smart harvester and skidding machinery, smart chainsaws, a forest sensor network - as physical and as simulated objects. 
An expert online information system for industry and forest owners: SEIL / Un sistema experto de información en línea para la industria y los propietarios forestales: SEIL

Carlos Büchner ${ }^{1}$, Marjorie Martin ${ }^{1}$, Rodrigo Sagardia ${ }^{1}$,Eduardo Molina ${ }^{1}$, Felipe Guzman ${ }^{1}$, Yasna Rojas ${ }^{1}$, Carlos Bahamondez ${ }^{1}$, Cristian Rojas ${ }^{2}$ ${ }^{1}$ Instituto Forestal,Valdivia,Chile; ${ }^{2}$ Consultor,Los Angeles, Chile(cbuchner@infor.cl; mmartin@infor.cl; rsagardia@infor.cl; emolina@infor.cl; fguzman@infor.cl;yrojas@infor.cl; cbahamon@infor.cl; cristianrojasp@gmail.com)

El Instituto Forestal de Chile, en su misión de transferir conocimiento y entregar información oportuna para la toma de decisiones ha desarrollado un Sistema Experto de Información en Línea para la industria y los propietarios forestales con el objetivo central de disponer de información sobre proyecciones del volumen de cosecha madera en pie, proveniente de plantaciones y bosque naturales, disponible durante para un horizonte de 10 años, a nivel de territorios. Información necesaria para el sector privado y público que permite la generación de políticas públicos, su monitoreo, y el desarrollo de nuevas inversiones, entre otros. Las estimaciones de volumen de madera en pie, se basan en la información que entrega el Inventario Forestal Nacional y el Programa de Actualización de Plantaciones de INFOR. Esto alimenta un modelo de programación matemático, que maximiza la oferta física de madera en pie, satisfaciendo una serie de restricciones o parámetros bases, la solución resultante es asignada al territorio utilizando métodos heurísticos (SA), y representando el territorio mediante una grilla, donde cada celda acumula la oferta de madera, diferenciada en productos pulpables y aserrables. SEIL es una plataforma de información web, con un visor de mapas y herramientas de consultas, implementada bajo un modelo de tres niveles que permite flexibilidad y rapidez a las consultas y visualización de datos. Nivel de datos (alfanuméricos como geoespaciales), bajo PostgreSQL y postgis 2.3. Nivel de servicios, publicación de datos web (Geoserver). Nivel de presentación desarrollo en PHP y Laravel (framework).

\section{Data analyses and modelling approaches for log-yard operations using discreet event mathematics}

Kalvis Kons ${ }^{1}$

${ }^{1}$ Swedish University of Agricultural Sciences, Umeå, Sweden (kalvis.kons@slu.se)

Terminals and log-yards play an essential role to secure a raw-material supply to industries. In the Nordic countries, the number of terminals with multiple incoming and outgoing transport methods and storage areas is increasing. An understanding of how to make changes to improve efficiency in existing log-yards is a challenging task. For instance, the simple act of introducing a new storage area at log-yard forces to consider not only construction costs associated with a storage place but also must foresee if there will be the need to modify an existing machine park due to driving distances and storage configuration. In this presentation, the company under study is running a log yard for the pulp mill. The company's log yard is receiving logs from three types of transport methods: trucks, trains and ships. The objective of the presentation is to show how to model such a system using data normalization for different transportations methods and implement them in two modelling approaches ("detailed" and "simplified") of discreet event mathematics, and the considerations required to properly tune these models according to data provided by a company. Possible model application for answering scientific and industry interested questions will be shown such as model suitability for further mathematical optimization and observations of detailed data processing within the log-yard operation to pinpoint possible bottlenecks in the system.

\section{C3c: FOREST OPERATIONS ENGINEERING AND MANAGEMENT INNOVATIONS FOR THE} FUTURE

\section{Advances in using robots in forestry operations}

Ola Lindroos ${ }^{1}$, Omar Mendoza-Trejo ${ }^{1}$, Daniel Ortiz Morales ${ }^{2,3}$, Pedro La Hera

${ }^{1}$ Swedish University of Agricultural Sciences, Umea, Sweden; ${ }^{2}$ Cranab, Vindeln, Sweden; ${ }^{3}$ The Cluster of Forest Technology, Umea, Sweden (ola.lindroos@slu.se; omar.mendoza.trejo@slu.se; daniel.morales@cranab.se; xavier.lahera@slu.se)

Forestry operations have a role to play in the supply of fossil-free raw material to present and future bio-economies. Advances in automation will enable forestry operations to be conducted in a more sustainable way, with better consideration of economic, ecological and ergonomic requirements. In this review, the challenges encountered and the current state-of-the art of the use of robots in the use forestry operations are presented. Current levels of automation are low because of the challenges of operating in unstructured, unknown terrain under extreme conditions. A shortage of data is limiting progress, and there is a strong focus on the integration of sensor technology and development of control systems. There has been some progress in making sensors perceive and understand the structure of the 'natural' forest landscape, the qualitative features of the desired end-products and how to control machine movements efficiently. However, it will still be some decades before fully autonomous forestry machines carry out harvesting and extraction operations.

\section{Automation of harwarder work: evaluation of effects on performance and user experience}

Rikard Jonsson ${ }^{1}$, Jussi Manner ${ }^{1}$, Anders Mörk' ${ }^{1}$, Martin Englund ${ }^{1}$, Hagos Lundström ${ }^{1}$

${ }^{1}$ Skogforsk,Uppsala, Sweden(rikard.jonsson@skogforsk.se; jussi.manner@skogforsk.se; anders.mork@skogforsk.se; martin.englund@skogforsk.se; hagos. lundstrom@skogforsk.se)

The harvester-forwarder system has dominated the cut-to-length logging operations for about 30 years. The systems productivity stagnated about a decade ago. Consequently, evaluation of alternative logging systems is important. One alternative is the harwarder, a single-machine system that fells, process, cuts and loads the stems directly onto the integrated load-space. The harwarder then transports the stems and unloads them at the landing. So far harwarder has failed to establish a market position, but its cyclic and predictable work is suitable for automation which can improve the harwarders competitiveness. In the study, parts of the harvesting and loading work have been automated on a virtual harwarder in a simulator environment. Three separate tasks have been automated and tuned to work in conjunction. The harvester head rotates to a felling direction that is suitable for the later processing and cutting the stem directly onto the load-space. At the operator's command, the crane follows a path to bring the felled stem to the load-space. The load-space rotates to keep parallel to the stem in the harvester head to facilitate placing the cut logs. We conducted a time study to compare the automated harwarder with an identical but manually operated machine model. We also interviewed the study operators on their attitude towards the automatic functions, real-life relevance and their subjective experience on productivity and workload. Preliminary results will be presented together with a discussion about the consequences of the results and possible next steps for development of the harwarder concept in cut-to-length-operations. 


\title{
Manual and machine operation team management through IOT for timber harvesting
}

Toshio Nitami ${ }^{1}$

${ }^{1}$ University of Tokyo, Tokyo, Japan (nitami@fra.u-tokyo.ac.jp)

Manual work often holds important role at a team work in timber harvesting operation. This is usual at the operations on steep hillsides, where are difficult for off-the-road vehicle locomotion. Manual operations are inevitable not only for felling trees but also for choking logs to yarding cable line, and they are needed to be kept synchronized to other operation processes such as hauling, processing and forwarding. IOT method was useful to have operation data at each operation points to know their advancing processes and harmonize them by knowing each other situations in order to make the day work follow well the results by the previous day at the operation site. A Logging Site Management System on IOT was constructed using GPS device and smart phone system. This is constituted with Daily Report, Operation Visualization, Operation Evaluations, Operation Heat Map, Landing Storage Management and their compilation Database. Logging enterprise can manage their logging projects on this computer system based on daily operation achievements at each work points. Daily morning meeting can utilize the processed information to distinguish the location to work advance following the former process by the previous work day. Database of the project is updated daily and udates data for regional forestry supply chain management system, which enables detailed production and purchase matching.

\section{Management automation by maximization of harvesting data utilization}

Angelo Conrado de Arruda Moura ${ }^{1}$, Elias Chagas Chagas ${ }^{1}$, Rafael Aparecido Rodrigues Junior ${ }^{2}$

${ }^{1}$ Suzano,Jacarei,Brasil; 2Suzano,Três Lagoas, Brasil (amoura@fibria.com.br; elias.chagas@fibria.com.br; rafael.rodrigues@fibria.com.br)

In the current days, the advances in Artificial Intelligence developments and its applications are largely known. In addition, that most technology automation relies on a good database. In this way, it is critical to have sensors collecting data in good amount and quality. As different sectors, agricultural and forestry machines are rapidly increasing the utilization of many sensors. The integration of sensors like cameras, Lidar, Sonar, etc., to the deep learning, is allowing the advance of autonomous operation, in proof of concept stage so far. Even considering that autonomous operation must be a reality in the near future, there are opportunities to advance in the utilization of data already available. Thus, the aim of this work was, to maximize the utilization of data generated by harvesting machines. The project consisted in collecting this data for three main purposes: generate productivity maps, create quality reports, and prepare forest productivity data for further studies of silviculture fertilizer application. It was developed machine and web App's, to collect Stanford files from on-board computers (georeferenced information on tree level), a web portal to receive this data, GIS analysis, and finally an user interface, using PowerBI platform, to show maps and reports. Also developed automation for all communication by web services. The project was done on a pilot scale, after validation was approved and defined to implement in all company applications. As main results, we highlight the useful tools to manage the operation, with minimum human interface, and opportunity to automate quality control process.

\section{Frontiers in wood and biomass supply chain optimisation}

Mauricio Acuna ${ }^{1}$

${ }^{1}$ University of the Sunshine Coast, Sippy downs, Australia (macuna@usc.edu.au)

In this presentation, state-of-the-art optimisation techniques and technologies for efficient biomass supply chains are presented. Supply chain optimisation is the application of processes and tools to ensure the optimal operation of a manufacturing and distribution supply chain. In wood and biomass supply chains this includes the optimal placement of inventory within the supply chain, minimising operating costs (including manufacturing costs, transportation costs, and distribution costs). This often involves the application of mathematical modelling techniques using computer software aiming to produce and to deliver the right product at the right time and for the right customer with the goal of maximising revenue and/or product margins. The presentation will also discuss opportunities for improvements in the wood and biomass supply chain including improved characterisation of the resources, log tracking and collaborative planning. In addition, the presentation will expose concepts and technologies around "Industry 4.0", name given to the current trend of automation and data exchange in manufacturing technologies, and the potential use of the technologies to optimise wood and biomass supply chains. Thus, some of the technologies supporting real-time data collection, internet of things, automation and robotics, and data analytics will be presented and discussed. These include mobile technologies, machine to machine technologies, artificial intelligence and big data analytics (deep learning, machine learning), and virtual and augmented reality, among others. The presentation will finalise discussing the challenges and opportunities of state-of-the-art supply chain optimisation for practitioners and researchers, and presenting future initiatives in supply chain optimisation for research and education.

\author{
Assessing the Mobile Mapping System applicability for mapping precision forest road networks in Korea \\ Sungmin Choi ${ }^{1}$, Joon-Woo Lee ${ }^{1}$, Myeongjun Kim², Hyeongkeun Kweon ${ }^{1}$ (D) Kyo-Won Jung ${ }^{3}$,Hakjun Rhee (D) \\ ${ }^{1}$ Chungnam National University, Daejeon, Republic of Korea; ${ }^{2}$ Forest Environment \& GeoSpatial Technology Research Institute, Daejeon, Republic of Korea; \\ ${ }^{3}$ The Korea Forest Engineer Association, Daejeon,Republic of Korea (goodday@cnu.ac.kr; jwlee@cnu.ac.kr; festri.kim@gmail.com; \\ hkkweon00@gmail.com,jgw@supsansa.net; hakjun.rhee@gmail.com)
}

This study assessed the applicability of MMS (Mobile Mapping System) to forest road mapping in Korea by applying it to 5 forest road networks in Korea, comparing the accuracy of MMS to total station with Global Navigation Satellite System (GNSS) and as-built drawing using point-comparison and buffering methods, and comparing the effectiveness and economics of the MMS with other mapping techniques. From the point-comparisons, the MMS was 6.8 times more accurate than GNSS and 71.6 times than as-built drawing. With a buffering width of $2 \mathrm{~m}$ the forest road networks from the MMS were overlapped with 93.3\% of the networks from total station, $96.21 \%$ from GNSS, and 50.99\% from as-built drawing. The as-built drawing, only available information for current forest road maintenance management, was not accurate, due to frequent design changes during forest road construction and not recording the changes. The MMS processed 11,547,319 data points/km, 46,000 and 401 times more data points than those of total station (251 points/km) and GNSS (28,800 points/km), with less than $16.4 \%$ and $17.8 \%(31.6 \mathrm{~min} / \mathrm{km})$ of the surveying time used for the total station $(195 \mathrm{~min} / \mathrm{km})$ and GNSS (178 min/km). The map-making costs using the MMS, total station, and GNSS were $\$ 538,182 / \mathrm{km}, \$ 581,125 / \mathrm{km}$, and $\$ 252,653 / \mathrm{km}$. The high costs from the car-mount MMS equipment rental and operator labor could be offset by high work efficiency. Considering the high accuracy, work efficiency, and economic feasibility, the MMS can be used to map precision forest road networks in Korea. 


\section{Model optimization of wood property and quality tracing based on wavelet transform and NIR spectroscopy}

Ying $L i^{1}$, Yaoxiang $L i^{1}$, Wenbin $L i^{2}$, Lichun Jiang ${ }^{1}$

${ }^{1}$ Northeast Forestry University, Harbin, China; ${ }^{2}$ Beijing Forestry University, Beijing, China (yingli@nefu.edu.cn; yaoxiangli@nefu.edu.cn;

wenbinlin@bjfu.edu.cn; jlichun@nefu.edu.cn)

Wood information intelligent acquiring is the key for timber quality tracing. It is also the prerequisite for timber sorting, processing and fine applications. This study aims to discuss the denoising of aspen wood near infrared spectroscopy (NIRS) with wavelet transform and develop the calibration model for wood density, to analyze the feasibility of NIR-based wood quality tracing. In this study, calibration model was developed for air-dried density of aspen wood based on NIRS and partial least squares (PLS) algorithm. Wavelet transform was used for NIR denoising treatment and model optimization. The best denoising method was determined. Aspen wood density predicted with NIR calibration model together with other wood information (species, locality of growth, measuring unit, ways of data acquisition etc.) was recorded with QR (Quick Response) code for the quick and effective tracing. The readability and effectiveness of the QR code with varied correction levels, number of characters, and pixel sizes were compared. Results showed that: (1) The best model fitting was achieved with the decomposition layer of 5 (db5 wavelet) under the heuristic hard threshold denoising treatment. (2) As the number of coded characters were 217 in this study, the readability of QR code was low with pixel size of $100 \times 100 \mathrm{px}$ while the QR code readability was higher than $90 \%$ with pixel size greater than $100 \times 100$ px. It can be concluded that QR code could be an effective carrier for timber tracing information acquired with NIRS.

\section{C3d: GLOBAL GREEN SUPPLY CHAINS AS A DRIVER FOR SUSTAINABLE FOREST} MANAGEMENT IN THE TROPICS

\section{Green tropical timber supply chains: legality, sustainability, profitability}

\section{Gerhard Dieterle}

1nternational Tropical Timber Organization, Yokohama, Japan (dieterle@itto.int)

Major markets for tropical timber and timber products are sending strong signals to importers on the need to demonstrate that forest products are not sourced at the expense of tropical forests. For example, the Lacey Act in the United States of America, the European Union Timber Regulation, Australia's Illegal Logging Prohibition Act and the Japan Clean Wood Act all require evidence of the legality of imported timber. Such initiatives, however, can be confusing for producers, importers and traders, who may be unclear on the documentation they need and the standards to which they must comply; this confusion can diminish market opportunities for tropical timber producers. What is needed is a systems-based approach that ensures legality and aims to achieve sustainability within integrated "green" supply chains. The ultimate aim of green timber supply chains is to ensure stable, reliable supplies of timber from legal and sustainable sources. It is also a pre-condition for advancing towards a bio-based and circular economy because the substitution of non-renewable materials and energy with "green" timber can only be counted if the timber has been produced sustainably (and shown to be so). From the point of view of private operators, green timber supply chains are not just about maintaining or increasing market share, although that is an important outcome. They are also about businesses ensuring efficiency, best practices and transparency at every link in the supply chain — in the forest, on the log truck, in the mill, on the ship and in the showroom. Companies that put in place green supply chains will become streamlined to the extent that they will know exactly where their products are coming from, where those products are in the supply chain at any given time, and how they have been produced. Ultimately, the efficiencies this information will bring will ensure profitability and increase other metrics of healthy businesses. Building green timber supply chains involves various levels of actions and commitments across a wide spectrum of stakeholders, who need to interact in a coordinated manner to ensure sustainable and legal production. Most tropical timber-producing countries lack sufficient infrastructure and technology to establish green supply chains. Public-private partnerships - domestically and with consumer countries - are necessary, therefore, for sharing the incremental costs and ensuring the viability of initiatives to create green supply chains. A long-term task is to reduce the multiplicity and complexity of the green supply-chain requirements applied in different countries. This is necessary to enable small and medium-sized forest producers in tropical countries to become competitive and confident actors in domestic and international markets and to build capacity for sustainable management and production. In many cases, such enterprises will need external assistance and training to prevail in domestic and international markets and to become drivers of sustainable forest management. We see an important role for ITTO and other international organizations as facilitators or "primers" of the shift towards green tropical timber supply chains. We can help build capacities among operators and other stakeholders across supply chains through knowledge-sharing, technical expertise, research, demonstration, the transfer of technology, and access to information and networking.

\section{Making sustainable wood value chains work for sustainable development: unlocking contributions to the SDGs and climate change}

Thais Linhares Juvenal ${ }^{1}$, Petri Lehtonen ${ }^{1}$

${ }^{1} F A O$, , OMA, Italy (thais.linharesjuvenal@fao.org; petri.lehtonen@fao.org)

Forests contribute to the objectives established in the UN 2030 Agenda in manifold ways. Recent assessments identified contributions to poverty alleviation through cash and in-kind income, food security through forest fruits and wood fuel, women employment, provision of ecosystem services, bioenergy, innovation, material efficiency and low carbon products. Reconciling these contributions is fundamental for achieving sustainable rural landscapes and cities. This article proposes the use of the value chain approach to achieve increased forest conservation and contributions to climate change and the SDGs. The article will: i) introduce the "basket of value chains" approach, proposing forests to be considered a basket of value chains (ecosystem services, biodiversity, tourism, wood and non-wood forest products) and their sustainability defined by the existing synergies and trade-offs. In a dynamic system, sustainability is achieved when all potential value chains are developed within its potential and does not prevent the existence of the other; ii) propose a sustainability assessment framework based on the three traditional pillars of sustainability (economic, social and environmental) and an additional one, institutional, to capture governance aspects; iii) discuss the nexus between sustainable forest very chains, sustainable landscapes and sustainable cities; and iv) suggest policies and measures to deliver sustainable jobs and contributions to the bioeconomy while increasing feasibility of sustainable forest management. 


\section{BOManejo software - harvest planning and control of the forest production}

José Francisco Pereira ${ }^{1}$, Fabricio Nascimento Ferreira ${ }^{2}$, Milton Kanashiro ${ }^{2}$

${ }^{1}$ Embrapa Amapá, Macapá, Brasil; ²Embrapa Amazônia Oriental, Belém, Brasil (jose-francisco.pereira@embrapa.br;fabricio.ferreira@embrapa.br; milton.kanashiro@embrapa.br)

BOManejo is a free software developed by Embrapa to assist the elaboration and execution of Sustainable Forest Management Plans (SFMP) in the Amazon. From the information of the forest inventory, together with the definitions of the desired selected criteria and the applicable legal restrictions, through an interactive process of planning and verification of results, this tool allows a more careful tree selection to be harvested and a better control of timber production, therefore improving production and sustainability of the managed forests. The control of the production is a legal and necessary requirement for the authorization of the logs transportation and commercialization, and also can be facilitated by the integration between BOManejo and the electronic control systems of the environmental agencies. A plug-in was developed for the QGis software to connect to BOManejo, adding features to facilitate the preparation of operational and licensing maps, with the location of trees to be harvested and preserved ones in the forest. It also permits to see the evolution of the harvesting on the map. BOManejo has a licensing module that can be used by environmental licensing agencies to assist in the analysis of the Annual Operational Plans (AOP) prepared with this software tool, in order to streamline and improve the analyzes for its licensing procedures. BOManejo is a platform where new technologies and knowledge can be more easily made available and potentially incorporated into the activities of sustainable forest management throughout the Amazon region.

\section{Rapid screening by fluorescence of finished wood products for targeted sampling}

Cady Lancaster ${ }^{1}$

${ }^{1}$ US Forest Service International Programs, Ashland, OR, USA (cadylancaster@fs.fed.us)

One of the many considerations for screening timber declarations is determining the presence of a mixture of species in a single shipment. The Wood Identification and Screening Center (WISC) of the US Forest Service International Programs (USFS-IP) has developed a screening protocol for targeted sampling of mixedwood products. The protocol uses fluorescence to identify probable inconsistencies in species declarations of finished products when multiple species are suspected. Many timber species have a native fluorescence that can be easily observed with exposure to $365 \mathrm{~nm}$ light. In traditional wood anatomy, fluorescence of water and ethanol extract of heartwood is used as an indicator in species identification. By using inconsistent fluorescence responses to guide sampling, the shipment can be efficiently targeted for more advanced forensic identification techniques (e.g. anatomy, chemistry). As part of this screening protocol for customs agents, WISC is developing a visual database of wood fluorescence for high and low risk species.

\section{Traceability system improves forest governance in Panama}

Felix Magallon ${ }^{1}$, Melanio Aguilar ${ }^{1}$, Victor Francisco Cadavid

${ }^{1}$ Ministry of Environment (MiAmbiente),Panama City, Panama (fmagallon@miambiente.gob.pa; vcadavid@miambiente.gob.pa)

A timber traceability system recently put in place in Darien, has already reduced forest illegality, with benefits for forests, managers, companies and Panama's Ministry of Environment. The traceability system enables the tracking of trees using electronic devices — chips — from the moment they are identified to the point at which the timber reaches consumers. In its phase, the system is collecting information on around 700 crop trees per day, and the Ministry of Environment is planning to expand its use to other regions of the country. According to Panama's Ministry of Environment, as reported in the newspaper La Estrella de Panama (6 May 2018), the timber-tracking system has helped reduce illegal logging in the country by 68\%. The system is an output of an ITTOfinanced project entitled "Strengthening the management capacity of ANAM to reduce illegal timber logging and trade in the East region of Panama (Bayano and Darien) through monitoring and control mechanisms" and is being executed by WWF-Panama in collaboration with the Panama Ministry of Environment.

\section{Technologies to verify the origin and species or genus of wood and wood products}

Andrea Olbrich ${ }^{1}$, Tereza Cristina Monteiro Pastore ${ }^{2}$

${ }^{1}$ Thünen Institute, Hamburg, Germany; 2Laboratório de Produtos Florestais, Serviço Florestal Brasileiro, Brasilia, Brazil (andrea.olbrich@thuenen.de)

For the implementation of national and international legislation that forbids the use of illegally logged or endangered species the identification of timbers in all kind of materials made of timber is becoming increasingly important. The Thünen Centre of Competence on the Origin of Timber is the central contact facility for government agencies, timber trade, consumers and associations to verify the species of wood and/or wood products and its origin. The Centre combines the analytical expertise and competence of the three Thünen institutes of Wood Research, Forest Genetics and International Forestry and Forest Economics responsible for wood identification, proof of origin, certification and timber trade structures. The timber identification in pulp, paper and fiber boards is aggravated since the most of the forensic anatomical characteristics of wood refer on the tissue and nearly all materials of fibers contain a mixture of timbers. Therefor the anatomical identification is the only established method by now. For hardwoods, the characteristics of vessel elements of an unknown sample have to match with the descriptions and high valued micrographs of the vessel elements of known timbers as references. In the past, such references for Asian timbers were missing. The team of authors from the Thünen Institute analyzed 38 species or species groups (including a bamboo and a palm) and published references for them, so now these timbers can be identified in paper and fiber boards as well.

\section{C3e: PRECISION FORESTRY}

\section{New generation of forestry based on precision management practices}

José Leonardo de Moraes Gonçalves ${ }^{1}$, Alexandre de Vicente Ferraz ${ }^{2}$

${ }^{1}$ Escola Superior de Agricultura "Luiz de Queiroz", Universidade de São Paulo, Departamento de Ciências Florestais, Piracicaba, Brasil; 'Instituto de Pesquisas e Estudos Florestais, Piracicaba, Brasil (jlmgonca@usp.br)

The development of improved forest planning and operations can minimize site impacts, increase utilization and minimize or avoid adverse environmental effects. Some principles, aims, strategies and silvicultural practices must be followed for developing sustainable forest plantations based on holistic approach of the productive process. Precision Forestry (PF) is a great tool that aims to provide a silviculture customized for each unit area. It is a new model of forest plantation management. Such tools are becoming more available and applicable to different stages of fast growth forest plantation, and with proven gains in 
both the increment of wood, and in reducing the use of inputs. PF may have applications in so much landscape level analyzes including several farms, such as applications within a single stand. Thus, GIS techniques with the use of GNSS, geostatistical and statistics have provided subsidies for the identification and correlation of variables that affect the forest productivity by storing, processing, crossing and overlapping of GIS data. These data are viewed and managed together with digital maps of vegetation, topography, soil, forest sites productive capacity so on, which allows the forest engineer to recognize and visualize in an integrated the distinct characteristics of production and preservation forest areas. The PF has enabled the adoption of some management practices and streamlined other difficult to operationalization through compilation of organized information. There has achieved higher accuracy and technical and financial detail of recommendations silvicultural increasingly specific which has resulted in better adaptation to the plant environment and reducing the occurrence of negative environmental impacts. At the same time, there is the optimization of operating earnings, the rational use of inputs and reduction of production costs. Higher the environmental contrasts, as in most regions of rugged relief, the greater the potential gains of technological capability and productivity. The biggest difficulty to work with this system is related to the large amount of information, usually derived from heterogeneous sources with large spatial and temporal variability, which creates the need for complex information systems to process the data. Moreover, successful cases are going on in many private companies worldwide.

Operational management units for eucalyptus using by the fuzzy logic method / Unidades de manejo operacionais para o eucalipto pelo método da lógica Fuzzy

Itamar Antonio Bognola ${ }^{1}$, Lorena Stolle ${ }^{2}$

${ }^{1}$ Embrapa Florestas, Colombo, Brasil; 2Universidade Federal do Mato Grosso do Sul, Chapadão do Sul, Brasil (itamar.bognola@embrapa.br; lorena.stolle@ufms.br)

As regiões de cultivos de eucaliptos apresentam uma infinidade de variações ambientais implicando em diferentes produtividades. Uma das explicações para esta variabilidade está relacionada ao meio físico. Desta forma, o entendimento integrado do clima, relevo, geologia e solo é decisivo na transferência dos conhecimentos adquiridos para obtenção de uma silvicultura de maior precisão, visando manter ou aumentar a produtividade da cultura. Para tanto, foi feito um levantamento pedológico detalhado de uma propriedade florestal com 4.660 ha, em Araraquara, SP, a fim de se obter Unidades de Mapeamentos Pedológicas (UMP's), identificando-se ainda as potencialidades e os fatores limitantes das mesmas com relação ao meio físico. Nesse contexto, as práticas de uma silvicultura com maior precisão seria dar tratamento diferenciado a cada uma destas UMP's. No entanto, este detalhamento pedológico por si só tem dificultado o manejo operacional, uma vez que as empresas florestais ainda não estão preparadas para tratar de modo diferenciado cada uma delas. Assim, estas UMP's foram agrupadas em um número bem menor de classes definindo-se as Unidades de Manejos Operacionais (UMO's), para facilitar as práticas silviculturais. A metodologia utilizada foi a da "Lógica Fuzzy" integrada com a extensão EMDS para o ArcGIS e o software livre "NetWeaver" definindo-se as referidas UMO's. Os resultados obtidos por esta metodologia foram semelhantes aos previstos pelo especialista em solo. Verificou-se, portanto, que o método proposto tem grande potencial como ferramenta em ambiente computacional para definir as classes de UMO's.

\title{
Assessing automated mechanized irrigation / Avaliação da automação do irrigador mecanizado
}

\author{
Murilo Marques ${ }^{1}$, Guilherme Oguri' ${ }^{2}$,Thiago Duarte ${ }^{3}$, Tiago Vasconcelos ${ }^{4}$, Saulo Guerra ${ }^{1}$

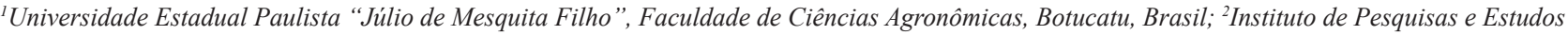 \\ Florestais, Piracicaba, Brasil; ' ${ }^{3}$ Suzano Papel e Celulose S.A., Limeira, Brasil; ${ }^{4}$ Suzano Papel e Celulose S.A (murilocaliente@gmail.com; \\ guilherme@ipef.br; tduarte@suzano.com.br; tvasconcelos@suzano.com.br; saulo.guerra@unesp.br)
}

O desenvolvimento de máquinas e equipamentos destinado à irrigação de plantios florestais visa o uso consciente do recurso natural, além de melhorar a qualidade e aumentar o rendimento operacional em campo. Este trabalho objetiva avaliar o uso do irrigador óptico automatizado em plantios de Eucalyptus spp. O módulo de irrigação automatizado utiliza um trator John Deere 61125J (92 kW) tracionando o conjunto de irrigação, fabricado pela empresa FM Copling, composto por tanque, braços mecânicos, bocais de aplicação de água e sistema de reconhecimento da linha de plantio e das mudas. A avaliação da qualidade da operação foi realizada através da contagem do número de mudas irrigadas e não irrigadas pelo conjunto na operação diurna e noturna. Verificou-se uma assertividade do conjunto de irrigação no modo diurno de $89 \%$ e no modo noturno de $94 \%$. A realização da operação durante o período noturno promoveu uma melhor na assertividade da irrigação.

\footnotetext{
Wood property mapping at the individual tree and landscape level to maximize production and enhance utilization of the forest resource

Mathew Leitch ${ }^{1}$, Scott Miller

${ }^{1}$ Lakehead University,Thunder Bay, Canada (mleitch@lakeheadu.ca; smiller4@lakeheadu.ca)

Major changes in global forest industries has forced Canadian companies to look at how they conduct business with our Northern forests. Vast forest resources found in Canada are utilized and contribute roughly $\$ 20$ billion to the GDP every year. In order to remain a significant forest products contributor globally and to increase our production from primarily commodity products to include a larger contribution of value-added or secondary manufacturing, the industry needs to better understand the wood properties of the forest resource and how to best maximize utilization of the resource. In the LUWSTF we have developed methods to map the inherent wood properties of individual standing trees and entire landscapes in order to optimize utilization. We have shown that this type of mapping of properties and utilizing the resource where it best suits products can increase the value of every tree by as much as $30 \%$. Additionally, we have been able to create tree and landscape wood property maps which, display species mixes and wood quality (lumber grades, mechanical properties) across a landscape. This will enable maximum production from each tree, industry to react to market demand quickly, have a better understanding of what is on the landscape and increase investment in primary and secondary industries based on knowledge of the resource and what wood quality an industry requires.
}

\author{
Assessment of automated chemical weeding / Avaliação da capina química automatizada \\ Augusto Locci ${ }^{1}$, Guilherme Oguri ${ }^{2}$, Jeovagno Rangel ${ }^{3}$,Osmar Menegol ${ }^{3}$, Marcelo Coutinho ${ }^{3}$, Saulo Guerra ${ }^{1}$ \\ ${ }^{1}$ Universidade Estadual Paulista "Júlio de Mesquita Filho", Faculdade de Ciências Agronômicas, Botucatu, Brasil; 'Instituto de Pesquisas e Estudos \\ Florestais,Piracicaba,Brasil; ${ }^{3}$ Fibria CeluloseS/A,Aracruz,Brasil (augustodefarialocci@gmail.com; guilherme@ipef.br; jeovagno.rangel@fibria.com.br; \\ omenegol@fibria.com.br; marcelo.coutinho@fibria.com.br; saulo.guerra@unesp.br)
}

A atividade de capina química de plantas daninhas se faz necessária para garantir um melhor desenvolvimento da cultura de interesse. Atualmente, em todos os sistemas de aplicação de herbicidas pós emergentes ocorre um desperdício de produto, pois é aplicado em faixas ou área total, independente 
ou não da presença destas plantas invasoras. A avaliação teve como objetivo analisar a eficiência do sistema de aplicação de herbicida automatizado, utilizando-se o sensor Weedit para identificação das plantas daninhas. Realizou-se um estudo de tempos e movimentos para a determinação dos rendimentos operacionais e, para avaliação da qualidade e do controle das ervas daninhas, foram instaladas aleatoriamente parcelas nos talhões onde houve a aplicação automatizada. Esta aplicação, resultou em uma redução de consumo de herbicida e de água em 53 e $51 \%$, respectivamente quando comparado com a aplicação sem o uso do sensor. Em relação ao rendimento operacional, o conjunto mecânico apresentou uma disponibilidade mecânica

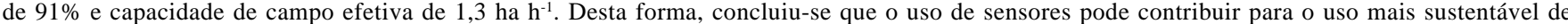
produtos químicos e água.

\title{
The importance of genotyping to specific site in precision silviculture
}

João Antonio Fowler ${ }^{1}$, Itamar Antonio Bognola ${ }^{1}$, Antonio Kalil Filho ${ }^{1}$, Luis Cláudio Maranhão Froufe ${ }^{1}$, Shizuo Maeda

${ }^{1}$ Embrapa Florestas, Colombo,Brasil (joao-antonio.fowler@embrapa.br; itamar.bognola@embrapa.br; antonio.kalil@embrapa.br;

luis.froufe@embrapa.br; shizuo.maeda@embrapa.br)

The term precision silviculture can mean the selection of individuals of a species in a natural population with characteristics suitable for a particular purpose of use. As each individual of the population occupies a specific site, in addition to the soil variables, it is fundamental to identify genotype environment interactions. In this way we are conducting experiments of precision silviculture in specific site in Morretes Paraná State with tree species, Calophylum brasiliensis, Liquidambar styraciflua and Bactris gasipae, to test influence of specific site on development of plants and future seed production. The variables evaluated in each specific site of each species is soil fertility, soil structure, soil water adsorption curve, resistance of soil penetration, depth of the water table, soil density, diameter at breast height and total height of plants. The same provenance of Calophylum brasiliensis and same clones of Liquidambar styraciflua and Bactris gasipae.The experimental design is randomized blocks in single three plot with 30 replications / specific sites of each species. The genotyping of each tree of each specific site, combined with variables of soil and climate conditions become possible a much more completely inferences of adequate specific site to each studied species.

\section{Different planting design with the same density yields no difference on the growth of conifer plantations in Sweden}

Mostarin Ara ${ }^{1}$, Ignacio Barbeito ${ }^{1}$, Bjorn Elfving ${ }^{2}$, Ulf Johansson ${ }^{1}$, Urban Nilsson ${ }^{1}$

${ }^{1}$ Swedish University of Agricultural Science, Alnarp, Sweden; ${ }^{2}$ Swedish University of Agricultural Science, Umea, Sweden (mostarin.ara@slu.se; ignacio.barbeito@slu.se; bjorn.elfving@slu.se; ulf.johansson@slu.se;urban.nilsson@slu.se)

Traditionally, in Swedish forestry, square planting design in a 2 x $2 \mathrm{~m}$ arrangement is used for plantation as it is claimed to maximize productivity. With this study based on long-term trials established in mid-1980s, we aimed to test if different planting designs (from square to different rectangular spacings) exert any effect on the growth of three coniferous forest in Sweden: Scots Pine, Lodgepole Pine and Norway Spruce. In these trials, an initial planting density of 2500 seedlings/ha was established using five different planting designs $(0.8 \times 5,2 \times 2,1 \times 4,1.33 \times 3$ and $1.46 \times 1.46 \times 4 \mathrm{~m})$. DBH, height of the sample trees and damage was recorded from each planting design. Our results show that the volume production, diameter distribution, spatial heterogeneity and damage were not significantly affected by the different spatial designs. This information greatly enhances our knowledge of planted forests, suggesting more flexibility for spatial layout of plantations and consequently for the machinery operations than previously thought when a quadratic planting design was preferred.

\section{A loblolly pine mid-rotation fertilization response model, accounting for response uncertainty}

\author{
Cristian Montes ${ }^{1}$, Henrique Scolforo ${ }^{2}$, Rachel Cook ${ }^{3}$, Lee Allen ${ }^{4}$, Timothy Albaugh ${ }^{5}$ \\ ${ }^{1}$ Warnell School of Forestry, University of Georgia, Athens, USA; ${ }^{2}$ Suzano, Limeira, Brasil; ${ }^{3}$ North Carolina State University, Raleigh, USA; ${ }^{4}$ Profor \\ Consulting, Raleigh, USA; ${ }^{5}$ Virginita Tech, Blacksburg,USA(crmontes@uga.edu; henriquescolforo@hotmail.com; rlcook@ncsu.edu; \\ allen.profo@gmail.com; talbaugh@vt.edu)
}

Mid-rotation fertilization presents an opportunity to increase the economic return of commercial plantation forests. Since the 1990s, a series of loblolly pine fertilization trials installed in the southeast US have shown responses to nitrogen $(\mathrm{N})$ and phosphorus $(\mathrm{P})$ fertilization, resulting in a sustained increase in stand production at rotation age. Observed fertilization responses had been site-specific, therefore under budgetary constraints, the use of decision tools to appropriately select candidate responsive sites becomes a critical step in the decision framework. There are several models of response to fertilization aiming at productivity gains evaluation. One drawback of such response models stays in their high dependability on empirical relations showing weak biological soundness, constraining use outside the domain of the data used to calibrate them. Mainly, these models are not bounded, failing to limit response rates as fertilizer amount increases plus an incomplete acknowledgment of the uncertainty associated with the predicted process. To bridge this gap, we developed a response model that evaluates the relative response to fertilizer addition, including site index and relative spacing as model parameters as well as to explicitly account for response uncertainty. The new stochastic model is bounded in the magnitude of the response, also allowing practitioners to visualize the areas with the highest chance to increase forest value.

\section{Assessment of the spatial variability in clonal eucalypt stands}

\author{
Rafael Dias ${ }^{1,2}$, José Molin ${ }^{1}$, Henrique Scolforo ${ }^{2}$, Maurício Simões $^{2}$, Clayton Alvares ${ }^{3}$ \\ ${ }^{1}$ Universidade de São Paulo, Piracicaba,Brasil; ${ }^{2}$ Suzano,Limeira, Brasil; ${ }^{3}$ Suzano, Itapetininga,Brasil (rafael.donizetti.dias@usp.br; jpmolin@usp.br; \\ hscolfor@suzano.com.br;msimoes@suzano.com.b; calcarde@suzano.com.br)
}

Better site-specific management is possible through spatially explicit site information. Conventionally, spatial information is generated through the interpolation of the inventory plots. The spatial information generates colorful maps, but are these maps useful for providing better site-specific management? The high uncertainty associated with the volume estimates (interpolated) does not ensure the information reliability. Consequently, the understanding of the factors that result in the high volume variation within a stand cannot be assessed. The advance of technology, however, appears as a chance to overcome this drawback. Thus, we propose the use of sensors in operations that are able to measure the volume of each harvested tree. A modeling approach (through kriging) combined to the highly detailed dataset furnishes spatially explicit volume information with great accuracy. The dataset are derived from a stand harvested in 2018. Data was recorded through sensors used in the harvesting operation. At the end, we offer a methodology that provides highly detailed spatial information with high degree of accuracy, while also enabling the assessment of the spatial variability within a stand. 


\section{C3f: PROMOTING THE ENVIRONMENTAL, SOCIAL AND ECONOMIC BENEFITS BY MONITORING THE PERFORMANCE OF FOREST MACHINES: NEW APPROACHES IN PRECISION FOREST OPERATIONS}

\section{Development of robotics technology for forestry machines}

Pedro La Hera ${ }^{l, 2}$

${ }^{1}$ Department of Forest Biomaterials and Technology, SLU, Umeå, Sweden; ${ }^{2}$ Swedish cluster of forest technology, Umeå, Sweden (xavier:lahera@slu.se)

Just like any other industry, forestry continues to be radically altered by technology. To date, two important machines for Scandinavian forestry are the harvester and forwarder. The former cuts trees into round-wood logs of specified lengths, while the latter transports logs out of the harvesting site -a working method known as cut-to-length. To perform this work, these machines use large hydraulic manipulators, known as cranes. To control these cranes, as well as the machine, operators use joysticks sitting inside the cabins. The problem, however, is that a machine operator sitting for an eight-hour shift faces a number of potential productivity-busters. One example is the complex coordination required to seamlessly produce joystick commands to move the crane or the vehicle. Precise control of the crane links usually requires a series of expertly coordinated actions that can prove tiring over time. The control technology commercially available is unintuitive to humans, because it involves multitasking the coordination of each individual cylinder composing the machine. In view of this, machine manufacturers have started leaning towards the idea of smart forestry machines as a technology that can tackle questions about increased productivity and efficiency, and go beyond the limitation of human abilities. However, introducing automation and smart software for forestry machines presents many challenges. This presentation talks about 1) the challenges to bring automation into forestry, 2) the progressive steps to develop automation software, and 3) it will also show results of nearly two decades of research carried out in Sweden.

\section{Process analysis of fully mechanized beech-harvesting - the effect of the piece-volume-law (H. Hilf, 1928)}

Fabian Böttcher', Bernhard Möhring ${ }^{1}$

${ }^{1}$ Georg-August-Universität, Göttingen, Germany (fabian.boettcher@uni-goettingen.de; bmoehri@gwdg.de)

Fully mechanized timber harvesting is under a constant technical development. This allows the use of harvesters also in old hardwood stands. Robust studies on the processing times of the individual work steps in these stands are lacking. This study aims at dividing the felling process into relevant sub-processes and analyzing the separate sub-processes to identify the respective time needed. These were separated between tree- and log-based sub-processes. According to the piece-volume-law by Hilf (1928), the relevant cost drivers for fully mechanized harvesting in hardwood stands were identified. To do so, the study analyzed the felling process of a Ponsse-Scorpion-King harvester in old beech-stands (Fagus sylvatica). Before harvest, all marked trees in the test area were evaluated according to various attributes (i.e. height, quality). The harvesting process was filmed with a camera from the harvester cockpit and subsequently evaluated according to the defined sub-processes. After the felling, the assimilated assortments were recorded for each sampling tree. The results of this study show the significant effect of single tree volume on the time required for work elements felling, delimbing, regripping and crown placement. A basic time requirement per tree was only found in the moving process. Additionally the influence of re-gripping the tree after a branch on the processing time was analyzed. The likelihood of re-gripping raises with increasing tree-volume: re-gripping was not required at tree-volumes lower than $0.5 \mathrm{~m}^{3}$, but occurred increasingly with volumes above $0.5 \mathrm{~m}^{3}$.

\section{Development of Japanese version of the felling safety game}

Yozo Yamada ${ }^{1}$ Efi Yuliati Yovi²

${ }^{1}$ Ehime University, Matsuyama, Japan; 2Bogor Agricultural University, Bogor, Indonesia (yamada.yozo.fi@ehime-u.ac.jp; eyyovi@ipb.ac.id)

The felling safety game was developed by Dr. Efi Yuliati Yovi to improve safety knowledge of Indonesian forestry workers and supervisors according as the OSH-MS. It is a unique and well-designed board game, and is one of very effective tools to educate novice or ignorant workers in Indonesia. In Japan, all forestry workers should have got safety training, but many working accidents still occur against basic safety operations. Many of skilled workers must forget basic safety knowledge, and might be ignorant about current or new information. The felling safety game is expected for them to awake their basic knowledge about safety felling operation. Each knowledge is appeared at random by a picked card during the progress of the safety game. It causes a positive educational effect on keeping workers' interests without boredom and sleepiness. The prototype of Japanese version was made by direct translation from the Indonesian version, so many problems were found during some trials in Japanese forestry entities. According as those claims and opinions, the revision of Japanese version was performed in the following three steps. First, Japanese version was divided into two versions; a basic version for novices and a management version for owners and supervisors. Second, types of cards were reduced from eight to five to make the safety game simple. Third, number of squares was decreased from 100 to 50 to shorten the playing time. The process of revision and trial results of the revised Japanese version of felling safety game will be introduced.

\section{Spatial interpolation of logging damages through the triangulated irregular network (TIN) method to quantify timber harvesting impacts in secondary Atlantic Forest}

Pedro Britto ${ }^{1,2}$ (D), Dirk Jaeger ${ }^{1}$, Stephan Hoffmann ${ }^{2}$, Renato Robert ${ }^{3}$, Alexander Christian Vibrans ${ }^{4}$, Alfredo Celso Fantini ${ }^{5}$

${ }^{1}$ University of Göttingen, Göttingen, Germany; ${ }^{2}$ University of Freiburg, Freiburg, Germany; ${ }^{3}$ Universidade Federal do Paraná, Curitiba, Brasil; ${ }^{4}$ Fundação Universidade Regional de Blumenau, Blumenau, Brasil; ${ }^{5}$ Universidade Federal de Santa Catarina, Florianólpolis (pcdbritto@hotmail.com;

dirk.jaeger@uni-goettingen.de; stephan.hoffmann@uni-goettingen.de;renatorobert@ufpr.br; acv@furb.br; alfredo.fantini@ufsc.br)

The lack of knowledge on potential timber-harvesting impact is one of the constraints causing conflicting goals between conservation and management of the remnant Atlantic Forest biome. In order to contribute to fill these gaps, our research assessed and compared the harvesting impacts of a conventional method (CM) with an alternative and improved method (AM). Permanent sample plots were installed and a full pre-harvesting inventory was performed. Every tree inside plots was tagged and its location ( $\mathrm{x}$ and $\mathrm{y}$ coordinates) was recorded. A post-harvesting inventory was conducted and the timber-harvesting impact on remnant stand was assessed. The positioning of every tree was further georeferenced within ArcGIS software. The geoprocessing methodology "triangulated irregular network" (TIN) was used for generating damage maps with the most affected area per plot. Felling direction and winching line bearings were georeferenced, analysed in ArcGIS and also plotted on these maps. Our results showed that the harvesting affected mainly trees in the lower DBH classes. The felling process in comparison to winching caused most of damage on remnant trees. The winching lines did not follow the shortest extraction distance from the 
tree location to the road, nor, were located on the most damaged area inside the plots. Small improvements on AM method allowed a reduction of damaged basal area; a reduction of the "high damaged area" per plot; and a reduction of the winching disturbed ground area. However, the high stand density and heterogeneity of these forests may limit the effectiveness of the efforts to reduce timber-harvesting damage.

\section{Analysis of time and volume variables influencing the grapple saws effective productivity by mathematical models

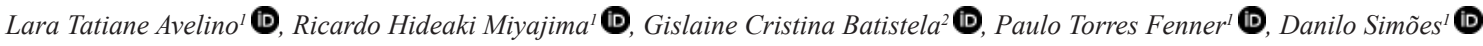 \\ ${ }^{1}$ Universidade Estadual Paulista "Júlio de Mesquita Filho”, Faculdade de Ciências Agronômicas, Botucatu, Brasil; " ${ }^{2}$ Universidade Estadual Paulista “Júlio de Mesquita Filho”, Campus Experimental de Itapeva, Itapeva, Brasil (laratatianeavelino@gmail.com; richidetoshimiyajima@hotmail.com; gislaine. batistela@unesp.br;fenner@fca.unesp.br;danilo.simoes@unesp.br)}

The productive machine hour (PMH) is influenced by numerous variables present in the field, being that the grapple saws can be affected by the effective time and volume of wood. In this way, mathematical modeling could be used to evidence the correlation degree between these variables. In this perspective, the objective was to analyze, by means of mathematical modeling, the influence of the variables time and volume of eucalyptus wood on the effective productivity of the machine. The grapple saw evaluated was a Caterpillar brand, model 320 DFM, in two operational conditions, where the Condition 1 was an area with terrain declivity of $11.9 \%$ uphill; Condition 2: area with $12.0 \%$ downhill. The determination of the PMH was obtained by the time and movements methods. In order to express the correlation degree between the variables, Pearson's $r$ was used, which showed that the productivity increased as the average timber volume increased, with an inverse relationship with the time variable. For the estimation of productivity in the uphill condition the regression model was adjusted, with coefficient of determination of 0.82 . For the downhill condition, the model was adjusted, with coefficient of determination of 0.82 , so the two conditions obtained a positive linear relationship. The average PMH in the uphill condition was $120.40 \mathrm{~m}^{3}$, while the downhill condition presented an average of $140.92 \mathrm{~m}^{3}$, which differed statistically, in other words, the productivity of the grapple saws, on average, differs by terrain slope.

\section{Monte Carlo method applied to the stochastic simulation of technical-economical risk of the forestry plotter

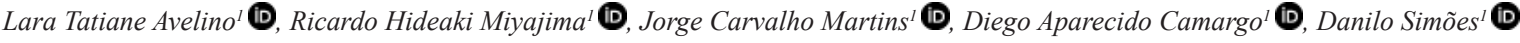 ${ }^{1}$ Universidade Estadual Paulista "Júlio de Mesquita Filho”, Faculdade de Ciências Agronômicas, Botucatu, Brasil (laratatianeavelino@gmail.com; richidetoshimiyajima@hotmail.com;jorgec.martins@hotmail.com; diegocamargoflorestal@gmail.com; danilo.simoes@unesp.br)}

The forestry grapple saws is an implement that integrates models that act in full-tree harvesting system, and has the function of tracing the stems. Thus, productive machine hour (PMH) is influenced by several technical factors that influence production costs. In this perspective, the objective was to apply the Monte Carlo method for the stochastic analysis of the technical-economical behavior of the eucalyptus tracing under uncertainty conditions. It was evaluated a grapple saws, Caterpillar brand, model 320 DFM, in two operational conditions, where the Condition 1 was an area with terrain declivity of $11.9 \%$ uphill; Condition 2: area with $12.0 \%$ downhill. Through the study of time and movements, the PMH was determined and the operational cost was obtained using the methodology suggested by FAO. The stochastic simulation generated 100.000 pseudorandom using the Monte Carlo method. Analyzing the operational cost, the distribution that adjusted best was Beta, with average of USD $83.47 \mathrm{~h}-1$, and the fuel presented a strong positive correlation, with 0.91 . Considering the PMH and the production cost for both operational conditions, the best model was the Normal distribution. The PMH of Condition 1 presented the average of 130.29 $\mathrm{m}^{3} \mathrm{PMH}-1$ and for Condition 2 the average was $162.33 \mathrm{~m}^{3} \mathrm{PMH}-1$, hence, the production costs were USD $0.96 \mathrm{~m}^{-3}$ and USD $0.74 \mathrm{~m}^{-3}$, respectively, evidencing that the position of the grapple saws in relation to the terrain declivity influences the PMH.

\section{The application of artificial neural network in wood harvest machines operators learning curve}

Millana Pagnussat ${ }^{1}$, Eduardo Lopes ${ }^{1}$, Izabel Bonete ${ }^{1}$

${ }^{1}$ Universidade Estadual do Centro-Oeste,Irati,Brasil (millanap@gmail.com; eslopes@unicentro.br; ipbonete@unicentro.br)

Due to the great complexity of wood harvesting machines operation, the great cost and long training period necessary, it is important to find a good way to quantify and compare expenses for a good planning. A computational tool with potential to be applied in the production of natural resources, that makes possible the relation of the database between the field and the operation, are the artificial neural networks (RNAs). The objective of the study was to evaluate the performance of RNAs in the estimation of productive efficiency (PE\%), as a function of training time (month), to construct the learning curve of feller-buncher operators. Data from 12 operators were analyzed under different operating conditions. For this purpose, operator's productivity targets $\left(\mathrm{m}^{3} / \mathrm{h}\right) \mathrm{were}$ calculated, based on forest quality and species, terrain and machine slope for 12 months. The operator's performance evaluation was calculated by the percentage reached by the target. The RNA was trained in $60 \%$ of the data and tested by $40 \%$. Using data from multiple inputs from operating time (month) and target ( $\mathrm{m}^{3} / \mathrm{ha}$ ). The results showed that operating time impacted forecasts by $99 \%$. However, the predictions associated with the goal were better, resulting on the productivity increase up to 8 months. The $\mathrm{R}^{2}$ was 0.54 , showing that the curve had a great correlation with time and showed a learning pattern. Although $\mathrm{R}^{2}$ was not ideal, it could be explained by differences in performance between operators about $50 \%$. The neural network was efficient in the estimated operational pattern.

\footnotetext{
Analyzing a tool for monitoring forest harvesting operations in real time / Análise de ferramenta para monitoramento de operações de colheita florestal em tempo real

Renata Aguayo Lopes da Silva ${ }^{1}$, Renato Cesar Goncalves Robert ${ }^{1}$

${ }^{1}$ Universidade Federal do Paraná, Curitiba, Brasil (renata_aguayo@hotmail.com; renatorobert@hotmail.com)

Os sistemas de gerenciamento das atividades florestais se tornaram ferramentas extremamente importantes para gestão das operações florestais em grandes empresas de base florestal. Especialmente nas operações de colheita florestal, o acompanhamento e monitoramento das operações são muito importantes para a precisa obtenção dos dados de desempenho das operações. Atualmente, esses sistemas de gerenciamento tem seu princípio baseado na comunicação satelital, que facilita o fluxo de informações e permite a obtenção de dados em tempo real. Com base neste cenário, este trabalho objetiva analisar o apontamento eletrônico de determinado sistema implantado em uma empresa florestal localizada no município de Santa Cecília - SC, e suas implicações no controle e monitoramento das atividades. Foram analisados os relatórios de produtividade, paradas operacionais e de manutenção, registros de abastecimento e horímetro das máquinas florestais. Observou-se que com a utilização do apontamento eletrônico e dos relatórios de gerenciamento a gestão das atividades se tornou mais fácil e eficiente. Com este resultado conclui-se que as tecnologias de apontamento eletrônico são ferramentas fundamentais para a gestão das atividades florestais, e nota-se que em pouco tempo se tornarão ferramentas indispensáveis para o bom gerenciamento e ganho de produtividade nas operações de colheita.
} 
Assessing the impacts of forest harvesting and quantifying wood waste in an area of community forest management in the Verde para Sempre Extractivist Reserve in Pará, Brazil / Avaliação dos impactos da colheita florestal e quantificação de resíduos de madeira em uma área de Manejo Florestal Comunitário na RESEX Verde para Sempre-PA

Marlon Costa de Menezes ${ }^{1}$, Suzana Ligoski Zeferino ${ }^{1}$, Natally Celestino Gama ${ }^{1}$, Flávia Ranara da Silva e Silva ${ }^{2}$, Saymon Roberto Pontes da Fonseca ${ }^{3}$ ${ }^{1}$ Universidade Federal do Pará, Altamira, Brasil; ' 2 Instituto Floresta Tropical, Porto de Moz, Brasil; ${ }^{3}$ Comitê de Desenvolvimento Sustentável de Porto de Moz-CDS, Porto de Moz,Brasil(marlon@ufpa.br; suzanaligosk@gmail.com; natallygama28@gmail.com; franarasilva@gmail.com;

saymonpontes21@gmail.com)

Os danos ambientais ocasionados durante a colheita florestal estão associados a uma exploração sem planejamento e geram excessiva quantidade de resíduos de madeira, produzindo significativa perda de renda nas comunidades extrativistas. O objetivo deste trabalho foi avaliar os danos ambientais da colheita florestal e quantificar o volume de estoque de resíduos produzidos e desperdiçados em Área de Manejo Florestal (AMF) da comunidade Arimum, na RESEX Verde para Sempre, município de Porto de Moz-PA. O estudo foi realizado na Unidade de Produção Anual (UPA) 06, onde avaliou-se as infraestruturas, danos as árvores remanescentes, abertura de dossel e quantificados (através do método de Huber) os resíduos aproveitáveis. Foram medidas e avaliadas 73 clareiras com dimensões que variavam de 149,00 a 924,00 m², de acordo com as características dendrológicas das espécies abatidas e técnicas de extração de impacto reduzido. A cada árvore explorada foram danificados 7,76 indivíduos, com danos variando de leves a severos distribuídos no fuste e copa. A abertura de dossel para a área foi 25,23 ha, equivalendo a 13,5\% da área da UPA. Mensurou-se amostras de resíduos florestais deixadas após a operação de corte de 57 árvores. A relação percentual encontrada entre volume de tora explorada e resíduos foi 50\%. Os danos provocados pela exploração podem ser minimizados com a capacitação, planejamento adequado da rede viária e corte de cipós. A utilização dos resíduos florestais pode constituir uma fonte de renda para as famílias extrativistas, entretanto são necessários estudos que avaliem o custo-benefício da operação de serragem e beneficiamento.

\section{C3g: THE FOREST AND FIRE OPERATIONS NEXUS: SYNTHESES AND PERSPECTIVES ON INTEGRATING FIRE RISK MANAGEMENT WITH FOREST ENGINEERING AND MANAGEMENT}

\section{Effectiveness of firewise approach in controlling forest fire: a case of Uluguru Nature Reserve, Morogoro, Tanzania}

Pilly Kagosi ${ }^{1}$, Siwa Ernest ${ }^{1}$, Innocent Babili ${ }^{2}$

${ }^{1}$ Tanzania Forestry Research Institute, Morogoro, United Republic of Tanzania; ${ }^{2}$ Sokoine University of Agriculture, Morogoro, United Republic of Tanzania (pjkagosi@yahoo.com; nkyasiwa@gmail.com; babhili@yahoo.com)

Forest fire has received considerable attention in literature because it is considered one of the most common factor causing disturbances in ecosystems and at the same time considered vital in maintaining ecosystems. Firewise approach (FWA) has been proposed and used for controlling forest fire for achieving sustainable forest management. The approach requires involvement of communities in managing forest fire incidences in adjacent reserved forests. Despite considerable period since FWA has been practiced, there is insufficient scholarly knowledge on the effectiveness of the approach in managing the forest fire. This paper examines the effectiveness of FWA in managing forest fires in Uluguru Nature Reserve. The study employed cross-section research designed that involved both quantitative and qualitative data collected from selected villages. Quantitative data were collected using structured questionnaire to 120 respondents selected randomly while qualitative data collected using Focus Group Discussion, observation and key informant interview. Quantitative data were analysed using percentages while qualitative data were analysed using content analysis. The study found alternating periods- firstly the period of overall decrease of wildfire incidences within initial five years of practicing the approach and another period of huge fire occurrence beyond five years. The study conclude that the Firewise-approach is useful in reducing forest fire incidences during early period of practicing the approach. However, the FWA has a challenge of sustaining successes in controlling forest fires including limited fire management training to common community. The study recommends on the need for enhancing and sustaining training of community members on forest fire management.

\section{Drying forest fuels and increasing wildfires in the western United States and adaptation options}

Yongqiang Liu', Fengjun Zhao ${ }^{2}$

${ }^{1}$ USDA Forest Service, Athens, GA, USA; '2Chinese Academy of Forestry, Beijing, China (yliu99@gmail.com; zhaofengjun1219@163.com)

The western U.S. has suffered prolonged droughts for nearly two decades, leading to drying forest fuels and frequent large wildfires. This study analyzes the historical variability of fuel moisture, drought, and wildfire in the western U.S., project their future trends, and discuss adaptation and mitigation options. Fuel moisture was calculated based on an algorithm from the U.S. National Fire Danger Rating System. Drought and fire potential were estimated using the KeetchByram Drought Index. Wildfires were simulated using a model developed based on the extreme value theory. Future trends were projected using dynamically downscaled climate change scenarios. The results show an overall drying trend in the atmosphere and forest fuels in the past three decades. Accordingly, wildfires, especially mega-fires, have increased dramatically. The current trends are projected to continue this century. The drying fuels and increasing wildfires impose a big challenge to fire management and safety. A number of methods could be used to mitigate the impacts. Tree species that can better conserve water and tolerate drought could be planted during vegetation regeneration in the burned area. Prescribed fires could be used more to reduce hazard surface fuels. And urban expansion to forested lands is restrained because urbanization would lead to the heat and dry island effects that could amplify fuel drying in nearby forested lands.

\section{Forest fire fighting: ergonomic and physiological aspects}

Elias Apud ${ }^{1}$, Felipe Meyer ${ }^{1}$

${ }^{1}$ University of Concepcion, Concepcion,Chile (eapud@udec.cl; fmeyer@udec.cl)

The present study was carried out with the aim to contribute to the organization of safe and efficient forest fire fighting. For this purpose, studies were carried out in real fires, where the physiological response imposed by the combination of heat exposure and physical work was measured continuously, recording the cardiac frequency. Temperatures were monitored and the slope of the terrain, the characteristics of the fuel and the quality of work were also evaluated in the field. Furthermore, line construction essays were performed to establish, under controlled conditions, the optimum size of crews, working on fuels with different degrees of difficulty and the effect of hydration, rest pauses and time limits for relay of workers. The results showed that forest fire fighting is a very heavy physical activity. The time that a forest fire last and the complexity of environmental conditions, may impose extremely high physiological demands leading to 
fatigue, diminishing output and the quality of work. On this basis, the importance of selection, training and alternatives for the organization of fire fighting is discussed, concluding that Ergonomics, with its multidisciplinary approach, is a useful tool to improve the organization of work that can contribute to reduce the risks for workers and the social and economic damage caused by forest fires.

\section{Sustainable forest management under fire risk: ecological options to reduce the fuel loads}

Teresa de Jesus Fidalgo Fonseca ${ }^{1,2}$, Marina Meca Ferreira de Castro ${ }^{3,4}$, Filipa da Conceição Silva Torres Manso ${ }^{1,5}$

${ }^{1}$ Universidade de Trás-os-Montes e Alto Douro, Vila Real, Portugal; ${ }^{2}$ Centro de Estudos Florestais, Universidade de Lisboa, Lisboa, Portugal; ${ }^{3}$ Instituto

Politécnico de Bragança, Bragança, Portugal; ${ }^{4}$ Centro de Investigação de Montanha, Bragança, Portugal; ${ }^{5}$ (tfonseca@utad.pt; marina.castro@ipb.pt; tforres@utad.pt)

Wildfire is a major abiotic disturbance in natural and planted forests, historically affecting larges areas of forests all over the world. In forest areas prone to forest fire, such as in the Mediterranean region, the risk of disturbance is continuously present (or recurrent) and need to be considered explicitly by the forest managers. As shown by the dramatic events of October 2017, in Portugal, wildfire suppression response does not guarantee, by itself, to be an adequate procedure to avoid damages caused by this disturbance. It is necessary to begin earlier, at the stand scale level, with preventive forest management procedures. Typical options include the selection of the tree species to plant, promoting the use of the essences most resistant to fire, coupled with their organization in space through compartmentation, and at the stand level, with the reduction of fuel loads of the understory vegetation and downed woody material. For existing forests, reduction of fuel loads can be achieved artificially by a prescribed burn or mechanical removal, or through ecologically based procedures of reducing the understory. This communication brings to analysis, under the umbrella of Project (Forestation of Agricultural Land with More Silviculture, Silvopasture, Innovation and Value), reduction of the understory fuel loads (a) by the management of the average density among trees; (b) by grazing. The effectiveness of the approaches to address the reduction of fuel loads over competing alternatives are evaluated and discussed for real case of studies.

\section{Joint international efforts and challenges for enhancing fire management capabilities in the Chernobyl Exclusion Zone, Ukraine}

Sergiy Zibtsev ${ }^{1}$, Victor Myroniuk ${ }^{1}$, Alan Ager ${ }^{2}$, Richard Lasko ${ }^{3}$, Joe Reinarz ${ }^{4}$, Johann Georg Goldammer ${ }^{5}$, Vladimir Usenia ${ }^{6}$, Vasyl Gumeniuk ${ }^{1}$,

Oleksandr Soshenskyi ${ }^{1}$

${ }^{1}$ Regional Eastern Europe Fire Monitoring Center, National University of Life and Enviornmental Sciences of Ukraine, Kyiv, Ukraine; ${ }^{2}$ Rocky Mountain Research Station, US Forest Service, Pendleton, USA; ${ }^{3}$ US Forest Service, Missoula, MT, USA; ${ }^{4}$ NIMO, United State Forest Service, Lakeview, Oregon, USA; ${ }^{5}$ Global Fire Monitoring Center, Freiburg, Germany; ${ }^{6}$ Institute of Forest, NAS, Gomel, Belarus (sergiy.zibtsev@nubip.edu.ua; victor.myroniuk@nubip.edu.ua; aager@fs.fed.us; rich.lasko920@gmail.com; jreinarz@fs.fed.us; johann.goldammer@fire.uni-freiburg.de; usenyaforinst@gmail.com; vasyl.gumeniuk@gmail.com; soshenskyi@nubip.edu.ua)

Three major wildfires in Chernobyl Exclusion Zone (CEZ) (2015) burnt 25,000 ha of contaminated lands, contributed to doses of firefighters, regional pollution outside the CEZ by releasing $137 \mathrm{Cs}, 90 \mathrm{Sr}, 238 \mathrm{Pu}, 239-240 \mathrm{Pu}$ and $241 \mathrm{Am}$. For preventing future catastrophic fires in CEZ two projects were implemented by U.S. Forest Service (USFS) and the Organization for Security on Cooperation in Europe (OSCE). Within the USFS project (2016-2018), five fire detection cameras installed that increased monitored area from 136,000 to 190,000 ha. Chernobyl firefighters were equipped with fire clothing and breathing-protection means. Improved inter-agency communication were achieved by convening five National Coordination Meetings. Within 12 trainings with USFS instructors firefighters trained with knowledge on fires, safety and incident management. A risk assessed to help manage the long-term effect of re-suspended radionuclides from wildfires. For development of fire management plan spatial dataset was created (fuel loads, contamination, suppression) to develop a cohesive fire management strategy and fire management goals. Within the OSCE project, attention was paid to preparedness of Belorussian and Ukrainian fire services for management of trans-border fires (TBF). Guideline for fire suppression and Belarussian-Ukrainian-English fire terminology were developed for improving coordinated response to TBF, as well as software for predicting doses to firefighters and analysis of legislation of two countries. A table-top exercise for fire command staff was organized by the OSCE, the Global Fire Monitoring Center (GFMC) and the Ukraine-based Regional Eastern Europe Fire Monitoring Center (REEFMC) aimed at strengths of interoperability in addressing radioactive fires.

\section{Sustainable forestry under fire risk: the use of fire operations research to inform forest operations in the interior Western United States}

Matthew Thompson ${ }^{1}$, Nathaniel Anderson ${ }^{1}$

${ }^{1}$ US Forest Service, Fort Collins, USA (mpthompson02@fs.fed.us; nathaniel.m.anderson@usda.gov)

Forest operations implement treatments that are prescribed to meet landowner and societal objectives, which on federal lands in the western United States continues to emphasize mitigating wildfire risk. The primary objectives of fuel treatments are to reduce the likelihood and intensity of wildfire, and to improve conditions for the control of fire when it occurs. Design principles for fuel treatment operations tend to be well-aligned with fire management objectives, and treatment strategihes have been the subject of engineering optimization for at least 15 years. However, for a variety of reasons, on-the-ground implementation rarely aligns with theory, and questions persist regarding treatment return-on-investment (ROI). Although treatment benefits are often estimated by evaluating post-treatment fire behavior, assessing the likelihood of such fire-treatment encounters even occurring is an equally if not more important determinant of ROI. Further, although facilitating fire control operations is often an assumed benefit of treatment, how this could or ought to materialize is not systematically incorporated into treatment design. Arguably what is needed is a treatment prioritization framework that jointly considers fire-treatment encounter likelihood with factors relevant to fire control operations. Recent progress on the latter front includes proactively differentiating landscapes on the basis of suppression difficulty and determining the likely effectiveness of various potential fire control locations, both of which could be ported from the incident response to the fuel treatment prioritization domain. This presentation highlights several ways that fire operations research can be used to inform and enhance the implementation of sustainable forestry under fire risk. 
Combatting wildfires in South African plantation forests with multi-faceted fuel load reduction measures: Is it working and is it sustainable?

Ben du Toit ${ }^{1}$, Christoff Gresse ${ }^{1,2}$, Angel Goldsmith ${ }^{1}$, Paul Viero ${ }^{3}$, Christopher Pickup ${ }^{1,4}$, Dean da Costa ${ }^{1,3}$

${ }^{1}$ Stellenbosch University, Stellenbosch, South Africa; ${ }^{2}$ MTO forestry, Witrivier, South Africa; ${ }^{4}$ SAFCOL, Graskop, South Africa; ${ }^{3}$ Mondi Limited, Hilton, South Africa(ben@sun.ac.za; christoff@mto.co.za; 22486771@sun.ac.za; paul.viero@mondigroup.com; christopherp@safcol.co.za;

dean.dacosta@mondigroup.com)

South African plantation forests have experienced an increase in wildfire damage during the last two decades, attributed to climate change and various sociopolitical realities. Fuel load reduction is pivotal to successful fire-fighting operations. We used long term experiments and operational case studies to evaluate the efficacy, cost, biotic effects and sustainability of various fuel reduction measures. Repeated under-canopy burning under semi-mature pines can significantly reduce forest floor fuel loads by an average of 6.3 and 12.9 t ha-1 per burining event in in $P$. elliottii and $P$. patula stands, respectively, with apparently no significant reduction in long-term stand productivity. The goal of forest floor reduction to values around $10-15 \mathrm{t}$ ha- 1 can be achieved with two to four prescribed burning events, depending on species. Partial incorporation of forest floor and slash residues through disc-harrowing in strips among tree lines has been successfully implemented in eucalypt plantations. Repeated disc-harrowing between tree lines led to significant reduction in forest floor fuel load and to significant changes in root distribution patterns with depth. Surprisingly, these operations only resulted in a non-significant growth reduction (4.5\% of basal area) in eucalypt stands tested to date. Biomass collection for energy, slash burning and mulching treatments are implemented by commercial growers to reduce fuel loads, taking soil erodibility and slope conditions into account. Post fire assessment procedures encourages the implementation of low intensity prescribed burning. The effects of various fuel load reduction treatments on soil erosion potential, soil chemical properties, nutrient budgets and long-term sustainability are presented and discussed.

Amazonia sin Fuego, a strategy to reduce forest fires and promote alternatives to burning in the Sierra and coastal regions of Ecuador I "Amazonia sin Fuego", una estrategia para la reducción de incendios forestales y promoción de alternativas al uso del fuego en las regiones Sierra y Costa del Ecuador

Daniel Segura ${ }^{1}$, Andrea Bustos ${ }^{1}$, Pietro Graziani², Jessica Coronel ${ }^{1}$

${ }^{1}$ Ministerio del Ambiente del Ecuador, Quito, Ecuador; ${ }^{2}$ Agencia Italiana para la Cooperación al Desarrollo, Roma, Italy daniel.segura@ambiente.gob.ec; andrea.bustos@ambiente.gob.ec; pietrogra@yahoo.it; jessica.coronel@ambiente.gob.ec)

El fuego ha sido una herramienta de trabajo en todas las culturas del mundo desde hace miles de años. Ha formado parte de la actividad agrícola y ganadera e incluso de fiestas locales, modelando el paisaje en todo el planeta y evolucionando a nuestra especie a través de los años. Por otro lado, el fuego sin control producto de su uso inadecuado, ha creado alarma social, destruyendo bosques y riquezas naturales, poniendo en riesgo a poblaciones enteras y generando pérdidas económicas cuantiosas. En el Ecuador esta problemática no dista del escenario global en materia de incendios forestales. Flagelos de este tipo han ocasionado pérdidas superiores a 200.000 ha en los últimos 10 años, afectando grandes extensiones de bosques naturales y plantados, además de otros tipos de vegetación natural, como los páramos andinos, de gran valor hídrico y abastecedores del recurso agua desde poblaciones pequeñas asentadas en su territorio, hasta las principales ciudades del país de la región sierra e inclusive de la costa. Bajo este escenario desde el 2017 el Programa de Reducción de Incendios Forestales y Alternativas al Uso del Fuego "Amazonia Sin Fuego" (PASF) se implementa en el Ecuador, brindando la oportunidad de continuar las acciones técnicas y tecnologías emprendidas exitosamente en Brasil y Bolivia desde 1999. El PASF Ecuador busca reducir la incidencia de los incendios forestales en la sierra y costa del país, potenciando acciones de prevención, fortaleciendo capacidades técnicas, construyendo política pública y promoviendo prácticas agropecuarias alternativas al uso del fuego en áreas rurales.

\section{Estimating wildland fires economic costs: a proposal}

Armando Gonzalez Caban ${ }^{1}$, Jose J. Sanchez ${ }^{1}$

${ }^{1}$ USDA Forest Service, Riverside,USA (agonzalezcaban@fs.fed.us; jsanchez@fs.fed.us)

Discussions on the costs of wildfires are generally limited in scope, short-term in nature, and by and large, address mainly suppression expenditures. Recent years have seen improvements on estimating the economic costs of wildland fires, though not to the point of being a common practice. Moreover, scant data is kept on costs of wildfire by federal, state, and local agencies and little research exists on this topic in general (Morton et al; 2003). Up to date few wildlandurban interface (WUI) fires economic costs have been estimated either by public, private and nonprofit sector agencies. Perhaps the reason for this is that the costs of these fires are so large and far reaching that it is a challenging research effort to quantify them. Estimating the economic costs of wildland fires requires accounting for many cost categories including but not limited to direct fire suppression and emergency response expenditures, post fire recovery, water quality mitigation and reimbursement expenditures, and loss of income generating potential or non-market value as a direct or indirect result of wildfire. For each of these categories information must be obtained for public, private and nonprofit organizations involved in the event. Valuation of ecosystem services, particularly those being intangibles or without market values are very difficult to obtain. In this presentation we will introduce a preliminary methodological framework for estimating wildland fires economic costs

\section{C3h: THE ROLE OF FOREST ERGONOMICS IN SUSTAINABLE FOREST MANAGEMENT IN} TROPICAL REGIONS

\section{Chilean workforce sustainability}

Felipe Meyer ${ }^{1}$

${ }^{1}$ University of Concepcion, Concepcion, Chile (fmeyer@udec.cl)

Sustainability principles have been acquiring greater significance in the forestry sector. This study deals with the contribution of the human-at-work systems for business sustainability since it is widely conceived that human performance is becoming a critical factor, in improving the sustainability of the organization. In this context, this research aims to contribute to achieving the balance between people capacity and system demand and expects to provide an understanding of these complex interactions and the benefits that this view could bring for the organisations. The forestry sector, this sector is facing a number of challenges that having direct or indirect in the impact the sustainability of the workforce and it's necessary to know it to understand the situation under a holistic point of view. 
In that sense, the purpose of this research is to explain, what is happened with the sustainability of the workforce of the forestry sector. To achieve the aim of this research, the author used an ergonomics approach, that has the purpose to identify the elements in the work environment that are affecting that the sustainability of the workforce in the Chilean forestry sector. The results show that the sustainability of the workforce in the Chilean forestry sector is under threatening, since an existing element in the sector that affecting it. The working conditions are a crucial element to improve the sustainability of the workforce.

A sawmill for social inclusion of family farmers in northern Argentina / Una tableadora para la inclusión social de los agricultores familiares del norte argentino

Carlos Alberto Derka ${ }^{1,2}$, Jorge Kostecki ${ }^{1}$, Orlando Jesus Pachinsky ${ }^{1}$, German E. Camprubi ${ }^{3}$

${ }^{1}$ INTA, Presidencia Roque Saenz Peña, Argentina; ${ }^{2}$ Universidad Nacional del Chaco Austral Presidencia Roque Saenz Peña, Argentina; ${ }^{2}$ Universidad

Nacionaldel Nordeste, Resistencia,Argentina (derka.carlos@inta.gob.ar;kostecki.jorge@inta.gob.ar; pachinsky.orlando@inta.gob.ar;

bio-german@hotmail.com)

En la Agricultura Familiar (AF), la sostenibilidad social resulta crucial. El concepto de innovación tecnológica está asociado con dos aspectos clave: su novedad y su adopción social. El objetivo de este trabajo es presentar una tableadora desarrollada en el Instituto Nacional de Tecnología Agropecuaria (INTA) y las posteriores acciones para extender su uso en el norte argentino. Tomando de referencia tecnología extranjera, las adaptaciones realizadas consideraron fundamentalmente la seguridad del operario de la tableadora y sus costos de fabricación. La transferencia de esta tecnología ha tenido dos ejes: los talleres para construir la tableadora y sus accesorios y los de su operación y mantenimiento. Es una herramienta fabricada con hierro y aluminio que mediante elementos de acople a la espada de distintas motosierras de tipo comercial admite el corte de tablas de diferentes espesores que van desde $1 / 2$ a 10 pulgadas. También se desarrollaron accesorios tendientes a preservar la seguridad de quienes operan la tableadora llegándose inclusive a la producción de guantes especiales. El uso de un trípode para elevar el tronco del árbol posibilita que el operario trabaje en forma ergonómica sumando una posición de trabajo más cómoda a la seguridad propia de esta herramienta. Un agricultor puede obtenerla a un valor final al menos un $40 \%$ por debajo de las que se ofrecen comercialmente. La tableadora INTA podría ser adaptada a diferentes tipos de bosque y contextos socioeconómicos y servir de referencia para otras iniciativas de inclusión social en el manejo de bosques naturales o plantados.

\section{Aerobic capacity, aerobic threshold, workload and output in forestry workers: an example based on pruning activities}

Felipe Meyer ${ }^{1}$, Elias Apud ${ }^{1}$, Esteban Oñate ${ }^{1}$

${ }^{1}$ Universidad de Concepcion, Concepcion,Chile (fmeyer@udec.cl; eapud@udec.cl; estebanonate@udec.cl)

The objective of this study is to analyze factors related to the impact of physical fitness of the workers on productivity and work load to determine if this population would be able to respond to the present and future production needs and the ergonomic adaptations required to get closer to the productive goals without undue overload of the workers. Laboratory and field techniques used in this study were described by Apud et al (1999) Results revealed that the aerobic capacity of the pruners $(\mathrm{n}=56)$ was $43 \mathrm{mlO} 2 / \mathrm{kg} / \mathrm{min}$, and he body composition of the average group was $20 \%$ fat mass. The aerobic threshold was equivalent to $47 \%$ of the aerobic capacity. The results of field studies showed that the group has a high dedication to the main activity, close to $80 \%$. The average cardiovascular load was very close to the threshold limit for these workers. In relation to production considering pruned trees per hour, it was found a decreasing trend in productivity as time went on along the shift in all the days evaluated. Consequently, according to the results of this study, ergonomic measures should aim to optimize all those aspects complementary to its main activities, such as clothing, tools, food and organization including the distribution of rest pauses, to mention the most important ones.

\section{Estimation of output in manual forest activities with special reference to pruning}

Felipe Meyer ${ }^{1}$, Elias Apud ${ }^{1}$

${ }^{1}$ University of Concepcion, Concepcion,Chile (fmeyer@udec.cl; eapud@udec.cl)

Output depends on the workload that a worker can sustain without fatigue or other risks and on the difficulties to carry out his job, mainly related to the type of trees, climate and ground. In other words, in forestry there is no chance to demand of a worker always the same amount of work. This puts a difficulty to calculate incentives and salaries, especially when workers are paid by piece rate. The objective of this paper is to propose reference tables for calculation of yields in manual forest workers. For the purpose of this presentation, data collected during pruning will be discussed. With respect of methods, work load was estimated from cardiac frequency measured minute by minute during complete shifts together with time studies. Slope of the ground, environmental temperature and characteristics of the trees were also monitored. Statistical procedures were applied to the data and equations were proposed to calculate output. Afterwards, the equations were tested in forests of different degree of difficulty. The equation to estimate pruned trees per hour from the work load and characteristics of the trees was highly significant. When tested afterwards in different conditions, the estimation was within the standard error of the experimental equation. In conclusion, the equation could be transferred to the operation and used for the calculation of expected output and for the calculation of basic salaries or basic salaries plus bonus.

\section{Evolution of the quality of life in Chilean forest camps in the last 40 years}

Elias Apud ${ }^{1}$, Felipe Meyer ${ }^{1}$

${ }^{1}$ University of Concepcion, Concepcion, Chile (eapud@udec.cl; fmeyer@udec.cl)

For an effective application of ergonomics in the forest sector, with the aim to improve wellbeing and productivity, there are preconditions, that are determined by the characteristics of the sector itself. In this respect, it is necessary to take into account that work is carried out far from urban areas and workers must remain in camps or travel long distances from home to the forests. Furthermore, in traditional manual forestry work that demands high energy expenditure, the quantity and quality of food is particularly important. The aim of this paper is to present an analysis of the evolution of the forest camps in Chile from the seventies until now, as well as to show the impact of improvements in the diets, not only in terms of quantity of food but also in quality and taste of the workers. Results show that living conditions in camps have improved. The participatory approach started in the early eighties gave the basis for positive changes that are observed at present. Although there is still space for improvements, changes are noticeable and well accepted by the workers. Better living conditions have been favored by a legal decree which establishes minimum hygienic conditions for camps. However, the most important is that companies and most contractors are motivated to innovate, because they are better informed about the importance of the quality of working life to reach good productivity without harmful effects on the workers, topics which will be discussed in the presentation. 


\section{Social sustainability: an issue of diversity and forest work}

Siegfried Lewark ${ }^{1}$, Marion Karmann ${ }^{2}$

${ }^{1}$ University of Freiburg, Freiburg, Germany; ${ }^{2}$ FSC International, Bonn, Germany (siegfried.lewark@fobawi.uni-freiburg.de; m.karmann@fsc.org)

Social Sustainability is one of the three dimensions of Sustainable Forest Management. This includes Sustainable Livelihood and by definition activities of women and men in forest work. Work in tropical forests is done for earning a livelihood, based on the use of forest resources, timber as well as NTFP. Most of this work is done in the informal sector, where social sustainability is a critical issue. Sustainable forest management in formal economy requires that the operations in the forests are carried out with employees, who know what tools and techniques to use and have the motivation to meet these requirements of the jobs. However, in many tropical countries, the working conditions provided to forest workers are very poor, lacking even the very basic facilities such as proper food and housing. Under such conditions, it must be expected that the work performed in the forest also lacks the quality required for sustainable management.

\section{Safety at forest work - survey and analysis of work accidents in leading state forests in Germany}

Udo Hans Sauter ${ }^{1}$, Svenja Bonadio ${ }^{1}$, Susanne Kaulfuss ${ }^{1}$, Stephanie Bethmann ${ }^{1}$, Hannes Weinbrenner ${ }^{1}$, Alisa Goedecke ${ }^{1}$

${ }^{1}$ Forest Research Institute Baden-Wuerttemberg, ${ }^{79100}$, Germany (udo.sauter@forst.bwl.de; svenja.bonadio@forst.bwl.de; susanne.kaulfuss@forst.bwl.de; stephanie.bethmann@forst.bwl.de; hannes.weinbrenner@forst.bwl.de; alisa.goedecke@googlemail.com)

In the state forest enterprise of Baden-Württemberg, one of the largest forest enterprises in Germany, the number of work accidents increased during last years while the number of work accidents in Germany as a whole showed the opposite trend. This situation gave motivation for a comprehensive analysis of health and safety in the forest working environment, i.e. causes and aspects of work accidents. The survey comprised all obvious work conditions like natural conditions of typical work places in diverse forest types in flat as well in steep terrain, tree dimensions, degree of mechanisation, stage of education of the forest worker, age, fitness and organisational framework. Part one of the study focused on the analysis of recorded work accident cases with respect to the aspects listed above. However, as excellent work related education and high-level personal safety gear are pre-requisites and standard for all forest workers employed by the state forest of Baden-Württemberg emphasis was given to a detailed analysis of the organisation structures, e.i. the relationship between forest workers and management, management routines within the enterprise as well its cooperate culture by methods of social sciences. Numerous guided interviews were realised given deep insights to routines and stress factors during typical work situations. These findings helped to validate, to revise or complement the results of the static accident analysis from part 1 and opened up a dynamic view onto factors for the accidents. Additional aspects like satisfaction on the job and identification with the enterprise can be evaluated.

\section{Concepts of International Forest Ergonomic Textbook for Developing Countries}

Yozo Yamada ${ }^{1}$ Efi Yuliati Yovi ${ }^{2}$, Witold Grzywinski ${ }^{3}$, Amaury De Souza ${ }^{4}$

${ }^{1}$ Ehime University, Matsuyama, Japan; ${ }^{2}$ Bogor Agricultural University, Bogor, Indonesia; ${ }^{3}$ Poznan University, Poznan, Poland; ${ }^{4}$ Federal University of Viçosa, Viçosa,Brasil (yamada.yozo.fi@ehime-u.ac.jp; eyyovi@ipb.ac.id; witold.grzywinski@up.poznan.pl; amaurypaulo@gmail.com)

Forest ergonomic textbooks might be issued in many developed countries. In those countries, students can study forest ergonomics with the native language textbook. However, most of developing and medium countries, including Japan also, don't have own forest ergonomic textbook. Students and researchers in those countries can't study the systematical forest ergonomic, so there are a strong demand to aspire for an international forest ergonomic textbook among them. In those countries, human problems become larger with the economic growth, so ergonomic knowledge will be more significant to solve those problems. Moreover, the evolution of information and robotic technologies is changing the world, and brings sophisticated and complicated problem in each industry. This problem occurs also in developing and medium countries as well as in developed countries. IUFRO RG3.03.00 decided to issue a basic and standard textbook of forest ergonomics including safety management for future new technologies. The main target of this textbook is students and researchers in developing and medium countries, moreover it will be very useful and educational for those of developed countries because it show a future aspect of forest ergonomics. The textbook will consist of nine chapters; 1 . History of ergonomics, 2. Worker's burden, 3. Working environment, 4. Work safety, 5. Operational technology, 6. Forestry labor, 7. Owner's responsibility, 8. Regional specific problems, and 9. Future roles of forest ergonomics.

\section{C3i: LPF/SFB - IAWA PANEL DISCUSSION: NEW METHODS AND APPLICATIONS OF TROPICAL TIMBER IDENTIFICATION TO PROMOTE LEGAL LOGGIN}

\section{New advances of DNA barcoding technology for wood identification in China}

Lichao Jiao ${ }^{1,2}$, Yafang Yin ${ }^{1,2}$

${ }^{1}$ Wood Anatomy and Utilization Department, Research Institute of Wood Industry, Chinese Academy of Forestry, Beijing, China; ${ }^{2}$ Wood Collections

(WOODPEDIA),Chinese Academy of ForestryBeijing China (jiaolichao@126.com; yafang@caf.ac.cn)

Excessive logging and trading in illegal timber are causing deforestation in natural forests, along with a great deal of ecological and economic damage. Wood identification is therefore so crucial and significant that it is a technical prerequisite for monitoring the chain of wood certification. Traditional wood identification relies on diagnostic anatomical features, either macroscopic or microscopic but rarely can provide a precise discrimination of wood at the species level. To overcome such limitations, the newly developed DNA barcoding method may significantly improve the resolution. The paper reviews the new progress of the identification method of wood DNA and its applications of China in recent years. We are establishing the optimized DNA extraction protocol for retrieving good quality and sufficient quantities of DNA from wood tissues, especially for the high-temperature dried wood and long-term stored wood. Besides the wood DNA extraction protocol, a reliable reference DNA barcode library is also one of the main obstacles to the application of DNA barcoding for the next few years. This study also confirmed that xylarium wood specimens are rich sources for reliable DNA sequence data, which will enhance the construction of wood DNA barcode reference libraries. The DNA barcode database of endangered and precious wood species internationally concerned, i.e. Dalbergia, Pterocarpus and Santalum, had been developed so far. Finally, a few cases indicated successful applications of DNA barcoding technology for law enforcement agencies in China. The work will contribute to the conservation of valuable species resources and timber trade monitoring internationally. 
Developing high-resolution DNA barcodes for timber species identification based on the complete chloroplast genome

Lichao Jiao ${ }^{1,2}$, Yafang Yin ${ }^{1,2}$

${ }^{1}$ Chinese Research Institute of Wood Industry, Chinese Academy of Forestry, Beijing, China; ${ }^{2}$ Wood Collections (WOODPEDIA), Chinese Academy of

ForestryBeijing China (jiaolichao@126.com; yafang@caf.ac.cn)

DNA barcoding, an effective tool for wood species identification, mainly focuses on universal barcodes and often lacks high resolution to differentiate species, especially for closely related taxa within the same genus. Therefore, more highly informative DNA barcodes need to be identified. This study is the first to report a strategy for developing specific DNA barcodes of wood tissues. The complete chloroplast genomes of leaf samples of three Pterocarpus species, i.e., $P$. indicus, $P$. santalinus and $P$. tinctorius, were sequenced, and thereafter, the most variable DNA regions were identified on the scale of the complete chloroplast genomes. Finally, wood DNA was extracted from wood specimens of the three Pterocarpus species, and DNA recovery rates of the selected regions were tested for applicability to verification on the wood specimens studied. The work will offer technical support for curbing illegal timber harvesting activities and for conserving endangered and valuable wood species.

\section{Tropical timber forensics: a multi-methods approach to tracing Bolivian Cedrela}

Kathelyn Paredes-Villanueval iD

${ }^{1}$ Universidad Autonoma Gabriel Rene Moreno, Santa Cruz, Plurinational State of Bolivia (kathypavi@gmail.com)

Illegal trade of tropical timber leads to economic and biodiversity losses worldwide. To date, the most common type of fraud concerns false declarations of species and geographic origin, as current legal procedures are generally based on certificates which can be falsified. With concerns about sustainable procurement of tropical timber, there is a need for effective tools to independently verify the source of traded timber. To this end, we applied Direct Analysis in Real Time Time-of-Flight Mass Spectrometry, stable isotopes $(\delta 13 \mathrm{C} / \delta 18 \mathrm{O})$ and microsatellites in Cedrela species, one of the major South American timber genera that includes species which are listed in the Convention on International Trade in Endangered Species of Wild Fauna and Flora (CITES). Heartwood, cambium and leaves from six Cedrela species were collected at 11 sites throughout Bolivia. First, DART-TOFMS detected 1062 chemical compounds; Principal Component Analyses (PCA) and Kernel Discriminant Analysis (KDA) of their relative intensities allowed species discrimination with 15-19\% mean error and site discrimination with 43-54\% mean error for $C$. fissilis and 42-48\% for C. odorata. Second, stable isotopes signatures were also analysed and it was possible to distinguish species, especially $C$. fissilis with $6.2 \%$ mean error. The isotopic site differentiation resulted in low discrimination success: $62.5 \%$ mean error for $C$. odorata and $70.5 \%$ for $C$. fissilis sites. Third, genetic discrimination assessed by KDA on allele frequency had a $33.7 \%$ mean error. Finally, our findings suggest that combining these methods to identify Cedrela species and sites could be favorable in some cases but detrimental in others.

\section{Forensic spectra of trees database: case study for rapid database development}

Meaghan Parkery-Forney ${ }^{1}$, Cady Lancaster ${ }^{2}$, Edgard Espinoza ${ }^{3}$, Alex Moad ${ }^{2}$

${ }^{1}$ World Resources Institute, Washington D.C., USA; ${ }^{2}$ US Forest Service International Programs, Ashland, OR, USA; ${ }^{3}$ National Fish and Wildlife Forensics Laboratory,Ashland,OR,USA (meaghan.parker@wri.org; cadylancaster@fs.fed.us; ed_espinoza@fws.gov; amoad@fs.fed.us)

The common thread of all species identification techniques is having a sufficiently large database for comparison. The US Fish and Wildlife Forensics Laboratory (NFWFL) developed wood identification protocols using Direct Analysis in Real Time Time-of-Flight Mass Spectrometry (DART TOF MS) in 2011. The immediate benefits of rapid analysis time, no sample preparation, inexpensive materials, and small sample size (slivers) paired with the high species identification resolution of tropical timbers, made the technique a robust tool for forensic identification of wood products. In 2016 , NFWFL and World Resources Institute with aid from US Forest Service International Programs began a combined effort to increase the database size for DART TOF MS. In under nine months, collection efforts of a single person increased the database by over 6000 samples, almost doubling the database size, and obtained reference samples of nearly every commercially (in many cases illegally) traded CITES and lookalike timber species. This presentation will summarize the reference collection, partnerships, and emphasize the utility of xylariums in modern timber identification research. Collection efforts established within this project continue with the development of a database for suspected violations of the U.S. Lacey Act.

\section{Wood identification by direct analysis in real time time-of-flight mass spectrometry}

Cady Lancaster ${ }^{1}$, Edgard Espinoza ${ }^{2}$

${ }^{1}$ US Forest Service International Programs, Ashland, OR, USA; ${ }^{2}$ National Fish and Wildlife Forensics Laboratory, Ashland, OR, USA (cadylancaster@fs.fed. us; ed_espinoza@fws.gov)

Wood identification by Direct Analysis in Real Time Time-of-Flight Mass Spectrometry (DART TOF MS) was developed at the National Fish and Wildlife Forensic Laboratory (NFWFL) in 2011 and continues to be used for forensic identification by NFWFL and by US Forest Service International Programs (USFSIP). In DART TOF MS, a sliver of heartwood is analyzed to generate the small molecule mass spectrum of the wood. Species-specific small molecule ( $<1000$ $\mathrm{m} / \mathrm{z}$ ) mass profiles, or chemotypes, which result from the interaction of the genotype with the environment, are obtained by evaluating multiple spectra from a single species. Combined efforts from the NFWFL and USFS-IP have analyzed over 200 forensic cases and 1000+ wood products ranging from roundwood to essential oils for species-level identification. While already a robust technique, identification capabilities continue to grow with improved reference collection efforts yielding the Forensic Spectra of Trees Database (ForeSTC) that holds over 10,000 reference spectra of CITES and commercially significant species. This presentation will cover case studies examining identification of tropical timber and chemotype persistence with time, storage, and geographic variability.

The importance of reference wood collections and complementary forensic species identification techniques for combatting illegal timber trade

Victor Deklerck ${ }^{1}$, Ed Espinoza ${ }^{2}$, Jan Van den Bulcke ${ }^{1}$,Hans Beeckman ${ }^{3}$, Joris Van Acker

${ }^{1}$ Ghent University - Laboratory of Wood Technology, Ghent, Belgium; ${ }^{2}$ U.S. National Fish and Wildlife Forensic Laboratory, Ashland, USA; ${ }^{3}$ Royal Museum

forCentralAfrica,Tervuren,Belgium (victor.deklerck@ugent.be; ed_espinoza@fws.gov; jan.vandenbulcke@ugent.be; hans.beeckman@africamuseum.be; joris.vanacker@ugent.be)

With the implementation of FLEGT and EUTR in 2003 and 2013 respectively by the EU and the expansion of the U.S. Lacey Act in 2008 by the USA, there is an increased focus to promote trade in legally produced timber and to put a stop to illegal timber trade. However, this requires complementary forensic timber 
identification techniques. Within the Herba Xyla Redd BELSPO- project, which aims at valorizing the Royal xylarium and herbarium in Belgium, we have been focussing on combining large wood collections and mass spectrometry for this purpose. The Royal Museum for Central-Africa (Tervuren, Belgium) houses the second largest wood collection in the world and at UGent-Woodlab we have been developing algorithms that are capable of classifying and identifying species based on their chemical fingerprint. The latter mass spectrometry-based technique has been developed at the US Fish and Wildlife Forensic Laboratory (Ashland, Oregon, USA) to identify traded timber or timber products. To obtain a chemical fingerprint, wood slivers are analysed with a DART-TOF Mass Spectrometer (JEOL, USA), leading to ionization and eventually a chemical pattern that is potentially unique per species. The main advantages are its speed, low cost and limited sample size (wood sliver) needed to analyse an unknown wood sample. It is clear that curated, reference, wood collections play a vital role in rapidly expanding this fingerprinting database with samples from all over the world. In this study we present this chemical fingerprinting method and the vital role wood collections play in database-building for timber identification techniques.

\title{
Determination of the origin of Swietenia macrophylla wood from five Latin American countries and discrimination between $S$. macrophylla and $S$. humilis using portable NIR devices and multivariate analysis
}

\author{
Diego C. Silva 1,2, Tereza C. M. Pastore, Liz F. Soares ${ }^{1,2}$, Filipe A. S. de Barros ${ }^{1,2}$, Maria C. J. Bergo ${ }^{1,2}$, Vera T. R. Coradin'2, Alexandre B. Gontijo2, \\ Myrna Herrera Sosa ${ }^{3}$, César Beltetón Chacón ${ }^{4}$, Jez W. B. Braga ${ }^{1}$ \\ ${ }^{1}$ Universidade de Brasilia, Brasilia, Brasil; ${ }^{2}$ Serviço Florestal Brasileiro, Brasília, Brasil; ${ }^{3}$ University of San Carlo, Guatemala City, Guatemala; ${ }^{4}$ Consejo \\ Nacional de Áreas Protegidas, Guatemala City, Guatemala(dcarvalho.silva@hotmail.com; tereza.pastore@gmail.com; liizsoares@hotmail.com; \\ filipesnel@gmail.com; mcjbergo@gmail.com; vera.coradin@gmail.com; alexandre.gontijo@florestal.gov.br; myrna_herrera_sosa@yahoo.com; \\ cesarbelte@gmail.com; jezwillian@gmail.com
}

The identification of the country of origin of timbers and the differentiation between an endangered very similar wood species are direct forms to combat the illegal logging. To this end, two methods are proposed using NIRS technology. The first one was dedicated to verifying the feasibility of the NIRS technology in determining the origin of the wood of Swietenia macrophylla from five Latin American countries - Bolivia, Brazil, Guatemala, Mexico, and Peru. The second one consisted in discriminating two species considered genuine mahogany: S. macrophylla and S. humilis. The methods were developed using portable NIR spectrometers and chemometrics. Two portable NIR spectrometers were used (MicroNIRTM and MicroPHAZIRTM), and the data analysis was performed using Partial Least Square for Discriminant Analysis (PLS-DA) and SIMCA (Soft Independent Modeling of Class Analogy). The Efficiency Rates (EFRs) showed that the Bolivian model obtained better results with MicroPHAZIR (EFR: 100\%) with both PLS-DA and SIMCA. The model for Brazil presented better results with MicroPHAZIR and PLS-DA (EFR: 100\%). For Guatemala, Mexico and Peru, the MicroNIR spectrometer with PLS-DA showed slightly better performance, obtaining ERFs equal to 100, 94.9 and 99.4\%, respectively, in comparison with the MicroPHAZIR and PLS-DA model. Therefore, the overall results indicated that MicroPHAZIR with PLS-DA was considered the most feasible method. For the analysis of S. macrophylla and S. humilis species, ERF of $100 \%$ was obtained for the PLS-DA model and $98.5 \%$ for the SIMCA, indicating the feasibility of the discrimination between these species belonging to the same genus.

\section{Timbers: Software to assist wood identification of tropical species (android version)}

Claudio S. Lisi ${ }^{1}$, Christiano S. F. Santana ${ }^{1}$, Nayanne A. Menezes ${ }^{1}$, Alexandre B. Gontijo², Juliana S. Rodrigues ${ }^{2}$, Vera T. R. Coradin ${ }^{2}$ ${ }^{1}$ Universidade Federal de Sergipe, São Cristóvão,Brasil; ${ }^{2}$ Serviço Florestal Brasileiro,Brasilia,Brasil (clcslisi@gmail.com; chris.santana.si@gmail.com; nay_ennes@hotmail.com; alexandre.gontijo@florestal.gov.br;juliana.rodrigues@florestal.gov.br; vera.coradin@gmail.com)

The currently technology, Smartphone's and tablets, portable and practical, enables the development of software with information about the wood anatomy of tropical species. M Timbers, "Madeiras Comerciais do Brasil", is a new version from "Brazilian Commercial Timbers: interactive identification key*". M Timbers, presents the macroscopic description of 157 species, 35 botanic families, being 154 of them tropical species, explored or indicated to commercial timbers. First, this software was designed to studies, but it proved to be very interesting for forest inspection and protection due to its facilities to compare the wood inspected with the database. The user have compare the wood characteristics observed in the wood examined and filter in software by distribution of species, wood color, tree ring, characteristics of vessels and parenchyma, wood macroscopic images and its descriptions. Then only a few species should be compared for identification anatomical comparison. The user can also photograph the wood and send the images and descriptions to specialists in wood identification. With this, we hope to contribute to facilitate studies and improve forest monitoring and conservation. *www.florestal.gov.br/projetos-lpf/85laboratorio-de-produtos-florestais-lpf/367-madeiras-comerciais-do-brasil-chave-interativa-de-identificacao-baseada-em-caracteres-gerais-e-macroscopicos.

\section{Xylarium bogoriense and development of wood identification system in Indonesia}

Ratih Damayanti ${ }^{1}$, Krisdianto Sugiyanto ${ }^{1}$, Listya Mustika Dewi ${ }^{1}$, Andianto Andianto ${ }^{1}$, Dwi Sudharto ${ }^{1}$, Wening Sri Wulandari ${ }^{1}$, Esa Prakasa ${ }^{2}$, Bambang Sugiarto $^{2}$, Riyo Wardoyo ${ }^{2}$, Yan Riyanto ${ }^{2}$, Isnaeni Isnaeni ${ }^{3}$, Maria Margaretha Suliyanti ${ }^{3}$, Danang Sudarwoko Adi ${ }^{4}$

${ }^{1}$ Forest Products Research and Development Center, Research, Development and Innovation Agency, Indonesian Ministry of Environment and Forestry, Bogor, Indonesia; ${ }^{2}$ Research Center for Informatics, Indonesian Institute of Sciences, Bandung, Indonesia; ${ }^{3}$ Res (ratih turmuzi@yahoo.com; kris. sugiyanto73@gmail.com; lizthya@gmail.com; andiant068@yahoo.co.id; galatan102@gmail.com; weningwulandari@yahoo.com; esa.prakasa@gmail.com; bambangsugiarto080373@gmail.com; riyo.war005@gmail.com;yan.rianto@lipi.go.id;isnaeni

Xylarium Bogoriense 1915 is an authentic wood collections located in the Forest Products Research and Development Center, the Ministry of Environment and Forestry, Indonesia. The wood has been collected from most regions in Indonesia since 1914. Nowadays, the Xylarium Bogoriense 1915 wood collection has more than 190,000 thousand specimens consisting of 110 families, 785 generas, and 3,667 authentic wood species. The wood collection has played an important role in wood identification process for research, education, as well as bio-forensic which is involving wood as legal evidence. However, the limitation of existing science, technology, and human resource capacity have caused the process of wood identification to date can only be undertaken by experienced and trained researchers or officers. We are developing methods that can be considered to facilitate the identification of wood species in the field and industry by using computer vision (AIKO). This method is supported by database of macroscopic images of wood cross section namely LignoIndo. The automatic wood identification system is also enhanced to differ of wood origin or geographic location. We are applying some methods for Indonesian tropical timber including bamboo identification by using NIR (Near Infra-red Spectroscopy), Raman Spectroscopy, and Laser Induced Plasma Spectroscopy. The results will be presented. 


\section{Effects of human-related and biotic landscapes features on occurrence and size of modern fires in Sweden.}

Guilherme A. S. J. Pinto ${ }^{1}$, François Rousseu ${ }^{2}$, Mats Niklasson ${ }^{1}$, Igor Drobyshev ${ }^{1,3}$

${ }^{1}$ Southern Swedish Forest Research Centre, Alnarp, Sweden; ${ }^{2}$ Université de Sherbrooke, Sherbrooke, Canada; ${ }^{3}$ CentreUniversité du Québec en Abitibi-

Témiscamingue Rouyn-Noranda, Canada (guilherme.pinto@slu.se; francois.rousseu@usherbrooke.ca; mats.niklasson@slu.se; igor.drobyshev@slu.se)

Forest fires are the main disturbance in boreal forests and are mainly controlled by climatic conditions. Additionally, landscape properties may influence fire occurrence and fire size. The role of humans can be influencing fire regimes in two ways, as either a source of ignition or the opposite, by suppressing fires. With this study, we aim to improve knowledge of the relationship and influence of landscape features on occurrence and size of boreal forest fires. We expect to see how our selected landscape variables (road, population density, vegetation zone, tree species, tree's age and firebreak area) and climate data can shed a light on those relationships. With Sweden as our study area we expect to advance fire management strategies regarding the surroundings of large fire events on the boreal region and aim to advance prediction skills of models. We analyzed fire data in Sweden from 1996 until 2012 using Bayesian based models to verify the interactions between those variables with fire events. The preliminary results shows that there is a positive correlation between fire occurrence and road and population density. In fire size, we observed a negative correlation with the same variables. In addition, forest composition and vegetation zones seems to play an important role on both occurrence and size of fires. In a warming and more unpredictable climate, the necessity of improving the knowledge on how the landscape and human-related structures influence large fires is of paramount importance.

\section{An adaptive active fire identification methodology using GF-4 PMI images}

Xianlin Qin ${ }^{1,2}$, Shuchao Liu ${ }^{1}$, Xiaotong Lit $i^{1}$,ian Liu ${ }^{1}$

${ }^{1}$ Institute of Forest Resources Information Technique, Chinese Academy of Forestry, Beijing, China; ${ }^{2}$ Forestry Remote Sensing and Information Technology Laboratory of State Forestry Administration,Beijing, China (noaags@ifrit.ac.cn; 83453418@qq.com; girl19950388@qq.com; olivia250864095@163.com)

As part of Chinese Earth Observing System, GF-4 satellite, launched in Xichang Satellite Launch Center on December 29, 2015, is the first geosynchronous orbit remote sensing satellite in China and equipped with one stare camera with spatial resolution of 50m visible/near-infrared channels and a $400 \mathrm{~m}$ medium wave infrared channel with over $400 \mathrm{~km}$ swath.To explore the forest fire monitoring method of GF-4 PMI images with multi-channels visible/near-infrared bands and a single medium wave infrared channel, an adapted windows thread condition for active fire identification methodology has been developed according to the character of GF-4 PMI images. This algorithm has been applied in the forest fire identification in China (such as in the Yulong Naxi autonomous county of Yunan province, the Yajiang county of Sichuan province, the Pingshun county of Shanxi province of China) and the Far East of Russia. And the results of visual interpretation and the relative MODIS fire productions have been used as reference to the detection accuracy assessment. The validation results showed that the commission is more than $80 \%$ and the omission is low than $15 \%$. So, the fire identification methodology can be satisfied the need for fire identification operation by using the GF-4 PMI images.

\section{Sustainable forestry under fire risk: synergies between the new bioeconomy and enhancing future fire suppression operations \\ Nathaniel Anderson ${ }^{1}$, Matthew Thompson ${ }^{1}$ \\ ${ }^{1}$ United States Forest Service, Missoula, USA (nathaniel.m.anderson@usda.gov; mpthompson02@fs.fed.us)}

Fuel treatments to reduce wildfire risk and improve conditions for fire suppression can be very costly to implement. In the interior western United States, prescribed burning can cost $\$ 300 \mathrm{ha}^{-1}$ to $\$ 1200 \mathrm{ha}^{-1}$. However, prescribed burning alone is not a viable option when the risks of crown fire, escaped fire and negative smoke impacts are unacceptable. The cost of mechanized fuel treatments can range from $\$ 2500 \mathrm{ha}^{-1}$ to $\$ 5000 \mathrm{ha}^{-1}$. Though they often include the harvest of marketable timber products, the low grade and poor quality of trees and vegetation cut and removed during fuel treatments generally limit value recovery. In most cases, large volumes of unmerchantable logs and biomass are burned for disposal, which has negative air quality and soil impacts. This paper synthesizes the results of multiple research studies focused on understanding the potential for using this biomass as feedstock for the production of advanced biofuels, bioproducts and distributed-scale combined heat and power. Recommendations are made to enhance value recovery from the low grade and low value materials flowing from fuel treatment and forest restoration operations. The goal is to better coordinate the planning and implementation of fuel treatments with harvest operations in ways that encourage efficient links with existing and new biomass end users. Given the vast extent of treatment required in the region under constrained budgets, leveraging the emerging bioeconomy to improve the financial viability of fuel treatment will be critical to treating more acres at lower cost, and improving suppression success in the future.

\section{Modeling annual fire occurrence probability with machine learning algorithms \\ Gabriel Prata 1 , Tiago Conto ${ }^{2}$, Luiz Rodriguez \\ ${ }^{1}$ Universidade de São Paulo, Piracicaba,Brasil; ${ }^{2}$ ForLiDAR, Piracicaba,Brasil (gaprata@usp.br; tdc.florestal@gmail.com; lcer@usp.br)}

Fire is one of the main causes of forest hazards and its occurrences are often associated to factors like weather and human actions. The aim of this study is to develop a probability model of fire occurrence, based on historical hazard data and a combination of biometric, climatic and socioeconomic variables at stand level. The study was carried out at large area of Eucalyptus plantation in the state of Bahia, northeastern Brazil. The biometric variables used to adjust the model considered the assessment of 13,042 forest inventory plots, measured from 2005 to 2017. The fire occurrences were registered from 2010 to 2017 , generating 1,840 records. Socioeconomic variables were obtained from official government sources. Random Forest and Logistic Regression models were adjusted with 10 -fold cross validation resampling. The accuracy reached up to $95 \%$ assertiveness on both algorithms. Both models matched about $95 \%$ of unburnt stands. Random Forest proved to be more accurate when dealing specifically with the burned stands, as it correctly assigned $77 \%$ of the cases classified as fire occurrences, against 33\% from the Logistic Regression. The results showed that the approach tested is capable of assisting forest managers and forest decision makers, reducing the costs of monitoring, firefighting, and potentially increasing revenues by reducing the proportion of burned areas. 
Fire risk zones and recommendations for observation towers / Zoneamento de risco de incêndios e recomendação de torres de observação

Brener de Almeida Oliveira ${ }^{(D)}$, Dayane Lopes Pinto ${ }^{1}$, Thamires de Souza Carvalho ${ }^{1}$, Josué Paoli Reis ${ }^{1}$, Cibele Hummel do Amaral ${ }^{1}$, Fillipe Tamiozzo Pereira Torres $^{1}$, Rodrigo Vieira Leite ${ }^{1}$, Lucas Arthur de Almeida Telles ${ }^{1}$, Nero Lemos Castro ${ }^{1}$, Alexandre Simões Lore

${ }^{1}$ Universidade Federal de Viçosa, Viçosa, Brasil(b.oliveiraefl@gmail.com,dayanelopesp@gmail.com; dsc.thamires@gmail.com; josuepaoli@gmail.com; cibeleha@gmail.com; tamiozzo@ufv.br; rvieiraleite@gmail.com; lucasarthur36@gmail.com; nerolmcastro@gmail.com; alexandre.

Incêndio florestal é um tema de grande importância no Brasil e no mundo, principalmente pelos danos severos que ele pode causar aos ecossistemas. Para proteger as florestas dos efeitos nocivos dos incêndios são essenciais estratégias e políticas efetivas de prevenção e combate. Uma estratégia eficaz é a utilização de torres de observação para a detecção de focos de incêndios. Esta abordagem reduz o tempo até o primeiro combate. O uso de ferramentas do SIG (Sistema de Informação Geográficas) também tem sido fortemente adotado para previsão de padrões de ocorrências de incêndios a longo prazo em diversos lugares do mundo. Nesse sentido, o presente trabalho teve como objetivo zonear as áreas de risco de incêndios da Reserva Natural Salto Morato - PR e com isso definir áreas prioritárias para implementação de torres de incêndio, a partir do uso de ferramentas de SIG. Para gerar o mapa de risco de incêndio sobrepôs-se dados de cobertura vegetal, atividades humanas, declividade, altitude, orientação das encostas e exposição das vertentes. Foram identificadas cinco regiões com risco variando de baixo a extremo. Para a alocação das torres foram usados o Modelo Digital de Elevação (MDE) e o limite da área da Reserva Natural, resultando na alocação de duas torres de observação. As duas torres possibilitaram a visualização de $74 \%$ da área. Dessa forma, o modelo utilizado para o zoneamento das áreas de risco e alocação das torres de observação atenderam às recomendações para o monitoramento adequado do local.

\section{Forest fire frequency in Brazil / Periodos de maior ocorrência de incêndios florestais no Brasil}

Dayane Lopes Pinto ${ }^{1}$, Sergio Guedes Barbosa ${ }^{1}$, Aline Gonçalves Spletozer ${ }^{1}$, Gumercindo Souza Lima ${ }^{1}$, Carlos Eleto Torres ${ }^{1}$, José Cola Zanuncio ${ }^{1}$, Fillipe Tamiozzo Pereira Torres ${ }^{1}$

${ }^{1}$ Universidade Federal de Viçosa, Viçosa, Brasil (dayanelopesp@gmail.com; sergioflora@hotmail.com; spletozer.algo@gmail.com; glima@ufv.br; carlos.eleto@ufv.br; zanuncio@ufv.br; fillipe.torres@ufv.br)

Incêndios florestais impactam ecossistemas e causam prejuízos. Programas de previsão de incêndios são importantes na formulação de estratégias de prevenção, combate e redução dos danos causados. O objetivo foi determinar os períodos com maior probabilidade de ocorrência de incêndios em vegetação no Brasil, também chamados de Estação Normal do Fogo (ENF). Registros de focos de calor detectados por satélites, entre 1999 e 2014 no Brasil, foram obtidos do Instituto Nacional de Pesquisas Espaciais. As médias mensais foram comparadas e os meses com maior ocorrência de focos de calor foram indicados como a ENF. O número de ocorrências de incêndios e tamanho das áreas queimadas, entre 2006 e 2014, foram obtidos dos Registros de Ocorrências de Incêndios em Unidades de Conservação (UCs) federais do Brasil. As médias mensais foram obtidas e utilizadas para verificar os períodos de ENF indicados. Os registros de focos de calor no Brasil foram maiores no inverno e primavera, com ENF de agosto a novembro. As ocorrências de incêndios em UCs do Brasil foram maiores entre agosto e outubro com maior área queimada (ha) em setembro. Os períodos de maior registro de focos de calor e ocorrência de incêndios variaram entre regiões, porém em todas foram maiores nas estações de seca com baixa pluviosidade e temperaturas mais altas. Características climatológicas e as mudanças no uso da terra influenciam nos períodos de maior ocorrência e nas características dominantes dos incêndios no Brasil, e por isto estratégias de prevenção e combate devem ser intensificadas na estação normal do fogo.

\section{Climate and tropical dry forest fire regime in the Upper Middle Magdalena River Valley, Colombia}

Julián Díaz-Timoté ${ }^{1}$ D, Angela Parrado-Rosselli ${ }^{1}$

${ }^{1}$ Universidad Distrital Francisco José de Caldas, Bogotá, Colombia (jjuliandiazt@hotmail.com; aparrador@udistrital.edu.co)

Causes of wildfires in tropical dry forests have been mainly attributed to land use change, while few information exists on the influence of climate on fire occurrence in these forests. We characterized fire occurrence and extent between 2000 and 2018 in the tropical dry forests of the Upper Magdalena River Valley in Colombia, and analyzed its relationship with annual and supra-annual variability of climatic variables such as precipitation, temperature and evapotranspiration. Using 18 years of high-quality satellite imagery and Moderate Resolution Imaging Spectroradiometer (MODIS) we identified burned area, frequency and spatial pattern of fires, and were associated to temperature, precipitation, and evapotranspiration. Results showed 232 fire events, with no particular pattern of spatial distribution. We found a positive correlation between previous-month's temperature and fire occurrence (number of fires and area), as well as between fire and real evapotranspiration. Major fire years tended to follow the switching from La Niña to El Niño conditions (e.g.2002-2003, 2006-2007, 2009-2010), probably due to higher fuel produced during the rainy season of La Niña, which when desiccated by the dry El Niño, created conditions for widespread wildfires. Considering the increasing frequency of extreme El Niño events due to climate change, results of this research should be considered in future risk maps and in restoration strategies of tropical dry forests.

\section{Socioeconomic constraints to biomass removal from forest lands for fire risk reduction in the western U.S.}

David Nicholls', Jeffrey Halbrook ${ }^{2}$, Michelle Benedum ${ }^{3}$, Han-Sup Han'2, Eini Lowell', Dennis Becker ${ }^{3}$, James Barbour ${ }^{4}$

${ }^{1}$ USDA Forest Service, Sitka, Alaska, USA; ${ }^{2}$ Northern Arizona University, Flagstaff, Arizona, USA; ${ }^{3}$ University of Idaho, Moscow, Idaho, USA; ${ }^{4}$ USDA Forest Service,Portland,Oregon,USA (dlnicholls@fs.fed.us; jeffrey.halbrook@nau.edu; mbenedum@uidaho.edu; han-sup.han@nau.edu; elowell@fs.fed.us; drbecker@uidaho.edu; roy.barbour@usda.gov)

Many socioeconomic constraints exist for biomass removals from federal lands in the western U.S. We examine several issues of importance, including biomass supply chains and harvesting costs, innovative new uses for bioenergy products, and the policy framework in place to provide incentives for biomass use. Western states vary greatly in the extent and utilization of forest resources, the proportion of land under federal ownership, and community and stakeholder structure and dynamics. Our research — which focused on the socioeconomic factors associated with biomass removal, production, and use-identified several important trends. Long-term stewardship projects could play a role in influencing project economics while being conducive to private investment. State policies are likely to help guide the growth of biomass utilization for energy products. New markets and technologies, such as biofuels, for use in the aviation industry, torrefied wood, mobile pyrolysis, and wood coal cofiring could greatly change the landscape of biomass use. Social needs of residents in wildland urban interfaces will play an important role, especially in an era of megafires. All of these trends-including significant unknowns, like the volatile prices of fossil energy - are likely to affect the economics of biomass removal and use in western forests. 


\section{Salvage harvesting for bioenergy in Canada: From sustainable and integrated supply chain to climate change mitigation}

Nicolas Mansuy ${ }^{1}$

${ }^{1}$ Canadian Forest Service, Edmonton, Canada (nicolas.mansuy@canada.ca)

The economic and environmental benefits of replacing fossil fuels with wood-based bioenergy are complex, and debates are ongoing on issues such as environmental sustainability of biomass procurement and carbon neutrality. With the greatest biomass per capita in the world, Canada could play an increasing role in the future of global bioenergy and the emerging bioeconomy. Here, we put in perspective the utilization of feedstock salvaged after natural disturbances to supply wood-based bioenergy, by addressing multidisciplinary questions: How much salvaged feedstock is available? How can sustainable practices to support increased removal of biomass be implemented? What are the constraints on development of an integrated supply chain and cost-effective mobilization of the biomass? What is the potential for climate change mitigation? In average, salvaged feedstock could theoretically provide about $100 \times 106$ oven Dry ton biomass per year, with high variability over time and space. Existing policies and guidelines for harvesting of woody biomass in Canadian jurisdictions could support sustainable biomass removal. However, uncertainties remain as to the development of competitive supply chains, because of the large distances between the locations of this feedstock and available processing sites. Another uncertainty lies in the time needed for a benefit in climate change mitigation to occur. Momentum in the wood-based bioenergy sector will develop only if both the forest industry sector and the energy sector collaborate toward innovative and integrated forest management and procurement solutions, making it possible to extract maximum value from the resource while maintaining its sustainability

Drivers and obstacles for high performances of machine contractors in forest harvesting operations: a qualitative case study on customer and contractor opinions

Malin Johansson ${ }^{1}$, Emanuel Erlandsson ${ }^{1}$, Ola Lindroos ${ }^{1}$

${ }^{1}$ Swedish University of Agricultural Sciences, Umeå, Sweden (malin.m.johansson@slu.se; emanuel.erlandsson@slu.se; ola.lindroos@slu.se)

With extensively outsourced forest harvesting operations, the operational performance of contractors is utterly important for the forest industry supply chain, as it affects both cost and availability of raw materials as well as environmental and social impacts of forestry. In this study, we investigate opinions of both key staff at a large forest company (service buyer) and its contractors (service suppliers) concerning what drives and hinders contractors to perform well in different value aspects of the harvesting operation services. By semi-structural interviews with four planning and decision chains constituting all three roles of production managers, production supervisors and contractors, a range of different perceived factors driving and hindering high performance are identified along with opinions of their underlying reasons. The results should be of interest to both researchers and practitioners interested to understand how interactions within business relationships between customers and service suppliers affect both parties' performances. Such knowledge is important for reshaping business practices to better target and use the mechanisms that drive high performance.

\section{Effects of timber extraction operations on soil physical properties and water erosion}

Sangjun Im ${ }^{1}$, Eunjai Lee ${ }^{2}$, Song Eu ${ }^{1}$, Qiwen $\mathrm{Li}^{1}$

${ }^{1}$ Seoul National University, Seoul, Republic of Korea; ${ }^{2}$ National Institute of Forest Science, Seoul, Republic of Korea (junie@snu.ac.kr; ejay0404@naver.com;dkarj@snu.ac.kr;gimunlee@snu.ac.kr)

In this study, a comparative study was conducted to quantitatively assess detrimental soil disturbance on small harvest sites associated with two timber extraction methods, wood grab and cable yarding operations. A 3.5-ha harvest unit in Korea was selected for study area, where wood grab and cable yarding were separately operated. Soil disturbance class was assessed using the McMahon (1995) visual assessment method. Soil physical properties, such as bulk density, porosity, and saturated conductivity of forest soil, were also measured according to soil disturbance class. The results showed that wood grab operation caused more serious disturbances than cable yarding operation. Deep disturbance accounted for nearly $43 \%$ in wood grab operation, where rutting affected $75 \%$ of deep disturbance through the heavy machine passes. In contrast, yarding produced about $21 \%$ deep disturbed soils with the most comprising undisturbed and shallow disturbance soils $(61 \%)$. Observations of soil properties in surface layer $(0-10 \mathrm{~cm})$ showed that bulk density is $39 \sim 54 \%$ higher and total porosity is $32 \sim 44 \%$ lower on the skid trail of wood grab operation compared to the undisturbed site. Soil erosion by water is one of key agents to represent the loss of forest productivity after mechanized timber harvest. Thus, numerical simulation has been operated to evaluate the changes in soil erosion rates on harvest units with different timber extraction techniques. Simulation showed that wood grab operation was estimated to be the most susceptible to water erosion, due to the removal of surface vegetation and increased vehicular traffic and heavy equipment passage

\section{Estimation of wheel ruts and soil compaction with different methods applied in a comparison between skidding and forwarding.}

Elena Marra ${ }^{3}$, Martina Cambi ${ }^{1}$, Andrea Laschi ${ }^{1}$, Fabio Fabiano ${ }^{1}$, Francesco Neri ${ }^{1}$, Cristiano Foderi ${ }^{1}$, Enrico Marchi ${ }^{1}$, Tomas Nordfjell ${ }^{4}$

${ }^{3}$ University of Florence (DAGRI), Florence, Italy; ${ }^{4}$ Swedish University of Agricultural Sciences (SLU), Umeå, Sweden (elena.marra@unifi.it; martina.cambi@unifi.it; andrea.laschi@unifi.it;fabio.fabiano@unifi.it; francesco.neri@unifi.it; cristiano.foderi@unifi.it; enrico.marchi@unifi.it; tomas.nordfjell@slu.se)

The soil damage extent and severity, caused by wood extraction, are related with soil condition, harvesting system and machine characteristics. Contrasting results have been published about soil damages caused by skidding and forwarding, thus highlighting the needs of further investigations on this topic. In order to analyses the spatial distribution of soil disturbance more accurately, new methods based on the 3D soil reconstruction have been developed. The overall objective of this study was to investigate new methods (portable laser scanner and close-range photogrammetry) and traditional methods (cone penetrometer, manual rut depth measurements, soil bulk density and porosity) for evaluating rutting and soil compaction caused by a loaded forwarder and skidder. Our findings mainly show a relationship between soil compaction (i.e. cone penetration resistance) and rutting (i.e. total reduction of soil volume) in low moisture soil condition. The shortest data acquisition was observed during the portable laser scanning, while in accuracy rutting estimation was higher in close-range photogrammetry. The comparison of photogrammetric and manually-measured profiles confirmed that Structure For Motion photogrammetry can be an accurate instrument for Digital Evolution Model and for morphology description of forest soil disturbance after forest logging. Furthermore, the results showed the effect of harvesting systems and terrain conditions on soil disturbance. In conclusion, soil disturbances were higher for skidder than for forwarder considering the same wood volume extracted. 


\section{Effect of soil compaction on tree physiology and growth: a meta-analysis}

Barbara Mariotti ${ }^{1}$, Martina Cambi ${ }^{1}$,Elena Marra ${ }^{1}$, Elena Paoletti $^{2}$, Zhaozhong Feng $^{3}$, Enrico Marchi $^{1}$ (D) Yasutomo Hoshika ${ }^{2}$ ${ }^{1}$ Dipartimento di Scienze e Tecnologie Agrarie, Alimentari, Ambientali e Forestali, Università degli Studi di Firenze, Firenze, Italy; ${ }^{2}$ National Council of Research, Firenze, Italy; ${ }^{3}$ College of Resources and Environment, University of Chinese Academy of (barbara.mariotti@unifi.it; martina.cambi@unifi.it; elena.marra@unifi.it; elena.paoletti@cnr.it;fzz@rcees.ac.cn; enrico.marchi@unifi.it; yasutomo.hoshika@cnr.it)

In recent decades, many papers about the effects of forest operation on soil compaction and thus tree growth and regeneration have been published. Most of them examined one or few compaction degrees, tree species, taxonomic groups or soil types, providing interesting result but without interconnections among studies. In order to fill this gap, our study aims to draw general conclusions concerning the impact of mechanized harvesting and soil compaction on tree growth by means of a meta-analysis. We specifically addressed (i) the effects of soil compaction on shoot morphological and physical traits as well as root parameters (ii) the effects of compaction degree according to soil type, taxonomy, age class, and experiment type. The data of several studies were collected taking into consideration peer-reviewed literature indexed in several databases and published between 1948 and 2017. A cross-disciplinary approach was applied including researches under natural environmental conditions and manipulative experiments. The analysis of the collected studies resulted in 56 articles with all the relevant details to be included in the meta-analysis. Our main results suggest that increasing levels of soil compaction affect plant development by an overall decrease of all morphological parameters, more evident in height and root depth; the effect varies according to soil type (generally less strong in arenic soil) and taxonomy, and decreases over time. Compaction significantly reduced net photosynthesis, did not affect leaf nitrogen content (as a proxy of nutrient uptake from roots) but decreased leaf water potential (as a proxy of water uptake from roots).

\section{New design methods to reduce energy consumption of forestry cranes}

Omar Mendoza-Trejo ${ }^{1,2}$, Pedro La Hera ${ }^{1}$, Daniel Ortiz Morales ${ }^{3}$

${ }^{1}$ Swedish University of Agricultural Sciences, Umeå, Sweden; ${ }^{2}$ Swedish Cluster of Forest Technology, Umeå, Sweden; ${ }^{3}$ Cranab, Umeå, Sweden (omar. mendoza.trejo@slu.se; xavier.lahera@slu.se; daniel.morales@cranab.se)

In Nordic countries, logging operations are carried out by the cut-to-length (CTL) method, which considers two forestry machines: a harvester for felling, delimbing, and bucking trees and a forwarder for transporting the logs from the felling to a landing area. Due to the relevance of this method, the scientific and technological development to improve forestry cranes has increased over the past years. Nowadays, forestry cranes are a powerful tool to perform forestry operations. Nevertheless, they are designed with the sole purpose of cutting and collecting logs. However, most of the cranes available in the market do not possess any sensing equipment. Hence, information about forces, positions and velocities of links are unknown. Designing cranes lacking this information leads to oversized designs, high energy consumption, and high vibration levels. One of the methods to modify this scenario is to use mathematical-modelbased designs aiming to reduce the energy consumption and the vibration levels. One example is Gravity compensation, which is a well-known technique to design industrial robots, and achieve equilibrium throughout the range of motion. As a result, this reduces the loads on the actuators and the vibration levels. There are different concepts for gravity compensation that can be applied for designing forestry cranes. Among those concepts are the gravity compensation by counterweights, gravity compensation by springs and gravity compensation by using auxiliary actuators. Gravity compensation concepts present advantages and disadvantages, which must be taken into account by the designer in order to reach a successful design.

\section{Productivity analysis of motor manual felling in a yellow pine (Pinus sylvestris) stand in Northeast of Turkey}

Ebru Bilici ${ }^{1}$, Dalia Abbas ${ }^{2}$, Abdullah Emin Akay $^{3}$, İnanç Taș ${ }^{3}$

${ }^{1}$ Giresun University, Giresun, Turkey; ${ }^{2}$ American University, Department of Environmental Sciences, Washington, D.C., USA; ${ }^{3}$ Bursa Technical University, Bursa,Turkey(ebru.bilici@giresun.edu.tr; daliaabbas@yahoo.com; abdullah.akay@btu.edu.tr; inanc.tas@btu.edu.tr)

Tree felling is the very first step in producing wood-based forest products. In Turkey, the motor manual method is the most common tree processing operation used for felling, delimbing, and bucking standing trees. In order to ensure the productivity of felling operations, a motor manual method should be well planned and the factors effecting the productivity should be considered. In this study, the productivity of chainsaw felling operation was evaluated using time study analysis. The felling operation was performed using a STIHL MS361 chainsaw in a yellow pine (Pinus sylvestris) stand located in the city of Ordu. During the time study, the felling operation was evaluated in four work stages including: moving and preparation, under cut, back cut, and felling. The effects of two stand structures (tree diameter and tree volume) on the felling productivity was analyzed using Pearson correlation coefficient. The average tree diameter and volume were found to be $37.1 \mathrm{~cm}$ and $1.09 \mathrm{~m}^{3}$, respectively. It was also found that the average felling productivity was $54.78 \mathrm{~m} / \mathrm{hr}$. The results indicated that the most time-consuming work stage was the undercut stage (37.08\%) followed by the back cut stage (27.25\%). Statistical analysis revealed that there was a statistically significant $(\mathrm{p}=001)$ positive relationship between productivity and specific stand structures.

\section{C3p: FOREST OPERATIONS AND THE WORKFORCE}

\section{Unsustainable workforce and the consequences over the productivity of the system.}

\section{Felipe Meyer ${ }^{1}$}

${ }^{1}$ University of Concepcion, Concepcion, Chile (fmeyer@udec.cl)

The forestry sector is facing a number of challenges that having an impact of the sustainability of the workforce and over the productivity of the system. This study examines the relationship between the working conditions in the forestry sector and the workers. In addition, examines the strategies the Chilean forestry companies are using. Finally, using two examples identify the consequence over the productivity of the system. The overall objective of this study was to investigate the impact of working conditions on the workforce in the Chilean forestry sector and over the productivity of the system. The study involved data collection from 350 forestry workers, both Chilean forest companies and contractors companies along with interviews with managers and experts in the area of forestry, ergonomics, working conditions and health and safety and the study cases. The findings indicate that even though working conditions in the Chilean forestry sector have been improving, they continue to have a negative impact on workers in terms of occupational health, market attractiveness and ageing population. Strategies that forestry organizations have implemented these are not enough to solve the problems mentioned before. The strategies are focused on the prevention of accidents rather the OH problems and none of the strategies pays attention to the wellbeing of the workforce and the development of resources, aspects the workers demand. Finally, due to the problem mentioned above, a negative impact on the productivity of the systems, based on examples related to pruning and harvesting. 


\section{Exposure to occupational noise of skidder operators during eucalyptus skidding}

Diego Aparecido Camargo ${ }^{l}$ (D), Rafaele Almeida Munis ${ }^{1}$ (D), Jorge Carvalho Martins ${ }^{1}$ (D), Emilio José Costa Filho ${ }^{l}$ (D), Danilo Simóes ${ }^{1}$ (D) ${ }^{1}$ Universidade Estadual Paulista “Júlio de Mesquita Filho”, Facudade de Ciências Agronômicas, Botucatu, Brasil (diegocamargoflorestal@gmail.com; rafaele.munis@gmail.com; jorgec.martins@hotmail.com; ecosta@eucatex.com.br;danilo.simoes@unesp.br

Occupational noise occupies an important position among the physical agents responsible for health problems for workers; in addition, high levels generated by mechanized forest harvesting operations may characterize jobs as unhealthy. The objective of this study was to evaluate if the noise levels emitted by the skidder during the drag of the eucalyptus wood are in line with the levels established by the Brazilian legislation. The study was developed in a forest area located in the State of São Paulo, Brazil. The skidding operation of entire eucalyptus trees during an eight-hour workday was considered, performed by: skidder 1: John Deere brand, model 948L; skidder 2: Caterpillar brand, model CAT 545D. The data were collected during the total working day by means of a personal dosimeter of Instrutherm brand, following the criteria established by the Occupational Hygiene Standard NHO 01 and by Regulatory Standard 15 adopted for purposes of insalubrity in Brazil. When assessing the noise dose received by the skidder 1 operator, it was verified that the dose was $123.39 \%$ and for skidder 2 the dose was $82.83 \%$. Regarding the average noise level (Lavg) for skidder 1 was 86.49 dB (A) and for skidder 2 was $83.64 \mathrm{~dB}$ (A). That said, the skidder 1 operator could be exposed without ear protection 390 minutes and the skidder 2 operator 580 minutes. During the evaluations the operators used hearing protectors that allowed the attenuation of $20 \mathrm{~dB}$, ensuring auricular protection for the eight-hour work day.

\section{Evaluation of occupational noise exposure in feller-buncher operators during eucalyptus tree felling

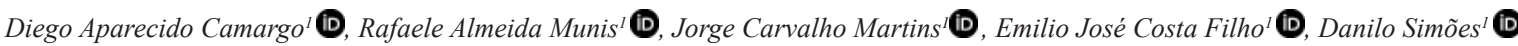 \\ ${ }^{1}$ Universidade Estadual Paulista "Júlio de Mesquita Filho”, Facudade de Ciências Agronômicas, Botucatu, Brasil (diegocamargoflorestal@gmail.com; rafaele.munis@gmail.com; jorgec.martins@hotmail.com; ecosta@eucatex.com.br; danilo.simoes@unesp.br}

A forest machine operator exposed to occupational noise levels above the established limits may have temporary or permanent deafness, as well as sleep disorders, stress, and changes in blood pressure, among other occupational diseases. The objective of this study was to evaluate if the levels of occupational noise emitted by a feller-buncher during the eucalyptus harvesting operation are in compliance with Brazilian legislation in force. The study was conducted in the State of São Paulo, Brazil, during the eucalyptus tree felling operation in the first rotation planting, executed by two fellers-bunchers: feller-buncher 1: Caterpillar brand, model CAT 541, feller-buncher 2: John Deere brand, model 903M. The data were collected during an eight-hour workday by means of a personal integrating meter in accordance with the criteria established by the Occupational Hygiene Standard NHO 01 and by the RegulatoryStandard 15 adopted for purposes of insalubrity in Brazil. When measuring the noise dose received by the feller-buncher 1 operator in the workday, the dose was $84.21 \%$ and the average noise level (Lavg) was $83.76 \mathrm{~dB}(\mathrm{~A})$, allowing 570 minutes as the maximum permissible time of exposure in a work day. Whereas, for the feller-buncher 2 the dose was $90.40 \%$ and the Lavg was $84.27 \mathrm{~dB}$ (A), which allows 531 minutes of exposure without auricular protection. It should be emphasized that the operators were using shell-type ear protectors, which used correctly allows the attenuation of $20 \mathrm{~dB}$. Nevertheless, the values obtained are above the action value, justifying the adoption of preventive actions.

\section{Study of occupational vibration in forest harvesting activity}

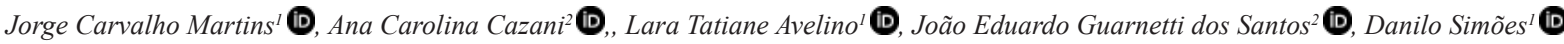

${ }^{1}$ Universidade Estadual Paulista "Júlio de Mesquita Filho”, Faculdade de Ciências Agronômicas, Botucatu, Brasil, ${ }^{2}$ Universidade Estadual Paulista “Júlio de Mesquita Filho”, Faculdadede Engenharia, Bauru,Brasil (jorge.martins@unesp.br; carolina.cazani@unesp.br; laratatianeavelino@gmail.com, guarneti@feb.unesp.br;danilo.simoes@unesp.br)

Forest harvesting operations can negatively affect the occupational health of operators, where they are susceptible to several non-ergonomic conditions, among them exposure to vibration levels. The objective of this study was to verify if the whole-body vibration load that the operators of two John Deere feller bunchers, models $903 \mathrm{k}$ (300 HP) and $903 \mathrm{M}$ (300 HP), with 20,688.4 hours of use and 7,803 hours of use respectively, receive in the different directions when operating in an eight-hour work day, are detrimental to the occupational health of the operators. A three-axis accelerometer, model HVM 200 of the Larson Davis brand, was used coupled to the accent of the operators. The results showed an equivalent acceleration for a normalized 8 hour period (A8) of $0.1726 \mathrm{~m} \mathrm{s-2}$ and 0.1153 $\mathrm{m} \mathrm{s}^{2}$ and a total vibration dose value (VDV) of 8.00 and 5.27 for the model $903 \mathrm{~K}$ and $903 \mathrm{M}$, respectively. The values are below the recommended for the same work day according to ISO 2631-5:2018, where A8 must be in the range of $0.5 \mathrm{~m} \mathrm{~s}^{-2}$ to $1.15 \mathrm{~m} \mathrm{~s}-^{2}$, and VDV according to the European directive that is $9.1 \mathrm{~m} / \mathrm{s}$. Although the usage time of the feller bunchers is unequal, both are in accordance with ISO 2631-5: 2018 and the European directive for the studied parameters of vibration, reflecting that it may not be an aggravating factor of the occupational disorder.

\section{Evaluation of occupational exposure to whole body vibration in forestry tractor skidder operator

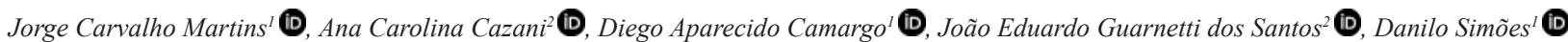 ${ }^{1}$ Universidade Estadual Paulista "Júlio de Mesquita Filho”, Faculdade de Ciências Agronômicas, Botucatu, Brasil; ${ }^{2}$ Universidade Estadual Paulista "Júlio de Mesquita Filho”, Faculdade de Engenharia, Bauru,Brasil (jorge.martins@unesp.br; carolina.cazani@unesp.br; diegocamargoflorestal@gmail.com, guarneti@feb.unesp.br;danilo.simoes@unesp.br)}

The vibration present in machines employed in the forest harvest, usually by means of the support surfaces, occurs as a result of the oscillation of any movement of these machines around a fixed point; therefore, the vibration is transmitted to the whole body of operators. This physical agent can cause several occupational disorders to the operators, limiting them to the execution of movements or the accomplishment of organic functions. The aim of this study was to evaluate the occupational exposure to the whole body vibration of a skidder operator in three work situation. It was evaluated a John Deere skidder, model 948 L, with tire wheels, motor with nominal power of $281 \mathrm{HP}$, mass of 22,416 kg, and 7,342 accumulated hours of use. This tractor performed the skidding of full eucalyptus tree, which were planted at the geographical coordinates $-22^{\circ} 96 \mathrm{~S}$ and $-48^{\circ} 56^{\prime} \mathrm{W}$. For the evaluation, an integrating meter was used in accordance with ISO 8041-1: 2017. The measurements were performed according to the three directions of an orthogonal coordinate system simultaneously, so the accelerometer was fixed to the forest tractor seat. The equivalent acceleration A (8) and the vibration dose value (VDV) were considered. The data were evaluated and compared with ISO 2631-5: 2018. The results showed that the equivalent acceleration values are in compliance with the limits established by ISO 2631-5: 2018, however, the VDV values were higher than the recommended by the European directive, which is $9.1 \mathrm{~m} / \mathrm{s}$. 


\section{Proposition of an Integrated Ergonomic Indicator (IEI) in the assessment of forest machines}

Felipe Oliveira', Eduardo Lopes ${ }^{1}$, Henrique Koehler ${ }^{2}$, Alexandre Behling ${ }^{2}$

${ }^{1}$ Universidade Estadual do Centro-Oeste, Irati, Brasil; ${ }^{2}$ Universidade Federal do Paraná, Curitiba, Brasil (eng.oliveirafm@gmail.com; eslopes@unicentro.br; koehler@ufpr.br; alexandre.behling@ufpr.br)

Ergonomic assessments in forest operations are performed in isolation due by of lack of an adequate methodology that correlates the ergonomic variables simultaneously. The objective this work was to propose new methodology for the ergonomic evaluation of forest machines, by the development of an Integrated Ergonomic Indicator (IEI), useful to relate ergonomic variables. Vibration, noise, heat, luminosity, posture, repeatability, visibility and productivity data were obtained during the day and night periods of the feller buncher, harvester, forwarder, skidder and processor in the Parana State, Brazil. The values, normalized by their deviations from the mean were subjected to factorial multivariate analysis determining the factors that would influence the IEI composition. The factor index was multiplied by the explained variance for each factor and the result was divided by the total variance explained, so that the values remained around 0 and the higher the result, the worse the ergonomic condition. The evaluation presented $\mathrm{R}^{2}$ of 0.9 and the variables that most influenced were vibration, noise and lateral visibility, relating to each other. The worst machine was the skidder in both work shifts, with IEI of 2.82 for the daytime period and 1.60 for the night, due to impacts and bumps in its displacement added to the high percentage of worker time with the rotated neck. The best machine were harvester B and processor at night with IEI of -1.36 and -0.96 , due to low vibration, noise and rotational deviation. The methodology proved to be useful in the integrated ergonomic evaluation

\section{Innovative and adapted harvesting methods for supporting the sustainable management of the southern Brazilian Atlantic Forest}

\section{Pedro Britto ${ }^{1,2}$ (D), Dirk Jaeger ${ }^{1}$, Stephan Hoffmann ${ }^{2}$, Renato Robert ${ }^{3}$, Alexander Christian Vibrans ${ }^{1}$, Alfredo Celso Fantini ${ }^{2}$}

${ }^{1}$ University of Göttingen, Göttingen, Germany; ${ }^{2}$ University of Freiburg, Freiburg, Germany; ${ }^{3}$ Universidade Federal do Paraná, Curitiba, Brasil, ${ }^{1}$ Fundação Universidade Regional de Blumenau, Blumenau, Brasil; ${ }^{2}$ Universidade Federal de Santa Catarina, Florianop (pcdbritto@hotmail.com; dirk.jaeger@unigoettingen.de; stephan.hoffmann@foresteng.uni-freiburg.de; renatorobert@ufpr.br;acv@furb.br; alfredo.fantini@ufsc.br)

Conservation and management of forest ecosystems are currently conflicting goals in the Brazilian Atlantic Forest biome. At present stage, all forest fragments are protected and commercial logging is highly restricted. This situation generated a lack of willingness of landholders to conserve and possibly even expand native forest areas. A suitable timber harvesting, aiming the sustainable forest management, can provide new income opportunities for landholders and thereby further actively support the process of ecosystem rehabilitation and protection of the Forest. Therefore, our research assessed and compared a conventional timber harvesting method (CM) with an alternative and improved timber harvesting method (AM). Permanent sample plots were installed and a full preharvesting inventory was performed. Production rates and associated costs were assessed through a time study analysis. A second inventory, directly after harvesting, was conducted to assess the timber harvesting impact on remnant stand. Our results showed that CM presented a higher productivity and lower cost (3.0 m $\mathrm{m}^{3} \mathrm{SMH}-1$ and $\left.12.05 € \mathrm{~m}-3\right)$ compared to AM (1.9 m³ SMH-1 and $\left.20.94 € \mathrm{~m}-3\right)$. The number of damaged trees per harvested trees, for CM, ranged from 0.8 trees ha ${ }^{-1}$ to 2.5 trees ha-1 and, for AM, from 0.6 trees ha- ${ }^{-1}$ to 2.2 trees ha-1. Improvements on AM method allowed a reduction of damaged basal area and a reduction of the winching disturbed ground area. Nonetheless, a suitable harvesting system should consider further improvements on the felling technique, and additionally, integrate the local knowledge of CM on the forest and tree species with technical improvements of AM.

\section{C3q: MOVING TOWARDS SUSTAINABLE FOREST OPERATION FOR A GREENER FUTURE}

\section{Technical and economic evaluation of a forest loader under uncertainty conditions

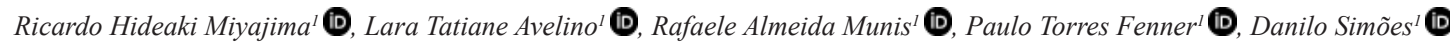 ${ }^{1}$ Universidade Estadual Paulista “Júlio de Mesquita Filho”, Faculdade Ciências Agronômicas, Botucatu, Brasil (richidetoshimiyajima@hotmail.com, laratatianeavelino@gmail.com; ,rafaele.munis@gmail.com; paulo.fenner@unesp.br; danilo.simoes@unesp.br)}

Forest loading is one of the operations subsequent to the forest harvesting. Its operational productivity is influenced by several factors, which means that it is under conditions of uncertainty. In this sense, the objective was to measure the technical-economic risk of loading eucalyptus under conditions of stochastic uncertainty by using Monte Carlo simulation. It was analyzed a Caterpillar forestry loader, model 320D2 FM, equipped with a claw of $0.80 \mathrm{~m}^{2}$ capacity. This loader was evaluated in two work situations, by two operators that had different time of professional experience. Operational productivity was determined from the timing and methodology studies. The hourly operating cost was calculated according to FAO (1992). Incorporation of the risk analysis was carried out through the pseudorandom generation of values obtained from the probability distributions. When evaluating the hourly operating cost, the adjustment was for Beta distribution with an average of USD $53.21 \mathrm{~h}^{-1}$. As for the operational productivity, the values adjustment for the operator with the highest experience was Weibull with an average of $207.76 \mathrm{~m}^{3} \mathrm{PMH}^{-1}$. Finally, for the operator with the shortest experience, the adjustment was the Triangular distribution with an average $143.67 \mathrm{~m}^{3} \mathrm{PMH}^{-1}$. Regarding the cost of production for both operators, the adjustment was the Lognormal; and for the operator with highest experience time, an average value of USD $0.31 \mathrm{~m}^{3}$ was obtained. However, for the operator with the shortest experience, the average value was USD $0.50 \mathrm{~m}^{3}$, which evidenced that the time of professional experience influenced the costs of production.

\section{Modeling of the effective productivity of forest loader according to the volume and loading time

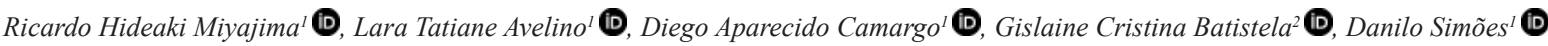 ${ }^{1}$ Universidade Estadual Paulista "Júlio de Mesquita Filho", Faculdade Ciências Agronômicas, Botucatu, Brasil; ${ }^{2}$ Universidade Estadual Paulista "Júlio de Mesquita Filho”, Campus of Itapeva, Itapeva, Brasil (richidetoshimiyajima@hotmail.com; laratatianeavelino@gmail.com; diegocamargoflorestal@gmail. com; gislaine.batistela@unesp.br; danilo.simoes@unesp.br)}

Mathematical modeling is a technique that can be applied in several areas, such as the forest loading, since this last is important from a technical-economic point of view considering that several variables can influence the effective productivity of the machine (PMH). Therefore, the objective of this study was to evaluate the influence of variables loading time and volume of eucalyptus wood on the effective productivity of a forest loader by means of mathematical modeling. The study was carried out in areas of a forest company located in the State of São Paulo, Brazil. It was evaluated the forest load conducted by two operators, with different professional experience times, through the methodology of time and methods considered as a premise for the PMH calculation. The average PMHs of 
the operators were significantly different, being $208.85 \mathrm{~m}^{3} \mathrm{PMH}^{-1}$ for the operator with the highest operating experience (1) and $114.59 \mathrm{~m}^{3} \mathrm{PMH}^{-1}$ for the operator with the shortest experience (2). Pearson's linear correlation showed that as the average volume of wood per cycle increased, productivity also increased, while this ratio was inverse for the loading time. For the estimation of the productivity of operator one, the regression model found was, prod $=131.98+97.21 \mathrm{x}$ volume $-2.89 \mathrm{x}$ time, which presented coefficient of determination 0.73 . In addition, for operator two, the model for estimating productivity involving the loading time and average volume of wood per cycle was, prod $=91.32+70.20 \mathrm{x}$ volume $-1.36 \mathrm{x}$ time, with coefficient of determination of 0.72 .

\title{
Valuation of stands at a standstill in the face of global warming: , sorting of products, analysis of the costs of work from the owner to the economic operator
}

Henri Husson ${ }^{1,2}$, Richard Emeyriat ${ }^{3}$, Riccardo Castellini ${ }^{4}$

${ }^{1}$ Centre Régional de la Propriété Forestière, Nouvelle-Aquitaine, Bordeaux, France; ${ }^{2}$ Centre National de la Propriété Forestière, Paris, France; ${ }^{3}$ Foret

Logistique Conseil, Bordeaux, France; ${ }^{3}$ Cesefor,Soria, Spain(h.husson@cnpf.fr; richard.emeyriat@foretlogistique.eu; riccardo.castellini@cesefor.com)

The valorization of poor or deadlocked forest stands is an important issue in Europe. The initial diagnosis of stands and the sorting of wood products will determine the future of future stands that will be better adapted to global warming. An analysis of 60 sites shows that the analysis of the value of wood and the value of products is often in deficit and leads to additional aid to carry out the work. A decision support guide is being developed as well as a database of tools adapted to the needs of very small forest companies. The European Rosewood programme will be an important element in the communication of the actors. ForLog is a forest site management software linked to a remote database accessible via the web. The software allows structured messages to be sent to field teams (mission orders) and customers (receipts). A mobile application on a smartphone allows you to enter data relating to site activities. The purpose of the study is to study the different operations from producer to operator in order to make an economic, social and environmental assessment. The effects of decisions will be highlighted, the impact on the improvement of global warming will complete the analysis of the economic tools put in place.

\section{Economic consequences of applying accurate bark thickness in mechanised harvesting of Scots pine (Pinus sylvestris L.)}

Zbigniew Karaszewski ${ }^{1}$, Jarosław Socha ${ }^{2}$, Mariusz Bembenek ${ }^{3}$, Piotr Mederski ${ }^{3}$

${ }^{1}$ Wood Technology Institute, Poznan, Poland; ${ }^{2}$ University of Agriculture in Kraków, Kraków, Poland; ${ }^{3}$ Poznan University of Life Sciences, Poznan, Poland

(z_karaszewski@itd.poznan.pl; rlsocha@cyf-kr.edu.pl; mariusz.bembenek@up.poznan.pl; piotr.mederski@up.poznan.pl)

Different bark thicknesses affect log volume and, consequently, have an impact (multidirectional) on income throughout the whole forest-wood chain, affecting forest owners, forest entrepreneurs, transport companies and customers. For forest owners and entrepreneurs, it may result in a decrease in income if the real roundwood volume is underestimated. An overestimation of the bark content on logs may also affect the weight of transported roundwood. These doubts show complexity of forest management and an unequal position of some actors on the forest-based industries. Proper wood measurement supports the idea of Sustainable Forest Operations in terms of three main principles: economics, quality optimization of products and production and people and society. The volume calculation of roundwood by a harvester is based on the measurements of diameter over bark and log length. To obtain the timber volume only, the bark thickness has to be subtracted by an on-board harvester computer according to the local regulations. These are usually based on the thickness classes of the roundwood or on the percentage of bark content in the roundwood diameter. The aim of the research was to: 1) verify the existing bark allowances with true pine bark thickness values and 2) analyse which factors influence the variation in pine bark thickness. The pine timber selected for the study was harvested by a harvester from trees of different age classes grown in different soil conditions. In this contribution, the final results, including full range variabilities and a statistical evaluation, will be presented in detail.

\section{Medium and long-term investigation on soil degradation after wood extraction operations: comparing skidding and forwarding}

Elena Marra ${ }^{1}$, Francesco Neri ${ }^{1}$, Andrea Laschi ${ }^{1}$, Giovanni Mastrolonardo ${ }^{1}$

${ }^{1}$ Universitàdi Firenze, Firenze, Italy (elena.marra@unifi.it; francesco.neri@unifi.it; andrea.laschi@unifi.it; giovanni.mastrolonardo@gmail.com)

Forest harvesting operations may have a significant impact on soil. The soil disturbance extent and severity are mostly related to soil condition and to the harvesting system. Impacts mainly consists on soil compaction, displacement, and rut formation. Several papers investigated soil damage caused by logging operations on the short-term, but information on the effects of logging on the medium and long-term are still missing. This contribution deals with the effects of wood skidding and forwarding on soil degradation on three sites located in Central Italy. The presented results are related to the medium- as well as the longterm impacts, considering three different periods after forest operations of six months, 1 year and 3 years, respectively. Changes in porosity, bulk density, shear and penetration resistances were investigated on two plots for each wood extraction system adopted, evaluating soil damage. The impact on forest regeneration was also investigated. We found that the restoring time of extraction tracks after logging operations is related to the previous soil compaction level. Skidder did not negatively affect natural regeneration as much as forwarder machine did, while the impact of this latter was lower on sandy soils. In conclusion, the effects on soil of forest machines are still apparent after a long period following forest operations, thus suggesting that the use of previous tracks must be encouraged to avoid the extension of soil disturbance.

\section{Life cycle assessment of carbon footprint of harvested wood products of Larix kaempferi in Korea}

\author{
YoungJin $\mathrm{KO}^{1}$, Cholho SONG ${ }^{1}$, Seulgi LEE ${ }^{1}$, Sungeun $\mathrm{CH}^{1}$, Hangnan YU ${ }^{1}$, Mina HONG ${ }^{1}$, Woo-Kyun Lee \\ ${ }^{1}$ Korea University, Seoul, Republic of Korea; ${ }^{1}$ Korea University, Seoul, Republic of Korea (ko871004@gmail.com; cholhosong@gamil.com; cristallize@, \\ naver.com; tgy2005@korea.ac.kr;willpower0129@gmail.com; alsdk920902@naver.com;leewk@korea.ac.kr)
}

This study was focused on harvested wood products (HWPs) of Larix Kaempferi, the second largest tree species in Korea. In this study, the amount of carbon storage by wood products needs to be quantitative using Life Cycle Assessment (LCA). LCA is a method to evaluate multiple issue environmental impacts attributed to a product of process. In particular, Larix kaempferi is with a distribution of 272,000 ha, 11.7 percent, followed by pine trees. In addition, it is used for various purposes, such as building materials, pulp, and particle boards. The use of HWPs in domestic forests is a role of carbon storage in wood products instead of being released back into the atmosphere. Therefore, the specific aim of this study is to estimate carbon storage for the HWPs of Larix kaempferi in Korea after pine trees. To estimate the amount of Larix kaempferi used in Korea, the total usage of it $\left(413,926 \mathrm{~m}^{3}\right)$ was estimated by checking the purchase amount by domestic product use as of 2016. This resulted in the estimation of the total carbon storage (379,432 ton $\left.\mathrm{CO}_{2}\right)$ of the Larix kaempferi used by multiplying the density of the lumber $\left(0.5\right.$ oven-dry ton $\left./ \mathrm{m}^{3}\right)$ and the carbon conversion factor $(0.5$ ton carbon/oven-dry ton of wood). 


\section{Decision criteria for deploying new forest roads / Critérios de decisão para implantação de novas estradas florestais}

Felipe Faria ${ }^{1}$, Claudio Ortolan ${ }^{1}$, Andreia Pimentel ${ }^{1}$, Jean Mileski ${ }^{1}$, James Stahl ${ }^{1}$, Everton Silva $^{1}$, Diogo Silva ${ }^{1}$, Yasmin Rocini ${ }^{1}$

${ }^{1}$ Klabin SA, Telemaco Borba,Brasil(ffaria@klabin.com.br; claudio.ortolan@klabin.com.br; anpimentel@klabin.com.br; jean.mileski@klabin.com.br;

jstahl@klabin.com.br; evgsilva@klabin.com.br;diasilva@klabin.com.br;yasmin.rocini@klabin.com.br)

Há que se lembrar que até pouco tempo o manejo incluía madeira para serraria e com a mudança do manejo (madeira para processo) e com novos equipamentos houve a oportunidade de aperfeiçoar o planejamento e as operações florestais, levando em consideração o alto custo de abertura e manutenção de estradas, a relação entre densidade de estrada e o risco de assoreamento dos rios, de erosão e danos nas APPs. Com objetivo de reduzir a abertura de estradas terciárias e aumentar as áreas produtivas, a Klabin S/A estabeleceu critérios e desenvolveu ferramentas para suporte a tomada de decisão de implantação de novas estradas terciárias. Foram levados em consideração os seguintes critérios: densidade de estradas (DE), distância média de extração dos equipamentos (DME), quantidade de madeira disponível em estradas cascalhadas, declividade (Lidar) e tipo de solo. Foram elaboradas duas matrizes de suporte, a primeira através da combinação dos fatores gera uma indicação de recomendação ou não da abertura de uma nova estrada. A partir desta primeira análise e nos casos "recomendados "utiliza- se os dados de solo e declividade, organizados nos mapas de fragilidade para analisar se a recomendação é mantida ou não. Nos casos em que o mapa de fragilidade indica riscos altos ou extremo a estrada não é construída.

\section{Integrating soil characteristics and routine weather data to enhance environment-friendly forest operations}

Anton Poje ${ }^{1}$, Matevž Mihelič', Vasja Leban ${ }^{1}$, Janez Krč ${ }^{1}$

${ }^{1}$ University of Ljubljana, Biotechnical faculty, Department of forestry and renewable forest resources, Ljubljana, Slovenia (anton.poje@bf.uni-lj.si; matevz.mihelic@bf.uni-lj.si; vasja.leban@bf.uni-lj.si;janez.krc@bf.uni-lj.si)

Considering soil types and their characteristics in forest operation is crucial for achieving its environmental viability and sustainable forest management. Soil type and soil water content are the main factors affecting ground bearing capacity and thus determining trafficability and damage to soil, particularly rutting. The aim of this research was to design a decision support system (DSS) prototype based on empirical data. Soil penetration resistance and soil water content were recorded on 4 different soil classes and 6 soil types, which correspond to $60 \%$ of Slovenia's soils. The results show that ground bearing capacity significantly depends on water content and soil type. Using limits for soil bearing capacity (i.e; 0.7 and 1.0 MPa), three zones regarding risk for soil damage during CTL harvesting can be determined, namely minimal, medium and high. The water content values between risk zones were estimated at $41 \%$ and $55 \%$ for cambisol, $22 \%$ and $40 \%$ for gleysol, $30 \%$ and 38\% for fluvisol, and $8 \%$ in 30\% for luvisol. Such simplified DSS is useful to diminish the risk for soil damages on a daily basis. Moreover, inclusion of routine weather data (e.g. forecast) would enlarge the DSS scope to anticipate soil damage risk for the following days. However, the main challenge remains in predicting the soil water content from routine weather data.

\section{C3r: LPF/SFB - IAWA PANEL DISCUSSION: NEW METHODS AND APPLICATIONS OF TROPICAL TIMBER IDENTIFICATION TO PROMOTE LEGAL LOGGING}

Building a pedagogical model to identify commercial wood species in post-conflict territories: the case of Colombia / Construcción de un modelo pedagógico para la identificación de maderas comerciales en territorios con pos-conflicto, el caso colombiano

Juan Francisco Guzman Zabala ${ }^{1}$

${ }^{1}$ Servicio Nacional de Aprendizaje SENA, Bogotá, Colombia (jfguzmanz@sena.edu.co)

De acuerdo con El Instituto de Hidrología, Meteorología y Estudios Ambientales (IDEAM, 2018) luego del Post-Conflicto generado por la firma del proceso de paz en Colombia con los grupos armados de las Fuerzas Armadas Revolucionarias de Colombia (FARC) y el Ejército de Liberación Nacional (ELN), la deforestación ilegal en Colombia ha ido aumentando constantemente, en 2015 se deforestaron 124 mil hectáreas de bosques, en 2016 se deforestaron 179 mil hectáreas, un 44\% más en relación con el año 2015, una cifra que aumentó en 2017 a 219 mil hectáreas deforestadas, 77\% más que en año 2015. Amenazando la biodiversidad de un país como Colombia que según Rivers, Oldfield y Smith (2017) posee el 9.6\% de todas las especies de árboles en el mundo, alrededor de 5776 especies forestales, convirtiendo a Colombia en el segundo país con la mayor diversidad forestal del planeta. El siguiente artículo presenta el modelo pedagógico diseñado por el Servicio Nacional de Aprendizaje (SENA) para la identificación macroscópica de 29 especies forestales comerciales encontradas en los municipios de Bogotá y Soacha, a través de la construcción de un modelo pedagógico innovador de Xiloteca, que fomenta el aprendizaje intuitivo, con base en la información recolectada en 150 encuestas realizadas a depósitos de madera, integrando las Tecnologías de la Información y la Comunicación (TIC), con el objetivo de capacitar gratuitamente a los actores del Pacto Intersectorial de la Madera Legal en Colombia (PIMLC), como estrategia para la reducción de deforestación ilegal causada por el Post-Conflicto.

\section{Discriminating Bertholletia excelsa Bonpl. (Brazilian nut) among similar Brazilian timber by NIRS technology}

Carolina C. Vieira ${ }^{1}$, Alexandre B. Gontijo ${ }^{2}$, Filipe A. S. Barros ${ }^{1}$, Jez W. Braga ${ }^{1}$, Tereza M. Pastore ${ }^{2}$, Vera Coradin ${ }^{2}$, Fernanda P. Pieruzzi ${ }^{2}$ ${ }^{1}$ Universidade de Brasília, Brasília, Brasil; ${ }^{2}$ Serviço Florestal Brasileiro, Brasília, Brasil (carolcv1190@gmail.com; gontijoab@gmail.com; filipesnel@gmail.com; jezwillian@gmail.com; tereza.pastore@gmail.com; vera.coradin@gmail.com; fernandapieruzzi@gmail.com)

Bertholletia excelsa Bonpl. is an Amazon native tree endangered with great economic importance. Despite the law protection, its timber have been illegally commercialized as another species from the same family because of their wood anatomy similarities. The aim of this work was the development of prediction models based on Near infrared Spectroscopy (NIRS) in order to improve the $B$. excelsa discrimination among other similar commercial timbers during inspection activities: Allantoma lineata (Mart. \& O. Berg.) Miers (Seru), Cariana micranta Ducke (jequitibá-rosa) e Lecythis pisonis Cambess (sapucaia-rosa). The spectra were obtained from Dr. Harry van der Slooten (Forest Product Laboratory - Brazilian Forest Service) wood collection. The NIR spectra (roughly 1595 to 2396 $\mathrm{nm}$ ) in transversal and longitudinal (radial and tangencial) wood sections were recorded by a handheld spectrometer MicroPHAZIR Analyzer. Discriminant analyzes modelling (PLS-DA) were done in MATLAB R2012 and PLS Toolbox 7.03. The efficiency of predicting species identification models ranged from $61.54 \%$ to $100 \%$. A higher efficiency (above $90 \%$ ) with low number of outliers could be reached for all models that considered the three sectional surfaces of the wood. Then, we could conclude that NIR technology was useful for B. excelsa timber discrimination from similar species with anatomic similarities. Besides, models considering both longitudinal and transversal sectional surfaces are more efficiently those considers just the longitudinal sections. The results encourages the use NIRS technology in order to optimize field inspection activities. 


\section{Identification of Dalbergia nigra and $D$. spruceana by NIR portable spectrometer}

Filipe A. Snel ${ }^{1,2}$, Tereza C. M. Pastore2, Vera T. R. Coradin' ${ }^{2}$, Jez W. B. Braga ${ }^{1}$

${ }^{1}$ University of Brasilia, Brasilia, Brasil; ${ }^{2}$ Forest Products Laboratory, Brasilia, Brasil (filipesnel@gmail.com; tereza.pastore@gmail.com;

veracoradin@gmail.com; jezwillian@gmail.com)

The Forest Products Laboratory of the Brazilian Forest Service and the University of Brasília has been studying the NIRS technology, infrared spectroscopy coupled to chemometrics to enable the wood species identification to support law enforcement operations at checkpoints. The method has shown favorable results for mahogany wood identification and has potential to be used in loco. In this work, this methodology was extended for Dalbergia species identification. Models were developed to identify two species of Dalbergia from Brazil: D. nigra and D. spruceana among 15 the species. Two chemometrics tools (PLS-DA and SIMCA) and two variable selections (all spectrometer spectral range and a spectral range that includes the main wood compounds bands) were compared aiming the best discriminatory efficiency. PLS-DA is the best potential tool to identify $D$. nigra samples, and this method presented $82.5 \%$ and $81.6 \%$ of efficiency in D. nigra discrimination using, respectively, all spectra range and spectra range focused in the main compounds of wood. Even though all spectra range presented better efficiency, it presented three more false positive samples. Therefore, the spectral range focused in the mains compounds of wood is recommended for $D$. nigra identification. SIMCA models presented efficiencies lower than $60 \%$ for $D$. nigra. Discrimination of $D$. spruceana was better with PLS-DA than SIMCA but presented lower efficiency with both tools, approximately $60 \%$. All spectra range showed relatively better discriminatory efficiency in most cases indicating that minority compounds are essential to the identification of species.

\section{Multi-isotope approach to provenancing sandalwood}

Ellyse Bunney ${ }^{1}$, Francesca McInerney ${ }^{1}$, Eleanor Dormontt ${ }^{2}$, Andrew Lowe ${ }^{2}$

${ }^{1}$ The University of Adelaide, Department of Earth Sciences, Adelaide, Australia; ${ }^{2}$ The University of Adelaide, Department of Biological Sciences, Adelaide, Australia(ellyse.bunney@gmail.com; cesca.mcinerney@adelaide.edu.au; eleanor.dormontt@adelaide.edu.au; andrew.lowe@adelaide.edu.au)

Sandalwood and the oil it produces are highly valuable and widely used forest products. Overharvest and poaching have greatly depleted natural populations of sandalwood resulting in Santalum album being listed as a vulnerable species on the International Union for the Conservation of Nature (IUCN) Red List. It is important to be able to distinguish sandalwood that is from sustainable and legal sources and sandalwood that has been poached from the wild. A newly emerging and complementary approach to assessing the origin of timber is isotopic provenancing of wood. Spatial variation of different isotope systems created by factors including differences in hydrology, climate, soil/bedrock type and agricultural practices should result in a unique isotopic signature for different geographical regions when multiple isotope systems are considered. These isotopic signatures are incorporated in to the tissue of organisms grown in that region and may be utilized as a means of identifying where an organic material originated from. This project aims to determine how multi-isotope analysis in sandalwood can be used for provenancing. Carbon, nitrogen, oxygen and strontium isotopic ratios in sandalwood will be measured within individuals, within sites and from different geographic regions to determine if isotopic signatures differ significantly between geographic regions. This project will support the enforcement of illegal logging laws and provide the sandalwood industry with tools to help verify and demonstrate compliance.

\section{Wood anatomy applied as a tool to identify tropical species against illegal wood trade in the state of Sao Paulo, Brazil \\ Luiz Santini-Júnior', Sandra Borges Florsheim², Mario Tomazello-Filho ${ }^{1}$ \\ ${ }^{1}$ Escola Superior de Agricultura "Luiz de Queiroz", Universidade de São Paulo, Departamento de Ciências Florestais, Piracicaba, Brasil; ${ }^{2}$ Instituto \\ Florestaldo Estado de São Paulo, São Paulo,Brasil (luizsantini82@gmail.com; sandra.florsheim@gmail.com; mtomazel@usp.br)}

The wood exploitation, specially in the Amazon region has increased in the last decades. It is estimated that, annually, 24 million $\mathrm{m}^{3}$ of wood in logs are extracted from the Amazon forest, and approximately 15\% is utilized processed on wooden planks in the market of the state of São Paulo. This statistic elevates the state of São Paulo to the position of the world's largest wood consumer from Amazon. The necessity to supervise and regulate the tropical timber trade prompted the São Paulo's government to implement the Project "São Paulo Amigo da Amazônia" (SPAA) in 2007. The inspection provided for the SPAA Project was based on surveys the wood sellers, control the Forest Origin Documents (FOD's) and identification of wood species of wood in their storage yards. In this context, a study was developed in 68 companies from 37 municipalities in the state of São Paulo that operate in the timber segment. Wood samples were collected and 90 tree species were identified through macro and microscopic analysis, and descriptive files and an identification key were elaborated. The results of the tree species identification pointed out 8 clusters of different species, whose timbers were mistakenly marketed by the same popular name. The results also indicated that the species identification through the wood anatomy is of fundamental importance for the success of the programs of inspection and regulation of the commerce of forest products, especially wood, in state of São Paulo and can be applied in other states of the country.

Determining anatomical patterns in wood from mountainous forests tree species in Rio de Janeiro, Brazil / Determinação de padrões anatômicos da madeira em espécies arbóreas de floresta montana, Rio de Janeiro, Brasil

Leonardo Bona do Nascimento ${ }^{1}$, Gláucia Crispim Ferrreira ${ }^{1}$, Pablo José Francisco Pena Rodrigues ${ }^{1}$, Arno Fritz das Neves Brandes ${ }^{2}$, Claudia Franca Barros ${ }^{1}$

${ }^{1}$ Instituto de Pesquisas Jardim Botânico do Rio de Janeiro, Rio de Janeiro, Brasil; ${ }^{2}$ Universidade Federal Fluminense, Niterói, Brasil (bona.nascimento@gmail.com; glaucia.crispim@yahoo.com.br;pablojfpr@hotmail.com; arnofritz@id.uff.br; claudiafrancabarros@gmail.com)

O Rio de Janeiro possui alta diversidade de espécies florestais, o que o torna estratégico para a conservação da Mata Atlântica. A análise das floras do estado por muitas vezes é realizada apenas por estudos fitossociológicos, que deixam algumas lacunas de conhecimento, por exemplo, as características anatômicas das espécies. Após a realização dos levantamentos fitossociológicos realizados pelo Instituto de Pesquisas Jardim Botânico através do projeto PPBio-Mata Atlântica as espécies com os maiores índices de valor de importância foram selecionadas para que sejam descritas a anatomia da madeira. Objetiva-se contribuir para 0 conhecimento da flora das espécies da Mata Atlântica do estado do Rio de Janeiro, através da realização de descrições anatômicas das madeiras de espécies com maior valor de importância coletadas através dos levantamentos fitossociológicos realizados na Reserva Biológica do Tinguá. O material botânico foi coletado na parcela RAPELD localizada na Floresta Ombrófila Densa Montana da Reserva Biológica (REBIO) do Tinguá, a 900 metros de altitude e processadas de acordo com as técnicas usuais para anatomia da madeira. Foram descritas microscopicamente 13 espécies selecionadas de acordo com as recomendações da IAWA destacando as características diagnósticas. Através deste estudo pode-se verificar convergências anatômicas entre as espécies e descrever o padrão anatômico da madeira para a área. Proporcionando assim esclarecer as estratégias anatômicas das espécies para as condições ambientais no qual estão inseridas. Além disso, tais descrições proporcionarão a realização de uma chave de identificação utilizando o software Xper e permitirão a identificação das espécies arbóreas mesmo sem material reprodutivo. 


\section{Anatomical assessment of $\mathbf{5 0}$ forest species in southern Ecuador / Evaluación anatómica de 50 especies forestales en el sur del Ecuador}

Andrés Armijos Montaño ${ }^{1}$, Darwin Pucha ${ }^{1}$

${ }^{1}$ Universidad Nacional de Loja, Loja, Ecuador (asarmijos32@gmail.com; darwin.pucha@unl.edu.ec)

La identificación de maderas tropicales a través de sus características anatómicas ha tomado mayor importancia en años recientes. Por ello, este estudio busca realizar la identificación de especies forestales a través de la anatomía de la madera, mediante un análisis estadístico de clasificación no supervisada por medio de clusters, dendrogramas, y heatmaps. Para ello se analizaron 50 especies forestales de la región sur del Ecuador dentro del laboratorio de Anatomía de Maderas Tropicales de la Universidad Nacional de Loja, y se identificaron 50 características anatómicas principales según la normativa IAWA. De éste análisis se encontró que la familia y género no influye directamente en las propiedades anatómicas de la madera, notándose grandes diferencias anatómicas entre las especies. Sin embargo, sólo en casos específicos, especies dentro de una misma familia comparten características comunes, como es el caso de Anadenanthera colubrina e Inga marginata (Fabaceae) que poseen vasos solitarios en patrones radiales y/o diagonales, y radios agregados con células cuadradas marginales de 2-4 filas; Cedrela odorata, Swietenia macrophylla, y Guarea kunthiana (Meliaceae) poseen en común anillos con poros difusos, vasos solitarios, parénquima axial difuso, radios con ancho de 1 a 3 series con células procumbentes y una sola fila de células verticales. Por todo ello, es necesario realizar un estudio más profundo de la relación entre propiedades anatómicas, clasificación taxonómica, sitio, y condiciones climáticas para lograr una mayor precisión en identificación de maderas tropicales.

Differentiating timber species from the Amazon forest in Paragominas, Pará, Brazil, using near infrared spectroscopy (NIRS) / Discriminação de espécies de madeiras da floresta Amazônica de Paragominas, estado do Pará, Brasil, pela aplicação da espectroscopia no infravermelho próximo (NIRS)

Caroline Américo da Silva ${ }^{1,2}$, Alinne Santos Da Silva ${ }^{1}$, Mario Tomazello-Filho ${ }^{1}$, Edson Vidal ${ }^{1}$, Gilles Chaix ${ }^{1,3}$

${ }^{1}$ Escola Superior de Agricultura Luiz de Queiroz, Universidade de São Paulo, Departamento de Ciências Florestais, Piracicaba, Brasil; ${ }^{2}$ Klabin S.A., São Paulo, Brasil; ${ }^{3} U M R$ AGAP, CIRAD, Univ Montpellier, Montpellier,France (caroline.silva@klabin.com.br; alinnewood@gmail.com; mtomazel@usp.br; edson.vidal@usp.br; gilles.chaix@cirad.fr)

O trabalho teve como objetivo discriminar 2 espécies florestais tropicais, ocorrentes na Unidade de Manejo Florestal, do município de Paragominas, estado do Pará, Brasil, monitorada há 25 anos pelo IMAZON. Foram selecionadas 41 e 46 árvores de Copaifera duckei Dwyer (copaíba) e de Cordia goeldiana Huber (freijó), respectivamente, e extraídas amostras do lenho do DAP, pelo método não destrutivo. As amostras do lenho foram fixadas em suportes de madeira, sua seção transversal foi polida, acondicionadas $\left(12 \%\right.$ umidade, UR $\left.65 \%, 20^{\circ} \mathrm{C}\right)$ e analisadas $(1 \mathrm{~cm}$ de distância, direção radial) no espectrômetro NIR MPA Bruker (módulo das sondas de fibra óptica 12800-4000 $\mathrm{cm}^{-1}$, resolução espectral $8 \mathrm{~cm}^{-1}$, dados médios de 32 leituras). Foram obtidos 2.161 espectros, tratados no software The Unscrambler ${ }^{\circledR}$ e simuladas as análises discriminantes com mínimos quadrados parciais (PLS-DA), compostas por 2 classes, (i) Copaifera duckei: valor esperado $=0$, e (ii) Cordia goeldiana: valor esperado $=1$, visando distinguir as 2 espécies pela análise quimiométrica das suas madeiras. Os resultados mostraram uma clara separação, com base nos valores esperados, permitindo a discriminação das espécies. A \% do erro de classificação foi para a madeira de (i) copaíba [classe $=0,0,6 \%$ (validação cruzada), $0,8 \%$ (validação independente)] e (ii) freijó [classe $=1,0,7 \%$ (val. cruzada), $0,2 \%$ (val. independente)]. Concluise que a metodologia NIRS permite a discriminação de $C$. duckei e $C$. goeldiana, com base nas simulações PLS-DA, utilizando-se amostras não destrutivas de madeira e, se constitui em eficiente ferramenta para a identificação de madeiras e controle da extração ilegal.

\section{C3s: TOOLS AND TECHNIQUES FOR BETTER WILDFIRE MANAGEMENT AND RESPONSE}

\section{Flammability of species for use as fuel breaks in forest fires prevention}

Bruna Kovalsyki ${ }^{1}$, João Francisco Labres dos Santos ${ }^{1}$, Andressa Tres ${ }^{1}$, Tiago de Souza Ferreira ${ }^{1}$, Antonio Carlos Batista ${ }^{1}$, Alexandre França Tetto ${ }^{1}$ ${ }^{1}$ Universidade Federal do Paraná,Curitiba,Brasil (kovalsyki.b@gmail.com; joaolabres@ufpr.br; tres.andressa@gmail.com; tiagoferreira@florestal.eng.br; batista.ufpr@gmail.com; tetto@ufpr.br)

In general, anthropic action is the main cause of forest fires. When these events occur in the Wildland-Urban Interface (WUI), they become a threat to local communities. One measure of forest fire prevention is the establishment of fuel breaks, which is strips of vegetation with species of lower flammability than those of the main cultivation, with the aim of reducing or avoiding fire spread. One of the characteristics observed for this purpose is the flammability of the combustible material. In this context, the aim of this study was to evaluate the flammability of Casearia sylvestris and Camelia sp., according to the methodology recommended by Valette (1990) and Petriccione (2006). To evaluate this species, 50 firing repetitions were performed in the epirradiator (250 to $\left.350{ }^{\circ} \mathrm{C}\right)$, each one consisting of $1 \pm 0.1 \mathrm{~g}$ of fine green combustible material $(\varnothing<0.7 \mathrm{~cm})$. The following combustion characteristics were analyzed: Ignition Frequency (IF), Ignition Time (IT), Duration of Combustion (DC) and Flame Height (FH). Subsequently, a flammability value was determined, considering the IT and IF of each species. According to the average values found, Casearia sylvestris (IF $=96 \%$; IT $=17.5 \mathrm{~s} ; \mathrm{DC}=5.3 \mathrm{~s} ; \mathrm{FH}=13.5 \mathrm{~cm}$ ) and Camelia sp. $(\mathrm{IF}=100 \%$; IT $=18.7 \mathrm{~s} ; \mathrm{DC}=14.7 \mathrm{~s} ; \mathrm{FH}=12.2 \mathrm{~cm}$ ) were classified as flammable species. Therefore, it is recommended that these species are submitted to combustion and calorimetry analyzes in future studies to corroborate with these results.

\section{Colorado homeowners' willingness to pay estimates for reducing wildfire risk: a comparison of survey methods}

Jose J Sanchez ${ }^{1}$, Armando Gonzalez Caban ${ }^{1}$, John Loomis ${ }^{2}$, Thomas Holmes ${ }^{3}$

${ }^{1}$ USDA Forest Service, Riverside, USA; ${ }^{2}$ Colorado State University, Ft. Collins, USA; ${ }^{3}$ USDA Forest Service, Triangle Park, USA (jsanchez@fs.fed.us; agonzalezcaban@fs.fed.us; john.loomis@colostate.edu; tholmes@fs.fed.us)

The loss of life, property, and natural resources has been more devasting in recent years due to the increase in frequency and severity of wildfires. To help reduce risk, the USDA Forest Service (USFS) has promoted private homeowner and public wildfire risk reduction actions. However, these are costly programs to private homeowners and county fire management agencies. To induce participation, cost share programs have been provided. However, there are very limited federal funds and it is important for the USFS to know what geographic areas have the highest economic values for reducing wildfire risk and the relative values of wildfire risk reduction actions to homeowners. In particular, the cost sharing only reduces the cost to the landowner, and if their willingness-to-pay (WTP) falls below their cost share, they will not engage in private actions to reduce wildfire risk on their properties or support homeowner associations' actions. To better understand this issue, a choice experiment survey of Colorado homeowners was conducted to estimate the amount homeowners' would pay for wildfire risk reduction programs in their community and around their home. Colorado homeowners received either an online or mail survey with three choice sets, each 
with three alternative programs (public, private, status quo). Using a split sample survey, we estimate Colorado homeowners' WTP for wildfire risk reduction programs and compare them by the survey methods. The results may help fire managers allocate their limited resources to fund public and private actions as well as determine if results vary by survey method.

\title{
Modeling the influence of eucalypt plantation on wildfire occurrence in the Brazilian savanna: a comparison of Random Forest, MaxEnt and Logistic Regression
}

\author{
Luiz Felipe de Castro Galizia ${ }^{1,2}$ (D), Marcos Rodrigues ${ }^{1}$ \\ ${ }^{1}$ University of Lleida, Lleida, Spain; ${ }^{2}$ University of Eastern Finland, Joensuu, Finland (luizf@uef.fi; rmarcos@eagrof.udl.cat)
}

Eucalypt plantations are expanding in Brazilian savanna, one of the most frequently burned ecosystems in the world. Wildfires are one of the main threats to forest plantations, causing economic and environmental loss. Modeling wildfire occurrence provides a better understanding of the processes that drive the fire activity. Furthermore, the use of spatially explicit models may promote more effective management strategies and support fire prevention policies. Machine Learning (ML) algorithms have shown their predictive accuracy to model wildfire occurrence. In this context, we implemented and compared Random Forest ML algorithm with Maximum Entropy (MaxEnt) and traditional methods like Logistic Regression (LR) to predict the ignition likelihood across the study area. The models were trained using several explanatory drivers related to fire ignition: accessibility, proximity to agricultural lands or human activities, among others. Specifically, we introduced the progression of eucalypt plantations on two-year basis. Fire occurrences in the period 2010-2016 were retrieved from the Brazilian Institute of Space Research (INPE) database. Results suggest that the use of ML algorithm leads to an improvement in the accuracy in terms of the AUC (area under the curve) of the model when compared to MaxEnt and LR outputs. The ML model denoted fairly good predictive accuracy (AUC $\approx 0.72$ ) being useful for evaluating the current occurrence likelihood distribution and unravel fire occurrence driving forces. Results suggested that fire occurrence likelihood was mainly linked to proximity agricultural and urban interfaces. Even though eucalypt plantations were not the main explanatory factor, it contributed to increasing wildfire likelihood.

\section{Use of cultural fire as a tool for territory management and for wildfire prevention}

Antonio Casula ${ }^{1}$, Gabriella Cuccu ${ }^{1}$, Michele Chessa ${ }^{1}$, Antonello Cannas ${ }^{1}$, Leandro Usai ${ }^{1}$, Lino Magari ${ }^{1}$, Livo Peluffo ${ }^{1}$; Franco Casula ${ }^{1}$, Salvatore Cabiddu ${ }^{1}$, Giancarlo Muntoni ${ }^{1}$

${ }^{1}$ Corpo Forestale e di Vigilanza Ambientale della Regione Sardegna, Cagliari, Italy (antcasula@regione.sardegna.it; gcuccu@regione.sardegna.it; michessa@regione.sardegna.it; acannas@regione.sardegna.it; leusai@regione.sardegna.it; lmagari@regione.sardegna.it; lpeluffo@regione.sardegna.it; fcasula@regione.sardegna.it; scabiddu@regione.sardegna.it; gmuntoni@regione.sardegna.it)

During the last 50 years, major socio-economic changes exacerbate fire regime of Sardinia (Italy), the second largest Mediterranean island, resulting into wildfires of unknown speed, intensity and magnitude together with brutal damage to the forests, homes and people lives. During the same period Italian and European culture experienced a diffuse demonization of fire itself and the criminalization of people that was traditionally accustomed to use fire. Sardinian firefight machine greatly increased its efficacy in suppressing fire and in judiciary investigation but despite its efficiency and a continuous growth of economic costs, wildfires continues to create severe damage to the ecosystem. On the contrary, a cultural shift from the paradigm "all fires must be put out" to the one "not all fires are bad fires" is the basis of a project carried out by the Sardinian Forest Service in "Planargia", a specific area located in the NW of the isle where the social conflict between people using fires in their work at the countryside and the firefight apparatus gave way to a collaboration of Forest Service with landowners and local administrations, for a rational use of the ancient cultural fire. The collaboration leaded to a drastic drop of ignitions and burned areas, to a strong effect of forest fire risk reduction and to a cancellation of the economic costs of wildfire suppression. The project, fully operational since 2012, consisted in an organic fuel load reduction program by the use of prescribed burning conducted by the same land owners, farmers and livestock farmers, assisted by Forest Service crews. The results are exceptionally encouraging not only for the strong reduction of wildfires and suppression costs but also for the proliferation of specific essences of natural fodder crops, for the insect species control (effect offered by the light burn that reduces the need to use pesticide), and, finally, for firefighters' training experience. By working together, forest service, local administrations and landowners developed a collaboration protocol that enhanced the environmental and social control of the whole territory.

\section{Spatio-temporal characterization of tree and stand level canopy structure of fire-tolerant eucalypt forests after wildfires of different severity using Lidar data}

Yogendra Karna

${ }^{1}$ School of Ecosystem and Forest Sciences, The University of Melbourne, Creswick, Australia (ykarna@student.unimelb.edu.au)

Fire-tolerant eucalypt forests are one of the major forest ecosystems of south-eastern Australia and thought to be highly resistant to frequent high severity wildfires. However, the impact of different severity wildfires on the canopy structure of this forest type is under-studied, and there are significant knowledge gaps in relation to the assessment of tree and stand level canopy structural dynamics and recovery after fire. Assessment of canopy structure is a complex task involving accurate measurements of the horizontal and vertical arrangement of the canopy in space and time. This study examined the utility of multitemporal, small-footprint lidar data to describe the changes in the horizontal and vertical canopy structure of fire-tolerant eucalypt forests eight years after wildfire of different severities from the tree- to stand level. Extensive ground measurements were carried out in four severity classes to describe and validate canopy cover and height metrics as they change after wildfire. The preliminary analysis revealed that there is a persistent effect of high severity fire 8 years after both on tree crowns and stand canopy. The tree level analysis results show that high severity fire increased crown depth but decreased the crown projective cover leading to a more open canopy.

Climate change, unsustainable development, outbreaks of heat and forest fires, the real reason why Amazonia "catches fire" / Mudanças climáticas, desenvolvimento insustentável, focos de calor e incêndios florestais, o real motivo da amazônia "pegar fogo"

Julie Alves da Silva ${ }^{1}$, Luiz Joaquim Bacelar de Souza ${ }^{1}$, Jakson França Guimarães ${ }^{2}$, Rogerio Fonseca ${ }^{1}$, Lauana Silva Da Costa ${ }^{1}$, José Wilson Pereira Gonçalves ${ }^{2}$ Brenda Corrêa de Castro ${ }^{1}$

${ }^{1}$ Universidade Federal do Amazonas, Manaus, Brasil; ${ }^{2}$ Corpo de Bombeiros Militar do Amazonas, Manaus, Brasil (juliealves72@gmail.com;

lsouza@ufam.edu.br; obm_franca@yahoo.com.br; rogeriofonseca@ufam.edu.br; lauana.costt@gmail.com; jwillsonbm@yahoo.com.br; bcastrocorrea@gmail.com)

Os efeitos das atividades antrópicas influenciam diretamente na incidência de incêndios florestais, atividades estas que aumentam susceptibilidade das florestas a incêndios. No estado do Amazonas as atividades antrópicas, como agricultura, pecuária e exploração madeireira aumentam a quantidade de materiais 
combustíveis disponíveis. Nossos resultados mostram que os meses com maiores incidências de focos de calor no estado ocorrem nos meses de agosto e setembro, concomitantemente são os meses de menor precipitação e maior temperatura média. As mesorregiões Sul e Centro foram as mais afetadas por focos de calor, havendo, nos anos 2000 a 2008, maior concentração dos focos na mesorregião Sul e, de 2009 a 2016, se formou uma "ponte" de focos de calor que acarretaram na maior incidência de focos de calor na mesorregião central, cenário esse que corroborou com o cenário previsto de desmatamento. O município de Lábrea possui a maior média anual de focos de calor, entretanto o município de Boca do Acre foi o município com maior área em quilômetros quadrados afetados por focos de calor. A diminuição dos focos de incêndios neste bioma depende de ações multiagências, muitas delas com suporte logístico insuficiente para um território continental como é o caso do estado do Amazonas. Iniciativas mediadas por técnicos tem auxiliado a melhor gerir o parco capital financeiro disponibilizado pelo estado brasileiro.

\section{C3t: FOREST OPERATIONS ENGINEERING AND MANAGEMENT}

\section{Lime and cement use in the chemical and granulometrical stabilization of soil for forest roads}

Breno Arrivabeni ${ }^{1}$, Carlos Machado ${ }^{1}$, Giovani Sant'Anna ${ }^{1}$

${ }^{1}$ Universidade Federal de Viçosa, Viçosa, Brasil (breno.arrivabeni@hotmail.com; carloscardosomachado@terra.com.br; santannagiovani@yahoo.com.br)

This work aimed to analyze the chemical and granulometric stabilization of a gravel soil for forest roads through the use of lime and cement. The sample was analyzed according to DNIT's different granulometries, related to its natural granulometric characteristics and also when added cement and lime to it as chemical additives, in the proportion of $4 \%$ and $8 \%$ of the dry soil mass, respectively. The development of this analysis was based on the gravel characterization followed by the compaction tests, California Bearing Ratio (CBR) and Resistance to Simple Compression (RSC). This latter test was based on the norm suggesting a value of 2.17 MPa for a 14 days cure period using lime and 2.1 MPa at 7 days using cement. The results obtained from CBR analysis were superior to the soil without additive, being greater than $300 \%$ using cement and greater than $100 \%$ using lime. For RCS analysis, the results were below the standards for both additives, but still higher than the natural soil. Therefore, these materials when mixed with lime and cement, have a high bearing capacity and resistance, especially when using cement, which indicates good parameters related to stability, erosion and vehicle traffic.

\section{Strategic investment: real options applied in a forest nursery for production of eucalyptus seedlings \\ Danilo Simões ${ }^{l}$ (D), Douglas Henrique da Fé ${ }^{2}$ (D), Magali Ribeiro da Silva ${ }^{1}$ (D) \\ ${ }^{1}$ Universidade Estadual Paulista "Júlio de Mesquita Filho”, Faculdade de Ciências Agronômicas, Botucatu; ' Universidade Estadual Paulista "Júlio de Mesquita Filho”, Campus of Itapeva, Itapeva, Brasil (danilo.simoes@unesp.br; douglas.fe@unesp.br; magali.ribeiro@unesp.br)}

The traditional methods of investment valuation in real assets don't include the uncertainties and strategies, that are inherent to competitive ambiances of the companies of forest base, therefore, can be limit the creation of value for the stakeholders. To mitigate these shortcomings was used the Real Options approach for evaluating an opportunity of investments in real assets to produce eucalyptus seedlings, owing to be a project with features that allow strategic decisions. The project intends to install a forest nursery in of State of São Paulo, Brazil, with the capacity to produce 3.600 million of seedling per year, thus, demanded a CAPEX of USD\$374,399.89. The cash flow was projected for a horizon of 10 years, which was discounted by the CAPM. Owing to the current scenario the investors have how strategies flexibilities the option of wait two years for beginning the activities and more, can expand the operational scale in $30 \%$ on the tenth year of the lifespan of the investments project in real assets. Owing to the price evolve over time, the behavior of the price follows the geometric Brownian motion, denoted for movements of up and down, therefore, was make a binomial decision tree in discrete time. In considering that the investments project was implanted after two years and mainly that the probability of $73 \%$ of alteration of the operational scale was executed, the results evidenced that there was an increment in the market value, that is the present value expanded was USD1,853,665.11.

Determining the moisture content of pine and eucalyptus logs using radio frequency capacitance / Determinação da umidade de toras de pínus e eucalipto empregando o método da capacitância em radiofrequência

Elisa Pizzaia Goltz ${ }^{1}$, André Simon ${ }^{1}$, Pedro Boing ${ }^{1,2}$

${ }^{1}$ Marrari Automação, Curitiba, Brasil; ${ }^{2}$ Universidade Federal do Paraná Curitiba Brasil (elisa.pizzaia@gmail.com; andre@marrari.com.br; calibracao@marrari.com.br)

O desenvolvimento de modelos matemáticos que correlacionem a permissividade elétrica relativa $\varepsilon$ ' e o fator de perda dielétrica $\varepsilon$ " à quantidade de água presente na madeira é um passo fundamental no desenvolvimento de medidores instantâneos de umidade. A correlação entre as variáveis é largamente aplicada na medição de umidade de madeira serrada e, recentemente, de cavacos de madeira, mas não é aplicada ainda na medição da umidade de toras. Este trabalho consistiu na avaliação deste método aplicado também à madeira em toras. Uma vez aprovado, o método pode ser empregado no comércio e na seleção das toras que entram na linha de produção de celulose ou que são alimentação da caldeira de força. No presente trabalho foram utilizadas toras de pínus com umidades entre $12 \%$ e $48 \%$ e de eucalipto com umidades entre $40 \%$ e $60 \%$ em base úmida, provenientes de plantios diferentes, todos localizados no Paraná. A avaliação se deu através da correlação entre a leitura crua de um sensor capacitivo quando inserido nas toras e a umidade da madeira obtida pelo método gravimétrico, que forneceu coeficientes de determinação $\left(\mathrm{R}^{2}\right)$ de 0,884 para toras de pínus e de 0,6088 para toras de eucalipto. A relação observada entre a leitura do sensor e a umidade das toras permitiu afirmar que o método pode ser aplicado para estimar a umidade dos dois gêneros investigados com o grau de acurácia suficiente para comercializar e classificar matéria-prima antes do processo produtivo de celulose ou a produção de energia a partir da biomassa.

Controlling pine regrowth in Caxambu State Park, in Castro, Paraná, Brazil / Controle de regeneração de pínus no parque estadual Caxambu, Castro, Paraná, Brasil

Luciana Leal ${ }^{1}$, Nelson Luiz Cosmo ${ }^{1}$, Felipe Fiuza de Lima ${ }^{2}$, Jorge Ricardo Camargo ${ }^{1}$, Cristóvam Sabino Queiroz ${ }^{3}$, Maria do Rocio Lacerda Rocha ${ }^{1}$ Copel Distribuição S.A., Curitiba, Brasil; ${ }^{2}$ Verdes Lagos, Chopinzinho, Brasil; ${ }^{3}$ Instituto Ambiental do Paraná, Curitiba, Brasil (lucianaleal.floresta@gmail.com; nelson.cosmo@copel.com; felipe@verdeslagos.com.br; jorge.camargo@copel.com; cristovamsq@iap.pr.gov.br; mrociola@iap.pr.gov.br)

No Estado do Paraná, Brasil, as espécies de Pinus spp. são reconhecidas em portaria estadual como exóticas invasoras, sendo previstos o monitoramento, o controle e sua erradicação em unidades de conservação de proteção integral. Em 2015 foram suprimidos os reflorestamentos de Pinus spp. existentes no Parque 
Estadual Caxambu, município de Castro, Paraná, em região de ocorrência da Floresta Ombrófila Mista. Como condicionante de licenciamento ambiental, o Instituto Ambiental do Paraná (IAP) solicitou à Copel Distribuição S.A. a execução do controle e monitoramento de pínus no parque, pois foi prevista a regeneração de grande número de indivíduos da espécie, devido à presença de banco de sementes no solo, de sua longevidade e da alta taxa de germinação. $\mathrm{O}$ controle foi realizado pelo método mecânico e variou emfunção do porte, com arranquio manual de plântulas e corte de indivíduos jovens, próximo à base do caule. Em aproximadamente 23,5 hectares, em abril de 2018, foram erradicados 13.133 indivíduos de pínus. Repetindo a ação após seis meses, a quantidade removida reduziu para 391 plântulas. Nas áreas que sofreram intervenção observou-se intensa regeneração natural da floresta nativa, promovendo o sombreamento do solo, fator que contribui para a redução de novas infestações de pínus, por ser espécie heliófila. Os resultados mostram a importância do monitoramento e de ações posteriores à supressão de reflorestamentos, para evitar e controlar a reinfestação de espécies exóticas invasoras. Destaca-se a influência da regeneração natural das espécies nativas, em ambiente florestal, na inibição da contaminação biológica por Pinus spp.

Integrated management of vegetation in creating power line transmission corridors / Aplicação de manejo integrado de vegetação na abertura de faixas de passagem de linhas de distribuição de energia elétrica

Luciana Leal ${ }^{1}$, Robinson Antonio Pitelli ${ }^{2}$

${ }^{1}$ Copel Distribuição S.A., Curitiba, Brasil; ; ${ }^{2}$ entro de Gestão de Tecnologia e Inovação (CGTI), Jaboticabal, Brasil (lucianaleal.floresta@gmail.com; rapitelli@ecosafe.agr.br)

O controle de vegetação sob sistemas elétricos nas áreas rurais é realizado pelas concessionárias brasileiras por meio da roçada manual ou mecanizada. Devido a rápida rebrota das plantas, o processo é bastante oneroso e com impactos ambientais. O projeto de pesquisa e desenvolvimento P\&D ANEEL 2866-0480/2017 "Manejo Integrado de Vegetação em Abertura de Faixa de Passagem em Linhas de Distribuição de Alta e Média Tensão", proposto pela Copel Distribuição S.A e o Centro de Gestão de Tecnologia e Inovação (CGTI), com unidades experimentais no estado do Paraná, Brasil, tem como objetivo estudar a viabilidade técnica, ambiental e econômica da abertura de faixa na modalidade de manejo integrado de vegetação, combinando a ceifa inicial com o uso de herbicidas não-agrícolas aplicados de maneira seletiva. Com isto, favorece vegetação cuja característica de crescimento não interfira no desempenho operacional das instalações elétricas ou que demande o mínimo de intervenções, além de prover benefícios como proteção para o solo e ambiente favorável para a fauna. Para viabilizar a operacionalização no setor elétrico, experimentos visam conhecer os efeitos dos tratamentos nas plantas alvo e não-alvo, necessidade de intervenções e magnitude da resiliência da vegetação, bem como impactos ambientais e externalidades da metodologia.

\section{Management of forests under power lines for mitigation of transmission disruptions \\ Andressa Ribeiro ${ }^{1}$, Antonio Carlos Ferraz Filho ${ }^{1}$, Mylla Vyctória Coutinho Sousa ${ }^{1}$, Alessandro Cesar de Sousa Berredo ${ }^{2}$ \\ ${ }^{1}$ Universidade Federal do Piaui, Bom Jesus, Brasil; ${ }^{2}$ Taesa, Rio de Janeiro, Brasil (andressa.florestal@ufpi.edu.br; acferrazfilho@ufpi.edu.br; myvyc@hotmail.com; alessandro.berredo@taesa.com.br)}

Brazil has a total of 150,338 MW of installed energy matrix, with many power transmission networks located in forest areas, which are prone to wildfires and responsible for costly power interruptions. Measures taken to reduce fire intensity, and thereby minimize risk of faults, include expansion of vegetation clearance around towers, reduction of vegetation maintenance intervals in high risk locations, management based on vegetation and fuel type, alteration of species composition from high flammability to lower flammability vegetation types, etc. Few studies have been found to date that address the question of what is the appropriate forest management under power lines in the Savannah type (Cerrado and Caatinga) Brazilian biomes. This project is conducted by TAESA in partnership with the Federal University of Piauí, GeoAmbiente and Ekocap, and is divided in five steps to accomplish the goal: 1) GIS mapping of power disruption risk areas evaluating different climate and spatial variables; 2) definition of key forest inventory variables, with specification of the most important tree species; 3) selection and research of the potential species of the region, studying growth cycles and wood properties; 4) seed collection and seedling production analysis and 5) field tests for recovery of degraded areas. *Funded by P\&D 2607-0044/2016 "Estudo de ações para mitigação de riscos de desligamentos das linhas de transmissão por queimadas e avaliação de métodos de manutenção de faixas de servidão".

\section{Assessing impacts from two modes of forest extraction using a tractor-hoist assembly in a mountainous region / Avaliação dos impactos em dois modais de extração florestal com conjunto trator agrícola-guincho em uma região montanhosa}

Rafael Oliveira Brown ${ }^{1}$, Marcelo Langer ${ }^{1}$, Dimas Agostinho Silva ${ }^{1}$, Renato Cesar Gonçalves Robert ${ }^{1}$

${ }^{1}$ UniversidadeFederaldoParaná,Curitiba,Brasil(brownrafael@gmail.com;marcelolanger@ufpr.br;dimas.agostinho.silva@gmail.com;renatorobert@ufpr.br)

O Brasil possui uma vasta área de plantios florestais, boa parte encontra-se em regiões montanhosas. Nestas regiões de relevo mais acidentado, a mecanização completa da colheita é imprópria. Para estas condições de relevo, o conjunto trator agrícola com guincho arrastador figura como uma alternativa de extração de madeira. O objetivo deste trabalho foi comparar o tempo de ciclo operacional, custo de produção, produtividade e rendimento energético de dois modais de operação na extração de árvores em uma região montanhosa. O estudo foi desenvolvido no Vale do Ribeira, região montanhosa do Paraná em um plantio florestal de Pinus, onde foram analisados os modais, tradicional com um tratorista e um operador de cabo e o modal alternativo com um tratorista e dois operadores de cabo. A metodologia empregada para cálculos de impactos foi a Avaliação do Ciclo de Vida de Produtos, tendo como unidade funcional a quantia de $\mathrm{CO}_{2}$ eq. emitidas para transportar $1 \mathrm{~m}^{3}$ de madeira em 100 metros de arraste. Os modelos foram ajustados para cada modal e comparados por teste de identidade desses modelos para verificar diferença estatística significativa. Os resultados apontaram para uma melhora de $22,24 \%$ no tempo de ciclo, $14,95 \%$ na produtividade e 4,94\% no custo de produção e 22,24\%no rendimento energético quando se trabalha com o modal alternativo em uma situação com distância de extração de 100 metros. Recomenda-se ainda que outros estudos sobreergonomia e segurança, além da utilização de dispositivos nos guinchos, sejam desenvolvidos.

Proposed concepts and developments for a forest harvester / Propostas de conceitos e desenvolvimentos voltados a uma colhedora florestal

Rafael Dias ${ }^{1,2}$, Luis Bernardino ${ }^{1}$, Raphael Mialhe ${ }^{1}$, José Molin' ${ }^{1}$, Henrique Scolforo ${ }^{2}$

${ }^{1}$ Universidade de São Paulo,Piracicaba,Brasil; 2Suzano, Limeira, Brasil (rafael.donizetti.dias@usp.br; lgmecanico@hotmail.com, raphael.mialhe@hotmail.com;jpmolin@usp.br; hscolforo@suzano.com.br)

É notável que a indústria florestal busca aumentar a mecanização na colheita de madeira através da inserção de diferentes equipamentos e técnicas, visando sempre à sustentabilidade do negócio florestal, diminuição de custos, aumento da produtividade, melhoria da qualidade da matéria prima e das condições de trabalho e menor impacto ambiental. O objetivo deste trabalho é realizar uma revisão bibliográfica dos desenvolvimentos e pesquisas voltadas a otimização da colhedora florestal e propor possíveis ajustes funcionais dos seus componentes a fim de otimizar quantitativamente e qualitativamente a atividade de colheita 
florestal. As propostas de melhorias estão voltadas na otimização e novos desenvolvimentos de sensores, atuadores e proposta de soluções que coletarão dados disponíveis na colhedora possibilitando melhorias no processo. Dentre os desenvolvimentos propostos, destacam-se os novos conceitos de mapeamento de produtividade, o emprego de sensores e atuadores capazes de mensurar fatores de qualidade de uma colheita, a análise preditiva de máquinas a partir de dados de telemetria e a colheita autônoma.

C4a: ADVANCEMENTS IN DIGITAL TECHNOLOGIES FOR DENDROMETRY AND QUALITATIVE INDICATORS OF FORESTS

\section{Augmentation of forest inventory measurements using under-canopy photogrammetry}

Demetrios Gatziolis ${ }^{1}$

${ }^{1}$ USDA Forest Service, Portland, Oregon, USA (dgatziolis@fs.fed.us)

The management of forest resources aiming at addressing diverse challenges while serving the needs of the people requires detailed and frequently updated information on their distribution, status, and trends. Timber-oriented national forest inventories do not always meet these requirements because many measurements on parameters of interest are deemed too costly or difficult to obtain using traditional techniques. Developments in under-canopy photogrammetry, an emerging, computer vision-based technology have the potential to complement inventory surveys. Based on series of images acquired with inexpensive, hand-held cameras, a three-dimensional representation of near-ground vegetation organized as a colored point cloud is obtained. The point density is typically so high that rendered trees or shrubs can be precisely mapped and measured. The survey thus becomes a snapshot in time that can be explored immediately or in the future, if alternative information is needed. Surveys can establish resource baselines for developing countries, support precise estimation of biodiversity, ecological indicators, and local terrain metrics, and where repeated, quantify change in growth rates or occupancy metrics for both trees and understory vegetation. In tests conducted across biomes in the US Pacific Northwest, photogrammetry-derived tree stem diameter measurements at various near-ground heights rivaled in precision those obtained by tape. Under conducive conditions, coarse woody debris volume estimation error was consistently under $2 \%$; elsewhere under $5 \%$. Observed error levels are substantially lower than those obtained using traditional, transect-based field measurements. With camera capabilities continuously improving and prices reducing, under-canopy photogrammetry emerges as an important tool for augmenting forest inventory operations.

\section{Estimation of crown architecture from point clouds}

Bogdan Strimbu ${ }^{1}$, Rong Fang ${ }^{1}$

1Oregon State University, Corvallis, USA (bogdan.strimbu@oregonstate.edu; rong.fang@oregonstate.edu)

Accurate description of crown architecture is pivotal for understanding physiologic processes and biomass allocation. The most common approach to describe tree crown architecture is by measuring the dimension of trunk and branches, which now can be executed using point clouds. This study compares the accuracy of the measurements executed manually and automatically, by the QSM algorithm, from a terrestrial laser scan of 10 neighboring Douglas-fir trees. The DBH of the sample trees ranged from 49 to $100 \mathrm{~cm}$, and total heights ranged from 38 to $54 \mathrm{~m}$. Diameters along the stem were measured every meter and the branches were measured for insertion angle, diameter at insertion, length, and azimuth. Our results reveled that QSM identified less first-order branches than the manual process. A paired t-test showed that stem diameters are similar for the lower portion of the bole, but QSM supplied significantly smaller values for the upper part. The branch length measured manually was 0.3 , and $0.26 \mathrm{~m}$, larger than QSM measurements by insertion height and aspect, respectively. However, the branch diameters were not different between measurements types. Nevertheless the branch insertion angle was $9^{\circ}$, and $10^{\circ}$, larger for manually measurements, by insertion height and aspect, respectively. Our results shows that automatic measurements using QSM for Douglas-fir are reliable for the lower portion of the stem, which is consistent with other studies. However, for heights $\geq 10 \mathrm{~m}$ QSM does not provides trustworthy values. The main issue of QSM measurements for Douglas -fir is the significant omission errors in branch identification.

\section{ForeStereo: a cost-effective approach for proximal-sensing field measurement}

Isabel Aulló -Maestro ${ }^{1,5}$, Cristina Gómez ${ }^{1}$, Antonio Vázquez de la Cueva ${ }^{1}$, Mariola Sánchez-González ${ }^{1}$,Jose Antonio Navarro ${ }^{2,5}$, Pablo Cruz ${ }^{3}$, Luiz Carlos Estraviz Rodriguez ${ }^{4}$, Isabel Cañellas ${ }^{1}$, Montes Fernando ${ }^{1}$

${ }^{1}$ INIA, Forest Research Centre, Dpt. of Forest Dynamics and Management, Madrid, Spain; ${ }^{5}$ MONTES (School of Forest Engineering and Natural Environment), Universidad Politécnica de Madrid, Madrid, Spain; ${ }^{2}$ Agresta Soc. Coop., Madrid, Spain; ${ }^{3}$ GEF Corredores Bi (isabel.aullo@inia.es; gomez. cristina@inia.es; vazquez@inia.es; msanchez@inia.es; janavarro@agresta.org; tacoral@gmail.com; lcer@usp.br; canellas@inia.es; fmontes@inia.es)

Forest inventories play a key role as a cost-efficient way to assess forest structure and to monitor forest dynamics. Remote sensing techniques, especially LiDAR, are increasingly used to retrieve some stand features, but ground-based data are still required for area based modelling. New technologies such as Terrestrial Laser Scanner enable data acquisition from ground plots to reconstruct detailed forest structure. However their limited efficiency in field surveys, the lack of standardized methods for estimation of common forest variables and the costly processing of big amounts of data have prevent their use in operational forest planning. ForeStereo, a passive optical sensor based on stereoscopic hemispherical images and developed by INIA-CIFOR, has demonstrated to be an advantageous system for obtaining ground-based information of forest structure. ForeStereo focus on single-scan plots, which simplify and reduce significantly field inventory costs. ForeStereo provides estimates of individual tree variables (DBH, height, volume and crown dimensions) and stand level variables (Leaf Area Index, number of trees, basal area, and volume, which can be summarized for each plot and by species and DBH class). Additionally, the 3D reference of the matched points allows stand structure characterization. These methods have been implemented in dedicated software to attain a cost-effective tool for forest inventories. We present the methodology and critical points of ForeStereo data processing, from the automated image segmentation and matching, to the methods dealing with instrument bias and tree occlusions linked to the single-point surveying. Examples in natural forests and plantations in Spain, Brazil and Chile are shown.

\section{DendroCloud: free terrestrial-based point cloud processing software for forestry}

Martin Mokroš $\check{1}^{1}$ Milan Koreñ²

${ }^{1}$ Czech University of Life Sciences Prague, Prague, Czech Republic; ${ }^{2} T e c h n i c a l$ University in Zvolen, Zvolen, Slovakia (mokros@fld.czu.cz; koren@tuzvo.sk)

The DendroCloud is a free software developed at the Technical University in Zvolen, Slovakia (http://gis.tuzvo.sk/dendrocloud/ [http://gis.tuzvo.sk/ dendrocloud/]). The software provides tools for estimation of tree parameters from terrestrial-based point clouds. Point clouds from terrestrial laser scanning 
[1] and close-range photogrammetry [ $\left.{ }^{2}\right]$ can be processed in DendroCloud. The main DendroCloud's features include DEM and DSM extraction, point cloud filtering, point cloud segmentation, tree identification, and estimation of tree parameters. The first step for tree diameter and height estimation is a DEM extraction. Then horizontal cross-sections at ${ }^{1} \cdot{ }^{3} \mathrm{~m}$ above the DEM are extracted from the input point cloud. Cross-sections are spatially clustered. The clusters represent cross-sections of individual trees. Clusters can be visually validated and edited before further processing. Positions and diameters of trees can be calculated by several methods [ $\left.{ }^{1}\right]$. Tree base and tree tip are estimated on the base of point cloud analysis at a tree position. Tree height can be calculated from canopy height model or from tree base and tree tip estimation. Multi-cross sections of trees can be extracted and diameters of trunks at different heights can be calculated. The DendroCloud performance will be presented by two case studies [1-2]; 1. Koreň, M., et. al. (2017). Accuracy of tree diameter estimation from terrestrial laser scanning by circle-fitting methods. International Journal of Applied Earth Observation and Geoinformation, 63, 122-128, 2. Mokroš, M., et. al (2018). Evaluation of close-range photogrammetry image collection methods for estimating tree diameters. ISPRS International Journal of Geo-Information, 7(3), 93.

\section{P sampling with a 360-degree spherical camera}

Yung-Han Hsu', HaoZhou Wang ${ }^{1}$, Ting-Ru Yang ${ }^{1}$, John Kershaw ${ }^{1}$

${ }^{1}$ University of New Brunswick, Fredericton, Canada (yhsu@unb.ca; hwang21@unb.ca; b00605080@gmail.com; kershaw@unb.ca)

An efficient sampling design is required to cost effectively estimate forest conditions. Since the most efficient sampling design is the one with selection probabilities proportional to the parameter of interest (Basu 1969, Ind J Stats 31:441), sampling with probability proportion to prediction (3P sampling) is potentially one of the most efficient sampling designs. To obtain the "prediction" for each sample point consistently and rapidly, remote sensing techniques, such as spherical cameras and airborne light detection and ranging (LiDAR) could be used to assist. In this study, plant fraction (PF), the proportion of area covered by vegetation, is estimated using a Ricoh $360^{\circ}$ spherical photo and is used as our prediction in 3P sampling. At each sample point a spherical photo is obtained near breast height (1.3m), downloaded to a smartphone, and a custom app is used to derive PF. PF is compared to a random number drawn from a design-specific range to determine if detailed measurements are collected at the sample point. The plant fraction is converted to volume using ratio estimation. Results of the accuracy of the volume estimates and sample efficiencies were evaluated and compared with results using raw LiDAR metrics (quantile $45^{\text {th }}$ LiDAR height, Q45) and LiDAR-derived volume estimates as predictors. Although Q45 was the most efficient covariate at the prediction phase, plant fraction performs as well as LiDAR-derived volume. Since a Ricoh $360^{\circ}$ spherical camera is relatively inexpensive, it has the potential to be an alternative selection criterion in areas without LiDAR scanning.

\section{Use of consumer 360-degree cameras to capture hemispherical photos for canopy structure analysis.}

Alexander Bilyk', Reino Pulkki ${ }^{1}$, Guy LaRocque ${ }^{2}$, Chander Shahi ${ }^{1}$

${ }^{1}$ Lakehead University, Thunder Bay, Canada; ${ }^{2}$ Canadian Forest Service, Quebec City, Canada (ambilyk@lakeheadu.ca; rpulkki@lakeheadu.ca; guy.larocque@canada.ca; cshahi@lakeheadu.ca)

While the use of hemispherical photos has been studied extensively, it is still challenging to capture images suitable for analysis. The systems used currently rely on a full size, digital SLR camera, gyro and fisheye lens. This presents challenges for use in the field, as the equipment is heavy and can be quite expensive. In this study we compared the use of the Ricoh Theta to the GoPro Fusion for the ability to capture under canopy 360-degree images for processing in gap light analyzer and WinSCANOPY. The images were captured across a variety of forest conditions, but all plots are part of the provincial forest plot network and have been extensively measured. A total of 50 plots were measured and the results are presented here. The cameras chosen represent a range in consumer 360-degree cameras, with the Ricoh Theta being more affordable and the GoPro fusion being at the higher end of the spectrum. The total data management workflow as well as the results from Gap Light Analyzer and WinSCANOPY will be presented.

\section{Remote tree diameter measurement through digital dendrometers}

José Scolforo ${ }^{1}$, Samuel Campos ${ }^{1}$, Ivonise Andrade $^{2}$, Arthur Neto $^{1}$, Danilo Lima ${ }^{1}$, Sérgio Teixeira ${ }^{1}$, Thiza Altoé ${ }^{1}$, Vitor Ferreira ${ }^{1}$, Pedro Bouzon $^{1}$, Leandro Silva ${ }^{1}$, Rafael Ribeiro ${ }^{1}$

${ }^{1}$ Federal University of Lavras, Lavras, Brasil; ${ }^{1}$ Federal University of Lavras, Lavras, Brasil; ${ }^{2}$ Inventar GMB, Lavras, Brasil; ${ }^{1}$ Universidade Federal de Lavras,Lavras,Brasil(hfscolfo@ncsu.edu; samuelcampos@lemaf.ufla.br;ivonise@inventargmb.com.br;arthur.miranda.neto@gmail.com;

danilo.delima@deg.ufla.br; sergio.teixeira@deg.ufla.br; thizafaltoe@gmail.com; vhg_ferreira@hotmail.com; peubouzon@gmail.com;

leandrobnsilva@gmail.com; rafa.ribeiro.bq@hotmail.com)

Accurate information on the present and future forest stock is desired. There are well developed sensors to measure forest surface through airbone laser scanning as well as to measure tree volume and stem form through terrestrial laser scanning. Although the use of these technologies has been increasing in forestry, there is still lack of tools to continuously measure tree and forest growth. To overcome this drawback, we offer a newly developed sensor that allows for real time forest monitoring. The sensor measures tree diameter in a daily basis or even in a shorter time step as well as it has the capability to record climate data, such as temperature and throughfall. We will demonstrate the sensor properties and a set of measurements under a variety of forest conditions and types for over 3 month-period.

C4b: ADVANCES IN REMOTE SENSING OF VEGETATION: SENSORS, METHODOLOGIES AND
APPLICATIONS

\section{ALOS-2 PALSAR-2 L-band cross-polarized data analysis for the assessment of carbon sequestration of Tropical Rainforest, Berkelah, Malaysia}

Robert Masolel ${ }^{1}$, Yousif Hussin ${ }^{1}$, Henk Kloosterman ${ }^{1}$, Zulkiflee Abd Latif ${ }^{2}$

${ }^{1} I T C$, University of Twente, Enschede, Netherlands; '2Universiti Teknologi MARA (UiTM), Shah Alam, Malaysia (robertnag@yahoo.com; y.a.hussin@utwente.nl; e.h.kloosterman@utwente.nl; zabdlatif@gmail.com)

In this thesis research, we examined the application ofL-band ALOS-2 PALSAR-2 SAR data to model the Above Ground Biomass AGB/carbon stock and carbon sequestration of the tropical rainforest. The SAR parameters were evaluated on the basis of the single SAR backscatter image and time series analysis 
of combined $\mathrm{HV}$ and $\mathrm{HH}$ polarizations. Also, the saturation effect of radar backscatter for AGB estimation was established by determining the saturation level at which AGB prediction tend to level off. The satellite SAR data used for this study were representing a time series of SAR images acquired in two dates: September 2016 and September 2017 by the ALOS-2 PALSAR-2 sensor. A relationship between forest AGB and L-band SAR backscatter were established using the linear, logarithmic, and multiple regression approaches. For a single scene, the best results were observed with HV-polarized backscatter (R2 $\approx$ 0.82, RMSE $\approx 79$ tons ha $\left.^{-1}\right)$ and $\left(\mathrm{R} 2 \approx 0.87, \mathrm{RMSE} \approx 68\right.$ tons ha $\left.^{-1}\right)$ using logarithmic regression for scenes acquired in September - 2016 and September -2017 conditions respectively. SAR backscatter saturation was estimated at 270tons ha- ${ }^{-1}$, the point at which SAR backscatter response to AGB started to decrease by $0.02 \mathrm{~dB}$. The strongerachievement was observed in the estimation of the amount of carbon sequestration between September 2016 to September 2017 . An estimated total of 3.62tons/ha of carbon was sequestered in Berkelah forest in one year. This study proved that combining temporal series of SAR scenes could be a better estimator of carbon sequestration.

\title{
High-resolution oil palm detection across South-East Asia
}

Olha Danylo ${ }^{1}$, Johannes Pirker ${ }^{1}$, Guido Lemoine ${ }^{3}$, Guido Ceccerini ${ }^{3}$, Linda See ${ }^{1}$, Inian Moorthy ${ }^{1}$, Neha Joshi $^{1}$, Ian McCallum ${ }^{1}$, Florian Kraxner ${ }^{1}$, Steffen Fritz ${ }^{1}$

${ }^{1}$ International Institute for Applied Systems Analysis, Laxenburg, Austria; ${ }^{2}$ KU Leuven, Catholic University of Leuven, Leuven, Belgium; ${ }^{3}$ European Commission, Joint Research Centre, Ispra, Italy(danylo@iiasa.ac.at; pirker@iiasa.ac.at; guido.lemoine@ec.europa.eu; guido.ceccerini@ec.europa.eu; see@iiasa.ac.at; moorthy@iiasa.ac.at; joshin@iiasa.ac.at; mccallum@iiasa.ac.at; kraxner@iiasa.ac.at; fritz@iiasa.ac.at)

Palm oil production has increased substantially over the last decade, from 10 to 21 Million hectares between 2000 and 2017 , almost 90\% of which is located in South-East Asia. Several studies have applied remote sensing techniques to estimate the extent of oil palm plantations in South-East Asia on a national scale or above. Most have deployed visual, expert-based interpretation methods or semi-automatic approaches with extensive field information. These approaches are very labor intensive, thereby limiting their utility for upscaling towards the development of a close to near real-time monitoring system. The availability of radar imagery has given rise to a new generation of remote sensing studies that benefit from robustness to cloud coverage and high revisiting frequency. Recent experimental studies have demonstrated the usability of free and open data from the Sentinel 1 mission for oil palm detection, particularly for detecting smallholder plantations and features such as plantation age. Against this backdrop, we present the first fullyautomated remotely sensed oil palm map of South-East Asia based on free and open radar data processed using Google Earth Engine. Furthermore, using very high resolution imagery for independent validation, we will demonstrate the accuracy of our product and compare it to other existing remote sensing products. This new radar-based approach could be used to develop a close to near real-time oil palm monitoring system at a national scale or above, thereby bridging the gap between detection of land cover and land use.

\section{Applicability of SAR Sentinel-1 data to distinguish drivers of deforestation in the Amazon}

Andrea Puzzi Nicolau ${ }^{1,2}$, Africa Flores-Anderson ${ }^{1,2}$, Robert Griffin ${ }^{1,2}$, Kelsey Herndon ${ }^{1,2}$

${ }^{1}$ University of Alabama in Huntsville, Huntsville, USA; ${ }^{2} N A S A-S E R V I R$ SCO, Huntsville, USA (an0052@uah.edu; africaixmucane.florescordova@nasa.gov; robert.griffin@nsstc.uah.edu; kelsey.e.herndon@nasa.gov)

The Amazon is the largest expanse of tropical rainforest globally and deforestation resulting from land use changes poses a major concern for sustainable resource management. Synthetic Aperture Radar (SAR) data have all-weather and all-day capability, and thus are well-suited for mapping land cover land use (LCLU) in tropical regions, which are seasonally influenced by cloud cover. Understanding drivers of deforestation is fundamental for the development of policies and measures to reduce emissions and for developing forest reference levels. Sentinel-1 data present unprecedented potential since the observations are free and openly available, providing for the first time dense and regular SAR data. This study analyzes the applicability of Sentinel-1 data to differentiate deforestation drivers, identified as a current need for early-warning deforestation systems. The study area covers a deforestation frontier in the Amazon where the landscape is characterized by a mosaic of LCLU. Collect Earth Online is used for reference LCLU data collection, and five classes are defined for this study: Forest, Secondary Vegetation, Agriculture, Pasture, Urban/Artificial, Mining, Water. Amplitude gamma-0 time-series spanning 2017-2019 are analyzed along with statistical metrics for each class, and a classification decision tree is developed in a cloud-based platform. Preliminary results show that water and artificial areas are easily distinguishable from other classes. The use of the polarization ratio $\mathrm{VV} / \mathrm{VH}$ is suggested to be useful to distinguish agriculture from pasture. It is expected that these analysis' results will complement the current forest and land cover monitoring systems by providing additional actionable information for decision-making.

\section{Forest growth dynamics of managed forests in the Southwestern Brazilian Amazon}

\author{
Marcus d'Oliveira', Luis Oliveira ${ }^{1}$, Mario Acuña ${ }^{2}$
}

${ }^{1}$ Embrapa Acre, Rio Branco, Brasil; ${ }^{2}$ IFAC, Rio Branco,Brasil (marcus.oliveira@embrapa.br; luis.oliveira@embrapa.br; mhacuna@gmail.com)

The objective of this work was to present the growth forest dynamics results obtained in two sites located in Acre and Amazonas states in the southwestern Brazilian Amazon. Both areas were submitted to selective logging following RIL technics. The harvesting intensity was low (around $10 \mathrm{~m}^{3}$. ha ${ }^{-1}$ ) and the cycles length varied from 20 to 25 years. The results showed individual trees growth rates (annual mean DBH increment) similar to the observed in other studied managed forest sites with low species composition and none timber specific weight variation along the monitoring time. Annual ingrowth and mortality rates were always high and, as a consequence, turnover rates (estimated as the necessary time to observe the mortality of half of the original population) very fast. The peaks observed in the mortality rates were not always associated with forest logging and shall compromise the biomass and commercial timber stocks recovery on the prescribed cycle. Several studies on forest dynamics indicate that turnover rates are accelerating since the 50' and that this acceleration increased during the 80 ' in pantropical forests. The values we found for turnover in the studied sites (below 30 years) indicate a still greater turnover acceleration in the first decade of the 21 first century in the region. These results indicate that forest management alone can not entirely explain the observed changes in the forest dynamics parameters and special care must be taken to the management and conservation of these forests. 


\title{
The potential of both SAR and optical data for mapping purposes in Southern Brazil
}

Aline Delfino Germano ${ }^{1,2}$, Veraldo Liesenberg ${ }^{2}$, João Vitor Frigeri ${ }^{2}$, Mariane Moura Andrade ${ }^{2}$, Marcos Benedito Schimalski ${ }^{2}$

${ }^{1}$ Universidade Federal de São Carlos, Sorocaba, Brasil; ${ }^{2}$ Universidade do Estado de Santa Catarina, Lages, Brasil (germanoad@outlook.com.br; veraldo.

liesenberg@udesc.br; joaovfrigeri@hotmail.com; enairamma@hotmail.com; marcos.schimalski@udesc.br)

The study aimed at evaluating the performance of optical (Landsat-5/TM) and full polarimetric SAR data (ALOS/PALSAR), alone and combined, for mapping purposes of a rural area in Southern Brazil. A total of 13 classification scenarios using both Support Vector Machine (SVM) and Random Forest (RF) were used. Results showed that the maximum Kappa index from the SAR dataset alone was 86\%; on the other hand, the value for optical sensor alone was $95 \%$. The integration of the two sensors achieved $97 \%$, showing that the combination of optical data with SAR data improves the supervised classification. Both RF and SVM methods have similarities in Kappa indexes for different scenarios. Z-test showed significance at five scenarios, including the combination of both optical and SAR data. Therefore, SAR data are recommended for mapping purposes at places that confer difficulty in obtaining images from optical sensors free of clouds. Sponsored by FAPESC, CNPq, CAPES.

\section{The importance of multifrequency SAR on successional forest stage mapping procedures}

Veraldo Liesenberg ${ }^{1}$

${ }^{1}$ Universidade do Estado de Santa Catarina, Lages, Brasil (veraldo.liesenberg@udesc.br)

Multi-frequency SAR scenes were evaluated for classification of successional forest stages and land use classes in Eastern Amazon. Advanced Land-Observing Satellite (ALOS) Phased Array L-band Synthetic Aperture Radar (PALSAR) data, RADARSAT-2 (C-Band), and TERRASAR-X (X-Band) data were used independently and combined in a dual SAR system approach. ALI/EO-1 image acquired at the same period was used as additional ground reference and input dataset. We evaluated backscattering intensity, polarimetric features, interferometric coherence and texture parameters for classification purposes using random forest $(\mathrm{RF})$ classification. Results showed that L-band data alone performed better than $\mathrm{C}$ - and X-bands alone but overall accuracies remain low. The combination of two SAR datasets showed similarity at the 5\% significance level when considering L-band with either C- or X-band. We show that in absence of optical data, polarimetric features and texture extracted at any frequency increase classification accuracies when compared to backscattering data alone.

\section{Evaluation of digital elevation models for drainage network extraction in a tropical forest area in Central Amazon}

Raildo Torquato Souza ${ }^{1}$, Veraldo Liesenberg ${ }^{2}$, Tiago Nunes Silva ${ }^{1}$, Louri Klemann Junior ${ }^{1}$, Luís Antônio de Araújo Pinto ${ }^{1}$, Ítala Lorena de Lima Ferreira ${ }^{1}$, Marcos Benedito Schimalski², Emanuel Arnoni Costa ${ }^{2}$

${ }^{1}$ Universidade do Estado do Amazonas, Itacoatiara, Brasil;; ${ }^{2}$ Universidade do Estado de Santa Catarina, Lages, Brasil (torquatto.92@gmail.com; veraldo. liesenberg@udesc.br; tgnunesftal@gmail.com; klemannjr@yahoo.com.br; lpinto@uea.edu.br; lorena.uea@hotmail.com; marcos.schimalski@udesc.br; emanuelarnonicost@hotmail.com)

This study aims to compare the drainage network elaborated through fieldwork and GPS measurements with those extracted from four freely available DEMs such as ALOS/PALSAR (Advanced Land Observing Satellite / Phased Array type L-band Synthetic Aperture Radar), ASTER/GDEM (Advanced Spaceborne Thermal Emission and Reflection Radiometer / Global Digital Elevation Map), SRTM (Shuttle Radar Topography Mission) and TOPODATA (Brazilian Full Coverage Refinement of SRTM Data). First, the drainage vector was vectorized manually taking into account trees whose diameter at the breast height (DBH) was $\geq 40 \mathrm{~cm}$, which were identified in the field as permanent presentation areas (PPAs). In addition, a drainage contribution area ranging from 10 to 150 was applied for each of the aforementioned DEM data sources. Afterward, comparisons between each generated drainage network with the ground reference was compared to each other using the Kappa index and Z-test (Global Accuracy). Results showed that the drainage network generated from the four DEM performed well in shape but had overestimation in total length. However, the drainage network extracted from both the SRTM and ASTER were the most similar to those obtained from the field network $(9.65 \mathrm{~km})$. They had $13.56 \mathrm{~km}$ and $12.97 \mathrm{~km}$, respectively. Statistically, the DEMs showed an overall accuracy higher than $94 \%$. It is recommended to evaluate other environmental conditions as well as high spatial resolution DEMs generated by airborne LiDAR data.

\section{C4c: BENCHMARKING IN FORESTRY - CHALLENGES AND SOLUTIONS FOR} ESTABLISHING BENCHMARKING SYSTEMS

\author{
Benchmarking of forest operations productivity and costs in industrial forest plantations in Uruguay \\ Alejandro Olivera Farias ${ }^{1}$, Pablo Santini ${ }^{2}$, Carlos Perdomo ${ }^{1}$, Mauricio Gervaz ${ }^{2}$ \\ ${ }^{1}$ Centro Universitario de Tacuarembo - Universidad de la Republica, Tacuarembo, Uruguay; ${ }^{2}$ MBOPU Servicios Forestales, Paysandu, Uruguay \\ (alejandro.olivera@cut.edu.uy; pablo.santini.consult@gmail.com; cperdomo@fagro.edu.uy; mauricio.gervaz@gmail.com)
}

Industrial forests plantations in Uruguay have increased rapidly in the last decades, from less than 100,000 hectares in 1990 to 1,100,000 in 2015. To accomplish this, forest service providers were developed, first for Silviculture, and later for harvesting operations. The production of more than 16 million $\mathrm{m}^{3}$ of round wood annually is export oriented; the majority of the production is pulpwood for local industries that export Celulose. Forest operation costs account for up to $80 \%$ of wood production costs. Comparing costs internationally is crucial for Uruguayan forest companies, because, to remain competitive companies need to improve continuously its operations, increase productivity, improve quality and reduce costs. Likewise, it is important to benchmark costs and productivity indicators locally as a tool to compare contractors' costs and productivity. Moreover, for contractors a benchmarking would be a tool to evaluate their costs and productivity to remain competitive within the local market, identify improvement opportunities, and develop improvement strategies. Furthermore, a benchmark managed by an independent organization (university) would give support for forest practitioners to cooperate in improving the sector competitiveness. The project aims to establish a benchmarking in Uruguay -updated annuallycollecting data from companies and contractors on productivity and costs for a list of forest operations (Silviculture and harvesting) identifying the conditions of each operation. The data will be collected annually between January and March via an anonymous online questionnaire, and a report with the results will be released in April. The results may be used for international benchmarking. 


\title{
Benchmarking in Austrian forestry - supporting management by means of Forest Accountancy Data Networks
}

Philipp Toscani ${ }^{1}$, Walter Sekot ${ }^{1}$

${ }^{1}$ University of Natural Resources and Life Sciences, Vienna; Institute of Agricultural and Forestry Economics, Vienna, Austria (philipp.toscani@boku.ac.at; walter.sekot@boku.ac.at)

A Forest Accountancy Data Network (FAN) is a special infrastructure for the systematic and continuous collecting of socio-economic information of forest enterprises. Austria has a long tradition in operating FANs, dating back to the 1960ies. There is one network addressing larger holdings and one focusing on small-scale farm forestry. Although an FAN is usually established for policy purposes, the collected data is also of great scientific interest. Furthermore, the standardized accounting scheme proved to be a most suitable basis for ratio analysis and interfirm comparisons. Starting from a sampling design, the expansion of the network of bigger forest enterprises has in fact been driven by the interest of forest owners and managers to participate and several benchmarking circles have been established in terms of a bottom-up approach. The individual reports have been adopted repeatedly to the requests of such 'pressure groups' and the set of ratios has been amended accordingly, thereby improving also the scientific significance of the database. Thus, this specific FAN turned into a transdisciplinary exercise. The latest developments in the FAN of farm forests were inspired by these experiences. A top-down initiative has been launched in order to enhance the significance of the results for the management of the participating farms. The individual reports were considerably improved and additional information for benchmarking is provided. The framework may well serve as a blueprint for related activities e.g. on behalf of extension services.

\section{The German forest accountancy data network - concept, application and harmonization to other networks}

Matthias Dieter ${ }^{1}$, Lydia Rosenkranz $^{1}$, Hermann Englert ${ }^{1}$, Walter Sekot ${ }^{2}$, Philipp Toscani ${ }^{2}$, Bernhard Pauli ${ }^{3}$, Patric Bürgi ${ }^{3}$, Nils Ermisch ${ }^{4}$, Bernhard Möhring ${ }^{5}$ ${ }^{1}$ Thünen Institute of International Forestry and Forest Economics, Hamburg, Germany; ${ }^{2}$ Institute of Agricultural and Forestry Economics, Vienna, Austria; ${ }^{3}$ Bern University of Applied Sciences, Zollikofen, Switzerland; ${ }^{4}$ Landwirtschaftskammer Niedersachsen, Neuenkirchen, Germany; ${ }^{5}$ Georg-August Universität Göttingen Abteilung Forstökonomie, Göttingen,Germany(matthias.dieter@thuenen.de; lydia.rosenkranz@thuenen.de; hermann.englert@thuenen.de; walter. sekot@boku.ac.at; philipp.toscani@boku.ac.at; bernhard.pauli@bfh.ch; partic.buergi@bfh.ch;nils.ermisch@lwk-niedersachsen.de; bmoehri@gwdg.de)

The German Forest Accountancy Data Network (FADN) of the Federal Ministry of Food and Agriculture (BMEL) was established over 40 years ago. It comprises roughly 350 private, communal and state forest enterprises with a forest area above 200 ha and is based on a uniform product plan of the booking system, developed by the German Forestry Council (DFWR). Its participating forest enterprises provide about 650 natural and economic key figures every year. The FADN provides invaluable data on the economic situation of forest enterprises and is therefore an important data base for the analysis of numerous forest policy issues like the financial burdens from nature protection measures in forests, as well as for Germanys reporting obligations like the European Forest Accounts or the National Accounting. Austria and Switzerland have comparable accountancy schemes in place, though they do not yet allow a direct comparison of key-figures across countries. Hence, in 2004 a data network cooperation of Germany, Austria and Switzerland was launched, the so called DACH-initiative, with the aim of harmonizing forest accountancy data across borders and comparatively analyse the economic situation of middle-European forestry. This presentation aims to show the concept, the range of uses and challenges of the German FADN. Moreover the establishment of the DACH-data network will be outlined with some results of the data harmonization and finally some considerations of the use of the DACH-network as a blueprint for a worldwide network on forest accountancy data will be presented.

\section{Possible explaining variables for the share of fully mechanized cut-to-length harvesting globally}

\author{
Mikael Lundbäck ${ }^{1}$, Carola Häggström ${ }^{1}$, Tomas Nordfjell ${ }^{1}$
}

${ }^{1}$ Swedish University of Agricultural Sciences, Umeå, Sweden (mikael.lundback@slu.se; carola.haggstrom@slu.se; tomas.nordfjell@slu.se)

Within an earlier part of this study, data on the share of fully mechanized cut-to-length (CTL) harvesting method of the annual harvested volume of industrial roundwood was obtained for 29 countries. To quantify the effect of some possible explaining variables a linear regression analysis based on ordinary least squares parameter estimation was done. For this the open source statistical software R (version 3.5.1) was used. The data for the studied variables was gathered based on hypothetical cause-effect relations with CTL. Initially 11 possible variables were compiled, out of these, 8 variables were included in the regression analysis, the others did not have data for all countries, however the final model include only three variables - diesel price, share of steep slope and gross domestic product per capita (GDP). All three variables as well as the full model have significant p-values at the $5 \%$ level and an adjusted R2 value of 0.57 . There are several imaginable variables that might improve the model but for which data does not exist currently, for example average tree volume. The model can be used for two purposes, first to predict the share of CTL in a country, compare the result of the model to what is known and try explaining the difference - no obvious explanation might imply market opportunities for manufacturers of CTL equipment. Second, the model explains the relations between some surrounding variables, and the share of CTL - higher diesel price and GDP favor CTL while higher share of steep slope does the opposite.

\section{Benchmarking harvesting systems costs in industrial forest plantations across different global regions}

Fulvio Di Fulvio ${ }^{1}$, Mauricio Acuna ${ }^{2}$, Pierre Ackerman ${ }^{3}$, Dalia Abbas ${ }^{4}$, Raffaele Spinelli ${ }^{5}$, Alejandro Olivera ${ }^{6}$, Sandra Sanchez ${ }^{7}$, Nopparat Kaakkurivaara $^{8}$ ${ }^{1}$ IIASA, Laxenburg, Austria; ${ }^{2}$ University of the Sunshine Coast, Sippy Downs, Australia; ${ }^{3}$ Stellenbosch University, Stellenbosch, South Africa; ${ }^{4}$ American University, Washington DC, USA; ${ }^{5}$ CNR, IVALSA, Sesto Fiorentino, Italy; ${ }^{6}$ Universidad de la República de (difulvi@iiasa.ac.at; macuna@usc.edu.au; packer@sun.ac.za; daliaabbas@yahoo.com; spinelli@ivalsa.cnr.it; alejandro.olivera@cut.edu.uy; ssanchez@cetemas.es; nopparat.manavakun@gmail.com)

In the global market, there is an increasing demand for wood products, which represents a challenge for the efficient supply of woody biomass resources and the protection of natural forest ecosystems. Within this context, industrial forest plantations, already account for one-third of the global roundwood supply, and they are expected to significantly increase their contribution in the future, due also to the rapidly increasing demand for bioenergy. Harvesting operations represent up to fifty percent of the total biomass supply cost from industrial forest plantations. Therefore, the future competitiveness of woody biomass supply from plantations in different global regions will depend on improving the financial performances of harvesting systems. Modeling the future competitiveness of woody biomass supply requires a better understanding of the adaptations of harvesting systems to plantation modules in different geographical regions and to their own unique economic situations, as well as understanding the factors explaining efficiencies and costs in the different regions. Accordingly, this study aims to compile and benchmark the many case studies appeared in the recent literature in order to summarize, describe and examine the major drivers affecting the efficiencies and costs of different harvesting systems used in industrial forest plantations across the globe. The knowledge gathered in this study will provide the opportunity for improved modeling of wood supply systems which in turn will provide useful insights to practitioners for designing future cost effective systems tailored to the needs of different regions of the World. 


\section{Characterization and comparison of forest productivity across countries and forest types}

Jianbang Gan ${ }^{1}$, JinHan Park ${ }^{1}$

${ }^{1}$ Texas A\&M University, College Station,USA (j-gan@tamu.edu; cupidjh@gmail.com)

Forest productivity is fundamental to the provisions of timber and ecosystem services. It varies with or is influenced by natural and human factors including climatic and soil conditions, disturbances (e.g., diseases, pest infestations, wildfire, storms, etc.), silvicultural practices, and forest age and structure, among others. We identify and characterize global forest productivity patterns and compare forest productivity in different countries and forest types in the world. We also estimate statistical associations between forest productivity and biophysical and socioeconomic factors. This study sheds new light on differences and similarities in forest productivity across countries and forest types and the reasons behind them. Our results also provide a benchmark of global forest productivity and are of value for improving global forest productivity and sustainability.

\section{Global timber investments, 2017}

Frederick Cubbage ${ }^{1}$, Rafael Rubilar ${ }^{1}$, Bruno Kanieski ${ }^{1}$

${ }^{1}$ Department of Forestry and Environmental Resources, NC State University, Raleigh, NC,USA(fredcubbage@yahoo.com; rafaelrubilar@udec.cl; bkanies2@ncsu.edu)

We estimated timber investment returns for 22 countries and 54 species/management regimes in 2017, for a range of global timber plantation species and countries at the stand level, using capital budgeting criteria, without land costs, at a real discount rate of $8 \%$. Returns were estimated for most years for the principal plantation countries in the Americas_-Brazil, Argentina, Uruguay, Chile, Colombia, Venezuela, Paraguay, Mexico, and the United States—as well as New Zealand, Australia, China, Vietnam, Laos, Spain, Finland, and Poland. South American plantation growth rates and their concomitant returns were generally greater, at more than $12 \%$ IRRs, as were those in China and Vietnam. These rates of return followed by returns to plantations in southern hemisphere countries of Australia and New Zealand and in Mexico, with IRRs around 8\%. Temperate forest plantations in the U.S. and Europe returned less, from 4\% to 8\%, but those countries had better risk ratings, timber markets, and infrastructure. Returns to most planted species and countries have decreased from 2005 to 2017.

\section{SilviBenchmark: Benchmarking forest production data based on "typical enterprises"}

Lydia Rosenkranz ${ }^{1}$, Bjoern Seintsch ${ }^{1}$, Sven Günter ${ }^{1}$, Walter Sekot ${ }^{2}$, Philipp Toscani ${ }^{2}$, Bernhard Pauli ${ }^{3}$, Patric Buergi ${ }^{3}$, Fulvio Di Fulvio ${ }^{4}$, Yelto Zimmer ${ }^{5}$ ${ }^{1}$ Thuenen Institute of International Forestry and Forest Economics, Hamburg, Germany; ${ }^{2} B O K U$, Institute of Agricultural and Forestry Economics, Vienna, Austria; ${ }^{3}$ Bern University of Applied Sciences, School of Agricultural, Forest and Food Sciences, Zollikofen, Switzerland; ${ }^{4} I$ ASA International Institute of Applied Systems Analysis, Laxenburg, Austria; ${ }^{5}$ Global Networks GUG, Braunschweig, Germany (lydia.rosenkranz@thuenen.de; bjoern.seintsch@thuenen. de; sven.guenter@thuenen.de; walter.sekot@boku.ac.at; philipp.toscani@boku.ac.at; bernhard.pauli@bfh.ch;patric.buergi@bhf.ch;difulvi@iiasa.ac.at; yelto.zimmer@agribenchmark.net)

The forest industry faces the challenges of globalization, e.g. rising demands for timber and price competitions of raw wood production. Also, increasing demands for forest ecosystem services can be leading to restrictions for forest production. The cost-effectiveness of forestry around the world is influenced by the respective regulatory policy frameworks, the choice of forest management type and the choice of harvesting and timber-transport system which lead to diverse factor costs or revenues for forest production. In a globalized world, in-depth knowledge of the different country-specific framework conditions, the resulting operations and management strategies of forestry and logging and finally the economics of these different systems is of great importance. In order to obtain comparable data across countries, a global network of experts as well as a harmonized approach of data collection for all participating countries is essential. So far, there is a lack of internationally comparable forest production data and no respective forum to develop and discuss concepts and methods for an international forest production database. Against this backdrop, we wish to establish a lasting international network for benchmarking forest production data using the "typical forest enterprise" approach, aiming to provide strategic insights to stakeholders from forestry, logging and timber industry, policy and development agencies. The presentation shall introduce our idea of establishing SilviBenchmark to potential partners from other countries and provide a systematic overview of the concept. Here, the long-term experience with Central European forest accountancy data networks and global agricultural benchmarking networks (agri benchmark) will be incorporated.

\section{C4d: CROWN STRUCTURE AND DYNAMICS AS CAUSE AND EFFECT IN MODELLING TREE} GROWTH, FORM, AND WOOD QUALITY

\section{Long-term dynamics of loblolly pine crown structure as affected by planting density and cultural intensity \\ Dehai Zhao ${ }^{1}$ Bronson Bullock ${ }^{1}$, Cristian Montes ${ }^{1}$ \\ ${ }^{1}$ University of Georgia, Athens, USA; '1niversity of Georgia,Athens,USA (zhaod@uga.edu; bronsonbullock@uga.edu; crmontes@uga.edu)}

Loblolly pine (Pinus taeda L.) is an important timber species in the southeastern US. A better understanding of loblolly pine crown relationships with growth will help improve productivity estimates and optimize management regimes. Loblolly pine culture/density study was initiated in $1995 / 96$ with 40 installations across the southern US. Each installation contains 12 plots planted at six levels of planting density (740 - 4448 trees/ha) in combination with two levels of cultural intensity (operational vs. intensive). With data from this study, we will report long-term effects of planting density, cultural intensity and site quality on loblolly pine growth and crown attributes. Destructive biomass sampling was also conducted and vertical distribution of foliage biomass were assessed. Lower planting density or more intensive treatment increased average crown length. Crown ratios declined over time, and the decrease rate increased with increasing initial density and cultural intensity. Foliage to branch biomass ratio decreased over time, and was not significantly affected by cultural intensity or planting density. Stem to crown biomass ratio was significantly affected by planting density but not by cultural intensity. More intensive stands or stands on more productive sites raised to a maximum foliage biomass at earlier ages, then flattened. Planting density significantly affected foliage biomass in early development stage, then this effect was no longer significant. However, vertical distribution of foliage biomass was still affected by planting density and cultural intensity. 


\section{Consequences of and factors that may affect coordinated growth between the live crown and the stem in populations of trees}

Thomas Dean ${ }^{1}$

${ }^{1}$ Louisiana State University, Baton Rouge, LA, USA (fwdean@lsu.edu)

Foliage expires; consequently, in order to live, trees must continually replace it. In forests, new foliage emerges from buds exposed to sufficient light while shaded buds die, cycling foliage to the top of the trees. Foliage on a branch terminated with a dead bud will eventually die as will the branch, causing the bottom of the crown to lift. The proximity and size of neighboring trees, which can be expressed in terms of stand density, determines the rate in which buds die, and together with height growth sets the length of the live crown. Trees are self-designing structures that manage strain due to water and mechanical stress. As the dimensions of the live crown change due to height growth and increasing stand density, stem cross-sectional area size and taper follows suit in a predictable manner to maintain efficient water conduction to existing and new foliage and to physically support the increasing gravitational and lateral forces created by crown growth. Trees are constrained however in the their response by genetic rules governing physiology and by developmental history. For instance, some species cannot respond to disturbances that allow light to impinge on the bottom of a mature stem. The presentation will discuss the coordinated growth that occurs with crown expansion, how silviculture practices affect crown growth and ultimately stem growth, and to what degree biotic and abiotic factors can affect the coordination between crown and stem morphology.

Crown structure and foliage distribution are influenced by site, genotype and planting density but may not explain differences in growth for native and exotic Pinus taeda

Timothy Albaugh ${ }^{1}$, Chris Maier ${ }^{2}$, Otávio Campoe ${ }^{3}$, Rachel Cook ${ }^{4}$, Rafael Rubilar ${ }^{5}$, David Carter ${ }^{1}$, Thomas Fox ${ }^{6}$

${ }^{1}$ Virginia Tech, Blacksburg, USA; ${ }^{2}$ USDA Forest Service, Research Triangle Park, USA; ${ }^{3}$ Universidade Federal de Lavras, Lavras, Brasil; ${ }^{4}$ North Carolina

State University, Raleigh, USA; ${ }^{5}$ Universidad de Concepcion, Concepcion, Chile; ${ }^{6}$ Rayonier, Yulee, USA (tim_albaugh@vt.edu; cmaier@fs.fed.us;

otavio.campoe@gmail.com; rlcook@ncsu.edu; rafaelrubilar@udec.cl; davidcarter@vt.edu; tom.fox@rayonier.com)

Pinus taeda L., a native in the southeastern United States, grows considerably faster when planted outside of its native range. Explanations for this phenomenon include differences in crown structure, foliage distribution and specific leaf area (SLA). To examine these factors, we destructively sampled 72 trees where all branch diameters and their distances from the tree top were measured. Foliage mass and SLA were determined for a representative subset. Trees were selected from three sites: North Carolina (NC; native range), Virginia and Brazil (BR; exotic locations). The same two genotypes were planted at 618 and 1853 trees ha-1 across sites under two levels of silviculture (operational and no nutrient limitation). We examined how site, genotype, planting density and resource availability influenced crown structure (branch number, size, and within crown position), foliage distribution and SLA. In general, branch diameter and within crown position were similar among sites, yet significant differences were observed due to all factors for branch number, branch diameter, foliage distribution and SLA. However, the observed differences did not necessarily explain greater growth in BR. For example, in some treatment combinations, BR trees had fewer, smaller diameter branches than trees from the US sites but the BR trees still grew faster. There was more foliage on the BR trees but the distribution of the foliage for the NC and BR sites was similar. Apparently, additional hypotheses need testing to identify the cause of greater growth of $P$. taeda in exotic locations.

Exploring the impact of spacing and silvicultural management on crown structure, light use efficiency and wood production of Pinus taeda varieties

Otávio Campoe ${ }^{1}$ (D; Timothy Albaugh ${ }^{2}$, Rachel Cook ${ }^{3}$, Rafael Rubilar ${ }^{4}$, David Carter ${ }^{2}$, Thomas Fox ${ }^{5}$

${ }^{1}$ Federal University of Lavras, Lavras, Brasil; ${ }^{2}$ Virginia Tech, Blacksburg, USA; ${ }^{3}$ North Carolina State University, Raleigh, USA; ${ }^{4}$ Universidad de Concepción, Concepción, Chile; ${ }^{2} V i r g i n i a$ Tech, Blacksburg, USA; ${ }^{5}$ Rayonier, Yulee,USA (otavio.campoe@gmail.com; tim_albaugh@vt.edu;

rlcook@ncsu.edu; rafaelrubilar@udec.cl; davidcarter@vt.edu; tom.fox@rayonier.com)

Canopy structure and dynamics, a key information to understand wood production in forest plantations, is highly influenced by genetic variability, silvicultural practices, and management. However, precise quantification of their specific impact, and potential interaction, on efficiency of wood production is lacking. To address this topic, we are using a group of three experiments, installed at Virginia-USA, North Carolina-USA, and Paraná-Brazil, six genetic entries of $P$. taeda (four clonal, one open pollinated, and one control mass pollinated), planted at three densities (618, 1235, and 1853 stems ha ${ }^{-1}$ ), with two levels of silviculture (operational and intensive). The objective of this study is to assess the effects of these different treatments on tree crown structure, light absorption and light use efficiency for wood production. To calculate light absorption (LA), we use MAESTRA, a process-based model parameterized for each individual tree within the plots. The model considers crown dimensions and leaf area of each tree, and how the neighbouring trees interact for light absorption. Light use efficiency (LUE) of wood production is calculated as the ratio between wood growth and absorbed light. Current results show that intensive silviculture increase crown volume, LA and also LUE. Wider spacings increase light absorption but not LUE. Different crown ideotypes from varieties, affects both LA and LUE. The tree-level approach allows analyses and simulations related to the impact of fertilization on leaf area, different varieties on crown ideotype, competition for light absorption at different spacings and thinning intensities, responses of leaf area reduction by pruning.

\section{Light interception and light use efficiency following thinning and fertilization in intensively managed Douglas-fir stands}

Douglas B. Mainwaring ${ }^{1}$, Douglas A. Maguire ${ }^{1}$, Jacob D. Putney ${ }^{1}$

1Oregon State University, Corvallis, USA (doug.mainwaring@oregonstate.edu; doug.maguire@oregonstate.edu; jacob.putney@oregonstate.edu)

Silviculture of Douglas-fir in western North America has become increasingly intensive, with focus changing from maximizing yield to maximizing return on investment. Accordingly, managers are seeking ever more efficient means of production, with yield gains from silvicultural treatments scrutinized ever more closely under economic criteria. Achievement of greater management precision in Douglas-fir plantations will rely in part on quantification and modeling of mechanisms represented by production, distribution, and photosynthetic efficiency of foliage within individual trees and across the entire stand canopy. Branch and foliage sampling has therefore become increasingly common in operational and experimental stands monitored simultaneously for biomass production and response of foliage spatial distribution and needle age class structure to silvicultural manipulation. In the synthesis described here, foliar N, specific leaf area, and vertical foliage distribution were estimated from multiple studies in intensively managed Douglas-fir plantations. These attributes and conventional tree measurements were used to simulate canopy light absorption, photosynthesis, and water balance with the model MAESPA to test the effects of fertilization and thinning on tree-level PAR absorption and subsequent light use efficiency. Results from MAESPA simulations indicated that non-dominant trees received the greatest benefit from thinning and dominant trees the greatest benefit from fertilization. This response is consistent with empirical tree-level modifiers 
representing direct thinning and fertilization effects measured in experimental and operational Douglas-fir plantations. Stands can be prioritized for treatment by characterization of site and stand conditions coupled with mechanistic insights provided by hybrid models of forest production.

\author{
Advances in crown and tree growth modelling in the tree and stand simulator (TASS) \\ Catherine Bealle Statland ${ }^{1}$, Ian R. Cameron ${ }^{2}$, James W. Goudie ${ }^{1}$ \\ ${ }^{1}$ British Columbia Ministry of Forests, Lands, Natural Resource Operations and Rural Development, Victoria, Canada; ${ }^{2}$ Azura Formetrics Ltd., Kamloops, \\ Canada; ${ }^{1}$ British Columbia Ministry of Forests, Lands, Natural Resource Operations and Rural Development (catherine.beallestatland@gov.bc.ca; \\ ian.cameron@azura.ca; jimgoudie@shaw.ca)
}

The Tree and Stand Simulator (TASS) is the primary growth and yield model used to project the growth and value of managed forests in British Columbia, Canada, for timber supply analysis and silviculture decision support. As a complex, individual-tree model that tracks the dynamics of tree crowns in three spatial dimensions, TASS has a flexible structure that can accommodate structurally and compositionally diverse stands. Growth, yield and wood quality predictions dynamically respond to silvicultural manipulations through treatment effects on crowns and their competitive environments. A long history of research into crown and stem morphology supports this functionality, involving detailed destructive analyses of stem, branch and foliage of many sample trees, and construction of sub-models that predict crown profiles, foliage density and biomass, tree bole increment and increment distribution. In-depth study of silvicultural field experiments and permanent sample plots is necessary to both understand the mechanisms of managed stand development and to test and calibrate the simulations. Ongoing experimentation with different degrees of abstraction strives to achieve performance that balances biological fidelity with a level of model complexity appropriate for operational needs. This presentation will briefly review the rationale behind and structure of crown-based modelling in TASS, then focus on the latest research into such things as crown profile representation, new formulations for bole increment and increment distribution models, and individual tree response to fertilization.

\title{
Branch longevity in Scots pine: Does latitude matter?
}

Olav Høibø ${ }^{1}$, Geir I Vestøl', Douglas Maguire², Urban Bergsten ${ }^{3}$

${ }^{1}$ Faculty of Environmental Sciences and Natural Resource Management, Norwegian University of Life Sciences, Aas, Norway; ${ }^{2}$ Department of Forest Engineering, Resources and Management, Oregon State University, Corvallis, USA; ${ }^{3}$ Forest Biomaterials and Technol (olav.hoibo@nmbu.no; geir.vestol@nmbu.no; doug.maguire@oregonstate.edu; urban.bergsten@slu.se)

Crown recession results from mortality of branches near crown base due to low light intensity. Light conditions vary greatly with latitude and stand structure, but simulations have demonstrated that at high latitudes longer crowns are more efficient. Few empirical studies have verified this apparent response to sun angle. We hypothesize that empirical testing of latitudinal effects on crown length will verify this theoretical effect of lower sun angle and more uniform vertical distribution of light intensity on increased branch longevity. Forty-two Scots pine trees were sampled from seven Swedish thinning trials managed by the Swedish University of Agricultural Sciences. Latitude ranged from $59^{\circ}$ to $67^{\circ}$ north. Branch whorls were sampled from stump height to first living branch. Branch longevity of the 1225 knots in these whorls was analysed with mixed models containing covariates for stand, tree and whorl fixed effects and standand tree-level random effects. Latitude had a positive parameter estimate of 1.07 , meaning that branch longevity increased by approximately one year per degree northern latitude. Other fixed-effect variables were positively correlated with branch longevity, including relative whorl height, knot diameter and mean annual ring width for ring interval 21 to 39 years at breast height, but the reverse was true of average height increment. Negative interaction effects between relative whorl height and knot diameter and between average height increment and knot diameter complicated interpretation of the results, but supported the hypothesized relationship between sun angle and branch longevity.

\section{Wood and fiber property variation within plantation-grown conifers and its relationship to crown structure and dynamics}

Laurence Schimleck ${ }^{1}$, Joe Dahlen², Douglas B. Mainwaring ${ }^{1}$

${ }^{1}$ Oregon State University, Corvallis, USA; '2University of Georgia, Athens, USA (laurence.schimleck@oregonstate.edu; jdahlen@ug.edu; doug.mainwaring@oregonstate.edu)

An understanding of the effect of silvicultural practices on wood property variation within-trees is critical. Wood properties exhibit large variability at multiple scales - within an annual ring, within-tree, among trees in a stand, and across regions (the phenotype) and all are the consequence of a complex interaction of genetic and environmental components. In terms of wood properties within-trees patterns of variation typical of common plantation conifers largely reflect growth trajectories determined by genetics. Environmental (silvicultural) factors cause these general patterns to vary, for example as reflected by changes to earlywood and latewood proportions within rings or the rate of change of properties across multiple rings. For a given species how properties vary will depend on silvilcultural decisions regarding a plantation - location, planting density, fertilization and thinning - all influence crown structure and dynamics which ultimately impact the wood property variation observed. In this paper we will describe patterns of wood property variation within common conifer plantation species and explore how crown structure and crown dynamics can cause these patterns to vary

Relationship between leaf area index and yield in commercial plantations of Eucalyptus pellita using different measurement methods and fertilizer treatments in the Colombian Orinoco region / Relación entre el índice de área foliar y el rendimiento en plantaciones comerciales de Eucalyptus pellita bajo diferentes métodos de medición y tratamientos de fertilización en la Orinoquia Colombiana

Luz Adriana Molina Garcia ${ }^{1,2}$, Pedro Emilio Martinez Ospina ${ }^{2}$

${ }^{1}$ Pontificia Universidad Javeriana, Bogota, Colombia; ${ }^{2}$ Universidad Distrital Francisco Jose de Caldas, Bogota, Colombia (adrianamoliga7@gmail.com, pemartinezos@gmail.com)

La productividad de plantaciones comerciales está dada por condiciones climáticas y productivas del sitio, las cuales se ven expresadas en el comportamiento de variables fisiológicas. Los múltiples esfuerzos por lograr un aumento de la productividad de las plantaciones muchas veces no resultan exitosos por diversas razones, como la falta de información relacionada al comportamiento fisiológico de las especies, calidad del sitio, entre otros. Por estas razones, se buscó integrar nuevos parámetros con el propósito de generar pautas de diagnóstico del crecimiento de plantaciones forestales relacionada con el indicador ecofisiológico índice de área foliar (IAF) para la especie Eucalyptus pellita en la Orinoquia, como un mecanismo de apoyo al modelamiento del crecimiento forestal. Se usaron y compararon tres métodos indirectos de medición del índice de área foliar. El resultado de esta investigación genero un coeficiente de correlación 
y comparación entre los métodos de medición empleados y un indicador general de cómo está cambiando el IAF de acuerdo a las diferentes condiciones ambientales y a la fertilización. Se encontró que la altura está en función del IAF y la humedad relativa y que fue significativo integrar a los modelos de regresión lineal variables ambientales como la humedad volumétrica de los suelos y la luz que ingresa bajo el dosel. Mediante el análisis de correlación se mostró que la variable IAF está fuertemente relacionada con variables dasométricas como la altura y el diámetro, y por tanto, con el volumen, siendo este un paso para integrar la variable IAF a los procesos de simulación

\section{Characterization of canopy structure, leaf area index and light interception of Eucalyptus clones}

Eduardo More de Mattos $^{1}$, Dan Binkley ${ }^{2}$, José Luiz Stape ${ }^{3}$, Otávio Campoe ${ }^{4}$, Clayton Alcarde Alvares ${ }^{5}$

${ }^{1}$ Geplant Tecnologia Florestal, Piracicaba, Brasil; ${ }^{2}$ Northern Arizona University, Flagstaff, USA; ${ }^{3}$ Departamento de Ciências Florestais, Universidade de São Paulo, Piracicaba, Brasil; ${ }^{4}$ Universidade Federal de Santa Catarina, Curitibanos, Cambodia; ${ }^{5}$ Instituto de Pesquisas e Estudos Florestais, Piracicaba, Brasil (eduardo@geplant.com.br; dan.binkley@alumni.ubc.ca; stape@suzano.com.br; otavio.campoe@ufsc.br; calcarde@suzano.com.br)

The production of forests depends on the interception of light for photosynthesis, and light interception depends on the area of leaves and how they are arranged within canopies. This study examined these aspects using 18 Eucalyptus clones, covering the most representative species and hybrids planted in Brazil, such as E. grandis, E. urophylla, E. benthamii, E. dunii and others, showing a broad variety of canopy structure, leaf area, crown shape and size. The experimental site is located at $23^{\circ} 51^{\prime} 10.8^{\prime \prime} \mathrm{S}, 48^{\circ} 42^{\prime} 3.6^{\prime \prime} \mathrm{W}, 685 \mathrm{~m}$ above sea level, in Buri-SP, southeast of Brazil, where the plots were planted in December 31 st, 2011 at $3 \mathrm{~m}$ x $3 \mathrm{~m}$ spacing (1111 stems ha-1) following standard management practices. Destructive sampling was conducted in 12 representative clones, along with optical assessment of canopies from 18 to 32 months after planting, during canopy closure period. Leaf area index, or LAI, ranged from 2.9 to 5.9, while optical methods ranged from 1.8 to 4.6. Self-shading of leaves was evident, as optical methods could not fully capture total leaf area, the clumping index varied from 0.5 to 0.9 and were highly correlated with crown surface area and crown volume. Avegare leaf inclination angle ranged from 32 to 70 degrees, with higher inclination angles genotypes correlated to lower average LAI. These traits reveal the tremendous variability within Eucalyptus genera and points to strategies that can be taken to match genotypes to environmental conditions, as well as helping breeding programs.

\section{Carbon fluxes and partitioning of different varieties of Pinus taeda with contrasting crown ideotypes}

Gerardo Rojas ${ }^{1}$, Otávio Campoe ${ }^{1,2}$, Timothy Albaugh ${ }^{3}$, Rachel Cook $^{4}$, Rafael Rubilar $^{5}$, David Carter $^{3}$

${ }^{1}$ Universidade Estadual Paulista "Júlio de Mesquita Filho”, Botucatu, Brasil; ' 2 Universidade Federal de Lavras, Lavras, Brasil; ${ }^{3}$ Virginia Tech, Blacksburg, USA; ${ }^{4}$ North Carolina State University, Raleigh,USA; ${ }^{5}$ Universidad de Concépcion, Concepción, Chile (gerardo.forestal03@gmail.com; otavio.campoe@gmail.com; tim_albaugh@vt.edu; rlcook@ncsu.edu; rafaelrubilar@udec.cl; davidcarter@vt.edu)

The growth of planted forests can be described in terms of the supply of ecosystem resources where they are established, the proportion of these resources that trees can actually absorb, and the efficiency with which they use the resources to convert $\mathrm{CO}_{2}$ from the atmosphere into above and belowground biomass. Patterns of carbon fluxes and partitioning to different components can significantly vary among varieties, depending on breeding strategy, history and objectives. To address this issue, we are measuring all the components of the aboveground net primary production (production of stems, leaves and branches) and total belowground carbon fluxes (the sum of root production, respiration and mycorrhizal production), and their partitioning on five different varieties of a 7-year-old of Pinus taeda (one open-pollinated, one mass control pollinated and three clones) planted in the south of Brazil. Additionally, leaf area index measurements are performed at peak and off-peak periods during the year. These varieties show contrasting crown ideotypes, from narrow to broad crown, and a consistent variation of leaf area index, leading to significant differences in productivity. Evaluating these patterns will increase our ability to understand how different varieties, with different crown ideotypes invest the absorbed carbon into wood production. The study is under development, and will be completed by July 2019.

C4e: DECISION SUPPORT APPROACHES FOR FORESTRY OF THE 21 TH CENTURY

\section{Recent advances in EMDS version 7 enhance decision support for adaptive forest management in the $21^{\text {st }}$ century}

\section{Keith Reynolds ${ }^{1}$}

${ }^{1}$ USDA Forest Service Research, Corvallis, USA (kreynolds@fs.fed.us)

The Ecosystem Management Decision Support (EMDS) system is a spatially enabled system for environmental analysis and strategic and tactical planning that was originally released by the Pacific Northwest Research Station in 1997. There have been major advances in system functionality in the past few years, and three new areas of advancement are coming in the next two years. Building on its core functionality of logic processing and multi-criteria decision modeling, which has been available as an ArcMap component since 2002, recent advances in version 7.0 include speed and capacity enhancements to geodatabase processing, release of EMDS as an extension to three open-source geographic information systems, implementation of two new analytical engines for Bayesian reasoning and Prolog-based decision trees, and integration of R, Python, and Java scripting tools to support advanced geoprocessing needs of EMDS developers. In addition, tutorials for all analytical engines are provided online, and demonstrations are now available on an EMDS YouTube channel. New advances coming in the next two years include implementation of a graphical workflow environment for advanced customization, and introduction of a cloud-based collaboration manager that allows teams of resource managers to collaborate synchronously and asynchronously on EMDS applications that have been exported from the desktop environments.

\section{Spatial pattern of climate change effects on Lithuanian forestry}

Gintautas Mozgeris ${ }^{1}$, Vilis Brukas ${ }^{2}$, Ekaterina Makrickiene ${ }^{1}$, Nerijus Pivoriunas ${ }^{1}$, Algirdas Augustaitis ${ }^{1}$, Marius Mikalajunas ${ }^{1}$, Gintaras Kulbokas ${ }^{1}$ ${ }^{1}$ Vytautas Magnus University, Kaunas, Lithuania; ${ }^{2}$ Swedish University of Agricultural Sciences, Southern Swedish Forest Research Centre, Alnarp, Sweden (gintautas.mozgeris@vdu.lt; vilis.brukas@slu.se; ekaterina.makrickiene@vdu.lt; npivoriunas@gmail.com; algirdas.augustaitis@vdu.lt; marius.mikalajunas1990@gmail.com; gintaraskulbokas@gmail.com)

The sensitivity of forests and forestry to climate change is widely reported. In Lithuania, the increase in air temperature, precipitation, nitrogen depositions during the vegetative period and reductions in $\mathrm{SO}_{2}$ concentrations and sulphur deposition during last 3-4 decades are associated with increased growth intensity of coniferous tree species and neutral reactions of deciduous. This presentation investigates how sensitive is the provision of ecosystem services to forest management, and to what extent may climate change influence the provision. We specified several alternative future scenarios with varying extent of efforts to mitigate the climate change, under differing assumptions for future forest yield, timber demand and price trends. Then we simulated forest resource development 
and forest use under conditions of alternative climate mitigation scenarios using decision support system and assuming that current forest management practices are continued. We analysed spatial and temporal patterns of ecosystem service provision at the level of regional branches of State forest enterprise. The main finding is that the increased efforts for climate change mitigation correlate positively with profits from forestry activities. Reduction of biodiversity values is lesser, despite increasing growth intensity. The study was conducted within the frames of H2020 project ALTERFOR and National research program FOREstRESS.

\section{Computer based decision support system for optimization of farm forestry land uses in kenya}

Jonah Kiprop ${ }^{1}$, Joshua Cheboiwo ${ }^{1}$

${ }^{1}$ Kenya Forestry Research Institute, Nairobi, Kenya (jonahkipsat@gmail.com; jkchemangare@yahoo.com)

In Kenya primary forest production takes place in four forest categories namely; public plantations, farm forests, community forests and private forests. In the last decades farm and private forests have high registered growth driven largely by high demand for forest products and returns to investment for the sector to leverage on operational efficiency to maximize profits. The sector will remain an important component of the forestry sector in the country in the future. However, the smallholder farm forest sector is faced with many challenges key being inadequate information on management operations, valuation techniques and markets and market specifications that results in low productivity and low quality trees hence low forest incomes. This Project entailed development of a web based decision support system (DSS) to enable individuals/investors make well informed decisions regarding investment in the forestry sector in Kenya. This project was developed by a team from Kenya Forestry Research Institute (KEFRI) and other experts in forestry and ICT. The main features of the interactive DSS are provision of information on forest management and operations (planting, spacing, silvi-cultural operations); Financial analysis-Cost benefit analysis of key forest enterprises (costs, yields, benefits, prices), Forestry land use comparative analysis (alternative forest enterprises, competing agricultural crops), markets and marketing analysis (list of products market, prices, market value chains, marketing efficiency). Users who include smallholder farmers, investors with interest in forestry can interact with the system though a portal and access information necessary for promoting investments and optimization of farm forestry farm uses in Kenya

\section{Claim your seat at the table: adaptive governance toolkit to bring in community voices into catchment and community regeneration}

Sandra J. Velarde ${ }^{1}$, Tim Barnard ${ }^{1}$, Tui Warmenhoven ${ }^{2}$, Pia Pohatu ${ }^{2}$,Lisa Sharma-Wallace ${ }^{3}$, Peter Edwards ${ }^{4}$, Lania Holt ${ }^{1}$, Andrew Dunningham ${ }^{1}$, Barbara King ${ }^{5}$, Jeff Coutts ${ }^{6}$

${ }^{1}$ Scion, Rotorua, New Zealand; ${ }^{2}$ He Oranga mo Nga Uri Tuku Iho Trust, Ruatorea, New Zealand; ${ }^{3}$ Independent, Cincinnatti, USA; ${ }^{4}$ Manaaki Whenua, Wellington, New Zealand; ${ }^{5}$ Barbara King Ltd., Taupo, New Zealand; ${ }^{6}$ Coutts J\&R, Toowoomba, Australia (sandra.velarde@scionresearch.com; tim.barnard@scionresearch.com; tuiaroha@gmail.com; pia@uritukuiho.org.nz; lisa.jean.wallace@gmail.com; edwardsp@landcareresearch.co.nz; Flania.holt@scionresearch.com; andrew.dunningham@scionresearch.com; barbkinganz@gmail

We reflect on lessons learnt from a 3 year action-research programme undertaken in one of the most environmentally degraded and socio-economic deprived areas of New Zealand. In partnership with indigenous researchers and the local community, we designed and tested an adaptive governance toolkit to bring community voices into catchment restoration, where forestry plays a key role in addressing a landscape-scale erosion problem. Adaptive governance approaches are a family of methods that facilitate multi-party dialogue that underpins sharing power and resources. Adaptive governance has been used to address a number of environmental problems around the world. The concept is founded on recognising the complexity of social-ecological problems and advocating for a flexible and collaborative approach to help solve them based on local context and livelihoods. Our toolkit combines social network analysis to identify and capitalise on community, government and business leadership, role-playing games to better understand complexity and to provide a safe space for experimentation and a monitoring and evaluation framework to document progress. We note the potential of our toolkit on several fronts: identifying unexpected consequences of forestry, building empathy between stakeholders, generating creative ideas, and increasing participants' awareness of the complex web of relationships, priorities, barriers, resources (people, time, financial) and enablers which sets the context for forestry in the 21 st century

\section{Threatened Plant Adviser: a decision support system for managing threatened flora species within the Tasmanian forest practices} system

Anne Chuter ${ }^{1}$, Mark Wapstra ${ }^{2}$, Angela Gardner ${ }^{1}$

${ }^{1}$ ForestPractices Authority, Hobart,Australia; ${ }^{2}$ ECOtas, Hobart,Australia(anne.chuter@fpa.tas.gov.au; mark@ecotas.com.au; angela.gardner@fpa.tas.gov.au)

Tasmania is an Island State of Australia and is home to approximately 500 threatened flora species. Many of these species occur in areas that may be subject to forest practices, including forestry operations. Management actions for threatened flora species have traditionally been applied on a case by case basis taking into consideration the local conditions at the time. This has lead to fine scale, short term approaches that can be expensive and inappropriate for some species and some forest communities. On recent years we have been working on a decision support system that delivers management advice and actions for threatened flora species. The decision support system is titled the Threatened Plant Adviser, and integrates information from species modelling, as well as research and monitoring to deliver on-ground management actions that are consistent and adaptable as new information becomes available. The Threatened Plant Adviser is a web based program that is designed to be accessible to all users. Here we present information on the development of this system from the initial species prioritisation process, species predictive habitat modelling, and implementation and effectiveness monitoring of the management actions.

\section{Tactical harvest planning of fast-growing forest plantations using heuristic optimization techniques}

Pedro Belavenutti ${ }^{1,2}$, Woodam Chung $^{1}$, Luis Diaz-Balteiro ${ }^{2}$

${ }^{1}$ Department of Forest Engineering, Resource and Management, Oregon State University, Madrid, Spain; ${ }^{2}$ Departamento de Ingeniería y Gestión Forestal, Universidad Politécnica de Madrid, Madrid,Spain (inv.florestal@gmail.com; woodam.chung@oregonstate.edu; luis.diaz.balteiro@upm.es)

Tactical harvest scheduling is a challenging problem in the management of industrial forest plantations. The problem consists of achieving strategic production targets by making spatial and temporal forest operations decisions, such as timber harvesting, road maintenance and log transportation. To solve the spatially explicit planning problem, we applied a GIS forest planning tool developed using an iterative heuristic optimization method. The tool integrates harvest scheduling and road network problems and minimizes both fixed and variable costs. Any quantifiable environmental costs of management actions can be also integrated and considered for multiple objective minimization problem and solving. In this presentation, we present the GIS tool and its applications developed for an industrial forest plantation located in Brazil. The usefulness, limitations and future improvement of the tool are also discussed. 


\section{Integrating ecosystem services research in forest planning using simulation models and open source tools}

Louise Sing ${ }^{1,2}$ D; Stephen Bathgate ${ }^{1}$, Marc J Metzger ${ }^{2}$, Duncan Ray ${ }^{1}$, Christina Tracey ${ }^{3}$

${ }^{1}$ Forest Research, Roslin, United Kingdom; ${ }^{2}$ University of Edinburgh, Edinburgh, United Kingdom; ${ }^{3}$ Forestry and Land Scotland, Torlundy, United Kingdom (louise.sing@forestresearch.gov.uk; stephen.bathgate@forestresearch.gov.uk; marc.metzger@ed.ac.uk; duncan.ray@forestresearch.gov.uk; christina.tracey@forestryandland.gov.scot)

Publicly owned forests have a special role in delivering multiple ecosystem services (ES) that society demands. Management decisions affect the supply of these benefits, which vary both spatially and temporally, creating a complex context for forest management decision making. For example, how much change in the forest is required to maintain or increase benefits? How much change can be made without affecting current benefits? We describe a simulation approach using dynamically coupled models to explore the effect of alternative forest management approaches on a range of ES using a case study in northwest Scotland. By simulating forest growth under climate change we explore the effects of decisions on ES indicators. We present our decision support tool developed using R Shiny, a free open source visualisation package, for disseminating the results to the forest planning manager, as well as lessons learnt from the case study and its wider applicability for supporting forest planning. In particular, we show how management decisions are limited by constraints imposed by existing forest stock, requiring a simulation of multiple rotations for changes to become apparent. Zoning for particular objectives allows the forest planning team to estimate the impact of long-term change in provision on overall ES outputs from the forest. This work helps our understanding of the trade-offs of changing management relative to 'business as usual' approaches. The project has shown the importance of collaboration between researchers and practitioners, as their involvement at each stage of the process increased decision support system uptake in decision making.

\section{Large-scale forest simulations for the prediction of bird diversity in Central Europe}

\section{Astor Toraño Caicoya ${ }^{1}$, Pedro Leitão ${ }^{2}$,Tord Snäll ${ }^{3}$, Laura Zeller ${ }^{1}$,Enno Uhl ${ }^{1}$, Hans Pretzsch ${ }^{1}$}

${ }^{1}$ Technical University of Munich, Freising, Germany; ${ }^{2}$ Technische Universität Braunschweig, Braunschweig, Germany; ${ }^{3}$ Swedish University of Agricultural Sciences,Uppsala,Sweden(astor.torano-caicoya@tum.de; p.leitao@tu-braunschweig.de; tord.snall@slu.se; laura.zeller@tum.de;

enno.uhl@lrz.tu-muenchen.de; hans.pretzsch@lrz.tu-muenchen.de)

This talk will focus on the results of the interdisciplinary BiodivERsA GreenFutureForest project, which has as main objective to investigate how to modify current forestry to secure both high future (sustainable) timber yield, and viable biodiversity based on simulations of landscape scenarios. As a key organism group in the context of biodiversity, this presentation focuses on forest bird species. Nowadays, the need of adapting forest management to fulfill the demands of a society that requires multifunctional forestry arises as one the current challenges to forest modelling. Thus, tests and optimization techniques for different alternatives and over the territory are particularly relevant. This is especially important for decision support in large administrative regions, under high population pressure, like in Central Europe. Spatial models that connect forest structures with the occurrence of a large number of forest bird species were coupled with the forest simulator SILVA. The resulting tool allows assessing how different forest bird species may be affected by different forest management strategies. Five management scenarios, spanning 100 years, were simulated for two large regions, the Swiss Canton of Zürich and the entire federal state of Bavaria in Southern Germany. These scenarios cover a broad range of management options, from monofunctional to explicitly multifunctional forestry. The novel coupled model will allow tuning timber production and bird diversity by iterative scenario modifications according to the goals of different stakeholders. The experiences made so far suggest, that the approach of model coupling for large area forest simulations significantly increases decision relevant information.

\section{C4f: FOREST ASSESSMENT, MODELLING AND MANAGEMENT FOR NONWOOD FOREST} PRODUCTS

\section{Ecological services of forest ecosystems in islands: production forest, exotic woodland and natural forest}

Lurdes Da Conceição Borges Silva ${ }^{1}$, Rui Elias ${ }^{2}$, Diogo Pavão ${ }^{1}$, Mónica Moura $^{1}$, João Porteiro ${ }^{1}$, Anunciação Ventura ${ }^{1}$, Fernando Lopes ${ }^{3}$, Francisco Silva ${ }^{3}$, Francisco Moreira ${ }^{4}$, Ana Moniz ${ }^{3}$, Luis Silva ${ }^{1}$

${ }^{1}$ CIBIO, Centro de Investigacão em Biodiversidade e Recursos Genéticos, InBIO Laboratório Associado, Pólo dos Açores - Faculdade de Ciências e Tecnologia da Universidade dos Açores, 9501-801 Ponta Delgada, Portugal., Ponta Delgada, Portugal; ${ }^{2} c E 3 c / A B G$ - Centre for Ecology, Evolution and Environmental Changes/Azorean Biodiversity Group \& University of the Azores, 9700-042 Angra do Heroismo, Azores, Portugal., Angra do Heroísmo, Portugal; ${ }^{3}$ Business and Economics Department, University of the Azores, Rua da Mãe de Deus, 9501-801, Ponta Delgada, Portugal., Ponta Delgada, Portugal; ${ }^{4}$ Institute of Agronomy, Centre for Applied Ecology, University of Lisbon, Portugal., Lisboa, Portugal (lurdes.cb.silva@uac.pt; rui.mp.elias@uac.pt; diogo.c.pavao@uac.pt; monica.mt.moura@uac.pt; joao.jm.porteiro@uac.pt; maria.am.ventura@uac.pt; fernando.rr.lopes@uac.pt; francisco.jf.silva@uac.pt; fmoreira@isa.utl.pt; ana.id.moniz@uac.pt; luis.fd.silva@uac.pt)

Forests provide a broad range of ecosystem services, but their contribution is not homogeneous. Due to land changes associated with anthropogenic activity, primordial forests have been replaced by production and secondary forest, often constituted by exotic woodland, particularly in islands. This research addresses ecological and economic valorisation of forests in the Azores, an interesting model region in studies devoted to biodiversity pattern changes, associated with anthropogenic activity. We assessed biodiversity, structure and carbon accumulation in a gradient of forest types in three islands, including 30 stands for each type (production forest - PF, exotic woodland - EW, and natural forest - NF). Regarding taxonomic diversity, there was ample evidence that NF harbored the highest biodiversity levels and PF the lowest. Dendrometric analysis of almost 3000 trees revealed the dominant tree species in each forest type: PF Cryptomeria japonica used for timber production; EW - theinvasive tree Pittosporum undulatum; NF - the endemic trees Juniperus brevifolia and Laurus azorica. Diversity levels were generally lower for structural than for taxonomic data, particularly for PF. Regarding carbon accumulation, although differences between soils were small, aboveground carbon stocks were much higher in PF. As a whole, we concluded that NF play an important role as native biodiversity hotspots, PF provides economic assets and could play a major role as carbon sink, while EW presently has a marginal role, for instance in honey and compost production, while its biomass has potential for energetic valorization. Other services, such as tourism and recreation are also discussed. 


\section{Success of artificial inoculation of Inonotus obliquus on living birches (Betula spp.)}

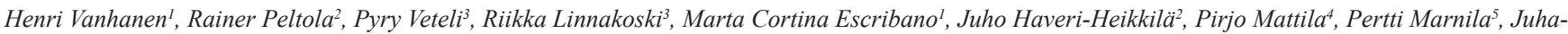
Matti Pihlava ${ }^{5}$, Jarkko Hellström ${ }^{5}$, Tytti Sarjala ${ }^{6}$, Niko Silvan ${ }^{6}$, Mikko Kurttila ${ }^{1}$, Jari Miina ${ }^{1}$

${ }^{1}$ Natural Resources Institute Finland (Luke), Joensuu, Finland; ${ }^{2}$ Natural Resources Institute Finland (Luke), Rovaniemi, Finland; ${ }^{3}$ Natural Resources Institute Finland (Luke), Helsinki, Finland; ${ }^{N}$ Natural Resources Institute Finland (Luke), Turku, Finland; ${ }^{5}$ Natural Resources Institute Finland (Luke), Jokioinen,

Finland; ${ }^{6}$ Natural Resources Institute Finland (Luke),Parkano,Finland (henri.vanhanen@luke.fi; rainer.peltola@luke.fi; pyry.veteli@luke.fi; riikka.linnakoski@luke.fi; marta.cortina.escribano@luke.fi; juho.haveri-heikkila@luke.fi; pirjo.mattila@luke.fi;pertti.marnila@luke.fi;

juha-matti.pihlava@luke.fi; jarkko.hellström@luk

Inonotus obliquusis a pathogenic fungus growing on broadleaves. Its sterile conks, also known as chaga in Asia and Russia or Pakuri in Finland, are considered as functional food. Due to a higher value of Pakuri compared to the wood of the tree which it is growing on, the cultivation of $I$. obliquus on living trees is expected to generate new income opportunities for forest owners. A total of 679 living birch trees (Betula pendula and B. pubescens) in 24 standsgrowing under different conditions throughout Finlandwere inoculated with two strains of I. obliquus and re-examined after 4-5 years. Our aim was to examinethe success of fungus inoculation and the appearance of sterile conks on birches, and to investigate factors that affect the success of inoculation. The average proportion of birches infected per stand was, $79 \pm 13 \%$ whereas $6 \pm 15 \%$ of birches per stand were bearing one or more conks.A part of infected trees (13\% of all trees studied) showed also a sign of bulged and/or cracked bark. Therefore, most birches were successfully inoculated, but so far only a few sterile conks were formed during 4-5 post-inoculation years. Due to aslow formation of conks, the cultivation of $I$. obliquus may be difficult to integrate into the management of commercial forests, but set-aside, low-productive birch, especially $B$. pubescens stands are recommended to be utilized in for cultivation.

\section{An X-ray based method to estimate pine nuts weight/cone weight ratio as a basis to increase cones price negotiation transparency}

Conceição Santos Silva ${ }^{l, 2}$, Isabel Carrasquinho ${ }^{3}$, Margarida Tomé ${ }^{4}$

${ }^{1}$ APFC, Coruche, Portugal; ${ }^{2} U N A C$, Lisboa,Portugal; ${ }^{3} I N I A V$, Oeiras, Portugal; ${ }^{4} C E F / I S A$, Lisboa, Portugal (css@apfc.pt; isabel.carrasquinho@iniav.pt; magatome@isa.ulisboa.pt)

A large percentage of Portuguese forests in the Mediterranean region are managed with a strong focus on NWFP, with particular emphasis on cork and pine nuts. These NWFP are an important source of income for the landowners, therefore the negotiation of price is of utmost importance. In the case of pine nuts, price strongly depends on the ratio pine nuts weight/ cones weight, from now on designated by pine nuts yield. The traditional way to estimate the pine nuts yield requires the sampling of some cones for further processing (sampling design not covered here): 1) elimination of wide pine nuts through water immersion; 2) opening the cones for shelled pine nuts extraction; 3) manual opening of the shelled pine nuts for the extraction and weighting of the edible part. This last step is very time consuming and reduces the possibility to increase sample within a reasonable cost. This presentation describes the research undertaken to define a methodology for determination of pine nuts weight without the manual opening. For this purpose, the shelled pine nuts were disposed and glued in a paper sheet and X-rayed. The X-rayed shelled pine nuts were 1) visually assessed for identification of damaged pine nuts; 2) several variables measured in each shelled pine nut with the software SmartGrain v1.2 with the objective to develop a model to estimate pine nuts weight from the variables available from the SmartGrain software. The study shows that using X-ray is a good methodology to estimate the pine nuts yield.

\section{Mapping cork caliper in Portugal using percentile regression}

\section{Joana Paulo 1 (D) Paulo Firmino ${ }^{1}$, Sónia Faias ${ }^{1}$, Margarida Tomé}

${ }^{1}$ Instituto Superior de Agronomia, Lisboa,Portugal (joanaap@isa.ulisboa.pt; pnfirmino@isa.ulisboa.pt; soniapf@isa.ulisboa.pt; magatome@isa.ulisboa.pt)

The 'montado' is an oak-dominated woodland ecosystem, distributed along the Iberian Peninsula. It is dominated by the cork oak (Quercus suber L.), the species responsible for the production of the cork. Maps concerning the species potential distribution in Portugal have been based on climate and soil thresholds. However, these maps do not express the potential cork production, which is essential for the farms economic sustainability and for defining regional policy measures. Using a quantile regression methodologic approach, the current work aimed to research the relationship of a set of variables with cork caliper, which is assessed by the value of the cork growth index (accumulated value of the eight first complete growth years). The dataset used includes 1339 cork samples. The developed models were used for mapping map, at the national scale, the potential cork calliper growth, considering the thresholds defined by the cork stoppers industry. Results showed a parabolic effect of annual precipitation in cork calliper, with an optimum value varying from more than $1000 \mathrm{~mm}$ for the lower percentiles to $500 \mathrm{~mm}$ in higher percentiles. A negative effect of maximum annual temperature and a positive effect of tree diameter for all percentiles were observed. A negative effect of the number of debarked branches was only significant at the percentiles equal or higher than 50. The potential cork calliper map obtained, shows a high variability within the percentage range of extracted cork usable for cork stoppers applied by the industry, with higher values at North of the Tagus river.

Legal barriers to the use of non-timber forest products from the Atlantic Forest in Paraná, Brazil / Entraves legais para a utilização de produtos florestais não madeireiros da Mata Atlântica Paranaense

Jaqueline de Paula Heimann ${ }^{1}$ (D; Vitor Afonso Hoeflich ${ }^{1}$

${ }^{1}$ Universidade Federal do Paraná, Curitiba,Brasil (jaquelineheimann@yahoo.com.br; vitor.ufpr@gmail.com)

A FAO define os Produtos Florestais Não Madeireiros como "Todos os bens de origem biológica, assim como os serviços derivados da floresta e terra sob uso similar e exclui a madeira em todas as suas formas” (FAO, 1995). Os principais PFNM do estado do Paraná, segundo dados do IBGE, são: erva-mate, palmito, pinhão, e nó de pinho. De acordo com a Lei Florestal Nacional, a coleta de PFNM como atividade eventual ou de baixo impacto é permitida, inclusive em áreas de Reserva Legal, desde que: para fins de subsistência e produção de mudas; ou exploração agroflorestal e manejo florestal sustentável, comunitário e familiar, desde que não descaracterizem a cobertura vegetal. Porém, o estado do Paraná, possui 99\% de seu território enquadrado como área do Bioma Mata Atlântica, que possui regulamentação própria, conhecida como Lei da Mata Atlântica, segundo a qual "A exploração eventual, sem propósito comercial direto ou indireto, de espécies da flora nativa, para consumo nas propriedades ou posses das populações tradicionais ou de pequenos produtores rurais, independe de autorização dos órgãos competentes, conforme regulamento". Ou seja, a exploração de PFNM da floresta nativa no Paraná, mesmo que praticada por populações tradicionais, quando possui propósito comercial, depende de autorização do órgão ambiental (BRASIL, 2006). Conclui-se com isso que, a falta de comunicação existente entre duas normas federais, impede a livre comercialização dos PFNM paranaenses, com isso cria-se um embaraço ao desenvolvimento da atividade extrativista. 
Sustainable models for collecting, processing, and marketing non-timber forest products in Chile / Modelos sustentables de recolección, procesamiento y comercialización de productos forestales no madereros (PFNM) en Chile

Gerardo Valdebenito Rebolledo ${ }^{1,2}$ (D)

${ }^{1}$ Instituto Forestal, Santiago, Chile; ${ }^{2}$ Universidad Mayor Santiago Chile (gvaldebe@infor.cl)

La dinámica económica y social de los PFNM en Chile ha experimentado un crecimiento relevante y sostenido en los últimos 20 años. Las Exportaciones al año 2017 registran montos por sobre los 93 MMUS\$, representando una cartera de 90 productos, los cuales se envían a más de 50 países. El mercado interno genera ingresos anuales a 200.000 personas del mundo rural, posee fuerte connotación de género y es factor determinante del ingreso familiar. Los productos recolectados y consumidos en Chile mueven un mercado de 370 MMUS\$ anuales, en base a 480 productos, de los cuales el $90 \%$ provienen del bosque nativo. El estudio identifica, caracteriza y prioriza los modelos de negocios sustentables vinculados a la recolección, procesamiento y comercialización de PFNM en Chile, desarrollados por agricultores, campesinos y comunidades del mundo rural y extrae a partir del rescate de esas experiencias empíricas, los factores de sostenibilidad de mayor relevancia en la dimensión silvícola (bosque), de agregación de valor (procesos) y comercial (negocios). Los resultados obtenidos identificaron tres modelos, de Menor a Mayor nivel de sostenibilidad: Tradicional, Colaborativo y Asociativo, donde los factores relevantes de sostenibilidad fueron el conocimiento empírico y cultural de las comunidades, los procesos de innovación que agregan valor, el endemismo, la condición de productos orgánicos y los productos vinculados a mercados de nicho. Respectos de los factores limitantes destacan la ausencia de información de mercados, catastro, inventario y cuantificación de los recursos disponibles, técnicas de manejo, recolección sustentable y la alta fragmentación de las cadenas de comercialización.

Constructing an agenda for managing non-timber forest products in Colombia / Hacia la construcción de una Agenda para la gestión de los Productos Forestales no Maderables en Colombia

Ren e Lopez Camacho ${ }^{1}$, Guillermo Orlando Murcia Ojeda ${ }^{2}$, Felipe Barney Arango ${ }^{3}$

${ }^{1}$ Universidad Distrital Francisco José de Caldas, Bogotá. D.C., Colombia; ${ }^{2}$ Ministerio de Ambiente y Desarrollo Sostenible, Bogotá. D.C., Colombia; ${ }^{3} W W F$, Cali,Colombia(rlopezc@udistrital.edu.co; gomurcia@minambiente.gov.co; fbarney@wwf.org.co)

Se reconoce a nivel mundial que los productos forestales no maderables -PFNM- proporcionan múltiples beneficios de subsistencia a las comunidades locales y a las economías regionales y nacionales. Estudios recientes han demostrado que se requiere de la vinculación comercialización-conservación y desarrollo para avanzar en la integración de los PFNM en las economías nacionales. Sin embargo, aún se desconoce la incorporación de estos productos en el diseño de políticas y como estrategia para lograr proyectos que permitan la mitigación de la pobreza, reducir la deforestación y el desarrollo de acciones en procesos de post-conflicto como es el caso de Colombia. Analizamos las políticas, legislación y potencialidades actualmente existentes frente a los Productos Forestales no maderables en Colombia, lo que nos permitió establecer 12 puntos claves que permiten facilitar la integración de los PFNMs en una agenda de desarrollo para Colombia permitiendo el beneficio de las comunidades locales. Estos puntos se basan en aspectos de inventario, aspectos ecológicos, directrices para el aprovechamiento de estos productos en distintos ecosistemas, decisiones de gestión de la tierra y el comercio, así como la incorporación de inclusión de los PFNM en el uso y manejo de la tierra y en medidas de compensación y restauración dentro de las licencias ambientales. Para cada uno de los puntos clave en el desarrollo de la agenda se presenta el estado actual de conocimiento y algunas propuestas para avanzar en su desarrollo.

\title{
Integrating non-timber forest products into forest assessments and management
}

James Chamberlain ${ }^{1}$, Gregory Frey², Christine Small ${ }^{3}$, John Munsell ${ }^{4}$

${ }^{1}$ US Forest Service, Blacksburg, USA; ${ }^{2}$ US Forest Service, Research Triangle Park, USA; ${ }^{3}$ Radford University, Radford, USA; ${ }^{4}$ VirginiaTech, Blacksburg, USA (jchamberlain@fs.fed.us; gregoryefrey@fs.fed.us; cjsmall@radford.edu; jfmunsel@vt.edu)

The plants and fungi harvested for non-wood products are critical to the health and resilience of forest ecosystems. Furthermore, the products derived from these species are essential to human sustenance, livelihoods, and security, and contribute significantly to local and national economies. And yet, these products rarely are managed as natural resources, integrated into forest assessments or management, or included in forest valuations or inventories. The findings and knowledge presented in a recent national assessment of nontimber forest products in the US are the foundation for this insightful presentation that examines efforts in the US to value the provisioning ecosystem services, estimate growth and yield, undertake product inventories, and monitor and track production of raw materials of non-timber forest products (NTFPs). An approach to compute a conservative and defensible estimate of the provisioning of marginal values of NTFPs is discussed. The presentation also explores a method developed to inventory NTFPs from plant roots based on modelling of below-ground biomass using above-ground metrics. Examples of tree-based NTFPs are presented to illustrate use of existing forest inventory data. Efforts to develop systems for tracking the harvest of medicinal forest products, which are needed to estimate volumes and values, are presented. The challenges that may impede efforts to undertake these essential activities are explored. Although this presentation focuses on research in the United States, these approaches and findings are applicable to countries and ecosystems around the world and should benefit every country that harvests NTFPs for sustenance, livelihoods, or economic gains.

C4g: FOREST INVENTORY AND MODELING: PAST SUCCESSES, CURRENT CHALLENGES AND FUTURE PROSPECTS

\section{The effect of natural and anthropogenic disturbances on the uncertainty of large-area forest growth forecasts}

\author{
Lara Climaco de Melo', Mathieu Fortin ${ }^{2}$, Robert Schneider ${ }^{1}$ \\ ${ }^{1}$ UQAR, Rimouski, Canada; ${ }^{2}$ AgroParisTech, Nancy,France(laracmelo@gmail.com; mathieu.fortin.re@gmail.com; robert_schneider@uqar.ca)
}

The uncertainty that disturbances induces in large-area growth forecasts has not been fully addressed. Thus, this study aimed to estimate the contribution of disturbances to the uncertainty of large-area forest growth forecasts. The case of study was the Bas-Saint-Laurent region, in Quebec, Canada. We focused on two major disturbances affecting that region: spruce budworm (SBW) outbreaks and harvest activities. Growth forecasts were carried out for a period of 100 years (2003-2103) using ARTEMIS-2009, a stochastic individual-based model. Using the Monte Carlo technique, we simulated four scenarios: a baseline; a harvest scenario; a SBW scenario; and a scenario including both harvest and SBW. Uncertainty estimation was performed using a bootstrap variance estimator that applies to the context of hybrid inference. In the Bas-Saint-Laurent region, omitting SBW outbreaks caused an overestimation of $7.4 \%$ in volume at the end of the $21^{\text {st }}$ century. The results revealed that the total variances increased over time. For the scenarios including SBW, the variances were three to six times 
greater than those in the scenarios without outbreaks. Harvesting did not greatly contribute to the total variance. We conclude that to reduce the uncertainty of large-area growth forecasts in the Bas-Saint-Laurent, considering SBW dynamics is a crucial issue.

\title{
Integrating canopy structure measurements in national inventories: challenges and opportunities
}

\author{
Daniel Augusto da Silva ${ }^{1}$, Heitor Felippe Uller ${ }^{2}$, Murilo Schramm da Silva ${ }^{2}$, Adilson Luiz Nicolleti ${ }^{3}$, Aline Klitzke ${ }^{2}$, Janine K. Likoski ${ }^{1}$, Alexander Christian \\ Vibrans $^{2}$ \\ ${ }^{1}$ Fundação Universidade Regional de Blumenau, Programa de Pós-Graduação em Engenharia Ambiental, Blumenau, Brasil; ${ }^{2}$ Fundação Universidade \\ Regional de Blumenau, Pós-Graduação em Engenharia Florestal, Brasil; ${ }^{3}$ Fundação Universidade Regional de Blumenau, Blumenau, Brasil \\ (danielaugusto@furb.br; heitor.ullerflorestal@gmail.com; murilo.sch.silva@gmail.com; adilson.ln@gmail.com; klitzkealine@gmail.com; \\ janinelikoski@hotmail.com; acv@furb.br)
}

Forest canopies are the main interface between forests and the atmosphere influencing climate at all levels, from local to global. The canopy of tropical forests is particularly complex, studying it can improve our understanding of the forest ecology, functioning and interaction with climate. Nevertheless, studies involving tropical forest canopies are rare and punctual, limiting the satellite estimates and climate models accuracy assessments, as well as our understanding of forest ecology and physiology. Digital Hemispherical Photographs (DHP) are a cheap, operationally simple and reliable way to estimate stand-level canopy structure parameters like Leaf Area Index, Canopy Opening and Radiation Absorption. However, accurate canopy estimations from DHP depend on clear overcast conditions to distinguish vegetation from sky, imposing an operational and financial limitation to large scale DHP-exclusive surveys. Integrating DHP surveys to national forest inventories can be a workaround to these limitations. The experience at the Forest and Floristic Inventory of Santa Catarina (IFFSC) demonstrated that the DHP survey can be done with almost no time penalty by the field team, overcoming the financial limitation. Even with an estimated data loss $(\sim 31 \%)$ due to non-ideal sky conditions under operational constraints, we are still able to generate a comprehensive estimation of the canopy structure, by means of 280 out of 418 units, with 20 DHPs each. Furthermore, improvements in image processing and classification can considerably lower data loss. This approach can drastically improve the ground data of canopy parameters in the tropics, crucial for global coupled atmosphere-biosphere models used in climate change assessments.

\section{Distance-dependent competition indices - when are they really needed?}

Margarida Tomé

${ }^{1}$ Universidade de Lisboa, Instituto Superior de Agronomia, Centro de Estudos Florestais, Lisboa, Portugal (magatome@isa.ulisboa.pt)

Inter-tree competition is a fundamental process in plant communities and has gained importance in recent research on forest ecosystem modeling. The effect of local neighbors on tree growth has been expressed by foresters using some mathematical formulation - commonly referred to as a "competition index" representing how much each tree is affected by its neighbors. Functions used to quantify competition range from simple formulations expressing the hierarchical position of the tree within the stand to more complex indices that express the size of, distance to, and number of local neighbors. Foresters have designated the last as distance-dependent, to express the need to register tree coordinates, but more recently ecologists have used the term spatially explicit individual-based models. There has been considerable debate in the literature as to whether tree spatial information improves prediction of individual tree growth. Conceptually, one would expect some improvement in precision when going from distance-independent to distance-dependent indices; however, most of the comparisons of competition do not report large differences. In this presentation, we analyzed some case studies for comparison of individual tree models using or not distancedependent competition indices. The case studies focus the use of distance-dependent competition indices as regressor in individual tree dbh increment models but also in thinning algorithms. The analysis includes the visual assessment of the long term resulting stand structure, both spatial distribution of the trees and diameter distributions.

\section{A Bayesian Model Averaging approach for modelling tree mortality in relation to site, competition and climatic factors for Chinese fir plantations}

Lele Lu $u^{1}$, Hanchen Wang ${ }^{1}$, Sophan Chhin ${ }^{2}$, Aiguo Duan ${ }^{1}$, Jianguo Zhang ${ }^{1}$, Xiongqing Zhang ${ }^{1}$

${ }^{1}$ Research Institute of Forestry, Chinese Academy of Forestry, 100091, China; 2Division of Forestry and Natural Resources, West Virginia University, Morgantown,USA(18553439861@163.com; xqzhang85@caf.ac.cn; xqzhang85@caf.ac.cn;xqzhang85@caf.ac.cn; xqzhang85@caf.ac.cn; xqzhang85@caf.ac.cn)

Relationships between tree mortality and endogenous factors and climate factors have emerged as important concerns, and logistic stepwise regression is widely used for modeling the relationships. However, this method subsequently ignores both the variables not selected because of insignificance, and the model uncertainty due to the variable selection process. Bayesian Model Averaging (BMA) selects all possible models, and uses the posterior probabilities of these models to perform all inferences and predictions.In this study, Bayesian Model Averaging (BMA) and logistic stepwise regression were used to analyze tree mortality in relation to competition, site index, and climatic factors in Chinese fir (Cunninghamia lanceolata (Lamb.) plantations established at five initial planting densities (A:1667, B: 3333, C: 5000, D: 6667, and E: 10000 trees/ha). Results showed that the posterior probability of the best model acquired by stepwise regression was less than that of the best model (highest posterior probability) acquired by BMA for pooling the data and density level D. Especially in the other planting densities, the model selected by stepwise regression was not in the BMA models. It indicates that the BMA method performed better than logistic stepwise regression, because BMA gave accurate posterior probability by taking into account the uncertainty of the model. In addition, the mortality increased with high competition and decreased with increasing temperature. The research has important implications for managing Chinese fir plantations under climate change.

\section{Forest inventory in changing landscape, going towards integrated multipurpose surveys}

Marco Marchetti ${ }^{1}$, Lorenzo Sallustio ${ }^{1}$

${ }^{1}$ University of Molise, Campobasso, Italy (marchettimarco@unimol.it; lorenzo.sallustio@unimol.it)

The strong interconnection among different land use and land cover change (LUC) dynamics such as land abandonment, forest regrowth and urban growth as well as their cumulative effects on ecosystems' structure and functionality, clearly underline the strategic role of land use inventory to support land management and planning while offering room for further analysis dealing with specific sectorial needs (i.e., forest inventory to support sustainable forest management, urban forestry, urban planning). This work aims to summarize recent outcomes and methodological remarks obtained by testing the Italian Land Use Inventory (IUTI) 
to support land policy and planning in Italy. Three main and interlinked LUC emerged in Italy since 1990: (i) the increase in forest lands (+ 1.7\% of the Italian territory); (ii) the loss of arable lands (-4.2\% of the Italian territory) due to both urban growth, shift to permanent crops, and natural reforestation particularly in mountain areas; (iii) the increase in built-up areas ( $+1.6 \%$ of the Italian territory). The in-depth analysis highlighted the spatial distribution and polarization of such phenomena and their ecological, economic and social impacts as well as the extension and characteristics of particularly important features such as urban forests, trees outside forests and clearings. Acting as a multipurpose land use inventory system, IUTI was proved to be effective in offering a comprehensive set of information not limited to forests ecosystems but enlarged to their relation with adjacent landscapes (e.g., urban and agricultural), thus setting the scene for a better operationalization of ecological principle into decision making contexts.

\title{
Developing site-index equation for loblolly pine using climatic water balance components \\ Anil Koirala ${ }^{1}$, Cristian R. Montes ${ }^{1}$, Bronson P. Bullock ${ }^{1}$ \\ ${ }^{1}$ Warnell School of Forestry and Natural Resources,University of Georgia, Athens, USA (anilk@uga.edu; crmontes@uga.edu; bronsonbullock@uga.edu)
}

Site-index models based on dominant height and age of trees are commonly accepted measures of site productivity in forest plantations. Therefore, reliable estimates of dominant height over time are critical, as they provide the foundations for site productivity estimates used in growth and yield models. Forest site productivity depends on the combination of many environmental factors, where as tree height is only a general proxy indicator of these factors interacting over time, and as such, subject to large errors. Hence, selection of appropriate environmental variables along with field-based data is expected to result in more consistent estimates. Although numerous studies have incorporated climatic variables in their site-index models, there is still lack of understanding among the research community with respect to the selection of suitable climatic variables. Models including the climatic water balance components such as water-deficit, excess water, and effective temperature are scarce. These components are especially important to address the influence of drought on plant growth. Therefore, the main question of interest for this study is to evaluate the change in dominant height estimates of forest stands with respect to changes in water balance components. High-resolution actual evapotranspiration (AET) and potential evapotranspiration (PET) were combined to determine water access/deficit of sites. These were incorporated into a loblolly pine site index model using generalized algebraic approach and maximum likelihood calibration methods that accounted for long-term uncertainty in the results. Our model is a step further to improve precision in dominant height estimates of loblolly pine in the southeast US.

\section{Diameter distribution of six clones of Eucalyptus under different ages and spacing}

\author{
Silvio Henrique Menezes Gomes ${ }^{1}$, João Luís Ferreira Batista ${ }^{1}$, Kálita Luis Soares ${ }^{1}$, Luciana Duque Silva ${ }^{1}$ \\ ${ }^{1}$ Escola Superior de Agricultura “Luiz de Queiroz”, Universidade de São Paulo, Piracicaba, Brasil (silviogomes@usp.br; batista.jlf@usp.br; \\ kalitasoares@usp.br; lucianaduques@usp.br)
}

Diameter distribution studies are an important tool for forest management planning and practice, particularly for stand growth and yield prediction models. In these studies, the stochastic distributions frequently fitted to data are beta, Johnson's SB, log-normal, Weibull and gamma; the last two more often show best fit and are applied to several forest management conditions. The goal of this study was to evaluate the change in the diameter distribution of six eucalyptus clones under three different planting spacing that were remeasured along six ages. The two stochastic models were applied to the diameter distributions in each specific condition. For each eucalyptus clone, the effect of age and planting spacing on the diameter distribution was investigated through seven models: 1) null model, there is no effect of age and spacing; 2) full model, for each combination of age and spacing; 3) age model, a distribution for each age; 4) spacing model, a distribution for each spacing; 5) age-function model, distribution parameters are linear function of age; 6) spacing-function model, distribution parameters are linear function of spacing; and 7) age-spacing-function model, distribution parameters are linear function of age and spacing. The models were fitted by maximum likelihood methods and were compared using Akaike Information Criterion (AIC). The full model (2) with Weibull distribution was the best model for all clones, but the age-spacing function model (7) was consistently the second best model. The likelihood profiles of scale and shape parameter estimates reveled that for some clones the age effect might be irrelevant.

\section{Development of a volume equation virtually invariant to location, age, and genetic material}

John Paul McTague 1 (1) Henrique Scolforo ${ }^{2}$, Jose Roberto Scolforo ${ }^{1}$

${ }^{1}$ UniversidadeFederaldeLavras,Lavras,Brasil; ${ }^{2}$ Suzano,Limeira,Brasil(forestbiometrician@yahoo.com;henriquescolforo@hotmail.com;jscolforo@dcf.ufla.br)

There exists an overreliance on the construction of new volume equations in Brazil. Equations are, of course, species-specific. Many times, however, separate equations are constructed for each farm (forest tract), and age class. The equations are developed with destructive sampling techniques. Quite frequently the constructed volume equations are of the form: $\mathrm{V}=(\mathrm{ff}) \mathrm{D} 2 \mathrm{H}$, where ff is the form factor. New model construction is expensive, and the models suffer from low sample sizes. An appealing alternative in Brazil, therefore, is the development of generalized tree volume equations. To calibrate a volume equation virtually invariant to location, age and genetic material, we offer the development of a new modeling framework for clonal eucalypt plantations. The dataset originates from inventory information of sites located in northern Minas Gerais State, Brazil. A total of 48 plots were selected and following the inventory measurements, all trees were bucked and scaled; 1844 trees compose the destructive sample. The combination of upper stem diameters and pre-defined stem heights in a taper equation, allowed for the development of a powerful modeling approach that displays higher accuracy when compared to conventional volume equations.

C4h: FROM LONG-TERM MONITORING AND TIME SERIES TO FORESIGHT ANALYSES AND PROJECTIONS

\section{Large trees have increased greatly in Finland during 1921-2013, old trees have not \\ Helena M. Henttonen ${ }^{1}$, Pekka Nöjd $d^{2}$, Susanne Suvanto ${ }^{1}$ (D) Juha Heikkinen ${ }^{1}$ (D, Harri Mäkinen ${ }^{2}$ (D)}

${ }^{1}$ Natural Resources Institute Finland, Helsinki, Finland; ${ }^{2}$ Natural Resources Institute Finland, Espoo, Finland (helena.henttonen@luke.fi; pekka.nojd@luke.fi; susanne.suvanto@luke.fi; juha.heikkinen@luke.fi; harri.makinen@luke.fi)

Large and old trees have a vital role in preserving biodiversity in forest ecosystems. Forest inventories provide detailed information about size distribution of trees, but long time series on the age distribution of individual trees are rarely available. The first sample-based National Forest Inventories (NFI) were established in the Nordic countries in the 1920s. We used Finnish NFI data for studying changes in the densities of large trees (diameter $\geq 40 \mathrm{~cm}$ ) over a time span of almost 100 years. The frequencies of old trees (age $\geq 150$ years) were studied for 1971-2013. Large trees have increased as much as $325 \%$, mainly since the 1970 s. Old trees have become slightly less common (-4\%) since the 1970s. The large majority of old trees in Finland were quite small. Trees that are both large and old showed a 
notable increase during 1971-2013. High densities of large and/or old trees were observed in areas with restrictions on wood production emphasizing their role in maintaining biodiversity. The results reflect the destructive effects of former land use and the transition from dimensional cuttings to clear cuts and thinning from below after the 1940s. Proportionally larger changes were observed for southern Finland, where a higher population density has resulted in more intensive land use. As the densities of large trees and old trees have developed in completely different manner, our results suggest that monitoring only the size distribution of trees will not sufficiently describe the role of old trees as constituents of biodiversity.

\section{Growth pattern of timber species in an ecotone among amazon forest types}

Aline Canetti ${ }^{1}$, Patrícia Póvoa de Mattos ${ }^{2}$, Evaldo Muñoz Braz², Afonso Figueiredo Filho

${ }^{1}$ Universidade Federal do Paraná, Curitiba, Brasil; ${ }^{2}$ Embrapa Florestas, Colombo, Brasil; ${ }^{3}$ Universidade Estadual do Centro-Oeste do Paraná, Irati, Brasil (alinecanetti@gmail.com; patricia.mattos@embrapa.br; evaldo.braz@embrapa.br;afigflho@gmail.com)

This work aimed to describe the individual growth of Apuleia leiocarpa (Vogel) J.F. Macbr., Erisma uncinatum Warm., Hymenolobium excelsum Ducke and Trattinnickia burserifolia Willd. in Mato Grosso State, Brazil. Growth analyzes were carried out using dendrochronology. We calculated mean increments and passage time between diameter classes, adjusted growth equations in diameter and derived volume increment curves at an individual tree level. The four species showed annual growth rings. Gompertz model showed better adjust to explain A. leiocarpa and H. excelsum growth and Johnson-Schumacher to E. uncinatum and T. burserifolia. The differences between diameter class increments, passage time and growth pattern over each species life span were related to their ecological groups. The diameter growth culmination and the maximum annual growth volume of $A$. leiocarpa occurred in smaller diameters and at younger ages when compared to the other species, which characterizes it as an early secondary species. E. uncinatum and T. burserifolia presented typical late secondary species characteristics, inverse to A. leiocarpa. H. excelsum is probably indifferent to light incidence, as trees presented constant increment during their lifetime. Our analyzes will be the basis of growth simulations at species population level, to be used in the elaboration of guidelines aiming at sustainable forest management.

\section{Applying tree rings and population models to improve future timber yield projections of Hymenaea courbaril (Jatobá) in the Eastern Amazon}

Isabela Marques ${ }^{1}$, Edson Vidal ${ }^{2}$, Mario Tomazello-Filho ${ }^{3}$, Peter Groenendijk ${ }^{1}$

${ }^{1}$ Departamento de Biologia Vegetal, Instituto de Biologia, UNICAMP, Campinas, Brasil; ' 2 Laboratório de Silvicultura Tropical, Esalq, USP, Piracicaba, Brasil; ${ }^{3}$ Laboratório de Anatomia e Identificação de Madeiras, Esalq, USP, Piracicaba, Brasil,; ${ }^{1}$ Departament (isabela.marques.bio@gmail.com; edson.vidal@usp.br;mtomazel@usp.br;peterg@unicamp.br)

To ensure sustainable timber productivity in polycyclic logging systems and to conserve forest function and services, it is crucial to adopt species-specific adaptive forest management systems. Yet, management plans are usually based on models that simulate future timber yields using limited, short-term growth, reproduction, and survival data, and that only poorly incorporate within-species variations in these vital rates. For growth data, tree-ring analyses allow for obtaining such long-term data that includes within-species growth differences. Here we combine 25 years of vital-rate data from experimental forest plots with different past exploitation (control, conventional exploitation and Reduced-Impact Logging (RIL)) with tree-ring analysis and state-of-the-art demographic models (Integral Projection Models) to simulate future timber yields of the tropical species Hymenaea courbaril. We simulated yields under conventional and RIL scenarios and assessed how using tree-ring data and including persistent growth differences between individuals affect timber yield projections. Future yields were below $100 \%$ of the initial exploited volume in all simulations. However, long-term yield recuperation was higher under RIL than under conventional exploitation. Using tree-ring based models and incorporating persistent growth differences lead to higher future yields. Our results suggest that timber volumes accumulated over many decades cannot grow back within current logging-cycle lengths (the "primary-forest premium"), but also that RIL practices are an important step to reach sustainable timber productivity. As more and more plot and tree-ring data comes available, approaches like ours - incorporating population dynamics and long-term vital rates - can be used to orient decision making to attain sustainable management of tropical forests.

\section{Analysis of the diametric structure of the Amazonian forests from the point of view of forest management \\ Evaldo Muñoz Braz'D (Dline Canetti ${ }^{2}$ (D), Patrícia Póvoa de Mattos ${ }^{2}$ (D) \\ ${ }^{1}$ Embrapa Florestas, Colombo, Brasil; ${ }^{2}$ Universidade Federal do Paraná, Curitiba, Brasil (evaldo.braz@embrapa.br; alinecanetti@gmail.com; patricia.mattos@embrapa.br)}

Natural forest management is currently the only land use activity that maintains approximately $88 \%$ of the number of initial trees. Nevertheless, the amazon forest management continues to be criticized. It is always questioned about its effectiveness as an environmental tool that guarantees the sustainability of natural forests. The reason for this criticism is a number of mistakes and misunderstandings about the analysis of monitoring results or simulations of natural forest management. The goal of this work was to enrich the understanding of Amazon Forest productivity when under management rules. This work also intended to analyze the misunderstandings about natural forests management. We analyzed the general diametric structure of the Amazon forest, identifying key points of transition to old forest, points of growth reduction, accumulation in basal area and decrease in timber volume production. The analysis of the species growth pattern, evolution of the individual species community over time and volumetric production help to explain the interruption of the structural balance of the Amazon forest after diameter class of $75 \mathrm{~cm}$. This imbalance limits the cutting cycles that must be estimated for management, since it shows that the forest is finishing its most productive phase. We can also conclude that pursuing the original structures of an Amazon natural forest after extraction is incompatible with forest management as senescent and stagnated trees (all pristine forest structure) represent an accumulated stock, but do not represent the productive capacity of the trees in a production forest.

\section{Forest responses to environmental perturbations in Central Europe: from permanent research plots to model projections}

Katarina Merganicova ${ }^{1}$, Jan Merganic ${ }^{2}$, Zuzana Sitkova ${ }^{3}$, Daniel Kurjak ${ }^{2}, Z_{\text {Zoltan Barcza }}^{1,5}$, Martin Mokros ${ }^{1}$, Peter Fleischer ${ }^{2}$, Hrvoje Marjanovic $^{4}$ Dora Hidy ${ }^{5}$, Katarina Strelcova ${ }^{2}$, Tomas Hlasny ${ }^{1}$

${ }^{1}$ Czech University of Life Sciences Prague, Faculty of Forestry and Wood Sciences, Prague, Czech Republic; ${ }^{2}$ Technical University Zvolen, Faculty of Forestry, Zvolen, Slovakia; ${ }^{3}$ National Forest Centre - Forest Research Institute Zvolen, Zvolen, Slovakia; ${ }^{4}$ Croatian Forests Research Institute, Zagreb, Croatia; ${ }^{5}$ Eötvös Loránd University, Budapest,Hungary (k.merganicova@forim.sk; merganic@tuzvo.sk; sitkova@nlcsk.org; kurjakd@gmail.com; zoltan.barcza@ttk.elte.hu; martin.mokros@gmail.com; p.fleischersr@gmail.com; hrvojem@sumins.hr; dori.hidy@gmail.com; katarina.strelcova@tuzvo.sk; tomas.hlasny@gmail.com) 
The knowledge of driving forces of forest growth helps foresters to assess the production potential of their forests, and supports their management decisions. Here we present a novel framework for the assessment of forest productivity drivers and responses along an extended environmental gradient across Central Europe. The framework consists of selected monitoring plots established within the European forest monitoring programme ICP Forests and highly-equipped intensively monitored plots situated in five European countries (Croatia, Hungary, Slovakia, Poland and the Czech Republic), and the regionally adapted biogeochemical process-based model Biome-BGCMuSo (Hidy et al; ${ }^{2016}$ ). We describe the overall concept of this framework and recent advances in the development of the applied ecosystem model, including its parameterisation for common forest tree species of the region. Finally, we exemplify the application of the framework for the assessment of forest productivity responses to selected perturbations. We highlight how linking of long-term monitoring data and ecosystem models can increase our capacity to simulate forest ecosystem dynamics and to address main challenges faced by the contemporary forestry with respect to ongoing global and regional environmental changes.

\title{
Applying empirical data of a forest accountancy network to show the effects of tree species diversity on financial risk and economic return in private forest enterprises
}

Johannes Wildberg ${ }^{1}$, Bernhard Möhring ${ }^{1}$

${ }^{1}$ University of Göttingen, Faculty of Forest Sciences and Forest Ecology, Department of Forest Economics, Göttingen, Germany (jwildbe@gwdg.de; bmoehri@gwdg.de)

The selection of tree species for the establishment of forest stands can be regarded as a financial investment with long-lasting economic consequences concerning entire rotation periods. An investment's success depends on the expected returns and volatility thereof. In finance theory the so called diversification effect reduces the risk of volatile returns. This study combines finance theory with empirical accounting data to support the hypothesis of reducing the risk of volatile return in forest enterprises through tree species diversification. Based on the data of a forest accountancy network in Germany, the effect of tree species diversity on risk and return was analyzed. We used economic parameters of 37 private forest enterprises in Western Germany documented over more than 45 years to calculate historic returns and volatility. The data revolves around the most relevant tree species in Germany including spruce, beech, oak and pine. The data demonstrated a positive diversification effect as species diversity in forest enterprises was negatively correlated with the volatility of return. While the economic return of all forest enterprises was equal to sum of the returns of the underlying tree species, the enterprises' volatility was lower than the summed volatility of the individual tree species. In summary, forest enterprises with a diversified tree species composition will not yield the highest returns possible, but are able to reduce risk for a given level of return. However, the non-stationary development of tree-species-assets as well as risk preferences need to be considered in management decisions.

\section{An imputation/copula approach to modeling long-term species dynamics in the Acadian Forest of northeastern North America}

\author{
John Kershaw ${ }^{1}$, Yung-Han Hsu ${ }^{1}$, Ting-Ru Yang ${ }^{1}$,Elizabeth McGarrigle \\ ${ }^{1}$ University of New Brunswick, Fredericton, Canada; ${ }^{2}$ Nova Scotia Department of Natural Resources, Truro, Canada (kershaw@unb.ca; yhsu@unb.ca; \\ tyang1@unb.ca; emcgarrigle@gmail.com)
}

Copulas are a special class of multivariate distributions whose marginals are all uniform. Through the process of translation, the marginal distributions can be transformed into any parametric or empirical distribution. Copulas have been widely applied in many fields for time series analyses. In medicine and economics, copulas have been used to model long-term dynamics of very complex systems with very good results. However, only recently have copula applications been developed in forestry. We propose a model that uses an iterative system of imputation and copula sampling to explore long-term dynamics in mixed species stands in the Acadian Forest in northeastern North America. The imputation step identifies nearest neighbors to subject trees or plots and copulas are built from this set of nearest neighbors. Random samples from the copula are then used to define the dynamic step. Long-term dynamics from a variety of different forest types are simulated and compared to expected dynamics based on successional theory. Copulas offer an alternative to parametric modeling and time series analyses. The imputation/copula model proposed here provides an approach for separating signal from noise in long-term forest dynamics data from multiple sources. The system is modular and can be easily expanded to include climatic and regional site factors enabling exploration of climate change effects on forest dynamics.

\section{C4i: INNOVATIVE APPLICATIONS OF UNMANNED AERIAL VEHICLES (UAVS) IN FOREST SCIENCE AND MANAGEMENT}

\section{Evaluation of three point cloud generation platforms used in forest inventory}

Cory Garms ${ }^{1}$, Chase Simpson ${ }^{1}$, Chris Parrish ${ }^{1}$, Michael Wing ${ }^{1}$, Bogdan Strimbu

${ }^{1}$ Oregon State University, Corvallis, USA (cory.garms@oregonstate.edu; chase.simpson@oregonstate.edu; chris.parrish@oregonstate.edu; michael.wing@oregonstateedu; bogdan.strimbu@oregonstate.edu)

Light detection and ranging (lidar) and structure from motion (SfM) are relatively new methods of describing terrestrial systems with 3D point clouds. The objective of the present study is to assess the effectiveness, measured as the cost/results quality, of three sensors producing point clouds. The sensors were mounted on three different platforms: 1) the multispectral sensor, mounted on an unmanned aerial vehicle (UAV-MS); 2) the Velodyne Puck lidar sensor, installed an octocopter UAV (UAV-P); and 3) the Velodyne HDL-32E lidar sensor, mounted on a truck, for a mobile terrestrial lidar scanner (MLS). The platforms scanned a 2.0 ha Douglas fir stand near Corvallis, Oregon, USA. The least expensive platform, UAV-MS, requires the least expertise, but also produces the lowest resolution point clouds ( $14 \mathrm{~cm}$ average point spacing versus $5 \mathrm{~cm}$ and $3 \mathrm{~cm}$ for UAV-P and MLS, respectively. The MLS platform is the most expensive but provides a profile perspective that allows tree stem delineation 50 meters into the stand. All platforms predicted the total height of individual trees with an r2> 0.83, but the MLS supplied also diameters along the stem. Our study suggests that for annual inventory a UAV-MS based approach is satisfactory, but for thinning or regeneration harvests a combination of UAV-MS with MLS is the best approach for areas with a well-developed road network, even that edge effects are present. A double sampling strategy removed the edge effect and provided unbiased estimates for volume. 


\title{
Comparative analysis of canopy heights estimated using UAV LIDAR and photogrammetry
}

Qingwang Liu ${ }^{1}$, Liyong $\mathrm{Fu}^{1}$, Shiming $\mathrm{Li}^{1}$, Zengyuan $\mathrm{Li}^{1}$, Mei Li ${ }^{1}$, Mengxi Wang ${ }^{1}$

${ }^{1}$ Research Institute of Forest Resource Information Techniques, Chinese Academy of Forestry, Beijing, China (liuqw@ifrit.ac.cn; fuliyong840909@163.com;

lism@ifrit.ac.cn; lizengyuan@ifrit.ac.cn; limei@ifrit.ac.cn;15501130818@163.com)

The forest structure and under-story terrain could be finely measured using Unmanned Aerial Vehicle (UAV) based Light Detecting and Ranging (LIDAR) and photogrammetry. Laser pulses has the ability of penetrating forest canopy and describe the vertical profile of vegetation. The stereo reconstruction of high-overlapped images can be used to generate dense point cloud finely reflecting the variation of canopy surface. The LIDAR-based Canopy Height Model (CHM) was generated using LIDAR point cloud subtracted by LIDAR-based Digital Terrain Model (DTM). The photogrammetry-based CHM was generated using photogrammetry point cloud subtracted by LIDAR-based Digital Terrain Model (DTM). This study compared the canopy heights between LIDAR and photogrammetry-based CHMs. The study area was located in Jigongshan National Nature Reserve, China. The result showed that there was high correlation between heights of LIDAR and photogrammetry. The LIDAR-based heights were slightly higher than that of photogrammetry. The overall mean of differences between canopy heights was $0.1 \mathrm{~m}$. The photogrammetry-based CHM has a decreased trend as the values of LIDAR-based CHM increased. The values of differences changed from negative to positive when the LIDAR-based CHM was higher than $16 \mathrm{~m}$. It indicates that photogrammetry will overestimate lower part of forest canopy and underestimate upper part of canopy to some degree.

\section{Innovative data capture and algorithms for improving outcomes from UAV image-based point clouds of forests}

\begin{abstract}
Luke Wallace ${ }^{1}$, Simon Jones ${ }^{1}$, Chris Bellman ${ }^{1}$, Mark Shortis ${ }^{1}$, Arko Lucieer ${ }^{2}$, Bryan Hally ${ }^{1}$, Darren Turner ${ }^{2}$, Samuel Hillman ${ }^{1}$, Jaime Hernandez ${ }^{3}$ ${ }^{1}$ RMIT University, Melbourne, Australia; ${ }^{2}$ University of Tasmania, Hobart, Australia; ${ }^{3}$ Universidad de Chile, Santiago, Chile (luke.wallace2@rmit.edu.au; simon.jones@rmit.edu.au; chris.bellman@rmit.edu.au; mark.shortis@rmit.edu.au; arko.lucieer@utas.edu.au; bryan.hally@rmit.edu.au;
\end{abstract} darren.turner@utas.edu.au; s3482969@student.rmit.edu.au; jhernand@uchile.cl)

Increasingly UAVs equipped with imaging sensors are being used to observe forest structure. In order to characterize forests accurately a core set of reliable information is required that describes the terrain surface and the upper parts of canopy. Several studies have demonstrated vulnerabilities in the workflow (camera quality and settings, flight parameters and weather conditions) used to reconstruct 3D forest descriptions that can result in inconsistent results. A method and a consistent set of guidelines for producing reliable and repeatable characterizations across a range of forest types is yet to be developed. This project investigates the pathologies within image-based point clouds and assesses novel strategies for ensuring reliable information describing the terrain and canopy from UAV data capture. In order to achieve this vulnerabilities at each step of the workflow are identified and novel approaches to overcome the resultant point cloud pathologies are developed. These approaches include ensuring camera quality and calibration are sufficient, choosing algorithms within the approach that best match the environment and novel multistage data capture methods. All approaches are tested in a series of real and simulated case studies with varying weather, canopy and terrain conditions. The outcome of this study is a matrix outlining the capture and and processing requirements for the optimum outcome in different forest types for target metrics. For example, improved terrain and forest description in high canopy cover environments can be achieved through the inclusion of off-nadir imagery to ensure small canopy gaps are exploited in the image matching process.

\section{The Potential of UAV Images in the Classification of Successional Forest Stages in Mixed Ombrophilous Forest Environments}

Felipe Matheus Pinto ${ }^{1}$, Marcos Benedito Schimalski ${ }^{1}$, Adelar Mantovani ${ }^{1}$, Veraldo Liesenberg ${ }^{1}$

${ }^{1}$ Universidade do Estado de Santa Catarina,Lages,_Brasil (felipe_matheus.p@hotmail.com; marcos.schimalski@udesc.br; adelar.mantovani@udesc.br; veraldo.liesenberg@udesc.br)

Due to the higher spatial resolution of images obtained by Unmanned Aerial Vehicles (UAV), pixel-to-pixel classification methodologies do not present good results. In addition, the cameras used for these vehicles usually record only the visible band, which impairs the identification of the vegetal cover. Therefore, new methodologies must be designed to obtain appropriate classifications using the visible information only. Regarding the spatial resolution, object-oriented classification methodologies tend to present more satisfactory results. Vegetation indices with visible bands, such as the Triangular Greenness Index (TGI), tend to improve results. The main objective of this study is to define a methodology for classifying images obtained by UAV with ultra-high spatial resolution and distinguish succession stages from forest fragments. The study was conducted in the municipality of Curitibanos, Santa Catarina, Brazil. Aerial mosaics were generated in the Agisoft Photoscan ${ }^{\circledR}$ software. The Segmentation and Classification toolset was employed for the object-oriented classification of regions. In addition, TGI was used coupled with the spectral bands. A confusion matrix was generated for the evaluation of partial results. The Kappa Index was calculated. Results showed 0.62 and 0.85 Kappa Index accuracy, which represents results considered to be "Very good" or "Excellent". The study found that satisfactory results were obtained for the classification even with bands only in the visible range, showing the potential of this methodology in the classification of ultra-high spatial resolution images.

\section{Predicting habitat suitability for greater glider (Petauroides volans) using remote sensing: implications for conservation planning Benjamin Wagner ${ }^{\text {D }}$, Patrick Baker ${ }^{1}$, Craig Nitschke ${ }^{1}$ \\ ${ }^{1}$ The University of Melbourne, Melbourne,Australia (bwagner@student.unimelb.edu.au,patrick.baker@unimelb.edu.au; craign@unimelb.edu.au)}

The greater glider (Petauroides volans) is Australia's largest gliding possum. Although distributed along the entire eastern coast, local populations are in decline and modelling predicts contractions of their habitat in the future. The species is now considered threatened in certain regions. Population declines have commonly been attributed to logging and burning activities, resulting in conservation measures emplaced accordingly. Other research indicates that the decline might be related to factors like forest nutrition, changes in foraging quality or climate, but are often not considered in conservation planning. Our project seeks to address interactions between these factors at a landscape-scale using a combination of UAV based remote-sensing, field validation and landscape modelling to answer the questions: 1) what are the main determinants of habitat suitability of greater gliders in southeastern Australia? and 2) what role does forest nutrition and climate have on glider occurrence and abundance? Using both fixed-wing and multirotor UAVs equipped with multi-spectral sensors over our study sites, we collected high-resolution imagery to correlate to tree nutrition and stand structure. While a multirotor device is used to cover small areas where ground surveys of forest structure, leaf and soil sample collection has taken place, the fixed wing system will be used to capture imagery of unsurveyed larger areas. These $>100$ ha areas are used to test our models of forest nutrition, derived from the plot level UAV data. Our aim is to identify glider habitat using high spatial and detailed nutrition models to improve reserve design and forest management. 


\section{What UAV remote sensing can tell us about sustainability of forest management at operational level: lessons learned from the EU-} funded FREShLIFE project

Anna Barbati ${ }^{1}$, Marco Balsi ${ }^{2}$, Francesca Giannetti $^{3}$, Diego Giuliarelli ${ }^{1}$, Bruno Laserre ${ }^{4}$, Davide Travaglini ${ }^{3}$, Gherardo Chirici ${ }^{3}$

${ }^{1}$ Università degli Studi della Tuscia, Viterbo, Italy; ${ }^{2}$ OBEN s.r.L., Sassari, Italy; ${ }^{3}$ Università degli Studi di Firenze, Firenze, Italy; ${ }^{4}$ Università degli Studi del

Molise, Isernia,Italy (barbati.sisfor@unitus.it; marco.balsi@gmail.com; francesca.giannetti@unifi.it; dgiuliarelli@unitus.it; lasserre@unimol.it;

davide.travaglini@unifi.it; gherardo.chirici@unifi.it)

Experiences from the EU LIFE project "FREShLIFE-Demonstrating Remote Sensing integration in sustainable forest management" are presented to discuss opportunities offered by UAV remote for monitoring sustainable forest management (SFM). The technical feasibility of mapping some Forest Europe's SFM indicators at the forest compartment level was evaluated. UAV data collection under leaf-on canopy conditions (RGB imagery and LIDAR) was combined with field sampling ( 150 plots, size $=530 \mathrm{~m}^{2}$ ) in temperate forests of Central Italy (3 sites, size 200-250 ha). Orthomosaic images from UAV imagery (pixel $10 \mathrm{~cm}$ ), were classified by visual interpretation to identify forest canopy species and tree defoliation. Compositionally distinct forest types were accurately mapped (per class accuracy $>70 \%$ ). Defoliation was detected on upper canopy trees, but only at its highest level ( $>70 \%$ of leaf loss). Combination of field and LIDARderived height metrics allowed the spatial estimation of growing stock and aboveground biomass by linear regression, at the plot size resolution ( $\mathrm{R}^{2}$ from 0.25 to 0.80 ). The variable performances of the predictive models can be related to different canopy penetration of the LIDAR, which affected the amount of ground returns and,accordingly, the DTM quality. LIDAR data acquisition also under leaf-off canopy conditions could address this limitation. Lessons learned ultimately highlight that traditional forest inventory can be efficiently complemented by UAV remote sensing to map the examined SFM indicators at operational scale. But planning of flight missions should be properly considered to optimize and standardize UAV data collection by different sensors (flight parameters, timing), so to generate high-quality data.

\section{C4j: REGIONAL FOREST OBSERVATIONS FOR SUSTAINABLE FOREST MANAGEMENT}

\section{Regional forest observations for annual change detection}

Yong Pang ${ }^{1}$, Zengyuan $\mathrm{Li}^{1}$

${ }^{1}$ Chinese Academy of Forestry, Beijing, China (pangy@ifrit.ac.cn; lizy@caf.ac.cn)

With rapid development of social and economic, forests face an increasing number of threats and pressures. How to effectively evaluate and assess the forest resource in large scale has become a common concern of many economies especially developing economies. Multi-temporal earth observation data characterize the forest gain and loss activities spatially and timely. This provides a good way to map the active forest gain and loss regions. With constant updating and developments of earth observation technologies, more and more medium-high spatial resolution remote sensing data are available free of charge or at a reasonably low cost. In this study, time series of optical remote sensing data from multiple satellites were used, including Landsat-5/7/8, Sentinel-2A/B, GaoFen-1/2/6 (GF-1/2/6) and Beijing-2 (BJ-2). These satellites provide repeat observations on a week to month cycle with spatial resolutions ranging from $4 \mathrm{~m}$ to $30 \mathrm{~m}$. We developed an algorithm for composition of cloud-free optical remote sensing imagery using weights for collection date, cloud contaminated extent and opaque degree calculated at pixel level. The weighted mean value was calculated for each pixel in the composition image, then time-series of forest cover indices were calculated to detect changes. Results from test sites in Guangxi (China), Laos, Malaysia and Thailand were analyzed. Field GPS points and screen interpreted changes were used for evaluation. Overall, the annual change accuracy using the annual composition images is about $82 \%$. The annual change accuracy using quarterly composition images increased to approximately $92 \%$.

\section{Monitoring of Alpine forests combining LiDAR and Sentinel 2 data}

Mathias Schardt ${ }^{1}$, Janik Deutscher ${ }^{1}$, Manuela Hirschmugl ${ }^{1}$

${ }^{1}$ Joanneum Research Forschungsgesellschaft mbH, Graz, Austria (mathias.schardt@joanneum.at; janik.deutscher@joanneum.at; manuela.hirschmugl@joanneum.at)

The international convention on the protection of the Alps (short: Alpine Convention) concludes that climatic change, catastrophic storm events and bark beetle calamities pose a growing threat to our Alpine forests. Forest administrations and forest owners undertake great planning efforts and mitigation measures to prevent forest degradation. To do so, these forest entities depend on the availability of relevant and timely information on the status of Alpine forests. Satellite remote sensing data in combination with LiDAR data are used to derive reliable information on forest status and forest change that forest owners and forest administration require to better manage and protect our Alpine forests. Two different types of services will be introduced: A near real-time alert system based on time series analyses of multi-temporal satellite images to rapidly and continuously map forest changes resulting from storm damage and insect calamities, and an inventory service that provides improved and updated information on selected forest parameters including timber volume, forest density, tree height and 3D structural characteristics on stand level. The method presented build on the one hand on Sentinel 2 data which forms an ideal basis for the establishment of a large-scale monitoring system. On the other hand full-waveform LiDAR data is used to assess the relevant inventory data mentioned above. The real time alert service developed is integrated and run in the EODC cloud processing environment that provides ample resources for timely production and delivery of information. The users will access the services through a conventional web browser.

\section{Influence of sample selection method and estimation technique on sample size requirements for wall-to-wall estimation using airborne} LiDAR

Ting-Ru Yang ${ }^{1}$, John A. Kershaw ${ }^{1}$, Aaron R. Weiskittel ${ }^{2}$, Tzeng Yih Lam ${ }^{3}$, Elizabeth McGarrigle ${ }^{4}$

${ }^{1}$ University of New Brunswick, Fredericton, Canada; ${ }^{2}$ University of Maine, Orono, USA; ${ }^{3}$ National Taiwan University, Taipei, Taiwan; ${ }^{4}$ Nova Scotia

Department of Lands and Forestry, Truro, Canada (tyang1@unb.ca; kershaw@unb.ca; aaron.weiskittel@maine.edu; tylam.forest@gmail.com; emcgarrigle@gmail.com)

Understanding how forests in response to climate change is important for designing and planning forest management and policy. However, due to the complex stand structure and forest dynamic, more detailed inventory information is required to have better predictive capability for a variety of forest inventory attributes over a range of forest ecosystems and geographic regions. Ground-based plots and various statistical modeling techniques are used to develop relationships between a desired forest attribute and a range of derived LiDAR metrics. The current modeling approaches are only as strong as the field data from which the LiDAR relationships are developed, and, unfortunately, some of the primary tenets of forest inventory design have been minimized or ignored. To improve our 
ability to predict future forest productivity under climate change, the sample design used to collect the necessary calibration data should be considered firstly over the calibration modeling approach. No analysis has systematically explored the influence of different selection methods on the efficiency of estimators of forest attributes using LiDAR-assisted estimation. To fill this knowledge gap, the influences of different sample selection methods, estimation techniques, and sample sizes on wall-to-wall LiDAR-derived inventory predictions are explored. Equal and variable probability selection designs are examined and model-assisted versus design-based estimators compared. Recommendations and considerations for efficient sample designs for future LiDAR inventories are presented.

\section{Spatio-temporal synergistic analysis and modeling of forest above-ground biomass dynamic information}

Xin Tian ${ }^{1}$, Zengyuan $\mathrm{Li}^{1}$, Erxue Chen ${ }^{1}$, Min Yan ${ }^{2}$, Chengyan $G u^{3}$

${ }^{1}$ Institute of Forest Resource Information Techniques, Chinese Academy of Forestry, Beijing, China; ${ }^{2}$ Aerospace Information Research Institute, Chinese academic of sciences, Beijing, China; ${ }^{3}$ Forestry Planning and Design Academy of Forest Products Industry, (tianxin@caf.ac.cn; zy@caf.ac.cn; chenerx@caf.ac.cn; yanmin@aircas.ac.cn; gudove3608@gmail.com)

Forest dominates the terrestrial carbon cycle and forest above-ground biomass (AGB) has been the critical index for carbon sequestration capacity. However, any individual method, such as ground-measurement-based method, remote-sensing-based method, and ecological model-based model, cannot efficiently describe the changing processes and driven mechanisms of forest AGB dynamics. Based on multi-mode remote sensing, time-space dynamic knowledge of forest ecological process, and continuous multi-disciplinary ground observation data, this project is planning to model spatial-temporal continuous, physical quantity-synergy forest AGB dynamics. Firstly, a highly accurate regional forest AGB product obtained by applying multi-mode remote sensing and scaling connection, is used as the AGB basis. Then, the uncertainties of simulation of forest growth processes are alleviated by use of model-model and model-data fusion strategies. Finally, modeling of forest AGB dynamics is accomplished by combining forest AGB basis with succeeding dynamic forest growth processes, which taking the effects of tree mortality, forest disturbance into account. The methodology of spatio-temporal synergetic modeling of Forest AGB dynamic information proposed by this project, can explore the eco-physiological mechanisms of spatio-temporal pattern of forest AGB dynamics and the driven forces of natural and anthropogenic disturbances. Moreover, this methodology can extend the spatial and temporal dimensions of forest AGB dynamics and in order to precisely improve forest quality and promote the national ecological civilization.

\section{Understanding stand characteristics of natural forest using airborne laser scanner data for sustainable forest management}

Yasumasa Hirata ${ }^{1}$, Naoyuki Furuya ${ }^{1}$, Toshiaki Owari ${ }^{2}$, Daisuke Sakaue ${ }^{3}$

${ }^{1}$ Forestry and Forest Products Research Institute, Tsukuba, Japan; ${ }^{2}$ THe University of Tokyo, Kamogawa, Japan; ${ }^{3}$ THe University of Tokyo, Furano, Japan

(hirat09@affrc.go.jp;nfuruya@affrc.go.jp; owari@uf.a.u-tokyo.ac.jp; sakaue@uf.a.u-tokyo.ac.jp)

Natural forests are expected to demonstrate multifaceted functions such as biodiversity preservation function andenvironment conservation function. On the other hand, accurate information on natural forest resources necessary for sustainable management is largely insufficient compared to artificial forests. In order to manage natural forests continuously, it is important to grasp information such as resource amount and growth amount at stand or landscape level. In this study, we aim to develop a method to grasp the stand characteristics of natural forest from tree height of forest stands and forest canopy transmittance of laser from data obtained by airborne laser scanner (ALS) measurement. The study area is the natural forest of the University of Tokyo Hokkaido exercise forest. First, DSM (digital surface model) and DEM (digital elevation model) were prepared from ALS data, and DCM (digital canopy height model) was created from the difference between them. The canopy transmittance of the laser beam irradiated from the aircraft was calculated by setting a grid of $5 \mathrm{~m} \times 5 \mathrm{~m}$. Using these data as explanatory variables, we created a model for grasping stand characteristics based on the sum total of breast height cross section and forest material volume as objective variables. In addition, the degree of openness was calculated with a $5 \mathrm{~m}$ mesh and compared with the elapsed years after selective logging in units of stands. It was clarified that information on forest canopy transmittance of laser light is important in grasping stand characteristics using ALS data.

\section{Planted forests exhibit longer spring phenology duration than natural forests in sub-alpine area of Southwest China}

Pengsen Sun ${ }^{1}$, Ning Liư ${ }^{2}$, Zhen Yu ${ }^{3}$, Lei Zhang, Jingxin Wang ${ }^{5}$, Shirong Liu ${ }^{6}$

${ }^{1}$ Research Institute of Forest Ecology, Environment and Protection, Chinese Academy of Forestry, Beijing, China; ${ }^{2}$ Department of Forest

Resources, University of Minnesota, Otto, USA; ${ }^{3}$ Department of Ecology, Evolution, and Organismal Biology, Iowa State University, Ames, USA; ${ }^{4}$ Research Institute of Forestry, Chinese Academy of Forestry, Beijing, China; ${ }^{5}$ Division of Forestry and Natural Resources, West Virginia University, Morgantown, USA; 'Chinese Academy of Forestry,Beijing, China (sunpsen@caf.ac.cn; liun@umn.edu; zyu@iastate.edu; zhangthunder@163.com; jxwang@wvu.edu; liusr@caf.ac.cn)

The Southwest China sub-alpine forests are composed large scale of planted forests, which are recently found to be prone to browning as a result of early spring water shortage. Spring phenology duration is strongly linked to subalpine eco-hydrological processes and thus the key to understand forest growing trends. However, spring phenology difference among planted (PF), natural (NF) and mixed forests (MF) under seasonal and inter-annual climate variation is poorly understood. The traditional and model-based phenology representations fail to capture the process and pattern of spring phenology. In this paper, we used a combination of surface meteorological data, forest inventory maps, $250 \mathrm{~m}$ resolution MODIS data, the spatial statistic histogram (SSH) method to analyze the spring phenological responses of PF, NF and MF. Our results demonstrate browning trend in planted forests and significantly greening trends in natural forests during the study period of 2001-2015. Advanced onset date of spring green up (SOS) in planted forests (DOY 148) than natural ones (DOY 156). SOS of planted forests exhibit high elevation sensitivity than natural forests. Mixed forest showed a decline in elevation sensitivity at $3500 \mathrm{~m}$ higher. All forests in subalpine area showed higher sensitivity to precipitation than to air temperature. The spring phenlogical duration (SOSd) of planted forests (47 days) was longer than natural ones (41 days), moreover, SOSd became variable and tend to be upward in all forests in most recent years, which indicates a sufficient sub-alpine water supply during spring and is likely a result of earlier snow melting.

\section{PROTEST project: towards a multidisciplinary methodology for forest territorial analysis}

Raphaël Aussenac ${ }^{1}$, Jean-Matthieu Monnet ${ }^{1}$, Thomas Carrette ${ }^{2}$, Sylvie Durrieu ${ }^{3}$, Pierre Paccard ${ }^{4}$, Catherine Riond ${ }^{5}$, Arnaud Sergent ${ }^{6}$, Patrick Vallet ${ }^{1}$ ${ }^{1}$ Univ. Grenoble Alpes, Irstea, LESSEM, Grenoble, France; ${ }^{2}$ FCBA, Saint Martin d'Hères, France; ${ }^{3}$ TETIS, Univ Montpellier, AgroParisTech, Cirad, CNRS, Irstea, Montpellier, France; ${ }^{4}$ Geopark Massif des Bauges, Le Chatelard, France; ${ }^{5}$ ONF R\&DI, Chambéry, France (raphael.aussenac@irstea.fr; jeanmatthieu.monnet@irstea.fr; thomas.carrette@fcba.fr; sylvie.durrieu@irstea.fr; p.paccard@parcdesbauges.com; catherine.riond@onf.fr; arnaud.sergent@irstea.fr; patrick.vallet@irstea.fr)

In French mountain areas, the heterogeneity of forests, the fragmentation of ownership and accessibility constraints hamper inventory and management actions. To ensure the sustainability of ecosystem services provided by forests, it is necessary to evaluate them while taking into account the local and global socio- 
economic context. The PROTEST project aims to build a methodology for territorial analysis of forest resources, based on advances in remote sensing, GIS, forest dynamics modelling and territorial foresight. The study area of the project is the Geopark Massif des Bauges (France) that contains 50000 ha of forests. The first task is to produce a map of forest resources, based on airborne lidar remote sensing, and of its accessibility, based on the Sylvaccess model. The second task is to implement a territorial foresight work and define forest management scenarios that combine environmental and societal determinants. Societal factors and their possible evolutions will be defined on the basis of field surveys and expert opinions. Depending on these factors and on a typology of parcels, scenarios of forest management will be proposed to simulate the behavior of owners. In the third task, these scenarios will be integrated into a spatialized model of forest dynamics, in order to simulate the evolution of the forest mosaic at the parcel level. Linker functions will be integrated to evaluate ecosystem services (wood production, biodiversity, carbon stock...) from simulated forest characteristics. The results will be used to support participatory workshops that will aim to define a forest management strategy supporting the territorial development.

Technological innovations for monitoring the impact of forest management in forestry dynamics and carbon flows in Latin America I Innovaciones tecnológicas para el monitoreo del impacto del manejo forestal en las dinámicas silviculturales y los flujos de carbono en Latinoamérica

Natalia Ruiz-Guevara ${ }^{1}$, Diego Delgado ${ }^{1}$,Fernando Carrera ${ }^{1}$, Mario Chacon ${ }^{1}$, Miguel Cifuentes Jara ${ }^{1}$

${ }^{1}$ Centro Agronómico Tropical de Investigación y Enseñanza,Turrialba, Costa Rica (natalia.ruiz@catie.ac.cr; ddelgado@catie.ac.cr; fcarrera@catie.ac.cr; mario.chacon@catie.ac.cr; miguel.cifuentes@catie.ac.cr)

Las innovaciones tecnológicas para el monitoreo de bosques en Latinoamérica se enfocan a medir el cambio de uso de tierras a gran y mediana escala, mientras que el monitoreo de unidades de manejo forestal no se realiza de manera regular o tecnificada. Se sistematizaron experiencias en países latinoamericanos para analizar el potencial de tecnologías disponibles para evaluar el impacto del manejo forestal, sobre la dinámica silvicultural y flujos de carbono. Estas, van desde imágenes de sensores remotos de distintas resoluciones, plataformas virtuales, drones para la teledetección forestal, dispositivos móviles y aplicaciones para el registro de inventarios en campo. Para la medición de flujos de carbono se identificó a las torres de medición de gases, plataformas virtuales colaborativas y calculadoras de carbono de uso forestal. El uso de dispositivos móvilesyaplicaciones destacan por su bajo costo, facilidad de difusión, compatibilidad con diversas funciones y sencillez de uso. Se recomienda desarrollar aplicaciones con funciones múltiples, para el registro geográfico de árboles y parcelas de corta; cálculo de volúmenes de aprovechamiento e indicadores económicos; registro de indicadores de impacto como área de claros, afectación a vegetación circundante y regeneración natural; y estimación de emisiones de gases de efecto invernadero. A nivel nacional, se resaltan las experiencias de Brasil, Guatemala, Panamá y Surinam. Además, se recomienda realizar investigaciones comparativas respecto del costo y precisión entre información proporcionada por sensores remotos y el monitoreo directo en campo en áreas bajo manejo forestal, a fin de tener certeza sobre su potencial para la toma de decisiones silviculturales.

\section{C4k: REMOTE SENSING AND GEOGRAPHIC INFORMATION SYSTEM FOR FOREST} MONITORING AND MANAGEMENT

\section{Forests in a changing planet: challenges for the sustainable development of tropical countries}

Luiz Aragão ${ }^{1}$

${ }^{1}$ Tropical Ecosystems and Environmental Sciences, National Institute for Space Research, São José dos Campos, Brasil (l.aragao@exeter.ac.uk)

Fully functional tropical forests are critical for maintaining the eco-climatic stability of the Earth system and for providing ecosystem services crucial for social and economic development of tropical nations. Using the Amazon as a study case, this presentation will focus on the concept of sustainable development to discuss how remote sensing of tropical forests can support nations to achieve this new global paradigm. The interaction between climate and natural forests is the first step to understand the functioning of this ecosystems and how they store carbon, cycle water and maintain their diversity. These forests, however, are constantly threated by human-climate interactions, which push these systems beyond their natural boundaries. Direct and indirect impacts of deforestation and fires are two of the most pressing issues in tropical countries, with consequences for the maintenance of the functioning of forests and their capacity to provide essential services for the development of these nations. Several studies using multiple spectral and spatial resolutions from passive and active remote sensors for Earth observation and climate are being developed to provide information on the extent of these forests, how they interact with climate and human-induced changes and what are the consequences of these interactions. From this understanding, I conclude by offering insights on to use this tool to generate fundamental information for supporting the long-term planning of the sustainable development of tropical nations.

\section{Detection of early stage bark beetle infestations in spruce stands using multitemporal low cost hyperspectral imaging}

Donatas Jonikavicius ${ }^{1}$, Gintautas Mozgeris ${ }^{1}$, Vytaute Juodkiene ${ }^{2}$, Henrikas Stravinskas ${ }^{3}$, Albinas Tebera ${ }^{3}$

${ }^{1}$ Vytautas Magnus university, Kaunas, Lithuania; ${ }^{2}$ University of Applied Sciences, Kaunas, Lithuania; ${ }^{3}$ Kaunas Forestry and Environmental Engineering University of Applied Sciences, Girionys,Lithuania (donatas.jonikavicius@vdu.lt; gintautas.mozgeris@vdu.lt; vytautejuodkiene@yahoo.com; h.stravinskas@kmaik.lm.lt; a.tebera@kmaik.lm.lt)

The insect outbreaks and resulting forest damages are becoming more intense nowadays. One of preconditions for successful control and fighting the insect attacks is early detection of the outbreaks. Recent advance of low-cost but effective remote sensing solutions offers new opportunities in monitoring forest conditions. The objective of this study was to develop operationalization proposals for using low-cost hyperspectral imaging technology for the identification of early stage bark beetle infestations in spruce stands. The study was carried out in Dubrava forest located in central part of Lithuania. Four imaging flights were conducted in summer seasons of 2017 and 2018, aiming to capture images after the infestation of spruce trees by bark beetle. Imaging system built on simultaneous use of a hyperspectral camera based on a tunable Fabry-Pérot interferometer and colour-near infrared (CIR) camera, installed on ultra-light type aircraft was used for data acquisition. Attacked trees were field identified and mapped, together with sample of not-infested trees. Images were processed to get image mosaics with ground sample distance (GSD) 15-20 cm for CIR images and GSD 40-60 cm for the hyperspectral images. The spectral characteristics of images were used to classify the crowns into two categories - infested and not-infested. The overall accuracy of classification was reached for the best case 77 $\%$ (Cohen's kappa: 0.54). Classification accuracies using hyperspectral data were up to $20 \%$ better than using the CIR data. The results suggested that novel remote sensing techniques could offer great potential for assessment of the health condition of spruce stands. 
Mapping deforestation and forest degradation in Mato Grosso, in the Brazilian Amazon region, using fraction imagery derived from LANDSAT-8 OLI images / Mapeamento do desmatamento e degradação florestal no estado do mato grosso, amazônia brasileira, utilizando imagens fração derivadas das imagens oli do Landsat-8

Yosio Edemir Shimabukuro ${ }^{1}$, Andeise Cerqueira Dutra ${ }^{1}$, Egidio Arai ${ }^{1}$, Valdete Duarte ${ }^{1}$

1Instituto Nacional de Pesquisas Espaciais, São Josédos Campos, Brasil (yosio.shimabukuro@inpe.br; andeise.dutra@inpe.br; egidio.arai@inpe.br; valdete.duarte@inpe.br)

Desmatamento é a substituição da floresta por outra cobertura da terra enquanto a degradação é uma modificação da cobertura florestal a longo prazo. Na Amazônia brasileira a degradação florestal é causada principalmente pelas atividades de exploração seletiva da madeira e queimadas descontroladas, e a sua contribuição para o cálculo da emissão de carbono continua a ser um desafio. A discriminação entre áreas afetadas por corte seletivo e fogo é importante para o programa do REDD+ (redução de emissões por desmatamento e degradação florestal) da UNFCCC (Convenção-quadro das Nações Unidas sobre mudança climática). Neste contexto, este trabalho apresenta um procedimento semi-automático para monitoramento da degradação florestal na Amazônia brasileira utilizando imagens fração derivadas do Modelo Linear de Mistura Espectral (MLMS). Imagens OLI (Operational Land Imager) do Landsat-8 obtidas de 2015 cobrindo o estado do Mato Grosso na Amazônia brasileira foram utilizadas no método proposto. Primeiramente, a abordagem consiste em mapear áreas de desmatamento e áreas de florestas degradadas pelo fogo utilizando segmentação das imagens fração. Em seguida, as áreas degradadas por exploração seletiva da madeira foram mapeadas usando um classificador baseado em pixel. Os resultados mostraram que as imagens fração são adequadas para mapear as áreas desmatadas e as áreas degradadas causadas por fogo e corte seletivo. Conclui-se que a resolução espacial desempenha um papel importante para o mapeamento de áreas de exploração seletiva da madeira, já que o tamanho dos pátios e carreadores utilizados para o arraste das árvores cortadas são menores do que a resolução espacial das imagens OLI.

\section{Assessing longitudinal variability in phenological characteristics of Shorea robusta forest in Nepal using remotely sensed data \\ Sanyog Basnet ${ }^{1,2}$, Anil Koirala $^{3}$, Damodar Gaire ${ }^{1}$, Cristian R. Montes ${ }^{3}$ \\ ${ }^{1}$ Institute of Forestry, Tribhuvan University, Hetauda, Nepal; ${ }^{2}$ Ministry of Forest and Environment, Government of Nepal, Kathmandu, Nepal; ${ }^{3}$ Warnell School of Forestry and Natural Resources, University of Georgia, Athens, USA (fr.sanyogbasnet@gmail.com; anilk@uga.edu; d.gaire@forestrynepal.org; crmontes@uga.edu)}

Shorea robusta is the most valuable timber species of Nepal in terms of distribution, utilization and financial gain. Despite its wide environmental distribution range and its phenological behavior across the country, silvicultural operations for this species are based only on a single operational calendar developed by government. The research on phenological characteristics of this species is very scarce. Thus, the aim of this study was to address the knowledge gap on phenological characteristics of Shorea robusta forests from different longitudinal ranges, which can eventually improve their overall management in the country. The study retrieved the seasonality parameters of four different Shorea robusta forest blocks in a longitudinal range within the time frame of 2012 to 2017 by analyzing the MODIS NDVI data layer with the spatial resolution of $250 \mathrm{~m}$ of 16 -day composite. For the selected time period, the phenological parameters of Shorea robusta forest were extracted using the TIMESAT program and mapped out the change in NDVI. The study revealed uneven start in growth initiation, ranging between 12 to 45 days for the study areas. Phenological start and ending times were found to be earlier in eastern Nepal as compared to the western part of the country. The length of growing season was highest in Middle Nepal while the peak NDVI found to be highest in western Nepal. Our study suggested the need for the appropriate adjustment in the schedule and annual calendar of silvicultural and forest management activities for Shorea robusta forest in order to achieve optimum financial return.

\section{Annual (2000-2016) maps of forest aboveground biomass in the Northwestern USA}

Andrew Hudak', Patrick Fekety², Steven Filippelli ${ }^{2}$, Michael Falkowski², Robert Kennedy ${ }^{3}$, Van Kane ${ }^{4}$, Grant Domke

${ }^{1}$ USDA Forest Service, Moscow, USA; ${ }^{2}$ Colorado State University, Fort Collins, USA; ${ }^{3}$ Oregon State University, Corvallis, USA; ${ }^{4}$ University of Washington, Seattle,USA; ${ }^{5}$ USDA Forest Service, St.Paul,USA (andy.hudak@gmail.com; patrick.fekety@colostate.edu; steven.filippelli@colostate.edu; michael.falkowski@colostate.edu; rkennedy@coas.oregonstate.edu; vkane@uw.edu; gmdomke@fs.fed.us)

Airborne lidar collections were associated with project-level field plots $(\mathrm{N}=3,805)$ to predict forest aboveground biomass $(\mathrm{AGB})$ with high confidence where lidar data were available. The plot and lidar reference data were contributed by 29 different stakeholders representing different forest types and conditions from across the northwestern USA, but nevertheless constituting a biased sample of the region. In this project, multiple project-level AGB maps served as training areas for predicting forest AGB synoptically; predicted AGB pixels were randomly drawn from the landscape-level forest AGB maps following post-stratification. Predictor variables in the regional model included annual tasseled cap indices (and annual delta indices) derived from LandTrendr (a Landsat image time series algorithm), the global forest canopy height product, a digital elevation model, and 30-year (1960-1990) climate normals produced for North America. At both the landscape and regional modeling scales, we used Random Forests (RF) as our predictive modeling tool. The regional model produced annual AGB maps at 30m resolution from 2000 through 2016 for the study region. Our verification approach was to compare the mapped annual biomass predictions to AGB estimated by the US Forest Inventory and Analysis (FIA) Program nationally at FIA plots coincident in space and time, and calculate a simple linear model bias correction to bring our AGB estimates in line with unbiased FIA estimates. National-scale forest cover maps generated independently from PALSAR data at 25-m resolution were used to mask non-forested areas from the final AGB maps prior to public archival and for monitoring, reporting, and verification (MRV).

The moja global open-source software library for integration of land sector data in support of climate change mitigation and other land management objectives

Robert Waterworth ${ }^{1}$, Werner Kurz ${ }^{2}$, Robert de Ligt ${ }^{1}$, Marcela Olguin ${ }^{3}$, Guy Janssen ${ }^{4}$

${ }^{1}$ Mullion Group, Canberra, Australia; ${ }^{2}$ Natural Resources Canada, Canadian Forest Service, Victoria, Canada; ${ }^{3}$ Mullion Group, Mexico City, Mexico; ${ }^{4}$ moja

global,Brussels, Belgium (robert.waterworth@mulliongroup.com; werner.kurz@canada.ca; robert.deligt@mulliongroup.com;

marcela.olguin@mulliongroup.com; guyjanssen ${ }^{07 j u n e @ g m a i l . c o m) ~}$

The land sector is expected to contribute to greenhouse gas emissions reductions and sinks at global, national and local levels. Policy instruments including Nationally Determined Contributions, Reducing Emissions from Deforestation and Forest Degradation, and carbon markets all require land sector greenhouse gas monitoring systems to advance rapidly if countries are to use the land sector to help meet emission reduction goals. Improving the 
spatial and temporal resolution of emissions estimates can inform policy development and verify that emissions mitigation activities are real. Access to remote sensing data that help inform land management has greatly increased in recent years, but tools to convert such data into emissions and removals estimates are still limited. Here we show the importance of spatially and temporally resolved emissions estimation methods using the Full Lands Integration Tool (FLINT), an open-source platform developed specifically to take advantage of the fine spatial and dense temporal activity data from remote sensing to produce spatially and temporally resolved emissions and removals estimates. FLINT is a modular platform that does not lock users to any specific data product, emissions estimation method or modelling approach. This allows users to start with basic methods such as global emission factors and progress to advanced models and add improved data over time within a single framework. To date, FLINT combined with scientific modules configured to country-specific needs has been applied in over 10 countries, helping build an open-source community (moja global) that ensures reduced development costs and long-term benefits for all users.

\title{
Estimating revenue and cost as well as profitability and availability of forest resources in the whole of Japan
}

Kazuhiro Arugal (D), Takahisa Yamamoto ${ }^{1}$, Yusuke Matsuoka ${ }^{1}$, Battuvshin Biligt ${ }^{2}$, Hiroaki Shirasawa

${ }^{1}$ Utsunomiya University, Utsunomiya, Japan; ${ }^{2}$ Tokyo University of Agriculture and Technology, Tokyo, Japan; ${ }^{3}$ Forestry and Forest Products Research Institute,Tsukuba, Japan (aruga@cc.utsunomiya-u.ac.jp,ma178506@cc.utsunomiya-u.ac.jp; mc196952@cc.utsunomiya-u.ac.jp; biligt.blizz@gmail.com; shirasawa@ffpri.affrc.go.jp)

We developed the model to estimate revenue and cost as well as profitability and availability of forest resources from each forestry operation site with appropriate forest operation system according to road networks and geography using GIS data processed by MATLAB in Tochigi prefecture, Japan (Yamamoto et al. online first, IJFE). We are expanding the model to the whole of Japan by obtaining GIS data for private and communal forests from other 46 prefectures and for national forests from the Japan Forestry Agency. The estimated revenue and cost as well as profitability and availability will be verified with the statistical data compiled by the Japan Forestry Agency obtained from each prefecture. Then, the model will be used to project those future values of each forestry operation site for sustainable forest management. Forest GIS data were developed separately for national forests by the Forestry Agency, and for private and communal forests by each prefecture. This is the first study of this kind combining private and communal forests with national forests, in the whole of Japan. Furthermore, existing studies developed similar models, but their units of forests were defined using $1 \mathrm{~km}^{2}$ mesh or municipality. MATLAB could be used to make estimations for the whole of Japan, within a reasonable timeframe, defining units as forestry operation sites.

\section{Multicollinearity effect on aboveground biomass estimation efficiency using spaceborne multispectral and full-waveform laser ranging data collected by the Landsat 7 ETM+ and the Global Ecosystem Dynamics Investigation (GEDI) missions}

\author{
Svetlana Saarela (D) Sören Holm $^{1}$, Paul P. Patterson ${ }^{2}$, Magnus Ekström ${ }^{1}$, Laura I. Duncanson ${ }^{3}$ (D), John Armston ${ }^{3}$ (D), James R. Kellner (D) Sean P. Healey $^{5}$,
} Göran Ståhl ${ }^{l}$ (D)

${ }^{1}$ Swedish University of Agricultural Sciences, Umeå, Sweden; ${ }^{2}$ USDA Forest Service, Fort Collins, USA; ${ }^{3}$ University of Maryland, College Park, MD, USA; 4Brown University, Providence, USA; ${ }^{5}$ USDA Forest Service, Ogden, USA (svetlana.saarela@slu.se; soren.holm@gronstenen.se; plpatterson@fs.fed.us; magnus.ekstrom@slu.se; lduncans@umd.edu; armston@umd.edu; jamesrrkellner@brown.edu; seanhealey@fs.fed.us; goran.stahl@slu.se)

Forests play a vital role in forming the environment as a habitat for multitude species influencing climate change largely by affecting the amount of carbon dioxide in the atmosphere. A need of information on state of forest attributes such as growing stock volume and aboveground biomass (AGB) is demanddriven by a number of international organizations. Typically, national forest inventory systems provide the information based on field measurements. However, the fieldwork is costly and for remote areas inefficient. With increased availability of remotely sensed (RS) data, opportunities to improve the information efficiency become noticeable. Recent developments of statistical methods within model-based inference allow to combine RS data with field measurements to obtain accurate estimates of AGB with corresponding estimated uncertainties. The two most popular estimation modes are (i) the conventional model-based, and (ii) hybrid estimator. The latter one utilizes sampled RS data. Although, the methods were proven efficient, their performances are largely dependent on the parameters of the regression models involved. In regression analysis, multicollinearity is often treated as a problem to be fixed. It is known to inflate the variance of estimated model parameters, which might lead to misjudged significant predictor variables. However, for prediction purposes, it is not clear whether multicollinearity leads to overestimation of prediction variance. This study analyzes an effect of multicollinearity on AGB estimation efficiency within modelbased inference using wall-to-wall Landsat 7 ETM+ data and sampled GEDI data. Our results show that multicollinearty lead to almost negligible effect on the AGB estimation efficiency.

\section{C4I: FOREST INVENTORY AND MODELING: PAST SUCCESSES, CURRENT CHALLENGES} AND FUTURE PROSPECTS - 2

\section{Local and regional patterns of stand development of Populus tremuloides in the southwestern United States}

Warren Moser ${ }^{1}$

${ }^{1}$ US Forest Service, Rocky Mountain Research Station, Flagstaff, AZ, USA (warren.k.moser@usda.gov)

Populus species exist across the northern hemisphere either as standalone forests or mixed with other tree species, particularly conifers. Quaking aspen (P. tremuloides Michx.) occurs in montane and high plateau environments across the Southwestern United States. Over the past several decades, reports of regional aspen decline have stimulated interest in the long-term health and viability of aspen. The U.S. Forest Service's Forest Inventory and Analysis (FIA) program has been collecting and analyzing data on aspen extent, growth and mortality since the 1990s. This paper analyzes seral and stable stands, based on patterns of disturbance, proportion of site occupancy by aspen and presence of adequate regeneration, on a national forest in Utah. The structure and dynamics of these stands are then compared with similar stands in the FIA database to evaluate trends in growth, regeneration and mortality. Of the 94 plots measured on the national forest, only $50 \%$ contained aspen trees in the understory plot and only $16 \%$ contained understory trees at least $1.9 \mathrm{~m}$ in height (20 trees in total). These results illustrate the challenge of appropriate aspen stand management: Will there be aspen trees in the future? Management actions geared to the successional state of aspen will be suggested. The patterns of dependence upon disturbance, vulnerability to successional pressures and management challenges in the face of herbivory and climate influences are common throughout the Populus genus and our results should interest anyone who manages this forest type. 


\section{A method to reduce inventory cost and projection uncertainty using a state space modeling with explicit uncertainty drivers}

Cristian Montes ${ }^{1}$, Bronson Bullock ${ }^{1}$

${ }^{1}$ Warnell School of Forestry, University of Georgia, Athens, USA (crmontes@uga.edu; bronson.bullock@uga.edu)

Under a continuing low-interest rate environment, volatile debt and equity markets, sustained yield with low uncertainty result in a very attractive incentive for timberland investors. However, in spite of the attractiveness of the investments, forest yield is also subject to volatility. Forest yield, being a function of available resources, such as nutrients, water and, temperature, is subject to variations that will depend on the inherent climatic variability at any given site. Forecasting climatic variability has become mainstream science over the last three decades, with variable rates of success; therefore, it is hard to suggest the use of climatic variables in forest applications without inducing bias in forest projections. To bridge the gap between state of the art in climate forecasting and the need to make better management decisions, we developed a framework to account for climatic uncertainty as part of the decision process, explicitly quantifying between-site differences in climatic variation and using the expected variation as part of the uncertainty term in a growth and yield model. We parametrized a loblolly pine state-space growth and yield model using the variation in climatic variables such as water deficit, excess water, and temperature as part of the uncertainty term. Our results show clear differences among areas where loblolly pine is planted in the southeast US, suggesting a potential path to include climate information as part of the decision-making framework. When combined with spatially explicit inventory data, our framework allows for a reduction in inventory costs and uncertainty projections on even-aged plantations.

\section{Comparing the form of different genetic materials of Eucalyptus using model fit and selection for taper equation}

Rafaela Pereira Naves ${ }^{1}$, Rildo Moreira e Moreira ${ }^{1}$, João Luís Ferreira Batista ${ }^{1}$

${ }^{1}$ Escola Superior de Agricultura "Luiz de Queiroz”, Universidade de São Paulo, Piracicaba, Brasil (rafaelapnaves@gmail.com; rmoreira@usp.br; batista.jlf@usp.br)

When the objective of commercial forest plantations is for the nobler uses of wood, there is the interest in genetic materials that have better forms, not only for those that produce more volume, because it is desirable trees with larger dimensions. There are several approaches to express the form of trees, simple approaches such as form factor and complex approaches such as the modeling of trunk profile through taper equations. Our objective is to identify genetic materials of Eucalyptus that have better form and search for alternatives that better express the form of trees. The experiment was performed in Itatinga, São Paulo, Brazil. We used data from 417 trees cubed from 18 genetic materials at 11 years old. Using model fit and selection, we describe the taper of trees (DBH ${ }^{2}$ as a function of height) through a linear heteroscedastic model using a trigonometric function with four parameters. The best model was the one that considered each material has its own parameters, i.e., the form of the trunk differs among them. It would not be efficient comparing the four parameters of the model among the 18 materials. We used the fitted trigonometric function to find the form factor and the Pressler Height (at which point the diameter is equal to half of the DBH). The difference in trunk profile of the genetic materials was better expressed by the Pressler height than by the form factor. We conclude that different genetic materials under the same condition may have different forms.

\section{Modelling the effects of pruning and thinning on tree- and stand-level growth for intensively-managed radiata pine plantations \\ Guillermo Trincado ${ }^{1,2}$, Roland Peters ${ }^{2}$, Luis Letelier ${ }^{2}$ \\ ${ }^{1}$ UniversidadAustraldeChile,Valdivia,Chile; ${ }^{2}$ ModeloNacionaldeSimulación(MNS),Concepción,Chile(gtrincad@uach.cl;rpeters@udec.cl;lletelier@udec.cl)}

Radiata pine (Pinus radiata D. Don) is the most important commercial tree species in Chile for producing pulp and solid wood products. These fast-grown plantations are intensively managed covering about 1.48 million hectares under a wide range of soils and climate conditions. For producing clear wood silvicultural interventions of thinning and pruning are applied on highly productive sites. The main goal of this research is to evaluate diverse approaches for modelling the short- and long-term response to pruning and thinning at individual tree- and stand-level to be incorporated into the growth and yield simulator INSIGNE. Data for this study will be obtained from long-term pruning and thinning experiments established by the MNS forest research center between 19871990 in eight locations. These experiments cover a wide range of thinning and pruning treatments (with three-repetitions) allowing for analysing long-term growth responses. Thinning and pruning response functions will be included at the stand-level basal area and at the tree-level diameter growth models. Using an independent dataset a comparison of predictive capabilities will be performed between the models including the thinning and pruning response functions over the baseline models. Furthermore, the best strategy for incorporating these response functions into the baseline models (e.g. additive or multiplicative) will be also explored.

\section{How well can we predict tree recruitment in the Acadian forest in New Brunswick using mathematical models?}

Marie-Andrée Giroux ${ }^{1}$, Ines Khedhri, ${ }^{1,2}$, Fidele Bognounou ${ }^{1,2}$, Gaétan Pelletier ${ }^{2}$, Stéphanie Landry ${ }^{2}$, Chris Hennigar ${ }^{3}$

${ }^{1}$ K.-C.-Irving Research Chair in Environmental Sciences and Sustainable Development, Université de Moncton, Moncton, Canada; ${ }^{2}$ Northern Hardwood Research Insitute Inc., Edmundston, Canada; ${ }^{3} \mathrm{New}$ Brunswick Department of Energy and Resource Development, Fredericton, Canada (marie-andree. giroux@umoncton.ca; ines.khedhri@umoncton.ca; fidele.bognounou@gmail.com; gaetan.pelletier@hardwoodsnb.ca; stephanie.landry@hardwoodsnb.ca; chris.hennigar@gnb.ca)

Natural forest regeneration is a highly variable and largely stochastic process. The patterns of forest regeneration are not well known with regards to the establishment, survival, and growth of commercial northern hardwoods species in the Acadian Forest Region. This represents an important research gap because with current global pressures such as climate change, there is a critical need to predict how commercial species will regenerate under various environmental and silvicultural scenarios. One approach to contribute filling this gap is to develop models to predict various characteristics of forest regeneration, and determine whether the predicted characteristics are correlated with observed values from field data. The main objective of this project is to compare the observed and predicted recruitment or ingrowth for different hardwood species found in the Acadian forest in New Brunswick using simulation models. Ingrowth corresponds to the number of trees in a sample plot that have grown into a required threshold size (diameter at breast height; $5 \mathrm{~cm}$ in our study) over a certain period. We used a tree list model to predict the ingrowth of sugar maple, American beech, black spruce, and balsam fir, and compared the predictions with observed values of ingrowth. The adjusted coefficients of determination (adjusted- $\mathrm{R}^{2}$ ) between the observed and predicted values varied between 0.06 and 0.4 . These results indicate that there is a need to adjust the model parameters in order to improve its prediction ability. This ongoing work will contribute producing critical modeling tools for managers, companies, and scientists from the forest sector. 


\section{Improving spatial distribution of growing stock volume (GSV) estimation using convolutional neural networks (CNNs)}

Sungeun Cha ${ }^{1}$, Hyun-Woo Jo ${ }^{1}$, Moonil Kim ${ }^{1}$, Cholho Song ${ }^{1}$, Woo-Kyun Lee

${ }^{1}$ Korea University, Seoul, Republic of Korea (tgy2005@korea.ac.kr; endeavor4_a1@naver.com; windy up@gmail.com; cholhosong@gmail.com;

leewk@korea.ac.kr)

In South Korea, where more than $63 \%$ of the country covered by forest, an accurate estimation of carbon stock is essential to understand the carbon cycle. However, current estimates of Korean growing stock volume (GSV) are mostly derived from expensive field data. Any techniques, which allows reducing amount of ground data with reliable accuracy, would save cost and time. The goal of this research is to test the Convolutional Neural Networks (CNNs) algorithm fed with a portion of the national forest inventory (NFI) data in order to predict the carbon stock for entire country using satellite imagery and auxiliary information. Spatial distribution of growing stock volume (GSV) of South Korean forests was predicted by CNNs algorithm, which is a sort of deep learning. NFI data was randomly sampled for the training from $90 \%$ to $10 \%$ in $10 \%$ increments. As a result of the analysis, more than $98 \%$ accuracy (Total GSV 713.25 $\mathrm{Mm}^{\wedge} 3$ ) of the total GSV of the NFI data was obtained when training over $20 \%$. However, when using $10 \%$ as training and $90 \%$ as validating, the estimated total GSV was $563.44 \mathrm{Mm}^{\wedge} 3$, and the accuracy was definitely reduced. Consequently, we found that the error rate of total GSV was less than $5 \%$ when using over $17 \%$ of NFI data as training.In this study, spatial distribution of growing stock volume of forests in South Korea was predicted by CNNs model based on satellite imagery, auxiliary information, and portions of NFI data.

Internet of trees: forest inventory in the internet of things age, the potential of using electronic sensors for asset monitoring and forest experiments

Esthevan Augusto Goes Gasparoto ${ }^{1}$, Maycow Berbert ${ }^{1}$, Mateus Yamoto ${ }^{1}$, Marcos Isaac Junior ${ }^{1}$, Emily Shinzato ${ }^{1}$

${ }^{1}$ Treevia Forest Technologies, São Josédos Campos, Brasil (esthevan@treevia.com.br; maycow.berbert@treevia.com.br; mateus.yamamoto@treevia.com.br; isaac.junior@treevia.com.br; emily@treevia.com.br)

The continuous forest inventory is one of the main support tools for proper management of forest assets. In order to estimate tree volume and forest growth rates, it is necessary to measure tree diameters. In spite of their extreme importance, within the forest science, the methodologies and tools to obtain and collect diameter over time, have undergone little technological evolution. Therefore, the present study aims to demonstrate the potential of using new technologies, which involve the application of IoT sensors and cloud computing, to obtain automated forest information. Electronic wireless dendrometers (IoT sensors), focused on industrial applications and fast-growing forests, have been developed and patented by the authors. Several IoT sensors were installed, along with partner companies, in commercial plantations of Pinus spp. and Eucalyptus spp. in 7 Brazilian states. The adoption of the technology has allowed to obtain data with very high precision and atsubmillimetricresolutions. In addition, it was possible to obtain real-time online information, eliminating expenses with displacement and mainly with the incidence of errors inherent to the human factor in the data collection. In addition, the technology allows the production of 600 times more information than the traditional methodologies used, helping forest researchers better understanding the interrelations of climate, site, management and forest growth.

Challenging the Peruvian government in leading the National Inventory of Forests and Wildlife: challenges and opportunities for Decision-Making / "Reto del Estado peruano en liderar el Inventario Nacional Forestal y de fauna silvestre: desafios y oportunidades para tomar decisiones"

Aurea Erica Castro Aponte

${ }^{1}$ SERFOR, LIMA, Peru (acastro@serfor.gob.pe)

El Perú, con 68,733,265 hectáreas en 2016, es uno de los 10 países con mayor cobertura forestal en el mundo y el segundo en Latinoamérica después de Brasil. En sus bosques habita gran diversidad biológica y su territorio es origen y fuente de suministro de ingentes cantidades de agua dulce proveniente de la gran cuenca amazónica. Sin embargo, estos bosques se talan anualmente a una tasa que supera las 120 mil hectáreas, tanto por acción de la agricultura migratoria y la ganadería, como por iniciativas privadas empresariales y por actividades mineras. Existe la necesidad de priorizar en la Política de Estado la generación de información actual del bosque En este contexto, el Estado peruano implemento el Inventario Nacional Forestal y Fauna Silvestre-INFFS el año 2012 como un esfuerzo conjunto del gobierno a través del Ministerio de Agricultura y Riego y el Ministerio del Ambiente, y del Programa Forestal Global FAO-Finlandia. El INFFS su objetivo es "proveer en forma continua información actualizada y confiable para la planificación del manejo sostenible de los recursos forestales de las regiones Selva, Sierra y Costa peruanas, colectando, procesando y reportando datos sobre la biomasa, reservas de carbono, deforestación, biodiversidad de árboles y fauna silvestre e información socioeconómica de las poblaciones rurales asentadas en su entorno". Finalmente, los inventarios son esenciales para la gestión forestal y como herramienta clave para los tomadores de decisión, posibilitando una gestión sostenible del recurso forestal para los privados (productores y empresas) y Administraciones públicas (ministerios y secretarias del Estado/Gobierno).

C4m: DECISION SUPPORT APPROACHES FOR FORESTRY OF THE $21 T H$ CENTURY - 2

\section{Simulating impacts of local forest policies on forest ecosystem functions}

Yusuke Yamada ${ }^{1}$; Yuichi Yamaura ${ }^{1}$, Masayoshi Takahashi ${ }^{1}, K_{a z u k i}$ Nanko $^{1}$, Toshiya Matsuura ${ }^{1}$, Shoji Hashimoto ${ }^{1}$, Norimasa Takayama ${ }^{1}$, Kenichiro Toda ${ }^{2}$, Tamotsu Sato ${ }^{1}$

${ }^{1}$ Forestry and Forest Products Research Institute, Tsukuba, Ibaraki, Japan; ${ }^{1}$ Forestry and Forest Products Research Institute, Tsukuba, Ibaraki, Japan,

${ }^{2}$ Nagano Prefecture Forestry Research Center, Shiojiri, Nagano, Japan (yamayu@ffpri.affrc.go.jp; yamaura@ffpri.affrc.go.jp; martaka@ffpri.affrc.go.jp;

knanko@ffpri.affrc.go.jp; matsuu50@ffpri.affrc.go.jp; shojih@ffpri.affrc.go.jp; hanri@ffpri.affrc.go.jp; toda-kenichiro@pref.nagano.lg.j

Forest policies are designed to achieve desirable forests, however, the policies might not produce the intended results due to multiple decision makers of forestry activities. Simulating influences of policies on forest functions are vital to support policymaking. This research aims to estimate impacts of local forest policies on forest ecosystem functions in Japan. The impacts of policies are estimated by comparing current and future situations. To predict the future forest conditions, forestry harvesting by decision makers in the region is simulated. The simulation specifies the location of forestry harvesting according to probabilities that are defined by analysis of past harvesting location. The past harvested forests are identified with Hansen's forest loss data (http://earthenginepartners.appspot.com/science-2013-global-forest). The probabilities of harvesting are modified in each simulation according to forest policies. This research predicts future forest conditions under policies to promote wood 
production and/or to alleviate the impacts of forestry harvesting. Then, forest ecosystem functions including wood production, biodiversity, soil conservation, carbon retention, protection from landslides, and recreation functions are evaluated for the current and simulated forests. The evaluation models are developed with national forest inventory data. Results of the simulation indicated that the increase in wood production impaired the future forest ecosystem functions, but not to the point where the local forest was harmed disastrously. The simulation also suggested that the regulation on harvesting in the appropriate area could alleviate the impacts. These results can support establishing policies to manage local forest sustainably.

\section{Mechanistic forest growth simulation versus empirical growth tables in spatio-temporal decision support for forest management}

Ilié Storms ${ }^{1}$, Bruno Verbist ${ }^{1}$, Jos Van Orshoven ${ }^{1}$, Christopher Reyer ${ }^{2}$, Bart Muys $^{1}$

${ }^{1}$ KU Leuven Division Forest, Nature and Landscape, Faculty of Bioscience Engineering, Leuven, Belgium; ${ }^{2}$ Potsdam Institute for Climate Impact Research,

Potsdam,Germany (ilie.storms@kuleuven.be; bruno.verbist@kuleuven.be; jos.vanorshoven@kuleuven.be; reyer@pik-potsdam.de; bart.muys@kuleuven.be)

Decision support systems (DSS) are becoming more widespread in forest management, helping to shape the forests of the future. These systems allow foresters to simulate future forest performances under expected or hypothetical conditions and select the most optimal forest management strategy based on the simulations results and stakeholders' preferences. To increase forest managers' awareness about the long-term effects of their management, a DSS called Sim4Tree was developed for Flanders, Belgium and has been operational for almost a decade. Sim4tree is a strategic and tactical planning tool that performs simulations of forest development based on traditional empirical growth curves, which, thanks to the flexible Sim4Tree structure, can be easily replaced by other growth models. Unfortunately, empirical growth curves do not allow easily taking into account dynamic processes such as those related to changing management practices and climate change. By plugging in the mechanistic forest growth model '4C (FORESEE)' these changing conditions can be accounted for, allowing to predict future biomass standing stock under different management and climate scenarios in Flanders. Our research shows the possibility of using national forest inventory (NFI) data to parameterize mechanistic models and illustrates the importance of mechanistic models in DSS by evaluating different management (business as usual, production oriented and recreation oriented) and climate scenarios and how these compare to the results from the empirical growth tables and the NFI. The results will improve the performance of Sim4Tree to support the choice for optimal future-oriented forest management scenarios.

\section{Harvest schedule under price endogeneity: linking field operations to market decisions}

Bruno Kanieski da Silva ${ }^{1}$, Frederick W. Cubbage ${ }^{1}$, Robert C. Abt ${ }^{1}$, Karen L. Abt ${ }^{2}$

${ }^{1}$ North Carolina State University (NCSU), Raleigh, USA; ${ }^{2}$ U.S. Forest Service, Southern Research Station, RTP, USA (bkanies2@ncsu.edu; cubbage@ncsu.edu;bob_abt@ncsu.edu; kabt@fs.fed.us)

Harvest schedule models are a common decision-making system used by forest planners and practitioners. These models assume timber prices are exogenous to timber supply and use operational and biological constraints to decide the optimal silvicultural prescriptions. However, this assumption does not necessarily hold since few landowners might have a large share of timberland in a market, and therefore their harvest decision might substantially affect the market supply and prices. We built a decision support system where timber prices are endogenous to timber suppliers; the silviculture operations are therefore a function of common production restrictions and also from the interaction with other market agents. Users have the option to estimate the optimum allocation of a resource based on other landowners' decision in a game theory set up. Initial results demonstrated a more realistic representation of business strategy in concentrated markets. In addition, the approach presented complements the partial equilibrium models by linking decision in the field and market shocks.

\section{FORSITE - a dynamic forest site classification to support adaptive forest management}

Harald Vacik ${ }^{1}$ (D; Herbert Formayer ${ }^{1}$, Klaus Katzensteiner ${ }^{1}$, Michael Grabner ${ }^{1}$, Marcus Wilhelmy $^{2}$, Michael Englisch $^{3}$, Klaus Klebinder $^{4}$, Herwig Proske $^{5}$, Walter Poltnig ${ }^{6}$, Gerfried Winkler ${ }^{7}$, Ralf Klosterhuber ${ }^{8}$, Alexander Podesser $^{9}$

${ }^{1}$ University of Natural Resources and Life Science, Vienna, Austria; ${ }^{2}$ ALPECON Wilhelmy e.U. Technisches Büro für Geowissenschaften, Telfes im Stubaital, Austria; ${ }^{3}$ Austrian Research Center for Forests, Vienna, Austria; ${ }^{4}$ Austrian Research Center for Forests Forest Office, Vienna, Austria; ${ }^{5}$ Joanneum Research, Graz, Austria; ${ }^{6}$ JR-AquaConSol GmbH, Graz, Austria; ${ }^{7}$ Karl-Franzens-Universität, Graz, Austria; ${ }^{8}$ WLM Tyrol - Vegetation Ecology and Environmental Planning, Innsbruck, Austria; ${ }^{9}$ Zentralanstalt für Meteorologie und Geodynamik, Wien, Austria (harald.vacik@boku.ac.at; herbert.formayer@boku.ac.at; klaus.katzensteiner@boku.ac.at; michael.grabner@boku.ac.at; m.wilhelmy@alpecon.at; michael.englisch@bfw.gv.at; klaus.klebinder@bfw.gv.at; herwig.proske@joanneum.at; walter.poltnig@jr-aquaconsol.at; gerfried.winkler@uni-graz.at;ralf.klosterhuber@wlm.at; alexander.podesser@zamg.ac.at)

For the selection of appropriate tree species mixtures forest management asks for a sound database on forest site information especially under the consideration of climate change. Adaptive forest management takes into account the likely effects of climate change and innovative decision support approaches can help to increase the resistance and resilience of forest ecosystems. The lack of forest site information in large parts of Austria asks for a new approach in forest site classification and mapping. Climate change will affect the classification of forest sites and the future choice of tree species. Theoretical concepts for a "dynamic site classification" exist, but its large scale implementation as an integrated site and forest classification is a scientific challenge. In this contribution we present the approach based on a GIS-based geo-ecological stratification model. The database is based on a digital elevation model, a geological base map, digitally available site and climate data as well as empirical site parameters. A map of forest types will be derived based on thematic maps, including information about energy, water and nutrient balance. Those parameters will be modelled on the basis of point and area related data, which are combined to forest types with a uniform combination of site factors. The model allows a dynamic stratification of the forest types based on a logical combination of the geo-ecological parameters. In addition to the ecological facts, each forest type is characterized by silvicultural guidelines containing information on the choice of tree species, potential hazards and adaptive forest management practices.

\section{Managing forests for water harvesting under changing future climate in Korea using the WEPP model

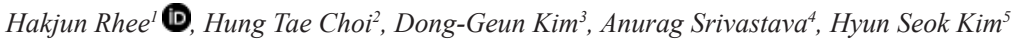 \\ ${ }^{1}$ Chungnam National University, Daejeon, Republic of Korea; ${ }^{2}$ National Institute of Forest Science, Seoul, Republic of Korea; ${ }^{3}$ Kyungpook National University, Sangju, Republic of Korea; ${ }^{4}$ Purdue University, West Lafayette, USA; ${ }^{5}$ Seoul National University, Se (hakjun.rhee@gmail.com; choiht@korea.kr; dgkim96@knu.ac.kr; srivas42@purdue.edu; cameroncrazies@snu.ac.kr)}

Forest provides various ecosystem services, and can be managed for water resources. This study accesses the effects of forest management on water harvesting by applying the Water Erosion Prediction Project (WEPP) model to unit area (1 hectare) of different forest stands (coniferous, deciduous, and mixed) and management activities (control, 30\%, 50\% thinning) under current and future climates at three locations in Gwangneung and Yangju, Korea. The modeling 
results from no management activities were compared to stream runoff monitoring data from 2003 to 2017, which showed the Nash-Sutcliffe efficiency of $0.700,0.660$, and 0.557 . The WEPP predicted the average runoff of 813,813 , and $736 \mathrm{~mm} / \mathrm{m}^{2} /$ year, compared to the monitored average runoff of 797,1011 , and $724 \mathrm{~mm} / \mathrm{m}^{2} /$ year for coniferous, deciduous, and mixed forests. The WEPP also predicted the runoff increase of 75.2 and $84.2 \mathrm{~mm} / \mathrm{m}^{2} / \mathrm{year}$ from $30 \%$ and $50 \%$ thinning for coniferous, 74.9 and $83.7 \mathrm{~mm} / \mathrm{m}^{2} /$ year for deciduous, and 59.5 and $67.5 \mathrm{~mm} / \mathrm{m}^{2} /$ year for mixed forest. These runoff increases were not enough to warrant thinning operations economically under current climate in Korea. The study finds that the WEPP can be used to accesses the effects of forest management on water harvesting. The WEPP will be further applied to the three forests under future climates, and up-to-date assessment on the modeling will be presented. The modeling approach from this study will be used to develop online WEPP interface for water harvesting that is later incorporated into multiobjective forest management decision support system in preparation for new climate era.

\section{Biodiversity assessment in plantation forests of Northern Portugal with fuzzy-logic approach}

Marija Cosovic ${ }^{1}$, Peter Biber ${ }^{2}$, Brigite Botequim ${ }^{1}$, Miguel Bugalho ${ }^{3}$, José Guilherme Borges ${ }^{1}$

${ }^{1}$ Forest Research Centre, School of Agriculture, University of Lisbon, Lisbon, Portugal; ${ }^{2}$ Center of Life and Food Sciences Weihenstephan, Technical University of Munich, Freising, Germany; ${ }^{3}$ Center for Applied Ecology "Prof. Baeta Neves”, School of Agric (cosovicmaja@gmail.com; peter.biber@lrz. tu-muenchen.de; bbotequim@isa.ulisboa.pt; migbugalho@isa.ulisboa.pt; joseborges@isa.ulisboa.pt)

Biodiversity in forest management planning recently became a necessity for ensuring regular ecosystem functioning, resilience and sustainability. The specific objective of this research was to examine biodiversity at the stand-level in plantation forests. The case study area in Vale de Sousa, the North of Portugal, (14.773 ha) is mainly taken by plantation forests of maritime pine and blue gum in pure and mixed stands. Fuzzy logic for evaluating biodiversity and other ecosystem services was recently proposed and demonstrated by P. Biber in the context of the EU project ALTERFOR. In this study, we applied a fuzzy-logic approach for testing three biodiversity indicators: tree speciescomposition, tree mortality and shrub biomass $\left(\mathrm{Mgha}^{-1}\right)$. This approach gives values between 0 (very low) and 1 (very high) provision of biodiversity categories and allows qualitative value-rules in relation to these four indicators. The value-rules are established according to stakeholder's knowledge and validated by experts. The values of each indicator are expressed in a form of colored matrices and a final fuzzy output of biodiversity is expressed as a continuous score between 0 and 1 . The results demonstrate that monoculture stands have the lowest score for biodiversity due to the zero level of each indicator after the clearcut. Mixed stands have different periods of clearcut and this contributes to a higher score for biodiversity in general (fuzzy-output). The fuzzy-logic approach is a very useful tool as it provides powerful reasoning resources for decision support, capturing the qualitative assessment given by stakeholders and subsequently enabling quantitative results.

\section{A multi-criteria decision support system for industrial forest plantations interactive management groups based on compromise programming}

Silvana Nobre ${ }^{1}$ (D; Luis Diaz-Balteiro ${ }^{1}$ (D); Luiz Carlos Rodriguez ${ }^{2}$ (D); Luiz Fellipe Arcalá ${ }^{3}$

${ }^{1}$ Universidad Politécnica de Madrid - ETSI de Montes, Forestal y del Medio Natural, Madrd, Spain; 'Escola Superior de Agricultura "Luiz de Queiroz", Universidade de São Paulo, Departamento de Ciências Florestais, Piracicaba, Brasil; ${ }^{3}$ Innovatech, Consultin (silvana.rnobre@gmail.com;

luis.diaz.balteiro@upm.es; lcer@usp.br; larcala@innovatech.com.br)

Forest plantation managers face many conflicts as they continuously seek higher productivity levels at lower costs and higher profits with minimum social and environmental impacts. Leading countries on timber, pulp, and fiberboard have their managers constantly interacting to fine-tune industrial and forest demands. The decision process needs a compromise solution to accommodate antagonisms. The multicriteria approach may be applied since it sustains that decision makers seek to find a balance between objectives usually in conflict. Decision Support Systems (DSS) employ computer-assisted optimization approaches, which have been used since the early 1960s. Nowadays, multi-objective Group Decision Making (GDM) techniques rely on new coming technology platforms that have empowered models and software developers. We present a DSS that overcomes the challenges brought by the real-life mix of goals confronted by the managers. We have applied the MCDM (Multi-Criteria Decision Making) approach to Forest Strategic Planning using a generalizable MOLP (Multi-Objective Linear Programming) and Compromise Programming embedded in a DSS that offers an interactive GDM (Group Decision Making) interface. It was tested on a Brazilian case to assess the capability of supporting decisions of stakeholders representing industrial, forest, social and environmental interests. The decisions concerned the management of 20 thousand hectares of eucalyptus plantations to supply a wood panel plant in the State of Mato Grosso do Sul, Brazil. As a result, the proposed DSS mapped the consequences to the future of the plantations as changes in macro-economic context, investors' strategies and climate interacted, creating challenging and conflictive situations.

\section{Achieving dynamic treatment units in forest planning using pixel proximity}

Pär Wilhelmsson ${ }^{1}$, André Wästlund ${ }^{1}$, Karin Öhman ${ }^{1}$

${ }^{1}$ Department of Forest Resource Management, SLU, Umeå, Sweden (par.wilhelmsson@slu.se; andre.wastlund@slu.se; karin.ohman@slu.se)

Conventional forest planning today is based on the stand approach. The forest is divided into stands, homogeneous in aspects relevant to the upcoming forestry and fixed over time. Most often treatments are applied the entire stand. Past studies have reasoned that this limits flexibility when striving for goal achievement and they have also shown that this is not the only approach possible. Another is the dynamic treatment unit approach. Here the concept of the stands is neglected. The forest data consists of small pixels which is made possible by advances in remote sensing. The treatment units exist only momentarily and are formed by clustering treatments in space and time. The objective of this study is to present a model for conducting forest planning by the dynamic treatment unit approach where the planning problem could be solved with an exact solution method. The spatial aspect of the model is represented by a metric which takes into account treatments of neighboring pixels within a radius from a given pixel. The presented model is in a case study included in a forest planning problem including the net present value, the spatial metric and harvest flow constraints. The data consists of 3587 pixels of $12,5 \times 12,5 \mathrm{~m}$ corresponding to 56 ha of forest land in the southwest of Sweden. The results proved the model to be successful in achieving the DTUs and solved the problem within reasonable time. This study adds a method to achieve dynamic treatment units in forest planning. 


\section{Use of unmanned aerial vehicles in forest consulting: opportunities and barriers}

Patrícia Nazário ${ }^{1}$

${ }^{1}$ Ekoflow Soluções Ambientais, União da Vitória, Brasil (pattyinpa78@gmail.com)

Unmanned aerial vehicles (UAVs), also known as Drones or RPAS, have been increasingly used in precision forestry, because allows the generation of images with a level of detail higher than traditional satellites. The use of UAVs in the forestry sector is broad, been possible to replace traditional methods of plant survival evaluations, with advantages in terms of accuracy and cost. Using a laser active sensor (LiDAR) platforms, data such tree height can be obtained directly and volume and basal area are obtained indirectly. From images captured by RGB sensors, it is possible to estimate the wood stock in the field by applications for mobile. Yet, the application still restricted, with great potential for growth as result of advances in scientific research, with about 3000 articles published on applications of UAVs in forests in 2018. Futhermore, the offer of UAVs with good cost and performance for different jobs in the forest area been increasing, some manufactured by DJI may be highlighted: Phantom and Mavic. However, it is necessary to invest in training and instruments, to offer good services and products, leveraging market. Although the cost of acquiring a UAV has become more affordable, equipment for image processing (hardware and software) are costly, and it is necessary investment in good processors, GPUs, RAM and devices with high storage capacity, the acquisition of a software license stay expensive. If the service is volume calculation of forest assets, may be necessary to invest more in the UAV acquisition and the LiDAR system.

\section{Unmanned Aerial System LiDAR data as basis for in-situ forest inventories}

Markus Hollaus ${ }^{1}$, Wilfried Karel ${ }^{1}$, Norbert Pfeifer ${ }^{1}$, Moritz Bruggisser $^{1}$, Martin Wieser ${ }^{1}$, Magnus Bremer ${ }^{2,3}$, Martin Rutzinger ${ }^{3}$, Di Wang $^{4}$, Guenther Bronner ${ }^{5}$ ${ }^{1}$ Department of Geodesy and Geoinformation, TU Wien, Vienna, Austria; ${ }^{2}$ Institute of Geography, University of Innsbruck, Innsbruck, Austria; ${ }^{3}$ Institute of Interdisciplinary Mountain Research (IGF), Austrian Academy of Sciences (ÖAW), Innsbruck, Austria; ${ }^{4}$ Department of Built Environment, Aalto University, Helsinki, Finland; ${ }^{5}$ Umweltdata GmbH, Wolfsgraben, Austria (markus.hollaus@geo.tuwien.ac.at; wilfried.karel@geo.tuwien.ac.at; norbert.pfeifer@geo.tuwien.ac.at; moritz.bruggisser@geo.tuwien.ac.at;martin.wieser@geo.tuwien.ac.at; magnus.bremer@uibk.ac.at; martin.rutzinger@oeaw.ac.at; di.wang@aalto.fi;g.bronner@umweltdata.at)

The investigation of new acquisition methods for acquiring in-situ forest inventories (FI) is an active research field today. The fast technological development of terrestrial laser scanner (TLS) during the last years allows the 3D reconstruction of entire forest scenes with cm-accuracy. Even though the estimation of tree position and diameter at breast height $(\mathrm{DBH})$ is possible with precisions that are comparable with traditional in-situ measurements, the tree height estimation is often hampered due to occlusions of the tree tops. In the last years several lightweight, survey-grade LiDAR sensors mounted on unmanned aerial systems (UAS) were developed and are available on the commercial market. These so-called UAS-LiDAR devices open up new possibilities for FIs. The acquired 3D point clouds enable the 3D modeling of individual trees up to branch level and thus tree position, tree height, taper function, DBH and forest structure can be derived with different levels of detail. The advantage of UAS-LiDAR is the estimation of tree heights with very high precision especially for the dominant and codominant trees. In the opposite suppressed trees are often not represented in the derived 3D point cloud and consequently their tree position and height can not be assessed. Within this contribution data sets from different survey-grade UAS-LiDAR systems will be shown. The accuracy and completeness of the derived forest attributes for several coniferous and deciduous forest sites in Austria will be presented. Finally, a framework of integrating this type of data into operational FIs will be discussed.

\section{Comparison of above canopy and below canopy laser scans using UAV and mobile laser scanning method}

Peter Surovy ${ }^{1}$, Karel Kuželka ${ }^{1}$,Martin Slavik ${ }^{1}$, Lukáš Bílek ${ }^{1}$

${ }^{1}$ Czech University of Life Sciences Prague, Prague, Czech Republic (surovy@fld.czu.cz; kuzelka@fld.czu.cz; mslavik@fld.czu.cz; bilek@fld.czu.cz)

Laser scanning from UAV based platforms is recently becoming innovative way to obtain data from forests ecosystems. It provides detailed 3D point clouds with accuracy within centimeters. In contrast to UAV photogrammetry the movement of sensor can be faster, and it also improve reconstruction of the ground and the partially shaded area.In this work we present a comparison of the same laser scanner type (Riegl VUX 1) deployed in the first case on the UAV platform Riegl Ricopter and in the second one on the ground using backpack career for acquisition of the data from the same forest stand. The aerial scanning is faster and more comfortable, on the other hand the terrestrial mobile scanning does not require flight permission and highly trained personnel. In terms of time consumption the ground acquisition takes more time, on the other hand flying requires pre- and post- flying procedures which makes the overall time requirements comparable for both scenarios.Studied stand is 60 year old pine forest (Pinus sylvestris) of 0.8 stocking density. By both methods the tree amount recovered was $100 \%$, the ground based method has higher error in terms of height and diameter at breast height mostly due to the misalignment of individual walks (scans), the aerial method provides more accurate and precise measurement of both of these two variables. The ground method, though provides higher density of points on the stems and bottom part of crowns and the stem cleanness and tapper can be more precisely estimated from these data.

\section{Inter-comparison of UAV SfM and UAV LiDAR to capture understorey structural characteristics}

Samuel Hillman ${ }^{1}$, Luke Wallace ${ }^{1}$, Arko Lucieer ${ }^{2}$, Karin Reinke ${ }^{1}$, Darren Turner ${ }^{2}$, Simon Jones ${ }^{1}$, Bryan Hally ${ }^{1}$

${ }^{1}$ RMIT University, Melbourne, Australia; ${ }^{2}$ University of Tasmania, Hobart, Australia (samuel.hillman@student.rmit.edu.au; luke.wallace2@rmit.edu.au; arko.lucieer@utas.edu.au; karin.reinke@rmit.edu.au; darren.turner@utas.edu.au; simon.jones@rmit.edu.au; bryan.hally@rmit.edu.au)

Estimates of below canopy vegetation have been identified as an important variable for wildlife habitat diversity, precision forestry, fuel hazard modelling and understorey forest competition dynamics. While Unmanned Aerial Vehicles (UAV) equipped with digital cameras and laser scanners are being increasingly used to measure overstorey canopy metrics variables, less emphasis has been placed on their ability to characterise the below canopy vegetation. The paper explores 3D information collected using UAV platforms for describing structural properties. Sensors including the Reigl mini-VUX, Velodyne Puck, Sony Alpha 6000 and DJI Phantom pro-4 were deployed in a range of common forest types in Australia to capture 3D information for comparison. Sub-canopy metrics including height and cover were derived and compared to reference data collected using a Terrestrial Laser Scanner. Results suggest that changes in canopy characteristics of density and height along with below-canopy characteristics of near-surface and surface cover and height can be resolved to varying degrees using both sensors. The image based approach is able to characterise the understorey of sparse cover environments with acceptable accuracy (cover $+/-10 \%$ and height $<$ $0.5 \mathrm{~m}$ ). However in higher cover, multi-storey environments this technology is not accurate. The LiDAR scanners perform better in these environments with the 
multiple returns offered by the mini-VUX scanner offering the greatest opportunity to observe below canopy structure. The relative low-cost in combination with accurate assessments of forest structure, UAV approaches represent a viable technique to provide forest policy makers with the information required to make informed decisions for implementing management strategies.

\title{
Regeneration behaviour of Okoume' Aucoumea klaineana in canopy gaps of a forest concession in Gabon
}

Christian Aeschlimann ${ }^{1}$

${ }^{1}$ Bern University of Applied Science,Bern, Switzerland (christian.aeschli@gmail.com)

From an economic perspective, Okoumé is the most important tree species of Gabon. However, since it is considered as a long living pioneer species regeneration under selective harvesting management is insufficient. In a first step, the current state was analysed based on intense literature review and conduction of expert knowledge. In addition, an inventory as a chrono sequence was performed on two sites where selective harvesting interventions took place in 2017, 2016, 2015, 2014 and 2010. In total 46 plots were installed in logging gaps in order to assess the regeneration dynamic of Okoumé. One site is embossed by aged Okoumé forest, while the other one is of very young Okoumé forest type. Even though regeneration in the logging gaps with an average size of $470 \mathrm{~m}^{2}$ was not sufficient, regeneration in the very young Okoumé forest type was significantly higher than in the aged Okoumé forest type. A correlation between average distance of seed trees to the logging gap could be observed. Additionally, a low-budget drone was used to surveying the area of inventory plots whereof orthomosaics were generated and an automatic model for detecting logging gaps was performed. As was already well known that regeneration of Okoumé in gaps smaller 0,25 ha is almost not possible, the study confirms these observations and concludes, that silvicultural treatments need to be adapted to the species requirements in order to guarantee sustained yield in the long run.

\section{Use of UAS thermal imagery to identify dead standing timber as part of forest mortality monitoring}

\author{
Alexander Bilyk', Reino Pulkki ${ }^{1}$, Guy LaRocque ${ }^{2}$, Chander Shahi ${ }^{1}$ \\ ${ }^{1}$ Lakehead University, Thunder Bay, Canada; ${ }^{2}$ Canadian Forest Service, Quebec City, Canada (ambilyk@lakeheadu.ca; rpulkki@lakeheadu.ca; \\ guy.larocque@canada.ca; cshahi@lakeheadu.ca)
}

The use of FLIR thermal cameras has risen with drones, especially in the search and rescue and fire-fighting fields. This has caused the price of these sensors to become more affordable and allow new and novel research ideas to be explored. In this study we flew over 50 forest research plots, capturing $6400 \mathrm{~m}^{2}$. The purpose of this flight was to identify the location of all dead-standing timber as part of the permanent growth and yield monitoring program. The current field method requires field staff to walk the entire area and attempt to identify all dead trees from the ground. This is both time-consuming and can lead to errors with trees being missed. The FLIR thermal images allow for the rapid identification of dead standing timber, as dead trees glow in the thermal spectrum. This information was compared to the mortality counts conducted by ground crews and a comparison was completed to look at the effectiveness of this technology in augmenting the field crew measurements. By making the identification of mortality trees an automated process, the ground crew was able to focus on collecting relevant information without walking aimlessly in the field. The images also act as a permanent record, allowing for scientists to look at how these plots are changing over time as trees mature and die out of the canopy.

\section{C40: REGIONAL FOREST OBSERVATIONS FOR SUSTAINABLE FOREST MANAGEMENT - II}

High-resolution spatial imagery for demarcating the forest in Galilea, Colombia: towards declaring protected areas / Imágenes de alta resolución espacial para la delimitación del bosque de Galilea, Colombia: hacia la declaratoria de áreas protegidas

Uriel Pérez Gómez ${ }^{1}$ (D); Luis Pérez Vasquez ${ }^{1}$ (D; Miguel Ángel Ouimbayo Cardona ${ }^{1}$

${ }^{1}$ Universidad del Tolima, Ibagué, Colombia(uperez@ut.edu.co; laperezv@ut.edu.co; miguelq@ut.edu.co)

Actualmente en el bosque de Galilea, localizado en el departamento del Tolima-Colombia, se realizan actividades de exploración petrolera. Hoy en el mundo una alternativa a esta situación es la declaratoria de área protegida.El objetivo de la investigación es proporcionar un área límite, como línea base para la definición de la protección del bosque de Galilea, a escala 1:25000. La metodología utilizada considera el uso de nueve imágenes de alta resolución espacial del sensor PlanetScope tomadas el 16 de mayo de 2017, con cobertura de nubes inferior al $10 \%$, correcciones radiométricas y geométricas, y ortorectificadas. Las imágenes fueron interpretadas en pantalla con el fin de delimitar la categoría Bosque y otras zonas naturales tomadas del sistema de clasificación Corine Land Cover adaptado para Colombia. El proceso consideró la actualización del límite del área de Bosque existente de otra fecha, y obtenido bajo el mismo sistema de clasificación. Para el trabajo de verificación en campo se utilizó un muestreo estratificado con afijación proporcional, y se analizó una matriz de confusión para determinar tanto la fiabilidad global como la del usuario y del productor. Finalmente, el límite del área propuesta se ajustó, apoyado en el análisis de otra información geográfica disponible y a los lineamientos proporcionados por el Ministerio de Ambiente y Desarrollo Sostenible paradeclaratoria de área protegida.Se construye un sistema de información geográfico bajo el sistema de coordenadas EPS:3116 y documentado de acuerdo a las normas establecidas por el grupo de trabajo 28 del Instituto Colombiano de Normas Técnicas

\section{Spatial patterns of logging-related disturbance events: preliminary results from a multi-scale analysis on forest management units located in the Central Brazilian Amazon}

Thais Almeida Lima ${ }^{1}$, René Beuchle ${ }^{2}$, Astrid Verhegghen ${ }^{2}$, Verena C. Griess ${ }^{1}$, Peter Vogt ${ }^{2}$

${ }^{1}$ University of British Columbia, Vancouver, Canada; ${ }^{2}$ European Commission, Joint Research Centre, Ispra, Italy (tha.almeida.lima@gmail.com; rene.beuchle@ec.europa.eu; astrid.verhegghen@ec.europa.eu; verena.griess@ubc.ca; peter.vogt@ec.europa.eu)

In the Brazilian Amazon selective logging can reach an area as big as that reported as deforested. Medium resolution satellites, such as Landsat, have long been used to assess the extent of selectively logged forests in the region. However, studies addressing the spatial pattern of logging are rare. In addition, the use of input data sets with less than $30 \mathrm{~m}$ spatial resolution are still scarce. The present study describes the spatial patterns of selective logging in 12 forest management units (FMU), located near the village of Santo Antônio do Matupi, State of Amazonas, Brazil. Selective logging was mapped for the years 2016-2017, using $10 \mathrm{~m}$ spatial resolution Sentinel-2 imagery. The input data for the spatial pattern analysis was a binary map of disturbedundisturbed forests produced using the Delta rNBR approach. Two pattern metrics (proportion and contagion) were extracted from square moving windows with different sizes. These two metrics were 
used to classify the disturbed areas in five classes of disturbance, ranging from very low to very high. These classes were compared with different categories of logging infrastructure mapped in the field. They were also linked with forest recovery by post-harvest values of the rNBR index. Log landings and logging roads were associated with high disturbance intensity classes, whereas very low disturbance intensity was linked with isolated disturbance types. Post-harvest values of rNBR showed different degrees of forest recovery for patches with different disturbance intensities, indicating that the five classes of disturbance can be linked with actual disturbance types.

Using satellite imagery components in spatial modeling of volume in stands of Eucalyptus sp. / Uso de componentes de imagens de satélites na modelagem espacial do volume em povoamentos de Eucalyptus sp.

Livia Lanzi Aló ${ }^{1}$, Cláudio Roberto Thiersch ${ }^{2}$, Antônio César Germano Martins ${ }^{3}$, Mônica Fabiana Bento Moreira Thiersch ${ }^{2}$, Rafael Mingoti ${ }^{4}$, José Raimundo de Souza Passos ${ }^{1}$, Rafael Costa Pinheiro ${ }^{1}$

${ }^{1}$ Universidade Estadual Paulista "Júlio de Mesquita Filho”, Faculdade de Ciências Agronômicas , Botucatu, Brasil; '2Universidade Federal de São Carlos, Sorocaba, Brasil, ${ }^{3}$ Universidade Estadual Paulista "Júlio de Mesquita Filho", Instituto de Ciência e Tecnologia de Sorocaba, Sorocaba, Brasil; ${ }^{2}$ Universidade Federal de São Carlos, Sorocaba, Brasil; 'Embrapa Gestão Territorial, Campinas, Brasil (livialanzi@yahoo.com.br; crthiersch@ufscar.br; amartins@sorocaba.unesp.br; monicathiersch@ufscar.br; rafael.mingoti@embrapa.br; jrpassos@ibb.unesp.br; rafamic_10@hotmail.com)

Uma maneira de conhecer o comportamento espacial de um plantio e aumentar a precisão das estimativas de volume seria utilizar interpoladores geoestatísticos, como a krigagem ordinária (KO) e a krigagem deriva externa (KDE), está última utiliza, além da variável espacial, variáveis auxiliares. As imagens de satélites possuem diferentes componentes que se correlacionam com as variáveis dendrométricas podendo ser usados como variáveis auxiliares. O objetivo foi avaliar o desempenho da KDE na estimativa do volume de um povoamento de Eucalyptus sp., utilizando componentes de imagens como variáveis auxiliares e comparála com a KO. Estimou-se o volume por parcela partir de um inventário de 210 parcelas. Foram extraídos das imagens (SPOT-6) obtidas da área, o nível de cinza das bandas, a razão entre as bandas, índices de vegetação, medidas de textura e índices gerados a partir das texturas. Para KDE, ajustou-se o modelo de covariância através do método Stepwise e a seleção pelo método AIC (Critério de Informação de Akaike). Os semivariogramas KDE e KO foram ajustados por diferentes modelos teóricos e a escolha do modelo se deu pelo menor valor do erro padrão residual. O modelo de covariância selecionado explicou 91\% do volume foi composto por banda verde, textura de correlação da banda verde, índice de textura de correlação multiplicado pela banda azul e pela idade. Nos dois semivariogramas, o modelo que melhor se ajustou foi o exponencial. As estimativas de volume geradas pela KDE produziram melhores resultados que as estimativas da KO, obtendo o menor valor de erro padrão residual.

\section{Rapid, automated tree coverage measurement using a convolutional neural network}

Tess Russo ${ }^{1}$, Courosh Mehanian², Shawn McGuire ${ }^{2}$, James Daniel ${ }^{3}$, Ben Wilson ${ }^{2}$, Marie Connett ${ }^{1}$

${ }^{1}$ Global Good, Bellevue, USA; ${ }^{2}$ Intellectual Ventures Laboratory, Bellevue, USA; ${ }^{3}$ Consultant, Nairobi, Kenya; ${ }^{2}$ Intellectual Ventures Laboratory, Bellevue,

USA (trusso@intven.com; cmehanian@intven.com; smcguire@intven.com; jd4consulting@gmail.com; bwilson@intven.com; mconnett@intven.com)

In the Bonn Challenge, multiple companies, NGOs, and governments committed to restoring nearly 350 million hectares of degraded lands by 2030. Data on land cover contributions to carbon fixation are needed by governments to comply with climate change treaties and can be critical to guide economic incentives for farmers. Current monitoring methods employed by the World Agroforestry Centre (ICRAF) and the US Geological Survey require individuals to view imagery and manually enter observations. At rates suggested, it would take nearly 730 FTE years to evaluate just $10 \%$ of the Bonn Challenge land restoration commitment, which almost certainly precludes ideal rates of monitoring to evaluate and refine the process of implementation. A rapid, automated, and easily implemented algorithm is required to inform sustainable forest management and land restoration with accuracy suitable for local scales and robustness required by broader regional geographies. We are developing a tool to evaluate percentage of tree cover from remote sensing imagery. The automated algorithm employs convolutional neural networks and is trained using observations from approximately 2000 high resolution 1-ha images with tree densities ranging between 0 and 98\%, making the method appropriate for regional assessments with a variety of land conditions. Accuracy of the algorithm is assessed against the dot-grid method, which varies as a function of tree coverage. Though intended for application on degraded, reforested, and mixed-use agroforestry land types, the method can be applied in other environments and for other purposes, e.g. quantifying tree coverage as input to tree carbon or soil-water-ecosystem restoration models.

\section{Product recovery predictions combining tree lists from a harvester stem database and estimated diameter distributions provided by a mobile laser scanner system}

Liviu Theodor Ene ${ }^{1}$, Johan Holmgren ${ }^{2}$, Jon Söderberg ${ }^{1}$, Erik Willén ${ }^{1}$

${ }^{1}$ Skogforsk, Uppsala, Sweden; '2Swedish University of Agricultural Sciences, Umeå, Sweden (liviu.ene@skogforsk.se; johan.holmgren@slu.se; jon.soderberg@skogforsk.se; rik.willen@skogforsk.se)

Accurate product recovery predictions are necessary for supporting an effective planning of harvesting operations and optimization of the wood flow. To meet this requirement, Swedish forest companies Skogforsk and Forbis have developed an extensive database infrastructure containing compiled CTL- harvester production files. The system allows imputing tree lists retrieved from the harvester data to stands scheduled to harvest in the operational planning. The potential yield on such areas can be estimated using bucking simulations on the imputed tree lists, hence it is important that the imputed DBH distributions match the true DBH distributions as close as possible. Currently, the DBH distributions are not provided in the forest registers, this information being coarsely estimated by low intensity preharvest inventories. A backpack-mounted system integrating a NovAtel SPAN-IGM-S1 INS and a Velodyne VLP-16 scanner was used for stem positioning and DBH measurements in preharvest inventories on 5 experimental blocks of 0.16 to 0.32 ha containing mixed coniferous forest, located in Northeaster Sweden. The estimated DBH distributions were matching well the ground true distributions from the harvester production files after the final cut. Tree lists from the harvester database were imputed to each block using DBH-related auxiliaries and nearest neighbor imputations. The imputation accuracies and the product recovery results remained relatively stable after thinning down the estimated diameter distributions about four times (50 trees per block), which translates into lower inventory costs and may recommend the mobile lasers as a feasible preharvest inventory method in boreal forests with relatively simple structures. 
Sample size reduction in forest inventories using importance indexes / Redução do tamanho amostral em inventário florestal através de indices de importância

Lucas Arthur de Almeida Telles ${ }^{1}$, Helio Garcia Leite ${ }^{1}$, Gustavo Eduardo Marcatti ${ }^{1}$, Liniker Fernandes da Silva ${ }^{2}$, Carlos Pedro Boechat Soares ${ }^{1}$, Rodrigo Vieira Leite ${ }^{1}$

${ }^{1}$ Universidade Federal de Viçosa, Viçosa, Brasil; 2Universidade Federal do Recôncavo da Bahia, Cruz das Almas, Brasil; (lucasarthur36@gmail.com; hgleite@gmail.com; gustavomarcatti@ufsj.edu.br; linikerfs@gmail.com; csoares@ufv.br; r.vieiraleite@gmail.com)

Continuamente novos métodos são propostos para reduzir o tamanho amostral de inventários florestais sem comprometer sua acurácia. Neste sentido, o objetivo do trabalho é propor uma metodologia para redução amostral de inventários baseada na representatividade de parcelas. A metodologia consiste em: Etapa 1 - seleção de parcelas, onde são propostos índices de importância (Delaunay, Variância e Combinado) e seleção aleatória (Aleatório) para identificar parcelas a constituir amostragens alternativas; Etapa 2 - avaliação dos critérios de seleção, onde estimativas de índice de local e volume geradas por krigagem de amostragens alternativas são comparadas com a original. Foram utilizadas reduções de 15, 30, 45 e 60\% em relação as 152 parcelas existentes no inventário original. O índice Delaunay prioriza parcelas espaçadas com maior número de vizinhas. Já o índice Variância prioriza parcelas com maiores variâncias da krigagem, assegurando maior ou menor intensidade amostral de acordo com a heterogeneidade da área. O combinado é a junção dos dois anteriores com um fator de ponderação de 0,5. A utilização dos índices de importância se mostrou mais eficiente em relação a seleção aleatória para índice de sítio (respectivamente, $\mathrm{R}^{2} \min =0,94$ e $\mathrm{R}^{2} \min =0,89$ ) e volume (respectivamente, $\mathrm{R}^{2} \min =0,96$ e $\mathrm{R}^{2} \min =0,70$ ), sobretudo em reduções superiores a $30 \%$. O índice Delaunay pode ser facilmente aplicado pois utiliza apenas as coordenadas das parcelas como input. Já o índice Variância pode viabilizar reduções a partir do inventário piloto. Neste trabalho, os três índices se mostraram eficientes, mas os resultados podem variar conforme características da área.

Deforestation from gold mining in the Madre de Dios region of Peru (2000-2017) / Deforestación por minería aurifera en madre de dios - Perú (2000 - 2017)

Lasmit Cerón Cancharis ${ }^{1}$, Natalia Miranda Samame ${ }^{1}$, Ethel Rubin de Celis Llanos ${ }^{1}$

${ }^{1}$ Universidad Nacional Agraria La Molina, Lima, Peru (20091044@lamolina.edu.pe; 20110152@lamolina.edu.pe; erubin@lamolina.edu.pe)

La investigación se desarrolló en el departamento de Madre de Dios - Perú con el objetivo de cuantificar la deforestación causada por actividad minera para los años 2000 y 2017 mediante imágenes satelitales LANDSAT 5 y LANDSAT 8, se realizó una clasificación supervisada mediante el algoritmo de árboles de decisión; proceso directo, rápido y con resultados a usar de forma individual o grupal. Los resultados muestran que entre los años 2000 y 2017 hubo una diferencia de 47657.43 ha con actividad minera. Se detectaron 1139.77 ha de actividad minera en el año 2000 recuperándose en el 2017. Se obtuvo un índice Kappa de 93\% de acierto, con validación de juicio de expertos. La pérdida de cobertura causada por la minería en Madre de Dios fue analizada en las categorías territoriales, donde se observó un incremento en 42.52\% (35 183.45 ha), siendo las más afectadas las comunidades nativas, concesiones para reforestación y zonas de amortiguamiento de Áreas Naturales Protegidas.

C4p: FOREST ASSESSMENT

\section{Prompt mapping of forest stand damages after windthrow event using unmanned aerial vehicle}

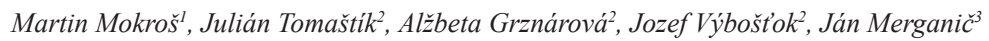

${ }^{1}$ Czech University of Life Sciences Prague, Prague, Czech Republic; ${ }^{2}$ Technical University in Zvolen, Zvolen, Slovakia; ${ }^{2}$ Technical University in Zvolen, Zvolen, Slovakia; ${ }^{2}$ Technical University in Zvolen, Zvolen, Slovakia; ${ }^{3}$ Technical University in Zvolen, Zvolen, Czech Republic (mokros@fld.czu.cz; tomastik@tuzvo.sk; grznarova@tuzvo.sk; vybostok@tuzvo.sk;merganic@tuzvo.sk)

In our research, we have focused on two important issues. Firstly, we have investigated the usage of fixed-wing UAV with real-time kinematic (RTK) which can offer the possibility to eliminate the usage of ground control points. In areas with complicated accessibility (especially forests), this can be highly beneficial. The eBee Plus was used; 43 check points have been placed in the area (300 ha) for evaluation of RTK accuracy. Processing of images was done in Agisoft Photoscan Professional. The positional accuracy was calculated based on check points. RMSE of $X, Y$ and $Z$ axis was as follows: $X=2.2 \mathrm{~cm}, \mathrm{Y}=2.3 \mathrm{~cm}$, $Z=4.9 \mathrm{~cm}$. Secondly, we have investigated the possibility of windthrow areas mapping within forest stands and the volume estimation of salvage logging. The windthrow areas were measured by multiple GNSS devices in the field and salvage logging volume from whole target area was measured by local foresters. Processing of images was done in Agisoft Photoscan Professional and windthrow areas identification was completed in ArcGIS for Desktop. Five windthrow areas were identified during the field campaign with the total area of 25.39 ha. The same areas were identified from UAS data with a total acreage of 25.09 ha ( 0.3 ha difference). The difference between the volume of salvage logging measured in the field and derived from UAV data and forest plan was only $5 \%$ $\left(525 \mathrm{~m}^{3}\right)$. The results are proving great potential for prompt forest land mapping. Additionally, the RTK accuracy meets the requirements for forestry purposes.

\section{Monitoring tropical forest disturbance using repeatedly acquired digital aerial photography from unmanned aerial vehicle}

Tetsuji Ota ${ }^{1}$, Sie Thu Minn', Tual Cin Khai ${ }^{1}$, Nobuya Mizoue ${ }^{1}$, Shigejiro Yoshida ${ }^{1}$

1Kyushu university,Fukuoka,Japan (ota.tetsuji.887@m.kyushu-u.ac.jp; sithumin.ttn@gmail.com; tualcinkhai@gmail.com; mizoue@agr.kyushu-u.ac.jp; gm.syoshida@gmail.com)

Small scale disturbance such as selective logging is one of the factors causing forest degradation in tropical forests. Here, we evaluate the utility of repeatedly acquired digital aerial photographs (DAPs) from a lightweight unmanned aerial vehicle (UAV) to monitor small scale disturbance in tropical forest. We constructed two 9-ha plots in Myanmar and partitioned two plots into subplots of size 0.25 ha. DAPs from a lightweight UAV were acquired three times, which were immediately before selective logging, immediately after selective logging and 1.5 year after selective logging. A photogrammetric point cloud (PPC) was created from DAPs. The aboveground biomass (AGB) changes due to small scale disturbance at subplot scale were regressed against metrics expressing forest changes calculated from PPC. This study demonstrates that repeatedly acquired DAPs from a lightweight UAV can be used to monitor small scale disturbance in tropical forests. 


\section{Using hemispherical photographs to evaluate the impacts of selective logging}

Daniel Augusto da Silva', Janine K. Likoski', Heitor Felippe Uller ${ }^{2}$, Aline Renata Klitzke ${ }^{2}$, Alafredo Celso Fantini ${ }^{3}$, Alexander Christian Vibrans ${ }^{2}$ ${ }^{1}$ Fundação Universidade Regional de Blumenau, Programa de Pós-Graduação em Engenharia Ambiental, Blumenau, Brasil; ${ }^{2}$ Fundação Universidade Regional de Blumenau, Programa de Pós-Graduação em Engenharia Florestal, Blumenau, Brasil; ${ }^{3}$ Universidade Federal de Santa Catarina, Programa de Pós-graduaçãoem Agroecossistemas, Florianópolis, Brasil(danielaugusto@furb.br; janinelikoski@hotmail.com; heitor.uller:florestal@gmail.com; arklitzke@furb.br;alfredo.fantini@ufsc.br;acv@furb.br)

Sustainable management of native forests can be an important conservation strategy, discouraging the conversion to other land uses. When applied to secondary forests, it takes out pressure on pristine primary stands, while giving revenue to the landowner and maintaining most of the environmental services and biodiversity. The canopy structure influences the climate inside and outside the forest, thus, interfering in environmental services (weather regulation) and understory biodiversity. We conduct a pilot management project in a 40-year-old secondary Atlantic Rainforest in Santa Catarina where we evaluated the canopy structure, and trees regeneration at nine $1600 \mathrm{~m}^{2}$ sample plots before and after various intensities of selective logging. Hemispherical photographs where processed in the CAN_EYE software to provide the canopy information, the logging intensity was determined by the percentage of tree basal-area harvested $(\Delta \mathrm{G})$ and we determined the density of pioneer species regeneration six months after logging. Linear regression determined the relation between the variables. The results show that the $\Delta \mathrm{G}$ influenced in the canopy opening $\left(\mathrm{R}^{2}=0.41, \mathrm{p}<0.05\right)$, but not on the leaf area index $\left(\mathrm{R}^{2}=0.16, \mathrm{p}>0.05\right)$; and that the canopy opening influenced the regeneration density of pioneer species $\left(R^{2}=0.25, p>0.05\right)$. This suggests that $\Delta \mathrm{G}$ has a relevant influence on the forest regeneration composition, but limited influence in processes linked to leaf area, such as photosynthesis, evapotranspiration and $\mathrm{CO}_{2}$ absorption. The monitoring of the area will provide an insight of the long-term consequences of the logging intensities on a secondary forest.

\section{Estimation of stand heights with Unmanned Aerial Vehicle (UAV) photographic image}

Shang-Chuan Huang ${ }^{1}$, Chaur-Tzuhn Chen ${ }^{1}$, Mu-Yu Huang ${ }^{1}$, Jan-Chang Chen ${ }^{1}$

${ }^{1}$ National Pingtung University of Science and Technology,Pingtung,Taiwan(j69212002@gmail.com; cct@gisfore.npust.edu.tw; b10312023@gmail.com; zzzjohn@mail.npust.edu.tw)

Forest resource inventory provides essential information for forest management, where the stand height is an important variable for estimating the stock volume of large-scale forests. Unmanned Aerial Vehicle (UAV) aerial photography has the advantages of quickly acquiring the large-scale surface information, highresolution image, and low flight cost. Nowadays, high-density stereo point cloud data can be obtained through image-matching, which is suitable for stand height extraction. The purpose of this study was to extract the stand height using the UAV aerial imagery produced a canopy height model (CHM) and to verify the tree height of each tree inventory data in the ground plots. The results indicates that aerial photogrammetry extracted by UAV should be used for generating digital elevation model (DEM) and a digital surface model (DSM). By integrating DEM and DSM, CHM information can be established based on UAV aerial photography, and no significant difference between the UAV stand height and the ground data was found. The spatial variability of the stand height generated by UAV could be used as forest resource monitoring tools which provides important information for decision makers in terms of forest management. However, further research on the application of forest resources inventory, the estimation of stocks and the application of forest management plans is necessary.

Landscape patterns associated with extraction in the Amazon: characteristics and mapping of potential areas of açai palms in Northeastern Pará, Brazil / Padrões da paisagem associados ao extrativismo na Amazônia: caracterização e mapeamento de áreas potenciais de ocorrência de açaí no nordeste Paraense

Anielli Rosane de Souza ${ }^{1}$, Maria Isabel Sobral Escada ${ }^{1}$, Gabriela Veneziani de Souza Santos ${ }^{2}$, Antônio Miguel Vieira Monteiro ${ }^{1}$ Instituto Nacional de Pesquisas Espaciais, São José dos Campos, Brasil; ${ }^{2}$ Universidade Estadual Paulista, Rio Claro, Brasil (anielli.souza@inpe.br; isabel.escada@inpe.br; ga.veneziani@gmail.com; miguel.monteiro@inpe.br)

A Amazônia legal brasileira apresenta diferentes padrões de paisagem relacionados com fatores naturais e antrópicos, gerados por múltiplos agentes, históricos de ocupação e por atividades econômicas como o extrativismo e a agropecuária. Os diferentes tipos de ocupação geram padrões de paisagem que podem ser observados a partir de dados de sensoriamento remoto. Na Amazônia, o extrativismo do açaí (Euterpe oleracea)é de suma importância para a economia local. Embora importante, esta atividade não é mapeada e nem contemplada nos sistemas existentes de monitoramento de uso e cobertura da terra da Amazônia (TerraClass, MapBiomas e IBGE), devido às limitações técnicas operacionais, gerando lacunas de conhecimento e dificuldades na elaboração de políticas que visem a estruturação de cadeias produtivas e a inserção das populações extrativistas nos arranjos produtivos locais (APL). As atividades de extração do açaí podem ser representadas por áreas de cobertura florestal, entretanto, essa informação é insuficiente para seu mapeamento, pois nem toda área de floresta apresenta ocorrência dessa palmeira. O objetivo deste trabalho é mapear as áreas potenciais de ocorrência de açaí combinando dados refinados de uso e cobertura da terra do TerraClass de 2014 com dados extraídos do Shuttle Radar Topography Mission (SRTM) e o uso do algoritmo Height Above the Neareast Drainage (HAND) que possibilita mapear áreas de várzea, ambiente natural de ocorrência de açaí. Como resultado obteve-se um mapa cuja classe de alto potencial de ocorrência de açaí representou 43\% da área de estudo. Esse resultado indica o grande potencial econômico da região analisada.

\section{A common problem: how to make the NFI data being used (and shared)}

Alexander Christian Vibrans ${ }^{1}$, Laio Zimermann Oliveira ${ }^{1}$

${ }^{1}$ Fundação Universidade Regional de Blumenau, Blumenau, SC,Brasil (acv@furb.br; laiozoliveira@gmail.com)

NFI are designed to collect, process and disclose forest resource data. NFI networks should attend a critical issue that is the challenge to get the generated information effectively used. Failure of communication with the general public and with decision-makers, in particular may be the background of this situation. While the initial question "why" (we need reliable data) is simply to respond, the following "who and how" (data will be used and shared) is decisive specially in countries where NFI are not deep-rooted and institutionalized. We discuss the matter within the context of the Brazilian NFI, about Santa Catarina state (95,000 $\mathrm{km}^{2}$ ). We discuss how multiple involvements with stakeholders at local, regional and international level may increase public awareness on NFI outcomes and, last but not least, may assure long-term financial support. As soon as first cycle was performed, we started an disclosure campaign targeting schoolchildren and the rural population; we reported results to environment agencies and councils; a multi-instituional working group prepared guidelines for a new, inventory data based forest policy; we designed an action plan to achieve the forest policy defined goals regarding forest land use and resource management rules, secondary forest restoration, rare and endangered species protection. We published scientific studies on biomass and carbon stock, on forest ecology and dynamics, on human impacts at different scales. Data-sharing with global research groups and databases like GFBI and sPlot/iDIV, cooperations with space agencies for sensor calibration and validation, among others, increased the inventory’s credibility. 


\author{
Growth pattern of Couratari stellata in a Tropical Rain Forest in the Southwestern Amazon \\ Caroline Gaspar ${ }^{1}$ (D) Evaldo Muñoz Braz ${ }^{2}$ (D) Patricia Povoa de Mattos ${ }^{2}$ (D) Luciano Watzlawick ${ }^{1}$, Andreia Taborda dos Santos ${ }^{3}$ (1) \\ ${ }^{1}$ Universidade Estadual do Centro-Oeste, Irati, Brasil; ${ }^{2}$ Embrapa Florestas, Colombo, Brasil; ; ${ }^{3}$ Universidade Federal do Paraná, Curitiba, Brasil \\ (gaspar.caroline@yahoo.com; evaldo.braz@embrapa.br; patricia.mattos@embrapa.br; farinha@unicentro.br; andreiatabordayahoo.com.br)
}

The natural forest management, especially from the Amazon rainforest, is an important source of income and employment generation. However, there gaps information about species that are managed, such as the growth pattern of commercial species, an important factor to ensure sustainable management. The aim was to describe the individual growth of Couratari stellata in the Jamari National Forest, Rondônia State, Brazil. Dendrochronology was used for growth analysis, for this, 12 stem discs were collected. The growth rings were marked and measured with the LINTAB, with $0.01 \mathrm{~mm}$ accuracy. Confirmation of the annual growth layer was performed by cross-dating. Six mixed models were tested to determine the growth pattern of $C$. stellata, and the best choice was based on statistical results and graphical analysis of residues and the adherence to real data. The Lundqvist model showed satisfactory statistical parameters for the growth $($ Syx $=18.30 \%, A I C C=1.07 \mathrm{E}+06$ and $B I C=1.07 \mathrm{E}+06)$. The trees had 143 years old (mean) and presented DBH $($ mean $)=65 \mathrm{~cm}$, ranging from 46.5 to $83.4 \mathrm{~cm}$ The diameter class that presented the largest average increment in diameter was $65 \mathrm{~cm}$ center class, with approximately $0.52 \mathrm{~cm} . y e a{ }^{-1}$, with the average annual increment $=0.45 \mathrm{~cm}$. There are indications that the cutting diameter for $C$. stellata is from $75 \mathrm{~cm}$ in diameter, ensuring the wood quantity for the next cycle, if it is considered a cut rate compatible with the diameter structure of the stand.

\title{
Growth performance of Macaranga tanarius from 4 provenances in Peninsular Malaysia
}

Rosdi bin Koter ${ }^{1}$, Moha Zaki bin Hamzah², Noraini Abd Shukor ${ }^{2}$,Hazandy Hamid ${ }^{2}$, A. K. Wan Rasidah ${ }^{1}$, Patahayah Binti Mansor ${ }^{1}$

${ }^{1}$ Forest Research Institute Malaysia (FRIM), Kepong, Malaysia; ${ }^{2}$ Faculty of Forestry, University Putra Malaysia, Selangor, Malaysia (rosdi@frim.gov.my; rosdi@frim.gov.my; rosdi@frim.gov.my; rosdi@frim.gov.my; rosdi@frim.gov.my; patahayah@frim.gov.my)

This study was initiated after recognizing the importance of growth and yield studies of plantation-grown pioneer fast growing species for future forest management decisions, coupled with a general paucity of knowledge on the growth and potential yield of the species planted under plantation condition. The species of Macaranga tanarius is regarded among the most promising Macaranga genus because of the seed availability throughout the year and potentially seed germinated after probing trial established compared with other species The studies will provide an opportunity to generate baseline information for future planting of M. tanarius under plantation condition. Information on growth and potential yield of the species can be used in the planning for future establishment and management planning for future M. tanarius plantations. Growth performance from each provenance were collected and planted in four established plantation plots in SPF Jeli, SPF Maya Ayer, SPF Selandar, Melaka and Field 52 Bukit Hari, FRIM HQ. The trial was laid out in a randomized complete block design with three replications. Generally all provenances were well adapted and performed well in their growth and significantly differ between genotip and environment. Varation exist in height, root collar, survival and biomass. North provenance planted at SPF Jeli showed the highest survival and height incement value followed by Mata Ayer ; Selandar and FRIM HQ. Based on the results of this study, M. tanarius is a promising species but futher study need to be futher explored on the genetic studies.

\section{C4q: FOREST ASSESSMENT}

\section{Changes in aflatoxin standards: implications for $\mathbf{E U}$ border controls of nut imports}

Ibtissem Taghouti ${ }^{1}$, José Maria Garcia-Alvarez-Coque ${ }^{2}$, Victor Martinez-Gomez ${ }^{2}$

${ }^{1}$ National Research Institute for Rural Engineering Water and Forestry, Ariana, Tunisia; ${ }^{2}$ Universitat Politècnica de València, Valencia, Spain (ibtissem.taghouti@gmail.com;jmgarcia@upv.es; vicmargo@esp.upv.es)

Food safety concerns about the risk of aflatoxin (AF) contamination have been growing in many regions, particularly in the EU. To protect consumers from health risks, the EU has established strict standards for maximum acceptable AF levels in food products. The EU's AF standards have changed several times. This article examines the Rapid Alert System for Food and Feed (RASFF) database, which contains notifications on border controls on AF levels in tree nuts and peanuts. A count data model was used to analyze the impact of political economy considerations, past alerts and path-dependence effects on RASFF border controls. Policy changes, including the harmonization and relaxing of EU's AF standards, significantly affected the frequency of border controls, with diverse effects among exporting countries. It is believed that the present study provides some insights to the modeling of food standards for explanation or forecasting purposes.

Quassia amara L. growth under different shading conditions: implications for the management of Costa Rica natural and planted forests

Joana Paulo 1 (D; Villalobos Roger ${ }^{2}$

${ }^{1}$ Instituto Superior de Agronomia, Lisbon, Portugal; ${ }^{2}$ Centro Agronómico Tropical de Investigación y Enseñanza, Turrialba, Costa Rica (joanaap@isa.ulisboa.pt; rvillalo@catie.ac.cr)

The overall objective of the present work is to research the impact of light conditions on the Quassia amara L. growth, both in young plantations and natural forests, discussing implications for the sustainable management and production of the species in Costa Rica. Illumination conditions are characterized, at the tree level, by the crown illumination index (cii). The working hypothesis is that the tree crown illumination index can help to determine the best illumination conditions to promote tree diameter growth. Results show that for young trees, growing in young forest plantations (pure, mixed or agroforestry stands), best illumination conditions for diameter growth are characterized by a cii value of 2.5, corresponding to high lateral light interception and under $10 \%$ of the vertical projection of the crown exposed to vertical light. These conditions characterize mixed plantation or agroforestry stands, with adult trees presenting developed crowns that reduce vertical light exposure to the Quassia amara L. growing bellow. For trees growing in natural forests, presumably older due to the traditional management strategies of these areas, best illumination conditions are characterized by a cii value of 4.5, corresponding almost to between full overhead light (more than $90 \%$ of the crown area exposed to vertical light and partial lateral light blocked) to a completely exposed to overhead and lateral light. Management of natural forests where Quassia amara L. is present should stand upon for later light conditions, in order to guarantee suitable illumination conditions for the natural regeneration and growth of the young trees. 


\section{Evaluating introduction and productivity of Vietnam Acacia hybrid in South China}

Yichen Zong ${ }^{1}$, Yongqi Zheng ${ }^{1}$, Furong Lin ${ }^{1}$, Ping Huang ${ }^{1}$, Wenying Guo ${ }^{1}$, Chengrong X ${ }^{2}$, Xiufang Yin ${ }^{3}$

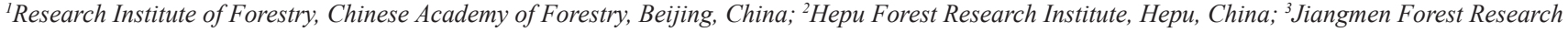
Institute, Jiangmen,China(zongyc@caf.ac.cn; zhengyq@caf.ac.cn; linfr888@163.com; pippin09@163.com; 13801288911@139.com; hepulks@163.com; 2667701329@qq.com)

Vietnam Acacia hybrid was selected by Acacia mangium across A. auriculiformis. Five clones was introduced from Vietnam by exchange forest seeds. Four test plantation was built in South China including Jiangmen(JM), Hepu(HP), Zhangzhou(ZZ) and Chuxiong(CX). Acacia hybrid could grow, flower and fruit at the four sites and productivity were all higher than CK after two years. Five hybrid Acacia clones were all higher than CK on high growth character, and were ranked as $\mathrm{ZZ}>\mathrm{JM}>\mathrm{HP}>\mathrm{CX}$. The height of clone No; 73 was $5.2 \mathrm{~m}$ and more $24 \%$ than CK. There were significant difference on diameter of breast height(DBH) betweenclones and $\mathrm{CK}$ at the four sites. Clones DBH were all bigger than $\mathrm{CK}$ and ranked as $\mathrm{HP}>\mathrm{ZZ}=\mathrm{JM}>\mathrm{CX}$. The DBH of clone No; 73 was $5.0 \mathrm{~cm}$ and more $35 \%$ than CK. The individual volume of clone No; 73 was $0.0042 \mathrm{~m}^{3}$ at HP site. The wind-fall rate of Acacia hybrid clones were $35 \%$, CK was $67 \%$ after typhoon Rammasun 2014 at HP site. The wind folding resistance of each clone of typhoon Rammasun was in order No.73= No.75>No.10>No.71 $>$ No. $16>$ CK. It was short-term snowed at CX site December 2013. The cold resistance which was evaluated by survival rate were No; $10>\mathrm{No} ; 73>\mathrm{No} ; 16=\mathrm{No} ; 75>\mathrm{CK}>\mathrm{No}$; 71. According to the comprehensive evaluation of different weight of volume (60\%), stem shape (20\%), survival rate (10\%) and stress resistance (10\%), clone No.73 was the best one, followed by No.71 and No.16.

\section{DBH and basal area growth by thinning intensity of major coniferous plantations in the Republic of Korea}

Yeongwan Seo ${ }^{1}$, Daesung Lee ${ }^{1}$, Jungkee Choi ${ }^{1}$

${ }^{1}$ Kangwon National University, Chuncheon 24341, Republic of Korea (ywseo@kangwon.ac.kr; daesung@kangwon.ac.kr; jungkee@kangwon.ac.kr)

The effect of thinning intensity was analyzed on the DBH growth of major coniferous plantations, which are Pinus densiflora (Pd), Pinus koraiensis (Pk), and Larix kaempferi (Lk) in the Republic of Korea. For the study permanent monitoring plots were installed in 37 sites, 45 sites and 45 sites of Pk, Pk, and Lk respectively from 2012 2015 with each plot consisting of non-thinning $(\mathrm{C})$, light thinning $(\mathrm{L})$ and high thinning $(\mathrm{H})$ plots. They were inventoried again during 2015 2018. The thinning ratio ranged in $0 \sim 5 \%$ for non-thinning, 10 28\% for low thinning, and 30 50\% for high thinning based on basal area. Thinning intensity was found to have an effect on the DBH increment and growth rate of the three species (C0.5) the thinning effect was found to be significant among the control, light thinning and heavy thinning plot. Unlike DBH increment total basal area increment per hectare were found to be $\mathrm{C}>\mathrm{L}>\mathrm{H}$, but the growth rate was $\mathrm{C}<\mathrm{L}<\mathrm{H}$.

Assessing periodic increment and mean annual increment in African mahogany (Khaya ivorensis Chev.) / Avaliação do incremento periódico e incremento médio anual do Mogno Africano (Khaya ivorensis Chev.)

Camilla de Almeida ${ }^{1}$, Sybelle Barreira ${ }^{1}$

${ }^{1}$ Universidade Federal de Goiás, Goiânia, Brasil (camilla_paulino@outlook.com; sybelle.barreira@gmail.com)

O mogno é apreciado por suas características madeireiras, que é muito utilizada para construção civil e movelaria. Possui densidade moderada, espécie de madeira com boa trabalhabilidade. Dessa forma, seu valor agregado é elevado no mercado de produtos nacionais e internacionais. Apresenta características semelhantes às do mogno brasileiro (Swietenia macrophylla King), além de boa adaptação às condições edafoclimáticas brasileiras. Para melhor compreender o desenvolvimento da espécie, o trabalho tem como objetivo analisar o incremento periódico (IP) e o incremento médio anual (IMA) de uma população de Kahya ivorensis Chev. localizada na região de Brasília, DF. A área possui 17,92 ha com 4.000 indivíduos em um espaçamento de 5,5 m x 5,5 m, e a cada 4 linha de plantio há um espaço de 26 m onde, atualmente, há pasto com braquiária. Foram amostradas 8 parcelas, entre 2015 a 2018 , totalizando 416 indivíduos. Para cálculo do IP e IMA, utilizaram-se os dados de DAP dos três anos. O incremento periódico mínimo foi de 2,5 cm e o máximo foi de 19,4 cm. O IMA foi de $8,04 \mathrm{~cm}$. Esses resultados mostram que a espécie apresentou boa adaptação com crescimento satisfatório. Porém, o Mogno Africano apresenta sensibilidade à deficiência hídrica, decorrente da distribuição irregular de chuvas que ocorrem na região, tendendo a ter o crescimento em diâmetro limitado.

Modeling through dynamic systems for the main silvicultural operations at a Colombian forestry company / Modelamiento vía dinámica de sistemas para las principales operaciones silviculturales en una empresa reforestadora colombiana

Wendy Katherin Lorenzana Velosa ${ }^{1}$, Valentina Montaño ${ }^{1}$

${ }^{1}$ Universidad distrital Francisco José de Caldas, Bogotá, Colombia (wklorenzanav@correo.udistrital.edu.co; valentina ${ }^{25}$ montano@gmail.com)

La siguiente investigación presenta el diseño de cuatro modelos basados en dinámica de sistemas para cada una de las operaciones principales de una empresa reforestadora en Colombia (Elaboración de casillas, fertilización, plantación y replantación). A través del análisis cuantitativo y cualitativo del estudio de métodos y tiempos con el cual se identificaron las variables criticas de cada proceso, las interacciones entre estas y la influencia del método usado por cada contratista sobre la calidad y los rendimientos, lo que permitió consolidar la estructura de cada operación mediante diagramas de Forrester individualizados. Dentro de los resultados se destaca la identificación de personal sobrecargado lo que genero reducciones en la eficiencia de la operación para la cuadrilla en conjunto, adicionalmente a través de análisis de correlación se encontró que una unidad de tiempo muerto (específicamente en la operación de plantación) presenta relación inversa con la productividad de forma exponencial de modo tal que se evidencio la necesidad de incluir personal de apoyo para reducir los tiempos empleados en desplazamientos y descanso a la vez que la productividad general de la cuadrilla se incrementa. Los resultados totales junto con los modelos establecidos se proyectan como insumo para la implementación de experimentos de simulación que garanticen la toma de decisiones eficientes con el uso de escenarios estadísticamente confiables y que le brinden al sector forestal un referente para minimizar la variación en sus procesos y productos a pesar de ser una industria donde no es posible controlar numerosas variables que la influencian.

\section{Dominant height model for Gmelina arborea incorporating stand and environmental variables}

Alonso Barrios ${ }^{1}$, Ana M. López

${ }^{1}$ Universidad del Tolima, Ibagué, Colombia (abarriost@ut.edu.co; amlopeza@ut.edu.co)

The aim of this research is to develop a site index model for Gmelina arborea plantations incorporating stand and environmental modifiers in its structure to increase its flexibility to the climatic changes that are beginning to be experienced. A total of 160 stands from 1 to 16 years-old, located in the Andean Region and 
the Atlantic Coast were used. At each stand, between 1 and 38 temporary sampling plots were established. At each plot, the dominant height was calculated as the average height of the 100 trees with the largest diameter per hectare and competition measures such as Reineke's Stand Density Index and Relative Spacing were determined. The study allowed to identify the growth function of Chapman-Richards as a base model for the projection of the dominant height and the determination of the site index of each plot. A correlation analysis allowed to identify elevation, annual precipitation and relative spacing as environmental and stand covariates associated with the productivity of these plantations. The incorporation of these covariates in the base model of dominant height allowed to increase by $30 \%$ and reduce by $43 \%$ and $40 \%$ the fit index, the absolute bias, and the root mean square error, respectively. The developed model will allow foresters to have a greater certainty in their projections, improving forestry planning, since changes in the productivity of the site will have an effect on the volumes of wood produced and this will be reflected in changes in the optimal rotation age and the profitability of plantations.

Estimating forest biomass using the multi-sensor approach and multi-stage sampling in the Brazilian Amazon / Estimativa de biomassa florestal por abordagem multi-sensor e amostragem em multiestágios na Amazônia Brasileira

Andeise Cerqueira Dutra ${ }^{1}$, Egídio Arai ${ }^{1}$, Valdete Duarte ${ }^{1}$, Yosio Edemir Shimabukuro

${ }^{1}$ Instituto Nacional de Pesquisas Espaciais, SãoJosédosCampos, Brasil (andeise.dutra@inpe.br; egidio.arai@inpe.br; valdete.duarte@inpe.br; yosio.shimabukuro@inpe.br)

A escassez de informações espaciais e temporais sistematizadas para quantificação da biomassa florestal tem se tornado uma limitação para o desenvolvimento de políticas públicas para conservação das florestas. Tais informações subsidiam o entendimento sobre a dinâmica florestal, o ciclo de carbono no planeta e quais os impactos ocasionados por mudanças no clima e no uso e cobertura da terra. O uso de tecnologias para a aquisição de dados remotamente coletados, como oLight Detection and Ranging(LiDAR), permitem coletar medições da estrutura vertical da floresta. No entanto, o custo elevado e a menor disponibilidade de dados LiDAR sobre grandes extensões ainda é um desafio. Neste contexto, este trabalho apresenta um método de integração de dados de sensoriamento remoto óptico em diferentes resoluções espaciais, dados LiDAR e de campo, para a geração de um mapa de biomassa florestal aérea na Amazônia Brasileira. Imagens dos sensoresModerate Resolution Imaging Spectroradiometer(MODIS)/Terra eOperational Land Imager(OLI)/Landsat foram adquiridas cobrindo o estado do Mato Grosso em 2015. A integração dos dados foi realizada por amostragem baseada em multiestágios, no qual cada estágio foi representado como: primário (MODIS), secundário (OLI) e terciário (LiDAR e campo). Em seguida, os dados LiDAR foram utilizados para a calibração do modelo de biomassa e, então, a biomassa foi estimada nos estágios posteriores. Por fim, os resultados obtidos pelo método proposto foram comparados com dados de biomassa disponíveis na literatura. Conclui-se que a utilização integrada dos produtos apresentou resultados satisfatórios para a estimativa de biomassa em escala regional.

C4r: MULTI-CRITERIA DECISION ANALYSIS FOR MULTIFUNCTIONAL FORESTS

\section{Utilizing multi-criteria decision analysis to assess tradeoffs between ecosystem services: alternative approaches and potential contributions}

Donald Hodges ${ }^{1}$, Lidija Zadnik Stirn ${ }^{2}$

${ }^{1}$ University of Tennessee, Knoxville, TN, USA; ${ }^{2}$ University of Ljubljana, Ljubljana, Slovenia (dhodges2@utk.edu; lidija.zadnik@bf.uni-lj.si)

Individual forests provide a wide range of ecosystem services that can often be managed simultaneously. As our ability to identify and measure these services increases, however, management decisions will become more difficult since we must determine which services to emphasize and how those actions affect other ecosystem services. These decisions will be based not only on biophysical factors, but must also weigh social, economic, and political implications. Consequently, planning becomes much more complex as we must include a variety of stakeholders who are not familiar formal decision making approaches, yet their participation is critical for achieving the required consensus in group decision making. Multi-criteria decision analysis (MCDA) and Group decision making methods (GDM) offer a number of techniques that will be critical for assessing the biophysical, social, and economic tradeoffs and identifying the optimal management decisions for managing multiple ecosystem services under several decision makers. This presentation will review the issues related to management planning for ecosystem services, identify MCDA and GDM techniques best suited for these management conditions, review advantages and disadvantages of each, and offer some conclusions as to what approaches hold the most promise.

\section{The regional forest management scenarios for the sustainable carbon neutrality in Finland}

Kalle Karttunen ${ }^{1}$, Soili Kojola ${ }^{2}$,Saija Huuskonen ${ }^{2}$, Anssi Ahtikoski ${ }^{3}$, Hannu Salminen ${ }^{4}$, Jari Hynynen ${ }^{2}$, Susanna Kujala ${ }^{5}$, Outi Hakala ${ }^{5}$, Hannu Törmä ${ }^{5}$, Jouko $^{2}$ Kinnunen ${ }^{6}$, Antti Karhunen ${ }^{7}$, Mika Laihanen ${ }^{7}$, Raghu K.C. Tapio Ranta $^{7}$

${ }^{1}$ LUT University, Mikkeli, Finland; ${ }^{2}$ Natural resources institute Finland, Vantaa, Finland; ${ }^{3}$ Natural resources institute Finland, Oulu, Finland; ${ }^{4}$ Natural resources institute Finland, Rovaniemi, Finland; ${ }^{5}$ University of Helsinki, Seinäjoki, Finland; ${ }^{6}$ Statistics and Research Aland, Mariehamn, Finland; ${ }^{7} L U T$ University,Mikkeli,Finland (kalle.karttunen@lut.fi; soili.kojola@luke.fi; saija.huuskonen@luke.fi; anssi.ahtikoski@luke.fi; hannu.salminen@luke.fi; jari.hynynen@luke.fi; susanna.kujala@helsinki.fi; outi.hakala@helsinki.fi; hannu.torma@helsinki.fi; jouko.kinnunen@asub.ax; antti.karhunen@lut.fi; mika.laihanen@lut.fi;raghu.kc@lut.fi; tapio.ranta@lut.fi)

The aim of the study is to promote ways to reach the goals of the carbon neutrality at the South Savo region in eastern Finland by examining the solutions for emission reductions and forest use. The study has taken the first step for reaching the carbon neutrality at the regional level in Finland considering also the regional economic effects. The carbon dioxide neutral region means that the region's internal activity does not change the carbon content of the atmosphere. The study has started by updating the regional energy balance and its carbon influence. Second, the carbon impact on forest use will be measured. Finally, the regional economic effects of alternative carbon neutrality solutions will be estimated. The study method has been developed by combining alternative forest management simulations with computable general equilibrium (CGE) modelling. Permanent National Forest Inventory plots has been used as an input of forest management simulation.Then, applying a modified CGE model (RegFinDyn), the socio-economic solutions will be assessed at the regional level. The aim is to inlude the carbon solutions to the CGE model as well. Earlier results have shown that a more intensive use of forest decreases the carbon sequestration potential but increases the regional socio-economic benefits. The carbon balance should be compensated either for emission reduction solutions or by controlling the use of forest. It is important to choose the solutions which are not only emission efficient but also economically sustainable at the regional level. 


\section{Benchmarking Brazilian State Forest Institutions: implementation of policy goals evaluated by the 3L Model}

Juliana da Motta Bustamante ${ }^{1}$, Mirjana Stevanov ${ }^{2}$, Max Krott $^{1}$, Edson Ferreira de Carvalho ${ }^{3}$

${ }^{1}$ Göttingen University, Göttingen, Germany; ${ }^{2}$ University of Novi Sad, Novi Sad, Serbia; ${ }^{3}$ Universidade de Viçosa, Viçosa, Brasil (jumotta85@gmail.com; mzavodj@gwdg.de; mkrott@gwdg.de; edsonf@ufv.br)

Worldwide, sustainable forest management became the most relevant forest policy goal. At the same time, it is brightly ambiguous goal as well. The challenge is to structure benchmarking approach in a way that all diverse aspects of this policy goal are covered and simultaneously the requirements of sharp scientific evaluation are satisfied. Differently from other approaches, the 3L-Model establishes a link between the Layer of politically relevant goals and the Layer of empirically feasible measurements through the Layer of theoretical frameworks. The vague policy formulations get more precise that way, resulting in the set of eight benchmarking criteria and 20 indicators, able to capture comprehensive performance of state forest institutions by using selected indicators on the empirical level. We apply the 3L- Model on the Brazilian state forest institutions and take the Forest Service (forest concessions) and the Ministry of Agriculture (plantation forestry) as examples. While doing that werely on participatory observation, survey and documents for empirical evidence.The results show that Brazilian forest policy strives toward sustainable forest management, as an overall goal. In more particular, the performance of both examined institutions is more market than public demand oriented. At the same time, there are constrains in keeping forest stands sustained. Even both institutions are recognized as strong representatives of sustained wood yield coalition, the Brazilian land use conflicts ask more for a facilitator of all diverse interests in forests. Ourstudy confirmed that the 3L-Model can well be applied also to the non-European countries after indicators are slightly adapted.

\section{Research on key technology and auxiliary design system for multi-functional forest management plan \\ Yangsheng Xie ${ }^{1}$, Yuanchang Lu ${ }^{1}$, Xiangdong Lei ${ }^{1}$, Xianzhao Liu ${ }^{1}$, Xiaoming Wang ${ }^{1}$, Daoxiong Cai ${ }^{2}$, Hong Guo ${ }^{1}$ \\ ${ }^{1}$ Institute of Forest Resource Information Techniques, Chinese Academy of Forestry, Beijing, China; ${ }^{2}$ Experimental Center of Tropical Forestry, Chinese Academy of Forestry,Pingxiang,China (xieys@ifrit.ac.cn; ylu@ifrit.ac.cn; xdlei@ifrit.ac.cn; liuxianzhao@ifrit.ac.cn; wxming35@163.com; \\ rlzxcdx@126.com; hongguo@ifrit.ac.cn)}

As China's forest management gradually enters the stage of multi-functional forest management, the task of compiling multi-functional forest management plans is becoming more and more urgent. The multi-functional forest management plan preparation technology is the basis and key for the formulation of multi-functional forest management plan, and has not yet formed a complete system. This paper starts with the multi-functional forest management plan technical system, and studies the theory and key technologies of multi-functional sustainable forest management plan, including multi-functional forest management zoning, silvicultural system design, sustainable harvest calculation, and the input-output of multi-functional forest management. This study puts forward the key technologies for the preparation of multi-functional forest management plans, sorts out the technical system, and completes the auxiliary design system. The results of the study provide technical specifications and auxiliary tools for the preparation of multi-functional forest management plans, and are a useful attempt to integrate technical development of multi-functional forest management plans. At the same time, it is of great significance to support the sustainable management of forest ecosystems, promote the preparation and implementation of forest management plan, and ensure the scientific and practical results of the preparation.

\section{Potential of system of intensive forestation}

\section{Pasuta Sunthornhao ${ }^{1}$, Kosum Mekmongkolchai ${ }^{2}$, Napak Karnasuta $^{2}$}

${ }^{1}$ Kasetsart University, Bangkok, Thailand; ${ }^{2}$ PTT Reforestation and Ecosystem Institute, Bangkok, Thailand (fforpts@ku.ac.th; kosum.m@pttplc.com, napak.k@pttplc.com)

The system of Intensive Forestation (SIF) define as an innovating technique of afforestation which first founded at Wangchan Forest Project, Rayong Province, Eastern region of Thailand under collaborating research programmed between Kasetsart University (KU) and Reforestation and Ecosystem Institute, Petroleum Authority of Thailand (PTT) since 2014. The different between SIF and national regular reforestation e.g. undertake on agriculture land, planted by over 50 native tree species, planting of 2,500-3,125 seedling/hectare with ratio between hard and soft wood species of 80:20, have no exactly spacing of planting, and intensive handle tender maintenance of weeding, fertilizing, water system, etc. The goal of SIF was rapidly generating artificial natural forest which it has to consist multi crown cover level and high potential of carbon dioxide sequestration through generate source of biodiversity and non-timber forest products (NTFPs). The finding of 4 years monitoring and evaluation stage by permanence plots based on $2.25 \%$ of sampling size in demonstrating area of 21.27 hectares,found density 1,960 tree/hectare, survival rate 68\%, average total height and diameter at breast height of 3.30 meter and 5.40 centimeter respectively, which rosewood species (Dalbergia cochinchinesis) was highest dominant species. Moreover, thebiomass was 15.46 ton/hectare, and carbon sink of 26.64. Anyway, above finding presentedseveral parameter higher doubles when compare with regular reforestation. Nowadays, we found some of natural enable mushroom and vegetable in the demonstrating site.

\section{Portfolio optimization of forest enterprise as a part of multifunctional management}

Jan Kaspar ${ }^{1}$, Robert Marusak ${ }^{1}$, Harald Vacik', Mikko Kurttila ${ }^{3}$

${ }^{1}$ Faculty of Forestry and Wood Sciences CULS Prague, Praha ${ }^{6}$ Suchdol, Czech Republic; ${ }^{2}$ University of Natural Resources and Life Sciences Vienna, Vienna, Austria; ${ }^{3}$ Natural Resources Institute Finland (Luke),Joensuu,Finland (kasparj@fld.czu.cz; marusak@fld.czu.cz; harald.vacik@boku.ac.at; mikko.kurtila@luke.fi)

Multifunctional forest management is focused on finding compromise between the using of individual ecosystem services. On the one hand, it requires more input data, which is often almost impossible to obtain, but also more sophisticated decision support tools. On the other hand, integrating the ecosystem services into a business plan expands the portfolio of services and products that a forestry company can offer. Opportunities for new sources of profits, jobs and marketing opens. The basis for success is the right choice and ratio of all services and products in the portfolio. This could be achieved by portfolio optimization. Portfolio optimizationis the process of selecting the best portfolio [https://en.wikipedia.org/wiki/Portfolio_(finance)] (asset [https://en.wikipedia. org/wiki/Asset] distribution), out of the set of all portfolios being considered, according to some objective. The objective [https://en.wikipedia.org/wiki/Multiobjective_optimization] typically maximizes factors such as expected return [https://en.wikipedia.org/wiki/Expected_return], and minimizes costs like financial risk [https://en.wikipedia.org/wiki/Financial_risk]. Factors being considered may range from tangible (such as assets [https://en.wikipedia.org/wiki/Asset], liabilities [https://en.wikipedia.org/wiki/Liability_(financial_accounting)], earnings [https://en.wikipedia.org/wiki/Earnings] or other fundamentals [https:// 
en.wikipedia.org/wiki/Fundamental_analysis]) to intangible (such as selective divestment [https://en.wikipedia.org/wiki/Divestment]). This study presents the portfolio optimization for the university forest enterprise in Czech Republic. Significant steps to achieve increased business profits were set in cooperation with business management as well as indicators of their achievement.

\section{Working across disciplines to incorporate values of the public in an integrated decision support system (DSS)}

Rebecca Ford ${ }^{1}$, Andrea Rawluk ${ }^{1}$, Kathryn Williams ${ }^{1}$

${ }^{1}$ The University of Melbourne, Parkville,Australia (fordr@unimelb.edu.au; andrea.rawluk@unimelb.edu.au; kjhw@unimelb.edu.au)

Forest managers are challenged with making decisions within complex social-ecological systems. Values (qualities and outcomes that are important to people) are a way of representing social parts of systems in decision-making. However, it is challenging to incorporate such values, with their social and political implications, into decision-making based in biophysical science and quantitative modelling. In this project, we used an action research methodology to contribute to, and observe, the early integration of a social concept of values into a biophysical DSS. Fifteen researchers at the University of Melbourne are developing the DSS to integrate their findings from many years studying biodiversity, carbon, water, fire and social values. As participants in this process, we identified key points where an imperative for integration across disciplines was perceived and then observed what followed. These points included a need to co-develop a definition of the term 'values' to enable decisions about what would be included within the scope of the DSS and a similar need to co-develop a definition of 'scenarios', to enable specification of scenarios for model testing. Development of these definitions began when team members realised they understood terms differently. They then needed to articulate and debate their different understandings, before integrated project definitions could be agreed. Some values of the public (identified through social research), such as experience of nature, were able to be incorporated together with ecosystem services and policy objectives to define an overall structure for the DSS. Other social values were not yet able to be adequately quantified.

\section{C4s: ASSESSING AND MODELLING NON-TIMBER FOREST PRODUCTS}

\section{Resin yield from the wound tapping method, prior to timber harvesting in Pinus pinaster Ait. stands in Galicia (NW Spain)}

Alberto García-Méijome ${ }^{1}$, María José Rozados Lorenzo ${ }^{1}$, Enrique Martínez Chamorro ${ }^{1}$, Edgar Fernández Blanco ${ }^{2}$, Esteban Gómez-García ${ }^{1}$ (1) ${ }^{1}$ Centro de Investigación Forestal de Lourizán. Xunta de Galicia, Pontevedra, Spain; ${ }^{2}$ Resinas Fernández, Vilagarcia, Spain (alberto.garcia.meijome@xunta.gal; maria.jose.rozados.lorenzo@xunta.gal; enrique.martinez.chamorro@xunta.gal; edgarfdnez@hotmail.com; esteban.gomez.garcia@xunta.gal)

Studies of the wound tapping method plus chemical stimulation, carried out in Galicia between 1950 and 1970, reported a mean resin production of 2-3 kg per tree for Pinus pinaster Ait. stands. The crisis in the sector and the lack of tradition of resin extraction in the region paralyzed these studies and promotion of the methods. However, interest in resin production has been reactivated in Galicia if production of quality timber can be guaranteed. Since 2015, the Lourizán Forestry Research Centre has investigated resin production in research plots located in pine stands due to be harvested in the near future. The objective is to estimate resin production in relation to the wound size and the wound number per tree, and evaluate the influence caused by resin tapping on timber destined for sawmills. The overall purpose of the research is to develop a method of resin extraction that is compatible with harvesting quality timber.

\section{Oleoresin tapping with the borehole method in Pinus pinaster Ait. stands prior to timber extraction in Galicia (NW Spain) \\ Alberto García-Méijome ${ }^{1}$, María José Rozados Lorenzo ${ }^{1}$, Enrique Martínez Chamorro ${ }^{1}$, Esteban Gómez-García ${ }^{1}$ ( ${ }^{1}$ Centro de Investigación Forestal de Lourizán.Xunta de Galicia, Pontevedra, Spain (alberto.garcia.meijome@xunta.gal; maria.jose.rozados.lorenzo@xunta.gal; enrique.martinez.chamorro@xunta.gal; esteban.gomez.garcia@xunta.gal)}

The borehole method of resin extraction consists of making one or more perforations at the base of trees and collecting the oleoresin in closed containers. This method is compared with the wound tapping method, which is usually used in the Iberian Peninsula. The advantage of the borehole method is that the timber is not affected because the perforations are basal. In addition, the use of closed containers yields higher quality oleoresin and decreases the emission of volatile substances that can attract pests. The main limitation of the method is the rapid crystallization of resin around the perforation, which reduces the amount of oleoresin produced. The proposed improvements involve the application of organic stimulants to inhibit crystallization and thus increase the oleoresin yield, without altering the quality of the product. Early results indicate that this method may be a viable alternative to the wound tapping method, with quality as a goal.

Plant diversity associated with productive Brazil nut trees (Bertholletia excelsa) in the major producing regions of Amazonas, Brazil / Diversidade vegetal associada a castanhais produtivos nas principais regiões produtoras do Amazonas

Nadiele Pacheco ${ }^{1,2}$, Nabor Pio ${ }^{1}$, Kátia Emídio ${ }^{2}$

${ }^{1}$ Universidade Federal do Amazonas, Manaus, Brasil; ${ }^{2}$ Instituto de Desenvolvimento Agropecuário e Florestal Sustentável do Estado do Amazonas, Manaus, Brasil; ²EmbrapaAmazônia Ocidental, Manaus,Brasil (nadielep@gmail.com;nspio@ufam.edu.br;katia.emidio@embrapa.br)

Bertholletia excelsa Bonpl., conhecida como castanheira, é uma espécie florestal que produz um fruto chamado ouriço, coletado por populações tradicionais que comercializam suas amêndoas, castanha-do-brasil, como alternativa na composição da renda familiar. Avaliou-se a diversidade vegetal associada a castanheiras no Amazonas, por meio da comparação das diferenças florísticas entre e dentro de seis castanhais naturais. A pesquisa foi conduzida nas principais regiões produtoras do Amazonas: Reserva de Desenvolvimento Sustentável Piagaçu Purus/Anori, Propriedade do Jutica/Tefé, Comunidade Jatuarana /Manicoré, Sítio Gostoso/Amaturá, Comunidade Mufuá/Lábrea e Reserva Extrativista do Rio Unini/Barcelos. As diferenças florísticas foram analisadas por meio da análise Cluster, agrupamento UPGMA (Média não ponderada entre pares de grupos). Todos os indivíduos com DAP $\geq 10 \mathrm{~cm}$, vizinhos às castanheiras selecionadas, foram marcados e identificados em 15 parcelas circulares de 15 metros de raio em cada castanhal. As parcelas foram instaladas ao redor de castanheiras selecionadas a partir da classe de produção de frutos ( 5 de alta, 5 de média e 5 de baixa produtividade). Foram registrados 3039 indivíduos, com Jatuarana tendo o maior número de indivíduos (577). Os ambientes florestais apresentaram grande diversidade florística - diversidade alfa, medida pelo índice de ShannonWeaver, que vario entre 3,65 a 4,19; porém estes valores não foram estatisticamente significativos (Kruskal Wallis) entre as localidades. No contexto das classes de produção não se observou um padrão de agrupamento das parcelas de mesma classe. Observou-se que os castanhais com maior similaridade florística são Sítio Gostoso e Mufuá; Unini como o mais diferente entre eles. 


\section{Use of multispectric images for identifying overwatering in eucalyptus plantation}

Anny Mery Marcon Ruiz', Edson Luiz Furtado ${ }^{1}$, Lisandro de Proença Pieroni ${ }^{1}$, Fábio Suzart Albuquerque ${ }^{2}$

${ }^{1}$ Universidade Estadual Paulista "Júlio de Mesquita Filho", Universidade de São Paulo, Departamento de Proteção Vegetal, Botucatu, Brasil; ${ }^{2}$ College of

Integrative Science and Arts, Science and Mathematics Faculty, Arizona State University, Phoenix, USA (annymery_ruiz@hotmail.com;

edson.furtado@unesp.br; lisandro.pieroni@hotmail.com;fabio.albuquerque@asu.edu)

With 5.63 million of hectares Eucalyptus represents the most established forest in Brazil. This corresponds to 91\% of all wood produced for industrial purposes, such as paper and pulp production. The productivity of Eucalyptus plantations, however, is strongly affected by abiotic and biotic diseases, such as water stress. Waterlogged soil is a key issue for the health of eucalyptus plantations. In this study, we used drones and multispectral sensors to fly over commercial plantations plots, to capture the light they reflect in four separate bands (red, red edge, green and infrared), and to generate custom images and index maps, such as the normalized difference vegetation index (NDVI). We used the NDVI map to visualize and understand the eucalyptus plantation health. Maps and images allowed us to observe abnormalities in only one forest plot. In this area, we observed higher spectral reflectance when compared to the rest of the plantation - NDVI values ranged from -0.02 to 0.96 . High NDVI values corresponded to dense vegetation (uniform plantation), while low values represented areas with sparse or no vegetation (planting failures). Field analyses revealed that overwatering as the main cause of the uneven plant development in the affected area. Our results allow us to conclude that multispectral sensors and drones offers a comprehensive, flexible and powerful solution to map damage to eucalyptus plantations. We also conclude that NDVI is an important tool for identifying problems derived from the overwatering on eucalyptus plantations.

\section{Evolution of mechanization index in forest companies}

Samara Maschetti ${ }^{1}$, Guilherme Oguri ${ }^{2}$, Saulo Guerra ${ }^{1}$

${ }^{1}$ Universidade Estadual Paulista "Júlio de Mesquita Filho", Faculdades de Ciências Agronômicas, Botucatu, Brasil; '2Instituto de Pesquisas e Estudos Florestais,Piracicaba,Brasil (maschettis@gmail.com; guilherme@ipef.br; saulo.guerra@unesp.br)

The increased demand for higher yield and quality associate with the cost reduction and labor shortage in some regions of Brazil, push the R\&D for mechanization and automation. Brazilian forest chain is world known by its high harvesting and logging technological level, however silvicultural operations have not reached the same level, where agricultural tractors and adapted agricultural implements are presented as the main tools towards mechanization. Based on these assertions, a survey was carried out in three forest-based companies for comparison in the index of mechanization in silvicultural activities in 2015 and 2018. The observed parameters were the tractor index and implement index. Among the determinations highlighting the increase in number of tractors at companies A and C, in $27.77 \%$ and $30.13 \%$, respectively, leading to the growth of the tractor index from 2015 to 2018. For the implement index, the observed growth was only 1.11\%.Therefore, it was concluded that, in the three evaluated companies, there was an increase in the investments on silviculture processes from 2015 to 2018, with the increase of the tractors fleet and in implements amount by area.

Hyperkeystone palm species demography: modelling and simulation of Mauritia flexuosa for sustainable harvest in Tena, Napo Maria Cristina Peñuela-Mora ${ }^{1}$,Mathew Tello ${ }^{1}$

${ }^{1}$ Universidad Regional Amazonica Ikiam,Tena,Ecuador (crisantema1995@gmail.com; matiutello@gmail.com)

Mauritia flexuosa is a versatile multipurpose palm. It is well known for its ability to colonize flooded forests where it creates monospecific dominant patches across the basin. It is of remarkable importance for the ecosystem and it has recently been proposed as a hyperkeystone species. Its consumption by human populations has had a considerable impact in the income of local communities in the Amazon region. Fruit extraction is commonly achieved by chopping down female individuals in the forest causing a huge pressure over natural populations due to its high demand, in spite of there being less harmful alternatives for collecting fruits (climbing). Despite its importance, little is known about its management. In Ecuador the market of $M$. flexuosa is growing, therefore the objective of this study is to propose a sustainable frequency and intensity of harvest and further identification of the age-stage that contributes the most to the population stability for management purposes. For this, a 1-ha plot was stablished on a flooded forest dominated by M. flexuosa in the Napo river basin where 375 individuals were sampled. Population vital rates and growth of every stage (from seedlings to adults) were registered while production and germination rates were also determined. For modelling the population dynamic, integral projection models (IPM) were applied and then harvesting was simulated. The study results show the need of implementing the proposed harvesting in order to prevent local population decline or complete extinction of the palm.

Volumetric yield in lumber for Amazonian species in a sawmill in Rio Branco, Acre, Brazil / Rendimento volumétrico em madeira serrada para espécies Amazônicas em uma serraria de Rio Branco, Acre

José Pedro Melo ${ }^{1}$, Marco Amaro

${ }^{1}$ Universidade Federal do Acre, Rio Branco,Brasil (florestalpedro22@gmail.com; marcoantonioamaro@hotmail.com)

O objetivo do estudo foi determinar o coeficiente de rendimento volumétrico (CRV) em madeira serrada das espécies Calycophyllum spruceanum, Apuleia leiocarpa e Manilkara bidentata, em uma serraria de médio porte no município de Rio Branco, Acre. Desse modo, foram utilizados dados provenientes de toras que tiveram suas dimensões mensuradas previamente ao seu processamento, assim como as dimensões das peças produzidas após o desdobro. As variáveis das toras mensuradas foram: comprimento, em metros; diâmetro 1 e diâmetro 2, medidos em uma das extremidades; e diâmetro 3 e diâmetro 4, obtidos na outra, todos em centímetros. Após o desdobro, foram obtidos: comprimento das peças, em metros; largura e espessura das peças, em centímetros. Para obtenção do volume das toras foi utilizado o método de Smalian, já o volume de madeira serrada foi obtido somando-se os volumes das peças geradas. O CRV foi calculado a partir da razão entre o volume de madeira serrada e o volume da tora, posteriormente, obteve-se o CRV médio por espécie. As estatísticas foram calculadas conforme o estabelecido pela Resolução CONAMA 411/2009. As espécies C. spruceanum, A. leiocarpa e M. bidentata apresentaram CRV médio de 61,06\%, 62,30\% e 50,10\%, respectivamente. As mesmas obtiveram valores superiores ao estabelecido pela Resolução CONAMA 474/2016, expressaram baixa variabilidade, com coeficientes de variação inferior à $10 \%$ e um erro amostral relativo abaixo do admissível pelo CONAMA. Desse modo, a serraria em estudo poderá adotar os CRV obtidos para a comercialização da madeira serrada destas espécies, desde que submetido e aprovado pelo órgão competente. 
Mathematical growth modeling of diameter and height of unthinned stands of Eucalyptus grandis in Northeastern Entre Ríos, Argentina / Modelación matemática del crecimiento del diámetro y altura de rodales sin raleo de Eucalyptus grandis en el Noreste de Entre Ríos, Argentina

María Fernanda Barrios ${ }^{1}$, Mónica Balzarini ${ }^{2}$, María Eugenia Videla ${ }^{3}$, María de los Ángeles García ${ }^{1}$

${ }^{1}$ Instituto Nacional de Tecnología Agropecuaria, Concordia, Argentina; ${ }^{2}$ Universidad Nacional de Córdoba, Córdoba, Argentina; ${ }^{3}$ Consejo Nacional de Investigaciones Cientificas y Técnicas, Córdoba, Argentina (barrios.fernanda@inta.gob.ar; mbalzari@gmail.com; eugeniavidela@gmail.com; garcia.mariaa@inta.gob.ar)

La modelación matemática del crecimiento es fundamental para la planificación, toma de decisiones en la gestión forestal y la comprensión de la dinámica de los rodales. A ello hay que sumarle la relación existente con la calidad de sitio, que influye sobre la capacidad productiva de las forestaciones de Eucalyptus grandis. Existen modelos matemáticos lineales y no lineales que permiten modelar el crecimiento y la calidad de sitio. Con el objetivo de predecir el crecimiento de diámetro normal y altura en rodales sin raleo, se evaluaron 520 parcelas temporales y permanentes de 1 a 20 años de edad, con medidas repetidas en el tiempo, de diferentes sitios y densidades iniciales, se ajustaron los modelos no lineales de Gompertz, Chapman-Richards, Weibull y Schumacher, y un modelo lineal mixto con efecto aleatorio de parcela. El modelo con mejor bondad de ajuste y valores bajos de criterio de Akaike (AIC) y criterio bayesiano de información (BIC) para las variables estudiadas, fue el modelo lineal mixto con efecto aleatorio de parcela, del que se obtuvieron además los BLUP (Best Linear Unbiased Prediction) para rankear las parcelas de acuerdo a los mejores crecimientos en altura y clasificarlos de acuerdo a calidades de sitio de manera sencilla. Además, se realizó el análisis de correlación espacial intraparcela para comprobar si los datos están correlacionados espacialmente. Estos resultados representan los datos base para la comparación de parcelas con raleos.

Estimating diameter distribution in a fragment of Atlantic Forest using artificial neural networks / Estimativa de distribuição diamétrica de um fragmento de Mata Atlântica utilizando redes neurais artificiais

Rodrigo Leite', Carlos Torres ${ }^{1}$, Samuel Rocha ${ }^{1}$, Leonardo Reis' ${ }^{2}$, Hélio Leite ${ }^{1}$

${ }^{1}$ Universidade Federal de Viçosa, Viçosa, Brasil; ${ }^{2}$ Instituto de Desenvolvimento Sustentável Mamirauá, Tefé, Brasil (r.vieiraleite@gmail.com;

carlos.eleto@yahoo.com.br; samueljoserocha@gmail.com; leonardopequenoreis@gmail.com; hgleite@gmail.com)

O crescimento e produção em florestas tropicais são objeto de estudo a muito tempo, porém, devido a sua complexidade, estimar sua dinâmica não é tarefa fácil, levando a aplicação de modelos pouco eficientes ou que necessitem de variáveis de difícil obtenção. Uma alternativa seria a utilização algoritmos de inteligência artifical, com destaque no setor florestal para as Redes Neurais Artificiais (RNA). Desta forma, objetivou-se estimar a distribuição diamétrica de um fragmento de Mata Atlântica, em Viçosa/MG, utilizando RNA. Foram utilizados dados de 10 parcelas de inventário medidas em 1994, 1997, 2000, 2004, 2007, 2010, 2013 e 2016. As árvores foram divididas em classes de diâmetro de 5cm, entre 5 e 85cm. As RNA foram treinadas utilizando os dados dos anos 1994 e 1997 e as estimativas foram feitas para os demais anos. As variáveis de entrada foram o número de árvores da classe e das 4 classes mais próximas; classe de diâmetro e período. Para análise dos resultados foi utilizado o teste K-S a 5\% de significância, entre a distribuição diamétrica estimada e observada em cada ano. O valor calculado do teste foi $0,003,0,02,0,03,0,02,0,04,0,04$ e 0,12 para os anos 1997, 2000, 2004, 2007, 2010, 2013 e 2016, respectivamente, sendo não significativo apenas no último ano. O estudo mostra que as RNA podem ser utilizadas para estimar distribuição diamétrica de fragmentos de Mata Atlântica no período de 22 anos, com a vantagem de inclusão de variáveis não paramétricas e variação no período a ser estimado.

Forest litter production in a plant succession gradient in a tropical dry forest in Colombia / Producción de hojarasca en un gradiente de sucesión vegetal de un bosque seco tropical en Colombia

Angie Viviana Montañez Salinas ${ }^{1}$, René López Camacho ${ }^{1}$, Roy Oswaldo González Martínez ${ }^{2}$

${ }^{1}$ Universidad Distrital Francisco José de Caldas, Bogotá, Colombia; ${ }^{2}$ Instituto de Investigación de Recursos Biológicos Alexander von Humboldt, Bogotá,

Colombia(avmontanezs@correo.udistrital.edu.co; rlopezc@udistrital.edu.co;rgonzalez@humboldt.org.co)

La producción de hojarasca es fundamental en el ciclo de nutrientes, el mantenimiento de la fertilidad del suelo y la regulación del carbono en ecosistemas terrestres. Diversos estudios han abordado su variación en diferentes niveles de sucesión vegetal en bosques tropicales, pero aún no es clara su dinámica ecológica en bosques secos tropicales, debido a la compleja interacción de factores bióticos y abióticos allí presentes. Este estudio analiza la variación anual de la caída de hojarasca en un gradiente de sucesión vegetal de bosque seco, localizado al norte del Tolima, Colombia. Siguiendo la metodología Tropi-Dry se establecieron 12 parcelas permanentes de 0.1 ha, las cuales se encuentran distribuidas en 4 estadios sucesionales (bosque maduro, intermedio, joven y rastrojos bajos). En cada parcela se establecieron 8 trampas circulares de hojarasca de $0.5 \mathrm{~m}^{2}$, con el fin de colectar mensualmente el material vegetal durante 2 años. Los resultados del primer año de muestreo evidencian que la caída de hojarasca es significativamente superior en los bosques maduros e intermedios en comparación con los bosques jóvenes y rastrojos bajos $(\mathrm{F} 3=14.52, \mathrm{P}<0.001)$. Estos resultados sugieren que la producción de hojarasca aumenta con el grado de sucesión, debido a mayores niveles de biomasa aérea y un dosel más desarrollado. La caída de hojarasca es sensible a la perturbación y puede ser utilizada como indicador de recuperación y restauración de funciones ecosistémicas.

\section{Development of a stand-level growth and yield simulation system for Eucalyptus tereticornis plantations growing in Colombia}

\section{Alonso Barrios ${ }^{1}$, Ana M. López ${ }^{1}$, Guillermo Trincado², Victor M. Nieto ${ }^{3}$}

${ }^{1}$ Universidad del Tolima, Ibagué, Colombia; ${ }^{2}$ Universidad Austral de Chile, Valdivia, Chile; ${ }^{3}$ Corporación Nacional de Investigación y Fomento Forestal, Bogotá,Colombia (abarriost@ut.edu.co; amlopeza@ut.edu.co; gtrincad@uach.cl; victornieto@conif.org.co)

Currently one of the most important tree species for establishing forest plantations in Colombia is E. tereticornis. During the last years, about 10.000 ha of this tree species have been planted in the country mainly in the Atlantic Coastal Region. This research represents the first effort to develop and implement a standlevel growth and yield simulation system: SimFOR. Data used in this study came from the measurement of a network of 85 permanent sample plots established on 70 stands from 1 to 12 years-old. In addition, 130 sample trees were selected for destructive sampling to develop taper equations. The simulation system is driven by three main transition functions: dominant height, basal area and mortality. All equations forms were derived applying the algebraic difference 
approach. Three types of taper model forms were evaluated: polynomials, segmented and variable-exponent models. The effect of autocorrelation generated by the longitudinal measurements taken along the stem was accounted using a continuous time autoregressive model (CAR) for the error structure. The validation of the stand-level growth and yield simulation system was performed using an independent dataset and measures of bias and error were calculated. Predicted stand volume for $E$. tereticornis under diverse projection scenarios was consistent with observed growth patterns.

Carbon storage in woody vegetation in the Cerradão dry forest in the Vermelho River Basin, Goiás, Brazil / Estoque de carbono na vegetação lenhosa de cerradão na Bacia Hidrográfica do Rio Vermelho, GO

Sabrina Miranda ${ }^{1}$, Cássio Cezare ${ }^{2}$, Weuler Vasconcelos ${ }^{3}$, Laerte Ferreira ${ }^{2}$

${ }^{1}$ Universidade Estadual de Goiás, Palmeiras de Goiás, Brasil; ' ${ }^{2}$ Universidade Federal de Goiás, Goiânia, Brasil; ${ }^{3}$ Universidade Federal do Tocantins,

Gurupi,Brasil(sabrinac.miranda@gmail.com; cassio_cezare@hotmail.com; weulervasconcelos@hotmail.com; lapig.ufg@gmail.com)

Este trabalho faz parte do projeto "Estimativa da biomassa aérea lenhosa em formações savânica e florestal do bioma Cerrado através de dados de campo e Lidar aerotransportado". Nosso objetivo foi estimar o estoque de carbono aéreo na vegetação lenhosa (CAVL) de cerradão a partir de dados de campo. Amostramos dois remanescentes na Bacia Hidrográfica do Rio Vermelho-Goiás localizados nos extremos do transecto (50 km x $200 \mathrm{~m})$ onde foram obtidos dados Lidar aerotransportado: Itapirapuã (cerradão típico/CT) e Goiás (cerradão transição para floresta estacional/CF). Em parcelas de $1.000 \mathrm{~m}^{2}$ foram amostrados indivíduos com diâmetro a altura do peito (DAP) $\geq 5 \mathrm{~cm}$. Nas estimativas de carbono utilizou-se equação alométrica específica. O CT com densidade de 1.259 ind/ha apresentou $73,93 \mathrm{Mg} / \mathrm{ha}$ de CAVL. Indivíduos com diâmetro $<15 \mathrm{~cm}(87,4 \%)$ somam $28,3 \%$ do CAVL, já aqueles com diâmetro $\geq 30 \mathrm{~cm}(1,5 \%$ do total) representam 36,2\% do CAVL. Os indivíduos com altura entre 4,0 e 7,9 m (70\%) somam 36,3\% do CAVL. Por outro lado, aqueles com altura $\geq 10 \mathrm{~m}(5,2 \%)$ representam 42,4\% do CAVL. No CF a densidade foi de 968ind/ha e o CAVL 154,38Mg/ha. Indivíduos (74,8\%) com diâmetro < 15 cm somam 12,6\% do CAVL e aqueles com diâmetro $\geq 30 \mathrm{~cm}(4,5 \%$ do total) $48,5 \%$ do CAVL. Indivíduos com altura entre 6,0 e 9,9 m (47,3\%) somam 10,1\% do CAVL, já aqueles com altura $\geq 15 \mathrm{~m}(13,8 \%)$ representam $69 \%$ do CAVL. Os remanescentes de cerradão são importantes em termos de armazenamento de carbono e emissões evitadas, com destaque para os indivíduos de maior porte.

Productivity of Eucalyptus spp. clones in different spacing arrangements in the semiarid region of Pernambuco, Brazil / Produtividade de clones de Eucalyptus spp. em diferentes espaçamentos no semiárido pernambucano

José Antonio Aleixo da Silva ${ }^{1}$, Rinaldo Luiz Caraciolo Ferreira ${ }^{1}$, José Wesley Lima Silva ${ }^{1}$, Marilia Regina Costa Castro ${ }^{2}$

${ }^{1}$ Departamento de Ciência Florestal da Universidade Federal Rural de Pernambuco, Recife, Brasil;; ${ }^{2}$ Instituto Federal de Educação, Ciência e Tecnologia,

Recife,Brasil(jaaleixo@uol.com.br; rinaldo.ferreira@ufrpe.br; wesleylima_16silva@hotmail.com; mariliarcastro@uol.com.br)

O efeito das mudanças climáticas no regime hídrico é evidente no semiárido nordestino, sendo o desmatamento da vegetação nativa um dos principais responsáveis. No Polo Gesseiro do Araripe, produtor de 95\% do gesso nacional, a vegetação da Caatinga já perdeu em torno de $70 \%$ de sua área em função da alta demanda energética pela indústria do gesso. Uma alternativa para suprir essa demanda é a implantação de florestas energéticas de rápido crescimento. Desta forma, este trabalho teve como objetivo avaliar a produtividade de três clones de Eucalyptus spp. (C39, C41, C11) plantados nos espaçamentos $3 \mathrm{~m}$ x $3 \mathrm{~m}$, 4 m x 2 m, 3 m x2 m, 2 m x 2 m e $2 \mathrm{~m}$ x 1 m, em um delineamento inteiramente aleatório. O índice histórico de precipitação acumulada por ano da região é $750 \mathrm{~mm}$, durante o período do experimento a média foi $529,4 \mathrm{~mm}$. Na idade de 8 anos foram cubadas rigorosamente pelo método de Smalian, 2896 árvores. O experimento apresentou produtividade média de $76,35 \mathrm{~m}^{3} \mathrm{ha}^{-1}$, e diferenças entre os tratamentos foram encontradas ( $\left.\mathrm{p}<0,05\right)$, sendo o clone C39, no espaçamento $2 \mathrm{~m} \mathrm{x} 1 \mathrm{~m}$, o mais produtivo com 136,398 $\mathrm{m}^{3} \mathrm{ha}^{-1}$, segundo o teste de Scott-Knott $(\mathrm{p}<0,05)$. O experimento apresentou um incremento médio anual (IMA) de 9,543 $\mathrm{m}^{3} \mathrm{ha}^{-1}$ para os clones. O clone C39, no espaçamento $2 \mathrm{~m} \mathrm{x} 1 \mathrm{~m}$, apresentou o maior IMA, 17,049 $\mathrm{m}^{3}$ ha ${ }^{-1}$. Comparando com o IMA da Caatinga, $4 \mathrm{~m}^{3} \mathrm{ha}^{-1}$, o uso de clones de Eucalyptus urophylla mesmo diante de condições de seca extrema é indicado como uma opção viável para suprir a demanda da indústria do gesso.

Machine learning models to estimate above-ground carbon in seasonal semideciduous forests using LIDAR data / Modelos de machine learning para estimativa de carbono acima do solo de Floresta Estacional Semidecidual com dados Light Detection and Ranging

Renata Paulo Macedo ${ }^{1}$, Cibele Hummel do Amaral ${ }^{1}$, Carlos Moreira Miquelino Eleto Torres ${ }^{1}$, Elpídio Fernandes Filho ${ }^{1}$, Walter da Silva Costa ${ }^{2}$, Rodrigo Vieira Leite ${ }^{1}$, Pedro Henrique Santos Mota ${ }^{1}$, Duberli Geomar Elera Gonzáles ${ }^{3}$, Lucas Arthur de Almeida Telles ${ }^{1}$

${ }^{1}$ Universidade Federal de Viçosa, Viçosa, Brasil,; ${ }^{2}$ Celulose Nipo-Brasileira S.A, Belo Oriente, Brasil; ${ }^{3}$ Universidad Cientifica del Sur, Lima, Peru (renata.macedoufv@gmail.com; chamaral@ufv.br; carlos.eleto@yahoo.com.br; elpidiofilho@gmail.com; walter.costa@cenibra.com.br; r.vieiraleite@gmail.com; pedromota.enf@gmail.com; duberelera@gmail.com; lucasarthur36@gmail.com)

O uso de novas tecnologias na mensuração de parâmetros biofísicos da floresta tem tornado o inventário florestal mais ágil, obtendo a mesma ou maior precisão das estimativas realizadas no inventário convencional. Dessa forma, esse trabalho tem como objetivo selecionar o melhor modelo de machine learning para estimar o estoque de carbono acima do solo de fragmentos da Floresta Estacional Semidecidual em Minas Gerais. Os dados são provenientes de inventário florestal para cálculo do carbono acima do solo e dados de sobrevoo utilizando a tecnologia laser aerotransportada para o cálculo de métricas LiDAR. A estimativa do carbono foi obtida através da multiplicação de um fator $(0,48)$ pela biomassa acima do solo, calculada utilizando o somatório de DAP, altura total e densidade básica de cada espécie dentro das 29 parcelas selecionadas em campo. Os modelos utilizados no trabalho foram: Random Forest, Support Vector Machine e Cubist; utilizando como variáveis explicativas as cinco métricas LIDAR, extraídas da nuvem de pontos normalizada, com maior valor de importância, de acordo com a ferramenta Recursive Feature Elimination do software R. Os coeficientes de determinação $\left(\mathrm{R}^{2}\right)$ para as três modelagens foram superiores a 0,91, com Erros Quadráticos Médios (RMSE) inferiores a 19\%. Diante dos resultados obtidos nesse estudo, conclui-se que é possível estimar de forma precisa o estoque de carbono acima do solo de Floresta Estacional Semidecidual por meio de dados LiDAR aerotransportado e modelos de machine learning. 


\author{
Modelling forest succession under a harvest regime in mixed stands in Quebec, Canada \\ Lara Climaco de Melo ${ }^{1}$, Robert Schneider ${ }^{1}$ \\ ${ }^{1}$ UQAR, Rimouski,Canada (laracmelo@gmail.com; robert_schneider@uqar.ca)
}

Understanding forest regeneration over large-scale and under harvesting regime is essential for natural resource management. In this study,we used a dataset from a network of monitoring plots in the regions of Bas-Saint-Laurent and Gaspésie, in Quebec, Canada, as a real-world case study. Based on statistical models, we combined different techniques into an approach that predicts forest succession under harvesting. Firstly, we fitted a binomial model to predict regeneration after harvesting. Once a regeneration was predicted, a gamma model was fittedto estimate the stocking. Forest composition before and after harvest, as well as climatic and topographic variables were used as explanatory variables. The models were evaluated and validated, and the results showed the potential of the approach to provide predictions of forest succession in the area of study. The probability of regeneration was strongly influenced by the topographic variables. The results also revealed the temporal evolution of post-harvest forest composition in terms of stocking. This modelling approach should overcome actual challenges reported by managers in the study regions.

\title{
Forest growth and minimal model of forest ecosystem organic matter turnover: implication for sustainable forest management analysis
}

Alexander Alekseev ${ }^{1}$

${ }^{1}$ Saint-Petersburg State Forest Technical University, Saint-Petersburg, Russian Federation (a_s_alekseev@mail.ru)

Forest growing stock change in time was derived from minimal model of organic matter turnover in forest ecosystem. Growth curve was calibrated on the base of growth and yield tables data and describe it with high precision as it measured by determination coefficient. Growth and organic matter turnover parameters relationships was established and interpreted. Increment and acceleration curves for growing stock changes were in special manner analyzed and 4 specific tree stands growth stages was formulated as they determined by acceleration curve singular points. Determined growth stages was interpreted and discussed from forest management point of view. Multi-criteria optimization of growing stock use in time was done on the base of special management problem decision and analyzed from point of view of sustainable forest management: carbon cycling, carbon uptake and storage, forest biodiversity conservation, soil and water protection as well as risk of natural and man-made hazards damage. Optimal parameter for continuous cover forestry approach to tree stands use such as proportion between harvested and remaining for further growth growing stock, number of thinning per rotation period and its intensity, time needed for growing stock recovering after harvesting as well as suitability of continuous cover forestry approach for tree stands of different productivity and rate of growth was determined and discussed. Sustainability and resistance of forest growth as well as organic matter turnover in forest ecosystem was examined by catastrophe theory approach and the edge values of external effects were determined in connection with tree stands productivity and growth rate.

Novel TLS device with eccentric automotiv scanner to avoid occlusion in single stand-point LIDAR scanning and obtain block-chain certified snapshots ready for AI-based single tree growth modelling

Guenther Bronner ${ }^{1}$, Martin Wieser ${ }^{2}$

${ }^{1}$ Umweltdata GmbH, Wolfsgraben, Austria; ${ }^{2}$ Technical University of Vienna, Vienna, Austria (g.bronner@umweltdata.at; wieser_martin@gmx.at)

Terrestrial Laserscanning (TLS) in forestry has to deal with occlusion unless scanning from multiple stand-points. A novel patented scanning device can significantly reduce this handicap. A horizontal protruding arm of $\sim 1$ meter is mounted on a tripod, rotating at $0.3 \mathrm{rot} / \mathrm{min}$. On the end of this horizontal arm, an (automotive) laser-scanner is rotating vertically at $30 \mathrm{rot} / \mathrm{sec}$. On the opposite end of the arm, CPU and battery help to balance the construction. A prototype will be available at the IUFRO conference. It can carry different sensors like VLP16, Quanergy M8 or the Riegl mini-VUX. Simulation scans with Riegl VZ2000 on multiple circular positions look promising, showing that this geometrical setup can avoid 90-95\% occlusion compared to conventional TLS. The resulting point cloud allows accurate reconstruction of DBH, height, taper functions, crown geometry, tree positions and relief properties within 20-50 m radius. This dataset can perfectly serve as input for AI based single tree growth simulation. In combination with digital images, this standardized geo-located snapshot can be certified by blockchain technology. The price of the device will be below 30,000 US\$. This technology has game-changing potential in forest inventory business, especially regarding NFI as well as standardized carbon monitoring. While point cloud interpretation and tree feature extraction will surely be further developed, the geo-located point cloud snapshots can be stored for future monitoring purposes. The device will be ready for testing by March 2019. Until the IUFRO conference we will have plenty of test-data available for presentation and discussion.

\section{Why is the error in top height predictions usually ignored and why is it an error to do so?}

Rubén Manso ${ }^{1}$, Catia Arcangeli ${ }^{2}$, Paul McLean ${ }^{1}$, Robert Matthews ${ }^{2}$

${ }^{1}$ Forest Research, Roslin, United Kingdom; ${ }^{2}$ Forest Research, Farnham, United Kingdom; (ruben.manso@forestresearch.gov.uk;

catia.arcangeli@forestry.gsi.gov.uk;paul.mclean@forestry.gsi.gov.uk; robert.matthews@forestry.gsi.gov.uk)

Top height has been an essential metric in forest practice and forest science over the last century. Despite the many issues that have been risen in regard to this metric, top height is still popular and useful these days. Crucially, top height is used as the engine of many growth and yield models worldwide, which are the base of national or regional forest planning. Unfortunately, predictions from most of these top height models do not come with an uncertainty assessment, which may have a non-trivial impact on decision making and therefore on forest policy. Our contribution seeks to identify the historical and technical reasons for this systematic omission and to explore the consequences of ignoring uncertainty in this context. To do this, the most popular modelling approaches are described along with the technical issues related to uncertainty. Then an alternative method to easily derive the uncertainty of top height predictions through a modification of the Generalized Algebraic Difference Approach is introduced. Finally, yield predictions are computed with M1, a top height-dependent yield model used to forecast timber production at the national level in Great Britain, both considering uncertainty in top height estimates and ignoring it. 


\section{A forest productivity analysis framework to estimate yields, gaps and manage production risks}

Arthur Vrechi ${ }^{1}$, Eduardo More de Mattos ${ }^{1}$, José H. Bazani ${ }^{1}$, Gabriela G. Moreira ${ }^{2}$, Luis Fernando Silva ${ }^{2}$

${ }^{1}$ Geplant Forest Technology, Piracicaba, Brasil; ${ }^{2}$ International Paperdo Brasil, Mogi-Guaçu, Brasil,(arthur@geplant.com.br; eduardo@geplant.com.br;

bazani@geplant.com.br; gabriela.moreira@ipaper.com; lfernando.silva@ipaper.com)

Comprehending and forecasting planted forests production is actually a challenge for forest managers, mainly due to combined, and generally misunderstood, influences of space-time weather oscillations, pests, abiotic disturbances and lack of management practices. Aiming to provide future stochastic yields estimations for risk assessment and KPI's for current productivity, considering distinctly climate and forest management effects, we developed a framework named GPT (portuguese acronym for total productivity management), that integrates a soil and climate (from 1980 up-to-date) database, a process-based ecophysiological model (an improved version of 3-PG), yield gap concept, Monte Carlo approach, probabilistic analysis, forest inventory and remote sensing. This framework was applied to a group of Eucalyptus plantation, ranging from 2 to 4 years old, in northeast Sao Paulo, Brazil, that suffered from defoliation and sporadic mortality due to an intense dry period in 2017. Landsat-8 imagery timeseries were used to estimate different levels of defoliation and eventual mortality. Reference productivity (a timeless reference given by the framework) for this plantation was $270 \mathrm{~m}^{3} / \mathrm{ha}$ (year 6). Optimist and pessimist scenarios (from probabilistic analysis) ranged from 301 to $223 \mathrm{~m} 3 /$ ha. Actual weather conditions impacted negatively the attainable productivity by $5,4 \%$. Defoliation and mortality impacts over future yield varied from $-2 \%$ up to $-20 \%$, considering optimistic and pessimistic future scenarios, with a most likely estimation of $-9,1 \%$. This approach was proven to be helpful for forest managers to predict and prevent yield losses, manage risks and take decisions considering the dynamics of forest growth under changing scenarios.

\section{Variance Estimation in Spatially Balanced National Forest Inventory Sampling}

\section{Minna Räty ${ }^{1}$ (D) Annika Susanna Kangas² (D); Juha Heikkinen ${ }^{1}$ (D)}

${ }^{1}$ Natural Resources Institute Finland (Luke), Helsinki, Finland; ${ }^{2}$ Natural Resources Institute Finland (Luke), Joensuu, Finland (minna.raty@luke.fi; annika.kangas@luke.fi;juha.heikkinen@luke.fi)

Local pivotal method (LPM) has proven to be an efficient approach to enhance the design phase of National Forest Inventory (NFI). It utilizes auxiliary information, for example remote sensing data, in sample selection aiming at a sample, which is similar to the population in terms of its distribution in the multidimensional auxiliary space i.e. spatially balanced. In Finland, LPM was piloted in the inventory of Åland region in summer 2018 . The increased efficiency should be reflected in our estimates of sampling error but for LPM we need a new variance estimator. 'vsb' estimator, which sums squared differences of observations between each pivot and its nearest neighbour in the auxiliary space in similar spirit to the Matérn variance estimator developed for square grid sampling, has been suggested. In a simulation study we assessed the suitability of vsb. We focused on total growing stock volume and compared vsb variance estimates to naive variance estimates associated to simple random sampling (SRS) and Matérn variance estimator. Expectedly, SRS estimates were the most conservative resulting in largest variances. Matérn and vsb variances were smaller than SRS and close to each other. We think that it might be possible to reduce overestimation of variance by alternative Matérn-type approaches.

\section{Climate effect on volume response for mid-rotation fertilization in clonal eucalypt stands}

Luciane Schmidt ${ }^{1}$, Henrique Scolforo ${ }^{2}$, José Roberto Scolforo ${ }^{1}$, Mateus Sanquetta

${ }^{1}$ Universidade Federal de Lavras, Lavras, Brasil; ${ }^{2}$ Suzano, Limeira, Brasil,; ${ }^{3}$ Universidade Federal do Paraná, Curitiba, Brasil

(lunaimekeschmidt@gmail.com; henriquescolforo@hotmail.com; josescolforo@gmail.com; mateus.sanquetta@gmail.com)

It is claimed that climate x mid-rotation fertilization interaction results in different volume gains in forest plantations. There is a dearth of studies, however, evaluating this interaction and its consequently effect on forest production. It is worth mentioning that volume gain is responsiveness to fertilization, although at different rates depending on the climate. To evaluate how volume gain is affected through the mid-rotation fertilization $\mathrm{x}$ climate interaction, we offer a modeling approach that relates clonal Eucalypt yields in fertilized vs non-fertilized stands as function of climate variables through the use of a semi-parametric regression. Ridge regression is a technique that enables the evaluation of how the interaction effects volume gain as well as to identify the climate variables that limit the most the fertilization effect on volume gain. The dataset come from inventory of 32 plots at age 14 years distributed in Eastern Brazil. The understanding of the mid-rotation fertilization $\mathrm{x}$ climate interaction is a critical step in the decision framework, since it allows better site-specific management, while respecting the budgetary constraints.

\section{Predicting Weibull parameters as a function of stand attributes}

Luciane Schmidt ${ }^{1}$, Gilson Silva², Clayton Fraga Filho², Mateus Sanquetta ${ }^{3}$, José Roberto Scolforo ${ }^{1}$

${ }^{1}$ Universidade Federal de Lavras, Lavras, Brasil; ${ }^{2}$ Universidade Federal do Espírito Santo, Alegre, Brasil; ${ }^{3}$ Universidade Federal do Paraná, Curitiba,

Brasil(lunaimekeschmidt@gmail.com; fernandes5012@gmail.com; claytonfraga@gmail.com; mateus.sanquetta@gmail.com; josescolforo@gmail.com)

Probability density functions are widely used for forest growth and yield purposes. The diameter distribution is performed by classes, providing detailed yield estimates and making it possible to obtain multiple products. The Weibull function has been used due to its flexibility and good correlation with stands attributes. This study aimed to evaluate the Weibull parameter prediction approach to describe the diameter distribution of clonal eucalypt stands. Data came from 56 permanent plots measured at 36, 60 and 72 months, located in central Minas Gerais. Regression models employing best-correlated stands attributes to Weibull parameters were fitted. The fitted equations presented RRMSE of $9.9 \%$ and $2.2 \%$ for the shape and scale parameters. The location parameter showed low correlation with stands attributes and its exclusion allowed best estimates. The parameter prediction approach consists in a fast alternative without computational effort demand, which results in accurate estimates that may help in scenarios of industry supply and independent wood producers to predict the amount of available resources at harvesting time. 


\section{Derivation of a set of biologically-based LiDAR attributes}

Ting-Ru Yang ${ }^{1}$, John A. Kershaw ${ }^{1}$

${ }^{1}$ University of New Brunswick,Fredericton, Canada (tyang1@unb.ca; kershaw@unb.ca)

Canopy surface-based and height distribution-based attributes are primarily used to model area-based forest attributes such as volume or biomass per ha, but those attributes are less effective at estimation of other commonly needed forest attributes, including basal area, density, mean tree size, canopy volume, leaf area, and many others. There is limited generalized theory that has emerged regarding the relationship between LiDAR point clouds and forest structure. To have better predictive capability for stand parameters such as leaf area distribution, structural diversity, and biodiversity, a series of biologically-relevant and generalized LiDAR attributes are required. These attributes should be derived from our biological understanding of forest structure and productivity. The approach we propose builds upon current forest inventory practices, stand development theories, and measures of stand structure and complexity. With these traditional measures, we propose to use them to inform the types of LiDAR attributes which should be extracted or calculated from point clouds. Initially, we perceive four types of LiDAR point cloud attributes: 1) height-based; 2) horizontal density-based; 3) horizontal and vertical variability; and 4) individual tree segmentation. The initial goal is generalizable forest inventory predictions. Implications for sample design, growth and yield modeling, and forest management decision making are explored.

\section{Forest stand 3D segmentation at the tree level from fused airborne LiDAR and Hyperspectral data}

Eduardo Tusa-Jumbo ${ }^{1,2}$, Jean-Baptiste Barré ${ }^{1}$, Jean-Matthieu Monnet ${ }^{1}$, Mauro Dalla Mura ${ }^{2}$, Raphaël Aussenac ${ }^{1}$, Jocelyn Chanussot ${ }^{2}$ ${ }^{1}$ Univ. Grenoble Alpes, Irstea, LESSEM, Grenoble, France; ${ }^{2}$ Univ. Grenoble Alpes, CNRS, Grenoble INP, GIPSA-lab, Grenoble, France (eduardo.tusajumbo@irstea.fr; jean-baptiste.barre@irstea.fr; jean-matthieu.monnet@irstea.fr; mauro.dalla-mura@gipsa-lab.grenoble-inp.fr; raphael.aussenac@irstea.fr; jocelyn.chanussot@gipsa-lab.grenoble-inp.fr)

Access to data with high spatial and spectral resolution is becoming more widespread and makes it possible to consider new applications for monitoring forest ecosystems. In particular, it is possible to consider studies of an entire stand but at the tree level. However, this raises questions about the joint use of data from different sensors such as LiDAR and hyperspectral imagers. This study presents a fusion methodology between high-density LiDAR data (45 pts/ $\mathrm{m}^{2}$ minimum) and VNIR hyperspectral images (HI) - (80 cm spatial resolution) acquired on french Alpine forests along an altitude gradient. The objective is to extract the main architectural characteristics of each individual tree and in particular the dimensions of crowns knowing the species. The methodology is based on the integration of HI and LiDAR data at different levels of fusion. First species are identified using the reflectance attributes contained in HI and the LiDAR canopy model, and then the 3D point cloud is segmented based on the allometric characteristics of the species. The integration of this additional information together with the segmentation algorithm provides an essential association strategy for LiDAR points located in the lower part of the canopy. Finally, the main dimensions of the crowns and associated trees are extracted from the 3D segmentation.

Seasonal change in forest cover in Northwestern Rio Grande do Sul, Brazil, using supervised Landsat image classifiers / Avaliação temporal da cobertura florestal no noroeste do Rio Grande do Sul por meio de classificadores supervisionados de imagens Landsat

Renato Santos ${ }^{1}$, Fábio Breunig ${ }^{1}$

${ }^{1}$ Universidade Federal de Santa Maria, Frederico Westphalen, Rio Grande do Sul, Brasil (renato.souzazf@gmail.com; fabiobreunig@gmail.com)

Classificação é o processo de extração de informação,em imagens, para reconhecer padrões e objetos homogêneos. Esse método é amplamente utilizado no sensoriamento remoto. Assim, o objetivo desse estudo foi observar a dinâmica florestal do noroeste do Rio Grande do Sul, utilizando diferentes métodos de classificação supervisionada. O estudo foi realizado em duas microrregiões localizadas no estado do Rio Grande do Sul, situado na região sul do Brasil. Para o estudo foram utilizadas imagens do satélite Landast 5 e 8, para recobrir os anos 1985, 1995, 2005, 2015 e 2018, sendo utilizadas duas imagens por ano, representando o verão e inverno. Os métodos de classificação de imagens utilizados foram os algoritmos Máxima verossimilhança, Spectral Angle Mapper e Support Vector Machine. Para tal, foram selecionadas diversas classes afim de caracterizar melhor a área. Para a avaliação da qualidade da classificação, foi utilizada a inspeção ponto a ponto de amostras sorteadas aleatoriamente (matriz de confusão). Dentre os classificadores testados, os que apresentaram uma melhor acurácia foram o Spectral Angle Mapper e Support Vector Machine. Verificou-se que houve um aumento na vegetação florestal nos últimos anos dessas áreas estudas, possivelmente está relacionado à influência de diversos fatores, como por exemplo a reformulação e aplicação efetiva do código florestal, dinâmica populacional e mudanças no padrão de uso do solo eminentemente agrícola para novas abordagens silviculturais.

\section{Improving forest inventory plot registration precision using field and LiDAR data}

Demetrios Gatziolis ${ }^{1}$, Przemyslaw Polewski ${ }^{2}$, Adam Erickson ${ }^{3}$, Nikolay Strigul ${ }^{3}$

${ }^{1}$ USDA Forest Service, PNW Research Station, Portland, Oregon, USA; ${ }^{2}$ Hong Kong Polytechnic University, Hung Hom, Kowloon, Hong Kong; ${ }^{3}$ Washington State University,Vancouver,Washington,USA(dgatziolis@fs.fed.us; przemyslaw.polewski@polyu.edu.hk; adam.erickson@wsu.edu; nick.strigul@wsu.edu)

Precise registration of forest inventory plots is a prerequisite for optimal integration of field measurements with high-resolution remotely sensed data, including ALS and very high resolution (VHR) satellite imagery. Plot positional uncertainty propagates through statistical modeling procedures and, ultimately, reduces the utility of obtained wall-to-wall inventory maps. In most national forest inventory systems, plot registration is obtained using recreational-grade, low-precision GPS devices. However, even industrial-grade devices yield low-precision coordinates in unfavorable conditions for GPS operation, including steep slopes, high canopy cover, and multilayered vegetation. We introduce a fully automated procedure relying on individual-tree height and position relative to the plot center, as recorded in co-located field and LiDAR data, to improve field data registration accuracy and precision. Results are furnished with an estimate of confidence in the optima obtained. Performance is evaluated using a sample of circular inventory plots stratified across classes of canopy cover and tree height in Oregon, USA. 


\section{Integrating remote sensing and process-based models to predict wood production of Eucalyptus plantations across large space-time} gradients

Marcos Augusto A. Dassan ${ }^{1}$,Eduardo More de Mattos $^{1}$, Arthur Vrechi ${ }^{1}$, José Henrique Bazani ${ }^{1}$

${ }^{1}$ Geplant Forest Technology, Piracicaba,Brasil (marcos@geplant.com.br; eduardo@geplant.com.br; arthur@geplant.com.br; bazani@geplant.com.br)

The extension of Brazilian silviculture brings challenges for monitoring large spatial and temporal gradients across 7.4 M ha of Eucalyptus plantations. Field assessment still one of the major tools to monitor forest growth, although the use of satellite imagery is already used in many companies. On the other hand, growth and yield models generally don't explicitly consider the effects of environmental drivers, such as rainfall amount and distribution, solar radiation, soil water holding capacity and so on. Therefore, the integration of remote sensing techniques and process-based models allows the characterization of a closer representation of the actual growth dynamics of trees. This study made the connection between both tools by deriving light interception estimates from vegetation indexes. To test the hypothesis, we applied this method in Eucalyptus sp plantations located at the municipality of Agua Clara MS, Brazil. Switching the sub-model that calculate light capture from the canopy in the 3-PG forest growth model we found a relationship between predicted and observed values with high precision $\left(\mathrm{R}^{2}=0.97\right.$ ) and accuracy (bias $=3 \%$ ), with a mean absolute error of $10.14 \mathrm{~m}^{3} /$ ha, along 61 observations in stands ranging from 1 to 4 years of age. As a result, this method can be applied to enhance the sensibility of production models over large spatial and time gradients, bringing analytical support and indicators for operational and planning decisions of forest assets.

\section{Mapping forest exploration under forest concession regime using RapidEye images}

João Vitor Frigeri ${ }^{1}$, Veraldo Liesenberg ${ }^{1}$, Mariane Moura Andrade ${ }^{1}$, Marcos Benedito Schimalski ${ }^{1}$

${ }^{1}$ Universidade do Estado de Santa Catarina, Lages, Brasil (joaovfrigeri@hotmail.com; veraldo.liesenberg@udesc.br; enairamma@hotmail.com; marcos.schimalski@udesc.br)

The concession of public native forests is an effort of the Brazilian government to avoid predatory exploration of forest resources in the Amazon region. The use of high spatial resolution satellites and different vegetation indices may help in the monitoring of public forest areas under concession regime. In this way, the objective of this chapter is to evaluate the performance of RapidEye images and four vegetation indices to monitor sustainable exploitation within the Jamari National Forest. An image of 2015 was used, the year in which the exploration of native trees in the area was recorded. Three classes of land occupation were determined, being forest infrastructure (FI), unexplored area (UA) and selective cutting (SEC). We collected 100 pixels for each class in which 70 pixels were used as training and 30 pixels as validation. Both Random Forest (RF) and Support Vector Machine (SVM) we used as classifiers. Our results showed that the forest infrastructure class (FI) obtained the highest reflectance values across Rapideye'waveleghts and the selective cutting (SEC) and unexplored areas (UA) obtained very close values in the visible region. The Kappa index varied from 0.50 to 0.80 . The best result was achieved for the RF classifier using the original RapidEye spectral bands.

\section{The importance of GRSS student grand challenge for promoting UAV applications for both precision forest and farming in Brazil}

David Robledo Di Martini ${ }^{1}$, Everton Castelão Tetila², José Marcato Junior ${ }^{1}$, Edson Takashi Matsubara1, Henrique Siqueira ${ }^{1}$, Amaury Antônio Castro Junior ${ }^{1}$, Márcio Santos ${ }^{1}$, Carlos Henrique Monteiro ${ }^{1}$, Hermerson Pistori ${ }^{2}$, Veraldo Liesenberg ${ }^{3}$

${ }^{1}$ Universidade Federal de Mato Grosso do Sul, Campo Grande, Brasil;; ${ }^{2}$ Universidade Católica Dom Bosco, Campo Grande, Brasil; ${ }^{3}$ Universidade do Estado de Santa Catarina, Lages,Brasil (daviddimartini2303@gmail.com; evertontetila@gmail.com; jrmarcato@gmail.com; edsontm@facom.ufms.br; henriquesiqueira.eng@gmail.com; amaury.ufms@gmail.com; marciogeoms@gmail.com; carloshenriquemonteirom@gmail.com; pistori@ucdb.br; veraldo.liesenberg@udesc.br)

The Geoscience and Remote Sensing Society (GRSS) promote on a yearly basis the Student Grand Challenge. It is intended to engage students and young professionals in solving a complex engineering problem within the scope of GRSS and other sister societies (e.g., Aerospace and Electronic Systems, Antennas and Propagation, Ocean Engineering, Computer, Microwave Theory and Techniques). Among five selected projects worldwide, one was selected from Brazil. The Grand Challenge consists on a joint program encompassing several small projects being conducted by students and professionals from UFMS, UCDB and UDESC. All the projects are related with the development of UAVs and innovative machine learning methods applied to both precision forest and farming. The developed UAVs and preliminary results achieved in both precision forest and farming applications will be also presented in this session. Key-words:data contest, student grants, student sponsorships. Sponsored by GRSS, CNPq, and CAPES.

Analyzing forest loss in land categories within Peruvian Amazonia, 2001-2016 / Analisis del comportamiento de pérdida de bosque en categorías territoriales de la amazonía peruana durante el periodo 2001 - 2016

Ethel Rubin-de-Celis Llanos ${ }^{1,2}$, Zoila Cruz Burga ${ }^{1}$, Maria de Los Angeles La Torre Cuadros ${ }^{1}$, Nelson Carlos Rosot ${ }^{2}$, Ana Paula Dalla Corte ${ }^{2}$, Hideo Araki ${ }^{3}$ ${ }^{1}$ Universidad Nacional Agraria La Molina, La Molina, Peru, ${ }^{1}$ Universidade Federal do Paraná. Programa de PósGraduação em Engenharia Florestal Paraná Brasil; ${ }^{2}$ Universidade Federal do Paraná, Programa de PósGraduação em Engenharia Florestal, Paraná, Brasil; ${ }^{3}$ Universidade Federal do Paraná, Paraná,Brasil(erubin@lamolina.edu.pe; zcruz@lamolina.edu.pe; mlatorrec@cientifica.edu.pe; nelson.rosot@gmail.com, anapaulacorte@gmail.com; haraki@ufpr.br)

Se analizó el patrón de la pérdida de bosques en 16 categorías territoriales pública y privada, así como de la administración en bosques amazónicos peruanos entre el 2001-2016. El análisis realizado fue descriptivo y multivariado de los datos oficiales de la pérdida de bosques definidos por el Estado peruano. Se revela un incremento gradual de la pérdida de bosque siendo los años 2009, 2014 y 2016 los de mayor incremento. Los departamentos de Martín, Loreto y Ucayali; y las categorías territoriales no categorizadas, comunidades nativas tituladas y predios rurales son los que presentan mayor pérdida de bosques. Se muestra que la categoría territorial no categorizada no afecta la tendencia general de deforestación en la Amazonía peruana siendo la dinámica de pérdida de bosques similar a las otras categorías con derechos asignados. 


\section{C4w: REMOTE SENSING AND GEOGRAPHIC INFORMATION SYSTEM FOR FOREST} MONITORING AND MANAGEMENT

\section{The use of landscape metrics to evaluate the direct influence zone of the Estação Ecológica de Águas Emendadas - Planaltina, Distrito Federal - Brazil}

Ana Paula Camelo ${ }^{1}$, Keila Sanches ${ }^{2}$, Eraldo Matricardi ${ }^{1}$

${ }^{1}$ Universidade de Brasília, Brasillia,Brasil; ${ }^{2}$ Instituto Federal de Brasília,Brasília, Brasil (paulaflorestal@gmail.com; keila.sanches@gmail.com; ematricardi@gmail.com)

The Estação Ecológica de Águas Emendadas (ESECAE-DF) located in Planaltina is one of the largest Conservations Units (CU) of the Distrito Federal/Brazil, and it is responsible for the conservation of the water springs of three biggest watersheds. The landscape fragmentation interferes with local socio-environmental quality and shatters the supply and the quality of drinking water. This study analyzes the dynamics of the soil use, the impact of the land use change and the fragmentation in the 3 kilometers buffer zone around the CU. We calculated the transitional matrices and landscape metrics from images of 1986 until 2016. The metrics calculated were: Number of Patches (NP), Total Core Area (TCA), Patches Density (PD), Edge Density (ED), Number of Disjunct Core Areas (NDCA) and Shannon's Diversity Index (SHDI). The biggest land use conversions were from "Savannas Formations" to "Agricultural Use" and from "Forest Formations" to "Savannas Formations". It was observed that $51 \%$ of the buffer zone was modified, directly influencing the water cycle. During the studied period, the NP of the Forest Formation and the Savannah Formations increased, and the TCA of those patches decrease, indicating a strong fragmentation. The year 2006 presented the highest fragmentation values and the year 2016 presents a greater uniformity, since, the agricultural use was already more dominant. It was concluded that the analysis of landscape metrics can be useful tools to help public policies to control and manage land use around the unit to prevent internal damage to the forest caused by anthropogenic actions.

\section{Major forest increase on the Loess Plateau, China (2001-2016)}

Muyi Kang ${ }^{1}$; Yuhang Wang ${ }^{1}$; Mingfei Zhao ${ }^{1}$

${ }^{1}$ Beijing Normal University, Faculty of Geographic Science, School of Natural Resources, Beijing, China (kangmy@bnu.edu.cn; wyhhappy1990@163.com; euler_mf@163.com)

The Loess Plateau in China is prone to widespread land degradation (soil erosion, deforestation and water loss) and therefore ecological restoration programmes aiming to re-establish the ecosystem by revegetation have been implemented during recent decades. Consequently, a widespread increase in vegetation cover has been reported, but the state and dynamics of forests remain largely unknown. Here we used field and satellite data to produce annual forest probability scores at $250 \times 250 \mathrm{~m}$ between 2001 and 2016 . We classified the forest dynamics into three types: net gain, net loss and fluctuation. Assuming that an increasing probability score reflects forest growth, we categorised the annual forest areas into different growing stages indicating the transition between planting and mature forest. In total, the area of forest increase was $48,786 \mathrm{~km}^{2}$ and the percentage of forested areas of the region changed from $8.19 \%$ to $15.82 \%$ within 16 years. In areas of forest net gain, there was a clear transition from low to high probability forest areas, providing evidence that a general forest transition is occurring on the Loess Plateau. The method developed for continuous monitoring of forest probability scores offers a benchmarking for further decisionmaking on ecological restoration of the region and for mapping of afforestation projects elsewhere. The findings on major forest increases demonstrate that land degradation is in fact reversible, with implications for many ecosystem services (e.g. carbon storage, provisioning of forest products).

Analysis of land use and occupation in the Joana Darc settlement complex and surrounding area in the Brazilian Amazon / Análise do uso e ocupação do solo no complexo de assentamentos Joana Darc e seu entorno, Amazônia Legal, Brasil

Isabela Floreano ${ }^{1}$, Luzia Moraes ${ }^{1}$

${ }^{1}$ Universidade Federal do Estado do Rio de Janeiro, Rio de Janeiro, Brasil (isabelafloreano@edu.unirio.br; Imoraes@unirio.br)

Desde a década de 70, a partir da criação do INCRA, assentamentos rurais vêm sendo implantados em diversos Estados do Brasil, com uma rápida expansão na região Norte. De acordo com dados do sistema PRODES- INPE, os focos de desmatamento vem aumentando devido ao corte raso da floresta e atividades agropecuárias. Além disso, a construção de complexos hidrelétricos vem causando impactos ambientais e sociais. A partir do cadastro ambiental rural, é possível realizar o monitoramento do uso e ocupação do solo no interior dos assentamentos, visando à manutenção das reservas legais. O estudo tem como objetivo analisar as mudanças no uso e ocupação do solo no período entre 2008 e 2018 no complexo de assentamentos Joana Darc, Rondônia, e seu entorno, bem como verificar as áreas suscetíveis a inundações. Foram utilizados os programas SPRING-INPE e ArcGIS-ESRI e imagens Landsat, obtidas no site USGS-NASA, para o processamento e classificação de imagens. Posteriormente, foram realizados cruzamentos com dados secundários obtidos em diversas instituições, e primários, obtidos no campo, por meio do projeto RAPATRA. Foi observado que houve um aumento da área ocupada em cerca de 27,3\% em 2018, enquanto que a área de mata nativa reduziu em cerca de 11,4\% no mesmo período. Observou-se ainda o aumento da massa d' água do Rio Madeira, possivelmente pela implantação de grandes hidrelétricas no local. Assim sendo, torna-se necessário o monitoramento e fiscalização das ocupações dentro e fora do assentamento, incluindo aquelas nas áreas de proteção permanente (APP).

\section{Developing of forest management and wood trading systems by utilizing airborne laser scanning data in Finland}

Kalle Karttunen ${ }^{1}$, Mika Laihanen ${ }^{1}$, Antti Karhunen ${ }^{1}$, Tapio Ranta ${ }^{1}$

${ }^{1}$ LUT University, Mikkeli,Finland (kalle.karttunen@lut.fi; mika.laihanen@lut.fi; antti.karhunen@lut.fi; tapio.ranta@lut.fi)

Forestry digital systems are developing fast. Innovation in forest inventory, data transparency and software management are bringing the opportunity to make a significant decision-making and additional information for the forestry sector. During the last years,airborne laser scanninghas been utilized in Finland's forest inventory. The detailed information can be utilized for the Internet based applications, likethe forest management and further wood trading services. The aim of the 
study wasto innovate the open source forest airborne laser scanning data for forest management and wood trading services. The data of forest biomass was based on the latest laser scanning from the final cutting proposals at the regional area of Finland. The laser scanning results indicated the volume of roundwood and the forest energy potentials from stumps and logging residues. However, some restrictions must be done when analysing the regional forest biomass potentials. For example, non-industrial private forest owners' willingness to sell forest biomass for energy purposes has significant role for availability of biomass. The study showed a huge regional potential of forest biomass according to the final cutting proposals. However, realistic and sustainable forest biomass potential must be carefully done by combining several study information.By using airborne laser scanning method, the forest resources can be evaluated more effectively and could be used more sustainable at the regional level. It also enables to develop the new solutions for the digital forest management and wood trading services.

\section{Detection and monitoring of forest cover in Gangwon Province, South and North Korea using Vegetation Index (VI) and time series satellite imagery}

Sujong Lee ${ }^{1}$,Eunbeen Park ${ }^{1}$, Sungeun Cha ${ }^{1}$, Hyun-Woo Jo ${ }^{1}$, Moonil Kim ${ }^{1,2}$,Hangnan Yu $u^{l}$ Woo-Kyun Lee

${ }^{1}$ Department of Environmental Science and Ecological Engineering, Korea University, Seoul, Republic of Korea; ${ }^{2}$ International Institute for Applied Systems Analysis,Laxenburg,Austria(leesj3610@gmail.com; heyevvin@gmail.com; tgy2005@korea.ac.kr; endeavor4_a1@naver.com; windy7up@gmail.com; willpower0129@gmail.com; leewk@korea.ac.kr

Recently, excessive and unreasonable development of forests causes environmental and ecological disturbances, and degradation of forests also impacts on the human ecosystem. For sustainable forest management, it is essential to detect the change of forest cover on time-series. In this study, we used the satellite imageries for time-series (1988, 1999, 2009 and 2018) analysis to focus on the change of forest area in Gangwon Province, which is the most forested area in Korean Peninsula. Reference data is essential for classification, but since North Korea's data are limited, national spatial data of south Korea was used. The classification was conducted using NDVI threshold-based on Gaussian probability density function, which is set for Gangwon province using the national land cover map. Both North and South Korea showed a decreasing trend in forest cover until the 2000s, while increasing trend in the 2010s. In the case of South Korea, the decreasing rate of forest cover from the 1980 s to 2010 s was $-9.34 \%$. However, North Korea showed a significant decline of $-26.40 \%$. Error matrix was calculated for validating the detected forest area. The result of the study indicates the lack of awareness of forest protection by North Korean and requires the improvement of policies and infrastructures for forest management. This study is meaningful in that detecting the change of forest areas on the Korean Peninsula by using satellite imagery. Especially, developing base map is an important point for forest management using NDVI threshold on North Korea which is an inaccessible area.

Expanding cultivation of eucalyptus for energy in center-west Brazil: the case of Rio Verde, Goiás / Expansão de cultivo de eucalipto para finalidades energéticas no Centro-Oeste: estudo de caso de Rio Verde, Go

Bruno Moreira Riani Costa ${ }^{l,}$ Claudio Cesar de Almeida Buschinelli ${ }^{2}$

${ }^{1}$ Universidade Estadual Paulista “Júlio de Mesquita Filho”, Rio Claro, Brasil, '2Embrapa Meio Ambiente, Jaguariúna, Brasil (bruno.riani@unesp.br; claudio.buschinelli@embrapa.br)

O município de Rio Verde (GO) ocupa hoje uma posição de destaque no cenário agropecuário do Centro-Oeste. O uso da terra em sua extensão territorial passou a sofrer mudanças profundas na segunda metade do século XX, principalmente a partir da década de 1970, na esteira do processo de modernizaçãoda agricultura brasileira; sua grande extensão territorial e alta capacidade produtiva agropecuária são alguns dos fatores que motivaram a instalação de grandes empresas e conglomerados do agronegócio em Rio Verde, o que lhe garantiu essa referida posição central no quadro regional. Assim, esse crescimento agroindustrial foi acompanhado de um expressivo aumento no plantio florestal de eucalipto no município de modo a suprir a demanda energética, proveniente principalmente da secagem de grãos e dos frigoríficos. E é isso que buscamos demonstrar no presente trabalho; para tanto, foram elaborados mapas de uso e ocupação da terra no município com base em imagens de satélite dos anos de 2006, 2011 e 2017. Através do processamento em SIG foi possível constatar de fato o crescimento do plantio florestal de eucalipto, que de cerca de 6.000 hectares em 2006 passa a ocupar 11.000 hectares no último mapeamento; foi verificado também que a expansão da silvicultura se deu principalmente sobre áreas de pastagem.

Using tablets in field surveys and forest audits: greater productivity and efficiency in protecting natural resources / Uso de tablets em vistorias de campo e fiscalizações florestais - maior produtividade e eficiência na proteção dos recursos naturais

Michel Simon ${ }^{l}$ Leonardo Tienne ${ }^{l,}$ Fabiano Grazziottil, Rômulo Cuzzuol ${ }^{l}$. Thiago Steffen ${ }^{1}$

${ }^{1}$ Instituto de Defesa Agropecuária e Florestal do Espírito Santo (IDAF),Vitória, Brasil (micheltesch@hotmail.com; ltienne@idaf.es.gov.br, fabiano.grazziotti@idaf.es.gov.br; rcuzzuol@idaf.es.gov.br; tsteffen@idaf.es.gov.br)

Em função do desafio que é a proteção dos recursos naturais em um país de grande extensão territorial, como o Brasil, o Instituto de Defesa Agropecuária e Florestal do Estado do Espírito Santo optou por inovar no método de realização de vistorias de campo e fiscalizações florestais. Nesse contexto, desenvolveu-se um novo método com o uso de Sistema de Informação Geográfica livre e de código aberto (Qgis), associado ao emprego de tablets, no campo, para registro de fotos, trilhas e informações geolocalizadas, além de navegação off-line. A metodologia consiste na geração de mapas georreferenciados no Qgis e exportação para um aplicativo no tablet, que utiliza o sistema de GPS para mostrar a localização em tempo real sobre o mapa gerado. Com isso foi possível dispensar o uso de câmeras fotográficas, gps de navegação e mapas impressos nas vistorias e fiscalizações. Empregado há 4 anos no licenciamento ambiental de silvicultura, o método permitiu agilizar procedimentos, saltando de cerca de 600 hectares para 1.944 hectares vistoriados por dia. Na prática representa monitorar três vezes mais área com a mesma equipe. Em paralelo, houve economia de $24 \%$ no montante investido para aquisição de equipamentos e o custo médio por hectare vistoriado foi reduzido em $69 \%$. Por fim, considerando o expressivo aumento na demanda de trabalho nas instituições, com a etapa de validação do Cadastro Ambiental Rural, torna-se imprescindível adotar métodos que permitam ganhos de produtividade e maior eficiência no uso dos recursos públicos. 
Determining the form factor for the Australian cedar (Toona ciliata M. Roem. var. australis (F. Muell.) Bahadur) / Determinação do fator de forma do cedro australiano (Toona ciliata M. Roem. var.australis (F. Muell.) Bahadur)

Antonio Nascim Kalil Filho ${ }^{1}$, Ivar Wendling ${ }^{1}$, Maria Augusta Doetzer Rosot ${ }^{1}$, Marcelo Lazzarotto ${ }^{1}$, Juliana dos Santos Guedes ${ }^{2}$

${ }^{1}$ Embrapa Florestas, Colombo, Brasil; ${ }^{2}$ Universidade Federal do Paraná, Curitiba, Brasil (antonio.kalil@embrapa.br; ivar.wendling@embrapa.br; augusta.rosot@embrapa.br; marcelo.lazzarotto@embrapa.br;julisguedes@hotmail.com)

O aumento da população mundial aliado à diversificação nos usos da madeira para a indústria moveleira, madeira tratada, indústria de papel, lenha, carvão e outros explica o aumento da demanda por novas espécies florestais como o cedro australiano (Toona ciliatavar. australis), plantado no Brasil, sendo oriundo da Austrália e parte da Ásia. Sua madeira pode ser utilizada para laminação, indústria moveleira (móveis finos) e acabamentos de construção. Tendo, em vista que equações de volume e estimativas de fator de forma inexistem para o cedro australiano, o objetivo do presente trabalho foi a determinação do fator de forma. O material foi constituído por 117 árvores plantadas em 1999 em espaçamento 3 x 2 m na Fazenda Berneck, Adrianópolis, Paraná, latitude 24³9’25” S, longitude 48 59’27”'W e altitude média de 150 metros. A seleção de árvores para a cubagem deu-se com base em classes de diâmetro. Tendo-se estabelecidos os limites das classes, foram calculadas as frequências (número de árvores) por classe diamétrica, alocando-se cada indivíduo à sua respectiva classe. Uma vez determinadas as sete classes diamétricas, procedeu-se à cubagem empregando-se o método de Smalian. Foram calculados para cada árvore o volume cilíndrico, volume comercial com e sem casca e o fator de forma (volume real / volume cilíndrico). O volume real médio com casca foi de 0,5212058 $\mathrm{m}^{3}$ e sem casca foi de $0,4921751 \mathrm{~m}^{3}$. Os fatores de forma médios calculados para árvores individuais com e sem casca foram de 0,541286 e 0,510058, respectivamente.

Determining the form factor for Calophyllum brasiliense Cambess. (guanandi) / Determinação do fator de forma do guanandi (Calophyllum brasiliense Cambess.)

Antonio Nascim Kalil Filho ${ }^{\text {, Ivar Wendling }}{ }^{1}$, Maria Augusta Doetzer Rosot ${ }^{1}$, Marcelo Lazzarotto ${ }^{1}$, Juliana dos Santos Guedes ${ }^{2}$

${ }^{1}$ Embrapa Florestas, Colombo, Brasil; ${ }^{2}$ Universidade Federal do Paraná, Curitiba, Brasil (antonio.kalil@embrapa.br; ivar.wendling@embrapa.br; augusta.rosot@embrapa.br; marcelo.lazzarotto@embrapa.br;julisguedes@hotmail.com)

O guanandi é uma espécie nativa que ocorre em áreas de várzeas, igapós e banhados desde a América Central (18º N) até o sul da América do Sul ( $28^{\circ} 10^{\prime}$ S), passando pela Amazônia. Com lento crescimento, a espécie é plantada comercialmente. Sua madeira, cuja cor vermelha assemelha-se ao mogno, possui densidade de 0,45 a 0,65 g/ $\mathrm{cm}^{3}$, sendo utilizada para dormentes, batentes de portas, construção civil e móveis. Tendo, em vista que equações de volume e estimativas de fator de forma inexistem para o guanandi, este trabalho objetivou a determinação do fator de forma. O material original foi constituído por 130 árvores plantadas em 1999 em espaçamento 3 × 2 m, na Cia. Berneck, Adrianópolis, Paraná, latitude 24 39' 25' S, longitude 48 59' 27" W e altitude média de 150 metros. A seleção de árvores para a cubagem deu-se com base em classes de diâmetro. Tendo-se estabelecidos os limites das classes, foram calculadas as frequências (número de árvores) por classe diamétrica, alocando-se cada indivíduo à sua respectiva classe. Uma vez determinadas as sete classes diamétricas, procedeu-se à cubagem empregandose o método de Smalian. Foram calculados para cada árvore, o volume cilíndrico, volume comercial com e sem casca e o fator de forma (volume real / volume cilíndrico). O volume comercial médio com casca foi de $0,1213265 \mathrm{~m}^{3}$ e o volume comercial médio sem casca foi igual a 0,1128535 m³. Os fatores de forma médios calculados para árvores individuais com e sem casca foram de 0,649320 e 0,600947, respectivamente.

\section{Teak (Tectona grandis) plantation management and financial analysis in Colombia}

Fernando VelezEscobar

${ }^{1}$ Independent professional, Medellin, Colombia (fernando.velez52@gmail.com)

Development of single tree volume and tape equations, yield and growth studies, including potential intermediate thinning and remaining stand density after management, and volume classification, at La Gloria project, Refocosta S.A. company, located at Monterrubio county, Magdalena province, Colombia, $10^{\circ} 23^{\prime}$ N 74 $23^{\prime}$ W, 55 m.a.s.l., tropical dry zone (Holdridge's life zones), are the technical bases to calculate productivity under forest management. Productivity and forest management is defined using stand density index concept, with a minimum desirable stand density of 475 stems of $25 \mathrm{~cm}$ per hectare, and thinning crops over $25 \mathrm{~m}^{3} / \mathrm{ha}$. A simulation model software developed by the author has been used, including all the equations developed on former studies. A financial analysis, based on official plantation costs, local logging costs and Itto's reported international wood prices, shows out and internal rate of return of $4,4 \%, 5.7 \%$ and $6.2 \%$ at ages of 20,25 and 30 years.

\section{Pinus patula plantation management under stand density index concept}

Fernando VelezEscobar ${ }^{1}$, John Byron UrregoMesa ${ }^{2}$

${ }^{1}$ Independent professional, Medellin, Colombia; ${ }^{2}$ Smurfit Kappa Cartón de Colombia S.A., Yumbo, Colombia (fernando.velez52@gmail.com, john.urrego@smurfitkappa.com.co)

A Pinus patula planted forest stand, located at Cauca province - Colombia, latitude $0^{\circ} \mathrm{N}$, longitude $75^{\circ} \mathrm{W}, 2.450$ m.a.s.l., 2.250 mm rain-fall, lower montane moist forest Holdridge's life zone, was managed using stand index concept, from age nine until age 25 years. A series of stand density index level, ranging from 200-1.400 stems-25 cm/hectare equivalent, were stablished every 100 stems-25 cm/hectare. Permanent plots of 2.000 m² were used, yearly measured, calculating yield and current annual increment for all variables, volume classified in five log different sizes, using tree and shape equations developed within the research. Maximum stand density index viable for the species is about 1.300 stems-25 cm/hectare equivalent. Volume growth under bark changed between $19-40 \mathrm{~m}^{3}$ /hectare/year. An under-stocked stand density level was found for less than 600 stems-25 cm/hectare, with a clear proportional growth increment; a full-stocked stand density was found between 650 - 900 stems-25 cm/hectare, with a closed to constant growth; and over-stocked stand density was gound ove 950 stems $-25 \mathrm{~cm} /$ hectare, without a clear growth patern. Forest management in full-stocked stand level can offer volume growth continuously concentrated in bigger saw-timber size, together with diminishing smaller log sizes. 
Effect of forest biomass ash on growth and nutrition of Pinus taeda and on the chemical characteristics of the soil / Efeito de cinza de biomassa florestal no crescimento e na nutrição de Pinus taeda e em características químicas do solo

Shizuo Maeda ${ }^{1}$ Itamar Antonio Bognola ${ }^{1}$, João Bosco Vasconcelos Gomes ${ }^{1}$

${ }^{1}$ Embrapa Florestas, Colombo,Brasil(shizuo.maeda@embrapa.br; itamar.bognola@embrapa.br; joão.bv.gomes@embrapa.br)

As características químicas e físicas dos resíduos gerados nos processos envolvidos na extração de celulose indicam um potencial para aplicação como insumo para a produção florestal, que em sua maior são exploradas em áreas de baixa fertilidade natural. Avaliou-se o efeito da aplicação de cinza de biomassa florestal gerada em caldeira na fertilidade do solo e no desenvolvimento e na nutrição de Pinus taeda em um LATOSSOLO BRUNO Distroférrico típico, no município de Vargem Bonita, Estado de Santa Catarina. O delineamento experimental utilizado foi o de blocos casualizados com quatro repetições. Os tratamentos foram constituídos pelas doses $0,10,20,40$ e $80 \mathrm{Mg}$ ha-1. Os materiais foram aplicados superficialmente em área total, sem incorporação, em plantio de $P$. taeda, com dois anos de idade. Para a avaliação do efeito dos tratamentos foram coletadas amostras de solos na camada 0 a 20 cm, tanto na instalação do ensaio quanto em 2007, 2008, 2011, 2012 e 2013, bem como coletadas amostras de acículas recém-maduras do verticilo inferior do terço superior da copa, em 2008 e 2017. Avaliações biométricas foram realizadas em 2017, com o abate de uma árvore por parcela. A aplicação das doses de cinza promoveu aumentos nos teores de cálcio, magnésio, potássio e fósforo, redução no teor de alumínio e aumentos no pH e na saturação por bases do solo. Observou-se um aumento quadrático no volume sólido de madeira e aumentos nos teores foliares de boro e zinco e redução no teor de enxofre, sem correlação com a biomassa produzida.

Trace elements in the soil after applying wood waste from pulp milling to plantations of Pinus taeda / Elementos-traço no solo como resultado da aplicação de resíduos do processamento de madeira para obtenção de celulose em plantio de Pinus taeda

Shizuo Maeda ${ }^{1}$, João Bosco Vasconcelos Gomes ${ }^{1}$, Itamar Antonio Bognola ${ }^{1}$

${ }^{1}$ Embrapa Florestas, Colombo,Brasil (shizuo.maeda@embrapa.br;joao.bv.gomes@embrapa.br; itamar.bognola@embrapa.br)

Pelas suas características químicas e físicas, os resíduos gerados nos processos envolvidos na extração de celulose apresentam um potencial para aplicação como insumo para o plantio de florestas, normalmente exploradas em áreas de baixa fertilidade natural. Avaliou-se o efeito da aplicação de mistura de lodo celulósico (lo) e cinza de biomassa florestal (ci) em teores de elementos-traço emum neossolo quartzarênico Órtico típico, no município de Piraí do Sul, Paraná Os tratamentos foram constituídos por cinco doses da mistura de lo e ci na proporção de 7:3, respectivamente. As doses estimadas para manter a condição original do solo e elevar a saturação por bases a 20, 40, 60 e 80\% foram 0, 14, 25, 49 e 60 Mg ha ${ }^{-1}$. Os materiais foram aplicados superficialmente, em área total, sem incorporação, em plantio de Pinus taeda que em junho de 2011 estava com seis meses de idade. A avaliação do efeito dos tratamentos foi feita em amostras coletadas na camada 0 a 20 cm, na instalação do ensaio e aos 50 e 60 meses após, sendo determinados os teores de Hg, As, Pb, Cr e Cd, nos tratamentos sem aplicação e na dose máxima da mistura dos resíduos. Os resultados obtidos indicam que, para os teores dos elementos analisados, nos tratamentos sem aplicação dos resíduos e na dose máxima nas três avaliações realizadas, não há indícios de contaminação dos solos pela aplicação da mistura dos resíduos. Os teores encontrados para o elementos analisados são inferiores aos valores de referência estabelecidos pela legislação brasileira.

A hypsometric equation for same-age populations of Pinus caribaea var hondurensis in the State of Rondônia, Brazil / Equação hipsométrica para um povoamento equiâneo de Pinus caribaea var hondurensis no estado de Rondônia, Brasil

Karine Silva ${ }^{1}$ D, Angélica Santos ${ }^{1}$, Sabina Ribeiro ${ }^{1}$, Lorena Tavares ${ }^{2}$, Janice Nascimento ${ }^{2}$, Paulo Magistrali ${ }^{2}$

${ }^{1}$ Universidade Federal do Acre, Rio Branco, Brasil; ${ }^{2}$ Instituto Federal de Rondônia, Ji-Paraná, Brasil (karinemilene26@gmail.com;

angelicams.ali@gmail.com; sabina.ufac@gmail.com; lorena.tavares@ifro.edu.br; janice.nascimento@ifro.edu.br; magistralipr@gmail.com)

Os plantios de pinus no Brasil estão concentrados nas regiões sul e sudeste, porém nos últimos anos foram difundidos também para a região Norte do país. Esses plantios carecem de equações que possibilitem a estimativa de variáveis chaves para se obter a produção do povoamento, como a altura. Visto que grande parte das equações hipsométricas disponíveis na literatura foram desenvolvidas para as regiões Sul e Sudeste, este estudo visa contribuir para a geração de equações hipsométricas adequadas para povoamentos na região norte do Brasil. Assim, o objetivo deste estudo foi gerar uma equação hipsométrica para um povoamento equiâneo de Pinus caribaea Morrelet var. hondurensis, no Município de Vilhena, Rondônia, Brasil. Para isso, foram estabelecidas de forma sistemática 15 parcelas de $20 \mathrm{~m} \mathrm{x} 20 \mathrm{~m}$ (0,02 ha), nas quais foi mensurada a circunferência a altura do peito (CAP) de todas as árvores (898 indivíduos) e foi obtida a altura total de 225 árvores com um hipsômetro Haglöf. Cinco modelos hipsométricos foram ajustados aos dados coletados usando-se o programa estatístico RStudio. Os critérios para seleção da melhor equação ajustada foram o maior valor de coeficiente de determinação ajustado ( ${ }^{2}$ aj.), menor Erro médio quadrático (RMSE) e a análise gráfica dos resíduos. A equação de melhor ajuste e com distribuição homogênea dos resíduos foi =0.6067+0.1760*d+عi (R²aj=0.9223; RSME=0.2129).

\section{SisPinus software and the management of Pinus taeda plantations attacked by Capuchin monkeys (Sapajus nigritus)}

Edilson Batista de Oliveira ${ }^{1}$, Sandra Bos Mikich ${ }^{1}$, Dieter Liebsch ${ }^{2}$, José Mauro Magalhães Avila Paz Moreira ${ }^{1}$

${ }^{1}$ Embrapa Florestas, Colombo, Brasil; ${ }^{2}$ DL Consultoria Ambiental, Curitiba, Brasil (edilson.oliveira@embrapa.br; sandra.mikich@embrapa.br; dieterliebsch@yahoo.com.br;jose-mauro.moreira@embrapa.br)

The Sispinus software have the objective to inform rural producers about suitable technologies that can be used in the planning and management of forests and provide information that can help optimize production and increase revenue. Through this software, users can consider various climate and soil conditions and test options for forest management, predict current and future production, conduct economic analyses, and finally, implement the best alternative in the field. To adjust the SisPinus software to estimate growth and yield of stands with different levels of damage caused by capuchin monkeys, a computational tool (Macacoprego_Calc) was developed to be used in association with this software. The procedure allows the Sispinus to quantify timber production, for the years following the attack, both in terms of total volume and volume per industrial use class. This can support forest producers in choosing the best strategy to minimize losses. Both the tool and the software are available for free download at Embrapa Florestas website (www.embrapa.br/florestas [http://www.embrapa.br/florestas]). 


\title{
C4y: FOREST ASSESSMENT, MODELLING AND MANAGEMENT
}

\author{
Evaluation of data continuity in Japanese National Forest Inventory \\ Fumiaki Kitahara ${ }^{1}$ \\ ${ }^{1}$ Forestry and Forest Products Research Institute, Kochi, Japan (bunsho@ffpri.affrc.go.jp)
}

The National Forest Inventory started in Japan in 1999 with the aim of understanding the state and dynamics of various aspects in forests such as wood production and biodiversity throughout the country. The Japanese NFI has established around 15,000 permanent sample plots in whole forest systematically located in a 4 x 4km grid, and the fourth NFI is completed in 2018. Since 2010, Japanese NFI has implemented a quality assurance program and the Forest Agency reports that the measurement accuracy is improved. Although, field surveyors tended to underestimate tree measurement, after implementation of quality assurance program, measurement accuracy has been corrected in recent years. Therefore, data continuity before and after quality assurance program has become a problem for NFI data analysis. The purpose of this study is to confirm the degree of continuity and evaluate discontinuity quantitatively. To evaluate data continuity, we focused on tree height and compared between time series data of dominant average trees height and reference tree height in the southern part of western Japan. Here, the reference tree height is based on dominant height growth model we developed using long-term forest monitoring data and short-term forest monitoring data.

\section{Research on the integration of multi-source spatial data of forestry}

Ruixia Hou ${ }^{1}$

${ }^{1}$ Research Institute of Forest Resources Information Techniques Chinese Academy of Forestry, Beijing, China (houreix@ifrit.ac.cn)

Spatial data of forest resources is the spatial object of data integration of forest management. The spatial data of various categories can provide a comprehensive picture of the changes in forest resources and the ecological environment. Through the analysis of its internal characteristics and its different manifestations, this paper reveals the relationship and internal change laws among the various factors contained in the forest. And on the other hand, through the analysis of the relevance of spatial data on forest resources, the unified expression of spatial data on multi-source forest resources is realized. So multi-source spatial data provides spatial information support for forest resource information management and shared services.

\section{The visual simulation technology in formatting forest management plan at unit level based on WF}

TingDong Yang ${ }^{1}$, HuaiQing Zhang ${ }^{1}$, YongLiang Li $^{1}$, XinJian Tan ${ }^{2}$

${ }^{1}$ Research Institute of Forest Resource Information Techniques, Chinese Academy of Forestry , Beijing, China; ${ }^{2}$ Experimental center of subtropical Forestry,

Chinese Academy of Forestry,Xinyu, China (yangtd@ifrit.ac.cn; zhang@ifrit.ac.cn; lyl@ifrit.ac.cn; bjtan@caf.ac.cn)

In view of the degree that the forest management plan combined with computer technology is not enough, as well as the solution is not intuitive, this paper used WF workflow technology, combined with the forest management plan of the Hunan Youxian Huangfengqiao state-owned forest farm, Hunan Pingiiang County state-owned Lutou forest farm and Inner Mongolia Chuoyuan forest farm, completed custom workflow modeling process, realized the visual formatting of forest management plan. The results show that the forest level forest management planning process has been displayed, the sub-compartment management measures, cutting volume, ecological benefits in the management period has been shown directly in the three-dimensional scene, this method has strong operability for the operators. In the process of the management plan, the types of forest management, the management measures, the calculation of logging, the effect evaluation and so on are all expressed in the form of flow module. The application of the visual simulation technology in forest management plan can achieve the visual operation of the management plan, realize the effect test of the management process and improve the digitization of forest management.

\section{Construction and application of National Sharing Infrastructure on Forestry Science Data}

Ping $J I^{1}$

${ }^{1}$ Research Institute of Forest Resources Information Techniques Chinese Academy of Forestry, Beijing, China (jiping@ifrit.ac.cn)

The National Sharing Infrastructure on Science Data of Forestry is one of the 28 National Science and Technology Infrastructure. The Platform collects traceable data on forestry scientific research, develops and implements data integration standards and provides for the sharing of integrated data on the Internet. The platform was construction in 2001 and was completed and put into operation in 2009. At present, the platform has 12 types of data, including: forest resources, grassland resources, wetland resources, desert resources, forest ecosystems, nature reserves, forest protection, forest cultivation, timber science and technology, forestry science and technology literature, forestry science and technology projects, and forestry development. A total of 177 databases were built. The platform also has 10 sub-platforms and more than 30,000 users. This paper describes the structure, content and application of The National Sharing Infrastructure on Science Data of Forestry.

\section{Forest adaptation scenarios using the Korean integrated model considering climate change}

Mina Hong ${ }^{1}$, Moonil Kim², Cholho Song ${ }^{1}$, Sea Jin Kim¹, Sungeun Cha ${ }^{1}$, Jiwon Kim ${ }^{1}$, Woo-Kyun Lee

${ }^{1}$ Korea University, Seoul, Republic of Korea; ${ }^{2}$ International Institute for Applied Systems Analysis, Wien, Austria (alsdk920902@naver.com; windy7up@gmail.com; cholhosong@gmail.com; bluegulcy@gmail.com; tgy2005@korea.ac.kr; keinesorge2@gmail.com; leewk@korea.ac.kr)

Forests contribute to climate change mitigation by absorbing atmospheric carbon dioxide through photosynthesis and storing it in biomass form. Therefore, 'Paris Agreement' encouraged active forest management to reduce greenhouse gas emissions. In this study, an integrated forest model was applied to predict the change in forest growth due to climate change based on RCP scenario. The model also could consider appropriate tree species, impacts of forest disaster (land slides, forest fire, and forest disease), and land cover change. Based on the model, the scenario of forest adaptation management (thinning, tree trimming according to normal cutting age, risk management etc.) was constructed under possible combinations of each options. According to the analysis, When all of the options above are not considered, the current forest growing stock volume is $154.1 \mathrm{~m}^{3} \mathrm{ha}^{-1}$. The forest accumulation of RCP4.5 and RCP8.5 will be $167.4 \mathrm{~m}^{3} \mathrm{ha}^{-1}$ and $166.9 \mathrm{~m}^{3}$ ha -1respectively in 2030. If the management (tree trimming, thinning) is performed after considering all of the above options, the forest accumulation of RCP 4.5 and RCP 8.5 will be $105.2 \mathrm{~m}^{3} \mathrm{ha}^{-1}$ and $133.5 \mathrm{~m}^{3} \mathrm{ha}^{-1}$ respectively in 2030 . Therefore, the amount of carbon stored would decrease as the forest becomes older. Thus, though the forest accumulation is reduced. If the reforestation is proceeded, forest growth sector can be managed through tree trimming and thinning to increase carbon absorption and wood production according to climate change. Futhermore, the government needs to develop appropriate policies.

Pesq. flor. bras., Colombo, v. 39, e201902043, Special issue, p. 1-768, 2019 


\section{Three-Dimensional Visualization Method of Editing Sub-Compartment Boundary in Forestry}

Yongliang Li $i^{1}$, Huaiqing Zhang ${ }^{1}$, Tingdong Yang ${ }^{1}$, Xinjian Tan ${ }^{2}$

${ }^{1}$ Research Institute of Forest Resource Information Techniques, Chinese Academy of Forestry, Beijing, China; ' ${ }^{2}$ xperimental center of subtropical Forestry, Chinese Academy of Forestry,Xinyu,China(lyl@ifrit.ac.cn; zhang@ifrit.ac.cn; yangtd@ifrit.ac.cn; bjtan@caf.ac.cn)

Combining 3D virtual scene rendering with forest sub-compartment boundary editing, a forest sub-compartment boundary editing method in the 3D virtual scene is proposed. First of all, the boundary nodes were calculated according to the sub-compartment vector boundary in the 2D, and the boundary nodes were represented by entities in the 3D scene. Secondly, the node entities that need to be edited were picked up by using the mouse, and then interactive editing operations could be done such as moving and building. Lastly, the sub-compartment boundary nodes sorting algorithms for the 3D visual editing such as moving, cutting and merging of the boundary were proposed. The sub-compartment 3D boundary was redrawn according to the order of reordering entities. Taking the $2 \mathrm{D}$ vector data and terrain data of the specific sub-compartment as an example, the 3D visualization method of editing the subcompartment boundary in forestry was verified based on the MOGRE rendering engine. The results show that this method can restore the real 3D existence form of the sub-compartment, reflect its 3D spatial structure characteristics, and directly implement the interactive editing operations and simulation results of 3D visual moving, cutting and merging for any sub-compartment boundary. This method can be directly applied to forest resources investigation, planning to improve the management ability.

\section{Spatio-temporal analysis of anthropogenic activities from ranger-collected data in W National Park of Benin \\ Tchegoun Blaise Tchetan ${ }^{1}$, Akomian Fortuné Azihou², Gerard Nounagnon Gouwakinnou ${ }^{1}$ \\ ${ }^{1}$ Laboratory of Ecology, Botany and plant Biology (LEB), University of Parakou, Parakou, Benin; ${ }^{2}$ Laboratory of Applied Ecology (LEA), University of \\ Abomey-Calavi,Abomey-Calavi,Benin(tchegounblaise@gmail.com; fazihou@gmail.com; gougerano@gmail.com)}

1. Background: Protected areas are currently the cornerstones for biodiversity conservation. However, numerous protected areas are under significant threats from anthropogenic activities which lead deeply to loss of biodiversity; 2. Objective:This study analyzed the spatio-temporal trends of anthropogenic activities in W Biosphere Reserve of Benin in order to provide guidance for planning the patrol system; 3. Methods: We used ranger-collected data on anthropogenic activities in the reservefrom 2012 to 2015; 4. Results: Illegal grazing is the most common anthropogenic activity observed in the reserve (1,137 incidents),followed by poaching (469 incidents), agricultural encroachment (285 incidents) and logging (69 incidents). The distribution of these activities in the reserve is highly dependent on zones and also varies between seasons. Generally, incidents of anthropogenic activities were more frequent during the non-hunting season than the hunting seasonbecause of flooding, impassability of tracks and closing of plant cover which limit patrol activities during the non-hunting season; 5 . Findings and perspective: From these findings, managers of the W National Park can identify high human pressure zones where ranger patrol efforts should be enhanced.However, becausespatial and temporal changes in anthropogenic activities occurred, regular patrols throughout the protected area,even in zones of low occurrence, are also required.We propose the use of emerging technologies such as Unmanned Aerial Vehicles to better monitor high pressure zones, especially during the non-hunting season when the reserve is practically inaccessible for rangers.

\section{Standardization of symbols for forest variables used in forest assessment and modelling}

Margarida Tomé1, Paula Soares ${ }^{1}$, Susana Barreiro', Alberdi Iciar ${ }^{2}$, Ole Martin Bollandsås ${ }^{3}$, Canellas Isabel ${ }^{2}$, Tron Haakon Eid ${ }^{2}$, Kiviste Andres $^{4}$, Róbert Marušák $k^{5}$, Daniel Moreno-Fernandez ${ }^{2}$, Christophe Orazio ${ }^{6}$, Heinrich Spiecker ${ }^{7}$, Jarek Socha $^{8}$, Jens Peter Skovsgaard ${ }^{9}$ : Michal Zasada ${ }^{10}$; Piermaria Corona ${ }^{11}$

${ }^{1}$ Universidade de Lisboa, Instituto Superior de Agronomia, Centro de Estudos Florestais, Lisboa, Portugal; ${ }^{2}$ CIFOR-INIA, Madrid, Spain; ${ }^{3}$ Fakultet for miljøvitenskap og naturforvaltning, Oslo, Norway; ${ }^{4}$ Estonian University of Life Sciences, Taru, Estonia; ${ }^{5}$ Czech University of Life Sciences Prague, Prague, Czech Republic; ${ }^{6}$ EFI - Planted forests facility, Bordeaux, France; ${ }^{7}$ University of Freiburg, Freiburg, Germany; ${ }^{8}$ University of Agriculture in Krakow, Krakow, Poland; 'Swedish University of Agricultural Sciences, Uppsala, Sweden; ${ }^{10}$ Warsaw University of Life Sciences, Warsaw, Poland; ${ }^{11}$ Research Centre forForestry andWood, Arezzo,Italy(magatome@isa.ulisboa.pt; paulasoares@isa.ulisboa.pt; smb@isa.ulisboa.pt; alberdi.iciar@inia.es; ole.martin. bollandsas@nmbu.no; canellas@inia.es; tron.eid@nmbu.no; andres.kiviste@emu.ee; marusak@fld.czu.cz; danielmoreno270@hotmail.com;

christophe.orazio@efi.int; instww@uni-freiburg.de; jaroslaw.socha@ur.krakow.pl; jps@slu.se; michal.zasada@wl.sggw.pl; piermaria.corona@crea.gov.it)

In 1959, IUFRO adopted and published a standardization of symbols for forest variables used for tree and forest measurements, in forest inventory and, more widely, in forest assessment and modelling. In 1965, these were updated and re-published. This standardization covered a limited set of variables; therefore, a larger set of symbols was proposed and approved at the IUFRO World Congress in 2014. The new set of symbols was based on the similar principles as used in 1959 and 1965. Even if some of the original symbols derive from the German language (e.g., basal area is represented by G, from Grundfläche), and these were retained, the new symbols were based primarily on abbreviations and contractions of the English terms. The symbols were selected in order to be easily recognized, being simple and not conflicting with common mathematical or other symbols commonly found in forest literature. The poster presents the updated list of symbols, organized in three groups: 1 . tree variables, represented by lower-case letters; 2 . mean tree variables, represented by the symbol for the variable and the letter g (or subscript g), indicating that the variable is for the mean tree (for example $\mathrm{dg}$ (or $\mathrm{dg}$ ) representing the quadratic mean diameter; 3. stand variables, represented by upper-case letters when referring to an area, or lower-case letters when representing a mean value, extreme values or other particular values for a group of trees (for example, $\mathrm{V}$ represents total stand volume per hectare; hdom represents dominant height).

\section{C4Z: FOREST ASSESSMENT, MODELLING AND MANAGEMENT}

\section{Finite element modelling of the wood disintegration using a single-pointed cutting tool

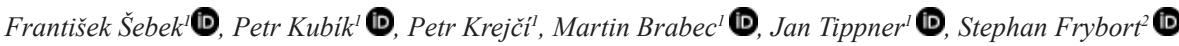 \\ ${ }^{1}$ Mendel University in Brno, Brno, Czech Republic; ${ }^{2}$ Wood K plus, Tulln, Austria (frantisek.sebek@mendelu.cz; petr.kubik@mendelu.cz; petr.krejci@mendelu.cz; martin.brabec@mendelu.cz;jan.tippner@mendelu.cz;s.frybort@kplus-wood.at)}

European wood industry is challenged by the demands on the increasing processing of hardwood due to the changes of species composition of the forests. The theory background of cutting force calculation during the hardwood disintegration is specific. Therefore, an advanced approach should be employed for the phenomena description. The experiments were carried out using a pendulum-based machine to approximately perform a linear cut on a European beech specimens. The cutting process was measured by a 3D force sensor and captured by a stereo vision with high-speed cameras. The numerical simulations were 
conducted accordingly using an explicit finite element method via the LS-DYNA software. The anisotropy was considered at every level - within the elasticity, plasticity and failure. Moreover, the non-symmetric fracture behaviour was taken into account distinguishing between the different properties in tension and compression. The chip generation as well as force responses were compared. The fracture formation was reproduced quite accurately, yet the forces were not captured very well due to some oscillations, which are subject to the further studies.

\section{Experimental and numerical investigation of hardwood impact behaviour}

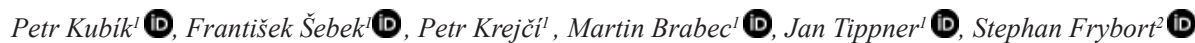

${ }^{1}$ Mendel University in Brno, Brno, Czech Republic; ${ }^{2}$ Wood K plus, Tulln, Austria (petr.kubik@mendelu.cz; frantisek.sebek@mendelu.cz; petr.krejci@mendelu.cz; martin.brabec@mendelu.cz,jan.tippner@mendelu.cz; s.frybort@kplus-wood.at)

It is important to know and describe the impact behaviour of wood in various industrial applications like the wood machining and disintegration. The impact response description can also be a source of information for mechanical properties under a wide range of strain rates. The impact response of European beech was studied. First, the experiments were carried out to create a reliable background for the comparison with numerical simulations. Secondly, the computations were conducted using an explicit finite element method via the commercial code of LS-DYNA R10.1.0. The wood specimen was modelled as a homogeneous orthotropic elastic-plastic continuum. The yield criterion was covered by Hill's formulation with an associated flow rule and isotropic hardening by *MAT_ HILL_3R_3D material model. Then, the failure model was coupled with plasticity using a weakening (softening) function, which decreases the magnitude of the flow stress of matrix. The dependence on the damage parameter was covered by *MAT_ADD_GENERALIZED_DAMAGE material model. Finally, the crack initiation and propagation were performed by the element deletion technique.

\section{Assessing sunlight in different row spacings of African mahogany (Khaya ivorensis A. Chev.) / Avaliação da radiação solar em diferentes} espaçamentos de Mogno africano (Khaya ivorensis A.Chev.)

Matheus Zampetrik Caetano ${ }^{1}$, Sybelle Barreira ${ }^{1}$

${ }^{1}$ Universidade Federal de Goiás, Goiânia, Brasil (matheuszampetrik@gmail.com; sybelle.barreira@gmail.com)

A luz é um recurso muito valioso e importante para o ecossistema florestal, porém, é evidente que em alguns ambientes esse recurso se mostra escasso, devido a densidade do dossel. A radiação solar que entra nesses ambientes decresce significativamente da copa das árvores em direção ao solo devido a absorção dos componentes da floresta determinando "microhabitats" no ecossistema florestal. Essa diferença de micro-clima afeta o crescimento e desenvolvimento de gramíneas, determinando seu desenvolvimento e sua produtividade. O experimento teve como objetivo avaliar o índice relativo de luz para que fosse possível caracterizar a influência do sombreamento na produção das gramíneas. Foi conduzido em um plantio de mogno africano com parcelas de diferentes espaçamentos entre plantas e nas entrelinhas desenvolveu-se a forrageira Brachiaria brizantha cv. Marandu. Em cada um dos 5 espaçamentos (3x3, 4x4, 5x5, 6x6 e 6x7) foram alocados 5 pontos de coleta. As coletas foram feitas mensalmente durante os meses de setembro, outubro e novembro de 2018 em 3 horários: 09:00, 12:00 e 15:00 horas. Em cada ponto foi coletada a intensidade de luz, utilizando-se um luxímetro além da coleta de gramínea utilizando um gabarito de $50 \times 50 \mathrm{~cm}$. A partir dos dados foram calculados o índice relativo de luz e a massa seca total das gramíneas. Foram comparados os resultados e foi possível quantificar que enquanto o espaçamento $3 \times 3$ apresentou $2.868,0 \mathrm{~kg} /$ ha o espaçamento $6 \times 7$ obteve $4.604,8 \mathrm{~kg} / \mathrm{ha}$ de produção da gramínea, mostrando que o espaçamento é um fator que influencia significativamente na produção dessa espécie.

Eucalyptus crown parameters and shading in silvopasture systems / Parâmetros de copa de eucalipto e sombreamento em sistemas silvipastoris

Ana Lúcia Hanisch ${ }^{1}$, Gilson José M. Gallotti ${ }^{1}$,Adilson Lino de Oliveira ${ }^{2}$

${ }^{1}$ Epagri,Canoinhas, Brazil; ${ }^{2}$ UniversidadedoContestado,Canoinhas,Brazil(analucia@epagri.sc.gov.br; gallotti@epagri.sc.gov.br;adilson.olivers@gmail.com)

Sistemas silvipastoris (SSP) envolvem a produção animal e florestal na mesma área e são excelentes estratégias de manejo sustentável da paisagem no meio rural. Em função de sua complexidade, um dos desafios da pesquisa é a adequação do número de árvores e sua distribuição na área, a fim de que o nível de sombreamento das árvores não prejudique o desenvolvimento das pastagens. O objetivo deste trabalho foi avaliar os parâmetros de copa de árvores de eucalipto em dois espaçamentos em SSP, visando melhor arranjo na projeção da sombra. A área experimental foi formada por oito linhas de $60 \mathrm{~m}$, distanciadas $30 \mathrm{~m}$ entre si, onde foram implantadas mudas de eucalipto em dois espaçamentos na linha: 1,5 m e 4,0 m entre árvores. Foi realizada a prática da desrama aos 12 e 36 meses após o plantio, com a retirada de dois terços dos galhos. Cinco anos após a implantação foram amostradas 48 árvores em cada espaçamento. Para cada árvore-amostra, foi calculado o diâmetro da copa, o comprimento da copa, a porcentagem da copa (\%) e o índice de abrangência. Não foram observados efeitos dos diferentes espaçamentos de eucalipto nas linhas do SSP sobre nenhum dos parâmetros avaliados. Esses resultados confirmam que o manejo de desrama realizado foi suficiente para homogeneizar a copa das árvores de eucalipto em SSP, independentemente do espaçamento utilizado. Cinco anos pós implantação, a prática da desrama apresenta mais influência nos parâmetros de copa do eucalipto em SSP, que os espaçamentos entre árvores na linha.

Artificial intelligence in estimating the productivity of Eucalyptus spp. clones in different spacing arrangements in the semiarid region of Pernambuco, Brazil / Inteligência artificial para estimativa da produtividade de clones de Eucalyptus spp. em diferentes espaçamentos no semiárido pernambucano

Rinaldo Luiz Caraciolo Ferreira ${ }^{1}$, José Antônio Aleixo da Silva1, José Wesley Lima Silva ${ }^{1}$, Rute Berger ${ }^{1}$

${ }^{1}$ Universidade Federal Rural de Pernambuco, Recife, Brasil (rinaldo.ferreira@ufrpe.br; jaaleixo@uol.com.br; wesleylima_16silva@hotmail.com; rute. berger@ufrpe.br)

No Polo Gesseiro do Araripe, semiárido pernambucano, responsável por 95\% da produção nacional de gesso do Brasil, a principal fonte energética da indústria gesseira é a lenha proveniente da Caatinga, o que tem aumentado o significativamente o desmatamento, geralmente, ilegal. Visando mitigar esse desmatamento, experimentos com florestas de rápido crescimento do gênero Eucalyptus foram implantados na região. Nos últimos anos novas técnicas de inteligência artificial foram desenvolvidas e aplicadas como alternativa nos processos de modelagem clássicos. O objetivo desta pesquisa foi avaliar o uso de técnicas da inteligência artificial na modelagem volumétrica de clones de Eucalyptus spp., ferramenta indispensável na condução de planos de manejo florestal sustentáveis. Foram utilizadas as seguintes técnicas: Redes Neurais Artificiais (RNA-MLP), Random Forest, Support Vector Regression (SVR) e como forma de comparação foi ajustado o modelo de Schumacher-Hall. Os dados foram provenientes de 2896 árvores de clones de Eucalyptus,em cinco espaçamentos na idade de 8 anos. As 
variáveis de entrada foram espaçamentos, clones, DAPs e alturas. Para comparação das técnicas, utilizaram-se: Índice de Ajuste Corrigido de Schlaegel (IAc), Erro Padrão da Estimativa (Sxy) e Raiz do Erro Quadrático Médio (REQM). A RNA com configuração 10-12-1 (neurônios por camadas) apresentou IA=0,97, $\mathrm{Sxy}=14,70 \%$ e REQM $=0,134 \mathrm{~m}^{3} \mathrm{ha}^{-1}$. O Random Forest apresentou IA=0,97, Sxy=14,06\% e REQM=0,139 $\mathrm{m}^{3} \mathrm{ha}^{-1}$. O SVR apresentou IA=0,98, Sxy=12.98\% e REQM=0,129 $\mathrm{m}^{3} \mathrm{ha}^{-1}$. O modelo de Schumacher-Hall apresentou IA=0,97, Sxy=12,98\% e REQM=0,129 $\mathrm{m}^{3}{ }^{-1}$. Para grandes amostras, as técnicas da inteligência artificial apresentam precisão semelhante ao modelo de Schumacher-Hall na prognose de volume.

\author{
Analyzing dynamics and changing tendencies in native forest coverage over a 20 pyear period in Cochabamba, Bolivia / Análisis de la \\ dinámica y tendencia de cambio de la cobertura forestal nativa para 20 años en el municipio de Cochabamba-Bolivia \\ Alvaro Rico ${ }^{1}$, Olivia Oporto ${ }^{1}$, Mauricio Ledezma ${ }^{1}$, Benjamin Gosweiler ${ }^{1}$ \\ ${ }^{1}$ Universidad Mayor de San Simon, Cochabamba, Plurinational State of Bolivia; ${ }^{1}$ Universidad Catolica Boliviana, Cochabamba, Plurinational State of \\ Bolivia(alvarorico.bolivia@gmail.com; olivia-2085@hotmail.com; mledezmap@gmail.com; benjamin.gosweiler@gmail.com)
}

El presente estudio se lleva a cabo en el municipio de Cochabamba - Bolivia, tiene como objetivo analizar los cambios de la cobertura forestal nativa en el área del municipio en un periodo de 20 años a través de la interpretación de imágenes satelitales y la relación que existe función de los cambios en el tiempo de los factores antrópicos y los físicos-naturales. La metodología incluye enfoques cuantitativos y cualitativos y como resultado se tiene una caracterizacion y el establecimiento de los factores que han inducido al cambio en la cobertura forestal nativa que determina la dinámica actual y proyección tendencial de estas. El estudio concluye en la importancia de la comprension de la dinámica de cambio de la cobertura forestal nativa a largo plazo.

Growth rings and their periodicity in mangrove species in the state of Tabasco, Mexico / Anillos de crecimiento y su periodicidad en especie de mangle del estado de Tabasco, México

Juan de La Cruz May ${ }^{1}$, Yesica Lopez Falcon ${ }^{1}$, Ana Guadalupe Sanchez Luna ${ }^{1}$, Guillermina Peña Padilla ${ }^{1}$, Miriam Gallegos Gonzalez ${ }^{1}$ ${ }^{1}$ Instituto Tecnológico de La Zona Olmeca, Villahermosa, Tabasco,Mexico (juancmmx@yahoo.com.mx; juancmmx@yahoo.com.mx; juancmmx@yahoo.com.mx; juancmmx@yahoo.com.mx; juancmmx@yahoo.com.mx)

La investigación tuvo como finalidad la evaluación dendrométrica de un rodal de mangle blanco (Laguncularua racemosa L.) en el Ejido La Solución Somos Todos, del municipio de Paraiso, Tabasco. Por medio de un estudio destructivo de 8 árboles se recabó información de sus variables dasométricas y posteriormente se realizó un análisis troncal que sirvió además para determinar en la especie en cuestión el crecimiento e incremento en Altura, Diámetro, Área Basal y Volumen (Incremento Corriente Anual (ICA) e Incremento Medio Anual (IMA), así mismo, el número de años que requiere un árbol en pasar de una categoría diamétrica inferior a otra superior (tiempo de paso). Se determinó que el rodal presenta una densidad de población de 2,933 árboles por hectárea, una edad promedio de 13 años,con altura total promedio de $13 \mathrm{~m}$, altura comercial promedio de $11 \mathrm{~m}$ y un diámetro normal promedio de $9 \mathrm{~cm}$, el crecimiento e incremento en altura logro su máximo crecimiento instantáneo aproximadamente a los 10 años; el incremento en diámetro esta retardado, debido tal vez a que existen muchos individuos por hectárea o el crecimiento de esta especie para la variable en cuestión inicia cuando culmina su incremento en altura, por su parte, el área basal y la altura presentan similitud con respecto a la variable diámetro. Finalmente, se requiere 4.2 años para pasar de una categoría diamétrica de 5 a una de 10 cm en esta especie de mangle.

\title{
C5a: CHARACTERIZING PROPERTIES OF PLANTATION WOOD FOR OPTIMAL VALUE
}

\section{Study on rapid measurement method for pulpwood characteristics using the near-infrared techniques}

Ting Wu $u^{1}$, Guigan fang ${ }^{1}$

${ }^{1}$ Institute of Chemical Industry of Forest Products, Chinese Academy of Forestry, Nanjing, China (wuting@icifp.cn; ppfangguigan@163.com)

To meet the demand of rapid analysis of pulpwood, a study was conducted to develop prediction models for the characteristics of pulpwood based on nearinfrared spectroscopy and chemometrics. The content of chemical components and basic density of 13 kinds of pulpwood were determined, and the actual moisture content was determined under the condition of artificial control. The NIR spectrum were pretreated by combination pretreatment methods in Matlab 8.0 after collected by a holographic grating spectrometer, and the models were established by loading PLS, LASSO, support vector machine method and artificial neural network algorithms. Then genetic algorithm were used to select the optimal bands. In the analysis of holocellulose content, the pretreatment method of smoothing, vector normalization, first derivative was adopted, $1331.0 \sim 2362.1 \mathrm{~nm}$ band was selected, and LASSO algorithm was used to establish the calibration model. The RMSEP value is $0.48 \%$, and the model is suitable for quality control. In the moisture content analysis, pretreatment method of smoothing, normalized, first derivative was adopted, the band of 1346.7 1477.4nm and 1790.0 1983.3nm was selected, and the PLS algorithm was used. The RMSEP value of the model is $1.19 \%$. In the basic density analysis, the pretreatment method of smoothing, vector normalization and first derivative was adopted, whole-band was selected and the LASSO algorithm was chosen. The RMSEP value of the model is $6.31 \mathrm{~kg} \cdot \mathrm{m}^{-3}$. The Klason lignin, pentosan, benzene-alcohol extractives and $1 \% \mathrm{NaOH}$ extractives models were also developed with good performance.The study provided possibility to realize the rapid analysis of pulpwood.

\section{Use of non-destructive techniques to optimise the production of Structural Products from Eucalyptus Plantations Grown for Fibre}

Michelle Balasso (D, Mark Hunt ${ }^{1}$, Gregory Nolan ${ }^{2,3,4}$, Nathan Kotlarewski $^{2,3}$, Andrew Jacobs ${ }^{5}$, Julianne O'Reilly-Wapstra ${ }^{1}$

${ }^{1}$ School of Natural Sciences and ARC Training Centre for Forest Value, University of Tasmania, Hobart, Australia; ; ${ }^{2}$ School of Technology, Environments \& Design, University of Tasmania, Launceston, Australia; ${ }^{3}$ ARC Training Centre for Forest, Value Hobart, Australia; ${ }^{4}$ Centre for Sustainable Architecture with Wood,Launceston, Australia; ${ }^{5}$ Forico Pty Limited, Launceston,Australia(michelle.balasso@utas.edu.au; m.hunt@utas.edu.au; gregory.nolan@utas.edu.au; nathan.kotlarewski@utas.edu.au; andrew.jacobs@forico.com.au; julianne.oreilly@utas.edu.au)

This study presents an investigation of acoustic testing and additional wood quality characterisation of a plantation Eucalyptus nitens resource along the processing chain from standing trees to products in a stand established and managed for fibre production in Tasmania. The role of Eucalyptus plantations in meeting market demand for non-fibre wood products is gaining importance as the availability of native forest resources is decreasing internationally. Fibremanaged eucalypt plantations constitute a resource that has potential to meet this increasing demand for structural applications as value-added engineered products. The challenge in meeting these potential markets is to better understand and communicate the wood quality characteristics of standing trees and logs and effectively and reliably relate these to performance attributes in the final products. Non-Destructive Testing (NDT) techniques can be used to characterise 
wood quality in standing trees and logs through the estimation of traits related to important structural attributes such as stiffness and density. However, the current ability to relate indirect measures of wood quality to final product performance is hindered by the need for further validation along the production chain (from standing tree to sawn board or engineered product). Trees were followed through the harvesting, segregation and sawing process; wood quality characteristics were tested at different stages to determine the relationships between traits measured with NDT techniques on trees, logs and sawn boards. The results of our study also provide information needed for a possible review of how plantation Eucalyptus logs are graded, potentially using a more product performance focussed approach.

\section{Fast basic wood density estimation of standing trees using drill shavings}

Fabrício Antônio Biernaski ${ }^{1}$, Letícia Miranda ${ }^{1}$,Everton Zanlorenzi ${ }^{1}$, Marco Aurélio Figura ${ }^{1}$, Regiane Abjaud Estopa ${ }^{1}$ KLABIN S.A., Telemaco Borba,Brasil (fbiernaski@klabin.com.br; lemiranda@klabin.com.br; ezanlorenzi@klabin.com.br; mafigura@klabin.com.br; restopa@klabin.com.br)

The basic wood density estimation with faster results and non-destructive techniques has been increasing in the forest sector. The traditional methodologies like wood wedges or cores are timing consuming in sampling and laboratory analysis. In the other hand, indirect technologies as near infrared spectroscopy and drilling resistance needs previous calibration for different tree species and environment. A simple and fast way to sampling and estimate basic wood density in standing trees (it can be used in logs too) was tested. Wood cores samples of $100 \mathrm{~mm}$ length by 12 mm diameter were collected from pines and eucalyptus trees at breast height $(1.30 \mathrm{~m})$ and near the same point wood shavings was collected using a $12 \mathrm{~mm}$ diameter cordless drill machine with an adaptation for delimitation of $100 \mathrm{~mm}$ depth. The bark was previously removed at the sampling points. All the shavings samples were collected individually from each perforation using a paper bag stapled on the tree. The cores basic wood density was predicted by standard gravimetric method. Each shavings sample was oven dried and weighted. The volume of the drill perforation (100 mm length by $12 \mathrm{~mm}$ diameter) was considered as the shavings sample volume, and the basic wood density was calculated dividing shavings dry weight by the perforation volume. The correlation between the two basic wood density methodologies was 0.98 . This high correlation allows implementing the use of drill shavings for specific wood density estimation in an easy, cheap and fast way.

\section{Physical, mechanical, and acoustical characterization to Leucaena leucocephala wood}

Cinthya Bertoldo ${ }^{1}$, Ryuji Somo ${ }^{1}$, Vinícius Pereira ${ }^{1}$, Matheus Garrido ${ }^{1}$, Gustavo Garcia

${ }^{1}$ Universidade Estadualde Campinas,Campinas,Brasil(cinthyabertoldo@gmail.com; jujuliosoma@gmail.com; vinicius1236589@gmail.com; matheusbgarrido@hotmail.com;gustavohlgarcia@gmail.com)

Leucaena leucocephala (Lam.) de Wit is an invasive tree that widely occurs in national territory and in different continents. This tree is often observed in abundance on many Brazilian states, occupying agricultural areas and in regeneration state. A strategy adopted in the state of São Paulo to contain its proliferation was establishing a more flexible environmental legislation regarding its suppression. Due to the suppression policy, the leucaena wood becomes abundant and available, however, most of this wood are destined to landfill, since there are few studies and data about the mechanical properties of its wood in scientific literature that justifies a technological application or more noble use. The nondestructive test employing ultrasound are being gradually more adopted to describe mechanicals properties of many materials, due to the methodology, technology and scientific knowledge advances. Therefore, the objective of this work is mechanical characterization, employing destructive and nondestructive tests, and the physically and acoustically characterization leucaena wood. To achieve the research goal were determinate acoustical parameters on trees and on freshly felled logs, the complete elastic characterization of wood was obtained employ the ultrasound tests on polyhedral specimens and mechanical parameters of Leucaena wood were determinate by compression and bending tests. With the research results it will be possible a more sustainable use to leucaena wood, due to the possibility of application in more nobles uses, with highest aggregate value.

\section{Structural chemical composition of eucalyptus aboveground and belowground biomass from commercial clones}

Elaine Cristina Leonello ${ }^{1}$, Fabiana Prieto Castanho ${ }^{1}$, Natália Laís Felisardo Veira Arruda ${ }^{1}$, Ana Carolina Lopes Amaral Costa ${ }^{1}$, Saulo Philipe Sebastião Guerra

${ }^{1}$ Universidade Estadual Paulista "Júlio de Mesquita Filho”, Faculdade de Ciências Agronômicas, Botucatu, Brasil (leonelloelaine@hotmail.com; fabianacastanho26@gmail.com; nfvarruda@gmail.com; cacostal@hotmail.com; saulo.guerra@unesp.br)

The residual biomass of the Eucalyptus stumps and roots is an alternative energy source and its structural chemical properties is important to help identify potential uses and applications for the biomass in question. The objective of this work was to compare the chemical content of hollocelulose, lignina and total extractives contents from crown root, stump and stem wood of four comercial clones of Eucalyptus (Eucalyptus urophylla-AEC-144, Eucalyptus urophylla $\times$ grandis - AEC-224, Eucalyptus urophylla $\times$ camaldulensis - VM-01 and Eucalyptus urophylla $\times$ grandis $-\mathrm{H}-77)$ in a 5.7 up to 7 years old first rotation. Were used ABNT Standards to determine the content of the desired compounds. Samples were colected from DBH from the stem and stump (aboveground biomass of the harvest residual stump-roots system) and crown root (central part and most representative mass of the harvest residual roots). Hollocellulose varies up 58.52 \% to $76.86 \%$. Lignin content varies from $16.51 \%$ to $29.38 \%$. Total extractives varies between $5.54 \%$ and $17.70 \%$. Stem and stump shows very similar higher values than crown root for lignin content. Hollocelulose presents higher content in the stem and the lower content in crown root. The total extractives are most present in crown root than stump and stem wood. The values are relevant and innovative for those who have interests on this potencial biomass source of energy

\section{Predicting sawn wood quality of standing Eucalyptus trees from non-destructive measurements}

Brand Wessels ${ }^{1}$, Ashlee Prins ${ }^{1}$

${ }^{1}$ Stellenbosch University, Stellenbosch Cape Winelands, South Africa (cbw@sun.ac.za; 17150558@sun.ac.za)

The genus Eucalyptus is the most widely planted hardwood worldwide due, mainly, to its adaptability and high growth rates. Most Eucalyptus species, however, are rarely processed into sawn lumber due to processing problems associated with poor dimensional stability, splitting, brittle heart, cell collapse, and checking after drying. Many of these traits could be improved through genetic tree improvement programs. The objective of this project was to identify and test potential non-destructive prediction tools and methodologies on standing trees of Eucalyptus grandis and Eucalyptus grandis X urophylla that can be used to estimate the splitting, warp, brittle heart, collapse, density and density gradient in sawn boards. The main use of such predictions will be for selecting superior genetic material for tree breeding programs. Several measuring methods including Resistograph, stress wave measurement, and wood density from increment cores were used. A new strain measurement technique was also developed and tested. Models were developed for prediction of sawn board properties in order to quantify and rank trees in terms of their wood quality. 
Exploring the possibilities of quantifying Heartwood of Tectona grandis Linn. f. using electrical resistivity tomography (ERT) for treeimprovement

Baragur Neelappa Divakara ${ }^{1}$, Chitradurga Umesh Nikhitha ${ }^{1}$, Anil Kumar Sethy ${ }^{1}$

${ }^{1}$ Institute of Wood Science and Technology, Indian Council of Forestry Research and Education, Bengaluru, India (bndsira@gmail.com; thoshitha.cu@gmail. com; sethyanil@gmail.com)

Accurate, cost-effective and non-destructive method of diagnostic technique for quantifying the heartwood content in Tectona grandis Linn. f.is indispensable as it helps in selection of trees with more heartwood for further genetic improvement. Tree Tronic tomograms like Electrical Resistivity Tomography (ERT) are one among the advanced non-destructive method aiding for tree inspection. This method gives high resolution with more precision in measuring the sapwood, heartwood, stress and decay in the living trees. In this study, main aim is to explore the possibility of using Electrical Resistivity Tomography (ERT) to determine the sapwood-heartwood (SW-HW) boundary in terms of electrical resistivity. The instrument used to measure electrical conductivity within the $T$. grandis disk was a PiCUS TreeTronic (Argus Electronic GmBH, Rostock, Germany), a multi-channel, multi-electrode resistivity system. ERT study of $T$. grandis disk revealed that, high resistivities occurring in the inner part of the cross-section, with much lower values towards the outside. The demarcation of SW-HW boundary was based on the distinct colour differentiation from blue (low resistance) to red (high resistance). A comparison between ERT and actual SW-HW area measured shows a slope of the linear regression close to unity $(=0.92)$ with a narrow spread of values $(\mathrm{R} 2=0.90)$. The range of resistivities observed among all the T. grandis disk were compared. Thus, this study indicates the potential application of ERT for quantifying SW-HW content in $T$. grandis.

\section{Wood properties inference from nursery seedlings}

Rafael Gustavo Mansini Lorensani ${ }^{1}$, Raquel Gonçalves ${ }^{1}$, Mônica Ruy ${ }^{1}$, Nádia Schiavon Veiga

${ }^{1}$ Universidade Estadual de Campinas, Campinas, Brasil(rafaelmansini@hotmail.com; raquelg@g.unicamp.br; monica.ruy@hotmail.com, nadiasveiga@gmail.com)

It is very important the early selection of trees considering its wood properties, allowing the proper targeting of processes (unfolding, drying etc.), avoiding unnecessary expenses. The objective of this research was to evaluate the viability of using parameters measured in nursery seedlings (Velocity of ultrasonic waves (VLs), basic density (BDs), height (Hs), diameter (Ds), strength (fts) and modulus of elasticity (Ets) in tension parallel to the grain), infer properties (basic density (BDt), modulus of elasticity (EMt) and modulus of rupture (fmt)) of the wood from 72-month-old trees (cutting age in Brazilian pulp and paper industry). Preliminary analysis was made to analyze the evolution of the parameters with age, followed by the use of these parameters to propose inference models. All parameters measured in seedlings have potential to be used in predictive model to anticipate selection of clones, but the degree of this anticipation would not be the same. The VLs was the only property that maintained, at the cutting age, the coherence of the differentiation between clones obtained on seedlings. The fts, Ets and Ds maintained coherence from 12-months-old, while the BDs since 24-months-old. The BDt cannot be predicted by any model involving parameters obtained in seedlings. On the other hand, a multiple regression model involving the Hs and VLs was adequate for predicting the EMt of the wood from 72-month-old trees. A simple regression model using the relationship betweenEts and fts of the seedling allowed a statistically significant prediction of the fmt of the wood from 72-month-old trees.

\section{Chemical extractives from knots: a comprehensive approach for stand-level forecast}

Rubén Manso', Paul McLean ${ }^{1}$, Philippe Gérardin'2, Zineb Kebbi-Benkeder², Stéphane Dumarcay², Francis Colin ${ }^{3}$

${ }^{1}$ Forest Research, Roslin, United Kingdom; ${ }^{2}$ Laboratoire d'Etude et de Recherche sur le Matériau Bois, Université de Lorraine, Vandœuvre les Nancy,

France; Institut National de la Recherche Agronomique, Champenoux, France(ruben.manso@forestresearch.gov.uk; paul.mclean@forestry.gsi.gov.uk; philippe.gerardin@univ-lorraine.fr; zineb.kebbi_benkeder@yahoo.fr; stephane.dumarcay@univ-lorraine.fr; francis.colin@inra.fr)

One of the main objectives of the biorefinery sector is to find alternative feedstocks for their industrial processes. Among the various raw materials biorefineries seek, chemicals are specifically relevant for the forestry sector because they can be found in different parts of trees such as the knots. Therefore assessing which chemicals can be provided to the industry, in which amount and from which species is a major challenge for forest scientists. For this information to be complete, predictions on chemical extractives need to be included in forest simulators, which are usually only aimed at forecasting timber production. In this contribution we introduce an approach that addresses these needs through case studies. First, models to predict knot volume and the concentration of extractives in knots are presented. This provides the unitary amount of chemicals per knot. Then we discuss a strategy to couple these results with growth models so that predictions on chemicals production from knots can be projected over time. On the practitioners side, the implementation of this approach would allow considering management alternatives to maximize the production of chemicals and to compare the profitability of such alternatives to others aimed at traditional forest products. On the biorefinery end, the approach would serve to inform on the potentiality of forests as feedstocks for the sector.

Constructing models to predict the basic density of Eucalyptus grandis W. Hill ex Maiden wood using near infrared spectroscopy (NIRS) / Construção de modelos preditivos da densidade básica da madeira de Eucalyptus grandis W. Hill ex Maiden pela espectroscopia no infravermelho próximo (NIRS)

Caroline Américo da Silva ${ }^{1,2}$ (D), Mariana Pires Franco ${ }^{1}$, Roger Chambi Legoas ${ }^{1}$, Lucas Sene Oste ${ }^{1}$, Samara Franzol ${ }^{1}$, Mario Tomazello-Filho ${ }^{1}$, Gilles Chaix ${ }^{1,3}$ ${ }^{1}$ Escola Superior de Agricultura Luiz de Queiroz, Universidade de São Paulo, Departamento de Ciências Florestais, Piracicaba, Brasil; ${ }^{2}$ Klabin S.A., São Paulo, Brasil; ${ }^{3}$ UMR AGAP, CIRAD, Univ Montpellier, Montpellier,France (caroline.silva@klabin.com.br; ma.pires@hotmail.com; rogerchl86@hotmail. com; lucas.oste@usp.br; samara_franzol@hotmail.com; mtomazel@usp.br; gilles.chaix@cirad.fr)

O presente trabalho teve como objetivo obter modelos de predição da densidade básica da madeira de árvores de Eucalyptus grandis, plantadas em espaçamento de 3 x 2m, fertilizadas com K e Na, submetidas ao estresse hídrico. Foram selecionadas 54 e 48 árvores, com 5 e 6 anos, respectivamente, cortando seções transversais do lenho na base e DAP do seu tronco. Foram analisadas a seção transversal de 1.222 corpos de prova de madeira, no espectrômetro NIR MPA da Bruker, nos módulos (i) esfera de integração $\left(12800-3600 \mathrm{~cm}^{-1}\right)$ e (ii) sonda de fibra óptica $(12800-4000 \mathrm{~cm}-1)$, com resolução espectral $8 \mathrm{~cm}^{-1}$, média de 32 leituras. Posteriormente, foi determinada a densidade básica dos corpos de prova pelo método do máximo teor de umidade. Os dados foram tratados no software The Unscrambler ${ }^{\circledR}$, sendo simuladas regressões com mínimos quadrados parciais (PLS), baseadas nas informações espectrais e na densidade básica, considerando 6 pré-tratamentos aplicados aos dados espectrais de validação cruzada e independente. Dos 36 modelos, os que apresentam os parâmetros mais adequados segundo a literatura foram (i) esfera de integração: pré-tratamento Derivative 1;R²cv:0,69;RMSECV: 0,021 g.cm-3, LV: 9; R²p: 0,68; RMSEP: 0,022 g.cm-3, RPD: 1,76; (ii) fibra óptica: sem pré-tratamento;R²v:0,65;RMSECV: 0,022 g.cm-3, LV: 5; R²p: 0,61; RMSEP: 0,024 g.cm-3, RPD: 1,62. Demonstrou- 
se, desta forma, que as regressões PLS que correlacionam as informações espectrais e a densidade básica da madeira de $E$. grandis, apresentam estatísticas satisfatórias, com coeficientes de correlação médios, baixos valores de erro padrão da predição, e RPD próximos a 2.

\section{Anatomical and thermochemical investigation on high-speed rotation welding of Australian and tropical hardwood species

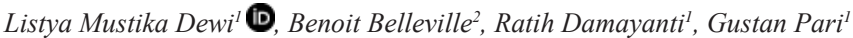 \\ ${ }^{1}$ Forest Products Research and Development Center; Research, Development and Innovation Agency; The Ministry of Environment and Forestry, Bogor, Indonesia; ${ }^{2}$ School of Ecosystem and Forest Sciences; Faculty of Science; The University of Melbourne, Melbourn (lizthya@gmail.com; benoit.belleville@ unimelb.edu.au; ratih_turmuzi@yahoo.com; gustanp@yahoo.com)}

Wood welding using high-speed rotation has been successfully applied to join two pieces of wood without using any glues or connectors. The mechanical frictions could generate heat that cause softening of lignin to be natural adhesive. The welded wood products are considered to be eco-friendly wood products as it could minimize the use of non-renewable resources. This research is aimed to investigate the influence of anatomical and chemical properties on wood welding performance and their changes induced by the mechanical friction process of 4 Australian and 1 tropical wood species. Three different parameters i.e. grain orientation, rotational speed, and dowel/hole diameter ratio were treated for Eucalyptus delegatensis, Eucalyptus pilularis, Eucalyptus saligna, Corymbia maculata, and Tectona grandis. The reference and welded wood samples were investigated for their anatomical and chemical properties. The results show that anatomical characteristics such as cell dimensions (fibre length and fibre wall thickness), fibres proportion, the type of vessels, tyloses, rays, and the presence of mineral inclusions appeared to influence the mechanical performance of welded joints. The deformation of anatomical structure i.e. fibre entanglement has occurred following the welding process. The importance of lignin during wood welding process has proven by the result of pyrolysis GC-MS analysis. Thermal welding has affected the changes of Syringyl, Guaiacyl and other chemical constituents.

\section{Surface knots classification of wood using k-Nearest neighbor and deep learning}

Hyunbin Kim ${ }^{1}$, Sang-Yun Yang ${ }^{1}$, Yonggun Park ${ }^{1}$,Hyunwoo Chung ${ }^{1}$, Ohkyung Kwon ${ }^{2}$, Hwanmyeong Yeo ${ }^{1,3}$ ${ }^{1}$ Seoul National University, Republic of Korea Seoul; ${ }^{2}$ National Instrumentation Center for Environmental Management (NICEM), Seoul National University, Seoul, Republic of Korea; ${ }^{3}$ Research Institute of Agriculture and Life Sciences, Seoul National Universi (youursea@snu.ac.kr; sly1357@snu.ac.kr; gunny007@snu.ac.kr; boltzman1223@gmail.com; zoom@snu.ac.kr;hyeo@snu.ac.kr)

Wood defects occur in various forms during growth and processing. Therefore, it is necessary to objectively assess the quality of the wood for its purpose by correctly classifying its defects. However, because visual classification and species identification by human beings can cause errors based on subjective judgments, automatic video analysis using computer vision is needed to speed up the production of wood. In this study, k-nearest neighbor model with the scale-invariant feature transform (SIFT+k-NN) and the convolutional neural network (CNN) model were used to implement and analyze the accuracy of knot classification models; 1,172 knots were acquired for learning and validation. For the SIFT+k-NN model, characteristics were extracted from the retaining image using SIFT technology, and the classification was carried out using k-NN, with the highest accuracy (approximately $60.53 \%$ ) when $\mathrm{k}$ index was 17 . The CNN model consisted of eight convolution layers and a third-story hidden layer and had an accuracy of approximately $88.09 \%$ at 1205 epochs, higher than that of SIFT+k-NN model. In addition, the SIFT+k-NN model showed a large variation in the number of images of each type of knots, but the CNN model showed higher classification performance due to its lack of bias in determining the number of knots. The results of this study show that the CNN model is more accurate than the SIFT+k-NN model in classifying wood knots.

\section{C5c: INNOVATIVE UTILIZATION OF BAMBOO AND RATTAN RESOURCES}

\section{Visualizing the microfibrils orientation distribution in moso bamboo by polarized laser Raman spectroscopy}

Jianfeng Ma ${ }^{1}$, XingE Liu ${ }^{1}$, Long Feng ${ }^{1}$

International Center for Bamboo and Rattan, Beijing, China (majf@icbrac.cn; liuxinge@icbr.ac.cn;fenglong@icbrac.cn)

The variation in the microfibrils orientation of the moso bamboo (Phyllostachys pubescens) multilayered fiber and parenchyma was studied by linear polarized laser Raman spectroscopy. Raman imaging revealed that the fiber secondary wall displayed a concentric structure with alternating broad and narrow layers, while parenchyma had no obvious layering structure probably due to the limited spatial resolution. Higher Raman C-O-C band intensity was visualized in the narrow layer of fiber wall, indicating the microfibrils (Mfs) in these regions were more parallel to the incident laser electric vector and more perpendicular to the cell axis. The Mfs orientation in parenchyma wall is uniform. Moreover, Raman band ratio (I1095/I2939) was used to predict microfibrils angle (MFA) in different cell wall types, qualitatively. The results showed that the ratio was highest in parenchyma, followed by narrow layer of fiber wall, and lowest in the broad layer of fiber wall, which indicated the higher MFA in the parenchyma. More importantly, the ratio remains constant in all the successive and alternating broad and narrow lamellae. This study provided a novel method and important theoretical guidance for the investigation on cell wall architecture and micromechanics.

\section{Lignin Topochemistry in Developmental Bamboo Fibre Based on Various Spectroscopic Imaging}

Shumin Yang ${ }^{1}$, Elin Xiang ${ }^{1,2}$, Xinge Liu ${ }^{1}$, Jianfeng $\mathrm{Ma}^{1}$, Genlin Tian ${ }^{1}$, Lili Shang ${ }^{1}$

${ }^{1}$ International Centre for Bamboo and Rattan, Beijing, China; ${ }^{2}$ Research Institute of Wood Industry, Chinese Academy of Forestry, Beijing, China (yangsm@icbr.ac.cn; xiangelin@163.com; liuxinge@icbr.ac.cn; majf@icbr.ac.cn; tiangenlin@icbr.ac.cn; shangll@icbr.ac.cn)

Bamboo has excellent mechanical properties that could offer high strength, toughness and ductility. The characteristic properties are determined to a large extent by the polylamellate structure and chemical composition of fibers.Compared with the structure receiving morecare, chemical composition of cell wall is only partially known so far. In this study, The heterogeneity of lignin in fiber cell walls of developing moso bamboo will be revealed through Confocal Raman Microscopy (CRM) combined with other spectroscopic imaging technique, such as UV-microspectrophotometry and confocal scanning laser microscope. The lignification rate is changing in different ages, tissues and anatomical regions. The vessel elements begins to be lignified before fiber and parenchyma. In same fibrous sheath, the fibers near the vessel lignified first, and then toward the periphery of the vascular bundle. Lignin content of secondary wall (SW), cell corner (CC) and compound middle lamellae (CML) of fibre increase gradually within 6 months, and then changed slowly. The average lignin content $\mathrm{CC}>\mathrm{CML}>\mathrm{SW}$. Guaiacyl, syringyl and p-hydroxyphenyl lignins can be found in cell wall of fibre, and showed obvious heterogeneous microdistribution. These complementary techniques provided accurate information with regard to chemical composition distribution. In situ CRM was an effective method that can be used in studying 
the microdistribution of lignin concentration, lignin unit, cellulose and hydroxycinnamic acid. These results will provide important references for further study of the biological formation mechanism, high value-added utilization of bamboo and bionic materials design.

\author{
A unique mechanical process for extraction of natural fibre from bamboo derived from a traditional practice in Kerala State, India \\ Muralidharan E.M. ${ }^{\text {(D) Thulasidas } P K^{2}}$ \\ ${ }^{1}$ Forest Genetics and Biotechnology Division, Kerala Forest Research Institute, Peechi, Thrissur, India; ${ }^{2}$ Wood Science and Technology Division, Kerala \\ Forest Research Institute,Peechi,Thrissur,India(emmurali@kfri.org; thulasidas@kfri.org)
}

Viscose or rayon produced from bamboo stems (culms) is often confused with or wrongly described as natural fibre yarn. Viscose production involves use of harsh chemicals and regeneration of cellulose fibres which does not retain the absorbent and antimicrobial properties of the natural fibre. Claims of commercial extraction of natural bamboo bast fibre, are relatively ambiguous and moslty use proprietary procedures. The process used in extraction of fibres from reed bamboo (Ochlandra species) in the traditional method adopted by artisans of the Kottiyoor area of Kerala State in India, is on the other hand primarily mechanical in nature and also involving retting. The salient features and uniqueness of the procedure, in comparison with similar described processes, is brought out in this paper. Applicability of the procedure to a variety of other bamboo species is demonstrated and prospects for sustainable commercial production and use in bamboo textiles and other products is discussed.

\title{
The effect of heat-treatment on fire performance of bamboo scrimber flooring
}

Hongzhong Xiang ${ }^{1}$, Tao Zhang ${ }^{1}$, Zehui Jiang ${ }^{1}$, Benhua Fei ${ }^{1}$, Zhijia Liu ${ }^{1}$

1International Center for Bamboo and Rattan,Beijing, China (532284269@qq.com; 1204624557@qq.com; jiangzehui@icbr.ac.cn; feibenhua@icbr.ac.cn; liuzj@icbr.ac.cn)

Fire characteristics of bamboo scrimber flooring produced from different heat-treated processes were investigated by thermogravimetric analysis (TGA) and cone calorimeter in this research. The results showed that combustion process of samples included moisture removal, oxidative and char combustion. All characteristic temperatures increased with increase in heating rates. Bamboo scrimber flooring treated with low temperature of $140^{\circ} \mathrm{C}$ for $3 \mathrm{hours}(\mathrm{LBSF})$ had a lower activation energy of $71.82-73.18 \mathrm{KJ} / \mathrm{mol}$ in the oxidative stage and a higher one of $106.17-110.97 \mathrm{KJ} / \mathrm{mol}$ in the char combustion stage than samples treated withhigh temperature of $190^{\circ} \mathrm{C}$ for 10 hours (HBSF). HBSF had a lower HRR and a larger TTI. But it had a higher THR, TSP and HHV. The results will be helpful for guiding and promoting the utilization of bamboo scrimber flooring in China.

\section{Development of a "flex" material combining glued laminated bamboo and wood: application in a prototype of a bus stop for public use in Brasilia, Brazil}

Divino Eterno Teixeira ${ }^{1}$, Jaime Gonçalves de Almeida², Julio Eustáquio de Melo², Sergio Alberto de Oliveira Almeida

${ }^{1}$ Serviço Florestal Brasileiro, Brasília, Brasil,;2University of Brasilia(UnB), Brasilia,Brasil (divinot@gmail.com; jagal@unb.br; alej@unb.br; seralm44@hotmail.com)

This article presents the development of a composite material combining bamboo and wood, called "flex material", in the form of glued laminates, as well as its application as a prototype of a bus directory for public use in the DF-Brazil. The research involved the bibliographical revision on bamboo and wood, a study of the regional socioeconomic context in view of the use of this material; development of industrial processes for laminating bamboo with wood and conducting mechanical tests with samples; exposure to the use of models manufactured to verify their performance against real use; and the formation of a working team involving researchers from several DF institutions. The objective of the research was to promote the use of bamboo with wood and its application experimentally in the combination of bamboo plies, known by the acronym BaLC (glued laminated bamboo), with wood from planted forest. The product was called "flex material" because it is a material resulting from the mixing of two versatile natural raw materials (bamboo and wood). The experimental was worked by the research as demonstration of the possibility of using the proposed flex material as a bus stop for public use in Brasília, DF. All bonding strength studies, production of reduced models, production of mock-ups and physical and mechanical tests, including connections with metallic pins, preceded the production and assembly of the final prototype within a public area of the University of Brasília. The post-construction performance of the structure is now under continuous evaluation.

\section{A contemporary interpretation of the traditional construction material "Bamboo" - INBAR Garden-Pavilion in 2019 Beijing Horticultural Expo}

Kewei Liu ${ }^{1}$, Mauricio Cardenas Laverde ${ }^{2}$, Changzhuan Shao ${ }^{4}$, Shidong Nie ${ }^{5}$

${ }^{1}$ International Bamboo and Rattan Organization, Beijing, China; ${ }^{2}$ Studio Cardenas Conscious Design, Milan, Italy; ${ }^{4}$ Tsinghua University, Beijing, China;

${ }^{5}$ Chongqing University, Chongqing, China (kwliu@inbar.int; m.cardenas@studiocardenas.it; shaochangzhuan@163.com; nieshidong@cqu.edu.cn)

Bamboo is a gift of nature which has been used for landscape, architecture and interior design for a long time. Since its establishment in 1997, International Bamboo and Rattan Organization (INBAR) has been dedicating to promote sustainable uses of bamboo in many countries. An innovative INBAR GardenPavilion with the area of 3600 square meters is under construction for 2019 Beijing Horticultural Expo, which will provide a great opportunity for INBAR to showcase contemporary uses of the traditional material "Bamboo". Following several highlights of the project: 1) It is a contemporary interpretation of the traditional concept of "a Pavilion in the Garden" by creating one single element Garden-Pavilion, where architecture, landscape and engineering are melted into each other; 2) The Pavilion is mainly a large-span round pole bamboo structure creating an open space beneath the garden. Through calculation and field loading test, it is proved that truss arches with variable cross-section of round pole bamboo structure are feasible as the main bearing members with a span of more than 30 meters; 3) Several innovative measures will be taken to improve its durability in northern China; 4) Engineering Procurement Construction (EPC) was adopted for the project in which an internationally, coordinated and inter-disciplinary way of collaboration was explored. It is expected that INBAR Garden-Pavilion will greatly improve scientific understanding of bamboo as a contemporary construction material for the public as well as other stakeholders like architects, engineers, policy makers, developers and etc. 


\section{Policy review: Why China has a successful bamboo industry?}

Zhiyong $L i^{1}$

${ }^{1}$ International Centre for Bamboo and Rattan, Beijing, China (zyli@icbr.ac.cn)

If there is a performance report of the bamboo industry in China, it would read like this: bamboo forest area reaching nearly 7 million hectares including the world's largest area of bamboo plantations, annual production valuing over 30 billion USD, more than 10,000 kinds of bamboo products manufactured, nearly 10 million jobs and livelihoods provided, and the world's largest trade volume of bamboo products scored. Many factors play their distinct part to produce such a remarkable performance, including industry policies whose role is both significant and irreplaceable. The key policies on resources, on businesses, on science and technology, on property rights and on trade have their own background, focus and effects. Particularly, in different development stages of bamboo processing industry, enterprises and bamboo farmers received necessary support, to varying degrees, in finance and tax policies from central and local governments, which show us today's complete industry chain and supply chain, upgraded value chain, and a large variety of products. Three provincial policy cases will be shared in paper.

\section{Quality analysis of charcoal from various species of bamboo converted using improved carbonization technologies in Kenya}

Nellie Oduor ${ }^{1}$,Emily Kitheka ${ }^{1}$, Nathan Nyamai ${ }^{1}$, James Kimwemwe ${ }^{1}$, Kevin Juma ${ }^{2}$

${ }^{1}$ Kenya Forestry Research Institute, Nairobi, Kenya; ${ }^{2}$ The Nature Conservancy, Nairobi, Kenya (noduor@kefri.org; emilykitheka@yahoo.com; nmaitha84@yahoo.com; jameskimwemwe@yahoo.com; kevin.juma@tnc.org)

Bamboo is a perennial grass in the family Poacea with over 1,600 species globally. It is one of the strongest and fastest growing plants in the world. Kenya has only one indigenous species Oldeania alpina found at altitudes above 2200 asl. Over twenty exotic species were introduced in the country and half of them are growing well in various agro-climatic regions. There are over 10,000 documented uses of bamboo which include fuelwood. Over 70\% of Kenya's population is dependent on biomass energy for cooking and heating. Bamboo is a potential source for domestic and industrial energy needs. Since the exotic species were introduced no studies have been carried out to determine their fuel properties as potential feedstock for energy production in Kenya. This study sought to carbonize nine bamboo species - Oldeania alpina, Bambusa vulgaris var. Vittata, B. vulgaris, B. chungii, B. tulda, Dendrocalamus giganteus, D. strictus, D. brandisii, and D. asper. Bambusa tulda recorded the highest calorific value ( $8.203 \mathrm{kcal} / \mathrm{g})$ fixed carbon $(74.1 \%)$, ash content (2.09\%) and volatile matter (15.\%). Heat value assessment and burning time using an energy saving stove boiling 5 litres of water was carried out. Dendrocalamus strictus attained the highest temperature $\left(662^{\circ} \mathrm{C}\right)$ and longest burn time (57 minutes) was observed with Bambusa tulda. Generally, the exotic species recorded high calorific values and heat values than the indigenous one, though the burning time was short ranging less than an hour. Bamboo charcoal can be recommended for light cooking, and if briquetted the densification would prolong the burning time.

\section{A simultaneous treatment of bamboo flattening and homogenization}

Changhua Fang ${ }^{1}$

${ }^{1}$ International Centre for Bamboo and Rattan, Beijing, China (cfang@icbrac.cn)

Owing to faster growth, shorter rotation and higher mechanical strength compared with other species, bamboo has great potential to supplement timber. However, the non-uniform distribution of vascular bundles embedded in the matrix makes bamboo a heterogeneous material with low density and low mechanical strength towards inner portion of bamboo culm. Furthermore, due to its arc shape, one of the widely used conventional processing of bamboo splits is to plan on the four sides to get uniform and rectangular bamboo strips, which has a very low material use efficiency. In this study, a simultaneous treatment of flattening and homogenization with thermo-hydro-mechanical processing on bamboo splits was performed to obtain flattened and homogeneous material. Green bamboo splits with high moisture content were compressed at $170^{\circ} \mathrm{C}$ with a special vapor releaser. After treatment, density and mechanical strength increased significantly with much less differences along the radial direction of bamboo culm wall. The hygroscopicity decreased significantly with much lower moisture adsorption rate after treatment.

\section{C5f: QUALITY REQUIREMENTS OF FOREST BIOMASS FOR BIOREFINERY}

\section{Forest biomass harvesting and chip quality in mixed hardwood forests for bioenergy production}

John Vance ${ }^{1}$, Jingxin wang $^{1}$, Shawn Grushecky ${ }^{1}$, Raffaele Spinelli ${ }^{2}$

${ }^{1}$ West Virginia University, Morgantown, USA; ${ }^{2}$ CNR IVALSA, Florence, Italy (jvance11@mix.wvu.edu; jxwang@wvu.edu; shawn.grushecky@mail.wvu.edu; spinelli@ivalsa.cnr.it)

A mechanized harvesting system combined with whole-tree chipping was investigated on two harvesting sites in central Appalachia, USA. Chips were sampled from the operations to characterize properties and evaluate whole-tree chips as a bioenergy feedstock according to ANSI Standard AD17225-4:2014 Solid Biofuels. Results of properties testing indicated $37.5 \%$ green moisture, $0.212 \mathrm{~g} / \mathrm{cm}^{3}$ bulk density, $10.5 \%$ bark content, $0.49 \%$ ash, and $18.59 \mathrm{MJ} / \mathrm{Kg}$ calorific heating value. Size distribution of wood chips were categorized into small (3-16mm), medium (16-45mm), and large (45-63mm). Chip sizes captured 46\% small, $45 \%$ medium, and $3 \%$ large by total mass, respectively. Fines $(<2.8 \mathrm{~mm})$ composed less than $1 \%$ while $4.5 \%$ were oversized $(>63 \mathrm{~mm})$. These whole-tree chips were found to meet the highest grade A1 requirements of the U.S. wood chip fuel quality standard. Production and machine rate data of the operations were collected through time-motion study, with chipping elements defined as feeding, chipping, and loading. Chipping cycles averaged 21.5 minutes to produce 13.35 dry metric tons per truckload, providing hourly rate of 37.32 dry metric tons/PMH. Total cycle time including truck delivery averaged 183 minutes, giving hourly production rate of 4.38 dry metric tons/PMH. The hourly cost of the harvesting system including one feller-buncher, two grapple skidders, and the chipper was $\$ 375.77 / \mathrm{PMH}$ or combined per unit cost gives a total cost of $\$ 19.99 /$ dry metric ton to produce in-woods chips at the landing. Total operational costs for felling, skidding, chipping, and truck delivery is estimated at \$23.30 to \$29.91 per dry metric ton. 


\author{
Identifying key factors of landscape and temporal boundaries to better understand the carbon-based forest bio-fuel economy \\ Dalia Abbas ${ }^{1}$, Lars Högbom ${ }^{2}$ \\ ${ }_{1}^{1}$ American University, Washington,DC,USA; ${ }^{2}$ Skogforsk,Uppsala,Sweden (daliaabbas@yahoo.com; lars.hogbom@skogforsk.se)
}

In a forest-based bio-economy energy supply from renewable biomass sources will have a central role. Bio-energy from forestry is derived from two main categories: i) primary energy sources e.g. logging residues, stumps and non-commercial wood, and ii) secondary sources e.g. bark, re-fuse, lye from pulp mills and chips and sawdust from saw mills. Depending on the fuel source, the carbon footprint is likely to differ significantly. Depending on how spatial and temporal system boundaries are defined the outcomes differ substantially. Temporal factors like length of rotation periods, to what extent regeneration occurs, decomposition or burning, and special factors such as single stand or landscape approaches will all impact the outcome of the estimates carbon emissions. In order to support an increase in the removal of forest material, improved and relevant estimations of greenhouse gas balance is important. For example, inconsistent results of published estimates of carbon balances in forest bio-fuel utilization, range from forest bio-fuels being no better than crude oil - from a carbon balance perspective - to one that is almost carbon neutral. The outcome of these estimates depend to a large extent on how, and why, the system boundaries are defined and other assumptions made by the authors. This discrepancy and inconsistency in the estimates of carbon emissions and boundaries in the forestry sector indicates there is an urgent need to synthesize and critically evaluate published reports to be able to better suggest improvements and more informed understandings of carbon emissions in the forestry sector and its "neutrality".

\title{
The degradation of softwood (Picea abies and Pinus sylvestris) bark extractives during storage: focus on tannins
}

\author{
Hanna Brännström ${ }^{1}$, Jarkko Hellström ${ }^{2}$, Tuula Jyske ${ }^{3}$, Juha Nurmi ${ }^{1}$, Johanna Routa ${ }^{4}$, Eelis Halmemies ${ }^{1,5}$, Raimo Alén ${ }^{5}$ \\ ${ }^{1}$ Natural Resources Institute Finland, Kokkola, Finland; ${ }^{2}$ Natural Resources Institute Finland, Jokioinen, Finland; ${ }^{3}$ Natural Resources Institute Finland, \\ Espoo, Finland; ${ }^{4}$ Natural Resources Institute Finland, Joensuu, Finland; ${ }^{5}$ University of Jyväskylä, Depa (hanna.brannstrom@luke.fi; \\ jarkko.hellstrom@luke.fi; tuula.jyske@luke.fi; juha.nurmi@luke.fi; johanna.routa@luke.fi; eelis.halmemies@luke.fi; raimo.j.alen@jyu.fi)
}

Biorefining industries with a focus on new extractives-based products set new kind of demands on raw material supply chain. Many initial extractives suitable for valuable applications are either volatile or chemically unstable. Especially, hydrophilic phenolic compounds which are abundantly present in softwood bark are chemically unstable during the supply chain. Not only storage, but also other phases of the wood handling process affect the extractives content of the biomass material, and the composition of the extractives fraction. In order to provide guidelines on new delivery regimes for biorefining industries storage studies on softwood bark (Picea abies and Pinus sylvestris) were arranged. The bark of these species is abundantly available from forest industry side-streams in Finland and Sweden. To study the way the different storage conditions affect the preservation of spruce bark extractives, such as tannins, two experimental setups were established: a single stem setup where spruce logs were stored with bark intact, and a bark pile setup of spruce saw mill bark. Also, the effect of the season on the behavior of bark tannins was studied. Storage study was also conducted on pine saw mill bark. It was detected that the content of condensed tannins in bark decreased quickly in piles. However, the rate and magnitude of decrease was different in different areas of the pile. Losses occurred at a slower rate when bark was stored intact on logs. Thus it could be concluded that the utilization of the bark should take place as soon as possible after debarking.

\section{Eucalyptus energy supply chain and the wood moisture content issue on the tropical conditions}

Humberto Eufrade-Junior ${ }^{1}$, Mauricio Acuna ${ }^{2}$, Mark Brown ${ }^{2}$, Adriano Ballarin ${ }^{1}$, Saulo Guerra ${ }^{1}$

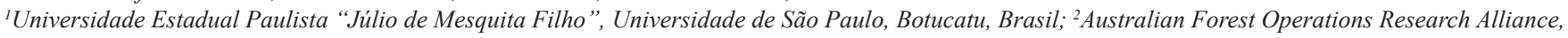
University of the Sunshine Coast, Sippy Downs,Australia (hdjejunior@gmail.com; macuna@usc.edu.au; mbrown2@usc.edu.au; adriano.ballarin@unesp.br; saulo.guerra@unesp.br)

The energetic and economic conjuncture faced in Brazil in recent years has made forest biomass an energetic source with great potential for expansion. The utilization of the wood in the form of chips for energy generation requires a more efficient production chain in the several steps that compose it: harvesting, forwarding, storage, chipping, transport and conversion systems. The moisture content of the wood is fundamental in the planning of the forestry operations of this chain, because it affects the harvesting season and the volume to be chipped, the number of trucks needed to transport the raw material, the time of storage in the field, among others, which economically affects the chain. The main objective of this work was to evaluate the Eucalyptus wood chip production chain for energy generation by assessing wood moisture content and quantifying its effect (in yield and costs) on different chains of forest operations. The results obtained so far make it hard to store the wood in the form of open - air chips piles on tropical conditions. On the other hand, considering the same period, logwood piles reached an average moisture content of $35.5 \%$ which is the minimum acceptable value to thermoelectric plant.Considering the scenarios studied, it is recommended to prioritize operations with the storage and transport of the wood in logs, and chipping the wood in the industry for reach a least costly scenario with lower wood moisture content.

\section{Role of wood extractives in emulsion stabilization capacity of hemicelluloses}

Petri Kilpeläinen ${ }^{1}$, Maarit Lahtinen ${ }^{2}$, Jaana Liimatainen ${ }^{1}$, Risto Korpinen ${ }^{1}$, Kirsi Mikkonen ${ }^{2}$

${ }^{1}$ Natural Resources Institute Finland, Espoo, Finland; '2University of Helsinki, Helsinki, Finland(petri.kilpelainen@luke.fi; maarit.lahtinen@helsinki.fi; jaana.liimatainen@luke.fi; risto.korpinen@luke.fi;kirsi.s.mikkonen@helsinki.fi)

There is a need for efficient biomass pretreatment methods for biomass utilization. Sawdust and grinding dust are side-streams of the forest industry, which are mostly combusted for energy. To fully utilize these side-streams, more value-added products are needed. Hemicelluloses can be extracted from wood by pressurized hot water flow-through extraction (PHWE). The PHWE extracts can be further utilized as hydrocolloids in the food industry, for example as emulsion stabilizers. Birch and spruce wood sawdust were extracted at $170{ }^{\circ} \mathrm{C}$ for 60 minutes and $180{ }^{\circ} \mathrm{C}$ for 60 minutes, respectively, using a laboratory scale flow-through reactor. Effects of wood extractives were studied by removing them before PHWE with lipophilic and hydrophilic solvents using accelerated solvent extraction. Extracts were collected and analyzed for hemicellulose and extractives composition. Oil-in-water emulsions were prepared by high-pressure homogenization with $5 \mathrm{wt}-\%$ stripped rapeseed oil and $1 \mathrm{wt}-\%$ hemicellulose-rich extracts. Physical and oxidative stability of emulsions was monitored by measuring the droplet size distribution and peroxide value during 16 weeks. The emulsions were further evaluated using optical microscopy. We conclude that wood hemicelluloses can be PHWE extracted and used as emulsion stabilizers. Removal of lipophilic and hydrophilic extractives decreased clearly the droplet size of emulsions, indicating that the extractive-free hemicelluloses produced physically more stable emulsions than the crude extracts. The effect of extractives on the oxidative stability of emulsions was different with spruce and birch hemicelluloses. This leads to the conclusion that mechanisms behind antioxidative properties of PHWE extracts may be different between these wood species. 


\section{Free formaldehyde phenolic resins for a potential use in adhesives formulation, wood coating and porous materials production}

Hamed Issaoui ${ }^{1}$, Pedro Luis de Hoyos Martinez ${ }^{1,2}$, Jalel Labidi ${ }^{2}$, Fatima Charrier - El Bouhtoury ${ }^{1}$

${ }^{1}$ University of Pau and Pays de l'Adour, IPREM, UMR 5254 CNRS/UPPA, IUT des Pays de l'Adour, Mont de Marsan, France; ${ }^{2}$ Chemical and Environmental Engineering department, University of the Basque Country, Donostia-San Sebastian, Spain

(hamed.issaoui@univ-pau.fr; pedroluis.dehoyos@ehu.eus; jalel.labidi@ehu.eus; fatima.charrier@univ-pau.fr)

Phenolic resins are materials of significant importance in the industry; they are employed in wide range of applications such as adhesives, composites or coatings. Seen that the component of this resinsare derived from petrochemicals, which are non-renewable and therefore ultimately limited in supply,the use of material with a low-carbon footprint is an important issue. In this context, the propose of this work is to fill the need for new commercial products using biobased raw materials and greener technologies to replace materials derived from fossil fuels. Among all the phenolic compounds, lignin and tannins are the most available, they present an environmentally friendly alternative to phenol and formaldehyde and they can be considerate as by-products of wood and paper industries that are interesting to valorize. Thus, different free formaldehyde resins were prepared using tannins and lignin, from pulp industry and organosolv process. The tannin-lignin based resins dedicated to wood-based composites gluing and porous insulating material production were elaborated using lignin previously modified with glyoxal and mixed with a tannin solution and a reticulation agent. In the case of coating for wood and wood derivatives protection, to the previous resin two different inorganic compounds namely organically modified montmorillonite (nanclay) and polyoligomeric silsesquioxanes (nanosilicate) were added.The obteined results are promising and indicate that the combination of tannins and lignin to produce free formaldehyde resins showed to be good candidates for being used in wood composites binding, wood coating as well as for porous insulating materials elaboration.

\section{Mass-flow-analysis of lignocellulosic resources in South Africa and Ethiopia (BioHome)

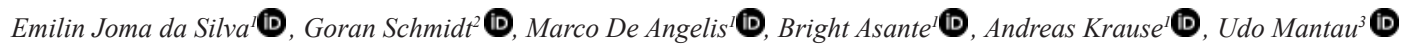 ${ }^{1}$ University Hamburg, Hamburg, Germany; ${ }^{2}$ Thünen Institute, Hamburg, Germany; ${ }^{3}$ Infro-Informationssysteme für Rohstoffe, Hamburg, Germany (emilin. joma.da.silva@uni-hamburg.de; goran.schmidt@thuenen.de; marco.de.angelis@uni-hamburg.de; bright.asante@uni-hamburg.de; andreas.krause@uni- hamburg.de; udo.mantau@infro.eu)}

The population growth has consequences on bio-resources consumption and waste production. The urbanization pressure in Sub-Saharan Africa skyrocket the demand for building materials as concrete and wood. The BioHome project investigate the availability, accessibility and competition demand of secondary resources in Ethiopia and South Africa. Resources as wood and non-wood lignocellulosic materials (invasive species, agricultural residues, bamboo, municipal pruning, waste wood), post-consumer thermoplastics (PP, PE, PVC) and ashes (coal, slag, biomass) were surveyed. The Ethiopian building industry is a net importer. In 2017 wood and wood products imports (except pulp and paper) accounted to USD 73 million. Plastic import summed USD 634 million, of which roughly $70 \%$ may potentially be recycled. In 2015, the South Africa energy mix contained 77\% mineral coal, i.e; 34.4 million tons of ashes. It is generally known that combustion residues are landfilled or utilized in low-value products, e.g. concrete. Latest research showed that those industrial residues can be also utilized in wood-plastic-composites (WPC) and geopolymer-wood-composites (GWC) for instance. This study helps to contextualize the development of such building materials, value addition to secondary resources and cooperate to reduce the trade deficit of building materials.

\section{How attractive is bioenergy production on degraded land? Landowner perceptions in Indonesia}

Yustina Artati ${ }^{1}$, Wanggi Jaung ${ }^{2}$, Kartika Juniwaty $^{1}$, Sarah Andini ${ }^{1}$, Soo Min Lee ${ }^{3}$, Hendrik Segah $^{4}$, Himlal Baral $^{1}$

${ }^{1}$ Center for International Forestry Research, Bogor, Indonesia; ${ }^{2}$ Department of Biological Sciences, National University of Singapore, Singapore, Singapore;

${ }^{3}$ National Insitute of Forest Science, Seoul, Korea, Democratic People’s Republic of; ${ }^{4}$ Global Green (y.artati@cgiar.org; dbsjw@nus.edu.sg;

k.juniwaty@cgiar.org; sarahandini08@yahoo.com; leesoomin@korea.kr; hendrik.segah@gggi.org;h.baral@cgiar.org)

Bioenergy is promising form of renewable energy which potentially has economic, social and environmental benefits. However, its production erodes its environmental benign due to land use competition. Recently, bioenergy production on degraded lands has gained global interest because of its potential to provide multiple benefits: to meet energy demand, improve degraded environment, and to enhance people' livelihood. These benefits have attracted many countries to promote bioenergy consumption and support technology, knowledge and policies in relate to its production. However, the production would be not feasible without active landowner participation. This paper presents study on investigating factors affecting landowner' preferences for bioenergy production by analyzing 150 landowners with ex-fire experience on their lands in Central Kalimantan Indonesia using Firth's logistic regression model. The results indicate that bioenergy production on degraded land using energy species, nyamplung (Calophyllum inophyllum) gains less landowner preference (8\%). Majority of them (76\%) preferred well-known species such as sengon (Albizia chinensis) and rubber (Hevea brasiliensis) for the restoration of degraded land and a readily available market. Landowner preferred nyamplung (Calophyllum inophyllum) are particular landowners revealed a capacity to handle the uncertainty of the bioenergy market because they had additional jobs and income, had migrated from Java where nyamplung is prevalent, and preferred agricultural extension to improve their technical capacity. These results contribute to identifying key conditions for a bottom-up approach to bioenergy production from degraded land in Indonesia: a stable bioenergy market for landowners, application of familiar bioenergy species, and agricultural extension support for capacity building.

\section{C5g: QUANTIFYING AND FORECASTING MARKET SPECIFIC FOREST PRODUCTS IN THE} FORESTRY WOOD CHAIN

\section{Prediction of structural lumber properties of standing Pinus patula trees}

Brand Wessels ${ }^{1}$, Justin Erasmus ${ }^{1}$, David Drew ${ }^{1}$

${ }^{1}$ Stellenbosch University, Stellenbosch Cape Winelands, SouthAfrica (cbw@sun.ac.za; erasj@sun.ac.za; drew@sun.ac.za)

A reduction in harvesting ages over the last three decades, due to accelerated tree growth, has resulted in reduced stiffness of lumber from South African pine saw-log resources. This has critical implications for the sawmill processors, since nearly $70 \%$ of all lumber is used in structural applications in South Africa. The objective of this study was to model the final product properties (MOE, MOR, warp) of young Pinus patula lumber from standing tree information in order to improve log processing decision-making. Experimental spacing trials were sampled and processed into sawn lumber which were destructively tested in bending. Information from both standing trees as well as data obtainable from increment cores were used including stem diameter, tree height, planting density, branch characteristics, wood density, microfibril angle, and year ring widths. Models were developed to predict individual board MOE and MOR as a function of the measured variables and the board radial position. 


\section{An imputation/copula approach to benchmarking stand and individual tree growth and yield models}

Yung-Han Hsu ${ }^{1}$, Ting-Ru Yang ${ }^{1}$, John Kershaw ${ }^{1}$, Elizabeth McGarrigle ${ }^{2}$

${ }^{1}$ University of New Brunswick, Fredericton, Canada; ${ }^{2}$ Nova Scotia Natural Resources, Truro, Canada(yhsu@unb.ca; b00605080@gmail.com;

kershaw@unb.ca; emcgarrigle@gmail.com)

When dealing with multiple species across multiple data sources collected over different points in time, traditional statistical methods are pushed to their limit. Linear and nonlinear modeling techniques were once the norm for analyzing and build prediction systems. These have largely been replaced my nonlinear mixed effects and Bayesian approaches. However, even these newer techniques have limitations, and require validation and/or benchmarking. We propose an alternative approach to modeling stand and tree dynamics using an iterative approach of imputation selection and copula sampling. In the first step, multiple imputation is used to identify a set of nearest neighbors based on tree and stand attributes. These data are used to build a copula and the copula is repeatedly sampled to obtain dynamics steps. Because the copula can be repeatedly sampled, uncertainties can be address across time and prediction envelops developed. We propose to use these prediction envelops as a benchmarking tool to assess how well statistical models are capturing forest and tree dynamics. Both short-term and long-term simulations for a variety of stand conditions in northeastern North America are compared with predictions from two statistically driven models of forest dynamics.

\section{CalcMadeira - Validation of sawn timber calculation by the Circumscript square (Block) and Longitudinal Methods \\ Thomaz Correa e Castro da Costa (D), Mônica Matoso Campanha ${ }^{1}$, Walfrido Albernaz ${ }^{2}$, Emanuel Pinto ${ }^{2}$, Renato Castro ${ }^{3}$, Luiz França ${ }^{1}$ Embrapa Milho e Sorgo, Sete Lagoas, Brasil; ; ${ }^{2}$ Emater, Sete Lagoas, Brasil; ; ${ }^{3}$ Universidade Federal de São João Del Rei, Sete Lagoas, Brasil; ${ }^{4}$ SIG Informatica, Sete Lagoas, Brasil (thomaz.costa@embrapa.br; monica.matoso@embrapa.br; walfrido.albernaz@emater.mg.gov.br; maravilhas@emater.mg.gov.br; renatocastro@ufsj.edu.br; luiz@siginformatica.com.br)}

CalcMadeira is a software with eight modules, which estimates sawed lumbers, based diameter and height measured of trees or diameters and length of the log. The logic uses trigonometric rules that differ from optimization techniques, applied in others algorithmics. The goal of this work was to validate Circumscript Square (Block) and Longitudinal Methods. Experiments were performed with Corymbia citriodora trees from seeds and Urograndis Clone GG100, which were cubed and sawed. The results were compared to three softwares, CalcMadeira, SawModel/SigmaE and CutLog, which use different logics for the calculation of the sawn wood. In the $1^{\text {st }}$ test, 32 pieces of lumber were sawed by Circumscript Square (Block) method and 33 pieces of lumber were calculated by CalcMadeira. In the $2^{\text {nd }}$ test (operational), the sawed lumber was 136 pieces and 121 pieces were calculated. In the $3^{\text {rd }}$ test (Longitudinal Method), CalcMadeira calculated 91 pieces of lumber and 93 pieces of lumber were sawed.

\section{Could the production of extracts contribute to the resilience of the wood-based industry?}

Mariana Hassegawa ${ }^{1}$, Nancy Gélinas $^{1}$, Daniel Beaudoin ${ }^{1}$, Alexis Achim ${ }^{1}$

${ }^{1}$ Laval University, Quebec, Canada (mariana.hassegawa@sbf.ulaval.ca; nancy.gelinas@sbf.ulaval.ca; daniel.beaudoin@sbf.ulaval.ca; alexis.achim@sbf.ulaval.ca)

Due to the large number of low-quality stems harvested from the hardwood forests of eastern Canada, the forest industry has been facing a decline in profit margins. One solution to this profitability problem would be to add value to the coproducts from sawmills by producing extracts such as betulin. The objective of this work was to estimate to what extent the inclusion of betulin in the traditional wood products portfolio could extend the profitability of the hardwood value chain. The profitability of a selection cut was evaluated from the sawmill perspective, followed by the evaluation of the potential financial gain of producing betulin. Finally, the potential inclusion of betulin in the value chain was assessed. Results showed that the profitability of selection cuts was very low in some forest stands. The sensitivity analysis demonstrated that, among selected costs and revenues, profit was more sensitive to variations in the value of coproducts and residues. If a fraction of coproducts volume was used for betulin extraction, it would generate enough revenue to offset the total costs. However, a major constraint for this integration would be the small size of the current betulin market. Despite that, our results demonstrate the potentially strong contribution of high value-added extracts to the profitability of the wood value chain.

\section{Trade war in the wood pulp global market: winners and losers}

Bruno Kanieski da Silva', Luis Henrique Ventrilho França , Luiz Carlos Estraviz Rodriguez ${ }^{2}$

${ }^{1}$ North Carolina State University (NCSU), Raleigh, USA; ${ }^{2}$ Escola Superior de Agricultura “Luiz de Queiroz”, Universidade de São Paulo, Piracicaba, Brasil (bkanies2@ncsu.edu; luis.franca@usp.br; lcer@usp.br)

The global wood pulp market is composed by a complex web of multiple consumers and producers. Driven by economic growth, the demand for wood pulp tends to increase in the upcoming decades. However, the alarming expansion of protectionism through tariffs, quotas and other barriers to trade might change the flux of wood pulp products and impact global welfare in the long run. For instance, during the last months of 2018 the United States and China have bilaterally imposed up to $25 \%$ duty on imports of wood pulp products. We use the Global Forest Production Model (GFPM) to simulate the impact of tariffs enforced by the United State and China on international trade of wood pulp products, then we compared to a scenario without tariffs. Our hypothesis is since China and United States are among the largest importers and exporters; the trade war between them will increase global prices of wood pulp products, and therefore create opportunities for other countries to expand their markets. We discuss in detail the effect of this dynamics in key countries like Brazil, Canada, and Germany.

\section{Contribution to modelling the growth of Pinus radiata with Yield-SAFE, a parameter sparse process based model}

Paulina Fernandéz ${ }^{1}$, João Palma ${ }^{2}$

${ }^{1}$ Department of Ecosystems and Environment, Pontificia Universidad Católica de Chile, Chile, Chile; ${ }^{2}$ Forest Research Centre, Lisboa, Portugal (pfernan@uc.cl; joaopalma@isa.ulisboa.pt)

Radiata pine (Pinus radiata D. Don), is one of the most important commercial conifer species in the world supporting a robust industrial production of pulp and paper, sawnwood, plywood, fiberboards, oriented strand boards, medium density fiberboards, and secondary industry products. Intensive silviculture and the genetic breeding programs of the species have improved considerably the productivity of the species. While deterministic modeling approach has been historically the way to give support to the productive forest system, changes in environmental conditions already experienced in different areas covered with $P$. radiata plantations are determining new site productivities risking scenarios for forest plantations. Modeling strategies need to include the new environmental 
scenarios and the use of process-based models seems to be the way forward. Process-based models are based on a theoretical understanding of relevant ecological processes, providing a useful framework to incorporate specific responses to altered environmental conditions. In the current work we contribute for the calibration of the parameter sparse process based model Yield-SAFE to simulate growth of radiata pine. In one hand this model provides the advantage to simulate growth under different environmental conditions and, reserves for future research the assessment of grass competition due to its undestorey competition module. This work provides results of calibration and validation with two independent datasets. During this process, is also shown the effect of a reverseadjustment of soil depth (while keeping tree parameters fixed) and its impact on model efficiency, bias and precision.

\section{C5h: RESEARCH AND INDUSTRIAL USE OF WOOD BIO-BASED (FORMALDEHYDE FREE)} ADHESIVES: RAW MATERIAL AND INTRODUCTION TO THE WOOD-BASED INDUSTRY

\section{Adhesivity of biobased anhydrous citric acid, tannin-citric acidand ricinoleic acid in the manufacture and properties offormaldehyde free particleboard}

Divino Eterno Teixeira ${ }^{1}$, Danielle do Carmo Pereira², Ana Paula Diniz Nakamura ${ }^{1}$, Sarah Silva Brum ${ }^{2}$

${ }^{1}$ Serviço Florestal Brasileiro, Brasilia, Brasil; ${ }^{2}$ Universidade de Brasilia,Brasilia,Brasil (divinot@gmail.com; daniellecarmop@gmail.com;

ana.nakamura@florestal.gov.br;sarahsbrum@yahoo.com.br)

Particles of Eucalyptus grandis were bonded using three biobased adhesives - anhydrous citric acid (CA), tannin-citric acid (TCA) and ricinoleic acid (RA) from renewable sources and hot pressed to produce medium density particleboard. The bonding capacity of such adhesives and properties of the particleboards were evaluated and compared to the requirements of seven grades of particleboards according to the EN 312:2010 standard. The RA did not create adhesion reaction with the wood particles. Adhesives formulated with CA and TCA presented capacity to bond eucalyptus particles into particleboard confirmed by esterification reactions of the FTIRS analysis. Particleboard bonded with CA met requirements as high as grade P5 of the EN 312:2010 standard for static modulus of elasticity (MOE) and internal bond (IB) and P2 for modulus of rupture (MOR). Panels bonded with TCA met requirements up to grade P3 for MOE, however did not withstand water intake.

\section{Ricinus oil based adhesive for glued wood products}

Caio Cesar Faedo Almeida ${ }^{1}$, Aline Maria Faria Cerchiari ${ }^{1}$, Diego Lima Aguiar ${ }^{1}$, Geraldo Bortoletto Júnior ${ }^{1}$, José Nivaldo Garcia ${ }^{1}$, Bruno Monteiro Balboni ${ }^{1}$, Marina Coelho ${ }^{1}$, Vanderlei Benedetti ${ }^{1}$

${ }^{1}$ Escola Superior de Agricultura “Luiz de Queiroz”, Universidade de São Paulo Piracicaba, Brasil (caio.cfalmeida@usp.br; alinemcfaria@gmail.com; diego.aguiar@usp.br;gbjunior@usp.br;jngarcia@usp.br; brunobalboni@gmail.com; marina.ulian@usp.br; vabenedetti@gmail.com)

The seek for natural resources and the reduction of anthropogenic environmental impacts increases the need of adhesives called "bio-polymers" or "green adhesives", in contrast to those usually applied on glued wood products. The objective in this study was to evaluate the performance of Ricinus communis oil based polyurethane (PU) in comparison to the traditional adhesive polyvinyl acetate (PVOH) on engineered wood products for interior use on two species Tectona grandis and Pinus sp. For that, we have evaluated the shear strength on the glue line for the two species with both adhesives, following the Brazilian Standard NBR7190. The PU was immediately applied to the wood pieces after being synthesized. The grammage of $260 \mathrm{~g} / \mathrm{m}^{2}$ was used for the specimens with both adhesives, which cured at room temperature under the pressure of $2 \mathrm{MPa}$. Each treatment was represented by 9 repetitions and their means were compared by an ANOVA followed by a Tukey Test at 5\% of probability. Both PU treatments and Pinus sp. with PVOH were superior to T. grandis with PVOH, the latter with resistance about 50\% inferior to the 3 former treatments. The high extractives content on the $T$. grandis wood might have influenced the PVOH adhesion, what was not observed on PU specimens. We advise against the use of PVOH on T. grandis wood on products with higher stress demand, on the contrary of the $R$. communis oil based polyurethane, which presented a higher performance additionally to its eco-friendly characteristics.

\section{Nanobioadhesives for use in wood-based composites bonding}

Dominika Janiszewska ${ }^{1}$, Patrycja Hochmańska ${ }^{1}$, Wojciech Bałęczny ${ }^{1}$

${ }^{1}$ Lukasiewicz Research Network-Wood TechnologyInstitute,Poznan, Poland (d_janiszewska@itd.poznan.pl; p_hochmanska@itd.poznan.pl; w_baleczny@itd.poznan.pl)

The aim of the research was to improve the mechanical board properties by reinforcing the industrial resins with silane-modified cellulose nanocrystals Adhesive compositions with a nanobiopolymer content of 1, 2 and $3 \mathrm{wt} \%$ based on solid resin were prepared. Laboratory-scale particleboards were produced and the tensile shear strength of lap joints, mechanical and physical properties as well as formaldehyde content were investigated. The work was improved by describing the viscosity and rheological characteristic related to prepared bio-based adhesives. Furthermore the stability of new nanocelullose-reinforced adhesive compositions, which is of great importance for amino resins producers and customers, was determined. Particleboards prepared with resin containing 1 wt\% CNC showed a reduced water absorption and formaldehyde content as well as improved bending and tensile strength in comparison to the boards produced with standard amino resin.The proper viscosity after 4 weeks of storage indicated the possibility to use CNC as a stabilizer extending the pot-life of resin. Concluding the adhesive joints were toughened by the addition of only $1 \%$ of modified nanocellulose. Moreover silane-modified nanocrystalline cellulose has proven to be promising material in reinforcement of amino adhesive compositions in terms of the properties of wood-based panels. The research was carried out within the project LIDER/14/0174/L-7/15/NCBR/2016 "New biopolymer adhesives modified with silanes and ionic liquids for application in wood-based materials technology" funded by the National Centre for Research and Development in Poland under the LIDER VII Programme. 
Technological profiles of babassu palm extractivist cooperatives in Maranhão, Piauí, and Ceará, Brazil / Análise do perfil tecnológico de cooperativas extrativistas do coco babaçu do Maranhão, Piauí e Ceará

Ana Paula Diniz Nakamura ${ }^{1}$, Thaise Sarmento ${ }^{1}$, Floriano Pastore ${ }^{2}$

${ }^{1}$ Serviço Florestal Brasileiro, Brasilia, Brasil; 2Universidade de Brasília, Brasília, Brasil (ana.nakamura@florestal.gov.br; taizsarmento@yahoo.com.br; fpastorej@gmail.com)

O babaçu (Orbignya sp.) é uma palmeira brasileira, pioneira, com alta capacidade de regeneração e proliferação, apresentando ampla distribuição no Brasil. Seu coco tem potencial para ser aproveitado integralmente e, no passado recente, teve grande importância econômica para comunidades tradicionais do Norte e Nordeste. No entanto, a produção da amêndoa de babaçu no Brasil está em queda, passando de 116.000 toneladas em 2000 para 67.000 toneladas em 2016, sendo baixa mecanização da cadeia produtiva umas das causas disto. Este trabalho discute a inserção de tecnologias nas cooperativas extrativistas de Babaçu. Em 2015 foram realizadas entrevistas com 7 associações e cooperativas, localizadas no Maranhão, Piauí e Ceará, que possuem pelo menos uma máquina para quebra do coco babaçu. Constatou-se que $80 \%$ das máquinas não estavam funcionando, e as que estavam em funcionamento apresentavam baixo rendimento. Consequentemente, todos os entrevistados dependiam do uso do machado para a quebra do coco (trabalho considerado penoso e de baixo rendimento). Os principais problemas observados nas máquinas são decorrentes da necessidade de alto impacto para superar a dureza do endocarpo e separar a amêndoa, o que confere baixa eficiência ao processo. Outros equipamentos desintegram excessivamente o coco, danificando a castanha. A inserção de tecnologias na cadeia produtiva de Babaçu é crucial para a produtividade, lucratividade e o aproveitamento integral do fruto. Para reverter esta realidade é essencial maior incentivo e investimento do Estado para o desenvolvimento e disseminação de tecnologias sociais de processamento do coco Babaçu

\section{Characterization of the extraction of Pequi (Caryocar brasiliense) pulp oil in the Northern Region of Minas Gerais State, Brazil}

Sandra Regina Afonso ${ }^{1}$, Luciano Mansor de Mattos ${ }^{2}$, Maria de Fátima Lima ${ }^{1}$, Alessandro Moreira ${ }^{1}$, João Chiles ${ }^{3}$, Ronaldo Almeida ${ }^{4}$

${ }^{1}$ Serviço Florestal Brasileiro, Brasília, Brasil, ${ }^{2}$ Embrapa Cerrados, Brasília, Brasil, ${ }^{3}$ Comunidade Pau D'arco, Montezuma, Brasil;; ${ }^{4}$ Centro de Agricultura Alternativa do Norte de Minas,Rio Pardo de Minas,Brasil(sandra.afonso@florestal.gov.br; luciano.mattos@embrapa.br; fatima.lima@florestal.gov.br; alessandro.moreira@florestal.gov.br; jmchiles@gmail.com;ronaldo.almeida@caa.org.br)

The pequi tree (Caryocar brasiliense) is the symbolic species of the Brazilian savannah and represents great social, environmental, cultural and economic importance for the Northern region of Minas Gerais State, Brazil. The pequi pulp oil utilized in culinary and nutraceutical industry is usually extracted handcrafted in rural properties or by extraction equipment in small industries. The objective of the current study was to analyze aspects related to the extraction characteristics of pequi pulp oil in the same region. All the activities involved in the oil extraction process were identified: harvest and peeling of the fruit; cooking, cooling and maceration of cooked pulp; extraction and washing of the pulp mass extracted; and melting and packaging of pequi pulp oil. It was observed the utilization of different containers in the cooking and varied forms of pulp maceration, then establishing different study scenarios. Questionnaires applied at street markets demonstrated the importance of the oil quality for the consumer, as well as the significant variation of prices practiced in the different municipalities studied. In general, it was observed that, in some cases, the labor value - counted by the time in hours dedicated to the oil extraction multiplied by the local daily value - does not guarantee the due remuneration to the local family farming. Nevertheless, the oil extraction is characterized as an important activity that avoids wasting of fruits with high perishability and values the tradition of the pequi pulp oil extraction by the local peasantry denominated "geraizeiros".

\section{BIOTEC: biodiversity, economy and technology for the conservation of Brazilian Savanna}

Sandra Regina Afonso ${ }^{1}$, Janaina Diniz ${ }^{2}$, Maria de Fátima de Brito Lima ${ }^{1}$, Carlos Antonio Ferreira Dantas ${ }^{1}$, Alessandro Cezar de Oliveira Moreira ${ }^{1}$, Ricardo de Oliveira Gaspar '2

${ }^{1}$ Serviço Florestal Brasileiro, Brasília, Brasil; ${ }^{2}$ Universidade de Brasilia, Brasilia, Brasil; ${ }^{2}$ Universidade de Brasília, Brasília, Brasil (sandra.afonso@florestal.gov.br; janadiniz@unb.br; fatima.lima@florestal.gov.br; carlos.dantas@florestal.gov.br; alessandro.moreira@florestal.gov.br; ricogaspar@unb.br)

The Brazilian Forest Service (SFB) and the University of Brasilia carry out economic and technological studies and research with a focus on the sustainable use of the various timber and non-timber forest products. Regarding non-timber products, it has been working to promote the valuation and conservation of biodiversity through the qualification of production, income generation and forest recovery, as well as contribute to the strengthening of the productive chains of forest products. For this, it has been developing economic studies on the products of sociobiodiversity, considering all the productive chain (handling, processing, commercialization, forest recovery), in addition to carrying out research activities aimed at improving productive practices, and, thus, adding value and promoting the improvement in the quality of life of those who produce. We highlight the actions of chemical characterization of oils extracted from products from the different Brazilian biomes, indicating the potential of their uses, such as cosmetics, pharmaceuticals, food and fuels. Concomitantly, studies are also carried out to ensure the economic viability of the activity by the producing communities. Research developed in partnership with local communities has contributed to the qualification of production, income generation and forest conservation. In the various study areas, the project has been contributing to the strengthening of productive chains of non-timber forest products in the various biomes, attracting companies interested in the acquisition and development of new products from Brazilian biodiversity. Examples of these products are the pequi (Caryocar brasiliense), the baru (Dyterix alata) and the curriola (Pouteria torta). 


\section{NTFP commercialization and the role of actors in Southwest Ethiopia: restoring the forest conservation premise of NTFPs}

Tefera Belay Endalamaw ${ }^{1}$, Dietrich Darr ${ }^{2}$

${ }^{1}$ Hawassa university, Wondo Genet College of Forestry, Wondo Genet, Ethiopia; ${ }^{2}$ Rhine-waal university of applied sciences, Kleve, Germany

(teferabelay@gmail.com; dietrich.darr@hochschule-rhein-waal.de)

Forests of Southwest Ethiopia are rich in Non-timber forest products (NTFPs), particularly spices, forest honey, wild coffee and bamboo and attracted diverse actors to the forest. The commercial potential of these resources which encourages their overexploitation is leading to the destruction of their very sources. This study, based on empirical data from southwest Ethiopia, explores the role of various actors and how NTFP-based incentives serve or disserve forest conservation ideals. The study showed that the myth of natives as conservationists and settlers as anti-conservation bloc overshadowed the real influence of markets and policy. It is found that forest conversion is determined by accessibility, market and policy conditions; and that all actors (natives, settlers and private agricultural investors) respond to markets and engage in deforestation for expansion of agricultural crops and domestication of NTFPs. Therefore, land-use decisions are mainly dependent on economic incentives rather than settlement history. The study further revealed that NTFPs make a substantial contribution to local livelihood and export income. However, NTFPs are generally undergoing changes from a forest product to an agroforestry product as a result of agricultural expansion and the conversion of the forest to agroforestry systems. This was effectively facilitated by state and market forces. Despite these challenges, NTFPs can still contribute to forest conservation if appropriate institutional reforms are put in place to encourage sustainable NTFP commercialization and halt uncontrolled domestication of the forest landscape.

\section{Eucalyptus oil as a natural pesticide: some insights and prospects for commercialization}

Daizy Rani Batish ${ }^{1}$

${ }^{1}$ Panjab University, Chandigarh, India (daizybatish@yahoo.com)

Forests serve as the major sources of various wood and non-wood products for human society. Among the non-wood products, plant essential oils are important as they possess ecological, biological and commercial significance. Eucalyptus, a diverse genus represented by over 700 species, is cultivated throughout the world for its various aesthetic and commercial values. The essential oil of Eucalyptus finds extensive use in perfumeries, and food and pharmaceutical industries and has also been investigated for the activity against pests, pathogens and weeds. However, as a commercially viable natural pesticide, it has not received much attention since little has been done to improve its pesticidal value. In view of the greater emphasis on natural pesticides, further efforts are required for the development of eucalypt oil as a commercially viable future pesticide. In this direction, eucalyptus oil-based formulations using adjuvants like thickeners, esterified oils, surfactants, etc., could be developed. Moreover, employing nanotechnology, nano-emulsions or nano-encapsulates of eucalyptus oil can be prepared to enhance its pesticidal efficiency by reducing volatilization and biodegradation and ensuring its controlled release. These techniques will profoundly enhance the commercial value of eucalyptus oil as a natural pesticide. During the deliberations of the conference, all these aspects on the improvement of the commercial value of eucalyptus oil as a natural pesticide would be discussed.

\section{Acacia saligna: food security option for semi-arid áreas / Acacia saligna: food security option for semi-arid áreas.}

Patricio Rojas ${ }^{1}$, Eduardo Caballero' ${ }^{2}$ Carmen Soto ${ }^{2}$

${ }^{1}$ INFOR, Santiago,Chile; ${ }^{2}$ CREAS, Valparaiso,Chile (parojas@infor.cl; ecaballero@creas.cl; carmensoto@creas.cl)

Food security is a strategic issue in coming decades, especially in semiarid areas zones of the planet. Acacia saligna occurs as exotic drought tolerant legume in low rainfall region of Chile (Coquimbo, around $100 \mathrm{~mm} /$ year) where more than 15.000 hectares were planted for degraded soils, fodder production, charcoal and erosion control since the seventies. Acacia seeds are processed in Australia for "bushfood" industry to create high value flavoring agents and functional flours. A project founded by FIA (Ministry of Agriculture of Chile) was developed with the participation of a technological network, agricultural "comuneros" and WorldVision Australia to obtain flours, nutritional and functional foods from Acacia saligna seeds. Current resource of $A$. saligna existing area and seeds yield/per tree and per hectare for raw material supply and profitability analysis were evaluated. A $5 \%$ contribution of pre-mix flours was as an optimum in food preparation that showed high percentage of acceptability among consumers. Research showed that toasted flours of Acacia saligna constitute an excellent raw material for breads and biscuits that have important functional properties as antioxidants (ORAC of 87,327 $\mu$ Mols ET / 100g in dry weight), antihypertensive activity (54\%), high protein content (26-28\%). The seeds contain also high percentage of djenkolic acid (1.9 gr /100 grams of seeds) that could control Diabetes Type 2. The innovation project proposes a technological and commercial link with the "comuneros" to supply the niche of functional and healthy foods of high commercial value to combat malnutrition and to improve profitability of plantations.

Strategies for adopting integrated crop-livestock-forest systems favoring livestock sustainability in the dry tropics of Colombia / Estratégias para a adoção de sistemas Agrossilvipastoris que beneficiem a a sustentabilidade pecuária no trópico seco colombiano

Cesar Augusto Forero Camacho ${ }^{1}$, Santaigo Andres Roa Ortiz ${ }^{1}$, Nelson Perez Almario ${ }^{2}$

${ }^{1}$ Corporación Colombiana de Investigación Agropecuaria, Bogotá, Colombia $;{ }^{2}$ Corporación Colombiana de Investigación Agropecuaria, Espinal, Colombia (cforero@agrosavia.co; sroa@agrosavia.co;nperez@agrosavia.co)

A pesquisa tem mostrado que a era do Antropoceno está mais presente hoje e tem sérias implicações sobre os recursos ambientais. O aumento da temperatura, causado principalmente pelo aumento das emissões de gases de efeito estufa (GEE) produzidos pela industrialização para atender a crescente população mundial todos os dias, tem mostrado que a pecuária está sendo considerada um problema global. Estima-se que a fermentação entérica dos ruminantes produz anualmente cerca de 5 giga toneladas de $\mathrm{CO}_{2}$-eq, principalmente em sistemas pecuários extensivos. A busca por novas áreas para a formação de pastagens tem provocado um desmatamento agressivo, especialmente na América do Sul. Na Colômbia as áreas desmatadas foram duplicadas entre 2016 e 2018 de acordo com dados do governo nacional. Cientes desse problema, pesquisadores da Corporação Colombiana de Pesquisa Agrícola (AGROSAVIA) avaliam a Agrossilvicultura como uma alternativa para mitigar esse problema. Apesar dos bons resultados, a adoção desses sistemas é baixa e, dessa forma, buscam-se alternativas sobre como favorecer a adoção tecnológica por parte dos produtores. Foi utilizada a metodologia proposta por Samorriba (2009) que permite avaliar previamente a adoção das tecnologias propostas e em desenvolvimento. Os resultados indicam percepção de adotabilidade de técnicos e produtores de 72,6\% e 65\%, respectivamente. Mesmo não apresentando significância estatística, os resultados sugerem uma grande valorização socioeconômica, uma vez que permite observar diferenças significativas de $20 \%$ a partir das dimensões de simplicidade, viabilidade, adotabilidade, observabilidade e compatibilidade. 


\section{Large-scale feasibility of forest-based biomass-to-bioenergy conversion in Queensland Australia}

Sam Van Holsbeeck', Mauricio Acuna ${ }^{1}$, Sättar Ezzati ${ }^{2}$

${ }^{1}$ University of the Sunshine Coast, Maroochydore,Australia; ${ }^{2}$ Université Laval, Quebec, Canada (svanhols@usc.edu.au; macuna@usc.edu.au; sattar.ezzati.1@ulaval.ca)

Logging residues are a large potential source of bioenergy to replace fossil fuels, however little is known about sustainable procurement of this resource in Australia. There are large volumes of forest fuel available. However, it is a low-value martial and it is very sensitive to procurement cost to make it profitable. This study aimed to estimate forest-based biomass feasibility and provide an optimal logistics network for biomass-to-bioenergy within the state of Queensland. Firstly, a spatial analysis was conducted to pre-analysis the feasibility of the industrial plan such as biomass availability over the landscape and identifying potential bioenergy locations (Strategic plan). Then we developed a location-allocation optimisation model to determine the economic feasibility of the strategic plan (Tactical plan). The preliminary results indicated that globally a total area of $13.5 \mathrm{M}$ ha of forest is available for biomass-to-bioenergy planning, which can provide $1 \mathrm{M}$ odt of biomass recovery on an annual basis. A total number of 847 potential sites were identified as candidate sites for the subsequent installation of bioenergy conversion plan. The number of identified sites was further optimised from the economic points of view.

\section{Production of cellulosic ethanol from steam-exploded Eucalyptus urograndis wood chips}

Luana Marcele Chiarello ${ }^{1}$, Carlos Eduardo Arnt Ramos ${ }^{1}$, Sara Zaccaron ${ }^{2}$, Sonja Schiehser ${ }^{2}$, Antje Potthast ${ }^{2}$, Luiz Pereira Ramos ${ }^{1}$

${ }^{1}$ Universidade Federal do Paraná, Departamento de Química, Curitiba, Brasil; ${ }^{2}$ Division of Chemistry of Renewable Resources, Universität für Bodenkultur, Vienna,Austria(luanamarcelechiarello@yahoo.com.br; carlosflorestal@itaytyba.com.br; sara.zaccaron@boku.ac.at; sonja.schiehser@boku.ac.at; antje.potthast@boku.ac.at; luiz.ramos@ufpr.br)

The use of lignocellulosic biomass for fuels and chemicals is increasingly important to mitigate the consumption of fossil fuels and increase the production of renewable energy. In this study, Eucalyptus urograndis wood chips were steam-exploded to assess the effect of pretreatment on their chemical composition and enzymatic hydrolysis for the production of cellulosic ethanol. The experiments were organized in a factorial design whose conditions ranged from 174 to $216{ }^{\circ} \mathrm{C}$ and from 4 to $11 \mathrm{~min}$ with three replicates at the center point $\left(195^{\circ} \mathrm{C}, 7.5 \mathrm{~min}\right)$. Mass recovery yields, cellulose degree of polymerization and glucose yields after enzymatic hydrolysis using Cellic CTec3 (Novozymes) showed a linear correlation with pretreatment severity. The best condition was set at $210{ }^{\circ} \mathrm{C}, 5$ min due to its higher final yield in glucose after pretreatment and hydrolysis. Pectins were almost completely solubilized after pretreatment while galactoglucomanans were more resistant than arabinoglucuronoxylans. Also, alkaline delignification led to $94 \%$ lignin removal from the steam-exploded material but its effect on enzymatic hydrolysis was almost negligible. Finally, enzymatic hydrolysss at $20 \%$ total solids led to $124 \mathrm{~g} \mathrm{~L}^{-1}$ glucose in $72 \mathrm{~h}$ and the hydrolysates were easily converted to ethanol with $1 \mathrm{~g} \mathrm{~L}^{-1}$ of the yeast Thermossac Dry (Lallemand), reaching productivities greater than $2.1 \mathrm{~g} \mathrm{~L}^{-1} \mathrm{~h}^{-1}$ in $12 \mathrm{~h}$ of fermentation. When a projection of the pretreatment, hydrolysis and C6 fermentation results was carried out, it was concluded that the eucalyptus wood chips had potential higher than sugarcane bagasse for the production of cellulosic ethanol.

\section{Improving enzymatic hydrolysis of Pinus radiata biofuel substrate using a novel pretreatment sequence}

Tripti Singh ${ }^{1}$, Alankar Vaidya ${ }^{1}$

${ }^{1}$ Scion, Rotorua, New Zealand (tripti.singh@scionresearch.com; alankar.vaidya@scionresearch.com)

Pre-treatment is a critical step in the enzymatic conversion of lignocellulosic substrate to sugars. A unique pre-treatment sequence involving thermo chemical treatment (steam explosion) followed by biological treatment (fungal exposure) was evaluated for Pinus radiata as a biofuel substrate. The effect of biological treatment using the white rot Trametes versicolor was investigated on control (sapwood blocks) and steam exploded wood (SEW) for changes in the profile of fungal enzyme activity and lignocellulose composition. The results indicated that compared to blocks, Trametes versicolor expressed more lignocellulose degrading enzymes when grown on SEW for 6 and 12 weeks. After fungal exposure, the biomass was mixed with a commercial enzyme cocktail for enzymatic hydrolysis. The maximum conversion of biomass to sugars was obtained for Trametes versicolor treated SEW, with a yield of $4.80 \mathrm{~g}^{\circ}$ of glucose $\mathrm{l}^{-1}$, which is greater compared to that obtained from non-fungal treated SEW (3.80 g of glucose $\left.\mathrm{l}^{-1}\right)$ and Trametes versicolor treated sapwood blocks $\left(0.80 \mathrm{~g}\right.$ of glucose $\left.\mathrm{l}^{-1}\right)$. Examination by microscopy suggests relative increase in the porosity of SEW after fungal treatment and compositional analysis indicate reduction in lignin content. Both these factors are likely to contribute to the improved hydrolysis of SEW.

Forest biomass as an alternative in energy generation for sustainable development and productive ventures: the results of an ongoing research program in Chile / Biomasa forestal como alternativa de generación de energía para el desarrollo sostenible y emprendimientos productivos, resultados de un programa permanente de investigación en Chile

Juan Carlos Pinilla Suárez ${ }^{1}$, Karina Luengo Vergara ${ }^{1}$, Mauricio Navarrete Torres ${ }^{1}$, Felipe Navarrete Ulloa

${ }^{1}$ Instituto Forestal de Chile, San Pedro de la Paz, Concepción, Chile (jpinilla@infor.cl; kluengo@infor.cl; mnavarre@infor.c; fenavarrete@udec.cl)

En Chile la biomasa forestal representa el $24 \%$ de la participación en la matriz energética primaria y el $43 \%$ del consumo final del sector residencial, donde la Política Energética de los Ministerios de Energía y Agricultura señalan que sedebe consolidar la contribución del sector forestal a la seguridad e independencia energética y descarbonización de la matriz de energía, incrementando la producción y utilización de biomasa forestal. El Instituto Forestal de Chile contribuye a ello a través de un programa permanente de investigación en la utilización de la Biomasa Forestal para generación de Energía. Se presentan los principales antecedentes, resultados, estudios empíricos y avances actuales, con la caracterización de la biomasa según especies, sitio y edad, además de nuevos escenarios por el cambio climático y los requerimientos de la comunidad, utilizando bosques de rápido crecimiento, sin descuidar objetivos asociados a una energía accesible, segura y económica. Se entregan antecedentes del caso del Pellet, producto que ha presentado un incremento en su consumo en Chile para calefacción domiciliaria o uso industrial, incluyendo la seguridad en el suministro permanente de biomasa, diversificando la oferta de ella (especies y materia prima de plantaciones o residuos) y la difusión de soluciones tecnológicas, fomentando la gestión y manejo forestal, y emprendimientos en beneficio de los propietarios forestales y el sector de la energía, considerando externalidades positivas (descontaminación, protección de suelos, captura de carbono, mitigación de cambio climático, generación de empleos), reconociendo el aporte de la biomasa forestal como energía renovable en el desarrollo sostenible. 


\section{Characterization of Eucalypt LignoBoost ${ }^{\mathrm{TM}}$ lignin for the production of lignin nanoparticles}

Giuliana Pavaneli ${ }^{1}$, Maria Juliane Suota ${ }^{1}$, Rilton Alves de Freitas ${ }^{1}$, Washington Luiz Esteves Magalhães ${ }^{2}$, Luiz Pereira Ramos $^{1}$ ${ }^{1}$ Universidade Federal do Paraná, Curitiba, Brasil; ${ }^{2}$ Embrapa Florestas, Colombo, Brasil (pavaneli@ufpr.br; julianesuota@gmail.com; rilton@quimica.ufpr.br;washington.magalhaes@embrapa.br;lramos@quimica.ufpr.br)

Lignin is one of the most abundant renewable resources found on Earth and has the potential of being the source of fuels, chemicals and materials for a wide range of industrial applications. For instance, lignin nanoparticles (LNPs) can be applied as biobased polymers, UV blocking materials, hydrophobic coatings, antimicrobial and antioxidant agents, among others. LNPs can be produced by solvent exchange and their chemical and physical properties may vary considerably, depending on the source, extraction procedure and recovery of the starting materials. For this reason, a detailed lignin characterization must be the first step towards its application in advanced materials or in any other conversion process. In this work, a comprehensive characterization of a technical eucalypt Kraft lignin from the LignoBoost ${ }^{\mathrm{TM}}$ process has been carried out with regard to its chemical composition (ash and carbohydrate content, carboxyl and methoxyl groups, aliphatic and phenolic hydroxyl groups and S-G-H ratio) and physical-chemical properties (solubility in various organic solvents, molar mass distribution and thermal properties). Also, batches of LNP were produced by solvent exchange using acetylated and non-acetylated lignin and their properties were tentatively correlated with the composition analysis of the starting material.

\section{Physico-chemical properties of bio-oil produced from Ficus exasperata Sawdust using Vacuum Reactor}

Gloria Titi Anguruwa ${ }^{1,2}$, Abiodun Oluwafemi Oluwadare ${ }^{1}$, Adejoke Akinyele ${ }^{1}$

${ }^{1}$ Department of Forest Products Development and Utilization, Forestry Research Institute of Nigeria., Ibadan, Nigeria; ${ }^{2}$ Department of Forest Production and Products, University of Ibadan Ibadan Nigeria (gloriaanguruwa@yahoo.com; femioluwadare@yahoo.com; akinyelejo@yahoo.co.uk)

This study was conducted to investigate and estimate bio-oil produced from biomass (wood residue) of Ficus exasperata through pyrolysis at varied temperature. The energy and chemical potentials of this species in various forms has not been discovered and technical information on the wood for biomaterial and biorefinery usage is not available. The physico-chemical and compositional analyses of the bio-oil were achieved through carbon-hydrogen-nitrogen-Oxygen (CHNO) studies, calorific value, Fourier Transform-Infra Red (FT-IR) spectroscopy and Gas Chromatography-Mass Spectrometry (GC-MS). The pyrolysis resulted in low bio-oil yield and high amount of bio-char at $600^{\circ} \mathrm{C}$, whereas at temperature 500 and $550^{\circ} \mathrm{C}$, pyrolysis produced significant amount of bio-oil with less bio-char yield. Temperature difference significantly influenced the CHNO content $(p<0.05)$. Carbon content increased with increase in temperature $(76.39$, 77.42 and $78.45 \%$ ) at 500,550 and $600{ }^{\circ} \mathrm{C}$ respectively. While Hydrogen, Nitrogen and Oxygen content decreased with increase temperature. The calorific value of bio-oil gave high heating value of $3.4 \mathrm{Mj} / \mathrm{Kg}$. The chemical components identified in bio-oils were classified into five major groups such as Hydrocarbons (Aliphatic and Aromatic), ketones, Amines, Oxygenated phenols and Ethers. The noticeable acid in the oil are the Oxylic, Phtalic and Benzoic acid. The study on bio-oil from Ficus exasperata biomass revealed its potentials for fossil fuel substitution and bio-chemical production.

Physical and chemical characteristics of wood from eucalyptus clone GFMO-27 / Propriedades fisico-química da madeira do clone de eucalipto GFMO-27

Danieli Cristina Bueno de Oliveira ${ }^{1}$, Flávia Alves Pereira ${ }^{1}$,Eleandro José Brun ${ }^{1}$

${ }^{1}$ Universidade Tecnológica Federal do Paraná,Dois Vizinhos, Brasil (danieli_cristina@hotmail.com; flaviapereira@utfpr.edu.br; flaviapereira@utfpr.edu.br)

Considerando a ampla variedade de espécies e clones de Eucalyptuscultivados no Brasil, informações sobre as propriedades da madeira tornam-se cada vez mais necessárias. O objetivo deste trabalho foi determinar as propriedades físico-químicas da madeira do clone GFMO-27 nas alturas de 0, 25, 50 e 100\% da altura comercial do tronco. A análise química imediata nos discos de eucalipto foi determinada baseando-se na metodologia descrita na norma ABNT/NBR 8112/83, com adaptações, e a massa específica básica a norma ABNT NBR 11941. A quantidade de materiais voláteis, cinzas e carbono fixo nas alturas avaliadas do clone GFMO-27 foram semelhantes, bem como sua massa específica básica. Além disso, não houve correlação significativa entre a massa específica e a análise química imediata. Os teores de materiais voláteis, cinzas e massa específica básica aparente não diferiram nas alturas estudadas. Os teores de carbono fixo diferiram somente a 50\% da altura e topo. Com isso, a madeira do clone GFMO-27, aos 5 anos, poderá ter um uso mais amplo, em qualquer posição do fuste por possui características semelhantes.

\section{A pilot scale of torrefied wood pellet production for serving small community enterprise and supply chain of bioenergy production}

Pongsak Hengniran ${ }^{1}$, Pavina Badan ${ }^{1}$, Darika Phewfai ${ }^{1}$

${ }^{1}$ Kasetsart University, Bangkok, 10900,Thailand (fforpsh@ku.ac.th; pv.badan@gmail.com; dphewfai@gmail.com)

The aim of this research was to find optimal technique for upgrading rubberwood residues to the next generation of bio-solid fuels - black pellets. After air dry condition to reduce their moisture content, abundant wood chips from traditional sawmill were gradually fed into a pilot-scale rotating drum reactor for turning them to black chips under controlled conditions (maximum temperature and tighten oxygen). The influence of fed and rotating speed was studied, therefore chips were fed into the reactor at 25,50 , and $75 \%$ by volume and the angular-speed was set at 5, 10 and $20 \mathrm{rpm}$, respectively. The results showed that the reaction time depended largely on the feed load of wood chip. The more feed load, the longer reaction time needed. However the angular-speed did not related to the residence time directly, it effected on the heating value of black chip products. Their testing properties revealed that when the lower angular-speed applied, the higher heating value and lower yield received. The heating value of torrefied chips increased about $17 \%$ compared to that of the original. Next, black chips were ground and mixed with three additives - cassava starch, corn starch, and glycerin - with percentages by weight of 1,2 and 5 , respectively. The properties of black pellets were tested following EN 14961-2 Standard. It was cleared that production yield could reach 56.21\%, while almost properties -calorific value, mechanical durability, ash fusion, etc. - passed the standard - only bulk density (max; $381.50 \mathrm{~kg} / \mathrm{m}^{3}$ ) still not met the standard requirement. 


\section{Use of a non-destructive technique to estimate the wood basic density in standing trees}

Nayara Bergamo Casagrande ${ }^{1}$, Martha Andreia Brand ${ }^{2}$, Alexsandro Bayestorff da Cunha ${ }^{2}$, Marcos Felipe Nicoletti ${ }^{2}$, Maísa Beatriz Koch ${ }^{2}$, Renato Augusto Pereira Damásio ${ }^{1}$

${ }^{1}$ Klabin S/A, Otacílio Costa, Brasil; ${ }^{2}$ Universidade do Estado de Santa Catarina, Lages, Brasil

(nayara.casagrande@klabin.com.br; martha.brand@udesc.br; alexsandro.cunha@udesc.br; marcos.nicoletti@udesc.br; maisa_beatriz@yahoo.com.br; rdamasio@klabin.com.br)

Among the wood properties that are affected by innumerable factors, such as growth conditions, environmental and silvicultural practices, the density stands out, which influences all other technological properties. The traditional methods used for density determination use wood samples, consuming time and making the process economically undesirable.Thus, the objective of this study was to establish model equations for the determination of basic density of Pinus taeda L., as a function of wave propagation velocity, moisture content of wood, tree diameter and height. Seventy-two trees from commercial plantations at 15 and 16 years of age were evaluated. In each tree, the impulse tomography was applied in the DBH cross-section. The trees were felled and sectioned in short logs at $0 \%, 33 \%, 66 \%$ of commercial height, in which the tomography was applied, to obtain the stress wave velocity (V), and a disc was removed to determine the basic density (BD) and moisture content (MC), according to ABNT standards NBR 11941 and NBR 14929, respectively. Several statistical models were tested to adjust the basic density of standing trees. As results, it was found for all situations analyzed, except for height at $66 \%$, the best equation was:In $\mathrm{BD}=\beta_{0}+\beta_{1} * \mathrm{~V}^{2}$ $+\beta_{2} *\left(\mathrm{~V}^{2 *} \mathrm{MC}\right)+\beta 3 *\left(\mathrm{~V}^{*} \mathrm{MC}^{2}\right)+\beta 4 * \mathrm{MC}^{2}$. The best models were those that had the variable wood moisture content present in an isolated way. However, for the conditions of this forest stand, the stress wave velocity could not explain the wood basic density, since the variation of this variable was extremely small.

\section{Colorimetric characterization of eight Amazonian wood species}

Maria de Fátima de Brito Lima ${ }^{1,2}$, Marcella Hermida de Paula², Divino Eterno Teixeira1, Joaquim Gonçalez', Álvaro Nogueira de Souza ${ }^{2}$ ${ }^{1}$ Serviço Florestal Brasileiro, Brasília, Brasil; 2Universidade de Brasília, Brasília, Brasil (fatima.lima@florestal.gov.br; marcella.hermida@hotmail.com; divino.teixeira@florestal.gov.br; goncalez@unb.br; alvarosouza@gmail.com)

Due to the importance of characterization and standardization of wood as raw material for different end uses, this work aimed to demonstrate the color variability of eight Amazonian woods species (Cumaru - Dipteryx odorata (Aubl.) Willd., Itaúba - Mezilaurus lindaviana Schwacke \& Mez., Muirapixuna - Cassia L. Maparajuba - Manilkara amazonica (Huber) Standl., Sapucaia - Lecythidaceae A. Rich A.Rich., Tauari - Couratari guianensis Aubl., Tanimbuca - Buchenavia capitata (Vahl) Eichler and Timborana - Piptadenia communis Benth.) using quantitative colorimetry. The determination of color of these wood species was conducted using the CIE La*b* system and the chromatic coordinates $\mathrm{L}^{*}, \mathrm{a}^{*}, \mathrm{~b}^{*}, \mathrm{C}^{*}$ and $\mathrm{h}$. The wood species, obtained at the Forest Products Laboratory (LPF) of the Brazilian Forest Service (SFB), were conditioned in a controlled room with temperature and humidity to reach $12 \%$ equilibrium moisture content. Ten samples were scanned per species at 10 random colorimetric reading points on the tangential face of each sample. According to results, the wood species were classified as: Cumaru and Sapucaia - brownish yellow., Itaúba - olive brown., Maparajuba - redish brown., Muirapixuna and Tanimbuca - olive., Tauari and Timborana - yellowish olive. Additionally, it was concluded by the clarity $\left(\mathrm{L}^{*}\right)$ that species Sapucaia, Tauari and Timborana were considered light-colored and the others dark-colored and the ink angle $\mathrm{h}$, in the $\mathrm{CIE} \mathrm{La} * \mathrm{~b} *$ system of all colors of wood studied, remained in the first quadrant $\left(\right.$ between $0^{\circ}$ and $\left.90^{\circ}\right)$. These results may assist in the identification of timber species in commercialization or control.

\section{Static and dynamic MOE of spruce and pine wood grown in the plantations of different initial stand density}

Benas Silinskas ${ }^{1}$, Marius Aleinikovas ${ }^{1}$, Mindaugas Skema ${ }^{1}$

${ }^{1}$ Institute of Forestry,LAMMC, Kaunas,Lithuania (benasil7@gmail.com;marius.aleinikovas@mi.lt; skeminis@yahoo.com)

To determine influence of stand density on wood mechanical and physical properties of Scots pine and Norway spruce, the data were obtained from experimental trials plots, which were established in 1990 by Lithuania Forest Institute. The experimental trial plots divided to 10 smaller plots with different initial stand density: 2 control plots left for natural selection; 2 plots with 4000-5000 trees per hectare, 2 plots with 2000-2400 trees per hectare, 2 plots with 1000-1200 trees per hectare and 2 plots with 500-600 trees per hectare. From each trial plot, except control plot and plots with rarest initial stand density, were chosen 6 model trees; 3 meters long logs were sampled from each tree for determination of MOE. By using nondestructive timber measurement methods, we can obtain information about wood mechanical and physical properties of growing trees and logs. The dynamic modulus of elasticity (MOElog) is obtained by calculating two parameters: sound velocity and wood density. In this study, the acoustic tomography "Arbotom 3D" was used to measure logs.To determine dynamic modulus of elasticity for samples (MOEdyn) Brokheus MTG device was used. By using international standard EN 408:2016, we can obtain information about samples static modulus of elasticity (MOEstatic) which is cut from logs. Results of this study show that highest values of all types modulus of elasticity have logs from trials plots with initial stand density 4000-5000 trees per hectare.

\section{Characterization of wood from tree roots and branches}

Raquel Gonçalves ${ }^{1}$, Cinthya Bertoldo ${ }^{1}$, Gustavo Garcia ${ }^{1}$, Nina Cavalcanti ${ }^{1}$

${ }^{1}$ Universidade de Campinas, Campinas,Brasil(raquelg@unicamp.br; cinthya.bertoldo@feagri.unicamp.br; gustavohlgarcia@gmail.com; nina.cavalcanti@gmail.com)

The internal structure of roots, branches and trunk differ because of their specific function in tree life and stability. Nevertheless, in general, only the wood from trunk is the frequent focus of studies aiming determining physical and mechanical properties, because of the economic interest in timber and wood composites. So, if properties of wood from root and branches are required, as for example in biomechanics studies aiming tree risk of falling, properties from these parts of the trees are considered like properties from trunk. The objective of this research was toverify the applicability and preliminary results of an ultrasound methodology for the complete characterization of root and branches wood. Complementarily, compression tests were performed to characterize the strength. The tests utilized six species Swietenia macrophylla, Gallesia integrifólia, Swietenia sp., Schinus molle, Handroanthus heptaphyllus and Acrocarpus fraxinifolius. Properties were obtained using ultrasound technology, that allow the determination of the 12 elastic constants of wood (modulus of elasticity in longitudinal (EL), radial (ER) and tangential (ET) directions, shear modulus on the three planes (GLR, GTR and GLT) and six Poisson's ratio (uLR,uLT,uRL,uTL,uRTanduTR). The obtained elastic parameters using ultrasound tests were comparable with the values expected, based on theoretical aspects related to the behavior of the wood. Ultrasound tests was adequate to obtain the 12 elastic constants of roots and branches wood and are feasible for these parts of the tree, because only one specimen is required to obtain these parameters. 


\section{Wood density in Plathymenia reticulata and Dalbergia nigra homogeneous plantations at different ages}

David Pessanha Siqueira ${ }^{1}$, José Gabriel de Souza Silva1, Deborah Guerra Barroso ${ }^{1}$

${ }^{1}$ Universidade Estadual do Norte Fluminense Darcy Ribeiro, Campos dos Goytacazes, Brasil (dps@pq.uenf.br; jgabrielshs@gmail.com; deborah@uenf.br)

The basic wood density is a characteristic directly related to the quality for commercial timber exploitation and with others properties, however, poor informations were found about the de wood density of brazilian forest species in homogeneous plantations at diferente ages. The work aimed to assess the basic density of the wood in homogeneous plantations of Plathymenia reticulata and Dalbergia nigra at different ages. We selected stands of P. reticulata and D. nigra with 6 and 27 years old in Linhares city (Espírito Santo state) and Trajano de Moraes city (Rio de Janeiro state), respectively. In $P$. reticulata stands were selected 48 trees and in D. nigra stands, 12 trees in each study site. The basic wood density was determined by the water immersion method. In addition, the diameter at $1.30 \mathrm{~m}$ $(\mathrm{DBH})$ was measured of all selected trees. The comparison between species and between ages was made by confidence interval ( $\mathrm{p}<0.05)$. P. reticulata showed DBH mean of 13.7 and $26 \mathrm{~cm}$ in young and old stands, respectively. The $D$. nigra showed DBH mean of 12.3 and $24.5 \mathrm{~cm}$ in young and old stands, respectively. In both species, the wood density was lower in younger stand, with $0.40 \mathrm{~g} . \mathrm{cm}-3$ in young and $0.51 \mathrm{~g} . \mathrm{cm}-3$ in the older stand of $P$. reticulata, and $0.61 \mathrm{~g} . \mathrm{cm}-3$ in the young and $0.71 \mathrm{~g} . \mathrm{cm}-3$ in the older stand of $D$. nigra. In homogeneous plantations, $P$. reticulata, present a softer wood than $D$. nigra independent of the age. There was no correlation between tree diameter and wood density.

\section{Using the Tree and Stand Simulator (TASS) model to predict the effects of stand management on quantity and value of carbon and} biomass in British Columbia, Canada

Carlos Mario Di Lucca ${ }^{1}$

${ }^{1}$ Ministry of Forests, Lands, Natural Resource Operations and Rural Development, Victoria, Canada (mario.dilucca@gov.bc.ca)

The Tree and Stand Simulator (TASS) enables forest managers and timber supply analysts to explore the stand level management impacts on quantity and value of carbon and biomass in British Columbia, Canada. TASS is a spatially explicit individual tree model that provides key growth and yield estimates for the managed forests in British Columbia. It incorporates individual tree biomass equations to predict stand biomass and carbon yields under different management scenarios. The presentation will demonstrate the use and operational applications of TASS with the emphasis on carbon yield and value forecasting.

\section{Interference of intrinsic wood parameters and live trees conditions on velocity of ultrasonic wave propagation}

Raquel Gonçalves ${ }^{1}$, Stella Palma ${ }^{1}$, Mariana Reis ${ }^{1}$, Candida Costa ${ }^{1}$

1Universidade Estadual de Campinas, Campinas,Brasil (raquelg@unicamp.br; sspalma@gmail.com; ma.nagle.reis@gmail.com; candidapcosta@gmail.com)

Many technologies related with inspection of wood are based on velocity of wave propagation. The acoustic tomography is based on the variation of the velocity inside the trunk, which is associated to colors using interpolations systems and image software. However, wood is heterogeneous, anisotropic and have natural conditions as knots, reaction wood etc., which causes natural velocity variations and can be mistaken for deterioration. Besides, as the test is made on live trees, there are other parameters that will cause the velocity variation, such as moisture content variations along the different year seasons and flow sap along the day. So, in this research we studied the interference caused by knots, wave propagation direction (radial and tangential), juvenile wood, reaction wood, moisture content and sap flow, on velocities. The objective was to verify if these variations are enough to causes misinterpretation of the ultrasonic tomography. From the results, it was concluded that some of these parameters can affect the interpretation of the tomographic image and so, more attention is necessary to take in account these interference, considering results quantification of those interference as, for example, correction coefficients.

\section{Numerical modeling (FEM) as a tool to evaluate the tree risk of falling \\ Mônica Ruy ${ }^{1}$, Raquel Gonçalves ${ }^{1}$, William Vicente ${ }^{1}$, Douglas Moraes ${ }^{1}$, Celso Milaneto Junior ${ }^{1}$ \\ ${ }^{1}$ Universidade de Campinas, Campinas,Brasil(monkaruy@gmail.com; raquelg@unicamp.br; william.vicente@feagri.unicamp.br; douglaspm1409@gmail.com; juniormilaneto1@gmail.com)}

News about trees falls in urban environment is published every year around the world. Therefore, better management of these trees is necessary in order to prevent its failures and to minimize damages caused to the population. The management of tree risk analysis involves multidisciplinary knowledge, including biology and engineering. Through of biomechanics, it is possible to ally biological aspects - growth characteristics, tree anatomy and biodeterioration agents - to the structural behavior of these individuals, that grow searching their structural balance. According to engineering principles, a structural analysis must consider three fundamental aspects: materials properties, structural geometry and loads. Thus, this research aimed to propose a structural model, through a finite element method (FEM) software, that represents the static scheme of a healthy tree. This model will be mixed to biological aspects in a future proposal of trees risk falling classes. We developed models with different levels of complexity through a FEM software. To develop the models, we used architetural and geometrical data of a common specie in urban arborization of the State of São Paulo in Brazil - Schinus molle. To insert the properties, the material was adopted as orthotropic and its properties were determined by physical and mechanical characterization of green wood from the same species. By comparing the results, it was possible to conclude about the most appropriate model to be used in futures researches involving tree risk falling assessment.

\section{C5q: CHARACTERIZING PROPERTIES OF PLANTATION WOOD FOR OPTIMAL VALUE}

\section{Development of Aquilaria plantations and eaglewood production in Southern China}

Daping Xü, Xiaojin Liu ${ }^{1}$, Dongguang Wang ${ }^{1}$

${ }^{1}$ Research Institute of Tropical Forestry, Chinese Academy of Forestry, Guangzhou, China (gzfsrd@163.com; xjliu@caf.ac.cn; 506566893@qq.com)

There are about 100,000 ha Aquilaria plantations in southern China. Tree species used for plantations are Aquilaria sinensis (Lour.) Spreng., A. yunnanensis S. C. Huang and A. crassna Pierre ex Lec. A. sinensis is the dominant species. The objective of the plantations is for eaglewood production for medicine, perfume and eaglewood oil. During seedling raising, it is very important to prevent root nematode invading; 2-3 years container-seedlings at the height about $1 \mathrm{~m}$ are suitable for plantation establishment. Early fertilizations are very favoured for fast growth of young trees. when average DBH of trees is about 10 $15 \mathrm{~cm}$ at the age of 5-10 years, it is possible for promoting eaglewood production.There is no eaglewood production without special treatments to the trees until natural injuring happened by insects, diseases or wind damage. Experiments have been conducted to select efficient treatments for promoting eaglewood 
production. Inoculation of fungi, dripping of chemicals and plant growth regulators to stem are helpful for eaglewood production. Cutting roots, section cutting bark and drilling holes on stem are useful for eaglewood production too. When trees were hurt or injured, stem-bark respiration was increased, then starch in stem wood was decreased, and finally formed volatile oil accumulated around injured sections.Agarwood formation was an inductive stimulus, resulting in defense response, and produce secondary metabolism during the dynamic process. Artificial wound, use of plant growth regulators and inorganic salt, and fungi inoculation were effective methods for agarwood formation. The stem defense response and respiration had the certain index to predict agarwood formation.

Calorimetric evaluation of wood from four Caatinga species after applying finishing products / Avaliação colorimétrica da madeira de quatro espécies da caatinga após aplicação de produtos de acabamento

Eduardo Reis ${ }^{1}$, Peter Wimmer ${ }^{1,2}$, Luciano Roitman $^{1,2}$, Marcella De Paula ${ }^{1}$, Robert Rossi ${ }^{1}$, Joaquim Gonçalez ${ }^{1}$

${ }^{1}$ Universidade de Brasilia, Brasilia, Brasil; ${ }^{2}$ Serviço Florestal Brasileiro,Brasilia, Brasil (eduardoreis1995@gmail.com; peter.wimmer@florestal.gov.br; luciano.roitman@florestal.gov.br; marcellahermida@hotmail.com; robertflorestal@gmail.com; goncalez@unb.br)

A cor é um dos atributos mais importantes para a valorização e comercialização da madeira. Esta pode ser influenciada por fatores genéticos inerentes a cada espécie, promovidos pelo ambiente ou pelo beneficiamento da madeira. Este trabalho teve como objetivo avaliar a alteração da cor da madeira de quatro espécies de árvores, típicas da Caatinga do estado do Piauí, com relação a dois produtos de acabamento. A determinação das cores das amostras foi realizada por meio do sistema CIELAB, 1976, pelas coordenadas cromáticas ( $\mathrm{L}^{*}, \mathrm{a}^{*}, \mathrm{~b}^{*}, \mathrm{C}$ e h*). Para isso foi usado um espectofotômetro ColorEye XTH, fazendo 10 leituras por amostra, sendo cinco amostras por espécie e cinco amostras para cada tratamento. Todas as espécies foram classificadas de acordo com a tabela de cores de madeira, proposta por Camargos e Gonçalez, 2001. Sem tratamento, as espécies Pterodon abruptus (Moric.) Benth, Terminalia fagifolia Mart., Diptychandra aurantiaca Tul.e Aspidosperma pyrifolium Mart. foram classificadas como marrom-oliva, marrom-claro, amarelo-amarronzado, e amarelo-claro. Após a aplicação de Cetol a madeira das mesmas espécies foi classificada como amarelo-amarronzado, marrom-escuro, marrom-avermelhado e amareloclaro, respectivamente. As amostras que receberam o tratamento de seladora foram classificadas como amarelo-amarronzado, marrom-avermelhado, amareloamarronzado e amarelo-claro. Sendo assim, ambos os tratamentos alteraram a coloração da madeira de $P$. abruptus sem distinção entre os tratamentos. Cada tratamento aplicado a espécie T. fagifolia, gerou uma coloração diferente. Para a espécie $D$. aurantiaca, apenas o Cetol gerou diferença na coloração e nenhum produto aplicado alterou a coloração de $A$. pyrifolium.

Performance of glued laminated beams made of Couratari oblongifolia Ducke \& R. Knuth using two types of adhesives / Desempenho de vigas laminadas coladas de Couratari oblongifolia Ducke \& $R$. Knuth utilizando dois tipos de adesivos

Peter Wimmer ${ }^{1,2}$, Divino Teixeira ${ }^{1}$, Maria Oliveira $^{2}$, Eduardo Reis $^{2}$

${ }^{1}$ Serviço Florestal Brasileiro, Brasília, Brasil; ${ }^{2}$ Universidade de Brasília, Brasília, Brasil (peterwimmer1983@gmail.com; divino.teixeira@florestal.gov.br; meoliveira.florestal@gmail.com; eduardo.reis@florestal.gov.br)

Couratari oblongifolia Ducke \& R. Knuth, conhecida popularmente por tauari, é a quarta espécie mais explorada nos planos de manejo florestal das concessões federais em Florestas Nacionais. Apesar do grande volume, a madeira desta espécie é atualmente utilizada para produtos de baixo valor agregado como cabos de vassouras, cabos de ferramentas e caixotaria, possuindo um baixo valor comercial. Por outro lado, a densidade básica média da madeira, sugere que seja possível utilizar esta espécie no desenvolvimento de produtos engenheirados para a construção civil, que envolvem o uso de adesivos. Entre os produtos em destaque atualmente estão as vigas de madeira laminada colada (MLC). Também conhecidas por "glulam", as vigas são compostas de lâminas (tábuas) de madeiras dispostas paralelamente, unidas entre si pelo uso de adesivos duráveis e resistentes a umidade, sendo um material arquitetônico extremamente versátil, uma vez que permite uma grande variedade de formas. Esse trabalho teve como objetivo avaliar o desempenho de vigas de MLC de C. oblongifolia, confeccionadas com dois tipos de adesivos: poliuretano (PUR) e poli(acetato de polivinila) crosslink (PVAc). As vigas compostas de cinco lâminas e dimensões finais de $5 \mathrm{x} 10 \mathrm{x}$ $210 \mathrm{~cm}$ foram testadas pelo ensaio destrutivo de flexão estática em quatro pontos, de acordo com a norma ASTM D-198/02 (2015). Todos os valores obtidos nos ensaios podem ser considerados altos quando comparados a dados de literatura, indicando o potencial da espécie e dos adesivos. No entanto, o adesivo PVAc gerou vigas mais rígidas e resistentes que o PUR.

Comparing cross-glued laminated wood panels of Eucalyptus sp., Araucaria angustifolia, Pinus sp. with commercial Pinus taeda panels / Comparação de painéis de madeira laminada colada cruzada de Eucalyptus sp., Araucaria angustifolia, Pinus sp. com painéis comerciais de Pinus taeda

Cecilia Manavella ${ }^{1}$, Peter Wimmer ${ }^{1}$, Divino Teixeira ${ }^{1}$

${ }^{1}$ Serviço Florestal Brasileiro,Brasilia,Brasil (cecilia.manavella@florestal.gov.br; peter.wimmer@florestal.gov.br; divino.teixeira@florestal.gov.br)

A madeira laminada colada cruzada (MLCC), amplamente utilizada na América do Norte e Europa, apresenta grande potencial para a construção civil no Brasil, incluindo a possibilidade de produção de painéis com diferentes espécies de reflorestamento e de madeiras nativas. O presente estudo comparou as propriedades físico-mecânicas de painéis de Eucalyptus sp., de Araucaria angustifolia e de Pinus sp.confeccionados em laboratório, com painéis comerciais de Pinus taeda. Os painéis testados eram compostos de três camadas de madeira, colados com adesivo à base de poliuretano. Os ensaios de flexão, compressão paralela e cisalhamento na linha de cola foram realizados segundo as normas COPANT 555, COPANT 464 e COPANT 463, respectivamente. Os painéis de Eucalyptus sp. e A. angustifolia apresentaram valores iguais ou superiores ao painel produzido comercialmente, enquanto os painéis de Pinus sp. apresentaram valores semelhantes aos do painel comercial de Pinus taeda. Nota-se uma tendência de divisão das espécies estudadas em duas classes homogêneas e significativamente distintas entre si. Todos os painéis tiveram bom desempenho nos ensaios de compressão paralela e cisalhamento na linha de cola, quando comparados a resultados obtidos em estudos anteriores. Verificou-se, para todas as espécies testadas, que os painéis apresentam maior resistência quando submetidos a carga com as camadas majoritariamente dispostas na direção longitudinal.

\section{Potential of non-destructive testing of wood and the contribution to climate change mitigation}

Haruna Seidu ${ }^{1}$, Reginald Tang Guuroh ${ }^{1}$, James Govina ${ }^{1}$,Emmanuel Appiah-Kubi ${ }^{1}$, Charles Essien ${ }^{1}$

${ }^{1}$ CSIR-Forestry Research Institute of Ghana, Kumasi, Ghana (harryzeib@gmail.com; rguuroh@gmail.com; jgo63@uclive.ac.nz; appiahkemma@gmail.com; amankyessien@gmail.com)

Meeting journal and international best practices in publishing research studies on technological properties of timber, at least 5 trees are required to take care of variability within and between trees. Felling of trees is inarguably a contributing factor to deforestation and to a lesser extent climate change across the globe as 
this is a destructive test method. However, presently there are technologies that can determine certain technological properties without necessarily cutting down trees. After executing the various technological tests in the laboratory, the prepared wood samples are mainly used locally as firewood which release $\mathrm{CO}_{2}$ into the atmosphere. The purpose of this study was to review and quantify the number of trees extracted from different ecological zones in Ghana from the year 1998 - 2018 for technological properties determination. Also, the study estimated the amount of biomass and eventually, carbon that might have been sequestrated over the study period. Data on trees and sample sizes based on mechanical, physical and anatomical property test methods were reviewed using Microsoft Excel and allometric equations. The results revealed that a total of 1010 trees were extracted for research only at CSIR-Forestry Research Institute of Ghana, with a total biomass of $920,332.9 \mathrm{~kg}$ (920.33 tons) over the 20 years period. It can be concluded that these 1010 trees could have continued the sequestration of carbon or at least maintain those sequestered. It is recommended that Non-destructive methods must be encourage in Ghana to safeguard the dwindling forest cover.

\section{Selected properties of plywood manufactured from alternate layers of densified and non-densified alder veneers}

Salca Emilia-Adela ${ }^{1}$, Pavlo Bekhta ${ }^{2}$

${ }^{1}$ Transilvania University of Brasov, Brasov, Romania; '2Ukrainian National Forestry University, Lviv, Ukraine (emilia.salca@unitbv.ro; bekhta@nltu.edu.ua)

The aim of this work was to evaluatesome selected physical and mechanical properties of plywood samples made of densified and non-densified veneers within the same plywood structure. In this study defect free samples of rotary-cut veneers made of black alder (Alnus glutinosa L.) were used. The veneers were densified under a constant hot-pressing schedule in laboratory conditions. To manufacture the 5-layers plywood samples a commercial urea-formaldehyde resin was used and a constant hot-pressing schedule was applied while the glue spread varied as a function of plywood structure type (control non-densified, control densified, and combinations of alternate layers of densified and non-densified veneers). In this study the glue spreading was reduced almost $50 \%$ of the recommended value under industrial conditions. Prior to any process step and test, all veneers and plywood samples were kept under constant room conditions for a week. Selected physical and mechanical properties have been determined according to specific standards. The obtained results showed that the selected adhesive ratiosprovided relevant results for plywood samples in terms of mechanical properties. Similar findings are provided in the specialty literature for plywood made of densified veneers only. Moreover such structural combinations of non-densified and densified veneers used together for plywood production resulted in improved physical and mechanical properties of the final product.It is expected that these plywood combinations would generate value-added woodbased products with low emissions of toxic compounds and low costs, as well, based on their reduced glue consumption.

\section{C5r: INNOVATIVE UTILIZATION OF BAMBOO AND RATTAN RESOURCES}

\section{Research on the influencing factors of bamboo certification market in China}

Enlong Xia

${ }^{1}$ International Centre for Bamboo and Rattan, Beijing, China (xiaenlong@icbr.ac.cn)

Bamboo is widely recognized as one of the most important forest resources and emerging as a critical substitute for wood. To develop bamboo resource, the bamboo certification is accepted as an efficient way to repond the environmental issues and global sustainable development. Several certification programs have been indentified as the primary mission by some NGOs including the Programme for the Endorsement of Forest Certification (PEFC) and the Forest Stewardship Council (FSC). China is also the first country to successfully create and maintain large FSC management units (FM) and chain of custody (COC), value-chain certificates for bamboo. However, the development of bamboo certification still has long way to go in China. Currently, its bamboo certification market is influenced by many factors, such as the global environmental protection action, the government's green procurement policy, the need for the development of domestic enterprises, and people's consumption concept and hibat. Based on a deep analysis the market development of bamboo industry and an updated status of its certification in China, this paper aims to provide some pratical suggestions for its future development. The suggestions include: (1)supporting the establishment of bamboo forest certification market; (2) encouraging the public people a to green consumption hibat of bamboo; (3) improving the supporting guarantee measures of bamboo forest certification; and (4) strengthening supervision of bamboo certification agencies.

\section{Current status and development opportunities of bamboo industry in Ethiopia}

Jinhe $F u^{1}$

${ }^{1}$ International Bamboo and Rattan Organization, Addis Ababa, Ethiopi (jfu@inbar.int)

Ethiopia has abundant bamboo resources, and owns more than 1.47 million ha of bamboo forest, which take up 5\% of the global bamboo forest area and $40 \%$ of the African bamboo forest area. Bamboo industry is still in its infancy in Ethiopia, which still adopts the traditional way to process bamboo products, and bamboo industry is encountered with a series of problems, such as lack of bamboo stand management, low level of market development, incomplete bamboo production chain and slow development in science \& technology and technical extension. Under the coordination and efforts of International Bamboo and Rattan Organization (INBAR), Chinese president announced to establish "China-African Bamboo Center" in Addis Ababa on the opening speech of China Africa Forum 3 September 2018 in Beijing, INBAR implemented value chain analysia and market assessment of bamboo products and is preparing a national bamboo strategy and action plan together with Ethiopia government, the bamboo industry in Ethiopia is embraced with the unprecedented development opportunity. Its rich bamboo resources and low labor costs create the foundation for the labor-intensive bamboo industry, and its huge market demand for bamboo products and the beneficial investment policies implemented embody the opportunity for investment. Hence, enterprises and investors are suggested to invest in Ethiopia for bamboo industry. Bamboo investors should focus on bamboo industrial products like bamboo pulp and paper, floor, furniture, charcoal and briquette, bamboo shoot etc as well bamboo plantation development.

\section{Analysis on fracture behavior of Moso bamboo (Phyllostachys pubescens) in tension and bending using synchrotron radiation micro-} computed tomography $(\mathrm{SR} \mu \mathrm{CT})$

Huanrong Liu', Guanyun Peng², Zehui Jiang ${ }^{1}$

${ }^{1}$ International Center for Bamboo and Rattan, Beijing, China; ${ }^{2}$ Shanghai Institute of Applied Physics, Chinese Academy of Sciences, Shanghai, China (huanrongliu@126.com; pengguanyun@sinap.ac.cn; jiangzehui@icbr.ac.cn)

Bamboo is a natural bio-composite material that is both tough and possesses excellent mechanical properties. Its delicate structure and fiber arrangements play an important role in the mechanical properties and the fracture performance of bamboo. In this study, the fracture behaviors of bamboo due to tensile strength 
and bending were investigated using synchrotron radiation micro- computed tomography and environmental scanning electron microscopy (ESEM). Both tension and bending tests revealed that fibers are the key factors for bearing extra load and impeding crack propagation. Crack paths were found to be different in bamboo strips with different fiber percentages, and the interface between pulled-out fiber bundles and fiber break (in helix breaks and shearing break) was observed to be typical fracture characteristics in tension. Moreover, advanced micro-matrix cracking, interface debonding, fiber bundle bridging and the splitting of cell wall layers were found to be important fracture characteristics in bending. Both in tension and bending, a reasonably weak interface appeared to be beneficial for improving fracture toughness of fiber-reinforced bamboo. Thus, it is clear that "fiber bridging" mechanisms and "shear-lag theory" are well exhibited in bamboo.

\title{
Long creep-recovery behavior of bamboo-based products
}

Xinxin $\mathrm{Ma}^{1}$

${ }^{1}$ International centre for bamboo and rattan, beijing, China (maxx@icbr.ac.cn)

This paper describes the bending creep behavior of two types of bamboo-based products, bamboo-laminated veneer lumber (BLVL), and glued-laminated bamboo (GLB, also called Bamboo Glulam) at different stress levels for half a year and recovery for the same time. It was found that the stress level of BLVL was more sensitive on creep property than that of GLB; the creep resistance of GLB was worse than that of BLVL in the stress levels of 30-50\%; the instantaneous recovery ratio (elastic recovery to elastic creep) decreased with an increase of the stress levels, while the residual ratio (residual deformation corresponded to the total creep deflections) increased with an increase of stress levels for all specimens; Burgers model fit creep data very well for both bamboobased products, while the recovery Weibull equation does not fit recovery data well for GLB.

\section{Effect of modification with methyl methacrylate on the mechanical properties of Plectocomia kerrana Rattan}

\author{
Lili Shang ${ }^{1}$, Zehui Jiang ${ }^{1}$, Xing'e Liu ${ }^{1}$, Genlin Tian ${ }^{1}$, Jianfeng Ma ${ }^{1}$, Shuming Yang \\ ${ }^{1}$ Internation center for bamboo and rattan,Beijing, China(shangll@icbr.ac.cn; jiangzehui@icbr.ac.cn; liuxinge@icbr.ac.cn; tiangenlin@icbr.ac.cn; \\ majf@icbr.ac.cn; yangsm@icbr.ac.cn)
}

This study aims to evaluate the mechanical properties of rattan/polymer composites prepared by polymerization with methyl methacrylate (MMA). The $P$. kerrana rattan samples were impregnated in a vacuum system and polymerized in an oven at $60^{\circ} \mathrm{C}$ for $8 \mathrm{~h}$, using 0.5 wt. $\%$ of azobisisobutyronitrile as a catalyst. The macro-mechanical properties of the treated and untreated samples were analyzed. The bending modulus and strength of the treated rattan increased by $206 \%$ and $215 \%$, respectively. Additionally, the compressive modulus and strength increased by $109 \%$ and $107 \%$, compared to untreated rattan. Scanning electron microscopy (SEM) images showed that MMA penetrated into the cell lumen. Furthermore, Fourier transform infrared spectroscopy (FTIR) analysis revealed that MMA diffused into the parenchyma and vessels, but it was not found in the fiber wall. Thus, it can be inferred that the improvement in the mechanical properties of treated rattan was mainly caused by the strengthened parenchyma and vessels. Modification with MMA was shown to be an effective way to enhance the macro-mechanical properties of P. kerrana.

\section{How HS code's development help promote market development of bamboo and rattan commodities?}

Junqi Wu ${ }^{1}$, Zhiyong Li $^{2}$, Lucy Binfield ${ }^{1}$

${ }^{1}$ International Bamboo and Rattan Organisation, Beijing, China; ${ }^{2}$ International Center for Bamboo and, Beijing, China (jqwu@inbar.int; icbrlzy@126.com.cn; lbinfield@inbar.int)

As two key Non Timber Forest Products, bamboo and rattan are responsible for a significant global market. The profile of these resources is steadily increasing, especially in the Global South, as is their market, with many new and innovative technologies and designs with good trade prospects. However, those wishing to promote trade in bamboo and rattan still face some challenges: How can the value of bamboo and rattan commodities in the international market be recognized? How can the contribution of bamboo and rattan to economy and trade be reviewed and evaluated? How can an enabling trade policy environment for the trade of these key products be facilitated? Identification and classification of bamboo and rattan as separate from wood and other similar categories in the Harmonizing Coding System (HS) will help to unlock the huge market potential of these two particular resources. HS classification is essential for transparent market monitoring and evaluation and to facilitate trade policies relating to bamboo and rattan. This paper introduces INBAR's work with the World Customs Organization and the Chinese Customs Authority in HS code development, and addresses key issues in this area. Foremost among these is the need for more collaboration among international agencies to push forward HS code improvement for favorable trade. This paper also provides a general picture of trends in bamboo and rattan products in the international market. Finally, recommendations are proposed for further improvements of the HS codes for bamboo and rattan to facilitate international trade and cooperation.

\section{Challenges and opportunities related to bamboo for small rural properties in the state of Paraná, Brazil / Desafios e oportunidades do bambu para pequenas propriedades rurais no Estado do Paraná \\ Thiago Rodrigues de Paula 1 (D), Vitor Afonso Hoeflich ${ }^{1}$ \\ ${ }^{1}$ Universidade Federal do Paraná, Curitiba,Brasil (thiago_ufpr@ufpr.br; vitorvitor.ufpr@gmail.com)}

O uso do Bambu se estende por uma miríade de produtos e serviços como construção civil, artesanato, móveis, energia, produtos engenheirados como painéis e vigas laminadas. Pode ser utilizado na contenção de encostas, proteção de solos contra erosão e até mesmo para sistemas de irrigação de baixo custo, o que o torna uma cultura multiuso com alto potencial de sucesso, no entanto é pouco explorado no Brasil e no Paraná. No presente trabalho apresenta-se um estudo desenvolvido para avaliar a aplicação de bambu como alternativa que economicamente viável, socialmente justa e ecologicamente correta para que o pequeno agricultor tenha condições de desenvolver sua propriedade. O resultado preliminar indica que, apesar dos avanços recentes no ambiente institucional, como Lei federal que estabelece a Política Nacional de incentivo ao manejo sustentado do bambu e a contemplação da cultura em uma novas legislações, propõe-se a necessidade de um planejamento estratégico para a cultura do bambu no Estado, como mais uma alternativa para o pequeno agricultor, em consórsio com a área florestal, partindo da sistematização da informação e da criação de uma agenda de ações para a criação deste planejamento culminando com a disseminação da informação aos pequenos produtores, via extensão rural. 
Physical and chemical characteristics of bamboo (Dendrocalamus asper) / Caracterización química y física del bambú (Dendrocalamus Asper)

Mary Flor Césare Coral ${ }^{1}$, Fatima Hilario ZAvala², Natalie Juana Callupe Vargas², Liz Ania López De La Torre ${ }^{1}$, Héctor Enrique Gonzales Mora ${ }^{1}$ ${ }^{1}$ Universidad Nacional Agraria La Molina, Lima, Peru; ${ }^{2}$ Universidad Nacional Agraria de La Selva, Tingo Maria, Peru (mcesare@lamolina.edu.pe; fatimaamparohz@gmail.com; julia.natalie.03@gmail.com; lldlt@hotmail.com; egonzales@lamolina.edu.pe)

El incremento de la población ha conllevado a presionar los bosques para satisfacer la demanda de materiales estructurales como son los árboles, los cuales requieren gran cantidad de años para su aprovechamiento, lo que no sucede con el bambú, el cual requiere entre 4 a 5 años para su aprovechamiento, esto hace al bambú Dendrocalamus asper una buena alternativa, para su aprovechamiento en diferentes usos por la alta resistencia que presenta por su gran contenido lignocelulosico. Por ello el objetivo de este trabajo consiste en realizar la caracterización química, lignocelulosica y física del bambú Dendrocalamus asper. El contenido lignocelulósico (celulosa, hemicelulosa, lignina) se basó en los métodos TAPPI, análisis elemental (ASTM D4239), análisis proximal (ASTM D7582) análisis del contenido energético (ASTM D5865-13), contenido de fibras y extractivos, así como sus propiedades físicas (pH, conductividad, densidad aparente, porosidad). Los resultados indican que el bambú presenta altos valores de compuestos lignocelulósicos, siendo la celulosa de mayor contenido seguido de lignina, sus propiedades físicas como la alta porosidad se relaciona con su bajo contenido energético. Concluyéndose que el bambú Dendrocalamus asper por su alto contenido de fibras puede ser destinado para la producción de fibras de papel, así como para la producción de biocombustibles de tercera generación por el alto contenido de celulosa.

C5s: FOREST PRODUCTS

Whitebark raspberries (Rubus spp.) in the Curitiba metropolitan area: implications for phytotherapy / Amoras-brancas do gênero Rubus na Região Metropolitana de Curitiba: implicações para a fitoterapia

Antonio Aparecido Carpanezzi ${ }^{1}$

${ }^{1}$ Embrapa Florestas, Colombo, Brasil (antonio.carpanezzi@embrapa.br)

A denominação popular amora-branca, tradicionalmente, é dada a três espécies nativas do gênero Rubus cujos frutos maduros apresentam cor predominante verde-clara: R. erythroclados Mart. ex Hook.f. - RE, R. brasiliensis Mart. - RB e R. imperialis Cham. \& Schltdl .- RI. Ao lado delas, na Região Sul do Brasil são encontrados outros táxons de Rubus de ocorrência natural ou introduzidos, nestes havendo tanto cultivados como asselvajados. Popularmente, às três amoras-brancas são atribuídas propriedades para a saúde humana, embora os estudos técnicos aprofundados pareçam ater-se a RI. Como é praxe no gênero, a diferenciação botânica baseia-se, grandemente, em caracteres vegetativos. As três amoras-brancas possuem atributos que permitem sua identificação em amostras secas processadas para comercialização, como cor e indumento dos ramos e dos folíolos e presença dos acúleos e sua robustez. Na Floresta Ombrófila Mista da Região Metropolitana de Curitiba - RMC, as espécies RE e RB são razoavelmente comuns em vegetações secundárias, ao passo que RI é rara, não sendo uma fonte plausível para a obtenção do produto comercializado. Amostras obtidas principalmente em lojas da RMC indicam que, comumente, o produto comercializado como amora-branca (a) não se refere a RE, RB ou RI, e (b) frequentemente abriga, em grande parte ou totalmente, matéria de $R$. niveus Thunb., espécie introduzida, invasora, abundante na região em terrenos (sub)urbanos abandonados, com caule e ramos esbranquiçados e frutos maduros escuros. No âmbito acadêmico, a literatura revela incertezas quanto à determinação botânica cotidiana de plantas vivas de RI, indicando ser necessário cuidados para evitar erros.

\section{Evaluation of a thinning under silvopastoral approach in a Nothofagus antarctica (ñire) in Chilean Patagonia}

Jaime Salinas ${ }^{1}$

${ }^{1}$ Instituto Forestal, Coyhaique, Chile (jsalinas@infor.cl)

In the Region of Aysen (Chilean Patagonia) there are about 109.000 ha of Nothofagus antarctica (ñire) forest (ñirantales), these ecosystems are classified as lenga forest type. This species presents intraespecífic polymorphism, which has adapted to the different biotypes, modifying its vegetative body and adopting different forms of life, such as; (i) tree-like, (ii) scrubby bush (iii) chamaephyte. The main use of these forests is the production of firewood and posts. At the same time, the pasture of domestic animals is a common practice in these places, evertheless, the real potential silvopastoral use that the ñirantales represent is unknown. In addition to this, the current forest legislation does not include plans of usage under a silvopastoral approach to encourage the activity. The present work presents preliminary information of the structure before and after of thinning the lower part in a pure forest of ñire (average domineering height 9,9 m), located in a humid place related to a mallín distant $45 \mathrm{~km}$ of the city of Coyhaique, Chile. The dasométric evaluation considered 10 circular plots of $100 \mathrm{~m}^{2}$ distributed in random form. The thickness before the intervention was 5.630 trees ha ${ }^{-1}$, with an average diameter quadratic (DMC) of 10,3 cm. During the year 2014, a thinning was done with an intensity of $34 \%$ of the basal area, up to coming to a residual thickness of 2.270 trees ha 1 that the DMC allowed to increase to $12,9 \mathrm{~cm}$.

Biometric characterization of fruits and seeds from Dipteryx odorata (Aubl.) Willd (cumarú-ferro) - Fabaceae / Caracterização biométrica de frutos e sementes de Dipteryx odorata (Aubl.) Willd (cumarú-ferro) - Fabaceae

Fiama Natacha Lima de Oliveira1, Keilyson Naazio Oliveira Moraes ${ }^{1}$, Marilene de Campos Bento ${ }^{2}$, Harley Araújo da Silva ${ }^{3}$, Antônio Gilson Gomes Mesquita

${ }^{1}$ Programa de Pós-Graduação em Ciência, Inovação e Tecnologia para a Amazônia, Universidade Federal do Acre, Rio Branco, Brasil; ${ }^{2}$ Parque Zoobotânico, Laboratório de Análise de Sementes Florestais, Rio Branco, Brasil; ${ }^{3}$ Universidade Federal do Acre, Parque Zoobotânico, Rio Branco, Brasil; ${ }^{4}$ Universidade Federal do Acre, Laboratório de Genética Molecular e de Microrganismo, Rio Branco, Brasil (fiamanatacha@hotmail.com;

keilysonmoraes@hotmail.com; marilenepz@yahoo.com.br; harleyaraujo@ufac.br;mesquitaagg@gmail.com)

Conhecida popularmente no Acre e no Pará como cumaru-ferro, está espécie é bastante utilizada na construção civil, na indústria de cosméticos e alimentícios. Esse estudo foi conduzido no Laboratório de Análise de Sementes Florestais da Universidade Federal do Acre, com objetivo de caracterizar biometricamente os frutos e sementes de Dipteryx odorata. Os frutos foram coletados de matrizes localizadas no Ramal Copaíba, BR 364, estrada de Sena Madureira - Acre, km 64 (68W 15'50”, 9S 43' 51"). Analisaram-se 200 frutos e 200 sementes quanto ao comprimento, largura e espessura, com auxílio de paquímetro digital $(0,01 \mathrm{~mm})$; quanto à massa fresca em balança digital de precisão $0,001 \mathrm{~g}$ e a massa seca das sementes em estufa elétrica a $105^{\circ} \mathrm{C} \pm 3{ }^{\circ} \mathrm{C}$, por 24 horas. Foram 
calculadas as médias, valores mínimos e máximos, desvio padrão, coeficiente de variação e correlação de Pearson (r). A estatística descritiva foi obtida através do programa BioEstat 5.3. Os frutos apresentaram média de massa fresca de 13,06 $\pm 1,82 \mathrm{~g}, 36,94 \pm 2,02 \mathrm{~mm}$ de comprimento, 15,84 $\pm 1,77 \mathrm{~mm}$ de largura e 21,78 $\pm 1,50 \mathrm{~mm}$ de espessura. As sementes apresentaram média de massa fresca e seca 1,32 $\pm 0,19$ e 0,87 $\pm 0,12 \mathrm{~g}$ respectivamente, $26,58 \pm 1,33 \mathrm{~mm}$ de comprimento, $9,0 \pm 0,64 \mathrm{~mm}$ de largura e $8,19 \pm 0,65 \mathrm{~mm}$ de espessura. A correlação $(\mathrm{r})$ foi forte e positiva entre massa fresca e largura dos frutos $(\mathrm{r}=0,6711)$ e entre massa fresca e seca das sementes $(r=0,8676)$. Os frutos e sementes de Dipteryx odorata apresentam baixa variação nas variáveis analisadas provavelmente devido a homogeneidade da espécie.

\section{“Papa-Papel,” an academic extension project / Projeto de extensão acadêmica "Papa-Papel”}

Joyce Fernanda Gondim ${ }^{1}$, Sybelle Barreira ${ }^{1}$

${ }^{1}$ Universidade Federal de Goiás, Goiânia, Brasil (joy_nanda@hotmail.com; sybelle.barreira@gmail.com)

A indústria de papel e celulose causa grandes impactos ao meio ambiente devido a grande demanda e elevado consumo de recursos naturais durante o processo produtivo. Apesar do avanço tecnológico e do uso cada vez mais intenso de computadores, o uso de papel para escrita e impressão continua aumentando, indo na contramão do senso comum. Pensando nisso, em 2015, foi criado o projeto de extensão "Papa-Papel" que tem como objetivo a coleta de papel, parcialmente utilizado, para confecção de blocos de notas, com o intuito de incentivar a reutilização do papel e também minimizar a quantidade consumida nas atividades acadêmicas desenvolvidas na Escola de Agronomia da Universidade Federal de Goiás (UFG). O projeto propôs a redução do consumo e reaproveitamento desse material como forma de educação ambiental, além de incentivar a redução de gastos com papel na unidade e ajudar na conservação dos recursos naturais. Durante os anos de 2016 e 2017 foram coletados 150 quilos de papel sulfite do tamanho A4, o equivalente a 30.000 mil folhas ou 60 resmas, gerando uma economia de aproximadamente $\mathrm{R} \$ 837,00$ e ainda evitando o consumo de 81 mil litros de água, que seriam utilizados para a fabricação dessa mesma quantidade de papel se não houvesse a reutilização. O projeto continua em andamento e visa, cada vez mais, aumentar a quantidade de papel reaproveitado dentro da escola. Além do impacto econômico, o projeto espera servir como exemplo para a sociedade acadêmica, de modo que seu exemplo seja seguido, gerando assim um efeito cascata.

\section{Characteristic features of cellulose nanofibers derived from different tree species with various manufacturing processes}

Haruka Suzuki ${ }^{1}$,Takeshi Fujiwara ${ }^{1}$, Hisashi Abe ${ }^{1}$, Youki Suzuki ${ }^{1}$, Tsutomu Ikeda ${ }^{1}$, Masanobu Nojiri ${ }^{1}$, Eiji Togawa ${ }^{1}$, Satoshi Kubo ${ }^{1}$, Reina Tanaka ${ }^{1}$, Noriko Hayashi $^{1}$, Kyoko Katsumata ${ }^{2}$,Yuji Matsumoto ${ }^{2}$, Tomoko Kuribayashi ${ }^{2}$, Kouta Ogura $^{3}$, Yoko Okahisa ${ }^{4}$, Michiko Shimizu $^{4}$; Takashi Endo

${ }^{1}$ Forestry and Forest Products Research Institute, Tsukuba, Japan; ${ }^{1}$ Forestry and Forest Products Research Institute, Tsukuba, Japan; ${ }^{2}$ Graduate School of Agricultural and Life Sciences, The University of Tokyo, Tokyo, Japan; ${ }^{3}$ Sugino Sugino Machine Limited, Toyama, Japan; ${ }^{4}$ Kyoto Institute of Technology, Kyoto, Japan; ${ }^{5}$ National Institute of Advanced Industrial Science and Technology, Higashi Hiroshima, Japan ((chunhua@ffpri.affrc.go.jp; fujiwara@ffpri.affrc.go.jp; abeq@ffpri.affrc.go.jp; youki@ffpri.affrc.go.jp; tikeda01@ffpri.affrc.go.jp;nojiri@affrc.go.jp; togawae@ffpri.affrc.go.jp; kubos@ffpri.affrc.go.jp; tanakar1101@ffpri.affrc.go.jp; hayashin@ffpri.affrc.go.jp; k-katsumata@woodchem.fp.a.u-tokyo.ac.jp; amatsumo@mail.ecc.u-tokyo.ac.jp; kuribayashi-tomoko@woodchem.fp.a.u-tokyo.ac.jp; k.ogura@sugino.com;okahisa@kit.ac.jp; simizumi@kit.ac.jp; t-endo@aist.go.jp)

Japanese softwood and hardwood were used in this study as raw materials for cellulose nanofibers (CNF). Each trunk of the sample trees was divided into juvenile wood and mature wood. They were chipped, pulped, and then converted into cellulose nanofibers. The Kraft pulping and the soda-AQ pulping were employed for pulp manufacturing. The mechanical fiber fibrillation technology, TEMPO-catalyzed oxidation, and enzyme biotechnology were used to produce various types of CNF. The specific surface area, width, 5\% weight loss temperature, and the crystallinity index of the CNFs were determined by the BET (Brunauer-Emmett-Teller) theory, UV-vis-NIR spectrophotometer, TGA (thermogravimetric analysis), and WAXD (wide-angle X-ray diffraction) respectively. The microscopic observations of the CNFs as well as pulps were carried out using both transmission electron microscope (TEM) and scanning electron microscope (SEM). The results of the study revealed that tree species, tree age, pulping method and CNF manufacturing process will all affect the CNF characteristics more or less. CNFs made by different manufacturing methods from different raw materials each have their own unique characteristics. Knowing this fact will help us make the best use of CNFs. This work was supported by a grant from New Energy and Industrial Technology Development Organization (NEDO), Japan. NEDO Project name: Development of Technologies for Manufacturing Processes of Chemicals Derived from Inedible Plants

\section{Potential energy crops from the wild and moist tropical secondary forests}

Wan Asma Ibrahim ${ }^{1}$, Wan Rasidah Kadir ${ }^{1}$, Nor Fadzilah Othman ${ }^{2}$, Puad Elham ${ }^{1}$, Wai Mun Ho ${ }^{1}$

${ }^{1}$ Forest Research Institute Malaysia, Kepong, Selangor, Malaysia; ${ }^{2}$ TNBR Research Sdn Bhd, Bangi, Selangor, Malaysia (asma@frim.gov.my; rashidah@frim.gov.my; fadzilah.othman@tnb.com.my; puad@frim.gov.my; howaimun@frim.gov.my)

Tropical rainforests store diverse plant species with wide range of uses and of significance to the community and industries. This study was conducted in collaboration with the local Energy Authority Research Institution to evaluate selected plant and tree species growing in the wild and also secondary tropical moist forest. Seven plant species namely Leucaena leucocephala, Shorea roxburghii, Pennisetum purpureum, Gliricidia sepium, Macaranga spp., Acacia mangium and Melaleuca cajuputi were screened for their energy properties. Data obtained showed that Melaleuca cajuputi was highly potential that produces the best index. However, final selection will also take into consideration species suitability for planting under transmission lines.

\section{C5t: FOREST PRODUCTS}

\section{Factors influencing consumer tea purchase behavior in China: a study of mianzi, renqing and sustainability awareness}

Lingyun Tong ${ }^{l, 2}$, Lei Wang ${ }^{1}$, Anne Toppinen ${ }^{2}$

${ }^{1}$ Zhejiang A\&F University, Hangzhou, China; ${ }^{2}$ UniversityOf Helsinki, Helsinki,Finland(2578719866@qq.com; waleland@foxmail.com; anne.toppinen@helsinki.fi)

Previous literature has used the concept of Consumer Style Inventory (CSI) to explore factors driving consumer purchase behavior in China. Yet, the role of underlying norms, in particular Chinese mianzi and renqing, remains unclear. Growing consumer awareness of sustainability is also a potentially influential factor. The aim of our study is to gain a better understanding of tea consumption by examining the impacts of mianzi, renqing and consumer sustainability 
awareness on tea purchase decision-making when tea is purchased either as a gift or for household self-use. We use factor analysis to identify five dimensions in Chinese consumers' tea purchase decision-making. Using logistic regression analysis on survey data from Zhejiang province, we examine the relationship between reclassified Chinese consumer decision-making styles and two consumer shopping purposes. The main findings of this study are as follows: Firstly, the likelihood of tea purchases for gift giving is positively influenced by brand and prestige consciousness, while the likelihood of tea purchases for selfconsumption is positively influenced by sustainability awareness. The implications are: firstly, consumer segmentation according to purchase purpose is a potentiality for tea suppliers; Secondly, there is also merit in studying the effects of brand and prestige consciousness on other consumer products that are popular in gift-giving traditions in China.

\section{Dermato-cosmetic plants uses in rural communities of the Kara District in Togo}

Koudjoukalo Judith Pouwéréou Nabade ${ }^{1,2}$, Wouyo Atakpama ${ }^{1,3}$, Hodabalo Pereki ${ }^{1}$, Komlan Batawila $^{1}$, Koffi Akpagana $^{1}$

${ }^{1}$ Université de Lomé, Laboratoire de Botanique et Ecologie Végétale, Lomé, Togo; ' Université de Lomé- Faculté des Sciences de la Santé, Lomé, Togo; ${ }^{3}$ Institut National de Formation Agricole de Tové, Kpalimé,Togo (judith.nabede@gmail.com; wouyoatakpama@gmail.com; perekihodabalo@gmail.com; batawilakomlan@gmail.com;koffi2100@gmail.com)

The present study is a contribution to the valorization of plant resources used in traditional cosmetics. More specifically, it aims to: (i) census plant species used in traditional cosmetics; (ii) describe the various forms of use of these resources and (iii) assess indigenous knowledge on cosmetic plant species according to ethnicity, age, sex, and occupation. Information was gathered based on ethnobotanical semi-structured individual and focus groups interviews of 316 informants. Data analyse was based on use indices of plant species and plant parts. One hundred twenty-five (125) plant species belonging to 109 genera and 47 families used in indigenous cosmetic practices were reported. The most represented families were: Poaceae, Papilionaceae, Combretaceae, Caesalpiniaceae, Malvaceae, and Rubiaceae. The listed plants were used for 24 cosmetic effects. The most reported species was Vitellaria paradoxa (26.26\%). Depending on the specific use, 3 cosmetic groups were discriminated: the classical cosmetics, the clothing cosmetics, and dermatological plants. Leaves were the most used organs (56\%). The poultice is the main method of preparation of dermatological plants. Remedies were essentially administered topically. Complementary studies, in particular the evaluation of efficacy and toxicological tests, are necessary for better valorization of plants for cosmetic purposes.

\section{Trade in pangolin parts in Southern Benin, West Africa}

Etotépé A. Sogbohossou ${ }^{1}$, Chabi Djagoun ${ }^{2}$, Brice Sinsin ${ }^{2}$, Ray Jansen ${ }^{3}$

${ }^{1}$ University of Abomey-Calavi, Cotonou, Benin; ${ }^{2}$ University of Abomey-Calavi, Abomey-Calavi, Benin; ${ }^{3}$ Tshwane University of Technology, Pretoria, South Africa (etotepe@gmail.com; dchabi@gmail.com; bsinsin@gmail.com;jansenr@tut.ac.za)

Our world is acknowledging an unprecedented species extinction crisis mainly due to human activities correlates such as habitat degradation and illegal trade. Pangolins are the animal species the most threatened by illegal trade. Despite increasing efforts, people continue to hunt the species in forests and the trade is still important. In Africa, research that should support conservation actions is relatively limited. In order to improve actions to save pangolins in West Africa, we surveyed seven markets in Southern Benin and few stakeholders around Lama Forest, the main protected area in southern Benin. Parts of pangolins were found in all investigated markets; $19.6 \%$ of sellers in markets had pangolin products but they have all sold once pangolin products. The most used parts are the head and scales. Pangolins products are bought by a variety of clients, mainly for magical purposes. Despite two pangolin species (Phataginus tricuspis, $P$. tetradactyla) are reported to be present in Benin, three species were identified in markets. Nigeria is the first foreign provider of pangolin products in the area. Sellers got pangolins by-products mostly from local and national markets and also from neighbouring countries. Most stakeholders were aware of the threatened status of the species. The pangolin trade is very profitable and products are sought-after. This study that confirms the importance of pangolin trade despite efforts by the government and NGOs and local people awareness. The law should be enforced but the dialogue with the poor local people should be considered.

Analysis of the locational pattern in the market for forest-based products in Paraná, Brazil: 2005-2015 / Uma Análise do padrão locacional para o setor paranaense de produtos de base florestal: 2005-2015

Keila Corrêa Bittencourt ${ }^{1}$ D, Vitor Afonso Hoeflich ${ }^{1}$ (D, João Carlos Garzel Leodoro da Silva ${ }^{1}$, Junior Ruiz Garcia ${ }^{1}$, Romano Timofeiczyk Junior ${ }^{1}$

${ }^{1}$ Universidade Federal do Paraná, Curitiba, Brasil; ${ }^{1}$ Universidade Federal do Paraná, Curitiba, Brasil (keila_cbittencourt@yahoo.com.br; vitor.ufpr@gmail.com; garzelufpr@gmail.com;jrgarcia1989@gmail.com; romano.timo@gmail.com)

A degradação dos recursos florestais nativos colocou em evidência a importância do desenvolvimento das plantações florestais como fontes alternativas de recursos naturais. Assim, o setor florestal tem assumido um importante papel econômico, social e ambiental nas estratégias de desenvolvimento das regiões. Neste contexto, o objetivo deste artigo foi analisar o Quociente Locacional (QL) para os principais produtos de base florestal por mesorregião paranaense entre 2005 e 2015, tais como sementes, mudas, lenha, serraria e laminador, papel e celulose, e outros (nó de pinho, álamo, mourão, lascas e resíduos florestais).O uso do QL se deve ao fato de se observar escassez de trabalhos utilizando tal método na área florestal. Além disso, o período foi selecionado de acordo com a disponibilidade de informações da Secretaria da Agricultura e Abastecimento (SEAB). Os resultados indicaram oscilações tanto positivas quanto negativas no período analisado. Essa dinâmica está relacionada as questões sazonais, burocráticas e de mercado. As conclusões levaram em consideração a cadeia produtiva da madeira para interpretar os resultados e não somente as especificidades de cada produto. Também, constatou-se que é imprescindível a atuação do Estado, por meio de suas instituições para que haja melhor desenvolvimento de cada região, bem como dos produtos comercializados.

Using cover crops for weed control in cultivating mate (Ilex paraguariensis) / Uso de coberturas vegetais no controle de plantas daninhas na cultura da erva-mate

Ives Clayton Gomes dos Reis Goulart ${ }^{1,2}$, Bruno Brasileiro' ${ }^{2}$, Delmar Santin ${ }^{3}$, Ivar Wendling ${ }^{1}$, Joel Ferreira Penteado Júnior ${ }^{1}$

${ }^{1}$ Embrapa Florestas, Colombo, Brasil; '2Universidade Federal do Paraná, Curitiba, Brasil; ${ }^{3}$ Cambona, Machadinho, Brasil (ives.goulart@embrapa.br; brasileiro@ufpr.br; desantinflorestal@yahoo.com.br; ivar.wendling@embrapa.br;joel.penteado@embrapa.br)

A erva-mate é uma espécie nativa do Brasil e seu cultivo é importante na Região Sul. Entretanto, alguns fatores limitam a produtividade, como a competição com plantas daninhas (PD). O objetivo deste trabalho foi avaliar a supressão de PD por coberturas vegetais (CV) em um plantio de erva-mate sombreada. O experimento foi instalado no município da Lapa, Paraná, Brasil, em erval comercial com 2 anos. O delineamento experimental foi blocos casualizados em parcelas subdivididas, sendo alocados nas parcelas o fator CV e na subparcelas o fator adubação da erva-mate em estágio de formação de copa. Foram testadas seis CV: PD, Arachis pintoi, Axonopus compressus, Lupinus albus+Cajanus cajan, Avena strigosa+Penissetum glaucum e $A$. strigosa+C. cajan. A adubação teve 
dois níveis: sem adubação e com adubação. Foi avaliada a massa seca (MS) das CV e das PD ao final dos ciclos hibernal e estival. Os dados foram submetidos à análise de variância e ao teste SNK. A espécie $A$. compressus reduziu $80 \%$ da MS das PD, sendo o maior efeito supressivo observado, enquanto que a combinação $L$. albus $+C$. cajan teve o menor efeito, sem redução de MS de PD. A adubação da erva-mate na fase de maturação de copa não afetou o incremento de MS das PD e das CV. As CV são uma alternativa interessantes para controlar PD em ervais, sem a necessidade de utilizar herbicidas.

Estimated potential yield of mate (Ilex paraguariensis) planted in São Mateus do Sul, Paraná, Brazil / Estimativa do rendimento potencial de erva-mate plantada em São Mateus do Sul, Paraná, Brasil

Ives Clayton Gomes dos Reis Goulart ${ }^{1,2}$, Bruno Brasileiro', Ricardo Oliveira², Delmar Santin ${ }^{3}$, Joel Ferreira Penteado Júnior

${ }^{1}$ Embrapa Florestas, Colombo, Brasil; ${ }^{2}$ Universidade Federal do Paraná, Curitiba, Brasil; ${ }^{3}$ Cambona, Machadinho, Brasil

(ives.goulart@embrapa.br; brasileiro@ufpr.br; rico@ufpr.br; desantinflorestal@yahoo.com.br; joel.penteado@embrapa.br)

A erva-mate é uma espécie nativa do Brasil e seu cultivo é importante na Região Sul. O avanço dos sistemas de produção e do melhoramento genético aumentou a produtividade da erva-mate. Entretanto, não é conhecido o rendimento potencial (RP) da espécie. O objetivo do trabalho foi estimar o RP utilizando modelos clássicos e discutir os principais fatores que afetam o rendimento da erva-mate comercial. O município selecionado foi São Mateus do Sul-PR. Foram obtidos da literatura o Índice de área foliar, a eficiência de uso da radiação e os dados necessários para calcular o índice de colheita da erva-mate (IC). O IC foi calculado dividindo-se a massa seca (MS) da erva-mate comercial pela soma da MS da erva-mate comercial com a MS de galhos grossos. A radiação solar, temperatura e horas de brilho solar foram obtidas da estação meteorológica São-Mateus-do-Sul-A874 (2583’56”'S/ 50³6’89”'W) do INMET. Os dados meteorológicos são referentes ao período de 02 de janeiro de 2017 a 02 de junho de 2018, totalizando um ciclo de 546 dias, correspondendo ao ciclo produtivo de um erval comercial. Os métodos utilizados foram propostos por Doorenbos e Kassam (DK), Sinclair (SI) e Loomis e Williams (LW). O RP estimado para São Mateus do Sul-PR foi de $154.039 \mathrm{~kg} / \mathrm{ha}, 64.550 \mathrm{~kg} / \mathrm{ha}$ e $17.576 \mathrm{~kg} / \mathrm{ha}$ pelos métodos DK, SI e LW respectivamente. Estudos sobre o RP da erva-mate servem como referência para o manejo de ervais e para pesquisas em melhoramento e sistemas de produção.

\section{User friendly forestry research}

Swoyambhu Amatya ${ }^{1}$, Shiva Sundar Shrestha ${ }^{2}$

${ }^{1}$ Former Secretary, Ministry of Forests and Soil Conservation, Kathmandu, Nepal; ${ }^{2}$ Former Director General, Ministry of Agriculture Development, Kathmandu, Nepal (swoyambhu_amatya@yahoo.com; shivastha1951@gmail.com)

Are we conducting forestry research that is conducive to user? Why should we, and for whom forestry research should be carried out? Obviously it is for the overall all development of end users (both large and small scale industries). But in most of the cases, we seldom seek the need of end user, pay attention while selecting research topic and help them out in accelerating their business. A country wide survey carried out in 2017 revealed that Nepalese forest based industries, both timber and non-timber, used to run depending on the raw materials available in natural forests. These industries used to be one of the important revenue sources for the government in the past. Ample and various type of employment were also generated and out migration of Nepalese youths were negligible. In the absence of raw materials available in nature most forest based industries are either not functioning or operating in a lower scale. One of the reasons for this was the unavailability of appropriate forestry research results that users can use and or apply in a simple way followed by complexity of implementing research results and policies related with forestry and industries. This paper examines the factors that hindered operating forestry based industries in Nepal and suggests how forestry research results help in providing industrial raw materials in perpetuity, and provides important features of existing policies that needs to be reviewed.

\section{C5U: FOREST PRODUCTS}

\section{Behavior of oriented strand board during natural weathering / Comportamento de painel de partículas orientadas (OSB) frente ao intemperismo natural}

Matheus Couto Crisóstomo ${ }^{1}$, Marcella Hermida de Paula ${ }^{1}$, Joaquim Carlos Gonçalez ${ }^{1}$, Cláudio Henrique Soares Del Menezzi ${ }^{1}$, Ana Paula Diniz Nakamura ${ }^{2}$ ${ }^{1}$ Universidade de Brasilia, Brasilia, Brasil; ${ }^{2 S}$ Serviço Florestal Brasileiro, Brasília, Brasil (matheuscc50@hotmail.com; marcellahermida@hotmail.com; goncalez@unb.br; cmenezzi@unb.br; ana.nakamura@florestal.gov.br)

A qualidade da madeira e seus derivados pode ser alterada por intempéries que podem diminuir sua vida útil, bem como alterar a sua cor, que é um fator preponderante no mercado madeireiro, muitas vezes determinando seu preço final, principalmente quando utilizada em ambientes externos. Nesse contexto, o objetivo deste estudo foi avaliar o processo de degradação de painel OSB (painel de partículas orientadas) submetida a exposição intemperismo natural, durante período de 12 meses. O teste de colorimetria foi realizado utilizando um espectrofotômetro, de acordo com os parâmetros colorimétricos definidos pelo sistema CIELAB proposto por Gonçalez (1993). Os painéis apresentaram alteração de cor muito apreciável $(\Delta \mathrm{E}=23,09)$ frente ao intemperismo já nos primeiros três meses, alterando da cor amarelo-claro para oliva. A variação da cor se manifestou, principalmente, pela redução na Luminosidade ( $L^{*}$ ), passando de 68,74 para 50,22, e das alterações do componente vermelho-verde (a*) de 9,38 para 5,48, do componente azul-amarelo (b*) de 33,16 para 13,39. O percentual de reflectância caiu sensivelmente para os períodos de 3 a 12 meses, comportamento que pode estar associado ao escurecimento apresentado pelo material. As condições climáticas de precipitação, radiação global e temperatura média apresentaram correlação negativa significativa com todos os parâmetros colorimétricos. Já a temperatura média não apresentou correlação definida com os parâmetros. Por tanto, o painel OSB não é recomendado para uso externo sem a aplicação de tratamentos complementares, pois apresentou alto grau de fotodegradação logo aos três meses de exposição ao intemperismo natural.

\section{Performance of acidic lignin-based surface coatings on plywood panels}

Rosilani Trianoski ${ }^{1}$, Christophe Belloncle ${ }^{2}$, Thiago Souza Rosa ${ }^{1}$, Sérgio Saraiva ${ }^{3}$

${ }^{1}$ Universidade Federal do Paraná, Curitiba, Brasil; '2École Superiéure du Bois, Nantes, France; ${ }^{3}$ Suzano Papel e Celulose SA, São Paulo, Brasil (rosilani@ufpr.br; christophe.belloncle@ecoledubois.fr; thiagosouzadarosa@gmail.com; ssaraiva@suzano.com.br)

Plasticized and resin-coated plywood panels have stood out in Brazil in the last years, especially in civil construction, for example in concrete forms, slabs, and scaffolding. This economical growth is mainly due to the characteristics of the coating, which provides greater resistance to humid environments and especially the possibility of reuse, which consequently reduces the costs. One way of adding more value to the plywood panels for this type of application is through the 
development of bio-resourced green coatings from lignin, especially acidic lignin, which main properties is their water insolubility. The aim of this study was to evaluate the performance of lignin-based coatings on plywood panels. Commercial Pinus Sp. panels were used (15 mm weight; 13 veneers; phenolic resin); two types of coatings were applied to the panels: 1 ) acidic lignin powder; 2) lignin aqueous solution (32.5\%) with addition of non-ionic surfactant. Coatings (180g/ $\mathrm{m}^{2}$ ) were dried at a temperature of $160{ }^{\circ} \mathrm{C}$ with a cure time of $5 \mathrm{~min}$. The performance of the coatings was evaluated by surface water absorption and thickness swelling after 2 and 24 hours, steam absorption, and abrasion resistance. Uncoated panels were used as control except for the latter. Coated Panels showed greater dimensional stability than the control. Both coatings absorbed a smaller amount of steam than the control. The wear rate ranged from 27.11 to 57.82 $\mathrm{mg} / 100$ cycles and the water-based coating had the best performance. It was concluded that acidic lignin-based coatings provide greater stability to plywood panels, which can increase durability and reusability.

Potential for Eucalyptus camaldulensis Dehnh wood in the production of oriented strand board panels / Potencial da madeira de Eucalyptus camaldulensis Dehnh para a produção de panéis estruturais OSB

Maximiliano Umlandt ${ }^{1}$, Thiago Souza da Rosa ${ }^{2}$, Estela Pan ${ }^{1}$, Juan Carlos Medina ${ }^{1}$, Vanesa Jiménez ${ }^{1}$

${ }^{1}$ Universidad Nacional de Santiago del Estero, Santiago del Estero, Argentina; ${ }^{2}$ Universidade Federal do Paraná, Curitiba, Brasil

(maximiliano.umlandt@gmail.com; thiagosouzadarosa@gmail.com; epan@unse.edu.ar; jcmedina@unse.edu.ar; paulavanesajimenez@gmail.com)

O presente trabalho teve como objetivo investigar o potencial da madeira de Eucalyptus camaldulensis Dehnh para a produção de painéis Oriented Strands Board (OSB). Para isso foi realizada uma intensa revisão bibliográfica a qual consistiu na análise de diversos artigos científicos e técnicos, livros, manuais, normas nacionais e estrangeiras, permitindo dessa forma, discutir as variáveis mais importantes no processo produtivo de painéis OSB, como: matéria-prima de utilizada, densidade do painel, geometria das partículas, processo de secagem, adesivos, aditivos, pressão, temperatura e umidade final; em relação às características que a madeira de Eucalyptus camaldulensis apresenta: massa específica, acidez, presença de extrativos e inclusão da casca. A partir da revisão pode-se afirmar que a densidade da madeira de Eucalyptus camaldulensis $\left(0,89 \mathrm{~kg} / \mathrm{dm}^{3}\right)$ é maior do que o recomendado para produção de painéis OSB, no entanto estudos realizados com madeiras cujos valores de densidade são semelhantes aos desta espécie, atenderam os requisitos mínimos exigidos pelas normas, concluindo assim que é viável para realizar testes com a madeira de Eucalyptus camaldulensis a fim de obter-se painéis OSB que atendam os valores exigidos pelas normas.

Propagating tension waves in assessing wood quality from two Amazonian tree species / Propagação de ondas de tensão na avaliação da qualidade da madeira de duas espécies arbóreas da amazônia

Claudete Catanhede do Nascimento ${ }^{1,2}$, Joelma Araujo Costa ${ }^{2,3}$, Giselle Larissa Rebouças Couto Silva ${ }^{2,4}$, Cristiano Souza do Nascimento ${ }^{5,6}$, Roberto Daniel de Araujo ${ }^{1,5}$

${ }^{1}$ Intituto Nacional de Pesquisas da Amazônia, COTEI, LEAM, Manaus, Brasil; ${ }^{2}$ Univeridade Federal do Amazonas, Programa de Pós-Graduação em Ciências Florestais e Ambientais, Manaus, Brasil; ${ }^{3}$ Universidade Federal do Acre, Cruzeiro do Sul, Brasil; ${ }^{4}$ Universidade do Estado do Amazonas, Itacoatiara, Brasil; ${ }^{5}$ Instituto Nacional de Pesquisa da Amazônia, Programa de Pós-Graduação em Ciências de Florestas Tropicais, Manaus, Brasil; ${ }^{6}$ Universidade Federal do Amazonas, Manaus, Brasil (catanhed@inpa.gov.br; joelmaalencar3@gmail.com; reboucasgiselle@gmail.com;

s-nascimento@hotmail.com; rdanielrda@gmail.com)

A avaliação não destrutiva (AND) é definida como a ciência que identifica as propriedades físicas e mecânicas de determinado material, sem alterar sua capacidade de uso final. Entre as técnicas mais empregadas para avaliação da qualidade da madeira, estão àquelas baseadas nas características acústicas, tais como: Propagação de Ondas de Tensão, Ondas de Ultrassom, Vibração Transversal e Vibração Longitudinal. O objetivo deste estudo foi determinar a qualidade da madeira das espécies nativas da Amazônia Jacarandá copaia (Vell). A. DC - Bignoniaceae (Caroba) e Pithecelobium racemosum Ducke - Fabaceae (Angelim rajado) por método não destrutivo. As amostras ensaiadas neste trabalho foram obtidas de uma serraria da cidade de Manaus (Amazonas/Brasil); 30 peças de madeiras nas dimensões de 25 mm x 100 mm x 660 foram manufaturadas no LEAM/COTEI/INPA e o Módulo de Elasticidade Dinâmico (MOEd) foi determinado a partir da emissão de ondas de tensão produzidas por Stress Waver Timer, onde o tempo de propagação de onda na peça de madeira foi utilizado nos cálculos. Para a Densidade Aparente considerou-se a umidade a $12 \%$, na determinação do volume por medição com paquímetro digital. As classes de qualidade pela resistência a partir do MOEd variou para Caroba de 103.088,77 - 147.126,09 kgf/ $\mathrm{cm}^{2}$, e para Angelim rajado de $138.677,93$ - 157.713,29 kgf/cm², enquanto a densidade aparente variou de $0,38-0,47$ e $0,94-0,98 \mathrm{~g} / \mathrm{cm}^{3}$, respectivamente. A técnica utilizada mostrou-se eficiente na avaliação destrutiva das madeiras da região quando comparado com a metodologia tradicional.

Exploring chemical compounds in extracts of Eschweilera coriaceae (DC.) S. A. Mori. e Eschweilera truncata A.C. Sm. (Lecythidaceae) I Prospecção de compostos químicos em extrativos de Eschweilera coriaceae (dc.) S. A. Mori. E Eschweilera truncata a.c. Sm. (Lecythidaceae)

Cristiano Souza do Nascimento ${ }^{1,2}$, Claudete Catanhede do Nascimento ${ }^{3,4}$, Niro Higuchi ${ }^{5}$, Maria da Paz Lima ${ }^{3}$, Irineide de Almeida Cruz ${ }^{3}$

${ }^{1}$ Programa de Pós-Graduação em Ciências de Florestas Tropicais, Instituto Nacional de Pesquisa da Amazônia, Manaus, Brasil; ${ }^{2}$ Universidade Federal do Amazonas, Manaus, Brasil; ${ }^{3}$ Instituto Nacional de Pesquisas da Amazônia, COTEI, Manaus, Brasil; ${ }^{4}$ Programa de Pós-Graduação em Ciências Ambientais e Florestais, Universidade Federal do Amazonas, Manaus, Brasil; ${ }^{5}$ Instituto Nacional de Pesquisas da Amazônia - INPA/CDAM, Manaus, Brazil (s-nascimento@hotmail.com; catanhed@inpa.gov.br;niro@inpa.gov.br; mdapazlima@inpa.gov.br;irineide@inpa.gov.br)

Espécies florestais do gênero Eschweilera são conhecidas na Amazônia como matá-matá. Apesar da grande variabilidade de espécies deste gênero, pouco se conhece sobre sua natureza química. Metabolitos secundários presentes na madeira podem auxiliar na identificação botânica atuando como marcadores taxonômicos. Propriedades físicas e biológicas da madeira também podem ser associadas à presença destes compostos, além de revelar características específicas que possam indicar o correto uso na indústria madeireira. Este trabalho teve como objetivo identificar a presença de compostos químicos em extrativos da madeira de Eschweilera coriaceae e Eschweilera truncata (Lecythidaceae). Três indivíduos de cada espécie foram obtidos da Estação Experimental de Silvicultura Tropical/INPA/BRASIL. A serragem a 60 mesh foi utilizada para a obtenção dos extratos hidrofílicos (50 oC), e a triagem fitoquímica foi realizada submetendo-se os extratos a diversos testes qualitativos de precipitação e coloração específicos (18 ensaios), a fim de obter o perfil dos constituintes químicos das espécies. Os resultados da prospecção indicaram a presença de antraquinonas, cumarinas, esteróides, saponinas e taninos condensados/hidrolisáveis nos extrativos das duas espécies. Os extrativos de E. coriaceae continham ainda alcalóides e catequinas, Substâncias detectadas têm funções de defesa contra patógenos, ação protetora contra temperaturas elevadas, radiação UV, influência no pH, densidade básica entre outros. O extrativo de E. coriaceae apresentou maior riqueza em classes químicas, sendo que estes resultados demonstram a importância da prospecção química na distinção das espécies, corroborando para a melhor indicação/uso de espécies tropicais de forma sustentável. 


\title{
Adding value to forest products of secondary atlantic forests in Southern Brazil
}

\author{
Alexander Christian Vibrans ${ }^{1}$, Alfredo Celso Fantini ${ }^{2}$, Daniel Augusto da Silva ${ }^{1}$, Heitor Felippe Uller ${ }^{1}$, Aline Renata Klitzke ${ }^{1}$, Geferson Piazza ${ }^{1}$, \\ Jackson Roberto Eleotério ${ }^{1}$ \\ ${ }^{1}$ Fundação Universidade Regional de Blumenau, Blumenau, Brasil; ${ }^{2}$ Universidade Federal de Santa Catarina, Florianópolis, Brasil (acv@furb.br; \\ alfrdeo.fantini@ufsc.br; daneflorestal@gmail.com; heitor.uller:florestal@gmail.com; klitzkealine@gmail.com; gefersonpiazza@gmail.com; eleoterio@furb.br)
}

Perception of the importance of secondary forests has grown recently. Their role as carbon sink, provider of ecosystem services and multiple forest products both for smallholders and for large scale industrialization has been recognized. However, legal restrictions on sustainable use are still hindering innovative practices within the Atlantic Forest Biome. We report the experience of a pilot management project in a 40 year old restored secondary stand of subtropical evergreen moist forest in Santa Catarina state. Native tree species had been originally planted in the 1970 ies; nowadays it's composition and structure is similar to a natural secondary forest. Different management strategies and harvesting intensities have been tested since 2012 . Early secondary species like Miconia cinnamomifolia are harvested at their final age and with DBH up to $35 \mathrm{~cm}$; long-lived secondary species like Hyeronima alchorneoides, Cedrela fissilis and Nectandra sp. are submitted to selective logging: poor quality trees are harvested, future crop trees are favoured. Harvesting damages, canopy cover parameters, increment of adults, regeneration and gap colonization are continuously monitored. The harvested timber is processed in the stand owner's sawmill. Boards and other sawnwood products achieve competitive prices, consisting in an important revenue for the landowner. In addition, local craftsmen transform small pieces of hardwood species like $H$. alchorneoides, as leavings from the harvesting process (stumps, branches and damaged trunks) and others from the sawmill processing, into unique and individualized artefacts used in indoor architecture, designed by associated architects and for an increasing local market for innovative and high standard habitations.

\section{Ilex microdonta Reissek (Aquifoliaceae) trees in high summits of Serra do Mar mountain range in Southern Brazil: a first approach for climate reconstructions}

Bruno Palka Miranda ${ }^{1}$, Carlos Vellozo Roderjan ${ }^{1}$, Paulo Cesar Botosso ${ }^{2}$, Tomaz Longhi-Santos ${ }^{1}$

${ }^{1}$ Universidade Federal do Paraná, Curitiba, Brasil; ${ }^{2}$ Embrapa Florestas, Colombo, Brasil; ${ }^{1}$ Universidade Federal do Paraná, Curitiba, Brasil

(brunopalka@gmail.com; roderjan@ufpr.br; paulo.botosso@embrapa.br;longhi@ufpr.br)

For climate reconstructions we need a network of climate stations with good, long, concise and high-quality data, that is current unavailable in the Serra do Mar mountain range, Paraná, Brazil. As so, tree-ring chronologies can provide important data on climate, that can be reconstructed to understand the temperature variability in these mountains. The most important species of the tropical cloud forests in Paraná State, Ilex microdonta, form distinct tree rings and are sensitive to climate change, playing an important role in these communities. The objective of this research is to reconstruct the minimum temperatures in Serra do Mar and indicate the applicability of the technique in this region. The 30 trees for the chronology building (1802-2016) were sampled in Mãe Catira and Sete peaks (1,430 $\mathrm{m}$ a.s.l.), and the climate data for reconstruction were obtained by CRU temperature dataset (25,5 $5^{\circ}$; 49 $\left.{ }^{\circ} \mathrm{W}\right)$. We used PCR methodology with minimum AIC criteria for the best model evaluation. We were able to reconstruct 100 years of late spring and summer minimum temperatures, with $\mathrm{RE}$ and $\mathrm{CE} \geq 0.498$ and $\mathrm{R}^{2}=0.32$. Although the results indicate low statistics for climate reconstruction, this was the first approach with tree rings in the Tropical Montane Cloud Forests in Serra do Mar, representing an important contribution for this study field. We also reinforce the need to improve climate research in these areas, in order to better understand the impact of global climate change local and regionally.

\section{C5v: FOREST PRODUCTS}

\section{Evaluation of the effect of species and varnish on the quality of surface finish of some amazonian woods}

Rosilani Trianoski ${ }^{1}$, Christophe Belloncle ${ }^{2}$, Mark Irle $^{2}$, Setsuo Iwakiri ${ }^{1}$, Franck Michaud ${ }^{2}$

${ }^{1}$ Universidade Federal do Paraná, Curitiba, Brasil; '2École Superièuredu Bois, Nantes, France (rosilani@ufpr.br; christophe.belloncle@ecoledubois.fr; mark.irle@ecoledubois.fr; setsuo@ufpr.br;franck.michaud@ecoledubois.fr)

The Amazon Rainforest is one of the main producers of tropical timber, covering an area of 550 million hectares. From this amount, 320 million (60\%) are within the Brazilian territory. Besides, it houses about $50 \%$ of the world's biodiversity and $50 \%$ of the world's tropical timber reserve, with variability of up to 300 wood-producing species per hectare. Due to this variability, many species are still technologically unknown and consequently they are not commercially used, especially for high value-added products. Good surface finish will improve the look and durability of these products. Thus, this research evaluated the quality of surface finishes on Amazonian wood species; namely, Byrsonima crispa, Eschweilera odora, Eschweilera coriacea, Manilkara amazonica and Inga alba, harvested from the Experimental Station of Tropical Silviculture, INPA. Specimens with the dimensions 10x150x650mm were cut and prepared by planing and sanding (60-320). Alkyd, Acrylic Water Based, Nitrocellulose, Polyurethane varnishes were applied with specifications for internal use. Statistical analysis (Anova/Tuckey) was applied to evaluate the effect of species/varnish factors. The properties of the finishes were evaluated via gloss, adhesion and abrasion resistance tests (ABNT 14535:2008). The adhesion was classified as G1, with up to $5 \%$ of the detached film area, the polyurethane presented the lowest performance. The abrasion wear rate, adhesion and gloss were affected only by the varnish factor. Regarding the abrasion test, the nitrocellulose and polyurethane presented the lowest and highest performances, respectively. Therefore, it was concluded that the species factor had no effect on the properties of finishes.

Physical, mechanical, and chemical characteristics of piãozinho wood (Micrandropsis scleroxylon W. Rod. Euphorbiaceae) / Caracterização física, mecânica e química da madeira piãozinho (micrandropsis scleroxylon w. Rod. Euphorbiaceae)

Roberto Daniel de Araujo ${ }^{1}$, Cristiano Souza do Nascimento ${ }^{1}$, Joaquimdos Santos ${ }^{2}$, Claudete Catanhede do Nascimento ${ }^{3}$,

Estevão Vicente Cavalcanti Monteiro de Paula

${ }^{1}$ Programa de Pós-Graduação em Ciências de Florestas Tropicais, Instituto Nacional de Pesquisa da Amazônia, Manaus, Brasil; ${ }^{2}$ Instituto Nacional de Pesquisas da Amazonia, CDAM, Manaus, Brasil; ${ }^{3}$ Instituto Nacional de Pesquisas da Amazonia, Cotei, Manaus, Brasil; ${ }^{4}$ Universidade do Estado do Amazonas, Manaus,Brazil (rdanielrda@gmail.com; s-nascimento@hotmail.com; joca@inpa.gov.br; catanhed@inpa.gov.br; estevaompaula@gmail.com)

Na Amazônia, madeiras efetivamente explorada para fins comerciais estão restrita a pouco mais de uma dezena de espécies, entretanto, a floresta produz uma grande variedade, com elevada densidade populacional. A espécie Micrandropsis scleroxylon ocorre com grande freqüência em florestas de terra firme no Amazonas/Brasil, entretanto, seu baixo diâmetro e a falta de informações técnicas impossibilitam uma aplicação dessa biomassa. O trabalho teve como objetivos 
determinar as propriedades físicas, mecânicas e químicas da madeira piãozinho utilizando metodologia tradicional e não destrutiva. Amostras de três árvores foram obtidas da Estação Experimental de Silvicultura Tropical/INPA/BRASIL. Para os ensaios químicos obteve-se a serragem a 60 mesh (ASTM, 2013) e para os testes físico-mecânicos foram confeccionados corpos-de-prova de acordo com as normas técnicas de cada ensaio (NBR 7190, 1997). As concentrações de extrativos totais, polifenóis totais, solubilidade em água quente e $\mathrm{NaOH}$ para a madeira de piãozinho foram de 5,17\%, 8,91\%, 14,69 e 9,00\% respectivamente. Nestes materiais encontram-se vários compostos de baixo peso molecular, tais como resinas, gomas, terpenos, alcalóides, flavonóides entre outros. Para os macrocomponentes lignina e celulose os resultados foram 34,30\% e 48,18\%. Os resultados das propriedades físico-mecânicas estão dentro daqueles obtidos para madeiras amazônicas. O teor de umidade da madeira foi de 14,03\%, e sua superfície apresentou grã regular com textura média. A densidade básica foi de 0,645 g/cm³ , com MOE de 14,212 MPa. A caracterização tecnológica da madeira de piãozinho é uma etapa primordial para indicação desta espécie no manejo sustentável da Amazônia.

\section{Efficiency of four acetylation methods onto bleached cellulose fibres}

Thiago Souza da Rosa', Rosilani Trianoski ${ }^{1}$, Setsuo Iwakiri', Franck Michaud ${ }^{2}$, Christophe Belloncle ${ }^{2}$

${ }^{1}$ Universidade Federal do Paraná, Curitiba, Brasil; ${ }^{2}$ Ecole Supérieuredu Bois, Nantes,France (thiagosouzadarosa@gmail.com; rosillani@gmail.com; setsuo.ufpr@gmail.com; franck.michaud@ecoledubois.fr; christophe.belloncle@ecoledubois.fr)

For the development of natural fibres and thermoplastic polymers composites, chemical modifications are generally required for compatibilization. The esterification reaction promotes fibre surface functionalization from the reaction of the hydroxyl groups which are transformed into hydrophobic ester linkages, which consequently increases the hydrophobicity of the fibres and, therefore, the compatibility between the fibre and polymer. Acetylation is the widely esterification method used and has been used at an industrial scale because it is relatively simple, safe and inexpensive. Numerous acetylation methods can be used by varying the type of solvent, catalyst, time and temperature of reaction. The objective of this work was to evaluate the efficiency of 4 acetylation methods onto bleached Eucalyptus cellulose fibres. Bleached cellulose fibres was obtained through paper mill process. The acetylation was conducted using acetic anhydride as an acetylating agent, acetic acid or toluene as the solvent and sulfuric acid as the catalyst. Temperatures of $30^{\circ} \mathrm{C}, 60^{\circ} \mathrm{C}$ and $120^{\circ} \mathrm{C}$ were used. The acetylation time was 3 and 24 hours. Acetylated fibres were characterized for physical, chemical, and morphological aspects by acid-base titration, Fourier transform infrared spectroscopy, thermogravimetric analysis, X-Ray diffraction and scanning electron microscopy. All acetylation methods showed partial substitution of the hydroxyl groups for the acetyl groups. The crystallinity of the fibres was reduced according to the efficiency of the method. Changes in fibre morphology were significant mainly in acetylation methods with prolonged reaction time (24h). It was concluded that the acetylation methods conducted with longer reaction times are more efficient.

\section{A preliminary study of a resistive moisture meter in five exotic species planted in Brazil}

Joyce de Almeida Pinto ${ }^{1}$, José Guilherme dos Santos Moreira ${ }^{1}$, Ana Carla Bezerra de Lima ${ }^{1}$, Lucas Braga Moulin ${ }^{1}$, Djeison Cesar Batista ${ }^{1}$ ${ }^{1}$ Universidade Federal do Espirito Santo, Jerônimo Monteiro, Brasil; ${ }^{1}$ Universidade Federal do Espírito Santo, Jerônimo Monteiro, Brasil (joyce.agro@gmail.com; guimoreir@gmail.com; anacarla_blima@hotmail.com; lucasbmoulin@gmail.com; djeison.batista@ufes.br)

Although widely used in the wood industry, moisture measurements made with electric hand-held meters are only estimates. For more accurate measurements it is necessary to perform calibrations and comparisons based on the oven-drying method. This work aimed to carry out a preliminary study to determine the best scale of use of a resistive moisture meter in five exotic timber species planted in Brazil. The resistive-type meter Gann Hydromette HT65 and the species Eucalyptus grandis x E. urophylla, Khaya sp., K. senegalensis, K. ivorensis, and Toona ciliata were used. According to the results of the Student's t-test (paired) performed between measurements of the four scales of the device vs. those of the oven-dried method, it is preliminarily recommended to use the following scales by species: 2 - E. grandis x E. urophylla, Khaya sp. and K. senegalensis; 3 - K. ivorensis; and 4 - Toona ciliata.

Technological properties of murici wood (Byrsonima crispa Juss. - Malpighiaceae) / Estudo das propriedades tecnológicas da madeira de Murici (Byrsonima crispa Juss. - Malpighiaceae)

Roberto Daniel de Araujo ${ }^{1}$, Cristiano Souza do Nascimento ${ }^{2}$, Joaquim dos Santos ${ }^{3}$, Claudete Catanhede do Nascimento ${ }^{1}$, Niro Higuchi ${ }^{3}$ ${ }^{1}$ Instituto Nacional de Pesquisas da Amazônia, COTEI/LEAM, Manaus, Brasil; ${ }^{2}$ Programa de Pós-Graduação em Ciências de Florestas Tropicais - PPGCFT/ INPA, Manaus, Brasil; ${ }^{3}$ Instituto Nacional de Pesquisas da Amazônia, CDAM/LMF, Manaus,Brazil (rdanielrda@gmail.com; cristian@inpa.gov.br; joca@inpa.gov.br; catanhed@inpa.gov.br; niro@inpa.gov.br)

A caracterização tecnológica consiste na avaliação das propriedades químicas, físicas e mecânicas da madeira, com objetivo de indicar o uso racional. Os ensaios das propriedades da madeira são em geral destrutivos que demandam alto custo e tempo. A espectroscopia no infravermelho próximo (NIR) vem sendo utilizada para predição da qualidade da madeira. Esta ferramenta permite estimar várias características sem a necessidade de preparação da amostra, em menor tempo e com a mesma confiabilidade dos resultados dos ensaios tradicionais. O objetivo deste estudo foi caracterizar a madeira de Murici por meio de metodologia não destrutiva (FT-NIR). Byrsonima crispa tem grande ocorrência nas parcelas onde são inventariadas em vários sítios do Amazonas/Brasil, e apresenta em geral baixo diâmetro $(20-50 \mathrm{~cm})$ em relação a espécies madeireiras. Sua madeira é castanha escura, apresenta grã regular com textura média, a densidade básica foi de $0,49 \mathrm{~g} / \mathrm{cm}^{3}$, enquanto o teor de umidade foi de $12,30 \%$ e o poder calorífico superior foi de $4.873 \mathrm{kcal} / \mathrm{g}$. O modulo de elasticidade foi de 11.535 MPa. Esses resultados são semelhantes aos descritos para madeiras da Amazônia. Nas estimativas químicas, polifenóis totais e extrativos totais foram de 6,05 e 5,53\%, respectivamente, enquanto, para lignina e celulose bruta as concentrações foram de 32,52 e 55,62\%, e cinzas 0,61\%. Estes resultados foram preditos de modelos FT-NIR com alto coeficiente de correlação $\left(\mathrm{R}^{2}<0,90\right)$ e baixos erros de calibração e previsão. O resultado desta caracterização indica que a madeira de Murici pode se adequada para uso interior e não estrutural.

Consumption and sale of acai palm fruit by extractivist families in the Amazon River Estuarine region / Consumo e venda de açaí por famílias extrativistas de região Estuarina do Rio Amazonas

Erick Silva dos Santos ${ }^{1}$, Claudia Azevedo-Ramos ${ }^{1}$, Marcelino Carneiro Guedes ${ }^{2}$

${ }^{1}$ Núcleo de Altos Estudos Amazônicos, Universidade Federal do Pará, Macapá, Brasil; '2Embrapa Amapá, Macapá, Brasil (ericks_santos@hotmail.com; claudia.azevedoramos@gmail.com; marcelino.guedes@embrapa.br)

O fruto açaí é relevante na alimentação e ganhos econômicos de famílias extrativistas da Amazônia. O crescente aumento da demanda nos mercados nacional e internacional pelos seus sub (produtos) amplia a renda e o poder de compra das famílias, gerando o risco de redução da soberania alimentar. Neste estudo 
foram quantificados o consumo e a venda de açaí (rasas) por famílias extrativistas da Ilha das Cinzas, Gurupá-Pará. A técnica utilizada foi o monitoramento com "calendário do açaí", onde 28 famílias preencheram diariamente o consumo, a produção e o valor (U\$) da rasa de açaí durante os meses de março a junho de 2018. O consumo total familiar de açaí foi 1203 rasas/16240,5 kg, sendo abril e junho os meses de menor e maior consumo, respectivamente, média/família de 43 rasas/580 kg, aproximadamente. A produção total de açaí vendida foi 1731,5 rasas/23375,25 kg, média de 62 rasas/837 kg/família. Em média, o consumo representou $41 \%$ da produção, devido ao período de entressafra. Os meses de março e junho foram os de menor e maior volume vendidos, 42 rasas/567 kg e 919 rasas/12406,5 kg, com valor médio da rasa de 21,86 e 6,2, respectivamente. Os valores mínimo e máximo por rasa foram 2,69 e 61,83. O volume de açaí consumido e vendido pelas famílias demonstra a importância do açaí para a soberania alimentar e da atividade econômica para a região estuarina amazônica. Isso corrobora com estudos que indicam sua contribuição elevada na renda de famílias extrativistas ribeirinhas, em torno de 70\%.

\section{Effect of chipping edge inclination angle on size distribution of pulp chips produced by a chipper-canter}

Victor Grubîi ${ }^{1}$, Claudia Cáceres ${ }^{1}$, Roger Hernández ${ }^{1}$, Carl Blais ${ }^{1}$

${ }^{1}$ UniversitéLaval,Québec, Canada (victor.grubii@gmail.com; claudia.caceres@sbf.ulaval.ca; roger.hernandez@sbf.ulaval.ca; carl.blais@gmn.ulaval.ca)

The effect of oblique cutting on the chipping mechanism of the chipper-canter was studied. A bent knife type was modified in order to obtain an inclination angle (IA) of $30^{\circ}$ and $50^{\circ}$ between the chipping edge and the log feeding direction. The standard knife had an IA of $40^{\circ}$. These three knives were tested on 15 logs each, under frozen and unfrozen conditions. Logs knot characteristics and physical properties were measured. Experiments revealed that IA had a significant effect on chip formation mechanism. The IA affected how the chipping edge entered the log and the form of the wood slice that was transform into chips. These changes provoked variations in the chip size. A $30^{\circ}$ IA produce wider chips, mostly in the first half of the cut, shaped as an elongated parallelepiped that resulted from a tangential, oblique, and radial splitting in a single chip. Chips obtained with IAs of $40^{\circ}$ and $50^{\circ}$ resulted in chips shaped more as an upright parallelepiped that were detached mostly by radial and/or oblique splittings. At the beginning and at the end of the cut, chips were produced by tangential splitting. As a result, chip mean thickness increased with the decrease in IA. Knot ratio, basic density, heartwood moisture content, and total knot area were the main covariates affecting chip size distribution. Chipping of frozen wood reduced the chip size. The amount of acceptable chips increased by $6 \%$ due to an increase in the IA from $30^{\circ}$ to $50^{\circ}$ and by $8 \%$ when chipping unfrozen wood compared to frozen wood.

\section{Preparation and activity evaluation of tyrosol derivatives from olive fruit residue}

Zhihong Wang ${ }^{1}$, Chengzhang Wang ${ }^{1}$, Hao Zhou ${ }^{1}$

${ }_{1}^{1}$ Institute of Chemical Industry of Forest Products,CAF,nanjing,China(926289861@qq.com; wangczlhs@sina.com; zhouhaolhs@163.com)

Olive fruit residue is rich in hydroxytyrosol and other polyphenols, which haveantioxidant, lipid regulation, anti-tumor and other biological activities. The hydroxyl group in the side chain of hydroxytyrogenol can produce new $\beta$-ketoester compounds by transesterification. $\beta$-keto ester is considered to be an effective intermediate in organic synthesis because of its electrophilic carbonyl group and nucleophilic carbon. In this study, hydroxy tyrosol was used as the substrate to prepare $\beta$-ketone ester by transesterification, and then dihydropyrimidinone derivatives were prepared from the intermediate. The inhibitory effects of different target compounds on $\alpha$-glucosidase and $\alpha$-amylase activities were also investigated. The results showed that tyrosol $\beta$-ketone derivatives prepared by benzyl protected phenolic hydroxyl groups had better inhibitory effects on the two enzymes. At the same time, the inhibitory effect of 3,4-dihydropyrimidinone derivatives prepared by this kind of compounds on enzyme activity was significantly increased, and compared with other substituents, The inhibitory effect of fluorine derivatives on the two enzymes was more obvious. This study provides a new idea for the efficient utilization of olive fruit dregs, and has a certain reference value for the development of new active drug intermediates for the treatment of diabetes.

\section{C5W: FOREST PRODUCTS}

\section{Study of laccase-catalysed synthesis of urushiol coumarin derivatives and as hCA inhibitor}

Zhiwen $\mathrm{Qi}^{1}$, Hao Zhou ${ }^{1}$, Chengzhang Wang $^{1}$

${ }^{1}$ Institute of Chemical Industry of Forest Products, CAF,nanjing, China (angelkissgod@163.com; zhouhaolhs@163.com; wangczlhs@sina.com)

Lacquer laccase coexists with lacquer urushiol in Toxicodendron vernicifluum (Stokes). And T1 Cu location redox potential of it is lower than that of some laccase from bacterial colony, just reaching $430 \mathrm{mV}$. Laccase catalysis reaction is generally realized by oxidizing to free radicals which are reoxidized to large volume or substrate molecules with high redox potential energy. ${ }^{1}$ Acting as novel antitumor ingredients ${ }^{2,3}$, urushiol easily converts to coumarin derivatives which show human carbonic anhydrase (hCA) inhibitory activity. Since hCA inhibition is one of the underlying mechanisms that account for the activities of some antiepileptic drugs (AEDs), it’s expected to have anti-seizure properties. ${ }^{4}$ Herein, we designed as well as synthesized a series of novel C15 triene urushiol derivatives, and the results indicated that they are effective in inhibiting HepG2 proliferation. Moreover, we first analyzed the probable binding-modes of the most active compound by molecular docking algorithms, and calculated their enzymatic bioactivity against hCA. Consequently, some derivatives can excellently reduce the hCA expression.

Assessing the efficacy of natural products and by-products for preserving Guadua spp. bamboo collected from different microenvironments within a secondary forest in Rio Branco, Acre, Brazil / Avaliação da eficiência do uso de produtos naturais e residuais para a preservação dos colmos de Guadua Spp. Coletados em diferentes microambientes de uma Floresta Secundária- Rio Branco, Acre

Sangela Rodrigues ${ }^{1}$, Lucas Romeu ${ }^{1}$, Patrícia Amorim ${ }^{1}$, Leila Peters ${ }^{1}$, Marianne de Sá ${ }^{1}$, Michaela Queiroz ${ }^{1}$, Janaira Sousa ${ }^{1}$, Jessica Silva ${ }^{1}$, Moisés Lobão ${ }^{1}$

${ }^{1}$ Universidade Federal do Acre, Rio Branco, Brasil (sangelalimaa@gmail.com; lucas.romeu14@gmail.com; patriciagomesribeiro@gmail.com,

leilappeters@gmail.com; mariane_ps_@hotmail.com; michaelaqueiroz3@outlook.com; janaira.js@hotmail.com; jsnunes239@gmail.com; moiseslobao6@gmail.com)

Há atualmente uma visão integradora que coloca a Terra e a humanidade como unidades de um único sistema, considerando o meio ambiente como fonte de recursos, comum a todos, que deve ser utilizado de forma consciente, dentro dos limites de aceitação da natureza para servir às gerações futuras. Nesse cenário, o bambu é introduzido como fonte alternativa para suprir as demandas sociais, pois é um material renovável e de baixo custo, encontrado em abundância em regiões tropicais e subtropicais. Porém, a maior parte das espécies de bambu são susceptíveis ao ataque de fungos e insetos. Portanto, este trabalho objetivou avaliar a eficiência do uso de produtos naturais (água salinizada) e residuais (óleo de cozinha) para aumentar a resistência do colmo de Guadua spp. contra 
o ataque de fungos. Foram realizadas as seguintes etapas: i) coleta e identificação de colmos de Guadua spp. no interior e na borda da floresta do Parque Zoobotânico da UFAC; ii) tratamento dos colmos. com água salgada e óleo residual de fritura; iii) realização de ensaios de apodrecimento acelerado; e iv) avaliação de perda de massa das taliscas do colmo de bambu. Os resultados estatísticos de perda de massa mostraram que não houve diferença significativa entre os tratamentos utilizados e a testemunha, mas que as amostras tratadas com óleo residual tiveram menor perda de massa, no entanto, recomenda-se que o tempo de ensaio em campo deva ser estendido em estudos futuros, para que se possa ter uma melhor conclusão a respeito desses resultados.

Impact on growth and yield of soybean plants after applying pyroligneous extract / Influência da aplicação de extrato pirolenhoso no crescimento e produtividade de plantas de soja

Darlan Einstein Livramento ${ }^{1}$, Adriana de Oliveira Vilela², José Urbano Alves², Núbia Rangel Cândido ${ }^{2}$, Karlane Oliveira Silva ${ }^{2}$, Ronaldo César Rizzo Ciancie $^{2}$

${ }^{1}$ Universidade do Estado de Minas Gerais, Unidade Passos, Passos, Brasil; ${ }^{2}$ Rima Industrial, Belo Horizonte, Brasil (darlan.livramento@uemg.br; adn@rima.com.br; urb@rima.com.br;nrc@rima.com.br;ksa@rima.com.br;rcc@rima.com.br)

O extrato pirolenhoso é obtido através da pirólise da madeira, sendo sua composição formada por substâncias de diferentes classes de compostos orgânicos. Entre suas funções destaca-se agente esterilizante, redutor de $\mathrm{pH}$, efeito quelante, antioxidante e indutor de resistência. Seu uso na agricultura ocorre a décadas, como melhoria da qualidade do solo, controle de pragas e doenças e como estimulante do crescimento de plantas. Sua combinação com fertilizantes também pode promover incrementos na produção. Dentro desse contexto o objetivo desse trabalho foi avaliar a aplicação de extrato pirolenhoso via foliar em plantas de soja (Glycine max (L.) Merr.), no estágio fenológico R1. O experimento de campo foi implantado em um delineamento em blocos casualizados (DBC) disposto em um esquema fatorial: quatro concentrações de pulverização: $0 \% ; 0,5 \%, 1,0 \%$ e 3,0\% e três variedades de soja. As avaliações realizadas foram de crescimento vegetativo: comprimento da parte aérea, comprimento de raízes e comprimento total realizado no momento da colheita e de crescimento reprodutivo: produção individual das plantas e produtividade. Os resultados obtidos demonstraram que houve diferença significativa $(\mathrm{p}<0,05)$ na interação concentração e variedades. Houve efeito das concentrações de pulverização na variedade BÔNUS 8579 RSF IPRO, onde a aplicação a 1,0\% promoveu maior comprimento em todas as características vegetativas avaliadas. Para a produtividade, independente da variedade, a concentração de pulverização a 1,0\% apresentou maior efeito nessa característica. Na análise da variedade foi observado que a Desafio RR - 8473RSF, foi mais produtiva em relação as demais também na concentração de pulverização a 1,0\%.

Assessing the volume of extraction and technique for harvesting Lepidocaryum tenue Mart. (Arecaceae) during the dry and flood periods of the Upper Itaya River Watershed, 2018-2019 / Evaluación del volumen de extracción y técnica de cosecha del irapay Lepidocaryum tenue Mart. (Arecaceae) en época de vaciante y creciente en la Cuenca Alta del río Itaya, 2018 - 2019

Adrian Alfredo Correa Huaman ${ }^{1}$, Roger Isuiza Naro ${ }^{1}$

${ }^{1}$ Universidad Cientifica del Perú, Iquitos, Peru (adrian.ingcorre@gmail.com; profeta.inca2051@gmail.com)

Lepidocarium tenue Mart. conocida en nuestra región como "irapay", usado tradicionalmente por el poblador amazónico como material de construcción en los techos de las casas. Esta investigación se realizó para ampliar nuestros conocimientos sobre el rol de este recurso en la vida del poblador de la selva. Se evalúan los volúmenes de extracción y la técnica de cosecha del "irapay" Lepidocarium tenue y se identifican las comunidades productoras del recurso en la cuenca alta del río Itaya; realizado entre los meses de agosto y noviembre del 2018, en época de vaciante. Para la obtención de datos, se realizaron encuestas semiestructuradas, fichas de registro y observación directa en campo. En el puerto Nuevo Cahuide, se ha registrado 850 cargas desembarcadas, equivalente a 283,334 plantas, procedente de la cuenca alta del río Itaya (comunidades categorizadas como productoras de materia prima), generando un ingreso promedio mensual de S/; 2,125.00 nuevos soles. Se ha encontrado, que solo el 60 \% aplican técnicas de manejo sostenibles en la cosecha del Irapay, no se destruye la planta, y se cosecha generalmente 3 hojas por individuo. En conclusión la mayor cantidad de cargas de Irapay son extraídas de los manchales de la comunidad Villa Belén debido a que la distancia ha permitido que pocos puedan acceder a este recurso y se encuentren en mejores condiciones en relación a las otras comunidades (Aguas Blancas, Luz del Oriente y 28 de Enero).

Technological innovations for traceability of forest products in Latin America / Innovaciones tecnológicas para la trazabilidad de productos forestales en Latinoamérica

Natalia Ruiz-Guevara ${ }^{1}$, Diego Delgado ${ }^{1}$, Fernando Carrera ${ }^{1}$, Mario Chacon ${ }^{1}$, Miguel Cifuentes Jara ${ }^{1}$

${ }^{1}$ Centro Agronómico Tropical de Investigación y Enseñanza,Turrialba, Costa Rica (natalia.ruiz@catie.ac.cr; ddelgado@catie.ac.cr; fcarrera@catie.ac.cr; mario.chacon@catie.ac.cr; miguel.cifuentes@catie.ac.cr)

La trazabilidad de productos de madera provenientes de bosques naturales, debe ser reforzada para reducir la ilegalidad y degradación de los bosques ligada a emisiones. El uso de tecnologías modernas puede ayudar a estos fines. Para identificar el potencial de innovaciones tecnológicas disponibles, se realizó una sistematización de experiencias de distintos países latinoamericanos.Se ha ensayado el uso de aplicaciones dispositivos móviles, códigos de respuesta rápida (QR), códigos de barras, censos forestales con chip, dispositivos de identificación por radiofrecuencia, polvo "Stardust" y análisis moleculares de ADN. Estas tecnologías, se integran con protocolos de monitoreo y uso de softwares de ordenamiento y procesamiento de datos, algunas veces vinculados a información geográfica y documentaria. Las aplicaciones para teléfonos móviles destacaron por su bajo costo, facilidad de difusión, compatibilidad con diversas funciones y sencillez de uso. Los códigos QR, ya sea impresos en documentos o en chips y etiquetas sobre productos forestales, destacan también por su bajo costo, capacidad para almacenar gran cantidad de información, facilidad de uso y compatibilidad de lectura a través de aplicaciones. Se recomienda la estandarización de los códigos de marcado e indicar información referente al área geográfica, permiso de aprovechamiento, especie forestal, año de cosecha y número de parcela de corta o árbol. Se recomienda el desarrollo de aplicaciones multiuso, para la cubicación de madera, identificación de especies comerciales, registro y control de la extracción y movilización de productos, lectura de dispositivos, entre otros. Se resaltan las experiencias de países como Brasil, Guatemala, Panamá y Surinam. 


\author{
Assessment of herbicidal potentials of three botanicals leave extract on weed associated with maize field in Oyo State, Nigeria \\ Nkechinyere Isienyi ${ }^{1,2}$, Ayodele Ipeaiyeda ${ }^{3}$, Joy Nwogwugwu ${ }^{1}$ \\ ${ }^{1}$ Forestry Research Institute of Nigeria, Ibadan, Nigeria; ${ }^{2}$ University of Ibadan, Ibadan, Nigeria; ${ }^{3}$ University of Ibadan, Ibadan, Nigeria, Ibadan, Nigeria \\ (isienyi.nc@frin.gov.ng; ayosade2003@yahoo.com; oluprince120@yahoo.com)
}

Maize is a major staple food crop widely grown in Nigeria but its production is constrained by weed-interference. Bio-herbicides are effective and eco-friendly in managing-weeds in some crops, its efficacy on maize have not been adequately documented. Therefore, herbicidal potential of Botanicals (Eucalyptus torreliana - Et, Eucalyptus camaldulensis - Ec and Leuceania leucocephala - Ll) extract in maize field were investigated. The experiment was laid out in CRD ( $\mathrm{r}=3$ ). Phytochemicals $(\mathrm{mg} / \mathrm{g})$ of the botanicals were determined using standard-procedures. Phytotoxicity of Botanicals at $100 \%, 75 \%, 50 \%, 25 \%$ were assessed on maize (DTMA-Y-STR) seed-germination using distilled-water as control in the Laboratory. Data on Percentage-Seed-Germination-PSG (\%) and Plumule-Length-PL $(\mathrm{cm})$ were assessed. In field, treatments: $100 \%, 75 \%, 50 \%, 25 \%, 0 \%$ of Botanicals and paraquat $(5 \mathrm{~mL} / \mathrm{L})$ were applied before-sowing and five weeks-after-sowing (WAS). Plant-height-PH (cm) and Grain-yield-GY (g/pot) were assessed at intervals of two-weeks starting from 3-WAS. RelativeImportant-Values-RIV were determined using standard-procedure. Data were analyzed using descriptive-statistics and ANOVA $\alpha 0.05$. The Phytochemical contents in Ec were higher in Total-phenols (32.0), tannins (27.4) and saponins (20.2). The PSG of maize in Ll was higher, ranged from $100.0 \pm 0.6$ in $25 \%$ to $100.0 \pm 1.2$ in $75 \%$. The PL was higher in Ll, ranged from $3.4 \pm 0.3$ to $11.3 \pm 0.6$. At 11-WAS, PH and GY both in Ec was significantly higher, ranged from $126.7 \pm 14.8$ to $140.5 \pm 12.3$, while GY ranged from $42.0 \pm 5.2$ to $68.4 \pm 8.5$. Mariscus-alternifolius had highest RIV of 48.7 at 3 -WAS in Ec-25\% and reduced to 18.9 in Ec-25\% at 9-WAS. Eucalyptus camaldulensis extract reduced weeds in maize-field, and enhanced grain-yield.

\title{
Inventory on deciphering interiors of commercially important Indian trees using 3D electrical resistivity tomography (ERT)
}

Nikhitha Cu${ }^{1}$, Baragur N. Divakara ${ }^{1}$, Mohan Karnat ${ }^{1}$

${ }^{1}$ Institute of Wood Science and Technology, Indian Council of Forestry Research and Education, Bengaluru, India (thoshitha.cu@gmail.com; bndsira@gmail.com; mohankarnat4@gmail.com)

Tree Tronic tomograms are one among the advanced non-destructive method aiding for tree inspection. This method gives high resolution with more precision in measuring the sapwood, heartwood, stress and decay in the living trees. Our study is to focus on the understanding of internal wood structural details using 3D images of Electrical Resistivity Tomography (ERT) of commercially important trees viz. Dalbergia latifolia Roxb. (Rosewood), Santalum album L. (Sandalwood), Tectona grandis L.f. (Teak) and Pterocarpus santalinus L.f. (Red sandalwood) of India. Initially, using ERT, the tree resistivity offered across the cross-sections of the stems at different heights from the ground were checked for the individual trees. The combined effect of moisture content in the sapwood and resistivity offered by heartwood gives a non-invasive 2D cross sectional images at each height with colour differentiation from blue (low resistance) to red (high resistance). In the healthy trees the concentric ring structure and the compactness of the wood at the center will offer maximum resistance and gradually decreases towards the bark. However, 2D images failed to give the overall scenario of the structural details at different heights of tree stem. Hence, the combination of 2D images of the individual trees was superimposed in the descending order with respect to the height measurements from the ground to give 3D images. The 3D imagery demonstrated in our study depicts the effective mode of representing the resistivity distributed along the stem to further differentiate the sapwood, heartwood, stress and decay in the standing tree.

Using dendochronology to assess yearly fruit production of Theobroma cacao L. in the Western Brazilian Amazon region / Uso da Dendrocronologia para avaliar a produção anual de frutos da espécie Theobroma cacao L. na Amazônia Ocidental brasileira

João Santos ${ }^{1}$,Neila Fernandes ${ }^{1}$,Michelle Siebra1, Maria Rosália Da Costa1, Gleyciane Dos Santos ${ }^{1}$,Moisés Lobão ${ }^{1}$
${ }^{1}$ Universidade Federal do Acre,Rio Branco,_Brasil (jo89ro@gmail.com; neila.fernandes@hotmail.com; michelle14florestal@gmail.com;
natureza.2@hotmail.com; annel8_5@hotmail.com; moiseslobao6@gmail.com)

A dendrocronologia é uma ciência que permite determinar a idade das árvores, e vários fenômenos naturais ocorridos durante a vida das árvores que ficam marcados em seus anéis de crescimento. Portanto, o objetivo desse trabalho foi analisar se os canais traumáticos existentes nos anéis de crescimento das árvores de Theobroma cacao são formados exclusivamente pelo pedúnculo desenvolvido para a nutrição dos seus frutos ou por outros tipos de traumas. Foram selecionadas aleatoriamente seis árvores em Dezembro de 2014, quando realizou-se injúrias na camada cambial do tronco em cada árvore a 1 metro acima do solo. Em Março de 2016 foram retiradas as amostras do lenho de forma não destrutiva em três pontos distintos: a- principal, b- $5 \mathrm{~cm}$ acima do principal e c- 5 cm abaixo do principal. Realizou-se o polimento desse material e com auxílio do estereoscópio (aumento 80x) foram obtidas fotos macroscópica na região radial do lenho: 1-próximo a casca, 2- região intermediária, 3- próximo a medula, para verificar os traumas presentes nas amostras. A reação dos tecidos caracterizou-se por camadas de células constituindo uma barreira química no tecido injuriado, diferindo do tecido formado nas regiões dos pedúnculos dos frutos caracterizado pela presença de canais gomíferos traumáticos, demonstrando que estes últimos são formados exclusivamente pelo pedúnculo do fruto. Diante do exposto podese inferir que a frequências do conjunto de canais traumáticos no lenho da árvore de Theobroma cacao possibilita estimar a produção anual de frutos das árvores através da analise de seus anéis de crescimento anuais.

C6a: THE ROLE OF FORESTS AND TREES IN THE NATURE-BASED SOLUTIONS DISCOURSE

\section{Moving beyond the nature-based solutions discourse: introducing nature-based thinking \\ Thomas Randrup ${ }^{1}$, Cecil Konijnendijk ${ }^{2}$ \\ ${ }^{1}$ Swedish University of Agricultural Sciences, Alnarp, Sweden; ${ }^{2}$ University of British Columbia, Vancouver, Canada (thomas.randrup@slu.se; cecil.konijnendijk@ubc.ca)}

The European Commission (2015) coined a frequently used definition of Nature-based Solutions (NBS); NBS being about "application of knowledge about nature, being inspired and supported by nature, and maintaining and enhancing natural capital". NBS may be a product of its times. In the 1980s 'Sustainability' was conceptualized with equal focus on environmental, economic and social considerations. Where Sustainability was a new paradigm in human relations with nature, NBS has an action focus. To date, NBS have primarily been considered as technical solutions (EEA, 2015). However, when implementing the SDG's (UN, 2015), actions needs to extend beyond sustainability thinking as well as beyond the current NBS technical approach. The EC (2015) stated that "there is a need to develop a systemic approach that combines technical, business, finance, governance, regulatory and social innovation related to NBS...". In line with this, we propose that the definition and scope of NBS are widened, to inspire a new Nature-based Thinking (NbT). We see NbT as an integrative way of 
acknowledging sustainability thinking, using the categorization of ecosystem services, and adapting these into a framework of knowledge about, inspiration and support from nature in our efforts to maintain and enhance natural capital, e.g. in the shape of forests and trees. NbT applies cross-disciplinary thinking, organizational approaches towards working beyond 'silos', and engaging with others across disciplines and sectors. It systemically involves stakeholders and activates citizens. We believe that NbT is a promising approach to securing long-term solutions to contemporary societal challenges.

\title{
Urban Forestry: in the vanguard of delivering nature-based solutions to our increasingly multi-cultural urban futures
}

\section{Alan Simson ${ }^{1}$}

${ }^{1}$ Leeds Beckett University, Leeds, United Kingdom (a.simson@leedsbeckett.ac.uk)

Cities are the fastest growing habitats on the planet, but research has shown that the degradation of our ecosystems caused by this rapid expansion has not only adversely affected 'nature' but also negatively affected human well-being. The multiple benefits to human well-being provided by urban forestry are increasingly being recognized but, over recent years, a number of related design concepts have been promoted to assist decision-makers in the task of improving the relationship between expanding cities and the natural world. One of the most recent is the concept of Nature-Based Solutions (NBS). Supporters argue that to inform decision-makers, natural assets should be assigned a value - financial or otherwise. Such an approach sees nature as an 'object' or a 'product', to have, to protect or ultimately to lose. Urban Forestry on the other hand, whilst acknowledging that giving nature a value can have some benefits, tends to see nature as a 'process'. Nature and recombinant ecology are activities, and an integral part of the design and life of the city. This presentation will consider whether nature and nature-based solutions should be deemed a 'product' or a 'process'. What cannot be denied is that trees have become a symbol of hope and life in our cities, and this presentation will conclude by suggesting that urban forestry is in the vanguard of delivering NBS and reconciliation ecology, and thus must be incorporated into the design of our increasingly multi-cultural cities as a pre-requisite of their future viability, both for humans and the natural world.

\section{Operationalizing nature based solutions through forests and trees}

Vincent Gitz ${ }^{1}$, Alexandre Meybeck ${ }^{2}$

${ }^{1}$ CIFOR, Bogor, Indonesia; ${ }^{2}$ CIFOR, Rome, Italy (v.gitz@cgiar.org; a.meybeck@cgiar.org)

"Nature based solutions" (NBS) are being increasingly promoted to address climate change and other societal challenges. They are defined as actions that use ecosystems to help societies address a variety of environmental, social and economic challenges in sustainable ways. NBS are explicitly considered as alternatives to human made infrastructures and integrate conservation and protection of biodiversity as a basis or a goal. The purpose of this intervention is to examine how the concept applies to forests and trees, how it relates to some other concepts that are already effectively used in forestry and to propose an operational framework to provide NBS through forests and trees. Three main types of NBS have been identified: making better use of existing natural or protected ecosystems, developing sustainable management protocols and procedures for managed or restored ecosystems, and creating new ecosystems. However, most NBS projects relate more to conservation or to the creation of new ecosystems than to improving managed ones. Paradoxically, NBS, to promote the use of nature as solution to human issues, first needs to separate nature and human made. Managed ecosystems are already managed for a purpose, or several, making the integration of a new objective more complex. We propose here to consider NBS as a binding concept between ecosystem managers and other stakeholders, including policy makers: a simple alternative solution to human infrastructures to be implemented by ecosystem managers through options integrated in the broader perspective of sustainable forest management and landscape approaches, thanks to an appropriate enabling environment.

\section{Nature-based solutions for everyone? A distributional and recognitional equity analysis}

Lorien Nesbitt ${ }^{1}$, Cecil Konijnendijk ${ }^{1}$, Michael Meitner ${ }^{1}$, Cynthia Girling ${ }^{1}$, Stephen Sheppard ${ }^{1}$

${ }^{1}$ University of British Columbia, Vancouver,Canada (lorien.nesbitt@ubc.ca; cecil.konijnendijk@ubc.ca; mike.meitner@ubc.ca; cgirling@sala.ubc.ca; stephen.sheppard@ubc.ca)

Urban forests increasingly provide nature-based solutions (NBS) to create more liveable cities. Given the importance of NBS to urban residents, it is important to evaluate 1) the distributional equity of urban forests that form part of NBS, and 2) the recognitional equity of processes to define and implement NBS at the local level. This research examined the distributional equity of urban forests in 10 US cities. Urban forests were characterized three ways (mixed vegetation, woody vegetation, and public parks), to reflect the variable NBS associated with different types of urban vegetation. Data were analyzed using Spearman's correlations and spatial autoregressive models. The research also examined the key dimensions of recognitional equity in defining and planning for NBS via an analysis and synthesis of relevant literature. Strong positive associations were observed between urban forests, higher education and income across most cities. Negative correlations between racialized status and urban forests were observed but were weaker and less common. Park area was more equitably distributed than mixed and woody vegetation, although inequities existed across all cities and vegetation types. Four dimensions of recognitional equity emerged from the analysis that can inform how NBS are defined and operationalized at the local level. Cities are spaces in which the world's populations meet and co-create NBS. This reality provides opportunities for mutual learning and improved resilience but can also lead to inequity in our access to and governance of NBS. Our findings can stimulate strategies to foster equitable planning and implemention of NBS.

\section{The fire, the storm, and the broom: nature based solutions to restore degraded ecosystems in Peri-urban protected areas}

\author{
Fabio Salbitano ${ }^{1}$, Cristiano Foderi ${ }^{1}$, Carlo Urbinati ${ }^{2}$, Fabrizio Furlani ${ }^{3}$ \\ ${ }^{1}$ University of Florence, Firenze, Italy; ${ }^{2}$ Marche Polytechnic University, Ancona, Italy; ${ }^{3}$ Regione Marche, Pesaro, Italy (fabio.salbitano@unifi.it; \\ cristiano.foderi@unifi.it; c.urbinati@staff.univpm.it; fabrizio.furlani@regione.marche.it)
}

On 7 August 2017, a wildfire affected 120 hectares of a cliff on the Adriatic Sea in the Nature Park San Bartolo, a protected area in the periurban fringe of the city of Pesaro (Marche, Italy) belonging to the European Natura 2000 network. The slopes of the cliff, no longer protected by the vegetation, were affected, at the end of March 2018, by dramatic erosion phenomena due to heavy storms causing drastic changes to ecosystems and landscape. The research concerned the process of evaluating the severity of disturbances and determining the best performing NBS to be used in such critial conditions. In parallel, we aimed to identify the perception and preferences of local communities towards the adoption of NBS. According to a discourses analysis and a preferences study, the Spartium junceum (weaver's broom) has been identified as a plant deeply felt as iconic for the Park, both by the locals and by the outsiders (e.g. tourists, city dwellers). Remote imageries sequencing was used to define the vulnerability index of the area so to priotirize the need for NBS applications. On the other hand, experimental trials on seeding and planting native species of shrubs (the broom, first of all), grasses, and trees were tested in order to design the best performing NBS solutions associated to soil bioengineering techniques. The results of the test served to implement the design of NBS for the whole area and became a keycommunicaiton tool for the community. The brooms bloomed again on the cliff. 


\section{Is classical biological control viable in large scale forest plantations?}

Carlos Wilcken ${ }^{1}$, Leonardo Rodrigues Barbosa ${ }^{2}$, Luiz Alexandre Sá ${ }^{3}$, José Zanuncio ${ }^{4}$

${ }^{1}$ Universidade Estadual Paulista “Júlio de Mesquita Filho”, Botucatu, Brasil; ' Embrapa Florestas, Colombo, Brazil; ${ }^{3}$ Embrapa Meio Ambiente, Jaguariuna, Brazil; ${ }^{4}$ Universidade Federal de Viçosa, Viçosa, Brazil (carlos.wilcken@unesp.br; leonardo.r.barbosa@embrapa.br; luiz.sa@embrapa.br; zanuncio@ufv.br)

The forest plantations (Eucalyptus, Pinus) have low biodiversity, increasing risks of pest outbreaks and difficulting biological control, mainly in Eucalyptus plantations due to short rotation (6-7 years). The last two decades had a substantial increase in the introduction of exotic pests, mainly to Eucalyptus. The strategy to manage these pests is only Classical Biological Control (CBC) wit the introduction of specific parasitoids from Australia. In Brazil, the use of Cleruchoides noackae x Thaumastocoris peregrinus in Eucalyptus and Xenostigmus bifasciatus x Cinara atlantica in Pinus had succesand that of Psyllaephagus bliteus x Glycaspis brimblecombei success and Anaphes nitens x Gonipterus platensis (parasitism decreasing since 2012 in SP and Parana States) partial success Selitrichodes neseri $\mathrm{x}$ Leptocybe invasa is under evaluation. The forest plantations have the advantages of receiving fewer spraying of chemical insecticides; maintenance of native forest in 25 to $30 \%$ of the total area in Brazil and understory, which promoting refuge areas; fast establishment of natural enemies in tropical and subtropical regions; few intense silvicultural procedures and better acceptance to CBC due to forest certifications systems. The main constraints are farmers without full information access on new exotic pests and to CBC programs; regulatory rules increasingly harder; slow parasitoid production in laboratory conditions; difficult field releasing in large areas; complicated logistic to shipping natural enemies in distant areas; lack of governmental programs and funds to implement them.

\section{Biocontrol in practice: managing Gonipterus platensis in Portugal}

Carlos Valente ${ }^{1}$, Catarina Gonçalves ${ }^{1}$, Manuel Rainha ${ }^{2}$, Ana Reis ${ }^{3}$, Manuela Branco ${ }^{4}$

${ }^{1}$ Instituto de Investigação da Floresta e Papel, Aveiro, Portugal; ${ }^{2}$ Navigator Forest Portugal, Valongo, Portugal; ${ }^{3}$ Altri Florestal, Olho Marinho, Portugal;

${ }^{4}$ Centro de Estudos Florestais, Lisboa,Portugal (carlos.valente@thenavigatorcompany.com; catarina.goncalves@thenavigatorcompany.com;

manuel.rainha@gmail.com; ana.reis@altri.pt; mrbranco@isa.ulisboa.pt)

In Europe, Portugal is the country with the largest area planted with Eucalyptus. These plantations are the main source of raw material for pulp and paper production, one of the most important industries in the country. The Tasmanian blue gum, Eucalyptus globulus, is the forest species most planted in the Country, covering more than 0.8 million ha. This species is particularly susceptible to the attacks of the Eucalyptus snout Beetle, Gonipterus platensis, an Australian insect present in Portugal since 1995. Even though the populations of the Snout Beetle have been partially controlled by the Australian egg parasitoid Anaphes nitens, wood losses have accrued to about 1 million $\mathrm{m}^{3}$ per year. In order to reduce the Snout Beetle's impact, an integrated pest management programme has been implemented. The programme includes the development of classical biological control with Australian egg and larval parasitoids, the replacement of vulnerable eucalypts with more resistant or tolerant ones, and the use of insecticides. In the present work we describe this strategy and discuss its results.

\section{Biocontrol in practice: managing Sirex noctilio in South Africa}

Brett Hurley ${ }^{1}$, Bernard Slippers ${ }^{2}$

${ }^{1}$ Department of Zoology and Entomology, Forestry and Agricultural Biotechnology Institute, University of Pretoria, Pretoria, South Africa; ${ }^{2}$ Department of Biochemistry, Genetics and Microbiology, Forestry and Agricultural Biotechnology Institute, Pretoria, (brett.hurley@fabi.up.ac.za;

bernard.slippers@fabi.up.ac.za)

The woodwasp Sirex noctilio was first reported in South Africa in 1994. Since then this invasive insect has spread throughout the main pine growing regions of the country. Mortality of pine trees caused by infestations of $S$. noctilio have been severe, especially in the summer rainfall areas of the country. In response to these infestations, a management programme was initiated, with biological control using the parasitic nematode, Deladenus siricidicola, as the main control method. Initial low and varying parasitism levels using this nematode led to studies to examine the influence of environment and genetic diversity on the establishment and virulence of $D$. siricidicola. Inoculation trials and laboratory experiments indicate that the tree environment, particularly the moisture content and bluestain fungi present in the wood, indirectly influence parasitism levels by competing for the fungal food source of the nematodes. Development of molecular markers for the nematode has enabled comparison of populations within South Africa and between other countries, revealing a clonal population in South Africa. This has led to the collection and characterisation of $D$. siricidicola populations from around the world, comparing the virulence of these populations and investigating possibilities to increase fitness through hybridisation. Research is ongoing to further our understanding of factors influencing parasitism and use this information to optimize the biological control programme.

\section{Biocontrol in practice: managing Thaumastocoris peregrinus (Hemiptera: Thaumastocoridae) in Brazil}

Leonardo Rodrigues Barbosa ${ }^{1}$, Luciane Becchi², Luis Renato Junqueira ${ }^{3}$, José Zanuncio ${ }^{4}$, Carlos Frederico Wilcken ${ }^{2}$ ${ }^{1}$ Embrapa Florestas, Colombo, Brasil; ' 2 niversidade Estadual Paulista “Júlio de Mesquita Filho”, Faculdade de Ciências Agronômicas, Departamento de Proteção Vegetal,Botucatu, Brasil; ${ }^{3}$ Instituto de Pesquisas e Estudos Florestais, Piracicaba, Brasil; ${ }^{4}$ Universidade Federal de Viçosa, Viçosa, Brasil (leonardo.r.barbosa@embrapa.br; luciane.becchi@hotmail.com; renato@ipef.br; zanuncio@ufv.br; cwilcken@fca.unesp.br)

Biological control is the main strategy to manage the bronze bug Thaumastocoris peregrinus (Hemiptera: Thaumastocoridae) in Brazil. This important exotic pest has been introduced in Brazil, severely damaging eucalypt plantations. The bronze bug biological control program has been supported by studies including pest life table analyzes, impact of native natural enemies and using the exotic parasitoid Cleruchoides noackae (Hymenoptera: Mymaridae). Laboratory studies indicated the specificity and efficiency of $C$. noacke to control bronze bug. After its first release in the field in 2012 , the establishment of $C$. noackae has been found in several Brazilian states. In 2013, the area infested with T. peregrinus decreased compared to 2012, which was attributed to parasitoid efficiency in field. Otherwise, variations in bronze bug infested area from 2013 to 2018 may be related to non-establishment of this parasitoid in some regions and the impact of chemical control. The results obtained with the biological control program of the bronze bug in Brazil show the efficiency of $C$. noackae in adequate conditions. Instead of its results controlling the bronze bug, several issues need to be addressed to increase its efficiency and use. Which include: establishing facilities for mass rearing; periodic releases of this parasitoid in the same site; evaluation of impact by chemical and microbiological insecticides and maintaining of the parasitoid in forestry companies, research institutes and universities. The successive use of $C$. noackae and the answers to questions addressed will increase the beneficial effects of this parasitoid in integrated management of T. peregrinus. 


\section{Biological control as a key tool for pest management in Uruguay forestry}

Gonzalo Martínez ${ }^{1}$ (D)

${ }^{1}$ INIA, Tacuarembó, Uruguay (gmartinez@inia.org.uy)

Commercial tree plantations cover around a million ha in Uruguay, mostly with stands of eucalypt and pine trees. Uruguayan forestry was relatively free of serious health threats until the end of the XX century. Beginning in the 90's, both forestry area and international trade exhibited an exponential growth, soon followed by an increase of invasive insect records. More than half of the pests currently affecting Eucalyptus entered the country after 1995 . The high percentage of plantation area currently under FSC and/or PEFC certification schemes (90\%) restricted the use of pesticides and pushed the Uruguayan forestry to rely mainly on silvicultural and biological control to suppress insect pest outbreaks. However, there was almost no regulations regarding the use of biological control agents until the last decade, even when biological control for forest pests in the country can be traced back to the 1940s. Here, we present the state-of-the-art of biological control in Uruguayan commercial forestry. Currently, biological control with entomophagous or entomopathogenic organisms has been, or is currently being, implemented for eight insect pests. More than five parasitoid wasps and a nematode have been released and installed in the field. There are also at least two cases of adventive introduction of entomophagous organisms, simultaneously with the pest. Building capacity for biological control and improving the regulatory framework are key issues towards the success of biological control of forestry pests under the current pest scenario.

\section{Ecology and behaviour of Megarhyssa nortoni, a parasitoid used as biological control agent against the invasive woodwasp Sirex noctilio}

Deborah Fischbein ${ }^{1}$, Andrés Martínez ${ }^{1}$, Victoria Lantschner ${ }^{1}$, José Villacide ${ }^{1}$, Juan Corley ${ }^{1}$

${ }^{1}$ Grupo de Ecología de Poblaciones de Insectos, IFAB (CONICET-INTA EEA Bariloche), Beriloche, Argentina (deborah.fischbein@gmail.com; andmarv77@gmail.com; vlantschner@gmail.com; josevillacide@gmail.com; elmallin@gmail.com)

The introduction of parasitoids in classical biological control programs is a key management method deployed against exotic pests in long-lived crops such as plantation forestry. Sirex noctilio is a pest of cultivated pines, for which several parasitoids, including the wasp Megrahyssa nortoni, have been released in the invaded range. Here, we examine some aspects of $M$. nortoni that can help explain the parasitoid performance as biocontrol agent: (1) climate matching and the climatic factors that best explain current parasitoid distribution in the Southern Hemisphere; (2) interindividual and sex differences in flight performance, in addition to the cost of flight on longevity and; (3) host location ability as mediated by chemical cues while foraging for hosts. Megarhyssa nortoni established well in regions with temperate and cold climates aseco-climatic models predicted. Particularly, parasitoid distribution constrains to regions with maximum temperature of the warmest month $\left(<32^{\circ} \mathrm{C}\right)$ and minimum temperature of the coldest month $\left(>-21^{\circ} \mathrm{C}\right)$.Flight performance was gender-specific: females flew greater distances than males in flight mills and also lived longer. Also, flight did not impact on post-flight longevity for any sex. Females discriminated the odors of infested wood from those of healthy trees and some pine trees over other. In the context of classical biological control studies on established cases allow identifying key attributes. We show that climate matching is necessary to predict establishment success and that knowledge of sex-specific life-history strategies and on the infochemicals use to locate hosts is likely crucial for improving introduction and impact success.

\section{The actual effect from stump treatment in a biological control programme to protect planted Norway spruce from Heterobasidion spp. root rot}

Jonas Rönnberg ${ }^{1}$, Michelle Cleary ${ }^{1}$, Mimmi Blomqvist ${ }^{1}$

${ }^{1}$ Swedish University of Agricultural Sciences, Alnarp, Sweden (jonas.ronnberg@slu.se; michelle.cleary@slu.se; mimmi.blomquist@slu.se)

Heterobasidion root rot causes tremendous economic loss to coniferous forests through reduced growth and quality all over the northern hemisphere. Climate change promotes spread of root rot and adds to the challenge to increase forest productivity. Control programs to reduce the effect from Heterobasidion species are needed and include treatment of stumps with various agents to block spore infection on the stumps following harvesting. In Sweden, automatized stump treatment including Phlebiopsis gigantea (Rotstop ${ }^{\circledR S}$ ) has been practised at mechanized thinnings in a big scale control programme since the mid 1990's but up until now no follow up of the efficacy have been made. In a study in mid- and southern Sweden, stumps from 15 thinnings were sampled for presence of $P$. gigantea added to the stump surface at thinning and the subsequent spore infection levels of Heterobasidion. Preliminary results indicate insufficient coverage of stumps and also that some stumps may still become infected after being treated. This might be an effect of imperfect coverage or lack of active $P$. gigantea due to mishandling of the treatment agent. There is an obvious need for education and encouragement of contractors to increase the effect in practice and to show the economic benefits from the stump treatment. There will also be a future pedagogic challenge to explain to landowners why seemingly treated stands may still suffer from development of Heterobasidion root rot.

\section{C7b: NEEDLE AND SHOOT DISEASES OF PINE}

\section{Population genomics of the forest pathogen Dothistroma septosporum reveal adaptations involving the dothistromin virulence factor}

Rosie Bradshaw ${ }^{1}$ (D; Andre Sim ${ }^{2}$, Pranav Chettri' ${ }^{2}$ Pierre-Yves Dupont ${ }^{3}$, Yanan Guo ${ }^{2}$, Lukas Hunziker ${ }^{2}$, Rebecca McDougal $^{4}$, Lindsay Bulman ${ }^{5}$, Shannon Ormond ${ }^{2}$, I. Kutay Ozturk ${ }^{2}$, Ariska Van der Nest $t^{6}$,Arista Fourie ${ }^{6}$, David Wheeler ${ }^{7}$, Murray Cox ${ }^{2}$, Irene Barnes ${ }^{6}$

${ }^{1}$ BioProtection Research Centre, Massey University, Palmerston North, New Zealand; ${ }^{2}$ Massey University, Palmerston North, New Zealand; ${ }^{3}$ Institute of Environmental Science and Research, Christchurch, New Zealand; ${ }^{4}$ Scion, NZ Forest Research Institute Ltd, Rotorua, New Zealand; ${ }^{5}$ Scion, Rotorua, New Zealand; ${ }^{6}$ Forestry and Agricultural Biotechnology Institute, University of Pretoria, Pretoria, South Africa; ${ }^{7}$ NSW Department of Primary Industries, Orange, Australia(r.e.bradshaw@massey.ac.nz; andre.sim@hotmail.com; pranav.chettri@agresearch.co.nz; pierre.dupont@esr.cri.nz;y.guo.1@massey.ac.nz; l.hunziker@massey.ac.nz; rebecca.mcdougal@scionresearch.com; llindsay.bulman@scionresearch.com; s.ormond@massey.ac.nz; kutayozturk@gmail.com; ariska.vandernest@fabi.up.ac.za; arista.fourie@fabi.up.ac.za; office@ngbs.co.nz;m.p.cox@massey.ac.nz;irene.barnes@fabi.up.ac.za)

Dothistroma needle blight is amongst the most serious diseases of pine trees. Epidemics have increased in the last 25 years, especially in the Northern Hemisphere, where associations have been made with changes in climate. The needle blight pathogen Dothistroma septosporum occurs world wide but most research into its molecular biology has been with Southern Hemisphere strains from populations with limited genetic diversity. The genome reference strain for the species, for which an in plantatrans criptome is also available, originates from New Zealand where the population of this species is virtually clonal following its introduction in the 1960s. Because of the worldwide significance of D. septosporum, we first compared the genome sequence of the New Zealand strain with genomes of 18 isolates from other parts of the world. There was substantial sequence variation within the species and a reciprocal chromosome translocation 
found only in New Zealand and Australian isolates. Very high levels of the virulence factor dothistromin produced by the ALP3 isolate from Germany appeared to be associated with chromosome duplications. Secondly, we studied $D$. septosporum isolates collected over a 50 year period in New Zealand forests. Genome analyses revealed insights into the early introduction and diversification of these isolates. Phenotype analyses revealed surprising insights into dothistromin production and virulence that suggest adaptation of this introduced pathogen over 50 years. These studies highlight the importance of population genomics studies for understanding the molecular basis of virulence in forest pathogens, both for populations spread across different regions and those spread across time.

\section{Dothistroma needle blight and the risk to jack pine in Alberta, Canada}

Tod Ramsfield ${ }^{1}$, Colin Myrholm ${ }^{1}$, Bradley Tomm ${ }^{1}$

${ }^{1}$ Canadian Forest Service, Edmonton, Canada (tod.ramsfield@canada.ca; colin.myrholm@canada.ca; bradley.tomm@canada.ca)

In Canada, Dothistroma needle blight is considered to be endemic and the disease has been recorded in the Forest Insect and Disease Survey of the Canadian Forest Service, and the Canadian Plant Disease Survey, since the 1960's. The disease has been recorded as "red skirt", "red band needle blight", "red banded disease" and "needle blight" in seven provinces on 15 different hosts, including jack pine (Pinus banksiana). The greatest impact of the disease has occurred in British Columbia on lodgepole pine (Pinus contorta var. latifolia). Recently, Dothistroma septosporum was observed infecting lodgepole pine at various locations in close proximity to jack pine in Alberta. As jack pine is a major component of the boreal forest, we are studying the interaction between $D$. septosporum and P. banksiana under controlled conditions as well as conducting field surveys. This talk will outline our progress to date in understanding the risk posed by $D$. septosporum to P. banksiana in Alberta.

\section{Invasive pine pathogens in Baltics, Northern Europe}

Rein Drenkhan ${ }^{1}$, Marili Laas ${ }^{1}$, Kristina Raitelaityte $\dot{2}^{2}$, Svetlana Markovskaja ${ }^{2}$, Kalev Adamson ${ }^{1}$

${ }^{1}$ Estonian University of Life Sciences, Tartu, Estonia; ${ }^{2}$ Nature Research Centre, Vilnius, Lithuania (rein.drenkhan@emu.ee; marili.laas@student.emu.ee; kristina.raitelaityte@gmail.com; svetlana.markovskaja@gamtc.lt; kalev.adamson@emu.ee)

During the last decades, several invasive tree pathogens have arrived in the northern Europe, damaging forest and urban green space trees. Invasive species (e.g. Lecanosticta acicola, Diplodia sapinea) are considered to cause economic loss and be an important threat to biodiversity. Winter warmings have diminished earlier restrictions for the southern pathogens caused by earlier cold winters. In addition, increasing global trade, when biological material is moved from one geographical location to another, rises the risks involved in the international plant trade and climate change. Pine needle pathogen $L$. acicola has spread by anthropogenic activity into the Baltic countries as a new area for that pathogen, whereby another invasive pine pathogen $D$. sapinea has spread naturally from South to North and possibly on the wave of climate change. In northern Europe ascomycete fungus L. acicola was found for the first time in 2008 from Estonia on non-native Pinus ponderosa and in 2009 from Lithuania on Pinus mugo. Since that time, up to 2016, these pathogens were found only on non-native hosts. Lecanosticta acicola was for the first time in northern Europe recorded on native Pinus sylvestris in 2016. In total 204 isolations and 11 microsatellite markers were used to analyse the genetic diversity and population structure of $L$. acicola in Baltics. The populations of $L$. acicola in Baltics indicated high number of clones. Both mating types of $L$. acicola were found to be present indicating the growing potential of the pathogen's vitality in northern Europe and increasing risk to native hosts.

\section{Diplodia sapinea outbreaks in Sweden. Climatic drivers and genetic diversity}

Jan Stenlid', Laura Brodde ${ }^{1}$, Jonàs Oliva ${ }^{2}$, Curt Almqvist ${ }^{3}$

${ }^{1}$ Swedish University of Agricultural Sciences, Uppsala, Sweden; ${ }^{2}$ University of Lleida, Lleida, Spain; ${ }^{3}$ Forestry Research Institute of Sweden, Uppsala, Sweden (jan.stenlid@slu.se; laura.brodde@slu.se; jonas.oliva@pvcf.udl.cat; curt.almqvist@skogforsk.se)

Diplodia sapinea has recently spread northwards in Europe. In 2016 it caused a severe outbreak in central Sweden and during 2018, massive mortality was associated with Diplodia and drought in the island of Gotland. Several lines of investigations are conducted to understand the driving forces behind the epidemics. A) When studying the local weather conditions, outbreaks seem to be particularly associated with early summer droughts. B) We also studied if there are potential new linages of the fungus. However, microsatellites do not reveal any genetic differentiation between Nordic and southern European populations of Diplodia, although there are specific clonal linages that caused the Swedish outbreaks. C) Community studies using NGS technology have been performed to characterize any difference in the endophytic communities that may explain variation in host susceptibility. D) Investigations are also carried out to track the patterns of susceptibility in the pine host that can be attributed to heritable factors.

\section{Genetic characterization and phylogenetic placement of Lophodermella montivaga Petrak and Lophodermella concolor (Dearn.) Darker causing needle cast in lodgepole pines in Colorado, USA}

Jessa Ata ${ }^{1,2}$, Kelly Burns ${ }^{3}$, Suzanne Marchetti ${ }^{4}$, James Worrall ${ }^{4}$, Jane Stewart ${ }^{1}$

${ }^{1}$ Colorado State University, Fort Collins, USA; ${ }^{2}$ University of the Philippines Los Baños, Los Baños, Philippines; ${ }^{3}$ USDA Forest Service, Golden, USA; ${ }^{4}$ USDA Forest Service, Gunnison,USA (jpata@colostate.edu; ksburns@fs.fed.us; sbmarchetti@fs.fed.us; jworrall@forestpathology.org; jane.stewart@colostate.edu)

Lophodermella montivaga and L. concolor within Rhytismataceae are common needle cast pathogens in lodgepole pine (Pinus contorta) in Colorado, USA. In recent years, severe disease has been observed in Gunnison National Forest (GNF), Colorado and there the disease has spread into new sites. Multiple needle pathogens occur in this region, therefore genetic information is important for efficient control and monitoring of these diseases. This study aims to establish a genetic background and improve understanding of the phylogenetic position of the pathogenic fungi causing Lophodermella needle cast. Symptomatic lodgepole pine needles from GNF were collected. Needle cast symptoms of trees infected with L. montivaga included brown coalesced longitudinal ridges along the needles, whereas $L$. concolor-infected needles had colorless hysterothecia turning pale pink at maturity. Morphological characteristics of both species matched previously described L. montivaga and L. concolor, both belonging to Hypodermella complex.Three loci were used for genetic characterization: internal transcribed spacer region and 5.8S ribosomal RNA (ITS), large subunit ribosomal nucleic acid (LSU), and translation elongation factor (EF1-a). All isolates of L. montivaga and L. concolor formed one well-supported clade at the ITS region distinctly delimited from a closely related species, Lophodermella arcuata. However, L. concolor isolates formed a well-supported sub-cluster separated from the Lophodermella group. Similar phylogenetic pattern was also observed at the EF1-a and LSU loci. This warrants further investigation of the taxonomic and phylogenetic relationships of Rhystimataceae species using molecular-based techniques. Results of the study will be useful for conifer needle disease monitoring and assessment, and future molecular studies. 


\section{News from Dothistroma and Lecanosticta needle blights in Switzerland}

Ludwig Beenken ${ }^{1}$

${ }^{1}$ Swiss Federal Institute for Forest, Snow and Landscape WSL, Forest health and biotic interactions, Swiss Forest Protection, Birmensdorf, Switzerland (ludwig.beenken@wsl.ch)

Fungal pine needle blights are dreaded diseases in plantations and natural forests worldwide. Dothistroma septosporum and D. pini, cause Dothistroma needle blight (DNB) and Lecanosticta acicola the brown spot needle blight (BSNB) of pine trees. Dothistroma septosporum can infect also other conifers like Norway spruce (Picea abies). In Switzerland, first reports of DNB date from 1989 and of BSNB from 1995. The causing pathogens are quarantine pest organisms that are monitored in Switzerland since 2009. Both diseases occurred first in urban habitats. Since 2013, D. septosporum was found on several pine species ( $P$. sylvestris, P. mugo and P. nigra) in native and planted forests. Since 2016, L. acicola was detected onmountain pines in bogs. We investigate six forest plots in Switzerland in 2018, to estimate the effects of DNB and BSNB on pine and spruce trees. Damages on P. sylvestris, respectively, P. mugo caused by D. septosporum were found in five plots. They were often overshadowed by damages cause by other needle pathogens like Lophodermella conjuncta. Dothistroma septosporum infected a few needles of five spruce trees in four of these plots. In the remaining plot, DNB was lacking but $L$. acicula caused heavy damages on $P$. mugo. Additionally, we analyzed the mating types of both fungi in order to test whether they reproduce sexually. We found two mating types of $D$. septosporum but only one of $L$. acicula. Consequently, D. septosporum can also reproduce sexually and the reproduction of $L$. acicula is solely asexual in Switzerland.

\section{Is the seed trade a significant pathway for the global dissemination of foliar pathogens like Dothistroma septosporum, causal agent of dothistroma needle blight?}

Katherine Tubby ${ }^{1}$, Shelagh McCartan ${ }^{1}$, Martin Mullett ${ }^{2}$

${ }^{1}$ Forest Research, Farnham, United Kingdom; ${ }^{2}$ Department of Forest Protection and Wildlife Management Mendel University, Brno, Czech Republic (kvtubby@gmail.com; shelagh.maccartan@forestry.gsi.gov.uk; martinmullett@hotmail.com)

The international plant trade is a conduit for the accidental movement of many invasive pests and pathogens between and within countries. Such anthropogenic dispersal has contributed significantly to recent range expansion of Dothistroma septosporum and D. pini, causes of dothistroma needle blight. In contrast seeds are considered to pose a lower biosecurity risk for pathogen spread than live plants. However, importation of Pinus contorta var latifolia seeds from North America to Britain in the mid-1900s, and similarities found in D. septosporum populations in Britain and British Colombia suggest that seed could be a significant pathway. Dothistroma has not been isolated in or on seeds, but poorly cleaned seed lots contain needle fragments potentially infected with the pathogen. Heat treatment routinely applied toopen up cones and extract conifer seeds might counter this risk. Our case study investigated whether seed treatments can be manipulated to reduce risks of Dothistroma transmission without affecting seed viability. Dothistroma infected Pinus spp. needles were (a) incubated with cones undergoing seed extraction in a commercial facility and (b) exposed to temperatures up to $70{ }^{\circ} \mathrm{C}$ in incubators; Dothistroma and seed viability were assessed after 48 hours. The $50{ }^{\circ} \mathrm{C}$ maximum temperature reached during commercial processing did not reduce seed or pathogen viability. In laboratory tests, however, $D$. septosporum could not survive $\geq 63.5^{\circ} \mathrm{C}$, whereas seed viability was not impaired. We conclude that commercial seed preparation conditions could allow transmission of pathogens such as Dothistroma, but additional elevated heat seed treatments could reduce this risk without damage to Pinus seeds.

\section{Epidemiology and control of red needle cast of pine in New Zealand}

Stuart Fraser ${ }^{1}$, Carol Rolando ${ }^{1}$, Mireia Gomez-Gallego ${ }^{1}$, Ralf Gommers ${ }^{1}$, Ian Hood ${ }^{1}$, Lindsay Bulman ${ }^{1}$, Nari Williams $^{1}$

${ }^{1}$ Scion, Rotorua, New Zealand (stuart.fraser@scionresearch.com; carol.rolando@scionresearch.com; mireia.gomez@scionresearch.com; ralf.gommers@scionresearch.com; ian.hood@scionresearch.com; lindsay.bulman@scionresearch.com; nari.williams@scionresearch.com)

Phytophthora pluvialisis the cause of red needle cast (RNC), a disease of Pinus radiata in New Zealand. Results from artificial inoculation experiments indicate that copper, applied as cuprous oxide, is effective in reducing disease severity. As well as identifying effective active ingredients, development of a control programme for RNC also requires a fundamental understanding of its epidemiology. This information will assist in the identification of the optimal time of year to spray and also aid disease forecasting to support decisions on whether to spray or not. Research has shown that disease expression, release of inoculum, and infection all peak during winter and spring, between June and November. Observations imply that $P$. pluvialis has a polycyclic life cycle that leads to an epidemic scenario in years when prolonged favourable conditions occur. They thus suggest that to control the disease a fungicide treatment should be applied in autumn to destroy inoculum at the beginning of the infection period, and possibly again several months later to maintain low inoculum build-up. An operational-scale copper spray trial was initiated at two sites in a mature stand of $P$. radiata. At each site, three blocks were treated with $0.84 \mathrm{~kg}$ ha ${ }^{-1} \mathrm{cuprous}$ oxide (operational standard rate for control of dothistroma needle blight) in February 2017, while three blocks were left unsprayed. Incidence and severity of RNC at disease peak in September 2017 was significantly lower in the sprayed blocks. An update will also be given on subsequent operational-scale spray trials.

\section{Genomics of adaptation to climate change in the Pine-Dothistroma pathosystem}

Richard Hamelin ${ }^{l, 2}$, Renate Heinzelmann ${ }^{1}$, Barbara Wong ${ }^{2}$, Sally Aitken ${ }^{1}$, Sam Yeaman ${ }^{3}$, Kishan Sambaraju ${ }^{4}$, Philippe Tanguay ${ }^{4}$, Mengmeng Lu ${ }^{3}$, Dragana Vidakovic ${ }^{1}$, Nick Ukrainetz ${ }^{5}$

${ }^{1}$ The University of British Columbia, Vancouver, Canada; ${ }^{2}$ Université Laval, Québec, Canada; ${ }^{3}$ University of Calgary, Calgary, Canada; ${ }^{4}$ Natural Resources Canada, Quebec City, Canada; ${ }^{5}$ Ministry of Forests, Lands and Natural Resource Operations, Victoria, Canada(richard.hamelin@ubc.ca; renate.

heinzelmann@ubc.ca; barb.wong@ubc.ca; sally.aitken@ubc.ca; samuel.yeaman@ucalgary.ca; kishan.sambaraju@canada.ca; philippe.tanguay@canada.ca; mengmeng.lu@ucalgary.ca; dragana@vidakovic.com; nicholas.ukrainetz@gov.bc.ca)

Climate fluctuation can be an important factor in modifying patterns of fungal phenology. For plant pathogens, a layer of complexity is added because climate change will also affect the host and its interaction with biotic stress agents, potentially resulting in changes in disease impact. Dothistroma septosporum is a fungal pathogen thatcauses Dothistroma needle blight (DNB), which results in early defoliation, growth losses, and regeneration failure in pines globally. The incidence of this disease has been increasing in severity on lodgepole pine in western Canada and this has been directly related to climate change. In the CoAdapTree project, we are studying the pine-Dothistroma-climate interactions. In artificial inoculations, RNA-Seq analysis of gene expression showed that resistant pines had DNB strain-specific up-regulation of over 900 genes and stronger gene expression response to DNB than susceptible trees. To conduct a genome-wide association study forty populations from across the range of $P$. contorta, P. banksiana and $P$. contortax, $P$. banksiana were inoculated with DNB. There was a clear negative correlation between latitude and susceptibility, suggesting that moving southern genotypes (more susceptible to DNB) north could 
have some major phytosanitary implications. The genomes of nearly 300 DNB isolates from North America and Europe have been sequenced to characterize adaptation to climate and hosts in the pathogen. We propose to use this data to develop climate-based seed-transfer policy and provide tree breeding strategies and genomic breeding tools.

\title{
C7c: SUSTAINABLE BIOMASS FOR A GREENER FUTURE
}

\author{
Assessing impacts of European Union demand for bioenergy on US forests using national forest inventory data \\ Houston Sudekum ${ }^{1}$ (D; Francisco Aguilar ${ }^{2}$, Ashkan Mirzaee ${ }^{1}$, Ram Dahal ${ }^{1}$, Ronald McGarvey ${ }^{1}$, Karen Abt ${ }^{3}$ \\ ${ }^{1}$ University of Missouri, Columbia, USA; ${ }^{2}$ Swedish University of Agricultural Sciences, Umea, Sweden; ${ }^{3}$ USDA Forest Service, Durham, USA \\ (hjs5td@mail.missouri.edu; francisco.aguilar@slu.se; amtwc@mail.missouri.edu; dahalr@missouri.edu; mcgarveyr@missouri.edu; kabt@fs.fed.us)
}

Global wood pellet production grew from 1.7 million tons in the year 2000, to 29.7 million tons in 2015. U.S. mills established over this period account for a large share of new supply triggered by renewable energy targets set by the European Union (EU). There is concern over the potential effects of exponential growth in wood pellet supply on US forests. We offer a systematic quantitative analysis to assess the effects of wood pellet production on forest conditions within wood pellet mill procurement areas. We rely on plot-level information from the US Forest Inventory and Analysis (FIA) database to estimate changes in forest conditions (e.g. trees per hectare, carbon in trees and soil, volume) between inventory years 2000, 2005, 2010, and 2015 across 31 US States. Using spatial analysis and panel-regression for a sample of 7495 plots we discern EU renewable energy policy effects associated with export-oriented pellet mill size and location. Propensity score matching was used as a re-sampling technique to select a subset of FIA plots to control for the non-random process of pellet mill sitting. Panel regression models controlled for various anthropogenic and natural factors measure the net impact of wood pellet production on average plot-level forest conditions over time. Preliminary results suggest that forest conditions within wood pellet procurement areas saw decreases in standing dead trees per hectare, and increases in carbon, volume and removal trees per hectare Our findings point to prospects and challenges to sustainable wood pellet production.

\section{Estimating availability of forest biomass resources in the whole of Japan}

Kazuhiro Aruga $^{1}$ (D); Yusuke Matsuoka ${ }^{1}$, Takahisa Yamamoto ${ }^{1}$, Battuvshin Biligt ${ }^{2}$, Hiroaki Shirasawa ${ }^{3}$

${ }^{1}$ Utsunomiya University, Utsunomiya, Japan; ${ }^{2}$ Tokyo University of Agriculture and Technology, Tokyo, Japan; ${ }^{3}$ Forestry and Forest Products Research Institute,Tsukuba,Japan (aruga@cc.utsunomiya-u.ac.jp; mc196952@cc.utsunomiya-u.ac.jp; ma178506@cc.utsunomiya-u.ac.jp; biligt.blizz@gmail.com; shirasawa@ffpri.affrc.go.jp)

We developed the model to estimate availability of forest biomass resources from each forestry operation site with appropriate forest operation system according to road networks and geography using GIS data processed by MATLAB in Tochigi prefecture, Japan (Yamamoto et al. online first, IJFE). We are expanding the model to the whole of Japan by obtaining GIS data for private and communal forests from other 46 prefectures and for national forests from the Japan Forestry Agency. The estimated availability will be verified with the statistical data compiled by the Japan Forestry Agency obtained from each prefecture. Then, the model will be used to project future availability of each forestry operation site for sustainable forest management. Forest GIS data were developed separately for national forests by the Forestry Agency, and for private and communal forests by each prefecture. This is the first study of this kind combining private and communal forests with national forests, in the whole of Japan. Furthermore, existing studies developed similar models, but their units of forests were defined using $1 \mathrm{~km}^{2}$ mesh or municipality. MATLAB could be used to make estimations for the whole of Japan, within a reasonable timeframe, defining units as forestry operation sites.

\section{Implementation of voluntary sustainability criteria for forest biomass: a case study from Denmark 2016-2018}

\author{
Søren Larsen ${ }^{1,2,3}$, Niclas Scott Bentsen ${ }^{3}$, Inge Stupak ${ }^{3}$ \\ ${ }^{1}$ Danish Energy, Copenhagen, Denmark; ${ }^{2}$ Ørsted A/S Gentofte Denmark; ${ }^{3}$ University of Copenhagen, Department of Geosciences and Natural Resource \\ Management, Frederiksberg C,Denmark (sla@danskenergi.dk; nb@ign.ku.dk; ism@ign.ku.dk)
}

During the last few decades there has been a substantial growth in forest biomass consumption for the Danish heat and electricity sector, but questions about its sustainability have been raised. Since 2016 Danish energy companies have addressed sustainability issues through a voluntary industry-initiated agreement. This agreement introduces risk-based sustainability criteria on forest biomass sourcing. We have analysed the Danish energy sector's biomass sourcing, compliance and deployment of sustainability criteria during 2016-2018 based on public sustainability reports. Additionally, we analysed supply chain levels and feedstock use of Danish medium to large energy companies. Results show that $57 \%$ and $70 \%$ of the biomass sourcing was in compliance with the sustainability criteria in 2016 and 2017 respectively with even larger volumes expected for 2018. Most of the volume is sourced by only a few large companies and wood pellets are sourced in much larger volumes than wood chips. Danish energy companies source woody biomass from different supply chain levels: local to global, but especially from the regional supply chain around the Baltic Sea. The Danish voluntary sustainability criteria have been effective in governing biomass sourcing. Overall, the Danish experience shows it is possible within a short time frame to implement sustainability governance with risk-based criteria on multiple energy companies sourcing solid biomass in the megaton scale. A similar approach has been chosen by the EU and will be implemented from 2021.

\section{Allocation and land use in LCA of forestry: case study on beech wood thinning}

\author{
Lars G. F. Tellnes ${ }^{1}$, Ellen Soldal ${ }^{1}$, Fredrik Moltu Johnsen ${ }^{1}$ \\ 1Ostfold Research,Fredrikstad,Norway (lars@ostfoldforskning.no; ellen@ostfoldforskning.no; fredrik@ostfoldforskning.no)
}

Beech wood is currently an underutilized resource in Eastern France, and wood thinning in this region is not extensively practiced due to low economic returns. The function of thinning is to clear enough space for some trees to grow large in the early stages of a forest stand. Without thinning, both the yield and quality of beech saw wood will be lower. From a Life cycle assessment (LCA) perspective, allocation between the forest products thinning wood and wood from final harvest is therefore of interest. Valorization of beech wood thinning for feed purpose is under development and it can substitute feed sources with known environmental controversies such as soy protein. In the LCA modelling, the environmental impact category of land use is assumed to be highly relevant for the stakeholders. The objective of this work was to introduce economic allocation and land use characterisation in LCA modelling for the case of beech wood chips from thinning, and to show the importance for the results. The results shows that land use decrease substantially for chips from thinning with economic allocation and specific land occupation data. The results also show that climate change is more important than land use in the previously recommended method 
in Europe, but with the new method the opposite is the case. Land use is an LCA impact category which may see increased attention in the near future. Based on the case and the models used, land use appears to be important to include in forestry LCA studies.

\section{Evaluating country-level forest area and biomass estimates using NFI data: a Portuguese application}

Susana Barreiro ${ }^{1,2}$, Margarida Tomé ${ }^{3}$,João Rua ${ }^{3}$, Francisco Goes $^{4}$, José Uva ${ }^{5}$, Mart-Jan Schelhaas ${ }^{2}$, Gert-Jan Nabuurs ${ }^{2}$

${ }^{1}$ Universidade de Lisboa, Instituto Superior de Agronomia, Centro de Estudos Florestais, Lisbon, Portugal; ${ }^{2}$ Forest Ecology and Forest Management Group, Wageningen University and Research, Wageningen, Netherlands, ${ }^{3}$ Universidade de Lisboa, Instituto Superior de Agronomia, Centro de Estudos Florestais, Lisboa, Portugal; ${ }^{4}$ CELPA - Associação da Industria Papeleira, Lisboa, Portugal; ${ }^{5}$ ICNF - Instituto da Conservação da Natureza e das Florestas, Lisboa, Portugal(smb@isa.ulisboa.pt; magatome@isa.ulisboa.pt; jcprua@isa.ulisboa.pt; francisco.goes@celpa.pt; jose.uva@icnf.pt; martjan.schelhaas@wur.nl; gert-jan.nabuurs@wur.nl)

The losses caused by severe forest fires in conjunction with the increase of wood demand for the pulp and paper industries led to the development of a scenario driven regional forest simulator (StandsSIM.sd). StandsSIM.sd is NFI-based and was designed to simulate forest condition under different scenarios of demand, fire occurrence, land-use changes and changes in management. The NFI4 (1995-1997) data was used to initialize the simulation and predict the evolution of forest area, standing volume, biomass and carbon stock for a period of 20 years. A business-as-usual scenario based on official statistics reflecting market demands, burnt areas and land-use-changes was prepared for the period of 1997-2015. The scenario was completed with a description of a general forest management approach prepared based on discussions with stakeholders. Simulations were run and the results for forest area, standing volume, biomass and carbon stock by age classes'/stand structure estimates were compared with NFI5 and NFI6 published values. Preliminary validation results showed that StandsSIM.sd' predictions were reliable except for forest area. The area of uneven-aged stands was being under-estimated because when even-aged stands were converted after final felling and no approach to generate uneven-aged stands had been integrated in the tool. To tackle this limitation a transition algorithm was developed. This new module is responsible for converting even-aged to uneven-aged stands through the simulation of events such as sanitary thinning or incomplete final harvest.

\section{Restoring land and growing renewable energy: opportunities, challenges and the way forward}

Himlal Baral ${ }^{1}$, Syed Ajijur Rahman ${ }^{1}$, Wanggi Jaung ${ }^{2}$

${ }^{1}$ Center for International Forestry Research, Bogor, Indonesia; ${ }^{2}$ National University of Singapore, Singapore, Singapore (h.baral@cgiar.org,

s.rahman@cgiar.org;w.jaung@cgiar.org)

Primary energy demand in Indonesia has rapidly been increased, i.e; 43\% between 2005 and 2016, while domestic energy supply failed to fulfill this needs and leading to the reliance on energy imports. Meanwhile, vast area of degraded lands in Indonesia have also created an opportunity for the biofuel production, fulfilling energy demand, as well as restoring land with environmental and socio-economic benefits. This paper provides an overview of identified potential and challenges associated with biofuel production from degraded land in Indonesia. Our preliminary findings highlighted that some biofuel species in Indonesia is suitable to grow in a degraded land and potentially restore the land that may not be suitable for common agricultural production and/or reforestation. The initial finding also shows that culturally familiar species and stable markets are favorable terms of biofuel species selection for the landowners. Supportive agricultural extension service such as knowledge and technology for honey production can providing an added value in this concept, in addition to social (e.g. strengthening social solidarity, employment opportunities) and environmental (e.g. carbon storage, soil moisture, erosion control, biodiversity) benefits. Meanwhile, to create this overall initiative to be successful, a supportive measure from the policy makers is needed. Further research on capacity of biofuel species to restore degraded lands in different biophysical profiles, analysis on biofuel production feedstocks and potential co-benefits, viable business model, and stable market are necessary to maximize benefit from biofuel production and to restore degraded lands in Indonesia.

\section{Technologies to generate energy from forest biomass / Tecnologias de aproveitamento energético a partir da biomassa florestal}

Ana Paula de Souza Silva ${ }^{1,2}$, Suani Teixeira Coelho ${ }^{1}$

${ }^{1}$ Grupo de Pesquisa em Bioenergia, Instituto de Energia e Ambiente, Universidade de São Paulo, São Pauli, Brasil; ${ }^{2}$ Instituto de Pesquisas Tecnológicas do estado de São Paulo, São Paulo,Brasil (aanapaula2010@gmail.com; suani@iee.usp.br)

A biomassa florestal pode ser convertida em combustíveis sólidos, líquidos ou gasosos que poderão ser utilizados para gerar energia em diferentes formas como calor, vapor, eletricidade e biocombustíveis. Essa conversão é feita por meio de processos termoquímicos, bioquímicos e mecânicos. Combustão, gaseificação, pirólise e liquefação são exemplos de processos termoquímicos. Dentre os processos bioquímicos tem a fermentação, para converter açúcar em etanol, e a digestão anaeróbica para produção de biogás. Os processos mecânicos não são exatamente um processo de conversão, uma vez que eles não alteram o estado físico da biomassa. Exemplos de processos mecânicos são a compactação de resíduos na forma de pellets, moagem ou picagem de biomassa e extração mecânica do óleo em filtro prensa (BRIDGWATER, 2006). Esse trabalho teve como objetivo avaliar o estágio de maturidade de algumas tecnologias para aproveitamento energético ou para a produção de biocombustíveis a partir da biomassa florestal. São elas: compactação de biomassa florestal para produção de pellets; pirólise rápida e gaseificação. Para o levantamento do panorama teórico das tecnologias selecionadas nesse estudo foramconsideradasas bases de dados disponíveis no portal de periódicos da Capes; banco de dados de teses e dissertações de universidades nacionais e internacionais; bancos de dados bibliográficos das principais instituições de pesquisa e ensino superior nacionais e internacionais, entre outros. Resultados preliminares mostram que as tecnologias estudadas possuem potencial para gerar energia e biocombustíveis a partir da biomassa florestal e, também de seus resíduos em diferentes escalas e, as tecnologias se encontram em diferentes estágios de maturidade tecnológica.

Components of assessing the effectiveness of a forest biomass system for generating bioenergy / Componentes de avaliação da eficácia de um sistema de biomassa florestal para geração de Bioenergia

Marcelo Langer ${ }^{1}$, Eloise Prates Gorte ${ }^{2}$, Rudson Silva Oliveira ${ }^{1}$, Dimas Agostinho da Silva

${ }^{1}$ Universidade Federal do Paraná, Curitiba, Brasil; ${ }^{2}$ Universidade Estadual do Centro-Oeste, Irati, Brasil (marcelolanger@ufpr.br; eloiseprates@yahoo.com.br; rudsonoliveirapbs@gmail.com; dimas.agostinho.silva@gmail.com)

A biomassa é fonte de matéria-prima para geração de biocombustíveis e em 2014, foi responsável por 10\% da oferta energética mundial (IEA,2016). O setor de geração de energia primária brasileira é o de menor emissão de carbono no mundo (IEA,2013). No Brasil, em 2017, a biomassa oriunda da lenha e carvão foi responsável por cerca de 8\% do total produzido. Na indústria brasileira, o consumo de energia a partir da lenha foi de 8,6\% (EPE, 2018). Em uma empresa de 
base florestal, a produção de biomassa, utiliza galhos, madeiras diversas, árvores quebradas ou mortas, materiais de limpeza de talhões e servem para a geração de energia térmica e vapor para geração de energia elétrica. Em uma empresa florestal brasileira, apesar de serem necessárias 5 toneladas de biomassa para suprir o potencial energético gerado por 1 tonelada de óleo BPF, o seu custo é 6,2 vezes menor (de $\mathrm{R} \$ 386,00$ contra $\mathrm{R} \$ 2400,00$ para a mesma geração de energia). Esta pesquisa analisou a influência da mistura de quatro diferentes fontes de biomassa florestal: biomassa da limpeza de áreas de pinus e eucaliptos; cavacos de madeira do mercado local e cascas oriundas do processo de descascamento de toras para celulose, para geração de bioenergia. Foram testadas diferentes misturas destas quatro fontes de biomassa e realizadas análises química imediata e elementar e o poder calorífico inferior de cada composição. Os resultados estatísticos não apresentaram diferenças significativas para as diferentes composições de produtos, o que demonstra a viabilidade do atual sistema de geração de bioenergia

C7d: WILL ACTIVE RESTORATION OF SECONDARY AND DEGRADED FORESTS (SDFS) HELP TO ADDRESS SUSTAINABLY THE GAP BETWEEN WOOD DEMAND AND SUPPLY?

\title{
Phenomenological modelling scenario of future wood demand by 2050
}

Jean-Marc Roda ${ }^{1,2}$, Ainuddin Nuruddin'², Chu Lee Ong ${ }^{2}$, Omar Hishamudin'2, Philippe Guizol ${ }^{3}$

${ }^{1}$ CIRAD, Serdang, Malaysia; ${ }^{2}$ Universiti Putra Malaysia, Serdang, Malaysia; ${ }^{3}$ CIRAD, Montpellier, France (roda@cirad.fr; a_ainuddin@yahoo.com; candice.ocl@gmail.com; omarhishamudin@gmail.com; philippe.guizol@cirad.fr)

For the last 5 decades, the main factors of the world timber demand are the construction dynamics, the demographics, the user's income, the price and availability of wood products relatively to alternative materials, and regulations and policies. We measured the long run demand elasticities the major regions of the world, and built phenomenological models which can predict the wood demand up to 2050 with known errors. For the prediction of the wood demand until 2050, factors such as GDP and prices which would only rely on arbitrary scenarios, are discarded, and we measure how much of the variability of the wood demand can be predicted from phenomenological and robust variables such as demographic factors. We find that wood demands of the tropical regions (Latin-America, Sub-saharan Africa, and Tropical Asia) can be reliably modelled with good prediction errors bellow $\pm 13 \%$ to $\pm 24 \%$. Conversely, the demand models of the temperate regions where the wood dynamics are more linked with the discarded variables, are less precise and their prediction errors escalate up to $\pm 60 \%$. We find that, by 2050, tropical regions will demand between 800 and 1100 million $\mathrm{m}^{3}$ of wood per year, with $95 \%$ of confidence. Until now most of the demand by tropical regions was met by a local production, totalling around 500 million $\mathrm{m}^{3}$ per year in 2016 . Our findings raises the question of how, by 2050, tropicalforests would be able to sustainably produce the double of what they produce today ?

\section{Different contexts, same concerns? Wood gap and forest restoration in Indonesia and Cameroon}

\author{
Philippe Guizol ${ }^{l, 2}$, Liboum Mbonayem ${ }^{2}$, Abdon Awono', Jean Marc Roda ${ }^{1}$, Richard Eba'a Atyi ${ }^{2}$ \\ ${ }^{1}$ CIRAD, Montpellier,France; ${ }^{2}$ CIFOR, Yaoundé, Cameroon(philippe.guizol@cirad.fr; l.mbonayem@cgiar.org; a.awono@cgiar.org; roda@cirad.fr; \\ r.atyi@cgiar.org)
}

The gap between demand and supply of sustainable wood, in countries rich forest with a poor governance, is one of the major causes of forest degradation. This phenomenon, which is combining with other major forest degradation causes as agriculture and fires, should not be overlooked as it results in dire deforestation. In Indonesia, uncontrolled development of wood industries, led to a growing wood demand disconnected with sustainable forest management capacity. This started in 70s with log exports development, followed by the plywood industry in the 80s', pulp and paper in the 90s' and the forest conversion to agro-plantations. Tree cover in permanent forest lands dropped from 113.1 million ha to 87.4 million ha, or by $23 \%$ in 34 years, from 1982 to 2016 . In Cameroon, the growing demand for timber is accelerated by domestic market paired with the population growth above $2.5 \%$ per year. Domestic timber and firewood are sourced from poorly managed non-permanent and permanent forest. The rate of deforestation at the national level remains low ( $0.2 \%$ per year), but deforestation is rapid around cities and along roads. Comparing the two countries, some similarities have been identified, 1) in each case wood gaps are filled by illegal practices, 2) there are miss-perceptions about sustainable wood supplies from forests, 3) governments are now planning forest restoration and 4) low wood prices are discouraging investment into forest plantations, secondary forest silviculture and forest restoration. Finally, we compare how, governments are addressing wood gap and forest restoration.

\section{Can a tropical rainforest destroyed by wildfire and logging recover by rehabilitation with enrichment planting and assisted natural regeneration?}

Jan Falck ${ }^{1}$, David Alloysius², Yap Sau Wai ${ }^{3}$, Ulrik Ilstedt ${ }^{1}$ (D

${ }^{1}$ Swedish University of Agricultural Sciences, Dept. of Forest Ecology and Management, Umea, Sweden; ${ }^{2}$ Yayasan Sabah, Tawau, Malaysia; ${ }^{3}$ Yayasan Sabah, KotaKinabalu,Malaysia (jan.falck@slu.se; dalloysius@gmail.com; yapsauwai@gmail.com; ulrik.ilstedt@slu.se)

In a carbon emission and biodiversity perspective there is a great demand for rehabilitation of extensive parts of the tropical rainforest (TRF), degraded by repeated timber harvesting or wildfire. In such forest in Sabah, in the north of Borneo burned during the El Niño droughts in 1983-84, the Swedish company IKEA and Yayasan Sabah in 1998 started investing in a rehabilitation planting under mostly pioneer canopies, dominated by Macaranga species. Twenty years later an area of 10,600 ha has been planted with in total 90 tree species, mainly of the Diptercarpaceae tree family and some wild fruit species. The more wellstocked land has got the treatment of Assisted Natural Regeneration (locally called "Liberation"). The planted area has been improved by "line planting" or "gap- cluster planting" with a density of between 200 and 400 seedlings per ha depending on land suitability for planting. Maintenance period for the planted seedlings has been up to 10 years. During the last 10 years several experiments and permanent plots has been established. The average survival after 10 years is between 20 and 50\%, but remnant seed trees, have added new seedlings to most plots. Several of the planted species have already started producing seeds. The largest tree, aShorea leprosula, planted 1998, had a diameter of $64 \mathrm{~cm}$ at age of 20 years. The survival and growth rates vary because of temporal variations, in rainfall and wildlife predation and variations in light at the forest floor, soil conditions and genetics. 


\section{Modeling forest restoration potential in Indonesia with G4M}

Dmitry Schepaschenko ${ }^{1}$ (D, Andrey Krasovskii ${ }^{1}$,Stephan A. Pietsch ${ }^{1}$, Johannes Pirker ${ }^{1,2}$, Anton Platov ${ }^{1}$, Betha Lusiana ${ }^{3}$, Subekti Rahayu ${ }^{3}$, Sidiq Pambudi ${ }^{3}$, Andree Ekadinata ${ }^{3}$, Ping Yowargana ${ }^{1}$, Esther Boere ${ }^{1}$, Florian Kraxner ${ }^{1}$

${ }^{1}$ International Institute for Applied Systems Analysis, Laxenburg, Austria; ${ }^{2}$ KU Leuven, Catholic University Leuven, Leuven, Belgium; ${ }^{3}$ World Agroforestry Center,Bogor, Indonesia (schepd@iiasa.ac.at; krasov@iiasa.ac.at; pietsch@iiasa.ac.at; pirker@iiasa.ac.at; platov@iiasa.ac.at; b.lusiana@cgiar.org;

s.rahayu@cgiar.org; s.pambudi@cgiar.org; a.ekadinata@cgiar.org;yowargan@iiasa.ac.at; boere@iiasa.ac.at; kraxner@iiasa.ac.at)

Indonesia experiences significant economic growth based on natural and planted forests. To sustainably meet the growing demand of forest products, an understanding of the economic and environmental contributions of current and future forest cover is pivotal. The Global Forestry Model (G4M, www.iiasa. ac.at/g4m [http://www.iiasa.ac.at/g4m]) is a biophysical model that predicts carbon stock, net primary productivity, increment, potential harvest and optimizes rotation time with a resolution of 1,10 or $50 \mathrm{~km}$. The model uses monthly weather records or projections and soil information as input and considers various management options. As part of the Restore+ project (http://www.restoreplus.org/ [http://www.restoreplus.org/]), a regionalized version of the G4M was developed for Indonesia in order to simulate forest productivity. The model considered plantations for timber (represented by Tectona grandis, Paraserianthes falcataria and Swietenia macrophylla); plantations for pulp\&paper (Acacia mangium, Eucalyptus pellita and E. grandis); non-assisted and assisted restoration on dryland (secondary forest); and assisted restoration on peatland (Dyera polyphylla, Shorea balangeran and Coffea liberica). The model was calibrated based on observations found in the literature and results of a plot-based bio-geochemical model (BGC-MAN, www.iiasa.ac.at/BGC-MAN [http://www.iiasa.ac.at/ BGC-MAN]). Using the spatially-explicit economic model GLOBIOM, estimates of G4M on current and potential locations of forest production are evaluated against competing land uses of the AFOLU-sector with the aim to satisfy a growing world demand. G4M estimates on forest carbon stocks are combined with emissions from the AFOLU-sector, enabling GLOBIOM to analyze to what extent and under what forestry-related policies Indonesia is able to meet its environmental targets.

\section{Management potential of secondary tropical cloud forests: implications for Mexico}

Tarin Toledo-Aceves ${ }^{1}$ (D, Manuel Guariguata ${ }^{2}$, Luciana Porter-Bolland ${ }^{3}$, Sven Günter ${ }^{4}$

${ }^{1}$ Instituto de Ecología A.C., Xalapa, Veracruz, Mexico; ${ }^{2}$ CIFOR, Lima, Peru; ${ }^{3}$ Instituto de Ecología A.C., Xalapa, Veracruz, Mexico; ${ }^{4}$ Institute of International Forestry and Forest Economics, Hamburgh, Germany(tarin.toledo@inecol.mx;m.guariguata@cgiar.org; luciana.porter@inecol.mx; sven.guenter@thuenen.de)

Tropical Montane Cloud Forests are of high strategic value for sustainable development due to theirexceptional diversity and their role in the provision of ecosystem services; however, they are threatenedby deforestation, climate change and overharvesting. Secondary cloud forest (SCF), a dominant component in cloud forest landscapes, could contribute to the provision of timber and ecosystem services. However, there is limited information regarding their potential for sustainable management via selective logging by smallholders.We both summarize the research and identify knowledge gaps through an expert review of the structure and dynamics of SCF and the out comes of silvicultural interventions in the Neotropics, and analyse the main constraints and potential benefits of their managementin Mexico. High heterogeneity in structure characterizes SCF and, as succession progresses, total stem density tends to decrease and the forest increases in height, basal area, timber volume and dominance of late successional species. In Mexico, the main benefits of planned selective logging in SCF could include the provision of timber and firewood at a sustainable rate, maintenance of continuous forest cover and management of biodiversity. Themain challenges are thesmall commercial timber volume, the lack of legal definitions for secondary forests and the absence of effective policy instruments and economic incentives for small-scale landowners. Given the high intrinsic heterogeneity of SCF and the important socioeconomic variation that exists among regions in Mexico, the requisites for management should be flexible to allow adjustment to regional variations, thus allowing the inclusion of adaptive management.

\section{Tropical forest restoration and rehabilitation management in Malaysia: opportunities and challenges}

Ahmad Nuruddin ${ }^{1}$, Musri Ismenyah ${ }^{2}$, Jean-Marc Roda ${ }^{1,3}$

${ }^{1}$ Universiti Putra Malaysia, Serdang, Selangor, Malaysia; ${ }^{2}$ Universiti Malaysia Sabah, Kota Kinabalu, Malaysia; ${ }^{3}$ CIRAD, Montpellier, France (ainuddin@upm.edu.my; mrieyza@ums.edu.my; roda.outofoffice@gmail.com)

Malaysia has been endowed with a beautiful tropical forest which provides various ecosystem services such as carbon dioxide absorption, water supply and soil stabilization to the community. It is also a timber source for wood-based industries generating RM22 billion in 2016. However, there are illegal encroachment activities in the forests causing the forests to be degraded as well as conversion of land use to agriculture. The enforcement activities carried out by the authorities have resulted in the degraded areas being reclaimed and the forest areas are being restored with planting of local species with commercial value. To date many degraded forest areas have been restored using different approaches. This paper aims at presenting Malaysia's experiences and initiatives in forest restoration and rehabilitation of degraded forests. These activities have created opportunities to improve the forest ecosystem. There are also many challenges need to be addressed in order the forest restoration and rehabilitation to be successful. These challenges will also be discussed.

\section{Active versus passive restoration: recovery of cloud forest structure, diversity and soil condition in abandoned pastures}

Alma Lucrecia Trujillo Miranda 1 (D, Tarin Toledo Aceves ${ }^{1}$, Fabiola López Barrera ${ }^{1}$, Patricia Gerez Fernández ${ }^{2}$

${ }^{1}$ Instituto de Ecología A. C, Xalapa, Mexico; ${ }^{2}$ Universidad Veracruzana, Xalapa, Mexico (almalucrecia90@gmail.com,tarin.toledo@inecol.mx; fabiola.lopez@inecol.mx; pgerez@uv.mx)

Tropical montane cloud forest is a priority ecosystem for restoration due to its high diversity and the provision of ecosystem services. We assessed the effectiveness of active (mixed plantation with native species) and passive (areas adjacent and non-adjacent to mature cloud forest) restoration strategies implemented in pastures with 21 years of exclosure, and compared these to a mature cloud forest, in Mexico. Active restoration proved more effective than passive restoration at recovering forest structure (higher basal area and tree height). Adult tree diversity was similar across all sites, while composition differed greatly between the mature forest and each of the restoration sites. The restoration sites presented very low tree seedling density $\left(0.39 \mathrm{individuals} / \mathrm{m}^{2}\right)$ relative to the mature forest ( 1.68 seedlings $/ \mathrm{m}^{2}$ ), probably due to the higher cover of competing vegetation in the restoration sites. In all of the restoration sites, soil $\mathrm{pH}$ was higher, and carbon content in the soil and litter was lower, than in the mature forest. In general, the passive restoration site non-adjacent to the forest presented the lowest recovery, indicating the importance of proximity to seed sources. Our results highlight the need, in both actively and passively restored areas, for management practices, in order to assist tree seedling recruitment of key species and recovery of forest attributes. Active and passive restoration strategies could be implemented as complementary strategies for the restoration of cloud forest landscapes. 


\section{Site productivity classification for secondary evergreen dipterocarp forests in South-Eastern Vietnam}

Thi Thanh Ha Do ${ }^{1,2}$, John Grant ${ }^{1}$, Heidi Zimmer ${ }^{1}$, Bon Trinh ${ }^{2}$, Hoang Nguyen ${ }^{2}$, J. Doland Nichols ${ }^{1}$, Jerry Vanclay ${ }^{1}$ (D

${ }^{1}$ Southern Cross University, Lismore, Australia; ${ }^{2}$ Silviculture ResearchInstitute, HaNoi,Vietnam (t.do.16@student.scu.edu.au; john.grant@scu.edu.au; heidi.zimmer@gmail.com; trinhngocbon85@gmail.com;nguyenhuyhoangvfu@gmail.com; doland.nichols@scu.edu.au; jerrry.vanclay@scu.edu.au)

Reliable forest site productivity estimation is key to site-specific forest management. Many studies have investigated the estimation of forest site productivity based on species-specific height-age equations for monoculture plantations, and on height-diameter equations for mixed-species forests. However, research into estimation of productivity in secondary forests is scarce. This research classified site productivity, based on a distance-independent individual-tree growth model, to simulate management regimes in native secondary forests in monsoonal Southern Vietnam. The model was based on the spatial variation and vegetation stage at the microsite scale, which was in turn associated with soil and topographic properties, which limit the natural climax vegetation type. Recovery stage of vegetation, after a known logging event, was entered into the model to determine site productivity class. The climax vegetation types (evergreen, deciduous and bamboos), and time to recovery were identified using: the year that the normalized difference vegetation index (NDVI) at the site achieved the asymptote (from 1988 to 2017, 199 sample plots [1000 $\left.\mathrm{m}^{2}\right]$ ), and the maximum ratio of evergreen:pioneer basal area (reference from old-growth forest sites). We assumed that climax stage was evergreen mixed dipterocarp forest. Finally, both soil and topographic and stage of recovered vegetation were identified in terms of their capacity for supporting high productivity evergreen dipterocarp forests. We classified the stages of vegetation recovery based on the productivity of dipterocarp trees, and the presence of invasive species (bamboos), and based on this, we describe the recovery potential of each site.

\section{Gaps and challenges for SF owners in Central America to build bankable forest businesses}

Jean Pierre M. Aymerich ${ }^{1}$

${ }^{1}$ CATIE, Turrialba, Costa Rica (jeanmorales.aymerich@gmail.com)

The sustainable development is driven by several national and international agendas such as Sustainable Development Goals, Green Growth, Low-Emission Development Strategies and other. Those initiatives look for public and private commitments to achieve their aims, the public and political sector are engagement, but it is important that the private embrace those initiative. The possibilities of private sector to contribute for reach SDG is huge, because of that it is possible to see initiative such as SDG Business Hub, Business for 2030 and SDG Business Forum. Moreover, it is necessary to move capital for develop small and medium rural business, the international efforts are focus on microfinance (mainly on financial inclusion), impact investment and other. The study focus on analysis of 42 forest business opportunities, the key findings are structuring in business case to show the main gaps and challenges of the forest owner in Central America to build bankable forest businesses cases. The analysis use business case approach as framework to explore viable alternatives, coherence between policies and business strategies, review the stakeholder and risk analysis, to build recommendation for forest owners and practitioners.

\section{C7p: DEVELOPING SUCCESSFUL BIOLOGICAL CONTROL PROGRAMS IN FOREST PLANTATIONS

\author{
occidentalis (Hemiptera: Psylloidea), in Brazil \\ Dalva Queiroz ${ }^{1}$ (D, Luiz Alexandre de Sá ${ }^{\text {(D, Valmir Costa }}{ }^{3}$ (D, Roosevelt de Paula Almado ${ }^{4}$, José Eduardo Mendes ${ }^{5}$, Daniel Burckhardt ${ }^{6}$ (D \\ ${ }^{1}$ Embrapa Florestas, Colombo, Brasil; ${ }^{2}$ Embrapa Meio Ambiente, Jaguariúna, Brasil; ${ }^{3}$ Instituto Biológico, Campinas, Brasil; ${ }^{4}$ ArcelorMittal BioFlorestas, \\ Vazante, Brasil; ${ }^{5}$ Fibria Celulose S/A, Três Lagoas, Brasil; ${ }^{6}$ Naturhistorisches Museum, Basel, Switzerlan (dalva.queiroz@embrapa.br, \\ luiz.sa@embrapa.br,valmircosta@gmail.com, roosevelt.almado@arcelormittal.com.br;jose.mendes@fibria.com.br; daniel.burckhardt@unibas.ch)
} \\ The parasitoid Psyllaephagus blastopsyllae (Hymenoptera: Encyrtidae), as potential control of the eucalypt psyllid Blastopsylla}

In view of future release for the control of the eucalypt pest Blastopsylla occidentalis, the parasitoid Psyllaephagus blastopsyllae was imported from South Africa into Brazil in 2015, where the specimens were kept in quarantine for preliminary bioecological studies. Within a few months, the specimens died and the establishment of a viable culture failed. While another introduction was planned, the parasitoid was found in eucalyptus plantations in Minas Gerais. This changed the focus of the project to monitor the population in the plantations in Minas Gerais and to search for the parasitoid in other areas in Brazil with eucalypt plantations. The monitoring of the parasitoid showed that the pest is associated with various eucalypt clones, especially those of Eucalyptus camaldulensis. The occurrence of the parasitoid was positively correlated $(0.82)$ with the pest population but indifferent to the type of clone. The percentage of parasitism was higher between June and August, the dry season, coinciding with the population peak of the pest. Besides Minas Gerais, the parasitoid was also found in São Paulo and Mato Grosso do Sul. In a survey in SP in October 2018, the observed percentage of parasitism was around 9\%. A similar survey in Três Lagoas, MS, in August, yielded a percentage of parasitization of about $11 \%$. Our data represent a small sampling in terms of total eucalypt plantations in Brazil. For promoting biological control, we suggest to increase the number of areas to be surveyed for the occurrence of the parasitoid and to study its control potential.

\section{Selectivity of mycoinsecticides and a pyrethroid to the egg parasitoid Cleruchoides noackae (Hymenoptera: Mymaridae)}

Maurício Magalhães Domingues ${ }^{1}$, Luciane K. Becchi ${ }^{1}$, Simone G. M. Velozo ${ }^{1}$, Amanda R. Souza ${ }^{2}$, Leonardo R. Barbosa ${ }^{3}$, José C. Zanuncio ${ }^{4}$, Carlos F. Wilcken ${ }^{1}$

${ }^{1}$ Universidade Estadual Paulista “Júlio de Mesquita Filho”, Faculdade de Ciências Agronômicas, Botucatu, Brasil; ${ }^{2}$ Gerdau Company, Três Marias, Brasil; ${ }^{3}$ Embrapa Florestas, Colombo, Brasil; ${ }^{4}$ Departamento de Entomologia, BIOAGRO, Universidade Federal de Viçosa, Viçosa, Brasil (mauriciomdomingues@gmail.com; luciane.becchi@hotmail.com; simonemvelozo@gmail.com; agroamandarodrigues@yahoo.com.br; leonardo.r.barbosa@embrapa.br; zanuncio@ufv.br; carlos.wilcken@unesp.br)

Thaumastocoris peregrinus (Hemiptera: Thaumastocoridae), is an exotic pest of great importance for Eucalyptus plantations.The use of the egg parasitoid Cleruchoides noackae (Hymenoptera: Mymaridae), is the most used control method. However, other techniques are studied, such as use of entomopathogenic fungi and chemical insecticides. The compatibility of chemical and biological control methods favors integrated pest management. The objective was to evaluate the action of mycoinsecticides and insecticides on the parasitoid $C$. noackae and its parasitism on T. peregrinus eggs. Two bioassays were performed: 1 ) cage surfaces (IOBC standard) were submitted to the application of Beauveria bassiana (Boveril) and Metarhizium anisopliae (Metarril), both with concentrations of 1 x 108 conidia/g, Bifenthrin (Capture), with a concentration of $400 \mathrm{~g} / \mathrm{L}$, and control (water); after drying, 20 adults of the parasitoid were released per replicate (cage); 2) in this bioassay eggs of T. peregrinus were submitted to the same treatments; after drying 10 eggs of $T$. peregrinus treated by cage, and released a 
couple of $C$. noackae by replicate. Parasitism was allowed for 24 hours $\left(T=25 \pm 2{ }^{\circ} \mathrm{C} ; \mathrm{UR}=70 \pm 10 \%\right.$ and photophase $\left.=12 \mathrm{~h}\right)$. The statistical desing was completely randomized with four treatments and five replicates. Mortality, parasitism and viability were evaluated. B. bassiana was selective to parasitism and viability, and slightly harmful to adults of $C$. noackae; $M$. anisopliae was innocuous to adults and the viability of offspring, but it reduced parasitism; and bifenthrin was non-selective to $C$. noackae in all bioassays.

\section{Effect of mycoinsecticides and insecticides on emergence of the pupae parasitoid Tetrastichus howardi (Hymenoptera: Eulophidae)}

Mauricio Magalhães Domingues ${ }^{1}$, Ana L. Favoreto ${ }^{1}$, Diego A. Nascimento ${ }^{1}$, Carlos F. Wilcken ${ }^{1}$

${ }^{1}$ Universidade Estadual Paulista “Júlio de Mesquita Filho”, Faculdade de Ciências Agronômicas, Botucatu, Brasil (mauriciomdomingues@gmail.com; analaurafavoreto@gmail.com; diego_acj@hotmail.com; carlos.wilcken@unesp.br)

Tetrastichus howardi (Hymenoptera: Eulophidae) is a gregarious endoparasitoid and a facultative hyperparasitoid. This parasitoid has potential to use to control lepidopterous pests in Eucalyptus plantations in Brazil. The use of mycoinsecticides and insecticides in pest management may have deleterious effects on nontarget organisms. The recommendation of selective insecticides has great appeal to the conservation of natural enemies and parasitoids. Therefore, the objective of the work was to evaluate the action of mycoinsecticides and insecticides used to Eucalyptus pests on the emergence of T. howardi. Pupae of Diatraea saccharalis were offered to T. howardi parasitoids, with parasitism allowed for 48 hours, after which they were individualized in glass tubes and maintained under controlled conditions $\left(25 \pm 2{ }^{\circ} \mathrm{C}\right.$; UR $=70 \pm 10 \%$ and $12 \mathrm{~h}$ photophase). The statistical design was completely randomized with seven treatments and 10 replicates. When the pupae were close to emerging the treatments were prepared: Beauveria bassiana and Metarhizium anisopliae (both with concentrations of 1 x 108conidia/g), tiamethoxam, bifenthrin, imidacloprid and clorfenapyr (under higher recommended doses) and control (water). The pupae were immersed in the treatments for 10 seconds. After drying, they were transferred to polystyrene tubes until the parasitoids emerged. It was evaluated the number of parasitoids emerged and were retained in pupa. The insecticides were classified according to the International Organization for Biological Control (IOBC). None of the treated pupae affected the emergence of parasitoid adults, therefore, all products classified as innocuous. However, studies to verify the direct effect on the parasitoid still need to be done.

\section{A phylogeographic approach for Glycaspis brimblecombei (Hemiptera: Aphalaridae) and its parasitoids in Brazil}

Fábio Araújo dos Santos ${ }^{1}$, Alberto Corrêa Soares ${ }^{2}$, Sidinei Dallacort ${ }^{1}$, Diego Arcanjo do Nascimento ${ }^{1}$, Coroline Dias de Souza ${ }^{1}$, Luis Renato Junqueira ${ }^{3}$, Carlos Frederico Wilcken ${ }^{1}$

${ }^{1}$ Escola Superior de Agricultura "Luiz de Queiroz", Universidade de São Paulo, Faculdade de Ciências Agronômicas, Botucatu, Brasil; ${ }^{2}$ Escola Superior de Agricultura “Luiz de Queiroz”, Universidade de São Paulo, Piracicaba, Brasil; 'Instituto de Pesquisas e Estudos Florestais, Piracicaba, Brasil (fabioaraujomf@outlook.com; ascorrea@usp.br; sidinei.dallacort@gmail.com;diego_acj@hotmail.com; xcarolinediasgmail.com; renato@ipef.br; carlos.wilcken@unesp.br)

Eucalyptus red gum lerp psyllid, Glycaspis brimblecombei (Hemiptera: Aphalaridae) is one of the most important Eucalyptus exotic pests. Its first report in Brazil was in 2003, in the state of São Paulo, damaging Eucalyptus camaldulensis plantations. The parasitoid, Psyllaephagus bliteus (Hymenoptera: Encyrtidae), was reported together with the psyllid and a new introduction of parasitoids from Mexico was performed to improve the efficiency of biological control programs of this pest. Our objectives were to evaluate the genetic diversity of the psyllid and its parasitoid in Brazil using mitochondrial genes sequencing. Insects of both species were collected from different regions in Brazil. Thirty-four individuals of G. brimblecombei and twelve samples of Psyllaephagus spp were successful sequenced. A single COI gene haplotype was found in G. brimblecombei populations from Brazil and this is the same haplotype that occurs in Portugal samples, indicating one (or few) introduction events of G. brimblecombei in Brazil is originated from an invasive lineage distributed in other regions from the world. This fact suggests that the invasion routes of G. brimblecombei in the world are interconnected, which seems to be a standard for invasive Eucalyptus pests. Two distinct haplotypes, with a high genetic distance between them, were identified for the parasitoid. It confirms the presence of two parasitoid species in Brazil, one already identified, P. bliteus, and a second species of Psyllaephagus not morphologically identified. However, we can confirm that both parasitoid species collected in Brazil are exotic species originated from Australia.

\section{Population dynamics of bronze bug, red gum lerp psyllid and its parasitoid in Eucalyptus plantations in three regions of São Paulo, Brazil}

Thais Alves da Mota ${ }^{1}$, Barbara Oliveira Puretz ${ }^{1}$, Luiz Renato Junqueira ${ }^{2}$, José Raimundo Passos ${ }^{3}$, Renato Meulman Leite da Silva ${ }^{4}$, Paulo Augusto de Souza Zingra Vomero ${ }^{1}$, Carlos Frederico Wilcken ${ }^{1}$

${ }^{1}$ Universidade Estadual Paulista "Júlio de Mesquita Filho", Laboratory of Biological Control of Forest Pests FCA, Botucatu, Brasil; ${ }^{2}$ Institute for Research

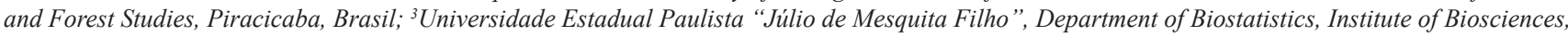
Botucatu, Brasil; ${ }^{4}$ International Paper from Brasil, Mogi Guaçu, Brasil(thaisalves_rvs@hotmail.com; bah_puretz@hotmail.com; renato@ipef.br; rexpialfa@gmail.com; renato.meulman@ipaper.com; paulovomero@gmail.com; cwilcken@uol.com.br)

The aim of this study was to evaluate the population dynamics of Thaumastocoris peregrinus (Hemiptera: Thaumastocoridae), Glycaspis brimblecombei (Hemiptera: Aphalaridae) and its parasitoid Psyllaephagus bliteus (Hymenoptera: Encyrtidae) in three distinct regions of São Paulo State (Mogi Guaçu, São Simão, and Altinópolis) during 2014 to 2017. The pests and parasitoid monitoringwas correlated with meteorological data: maximum temperature (Tmax.), minimum temperature (Tmin.) and average (Tmed.); rainfall (P); daily solar radiation (R) and vapor pressure deficit (DPV). The insects monitoring was carried out with yellow stick traps $(12.5 \times 10 \mathrm{~cm})$ monthly during for four years, totaling 275 sample sites. T. peregrinus population index declined over the years, differing from G. brimblecombei and P. bliteus, which ones increased. The correlation between T. peregrinus and meteorological data was positive with the considering Tmax., Tméd., R and DPV. Rainfall and Tmin. was negative for G. brimblecombei, but positively for Tmax., R and DPV. P. bliteus population had positive correlation for the population increasing and Tmax., R and DPV. These results were similar to field observations, demonstrating monitoring may be essential in decision making for pest control. 


\section{Predation of Thaumastocoris peregrinus (Hemiptera: Thaumastocoridae) by Atopozelus opsimus (Hemiptera: Reduviidae) under different} temperatures

Caroline Dias de Souza ${ }^{1}$, Luciane Katarine Becchi ${ }^{1}$, Thais Alves Mota ${ }^{1}$, Fábio Araújo dos Santos ${ }^{1}$, Carlos Frederico Wilcken ${ }^{1}$

${ }^{1}$ Universidade Estadual Paulista "Júlio de Mesquita Filho", Faculdade de Ciências Agronômicas, Botucatu, Brasil (xcarolinedias@gmail.com; luciane.becchi@hotmail.com; thaisalves9393@gmail.com; fabioaraujomf@outlook.com; cwilcken@fca.unesp.br)

The bronze bug Thaumastocoris peregrinus (Hemiptera: Thaumastocoridae), native of Australia, is one of the main Eucalyptus pest in Brazil. This pest can cause silvering, followed by bronzing and defoliation. The determination of predation rate of Atopozelus opsimus (Hemiptera: Reduviidae) on T. peregrinus is essential to improve biological control program of this pest. The objective was to evaluate the predation rate of $T$. peregrinus by $A$. opsimus, in different temperatures to promote the most efficient use of this predator. Ten adults of $A$. opsimus with different ages were individualized in Petri dishes containing cotton soaked in deionized distilled water.Ten adults and five T. peregrinus nymphs were offered for 24 hours, at 18,24 and $30 \pm 1{ }^{\circ} \mathrm{C}(\mathrm{RH}: 60 \pm 10 \%$; photophase: $12 \mathrm{~h}$ ). The number of $T$. peregrinus preyed was recorded. The experiment had ten replications anddata analyzed by ANOVA andcompared by the Tukey test. The mean predation rate of adults and nymphs of $T$. peregrinus by $A$. opsimus at 18,24 and $30{ }^{\circ} \mathrm{C}$ was $0.7,2.5,3.1$ and $0.3,0.7,0.9$, respectively. The number of insect (adults and nymphs) preyed at $24 \mathrm{e} 30^{\circ} \mathrm{C}$ did not differ significatively. The predator $A$. opsimus is a potential agent to control of $T$. peregrinus, with a tendency to increase predation as the temperature increases.

\section{Bioecology and management of Leptocybe invasa in Uruguay}

Carolina Jorge ${ }^{1,2}$, Edson L.L. Baldin ${ }^{3}$, Gonzalo Martínez ${ }^{4}$, Carlos Frederico Wilcken ${ }^{5}$

${ }^{1}$ Instituto Superior de Estudios Forestales. Centro Universitario de Tacuarembó. UdelaR., Tacuarembó, Uruguay; 'Escola Superior de Agricultura Luiz de Queiroz, Universidade de São Paulo, Faculdade de Ciências Agronômicas, Botucatu, Brasil; " ${ }^{2}$ niversidade Estadual Paulista "Júlio de Mesquita Filho", Laboratório de Resistência de Plantas a Insetos e Plantas Inseticidas Faculdade de Ciências Agronômicas, Botucatu, Brasil; ${ }^{4}$ INIA Tacuarembó, Uruguay., Tacuarembó, Uruguay; ${ }^{5}$ Universidade Estadual Paulista "Júlio de Mesquita Filho, Faculdade de Ciências Agronômicas, Laboratório de Controle Biológico dePragas Florestais, Botucatu,Brasil(carolina.jorge@cut.edu.uy; edson.baldin@unesp.br; gmartinez@inia.org.uy; cwilcken@fca.unesp.br)

The blue gum chalcid wasp, Leptocybe invasa Fisher \& La Salle, 2004 (Hymenoptera: Eulophidae) is a pest native from Australia that causes economical losses in Eucalyptus plantations. It was first detected in 2011 in Uruguay. Damage resulting from L. invasa galls can be particularly severe in Eucalyptus nurseries and in young plantations. The use of biological control agents (BCA) and plant resistance have proven valuable tools in keeping $L$. invasa populations under control worldwide. To date, the bioecology and population dynamics of this pest in Uruguay is unknown. The objective of this work was to study the population fluctuation, distribution and management strategies for $L$. invasa in Uruguay. We conduct a survey among foresters. Four yellow sticky traps (YST) were distributed in an area of 0.5 ha of Eucalyptus spp. in Tacuarembó and replaced monthly from December 2015 to November 2018. Captures in YST were correlated with temperature and precipitation data. Some genotypes of Eucalyptus grandis, E. benthamii and E. grandis x E. camaldulensis hybrids recorded more damage by $L$. invasa. Currently, this species distributed mostly in the North and West parts of the country. Captures in YST peaked on February, May and November and was negatively linked to accumulated precipitation. This study provides key data towards the implementation of biological control of $L$. invasa with Selitrichodes neseri (Hymenoptera: Eulophidae) which is currently ongoing in the country.

\section{Effect of trap position to monitoring of Thaumastocoris peregrinus (Hemiptera: Thaumastocoridae) in Eucalyptus plantations}

Flavia Galvan Tedesco ${ }^{1}$, Luciano Ramos ${ }^{2}$, Luaciane Becchi ${ }^{1}$, Sidinei Dallacortt, Barbara Puretz ${ }^{1}$, Claudinéia Paes Fogaça ${ }^{1}$, Carlos Frederico Wilcken ${ }^{1}$ ${ }^{1}$ Escola Superior de Agricultura "Luiz de Queiroz", Universidade de São Paulo, Faculdade de Ciências Agronômicas, Botucatu, Brasil; 'Eldorado Brasil, Três Lagoas,Brasil (flaviagtedesco@gmail.com; luciano.ramos@eldoradobrasil.com.br; luciane.becchi@hotmail.com; sidinei.dallacort@gmail.com; barbarapuretz@gmail.com; fer.paes@yahoo.com.br; carlos.wilcken@unesp.br)

The bronze bug is one of the main exotic pests occurs in Eucalyptus plantations in Brazil, affecting wood production. Monitoring is one of the most important motions for detection and also for pest control decision making in the field. This experiment had the objective of evaluating the effect of trap position on capture of adults and nymphs of Thaumastocoris peregrinus (Hemiptera: Thaumastocoridae). The study was carried out in October, 2018, in the municipality of Três Lagoas, MS, using yellow adhesive traps in three positions, 1) traps in the trunk, 2) traps between two trees in vertical position and 3) traps between two trees in horizontal position. The traps were installed at $1.60 \mathrm{~m}$, with the aid of strings, having a total of 30 replicates per treatment. After 30 days all traps were collected and sent to laboratory to proceed the insects counting. The average number of adult insects collected was 15 in the trunk, 36 in horizontal and 6 in vertical, and for nymphs this number was seven in the trunk, 39 in horizontal and seven in vertical. There was no significant difference among the traps positions (Scott-Knott test, p $0.05 \%$ ). More tests will be carried out in different regions of Brazil to confirm the best method of monitoring T. peregrinus.

\section{C7q: DEVELOPING SUCCESSFUL BIOLOGICAL CONTROL PROGRAMS IN FOREST} PLANTATIONS - 2

\section{Detection and transmission of endosymbionts in populations of Glycaspis brimblecombei (Hemiptera: Aphalaridae) and its parasitoid}

Ana Favoreto ${ }^{1}$, Vanessa Rafaela de Carvalho ${ }^{1}$, Murilo Fonseca Ribeiro ${ }^{1}$, Mauricio Magalhães Domingues ${ }^{1}$, Carlos Frederico Wilcken ${ }^{1}$

${ }^{1}$ Universidade Estadual Paulista "Júlio de Mesquita Filho”, Faculdade de Ciências Agronômicas, Botucatu, Brasil (analaurafavoreto@gmail.com; vanessa.carvalho@unesp.br; murilo.fon.rib@gmail.com; mauriciomdomingues@gmail.com; carlos.wilcken@unesp.br)

The Redgum Lerp Psyllid Glycaspis brimblecombei (Hemiptera: Aphalaridae) has defoliated Eucalyptus plantations in several regions in Brazil. The main control tactic is biological control with the nymph parasitoid Psyllaephagus bliteus (Hymenoptera: Encyrtidae). Associations between insects and endosymbionts are common and these bacteria can aid in food processing, detoxification of plant substances, reproduction and even in the defense of insects against infections. This complex relationship with hosts can influence biology, behavior and interaction with other organisms and the environment. The objective of this work was to identify and to correlate symbiotic bacteria in pest and parasitoid populations. Two populations of G. brimblecombei and P. bliteus from Botucatu and Mogi-Guaçu (SP, Brazil) were evaluated. Identifications were performed by molecular analysis (PCR) with specific primers for Arsenophonus, Carsonella, Hamiltonella, Wolbachia and Rickettsia. After the product amplification, Sanger purification and sequencing were performed comparing the results with GenBank. The population of G. brimblecombei from Botucatu presented Carsonella and Arsenophonus, primary and secondary intestinal symbionts, respectively. However, for 
P. bliteus from Botucatu no endosymbionts were detected. G. brimblecombei population from Mogi-Guaçu presented Arsenophonus, Carsonella and Wolbachia, while the parasitoid $P$. bliteus presented Wolbachia. Thus, this infection is characterized as horizontal, by passing from the host to the parasitoid. Wolbachia may influence both the feminization of males and / or increase in the reproductive capacity of the pest and parasitoid. These aspects will be studied.

\section{Effect of temperature on flight of Cleruchoides noackae (Hymenoptera: Mymaridae), parasitoid of Eucalyptus bronze bug}

Luciane Katarine Becchi ${ }^{1}$, Thamires Lima dos Santos ${ }^{1}$, Flávia Galvan Tedesco ${ }^{1}$, Carolina Jorge ${ }^{1}$, Caroline Dias de Souza ${ }^{1}$, Leonardo Rodrigues Barbosa $^{2}$, Carlos Frederico Wilcken ${ }^{1}$

${ }^{1}$ Universidade Estadual Paulista “Júlio de Mesquita Filho”, Faculdade de Ciências Agronômicas, Campus Botucatu, Botucatu, Brasil; ${ }^{2}$ Embrapa Florestas, Colombo,Brasil(becchiluciane@gmail.com; tlsantos111@gmail.com; flaviagtedesco@gmail.com; carolina.jorge@cut.edu.uy; xcarolinedias@gmail.com; leonardo.r.barbosa@embrapa.br; cwilcken@fca.unesp.br)

The egg parasitoid Cleruchoides noackae (Hymenoptera: Mymaridae) is the main biological control agent of Thaumastocoris peregrinus (Hemiptera: Thaumastocoridae), an exotic pest that threatens Eucalyptus plantations worldwide.Was evaluate the quality of $C$. noackae in the laboratory by the flight test, at different temperatures. The ESALQ model test unit was used, consisting of a PVC cylinder with the interior covered by black cardboard. On the inner wall an entomological stick ring $(0.5 \mathrm{~cm}$ wide) was placed to $3.5 \mathrm{~cm}$ from the lower to determine parasitoid walkers. To determine flying parasitoids, a Petri dish with stick was embedded in the upper part of the cylinder. A hundred eggs of T. peregrinus parasitized by C. noackae were individualized in glass tubes, fixed in the center of the test units and placed in climatic chamber at 20, 25 and $30 \pm 2{ }^{\circ} \mathrm{C}$, RH: $60 \pm 10 \%$ and 24:0 photoperiod (L/D).The experimental design was completely randomized with five replicates. Data were analyzed by ANOVA andcompared by Tukey test.The increase in the percentage of flying parasitoids was directly proportional to the temperature increase, varying from 29 to $74 \%$, at 20 and $30^{\circ} \mathrm{C}$, respectively. Highest percentage of walking parasitoids ( $60 \%$ ) was observed at $20^{\circ} \mathrm{C}$, while at $25^{\circ} \mathrm{C}$ there was no difference between flying and walkers. At $30^{\circ} \mathrm{C}, 74 \%$ of the parasitoids were classified as flying and $20 \%$ as walkers. The temperature affected the $C$. noackae flight in the laboratory. It is suggested to release $C$. noackae in the field at temperatures above $20^{\circ} \mathrm{C}$.

Lignocellulase from Basidiomycota fungi cultivated in woody biomass / Lignocelulases de fungos Basidiomycota cultivados em biomassa lenhosa

Anna Sofya Vanessa Silvério da Silva ${ }^{1}$ (D, Fernando Nunes Gouveia ${ }^{1}$ (D, Marcelo Fontana da Silveira ${ }^{1}$ (D), José Roberto Victor de Oliveira ${ }^{1}$ Helson Mario Martins do Vale ${ }^{2}$ (D) Eliane Ferreira Noronha ${ }^{2}$ (D)

${ }^{1}$ Serviço Florestal Brasileiro, Brasília, Brasil; ${ }^{2}$ Universidade de Brasília,Brasilia,Brasil (anna.silva@florestal.gov.br; fernando.gouveia@florestal.gov.br; marcelo.silveira@florestal.gov.br,jose.oliveira@florestal.gov.br; helson@unb.br; elinoronha@gmail.com)

A madeira é uma matéria-prima obtida das árvores, de constituição heterogênea e variável por ser um produto do seu metabolismo. Em virtude da sua composição química básica (celulose, hemicelulose e lignina) pode representar importante substrato para produção de enzimas por organismos xilófagos, especialmente por fungos do Filo Basidiomycota, os quais desenvolveram sistemas bioquímicos complexos capazes de converter e mineralizar a lignocelulose. Esse processo natural pode ser utilizado para fins industriais, como na produção de celulose e na conversão, de alto valor agregado, de resíduos lignocelulósicos em biorrefinarias. Foi realizado screening em meio sólido MYG modificado. Em seguida, foi avaliada a produção de enzimas celulolíticas, hemicelulolíticas e ligninolíticas por fungos de podridão branca e parda cultivados em meio mínimo líquido contendo serragem de Swartzia psilonema como única fonte de carbono. Foram determinadas as curvas de crescimento por quantificação da proteína intracelular. Os fungos Trametes versicolor/Mad 697, Bjerkandera fumosa/L-15918-Sp, Gloeophyllum trabeum/Mad 617 e Meruliporia incrassata/Piirto-31 apresentaram maior halo de degradação. Trametes versicolor/Mad 697 apresentou as maiores atividades específicas de lacases, xilanases e endoglucanases. Bjerkandera fumosa/L-15918-Sp apresentou maior taxa de crescimento. A maior atividade de celulases totais foi observada em Meruliporia incrassata/Piirto-31. Os extratos brutos fúngicos que apresentaram atividade específica representam fonte potencial de enzimas que podem ser empregadas em coquetéis destinados à despolimerização da biomassa lenhosa.

\section{Effects of parasitism by Tetrastichus howardi (Hymenoptera: Eulophidae) on Oxydia vesulia caterpillars (Lepidoptera: Geometridae)}

Rafaela Freitas Pavani ${ }^{1} \bullet$, Ana Laura Favoreto ${ }^{1}$, Murilo Fonseca Ribeiro ${ }^{1}$, Carolina Jordan ${ }^{1} \bullet$, Carlos Frederico Wilcken ${ }^{1}$

${ }^{1}$ Universidade Estadual Paulista "Júlio de Mesquita Filho”, Faculdade de Ciências Agronômicas, Botucatu, Brasil (rfpavani@gmail.com; analaurafavoreto@gmail.com; murilo.fon.rib@gmail.com; carolinajordan@gmail.com,carlos.wilcken@unesp.br)

Adaptation of dietary habits of native lepidopteran species to eucalyptus plantations has become a treat to productivity in Brazil. Considered as a secondary pest, Oxydia vesulia (Lepidoptera: Geometridae) is frequently reported in Eucalyptus plantations and associated with outbreaks and economic damages. New methods have been tested to control several lepidopterous-pests and Tetrastichus howardi (Hymenoptera: Eulophidae), a pupae endoparasitoid, that has been reported as efficient for control caterpillars on major crops. Despite being a pupae parasitoid, its parasitism was tested in $O$. vesulia caterpillars. Fourth instar caterpillars were offered to the parasitoids, 10 parasitoids per larvae, with 24 hours old. After exposure larvae were kept in pots with leaves of Eucalyptus urophylla changed daily until the pupal stage, kept under laboratory controlled conditions ( $25 \pm 1{ }^{\circ} \mathrm{C}, \mathrm{RH}: 60 \pm 10 \%$ and photophase: $\left.12 \mathrm{~h}\right)$. T. howardi did not emerged from parasitized $O$. vesulia caterpillars, however positive results were found for pest control. A total of $40 \%$ of the caterpillars died before reaching the prepupal stage, other $40 \%$ reached the pupal stage and died due poor formation or problems at emergence and $20 \%$ survived. Although the parasitoid has not been able to complete its cycle in caterpillars, it shows itself as promising in controlling the pest in its most critical stage of occurrence. Studies on the potential parasitism of $T$. howardi on $O$. vesuliain the field must be developed to verify the effectiveness of this parasitoid.

\section{Multiplication and release of the imported natural enemy Selitrichodes neseri (Hymenoptera: Eulophidae) for the biological control of the wasp, Leptocybe invasa (Hymenoptera: Eulophidae) in Eucalyptus plantations in Brazil}

Luiz Alexandre Nogueira de Sá ${ }^{1}$ (D, Bárbara Oliveira Puretz ${ }^{2}$, Carlos Frederico Wilcken², Leonardo Rodrigues Barbosa ${ }^{3}$, Luis Renato Junqueira ${ }^{4}$, José Cola Zanuncio ${ }^{5}$

${ }^{1}$ Embrapa Meio Ambiente, Laboratório de Quarentena "Costa Lima”, Jaguariúna, Brasil; 'Universidade Estadual Paulista "Júlio de Mesquita Filho", Faculdade de Ciências Agronomicas, Botucatu, Brasil; ${ }^{3}$ Embrapa Florestas, Colombo, Brasil; ${ }^{4}$ Instituto de Pesquisas e Estudos Florestais, Piracaicaba, Brasil(luiz.sa@embrapa.br, barbarapuretz@gmail.com; carlos.wilcken@unesp.br; leonardo.r.barbosa@embrapa.br; renato@ipef.br; zanuncio@ufv.br)

High productivity and short rotation have made Eucalyptus the most cultivated plant in the world for the production of raw material for various industrial sectors. The exotic wasp, Leptocybe invasa (Hymenoptera: Eulophidae) from Australia, has spread rapidly in the world. Leptocybe invasa was registered in 
Brazil in eucalyptus nurseries in the Bahia State in 2007, which made it necessary, in 2015, to import through the Quarantine Laboratory "Costa Lima", Embrapa Meio Ambiente of Jaguariúna, Sao Paulo, Brazil, the exotic control bioagent, Selitrichodes neseri (Hymenoptera: Eulophidae) from the University of Pretoria in Pretoria, South Africa. This introduction was requested by FCA/UNESP-Botucatu Campus (University of São Paulo State, Faculty of Agrarian Sciences) and by the PROTEF/IPEF (Programa Cooperativo em Proteção Florestal/Instituto de Pesquisas e Estudos Florestais/IPEF). Seedlings of hybrid clones of Eucalyptus grandis $x$ Eucalyptus camaldulensis were planted in $1.7 \mathrm{~L}$ pots with soil sterilized with a mixture of soil-sand-manure (1:1:1) and irrigated daily to obtain the parasitoid galls. These seedlings were kept in an open nursery at FCA/UNESP and infested, naturally, by $L$. invasa. Approximately seventy days after the infestation, the plants with galls were taken to Embrapa and offered to parasitism to multiply $S$. neseri in the laboratory. The production of $S$. neseri adults was 3,020 in 2015, 8,616 in 2016/2017 and 4,700 in 2018; which were sent to UNESP and then to forestry companies associated to PROTEF for releasing in Eucalyptus plantations. Acknowlegments: Embrapa, CNPq, FCA/UNESP, IPEF/PROTEF, UFV

\section{First record of microsporidium infection in Eucalyptus snout beetle Gonipterus platensis (Coleoptera: Curculionidae)}

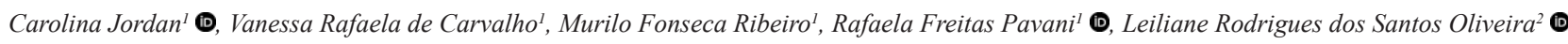
Lorena Estevo Del Compare Hilário ${ }^{1}$, Carlos Frederico Wilcken ${ }^{1}$

${ }^{1}$ Escola Superior de Agricultura "Luiz de Queiroz", Universidade de São Paulo, Faculdade de Ciências Agronômicas, Botucatu, Brasil; ${ }^{2}$ Escola Superior de Agricultura "Luiz de Queiroz", Universidade de São Paulo, Faculdade de Medicina, Botucatu, Brasil (carolinarjordan@gmail.com; vanessa.carvalho@unesp.br;murilo.fon.rib@gmail.com;rfpavani@gmail.com;lrs.oliveira@unesp.br,lorenadel2010@hotmail.com;carlos.wilcken@unesp.br)

Gonipterus platensisis the main beetle pest of Eucalyptus plantations. This species is from Australia and it has high destructive potential. Several environmental, biological and genetic factors can influence the life cycle of the insect. The presence of intracellular pathogens as microsporidia in insect populations can cause morphological and behavioral changes, such as increase in larval mortality, delay in development, reduction in fecundity and adult longevity, and may also be associated with the failure of parasitism. However there are no records of microsporidia in populations of $G$. platensis. Thus, the objective of this work was to identify possible microsporidia in adults of G. platensis. The insects with aspects of microsporidiosis were collected in Botucatu, in June, 2018 in Eucalyptus hybrid plantations ("Urograndis"). The insects were evaluated by the molecular PCR technique with the use of specific primers to identify possible microsporids. The purified PCR products were subjected to Sanger sequencing and the sequences obtained were compared to the GenBank database. The presence of intracellular parasites of the genus Microsporidia sp. was confirmed in adults of G. platensis. This same genus was also reported in other coleopteran species, causing several deleterious effects. Thus, the first report of the detection of this microsporidium in G. platensis. Further studies are needed to identify the species, as well as to know the insect-pathogen interaction, and can also be used as a strategy for biological control of $G$. platensis.

\section{Detection of symbiotic bacteria in Anaphes nitens (Hymenoptera: Mymaridae) and Gonipterus platensis (Coleoptera: Curculionidae) eggs}

Murilo Fonseca Ribeiro ${ }^{1}$, Vanessa Rafaela de Carvalho ${ }^{1}$, Ana Laura Favoreto ${ }^{1}$, Carolina Jordan ${ }^{1}$, Rafaela Freitas Pavani ${ }^{1}$,

Lorena Estevo Del Compare Hilário", Carlos Frederico Wilcken ${ }^{1}$

${ }^{1}$ Escola Superior de Agricultura "Luiz de Queiroz", Universidade de São Paulo, Faculdade de Ciências Agronômicas, Botucatu, Brasil

(murilo.fon.rib@gmail.com; vanessa.carvalho@unesp.br; analaurafavoreto@gmail.com; carolinarjordan@gmail.com; rfpavani@gmail.com;

lorenadel2010@hotmail.com; carlos.wilcken@unesp.br)

Outbreaks of Gonipterus platensis (Coleoptera: Curculionidae) in Eucalyptus plantations have occurred in the States of São Paulo and Paraná, Brazil, in the last years, due to low parasitism rates of the egg parasitoid Anaphes nitens (Hymenoptera: Mymaridae). Symbiont bacteria can act in different ways on hosts, influencing the parasitism's efficiency. However, there are no records of symbionts in A. nitens. This work aims to identify symbiotic bacteria in different parasitoid populations and eggs of their host. Adults of six populations of A. nitens (five form São Paulo and one from Espírito Santo state) and eggs from a laboratory population of G. platensis were evaluated by PCR using specific primers for identification of nine different genera of cellular endosymbionts. The purified PCR products were sequencied and the sequences obtained were compared to GenBank database. The bacterium Serratia grimesii was identified in the eggs of $G$. platensis, it was already reported in midgut of other Coleoptera. All populations of A. nitens had presence of cellular endosymbiont Rickettsia belliand bacteria Erwinia amylovora, Yersinia massiliensis and S. grimesii. Bacteria E. amylovora and Y. massiliensis probably act as intestinal symbionts for the host. S. grimesii, found in the parasitoid and host, probably is acquired by horizontal transmission from G. platensis. Studies to verify the bacteria quantitative aspects and the effects on $A$. nitens biological parameters are ongoing.

\section{Comparison of antifungal microorganism Streptomyces blastmyceticus and the Fungicide Alamo ${ }^{\circledR}$ for the control of oak wilt disease by trunk Injection and macro-infusion at root flare}

Jin Heung Lee ${ }^{1,2}$, Soo Wan Park', Joo Hyun Yong'2, Sang-Tae Seo ${ }^{3}$, Sun Keun Lee ${ }^{3}$, Dong-Hyeon Lee ${ }^{3}$, Jong Kyu Lee

${ }^{1}$ Gyeonggi-Do Forestry Environment Research Institute, Gyeonggi Province, Republic of Korea; ${ }^{2}$ Kangwon National University, Chuncheon, Republic of Korea; ${ }^{3}$ Division of Forest Insect Pests and Diseases, National Institute of Forest Science, Seoul, Republic of Korea (leejinheung@gg.go.kr; swpark@kangwon.ac.kr; joohyuny@kangwon.ac.kr; stseo@korea.kr; lskyou@korea.kr; leedh2009@korea.kr; jongklee@kangwon.ac.kr)

Disease management for oak wilt of Quercus mongolicae caused by Raffaelea quercus-mongolicae in Korea have been mainly focused on the control of insect vector (Platypus koryoensis) by applications of insecticide, pheromone, sticky roll trap, and fumigation of dead or dying trees and so on.For the control of the pathogen in trees, culture suspension of antifungal Streptomyces blastmyceticus was injected into trees by trunk (ChemJet $(\mathbb{R})$ or root flare (Macro-infusion) injection before or after artificial inoculation of the pathogen, and then the ratios of non-conductive area, discolored area, and re-isolation of the pathogen from the treated trees were compared for evaluating preventive or curative efficacy. Injection of S. blastmyceticus or the fungicide (Alamo ${ }^{\circledR}$ ) showed $41.7 \%$ and $45.8 \%$ in non-conductive area(\%), respectively. In addition, S. blastmyceticus did not show much differences between injection methods or timings in control effect, but fungicide was better in Macro-infusion at root flare or curative treatments. Re-isolation rates of the pathogen from the treated tree woods in the treatments of pathogen only, preventive and curative were $56.9 \%, 20.6 \%$, and $36.1 \%$, respectively. These results indicated that $S$. blastmyceticus showed better control efficacy for the control of oak wilt caused by Raffaelea quercus-mongolicae in korea than the fungicide Alamo ${ }^{\circ}$, which is being widely used for the control of oak wilt caused by Ceratocystis fagacearumin the United States. 


\section{C7r: DEVELOPING SUCCESSFUL BIOLOGICAL CONTROL PROGRAMS IN FOREST} PLANTATIONS - 3

\section{Residual tree species diversity in degraded rainforest ecosystems of Nigeria: potentials for restoration and rehabilitation}

Samuel Olajuyigbe ${ }^{1}$, Ayodeji Adaja

${ }^{1}$ University of Ibadan,Ibadan, Nigeria (lekito2001@yahoo.com; dejiadaja@gmail.com)

Nigeria's forest ecosystem is heavily degraded, while secondary succession is impeded by species invasions, agricultural expansion, land encroachment, bush burning, illegal logging and de-reservations. Selective logging and clear felling of economic trees are the predominant methods of timber extraction, with negative impacts on ecological integrity. Tree species composition and diversity, tree canopy structure and regeneration were assessed in some degraded rainforest (AkureOfosu and Eda forest reserves), using a systematic line-transect sampling technique. Trees with $\mathrm{dbh}>10 \mathrm{~cm}$ were enumerated for diameter and height. Basal area, volume, density, and community diversity indices were determined. Trees species richness ranged from 38-46 with density ranging $172-280$ trees ha ${ }^{-1}$. Plant species from Fabaceae, Sterculiaceae and Moraceae families dominated these forests. The dbh distribution revealed more trees in the lower dbh classes,

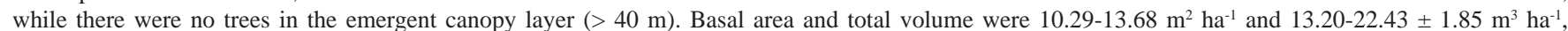
respectively. A high level of species diversity was observed with Shannon - Weiner and Species Equitability indices ranging from 3.14-3.65 and 0.93-0.97, respectively. A significant number of species were naturally regenerating (seedlings and saplings). These forests have good regeneration and recruitment potentials, inspite of the continuous pressure from anthropogenic interference which was limiting the ecological recovery process. Nevertheless, there is great potential for restoration through silvicultural interventions such as enrichment planting, seed supplementation and naturally assisted regeneration. Secondary forests require protection from repeated clearing because of limited seed availability and dispersal, as well as competition from pioneer species.

Biochar from sewage sludge: an alternative use for planting Corymbia citriodora seedlings / Biocarvão de lodo de esgoto: uso alternativo para o desenvolvimento de mudas de Corymbia citriodora

Elton Joneis Souza de Matos ${ }^{1}$, Alessandra Maria Ferreira Reis ${ }^{1}$, Michelle Conceição Vasconcelos ${ }^{1}$

${ }^{1}$ Universidade Federal de Sergipe, São Cristóvão,Brasil(jo.neis@hotmail.com; areisgarcia@yahoo.com; michelle_florestal@yahoo.com.br)

O elevado volume de resíduos gerados diariamente de biossólidos ou lodo de esgoto representam um dos principais problemas ambientais do mundo moderno. Uma proposta atual e de grande potencialidade é a utilização como biocarvão de lodo de esgoto para o condicionante físico e químico de solos e substratos. Com o presente trabalho visa-se avaliar o potencial de utilização de diferentes dosagens do biocarvão do lodo de esgoto, em substrato comercial de mudas de Corymbia citriodora.Os tratamentos com $(0 \%, 10 \%, 15 \%, 20 \%, 25 \%$ e $30 \%$ doses do biocarvão) foram dispostos em delineamento inteiramente casualizado, com seisrepetições e as avaliações foram realizadas aos 30, 60 e 90 dias após a semeadura, obtendo-se altura da parte aérea, diâmetro do coleto, peso da matéria fresca e seca da parte aérea, o teor de clorofila e o índice da qualidade de Dickson (IQD). Não foi verificado diferença significativa ( $\mathrm{p}<0,05)$ entre os tratamentos para todos os parâmetros avaliados, porém observou-se que a adição de $15 \%$ e $20 \%$ proporcionaram um acréscimo nas médias para a altura e diâmetro. O uso de biocarvão do lodo de esgoto para produção de mudas de Corymbia citriodora influenciou positivamente no crescimento e nas características morfológicas das mudas, podendo ser então utilizado o máximo da dosagem testada. Sendo assim, uma boa alternativa de uso do biossólido e economicamente viável, pois reduz o custo com substratos comerciais.

\section{Population structure of the brown spot needle blight pathogen Lecanosticta acicola in Southeast Europe}

Dušan Sadikovićl, ${ }^{1,2}$,Barbara Piškur ${ }^{1}$, Irene Barnes ${ }^{3}$, Tine Hauptman², Danko Diminić, ${ }^{4}$, Michael J. Wingfield ${ }^{3}$, Dušan Jurc ${ }^{1,2}$

${ }^{1}$ Department of Forest Protection, Slovenian Forestry Institute, Ljubljana, Slovenia; ${ }^{2}$ Department of Forestry and Renewable Forest Resources, Biotechnical Faculty, University of Ljubljana, Ljubljana, Slovenia; ${ }^{3}$ Department of Biochemistry, Genetics and Microbiology, Forestry and Agriculture Biotechnology Institute (FABI), University of Pretoria, Pretoria, South Africa; ${ }^{4}$ Faculty of Forestry, University of Zagreb, Zagreb, Croatia(dusan.sadikovic@gmail.com; barbara.piskur@gozdis.si; irene.barnes@fabi.up.ac.za; tine.hauptman@bf.uni-lj.si; diminic.sum.fakultet@gmail.com; mike.wingfield@fabi.up.ac.za; dusan.jurc@gozdis.si)

Lecanosticta acicola, the causal agent ofbrown spot needle blight (BSNB), has been present in Croatia for more than forty years but only in Slovenia since 2008 . New discoveries regarding the global distribution of $L$. acicola, and recent outbreaks in Slovenia prompted this study to confirm the identity of the pathogen in these recent outbreaks and to compare populations in these two neighbouring European countries. Sixty-nine isolates obtained from Pinus mugo, P. halepensis and $P$. nigra were used to verify the species identity as well as to investigate phylogenetic relationships, mode of reproduction and the genetic structure the populations. All isolates were confirmed to represent $L$. acicola.EF1- $\alpha$ region sequencing revealed a novel haplotype and common ancestry of Slovenian and Croatian populations with populations from Central and Northern Europe. Population structure analyses revealed four distinct genetic clusters present in $L$. acicola populations from Slovenia and Croatia, generally corresponding to their respective geographic location. Unequal ratio of mating types, low haplotype count and low genetic diversity suggest asexual proliferation in analysed populations. Although the analysed Croatian population originates from the area where one of the first European occurrences of BSNB were recorded, the results suggest that the outbreaks in Slovenia are the result of unidentified multiple sources.

\section{An assessment of energy forests in Paraguay / Diagnóstico de plantaciones forestales con fines energeticos en el Paraguay}

Blas Antonio Otazu Feltes ${ }^{1}$, Cesar Ernesto Paredes Bogarin ${ }^{1}$, Maria Laura Quevedo Fernanez ${ }^{1}$, William Tomaz Folmann ${ }^{2}$

${ }^{1}$ Universidad Nacional de Asuncion, Asuncion, Paraguay; ${ }^{2}$ Independiente, Asuncion, Paraguay(blasotazu95@gmail.com; cesar.epb@gmail.com; marialauraquevedo@gmail.com;wfolmann@gmail.com)

Para el diagnostico de plantaciones con fines energéticos fue aplicado un cuestionario en siete empresas y fueron instaladas parcelas permanentes en tres de ellas. Fueron identificados 10 materiales plantados, destacándose el VM01, A08, H13 y I144, generalmente implantados en 1.250 plantas/ha. La limpieza del área $38 \%$ de las empresas realiza de forma mecanizada así como la preparación de terreno, que es realizada por lo general entre enero a abril y agosto a noviembre, con rastras pesadas en algunos casos combinadas con rastras liviana y en todos los casos con subsolado, ya sea este con taipeado o no; $71 \%$ de las empresas no realiza los trabajos de canalización; la plantación en 100\% de las empresas es realizada de forma manual por lo general entre los meses de abril a mayo y setiembre a noviembre, para el combate de hormigas, todas las empresas utilizan el fipronil; todas realizan fertilización y $43 \%$ de ellas encalado, el control de maleza en línea de plantación es realizada de forma química o química y manual en cuanto que en la entre línea se destaca el método mecánico con químico; 
$71 \%$ de las empresas maneja rebrote y los principales productos leña y chips. El principal factor crítico es el riesgo a incendios. El material VM01 en la empresa 2 se destaca con 36,36m³/ha/año; y la viabilidad económica la empresa 2 resulto con los indicadores mayormente viables con un VPE de 340,76US\$/ha/año. Variaciónen el precio de venta afecta en mayor medida la viabilidad económica del proyecto.

\title{
Diameter growth of Croton sonderianus in natural vegetation areas of the Caatinga biome, Brazil \\ Andreia Taborda dos Santos ${ }^{1}$ (D, Patrícia Póvoa de Mattos $^{2}$ (D, Evaldo Muñoz Braz ${ }^{2}$ (D, Sebastião Machado ${ }^{1}$ \\ ${ }^{1}$ Universidade Federal do Paraná, Curitiba, Brasil; ${ }^{2 E m b r a p a ~ F l o r e s t a s, ~ C o l o m b o, ~ B r a s i l ~(a n d r e i a t a b o r d a @ y a h o o . c o m . b r ; ~ p a t r i c i a . m a t t o s @ e m b r a p a . b r ; ~}$ evaldo.braz@embrapa.br; samachado@ufpr.br)
}

The Caatinga is the only Brazilian natural region that is entirely restricted in the national territory. The species richness of this biome contrasts with the lack of information about tree species with economic potential, restricting its use. The aim of this study was to determine the pattern and the growth rate of Croton sonderianus in natural vegetation of Caatinga, to be used as basic information for forest plantation and restoration of degraded areas. Discs samples were collected at $1.30 \mathrm{~m}$ above ground level $(\mathrm{DBH})$ for dendrochronological analysis and growth modeling. The trees presented DBH $(\mathrm{mean})=4.7 \mathrm{~cm}$, ranging from $4.1 \mathrm{~cm}$ to $5.7 \mathrm{~cm}$ and mean annual increment of $0.40 \mathrm{~cm}$. The trees had 18 years (mean), with a minimum of 15 and maximum of $23 \mathrm{years}$. JohnsonSchumacher growth model showed satisfactory statistical parameters ( $\mathrm{R}^{2}$ adjust $=0.99 ; \mathrm{CV} \%=19 \mathrm{e} \mathrm{F}=13,773.8$ ), residue distribution and adherence to real data. The application of this model will allow the prediction of the diameter growth dynamics of $C$. sonderianus in natural conditions in Caatinga biome, Brazil.

\section{Liquefied wood polyols based wood modification for uv resistance and dimensional stability of wood}

\author{
Anil Kumar', Asieleavio John ${ }^{1}$, Tara Singh Mehra ${ }^{1}$, B. N. Hazarika ${ }^{1}$ \\ ${ }^{1}$ College of Horticulture and Forestry, Central Agricultural University, Pasighat, Arunachal Pradesh, India, Pasighat, India (anil19wst@gmail.com; \\ asieleavio@gmail.com; mehra_chf@hotmail.com; chfdeanpsg@gmail.com)
}

The major problems encountered in both indoor and outdoor utilization of wood are photo instability and dimensional instability.The modification of Melia dubia wood for ultraviolet resistance and dimensional stability with liquefied wood has been carried out through impregnation method under solvent free conditions. The level of impregnation was estimated by determining the weight percent gain and modified wood was characterized by FTIR-ATR and CP/MAS 13C NMR spectroscopy. The effect of liquefied wood polyols on wood percent gain was studied. UV resistance, moisture adsorption and dimensional stability of modified wood were also evaluated. UV resistance of modified wood was evaluated by exposing unmodified and modified wood to UV irradiation in a QUV accelerated weathering tester. Unmodified wood showed rapid colour changes and degradation of lignin upon exposure to UV light. The modification of wood with liquefied wood polyols was effective in reducing light induced colour changes (photo-yellowing) at wood surfaces. In contrast to Unmodified wood, modified wood exhibited bleaching. FTIR analysis of modified wood exposed to UV light indicated stabilization of wood polymers against UV degradation. Modified wood showed good dimensional stability and hydrophobicity. Thermogravimetric analysis showed that modification with liquefied wood polyols improved thermal stability of wood. The results indicates that liquefied wood polyols is a promising reagent for improving dimensional stability and UV resistance of modified wood.

\section{Rehabilitation of burnt coastal forest by three selected indigenous species at Pekan, Pahang \\ A Ainuddin Nuruddin ${ }^{1}$, Nur Farhani Ellias ${ }^{1}$ \\ ${ }^{1}$ Universiti Putra Malaysia, Serdang, Selangor, Malaysia (ainuddin@upm.edu.my; n.farhani9@gmail.com)}

Rehabilitation programme that have been conducted to recover the degraded ecosystem can fully achieve its objective if planning is being done properly. A study was conducted at coastal forest of Pantai Nenasi, Pekan, Pahang with the aims to investigate the suitable species combinations for rehabilitation of disturbed coastal forest and the effectiveness of shelter applied. The study consisted of six plots which 3 tree species planted randomly. In three plots, seedlings were sheltered by a shade net of $1 \mathrm{~m} \mathrm{x} 1 \mathrm{~m}$ x $1 \mathrm{~m}$. while seedlings for the 3 species for other three plots were not sheltered. Total seedlings planted were 180 but 145 seedlings survived. Diameter and height growth data were recorded for 1-year study period. Based on One-way ANOVA result, there were highly significant difference of tree species on height but diameter increment of tree species were not significant at $(\mathrm{p}<0.05)$. Post-hoc tests show only $C$. equisetifolia had highly significant difference on height and diameter $(\mathrm{p}<0.05)$ compared to the other two species while there was no significant difference between $C$. inophyllum and $S$. grande on height and diameter $(\mathrm{p}>0.05)$. There was highly significant difference between shelter treatment on height $(\mathrm{p}<0.05)$ while there was no significant difference between shelter treatment on diameter $(\mathrm{p}>0.05)$. This study indicate that this three species suitable to be used in other rehabilitation effort on coastal dune area due to the trees are well-adapted to the environment. The shelter treatment create more desirable condition compared to non-shelter treatment.

\section{First record of Quadrastichus mendeli (Hymenoptera: Eulophidae) in Brazil: the Australian parasitoid of Blue Gum Chalcid wasp not recognize geographical barriers}

Barbara de Oliveira Puretz ${ }^{1}$, Carolina Jorge $e^{2}$, Thais Alves da Mota ${ }^{1}$, Sidinei Dallacort ${ }^{1}$, Vanessa Rafaela de Carvalho ${ }^{1}$, Renato Meulman ${ }^{3}$, Carlos Frederico Wilcken ${ }^{1}$

${ }^{1}$ Escola Superior de Agricultura Luiz de Queiroz, Universidade de São Paulo, Faculdade de Ciências Agronômicas, Botucatu, Brasil; ${ }^{2}$ UdelaR, Tacuarembó, Uruguay; ${ }^{3}$ International Paper, Mogi-Guaçu,_Brasil (barbarapuretz@gmail.com; carolina.jorge@cut.edu.uy; thaisalves_rvs@hotmail.com;

sidinei.dallacort@gmail.com; vanessa@fca.unesp.br; renato.meulman@ipaper.com; cwilcken@fca.unesp.br)

The Blue Gum Chalcid wasp Leptocybe invasa (Hymenoptera: Eulophidae) is considered one of the major exotic pests in Eucalyptus plantations worldwide. The biological control with parasitoids and genetic resistance are considered the most adequate methods for management of this pest. More than ten parasitoid species was found associated with L. invasagalls in Australia. The most species used in biological control programs of L. invasa are Quadrastichus mendeli Kim \& La Salle and Selitrichodes neseri Kelly \& La Salle (Hymenoptera: Eulophidae). The latest was imported to Brazil from South Africa in 2015 and are currently released to controlthis pest.Q. mendeli was recently found in unintentional introductions in Italy (2013), South Africa (2016) and Argentina (2016) and in December of 2018 where found in São Paulo state, Brazil. The aims of this work was report for the first time the presence of $Q$. mendeli in Brazil and to evaluate heir impact in the biological control of $L$. invasa. Branches of Eucalyptus grandis hybrid with mature $L$. invasa galls were collected in a plantation in the municipality of Luís Antônio in São Paulo State, Brazil on 07/12/2018 and maintained in an acrylic cage. Together with $L$. invasa females emerged 30 females of a one different species from the galls. The specimens were confirmed as a $Q$. mendeli by morphological characteristics and by molecular analysis. Future prospects will be study the bioecology, dispersion and a possible interaction with $S$. neseri of this parasitoid that not recognize geographical barriers. 


\title{
Active versus passive restoration: recovery of cloud forest structure, diversity and soil condition in abandoned pastures
}

\author{
Alma Lucrecia Trujillo Miranda ${ }^{1}$ iD, Tarin Toledo Aceves ${ }^{1}$, Fabiola López Barrera ${ }^{1}$, Patricia Gerez Fernández ${ }^{2}$ \\ ${ }^{1}$ Instituto de Ecología A. C, Xalapa, Mexico; ${ }^{2}$ Universidad Veracruzana,Xalapa, Mexico (almalucrecia90@gmail.com,tarin.toledo@inecol.mx; \\ fabiola.lopez@inecol.mx; pgerez@uv.mx)
}

Tropical montane cloud forest is a priority ecosystem for restoration due to its high diversity and the provision of ecosystem services. We assessed the effectiveness of active (mixed plantation with native species) and passive (areas adjacent and non-adjacent to mature cloud forest) restoration strategies implemented in pastures with 21 years of exclosure, and compared these to a mature cloud forest, in Mexico. Active restoration proved more effective than passive restoration at recovering forest structure (higher basal area and tree height). Adult tree diversity was similar across all sites, while composition differed greatly between the mature forest and each of the restoration sites. The restoration sites presented very low tree seedling density ( 0.39 individuals/ $\left.\mathrm{m}^{2}\right)$ relative to the mature forest (1.68 seedlings $/ \mathrm{m}^{2}$ ), probably due to the higher cover of competing vegetation in the restoration sites. In all of the restoration sites, soil $\mathrm{pH}$ was higher, and carbon content in the soil and litter was lower, than in the mature forest. In general, the passive restoration site non-adjacent to the forest presented the lowest recovery, indicating the importance of proximity to seed sources. Our results highlight the need, in both actively and passively restored areas, for management practices, in order to assist tree seedling recruitment of key species and recovery of forest attributes. Active and passive restoration strategies could be implemented as complementary strategies for the restoration of cloud forest landscapes.

\section{Site productivity classification for secondary evergreen dipterocarp forests in South-Eastern Vietnam \\ Thi Thanh Ha Do ${ }^{1,2}$, John Grant ${ }^{1}$, Heidi Zimmer ${ }^{1}$, Bon Trinh ${ }^{2}$, Hoang Nguyen ${ }^{2}$, J. Doland Nichols ${ }^{1}$, Jerry Vanclay ${ }^{1}$ \\ ${ }^{1}$ Southern Cross University, Lismore, Australia; ${ }^{2}$ Silviculture Research Institute, HaNoi, Vietnam (t.do.16@student.scu.edu.au; john.grant@scu.edu.au; heidi.zimmer@gmail.com; trinhngocbon85@gmail.com;nguyenhuyhoangvfu@gmail.com; doland.nichols@scu.edu.au; jerrry.vanclay@scu.edu.au)}

Reliable forest site productivity estimation is key to site-specific forest management. Many studies have investigated the estimation of forest site productivity based on species-specific height-age equations for monoculture plantations, and on height-diameter equations for mixed-species forests. However, research into estimation of productivity in secondary forests is scarce. This research classified site productivity, based on a distance-independent individual-tree growth model, to simulate management regimes in native secondary forests in monsoonal Southern Vietnam. The model was based on the spatial variation and vegetation stage at the microsite scale, which was in turn associated with soil and topographic properties, which limit the natural climax vegetation type. Recovery stage of vegetation, after a known logging event, was entered into the model to determine site productivity class. The climax vegetation types (evergreen, deciduous and bamboos), and time to recovery were identified using: the year that the normalized difference vegetation index (NDVI) at the site achieved the asymptote (from 1988 to 2017, 199 sample plots [1000 $\left.\mathrm{m}^{2}\right]$ ), and the maximum ratio of evergreen:pioneer basal area (reference from old-growth forest sites). We assumed that climax stage was evergreen mixed dipterocarp forest. Finally, both soil and topographic and stage of recovered vegetation were identified in terms of their capacity for supporting high productivity evergreen dipterocarp forests. We classified the stages of vegetation recovery based on the productivity of dipterocarp trees, and the presence of invasive species (bamboos), and based on this, we describe the recovery potential of each site.

\section{Gaps and challenges for SF owners in Central America to build bankable forest businesses}

Jean Pierre M. Aymerich ${ }^{1}$

${ }^{1}$ CATIE, Turrialba, Costa Rica (jeanmorales.aymerich@gmail.com)

The sustainable development is driven by several national and international agendas such as Sustainable Development Goals, Green Growth, Low-Emission Development Strategies and other. Those initiatives look for public and private commitments to achieve their aims, the public and political sector are engagement, but it is important that the private embrace those initiative. The possibilities of private sector to contribute for reach SDG is huge, because of that it is possible to see initiative such as SDG Business Hub, Business for 2030 and SDG Business Forum. Moreover, it is necessary to move capital for develop small and medium rural business, the international efforts are focus on microfinance (mainly on financial inclusion), impact investment and other. The study focus on analysis of 42 forest business opportunities, the key findings are structuring in business case to show the main gaps and challenges of the forest owner in Central America to build bankable forest businesses cases. The analysis use business case approach as framework to explore viable alternatives, coherence between policies and business strategies, review the stakeholder and risk analysis, to build recommendation for forest owners and practitioners.

C8a: INTENSIFICATION WITHIN LIMITS: INCREASING PRODUCTIVITY WITHOUT COMPROMISING ECOSYSTEM SERVICES

\section{Intensified forest management calls for new protective agents for biocontrol of Heterobasidion spp. on Norway spruce}

Jonas Rönnberg', Zelma Magazniece ${ }^{2}$

${ }^{1}$ Swedish University of Agricultural Sciences, Alnarp, Sweden; ${ }^{2}$ Augu Aizsardzības Serviss, Jelgava, Latvia (jonas.ronnberg@slu.se; zelma.gzibovska@inbox.lv)

Heterobasidion root rot causes tremendous economic loss to coniferous forests through reduced growth and quality in the northern hemisphere. Climate change promote spread of root rot and add to the challenge to increase forest productivity. Heterobasidion spores can be prevented by treating stumps with e.g. Phlebiopsis gigantea. In Sweden this is the only commercially available alternative with proven effect. Other treatment agents and more effective genotypes of $P$. gigantea benefit the forest sector and reduce ecological risks from using one genotype. The forestry sector is therefore interested in new biological agents. The competitive ability against Heterobasidion of ten different isolates of $P$. gigantea, including the commercially available Rotstop ${ }^{\circledR}$ S and a Pseudomonas spp. bacteria (Proradix ${ }^{\circledR}$ ), were therefore tested in laboratory and in two field studies. Results of the in vitro study indicated that $P$. gigantea (isolate S2384_2_VI) was superior $(\mathrm{p}<0,05)$ to the other 9 isolates by means of average growth rate per day on top of wood heavily infected by Heterobasidion. Rotstop ${ }^{\circ} \mathrm{S}$ together with one P. gigantea isolate (PG342) had the fastest growth in the first two days. Wood colonized by Pseudomonas spp. bacteria in vitro was competitive against Heterobasidion even after 25 days. In both field studies the regular $P$. gigantea (Rotstop ${ }^{\circledR}$ S) performed the best, even though Pseudomonas spp. show some 
promising reduction in infection frequency of Heterobasidion. Conclusively the use of $P$. gigantea can be further developed and after longer term experiments Pseudomonas spp. bacteria may be considered an alternative to $P$. gigantea.

\author{
Nitrous oxide $\left(\mathrm{N}_{2} \mathrm{O}\right)$ and methane $\left(\mathrm{CH}_{4}\right)$ efflux: impacts of silvicuture and climate variation \\ Daniel Markewitz ${ }^{1}$ (D, Brian Strahm ${ }^{2}$, Jason Vogel ${ }^{3}$, Kristin McElligott ${ }^{2}$, Raj Shrestha ${ }^{2}$, Carla Gann ${ }^{1}$, Lori Sutter ${ }^{1}$ \\ ${ }^{1}$ The University of Georgia, Athens, USA; ${ }^{2}$ Virginia Tech, Blacksburg, USA; ${ }^{3}$ University of Florida, Gainesville, USA (dmarke@uga.edu, \\ brian.strahm@uga.edu; jvogel@ufl.edu; kmc2@vt.edu; raj.shrestha@osu.edu; karla14@uga.edu; lsutter@uga.edu)
}

Nitrous oxide $\left(\mathrm{N}_{2} \mathrm{O}\right)$ and methane $\left(\mathrm{CH}_{4}\right)$ are greenhouse gases that are increasing in the Earth's atmosphere and impact the global energy budget. Globally, forests play a substantial role in GHG budgets and $\mathrm{N}_{2} \mathrm{O}$ or $\mathrm{CH}_{4}$ might be released or consumed in response to forest management or climate variation. In the southeastern USA we investigated the impacts of a throughfall exclusion $\mathrm{x}$ fertilization manipulation in loblolly pine, over two years, in three locations. Fertilization increased $\mathrm{N}_{2} \mathrm{O}$ efflux but not $\mathrm{CH}_{4}$ efflux. Efflux of $\mathrm{CH}_{4}$ significantly responded to throughfall exclusion. A test of $\mathrm{N}$ fertilizers(urea, ammonium nitrate, or diammonium phosphate) foundsignificantly increased $\mathrm{N}_{2} \mathrm{O}$ efflux from all forms. $\mathrm{N}_{2} \mathrm{O}$ and $\mathrm{CH}_{4}$ efflux were also measured over one year in three sites of a Silviculture $\mathrm{x}$ Initial planting density study and three sites of a Mid-Rotation Treatment study.In the silviculture $\mathrm{x}$ density study there was no main effect of silviculture or density on $\mathrm{N}_{2} \mathrm{O}$ or $\mathrm{CH}_{4}$ efflux. In the mid-rotation treatment study, where $\mathrm{N}$ fertilization had recently occurred, there was an effect of thinning, herbicide, and fertilization treatments on $\mathrm{N}_{2} \mathrm{O}$ but not on $\mathrm{CH}_{4}$. Responses in $\mathrm{N}_{2} \mathrm{O}$ and $\mathrm{CH}_{4}$ efflux to silviculture and climate variation are important considerations in evaluating the ecosystem services of managed forests.

\title{
Whole ecosystem NPP and growth efficiency of four coniferous species growing under contrasting vegetation management treatments in the PNW United States
}

\author{
Carlos Gonzalez-Benecke ${ }^{1}$, Maxwell Wightman ${ }^{1}$, Herman Flamenco ${ }^{1}$ \\ 1Oregon State University, Corvallis, USA (carlos.gonzalez@oregonstate.edu; maxwell.wightman@oregonstate.edu; hnoeflamenco@gmail.com)
}

Silvicultural treatments applied during the early stages of stand development can have long-lasting impacts on forest ecosystems. Forest vegetation management (VM) is an important component of many reforestation programs and although several studies have demonstrated the benefits of VM on planted conifer growth and survival, few reports have been published on the long-term effects of VM treatments on total ecosystem Net Primary Productivity (NPP) and Growth Efficiency (GE). In this study we assessed the effects of two contrasting VM treatments on total tree and ecosystem NPP and GE for Douglas-fir, western hemlock, western redcedar, and grand fir growing in Oregon's central Coast Range and Cascade foothills. The study contained two VM treatments: control and sustained vegetation control using herbicides during the first 5 years after planting. The assessments were made during 3 years, starting at age 16 years, 11 years after treatment application ended. For all species at both sites, VM treatments increased LAI and NPP of crop trees at age 16-19. Sustained VM had no effect on ecosystem NPP. Western red cedar showed lower GE, as allocated proportionally more growth to foliage than other conifers being compared. VM treatments did not affect GE at the Coast Range site, but reduced it for WRC at the Cascade foothills site. The results of this study demonstrate that sustained VM treatments during the first 5 years of stand establishment increases LAI and NPP of crop trees, directing site resources towards planted crop trees.

\section{Pathways to decreased fertilizer use and increased productivity in Southern pine plantations}

\author{
Jason Vogel ${ }^{1}$, Eric Jokela ${ }^{1}$, Praveen Subedi ${ }^{1}$, Ignacie Tumushime ${ }^{1}$, Salvador Gezan ${ }^{1}$, Timothy Martin ${ }^{1}$, Tania Quesada ${ }^{1}$, Gary Peter ${ }^{1}$ \\ ${ }^{1}$ University of Florida, Gainesville,USA (jvogel@ufl.edu; ejokela@ufl.edu; praveensubedi@ufl.edu; tumushime09@tamu.edu; sgezan@ufl.edu; \\ tamartin@ufl.edu; tquesada@ufl.edu; gfpeter@ufl.edu)
}

Plantation forests grown for maximum productivity are often fertilized, but when excess fertilizer is lost to the atmosphere or water bodies it can compromise ecosystem services. Avoiding this compromise is valuable to society, and the forest landowner, as nutrient loss can represent an economic loss. Here we discuss a series of studies carried out in the Southeastern United States that illustrate ways that forest managers can optimize fertilizer use. One longstanding observation is that sites with inherently high productivity are unlikely to respond to added fertilizer, and that past-fertilized agricultural fields can have background levels of nutrients that support rapid forest growth. New research suggests that fertilization in the previous rotation can contribute to early tree growth and prolong the Assart effect-All indicators of where fertilization can be reduced. Applications of macronutrients other than $\mathrm{N}$ and P, or in some soils micronutrient applications, can increase growth and the uptake efficiency for all elements. In addition, recent research suggests that other macronutrients or micronutrients can facilitate the cycling of $\mathrm{N}$ and $\mathrm{P}$ through altered decomposition rates. Ongoing changes in the effectiveness of competition control, atmospheric $\mathrm{N}$ deposition, precipitation amounts, atmospheric $\mathrm{CO}_{2}$, and tree genetics are also likely affecting the need for fertilizer but significant knowledge gaps exist on how these factors interact with nutrient demands. New experiments and modeling approaches are needed to take into account these changing conditions as they relate to nutrient interactions, uptake, and supply.

\section{Impact of aerial pesticide applications on water quality in New Zealand in an intensifying forest management regime to increase productivity}

Brenda Baillie ${ }^{1}$, Daniel Neary ${ }^{2}$

${ }^{1}$ Scion, Rotorua, New Zealand; 2USDA Forest Service, Flagstaff, New Zealand (brenda.baillie@scionresearch.com; dan.neary@usda.gov)

The New Zealand forest industry has a long-term vision to sustainably double productivity on a per hectare basis from its forest estate. Implicit in achieving this vision will be the challenge to continue to provide a sustainable source of wood and fibre along with the provision of well-maintained and high quality water resources. Having healthy and productive forests is particularly important in the face of increasing global wood demand trends and forest certification requirements. Forest site establishment and silvicultural activities that enhance site productivity and maintain forest health, such as pesticide use, have the potential to affect water quality. Studies covering a range of New Zealand sites with varying geology, climate and hydrology found that if best management practices are applied during the aerial operations of pesticides, the potential risk to receiving water should be minimised. Highest risks were associated with aerial applications on the day of application or during rainfall events occurring shortly thereafter. It was during these periods that the main pulse of pesticides was detected in stream water and sediments. In general, concentrations returned to baseline levels within hours of application or several weeks after application. Concentrations and exposure times in stream water and sediment indicated a low risk to human health and aquatic environments based on these studies. While planted forests can potentially affect water yield, they produce high water quality for a large portion of the forestry cycle, providing a valuable ecosystem to downstream water users and aquatic biota. 
Coverings for clonal nurseries and seasonal weather conditions affect physiological variables of Eucalyptus urophylla S. T. Blake and Corymbia citriodora F. V. Muell x Corymbia torelliana Hook hybrids / Estruturas de cobertura de jardim clonal e estações climatológicas afetam variáveis fisiológicas de cepas de Eucalyptus urophylla S. T. Blake e Corymbia citriodora F. V. Muell x Corymbia torelliana Hook

Rafael Lima dos Santos ${ }^{1}$, Gabryella de Farias Duarte ${ }^{2}$, Andrew Kim Lopes Ferraz ${ }^{1}$, Fabrício Palla Teixeira ${ }^{1}$, Richardson Barbosa Gomes da Silva ${ }^{1}$, João Domingos Rodrigues ${ }^{2}$, Magali Ribeiro da Silva ${ }^{1}$

${ }^{1}$ Universidade Estadual Paulista “Júlio de Mesquita Filho”, Faculdade de Ciências Agrônomicas, Botucatu, Brasil; ${ }^{2}$ Universidade Estadual Paulista "Júlio de Mesquita Filho”, Instituto de Biologia,Botucatu,Brasil(engftal.rafaelsantos@gmail.com; gabryelladuarte21@gmail.com; fabriciopallas@yahoo.com. br; andrewkim.lf@gmail.com; richardsonunesp@gmail.com;mingo@unesp.br; magali.ribeiro@unesp.br)

A cobertura do jardim clonal com filmes agrícolas pode ocasionar modificações nas condições climáticas do ambiente, e consequentemente, algumas das principais atividades fotossintéticas da planta. O objetivo deste trabalho foi avaliar como as estruturas do jardim clonal e as estações do ano afetam as atividades fisiológicas de cepas de Eucalyptus urophylla S. T. Blake e Corymbia citriodora F. V. Muell x Corymbia torelliana Hook. Foram instalados dois experimentos (dois clones) em esquema fatorial 4 x 2. Os fatores avaliados foram: estruturas de cobertura de jardim clonal (pé direito alto - PDA; minitúnel difusor - MTD; minitúnel azul - MTA e descoberto - DESC) e estações do ano (outono/inverno denominada inverno e primavera/verão denominado verão). Foram avaliadas: assimilação de $\mathrm{CO}_{2}(\mathrm{~A})$, radiação fotossintéticamente ativa interceptada (PARi), condutância estomática (gs) e transpiração (E), concentração interna de CO (Ci) e eficiência de carboxilação (A/Ci). Para ambos os experimentos as variáveis E e A foram maiores no inverno e a Ci foi maior no verão, com as maiores concentrações nas estruturas MTA e MTD no experimento com clone de Corymbia, acrescentando a estrutura PDA no experimento com o clone de Eucalyptus. As maiores gs foram encontradas nas mudas do MTA e MTD em ambos os experimentos. A PARi foi maior no verão em todas estruturas nos dois experimentos e no experimento de verão não houve diferença entre tratamentos, já no inverno o DESC teve valores superiores às demais estruturas. Em ambos os experimentos ocorreu maior A/Ci no inverno e na estrutura DESC.

Productivity gains in Pinus taeda using phosphate fertilization in Southern Brazil / Ganhos de produtividade em Pinus taeda com uso de adubação fosfatada na região Sul do Brasil

James Stahl ${ }^{1}$, Djalma Chaves ${ }^{2}$, Marco Aurélio Figura ${ }^{1}$, Fabricio Antonio Biernaski ${ }^{1}$

${ }^{1}$ Klabin S.A, Telêmaco Borba, Brasil; 2DMC Consultoria,Lages,Brasil (jstahl@klabin.com.br; dm.chaves@terra.com.br; mafigura@klabin.com.br; fbiernaski@klabin.com.br)

As áreas reflorestadas com Pinus taeda constituem a mais importante fonte da base florestal para a cadeia produtiva do setor madeireiro do Sul do Brasil. Em função da sua boa adaptação e dos níveis satisfatórios de produtividade o Pinus taeda ficou sendo considerado uma espécie rústica e de baixa exigência em manejo silvicultural pela grande maioria de seus produtores. Entretanto, as informações sobre manejo e resposta a adubação para esta espécie ainda são pontuais. Os dados deste trabalho fazem parte de uma rede experimental instalada com o objetivo de avaliar a resposta a adubação fostadada de plantios no Planalto Sul Catarinense e na região de Telêmaco Borba, PR. Foram aplicadas doses crescentes de fósforo de 0 a 100 kg.ha-1 de $\mathrm{P}_{2} \mathrm{O}_{5}$ de forma localizada em duas covetas laterais 30 dias após o plantio das mudas, em parcelas de 60 plantas para cada tratamento com quatro repetições em delineamento de blocos casualizados. As medições foram realizadas aos dois e sete anos para o cálculo de volume por área. Os resultados mostraram que o uso de adubação fosfatada promoveu ganhos significativos na produtividade de Pinus taeda até sete anos de idade nos solos de textura média, com a máxima produção para a dose de 100 kg.ha-1 de $\mathrm{P}_{2} \mathrm{O}_{5}$. Para os solos de textura argilosa não houve resposta significativa ao uso de adubação fosfatada, indicando que o manejo nutricional de fósforo em Pinus taeda responde de forma sitio-especifica.

\section{Long-term effects of vegetation management on whole ecosystem nutrient allocation in four different conifer species in the Pacific} Northwest United States

Callan Cannon ${ }^{1}$, Carlos Gonzalez-Benecke ${ }^{1}$, Maxwell Wightman ${ }^{1}$

${ }^{1}$ Oregon State University, Corvallis, USA (callan.cannon@oregonstate.edu; carlos.gonzalez@oregonstate.edu; maxwell.wightman@oregonstate.edu)

Silvicultural treatments are used to alter stand growth and development and can have long-term effects on forest ecosystem structure. Vegetation management (VM) is a common silvicultural treatment used for reforestation in the U.S. Pacific Northwest. While it has been shown that VM treatments increase the biomass yield of crop trees, the effects on forest structure and ecosystem nutrient budgets are not well understood. This study will examine the effects of two different vegetation management treatments on the distribution of 6 macronutrients and 10 micronutrients in stands of 4 different conifer species (Douglas-fir, grand fir, western redcedar and western hemlock) growing in the central Oregon Coast Range, as well as 2 conifer species (Douglas-fir and western hemlock) growing in the Cascade foothills in Oregon. The treatments to be compared are control, consisting only of a pre-planting herbicide application, and the vegetation management treatment, consisting of annual herbicide application for 5 years after planting in addition to the pre-planting application. In a previous study, we showed that while there is a difference in the distribution of biomass between treated and untreated plots, there is no effect on total ecosystem productivity. We will dive further into this finding and report the effects of these treatments 16 years after planting on total ecosystem nutrient levels as well as nutrient pools in various parts of the forest ecosystem including crop trees, understory vegetation, forest floor and soil up to 1 meter in depth.

Economic feasibility of applying doses of nitrogen, phosphorus, and potassium to plantations of Eucalyptus urophylla S.T. Blake ex E. grandis Hill ex Maiden / Viabilidad económica de la aplicación de dosis de nitrogeno, fosforo y potasio en plantaciones de Eucalyptus urophylla S.T. Blake x E. Grandis Hill ex Maiden

Marco Antonio Martinez Baez ${ }^{1}$, Melanie Niederberger Heilbrunn ${ }^{1}$, Maria Laura Quevedo Fernandez ${ }^{1}$, William Tomaz Folmann², Carlos Andres Leguizamon Rojas ${ }^{1}$

${ }^{1}$ Universidad Nacional de Asuncion, Asuncion, Paraguay; ${ }^{2}$ Independiente, Asuncion, Paraguay (marcmarti1994@gmail.com; melaniederheil@gmail.com, marialauraquevedo@gmail.com; wfolmann@gmail.com; carlos.leguizamon@agr.una.py)

El presente trabajo tuvo como objetivo estimar la viabilidad económica de la aplicación de fertilizantes en plantaciones con fines energéticos de Eucalyptus urophylla S.T. Blakex E. grandis Hill ex Maiden. La experimentación se llevó a cabo en el departamento de Paraguarí, Paraguay. Se instalaron 15 unidades experimentales por elemento, en 3 bloques completamente al azar que contuvieron 36 plantas cada una; en estas unidades fueron aplicadas 0, 20, 40, 60 y 80 $\mathrm{Kg} / \mathrm{ha}$ de nitrógeno, para fosforo los tratamientos consistieron en dosis de 0, 25, 50, 75 y $100 \mathrm{Kg} / \mathrm{ha}$; para los tratamientos con potasio los tratamientos fueron de 0, 30, 60, 90 y $120 \mathrm{Kg} / \mathrm{ha}$. Las mediciones correspondientes al DAP y altura se realizaron a los dos años de haber sido instalada la plantación, con las mismas 
se pudo hallar el área basal que sirvió como fuente principal de datos para estimar el crecimiento a los 5 años con el programa SISeucalipto, los datos brindados por el programa, además de los costos proveídos por la empresa, sirvieron para estimar los indicadores financieros (VAN, TIR, RB/C y VPE) de los ciclos de rotación. Se realizó un análisis de sensibilidad de con una variación de $\pm 15 \%$ en el precio y $\pm 15 \%$ en la tasa de interés. El elemento que proporcionó un mayor incremento en cuanto a volumen fue el nitrógeno con una dosis de $100 \mathrm{Kg} / \mathrm{ha}$ con $30,904 \mathrm{~m}^{3} / \mathrm{ha}$ a los 2 años. De todas maneras, se tiene como escenario más viable económicamente al de fosforo con una dosis de $75 \mathrm{Kg} / \mathrm{ha}$

Coverings for clonal nurseries and seasonal weather conditions alter the productivity of strains of Eucalyptus urophylla S. T. Blake and Corymbia citriodora F. V. Muell x Corymbia torelliana Hook / Estruturas de cobertura de jardim clonal e estações climatológicas alteram a produtividade de cepas de Eucalyptus urophylla S. T. Blake e Corymbia citriodora F. V. Muell x Corymbia torelliana Hook

Rafael Lima dos Santos ${ }^{1}$, Gabryella de Farias Duarte ${ }^{2}$, Fabrício Palla Teixeira ${ }^{1}$, Andrew Kim Lopes Ferraz ${ }^{1}$, Richardson Barbosa Gomes da Silva ${ }^{1}$, João Domingos Rodrigues ${ }^{2}$, Magali Ribeiro da Silva ${ }^{1}$

${ }^{1}$ Universidade Estadual Paulista "Júlio de Mesquita Filho", Faculdade de Ciências Agrônomicas, Botucatu, Brasil; ${ }^{2}$ Universidade Estadual Paulista "Júlio de Mesquita Filho”, Instituto de Biologia, Botucatu,Brasil(engftal.rafaelsantos@gmail.com; gabryelladuarte21@gmail.com; fabriciopallas@yahoo.com.br; andrewkim.lf@gmail.com; richardsonunesp@gmail.com;mingo@unesp.br; magali.ribeiro@unesp.br)

O viveiro florestal é responsável pelo abastecimento de mudas para a implantação de povoamentos florestais. Para atender essa demanda, os viveiros florestais vêm adotando tecnologias com a finalidade de aumentar a produtividade sem aumentar a área do viveiro, entre elas diferentes estruturas de jardim clonal. O objetivo dessa pesquisa foi avaliar o quanto os microclimas das estruturas do jardim clonal e as estações do ano afetam a produtividade das cepas de Eucalyptus urophylla S. T. Blake e Corymbia citriodora F. V. Muell x Corymbia torelliana Hook. O experimento foi instalado no viveiro de produção de mudas da FCA/ UNESP, em Botucatu - SP, e foram instalados dois experimentos, o primeiro com um clone de Eucalyptus e o outro com o um clone Corymbia, em esquema fatorial 4 x 2. Os fatores avaliados foram: estruturas de cobertura de jardim clonal (pé direito alto - PDA; minitúnel difusor - MTD; minitúnel azul - MTA e descoberto - DESC) e estações do ano (outono/inverno, denominada inverno e primavera/verão, denominada verão). Foi avaliado mensalmente o número de brotos/cepa/estrutura, durante o ano de 2018. A estrutura de jardim clonal MTD foi a mais produtiva em todas as estações para ambos os experimentos (Eucalyptus 15 e 20 brotos e Corymbia 12 e 15 brotos no verão e inverno, respectivamente). Entre as estações, ambos os minitúneis produziram mais brotos no inverno, nos dois experimentos, ao passo que PDA e DESC apresentaram maior produtividade no verão para o experimento com Corymbia e não havendo diferença estatística entre as estações para o experimento com Eucalyptus.

Using LIDAR (light detection and ranging) to monitor forest succession in areas of native vegetation / Uso da ferramenta LiDAR (Light Detection And Ranging) para monitoramento de sucessão florestal nas áreas de vegetação nativa

Gabriela Sanches Dolenc ${ }^{1}$, Cristiano Cardoso Stétz ${ }^{1}$, Samantha Nazaré de Paiva ${ }^{1}$, Clewerson Frederico Scheraiber ${ }^{1}$

1Klabin,Telemaco Borba,Brasil (gabrielasdolenc@gmail.com; ccstetz@klabin.com.br; snpaiva@klabin.com.br; cscheraiber@klabin.com.br)

As áreas de vegetação nativa da Klabin no Paraná totalizam 142.094,76 hectares. A preservação dessas áreas aliada com o manejo em mosaico das áreas produtivas proporciona a proteção dos recursos hídricos e possibilita a conectividade entre os fragmentos nativos, o que contribui para um maior fluxo biológico e a conservação de aproximadamente 2 mil espécies de flora e 898 espécies de fauna. No entanto, além da extensão florestal outro critério importante a ser monitorado ao longo do tempo é a sucessão ecológica, que determina o grau de conservação da vegetação nativa. Tais critérios garantem não somente a sustentabilidade dos fragmentos, mas também vem atender aos compromissos da empresa firmados com as certificações. O objetivo deste trabalho foi criar uma metodologia para otimizar a classificação sucessional das áreas de vegetação nativa. Assim, foi utilizado a tecnologia LiDAR (Light Detection and Ranging) para gerar um mapa de altura de uma das Regiões Florestais da Klabin. Depois foram coletados em campo 30 pontos aleatórios na intensidade amostral de 1 ponto a cada 15 hectares, fazendo-se o registro em campo do estágio de sucessão (baseado na normativa do CONAMA n 2 de 1994). Os pontos amostrais foram correlacionados com mapa de altura e por meio de ferramentas de geoestatística foi realizado uma interpolação para extrapolar a classificação da sucessão florestal das parcelas para as demais áreas de vegetação nativa.

\section{C8b: SUSTAINABLE MANAGEMENT OF FOREST SOILS FOR TIMBER AND BIOENERGY} PRODUCTION

\section{Effect of whole-tree-harvesting on soil properties and reuse of wood ash produced from woody biomass power plant for nutrient compensation to the forest in Japan}

Keizo Hirai ${ }^{1}$, Tsuyoshi Yamada ${ }^{1}$, Junko Nagakura ${ }^{1}$, Mayumi Y. Ogasa ${ }^{2}$, Masahiro Inagaki ${ }^{3}$

${ }^{1}$ Forestry and Forest Products Research Institute, Tsukuba, Japan; ${ }^{2}$ Kansai Research Center, Forestry and Forest Products Research Institute, Kyoto, Japan; ${ }^{3}$ Kyushu Research Center, Forestry and Forest Products Research Institute, Kumamaoto, Japan (hirai@ffpri.affrc.go.jp; yamadan@ffpri.affrc.go.jp; kurya@ffpri.affrc.go.jp; mayumiogasa@ffpri.affrc.go.jp; inagaki@ffpri.affrc.go.jp)

Newly operation of woody biomass power plants increased drastically with a demand of renewable energy after Great East Japan Earthquake in 2011. Wholetree-harvesting became popular at forest management in Japan. In these background, we studied the effect of whole-tree-harvesting on soil properties and the reuse of wood ash produced from woody biomass power plant for nutrient compensation to the forest. Our field study demonstrates that the amounts of nutrient removal afterwhole-tree-harvesting was two times higher than those afterstem-only-harvesting regardless of thinning or clear-cutting. Nutrient, especially potassium (K) was stored in above ground biomass at similar levels as those in soils of 0-100 cm depth calculated from Japanese national forest inventory data. K was one of the major nutrients with high concentration in wood ash. We applied to the forest soils and growing media of containerized tree seedlings to reuse ash and compensate soil nutrient loss. Ash recycling to the young Japanese cedar (Cryptomeria japonica) and cypress (Chamaecyparis obtusa) stands increased or maintained surface soil $\mathrm{pH}$ and $\mathrm{K}$, calcium and magnesium until the end of second growing season compared with the stands without ash recycling. Seedling growth of these species grown under different mixing ratios of ash did not increase, but was inhibitedunder $25 \%$ and $10 \%$ ash mixing to grown media in Japanese cedar and Japanese cypress respectively. These results suggest the need to establish a guidelines for adequate harvest intensity to maintain long-term soil productivity and for wood ash recycling to the forest. 


\section{Impact of intensified timber harvesting on heavy metal export from peatland forest}

Liisa Ukonmaanaho' ${ }^{1}$, Mika NIeminen ${ }^{1}$, Sakari Sarkkola', Ari Laurén ${ }^{2}$, Tiina M. Nieminen ${ }^{1}$

${ }^{1}$ Natural Resources Institute Finland, Helsinki, Finland; '2University of Eastern Finland, Joensuu, Finland (liisa.ukonmaanaho@luke.fi;

mika.nieminen@luke.fi; sakari.sarkkola@luke.fi; ari.lauren@uef.fi; tiina.m.nieminen@luke.fi)

Increasing demand for bioenergy production has led to an interest on the forest harvesting method which removes also logging residues (tree tops, branches, stumps) in addition to stemwood. However, the impacts of whole-tree harvesting on biogeochemical cycles, tree growth and water quality are largely unknown, especially in drained peatlands. In Finland 4.9 million ha of peatlands have been drained for forestry purposes, and much of them will be harvested in coming years. This biomass would provide a major source of bioenergy. However, forest harvestings, especially the intense whole-tree-harvesting with stump lifting (WTHs), may increase the export of nutrients and heavy metals to recipient water courses. This effect can be enhanced if the underlying bedrock and overburden soil contain heavy metals. In addition, anoxic conditions can develop in stagnant water pools formed as a result of harvesting, especially after stump removal. Anoxic conditions may result in mobilization of heavy metals that have accumulated in the soil, and their subsequent transport to surface waters constitutes an ecotoxicological risk. The impact of stem-only harvesting ( $\mathrm{SOH}$ ), whole-tree harvesting (WTH) and WTHs on the concentrations and loads of $\mathrm{Cu}$, Fe, $\mathrm{Hg}$, $\mathrm{Mn}$, $\mathrm{Ni}, \mathrm{MeHg}$ and DOC in the ditch water was studied using a paired catchment approach in three locations and in total 24 drained peatland dominated catchments in Finland 2007-2015. Results indicate that there are significant differences in drainage water quality and quantity before and after harvesting(SOH,WTH,WTHs). The change was strongest afterfirst two years since harvesting.

Distribution of biomass in first and second rotation Eucalyptus trees / Distribuição da biomassa em árvores de eucalipto cultivadas em primeira e segunda rotação

Gileno Brito de Azevedo ${ }^{1}$, Glauce Taís de Oliveira Sousa Azevedo ${ }^{1}$, Aldair Ricardo Baréa ${ }^{1}$, Jean de Jesus da Silva ${ }^{1}$, Humberto de Jesus Eufrade-Junior ${ }^{2}$ ${ }^{1}$ Universidade Federal de Mato Grosso do Sul, Chapadão do Sul, Brasil; ${ }^{2}$ Universidade Estadual Paulista, Botucatu, Brasil (gileno.azevedo@ufms.br; glauce.azevedo@ufms.br; aldair.ricardo@hotmail.com; jean_djesus@hotmail.com; hdjejunior@gmail.com)

Conhecer a distribuição da biomassa nos compartimentos das árvores é fundamental na tomada de decisões relacionadas ao uso da madeira e aproveitamento dos resíduos florestais, como cascas, galhos, folhas, tocos e raízes. Essa distribuição pode ser influenciada por diferentes fatores, como o regime de condução do povoamento. Portanto, objetivou-se avaliar a distribuição da biomassa de árvores de Eucalyptus urophylla (clone AEC0144) em primeira e segunda rotação. O estudo foi realizado em Ribas do Rio Pardo/ MS, em dois talhões plantados no espaçamento de 3 x 3 m, com idade de 7,2 anos na primeira rotação e de 14,0 anos na segunda rotação (6,3 anos pós-corte). Em cada talhão foram abatidas cinco árvores e arrancadas suas raízes com retroescavadeira. De cada árvore foi obtida a biomassa seca dos compartimentos: galhos + folhas (GF), fuste sem casca (F), casca do fuste (CF), toco + raízes sem casca (TR) e casca de toco + raízes (CR), sendo seus valores expressos em porcentagem da biomassa total da árvore (BT). Utilizou-se o teste t para comparar a distribuição das biomassas entre rotações. A média de BT foi de 186,4 kg na primeira e 186,5 kg na segunda rotação. Em ambas as rotações, a distribuição da biomassa nos compartimentos apresentou a seguinte ordem: FTRGFCFCR, com respectivamente, 65,0\%, 18,3\%, 8,7\%, 6,7\% e 1,3\% na primeira rotação e 62,9\%, 17,1\%, 9,4\%, 9,2\% e 1,4\% na segunda rotação. Apenas CF apresentou diferença significativas entre as rotações. Portanto, a distribuição da biomassa nos compartimentos foi pouco influenciada pela rotação do povoamento.

\section{Strategic options for poplar based planted forests considering both material and energy options}

Joris Van Acker ${ }^{1}$

${ }^{1}$ Ghent University - Laboratory of Wood Technology, Ghent, Belgium (joris.vanacker@ugent.be)

The potential of woody biomass production in both volume and quality is key for the future of the forest-based sector. Vertical integration alongside a better tree and wood quality concept should lead to a more structured approach dealing with whether some wood products need to be prioritized and how we could deal with substitution of man-made (building) materials that require more energy. Combining the production of low energy wood products with the important option to produce green energy based on woody biomass is a major challenge for the future. Both structural and chemical mapping can contribute to fit-forpurpose usage, as accurate and detailed knowledge of the material enables guided utilization and optimal performance of wood. At Ghent University - Woodlab a platform has been developed using poplar disks for early selection with a focus on collecting data in the NIR, visual and X-ray spectrum in maximum 30 min per wood disk. Amongst the new methods to produce woody biomass, options to produce chips as well as timber are being assessed in a wide range of agricultural systems. Some are indicated as polycyclic plantations, other are classified under short rotation agroforestry systems. These dual-purpose production systems could be an option to provide, in a sustainable way and based on mid-term strategic decision making processes, lignocellulosic raw materials for material and energy use. The use of fast growing poplar for high end-products will also profit from developments in using hardwoods for construction and several wood modification options.

\section{Impact of biochar soil amendment on growth and physiology of urban tree species in Southern United States}

Kamran Abdollahi', Zhu Hua Ning ${ }^{1}$

${ }^{1} S U$ Agricultural Research and Extension Center, Baton Rouge, USA (kamran_abdollahi@subr.edu; zhu_ning@subr.edu)

Biochar from pyrolysis of wood waste in Louisiana was applied as soil amendment in a randomized completely block design study to quantify the impact of biochar soil treatment on the growth and physiology of live oak saplings. Height and diameter growth were measured. Net photosynthesis, respiration, and transpiration of live oak saplings were measured using portable photosynthesis system after biochar soil amendment treatment during three growing seasons. In addition, impact of biochar on chemical properties of the soil was quantified. The results indicated statistically significant impacts on growth and physiology of live oak saplings treated by biochar soil amendment. Chemical soil properties were also significantly impacted by the biochar amendment. 


\section{Comparative evaluation of subsoilers for deep soil preparation}

Rafael Ribeiro Soler ${ }^{1}$ (D, Guilherme Oguri², Anderson Cleiton Pauli Bogo ${ }^{3}$, Saulo Philipe Sebastião Guerra ${ }^{1}$

${ }^{1}$ Universidade Estadual Paulista "Júlio de Mesquita Filho", Faculdade de Ciências Agronômicas, Botucatu, Brasil; '2Instituto de Pesquisas e Estudos

Florestais, Piracicaba, Brasil; ${ }^{3}$ Bahia SpecialtyCellulose/Copener, Alagoinhas, Brasil (rrsoler22@hotmail.com, guilherme@ipef.br;

bogoflorestal@gmail.com; saulo.guerra@unesp.br)

Tabuleiros Costeiros region located at Brazilian northeast hascohesive soils with pedogenic horizons, densified, very hard or extremely hard in dry conditions, hardly to be broken in smaller fragments, known as fragipãs and duripãs (Embrapa, 2015). Under these conditions, afforestation requires a deep soil preparation and capable of breaking up the impeditive layers, aiming a better root development. Therefore, this evaluation compared two trident rods of different dimensions attached in excavators, model Volvo EC210 LC, for the deep soil preparation at the Bahia state. The conventional trident had $1.1 \mathrm{~m}$ of length on the central rod and the prototype had $1.4 \mathrm{~m}$. The experiment was located at Araçás/BA, and Esplanada/BA, where the prototype obtained an average performance of 5.0\% and prepared soil volume was $76 \%$ higher than the conventional trident. Thereat, it was concluded that the prototype trident subsoiler obtained higher performance and quality in operation compared to the current system.

An assessment of the production chain of Eucalyptus for energy in Rio Verde, Goiás, Brazil / Diagnóstico da cadeia produtiva de eucalipto para uso energético em Rio Verde, Go

Marcelo Ricardo Formolo Júnior ${ }^{1}$, Tamires Nedel ${ }^{1}$, Flávio José Simioni ${ }^{1}$, José Mauro Magalhães Avila Paz Moreira²,

Cláudio Cesar de Almeida Buschinelli ${ }^{2}$

${ }^{1}$ Universidade do Estado de Santa Catarina, Lages, Brasil; ${ }^{2}$ Embrapa Florestas, Colombo, Brasil; ${ }^{2}$ Embrapa Meio Ambiente, Jaguariúna, Brasil (marcelorformolojunior@gmail.com;tamiresnedel@hotmail.com;flavio.simioni@udesc.br;jose-mauro.moreira@embrapa.br;claudio.buschinelli@embrapa.br)

A biomassa florestal representa uma importante alternativa de fonte de energia renovável para compor a matriz energética brasileira. Contudo, o avanço dos plantios florestais para regiões denominadas como "novas fronteiras" apresentam desafios a serem enfrentados para a consolidação das cadeias produtivas. Assim, este trabalho objetiva identificar os principais fatores limitantes e propulsores encontrados na cadeia produtiva de eucalipto para geração de energia no município de Rio Verde (GO). Em parceria com o Sebrae-GO, a pesquisa foi realizada em 2018 e contemplou quinze agentes dos diferentes segmentos da cadeia produtiva (fornecedores de insumos, produtores, colheita, transporte e consumidores). Efetuaram-se visitas a campo, realização de painéis e aplicação do roteiro de entrevistas semiestruturado para obtenção de dados e informações. Os resultados indicaram uma cadeia produtiva estruturada para o fornecimento de biomassa florestal, na forma de lenha e cavaco de eucalipto, destinados à secagem e processamento de grãos. A produção local enfrenta uma reestruturação do mercado, em decorrência de excesso de oferta com consequente queda dos preços, com importantes implicações para o cenário futuro. As informações geradas pelo diagnóstico da cadeia produtiva contribuirão para auxiliar investidores e formuladores de políticas públicas para a definição de estratégias de enfrentamento dos fatores que limitam o seu desempenho competitivo.

An assessment of the production chain of Eucalyptus for energy in Cristalina, Goiás, Brazil / Diagnóstico da cadeia produtiva do eucalipto para uso energético em Cristalina, Go

Tamires Nedel'®, Lucas Gerber Soares ${ }^{1}$, Marcelo Ricardo Formolo Júnior ${ }^{1}$, Flávio José Simioni ${ }^{1}$, José Mauro Magalhães Ávila Paz Moreira ${ }^{2}$, Cláudio Cesar de Almeida Buschinelli $i^{3}$

${ }^{1}$ Universidade do Estado de Santa Catarina, Lages, Brasil; ${ }^{2}$ Embrapa Florestas, Colombo, Brasil; ${ }^{3}$ Embrapa Meio Ambiente, Jaguariúna, Brasil (tamiresnedel@hotmail.com; gerbersoares@outlook.com; mformolojr.ambiental@gmail.com; flavio.simioni@udesc.br; jose-mauro.moreira@embrapa.br; claudio.buschinelli@embrapa.br)

O uso da biomassa florestal de eucalipto é uma das principais fontes para geração de energia térmica para as indústrias de processamento de alimentos no Brasil. Contudo,a inserção de florestas plantadas para atender este tipo de demanda em regiões não consolidadas, como por exemplo, a região Centro-Oeste, tem enfrentado desafios para a estruturação e consolidação da cadeia produtiva. Por esta razão, diagnosticar os pontos propulsores e restritivos ao desempenho competitivo da cadeia produtiva de eucalipto em Cristalina (GO), foi o objetivo deste trabalho. Em parceria com o Sebrae-GO, a pesquisa foi realizada em 2018, utilizando-se como instrumentos de coleta de dados as visitas a campo, realização de painéis e aplicação do roteiro de entrevistas semiestruturado. De modo a contemplar os diferentes segmentos da cadeia, foram amostrados dez agentes de oito segmentos do setor florestal, cujos dados foram examinados por meio da análise de conteúdo. Os resultados indicaram uma cadeia estruturada, essencialmente coordenada por uma cooperativa de produtores florestais. Os principais consumidores são indústrias de alimentos, secagem e processamentos de grãos, revelando a tendência de substituição da lenha por cavaco para produção de energia térmica na forma de calor e vapor. Os sistemas de produção florestais caminham para novas oportunidades de mercado, tais como a integração lavourapecuária-floresta ou pecuária-floresta e a implantação e manejo da floresta objetivando outros usos da madeira, tais como o desdobro em serrarias. Assim, as informações obtidas no presente trabalho contribuirão para os diferentes agentes da cadeia estabelecer estratégias de ação visando a consolidação da cadeia produtiva.

C8c: THE BIOECONOMY AND NON-WOOD FOREST PRODUCTS

Commercialization of non-wood forest products through small and medium enterprises as a strategy for rural development: a review

Kathrin Meinhold ${ }^{1}$ Dietrich Darr

${ }^{1}$ Rhine-Waal University of Applied Sciences, Kleve, Germany (kathrin.meinhold@hochschule-rhein-waal.de; dietrich.darr@hochschule-rhein-waal.de)

Non-wood forest products (NWFPs) such as wild foods, medicinal plants, or raw materials for handicrafts make significant contributions to rural livelihoods in the developing world. NWFPs can help fulfil households' subsistence and consumption needs, serve as a safety-net in times of crises, and provide cash income. Benefits from commercializing NWFPs are potentially significant in terms of improved livelihoods for local communities. However, despite rising interest and recognition of the potential contribution of such industries as a key source of employment and their strategic role in the overall growth strategies of developing countries, many NWFP enterprises remain in the informal sector and in-depth understanding of underlying factors remains limited. This review synthesizes the current evidence base examining the contribution of commercialised NWFPs to livelihoods and factors positively affecting NWFP commercialisation and SME development in contrast to subsistence use. Using systematic review methodology studies investigating commercialised NWFPs and their economic impacts have been identified. Despite the diverse nature of NWFPs preliminary findings identify a number of constraining as well as enabling factors affecting NWFP 
commercialisation. The former include aspects such as lack of resource access (finances, skills, technologies, etc.), market information or basic infrastructure, the latter amongst others the role of key entrepreneurs, transparency across the value chain, partnerships and producer organisations or clear tenure rights. Negative implications of NWFP commercialisation such as overexploitation of the resource as well as their potentially more significant role in preventing a deepening of poverty are discussed.

\section{The national-level economic importance of environmental products in the bioeconomy: medicinal plants in and from Nepal}

Carsten Smith-Hall ${ }^{1}$ (D), Mariève Pouliot ${ }^{1}$, Thorsten Treue ${ }^{1}$

${ }^{1}$ University of Copenhagen,Frederiksberg,Denmark(cso@ifro.ku.dk; mapo@ifro.ku.dk; ttr@ifro.ku.dk)

Environmental products, harvested in forests and other natural non-cultivated environments, constitute a significant source of income to harvesters, traders, industries and governments in a large number of countries. In Nepal, the subset of medicinal plants is subject to large-scale national processing and cross-border trade that are poorly understood. The trade appears to involve millions of low-income small-scale harvesters, thousands of traders and hundreds of industries; the trade is made up of more than one hundred plant species; and annual traded volumes are thousands of tonnes worth hundreds of millions USD. Here we present an overview of the functions and structure of the medicinal plant production networks, with particular emphasis on quantitatively estimating the national-level economic importance of the current medicinal plant trade. Data were collected for the fiscal year 2014-15 and included structured quantitative interviews in Nepal with 362 harvesters, 393 traders, 58 central wholesalers, and 108 processors, as well as 89 regional wholesalers (30 in India and 59 in Tibet). We find that the de facto, but largely unrecorded, medicinal plant export constitutes Nepal's most valuable export product group, and we assess the potential as well as possible constraints of these products to support a transition to green growth as part of the country's bioeconomy.

\section{An assessment of non-timber forest products in the United States under changing conditions}

Susan Alexander ${ }^{1}$, James Chamberlain ${ }^{2}$, Toral Patel-Weynand ${ }^{3}$, Marla Emery ${ }^{4}$

${ }^{1}$ US Forest Service, Pacific Northwest Research Station, Juneau AK, USA; ${ }^{2}$ US Forest Service Southern Research Station, Blacksburg VA, USA; ${ }^{3}$ US Forest

Service Research and Development, Washington DC, UAE; ${ }^{4}$ US Forest Service, Northern Research Station, Burl (salexander@fs.fed.us;

jchamberlain@usda.gov; tpatelweynand@usda.gov; memery@usda.gov)

Non-timber forest products (NTFPs) are fundamental to the functioning of healthy forests and play vital roles in the cultures and economies of the people of the United States. However, these plants and fungi used for food, medicine, and other purposes have not been fully incorporated into management, policy, and resource valuation. This presentation will summarize a forest-sectorwide assessment of the state of knowledge regarding NTFPs science and management information for U.S. forest and rangelands. The assessment serves as a baseline science synthesis and provides information to inform management of NTFPs in the U.S. In addition, the assessment provides information for national-level reporting on natural capital and the ecosystem services NTFP provide. The report includes chapters on products and production; ecological dimensions; cultural dimensions; social dimensions; economics; laws, policies and regulations; and implications in an era of changing climate. Few policies and assessments address the dependence of forest-based communities on NTFPs and the vulnerability of associated social, cultural, and economic systems to climatic variability. This report takes an important first step, by providing a comprehensive assessment of the multiple dimensions of NTFPs, the ecosystem goods and services they provide, and threats that climate variability and change may pose to their long-term availability. This presentation will summarize the U.S. Report, highlighting findings and recommendations for management and data collection.

\section{A case study on how bamboo contributes to a circular economy in Southwestern China}

Yanxia $\mathrm{Li}^{1}$

${ }^{1}$ International Bamboo and Rattan Organisation, Beijing, China (yxli@inbar.int)

Commonly referred to as "poor man's gold", bamboo is a multiuse woody resource that is widely used in construction, pulping, plywood, handicrafts, and a diverse range of subsistence applications, generating job opportunities and cash income. Bamboo is an exceptional plant that offers climate smart benefits and is useful for creating a myriad range of products which in turn help in the sustainable development of the economy. Taking a case study from a famous bamboo town, Chishui municipality in Southwestern China, this paper sheds lights on how bamboo has been used to contribute to a green growth in local economy while offering opportunities to enhance the yield in form of a number of other products. It also indicates the results achieved not only the production value of bamboo created, but also how many job opportunities generated (especially for women) and a circular economy shaped.

\section{From bioprospecting to biorefinery and bioeconomy: valorization strategies of native non-wood forest products in Uruguay}

Zohra Bennadji

${ }^{1}$ INIA Uruguay, Tacuarembó, Uruguay (zbennadji@inia.org.uy)

Since the nineteens, Uruguayan native forests have been protected by law and their utilization reduced to some scarce traditional uses if not literally left untouched in many cases. However, in the last years, discussions raised around the ecological significance and the socio-economic future of this natural patrimony and a new national strategy was designed with a quite wide stakeholders participation. In parallel, as part of a national prospective study, the government conducted a bioeconomy study, applied to both planted and native forests. Biorefinery, through the extraction of high-value molecules from non-wood products for green chemistry was identified as one of the challenging approaches to fulfill the expectations of the bioeconomy implementation in the country. This works reports the research advances obtained by the Forestry Department of the National Agricultural Research Institute (INIA-Uruguay) in the field of: (i) the identification, extraction and characterization of secondary metabolites of native forest species as a raw material for biomaterials production and (ii) the way to increase its production through high-value tree domestication for ex situ cultivation providing knowledge to improve the reproduction, growth and yield of promising forest species. Two target native forest species (Quillaja brasiliensis and Prosopis affinis) were systematically studied through an interdisciplinary agenda and with an interdisciplinary team, covering different steps from the field to the laboratory: bioprospecting, cutting and plant production in vitro, seedling propagation in nursery, laboratory extraction and characterization of secondary metabolites, industrial scaling up and diffusion and technology transfer. 


\title{
Conservation of the Cerrado from the valorization of socio-biodiversity products: the importance of production chains and local
} marketing channels

\author{
Janaina Diniz', Stephane Gueneau', Sandra Afonso ${ }^{3}$ \\ ${ }^{1}$ Universidade de Brasilia, Brasilia, Brasil; ${ }^{2}$ CIRAD, Montpellier, France; ${ }^{2}$ Universidade Federal do Maranhão São Luís Brasil; ${ }^{3}$ Serviço Florestal Brasileiro, \\ Brasilia,Brasil (janadinizbr@gmail.com; stephane.gueneau@cirad.fr; sandra.afonso@florestal.gov.br)
}

The Cerrado occupies an area of about 20 million $\mathrm{km}^{2}$ (approximately 20\% of the Brazilian territory), being the second largest national biome and the richest savanna in biodiversity of the planet. Although it covers three regions of the country (Northeast, Midwest and Southeast) and housing a significant number of traditional communities and family farmers, is the biome with the lowest percentage of protected areas and therefore one of the most threatened. Strategies for the promotion of non-timber forest products (NTFP) for the conservation of the biome and promotion of sustainable development, with job creation and poverty reduction have been implemented. There are several cases in different states, of products with local supply and demand, but, in the meantime, there are fewer cases of large-scale impacts, reaching in more distant markets. Based on field research carried out in the last five years, we present a comparison of cases of promotion of NTFP chains in different regions of the Cerrado, where we highlight experiences and products of greater demand and occurrence, with the cases of Baru (Dipteryx alata), pequi (Caryocar brasiliense) and babassu (Attalea speciosa), which, based on different strategies of market insertion of agro-extractive organizations, promoted important changes in terms of income generation with local communities and conservation of the biome. Other products, such as buriti (Mauritia flexuosa), macaúba (Acrocomia aculeata) and other species of lesser occurrence, although less demanded, contribute to the maintenance of the diversity of forest species and the generation of complementary income to the communities.

\section{Contribution of non wood forest products to household income and livelihood improvement in Tunisia: the case of Aleppo pine}

Ibtissem Taghouti ${ }^{1}$,Emna Ouertani ${ }^{2}$, Bouali Guesmi ${ }^{2}$, Marwa Arfaoui ${ }^{2}$

${ }^{1}$ national research institute for rural engineering water and forestry, Ariana, Nigeria; ${ }^{2}$ University of Carthage, Mograne Agricultural High School, Zaghouan, Tunisia(ibtissem.taghouti@gmail.com; ouertaniemna2015@gmail.com; bouali.guesmi@upc.edu; marwaarfaoui1992@gmail.com)

Recently, there is a growing interest in the contribution of Non-Wood Forest Products (NWFPs) to livelihoods and food security among the local population. This has gained special attention given the relevance of forest heritage to alleviate poverty and improve household economies. This study focuses on determining the contribution of Aleppo pine production in Siliana province to household livelihood and food security. Data were obtained using structured surveys administered to 250 randomly selected rural household heads during the collection season. The relevance of this region as a leading Tunisian Aleppo pine producer makes the analysis especially interesting. A logistic regression, as well as food security indicators, have been performed to evaluate the contribution of NWFPs to improving household living conditions. Results support evidence that there is a significant difference between the alternative sources of revenues. The utilization of Aleppo pine was significantly influenced by age, gender, household size, distance to market, the importance of off-farm revenue. Finally, Aleppo pine plays an important role in supporting livelihoods and provides an important safety net for local population throughout the year.

\section{C8d: INTENSIFICATION WITHIN LIMITS: INCREASING PRODUCTIVITY WITHOUT COMPROMISING ECOSYSTEM SERVICES}

\author{
Linking soils, physiology and silviculture to optimize productivity and sustainability of planted forests \\ Thomas Fox \\ ${ }^{1}$ Rayonier, Inc, Yulee, USA (tom.fox@rayonier.com)
}

Precision forestry uses detailed knowledge of soils and physiology to prescribe silvicultural treatments that are applied at the right time in the right location to optimize growth, productivity, and sustainability of the forest.This involves matching species and genotype to each site with an integrated silviculture regime with inputs throughout the rotation to produce the desired products and environmental services from the forest. Because of the variation that exists in soils and site quality, growth responses to silvicultural treatments often vary within a stand and across the landcape. Silvicultural treatments must therefore be implemented at these same spatial scales to address the specific limiting factors. Environmental considerations, local, regional and global markets for timber, non-timber products, and environmental services provided by forests interact with soil quality and the response to silvicultural treatments to determine the limits on intensive management. This will create a mosaic of different management regimes across the landscape that range from intensive plantation management to extensively managed natural stands to forests managed for non-timber objectives and environmental considerations. This presentation will describe how Rayonier, a timber REIT that owns 2.6 million acres, has developed Market Driven Precision Forestry to optimize the productivity, profitability and sustainability of its forest estate in the United States and New Zealand.

\section{Site and stand productivity impacts of slash harvest for energy: experiences from the Nordic countries \\ Gustaf Egnell ${ }^{1}$, Ulrik Ilstedt ${ }^{1}$ \\ ${ }^{1}$ Swedish University of Agricultural Sciences, Department of Forest Ecology and Management, Umeå, Sweden (gustaf.egnell@slu.se; ulrik.ilstedt@slu.se)}

After the oil crises in the 1970s forest biomass was considered a potential energy source and a way to decrease the oil dependence in the Nordic countries. Apart from residues from the forest industry this also included primary residues such as branches and tops available following harvest of round wood. One concern was that the moderate increase in biomass harvest, when also branches and tops were harvested, was gained at the expense of a significant increase in the nutrient export from the site. Knowing that growth in the Nordic forests primarily is limited by nutrient availability a negative impact of this additional nutrient export on site productivity and hence the production of the subsequent stand was anticipated. Therefore, a number of field experiments were established from the late 1970s and onwards with the aim to study long-term effects of whole-tree harvest on future site and stand productivity. Here we use a meta-analysis approach on published and unpublished data retrieved from 17 experimental sites planted with Norway spruce and 14 planted with Scots pine, distributed over a wide range of site types in Finland and Sweden. Results include effects on seedling survival, site productivity and stand productivity. Based on the experimental design and silvicultural measures applied over time in these long-term experiments the relevance and the practical implications of the results for whole-tree harvest operations are discussed. 


\section{Comparing indicators of site suitability to biomass extraction at the national scale}

David Paré ${ }^{1}$, Julie Barrette ${ }^{2}$, Brian Titus ${ }^{1}$, Francis Manka ${ }^{1}$, Fougère Augustin ${ }^{1}$, Julien Beguin ${ }^{1}$

${ }^{1}$ Canadian Forest Service, Quebec, Canada; ${ }^{2}$ MFFP,Quebec, Canada(david.pare@canada.ca; julie.barrette@mffp.gouv.qc.ca; brian.titus@canada.ca;

francis.manka@canada.ca; fougere.augustin@canada.ca; julien.beguin@canada.ca)

There is a growing interest in using logging residues as feedstock in the bioeconomy. There are different approaches, using different rationales, to evaluate sites that are suitable to the extraction of logging residues. However, there are no consensus regarding the best approach to use. This project aims to compare and contrast the results obtained by the use of several types of indicators in a map format, in order to get an understanding of the concordance or discrepancy between indicators and to better evaluate the implications of choosing an indicator. Three types of approach are used: (1) site properties thresholds: thresholds for site properties such as soil $\mathrm{pH}, \%$ sand or slope are commonly used to define site suitability to intensive biomass extractions; (2) nutrient budget approaches: including the geochemical balance of nitrogen as well as that of base cations and phosphorus and (3) nutrient ratio: this approach evaluates the ratios of harvested nutrient stocks to the status of nutrient reserves in the soil and defines a critical threshold. The nutrient budget approach showed more contrast with the two others. This observation calls for a better scrutiny of the meaning of indicators and a better evaluation of the properties that make a site sensitive to biomass extraction. These results also indicate that there remains much unknown in forest nutrient cycling and that a coordinated research agenda is needed to deal with the greater pressure that is put on forest ecosystem nutrient cycling.

\section{Environment-induced growth changes in the Finnish forests during 1971 - 2010: an analysis based on National Forest Inventory}

Helena M. Henttonen ${ }^{1}$, Pekka Nöjd², Harri Mäkinen ${ }^{2}$

${ }^{1}$ Natural Resources Institute Finland, Helsinki, Finland; ${ }^{2}$ Natural Resources Institute Finland, Espoo, Finland (halena.henttonen@luke.fi; pekka.nojd@luke.fi; harri.makinen@luke.fi)

The annual growth of the Finnish forests has more than doubled in less than a century. We quantified the magnitude of increment changes not attributable to changes in growing stock, forest structure and silvicultural practices. The data from National Forest Inventories during 1971 - 2010 were used to develop models for volume, basal area and height increment of individual trees on mineral soils with tree and stand characteristics as predictor variables. Differences between the measured and predicted increment were used to quantify environment-induced increment changes. Then, we estimated the average changes of volume increment per hectare and totals in millions of $\mathrm{m}^{3}$. From 1971 - 1975 to 2006 - 2010, the environment-induced volume increment increase was 8.98 million $\mathrm{m}^{3} \mathrm{a}^{-1}\left(0.69 \mathrm{~m}^{3} \mathrm{ha}^{-1} \mathrm{a}^{-1}\right)$, which equals to $37 \%$ of the total observed volume increment increase. During 1971 - 1990 , the difference between the observed and predicted change was small. A large shift was observed after the mid-1990s. While the environment-induced increment change was substantial, a considerably larger increase $63 \%$ of the change was attributed to growing stock volume and forest structure, which both changed due to differences in forest management. A comparison between the environment-induced increment changes and growing season temperature sums revealed similarities. In the southern Finland, April-May seemed to be influential, while in the north the temperature sum of May-September showed similar variation. As climate change is predicted to increase growing season temperatures, the trend can be expected to continue in the boreal conditions of Finland.

\section{Stream runoff and nitrate recovery times: evaluating ecosystem response to forest disturbance in the USA and Japan}

Mary Beth Adams ${ }^{1}$ (D, Tomoki Oda ${ }^{2}$, Mark Green $^{3}$, Rieko Urakawa ${ }^{4}$, Todd M. Scanlon ${ }^{5}$, Stephen D. Sebestyen ${ }^{6}$, Kevin J. McGuire $^{7}$, Masanori Katsuyama $^{8}$, Karibu Fukuzawa ${ }^{9}$, Nobuhito Ohte ${ }^{8}$

${ }^{1}$ USDA Forest Service, Morgantown, WV, USA; ${ }^{2}$ University of Tokyo, Tokyo, Japan; ${ }^{3}$ Plymouth State University, Plymouth, NH, USA; ${ }^{4}$ Asia Center for Air Pollution Research, Niigata, Japan; ${ }^{5}$ University of Virginia, Charlottesville, VA, USA; ${ }^{6}$ USDA Forest Service, Grand Rapids, MN, USA; ${ }^{7}$ Virginia Water Resources Center, Blacksburg, VA, USA; ${ }^{8}$ Kyoto University, Kyoto, Japan; ${ }^{9}$ Hokkaido University, Sapporo, Japan (mbadams@fs.fed.us;

oh-dah@fr.a.u-tokyo.ac.jp; mbgreen@plymouth.edu; urakawa@acap.asia;.tms2v@eservices.virginia.edu; ssebestyen@fs.fed.us; kevin.mcguire@vt.edu; katsuyama.masanori.5m@kyoto-u.ac.jp; caribu@fsc.hokudai.ac.jp;nobu@bre.soc.i.kyoto-u.ac.jp)

Provision of clean water and regulation of nutrients are important ecosystem services provided by forests, and it is important that we can predict how those services will be affected by intensive forest management. One way to evaluate the mechanisms of long-term hydrological and biogeochemical recovery after forest disturbance is to compare recovery times of stream runoff and nitrate concentration. Previous studies have focused on either the response of runoff or stream nitrate concentrations, and some have specifically addressed recovery times following disturbance. However, seldom have these been analyzed together. We explored the relationship between runoff and nitrate recovery times to identify potential factors controlling each, using long-term runoff and stream nitrate concentration data from 20 sites in the USA and Japan. Forest disturbance included clearcutting, partial cutting, tree mortality/defoliation from insects and disease, understory vegetation removal and herbicide application. We examined the relationship between runoff and nitrate recovery times at these sites. Nitrate response was detected at all study sites, while runoff responses were detected at all sites with disturbance intensities greater than $75 \%$ of the catchment area. Runoff recovery time was significantly correlated with nitrate recovery time for catchments that had a runoff response. For these catchments, hydrological recovery times were slower than nitrate recovery times. The relationship between these two recovery times suggests that forest regeneration was a common control on both recovery times. However, the faster recovery time for nitrate suggests that nitrogen was less available or less mobile in these catchments than water.

\section{Using herbicides and insecticides to increase site productivity without degrading ecosystem quality and services}

Daniel Neary ${ }^{1}$

${ }^{1}$ USDA Forest Service, Flagstaff, USA (dan.neary@usda.gov)

Forests throughout the world are being evaluated and managed to produce greater outputs of wood fiber and other environmental goods and services for expanding human populations. Any program designed to increase the productivity of production forests must deal with weed and insect infestations that reduce growth rates and tree survival. Cumulative impacts of chemical usage is a topic of concern with many people, agencies, and governments. Modern herbicides and insecticides have been developed to economically control pest species without degrading environmental quality, adversely affecting non-target biota, or impacting human health. Chief concerns are for water quality, aquatic biota, terrestrial non-target plants and animals, recreational uses of forests and their streams and lakes, and human health and safety. Impacts of forest chemical use are a function of toxicity, mode of action, timing of use, loading, and application system. This paper and panel discussion subtopic address the topic of using chemicals to control forest pests in an environmentally sustainable manner and increase forest productivity. 


\section{Sustainability of resin production systems in Europe according to harvesting methods and contexts based on the evolution of the international pine resin market}

Armand Clopeau ${ }^{1}$, Christophe Orazio ${ }^{1}$

${ }^{1}$ European Forest Institute, Cestas, France (armand.clopeau@efi.int; christophe.orazio@efi.int)

The European natural resin extraction industry went through a period of deep crisis during the end of the last century. Public and Private initiatives have been taken in Spain, France and Portugal. The main initiatives implemented are presented in this study which was carried out as part of SustForest+ Project, funded by Interreg Sudoe and the European Regional Development Found (ERDF). First, the study consists in a description of the different production contexts in the world and the associated harvesting methods. This technical information is supplemented by economic data on the past and current resin market. This state of play makes it possible to formulate proposals concerning the evolution of the international resin market. Two scenarios are proposed, favorable or unfavorable to the development of resin production in Europe. The European potentialities of production are then estimated by cost-benefit analysis for each method in each European country, in order to know the profitability thresholds in different production contexts and thus to estimate the viability and sustainability of the various forest management systems designed to harvest resin in south west Europe.

\section{How municipalities can increase their revenue by managing non-timber forest products}

Sarah Melo ${ }^{1}$, Sarah Linhales ${ }^{1}$, Lorena Pinto ${ }^{2}$, Sandra Regina Afonso ${ }^{3}$, Edson Logato ${ }^{4}$, Maria Auxiliadora Drumond ${ }^{1}$

${ }^{1}$ Universidade Federal de Minas Gerais, Belo Horizonte, Brasil; ${ }^{2}$ Instituto Interdisciplinar de Estudos e Pesquisas em Sustentabilidade, Brumadinho, Brasil; ${ }^{3}$ Serviço Florestal Brasileiro, Brasilia, Brasil; ${ }^{4}$ Empresa de Assistência Técnica e Extensão Rural do Estado de Minas Gerais, Belo Horizonte, Brasil (sarahmelo.pequi@gmail.com; sarah.linhales@gmail.com; lorenalana.bio@gmail.com; sandra.afonso@florestal.gov.br; edson.logato@emater.mg.gov.br; alatus@ufmg.br)

Non-timber forest product (NTFP) extractivism's value is invisible to governments and society, and is low priority in the formulation and implementation of Public Policies (PP). Looking to propose PP adaptations for the valuation and valorization of NTFPs, we analyze Brazil's Agricultural ICMS - goods and services tax - which is one of the Robin Hood Law's 17 criteria regarding the distribution of ICMS within the state of Minas Gerais (MG), Brazil. It is calculated based on food production and family farmer data from MG municipalities. Although the LRH also considers extractivists who promote the sustainable management of native forests as family farmers, calculation for distribution of this incentive is based on the area cultivated for food production only, added to pasture areas, and does not take extractive production into account. This calculation excludes all the production of food extracted from municipalities'native vegetation, and devalues the work of extractivists, who are often traditional populations and small farmers who are recognized guardians of biodiversity. Thus, we propose that this calculation be based on the agricultural production of the municipality, including the production of food derived from extractivism, thus contributing to the conservation of NTFPs and generating even more income for the municipalities involved. In the analyzed case of the municipality of São João da Lagoa, this change would provide an increase of approximately $7 \%$ in the transfer of resources considering only the harvest of the pequi fruit in 2016 . This percentage would be even greater if the production of other extracted NTFPs were considered too.

\section{Development of undergrowth-based economy benefits farmers and rural economic development}

Yiqian Zhu', Yanru Zeng

${ }^{1}$ The State Key Laboratory of Subtropical Silviculture, Zhejiang A\&F University, Hangzhou, China (631160118@qq.com; yrzeng@zafu.edu.cn)

Decreased tree felling for purposes of ecosystem conservation and improvement has led to fast development of undergrowth-based economy in Zhejiang Province of China. An investigation of 16 undergrowth species produced by 30 organizations in Hangzhou, Lishui, Jinhua, Ningbo and Quzhou of the province has found that Zhejiang is rich in various NTFPs (Non-timber forest products) including both traditional Chinese medicine and edible fungi produced in such forest types as pure plantations and secondary natural forest. There are various undergrowth planting modes with no chemical fertilizer and pesticide applied, which are close-to-organic cultivation with no damage to the original forest ecological environment and have improved forest production through management of planted undergrowth species. In addition, there exist diverse organizational forms such as state-owned enterprises, household-based farms and cooperatives for production and management. The government supports undergrowth economic development by issuing red-headed documents in terms of policy. Researchers from higher learning institutions and local forestry bureaus also actively participate in and technically support the production of undergrowth NTFPs. Moreover, undergrowth planting has not only produced economically profitable NTFPs but also promoted the development of forest tourism, forest-based health industry and tourist products. Some undergrowth NTFP producers are economically strong and play a leading role, which has led to a large radiation area and quickened the transformation of business modes in forestry to increase farmers' income. And finally farmers are happily involved in this form of production. Therefore, Zhejiang Province has a broad prospect for the production of undergrowth NTFPs.

Ecosystem services provided by mammal species in traditional medicine: a biological prospection and conservation implication in Benin

Chabi Djagoun ${ }^{1}$, Hugues Akpona ${ }^{1,2}$, Brice Sinsin ${ }^{1}$

${ }^{1}$ Laboratory of Applied Ecology, University of Abomey Calavi, Abomey Calavi, Benin; ${ }^{2}$ Direction Générale des Forêts et des Ressources Naturelles, Cotonou, Benin(dchabi@gmail.com; hakpona@gmail.com; bsinsin@gmail.com)

Mammals is considered as a high proportion of global species diversity among vertebrate and include species that are widely distributed worldwide and play a variety of roles that benefit humans. There are commonly used in traditional medicine, both for the treatment of ailments and for symbolic purposes, such as improving relationships and attaining good fortune. The aim of this study was to identify the mammal species used in traditional medicine and evaluate the contribution of these highly diverse groups to human welfare. We conducted the semi-structured interviews in 22 animal-based medicine markets throughout the country with a total of 110 sellers. Among the 87 mammal species traded on the traditional medicine market in Benin, 46 species were sold by at least half of those traders surveyed; the conservation status of these animals included near threatened, vulnerable and endangered species. This study also found that rarer species were more costly and this constitutes an economic motivation for sellers to develop strategies for the availability of threatened species on their displays. All species are said to have both medicinal and magical values; however their use for magical purposes predominated. This study is a preliminary assessment of mammal used for animal-based medicine purposes in Benin; further investigation is required to increase our understanding of the harvesting and trade of those species, and to assess the impacts caused by the commercial exploitation.

Pesq. flor. bras., Colombo, v. 39, e201902043, Special issue, p. 1-768, 2019 


\title{
Açai (Euterpe oleracea) in the Amazon: until when a non-timber forest product?
}

Janaina Diniz ${ }^{1}$, Nathalie Cialdella ${ }^{2}$

${ }^{1}$ Universidade de Brasilia, Brasilia, Brasil; 2CIRAD, Montpellier, France (janadinizbr@gmail.com; nathalie.cialdella@cirad.fr)

Until the 1990s the açai was a product basically of local consumption in the states of the Brazilian Amazon, being even known as "food of the poor". Since then, following the expansion of its market, the exploitation of this fruit has undergone numerous transformations. Nowadays, besides being nationally known, it also has its demand expanded in the international markets, being considered now as a superfood. Such increase in demand has consequently influenced an increase in consumer prices and, in most cases, in the remuneration of extractivists, originally the exclusive suppliers of the fruit. The increase in supply has been due to the multiplication and diversification of actors in the chain, as well as the diversification of management and production practices (native acai trees densification, increase of monoculture or consortium plantations), depending on the economic context of the producing region, proximity to the industry and time in the activity of the primary suppliers. These changes can also bring vulnerability to more traditional forms and with smaller scale of production. Considering the trajectory of other extractive products that had their demands increased and, in order to meet them, had to identify substitutes, or to change the type of production system, this paper discusses, from recent data, if the main form of açai offer in the future will still remain through extraction or through cultivation systems. The paper also discusses what forms of market regulation and maintenance of traditional practices could guarantee the permanence of diversified and more sustainable systems.

Traditional knowledge of ecology and Carapa guianensis (andiroba) oil extraction from the Mamiraua and Amanã Sustainable Development Reserves in Amazonas, Brazil / O conhecimento tradicional sobre ecologia e extração do óleo de andiroba nas reservas de de-senvolvimento sustentável Mamiraua e Amanã, AM, Amazônia Brasileira

Emanuelle Raiol Pinto ${ }^{1}$, Ana Cláudia Lira-Guedes², Auristela Santos Conserva ${ }^{3}$

${ }^{1}$ Instituto de Desenvolvimento Sustentável Mamirauá, Tefé, Brasil; ' 2 Embrapa amapá, Macapá, Brasil; ${ }^{3}$ Autonoma, Manaus, Brasil

(emanuelle@mamiraua.org.br; ana-lira.guedes@embrapa.br; asconserva@gmail.com)

Por trás do aparato comercial das indústrias de produtos naturais, existe o conhecimento das populações que, tradicionalmente, extraem o óleo de andiroba e encontram dificuldades de acesso ao mercado. O objetivo deste foi identificar o conhecimento tradicional sobre a andiroba e caracterizar o modo de extração dos ribeirinhos das Reservas Mamirauá e Amanã, Amazonas, Brasil. Foram realizadas 30 entrevistas, em 18 comunidades. A maioria dos entrevistados possui ensino fundamental incompleto, a renda familiar é composta pelo extrativismo e bolsas sociais. A extração do óleo de andiroba é realizada prioritariamente para o consumo, embora haja potencial para a comercialização. Os extratores visitam o andirobal uma única vez no ano para coletar as sementes. Não identificam claramente as fases fenológicas, mas, sabem quando é o "tempo de coletar", por exemplo. A maioria dos informantes afirma que as andirobeiras frutificam entre novembro e junho e a dispersão acontece entre dezembro e julho, sendo melhor para coletar em maio. Declaram que as sementes são todas iguais, porém dizem ter diferença na madeira: branca ou vermelha.Todos os entrevistados relataram saber extrair o óleo e que esta é uma atividade realizada principalmente pelas mulheres. As etapas são: coleta das sementes, cozimento, secagem, descascamento, preparo da massa e escorrimento do óleo. Estas informações facilitam o manejo da atividade nessas áreas, valorizam o conhecimento tradicional associado e o empoderamento feminino na exploração de óleos de sementes florestais. Podendo alavancar a organização social para a comercialização de um produto amazônico de forma sustentável, mantendo a floresta em pé.

\section{C9a: DISCOVERY, CURATION, AND USES OF LEGACY TROPICAL FOREST DATA SETS}

\author{
The search for legacy tropical forest datasets \\ Sheila Ward 1 ; Gillian Petrokovsky² \\ ${ }^{1}$ Mahogany for the Future, Inc., San Juan, Puerto Rico; ${ }^{2}$ University of Oxford, Oxford, United Kingdom (mahoganyforthefuture@gmail.com; \\ gillian.petrokofsky@zoo.ox.ac.uk)
}

Tropical forest tree inventories and plot projects have generated large amounts of data over many decades, but much of this data is in paper or older digitized formats, or still undiscovered. These data sets are in danger of being lost and with them our ability to assess historical changes that can inform research and policy development for land use change and landscape resilience. These legacy datasets are invaluable for understanding how tropical forests, biodiversity, and carbon storage change through time, including the cumulative impacts of changes in land use and climate. Historical data can also help instruct current and future forest management. To locate these data sets, we are reaching out via various electronic media and contacting academics and practitioners. We are also searching older compilations of these data sets such as ATROFI-UK which has metadata on c; 30 studies in need of curation and TROPIS which refers to 6000 plots with uncertain status. The inventories and plots located will be cross referenced against lists of curated datasets such as Forestplots.net and others under the Global Index of Vegetation-Plot Databases (GIVD), to determine which datasets are not already in a long-term data repository. Currently the project has identified some 20 inventory and plot-based studies in need of curation, in countries ranging from Vanatu to Ghana to Belize. We invite wide participation in the quest for unsecured historical data sets. The guiding principle of the project is that the past can help enlighten the future.

Database of arboreal flora in Northwestern São Paulo, Brazil: importance for conservation, management, and restoration of natural forests in ecotone areas / Base de dados da flora arbórea do Noroeste do Estado de São Paulo, Brasil: importância para a conservação, manejo e restauração de florestas naturais em áreas de ecótono

Natalia Ivanauskas ${ }^{1}$, Maria Teresa Toniato $^{1}$, Pablo Figueiredo ${ }^{2}$, Alessandra Penha ${ }^{3}$, Ricardo Rodrigues ${ }^{2}$, Neusa Ranga $^{4}$, Andréia Rezende ${ }^{5}$

${ }^{1}$ Instituto Florestal, São Paulo, Brasil; ${ }^{2}$ Universidade de São Paulo, Piracicaba, Brasil; ${ }^{3}$ Universidade Federal de São Carlos, Araras, Brasil;; ${ }^{4}$ Universidade Estadual Paulista, São Josédo Rio Preto,_Brasil; ${ }^{5}$ Universidade Estadual Paulista, Ilha Solteira, Brasil (nivanaus@yahoo.com.br; mate_zt@yahoo.com.br; pablo_figueiredo@yahoo.com.br; penha.alessandra@gmail.com;rrresalq@usp.br;neusatr@ibilce.unesp.br; andreia.rezende@unesp.br)

O conhecimento sobre a vegetação natural remanescente na região Noroeste do Estado de São Paulo, Brasil, foi significativamente ampliado na última década por meio de estudos científicos que se dedicaram a caracterizar a flora e a vegetação de 18 fragmentos naturais, a partir de inventários quantitativos realizados em unidades amostrais permanentes ( 1 ha em cada fragmento), onde a comunidade arbórea (DAS $\geq 5,0 \mathrm{~cm}$ ) foi registrada em parcelas de $10 \mathrm{~m} \times 10 \mathrm{~m}$ e o componente regenerante (altura $>1$ m e DAS $<5,0 \mathrm{~cm}$ ) em sub-parcelas de 2,5 x 2,5 m. Levantamentos qualitativos (coletas de material botânico fértil em caminhamentos) nas mesmas áreas complementaram as informações sobre a flora regional. O banco de dados conta com o registro de 20.853 indivíduos 
arbóreos marcados, pertencentes a 292 espécies e 59 famílias. Acrescidos os dados qualitativos, resultam em 347 espécies e 60 famílias. No componente regenerante foram registrados 5.989 indivíduos de 207 espécies. Foram reconhecidas as seguintes formações florestais presentes na região: Savana Florestada (sete fragmentos), Floresta Estacional Semidecidual (seis) e ecótono Floresta Estacional Semidecidual - Savana (cinco). A caracterização dos remanescentes naturais, as unidades amostrais permanentes e o patrimônio constituído pelo conjunto de dados são valiosos e fundamentais para fomentar estudos subsequentes, em especial os relacionados à dinâmica da comunidade e à manutenção de populações ameaçadas de extinção, na busca de indicadores para monitoramento e subsídios para ações de manejo adaptativo, de modo a potencializar o papel desses remanescentes na conservação e restauração da biodiversidade paulista e de seus serviços ecossistêmicos.

\title{
Scale and context dependency of deforestation drivers: insights from spatial econometrics in the tropics (Zambia, Ecuador and Philippines)
}

Rubén Ferrer Velasco ${ }^{1,2}$, Margret Köthke ${ }^{1}$, Melvin Lippe ${ }^{1}$, Sven Günter ${ }^{1,2}$

${ }^{1}$ Thünen Institute of International Forestry and Forest Economics, Hamburg, Germany; ${ }^{2}$ Technical University of Munich, School of Life Sciences Weihenstephan, Department of Ecology and Ecosystem Sciences, Chair of Silviculture, Munich, Germany (ruben.ferrer@thuenen.de; margret.koethke@thuenen.de; melvin.lippe@thuenen.de; sven.guenter@thuenen.de)

It is so far unclear if the well-studied drivers of tropical deforestation behave similarly across nested subnational jurisdictions. A better understanding is a precondition for designing efficient policies and coherent land use planning strategies. We focused on three countries in Africa, America and Asia, which present very different pantropical contexts. Making use of spatial econometrics and a multi-level approach, we conducted a set of spatial regressions. Overall, the final sample comprised 3,035 administrative units from the three countries at micro-level, plus 361 and 49 at meso- and macro-level, respectively. We included forest cover as dependent variable and seven physio-geographic and socioeconomic indicators for well-known drivers of deforestation as explanatory variables. Uniform tropical determinants of forest cover change were detected with highly significant models. As expected, these recurrent drivers are related to population pressure and the natural condition of land suitability for crop production. However, clear differentiations across countries and spatial levels were visible. We also observed more and stronger spatial dependencies at smaller spatial scopes of higher heterogeneity, including spatial errors an interactions between neighboring units. The results provide arguments for both sides of the land sharing vs. land sparing debate. We therefore advocate, that the design and enforcement of policy instruments - such as REDD+ - should start from common international entry points. At the same time, these strategies have to be modified and adapted to particular national, regional or local conditions, avoiding a one size fits all solution.

\section{Resurrecting the dead: re-establishing the rainforest permanent network of the Queensland Forestry Department}

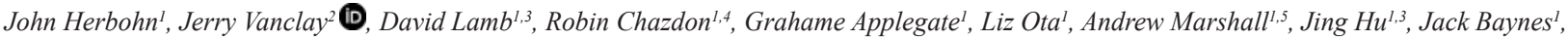 \\ Phan Quang ${ }^{1}$, Shariff Mukul', Robert Colwell ${ }^{1,4}$, \\ ${ }^{1}$ The University of the Sunshine Coast, Sippy Downs, Australia; ${ }^{2}$ Southern Cross University, Lismore, Australia; ${ }^{3}$ The University of Queensland, Brisbane, \\ Australia; ${ }^{4}$ University of Connecticut, Storrs, USA; ${ }^{5}$ University of York, York, United Kingdom (jherbohn@usc.edu.au; jvanclay@scu.edu.au; \\ d.lamb@uq.edu.au; rchazdon@usc.edu.au; gapples@usc.edu.au; lota@usc.edu.au; amarsha1@usc.edu.au;jing.hu1@uq.net.au; jbaynes@usc.edu.au; \\ m_p107@student.usc.edu.au; smukul@usc.edu.au; robertkcolwell@gmail.com)
}

Over a period of over 100 years, scientists from the Queensland Department of Forestry (QDF) and Commonwealth Scientific Industrial Research Organisation (CSIRO) undertook research into the management of tropical rain forests in north Queensland, Australia as part of their commitment to sustainable utilisation of these forests for timber production. Much of this experimental research and growth and yield monitoring was unique and scientifically significant and has been recognised as such by the international forestry community. As part of that research, over 800 'plots' were established, including to monitor growth (28), effects of enrichment planting (585), logging damage (32), regeneration (39) and various forest treatments to improve productivity (91). Many of these plots were established during the 1940's and 1950's, covering a range of rainforest types, altitudes, parent material, and rainfall; and including undisturbed, logged and experimentally-treated forests. The QDF plots were abandoned in 1987 when NQ rainforests were World Heritage Listed. This paper describes the substantial legacy dataset associated with the NQ rainforest plot network and the recent efforts by researchers from the Tropical Forests and People Research Centre. The initial recovery process has focussed on 60 priority plots which were last remeasured in 1997 and a database of over 200,000 records associated with these 60 plots has been created. We outline the challenges faced and the lessons learnt. We also present some contemporary research questions that can be addressed using the legacy datasets that were not envisaged at the time the experiments and associated plots were established.

\section{Biodiversity monitoring and carbon assessment: vital in sustaining ecosystem and governance of rehabilitated mangroves and uplands for resilient communities in Quezon Province, Philippines}

Nelson M. Pampolina ${ }^{1}$, Dixon T. Gevana ${ }^{2}$, Mutya Maria Q. Manalo ${ }^{1}$, Keshia N. Tingson ${ }^{3}$, Juancho B. Balatibat ${ }^{1}$, Jesa P. Ata ${ }^{1}$, Lorena A. Sabino ${ }^{2}$, Raffy D. Gordula ${ }^{1}$, Erwin L. Tabaco ${ }^{1}$, James G. Petonio ${ }^{1}$, Ronaldo A. Altamirano ${ }^{4}$

${ }^{1}$ Department of Forest Biological Sciences, College of Forestry and Natural Resources. University of the Philippines Los Banos, Laguna, Philippines; ${ }^{2}$ Department of Social Forestry and Forest Governance, College of Forestry and Natural Resources Universiyt of the Philippines Los Banos, Laguna, Philippines; ${ }^{3}$ Institute of Renewable Natural Resources, College of Forestry and Natural Resources. University of the Philippines Los Banos, Laguna, Philippines; ${ }^{4}$ TeaM Energy Foundation, Inc., Taguig City, Philippines (nmpampolina@up.edu.ph; dtgevana@up.edu.ph; mqmanalo1@up.edu.ph; kntingson1@up.edu.ph; jbbalatibat@up.edu.ph;jpata@up.edu.ph; lsabino@up.edu.ph;raffygordula_17@yahoo.com; eltabaco@up.edu.ph; jpetonio@up.edu.ph; altamirano@teamenergy.ph)

Permanent Biodiversity and Carbon Monitoring Areas (PBCMA) were established in 2015 across 10yo rehabilitated mangroves in five villages of Padre Burgos and three ameliorated mountainous Protected Areas in Pagbilao-Atimonan Quezon, Philippines. The objective was to generate long-term biodiversity data and carbon estimates that govern regional sustainability and climate resiliency. Twenty six PBCMAs totaling 8,000-80,000 $\mathrm{m}^{2}$ were randomly demarcated (5x40 and 20x100 $\mathrm{m}^{2}$ plot $^{-1}$ ) to baseline biodiversity and monitor biometrics, carbon, plant growth, and succession. Communities and stakeholders were profiled to capacitate through focus group discussion and trainings for participatory monitoring, assessment, and presentation. Ecosystem sustainability and resiliency were evaluated to prepare local policy. Six mangroves and 73 upland species were identified and monitored at PBCMAs, totaling 2,513 individuals over three years. Most indigenous species were dipterocarps and mangroves considered threatened where DBH and height ranges were $0.5-65 \mathrm{~cm}$ and $0.5-37 \mathrm{~m}$, respectively. Importance value was high in mangrove $(50.3 \%)$ though low diversity $\left(H^{\prime}=0.4965\right)$ unlike upland. Ecologically, rehabilitated ecosystems were habitats to 33 vertebrates, 37 fungi, 29 macrobenthos, and enumerable bacteria. Mangrove soil was basic with higher organic carbon than upland. Mangrove aboveground 
biomass (15.4-93.3 tons ha-1) was lower than upland (39.4-174.8 tons ha-1) with total carbon (909.83 tons ha $\left.{ }^{-1}\right)$ sequestration potential to offset local $\mathrm{CO}_{2}$ emission. Communities and stakeholders expressed interest to discover biodiversity and support carbon management through peoples organization but suggest livelihood incentives and local legislation. Overall, biodiversity and carbon values are realized landscape-wise locally but necessitate regular monitoring and networking across country to sustain ecological functions and strengthen resiliency against climate change.

\title{
Uses of legacy data sets for long-term monitoring of tropical Pacific island rainforests
}

\author{
Hans Juergen Boehmer
}

${ }^{1}$ University of the South Pacific, Suva, Fiji (neobiota@web.de)

Long-term vegetation records are of crucial importance for investigating plant species' responses to global change, in particular to climate change and biological invasions. Some of the strongest evidence for the impacts on forest ecosystems comes from long-term studies through comparisons of current with previous data, based on methodological consistency and spatially explicit datasets. In the tropical Pacific islands, however, long-term ecological studies in rainforests are limited and often hampered by geographical isolation and the lack of funding and specialized experts, thus not allowing for the necessary institutional persistence. While long-term monitoring of forest plots has been integrated into ecological studies in Hawaii (U.S.A.) and New Caledonia (France), published studies based on permanently marked plots and locations are almost entirely lacking in the other tropical Pacific islands, predominantly belonging to the territories of small island developing states (SIDS). We use legacy data sets for long-term monitoring of tropical island rainforests in Hawaii and Fiji to better understand long-term rainforest dynamics, and to demonstrate challenges, possibilities and limitations in the use of such data sets. This will be discussed in the light of relevant institutional differences between a developed island state, and a small island developing state.

\section{Embracing old, imperfect, long-term, field Data}

Andrew Marshall ${ }^{1}$, Robin Chazdon ${ }^{1}$, Liz Ota ${ }^{1}$, Jerry Vanclay ${ }^{3}$ D, David Lamb ${ }^{4}$, Grahame Applegate ${ }^{1}$, Rob Colwell ${ }^{5}$, Jing HU , Jack Baynes $^{1}$, John Herbohn ${ }^{1}$ ${ }^{1}$ University of the Sunshine Coast, Sippy Downs, Australia; ${ }^{2}$ University of York, York, United Kingdom; ${ }^{3}$ Southern Cross University, Lismore, Australia; ${ }^{4}$ University of Queensland, Brisbane, Australia; ${ }^{5}$ University of Connecticut, Connecticut, USA (amarsha1@usc.edu.au; rchazdon@gmail.com; lota@usc.edu.au; jerry.vanclay@scu.edu.au; david.lamb@uq.edu.au; gapples@usc.edu.au; robertkcolwell@gmail.com; jing.hu1@uq.net.au; jbaynes@usc.edu.au; jherbohn@usc.edu.au)

Permanently marked ecological experiments have been in existence for decades, particularly in the field of forest ecology and management. However, many of these were designed and implemented according to outdated scientific procedures, or with limited resources. These data therefore require careful consideration for statistical analysis and subsequent interpretation, to address limited replication, spatial and temporal data gaps, and other imperfections. These data are however irreplaceable, often meticulous, and essential to global change science. Our aim is to highlight the utility of old, imperfect, long-term datasets, for the field of applied ecology, with a primary focus on forests. We identify essential contributions that these datasets can make, based on their previous contributions to the advancement of fundamental ecology, and on unanswered ecological questions for which they will be essential. We then identify how imperfections in these data can be overcome by the application of realistic research questions, analyses, and/or written justification for their urgent consideration, despite lacking contemporary aspects of study design.

\section{C9b: PLANTED FORESTS FOR A GREENER FUTURE AND ACHIEVING SUSTAINABLE} DEVELOPMENT GOALS (SDGS)

\section{Market driven precision silviculture: linking silviculture with financial analysis and environmental considerations to optimize productivity and sustainability of planted forests}

Thomas Fox ${ }^{1}$

${ }^{1}$ Rayonier, Inc., Yulee, USA (tom.fox@rayonier.com)

Precision plantation forestry uses detailed knowledge of soils and physiology to prescribe silvicultural treatments that are applied at the right time in the right location to optimize growth, productivity, and sustainability. This involves matching species and genotype to each site with an integrated silviculture regime with inputs throughout the rotation to produce the desired products and environmental services from the forest. Modern technology such as field computers, GIS, satellite navigation, drones, and remote sensing tools such as LiDAR are needed to provide foresters the tools needed to efficiently implement precision silviculture. Precision requires a comprehensive understanding of markets and the short term and longer value of timber needed to justify the expenditures that are being made. In order to ensure that precision forestry is sustainable, environmental, social, and governance issues (ESG) must be incorporated into the decision process. Because of the variation that exists in soils and site quality, growth responses to silvicultural treatments, environmental issues, and the local, regional and global markets for timber, non-timber products, and environmental services provided by forests, market driven precision silviculture will create a mosaic of different management regimes across the landscape that range from intensive plantation management to extensively managed natural stands to forests managed for non-timber objectives and environmental considerations. This presentation will describe how Rayonier, a timber REIT that owns 2.6 million acres, has developed Market Driven Precision Forestry to optimize the productivity, profitability and sustainability of its forest estate in the United States and New Zealand.

\section{Forest plantations investments in Southwestern Europe: a comparative trend analysis on returns, markets and policies}

Alex Pra ${ }^{1,2}$, Mauro Masiero ${ }^{2}$, Susana Barreiro ${ }^{3}$, Lucio Brotto ${ }^{1}$, Gabriel Orrandre ${ }^{5}$, Aitor Onaindia ${ }^{6}$, Margarida Tomé $^{3}$, Davide Pettenella ${ }^{2}$ ${ }^{1}$ ETIFOR, Padova, Italy; ${ }^{2}$ University of Padova, Padova, Italy; ${ }^{3}$ University of Lisbon, Lisbon, Portugal; ${ }^{4}$ Wageningen University and Research, Wageningen, Netherlands; ${ }^{5}$ Bosqalia, Pamplona, Spain; ${ }^{6}$ BASOA Fundation, Bilbao, Spain (alex.pra@etifor.com; mauro.masiero@unipd.it; smb@isa.ulisboa.pt; lucio.brotto@etifor.com; gorradre@bosqalia.es; basoekin.a@basoa.org;magatome@isa.ulisboa.pt; davide.pettenella@unipd.it)

At global level there is a growing interest towards forest plantations as investment opportunities for profit generation, for building strategic assets, but also to address sustainable development challenges with the production of provisioning, regulating and cultural services. In southwestern Europe, forest plantations represent a consolidated segment of investment for landowners. In future years, the increasing demand for timber and fibers driven by bioeconomy and bioenergy policies, might boost the interest towards forest plantations investments, with an increasingly important role played by financial investors as well as 
by strategic partnerships. In this study we analyzed and compared potential investment returns at aggregate level for some of the most important forest plantation species in Southwestern Europe, focusing on some regions of Italy, Spain and Portugal. In addition, we carried out a trend analysis, estimating how returns have changed in recent years as a result of the evolution of the key economic and policy drivers. Overall, our results indicate that in southwestern Europe there are some opportunities for reasonably interesting returns for sectorial investors, i.e. landowners and forest-based industry, and in some cases also for financial investors. Nevertheless, it emerges that the regional context is characterized by structural factors - i.e. the dynamicity of the regional timber market structure, the increasing role of forest damage risk, the social demand biodiversity and landscape conservation and the small-scale fragmented forest holdings - that new investors would have to take into consideration, and which could limit the attractiveness of plantations in this region.

\section{Forest plantations and local economic development: evidence from the municipalities of the State of Minas Gerais, Brazil}

Roberta Afonso ${ }^{1,2}$, Daniel Miller ${ }^{1}$

${ }^{1}$ Department of Natural Resources and Environmental Sciences - NRES - University of Illinois at Urbana-Champaign, Urbana - IL, USA; ${ }^{2}$ Central Bank of Brasil,Brasilia,DF, Brasil (rafonso@illinois.edu; dcmiller@illinois.edu)

Brazil is one of the most important producers of wood products from forest plantations. Forest plantations are of increasing economic importance for the national economy; however, little is known about its economic impacts at regional and local levels. This study begins to fill an existing gap in the literature regarding empirical research on plantations at local level over a relatively long period of time. The research focuses on the socioeconomic effects of forest plantations in municipalities of the State of Minas Gerais, Brazil, over a twenty-year time period. Minas Gerais, with the largest plantation area since 1970, is the third richest state, but encompasses very unequally developed areas. We employed panel data methods with data from the National Censuses - 1991, 2000, and 2010 -, and Global Forest Watch/TW. Our primary dependent variables were the level of poverty, extreme poverty, migration, and per capita income. Results show that plantation areas are associated with less poverty over time, a positive migration rate, and higher per capita income for the third and fourth poorest quintiles. Plantations did not show direct effects on extreme poverty. Previous studies have found that plantations are associated with more poverty because their expansion occurs in poor areas. In our case, we found this association changed over time, suggesting they bring overall economic improvement. Additionally, migration was found positive over the years, contradicting other qualitative studies. These findings are important, as they provide insights on how plantations are shaping local development and who is benefiting from it.

\section{The potential of investing in breeding forest material for a sustainable intensification of planted forests: management and micro- economic effects in 3 European study cases}

Hernán Serrano-León ${ }^{1}$, Anssi Ahtikoski², Christophe Orazio ${ }^{1}$

${ }^{1}$ European Forest Institute, Cestas, France; ${ }^{2}$ Natural Resources Institute Finland (Luke), Oulu, Finland; ${ }^{1}$ European Forest Institute, Cestas, France (hernan serrano@efi.int; anssi.ahtikoski@luke.fi; christophe.orazio@efi.int)

Given the limited land resources, increasing the productivity of planted forests and strengthening their management is essential to support a bioeconomy transition that can achieve the Sustainable Development Goals. One way to address the growing global demands for wood and fiber resources and enhance climate change mitigation is by investing in improved forest reproductive material. In addition to improving tree survival to adverse conditions, tree breeding enhances forest growth and resources quality, while reducing the required area for productive land. We analyze the effects of using genetically improved material in terms of silvicultural management, wood production and economic impact in three study cases in Europe with developed breeding programmes (maritime pine in French Landes, Scots pine in Central France, Scots pine in Finland). The growth development of improved stands was simulated assuming standard forest management guidelines and different genetic gain scenarios estimated for the available breeding material; while the financial performance was assessed considering the effect of different wood prices. The improved performance of breeding material resulted in substantially higher production and profitability in all cases, what can encourage forest owners to invest in forest management even in less productive sites. A higher financial stability against the price fluctuations in comparison with using unimproved material can be especially important to reduce the economic impact of unexpected changes in global wood markets. These potential gains from breeding material investment can play an important role on sustainable intensification of forest management under a context of global change.

\section{The importance of non-native tree species for European forest: history, current state and outlook}

Elisabeth Pötzelsberger $\mathbb{D}^{\mathbb{D}, \text { Hubert Hasenauer }}{ }^{1}$, Monika Konnert ${ }^{2}$, Frits Mohren ${ }^{3}$, Anna Gazda ${ }^{4}$, Martin M. Gossner ${ }^{5}$, Thomas Wohlgemuth ${ }^{5}$, Pilar CastroDiez ${ }^{6}$, Joana Vicente ${ }^{7}$, Heinrich Spiecker ${ }^{8}$

${ }^{1}$ University of Natural Resources and Life Sciences, Vienna, Vienna, Austria; ${ }^{2 B}$ Bavarian Office for Forest Seeding and Planting, Teisendorf, Germany; ${ }^{3}$ Wageningen University, Wageningen, Netherlands; ${ }^{4}$ University of Agriculture, Krakow, Poland; ${ }^{5}$ Swiss Federal Research Institute WSL, Birmensdorf, Switzerland; ${ }^{6}$ Universidad de Alcalá, Alcalá de Henares, Spain; ${ }^{7}$ CIBIO, Universidade do Porto, Vairão, Portugal; ${ }^{8}$ Albert Ludwig University of Freiburg, Freiburg, Germany (elisabeth.poetzelsberger@boku.ac.at; hubert.hasenauer@boku.ac.at; monika.konnert@gmx.de; rlgazda@cyf-kr.edu.pl; martin.gossner@wsl.ch; thomas.wohlgemuth@wsl.ch; mpilar.castro@uah.es; jsvicente@fc.up.pt; instww@uni-freiburg.de)martin.gossner@wsl.ch; thomas.wohlgemuth@wsl.ch; mpilar.castro@uah.es; jsvicente@fc.up.pt; instww@uni-freiburg.de)

The management of non-native tree species has a long tradition in European forestry. Over centuries, new species have been introduced to Europe for various purposes. Besides planting fast growing trees to meet the resource demand from industrialisation, e.g. finding suitable species for afforestation of degraded areas was a strong motivation for introduction. Today, the number of non-native tree species planted in forestry exceeds two hundred, and strong regional differences in the species choice, management goals and regulation of non-natives are apparent. Nevertheless, only seven species or hybrid groups make up for $90 \%$ of the growing stock of non-natives - five from North-America (Robinia pseudoacacia, Picea sitchensis, Pseudotsuga menziesii, Pinus contorta, Populus hybrids), one from Australia (Eucalyptus globulus) and one from Asia (Larix kaempferi and hybrids thereof). The demands and expectations to non-native forest tree species are increasing and include the provision of ecosystem services and climate change adaptation. But also the ecological risks have come into focus, since the current distribution of non-native trees is artificial and does not reflect a long-term evolution. On the other hand, additional species options may be important for diversification and risk reduction in the forests, as the number of native tree species in central and northern Europe is rather low. To address all these challenges and opportunities, we established a large network of on non-native tree species experts in the form of the COST Action FP1403 NNEXT. Results from NNEXT will be presented. 


\section{Silviculture and management of non-native tree species in Europe}

Frits Mohren ${ }^{1}$, Valeriu0-Norocel Nicolescu' ${ }^{2}$,Bill Mason ${ }^{3}$,Heinrich Spiecker ${ }^{4}$, Jean-Marc Henin ${ }^{5}$, Hubert Hasenauer ${ }^{6}$,Elisabeth Pötzelsberger ${ }^{6}$ ${ }^{1}$ Forest Ecology and Forest Management Group, Wageningen University and Research, Wageningen, Netherlands; ${ }^{2}$ Faculty of Silviculture and Forest Engineering, Transylvania University, Brasov, Romania; ${ }^{3}$ Forest Research, Northern Research Station, Roslin, Midl (frits.mohren@wur.nl; nvnicolescu@ unitbv.ro; bill.mason@forestry.gsi.gov.uk; instww@uni-freiburg.de; jeanmarc.henin@spw.wallonie.be; hubert.hasenauer@boku.ac.at; elisabeth. poetzelsberger@boku.ac.at)

As part of the COST Action FP1403 'Non-native Tree Species for European Forests: Experiences, Risks and Opportunities' (NNEXT) general and nationallevel information and experiences on forest management systems and silvicultural models for the main non-native tree species in Europe (Abies grandis, Eucalyptus sp., Picea sitchensis, Pinus contorta, Pseudotsuga menziesii, Quercus rubra, Robinia pseudoacacia) have been compiled. We have compared these data with the standard silviculture and productivity of appropriate native tree species. Non-native tree species have been introduced into the landscape either to increase stand productivity, or to improve soil conditions for tree growth. Selection for increased productivity may come at greater risk of disturbance. An overall comparison of productivity in non-native tree species compared with native species, based variously on reported national performance, yield tables, or national forest inventories, point to an increase that is $20-30 \%$ above productivity of native tree species on comparable sites. Throughout Europe, silviculture of non-native tree species mostly focusses on timber production, as the main forest function, using an even-aged system with rotation age defined by growth rate and wood quality. As stands of introduced species age, and management objectives extends beyond productivity, the use of spontaneous regeneration and the development of mixtures of native and non-native tree species is becoming increasingly important, and silviculture increasingly includes management of interspecific competition to maintain mixed stands. In addition, adapting forest management to increase stand resilience to the impacts of climate change, while controlling invasiveness of some species, is of increasing importance

\section{Tree plantations that utilize a landscape approach will help support the Sustainable Development Goals}

Gary Dunning ${ }^{l, 2}$, Peter Kanowski ${ }^{3}$

${ }^{1}$ Yale University, New Haven, USA; ${ }^{2}$ The Forests Dialogue, New Haven, USA; ${ }^{2}$ Australian National University, Canberra, Australia (gary.dunning@yale.edu; peter.kanowski@anu.edu.au)

The increasing global demand for wood products, and the importance of trees for delivering ecosystem services, suggest a key role tree plantations in realizing the sustainable development goals. However, conflicts over land use and stakeholder involvement persist for tree plantations, as do concerns about their negative impacts on the environment and on local communities. The Forests Dialogue (TFD), a multi-stakeholder dialogue platform, co-convened a series of Tree Plantations in the Landscape (TPL) dialogues in Chile (June 2016), Brazil (March 2018), and New Zealand (November 2018). Key stakeholders focused on 5 priority areas: tree plantations in the context of the global development agenda; tree plantations in the context of the landscape approach; enabling good governance and inclusive development; key externalities associated with tree plantations; and diversification of species composition and the sustainability of plantation forestry systems. All TPL dialogues highlighted opportunities to improve governance, allow for more diverse participation in forestry, support community rights and autonomy, and promote cooperation across sectors. Conversations pointed to the importance of knowledge exchange, the need for truly inclusive dialogue, and the importance of monitoring, reporting and transparency. Most recently, discussions in New Zealand focused on sustainability in intensive production systems, indigenous forestry models, and the role of plantation forests in meeting Paris Agreement commitments. Continued dialogue provides a clearer picture of the current state of tree plantations in landscapes, refines keys considerations for future development, and identifies specific policy implications for tree plantations to deliver against the sustainable development goals.

\section{Planted forests and their role in conserving biodiversity in Brazil / Florestas plantadas e seu papel para a conservação da biodiversidade} no Brasil

Laura Antoniazzi ${ }^{1}$

1Agroicone, São Paulo, Brasil (laura@agroicone.com.br)

De acordo a FAO, existem 278 milhões de hectares de florestas plantadas no mundo, o que representa $7 \%$ do total da área de florestas do globo. Diante do crescimento populacional, que deve alcançar 9,1 bilhões de pessoas até 2050, a área de florestas plantadas deverá aumentar em mais 250 milhões de hectares. No Brasil, a área ocupada com florestas plantadas é de 7,8 milhões de hectares, divididos em 5,6 milhões de plantios de eucalipto e 1,6 milhões de plantios de pinus. As florestas plantadas estão em diferentes biomas, especialmente Mata Atlântica e estima-se crescimento de até 2 milhões de hectares até 2030. Para cada hectare plantado, há 0,7 hectares de florestas nativas conservadas, com a criação de corredores ecológicos que favorecem conectividade e redução do efeito de borda. Somadas às boas práticas de manejo e colheita florestal, grande número de espécies registradas no Brasil foram encontradas áreas conservadas pelas empresas florestais, compreendendo: 161 espécies de anfíbios, 174 répteis, 985 aves, 241 mamíferos e mais de 1.570 espécies da flora. Considerando que até 2020 novas metas de biodiversidade serão acordadas no âmbito da Convenção sobre Diversidade Biológica, alinhadas aos Objetivos de Desenvolvimento Sustentável, exploraremos de que formas o setor pode contribuir, cada vez mais, com a conservação da biodiversidade. Dentre as opções destacam-se o fomento a intensificação sustentável sobre áreas antropizadas, manejo, bom relacionamento com as comunidades, dentre outras. Ademais, incentivar a pesquisa e inovação no setor, fomentar certificação e benefícios sociais dos produtos das florestas plantadas é essencial.

\section{Creating shared value between academia, the forest sector \& civil society: the New Generation Plantations - IUFRO Planted Forest Task Force collaborative research program}

Luis Neves ${ }^{1,4}$, Peter Freer-Smith ${ }^{2,5}$, Miguel Bugalho ${ }^{3}$

${ }^{1}$ WWF, São Paulo, Brasil; ${ }^{4}$ IUFRO Task Force Sustainable Planted Forests for a Greener Future, Viena,Austria; ${ }^{2}$ University of California at Davis, Davis, USA; ${ }^{5}$ Forestry Commission Edinburgh, United Kingdom; ${ }^{2}$ IUFRO Task Force Sustainable Planted Forests for (lnsilva@wwfint.org; pfreersmith@ucdavis. edu; migbugalho@isa.ulisboa.pt)

The 2018 New Generation Plantations (NGP) Encounter was held alongside the 4th International Congress on Planted Forests, in Beijing. The joint event was a landmark in the NGP ongoing collaboration with the IUFRO Task Force on Planted Forests for a Greener Future. Scientific knowledge is essential for informing good policies and management practices and addressing major emerging issues. All NGP Participants work with researchers, so by working together with IUFRO, NGP can help to both set the research agenda, and provide focus on key topics of concern to the forestry sector. The partnership aims to aggregate and analyse research findings. Since the objectives of NGP participants and IUFRO Task Force members often overlap there is scope for co - design 
of research work. The objectives are to provide data supporting the NGP Principles and to mine data from "hidden research". The collaboration will move forward through the development of a joint research program, involving the NGP Participants and IUFRO Universities and Research Centers. The program will set common Research questions, mostly of multidisciplinary nature, including questions addressing social, environmental and business-oriented issues. Data already collected by the NGP Participants during their daily basis activities, as well as new data collectd by the research partners within the research program, will be used to reply to those questions. Ultimately, the NGP/IUFRO research program will show how best practices in plantations may contribute to the sustainable use of the land and to tackle several of the global environmental challenges humankind is currently facing.

\section{International Commission on Poplars and Other Fast-Growing Trees Sustaining People and the Environment (IPC) - a model for} international technical cooperation in forestry

Jim Carle 1 , Teresa Cerrillo ${ }^{2}$, Sharon Doty ${ }^{3}$ Emile Gardiner ${ }^{4}$, Julia Kuzovkina ${ }^{5}$, Mirko Liesebach ${ }^{6}$, Ian McIvor ${ }^{7}$, Giuseppe Nervo ${ }^{8}$, Joris Van Acker ${ }^{9}$, Martin Weih $^{10}$, Benjamin Caldwell ${ }^{11}$

${ }^{1}$ Jim Carle and Associates, Mount Mauganui Bay of Plenty, New Zealand; ${ }^{2}$ Instituto Nacional de Tecnología Agropecuaria, Campana, Argentina; ${ }^{3}$ University of Washington, Seattle, USA; ${ }^{4}$ US Forest Service, Stoneville, USA; ${ }^{5}$ University of Connecticut, Hartford, USA; ${ }^{6}$ Thünen Institute of Forest Genetics, Grosshansdorf, Germany; ${ }^{7}$ New Zealand Poplar and Willow Research Trust, Palmerston North, New Zealand; 8Ministry of Agricultural, Food, Forestry and Tourism Policies, Casale Monferrato, Italy; ${ }^{9}$ Ghent University, Gent, Belgium; ${ }^{10}$ Swedish University of Agricultural Sciences, Uppsala, Sweden; ${ }^{11}$ FAO, Rome,Italy_carle.jim@gmail.com; tcerrillo@gmail.com; sldoty@uw.edu; egardiner@fs.fed.us; jkuzovkina@uconn.edu; mirko.liesebach@thuenen.de; ian.mcivor@plantandfood.co.nz;giuseppe.nervo@crea.gov.it;joris.vanacker@ugent.be;joris.vanacker@ugent.be;martin.weih@slu.se;benjamin.caldwell@fao.org)

Sustainable forest management is necessary to achieve Sustainable Development Goal fifteen; as well, forests are an acknowledged pathway to achieving the other Sustainable Development Goals (SDGs). The IPC is a statutory body within the framework of the FAO that focuses on improvement of rural livelihoods through ecosystem goods and services from fast-growing tree species. These fast-growing trees are part of planted forests established in thirty-eight IPC Member Nations in five continents. Among other work, the IPC helps Member Nations obtain and use improved cultivars and preserve species, with emphasis on an environmentally sustainable systems and on improving people's livelihoods. Breeding programs have contributed significantly to the main quantitative and qualitative advances achieved by the cultivation of fast growing trees, with important benefits throughout the world. There has been significant expansion in recent years in terms of methodologies, the use of genomic tools, of early selection techniques (especially for adaptation and technology), and of lines of research that provide specific genotypes. The IPC makes this information available to the international community and particularly to Member Nations of the IPC. A case study of the IPC's global work on cottonwood (Populus deltoides) is presented. This case illustrates how forests can help achieve the sustainable development goals. Through the IPC, it also demonstrates a practical institutional model for international technical exchange, facilitating implementation of improvements in forest science in order to achieve the SDGs.

\section{Planted forests vs. natural forests: an inverse environmental kuznets curve?}

Daowei Zhang ${ }^{1}$

${ }^{1}$ FAO, Rome, Italy (daowei.zhang@fao.org)

This study investigates on the relationship between planted forest development and natural forest conservation at country and sub-national levels. Using country level data from 60 countries that have most planted forests and sub-national data from China and United States, we found that planted forests and natural forests are either unrelated or weakly correlated as in an inverse Environmental Kuznets Curve. This finding fits in the division of land theory and the forest transition model. Further studies need to be carried out in other countries.

\section{C9c: RESOURCE EFFICIENCY OF WOOD-BASED PRODUCTS AND MANUFACTURING}

\section{Dust emission during helical planing sucupira wood}

Bruna Ugulino ${ }^{1}$, Roger Hernández ${ }^{1}$, José Tarcísio Lima

${ }^{1}$ UniversitéLaval,Quebec, Canada; ${ }^{2}$ UniversidadeFederaldeLavras,Lavras,Brasil(braugulino@msn.com;roger.hernandez@sbf.ulaval.ca;jtlima@dcf.ufla.br)

Concerns have been raised by the repeated exposure to wood dust. Dust produced during the usual operations of wood machining may not be totally captured by the devices integrated to machinery, and be dispersed in the workshops. Thus, the decrease of dust emissions during wood machining is of great interest. The dustiness of the working environment depends, among other things, on the cutting parameters. These parameters act directly in the formation of wood chips and fine particles. On the other hand, helical planing has been proposed as an alternative method to reduce the need for sanding during wood finishing. This process is less noisy than conventional planing and improves the surface quality. The aim of this study was to determine the effects of moisture content ( 8 and $12 \%$ ) and feed speed (from 8.5 to $20 \mathrm{~m} \cdot \mathrm{min}^{-1}$ ) on dust emission $(0.1$ to $15 \mu \mathrm{m})$ and surface roughness during helical planing sucupira (Diplotropis sp.) wood. The results showed that dust emission decreased as feed speed increased with the increase of average chip thickness. Moisture content also affected the amount of dust. Dust emission increased for the higher moisture content but for thicker chips $(0.10 \mathrm{~mm})$. For thinner chips, dust emitted was similar for the two studied moisture contents. Furthermore, higher values of feed speed produced higher surface roughness. The best planing condition was obtained when using $8 \%$ moisture content and 16 m.min-1 feed speed. This condition was the fastest feed speed allowable to obtain the best surface quality while minimizing dust production.

\section{Experimental methodology to monitor the development of wood drying cracks in real-time \\ Hanna Botter-Kuisch ${ }^{1,2}$ (D), Jan Van den Bulcke ${ }^{\text {D }}$, Jan Baetens ${ }^{2}$ (D), Joris Van Acker ${ }^{2}$ (D) \\ ${ }^{1}$ Anton de Kom University of Suriname, Paramaribo, Suriname; ${ }^{2}$ Ghent University, Gent, Belgium (hanna.kuisch@ugent.be; jan.vandenbulcke@ugent.be; jan.baetens@ugent.be; joris.vanacker@ugent.be)}

Drying is a fundamental step in solid wood processing, yet it is very challenging because of potential drying defects negatively affecting the final product quality. Successful kiln drying depends largely on the diffusivity and permeability of the wood species. Despite many research efforts, predicting kiln-drying schedules for a given wood species is not yet possible. The main reason is that important spatio-temporal variables such as moisture and temperature gradients, and wood anatomical features are considered insufficiently in the predictive modelling framework. We expect that monitoring and controlling drying up to the limit states can be used for any wood species. To understand the influence of parameters determining these limit states we developed an experimental measurement set-up. This set-up allows real-time monitoring of local moisture content gradient inferred from the electrical resistance gradient, wood temperature gradient 
and average moisture loss in function of time for any wood species. The obtained data is linked directly to the wood anatomical structure on the end grain, the occurrence of cracks and the transversal shrinkage. This methodology enables to unveil interrelationships between physical parameters and changes of the wood anatomical structure. We present a proof-of-concept with basralocus (Dicorynia guianensis).

\section{Comparative assessment of the sustainability performance of glue laminated timber and non- renewable material-based value chains}

Marius Aleinikovas ${ }^{1}$, Povilas Žemaitis ${ }^{1}$, Edgaras Linkevičius ${ }^{2}$

${ }^{1}$ Institute of Forestry, LAMMC, Girionys, Lithuania; ${ }^{2}$ Vytautas Magnus University Agriculture Academy, Akademija,Lithuania (marius.aleinikovas@mi.lt; povilas.zemaitis@mi.lt; edgaras.linkevicius@asu.lt)

Mitigation of climate change, carbon sequestration and low carbon economy are some of the corner stones of the European bioeconomy strategy. Lithuania has sufficient forest resources and a competitive wood industry, and more than $20 \%$ of annual harvest level is exported. Also, Lithuania exports about $80 \%$ of glue laminated timber for wooden constructions using only $20 \%$ for national house construction. Because of this, Lithuania losses possibility to develop its low carbon economy based on high value added products. The production of glue laminated timber (GLT) is rapidly growing in Lithuania. Timber can be a viable and long-term alternative for storing green Carbon in buildings and substituting GHG emissions from more energy intensive materials. The aim of the study is to quantify and to compare sustainability impacts and climate change mitigation potential of national value chains for non-renewable materials (reinforced concrete (RC)) and renewable materials (GLT) used in construction sector. GLT value chain involve: forest logging-transporting-timber sawing-GLT producing processes; RC value chain involve: raw material extraction for cement and concrete-transporting-cement producing-RC producing. In order two compare sustainability impacts of GLT and RC constructions in practical application, it was designed two flor (765 $\left.\mathrm{m}^{2}\right)$ and five flor (1913 $\left.\mathrm{m}^{2}\right)$ GLT and RC buildings.

\section{Understanding the nature of underutilised timber (UUT) products for the built environment}

Harry Mills ${ }^{1}$, Joe Gattas ${ }^{1}$, Kim Baber ${ }^{1}$

${ }^{1}$ The University of Queensland,Brisbane,Australia(harry.mills@uqconnect.edu.au; j.gattas@uq.edu.au; k.baber@uq.edu.au)

This project looks at the quantity, quality and values associated with the softwood sawn timber milling and manufacturing industry in Australia. The research highlights the potential quandary facing the timber industry with the rise in Mass Timber Construction (MTC). Undertaking a review of products from local and national merchants in Australia, the research analyses volume and value associated with typical products from softwood milling. With an increasing amount of underutilised timber (UUT) being generated from current milling and manufacturing processes, the ongoing research aims to highlight the potential outcomes as the industry moves into the age of MTC.

\section{Combined FTIR spectroscopy and rheology for measuring adhesive curing as influenced by wood extracts}

Merve Özparpucu ${ }^{1}$, Elisabeth Windeisen ${ }^{1}$, Klaus Richter $^{1}$

${ }^{1}$ TU Munich, Munich, Germany(oezparpucu@hfm.tum.de; windeisen@hfm.tum.de; richter@hfm.tum.de)

Reliable wood-adhesive bonds are crucial for future wood-biomass utilization. Our ongoing research aims at systematically investigating interactions between structural adhesives and extractable wood constituents. The simultaneous examination of the progress of chemical reactions and changes in viscosity of both pure adhesives and adhesive-extract mixtures using a combination of FTIR spectroscopy and rheology, confirms major influences on the curing process and provides fundamental information for their chemical interpretation. First results based on MUF (in combination with chestnut hardwood) and 1 K-PUR adhesive (in combination with larch hard wood) will be presented and discussed.

Strengthening the Suministro forest supply chain through innovative experiments in sawmilling Acacia mangium Willd. in Eastern Colombia / Fortalecimiento de la Cadena Forestal de Suministro a través de Experiencias Novedosas en el Aserrio de Acacia mangium Willd. para el Oriente Colombiano

César Polanco Tapia ${ }^{1}$, Leidy Natalia Vargas², Jose Nivaldo Garcia ${ }^{3}$

${ }^{1}$ Universidad de Sao Paulo, Bogotá, Colombia; ${ }^{2}$ Universidad Distrital Francisco Jose de Caldas, Bogotá, Colombia; ${ }^{3}$ Universidad de Sao Paulo, Sao Paulo, Brasil(cpolanco@udistrital.edu.co; nataliavargasro@gmail.com; jngarcia@usp.br)

Colombia posee 310.138 hectáreas de bosque plantado de las cuales 36.986 hectáreas pertenecen a la especie Acacia mangium, esta especie fue introducida en Colombia desde 1990 y es reconocidapor su rápido crecimiento y capacidad para desarrollarse satisfactoriamente en suelos degradados y erosionados. Esta especie no cuenta con información disponible respecto a los procesos de aserrío en el país, ignorando la productividad potencial de la madera para el sector de muebles y construcción. Para contrarrestar lo anterior, este estudio evaluó el rendimiento en aserrío de 556 individuos de pequeños diámetros, 278 de clase diamétrica de 10 a 14,99 cm y 278 de 15 a 20 cm, provenientes de plantaciones ubicadas en la Orinoquia Colombiana. Los árboles muestreados presentaron valores medios de altura total de 12,76 m, altura comercial de $7 \mathrm{~m}$, DAP de 0,14 $\mathrm{m}$ y factor forma de 0,79. Fabricando dos tipos tradicionales de producto para el mercado, el coeficiente de aprovechamiento llegó al 37\%. Adicionando dos espesores de corte no tradicionales, el aprovechamiento llegó hasta el 49\%, esto re-aserrando costaneras y utilizando trozas curvas, generando nuevas piezas articuladas a la cadena productiva nacional e involucrando procesos del tipo finger joint. La experiencia demostró que procesos mejor planificados desde la realidad de la silvicultura nacional de la especie, pueden mejorar sosteniblemente los beneficios económicos y por ende sociales de las plantaciones forestales de A. mangium en la Orinoquia colombiana.

Life cycle assessment within the context of wood frame construction systems: a bibliographic and bibliometric review / Avaliação do Ciclo de Vida no contexto do sistema construtivo wood frame: uma revisão bibliográfica e bibliométrica

Camila Sanchotene ${ }^{1}$, Anna Claudia Fischer ${ }^{2}$, Marcelo Langer ${ }^{1}$, Dimas Agostinho Silva ${ }^{1}$, Sérgio Fernando Tavares ${ }^{2}$

${ }^{1}$ Universidade Federal do Paraná, Programa de Pós-Graduação em Engenharia Florestal, Departamento de Ciências Florestais, Curitiba, Brasil; ${ }^{2}$ Universidade Federal do Paraná, Programa de Pós-Graduação em Engenharia de Construção Civil, Departamento de Const (camilasanchotene@gmail. com; fischerannaclaudia@gmail.com; malanger04@yahoo.es;dimas.agostinho.silva@gmail.com; sergioftavares@gmail.com)

Um importante segmento da produção madeireira de florestas plantadas é o de produtos de madeira destinados à construção civil. O uso da madeira em sistemas construtivos industrializados, como o wood frame (WF), pode contribuir para a redução de resíduos e emissão de Gases do Efeito Estufa oriundos desta 
indústria. Contudo, o processo produtivo dos materiais de madeira impacta o meio-ambiente. Neste sentido, a Avaliação do Ciclo de Vida (ACV) possibilita a avaliação de impactos ambientais potenciais associados ao WF, que passou a ter maior aplicação no Brasil a partir de 2011. Por meio de uma análise bibliométrica e bibliográfica, esta pesquisa investigou o progresso dos estudos de ACV relacionados ao WF e produtos de madeira relacionados a sua cadeia. As bases de dados utilizadas foram ProQuest, EBSCO, Scopus, Web of Science e Engineering Village, entre 2002 e 2018. Após o levantamento e seleção dos estudos, foram realizadas análises temporal e espacial e dos tipos de ACV construídas. As análises foram conduzidas em cinco eixos temáticos: Operações Florestais; Materiais de Madeira; Edificações em WF; Comparação de Sistemas Construtivos; e Revisão de Literatura. As publicações concentram-se nos últimos 5 anos, com destaque para 2018. A Europa e a América do Norte lideram as pesquisas no tema, representando 50 e $40 \%$ respectivamente. Foi possível estabelecer um framework do tema e sua evolução, com identificação de lacunas científicas para que sirvam como pontos norteadores de estudos do WF na construção civil brasileira.

\section{Inclusión de defectos en la madera estructural como elemento estratégico en la gestión sostenible de los bosques tropicales}

Cesar Polanco ${ }^{1,2}$, Jose Nivaldo Garcia ${ }^{2}$, Juan Francisco Correal Daza ${ }^{3}$

${ }^{1}$ Universidad Distrital Francisco José de Caldas, Bogota, Colombia; ${ }^{2}$ Universidade de São Paulo, Piracicaba, Brasil (cpolanco@usp.br; jngarcia@usp.br; jcorreal@uniandes.edu.co)

Una premisa de la madera estructural es la eliminación de los defectos naturales de los árboles. Desde nudos hasta pudriciones, han sido considerados como obstáculos en el desempeño estructural, sin ninguna discriminación. Tal situación, trae como consecuencia grandes volúmenes desperdiciados y/o productos de menor valor económico que no alcanzan a cubrir sus costos de producción, incidiendo negativamente en la gestión forestal sostenible (GFS), pues solo el 5 a $20 \%$ de los árboles se convierte en producto final. En vista que la madera para construcción civil correctamente especificada y con propiedades mecánicas definidas, se cotiza mejor en los mercados, esta publicación tiene como objetivo presentar los resultados de la inclusión sistemática de defectos en madera laminada encolada (GLULAM) de gran formato con fines estructurales, elaborada con una especie de alta abundancia en el bosque muy húmedo del Litoral Pacífico colombiano, Campnosperma panamense Standl. Siete vigas GLULAM de 7500x500x50 mm fueron elaboradas; tres siguiendo estándares tradicionales de fabricación sin defectos y cuatro con defectos no aceptados para estos productos, los defectos fueron predefinidos y localizados estratégicamente. Se registraron todas las variables del proceso productivo. Como resultados se mejoró el aprovechamiento en madera con defectos y no se encontraron diferencias significativas entre los valores de resistencia a flexión para la madera con defectos y sin defectos. Se abre la posibilidad de hacer menos estricta la clasificación para reducir el desperdicio de material, contribuyendo a los objetivos de GFS, al procurar menor cantidad de árboles y el uso integral de los mismos.

\section{C9d: SOCIETAL PERCEPTIONS, NEW PRODUCTS, MARKETS, AND BUSINESS MODELS OF THE CIRCULAR FOREST BIOECONOMY}

\section{Perceiving the Forest-based Bioeconomy (PerForm)}

Alex Giurca ${ }^{1}$

${ }^{1}$ Chair of Forest and Environmental Policy, University of Freiburg, Freiburg, Germany (alex.giurca@ifp.uni-freiburg.de)

In this presentation I will talk about the PerFormproject- a European cooperation network of social scientists investigating societal perceptions of the forestbased Bioeconomy. The aim of the projectis to better understand regional disparities of national bioeconomy policies and the perceptions of a forest-based bioeconomy. We explore the diversity of perceptions and acceptance of a forest-based bioeconomy in Europe in order to foster participation of different forest stakeholders and the broader public through an informed and open dialogue. We analyze perceptions of various stakeholder groups across Europe (Germany, Austria, Slovakia, France, Italy, Sweden, Finland). Methodologically, we build extensively on qualitative document analysis, stakeholder interviews and innovative communication tools.

\section{Bioeconomy perception by future stakeholders: hearing from European forestry students}

Mauro Masiero ${ }^{1}$, Hanna Bernö ${ }^{2}$, Ariane Carreira ${ }^{3}$, Riccardo Da Re ${ }^{1}$, Alexander Dobrovolsky ${ }^{4}$, Blanka Giertliová $a^{5}$, Alexander Giurca ${ }^{6}$, Sara Holmgren ${ }^{2}$, Daniela Kleinschmit ${ }^{6}$, Arttu J Malkamäki ${ }^{7}$, Cecilia Mark Herbert ${ }^{2}$, Lenka Navrátilováa ${ }^{5}$, Davide Matteo Pettenella ${ }^{1}$

${ }^{1}$ TESAF Dept. University of Padova, Padova, Italy; ${ }^{2}$ Swedish University of Agricultural Sciences (SLU), Uppsala, Sweden; ${ }^{3}$ National Research Institute of Science and Technology for Environment and Agriculture (Irstea), Bordeaux, France; ${ }^{4}$ Saint-Petersburg State Forest Technical University, Saint-Petersburg, Russian Federation; ${ }^{5}$ Department of Economics and Management of Forestry, Faculty of Forestry, Technical University in Zvolen, Zvolen, Slovakia; ${ }^{6}$ Chair of Forest and Environmental Policy, University of Freiburg, Freiburg, Germany; 'Department of Forest Sciences, University of Helsinki, Helsinki, Finland; ${ }^{8}$ University of Natural Resources and Life Sciences (BOKU), Vienna, Austria; '9Albert Ludwig University, Freiburg, Germany (mauro.masiero@unipd.it; hano0003@stud.slu.se; ariane.carreira@irstea.fr; riccardo.dare@unipd.it; alexander-83@ya.ru; giertliova@tuzvo.sk; alex.giurca@ifp.uni-freiburg.de; sara. holmgren@slu.se; daniela.kleinschmit@ifp.uni-freiburg.de; arttu.malkamaki@helsinki.fi; cecilia.mark-herbert@slu.se; lenka704@gmail.com; davide.pettenella@unipd.it; helga.puelzl@boku.ac.at; lea.ranacher@boku.ac.at; alessandrasalvalaggio33@gmail.com; laura.secco@unipd.it; arnaud. sergent@irstea.fr; juuso.sopanen@helsinki.fi; christoph.stelzer@students.boku.ac.at; lauri.valsta@helsinki.fi; ida.wallin@ifp.uni-freiburg.de)

The forest sector plays a pivotal role within the European bioeconomy and forestry students should be regarded as key-future stakeholders for the development of a forest-based bioeconomy. Nonetheless, while a number of studies have been conducted on public perception of bioeconomy and bio-based products in Europe, none of them has been specifically focused on forestry students.Researchers of the PerForm European cooperation network developed a quantitative online survey targeted at forestry students, including Bachelor, Master and Doctorate ones. The survey addresses students within eight countries across Europe (Austria, Finland, France, Germany, Italy, Slovakia, Sweden and Russian Federation) and aims to analyse and compare their knowledge and perception of forest-based bioeconomy today and in a future perspective. It consists of a multi-language online questionnaire structured into six sections: from students' knowledge and perception of key-concepts and topics, to concrete application for future job opportunities. A stratified sampling approach is adopted to cover the main forestry courses in selected countries. Data collection and analysis are performed as part of Master theses. Responses are analysed and compared among countries and programmes across Europe, in order to gain an up-to-date and in depth picture of the level of knowledge and perception of forest-based bioeconomy by students, as well as gaps and expectations. Findings from the survey provide useful inputs to develop future action for the promotion of education, training and skills opportunities in forest-based bioeconomy across Europe, thus contributing to key-actions defined by the 2018 European Union (EU) Bioeconomy Strategy Action Plan. 


\author{
What'all about the fuss? Bioeconomy as perceived by Austrian next generation stakeholders \\ Helga Pülzl D, Lea Ranacher ${ }^{2}$ \\ ${ }^{1}$ University of Natural Resources and Life Sciences, Vienna (BOKU), Vienna, Austria; ${ }^{2}$ Wood K plus - Kompetenzzentrum Holz GmbH, Linz, Austria \\ (helga.puelzl@boku.ac.at; l.ranacher@wood-kplus.at)
}

Bioeconomy strategies are devised all over the world, (to some extent) stakeholders are consulted, and researchers have started to show a growing interest into the topic. Forests, their biomass and related products are central to such a new economic format. However to date only initial evidence (see Hodge et al., 2017; Stein, 2017) is provided as to how forest stakeholders perceive this bioeconomy. The present paper will contribute therefore to closing this knowledge gap as it investigates perceptions and expectations of future forest stakeholders in Austria, a highly forested country. We base our research on data collected via an online survey targeted at all forestry students in Austria. We expect the study to provide insights on the future forest stakeholders' perceived problems and chances associated with bioeconomy. From a practical perspective, the results will help to design bioeconomy strategies tailored to stakeholder needs and contribute to its societal acceptance.

\title{
How urban people perceive a forest-based bioeconomy in Finland?
}

Tuuli Suomala ${ }^{1}$, Jaana Korhonen ${ }^{1,2}$, Arttu Malkamäki ${ }^{1,2}$, Lauri Valsta ${ }^{1,2}$

${ }^{1}$ University of Helsinki, Helsinki, Finland; ${ }^{2}$ Helsinki Institute of Sustainability Science, Helsinki, Finland (tuuli.suomala@helsinki.fi; jaana.e.korhonen@helsinki.fi; arttu.malkamaki@helsinki.fi; lauri.valsta@helsinki.fi)

Forests have an important role in the Finnish bioeconomy strategy. The forest-based bioeconomy has on a vision that forest industry firms will enter into new sectors and firms from other sectors will enter the forest sector. The sustainability proposition of new forest-based products is based on the substitution of oil with renewables. Nonetheless, the sustainability of the transition toward forest-based bioeconomy raises concerns related to e.g. acceptable level of use of forest resources. In parallel with accelerating urbanization, it is foreseeable that the urban consumers will become increasingly influential actors for legitimizing the bioeconomy policies in the future. Thus, understanding how urban consumers perceive the forest-based bioeconomy becomes increasingly relevant. Relying on the Integrative Worldview Framework (IWF), this study aims to assess the worldviews and how these worldviews are connected with the perception forest-based bioeconomy among urban consumers in Finland. We hypothesize that the worldviews explain the acceptance, understanding and risks of urban consumers associated with the forest-based bioeconomy development. The results will help to coordinate the public discussion and provide information to increase the inclusiveness of forest bioeconomy policies. The analysis is based on a quantitative survey, collected in the center of Helsinki in December 2018. To our knowledge, this is the first study exploring the urban consumers' views on bioeconomy in Finland and conducted as a part of the Perform Bioeconomy project, which is a collaboration of eight European research institutes aiming to understand the regional differences regarding perceptions and acceptance of the forest-based bioeconomy.

\section{Experiencing the implementation of a regional Forest based bioeconomy strategy. The case of SYLVAPOLIS in the New Aquitaine} region, France.

Arnaud Sergent ${ }^{1}$, Ariane Carreira ${ }^{1}$

1rstea, Cestas Gazinet,France (arnaud.sergent@irstea.fr; ariane.carreira@irstea.fr)

Since 2017 the regional council of New Aquitaine (France) is leading a project, called SYLVAPOLIS, which aims to implement a regional forest based bioeconomy. Within the framework of a call for tender for "innovative territorial systems" launched by the French state, SYLVAPOLIS seeks to promote sustainable regional growth through the development of forest based bioeconomy and cooperation between rural and urban areas. The strategy consists of increasing investments in the forest based activities related to the construction, the production of consumer goods and ecosystem services. Priority is given to the demand side sectors in order to better articulate innovations (products, process and institutions) with market and people expectations. In a context of emerging bioeconomy concepts, SYLVAPOLIS promotes an eco-economy approach (Marsden $T$. and Farioli F., 2015) which places an emphasis upon placebased production and consumption chains. This paper aims to provide an empirical experience of the implementation of a regional forest based bioeconomy strategy and to discuss the implications for bioeconomy developments in the forest sector. First it presents the roles attributed to territorial approach and forest sector in the French national bioeconomy strategy. Then it analyzes the implementation process of the SYLVAPOLIS project. Finally it draws on insights from this experience to provide a conceptual basis for forest based eco economy.

\section{Student perceptions on the use of wood in multistory construction in Finland}

Jonne Nurminen ${ }^{1}$, Eliisa Kylkilahti ${ }^{2}$, Minna Autio $^{2}$, Sami Berghäll ${ }^{1}$, Noora Miilumäki ${ }^{1}$, Ritva Toivonen ${ }^{1}$, Heini Vihemäki ${ }^{1}$, Florencia Franzini ${ }^{1}$, Katja Lähtinen ${ }^{3}$, Anne Toppinen ${ }^{1}$

${ }^{1}$ University of Helsinki, Department of Forest Sciences, Helsinki, Finland; ${ }^{2}$ University of Helsinki, Department of Economics and Management, Helsinki, Finland; ${ }^{3}$ University of Vaasa (jonne.nurminen@helsinki.fi; eliisa.kylkilahti@helsinki.fi; minna.autio@helsinki.fi; sami.berghall@helsinki.fi; noora.miilumaki@helsinki.fi; ritva.toivonen@hesinki.fi; heini.vihemaki@helsinki.fi; florencia.franzini@gmail.com; atja.lahtinen@uwasa.fi; anne

Wooden multistory construction (WMC) has been identified as an important new business opportunity at the cross-section of wood and construction industries and a way to meet demand for sustainable urban living. In several countries, such as Canada, Norway and Finland, WMC has been piloted in the context of student housing. However, there is a very limited evidence base on young consumers' material preferences for wood. Our study investigates which attributes are important for Finnish students' material preferences between brick, concrete, steel and wood, and how these associate with students' environmental attitudes and knowledge and experience about living with wood. Our data was collected using a semi-structured online questionnaire filled by 530 inhabitants of Helsinki metropolitan area student housing company HOAS during the fall 2018. The results indicate that the respondent's living history significantly affects his/her preferences of future housing. The type of family (single, married, with/without kids or pets) also affects their future housing ideal. Those respondents with experience from living in a wooden house were significantly more interested in buying or renting an apartment from a WMC building than the ones with less experience. Willingness to live in a WMC building was predicted by the perceived indoor air quality, sound insulation and structural strength with ecological sustainability also being close to significance. Results can be used to develop higher quality student housing services. Results can be also used in evaluating material competitiveness and acceptability of wood among future homeowners. 
To export products or projects? Assessing lucrative export markets for innovative WMC business: cases from Nordic Countries

Anna Lilja ${ }^{1}$, Ritva Toivonen ${ }^{1}$, Heini Vihemäki ${ }^{1}$, Anne Toppinen ${ }^{1}$

${ }^{1}$ Univeristy of Helsinki, Department of Forest Sciences, University of Helsinki, Finland (ritva.toivonen@helsinki.fi;

ritva.toivonen@helsinki.fi; heini.vihemaki@helsinki.fi; anne.toppinen@helsinki.fi)

In the era of bioeconomy, wooden multistorey construction (WMC) has rapidly gained interest due to the demonstrated high environmental and technological performance of wood material, and the high carbon-absorption ability of wood material. WMC projects are mainly based on using new wood-based products, such as Cross Laminated Timber (CLT), which allow industrial module-based production, and building higher-rise buildings. This supports global efforts to develop sustainable housing solutions for the growing urban regions. However, in any part of the world, WMC projects are still mainly pilot cases, and manufacturing of CLT remains as domestic business. We hypothesize that rapid market growth would necessitate the markets of wood-based construction materials, and the WMC project business itself to become truly international. However, successful internationalization of new products is amongst the most difficult tasks in marketing. In this paper, we first design a theory-based general framework of critical issues for identification of lucrative export markets in the case of new wood-based construction products/construction project business. Second, qualitative interview data of experts and company specialists from Finland and Sweden is utilized to apply the framework on particularly CLT products and WMC business. Then, a scenario of WMC export markets in 2030 is compiled using back-casting method in the case of Finland, based on qualitative data from futures workshop and group interviews of experts. In conclusion, we discuss the identified differences between the two case countries, the efficient policy measures portfolios enhancing exports, and the applicability of the theory framework.

\section{Comparing millennial and other generations' perceptions of tall wood buildings: Are they really different?}

Pipiet Larasatie ${ }^{1,2}$, Jose Guerrero ${ }^{1}$, Eric Hansen ${ }^{1}$

1'OregonStateUniversity,Corvallis,USA; ${ }^{2}$ LPDP,Jakarta,Indonesia (larasatp@oregonstate.edu;jose.guerrero@oregonstate.edu; eric.hansen@oregonstate.edu)

Tall wood buildings (TWBs) constructed from engineered wood products are becoming more popular globally. However, little research has been conducted to assess end user perceptions of these structures, and none have focused on perceptions from various generations. This study compares the perceptions of Millennials and other generations regarding TWBs (structures made primarily from wood that are at least five stories tall). We utilize an online panel of 502 respondents in the Portland, Oregon and Seattle, Washington metropolitan areas in the United States. A majority of respondents believe that layout/floorplan, amount of natural light, and structural materials used are important considerations in the TWB design as a housing option. Regarding to the development of tall wood buildings, respondents only consider the cost of insurance as a barrier and, surprisingly, fewer consider aspects such as flammability, durability, amount of wood required, construction cost, and building code requirements as barriers. To conclude, there are few meaningful differences between respondents described as millennials and other generations, yet those belonging to the other generations assessed TWBs slightly more positively.

\section{Sustainability: a concealed opportunity for global market diffusion for CLT in the urbanizing society - a literature-based meta- analysis}

Ritva Toivonen ${ }^{1}$, Katja Lähtinen ${ }^{2}$

${ }^{1}$ Univeristy of Helsinki, Faculty of Agriculture and Forestry, Department of Forest Sciences, University of Helsinki, Finland; ${ }^{2}$ University of Vaasa, Department of Marketing and Communication,Vaasa, Finland (ritva.toivonen@helsinki.fi;katja.lahtinen@uwasa.fi)

In the urbanizing society, the energy-intensive construction sector plays major role in enhancing sustainable bio-economy, e.g., through selecting sustainable materials. Cross-laminated timber (CLT) is an engineered wood product enabling, e.g., industrial prefabrication and wooden multistorey construction (WMC). CLT also provides relatively low energy-intensity, and long-term carbon storage. The main markets for the CLT are in Europe, but there is potential for international market diffusion, due to sustainability benefits, and further standardization. However, some experts or consumers are still suspicious about using wood in construction, and knowledge on the issue is limited. For evaluating the existing knowledge on sustainability aspects, the purpose of this paper is to evaluate the sustainability-related strengths and weaknesses of CLT by WMC life-cycle phases. As materials and methods, we first developed a theory-based model of construction material sustainability, which incorporates a building's various life-cycle phases, and the recognized dimensions of sustainability. Then we performed a systematic literature review and a meta-analysis of CLT-based WMC sustainability by utilizing the developed model. The results clearly demonstrate that research on sustainability of CLT is concentrated on technological aspects at the building construction phase, and on environmental issues at the building usage phase. Contrastingly, comprehensive information on social or economic impacts is scarce. The results clearly indicate the need for life-cycle assessment, and consideration of the multiple dimensions of sustainability for well-justified assessments on material sustainability. Thus, to enhance CLT market diffusion, more balanced research on sustainability, and related stakeholder communication is required.

Challenges and opportunities related to wood frame construction systems in Paraná, Brazil: actor perceptions / Desafios e oportunidades do sistema construtivo wood frame no estado do Paraná: a percepção dos atores

Thiago Rodrigues de Paula ${ }^{1}$ (D) Vitor Afonso Hoeflich ${ }^{1}$, Jorge L. M. Matos ${ }^{1}$

${ }^{1}$ Universidade Federal do Paraná, Curitiba,Brasil(thiago_ufpr@ufpr.br; vitor.ufpr@gmail.com; jmatos.ufpr@gmail.com)

Dentre os sistemas construtivos inovadores, baseados em madeira, o wood frame possui o maior potencial de uso em larga escala. A madeira tem função estrutural, podendo o sistema ser industrializado ou construído no local. Apesar das diversas vantagens desta tecnologia, a grande maioria das unidades residenciais no Brasil ainda são construídas com métodos e materiais tradicionais da construção civil e portanto se faz necessário conhecer o grau de percepção da inserção do wood frame por atores da cadeia produtiva. Foi conduzida uma pesquisa qualitativa, para identificar a percepção de diversos atores da cadeia produtiva da tecnologia Wood frame e propor ações para acelerar a sua inserção no Estado do Paraná. Foi utilizado a escala SERVQUAL, cujos resultados foram analisados via estatística descritiva e métodos não-paramétricos. A diferença entre o nível mínimo aceitável e o nível percebido foi de - 53,4\%, indicando que a inserção do Wood frame no Estado do Paraná não está satisfatória. Houve disparidade entre as percepções dos diferentes atores, com maior frequência de diferença entre os grupos de atores Construtores e Organizacional. Isto indica que, apesar da relativa proximidade entre estes atores, não há consenso sobre o que deve ser feito, e principalmente sobre quem deverá fazer. Propõe-se a integração dos diversos atores, como a promoção do sistema entre Engenheiros e Arquitetos, lançamento da norma específica, linhas de financiamento adequadas, criação e utilização de infraestrutura de suporte. A partir da experiência acumulada em outros países é possível definir linhas de ação para acelerar a inserção da tecnologia. 


\section{Company-level cross-sector collaborations in transition to the bioeconomy: a multi-case study}

Jose E. Guerrero ${ }^{1,2}$, Eric Hansen ${ }^{1}$

${ }^{1}$ Department of Wood Science and Engineering, College of Forestry, Oregon State University, Corvallis, USA; ${ }^{2}$ Grupo Argos S.A., Medellín, Colombia (jose.guerrero@oregonstate.edu; eric.hansen@oregonstate.edu)

Existing strategies and policies have emphasized the need for cross-sector collaboration to achieve successful transition a bioeconomy. Cross-sector collaborationinitiatives of forest companies with neighboring sectors such as textiles, energy, chemicals,packaging,or plastics are gaining increasing attention as a necessary element for successful a transition. Thissituation presents a significant opportunity for forest companies to develop new products, explore new markets, improve competitiveness and replace human dependence on fossil-based products with renewable, bio-based materials.Despite this, no research results describe why and how forest companies collaborate with companies fromneighboringsectors. This research seeks to document case examples of crosssector collaboration between forest-based and neighboring sector companies aimed at developing new products. A qualitative,explanatory case study approach is employed todocument the case examples.Semi-structured interviews with top executive members(CEOs, VPs, managing directors, etc.), of the companies involved, direct observation of the company operations, and secondary data are used. In total, four cross-sector collaboration cases involving Northern European and North American companies are profiled. Two of the cases are situations where partners expectations were not met and two are ongoing, successful cases. Findings will help to identify best practices, hurdles, andsuccesses, andproviderecommendations for successful knowledge-driven, cross-sector collaborations led by forest companies.

\section{Design for recycling in wood construction. Opportunities and barriers in Germany}

Helena Braitmayer ${ }^{1}$, Michael Risse ${ }^{1}$, Klaus Richter ${ }^{1}$

${ }^{1}$ TU Munich, Munich, Germany(helena.braitmayer@tum.de; risse@hfm.tum.de; richter@hfm.tum.de)

An increased consumption of solid wood products requires a rethinking of the current types of construction to guarantee the continued sustainable use of the resource. The "Design for Recycling" concept aims to establish a resource-efficient handling of wood. Reusing the originally used product with little material loss would allow the reduction of the future resource consumption. Various research results suggest that the cascade use of wood can contribute to a more efficient use of wood and can reduce environmental impacts. However, despite numerous theoretical work, the practical implementation is still in its infancies. By interviewing various stakeholders, the current awareness and dissemination of the topic in practice were recorded. Furthermore the opportunities for an increased implementation of DfR in timber construction and the barriers for the low level of practical execution of DfR in timber construction were determined

\section{C9e: TRADITIONAL, EMERGING AND NEW FOREST PRODUCTS IN A BIOECONOMY: ADVANCES AND APPLICATIONS IN MODELLING THE MARKET POTENTIALS AND SECTORAL IMPACTS \\ Traditional and upcoming wood-based products in global forest sector scenario analysis \\ Franziska Schier ${ }^{1,2}$, Christian Morland ${ }^{1}$, Matthias Dieter ${ }^{1}$, Holger Weimar $^{1}$ \\ ${ }^{1}$ Thuenen Institute of International Forestry and Forest Economics, Hamburg, Germany; ${ }^{2}$ University of Göttingen Göttingen Germany \\ (franziska.schier@thuenen.de; christian.morland@thuenen.de; matthias.dietet@thuenen.de;holger.weimar@thuenen.de)}

The forest sector takes a major share in the growing bio-based economy. Wood-based industries depend mainly on the use of industrial roundwood from forest or wood processing residues. Long-term resource availability and allocation will be a major challenge for the further development of a bio-based economy. Moreover, wood is a multifunctional raw material, and thus, the forest sector faces various and potentially conflicting interests. Traditional wood processing industries are characterized by a twofold transformation: a technological change and a change in market pattern; new technologies - demanding additional raw materials - are emerging and compete with traditional materials. These changes require a reshaping of wood market analysis in order to reflect new products and demand for wood raw material. In this regard lignocellulose-based products can be seen as most promising. Therefore, this study adds three major lignocellulose-based products (dissolving pulp, cellulose derivatives and cellulose fibres) into partial equilibrium analysis. For this purpose, we use an econometric approach to analyse global data of yet niche but emerging products in order to compute demand and trade elasticities. Second, we apply market elasticities in a modified version of a partial equilibrium model, the GFPM. Thirdly, we implement different bioeconomy scenario pathways on a range from business-as-usual to utopian developments in the modified GFPM. The analysis identifies potential trade-offs, possible shifts in market pattern between subsectors and unfeasible pathways due to resource or market constraints.

\section{Impacts of an implementation of biorefineries on the entire wood-based value chain in Austria}

Martin Braun ${ }^{1}$, Peter Schwarzbauer ${ }^{1,2}$

${ }^{1}$ University of Natural Resources and Life Sciences, Vienna (BOKU); Institute of Marketing \& Innovation, Vienna, Austria; ${ }^{2}$ Team for Market Analysis and Innovation Research, Wood K plus - Kompetenzzentrum Holz, GmbHLinz,Austria (martin.braun@boku.ac.at; peter.schwarzbauer@boku.ac.at)

The European forest-based sector is facing structural changes with increasing pressure on competitiveness and sustainability requirements becoming an important issue for forest product markets. The presented study considers the effect as well as interdependencies of the implementation of biorefineries on the Austrian forest-based sector. Four scenarios were considered including three versions of biorefinery implementation: -Base scenario: without development and implementation of wood-biorefinery technologies by pulp mills. It is used as a reference to comparatively assess the potential impacts of an implementation of biorefineries -Single firm scenario: Simulation of the impacts of biorefineries on the economic situation of a single firm implementing a biorefinery with outputs small enough to focus on high-value added -National biorefinery implementation: Assumption that in one country almost all pulp mills would implement biorefinery technology with an assumed shift to high-volume, low-value commodities -European biorefinery implementation: Assumption that biorefinery technology will become industrial standard. Additional revenues from lignin, hemicelluloses and extractives were defined as revenues relative to weighted average pulp prices (for different pulp grades). The study compared results of previous simulations applied to the partial-equilibrium system dynamics forestsector model FOHOW with new simulation results from a modelling framework including a climate-sensitive forest growth model (including a basal area increment model, a height increment model, and an ingrowth model) in combination with FOHOW. We analysed socio-economic impacts on the pulp and paper industry as well as on the entire forest-based sector including long-term employment perspectives through biorefinery implementation as well as medium-term employment in construction and engineering 


\title{
Modelling wood biomass use for salmon feed under different reference scenarios
}

Alexander Moiseyev ${ }^{1}$, Birger Solberg ${ }^{1}$

${ }^{1}$ Norwegian University of Life Sciences, As, Norway (alexander.moiseyev@nmbu.no; birger.solberg@nmbu.no)

Decreasing use of fishmeal derived from wild fish is currently a challenge for the salmon farming sector in Norway. Yeast produced using chips from Norwegian spruce trees can become high quality proteins for farmed fish serving as fishmeal replacement. Adding 20 percent yeast in the feed, prevented the development of intestinal inflammation. However, success of feed from wood biomass will depend on the market prices of the protein ingredients as well as the cost of the tree biomass processing. The objective of the analysis is to examine wood biomass for salmon feed economic availability in terms of supply quantities, prices and sourcing: additional three harvesting, imports and diversion of wood from other uses. Partial equilibrium model EFI-GTM was utilized to analyze the impact of different reference scenarios of the wood use in the EU /EFTA region on the potential supply of wood biomass for salmon feed in Norway. To make the yeast production from wood economically viable, maximum of 65-70 euro/ $\mathrm{m}^{3}$ of wood can be paid at a mill gate. With this high maximum price, wood for salmon feed can be supplied up to 10 million $\mathrm{m}^{3}$ under the Base and Maximizing Bioenergy reference scenarios. However, such price would be rather high for pulp \& paper and wood panel industry and the major additional supply for wood yeast would be sourced from redirection of wood from material and energy use to wood for feed. Additional harvest is projected to be a minor source of wood for feed.

\section{Modelling prospects for dissolving and other pulps for textile applications and their impacts on global forest sector}

\author{
A. Maarit I. Kallio ${ }^{1}$ \\ ${ }^{1}$ Norwegian University of Life Sciences, As, Norway (maarit.kallio@nmbu.no)
}

Wood-based cellulose fibres for textiles, hygiene and health products have been in the market for long time, but competition with other natural (cotton, wool, linen) or synthetic materials has kept their market share relatively modest. The shortage of land for the expansion of cotton production, environmental concerns, changes in fashion styles, and new technologies for producing textile fibres from wood are changing the market framework for the favour of cellulosic fibres. Assuming that the demand for the cellulosic man-made fibres will increase in the next coming decades, we model alternative market scenarios with varying degrees of competition with other pulpwood demands and with varying growth assumptions on the wood-based textile fibres. For investments, we allow conversion of the existing chemical pulp mills to dissolving pulp in addition to greenfield mills. We discuss the impacts on these developments into chemical pulp production, wood markets, and the forest sector in more general. We also show market effects of the assumed alternative locations for the textile pulps industries: close to the market vs. close to the raw material. Generally, the results suggest that the negative effects of new pulp production to the other products using pulpwood and chips (papers and boards) and positive effects to industries producing chips as by-products are relatively modest. Due to inelastic demand for the forest products, the production adjustments mainly take place in the roundwood harvests. This may lead to new plantation developments.

\section{Climate change mitigation through product substitution: Participative backcasting study on the uses of wood in Finland}

Janni Kunttu ${ }^{l, 3}$, Elias Hurmekoski ${ }^{2}$, Pekka Leskinen ${ }^{1}$, Teppo Hujala ${ }^{3}$, Henrik Heräjärvi ${ }^{4}$, Tanja Myllyviita ${ }^{5}$, Jyri Seppälä ${ }^{5}$

${ }^{1}$ European Forest Institute, Joensuu, Finland; ${ }^{2}$ Ministry of Agriculture and Forestry of Finland, Helsinki, Finland; ${ }^{3}$ University of Eastern Finland, Joensuu, Finland; ${ }^{4}$ Natural Resources Institute Finland, Joensuu, Finland; ${ }^{5}$ Finnish Environment Institute, Helsinki, Finland (janni.kunttu@efi.int; elias.hurmekoski@ gmail.com; pekka.leskinen@efi.int; teppo.hujala@uef.fi; henrik.herajarvi@luke.fi; tanja.myllyviita@ymparisto.fi; jyri.seppala@ymparisto.fi)

Wood utilisation can mitigate climate change, if wood products are used to substitute more emission-intensive materials and fuels. Displacement factor (DF) refers to avoided emissions per unit of wood used when replacing non-wood based products with equal functionality. However, the development of forest carbon sinks should be taken into account too. Recent studies show that the average DF should be at least 2 to compensate the emissions from planned additional harvestings in Finland and result in net avoided emissions in the short-term. The aim of this study is to explore, what structural changes are needed to reach $\mathrm{DF}=2$ level in Finland by 2050. Qualitative descriptions of the future scenarios resulting this do not offer enough information on the magnitude of the changes needed. Furthermore, climate change mitigation scenarios are not necessarily market viable. Thus, a participative backcasting approach combined with explorative scenario development is adopted, and we identify strategic pathways to make different climate change mitigation scenarios market viable. The scenarios assume that average DF must reach the value of 2. To indicate future DFs for different products, a literature review on the future emission reduction potentials is applied to the scenario estimations. In the workshop, the selected stakeholder groups will assess the structural developments for each scenario step by step backwards from the year 2050 to today, by using periodical ten-year milestones. The study shows the extent of transformations needed to strive towards a competitive and climate optimal allocation of wood resources to develop an adaptive strategy.

\section{From early attempts to recent trends: economic simulation as an investigation tool for the forest sector}

Sylvain Caurla ${ }^{1}$, Miguel Rivière ${ }^{2}$

${ }^{1}$ Institut National de la Recherche Agronomique, Nancy, France; ${ }^{2}$ AgroParisTech, Nancy, France (sylvain.caurla@inra.fr; miguel.riviere@inra.fr)

Within the field of forest economics, simulation has been used and accepted as a research method since the second half of the 20 th century through the use of Forest Sector Simulation Models (FSSM). Our contribution seeks to investigate what FSSM are, how they relate to the concept of simulation and to question the epistemic value of their results. We also aim at exploring the reasons behind the early adoption of simulation as a valid investigation tool in this particular field of economics. First, we discuss the concept of simulation and the extent to which FSSM can be considered simulation tools based on their use by economists. Second, we retrace the early history of FSSM development from the 1950s onwards, and discuss the emergence of several paradigms for modeling the forest sector. Third, we reveal and describe current trends in FSSM development, and reflect on publishing dynamics within the field. Fourth and finally, we question the role of FSSM for policy makers and practitioners. We argue that the strength of a simulation result resides more in its capacity to reveal underlying characteristics of the modeled bioeconomic system's functioning than in its numerical value. We show that because the validation of a simulation is not possible per se, it is only possible to analyze the results of FSSM with regards to the paradigms on which models are built. 


\section{The role of forest certification on the conservation of biodiversity and ecosystem services}

Miguel Nuno Bugalho ${ }^{1}$, Luís Neves Silva ${ }^{2}$

${ }^{1}$ Centre for Applied Ecology, School of Agriculture, University of Lisbon, Lisbon, Portugal; ${ }^{2}$ WWF International, Gland, Switzerland (migbugalho@isa. ulisboa.pt; lnsilva@wwfint.org)

Forests harbour half of the world biodiversity, provide raw materials (e.g. timber and fiber) and generate ecosystem services of local, regional and global importance, including carbon sequestration and storage or regulation of the water cycle. For forests to keep generating benefits to the humankind, it is necessary that they are sustainably managed. That is, forest management practices must assure the ecological perpetuity of the forest ecosystem, including promotion of adequate tree regeneration and protection of biodiversity. Forest certification, usually seen as a proxy of sustainable forest management, is a voluntary mechanism under which forest landholders must comply with a third party audited standard of management practices respecting environmental and socioeconomic criteria. Although forest certification is expanding globally, there is a dearth of quantitative data informing on how certified forest management practices may be contributing to forest conservation. Establishing certified conservation zones, for example, will influence biodiversity and affect ecosystem services (e.g. carbon storage, risk of wildfire) trade-offs. Complying with forest certification also implies systematic identification, monitoring and appropriate management of conservation values. Inventorying of biodiversity and ecosystem services, together with certified management practices, may be used to develop and implement payment for ecosystem services schemes contributing to forest conservation, which examples will be presented here.

\section{Risk-based approach for forest management certification in Ukraine}

Pavlo Kravets ${ }^{1}$, Yevhenii Khan ${ }^{1}$, Oksana Pavlishchuk ${ }^{2}$, Ivan Lakyda ${ }^{2}$

${ }^{1}$ FSC Ukraine, Kyiv, Ukraine; ${ }^{2 N a t i o n a l ~ U n i v e r s i t y ~ o f ~ L i f e ~ a n d ~ E n v i r o n m e n t a l ~ S c i e n c e s ~ o f ~ U k r a i n e, ~ K y i v, ~ U k r a i n e ~(p . k r a v e t s @ u a . f s c . o r g ; ~ e . k h a n @ u a . f s c . o r g ; ~}$ pavlishchuk_o@nubip.edu.ua; i.lakyda@nubip.edu.ua)

Unified approaches to forest management in all forests of the world, implemented in the FSC Principles and Criteria and IGIs, are increasingly confronted with risk-accounting requests. Conservative risk factors that are due to natural conditions, historical and cultural peculiarities are reflected at the stage of development of a forest stewardship standard. The SIR conception has enabled the SDG to distinguish a number of indicators, where high risk of adverse effects is due to natural factors such as mountain conditions etc. On the other hand, risk factors that are due to socio-economic conditions of forest management are dynamic and require update more than standard's revision period. Their consideration is relevant for countries with high corruption, low enforcement and unbalanced legislation. In this case, consideration of risk factors is viable at the stage of implementation of the standard. The country's risk profile as a set of information layers on state of forests and forest management on the basis of analysis of non-conformances, official statistics, independent studies and reports of stakeholders should serve as basis for assessing risks of deviation in meeting the standard's requirements mainly due to influence of socio-economic factors. FSC Ukraine, with the assistance of NULES of Ukraine, has begun establishing such system. Incorporating a risk-based approach to certification procedures will enable adequate planning and auditing, focusing on the key parameters of forest management, avoiding unnecessary labor costs, thereby contributing to increased efficiency and confidence in the FSC system in response to global and national challenges.

Forest certification for small producers, an alternative for sustainable practices / Certificação florestal de pequenos produtores, uma alternativa à prática da sustentabilidade

Alissa Mayla Pereira ${ }^{1}$, Victoria Rizo ${ }^{1}$

${ }^{1}$ Tree Consultoria e Meio Ambiente, Telêmaco Borba, Brasil (alissamayla@2treeconsultoria.com.br; victoriarizo@2treeconsultoria.com.br)

Obtida no passado pela exploração de fragmentos florestais naturais, sem amparo legal ou consciência ambiental da maioria da população, a madeira, hoje em grande parte proveniente de florestas plantadas, é responsável por compor uma parcela considerável no cenário econômico nacional, através da produção de papel e celulose, madeira serrada, painéis e também, por promover ganhos significativos na esfera ambiental e social. Um caminho para promover a sustentabilidade, é a Certificação Florestal de pequenos produtores. No Paraná e em estados adjacentes, ocorre desde 2014, com a implantação da norma FSC ${ }^{\circ}$ (padrão SLIMF), na modalidade de grupos. O projeto é custeado por empresa do segmento florestal e aplicado aos silvicultores pela 2Tee Consultoria e Meio Ambiente. Atualmente, são 554 imóveis, manejados por 302 produtores, que ocupam área total de 74.217,16 ha, dos quais 36.410,81 ha referem-se a plantio de Pinus e Eucalipto. Nos quatro anos do projeto, percebe-se que houve mudanças no dia-a-dia das pessoas que estão relacionadas à atividade, através da melhoria nas condições de saúde e segurança do trabalho, atenção às comunidades e incentivo à educação e saúde. Pensando nos remanescentes naturais, adotouse medidas de proteção destes recursos, tais como recomposição de áreas de preservação permanente, contenção de processos erosivos e intensificação de monitoramento da fauna e flora. No viés econômico, há ascensão no mercado e valorização do produto, por disporem de um selo internacionalmente conhecido, que traz consigo a certeza da preservação ambiental, do respeito à sociedade e das boas práticas de manejo.

Group certification: a tool for competitiveness among small producers and forest companies, and for sustainability of the sector in Argentina / Certificación en grupo: una herramienta para la competitividad de los pequeños productores y empresas forestales y la sostenibilidad del sector en Argentina

Roberta Amaral de Andrade ${ }^{1}$, Florencia Chavat ${ }^{2}$

${ }^{1}$ Secretaría de Agroindustria de la Nación Argentina, Buenos Aires, Argentina; ${ }^{2}$ CERFOAR - PEFC Argentina, Buenos Aires, Argentina

(betinha.amaral@gmail.com; fchavat@cerfoar.org.ar)

La certificación forestal es una herramienta para la competitividad y sostenibilidad del sector. Por un lado, trabaja la gestión de los procesos productivos, impulsando la mejora continua y facilitando la inserción en mercados exigentes. Por otro, abarca el cumplimiento legal actuando en temas como la tenencia de la tierra, regulaciones ambientales, normas laborales, impuestos y comercialización. Una empresa certificada cumple con requisitos que pueden contribuir al logro de los Objetivos de Desarrollo Sostenible (ODS) y alcanzar progresos simultáneos, agregando, además, valor al negocio. Argentina cuenta con 143 certificados entre Cadena de Custodia (CdC) y Gestión Forestal Sostenible (GFS) de los principales sistemas (FSC y PEFC), abarcando un área de aproximadamente 500.000 ha. Debido a la falta de recursos económicos y técnicos, los pequeños productores y empresas son los que tienen mayores dificultades para alcanzar los niveles de legalidad y sostenibilidad exigidos en la certificación. Por ello, la certificación en grupo puede ser una alternativa al reducir los costos individuales 
del proceso y proporcionar escala a la comercialización. Actualmente se desarrolla en Argentina el "Programa Certificación en Grupo", liderado por el Sistema Argentino de Certificación Forestal con apoyo del gobierno de la Nación, que invierte en la asistencia técnica para la formación de grupos y en los costos iniciales de la certificación. La actual coyuntura económica del país, favorable a la exportación, sumada a la perspectiva de aumento de la demanda global por madera y a políticas de desarrollo del potencial forestal argentino, apuntan a una gran impulso para la certificación.

\author{
Monitoring of non-conformities of FSC forest certification audits in Brazil in 2018 \\ Gabriel Coimbra Rafael ${ }^{1}$, Mario Henrique Andrade de Melo ${ }^{2}$ \\ ${ }^{1}$ Instituto de Pesquisas e Estudos Florestais, Piracicaba, Brasil; ${ }^{2}$ Universidade Federal dos Vales do Jequitinhonha e Mucuri, Diamantina, Brasil \\ (gabriel@ipef.br; marioandrademelo@gmail.com)
}

Forests are an important wealth for human being development providing shelter, food and wood for several uses. Despite its importance, many forests worldwide lack sustainable management practices and, in this sense, forest certification emerges as an important tool to regulate and ensure that wood products are made considering social, environmental e economic aspects of forests. However, forest certification still needs to overcome some challenges to be more implemented. This research aimed to analyse the non-conformities (NCs) of public reports of FSC forest certification audits to identify the difficulties and possible challenges for companies to obtain or maintain the label. In total, 64 public reports from 2018 were systematically analysed and 419 NCs were categorized according the FSC principles, criteria and themes. The results showed that FSC principles 4 (Community relations and worker's rights) and principle 6 (Environmental Impact) presented the greatest number of NCs, representing $52 \%$ of all NCs of forest plantations, $62 \%$ for native forests and $44 \%$ for small scale (SLIMF). Overall, the topics more recurrent in NCs were labour, employment and gender equity (19\%), monitoring the implementation of the management plan and its results (14\%), the management plan itself (13\%) and engagement and communication processes (12\%). These results showed that companies seem to have difficulties to comply with social requirements as well as, developing and implementing the forest management plan. Social programs could be developed by companies and governments to enhance social approach of forest operations and there are opportunities to develop more literature regarding forest management plans.

\title{
Non-conformities related to pest management in companies certified by the forest stewardship council (FSC) in Brazil
}

Pedro Guilherme Lemes ${ }^{1}$, Daniela Caroline Silva ${ }^{1}$, José Cola Zanuncio ${ }^{2}$

${ }^{1}$ Universidade Federal de Minas Gerais, Montes Claros, Brasil; ${ }^{2}$ Universidade Federal de Viçosa, Viçosa, Brasil (pedroglemes@ufmg.br; danielacaroline43@yahoo.com.br; zanuncio@ufmg.br)

The Forest Stewardship Council (FSC) Pesticide Policy seeks the identification and prevention on the use of "highly hazardous" pesticides, the reduction and appropriate use of pesticides, and the use of alternative pest control strategies. Certified producers, mainly from tropical countries in the Southern Hemisphere, have experienced negative consequences of this policy on integrated pest management. The objective was to determine the most common nonconformities related to pest management in audits conducted in FSC certified companies in Brazil. All available reports on the FSC platform until March 2017 were downloaded, evaluated and separated by type of certificate (FM, FM/COC, FM/COC/SLIMF or FM/CW). Nonconformities were quantified and grouped into 13 categories and separated as a major or minor corrective action request (CAR). One hundred and eighty-seven reports were evaluated, of which 153 were FM/ COC, 24 FM/COC/SLIMF, 7 FM/CW and 3 FM. Problems related to inadequate storage of pesticides, use of prohibited pesticides, absence or inappropriate use of PPE (personal protective equipment), misuse of chemicals, non-guarantee of pest management worker's rights and health, and absence of the environmental impact assessment plan associated with pesticide use, were the most common nonconformities. The certification has improved the integrated management of forest pests in Brazilian companies, specially with better security in the use and storage of pesticides and in the health and safety conditions of the workers.

\section{Shaping the implementation of the FSC standard: the case of auditors in Brazil}

Marie-Gabrielle Piketty ${ }^{1}$, Isabel Garcia-Drigo ${ }^{2}$

${ }^{1}$ CIRAD, Montpellier, France; ${ }^{2}$ Nexus Socioambiental, Sao Paulo, Brasil (marie-gabrielle.piketty@cirad.fr; isabel.drigo@gmail.com)

The Forest Stewardship Council (FSC) label is one of the most robust and widely accepted standards aimed at assessing long-term sustainable forest management worldwide. Through audits, accredited certification bodies assess the level of conformity of a company's performance against the standard to grant or not the certificate on behalf of the FSC. In this paper, we assess the scope auditors have to shape the implementation of the FSC standard in Brazil. Our work is based on the analysis of certification bodies' rules and of 250 full assessment and annual audit reports covering the period 2005-2017, including native and plantations reports. All reports were publicly available on FSC database. The analysis was completed with interviews with key informants. We show that most indicators of the Brazilian FSC standard leave no scope for interpretation. However, companies are certified and re-certified with a significant number of minor non-conformance with social, legal and environmental indicators. We conclude that some indicators are too broad and need to be clarified. Also, conformity with some indicators depends on actions from governments. The development of new national standards is an opportunity to limit the risks of interpretation of indicators. The updating of standards is also an opportunity to clarify the role of public policies in respect of specific indicators. States wishing to promote FSC certification could seize this opportunity to identify what improvements are needed in the functioning of their institutions and public policies.

\section{FSC’s knowledge management journey}

Michael Marus ${ }^{1}$, Kim Carstensen ${ }^{1}$

1FSC International,Bonn, Germany (m.marus@fsc.org; director.office@fsc.org)

Initiated in the 1990th, 3rd party, voluntary certification of forest management (FM) evolved over time. The Forest Stewardship Council's (FSC) FM public audit reports yield a rich corpus of economic, social and environmental data (e.g., species, set-aside areas, ecosystem services, health and safety), needed to measure and demonstrate compliance of FM with the certification standard, and the effects of certification. To facilitate access to these data, FSC has set out on a journey to be fully digitally data driven, extracting knowledge and gaining insights from hard data from FM reports and forest products trade. With this journey FSC implements it members" General Assembly Motion to "Harnessing audit data to improve assurance integrity, monitoring and evaluation, and the value proposition for FSC" (Motion 2017/16). The modernized FSC audit capture and data analytics and reporting platform will enable FSC and stakeholders to use comparative analytical capabilities to test and compare reach and effectiveness of a variety of FSC strategic scenarios and improvements. Improved access to data will strengthen robustness of certification decision processes, allow evaluation of impacts of certification interventions. This will result in better demonstration of the value proposition for sustainable FM to inform decision making of forest managers, politicians, product buyers, and other stakeholders. We will present the set of knowledge products as key outcomes of this journey towards outcome-based decision making, such as dashboards, open data, real-time management and stakeholder reporting. 


\title{
Price premium of the FSC certified wood products in Japan: a case study on cutting boards made of Hinoki (Chamaecyparis obtusa)
}

Ikuo OTA ${ }^{1}$, Masumi Kamakura², Masashi Konoshima ${ }^{1}$

${ }^{1}$ Faculty of Agriculture, University of the Ryukyus, Okinawa, Japan; ${ }^{2}$ Shikoku Kako Co. Ltd., Ehime, Japan (ikuota@agr.u-ryukyu.ac.jp;

masumi@yoroi-kabuto.com; konoshim@agr.u-ryukyu.ac.jp)

The authors conducted a series of experimental sales of FSC certified wood products. Several types of cutting boards, with different design and size, made of Hinoki were sold on an internet shopping site. We prepared the same type of products from FSC certified wood and non-certified wood, and simultaneously sold them at different prices. Customers who are interested in purchasing cutting board could choose each of them while watching the price of products. We set the price difference of 4 level, between $20 \%$ and $50 \%$, by shifting the timing. The most large size of the cutting board was $460 \mathrm{~mm} \times 240 \mathrm{~mm} \times 30 \mathrm{~mm}$ with the basic price about 33 USD, and the smallest one was $200 \mathrm{~mm} \times 200 \mathrm{~mm} \times 25 \mathrm{~mm}$ with the basic price about 26 USD. The result is as follows: Twenty seven percent of customer chose certified product for $20 \%$ price premium, $18 \%$ of customer chose certified product for $30 \%$ price premium, $11 \%$ of customer chose certified product for $40 \%$ price premium, and $8 \%$ of customer chose certified product for $50 \%$ price premium. All of these price premium was found to be statistically significant. The authors conclude that the price premium of the FSC certified products can exist up to $50 \%$ in the case of small wood products like cutting boards.

\section{Tetra Pak and FSC: responsible sourcing and its impacts on consumer awareness}

\section{Luana Pinheiro}

${ }^{1}$ Tetra Pak Ltda, Monte Mor, Brasil (luana.pinheiro@tetrapak.com)

Tetra Pak is the world's leading food processing and packaging solutions company. Together with our customers and suppliers, we provide safe, innovative and environmentally sound products that each day meet the needs of hundreds of millions of people in more than 160 countries. Our motto, "Protects what's good" reflects our vision to make food safe and available, everywhere and in a sustainable way. For us, responsible sourcing consists of looking at what we purchase beyond aspects of cost, quality and delivery time. This is one of the strategic objectives for our supply chain operations, and means we consider ethics, labour rights, social and environmental issues when sourcing products and services. Our goal is to minimise negative impacts and make a positive contribution to the businesses, people and communities. Around 75\% of a Tetra Pak carton by weight is paperboard. Although we don’t own or manage any forests, we apply our purchasing power to promote sustainable forest management. We see FSC as offering a credible universal standard and we actively encourage our customers to display the logo on their packages. Since the introduction of the FSC label on our first package in 2007, we have produced 350 billion FSC-labelled packs globally. Having achieved full FSC Chain of Custody certification for all our operations, we can now supply FSC-labelled packages from anywhere in the world. By communicating with consumers in this way, we areraising the bar for sustainable sourcing across our industry and beyond.

\author{
The importance of local and diverse stakeholder's engagement to improve the certification schemes: the Brazilian plantation sector \\ case \\ Camilla Marangon ${ }^{1}$, Nathalia Granato Loures ${ }^{1}$ \\ ${ }^{1}$ Indústria Brasileira de Árvores, São Paulo,Brasil (camilla.marangon@iba.org;n.granato@iba.org)
}

The engagement of NGOs, researchers and companies in the forest certification schemes is key for its continuous improvement and growth, especially to make its standards more locally relevant, outcome-orientated, data-driven and recognized by the market. The commitment of this sector with the sustainable forest management goes far beyond the implementation of standards on its 5,8 million hectares and implies in deeply engagement within the certification schemes. This sector has been expressively taking part of FSC and PEFC, joining General Assemblies (GA), proposing motions, attending regional meetings, participating in the revision and development of the standards. In 2016, Ibá (Brazilian Tree Industry) and IPEF (Forestry Science and Research Institute) were informally nominated as secretariat of the FSC Latin America economic chamber and were responsible for preparing the members for the 2017 GA. This leadership has played an important role in South America with positive impacts within FSC system and has been recognized by the FSC and its members worldwide. In the PEFC system, the sector has been closely working with the Cerflor (Brazilian certification scheme endorsed by PEFC) to boost its performance, raise the level of recognition by the market and ensure its financial sustainability. This engagement has been producing gains and helping the sector to positively influence the certification agenda in order to make it more efficient and feasible and thus spreading the sustainable forest management to new areas.

\section{Negotiation process of setting national FSC standards: what matters in different contexts}

Marine Elbakidze ${ }^{1}$, Constance McDermott ${ }^{2}$, Sara Teitelbaum ${ }^{3}$, Maria Tysiachniouk ${ }^{4}$

${ }^{1}$ Swedish University of Agricultural Sciences, Skinnskatteberg, Sweden; ${ }^{2}$ Oxford University, Oxford, United Kingdom; ${ }^{3}$ Montreal University, Montreal, Canada; ${ }^{4}$ Center for Independent Social Research, St Petersburg, Russian Federation (marine.elbakidze@slu.se; constance.mcdermott@ouce.ox.ac.uk; sara.teitelbaum@umontreal.ca; tysiachn@yandex.ru)

Biodiversity conservation and local/indigenous communities' wellbeing are amongst the crucial sustainability targets of global policy, designed to steer global development for the coming decades. The FSC system provides an excellent case study for understanding how certification as a non-state market-driven approach addresses global sustainability goals. In many countries FSC certified forest management has also provoked considerable public debate, reflecting the diversity of interests and perspectives of actors who hold a stake in its outcomes. We provide an overview of findings from an international research project that compares how these differences have shaped FSC's approach to biodiversity conservation and wellbeing of local/indigenous communities across the circumboreal forests in the three countries with the large FSC certified area (Sweden, Canada, and the Russian Federation). Forests as complex socialecological systems create a greater challenge to the design of sustainable institutions, including the FSC certification system. This study applied Ostrom's Institutional Analysis and Development framework to analyse how institutions affect actions and outcomes of FSC-negotiation processes in different contexts. Key informant interviews were done at the national level in each country with (i) stakeholders directly involved in FSC national initiatives, and (ii) stakeholders from private, public and private sectors that are critical to FSC. We discuss how differences in understanding a resource system and resource units that are governed by diverse organizations with different rules create conflicts and debates in negotiating FSC processes and how these influence outcomes in terms of the content of national FSC standards. 


\title{
Sustainable intensification: the role of the forest certification in a world that will triple its wood consumption by 2050
}

Estevao Braga ${ }^{1}$, João Carlos Augusti ${ }^{1}$, Michael May

${ }^{1}$ Suzano S.A., São Paulo, Brasil (estevaob@suzano.com.br; joao.augusti@suzano.com.br; mike@futuragene.com)

The population growth, combined with changes in purchasing power, replacement of fossil-based raw materials by renewable sources, and megatrends such as growth in Asia and packaging for e-commerce will increase the demand for wood and fibers. Wood consumption is predicted to triple to 10 billion $^{3}$ per annum, far exceeding the productivity of present-day natural forests and forest plantations combined. The production of adequate wood and forest-based products to meet this demand while avoiding potential social and environmental externalities will be one of the most important issues for the next generation. This means also increased pressure to improve forest management in a sustainable way. The sustainable intensification encompasses several scientific innovations, technologies, and approaches aiming to produce more food and fibers while using less or equal natural resources while conserving or improving environmental values and promoting shared value to society.The forest certification has a great potential in setting policies and standards to ensure a responsible and sustainable origin of the forest-based products while exploring the opportunities of expanding its presence in the global market share.The discussion about the role of the forest certification in driving the intensification of the production to a sustainable path has already started in FSC and PEFC. Both schemes are exploring their roles in leading a dialogue on sustainable intensification, given their governance structure that blends different perspectives, providing a neutral platform suited for managing complex discussions such as sustainable intensification aiming to produce more from less with sound social and environmental footprints.

\section{Future perspectives on the role of forest certification}

Kim Carstensen ${ }^{1}$, Jeremy Harrison ${ }^{1}$, Michael Marus ${ }^{1}$

${ }^{1}$ FSC International, Bonn, Germany (director.office@fsc.org; j.harrison@fsc.org; m.marus@fsc.org)

The future role of forest certification in the context of the global sustainable development agenda is influenced by a range of powerful forces and is under constant pressure to evolve and adapt. The success of certification as a solution for driving sustainable development in forest value chains will depend on its ability to understand the implications of these forces and respond appropriately in collaboration with value-chain stakeholders. The drivers of future global demand for forest products include industrial consumption patterns, consumer behaviour and the need for climate change mitigation measures. These demand drivers will lead to a corresponding pressure on the supply of forest products and production systems, with profound implications for smallholder producers and plantation production. In addition, these pressures must be viewed within the context of multiple land-use needs (e.g. production of other commodity crops) and the need for broader sustainable landscape management solutions. Other forces at play include consumer attitudes towards sustainable development, government and business interventions and the role of academic institutions and NGOs. Probably more importantly for certification and other sustainable development solutions will be the ways in which these stakeholders interact, and the extent to which effective collaboration can be achieved. This presentation and panel discussion will examine the forces that are shaping future forest value chains and provide perspectives on the future role of forest certification as a solution to ensure forests and wider landscapes are managed sustainably.

\section{Trees outside forests: magnifying the contribution of forests and trees to societal challenges}

\author{
Ben Gunneberg ${ }^{1}$, Thorsten Arndt \\ ${ }^{1}$ PEFC - Programme for the Endorsement of Forest Certification, Geneve, Switzerland (ben.gunneberg@pefc.org; t.arndt@pefc.org)
}

Trees grow in forests, but they also grow beyond the forest, throughout landscapes and within cities. These trees outside forests (TOF) provide vital ecosystem services like clean air and water, habitat for animals, and climate regulation. They also provide food, materials and rural livelihoods for millions of people. Until now, it has not been possible for the owners of TOF - often small-scale farmers - to achieve certification of their sustainable management practices. However, with the release of our latest PEFC forest management standard, smallholder farmers can now obtain PEFC certification. TOF certification offers, among others, the following benefits: Extending the impact of certification beyond the forest:Through encouraging the planting of trees and improved management of trees outside forests in ways that optimize their social, environmental and economic contributions, we can promote an additional natural solution to climate mitigation within forest certification. Supporting rural development:TOF certification encourages and recognizes agroforestry practices and support small landowners to access markets that are requiring proof of sustainably management as delivered through PEFC certification. Improving sustainability of urban forests:TOF certification will better support cities and municipalities in improving the sustainable management of their trees and urban forests. Taking the pressure off natural forests:TOF certification also stands to take the pressure off natural forests in countries where the pressure and exploitation of the resource is too great or where there are already logging bans in place.

The Brazilian forest certification program: factors for success and future prospects / Programa Brasileiro de Certificação Florestal: fatores de sucesso e perspectivas futuras

Alessandra Julião Weyandt ${ }^{1}$, Cristiane Sampaio ${ }^{1}$

${ }^{1}$ Inmetro, Rio de Janeiro,Brasil (weyandt.alessandra@gmail.com; cmsampaio@inmetro.gov.br)

A demanda global por madeira pode triplicar até 2050. Essa estatística reflete o crescente consumo de madeira sólida e produtos de papel, em decorrência do crescimento populacional e econômico. No entanto, a cada ano o mundo perde uma parcela considerável de suas florestas naturais, tendo como principais causas a exploração de madeira, a agricultura e as políticas públicas de desenvolvimento. A certificação florestal é um mecanismo para que as florestas sejam gerenciadas para alcançar as metas econômicas, ambientais e sociais que são a base do manejo florestal sustentável e do desenvolvimento sustentável. No Brasil, o Programa Brasileiro de Certificação Florestal (Cerflor) foi concebido na década de 1990, tendo sido lançado oficialmente pelo INMETRO, Instituto Nacional de Metrologia, Qualidade e Tecnologia, em 2002. Neste mesmo ano, foi solicitado o endosso do Cerflor pelo PEFC (Programme for the Endorsement of Forest Certification), que foi obtido em 2005. O Cerflor é um programa voluntário desenvolvido com representantes de partes interessadas em nível nacional, que têm oportunidade de expressão, quanto às questões relacionadas a sua realidade. A estruturação participativa e o endosso pelo PEFC são fatores de sucesso do Cerflor, que é uma importante ferramenta para promover as boas práticas no manejo florestal sustentável e a competitividade dos produtos madeireiros de base florestal brasileiros. Buscando potencializar a excelência do Cerflor, sua gestão está sendo aperfeiçoada e ações estão sendo empreendidas, desde o ano de 2018, com perspectiva para sua total implementação em até dois anos. Dentre estas, destacam-se marketing, pesquisa, capacitação e independência financeira. 


\title{
C9p: FOREST POLICY AND ECONOMICS - I
}

\author{
Where does your panel fit into society? Production and usage of reconstituted wood panels / "Qual seu painel na sociedade?” Produção \\ e uso de painéis reconstituidos de madeira \\ Flávia Alves Pereira ${ }^{1}$, Eleandro José Brun ${ }^{1}$ \\ ${ }^{1}$ Universidade Tecnológica Federal do Paraná, Dois Vizinhos, Brasil (flaviapereira@utfpr.edu.br; flaviapereira@utfpr.edu.br)
}

A madeira é matéria prima para processos, como celulose e papel, geração de energia e produção de painéis de madeira. Suas dimensões e características, como anisotropia, densidade e seus defeitos naturais podem limitar sua utilização. Os painéis de madeira se destacam como alternativa para aumentar a oferta de produtos gerados, com melhor custo/benefício, e ampliar o uso da madeira. O objetivo deste trabalho foi ensinar alunos do ensino fundamental de escolas públicas e organizações não governamentais do sudoeste do Paraná, sobre painéis reconstituídos de madeira e suas aplicações. Este trabalho vem sendo desenvolvido há três anos por graduandos do curso de Engenharia Florestal. Num primeiro momento, há o contato com professores e diretores das escolas da região para programar as atividades. Uma apresentação sobre painéis é realizada, utilizando-se recursos digitais e/ou figuras, que representem o processo produtivo. Ressalta-se que alunos de diferentes faixas etárias são contemplados. Para fixar o conteúdo e facilitar a compreensão do assunto, atividades lúdicas educativas são elaboradas e aplicadas. É interessante que este tema seja ambientado desde a infância e adolescência, para que haja maior difusão do conhecimento. Através deste trabalho foi possível a interação entre alunos universitários e do fundamental e a experiência didática, com a transformação da linguagem acadêmica em uma linguagem mais simples para a apresentação do conteúdo. Estas atividades reforçam a importância da madeira e seus produtos. O Paraná é um dos maiores produtores de painéis do país e essa atividade tem relevância social e econômica em todo estado.

\section{Demographic changes and their influence on the demand for wooden houses in Japan}

Koji Matsushita1, Kozo Yamaguchi ${ }^{1}$, Yoshio Yoshida ${ }^{1}$, Tetsuji Senda ${ }^{1}$

1KyotoUniversity,Kyoto,Japan (matsu@kais.kyoto-u.ac.jp; yamaguchi.kozo.5e@kyoto-u.ac.jp; yoshidayoshio.2z@kyoto-u.ac.jp; senda@media.kyoto-u.ac.jp)

The total population of Japan has been decreasing since 2010. Such demographic changes influence the demand for wooden housing, which is an important timber consumption sector in Japan. The decrease in total population and increasing tendency for young people to move from rural to metropolitan areas has resulted in a decrease in wooden housing construction in rural areas. As the average number of people per household has decreased (to 2.33 persons, according to the 2015 Population Census of Japan), the total number of wooden houses constructed and their average floor areas have decreased accordingly. The proportion of the population $\geq 65$ years of age reached $26.6 \%$ in 2015 (Population Census), which was among the highest in national proportions worldwide, and is predicted to further increase with time. As Japanese households continue to decrease in size and their occupants increase in age, the percentage of one- to twoperson households is increasing. Some occupants select non-wooden condominiums or other compact dwellings as they increase in age; as a result, decreases are expected in the percentage of homes constructed with wood and in the total floor area of wooden housing for aging people. In summary, the trend in total timber demand for wooden housing will decrease in Japan in the future. Forestry policies relating to domestic timber production in Japan are therefore at a turning point as changes in population demographics affect domestic timber consumption.

\section{Estimating the impact of the national forest conservation program on the timber product industry in Heilongjiang province, China: use of a synthetic control method}

Hongge Zhu', Zhujun Han'2, Mengshi Feng', Yihao Li ${ }^{1}$

${ }^{1}$ Northeast Forestry University, Harbin, China; ${ }^{2}$ Nanjing University, Nanjing, China (honggebill@163.com; 1203553269@qq.com; 1051856587@qq.com; 592134959@qq.com)

Based on data from the China Forestry Statistical Yearbook between 2001 and 2015, this study analyzed the impact of the second phase of the National Forest Conservation Program on the timber product industry in Heilongjiang province, China. Due to the implementation of the program and logging ban policy, the timber harvest in Heilongjiang was reduced to 1.568 million $\mathrm{m}^{3}$ in 2015 from 7.739 million $\mathrm{m}^{3}$ in 2001, corresponding to a reduction of79.7\%. A descriptive analysis indicated that the output of the timber product industry in Heilongjiang continued to increase during the second phase of the program. An analysis based on the synthetic control method indicated that the timber product industry in Heilongjiang has been significantly affected by the implementation of the second phase of the program. The output of the timber product industry was reduced by $62.79 \%$.

\section{Pages from Forest Technology Transfer (TT Florestal): making information accessible to users / Páginas de Transferência de Tecnologia} Florestal (TT Florestal): tornando a informação acessivel ao usuário

Simone Santos Soares ${ }^{1}$, Luciane Cristine Jaques ${ }^{1}$, Katia Regina Pichelli ${ }^{1}$

1Embrapa Florestas, Colombo,Brasil (simone.santos@embrapa.br; luciane.jaques@embrapa.br; katia.pichelli@embrapa.br)

Muitos produtores rurais e até mesmo pessoas que estão começando a plantar espécies florestais procuram a Embrapa Florestas para saber informações básicas sobre como cultivar florestas. Isso ficava evidente ao analisar as principais demandas que chegavam ao Serviço de Atendimento ao Cidadão (SAC) da empresa, com a grande maioria das demandas sobre os diferentes itens de um sistema de produção. Estas informações estavam em diferentes locais no site da Embrapa Florestas ou, então, acessíveis somente em publicações com linguagem técnico-científica, dificultando o entendimento por parte do usuário. Para solucionar este problema, os setores de Transferência de Tecnologia e Comunicação da Embrapa Florestas trabalharam na proposição de uma solução, que consiste na publicação das "Páginas de Transferência de Tecnologia", sendo uma para cada tema definido como prioritário. Temas que já foram publicados: eucalipto, ervamate, pupunha, pragas florestais, sistemas silvipastoris, softwares florestais. Cada página/tema, hoje, conta com: perguntas e respostas; principais publicações sobre o tema; reportagens; vídeos; programas de rádio; soluções tecnológicas. O fluxo de trabalho contemplou: análise das demandas do SAC; definição de conteúdo; elaboração de perguntas e respostas, com adequação de linguagem; aprovação por parte dos pesquisadores; levantamento de materiais; definição de layout. Um trabalho de divulgação, em especial em mídias sociais, alavancou a audiência das páginas, que hoje são as mais acessadas dentro do Portal da Embrapa Florestas. 


\section{Multi-national pulp industries within the global value networks: systemic assessment on the changing operational environment}

Veera Tahvanainen ${ }^{1}$, Ossi Pesälä ${ }^{1}$, Teppo Hujala ${ }^{1}$ Lucía Pittaluga ${ }^{2}$, Jouni Pykäläinen ${ }^{1}$

${ }^{1}$ University of Eastern Finland, Joensuu, Finland; '2Universidad de la República (Uruguay), Montevideo, Uruguay (veera.tahvanainen@uef.fi;

ossi.pesala@uef.fi; teppo.hujala@uef.fi; luciapittaluga@gmail.com;jouni.pykalainen@uef.fi)

The operational environment of the Multi-National Pulp Industries is affected by numerous of factors, such as: climate change, changes in economic conditions and society, new technologies and emerging innovations. The changes in operational environment affect both the multi-national organizations and the SMEs in local levels. The recent developments have disrupted the existing market structures, enabled birth for novel value creation mechanisms, and brought up increasing recognition and utilization for the evolving value networks. This calls for systemic assessment of the factors capable of altering the operational environment within the global pulp industries. In this study the present situation and future perspectives of pulp industry of Uruguay and Finland is presented and their relation to each other in a frame work of global challenges and bioeconomy is studied. These challenges are identified and possible future changes and innovations evaluated. The data consists of document analysis and expert interviews collected during fall 2018 and spring 2019 in Uruguay and Finland. The multi-level perspective model is used to analyze the socio-technical regime, landscape level issues and niche innovations in a country level. The pulp industry forms a considerable part of the production matrix of both countries and they share the global challenges facing the multi-national pulp industry, however the socio-technical regimes in these countries are rather different. The objective of the study is to provide multi-level insight on future aspects, opportunities, and threads related to pulp industries from national and international perspectives to support the transition to a more sustainable bioeconomy.

\section{Governmetrics for sustainable forest management in Romania}

Stefan Neagu ${ }^{l}$ (D, Catalin Calota ${ }^{1}$, Gheorghe Marin ${ }^{1}$, Marius Dumitru $^{1}$, Marius Nitu $^{1}$, George Florin Garbacea ${ }^{1}$

${ }^{1}$ National Institute for Research and Development in Forestry "Marin Drăcea”, Voluntari, Romania (stefanneagu@yahoo.com; catalin.calota@roifn.ro, ghmarin@roifn.ro;mariusd@roifn.ro; dannitu@roifn.ro; george.garbacea@yahoo.com)

The main purpose of the National Forest Inventory (NFI) is to document the present-day circumstances and latest trend of the Romanian wooded area in a descriptive and verifiable manner, by means of implementing various data sources and methods for a methodically analysis of sustainable forest management (SFM). Relating SFM goals with data needs is a staggering undertaking since data are stockpiled in relational databases by several stakeholders (environment and socio-economic data) and assessed by means of specifically developed methods. Forest policy governmetrics represented by SFM indicators are necessary new models and tools based on existing information for analysis and predictions in order to generate an effective and pertinent decision support system (DSS) at national and regional levels. The evaluation of information sources, features, and classification is described in the methodology, which will furthermore explore their integration procedures to generate trustful and reliable SFM metrics matching the European wide requirements (MCPFE, 2011, 2015). The outcomes and conclusions wrap up the available data features and suitability for producing SFM parameters relevant to stakeholders and decision makers. References: MCPFE, 2011, Proceedings of Forest Europe Ministerial Conference, Forest Europe Ministerial Conference on Protection of Forests in Europe, Oslo, p; 216. MCPFE, 2015, Proceedings of Forest Europe Ministerial Conference, 7th FOREST EUROPE Ministerial Conference and FOREST EUROPE Extraordinary Ministerial Conference, Madrid, p; 246

\section{Modelling the effects of regeneration method on growth and economy of Scots Pine stands}

Mikolaj Lula ${ }^{1}$, Renats Trubins ${ }^{1}$, Urban Nilsson ${ }^{1}$

${ }^{1}$ Swedish University of Agricultural Sciences, Southern Swedish Forest Research Centre, Alnarp, Sweden (mikolaj.lula@slu.se; renats.trubins@slu.se; urban.nilsson@slu.se)

Scots pine (Pinus sylvestris L.) is the most widely distributed conifer in the world and, presently, the second most important commercial tree species in Sweden after Norway spruce (Picea Abies L.). However, the share of Scots pine in regenerations in southern Sweden has decreased alarmingly during the last twenty years, yielding space to Norway spruce. Recent surveys have shown that Scots pine is rarely the species of future crop trees in young stands. Forest owners' perception of the uncertainty of Scots pine regeneration outcomes has been identified as one of the main factors causing this trend. Conventional regeneration methods for Scot Pine in southern Sweden are planting, direct seeding and natural regeneration with seed trees or under shelterwood. There is still a lack of knowledge about the long term effects of the regeneration method on growth and economy of Scots pine stands in the region. In present study long term development of Scots pine stands is simulated starting from short term regeneration outcomes observed in actual field experiments. Economy of the stand management is analysed in terms of cash-flow and Land Expectation Value (LEV), volume growth in terms of mean annual increment (MAI) for whole rotation. Effects of different discount rates and regeneration costs on the LEV outcomes are tested.

Gains in nature conservation based on compensatory plantations in the Atlantic Forest, Brazil / Ganhos em conservação da natureza com base em plantios compensatórios na Mata Atlântica, Brasil

Natasha Choinski ${ }^{1}$, Marcelo Pinto ${ }^{1}$,Felipe do Vale ${ }^{1}$, Alessandra Xavier de Oliveira ${ }^{1}$, Romulo Silva $^{1}$, Marlon Prestes ${ }^{1}$, Daniela Bussmann ${ }^{2}$ ${ }^{1}$ Instituto de Pesquisa em Vida Selvagem e Educação Ambiental, Curitiba, Brasil; ' 2 Arteris, Joinville, Brasil (natasha.choinski@spvs.org.br; marcelob@spvs.org.br; felipe.vale@spvs.org.br; alessandra.xavier@spvs.org.br; romulo.silva@spvs.org.br; sig@spvs.org.br; daniela.bussmann@arteris.com.br)

A Mata Atlântica é considerada um hotspot global que recobria 15\% do território brasileiro, o equivalente a 1.306 .421 km². Distribuída ao longo da costa brasileira é formada por um conjunto de ecossistemas de grande importância para manutenção de serviços ecossistêmicos. Porém, com o processo de desenvolvimento brasileiro, à área original do bioma foi reduzida para 7,84\%, e estudos indicam a continuidade do desmatamento que no período entre 2016 / 2017 foi de 12.562 hectares $\left(125 \mathrm{~km}^{2}\right)$. Por causa da fragmentação florestal, projetos de restauração em parceria com o setor empresarial são importantes e podem integrar ações para a conservação da natureza em um cenário em que medidas compensatórias para obras de infraestrutura que causam impactos negativos a biodiversidade são regra no Brasil. Nesse contexto, uma cooperação técnica inovadora entre uma empresa do setor de infraestrutura e uma instituição que trabalha pela conservação da natureza foi estabelecida. A cooperação objetiva direcionar uma compensação ambiental para a restauração de áreas protegidas da Mata Atlântica, ecossistema de Restinga, ameaçado de extinção, e conta com as seguintes etapas: a) delimitação da área de trabalho para implantação das técnicas de restauração (núcleos de Anderson, galharias e poleiros artificiais); b) corte e controle de espécies exóticas invasoras; c) marcação de matrizes florestais porta sementes; d) coleta de sementes; e) produção de mudas; f) implementação das técnicas de restauração e g) monitoramento. Além dos resultados ambientais, essa iniciativa serve como um modelo para futuras ações de compensação ambiental no Brasil, que envolve um ciclo completo de restauração ecológica. 


\title{
C9q: FOREST POLICY AND ECONOMICS - II
}

\author{
Forest investment in Toona ciliata: real options approach as a competitive strategy \\ Danilo Simões 1 (D), Rafael Macedo Prestes ${ }^{2}$ (D) \\ ${ }^{1}$ Universidade Estadual Paulista "Júlio de Mesquita Filho", Faculdade de Ciências Agronômicas, Botucatu; ${ }^{2}$ Centro Universitádio Internacional UNINTER, \\ Indaiatuba,Brasil(danilo.simoes@unesp.br; rafaelmprestes@gmail.com)
}

Investments in forest assets are irreversible and have associated uncertainties. Therefore, the forestry producer must wait for favorable market conditions for decision making, in addition, to consider strategies that allow adding value during the life of the investment project. In this perspective, the objective was to evaluate an investment project in Toona ciliata using the approach of the Real Options Theory with combined options, with the perspective of measuring the economic feasibility and the probabilities of executing these options. The evaluation considered the plantation of one hectare with 816 trees of Toona ciliata located in the State of São Paulo, Brazil. The cash flow was projected considering the clearcutting, that is, for a horizon of 15 years. The discount rate was calculated using the Capital Asset Pricing Model (CAPM). The asset was modeled using the binomial pricing model, where the deferral option was weighted in the second year, in order that the uncertainties are eliminated for project continuity, and the expansion option of $30 \%$ of the planted area in the seventh year, in response to possible favorable market conditions. The jointly exercised options indicated $51 \%$ possibility of the forest producer to wait for two years to execute the investment project in forest assets and 13\% to perform the expansion of the planted area of Toona ciliata.The value of both options was USD 11,256.01, resulting in an expanded net present value of USD 20,379.50, which allowed to add 123\% of value to the forest investment project.

Economic viability of cultivating Schizolobium parahyba var. amazonicum Huber ex (Ducke) Barneby as a function of soil management practices in an agroforestry system / Viabilidade econômica do cultivo de Schizolobium parahyba var. amazonicum (Huber ex Ducke) Barneby em função de práticas de manejo do solo em sistema agroflorestal

Agust Sales ${ }^{1}$, Sílvio Nolasco de Oliveira Neto ${ }^{1}$, Haroldo Nogueira de Paiva ${ }^{1}$, Márcio Lopes da Silva ${ }^{1}$, Helio Garcia Leite ${ }^{1}$, Marco Antonio Siviero ${ }^{2}$, Sabrina Benmuyal Vieira ${ }^{3}$

${ }^{1}$ Universidade Federal de Viçosa, Viçosa, Brasil; ${ }^{2}$ Grupo Arboris, Dom Eliseu, Brasil; ${ }^{3}$ Universidade Federal do Pará, Belém, Brasil (agustsales@hotmail.com; snolasco@ufv.br; hnpaiva@ufv.br;mlopes.ufv@gmail.com; hgleite@gmail.com;m.g@masiviero.com.br; sabrina.benmuyal@grupoarboris.com.br)

Análise econômica é fundamental para definição de arranjos estruturais e manejo de sistemas agroflorestais. Analisou-se a rentabilidade e o risco de investimento do cultivo de paricá (Schizolobium parahyba) em sistema agroflorestal em função de práticas de manejo solo, em Ulianópolis, Pará, Brasil. Implantou-se o paricá no espaçamento 5 × 2 m, consorciado com soja (Glycine max), no primeiro ano, e milho (Zea mays) no segundo. Para o cultivo de paricá aplicou-se os tratamentos T1 = subsolagem, adubação de base, adubação de cobertura, inoculação, consórcio com soja/milho; nos T2, T3, T4 e T5 aplicou-se as mesmas práticas do T1, exceto subsolagem (T2), adubação de base (T3), adubação de cobertura (T4) e inoculação (T5); sendo o T6 a testemunha sem práticas de manejo do solo. Considerando horizonte de planejamento de cinco anos e taxa de juros de 6,75\% a.a., realizou-se análise econômica através do VPL (Valor Presente Líquido), VAE (Valor Anual Equivalente), CMP (Custo Médio de Produção de madeira), Razão B/C (Benefício/Custo) e VET (Valor Esperado da Terra), incluindo análises de riscos de investimentos. O VPL, VAE, CMP, Razão B/C e VET indicam que os tratamentos tornam o sistema viável economicamente, com risco inexistente de VPL zero ou negativo. Custos, preço e produção de madeira em pé de paricá foram as variáveis que mais influenciaram o VPL. As receitas dos cultivos agrícolas amortizam, em média nos tratamentos, $88 \%$ do custo total, indicando aviabilidade econômica das práticas de manejo do solo e do cultivo de paricá em sistema agroflorestal.

Monitoring a degraded area undergoing forest restoration as environmental compensation for a paper mill in Piraí, Rio de Janeiro, Brazil I Monitoramento de uma área degradada em processo de restauração florestal como compensação ambiental de uma indústria de fabricação de papel de Pirai, RJ

Barbara Costa ${ }^{1,2}$

${ }^{1}$ Escola Nacional de Botânica Tropical, Jardim Botânico do Rio de Janeiro, Rio de Janeiro, Brasil; ${ }^{2}$ Costa Consultoria Ambiental, Rio de Janeiro, Brasil (contato@costaconsultoria.com)

No âmbito do licenciamento ambiental, a restauração florestal vem sendo utilizada como ferramenta para as mais variadas compensações ambientais. Após a implantação de projetos, é estritamente necessário o devido monitoramento para avaliação do desenvolvimento da área a ser restaurada. Este estudo avaliou uma área de aproximadamente 1,5 hectares em processo de restauração há um ano, em Piraí - RJ, baseado nos critérios da Resolução INEA nº 143/2017. Foram analisados todos os parâmetros pertinentes a metodologia do Diagnóstico Ecológico Rápido e catalogados os indivíduos existentes em cinco parcelas de $100 \mathrm{~m}^{2}$ cada. Registrou-se 36 espécies, das quais $44 \%$ são zoocóricas, distribuídas em 17 famílias botânicas. A densidade encontrada foi de 1.740 ind.ha-1, com percentual de cobertura de gramíneas de $80 \%$ e altura média de 2,5 m. Os índices de Diversidade (H’) e Equidade (J) foram 3,58 e 0,84, respectivamente. Após análise da pontuação dos parâmetros avaliados a partir dos resultados do levantamento, obteve-se a nota 6,14, considerada compatível com a idade de implantação do projeto. Os parâmetros em que não se atingiu pontuação mínima foram: percentual de indivíduos zoocóricos, cobertura de gramíneas/copa e altura média. É necessário implantar enriquecimento com pelo menos cinco espécies zoocóricas. Além das boas características do solo de várzea, aceiros contínuos para prevenção de possíveis queimadas, manutenção de cercas, assim como controle contínuo de formigas cortadeiras, vem contribuindo para o sucesso do projeto. 
Optimizing agricultural and forest production, considering remediation of conservation areas via complete planning and land use capacity / Otimização da produção agrícola-florestal considerando recuperação de áreas destinadas a conservação através de programação inteira e capacidade de uso do solo

Lucas Arthur de Almeida Telles ${ }^{1}$, Marcio Lopes da Silva1, Helio Garcia Leite ${ }^{1}$, Daniel Henrique Breda Binoti ${ }^{2}$, Gustavo Eduardo Marcatti ${ }^{3}$, Pedro Henrique Santos Mota ${ }^{4}$, Nero Lemos Martins Castro ${ }^{1}$, Alexandre Simões Lorenzon ${ }^{1}$, Brener de Almeida Oliveira ${ }^{1}$

${ }^{1}$ Universidade Federal de Viçosa, Viçosa, Brasil,; ${ }^{2}$ Centro Universitário São Camilo, São Paulo, Brasil; ${ }^{3}$ Universidade Federal de São João Del Rei, Sete

Lagoas, Brasil; ${ }^{4}$ Plantar Reflorestamento S/A,Curvelo,Brasil llucasarthur36@gmail.com; mlopes.ufv@gmail.com; gleite@gmail.com;

danielhbbinoti@gmail.com; gustavomarcatti@ufsj.edu.br; pedromotaenf@gmail.com;nerolmcastro@gmail.com; alexandre.lorenzon@ufv.br;

b.oliveiraefl@gmail.com)

A produção agrícola e florestal tem demandado a utilização otimizada de recursos aliada a definição precisa de atividades operacionais. Modelos matemáticos podem conciliar capacidade de uso do solo, atividades de ciclo longo e recuperação de áreas destinadas a conservação em um contexto espaço-temporal. Logo, o objetivo deste estudo foi desenvolver um modelo de programação matemática para maximizar o valor presente líquido de atividades florestais e agrícolas, considerando a capacidade de uso do solo da propriedade. O modelo de programação inteira formulado possui restrições de saldo mínimo, duração máxima, singularidade, nulidade, capacidade de uso do solo, produção mínima e máxima, opções de recuperação e reflorestamento. O modelo foi aplicado a uma propriedade simulada de 36 hectares, com atividades produtivas e presença de passivo ambiental, considerando um horizonte de 30 anos. Prescrições envolveram atividades agrícolas, fruticultura, reflorestamento e recuperação em um cenário de restrições de demanda variável segundo culturas e saldos anuais positivos. Através da aplicação do modelo, áreas produtivas foram utilizadas segundo sua capacidade de uso do solo enquanto áreas destinadas a conservação foram recuperadas ao longo do horizonte de planejamento. Quando possível, demandas foram atendidas sem a máxima exploração de unidades produtivas. A recuperação foi financiada pela receita da produção, tornando-a independente de recursos externos. A transição da produção foi eficiente e a propriedade gerenciada por demanda de culturas e saldo. Logo, o modelo proposto constitui uma ferramenta de gestão que viabiliza uma produção menos agressiva ao solo, recupera áreas destinadas a conservação e maximiza o lucro da produção.

Communications to overturn myths and encourage knowledge about the Araucaria / Ações de comunicação para desmistificar conceitos e incentivar o conhecimento sobre a araucária

Katia Regina Pichelli ${ }^{1}$, Paula Geron Saiz ${ }^{1}$, Luciane Cristine Jaques ${ }^{1}$

${ }^{1}$ Embrapa Florestas, Colombo,Brasil (katia.pichelli@embrapa.br; paula.saiz@embrapa.br; luciane.jaques@embrapa.br)

A araucária (Araucaria angustifolia) faz parte do ecossistema "Floresta com Araucária", presente nos estados do Paraná, Santa Catarina e Rio Grande do Sul, e de forma esparsa na região Sudeste do Brasil. A exploração intensiva da araucária a levou à lista das espécies brasileiras ameaçadas de extinção. Isso aconteceu pelo avanço da fronteira agrícola, crescimento das cidades, possuir madeira de qualidade para móveis e ser boa matéria-prima para papel e celulose. No entanto, a proteção da lei a está prejudicando: muitos produtores rurais não a plantam mais ou permitem sua regeneração natural, por medo de serem punidos caso precisem mexer nas árvores. Também existem mitos junto ao público urbano, que protege a espécie de forma radical, sem conhecer melhor as possibilidades de uso, manejo e conservação. Em paralelo, a Embrapa Florestas, órgão federal de pesquisa florestal, tem trabalhado com pesquisas e transferência de tecnologia com araucária. Por isso, diversas ações de comunicação acontecem em apoio a estes trabalhos, para desmistificar conceitos e fazer com que os diversos públicos entendam a espécie, sua importância, possibilidades de uso e conservação. Diversas estratégias são utilizadas, como produção de materiais impressos e digitais em linguagens específicas para cada público, inclusive o urbano; participação em eventos (feiras, exposições, aulas de culinária etc, atingindo mais de 5.000 pessoas), com materiais elucidativos; lançamentos de publicações e tecnologias; trabalhos junto à imprensa e mídias sociais. Este conjunto de ações de comunicação tem contribuído para que a sociedade repense a importância da araucária, seus aspectos econômicos, sociais e ambientais.

The science behind food: Embrapa Florestas' participation in a food week event highlighting the seed of Araucaria angustifolia / $A$ ciência por trás dos alimentos: produção de materiais para participação da Embrapa Florestas na Semana Sabores do Pinhão

Paula Geron Saiz ${ }^{1}$ Katia Regina Pichelli ${ }^{1}$, Luciane Cristine Jaques ${ }^{1}$

${ }^{1}$ Embrapa Florestas, Colombo,Brasil (paula.saiz@embrapa.br;katia.pichelli@embrapa.br; luciane.jaques@embrapa.br)

Mostrar ao público urbano a ciência por trás da produção de alimentos oriundos da floresta, como o pinhão. Esta foi a proposta da Embrapa Florestas durante a Semana Sabores do Pinhão, promovida pela Secretaria de Abastecimento de Curitiba, em parceria com o Mercado Municipal e a Abrasel, em junho de 2018. Para atingir um público de 3 mil visitantes, a elaboração dos materiais usados no estande da Embrapa Florestas focou na adequação da linguagem, no impacto visual e no baixo custo de produção. Foram produzidos materiais digitais (telas) e impresso (cartão postal). Os digitais, exibidos em TV, traziam de forma objetiva, de fácil entendimento e visualmente atrativa, informações sobre pesquisas e tecnologias com araucária e pinhão, desenvolvidas na Unidade. Abordaram-se os temas: -Conservação da araucária: Destaque para a tecnologia de araucária de pinhão precoce ecuriosidades sobre a árvore símbolo do Paraná (formato, reprodução, etc); -Projeto Estradas com Araucárias: Incentivo ao produtor para plantio de araucária nas divisas com rodovias, por meio do pagamento por serviços ambientais; -Pinhão- saudável e rico em possibilidades para culinária: Informações sobre aspectos nutricionais do pinhão e sua versatilidade em receitas doces e salgadas. O postal impresso, distribuído aos visitantes, continha no verso QR Codes remetendo a conteúdos disponíveis no site da Unidade, reunidos em página organizada especialmente para o evento. Os materiais chamaram a atenção dos visitantes, mostrando-se ótimas alternativas para levar informações de pesquisa ao público leigo quando trabalhados em linguagem acessível e com atrativos visuais, em função do baixo custo e praticidade.

\section{Charging for water use in pulp production / Cobrança pelo uso da água na produção de celulose}

Gabriel Soares Lopes Gomes ${ }^{1}$, Júlia Graziela da Silveira ${ }^{1}$, Laércio Antônio Gonçalves Jacovine ${ }^{1}$, Amana de Magalhães Matos Obolari ${ }^{1}$, Maria Tereza Angeletti Nunes ${ }^{1}$

${ }^{1}$ Universidade Federal de Viçosa,Viçosa,Brasil (gabriel.flo@hotmail.com; juliagrazielasilveira@gmail.com; jacovine@ufv.br; amanaobolari@gmail.com; mtangeletti@hotmail.com)

$\mathrm{Na}$ indústria de papel e celulose há grande preocupação quanto ao consumo de água e tratamento dos efluentes. Umas das alternativas para incentivar a racionalização de uso e gerar recursos financeiros para financiar a recuperação das bacias hidrográficas é a cobrança pelo uso da água . O objetivo do estudo foi comparar os custos de empresas de celulose brasileira quanto ao emprego dos recursos hídricos para produção da celulose e identificar medidas adotadas por estas para minimizar os gastos hídricos durante todo o processo. O estudo foi realizado com referência à quatro fábricas de celulose: “A” (Aracruz- ES), 
"B" (Jacareí- SP), “C” (Belo Oriente- MG) e "D” (Limeira- SP). Com base no ano 2017, realizou-se o cálculo do custo d'água (R\$/ton) através da relação entre o valor pago pelo uso d'água e a tonelada de celulose produzida para cada empresa estudada. A empresa "A" apresentou o menor custo, o qual atingiu $\mathrm{R} \$ 0,55$, enquanto a empresa "C" atingiu o maior valor $\mathrm{R} \$ 1,41$, seguido pela empresa " $\mathrm{D}$ " com custos de $\mathrm{R} \$ 1,37$. A diferença no valor pode estar associada à eficiência na utilização de água entre as empresas. A empresa "A" investiu na modernização nas etapas de branqueamento, assim como investiu na reutilização de condensados de evaporação, o que proporcionou reduções de 50\% e 30\%, respectivamente, no consumo de água durante o processo. Assim, empresas que utilizam técnicas que favoreçam a reutilização da água podem diminuir o custo pelo uso desse recurso natural.

Project Terracert: a new paradigm in forest legislation for building efficient landscapes in municipalities within the Amazon / Projeto Terracert: um novo paradigma na legislação florestal para construir paisagens eficientes em municipios da Amazônia

Jaqueline Carvalho ${ }^{1}$, Rene Poccard ${ }^{2}$, Marie Gabrielle Piketty ${ }^{3}$, Isabel Drigo ${ }^{4}$, Mario Oliveira Gomes ${ }^{5}$, Pablo Pacheco ${ }^{6}$

${ }^{1}$ Prefeitura Municipal de Paragominas, Secretaria de Assuntos Juridicos, Paragominas, Brasil; ${ }^{2}$ CIRAD, Paragominas, Brasil; ${ }^{3}$ CIRAD, Bogota, Colombia; ${ }^{4}$ Instituto de Manejo e Certificação Florestal e Agrícola, Piracicaba, Brasil;; ${ }^{5}$ Embrapa Oriental, Paragominas, Brasil; ${ }^{6} \mathrm{WWF}$, Washington, USA(jaquelineadvambiental@gmail.com; renepoccard@gmail.com; piketty@cirad.fr; isabel.drigo@gmail.com; mario.gomes@embrapa.br; pablo.pacheco@wwf.gov)

A gestão florestal na Amazônia Brasileira alcançou bons resultados nos últimos 15 anos, em termos de combate ao desmatamento. Em Paragominas, o conjunto de ações implementadas pela política de combate ao desmatamento obteve grande sucesso no seu controle, contudo, referida política nunca considerou a eficiência da matriz florestal para produção de serviços ecossistêmicos. Fragmentação florestal, extração madeireira ilegal e incêndios recorrentes causam degradação florestal acelerada, acarretando prejuízos ambientais bem superiores ao desmatamento, necessitando de adaptações na legislação. Atualmente, os produtores agrícolas intensificam os sistemas de produção, selecionando para isso, as áreas de maior aptidão agronômica e abandonando as outras. A politica municipal de paisagem eficiente visa reordenar essas matrizes espaciais de uso agropecuário e de uso florestal. A cartografia das aptidões permite delimitar áreas prioritárias para serviços ecossistêmicos e outras para intensificação agropecuária, sendo a base para uma lei municipal de microzoneamento. Referida lei define protocolos de recomposição eficiente da paisagem para cada propriedade. A adesão a esses protocolos é voluntaria, trazendo as seguintes vantagens ao produtor: acesso a crédito para intensificação, contabilização dos ativos ambientais ligados a restauração em áreas prioritárias, autorização de remoção da vegetação nas áreas de aptidão para a produção. A competência do município para a gestão florestal é limitada as florestas secundarias. Para incluir no ordenamento todos os tipos de floresta, e assim, ganhar eficiência, o município vem construindo diálogos nos níveis estaduais e federais. Esse projeto piloto é construído de forma a ser replicado em outras jurisdições da região amazônica.

\section{THEME D: BIODIVERSITY, ECOSYSTEM SERVICES AND BIOLOGICAL INVASIONS}

\section{D1c: DISTURBANCE, ECOSYSTEM MEMORY, RISK AND FOREST MANAGEMENT IN A CHANGING SOCIO-ECOLOGICAL ENVIRONMIENT'}

\section{Forest owner's preferences towards risk and uncertainty, and adaptation decisions towards climate change}

Marielle Brunette ${ }^{1}$, Marc Hanewinkel ${ }^{2}$, Rasoul Yousefpour

${ }^{1}$ Institut National de la Recherche Agronomique, Nancy, France; '2University of freiburg, Freiburg, Germany (marielle.brunette@inra.fr; marc.hanewinkel@ife.uni-freiburg.de; rasoul.yousefpour@ife.uni-freiburg.de)

Natural disasters represent the main risk that European forest managers face. In addition, climate change increases the frequency and intensity of these disasters, introducing uncertainty (in addition to risk) in the decision-making process. In this context, we focus on the forest manager's preferences towards risk and uncertainty, and also on their impact on adaptation decisions. More precisely, we propose to: i) quantify risk aversion and uncertainty aversion coefficients of forest managers; ii) observe the effect of the obtained coefficients on the fact to adapt (or not) and on the type of adaptation strategy; iii) compare forest managers from France and Germany as regard to their preferences towards risk and uncertainty, and also as regard to their adaptation decisions. For that purpose, we realize a computerized survey sent by email in September 2018 to forest managers (private and public) in Grand-Est region in France and Baden-Wurttemberg in Germany. The questionnaire is composed of four parts. The first and second parts are dedicated to the measurement of risk and uncertainty aversion through lottery choices. The third part is about climate change and adaptation. One question is about perception of climate change, and the others are related to the adaptation strategies implemented and those that the managers forecast to implement in a near future. The adaptation strategies considered in the questionnaire are: plant genetically modified species, assist in tree regeneration, species mix, forest fertilization, harvesting age, thinning, forest insurance, and other measures. The last part is dedicated to questions about socio-economics characteristics.

\section{Multiple uncertainties require a change of conservation practices for saproxylic beetles in managed temperate forests}

Andrey Lessa Derci Augustynczik ${ }^{1}$, Rasoul Yousefpour ${ }^{1}$, Marc Hanewinke ${ }^{1}$

${ }^{1}$ University of Freiburg, Freiburg, Germany (andrey.lessa@ife.uni-freiburg.de; rasoul.yousefpour@ife.uni-freiburg.de; marc.hanewinkel@ife.uni-freiburg.de)

In Europe, intensive forest management has severely compromised the habitat of forest insects, especially saproxylic beetles, due to the removal of deadwood and veteran trees. The loss of insect diversity may disrupt ecosystem functioning and affect the provision of important ecosystem goods and services in the future. Here we propose a novel approach for the implementation of conservation policies, by optimally allocating forest reserves and deadwood islands under multiple sources of uncertainty and minimizing economic risk. We use the saproxylic beetle Lucanus cervus as umbrella species, requiring that deadwood islands were spaced within its dispersal capacity. We show that current management and conservation practices are increasingly inefficient under changing environmental conditions and that the consideration of uncertainty requires a major expansion of conservation areas. Moreover, our results indicate that a strong diversification of management regimes, with a focus on selection forest systems, is required to reduce economic risk of forest management. We conclude that the integration of uncertainty into conservation planning may reduce the tradeoff between production and conservation objectives in forest landscapes and is key to increase the efficiency of forest management in the future. 


\title{
Bark beetle risk management in the framework of strategic planning
}

Jan Kaspar', Robert Marusak ${ }^{1}$, Harald Vacik ${ }^{2}$

${ }^{1}$ Faculty of Forestry and Wood Sciences CULS Prague, Prague, Czech Republic; ${ }^{2}$ University of Natural Resources and Life Sciences Vienna, Vienna, Austria (kasparj@fld.czu.cz; marusak@fld.czu.cz; harald.vacik@boku.ac.at)

The Czech Republic's largely coniferous forests are facing the worst bark beetle infestation in at least 200 years. The amount of spruce wood damaged by bark beetles has risen steadily in the past few years, from $12 \%$ of annual total cut in 2015 to more than $100 \%$ of annual total cut in 2018. Experts are warning that the nation's forests could be wiped out if the current monoculture forestry format is not unchanged. The ongoing bark beetle disturbances and climate change have been forced to find rapidly new approaches of forest management which allow to react to new conditions on the wood market. One of the proposed solutions is to keep the dead trees without cutting and concentrate all human and financial capacities to protect the forest sites where there are still living trees. It will be necessary to create buffer zones in which management will need to be very effective and accurate in order to optimize all available resources and at the same time to prevent further spread of bark beetle. The presented study is aimed at possible way of risk management of forest stands damaged by bark beetle associated with spatial planning of management interventions in buffer zones.

\section{Species mixture vs. age mixture: how to conciliate wood production and carbon sequestration objectives under drought and windstorm risks in forest}

Sandrine Brèteau-Amores ${ }^{1}$ Rasoul Yousefpour ${ }^{2}$, Marc Hanewinkel ${ }^{2}$, Mathieu Fortin ${ }^{3}$

${ }^{1}$ Institut National de la Recherche Agronomique - BETA, Nancy, France; ${ }^{2}$ University of Freiburg, Freiburg-in-Breisgau, Germany; ${ }^{3}$ Canadian Forest Service, Ottawa, Canada (sandrine.breteau-amores@inra.fr; rasoul.yousefpour@ife.uni-freiburg.de; marc.hanewinkel@ife.uni-freiburg.de; mathieu.fortin@agroparistech.fr)

Forests provide ecosystem services such as wood production and carbon sequestration. However, forests are sensitive to climate change, and financial and amenity losses are expected for forest owners and society, respectively. The forests in the Grand-Est region (France) are dominated by beech, which is predicted to decline in the future due to repeated drought events driven by climate change. Forests in this region are also threatened by windstorm event. Beech forests need to adapt and mixture is known to decrease drought and storm risks. In this context, the objective of the paper was to compare, from an economical perspective, different forest adaptation strategies with the objective of reducing drought-induced and storm-induced risks of decline. For this purpose, we studied two types of mixture that we analysed separately and jointly: species mixture with oak and age mixture (i.e. from an even-aged to an uneven-aged forest). We also considered two types of loss (financial, and in terms of carbon sequestration) under different frequencies of drought and storm risks. We combined a forest growth simulator (MATHILDE) with a classical forest economic approach (Hartman's LEV). Maximizing the LEV criterion allowed the identification of the best adaptation strategies in economic terms. An optimisation of forest management was performed according to wood production and carbon sequestration objectives. The results are discussed taking into account the trade-offs between the financial balance and the carbon balance, and the underlying question of the additivity (or not) of the two risks as well as of the two adaptation strategies.

\section{Impact of clear cuttings on biodiversity of boreal forests}

\author{
Remigijus Daubaras ${ }^{1}$, Laima Cesoniene², Vidas Stakenas ${ }^{3}$, Vytautas Tamutis ${ }^{2}$, Marcin Zych ${ }^{4}$ \\ ${ }^{11}$ Botanical Garden of Vytautas Magnus University, 46324, Lithuania; ${ }^{2}$ Botanical Garden of Vytautas Magnus University, 46324, Lithuania; ${ }^{3}$ Institute of \\ Forestry of Lithuanian Research Centre for Agriculture and Forestry, 53101, Lithuania; ${ }^{4}$ Botanic Garden, Faculty of Biology, University of Warsaw, 00478, \\ Poland(remigijusd@hotmail.com; laima.cesoniene@vdu.lt; vidas.stakenas@mi.lt; dromius@yahoo.lt; mzych@biol.uw.edu.pl)
}

The dynamic of chemical composition of forest soil, understory plants and variation of insects were investigated in Pinus sylvestris dominated forests after clear-cuts. We detected an increase in litter $\mathrm{pH}$, while soil investigations have shown that concentrations of $\mathrm{Ca}^{2+}$ and $\mathrm{Mg}^{2+}$ also increased in the clear-cut areas. Significantly higher amounts of $\mathrm{NO}_{3}-\mathrm{N}+\mathrm{NO}_{2}-\mathrm{N} \mathrm{mg} \mathrm{kg}^{-1}$ and NH4-N mg kg${ }^{-1}$ were determined after clear-cutting, while the mobile $\mathrm{P}_{2} \mathrm{O}_{5}$ and $\mathrm{K}_{2} \mathrm{O}$ decreased in forest litter and mineral soil (in 0-10 cm depth) in clear-cut plots. We predict that suddenly increased supplies of $\mathrm{NO}_{3}-\mathrm{N}^{2} \mathrm{NO}_{2}-\mathrm{N}$ and $\mathrm{NH}_{4}-\mathrm{N}$ influenced the development of Ericaceae species negatively. Logging residues could be extracted in Arenosols in order to avoid enhanced leaching of organic carbon and nutrients, especially mineral nitrogen. Clear-cuttings demonstrated a negative effect on the abundance of forest-related dwelling beetles, both in terms of species number and individuals in litter assemblages. However, clear-cuttings did not significantly reduce the total species richness because the quantity of beetle assemblages was supported by numerous open land or eurytopic species. Increased amount of new flowering plant species in clear cut areas effected mutualistic relationships of pollinators positivelly. Reaction and possibilities to restore different populations of Ericaceae are species-specific. Vaccinium vitis-idaea is able to survive after clear-cut damages The ability of this drought resistant species to spread through underground rhizomes would promote its reproducibility. Nevertheless, the rhizomatous plant Vaccinium myrtillus demonstrated significantly stronger negative response in the cutted forests.

\section{Ecosystem memory of boreal slash and burn forests}

Pille Tomson ${ }^{1}$, Kalev Sepp ${ }^{1}$

1Estonian University of Life Sciences, Tartu,Estonia (pille.tomson@emu.ee; kalev.sepp@emu.ee)

Slash and burn cultivation (SB) lasted up to the beginning of 20th century in Northern Europe. In South-Estonia SB was carried out in special areas named buschlands in the 19th century. Some plots were used for SB every year but the rest of the buschlands were a mosaic landscape with recovering forests. The aim of current study is to analyse the legacies of historical slash and burn cultivation in boreal forests. The study based on fieldworks in 80 grown-up forests stands in Southern Estonia, where 45 stands were chosen on former SB land (SBL) and 35 in forest land (FL) identified using the 19th century maps. Light differences were found between SBL and FL in ground vegetation. Samplings of deciduous trees and large relict trees were more present in SBL. Also abiotic legacies like field banks, gullies, clearance cairns were found in SBL. Analyses did not reveal any differences in soil chemical characteristics. Despite the evident legacies, the SBL are well-restored forest habitats. SB was stand-replacing disturbance but at the landscape level it was likely less disturbing than deforestation for permanent fields because of its mosaic landscape and short cultivation period. The bigger number of deciduous tree samplings in these forests allow to predict the faster changes in tree layer composition than in FL under the pressure of climate changes. Therefore, in the management practises of these forests for producing ecologically stable ecosystems today the legacies of the SB should be considered. 


\author{
After the catastrophe. Turning off or speeding up? How French forest owners cope with climatic extreme events \\ Philippe Deuffic ${ }^{1}$, Vincent Banos ${ }^{1}$ \\ IIRSTEA, Cestas, France (philippe.deuffic@irstea.fr; vincent.banos@irstea.fr)
}

Although climatic catastrophes are scrutinized for a long time, their impacts on change of practices by forest owners remain ambiguous. For some researchers, extreme events act as a window of opportunity which induces major changes. On the opposite others observe, after the initial trauma, a return to routines. Our contribution aims to question if socio-ecological memory of past extreme weather events guides future conducts and induce changes in forest management. Based on two catastrophes (a severe drought in 2003 and a windstorm in 2009 in France), we assume extreme events do not entail disruption, nor status quo but a so-called 'assisted deviation'. Our analysis shows that strategies range from a return to routine to an acceleration of changes in forest practices. On one hand the lack of social memory affects the capacity to learn from experience and contributes to modest changes of practices also induced by a loss of economic flexibility. On the other hand, major changes of practices are often encouraged by economic and cognitive capability to implement new forest practices but also by a vivid memory of past catastrophes and lessons learnt from their recurrence. However, the ecosystem memory and the forest sector economic legacy and structure may lead to two very different adaptive strategies: the intensification of past practices based on resistance of ecosystem or the introduction of innovative practices based on resilience. Finally, we suggest catastrophes should are not only risks for the future but also experience which test the relevance and efficiency of adaptive strategies

\title{
Dealing with risk and uncertainty in forestry with multi-criteria decision analytic approaches
}

Donald Hodges ${ }^{1}$, Lidija Zadnik Stirn ${ }^{2}$, Donald Grebner ${ }^{3}$

${ }^{1}$ University of Tennessee, Knoxville, TN, USA; ${ }^{2}$ University of Ljubljana, Ljubljana, Slovenia; ${ }^{3}$ Mississippi State University, Mississippi State, MS, USA (dhodges2@utk.edu; lidija.zadnik@bf.uni-lj.si; don.grebner@msstate.edu)

Forest management always has required planners to make decisions in an environment that included physical and financial risk factors, the probability of disturbance, and a wide range of uncertainty. The level of risk and uncertainty is projected to increase substantially in the future, due to changes in climate, threats from native and invasive pests, and increasing interest in a range of ecosystem services that goes beyond the commodities from past forest management planning. While traditional economics-based forest management approaches, such as Faustmann, offers a means by which risk and uncertainty can be incorporated into decision making, today's management planning requires approaches that maximize forest functions and values that frequently are in the form of multi-criteria and indicators. Multi-criteria decision analysis (MCDA) techniques such as Analytic hierarchy process (AHP) have been introduced to incorporate social values into the decision-making process, and offer a more robust approach to risk factors and uncertainty. The presentation will explore the current and probable future environment in which management decisions must be made, review traditional approaches to decision making with risk and uncertainty, present MCDA approaches, and evaluate the ability of these techniques to address risk and uncertainty in forest management decisions.

Catastrophic fire and ecological memory drive the habitat trajectories of a critically endangered arboreal marsupial in the mountain ash forests of Victoria, Australia

Patrick Baker ${ }^{1}$, Raphael Trouve ${ }^{1}$, Craig Nitschke

${ }^{1}$ University of Melbourne,Richmond, Australia (patrick.baker@unimelb.edu.au; raphael.trouve@unimelb.edu.au; craign@unimelb.edu.au)

The Eucalyptus regnans (mountain ash) forests of Victoria's Central Highlands are amongst the most productive forests in the world and support a range of threatened species. The management of these forests has become highly contentious in recent decades due to competing demands for habitat conservation and forest products. Catastrophic bushfires are the driving disturbance within these landscapes. Soil seed banks and the density of standing trees (both alive and dead) are critical components of the ecosystem's memory, shaping post-fire stand development and landscape-scale heterogeneity. Leadbeater's Possum, a critically endangered arboreal marsupial that is heavily dependent on the mountain ash forests, requires large hollow-bearing trees for nesting and dense Acacia for foraging and movement within the forest. However, these two features of the forest develop at very different rates after fire and persist for different lengths of time. Hollow-bearing trees may take a century or more to form and can persist for several centuries, whereas the Acacia component establishes rapidly after the fire, but senesces and returns to the soil seed bank in less than 100 years. Forest management strategies that aim to conserve Leadbeater's Possum must accommodate both the fast cycling of the ephemeral Acacia component and the slow cycling of hollow-bearing trees within the broader landscape.

\section{After removing the Chusquea understory, is it necessary to underplant to restore degraded evergreen North-Patagonian forests? \\ Jan R Bannister ${ }^{1}$, German Travieso ${ }^{1}$, Manuel Acevedo ${ }^{2}$, Eduardo Cartes ${ }^{2}$, Marta González ${ }^{2}$, Nicole Galindo ${ }^{1}$ ${ }^{1}$ Instituto Forestal, Castro, Chile; ${ }^{2}$ Instituto Forestal, Concepción, Chile (jbannister@infor.cl; gtravieso@infor.cl; macevedo@infor.cl; ecartes@infor.cl; mgonzale@infor.cl;ngalindo@infor.cl)}

In order to facilitate the restoration of the structure and tree species composition in North-Patagonian forests that were opened by illegal logging, a common discussion between managers has been the advantage of removing the dense Chusquea quila understory that grows after selective cutting in these forests. In this study, using a restoration experiment established in 2014 along a gradient of varying residual basal area in a high graded North-Patagonian forest on Chiloé Island, we aim to evaluate the early performance of natural regeneration and restoration cluster underplantings after the removal of the $C$. quila understory. After 4 years, seedlings of Nothofagus nitida seedlings had 74\% survival, and a mean height growth of $14.7 \mathrm{~cm} /$ year. The mean height growth of $N$. nitida seedlings was positively correlated with the percentage of photosynthetic photon flux density (PPFD), and negatively correlated with the residual basal area of the degraded forest $(\mathrm{p}<0.01)$. On the other hand, all tree species present in undisturbed conditions (15 tree species) were regenerating in the experiment with a mean density of 9.7 plants $/ \mathrm{m}^{2}$. The highest density of natural regeneration was in areas with $60-70 \mathrm{~m}^{2} / \mathrm{ha}$ of residual basal area and between $30-80 \%$ of PPFD. Our results show that natural regeneration from residual trees can assist the recovery of degraded North-Patagonian forests in Chiloé Island following the removal of the $C$. quila understory. Supplementary planting of valuable pioneer tree species that tolerate shade may assist the natural recovery, especially in areas with lower nurse canopy. 


\title{
Restoring native temperate forests from Pinus radiata plantations in Chile: effects of different harvesting treatments and environmental conditions on regeneration success
}

\author{
Klaus Kremer ${ }^{1}$, Jürgen Bauhus ${ }^{1}$ \\ ${ }^{1}$ University of Freiburg,Freiburg im Breisgau, Germany (klaus.kremer@waldbau.uni-freiburg.de;juergen.bauhus@waldbau.uni-freiburg.de)
}

Over the last decades, an important expansion of commercial tree plantations took place in south-central Chile, in some cases at the expense of native vegetation. This has significant consequences on biodiversity and ecosystem services, which cannot be provided to the same extent by plantations as by native ecosystems. In response to requirements of FSC certification, forestry companies are beginning to restore the native ecosystems replaced by exotic tree plantations after 1994. Owing to the lack of knowledge for this process, we have conducted two studies in P. radiata plantations. The first study aims at determining the effect of different harvesting treatments (clear-cut, strip felling and control) on the early establishment of natural and artificial regeneration of native tree species. Preliminary results show that strip felling provides the best performance of artificially established seedlings of six species of different shade tolerance. The intermediate cover achieved might provide shelter against extreme conditions, while allowing enough sunlight to reach the forest floor. In our second study we aim at determining the potential for restoration of native forests from natural advance regeneration in $P$. radiata plantations, and to ascertain suitable conditions for its development in the mid-term. We sampled 257 plots in 20-year old plantations of $P$. radiata, along a $432 \mathrm{~km}$ latitudinal gradient in the Coastal Range. For each plot we assessed native woody species regeneration, and potential explanatory factors at the site and landscape scale. Results from both studies will provide guidance for the conversion of $P$. radiata plantations to native forests.

\section{Natural forest islands in a matrix of forestry plantations: a refuge of biodiversity and an opportunity for restoration}

Rodrigo Vargas-Gaete ${ }^{1}$ Paola Arroyo-Vargas ${ }^{2}$, Carla Manríquez ${ }^{1}$

${ }^{1}$ Laboratorio de Biometría, Depto de Cs. Forestales Universidad de La Frontera, Temuco, Chile; ${ }^{2}$ Department of Geography, Portland State University,

Portland,OR,USA (rodrigo.vargas@ufrontera.cl; paola.arroyovargas@pdx.edu;c.manriquez03@gmail.com

Most forest plantations are managed as monocultures of fast-growing species, covering large areas. In Chile, forest plantations of exotic species currently cover $>3$ million ha, principally with Pinus radiata. In the coastal mountain range of Chile (35-38 $\mathrm{S})$, plantation establishment has generated areas in which natural forests have become "islands" of biodiversity, surrounded by an "ocean" of plantations. An understanding of how remnant natural patches contribute to biodiversity retention is needed. Natural forest patches retain native plant species inside the patches but also can influence nearby areas into the plantation matrix. This proposal aims at determining attributes of natural forest patches surrounded by plantations, that contribute to retaining plant biodiversity within adjacent plantations. Using as study area $\sim 250,000$ ha in the coastal range of Southcentral Chile ( $338 \mathrm{~S}$ ), we (a) quantified the frequency by size, shape, and isolation of natural forest islands found. Afterward, we selected 18 Nothofagus forest patches, considering a range of sizes for fieldwork, sampling vegetation, site, structure, and other variables. We (b) analyzed natural forest attributes that influenced plant species richness, and (c) we assessed site attributes that promote the establishment of native species on its understory. Nothofagus dominated patches vary in size ( 0.5 to $>200$ ha), but most presented $<8$ ha. Plant diversity underneath plantations was primarily explained by plantation attributes, and tree regeneration in the understory of pine plantations was influenced by the distance to natural patches. We discuss current knowledge on fragmented ecosystems and the opportunity that remnant forest patches can offer for the restoration and/or conversion of forestry plantations.

Using Acacia auriculiformis plantations as a pathway to restore naturally regenerating forest in the Western Ghats, India: a case study and a call for future investigations

Benjamin Caldwell ${ }^{1}$, Sanjai Mohan ${ }^{2}$

${ }^{1}$ FAO, Rome, Italy; ${ }^{2}$ Indian Forest Service, Bengaluru, India (benjamin.caldwell@fao.org; kt090@ifs.nic.in)

Restoration of degraded forest is a critical path to mitigate climate change and improve rural livelihoods. There are millions of hectares pledged for restoration worldwide, but pathways to achieve those pledges are still emerging. Restoration in highly modified or degraded sites is expensive and problematic; plantations can be one solution: a profitable plantation is established and then maintained for one or two rotations. The plantation is then used as a nurse crop for shadetolerant indigenous species. Here we present such a case from India. Running along most of India's western coast, the Western Ghats are one of the world's eight hottest biodiversity hotspots. However, their forests are degraded from centuries of timber logging, fuelwood extraction, and conversion for coffee plantations. In response to this, India's Forest Departments began restoration of forestlands converted to agriculture and then abandoned. In many cases, the residual lateritic soils were so degraded and recalcitrant that only Acacia auriculiformis showed the capacity to successfully occupy the site. They also planted indigenous tree species under the acacia in a nurse crop trial. Supported by the USAID funded Forest-PLUS project and the Karnataka Forest Department, we determined which species had been most successful in this trial. In adjacent forest, basal area and tree species data from natural forest was also used to construct models that describe structure and composition to guide management targets within degraded indigenous forest. Together, such tools provide means for forest managers to cost-effectively restore indigenous Indian forests at a landscape level.

Regeneration of Acacia auriculiformis A. Cunn. ex Benth. plantation in Mt. Makiling Forest Reserve, Philippines: implications to restoration ecology

Marilyn Combalicer ${ }^{1}$, Jonathan Hernandez ${ }^{1}$, Jessa Ata ${ }^{1}$

${ }^{1}$ Department of Forest Biological Sciences, College of Forestry and Natural Resources, University of the Philippines Los Baños, Los Baños, Philippines (mscombalicer@up.edu.ph; johernandez2@up.edu.ph; jpata@up.edu.ph)

There have been a number of debates on the use of exotic species plantations especially for restoration in the Philippines, mainly due to some ecological concerns (e.g. loss of genetic variation). Hence, the potential of Acacia auriculiformis A. Cunn. ex Benth., an exotic species, for restoration of a degraded land in Mt. Makiling Forest Reserve (MMFR), Philippines was examined. The composition and structural changes of the grassland under $A$. auriculiformis plantation over a 20-year and 28-year old study periods were analyzed. Results suggest a general trend of changes in A. auriculiformis plantation which was once a grassland dominated by Imperata cylindrica and Saccharum officinarum. Both stems $\left(\mathrm{ha}^{-1}\right)$ and basal area $\left(\mathrm{m}^{2} \mathrm{ha}^{-1}\right)$ increased significantly in 2010-2018. Increase in the 
dominance of native overstory trees coupled with a decrease in the dominance of exotic species was also observed. Lastly, results revealed an increase in species richness and species diversity with the presence of more native trees naturally occurring in MMFR (e.g., Pterocymbium tinctorium and Celtis luzonica). These are all attributed to ecological processes, including improved soil fertility and microclimate, disturbance, soil seed banks, seed flow of adjacent forests, seed dispersal, and mortality rate along with the $\mathrm{N}$-fixing ability of $A$. auriculiformis. This study, therefore, provides insights that $A$. auriculiformis plantation is potential for restoration of degraded lands in the Philippines. However, this may require in-depth ecological knowledge, silvicultural management practices, and continuous field-based monitoring studies to enhance understanding of the management aspect of a restored landscape.

\section{Floristic composition and diversity in a 50-year old Terminalia ivorensis (A. Chev) plantation in Sakponba Forest Reserve, Nigeria}

Ekeoba Matthew Isikhuemen ${ }^{1}$

${ }^{1}$ University of Benin, Benin City, Nigeria (ekeoba.isikhuemen@uniben.edu)

The paper evaluates composition, diversity and evenness of trees/shrubs in a 20 ha Black afara (Terminalia ivorensis A. Chev.) plantation established in Sakponba Forest Reserve, Nigeria in 1967. In 2016, all trees/shrubs $\geq 19$ diameter at breast height (dbh) were enumerated. Height was measured using a Range Finder while girth was measured at breast height $(1.3 \mathrm{~m})$ with Girthing tape. Data were analysed using biodiversity and Important Value (IV) indices. Overall, 2131 trees/shrubs distributed among 87 species, 80 genera and 36 families were recorded. T. ivorensis accounted for $7 \%$ of total trees (>19cm dbh) recorded at the site. Species rank abundance curve and IVI revealed that Funtumia elastica (Preuss) Stapf. was the most abundant and important species followed by $T$. ivorensis. The three most important families (based on IVI ranking) were Apocynaceae, Rubiaceae and Mimosodiae. Of the total stems ( $>60 \mathrm{~cm}$ dbh) recorded among 87 species, T. ivorensis accounted for 76\%; it also had the largest number of trees (75\%) that grew >30m height. The result of Shannon-Wiener's index was relatively high (3.2) while Shannon Wiener's and Pielou's evenness indices were 0.81 and 0.82 respectively. The study revealed that all the $T$. ivorensis trees (tropical rainforest pioneer) were matured and tending toward the degrading stage of tree growth cycle. Following the outcome of this study, wherein 86 naturally introduced species were enumerated at the study site, it is safe to conclude that the single species plantation established 50 years ago with Black afara has ultimately metamorphosed into a heterogeneous forest.

\section{On the competition for light and nutrients in mixed plantations of Eucalyptus and a high diversity of native tree species}

Nino Amazonas ${ }^{1}$, David Forrester ${ }^{2}$, Carina Silva ${ }^{1}$, Danilo Almeida ${ }^{1}$, Rafael Oliveira $^{3}$, Ricardo Rodrigues ${ }^{4}$, Pedro Brancalion $^{1}$

${ }^{1}$ University of São Paulo, “Luiz de Queiroz”' College of Agriculture, Forest Sciences Department, Tropical Silviculture Laboratory, Piracicaba, Brazil; ${ }^{2}$ Swiss Federal Institute for Forest, Snow and Landscape Research WSL, Birmensdorf, Switzerland; ${ }^{3}$ University of Campinas, Institute of Biology, Department of Botany, Campinas, Brazil; ${ }^{4}$ University of São Paulo, "Luiz de Queiroz” College of Agriculture, Biology Department, Forest Ecology and Restoration Laboratory,Piracicaba,Brazil(namazonas@gmail.com; david.forrester@wsl.ch; carina.camargosilva@gmail.com;daniloflorestas@gmail.com; rafaelsoliv@gmail.com; rrresalq@usp.br; pedrob@usp.br)

Mixed plantations composed of Eucalyptus intercropped with a high diversity of native trees are a promising option for combining wood production with biodiversity recovery in forest landscape restoration. Together with ecological advantages, mixtures provide economic benefit during the first years of forest restoration. We investigated facilitation by N-fixing native trees and competition for light and nutrients in three experimental sites in the Atlantic Forest of Brazil. We compared (1) monoculture plantations of Eucalyptus, (2) mixed restoration plantations (10 pioneer species and 30 non-pioneer species), and (3) mixed plantations with the same 30 non-pioneer species intercropped with Eucalyptus. We compared Intercepted Photosynthetically Active Radiation (IPAR) to investigate competition for light and leaf and wood nutrient concentrations to assess competition for nutrients and between Eucalyptus and native species. We also performed a tree-level analysis using neighborhood indices to investigate the facilitation effect mediated by $\mathrm{N}$-fixing native trees on the growth of Eucalyptus in mixtures. Contrary to our expectations, we found IPAR was higher in native tree plots, while the lower IPAR in Eucalyptus monoculture or mixed plots did not differ. So, native non-pioneers faced stronger competition for light from native pioneers than from Eucalyptus. Also, we found no differences in nutrient concentration in leaves and wood when we compared our treatments. Moreover, native N-fixers did not enhance the growth of Eucalyptus. Under the traditional silvicultural treatment, the growth differences were not explained by competition for light or nutrients.

\section{Nurse trees as a forest restoration tool for creating mixed, productive and native plantations}

\section{Magnus Löf}

${ }^{1}$ Swedish University of Agricultural Sciences, Alnarp, Sweden (magnus.lof@slu.se)

Two-storied mixed plantations can be designed to meet social, economic and environmental objectives during forest reforestation and restoration. In addition, the rapid re-establishment of forests for afforestation or following large disturbances is being seen as one option to increase the contribution of forests to climate change mitigation. The temporary inclusion of pioneer trees as nurse crops can facilitate the establishment of native tree species and may also improve biodiversity, productivity and soil fertility. However, there is little practical experience with the method. This study, from southern Scandinavia, reports how fast-growing nurse trees influence the ecological growing conditions, survival and growth in native target tree species, and in addition report results from different studies around the world concerning the influence of nurse tree species on the growth and performance of target tree species. Transgressive overyielding has been observed in several studies that measured productivity in North America, Scandinavia and elsewhere. Long-term experiments using nurse trees and both native and exotic shade tolerant target tree species are presently being established in southern Scandinavia. Even if productivity is increased, the more complex forests structures may be an obstacle for cost-effective management. However, for restoration practitioners, using nurse trees for rapidly building a new forest structure and simultaneously increase productivity, might be a cost-effective strategy for forest restoration.

\section{On the Restoration of Korean Fir (Abies koreana) Forests: the survival rates of reintroduced seedlings on in situ and ex situ}

Jaehoon Kim ${ }^{1}$, Byoungki Choi ${ }^{1}$, Kukman Song ${ }^{1}$

${ }^{1}$ Warm Temperate and Subtropical Forest Research Center, National Institute of Forest Science, Seoqwipo, Republic of Korea (jkim1922@korea.kr; vegetation01@korea.kr;kukman@korea.kr)

This study was carried out to verify the possibility of restoration of Korean fir forest by the reintroduction of sapling at in situ and ex situ; 460 of seedlings were planted in its natural habitat in 2017 and 2,300 of grafted saplings were planted out of its natural habitat in 2018 . The survival rate has been monitored. The relative survival rate gradually decreased from 82.2\% in August 2017, 87.6\% in October 2017, 84.0\% in May 2018, and 75.2\% in September 2018. The tendency for the death rate was increased especially during the transition from summer to autumn respectively. The relative survival rate of two ares (relatively 
open area and understorey area) was stable over time. The seasonal variation of the survival rate was considered to be a sensitive factor for summer climate change compared to winter season. Especially, long term drought in summer and typhoons accompanied by heavy rainfall tended to increase mortality rate in all types of restoration sites. The survival rate of saplings planted out of its natural habitat was $88.9 \%$. Especially in summer 2018 when summer drought and typhoon damage occurred, the survival rate was relatively high, and it was confirmed that it could be used for restoration of damages. Since the research monitoring period has not been long enough, complex interpretation of various factors for restoration is difficult. We will continue to monitor the survival rate of re-introduced seedlings and the possibility of restoration for the actual application

\title{
D1e: FOREST LANDSCAPE RESTORATION FOR CLIMATE CHANGE MITIGATION AND
} ADAPTATION: INTEGRATING RESEARCH INTO POLICY

\author{
African forest landscape restoration initiative: progress and challenges in implementation \\ Joseph Cobbinah ${ }^{1}$, Ernest Foli ${ }^{1}$ \\ ${ }^{1}$ CSIR-Forestry Research Institute of Ghana, Kumasi, Ghana (joe.cobbinah@ymail.com; efoli@hotmail.com)
}

African development is driven largely by natural resources. Unfortunately these resources are declining in quantity and quality. Only 20 percent of tropical Africa forests remains from previous high of 50 percent. FAO forest resources assessment estimated annual loss of 2.8 million hectares between 2010 and 2015 . The continued over-exploitation of forest resources coupled with poor public service resource management systems have led to forest degradation. There is therefore the urgent need to reverse the progressive decline of forest assets which is impacting negatively on the social, economic and environmental well-being of the African populace. The AFR 100 was launched in 2015 to bring 100 million hectares of degraded lands in Africa to restoration. As of mid-September 2018 , 27 countries had made restoration commitments totaling 96.4 million hectares. The initiative has potential not only for reversing the decline in forest assets but also ehancing carbon stocks and removal of GHG and resilience to forest and communities to climate variability and change. The paper will present country by country commitment, up to date progress in the implementation of commitment, and country specific challenges to guide planning and share knowledge and experiences in forest landscape interventions.

\author{
Improving rural livelihoods and contributing to climate change mitigation and adaptation through reforestation: examples from \\ Ghana \\ Reginald Tang Guuroh ${ }^{1,2}$, Ernest G. Foli ${ }^{1}$, Daniel A. Ofori ${ }^{1}$ \\ ${ }^{1}$ Council for Scientific and Industrial Research, Forestry Research Institute of Ghana, Kumasi, Ghana; ${ }^{2}$ University of Cologne, Range Ecology and Range \\ Management Group, Botanical Institute, Cologne,Germany(rguuroh@gmail.com; efoli@hotmail.com; dofori12@gmail.com)
}

Improving forest cover and avoiding deforestation are useful pathways for climate change mitigation and adaptation. Thus, the restoration of degraded lands is of major significance, and underpins African countries' commitment to restore 100 million hectares of degraded lands under the AFR100 initiative. We present examples of forest restoration efforts from the dry semi-deciduous and moist semi-deciduous zones of Ghana to share knowledge and experiences across the continent on successful restoration efforts that do not only have potential of climate change mitigation and adaptation but that also contribute to food security and livelihood improvement. The examples are drawn from two case studies involving public-private partnerships in forest landscape restoration. So far, approximately 3,205 hectares of plantation have been established under partnership between the Forestry Commission and Timber Industry, while under the Forest Investment Programme 24,925 hectares of native species have been established, involving about 159 forest fringe communities. These projects have provided direct jobs to over 1,000 local people and serve as regular source of income for livelihood support. Several tons of various stable food crops such as maize, plantain, beans are also produced yearly by farmers who have been given the opportunity to integrate food crops into these plantations. These outcomes provide evidence that there are possibilities for government agencies and the private sector to effectively collaborate with rural communities in a participatory manner to bring about successful interventions and that restoration initiatives could be planned to provide multiple benefits.

\section{A decade of adaptation to climate change in Southern and Eastern Africa, opportunities and challenges}

Felix Kalaba

${ }^{1}$ School of Natural Resources, Copperbelt University, P.O Box 21692, Kitwe, Zambia (kanungwe@gmail.com)

Development efforts targeted on poverty reduction, food security and sustainable environmental management are being threatened by climate change in subSaharan Africa. This is particularly true for southern and eastern Africa, which has seen an increase in incidences of negative environmental hazards such as extreme temperatures, droughts, and floods. The negative impacts of climate change in this region have increased in the past decades thus negatively affecting rural households who are highly dependent on forest and agriculture. Future climate change forecasts suggests that sub-Sahara Africa will continue to face negative impacts of climate change, and hence the need to develop national level adaptive strategies to help improve the adaptive capacity people especially in rural households. This paper explores current adaptation strategies, options and challenges to climate change in southern and Eastern Africa drawing on evidence from the United Nation's Framework Convention on Climate change (UNFCCC)'s National Adaptation Plans of Action (NAPAs). A content analysis of nine (9) NAPAs from southern and eastern African countries (Angola, Democratic Republic of Congo, Lesotho, Madagascar, Malawi, Mozambique, Tanzania, Uganda and Zambia) was conducted to understand national adaptation strategies proposed in different countries to adapt to climate change. Additionally, opportunities and challenges of implementation of adaptation strategies are discussed drawing on evidence from adaptation research conducted in southern and eastern Africa over the last decade.

\section{Managing the carbon dynamics of afromontane forests in northern Ethiopia}

Hubert Hasenauer ${ }^{1}$, Beyene Belay Alem ${ }^{2}$, Elisabeth Pötzelsberger ${ }^{1}$, Douglas L. Godbold ${ }^{1}$

${ }^{1}$ University of Natural Resources and Life Sciences, Vienna, Austria; ${ }^{2}$ Amhara Agricultural Research Institute, Bahir Dar, Ethiopia

(hubert.hasenauer@boku.ac.at; beyene.belay@yahoo.com; elisabeth.poetzelsberger@boku.ac.at; douglas.godbold@boku.ac.at)

The Ethiopian government is working on restoring degraded areas and set the forest sector as one pillar in the country's green economy strategy. The aim was to (i) identify potentially suitable reforestation areas in Amhara region, and (ii) predict the carbon sequestration potential and forest management impacts. We collected forest and soil data in four study areas located across the region and use a ecosystem model to predict the net primary productivity (NPP). Potentially 
suitable reforestation areas in the Amhara region were identified based on land use suitability, potential vegetation/elevation belt and aridity index. The carbon sequestration potential of identified area was predicted using the ecosystem model under different forest management scenarios: (i) unmanaged (ii) light thinning (thinning 1,5\%,20yr intervals) and (iii) heavy thinning (thinning 2, 10\%, 20yr intervals) and with different rotation periods (10,30,50 years). The inventory results of soil carbon ranged from 61 to $206 \mathrm{t} \mathrm{C} \mathrm{ha}^{-1}$, whereas the aboveground carbon ranged from 13 to $60 \mathrm{t} \mathrm{C} \mathrm{ha}^{-1}$. About $3.4 \mathrm{Mha}$ (Mha $=$ Million hectare) of land, including bare land (0.7 Mha), grass land (1.2 Mha) and shrub land (1.5 Mha) is suitable for reforestation in the Amhara region. Following the Normal Forest idea, and assuming that all identified areas are reforested in a 50 year rotation period, net carbon sequestration (soil and aboveground) could be up to 178 $\mathrm{Tg} \mathrm{C}$ (Teragram $=1012$ gram) in unmanaged, $168 \mathrm{Tg} \mathrm{C}$ in light thinned and $159 \mathrm{Tg} \mathrm{C}$ in heavy thinned forests.

\title{
Science-based continental and regional policy interventions will help to sustain productivity of African forests under changing climatic conditions and contain devastation by invasive insect tree pests and diseases
}

\author{
Mercy Gichora ${ }^{1}$, Harrison Kojwang ${ }^{2}$, Paul Bosu ${ }^{3}$, Alemu Gezahgne ${ }^{4}$, Mohamed Lahbib Ben Jamaa ${ }^{5}$ \\ ${ }^{1}$ Kenya Forestry Research Institute, Nairobi, Kenya; ${ }^{2}$ Hakon Consultants, Windhoek, Namibia; ${ }^{3}$ Forestry Research Institute of Ghana, Kumasi, Ghana; \\ ${ }^{4}$ Ethiopian Environment and Forest Research Institute, Addis Ababa, Ethiopia; ${ }^{5}$ National Research Institute for Rural Engineering, Water and Forestry \\ (INRGREF), University of Carthage,INRGREF,Tunis,Tunisia (mewagi05@yahoo.com; hokojwang@gmail.com; paulbosu@yahoo.com; \\ alemu.gezahgne@gmail.com; benjamaaml@gmail.com)
}

One of Africa's aspirations is to participate in global efforts for climate change mitigation that support and broaden the policy space for sustainable development on the continent. Africa also wishes to continue to speak with one voice and unity of purpose in advancing its position and interests on climate change. By 2063 , Africa's unique natural endowments, its environment and ecosystems, including its wildlife and wild lands will hopefully still be healthy, valued and protected, with climate resilient economies and communities. Natural forests are one such terrestrial ecosystem which on the contrary is rapidly diminishing as a result of land use conversions to meet diverse needs of an increasing human population. In its place, there has been wide promotion of exotic plantation forestry both on public and private land. The health status of the different forest types is examined closely in this study of forest pests and diseases in Africa. Based on case studies and literature review, plantation forests are found to be particularly vulnerable to biological invasions. The greatest concern remains the fragmented efforts by individual countries in tackling biological invasions by exotic species. Cross-boundary efforts are recommended in managing the spread of pest and disease infestations. African countries therefore require continental and regional policies to keep forests free of pests and diseases. Such policies will not only support sustainable forest management and climate change mitigation but also reverse forest degradation while catering for consumptive and non-consumptive needs of the continent.

\section{Phytoremediation using trees: a case study of native species in Zambia}

Emma Sandell Festin ${ }^{1}$, Carl Salk ${ }^{1}$, Mulualem Tigabu ${ }^{1}$, Stephen Syampungani ${ }^{2}$, Henrik Bohlenius $^{1}$, Per-Christer Odén ${ }^{1}$ ${ }^{1}$ Southern Swedish Forest Research Centre, Alnarp, Sweden; ${ }^{2}$ School of Natural Resources, Department of Plant and Environmental Sciences, Kitwe, Zambia (emma.sandell@slu.se; carl.salk@slu.se; mulualem.tigabu@slu.se; ssyampungani@yahoo.com; henrik.bohlenius@slu.se; per.christer.oden@slu.se)

Extensive areas around the world have soils polluted with heavy metals due to human activities and are in need of restoration. Tailing dams are sources of toxic dust particularly hazardous to human health through accumulation in the food chain. Natural regeneration or active restoration of vegetation is difficult due to soils' homogenous grain size, lack of nutrients and elevated levels of heavy metals. Phytostabilization is a new and cost-effective method using plants to stabilize or remove heavy metals from the soil. In this study, we conducted a greenhouse trial of five selected tree species commonly found in the natural forest ecosystem and on tailing dams in the Copperbelt region, Zambia: Albizia amara, Brachystegia bohemii, Cassia abbreviata, Combretum collinum and Senna singuena. They were raised from seeds and after four weeks, polluted with different concentrations of copper chloride to mimic the growing conditions on a tailing dam. The seedlings grew for 6 months and were then harvested to analyse the uptake of $\mathrm{Cu}$ in roots and above ground biomass. None of the tested species were accumulators as they all regulated their uptake. Based on a previous field trial, several of the species were found on both tailing dams and in the natural forest regulate their $\mathrm{Cu}$ uptake, making them into facultative metalophytes, or possibly even excluders. Restoration of degraded lands would be aided by field trials targeting species with these traits to identify suitable plants to accelerate the revegetation process.

\section{Effect of enclosures age on restoration of degraded woodlands surrounding Kakuma refugee camp, Turkana County, Kenya}

John Kigomo', Stephen Ndung' $u^{1}$, Eliud Macharia ${ }^{1}$

${ }^{1}$ Kenya Forestry Research Institute, NAIROBI, Kenya (kiggs2012@gmail.com; stephenmn06@gmail.com;eliud_waweru@yahoo.com)

The settlement of refugees from 1990s mainly in Kakuma and Dadaab in Kenya have degraded woodlands resource base due to high demand of wood products. Various government agencies and development partners in collaboration with local communities have been undertaking rehabilitation of degraded woodlands surrounding Kakuma refugee camp using enclosures. Despite all these efforts there is scanty information on the recruitment and succession process of vegetation within the intervention areas. Enclosures aged between 6 to 12 years were selected to determine the effects of enclosures age on natural regeneration in terms of structural characteristics, composition and diversity. Vegetation data was collected through laying systematic nested plots along diagonally established transect within the selected enclosures. The occurrence of woody vegetation increased progressively from $29 \%$ to $36 \%$. The mean height, diameter at $30 \mathrm{~cm}$ above ground, crown diameter and species diversity were significant different at different ages of enclosures $(p<0.05)$. The herbaceous species occurrences were higher in early years (33\%) then decreased to 29\% but increased to 37\% when the enclosures were 12 years. The mean cover and species diversity were not significantly different along enclosure ages $(\mathrm{p}>0.05)$. However, relative occurrences were significantly different along the enclosure ages $(\mathrm{p}<0.05)$. The study has demonstrated the impact of long term enclosures in recruitment of important trees and grass species. The increasing recruitment of woody vegetation and alternating occurrence of herbaceous species indicates the enclosures are yet to reach species climax levels. This study recommends continued protection and monitoring to achieve the goals of enclosures. 


\title{
Integrating bioenergy and food production on degraded landscapes in Indonesia for improved socio-economic and environmental outcomes
}

Syed Rahman ${ }^{1}$, Himlal Baral ${ }^{1}$

${ }^{1}$ Center for International Forestry Research (CIFOR), Bogor, Indonesia (sumonsociology@yahoo.com; h.baral@cgiar.org)

Growing bioenergy crops is a promising solution to meet the need for energy security, income security and land restoration. This paper assesses the socioeconomic and environmental benefits of agroforestry systems based on nyamplung (Calophyllum inophyllum L.) in the Wonogiri district of Central Java, Indonesia. Data was collected through field observations and focus group discussions (FGD) involving 20 farmers who intercrop nyamplung with maize, paddy and peanuts, and utilize the species in honey production. Calculating each crop's net present value (NPV) demonstrates that when grown as monocultures, staple crops paddy and peanuts lead to negative profitability, while maize generates only a marginal profit; yet honey production utilizing nyamplung produces a NPV nearly 300 times greater than maize. However, when utilizing nyamplung, honey is also the commodity most sensitive to decreases in production, followed by nyamplung-peanut and nyamplung-paddy combinations. While decreases in production have little effect on the NPVs of paddy, peanuts and maize, these annual crops can only be cultivated for a maximum of six years within the nyamplung's 35-year cycle, due to canopy closure after this time. Nyamplungbased agroforestry systems can provide economic, social and environmental gains on different scales. However, when considering the high profit potential of nyamplung combined with honey production, further research is needed to improve and develop bee husbandry practices so this becomes a viable option for local farmers.

\section{Study on the performance of forest tendging sbusidies in China}

Yukun Cao ${ }^{1}$, Hongge Zhu ${ }^{1}$, Xiangyue Liu ${ }^{1}$, Tianbo Wu ${ }^{1}$, Weiwei Jia ${ }^{1}$, Dan Zhou ${ }^{1}$

${ }^{1}$ Northeast Forestry University,Harbin,China (cyklk@163.com; honggebill@163.com; 1335759586@qq.com; 136433355@qq.com; jiaww2002@163.com; 1328262702@qq.com)

In order to protect natural forest resources, the Chinese Government has spent a lot of money on forest tending subsidies for the state-owned forests in Heilongjiang Province. In methodology, data collected by the sampling techniques from forest tending subsidy areas, and site inspections carried out at the various forest nurseries located at key state-owned forest region in the Heilongjiang province. Considering the aspects of ecology, economy and society, we used the methods of qualitative and quantitative analysis, which has calculated and compared the effects between the increment of ecological value and the amount of investments, and put forward relevant policies and suggestions. Conclusions: (1) From the ecological, social and economic perspectives, the paper analyzed the positive impact on the implementation of forest tending subsidy policy on the key state-owned forest regions in Heilongjiang province; (2) The degree of forest-laborers' participation in forest tending needs to be improved, but they are satisfied with the policy of forest tending subsidies; (3) The values of carbon fixation and oxygen release have increased, and the economic value of biodiversity assessed as 66.158 billion yuan, that is 152 times higher than investment of the same period.

\section{Diameter distribution of indigenous trees as possible criterion for indicating stable adapted species in semi-arid rangelands}

\section{Edward Mengich ${ }^{1}$, Joseph Macharia ${ }^{2}$, Ralph Mitloehner ${ }^{3}$, Daniel Too ${ }^{4}$, Gabriel Muturi ${ }^{5}$}

${ }^{1}$ Kenya Forestry Research Institute, Rift Valley Eco-region Research Programme, Londiani, Kenya; ${ }^{2}$ Department of Botany, Egerton University, Njoro, Kenya; ${ }^{3}$ Institute of Silviculture, Georg-August University, Goettingen, Germany; ${ }^{4}$ Department of Natural Resources, Egerton University, Njoro, Kenya; ${ }^{5}$ Kenya Forestry Research Institute Headquarters, Nairobi, Kenya(emengich3@hotmail.com; jmmacharia@egerto.ac.ke; rmitloe@gwdg.de; dktoo@egerton.ac.ke; gabrielmukuria2012@gmail.com)

Declining woody vegetation and climate change are major drawbacks to livelihoods in semi-arid rangelands. Efforts to reverse their impacts through tree planting have been slow due to poor selection criteria for adapted species. This study assessed diameter distributions of indigenous trees as possible criteria for indicating adapted species in these areas. Study sites were identified at Nthangu, Kathonzweni and Kibwezi forests of Makueni County, Kenya using existing vegetation, agro-climatic maps and Landsat Images. The sites have mean annual rainfalls of 974 mm, 700 mm and 616 mm, respectively, and moisture indices of $49 \%$, 35\% and 32\%. Data were collected by establishing $2500 \mathrm{~m}^{2}$ sample plots and assessing tree diameters at breast height (DBH) and DBH distributions. Shapiro-Wilk test was applied on species that occurred in two of the sites to determine normality of their DBH distributions. T-tests were conducted to determine if mean DBHs differed significantly. Statistically significant differences were declared at $\mathrm{p}<0.05$. Mean DBH was higher at both Kibwezi ( $7.6 \mathrm{~cm})$ and Kathonzweni $(6.4 \mathrm{~cm})$ than at Nthangu $(4.6 \mathrm{~cm})$. Most ecologically important trees were characterized by high populations of juvenile individuals and near-perfect inverted J-shaped distributions. This indicated regenerating, sustainable and stable populations that were adapted to respective sites. Indigenous trees adapted to Nthangu were Searsia spp., A. hockii and Diospyrus mespiliformis. At Kathonzweni, they were C. collinum, C. apiculatum and A. tortilis. At Kibwezi, they were A. tortilis, A. mellifera and C. Africana. These were candidates for enrichment planting to rapidly rehabilitate degraded sections of these sites.

\section{D1f: AGROFORESTRY FOR ECOSYSTEM SERVICES}

\author{
Assessment of indicators of ecosystem services across a gradient of land uses in Southern Brazil \\ Lucilia Maria Parron", Junior Ruiz Garcia ${ }^{2}$, Nerilde Favaretto ${ }^{2}$, Claudia Maria Branco de Freitas Maia ${ }^{1}$, George Gardner Brown ${ }^{1}$, Denise Jeton Cardoso ${ }^{1}$, \\ Vanderley Porfirio-da-Silva ${ }^{1}$ \\ ${ }^{1}$ Embrapa Florestas, Colombo, Brazil; 2Universidade Federal do Paraná, Curitiba, Brazil (lucilia.parron@embrapa.br; jrgarcia1989@gmail.com; \\ nfavaretto@gmail.com; claudia.maia@embrapa.br; george.brown@embrapa.br; denise.cardoso@embrapa.br; vanderley.porfirio@embrapa.br)
}

Ecosystem services (ES) are the benefits people obtain from ecosystems. The conversion of forests to production systems can have large effects on ES delivery. The aim was to assess how agricultural systems can be managed to maximize the supporting, regulating and provision of ES across of land uses and soil management in Campos Gerais, Southern Brazil. We used a set of indicators to assess the strength of ES delivery: soil organic carbon (SOC) and nitrogen ( $\mathrm{SON}$ ) stocks, nitrous oxide emissions and methane oxidation, aboveground carbon stocks, nitrate, ammonium and phosphorus leaching, water infiltration and drainage, diversity of soil fauna, grain, pastures and timber yields. We compared ES from the Native Forest (NF), Eucalyptus Plantation (EP) and systems which employed no-tillage soil management: No-Tillage (NT), Crop-Livestock only (CL) and Agroforestry Crop-Livestock-Tree (CLT). Among the land uses, NF presented greater complexity and the delivery of ES. EP was the second at SOC stocks, water infiltration and soil fauna richness. CLT and CL provided more ES than NT. Shadow of the trees in CLT promotes the well-being to the livestock, however it difficults the recovery of the damages caused by grazing and trampling. 
Trees in CLT reduce soil erosion, increase soil quality and C sequestration. Agricultural residues provide biomass for land recovery in NT, CL and CLT, but they do not improve the stability of aggregates and the retention of water into soil. CLT as part of multifunctional landscape can be a viable agroforestry land use option that, in addition to providing food security, it offers a number of ES.

\section{Changes in ecosystem carbon stocks from the conversion of disturbed forest to oil palm plantation in the Peruvian Amazon}

Natalia Málaga Durán ${ }^{1,2}$, Hergoualc'h Kristell ${ }^{1}$

${ }^{1}$ CIFOR, Lima, Peru; ${ }^{2}$ TU Dresden,Dresden, Germany (natalia.malaga.duran@gmail.com; k.hergoualch@cgiar.org)

Land use, land use change and forestry in Peru is the main contributing sector to national GHG emissions (51\%). While Peru has pledged to reduce GHG emissions, oil palm plantations are currently under expansion in the Amazon at the risk of forest conversion. The study aimed to characterize the structure and composition of remnant disturbed forests adjacent to oil palm plantations in the Peruvian Amazon, to determine the carbon stock change from such transition. The research was based on full inventories performed in four disturbed forest and six oil palm stands. The latter ones using a space-for-time substitution approach (stand ages 1,4,7,15,23, 28) to assess the carbon stock change over a rotation period. All carbon pools were measured and compared over the land use transition. Previous forest practices linked to logging activities showed a negative effect in composition and structural parameters of the forest, e.g. the mean basal area was 22 (SE 1.4) $\mathrm{m}^{2}$ ha -1. Overall, converting disturbed forests to oil palm plantations resulted in a carbon debt scenario; the carbon stock changed from 140.7 (SE 5.8) $\mathrm{Mg} \mathrm{C} \mathrm{ha}^{-1}$ in forests to a time-averaged carbon stock of 74.3 (SE 2.2) $\mathrm{Mg} \mathrm{C} \mathrm{ha}^{-1}$ in oil palm plantations. Above ground carbon was the main contributing pool; followed by soil organic carbon and necromass. This research contributes to the sustainable management of forest landscapes under a climate smart strategy, as it concludes, in terms of carbon footprint, that disturbed forests should be excluded from the conversion to oil palm production.

\section{Collective construction of multifunctional landscapes / Construção coletiva de paisagens multifuncionais}

Mariella Camardelli Uzêda ${ }^{1}$, Elaine Fidalgo ${ }^{2}$, Julian Wilmer ${ }^{3}$, Rodrigo Alves ${ }^{4}$

${ }^{1}$ Embrapa Agrobiologia, Seropédica, Brasil; ${ }^{2}$ Embrapa Solos, Rio de Janeiro, Brasil; ${ }^{3}$ Universidade Federal do Rio de Janeiro, Rio Janeiro, Brasil;

${ }^{4}$ Universidade Federal do Paraná, Curitiba,_Brasil (mariella.uzeda@embrapa.br; elaine.fidalgo@embrapa.br; julian_willmer@hotmail.com;

rodrigo@zhouse.com.br)

Na escala da paisagem, a agrobiodiversidade é responsável por inúmeros serviços ecossistêmicos como a qualidade da água, a polinização e o controle de pragas. A intensificação ecológica consiste em manter a produção agrícola, conservando a agrobiodiversidade, usufruindo dos serviços ecossistêmicos. O processo de condução da investigação está amparado em métodos participativos de pesquisa, iniciados há 10 anos na Bacia Hidrográfica do rio Guapi-Macacu (Rio de Janeiro), junto ao assentamento São José da Boa Morte. Os resultados representam um importante conhecimento sobre espécies arbóreas e práticas de manejo adaptativo, voltados a: 1 . Projetar e testar sistemas agrícolas resilientes baseados na biodiversidade local; 2 . Aumentar a segurança alimentar, resgatando cardápios tradicionais baseados em recursos locais; 3. Estudar os serviços ambientais de intensificação ecológica avaliando o papel do elemento arbóreo para a presença de agentes de controle biológico e polinizadores (abelhas, vespas e aves). Os resultados deste trabalho representam uma importante contribuição no processo de adequação dos sistemas produtivos as mudanças climáticas e conservação da biodiversidade, principalmente no sentido de tornar a biodiversidade um recurso concreto do ponto de vista da unidade produtiva e para a soberania alimentar das famílias agricultoras, além de permitir aos produtores maior autonomia na seleção de tecnologias que melhor atendam às necessidades locais, a fim de colaborar com o processo de recuperação da resiliência de paisagens degradadas.

\section{Ungulates affect ecosystem functioning and mediate biodiversity and ecosystem services in Mediterranean oak woodlands}

Miguel Nuno Bugalho ${ }^{1}$, Xavier Lecomte ${ }^{2}$, Maria Conceição Caldeira ${ }^{2}$

${ }^{1}$ Centre for Applied Ecology, School of Agriculture, University of Lisbon, Lisbon, Portugal; ${ }^{2}$ Forest Research Centre, School of Agriculture, University of

Lisbon,Lisbon, Portugal(migbugalho@isa.ulisboa.pt; xlecomte@isa.ulisboa.pt;

mcaldeira@isa.ulisboa.pt)

Ungulate herbivores are rapidly expanding across their geographical areas of distribution. By consuming vegetation, ungulate herbivores reduce plant biomass, change plant species composition and may negatively affect regeneration of tree species. Through effects on vegetation, therefore, ungulate herbivores affect ecosystem functioning and mediate trade-offs between biodiversity and ecosystem services. Here, we describe a long-term (over 14 years) browsing and grazing exclusion experiment to assess how a wild ungulate (red deer Cervus elaphus and fallow deer Dama dama) population affected trade-offs among plant diversity, ecosystem functioning and ecosystem services of a Mediterranean oak woodland of Southern Portugal. Deer halted shrub encroachment into the ecosystem and, through reduction of the competitive shrub cover, increased the diversity of the grassland understory. Through changes in plant species composition deer also led to increased soil moisture and temperature which accelerated rates of litter decomposition and nutrient cycling. Additionally, by reducing shrub cover, deer decreased the aboveground vegetation carbon stocks but also the probability of severe wildfires. This may ultimately enhance adult oak survival and indirectly benefit long-term ecosystem carbon storage. Biodiversity and ecosystem services trade-offs need to be considered when considering ecosystem management, including decisions related with ungulate ecology and management.

\section{Forest gardens increase the resilience of farming enterprises}

Kamal Melvani ${ }^{1,2}$

${ }^{1}$ Neo Synthesis Research Centre, Polgasowita, Sri Lanka; ${ }^{2}$ Charles Darwin University, Darwin, Australia (neosynth@sltnet.lk)

Traditional farming enterprises challenged by increased climate variability stay resilient because they are tree-dominated, and farmers have acquired skills in adaptive land management from ancestors or local experience. Although farming enterprises are well studied, land management practices and landscape patterns underlying their adaptive capacity are less explored. Using mixed methods, this study investigated 85 farming enterprises across nine locations of Sri Lanka's Intermediate zone to understand which land use contributes to their adaptive capacity and best fulfills household needs. Farming enterprises incorporate On- and Off-farm components. On-farm comprises land uses including forest gardens (FGs), paddy, cash crops, swidden plots, plantations and livestock. Off-farm mainly involves employment. Locations were investigated by their socioeconomic determinants, water availability and rainfall variability, and land uses characterised and compared by area, age, tenure, agrobiodiversity and utility benefits. Results revealed that most farmers were female and had primary 
education. Off-farm engagement was minimal. Farming enterprises were predominantly rainfed and farmers' perceptions of rainfall variability substantiated by meteorological data. Interannual and seasonal rainfall variability prevailed in the reference and preceding years. Forest gardens were the oldest land use, had the greatest area, highest plant and crop species richness, crop diversity, numbers of primary and secondary crops, and products. They provided several benefits to households and their tree-dominance ensured strong adaptive capacity. However, farmers adopted multiple land uses with diverse landscape designs because this offered greater opportunities, buffered risk and fostered resilient farming enterprises. Policy-makers must engage farmers when planning for resilient farming enterprises in a changing climate.

\title{
Horizontal distribution of the soybean yield in integrated crop-livestock-forest system in the north of Mato Grosso, Brazil
}

Maurel Behling', Géssica de Carvalho', Andre Luiz de Souza², Diego Camargo ${ }^{3}$, Jonas Fallgatter ${ }^{3}$

${ }^{1}$ Embrapa Agrossilvipastoril, Sinop, Brasil, ${ }^{2}$ Mestrado em Agronomia, PPGA, Universidade Federal do Mato Grosso/Sinop-MT, Sinop, Brasil, ${ }^{3}$ Universidade Federal de Mato Grosso, Sinop, Brasil (maurel.behling@embrapa.br; gessikaengflorestal@gmail.com; andre_itauba@hotmail.com; camargo.die@gmail.com;j.fallgatter@hotmail.com)

The integrated crop-livestock-forest system can enhance the overall production, especially of soybeans, and economics of farming in regions characterized by warm climate. The aim of this study was to evaluate whether strip of trees in the integrated crop-livestock-forest systems (ICLF) change the horizontal distribution of the soybean yield and reduces the production by area four years after the establishment of eucalyptus, in the north region of Mato Grosso State, Brazil. The experiment was conducted at Sinop/MT, evaluating the following treatments: 1) crop with soybean during the main season and maize intercropped with Brachiaria brizantha during the second season and 2) Crop-livestock-forest system with triple rows (3.5 m x $3.0 \mathrm{~m}$ ) of eucalyptus, spacing of $30 \mathrm{~m}$ and east-west orientation, annually cultivated with soybean crop (main season) and maize intercropped with $B$. brizantha (second season). The experimental design was in randomized blocks with four replicates. In the production systems with trees, evaluations were carried out in four equidistant transects, at 3, 6 , 10 and $15 \mathrm{~m}$ from the rows on the northern and southern sides. Significant differences were verified in the agronomic characteristics of soybean, difference in productivity was verified comparing the exclusive and integrated systems. The tree component affect the soybean yield by area in the fourth year of the system implementation. The interference of eucalyptus reduced the soybean grain yield by $20.0 \%$ and the effect was stronger close to the tree rows.

\section{D1G: CLOSE-TO-NATURE SILVICULTURE: FOR PEOPLE, PRODUCTS AND NATURAL} PROCESSES

\section{Legacies of previous disturbances structure contemporary forests}

\author{
John Stanturf ${ }^{1}$ Kalev Jogiste ${ }^{1}$, Lee Frelich ${ }^{2}$, Marek Metslaid ${ }^{1}$, Ahto Kangur ${ }^{1}$, Palle Madsen ${ }^{3}$ \\ ${ }^{1}$ Estonian University of Life Sciences, Tartu, Estonia; ${ }^{2}$ University of Minnesota, St. Paul, USA; ${ }^{3}$ InNovaSilva, Vejle, Denmark(drdirt48@gmail.com; kalev. \\ jogiste@emu.ee; freli001@umn.edu; marek.metslaid@emu.ee; ahto.kangur@emu.ee; pallemadsen47@gmail.com)
}

\begin{abstract}
Alternative forest management approaches seek to emulate natural disturbance regimes and produce more diverse forest structure and composition with lesser emphasis on traditional timber objectives. These alternative management paradigms, including continuous cover forestry, biodiversity restoration, and close-to-nature forestry, all emphasize "natural" conditions, including natural disturbance regimes. Although they may differ in their approach to managing complexity and defining what is "natural", they all recognize that ecosystems are dynamic and that persistent effects of previous disturbances play a significant role in structuring ecosystems. Ecosystem legacies, remnants of previous conditions persisting after disturbances, collectively comprise ecosystem memory. Ecosystem memory in turn contributes to resilience and possibilities of ecosystem reorganization following further disturbance. Overlapping legacy concepts (disturbance, biological, soil, land-use, and silvicultural) are subsumed in the new terms "material legacy" (individuals or matter, e.g., survivors, coarse woody debris, nutrients left after disturbance) and "information legacy" (adaptations to historical disturbance regimes). The resulting six legacy types (above- and belowground, biotic and abiotic material legacies and above- and belowground information legacies) are influenced by differential patterns of editing and conditioning by "legacy syndromes" that result from natural or human-manipulated disturbance regimes. These legacy syndromes in turn influence forest response to management actions and constrain resilience, leading to a mosaic of natural, manipulated, and artificial (novel) ecosystems across the landscape. The condition of forest ecosystems depends on the temporal and spatial pattern of natural and anthropogenic disturbances and the legacies that are produced and persist.
\end{abstract}

\section{Close to nature forest management for multiple purposes: an option for China}

\section{Shuirong Wu ${ }^{1}$, Heinrich Spiecker}

${ }^{1}$ Chinese Academy of Forestry, Beijing, China, ${ }^{2}$ University of Freiburg, Freiburg, Germany (shuirongwu@126.com;instww@iww.uni-freiburg.de)

The ecological, economic and social benefits of forestry are of high importance worldwide. After a heavy decline in forest area up to the 1950s, the Chinese government has implemented ambitious afforestation plans, initially mainly to counteract environmental consequences of deforestation like floods and landslides. During the last four decades, China's forest area increased from $12 \%$ to $22 \%$. In response to climate change, China planned to increase another 40 million ha by 2020 and 4.5 billion $\mathrm{m}^{3}$ more by 2030 from the 2005 level. However, many of the Chinese forests are of low vitality and low productivity. On the other hand, China's fast growing economy requires additional resources especially renewable resources such as wood. Furthermore, forest environmental services are gaining more and more importance. The huge demand on timber and the increase in protected forest area at the same time result in a severe shortage of wood. Highly productive and healthy forests are needed which provide not only wood and non-wood forest products but also urgently needed ecosystem services. A strategic transition in China's forest management is needed, with a shifting emphasis from area expansion to stand productivity and quality enhancement, from overwhelming timber production to multipurpose management for various forest goods and services, and from monoculture plantations to biodiversity rich mixed forests. Based on an overall view of the challenges of China's forests and the alternative management options, this paper presents case studies and suggestions on close to nature forest management for China. 


\title{
Introducing complexity through silviculture: transforming plantations one step at a time
}

\author{
Robert Schneider ${ }^{1}$,Luc Sirois, Laurie Dupont-Leduc ${ }^{1}$,Emmanuel Duchateau ${ }^{1}$, Tony Franceschini ${ }^{1}$ \\ ${ }^{1}$ UniversitéduQuébec à Rimouski, Rimouski,Canada (robert_schneider@uqar.ca; luc_sirois@uqar.ca;laurie.dupont-leduc@uqar.ca; \\ emmanuel.duchateau.1@ulaval.ca; tony.franceschini@uqar.ca)
}

The province of Quebec, in Eastern Canada, has implemented ecosystem-based forest management practices that obliges managers to emulate natural stands in managed forests. These guidelines must also be applied to intensively managed plantations. New silvicultural practices such as thinning by elite tree release have been proposed to achieve both wood production and ecological services goals. Early results from silvicultural trials have shown that differences in wood production between elite tree, thinning from below and control plots are very small at the stand level. Trees released by elite tree thinning have however higher increment rates as the competition is less important. Even though there are differential tree growth rates, combined with different harvesting patterns, the changes in stand structure remain very small. Using simulation results, thinning patterns alone do not greatly influence stand structure. The use of gaps must also be considered in order to significantly change the spatial structure of the stands. Gaps, however, come at a cost, whereby stand production is decreased proportionally to the size of the gaps. Prior to deciding which path to follow, more information is needed on the stand structure of old, unmanaged stands. An ongoing study of old, unmanaged stands will enable managers to set their ecological goals. Simulation tools can then be used for a first estimate of stand productivity trajectories.

\section{A retention forestry experiment in a planted conifer forest in Hokkaido, Japan: initial responses of understory plants to harvesting}

\author{
Nobuhiro Akashi ${ }^{1}$, Yasuyuki Ohno ${ }^{1}$,Noritoshi Nitta ${ }^{1}$
}

${ }^{1}$ Hokkaido Research Organization, Forestry Research Institute, Hokkaido, Japan (akashi-nobuhiro@hro.or.jp;ohno-yasuyuki@hro.or.jp; nitta-noritoshi@hro.or.jp)

The montane region of Hokkaido, northern Japan, was once dominated by mixed deciduous broadleaf and evergreen conifer forests. Timber has been harvested selectively since the 19th century, although natural regeneration was often difficult because dwarf bamboo (Sasa spp.) prevented seedling establishment. During the late 20th century, Abies sachalinensis, a native conifer species, and Larix kaempferi, an introduced conifer species, were planted after massive clear-cutting. Most timber is now produced from planted forests. Recently, maintaining biodiversity has become a requirement in planted forests. In this context, the Retention Experiment for Plantation Forestry in Sorachi, Hokkaido (REFRESH) was launched in 2013, with an A. sachalinensis forest plantation. We surveyed understory plants at REFRESH before and after harvesting to evaluate the effectiveness of retention forestry. In dispersed retention sites, naturally regenerated broadleaf trees were retained. Each aggregated retention site included a 0.36-ha intact patch. The understories of broadleaf stands were commonly covered with Sasa spp., and species richness was low. In contrast, closed conifer canopies eliminated Sasa and provided varying habitats for understory plants, depending on disturbance by forestry operations. After harvesting, both clear-cut and dispersed retention sites were dominated by disturbance-dependent herbaceous species. Species composition was not altered within retention patches at aggregated retention sites; however, most of the trees retained in one of three retention patches had become windfall within a few years of harvesting. Therefore, planted $A$. sachalinensis forests with retained broadleaf trees may provide various habitats for native plant species, although intact patches are necessary to maintain understory plants

\section{Rodent-mediated seed dispersal of Juglans mandshurica regulated by gap size and position in larch plantations: implication for converting pure larch plantations into mixed larch-broadleaf forests}

Qiaoling Yan ${ }^{1}$, Jing Wang ${ }^{1}$, Jiaojun Zhu', Jinxin Zhang

${ }^{1}$ CAS Key Laboratory of Forest Ecology and Management, Qingyuan Forest CERN, Institute of Applied Ecology, Chinese Academy of Sciences, Shenyang, China(qlyan@iae.ac.cn; yanqiaoling1978@126.com; jiaojunzhu@iae.ac.cn;zhangjinxin@iae.ac.cn)

Larch (Larix spp.) is extensively planted after clear-cut of secondary forests in Northeast China to satisfy enormous timber demands. However, some serious problems in larch plantations (LPs) (e.g., soil fertility decline, acidification of surface runoff) become prominent due to mono-species composition. Converting pure LPs into mixed larch-walnut forests would solve these issues. Rodent-mediated seed dispersal of walnut (Juglans mandshurica) determines the regeneration success (or not) and is closely related with stand structure. Forest gap is an uneven thinning by changing stand structure in plantation management, and rodentmediated seed dispersal of photophilous walnut may be changed with two key characteristics of gaps (i.e., gap size and within-gap position). The field trial was carried by releasing tagged seeds of walnut in artificial gaps of LPs with two sizes and at four positions of gap edges during two continuous years. Our results showed that gap size significantly affected the seed removal rates, i.e., the rate in medium gaps (2.05 grains/day) was faster than in small gaps (1.81 grains/day). The interannual variation of seed production changed the rodents behavior and seed dispersal process, and caused faster removal rate (2.86 grains/day) with numerous dispersal quantity (43.27\%) and shorter dispersal distance (7.84 m) in the non-mast year (2015). Besides, 7.00\% of J. mandshurica seeds was cached in the canopy gaps by rodents. It can be concluded that creating gaps with bigger size in LPs is a feasible practice of converting LPs into mixed larch-broadleaf forests by promoting the rodent-mediated seed dispersal of walnut.

The need for new approaches to managing native forests in central-Southern Chile: a proposal from forest degradation / Necesidad de nuevos enfoques para el manejo de bosques nativos del centro-sur de Chile: una propuesta a partir de la degradación forestal

\author{
Bastienne Schlegel ${ }^{1}$, Christian Little ${ }^{1}$, Gerardo Vergara ${ }^{1}$, Carlos Bahamondez ${ }^{1}$ \\ 1Instituto Forestal (INFOR),Valdivia,Chile (bschlegel@infor.cl; clittle@infor.cl; gvergara@infor.cl; cbahamon@infor.cl)
}

Los bosques templados del centro sur de Chile han sido clasificados como de importancia mundial dado su estado de conservación y endemismo; y valorados positivamente por rol en la regulación de funciones ecológicas y oferta de bienes y servicios. Sin embargo, la historia de uso de estos bosques, asociada a procesos de deforestación y degradación, han cambiado el paradigma respecto a su destino, observándose estrategias divergentes -públicas y privadaspara su conservación y manejo en el mediano y largo plazo. La presencia de bosques en sitios de buena calidad, como aquellos dominados por especies del género Nothofagus, permite proyectar algunas estrategias de manejo como sistemas productivos multifuncionales que cumplen un importante rol social, como por ejemplo la producción de madera. Sin embargo, cabe preguntarse si los actuales métodos de corta y regeneración permitidos por el Estado para obtener productos del bosque, son los más adecuados para cumplir con este objetivo y asegurar la sostenibilidad de las intervenciones. A través de un enfoque metodológico basado en una definición clara del concepto degradación forestal y una evaluación de los resultados de planes de manejo forestal, discutiremos si los actuales tratamientos silviculturales aplicados en bosques nativos son los más efectivos para asegurar el proceso de regeneración. Concluiremos respecto a la necesidad de modificar las alternativas de manejo silvícolas basadas en el entendimiento de la dinámica forestal, el control de las amenazas que afectan la composición y estructura de los bosques, y las múltiples funciones que éstos proveen para el bienestar social. 


\title{
Biodiversity benefits with uneven-aged silviculture
}

Joakim Hjältén ${ }^{1}$, Klara Joelsson ${ }^{1}$, Therese Löfroth ${ }^{1}$, Jean-Michel Roberge ${ }^{1}$, Timothy Work ${ }^{2}$, Heloise Gibb ${ }^{3}$

${ }^{1}$ Department of Wildlife, Fish and Environmental Studies, Swedish University of Agricultural Sciences, Umeå, Sweden; ${ }^{2}$ Département des sciences

biologiques, Université du Québec à Montréal, Quebec, Canada; ${ }^{3}$ Department of Zoology, La Trobe University, Melbourne, Australia (joakim.hjalten@slu.se; klara.joelsson@sodra.com; therese.lofroth@slu.se;jean-michel.roberge@skogsstyrelsen.se; work.timothy@uqam.ca; h.gibb@latrobe.edu.au)

Large scale use of even-aged silviculture (clear-cutting) commencing in the mid-20th century has had negative impacts on forest biodiversity. As a consequence, uneven-aged silviculture, involving selective removal of some older trees in a stand which mimics natural small scale stand dynamics and thus potentially benefit species associated with old forests, is currently being considered to help meet the ecological and social criteria required for sustainable forest management. We used a large-scale chronosequence study spanning 50 years to study beetle diversity in uneven-aged silviculture compared with both short-term impacts and the longer-term legacy of even-aged silviculture. We compared: (1) even-aged recently clear-felled stand, (2) even-aged recently thinned stand, (3) uneven-aged stands subjected to selective felling with (4) uneven-aged reference stands to assess how abundance, species richness and composition of beetles were affected by even-aged and uneven-aged management. Both even-aged silviculture treatments (clear-felling and thinning) had different beetle composition compared to the reference stands, indicating that assemblages had yet to recover even 50 years into the rotation. However, beetle composition did not differ between uneven-aged managed and thinned stands. The result supports our prediction that uneven-aged silviculture better maintains beetles assemblages associated with semi-natural mature forest than even-aged silviculture. The greater temporal continuity in selectively felled stands could benefit species dependent of mature or old growth forest since some of the needed habitat qualities are continuously available. Uneven-aged silviculture could therefore serve as an important tool for landscape planning to benefit biodiversity and thus help fulfil environmental commitments.

\section{Microsite availability and planted black spruce growth responses to disturbance by mechanical site preparation in Canadian paludified forests \\ Mohammed Henneb ${ }^{1,2}$, Osvaldo Valeria ${ }^{1,2}$, Nelson Thiffault ${ }^{3}$, Nicole Fenton ${ }^{1,2}$, Yves Bergeron ${ }^{1,2}$ \\ ${ }^{1}$ Université du Québec en Abitibi-Témiscamingue, Rouyn-Noranda, Canada; ${ }^{2}$ Institut de Recherche sur les Forêts (IRF), Rouyn-Noranda, Canada; ${ }^{3}$ The Canadian Forest Service (CFS), Quebec, Canada (mohammed.henneb@uqat.ca; osvaldo.valeria@uqat.ca; nelson.thiffault@canada.ca; nicole.fenton@uqat.ca; yves.bergeron@uqat.ca)}

Eastern Canadian boreal ecosystems dominated by black spruce (Picea mariana (Mill.) B.S.P.) have a high potential for fibre production. Some sites are, however, characterized by a low productivity due to paludification; a natural process by which organic layer thickness (OLT) increases on clay soils over time. Paludification leads to a decline in growth and regeneration due to the poor quality of microsites, which offer low nutrient availability and low temperatures. Little information is available on the potential of silviculture to restore productivity of paludified sites. In this context, our objectives were to 1) evaluate the effects of disturbances generated by three silvicultural treatments (partial harvest, disk trenching scarification and plowing) on the availability of microsites and their impacts on planted black spruce seedlings growth; and 2) determine treatment effects on Sphagnum and ericaceous shrub recovery and growth. Our results show that microsites availability and short-term seedlings growth were influenced by post-harvest OLT and silvicultural treatments. Plowing was most effective in low-moderate paludified areas (post-harvest OLT $\leq 45 \mathrm{~cm}$ ), whereas scarification performed best in highly paludified areas (post- harvest OLT $>45 \mathrm{~cm}$ ) Seedlings growth was also influenced by planting quality and microtopography. Sphagnum and ericaceous shrub recovery varied according to treatments. Our results will provide a better understanding of the conditions for successful regeneration establishment in paludified forests, hence supporting the restoration of site productivity.

\section{D1p: DISTURBANCE, ECOSYSTEM MEMORY, RISK AND FOREST MANAGEMENT IN A} CHANGING SOCIO-ECOLOGICAL ENVIRONMIENT's

\section{Lifecycle management techniques for large timber of Larix principis-rupprechtii Mayr plantations}

\author{
Xianzhao Liu', Xuanrui Huang', Zhidong Zhang', Wenbin Han ${ }^{3}$, Ruidong Gao ${ }^{3}$ \\ ${ }^{1}$ Institute of Forest Resource Information Techniques, Chinese Academy of Forestry, Beijing, China; ${ }^{2}$ College of Forestry, Agricultural University of Hebei, \\ Baoding, China; ${ }^{3}$ Guancen mountain State-owned Forest Administration, Shanxi Province, Ningwu, China (lxz9179@163.com; hxr1962@163.com; \\ 877703546@qq.com; 596080552@qq.com; 497386874@qq.com)
}

Larix principis-rupprechtii Mayr, a fast-growing planted tree, is one of the main tree species for timber supply in China. As a native species, Larix principisrupprechtii Mayr has been widely planted in north of China due to its high quality timber (i.e., straight shape, and decay resistant wood). However, the highquality large-size timbers of Larix principis-rupprechtii Mayr are still rare and demanded for industry development. Reviewing the theories of multi-function forestry and close-to-natural forestry, we proposed a technical system of lifecycle silviculture, including: (1) theory and principle of large timber management; (2) indexes system of management technology; (3) management planning and operation designing; (4) silvicultural systems; (5) standardization of operation measures. The proposed technique system generally formed from theory, index, technologies, processes, and measures to the demonstration case of integrated large timber management technology system, will be helpful for large size timber supply of Larix principis-rupprechtii Mayr.

\section{Rare, endemic and endangered tree species in secondary forest fragment in the Atlantic Forest, Brazil}

Jônio P. Caliman ${ }^{1}$, Maria G. F. Reis ${ }^{1}$ Geraldo G. Reis $^{1}$, Filipe V. P. Cacau ${ }^{1}$, Thales G. V. Martins ${ }^{1}$, Lydiane L. S. Bastos ${ }^{1}$

${ }^{1}$ Universidade Federal de Viçosa, Departamento de Engenharia Florestal, Viçosa, MG, Brasil (jpcaliman@gmail.com; mgfreis@ufv.br; greisufv@gmail.com; filipecacau@gmail.com; thales.eng:florestal@gmail.com; lbastos@ufv.br)

The Atlantic Forest, in Brazil, a world biodiversity hotspot, was highly degraded and, nowadays the remaining fragments are mostly of medium and small size. Many tree species from this biome are considered rare, endemic and, or at risk of extinction. A floristic study of natural regeneration (greater than $10 \mathrm{~cm}$ height and smaller than $5 \mathrm{~cm}$ diameter) and adult trees (greater than $5 \mathrm{~cm}$ diameter) was undertaken in ten sites in a secondary forest fragment. It was sampled 5,601 individuals of 51 families, 128 genus and 226 species. There were 26 rare species (with only one individual in the inventory) being one endemic (Guatteria australis) and one at risk of extinction (Melanoxylon brauna). Half of the rare species was sampled only as adult trees. Eight species are endemic of this biome, being four sampled at both natural regeneration and adult trees. From six species that are in the list of species at risk of extinction, three (Dalbergia nigra. 
Euterpe edulis and Ocotea odorifera) were sampled in more than $50 \%$ of the sites studied in this fragment. Knowing the ecology of these species helps planning actions related to conservation of specific forest fragments and, or their inclusion in degraded land recovery projects (Supported by CNPq, FAPEMIG, CAPES and UFV).

\section{Multivariate analysis use in the evaluation of mosaics of forest vegetation relating to soil attributes and edge effect}

Maria Teresa Vilela Abdo ${ }^{1}$, Sergio Valiengo Valeri ${ }^{2}$, Antonio Sergio Ferraudo $^{2}$, João de Sousa Neto ${ }^{3}$, Maria Beatriz Bernardes Soares ${ }^{1}$, Gulherme Xavier Lucio dos Santos ${ }^{3}$, Matheus Siqueira Oliveira ${ }^{4}$, Paulo Sergio Cordeiro Junior ${ }^{3}$, Bruna Aparecida Bettini ${ }^{5}$, Monica Helena Martins ${ }^{1}$ ${ }^{1}$ APTA, Pindorama, Brasil; ' ${ }^{2}$ niversidade Estadual Paulista “Júlio de Mesquita Filho”, Jaboticabal, Brasil; ${ }^{3}$ UNIRP, São José do Rio Preto, Brazil; ${ }^{4}$ UNIFEB, Barretos, Brazil; ${ }^{5}$ Universidade Federal de São Carlos, Araras,Brasil (mtvilela@terra.com.br; sergio.valeri1@gmail.com; fsajago@gmail.com; neto_sousa14@hotmail.com; beatriz@apta.sp.gov.br; guilhermexaviersantos@hotmail.com; matheus_oliv@hotmail.com; paulo-gege@hotmail.com; bruna_ bettini@hotmail.com;mo-martinss@hotmail.com)

Atlantic forest biome in Brazil has high biodiversity that is threated due to fragmentation and its remnants retain important residual flora that should be preserved. Studies of environmental conditions that influence species occurrence in those areas are very important to preserve them. This study characterized remnants vegetation in the Biological Reserve, Pindorama-SP, Brazil, classified as seasonal semideciduous forest sampled, using soil attributes and vegetation data. Soil attributes altitude, basal area, height and number of trees with diameter at breast height $(\mathrm{DBH})=5 \mathrm{~cm}$ and distance from remnant edge were evaluated .. The hierarchical clustering, based on parameter evaluated separated groups of plots according to similarity . Soil attributes and distance from the edge influenced endemic trees and non-arborous vegetation showing that preservation of native vegetation should consider these species relationships. Plots with higher clay percentage, higher fertility and closer to remnants edge had higher infestation of non-arboreous plants as bamboo, lianas and different grasses species and had lower species diversity, basal area and height of tree species. Multivariate analysis techniques can be very helpful to explain vegetation mosaics and species interactions in surveys for forest evaluations.

\section{Post-fire regeneration of an Andean subparamo, in Colombia}

Korina Ocampo-Zuleta ${ }^{1}$, Angela Parrado-Rosselli ${ }^{2}$

${ }^{1}$ Bogotá Botanical Garden, Bogotá, Colombia; ${ }^{2}$ Universidad Distrital Francisco José de Caldas, Bogotá, Colombia (korinaocampozuleta@gmail.com, aparrador@udistrital.edu.co)

The effect of fire in burned ecosystems depends on the dominance of characteristic traits that allow plants to recruit new individuals. Regenerative characteristics such as resprouting and wind-dispersal are considered fire-adaptive traits as they allow the rapid establishment of individuals to post-fire conditions. Recently, the Andean subparamo in Colombia has experienced severe forest fires, but little is known on its ability to recover or not after a fire. Therefore, we examined whether plant regeneration after a subparamo fire in 2016 was associated to fire tolerance traits such as resprouting, dispersal mode and fruit type. We sampled, every four months, from 1 to 3 years after the fire, all recruits found in $245 \times 5 \mathrm{~m}$ plots. New individuals were classified as resprouts or seedlings. Among seedlings we characterized the dispersal mode and the fruit type. Results showed that trees comprised 55\% of the taxa. More tree (100\%) than herb (92\%) taxa resprouted. Although seed was not the main regeneration mechanism (72\%), seedling abundance increased with time. The number of seedlings emerged from wind dispersed seeds was higher than other dispersal modes; however, seedlings emerged from zoochorus seeds increased with time. Achenes and capsules, with woody and coriaceous pericarps, were the most important fruit types. We discuss that although the Andean subparamo is not a fire-prone ecosystem, it has fire-adaptive traits such as resprouting and wind dispersal, which should be considered in restoration programs. We also, highlight the importance of animal (mainly birds) dispersal for the arrival of new propagules after a fire.

\section{Charcoal hearth soils: a tremendous environmental and cultural heritage.}

Giovanni Mastrolonardo ${ }^{1}$, Valentina Pescini ${ }^{2}$, Elisa Carrari ${ }^{3}$, Giacomo Certini ${ }^{1}$

${ }^{1}$ Università di Firenze, Firenze, Italy; ${ }^{2}$ Università di Genova, Genova, Italy; ${ }^{3}$ CNR-IPSP, Sesto Fiorentino, Italy (giovanni.mastrolonardo@gmail.com; valpes87@gmail.com; elisa.carrari@ipsp.cnr.it; giacomo.certini@unifi.it)

Charcoal making is one of the oldest forms of forest exploitation. For this purpose, firewood domes were built in the forests in appositely shaped emplacements, then left to burn for days under controlled semi-anoxic conditions. Lots people were involved over time, directly or indirectly, in this activity, which has left a trace in the collective memory and has shaped a variety of landscapes. The legacy of such an activity is a plethora of abandoned charcoal hearths, where soil shows a thick, black, charcoal-rich top layer, which often overlies a complex sequence of pedogenic horizons that reveals successive land uses and/or climatic phases. Charcoal heart sites can be considered as ecological micro-islands, being often characterized by a peculiar understory and by lack of tree regeneration. A multidisciplinary study of relict hearth soils may allow reconstructing past forests composition and exploitation, as well as the ecological and socio-cultural history of the region. Charcoal hearth soils are also impressive carbon reservoirs, particularly appreciable in terms of contrast to climate change, as much of the carbon present in them is charcoal, which is a form of carbon with extremely long residence times in soil. This contribution deals with some studies we carried out in Tuscany (Italy), which demonstrate the high potential of charcoal hearth soils for storing carbon and revealing the evolution of the landscape over time, including its anthropic component. Forest management should also be aimed at preserving charcoal hearth soils, with their important environmental and historical significance.

Predicting diameter at breast height from diameter at ground level in a mixed ombrophile forest: a tool for forestry expertise / Predição do diâmetro à altura do peito a partir do diâmetro à altura do toco em Floresta Ombrófila Mista: uma ferramenta para peritagem florestal

Mauricio Gorenstein ${ }^{1}$ Veridiana Weber ${ }^{1}$, Elisabete Vuaden ${ }^{1}$, Álvaro Boson Castro Faria ${ }^{1}$, José Agostinho Rosa Júnior ${ }^{1}$

${ }^{1}$ Universidade Tecnológica Federaldo Paraná,Dois Vizinhos, Brasil (mauriciorg@utfpr.edu.br; veridianapadoin@utfpr.edu.br; elisabetev@utfpr.edu.br; alvarob@utfpr.edu.br; juniormetall.79@gmail.com)

A área basal e a distribuição diamétrica são importantes indicadores da estrutura florestal. Esses atributos têm forte relação com a idade, valor ecológico e econômico da floresta. Equações preditoras do diâmetro a altura do peito (dap) a partir do diâmetro a altura do toco (dat) são necessárias para o cálculo da área basal e consequente valoração florestal. Em trabalhos de peritagem florestal a determinação do estádio sucessional de povoamentos cortados somente é possível através da aplicação dessas equações. O ajuste da equação linear em dados de diferentes povoamentos de Floresta Ombrófila Mista mostrou que o uso do fator 
de conversão de 0,8 é uma alternativa prática e genérica para a obtenção do dap a partir do dat para as florestas com maior presença de Araucaria angustifolia em sua composição. Nas florestas com maior quantidade de angiospermas o melhor ajuste foi com o modelo linear simples completo dap $=3,7842+0,7661$ dat

\section{Is the seed rain sufficient to passive restoration areas?}

Camila Rocha Pergentino da Silva ${ }^{1}$, Leonardo Augusto Martins ${ }^{1}$, Rita Camila Nobre Sampaio ${ }^{1}$, Vera Lex Engel ${ }^{1}$

${ }^{1}$ Escola Superior de Agricultura Luiz de Queiroz, Universidade de São Paulo, Faculdade de Ciências Agronômicas, Botucatu, Brasil

(camilapergentino@hotmail.com; leonardomartins@gmail.co; ritacamilasampaio@gmail.com; vera.lex@unesp.br)

Passive restoration has been used as a strategy for the restoration of ecological corridors of native vegetation in forest plantations. Ecological filters restrict the dispersal, formation and maturation of a natural community and knowing them allows them to be manipulated to reassemble the desired native community. The objective was to test the hypothesis that the passive restoration of ecological corridors can be limited by the low arrival of propagules through the seed rain. The study consisted of three ecological corridors ranging from 1 to $2.6 \mathrm{~km}$ in length. In each one, 36 plots of $400 \mathrm{~m}^{2}$ were drawn, at distances varying from 24 to 790 $\mathrm{m}$ from the edge of the nearest fragment. In each plot were installed four circular collectors of $0.25 \mathrm{~m}^{2}$, totaling 144 . The collection was performed monthly, during 12 months. Most of the seed rain species were autochthonous (from trees already established in the corridors themselves). The abundance and richness of seed rain of the tree species decreased significantly with the increase of the distance of the fragment, showing the existence of a dispersion filter for these species in these corridors. Although the propagules arrive in significant quantities in the areas, the passive restoration does not occur properly, due to the large amount of grasses present in the corridors and the presence of the dispersion filter in the places near the fragments of the surroundings. The addition of alóctones propagules should increase the permeability of this filter, however, this would only work if there were control of the amount of grasses.

\section{Forest degradation and effect on water resources in Aravali Mountains of Haryana, India \\ Subhash Chander ${ }^{1}$, Jagdish Chander ${ }^{2}$ \\ ${ }^{1}$ Haryana Forest Development Corporation, Gurugram, Indi; ${ }^{2}$ Haryana State Biodiversity Board, Panchkula, India (syadavhfs02@gmail.com; jagdish.chander@hotmail.com)}

Aravalis are the oldest mountain chain in the world. The range of these mountains falls under arid and semi-arid regions of India in the states of Gujrat, Rajasthan, Haryana ending in national capital Delhi. The best forests of these mountains comprise of Annogeissus pendula and its associates. But now most of the forests have been invaded by Procopis juliflora. Fuelwood collection, grazing and invasion by Procopis juliflora are major causes of forest do. Lots of regular water streams and falls used to be there in Aravalis of Haryana State. But due to degradation of forests, the water in most of the streams have dried and others the discharge has come at a point of extinction of these water streams or falls. An analysis of these water resources of Haryana Aravalis will be presented.

\section{D1q: AGROFORESTRY FOR ECOSYSTEM SERVICES}

Estimating carbon storage by tree in an integrated agriculture production system in a protected area in the Brazilian subtropic / Estimativa de sequestro de carbono por árvores em um sistema integrado de produção agropecuária em área de proteção ambiental no subtrópico brasileiro

Silvano Kruchelski ${ }^{1}$,Vanderley Porfirio-da-Silva², Thales Baggio Portugal ${ }^{1}$, Gilmar Paulinho Triches ${ }^{3}$, Anibal de Moraes ${ }^{1}$

${ }^{1}$ Universidade Federal do Paraná, Curitiba, Brasil; ${ }^{2}$ Embrapa Florestas, Colombo, Brasil; ${ }^{3}$ Instituto Federal de Santa Catarina, Rio do Sul, Brasil (silvanokr65@gmail.com; vanderley.porfirio@embrapa.br; baggio.thales@gmail.com; gilmartriches@gmail.com; anibaldemoraes@gmail.com)

Florestas e árvores sequestram carbono e são componente chave em relação às mudanças climáticas, em termos de mitigação e resiliência. O setor de Agricultura, Silvicultura e Uso da Terra é responsável por quase $25 \%$ emissões antropogênicas de gases de efeito estufa, principalmente pelo desmatamento, manejo de gado, solo e nutrientes. Foi conduzido um experimento na Estação Experimental da Universidade Federal do Paraná (Pinhais, PR), com árvores de Eucalyptus benthamii, plantadas em 2013 no espaçamento de 14 X 2m (357 árvores/ha) integradas com pecuária (PF) e com lavoura-pecuária (LPF). As desramas foram feitas aos 21 e 33 meses; aos 44 meses fez-se o desbaste, diminuindo a densidade para 156 e 147 árvores/ha, respectivamente para PF e LPF. Aos 56 meses de idade as árvores apresentavam volume individual médio de $0,30 \mathrm{~m}^{3}$ para $\mathrm{PF}$ e $0,34 \mathrm{~m}^{3}$ para $\mathrm{LPF}$, fixando $0,31 \mathrm{tCO}_{2}$ e $0,34 \mathrm{tCO}$, respectivamente. Com base no fator de emissão de metano entérico de $56 \mathrm{~kg} /$ animal/ano, parametrizado pelo IPCC para bovinos de corte, foi estimada a mitigação realizada pelas árvores, são necessárias pelo menos 4 árvores para mitigar a emissão de um bovino de $450 \mathrm{~kg}$ (UA). Cada hectare dos sistemas estudados pode mitigar a emissão de metano de pelo menos 36 UAs. No ciclo de 2017/18, os sistemas PF e LPF suportaram carga animal de 1,7 UA/ha e 1,4 UA/ha, com emissão estimada em 2,2 tCO 2 /ha e 1,9 tCO $/$ /ha, contra o sequestro médio anual nas árvores de 7,9 tCO $/$ /ha e 8,6 tCO $/$ /ha, respectivamente.

\section{Agroforestry-based application of microbial inoculant for sustainable upland forest farms in the Philippines}

\section{Nelson M. Pampolina ${ }^{1}$, Julieta A Anarna ${ }^{2}$, Mercedes U. Garcia ${ }^{1}$}

${ }^{1}$ Department of Forest Biological Sciences, College of Forestry and Natural Resources. University of the Philippines Los Banos, Laguna, Philippines; 23IOTECH, University of the Philippines Los Banos, Laguna, Philippines (nmpampolina@up.edu.ph; j_anarna@yahoo.com; mugarcia@up.edu.ph)

Ecological balance is necessary for productive agroforestry system where beneficial microbes can function in improving growth, biomass, harvest, and carbon sequestration. This paper demonstrated the importance of indigenous microbial inoculation through community-based approach in nursery and agroforest production to reduce usage of chemical fertilizer while enhancing growth and simultaneously improve livelihood potentials in uplands near mountainous ecosystem in Southern Luzon, Philippines. Local isolates of beneficial bacteria and endomycorrhizal fungi were obtained from rhizosphere of nine agroforest crops (Mormodica charantia, Solanum melongena, Cucurbita maxima, Abelmoschus esculentus, Capsicum baccatum, Vigna unguiculate, Solanum lycopersicum) that were traditionally raised as ingredient for nutritious native dish planted with Theobroma cacao and Coffea arabica. These high value crops are commercially known around the urbanized region where woody perennials were maintained as forest cover to favor soil, microclimate, and carbon sequestration. Microbial isolates were described, purified, mass-produced with Centrosema pubescens and Leucaena leucopcephalla as hosts, and tested in nursery and field growth performance following standard procedures. Effects of inoculant were significant $(p<0.05)$ in improving parameters (eg. height, diameter, biomass, yield) of selected crops. Combining inoculant with farmers practice increased crop production by about half and prolong generally lifespan 
of crops. Use of inoculant can improve agroforest farmer's income by $30-40 \%$, reduce chemical application by half of their consumption, ensure local food security, and encourage soil biodiversification. Further verification trials in other climatic, edaphic, and socio economic conditions across the region are important to appreciate values of soil inoculant for sustainable upland forest farming in the Philippines.

\section{A systematic map of agroforestry research focusing on ecosystem services in the Asia-Pacific Region}

Seongmin Shin ${ }^{1}$, Khaing Thanda Soe ${ }^{2}$,Haeun Lee ${ }^{1}$, Tae Hoon Kim ${ }^{1}$, Seongeun Lee ${ }^{1}$, Mi Sun Park ${ }^{1}$

${ }^{1}$ Seoul National University, Pyeongchang, Republic of Korea; ${ }^{2}$ Seoul National University, Seoul, Republic of Korea (seongmin@snu.ac.kr; haingthandasoe@gmail.com; haeunl630@snu.ac.kr; switch-thkim@snu.ac.kr; lse1229@snu.ac.kr; mpark@snu.ac.kr)

Agroforestry is an intensive land management system through integration of trees into crop and animal farming. Agroforestry provides diverse ecosystem services by bridging the gap among agriculture, forestry and husbandry. In particular, agroforestry is a significant approach for improving environmental, economic and social benefits in the Asia-Pacific region. This research aims to examine the research trend of agroforestry focusing on ecosystem services in the Asia-Pacific region. Systematic mapping methodology was applied to this research. Analysis units are academic articles related to agroforestry practices in the Asia-Pacific region. The articles published within almost 50 years (1970-2018) were collected through the international specialized academic database, SCOPUS. The selected articles include various types of agroforestry including silvorable/agrosilviculture, silvopasture, forest farming and so on. Three types of ecosystem services captured in agroforestry were coded and mapped; 1) provisioning services, 2) regulating and supporting services, and 3) cultural services. Consequently, the results indicate the research focuses of agroforestry and their changes in the Asia-Pacific region. In particular, the ecosystem service related result implies social, environmental and economic approach to agroforestry. Therefore, this study helps us understand dominant research on ecosystem services of agroforestry in the Asia-Pacific Region and supports design of future research of agroforestry by presenting the historical changes and the current status of agroforestry research.

\section{Adaptation measures for minimizing the impacts of disturbances in protective forests: projects “RockTheAlps” and “GreenRisk4ALPs”}

Jurij Beguš ${ }^{1}$, Andrej Breznikar ${ }^{1}$, Andreja Nève Repe ${ }^{1}$, Aleš Poljanec ${ }^{1}$

${ }^{1}$ Slovenia Forest Service,Ljubljana, Slovenia (jurij.begus@zgs.si; andrej.breznikar@zgs.si; andreja.repe@zgs.si; ales.poljanec@zgs.si)

Ecosystem management of protection forests aims at maintaining forests near a state at which their protection function is secured. Due to climate changes, the uncertainty about forest management in mountainous areas has increased in the last decades. The magnitude, frequency and type of natural disturbances have changed resulting in more frequent and higher damages of forest stands. Additionally forests are threatened by the rapid spread of invasive alien species and other harmful organisms. In natural hazard management and disaster risk reduction, forests are increasingly considered equal to technical or civil engineering measures. Thus, the role of forests in protection against erosion, floods, snow and earth avalanches, torrents and falling rocks is considered irreplaceable in the light of changing environment. In the frame of two Alpine Space Programme projects, the RockTheAlps and GreenRisk4ALPs, current forest management practices were analysed and adoption measures to decrease risks in forest management were discussed. Quick sanitation measures in damaged forests including timely detection and removal of weakened trees are necessary to prevent the gradation of harmful organisms. In addition, adequate silviculture measures are relevant to increase stability and vitality of forest stands. Key measures include small-scale regeneration, regulation of tree species composition in line with changing site conditions, gradual and early regeneration of potentially threatened forests and prevention and limitation of the spread of invasive alien species. The results of both projects will be presented and future challenges in preventing forest damage due to extreme weather events will be further discussed.

\section{The future of adoption of agro ecology farming system in Uganda: apportunities and challenges}

Bosco Bua ${ }^{1}$

Kyambogo University, Kampala, Uganda (bbua@kyu.ac.ug)

Agroecology is an approach whereby agriculture is practiced bearing in mind the role of the surrounding environment. Agroecology emerged as alternative farming system due to the realization of the devastating effects of the continuous and indiscriminate use of agrochemicals such as pesticides and fertilisers to enhance agricultural production. However, it soon became evident that some of the chemicals have long lasting residual and debilitating effects on the environment as well as toxicity to humans and animals. In Uganda, the adoption of agroecology is manifested in many ways including the use of agroforestry, the formulation and adoption of a policy on organic agriculture, the development and running of academic course/programmes at universities and other higher institution of learning. In the fact, though relatively new, a number of individuals have been trained at bachelors, masters and also PhDs. Additionally, a number of trainer of trainers have been trained in different aspects of agroecology. Therefore, at the national level the government is very supportive on the implementation of pro-agroecology related practices that are user- friendly and environmentally sensitive. However, the targeted beneficiary especially the farmers and other stakeholders are the major challenge. This paper therefore discusses the opportunities and challenges in adoption adopting agroecology as an alternative farming system in Uganda.

Integrated crop-livestock-forest systems for neutralizing greenhouse gases / Sistema integração lavoura-pecuária-floresta para neutralização de gases de Efeito Estufa (GEE)

Karina Pulrolnik ${ }^{1}$, Kleberson de Souza ${ }^{1}$, Roberto Guimarães-Júnior ${ }^{1}$, Robélio Marchão ${ }^{1}$, Lourival Vilela ${ }^{1}$, Arminda Carvalho ${ }^{1}$, Sebastião Moraes Neto ${ }^{1}$

${ }^{1}$ Embrapa Cerrados, Brasilia,Brazil (karina.pulrolnik@embrapa.br; kleberson.souza@embrapa.br; roberto.guimaraes-junior@embrapa.br; robelio.marchão@embrapa.br; lourival.vilela@embrapa.br; arminda.carvalho@embrapa.br; sebastião.moraes@embrapa.br)

A integração lavoura-pecuária-floresta - ILPF, é um sistema de produção propício para alcançar produtividade satisfatória e mitigar os gases de efeito estufa da atividade pecuária, proporcionando ainda balanço positivo de carbono, conciliando produtividade e sustentabilidade. O objetivo deste trabalho é demonstrar o potencial do sistema ILPF como estratégia para a compensação das emissões de gases de Efeito Estufa (GEE). O estudo foi realizado no campo experimental da Embrapa Cerrados (Planaltina-DF) em um experimento com ILPF implantado no ano de 2009. Para as medições de balanço de carbono foram avaliados o tratamento sem árvores (sistema integração lavoura-pecuária - ILP) e o tratamento com fila dupla de árvores de eucalipto espaçadas 22 m entre os renques (ILPF), totalizando 417 árvores por hectare. No sistema ILPF implantado na Embrapa Cerrados, uma única árvore foi capaz de acumular, em média, 30,2 kg de C.ano-1 (considerando 45\% de C da massa seca de biomassa aérea da planta). Isto equivale ao sequestro 110,5 kg de CO eq.ano-1 da atmosfera por cada árvore inserida no sistema. Dados ainda preliminares demonstram que uma população de 417 árvores/ha em 15\% da área total de produção em um sistema de 
ILPF seria suficiente para neutralizar todas as emissões de GEEs oriundas dos animais em recria $\left(\mathrm{CH}_{4}\right)$ e da pastagem $\left(\mathrm{N}_{2} \mathrm{O}\right)$, deixando ainda um saldo positivo de carbono. Assim, pode-se afirmar que a introdução do componente florestal no sistema ILPF é uma opção viável para estocar o $\mathrm{CO}_{2}$ atmosférico na forma de madeira.

Influence of shading on the growth of a native shrub species, Cestrum intermedium Sendtn (Solanaceae), and its implications for forest restoration projects / Influência do sombreamento sobre o crescimento de uma espécie arbustiva nativa, o Cestrum intermedium Sendtn (Solanaceae), e suas implicações em plantios de restauração florestal

Gabriela Sanches Dolenc1, Susane Rasera ${ }^{2}$, Girlei Costa da Cunha ${ }^{3}$,Eduardo Gusson ${ }^{3}$, Frederico Miranda ${ }^{3}$, Flávio Bertin Gandara Mendes ${ }^{2}$ ${ }^{1}$ Klabin SA, Brazil; ${ }^{2}$ Escola Superior de Agricultura "Luiz de Queiroz", Universidade de São Paulo, Piracicaba, Brazil; ${ }^{3}$ Biodendro, Piracicaba, Brazil (gabrielasdolenc@gmail.com;susane.rasera@gmail.com;girlei.cunha@gmail.com;eduardogusson@gmail.com;fredtsmiranda@gmail.com;fgandara@usp.br)

O trabalho, que faz parte da temática de introdução de espécies não-arbóreas do projeto de P\&D "Metodologia para a formação de microclima favorável ao estabelecimento de biodiversidade no entorno de reservatórios hidroelétricos" financiado pela AES Tiête, teve como objetivo estudar a adaptação às diferentes condições de luz de uma espécie arbustiva nativa, o Cestrum intermedium Sendtn (Solanaceae), a fim de avaliar sua plasticidade ecológica e sua implicação de cultivo com base em seu papel funcional na dinâmica de regeneração de florestas. O estudo consistiu em três experimentos - teste de germinação no Laboratório de Ecologia Vegetal Aplicada e Agroecologia, semeadura em tubete no viveiro do Departamento de Ciências Florestais e implantação em campo na Estação Experimental da Genética da ESALQ/USP. Os resultados obtidos apontam o potencial da espécie para enriquecimento de biodiversidade em projetos de restauração. Mesmo que seu desenvolvimento tenha sido lento em ambiente sombreado durante o período avaliado, sua taxa de sobrevivência foi satisfatória. Em ambiente a pleno sol, o resultado foi ainda mais interessante, indicando seu potencial para ser utilizada na fase inicial dos projetos de restauração. $\mathrm{O}$ arbusto, que teve rápida resposta fenológica em campo quando recebendo radiação solar direta, terá papel fundamental de atração de fauna nos primeiros anos do projeto, o que favorecerá a dispersão de sementes. Além disso, seu desenvolvimento em altura e diâmetro de copa poderá oferecer melhoria da condição microclimática do solo, facilitando o estabelecimento de regenerantes, controlando a mato competição e protegendo as mudas arbóreas de pequeno porte.

D1r: AGROFORESTRY FOR ECOSYSTEM SERVICES

Remediating degraded areas at the Pirapitinga Ecological Station / Recuperação de áreas degradadas na Estação Ecológica de Pirapitinga

Suzi Theodoro' ${ }^{1}$, Fernanda Medeiros ${ }^{2}$, Marco Ianniruberto ${ }^{1}$

${ }^{1}$ UniversidadedeBrasília,Brasilia,Brazil;:2UniversidadeFederaldeViçosa,Viçosa,Brazil(suzitheodoro@unb.br;fafeh2802@gmail.com;ianniruberto@unb.br)

A pesquisa foi desenvolvida na Estação Ecológica de Pirapitinga, localizada no reservatório de Três Marias/MG. O principal objetivo da pesquisa foi a recuperação de uma área degradada. Foram utilizados os princípios da rochagem e dos sistemas agroflorestais. O delineamento da área contou com sete tratamentos e três repetições, que resultaram em 21 blocos (Controle; Composto Orgânico; Sedimento; Remineralizador; Sedimento + Remineralizador; Sedimento + Composto Orgânico e Sedimento + Remineralizador + Composto Orgânico). Cada bloco teve uma área de $4 \mathrm{~m}^{2}$. A proporção de remineralizador e de sedimento utilizada foi de 5ton/ha e de composto orgânico de 10 ton/ha. As sementes de hortaliças, leguminosas, agrícolas e florestais nativas do Cerrado (Cedro, Jatobá, Copaíba, Gonçalo Alves, Mutamba e Baru) tiveram a mesma distribuição espacial. Foram semeadas três sementes de cada espécie florestal. Após sete anos de pesquisa averiguou-se que todas as espécies se beneficiaram de diferentes maneiras dos insumos minerais/orgânicos e da forma de manejo. Ocorreu a redução da toxidez de $\mathrm{Al} 3$ no solo que ampliou as possibilidades de desenvolvimento das plantas. A presença de matéria orgânica foi positiva para a produção das hortaliças e das espécies agrícolas, bem como para proteger o solo. A espécie florestal que apresentou a melhor taxa de germinação foi o Gonçalo Alves e a Mutamba foi a espécie com maior crescimento (12m). Os blocos com Sedimento+Rocha tiveram as maiores taxas de sobrevivência. Após sete anos, os resultados mostram que a remineralização do solo somado a cobertura vegetal são ferramentas que revertem os processos de erosão e degradação.

COPABASE: Cooperativism and agro-extractivism allied with sustainability and preservation of the Cerrado Biome / COPABASE: cooperativismo e agroextrativismo aliados a sustentabilidade e preservação do Bioma Cerrado

Flavio Macedo ${ }^{1}$, Livia Amorim ${ }^{1}$

${ }^{1}$ Secretaria de Educação do DF, Brasília, Brasil (flavioxavierxe10@gmail.com; liviaamorimdosreis@gmail.com)

O presente artigo tem por objetivo analisar a exploração de frutos do Cerrado na região noroeste de Minas Gerais, utilizando como base os conceitos do cooperativismo e agroextrativismo. É fundamental para a preservação do Cerrado a aplicação de novos modelos econômicos e políticos que possam incorporar estratégias de uso do bioma a partir do conhecimento científico, de projetos de educação e sensibilização junto à população, da garantia de proteção formal eficaz de espécies e ecossistemas e do reconhecimento dos recursos naturais e serviços ambientais do bioma. As cooperativas vêm a cada dia aumentando sua área de atuação, evidenciando a importância de se olhar para os recursos disponíveis em cada local - recursos naturais, frutos do cerrado, práticas de cultivo, incentivando a preservação e ampliando o estímulo às novas gerações de buscar o mínimo impacto ao meio ambiente. A Copabase tem como finalidade fortalecer, beneficiar e comercializar com sustentabilidade produtos da agricultura familiar e do extrativismo de frutos do Cerrado no vale do Rio Urucuia Fundada a partir da necessidade de organização de famílias de alguns municípios do noroeste de Minas Gerais para exploração dos frutos do Cerrado, a cooperativa se dedica à agricultura familiar e à Economia Solidária desenvolvendo também ações socioeducativas no âmbito do agroextrativismo, agroecologia e cooperativismo, educação de jovens e adultos, preservação ambiental, segurança alimentar e boas práticas de fabricação de alimentos. Devido a sua atuação, a Copabase é de extrema importância para o cooperativismo e preservação do Bioma Cerrado no noroeste de Minas Gerais.

Accumulated leaf litter in an integrated silvopasture system with eucalyptus clones in the Northwest region of Goiás, Brazil / Serapilheira acumulada em sistema silvopastoril com clones de eucalipto na região Noroeste do Estado de Goiás

Francine Neves Calil ${ }^{1}$, Jorge Luis Sousa Ferreira

${ }^{1}$ Universidade Federal de Goiás, Goiânia, Brazil (fncalil@gmail.com; jorgeluisferreira89@hotmail.com)

A produção de serapilheira e a devolução de nutrientes em ecossistemas florestais, e constituem a via mais importante do ciclo biogeoquímico de nutrientes (fluxo no sistema solo-planta-solo). O objetivo deste estudo foi analisar a serapilheira acumulada em três clones de eucalipto em sistema silvopastoril (SSP) no município de Nova Crixás - GO. Os três clones implantados são: AEC 2034 (E. camaldulensis $x$ E. grandis) x E. urophylla, AEC 2111 (E. camaldulensis $x$ E. 
grandis) x E. urophylla e AEC 0043 (C. citriodora x C. torelliana). Foram plantados em arranjo formados por renques de quatro linhas, distanciadas de $3 \mathrm{~m}$ e de 2,5 m entre plantas na linha e entre renques de $34 \mathrm{~m}$. No momento de coleta as árvores apresentavam 2,5 anos. Para a coleta de serapilheira foi utilizado um gabarito de $0,0625 \mathrm{~m}^{2}$, onde foram coletadas 10 amostras aleatórias em cada área. O material foi levado ao laboratório, colocado para secagem e após obter peso constante, foi pesado. Foi feita uma extrapolação dos valores para $\mathrm{kg} \mathrm{ha}^{-1} \mathrm{e}$ feita uma média para a produção de serapilheira produzida por cada clone. O clone AEC 0043 apresentou 9.425,76 $\mathrm{kg} \mathrm{ha}^{-1}$, que foi o clone com maior produtividade. Os clones AEC 2034 e AEC 2111 apresentaram, respectivamente, 8.446,40 $\mathrm{kg} \mathrm{ha}^{-1}$ e $4.576,48 \mathrm{~kg} \mathrm{ha}^{-1}$.

Management systems for Yerba Mate (Ilex paraguariensis St. Hilaire) in Comandante Andresito, Misiones: soil and tree community characteristics / Sistemas de manejo de Yerba Mate (Ilex paraguariensis St. Hilaire) en Comandante Andresito, Misiones: caracterización de suelo y comunidad arbórea

Rocio Bermudez Pose', Alejandra Gil², Ivan Crespo ${ }^{3}$

${ }^{1}$ Fundación Agroecológica Iguazú, Comandante Andresito, Argentina; ${ }^{2}$ Facultad de Agronomía de la Universidad de Buenos Aires, Buenos Aires, Argentina; ${ }^{3}$ Universidade Federal do Paraná, Curitiba, Brasil (rocio@guayaki.com;agil@agro.uba.ar; ivancrespo@ufpr.br)

La yerba mate, especie nativa de la Selva Misionera, se encuentra adaptada a ambientes parcialmente sombreados. No obstante, en Misiones se implanta en áreas abiertas previamente desmontadas. Los antecedentes indican que su cultivo bajo manejo convencional, va perdiendo productividad a lo largo de su ciclo de vida asociado principalmente a la degradación del suelo. Esto se relaciona con características climáticas y topográficas regionales y un manejo agrícola inapropiado. Se caracterizaron los aspectos físicoquímicos del suelo y, a su vez, la composición arbórea del estrato medio y alto, en yerbales bajo un gradiente de diferentes manejos productivos: monocultivo, yerbal convencional regenerado, yerbal bajo monte y selva, en Comandante Andresito, Misiones. A través de un análisis multivariado de las variables fisicoquímicas del suelo, se ha observado un contraste entre los manejos de selva y agroforestería con respecto al manejo convencional. La MO y el Ca presentaron una tendencia decreciente en el monocultivo vs selva y agroforestería a diferencia del P. La infiltración mostró la misma tendencia, presentando menor tasa en el sistema convencional, comparado a los otros manejos. La caracterización arbórea de los distintos sistemas, permitió identificar tres comunidades asociadas a cada uno de ellos, presentando el sitio agroforestal una mayor riqueza. Este trabajo nos permite aproximar que el cultivo de yerba mate en agroforestería posibilita una mayor diversidad arbórea y mayor conservación relativa (y reestablecimiento inclusive) de ciertos atributos físicoquímicos del suelo respecto al manejo convencional. Esta información ha de ser complementada en futuros estudios que incluyan otras variables del sistema.

\title{
Analysis of ecosystem services through non-timber forest products (NTFPs) provided by the Baban Rafi Forest in Niger \\ Moussa Massaoudou ${ }^{1}$, Rabiou Habou ${ }^{2}$, Tougiani Abasse ${ }^{3}$ \\ ${ }^{1}$ National Institute for Agricultural Research, Maradi, Niger; ${ }^{2}$ Université de Diffa, Diffa, Niger; ${ }^{3}$ National Institute for Agricultural Research of Niger \\ (INRAN),Niamey,Niger(mmassaoudou13@gmail.com; rabiouhabougarba@yahoo.fr; abasse.tougiani@gmail.com)
}

In the Sahelian, forest and agroforestry ecosystems constitute the main source of income and food supplement for the populations, especially in the rural part where the socio-economic life is inseparable from the exploitation of products they offer. The Baban Rafi Forest is one of the forests where local communities reconciled exploitation with conservation through interventions of national planning policies and strategies. The objective of this study is to identify and analyze the indicators of use and pressure related to the exploitation of Non-Timber Forest Products of this forest. Ethnobotanical and forest inventory surveys were conducted in the peripheral villages of the forest. The analysis of the results made it possible to identify 70 ligneous species belonging to 55 genera and 28 families; used either in food, in fodder or in the traditional pharmacopoeia. The structural and regenerative analysis of six priority woody species for the populations, showed a regressive dynamic which would be due to a strong anthropic pressure, linked to the demographic growth in the zone. Domestication of these priority species would help conserve them and sustainably meet the needs of these local communities.

An integrated agroforestry system for small rural producers using clones of eucalyptus, angico, and aroeira intercropped with cowpeas in the region of Itaparica, Pernambuco, Brazil / Sistema agrossilvicultural para pequenos produtores rurais, com clones de eucaliptos, angico e aroeira consorciados com feijão-caupi, na região de Itaparica, Pernambuco, Brasil

\begin{abstract}
José Antonio Aleixo da Silva ${ }^{1}$, Rinaldo Luiz Caraciolo Ferreira ${ }^{1}$, Francisco Tiberio Alencar Moreira ${ }^{1}$, Marilia Regina Costa Castro ${ }^{2}$ ${ }^{1}$ Universidade Federal Rural de Pernambuco, Departamento de Ciência Florestal, Recife, Brasil; ${ }^{2}$ Instituto Federal de Educação Ciência e Tecnologia, Recife,Brasil(jaaleixo@uol.com.br; rinaldo.ferreira@ufrpe.br; tiberioflorestal@gmail.com; mariliarcastro@uol.com.br)
\end{abstract}

O objetivo desta pesquisa foi avaliar o crescimento e retorno econômico de dois clones de eucaliptos e duas essencias nativas: angico e aroeira, em um sistema agrossilvicultural com feijão-caupi, usando três fontes de nutrientes: resíduos de tanques de piscicultura e sedimento de lago e controle, em três espaçamentos, em um experimento no Instituto Agronômico de Pernambuco na região de Itaparica, semiárido pernambucano. Foram instaladas 144 parcelas, nos espaçamentos 3mx2m e 4mx2m em monocultivo e 4mx2m em consórcio, distribuídas aleatoriamente com quatro repetições. O feijão-caupi foi semeado no espaçamento $0,80 \mathrm{mx} 0,30 \mathrm{~m}$, plantando na área útil de cada parcela do sistema agrossilvicultural. O delineamento estatístico foi o multivariado de medidas repetidas. Para a análise econômica do sistema agroflorestal e dos monocultivos foram considerados os custos e as receitas com a produção do feijão-caupi ao longo do período de avaliação, três anos. As fontes de nutrientes, resíduos dos tanques de piscicultura e sedimentos do lago de Itaparica, contribuíram significativamente no crescimento em alturas das culturas florestais e do feijão-caupi, tornando-se alternativas para serem usados como biofertilizantes em plantios florestais e agrícolas na região de Itaparica. As maiores médias em altura do foram do clone MA-2001, no espaçamento 3mx2m. Os consórcios com as espécies nativas apresentaram os melhores resultados na produtividade do feijão-caupi que por sua vez obteve maior produtividade em relação ao sistema agrossilvicultural quando plantado em monocultivo. Na análise econômica das essencias florestais, a venda de lenha e estacas proporcionou as maiores receitas, quando comparado com a venda de apenas lenha. 


\section{Tree diversity and use in agricultural and livestock landscapes in the Colombian Caribbean región}

Milton Rivera Rojas ${ }^{1}$, Sonia Camargo Roa ${ }^{2}$, Jaime Andres Arias Rojas ${ }^{1}$, Darwin Fabian Lombo ${ }^{1}$, Jose Edwin Mojica ${ }^{1}$

${ }^{1}$ Agrosavia, Agustín Codazzi Cesar, Colombia; ${ }^{2}$ ICA, Santa Marta, Colombia (mrivera@agrosavia.co; soniacatalinacamargo@gmail.com;

jarias@agrosavia.co; dlombo@agrosavia.co;jmojica@agrosavia.co)

Bs-T is one of the most intervened ecosystems due to the increase of extensive livestock and agriculture. Livestock is used to occupy the territory based on integration of invasive plants, mainly grasses. Because of the lack of documentation about the uses of the tree species in Colombia, farmers, guided by organizations, have been working on sustainable livestock, promoting the incorporation of native trees into the production systems. Due to the lack of information on the uses of the native trees in the Caribbean Region, a non-probabilistic sampling was used to obtain primary information, which was focused on three consultation groups. The "Expert" group, consisting of professionals, scientists, among others, who after being surveyed, referred to the second group called "knowledgeable", consisting of technical assistants and some professionals. The last group, "producers", was named after the "knowledgeable", consisting of farmers. Moreover, tree species, their uses and used parts of the plant, were variables included in the above survey. The information was tabulated, getting the descriptive statistical analysis and recognizing diversity into the landscapes of the region; 294 tree species were reported which belong to 53 families. According to the species uses, 18 categories were reported; within construction (152), fence posts (132), firewood (110), among others. Furthermore, the main environmental values that were mentioned are; water protection (72), soil protection (85), thermal comfort on livestock (79) and fauna feeding (150). Finally, medicinal uses (143), cultural symbols (28), ornamental uses (71) and domestic uses (107) were the main uses mentioned in sociocultural perspectives.

\section{Willows beyond wetlands: uses of Salix $\mathbf{L}$. species for ecosystem services}

Julia Kuzovkina ${ }^{1}$

${ }^{1}$ University of Connecicut, Storrs, USA (jkuzovkina@uconn.edu)

Species of Salix characterized by ecological resilience are predisposed for use in conservation and environmental projects in many climatic zones. The economic importance of Salix is increasing and emerging in a wide array of practical applications to restore ecosystems and to provide various ecosystem services. These uses include bioengineering, phytoremediation, and biomass production for fuel and lumber. Willow plantation systems offer promise for carbon sequestration, water quality improvement, soil enrichment, biodiversity conservation, and production of specialty products for crafts. Most recently, the importance of Salix to support a broad range of wildlife became important. It was reported that willow stands support a high density of breeding bird communities and willow thickets provide stopover sites for about sixty bird species, the highest number for all studied habitats. Numerous invertebrate herbivores from aphids to caterpillars feed upon willows, which support a large food-web of higher trophic level organisms. There is evidence for a rich insect fauna (up to 450 species) associated with willows. Salix is listed as number two on a list of host plants after oaks supporting 456 Lepidoptera species. Willows are becoming very important for sustaining fruit and berry pollinating insects as they are the earliest nectar and pollen sources for bees. They provide for a diverse pollinator group and ensure full pollination services to the surrounding plant communities - an important service considering the problem related to the bee colony collapse in North America. Current investigation generates specific knowledge about the overall insect values of various species of Salix.

\section{D2a: APPLIED GENETICS FOR FOREST MANAGEMENT AND CONSERVATION}

\section{Identifying the United States tree species and populations most vulnerable to genetic degradation}

Kevin Potter ${ }^{1}$ Maria Escanferla ${ }^{2}$, Barbara Crane ${ }^{3}$, Robert Jetton ${ }^{4}$, John Hastings ${ }^{5}$, William Hargrove ${ }^{6}$, Gary Man ${ }^{7}$

${ }^{1}$ Department of Forestry, North Carolina State University, Research Triangle Park, NC, USA; ${ }^{2}$ Department of Forestry, North Carolina State University, Raleigh, NC, USA; ${ }^{3}$ Southern Region, National Forest System, USDA Forest Service, Atlanta, GA, USA; ${ }^{4}$ Camcore, North Carolina State University, Raleigh, NC, USA; ${ }^{5}$ USDA Animal and Plant Health Inspection Service (APHIS), Raleigh, NC, USA; ' ${ }^{6}$ Southern Research Station, USDA Forest Service, Asheville, NC, USA; ${ }^{7}$ Forest Health Protection, USDA Forest Service, Washington, DC, USA (kpotter@ncsu.edu; mescanf@ncsu.edu; barbaracrane@fs.fed.us;

rmjetton@ncsu.edu; hastings.john.m@gmail.com;whargrove@fs.fed.us; gman@fs.fed.us)

A variety of threats, most importantly insect and disease infestation and climate change, will increase the likelihood that forest tree species could experience species-level genetic degradation or population-level extirpation during the next century. Scientists and managers from throughout the U.S. Forest Service therefore developed a framework for forest tree and population conservation priority-setting assessments. This Project CAPTURE (Conservation Assessment and Prioritization of Forest Trees Under Risk of Extirpation) framework is data-driven and guided by expert opinion, and allows for the quantitative grouping of species into vulnerability classes that may require different management and conservation strategies. We have applied this framework twice to categorize and prioritize North American tree species for gene conservation, monitoring, management and restoration: once for insect and disease threats (419 tree species) and once for climate change exposure (339 species). These categorizations are based on risk factors relating to each species' (1) exposure to the threats, (2) sensitivity to the threats, and (3) capacity to adapt to the threats. We used K-means clustering to group species into classes based on these vulnerability dimensions. The most vulnerable classes encompass the species that will require immediate conservation intervention. Other groups of species will require different management approaches. We have further assessed populations within highly vulnerable species to prioritize them for ex situ seed collection. These assessment tools are flexible and designed for repeated application with the availability of new information. They also are valuable for determining which species and populations to target for pro-active gene conservation and management actions.

\section{The geographic origin of old Italian cypresses in North Italy revealed by nuclear SSR markers}

Nicola La Porta ${ }^{1,2}$, Paolo Baldi ${ }^{1}$

${ }^{1}$ IASMA Research and Innovation Centre, Fondazione Edmund Mach, Via Edmund Mach 1, 38010 San Michele all'Adige (Trento), Italy; ${ }^{2}$ EFI Project Centre on Mountain Forests (MOUNTFOR),Via Edmund Mach 1, 38010 San Michele all'Adige (Trento), Italy (nicola.laporta@fmach.it; paolo.baldi@fmach.it)

The Italian cypress (Cupressus sempervirens L.) has an important role in the characterization of Mediterranean landscape mainly for its aesthetic and ornamental function and also because it is an excellent pioneer specie for reforestation and for timber production. Since antiquity cypress has been cultivated far beyond its natural geographic range for religious and aesthetic reason. At present its geographic distribution is characterized by disjoint populations or single plants. In this study genetic variability of 600 old cypress trees belonging to 26 populations from different part of North and Central Italy and one population from Turkey has been studied using SSR markers. Nine polymorphic SSR primers couples producing a total of 104 alleles. Turkey showed 15 private alleles. The number of observed alleles in all the populations per locus varied from 8 to 22. Values of Nei's gene diversity and Shannon information index suggesting that 
populations are characterized by low genetic variability probably due to the strong anthropic pressure that this species has undergone. AMOVA revealed a very strong differentiation between Turkey and all Italian populations and a good significant differentiation among Italian groups. UPGMA dendrogram shows two main clusters, one with all the North-Estern Italian populations and the second one with Tuscanians and North-Western Italian populations. The only exception is the population from Bozen. These results suggest that the artificial transfer of cypress reproductive materials highlighting the human-mediated manipulation of cypress populations in Italy and the political and commercial barriers that were present before the first world war.

Forest genetic monitoring: preliminary results of a microsatellite-based genetic study of Fagus orientalis (Lipsky) from iran and Fagus sylvatica (L.) from Germany and Ukraine

Barbara Fussi ${ }^{1}$, Darius Kavaliauskas ${ }^{1}$, Saboura Rahanjam ${ }^{2}$, Nataliya Hrunyk $^{3}$, Yurii Yusypovych ${ }^{3}$, Vasyl Lavnyy ${ }^{3}$,Khosro Sagheb-Talebi ${ }^{4}$ ${ }^{1}$ Bavarian Office for Forest Seeding and Planting, Teisendorf, Germany; ${ }^{2}$ Faculty of Natural Resources, University of Tehran, Karaj, Islamic Republic of Iran; ${ }^{3}$ Ukrainian National Forestry University, Lviv, Ukraine; ${ }^{4}$ Forest Research Division, Research Institute of Forests and Rangelands, Agricultural Research, Education and Extension Organization (AREEO), Tehran, Islamic Republic of Iran (barbara.fussi@asp.bayern.de; darius.kavaliauskas@asp. bayern.de; rahanjam.saboura@gmail.com; hrunykn@gmail.com; jojusse@gmail.com; lavnyy@gmail.com; saghebtalebi@yahoo.com)

Natural disturbances and human activities effects diversity of forests on various levels: genetic, species and ecosystems. High genetic diversity of forest trees ensures that forests can grow, adapt and evolve under environmental change, but they may face threats when such change occurs faster than the species' adaptive and evolutionary mechanisms can handle. Therefore it is necessary to implement a forest genetic monitoring (FGM) system which could to assess a forest population's capacity to survive, reproduce, and persist under rapid environmental changes on a long-term scale. Consequently two FGM plots in Germany; one in Ukraine for European beech and one in Iran for Oriental beech were established based on Konnert et al. (2011) FGM plot design. Through an intensive selection procedure in each FGM plot we sampled 250 adult trees (DBH> $15 \mathrm{~cm}$ ) and leaves from 200 saplings in four natural regeneration subplots (50 individuals in each). Subsequent genetic analyses were based on 16 nuclear microsatellite markers. Data regarding genetic variation and genetic differentiation among four FGM plots and among adult trees and natural regeneration within the plots will be presented. First results indicate that genetic diversity was distributed evenly from adults to natural regeneration. Genetic diversity within the Iranian Oriental beech population is slightly higher than in a Central European beech populations. Continuation of FGM in future will allow us to draw conclusions about the population's evolutionary potential through comparison to the now assessed baseline data.

\title{
Application of molecular genetics in certification of forest reproductive material: testing the origin and genetic diversity of European beech (Fagus sylvatica L.) seed collected by commercial nurseries in Slovenia
}

\author{
Marko Bajc ${ }^{1}$, Barbara Štupar ${ }^{1}$, Nataša Šibanc ${ }^{1}$, Hojka Kraigher ${ }^{1}$, Marjana Westergren ${ }^{1}$ \\ Slovenian Forestry Institute, Department of Forest Physiologyand Genetics, Ljubljana, Slovenia (marko.bajc@gozdis.si; barbara.stupar@gozdis.si; \\ natasa.sibanc@gozdis.si; hojka.kraigher@gozdis.si; marjana.westergren@gozdis.si)
}

Long-term success of afforestation and reforestation, especially in changing environment, depends on the origin of forest reproductive material (FRM) and its genetic variation. Paper control of FRM origin is embedded in European legislation, while use of molecular tools for verification of FRM origin and its genetic variation are not obligatory. Nevertheless, such tools may be used to improve control over the origin and genetic quality of FRM, consequently contributing to more resilient forests in the future. European beech seed collected by commercial nurseries from seven forest seed stands (FSS) were submitted for certification to Slovenian Forestry Institute (SFI) in 2016 and 2018 in accordance with the Forest reproductive material act. Verification of origin and testing of genetic diversity of the individual tree seed samples and seed lots were based on the analysis of 16 nuclear microsatellite markers. Seed origin was verified through comparison against reference samples collected by SFI from the specified FSS. Tests revealed that two seed lots from 2016 did not originate from the specified FSS, in addition to exhibiting very low levels of genetic diversity. Consequently, they were not approved for use in Slovenian forests. Significantly lower levels of genetic diversity were associated with seed samples collected from too few seed trees, highlighting the importance of collecting FRM from a sufficient number of trees - a minimum of 25 trees, at least two adult tree heights apart from one another, as required by Decree on approval issued by SFI, to maintain the genetic diversity observed in natural stands.

\section{Interim genetic monitoring application in the presence of incidental data: theory and application}

Filippos Aravanopoulos ${ }^{1}$, Nickos Tourvas ${ }^{1}$, Ermioni Malliarou ${ }^{1}$, Evangelia Avramidou ${ }^{1}$, Anna-Maria Farsakoglou $^{1}$, Paraskevi Alizoti $^{1}$, Evangelos Barbas $^{1}$, Ioannis Ganopoulos ${ }^{1}$, Fotios Kiourtsis ${ }^{2}$, Barbara Fussi ${ }^{3}$, Hojka Kraigher ${ }^{4}$

${ }^{1}$ Sristotle University, Thessaloniki, Greece; ${ }^{2}$ Secentralized Administration of Macedonia-Thrace, Thessaloniki, Greece; ${ }^{3}$ Bavarian Office for Forest Genetics, Teissendorf, Germany; ${ }^{5}$ Slovenian Forestry Insitute, Ljubljana, Slovenia (aravanop@for.auth.gr; nikostourvas@gmail.com; ermionimalliarou@yahoo.gr; aevaggelia@yahoo.com; amfarsakoglou@gmail.com; alizotp@for.auth.gr;vbarbas@for.auth.gr; giannis.ganopoulos@gmail.com;

fkiourts@gmail.com; barbara.fussi@asp.bayern.de; hojka.kraighe)

Species demography and genetic diversity are affected by climatic oscillations and anthropogenically induced stresses. Their potential for future rapid adaptation is questioned, given the pace of environmental change. Quantifying temporal alterations (at $\geq 10$ year intervals for genetic markers) in genetic structure and diversity (forest genetic monitoring, FGM), brings prognosis before irreparable harm befalls. As the first evaluation will only create baseline data, true comprehensive FGM will materialize at the second assessment several years later. FGM may circumvent this problem by incorporating incidental comparative data from earlier studies or from younger cohorts at the baseline study, by examining: information capacity (IC) of the marker system (depending on locus numbers, polymorphism level, gene action mode), and direction of differences in allelic richness and evenness. This approach is applied in a Mt. Olympus FGM population of Greek hybrid fir using $11 \mathrm{f}$-nSSRs in two cohorts ( 250 adults, 200 juvenile plants). Comparisons between this and a previous study, and between cohorts showed: (a) present IC is high indicating a better representation of the underlying genome variation, (b) genetic diversity (nA, nE, LGP, I, HE) is significantly higher in the present study, (c) genetic diversity is higher in the mature cohort as seen in other studies, but differences in some metrics are not statistically significant. Conclusions: no indication for adverse effects; a gene conservation unit can be established; the interim FGM assessment proved a valuable tool for evaluating conservation potential in the absence of more complete temproral-scale data. This work is funded by project EC-LIFE13 ENV/ $\mathrm{SI} / 000148$. 


\section{Development of a system for forest genetic monitoring through the implementation project LIFEGENMON}

Hojka Kraigher ${ }^{1}$

${ }^{1}$ Slovenian Forestry Institute, Ljubljana, Slovenia (hojka.kraigher@gozdis.si)

Forest genetic monitoring (FGM) gives the possibility to detect changes in the adaptability of forest genetic resources (FGR) to the changing environments before any visual signs can be observed. The European Forest Genetic Resources programme (EUFORGEN) has been promoting conservation of FGR since its establishment in 1994, and almost as long FGM has been discussed by the FAO group on FGR. However the first implementation project to support its development in Europe with special emphasis on South-Eastern Europe, is the LIFE project LIFEGENMON, followed by several research projects within the European Horizon sheme. With the session "Applied genetics for forest management and conservation" we are contributing to the long-term goals of sustaining forests threatened by the range of impacts due to the fast climate change, as well as support a better definition and control of sustainable forest management practices through implementation of FGM. For this, not only the sampling desing, and definition of indicators and verifiers of genetic diversity changes in time need to be defined per species, but also silvicultural guidelines, the FGM Manual and Decision support tool, as well as regulative background need to be prepared and accepted at the national, regional and continental scale, and general support for forestry raised. The presentation contributes to the aims and means of the project LIFEGENMON (LIFE13 ENV/SI/000148) LIFE For European Forest Genetic Monitoring System which is in line with goals of EUFORGEN (European Programme for Forest Genetic Resources).

\section{Alternative sampling design for forest genetic monitoring \\ Natalija Dovč ${ }^{1}$, Rok Damjanić ${ }^{1}$, Marjana Westergren ${ }^{1}$, Marko Bajc $^{1}$, Domen Finžgar ${ }^{1}$, Darius Kavaliauskas ${ }^{2}$, Dalibor Ballian $^{3}$, Barbara Fussi $^{2}$, Filippos A. Aravanopoulos ${ }^{4}$, Hojka Kraigher ${ }^{1}$ \\ ${ }^{1}$ Slovenian Forestry Institute, Ljubljana, Slovenia; ${ }^{2}$ Bavarian Office for Forest Seeding and Planting, Teisendorf, Germany; ${ }^{3}$ Faculty of Forestry, University of Sarajevo, Sarajevo, Bosnia and Herzegovina; ${ }^{4}$ Aristotle University of Thessaloniki, University Campus, Thessaloniki, Greece (natalija.dovc@gozdis. si; rok.damjanic@gozdis.si; marjana.westergren@gozdis.si;marko.bajc@gozdis.si; d.finzgar@sms.ed.ac.uk; darius.kavaliauskas@asp.bayern.de; balliandalibor9@gmail.com; barbara.fussi@asp.bayern.de; aravanop@for.auth.gr; hojka.kraigher@gozdis.si}

The existing sampling design for forest genetic monitoring (FGM), used in the LIFEGENMON project, is based on "The German concept". According to this concept, the experimental plot should have a total area of 4 hectares with intensive section of $100 \mathrm{x} 100 \mathrm{~m}$ surrounded by extensive section with dimensions of $200 \times 200 \mathrm{~m}$. Within the intensive section 250 adult trees are to be randomly selected. If the tree density is too low in the intensive section, the remaining trees are to be included in the extensive section. During the first assessment of the beech monitoring plot questions about the appropriateness of the above described design arose. It is difficult to claim that a plot, established in accordance with the above-mentioned requirements, is representative of the beech stand within which it is located. In order to assess genetic diversity and its changes over time as objectively as possible, we have designed an alternative sampling design that meets the demands of replications, independence, randomness and interspersion to the greatest extent possible, making the sample representative of the studied population. The alternative sampling design consists of 5 plots, randomly distributed within the entire stand (100 ha). Within each plot 50 adult trees and 40 natural regeneration trees are randomly selected. A comparison between two sampling designs will show whether there are differences in the genetic diversity assessment and the direction in which a sampling design for FGM should develop to give the most relevant results with managable amount of effort.

\section{Phenology of European beech (Fagus sylvatica L.) as part of forest genetic monitoring in Slovenia}

Rok Damjanic ${ }^{1}$, Marjana Westergren ${ }^{1}$, Domen Finžgar ${ }^{1}$, Natalija Dovčํ․ Melita Hrenko ${ }^{1}$, Barbara Fussi ${ }^{2}$, Filippos A. Aravanopoulos ${ }^{3}$, Hojka Kraigher ${ }^{1}$ ${ }^{1}$ Slovenian Forestry Institute, Ljubljana, Slovenia; ${ }^{2}$ Bavarian Office for Forest Seeding and Planting, Ljubljana, Slovenia; ${ }^{3}$ Aristotle University of Thessaloniki,Thessaloniki,Slovenia(rok.damjanic@gozdis.si; marjana.westergren@gozdis.si; d.finzgar@sms.ed.ac.uk; natalija.dovc@gozdis.si;melita. hrenko@gozdis.si; barbara.fussi@asp.bayern.de; aravanop@for.auth.gr;hojka.kraigher@gozdis.si)

Phenology is a highly important adaptive trait, which determines the growing season and the reproductive period of plants. Climate change, the associated increased temperature and late spring frost damage are the main reasons why phenology is changing over the years. From 2016 we are monitoring the spring and autumn phenology of European beech (Fagus sylvatica L.), one of ecologically and economically most important broadleaves in Europe. In the beginning 40 trees were monitored for bud break, leaf senescence, flowering and fructification. The number of trees was extended to 250 in the last 2 years. Each tree on the plot was georeferenced and its crown projection was measured. The presented data shows the comparison of phenology between trees and tree groups. Data analysis and representation of phenology was also performed in the spatial dimension, representing trees in different phenological stages with their tree crowns on a spatial plot. In this way we can easily observe spatial patterns of trees and/or recognize single trees which have different phenology than others. The presentation contributes to the aims and means of the project LIFEGENMON (LIFE13 ENV/SI/000148) LIFE For European Forest Genetic Monitoring System, cofinanced by the Ministry for the environment and spatial planning RS, and in Slovenia by the Ministry for agriculture, forestry and food and the Slovenian Forestry Institute.

\section{Variation in genetic diversity of European beech (Fagus sylvatica L.) seed from different reproductive year (2006 vs 2016 ) and its importance for forest genetic monitoring}

Darius Kavaliauskas ${ }^{1}$, Barbara Fussi

Bavarian Office for Forest Seeding and Planting, Teisendorf, Germany (darius.kavaliauskas@asp.bayern.de; barbara.fussi@asp.bayern.de)

Regular reproductive cycles and seed formation in forest trees ensure that the population is able to survive and reproduce. Over the last few decades, forests have been facing many threats and pressures, especially those related to climate change and human impact. As a result of changing environment frequency of reproductive years become more irregular and the amount of reproducing trees and viable seeds can decrease drastically in different populations. Furthermore, natural regeneration can be influenced by annual variation in flowering abundance as well as flowering synchronization, which typically have a genetic and an environmental component, affecting the genetic composition of the seed crop and the subsequent natural regeneration in a forest stand. To fully understand how these threats affect genetic diversity forest genetic monitoring (FGM) should be used as an early warning system. For this aim an FGM plot for European beech in south of Germany was established in 2006. Seeds from 20 single trees at different reproductive years (2006 / 2016) were collected and genotyped based on 16 nuclear microsatellite loci (in total 800 seeds). Based on gained data the questions we are trying to answer are: (i) Are there significant changes in genetic diversity parameters of seeds over years? (ii) Are there significant changes in the mating system over years? First results indicate that there are no significant changes in genetic diversity measures of seeds from different reproductive year. Further results regarding FGM mating system parameters based on seeds genetic variation from different reproductive year are presented. 


\section{Use of microsatellite markers for clonal identification in European larch seed orchard}

Pavlina Máchová ${ }^{1}$, Helena Cvrčková1, Olga Trčková ${ }^{1}$

${ }^{1}$ Forestry and Game Management Institute, Czech Republic Jíloviště (machova@vulhm.cz; cvrckova@vulhm.cz; trckova@vulhm.cz)

The Simple Sequence Repeats (SSR) method of DNA analyses was used to clonal identification in a model European larch (Larix decidua Mill.) seed orchard. Total genomic DNA was extracted by DNA Plant Mini Kit (QIAGEN) from needles taken from 170 sampled trees of seed orchard. Samples were screened using selected 13 polymorphic nuclear microsatellite markers. Measuring the size of amplification products was carried out using the genetic analyser Applied Biosystems 3500. The obtained data were analysed using the statistical programs CERVUS, GenAlEx 6.503 and Micro-Checker. There were detected 133 different alleles at 13 loci in the 170 European larch tree individuals from seed orchard. The most polymorphic in our set of samples was locus bcLK211. By applying the 13 suitable markers to the 42 clones from model seed orchard we obtained multilocus genotypes (MLG). Clone affiliation declared by its owner was confirmed in $71 \%$ of sampled trees, but on the basis of obtained genotypes, it is possible to assign $98 \%$ of sampled tree to clones from seed orchards. The obtain results illustrate the utility of the microsatellite loci for assessing spatial patterns of genetic diversity and for individual identification. This work was supported by the Ministry of Agriculture of the Czech Republic, institutional support MZE-RO0118.

\section{Evaluation of the genetic diversity of selected Czech Norway spruce stands}

Helena Cvrčková ${ }^{1}$, Pavlina Máchová ${ }^{1}$ Olga Trčková ${ }^{1}$

${ }^{1}$ Forestry and Game management Research Institute, Czech Republic Jiloviště (cvrckova@vulhm.cz; machova@vulhm.cz; trckova@vulhm.cz)

The genetic structure of selected Norway spruce stands from the Jeseníky Mts., Orlické hory Mts., and Krušné hory Mts. (Czech Republic) was studied to verify the genetic quality. The genetic variability of tree populations ensures the stability and sustainability of forest ecosystems. DNA polymorphism at twelve nuclear microsatellites of fourteen Norway spruce stands was investigated. The level of genetic diversity within 14 investigated Czech Norway spruce stands was relatively high. Mean values for number of different alleles ranged from 12.25 (stand SM J51) to 15.92 (stand SM T1). The values of observed heterozygosity (Ho) ranged from 0.65 to 0.81 , and expected heterozygosity (He) from 0.81 to 0.86 . Pairwise population FST values ranging from 0.007 to 0.030 indicated low genetic differentiation between units, and values of Nei's genetic distance among Norway spruce units ranged from 0.083 to 0.313 . The structuring of investigated Norway spruce stands was also confirmed by different ratios of genetic profiles according to the Bayesian clustering method results. Closer genetic similarity was seen in the stands from the gene conservation unit in the Orlické hory than in other studied stands. The most genetically different stand was from the Krušné hory. Knowledge based on DNA analyses regarding the variability of genetic resources will contribute to the quality of the reproduction material and to creation of an optimal species composition in forests. This work was supported by the projects of the Ministry of Agriculture of the Czech Republic - institutional support MZE-RO0118 and no. NAZV QK1810129

Genetic structure of Bertholletia excelsa throughout the Brazilian Amazon region / Estrutura genética de Bertholletia excelsa ao longo da Amazônia brasileira

Laura Luciana de Melo Moreira Silva ${ }^{1}$, Patricia da Costa ${ }^{2}$, Lúcia Helena de Oliveira Wadt ${ }^{3}$, Marília de Castro Rodrigues Pappas ${ }^{4}$, Tatiana de Campos 5 , Marcelino Guedes Carneiro, Kátia Emídio da Silva7, Eulalia S. S. Hoogerheide ${ }^{8}$, Aisy Botega Baldoni Tardin ${ }^{8}$, Ricardo Scoles ${ }^{9}$, Lucieta Guerreiro Martorano $^{10}$, Evert Thomas ${ }^{11}$, Renato K. Kimura ${ }^{12}$, Karina Martins ${ }^{12}$

${ }^{1}$ Universidade Federal de São Carlos, Licenciatura em Ciências Biológicas, Sorocaba, Brasil; ; ${ }^{2}$ Embrapa Roraima, Boa Vista, Brasil;; ${ }^{3}$ Embrapa Rondônia, Porto Velho, Brasil; ${ }^{4}$ Embrapa Recursos Genéticos e Biotecnologia, Brasilia, Brazil; ${ }^{5}$ Embrapa Acre, Rio Branco, Brasil; ${ }^{6}$ Embrapa Amapá, Macapá, Brasil; ${ }^{7}$ Embrapa Amazônia Ocidental, Manaus, Brasil; ${ }^{8}$ Embrapa Silvipastoril, Sinop, Brasil; ${ }^{9}$ Universidade Federal do Oeste do Pará, Santarém, Brasil; ${ }^{10}$ Embrapa Amazônia Oriental, Santarém, Brasil; ${ }^{11}$ Bioversity International, Cali, Colombia; ${ }^{12}$ Universidade Federal de São Carlos, Sorocaba, Brasil(laurasilva@live.com; patricia.da-costa@embrapa.br; lucia.wadt@embrapa.br; marilia.pappas@embrapa.br; tatiana.campos@embrapa.br; marcelino.guedes@embrapa.br; katia.emidio@embrapa.br; eulalia.hoogerheide@embrapa.br; aisy.baldoni@embrapa.br; ricardscoles@yahoo.es; lucieta. martorano@embrapa.br; e.thomas@cgiar.org;renato-kimura@ufscar.br;karimartins@yahoo.com)

A Bertholletia excelsa Bonpl. (Lecythidaceae) é uma espécie arbórea endêmica das matas de terra firme e com ampla distribuição ao longo de toda a Floresta Amazônica. De grande relevância econômica devido à extração das sementes realizada por populações locais, está entre os produtos mais exportados da Amazônia. Atualmente, faz parte da lista oficial das espécies em extinção, sendo classificada como vulnerável. Tendo em vista este contexto torna-se de suma importância o estabelecimento de estratégias para definição de áreas prioritárias para a conservação da espécie. Uma dessas ferramentas é a caracterização da diversidade e estrutura genética em populações naturais. Esse trabalho amostrou árvores em 22 populações naturais da $B$. excelsa ao longo da Amazônia brasileira, totalizando 140 amostras em todos os estados da região Norte. Foram construídas bibliotecas genômicas NextRAD, e o sequenciamento resultou na identificação de $\sim 30.000$ locos SNPs (Single Nucleotide Polymorphism). Com os genótipos SNPs foram estimados parâmetros de diversidade e estrutura genética. Observamos níveis elevados de diversidade genética e identificamos regiões da Amazônia brasileira com diversidade genética única. São apresentados resultados das estatísticas F de Wright, bem como a correlação entre distâncias genéticas e geográficas. Utilizamos o método Bayesiano de agrupamento implementado no pacotegenelandpara visualizar a estruturação genética na paisagem, que usamos para discutir propostas de áreas prioritárias para conservação. Apoio financeiro: Embrapa (Processo SEG: 02.13.05.017.00.00).

\section{Lack of interaction between provenances and habitats of scots pine (Pinus sylvestris L.) in two experimental plots in Bosnia and Herzegovina}

Mirzeta Memišević Hodžić ${ }^{1}$, Dalibor Ballian ${ }^{1,2}$, Hojka Kraigher ${ }^{2}$

${ }^{1}$ University of Sarajevo, Sarajevo, Bosnia and Herzegovina; ${ }^{2}$ Slovenian Forest Instiutute, Ljubljana, Slovenia (mirzeta.mh@sfsa.unsa.ba; balliandalibor9@gmail.com; hojka.kraigher@gozdis.si)

The research studies interactions between provenances of Scots pine in two test planes (Romanija Glasinac, $1000 \mathrm{~m}$ and Gostović Zavidovići, $480 \mathrm{~m}$ above sea level) of different ecologic conditions in Bosnia and Herzegovina. The test includes 11 provenances with 10 families in each, and in five repetitions. All interactions are calculated on the basis of value of diameter at breast height and height of plants that are 21 years old. Šipovo was the best provenance in Glasinac plane, with average breast-height diameter amounting to $14.04 \mathrm{~cm}$ and $8.82 \mathrm{~m}$ height, while Olovo showed lowest results $-11.99 \mathrm{~cm}$ and $7.72 \mathrm{~m}$. In Gostović plane, Bosanski Petrovac had the biggest average breast-height diameter $-12.28 \mathrm{~cm}$ while maximum height was recorded in Rogatica provenance - $10.96 \mathrm{~m}$. Smallest average breast-height diameter $(9.74 \mathrm{~cm})$ and minimum height was recorded in Doboj seed orchard provenance. Variance analysis showed statistically significant differences between provenances in terms of diameter at breast height and height values. The obtained values of coefficient have shown that there 
is no interaction between provenances and habitats in any provenance located in the observed planes. The reason for lack of interaction lies within the species biology. It is a pioneering species with fast flow of genes. This is the reason for weak differentiation of provenances in Bosnia and Herzegovina which is seen in relatively small areas of Central Dinarides. Considering the lack of interaction, best provenances in each plane indicate that they should be used in the given ecologic conditions.

\section{D2b: CONSERVATION, DOMESTICATION AND BREEDING OF NATIVE SPECIES}

\section{Tree for the future program: prototyping conservation of threatened trees in the Philippines}

Pastor Jr. Malabrigo ${ }^{l, 2}$, Ronino Gibe ${ }^{2}$, Allan Barcena ${ }^{2}$, Jimson Solatre ${ }^{2}$,Ernesto Jr. De Guzman ${ }^{2}$

${ }^{1}$ Department of Forest Biological Sciences, College of Forestry and Natural Resources, University of the Philippines Los Baños, Los Banos, Philippines;

${ }^{2}$ Energy Development Corporation, Pasig,Philippines (plmalabrigo@up.edu.ph; gibe.rc@energy.com.ph; barcena.av@energy.com.ph;

solatre.js@energy.com.ph; ernestoboydg@yahoo.com)

Philippine biodiversity is highly considered the most threatened in the planet being the 2ndbiodiversity hottest spot and the4thmost endangered forest ecosystems with only $7 \%$ of the original forest cover remaining.Same with deforestation, Philippines has a very long history of reforestation. Unfortunately, until very recently, more than $90 \%$ of the reforestation projects used exotic species. With the increasing number of tree species being included in the Philippine Red List for Plants, the Energy Development Corporation (EDC) initiated a corporate social responsibility program called Tree for the Future (TFTF). Its main objective is to mainstream planting of threatened trees and bring the species back to abundance. TFTF follows four key steps in trying to prevent the extinction of Philippine threatened trees namely: 1) species rescue and protection; 2) mass propagation; 3) establishment of future mother trees; and 4) advocacy and awareness campaign. Since 2008, EDC has been exploring almost every island of the Philippines to document remaining natural populations of the most threatened native trees. With coordination and partnership with concerned agencies, propagules were collected and mass propagated through vegetative material recovery (VMR) facility. Its clonal facility has developed propagation protocols for 20 threatened species. Propagules produced from the VMR were donated and planted to schools and parks. To date, EDC has planted around 8,000 threatened trees in 164 partner schools all over 16 regions of the country with $90 \%$ survival rate. To promote awareness and better appreciation, EDC chronicles its learning experiences through books and media publications.

\section{Participative tree domestication as a strategy for use and conservation of high-value native forest species in Uruguay}

Zohra Bennadji $i^{1}$ Marcelo Alfonso ${ }^{1}$, Stefani Mello ${ }^{1}$, Pablo Nuñez ${ }^{1}$

${ }^{1} I N I A$ Uruguay,Tacuarembó,Uruguay (zbennadji@inia.org.uy; malfonso@inia.org.uy;.smello@inia.org.uy; pnunez@inia.org.uy)

As a traditional livestock country, Uruguay is still an emergent forestry country despite the commercial plantations boom of the nineteens, based on exotic fast growing species. There is a scarce experience on the conservation, domestication and breeding of native forest species in the country and this situation has a negative impact on the establishment of agroforestry systems and on the implementation of native forests conservation and restauration actions. The purpose of this work is to present the knowledge generated in participative tree domestication of high-value native forest species in Uruguay as a strategy for shortening the way and opening opportunities for: (i) the improved seed and seedling production, (ii) the forest species diversification, (iii) the small scale forestry establishment, (iv) the use/incorporation of high-value native forest trees in livestock and agriculture activities and (v) the awareness on climate change impacts and it relationship with deforestation-afforestation, land use and land restoration.

\section{NZ Kauri: an iconic ancient species in crisis from kauri dieback}

Rosie Bradshaw ${ }^{1}$ (D), Yanan Guo ${ }^{1}$, Pierre-Yves Dupont ${ }^{2}$, Carl Mesarich ${ }^{1}$, Joe Win $^{3}$, Preeti Panda ${ }^{4}$, Nari Williams $^{4}$, Rebecca McDougal ${ }^{4}$ ${ }^{1}$ BioProtection Research Centre, Massey University, Palmerston North, New Zealand; ' Institute of Environmental Science and Research Limited, Christchurch, New Zealand; ${ }^{3}$ The Sainsbury Laboratory, Norwich, United Kingdom; ${ }^{4}$ Scion, NZ Forest Research Institute, Rotorua, New Zealand (r.e.bradshaw@massey.ac.nz;y.guo.1@massey.ac.nz; pierre.dupont@esr.cri.nz; c.mesarich@massey.ac.nz; joe.win@sainsbury-laboratory.ac.uk; preeti.panda@scionresearch.com; nari.williams@scionresearch.com; rebecca.mcdouga@scionresearch.com)

In New Zealand, $99 \%$ of the ancient, iconic and culturally significant native kauri (Agathis australis) were destroyed by early settlers seeking a living in the new land. Now the species is close to crisis point due to an epidemic of kauri dieback, caused by the root-infecting oomycete pathogen, Phytophthora agathidicida. No-one has yet managed to eradicate a Phytophthora pathogen from a forest, so current methods to manage this disease have included considerable efforts to prevent its spread into uninfected forests. Some success in slowing the progression of the disease has been made by injecting phosphite into infected trees and a citizen science project has helped to expand the number of trees that could be treated in this way. Further hope for the future lies in screening kauri for resistance or tolerance to the disease and a screening programme in progress at Scion (NZ) suggests that dieback tolerance may be present in kauri populations. Work on the genomics of kauri itself is subject to cultural restrictions. However, insights into the genome of the pathogen, and the use of alternative plants for initial screening, have enabled identification of pathogen effector proteins that may help cause disease or elicit host defence. We hope to screen these effector proteins in kauri tissue to determine if they show the same functions in the natural host. Ultimately, we aim to identify host targets that interact with the effector proteins to help determine the genetic basis of susceptibility and resistance in kauri.

\section{Genetic variation, trade-offs and association genetics for growth, bud burst and pathogen susceptibility in maritime pine}

Agathe Hurel ${ }^{1}$,Marina De Miguel ${ }^{2}$,Cyril Dutech ${ }^{1}$, Marie-Laure Desprez-Loustau ${ }^{1}$,Christophe Plomion ${ }^{1}$, Isabel Rodriguez-Quilón ${ }^{3}$, Agathe Cyrille ${ }^{1}$, Thomas Guzman ${ }^{1}$, Ricardo Alia ${ }^{3}$, Santiago C. González-Martínez ${ }^{1}$, Katharina B. Budde ${ }^{1}$

${ }^{1}$ BioGeCo, INRA - Université de Bordeaux, Cestas, France; ${ }^{2}$ BioGeCo, INRA - Université de Bordeaux, Cestas, France; ${ }^{3}$ Department of Forest Ecology and Genetics, Forest Research Centre, INIA, Madrid, Spain (agathe.hurel@inra.fr; marina-amapola.de-miguel-vega@inra.fr; christian-cyril.dutech@inra.fr; marie-laure.desprez-loustau@inra.fr; christophe.plomion@inra.fr; irodriguezquilon@gmail.com; agathe.cyrille@gmail.com; thomas.guzman@etu.u-bordeaux.fr; alia@inia.fr; santiago.gonzalez-martinez@inra.fr; katharina.budde@inra.fr)

Forest ecosystems are increasingly challenged by extreme events, e.g. pest and pathogen outbreaks, which cause severe ecological and economical losses. A key to preserve forest ecosystems is the understanding of the genetic basis of adaptive traits in forest trees. Maritime pine, a conifer widely distributed in southwestern Europe and North Africa, grows under contrasted environmental conditions promoting local adaptation. Adaptive phenotypes, such as height, bud 
burst, and presence/absence of nests of pine processionary moth were assessed in a clonal common garden, that comprises trees from range-wide populations. Additionally, we implemented experimental approaches to assess susceptibility to the pathogens Diplodia sapinea and Armillaria ostoyae by excised shoot inoculations. The presence/absence of nests of pine processionary was not heritable, whereas heritability for height (0.156) and bud burst (0.241) was moderate. Heritability for susceptibility to pathogens was lower, 0.096 for $D$. sapinea and 0.021 for $A$. ostoyae, but still significant. Genetic correlations between traits revealed a trade-off in pathogen susceptibility between $D$. sapinea and $A$. ostoyae necrosis length. Pathogen susceptibility was also genetically correlated with tree height, positively for $D$. sapinea and negatively for $A$. ostoyae. Trees from the southern populations tended to be smaller and showed lower susceptibility to $D$. sapinea but higher to A. ostoyae while the opposite was found for northern Atlantic populations. Genotype-phenotype associations using 4,227 genome-wide SNPs revealed several loci significantly associated to each trait. While current breeding programs of maritime pine mainly focus on growth traits, this study provided important results to develop strategies that consider forest resilience to pathogen outbreaks.

\section{Methodology for environmental and genetic characterization of Araucaria populations for conservation and sustainable use of genetic resources / Metodologia orientada à caracterização ambiental e genética de populações de araucária para conservação e uso sustentável dos recursos genéticos}

Marcos Silveira Wrege ${ }^{1}$, Valderês Aparecida Sousa ${ }^{1}$, Ananda Virginia de Aguiar ${ }^{1}$, Márcia Toffani Simão Soares ${ }^{1}$, Elenice Fritzsons ${ }^{1}$, Itamar Antonio Bognola ${ }^{1}$, João Bosco Gomes ${ }^{1}$, Letícia Penno de Sousa ${ }^{2}$, Cristiane Vieira Helm, Patrícia Póvoa de Mattos ${ }^{1}$ (D

${ }^{1}$ Embrapa Florestas, Colombo, Brasil, ${ }^{2}$ Embrapa Clima Temperado, Pelotas Brasil (marcos.wrege@embrapa.br; valderes.sousa@embrapa.br; ananda.aguiar@embrapa.br; marcia.toffani@embrapa.br; elenice.fritzsons@embrapa.br; itamar.bognola@embrapa.br; joao.bv.gomes@embrapa.br; leticia.penno@embrapa.br; cristiane.helm@embrapa.br;patricia.mattos@embrapa.br)

Araucaria angustifolia (Bertol.) O. Kuntze. está presente no bioma Mata Atlântica, predominantemente na Floresta Ombrófila Mista e se encontra na lista vermelha das espécies criticamente em perigo de extinção da IUCN, sendo vulnerável em função das mudanças climáticas. O acordo firmado pelo Brasil em 2015 na COP21 enfatiza a necessidade de 'incrementar a capacidade nacional em conservação e uso sustentável da biodiversidade'. Com base nesta demanda, desenvolvemos uma metodologia orientada à caracterização ambiental e genética de populações de $A$. angustifolia, como subsidio à sua conservação e uso sustentável. O método consiste em 5 etapas: 1) definição de margens de ocorrência e seleção de regiões prioritárias para amostragens; 2) amostragens para genotipagem e dendrocronologia; 3) amostragens de solos; 4) estudo do clima e 5) identificação de nichos ecológicos das populações. Ao agregar abordagem multidisciplinar, foi possível propor novos métodos de coleta de material genético e de análise das condições pedoclimáticas, aumentando a eficácia, acurácia e segurança no processo de geração de informações referentes ao comportamento da espécie. Os resultados preliminares indicam que a maior parte das populações de $A$. angustifolia ocorre em regiões com características ambientalmente parecidas e que uma pequena parte ocorre em situações diferentes. Neste último caso, as populações devem ser priorizadas para coleta de germoplasma e é onde devem ser priorizados testes experimentais, uma vez que a chance de encontrar indivíduos mais adaptados às regiões típicas de ocorrência é maior. A metodologia desenvolvida é passível de aplicação a outras espécies florestais nativas semelhantes, com pequenas adaptações.

\section{Geographic structuring of the genetic variability of Ilex paraguariensis St. Hil. in Uruguay / Estructuración geográfica de la} variabilidad genética de Ilex paraguariensis St. Hil. en el Uruguay

Pablo Hernández ${ }^{1}$, Alexandra Gottlieb ${ }^{2}$, Arley Camargo ${ }^{3}$, Magdalena Vaio ${ }^{4}$, Pablo Speranza ${ }^{1}$

${ }^{1}$ Facultad de Agronomía, Universidad de la República, Montevideo, Uruguay; ${ }^{2}$ Universidad de Buenos Aires, Facultad de Ciencias Exactas y Naturales - Ciudad Universitaria, Pabellón II, 4to piso, Departamento de Ecología, Genética y Evolución, Lab; 62, C1428EHA, Buenos Aires, Argentina; ${ }^{3}$ Centro Universitario de Rivera, Universidad de la República, Rivera, Uruguay; ${ }^{4}$ Facultad de Agronomía, Universidad de la República, Montevideo, Uruguay (pablohernandez27@gmail.com; alexandramgottlieb@gmail.com; arley.camargo@gmail.com; magdalenavaio@gmail.com; pablorsperanza@gmail.com)

Ilex paraguariensis St. Hil. es una planta subtropical perteneciente a la familia Aquifoliaceae, posee follaje siempre verde, porte arborescente y es longeva. Su distribución natural abarca los territorios de Brasil, Argentina, Paraguay y Uruguay. Es una especie de gran interés socio-cultural y comercial porque con sus hojas se elabora la yerba, principal ingrediente de la bebida del "Mate" o "Tereré". En Uruguay las poblaciones naturales de I. paraguariensis representan el límite sur de la distribución de la especie, localizándose en áreas de refugio o "Hot Spots" ubicadas en el norte y este del país. Se tiene escasa información sobre las poblaciones uruguayas, pero se cree que pueden aportar variantes de interés para el mejoramiento y conservación de la especie. Este trabajo se dispone probar que se detecta estructuración geográfica de la variabilidad haplotípica de I. paraguariensis en el territorio uruguayo y que la diversidad entre dichas poblaciones es mayor que la encontrada en el resto de su distribución. Para probar esta hipótesis se obtuvo el ADN de 273 individuos georreferenciados, distribuidos a lo largo de 17 sitios de colecta en bosques relictuales y se analizó la información conjunta obtenida de la amplificación del ADN con 30 marcadores microsatélites cloroplásticos. Las poblaciones uruguayas aparecen altamente estructuradas y diferenciadas de las muestras de Paraguay, Argentina y Brasil. Se observa una diferenciación genética clara y ausencia de flujo de semillas entre poblaciones, con importantes implicancias para la conservación y exploración del germoplasma.

\section{Estimating realized gene flow patterns in the Kenyan population of Acacia senegal (syn. Senegalia senegal): an empirical comparison of SNP and microsatellite variations}

Stephen F. Omondi $i^{1}$ Damase Khasa ${ }^{2}$

${ }^{1}$ Kenya Forestry Research Institute, Nairobi, Kenya; ${ }^{2} L a v a l$ University, Quebec, Canada (stephenf.omondi@gmail.com; damase.khasa@ibis.ulaval.ca)

Despite the importance of seed and pollen dispersal for survival of tree species a cross landscapes, data on gene dispersal on important tropical dryland species that are undergoing various population dynamics remain scarce. Understanding the patterns of gene dispersal in these ecosystems is important for conservation and tree improvement purposes. We investigated pollen and seed mediated gene flow in disturbed and undisturbed populations of $S$. senegal based on microsatellite and genotyping-by-sequencing (GBS) multilocus genotypes of seedlings and adult trees. We performed parentage assignments using likelihood and seedling neighborhood approaches. We also undertook spatial genetic structure (SGS) analyses for the two growth stages. The SNPs showed higher resolution power and assignment rates than microsatellites, however, a combination of the two marker types provided a robust parentage assignments. We found occurrence of high frequency of long-distance pollination events in disturbed than undisturbed population, however, localized seed dispersal were evident in both populations. Parentage analysis showed high amounts of pollen $(40 \%)$ and seed $(20 \%)$ immigration in both populations. Significant positive spatial genetic structure was found for the adult cohorts in undisturbed population for distance classes 25 and $50 \mathrm{~m}$, indicating short distance of historical seed dispersal. Our results suggest long distance gene flow within the species and recommend conservation of remnant and isolated populations and/or individual 
trees to promote genetic connectivity among populations. Seed collection for tree improvement or conservation should observe a minimum distance of $60 \mathrm{~m}$ to avoid sampling of closely related individuals.

\section{Efficiency of artificial neural networks to predict genetic values and genetic gains in Bactris gasipaes}

Gustavo Rodrigues ${ }^{1}$, Antonio Nascim Kalil Filho², Wanderley Santos ${ }^{3}$, Karina Martins ${ }^{1}$, Ananda Virginia de Aguiar ${ }^{2}$

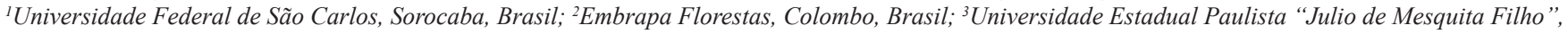
IlhaSolteira,Brasil (henriquesr.gustavo@gmail.com; antonio.kalil@embrapa.br; wanderley.dossantos@hotmail.com; karimartins@yahoo.com; ananda.aguiar@embrapa.br)

Bactris gasipaes, popularly known in Brazil as pupunha, is a palm species native to tropical America. The heart-of-palm and the fruits are edible and commercially harvested from plantations. Brazil is the main producer in the world, but the domestic market consumes almost the entire annual production. Strategies to maximize their productivity through breeding are therefore necessary. In this study we propose the use of Artificial Neural Networks (ANN) with Multilayer Perceptron method to predict genetic gains and values and capture genotype information that are not contemplated in conventional stochastic procedures. The germplasm used in this study is composed by progeny tests from open-pollinated seeds. Those tests were established in Paraná, Amazonas and Roraima states, in complete block design with one plant per linear plot, in 2 x 1m spacing. The phenotypic traits were height, diameter and heart-of-palm production. We used ANN to predict genetic values and rank genotypes for selection. In ANNs, we used as input of the network the individual breeding and genotypic values. The data was randomly divided into training (80\%) and extrapolation (20\%) data. The best ANN architecture was three hidden layers with 14-5-5 neurons, and showed a root mean square error (RMSE) of 0.3999, a mean absolute error (MAE) of 0.3898 and coefficient of determination $\left(\mathrm{R}^{2}\right)$ of 0.9596 with the residual graph showing no bias. The performance of ANN showed superiority than multiple regression models in predict genetic gains and genetic values.

\section{D2c: CONSERVATION, SUSTAINABLE MANAGEMENT AND DEVELOPMENT OH FOREST GENETIC RESOURCES ACROSS THEIR RANGES: REGIONAL RESEARCH AND COLLABORATION}

\section{Assessing the value, performance and potential implementation of assisted migration across Canada's forests \\ Guillaume Peterson St-Laurent ${ }^{1}$, Shannon Hagerman ${ }^{1}$, Robert Kozak ${ }^{1}$ \\ ${ }^{1}$ Faculty of Forestry, University of British Columbia, Vancouver, Canada (peterson.guil@gmail.com; shannon.hagerman@ubc.ca; rob.kozak@ubc.ca)}

Proponents of assisted migration — the intentional movement of tree species (either within or outside of native range) to more suitable areas based on climatic projections and genetically-informed seed selection - see this novel forest management strategy as a means to enhance forest resilience in an era of global climate change. Others express caution or outright objection, pointing to the potential risks associated with assisted migration, such as the introduction of invasive species or pests/diseases and planted tree species failing to establish. This study used a cross-Canada survey to quantify the judgements of forestry and conservation specialists about the possible implementation of five climate-adaptive reforestation options representing a continuum from business-asusual to technologically intensive interventions in Canada's forests, and including assisted migration within and outside of native range. Results from the survey highlight the diversity of professional judgements on the relative importance of forest management objectives in the context of climate change and the likely performance of reforestation options in Canada's forests. The study also explores the influence of four key factors $3 / 4$ economic, governance, scientific knowledge and social licence $3 / 40$ on the implementation of assisted migration strategies in Canada's forests and assesses the anticipated risks and benefits of such actions. Finally, the analysis outlines positive and negative attitudes regarding assisted migration strategies as a means of adapting to climate change within the practitioners' community.

\section{Predicting the potential habitation and threats of a near threaten and cross-border rosewood species (Dalbergia cultrata) \\ Ping Huang ${ }^{1}$, Yu Liu ${ }^{1}$, Wenyun Yang ${ }^{2}$, Yichen Zong', Yongqi Zheng \\ ${ }^{1}$ State Key Laboratory of Tree Genetics and Breeding; Laboratory of Forest Silviculture and Tree Cultivation; Research Institute of Forestry, Chinese Academy of Forestry, Beijing, China; ${ }^{2}$ Research Institute of Resources Insects, the Chinese Academy of Forestry, Kunming, China (huangping@caf.ac.cn; nefuly@126.com; yangwenyun1@163.com; zongyc@caf.ac.cn; zhengyq@caf.ac.cn)}

Dalbergia cultrata is a rosewood species and widely distribute in a tropical and subtropical zone in Indo-China peninsula, and the south of China. In recent decades, its nature population has been shrinking seriously due to anthropogenic activities or other threats. Understanding the habitat requirements of this species, evaluating habitat quality, and predicting its potential habitat are also essential to conserve the target species. Hence, the following work had been carried out: (1) the preliminary survey of natural population of $D$. cultrata was investigated; (2) based on the public and realistic occurrences including China and neighboring countries, the potential habitat and its requirements of were predicted. (3) habitat suitability of $D$. cultrata for double $\mathrm{CO}_{2}$ level scenario were calculated. The results showed that (1) natural populations distributed in tropical zone in the south of China is sporadic, small and young. Their habitation is fragmented by criss-crossed road and rubber plantation, which may increased difficulties of natural regeneration and gene flow. (2) distribution of $D$. cultrata is mainly influenced by the isothermality, annual range of temperature, and precipitation of wettest and warmest quarter, which suggested it is sensitive to climate change. (3) Habitat suitability will be reduced in for double $\mathrm{CO}_{2}$ level scenario. Therefore, making a priority to conserve the natural resource of $D$. cultrata is imperative and significant in response to threats. However, $D$. cultrata is cross-border and vulnerable species, we also appeal and desire to seek further cooperation with resource-owner countries on the conseravtion and sustainble use of $D$. cultrata .

\section{Conservation approaches for forest genetic resources of the Indian Himalayan Region}

Manisha Thapliyal ${ }^{1}$, Pravin Rawat ${ }^{1}$, Amit Simalti ${ }^{1}$, Neha Pant ${ }^{1}$

${ }^{1}$ Forest Research Institute,Dehradun,India (manishathapliyal98@gmail.com; pravinrawat15@gmail.com; amit.simalti90@gmail.com; neha.pant55555@gmail.com)

The Himalayas well known for complex and diversified biological and physical attributes, are spread over the north-western and north-eastern states of India. Due to richness and uniqueness of biodiversity elements, the region has been recognized as one of the 35 global biodiversity hotspots. However, increased use of its forest resources and shrinking forest land base threaten the sustainability of forest genetic resources and highlight the importance of conservation 
and sustainable management of these resources both in situ as well as ex-situ. We have undertaken a research programme on conservation of Forest Genetic Resources (FGRs) with special focus on the exploration and conservation of FGRs of North-West Himalayas. The major activities under the programme are documentation, characterization, seed and Germplasm Storage of FGRs. The population of the prioritized species (including rare, endangered, threatened and vulnerable) are being explored, populations geo-tagged, phenological observations and species associations recorded. Their seeds are collected, processed, tested for physical and physiological quality and desiccated to safe moisture levels for storage. The seed storage physiology of important Himalayan species like Birch, Carpinus, Fraxinus, pines, spruce, fir, oaks, rhododendrons, walnut, Corylus jacquemontii, high-altitude medicinal plants, etc. is being studied for chalking out a long-term ex situ conservation programme. The orthodox seeds are processed for conservation after slow desiccation to lowest safe moisture levels. Desiccated seeds are then vacuum sealed in triple-layered aluminium bags and stored in Seed bank at -180C. Thus, ex situ conservation becomes the focal point of gene conservation programme of FGRs of Indian Himalayan Region.

\title{
Morphological differences in Pinus strobiformis across latitudinal and elevational gradients
}

\author{
Alejandro Leal-Saenz ${ }^{1}$, Kristen Waring $^{2}$, Samuel Cushman ${ }^{3}$,Andrew Eckert ${ }^{4}$, Lluvia Flores-Rentería ${ }^{5}$, Mitra Menon ${ }^{4}$, Christian Wehenkel ${ }^{6}$ \\ ${ }^{1}$ Universidad Juárez del Estado de Durango, Durango, Mexico; ${ }^{2}$ School of Forestry, Northern Arizona University, Flagstaff, USA; ${ }^{3}$ USDA Forest Service, \\ Flagstaff, USA; ${ }^{4}$ Department of Biology, Virginia Commonwealth University, Richmond, USA; ${ }^{5}$ Department of Biology, San Diego State University, San \\ Diego, USA; 'Instituto de Silvicultura e Industria de la Madera, Universidad Juárez del Estado de Durango, Durango, Mexico (aleals@ujed.mx; kristen. \\ waring@nau.edu; sam.cushman@gmail.com; aeckert2@vcu.edu; lfloresrenteria@sdsu.edu; menonm2@vcu.edu; wehenkel@ujed.mx)
}

The variation in morphological tree traits may occur in response to environmental conditions and other factors, including evolutionary adaptation. Evaluating the variability in tree morphology is therefore critical for testing ecological and evolutionary models that predict the functional or adaptive nature of phenotypic plasticity. However, quantifying morphological variation within a widespread tree species such as Pinus strobiformis (SWWP) across a large spatial scale is preferable in order to identify the relative importance of different environmental and genetic factors in relation to variations in intraspecific morphological traits. SWWP is the most widely distributed white pine in Mexico. This species is a key component of mixed conifer forests in the region in both north-western Mexico and south-western USA and highly susceptible to the invasive tree disease, white pine blister rust, caused by the fungus Cronartium ribicola. The dual threats of this non-native fungal pathogen and a warmer, drier projected future climate have created an uncertain future for SWWP. The objectives of the present study were a) to model and map the spatial distribution of cone and seed morphological traits of SWWP and b) to estimate the relative importance of different environmental and genetic factors on these morphological traits. We found that both genetic and environmental factors influenced the morphological traits but influential factors varied by trait. The variation results from both the ability of genotypes to produce morphological phenotypes and regional selection. Morphological phenotypes may arise as a response to environment conditions.

\section{Conservation and sustainable use of oak Forest Genetic Resources in Romania}

Ecaterina Nicoleta Apostol ${ }^{1}$, Marius Budeanu ${ }^{1}$, Flaviu Popescu $^{1}$, Ovidiu Badea ${ }^{1}$, Dragos Postolache $^{1}$, Ioana Plesca, Constantin Nechita ${ }^{1}$, Cristian Sidor ${ }^{1}$, Stefan Leca ${ }^{1}$

${ }^{1}$ National Institute for Research and Development in Forestry (INCDS), Marin Drăcea, 077190, Romania (cathyches@yahoo.com; budeanumarius@yahoo.com; flaviu.popescu@icashd.ro; obadea@icas.ro;dragospostolache@yahoo.com; ioana0407@yahoo.com; nechitadendro@gmail.com; cristi.sidor@yahoo.com; stefan.leca@icas.ro)

Our research aimed to show the influence of climate change on Forest Genetic Resources (FGR) consisting of thermophilic and xerophyte, or relatively thermophilic and mezoxerophyte oak taxa. Changes that can occur in the phenology of biological processes, considered as the most sensitive and prominent responses to global climate change were investigated. Five native species Quercus pedunculiflora K. Koch, Q. robur L., Q. petraea (Matt.) Liebl., Q. pubescens Willd., Q. virgiliana Ten. were evaluated in Romania. Phenological observations were made in the entire crown at a two-four days interval; in addition, wood microcores were collected weekly in order to study the xylogenesis phenology. The findings of the survey show that there is a significant correlation $(\mathrm{r}=0.8, \mathrm{p}<0.05)$ between leaves unfolding and environmental factors (average daily temperatures). A weakly positive correlation between the time of bud burst and cambium activity $(\mathrm{r}=0.36, \mathrm{p}=0.172)$ was registered. The presence of the representative taxa specimens in all three phenological categories: precocious, intermediate and tardy shows a high level of the variability and adaptability of the natural regenerated population. As expected, the tardy specimens, who have a share of $6 \%$ of all analyzed trees, can avoid the late frost (especially in the flowering period) and the early spring defoliators. The identified adapted phenotype are recommended as forest reproductive base material for the corresponding provenance region and for the ex situ conservation of the specie.

\section{Germination of various dryland tree species important to the Turkana Community in Kenya}

Jesse Owino ${ }^{1}$, Julius Wachira ${ }^{1}$, Grace Enyang ${ }^{1}$, Christopher Etiir ${ }^{2,1}$, Francis Emanikor ${ }^{1}$, Jackline Kemboi ${ }^{3,4}$, Simon Waweru ${ }^{1}$, Gabriel Muturi ${ }^{5}$, David Langat ${ }^{6}$ ${ }^{1}$ Kenya Forestry Research Institute- Turkana Forestry Research Sub-Centre, Lodwar, Kenya; ${ }^{2}$ Masinde Muliro University of Science and Technology, Kakamega, Kenya; ${ }^{3}$ Kenya Forestry Research Institute, Lodwar, Kenya; ${ }^{4}$ University of Nairobi- College of agriculture and veterinary science, Nairobi, Kenya; ${ }^{5}$ Kenya Forestry Research Institute, Nairobi, Kenya; ${ }^{6}$ Kenya Forestry Research Institute- Rift Valley Ecoregion Research Program, Londiani, Kenya (owinojesse@gmail.com; miricho.wachira@gmail.com; enyanggrace@gmail.com; lodungetiir@gmail.com; emanikorfrancis@gmail.com;

jackiekmb@gmail.com; gathumbiwa@gmail.com; gabrielmukuria2012@gmail.com; dkipkirui@yahoo.com)

Acacia tortilis, Acacia senegal, Acacia oerfota, Terminalia brownii and other tree species are important tree species in several parts of the world more so in African pastoral lands. The trees occur naturally in mostly the arid and semi-arid regions of Africa from north to southern parts, The trees apart from providing ecosystem services have various parts including; leaves, pods, gum exudates, and barks have several uses ranging from food, fodder, medicines and commercial use. The major challenge is the lack of successive young generations of trees in these pastoralism areas due to the land tenure system and existing browsing by livestock; there is thus need to know how these germinate to act as a source of knowledge guiding afforestation of rangelands and improve the availability of seed. The aim of this paper is to show how these trees germinate in a controlled arid environment and the growth characteristics of the seedlings in order to predict the early growth of above-ground biomass. The methods begin with selective collection of seeds from wild sources in various areas of Turkana County, Kenya. Subsequent seed pre-treatments, sowing and measurement of growth data to show the tree seed performance under certain controlled conditions and how growth is influenced under the specific controlled conditions under review in relation to its naturally occurring environments. the key observations were there wasn’t uniform germination with some new pre-treatments showing better performance, though once germinated various height to Root Collar Diameter equations were compared and showed areas to improve. 


\section{Applications of genomic data in European conifers}

Sanna Olsson ${ }^{1}$ Francesca Bagnoli ${ }^{2}$, Guia Giovannelli ${ }^{3}$, Caroline Scotti-Saintagne ${ }^{3}$, Ricardo Alia ${ }^{1,4}$, Bruno Fady ${ }^{3}$, Santiago C. González-Martínez ${ }^{4,5,6}$ Maria Mayol ${ }^{6}$, Giovanni G. Vendramin ${ }^{2}$, Delphine Grivet ${ }^{1,4}$

${ }^{1}$ INIA (Instituto Nacional de Investigación y Tecnología Agraria y Alimentaria), Madrid, Spain; ${ }^{2}$ Institute of Biosciences and Bioresources, National Research Council, Florence, Italy; ${ }^{3} I N R A$, Avignon, France; ${ }^{4}$ Sustainable Forest Management Research Institute, INIA - University of Valladolid, Palencia, Spain; ${ }^{5}$ UMR BIOGECO, INRA, University of Bordeaux, Bordeaux, France; ${ }^{6}$ CREAF, Bellaterra, Spain (sanna.olsson@inia.es; francesca.bagnoli@ibbr.cnrit; guiagiovannelli@gmail.com; caroline.scotti-saintagne@inra.fr; alia@inia.es; bruno.fady@inra.fr; santiago.c.gonzalez.martinez@gmail.com; maria.mayol@uab.es; giovanni.vendramin@ibbr.cnr.it; dgrivet@inia.es)

Genomic and transcriptomic datasets offer ample possibilities to increase Forest Genetic Resources by providing relevant markers such as SSR, SNPs, exon capture and single-copy genes. Developing these "omic" resources in conifers is challenging due to their large genome size, long repetitive segments as well as gene and genome duplications, which has limited available reference genomes. However, during the last decades more markers have been made available, with their use depending on the objectives of the studies. At the interspecific level, single-copy genes from nuclear, chloroplast or mitochondrial genomes are a preferred source to be used in studies focusing on phylogeny, biogeography, demographic history and adaptation. At intra-specific level, SSR and SNP markers are useful for a wide range of applications ranging from breeding, genetic conservation and wood trade control to association studies. In this presentation, examples of uses, applications and limitations of various molecular markers will be given for conifers. In particular, markers and results based on the transcriptomes of English yew (Taxus baccata), Aleppo and Brutia pines (Pinus halepensis-brutia species complex) as well as European black pine (Pinus nigra) will be presented.

Implications for the conservation, genetic diversity, and population structure of rosewood (Aniba rosaeodora Ducke) in the Peruvian Amazon region using ISSR markers / Implicaciones para la conservación, diversidad genética y estructura poblacional de Aniba rosaeodora Ducke "palo de rosa" en la Amazonia Peruana empleando marcadores ISSR

Stalin Juan Vasquez Guizado', Juan Carlos Castro Gomez ${ }^{1}$, Muhammad Azhar Nadeem², Fawad Ali', Tedi Pacheco Gómez , Jhon Antoni Vargas Santillan ${ }^{4}$, Esperanza Torres Canales ${ }^{4}$, Gyuhwa Chung ${ }^{5}$, Faheem Shehzad Baloch ${ }^{2}$

${ }^{1}$ Centro de Investigaciones de Recursos Naturales de la Amazonia de la Universidad Nacional de la Amazonia Peruana, Iquitos, Peru; ${ }^{2}$ Universidad Bolu Abant Izzet Baysal, Bolu, Turkey; ${ }^{3}$ Universidad Quaid-I-Azam, Islamabad, Pakistan; ${ }^{4}$ Universidad Nacional de la Amazonia Peruana, Iquitos, Peru; ${ }^{5}$ Universidad Nacional de Chonnam, Chonnam, Democratic People’s Republic of Korea (stalinvg2388@gmail.com; juanccgomez@yahoo.es; azharjoiya22@gmail.com; fawadali365@gmail.com; tepago@gmail.com; biovargas17@gmail.com; torrescanales2@gmail.com; chung@chonnam.ac.kr; balochfaheem13@gmail.com)

Aniba rosaeodora Ducke "palo de rosa" es un árbol forestal en peligro de extinción en la Amazonía, contiene un compuesto aromático de alto valor económico "Linalool" utilizado en la industria de la perfumería. Los bosques naturales de palo de rosa se han agotado considerablemente debido a la sobreexplotación y el uso excesivo de la industria cosmética. Para evaluar la diversidad genética de esta especie se colectaron 90 genotipos provenientes de 8 poblaciones. A partir de ello, se amplificaron 11 marcadores ISSR, obteniendo 375 (99,2 \%) bandas polimórficas y un PIC promedio de 0,774. El promedio del número efectivo de alelos $(\mathrm{Ne})$, la diversidad genética de Nei (He) y el índice informativo de Shannon (I) fue 1,485, 0,294 y 0,453 respectivamente. El resultado del AMOVA, reveló una alta variación genética dentro de las poblaciones (88\%) y baja entre las poblaciones (12\%). La estructura genética, el Neighbor Joining y el análisis principal de coordenadas, agruparon los 90 genotipos de Aniba rosaeodora Ducke en tres grupos (A, B y C). Se calcularon diversos parámetros de diversidad a nivel interpoblacional que reveló una mayor diversidad genética en el grupo A debido al mayor flujo de genes. El análisis Neighbor Joining unió los grupos A y B, mientras que el grupo $\mathrm{C}$ se encontró bastante divergente. Se concluye que las poblaciones de palo de rosa con mayor diversidad genética, deben tener prioridad para la conservación in situ y, mientras tanto, deben realizarse esfuerzos serios para recolectar más poblaciones de palo de rosa para la conservación ex situ.

D2d: GENETICS, MANA GEMENT AND CONSERVATION OF CERRADO FOREST SPECIES: THEIR CHALLENGES AND ACHIEVEMENTS.

\section{Genetic selection of regenerants of Astronium fraxinifolium Schott in a natural population in South Mato Grosso Cerrado degraded area}

Marcelo Augusto Mendes Alcantara ${ }^{1}$, Maiara Ribeiro Cornacini ${ }^{1}$, Darlin Gonzalez Zaruma ${ }^{2}$, José Cambuim² ${ }^{2}$ Ricardo de Oliveira Manoel ${ }^{1}$, Patrícia Ferreira Alves², Mário Luiz Teixeira Moraes², Celso Luis Marino ${ }^{1}$

${ }^{1}$ Universidade Estadual Paulista “Júlio de Mesquita Filho”, Botucatu, Brasil; ${ }^{2}$ Universidade Estadual Paulista “Júlio de Mesquita Filho”, Ilha Solteira, Brasil(marcelo.alcantara@unesp.br; maiaracornacini@gmail.com;dgzaruma@gmail.com; josecambuim@yahoo.com.br; rickom.is@gmail.com; pattyfalves@gmail.com; mario.moraes@unesp.br; cl.marino@unesp.br)

The environmental impact caused by large enterprises and construction sites are a challenge for modern society where recovering diversity and plant cover becomes essential. For this, studies with native tree populations are of great importance. In this sense, the objective of this study was to select patterns of Astronium fraxinifolium Schott, regenerators of a Cerrado degraded area with high genetic value (BLUP), aiming to provide subsidies for the study of the specie, reforestation and conservation. Within a parcel of degraded area previously demarcated of approximately 170ha, located at the Teaching, Research and Extension Farm - FEPE of the São Paulo State University - UNESP, the population was mapped and divided into a grid of 10 rows by 10 columns. A total of 338 adult specimens were randomly selected and measurements were made of the Diameter at breast height (DAP) and Height. Selections of the genotypes were obtained using the BLUP procedure from the SELEGEM REML / BLUP Software with the supply of known heritability and phenotypic variance values from a progeny test of $A$. fraxinifolium near the site. We selected the 50 best individuals for both characters. The results obtained show a selection gain of $48.59 \%$ for DAP and 34.30\% for Height. These data show the potential of this regenerating natural population for a possible seed breeding or breeding program, providing possible progenies with superior genetic quality for the recovery of degraded areas, reforestation, conservation or timber production. 
Unmanaged tree gene banks may hinder full-potential phenotypic traits expression in Myracrodruon urundeuva Fr. Allemão (Anacardiaceae), a highly endangered Cerrado timber species but yet showing genetic variability.

\author{
Luciane Sato $^{1,2}$ José Cambuim $^{1}$, Daniele Zulian ${ }^{1}$, Francieli Saul $^{1}$, Lara Riva ${ }^{1}$, José Oliveira-Júnior ${ }^{3}$, João Antônio Andrade ${ }^{1}$, Damase Khasa $^{2}$, \\ Miguel Freitas ${ }^{4,1}$, Mário Moraes ${ }^{1}$ \\ ${ }^{1}$ Universidade Estadual Paulista “Júlio de Mesquita Filho”, Ilha Solteira, Brasil; ${ }^{2}$ Université Laval, Québec, Canada; ${ }^{3}$ FAIT, Itapeva, Brazil; ${ }^{4}$ Instituto \\ Florestal de São Paulo,São Paulo,Brasil (lucianessato@yahoo.com.br;josecambuim@yahoo.com.br;danizullian@gmail.com; \\ francieli_eng.ambiental@yahoo.com.br; lara-comar@hotmail.com;jose089797@hotmail.com; joao.ac.andrade@unesp.br; damase.khasa@ibis.ulaval.ca; \\ miguellmfreitas@yahoo.com.br;mario.moraes@unesp.br)
}

Ex situ conservation in gene banks is an important strategy to safeguard endangered plant species avoiding the narrowing of species genetic base. The South American native timber species Myracrodruon urundeuva has experienced rampant exploitation and destruction. Its gene bank (BAG-A) was set up in 1987 in West Central Brazil and currently has 20 preserved Brazilian populations from distinct biomes in different common garden experiments. This study aimed at assessing genetic variability of two ex situ conserved $M$. urundeuva Cerrado populations -25 local (S) and 25 non local (A)- based on their progenies (6 replications, 25 families/experiment, 8 plants/plot). Variance components and genetic parameters were estimated using mixed linear models based on height (h), diameter at breast height (DBH) and mean crown diameter (MCD). Deviance analyses were conducted to verify significance of predicted models. Differences in progenies' traits were neither explained by genotypes $\left(\chi^{2}\right.$ values for $\mathrm{DF}=1 ; \alpha=1 \%$ : $(\mathrm{A}) \mathrm{h}=0.2, \mathrm{DBH}=0.42, \mathrm{MCD}=0.37 ;(\mathrm{S}) \mathrm{h}=2.31, \mathrm{DBH}=3.25, \mathrm{MCD}=$ $2.92)$ nor by origin $\left(\chi^{2}\right.$ values for $\left.\mathrm{DF}=1 ; \alpha=1 \%: \mathrm{h}=0.3, \mathrm{DBH}=1.90, \mathrm{MCD}=0.00\right)$. Significance was found for all traits for block effects $\left(\chi^{2}\right.$ values for $\mathrm{DF}=$ $1 ; \alpha=1 \%$ : $(\mathrm{A}) \mathrm{h}=236.54, \mathrm{DBH}=152.28, \mathrm{MCD}=150.11$; $(\mathrm{S}) \mathrm{h}=186.82, \mathrm{DBH}=93.91, \mathrm{MCD}=113.54)$. Results suggest genetic variability may reveal higher in BAG-A if specific management is established to counteract environmental effects

\title{
Flowering in test of provenance and progenies of Astronium fraxinifolium Schott (Anacardiaceae) in three reproductive events
}

Maiara Ribeiro Cornacini ${ }^{1}$, Marcelo Augusto Mendes Alcantara ${ }^{1}$, Janaina Rodrigues da Silva ${ }^{2}$, Aparecida Juliana Martins Corrêa ${ }^{3}$, José Cambuim ${ }^{2}$, Ricardo de Oliveira Manoel ${ }^{1}$, Patrícia Ferreira Alves ${ }^{2}$, Ananda Virrginia de Aguiar ${ }^{4}$, Mário Luiz Teixeira de Moraes ${ }^{2}$, Celso Luis Marino ${ }^{1}$

${ }^{1}$ Universidade Estadual Paulista “Júlio de Mesquita Filho”, Botucatu, Brasil; ' ${ }^{2}$ niversidade Estadual Paulista “Júlio de Mesquita Filho”, Ilha Solteira, Brasil; ${ }^{3}$ Universidade Federal de São Carlos, Sorocaba, Brasil; ${ }^{4}$ Embrapa Florestas, Colombo, Brasil (maiara.cornacini@gmail.com; marcelo.alcantara@unesp.br; janainars_t@hotmail.com;jumartinscorrea@gmail.com; josecambuim@yahoo.com.br; rickom.is@gmail.com; pattyfalves@gmail.com; ananda.aguiar@embrapa.br;mario.moraes@unesp.br; cl.marino@unesp.br)

The unbalanced sex ratio in dioecious species implies the unequal contribution of the number of gametes, thus reducing the effective population size. In this sense, we did the sexual identification of individuals of Astronium fraxinifolium, a timber specie belonging to Anacardiaceae family, dioecious, and that naturally inhabits the Cerrado. The individuals are located in a provenance and progeny test at the UNESP’s farm, in Selvíria - MS, Brazil, installed in 1996 in a randomized complete block design with 30 families from Mato Grosso do Sul (MS) and 30 from São Paulo (SP), 5 replicates and 10 plants per plot, spaced $3 \mathrm{~m} \times 1.5 \mathrm{~m}$, alternating with Jacaranda cuspidifolia. The sexual identification of the trees occurred in 2014,2017 and 2018 based on the visualization of the male and female flowers, we observed at 130, 186 and 335 trees from SP and 194, 331 and 542 trees from MS respectively. In all the events the provenance of MS had a higher flowering percentage (16\%, 28\% and 47\%) than SP (11\%, 17\% and 31\%). The sex ratio was biased for the male flowers: $2.34,2.0$ and 1.14 for MS and 2.78, 1.69 and 1.39 for SP. We observed a flowering increase and a tendency to a balance between the sex ratio. This could occurred for some reasons: by the natural decrease of $J$. cuspidifolia in the test, by a later maturation of some individuals or by the age of individuals, so further investigations are necessary to better understand the species reproductive biology.

Genetic variation in and between progenies of Myracrodruon urundeuva in anthropized areas / Comportamento da variação genética entre e dentro de procedências e progênies de Myracrodruon urundeuva em áreas antropizadas

Lara Comar Riva ${ }^{1}$, Francieli Alves Caldeira Saul ${ }^{1}$, Luciane Missae Sato ${ }^{1}$, José Cambuim ${ }^{1}$, Marcela Aparecida de Moraes ${ }^{2}$, Mario Luiz Teixeira de Moraes ${ }^{1}$ Universidade Estadual Paulista "Júlio de Mesquita Filho”, Ilha Solteira, Brasil; ' Universidade de São Paulo, Ribeirão Preto, Brasil; ${ }^{1}$ Universidade Estadual Paulista “Júlio de Mesquita Filho”, Ilha Solteira, Brasil (lara-comar@hotmail.com; francieli_eng.ambiental@yahoo.com.br; luciane_sato@yahoo.com.br; josecambuim@yahoo.com.br; marcela.apmoraes@gmail.com;mario.moraes@unesp.br)

A M. urundeuva é uma espécie arbórea endêmica da América do Sul, conhecida pela madeira. O objetivo desse estudo foi avaliar o comportamento e a variação genética para a forma do fuste em um teste de procedências (Bauru/SP e Selvíria/MS) e progênies aos 31 anos de idade. O experimento foi instalado na Fazenda de Ensino, Pesquisa e Extensão, da FEIS/UNESP, Selviria-MS, utilizando o delineamento experimental de blocos casualisados, com 28 progênies de cada procedência, 3 repetições e 10 plantas por parcela. As estimativas dos parâmetros genéticos foram obtidas a partir do procedimento REML/BLUP, SELEGEN. A forma do fuste não apresentou diferenças significativas entre procedências e progênies, apenas nas parcelas, sugerindo a influência ambiental no experimento. Isto se confirma com os baixos valores de herdabilidade (menor que 0,1), mostrando pouco controle genético, e os altos valores do coeficiente experimental e coeficiente de determinação dos efeitos de parcelas (acima de 10\%). Já o coeficiente de variação genética foi maior na procedência de Selvíria (5,26\%) do que em Bauru (1,60\%). A arquitetura das plantas não foi influenciada pelas procedências, mostrando que a maioria das plantas teve a tendência de bifurcação acima de 1,30 m com diâmetro igual ao fuste principal e tortuosidade acentuada abaixo do DAP. Em razão dos baixos valores obtidos nas herdabilidades a próxima geração de melhoramento deve apresentar baixos incrementos médios para a forma do fuste, devido este caráter apresentar baixo controle genético, porém, apresentará níveis apropriados de variabilidade genética, justificando a sua conservação ex situ.

\section{Micro propagation of Nothapodytes nimmoniana Graham through adventitious mode of regeneration}

P. V. Somashekar ${ }^{1}$, K. C. Nitesh ${ }^{1}$, Malllesh Lingachar ${ }^{1}$, K. T. Chandrashekar ${ }^{1}$

${ }^{1}$ SandalwoodSocietyof India,Bangalore,India (drsomashekarpv@gmail.com;niteshosmane@gmail.com;mallesh@itrads.com;ktchandrashekar2@gmail.com)

Nothapodytes nimmoniana or Nothapodytes foetida Syn. Mappia foetida belonging to Icacinacea family is an endangered tree species of Western Ghats of India. It is an excellent source of quinoline alkaloids, Camptothecin (CPT) and 9-methoxy camptothecin (9-OMeCPT) used clinically as anticancer agents for the treatment of solid tumors. Over exploitation for raw material of CPT from $N$. nimmoniana and habitat destruction has led to population decline by $50-80 \%$ in the last decade. Development of in vitro propagation and conservation techniques are highly desirable as there is no reported cultivation or conservation protocols of this species. In this study rapid in vitro cloning of $N$. nimmoniana through adventitious mode of regeneration was tried. MS medium supplemented 
with additives and various PGRs were tried to optimize the protocol for multiple shoot induction and multiplication. In vitro germinated seedlings were used as a source of explant such as leaf, nodal, intermodal, root, cotyledon and hypocotyls. Only leaf segments and hypocotyls induced multiple shoots. Among the various cytokinins and its concentrations tested, MS agar gelled medium supplemented with additives. Hypocotyl as an explant showed base swelling in the medium containing additives + BAP 1.0mg/l and BAP $5.0 \mathrm{mg} / \mathrm{l}$ without shoots at initial stage, where as medium with additives + BAP $2.5 \mathrm{mg} / \mathrm{l}$ showed single shoot of $1.5 \mathrm{~cm}$ in length with dwarf leaf and well developed roots. Sub culturing of shoots was found essential for further shoot multiplication on fresh medium within 3 weeks interval.

\section{Genetic variation for morphological traits of Handroanthus impetiginosus in active germplasm bank}

Camila Amaro dos Santos ${ }^{1}$, Maiara Ribeiro Cornacini ${ }^{1}$, Marcelo Augusto Mendes Alcantara ${ }^{1}$, Marcos Vinícius e Silva Bottaro ${ }^{1}$, Ana Carla Farias Pardo ${ }^{1}$ Darlin Gonzalez Zaruma ${ }^{1}$, Bruno César Rossini ${ }^{1}$, José Cambuim², Alexandre Marques da Silva ${ }^{2}$, Mário Luiz Teixeira de Moraes ${ }^{2}$, Celso Luis Marino ${ }^{1}$ ${ }^{1}$ Universidade Estadual Paulista "Júlio de Mesquita Filho", Botucatu, Brasil; '2Universidade Estadual Paulista "Júlio de Mesquita Filho", Ilha Solteira, Brasil(camilaamaro912@gmail.com; maiara.cornacini@gmail.com; marcelo.alcantara@unesp.br; m.franceis@hotmail.com; ana_carlafp@hotmail.com; dgzaruma@gmail.com; bruno.rossini@unesp.br; josecambuim@yahoo.com.br; alexandre.marques@unesp.br; mario.moraes@unesp.br; cl.marino@unesp.br)

Handroanthus impetiginosus (ipê roxo) has great economic and ecological importance. Due to the quality of wood, it's one of the most hunted species in Brazil and the second most expensive wood. Thus, the work estimated the genetic variation of a population of $H$. impetiginosus located in the Active Germplasm Bank (BAG), at the city of Rosana - SP. The BAG was introduced in the year 2000 and has 32 species with 30 families, three replicates and plots with eight plants in linear form, at spacing of $1.5 \mathrm{~m} \times 3.0 \mathrm{~m}$. Survival, diameter at breast height (DAP) and height were measured at 17 years old. Estimates of variance components and genetic parameters were obtained using the genetic-statistical software SELEGEN-REML / BLUP. We observed a good adaptation of the population to the place with survival above $75 \%$. The DAP mean was $9.34 \mathrm{~cm}$ and height was $7.78 \mathrm{~m}$. The coefficient of genetic variation for DAP was $9.83 \%$ and for height of $2.69 \%$. Among the traits the DAP was considered as a candidate to guide the selection of individuals in future strategies for seed collection or thinning, as we verified intermediary values of coefficient of relative variation $(0.26)$ and accuracy $(0.43)$. The effective population size was 101.2 which provides for the conservation of alleles with frequency $\geq 6 \%$. Therefore, the results indicate that there is genetic variability and the population may be used as a basis for future programs of breeding and conservation for the specie.

Genetic conservation of Hymenaea stigonocarpa Mart ex Hayne in the Bolsão region of Mato Grosso do Sul, Brazil / Conservação genética de Hymenaea stigonocarpa Mart ex Hayne na região do Bolsão Sul-Mato-Grossense

Darlin Gonzalez Zaruma ${ }^{1}$,Fernando Brandão de Andrade², Murilo da Serra Silva ${ }^{3}$, José Cambuim ${ }^{4}$, Silvelise Pupin ${ }^{4}$, Marcela Aparecida de Moraes $^{5}$, Mario Luiz Teixeira de Moraes ${ }^{4}$

${ }^{1}$ Universidade Estadual Paulista "Júlio de Mesquita Filho”, Botucatu, Brasil; ${ }^{2}$ Companhia Energética de São paulo, CESP, Presidente Epitácio, Brasil,; ${ }^{3}$ Instituto Federal, Maraba, Brasil; ${ }^{4}$ Universidade Estadual Paulista "Júlio de Mesquita Filho", Ilha Solteira, Brasil; ${ }^{5}$ Universidade de São Paulo, Ribeirão Preto,Brasil(dgzaruma@gmail.com; fernando.brandao@cesp.com.br; mserrasilva@yahoo.com.br; josecambuim@yahoo.com.br; silvelise.pupin@gmail.com; ma_apmoraes@yahoo.com.br; teixeira@agr.feis.unesp.br)

O aumento dos remanescentes causados pela fragmentação do bioma Cerrado está acarretando o isolamento das populações arbóreas e diminuição do fluxo gênico entre elas. Nesse contexto o conhecimento sobre os parâmetros genéticos relacionados aos caracteres silviculturais contribui para a melhor escolha de estratégias de conservação in situ e ex situ. Hymenaea stignocarpa é uma espécie restrita à Caatinga e ao Cerrado da região central e sudoeste do Brasil, de importância ecológica, econômica, social e cultural. O objetivo do presente estudo foi avaliar a variação genética para caracteres de crescimento de $H$. stigonocarpa, em um teste de progênies instalado em Selvíria-MS (ex situ) em junho de 2013, a partir de 41 arvores matrizes de uma população da Reserva Particular do Patrimônio Natural em Brasilândia-MS (in situ). O delineamento experimental foi de blocos casualizados, com uma planta por parcela, 20 repetições, no espaçamento de 3,0 × 1,5m. Foram obtidos dados de altura (ALT), diâmetro à altura do peito (DAP) e sobrevivência (SOB) aos 4 anos de idade. O valor médio para ALT, DAP e SOB foi de $2,6 \mathrm{~m}, 3,3 \mathrm{~cm}$ e 74,7\%, respectivamente, que indicam boa adaptação da espécie ao local. O coeficiente de variação genética () para os caracteres ALT e DAP foi de 42,8 e 27,2\%, respectivamente e a herdabilidade individual (), para esses dois caracteres, variou de 0,46 a 0,32, respectivamente. Desse modo, as progênies apresentam bom desempenho e variação genética proporcional a população de referência (Brasilândia), o que permite que o teste de progênies possa ser utilizado em programas de conservação.

Genetic variation for growth traits in progenies of Myracrodruon urundeuva in Selvíria, Brazil / Variação genética para caracteres de crescimento em progênies de Myracrodruon urundeuva em Selvíria, Brasil

Francieli Alves Caldeira Saul ${ }^{1}$, Daniele Fernanda Zulian ${ }^{1}$, José Cambuim ${ }^{1}$, Alexandre Marques da Silva ${ }^{1}$, Maiara Ribeiro Cornacini ${ }^{2}$, Regivan Antônio de Saul ${ }^{1}$, Mario Luiz Teixeira de Moraes $^{1}$

${ }^{11}$ Universidade Estadual Paulista "Júlio de Mesquita Filho", Ilha Solteira, Brasil; ${ }^{2}$ Universidade Estadual Paulista "Júlio de Mesquita Filho", Botucatu, Brasil(francieli_eng.ambiental@yahoo.com.br;danielezullian@gmail.com; josecambuim@yahoo.com.br; alexandre.marques@unesp.br; maiara.cornacini@gmail.com; regivanantonio@zipmail.com.br;mario.moraes@unesp.br)

A Myracrodruon urundeuva possui ampla distribuição no Brasil, pertence à família Anacardiaceae. Atualmente a espécie encontra-se em extinção, sendo fundamental estratégias que assegurem sua conservação genética. Verificou-se a variação genética em um teste de progênies de $M$. urundeuva. O teste foi instalado em outubro de 2017 na região de Selvíria-MS. O delineamento experimental utilizado foi o de blocos casualizados: uma planta por parcela, 48 repetições, no espaçamento de 8,0 m x 4,0 m x 1,0 m, consorciada com três espécies. Foram utilizadas 45 progênies, procedentes de árvores matrizes da região de Iturama-MG. Aos 12 meses de idade foram obtidos dados de altura (ALT), diâmetro à $30 \mathrm{~cm}$ do solo (D30) e sobrevivência (SOB). As estimativas de componentes de variância e parâmetros genéticos foram obtidas pelo método da máxima verossimilhança restrita e melhor predição linear não viciada (REML/ BLUP). A SOB foi alta (>87,0 \%), a média de ALT e D30 foi de $95 \mathrm{~cm}$ e 9,3 mm, respectivamente, apresentando boa adaptação inicial, contribuindo com a conservação da espécie. Foram obtidas diferenças significativas entre progênies a 1\% de significância, para todos os caracteres analisados. Para o caráter ALT, o coeficiente de herdabilidade em nível de média de progênies, acurácia e coeficiente de variação genética em nível de progênies foram de 0,$62 ; 0,78$ e $10,2 \%$. Para o D30, os valores foram de 0,57; 0,76 e 8,0\%. A variação genética detectada para os caracteres ALT e D30 é um indicativo de que essa população possa ser utilizada em programas de conservação e melhoramento genético. 
Sex ratio of a base population of Myracrodruon urundeuva in Selvíria, Mato Grosso do Sul, Brazil / Proporção sexual de uma população base de Myracrodruon urundeuva em Selvíria, MS

Daniele Fernanda Zulian ${ }^{1}$, Francieli Alves Caldeira Saul ${ }^{1}$, José Oliveira Júnior ${ }^{2}$, Luciane Missae Sato ${ }^{3}$, José Cambuim ${ }^{1}$, Lorena Frigini Moro Capo ${ }^{1}$, Mario Luiz Teixeira de Moraes ${ }^{1}$, Ananda Virginia de Aguiar ${ }^{4}$

${ }^{1}$ Faculdade de Engenharia de Ilha Solteira, Unesp, Ilha Solteira, Brazil; ${ }^{2}$ Faculdade de Ciências Sociais e Agrárias de Itapeva, Itapeva, Brazil; ${ }^{3}$ Faculdade de Ciências Sociais e Agrárias de Itapeva, Ilha Solteira, Brazil; ${ }^{4}$ Embrapa Florestas, Colombo, Brazil (danizullian@gmail.com;

francieli_eng.ambiental@yahoo.com.br; ze0897@gmail.com; luciane_sato@yahoo.com.br; josecambuim@yahoo.com.br; lorenafmc@gmail.com; mario.moraes@unesp.br; ananda.aguiar@embrapa.br)

Nativa da América do Sul, a M. urundeuva ocorre em diferentes formações florestais. A espécie apresenta uma madeira de alto valor econômico, e devido à exploração predatória de sua madeira foi incluída na lista oficial do IBAMA como espécie ameaçada de extinção. É uma espécie dioica, e os povoamentos florestais exibem desvios da expectativa de equilíbrio de 1:1 da razão sexual. Assim, a proporção sexual dos indivíduos em uma população base de $M$. urundeuva aos 31 anos de idade foi estimada. O teste foi instalado em dezembro de 1987 na Fazenda de Ensino, Pesquisa e Extensão (FEPE/Unesp), em Selvíria - MS. O povoamento é composto por 28 árvores matrizes de duas populações, Bauru - SP e Selvíria - MS. O sistema de plantio foi aleatório, no espaçamento 3 X 3 m, com um total de 1.662 indivíduos. Em agosto de 2018, foi realizada a sexagem (macho e fêmea) dos indivíduos em floração. A porcentagem de florescimento foi de 89,3 \% (1.210 indivíduos). Isso indica uma boa adaptação da espécie ao local de plantio, e que as condições ambientais foram favoráveis para este evento reprodutivo. A razão sexual entre plantas femininas e masculinas foi de 0,55 (1,2 $\left.+1{ }^{\Uparrow}\right)$. A população base de $M$. urundeuva aos 31 anos apresenta

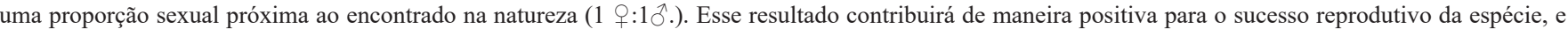
consequentemente para sua conservação e melhoramento genético, principalmente, se no manejo do povoamento esta razão sexual for mantida aos longos dos anos.

Genetic correlations and groupings in progenies of Myracrodruon urundeuva / Correlações genéticas e agrupamentos em progênies de Myracrodruon urundeuva

Francieli Alves Caldeira Saul ${ }^{1}$, Daniele Fernanda Zulian ${ }^{1}$, Luciane Missae Sato ${ }^{1}$, Lara Comar Riva ${ }^{1}$, José Cambuim ${ }^{1}$, Alexandre Marques da Silva ${ }^{1}$, Mario Luiz Teixeira de Moraes ${ }^{1}$

${ }^{1}$ Universidade Estadual Paulista “Júlio de Mesquita Filho”, Ilha Solteira, Brasil (francieli_eng.ambiental@yahoo.com.br; danielezullian@gmail.com; luciane_sato@yahoo.com.br; lara-comar@hotmail.com; josecambuim@yahoo.com.br; alexandre.marques@unesp.br; mario.moraes@unesp.br)

Myracrodruon urundeuva possui alto valor econômico pela excelente qualidade da madeira, estudos de correlações entre caracteres de importância econômica têm sido uma ferramenta fundamental para trabalhos de conservação e melhoramento genético. $O$ trabalho verificou a correlação genética entre caracteres de crescimento e aplicou-se um teste de agrupamento em um teste de progênies de polinização aberta de $M$. urundeuva. O teste foi instalado na Fazenda de Ensino, Pesquisa e Extensão (FEPE/Unesp), em Selvíria-MS, em outubro de 2017. O delineamento experimental foi o de blocos casualizados: 45 tratamentos (progênies), uma planta por parcela e 48 repetições, no espaçamento de 8,0 m x 4,0 m x 1,0 m, consorciada com três espécies. As sementes das árvores matrizes foram coletadas na região de Iturama-MG. Aos 12 meses de idade foram obtidos dados de altura (ALT), diâmetro à $30 \mathrm{~cm}$ do solo (D30). As correlações genéticas entre os caracteres e análise de agrupamento pelo método de otimização de Tocher foram realizadas a partir do procedimento REML/BLUP. A estimativa do coeficiente de correlação genética entre os caracteres ALT e D30 foi alta (89,4\%). Isso sugere que a possibilidade de seleção em um caráter e a obtenção de ganhos indiretos em outro é relativamente alta. O agrupamento de Tocher com base na distância de Mahalanobis, possibilitou a formação de sete grupos distintos, com concentração de aproximadamente 66,66\% das progênies no primeiro grupo. Indivíduos mais contrastantes e produtivos obtidos a partir do agrupamento de Tocher serão selecionados para cruzamentos, contribuindo para o melhoramento genético da espécie.

Diversity of flora composition in a restored area of Cerrado / Diversidade da composição florística de uma área restaurada no Cerrado

Francieudes Pereira do Nascimento ${ }^{1}$, Sybelle Barreira ${ }^{1}$

${ }^{1}$ Universidade Federal de Goiás, Goiânia, Brazil (framurilo@gmail.com; sybelle.barreira@gmail.com)

Nas últimas décadas, o Cerrado perdeu mais de $50 \%$ da vegetação original pela expansão da agricultura e pecuária. A flora dos remanescentes encontra-se bastante ameaçada, com o desaparecimento de espécies nativas endêmicas ao longo do tempo. Diversos fatores atuam na mudança da composição florística e na densidade populacional destes fragmentos, como aqueles ligados as taxas de ingresso, de recrutamento, de mortalidade e crescimento, bem como aqueles relacionados às perturbações que podem ocorrer na comunidade vegetal, como os incêndios. Diante disso, o objetivo deste trabalho foi avaliar as alterações na diversidade florística, com base nos levantamentos passados e atuais, com isso, podendo se fazer uma inferência sobre a efetividade da restauração. Foram identificados e mensurados todos os indivíduos lenhosos com DAP maior que $15 \mathrm{~cm}$ e coletado a altura. A composição, riqueza e diversidade de espécies lenhosas foram comparadas entre os anos de avaliação, a partir do cálculo do índice de diversidade Shanon, já para avaliar a abundância relativa das espécies, foi calculado Equabilidade de Pielou e por fim, foi usado índice de dominância de Simpson, já que este dá maior peso às espécies comuns. Não houve variância e, para diversidade o resultado encontrado foi de 10,392, portanto, tal resultado indica que não houve aumento na diversidade de espécies em relação ao senso anterior, porém ainda há diversidade de espécies na área. Sendo assim, foi possível verificar ao longo do tempo que não houve o aparecimento de novas espécies. Contudo, medidas são necessárias para que se garante o equilíbrio dinâmico. 
D2f: INTEGRATING TREE RESISTANCE DEVELOPMENT WITH DEEPER UNDERSTANDING OF LOCAL AND LONG-DISTANCE MOVEMENT OF PEST POPULATIONS TO IMPROVE MANAGEMENT OF INVASIVE PESTS

\author{
Integration of rapid phenotyping technologies into management of invasive alien forest pathogens and insect pests: realistic approach \\ or false hope?
}

Pierluigi (Enrico) Bonello ${ }^{1}$

${ }^{1}$ The Ohio State University, Columbus, OH, USA (bonello.2@osu.edu)

The classic conceptual triangle that models the main, necessary factors contributing to plant disease or insect outbreaks includes a susceptible host, a virulent or aggressive pathogen/pest, and a conducive environment. If even just one of the three factors is missing, then disease or insect outbreak will not occur. This model functions very well in agriculture, where the three factors are often controllable in one way or another. The same cannot be said for forests, where the environment is hardly modifiable (except for silvicultural adjustments in some specific cases) and where pathogen inoculum load/insect populations are almost never controllable. This situation suggests that very often the only leverage we have is on the host side of the equation, i.e. host resistance. Yet, the vast majority of current approaches to dealing with invasive, endemic or alien forest pathogens and insects is to tackle pathogen/insect populations, sometimes silviculture, and very rarely, and often only as a last resort, host resistance. This approach, however, belies a poor understanding of how far the science of tree resistance selection and development has progressed in the last 10-15 years. Therefore, I propose that host resistance should be a first response to dealing with invasive forest pathogens and insects, supported by several studies demonstrating that resistance phenotyping can be quickly accomplished using chemometrics. These tools present very promising opportunities to incorporate host resistance up front in a holistic and arguably much more effective future approach to disease and insect pest management in forest environments.

\title{
Prospects of gene manipulation and genome editing for understanding tree defense mechanisms
}

Chung-Jui Tsai ${ }^{1}$, Maria Ortega ${ }^{1}$, Chhana Ullah ${ }^{2}$, W. Patrick Bewg ${ }^{1}$, Scott Harding ${ }^{1}$

${ }^{1}$ University of Georgia, Athens, USA; ${ }^{2}$ Max Planck Institutefor Chemical Ecology, Jena, Germany (cjtsai@uga.edu; ortega77@uga.edu; cullah@ice.mpg.de; bewg@uga.edu; sharding@uga.edu)

Trees in natural and managed forests face constant threats of insects and pathogens, made worse by introduced pests and increasing frequency and severity of abiotic stress due to climate change. Understanding the mechanisms of tree-pest interactions and defense strategies can inform pest management practices, and shed light on breeding for resilient trees by conventional, molecular or biotechnological means. This presentation will highlight the utility of gene manipulation and genome editing in Populus for investigating biotic and abiotic stress responses, with case studies of chemical as well as physical defense traits. The defense hormone salicylic acid has a well-established role in disease resistance of herbaceous annuals against biotrophs; however, a similar role in trees remains equivocal. Populus differs from Arabidopsis in many aspects of salicylic acid biosynthesis, signaling and homeostasis, and in growth-defense tradeoffs. Specifically, elevated salicylic acid in transgenic poplar, but not Arabidopsis, activates biosynthesis of condensed tannins- flavonoid end products that possess antimicrobial activities against several fungal pathogens. Identification of tree-specific mechanisms like this can offer more relevant gene targets for molecular breeding or transgenic improvement. With the advent of CRISPR genome editing technology, it is now possible to obtain null mutants in long-lived trees with unprecedented precision and efficiency. We show that knockout of three trichome-regulating MYB genes in poplar resulted in glabrous mutants with altered photosynthetic properties, metabolite profiles and biotic and abiotic stress responses. These plants facilitate dissection of the roles trichomes play in physical and chemical defenses.

\section{Global movement of Eucalyptus pathogens successfully managed by species selection or resistance breeding}

Treena Burgess ${ }^{1}$, Michael J. Wingfield ${ }^{2}$

${ }^{1}$ Murdoch University, Perth, Australia; ${ }^{2}$ University of Pretoria, Pretoria, South Africa (tburgess@murdoch.edu.au; mike.wingfield@fabi.up.ac.za)

Eucalypts constitute the largest component of global hardwood plantations, contributing substantially to the economies of many countries. But they are increasingly plagued by pathogens, all of which are inconsequential in the native forests. Eucalypts provide a particularly interesting model to study tree diseases because plantations have been established in countries where these trees are non-native but also in Australia where they are commonly established adjacent to native eucalypt forests. These situations present opportunities for pathogen movement between the two systems. Of the many eucalypt diseases found in plantations globally, the leaf diseases caused by pathogens in the Teratosphaeriaceae have resulted in the most serious damage. Our research groups have conducted several population genetic studies showing how these pathogens have been distributed globally with gemplasm. For the most part, the resulting diseases have been successfully managed through the deployment of resistant clones. However, when a new pathogen emerges such as in the case of Teratosphaeria pseudoeucalypti, a considerable period of time is needed to develop disease-resistant planting stock. The selection for, as well as the durability of, this resistance is dependent upon the genetic diversity of the pathogen. It is consequently essential to ensure vigilant biosecurity is established and/or maintained to prevent introductions of pathogens to new areas. It is equally important to prevent the introduction of new genotypes of pathogens that have already become established as invasive aliens as these can contribute to the rapid breakdown of resistace in planting stock.

\section{The population structure and genetic diversity of the pine needle pathogen, Dothistroma pini in Europe}

Ariska van der Nest ${ }^{1}$, Michael J. Wingfield ${ }^{1}$, Vimbai I Siziba ${ }^{1}$, Petra Vesela ${ }^{2}$, Irene Barnes ${ }^{1}$

${ }^{1}$ Forestry and Agricultural Biotechnology Institute (FABI), University of Pretoria, Pretoria, South Africa; ${ }^{2}$ Department of Forest Protection and Wildlife

Management, Mendel University, Czech RepublicBrno (ariska.vandernest@fabi.up.ac.za; mike.wingfield@fabi.up.ac.za; vi.siziba@gmail.com;

petra.vesela@mendelu.cz; irene.barnes@fabi.up.ac.za)

Dothistroma needle blight is an important disease of Pinus species that is caused by two different pathogens, Dothistroma pini and D. septosporum. Dothistroma pini is known only from the northeastern USA and Europe. There is a distinct lack of knowledge regarding the population structure and diversity of this pathogen or its origin. Recently, sixteen microsatellite markers were developed for $D$. pini. This provided an opportunity to investigate the population diversity and structure and to determine its mode of reproduction for populations that have been collected in twelve countries on eight different hosts in Europe over a period of twelve years. In total, 285 isolates from Belgium, Czech Republic, France, Hungary, Romania, Russia, Serbia, Slovakia, Slovenia, Spain, Switzerland 
and Ukraine were screened with microsatellite markers and species-specific mating type markers. A total of 120 unique multilocus haplotypes were identified. AMOVA results suggests that the population structure is not influenced by host distribution. Populations from Mykolaiv Oblast and Hola Prystan in Ukraine displayed the highest level of genetic diversity followed by populations from Russia, Spain and La Bouyale in France. Both mating types were detected in most populations but not those from Russia, Slovenia and a population from Mykolaiv Oblast in Ukraine. Evidence for sexual recombination, was however, only supported in the population from Spain. The observed population structure and several shared haplotypes between non-bordering countries in Europe suggests a human influence on the dispersal of the pathogen on the continent.

\section{Perspectives of biotic and abiotic molecular studies to improve teak tree}

Helaine Carrer ${ }^{1}$, Perla Oliveira ${ }^{1}$, Fernando Hurtado ${ }^{1}$, Esteban Galeano ${ }^{2}$

${ }^{1}$ Escola Superior de Agricultura Luiz de Queiroz, Universidde de São Paulo, Piracicaba, Brasil; ${ }^{2}$ University of Alberta, Edmonton, Canada (hecarrer@usp. br;perla.oliveira@usp.br;fermathur1992@usp.br;galeanog@ualberta.ca)

Teak tree (Tectona grandisL.f.) is a tropical hardwood tree species, belongs to Lamiaceae family and it is native to South and Southeast Asia. Teak has been introduced in several tropical countries in Latin America during the last 50 years. This tree has a high value in the timber trade for manufacturing of woody products due to its extraordinary qualities of color, density and durability. Despite the importance of this species, genetic and molecular studies available are limited. Water deficit and diseases as rust and teak canker are the main challenges for the improvement of teak productivity. Molecular studies of transcriptomic profiling and gene expression are essential to improve knowledge of genes related to water deficit tolerance and disease resistance. In this respect, using RNA-seq, it was performed a total of 462,260 transcripts from different organs such as seedlings, leaves, flowers, root, stem and branch. All of them were phylogenetically grouped with several gymnosperms and flowering plants. In this presentation, teak molecular genetic improvement, marker-assisted selection and plant transformation research will be presented.

Insights from population genetics and genomics for the management of the invasive pest Sirex noctilio

Bernard Slippers ${ }^{1}$

${ }^{1}$ Forestry and Agricultural Biotechnology Institute, University of Pretoria,0002,South Africa (bernard.slippers@fabi.up.ac.za)

The Sirex woodwasp, Sirex noctilio, is a serious invasive forest pest around the world. Information from population genetics studies over the last two decades and the emerging information from genomics studies are transforming the understanding of the biology of this pest and its invasion, including options for management. When it was first introduced, population genetics revealed the extensive distribution of clonal lineages of the mutualistic fungus, Amylostereum areolatum, associated with the wasp. These lineages were sometimes distributed across continents, highlighting the routes of spread of the wasp. Subsequent studies have revealed multiple sources of introduction in most environments, with complexity increasing over time. This is in contrast to the reduced diversity in biocontrol agents in these same environments, bar some notable exceptions in presumably native and some non-native environments. The patterns in the diversity in populations of the wasp, fungus and biocontrol agents and their interactions have also been shown to have relevance to the management of the wasp. Recent genomics studies are now unlocking insights into reproductive and physiological mechanisms that influence the interactions amongst these symbionts, including previously unknown symbionts. This information is also making it possible to explore the role of gene editing, such as through CRISPR, for the management of the wasp in invasive populations.

\section{D2p: CONSERVATION, DOMESTICATION AND BREEDING OF NATIVE SPECIES}

\section{Mating patterns of Virola surinamensis trees reveal Amazonian estuary populations might be under risk}

Taruhim Miranda Cardoso Quadros ${ }^{1}$, Fátima Conceição Marquez Piña-Rodrigues ${ }^{2}$, Laura Luciana de Melo Moreira Silva ${ }^{3}$, Ivonir Piotrowski Miguel Luiz Menezes Freitas ${ }^{4}$, Karina Martins ${ }^{5}$

${ }^{1}$ Universidade Estadual de Santa Cruz, Centro de Biotecnologia e Genética, Ilhéus, Brazil; ${ }^{2}$ Universidade Federal de São Carlos, Departamento de Ciências Ambientais, Sorocaba, Brazil; ${ }^{3}$ Universidade Federal de São Carlos, Sorocaba, Brazil; ${ }^{4}$ Instituto Florestal de São Paulo, Setor de Melhoramento Florestal e Genética da Conservação, São Paulo, Brazil; ${ }^{5}$ Universidade Federal de São Carlos, Departamento de Biologia, Sorocaba, Brazil (talumcq@hotmail.com; fpina@ufscar.br; laurasilva_@live.com; ivonir@ufscar.br;miguellmfreitas@yahoo.com.br;kmartins@ufscar.br)

Virola surinamensisis an Amazonian tree species commonly found in floodplain areas. The species' high economic value arises from its several commercial uses, varying from seed oil for cosmetics destinations to woody products. Consequently, virola's natural populations in Brazil have been intensively exploited, leading the species to a status of endangered. Although characterized as dioecious, a high level of homozygosity was found in Eastern Amazon remaining adult populations, possibly as a result of extensive logging. In order to understand the high level of inbreeding, this study aimed to evaluate seeds sampled in eleven V. surinamensis seed trees in remaining populations located in two areas (Cotijuba and Cametá) in Pará state, Brazil. Offspring from eleven maternal trees (12 to 20 seeds per tree) were sampled in seed traps and genotyped for seven microsatellite loci. Inbreeding coefficients corrected for null alleles were very high, $F \mathrm{IS}=0.233$ in Cametá and FIS $=0.244$ in Cotijuba. This result may reflect the impact of drastic reduction in population sizes, in which few remnant trees effectively mate. The average coancestry coefficient within fruit traps was 0.047 (0.024 - 0.079 range) in Cametá and 0.086 in Cotijuba (0.025 - 0.159 range). Significant spatial genetic structure was detected, with low relatedness occurring in seed trees with distances smaller than $23 \mathrm{~m}$ in Cotijuba and $47 \mathrm{~m}$ in Cametá $(\rho \mathrm{ij}=0.093$ and 0.052 , respectively). Overall, our results suggest that non-random mating pattern might be due to the small number of mating adults, precluding long term persistence of these populations. Funding: TMCQ scholarship by São Paulo Research Foundation (FAPESP 2016/19618-2) 
Environmental and genetic characterization of maté (Ilex paraguariensis) for conservation and sustainable use of genetic resources I Proposta para caracterização ambiental e genética de erva-mate com vistas à conservação e uso sustentável dos recursos genéticos

\author{
Marcos Silveira Wrege ${ }^{1}$, Valderês Aparecida de Sousa ${ }^{1}$, Márcia Toffani Simão Soares ${ }^{1}$, Elenice Fritzsons ${ }^{1}$, Ananda Virginia de Aguiar ${ }^{1}$, \\ Itamar Antonio Bognola ${ }^{1}$, João Bosco Gomes ${ }^{1}$, Letícia Penno de Sousa ${ }^{2}$, Cristiane Vieira Helm ${ }^{1}$, Patrícia Póvoa de Mattos ${ }^{1}$ \\ ${ }^{1}$ Embrapa Florestas, Colombo, Brasil; ${ }^{2}$ Embrapa Clima Temperado, Pelotas, Brasil (marcos.wrege@embrapa.br; valderes.sousa@embrapa.br; \\ marcia.toffani@embrapa.br; elenice.fritzsons@embrapa.br; ananda.aguiar@embrapa.br; itamar.bognola@embrapa.br; joao.bv.gomes@embrapa.br; \\ leticia.penno@embrapa.br; cristiane.helm@embrapa.br;patricia.mattos@embrapa.br)
}

Ilex paraguariensis St-Hil. está predominantemente no bioma Mata Atlântica, na Floresta Ombrófila Mista, sendo vulnerável às mudanças climáticas. O acordo firmado pelo Brasil na COP21 enfatiza a necessidade de 'incrementar a capacidade nacional em conservação e uso sustentável da biodiversidade'. Com base nesta demanda, desenvolvemos uma metodologia orientada à caracterização ambiental e genética de populações de I. paraguariensis, como subsidio à conservação e uso sustentável. A proposta visa determinar como os fatores ambientais e genéticos influenciam nas zonas de ocorrência das populações e de que forma as mudanças climáticas influenciarão no seu deslocamento, em sua base genética e adaptação na região de ocorrência, nos bancos de germoplasma e nos plantios. O trabalho envolveu o seguinte passo-a-passo: 1) definição das margens de ocorrência e seleção de regiões prioritárias para amostragens; 2) caracterização genética das populações; 3) caracterização das propriedades fisicoquímicas do solo; 4) determinação dos compostos fitoquímicos e 6) identificação dos nichos ecológicos das populações. Ao agregar multidisciplinariedade na definição de zonas, parâmetros e novos métodos de amostragens de material genético, incrementou-se a a eficácia, acurácia e segurança no processo de geração de informações quanto ao comportamento da espécie. Os resultados indicam que a maior parte das populações de I. paraguariensis ocorre em regiões com características parecidas; uma minoria ocorre em situações distintas, as quais devem ter prioridade para coleta de germoplasma e testes experimentais, pois a chance de encontrar indivíduos melhor adaptados às regiões típicas é maior. A metodologia desenvolvida é passível de aplicação a espécies semelhantes, com pequenas adaptações.

\title{
Genetic material production unit for Pinus cembroides Zucc / Unidad Productora de Germoplasma Forestal de Pinus cembroides Zucc
}

Juan Carlos Cuevas Cruz ${ }^{1}$

${ }^{1}$ Universidad Autónoma Chapingo, Texcoco, Estado de México, Mexico (jcuevas chapingo@hotmail.com)

Los bosques de Pinus cembroides Zucc. son característicos de las zonas áridas del norte y centro de México, es la principal especie de pinos piñoneros del país, crece sobre laderas de montaña en suelos delgados y pedregosos; por su amplia adaptabilidad y resistencia a condiciones extremas ha sido utilizada para proyectos de reforestación y restauración ecológica. Con el propósito de conservar y producir germoplasma de procedencia y calidad fenotípica conocida de Pinus cembroides, en el 2018 se estableció y procedió a la certificación de una Unidad Productora de Germoplasma Forestal (UPGF), Fuente IdentificadaRodal-Semillero de ocho hectáreas, ubicada en los Bienes Comunales de Sombrerete, Municipio de Cadereyta, Querétaro, México. Mediante ésta estrategia de conservación se busca beneficiar a 224 comuneros y a sus familias, dedicados a la recolección y venta de piñón. El total de individuos de la UPGF es de 2880; 94 árboles fueron seleccionados como fenotípicamente superiores, considerando sus características de altura total, diámetro normal, volumen, diámetro de copa, rectitud de fuste y conformación de copa. Se encontró una amplia variación fenotípica, con un coeficiente de variación mayor a 30 \% para cuatro de las seis características consideradas, con excepción de la altura total y rectitud de fuste, siendo el coeficiente de variación de 24 y $25 \%$, respectivamente. Se obtuvo un diferencial de selección de $2.0 \mathrm{~m}$ en altura, $5.4 \mathrm{~cm}$ en diámetro normal y $0.104 \mathrm{~m}^{3} \mathrm{en}$ volumen, de tal manera que se pueden obtener ganancias en las características de crecimiento con la selección de los árboles.

Biometry of fruits and seeds from Brazil nut trees selected for genetic improvement in Rondônia, Brazil / Biometria de frutos e sementes de castanheiras selecionadas para o melhoramento genético, em Rondônia

Danielli Carvalho dos Santos ${ }^{1}$, Hebson Carvalho do Nascimento ${ }^{2}$, Lúcia Helena de Oliveira Wadt ${ }^{2}$

${ }^{1}$ Faculdade de Rondônia, Porto Velho, Brazil; ${ }^{2}$ Embrapa Rondônia, Porto Velho, Brazil (engf.danielli@gmail.com; hebson.nascimento@embrapa.br; lucia.wadt@embrapa.br)

Estudar a variabilidade genética na produção da castanheira é importante para seleção de genótipos de alta qualidade e também para estratégias de conservação. A biometria dos frutos e sementes possibilita quantificar a variabilidade genética dentro e entre populações além de analisar os caracteres morfológicos da planta. O presente trabalho apresenta dados biométricos de frutos e sementes de Bertholletia excelsa coletados em Costa Marques (10 genótipos) e GuajaráMirim (11 genótipos), RO. Dados de massa fresca (MFF), espessura da casca (EC), diâmetro do fruto (DF), altura do fruto (AF) foram anotados para cada fruto (5 por genótipo). De cada fruto foram amostradas 10 sementes e avaliados o número de sementes por fruto (NSF), altura da semente (AS), largura mediana (LMS) e espessura mediana (EMS). No geral os frutos e sementes de Costa Marques foram maiores e mais pesados que os de Guajará-Mirim, mas como representam uma mesma região do Estado de Rondônia, serão apresentadas as médias gerais. O peso fresco médio dos frutos foi 463,3 gr variando de 129,4 a 857,2 gr. A espessura média da casca do fruto foi 16,11 mm, com mínimo de 6,23 mm e máximo de 10,75 mm. O número médio de sementes por fruto foi 16,5, variando de 5 a 24. O comprimento médio das sementes foi de 4,22 cm, com mínimo de 2,03 cm (Guajará-Mirim) e máximo de 5,78 cm (Costa Marques). No geral, as sementes de ambos locais foram semelhantes em termos de tamanho médio, mas com alta variação entre genótipos.

Assessing an improved population of açai palms established on dry land in Amapá, Brazil / Avaliação de uma população melhorada de açaizeiros estabelecida em terra firme no Amapá

Larissa Favacho ${ }^{1}$, Rayane Rios ${ }^{2}$, Silas Mochiutti

${ }^{1}$ Universidade do Estado do Amapá, Macapá, Brasil; ${ }^{2}$ Universidade Federal do Amapá, Macapá, Brasil; ${ }^{3}$ Embrapa Amapá, Macapá, Brasil

(l_avacho@hotmail.com; rayanerios7@gmail.com; silas.mochiutti@embrapa.br)

O açaizeiro (Euterpe oleracea Mart.) é a espécie de maior ocorrência nas florestas inundáveis da Amazônia Oriental. A polpa do fruto desta palmeira vem ganhando mercado, propiciando o seu cultivo em áreas de terra firme pela utilização de técnicas de fertilização e irrigação. A disponibilidade de sementes melhoradas para plantios comerciais é somente da cultivar BRS-Pará. Neste estudo, avaliou-se as características das plantas e dos frutos de um plantio de açaizeiro com seis anos de idade, estabelecido com sementes oriundas da segunda geração de melhoramento da BRS-Pará. A população avaliada apresentou média de 5,50m de altura, 10,7cm de DAP e 57,2cm comprimento de cinco entrenós, indicando que as plantas apresentaram baixa estatura e boa estrutura, 
oferecendo facilidade de colheita dos cachos. Cerca de $83 \%$ dos açaizeiros apresentaram perfilhamento e $100 \%$ das plantas encontravam-se produzindo frutos, sendo que $67 \%$ destas plantas possuíam duas ou mais estipes produzindo. A emissão de espatas foi de 1,38 planta/mês e a produção de frutos de 1,15 cachos/ planta/mês. O mês com maior produção de frutos foi janeiro (1,44 cachos/planta) e o menor foi abril (1,04 cachos/planta). O peso médio de cacho foi de 2,51kg. Os frutos apresentaram 12,1 $\mathrm{mm}$ de diâmetro longitudinal e 14,0 mm de transversal, com peso de 1,57g por fruto. O rendimento de polpa dos frutos foi de 25,9\%, bem superior ao obtido pela BRS-Pará. A segunda geração de seleção apresentou características desejáveis superiores aos da BRS-Pará, indicando a possibilidade de lançamento de uma nova cultivar de açaizeiros para produção de frutos.

Genetic diversity and structure of Anadenanthera spp. populations in tropical dry forests using microsatellite markers / Diversidade genética e estrutura de populações de Anadenanthera spp. em florestas secas tropicais usando marcadores microssatélites

Fabricio Francisco Santos da Silva ${ }^{1}$, Lucia Helena Piedade Kiill ${ }^{2}$, Tatiana Ayako Taura ${ }^{2}$, Claudinéia Regina Pelacani ${ }^{1}$, Barbara França Dantas ${ }^{2}$, Carlos Antônio Fernandes Santos ${ }^{2}$

${ }^{1}$ Universidade Estadual de Feira de Santana, Feira de Santana, Brazil; ${ }^{2}$ Embrapa Semiárido, Petrolina, Brazil (fabriciofrancisco2006@gmail.com; lucia.kiill@embrapa.br; tatiana.taura@embrapa.br; claudineiapelacani@gmail.com; barbara.dantas@embrapa.br; carlos-fernandes.santos@embrapa.br)

Anadenanthera colubrina e Anadenanthera peregrina são árvores de ampla distribuição em florestas secas tropicais. Ferramentas que auxiliem no estudo de espécies florestais são importantes para conservação dos recursos genéticos deste grupo. Buscamos responder duas questões: (1) quais os níveis de variabilidade genética e estrutura de populações em Anadenanthera spp.? (2) o uso de microssatélites pode auxiliar na identificação taxonômica deste grupo? A extração de DNA de folhas foi realizada pelo método $2 \mathrm{X}$ CTAB, e os produtos da PCR foram separados em géis de poliacrilamida a 6\%. O dendrograma UPGMA foi gerado usando o índice de Jaccard, com base na distância genética em 39 alelos de nove loci. A análise da variância molecular foi realizada usando a decomposição total entre e dentro de populações de Anadenanthera spp. O fluxo gênico (Nm) foi estimado pelo número de migrantes, com base no parâmetro ФST. O tamanho dos alelos variou de $175 \mathrm{pb}$ a $794 \mathrm{pb}$. A média da frequência alélica, Conteúdo de Informação de Polimorfismo (PIC) e heterozigosidade foram de $0.58,0.52$ e 0.45 , respectivamente, demonstrando uma alta capacidade de detecção de variabilidade genética. O coeficiente de similaridade variou entre 20 e $80 \%$, com valor cofenético de 0.81 . Os dois agrupamentos bayesianos dividem-se em $A$. colubrina e $A$. peregrina. A variabilidade genética entre as populações é alta, $\Phi S T=$ $0.217(P<0.001)$, restringindo o Nm para um migrante por geração $(0.9)$. O uso destes marcadores possibilita o estudo de genética de populações, bem como auxilia na identificação taxonômica de Anadenanthera Speg.

\section{Efect of self-fertilization on heritability estimates in Bactris gasipaes Kunth}

Dayane Tomigian', Gustavo Henrique Sousa Rodrigues ${ }^{2}$, Ananda Virginia de Aguiar ${ }^{3}$, Valderes Aparecida de Sousa ${ }^{3}$, Antonio Nascim Kalil Filho ${ }^{1}$ ${ }^{1}$ Embrapa Florestas, Colombo, Brasil; ${ }^{2}$ Universidade Federal de São Carlos, Sorocaba, Brasil (dayane.tomigian@gmail.com; henriquesr.gustavo@gmail.com; ananda.aguiar@embrapa.br; valderes.sousa@embrapa.br; antonio.kali@@embrapa.br)

The pupunha (Bactris gasipaes) is distinguished by production of two food products: the palm-heart and the fruit. It is a monoicousspecies. While the species is allogamous, self-pollination may occur in the same inflorescence; between inflorescences of the same stipe and between inflorescences in different stipes in the same grouping. Self-pollination and inbreeding reduce heterozygosity and genetic variability. As a consequence, populations will tend to be more homogeneous genertically. The endogamy is cumulative over the generations due to the crosses between relatives. The objective of this work was to determine the effectsself-fertilization rates on $B$. gasipaesprogenies. The phenotypic traits evaluated were productions of palm heart in 108 progenies of half siblings located in the Brazilian states of Paraná, Amazonas and Roraima. states.The experimental and statistical designs were completely randomized blocks with one plant per linear plot, in $2 \mathrm{x} 1$ meters. Six different self-fertilization rates were used: $0,0.05,0.10,0.15,0.20$ and 0.25 to estimate theheritability. The selffertilization rates were estimated for production traits using Selegen REML-BLUP software considering six different rates: $0 \%, 5 \%, 10 \%, 15 \%, 20 \%$ and $25 \%$. The self-pollination negatively affected the heritability of palm-heart production trait. The heritability showed a drop in value from $3.15 \%$ to $1.33 \%$ in Roraima, $6.62 \%$ to $0.98 \%$ in Amazonas, and didn't show different values to Paraná.

\section{Genetic divergence in Bactris gasipaes progenies}

Dayane Tomigian ${ }^{1}$, Gustavo Henrique Sousa Rodrigues ${ }^{2}$, Ananda Virginia de Aguiar ${ }^{1}$, Valderês Aparecida de Sousa ${ }^{1}$, Antonio Nascim Kalil Filho ${ }^{1}$ ${ }^{1}$ Embrapa Florestas, Colombo, Brasil; ${ }^{2}$ Universidade Federal de São Carlos, Sorocaba, Brasil (dayane.tomigian@gmail.com; henriquesr.gustavo@gmail. com; ananda.aguiar@embrapa.br; valderes.sousa@embrapa.br;antonio.kalil@embrapa.br)

Pupunha (Bactris gasipaes) is a species with a large socioeconomic importance. This species is cultivated for two products widely used in culinary activities; more specifically, the palm-heart and its fruit. However,the majority of its production is destined for domestic consumption. As a result, it becomes necessary to implement breeding tools to increase its productivity. Controlled crosses between more productive and genetically divergent genotypes are very important procedures used to improve the production. The purpose of this work was to verify which progeny were the most genetically divergent in three progeny tests, and the phenotype traits most related to the production of palm-heart. The tests were implanted in Paraná, Amazonas and Roraima states, composed of a total 103 different progenies in a randomized complete block design with one plant per linear plot in a spacing 2 x1 meters. The traits height, diameter and different palm heart production (as basal, apical and total) were measured. For the genetic divergence the Mahalanobis distance and the Tocher grouping were applied using the software Selegen REML/BLUP. Genetic correlations among the traits were also estimated. Positive and significant genetic correlations were verified between palm-heart production traits. Progenies were clustered in 11, 8, and 6 different groups for the progeny's tests in Parana, Amazonas, and Roraima. Progenies from divergent groups will be used for controlled crosses.

\section{D2q: CONSERVATION, DOMESTICATION AND BREEDING OF NATIVE SPECIES}

\section{Genetic diversity of Afzelia africana Sm. (African mahogany) from southwestern Nigeria}

\section{Adejoke Akinyele ${ }^{1}$, Steele Katherine A. ${ }^{2}$, Mark Quinton-Tulloch ${ }^{2}$}

${ }^{1}$ Department of Forest Production and Products, University of Ibadan, Ibadan, Nigeria; ${ }^{2}$ School of Environment, Natural Resources and Geography, Bangor University, Bangor, United Kingdom (akinyelejo@yahoo.co.uk; k.a.steele@bangor.ac.uk;m.quinton-tulloch@bangor.ac.uk)

Uncovering the genetic variation of different populations of Afzelia africana as well as their variability and/ relatedness at the inter- and intra-population levels is important for conserving the genetic diversity and managing the existing population of this species. In this experiment, we extracted DNA samples from young 
healthy leaves collected from a total of 50 seedlings of $A$. africana from three naturally growing populations in Southwestern Nigeria. The extracted DNA were tested using different microsatellite markers. The amplified products were visualized in a $3 \%$ super fine resolution agarose gel and photographed for further analysis. The microsatellite markers were applied on duplicate samples from each individual tested, and only the clear, unambiguous and reproducible bands amplified in both cases were considered for scoring the data to get a binary data matrix. The number of polymorphic and monomorphic amplification products was determined for each primer and all the individuals. Cluster analysis was used to generate a Principal component analysis (PCA) and dendrogram showing relatedness/diversity in the samples using R studio. A total of 28 potential microsatellite loci were tested for amplification and polymorphism, and 8 successfully amplified. Result obtained was used to compare the efficiency of primers and to estimate the overall utility of each marker system. Level of similarity among individuals was established as a percentage of polymorphic bands. The 8 microsatellite loci can be used for further genetic studies of $A$. africana, to determine its conservation status.

\section{Variation in early characters for genetic improvement of Virola surinamensis (Rol. Rottb ex.) Warb. (Myristicaceae), a multipurpose tree species of Amazonian floodplains}

Aparecida Juliana Martins Corrêa ${ }^{1}$, Fatima Conceição Márquez Piña-Rodrigues ${ }^{1}$, Karina Martins ${ }^{1}$, Mario Luiz Teixeira de Moraes ${ }^{2}$, Miguel Luiz Menezes Freitas ${ }^{3}$

${ }^{1}$ Universidade Federal de São Carlos, Sorocaba, Brasil; ${ }^{2}$ Universidade Estadual Paulista “Júlio de Mesquita Filho", Ilha Solteira, Brasil; ${ }^{3}$ Instituto Florestal,SãoPaulo,Brasil (jumartinscorrea@gmail.com; fpina@ufscar.br; kmartins@ufscar.br; mario.moraes@unesp.br; miguellmfreitas@yahoo.com.br)

Classified as endangered due to its intense logging, Virola surinamensis has high silvicultural commercial value due to its diversity of products (bark, fruit, seeds, wood, etc.). The use of phenotypic characters for early selection is an important improvement tool, due to the ease of obtaining data to be evaluated. Seeds and seedlings of 95 mother-trees were sampled throughout Brazilian Amazon. We measured length (L, mm) and width (W, mm) of seeds; diameter of neck height (DNH, mm), total height (HT, cm), epicotyl height (EHT, cm) and hypocotyl height (HHT) from seedlings at six months aged. We used the completely randomized design in " $y=u+g+e "$ model, by maximum likelihood restricted and selection for best unbiased linear prediction methods (REML/BLUP), in a joint analysis for the characters evaluated. The likelihood ratio test (LRT, $\alpha(1 \%)=6.63)$ showed that the analyzed characters can be used for the selection, since they present high variation among the matrices, either for seeds (LRTL $=1988,57$; LRTW $=1615.28)$ and for seedlings $(\mathrm{LRTHT}=1050.37$, LRTDNH $=$ 162.67, LRTEHT $=1341.49$, LRTHHT $=1037.04)$. Early vegetative traits in this case will not only help to anticipate the selection processes of the best genetic material before going to the field, but also to anticipate stages of cycle production and reduce implementation costs in long term.

\section{Flowering and fruiting patterns, seed characteristics and germination of indigenous forest trees in Mount Makiling Forest Reserve, Philippines: implications to sustainable germplasm conservation}

Lerma Maldia ${ }^{1}$, Dianne Joy Aguilon ${ }^{1}$, Jessa Ata ${ }^{1}$, Marilyn Combalicer ${ }^{1}$, Reynaldo Lorida ${ }^{2}$, Amelita Luna ${ }^{3}$, Marilyn Quimado ${ }^{1}$, Crusty Tinio ${ }^{1}$ ${ }^{1}$ Department of Forest Biological Sciences, College of Forestry and Natural Resources, University of the Philippines Los Baños, Laguna, Philippines; ${ }^{2}$ University of the Philippines Land Grant Management Office, University of the Philippines Los Baños, Laguna, Philippines; ${ }^{3}$ Office of the Coordinator for Research, Extension, and Linkages, College of Forestry and Natural Resources, University of the Philippines Los Baños, Laguna, Philippines (lsmaldia@up.edu.ph;ddaguilon@up.edu.ph;jpata@up.edu.ph; mscombalicer@up.edu.ph; relorida@up.edu.ph; acluna@up.edu.ph; marilyn.quimado@gmail.com; cetinio@up.edu.ph)

Genetic resources of a country are important assets. Their conservation must be established and is fundamental to the sustainable and productive management of the forest ecosystem in which they occur. This presentation summarizes our recent three-year observation on flowering and fruiting patterns, seed calendar, seed characteristics, including dormancy and germination, seed technology and other activities on germplasm conservation of indigenous forest trees in Mount Makiling Forest Reserve in Luzon, Philippines. MMFR is a protected and key biodiversity area, with an extremely high biodiversity conservation priority, and one of the country's key ecotourism sites. The number of candidate mother trees varied widely across target species. Of 29 species, with a total of 312 candidate mother trees selected and geo-tagged, 17 species showed widely varied phenological patterns across mother trees within and among species. There are general trends observed for flowering and fruiting, to wit: synchronous flowering and fruiting among mother trees within species at defined periods annually; asynchronous flowering among mother trees within species or at irregular intervals within species during the observation period, and the rest have not flowered within the period. This resulted to varied periodicity and intensity of seed fall within and among species. Significant number of species had short seed dormancy and produced less fruits, making seed availability for seed technology and seedling production activities for in situ and ex situ conservation a crucial concern. Flowering, fruiting and seed fall patterns, dormancy, and other seed characteristics, therefore, should be well-understood in order to achieve sustainable germplasm conservation.

\section{Application of artificial neural networks for ecological niches modelling in Araucaria angustifolia and Ilex paraguariensis \\ Gustavo Rodrigues ${ }^{1}$, Ananda Vírginia de Aguiar 2 , Marcos Silveira Wrege ${ }^{2}$, Marcia Toffani Simão Soares $^{2}$, Valderês Aparecida de Sousa ${ }^{2}$, Elenice Fritzsons ${ }^{2}$, Karina Martins ${ }^{1}$ \\ ${ }^{1}$ Universidade Federal de São Carlos, Sorocaba, Brasil; ; ${ }^{2}$ mbrapa Florestas, Curitiba, Brasil Curitiba, Brazil \\ (henriquesr.gustavo@gmail.com; ananda.aguiar@embrapa.br; marcos.wrege@embrapa.br; marcia.toffani@embrapa.br; valderes.sousa@embrapa.br; elenice.fritzsons@embrapa.br; karimartins@yahoo.com)}

Nowadays, discussions about the conservation of natural populations around the world is focused on the risks of global climate change. In trees, adaptive selection processes occur slower than the actual pace of climatic changes. So cold-adapted species such as Araucaria angustifolia and Ilex paraguariensis may suffer a range reduction and even extinction of entire populations in some regions. In the context of the adaptation of climate change, an interesting strategy regarding breeding and genetic conservation programs is developing to select genotypes potentially able to cope with future climate change. Ecological Niche Modelling (ENM) methods are helpful to identify geographic regions where species grow better. Artificial Neural Network is an ENM method that results in niche models with high accuracy and efficiency. This study used the Artificial Neural Network to model regions where A. angustifolia and I. paraguariensis might grow better, considering the present and future climate scenarios. Two phenotypic variables (total height and diameter at breast height) measured in trees from six natural locations and several climate and edaphic data were used for the ANNs. These were constructed using the technique Multilayer Perceptron, in software R, where the number of neurons and layers were tested. We presented the best ANN architecture for each species, based on different accuracy metrics, and discuss differences between current and future range based on ANNs models. We, then, will discuss how these results would be applied in specific conservation and breeding strategies. 
Fingerprinting of sengon (Falcataria moluccana (Miq.)) accessions resistant to boktor pest and gall rust disease using microsatellite markers

Ulfah J Siregar ${ }^{I, 2}$, Dewi Rahmayanti ${ }^{2}$, Apriliya Damayanti ${ }^{1}$

${ }^{1}$ Bogor Agricultural University, Bogor, Indonesia; ${ }^{2}$ SEAMEO BIOTROP, Bogor, Indonesia (siregaruj@gmail.com; dewi@biotrop.org; ${ }^{407}$ april@gmail.com)

Sengon (Falcataria moluccana Miq.) is multipurpose fast growing tree species, which is widely planted in community forest. Sengon is an alternative resource for biomass energy and it can be used for wood-pellet. However, sengon has treats to the disease is caused by a fungi called Uromycladium falcatarium and stem borer called boktor (Xystrocera festiva). This research was aimed to provide genetic information of resistant and susceptible to gall rust disease as well as stem borer to obtain SSR markers which are able to differentiate the accessions. Sengon DNA was extracted using Dneasy plant mini kit from QIAGEN. The result showed that eight SSR markers (Pafa02, Pafa03, Pafa04, Pafa05, Pafa06, Pafa07, Pafa08 and Pafa10) could amplify most of the sengon accessions used in this study. However, only four primer pairs (Pafa06, Pafa07, Pafa08 and Pafa10) were able to produce polymorphic fragments on stem borer of sengon accessions. The population of sengon susceptible and resistant to gall rust disease from Sukabumi and Kediri has a high genetic diversity (He) value ranging from 0.431 to 0.518 . Sengon resistant to stem borer has the highest He (0.650) than susceptible population (He $=0.623)$. Sengon accessions of gall rust disease has genetic distance of 0.267 to 0.495 and sengon accessions of stem borer resistant was closely related to susceptible population with 0.160 genetic distance.

\section{Developing procedures for bamboo hybridization: Learning from the synchronous flowering of six bamboo species in Kerala, India}

Vidya R Sankar ${ }^{1}$, Muralidharan $E M^{1}$

${ }^{1}$ Kerala Forest Research institute, Thrissur, India (vidyacheruvallil@gmail.com; emmurali@kfri.org)

The fortuitous synchronous flowering of six species of bamboo in the KFRI Bambusetum at Thrissur, India and vicinity during 2014 to 2017 offered the rare window of opportunity to study the phenomenon and exploit the benefits of hybridization. Clumps of Dendrocalamus asper, D. giganteus, Pseudoxytenanthera stocksii, D. strictus and Ochlandra travancorica in the bambusetum and a natural population of Bambusa bambos flowered during the same time in the district. Floral biological features of the species such as anther dehiscence, pollen production, pollen viability and pollen germination were compared. Pollen viability varied from $35 \%$ in $P$. stocksii to $83 \%$ in D. giganteus and germination from $22 \%$ in $P$. stocksii to $78 \%$ in $D$. asper. Hybridization was attempted through reciprocal crosses between the different species. Attempts to improve the anther dehiscence was carried out employing direct sunlight, silica gel, calcium chloride etc. Hurdles in cross pollination were overcome using procedures like use of germination media on the stigma, cut-style pollination, in ovulo fertilization and in vitro culture excised pistils and vitro pollination/fertilization in D. asper, D. giganteus and P. stocksii. Surface sterilization procedures without compromising the viability of the pollen and ovules were developed. Pollen stored in organic solvents survived upto 280 days at $4^{\circ} \mathrm{C}$. The precise nutritional and environmental conditions essential to maintain the female receptivity and seed set, time of excising the ovule was determined. Valuable information on pollen storage and in vitro conditions conducive to carrying out hybridization was generated that can facilitate future hybridization efforts.

\section{Phylogeography of Tamarix austromongolica inferred from the trnQ-rpS16 and ITS sequence variation}

Wen Yuexian ${ }^{1}$, Gan Honghao ${ }^{1}$, Shi Shengqing ${ }^{1}$, Chu Jianmin ${ }^{1}$

${ }^{1}$ Research Institute of Forestry, Chinese Academy of Forestry, Beijing, China (wenyuexian123@163.com; ganhonghao@163.com; shi.shengqing@caf.ac.cn, cjmcaf@163.com)

In order to explore the geographical structure and migration of the lineages among the populations of Tamarix austromongolica in the Yellow River Basin, China. The samples from seventeen T. austromongolica populations were analyzed by one pair of chloroplast genes (trnQ-rpS16) and one pair of nuclear gene ITS sequences in this paper. Four chloroplast haplotypes and 32 nuclear haplotypes were detected.AMOVA analysis showed that the genetic variation of tamarix tamarix populations mainly occurred in the population, the genetic differentiation coefficient Nst (0.154) was less than Gst (0.191), and there was no obvious genealogical geographic structure among the populations. The results of neutrality test showed that Tajima's D and Fu's Fs were both significantly negative. Combining with the mismatch distribution analysis, it showed that $T$. austromongolica population experienced rapid expansion.the haplotype distribution and network structure showed that the population near Jishishan County and Yonging County in Gansu Province are oldest. Then the differentiated haplotypes are relatively old, which started from Taiji Town (TJ) in Yongjing County and down to Dongying City (DY) in Shandong Province. The unique haplotypes R10, R11 and R12 of Qinghai Province are differentiated by R1. The group distance is relatively long and relatively young. It is speculated that the T. austromongolica population migrated from the upstream to the downstream. Finally, the upstream source of the Yellow River was lengthened, and the group of T. austromongolica migrated to Qinghai Province. which is consistent with the formation direction of the Yellow River.

\section{D2r: CONSERVATION, SUSTAINABLE MANAGEMENT AND DEVELOPMENT OF FOREST GENETIC RESOURCES ACROSS THEIR RANGES: REGIONAL RESEARCH AND COLLABORATION}

\section{Floristic biodiversity in Meghalaya: an indo-burma hotspot area of India}

Sangeeta Gupta

${ }^{1}$ Forest Research Institute, Dehradun, India (sangeeta.fri@gmail.com)

Meghalaya, meaning the abode of clouds is one of the states of India that falls under the Indo-Burma hotspot. The total forest area of the State is 15584 sq km which is about $69 \%$ of the geographical area of the state. However, only 1027.20 sq km is under the control of State Forest Department, which constitutes only $4.58 \%$ of the total geographical area of the State and $6.56 \%$ of the total forest area of the State. Rest of the area is community owned and is under control and management of the Autonomous District Councils. About $5.06 \%$ of the State's Geographical Area is covered by the protected area network in Meghalaya that includes 2 national Parks, 4 wildlife Sanctuaries and 1 Biosphere Reserve, playing an important role in in-situ conservation of Biodiversity. There are 79 sacred forests covering approximately $90 \mathrm{sq} \mathrm{km}$. For a state of 22,429 sqkm it may appear that Meghalaya flora is well protected but looking at the extent of floristic diversity still more needs to be done. A study was carried out to estimate the floristic biodiversity of Meghalaya and the results showed an estimated figure of about $60-80 \%$ flora being different at an interval of every $30 \mathrm{~km}$ distance. Comparison of floristic of three areas viz. Jowai (altitude $100-1800 \mathrm{~m}$ ), Nongpoh (160-1300 m) and Balphakram (50-1026 m) were made. The presentation shall focus upon further areas that need to be covered under protected area network based on the floral diversity. 


\section{Genetic Diversity of Casuarina equisetifolia}

Pan Hu', Chonglu Zhong ${ }^{1}$, Yong Zhang ${ }^{1}$, Khongsak Pinyopusarerk ${ }^{2}$

${ }^{1}$ Research Institute of Tropical Forestry, Chinese Academy of Forestry, Guangzhou, China; ${ }^{2}$ CSIRO National Research Collections Australia, Canberra,

Australia(hupan622@139.com; zclritf@126.com; seamanzhy@163.com; khongsak.pinyopusarerk@csiro.au)

Casuarina equisetifolia natural distributed in Australia, Thailand, Malaysia, Indonesia, the Philippines, Melanesia, Polynesia and Guam, etc. The EST-SSR markers were used to determine the genetic diversity and population structure among the 29 typical natural and introduced populations. Based on 13 pairs of EST-SSR primers with amplified stability, clear band and higher polymorphism were obtained and used. The 308 alleles can be identified from the 13 SSR loci, average alleles number per loci was 23.69 , range of alleles number was from 11 to 48 . Range of effective alleles number, Shannon's index, observed heterozygosity and effective heterozygosity were 1.533-7.029, 0.691-2.139, 0.270-0.655 and 0.393-0.858, respectively. According Shannon's index, the order of genetic diversity level from high to low of the 5 regions was: African introduced (AF) $>$ Asia natural $(\mathrm{AN})>$ Oceania natural $(\mathrm{OP})>$ Central American introduced (CI)>Asia introduced (AI);the order of genetic diversity level of the 29 populations was given. The serious inbreeding between populations was occurred during the whole distribution. The $70.12 \%$ of total variance was from the individuals within populations. The order of variance was: AN (81.15\%) $>$ AI $(74.58 \%)>\mathrm{CI}(72.29 \%)>\mathrm{AF}(68.43 \%)>\mathrm{OP}(61.45 \%)$. Though variation from populations accounted for only $25.42 \%$ to $38.49 \%$ of the total variation, given the serious inbreeding that identified in the population, population selection should also attach great importance in future. Based on UPGMA dendrogram of the 29 populations proved that introduced populations of China should be from Asia natural populations, while introduced populations of Kenya, and India and Veitnam might from Oceania natural populations.

\section{Population structure and regeneration status of Prunus africana (Hook.f.) Kalkm. after selective and clear felling in Kibale National Park, Uganda}

Arthur Arnold Owiny ${ }^{1,2}$

${ }^{1}$ Uganda Christian University, Mukono, Uganda; ${ }^{2}$ Makerere University Biological Field Station, Kampala, Uganda (owinyiarthur@yahoo.com)

Prunus africana is a globally threatened indigenous medicinal tree species, and food for many primates. Its population has declined in Sub-Saharan Africa due to unsustainable harvest and poor protection. In this study, we determined the population density, population structure and regeneration status of $P$. africana in the former clear felled, selectively logged, and primary forests of Kibale National Park, and assessed the effects of dense cover of $A$. pubescens on its regeneration. Trees were measured from 180 randomly established plots. The densities of $P$. africana seedlings and saplings differed significantly among the three forests while that of poles and mature trees did not. The density of seedlings was significantly higher in the selectively logged than in primary forests. The density of saplings was higher in clear felled than in selectively logged forests. Tree density was not negatively affected by A. pubescens cover. Clear felled areas had a more stable population structure with better regeneration, while selectively logged and primary forests had unstable population structures with poor recruitment potential. Our results show that $P$. africana regenerates more in intensively disturbed forest areas than less disturbed or primary forests, highlighting the importance of regenerating forests in the conservation of $P$. africana.

\section{High-throughput development of SSR markers in diverse Liriodendron chinense germplasm}

Bin Li ${ }^{1}$, Ping Huang ${ }^{1}$, Yongqi Zheng ${ }^{1}$

${ }^{1}$ Chinese Academy of Forestry, Beijing, China (libin1200@163.com; pippin09@163.com; zyq8565@126.com)

Liriodendron chinense, ranges widely in subtropical China and northern Vietnam, however, inhabits several small isolated populations and is now an endangered species due to its limited seed production. The objective of this study was to develop a set of SSR markers useful for genetic studies inL. chinenseand their characterization in diverse germplasm. We developed novel SSR markers for L. chinensefrom randomly sequenced regions of the genome using next-generation sequencing. In total, 6,147 SSR markers were isolated from 2.84 GB genomic sequences. The most common of SSR motifs were dinucleotide (70.09\%), followed by trinucleotide motifs (23.10\%). The motif AG/TC (33.51\%) was the most abundant, followed by TC/AG (25.53\%). A set of 13 SSR primer combinations were tested for amplification and their ability to detect polymorphisms in a set of $109 \mathrm{~L}$. chinenseindividuals, representing distinct varieties or germplasm. The number of alleles per locus ranged from 8 to 28 with an average of 21 alleles.The expected heterozygosity (HE) varied from 0.19 to 0.93 and observed heterozygosity (HO) ranged from 0.11 to 0.79 . The SSR markers characterized and tested in this study provide a valuable tool to detect polymorphisms inL. chinensefor future genetic studies and breeding programs.

Grafting selected Brazil nut (Bertholletia excelsa) genotypes in Acre, Brazil: sprout survival and vigor / Enxertia de genótipos de castanheira selecionados no Estado do Acre: pegamento e vigor dos brotos

Joana Keila da Silva Gomes ${ }^{1}$, Fernanda Lopes da Fonseca², Manoel Freire Correia², José Ricardo de Oliveira Duarte', Joziane Silva Evangelista ${ }^{3}$, Lúcia Helena de Oliveira Wadt ${ }^{4}$

${ }^{1}$ Faculdade de Ciências Humanas, Exatas e Letras de Rondônia, Porto Velho, Brasil; ${ }^{2}$ Embrapa Acre, Rio Branco, Brasil; ${ }^{3}$ Universidade Federal do Acre, Rio Branco, Brasil; ${ }^{4}$ Embrapa Rondônia, Porto Velho, Brasil (keylasg@hotmail.com; fernanda.fonseca@embrapa.br; manoel.correia@embrapa.br; jose-ricardo.duarte@embrapa.br; joziane.gestorambiental@gmail.com; lucia.wadt@embrapa.br)

O manejo da castanheira-da-amazônia, atividade reconhecida como alternativa para a conservação da Amazônia, tem suas limitações quanto a produtividade, logística e acesso aos castanhais nativos. Isso justifica investimentos para seleção e disponibilização de material genético de alta qualidade. A Embrapa iniciou, em 2013, um programa de melhoramento genético com materiais do AC, RR e AP. No Acre foram selecionados 20 genótipos, nos Seringais Filipinas e Cachoeira, os quais foram caracterizados e enxertados em pomar clonal. Este trabalho apresenta o pegamento dos enxertos aos 180 dias, além do vigor das brotações aos 470 dias. Genótipos do Filipinas tiveram melhor pegamento (87,5\%) que os do Cachoeira (67\%). Os genótipos C204, F217 e F391 foram os melhores, com destaque para o F391 que apresentou melhor desenvolvimento dos brotos. Considerando que o enxertador e a forma de conservação das hastes foram semelhantes, as diferenças observadas podem estar associadas à época de coleta das hastes, uma vez que no Cachoeira foi final de outubro e no Filipinas início de novembro. Além disso, dos 11 brotos classificados como vigorosos, 10 foram do Filipinas. Diferenças genéticas também podem explicar as variações observadas, embora a incompatibilidade entre enxerto e porta-enxerto seja um aspecto que ainda precisa ser estudado. 
Analyzing the biodiversity of wild fauna in the Galilea forest for conservation in the Cordillera Oriental in Tolima, Colombia / Análisis de la biodiversidad de la fauna silvestre del bosque de Galilea para su conservación en la cordillera Oriental del Tolima (Colombia)

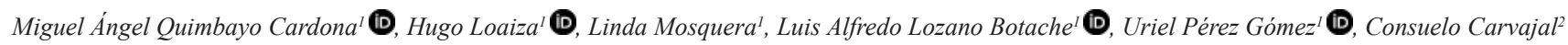
${ }^{1}$ Universidad del Tolima, Ibagué,Colombia; ${ }^{2 C O R T O L I M A, ~ I b a g u e ́, C o l o m b i a ~(m i g u e l q @ u t . e d u . c o ; ~ h n l o a i z a h @ u t . e d u . c o ~ h, ~ l c e l e s t e m o s q u e r a @ u t . e d u . c o ; ~}$ llozano@ut.edu.co; uperez@ut.edu.co; consuelo.carvajal@cortolima.gov.co)

El bosque de Galilea, localizado sobre la margen occidental de la cordillera Oriental en el departamento del Tolima (Colombia) tiene un área de 33.000 ha entre los 1.200 y $2.800 \mathrm{~m}$, con temperaturas entre $12^{\circ}$ y $24^{\circ} \mathrm{C}$. Es un ecosistema estratégico por la producción de agua que alimenta el embalse del río prado que provee energía a la región. Presenta bosques primarios y fragmentos generados por actividades antrópicas. En el marco de los estudios para la declaratoria como área protegida durante el año 2018 se realizaron caracterizaciones fauna silvestre en las localidades Río Naranjo (1.600 m) y Campo Hermoso (1.900 m). Se realizaron búsquedas intensivas, observaciones directas, capturas y grabaciones de cantos. Se han registrado 29 especies de herpetos (24 anfibios y 5 reptiles), 225 de aves y 34 de mamíferos. Herpetofauna: una especie endémica, una especie casi endémica, dos especies en CR, una especie en VU y una especie en NT a nivel internacional. Avifauna: una especie en Apéndice I CITES, 44 especies en Apéndice II CITES, dos especies endémicas, 17 especies casi endémicas y cuatro especies en VU a nivel nacional. Mamíferos: una especie en Apéndice I CITES, tres especies en Apéndice II CITES, dos especies en VU a nivel nacional, una especie en VU y una especie en NT a nivel internacional. Se tienen nuevos registros de distribución de dos especies de aves y una especie de anfibio para esta área. Se están evaluando cuatro especímenes de anfibios que podrían ser especies nuevas para la ciencia.

\section{Ex situ conservation of European beech (Fagus sylvatica L.) in Romania}

Ecaterina Nicoleta Apostol ${ }^{1}$, Marius Budeanu ${ }^{1}$, Marin Tudoroiu ${ }^{1}$, Cristiana Georgeta Ciuvat ${ }^{1}$, Robert Ivan ${ }^{1}$, Stefan Leca, Albert Ciceu ${ }^{1}$ ${ }^{1}$ National Institute for Research and Development in Forestry (INCDS) Marin Drăcea, 077190, Romania (cathyches@yahoo.com; budeanumarius@yahoo.com; borys19@gmail.com; cristiana_pif@yahoo.com;ivan_robert89@yahoo.com; stefan.leca@icas.ro; albert.ciceu@yahoo.ro)

With large distribution range, European beech (Fagus sylvatica) is one of the most ecological and economical important tree species in Europe. In the context of climate change, the European Programme for the Conservation of Forest Genetic Resources (EUFORGEN) has a special network for broadleaf species, including beech, which is considered important for its adaptability, plasticity and wood production. In Romania is considered one of the most important specie for conservation of local genofond, seed source, protection area, as well as for wood production; 60 European beech natural populations, mapped as base material for production of forest reproductive material, were sampled in representative of the full range of the specie in the country. Qualitative and quantitative characters for trunk and stem for 30 trees per population were described in order to evaluate inter- and intrapopulational phenotypic variability. The results show that the trees in the studied populations have superior phenotypic, both in quantitative and qualitative traits. In order to conserve Romanian beech genetic diversity, seeds from 15 Forest Genetic Resources were collected and used to install provenance trials.

\section{Production and growth of key species seedlings of the Atlantic Forest in danger of extinction in response to mycorrhizal fungus}

Rozimar De Pereira ${ }^{1}$, Erick Johnson Cruz ${ }^{1}$, Anna Fridha Ott ${ }^{1}$, Luana Souza Cruz ${ }^{1}$

${ }^{1}$ Universidade Federal do Recôncavo da Bahia, Cruz das Almas,Brazil (rozimarcp@gmail.com; erickjohnson1492@gmail.com; annafridha@gmail.com; luuuanacruz@gmail.com)

The type of substrate used in seedling production has a significant effect in the quality and growth characteristics of a plant. This work reports on a greenhouse experiment designed to assess the development of seedlings of Paubrasilia echinata, Dalbergia nigra, Astronium fraxinifolium, and Schinopsis brasiliensis inoculated with the following arbuscular mycorrhizal fungi (AMF): Glomus clarum Becker and Gerdemann, and Gigaspora margarita. A completely randomized factorial design was set up with 3 treatments and 25 replicates. The inoculation of AMFs was made while transplanting the seedlings to plastic sacks containing $10 \mathrm{~g}$ of inoculate. The morphometric parameters evaluated were: height, H; diameter, D; Relation H/D; weight of the fresh and the dry matter of the aerial and root parts, and leaf area. The results showed that the most effective method for dormancy breaking of P. brasilia, D. nigra seeds was the immersion in a $70 \%$ H2SO4 solution for 5 min, whereas for A. fraxinifolium and $S$. brasiliensis the best efficiency were attained through immersion in water at ambient temperature for $48 \mathrm{~h}$ and mechanical scarification, respectively. The control treatment for $S$. brasiliensis resulted in higher seedlings with smaller diameters as compared to those obtained using AMFs. The most efficient fungus for height and diameter growth rates of $S$. brasiliensis was $G$. margarita. The best response for $D$. nigra seedlings was also obtained with the inoculation of G. margarita, which showed the highest observed maximum height and diameter of the forest species studied in this work.

\section{D4a: CLOUD COMPUTING AND REMOTE SENSING TO UNDERSTAND 30-YEAR DYNAMICS} OF BRAZILIAN FORESTS

\section{Introduction to MapBiomas session: cloud computing and remote sensing to understand 30-year dynamics of Brazilian forest}

Tasso Azevedo

${ }^{1}$ MapBiomas, São Paulo, Brazil (tasso.azevedo@gmail.com)

There are a number of mapping and monitoring initiatives for forest cover, but there is still a lack of understanding of the dynamics, factors, and pressures that impact forests over time in the landscape. The MapBiomas project is a large-scale, rapid and collaborative initiative to monitor the dynamics of land cover and land use, and thus contributes to understanding processes that affect forest conservation. The project started in Brazil three years ago, providing free annual land cover and land use maps in the country from 1985 to 2017 on an interactive platform (www.mapbiomas.org), and recently with local institutions, it was expanded in the entire Amazon Basin (http://amazonia.mapbiomas.org) and Chaco region (http://chaco.mapbiomas.org), besides the possibility of expansion to other countries and regions. 
Evaluation of land use and land cover patterns in the Caatinga Biome from a 30-year time perspective (1987 - 2017)

Khalil Ali Ganem ${ }^{1}$, Washington Franca Rocha ${ }^{2}$, Rodrigo Vasconcelos ${ }^{2}$, Soltan Duverger ${ }^{3}$, Diego Pereira Costa ${ }^{2}$

${ }^{1}$ Universidade de Brasilia, Brasília, Brasil; ${ }^{2}$ Universidade Estadual de Feira de Santana, Feira de Santana, Brasil; ${ }^{3}$ Universidade Federal da Bahia,

Salvador,Brasil (khalilganem@hotmail.com; wrocha@uefs.br; rnvuefsppgm@gmail.com; solkan1201@gmail.com; costapdiego@gmail.com)

The Brazilian Annual Land Use and Land Cover Mapping project - MapBiomas - has been globally outstanding for producing, within the framework of the Google Earth Engine platform, a robust and open access database on land use and land cover of the six Brazilian biomes, with a spatio-temporal approach. This mapping has used machine learning algorithms and cloud computing in a highly functional environment with great computational capacity, where results have been applied to study current and relevant environmental topics, such as deforestation, drought, natural disasters, water availability and climate monitoring. In this work, we present a statistical analysis of the land use and land cover patterns of the Caatinga biome for the period 1987 to 2017 . To do this, from the access to the MapBiomas' online platform (mapbiomas.org), data on the area of each major class of the legend of the project were collected for the Caatinga, in the given period. The classes are: forest formations, non-forest natural formations, farming, non-vegetated areas and water bodies. These data had their reduction and growth patterns evaluated comparatively with each other and with data from other sources. At the end, there was a decrease of approximately $5.8 \%$ (4.84 million hectares) of the class area that corresponds to the forest formations in the biome over the 30 years evaluated. At the same time, data from farming class increased by about 5.4\% (4.55 million hectares), which may be a strong evidence that the forests have been removed from the Caatinga in favor of farming expansion.

\section{Mapping the different formations of native vegetation in the Cerrado over the past $\mathbf{3 0}$ years / Mapeamento das diferentes formações de vegetação nativa do Cerrado nos últimos 30 anos \\ Vera Arruda ${ }^{1,2}$, Camila Balzani ${ }^{1}$, Ane Alencar ${ }^{1}$, Felipe Lenti $^{1}$, Julia Shimbo ${ }^{1}$, Carol Nóbrega ${ }^{1}$ \\ ${ }^{1}$ IPAM Amazônia, Brasilia, Brasil; ${ }^{2}$ Universidade de Brasilia, Brasilia, Brasil (vera.arruda@ipam.org.br; camila.balzani@ipam.org.br; ane@ipam.org.br; felipe.lenti@ipam.org.br; julia.shimbo@ipam.org.br; caroline.correa@ipam.org.br)}

O Cerrado é o segundo maior bioma sul-americano e a savana mais rica e ameaçada do mundo. Caracterizado por um mosaico de formações vegetais naturais (florestas, savanas e campos) com influência da sazonalidade climática, a classificação desse bioma por imagens de satélite é de alta complexidade. Neste trabalho, apresentamos uma estratégia de classificação de imagens de satélite para mapear anualmente os três principais tipos de vegetação do Cerrado baseada na computação em nuvem usando a plataforma Google Earth Engine. Utilizando imagens Landsat dos últimos 30 anos, selecionamos pixels sem nuvem dentre as imagens disponíveis e extraímos 46 métricas espectrais que explicam o comportamento do pixel em cada ano de 1985 a 2017 . A classificação foi realizada por aprendizado de máquina na forma do algoritmo Random Forest, usando 18.000 amostras sorteadas em cada formação nativa, e aplicação de técnicas de pós-classificação como filtros espacial e temporal. Ao longo de três décadas, a vegetação nativa no Cerrado diminuiu de 136 para 112 Mha (com 55\% de áreas naturais remanescentes em 2017). A classe Savana predomina no bioma e apresentou a maior mudança em área, com 15,6 Mha convertidos em agropecuária, enquanto a classe Floresta perdeu 9,3 Mha. Como o Cerrado possui apenas 7,8\% de sua cobertura em áreas protegidas, é imprescindível identificar áreas críticas de perda de vegetação nativa como estratégia para deter o desmatamento e garantir a persistência de paisagens naturais representativas em regiões com alta pressão de conversão.

\section{Beyond processing capacity and image availability: the role of training samples in satellite land use classifications}

Diego De Abelleyra', Santiago Banchero ${ }^{1}$, Santiago Verón ${ }^{1}$, Hernan Elena ${ }^{2}$, Martín Perez ${ }^{3}$, Juan José Gaitan ${ }^{1}$, Fabiana Arevalos ${ }^{4}$, Marcos Rosa $^{5}$, José Volante ${ }^{2}$

${ }^{1} I N T A$, Hurlingham, Argentina; ${ }^{2} I N T A$, Salta, Argentina; ${ }^{3} I N T A$, Mendoza, Argentina; ${ }^{4}$ Guyra, Asunción, Paraguay; ${ }^{5}$ Departamento de Geografia - FFLCH, SaoPablo,Brasil(deabelleyra.diego@inta.gob.ar; banchero.santiago@inta.gob.ar; veron@agro.uba.ar; elena.hernan@inta.gob.ar; perezmartin@inta.gob.ar; gaitan.juan@inta.gob.ar; fabiana@guyra.org.py; mrosa@arcplan.com.br; volante.jose@inta.gob.ar)

The advent of cloud computing platforms like Google Earth Engine and the extensive availability of high resolution images changed the land use - land cover classification paradigm. Within this context, the relative importance of accurate ground truthing has increased compared to processing capacity. We here provide a general guide to sample collection and processing developed in the framework of the Project MapBiomas Chaco to produce annual land cover maps for the Gran Chaco Americano. Our proposal identifies good practices for the generation of high quality samples through visual interpretation of LANDSAT and Google Earth images with the support of MODIS time series. Mapbiomas interpreters consensuated the map legend with class definitions based on FAO LCCS, a common criteria to assign the classes based on visual interpretation and time series visualization, and recommendations to draw polygon samples. These recommendations were related to: spatial distribution of samples, balanced number of samples, scale of viewing, class homogeneity of pixels, temporal stability of classes. The workflow included an iterative process of reviewing of samples by different participants, including the redefinition of recommendations and criteria. In parallel, an outlier filter was applied to samples to avoid training the classifications with noisy pixels values for a same class. Results showed in general that both the redefinition of recommendations and reviewing of samples, as well as the application of outliers filtering have a significant increment in the overall accuracy.

\section{Recent land use and land cover change dynamics in the Chaco Argentino}

Santiago Banchero ${ }^{1}$, Diego De Abelleyra ${ }^{1}$, Santiago Verón ${ }^{1}$, Elena Hernán ${ }^{2}$, Martin Perez ${ }^{3}$, Juan José Gaitan ${ }^{1}$, José Volante ${ }^{2}$

${ }^{1}$ INTA, Hurlingham, Argentina; ${ }^{2}$ INTA, Salta, Argentina; ${ }^{3}$ INTA, Mendoza, Argentina (banchero.santiago@inta.gob.ar; deabelleyra.diego@inta.gob.ar; veron@agro.uba.ar; elena.hernan@inta.gob.ar;perez.martin@inta.gob.ar; gaitan.juan@inta.gob.ar; volante.jose@inta.gob.ar)

Land transformation is one of the most significant human changes on the Earth's surface processes. Therefore, land use land cover time series are a key input for environmental monitoring, natural resources management, territorial planning enforcement at national scale. We here capitalize from the MapBiomas initiative to characterize land use land cover (LULC) change in the argentine Chaco between 2010 and 2017. Specifically we sought to a) quantify annual changes in the main LULC classes; b) identify the main LULC transitions and c) relate these transitions to current land use policies. Within the MapBiomas project, Landsat based annual maps depicting natural woody vegetation, natural herbaceous vegetation, dispersed natural vegetation, cropland, pastures, bare areas and water were generated using Random Forest machine learning algorithms trained by samples produced by visual interpretation of high resolution images. Annual overall accuracy ranged from 0,69 to 0,71. Our results show that, between 2010 and 2017, agriculture and pasture lands increased ca; 1.7 Mha while forest and herbaceous vegetation decreased by 0.56 Mha and 0.75 Mha. Transitions from forests to agriculture accounted for $5.77 \%$ of the overall deforestation while 
$86 \%$ was associated to pastures and natural herbaceous vegetation. Forest loss occurred primarily (39\%) on areas non classified by the territorial planning Law, followed by medium (33\%), high (19\%) and low (9\%) conservation priority classes. These results illustrate the potential contribution of remote sensing to characterize complex human environmental interactions occurring over extended areas and timeframes.

\author{
Change in land coverage and use in the Amazon basin, 2000-2017 / Cambio de cobertura y uso del suelo en la Cuenca Amazónica para \\ el periodo 2000 - 2017 \\ Cicero Cardoso ${ }^{1,2}$, Sandra Rios ${ }^{3,2}$, Saul Cuellar ${ }^{4,2}$, Rodrigo Lazo $^{5,2}$, Andres Llanos ${ }^{6,2}$, Maria Borja $^{7,2}$, Antonio Victor ${ }^{8,2}$ \\ ${ }^{1} I S A$, Sao Paulo, Brazil; ${ }^{2} R A I S G$, Sao Paulo, Brazil; ${ }^{3} I B C$, Lima, Peru; ${ }^{4} F A N$, Santa Cruz, Plurinational State of Bolivia; ${ }^{5}$ PROVITA, Caracas, Venezuela \\ Republic of Bolivarian; ${ }^{6}$ GAIA, Bogotá, Colombia; ${ }^{7}$ ECOCIENCIA, Quito, Ecuador; ${ }^{8} I M A Z O N$, Belem do Para, Brazil (caugusto@socioambiental.org; \\ srios.ibc@gmail.com; scuellar@fan-bo.org;rlazo@provitaonline.org; allanos@gaiaamazonas.org;maolgaborja@gmail.com; \\ antoniovictor@imazon.org.br)
}

La Red Amazónica de Información Socioambiental Georeferenciada (RAISG) -un consorcio de organizaciones de la sociedad civil de los países amazónicos orientado a la sostenibilidad socioambiental de la Amazonía- en un esfuerzo por contribuir en el análisis de los cambios de la cobertura y el uso del suelo en la cuenca Amazónica, viene liderando conjuntamente con la Iniciativa Mapbiomas, la elaboración de estos mapas anuales para el periodo 2000 - 2017. Esta iniciativa ha sido posible gracias a la contribución de cada uno de los miembros de la RAISG, 7 ONGs miembros de la red que representan a 6 de los 9 países de la Cuenca Amazonica, y a la coalición con el equipo de Mapbiomas Brasil. Esta coalición ha permitido robustecer la metodología Mapbiomas Brasil para que la herramienta responda a las características propias del resto de la cuenca, pues la cuenca incluye otros biomas que no están presentes en Brasil como son las áreas andinas de los países de Bolivia, Perú y Ecuador. El interés de la red es producir información y conocimientos capaces de incidir sobre la generación de políticas públicas sostenibles. Dar a conocer los resultados obtenidos en cifras y mapas para todo el ámbito amazónico -partiendo de la premisa que la Cuenca Amazónica debe ser entendida y planificada de manera integral, transfronteriza y holística- contribuirá a mejorar nuestro conocimiento sobre los bosques amazónicas, las dinámicas de uso y demás coberturas vegetales de la cuenca. Asimismo, contribuirá a la planificación y ordenamiento territorial.

\title{
Tree species classification with multivariate neural networks and time series of satellite data
}

André Wästlund ${ }^{1}$, Eva Lindberg', Johan Holmgren ${ }^{1}$, Heather Reese ${ }^{2}$, Håkan Olsson ${ }^{1}$

${ }^{1}$ Swedish University of Agricultural Sciences, Umeå, Sweden; ${ }^{2}$ University of Gothenburg, Gothenburg, Sweden (andre.wastlund@slu.se; eva.lindberg@slu.se; johan.holmgren@slu.se; heather.reese@gu.se; hakan.olsson@slu.se)

Accurate information about tree species is of great interest for the forestry sector, as well as for ecological modelling. Medium to fine spatial resolution satellite images can be used to identify tree species, particularly when multi-seasonal data are available. With the current availability of satellite data time-series with high temporal resolution, phenology information expressed as seasonal variations in the signal, can be used to improve tree species mapping. In this study we use a dense time-series of freely available optical satellite data (Sentinel-2) and sample plots from the Swedish National Forest Inventory, to classify tree species all over Sweden. Computing power from the cloud-based Google Earth Engine gives us the possibility to process and analyze time-series data for thousands of images, an analysis that was not possible before. Characteristic patterns in the time-series are used by a Deep-Learning neural network (Convolutional neural network and Long short-term memory are tested) to classify tree species. Preliminary results indicate that dense time-series of freely available satellite data and Deep-Learning neural networks can improve tree species classification.

\section{Mapbiomas Arida: monitoring degradation in the semi-arid and the regeneration in the units of recovery of degraded areas in the Northeast of Brazil}

Washington Franca Rocha ${ }^{1,2}$, Jocimara Souza Britto Lobão ${ }^{1}$, Rodrigo Vasconcelos ${ }^{1,3,2}$, Diego Pereira Costa ${ }^{1,2,3}$, Deorgia Tayane Souza ${ }^{1}$, Marcos Reis Rosa ${ }^{4,5}$, Frans Germain Corneel Pareyn ${ }^{6,7}$, Tasso Azevedo ${ }^{5}$

${ }^{1}$ Universidade Estadual de Feira de Santana, Feira de Santana, Brazil; ${ }^{2}$ Mapbiomas, Feira de Santana, Brazil; ${ }^{3}$ Geodatin - Inteligência em Dados e Geoinformção, Feira de Santana, Brazil; ${ }^{4}$ Universida de São Paulo, São Paulo, Brazil; ${ }^{5}$ Mapbiomas, São Paulo, Brazil; ${ }^{6}$ APNE - Associação Plantas do Nordeste, Recife,Brazil; '7Mapbiomas, Recife,Brasil (wrocha@uefs.br; juci.lobao@uefs.br; rnvuefsppgm@gmail.com; costapdiego@gmail.com; dtmsouza@uefs.br;mrosa@arcplan.com.br; franspar@rocketmail.com; tasso.azevedo@gmail.com)

The MapBiomas - Arida platform is one of the spin - offs of the Mapbiomas Project (www.mapbiomas.org) and aims to create a system to support managers and the local community so that they can follow the evolution in time of the biophysical processes that trigger the desertification and the actions developed in the Units of Recovery of Degraded Areas - URAD, aiming at the Land Degradation Neutrality - LDN, which is one of the Sustainable Development Objectives - SDO, established by the United Nations - UN. In this platform On this platform are available annual biophysical data from 2000 to 2018 derived from remote sensing products processed from the GEE (Google Earth Engine). These are: Annual Coverage and Land Use Maps; Annual transitional matrix maps; Annual Net Primary Productivity Maps; Annual $\mathrm{CO}_{2}$-Soil maps and Annual water mirror maps. In addition, it has a Workspace environment, that is, an interactive online environment where managers and specialists can monitor the evolution of the areas imaged by various sensors (Landsat 7 and 8 , Modis and Sentinel) in each pixel of the images. Arida also has makes available an App for mobile devices for field data collection and registration of new URADs.

\section{Identifying areas for native vegetation restoration in degraded lands with the help of MapBiomas and GLOBIOM-Brazil}

Wanderson Costa ${ }^{1}$, Marluce Scarabello ${ }^{1}$, Aline Soterroni ${ }^{1}$, Fernando Ramos ${ }^{1}$

${ }^{1}$ Instituto Nacional de Pesquisas Espaciais, São Josédos Campos, Brasil (wcosta.comp@gmail.com; mascarabello@gmail.com; alinecsoterroni@gmail.com; fernando.ramos@inpe.br)

Created by Greenhouse Gas Emissions Estimation System (SEEG) in 2015, MapBiomas (Brazilian Annual Land Use and Land Cover Mapping Project) is one of the most recent Brazilian initiatives to generate annual land cover/use maps. Its mapping methodology is fully automated and integrated with Google Earth Engine and allows the possibility of comparing historical data since 1985. This mapping methodology facilitates the application of the Brazilian Forest Code, in addition to monitoring protected areas and pointing out opportunities for forest restoration. This study aims at using MapBiomas as the initial land cover/use map of the GLOBIOM-Brazil model. GLOBIOM-Brazil is a global economic partial equilibrium model that simulates, in a spatially explicit way, the competition for land among the main sectors of the land-use economy subjected to technology, resource and policy restrictions. Brazil's new Forest Code, including its debt offset mechanism (CRA), is explicitly included in our scenarios. Potential forest restoration areas are taken from the Rural Environmental 
Registry (CAR). Final identification of forest restoration areas also takes into account the opportunity costs, estimated by GLOBIOM-Brazil. Restoration costs take into account the previous use of the land, i.e., if it was cropland, pasture, abandoned land or degraded land. Our results emphasize the use of MapBiomas and GLOBIOM-Brazil as a support in the development of forest restoration policies.

\author{
Agricultural losses from biogeophysical climate change in Brazil: A business case for ecosystem protection? \\ Avery Cohn ${ }^{1}$, Sally Thompson ${ }^{2}$ \\ ${ }^{1}$ Tufts University, Boston, USA; ${ }^{2}$ University of California, Berkeley, Berkeley, USA (avery.cohn@tufts.edu; sally.thompson@berkeley.edu)
}

In the Amazon and Cerrado biomes of Brazil, slowing ecosystem conversion could help to protect valuable ecosystem services, but comes at the cost of foregone revenue from the expansion of agricultural activities. As part of a wider effort to estimate the likelihood that reducing ecosystem conversion will be net beneficial to key agricultural and government actors, we produced spatially explicit, near-term, probabilistic estimates of economic damage to the agricultural economy stemming from ecosystem services lost under ecosystem conversion. Underlying these estimates was an ecological forecasting framework. We assembled the framework using two sets of statistical models, selected for their predictive skill and drawing on remotely sensed and in situ evidence. Agricultural land use and native ecosystem area were extracted from Mapbiomas 3.0. The first model set predicted the response of agriculturally relevant rainfall and temperature parameters to regional land use and land cover change. The second set predicted the response of agricultural productivity to changes in the regional climate. Together with idealized land use and land cover scenarios, we linked these models and used them to forecast economic damage to the agricultural sector stemming from ecosystem conversion. The results of the forecast exhibited a high degree of uncertainty, but nevertheless revealed the costs of damage from a considerable area of ecosystem conversion to robustly exceed the opportunity cost of conservation. Partitioning the uncertainty demonstrated several priority areas for improved modeling and data in the agricultural, ecological, and climatological domains.

\title{
Understanding the importance of the Cerrado for deforested-driven greenhouse gas (GHG) emissions in Brazil from 1990 to 2017
}

Felipe Lenti ${ }^{1,2}$, Júlia Shimbo ${ }^{1}$, Vivian Ribeiro ${ }^{1}$, Ane Alencar ${ }^{1}$, Amintas Brandão Jr. ${ }^{3}$, Tasso Azevedo ${ }^{4}$

${ }^{1}$ Instituto de Pesquisa Ambiental da Amazônia, Brasília, Brasil; ${ }^{2}$ Universidade de Brasília, Departamento de Ecologia, Brasília, Brasil; ${ }^{3}$ University of

Wisconsin, Nelson Institute, Madison, USA; ${ }^{4}$ Observatório do Clima, São Paulo, Brasil (felipe.lenti@ipam.org.br; julia.shimbo@ipam.org.br;

vivian.ribeiro@ipam.org.br; ane@ipam.org.br; brandaojr@gmail.com; tasso.azevedo@gmail.com)

The Cerrado, second largest biome in Brazil, is characterized by a savanna-dominated matrix enfolding forest and grassland patches. Native vegetation was already suppressed in $45 \%$ of its $2 \mathrm{M} \mathrm{km}^{2}$ territory in 2017. Cerrado remnants reserves $9 \mathrm{GtC}$, but this stock is prone to rapid conversion due to lack of protection and agricultural suitability. Governmental monitoring of GHG emissions associated with Cerrado deforestation covers the period of 1990-2010, leaving an information gap about the role Cerrado plays in the national emission profile in recent years. Here we present trends in land-use change emissions estimates for Cerrado from 1990 to 2017, produced by the SEEG (System for Estimating Greenhouse Gas Emissions) initiative. To estimate deforestation-driven emissions we used country specific emission factors and annual deforestation rates derived from the MapBiomas time-series. Deforestation was defined as pixels that remained in a vegetation class for at least three years and then transitioned to a land-use class, remaining in the later for two years or longer. Emissions from 1990 to 2017 were summed $18 \%$ of Brazil land-use change sector $\left(7 \mathrm{GtCO}_{2} \mathrm{e}\right)$. Cerrado average contribution to the land-use change sector was $22 \%$ from 1990 1999, 15\% from 2000-2009 and 20\% from 2010-2017. The increase in Cerrado contribution in recent years indicates accelerated conversion in Cerrado in relation to other biomes. The Brazilian Forest Code allows for legal suppression of $325.000 \mathrm{~km}^{2}$ and an associated emission of $3.2 \mathrm{GtCO}_{2} \mathrm{e}$. Reducing national land-use change emissions requires urgent efforts by both public and private sectors to halt deforestation in Cerrado.

\section{D4b: TECHNOLOGICAL INNOVATIONS FOR NATIVE FOREST MANAGEMENT IN} DIFFERENT BRAZILIAN BIOMES

Forest management 4.0: planning with drones / Manejo Florestal 4.0 - planejamento com aeronaves remotamente pilotadas (RPAs)

Evandro Orfanó Figueiredo ${ }^{1}$, Symone M Melo Figueiredo², Marcus V.N. d'Oliveira ${ }^{1}$,Erica K.M. Santos ${ }^{2}$

${ }^{1}$ Embrapa Acre, Rio Branco, Brasil; ${ }^{2}$ Universidade Federal do Acre, Rio Branco, Brasil

(evandro.figueiredo@embrapa.br; symone.figueiredo@ufac.br; marcus.oliveira@embrapa.br; ericakerolaine@gmail.com)

A cada dia se fazem mais presente no campo, os processos que envolvem as geotecnologias de precisão, com inclusão de máquinas robotizadas e guiadas por computadores, sensores de presença e GNSS. Importantes aliadas nessa nova era do planejamento florestal de grande teor digital, são as aeronaves remotamente pilotadas (RPAs) ou mais conhecidas como drones. O manejo de precisão de florestais tropicais na Amazônia também acompanha a nova geração tecnológica, contemplando para isso: os inventários florestais semiautônomos a partir de RPAs, GNSS pós-processado e uso de algoritmos para segmentação e geolocalização automática de árvores. O objetivo do trabalho foi propor um calendário preliminar de inventário florestal com uso de RPAs (classe III), contemplando as árvores codominantes e dominantes, acima de $50 \mathrm{~cm}$ de DAP1,3m. O mapeamento da cobertura florestal a partir de ortofotos de alta resolução $(<7 \mathrm{~cm})$ será uma etapa que deverá preceder a entrada da equipe de inventário em campo. Dessa maneira, a equipe de inventário florestal iniciará seus trabalhos com a geolocalização precisa de todas as árvores dominantes, facilitando significativamente a busca por espécies de interesse. $\mathrm{O}$ trabalho foi na reserva florestal da Embrapa Acre, na Amazônia Brasileira, com a RPA DJI P4Pro, por meio de voos semiautônomos. Para segmentação foram testados diversos parâmetros utilizando o algoritmo GEOBIA. O acompanhamento mensal da floresta a partir de ortofotos de alta resolução, possibilita traçar um perfil modal preliminar das fenofases de cada uma das 14 espécies estudadas, demonstrando assim a viabilidade do inventário automatizado com as RPAs. .

Alternative systems for primary transport of wood planks in low-intensity sustainable forest management / Sistemas alternativos para o transporte primário de pranchas de madeira no manejo florestal sustentável de baixa intensidade

Iran Pires ${ }^{1}$, João Melo ${ }^{1}$, Ana Carolina Vieira ${ }^{1}$, Ana Luiza Violato Espada ${ }^{1,2}$ (D), Elias Serejo ${ }^{1}$ Instituto Floresta Tropical, Belém, Brasil; ${ }^{2}$ University of Florida, Gainesville, USA (iran@ift.org.br; joao@ift.org.br; carolina@ift.org.br; violatoespada@ufl.edu,elias@ift.org.br)

Na Amazônia existem diversas experiências de transporte primário de madeira na modalidade de Plano de Manejo Florestal Sustentável (PMFS) Pleno, com inúmeros arranjos de equipamentos e planejamentos já definidos em função do terreno, equipamentos disponíveis e graus de investimentos. Mas na modalidade 
PMFS de baixa intensidade, comumente realizado por comunidades tradicionais, muitas experiências têm baixo investimento tecnológico. Atividades manuais ainda são frequentes, com pouca diversidade de planejamento operacional e excessivo esforço físico. Com a finalidade de testar sistemas alternativos para o transporte primário de pranchas de madeira no manejo florestal de baixa intensidade, o Instituto Floresta Tropical (IFT) realizou testes na Reserva Extrativista Ituxi, Lábrea-AM. A área total da Unidade de Manejo Florestal é de 1.403,53ha. A área destinada para o teste corresponde à $1^{\text {a }}$ Unidade de Produção Anual, com 136ha. Com a finalidade de melhorar os índices de produtividade e diminuir o esforço humano, foram testados o uso do microtrator e motocicleta para o transporte de pranchas de madeira. $\mathrm{O}$ uso desses equipamentos, por serem de pequeno porte e ágeis, é uma boa alternativa de aplicação para o manejo de baixa intensidade, em que a aquisição de tratores convencionais se torna inviável. Microtratores e motocicletas têm como principais características a acessibilidade de preços de aquisição, baixo consumo de combustível e custos reduzidos de manutenção. Também a diminuição do esforço físico para a realização da atividade florestal leva à uma maior motivação dos manejadores, diminuindo a evasão da mão-de-obra durante as operações florestais e aumentando o envolvimento do manejador.

Equipment for drying shell-on Brazil nuts in family extractive operations / Equipamentos para secagem de castanha-da-amazônia com casca em unidades familiares extrativistas

Virgínia Alvares ${ }^{1}$, Marcelino Guedes ${ }^{2}$, Fernanda Fonseca $^{1}$, Cleísa Cartaxo ${ }^{1}$

${ }^{1}$ Embrapa Acre, Rio Branco, Brasil; '2Embrapa Amapá, Macapá, Brasil (virginia.alvares@embrapa.br; marcelino.guedes@embrapa.br; fernanda.fonseca@embrapa.br; cleisa.cartaxo@embrapa.br)

Secagem, armazenamento e transporte de castanha-da-amazônia na floresta são etapas críticas da produção. Seu manejo inadequado favorece a contaminação por fungos filamentosos e toxinas de potencial carcinogênico. As tecnologias de manutenção da qualidade e segurança alimentar da castanha devem considerar o custo de adoção e a disponibilidade local de energia, infra-estrutura e mão-obra. Este estudo apresenta resultados da avaliação, em conjunto com produtores extrativistas, dos seguintes equipamentos de secagem de castanha-da-amazônia: 1) secador a ar quente (troca de calor indireto) por convecção natural, instalado na RESEX Chico Mendes (Acre), com capacidade para secagem de 200 a 300 litros de castanha com casca; e 2) paiol solar para secagem e armazenamento, construído em madeira, com câmara de aquecimento coberta com telhas translúcidas, instalado na RESEX Cajari (Amapá), com capacidade para 3000 litros de castanha com casca lavada. O primeiro reduziu o tempo de secagem de 15 dias para 6 horas, controlando fungos filamentosos totais e mantendo os níveis de aflatoxinas abaixo dos limites legais. Como contribuição, os produtores apontaram: necessidade de homogeneização da temperatura no trocador de calor; isolamento térmico da fornalha e redução do fluxo de ar na fornalha. O segundo reduziu o peso inicial em $20 \%$ após três dias, fornecendo castanhas limpas e de melhor aparência, atributos desejados pela comunidade por facilitar o transporte e manuseio e, consequente, agregar valor. Ajustes nos equipamentos deverão ser realizados para que o produto atinja os padrões de qualidade e segurança normatizados, possibilitando renda às famílias extrativistas e garantindo a sustentabilidade da atividade.

Optimization of trails and adding value to Brazil nut extractivism (Bertholletia excelsa Bonpl.): a case study / Otimização de trilhas e valoração da atividade extrativista da Castanha-da-amazônia (Bertholletia excelsa Bonpl.): um estudo de caso

Katia Silva ${ }^{1}$, Thais Vieira ${ }^{2}$, Carlos Ribeiro ${ }^{3}$, Gustavo Marcatti ${ }^{4}$, Alisson Munaretti ${ }^{5}$, Danilo Almeida6, Rosiele Vasconcelos ${ }^{7}$, Lúcia Helena de Oliveira Wadt ${ }^{8}$ ${ }^{1}$ Apa Amazonia Ocidental, Manaus, Brasil; ${ }^{2}$ UFAM, Manaus, Brasil;: ${ }^{3}$ Universidade Federal de Viçosa, Viçosa, Brasil; ${ }^{4}$ Universidade Federal de São João Del Rei, São João Del Rei, Brasil,; ${ }^{5}$ UFAC, Rio Branco, Brasil; ${ }^{6}$ Universidade Federal de São Paulo, São Paulo, Brazil; ${ }^{7}$ IDAM, Manaus, Brazil; ${ }^{8}$ Embrapa Rondônia,PortoVelho,Brasil((katia.emidio@embrapa.br; thais.vieira.alves@hotmail.com; caas.ribeiro@gmail.com; gustavomarcatti@ufsj.edu.br; alissonmm.florestal@gmail.com; daniloflorestas@gmail.com; rosi.engflorestal@hotmail.com; lucia.wadt@embrapa.br)

A coleta da castanha-da-amazônia envolve grande número de pessoas, que tem nesta atividade uma importante complementação da renda familiar. Apesar desta importância, a atividade precisa ser cada vez mais valorizada e valorada. A dinâmica de coleta da castanha envolve um grande esforço laboral, com grandes deslocamentos dentro dos castanhais, afim de se realizar a amontoa e quebra de ouriços, para posterior transporte das castanhas in natura. A otimização do traçado de trilhas visa identificar o melhor percurso, combinando fatores que determinam o grau de dificuldade de se percorrer determinada região e uma maior eficiência de acesso a árvores selecionadas, utilizando variáveis de relevo, hidrografia e localização espacial de castanheiras, integradas por meio de geotecnologias, com enfoque em análise de redes. Um estudo de caso foi realizado em um castanhal de aproximadamente 145 ha, localizado no município de Epitaciolândia, Acre, onde se aplicou a metodologia para acesso a 115 castanheiras produtivas, Na geração de trilhas otimizadas, superfícies de custo (tempo) são obtidas, as quais permitem o cálculo do tempo gasto na atividade de coleta da castanha, incluindo deslocamentos no terreno até as árvores produtivas, amontoa, quebra de ouriços e transporte até o destino final. O tempo total gasto na coleta em 115 castanheiras foi de 33 dias/homem, que convertidos ao valor da diária local, resultou em um custo com mão-de-obra de aproximadamente R \$ 1.650,00. O estudo demonstrou ser possível contribuir para a valoração da etapa de coleta, auxiliando em uma mais justa definição de preços do produto para os agroextrativistas. .

Approach to estimating fruit production in native populations of Euterpe precatoria Mart. palms in southwestern Amazonia: experience at the Chico Mendes Extractive Reserve, Acre, Brazil / Abordagem para estimativa a produção de frutos de populações nativas de açai solteiro (Euterpe precatoria Mart.) na Amazônia Sul-ocidental: a experiência da Reserva Extrativista Chico Mendes, Acre

Fernanda Lopes da Fonseca ${ }^{1,2}$, Cleísa Brasil da Cunha Cartaxo ${ }^{1}$, Lúcia Helena de Oliveira Wadt ${ }^{3}$

${ }^{1}$ Embrapa, Acre, Brasil;: ${ }^{2}$ Universidade Federal de Santa Catarina, Florianopolis, Brasil; ${ }^{3}$ Embrapa Rondonia, Porto Velho, Brasil

(fernanda.fonseca@embrapa.br; cleisa.cartaxo@embrapa.br; lucia.wadt@embrapa.br)

O principal desafio relacionado à qualidade da castanha-da-amazônia é a presença de aflatoxinas, problema que já chegou a afetar severamente o mercado internacional da amêndoa. O uso de boas práticas de manejo (BPM) tem reduzido significativamente esse tipo de contaminação, possibilitando a retomada do mercado. Se por um lado identificam-se aspectos favoráveis à adoção das BPM por produtores extrativistas, como a adequação das práticas à realidade produtiva, a redução da contaminação e o melhor rendimento no processamento nas usinas, por outro, um conjunto de fatores restringem seu uso. Este resumo tem como objetivo discutir os principais desafios identificados para a adoção das BPM em Brasiléia, Acre, município brasileiro localizado na fronteira com o Peru e Bolívia. A pesquisa aborda elementos sobre o processo de transferência de tecnologia, sua apropriação e os fatores que interferem na tomada de decisão do extrativista sobre a adoção das diretrizes técnicas de manejo. O estudo se baseou em observações em campo e narrativas de manejadores de castanha. Com base nas informações levantadas, pode-se afirmar que as BPM para a produção da castanha, foram apropriadas pelos extrativistas na etapa de pré-coleta. Entretanto, nas etapas de coleta e pós-coleta, as BPM apresentaram baixa adoção em virtude de fatores como não diferenciação de preço para o produto manejado; elevada concorrência de compradores na região da tríplice fronteira; baixa capacidade de gestão das associações de produtores para buscar mercados diferenciados; e insuficiente assistência técnica para orientar a adoção das práticas e apoiar o monitoramento da qualidade do produto. 
Approach to estimating fruit production in native populations of Euterpe precatoria Mart. palms in southwestern Amazonia: experience at the Chico Mendes Extractive Reserve, Acre, Brazil / Abordagem para estimativa a produção de frutos de populações nativas de açai solteiro (Euterpe precatoria Mart.) na Amazônia Sul-ocidental: a experiência da Reserva Extrativista Chico Mendes, Acre

Andrea Alechandre ${ }^{1}$, Elaine Lopes ${ }^{1}$, Daniel Papa ${ }^{2}$, Dorila Gonzaga ${ }^{2}$

${ }^{1}$ Universidade Federal do Acre, Rio Branco, Brasil; ${ }^{2}$ Embrapa Acre, Rio Branco, Brasil (andreaalechandre@gmail.com; lopes.elaine7@gmail.com; daniel.papa@embrapa.br;dorila.gonzaga@gmail.com)

Os frutos de açaí são o principal produto do extrativismo vegetal no Brasil, tanto pela quantidade produzida quanto pelo valor obtido. A Euterpe precatoria Mart. (açaí solteiro) tem ocorrência na Amazônia Ocidental, respondendo por 26\% da produção brasileira de frutos, sendo a E. oleracea Mart. (açaí-do-pará) responsável por 3/4 da produção total. Apesar do grande potencial econômico, o açaí solteiro ainda é pouco utilizado economicamente no estado do Acre. O objetivo desse trabalho foi desenvolver e testar uma abordagem para estimar o potencial produtivo do E. precatoria em comunidades da Reserva Extrativista Chico Mendes. Para tanto foram seguidas as seguintes etapas: mobilização das lideranças para definição das áreas de levantamento; capacitação de técnicos extrativistas no mapeamento de açaizeiros; mapeamento com GPS de navegação; elaboração de mapas a partir de softwares de SIG (TrackMaker, Google Earth Pro e ArcGis); cálculo da estimativa de produção de frutos; validação dos mapas com a comunidade; uso dos mapas para planejamento de coleta e comercialização. A aplicação desta abordagem permitiu: a melhoria da organização comunitária voltada à comercialização de açaí; técnicos extrativistas capacitados em mapeamento; "colocações" (unidade produtiva familiar) com produção de açaí estimada; comprador de matéria-prima compromissado com a aquisição da produção; e o interesse de outros produtores extrativistas em aplicar a metodologia. A maior dificuldade encontrada foi para o deslocamento no período chuvoso devido as más condições de trafegabilidade dos ramais. Esta é uma abordagem aplicável para estimar o estoque da produção de quaisquer produtos florestais não madeireiros manejado por populações tradicionais.

Challenges in adopting good management practices for sustainable extraction of Brazil nuts in Acre, Brazil / Desafios para a adoção das boas práticas de manejo para o extrativismo sustentável da castanha-da-amazônia no Acre

Fernanda Lopes da Fonseca ${ }^{1,2}$, Cleísa Brasil da Cunha Cartaxo ${ }^{1}$, Lúcia Helena de Oliveira Wadt ${ }^{3}$

${ }^{1}$ Embrapa, Acre, Brasil; ${ }^{2}$ Universidade Federal de Santa Catarina, Florianopolis, Brasil; ${ }^{3}$ Embrapa, Rondônia, Brasil (fernanda.fonseca@embrapa.br;

cleisa.cartaxo@embrapa.br; lucia.wadt@embrapa.br)

O principal desafio relacionado à qualidade da castanha-da-amazônia é a presença de aflatoxinas, problema que já chegou a afetar severamente o mercado internacional da amêndoa. O uso de boas práticas de manejo (BPM) tem reduzido significativamente esse tipo de contaminação, possibilitando a retomada do mercado. Se por um lado identificam-se aspectos favoráveis à adoção das BPM por produtores extrativistas, como a adequação das práticas à realidade produtiva, a redução da contaminação e o melhor rendimento no processamento nas usinas, por outro, um conjunto de fatores restringem seu uso. Este resumo tem como objetivo discutir os principais desafios identificados para a adoção das BPM em Brasiléia, Acre, município brasileiro localizado na fronteira com o Peru e Bolívia. A pesquisa aborda elementos sobre o processo de transferência de tecnologia, sua apropriação e os fatores que interferem na tomada de decisão do extrativista sobre a adoção das diretrizes técnicas de manejo. O estudo se baseou em observações em campo e narrativas de manejadores de castanha. Com base nas informações levantadas, pode-se afirmar que as BPM para a produção da castanha, foram apropriadas pelos extrativistas na etapa de pré-coleta. Entretanto, nas etapas de coleta e pós-coleta, as BPM apresentaram baixa adoção em virtude de fatores como não diferenciação de preço para o produto manejado; elevada concorrência de compradores na região da tríplice fronteira; baixa capacidade de gestão das associações de produtores para buscar mercados diferenciados; e insuficiente assistência técnica para orientar a adoção das práticas e apoiar o monitoramento da qualidade do produto.

The rural environmental register system as a georeferencing base for planning rural production and conservation of native forests in Brazil / A experiência do sistema de cadastro ambiental rural como base georeferenciada para planejamento da produção rural e conservação de florestas nativas no Brasil

Janaina Rocha ${ }^{1}$, Rejane Mendes ${ }^{1}$, Raimundo Deusdaráa ${ }^{1}$, Bernardo Trovão ${ }^{1}$, Kimberly Castro $^{1}$, Leandro Biondo ${ }^{1}$, Gustavo Oliveira ${ }^{1}$, Pedro Salles $^{1}$, Carlos Sturm ${ }^{1}$, Pamella Goncalves ${ }^{2}$, Gabriela Gonçalves ${ }^{2}$, Tatiana Calçada ${ }^{1}$, Lilianna Mendes ${ }^{1}$

${ }^{1}$ Serviço Florestal Brasileiro, Brasilia, Brazil (drivejrocha@gmail.com; rejane.mendes@florestal.gov.br; raimundo.deusdara@florestal.gov.br; bernardo.trovao@florestal.gov.br; kimberly.castro@giz.de; leandro.biondo@florestal.gov.br; gustavo.oliveira@florestal.gov.br;

pedro.salles@florestal.gov.br; carlos.sturm@florestal.gov.br; consultora4.gecaf@florestal.gov.br; gabriela.goncalves@florestal.gov.br; tatiana.calcada@florestal.gov.br; lilianna.mendes@florestal.gov.br)

O Cadastro Ambiental Rural (CAR), instituído pelo Código Florestal Brasileiro (CFB), integra as informações georreferenciadas da vegetação nativa de todos imóveis rurais, e configura-se a principal plataforma digital de planejamento do uso do solo para produção rural sustentável do mundo. As informações autodeclaratórias dos produtores rurais, são armazenadas em um banco de dados geoespacial, integrado e desenvolvido em plataformas livres, para todo o território nacional e composto por diversas regras de negócios baseadas na legislação vigente e estruturadas por requisitos do Serviço Florestal Brasileiro (SFB), gestor nacional do SICAR. A representação espacial dos imóveis rurais a partir do uso de imagens de satélite de alta resolução permite semi-automatização da análise da cobertura de vegetação nativa para diagnosticar o cumprimento da regularidade ambiental dos imóveis rurais, bem como áreas para recomposição da vegetação nativa. Este trabalho descreve, os cinco anos de implantação e dados contextualizados com as informações por bioma, a partir dos remanescentes de vegetação nativa declarados e respectivo detalhamento das informações florestais sob a ótica estratégica de conservação florestal provida pelos imóveis rurais no Brasil. Desde sua implantação, o SICAR recebeu cerca de 5,5 milhões de imóveis rurais, totalizando área de mais de 503,5 milhões de hectares. Nos dados declarados, 40,6\% representa a cobertura de vegetação nativa, 27,6 \% as áreas de Reserva Legal e 3,9\%, as Áreas de Preservação Permanente - APP. Nestes, 79,2\% das áreas de Reserva Legal e 59\% das APP cobertas de vegetação nativa. Ademais, 58,1\% dos imóveis rurais declaram adesão aos Programas de Regularização Ambiental - PRA. 


\section{A first Amazon $\mathrm{CH}_{4}$ budget and its controls based on atmospheric data from vertical profiles measurements}

Luana S. Basso ${ }^{1}$, Luciana V. Gatti ${ }^{1,2}$, Luciano Marani ${ }^{1}$, Henrique L.G. Cassol ${ }^{3}$, Graciela Tejada ${ }^{1}$, Caio S.C. Correia ${ }^{1,2}$, Lucas G. Domingues ${ }^{1,2}$, Stephane P. Crispim ${ }^{1}$, Raiane A.L. Neves ${ }^{1}$, Egidio Arai ${ }^{3}$, John B. Miller ${ }^{4}$, Manuel Gloor ${ }^{5}$, Liana O. Anderson ${ }^{6}$, Luiz E.O.C. Aragão ${ }^{3}$ ${ }^{1}$ Earth System Science Center (CCST), National Institute for Space Research (INPE), São José dos Campos, Brazil; ${ }^{2}$ Nuclear and Energy Research Institute (IPEN), São Paulo, Brasil; 3Remote Sensing Division, National Institute for Space Research (INPE), São José dos Campos, Brasil; 4 Global Monitoring Division, Earth System Research Laboratory, National Oceanic and Atmospheric Administration (NOAA), Boulder, USA; 5School of Geography, University of Leeds, Leeds, United Kingdom; 6National Center for Monitoring and Early Warning of Natural Disasters - CEMADEN, São José dos Campos, Brasil (luanabasso@gmail.com; lvgatti@gmail.com;lmarani@gmail.com; hlcassol@hotmail.com; gracielatejadap@gmail.com; cacorreia@gmail.com; lgtdomingues@gmail.com; stephane.crispim@gmail.com; raiane.lopesneves@gmail.com; egidio.arai@inpe.br; john.b.miller@noaa.gov; eugloor@gmail.com; liana.anderson@gmail.com; laragao@dsr.inpe.br)

The role of tropical regions in the global $\mathrm{CH}_{4}$ balance remained uncertain, due these regions have until recently been poorly observed with large-scale integrating in-situ observations. To contribute in understanding the $\mathrm{CH}_{4}$ balance in tropical regions, we have started a lower-troposphere greenhouse gas-monitoring program over Brazilian Amazon Basin consisting of regular vertical profile greenhouse gas observations at four sites. Samples are collected regularly each 2 weeks, using light aircraft. We will present an analysis of these data and what they tell us about the Amazon $\mathrm{CH}_{4}$ cycle and its contribution to global $\mathrm{CH}_{4}$ concentration. We estimate fluxes upwind of the sites from the profile data using a column budgeting approach (Miller et al., 2007). Over the full period (2010-2017) the Amazon Basin was a source of $\mathrm{CH}_{4}$, but with regional variations. There are comparably high and highly variable emissions from the eastern part of the basin exhibiting strong variability, with particularly high $\mathrm{CH}_{4}$ fluxes in two different periods of the year (beginning of the wet season and in the dry season). In contrast to this, a clear seasonality was observed at the other three sites, with the largest emissions occurring at the beginning of the wet season (January to March). Emissions from biomass burning contribute with a small part of the total flux at each site. We will finally discuss what is the influence from precipitation and temperature in the Amazon $\mathrm{CH}_{4}$ emissions. Acknowledgment: FAPESP, NERC, CNPq, MCTI, NOAA, IPEN and INPE.

\section{Understanding the relationships between local deforestation and $\mathrm{CO}_{2}$ atmospheric measurements in the Brazilian Amazon}

Graciela Tejada ${ }^{1}$,Luciana Gatti ${ }^{1,2}$, Luana Basso ${ }^{1}$, Henrique L.G. Cassol ${ }^{3}$, Luciano Marani ${ }^{1}$, Caio Correia ${ }^{1,2}$, Lucas Domingues ${ }^{1,2}$, Stephane Crispim ${ }^{1}$, Raiane $^{2}$ Neves $^{1}$, Liana O. Anderson ${ }^{4}$, Luiz EOC. Aragão ${ }^{3}$, Egidio Arai ${ }^{3}$, Manuel Gloor ${ }^{5}$, John B. Miller ${ }^{6}$, Celso von Randow ${ }^{1}$

${ }^{1}$ Earth System Science Center (CCST), National Institute for Space Research (INPE), São José dos Campos, Brazil; 2Nuclear and Energy Research Institute (IPEN), São Paulo, Brazil; ${ }^{3}$ Remote Sensing Division, National Institute for Space Research (INPE), São José dos Campos, Brazil; ${ }^{4}$ National Center for Monitoring and Early Warning of Natural Disasters (CEMADEN), São José dos Campos, Brazil; ${ }^{5}$ School of Geography, University of Leeds, Leeds, Leeds, United Kingdom; ${ }^{6}$ Global Monitoring Division, Earth System Research Laboratory, National Oceanic and Atmospheric Administration (NOAA), Boulder, USA(gracielatejadap@gmail.com; lvgatti@gmail.com; luanabasso@gmail.com; hlcassol@hotmail.com; lmarani@gmail.com; cacorreia@gmail.com; lgtdomingues@gmail.com; stephane.crispim@gmail.com; raiane.lopesneves@gmail.com; liana.anderson@gmail.com; laragao@dsr.inpe.br; egidio.arai@inpe.br; eugloor@gmail.com; john.b.miller@noaa.gov; celso.vonrandow@inpe.br)

Amazon forests play a fundamental role in the global carbon balance as a carbon sink, but temperature elevations and frequents extreme events as droughts and floods could make the forests a source of $\mathrm{CO}_{2}$. Local atmospheric measurements of greenhouse gases are needed to better understand how forest will respond to climate change. The lower-troposphere greenhouse gas (GHG) monitoring program over Brazilian Amazon Basin, has been collecting biweekly GHGs vertical profiles in four sites since 2010. We aim to understand the relationships between local deforestation and $\mathrm{CO}_{2}$ aircraft measurements in the Brazilian Amazon. We calculated annual deforestation (using the Amazon Deforestation Calculation Program - PRODES), land use and cover change data (using the Brazilian Institute of Geography and Statistics - IBGE) and fire data (using the Fire Monitoring System) in each annual influence area at the four flight measurement sites of the Brazilian Amazon from 2010-2017 (and also in the mean influence area of all years by sites). We found that when we see total deforestation, it has a relationship with global $\mathrm{CO}_{2}$ emissions in the Brazilian Amazon biome. Fire has a strong relationship in the drought years, mostly in 2012. Looking at each site, we found specific correlations with deforestation, fire and land use. The biggest challenge was to compare spatial analyzes of land use change and fire with punctual data of airplane GHGs measurements. This study will contribute in our understanding of anthropogenic activities over the Amazon forest in a changing climate.

D4c: VALUATION ISSUES FOR WOOD AND NONWOOD FOREST PRODUCTS TO BALANCE BIODIVERSITY AND ECOSYSTEM SERVICES IN MANA GED FORESTS

\section{A spatially-explicit empirical model for assessing conservation values of conifer plantations}

Yuichi Yamaura ${ }^{1,2}$, David Lindenmayer ${ }^{2}$, Yusuke Yamada ${ }^{1}$, Hao Gong ${ }^{1}$, Toshiya Matsuura ${ }^{1}$, Yasushi Mitsuda ${ }^{3}$, Takashi Masaki ${ }^{1}$

${ }^{1}$ Forestry and Forest Products Research Institute, Ibaraki, Japan; ${ }^{2}$ Australian National University, Canberra, Australia; ${ }^{3}$ University of Miyazaki, Miyazaki, Japan(yamaura@ffpri.affrc.go.jp; david.lindenmayer@anu.edu.au; yamayu@ffpri.affrc.go.jp; hiro.gonghao@gmail.com; matsuu50@affrc.go.jp; mitsuda@cc.miyazaki-u.ac.jp; masaki@ffpri.affrc.go.jp)

Plantations are expanding globally and dominate landscapes in many parts of the world. Older plantations can provide habitat for some native trees and associated biota, and the amount of native trees may be a simple indicator of conservation value of plantations. We modeled basal area (BA) of native broad-leaved trees in Japan's conifer plantations. We quantified relationships between rates of increase in BA of broad-leaved trees and plantation tree species, density of planted trees, climatic, topographic and landscape covariates using the extensive plot data from the National Forest Inventory. Identity of plantation species had a strong effect on the BA of native trees. Japanese cedar Cryptomeria japonica and hinoki cypress Chamaecyparis obtuse, which are two primary plantation species in Japan (both from the cypress family), had low rates of increase in BA of broad-leaved trees with increasing stand age. In plantations of other species (pine, larch, fir and spruce from the pine family), broad-leaved trees started to increase in BA at 20 years old. Planted tree density also had important, but nonlinear effects on the BA of broad-leaved trees in plantations. Stands with fewer planted trees had higher rates of increase in the BA of broad-leaved trees. Management practices such as selection of plantation tree species, intensive thinning and long rotation time would greatly contribute to the conservation value of plantations. Native trees can also regenerate in plantations depending on environments, and their retention during silvicultural practices can have a positive benefit for conservation. 


\section{Retention forestry to balance biodiversity and timber production in planted forests}

Kenichi Ozaki ${ }^{1}$, Yuichi Yamaura ${ }^{1}$, Nobuhiro Akashi ${ }^{2}$, Akira Unno $^{3}$, Toshiyuki Tsushima ${ }^{3}$, Katsuhiko Sayama $^{4}$,Shigeho Sato ${ }^{5}, S_{\text {Satoshi Yamanaka }}^{4}$ ${ }^{1}$ Forestry and Forest Products Research Institute, Tsukuba, Japan; ${ }^{2}$ Hokkaido Research Organization, Forestry Research Institute, Hokkaido, Japan; ${ }^{3}$ Hokkaido Research Organization, Forestry Research Institute, Bibai, Japan; ${ }^{4}$ Forestry and Forest Products Research Institute, Sapporo, Japan; ${ }^{5}$ Forestry and Forest Products Research Institute, Kouchi, Japan

(ozaki@affrc.go.jp; yamaura@ffpri.affrc.go.jp; akashi-nobuhiro@hro.or.jp; unno-akira@hro.or.jp; tsushima-toshiyuki@hro.or.jp; sayama@ffpri.affrc.go.jp; shigeho@affrc.go.jp; yamanakas@affrc.go.jp)

Ongoing global expansion of planted forests increases the need to develop silvicultural practices that conserve biodiversity in planted forests. Retention forestry, the practice of intentionally leaving important forest structure and organisms within logged areas, is increasingly implemented globally as an alternative to clearcut harvesting. However, there is little empirical information available for applying retention forestry in planted forests. We initiated a large-scale experiment (REFRESH) in 2013 in native fir plantations in Hokkaido, northern Japan to establish a forest management system that balances the ecological and economic values of planted forests. The REFRESH study involves eight treatments including aggregated and dispersed retention. In dispersed retention, naturally regenerated broad-leaved trees are retained in three levels to restore structures and elements of original natural forests in the region. We conducted field surveys to test the initial response of biodiversity (birds, plants and insects) and forestry efficiency. For birds, decline in the abundance of forest species were smaller with higher degree of tree retention. For understory plants, species composition changed largely due to heavy soil disturbance caused by harvest practices and preparation before tree planting, although forest aggregates serve as refugia for forest species. For insects, abundance of saproxylic beetles such as cerambycids increased after harvest but did not respond to retention level. For forestry efficiency, increase in the cost of harvesting operations was only $5 \%$ in the highest retention level. Overall, retention forestry is a promising method to balance timber production and biodiversity conservation in planted forests.

\section{Retention harvesting mitigates harvesting impact on ground beetles in planted forests in Hokkaido, Northern Japan}

Satoshi Yamanaka ${ }^{1}$, Yuichi Yamaura ${ }^{2}$, Katsuhiko Sayama $^{1}$, Shigeho Sato ${ }^{3}$, Kenichi Ozaki $^{2}$

${ }^{1}$ Forestry and Forest Products Research Institute (FFPRI) Hokkaido, Sapporo, Japan; ${ }^{2}$ Forestry and Forest Products Research Institute, Tsukuba, Japan; ${ }^{3}$ Forestry and Forest Products Research Institute Shikoku, Kochi, Japan (yamanakas@ffpri.affrc.go.jp; yamaura@ffpri.affrc.go.jp; sayama@ffpri.affrc.go.jp; shigeho@ffpri.affrc.go.jp; ozaki@affrc.go.jp)

Retention harvesting is a silvicultural method in which important forest structures and organisms are retained at the time of harvesting. Although retention harvesting can potentially contribute to balance biodiversity conservation and timber production in managed forests, its effects on biodiversity and ecosystem services have been investigated in limited regions and forest types. We launched a large-scale retention forestry experiment in fir-plantation forests in Hokkaido, Northern Japan. Our experiment has five treatments (clear-cutting, three levels of dispersed retention, and aggregated retention with a 0.36 ha intact forest patch) and two controls (unharvested natural forest and unharvested plantation). We compared ground beetle assemblages before and after harvesting and found that the abundance of most forest species decreased while non-forest species increased after harvesting in the clear-cut sites. We also found that the decrease in the abundance of some forest species was mitigated increasingly with the levels of dispersed retention and that the abundance of most forest species also increased inside the intact forest patches in aggregated retention sites. Our findings indicate that dispersed retention can mitigate the impact of harvesting on some forest species and that aggregated retention can provide a refuge for forest species after harvest.

\section{Trade-offs between ecosystem services in response to tree species diversity and values}

Austin Himes $^{1,2}$, Klaus Puettmann ${ }^{3}$

${ }^{1}$ Oregon State University, Corvallis, USA; ${ }^{2}$ GreenWood Resources Inc., Portland, Oregon, USA; ${ }^{3}$ Oregon State University, Corvallis, Oregon, USA (austin.himes@oregonstate.edu; klaus.puettmann@oregonstate.edu)

Trade-offs between incommensurate services are a core challenge to the implementation of the ecosystem services (ES) framework. Integral to the challenge of ES trade-offs is how to incorporate multiple types of value in ES assessments. The International Platform of Biodiversity and Ecosystem Services (IPBES) recommends pluralistic valuations of ES that include intrinsic, instrumental, and relational values to better communicate to decision makers the different ways people value ES. In order to understand how value pluralism may effect trade-offs between ES, we conducted a study quantifying ecosystem ES proxies along a tree species diversity gradient in similarly aged intensively managed plantation forests of coastal Pacific Northwest, USA. Our objective was to determine what tree species composition and diversity minimize trade-offs between nine ES. Further, we developed four management frameworks emphasizing different bundles of the nine ES based on how ES clumped within a matrix of value types and level of social organization at which benefits are likely to accrue. We then determined tree species compositions that optimize priority ES under the four frameworks. Some ES responded in sync, but we found trade-offs between provisioning ES with primarily instrumental value and cultural ES with eudemonic relational values. Most individual ES were optimized by monocultures. We also found that high levels of tree species diversity supported the largest plurality of value types and hypothesize that biodiversity may be important not just for increasing ecosystem functions and services, but also increasing the types of values supported by ecosystem services.

\section{Economic value of the mau forest complex, Cherangany Hills, and Mount Elgon Water Towers in Kenya}

Joshua Cheboiwo ${ }^{1}$, Jonah Kiprop ${ }^{1}$, David Langat ${ }^{1}$

${ }^{1}$ Kenya Forestry Research Institute, Nairobi, Kenya (jkchemangare@yahoo.com; jonahkipsat@gmail.com;dkipkiruilangat@gmail.com)

Water Towers play a critical role in supplying provisioning and regulating ecosystem services. In Kenya there are five main Water Towers (Mt Elgon, Mau, Cherangany Hills, Aberdares and Mt. Kenya). Despite their importance, there has been widespread degradation and deforestation in the Water Towers. This Ecosystem Services Valuation (ESV) study was undertaken by Kenya Forestry Research Institute with funding and technical support from US Forest Service and USAID Kenya. The aim of the study was to highlight the significance of the Kenya Water Towers ecosystems through quantitative assessment. The ESV study focused on three of the five main Water Towers-Mau, Cherangany Hills, and Mt. Elgon — and used internationally recognized methodologies, such as the total economic value approach, and assessments, such as those used in the Economics of Ecosystems and Biodiversity (TEEB) study. From this assessment, the total economic value (TEV) of the three ecosystems is about KES 357 billion (USD 3.5 billion) per year. Disaggregated data show that the Mau, Cherangany, and Mt. Elgon ecosystems contribute an estimated KES 197 billion (USD 1.97 billion), KES 46 billion (USD 461 million) and KES 114 billion (USD 1.15 billion) respectively. Aggregated data show the dominance of regulating services from the three Water Tower ecosystems with 82 percent, 66 percent, and 95 percent (of TEV) respectively in the Mau, Cherangany, and Mt. Elgon ecosystems, underscoring the importance of indirect-use values in forest ecosystems. The provisioning services contributed 16 percent, 30 percent, and 4 percent of TEV for the three water towers 


\section{Experiences in monetizing forest ecosystem service values related to biodiversity and climate change}

Lauri Valsta ${ }^{1}$ Brent Matthies ${ }^{2}$

${ }^{1}$ Department of Forest Sciences, University of Helsinki, Helsinki, Finland; ${ }^{2}$ Helsinki Institute of Sustainability Science, University of Helsinki, Helsinki, Finland (lauri.valsta@helsinki.fi; brent.matthies@helsinki.fi)

Boreal forests provide significant ecosystem services locally and globally. We analyzed the importance of forest species composition for provisioning, regulating and supporting services. In our case studies, forest mixtures of conifers and broadleaved trees were considered. The ecosystem service approach entails important questions concerning valuation of services, additionality, leakage, and policy options. We used the Finnish policy environment as the basis of analysis. We reviewed case studies that target forest management alternatives both at single stand level and at forest region level. Ecosystem services were assessed in terms of tree species composition, PES scheme, climate change mitigation values and commercial wood values. In general, our results indicate that the sum of ecosystem service values from mixed species forests often exceed those from pure, single stand forests. There are significant trade-offs among ecosystem service values, but a balanced management between providing for multiple objectives seems to provide a highest total value of services.

\section{Economic contributions of non-timber forest products in the United States: frameworks, analytical approaches, and key findings}

Susan Alexander ${ }^{1}$, Gregory Frey ${ }^{2}$, Keith Blatner ${ }^{3}$, Michael Jacobson $^{4}$, C. Meghan Downes ${ }^{5}$, Erin Sills ${ }^{6}$, D. Evan Mercer ${ }^{7}, J_{a m e s}$ Chamberlain $^{7}$, Michael Gold $^{8}$, Larry Godsey ${ }^{9}$, Marla Emery ${ }^{10}$, Alisa Coffin ${ }^{11}$, Rebecca Barlow ${ }^{12}$, Luanne Lohr ${ }^{13}$

${ }^{1}$ US Forest Service, Pacific Northwest Research Station, Juneau AK, USA; ${ }^{2}$ US Forest Service, Southern Research Station, Research Triangle Park, NC, USA; ${ }^{3}$ Washington State University, Pullman WA, USA; ${ }^{4}$ Penn State, University Park, PA, USA; ${ }^{5}$ Columbus State University, Columbus, GA, USA; ${ }^{6}$ North Carolina State University, Raleigh, NC, USA; ${ }^{7}$ US Forest Service, Southern Research Station, Blacksburg, VA, USA; ${ }^{8}$ University of Missouri, Kansas City, MO, USA; ${ }^{9}$ Missouri Valley College, Marshall, MO, USA; ${ }^{10}$ US Forest Service, Northern Research Station, Burlington, VT, USA; ${ }^{11}$ USDA Agriculture Research Service, Tifton, GA, USA; ${ }^{12}$ Auburn University, Auburn, AL, USA; ${ }^{13}$ USDA Forest Service Research and Development, Washington DC, USA (salexander@fs.fed.us; gregory.e.frey@usda.gov; blatner@wsu.edu; mgj2@psu.edu; downes_meghan@columbusstate.edu; sills@ncsu.edu; evan.mercer@usda.gov; jchamberlain@usda.gov; goldm@missouri.edu; godseyl@moval.edu; memery@usda.gov; alisa.coffin@usda.gov; rjb0003@auburn.edu; luannelohr@usda.gov)

Non-timber forest products (NTFPs) are one of many economic benefits that forests provide to society, and understanding their value helps us understand the broad range of economic contributions of forests. NTFPs contribute to national, state, local and household economies through monetary and nonmonetary benefits. These resources serve a number of economic and social functions such as recreation, seasonal income, and subsistence. Market channels, level of market formality, and production methods are widely diverse. Impacts may be spread over a wide geographic range or be relatively local. Uses may be largely commercial to mostly personal. A consistent understanding of how NTFPs benefit individuals, communities, and regions across the U.S. has been hampered due to the informal and even secretive nature of many parts of NTFP business and trade, and to the diversity of products and data on the many products and markets in this broad industry. A recent assessment of non-timber forest products in the United States under changing climate examined the economic dynamics relative to these products. The synthesis of knowledge considered micro and macro, as well as market and nonmarket issues, and provides the foundation for this presentation. It explores valuation of broad benefits of NTFPs, as well as financial returns from production of NTFPs. This presentation will discuss applicable economic theories, what we know and don't know about the economics of NTFPs in the U.S., and some priorities for future research and policy.

Economic analysis of Brazil's main non-timber forest products / Análise econômica dos principais produtos florestais não madeireiros do Brasil

Anadalvo Santos ${ }^{1}$, Aline Vaes ${ }^{1}$, Thiago Paula ${ }^{1}$

${ }^{1}$ Universidade Federal do Paraná, Curitiba, Brasil (ajsantos.ufpr@gmail.com; alinevaesm@gmail.com; uf_floresta@hotmail.com)

Esta pesquisa tem por objetivo analisar a evolução de mercado dos seis principais Produtos Florestais Não Madeireiros - PFNMs do Brasil. A metodologia consistiu em analisar o deslocamento das curvas de oferta e demanda em função das taxas de crescimento dos preços e das quantidades dos PFNMs, disponíveis na Pesquisa Produção da Extração Vegetal e da Silvicultura - PEVS disponibilizada pelo Instituto Brasileiro de Geografia e Estatística - IBGE durante o período de 2006 a 2016. A proxy do preço de cada produto foi obtida por meio da razão entre o valor bruto da produção e a quantidade produzida, seguido de deflacionamento pelo Índice de Preço ao Consumidor Amplo - IPCA. As taxas obtidas permitiram enquadrar os deslocamentos das curvas de oferta e demanda em cenários pré-definidos. Os resultados indicam que: a) os produtos açaí, castanha-do-brasil, erva-mate e piaçava apresentaram variação positiva na quantidade e no preço, que expressa um deslocamento dominante da demanda para direita, indicando que o mercado está em expansão; b) o babaçu apresentou variação negativa na quantidade e no preço, que expressa um deslocamento dominante da demanda para esquerda, por conta da concorrência com outras oleaginosas; c) a carnaúba apresentou variação negativa da quantidade e uma variação positiva no preço, que expressa um deslocamento dominante da oferta para esquerda, reflexo do desmatamento de carnaubais nativos para a implantação de outras atividades produtivas. A partir dos resultados, conclui-se há potencial de ampliação dos mercados, bem como a necessidade de novas estratégias para reverter as tendências negativas observadas.

Management scenarios and ecosystem service provision in Large German Forest landscapes. selected methods, results, and lessons learned

Peter Biber ${ }^{1}$, Fabian Schwaiger ${ }^{1}$, Werner Poschenrieder ${ }^{1}$

${ }^{1}$ Technical University of Munich, Chair for Forest Growth and Yield Science, Freising, Germany (peter.biber@lrz.tum.de; fabian.schwaiger@lrz.tum.de; werner.poschenrieder@lrz.tum.de)

The traditional perception that virtually all relevant forest ecosystem services would be provided to a sufficient extent just "in the wake" of sustainable wood production is long outdated by the actual requirements of modern societies. Consistent approaches for quantifying a broad range of ecosystem services as resulting from different forest management options are urgently required by decision makers from the political down to the operational level. Meanwhile, flexible management-oriented models for forest dynamics became standard tools, but the information they provide usually focuses on wood production. Helping to overcome this limitation based on ten case study landscapes in nine European countries is among the goals of the EU-project ALTERFOR (https://www. alterfor-project.eu/). The authors, being responsible for the modelling work in Germany, selected two landscapes ( 100,000 ha) with very different forestal and socio-economic conditions. We implemented a set of contrasting management scenarios in our forest model SILVA, corresponding to the results of stakeholder studies by our partner social scientists. In addition, expected climate and frame socio-economic trends had to be taken into account. For assessing the provision 
of ecosystem services like regulatory services, recreation, biodiversity, sustainable wood production, water related services, and carbon sequestration we developed evaluation methods partly based on fuzzy logic and systematic studies with an ecophysiological model. The results of 100 -year simulations reveal how strongly the initial forest conditions influence dynamics and management options even on the long run, as well as partly unexpected but plausible tradeoffs between ecosystem services under different management.

\section{Novel business models and mechanisms for the sustainable supply of and payment for forest ecosystem services

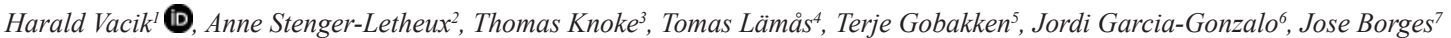 ${ }^{1}$ University of Natural Resources and Life Sciences, Vienna, Austria; ${ }^{2}$ French National Institute for Agricultural Research, Paris, France; ${ }^{3}$ Technische Universität München, Munich, Germany; ${ }^{4}$ Swedish University of Agricultural Sciences, Umea, Sweden; ${ }^{5}$ Norwegian University of Life Sciences, Oslo, \\ Norway; ${ }^{6}$ Forest Sciences Centre of Catalonia, Solsona, Spain; ${ }^{7}$ School of Agriculture, InstitutoSuperior de Agronomia, Lisbon, Portugal \\ (harald.vacik@boku.ac.at; anne.stenger-letheux@inra.fr; knoke@tum.de; tomas.lamas@slu.se; terje.gobakken@nmbu.no; j.garcia@ctfc.es; joseborges@isa.ulisboa.pt)}

Research has identified Payments for Ecosystem Services (PES) as an important mechanism to close the gap between the demands of the society and the service providers (i.e., forest owners). Two main approaches can be identified: (i) payments to landowners to maintain or enhance services that an ecosystem provide and (ii) payments to mitigate and reduce pressures on ES, or prevent a change of land-use with potential negative impacts on service provisioning. In this contribution we will screen different business models and mechanisms to internalise the socio-economic value of forest ecosystems and combine public policy tools with business models for supporting the implementation of payments for forest ecosystem services (FES). Three types of business models will be considered a) private households or businesses companies directly pay providers for the provision of FES, b) Business companies pay providers for the FES and pass the costs to their clients, and c) government pays providers for the FES and pass the costs to consumers via taxes or fees. In implementing these business models, alternative mechanisms for the payments (e.g. voluntary payments, natural capital markets) will be explored. The demands for the provision of FES resulting from existing policies will be identified and the governance settings of successful business models will be discussed. This will help to facilitate the understanding of the importance of a target oriented sustainable management of forests.

\section{D4p: FOREST ASSESSMENT AND ECOSYSTEM SERVICES}

\section{Local people's perceptions of forest and trees ecosystem services: case of managed Kalounaye classified forest}

Antoine Sambou ${ }^{1}$

${ }^{1}$ Assane Seck University of Ziguinchor, Ziguinchor, Senegal (tonysambouegos@yahoo.fr)

Analysis of the relationships between communities at the peripheriesof protected areas and their natural environments increasingly uses the notion of ecosystem services. Our study aims to identify the ecosystem services of the Kalounaye managed forest and woody species for the surrounding villages in the communes of Ouonck and Coubalan. To do that, surveys based on individual interviews and focus group discussions and field observations were carried out; ${ }^{179}$ individual interviews and ${ }^{12}$ focus group discussions were done. A semi-structured with free-listing approach was used to collect ethno botanical and ecosystem services data. The relative importance and the use of ecosystem services by rural people were assessed. The importance attributed to each category of ecosystem services and species was evaluated using use value (UV), informant consensus factor (ICF), citation frequency (CF) and fidelity level (FL). Local people considered Provisioning services characterized by a use value of $79 \%$ as the most important forest and trees function. Cultural srvices (13\%) were the second most important ecosystem services provided by forest and trees followed by regulating/supporting services (8\%). Among the provisioning ecosystem services, food, medicinal products, firewood and fodder were the most cited and used. A total of 27 species listed by the populations participated in the provision of three types of ecosystem services (provisioning, regulating/supporting and cultural services). However, the informant consensus factor for ecosystem services was greater than $80 \%$. The Kalounaye managed forest is rich in very important species that provided provisioning, regulating/supporting and cultural services for the surrounding populations.

\section{Improved model for semideciduous seasonal forest production of leaves and deciduousness}

\section{Thomaz Costa ${ }^{1}$}

${ }^{1}$ Embrapa Milho e Sorgo, Sete Lagoas, Brasil (thomaz.costa@embrapa.br)

The climate, mainly the water availability and temperature, drive the renewal of biomass in the seasonal forest ecosystem, and the greenness and leaf area of its canopy are responsive by climate variations. This study verified models to explain the phenomenon of leaf production and deciduousness, with LAI (Leaf Area Index), NDVI (Normalized Difference Vegetation Index) and climate variables, on the period 2011-2016. The data were obtained in satellite images and in plots installed at forest monitoring sites, visited monthly. The analysis incorporated the water balance. Three equations were compared, two already published and the equation that was adjusted in the last work. The model was improved and validated with new variables and data. It is possible to estimate the fall and renew of leaves biomass in semideciduous forests with reasonable precision.

\section{Decline of giant trees in Brazil, the state of the art in Santa Catarina and the future}

Marcelo Scipioni ${ }^{1}$, Rafael de Paiva Salomão ${ }^{2}$, Alexander Christian Vibrans ${ }^{3}$

${ }^{1}$ Universidade Federal de Santa Catarian, Curitibanos, Brasil; ${ }^{2}$ Museu Paraense Emílio Goeldi, Belém, Brasil; ${ }^{3}$ Fundação Universidade Regional de Blumenau,Blumenau,Brasil (marcelo.scipioni@ufsc.br; rpsalomao17@gmail.com; acvibrans@gmail.com)

The loss of large trees is a global problem due to the indiscriminate cutting of timber and the opening of new areas for various human uses. Brazil presents many tree species and extensive forest areas covering different biomes. The species nut brazil and kapok are the giant trees of the Amazon. The jequitiba tree and the brazilian pine are among the largest Brazilian trees in the Atlantic Forest. The decline scenario of the population of large trees can be compared with data from the National Forest Inventory (NFI) in comparison to specific surveys of each species in the regional and national scenario. Santa Catarina is the first state to finalize its forest inventory. Few large trees were sampled in the NFI by systematic sampling. Brazil has trees with diameters greater than $3 \mathrm{~m}$ and historical records of $5 \mathrm{~m}$. Recognition of maximum tree growth is important for the ecological management and tourism potential of giant trees. New researches and public policies should be developed for the cataloging and management of these resources in order to avoid permanent loss. 
Seasonal changes in flora diversity in native açai palm groves in the Amazon estuary / Modificações temporal na diversidade florística em açaizais nativos do estuário amazônico

Danielle Rodrigues ${ }^{1}$, Silas Mochiutti ${ }^{2}$, José Queiroz ${ }^{3}$

${ }^{1}$ Universidade Federal do Amapá, Macapá, Brasil; ${ }^{2}$ Embrapa Amapá, Macapá, Brazil; ${ }^{3}$ Embrapa Amazônia Oriental, Belém, Brazil

(dani_enflor23@yahoo.com.br; silas.mochiutti@embrapa.br; jose.queiroz@embrapa.br)

O fruto do açaizeiro (Euterpe oleracea Mart.) vem ganhando destaque no mercado de polpas e com isso se intensificaram as intervenções nas florestas de várzeas com maciços desta espécie. Neste estudo avaliou-se alterações ocorridas, num intervalo de dezessete anos, na diversidade florística em açaizais nativos destinados para produção de frutos. O estudo foi desenvolvido em 32 açaizais localizados na região do braço norte do estuário amazônico. Foram realizados dois inventários florísticos no mesmo açaizal, um em 2001 e outro em 2018. Em cada inventário foram marcadas parcelas de $20 \mathrm{~m}$ x $50 \mathrm{~m}$, onde foram identificados e mensurados todos os indivíduos com CAP $\geq 15 \mathrm{~cm}$. Além do açaizeiro, as quatro espécies com maior valor de importância foram: Virola surinamensis, Pterocarpus amazonicus, Pentachletra macroloba e Spondias mombin. Foram encontrados nas 35 parcelas avaliadas um total de 3311 indivíduos distribuídos em 110 espécies em 2001, sendo 1759 de açaizeiros e 1552 de outras espécies. Em 2018, nestes mesmos açaizais, foram encontrados 2706 indivíduos distribuídos em 70 espécies, sendo 2137 de açaizeiros e 569 de outras espécies. O número médio de estipes adultos de açaizeiros por parcela foi de 39 em 2001 e de 79 em 2018. A riqueza de espécies diminuiu em 36,4\% entre 2001 e 2018 e o índice de Shannon Wiener (H’) foi de 2,41 em 2001 e de 1,26 em 2018, observando uma redução significativa $(\mathrm{t}=21,4 \mathrm{p}<0,001)$ da diversidade florística nos açaizais estudados. Os resultados indicam uma homogeneização dos açaizais nativos devido ao favorecimento do açaizeiro, palmeira de maior interesse econômico.

Modeling spatial dynamics to identify areas where land cover can be converted / Modelagem dinâmica espacial para identificação de áreas passíveis de conversão de cobertura da terra

Rodrigo Macedo ${ }^{1}$, Claudia Moster², Cláudia Almeida ${ }^{3}$

${ }^{1}$ Universidade Federal do Paraná, Curitiba, Brasil; ${ }^{2}$ Universidade Federal Rural do Rio De Janeiro, Seropédica, Brasil; ${ }^{3}$ Instituto Nacional de Pesquisas

Espaciais,São Josédos Campos, Brasil (rodrigo_c_macedo@yahoo.com.br; claudiamoster@usp.br; almeida@dsr.inpe.br)

A deteç̧ão de mudanças de cobertura e uso da terra é extremamente relevante na gestão ambiental, nos processos de zoneamento e de avaliação de impactos ambientais. Simular estas mudanças é um desafio devido à incapacidade para prever ações que ainda ocorrerão. Porém, através de modelagem dinâmica espacial (MDE) é possível gerar cenários futuros, com critérios pré-definidos e rigor metodológico. Desta forma, os cenários gerados apóiam processos de tomadas de decisão no cenário político-administrativo. Tal ensaio é dedicado ao entendimento da lógica funcional da MDE e seu potencial em estudos de mudançasno território. Há uma grande demanda para a utilização e/ou desenvolvimento de ferramentas computacionais aptas para lidar com a complexidade envolvida na caracterização das funções ecossistêmicas e, conseqüentemente, no monitoramento de seus serviços ambientais. A avaliação ambiental é parte integrante nas análises de mudança de cobertura e uso da terra, pois os serviços ambientais prestados pelos ecossistemas variam de acordo com a própria mudança dapaisagem. O presente estudo expressou o quadro geral de um processo de simulação de cenário futuro na plataforma computacional de MDE intitulada Dinamica EGO, que demonstrou ser apta para a análise das mudanças de cobertura e uso da terra e do monitoramento de seus respectivos serviços e bens ambientais, uma vez que possibilita a explicitação das variáveis espaciais e temporais, além de propiciar o acoplamento de fenômenos biofísicos e socioeconômicos.

Roadways and landscape changes in Canaã dos Carajás (Pará, Brazil): ongoing multi-temporal analysis / Vias de circulação e evolução da paisagem em Canaã dos Carajás (Pará, Brasil): análise multitemporal contínua

Anderson Amaral

${ }^{1}$ Universidade de São Paulo, São Paulo,Brasil (geoandersonanderson@gmail.com)

Com o objetivo de relacionar os padrões de vias de circulação e a evolução da paisagem em um município de fronteira agropecuária e mineral amazônico, a pronta disponibilidade dos produtos do Projeto Mapbiomas em sua terceira coleção com ampla cobertura temporal (1985-2017) ofertou subsídios diretos e indiretos para alcançar avanço da pesquisa em andamento (nível mestrado). Como produto direto, seus dados qualitativos e relacionais de classes de uso e cobertura da terra de forma gráfica e de fácil visualização dos períodos em sua plataforma online, incluindo-se os primordiais dados sobre desmatamento, asseguraram caminho metodológico para seleção temporal de imagens a serem investigadas em outras técnicas empregadas em nossa pesquisa, como a SVD (Substract, Vegetation, Dark) que utiliza análise de imagens Landsat para aplicar o Modelo Linear de Mistura Espectral. A classificação de uso e cobertura da terra do Projeto Mapbiomas auxiliou fornecendo dados primários que utilizamos para produzir uma série de mapas multitemporais com esse tema, auxiliando no entendimento da evolução do território e paisagem da área de estudo ampliando a gama de variáveis a serem relacionadas. Como produto indireto, as vias de circulação que reconstituímos, por classificação não automatizada e com o suporte de outros produtos cartográficos ou dados oficiais do Governo, só foram possíveis devido ao acesso as imagens-mosaico anuais de qualidade, que por serem sem interferência de nuvens ou com melhor pixel disponível para cada ano e seleção de datas escolhidas em nosso estudo, foram fundamentais na reconstituição da evolução histórica da infraestrutura.

\section{The research of state-owned forestry regions contribution of eco-civilization in Heilongjiang province based on gross ecosystem production}

Xiangyue Liu ${ }^{1}$, Zhifang Wan ${ }^{1}$, Yukun Cao

1Northeast Forestry University, Harbin, China (1335759586@qq.com;1911686519@qq.com;cyklk@163.com)

Forestry ecological civilization is to protect and create a pleasant ecological environment, which is different from the industrial civilization. The value of ecological service and gross domestic product (GDP) belong to two different value systems. Externalities determine ecological civilization cannot measure by the traditional economic system GDP. Thus, the progress of the construction of ecological civilization needs a new scientific accounting system and more ecological indicators to verify the development of ecological civilization. As a result, the world conservation union IUCN proposed the ecosystem GEP (Gross Ecosystem Production) concept, GEP refers to the total ecological system of production and service, which reflects production and service function of ecosystem products and calculates the total of the ecological system's existing natural assets. This paper analyses the related research and summarizes them on ecological civilization with GEP status in China stated-owned forest regions. Also, it concludes the total cost of GEP stated-owned forest regions in Heilongjiang Province, particularly the current problems in ecological civilization development which restrict development of Heilongjiang province. Furthermore, this paper has changed the way of measuring forest industry from GDP to GEP, and calculate Heilongjiang stated-owned forest ecosystem gross production. 


\title{
Ecosystem services provided by Bertholletia excelsa in the Brazilian Amazon
}

Lucieta Martorano $^{1,2}$, Marcelino Guedes $^{3}$, Lúcia Helena de Oliveira Wadt $^{4}$, Fátima Reale $^{5}$, Daiana Tourne ${ }^{6}$, Pedro Martorano $^{7}$, Kátia Silva $^{8}$ ${ }^{1}$ Embrapa Amazônia Oriental, NAPT-MA, Santarém, Brazil; ${ }^{2}$ PPG, Rede Bionorte, Santarém, Brazil; ${ }^{3}$ Embrapa Amapá, Macapá, Brazil; ${ }^{4}$ Embrapa Rondonia, Porto Velho, Brazil; ${ }^{5}$ Secretaria de Educação do Estado do Pará, Oriximiná, Brazil; ${ }^{6}$ Universidade Estadual de Campinas, Pós-doc em Ambiente e Sociedade, Campinas, Brazil; ' ${ }^{7}$ niversidade Federal de Rural da Amazônia, Belém, Brazil; ${ }^{8}$ Embrapa Amazônia Ocidental, Manaus, Brazil (lucieta.martorano@embrapa.br; marcelino.guedes@embrapa.br; lucia.wadt@embrapa.br;fc.reale64@gmail.com; monteiro.dca@gmail.com; pmartorano60@gmail.com; katia.emidio@embrapa.br)

The development of regions such as the Amazon must not consider forest removal as a part of a purely mechanistic strategy because this will compromise the provision of ecosystem services to current and future populations. The objective of this work was to evaluate basic ecosystem services provided by Bertholletia excelsa (Brazil nut tree) as a conservation strategy for this important Amazon species. The RADAM Brazil Project conducted an inventory of individual stems and quantified human-modified areas as quantified by TerraClass by 2008 . Ecosystem services provided by this species were categorized and analyzed in the MAPCAST project. Approximately $46 \%$ of the inventoried stems were located in human-modified areas in 2008 . In native Bertholletia excelsa stands the ecosystem services provided, among others, were a natural source of selenium, fruit production, a food and economic resource for extractivist populations and wildlife, and attraction of pollinators (bees), which indicates a process of perpetuation of this species. With respect to climate regulation, using concepts from the "flying river" studies as a base, the total daily volume of water vapor pumped to the atmosphere (300 L) by evapotranspiration from a mature stem of Bertholletia excelsa contributes to thermal regulation and above- and below-ground carbon stocks, among others. Furthermore, socialization among extractivists during the fruit harvest period is an important cultural service provided by this species. Payment for environmental services (PES) is an important conservationist strategy, and in this sense the Brazil nut tree should a species included in agroforestry systems in the region.

\section{D4q: FOREST BIOMASS ESTIMATION}

\section{Ratio and regression estimate applied to biomass modeling}

Sylvio Péllico Netto ${ }^{1}$, Alexandre Behling ${ }^{1}$

${ }^{1}$ Universidade Federal do Paraná, Curitiba,Brasil (sylviopelliconetto@gmail.com; alexandre.behling@yahoo.com.br)

Biomass in native and planted forests has been increasingly estimated for several purposes in Brazil. The idea was to make two assumption before defining the model, using regression or ratio to estimate biomass: $i$ ) the metric units of independent variables in a model should be composed to keep the same metric unit of the dependent variable, $\mathrm{ii}$ ) the additivity of the components. The objective was to introduce a simple and consistent biological model using ratio estimate and compare its performance with regression modeling WNSUR (weighted-nonlinear seemingly unrelated regressions). The biomass estimation model was applied on stands of Acacia mearnsii in the state of Rio Grande do Sul, Brazil, using a sample of 670 trees in an age range of 1 to 10.75 years. The modeling of the biomass components was performed using: $i$ ) ratio estimate applied to the general model: Yij=Rj*Xij, where Yij= biomass of a given component: stem, crown or total, in $\mathrm{kg}$; $\mathrm{Rj}=$ Scalar Coefficients Proxy of Density, kg.m-3; Xij= cylinder volume in $\mathrm{m}^{3}$, which is based in quadratic diamenter of the stem, in $\mathrm{m}$; $i$ ) Spurr and Shumacher-Hall' models fitted by WNSUR. The results obtained by ratio estimates and WNSUR were similar. The fitted model by ratio estimate, for total biomass or its components, proved to be of great interest for biomass estimation and consistent when compared to the results obtained by WNSUR estimates (traditional method). The proposed model, using ratio estimates, is appropriate and promising for modeling of tree biomass.

Estimated biomass in the accumulated leaf litter in the Cerrado region of Niquelândia, Goiás, Brazil / Estimativa da biomassa de serrapilheira no Cerrado em Niquelândia, Goiás

\author{
Amanda Portela Pereira ${ }^{1}$, Camilla Nascimento Brito ${ }^{1}$, Rafael Tassinari Resende ${ }^{1}$, Fábio Venturoli ${ }^{1}$ \\ ${ }^{1}$ Universidade Federal de Goiás, Goiânia,Brasil(portelaamanda0@gmail.com; canascimento@gmail.com; rafael.tassinari@gmail.com; \\ fabioventuroli@gmail.com)
}

Este trabalho objetivou aplicar equações alométricas para estimar a biomassa seca (serapilheira) em quatro fitofisionomias no Bioma Cerrado. A data dos ajustes vem da região de Niquelândia, em Goiás, em uma Reserva Particular para o Desenvolvimento Sustentável no Legado Verde do Cerrado. O modelo utilizado foi a regressão simples, para estimar a biomassa da serapilheira seca (variável independente) em função da profundidade da serapilheira (variável dependente). A biomassa estimada (kg.ha-1) no Cerrado típico, Cerradão, Mata Seca e Mata Ciliar foram, respectivamente, 403,2; 1,329,6; 1,441,4; 1,761,4, respectivamente. Foram utilizadas duas estimativas para estimar a biomassa, sendo a primeira todas as subparcelas das 20 parcelas e a segunda considerando apenas a parcela central das 20 parcelas, para cada fitofisionomia. Os coeficientes de determinação das equações considerando todas as subparcelas foram insatisfatórios e na subparcela central apenas a fitofisionomia Mata Seca $\left(\mathrm{R}^{2}=0,72\right)$ e Típica Fechada $\left(\mathrm{R}^{2}=0,66\right)$. B $\mathrm{e} \beta_{1}$ foram testados entre as fitofisionomias foram estatisticamente significantes para um modelo único $(\mathrm{p}<0,05)$. No entanto, para as duas análises, um modelo com diferentes $\beta$ para cada fitofisionomia é mostrado, e $\beta$ é comum para todas as subparcelas. O modelo ajustado na subparcela central apresentou $\mathrm{R}^{2}=0,82$ e o modelo considerando todas as subparcelas em $\mathrm{R}^{2}=0,85$. Embora o coeficiente de determinação tenha sido alto, o CV\% (coeficiente de variação) foi considerado alto, sendo 51,3\% e 48,2\%, respectivamente. O trabalho foi apoiado e apoiado pelo Serviço Florestal Brasileiro, Universidade Federal de Goiás e Legado Verdes do Cerrado.

Biomass from natural regeneration of different plant physiognomies in the Cerrado Biome / Biomassa da regeneração natural de diferentes fitofisionomias no Bioma Cerrado

Camilla Brito $^{1}$, Amanda Portela Pereira ${ }^{1}$, Fábio Venturoli ${ }^{1}$

${ }^{1}$ Universidade Federal de Goiás, Goiânia, Brazil (canascimentobrito@gmail.com; portelaamanda0@gmail.com; fabioventuroli@gmail.com)

A regeneração natural representa a atividade de renovação das árvores de uma floresta. Este trabalho teve por objetivo quantificar a biomassa da regeneração natural em diferentes fisionomias vegetais dentro da reserva particular de desenvolvimento sustentável Legado Verdes do Cerrado, localizada no Município de Niquelândia, Goiás. A área experimental consistiu-se de 80 parcelas de $10 \mathrm{~m}$ x 10m, sendo cada parcela constituída de cinco subparcelas de 1m x 1m. Considerou-se indivíduos regenerantes aqueles que apresentavam altura total menor que 1,5m e diâmetro a altura do peito menor do que 5 cm, que foram abatidos e pesados em campo, e as amostras foram enviadas ao laboratório de Inventário Florestal da UFG para a determinação do peso seco. Quantificouse 31,61 kg de biomassa úmida que correspondeu a 13,26 kg de biomassa seca em toda a área amostrada. A partir da análise de variância observou-se diferença significativa na quantidade de biomassa presente em cada fisionomia vegetal amostrada, e para a estimativa da biomassa seca foram construídos modelos. A 
biomassa seca apresentou relação linear à biomassa úmida e as equações apresentaram bom ajuste com altos valores de coeficiente de determinação, $\mathrm{R}^{2}=0,96$ para Mata Seca, $\mathrm{R}^{2}=0,90$ Cerrado típico, $\mathrm{R}^{2}=0,97$ Cerradão, $\mathrm{R}^{2}=0,96$ Mata Ciliar, e boa distribuição entre os valores observados e ajustados. $\mathrm{O}$ trabalho recebeu apoio e suporte do Serviço Florestal Brasileiro, Universidade Federal de Goiás e Legado Verdes do Cerrado.

\section{Compatible taper and stem outside-bark volume equations for five pine species in Mexico}

Geronimo Quiñonez Barraza1 Dehai Zhao ${ }^{2}$ Héctor Manuel De los Santos Posadas ${ }^{3}$

${ }^{1}$ Campo Experimental Valle del Guadiana, Instituto Nacional de Investigaciones Forestales Agricolas y Pecuarias (INIFAP), Durango, DGO, Mexico; ${ }^{2}$ Warnell School of Forestry and Natural Resources, University of Georgia, Athens, GA, USA; ${ }^{3}$ Postgrado en Ciencias Forestales, Colegio de Postgraduados, Campus Montecillo,Texcoco,Estadode Mexico,Mexico (quinonez.geronimo@inifap.gob.mx; dzhao@warnell.uga.edu; hmsantos@colpos.mx)

Taper and volume equations are essential components of forest inventory, growth and yield prediction, and forest management-planning in mixed-species forests. Ten taper and stem outside-bark equations system derived from upper-height-based volume ratio functions were compared with a segmented compatible taper-volume system. All compatible systems were simultaneously fit to taper and stem outside-bark volume data of 46, 51, 69, 26 and 30 trees of Arizona pine, Aztec pine, Durango pine, Mexican white pine, and Smooth-leaved pine, respectively in mixed-species forests in Durango, Mexico. Total stem outside-bark volume and cumulative volume from the butt to successive bolt heights were calculated using the overlapping bolts method. In general, the systems derived from volume ratio equations performed better than the segmented compatible taper-volume system for most species with good of fit statistics such as the average error, relative error, standard error of estimate, relative standard error of estimate, and Akaike's information criterion. The resultant top three systems might be easier to implement than the segmented compatible taper-volume system for predicting upper-stem height, upper-stem diameter, variable-top merchantable volume and total stem outside-bark volume for considered species.

Using regression models and artificial neural networks to estimate the height of Eschweilera idatimon (Aubl.) Nied. in the Amazon region / Uso de modelos de regressão e redes neurais artificiais para estimativa da altura de Eschweilera idatimon. (Aubl.) Nied. na Amazônia

Fernanda Raquel Lambrecht ${ }^{1}$, Harliany de Brito Matias ${ }^{2}$, Carlos Moreira Miquelino Eleto Torres ${ }^{1}$, Perseu da Silva Aparicio ${ }^{3}$, Robson Borges de Lima ${ }^{3}$, Jadson Coelho de Abreu

${ }^{1}$ Universidade Federal de Viçosa, Viçosa, Brazil; ${ }^{2}$ DAP Engenharia Florestal Ltda, Jêronimo Monteiro, Brazil; ${ }^{3}$ Universidade do Estado do Amapá, Macapá, Brazil (fernanda.lambrecht@hotmail.com; harlianymatias@gmail.com; carlos.eleto@ufv.br; perseu_aparicio@ueap.edu.br; rbl_florestal@yahoo.com.br; jadson.abreu@ueap.edu.br)

As relações hipsométrica são amplamente estudadas por meio de modelos de regressão. Recentemente cresce a utilização de Redes Neurais Artificiais (RNAs) como ferramenta de estimativa desta e de outras variáveis usuais no setor florestal. Assim, objetivou-se neste trabalho testar duas propostas para estimativa de altura de Eschweilera idatimon (Aubl.) Nied. Os dados de altura e DAP são do módulo II da Floresta Estadual do Amapá (FLOTA/AP), Amapá, Amazônia, Brasil. Foram testados 8 modelos de relação hipsométrica (5 aritméticos, 2 logarítmicos e 1 não linear). A melhor equação foi selecionada com base nos seguintes critérios estatísticos: Coeficiente de determinação ajustado ( $\mathrm{R}^{2}$ aj), Erro padrão da estimativa (Syx\%), Coeficiente de variação e Distribuição dos resíduos. A estimativa de altura também foi realizada por Redes Neurais Artificiais (RNAs). Foram treinadas de forma supervisionada 100 redes do tipo Multilayer Perceptron, empregando o algoritmo de aprendizagem Backpropagation e utilizando como neurônio de entrada a variável DAP. A escolha do melhor ajuste pelas RNAs consistiu na correlação entre alturas observadas e estimadas, desvio padrão e distribuição residual. Os dados coletados para DAP variaram de $10,06 \mathrm{~cm}$ a $90,43 \mathrm{~cm}$; e para a altura foi de $3 \mathrm{~m}$ a $26,8 \mathrm{~m}$. O modelo com melhor resultado foi Stoffels, com $\mathrm{R}^{2}$ aj de $57,76 \%$, Syx $\%$ de $26,28 \%$. A rede treinada que obteve menor RSME (4,71\%) foi a RNA 2 com estrutura 1-2-1. A estimativa de altura pode ser feita pela equação de Stoffels, contudo em termos de validação a estimativa por RNA apresentou melhor precisão.

\section{Leaf area index to estimate interception, litter layer and above ground biomass}

Yusuf Serengil

${ }^{1}$ Istanbul University Cerrahpasa, Istanbul,Turkey (serengil@istanbul.edu.tr)

Leaf Area Index (LAI) is an easy to measure parameter with indirect methods. It may however provide some good estimates related to the stand structure and ecosystem functioning. The LAI of a stand helps to identify forest canopy attributes like crown closure, illumination and stand density. It may also be used to estimate forest floor parameters that are controlled by light penetration to the forest floor. An abundant below canopy shrub or herbaceous vegetation may form and survive if enough amount of light and water passes through the canopy. The deposition and decomposition of litter layer is also affected from light and throughfall (precipitation-interception) that determine temperature and moisture conditions. In this study we present our findings of a 3 year study that has been performed around the deciduous, coniferous and mixed stands of Istanbul. The main objective of the study was to estimate and evaluate the hydrology, carbon, biodiversity and water related ecosystem services. To reach this objective, among several observations, we measured aboveground biomass, litter layer mass, and LAI. While we sampled 48 plots in deciduous, coniferous and mixed forest stands we also established 8 stationary plots to monitor temporal changes in LAI since it is quite variable especially in deciduous stands. Our results suggest that litter layer carbon stocks are positively correlated with LAI which means that as the amount of leaf area increase the carbon stock in litter layer increase. The relationship between LAI and above ground biomass was opposite.

\section{Reduction of sample size of trees to calibrate biomass regression}

Maria Lucia ${ }^{1}$, David Affleck ${ }^{2}$, Henrique Koehler ${ }^{1}$, Sylvio Péllico Netto ${ }^{1}$, Alexandre Behling ${ }^{1}$

${ }^{1}$ Universidade Federal do Paraná, Curitiba, Brasil; ${ }^{2}$ Univeristy of Montana, Montana, USA (maluh.siqueira@gmail.com; david.affleck@umontana.edu; koehler@ufpr.br; sylviopelliconetto@gmail.com; alexandre.behling@yahoo.com.br)

The objective was to test if the measurement of 3,5, 7 and 10 trees is enough to calibrate biomass equations to the stand level, since the coefficients are different between stands. Two samplings were conducted in Acacia mearnsii stands in Rio Grande do Sul, Brazil. Variables measured: above ground biomass $(B Y)$, diameter $(d)$ and height $(h)$ of 745 trees, collected in stands which ages vary from 1 to 10 years. These steps were performed: $i$ ) The Schumacher-Hall model $(\ln B Y=B 0+B 1 \ln d+B 2 \ln h)$ was fitted by means of mixed effects, the random effects structure was specified by age, at the stand level using the first sampling data. $i$ ) For the second sampling data, the model $\ln B Y=B 0+B 1 \ln d+B 2 \ln h+b 0+b 1 \ln d+b 1 \ln h$ was calibrated for each age. The fixed effects $(B i)$ were obtained in step $i$ and random effects ( $b i)$ were predicted from 3, 5, 7, and 10 randomly selected trees at each age. iii) A traditional regression was fitted for each age, using the same traditional model, using the second dataset. The estimates in $i i$ and $i i$ were compared with each other by means of a Chi-square test. The 
differences of the values estimated by the two equations were less than $5 \%$ and the Chi-square tests were not significant. The specific equation is more accurate than the calibrated - however, the calibration allowed to reduce sampling to 3 trees. It is concluded that only a small number of trees (as few as 3 ) are needed to calibrate biomass equations in local conditions.

\section{Biomass of Hymenaea stigonocarpa, a large tree species from the Brazilian savanna}

Suzana Maris Salis ${ }^{1}$, Patrícia Póvoa de Mattos $^{2}$

${ }^{1}$ Embrapa Pantanal, Corumbá, Brazil; ㄹmbrapa Florestas, Colombo, (suzana.salis@embrapa.br; patricia.mattos@embrapa.br)

Hymenaea stigonocarpa Mart. ex Hayne is a fruit tree frequently present in Brazil's central-western savannas and Pantanal wetland region. Trees may reach $20 \mathrm{~m}$ high, presenting architecture and size very different from most Brazilian savanna species, which are smaller and branched. Despite its large size and an important source of food and timber, there is little information available regarding biomass and carbon accumulation. Therefore, the objective was to develop an equation to estimate more accurately the biomass of $H$. stigonocarpa in savanna areas. Eight trees, with the diameter at ground level (DGL) from 8 to 55 cm, were cut and measured the weight in Pantanal. In average, the species invest $58 \% \pm 12$ in trunks, $38 \% \pm 11$ in branches and $5 \% \pm 4$ in leaves, presenting total tree aerial biomass varying from 5 to $2.758 \mathrm{~kg}$. The best equations ( $\mathrm{R}^{2}$ greater than 0.8 ) were obtained using DGL instead of DBH (diameter at breast height) for total aerial biomass (Biomass $=0.0111$ DGL3.0743; $\mathrm{R}^{2}=0.9937$ ), and for the components individually (trunk, branches, and leaves). Generation of consistent biomass equations should be prioritized for a larger number of savanna species, aiming a better estimation of biomass and carbon stocks for national and global carbon inventories.

\section{D4r: FOREST ASSESSMENT - HEIGHT, VOLUME, BIOMASS AND CARBON ESTIMATION}

\section{Carbon storage in soils in forest plantations in the Amazon region / Estocagem de carbono nos solos de plantios florestais na Amazônia}

Alexis Bastos ${ }^{1,2}$, Carlos Sanquetta ${ }^{3}$, Vanderlei Maniesi ${ }^{2}$, Ana Paula Dalla Corte ${ }^{3}$, Mateus Inoue Sanquetta ${ }^{3}$, Ueliton Pinheiro ${ }^{1}$, Marcelo Ferronato $^{4}$ ${ }^{1}$ Centro de Estudos Rioterra, Porto Velho, Brasil; ${ }^{2}$ Universidade Federal de Rondônia, Porto Velho, Brasil; ${ }^{3}$ Universidade Federal do Paraná, Curitiba, Brasil; ${ }^{4}$ Ação Ecológica Guaporé, Porto Velho,Brasil (alexis@rioterra.org.br; carlossanquetta@gmail.com; vanmaniesi@hotmail.com; anapaulacorte@gmail.com; mateus.sanquetta@gmail.com; ueliton.pinheiro10@gmail.com; marcelo@ecopore.org.br)

Mudanças do uso da terra ocorrerão para ampliar a produção de alimentos necessária à crescente população mundial. Nos países em desenvolvimento situados nos trópicos essas mudanças implicam na emissão de gases de efeito estufa, tendo como principal vetor, a conversão de florestas nativas para áreas agricultáveis. Para Amazônia, área de expansão da fronteira agrícola, se estabelece uma ameaça sobre seus serviços ecossistêmicos, não apenas pelas emissões advindas da supressão vegetal, mas pelas perturbações causadas no solo, compartimento que abriga os maiores estoques de carbono no planeta. Foram realizados estudos em Rondônia, para quantificar carbono nos solos em áreas de restauração florestal (idades entre 5 e 7 anos). O material foi obtido através de amostras indeformadas, retiradas com anéis volumétricos (100 $\left.\mathrm{cm}^{3}\right)$, em 36 pontos, nas profundidades de $0-5,5-10,10-20$ e 20-40 cm pela obtenção das densidades e teores de carbono por combustão. Os valores das médias dos teores de carbono (\%) foram de 1,762; 1,327; 0,923 e 0,697 para as profundidades de 0-5, 5-10, 10-20 e 20-40 cm, respectivamente. A profundidade de 0-5 apresentou 11,791 Mg/ha em média. A faixa entre 5-10, média de 9,940 Mg/ha. As amostras retiradas dos horizontes entre 10-20 e 20-40 cm continham 13,653 e 20,013 Mg/ha, respectivamente. O carbono total estocado entre 0-40 cm variou de 36,932 a 89,647 Mg/ha, sendo a média de 54,897 Mg/ha. Conclui-se que o plantio de florestas ajuda a manter a estabilidade dos estoques de carbono nos solos, sendo importante no enfrentamento às mudanças climáticas.

Impact of rectangular plantation spacing on productivity of Eucalyptus clones / Influência da retangularidade do espaçamento de plantio sobre a produtividade de clones de Eucalyptus

Marco Aurélio Figura ${ }^{1}$ Regiane Abjaud Estopa ${ }^{1}$, James Stahl ${ }^{1}$

${ }^{1}$ Klabin SA, Telêmaco Borba - PR,Brasil (mafigura@klabin.com.br; restopa@klabin.com.br; jstahl@klabin.com.br)

A densidade inicial de árvores plantadas por hectare é uma decisão silvicultural que impacta diretamente a produtividade de clones do gênero Eucalyptus. Entretanto, para uma mesma densidade inicial, o arranjo das mudas no momento do plantio altera a competição por luz, água e nutrientes, agindo também sobre a produtividade florestal. Este arranjo pode ser quantificado pela relação entre a maior distância de plantio (entre linhas e entre plantas) dividida pela menor, originando um indicador conhecido como retangularidade (R). Um experimento foi conduzido em ensaio fatorial com 4 clones ( 2 híbridos de $E$. grandis x $E$. urophylla e 2 híbridos de E. urophylla x E. globulus) e 2 espaçamentos (3,75m x 2,40m - R=1,56 e 6,00m x 1,50m - R=4,00), ambos com 9 m²árvore (1.111 árvores/ha). O experimento contou com 6 repetições e foi avaliado na idade de 7 anos. A interação entre clone e espaçamento não foi significativa ( $\mathrm{p}=0,6033$ ). A diferença entre clones foi significativa $(\mathrm{p}<0,001)$, mostrando a superioridade dos híbridos de $E$. grandis $\mathrm{x} E$. urophylla (média de incremento médio anual em volume (IMA) de 58,6 e 56,4 m³/ha/ano) frente aos híbridos de E. urophylla x E. globulus (média de IMA de 32,9 e 25,1 m³/ha/ano). Os espaçamentos diferiram estatisticamente $(\mathrm{p}<0,001)$, com IMA médio para os 4 clones de 45,6 e 40,4 $\mathrm{m}^{3} /$ ha/ano, respectivamente para os espaçamentos de 3,75m x 2,40m ( $\left.\mathrm{R}=1,56\right)$ e $6,00 \mathrm{~m} \times 1,50 \mathrm{~m}(\mathrm{R}=4,00)$, confirmando a importância de um correto arranjo de plantio sobre a produtividade do gênero Eucalyptus.

\section{Qualitative variables and the selection of volume equation models in forest inventory}

Vinícius Pizzo Ferreira ${ }^{1}$, João Luís Ferreira Batista

${ }^{1}$ University of São Paulo, Piracicaba, Brasil (vinicius.pizzo.ferreira@usp.br; joaoluis.fbatista@gmail.com)

Individual tree volume equations are essential tools for forest inventories, since wood content of individual trees can not be measured precisely, except by means of destructive methods. In eucalyptus forests, the prediction of tree volumes is seldom done by the application of a single volume equations for the entire forest. Volume equations are usually specific for genetic material (clones), properties and project/age of the forest. In this study, we consider the influence of including the qualitative variables related to the spacial scale (municipalities, properties, projects and stands) in volume equation models and its impact in model selection. A total of 11 linear models were fitted, including both standard volume equation models (DBH and height as predictors) and local volume equation models (only DBH as predictor). Models were fitted by least squares and were compared using the coefficient of determination, residual standard error and several indexes based on model residuals. The qualitative variables were fitted as dummy variables changing only the intercept regression coefficient and changing both the intercept and the slope coefficients of all predictors in the model. The performance of all models was improved by adding the qualitative variables. As 
expected, the improvement increased as the qualitative variable increased in spacial resolution from municipalities to properties, to project and to stands, but the difference in performance among the models decreased with spacial resolution. The selection of the appropriate spatial resolution (qualitative variable) was more important to determine volume equation performance than the selection of the actual model.

Machine learning and the fixed and mixed effect models in predicting total tree height / Aprendizado de máquina e modelo de efeito fixo e misto na predição da altura total de árvores

Ivaldo da Silva Tavares Júnior ${ }^{1}$ D, Carlos Moreira Miquelino Eleto Torres ${ }^{1}$, Jadson Coelho de Abreu ${ }^{2}$, Samuel José Silva Soares da Rocha ${ }^{1}$ ${ }^{1}$ Universidade Federal de Viçosa, Viçosa, Brasil; '2Universidade Estadualdo Amapá, Macapá, Brasil (ivaldojr8@hotmail.com; carlos.eleto@ufv.br; jadson. abreu@ueap.edu.br; samueljoserocha@gmail.com)

A altura total das árvores é essencial para entender a dinâmica da floresta e estimar a biomassa e estoque de carbono. Contudo, a mensuração dessa variável em florestas nativas é difícil devido à complexidade da estrutura. Objetivou-se comparar a acurácia do modelo de Gompertz com efeito fixo (GEF), modelo misto de Gompertz com efeitos fixo e aleatório (GEM), máquina de vetor de suporte (MVS) e rede neural artificial (RNA) na predição da altura total (Ht) de árvores na Mata Atlântica. O estudo foi realizado em um fragmento de 17 ha. Dez parcelas com 0,1 ha cada foram instaladas. Os dados: CAP (cm), Ht (m) e nomes científicos das árvores com CAP $>15 \mathrm{~cm}$ foram utilizados. A avaliação de todos os modelos foi realizada por meio da validação cruzada com 10 folds, repetida 50 vezes. Para cada repetição, médias da raiz do erro quadrático médio (RMSE) e erro absoluto médio (EAM) foram calculadas. As médias de RMSE e EAM das repetições de todos os modelos foram comparadas pelos testes de Friedman e Nemenyi. A MVS apresentou as menores médias de RMSE $(2,79)$ e EAM $(2,02)$ e o modelo GEF as maiores, RMSE $(2,99)$ e EAM $(2,18)$. No teste de Friedman, as predições de Ht entre os modelos diferiram (p<0,05). No teste de Nemenyi, as distâncias entre os modelos de MVS e RNA para os modelos de GEF e GEM foram maiores que a distância crítica (0,66). Portanto, a MVS e a RNA foram mais eficientes na predição da altura total de árvores.

\section{Multi-3D-window dead tree detection of dead standing Eucalyptus camaldulensis from voxelised full-waveform LiDAR data for tackling high differences in native forests}

Milto Miltiadou ${ }^{1}$, Maria Prodromou ${ }^{1}$, Susana Gonzalez Aracil ${ }^{2}$, Diofantos G Hadjimitsis $^{1}$

${ }^{1}$ Cyprus University of Technology, Limassol, Cyprus; ${ }^{2}$ Interpine Group Ltd, Rotorua, New Zealand (milto_miltiadou@hotmail.com;

ml.prodromou@gmail.com; susana.gonzalez@interpine.nz;d.hadjimitsis@cut.ac.cy

Detection of dead trees is an important for managing biodiversity in native Australian forests. Most of the previous work on dead standing trees detection performs single tree crown delineation before health assessment. Nevertheless, classifications at tree level, while working with native forest is a challenge for multiple reasons: big spatial resolution, variance density of trees, different tree heights and sizes. Tree crown delineation is usually done by detecting local maxima from the canopy height model (CHM) and then segmenting trees using the watershed algorithm, but Eucalypt trees has multiple trunk splits making tree delineation difficult. Shendryk et al, 2016, published an interesting Eucalyptus delineation algorithm that performs segmentation from bottom to top, but pulse density was 36 points $/ \mathrm{m}^{2}$ around forested areas (expensive to acquire for big spatial resolution). Miltiadou et al, 2018, attempted detection of dead Eucalypt trees without tree delineation using 3D-windows and showed that it is possible, but the methodology can be improved. The presented work, takes that research a step forward and uses multiple 3D windows charactering dead trees. A random forest classifier, a weighted-distance KNN algorithm are used to create a $2 \mathrm{D}$ probabilistic field for each 3D-window size. Then the results are merged, and the locations of the dead trees are predicted. It is shown that the multi-3D-window approach improved the results of the original research published work in 2018.

\section{Reducing the bias effect in tree height estimation in black wattle stands}

Mateus Sanquetta ${ }^{1,2}$, Henrique Scolforo $^{3,2}$, Cristian Montes ${ }^{4}$, Luciane Schmidt ${ }^{5}$, Alexandre Behling ${ }^{1}$, Carlos Sanquetta ${ }^{1}$ Universidade Federal do Paraná, Curitiba, Brasil; ' 2 Suzano, Limeira, Brazil; ${ }^{3}$ North Carolina State University, Raleigh, USA; ${ }^{4}$ University of Georgia, Athens, USA; ${ }^{5}$ Universdade Federal de Lavras, Lavras,Brasil (mateus.sanquetta@gmail.com; hscolforo@suzano.com.br; crmontes@uga.edu; lunaimekeschmidt@gmail.com; alexandre.behling@yahoo.com.br; carlossanquetta@gmail.com)

Censored data implies that a certain inventory variable was somehow not fully measured for all the trees. Assuming truncated values for the taller tress as it is typically observed in forest experiments result in volume under-estimation. Consequently, any inference about the forest pattern may be compromised by using these biased tree height values (truncated values). To overcome this problem, we present a methodology that treats the truncated tree height values differently. Different models were fitted to height-diameter data from black wattle stands. A total of 12 plots were fully inventoried with diameter at 1.30 meters aboveground and total height always being measured. To provide a framework of how dealing with censored data in field experiment analysis, we created a second dataset in which tree heights above $17 \mathrm{~m}$ were set to the constant value of $17 \mathrm{~m}$. Hence, it is possible to compare the true regression line to the censored regression. The use of censored regression in the presence of censored data proved to be very powerful, since the tree height values can be substantially improved through estimation instead of being assumed as truncated, which naturally reflects in less biased volume estimation as well.

\section{Influence of sample unit types on quantitative attributes analysis in tropical forests}

Renata Aparecida Serio Abranches Junqueira ${ }^{1}$, Rafaela Pereira Naves ${ }^{1}$, João Luís Ferreira Batista ${ }^{1}$

${ }^{1}$ Universidade de São Paulo, Piracicaba, Brasil (renatabranches@yahoo.com.br; rafaelapnaves@gmail.com; joaoluis.fbatista@gmail.com)

Sampling procedures allow a more precisely knowledge of the parameter of interest and can define better the plant communities and its potential for wood production and guidelines for conservation or environmental preservation, whether in native or planted forests. Considering different types of sample units, it's necessary to know whether the choice of a unit can influence on quantitative parameters to be analyzed. The objective of this work was to evaluate the influence of three different types of sample units such as circular, rectangular and Bitterlich points analyzing quantitative attributes such as density, basal area, mean diameter and mean squared diameter. These analyzes were carried out in three tropical phytophysiognomies, dense ombrophylous forest, semidecidual forest and cerradão. In general, the Bitterlich method differed from circular and rectangular units when analyzing structures of size and diversity. Phytophysiognomy also influenced the analyzes due to the structure of differentiated size and aggregate patterns of the species. Therefore, caution is required when choosing a sample unit, because depending on the physiognomy the quantitative attributes can show different behaviors and responses. 


\section{Mangrove condition and carbon stocks in African deltas and estuaries}

Carl Trettin ${ }^{1}$, Temilola Fatoyinbo ${ }^{2}$, Wenwu Tang ${ }^{3}$, Mwita Mangora $^{4}$, Zhaohua Dai ${ }^{5}$, David Lagomasino ${ }^{6}$, Seung Kuk Lee ${ }^{6}$, Marc Simard 7 , Salomao Bandiera ${ }^{8}$ ${ }^{1}$ US Forest Service, Cordesville, USA; ${ }^{2} N A S A$, Greenbelt, USA; ${ }^{3}$ Univ. North Carolina Charlotte, Charlotte, USA; ${ }^{4}$ Univ. Dar es Salaaam, Zanzibar, Tanzania, United Republic of; ${ }^{5}$ Michigan Tech. Univ., Houghtont, USA; ${ }^{6}$ Univ. Maryland, Greenbelt, USA; ${ }^{7}$ NASA/JPL, Pasadena, USA; ${ }^{8}$ Univ. Eduardo Mondlane, Maputo,Mozambique(carl.c.trettin@usda.gov; lola.fatoyinbo@nasa.gov; wtang4@uncc.edu; mmangora@yahoo.com; zdai@fs.fed.us; david.lagomasino@nasa.gove; seungkuk.lee@nasa.gov;marc.simard@jpl.nasa.gov; salomao.bandeira4@gmail.com)

While mangroves have been shown to contain significant carbon $(\mathrm{C})$ pools, there have been few objective inventories which characterize the distribution across large areas. We conducted objective field inventories using remote sensing data and a spatial decision support system to estimate above- and below-ground C stocks of mangroves within the Rufiji and Zambezi River Deltas, and the Gabon estuary. Carbon content in biomass in the deltas ranged from 89.6 to $224.9 \mathrm{Mg}$ $\mathrm{C} \mathrm{ha}^{-1}$ in Rufiji and 99.2 to $341.3 \mathrm{Mg} \mathrm{ha}^{-1}$ in Zambezi and $2.9 \mathrm{Mg} \mathrm{C}^{-1}$ to $591.7 \mathrm{Mg} \mathrm{C}^{-1}$ in the Gabon Estuary. Live tree biomass contained more than $80 \%$

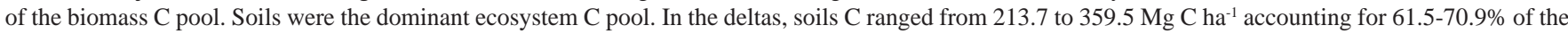
ecosystem C stock in the Rufiji and 354.7 to $644.9 \mathrm{Mg} \mathrm{ha}^{-1}$ that comprises $47 \%$ to $72 \%$ of the ecosystem C stock in Zambezi. In the Gabon estuary the range in soil carbon was ranged from $393.7 \mathrm{Mg} \mathrm{C}^{-1}$ to $899.5 \mathrm{Mg} \mathrm{C} \mathrm{ha}^{-1}$, accounting for $57.8 \%-99.6 \%$ of the ecosystem carbon stock. Both soil and biomass $\mathrm{C}$ pools in the mangroves in Rufiji and Zambezi deltas were lower than in the Gabon estuary. The variation in carbon stocks are due to differences in species composition, disturbance regimes, and inherent site conditions.

\section{D4s: FOREST ASSESSMENT AND PLANT COMMUNITIES}

\section{Interconnection among species of dominant tree populations of Castanopsis community in Three Gorges Reservoir region, China}

Ruimei Cheng ${ }^{1}$, Wenfa Xiao ${ }^{2}$

${ }^{1}$ Istitute of Forest Ecology, Environment and Protection, Chinese Academy of Forestry, Beijing 100091, China; ${ }^{2}$ Chinese Academy of Forestry, Beijing 100091, China (chengrm9533@sina.com; chengrm9533@sina.com)

Interconnection among the 19 dominant species, 171 species pairs in tree layer of Castanopsis community in Three Gorges Reservoir region in China was studied by using variance analysis, together with $\chi 2$ test, percentage co-occurrence( PC) and association coefficient (AC). The results indicated that Castanopsis carlesii var. spinulosa was the constructive species of Castanopsis community in Three Gorges Reservoir region, China. The overall associations between dominant species in the community were not significantly negative, suggesting that the Castanopsis community was not mature and in the phase of active succession. The $\chi 2$ test showed that among these 19 dominant species, 12 species pairs exhibited significantly positive association and 7 species pairs showed that significant negative association. However, most of the total 171 species pairs did not show significant interconnection, reflecting that the plant communities tended to distribute independently and still were in the unstable succession.

\section{Assessment of implementation pathways for Sustainable Development Goal 15 based on spatio-temporal information}

Sugyeong Park', Sea Jin Kim', Soo Jeong Lee', Mina Hong ${ }^{1}$, Woo-Kyun Lee

'KoreaUniversity,Seoul, RepublicofKorea(ss2432@naver.com; bluegulcy@gmail.com; cuarzolee@gmail.com;alsdk920902@naver.com;leewk@korea.ac.kr)

The United Nations established the 17 Sustainable Development Goals (SDGs) in 2015 and encourages states to achieve global agenda. For life on land, UN set the independent goal for protecting restoring and promoting the sustainable use of terrestrial ecosystems. This study aims to assess the implementation pathways for SDG15 in Republic of Korea (ROK). To figure out the pathways, the study firstly explores the possibility to develop new indicators, while analysing the existing indicators and assessment by United Nations organization. On the basis of the reviewing indicators, the study represents the value of indicators in the district level of ROK. Along with this, the synergy and trade-off can be examined between other goals to identify the multiple role in terrestrial Ecosystem. As a result, existing UN indicators are not enough to represent the circumstance in ROK, while the proxy indicators from national statistics are more likely to represent it. Also Goal 15 has closely link with agriculture, water, consumption and production, providing socio-economic environmental benefits to life. The study found that it is necessary to have integrated polices for achieving the SDG 15 rather than the separate approach of local government. In the future study, it needs to develop the nexus evaluation with synergy and trade-off as well as spatial implementation pathways in order to assess the implementation pathway for SDG15.

\section{Establishment of resident participatory governance type for management of Mongolian Green Belt}

Chang-Jun Lee ${ }^{1}$, Sebin Kim, Bohwi Lee ${ }^{1}$

${ }^{1}$ Department of Environment and Forest Resources, Chungnam National University, Daejeon, Republic of Korea (lcj3529@naver.com; sbkim@cnu.ac.kr; bohwi00@gmail.com)

This study aims to develop a model for sustainable use and management of afforested areas through resident participatory governance. Korea Forest Service carried out the afforestation project in Mongolia for 10 years (2007-2016) in order to reduce desertification, reduce yellow sand dust and increase in forest area. Manpower and costs to manage the afforestation area occur annually, but Mongolia's local government is burdened with direct management. In order to overcome these problems, this study conducted literature and case studies. After that, we surveyed the status of afforested areas, available human resources and infrastructure, and interviewed stakeholders to build a resident participatory governance model. The core members for forming regional governance are retired teachers with guidance experience and existing afforestation area managers with management competencies. Other members are made up of residents, external institutions are local government forestry officials, NGO, and environmental agencies. Resident participatory governance can gain new revenue streams by leveraging regional afforested area. Agroforestry is an exemplary way to utilize empty space within the plantation area. In this space, agroforestry can be applied because of the advantages of windproofing of trees, water supply using irrigation pipes, and blocking of animal access through fence installation. Residents can produce crops such as cucumbers, pumpkin, corn, potato, tomato, chili pepper, and zucchini. In addition, the empty spaces can be utilized as silvopasture forms for livestock. In order for this type of governance to spread, not only income but also awareness of agroforestry and education about the community should be done together. 


\section{Plant community structure of the floating meadows of a hypereutrophic wetland in the Indo-Burma Biodiversity Hotspot}

Syed Ainul Hussain ${ }^{1}$, Chongpi Tuboi, Ruchi Badola

${ }^{1}$ Wildlife Institute of India, Dehradun, India (hussain@wii.gov.in; chongpituboi@gmail.com; ruchi@wii.gov.in)

Floating meadows are widespread globally, but ecological information on their vegetation structure and functions is lacking which hinders their conservation. We examined the vegetation composition of the floating meadows of Loktak Lake located in the Indo-Burma Biodiversity Hotspot. The floating meadows in the park are crucial for the survival of the globally threatened Eld's deer (Rucervus eldii eldii) and the hog deer (Axis porcinus anamiticus). Vegetation data were collected from 936 plots of size $0.5 \mathrm{~m} \times 0.5 \mathrm{~m}$ during winter and summer. The vegetation data were analyzed using two-way indicator species analysis (TWINSPAN) with PC-ORD version 4.20. Nine plant communities were observed in summer and eight in winter, with two communities being common to both seasons. The overall Shannon and Simpson diversity indices, species richness and evenness of the communities varied significantly between summer and winter. The evenness $(0.713)$ and diversity $\left(H^{\prime}, 1.335\right)$ indices in summer indicate high species diversity, due to homogenous distribution of the species. The Ivlev Electivity Index (IVI) indicates that plant communities have a specific preference for meadow thickness, i.e., communities that prefer thick meadows avoid thin meadows. Competition among plant communities in terms of moisture and nutrient availability was low due to hypereutrophic condition of the lake and floating nature of meadows. But Capillipedium spp., Phragmites karka, Leersia hexandra and Zizania latifolia exhibit monodominance indicated by their frequency and abundance in most of the communities. Protection of areas with thick meadow is crucial for long-term conservation of the Eld's deer and associated wild ungulates.

\section{Brazil’s national forest inventory: quality data / Inventário florestal nacional do Brasil: dados com qualidade}

David Fagner de Souza e Lira ${ }^{1}$, Raquel Leao ${ }^{1}$, Doádi Antônio Brena ${ }^{1}$, Claudia Maria Mello Rosa ${ }^{1}$, Joberto Veloso de Freitas ${ }^{1}$ ${ }^{1}$ Serviço Florestal Brasileiro,Brasília,Brasil(liradfs@gmail.com; raquel.leao@florestal.gov.br; dabrena@gmail.com; claudia.rosa@florestal.gov.br; joberto.freitas@florestal.gov.br)

O Inventário Florestal Nacional do Brasil (IFN-BR) dispõe de um programa de avaliação e controle da qualidade, desenvolvido pelo Serviço Florestal Brasileiro, que serve de referência para avaliação dos trabalhos das equipes de campo. Os principais objetivos do controle de qualidade são: assegurar que os procedimentos metodológicos previstos sejam rigorosamente seguidos em campo, dar transparência ao processo de gestão do Inventário Florestal e promover a melhoria contínua da metodologia. O Controle de Qualidade (CQ) é baseado na checagem de componentes, itens e verificadores relacionados aos produtos entregues, ao sistema de amostragem, informações sobre uso e cobertura da terra, às medições biofísicas, à composição das equipes, ao rendimento dos trabalhos, às condições de acesso, à qualidade dos dados coletados, à logística e aos demais procedimentos previstos em sua metodologia. São analisados 42 verificadores distribuídos em 6 indicadores da qualidade. Até o início de 2019 foram realizados levantamentos de dados do IFN-BR em 24 estados, todos os biomas e 9.931 Unidades Amostrais. O Programa de Avaliação e Controle da Qualidade realizou a análise em todos os estados com levantamento de dados e o resultado conjunto dos Indicadores da Qualidade revelou alto nível de confiabilidade dos dados (87\%). O indicador 1 - Recursos humanos e materiais, obteve o maior nível de confiabilidade (94\%) e o menor foi o 5 - Características qualitativas (81\%). A análise do Programa de Avaliação e Controle da Qualidade é um processo evolutivo e contínuo com intuito de aumentar a precisão e confiabilidade dos dados.

\section{D5a: IMPROVING FOREST MANAGEMENT CERTIFICATION: INTEGRATING ECOSYSTEM SERVICES WITH FOREST ASSESSMENTS}

\section{Certifying forest-based ecosystem services: results from the world-first application of the FSC ecosystem service procedure in Italy}

Alex Pra ${ }^{1,2}$, Federico Pinato ${ }^{1}$, Lucio Brotto ${ }^{1}$, Mauro Masiero' ${ }^{2}$, Paola Gatto ${ }^{2}$, Davide Pettenella ${ }^{2}$

${ }^{1}$ ETIFOR, Padova, Italy; ${ }^{2}$ University of Padova,Padova, Italy_alex.pra@etifor.com; federico.pinato@etifor.com; lucio.brotto@etifor.com; mauro.masiero@unipd.it; paola.gatto@unipd.it;davide.pettenella@unipd.it)

In recent years, several mechanisms have been put in practice to value forest-based ecosystem services in order to maintain or enhance their provision. Mechanisms range from more traditional - e.g. regulation of land use, taxes and subsidies - to more innovative market-based ones such as Payments for Ecosystem Services (PES). More recently, the use of voluntary third-party forest certification schemes based on standards and procedures specifically aimed at considering the provision of ecosystem services has gained interests. Certification schemes have already been established for specific ecosystem services, in particular focusing on carbon, in some cases including biodiversity conservation as a co-benefit. The Forest Stewardship Council (FSC) is currently the only scheme promoting the certification of multiple ecosystem services by demonstrating the positive impacts of FSC-certified forest management practices on five regulating and cultural services. A dedicated procedure has been developed, that allows the assessment of the impact of forest management on carbon sequestration and storage, biodiversity conservation, watershed services, soil conservation and recreational services, by means of specific methodologies and indicators. We critically analyzed the world-first application of the FSC ecosystem services certification procedure with reference to the forest certification group Waldplus and Associazione Forestale di Pianura (Lowland Forest Association) in northern Italy. The case study includes 1,043 hectares of different forest types, from semi-natural productive forests to conservation forests, traditionally managed to deliver multiple benefits. Our objective is to give insights that could inform and improve future developments in the field of certification, promotion and marketing of ecosystem services.

Open access/source, calibratable tool for planning and assessments makes sustainable forestry more assured and valuable for commodity and non-commodity values

Chadwick D. Oliver ${ }^{1}$, Gediz Metin Kocaeli ${ }^{2}$,Kagan Ozkal ${ }^{2}$, Davut Atar ${ }^{2}$,Luke Rogers ${ }^{3}$,Andrew Cooke ${ }^{3}$, Jeffrey Comnick ${ }^{3}$, Jason Cross $^{3}$, Anna Schuerkman ${ }^{1}$, Bahtiyar Kurt ${ }^{4}$, Nuri Ozbagdatli ${ }^{4}$

${ }^{1}$ Yale University, School of Forestry and Environmental Studies, New Haven, USA; ${ }^{2}$ General Directorate of Forestry of Turkey, Ankara, Turkey; ${ }^{3}$ University of Washington, College of the Environment, Washington, USA; ${ }^{4}$ UN Development Programme,Ankara, Turkey (chad.oliver@yale.edu; gmkocaeli@ogm.gov.tr; mustafakaganozkal@ogm.gov.tr;davutatar@ogm.gov.tr; lwrogers@uw.edu; chad.oliver@yale.edu; chad.oliver@yale.edu; chad.oliver@yale.edu; chad.oliver@yale.edu; chad.oliver@yale.edu; chad.oliver@yale.edu)

Ensuring forests are sustainably managed presents many opportunities but also different ways of thinking. Certifying sustainability is to ensure that values are neither depleted nor unnecessarily hoarded. Some forest values are sustained by actions that maintain a dynamic forest where different stands provide different 
subsets of values at different times, but altogether dynamically providing the values at all times. Other values are sustained by actions that preserve some areas. Sustaining many forest values requires complex analyses to determine, coordinate, and assess the impact of various actions. The analyses require much data, calibration to each forest, and calculations. These can now be done with computers and satellite technologies. A transparent, on-line open-source planning/ coordinating/impact assessment tool will soon be available online cooperatively by the United Nations Development Programme, the General Directorate of Forestry of Turkey, Yale University, and the University of Washington. It is based on the University of Washington LMS (Landscape Management System) and the U.S. Forest Service "Suppose." It allows many values to be simultaneously sustained and can be calibrated throughout the world. Online posting of longterm management plans will enable anyone to assess adherence and impact of a plan from the ground or satellites. The transparency both reduces management costs and increases prices and diversity of values provided. The transparency will allow forest operations/equipment to be efficiently planned for expected terrain and species; and more people can plan and target diverse values by knowing beforehand when and where the operations will/will not be done.

\section{Water conservation of the rivers of the amazon forest fragment based on economic valuation mechanisms}

Mônica de Souza Barbosa ${ }^{1}$, Rogério Fonseca ${ }^{1}$

${ }^{1}$ Universidade Federal do Aamazonas Manaus, Brasil (barbosamonica11@gmail.com; rogeriofonseca@ufam.edu.br)

Considering the scarcity of information related to studies on the forest fragment of UFAM and on payment for environmental services, research initiatives on economic valuation are essential for the preservation and conservation of the ecosystem. The present study aimed to suggest a methodology for economic valuation of UFAM water resources and identify the demand for payments for environmental services among residents who use the university's water resources. It's difficult to attribute monetary value to forest products and services, so to determine the values of the willingness to pay given to the interviews, four specialists were consulted. A stratified sampling with a $10 \%$ safety margin was applied and 440 questionnaires, both physical and online, were applied in Manaus during one week of September 2018 using the contingent valuation method, where a hypothetical scenario was presented in which one institution would be responsible for UFAM's water resources. The results were submitted to logistic regression and a socioeconomic profile of the population was made. The methodology was satisfactory, since it minimized the economic cost of the research and allowed the reach of a larger number of people in a short period of time. Through logistic regression it was noted that younger people are more willing to pay; 55.91\% were willing to pay for the conservation of the water resources of UFAM, being one of the most cited limiting factors in relation to those who were not willing was the economic one. Thus, there is a possible market for the university's water resources.

\section{Using the ecosystem services approach to inform sustainable forest management and forest certification in New Zealand}

\section{Richard Yao ${ }^{1}$, Tim Payn ${ }^{l, 2}$, Sally Strang ${ }^{3}$, Colin Maunder ${ }^{4}$}

${ }^{1}$ Scion (New Zealand Forest Research Institute), Rotorua, New Zealand; ${ }^{2}$ Toi Ohomai Institute of Technology, Rotorua, New Zealand; ${ }^{3}$ Hancock Forest

Management (NZ) Ltd, Tokoroa, New Zealand; ${ }^{4}$ Timberlands Limited, Rotorua, New Zealand (richard.yao@scionresearch.com;

tim.payn@scionresearch.com; sstrang@hnrg.com; colin.maunder@tll.co.nz)

The importance of incorporating non-market ecosystem service values of planted forests in decision making gained increasing attention over the last decade. A tool that helped facilitate discussions between researchers, industries and governments on this issue is the ecosystem services (ES) framework. The framework has been widely used to assess and demonstrate forestry’s economic, environmental and social values. Key non-market ecosystem services have been incorporated into major certification initiatives. The Forest Stewardship Council has recently considered including water, carbon, biodiversity, soil and recreational services. This study demonstrates how to assess relevant non-market ES values of selected forests to support sustainable management and certification. At least four New Zealand forestry companies have either commissioned or supported the ES assessment of their respective forest estates. The objectives of the ES assessment included renewal of certification and demonstration of the environmental and social values of forests to inform sustainable forest management. These assessment objectives were achieved. Forest managers were also satisfied that the quantified non-market monetary values, using the appropriate protocols, can help inform management decisions. The study also found that the ES values estimated (e.g. carbon sequestration, avoided erosion) can contribute to the further development of forest certification systems to sustain and enhance the provision of non-market ecosystem services in planted forests. Recommendations were provided by forest managers to improve future ES assessment projects such as assessing other relevant ecosystem services (e.g. water regulation, carbon storage) and to identify the appropriate metrics for each non-market ecosystem service.

\section{The effectiveness of standards in driving adoption of sustainability practices: a State of Knowledge evidence review}

Gillian Petrokofsky', Steve Jennings ${ }^{2}$

${ }^{1}$ University of Oxford, Oxford, United Kingdom; ${ }^{2}$ Keel LLP, Oxford, United Kingdom (gillian.petrokofsky@zoo.ox.ac.uk; steve.jennings@3keel.com)

Voluntary sustainability standards are an important means of providing assurance that products and materials traded in complex, global supply chains have been produced in an ethical and environmentally benign way. Understanding what these standards deliver on the ground is an important part of the debate about their ongoing relevance. An evidence evaluation was undertaken to understand the effectiveness of sustainability standards and certification tools in driving the adoption of more sustainable practices in certified entities, thereby contributing to the achievement of key sustainability outcomes. The report focuses on the changes of practices by organisations or individuals - such as the use of chemical inputs, retention of wildlife habitat, and providing better conditions for hired workers - as a necessary step towards the final impacts of standards systems. A total of 116 controlled studies (before-and-after, controlled intervention, or a combination) which reported relevant outcomes from entities certified with a sustainability standard, were filtered from an original body of over 13,000 studies from the peer-reviewed and 'grey' literature. We report results of the systematic mapping of the studies in six thematic areas: Conservation and Biodiversity; Input Use, Community Benefits and Development; Occupational Health and Safety; Good Production Practices, and Management Systems. There is a focus on research in developing countries in the tropics and sub-tropics, with comparatively little on developed and temperate countries. Most of the research was on coffee and forestry, and on Rainforest Alliance, Organic, Fairtrade and FSC standards. We demonstrate an interactive visualisation of our review findings.

\section{Bundling ecosystem services to increase forestland value and enhance sustainable forest management in the USA}

Robert Deal ${ }^{1}$, Vitalie Gulca ${ }^{2}$, Nikola Smith ${ }^{3}$

${ }^{1}$ USDA Forest Service, PNW Research Station, Portland, USA; ${ }^{2}$ Ethno-Cultural Center-VATRA, Chisinau, Moldova, Republic of; ${ }^{3}$ USDA Forest Service, Portland,USA (rdeal@fs.fed.us; vitalie.gulca@gmail.com; nmsmith@fs.fed.us)

The ecosystem services concept has emerged as a way of framing and describing the broad suite of benefits that people receive from ecosystems. These services include commonly recognized goods like timber, forest products and fresh water, as well as climate regulation, and cultural assets. There has been interest in 
the use of incentives and market-based strategies to increase forestland value and to help accomplish conservation goals. These can be in the form of direct payments to landowners, through trading credits or other market-based approaches. Ecosystem services including carbon credits, water quality and quantity, and conservation values can add substantial economic return from forests. One promising option is to allow landowners to bundle or stack payments for ecosystem services. We use an integrated approach to bundle values of different ecosystem services including carbon, water, and fish and wildlife conservation. We outline some of the policy and regulatory frameworks for some of the emerging markets for ecosystem services in the United States, and discuss the role that different regulatory agencies play for each of these services. We then assess the potential benefits for bundling different ecosystem services including carbon credits, water quality trading, and wetland and species mitigation banking. Our purpose is to establish a framework for assessing the potential value for different ecosystem services, understand the process for combining these services, and develop an integrated approach for bundling these services. This process can be used to restructure public incentive programs so that multiple resource benefits can be captured.

\title{
Ecosystem services certification in China
}

\author{
Lu Wenming ${ }^{1}$ \\ ${ }^{1}$ Chinese Academy of Forestry, Beijing, China (luwenmingcaf@126.com)
}

Independent third-party forest certification emerged in the 1990s as a tool for assessing and communicating the environmental and social performance of forest management operations. Today, forest certification is mainstream, supported worldwide by major producers and buyers, and elements of certification are directly or indirectly required in a number of national forestry or government/public procurement policies. There are 2 international forest certification schemes and dozens of national ones. All these schemes have promoted environmental, social and economic sustainability for forest management, and ecosystem services play a very important role in the whole forest certification process, but all international and national forest certification schemes, except in China, do not have any scope of ecosystem service certification or special and independent ecosystem service certification standard(s) assessing the special requirements of ecosystem service. The paper will discuss the design, development, operation and management of ecosystem service certification in China as 2 kinds of other special scopes of forest certification apart from certification of forest management and chain of custody (COC). China, through the China Forest Certification Scheme (CFCS) which is managed by the China Forest Certification Council (CFCC) has identified 2 scopes of ecosystem service certification covering forest parks and nature reserves, and 2 independent certification standards for assessing them. China also developed audit directives and operational guidelines for certification of forest parks and nature reserves in corresponding certification standards. The paper also analyzes 2 case studies of CFCC certified forest parks and nature reserves with its impact of ecosystem service management.

\section{Development of voluntary forest certification schemes in Russia and their impact on forest management}

\author{
Andrey Ptichnikov ${ }^{1}$ \\ ${ }^{1}$ Institute of Geography Russian academy of sciences, Moscow, Russian Federation (aptichnikov@igras.ru)
}

Recently at public hearings in the Russian Parliament (State Duma) of the Russian Federation, at the media the issues of voluntary forest certification were actively discussed. Some politicians would like to see forest certification that is fully consistent with the current state strategies and existing interests in the forest sector. There are fears that international certification organizations may somehow "disconnect" Russia from certification and thereby deprive the forest business of the international market. Some statements were done that "The national certification scheme will be driven by national interest and will defend Russia's position on global markets". The article explores all policy and trade implications of the potential national forest certification scheme, which is fully in line with existing national legislation and government interests. The following aspects are analyzed: - Fundamental difference between stakeholder based international forest management standards and expert based national legislation; -The concept of risks from the point of view of international stakeholders and national governments; - Independence and credibility of certification in relation to market demand for certified forest products; -The possibility of acceptance of national forest certification schemes by buyers through intergovernmental agreements; -The possibility of suspension of countries from international forest certification schemes in case national legislation will create a significant barrier for international certification scheme; - Harmonization of certification requirements and regulatory framework of forest management. The study is the first of its kind to describe the limits of national regulations in international forest certification and forest product trade.Supported by Institute of Geography RAS assignment 0148-2019-0006.

\section{Environmental Impact Assessments for rural properties: case studies from producing eucalyptus energy wood in Goiás, Brazil / Avaliação de impacto socioambiental de propriedades rurais: estudos de caso da produção de lenha de eucalipto em Goiás}

Claudio Cesar de Almeida Buschinelli ${ }^{1}$, Flávio José Simioni², José Mauro Magalhaes Ávila Paz Moreira ${ }^{3}$

${ }^{1}$ Embrapa Meio Ambiente, Jaguariúna, Brasil; ${ }^{2}$ Universidade do Estado de Santa Catarina, Lages, Brasil; ${ }^{3}$ Embrapa Florestas, Colombo, Brasil (claudio.buschinelli@embrapa.br; flavio.simioni@udesc.br; jose-mauro.moreira@embrapa.br)

A avaliação de impacto de atividades produtivas rurais é apontada como importante ferramenta de apoio aos produtores para atingir patamares de produtividade com a adequada conservação dos recursos naturais, além de possibilitar ajustes para a obtenção de certificações de produção sustentável. A demanda por biomassa para geração de energia vem aumentando e o cultivo de eucalipto é a opção mais lucrativa para o setor, expandindo-se para novas fronteiras de produção. O trabalho avaliou duas propriedades de referência em 2018 no cultivo de eucalipto para produção de lenha nos Municípios de Rio Verde e Cristalina, em Goiás. Para tanto, foi utilizado o Sistema Ambitec-Agro (Sistema de Avaliação de Impacto Ambiental de Inovações Tecnológicas Agropecuárias), desenvolvido pela Embrapa e que integra 125 indicadores quantitativos de 24 critérios de avaliação de desempenho socioeconômico e ambiental da atividade produtiva, sempre comparando o uso atual da terra frente ao anterior. A atividade contou com apoio financeiro do Sebrae/Goiás. Os resultados apontaram para a adequação dos sistemas de produção adotados, já que as duas propriedades apresentaram índices de impacto final positivos de 3,1 em Rio Verde e 5,8 em Cristalina. O Sistema Ambitec-Agro não visa comparar propriedades rurais, já que cada uma possui um contexto próprio de produção ajustado à sua localização geográfica e histórico do produtor; mas sim, avaliar o sistema de produção adotado no contexto geral da propriedade. Ao apontar impactos positivos e negativos, os resultados auxiliam na gestão ambiental da propriedade com critérios de qualidade e sustentabilidade produtiva. 
Workplace health and safety, an approach according to Social Life Cycle Assessment (LCA-S) / Saúde e Segurança do Trabalho, uma abordagem segundo a Avaliação Social do Ciclo de Vida (ACV-S)

Vitor Gomes Bevilacqua Junior ${ }^{1}$, Marcelo Langer ${ }^{1}$, Sandro Andrioli Bittencourt ${ }^{1}$, Dimas Agostinho da Silva ${ }^{1}$

${ }^{1}$ Universidade Federal do Paraná, Curitiba,Brasil (vitorgbjr_uff@yahoo.com.br; marcelolanger@ufpr.br; sandro.bittencourt@ufpr.br; dimass@ufpr.br)

O setor florestal é enquadrado na alíquota máxima do GIIL-RAT - Grau de Incidência de Incapacidade Laborativa dos Riscos Ambientais do Trabalho, que acarreta um aumento dos custos previdenciários e tributários das empresas. Também é um dos setores hot spots em acidentes e questões relacionadas a Saúde e Segurança do Trabalho (SST). A média anual de acidentes laborais neste setor, entre os anos de 2006 a 2016 foi de $3 \%$ do total de ocorrências laborais registradas em todos os setores do Brasil. Neste período, o setor florestal apresentou redução do número de acidentes em $37 \%$, entretanto, essa quantidade representa 22.748 pessoas acidentadas em média por ano. Algumas ferramentas de gestão de desempenho dos programas de SST, como a ACV, têm apoiado nas decisões dos tomadores de decisão para o monitoramento de impactos e resultados gerenciais da Organização. A ACV-S é uma técnica mundial para mensurar impactos sociais incluindo os acidentes do trabalho e identificar os principais fatores contribuintes na melhora dos sistemas de gestão de produtos. O objetivo deste trabalho foi parametrizar os padrões da ACV-S aos princípios das certificações florestais utilizando a ACV e a pesquisa em bases de dados. Os resultados prévios apontaram que os fatores prováveis para a redução de acidentes observados no Brasil foram: avanço da legislação trabalhistas, principalmente a NR31 de segurança e saúde para o setor florestal; aumento em 51\% das notificações trabalhistas no período de 2006 a 2015 e o crescimento das certificações voluntárias como FSC em 23,58\% de 2012 a 2016.

\section{D5c: PRODUCTIVE CONSERVATION: MORE SUSTAINABLE SYSTEMS}

\section{Social and economic impacts of gem harvesting in resinous silviculture}

Henri Husson ${ }^{1}$, Javier Calvo ${ }^{2}$

${ }^{1}$ Centre régional de la Propriété forestière de Nouvelle-Aquitaine, Bordeaux, France; ${ }^{2}$ CESFOR, madrid, Spain (h.husson@cnpf.fr; javier.calvo@cesefor. com)

The natural resin harvest is back in the spotlight in European countries . The natural resin extraction represents an asset for the local economy and an enhancement of the ecosystem forest services. Some of the main sectoral European stakeholders have joined their efforts in SustForest Plus, a cooperation project supported by the European Interreg Sudoe Program, aimed to improving resin harvesting techniques, supporting the resin tappers workers activity and reinforcing the status of resinous local forests as natural resin source for the European industry. One of the goals is to make compatible the resin harvesting activity with wood quality production. The impact of this additional harvest is being studied to qualify the mechanical qualities of the wood. The use of the local crude pine oleoresin will make it possible to rediscover very varied and ecological uses of this natural raw material that fits perfectly in the new bioeconomy, compared to synthetic and petrochemical products. The aim of the project is to satisfy the demand for natural resins of the industry in south-west Europe, generating at the same time stable and quality employment in the rural areas of the south-west European region.

\section{An assessment of clonal forest nurseries in Paraguay / Diagnostico de viveros forestales clonales en el Paraguay}

Julia Maria Tileria Ferreira ${ }^{1}$, Maria Laura Quevedo Fernandez ${ }^{1}$, William Tomaz Folmann ${ }^{2}$

${ }^{1}$ Universidad Nacional de Asuncion, Asuncion, Paraguay; ${ }^{2}$ Investigador,Asuncion, Paraguay (julia.tileria@gmail.com; marialauraquevedo@gmail.com; wfolmann@gmail.com)

En Paraguay se dio un aumento en la superficie plantada principalmente con Eucalipto producido mediante miniestaquia, por lo cual el trabajo busco realizar una caracterización de los viveros forestales clónales en el país, ella fue realizada utilizándose un cuestionario para colectar datos. En el año 2007 se inició la producción clonal y actualmente existen 12 viveros clonales de comercialización, todos correspondientes al sector privado con origen del capital nacional. La capacidad productiva anual es de 45.180 .000 mudas de las cuales se producen aproximadamente actualmente 29.730 .000 . El $100 \%$ de las empresas venden a particulares y $75 \%$ a empresas privadas. Las empresas consideran categorías de precios diferenciados siendo entre 0,23 a 0,33US\$ minoristas y los mayoristas entre 0,17 a 0,25US\$, el rubro genera mano de obra de 145 personas fijas, principalmente femenino. Con relación a los materiales, se comercializan 32 de los cuales el $60 \%$ proviene de Brasil, siendo más utilizados el VM01, I144, A08 y H13. Se han identificado materiales que se han descartado, en su mayoría por ser suceptibles a Leptocybe invasa, entre los materiales que serán introducidos se destaca el C. torreliodora. En canaletones, $10 \mathrm{x} 10 \mathrm{~cm}$ es el espaciamiento más utilizado, ahí el fertiriego es realizado por goteo y $100 \%$ utiliza tubetes plásticos. En casa de vegetación la temperatura varía de 30 a $38 C^{\circ}$ con humedad entre 60 a $80 \%$, considerándose alrededor de 90 días para expedición manteniendo altura promedio de $25 \mathrm{~cm}$. El factor más crítico identificado por las empresas fue la competencia desleal.

\section{Integrated forest management: a European approach?}

Jakob Derks ${ }^{1}$, Agata Konczal ${ }^{1}$, Joost de Koning ${ }^{1}$

${ }^{1}$ European Forest Institute, Bonn, Germany (jakob.derks@efi.int; agata.konczal@efi.int; joost.dekoning@efi.int)

Integrated forest management (IFM) is a topical issue, but the definition varies quite a bit. Even within a continent so small as Europe, different local cultures, climatic and geographic conditions and forestry traditions have led to very different applications of this concept. The project "Integrated Forest Management Learning Architecture" (INFORMAR) of the European Forest Institute (EFI) analyses existing knowledge relating to the implementation of IFM in order to address and fill potential knowledge gaps. Thirty-six selected cases in twelve European countries are explored to find answers to research questions that have been jointly developed together with the project stakeholders (foresters, researchers, policymakers, forest owners, NGOs). The selected case studies will cover different ownerships structures, sizes and geographical regions. Doing this, we hope to understand and map out the current and future ecological, socio-political and economic driving forces of IFM we hope to establish a comprehensive overview of how nature conservation and wood production can be integrated in the same stand under very different conditions. Doing this, we hope to establish a comprehensive overview of how nature conservation and wood production can be integrated in the same stand under very different conditions. 


\section{Procitrópicos: american network for sustainble systems}

Jamil Macedo ${ }^{1}$

${ }^{1} I I C A$ Brasil / IICA - Instituto Interamericano de Cooperação para Agricultura (jamil.macedo@iica.int)

The first Cooperation Agreement between the agricultural research institutions of the tropical countries and IICA for the execution of the activities of the Cooperative Program for Research, Development and Agricultural Innovation for the South American Tropics (PROCITROPICOS), entered into force on June 20, 1991 and, since then, new agreements were signed. In December 2014, the directors decided to carry out an External Evaluation, which involved diversified and representative interest groups, including members, allies, the public and private sectors, universities, embassies, regional consortiums and international organizations around an agenda structured, which verified the strategic importance of PROCITROPICOS as a geopolitical instrument to share the advances of science, technology and agricultural innovation for the tropics. In summary, the evaluators concluded that the Program has managed to implement a large part of its objectives, with significant results, operational efficiency and good capacity for mobilizing competencies and indicated the corrections of the route for the full exercise of its mission.

\section{Conservation production: network for sustainable management of forest seed and seedlings}

${ }^{1}$ Dan Érico Lobão

${ }^{1}$ Fundação Pau Brasil, Bahia, Brasil (ericolobao@hotmail.com)

The project proposes to economically make possible the exploitation of forest by the rural property in the Cacao Region of Bahia, through the creation of a network of seeds and forest seedlings, guaranteeing the conservation of associated natural resources the continuity of harmony between production and conservation, that is, man and nature, provided by the traditional system of cocoa cultivation, cacao-cabruca.

\section{Revisiting the changing role of forest beekeeping in Ethiopia: when does honey production assist conservation?}

Tefera Belay Endalamaw ${ }^{1}$, Dietrich Darr ${ }^{2}$

${ }^{1}$ Hawassa university, Wondo Genet, Ethiopia; ${ }^{2}$ Rhine-waal university of applied sciences, Kleve, Germany(teferabelay@gmail.com; dietrich.darr@hochschule-rhein-waal.de)

Beekeeping has been accepted as a tool for improving the livelihoods of forest communities, while simultaneously contributing to forest ecosystem conservation attaching additional economic value to keeping forests intact. However, while this relationship was the case for traditional beekeeping, which largely takes place inside forests, it is less clear how technological advances in beekeeping and its transfer to domesticated environments affect the farmers' incentives to conserve the forests. Based on a case study on 91 beekeepers in southwest Ethiopia where modern beekeeping had been promoted, we find evidence for a gradual detachment of beekeepers from their forests. For example, farmers do no longer need trees to hang their hives. Moreover, forests are no more a nonsubstitutable source of pollen and hive construction material. Hence, the strategic role of trees and forests for beekeepers is decreasing, reducing the additional incentives for beekeepers to conserve forests. However, we also found that income from modern beekeeping was significantly larger, which may help reduce the excessive extraction of forest products for subsistence purposes. In conclusion, while beekeeping is still an important source of sustainable forest-based income, technological development and domestication in beekeeping fundamentally altered the role of forests in modern apiculture.

\section{Qualitative and quantitative characteristics of mixed scotch pine and norway spruce in the North-West of Russia}

Dmitriy Danilov ${ }^{I, 2}$, Natalia Beliaeva ${ }^{1}$

${ }^{1}$ St. Petersburg State Forest Engineering University named after S. M. Kirov»., St. Petersburg, Russian Federation; ${ }^{2}$ Leningrad Research Institute for Applied Agricultural Science (Belogorka),Leningrad region, Gatchina district, Russian Federation (stown200@mail.ru; galbel06@mail.ru)

Growth and the formation of pine and spruce in a mixed tree stand due to the composition of the stand, which affects the entire life cycle of its development. In mixed stands of pine and spruce, by age, the pine part of the forest is older than the spruce part of the stand for 15-20 years. Mixed stands of pine and spruce in the boreal zone are notable for their high productivity. In the most productive forest conditions, their stock by the age of 80-100 years exceeds the stock of pure plantations of pine and spruce by 1.5 times. An analysis of the mutual influence between conifers showed that the composition of the plantation has a significant effect on the average diameter and height of the tiers in the mixed coniferous stand of spruce and pine. The quantitative characteristics of mixed stands of pine and spruce are reflected in the quality indicator, which is the density of the wood. In coniferous stands mixed in composition, higher rates of pine wood density are noted compared to pure pine forests. The density of spruce wood in mixed stands increases with its predominance in the composition of plantings to a greater extent than that of pine. In mixed stands of spruce and pine, the dependence of the basic density of wood from the distribution of trees by diameter classes is more pronounced when the share of pine in the composition of tree stands is smaller.

\section{D6a: ETHICS AND VALUES IN RELATION TO FOREST, RECREATION AND WILDLIFE} MANAGEMENT

\section{Relational values: the key to pluralistic valuation of ecosystem services.}

Austin Himes ${ }^{1,2}$, Barbara Muraca ${ }^{1,3}$

${ }^{1}$ Oregon State University, Corvallis, Oregon, USA; ${ }^{2}$ GreenWood Resources Inc., Portland, Oregon, USA; ${ }^{3}$ University of Oregon, Eugene, Oregon, USA (austin.himes@oregonstate.edu; barbara.muraca@oregonstate.edu)

Multiple frameworks have recently been proposed adopting relational values as a new domain of value articulation distinct from the dichotomy of intrinsic and instrumental values that has dominated environmental ethics for decades. In this article, we distinguish between the innate relationality of all evaluative processes and relational values as the content of valuation which is a new and fruitful category for expressing the importance of specific relationships people hold with non-human nature. We examine the concept of relational values used in recent frameworks and propose a simple conceptualization with clear distinctions between relational, instrumental, and intrinsic (inherent moral) values. We argue that as a new category of value articulation, relational values provide conceptual and empirical insights that the intrinsic/instrumental value dichotomy fails to deliver. Finally, we draw on theoretical and empirical research to show why a clear distinction between instrumental and non-instrumental relational values is important for environmental conservation, sustainability, and 
social justice. From the perspective of conflict associated with forest management, relational values provide a mode of articulating what diverse stakeholders deem important in their own context specific language. When considered alongside instrumental and inherent moral values, relational values provide more fulsome articulation of the impacts of forest management on services and disservices that diverse people derive from forests.

\section{The stability of public preferences for novel forest management: the case of assisted migration}

Findlater Kieran ${ }^{1}$, Guillaume Peterson St-Lauren1t, Shannon Hagerman ${ }^{1}$, Robert Kozak ${ }^{1}$

${ }^{1}$ University of British Columbia, Vancouver, Canada(kmf@mail.ubc.ca; guillaume.peterson@ubc.ca; shannon.hagerman@ubc.ca; rob.kozak@ubc.ca)

A major policy challenge created by emerging technologies is that public preferences tend to be unstable. Typically, surveys are used to measure such preferences, but survey questions tend to evoke quick decisions, rather than allowing for deeper, deliberative thinking to emerge. Within the realm of forest management, technical solutions to climate change adaptation may be particularly fraught as survey respondents could be unfamiliar with the issues at hand, but nonetheless, must make challenging trade-offs between novel technological risks and uncertain climate change impacts within dynamic and complex socioecological systems. This is further complicated by the fact that public preferences of risk, support, or opposition for novel technologies are constructed and driven by a combination of ethical, values-based and social factors. Here, we use data from a survey of 1926 residents of British Columbia (BC), Canada to evaluate the stability of public preferences around climate change adaptation in commercial forestry, specifically genomics-based assisted migration (AM) of tree seedlings during reforestation following harvest. We show that preferences are highly unstable when people are given new information about AM's potential implementation and impacts. The magnitude of this instability varies with the degree of the proposed intervention (within or outside of species' historic natural range), the type of information being provided (e.g., data on climate change vs. forest resilience), and individuals' demographic and attitudinal characteristics. More broadly, the labile nature of public preferences among diverse publics and stakeholders points to the crucial need to study novel risk contexts using robust, mixed-methods approaches.

\section{Environmental violations observed by the environmental police in the Northern region of Santa Catarina State, Brazil}

Jessica Silva Costa ${ }^{1}$, Raquel Valério Sousa ${ }^{1}$, Veraldo Liesenberg ${ }^{1}$

${ }^{1}$ Universidade do Estado de Santa Catarina, Lages, Brasil (jessica.dsilvacosta@gmail.com; raquel.sousa@udesc.br; veraldo.liesenberg@udesc.br)

The performance of the Environmental Military Police (PMA) in monitoring and applying the environmental legislation includes the prevention, combat and control of practices that cause environmental damage. This study aimed to diagnose the environmental infractions that occurred in the northern region of the state of Santa Catarina from 2014 to 2016. It was possible to show that the PMA's efforts should be directed to fight the environmental violations regarding the damage caused in native vegetation without authorization from the competent environmental authority, in the activity of maintaining birds in captivity and in the functioning of potentially pollutant activities or establishments that do not have a license of the competent environmental agencies, to ensure the protection and preservation of the fauna and flora in the northern region of the State of Santa Catarina (Brazil).

\section{A tale of two squirrels: exploring the conflict arising from efforts to conserve and control}

\section{Mike Dunn ${ }^{1}$, Mariella Marzano ${ }^{1}$, Jack Forster ${ }^{2}$}

${ }^{1}$ Forest Research, Roslin, United Kingdom; ${ }^{2}$ Forest Research, Farnham, United Kingdom (michael.dunn@forestresearch.gov.uk; mariella.marzano@forestry.gsi.gov.uk; jack.forster@forestry.gsi.gov.uk)

Impacts of the non-native, invasive grey squirrel (Sciurus carolinensis) on broadleaf woodlands and red squirrel (Sciurus vulgaris) populations are well recognised among the UK's foresters and conservationists. In response, wildlife managers, landowners and volunteers dedicate substantial time and resources to controlling the species across its expanding range. However, attempting to eradicate one species in order to conserve another is controversial, particularly when the targeted species has been prevalent in gardens, parks and the countryside for decades, as is the case for the UK's grey squirrels. Drawing on survey responses from the general public and interviews with those participating in red and grey squirrel management, we seek to understand the underlying factors which give rise to the controversy surrounding grey squirrel control. Specifically, we contrast the orthodoxy of the grey squirrel as a pest species with the perceptions of the wider public, many of whom neither recognise nor experience the species' negative impacts. Additionally, we assess the relative acceptability of management methods, and examine how their attributes and application can lead to certain approaches being regarded as more (or less) contentious than others. Finally, we highlight how conflicts around squirrel management manifest and propose a number of actions that can help to reduce tensions among those with starkly different values. We contend that these findings are pertinent to other wildlife management conflicts, particularly when dealing with charismatic species or contested notions of so-called pests.

\section{Moose or spruce: Systems analysis for managing conflicts between wildlife, forestry, and society in Sweden}

Oskar Franklin ${ }^{1}$, Andrey Krasovskii ${ }^{1}$, Dmitry Schepaschenko ${ }^{1}$, Sylvain Leduc ${ }^{1}$, Anton Platov ${ }^{1}$, Florian Kraxner ${ }^{1}$

1IIASA, Laxenburg, Austria (franklin@iiasa.ac.at; krasov@iiasa.ac.at; schepd@iiasa.ac.at; leduc@iiasa.ac.at; platov@iiasa.ac.at; kraxner@iiasa.ac.at)

Sweden has the world's highest density of moose. Moose is not only a valuable game species, it also causes forest damages and traffic accidents. To avoid moose browsing, foresters respond by planting spruce to an extent that reshapes the forest landscape with impact on both production and biodiversity. To address this problem and maintain a healthy moose population in balance with the other interests, an adaptive management based on the knowledge and experiences of local hunters and landowners is advocated. However, the different stakeholders do not agree on what is an appropriate moose population, which leads to conflicts that are hard to resolve. A key problem is that it is very difficult to encompass and foresee long term consequences of different options for moose hunting and forest management. This makes it challenging to form coherent strategies that integrate different sectorial interests at a national level. To address this issue we have developed a systems analysis framework for integrated modeling of the moose population, forestry, and their interactions and consequences for biodiversity and traffic accidents. We analyze the short and long term consequences for multiple scenarios of moose hunting and forest management. Based on the results we elucidate and quantify the trade-offs and possible synergies between moose hunting, forest production, biodiversity and the risk of traffic accidents. This analysis will be used to support better informed and more constructive discussions among the stakeholders in the Swedish forest sectors, and to support policies for long term sustainable forest and moose management. 


\section{Deer and forest management in Hokkaido, Japan: roles of recreational hunting and culling by forest managers to reduce forest} damage

Nobuhiro Akashi ${ }^{1}$

${ }^{1}$ Hokkaido Research Organization, Forestry Research Institute, Hokkaido, Japan (akashi-nobuhiro@hro.or.jp)

The sika deer population in Hokkaido, Northern Japan, increased during the second half of the 20th century and caused various problems, such as damage to forests and agriculture, degradation of natural vegetation, and collisions with vehicles. Hunting regulations have been changed since the 1990s to increase the number of deer culled by hunters. Since 2004, there has been no limit on the number of female deer a hunter can take each day during hunting season, but the deer population continued to increase until around 2010. In 2013, a new subsidy from the national government to local hunters was introduced, and the deer population began to decrease. I evaluated the current impact of deer on forest regeneration and estimated deer density using a distance sampling method in a forest managed by Hokkaido government in two neighboring municipalities, and also interviewed representatives of local hunting associations in each municipality. The estimated deer density in November was $8 \mathrm{deer} / \mathrm{km}^{2}$. This is still too high for hardwood species. One of the two representatives of the local hunting associations stated that hunting is a recreational endeavor for hunters, while the other emphasized that hunters should play a role in controlling local problems. Recently, hunters have been shooting deer around farmland for almost the entire year to get the subsidy, and this has led to a decrease in recreational hunting in forests. Culling by forest managers is necessary to maintain hardwood trees, but it costs more than the income obtained from forest management.

\section{Managing conflict through shared values in the New Forest, England}

Helen Dancer ${ }^{1}$

${ }^{1}$ University of Sussex, Brighton, United Kingdom (h.e.dancer@sussex.ac.uk)

This paper explores local forest values and governance in England's most extensive ancient forest landscape - the New Forest. The New Forest's international and national importance lies in its natural and cultural heritage - a mosaic of habitats, high biodiversity and ancient commoning practices. The legal origins of commoners' rights predate the Forest's establishment as a Royal Forest by William the Conqueror in c.1079. Conflicts between the interests of the Crown and commoners spanned centuries. In recent decades, the importance of conservation and recreation has generated new challenges and tensions between Forest stakeholders and shifted governance priorities and values, most recently with the Forest's designation as a National Park in 2005. The New Forest now has the most complex legal frameworks and governance structures of any forest in the UK. This paper draws upon extensive fieldwork conducted by the author in the New Forest between 2018 and 2019, exploring the legal and cultural dimensions of human-forest relationships in practice. The paper takes as its focus the priorities and approaches of the Forest's key governance bodies - the Court of Verderers, Forestry England, Natural England and the National Park - the values they embody, and their management of conflict and disputes in the Forest. The paper explores the relationships and significance of shared values between the statutory bodies, the local community and wider public, towards ensuring effective forest governance and conflict management.

\section{Value orientations of prospective forest, nature and wildlife management professionals}

Christian Gamborg ${ }^{I}$, Sofia Stamati ${ }^{1}$, Frank Søndergaard Jensen ${ }^{1}$

${ }^{1}$ University of Copenhagen, Copenhagen,Denmark(chg@ifro.ku.dk; cqb859@alumni.ku.dk; fsj@ign.ku.dk)

Values underlie our attitudes, and attitudes in turn might predict our behavior. While values cannot be observed directly, value orientations are more numerous and may be seen as an expression of values. This study examined value orientations among prospective forest, nature and wildlife management professionals in Denmark - that is students at five MSc study programs at the University of Copenhagen enabling them to a professional career. We focused on value orientations towards wildlife and used a US developed survey instrument on Wildlife Value Orientation types ('utilitarian', 'mutualist', 'pluralist', 'distanced') delivered via an Internet-based questionnaire in $2018(n=180)$. The majority of prospective management (and policy) professionals were mutualists as general orientation. However, Forest and Nature Management respondents were more utilitarian than other study programs, and females among the five study programs were more mutualist oriented than males. As a whole, prospective professionals were more mutualist oriented than stakeholders such as hunters and landowners (found to be notably utilitarian) and more mutualist oriented compared to members of the general public (found to be especially distanced). Information about forest, nature and wildlife management professionals' value orientations can be used to check on, or anticipate potential differences in value orientation viz a viz stakeholders and the public in general. Whether professionals or the public should adjust their values is an open question. Nevertheless, knowledge about value orientations can be helpful in improving communication and limit potential conflicts. Future studies should explore value orientations of accomplished forest, nature and wildlife management professionals.

\section{D6b: FOREST AND ECOSYSTEM SERVICES IN CITIES: ACHIEVEMENTS AND} EXPECTATIONS

\section{Providing environmental, economic and health benefits through nature-based solutions across cities: the case of the progireg project}

Giuseppina Spano $^{1}$, Vincenzo Giannico ${ }^{1}$, Mario Elia ${ }^{1}$, Giuseppe Colangelo ${ }^{1}$, Raffaele Lafortezza ${ }^{1,2}$, Giovanni Sanesi ${ }^{1,3}$ ${ }^{1}$ Department of Agricultural and Environmental Sciences, University of Bari, Bari, Italy; ' ${ }^{2}$ Department of Geography, University of Hong Kong, Hong Kong, China; ${ }^{3}$ SISEF - Società Italiana di Selvicoltura ed Ecologia Forestale, Viterbo, Italy (giuseppina.spano@uniba.it; vincenzo.giannico@uniba.it; mario.elia@uniba.it; giuseppe.colangelo@uniba.it; raffaele.lafortezza@uniba.it; giovanni.sanesi@uniba.it)

ProGIreg (productive Green Infrastructure for post-industrial urban regeneration) is an EU-funded H2020 project that seeks to implement eight nature-based solutions (NBS) in four "front runner cities" in Europe and China for their replication in five "follower cities" in Europe. The overarching goal is to embed business models stamming from the project outcomes into urban planning through the assessment of social, economic, environmental and health benefits resulting from each NBS at city, district and "Living Lab" level where the NBS will be realized. Examples of NBS to be implemented are: renaturing landfill sites; regenerated soil for urban farming; community-based urban gardening; and accessible river corridors. A preliminary baseline evaluation has been conducted on indicators of socio-cultural inclusiveness, human health and wellbeing, ecological and environmental restoration as well as economic and labor market benefits. At present, the implementation and monitoring of specific NBS are under way. The second phase of proGIreg will involve the assessment of short-term NBS benefits; the following results are expected: a) positive impact on physical health and wellbeing, local identity and community cohesion; b) 
reduction of inequality, social exclusion and criminality; c) accountability and stewardship of the environment by the local community; and d) eradication of marginalization and poverty for residents and immigrants in deprived urban neighborhoods. The effectiveness of active collaboration among citizens, NGOs, political authorities, research institutions and the private sector to address the social, economic and environmental challenges in today's post-industrial urban society will be investigated.

\section{The hidden benefits of urban trees enjoyed by local communities}

Alan Simson ${ }^{I}$

${ }^{1}$ Leeds Beckett University, Leeds, United Kingdom (a.simson@leedsbeckett.ac.uk)

The benefits that trees can bring to urban areas have been known for a long time, but it was only with the advent of the concept of urban forestry in the latter years of the 20th century, and the resulting research into the potential benefits of urban forestry that has subsequently taken place, that the very broad spectrum of these benefits has been established and quantified. Without a doubt, trees and woodlands have the potential to play a significant role in the viability and experiential quality of our urban environments, and thus urban forestry has increasingly gained political traction in many towns and cities around the world, improving the health and well-being of their citizens as a result. It could be argued however that Urban Forestry Strategies have all too often centred upon promoting a fairly narrow spectrum of scientific benefits, which have not always convinced local communities. This presentation will suggest that a broader perspective is required when promoting urban forestry and engaging with local communities, a perspective that takes into consideration the deep psychological and emotional ties that people have with their urban forests. It will cite a case study from the City of Sheffield in the UK, where the City Council started to fell thousands of streets trees, falsely claiming that they were 'dangerous, dying, diseased, dead or damaging', which resulted in a violent community uprising. As a result, the UK Government has recently announced plans to give communities a greater say in protecting their local trees.

\section{Nature-based solutions for restoration of urban ecosystems in Portugal}

Thomas Panagopoulos ${ }^{1}$, Dulce Antunes ${ }^{1}$, Ana Paula Barreira ${ }^{1}$, Luis Loures ${ }^{2}$

${ }^{1}$ University of Algarve,Faro,Portugal; ${ }^{2}$ IPP, Elvas, Portugal (tpanago@ualg.pt; mantunes@ualg.pt; aprodrigues@ualg.pt; luisloures@gmail.com)

Unsustainable, non-resilient urbanisation and neglect of urban areas have caused the fragmentation, depletion and destruction of habitats, biodiversity loss and the degradation of urban ecosystems and their services. Restoring urban ecosystems through nature-based solutions (NBS), is necessary to enhance ecosystem resilience and adaptive capacity to cope with the effects of climate change and to enable ecosystems to deliver their services for more liveable, healthier and resilient cities. The main objective of the study is to co-create with stakeholders and informed citizens the development and implementation in demonstration areas as "living laboratories", of innovative, replicable, and locally adapted NBS for inclusive urban regeneration. The study aim to develop smarter, environmentally just, inclusive, resilient and increasingly sustainable societies through nature-based innovation jointly created by and for people. The project's ambition is to reassess the role and responsibility of local government to facilitate co-design and co-creation within an innovative socially engaged, citizen-driven paradigm. A range of local actors were engaged, including local authorities, planners, designers, landscape architects, private business (the tourism sector), the voluntary sector (associations representing deprived communities and particular social groups), to design and take responsibility for sustainable future cities emphasizing NBS. The approach will be demonstrated in Faro and Elvas, Portugal and upscaled to the city Masterplan representing a variety of urban regeneration contexts and issues. Specific objectives were to design NBS for restoration and rehabilitation of urban ecosystems at a derelict industrial site of Faro and to develop a sustainable city Masterplan that systemically embeds and integrates NBS.

\section{Legislation for urban green space management in Democratic People’s Republic of Korea}

Mi Sun Park ${ }^{1}$

'Seoul Natioal University, Pyeongchang, Republic of Korea (mpark@snu.ac.kr)

Democratic People's Republic of Korea (DPRK) faces a problem of deforestation and forest degradation. DPRK has established and implemented greening policies in rural and urban areas. In particular urban greening policies have been emphasized for two decades. Urban greening policies include management of ecosystem services including provisioning, regulating, supporting and cultural services. This study focuses on legislation for urban green space management in DPRK. In this research, the relevant legal texts about urban green space management were collected and analyzed including, the Forest Act, the Act of Urban Green Space, the Act of Urban Planning, the Act of Urban Management. The legislation includes the principles of building and protecting urban green spaces, management of urban greening projects and the plan of urban greening. The contents were analyzed focusing on ecosystem services. The results were compared with Vietnamese legislation for urban green space management including the Urban Planning Law and the Decree of Urban Plant Management. Both DPRK and Vietnam emphasize green space management in urban planning. Their approach reveals integrated approach between forestry and urban sector. In conclusion, the research findings do contribute to a better understanding of legal systems for urban green space management in DPRK. It can be expected that the research findings contribute to modifying legislation for urban green space management towards urban sustainability in DPRK.

\section{Ecosystem services of urban forest: development of a forest education strategy for students of secondary level in Colombia}

Diana Patricia Morales Epinosa ${ }^{1}$, Liz Villarraga ${ }^{1}$

${ }^{1}$ Universidad Distrital Francisco José de Caldas, Bogotá, Colombia (dpmoralese@gmail.com; lizv@udistrital.edu.co)

Educational institutions should find strategies that serve to promote and accomplish the Sustainable Development Goals (SDG); among all of the aspect to consider, citizens of urban areas need to be awarded all of the conflicts that may cause urbanization and all the benefits that urban green areas provided. This is a longitudinal study aims to assess secondary level students' changes in perception about the ecosystems services of urban forest after receiving a 6-month module of forestry classes. The experimental sample population consists of 126 students of grades eighth and ninth of a private secondary school in Bogotá Colombia, and the control group consists of 126 students of same grades and of the same institution. An instrument of 38 statements is applied in three times, before the classes, after the classes, and six months later. The module or intervention is composed of three sections: 1) general concepts about urban forest ecosystem services and their relation to the SDGs, 2) applied projects where students will relate those concepts with their surroundings, 3) visual representation (infographic) of their learning. This is a work in progress, the first application of the instrument is completed and classes will be finished by July 2019 . We will use non-parametric statistical test Mann Whitney and Wilcoxon sign rank tests, along with Cronbach alpha. The final goal of this study is twofold, to sensibilize young students about the importance of green areas in the cities, and to develop a forest education program that can be applied in other schools. 


\section{Governing for urban forest resilience: the Canadian experience}

Cecil Konijnendijk $k^{1}$, Lorien Nesbitt, Zach Wirtz ${ }^{1}$

'University of British Columbia, Vancouver, Canada (cecil.konijnendijk@ubc.ca; lorien.nesbitt@ubc.ca; wirtzz@mail.ubc.ca)

Knowledge about urban forest governance is still limited in many countries, especially in the case of medium-sized, lower-profile cities. This research analyses urban forest governance in selected medium-sized cities in Canada in order to identify success factors and promising governance arrangements that foster resilience in the context of climate change and urbanization. Policy analysis, semi-structured interviews with key governance actors, and focus group discussions were carried out in four case study cities. Surrey (BC) and Oakville (ON) are both recognised for their successful urban forestry programs. Both cities are situated in a larger metropolitan area with dominant 'first cities' (Vancouver and Toronto, respectively), which leads to both challenges and opportunities. Fort McMurray (AB) and Prince George (BC) are 'stand alone' cities in rural areas that have both faced recent major urban forest loss due to devastating wildfire and mountain pine beetle infestation, respectively. Initial findings show that urban forest governance in the cities has changed over time in terms of governance arrangements, leading discourses, actors and alliances involved, the 'rules of the game' set for governance, and the power and resources mobilised by actors. Where Surrey and Oakville developed comprehensive governance in the face of rapid urban development, governance in Fort McMurray and Prince George was challenged due to climate change calamities and related changed discourses, but also saw new opportunities due to involvement of a wider range of actors and interests. Study findings can be used to inform urban forest governance and resilience planning in Canada and internationally.

\section{The national strategy for urban green space: Italy as case study}

Marco Marchetti ${ }^{1}$, Lorenzo Sallustio ${ }^{2}$, Giovanni Santopuoli ${ }^{1}$

${ }^{1}$ Università degli Studi del Molise, Campobasso, Italy; ${ }^{2}$ Università degli Studi del Molise, Pesche, Italy (marchettimarco@unimol.it; lorenzo.sallustio@unimol.it; giovanni.santopuoli@unimol.it)

Recently the Italian Ministry for the Environment, Land and Sea Protection, adopted the National Strategy for Urban Green Space. The Strategy assigns to urban forests a central role as providers of goods and ecosystem services that are essential for human welfare and the climate change mitigation. The strategy aims to promote the conservation of biodiversity and the provision of ecosystem services, to mitigate climate change and to improve the quality of life through communication programmes, planning activities and monitoring. In this study we present a clustering approach that classify the municipalities, according to territorial homogeneity and population density, in order to support decision makers in planning activities for reaching the aims of strategy. Six clusters were defined considering urban forms (monocentric versus sprawl), primary infrastructures, population density and the ecoregions. Results show that more than $50 \%$ of municipalities present a good condition and only actions aimed to improve the ecological connectivity between urban forests and other green spaces are necessary. Significant interventions, such as the implementation of green belt, are necessary in $43 \%$ of municipalities in order to improve not only the ecological connectivity but also to promote the provision of ecosystem services. Finally, for the cities with high population density (3\% of total), it is strongly necessary to introduce green belt or other green spaces in order to accomplish the strategy aims. In this case it is strongly important to consider also the surrounding little municipalities which can play an important role to support the human wellbeing.

\section{The ages of ecosystem services: an historical dialogue between cities and forests}

\section{Fabio Salbitano ${ }^{1}$}

${ }^{1}$ University of Florence, Firenze, Italy (fabio.salbitano@unifi.it)

Ecosystem services refer to a relatively new concept, popularized after 2000 and very often associated to urban societies. No doubts that trees and forests are a key provider of ecosystem services in Anthropocene. But can we associate the concept of ecosystem services along the history of human societies particularly focusing on the urban adventure? Which kind of relationships cities in different cultural/environmental contexts had with forest and trees? Is it useful to apply the Ecosystem services framework to understand the significance of this relationship and what can we learn from the past for the future? Since the dawn of permanent proto-urban settlements forest and trees accompanied cities in their trajectory of development as favourite living places for human communities. A controversial but often reciprocal relationship. Nevertheless, by adopting the ecosystem services concept as key factor of interpretation, we could try to trace back and highlight the changing role of forest and trees during cities development process. By using primary sources, historical and archeological evidences, narratives, iconography, and oral history approaches, the research focuses on qualifying and quantifying the changing interactions between forests/trees and urban communities. From the Age of Dependance to the Age of Otherness, we tried to stress a periodization of behaviours and associated benefits (identified as ecosystem services ante litteram) that city dwellers felt and attributed to forest and trees. The periodization was filtered through the prepositional declination of forest/city relationships, i.e. forest in/around/of/for/with/without/versus the cities.

Preliminary assessment of green areas of Politecnico Campus, to develop an urban forestry plan for the UFPR campi / Avaliação preliminar de áreas verdes do campus centro politécnico, para a elaboração do plano de arborização dos campi da UFPR

Carla Maria Camargo Corrêa ${ }^{1}$, José Elias Emellek ${ }^{2}$, Rodrigo Dall"agnol Trompczynski ${ }^{1}$, Leonardo Rogal ${ }^{1}$, Vitória Maria Bisewski ${ }^{1}$, Priscila Caldas ${ }^{1}$ ${ }^{1}$ Universidade Federal do Paraná, NIMAD, Curitiba, Brasil, ${ }^{2}$ Universidade Federal do Paraná, Curitiba, Brasil (cmcamargocorrea@gmail.com; eemellek@yahoo.com.br; rtrompczynski@gmail.com; leonardorogal98@gmail.com; vibisewski@gmail.com; priscilacaldass@gmail.com)

A falta de planejamento e de manejo das áreas verde dos campi da UFPR vem causando diversos problemas em edificações, nos sistemas de infraestrutura, nas pavimentações do sistema viário, causadas por raízes de árvores, além da interferência de galhos nas redes de energia elétrica, entupimento de calhas e danos às coberturas, causados por quedas de folhas e grimpas nas edificações próprias e de terceiros e principalmente a disseminação descontrolada de espécies exóticas invasoras nos campi. Os problemas acima relacionados tem trazido uma série de consequências à UFPR, seu patrimônio, seus usuários e a terceiros como: aumento significativo nos custos de manutenção das edificações e dos sistemas de infraestrutura e viário, risco de queda de energia e acidentes graves com as redes elétrica, infiltrações e vazamentos de grandes proporções nas edificações da instituição, restrição à implantação de novas edificações nos escassos terrenos livres da UFPR, devido ao plantio de árvores sem planejamento e redução da biodiversidade das comunidades vegetais nativas em áreas de preservação internas e vizinhas da UFPR, devido à proliferação de espécies exóticas invasoras além de senescência acelerada de árvores devido à falta de manejo. Visando reduzir os problemas apresentados, a UFPR vem elaborando um plano de arborização para seus campi, que deverá contemplar os campi: Centro Politécnico, Setor de Ciências Agrárias e Jardim Botânico. Os dados apresentados representam a fase de diagnóstico do plano, no Centro Politécnico, onde foram inventariadas 4335 árvores, sendo que 69 \% das espécies amostradas são exóticas, em grande parte invasora ou com potencial. 


\title{
Eyes on the trees: forest health monitoring at a 'human' level
}

Michelle Cleary ${ }^{1}$, Johanna Witzell ${ }^{1}$

'Swedish University of Agricultural Sciences, Alnarp, Sweden (michelle.cleary@slu.se; johanna.witzell@slu.se)

Citizen Science (CS) has taken a big leap forward from the traditional volunteer engagements in science. Some of the biggest global societal challenges like global warming and invasive species can only be resolved through a better recognition of the 'shared responsibility' in society, outside of the regular 'blamed' players (industries or sector trades). The power of CS allows for capacity building in society, foster learning, promote networking among public stakeholders and better exchange of information between the public and the scientific community. CS can play an important role in forest health monitoring allowing for better spatial and temporal resolution of data capture of new and emerging threats which can then alert a decision response for control actions to be taken. Many polices dealing with invasive alien species (IAS) stress the importance of raising public awareness and commitment to own part of the problem such that it will encourage private efforts and voluntary compliance, and influence behavioral changes in stakeholders, decision makers (politicians) and citizens (consumers) who often play a role in the movement of IAS. However there are many challenges to gathering information when it comes to e.g. data flow, ensuring effective engagement, and quality of the data that is received. Relevant EU COST Action networks in CS including "ALIEN CSI: Increasing understanding of alien species through citizen science" aim to explore possibilities to establish a European-wide CS IAS network that will among other things, help inform decisionmaking and implementation of requirement for compliance to the EU regulations on IAS.

\section{Methods of public engagement in forest health research}

\section{Joseph Hulbert}

${ }^{1}$ Forestry and Agricultural Biotechnology Institute, University of Pretoria, Pretoria, South Africa (joey.hulbert@fabi.up.ac.za)

Recognition of the value of non-scientist participation in research is increasing and stimulating the application of citizen science approaches in many fields of ecology. For example, the benefit of enhanced sampling capacity has led to the inclusion of many non-scientists in projects that monitor forest pest outbreaks and disease epidemics. However, each of these projects generally engage citizens through different methods. Many projects are collection based, inviting nonscientists to submit physical samples (e.g. soil, plant tissues, insects, etc.) and other projects invite citizens to share observations online, or some mixture of both. Projects also vary in their provisions of sampling equipment (sampling-kits or recycled household materials) and the platforms of their online environments (grassroots or pre-existing applications). Determining the appropriate methods also depends on the desired complexity of the experimental design and the target group of participants. In general, whether citizens are participating in a collection-based microbiome study or monitoring for a specific insect pest, there are many methods to consider. The objective of this presentation is to review the approaches used by many of the forest health based citizen science projects internationally and to provide recommendations for those interested in engaging the public in their research programs.

\section{Observatree: the evolution of a citizen science programme as a contribution to a tree health early warning system for Britain \\ Chris Quine (D), Peter Crow ${ }^{2}$, Jake Morris ${ }^{3}$ \\ ${ }^{1}$ Forest Research, Edinburgh, United Kingdom; ${ }^{2}$ Forest Research, Farnham, United Kingdom; ${ }^{3}$ Department for Environment, Food and Rural Affairs, Defra, London, United Kingdom (chris.quine@forestresearch.gov.uk; peter.crow@forestresearch.gov.uk; jake.morris@defra.gov.uk)}

We describe the development and operation of Observatree, a citizen science programme which has mobilised and trained a network of volunteers to look out for pests and diseases and so contribute to a tree health early warning system. The programme was initiated in response to growing concern over the rise of new pests and diseases in British woodlands and was developed with support from EU LIFE funding by a consortium of seven partners spanning governmental and third sector organisations. The partnership has proved robust and a second phase of the programme, beyond the initial funding, has been progressed. We review the lessons of the first Phase, how observations were targeted on specific pests and diseases, the data collected and the evaluation of volunteer motivations and responses. We introduce the range of training materials developed, and the data collection processes that have evolved. Steps have been taken within the second phase to enhance both the volunteer experience and the quality of the data made available for early warning including through the use of sentinel trees and null reports. The programme design, and activities requested of the citizen scientists has evolved over time. In particular, it has to strike a balance between engagement and awareness raising, and the provision of scientifically robust data. We summarise the rationale for the current mix of volunteer activities and identify prospects for further improvement.

\section{Dissecting a successful Citizen Science program and increasing buy-in from professionals}

\author{
Matteo Garbelotto ${ }^{1}$ \\ 'University of California, Berkeley, USA (matteog@berkeley.edu)
}

The Sudden Oak Death (SOD) Blitz program enlists over 500 volunteers yearly to monitor the spread across California of the exotic forest disease SOD, and ranks as one of the oldest Citizen Science programs in the world focused on tree diseases. Here, we present results of questionnaires filled out by participants during the 12 year-long program, to compare answers across different regions, years, and professional background of participants. We also compare answers from SOD blitzes with answers provided in similar questionnaires handed out during informational non-citizen science programs. The main aims of this "exercise" were to: 1)-Identify motivational drivers unique to volunteers participating in Citizen Science; 2) Compare and contrast answers between more and less successful SOD Blitzes, where success is determined by number of participants and number of trees surveyed, and; 3) Determine whether some participants contribute more than others, and "profile" them. Results highlight motivational drivers of citizen scientists, and identify participants significantly more committed to Citizen Science than the average volunteer. Often, this subset comprises skilled workers in the sector and professionals. Although we show that participation in ad hoc trainings results in equal proficiency across all SOD Blitz volunteers, scientific returns from skilled volunteers can be significantly higher. Based on this information, we launched a program dedicated to skilled professionals in the "art" and profession of tree care: we briefly describe the program and rename Citizen Science aimed at professionals wanting to elevate their "art" to a science, as "Artisan Science". 


\section{Validating maps of land cover and land degradation with citizen science and mobile gaming}

Inian Moorthy ${ }^{1}$, Neha Joshi ${ }^{1}$, M Thoha Zulkarnain ${ }^{2}$, Andree Ekadinata $^{2}$, Tobias Sturn ${ }^{1}$, Fathir Mohamad $^{3}$, Bunga Goib $^{3}$, Ping Yowargana $^{1}$, Olha Danylo ${ }^{1}$, Ian McCallum ${ }^{1}$, Florian Kraxner ${ }^{1}$, Linda See ${ }^{1}$, Steffen Fritz ${ }^{1}$

${ }^{1}$ International Institute for Applied Systems Analysis (IIASA), Laxenburg, Austria; ${ }^{2}$ World Agroforestry Centre (ICRAF), Bogor, Indonesia; ${ }^{3}$ World Resources Institute(WRI),Jakarta,Indonesia (moorthy@iiasa.ac.at; joshin@iiasa.ac.at; m.zulkarnain@cgiarorg; a.ekadinata@cgiarorg; sturn@iiasa.ac.at; fathir.mohamad@wri.org; bunga.goib@wri.org;yowargan@iiasa.ac.at; danylo@iiasa.ac.at; mccallum@iiasa.ac.at; kraxner@iiasa.ac.at; see@iiasa.ac.at; fritz@iiasa.ac.at)

Peatland comprises around $24 \%$ of South Sumatra, a province on the island of Sumatra in Indonesia. Following catastrophic fires in 2015 , peat restoration has become a priority for this area. To identify candidate areas for restoration, both land cover over time and land degradation have been mapped using optical and radar remote sensing. Limited field data have been used to help validate these maps but more validation data are still needed. One way to fill this gap is to tap into the power of citizen science, which has become an emerging area of interest. In citizen science, any member of the public can take part in scientific research, whether this is through data collection, analysis of the data or hypothesis generation. Here we present the results from a citizen science campaign using the Urundata mobile gaming application, which has been developed as part of the Restore+ project. Urundata has two main components: a rapid image assessment tool that allows users to classify satellite imagery by the type of land cover/land use visible or to examine pairs of images for detection of change over time (developed from an application called Picture Pile). The second component sends users to specific locations on the ground via a mobile device and asks for information related to land cover and evidence of land degradation (developed from an application called FotoQuest Go). Together these two components have been used to help validate land cover and land degradation maps of South Sumatra through citizen science.

\section{P-FOR INIA: a smartphone app for pest management and reporting sanitary issues in commercial forestry}

Sofia Simeto ${ }^{1}$, Gonzalo Martínez ${ }^{1}$, Demian F. Gómez ${ }^{2}$, Gustavo Balmelli ${ }^{1}$

${ }^{1}$ INIA, Tacuarembó, Uruguay; ${ }^{2}$ University of Florida, Gainesville, USA (ssimeto@inia.org.uy; gmartinez@inia.org.uy; demiangomez@ufl.edu; gbalmelli@inia.org.uy)

TICs can be a great ally to deal with the global increase in pest and disease invasions in forestry, providing tools for early detection of health issues and allowing the deployment of management strategies. The pest and disease recognition smartphone app P-FOR INIA, has been available for 4 years for foresters, students and general public. Here we assess its potential as a tool for early alert of new sanitary issues in commercial plantations. The app contains a library, a symptom key, and a query module. The latter enables users to take georeferenced pictures and post a query about the observed signs, symptoms or organisms. The queries are sent to a central database and answered by a group of forest health experts. This tool allows incidental data collection on distribution and seasonality of key forest pests and diseases. In the last year, a new strategy for involving forester in data collection via directed requests was implemented. By using push messages via the app, we asked the users to look for particular signs or symptoms. This has proven useful to locate local pest resurgence for the release of biological control agents. We are also working on the integration of the data collected by P-FOR INIA into phytosanitary official databases.

\section{Citizen science in a common garden: one pine at a time}

Ethan Bucholz ${ }^{1}$, Jared Swenson ${ }^{1}$, Ehren Moler ${ }^{1}$, Mike Chizhov $^{2}$, Ella Colella ${ }^{3}$, Lara Schmit $^{3}$, Julia Hull $^{1}$, Emily Musta , Amy Whipple $^{1}$, Kristen Waring ${ }^{1}$ ${ }^{1}$ Northern Arizona University, Flagstaff, USA; ${ }^{2}$ Grand Canyon Trust, Flagstaff, USA; ${ }^{3}$ Northern Arizona University: Southwest Experimental Garden Array, Flagstaff, USA; ${ }^{4}$ FlagstaffHigh School,Flagstaff,USA (eb692@nau.edu; jks383@nau.edu; erm287@nau.edu; michael.chizhov@gmail.com; ella.colella@ nau.edu; lara.schmit@nau.edu; julia.b.hull@gmail.com; emusta@fusd'.org; amy.whipple@nau.edu; kristen.waring@nau.edu)

Climate change and pests threaten native conifer species globally. Our research group incorporated citizen science volunteers in a large-scale common garden experiment studying climate adaptation in southwestern white pine (Pinus strobiformis). Citizen scientists have gathered phenological and morphological data on over 20,000 P. strobiformis seedlings planted in three elevationally-varied common gardens on the north rim of Grand Canyon, Arizona. This large-scale ecological research enables a better understanding of climate adaptation in P. strobiformis, while also facilitating crucial networking opportunities between scientists and the general public. Through collaboration with researchers at Northern Arizona University (NAU), a local nonprofit called Grand Canyon Trust (GCT), Flagstaff High School, and infrastructure provided by the Southwestern Experimental Garden Array (SEGA), our team has generated detailed, meaningful data sets and created lasting community connections. Further involvement with undergraduate coursework at NAU provides undergraduates authentic experiences with field research and data analysis. NAU researchers assisted high school students in the development of their own common garden, serving as a study system for multiple senior research projects. Our partnership with the GCT has provided additional opportunities for high-school students, as well as interested citizen volunteers, to gain field experience while enabling researchers to develop effective strategies for communicating with broad audiences. Using preliminary data, we discuss the benefits and difficulties in creating meaningful partnerships, relying on citizen science volunteers, and incorporating educators and underrepresented youth in climate change research with emphasis placed on the value of collaborative science for the promotion of meaningful STEM opportunities.

\section{Citizen science and tree health assessment: how useful are the data?}

Richard Hallett ${ }^{1}$

${ }^{1}$ USDA Forest Service, NYC Urban Field Statio, Bayside, NY 11359, USA (rhallett@fs.fed.us)

Emerald ash borer (Agrilus planipennis) has killed millions of trees in the United States. Community managers face treatment or removal decisions for all publicly owned ash (Fraxinus spp.) trees. These decisions are based on the overall condition of each tree. In this study, the U.S. Forest Service trained a Boy Scout troop in Oconomowoc, Wisconsin, U.S., in a tree health assessment protocol that used rubrics designed to measure physiological stress symptoms. The city provided tree inventory data, which included the location of 316 city-owned ash trees. After a two-hour training session, the Scouts and adult leaders assessed all ash trees in August 2015. A tree health expert re-assessed 20\% of the trees. The protocol measured diameter at breast height and included a suite of tree stress assessment variables. Researchers used a five-class system for defoliation, leaf discoloration, and overall vigor. Fine-twig dieback was estimated in 5\% classes. Digital photographs were taken and automatically processed so as to measure percent crown transparency. Expert/volunteer agreement for diameter at breast height was within $2.5 \mathrm{~cm} 92 \%$ of the time; defoliation, discoloration, and vigor were within two classes $100 \%$, $93 \%$, and $92 \%$ of the time, respectively. Crown dieback estimates were within $10 \%$ of each other $76 \%$ of the time, and transparency estimates were within $15 \%$ of each other $76 \%$ of the time. Researchers calculated an overall stress index value and ranked the trees from lowest to highest stress. The volunteer-generated data enabled Oconomowoc to make science-based management decisions for its infested ash trees. 


\section{Silvalert: reporting forest damages in South West Europe}

Sarah Yoga ${ }^{I}$, Christophe Orazio ${ }^{\prime}$, Eduard Mauri ${ }^{\perp}$

'European Forest Institute, Cestas, France (sarah.yoga@efi.int; christophe.orazio@efi.int; eduard.mauri@efi.int)

Forest ecosystems occupy more than 30\% of the land area in South West Europe. Forests in France, Portugal, and Spain are vulnerable to the increasing occurrence of biotic and abiotic hazards. Forest hazards can cause important and complex damages visible even beyond administrative borders. The risk of occurrence of multiple forest hazards has remained high for the past years requiring an on-going surveillance program by local forest authorities. Collecting field data on a regular basis is, however, cost-demanding. Participatory observations can help improve and diversify data collection. Silvalert is a mobile application that has been designed to report forest damages caused by diverse hazards. It is an open access application that can be downloaded after registration. The application has a simple user-friendly interface built to geolocate and capture photos of an encountered forest damage. Forest users can create offline reports and provide information on the type, extent, or severity of a forest damage. The information can later be uploaded to a server when internet coverage/ signal is recovered. Reports are verified by the forest authorities who can use them as decision tools to determine for example, where to conduct extensive field surveillance. They are open access to the registered users who can visualize the type and extent of reported forest hazards which are currently prevailing at a European scale. Scientists can have an exhaustive access to all the reports and associated data.

\section{Non-scientist contributions to plant disease research in South Africa}

Joseph Hulbert ${ }^{1,2}$, Francois Roets ${ }^{2}$, Treena Burgess ${ }^{3}$, Michael J. Wingfield ${ }^{1}$

${ }^{1}$ Forestry and Agricultural Biotechnology Institute, University of Pretoria, Pretoria, South Africa; ${ }^{2}$ Department of Conservation Ecology and Entomology, Stellenbosch University, Stellenbosch, South Africa; ${ }^{3}$ Centre for Phytophthora Science and Management, Environmental and Conservation Sciences, Murdoch University, Murdoch, Australia (joey.hulbert@fabi.up.ac.za;fr@sun.ac.za; t.burgess@murdoch.edu.au; mike.wingfield@fabi.up.ac.za)

Cape Citizen Science (http://citsci.co.za) is a program in South Africa that engages the public in plant health research. Many non-scientists were engaged in the pilot study about the diversity and distribution of Phytophthora species in the Greater Cape Floristic Region, a biodiversity hotspot. Citizens collected samples from private properties, plant productions, botanical gardens, nature reserves, and national parks. The project also provided a platform for citizens to report unhealthy plants online. Multiple species of Phytophthora that were previously undocumented in South Africa and at least one novel species were recovered from their contributions. Online reports also revealed multiple potential novel plant-microbe interactions. Non-scientist engagement therefore increased the breadth of the sampling distribution and facilitated discoveries that would still be unknown without their participation. The results of the pilot study demonstrate that non-scientist engagement can be valuable and that there are many methods to engage the public in plant health research.

D6e: FOREST AND ECOSYSTEM SERVICES IN CITIES: ACHIEVEMENTS AND EXPECTATIONS

\section{Designing green public squares with suitable tree species for optimum ecosystem services}

Mohammad A Rahman ${ }^{1}$, Moser-Reischl Astrid ${ }^{\prime}$, Thomas Rötzer, Stephan Pauleit ${ }^{1}$

${ }^{1}$ Technical University of Munich, Germany,Freising, Germany(ma.rahman@tum.de; astrid.moser@lrz.tum.de; thomas.roetzer@lrz.tu-muenchen.de; pauleit@tum.de)

Greenspaces can moderate the effects of climate change and urbanization through the provision of ecosystem services (ES). However, due to high heterogeneity at micro-scales, there are still uncertainty concerning the magnitude, pattern and the process of mitigation. Over the last four years we continuously measured eco-physiological, dendrochronological, meteorological and edaphic variables along with the heat fluxes below and above canopy of contrasting tree species at different street canyons in Munich, Germany. Species characteristics leading to different growth patterns influenced shading and transpirational cooling with an decrease in air temperature up to $2{ }^{\circ} \mathrm{C}$ at the centre of the crown and around $1{ }^{\circ} \mathrm{C}$ at $1.5 \mathrm{~m}$ height from the ground. Trees with higher above and below ground growth also linearly increased the soil infiltration potential. Largely, ES were also dependent on various meteorological variables and below-canopy surfaces. Trees grown over paved surfaces and within narrow-street canyons provided lower boundary layer cooling and also hinder the wind flow; where grass meadows were more efficient. Conversely, on wider street canyons, trees in combination with grasses were more efficient. Overall, trees with less water demand and lower canopy density showed higher potential of cooling and runoff reduction once they are planted over grass surface than over built surfaces through the grass evapotranspiration and extended fine rooting system. However, there were trade-offs between different indicators for ES such as carbon gain and transpiration; number of trees and wind flow. Thus the study provided new insights on designing public squares and choice of species.

\section{Quantifying growth and ecosystem services of urban trees under present and future climate conditions}

Thomas Rötzer ${ }^{1}$, Mohammad Rahman², Hans Pretzsch ${ }^{1}$, Stephan Pauleit ${ }^{2}$

${ }^{1}$ Chair for Forest Growth and Yield Science, TU Münchenn, Freising, Germany; ${ }^{2}$ Chair of Strategic Landscape Planning and Management,TU München,

Freising, Germany (thomas.roetzer@lrz.tum.de;ga95pas@mytum.de; hans.pretzsch@lrz.tu-muenchen.de; pauleit@wzw.tum.de)

UN forecasts predict that in the year 2030 the urban population will amount to more than $60 \%$ of the global population and exceed six billion people in 2050 . Because of the increasing urbanization and along with the global climate change the climate of a city will be modified substantially. The urban green and especially urban trees can mitigate the negative effects of climate change by providing ecosystem services. These are among others the reduction of rainwater runoff, pollutant filtering, carbon storage, shading, or cooling by transpiration. The amount of the individual ecosystem services are closely associated with the tree species as well as with a tree's age, size, structure and vitality. By using the newly developed process based tree growth model CityTree growth and ecosystem services of individual trees, of the green of a city's square or of an entire city can be estimated. In a recent study tree growth and ecosystem services of the main tree species were simulated and analyzed for Central European cities both under current climate conditions and for climate scenarios. The simulations reveal that the urban green and urban trees can significantly improve the urban climate and mitigate climate change effects. The quantity of the improvements depends on tree species and tree size as well as on the specific site conditions. This way, urban green can contribute significantly to adapt cities to climate change. 


\section{Natural regeneration in the city: comparing plant recruitment dynamics in urban and rural forested natural areas}

Max Piana ${ }^{1}$, Steven Handel ${ }^{2}$, Myla Aronson ${ }^{1}$, Richard Hallett ${ }^{3}$, Steward Pickett ${ }^{4}$, Peter Morin ${ }^{1}$

${ }^{1}$ Rutgers University, New Brunswick, USA; ${ }^{2}$ Rutgers, University, USA; ${ }^{3}$ USDA Forest Service, New York City, USA; ${ }^{4}$ Cary Institute of Ecosystem Studies, Millbrook,USA(max.r.l.piana@gmail.com; steven.handel@rutgers.edu; myla.aronson@rutgers.edu; rahallet@gmail.com;

stapickett@caryinstitute.org; peter.morin@rutgers.edu)

Understanding the functional differences between urban and rural habitats is a critical focus for urban ecology theory and the basis for sustainable management of urban forested natural areas. While studies have observed suppressed recruitment of native woody species in urban forests, the ecological barriers to regeneration are not well understood and remain understudied. Here we present a conceptual framework for recruitment limitation in urban plant populations and the results from a three-year experiment comparing seed production, dispersal, seed predation, and early-establishment in urban and rural forests located in the greater New York City area. The findings from this experiment point towards functional shifts in ecological processes critical to natural regeneration, which may represent significant barriers to native plant recruitment. For example, we observed strong preference for seeds of native species and a deviation from the inter-annual patterns of seed predation that are commonly observed in rural forests dominated by masting tree species. Seed predation represents a significant, and overlooked, barrier to native species recruitment in urban forests with implications for future forest composition and structure, and as a result, forest function and associated ecosystem services. Advancing a mechanistic understanding of how these drivers alter plant population dynamics will improve the conservation, restoration, and management of urban forested natural areas.

\section{Measuring the effects of governance on the demand for forest ecosystem services and disservices in Bogota, Colombia}

Alexandra Pineda Guerrero ${ }^{1}$, Francisco J. Escobedo ${ }^{2}$, Fernando Carriazo ${ }^{2}$

${ }^{1}$ Jardin Botanico de Bogota, Bogota, Colombia; ${ }^{2}$ Universidad del Rosario, Bogotá, Colombia (alepineda02@gmail.com; franciscoj.escobedo@urosario.edu.co; fernando.carriazo@urosario.edu.co)

Governance is frequently mentioned as a requirement for improved management of, and provision of benefits from urban and peri-urban forests. However the concept has many definitions and applications. In addition, there is little information on how people in Latin American cities perceive these benefits as well as costs or ecosystem services (ES) and disservice (ED), respectively. We used semi-structured surveys, econometrics, and spatial analyses to explore the effect of governance on the perceptions towards urban and peri-urban forests and their willingness to pay or not for their conservation. We focused on an urban sub-basin in the city of Bogota, Colombia and specific green areas and forests including wetlands, parks, and other socioeconomic contexts. We also correlated green space cover with responses from a city-level survey on community well-being. Results identified a suite of perceived ES-ED and the influence of governance on how people valued these. Our analyses shows that air quality and biodiversity were very important to respondents, while flood regulation was the least important despite the sub-basin's acute problems with stormwater. The ED of the feeling of insecurity due to crime was significantly related to poor levels of maintenance and infrastructure in the green areas. We also correlated the amount and size of green spaces with citizen well-being. Perceived transparency, corruption and poor government performance influenced people's unwillingness to pay for green space conservation. Results identified the socioeconomic backgrounds and government processes that most influenced the perception and willingess to pay for urban/peri-urban forest conservation.

\section{The role of the Simón Bolívar Central Park (Bogotá, Colombia) in the provision of ecosystem services: analysis of synergies, trade-offs and service packages}

Nicole Morales-Freese ${ }^{1}$, Luz Piedad Romero-Duque ${ }^{I}$ (D)

${ }^{1}$ Universidad de Ciencias Aplicadas y Ambientales UDCA, Bogotá, Colombia (nishaoran210@gmail.com; luz.romero@udca.edu.co)

Knowing the interactions between ecosystem services (SE) makes possible to improve management strategies to meet the needs of adaptation to environmental changes in cities. Urban parks provide SE, whose type and supply varies with the elements and spaces that constitute these parks. From the context of the biophysical evaluation, we identify the interactions between 14 SEs provided by the 8 land covers of the Simón Bolívar Central Park (Bogotá, Colombia). We also apply 120 semi-structured surveys to users over 18 years of age to assess the same 14 SEs. Forests, sparsely wooded pastures and densely wooded pastures supply the most provision and regulation services. Unwooded pastures provide more recreation and recreation services. Forests and the lake provide more sense of well-being, scenic beauty and spiritual value. The Park is well perceived from the physical, mental and emotional well-being as well as from the environmental field, since most users recognize and value the diversity of services it provides. Results show that the variety of land covers in the parks allows the supply of multiple SEs that are identified, valued and used by the beneficiaries in different ways. This allows guiding decision-making on urban park planning based on the needs of the immediate context. The next step is to know these interactions between different parks in order to enhance synergies in the distribution of SE throughout the city.

Impact of built-environment on woody tree species diversity in a nigerian university: implications for enrichment planting and in-situ conservation strategies

Peter Oni ${ }^{1}$

${ }^{1}$ Federal University, Wukari, Nigeria (petidowu2000@yahoo.co.uk)

The impact of built-environment on woody tree species loss and biodiversity within Federal University Wukari, Taraba state, Nigeria was investigated. The built-environment of the campus was sub-divided into four compartments (I, II, III, and IV) based on buildings distribution and formed criteria for land areas determination $\left(\mathrm{ha}^{-1}\right)$. All wood tree species in each compartment were counted, identified and frequency of occurrence determined. All were classified into taxonomic families, relative abundance (RA) and their diversity index computed. Findings indicated that the surveyed area covered approximately 67.1 hectares. Compartment IV had the highest land area (32.57 ha, 48.54\%) while compartment II was least (5.51 ha, 8.21\%). A total of 28 individual wood tree tress species belonging to 17 taxonomic families were encountered. Fabaceae was most represented (5) RA 18.5\%) while seven other families had only 2 species. Verbanaceae was the least represented (1 individual). Compartment IV had the highest number of woody tree species (20 individuals), while compartments I and III had (18) individuals each and compartment II had the least (9 individuals). On individual species basis, Eliaes guineensis had the highest frequency of occurrence (11.60\%) followed by Danielia oliveri (10.78 \%) while Eucalyptus camaldulensis was least (0.16\%). Species diversity index indicated highest value (2.495) in compartment IV and least (2.009) in compartment II. Relating the total land area assessed (67.1 hectares) with total species frequency (602) stems, it translated to approximately 8.97 trees $\mathrm{h}-1$. The number of species ha ${ }^{-1}$ appears moderate within the built-environment, the need for enrichment planting and conservation efforts are implicated 
A review on the roles of urban forests on different scales in atmospheric particulate matter

Donghui Han', Lixin Chen', Hailong Shen', Wenbiao Duan ${ }^{1}$

'Northeast ForestryUniversity, Harbin,China (hdh_nefu@yeah.net; chenlixin@nefu.edu.cn; shenhl-cf@nefu.edu.cn; duanwenbiao@nefu.edu.cn)

Urban forests perform a vital function for atmospheric particles and an increasing number of relevant studies have been done during recent years as environmental quality issues induced by particulate matter are drawing more attention. On the basis of previous articles, this review discussed how urban forests influenced particles at three levels, including plant level, stand level and regional level; in addition, the physical characters of particles were analyzed in vertical and horizontal directions at stand level. As an individual tree, it captured particles through each organ like leaf, bark, branch or shoot, the existing results in this aspect were related to plant characteristics and experimental methods. At stand level, in vertical direction those studies focused on the models of dry deposition velocity which suggested the differences in plant species and weather condition. On regional scale, this review revealed that the removal of atmospheric particles by urban forest depended on particulates concentration, greening coverage area and leaf area index. Multi-scale analyses on effects of atmospheric particles could better understand the role of urban forest as a complex system and provide foundation for future research.

\section{The importance of conserving natural forests in and around cities: analyzing ecosystem services for resilience along an urban-rural gradient}

Tahia Devisscher ${ }^{1}$, Matthew Mitchell ${ }^{1}$

${ }^{1}$ University of British Columbia, Vancouver, Canada (tahia.devisscher@ubc.ca; matthew.mitchell@ubc.ca)

Managing urban landscapes is one of the greatest challenges of this century. As cities continue to grow, they become increasingly vulnerable to multiple risks caused by urbanization and climate change interactions. The state of ecosystems and the wellbeing of urban dwellers will greatly depend on the way cities anticipate and prepare for rapid change in the next decade. Urban forests have an important role to play in this regard, yet little has been done to measure the effects of urbanization on the multiple, essential ecosystem services (ESs) these forests provide for urban resilience. Pressure on land in and around cities is increasing, and some cities are struggling to conserve their natural forest and biodiversity. In these cities, there is a growing demand to better understand the role of surrounding forests and natural forest fragments in terms of their potential contribution to urban resilience and human wellbeing. This study will show results of research conducted along an urban-rural gradient in the City of Maple Ridge, Canada, selected due to its very rapid urbanization rate and expansion into surrounding forests. Structure, composition, and ecosystem services deemed important for urban resilience were evaluated in forest plots along the gradient. Citizens were also engaged along the gradient to evaluate their interaction with the urban forest and perceptions of the benefits these forests provide. Findings will be used by Maple Ridge to inform future land policies, and the conservation of forest areas that play a key role in the resilience and sustainability of the city.

\section{Urban pollution writes in tree rings the history of anthropic events, detectable through dendrochemistry}

Claudia Cocozza1 ${ }^{1}$ Roberto Tognetti ${ }^{2}$, Paolo Cherubini ${ }^{3}$

${ }^{1}$ University of Florence, Florence, Italy; ${ }^{2}$ University of Molise, Campobasso, Italy; ${ }^{3}$ WSL, Birmensdorf, Switzerland (claudia.cocozza@unifi.it; tognetti@unimol.it; paolo.cherubini@wsl.ch)

Tree rings record environmental events as they have changed in the past. Trees are affected by environmental pollution in relation to the level of pollutants and their exposure to them, tree species, environmental conditions, geographical context and the location of trees in relation to pollution sources. Tree-ring chemical analyses, i.e., dendrochemistry, provide a tool to reconstruct the temporal and spatial dynamics of pollutants in the environment. Different pollution levels and sources, exposure intervals, and industrial process intensities require increasingly investigation to validate and implement the approach to detect pollution signals. The chemical content of tree rings allows to characterize the peculiarity of different industrial urban areas. Different study cases reveal the potential of tree rings, e.g. Quercus pubescens and Pinus sylvestris, as sensitive indicators of changes in anthropized ecosystems, detecting specific signals of the considered pollutants to reconstruct past environmental conditions in urban areas. However, taking into account that trace elements can be deposited onto plant surfaces (e.g., stem, bark), absorbed from the atmosphere by foliage and up-taken from the soil by the roots (and accumulated in the xylem), physiological processes are involved in the definition of the pollution signal in tree rings. Copious study cases are necessary to increase the resolution of the dendrochemistry for its application in urban areas.

\section{Managing cities green infrastructure to enhance the provision of ecosystem services to create more liveable and resilient cities}

Pedro Pinho ${ }^{1}$, Paula Matos ${ }^{1}$, Ana Luz ${ }^{1}$, Natália Koch ${ }^{2}$, Filipa Grilo ${ }^{1}$, Bernardo Rocha ${ }^{1}$, Joana Vieira ${ }^{1}$, Teresa Mexia ${ }^{3}$, Cristiana Aleixo ${ }^{1}$, Cristina Branquinho ${ }^{1}$ ${ }^{1}$ Centre for Ecology, Evolution and Environmental Changes, Faculdade de Ciencias, Universidade de Lisboa, Portugal, Lisboa, Portugal; ${ }^{2}$ Universidade Federal do Rio Grande do Sul, Porto Alegre, Rio Grande do Sul, Brasil, Porto Alegre, Brazil; ${ }^{3}$ Centro de Estudos Florestais, Instituto Superior de Agronomia,Universidade de Lisboa,Portugal,_Lisboa,Portugal(ppinho@fc.ul.pt;psmatos@fc.ul.pt; acluz@fc.ul.pt; natimkoch@gmail.com; afgrilo@fc.ul.pt; brerocha@fc.ul.pt; jivieira@fc.ul.pt; tmmexia@fc.ul.pt; caaleixo@fc.ul.pt; cmbranquinho@fc.ul.pt)

Urban areas are hubs for human development and will host an increasingly larger share of global human population. Yet, urbanization creates challenges to human life, such as atmospheric pollution and urban heat island effect. Cities' green infrastructure is suggested by UN New Urban Agenda to tackle such environmental problems. Wooded areas, such as parks and urban forests are critically important for this, as they provide important support \& regulation ecosystem services, such as microclimate and air quality regulation. Its importance to human wellbeing was made evident by Lisbon citizens movements across the city to visit green areas. However, ecosystem services provision depends of ecosystem's biodiversity, but this biodiversity is in turn affected by the same problems that challenge human life, such as atmospheric pollution and the urban heat island effect, added to other factors that influence ecosystem functioning, such as habitat fragmentation. Because monitoring stations cannot measure impacts in ecosystems, we used ecological indicators in urban areas of Portugal and Brazil, to show how accumulation of metals, satellite and microclimate measures, and metrics of lichen diversity - more importantly trait-based metrics related to growth form and tolerance to disturbances, can be used as to quantify the impacts of urbanization. This effect was modelled at city, park and square spatial scales, allowing us to map, with high resolution the provision of multiple ecosystem services. This provided evidences of the trade-offs that occur between ecosystem services, and also how can management and city planning can influence the provision of ecosystem services. 


\author{
A comparison of leaf litter decomposition intensity: peri-urban forests vs. urban green spaces \\ Lina Straigyte (D) Tadas Vaidelys ${ }^{1}$, Michael Manton (D) \\ IVytautas Magnus University,_LT53361,Lithuania(lina.straigyte@vdu.lt; tadas.vaidelys@vdu.lt; michael.manton@vdu.lt)
}

Urban green space environments are different from peri-urban forest environments. However, there are knowledge gaps on how urban environments and periurban forests affect tree leaf decomposition intensity. To fulfill these gaps, we measured biomass loss of the leaf litters of four dominant native deciduous tree species: Tilia cordata, Acer platanoides, Betula pendula, and Quercus robur collected from peri-urban forests (control) and four different types of urban green spaces in Kaunas, Lithuania. We collected leaf litter samples from 60 sites and used the modified litter bag technique. The results indicated that the decomposition of leaf litter among tree species as well as the five types of urban green spaces are different. We found the leaves of B. pendula and A. platanoides decayed faster in green street spaces. The composition rates of these species accelerated during summer. The leaf litter decomposition of $T$. cordata was not influenced by the types of green spaces, and the losses of leaf litter mass between green spaces were insignificant. Q. robur leaf litter decomposed faster in peri-urban forest than in urban green spaces but the leaf litter mass loss differences between green spaces were small but significant. In conclusion, environmental processes are different between green spaces and tree species, results showing that $T$. cordata and $Q$. robur were the least affected species in all types of green spaces and maybe the most suitable species to cope with the demands and change of urban green spaces. However, rapid decomposition of B. pendula and A. platanoides leaf litter from street greeneries indicates that these leaves can be left as fertilizer.

Diversity of the urban forest network along roads in the São Francisco Xavier district of Dois Vizinhos, Paraná, Brazil, using the Odum index / Diversidade da arborização urbana viária do Bairro São Francisco Xavier em Dois Vizinhos, Paraná usando o indice de Odum

Davidson da Silva Novaes', Flávia Gizele Konig Brun ${ }^{1}$

'Universidade Tecnologica Federal do Paraná, Dois Vizinhos, Brazil (davidson.novaes@gmail.com; flaviagbrun@gmail.com)

Conhecer a diversidade da arborização urbana viária permite tomar várias decisões importantes quanto a sanidade das árvores que compõe a vegetação urbana. O Bairro São Francisco Xavier possui 1.479 habitantes e pertencente ao Município de Dois Vizinhos e foi usado como local de estudo para o presente trabalho. Foram percorridas as 13 ruas do bairro, onde foram levantados 910 Indivíduos de 82 espécies distintas. Cada rua teve seu próprio índice calculado e com esses valores foi calculado a média, que foi considerada como a diversidade do bairro. A Índice de Odum do bairro São Francisco Xavier é de 3,97. O número de indivíduo médio por rua é igual a 71 , com coeficiente de variação de $36,75 \%$. A quantidade de espécies por rua é igual a 18 , com coeficiente de variação de $29,79 \%$. O coeficiente de variação para o indice de Odum foi igual a 24,63\%. O índice de Odum deve variar entre 2,45 e 26,99, não sendo desejável valores extremos, mas sim os mais próximos da média. O bairro São Francisco Xavier possui um indice de diversidades de Odum considerável, mas não aceitável. O valor calculado mostra que a arborização do bairro está mais próxima da homogeneidade. Este é o reflexo de plantios não criteriosos. A baixa diversidade gera monotonia na paisagem e abre precedente para dizimar parte da arborização em caso de ataque da pragas e doenças. A Principal forma de melhorar a diversidade é substituir parte dos indivíduos pôr os de outras espécies, enriquecendo gradualmente a arborização do bairro.

\title{
Surveying exotic species used in urban forestry in Brazil / Levantamento de espécies exóticas na arborização urbana no Brasil \\ Ana Cláudia Nogueira da Silva', Hiohanes Moura Cardoso', Thamires de Souza Carvalho', Angeline Martini ${ }^{\prime}$ \\ 'Universidade Federal de Viçosa, Viçosa,Brasil (anasilvanogueira@yahoo.com.br; hiohanes.cardoso@gmail.com; dsc.thamires@gmail.com; martini@ufv.br)
}

As espécies exóticas invasoras são a segunda maior causa de perda da biodiversidade no mundo, essas espécies quando introduzidas em novos ecossistemas, livres de predadores naturais, se adaptam e começam a reproduzir-se a ponto de ocupar o espaço de espécies nativas e provocar alterações nos processos ecológicos naturais, tornando-se dominantes após o período de tempo necessário para sua adaptação. Nesta premissa, foi realizado um levantamento de 21 inventários da arborização urbana brasileira, publicados em artigos científicos nos últimos 15 anos, visando avaliar a presença de espécies exóticas invasoras. Dentre os inventários, buscou-se aqueles que demonstraram de forma representativa a arborização em áreas consolidadas, tanto em capitais quanto cidades interioranas, nas cinco regiões geopolíticas do Brasil. Foram avaliados 4 inventários na região norte, 5 na região nordeste, 4 na região centro-oeste, 4 na região sudeste e 4 na região sul. Foram identificadas 190 espécies vegetais exóticas na arborização urbana, sendo que 67 (35\%) das exóticas identificadas possuem potencial de invasão. Este estudo apontou 16 (8\%) espécies presentes na lista de espécies invasoras no Brasil, as espécies exóticas com maior potencial de invasão utilizadas na arborização urbana foram Ficus benjamina, Mangifera indica, Syzygium cumini, Leucaena leucocephala e Terminalia catappa. Este estudo irá auxiliar em futuros planos diretores de arborização urbana e projetos de manejos, recomenda-se a substituição das espécies com grande potencial invasor. Esta pesquisa corrobora com a Estratégia Nacional para Espécies Exóticas Invasoras enfatizando a importância da utilização de plantas nativas, diminuindo a introdução, dispersão de exóticas invasoras.

\section{Silviculture in the city: can traditional silvicultural practices inform urban forest management?}

Richard Hallett ${ }^{1,2}$, Max Piana ${ }^{3}$, Clara Pregitzer ${ }^{4,5}$

${ }^{1}$ USDA Forest Service, New York City, USA; ${ }^{2}$ New York Urban Field Station, New York City, USA; ${ }^{3}$ Rutgers University, New Brunswick, USA; ${ }^{4}$ Yale School of Forestry and Enviromental Studies, New Haven, USA; ${ }^{5}$ Natural Areas Conservancy, New York City, USA (rahallett@gmail.com; max.r.l.piana@gmail.com;

clara.pregitzer@yale.edu)

Cities around the world are focusing attention on trees and green space within city limits motivated by a wide range of documented economic, ecological and social benefits of urban forests. Urban forested natural areas are a subset of what is commonly thought of as the "urban forest". These natural areas are morel like rural forests than street, park, and yard trees. In addition, the urban forested natural areas are often overlooked and under-managed. Yet these areas may contain the majority of the trees within the city. In this talk we present a conceptual framework that borrows from traditional silvicultural and forest management practices typically applied to rural forests. While similar to rural forests, the impacts of urban conditions (e.g. heat island, heavy metals, altered soils) on forest ecosystem patterns and processes requires modified management practices. Also, forests in cities need to provide ecosystem services not lumber. For these reasons we suggest the need for an urban silvicultural framework. As we discuss this framework, we will synthesize emerging research in urban forest management and identify challenges and opportunities for advancing goal setting, assessments, and on-the ground management strategies for urban forested 
natural areas. Adopting the urban silviculture concept will support innovative research and management strategies capable of addressing the impacts of urban stressors and climate change, and therefore sustain the benefits of urban forests over time.

\author{
Assessing the performance of least cost path modelling in defining ecological corridors for birds in urban landscapes \\ Gabriela Graviola ${ }^{1}$, João Pena ${ }^{1}$, Milton Ribeiro ${ }^{1}$ \\ ${ }^{1}$ Universidade Estadual Paulista “Júlio de Mesquita Filho”, Rio Claro,Brasil (gabriela.rosa@unesp.br; joaocpena@gmail.com; mcr@rc.unesp.br)
}

Although connectivity is fundamental for species conservation, this topic in urban landscapes remains understudied. In order to fill this gap, this project aims to verify the accuracy of least-cost path (LCP) modeling in finding the best routes for birds between urban parks. We also intend to evaluate how different aspects of urban landscapes (such as tree density and exposure to noise) influence the taxonomic and functional characteristics of bird communities inhabiting streets and urban parks of a Neotropical city (Bauru, São Paulo, Brazil). First, we produced a land use/land cover map to characterize the urban landscape structure. The connectivity was assessed by simulating least-cost paths between 10 urban parks using the LSCorridors software. With the simulation results, we selected 10 streets considered as preferential routes and 10 streets not crossed by least cost paths. Currently we are performing bird surveys using the point count method in these three contexts (30 sampling points). We expect that streets nearby or considered as preferential routes will present higher species richness, number of individuals, functional richness and evenness. We also expect that urban parks and streets with higher tree density and lower exposure to noise will positively influence the taxonomic and functional characteristics of these urban bird communities. With these results, it will be possible to suggest guidelines for urban planning in order to create multifunctional urban ecological corridors and management strategies to assist in the conservation of bird species inhabiting Neotropical cities.

\title{
Conservation of natural ecosystems within urban ecosystems in Eastern Amazonia
}

Pedro Martorano ${ }^{1}$, Francisco Oliveira ${ }^{1}$, Lucieta Martorano ${ }^{2}$

${ }^{1}$ Universidade Federal Rural da Amazônia, Belém, Brazil; ; Embrapa Amazônia Oriental, Santarém, Brazil (pmartorano60@gmail.com;

fdeassis@gmail.com; lucieta.martorano@embrapa.br)

The Macrodrainage project in Belém, Capital of Pará, was a public policy strategy that aggregated value and quality of life to the urban population, principally in low-lying areas and peripheral neighborhoods at the end of the 1990's. Projects such as "Ação Metrópole" (Metropolitan Action) amplified the Trabalhadores Highway by removing vegetation from a nearby park. The objective of this work was to evaluate loss of tree cover in the area of the park called "Gunnar Vingren" due to these projects by quantifying the percentage of the natural ecosystem converted to urban area. A forestry inventory was done of trees with $\mathrm{CAB} \geq 15 \mathrm{~cm}$ in a $44.06 \mathrm{ha}$ area, and geoprocessing and GIS methods were applied to evaluate vegetation removal. The results show that there are stands of pioneer species in large openings with a predominance of formations of macega, an open field transition area with aquatic macrophytes (17.94\%). Secondary vegetation typical of shrubby secondary forest was present in low-statured (6.03\%) and high-statured (2.95\%) formations. High-statured forest was present in the várzea (river margin) $(65.36 \%)$ and terra firme (upland) (2.89\%) areas. Of the 3,160 stems inventoried there were 21 families, 42 genera and 48 species. The "Ação Metrópole" project caused significant disappearance of terra firme forest and exposed the flora and fauna of the northeastern portion of the park to human pressure. There is a great necessity to conserve this ecosystem and its water springs as a strategy of environmental compensation for ecosystem services for the population of Belém.

\section{Developing and evaluating the Korean Green Gym for implementing citizen-participatory forest- management activities}

Dawou Joung ${ }^{1}$, Bum-Jin Park

${ }^{1}$ Department of Environment and Forest Resources, Chungnam National University, Daejeon, Republic of Korea (dawo.jeong@gmail.com; bjpark@cnu.ac.kr)

The present study proposed an operational model for a citizen-participatory forest-management activity based on forest welfare to encourage active public participation in forest management. The Green Gym initiative introduced in England is a representative regional forest-improvement activity. This initiative is concerned not only with environmental conservation but also with individuals' health statuses. Therefore, the present study involved the development and evaluation of model citizen-participatory forest-management activities based on forest welfare by referring the Green Gym. In the field experiment, the model Green Gym program involved removing vines, pruning, stacking cut branches following pruning, planting containerized seedlings, and cleaning the forest (picking up trash). The Ovako Work Posture Analysis System was used to investigate any potential harm to the musculoskeletal system based on the forest management activity performed. Workload index was analyzed using the percentage of heart rate reserve to determine the work level associated with each activity. In addition, the psychological states of the participants before and after performing forest management activities were evaluated using the following tests: Positive and Negative Affect Schedule, Rosenberg Self-Esteem Scale, WHO Quality of Life, and Perceived Restorativeness Scale. Thus, we found that forest management activities were light work-level activities, which did not burden the musculoskeletal system and had positive physical and mental effects. The application of the proposed model can help in providing forest welfare service with personal and social benefits concerning the forests.

\section{Studies on the relationship between primary production of Pinus densiflora forest and climate change factors in Mt. Namsan, Seoul Metropolitan City}

Eungpill Lee ${ }^{1}$, Sooin Lee ${ }^{2}$, Seungyeon Lee ${ }^{1}$,Euijoo Kim ${ }^{3}$, Yongsik Hong ${ }^{1}$, Youngho Jung ${ }^{4}$, Jaehoon Park ${ }^{5}$, Sanghoon Lee ${ }^{6}$, Younghan You ${ }^{1}$ ${ }^{1}$ Kongju National University/Life science, Gongjusi, Republic of Korea; ${ }^{2}$ Baekdudaegan National Arboreum/Forest Plant Industry, Bonghwagun, Republic of Korea; ${ }^{3}$ Kongju National University, Gongjusi, Republic of Korea; ${ }^{4}$ Baekdudaegan National Arboreum/Seed Vault Department, Bonghwagun, Republic of Korea; ${ }^{5}$ Kwater convergence institute, Daejeonsi, Republic of Korea; ${ }^{6}$ National Institute of Ecology/Division of basic Ecology, SeoCheongun, Republic of Korea(lyp2279@kongju.ac.kr; ecolove093@kongju.ac.kr; ecolee21@kongju.ac.kr; euijoo@kongju.ac.kr; hongfin@smail.kongju.ac.kr; jyh5250@kongju.ac.kr;kn5314@smail.kongju.ac.kr;sanghunlee@nie.re.kr;youeco21@kongju.ac.kr)

To find out the impact of climate change on the carbon budget and cycle, we monitored standing biomass, litter production, net primary production and soil respiration for 10 years in Pinus densiflora forest of Namsan Mountain, South Korea's representative urban forest ecosystem. Also regression analysis was performed to find correlation between its ecological change phase and climate change components (average annual temperature, average monthly amounts of precipitation, tree days, average monthly temperature from March to May (in the beginning period of growing season), average monthly amounts of precipitation from March to May (in the beginning period of growing season), number of typhoons). Standing biomass was related positively with average annual temperature and frequency of monsoon typhoons. Litter production was related negatively with frequency of monsoon typhoons. Net primary production was related positively with average monthly amounts of precipitation at the beginning period of growth season, but average annual temperature and number of monsoon 
typhoons negatively. Soil respiration was related positively with average temperature at the beginning of growth, but average monthly amounts of precipitation were vice versa. These result mean that ecological functions of urban forest in Seoul Metropolitan City are affected by climate change in recent years. This work was supported by the National Research Foundation of Korea (NRF) grant funded by the Korea government (MSIT) (No. NRF- 2018R1A2B5A01021358) and Research on Ecosystem Climate Change (NIE-Based Research-2018-21) funded by National Institute of Ecology.

\section{D6q: FOREST AND ECOSYSTEM SERVICES IN CITIES: ACHIEVEMENTS AND} EXPECTATIONS

\section{Epitaph: the forest leaves the city?}

Júlia Senra ${ }^{1}$ Bernardo Gontijo ${ }^{I}$

'Universidade Federal de Minas Gerais, Belo Horizonte,Brazil (juliabenficas@gmail.com; gontijobm@yahoo.com.br)

Mata da Izidora (Izidora Woods) is a threatened urban forest located in Belo Horizonte, Brazil. It is the most extensive remnant of vegetation of this municipality that is not a protected area, covering an approximate area of $10,000,000 \mathrm{~m}^{2}$, with a biodiversity relative to the Atlantic Forest and Brazilian Savanna Biomes. It is susceptible to complex interactions inside and outside its boundaries. In its interior, there are particular rural properties, one quilombola community and three urban occupations. In addition to the internal interactions that influence the local dynamics, the interests of the public power and the real estate sector should also be taken into account. This study main aim was to "identify possibilities for the survival of urban forest fragments through social appropriations". In order to achieve this objective, we sought to extensively present the addressed issue through documents, reports, maps, figures, semi-structured interviews and poetry. In this scenario, a problematization of the reality of space were carried out with the data obtained, in order to analyze the motivations for social coexistence or not with Mata da Izidora. As a result of the possibilities identified, this work recommended the creation of a conservation unit as an alternative to reconcile some of the yearnings for the area, corresponding to category VI "Protected area with sustainable use of natural resources" of the IUCN Protected Area Categories System. This work intends to contribute to the discussions on urban forest fragments and with other possibilities for the coexistence between nature and city.

\section{Tourist uses of urban green infrastructure in Europe: a cross-cultural study}

Theano Terkenli ${ }^{1}$, Simon Bell ${ }^{2}$, Ivana Zivojinovic ${ }^{3}$, Jelena Tomicevic ${ }^{4}$, Thomas Panagopoulos ${ }^{5}$, Inga Straupe ${ }^{6}$, Oliver Toskovic ${ }^{7}$, Katarina Kristianova ${ }^{8}$, Lina Straigyte ${ }^{9}$, Liz O'Brien $^{10}$

${ }^{1}$ Department of Geography, University of the Aegean, University Hill, Lesvos, Greece; ${ }^{2}$ Department of Landscape Architcture, Estonian University of Life Sciences, Tartu, Estonia; ${ }^{3}$ Institute of Forest, Environment and Natural Resource Policy, University of Natural Resources and Life Sciences, Vienna (BOKU) and European Forest Institute, Forest Policy Research Network, Vienna, Austria; ${ }^{4}$ University of Belgrade, Faculty of Forestry, Department of Landscape Architecture and Horticulture, Belgrade, Serbia; ${ }^{5}$ Research Centre for Tourism, Sustainability and Well-being (CinTurs), University of Algarve, Faro, Portugal; ${ }^{6}$ Latvia University of Agriculture, Forest Faculty, Jelgava, Latvia; ${ }^{7}$ Laboratory for Experimental Psychology, Faculty of Philosophy, University of Belgrade, Belgrade, Serbia; ${ }^{8}$ Faculty of Architecture, Slovak University of Technology in Bratislava, Bratislava, Slovakia; ${ }^{9}$ Aleksandras Stulginskis University, Faculty of Forest Science and Ecology, Institute of Forest Biology and Silviculture, Kaunas, Lithuania; ${ }^{10}$ Centre for Ecosystems, Society and Biosecurity,Forest Research,Farnham,UnitedKingdom(terkenli@aegean.gr; simon.bell@emu.ee; ivana.zivojinovic@boku.ac.at; tomicevicj@yahoo.com; tpanago@ualg.pt; inga.straupe@llu.lv; otoskovi@gmail.com; kristianova@fa.stuba.sk; straigyte@gmail.com; liz.o'brien@forestry.gsi.gov.uk)

Urban landscapes are often determined by their green areas, which fulfils various needs of both inhabitants and visitors, hence urban green infrastructure (UGI) has a highly potential role in city branding. This research contributes to knowledge regarding trends of tourists' uses of UGI in Europe. In order to achieve a broader applicability of the study, a cross-cultural approach was adopted and carried out with the aid of face-to-face interviews with foreign tourists in the Czech Republic, Greece, Latvia, Lithuania, Portugal, Serbia, Slovakia and United Kingdom. The study research questions addressed tourists' perceptions, understanding and uses of UGI, and the ways that this understanding influences tourists' choice of visiting a certain city. The selection of case studies follows a roughly comparative logic, namely on-site questionnaire surveys administered in large and medium size cities in these Southern, Central and Northern European countries. In the context of a series of very interesting findings responding to our study's research questions, our results show that tourists visiting Northern and Central European cities show more interest in and intention to visit UGI, than tourists visiting Southern European cities. Such north-south differences emerged concerning more than one of our study variables, including willingness to pay for the use of UGI, thus opening up a broad field for data interpretation and discussion, which helps in understanding how tourists view, use, benefit from, and impact UGI. This may support future improvement of UGI planning and management, and strengthen the role of UGI in cities tourism development.

\section{Urban residents’ preferences of ecosystem services of urban forests: the case of Beijing}

Zhi-Ying Han ${ }^{1}$, YOUN Yeo-Chang ${ }^{1}$, Mi Sun Park ${ }^{1}$

${ }^{1}$ Seoul National University, Seoul, Korea,Republic of (335640510@qq.com; youn@snu.ac.kr; mpark@snu.ac.kr)

This paper aims to investigate the Beijing citizens' preferences over various options of urban forest management strategies. The literature review and expert Delphi method were employed to rank the importance of 18 ecosystem services (ESs) and to classify the ecosystem services of urban forests into 6 categories: (1) fresh water, (2) noise reduction, (3) moderation of extreme events, (4) air quality regulation, (5) species diversity and wildlife habitat, and (6) recreation and spiritual experience. The main choice experiment survey was conducted by interviewing Beijing citizens who have visited any one of the urban forests located in Beijing. The results are as follows: Firstly, the air quality regulation ES was considered as the most influential service received from urban forest for citizens. They were willing to pay 85 264 RMB/year to invest in urban forest expansion for improving air quality. In addition, they regarded the fresh water as the second-most important ES. Secondly, citizens with high monthly household income were more willing to pay for urban forest ESs. Thirdly, apartment owners were willing to pay municipality tax more compared to non-apartment owners. Fourthly, citizens emotionally connected to Beijing tend to willing to pay more municipality tax. The results indicate that citizens are willing to pay a higher tax for supporting urban forestry for air quality improvement. This research suggests for urban environmental policy makers in Beijing to pay more attention to air quality regulation function of forests when designing and managing urban forests to satisfy its visitors' preferences and improve citizens' welfare. 


\section{Perception of ecosystem services in urban green areas of Curitiba, Brazil}

Alessandro Panasolo ${ }^{1}$, Franklin Galvão ${ }^{1}$, Hermes Yukio Higachi ${ }^{2}$, Edilson Batista de Oliveira ${ }^{3}$, Fernando Campos de Oliveira ${ }^{4}$, Carlos Augusto Wroblewski ${ }^{1}$ ${ }^{1}$ Universidade Federal do Paraná, Curitiba, Brasil; '2Universidade Estadual de Ponta Grossa, Ponta Grossa, Brasil; ${ }^{3}$ Embrapa Florestas, Curitiba, Brasil; Fundação Boticário,Curitiba,Brasil (apanasolo@gmail.com;fgalvao@ufpr.br; hhigachi@uepg.br; edilson.oliveira@embrapa.br; fercampos@gmail.com; carloswroblewski@ufpr.br)

This present research aims to identify the ecosystem services (SE) of urban green areas of Curitiba, capital city of Paraná, Brazil. Using an exploratory method, a qualitative research was carried out with specialists in the environment through the Ecosystem Services Review (ESR) tool, in order to identify the most important SEs related to the generation of socioeconomic well-being. The study sites are representative of the main geographic and phytophysiognomic contexts of the city, which together accumulate a total of 40 protected hectares, encompassing a fragment of Mixed Ombrophilous Forest, as well as the last remnants of Steppes of Curitiba. It is possible to conclude that the ecosystem services studied, especially those identified as more relevant, should be carefully observed and incorporated into the management of urban green areas. In addition, it was possible to identify which SEs are considered irreplaceable, in the case of suppression of green areas.

\section{Urban high voltage power line right of way and urban forests: conflict or harmony?}

Paulo Guilherme Molin ${ }^{1}$,Frederico Tomas de Souza e Miranda ${ }^{2}$, Nathalia Veloso Aguiar ${ }^{1}$, Girlei Costa da Cunha², Luciana Cavalcante Pereira ${ }^{3}$, Luiz Eduardo R. C. Rielli', Guilherme Bazan ${ }^{5}$, Giulio Brossi Santoro ${ }^{1}$

${ }^{1}$ Universidade Federal de São Carlos, CCN, Buri, Brasil; ${ }^{2}$ Biodendro, Piracicaba, Brasil; ${ }^{3}$ Nace Pteca, Piracicaba, Brasil; ${ }^{4}$ NOVi Soluções Socioambientais, São Paulo, Brasil; ${ }^{5}$ ISA CTEEP, São Paulo,Brasil (pgmolin@ufscar.br; fredtsmiranda@gmail.com; https://app.oxfordabstracts.com/dashboard; girlei.cunha@biodendro.com.br; lcavalpereira@gmail.com; luiz.rielli@noviconsult.com.br; gbazan@isacteep.com.br)

The irregular occupation of high voltage power line right of ways is a reality in multiple countries, especially in metropolitan areas. In Minas Gerais, Brazil, there are estimates of nearly 80.000 people living in these right of ways. Irregular occupation causes hazards not only for the population living in theses areas, but are also a conflict for the concession companies that depend on these areas for access, repairs and maintenance. The occupation problem needs to be treated with multiple solutions, including prevention of new occurrences through sustainable land uses and practices. One of the sustainable management models proposed is implementing urban forests along the right of way, not only increasing ecological corridors and landscape connectivity in urban landscapes but also increasing quality of life for the population. The problem encountered in this solution is the conflict between power lines, vegetation height, legislations and standards. We present an overview of the conflicts, harmonies and synergies that exist in Brazil and other countries with similar cases. We also make a diagnostic of São Paulo metropolitan area and the concession lines of ISA CTEEP. Finally, we propose a regional zoning where urban forests could be implemented and the probable social and environmental gains.

Valuing green urban areas in the Polytechnical Campus to develop an urban forestry plan for the UFPR campi / Valoração de áreas verdes urbana no campus Centro Politécnico, para a elaboração do plano de arborização dos campi da UFPR

Vitória Maria Bisewski ${ }^{1}$, Carla Maria Camargo Corrêa ${ }^{1}$, Priscila Caldas ${ }^{1}$, Rodrigo Dall"agnol Trompczynski ${ }^{\prime}$, Leonardo Rogal ${ }^{1}$ 'Universidade Federal do Paraná, NIMAD, Curitiba, Brasil (vibisewski@gmail.com; cmcamargocorrea@gmail.com; priscilacaldass@gmail.com; rtrompczynski@gmail.com; leonardorogal98@gmail.com)

Este trabalho avaliou a importância da arborização no campus Centro Politécnico, foi realizado uma revisão bibliográfica e um estudo de caso, com aplicação de um questionário de sensibilização com o propósito de conhecer o perfil da comunidade acadêmica e transeuntes que frequentam o campus. Foram avaliados os seguintes parâmetros: gênero, idade, estado civil, escolaridade, profissão, tipo de relacionamento com a instituição, forma de deslocamento até a instituição, tempo de permanência, assim como informações pertinentes a arborização urbana, como: qual a importância da arborização nos campi, qual a importância de um programa de educação ambiental nos campi, qual a importância da arborização na qualidade de vida, além de um espaço destinado a sugestões. Os resultados representam cerca de 1\% da comunidade acadêmica (333 avaliações), onde foi constatada a predominância do gênero feminino, em comparação ao gênero masculino, a faixa de idade variou entre 20 e 30 anos representando cerca de $60 \%$, o estado civil da população avaliada é predominantemente solteiro e cerca de $50 \%$ tem como grau de escolaridade a graduação, desse montante $72 \%$ são alunos, que utilizam automóvel particular ou coletivo como forma de deslocamento até a instituição, o tempo de permanência na instituição varia de 20 a 40 horas. Quanto às questões relacionadas à arborização urbana: cerca de $85 \%$ considera muito importante a arborização nos campi associado a implementação de programas de educação ambiental e 94\% considera muito importante a arborização urbana para a qualidade de vida. Principais sugestões: substituição de espécies exóticas por nativas e por frutíferas.

\section{Quality index for urban green spaces (IQAVU) / Índice de qualidade das áreas verdes urbanas-IQAVU \\ Silvia Méri Carvalho ${ }^{1}$ (D) Dulcina Aquino Hernandez de Oliveira Queiroz ${ }^{1}$ \\ 'Universidade Estadual de Ponta Grossa, Ponta Grossa,Brasil(silviameri@brturbo.com.br; dulcinah@gmail.com)}

Nos cenários urbanos dos dias atuais, um dos problemas que mais preocupam governos, empresas, meio acadêmico, instituições globais e a comunidade de forma geral é a escassez de elementos naturais nos ambientes urbanos. Uma maneira de combater esse problema consiste em considerar as áreas verdes como elemento integrante do processo de planejamento das cidades. A qualidade das áreas verdes em um determinado espaço urbano é diretamente influenciada pelos atributos incluídos em cada função, os quais são importantes provisões de bens e serviços (BOLUND; HUNHMMAR, 1999; YOUNG, 2010). A avaliação de áreas verdes urbanas é útil para a análise do nível de sustentabilidade das cidades, sendo que um dos desafios consiste em identificar as diferentes funções das áreas verdes a fim de avaliar de forma equitativa e integrada a qualidade desses elementos em ambientes urbanos. Nesse sentido, o presente trabalho apresenta o Índice da Qualidade das Áreas Verdes Urbanas (IQAVU), que avalia a qualidade das mesmas em ambientes urbanos por meio de uma média geométrica entre indicadores das funções Social, Ambiental e Estética. Portanto, uma área verde urbana com deficiência em ao menos uma de suas funções, não pode ser considerada uma área verde funcional. Pretende-se que a aplicação do índice seja possível a qualquer área urbana, independente da realidade demográfica, geográfica ou política. O cálculo do IQAVU, realiza-se mediante à aplicação de uma média geométrica, onde as três funções das áreas verdes tornaram-se subíndices, caracterizadas por um conjunto de indicadores a elas associadas. 
Getting real: the costs and benefits of urban forests and flow of ecosystem services in dynamic environments: who should pay? Insights from a multidisciplinary dialogue

Sandra J. Velarde ${ }^{1}$, Lisa Sharma-Wallace ${ }^{2}$, Marie McCarthy $^{1}$, Andrea Stocchero $^{1}$, Karen Bayne $^{3}$, Robert Radics $^{3}$, Emily Telfer ${ }^{1}$, Georgia Garrard $^{4}$, Wendy Jackson ${ }^{5}$, Asenaca Nawaqalevu', Alan Leckie ${ }^{3}$, Richard Yao ${ }^{1}$

${ }^{1}$ Scion, Rotorua, New Zealand; ${ }^{2}$ Independent, Cincinatti, USA; ${ }^{3}$ Scion, Christchurch, New Zealand; ${ }^{4}$ RIT, Melbourne, Australia; ${ }^{5}$ Ministry of Foreign Affairs and Trade, Wellington, New Zealand; ${ }^{6}$ University of South Pacifi,Suva,Fiji (sandra.velarde@scionresearch.com; lisa.jean.wallace@gmail.com; marie.mccarthy@scionresearch.com; andrea.stocchero@scionresearch.com; karen.bayne@scionresearch.com;robert.radics@scionresearch.com; emily.telfer@scionresearch.com; georgia.garrard@rmit.edu.au; wendy.jackson@gmail.com; asenaca.nawaqalevu@usp.ac.fj;

alan.leckie@scionresearch.com; richard.yao@scionresearch.com)

Our cities are rapidly changing. Urban planners need to adapt to the new demands posed by a constantly evolving social fabric. People living in cities increasingly have a transient and mobile lifestyle within the 'gig economy' creating disruption to sense of place and 'ownership' of the urban environment. In this context, integrating nature into cities brings up unique challenges that need to respond to these evolving needs. In 2018, we held a multidisciplinary dialogue to explore practical examples of the process of greening cities in the Oceania region and around the world. We brought together local government officials, urban planners, economists, architects, urban foresters, ecologists, biologists, conservationists, geneticists, policy experts and community engagement specialists to explore the costs and benefits of 'urban green spaces' including forests and their ecosystem services. We discussed the emerging issues of 'biodiversity sensitive' urban design, urban planning in space-constrained areas and urban green sacred spaces. Participants highlighted the need for reconnecting people with nature, and how urban green spaces could provide these opportunities so that people benefit from forests and their ecosystem services in cities. While successful examples of integration of nature into cities highlight measurable benefits such as increased environmental sustainability, lifestyle affordability and quality of life, including mental health, integrating nature into cities come at a cost as well. This paper also reports insights into who should pay to make forests and their ecosystem services available for people in a world of rapid change. planejamento florestal de grande teor digital, são as aeronaves remotamente pilotadas (RPAs) ou mais conhecidas como drones. O manejo de precisão de florestais tropicais na Amazônia também acompanha a nova geração tecnológica, contemplando para isso: os inventários florestais semiautônomos a partir de RPAs, GNSS pós-processado e uso de algoritmos para segmentação e geolocalização automática de árvores. O objetivo do trabalho foi propor um calendário preliminar de inventário florestal com uso de RPAs (classe III), contemplando as árvores codominantes e dominantes, acima de $50 \mathrm{~cm}$ de DAP1,3m. O mapeamento da cobertura florestal a partir de ortofotos de alta resolução ( $<7$ cm) será uma etapa que deverá preceder a entrada da equipe de inventário em campo. Dessa maneira, a equipe de inventário florestal iniciará seus trabalhos com a geolocalização precisa de todas as árvores dominantes, facilitando significativamente a busca por espécies de interesse. O trabalho foi na reserva florestal da Embrapa Acre, na Amazônia Brasileira, com a RPA DJI P4Pro, por meio de voos semiautônomos. Para segmentação foram testados diversos parâmetros utilizando o algoritmo GEOBIA. O acompanhamento mensal da floresta a partir de ortofotos de alta resolução, possibilita traçar um perfil modal preliminar das fenofases de cada uma das 14 espécies estudadas, demonstrando assim a viabilidade do inventário automatizado com as RPAs.

\section{D7b: BIODIVERSITY, BIOTIC INTERACTIONS AND THREATS TO FOREST ECOSYSTEM SERVICES ASSOCIATED WITH TREE REPRODUCTIVE STRUCTURE INSECTS AND PATHOGENS IN A CHANGING WORLD}

\section{Variation in cone crop, trap catch and density of larvae between orchards and years: a challenge for Integrated Pest Management}

Olle Rosenberg ${ }^{1}$

${ }^{1}$ Skogforsk, Uppsala, Sweden (olle.rosenberg@skogforsk.se)

For some years, Integrated Pest Management (IPM) has been obligatory for controlling pests. This means that countermeasure decisions against pests should be based on e.g. monitoring in the field to avoid unnecessary treatments. In Sweden, synthetic sex pheromones are available for monitoring of male lepidopteran pest species in Norway spruce seed orchards. During a study period of four to five years, cone crop was estimated and trap catches and larvae in cones counted in two different seed orchards. The preliminary results demonstrated a great variation in both cone crop and insect density between years, and between seed orchards within a year. Low trap catches and a relatively high number of larvae found implies that trap catch may not be a reliable method for decision of pest management actions.

\section{Pheromones for monitoring and control of insect pests in spruce seed orchards}

Olle Anderbrant ${ }^{1}$ iD, Olle Rosenberg ${ }^{2}$, Hong-Lei Wang ${ }^{1}$, Erling V. Jirle ${ }^{1}$, Ilme Liblikas ${ }^{3}$, J. Michael Chong ${ }^{4}$, Christer Löfstedt ${ }^{1}$, Glenn P. Svensson ${ }^{1}$ ${ }^{1}$ Department of Biology, Lund University, Lund, Sweden; ${ }^{2}$ The Forestry Research Institute of Sweden, Skogforsk, Uppsala, Sweden; ${ }^{3}$ Institute of Technology, University of Tartu, Tartu, Estonia; ${ }^{4}$ Department of Chemistry, University of Waterloo, Waterloo, Canada (olle.anderbrant@biol.lu.se; olle.rosenberg@skogforsk.se; hong-lei.wang@biol.lu.se; rerling.jirle@biol.lu.se; ilme.liblikas@ut.ee; jmchong@uwaterloo.ca; christer.lofstedt@biol.lu.se; glenn.svensson@biol.lu.se)

The production of high quality trees, adapted to local environments, requires reliable access to seeds from selected clones. Seed production for some species, notably Norway spruce, Picea abies, is especially challenging due to irregular flowering and fungal and insect pests destroying or consuming the seed yield. Some of the insects spend much of their life inside the cones, well protected from chemical or biological pesticides. For these species the use of pheromones or possibly kairomones might contribute to reduced damage and higher seed yield. The female produced sex pheromones have been identified for three moth species, Cydia strobilella, Dioryctria abietella and Eupithesia abietaria. The two former pheromones are used commersially for monitoring and experimentally for mating disruption in spruce seed orchards in Sweden. Pheromone traps are useful for determining flight periods, but catches are not yet able to reliably mirror or predict the population size or future damage. However, improved methodology and longer data series might generate valuable results in the future. The sensitive traps can also be essential for locating pest-free areas for site selection of future seed orchards and for quarantine purposes. Mating disruption attempts have shown mixed results and a number of improvements related to formulation and application of the compounds will be suggested. 


\title{
Genotypic diversity and reproductive biology of Thekopsora areolata, the causal agent of cherry spruce rust in Norway spruce seed
} orchards

\author{
Hernán Capador ${ }^{1}$, Berit Samils', Juha Kaitera², Ake Olson ${ }^{1}$ \\ ${ }^{1}$ Swedish University of Agricultural Sciences, Uppsala, Sweden; ${ }^{2}$ Natural Resources Institute Finland, Oulu, Finland (hernan.capador@slu.se; \\ berit.samils@slu.se; juha.kaitera@slu.se; ake.olson@slu.se)
}

Swedish forestry is sustained by planting about 200 million Norway spruce (Picea abies) seedlings every year. Most of these seedlings come from seeds orchards, which have been established to transfer the genetic gain in growth and yield achieved through plant breeding since the 1940s. However, today there is a deficit of seeds coming from Swedish seed orchards because of irregular flowering and cone set, but also due to pest and pathogen infections such as Thekopsora areolata - the causal agent of cherry spruce rust, a fungus that reduces significantly seed production in Fennoscandia. To investigate the reproduction mode and population structure of the pathogen, newly developed microsatellite markers and a hierarchical sampling strategy were used. From one location in Norway, one location in Finland and five locations in Sweden, one aecium per infected cone was analysed. In addition, multiple aecia per scale and cone were sampled at two locations in Sweden. The results show an over-all high genotypic diversity, at country and location levels no genetic structure was found which indicates high gene flow and random mating in T. areolata. At the cone/scale level multiple identical genotypes were found and non-random mating was observed. These results suggest that $T$. areolata has long distance spore dispersal in Fennoscandia with common recombination events and clonal or vegetative spread in cones and scales.

\section{Disease problems in seed, seedling and plantation of Dalbergia oliveri Gamble ex Prain in Myanmar \\ Wah Wah Linn', Wai Wai Than ${ }^{1}$ \\ ${ }^{1}$ Forest Research Institute, Nay Pyi Taw, Myanmar (wahwahlinn48@gmail.com; waiwaikyaw2007@gmail.com)}

The Rose Wood, Dalbergia oliveri Gamble ex Prain. is popular in the markets, very good price in furniture due to the good color and very hard. Nowadays, it is one of the CITES species as an endangered (IUCN Red List Nghia, 1998). Previously, the disease problems are not studied yet not only in Myanmar but also in the growing regions, therefore it was conducted in 2016. Objective was: preliminary study the disease problems in seed, seedling and plantation of Dalbergia oliveri Prain. Five study sites were surveyed and recorded of symptoms. In the laboratory, disease isolation, identification, and disease occurrence using the formula: disease occurrence $\%=\mathrm{n} / \mathrm{N}$ x 100 (Mao, 1996). About dead trees 47.4\% in Moe Nyin Tamalan Plantation, 18.86\% in the Katha Tamalan Plantation, $6.2 \%$ in Katha Nursery; and 3.8\% in Yezin Nursery were found. Symptoms necrosis, tar spot, dieback, yellowing, were observed. Pathogenicity were found Rhizotonia solania in Necrosis of leaf; Cladosporium sp. in tar spot of leaf; R. solania, Cladosporium sp. in dieback of shoot tip; Perithecia sp., Pythium sp., Caldosporium sp., $R$. solania from leaf and, Fusarium sp. from root in yellowing of leaf. Dieback was the most occurrences and serious among the four common diseases and found larva of beetle borer insect infestation. This preliminary study is just information and probably to approach application treatments for future rose wood plantation.

\author{
Beekeeping: a source of income and sustainable development in the Ntacuja community in the Niassa National Reserve, Mozambique \\ I Apicultura: fonte de renda e desenvolvimento sustentável na comunidade de Ntacuja - Reserva Nacional do Niassa \\ Felipe André Angst ${ }^{1}$, Vitalina Temporário ${ }^{\prime}$ \\ IUCM, Lichinga, Mozambique (fangst@ucm.ac.mz; vtemporario@ucm.ac.mz)
}

As comunidades que residem dentro e na zona-tampão da Reserva Nacional do Niassa (RNN) na busca de meios alternativos de fontes de rendimento tem efetuado práticas prejudiciais ao meio ambiente que influenciam na redução da biodiversidade condicionada pelo desflorestamento, caça furtiva, mineração ilegal (garimpo) e pelas queimadas descontroladas. Com isso a Universidade Católica de Moçambique - Faculdade de Gestão de Recursos Florestais e Faunísticos esta a implementar o Projeto "Apicultura Sustentável - Mel 100\% Puro" na comunidade de Ntacuja dentro da RNN na tentativa de oferecer meios alternativos sustentáveis de fontes de rendimento visto que as abelhas, símbolo do desenvolvimento sustentável, são "parceiros estratégicos" na manutenção da biodiversidade devido a sua capacidade polinizadora e mantenedora de espécies naturais. A pesquisa tem como objetivo identificar e analisar os resultados alcançados pelo projeto a nível florístico e socioeconómico em Ntacuja-RNN. Será feito um levantamento fitossociológico da estrutura horizontal, vertical e da regeneração natural da espécies em 40 parcelas de 10 m x 10 m, distribuídas nos dez (10) apiários do projeto (quatro para cada) e serão analisados o índice de desenvolvimento humano e o índice de condições de vida dos beneficiários a fim de s obter-se mudanças da composição florística bem como das condições de vida dos beneficiários do projeto.

\section{Simulating wind and bark beetle disturbances in Austrian Forests \\ Werner Rammer ${ }^{1}$, David Leidinger ${ }^{2}$, Herbert Formayer ${ }^{2}$, Manfred J. Lexer ${ }^{2}$ \\ ${ }^{1}$ University of natural Resources and Life Sciences, Vienna, Austria; ${ }^{2}$ University of Natural Resources and Life Sciences, Vienna, Austria (werner.rammer@boku.ac.at; david.leidinger@boku.ac.at; herbert.formayer@boku.ac.at;mj.lexer@boku.ac.at)}

In European forests disturbances cause substantial damage to timber stocks. In Austria between 20-50\% of annual harvests are triggered by disturbances. By far the most important disturbance agents are wind and bark beetles. Under climate change disturbance regimes are expected to intensify. Emerging disturbance regimes not only will affect future forest composition and structure but also the provisioning of ecosystem services. In order to project impacts on forests and related ecosystem service provisioning forest ecosystem models are inevitable tools for simulation-based impact assessments and adaptation planning. So far, weak point of many climate change impact assessments in forestry has been the lack of consistent inclusion of disturbance regimes. In this study we present the simulation of timber damaged by wind and bark beetles in Austria in the period 2003-2015 by linking a state-of-the-art dynamic forest model, including interacting disturbance modules for wind and bark beetles, with weather data at $1 \mathrm{x} 1 \mathrm{~km}$ spatial resolution. Simulated damages are compared with data from the Austrian Forest Damage Monitoring System which records damages by disturbance agent at the resolution of 70 Austrian administrative districts. We describe the simulation setup of 4 mill ha forest land paying particular attention to (i) the interacting disturbance modules for wind and bark beetles, (ii) providing the initial forest state in 2003 based on data of the Austrian National Forest Inventory, and (iii) the use of weather data including wind gust speed to drive the simulations. Pattern of deviances between simulations and observations are explained by ecological and socio-economic attributes. 


\title{
Improved forest insect outbreak modeling under climate variability
}

Steve McNulty', John Cobb III', Ge Sun ${ }^{1}$

IUSDA Forest Serivce, Research Triangle Park,USA (smcnulty@fs.fed.us; jgcobb@fs.fed.us; gesun@fs.fed.us)

The Southern pine beetle (Dendroctonus frontalis, SPB) is a major commercial pest across the southeastern United States (US). The insects target highly valuable southern pine species including loblolly pine (Pinus taeda). Beetle Outbreaks are episodic with many years between major population increases. A rapid response of cutting and burning infected trees is the best control measure for reducing the outbreak severity, and a model to predict outbreaks would assist in the budgeting and personal planning for beetle control. Therefore, this study used combination of southern pine beetle survey data, US Forest Service Forest Inventory and Assessment Data, gridded historical climate data, National Oceanographic and Atmospheric Administration (NOAA) short term climate prediction forecasts, Coupled Model Intercomparison Project Phase 5 (CMIP 5) long-term climate change scenarios, and the WASSI Hydrologic Model to develop a southern pine Beetle Outbreak Model (BOM). Using previous years beetle location, stand density, adjacency to other counties with beetle outbreaks, maximum monthly air temperature and estimated stand evapotranspiration, BOM predicted 67\% of interannual variability in SPB outbreaks when model predictions were compared to reserved outbreak data not used in model development. The validated model was then used with short- and long-term climate forecasts to predict annual outbreak locations and to examine the impact of long-term climate change on SPB populations across the southeastern US. This paper will discuss the model and implications for its use.

\section{D7c: BIOLOGICAL INVASIONS, BIODIVERSITY AND ECOSYSTEM SERVICES - 1}

\section{Regional impacts of forest insect and disease invasions on forest carbon loss}

Andrew Liebhold ${ }^{1,2}$, Songlin Fei ${ }^{3}$, Randall Morin ${ }^{4}$, Christopher Oswalt ${ }^{5}$

${ }^{1}$ USDA Forest Service Northern Research Station, Morgantown, USA; ${ }^{2}$ Czech University of Life Sciences, Prague, Czech Republic; ${ }^{3}$ Purdue University, West Lafayette, USA; ${ }^{4}$ USDA Forest Service Northern Research Station, Newtown Square, USA; ${ }^{5}$ USDA Forest Service Southern Research Station, Knoxville, USA (aliebhold@gmail.com; sfei@purdue.edu; rsmorin@fs.fed.us; coswalt@fs.fed.us)

Worldwide, forests are increasingly affected by non-native insects and diseases, some of which cause substantial tree mortality. Forests in the USA have been invaded by a particularly large number $(>450)$ of tree-feeding pest species. While information exists about ecological impacts of certain pests, a region-wide assessment of the composite ecosystem impacts of all species is lacking. Here we analyze 92,978 forest plots distributed across the USA to estimate carbon loss associated with elevated mortality rates caused by the 15 most damaging non-native forest pests. We find that these species caused an additional (above background levels) annual tree mortality rate of $7.48 \mathrm{TgC} / \mathrm{yr}$, which is comparable to annual carbon emissions from 5.9 million automobiles or $25.2 \%$ of all wildfires in the USA. In addition, $41.1 \%$ of total live forest biomass in the USA are at risk to loss from these 15 pests. These results indicate that forest pest invasions, driven primarily by globalization, are casting a huge risk to forests in the USA and have significant impacts on carbon dynamics.

\section{Eucalypt insect pests in Africa: spread, threats and opportunities for management}

Brett Hurley ${ }^{1}$, Mesfin Wondafrash ${ }^{1,2}$, Michelle Schröder ${ }^{1}$, Gudrun Dittrich-Schröder ${ }^{1}$, Caitlin Gevers ${ }^{1}$, Samantha Bush ${ }^{1}$, Bernard Slippers ${ }^{3}$ ${ }^{1}$ Department of Zoology and Entomology, Forestry and Agricultural Biotechnology Institute (FABI), University of Pretoria, Pretoria, South Africa; ${ }^{2}$ School of Plant Sciences, Haramaya University, Dire Dawa, Ethiopia; ${ }^{3}$ Department of Biochemistry, Genetics and Microbiology, Forestry and Agricultural Biotechnology Institute (FABI),University of Pretoria, Pretoria, SouthAfrica (brett.hurley@fabi.up.ac.za; mesfin.gossa@fabi.up.ac.za; michelle.schroder@fabi.up.ac.za; gudrun.dittrich@fabi.up.ac.za; caitlin.gevers@fabi.up.ac.za; samantha.bush@fabi.up.ac.za; bernard.slippers@fabi.up.ac.za)

Native to Australasia, Eucalyptus is one of the most planted genera of trees in the world. These trees provide an important socio-economic role in many countries of sub-Saharan Africa, providing fuel and fibre and supporting a diverse range of stakeholders. However, the sustainability of Eucalyptus as a plantation species is challenged by the introduction of Eucalyptus-feeding insects from Australia that have become serious pests in their invasive range. We provide a summary of current and ongoing studies to better understand this threat and investigate suitable management responses. A recent survey across 14 countries in sub-Saharan Africa showed a broad distribution of many of the major insect pests. Analysis of genetic diversity indicated a common origin of geographically distant populations for some of these insects, whereas high diversity and even distinct lineages were present for other species. Screening trials and field surveys have indicated high variation of susceptibility between host species for some of the insect pests. Survey data has also confirmed the establishment of released biological control agents. In addition, the occurrence of natural enemies unintentionally introduced and native parasitoids expanding their host range to these invasive insects have been reported. Ongoing research is continuing to increase our understanding on host resistance and biological control approaches for these pests, and to investigate other opportunities for their management. Efforts are also being made to facilitate exchange of information and collaboration between countries in the region on issues pertaining to invasive species.

\section{Spatial patterns of discovery points and invasion hotspots of non-native forest pests}

\author{
Samuel Ward ${ }^{1}$, Songlin Fei ${ }^{1}$, Andrew Liebhold ${ }^{2}$
}

${ }^{1}$ Purdue University, West Lafayette, USA; ${ }^{2}$ USDA Forest Service, Morgantown, USA (ward225@purdue.edu;sfei@purdue.edu; aliebhold@gmail.com)

Establishments of non-native forest insects and pathogens continue to increase worldwide with intensification of invasion pathways. Quantifying spatiotemporal patterns in establishment locations and subsequent invasion dynamics may provide insight into the underlying mechanisms driving invasions and assist biosecurity agencies with prioritizing areas for proactive surveillance and management. Using locations of first discovery and county-level occurrence (presence/absence) data for 101 major non-native forest insects and pathogens across the contiguous USA, we (1) quantified spatial patterns in discovery points and county-level species richness and (2) identified environmental correlates of these observed spatial patterns. We found that discovery points were highly aggregated in space and located in areas with high densities of ports and roads. Though concentrated in the northeastern USA, discovery points occurred farther west and became less aggregated as time progressed. Invasion richness was statistically higher in several counties in the northeast. However, patterns of discovery points and invasion richness varied substantially among pest origins (i.e., world region of pests' native ranges) and pest feeding guilds. Significant variation in invasion richness was attributable to patterns of first discovery locations. Our results indicated that spatiotemporal variability in the intensity of invasion pathways has resulted in marked geographical patterns of establishment and contributed to current macroscale patterns in invasion richness in the USA. 


\section{Tracing the role of human civilization in the globalization of plant pathogens}

Alberto Santini ${ }^{1}$ D, Andrew Liebhold ${ }^{2}$, Duccio Migliorini ${ }^{1}$, Stephen Woodward ${ }^{3}$

${ }^{1}$ Institute for Sustainable Plant Protection - C.N.R., Sesto fiorentino, Italy; ${ }^{2}$ US Forest Service Northern Research Station, Morgantown, USA; ${ }^{3}$ University of Aberdeen, Department of Plant and Soil Science, Institute of Biological and Environmental Sciences, Aberdeen, United Kingdom (alberto.santini@cnrit; aliebhold@fs.fed.us; duccio.migliorini@ipsp.cnr.it; s.woodward@abdn.ac.uk)

The last three decades have witnessed a flood of invasive plant pathogens appearing around the world. It is accepted that $1500 \mathrm{CE}$ is a starting date for anthropogenic biological invasions; however prehistoric findings and historical reports suggest an earlier connection between human migration and movement of invasive plant pathogens. Pathogens have several pathways of entry into new environments, the great majority of which are human mediated. The fossil record provides evidence that diseases commonly affected plants some 250 million years ago. In the last 200 years the incidence of diseases affecting plants has increased exponentially in terms of both numbers and severity. Most of newly emerging plant diseases arose following the introduction of exotic pathogens into a new environment. The introduction of alien pathogens can lead to novel host-pathogen associations or indeed novel pathogen-pathogen combinations, for which there is no previous co-evolutionary history. Technological developments have facilitated trade in goods, and a consequent transport of pathogens. Historical geopolitics and regulation of trade have influenced the establishment of pathogens in different world regions. Here we provide an analysis of this phenomenon focusing on the means of introduction of these organisms, which generally can be attributed to technological developments, human behaviour and government policies. Developing an in depth understanding of the historical context of these invasions could reduce the rate of future invasions leading to significant impacts on economics, ecology and on human health and wellbeing.

\section{Using interception and establishment data to reconstruct invasions of bark and wood boring beetles}

\section{Eckehard Brockerhoff ${ }^{1}$, Rebecca Turner ${ }^{2}$, Andrew Liebhold ${ }^{3,4}$}

${ }^{1}$ Swiss Federal Institute WSL, Birmensdorf, Switzerland; ${ }^{2}$ Scion (New Zealand Forest Research Institute), Christchurch, New Zealand; ${ }^{3}$ USDA Forest Service Northern Research Station, Morgantown, USA; ${ }^{4}$ Czech University of Life Sciences, Prague, Czech Republic (eckehard.brockerhoff@gmail.com; rebecca.turner@scionresearch.com; aliebhold@gmail.com)

Invasions of forest insects can have severe environmental and economic consequences. Although actual invasion events of insects are very rarely observed, and most invasions are only detected years later when incipient populations are larger, analysis of border interception and establishment data can provide valuable information about insect invasion processes. Interception data can be used as a proxy of arrival rate, a key driver of invasions. We used interception and establishment data from New Zealand, the USA and other countries to illustrate their usefulness for documenting the role of propagule pressure in invasions, temporal and geographic patterns of interceptions and establishments, and bridgehead effects (i.e., invasions originating not from the native region of an invasive species but from other invaded regions). Our analyses focus mainly on bark and wood boring beetles (Scolytinae, Cerambycidae, and Buprestidae) as these taxa are comparatively well-known and interceptions are often documented at the species level which allows more conclusive analysis. We will also discuss the reasons why interception data may be less informative for some taxa to illustrate how future gathering of interception data could be improved to provide better data for future assessments of invasion risks and processes.

\section{Impacts and management cost of pine invasions in Patagonia}

Martin Nuñez ${ }^{1}$, Romina Dimarco ${ }^{2}$,Yamila Sasal ${ }^{3}$, Carolina Quintero ${ }^{3}$, M. Noelia Barrios Garcia ${ }^{3}$, Mauro Sarasola ${ }^{4}$, Juan Pablo Diez ${ }^{4}$, Andres S. Martinez Von Ellrichshausen', Mariano Rodriguez Cabal ${ }^{3}$, Juan Paritsis ${ }^{3}$

${ }^{1}$ Universidad del Comahue/CONICET, Bariloche, Argentina; ${ }^{2} I N T A / C O N I C E T$, Bariloche, Argentina; ${ }^{3}$ CONICET, Bariloche, Argentina; ${ }^{4} I N T A$, Bariloche, Argentina(nunezm@gmail.com; rominadimarco@gmail.com; shamilacony@gmail.com; quintero.carolina@gmail.com; x@eee.edu; sarasola.mauro@inta.gob.ar;diez.juan@inta.gob.ar; andmarv77@gmail.com; rodriguezcabal@gmail.com; j.paritsis@gmail.com)

Forestry plantations with nonnative species is an important economic resource in many parts of the world, but these plantations can generate environmental problems. One of these problems is the invasions in neighboring communities. Here we study the impacts of Lodgepole pine (Pinus contorta) invasion, probably the most invasive forest species in the southern hemisphere. We analyzed its impact on biodiversity, ecosystem services, and fuel load. We compared non-invaded zones with invaded zones of contrasting densities, and areas where invasive trees had been removed. We also evaluated the costs of pine invasion removal. We found that Pinus contorta has a high impact only when it reaches high densities This gives some hope because it indicates that there is a relatively long period (10 years from the beginning of the invasion) during which appropriate management should be conducted. Removing pine invasions was very effective to reduce fire risk. However, after one year the removal of pines did not result in improvements in biodiversity indices or ecosystem services metrics. Post-removal sites in areas with previous high pine density were colonized by nonnantive plants. Control costs grew with the increase in density of pines. Our results show that if managers focus on early interventions, numerous environmental impacts can be avoided and the costs of invasion management will be reduced. However, if forestry practices continue to ignore invasions, environmental impacts may reach an unprecedented level given the high probability of future pine invasion in the Southern hemisphere.

\section{(Towards) a global strategy for invasive alien trees}

Giuseppe Brundu ${ }^{1}$, Anibal Pauchard ${ }^{2}$, Petr Pyšek ${ }^{3}$, David M. Richardson ${ }^{4}$

${ }^{1}$ Department of Agriculture, University of Sassari, Sassari, Italy; ${ }^{2}$ Laboratorio de Invasiones Biológicas, Facultad de Ciencias Forestales, Universidad de Concepción, Concepción, Chile; ${ }^{3}$ Institute of Botany, Department of Invasion Ecology, The Czech Academy of Sciences, Prühonice, Czech Republic; ${ }^{4}$ Centre for Invasion, Biology, Department of Botany \& Zoology, Stellenbosch University, Stellenbosch, South Africa (gbrundu@tin.it; pauchard@udec.cl; petr. pysek@ibot.cas.cz; rich@sun.ac.za)

Forests, woodlands and plantations are among the world's most productive land-based ecosystems and are essential to life on earth and for providing a plethora of ecosystem services. We argue, however, that a significant number of alien tree species (apart from suffering from invasive alien pests) are invasive or might become invasive - i.e. they spread from planting sites into adjoining areas, sometimes causing substantial damage to biodiversity and ecosystem services. The challenge is to manage alien trees and existing and future planted forests of alien trees to maximize current benefits and opportunities, while minimising risks and negative impacts, without compromising future benefits and land uses. Besides their use in provenance trials and planted forests, alien trees have been and are introduced and used for multiple reasons, such as gardening and landscaping, protective functions, arboreta, erosion protection, soil phytoremediation and for increasing the forest area through afforestation of abandoned or derelict land. The notion that forested areas are of major conservation and societal value over treeless environments has halted efforts to control invasive tree species. However, evidence is mounting that invasive trees can have major impacts on 
biodiversity, ecosystem services with relevant economic costs. We suggest that the European Code of Conduct for Invasive Alien Trees could be a suitable discussion and working basis to implement a more general Global Strategy for Invasive Alien Trees. Such a Strategy would not just recognise that there is a global problem, but also call for best practices, innovative solutions and a better-coordinated global approach.

\title{
The presence of exotic tree species may not necessarily limit natural regeneration in tropical forest restoration
}

\author{
Nino Amazonas ${ }^{1}$, Tiago Barreto ${ }^{1}$, Paulo Sérgio Sampaio de Oliveira ${ }^{2}$ \\ ${ }^{1}$ Fundação Espaço ECO, São Bernardo do Campo,Brazil; ${ }^{2}$ REVERDE, Guaratinguetá, Brazil (namazonas@gmail.com; tiagoebarreto@yahoo.com.br; \\ reverdeguara@gmail.com)
}

When forest restoration started spreading in Brazil, species diversity was not a serious concern, nor was the exclusive use of native species. In that context, Syzygium jambolanum (Lam.) DC. was widely planted. Nowadays, eliminating exotic trees is an important component of management plans as it is a common belief that natural regeneration is limited by allelopathic effects or by characteristics of the leaf litter of exotic species. However, this limitation must be evaluated case by case. We are evaluating natural regeneration in a restoration project located in Guaratinguetá, São Paulo, in the Atlantic Forest of Brazil to test the hypothesis that $S$. jambolanum is hindering natural regeneration. We measured sapling density under the canopy of $S$. jambolanum and under native trees and used a general linear model to test if density was related to the canopy species, leaf litter thickness or forest age (older, intermediate and younger patches). In this first assessment, we found that sapling density was not influenced significantly by canopy species nor litter thickness. However, forest age was an important factor related to sapling density, with higher sapling density the older the patches, regardless of other factors tested. From our initial results, we suggest that management plans should be designed considering careful evaluations of the real impacts of tree species. In some cases, eliminating exotic species may be a disadvantage and other management measures, such as enrichment plantings, should be preferred instead. Moreover, we believe native species will gradually replace exotic trees when these start senescing.

\section{D7D: COMPLEX INTERACTIONS OF MISTLETOE, ECOSYSTEMS, AND PEOPLE.}

\author{
The cascade impacts of climate change could threaten key ecological interactions: insights from a keystone mistletoe \\ Francisco Fonturbel ${ }^{1}$ iD, Antonio Lara ${ }^{2,3}$, David Lobos ${ }^{2,4}$, Christian Little ${ }^{2,5}$ \\ ${ }^{1}$ Pontificia Universidad Católica de Valparaiso, Valparaiso, Chile; ${ }^{2}$ Universidad Austral de Chile, Valdivia, Chile; ${ }^{3}$ Center for Climate and Resilience \\ Research, Santiago, Chile; ${ }^{4}$ Fundación FORECOS, Valdivia, Chile; ${ }^{5}$ INFOR, Valdivia, Chile(francisco.fonturbel@pucv.cl; antoniolara@uach.cl; \\ david.lobosvega@gmail.com; little.christian@gmail.com)
}

Climate change is triggering ecological responses all over the world as a result of frequent, prolonged drought events. The effects of climate change on species distribution and performance have been widely studied in the past decade, but its effects on ecological interactions remain little understood. However, the potential effects on ecological interactions, and particularly pollination and seed dispersal that play a key role in plant reproduction, may be compromising the future viability of many ecosystems. To gain insight into this issue we used a tripartite mutualistic interaction with a hemiparasitic mistletoe (Tristerix corymbosus), its pollinator (the hummingbird Sephanoides sephaniodes) and its disperser (the relict marsupial Dromiciops gliroides). We studied flower and fruit production, and visitation rates of the mutualist animals during average (2012) and dry (2015) austral summers. Drought in our study area affected precipitation and soil water availability. Although pollinator visits did not significantly differ in these summers, during the dry summer flower and fruit production experienced an important decline, as did seed disperser visits. Also, T. corymbosus mortality increased from $12 \%$ in 2012 to $23 \%$ in 2015 . This empirical evidence suggests that the cascade effects of climate change may indirectly be hindering ecological interactions in the Valdivian temperate rainforest ecosystem we studied. Due to their specialized plant-animal and plant-plant interactions, mistletoes constitute a good study model for studies on climate change. Long-term research is essential to provide the knowledge necessary to understand how key ecological processes may be affected in a changing (and warming) world.

\section{The African Mistletoe: from noxious weed to cure-all medicine: a synthesis of experience from empirical and indigenous knowledge domains}

Ekeoba Matthew Isikhuemen ${ }^{1}$, Musa Mohammed ${ }^{2}$, Uche O. Olisaemeka ${ }^{1}$

${ }^{1}$ University of Benin, Benin City, Nigeria; ${ }^{2}$ Raw Materials Research and Development Council (RMRDC), Abuja, Nigeria (ekeoba.isikhuemen@uniben.edu; moh2musa@yahoo.com; ucheyonyi@gmail.com)

The term "African Mistletoe" is used for a group of woody hemi-parasitic plants that grow on, and obtain nourishment from shoot/branches of trees and shrubs. These parasites confer high nuisance value and cause serious damage to host plants resulting in economic and production loses. However, they are valuable in ethnomedicine - act as safety-net and/or booster to healthcare security for herbal medicine users. This paper examines the uses and phytochemical constituents of leaves of mistletoe obtained from selected trees/shrubs in Edo State, Nigeria. Data were collected through Key informants' interview/questionnaire and laboratory investigations. The Result of socio-economic survey revealed that herbalists, vendors and dispensers/users treat diverse ailments (diabetes, hypertension, cancer, diuretic, ulcer, memory loss, inflammatory conditions, irregular menstruation, epilepsy, arthritis, etc.) with leaves of mistletoe. These are largely obtained from cultivated fruit- and wild trees/shrubs - Azadirachta indica L. (Neem), Citrus sinensis L. (Sweet Orange), Spondias monbin L. (Hogplum), Persea americana (Mill.) (Avocado), Psidium guajava (Linn.) (Guava), etc. The outcome of laboratory analysis of mistletoe leaves and twigs of host plants revealed varying amounts of metabolites (alkaloid, anthraquinone, cyanogenic glycoside, flavonoid, phenol, saponins, tannin, etc.). The juxtaposition of socio-economic and laboratory surveys indicated that the mistletoe species, Phragmanthera capitata, associated with Hog plum and Guava trees had more metabolites (alkaloids, anthraquinons, flavonoids, phenol, tannins, and saponins) than other host plants. Although this study did not produce enough empirical evidence to substantiate the use of mistletoe as cure-all for ailments, further investigation on host specificity and/or plant - mistletoe associations is recommended.

\section{Comparative wood anatomy of Brazilian mistletoes genera of Loranthaceae}

Victor Sibinelli ${ }^{1}$, Luiza Teixeira-Costa ${ }^{1}$, Gregório Ceccantini ${ }^{1}$ 
IUniversidade de São Paulo,Sao Paulo,Brazil (sibinelli95@gmail.com; luiza.teixeirac@gmail.com; gregorio@usp.br)

Parasitic plants are organisms able to obtain some nutrients from other plants, often causing a significant impact on their host's fitness. Parasitic plants may cause great losses on crop productivity or disturbances in the dynamics of natural environments. Many functional and morphological features are responsible for the success of these plants in nature. Wood anatomy is one major aspect, given the stem wood provides connection between the haustoria (sucking organs) and the parasite's crown. Wood structure associated to stomata functioning play a major role in sap supply and transport security. The Loranthaceae is one of the largest parasitic groups, gathering the largest number of genera within the Santalales order. It comprises both root and stem hemiparasites. In Brazil 12 genera occur naturally, distributed in different biomes and habitats. The present work aimed to extend the knowledge on wood anatomy of Loranthaceae by studying and comparing all Brazilian genera. The morphological profile of the parasitic stem wood shows great diversity regarding vessel lumen size ( $\leq 50$ up to $\geq 200$ $\mu \mathrm{m}$ ), with vessel dimorphism common, i.e. wider vessels associated with very narrow vessel elements and/or tracheids; also, diverse types of vessel groupings and well-developed banded parenchyma; very thick-walled fibres, and tall rays. These features seem to be associated with the evolution of the group, that had a change of habitat from root to stem parasitism, given that most of them are not shared with the basal root parasite Gaiadendron punctatum.

\section{Morphogenesis and evolution of mistletoes' haustoria \\ Luiza Teixeira-Costal (D), Gilberto Ocampo (D), Gregório Ceccantini ${ }^{(D)}$ \\ ${ }^{1}$ Universidade de São Paulo, São Paulo, Brasil; ${ }^{2}$ Universidad Autonoma de Aguascalientes, Aguascalientes, Mexico(luiza.teixeirac@gmail.com; \\ gilberto.ocampo.uaa@gmail.com; greg@usp.br)}

Mistletoes, shrubby to arboreal parasitic plants infesting the above-ground organs of their hosts, have evolved at least three times within the Santalales. Currently accounted to include 89 genera, representing nearly half of the diversity within the order, this parasitic life form has been successful in infesting a wide array of hosts and colonizing all forested continents. Such success can be partially attributed to the emergence and specialization and of different types of host-parasite connection via an organ known generically as haustorium. Details obtained from broad studies on the morphogenesis of mistletoe haustoria in different species were used for a phylogenetic analysis of ancestral character state reconstruction, which was coupled with divergence time estimations for all clades within Santalales. Our results suggest that the change from root to aerial parasitism could have been facilitated by a common background for haustorium development shared by root parasites and epicortical root-forming mistletoes. From an ancestor with either root or epicortical root haustoria, drier climates may have acted as a driver for the expansion and specialization of mistletoe's endophytic tissues, leading to the emergence of a structure known as cortical strands, which help proliferating the parasite within the host bark. This crucial evolutionary step probably conferred great advantages to mistletoes, enabling groups such as Visceae to expand to a wider distribution, regardless of climatic conditions. The development of cortical strands would have also promoted host tissue proliferation, leading to the formation of convergent haustorium types known as woody galls and woodrose formations.

\section{Urban mistletoe: The final frontier in ecological restoration?}

David Watson ${ }^{1}$, Lee Harrison ${ }^{2}$, Melinda Cook ${ }^{3}$, Rodney van der Ree ${ }^{2}$

${ }^{1}$ Charles Sturt University, Albury, Australia; ${ }^{2}$ City of Melbourne, Melbourne, Australia; ${ }^{3}$ University of Technology, Sydney, Sydney, Australia

(dwatson@csu.edu.au; lee.harrison@melbourne.vic.gov.au; lizzieb_lou01@hotmail.com; rodney.vanderree@melbourne.vic.gov.au)

Although often presumed to be ecologically barren, cities can provide safe havens for biodiversity. As well as supporting populations of native species, urban green spaces contribute to the well-being of people living and working in cities, and there is an emerging understanding of the reciprocal benefits of making our cities 'greener'. Despite being the second largest city in Australia, Melbourne has an extensive network of parks, gardens and street trees, collectively an urban forest comprising some 70,000 trees. As part of a broader initiative to increase the value of these managed habitats to wildlife, The City of Melbourne council in partnership with Charles Sturt University conducted a mistletoe inoculation program to measure the ecological and potential social benefits of mistletoes in urban areas. Instead of replacing established exotic trees with indigenous species, can adding mistletoe to street trees make significant improvements to biodiversity? Here we review the first two years of the project, demonstrating that as well as boosting resource availability for wildlife, adding mistletoe to the urban forest will increase amenity of streetscapes for Melbournians. In addition to being important components of woodlands and forests, mistletoes are well suited for urban restoration initiatives, buffering climatic extremes and affording valuable opportunities for educating the general public about nature.

\section{Mistletoe dispersing birds rely on spatial-memory and established search images to find fruiting mistletoes \\ Melinda Cook ${ }^{1}$, Andrea Leigh ${ }^{1}$, David Watson ${ }^{2}$ \\ ${ }^{1}$ University of Technology Sydney, Sydney, Australia; ${ }^{2}$ Charles Sturt University, Albury-Wodonga, Australia (melinda.cook01@gmail.com; andrea.leigh@uts.edu.au;dwatson@csu.edu.au)}

Mistletoes are characteristically patchy, grow at low densities and can be difficult to discern within host canopies. Yet, they are consistently visited by a suite of fruit eating birds that find them and disperse their seeds. To investigate the behavioural basis to this pattern, we combined observational studies of mistletoe visitation with experimental manipulation of mistletoe locations in semi-arid woodland in Southern Australia, removing entire mistletoe plants from their host and affixing them in novel locations. Comparing visitation to mistletoes placed in primary host trees (Acacia) with mistletoes placed in adjacent trees which do not act as hosts (Callitris) demonstrated that some birds used the host tree rather than the mistletoe itself as the primary search image. Relocated mistletoe received comparable levels of visitation by specialist Mistletoebirds influenced by the number of fruits on the mistletoe clumps but significantly fewer visits by dietary generalists and opportunists including the generalist Spiny-cheeked Honeyeater, one of the principal mistletoe vectors for dispersal in this system. Rather than using visual cues, these birds were relying on recent experience and fine-grained spatial memory to locate fruiting mistletoe plants. In addition to explaining observed patterns of host preference in this system, this host-mediated foraging behaviour may contribute to observed patterns of host mimicry in this system, birds visiting both infected and uninfected hosts to search for cryptic mistletoes, increasing dispersal effectiveness and iteratively selecting for mistletoes which more closely resemble their hosts.

\section{Wood anatomy of Santalales: Is there a convergent syndrome in mistletoe's wood structure related to parasitism evolution? Gregorio Ceccantini ${\text { (D), Victor Sibinelli }{ }^{1} \text {, Luiza Teixeira-Costa }}^{l, 2}$ (D)}


${ }^{1}$ Universidade de São Paulo, Sao Paulo, Brazil;; ${ }^{2}$ Harvard University Herbaria, Cambridge,USA (gregorio@usp.br; sibinelli95@gmail.com; luiza.teixeirac@gmail.com)

The order Santalales comprises both parasitic and non-parasitic plants under strong controversy about the internal relationship and circumscription of families in the past ten years (ca; 6 up to 21). They totalize almost $2000 \mathrm{spp}$ in ca. of 151 genera, with a habit diversity ranging from totally holoparasitic underground non-woody herbs, such as Balanophoraceae, typical autotrophic trees, endophytic herbs, typical mistletoes (Psittacanthus, Viscum), up to giant hemiparasitic trees as sandalwood (Santalum). This work aimed compare the structure of the woody representants, understand its diversity and test if there are an assemblage of features typic of the 'mistletoe' habit, considering as mistletoe an hemiparasitic plant growing on the stem of a woody host. For doing so, wood samples of dozens of genera have been collected in the past decade, in nature, herbaria and xylaria trying to understand their anatomy. Comparing mistletoes and nonmistletoe parasitic plants, a convergent organization arises what might be called as a 'parasitic wood anatomy syndrome'. Most woods show extremely short vessel elements (70 $\mu \mathrm{m}$ long), several arrangements of vessel grouping (number and form of groups), high vessel frequency, association with perivascular tracheids. Fibres are very thick-walled and axial parenchyma usually is paratracheal and abundant. The features found to suggest that their hydraulic systems are very redundant and safe, capable of working in very low water potentials with minimal failure. This set of characters is very recurrent and indicates convergent evolution in hemiparasitic plants driven by the habit of growing on trunks of other plants.

\title{
Did mammals bring the first mistletoes into the tree-tops?
}

David Watson ${ }^{\prime}$

'Charles Sturt University, Albury, Australia (dwatson@csu.edu.au)

As the only woody parasitic plants that attach to host canopies, the growth habit of mistletoes represents a key innovation. How this aerially-parasitic habit originated is unknown - mistletoe macrofossils are relatively recent, from long after they adapted to canopy life and evolved showy bird-pollinated flowers, sticky seeds within bird-dispersed fruits and woody haustoria to attach to host branches. By integrating fully-resolved phylogenies of the most diverse mistletoe lineages, I align the timing and sequence of these events, demonstrating that the shift from root-parasitic shrub to aerial hemiparasite predates the evolution of their contemporary avian dispersers. Reconciling this mismatch with recent research on dispersal ecology, I identify two groups as the most likely original dispersal agents; basal primates for the Viscaceae in the Cretaceous and Microbiotherian marsupials for the Loranthaceae in the Eocene. Having colonized the canopy, subsequent mistletoe evolution and diversification coincided with the rise of nectar and fruit-dependant birds.

\section{The European mistletoe in Sonoma County California, USA}

\author{
David Shaw ${ }^{1}$, Christopher Lee ${ }^{2}$ \\ ${ }^{1}$ Oregon State University, Corvallis, USA; ${ }^{2}$ California Department of Forestry and Fire Protection, Fortuna, USA (dave.shaw@oregonstate.edu; \\ christopher.lee@fire.ca.gov)
}

The European mistletoe (Viscum album) was introduced to Sebastopol, Sonoma County, California, USA in about 1900 by the horticulturist Luther Burbank to developi a trade in ornament and medicinal tincture. The mistletoe has since spread from the point of introduction on hardwood trees, especially non-native hardwoods in yards and farms. Surveys of the mistletoe were done in 1971, 1986, and 1991. We re-surveyed the distribution of V. album in Sonoma County in February 2019, providing a $\sim 119$-year estimate of spread. The estimated area encompassed by mistletoe-infected hosts increased greatly, from $184 \mathrm{~km}^{2}$ in 1991 to $606 \mathrm{~km}^{2}$ in 2019, although the furthest distance from origin was only $24.6 \mathrm{~km}$. Although the mistletoe has intensified, it has not jumped great distance. The dominant vegetation of the uplands in the region is coniferous trees (Sequoia sempervirons, Pseudotsuga menziesii) and Quercus species in the white oak group. These native trees are not hosts, and therefore restrict the spread. However, non-native-to-California hosts such as Malus spp. Robinia pseudoacacia, Acer saccharinum are commonly colonized, as well as the native trees of riparian areas, including Populus fremontii, Alnus rubra, Salix lasiandra and Fraxinus latifolia. The mistletoe has been associated with decline of heavily infected hosts such as $P$. fremontii, and is a significant pest on multiple hosts. It appears that urban forest areas, such as Santa Rosa (population $\sim 175,000$ ) and native riparian forests in Sonoma County are most threatened by this invasive mistletoe but vectors of the seed apparently do not travel great distances.

\section{D7e: DISEASE AND ENVIRONMENT INTERACTIONS ASSOCIATED WITH FOREST DECLINE}

\section{A recent fungal introduction event revealed by the current genetic landscape of Raffaelea quercus-mongolicae population in South Korea}

Dong-Hyeon Lee ${ }^{l}$, Sun Keun Lee ${ }^{1}$, Ji-Hyun Park', Sang-Tae Seo', Sang-Hyun Lee ${ }^{1}$

'Division of Forest Insect Pests and Diseases, National Institute of Forest Science, Seoul, Republic of Korea (leedh2009@korea.kr; lskyou@korea.kr; jhpark10@korea.kr; stseo@korea.kr; shlee4@korea.kr)

Raffaelea quercus-mongolicae is a mycangial symbiont of a wood boring ambrosia beetle, Platypus koryoensis (Coleoptera: Curculionidae: Platypodidae), which is believed to be associated with oak mortality in South Korea. Despite the fact that the oak mortality has continued to spread across the country since its first discovery of the disease in 2004 and the significant impact that the pathogen has been on forest ecosystem in the country, little is known regarding its biology of the fungus. During a recent survey carried out to investigate the status of the oak wilt disease in Jeju island, Korea, visible signs of bark beetle attack, including bark beetle frass and galleries, were consistently observed on Quercus serrata, and $R$. quercus-mongolicae was successfully recovered from the tree. To infer whether the fungus has been introduced from the inland areas of Korea to the Jeju island, the genetic diversity and population structure of the $R$. quercus-mongolicae isolates collected from various geographical regions and hosts in Korea were investigated using a combination of eight microsatellite markers designed from the genome of the fungus in this study. The results showed that low levels of genetic diversity were found for the population of $R$. quercus-mongolicae from the Jeju island, compared to those from the inland areas of the country. This suggests that a limited number of individuals have recently been introduced into the Jeju island, indicating that a novel disease problem might occur in the area.

Quantifying southern pine decline: the role of Leptographium terebrantis 
John K. Mensah', Mary A. Sword Sayer ${ }^{2}$, Ryan L. Nadel ${ }^{1}$, George Matusick ${ }^{3}$, Zhaofei Fan ${ }^{1}$, Lori G. Eckhardt ${ }^{1}$

${ }^{1}$ Auburn University, Auburn AL, USA; ${ }^{2}$ USDA Forest Service, Pineville/Louisiana, USA; ${ }^{3}$ New York City Department of Environmental Protection, Bureau of WaterSupply,Natural Resources Division,NewYork,USA (jkm0042@auburn.edu; msword@fs.fed.us; ryan.nadel@auburn.edu; gmatusick@dep.nyc.gov; zzf008@auburn.edu; eckhalg@auburn.edu)

Pinus taeda L (loblolly pine), one of the economically important and predominant timber species in the Southeastern United States but suffers from growth decline and mortality. Southern pine decline is one of the disease complexes associated with root-feeding bark beetles and their ophiostomatoid fungal associate after predisposition by environmental stressors. Nonetheless, the role of the bark beetle vectored fungi in southern pine decline remains unresolved among researchers. In contributing to the ongoing debate, a study was designed to evaluate the role of the root pathogen, Leptographium terebrantis and quantify the amount of growth decline associated with the pathogen. The study was installed in a 13-year-old loblolly pine plantation at Eufaula, Alabama and dendrometer bands were permanently installed on the trees to measure radial growth on a monthly basis. Artificial inoculations were done using sterilized and $L$. terebrantis colonized toothpicks to simulate the natural feeding habits of bark beetles. Twenty-one months of post inoculation treatment, the pathogen caused a $16.3 \%$ reduction in basal area increment and 13\% mortality in the high inoculum treatment trees. The results demonstrate that the pathogen, $L$. terebrantis is involved in loblolly pine decline.

\title{
Ceratocystis wilt affecting Eucalyptus plantations in Riau, Indonesia
}

Leonardo Oliveira', Álvaro Durán', Pantun David Gaol ${ }^{1}$, Danar Wicaksono ${ }^{1}$

'April Asia Agri RGE Technology Center, Pangkalan Kerinci,Indonesia (fioteoliveira@yahoo.com.br; alvaro_duran@aprilasia.com; pantun_gaol@kerinci.lcl; danar_wicaksono@kerinci.lcl)

Ceratocystis wilt is one of the most important diseases on woody plants worldwide. In Southeast Asia, this fungal disease was able to decimate forest plantations of Acacia mangium, making unviable the commercial establishment of this crop in the region. As an alternative to this problem, Eucalyptus species have been widely planted in mineral soils. Recently, wilting, die-back, xylem discoloration, epicormics shoots sprouting along the stem and consequently death of eucalyptus trees were observed in clones planted in the province of Riau, Indonesia. Infected plant material was examined in the laboratory and Ceratocystis sp. was isolated by carrot baiting method. Inoculation of the fungus into healthy plants with subsequently re-isolation was conducted to fulfill Koch's postulate which successfully confirmed the pathogenicity of Ceratocystis on Eucalyptus. To understand the economical impact of this disease, an extensive survey was conducted. Three clones were identified as susceptible to Ceratocystis wilt. Infections have started either from the roots or by stem wounds possibly caused by boring insects, bark cracking or mechanical damage. Infection levels ranged from $1 \%$ to $42 \%$, depending on the area or susceptibility of a given clone. Disease progression studies conducted in two compartments planted with the most susceptible clone showed that the disease incidence has increased in 10 months from $15 \%$ to $40 \%$, in average, but still low levels of mortality. To successfully control this disease, susceptible clones were removed from the genetic deployment program and a screening system has been implemented for the selection of resistant clones.

\section{Occurrence of chlorosis and mortality in Pinus taeda trees in Southern Brazil / Ocorrência de clorose e mortalidade em árvores de Pinus taeda na região Sul do Brasil}

Celso Garcia Auer', João Bosco Vasconcellos Gomes ${ }^{1}$, Antonio Francisco Jurado Bellote ${ }^{1}$, Guilherme de Castro Andrade ${ }^{1}$, Susete Rocio Chiarello Penteado ${ }^{1}$, Erich Schaitza ${ }^{1}$, Alvaro Figueredo dos Santos ${ }^{1}$

'Embrapa Florestas, Colombo,Brasil(celso.auer@embrapa.br; joao.bv.gomes@embrapa.br; antonio.bellote@embrapa.br; guilherme.andrade@embrapa.br; susete.penteado@embrapa.br; erich.schaitza@embrapa.br;alvaro.santos@embrapa.br)

Desde 2014, uma clorose de acículas vem sendo constatada em árvores adultas de Pinus taeda, em localidades da região Sul do Brasil, notadamente no estado de Santa Catarina. Os sintomas começam a serem constatados em plantios com 10 anos de idade, na forma de tufos de acículas cloróticas em ramos e ponteiros e, em situações extremas, mortes de árvores com idades acima de 16 anos. Ações sistemáticas com parcelas de monitoramento e de mitigação foram estabelecidas para caracterização do problema. Exames de árvores doentes revelaram: i) raízes mais grossas com lesões escuras e ii) baixa presença e/ou, ausência de raízes de absorção vivas e de ectomicorrizas ativas. Também, se observou baixa incidência de insetos associados. Isolamentos feitos a partir de amostras de raízes de árvores sintomáticas e de solo revelaram a presença de fungos e oomicetos. Análises preliminares de nutrientes em acículas doentes não constataram relações de causa e efeito sobre a nutrição das árvores. Sítios com a presença de árvores com clorose ocorrem em sua grande maioria em solos desenvolvidos de rochas eruptivas básicas/intermediárias, mas também sem uma aparente relação de causa e efeito. Assim, a clorose do Pinus no Brasil é ainda um problema de caracterização difusa e etiologia desconhecida. Inferências iniciais vislumbram uma interação biótica/abiótica, envolvendo agente patogênico, regime hídrico e química do solo.

\section{How anthropogenic activities have predisposed a keystone tree species to a native co-evolved pathogen to cause a severe and widespread canker disease}

\author{
Sarah Sapsford ${ }^{1,2}$, Giles Hardy', Treena Burgess' ${ }^{2}$, Trudy Paap ${ }^{3,2}$ \\ ${ }^{1}$ University of Canterbury, Canterbury, New Zealand; ${ }^{2}$ Murdoch University, Perth, Australia, ${ }^{3}$ University of Pretoria, Pretoria, South Africa \\ (sarah.sapsford@gmail.com; g.hardy@murdoch.edu.au; t.burgess@murdoch.edu.au; trudy.paap@fabi.up.ac.za)
}

Quambalaria coyrecup is a native pathogen that causes a devastating canker disease in the endemic and keystone tree Corymbia calophylla (Marri) in the Southwest of Western Australia. In the last 20 years, the impact and severity of this pathogen has increased substantially throughout the range of marri over thousands of square kilometers. Why is this pathogen that co-evolved with its host now so devastating? To answer this question, we used Manion's 'tree decline spiral' as a template to examine the possible predisposing, inciting and contributing factors that could be linked to increased occurrence and severity of the canker disease. We looked at anthropogenic pressures including fragmentation, pesticides and fertilizer inputs, physical and chemical soil changes, changes in mycorrhizae and other soil microflora, the presence of Phytophthora species, and the role of a drying and warming climate on the incidence and severity of the disease. We found anthropogenic pressures to play a key role in the disease syndrome, together with changes in key soil nutrients such as phosphorous, ammonium nitrogen, zinc, sodium, and iron, changes in mycorrhizal communities and richness, pH, overstorey diversity, stand basal area and the presence of Phytophthora species with canker incidence and severity. These together with their interactions with the host and pathogen will be discussed in detail. 


\title{
The physiological effects of Phytophthora agathidicida infection on New Zealand kauri (Agathis australis) water relations

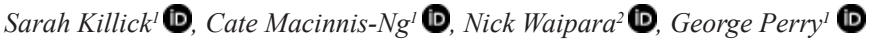 \\ ${ }^{1}$ University of Auckland, Auckland, New Zealand; ${ }^{2}$ Plant and Food Research, Auckland, New Zealand (s.killick@auckland.ac.nz; \\ c.macinnis-ng@auckland.ac.nz; nick.waipara@plantandfood.co.nz; george.perry@auckland.ac.nz)
}

New Zealand kauri (Agathis australis) is one of the world's largest and longest-lived trees and is a cornerstone species in northern New Zealand forests. Recently, kauri has experienced substantial declines due to the newly emergent kauri dieback disease. The disease is caused by a novel pathogen, Phytophthora agathidicida, which has spread across most of the natural kauri range. Infected kauri display large bleeding basal cankers followed by crown dieback and eventual tree death. In similar diseases, such as Phytophthora ramorum infection in tanoak, drought-like crown symptoms are associated with infection of the xylem leading to hydraulic failure; however, $P$. agathidicida is only known to occur in the phloem and external tissues. To understand the mechanisms by which $P$. agathidicida causes tree mortality and the environmental conditions that promote increased susceptibility, we propose a physiological approach to study of the effects of $P$. agathidicida infection. In this presentation, I will overview the design of this study which uses a combination of field observations, laboratory experiments, and computational modelling. As a new PhD student, I greatly value your feedback on study methodology; please feel free to approach me with any recommendations.

\author{
Management of Erwinia sp. in Eucalyptus: initial studies using Trichoderma harzianum and Paicelomyces lilacinus \\ Gabriel Leonardi Antonio ${ }^{1}$, Lucas da Silva Souza ${ }^{1}$, Ródney Lúcio Pinheiro Henrique ${ }^{1}$, Izabela Ponso Magalhães ${ }^{1}$, Aline Marchetti Silva Matos ${ }^{1}$, \\ Ana Carolina Firmino ${ }^{1}$ \\ ${ }^{1}$ Universidade Estadual Paulista “Júlio de Mesquita Filho”,Dracena,Brasil (gabriel-leonardi@bol.com.br; lucas.souza011996@gmail.com; \\ rodney.lucioh@hotmail.com; izabelaponso@gmail.com; aline_marchetti_57@hotmail.com; anacarfir@gmail.com)
}

The objective of this project was to study the use of Trichoderma harzianum and Paicelomyces lilacinus in the management of Erwinia sp. in soil. The following treatments were carried out for each biological control agent: (A) Eucalyptus plants with roots immersed in the biological agent suspension; (B) Plants placed in the pot with hydrogel incorporated to the biological control agent; (C) Plants placed in the pot and irrigated with the biological control agent; (D) Plants placed in the pot in which the biological control agent was placed directly in the seedling; Two control treatments: (E) seedlings in pots with soil infested only with Ralstonia and (F) in pots with soil without bacteria's infestation. All treatments were applied in two eucalyptus clones (SusR and 144 clones). The analyzed variables were mortality rate of Eucalyptus seedlings and dry mass of the plants. When T. harzianum was used, no dead plant of the SusR clone for treatment B was observed and there was only $20 \%$ mortality of clone 144 in treatments A and B. The fungus P. lilacinus was effective only for the SusR clone, where only $16 \%$ of plant mortality was observed in treatment A. The increase in the dry mass of the plants was observed in treatments A and B with T. harzianum in clone 144. Therefore, the use of T. harzanium was better for the sustainable management of Erwinia.

\section{Management of Ralstonia solanacearum in Eucalyptus: initial studies using Trichoderma harzianum e Paicelomyces lilacinus}

Ana Carolina Firmino ${ }^{1}$, Lucas da Silva Souza ${ }^{1}$, Ródney Lúcio Pinheiro Henrique ${ }^{1}$, Izabela Ponso Magalhães ${ }^{1}$, Aline Marchetti Silva Matos ${ }^{1}$, Gabriel Leonardi Antonio ${ }^{1}$

${ }^{1}$ Universidade Estadual Paulista “Júlio de Mesquita Filho”, Faculdade de Ciências Agrárias e Tecnológicas, Dracena, Brasil (ana.firmino@unesp.br; lucas.souza011996@gmail.com; rodney.lucioh@gmail.com; izabelaponso@gmail.com; aline_marchetti_57@hotmail.com; gabrielleonardirex@gmail.com)

The objective of this project was to study the use of Trichoderma harzianum and Paicelomyces lilacinus in the management of $R$. solanacearum in soil. The following treatments were carried out for each biological control agent: (A) Eucalyptus plants with roots immersed in the biological agent suspension; (B) Plants placed in the pot with hydrogel incorporated to the biological control agent; (C) Plants placed in the pot and irrigated with the biological control agent; (D) Plants placed in the pot in which the biological control agent was placed directly in the seedling's; Two control treatments: (E) seedlings in pots with soil infested only with Ralstonia and (F) in pots with soil without bacteria's infestation. All treatments were applied in two Eucalyptus clones (SusR and 144 clones). The analyzed variables were mortality rate of eucalyptus seedlings and dry mass of the plants. The method of incorporation of the biological control agent influenced the control of Ralstonia. Treatments B and C were the most effective. The T. harzianum fungus presented only $12 \%$ mortality of the SusR clone and $0 \%$ and mortality of clone 144 in treatments B and C, respectively. When treatment B was used, fungus P. lilacinus presented 25\% and 20\% dead plants of the SusR clone and clone 144, respectively. The two biological agents increased the dry mass of the plants. Therefore, the use of $T$. herzanium and $P$. lilacinus can serve as a support in the sustainable management of areas where there have been cases of Ralstonia.

\section{Emission of $\mathrm{CO}_{2}$ from soil contaminated with Ralstonia solanacearum treated with Trichoderma agents associated with fertilizer}

Marcela Eloi Gomes ${ }^{1}$, Heloísa Noemi Bello Paulo ${ }^{1}$, Marcela Bergamini Pagoto-Lopes ${ }^{1}$, Izabela Ponso Magalhães ${ }^{1}$, Paulo Renato De Matos Lopes ${ }^{1}$, Gabriel Leonardi Antonio ${ }^{1}$, Ana Carolina Firmino ${ }^{1}$

${ }^{1}$ Universidade Estadual Paulista “Júlio de Mesquita Filho”, Faculdade de Ciências Agrárias e Tecnológicas, Dracena, Brasil (marcelaeloi14g@gmail.com; heloisa.bello@unesp.br; marcela.pagoto@gmail.com; izabelaponso@gmail.com; prm.lopes@unesp.br; gabriel-leonardi@bol.com.br; ana.firmino@unesp.br)

The emission of $\mathrm{CO}_{2}$ was evaluated in interaction systems between the pathogen Raltonia solanacerum (R) and the biological control agent Trichoderma stromaticum (T) associated with a liquid fertilizer (F) in the soil (S). The evaluation of the $\mathrm{CO}_{2}$ emission was carried out using the Bartha breathalyzer methodology, with 8 treatments ( $, S+T, S+R, S+T+R, S+M, S+M+T, S+M+R, S+M+T+R)$ with 4 replicates each, all of which were maintained in BOD at a temperature of $28^{\circ} \mathrm{C}$ and evaluations were performed every 2 days for 30 days. The addition of Trichoderma increased the $\mathrm{CO}_{2}$ emission, but it was observed that the $\mathrm{CO}_{2}$ emission was higher and more constant in the treatments containing the fertilizer, indicating that this factor has a direct effect on the microbial activity. It is known that Trichoderma presents action versatility, and can degrade the cell walls of other microorganisms through the production of enzymes or toxic substances, which may explain the increased respiration of the treatments that involved these fungi since it can intensify its activity in the presence of Ralstonia increasing oxygen consumption and $\mathrm{CO}_{2}$ emissions. When only the pathogen was used in the treatment, lower numerical values were observed, which may be related to the lower activity of the pathogen in the absence of a host. 


\section{Effect of temperature and wetting period in germination and appressorium formation of Colletotrichum spp. from rubber trees (Hevea} brasiliensis)

Izabela Ponso Magalhaes ${ }^{1}$, Gabriel Leonardi Antonio ${ }^{1}$, Ivan Herman Fischer ${ }^{2}$, Edson Luiz Furtado ${ }^{3}$, Ana Carolina Firmino ${ }^{1}$

${ }^{1}$ Universidade Estadual Paulista "Júlio de Mesquita Filho”, Dracena, Brazil; ' $A$ PTA- Centro Oeste, Bauru, Brazil; ${ }^{3}$ Universidade Estadual Paulista "Júlio

de Mesquita Filho”, Botucatu,Brazil (izabelaponso@gmail.com; gabriel-leonardi@bol.com.br;ihfische@gmail.com; edson.furtado@unesp.br;

ana.firmino@unesp.br)

The objective of this study was to evaluate the effect of temperature and wetting period on the germination and appressorium formation of two isolates of $C$. gloeosporioides and C. accutatum obtained from rubber trees in vitro. Droplets of $40 \mu \mathrm{L}\left(105\right.$ conidia. $\left.\mathrm{mL}^{-1}\right)$ were deposited on plastic petri dishes, incubated in a humid chamber at $20,25,30,35 \pm 1^{\circ} \mathrm{C}$ and under wet periods of 4, 6, 12 and 24 hours (h). After the established periods, the plates were removed from the humid chamber and the drops were dried; $40 \mu \mathrm{L}$ of lactoglycerol was deposited on this dry area to quantify the percentages of germinated conidia and appressory. The germination of conidia was observed from $30^{\circ} \mathrm{C}$ with minimum wetting period of $4 \mathrm{~h}$ for C. accutatum. For C. gloeosporioides the germination of conidia was observed from $25^{\circ} \mathrm{C}$ with minimum wetting period of 6 h. Appressory formation was observed only in C. gloeosporioides between 20 and $30{ }^{\circ} \mathrm{C}$, with a minimum wetting period of $24 \mathrm{~h}$. Increased wetting period resulted in higher percentages of germinated and appressory conidia formed. The optimum temperature range for conidia germination was $25^{\circ} \mathrm{C}$ at $30^{\circ} \mathrm{C}$ for C. gloeosporioides with $24 \mathrm{~h}$ of wetting. For C. accutatum the optimum temperature range for conidia germination was $25^{\circ} \mathrm{C}$ at $35^{\circ} \mathrm{C}$, with $24 \mathrm{~h}$ of weting. This information can contribute to the understanding of the beginning of the infection in the field since this fungus tolerates high temperatures.

\section{D7f: FOREST MICROBIOME AND FOREST HEALTH}

\section{Tree microbiomes: functional roles and impact on forest health}

Fred Asiegbu ${ }^{1}$

'University of Helsinki, Helsinki, Finland (fred.asiegbu@helsinki.fi)

Forest trees are known to live in close association with microbial organisms. The nature of this close association can be mutualism or commensalism, parasitism. The term microbiota has been used to describe this ecological community of plant associated pathogenic, mutualistic and commensal microorganisms. Many of these microbiota inhabiting forest trees could have potential impact on the health and disease progression. Comparatively, studies on forest tree microbiomes lags far behind parallel work on agricultural crop and human microbiome projects. Our understanding and perception of plant and tree microbiomes have recently been facilitated due to novel technological advances using metabarcoding and metagenomics approaches. Also the availability of massive DNA databases as well as powerful computational and bioinformatics tools have helped to facilitate data mining by researchers across diverse disciplines. Available data demonstrate that plant bacterial communities are dominated by members of a few phyla (Proteobacteria, Actinobacteria). Interestingly, our survey of bacterial communities of Norway spruce revealed high abundance of the phylum Acidobacteria. Fungal communities of phyllosphere, rhizosphere and surrounding soils also show pronounced differences. In bulk soil, we found that basidiomycota is the dominant fungal group whereas in needle tissues, trunk and suberized roots, Ascomycota is the most prevalent group. Further studies are ongoing to unravel the functional roles of these microbes and their potential impact on forest tree health. It has been acknowledged that phytobiomes play important roles in health and development of diseases. The acquisition of such fundamental knowledge will have huge potential impact in future translation into sustainable forestry management

\section{Metagenomic approaches to examine relationships of soil microbial communities with Armillaria root disease}

Jane Stewart ${ }^{1}$,Bradley Lalande ${ }^{1}$,Zaid Abdo ${ }^{1}$, John Hanna ${ }^{2}$, Deborah Page-Dumroese ${ }^{2}$, Marcus Warwell ${ }^{2}$, Joanne Tirocke ${ }^{2}$, Mee-Sook Kim ${ }^{3}$, Ned Klopfenstein ${ }^{2}$ ${ }^{1}$ Colorado State University, Fort Collins, USA; ${ }^{2}$ USDA Forest Service, Rocky Mountain Research Station, Moscow, USA; ${ }^{3}$ USDA Forest Service, Pacific Northwest Research Station,Corvallis,USA (jane.stewart@colostate.edu; brad.lalande@colostate.edu; zaid.abdo@colostate.edu; jhanna@fs.fed.us; ddumroese@fs.fed.us; mwarwell@fs.fed.us; jtirocke@fs.fed.us; mkim02@fs.fed.us; nklopfenstein@fs.fed.us)

Forests harbor highly complex microbial communities that play diverse ecological roles, potentially including protection from root diseases. Armillaria root diseases are among the most damaging and broadly distributed group of forest diseases in the world, but it is notoriously difficult to manage in forests. Because Armillaria root disease impacts are dependent on complex ecological interactions among the host, soil microbial community, and environment, novel management approaches are needed that consider soil interactions that suppress the disease. Soil metagenomic/transcriptomic methods allow a better understanding of complex interactions among soil microbial communities, environmental factors (i.e., soil properties), tree health, and Armillaria spp. (i.e., pathogenic vs. saprophyte) that influence Armillaria root disease in forest ecosystems. Soil cores, Armillaria samples, and tree health data were collected in a western white pine (Pinusmonticola) plantation at the Priest River Experimental Forest in northern Idaho, USA. DNA and RNA were extracted from each soil sample, and the ITS-2 and 16S rDNA regions were sequenced through metagenomic techniques to determine the fungal and bacterial communities. Soil microbial communities were compared in association with two Armillaria species: A. solidipes (pathogenic) and A. altimontana (weak pathogen, saprophyte, and potential biocontrol agent). Ongoing analyses are determining if microbial populations differ in relation to Armillaria species associated with diseased/ healthy trees and with varying soils properties. Results for this study will be applied to develop novel management approaches for suppressing Armillaria root disease by favoring beneficial microbial communities with potential biocontrol activity against Armillaria pathogens and enhance forest resilience.

\section{Effects of European monocultures and multispecies forests on specific soil fungal communities depends on tree traits and implies changes in soil nutrients functionality}

Luis Daniel Prada Salcedo 1,2, Thomas Reitz', Anna Heintz-Buschart', , Kezia Goldmann'2, François Buscot2,4

${ }^{1}$ Leipzig University, Leipzig, Germany, Germany; ${ }^{2}$ UFZ-Helmholtz-Centre for Environmental Research, Department of Soil Ecology, Halle (Salee), Germany; ${ }^{31}$ UFZ-Helmholtz-Centre for Environmental Research, Department of Soil Ecology, Leipzig, Germany, Germany; ${ }^{4}$ German Centre for Integrative Biodiversity Research(iDiv),Leipzig, Germany, Germany (luis.salcedo@ufz.de; thomas.reitz@ufz.de; anna.heintz-buschart@ufz.de; kezia.goldmann@ufz.de; francois.buscot@ufz.de)

At the global scale most forest research focuses on aboveground biodiversity. Consequently, we still lack a deeper understanding of belowground biodiversity. Microorganisms such as fungal communities are closely linked to the dominant tree vegetation due to the often occurring mutualistic relationships. Within the project SoilForEurope, we evaluated how tree diversity or identity affects fungal communities and the soil-system functions. The project's study sites are mature 
forests from four different European countries in Finland, Poland, Romania and Italy. They encompass monocultures to multispecies forests and different tree species compositions. Therefore, we extracted fungal ITS rDNA from 320 soil samples. PCR-based amplicon libraries were produced and sequenced using the Illumina MiSeq NGS. Besides, functional effects on C, N and P nutrient cycling were evaluated through soil enzymatic activities. The overall results between multispecies and monocultures plots did not show significant differences of fungal communities within countries. Nonetheless, specific functional fungal groups such as saprotrophs and symbiotrophs increase their alpha diversity under multispecies systems. The community composition differed strongly between countries and its differences are rather driven by the tree identity than by tree diversity. Moreover, changes in fungal diversity are reflected at functional stages: higher nutrients dynamics were displayed in multispecies plots. The trees influence over fungal communities is mainly due to roots and revealed in traits like nitrogen content or specific root length. This showed the consequences of decreasing tree biodiversity or forest compositions can impact not only fungal biodiversity, but also forest functionality.

\title{
Disturbance and extreme weather events impact soil microbial processes and fungal communities in a mountain beech forest
}

Mathias Mayer ${ }^{1}$, Markus Gorfer ${ }^{2}$, Bradley Matthews ${ }^{1}$, Harald Berger ${ }^{3}$, Andrea Bittner ${ }^{1}$, Hans Sandén ${ }^{1}$, Boris Rewald ${ }^{1}$, Klaus Katzensteiner ${ }^{1}$, Douglas L. Godbold ${ }^{1}$

${ }^{1}$ University of Life Sciences and Natural Resources, Institute of Forest Ecology, Vienna, Austria; ${ }^{2}$ Center for Health \& Bioresources, AIT Austrian Institute of TechnologyGmbH, Tulln, Austria; ${ }^{3}$ Symbiocyte, Tulln,Austria(mathias.mayer@boku.ac.at; markus.gorfer@ait.ac.at; bradley.matthews@boku.ac.at; harald.berger@symbiocyte.com; andrea.bittner@students.boku.ac.at; hans.sanden@boku.ac.at; boris.rewald@boku.ac.at; klaus.katzensteiner@boku.ac.at; douglas.godbold@boku.ac.at)

In mountainous regions forests are important ecosystems for slope stabilization and provision of drinking water for a growing world population. Shallow soils overlying limestone bedrock, as can be observed on slopes, are especially vulnerable to degradation and erosion. Microbial processes and fungal communities were studied in a mountain beech forest in the Austrian Calcareous Alps over the course of four years. Girdling and clearcut treatments and years with extreme summer drought allowed us to study effects of disturbances and climate change scenarios on functioning and composition of soil microbial communities. Soil physicochemical characteristics like high $\mathrm{pH}$ and high content in organic carbon lead to a distinct soil fungal community, which is dominated by saprophytic ascomycota. Ectomycorrhizal abundance is low and shows deviating patterns from other beech stands in Europe. Seasonal variation seems to strongly shape the ectomycorrhizal community, while summer drought can promote the abundance of potentially pathogenic fungi. Effects can still be observed in spring and after summer drought. This finding is in line with a well known increase in diseases upon extreme weather events. Disturbances increase litter decomposition and lead to a decrease in the abundance of ectomycorrhizal fungi. Taken together the results highlight the risks imposed by extreme weather events and disturbance to ecosystem services provided by mountain forests.

\section{Comparison of microbial communities across the bulk soil, rhizosphere and fine root endosphere of declining English oak trees}

Kelly Scarlett ${ }^{1,2}$, Corinne Whitby ${ }^{2}$, Xiangming Xu ${ }^{3}$, David Clark ${ }^{2}$, Greg Deakin ${ }^{3}$, Elena Vanguelova ${ }^{1}$, Sandra Denman ${ }^{1}$ ${ }^{1}$ Forest Research, Surrey, United Kingdom; ${ }^{2}$ University of Essex, Colchester, United Kingdom; ${ }^{3}$ NIAB East Malling Research, Kent, United Kingdom (kelly.scarlett@forestry.gsi.gov.uk; cwhitby@essex.ac.uk; xiangming.xu@emr.ac.uk; dclarkb@essex.ac.uk; greg.deakin@emr.ac.uk; elena.vanguelova@forestresearch.gov.uk; sandra.denman@forestresearch.gov.uk)

Oak declines are serious and widespread disorders threatening native British oak (Quercus robur and Q. petraea) in England. The causes of decline are thought to involve complex interactions of abiotic and biotic agents resulting in the deterioration of tree condition. Soil microbe communities contribute significantly towards tree health with both bacteria and fungi playing a vital role in cycling of essential elements as well as mobilization, acquisition and translocation of nutrients. Oak fine roots are the primary sites of nutrient import and they rely on close, often symbiotic, relationships with associated soil microbial communities. Fine roots and their associated microbial communities have both direct and indirect effects on each other, however the relationship between cause and effect on microbial community changes is often very complex. In this study we test the hypothesis that tree health modulates the oak fine root microbiome. In 7 sites across England, we characterised the fungi and bacteria in the bulk soil, rhizosphere soil and fine root endosphere of symptomatic and asymptomatic oak trees using high throughput Illuminia sequencing. We are comparing between these co-occurring communities with the aim to understand the relationship between tree health and the soil biotic environment.

\section{Are there hopes for European elms?}

\author{
Alessia Pepori ${ }^{1}$, Priscilla Bettini ${ }^{2}$, Alberto Santini ${ }^{1}$ (D \\ ${ }^{1}$ Institute for Sustainable Plant Protection, Sesto fiorentino, Italy; ${ }^{2}$ Department of Biology, University of Florence, Firenze, Italy (alessia.pepori@ipsp.cnrit; \\ priscilla.bettini@unifi.it; alberto.santini@cnr.it)
}

In Europe as in North America elms are devastated by Dutch elm disease (DED), caused by the alien ascomycetes Ophiostoma ulmi and O. novo-ulmi (ONU). Pathogen dispersal and transmission are ensured by local species of bark beetles (Coleoptera: Curculionidae, Scolytinae), which established a novel association with the alien fungi. Elm bark beetles also transport fungi of the genus Geosmithia, that are commonly found in scolytids' galleries colonized by ONU. Widespread horizontal gene transfer between ONU and Geosmithia was recently observed. In order to define the relation between these two fungi in the DED pathosystem, ONU and Geosmithia species from elm, including a GFP-tagged strain, were grown in dual culture and mycelial interactions were observed by light and fluorescence microscopy. Growth and sporulation of ONU resulted significantly higher in the presence of Geosmithia than in its absence. Signs of mycoparasitism by Geosmithia on ONU hyphae, such as formation of coilings, appressoria-like branches, pseudopod-like structures or short hooks, were commonly observed at microscopy. Finally, the addition of spores of Geosmithia species to suspensions of ONU spores used for artificial inoculations significantly reduced DED symptoms. A close and stable relation was observed between the two fungi, which may be classified as mycoparasitism by Geosmithia on ONU. These results prove the existence of a new component in the complex of organisms involved in DED, which might be capable of reducing the disease impact. If this activity will be confirmed, it will then be possible to exploit it to control the spread of the disease. 


\section{What is causing beech leaf disease? A metabarcoding approach}

Carrie Ewing ${ }^{1}$, Cristina Rosa ${ }^{2}$, Maria-Soledad Benitez ${ }^{3}$, Lucy Stewart ${ }^{4,3}$, Jason Slot $^{1}$, Pierluigi (Enrico) Bonello ${ }^{1}$

${ }^{1}$ The Ohio State University, Columbus, OH, USA; ${ }^{2}$ The Pennsylvania State University, University Park, PA, USA; ${ }^{3}$ The Ohio State University/Ohio

Agricultural Research and Development Center, Wooster, OH, USA; ${ }^{4}$ Agricultural Research Service, United States Department of Agriculture, Wooster, OH,

USA (ewing.244@buckeyemail.osu.edu; czr2@psu.edu; benitezponce.1@osu.edu; lucy.stewart@ars.usda.gov; slot.1@osu.edu; bonello.2@osu.edu)

First discovered in 2012, beech leaf disease (BLD), a currently undiagnosed and seemingly lethal disease, is affecting American beech trees (Fagus grandifolia) in forests in the northeastern United States. The initial symptoms of the disease appear in the lower canopy foliage as a dark, green interveinal banding pattern, while the later symptoms are solidly darkened leaves that are shrunken and crinkled. BLD poses a significant threat to global forests as similar symptoms were detected on American, European (F. sylvatica), and oriental (F. orientalis) beech species in Ohio nurseries. These symptoms and the distribution patterns of BLD do not fit an abiotic disorder, thus it is suspected that BLD is caused by a microorganism. To uncover the causal agent, we are using a comparative metabarcoding approach to profile the microbial communities in symptomatic and asymptomatic leaves in areas of infestation, as well as leaves from areas not known to be affected by disease. Specifically, we are employing next generation sequencing and associational analysis of leaf microbiomes based on 16S rDNA and the ITS region of total beech leaf DNA to screen for bacteria, phytoplasmas, and fungal communities, using the Illumina MiSeq platform. To screen for viruses, rRNAdepleted multiplexed libraries are being sequenced on the Illumina HiSeq platform. The microbial communities will then be compared by symptom type and known libraries of each pathogen type to potentially determine a known or unknown pathogen most closely associated with BLD.

\section{The elusive convergence of endophyte diversity and tree vitality: Will we ever understand it?

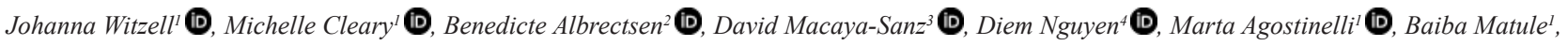
Juan A. Martín

${ }^{1}$ Swedish University of Agricultural Sciences, Southern Swedish Forest Research Centre, Alnarp, Sweden; ${ }^{2}$ Umeå University, Department of Plant Physiology, Umeå, Sweden; ${ }^{3}$ West Virginia University, Morgantown, USA; ${ }^{4}$ Uppsala University, Department of Organismal Biology, Systematic Biology, Uppsala,

Sweden; ${ }^{5}$ Universidad Politécnica de Madrid, Departamento de Sistemas y Recursos Naturales ETSI de Montes, Forestal y del Medio Natural, Madrid, Sweden(johanna.witzell@slu.se; michelle.cleary@slu.se; benedicte.albrectsen@plantphys.umu.se; akanseh@gmail.com; diem.nguyen@ebc.uu.se; marta.agostinelli@slu.se; bale0001@stud.slu.se; juan.martin.garcia@upm.es)

Vitality of a tree reflects the strength of the active processes that enable its growth and reproduction, despite the environmental stress that it is experiencing. Understanding the dynamics and variations in tree vitality is essential in tree care in urban environments, where the trees are often exposed to high stress. Forest management strategies could also benefit of more detailed knowledge about the factors contributing to tree vitality, especially as the climate change and new and emerging pests and pathogens are amplifying the stress in forest settings. Vitality is often measured using physiological or growth responses, or judged by visual assessments. A potential indicator of tree vitality, and a trait affecting or being affected by it, is also the diversity of associated microbes, such as asymptomatic, endophytic fungi. In a series of studies during the past ten years, we have addressed the relation between endophytic fungi and tree health and vitality, focusing especially on perennial organs, bark and wood (younger, active xylem tissues). The studied tree species include Quercus robur, Fraxinus excelsior, Populus spp., and Ulmus spp., grown in orchards, peri-urban and production forest settings, or in greenhouse. The vitality of the trees was compromised by unspecific factors or by pathogens, including Phytophthora spp., Hymenoscyphus fraxineus, Venturia tremulae, and Ophiostoma spp. Endophyte diversity was characterized by culture-dependent techniques or by direct sequencing. A synthesis of the results is presented and discussed in relation to a theoretical model for practical possibilities to utilize endophytes in resilience-oriented forest management.

\section{D7g: FOREST PATHOGEN MIGRATION IN A GLOBALIZED ECONOMY}

\section{A diverse set of forest pathogens is emerging in the Pacific region and causing havoc \\ Philip Cannon ${ }^{1}$ \\ 'State and Private Forestry, United States Forest Service, Vallejo, USA (pcannon@fs.fed.us)}

Historically, trees growing on islands in the Pacific region had escaped contact with many tree pathogens because of the sheer remoteness of these islands. However, with increasing levels of commerce and travel three pathogens have now found their way to some of these islands and are causing major damage. The pandemic strain of the rust Austropuccinia psidii arrived in Honolulu in 2006 and spread quickly to every major island in Hawaii. This fungus can infect 20 of Hawaii's 39 myrtaceous species. Since then, this pandemic strain has also spread to Australia and New Zealand where it has infected hundreds of additional myrtaceous species. There are at least 8 other strains of $A$. psidii. Ceratocystis lukuohia and C. huliohia are new Ceratocystis species discovered in Hawaii. Currently they are causing massive amounts of mortality to the ohia tree (Metrosideros polymorpha), a species constituting $80 \%$ of the natural forest of Hawaii. The etiology and management of this disease is complicated because boring dust of ambrosia beetles tunneling into infected xylem tissue appears to be involved in the spread of this disease. Pyrrhoderma noxium (Phellinus noxius) is an exceptionally aggressive root rot pathogen that has now been found on most major island groups in the Pacific (except Hawaii). This pathogen can attack and kill over 100 of the most common species found on these islands. The detection of this fungus is easy but the eradication of infection foci, so far, has proven laborious.

\section{Stopping the spread of myrtle rust}

Beccy Ganley ${ }^{\prime}$

${ }^{\prime}$ The New Zealand Institute for Plant and Food Research Ltd, Te Puke, New Zealand (beccy.ganley@plantandfood.co.nz)

Myrtle rust, caused by the rust fungus Austropuccinia psidii, is a highly invasive pathogen that affects a wide range of taxa within Myrtaceae. Plant movement associated with trade in the early 1900's saw the first spread of this pathogen beyond its native range and in the last two decades, increased globalisation has enabled it to spread further across a range of Myrtaceae-diverse countries in the southern hemisphere. In each instance its introduction has caused serious damage to a wide range of Myrtaceae species. The pathogen was first reported in New Zealand in 2017 and is thought to have spread from Australia via windborne spores. Based on the learnings from Australian experience with this disease New Zealand was able to prepare for a myrtle rust incursion, this included the development of a Myrtaceae barcoding database for plant species present in New Zealand, which was of great assistance in the incursion response. Although New Zealand undertook an immediate incursion response with successful localised eradication in some regions, full eradication of $A$. psidii was not possible 
and the response subsequently was transitioned to long-term management. Whilst the focus is now on disease management, our border biosecurity fight against myrtle rust is not over. With numerous strains of this pathogen present worldwide the need to prevent further spread of different rust strains is paramount and relies on a global effort.

\title{
Factors influencing growth, sporulation and virus transfer in Cryphonectria parasitica isolates from Castilla and León (Spain)
}

Paula Zamora ${ }^{1}$, Alejandro González-Casas ${ }^{1}$, M. Dueñas ${ }^{1}$, Roberto San Martín ${ }^{2}$, Julio J. Diez ${ }^{2}$

${ }^{1}$ Centro de Sanidad Forestal de Calabazanos. Consejería de Fomento y Medio Ambiente. JCyL. Polígono de Villamuriel, Villamuriel, Spain; ${ }^{2}$ University of Valladolid, Palencia, Spain (zamora.paula@gmail.com; agonza16@tragsa.es; zamora.paula@gmail.com; rsmartin@ieo.uva.es; jdcasero@pvs.uva.es)

Globalization is increasing the spread of forest diseases. Cryphonectria canker is nice example of the effect of the globalized economy and the migration of invasive species. On the other hand, Cryphonectria parasitica is one of the few diseases that can be managed by biological control agents. So, the use of Cryphonectria hypovirus CHV1 in the biological control of chestnut blight, caused by the fungus Cryphonectria parasitica, has reduced the impact of the disease in Europe. In this study, we investigated growth and sporulation of the fungus and horizontal transmission of the virus at different temperatures. We infected four isolates of $C$. parasitica with hypovirus subtypes CHV1-F1 and CHV1-I, to determine the influence of virus subtype. We assessed growth of fungal colonies and horizontal transmission of the virus at $15^{\circ} \mathrm{C}$ and $25^{\circ} \mathrm{C}$. Colony growth was affected by an interaction between vc type and virus at both $15^{\circ} \mathrm{C}$ and $25^{\circ} \mathrm{C}$. However, horizontal transmission of the virus was only influenced by vc type, and spore production was only affected by the virus subtype. Vertical transmission was also influenced by the fungal isolate and virus subtype. Growth of the fungal isolates varied depending on the virus subtype with which they were infected. This supports the theory that fungal host and virus subtype strongly influence transmission and dissemination of hypovirulence. Selection of the fungal isolate is therefore very important because the genotype of isolates belonging to specific vc types may influence the prevalence of hypovirulence in $C$. parasitica. This is an important issue for the control of chestnut blight spread.

\section{Interconnected global populations of forest pathogens created through anthropogenic spread}

\author{
Bernard Slippers ${ }^{1}$, Emma Steenkamp ${ }^{1}$, Fahimeh Jami ${ }^{1}$, Michael J. Wingfield ${ }^{1}$ \\ ${ }^{\prime}$ FABI, University of Pretoria, Pretoria, South Africa (bernard.slippers@fabi.up.ac.za; emma.steenkamp@fabi.up.ac.za; fahimeh.jami@fabi.up.ac.za; \\ mike.wingfield@fabi.up.ac.za)
}

Despite the development of increasingly strict biosecurity measures during the course of the past two decades, the rate of introduction and emergence of invasive tree pathogens continue to increase. Population genetics studies show that many of these pathogens have globally distributed genotypes and that they establish seemingly unstructured global populations. These population genetic patterns can be explained only by introductions of large numbers of genotypes and/or multiple introductions over time. The apparent scale and frequency of these introductions increase the threat that these invasions pose, for example through increased rates of evolution of these pathogens and their potential to overcome host resistance and environmental variation. Here we analyze common patterns emerging from population genetics and phylogeographic studies of selected globally distributed forest pathogens to visualize the growing interconnected "worldwide web" of forest pathogens. Furthermore, we consider mechanisms that facilitate the movement and establishment of these pathogens, in particular, latent infections in live plant material.

\section{Understanding the invasion of ash dieback: Are there lessons to be learned?}

Michelle Cleary ${ }^{1}$, Stephen Woodward ${ }^{2}$

${ }^{1}$ Swedish University of Agricultural Sciences, Alnarp, Sweden; ${ }^{2}$ University of Aberdeen, Aberdeen, United Kingdom (michelle.cleary@slu.se; s.woodward@, abdn.ac.uk)

The alien invasive fungus (Hymenoscyphus fraxineus) has resulted in severe dieback and mortality of European ash (Fraxinus excelsior) throughout much of its natural distribution range in northern and central Europe. The disease was first noticed in Poland (and Lithuania) around 1992. A lag time between its first observations and confirmation of the causal agent took 14 years, and then another lag of four years to confirm that it was indeed a cryptic species that differed from the 'misidentified' causal agent - its native European relative Hymenoscyphus albidus. In parallel, the fungus was discovered in Japan where it was known to exist since about 1993, but under a different name: Lambertella alibda which occurs on decaying rachises of the native Fraxinus (Fraxinus mandshurica). Examination of type specimens from Europe and Japan showed that they were indeed conspecific. Population studies of $H$. fraxineus in Europe show high genotypic diversity suggesting an outbreeding mating system and long-range dispersal via ascospores, and low allelic richness and low differentiation among European populations of $H$. fraxineus. Pathogen genetic diversity across Europe and in eastern populations, reveals a strong bottleneck in Europe and studies points to the founding by two divergent haploid individuals. Though it is not known, likely $H$. fraxineus arrived into eastern Europe on nursery stock of $F$. mandshurica which has been widely planted as an amenity species in urban areas and botanical gardens across Europe. Several lessons can be learned from this now 'text-book' example to prevent future incursions.

\section{Mitigating forest pathogen introductions through a horticultural accreditation scheme. Is it feasible?}

Mike Dunn ${ }^{1}$, Mariella Marzano ${ }^{1}$, Tim Pettitt ${ }^{2}$, Jack Forster ${ }^{3}$, Sarah Green ${ }^{1}$

${ }^{1}$ Forest Research, Roslin, United Kingdom; ${ }^{2}$ University of Worcester, Worchester, United Kingdom; ${ }^{3}$ Forest Research, Farnham, United Kingdom (michael.dunn@forestresearch.gov.uk; mariella.marzano@forestry.gsi.gov.uk; t.pettitt@worc.ac.uk; jack.forster@forestry.gsi.gov.uk; sarah.green@forestry.gsi.gov.uk)

The large-scale movement of live plant material through the horticultural trade is recognised as a recurrent pathway for the introduction and spread of tree pathogens. Threats such as Hymenoscyphus fraxineus, Phytophthora ramorum and Xylella fastidiosa have prompted calls for preventative measures and monitoring programmes at key points of the horticultural supply chain. An accreditation scheme underpinned by best biosecurity practice represents one approach to delivering these recommendations. Through surveys and in-depth interviews, we examine the receptiveness of the UK's horticultural stakeholders to adopting several biosecurity practices which our sampling and analysis show to mitigate tree pathogen related risks. We then consider what implications the perceived barriers and benefits associated with these practices have for establishing a scheme that is both impactful and appealing. We further assess the feasibility of an accreditation scheme underpinned by these practices through analysis of responses not only from industry, but also the country's plant-buying public. Specifically, we examine levels of support for the establishment of an accreditation scheme designed to mitigate the introduction and spread of forest pathogens, and assess whether consumers are likely to alter their purchasing behaviour in order to support such a scheme. We conclude by summarising the challenges and opportunities of establishing an accreditation scheme in the sector, and provide recommendations for the scheme's breadth and administration, as well as the framing required to generate appeal among the plant-buying public. 


\title{
Effective forest protection is a multifaceted endeavour
}

Michael Ormsby ${ }^{1}$, Tod Ramsfield ${ }^{2}$ Beccy Ganley ${ }^{3}$

${ }^{1}$ Ministry for Primary Industries, Wellington, New Zealand; ${ }^{2}$ Canadian Forest Service, Edmonton, Canada; ${ }^{3}$ Plant and Food Research, Te Puke, New Zealand (michael.ormsby@mpi.govt.nz; tod.ramsfield@canada.ca; beccy.ganley@plantandfood.co.nz)

With changing trade patterns and forest stewardship as a result of globalisation, an successful example of a multifaceted response to a new pathogen incursion could serve as a model to prevent future introduction of exotic organisms. This presentation will focus on the various contributing factors that resulted in the identification and mitigation of a potentially devastating pathogen; Fusarium circinatum. As members of the team that were involved with the detection and with the benefit of hindsight and contemplation, we outline what we feel were the important contributing factors that lead to the successful outcome.

\section{D7h: IMPROVING TREE HEALTH IN URBAN FORESTS FOR HUMAN WELL-BEING}

\section{Urban trees facilitate the establishment of alien forest insects}

\author{
Manuela Branco ${ }^{1}$, Pedro Nunes ${ }^{1}$, Rosário Fernandes ${ }^{1}$, Alain Roques², Christophe Orazio ${ }^{3}$, Hervé Jactel ${ }^{4}$ \\ ${ }^{1}$ ISA, Lisbon, Portugal; ${ }^{2}$ INRA, Orléans, France; ${ }^{3}$ EFI, Cestas, France; ${ }^{4} I N R A$, Cestas, France(mrbranco@isa.ulisboa.pt; pedrocatelanunes@hotmail.com; \\ mrfernandes@isa.ulisboa.pt; alain.roques@inra.fr; christophe.orazio@efi.int; herve.jactel@inra.fr)
}

We investigate whether urban trees are main facilitators of establishment of alien forest insects. Based on scientific literature and a pan European database on alien invasive species we analysed where introduced forest insects were first detected in European countries. In total 508 first country-specific records were retrieved. We collected site location data, tree cover density and urban landscape suitable habitats (green areas with trees) in buffers (of $500 \mathrm{~m}$ radius) around detection points. Large majority of first records were found in urban or peri-urban areas (within $10 \mathrm{~km}$ from city limits), varying from $81 \%$ for bark beetles and wood borers to $92 \%$ for sap feeders and seed or fruit feeders. Only $7 \%$ of the cases were found in forests far from cities. Some reports were in rural areas and nurseries. Site types of first detection in cities were highly variable including, public parks, street trees, zoos and botanical gardens. More than $72 \%$ of the cases occurred in sites with less than $20 \%$ of tree cover proportion in term of surface. More than $50 \%$ of the cases in urban areas had less than $10 \%$ proportion of suitable habitat. We conclude that urban forest areas and urban trees are hotspots for the establishment of forest pests and that should be intensely surveyed.

\section{Urban trees: effective solutions to reduce increasing ozone levels in cities}

Pierre Sicard ${ }^{1}$, Evgenios Agathokleous ${ }^{2}$, Valda Araminiene ${ }^{3}$, Elisa Carrari ${ }^{4}$, Yasutomo Hoshika ${ }^{4}$, Alessandra De Marco ${ }^{5}$, Elena Paoletti ${ }^{4}$

${ }^{1}$ ARGANS, Biot, France; ${ }^{2}$ Research Faculty of Agriculture, Hokkaido University, Sapporo, Japan; ${ }^{3}$ Lithuanian Research Centre for Agriculture and Forestry, Institute of Forestry, Girionys, Lithuania; ${ }^{4}$ Consiglio Nazionale delle Ricerche, Sesto Fiorentino, Italy; ${ }^{5}$ ENEA, Rome, Italy (psicard@argans.eu; evgenios_ag@hotmail.com; valda.araminiene@mi.lt; eli.carrari@gmail.com; hoshika0803@gmail.com; alessandra.demarco@enea.it; elena.paoletti@cnrit)

Cities have to cope with the challenges due to poor air quality impacting human health and citizen well-being. The annual mean concentrations of tropospheric ozone increased by on average $0.16 \mathrm{ppb}$ per year in cities worldwide over the period 1995-2014. Green urban infrastructure can improve air quality by removing ozone. To efficiently reduce ozone in cities, it is important to define suitable urban forest management, including proper species selection, with focus on the removal ability of ozone and other air pollutants, biogenic emission rates, allergenic effects and maintenance requirements. This review aims to i) quantify ozone removal by urban vegetation categorized into trees/shrubs and green roofs; ii) rank 95 urban plant species based on the ability to maximize air quality and minimize disservices, and iii) provide novel insights on the management of urban green spaces to maximize urban air quality. Trees showed higher ozone removal capacity $\left(3.4 \mathrm{~g} \mathrm{~m}^{-2}\right.$ year $\left.{ }^{-1}\right)$ than green roofs $\left(2.9 \mathrm{~g} \mathrm{~m}^{-2}\right.$ year-1) on average with lower installation and maintenance costs. To overcome present gaps, a novel Species-specific Air Quality Index (S-AQI) of suitability to air quality improvement is proposed for tree/shrub species. We recommend city planners to select species with an S-AQI>8, i.e. with high ozone removal capacity, ozone-tolerant, resistant to pests and diseases, tolerant to drought and non-allergenic (e.g. Acer sp., Carpinus sp., Larix decidua). Green roofs can be used to supplement urban trees in improving air quality in cities. Urban vegetation, as a cost-effective and nature-based approach, aids in meeting clean air standards and should be taken into account by policy-makers.

\section{Insect and pathogen invasions: from urban environment to natural forests}

Trudy Paap ${ }^{1}$, Massimo Faccoli ${ }^{2}$, Alberto Santini ${ }^{3}$ (D)

${ }^{1}$ Forestry and Agricultural Biotechnology Institute (FABI), University of Pretoria, Pretoria, South Africa; ${ }^{2}$ Department of Agronomy, Food, Natural Resources, Animals and Environment (DAFNAE), University of Padova, Padova, Italy, ${ }^{3}$ Institute for Sustainable Plant Protection - C.N.R., Sesto fiorentino, Italy(trudy.paap@fabi.up.ac.za; massimo.faccoli@unipd.it; alberto.santini@cnr.it)

Urban trees are increasingly appreciated for the many benefits they provide. However, as concentrated hubs of human-mediated movement, urban landscapes are often the first point of contact for alien insects and pathogens. Once established in urban environments there is potential for populations to build, and dispersal can proceed to natural forests. Consequences of these invasions include damage to natural ecosystems, costly attempts at eradication and post establishment management. Here we present two case studies of alien pests which used urban forests as bridgeheads to invade natural environments. After their arrival most species of alien wood-boring beetles spread in surrounding forests with an invasion success strongly correlated to the landscape characteristics, in terms of forest cover and forest composition. The Asian ambrosia beetle Xylosandrus compactus (Coleoptera Scolytinae) was first recorded in Europe in 2011 in urban parks of Naples (central Italy). Since 2016, strong outbreaks were recorded in the Circeo Italian National Park, representing the first report of the black twig borer in European natural forests. Ceratocystis platani (CP) causes a vascular wilt and canker disease of Platanus spp. The fungus, native to North America, was introduced during WWII into Europe. CP penetrates the host through wounds or by root anastomosis. CP caused widespread mortality of London plane in Italy, France and Switzerland, but the most dramatic impact has been in Greece. Once established in urban trees, it jumped to natural stands of oriental plane, killing each year thousands of trees that do not exhibit any sign of resistance. 


\section{Top-down control of insect herbivory in urban trees: does tree diversity matter?}

Bastien Castagneyrol ${ }^{1}$, Yasmine Kadiri ${ }^{1}$, Hervé Jactel ${ }^{1}$, Alain Paquette ${ }^{2}$ ${ }^{1} I N R A$, Cestas, France; ${ }^{2} U Q A M$, Montreal, Canada (bastien.castagneyrol@inra.fr; yasmine.kadiri@inra.fr; herve.jactel@inra.fr; alain.paquette@gmail.com)

Trees and tree diversity are increasingly acknowledged as key components of human wellbeing in urban ecosystems. Yet, pest insects can cause major damage and affect urban tree health. It has been proposed that tree diversity can reduce insect herbivory in forest through an increase in the diversity and activity of herbivore enemies. However, whether such benefits of tree diversity also occur in cities is still ignored. We addressed this question by quantifying insect herbivory in six tree species in parks of Montreal City (Canada) growing among conspecific or heterospecific neighbouring trees and by counting predation marks on dummy caterpillars. Insect herbivory and predator activity both varied among parks and tree species. Predator activity in spring correlated negatively with insect herbivory in mid-summer, suggesting a top-down control of herbivores by natural enemies. Differences among parks and tree species were partially mediated by changes in tree diversity and density. Our results show that predators can contribute to reduce herbivore damage on urban trees and provide insights into management options likely to favor this biological control.

\section{Managing urban trees and forests under the threats of climate change, urbanization, and pollution}

Iulia Milena Almeida Yakouchenkova ${ }^{1}$, Gerhard Sardemann ${ }^{1}$, Annika Fricke ${ }^{1}$,Sarah Meyer-Soylu ${ }^{1}$, Helena Trenks ${ }^{1}$, Colette Waitz ${ }^{1}$, Oliver Parodi ${ }^{1}$, Andreas Seebacher ${ }^{1}$, Jürgen Kopfmüller ${ }^{1}$, Christine Rösch ${ }^{1}$, Axel Albrecht ${ }^{2}$, Andreas Matzarakis ${ }^{3}$, Martin Reuter ${ }^{4}$, Bernd Stähler ${ }^{5}$, Volker Stelzer ${ }^{1}$, Somidh Saha ${ }^{1}$ ${ }^{1}$ Karlsruhe Institute of Technology, Karlsruhe, Germany; ${ }^{2}$ Forest Research Institute of Baden-Württemberg, Freiburg, Germany; ${ }^{3}$ German Weather Service, Offenbach-Frankfurt, Germany; ${ }^{4}$ Municipality of Rheinstetten, Rheinstetten, Germany; ${ }^{5}$ Municipality of City Karlsruhe, Karlsruhe, Germany (iulia.yakouchenkova@kit.edu; gerhard.sardemann@kit.edu; annika.fricke@kit.edu; sarah.meyer@kit.edu; helena.trenks@kitedu; colette.waitz@kit.edu; oliver.parodi@kit.edu; andreas.seebacher@kit.edu; juergen.kopfmueller@kit.edu; christine.roesch@kit.edu; axel.albrecht@forst.bwl.de; andreas.matzarakis@dwd.de; martin.reuter@rheinstetten.de; bernd.staehler@gba.karlsruhe.de; volker.stelzer@kit.edu; somidh.saha@kit.edu)

Cities and heavily urbanized areas in Germany are facing the challenge of preserving their green spaces ("green lungs") under pressure from growing population and expanding infrastructure. At the same time, the vulnerability of cities to climate change-induced extreme weather events such as drought and heat waves has been increasing. Forests in urban areas reduce air pollution, mitigate heat stress and provide other ecosystem services. But they too are vulnerable to climate change and air pollution (e.g. NOx). Therefore, there is an urgent need to assess the resilience of urban trees and forests to climate change and pollution impacts in order to reduce vulnerability. Significant trade-offs may exist between conflicting management goals in urban trees and forest management which should be minimized through participatory decision making. In this context, participation of civil society, research institutions, local public institutions, and other stakeholders is of vital importance for future adaptation planning for urban green areas. In this presentation, we will present an innovative transdisciplinary concept to increase the resilience of urban trees and forests to multiple stressors of climate change and pollution. We will demonstrate how we could combine basic research, applied research, policy research, governance, and civil society under a transdisciplinary framework. We will present a case of on-going research in the city of Karlsruhe, Germany which is funded by the "Future Cities" program of the German Government. Our presentation may motivate international researchers, city planners, and policy makers to formulate similar transdisciplinary research for urban trees and forests in other cities.

Falling trees in Belo Horizonte: analysis of health conditions in individual trees / A ocorrência de queda de árvores em Belo Horizonte: análise das condições fitossanitárias dos indivíduos

Marina Souza ${ }^{1}$, Agnus Bittencourt ${ }^{2}$, Angeline Martini ${ }^{3}$

${ }^{1}$ CEMIG, Belo Horizonte, Brazil; ${ }^{2}$ Prefeitura Municipal de Belo Horizonte, Belo Horizonte, Brazil; ${ }^{3}$ Universidade Federal de Viçosa, Viçosa, Brazil (mourasouzam@gmail.com; agnus@pbh.gov.br; martini.angeline@gmail.com)

As árvores urbanas proporcionam inúmeros benefícios para a população, contribuindo significativamente para a melhoria da qualidade de vida. Contudo, nos últimos tempos, foram frequentes os transtornos ocasionados por queda de árvores nas grandes cidades, tornando-se fundamental realizar investigações sobre este assunto. Desta forma, o objetivo da presente pesquisa foi analisar as condições fitossanitárias dos indivíduos arbóreos que caíram no município de Belo Horizonte. Para isso, os dados foram coletados por meio de amostragem aleatória após a ocorrência das quedas, entre os anos de 2015 e 2018 . As variáveis coletadas foram: porte, condição de plantio, local de ruptura; qualidade da copa, troco e colo; presença de pragas ou sinais de doença. A análise, realizada em 69 exemplares arbóreos indicou que apenas 20,3\% das árvores apresentaram problemas fitossanitários, desencadeados principalmente pelo ataque do besouro metálico e por cupins nas raízes. A maioria das árvores foram plantadas em calçadas e apresentavam grande porte (76,8\%), com boas condições de copa (88\%), tronco (88\%) e colo (95\%), não evidenciando problemas, sendo a ruptura ocorrida principalmente nas raízes (82,6\%). Conclui-se, portanto, que a condição fitossanitária da árvore não deve ser o foco principal na análise de risco, pois na maioria dos casos de queda não se constatou este problema. A condição de plantio que promove a falta de espaço ou a dificuldade de enraizamento no solo urbano, teve relação mais expressiva com os casos de queda, evidenciando a dificuldade de ancoragem em árvores de grande porte.

\section{About the effects of an climate change adapted species selection for the cooling ability of roadside trees}

Laura Stratopoulos ${ }^{1}$, Chi Zhang', Swantje Duthweiler', Karl-Heinz Häberle'2, Thomas Rötzer' ${ }^{2}$, Stephan Pauleit ${ }^{2}$

${ }^{1}$ Weihenstephan-Triesdorf University of Applied Sciences, Freising, Germany; ${ }^{2}$ Technical University of Munich, Freising, Germany

(laura.stratopoulos@hswt.de; forestrychi.zhang@tum.de; swantje.duthweiler@hswt.de; haeberle@wzw.tum.de; thomas.roetzer@lrz.tu-muenchen.de; pauleit@wzw.tum.de)

The role of trees in city cooling has warranted much attention based on concerns over climate change and urban expansion. Simultaneously, there is an interest in introducing species from dry habitats to cope with the increasing risks of drought under climate change. The physical performances of six frequently planted species, originating from two contrasting habitats, were tested in a drought experiment. We (1) investigated if species from drier habitats are more drought tolerant than species that have evolved in Central European woodlands under a temperate climate regime and (2) discussed the effect of tolerance on the cooling potential of these trees. Native species from mesic habitats maintained only $48 \%$ of their controls sap flux and of these species, Tilia cordata had the worst performance with premature leaf senescence. Species from drier habitats had less reduction in sap flux (60\%) but lower stem growth, possibly favouring (fine) root development into deeper soil layers, as observed for Tilia tomentosa. Species’ performance was obviously linked to within-plant carbon partitioning. A particularly high root:shoot ratio measured for Acer campestre made it presumably less susceptible to droughts. Higher stem water exploitation and stronger 
regulation of water use at high evaporative demand were further reaction patterns that likely helped species from dry habitats maintain good physiological functions. Therefore, even under sustained drought, we expect them to have a high cooling capacity. Consequently, we recommend to plant them in extreme urban environments and to use the native habitat as a criterion to diversify and improve species selection.

\section{Can forests take the heat? Managing pests and ecosystem services in urban landscapes}

Steven Frank ${ }^{l}$

${ }^{\prime}$ North Carolina State University, Raleigh, USA (sdfrank@ncsu.edu)

Urban forests provide important benefits to urban residents and in mitigating climate change. However, US urban forests are shrinking due in large part to arthropod pests which are more abundant and damaging in urban than rural forests. Our hypothesis was that elevated temperatures and drought due to impervious surface cover drive arthropod pest abundance through several ecological mechanisms. We found that the urban heat island effect increases scale insect survival and that high temperatures create a phenological mismatch between scale insects and their parasitoids. This reduces biological control and increases scale reproduction. Finally, heat and drought stress combine to increase scale insect fecundity by 50 percent in sites with the most impervious surface cover. To counter these effects we developed impervious surface thresholds that planners and planters can use when designing sustainable urban landscapes.

\section{D7i: PATTERNS IN FOREST INSECT HERBIVORY}

\section{Biases in studies of spatial patterns in insect herbivory}

Elena L. Zvereva ${ }^{I}$, Mikhail V. Kozlov ${ }^{I}$

${ }^{1}$ University of Turku,Turku,Finland (elezve@utu.fi; mikoz@utu.fi)

The properties of the human mind are responsible for a number of biases that affect the quality of scientific research. However, scientists working in the fields of ecology and environmental science rarely take these biases into account. We conducted a meta-analysis of data extracted from 125 publications comparing woody plant damage by defoliating insects in different environments in order to understand the extent to which our knowledge on spatial patterns in herbivory is affected by various biases. The effects sizes (ESs) decreased with increases in the numbers of plant species involved in the study, with $61 \%$ lower ESs for herbivory estimated on all plants growing in study plots compared to herbivory on selected species. When all leaves from a tree or branch were sampled for measurements of herbivory or when random or systematic selection protocols were applied, ESs were $74 \%$ smaller than in cases of more subjective haphazard selection. In addition, ESs were 97 and 135\% greater when the person conducting sampling and measuring was aware of the research hypothesis or sample origin, when compared with situations when the observer was blinded to these factors. We concluded that our ecological and environmental knowledge is considerably biased due to an unconscious tendency of researchers to find support for their hypotheses and expectations. Cognitive biases can be avoided by applying randomization procedures in sampling and blinding of research hypotheses and sample origins, and these measures should be seen as obligatory to prevent false general conclusions in subsequent research synthesis.

\section{How much leaf do insects eat? Patterns in herbivory and florivory for tropical plants}

Tatiana Cornelissen ${ }^{1,2}$, Maria Gabriela Boaventura ${ }^{1}$, Cassio Pereira ${ }^{1}$, Gisele Mendes ${ }^{1}$ ${ }^{1}$ Universidade Federal de Minas Gerais, Belo Horizonte, Brasil; ${ }^{2}$ Universidade Federal de São João Del Rei, Sao Joao del Rei, Brazil (tatiana@ufsj.edu.br; mgabiboaventura@ufmg.br; cassio.cardozo@hotmail.com; giselemm@ufmg.br)

Herbivory has been shown to shape plant evolutionary paths, to affect plant population dynamics, community organization and ecosystem functioning. Insect herbivory, although ubiquitous, remains largely undocumented for tropical plants, which are host to more and sometimes more specialized herbivores, which might inflict higher damage. We reviewed the evidence for levels of herbivory for tropical plants based upon the published literature over the past 25 years and also collected data using a standardized protocol to evaluate herbivory and florivory levels for common tree species in tropical forests in Brazil. Herbivores removed approximately $12 \%(11.18 \pm 2.61 \%)$ of leaf area of 61 plant species in 30 botanical families based upon published data. For data sampled using a standard protocol, a total of 3.791 leaves and 3.025 flowers were measured. Florivory, contrary to the expectations, exhibited highest tissue losses (7.6\%) compared to herbivory (6.13\%) for 14 plant species. These two antagonistic interactions occurred independently, but exhibited a direct relationship with functional traits of leaves and flowers, as herbivory levels were directly related to the specific leaf area (SLA) and florivory was positively related to corolla morphology, leaf duration and plant apparency. Plants without extra-floral nectaries (EFNs) were not patrolled by ants and exhibited much higher damage $(10.29 \pm 0.53 \%)$ than plants with EFNs $(4.81 \pm 0.28 \%)$ for six plant species examined in a single family. Our data shows that levels of herbivory in the tropics might have been underestimated by previous inventories and mechanisms shaping its occurrence and variation are under investigation.

\section{Re-evaluating determinants on leaf herbivory of woody plants at global scale based on machine learning algorithm}

Jian-Feng Liu ${ }^{1}$, Qi Wang ${ }^{2}$, Ze-Ping Jiang ${ }^{1}$

${ }^{1}$ Research Institute of Forestry, Chinese Academy of Forestry, Beijing, China $;{ }^{2}$ Guangdong Institute of Eco-Environmental and Soil Sciences, Guangzhou, China (liujf2000cn@126.com; jenniferqi520@gmail.com; jiangzp@caf.ac.cn)

Herbivory rates are influenced by multiple biotic and abiotic factors. Quantifying the relative importance of these factors and how they interact are of great importance to elucidate driven mechanism and forecast associated carbon loss in the terrestrial ecosystems. In the present study, we compiled a large herbivory dataset ( $\mathrm{n}=1478$, including 788 species, 432 genus and 128 families) around the world from previous studies and corresponding environmental factors (e.g., bioclimatic and UVB variables), as well as phylogenetic age. The machine learning algorithm, Random Forest regressions, was used to identify relative importance and interaction between factors on leaf herbivory rate of woody plants. Our results showed that phylogenetic age accounted for the most important factor on herbivory variations, followed by soil organic carbon content (SOC) and mean UVB of the lowest month. Partial dependent analysis further revealed that leaf herbivory rates decreased nonlinearly with an increase of phylogenetic age and SOC, but increased with mean UVB of the lowest month. And Leaf herbivory rates increased more markedly toward the equator at the north hemisphere relative to the south hemisphere. These results would improve our understanding on geographical pattern of leaf herbivory. 


\section{Latitudinal variation in herbivory: hemispheric asymmetries, the role of climatic drivers and leaf traits}

Shuang Zhang ${ }^{1}$, Yuxin Zhang ${ }^{1}$, Keming $\mathrm{Ma}^{1}$

'State Key Laboratory of Urban and Regional Ecology, Research Center for Eco-Environmental Sciences, Chinese Academy of Sciences, Beijing, China

(shuangzhang@rcees.ac.cn; yxzhang@rcees.ac.cn;mkm@rcees.ac.cn)

We tested the latitudinal herbivory hypothesis (LH hypothesis) and the relationship of temperature,precipitation and leaf traits to herbivory. Based on a large dataset from more than 1000 plant species, our results show that herbivory decreased with latitude and increased with temperature only in the Northern Hemisphere. At the interspecific level herbivory had a hump-shaped relationship with leaf lifespan and a positive relationship with leaf size. Surprisingly, our data show that nutritional traits have little relationship to herbivory. Our study provides new insights relevant to the recent debate on the LH hypothesis and leaf trait-herbivory relationships. These findings are especially helpful in explaining the general patterns of herbivory detected on the global scale.

\section{Humans don't eat leaves: human population reduces herbivory in the Mediterranean ecosystem}

Juan Antonio Hernández-Agüero ${ }^{1}$, Ildefonso Ruiz-Tapiador ${ }^{2}$, Luis Cayuela ${ }^{1}$

${ }^{1}$ Universidad Rey Juan Carlos, Móstoles, Spain; ${ }^{2}$ Universidad Politécnica de Madrid, Madrid, Spain (juan.aguero@urjc.es; ildefonso.ruiztapiador@upm.es; luis.cayuela@urjc.es)

The degree of urbanization directly affects both biodiversity and abundance of animals and plants. Pollution may decrease the diversity of herbivorous insects but also the abundance of their predators. Moreover, it also increases the abundace of a few specialized herbivores. This would ultimately result in higher herbivory in urban areas. In this study, we investigated herbivory in leaves of six species, including Quercus ilex, in 12 natural and semi-natural areas along a population density gradient in Mediterranean woodlands of Spain. Our gradient encompasses unpopulated areas included within protected sites to the most populated city of the country. We used linear mixed models to asses the effect of population density on leaf damage while accounting for the autocorrelation of samples taken within the same site. Opposite of our expectations, we found an effect between the population density and the leaf damage, in which the more populated areas have lower levels of herbivory. This could be due to a reduction of both biodiversity and abundance of insects as a result of the synergistic effects of fragmentation and isolation of urban and peri-urban forests in addition to the effects of pollutants.

\section{Temporal dynamics of associational resistance in mixed forests}

Bastien Castagneyrol ${ }^{1}$, Mikhail V. Kozlov ${ }^{2}$, Charlotte Poeydebat ${ }^{1}$, Maude Tö̈go ${ }^{1}$, Hervé Jactel ${ }^{1}$ INRA, Bordeaux, France; ${ }^{2}$ Univ. Turku, Turku, Finland (bastien.castagneyrol@inra.fr; mikoz@utu.fi; charlotte.poeydebat@inra.fr; maude.toigo@inra.fr; herve.jactel@inra.fr)

Tree diversity is one of the drivers of forest resistance to herbivores. Most of current understanding of diversity-resistance relationship comes primarily from short-term studies. At yet, knowing whether tree diversity effects on herbivores is maintained over time is important for perennial ecosystems like forests. We addressed the temporal dynamics of the diversity-resistance relationship by conducting a six-year survey of pine attacks by the pine processionary moth (Thaumetopoea pityocampa, PPM) in a tree diversity experiment where we could disentangle tree composition vs. host density effects. During the first years after planting the trees, PPM attacks on maritime pine (Pinus pinaster) were reduced in presence of birch (Betula pendula), a fast-growing non-host tree (i.e., associational resistance). This effect maintained but faded with time as pines eventually grew taller than neighbouring birches. The probability of individual pine trees being repeatedly attacked year after year also decreased in mixed pine - birch stands. Pine density had a positive effect on stand colonisation by PPM, and a negative effect on the proportion of attacked trees. Year-to-year variability in individual pine probability of attack also increased with pine density, attacks being spread over a larger number of host trees. Collectively, these results unravel the independent contribution of tree species composition and host density to tree resistance to herbivores. We show both processes had directional changes with time. These results indicate that the resistance of planted forests herbivores can be improved by carefully choosing the composition of mixed forest and the timing of species planting.

\section{Positive outcomes between herbivore diversity and tree survival: effects of management on a Patagonian forest}

Marcos Nacif ${ }^{1}$, Thomas Kitzberger ${ }^{2}$, Lucas Garibaldi ${ }^{1}$

${ }^{1} U N R N-I R N A D, S . C$.de Bariloche,Argentina; ${ }^{2} C R U B-I N I B I O M A, S . C . d e$ Bariloche,Argentina (mnacif@unrn.edu.ar; kitzberger@gmail.com; lgaribaldi@unrn.edu.ar)

Sustainable forest management aims to enhance biodiversity and tree productivity. However, trade-offs may exist between these objectives, such as when insect diversity and associated herbivory decreases tree growth and survival. In addition, biodiversity and tree productivity can show non-linear responses to management intensity, making applied recommendations even more challenging. We studied the effects of thinning intensity on leaf damage diversity (as a proxy of insect folivore diversity), leaf damage frequency, growth and survival of planted trees in a North Patagonian shrubland (Argentina). We randomly applied four levels of thinning intensity $(0,30,50$, and $70 \%$ of basal cover removal) to experimental plots, and followed the responses during two years. Generalized mixed-effects models were estimated for each response variable. Leaf damage diversity and frequency showed non-linear responses to thinning, both increasing at intermediate thinning intensities. Such responses were consistent for contrasting feeding guilds, different diversity indexes, and during the two study years. Despite greater leaf damage (around $45 \%$ of the leaves were damaged), plant survival also showed a non-linear response to thinning, with higher values at intermediate thinning intensities during the two years. Similarly, planted trees grew more at intermediate thinning intensities, but only during the second year (tree growth increased linearly with thinning intensity during the first year). In North Patagonian shrublands, trees may face less competition for light and soil resources at intermediate thinning intensities, while at high thinning intensities water stress typical of dry Patagonian summers could reduce tree survival. Such benefits were not offset by the greater leaf damage observed at intermediate thinning intensities. Therefore, certain intermediate levels of forest management can provide the double service of increasing arthropod biodiversity and maximizing tree survival and growth. 


\section{Insect defoliation rates and human land use in forests in the southern Peruvian Andes}

Norma Salinas $^{1,2}$, Eric Cosio ${ }^{3}$, Yolvi Valdez ${ }^{1}$,Alex Nina ${ }^{1}$, Percy Chambi ${ }^{1}$, Vicky Huaman ${ }^{4}$, Gloria Rayme $^{4}$, Melania Mendez $^{4}$

${ }^{1}$ Laboratorio de Ciencias Ecosistémicas, Instituto de Ciencias de la Naturaleza, Territorio y Energías Renovables, Pontificia Universidad Católica del Perú (Perú), Lima, Peru; ${ }^{2}$ School of Geography and the Environment, Environmental Change Institute, University of Oxford, Oxford, United Kingdom; ${ }^{3}$ Sección Química, Pontificia Universidad Católica del Perú (Perú), Lima, Peru; ${ }^{4}$ Escuela de Biología, Facultad de Ciencias, Universidad Nacional de San Antonio AbaddelCusco (Perú),Cusco,Peru (nsalinasr@pucp.pe; ecosio@pucp.pe; yvaldezt@pucp.pe; anina@pucp.pe; percychambip@gmail.com; vickyhq@gmail.com; glor_3@hotmail.com; melanimv.123@gmail.com)

Peru is a megadiverse country where the combination of tropical latitude, mountain ranges, and ocean upwelling (Humboldt current) generates a large diversity of climates. Despite their harsh climate, the Andes mountains have had highly diverse forests which have undergone massive land-use changes since human settlement with severe impacts on biota and forest structure. To evaluate the impacts of land use changes on the stability of the interactions between trees and plant feeding insects, we quantified the percentage of leaf area lost to or affected by defoliation (chewing insects). This was carried out in tone tree species in three types of forest: pristine or semi-natural, plantation, and urban or peri-urban forests around the city of Cuzco. The selected tree species was Escallonia resinosa which can be found in all aforementioned categories of forests around Cuzco. Our results show that defoliation rates increased in urban forests by 65$85 \%$ and in plantation forests by $0-40 \%$ when compared to natural forests, and that defoliation rates correlate negatively with plant diversity. We conclude that land use change and deficient management results in significant plant biomass losses in urban and plantation forests. The reduction in plant biodiversity and human forest management patterns can affect the presence and activity of insectivorous birds affecting both the productivity and the structure of these forest systems.

\section{D7j: PHYTOPHTHORAS AS EMERGENT FOREST THREATS IN THE HUMAN-WILDLAND INTERFACE.}

\section{Exotic Phytophthora species are being systematically introduced in California wildlands during restoration projects}

Matteo Garbelotto ${ }^{1}$, Laura Sims ${ }^{1,2}$

${ }^{1}$ University of California, Berkeley, USA; ${ }^{2}$ Louisiana Tech University, Ruston, USA (matteog@berkeley.edu; simsla@latech.edu)

This study describes the identification of several Phytophthora species previously found in San Francisco Bay Area nurseries from multiple sites at the urban wildland interface within the greater San Francisco Bay Area. Isolation success was highest from the three plant species Diplacus aurantiacus (sticky monkeyflower), Ceanothus thyrsiflorus (blueblossum), and Frangula californica (California coffeeberry), growing in restoration sites and in adjacent disturbed sites. Isolation success instead was zero in control undisturbed "natural" areas adjacent to infested sites. In order to confirm plant production facilities were the source of the Phytophthora strains isolated from restoration sites, genetic and phenotypic analyses were performed on Phytophthora crassamura, one of the most common species identified during the course of this and other studies. Results indicated that field isolates were genetically identical to those found in plant production nurseries. Furthermore, resistance to fungicides such as phosphites and mefenoxam was identified in a select number of isolates found both in pant production facilities and wildland sites, further corroboration of a "nursery" origin of wildland infestations. Spatial landscape-level analysis identified patterns of Phytophthora spread consistent with an outward expansion from sites that were planted and with topography, although the presence of some species was not associated with water accumulation patterns. Phytophthora species assemblages were site-specific and possibly related to site type, nursery where plants were grown, and time since planting. To our knowledge, this is one of the first studies providing robust evidence that exotic Phytophthoras are being systematically introduced through the use of infected plants in restoration projects.

\section{PHYTO-THREATS: an analysis of Phytophthora communities in plant nurseries}

Sarah Green ${ }^{1}$, David Cooke ${ }^{2}$, Debbie Frederickson-Matika ${ }^{1}$, Mike Dunn ${ }^{1}$, Beatrix Clark $^{2}$, Eva Randall $^{2}$, Peter Thorpe ${ }^{2,3}$, Leighton Pritchard ${ }^{2}$, Peter Cock ${ }^{2}$, Tim Pettitt ${ }^{4}$, Alexandra Schlenzig ${ }^{5}$, Jane Barbrook ${ }^{6}$

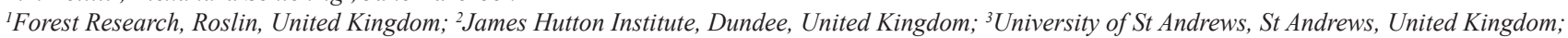
${ }^{4}$ University of Worcester, Worcester, United Kingdom; ${ }^{5}$ SASA, Edinburgh, United Kingdom; ${ }^{6}$ APHA, York, United Kingdom (sarah.green@forestry.gsi.gov.uk; david.cooke@hutton.ac.uk; debbie.frederickson@forestry.gsi.gov.uk; michael.dunn@forestresearch.gov.uk; beatrix.clark@hutton.ac.uk; eva.randall@hutton.ac.uk; pjt6@st-andrews.ac.uk; leighton.pritchard@hutton.ac.uk; peter.cock@hutton.ac.uk; t.pettitt@worc.ac.uk; alexandra.schlenzig@sasa.gsi.gov.uk; jane.barbrook@apha.gsi.gov.uk)

PHYTO-THREATS is a multidisciplinary project which aims to address global threats from invasive Phytophthora species through understanding drivers of emergence and opportunities for mitigation through nursery best practice. One of the project's objectives is to examine the distribution and diversity of phytophthoras in plant nursery systems in Britain and to relate Phytophthora community composition to key factors such as nursery size, management practice and geographical location. Fifteen partner nurseries operating a range of management practices were intensively sampled across Britain between 2016 and 2018, resulting in 59 sampling missions and over 4000 root and water samples. In addition, a broader scale survey involving 101 nurseries nationwide was undertaken over the same time period resulting in 653 root samples. Samples were tested for Phytophthora DNA using a nested PCR targeting the Phytophthora ITS1 region. The species assemblage in each positive sample (approximately $50 \%$ of all samples) was then determined using an Illumina metabarcoding approach which involved the development and validation of a bioinformatics pipeline and custom curated database of verified Phytophthora ITS1 sequences. Sample results were reported back to each nursery manager as soon as available along with advice on the implications of each species detected and suggested improvements to management practice. Data will be presented on Phytophthora findings in relation to the key factors outlined above and linked to Phytophthora data from natural ecosystems in Britain as part of other, concurrent projects. The risk of transmission of species through trade and from nursery to wider landscapes will be discussed. 


\section{Urban forests: bridge-heads and sentinels for Phytophthora introductions}

Treena Burgess ${ }^{1}$, Trudy Paap ${ }^{2}$, Giles Hardy ${ }^{1}$

${ }^{1}$ Murdoch University, Perth, Australia; ${ }^{2}$ University of Pretoria, Pretoria, South Africa (tburgess@murdoch.edu.au; trudy.paap@fabi.up.ac.za;

g.hardy@murdoch.edu.au)

Recent studies of the routes of worldwide introductions of alien organisms suggest that many widespread invasions could have stemmed not from the native range, but from a particularly successful invasive population, which serves as the source of colonists for remote new territories. This phenomenon is known as the bridgehead effect. Urban forests are an attractive proposition to invasive pests; they consist of a mixture of native and exotic plant species, the environmental conditions are often not ideal for the tree resulting in stress which is further exacerbated by weed pressure, salinity, drought, excess nutrients, the heat island effect and fragmentation. In addition, the urban forest consists of a range of environments from intensely managed spaces to conservation areas. We have studied this phenomenon in Perth, Western Australia a city situated in one of the world's biodiversity hot spots (the south-west botanical province). Due to the huge impact of Phytophthora cinnamomi in the region, there has been extensive sampling within natural vegetation over 40 years providing an incomparable background data set. Urban studies have only just begun and yet more than twice the number of species have been found associated with declining trees within the city compared to native vegetation in the whole of the south-west of Western Australia.

\section{Early detection of tree declines in urban and natural landscapes associated with Phytophthora diseases using airborne remote sensing systems}

Giles Hardy ${ }^{1}$, Treena Burgess ${ }^{1}$, Mohammed Baidhani ${ }^{1}$, Paul Barber ${ }^{2}$

${ }^{1}$ Murdoch University,Perth,Australia; ${ }^{2}$ ArborCarbon,Perth,Australia(g.hardy@murdoch.edu.au; t.burgess@murdoch.edu.au; m.baidhani@murdoch.edu.au; p.barber@arborcarbon.com.au)

Numerous Phytophthora species cause devastating diseases in a broad range of tree and shrub species across urban and natural landscapes worldwide. Early diagnosis is critical for effective mitigation and implementation of management strategies to minimise their spread and impact. Remote sensing of vegetation health using hyperspectral and multi-spectral imagery from satellite, fixed-wing aircraft and unmanned vehicles (drones) increasingly offer high-resolution, cost-effective and robust ways of monitoring the presence, impact and spread of plant diseases. In addition, these tools can be used to monitor the effectiveness of fungicides and other management tools associated with re-routing tracks, roads and other hygiene or quarantine measures. This talk will discuss the use of narrowband multi-spectral imagery together with on-ground diagnostics using traditional and molecular methods to detect the presence of Phytophthora species in urban and natural landscapes together with continued monitoring to follow the effectiveness of management strategies. A number of different urban and natural landscapes together with different Phytophthora species will be discussed.

\section{The emergence of Phytophthora species as foliar pathogens of forest plantations}

Nari Williams ${ }^{1}$, Stuart Fraser ${ }^{1}$, Mireia Gomez-Gallego ${ }^{1}$, Rebecca McDougal ${ }^{2}$, Ian Hood ${ }^{1}$, Lindsay Bulman ${ }^{1}$

${ }^{1}$ Scion, Rotorua, New Zealand; ${ }^{2}$ Scion, Rorotua,NewZealand (nari.williams@scionresearch.com; stuart.fraser@scionresearch.com;

mireia.gomez@scionresearch.com; rebecca.mcdougal@scionresearch.com; ian.hood@scionresearch.com; lindsay.bulman@scionresearch.com)

Since the year 2000, the emergence of Phytophthora species as significant foliar pathogens of forest trees has challenged paradigms for the management of the diseases this group of pathogens cause within forest plantations. Phytophthora pinifolia, P. pluvialis and $P$. ramorum are all now recognized as having significant impact within conifer plantations in Chile, New Zealand and the United Kingdom, respectively, while other species including $P$. lateralis, $P$. kernoviae, $P$. fallax and $P$. captiosa have each been demonstrated as potentially significant pathogens of trees within forest plantations. The aerial nature of these pathogens in contrast to soil-borne activity of most Phytophthora species has seen them emerge rapidly with few limitations to their spread following establishment. This talk will discuss the recognition and emergence of Phytophthora pathogens impacting the foliage of plantation forest species with focus on Phytophthora pluvialis as the cause of a new disease, red needle cast on radiata pine and Douglas-fir plantations in New Zealand. An update will be given on the current status of the disease and responses by local foresters and researchers in managing the impacts of these pathogens of forest productivity.

\section{Anthropogenic activities mediate pathogen movement and alien invasions into new and natural environments contributing to the} formation of new hybrid species

Angela Dale ${ }^{1,2}$, Nicolas Feau², Jean Bérubé ${ }^{3}$, Julien Ponchart', Guillaume Bilodeau ${ }^{5}$, Richard Hamelin ${ }^{2}$

${ }^{1}$ FPInnovations, Vancouver, Canada; ${ }^{2}$ University of British Columbia, Vancouver, Canada; ${ }^{3}$ Natural Resources Canada, Quebec, Canada; ${ }^{4}$ Université Laval, Quebec, Canada; ${ }^{5}$ Canadian Food Inspection Agency, Ottawa, Canada (angela.dale@fpinnovations.ca; feaunico@mail.ubc.ca; jean.berube@rncan-nrcan.gc.ca; julien.ponchart.1@ulaval.ca; guillaume.bilodeau@canada.ca; richard.hamelin@ubc.ca)

Globalization and anthropogenic activities often result in human-mediated dispersal of pathogens causing a breakdown in biogeographic barriers and change in the range and distribution of species. Outside of high profile invasions, the general impact of anthropogenic activities on plant pathogen communities is still poorly understood. To study the effect of anthropogenic impacts, we compared pathogen communities in urban, natural and interface (e.g. parks) environments. We surveyed communities of oomycetes, using metabarcoding and Phytophthora, using metabarcoding and baiting methods. Oomycetes are a class comprising important crop and tree pathogens including Phytophthora, a genus comprising some of the world's most destructive pathogens. Phytophthoras introduced from nurseries or spread by human movement have caused landscape level outbreaks. Diversity and abundance in both groups was highest in human impacted urban environments and lowest in natural environments, while interface environments were intermediate. Urban environments had the largest proportion of sites where the plant pathogenic genus Phytophthora was found and also the largest number of unknown and hybrid Phytophthora species. The higher frequency of hybrids suggests that expanding Phytophthora species ranges could result in more opportunities for hybridization. The taxa overlap between urban and interface environments was five to seven times higher than between urban and natural environments. Our data suggests urban/natural interface areas likely act as bridges for invasion into natural environments. This could impact both natural biota and natural ecosystem processes. Shifting patterns in Oomycete communities could interfere with natural ecosystem processes and result in an increase in disease or ecosystem declines. 
Division of labor among Nasutitermes corniger termites in the deterioration of forest species / Divisão de trabalho de cupins da espécie Nasutitermes corniger na deterioração de espécies florestais

Amanda Silva Soledade ${ }^{1}$, Rimer Oliveira Maduro ${ }^{\prime}$, Norma Bustamante ${ }^{1}$, Rogério Fonseca ${ }^{1}$

${ }^{1}$ Universidade Federal do Amazonas, Manaus, Brasil (rogeriofonseca@ufam.edu.br; rimer.oliveira@gmail.com; ncbustamante@gmail.com;

rogeriofonseca@ufam.edu.br)

Os cupins ou térmitas são insetos eussociais, que formam colônias com sobreposição de gerações, cuidado cooperativo da prole e divisão de trabalho. Para estudar a divisão de trabalho da espécie Nasutitermes corniger foi identificado um cupinzeiro na área do viveiro florestal, na Universidade Federal do Amazonas, coletado os cupins para cada experimento e levados ao laboratório para a realização dos testes. Foram realizados 6 experimentos para realizar a divisão de trabalho, comportamento exploratório, cuidado com os ovos, cuidado larval, cuidados com a rainha e frequência de alarme. As operárias fazem a maior parte dos trabalhos na colônia como cuidado com a rainha, larvas, alimentação das outras castas e reparação das paredes das colônias quando estas eram destruídas. Os soldados além da defesa do cupinzeiro também podem apresentar cuidado larval, porém com menos frequência do que o observado pelas operárias. As larvas são frágeis e não sobreviveriam sem o cuidado da colônia, quando colocadas em placa de petri apresentaram dificuldade de locomoção, mas o mesmo não foi observado quando estavam sobre superfícies ásperas. A rainha por apresentar dificuldade de locomoção precisa ficar cercada por operárias que a alimentam e fazem sua higiene por meio da trofalaxia de modo a manter a saúde da rainha do cupinzeiro. É necessário desenvolver estudos semelhantes em outros biomas e utilizando novos gêneros para que se possa alcançar um parecer final sobre a divisão de trabalho dos cupins, especialmente em espécies florestais de interesse madeireiro.

\section{Temporal patterns of airborne Phytophthora spp. in a woody plant nursery area detected using real-time PCR}

Duccio Migliorini ${ }^{1}$, Luisa Ghelardini ${ }^{2}$, Nicola Luchi $^{1}$, Francesco Pecori ${ }^{1}$, Paolo Capretti ${ }^{2}$, Alberto Santini ${ }^{1}$ (D)

${ }^{1}$ Institute for Sustainable Plant Protection - C.N.R., Sesto fiorentino, Italy; ${ }^{2}$ Dipartimento di Scienze delle Produzioni Agroalimentari e dell'Ambiente DiSPAA, University of Florence,Firenze, Italy)(duccio.migliorini@ipsp.cnr.it; luisa.ghelardini@unifi.it; nicola.luchi@ipsp.cnr.it; francesco.pecori@ipsp.cnr.it; paolo.capretti@unifi.it; alberto.santini@cnr.it)

In this study, spore trap monitoring was applied to provide a proof of concept for the use of qPCR to detect Phytophthora in aerial samples and provide valuable information for epidemiological studies in nurseries. Two qPCR TaqMan assays were developed to detect pathogen DNA: the first used a generic probe to detect Phytophthora spp., and the second was based on a specific probe for detecting $P$. ramorum and $P$. lateralis. All samples tested positive for the genus Phytophthora, although P. ramorum and P. lateralis were not detected. In late spring and in autumn, two main peaks of Phytophthora sporulation were observed. Peaks were preceded by rainfall, high relative humidity, and mild temperature. From mid-May to the end of August, Phytophthora DNA detected in the air increased with relative humidity, while it decreased with increasing mean temperature. There was also a positive correlation between Phytophthora DNA detected and rainfall in the same period. No significant correlations between Phytophthora DNA and temperature or rainfall were found from the end of August to December. Our results are in agreement with those obtained with classical diagnostic methods based on microscopy, but the approach used here enabled rapid detection and relative quantification of the target organisms, thus assisting in the implementation of disease management strategies.

\section{The role of Phytophthora in urban Bushland decline in Southeast Australia}

Craig Nitschke ${ }^{1}$, Muhammad Farrakh Nawaz', Linda Parker', Stefan Arndt ${ }^{1}$

${ }^{1}$ The University of Melbourne, Richmond, Australia; ${ }^{2}$ University of Agriculture Faisalabad, Faisalabad, Pakistan (craign@unimelb.edu.au; kf_uaf@yahoo.com; parker.l@unimelb.edu.au; sarndt@unimelb.edu.au)

Maroondah Council in Southeast Australia have raised concern about the decline of adult Eucalypt trees, particularly in some of their managed reserves. Multiple factors may be contributing to Eucalyptus decline in these reserves including drought, herbivory, and disease. We conducted a broad scale investigation of tree decline in 35 parks and reserves and found a wide spread decline of eucalypts and ubiquitous presence of Phytophthora. To determine if Phytophthora was contributing to the decline in eucalypts 10 healthy and 10 declined trees were selected randomly within two reserves and tested for the occurrence of the pathogen. We also measured physiological traits of healthy and declined trees. Declined trees all had infected roots, while $>50 \%$ of healthy trees also had Phytophthora in the roots. No differences in physiological traits of healthy or declined trees was found. Healthy and declined trees had the same water status, the same level of maximum drought stress and the same nutrient status. Declined trees had slightly lower starch concentration but a similar non-structural carbohydrate concentration. It is likely that Phytophthora infection decreased nutrient and water uptake, but this was compensated by leaf area adjustment by shedding leaves thereby minimizing water and nutrient requirements. The widespread presence of Phytophthora in urban green spaces has consequences for management and urgent action is required to minimize the spread of the disease and long-term action should be considered to future proof the green spaces to minimize a further spread of the pathogen.

D7k: PINE PITCH CANKER: STRATEGIES FOR MANAGEMENT OF FUSARIUM CIRCINATUM IN GREENHOUSES AND FORESTS (PINESTRENGTH)

\section{COST Action FP1406: pine pitch canker: strategies for management of Gibberella circinata in greenhouses and forests (PINESTRENGTH)}

Jorge Martin-Garcia ${ }^{1,2}$, Stephen Woodward ${ }^{3}$, Renaud Ioos ${ }^{4}$,Eeva Vainio ${ }^{5}$, Margarita Elvira-Recuenco ${ }^{6}$, Mercedes Fernandez ${ }^{2}$, Jarkko Hantula ${ }^{5}$, Paolo Capretti ${ }^{7}$, Anna Maria Vettraino ${ }^{8}$, Rosa Raposo ${ }^{6}$, Andrea Vaninni $^{8}$, Tugba Dogmus ${ }^{9}$, Artur Alves ${ }^{1}$, Verica Vasic ${ }^{10}$, Marta Vasconcelos $^{11}$, Pablo Martinez-Alvarez ${ }^{12}$, Julio J. Diez ${ }^{2}$

${ }^{1}$ Universidade de Aveiro, Aveiro, Portugal; ${ }^{2}$ Universidad de Valladolid, Palencia, Spain; ${ }^{3}$ University of Aberdeen, Aberdeen, United Kingdom; ${ }^{4}$ ANSES, Manzeville, France; ${ }^{5}$ LUKE, Helsinki, Finland; ${ }^{6} I N I A$, Madrid, Spain; ${ }^{7}$ University of Florence, Florence, Italy; ${ }^{8}$ Univesity of Viterbo, Viterbo, Italy; ${ }^{9}$ Suleyman Demirel University, Isparta, Turkey; ${ }^{10}$ Institute of Lowland Forests and Environment, Novi Sad, Serbia; ${ }^{11}$ Universidade de Porto, Porto, Portugal; ${ }^{12}$ Gobierno de Cantabria, Santander,Spain (jorge.martin@ua.pt; s.woodward@abdn.ac.uk; renaud.ioos@anses.fr; eeva.vainio@luke.fi; elvira@inia.es; mffernan@agro.uva.es; jarkko.hantula@luke.fi;paolo.capretti@unifi.it; vettrain@unitus.it; raposo@inia.es; vannini@unitus.it; tugbadogmus@sdu.edu.tr; artur.alves@ua.pt; vericav@uns.ac.rs; ${ }^{1}$ mvasconcelos@porto.ucp.pt; pmtnez@pvs.uva.es; jdcasero@pvs.uva.es)

Fusarium circinatum (teleomorph: Gibberella circinata) was first detected in North America, since when the pathogen has spread into Central and South America, South Africa, Asia and, more recently, Europe. F. circinatum is now considered the most important pathogen affecting Pinus seedlings and mature 
trees in many countries globally; asymptomatic seedlings may be planted out, resulting in very serious losses in forests. The main aim of PINESTRENGTH is to establish a European-focused network to increase knowledge of the biology, ecology and pathways of spread of F. circinatum, to examine the potential for the development of effective and environmentally-friendly prevention and mitigation strategies and to deliver these outcomes to stakeholders and policy makers. To that end, a multidisciplinary approach is being taken, including researchers, forest managers and policy makers from 35 countries to date. Furthermore, any interested party is encouraged to join this COST Action, participating in some of the six Working Groups (WG1 The pathogen-diagnosis, WG2 Interactions with other forest pests and pathogens, WG3 Pathway of disease spread, WG4 Pest risk analyses, WG5 Management of the disease in forest and nurseries and WG6 Coordination, identifying research gaps and dissemination). For further information, please check http://www.pinestrength.eu/.

\section{First report of pitch canker caused by Fusarium circinatum in Portuguese pine forest: detection, eradication and management}

Helena Bragança ${ }^{1}$, Eugénia Andrade ${ }^{1}$,Eugénio Diogo ${ }^{1}$, Clara Fernandes ${ }^{1}$, Luis Fernandes ${ }^{2}$, Diana Paiva ${ }^{2,3}$, António Portugal $^{2,3}$, Dina Ribeiro ${ }^{4}$ ${ }^{1}$ Instituto Nacional de Investigação Agrária e Veterinária I.P. (INIAV I.P.), Quinta do Marquês, 2780- 159 Oeiras, Portugal; ${ }^{2}$ Fitolab- Laboratory for Plant Health, Instituto Pedro Nunes, 3030-199 Coimbra, Portugal; ${ }^{3}$ Centre for Functional Ecology - Science for People \& the Planet, Department of Life Sciences, University of Coimbra, Calçada Martim de Freitas, 3000-456 Coimbra, Portugal; ${ }^{4}$ Instituto da Conservação da natureza e das Florestas I.P. (ICNF, I.P, Avenida da República, 16 a 16B, 1050-191 Lisboa, Portugal (helena.braganca@iniav.pt; eugenia.andrade@iniav.pt; eugenio.diogo@iniav.pt; clara.fernandes@iniav.pt; aportuga@bot.uc.pt; dpaiva@ipn.pt; aportuga@bot.uc.pt; dina.ribeiro@icnf.pt)

Fusarium circinatum, the causal agent of Pine Pitch Canker is one of the most aggressive pathogens for pine. The fungus, considered to be native in America, was detected in several countries in America, Asia and also in South Africa. In Europe, the fungus was first reported in Spain, and then in Italy, France and Portugal. After the first detection in Portugal in 2007, an action plan was implemented by the Portuguese forest authority (ICNF), following EU regulation (Commission Decision 2007/433/EC). In the scope of that plan, an intensive survey was implemented every year (in nurseries, forests and seed production Centre) and hundreds of samples were analysed in three national laboratories. During consecutive years, positive results were only found in nurseries and none in forest samples. In 2016, a positive result was recorded by INIAV Mycology laboratory in an allotment of $P$. radiata seeds. Tracing the track of those seeds, a deep survey was done on the $P$. radiata provenance forest site. Despite few symptomatic trees were observed in that area, F. circinatum was detected for the first time in forest samples. Also in 2016, the fungus was detected in another site of young P. radiata trees in the center of Portugal. After these two records in field, nine years after the first detection in Portugal, ICNF forced the eradication of these two foci and intensified the management in field using a combination of tools and procedures to control and prevent the disease's spread in forest.

\section{Pine nursery: and transplanting-disease associated with Fusarium circinatum in South Africa}

Andrew Morris ${ }^{1}$, Nicky Jones ${ }^{2}$, Emma Steenkamp ${ }^{3}$

${ }^{1}$ Institute for Commercial Forestry Research, Pietermaritzberg, South Africa; ${ }^{2}$ Sappi Forests Research, Hilton, South Africa; ${ }^{3}$ University of Pretoria, Pretoria, SouthAfrica (andrew.morris@icfr.ukzn.ac.za; nicky.jones@sappi.com; emma.steenkamp@up.ac.za)

The pitch canker fungus (PCF), Fusarium circinatum, that has become distributed around the globe, is well known as the cause of resinous stem cankers of pine. In South Africa, PCF is also the cause of nursery and post-planting disease mortality. PCF was first identified in a forestry nursery in South Africa in 1990 and within a decade was found in all forest nurseries in the country. Production of the two main pine species planted, Pinus patula and P. radiata, was severely impacted. Following the nursery infections, post-planting mortality, up to two years after planting, was observed associated with PCF. Genetic diversity studies on PCF indicated that subsequent outbreaks of pine pitch canker disease in established plantations in South Africa were associated with nursery incidence of PCF. This presentation reviews the industry and research response to this serious problem. Post-planting mortality was shown to result from asymptomatic, infected planting stock despatched from nurseries rather than tree-to-tree infection processes in-field. Two interventions were developed to combat the disease. Firstly, hygiene measures were identified to reduce nursery inoculum to levels that thus diminishing not only nursery disease losses but also asymptomatic infection incidence and transplant mortality in field. Secondly, planting stock, genetically tolerant to PCF was developed for certain planting sites in the form of P. patula x P. tecunumanii hybrids. Development of a genetically diverse, asexual PCF population presents challenges for continued control of this disease. The presentation reflects on the importance of industry and academic collaboration and opportunities for further research.

\section{Differential gene expression of Pinus radiata infected by an isogenic strain of Fusarium circinatum harbouring mitovirus FcMV2-1 and mycovirus-free}

Cristina Zamora-Ballesteros ${ }^{1,2}$ (D), Alex Douglas ${ }^{3}$, Julio Diez ${ }^{1,2}$, Jorge Martín-García ${ }^{1,4}$

${ }^{1}$ Sustainable Forest Management Research Institute, University of Valladolid - INIA, Palencia, Spain; ${ }^{2}$ Department of Vegetal Production and Forest Resources, University of Valladolid, Palencia, Spain; ${ }^{3}$ School of Biological Sciences, University of Aberdeen, Aberdeen, United Kingdom; ${ }^{4}$ Department of Biology and CESAM (Centre for Environmental and Marine Studies), University of Aveiro, Campus Universitário de Santiago, 3810-193, Aveiro, Portugal (cristinazamoraballesteros@gmail.com; a.douglas@abdn.ac.uk; jdcasero@pvs.uva.es; jorgemg@pvs.uva.es)

Pinus radiata is one of the most economically important pine species in the world due to its fast growth rate. Nevertheless, in turn, this conifer specie is the most susceptible host to Pine Pitch Canker disease caused by the fungal pathogen Fusarium circinatum. The fact that there are no effective means of controlling this devastating disease has led the search for new measures such as virocontrol. The infection of $F$. circinatum by putative mycoviruses apparently reduces the percentage of spore germination and mycelial growth, although it does not seem to affect the size of the lesions caused in $P$. radiata seedlings. In this investigation, mRNA sequencing (RNA-Seq) is used to identify differentially expressed genes during the interaction of $P$. radiata with isogenic strain of $F$. circinatum infected by mitovirus FcMV2-1 and free of mycoviruses including uninfected plants. The essay was carried out at two time points (4 and 11 days post inoculation) in order to obtain a more comprehensive view of the fungal invasion. Transcriptome analysis showed altered gene expression during the different interactions in the pathosystem formed by virus-fungus-plant. 
An integrative toolbox to decipher defence mechanisms in Pinus species with differential responses to Fusarium circinatum infection: from physiology to Omics

Joana Amaral ${ }^{1}$, Barbara Correia ${ }^{1}$, Mónica Escandón ${ }^{1}$, María Ángeles Castillejo ${ }^{1}$, Luis Valledor ${ }^{2}$, Jorge Martín-Garcia ${ }^{1,3}$, Artur Alves ${ }^{1}$, Glória Pinto ${ }^{1}$ ${ }^{1}$ Department of Biology and CESAM, University of Aveiro, Aveiro, Portugal; ${ }^{2}$ Department of Organisms and Systems Biology, University of Oviedo, Oviedo, Spain; ${ }^{3}$ Sustainable Forest Management Research Institute, University of Valladolid_INIA, Palencia, Spain (jsamaral@ua.pt; bscorreia@ua.pt; m.escandon. martinez@gmail.com; bb2casam@uco.es; valledorluis@uniovi.es;jorge.martin@ua.pt; artur.alves@ua.pt; gpinto@ua.pt)

Pine pitch canker, caused by Fusarium circinatum, represents a considerable threat to conifer forests worldwide and is currently associated to significant economic losses. Although essential for the development of disease mitigation strategies, little research focused on host susceptibility/tolerance mechanisms has been conducted. Therefore, we aim to explore the response of Pinus spp. with contrasting responses to F. circinatum infection using a multidisciplinary approach. A highly susceptible and a relatively tolerant pine species (Pinus radiata and Pinus pinea, respectively) were artificially infected with the pathogen and several analyses were carried out for both species when infected $P$. radiata seedlings exhibited disease symptoms. Morpho-physiological, hormonal and oxidative stress-related changes were assessed, as well as targeted gene expression, proteomic and metabolomic profiles, and epigenetic variation. Several species-specific responses were found by applying this holistic methodology. These are likely to be correlated with the outcome of $F$. circinatum infection for each species. Moreover, the integration of the data obtained and the construction of networks provide a comprehensive overview of pine defence mechanisms upon $F$. circinatum attack, defining new interaction, signalling pathways and related targets according to species susceptibility. These studies contribute to fulfil knowledge gaps on tree stress responses and allow developing markers for the implementation of environmentally sound integrated pest management solutions to control pine pitch canker.

\section{Composition of endophytic community at different heights in Pinus radiata trees inoculated with Fusarium circinatum}

Carmen Romeralo ${ }^{1}$, Esteban Torres ${ }^{2}$, Román Moreno ${ }^{2}$, Jordán Muñoz ${ }^{2}$, Pablo Martínez-Alvarez ${ }^{2}$, Jorge Martín-García ${ }^{3}$, Julio Diez ${ }^{2}$ ${ }^{1}$ Swedish University of Agricultural Sciences, Alnarp, Sweden; ${ }^{2}$ University of Valladolid, Palencia, Spain; ${ }^{3}$ University of Aveiro, Aveiro, Portugal (carmenromeralo@gmail.com; estosa93@outlook.es; roman.moreno.helguera@gmail.com; ejordanmunoz@hotmail.com; pmtnez@pvs.uva.es; jorgemg@pvs.uva.es; jdcasero@pvs.uva.es)

The endophytic community is mainly composed by fungi and bacteria that live inside the trees without causing any visible symptom and together with the epiphytes conform the microbiome of a plant. The microbiome is currently considered as an integral determinant of a plant phenotype, and influencing ecologically important characteristics of the host, such as stress or disease tolerance. It has been shown that the structure and diversity of endophyte communities depend on the host, the geographical location and abiotic and biotic factors. However, there is a lack of studies investigating the vertical stratification of endophyte communities. In this study we analyze the composition of the endophyte communities in different heights of several Pinus radiata trees previously inoculated with the forest pathogen Fusarium circinatum, responsible for the Pine Pitch Canker disease. The total DNA was extracted and subjected to a NGS analysis with the Illumina platform. A total of 536 taxa of fungi were obtained in the 20 samples analyzed. We observed that the communities of endophytes were similar in the heights of 15,65 and $115 \mathrm{~cm}$ but different from the species found at $165 \mathrm{~cm}$ and from the samples collected in the branches. The results of this study can provide further knowledge of the ecology of fungal endophytes and their paper as biological antagonists.

\section{Fusarium circinatum: a great challenge in nursery production and the establishment of Pinus radiata plantations in Chile}

Rodrigo Ahumada ${ }^{1}$ Alessandro Rotella ${ }^{1}$

'Bioforest SA., Concepcion, Chile (rodrigo.ahumada@arauco.cl; alessandro.rotella@arauco.cl)

Fusarium circinatum is present in Pinus radiata nurseries in Chile since 2001 when was first reported by Wingfield et al (2001). The fungus is present in most of the $P$. radiata nurseries and is well-established despite the permanent effort made to reduce its negative impact in plant production and plantations establishment. This pathogen is still confined to nurseries and there is no evidence of the pitch canker disease in plantations in Chile or in other country in South America where is present. Monitoring is focused to have early detection in plantations and for that a national effort is made by forestry companies and the government, with special attention to insects that could be associated with F. circinatum, like the small banded pine weevil Pissodes castaneus, among others. Fusarium circinatum in Chile has very low genetic diversity and only one mating type, probably related with a low number of introductions into the country. Some initiatives have been made to select genetic material of $P$. radiata tolerant to $F$. circinatum and also on the definition of risk areas where $P$. radiata could have high stress, allowing the fungus its expression. Good practices at the nursery are crucially important to reduce the amount of inoculum, and these practices should include a rigorous elimination of symptomatic plants, sanitization of machines, tools, hands and shoes of the workers. A combination of tools whit chemical and biological fungicides, bioestimulants, sanitization and quality plant improvement, show that is possible to reduce mortality during the plantations establishment.

\section{Advances on Fusarium circinatum research: a case studies of COST FP 1401 STMS}

Tomasz Oszako ${ }^{1}$, Katerina Davydenko ${ }^{2}$, Kristina Raitelaityte $\dot{e}^{3}$, Roberto Faedda ${ }^{4}$, Katarzyna Sadowska $^{5}$, Tadeusz Malewski ${ }^{6}$, Dymitri Voitka $^{7}$, Magdalena Gawlak ${ }^{5}$, Julio Javier Diez Casero ${ }^{8}$, Pola Wartalska ${ }^{1}$

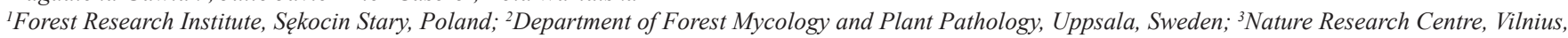
Lithuania; ${ }^{4}$ Dipartimento di Gestione dei Sistemi Agroalimentari e Ambientali, Università degli Studi, Catania, Italy; ${ }^{5}$ Institute of Plant Protection, National Research Institute, Poznań, Poland; ${ }^{6}$ Museum and Zoology Institute, Polish Academy of Science, Warszawa, Poland; ${ }^{7}$ Institute of Plant Protection, Minsk, Belarus, ${ }^{8}$ Universidad de Valladolid Escuela Técnica Superior de Ingenierías Agrarias, Palencia, Spain (pwartalska@gmail.com; t.oszako@ibles.waw.pl; kateryna.davydenko@yandex.ua; kristina.raitelaityte@gmail.com; rfaedda@unict.it; ksadowska@iorpib.poznan.pl; tmalewski@miiz.waw.pl; d.voitka@tut.by; mgieta.post@home.pl;jdcasero@pvs.uva.es)

Pathogenicity tests with Polish and Lithuanian Scots pine provenances were carried out revealing tolerance of some of them to Fusarium circinatum infections performed via wounds and via soil. While 3 month-old seedlings were not successfully infected (no symptoms and positive results of pathogen DNA tests in the tissue of roots and shoots) in contrast to the older plants (1 year-old and more), which showed external symptoms of disease (and positive DNA tests). Interaction between soil borne fungi Fusarium genus and Phytophthora species revealed different reaction of $F$. circinatum and other species of fusaria, sometime stimulating growth of its mycelium another time inhibiting it. SEM photographs show the interaction zones. Biological control with the use of bacteria Bacillus subtilis and hyper parasite Trichoderma asperellum was quite efficient in dual organism tests in vitro. Detection and identification of pathogens with an electronic nose is a promising tool for quarantine organisations. Chromatograms from GCMS reveal specific substances differencing fungi from oomycets. 


\section{Disclosing effective methods in the Pinus spp. seeds treatment to the Pine Pitch Canker prevention}

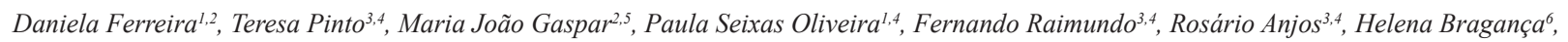
Dina Ribeiro ${ }^{7}$, Luis Miguel Ferreira Martins ${ }^{1,4}$

${ }^{1}$ Departamento de Ciências Florestais e Arquitetura Paisagista (CIFAP), Universidade de Trás-os-Montes e Alto Douro (UTAD), Vila Real, Portugal; ${ }^{2}$ BioISI-UTAD, Biosystems and Integrative Sciences Institute, Universidade de Trás-os-Montes e Alto Douro, Vila Real, Portugal; ${ }^{3}$ Departamento de Biologia e Ambiente (DeBA), Universidade de Trás-os-Montes e Alto Douro (UTAD), Vila Real, Portugal; ${ }^{4}$ Centro de Investigação e Tecnologias Agroambientais e Biológicas (CITAB), Universidade de Trás-os-Montes e Alto Douro (UTAD), Vila Real, Portugal; ${ }^{5}$ Centro de Estudos Florestais, Instituto Superior de Agronomia, Universidade de Lisboa, Tapada da Ajuda, Lisboa, Portugal, ${ }^{6} I N I A V$, Oeiras, Portugal; ${ }^{7} I C N F$, Lisboa, Portugal (daniela p ferreira@hotmail. com; tpinto@utad.pt; mjgaspar@utad.pt; paula.s.oliveira@utad.pt; fraimund@utad.pt; ranjos@utad.pt; helena.braganca@iniav.pt; dina.ribeiro@icnf.pt; lmartins@utad.pt)

Fusarium circinatum is a fungus and is the causal agent of the Pine Pitch Canker. It affects different Pinus spp. and is characterized by resinous lesions and branch dieback, causing reduced growth and extensive tree death. Fusarium circinatum may also be present in Pinus spp. seeds without showing symptoms and its detection in nurseries results in the inhibition of sale for a period of two years. Thus, it is essential to determine the most efficient methods in the treatment/ elimination of $F$. circinatum in Pinus spp. seeds. Here, we used seeds from P. pinaster, P. radiata and $P$. pinea, inoculated with $F$. circinatum to analyze the effects of different concentrations of hydrogen peroxide $\left(\mathrm{H}_{2} \mathrm{O}_{2}\right)$, sodium hypochlorite $(\mathrm{NaClO})$, thiophanate-methyl and difenoconazole. In order to prove the efficiency of the treatment, the seeds were plated in specific medium and incubated at $22^{\circ} \mathrm{C}$ during 7 days; after that, the Fusarium spp. colonies were transferred to PDA and SNA medium, for morphological identification; it was also extracted DNA from the PDA colonies and it was performed a PCR reaction with $F$. circinatum specific primers. The treatment with $\mathrm{H}_{2} \mathrm{O}_{2}(20 \%$ and $30 \%)$ was the one with the best outcome in all Pinus spp. seeds tested. With this treatment, we were able to eliminate the presence of Fusarium circinatum in all the tested seeds, being a reproducible result. Furthermore, it was possible to observe germinating seeds in the DCPA medium in 7 days of growth, which means that the $\mathrm{H}_{2} \mathrm{O}_{2}$ treatment might not affect the germination capacity.

\section{Gene expression profile of Fusarium circinatum in response to the infection of the putative Mitovirus FcMV1}

\section{Cristina Zamora-Ballesteros ${ }^{1,2}$ (D), Brenda Wingfield ${ }^{3}$, Jorge Martin-Garcia ${ }^{4,5}$, Julio Diez $^{1,2}$}

${ }^{1}$ Sustainable Forest Management Research Institute, University of Valladolid - INIA, Palencia, Spain; ${ }^{2}$ Department of Vegetal Production and Forest Resources, University of Valladolid, Palencia, Spain; ${ }^{3}$ Department of Genetics, Forestry and Agricultural Biotechnology Institute, University of Pretoria, Pretoria, South Africa; ${ }^{4}$ Department of Biology and CESAM (Centre for Environmental and Marine Studies), University of Aveiro, Campus Universitário de Santiago, 3810-193, Aveiro, Portugal; ${ }^{5}$ Sustainable Forest Management Research Institute, University of Valladolid-INIA, Avenida de Madrid 44, 34071, Palencia,Spain (cristinazamoraballesteros@gmail.com; brenda.wingfield@up.ac.za; jorgemg@pvs.uva.es; jdcasero@pvs.uva.es)

Virus infections generally are ubiquitous in major fungal families including plant-pathogenic fungi. The effects of these mycoviruses range from asymptomatic to detrimental conferring hypovirulence to their host. Three different mycoviruses of the genus Mitovirus has been identified infecting Spanish isolates of the conifer pathogen Fusarium circinatum (FcMV1, FcMV2-1 and FcMV2-2). Mitoviruses has been associated with the hypovirulence phenomenon in many phytopathogenic fungi, motivating the study of F. circinatum mycoviruses in an attempt to limit the effects of the devastating Pine Pitch Canker disease. Although the presence of mitoviruses does not seem to affect the size of the lesions caused by F. circinatum, it does so reducing the percentage of spore germination and mycelial growth. Thus, metabolic activity reduction could be related to the presence of mitoviruses but it is necessary the use of more accurate methods to determine their effect beyond the visible symptoms. The development of new tools based on host genome studies helps to address the intellectual challenge of understanding the fungal-virus interactions. For the purpose to identify genes linked to the presence of the mitovirus FcMV1, standard differential expression analysis was carried out using RNA-Seq. Total RNA from virus-infected and cured isogenic $F$. circinatum strains was isolated and sequenced. CLC Genomics Workbench V7.5 was used to perform the bioinformatic analysis. As a result, 14 genes were differentially expressed in response to mitovirus FcMV1 infection. Our analysis provides further detailed insights into mitovirus-F. circinatum interaction.

\section{Fusarium species associated with bark beetles in pinus radiata plantations affected by Pine pitch canker}

Diana Bezos ${ }^{1}$, Pablo Martínez-Alvarez ${ }^{1}$, Antonio Sanz-Ros ${ }^{1}$, Jorge Martin-Garcia ${ }^{1}$, Mercedes Fernańdez ${ }^{1}$, Julio J. Diez ${ }^{1}$

IUniversidad de Valladolid,Palencia,Spain(diana.bezos@uva.es; pmtnez@pvs.uva.es; asanzros@gmail.com; jorgemg@pvs.uva.es; mffernan@agro.uva.es; jdcasero@pvs.uva.es)

Fusarium species, as well as other endophytic or pathogenic fungi forming fungal communities, have been reported to be phoretically associated with bark beetles vectors worldwide. This is the case of Fusarium circinatum, the causal agent of pine pitch canker, which threats Pinus radiata plantations in northern Spain. The main objective of this study was to study the fungal communities present on bark beetles and their galleries in pine pitch canker diseased stands with special attention to Fusarium species. Ten funnel traps and 12 piles of logs were displayed in a P. radiata plot affected by F. circinatum. Traps were baited with different attractive compounds, four with pityol and six with ethanol and $\alpha$-pinene. In addition, fresh green shoots with Tomicus piniperda's feeding galleries were collected from the ground in 25 P. radiata affected plots. Collected insects and gallery tissues were processed and cultured with the aim of isolating and identifying associated fungi. A total of 24 different fungal species were obtained from the bark beetles galleries from logs and shoots while 18 were obtained from the insects' exoskeleton.. Ten different Fusarium species were isolated from tissues and insects. Fusarium circinatum was isolated from bark beetles exoskeletons (1.05\% of the P. pubescens) and from their galleries (3.5\% of $T$. piniperda's feeding gallery). These results are an approach to the fungal communities associated with bark beetles in $P$. radiata PPC diseased stands in northern Spain, suggesting an association between bark beetles and Fusarium species, which is highlighted by the presence of F. circinatum in T. piniperda's galleries.

\section{Vertical transmission of Fusarium circinatum mitoviruses FCMV1 and FCMV2-2 via microconidia}

Carmen Romeralo 1 , Diana Bezos ${ }^{2}$, Pablo Martinez-Alvarez ${ }^{2}$, Julio Diez ${ }^{2}$

${ }^{1}$ Swedish University of Agricultural Sciences, Alnarp, Sweden; ${ }^{2}$ University of Valladolid, Palencia, Spain (carmenromeralo@gmail.com; dianabezos@gmail. com; pablomtnez@hotmail.com;jdcasero@pvs.uva.es)

Pine Pitch Canker disease, caused by the pathogenic fungus Fusarium circinatum, affects conifer species worldwide. However, the virulence of the pathogen may be affected by the presence of mycoviruses. The aim of this laboratory-based study was to investigate the probability and rate of transmission of $F$. circinatummitoviruses FcMV1 and FcMV2-2 via microconidia. Ten isolates of mitovirus-infected F. circinatum were subcultured to produce a total of 100 single-spore colonies (ten replicates per isolate). The total RNA and cDNA obtained from each spore isolate (monosporic culture) were amplified by PCR 
with specific primers for detection of F. circinatum mitoviruses FcMV1 and FcMV2-2. The mitoviruses were detected in a high percentage of the individual spore isolates (between $60 \%$ and $100 \%$ depending on the fungal isolate). However, the probability of transmission was not statistically significantly associated with either the F. circinatum isolate or the viral strain. A high proportion of transmission via microconidia is critical for development of a biological control program against Pine Pitch Canker (PPC) disease in forests. However, further studies are needed to establish the effect of these mitoviruses on the virulence of F. circinatum.

\section{Unravelling pathogenicity and resistance mechanisms in the Pinus spp / Fusarium circinatum pathosystem}

Jorge Martín-García ${ }^{1,2}$, Joana Amaral ${ }^{1}$, Emigdio Jordan Muñoz-Adalia ${ }^{2,3}$, Julio Javier Diez ${ }^{2,3}$, Glória Pinto ${ }^{1}$, Artur Alves ${ }^{1}$ ${ }^{1}$ Department of Biology and CESAM, University of Aveiro, Aveiro, Portugal; ${ }^{2}$ Sustainable Forest Management Research Institute, University of ValladolidINIA, Palencia, Spain; ${ }^{3}$ Department of Plant Production and Forest Resources, University of Valladolid, Palencia, Spain (jorge.martin@ua.pt; jsamaral@ua.pt; ejordanmunoz@hotmail.com; jdcasero@pvs.uva.es; gpinto@ua.pt; artur.alves@ua.pt)

Nowadays, European forests are exposed to a high number of invasive alien pathogens. Among them, Fusarium circinatum is considered as one of the most important pathogens of conifers globally. Little is known regarding the infection and defense mechanisms involved in this pathosystem, even though this information is crucial to develop management strategies. Interspecific variation in pine susceptibility against $F$. circinatum is the key to identify the genes involved in these mechanisms. In the present study three pine species ( $P$. radiata, $P$. pinaster and $P$. pinea) were selected according to a negative gradient of susceptibility. RT-qPCR was used to identify the differential expression of 8 target genes ( ${ }^{5}$ from the pathogen and ${ }^{3}$ from the host) according to the host species at two different sampling points (12 and 20 days after inoculation). Differential expression of $F$. circinatum pathogenicity genes was dependent on the host species and sampling point. In particular, the lowest and highest expression level of $F$. circinatum genes were found in $P$. radiata and $P$. pinea, respectively. This concurs with the susceptibility of these pine species. An opposite pattern was found between both pine species according to disease progression (12 vs; 20 dpi), which seems to point out that seedlings could not avoid infestation but the resistant species $(P$. pinea) could develop any resistance mechanism to prevent its progress. Pathogenesis-related genes of the host showed significant differential expression according to the species, but no effect of the sampling point was found.

\section{Biodiversity of fungal endophytic community in several pine species previously inoculated with Fusarium circinatum}

Carmen Romeralo ${ }^{1}$, Esteban Torres ${ }^{2}$, Román Moreno ${ }^{2}$, Jordan Muñoz ${ }^{2}$, Pablo Martínez-Alvarez ${ }^{2}$, Jorge Martín-García ${ }^{3}$, Julio Diez ${ }^{2}$ ${ }^{1}$ Swedish University of Agricultural Sciences, Alnarp, Sweden; ${ }^{2}$ University of Valladolid, Palencia, Spain; ${ }^{3}$ University of Aveiro, Aveiro, Portugal (carmenromeralo@gmail.com; estosa93@outlook.es; roman.moreno.helguera@gmail.com; ejordanmunoz@hotmail.com; pmtnez@pvs.uva.es; jorgemg@pvs.uva.es; jdcasero@pvs.uva.es)

The microbiome of a plant is composed of endophytic (internal) and epiphytic (external) microbes, mainly bacteria and fungi. The endophytic community (i.e. organisms that live inside the plant without causing any visible symptom) is increasing in importance because their interaction with the host and with other organisms such as pathogens. It is known that the degree of tolerance of a host to a certain pathogen is a combination of genetic resistance, the environment and the microbes that live inside the plant. In the present study we focus on the diversity of fungal endophytic communities in different pine species (Pinus radiata, $P$. pinaster, $P$. sylvestris, $P$. nigra and $P$. uncinata) previously inoculated with the forest pathogen Fusarium circinatum and grown in the same environment. The study of fungal species was carried out with NGS (Next Generation Sequencing) technologies. The results of our study showed that existed a common core microbiome among all the samples that was composed of several endophytic fungi: Alternaria alternata, Pleospora herbarum, Cryptococcus terreus and Cladosporium shpaerospermum. We also found differences between the endophytic communities of each pine species being the community of Pinus uncinata the one that presented more dissimilarities with the others. The results of our study could provide valuable information about species composition and the role of the fungal species as biological antagonists of forests pathogens.

\section{D7l: VANGUARDS FOR RESEARCH OF MYRTLE RUST, AUSTROPUCCINIA PSIDII}

\section{Global invasive threats of myrtle rust: genetic diversity and bioclimatic modeling of Austropuccinia psidii in the Americas and Hawaii}

Jane Stewart ${ }^{1}$, Amy Ross-Davis ${ }^{2,3}$, Rodrigo Graca ${ }^{4}$, Acelino Alfenas ${ }^{5}$, Tobin Peever ${ }^{6}$, John Hanna ${ }^{2}$, Janice Uchida ${ }^{7}$, Phil Cannon ${ }^{8}$, S Namba ${ }^{9}$, S Simeto ${ }^{10}$, Robert Hauff ${ }^{11}$, C Kadooka ${ }^{7}$, Carlos Pérez ${ }^{12}$, Min Rayamajhi ${ }^{13}$, Jean Lodge ${ }^{14}$, M Arguedas $^{15}$, Paula Tennanet ${ }^{16}$, Morag Glen $^{17}$, Patricia Machado ${ }^{5}$, Rosario Medel-Ortiz ${ }^{18}$, M.A López-Ramirez ${ }^{18}$, Alistair R. McTaggart ${ }^{19}$, Angus Carnegie ${ }^{20}$, Mee-Sook Kim ${ }^{21}$, Ned Klopfenstein ${ }^{2}$

${ }^{1}$ Colorado State University, Fort Collins, USA; ${ }^{2}$ USDA Forest Service, Rocky Mountain Research Station, Moscow Forestry Sciences Laboratory, Moscow, USA; ${ }^{3}$ Oregon State University, Corvallis, USA; ${ }^{4}$ FuturaGene Brasil Tecnologia, Itapetininga, Brazil; ${ }^{5}$ Department of Plant Pathology, Universidade Federal de Viçosa, Viçosa, Brazil; ' Department of Plant Pathology, Washington State University, Pullman, USA; 'Department of Plant and Environmental Protection Sciences, University of Hawaii at Manoa, Honolulu, USA; ${ }^{8}$ USDA Forest Service, Forest Health Protection - Region ${ }^{5}$, Vallejo, USA; ${ }^{9}$ Department of Agricultural and Environmental Biology, The University of Tokyo, Tokyo, Japan; ${ }^{10}$ National Forestry Research Program, Instituto Nacional de Investigación Agropecuaria (INIA), Tacuarembó, Uruguay; ${ }^{11}$ Division of Forestry and Wildlife, Department of Lands and Natural Resources, Honolulu, USA; ${ }^{12}$ Departamento de Protección Vegetal, EEMAC, Facultad de Agronomía, Universidad de la República, Paysandú, Uruguay; ${ }^{13}$ USDA, Agricultural Research Service, Invasive Plant Research Laboratory, Fort Lauderdale, USA; ${ }^{14}$ USDA Forest Service, Northern Research Station, Luquillo, USA; ${ }^{15}$ Escuela de Ingeniería Forestal, Instituto Tecnológico de Costa Rica, Cartago, Costa Rica; ${ }^{16}$ The Biotechnology Centre, University of the West Indies, Mona, Jamaica; ${ }^{17}$ Tasmanian Institute of Agriculture, University of Tasmania, Hobart, Australia; ${ }^{18}$ Instituto de Investigaciones Forestales, Universidad Veracruzana, Xalapa, Mexico; ${ }^{19}$ Queensland Alliance for Agriculture and Food Innovation, Brisbane, Australia; ${ }^{20} \mathrm{NSW}$ Department of Primary Industries, NSW Forest Science, Parramatta, Australia; ${ }^{21}$ USDA Forest Service, Pacific Northwest Research Station, Corvallis, USA (jane.stewart@colostate.edu; alrossdavis@gmail.com; rodrigo@futuragene.com; aalfenas@ufv.br; tpeever@wsu.edu; jhanna@fs.fed.us; juchida@hawaii.edu; pcannon@fs.fed.us; snamba@ims.u-tokyo.ac.jp; ssimeto@tb.inia.org.uy; orobert.d.hauff@hawaii.gov; kadooka@hawaii.edu; caperez@fagro.edu.uy; min.rayamajhi@ars.usda.gov; dlodgester@gmail.com; marguedas@itcrac.cr; paula.tennant@uwimona.edu.jm; morag.glen@utas.edu.au; patysmachado85@gmail.com; romedel@uv.mx; armlopez@uv.mx; alistair.mctagart@gmail.com; angus.carnegie@dpi.nsw.gov.au; mkim02@fs.fed.us; nklopfenstein@fs.fed.us)

In recent decades, the myrtle rust pathogen, Austropuccinia psidii, has spread worldwide on diverse myrtaceous species. Genetic and genotypic diversities within and among A. psidii populations were evaluated in Brazil and other areas of myrtle rust emergence in the Americas and Hawaii. Several unique multilocus genotypes (MLGs) were identified by microsatellite markers, which were grouped into nine distinct genetic clusters: $\mathrm{C} 1$ - diverse hosts in Central America, 
Caribbean, and USA-Hawaii, and USA-California; C2 - eucalypts (Eucalyptus spp.) in Brazil/Uruguay and rose apple (Syzygium jambos) in Brazil; C3 eucalypts in Brazil; C4: from diverse hosts in USA-Florida; C5 - Java plum (Syzygium cumini) in Brazil; C6 - guava and Brazilian guava (Psidium guineense) in Brazil; C7 - pitanga (Eugenia uniflora) in Brazil; C8 - allspice (Pimenta dioica) in Jamaica and sweet flower (Myrrhinium atropurpureum) in Uruguay; and C9 - jabuticaba (Myrciaria cauliflora) in Brazil. One C1 MLG was associated with multiple hosts and diverse geographic regions. The C1 and C4 cluster are considered as a "Pandemic biotype," associated with myrtle rust emergence in Central America, Caribbean, USA-Florida/Hawaii, Australia, China-Hainan, New Caledonia, Indonesia, and Colombia. Geographic locations with suitable climate for $A$. psidii that are at risk from invasion were predicted using maximum entropy bioclimatic modelling using 19 bioclimatic variables, documented occurrences of $A$. psidii, and sets of genetic clusters (subnetworks, considered as biotypes). When assessing the invasive threats posed by $A$. psidii around the globe, it is important to consider the genetic diversity of $A$. psidii and its biotypes.

\section{Myrtle rust: impact on native Australian Myrtaceae and associated plant communities}

Geoff Pegg ${ }^{1}$, Angus Carnegie ${ }^{2}$, Fiona Giblin ${ }^{1}$, Louise Shuey ${ }^{1}$

${ }^{1}$ Horticulture \& Forestry Science, Department of Agriculture \& Fisheries, Brisbane, Australia; ${ }^{2}$ NSW Department of Primary Industries - Forestry, Sydney, Australia (geoff.pegg@daf.qld.gov.au; angus.carnegie@dpi.nsw.gov.au; fiona.giblin@daf.qld.gov.au; louise.shuey@daf.qld.gov.au)

Austropuccinia psidii (myrtle rust) has long been considered a significant threat to Australian plant industries and ecosystems. The rust was first detected in Australia in April 2010 on the central coast of New South Wales and has continued to spread with detections extending from Tasmania in the south, Cape York Peninsula in the North East, and west to Arnhem Land in the Northern Territory. The current host list for Australia includes $>350$ species from 57 genera. Austropuccinia psidii severely affects key species in natural ecosystems, with localised extinctions recorded (Rhodomyrtus psidioides and Rhodamnia rubescens) and with many species no longer ecologically functional. Our studies have demonstrated severe impacts of myrtle rust on native plant communities. Austropuccinia psidii has caused significant disturbance in lowland subtropical rainforest and wet sclerophyll environments where Myrtaceae dominate the rainforest understorey. Similar impacts have been recorded in coastal heath environments affected by wildfire (Melaleuca nodosa, Leptospermum spp.) with severe decline in once dominant species and little evidence of regeneration potential. Keystone species such as Melaleuca quinquenervia are also being impacted, with tree deaths and reduced flowering rates recorded. Future research programs are required to identify and monitor species and plant communities at greatest risk of decline. The implementation of a disease screening and tree breeding program may be required for some species as without intervention, regaining lost genetic diversity within these populations may not be possible. The rate of decline of some species is alarming and retaining viable germplasm for conservation purposes is essential.

\section{The impact of myrtle rust in New Zealand}

Beccy Ganley ${ }^{1}$, Julia Soewarto ${ }^{2}$, Roanne Sutherland ${ }^{2}$

${ }^{1}$ The New Zealand Institute for Plant and Food Research Ltd, Te Puke, New Zealand; ${ }^{2}$ Scion, Rotorua, New Zealand (beccy.ganley@plantandfood.co.nz; julia.soewarto@scionresearch.com; roanne.sutherland@scionresearch.com)

Austropuccinia psidii was first found in New Zealand in spring 2017 and an incursion response was immediately instigated. During this response Myrtaceae across large areas of New Zealand were surveyed for the presence of myrtle rust. The disease has now spread across the majority of the North Island and the top of the South Island, and is known to be present in urban and native trees. Long-term monitoring plots have been established in native forests to determine the impact of myrtle rust on foliage, flowers and fruits of mature trees and on seedling survival. The monitoring plots established have focused on one of New Zealand's most susceptible native species Lophomyrtus bullata (ramarama) and its natural hybrids with Lophomyrtus obcordata (rohutu), but also include a range of other myrtaceous plants present within the plots such as Metrosideros spp. and Leptospermum scorparium. Here we discuss the impact this disease has had on the plant species in these plots and the implications for native New Zealand Mrytaceae, as well as the long-term surveillance and management options underway for this disease.

\section{Alternative fungicides for the control of myrtle rust on Metrosideros excelsa}

Karanjeet Sandhu ${ }^{1}$, Amin Pathan ${ }^{2}$, Mark Kimberly², Robert Park ${ }^{1}$

${ }^{1}$ University of Sydney, Sydney, Australia; ${ }^{2}$ Ministry for Primary Industries, Rotorua, New Zealand (karanjeet.sandhu@sydney.edu.au; amin.pathan@mpi.govt.nz; mark.kimberley@scionresearch.com;robert.park@sydney.edu.au)

Myrtle rust caused by fungus Austropuccinia psidii was first detected in Australia and New Zealand in 2010 and 2017 respectively. Pathogen A. psidii with vast host range can be determinantal to numbers of potentially vulnerable native species of Myrtaceae. Metrosideros excelsa 'Nana' an evergreen native tree, also known as pohutukawa and culturally significant to Māori people, is highly susceptible to myrtle rust. Greenhouse replicated trials were conducted to assess preventative and curative efficacy of different fungicides against myrtle rust on $M$. excelsa 'Nana' plants. Nineteen treatments included six fungicides alone (AmistarâXtra, Bayfidanâ 250 EC, Dedicateâ, Radialâ, Saprolâ and tea tree oil based organic fungicide TimorexGold®), each fungicide plus adjuvant 'Hasten' and 'Spreadwett' separately and only water treated controls. Treatments were applied 7 and 14 days before inoculation (DBI) and at 7,14 and 21 days after inoculation (DAI) using $500 \mathrm{~L} \mathrm{ha}^{-1}$ spray volume with Generation III spray booth. Post inoculation treatments were resprayed at 10 days interval from the previous treatment. Percent leaf area infected (\%LAI) with active sporulation on abaxial side of leaves was recorded at 14DAI. All fungicides significantly reduced \%LAI as compared to controls in both pre and post inoculation treatments. Treatments at 7DBI followed by 7DAI were most effective and $21 \mathrm{DAI}$ timing was least effective. Among the fungicides, Amistar ${ }^{\circledR}$ Xtra was most effective and TimorexGold® was least effective in reducing \%LAI. Both adjuvants didn't make any difference and results suggested that fungicides efficacy is reduced if used beyond 7DBI and 7DAI spray timings.

\section{Chemical and physical foliar response of Corymbia citriodora subsp. variegata inoculated with two pathogen species}

Flavia Sarti Bonora ${ }^{\prime}$, Andrew Hayes ${ }^{I}$, David Lee ${ }^{\prime}$, Helen Nahrung ${ }^{\prime}$

'University of the Sunshine Coast,Sunshine Coast,Australia (fsartabo@usc.edu.au; rhayes@usc.edu.au; dlee@usc.edu.au; hnahrung@usc.edu.au)

Spotted gums (Corymbia spp) are a valuable source of commercial timber, gaining importance in South Africa, Brazil, China and Australia. In Australia, spotted gums are severely damaged by the endemic fungal pathogen Quambalaria pitereka which infects new foliage, causing spotting, necrosis and distortion. Myrtle rust (Austropuccinia psidii), a highly invasive exotic fungal pathogen, also infects spotted gums and has been present in Australia for less than a decade. Both pathogen can reduce tree fitness and productivity. As well as differing co-evolutionary histories with spotted gums, the two pathogens have different mechanisms of infection and colonization, with $Q$. pitereka entering via stomata and only growing intercellularly, and $A$. psidii penetrating directly through the cuticle, entering the cell and producing haustoria. Both pathogens exhibit significant variation in their infection of spotted gum provenances. Leaf oil compounds such 
as terpenes are recognized for their fungicidal effects and may support plant protection strategies against fungal pathogens. Fungal pathogens may also affect and be affected by - leaf physical traits such as leaf toughness. Seedlings of Corymbia citriodora subsp. variegata were inoculated with spores of $Q$. pitereka, $A$. psidii or no spores. Leaf samples were collected when the seedlings were showing signs of infection. We determined leaf toughness and leaf oils were identified by gas chromatography-mass spectrometry. This research examined the variation of fungal susceptibility and the interaction of pathogens with plant leaf oils and physical traits for Q. pitereka and A. psidii, considering their different mechanisms of infection.

\section{Does Austropuccinia psidii reproduce sexually in Australia?}

Alistair R. McTaggart ${ }^{1}$, Louise Shuey², Stuart Fraser ${ }^{3}$, Andre Drenth ${ }^{1}$, Geoff Pegg ${ }^{2}$

${ }^{1}$ University of Queensland, Brisbane, Australia; ${ }^{2}$ Department of Agriculture and Fisheries, Brisbane, Australia; ${ }^{3}$ Scion, Rotorua, New Zealand

(a.mctaggart@uq.edu.au; louise.shuey@daf.qld.gov.au; stuart.fraser@scionresearch.com; a.drenth@uq.edu.au; geoff.pegg@daf.qld.gov.au)

Invasions and epidemics of Austropuccinia psidii are caused by its clonal spore stage, urediniospores. Recombination was thought uncommon, even in areas in which it was native. In a previous study, we showed that basidiospores (the gametic spores) of $A$. psidii infected species of Myrtaceae and sexual reproduction was part of its life cycle. We supported this finding with evidence that recombination and infection of Myrtaceae by basidiospores occurred in natural ecosystems of New Zealand and South Africa. We used three lines of evidence to test for sexual reproduction, the sexual stage was present, there was high genotypic diversity and there was no linkage between microsatellite loci. Our current study tests whether sexual reproduction has occurred in Australia. We have sampled single pustules at one location over several years. We will screen over 50 single pustules with 12 microsatellite markers to determine whether the population at this field site is recombinant. Our research findings so far show that teliospores and basidiospores play a role in the life cycle and spread of disease. We have flagged questions relevant to Eucalyptus forestry such as whether different strains of $A$. psidii can outcross and overcome disease resistance.

\section{Assessment of the susceptibility of native New Zealand Myrtaceae to infection by the South African strain of Austropuccinia psidii}

Julia Soewarto ${ }^{1}$, Chanatda Somchit ${ }^{1}$,Esna Du Plessis ${ }^{2}$, Irene Barnes ${ }^{2}$, Michael J. Wingfield $^{2}$, Michael Bartlett $^{1}$, Peter Scott $^{3}$, Elizabeth Miller $^{1}$, Louise Shuey $^{4}$, Nick Waipara ${ }^{5}$, Ginna Granados ${ }^{2}$, Roanne Sutherland ${ }^{1}$, Beccy Ganley ${ }^{3}$

${ }^{1}$ SCION, Rotorua, New Zealand; ${ }^{2}$ Forestry and Agricultural Biotechnology Institute (FABI), Pretoria, South Africa; ${ }^{3}$ The New Zealand Institute for Plant \& Food Research Ltd, Te Puke, New Zealand; ${ }^{4}$ Horticulture \& Forestry Science, Department of Agriculture \& Fisheries, Brisbane, Australia; ${ }^{5}$ The New Zealand Institute for Plant \& Food Research Ltd, Auckland,New Zealand (julia.soewarto@scionresearch.com; chanatda.somchit@scionresearch.com; esna1706@gmail.com; irene.barnes@fabi.up.ac.za; mike.wingfield@fabi.up.ac.za; michael.bartlett@scionresearch.com; peter.scott@plantandfood.co.nz; elizabeth.miller@scionresearch.com; louise.shuey@daf.qld.gov.au;nick.waipara@plantandfood.co.nz;ginna.granados@fabi.up.ac.za; roanne.sutherland@scionresearch.com; beccy.ganley@plantandfood.co.nz)

At least nine strains of Austropuccinia psidii (the myrtle rust pathogen) are known to occur internationally. Most of these are found in Central and South America and specifically associated with hosts in the Myrtaceae family. However, two aggressive and unique strains has been reported outside the presumed native range of $A$. psidii. One strain, known as the pandemic strain, infects a wide spectrum of hosts and has an extensive geographical range. It has been found in Colombia, California, Hawaii, Indonesia, Australia, New Caledonia and more recently in New Zealand. The other myrtle rust strain occurs in South Africa, where it infects both native and introduced Myrtaceae. Knowledge regarding the level of susceptibility of native Myrtaceae to the different strains of $A$. $p$ sidii and the biology of the pathogen is essential to address the best management options for Myrtle rust in New Zealand. In this study, we considered the levels of resistance and/or susceptibility of four native New Zealand species (Leptospermum scoparium, Metrosideros excelsa, Kunzea linearis and K. robusta) to the South African strain of A. psidii. Seeds from geographically distant populations were collected for screening that was conducted in a greenhouse in South Africa. The results revealed interspecific variability in susceptibility to the South African A. psidii strain, with the Kunzea species more tolerant and/or resistant than the other tested species. This study demonstrated the potential threat that the South African $A$. psidii strain could have in native forests, nurseries and plantations in New Zealand.

\section{D7m: FOREST HEALTH CHALLENGES FROM GLOBALISATION AND CLIMATE CHANGE}

\section{BioSurveillance of Alien Forest Enemies: the bioSAFE initiative}

\section{Richard Hamelin}

${ }^{1}$ The University of British Columbia, Vancouver, Canada. Université Laval, Quebec city, Canada (richard.hamelin@ubc.ca)

The world's forests face unprecedented threats from invasive insects and pathogens that can cause large irreversible damage to the ecosystems. This threatens the capacity to provide long-term fibre supply and ecosystem services that range from carbon storage, nutrient cycling, water and air purification, soil preservation and maintenance of wildlife habitat. The key to reduce this threat is via vigilant biosurveillance to increase preparedness and facilitate early interventions. This requires collecting and sharing data that can be used to rapidly and accurately identify samples from various life stages of insects and pathogens and assign them to taxa and sources so that pathways of introduction can be discovered. Assessing the risk that is posed by alien species also requires a better understanding of the traits underlying invasiveness. Genomics provides a toolbox that can address some of these challenges. The BioSAFE (BioSurveillance of Forest Alien Enemies) project is developing a pipeline to generate genomic tools that will provide accurate identification of pests and pathogens, assign outbreak or survey samples to putative sources to identify pathways of spread and assess risk based on traits that impact the outbreak outcome. These next generation biosurveillance tools will help prevent and contain future forest pest and disease outbreaks.

\section{Inter-institutional cooperation for the management of forest's health issues}

Patrícia Machado

${ }^{1}$ Indústria Brasileira de Árvores, São Paulo, Brasil (patricia.machado@iba.org)

The world trade has increased the risk of pest's outbreaks. Exotic pests, when introduced in new areas, may be responsible for economic and environmental damages. In this sense, a properly forest biosecurity management can avoid, or at least, minimize the risk of introducing and spreading pests in a country. Different initiatives have been organized for several countries, but information sharing is necessary to increase the efficiency of activities. In Brazil, different entities such as companies, research institutes, and government agencies have been working together for the management of forest's health issues. This cooperation for the benefits of planted forest health has achieved results more efficiently, increased the access to stakeholders, and provided technical and institutional representation for the Brazilian planted tree sector. 


\section{Scotland's Plant Health Centre: a multi-sectoral response to challenges from globalisation and climate change}

Chris Quine ${ }^{1}$ D, Ian Toth ${ }^{2}$, Sonia Humphris ${ }^{2}$, Fiona Burnett ${ }^{3}$, Peter Hollingsworth ${ }^{4}$

${ }^{1}$ Forest Research, Edinburgh, United Kingdom; ${ }^{2}$ James Hutton Institute, Dundee, United Kingdom; ${ }^{3}$ SRUC - Scotland's Rural College, Edinburgh, United Kingdom; ${ }^{4}$ Royal Botanic gardens Edinburgh, Edinburgh, United Kingdom (chris.quine@forestresearch.gov.uk; ian.toth@hutton.ac.uk; sonia.humphris@hutton.ac.uk; fiona.burnett@sruc.ac.uk; phollingsworth@rbge.org.uk)

Plants underpin many ecosystem services. However, these contributions can be disrupted by pests and diseases and disruption is increasing as a result of changing climates and introductions through trade; some of these problem species have wide host ranges or complex life-cycles impacting vegetation across many environments. We describe the development of a novel co-ordinated approach taken by the Scottish Government to tackle these challenges through a Centre of Expertise for Plant Health. The Centre brings together expertise from natural environment and horticulture, forestry and woodlands, agriculture, drawing on a range of skills from social sciences to mathematical modelling to focus on those risks most pertinent to Scotland, and the plants of most importance to its natural heritage, economy and social wellbeing. We will summarise recent studies initiated by the Centre including assessments of the threats of the bacterial pathogen Xylella fastidiosa which has over 500 host plant species worldwide and is currently causing major economic losses in Europe. For this and other threats, the Centre's activities will include a focus on understanding possible routes of entry into Scotland, the ability to spread to and infect our major plant species under our climatic conditions, as well as the best methods for control and when to implement them, and how to involve stakeholders to minimise the risk. We will conclude with a summary of the benefits of a cross-sectoral approach for forestry, and lessons learnt in the operation of the Centre.

\section{Improving the international regulatory framework for managing alien invasive species in trade \\ Michael Ormsby ${ }^{1}$ \\ INZMPI, Wellington, New Zealand (michael.ormsby@mpi.govt.nz)}

With the international trade of forest products comes the risk of the movement of pests that can be extremely damaging to forest ecosystems and forest economies. Although impacts of biological invasions may be local, at least at first, the causes of introduction are mostly international. International phytosanitary guidelines have been created to help countries that import wood products develop import requirements to minimize pest movement. There are numerous international and regional instruments, binding and nonbinding, which have been developed to deal with the problem of the movement of alien invasive species, however there are gaps in the current international framework. In particular there is a need for regional and global support for countries that lack sufficient resources to implement effective phytosanitary systems. This presentation discusses various initiatives that could reduce the resource burden of regulatory frameworks to improve implementation and therefore reduce global impacts of biological invasions in forests.

\section{Collaborative strategies to reduce the introduction of exotic Eucalyptus pests in Brazil}

Luis Renato Junqueira ${ }^{1}$, Leonardo Rodrigues Barbosa ${ }^{2}$, Patrícia Machado ${ }^{3}$, Jose Cola Zanuncio ${ }^{4}$, Luiz Alexandre Nogueira de Sá ${ }^{5}$, Carlos Frederico Wilcken ${ }^{6}$ ${ }^{1}$ Instituto de Pesquisas e Estudos Florestais, Piracicaba, Brasil; ${ }^{2}$ Embrapa Florestas, Colombo, Brasil; ${ }^{3}$ Indústria Brasileira de Arvores, São Paulo, Brasil; ${ }^{4}$ Universidade Federal de Viçosa, Departamento de Entomologia/BIOAGRO,, Viçosa, Brasil; "Laboratório de Quarentena "Costa Lima”, Embrapa Meio Ambiente, Jaguariúna, Brasil; ' 'Universidade Estadual Paulista "Júlio de Mesquita Filho", Faculdade de Ciências Agronômicas, Departamento de Proteção Vegetal, Campus Botucatu,Botucatu,Brazil(renato@ipef.br; leonardo.r.barbosa@embrapa.br; patricia.machado@iba.org; zanuncio@ufv.br; luiz.sa@embrapa.br; carlos.wilcken@unesp.br)

The introduction of exotic pests has increased over time due to the growing traffic of people and goods. Just in the last decade, three new eucalypt pests were introduced in Brazil. Responsibility for biosecurity must be shared between government and productive sector, seeking for prevention or contingency of these invaders, avoiding their dispersion to main productive zones in the country. In this regard, the planted forests sector in Brazil has developed a collaborative work, involving research institutions, productive sector and government. Once well consolidated, cooperative research between academy and forest companies has brought besides productivity gains, new tools for pest management, especially biological control programs development. In addition, the BiCEP (Biological Control for Eucalyptus Pests) project was launched in 2013 as an alliance among research institutes from Australia, Brazil, South Africa and Portugal to share information about management of exotic pests and research about new pests and their natural enemies, providing essential knowledge to prevent new introductions or enable their early detection. The access and relevance understanding of this information by government is essential to improve national biosecurity, role played by sectoral associations. Finally, the establishment of partnerships and approximation among different institutions has generated positive signs for reduction of exotic pest introductions in the long-term.

\section{Genome sequencing uncovers mitotic recombination and rapid evolution in the sudden oak death and sudden larch death pathogen,} Phytophthora ramorum

Angela Dale ${ }^{1,2}$, Nicolas Feau ${ }^{2}$, Sydney Everhart ${ }^{3,4}$, Guillaume Bilodeau ${ }^{5}$, Javier Tabima ${ }^{4}$, Renate Heinzelmann ${ }^{2}$, Clive Brasier ${ }^{6}$, Brett Tyler $^{4}$, Niklaus Grünwald ${ }^{4}$, Richard Hamelin ${ }^{2,7}$

${ }^{1}$ FPInnovations, Vancouver, Canada; ${ }^{2}$ University of British Columbia, Vancouver, Canada $;{ }^{3}$ University of Nebraska, Lincoln, USA; ${ }^{4}$ Oregon State University, Corvallis, USA; ${ }^{5}$ Canadian Food Inspection Agency, Ottawa, Canada; ${ }^{6}$ Forest Research, Farnham, United Kingdom; ${ }^{7}$ Université Laval, Quebec, Canada (angela.dale@fpinnovations.ca; feaunico@mail.ubc.ca; everhart@unl.edu; guillaume.bilodeau@canada.ca; caifaz01@gmail.com; renate.heinzelmann@ubc.ca; live.brasier@forestry.gsi.gov.uk; brett.tyler@oregonstate.edu; grunwaln@science.oregonstate.edu; richard.hamelin@ubc.ca)

Genome sequencing is an important tool to monitor outbreaks of invasive species and to understand how evolution and adaptation may occur. Many invasive alien species rapidly adapt to new environments, overcoming small population numbers and reduced genetic diversity. Phytophthora ramorum, an Oomycete forest pathogen causing sudden oak and sudden larch death is one such invader. It is limited to asexual reproduction within four lineages, and presumed clonal. We sequenced 107 genomes to monitor pathogen spread and to determine how this pathogen might be able to adapt to new environments with such limitations. Two mechanisms acting at the genomic level may contribute to adaptability and invasiveness in this pathogen. Within lineages, mitotic recombination (MR) associated with transposons and low gene density has generated runs of homozygosity (ROH), resulting in novel genotypic diversity. One ROH enriched in putative pathogenicity genes was fixed in lineage NA1. An independent ROH affected the same scaffold in lineage EU1 suggesting an MR hotspot and selection target. Between the lineages, non-core regions (not shared by all lineages) may undergo rapid evolution. These regions were enriched in putative pathogenicity genes and transposons. There was a striking pattern of gene loss, including all effectors, in the non-core genome of lineage EU2. Furthermore, effectors were under positive selection. P. ramorum lineages are diverging via a rapidly evolving non-core genome and the invasive asexual lineages are not clonal, but display genotypic diversity caused by MR. This provides important insights into evolution and potential for adaptation in invasive pathogens. 


\section{What economics can tell us about pest in forest?}

Montagne-Huck Claire', Brunette Marielle ${ }^{I}$

IINRA, BETA, Nancy, France (claire.montagne-huck@inra.fr; marielle.brunette@inra.fr)

Insect pests are important forest disturbance agents, reshaping forests and having large economic, environmental, and social impacts. Such hazards are likely to increase in the near future due to rising temperatures and an increased recurrence of major climatic events. Human activities, such as international trade, are also likely to increase pests displacement rates. As a result, populations have to adapt their activities and decisions to the presence of forest pests, as an integral part of sustainable forest management. In this paper, we provide a literature review on how economics deal with pests. We realized a systematic research by keywords, and we selected more than 100 economics paper dealing with pests in forest. We provide some descriptive statistics of the database by country, pest, journal, year of publications, etc. One of the main results is that a large part of the literature deals with bark beetle outbreaks in North America. In addition, we provide a categorization and analysis of the literature in three parts: i) How economic theory understand pests (externalities, public goods, etc.); ii) what are the economic impacts of pests (on timber market, local/regional economies, residential/property value, tourism, ecosystem services, etc.); iii) how economic analysis can advise and evaluate pest management programs (organization, techniques, etc.). We also provide a discussion about public policy implications and gaps in the literature.

\section{Can 3-PG be used to assist forest managers assessing the impact of defoliation?}

João Rua ${ }^{1}$, Susana Barreiro', Manuela Branco ${ }^{1}$, Margarida Tomé

${ }^{1}$ Universidade de Lisboa, Instituto Superior de Agronomia, Centro de Estudos Florestais, Lisboa, Portugal (joao.c66@gmail.com; smb@isa.ulisboa.pt; mrbranco@isa.ulisboa.pt; magatome@isa.ulisboa.pt)

The 3-PG model predicts GPP from light intercepted taking into account environmental effects through multiplicative modifiers for climate, soil and water availability. NPP is estimated as a constant fraction of GPP and allocation to roots, leaves and woody biomass pools depends on the environment and tree age. Eucalypt plantations are of extreme economic importance in Portugal and with globalisation and climate change Gonipterus platensis became a serious threat. Being 3-PG a growth model based on light interception and, consequently, on leaf biomass, a methodology based on leaf biomass reduction was developed to simulate the impact of this defoliator on stand growth. Two sets of scenarios, for the period of time during which the insect is active, were defined considering defoliations occurring every year in spring and both in spring and autumn, and starting at different stand ages. Under each scenario, five defoliation levels were tested ranging from $0 \%$ to $100 \%$ considering the first attack to occur from age 2 until age 10 . The preliminary results suggest the potential of the 3PG model as a management support tool that will enable forest managers to study not only the best timing for insecticide application as well as the trade-offs of pesticide application during a rotation period. The next steps will encompass field plot monitoring to validate the magnitude of volume losses resulting from defoliations and to study changes in allocation patterns resulting from pest attacks.

\section{Expansion of altitudinal range in a forest pest: can parasitoids track their hosts?}

Jose Antonio Hódar ${ }^{1}$, Luis Cayuela ${ }^{2}$

${ }^{1}$ Universidad de Granada, Granada, Spain; ${ }^{2}$ Universidad Rey Juan Carlos, Madrid, Spain (jhodar@ugr.es; luis.cayuela@urjc.es)

Gradients in elevation impose changes in environmental conditions, which in turn modulate species distribution and abundance as well as the interactions they maintain. Along the gradient, interacting species (e.g. predators, parasitoids) can respond to changes in different ways, and experience different climatic conditions from one year to another. This study aims to investigate how egg parasitism of a forest pest, the pine processionary moth (PPM), Thaumetopoea pityocampa (Denis et Schiffermüller, 1775), vary along an altitudinal gradient (120-2050 m.a.s.l.) in a mountain range of SE Spain, including areas of recent altitudinal expansion, for a seven years period. We used generalized linear mixed effects models to ascertain the effect of altitude on three response variables, namely rate of parasitism, and probability of occurrence of two parasitoid species: a PPM specialist, Baryscapus servadeii (Dom.), and a generalist species Ooencyrtus pityocampae (Mercet). Results showed a decrease of rate of parasitism, and probability of occurrence of the two main parasitoid species with altitude, although decline was more severe for $B$. servadeii. In a context of climate warming scenario, and with PPM in clear process of altitudinal and latitudinal expansion, it is crucial to mitigate this process by enabling the synchronization of the PPM-parasitoids interaction. This can be done by reducing the possibilities of PPM progression and, simultaneously, favouring the establishment of parasitoids, for example by increasing tree diversity at the PPM expansion areas.

\section{D7n: BIOLOGICAL INVASIONS, BIODIVERSITY, AND ECOSYSTEM SERVICES - 2}

\section{Exploring global patterns of bark and ambrosia beetle invasions and their relationships with international trade}

María Victoria Lantschner ${ }^{1}$, Juan C. Corley ${ }^{1}$, Andrew M. Liebhold ${ }^{2}$

${ }^{1}$ Instituto de Investigaciones Forestales y Agropecuarias Bariloche (INTA-CONICET), Bariloche, Argentina; ${ }^{2}$ USDA Forest Service, Northern Research

Station,Morgantown,WV,USA (lantschnerv@inta.gob.ar; elmallin@gmail.com; aliebhold@fs.fed.us)

Invasion by non-native insects are increasing worldwide, often with strong negative economic and ecological impacts on forest ecosystems. Understanding the global patterns and processes driving invasions of forest insects is important for predicting future invasions and improving mitigation strategies. Bark and ambrosia beetles (Coleoptera: Curculionidae, Scolytinae) are a large and diverse group of insects commonly recognized as important forest pests and invaders. In this study, we analyze historical global invasion patterns of scolytines, by evaluating the number of species native to each biogeographic region (i.e., Palearctic, Indo-Malay, Nearctic, Neotropic, Afrotropic, Austro-Pacific) that have invaded other regions, and we explore relationships between invasion patterns and historical volumes of trade between regions during the period 1870-2014. We found that there are a total of 120 species that have established outside of their native range. The Palearctic region was the largest source of invasive species (50), followed by the Indomalayan region (32), comprising 7.7\% and 3.1\% of the native species pool of these regions respectively. In contrast, the Nearctic region was the region that received the greatest number of non-native species (68), followed by the Neotropic (46). The largest trade volume ( $40 \%$ of the global total) occurred between the Nearctic and the Palearctic regions. We found a significant regression between the number of species that invaded from one region to another, and the trade volume between these regions. We conclude that bark beetles have successfully invaded forest systems worldwide, and that global trade is likely to strongly influenc invasion patterns in the future. 


\section{Teratosphaeria leaf diseases: a major threat for eucalypts plantations in Uruguay}

Carlos Perez ${ }^{1}$, Gustavo Balmelli², Sofia Simeto ${ }^{2}$,Nazaret Ramirez ${ }^{1}$, Robert Blanchette ${ }^{3}$, Michael J. Wingfield

${ }^{1}$ Facultad de Agronomía, Universidad de la Republica, Paysandu, Uruguay; ${ }^{2} I N I A$ Uruguay, Tacuarembo, Uruguay; ${ }^{3}$ Department of Planta Pathology, University of Minnesota, Saint Paul, USA; ${ }^{4}$ FABI, University of Pretoria, Pretoria, South Africa (caperez@fagro.edu.uy; gbalmelli@tb.inia.org.uy; ssimeto@inia.org.uy;nazaret.berrutti@gmail.com; robertb@umn.edu; mike.wingfield@up.ac.za)

Many Teratosphaeria species are associated with leaf diseases on Eucalyptus spp. (Myrtaceae). However, only a few of these are major pathogens that cause serious losses, particularly to plantation forestry globally. Several species in the Teratosphaeraceae and Mycosphaereaceae species are known to occur in Uruguay where they cause leaf and shoot diseases on Eucalyptus plantations, but most are of minor importance. However, two species have had a serious negative impact on the performance of certain Eucalyptus species. Since its first detection in 2007, Teratosphaeria nubilosa has eliminated Eucalyptus globulus from the available species for pulpwood production. Species substitution has been the main management tool for this pathogen resulting in negative consequences such as limited access to external markets. More recently, in 2011, Teratosphaeria pseudoeucalypti was reported causing leaf blight that has resulted in severe defoliation and death of established Eucalyptus camaldulensis, E. tereticornis, and their hybrids. This pathogen was first described in Australia in 2010 and simultaneously reported in Argentina, Brazil and Uruguay four years later. This disease is a serious threat to Uruguayan plantations and has already imparted a significant social and economic impact in the country where it has damaged urban parks and plantations used for shelter and shade for livestock production. These two examples of serious diseases caused by Teratosphaeria spp. have highlighted that accidentally introduced non-native pathogens can have in a country. They have also raised concerns that such pathogens could threaten the many native Myrtaceae found natural forest ecosystems in Uruguay.

\section{Red Gum Lerp Psyllid (Glycaspis brimblecombei) prevalence, host damage and host preference in Central Highlands of Kenya}

Miriam Gathogo ${ }^{1}$

'KEFRI(Kenya Forestry Research Institute),Nairobi, Kenya (gathogomiriam@gmail.com)

Glycaspis brimblecombei (Hemiptera:Psyllidae) locally termed as Red Gum Lerp Psyllid (RGLP) has been a pest of significant importance since its invasion in Kenya forestry systems in 2014. A survey in the Central Highlands of Kenya was carried out to determine spread, host damage and species preference by Red Gum Lerp Psyllid. A transect cutting through Counties in Central Highlands Ecoregion of Kenya including Kiambu, Murang'a, Nyeri, Embu, Kirinyaga, Meru, Laikipia and Nyandarua Counties was laid to enable data collection. The spread determined by taking coordinates of assessed Eucalyptus trees and degree of attack, determined through assigning different damage category levels on different Eucalyptus spp. and hybrid clones growing in Kenya, were the key parameters assessed in this study. Collected data was managed using MS excel and analyzed using SPSS and results presented using descriptive charts and tables. Results showed that the drier parts of Central Highlands of Kenya including Embu, Kirinyaga and some parts of Meru counties had heavier infestation of RGLP compared to other counties studied, with Tharaka Nithi which receive more rainfall compared to other regions having lesser infestation. Preference was majorly on E. camaldulensis, followed by Clones and E. saligna. The frequent damage levels were at category 1 and 2 on E. camaldulensis trees. Information from this study will inform implementation of bio-control, identification of natural-control-release sites, the time of release and identification of host plant resistant species for sustainable management of RGLP in the forestry systems of Kenya.

\section{The emergence of a forest pest: a transdisciplinary approach \\ Bart Nyssen ${ }^{1}$ D, Frank Moulaert², Constanza Parra Novoa², Bart Muys², Erik Mathijs ${ }^{2}$ \\ ${ }^{1}$ Bosgroep Zuid Nederland, Heeze, Netherlands; '2University of Leuven, Leuven, Belgium (b.nyssen@bosgroepen.nl; frank.moulaert@icloud.com; constanza.parra@kuleuven.be; bart.muys@kuleuven.be; erik.mathijs@kuleuven.be)}

Since the 1980's invasion ecology has made a strong progress. Today we understand rather well how ecological invasions take place. Crucial for the further development of invasion ecology is interdisciplinary collaboration since this subject spans a wide spectrum of biological and social science topics. Especially the understanding of when, why and how invasive species become a threat needs close scientific collaboration exceeding the borders of ecological an biological sciences. This paper presents the results of a transdisciplinary collaboration of authors with a background in forest management and ecological, sociological, geographical and economic research. The insights from this transdisciplinary work will be presented centred around the case how Black cherry (Prunus serotina) - introduced to North-West Europe in 1623 - became a 'forest pest', a threat to Belgian, Dutch and German forests 350 years later. Research in social and ecological sciences shows that a broad range of conditions must be present to make an event happen. The potential of an introduced tree species to become invasive is only realised under the proper settings. Structuralist approaches emphasise the causal analysis of the conditions under which the event takes place and behavioural studies stress the role of agency causing the event to take place. The ASID approach, developed in interdisciplinary collaboration, overcomes this structure-agency dichotomy and offers a way to understand why after 350 years an introduced species emerges as an invasive species. This approach offers a tool for further investigation into the social-ecological context of specific ecological invasions.

\section{Towards a strategy to combat the Polyphagous Shot Hole Borer (PSHB) invasion in South Africa}

Wilhelm de Beer', Trudy Paap ${ }^{1}$

${ }^{1}$ Forestry and Agricultural Biotechnology Institute, FABI, Pretoria, South Africa (wilhelm.debeer@fabi.up.ac.za; trudy.paap@fabi.up.ac.za)

The impact of the Polyphagous Shot Hole Borer (PSHB) and its Fusarium fungal symbiont on forest ecosystems in South Africa is alarming. The beetle-fungus combination was first detected killing London plane trees in the KwaZulu-Natal province in early 2017. Since then infestations have been observed on more than 80 species of trees in seven of the nine provinces. These include commercial pecan orchards in the Northern Cape, and many common street and garden tree species in urban areas in six of the provinces. Most concerning are native trees that are infested and dying in urban and natural forests. The impact of all other serious tree pests that South Africa had to deal with in the past, was restricted to the agriculture and forestry sectors. Now, for the first time the country has to deal with a pest that ignores all boundaries, including those between climatic regions, or host tree genera, or orchards, commercial plantations, natural forests, streets, parks, and gardens. Current frameworks in government and other institutions for monitoring, reporting, impact assessment, research, control measures, management strategies, funding, and legislation, are not adequate to deal with the PSHB invasion. A coordinated, national strategy and network is needed to combat the PSHB, or else valuable resources and time will be wasted while the pest is destroying our trees and expanding its territory. Attempts are being made from within and outside government structures to align the different strategies with the needs and agendas of stakeholders. 
Towards the resolution of taxonomic species complexes by an integrated approach: the case of the ambrosia beetle (Euwallacea fornicatus)

Demian F. Gomez ${ }^{1}$ (D, James Skelton ${ }^{1}$, Sedonia Steininger ${ }^{2}$, Richard Stouthamer ${ }^{3}$, Paul Rugman-Jones ${ }^{3}$, Wisut Sittichaya ${ }^{3}$, Robert Rabaglia ${ }^{4}$, Jiri Hulcr ${ }^{1}$ ${ }^{1}$ University of Florida, Gainesville, USA; ${ }^{2}$ USDA, Gainesville, USA; ${ }^{3}$ University of California, Riverside, USA; ${ }^{4}$ USDA-Forest Service, Washington, USA (demiangomez@ufl.edu; skelto3@gmail.com; m.sedonia@gmail.com; richards@ucr.edu; paulrj@ucr.edu; wisut.s@psu.ac.th; brabaglia@fs.fed.us; hulcr@ ufledu)

Many forest pests defy standard species concepts and are difficult to identify. Some of the most morphologically cryptic, economically damaging, and frequently intercepted pests are ambrosia beetles, such as Euwallacea fornicatus (Curculionidae: Scolytinae), a complex of genetically divergent pests. All lineages within this complex are considered morphologically identical, their identification relies on DNA, and only common names are used, which is problematic for detection and management. The objectives of this work were to reconstruct relationships between clades and populations, find morphological characters for delimiting the genetic lineages, and propose taxonomic species. Rather than using the traditional taxonomic species concept tied to a single reference individual, we classify individuals to putative species by the correlation between multiple morphological features and phylogenetic placement using multivariate analysis. The integrated molecular and morphological evidence suggested four clades that differ morphologically, but with overlap. The morphological corroboration of this species complex now allows for the proper naming of the different genetic lineages based on museum material. The following names are proposed: $E$. fornicatus (Eichhoff 1868) (= 'Tea Shot Hole Borer Clade a'); E. fornicatior (Eggers 1923), stat. rev. (= 'Tea Shot Hole Borer Clade b'); E. whitfordiodendrus (Schedl 1942), stat. rev. (= 'Polyphagous Shot Hole Borer'); and E. kuroshio Gomez and Hulcr, sp. nov. (= 'Kuroshio Shot Hole Borer'). This approach delivers a practical, evidence-based guidance for species delineation that can address overlapping variation in morphological characters of an emerging pest species complex.

\section{Molecular tools advance the management of invasive gall-forming wasps associated with plantation forestry}

Gudrun Dittrich-Schroder ${ }^{1}$, Brett P Hurley ${ }^{1}$, Michael J. Wingfield ${ }^{1}$, Bernard Slippers ${ }^{2}$

${ }^{1}$ Forestry and Agricultural Biotechnology Institute (FABI) and Department of Zoology and Entomology, University of Pretoria, Pretoria, South Africa; ${ }^{2}$ Forestry and Agricultural Biotechnology Institute (FABI) and Department of Department of Biochemistry, Genetics and Microbiology, Pretoria, South Africa (gudrun.dittrich@fabi.up.ac.za; brett.hurley@fabi.up.ac.za; mike.wingfield@fabi.up.ac.za; bernard.slippers@fabi.up.ac.za)

Effective management of invasive insect pests relies on fast and accurate identification. Accurate identification is frequently delayed or not possible due to the shortage of taxonomists and the shortcomings of morphological comparisons for identifying cryptic lineages. Molecular tools, such as common sequence barcoding methods can assist to overcome these challenges. Sequence databases are, however, often poorly curated and incomplete with reference to emerging pest species, for example for insect pests associated with Eucalyptus plantation forestry. Many recently introduced gall-forming Eucalyptus pest species lack taxonomic descriptions, and detailed information regarding their biology is sparse or unknown. The existence of cryptic species further complicates the identification of these pests. To address the increasing number of invasive insects pests of Eucalyptus plantation forestry, a forest insect mitochondrial (FIMT) online database was developed. This database facilitates the identification of unknown specimens through sequence comparisons with a curated database of identified insects pests. This information can be essential for management of these invasive species through breeding or biological control, which may be highly species specific.

\section{Expansion of a native invasive plant is modulated by soil decomposers}

Junwei Luan', Shirong Liu' ${ }^{2}$, Siyu Li ${ }^{1}$, Joann Whalen ${ }^{3}$, Scott Chang', Jingxin Wang ${ }^{5}$, Yi Wang ${ }^{1}$

${ }^{1}$ International Centre for bamboo and Rattan, Beijing, China; ${ }^{2}$ Institute of Forest Ecology, Environment and Protection, Chinese Academy of Forestry, Beijing, China; ${ }^{3}$ Department of Natural Resource Sciences, Macdonald Campus, McGill University, Ste-Anne-de-Bellevue, Canada; ${ }^{4}$ Department of Renewable Resources, University of Alberta, Edmonton, Canada; ${ }^{5}$ West Virginia University, Division of Forestry and Natural Resources, Morgantown, USA(junweiluan@icbr.ac.cn; liusr@caf.ac.cn; siyu_li0723@163.com; joann.whalen@mcgill.ca; scott.chang@ualberta.ca; jingxin.wang@mail.wvu.edu; wangyi@icbrac.cn)

The impacts of non-native/exotic invasive species on ecosystem processes and functions have been extensively studied, less recognized but also common are "native invaders" that become invasive in their native range due to human-mediated processes. However, we have limited knowledge on how the invasion of natives alter the ecosystem process, and if the hypothesized mechanisms that provide non-native invasive species an advantage are the same for native invaders. There is a general belief that non-native plant invasion is the results of a positive feedback on litter decomposition, whether native invaders could also adopt this positive feedback strategy is unknown. Furthermore, how invasive plants interact with the decomposer community and environment to stimulate litter decomposition is poorly understood. Bamboo expansion has been widely reported across the world, most of times as a native invader, provide us an opportunity to elucidate abovementioned questions. We chose seven locations across a national scale along a climatic gradient $\left(15.6 \sim 24.5^{\circ} \mathrm{C}\right)$, in each location, sites with different bamboo density (pure bamboo forest, forest expanded by bamboo, local forest) were established in order to conduct both in situ and reciprocal decomposition experiment. Soil biota community was manipulated by employing three mesh sizes litter bags or microcosms, enable us to distinguish three increasingly complete decomposer communities (small, medium-sized and complete). By investigating mass loss and nutrient release of all our decomposition experiments, to answer above-developed questions.

D70: PATTERNS IN FOREST INSECT HERBIVORY - 2

\section{Main factors influencing insect attacks of debarked-medicinal plants in Lama Forest Reserve and Lokoli swampy forest}

Yvonne T. Cakpo ${ }^{1,2}$, Judith Korb ${ }^{2}$, Brice Sinsin ${ }^{1}$, Chabi Djagoun ${ }^{3}$

${ }^{1}$ Laboratory of Applied Ecology/University of Abomey-Calavi (Benin), Abomey-Calavi, Benin; ${ }^{2}$ Faculty of Biology I/ University of Freiburg, Freiburg, Germany; ${ }^{3}$ Laboratory of Applied Ecology/University of Abomey-Calavi (Benin), Cotonou,Benin (ycakpo@gmail.com; judith.korb@biologie.uni-freiburg.de; bsinsin@gmail.com;dchabi@gmail.com)

The spatio-temporal variability of tree attacks by foraging xylophagous insects has been studied on most debarked-medicinal tree species in Lama Forest Reserve and in Lokoli swampy forest in Benin. For achieving that, different factors such as habitat type (crop fields, degraded forest and non-degraded forest), season (dry and rainy season), debarking level (T0: control, T1: $10 * 20 \mathrm{~cm}^{2}$ and T2: $20 * 50 \mathrm{~cm}^{2}$ ), and tree species (A. leiocarpa, D. guineense, D. mespiliformis, 
F. trichopoda, K. africana, L. barteri, L. acida and S. owariense) were considered. Data were collected during one year (from October 2014 to November 2015) using both interception and emergence traps. Per season, 72 and 81 traps were established in Lama and Lokoli respectively. Data collected were abundance of insects, presence or absence of insect holes, number of insect hole recorded on the tree. Four different orders (Coleoptera, Hymenoptera, Diptera and Blattodae) were collected including 284 morpho-species with 3771 insect individuals. The present study showed that habitat type, season, debarking level and tree species had significant effects on xylophagous attacks as well as the severity (number of insect holes) of those attacks and the abundance of xylophagous insects. High xylophagous diversity was recorded in degraded-forest and crop fields while non-degraded forests were lesser invaded in xylophagous beetles. Xylophagous insect attacks increased in crop fields and in degraded forest during rainy season on large debarking surface trees. Which implies debarking of most vulnerable medicinal tree species must be done during dry season in small patchs.

\section{Quantifying Ormiscodes outbreaks in Southern Chile: combining remote sensors and field validation}

Sergio Estay ${ }^{1,2}$ (D), Roberto Chávez ${ }^{3}$, Alvaro Gutierrez ${ }^{4}$, Ronald Rocco ${ }^{3}$

${ }^{1}$ Universidad Austral de Chile, Valdivia, Chile; ${ }^{2}$ Center of Applied Ecology and Sustainability, Santiago, Chile; ${ }^{3}$ Pontificia Universidad Católica de Valparaiso,Valparaiso, Chile; ${ }^{4}$ Universidad de Chile, Santiago, Chile (sergio.estay@uach.cl; roberto.chavez@pucv.cl; bosqueciencia@gmail.com; r.roccogatica@gmail.com)

Although abundant literature of insect outbreaks exists in the Northern Hemisphere, studies for the Southern Hemisphere are rare. Recently, massive outbreaks of the native moth Ormiscodes amphimone (Fabricius) (Lepidoptera: Saturniidae) have been reported in the southern cone of South America. Ormiscodes amphimone (Lepidoptera: Saturniidae) is a native phytophagous moth (Fig; 2) feeding on several host plants such as Nothofagus spp., Populus spp., among many other tree species. These $O$. amphimone outbreaks have defoliated large areas of temperate forests, raising great concern among local inhabitants, but yet the spatio-temporal patterns of these events have not been evaluated. Here we quantify the extension of the massive O. amphimone outbreaks occurred in the Aysén region (Southern Chile) in the period 2000-2017. Remote sensing detections were strongly in agreement with field observations and showed that massive outbreaks of $O$. amphimone are among the largest biotic disturbances in the forests of the Southern Hemisphere. Considering only field-confirmed outbreaks, the defoliated area reached $164^{\circ} 00$ hectares in total between 2000 and 2017, with some years reaching over $20^{\circ} 00$ ha defoliated in a single locality. The estimation of the spatial impact of $O$. amphimone, and its recurrence, represents the first step for the search of management alternatives of this massive disturbance.

\section{Polyphagozerra coffeae (Lepidoptera: Zeuzerinae: Cossidae): identification, notes on biology, natural enemies, damage characterization, and addition of Eucalyptus (Myrtaceae) as a new host in Indonesia}

Wagner Tavares ${ }^{1}$, Srikumar Kkadan ${ }^{1}$, Ade Hendrik, Rianza Asfa ${ }^{1}$, Marthin Tarigan ${ }^{1}$, Alvaro Durán ${ }^{1}$

${ }^{1}$ Asia Pacific Resources International Holdings Ltd., Pangkalan Kerinci, Indonesia (wagnermaias@yahoo.com.br; sreeku08@gmail.com;

ademeizon9@gmail.com; rianza_asfa@kerinci.lcl; marthin_tarigan@aprilasia.com;duransandoval@gmail.com)

The red coffee borer, Polyphagozerra (= Zeuzerra) coffeae (Lepidoptera: Zeuzerinae: Cossidae) is one of the most destructive lepidopteran borer in the world. The objective of this study was to identify the species name and evaluate some biological parameters of $P$. coffeae in the laboratory. Also, the natural enemies were identified and the damage caused on Eucalyptus (Myrtaceae) commercial plantations by this pest was characterized in Riau, Indonesia. Caterpillars and pupae of $P$. coffeae, obtained from Eucalyptus spp. plantations, were reared in a laboratory on ripe apple fruits, Malus pumila (Rosaceae). Male moths were identified as P. coffeae after aedeagus (male genitalia) analysis. Five groups of natural enemies were recovered from the P. coffeae stages: the hyperparasitoid Brachymeria sp. (Hymenoptera: Chalcididae: Chalcidinae), the gregarious parasitoids Cossidophaga sp. (Diptera: Tachinidae) and a eulophid (Hymenoptera: Tetrastichinae) species, a nematode (Nematoda), and a fungus entomopathogen. The damage caused by $P$. coffeae on the Eucalyptus trees was evident when tree tops were hanging and fallen, and presence of galleries and pupation chambers. Adult longevity ( \pm SD) was $5.88 \pm 0.54$ days. Each $1.66 \pm 0.28$ day old female was able to lay an average of $591.80 \pm 126.33$ eggs. Caterpillars stayed in the tree stem longer than 60 days. The pupal stage lasted $18.96 \pm 1.44$ days. The current study adds E. pellita and E. pellita $\times$ E. grandis as new hosts of $P$. coffeae and describes several knowledge aspects of $P$. coffeae as a pest of Eucalyptus in Riau, Indonesia.

\section{Does Paropsis atomaria larval feeding induce chemical responses in Corymbia citriodora subsp. variegata?}

Flavia Sarti Bonora ${ }^{\prime}$,Helen Nahrung ${ }^{1}$, David Lee, Andrew Hayes ${ }^{1}$

${ }^{1}$ University of the Sunshine Coast, Sunshine Coast, Australia (fsartabo@usc.edu.au; hnahrung@usc.edu.au; dlee@usc.edu.au; rhayes@usc.edu.au)

Corymbia citriodora subsp. variegata (CCV) is promising for hardwood plantations in areas considered marginal for many commercial forestry species, as it presents desirable field performance, wood quality and form and suits a range of site conditions. The eucalypt tortoise beetle Paropsis atomaria Olivier (Coleoptera: Chrysomelidae) is a major pest of eucalypt plantations in Queensland, including areas planted with CCV. P. atomaria can cause severe defoliation in young trees, reducing plantation productivity and quality. Studies with Corymbia spp demonstrated that plant secondary metabolites, such as terpenes, are correlated with arthropod herbivory and can be effective as insect growth inhibitors. Changes in plant chemistry can occur in plants as a response to herbivory, potentially reducing further damage. To provide a better understanding of plant-herbivore interactions and possible resistance mechanisms, this study evaluated the chemical response of CCV challenged by $P$. atomaria. Seedlings of CCV were submitted to one of three treatments: no damage; mechanical damage and $P$. atomaria larval damage. After 15 days seedlings were removed from the treatments and leaf samples were analysed to determine the leaf-oil gas chromatography-mass spectrometry. The results revealed that $P$. atomaria larval feeding induced chemical response in CCV with up-regulation of waxes and down-regulation of terpenoids. The same pattern was not observed on plants under mechanical damage, suggesting an interaction between plant-herbivore.

\section{Four species of mirid bugs (Hemiptera) and parasitism of Helopeltis bradyi by Leiophron sp. (Hymenoptera: Braconidae) on Eucalyptus (Myrtaceae) commercial plantations in Indonesia}

Srikumar Koda Kkadan ${ }^{1}$, Wagner Tavares ${ }^{1}$, Ade Hendrik ${ }^{1}$, Irfan Pasaribu ${ }^{2}$, Marthin Tarigan $^{1}$, Alvaro Duran ${ }^{1}$

${ }^{1}$ Asia Pacific Resources International Holdings Ltd., Pangkalan Kerinci, Indonesia; ${ }^{2}$ PT Toba Pulp Lestari Tbk., Porsea, Indonesia (sreeku08@gmail.com; wagnermais@yahoo.com.br; ameizon_hendrik@kerinci.lcl; irfan_pasaribu@globalnet.lcl; marthin_tarigan@aprilasia.com; duransandoval@gmail.com)

Mirid bugs (Hemiptera: Miridae) are important pests of young and old Eucalyptus (Myrtaceae) trees in Indonesia. Young Eucalyptus plantations are mainly affected by Helopeltis (Hemiptera: Miridae). This damage resulted in die-back of young shoots, curling, deformed, and drying, usually irrespective of the clones. In North Sumatra, damage of Eucalyptus is associated to Helopeltis bradyi Waterhouse despite the presence of $H$. theivora in the region. Important alternate host plants as reservoirs of $H$. bradyi in vicinity to Eucalyptus plantations were Coffea sp. (Rubiaceae), Persea sp. (Lauraceae), Psidium guajava (Myrtaceae), and 
Theobroma cacao (Malvaceae). Leiophron sp. (Hymenoptera: Braconidae) is reported as an important parasitoid with parasitism of $25.71 \%$ on the $H$. bradyi nymph and adult individuals sampled. Helopeltis theivora Waterhouse were recorded as the only species affecting Eucalyptus plantations in Riau Province, so far no other Helopeltis spp. was identified in the Province. Ragwelellus festivus Miller was reported for the first time damaging Eucalyptus trees in Riau, North Sumatra and East Kalimantan of Indonesia. Pachypeltis sp. was also recorded along with Helopeltis species and R. festivus in North Sumatra and Riau Provinces. Sex pheromone traps using virgin female body extract were developed for $H$. bradyi and $H$. theivora and found to be compelling in attraction and trapping. Insecticides belonging to synthetic pyrethroid group and others applied using sprayers and foggers found to be effective against these pests. Four species of mirid bugs damaging Eucalyptus trees and the parasitoid Leiphron sp. were reported for the first time in Indonesia.

\title{
Population progression of Eucalyptus leaf roller complex and Helopeltis theivora, and factors affecting their chemical control in young Eucalyptus plantations in Riau, Indonesia
}

Srikumar Koda Kkadan', Wagner Tavares ${ }^{I}$, Rianza Asfa ${ }^{I}$, Ignatius Andri Ferlianda', Marthin Tarigan ${ }^{I}$, Alvaro Duran ${ }^{I}$

'Asia Pacific Resources International Holdings Ltd., Pangkalan Kerinci, Indonesia (sreeku08@gmail.com; wagnermais@yahoo.com.br; rianza_asfa@kerinci.lcl; ignatius_ferlianda@kerinci.lcl; marthin_tarigan@aprilasia.com; duransandoval@gmail.com)

Eucalyptus leaf roller complex (Lepidoptera: Tortricidae) and Helopeltis theivora Waterhouse (Hemiptera: Miridae) cause severe damage on juvenile foliage of Eucalyptus (Myrtaceae) plants. Population progression of leaf roller and H. theivora on E. pellita and E. grandis $\times$ E. pellita plantations was studied based on the damage incidence and severity in six locations in Riau Province, Indonesia. Leaf roller infestation on E. pellita and E. grandis $\times$ E. pellita clones commenced from three weeks after planting (WAP). Incidence remained maximum (80-100\%) from four to 12 WAP. Decline in population commenced since 14 WAP and reached further low in 16 WAP. Severity of infestation reached extreme (84\%) through five to nine WAP. Helopeltis theivora infestation instigated from six WAP and advanced from 12 WAP. Incidence reached maximum (80\%) in 15 WAP and declined in 18 WAP. Crosses of $E$. grandis and $E$. pellita were found to be more susceptible to leaf roller and $H$. theivora infestation than pure $E$. pellita. Currently insecticide application is sole remedy for control of leaf roller and H. theivora outbreaks. Analysis (January 2017 to May 2018) indicated that rainfall (>15 mm) affected negatively the efficiency of spraying insecticides. There was also significant relationship between control size area and rounds of insecticide application. Current study formulated effective management strategies for leaf roller complex and $H$. theivora.

\section{Herbaria as distorting mirrors in studies of insect herbivory}

Vitali Zverev', Irina Sokolova², Mikhail V. Kozlov ${ }^{1}$, Alexander Egorov ${ }^{3}$, Mikhail Goncharov ${ }^{4}$,Elena Zvereva ${ }^{1}$ ${ }^{1}$ University of Turku, Turku, Finland; ${ }^{2}$ Komarov Botanical Institute, St. Petersburg, Russian Federation; ${ }^{3}$ St. Petersburg State University, St. Petersburg, Russian Federation; ${ }^{4}$ St. Petersburg Chemical-Pharmaceutical University, St. Petersburg, Russian Federation (vitzve@utu.fi; isokolova@yandex.ru; mikoz@utu.fi; egorovfta@yandex.ru; mgonch@mail.ru; elezve@utu.fi)

Herbaria were recently advertised as reliable sources of information on historical changes in plant damage by insects and pathogens. Our aim was to explore, whether the levels of insect herbivory occurring in nature can be invoked from herbarium specimens. Losses of leaf area to insects in herbarium specimens collected by botany students $(4.87 \%)$ were significantly lower than losses measured from ecological samples $(7.96 \%)$ collected simultaneously in unbiased way. The differences in herbivory between herbarium specimens and ecological samples varied with plant species and increased with the increase in plant damage; as the result, there was no correlation between leaf damage in herbarium specimens and the actual level of herbivory. Curators asked to select one of two specimens for museum collections generally preferred specimens with lower leaf damage. Both collectors and curators significantly differed in their attitudes to plant damage, from careful selection of branches with nearly undamaged leaves to neglecting the extent of leaf damage by insects or even preferring specimens with high infestation by identifiable herbivores, e.g. leaf miners. We conclude that leaf damage measured from herbarium specimens not only underestimates field herbivory, but is not proportional to the level of damage that occurred in nature at the time of sampling due to multiple factors that cannot be controlled in data analysis. In terms of quantitative data on overall losses of leaf area to insects, herbaria act as distorting mirrors, and therefore cannot be recommended for studying past levels of herbivory.

\author{
Herbivory reduction through plant-spider associations in undergrowth species in a cloud forest of Peru \\ R. Jaemy Romero-Herrada ${ }^{1,2}$ \\ ${ }^{1}$ Universidad Austral de Chile, Valdivia, Chile. ${ }^{2}$ Departamento de Ecología, Museo de Historia Natural, Universidad Nacional Mayor de San Marcos, Lima, \\ Peru(roy.romero@alumnos.uach.cl)
}

One of the most successful anti-herbivory strategies for plants has been to establish mutualistic relationships with predators that consume herbivores, such as spiders. The success of spiders in herbivory reduction may be related to their ability to prey on various herbivore guilds. Despite the strong impact that spiders exert on the density and spatial distribution of herbivores, the effect they have on host plants is variable and dependent on environmental conditions. In this sense, you will seek to determine if the association with spiders has an effect on the proportion of herbivory presented by juvenile plants of three common shrub species of the undergrowth of the cloud forests of Peru through three altitude levels (2400, 2600 and 2800 m.a.s.l.). These species are: Hedyosmum cuatrecazanum Occhioni. (Chloranthaceae), Miconia sp. (Melastomataceae) and Psychotria sp. (Rubiaceae). To evaluate this effect I established two Bayesian models, one where the effect of the association is included in a generalized manner and another where the effect of the association is dependent on the species. The proportion of herbivory presented by spider-associated plants (mean $\pm \mathrm{SD}=0.041 \pm 0.031$ ) was lower than the proportion of herbivory in non-associated plants (mean $\pm \mathrm{SD}=0.076 \pm 0.048$ ). I found a significant herbivory reducing effect when plants are associated with spiders in all three species and for both models. Additionally, I observed that the greatest herbivory reducing effect occurs in Hedyosmum cuatrecazanum-spider associations, and that the reducing effect on Miconia sp. and Psychotria sp is similar.

Sprout dynamics in Ormiscodes amphimone: the role of the thermal landscape as an environmental force in the Aysen region of Chile I Dinámica de brotes de Ormiscodes amphimone: rol del paisaje térmico como forzarte ambiental en la Región de Aysén, Chile

Nicolhole Atero ${ }^{1}$

${ }^{1}$ Universidad Austral de Chile, Valdivia, Chile (nicolhole.af@gmail.com)

La dinámica de brotes de insectos ha cambiado en las últimas décadas como consecuencia del aumento de la temperatura, generando severas repercusiones en el funcionamiento de los bosques. Recientemente, se han observado brotes masivos de la polilla nativa Ormiscodes amphimone en los bosques Patagónicos de 
América del Sur. En este estudio se evaluó el rol del paisaje térmico como forzante ambiental en la fenología de O. amphimone en la Región de Aysén, Chile. Se utilizaron datos de temperatura del proyecto MERRA-2 para reconstruir el paisaje térmico de los últimos 15 años, utilizando los grados-días acumulados (GDA) como proxy de la idoneidad térmica, y mediante un modelo logístico, se estimó la probabilidad de tener un brote en función de los GDA en cada localidad. Además, se construyó un modelo fenológico regional para conocer la respuesta térmica de $O$. amphimone respecto a los GDA.Los GDA muestran un patrón heterogéneo en toda la región, lo que hace que la fenología de $O$. amphimone sea altamente variable entre localidades, y que la probabilidad de ocurrencia de brotes este determinada por distintos umbrales térmicos. Finalmente el modelo fenológico sugiere una relación positiva entre la acumulación térmica y la abundancia poblacional relativa de la especie, sin embargo, esta relación es específica para cada sitio. Este estudio es un primer paso en el desarrollo de herramientas para evaluar el riesgo de brotes en todo el territorio, y de este modo, optimizar las estrategias de manejo para minimizar el impacto de esta plaga en América del Sur.

\section{Susceptibility of three commercially significant Amazonian trees to termite attack (Isoptera: Insecta) / Susceptibilidade de três árvores} amazônicas de interesse comercial ao ataque de térmitas (Isoptera: Insecta)

Diulio Andrew Torres de Souza ${ }^{1,2}$, Norma Cecília Rodrigues Bustamante', Rayssa Gomes Vasconcelos ${ }^{1}$, Luiz de Moura Neto ${ }^{1}$, João Victor Barros Wezen ${ }^{1}$ ${ }^{1}$ Universidade Federal do Amazonas, Departamento de Ciências Florestais Manaus, Brazil; ${ }^{2}$ Instituto Nacional de Pesquisas da Amazônia, Manaus, Brazil (diulio51@gmail.com; ncbustamante@gmail.com; rayssagomes85@gmail.com; luizmouraneto@yahoo.com.br;jaowezen@gmail.com)

$\mathrm{O}$ conhecimento acerca do comportamento de térmitas em relação às espécies florestais amazônicas de interesse comercial ainda é incipiente. O presente estudo objetivou avaliar a susceptibilidade de cupiúba (Goupia glabra), guariúba (Clarisia racemosa) e marupá (Simarouba amara), ao ataque de Nasutitermes surinamenses, Nasutitermes corniger e Cornitermes acignathus. Foram confeccionados corpos-de-prova (estacas) de cada espécie, totalizando 108 estacas. As mesmas foram numeradas, pintadas com diferentes cores na extremidade e tiveram o volume, peso úmido e densidade básica, determinados. Para a obtenção do peso seco, as amostras foram separadas por espécie e acondicionadas em estufa $\left(103^{\circ} \mathrm{C}\right)$. No Campus-UFAM, instalou-se 3 áreas amostrais, cada uma com 12 pontos próximos a atividade térmitica. Ao redor de cada ponto, foram enterradas 3 estacas (1 por espécie). Aos 90 e 120 dias, foram removidas 6 estacas por espécie, de cada área, que passaram pelo processo de secagem; $55 \%$ das madeiras estavam infestadas, a espécie marupá, apresentou a maior frequência de ocorrência de térmitas (81\%), guariúba (44\%) e cupiúba (39\%). O marupá sofreu maior ataque de $N$. surinamenses e N. corniger, enquanto que a cupiúba foi a menos infestada. Já C. acignathus demonstrou maior atração pelas estacas de marupá e guariúba.

The relationship between the distribution range of Nothofagus species and herbivore species richness in Chile / Relación entre la amplitud del rango de distribución de especies del género Nothofagus y la riqueza de especies herbivoras en Chile

Daniela López ${ }^{1}$ Carmen Paz Silva ${ }^{1}$, Carlos Riquelme ${ }^{2}$, Sergio Estay ${ }^{1,3}$

${ }^{1}$ Universidad Austral de Chile, Valdivia, Chile; ${ }^{2}$ Pontificia Universidad Católica de Chile, Santiago, Chile; ${ }^{3}$ Centro de Ecología Aplicada y Sustentabilidad (CAPES),Santiago,Chile (danyelalopez@gmail.com; carmenpazsilva@gmail.com; carlosriquelmemv@gmail.com; sergio.estay@gmail.com)

El género Nothofagus en Sudamérica se extiende desde los $30^{\circ}$ a los $56^{\circ}$ S. En Chile, las especies arbóreas que componen el género Nothofagus presentan diferentes amplitudes de su rango de distribución, se caracterizan por tener hojas tanto hojas caducas como perennes, y albergar diferentes especies de herbívoros, los cuales depredan las especies arbóreas generando diferentes tipos de daño. En este trabajo, nosotros evaluamos la relación entre la amplitud del rango de distribución de ocho especies del genero Nothofagus y la riqueza de especies herbívoras, cuantificando el mecanismo de daño predominante. Nosotros encontramos una relación débil entre la amplitud del rango de distribución y la riqueza de especies herbívoros que depredan las especies arbóreas ( $\mathrm{r}=0.60$, I.C. $[-0.19,0.92])$. En total, se cuantificaron 145 especies herbívoras que depredan al género Nothofagus, y el mecanismo de daño predominante fue la defoliación $\sim 30 \%$. En términos especie - específico, Nothofagus dombeyi, fue la especie arbórea que presentó la mayor presión de depredación, i.e una mayor riqueza de especies defoliadoras asociadas esta especie.

Ambrosia and bark beetle community along with latitudinal gradient: temporal dynamics of the community and phylogenetic effects of plants on the community

Naoto Kamata ${ }^{1,2}$, Sunisa Sanguansub ${ }^{2}$, Yong Peng ${ }^{1}$, Teerapong Saowaphak ${ }^{3}$, Sawai Buranapanichpan ${ }^{3}$, Anut Buranapanichpan ${ }^{1,4}$

${ }^{1}$ The University of Tokyo, Furano, Japan; ${ }^{2}$ Kasetsart University, Kamphaeng Saen, Thailand; ${ }^{3}$ Chaing Mai University, Chiang Mai, Thailand; ${ }^{4}$ Royal

Department of Agriculture Thai, Bangkok,Thailand (kamatan@uf.a.u-tokyo.ac.jp; agrssss@ku.ac.th; pengyong@uf.a.u-tokyo.ac.jp; agitswph@gmail.com; sawai.b@cmu.ac.th; turtlekung@hotmail.com)

Ambrosia and bark beetles are recognized as important forest insect groups because they sometimes cause devastating damage to forest ecosystems. Our aim is to clarify ambrosia and bark beetle community and their relationship with host plants along with a latitudinal gradient. In this paper, comparison among three locations, 2 sites in Japan and 1 in Thailand, will be introduced. Ethanol baited traps ('traps') and bait logs were used in this study. Seasonal changes in the community obtained by the traps and a relationship between phylogenetic distance of host plants and community similarity of the beetles obtained by the bait logs were compared among the three sites. The species richness captured by the traps tended to decrease with latitude. In Thailand, beetles were captured throughout the season but not in Japan. Seasonal dissimilarity tended to be greater but annual dissimilarity tended to smaller with latitude. Changes in the community (turnover rate) was greater in Thailand than Japan, partly because of the faster life cycle duration, partly because of the more rapid changes in the breeding material, as a result of higher average temperatures. Beetles have to disperse and seek out new breeding sites more frequently in Thailand than in Japan. Results of the bait log experiment also support the hypothesis. A negative correlation between the phylogenetic distance between host plants and similarity in the beetle community was stronger in Japan. The community tended to be more equivalent with latitude.

\section{Mixed plantation and insect herbivory across a harvesting gradient in North Patagonian forest}

Marcos Nacif ${ }^{\prime}$, Lucas Garibaldi', Carolina Quintero ${ }^{1}$

${ }^{1} U N R N-I R N A D$, S.C.de Barilche,Argentina (mnacif@unrn.edu.ar; lgaribaldi@unrn.edu.ar; quintero.carolina@gmail.com)

Sustainable forest management should optimize tree productivity and biodiversity conservation. However, it is unknown how different tree species and their associated herbivores respond to a gradient of forest extraction or if exists an optimum harvesting level for plant performance and herbivore guild diversity. In an experimental management program in Patagonian shrublands, were planted Austrocedrus chilensis, Nothofagus alpina, N. pumilio, N. antarctica, N. 
dombeyi and N. obliqua, in plots with different harvesting intensities. Plant survival, growth and leaf damage of herbivore guilds were measured. Mixed model effects were used. The plants survived more and grew better at intermediate harvesting intensities. Two groups of plants presented similar consumption patterns, coincidentally with their phylogenetic proximity. These responses were obtained with different guilds. $N$. obliqua and $N$. alpina were more consumed at intermediate harvesting intensities, and $N$. pumilio, $N$. antarctica and $N$. dombeyi were more consumed at lower harvesting intensities. A non-deciduous species was the less consumed ( $N$. dombeyi). Diversity patterns are similar to herbivory rates (not for $N$. dombeyi in the second year). Intermediate harvesting is optimal for plant performance and herbivore guild diversity. In a productive forest scenario, harvesting is necessary, also ensure herbivore guild diversity.

\title{
D7p: FOREST HEALTH
}

\author{
Silver nanoparticles stimulate the formation of ectomycorrhizae in seedlings of pedunculate oak (Quercus robur L.)

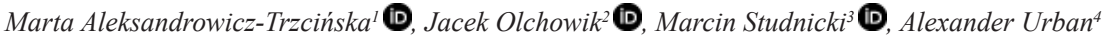 \\ ${ }^{1}$ Department of Forest Protection and Ecology, Faculty of Forestry, Warsaw University of Life Sciences, Warsaw, Poland; ${ }^{2}$ Department of Plant Pathology; \\ Faculty of Horticulture, Biotechnology and Landscape Architecture; Warsaw University of Life Sciences, Warsaw, Poland; ${ }^{3}$ Department of Experimental \\ Design and Bioinformatics, Faculty of Agriculture and Biology, Warsaw University of Life Sciences, Warsaw, Poland; ${ }^{4}$ Department of Botany and \\ Biodiversity Research, Faculty of Life Sciences, University of Vienna, Vienna, Austria (marta_aleksandrowicz_trzcinska@sggw.pl; jacek_olchowik@sggw.pl; \\ marcin_studnicki@sggw.pl; alexander.urban@univie.ac.at)
}

Metal nanoparticles are gaining ever-wider application in agriculture and forestry, as alternatives to chemical agents used as fertilisers, growth stimulators and pesticides, establishing a need for eco-toxicological risk assessment of these agents. We tested the effects of foliar-applied silver nanoparticles (AgNPs) on chlorophyll a fluorescence and on abundance and species composition of ectomycorrhizal (ECM) colonisation. The application of AgNPs at concentrations of 5,25 and $50 \mathrm{ppm}$ was found to stimulate the formation of mycorrhizae in seedlings of pedunculate oak, with the highest effect at intermediate concentrations (25 ppm). There were non-linear effects on the relative abundance of ECM fungal species. The proportion of dominant $T$. terrestris was highest in the control group, whereas the shares of ECM formed by the two other species, S. brunnea and P. involutus, were higher in the treatments with intermediate and maximal concentrations of AgNPs, respectively. Maximum quantum yield of photosystem II (Fv/Fm) assessed by chlorophyll $a$ fluorescence measurements revealed slight debilitation of oak seedlings irrespective of the application of AgNPs and their concentrations. This result offered an indirect indication that photosynthesis capacity had no influence on the level of mycorrhization. We hypothesise that foliar AgNPs treatments at concentrations below thresholds of acute toxicity and in the absence of significant effects on chlorophyll a fluorescence may still exert significant influence on biotic interactions including mycorrhizal symbioses by impacting plant hormonal balance, particularly ethylene, and regulatory pathways involved in host control of ECM colonisation.

\section{Biochemical characterization of bacterioses diseases in nurseries and plantations of Eucalyptus spp.}

Daniella Flávia Said Heid Schettini Silva ${ }^{1}$, Helena Piedade Farsoni ${ }^{1}$, Sharlles Christian Moreira Dias ${ }^{2}$, Anderson Jones Bobko², Luciano Flávio Neves Ramos ${ }^{2}$, Celso Luis Marino ${ }^{3}$ Edson Luiz Furtado

${ }^{1}$ Departament of Plant Protection, São Paulo State University, Botucatu, Brazil; ${ }^{2}$ Eldorado Brasil Company, Três Lagoas, Brazil; ${ }^{3}$ Departamento of Genetics, São Paulo State University, Botucatu, Brazil (daniellaflaviaschettini@gmail.com; helenap_farsoni@hotmail.com; sharlles.dias@eldoradobrasil.com.br; anderson.bobko@eldoradobrasil.com.br; luciano.ramos@eldoradobrasil.com.br; cl.marino@unesp.br; edson.furtado@unesp.br)

Brazil is a world reference in eucalyptus production due to its action based on sustainability, competitiveness and innovation. Accordingly, factors that affect production, such as diseases caused by pathogenic biotic agents, including those of fungal and bacterial origin, need to be studied. Bacteria encompass a group of pathogens of complex morphological differentiation, requiring studies to characterize them. Among the methods for separating bacterial groups, the biochemical characterization allows to distinguish these according to their characteristics, such as types of respiration, production of specific enzymes or carbohydrates, among others. Thus, 39 pathogenic isolates obtained through eucalyptus seedlings with symptoms of die-back and wilting and lesions on the branches, petiole and midrib were evaluated biochemically, in order to evaluate the pathogen group. Consequently, these isolates were submitted to the tests proposed by Schaad (2001), such as potassium hydroxide or Gram test (positive or negative), oxidation and fermentation test, hypersensitivity to tobacco (Nicotiana tabacum), pectinolytic enzyme production, reductive phosphatase activation, reduction of nitrate to nitrite, production of carbohydrates from mannitol and production of catalase. Therefore, the tests demonstrated the bacterium is Gram negative, that is, pathogenic. In addition, the results of the tests of the oxidation and fermentation, reductive phosphatase, nitrate to nitrite reduction, mannitol and catalase were positive and for pectinolytic enzyme production and hypersensitivity to tobacco were negative, indicating the isolates belong to the group of the Enterobacteria.

\section{Parasitism of three species of eulophid gall wasps by eupelmid, eulophid, eurytomid, and torymid on Eucalyptus (Myrtaceae) commercial plantations in Sumatra, Indonesia}

Wagner Tavares ${ }^{1}$, Srikumar Kkadan ${ }^{1}$, Ade Hendrik', Marthin Tarigan ${ }^{1}$, Jupiter Abad $^{2}$, Álvaro Durán ${ }^{1}$

${ }^{1}$ Asia Pacific Resources International Holdings Ltd., Pangkalan Kerinci, Indonesia; ${ }^{2}$ Toba Pulp Lestari, Porsea, Indonesia

(wagnermaias@yahoo.com.br; sreeku08@gmail.com; ademeizon9@gmail.com; marthin_tarigan@aprilasia.com;jupiter_abad@tobapulp.com;

duransandoval@gmail.com)

Eulophid gall wasps are a threat to the Eucalyptus (Myrtaceae) commercial plantations around the world. The objective of this study was to identify species of gall wasps and their associated parasitoids besides the parasitism level on galls collected from commercial Eucalyptus plantations in Sumatra, Indonesia. The gall wasps recovered were Leptocybe invasa Fisher \& La Salle (Tetrastichinae), Ophelimus eucalypti (Gahan) and Ophelimus maskelli (Ashmead) (Opheliminae), all belonging to the family Eulophidae. The parasitoid Megastigmus Dalman (Torymidae: Megastigminae) emerged from the galls of $L$. invasa; Aprostocetus Westwood (Tetrastichinae), Chrysonotomia Ashmead, Closterocerus chamaeleon (Girault) (Entedoninae), Quadrastichus Girault (Tetrastichinae: Eulophidae), Eupelmus Dalman (Eupelmidae: Eupelminae), Eurytoma Illiger (Eurytomidae: Euritominae), and Megastigmus from the galls of O. eucalypti; and $C$. chamaeleon and Megastigmus from the galls of $O$. maskelli. The parasitism on $O$. eucalypti and $O$. maskelli was 30.23 and $100.00 \%$, respectively. Closterocerus chamaeleon, native to Australia, shows the ability to parasitize the galls of both Ophelimus species therefore with a greater parasitism level on $O$. maskelli, and Megastigmus parasitizes all gall wasp species. As far as is known, no activity of artificial introduction of parasitoids of Eucalyptus gall wasps was conducted in Indonesia so far, indicating a natural introduction of parasitoids or origin of some of them to Sumatra and adaptation to parasitize the introduced gall wasp species. The maintenance of parasitoid species, combined with the selection of resistant and tolerant plant genotypes are management measures being currently adopted to control the Eucalyptus gall wasps in Sumatra, Indonesia. 
Modeling the invasive capacity of Chilecomadia valdiviana / Modelamiento de la capacidad invasora de Chilecomadia valdiviana

Carlos Riquelme ${ }^{1,2}$, Carmen Paz Silva ${ }^{3}$, Daniela López ${ }^{3}$, Sergio A Estay ${ }^{2,3}$

${ }^{1}$ Pontificia Universidad Católica, Santiago, Chile; ${ }^{2}$ Center of Applied Ecology and Sustainability (CAPES), Santiago, Chile; ${ }^{3}$ Universidad Austral de Chile,

Valdivia,Chile(carlosriquelmemv@gmail.com; carmenpazsilva@gmail.com; danyelalopez@gmail.com; sergio.estay@gmail.com)

Las especies invasoras actualmente son una amenaza para la biodiversidad y para la economía a nivel global. Debido a los cambios ambientales, la transformación del hábitat y el incremento del comercio internacional las especies invasoras han logrado expandirse y establecerse en todo el mundo. Una especie potencialmente invasora es Chilecomadia valdiviana, una polilla de la familia Cossidae nativa de Chile que en su estado larval es de hábitos xilófagos generando galerías en los arboles afectados. Se ha descrito que $C$. valdiviana utiliza principalmente especies nativas, sin embargo se ha detectado su presencia en arboles del género Eucalyptus, generando pérdidas económicas. Para evaluar la capacidad de invasión de este insecto se utilizó un modelo de distribución de especies utilizando el programa R y el paquete "dismo". Se utilizaron 19 variables disponibles en la base de datos Worldclim, a las cuales se les realizó un análisis de correlación para eliminar las que estuvieran altamente correlacionadas. El valor del AUC obtenido fue sobre 0.7 lo que indica un gran valor predictivo del modelo. El resultado del modelo indica que C. valdiviana tiene una alta capacidad invasora.

\section{Quambalaria eucalypti a new pathogen of Eucalyptus globulus in Northern hemisphere}

Helena Bragança ${ }^{1}$, Eugénio Diogo ${ }^{1}$, Lucinda Neves ${ }^{2}$, Carlos Valente ${ }^{3}$, Luis Bonifácio ${ }^{1}$, Alan Phillips ${ }^{4}$

${ }^{1}$ Instituto Nacional de Investigação Agrária e Veterinária I.P. (INIAV I.P.), Quinta do Marquês, 2780- 159 Oeiras, Portugal; ${ }^{2}$ Altri Florestal SA, Quinta do Furadouro, 2510-582 Olho Marinho, Portugal; ${ }^{3} R A I Z$, Navigator, Quinta de S. Francisco, Ap; 15, 3801-501 Eixo-Aveiro, Portugal; ${ }^{4}$ Universidade de Lisboa, Faculdade de Ciências, Biosystems and Integrative Sciences Institute (BioISI), Campo Grande, 1749-016 Lisboa, Portugal (helena.braganca@iniav.pt; eugenio.diogo@iniav.pt;.loliveira.neves1@gmail.com; carlos.valente@thenavigatorcompany.com; helena.braganca@gmail.com; alan.jl.phillips@gmail.com)

The Eucalyptus pathogen Quambalaria eucalypti has been reported from several subtropical and tropical countries of the Southern Hemisphere. During the course of a nationwide monitoring program aimed at the detection of pathogens in commercial eucalypt plantations in Portugal, Q. eucalypti was found affecting Eucalyptus globulus. The identity of the pathogen was confirmed by sequence analyses of the internal transcribed spacer (ITS) region of the rDNA operon, as well as morphological characteristics. Quambalaria eucalypti is widespread throughout the eucalypt producing areas of Portugal. Pathogenicity studies revealed that different host genotypes showed various degrees of susceptibility to the pathogen. To our knowledge, this is the first report of $Q$. eucalypti on Eucalyptus spp. in Portugal and in the Northern hemisphere.

\section{Determination of within-tree distribution of the witches' broom pathogen Taphrina wiesneri in Prunus yedoensis using loop mediated isothermal amplification (LAMP) detection}

Sun Keun Lee ${ }^{I}$, Ji-Hyun Park', Dong-Hyeon Lee ${ }^{I}$, Sang-Tae Seo ${ }^{I}$, Sang-Hyun Lee ${ }^{I}$

'Division of Forest Insect Pests and Diseases, National Institute of Forest Science, Seoul, Republic of Korea (lskyou@korea.kr; jhpark10@korea.kr; leedh2009@korea.kr; stseo@korea.kr;shlee4@korea.kr)

Flowering cherries trees, including (Prunus yedoensis), an important landscape tree species in South Korea, have been widely planted for urban forests (park, garden, etc.) and street trees in the country. One of the most damaging diseases of P. yedoensis is the witches' broom disease caused by Taphrina wiesneri, an ascomycetous fungus. When the tree is infected by T. wiesneri, abnormal growth occurs on affected branches of the tree, resulting in the witches' broom symptom, and the branches no longer bloom. Pruning out infected parts of the tree has been commonly used to prevent the disease from spreading. To determine where the pruning cuts should be made, we investigated the distribution of $T$. wiesneri within the $P$. yedoensis tree based on a loop-mediated isothermal amplification (LAMP) technique, targeting the ITS rDNA region of the pathogen. To determine whether the LAMP technique developed in this study could specifically detect the pathogen from the infected areas of the tree, its specificity was confirmed by testing the other Taphrina species together. Wood samples were obtained at every interval of five centimeters from all branches and main stems of three affected trees. Taphrina wiesneri was detected in the wood samples up to ten centimeters above and below the brooms in the symptomatic branches. Therefore, pruning out infected branches more than $10 \mathrm{~cm}$ below the brooms would help managing infected trees. The results also indicate $T$. wiesneri would easily spread by ascospores between trees or branches.

\section{Potential of endophyte-mediated resistance against Austropuccinia psidii}

Julia Soewarto ${ }^{1}$, Beccy Ganley ${ }^{1}$, Fernanda Jacobo $^{2}$, Roanne Sutherland ${ }^{1}$, Hayley Ridgway ${ }^{2}$

${ }^{1}$ SCION, Rotorua, New Zealand; 2Plant and Food Research, Lincoln, New Zealand (julia.soewarto@scionresearch.com; rebecca.ganley@scionresearch.com; fernanda.jacobo@plantandfood.co.nz; roanne.sutherland@scionresearch.com; hayley.ridgway@plantandfood.co.nz)

The impact of endophytes of myrtaceous species on infection and epidemiology of Austropuccinia psidii (myrtle rust) is unknown. Preliminary work on Leptospermum scoparium substantiates a functional role for endophytes in growth, chemistry and plant protection. Additional work has shown that endophytes can mediate resistance against rust fungi in other pathosystems, thus suggesting a potential for using endophytes as biocontrol agent against $A$. psidii. In this research we test the hypothesis that the endophyte communities within myrtaceous species differ between species, site and tissue and that some plant genotypes contain members antagonistic towards A. psidii. Foliar samples (leaves and stems) from healthy Leptospermum scoparium, Lophomyrtus bullata and Metrosideros excelsa have been collected from three different locations in New Zealand. A curated collection of $>500$ culturable endophytes has been generated, proportionally comprising approximately $50 \%$ bacteria, $10 \%$ actinobacteria and $40 \%$ fungi. DNA from replicate plants and plant tissues, at multiple sites, have been prepared for DNA extraction, with subsequent amplicon sequencing (Illumina) to be used to describe the full foliar endomicrobiome of these species. From this data multivariate analysis will be used to identify taxa that correlate with plant susceptibility both within and across myrtaceous species. In parallel with microbial community analysis, the antifungal potential of key cultured taxa will be determined through in vitro assays as a primary selection criteria. The completion of this work will identify microbial endophytes that may strengthen plant resistance to A. psidii and have the potential to play a long-term role in the effective management of myrtle rust. 


\author{
Hosts and distribution range of juniper dwarf mistletoe (Arceuthobium oxycedri) in the Crimean Peninsula \\ Yuliya Krasylenko ${ }^{1,2}$, Oleg Kukushkin ${ }^{3}$ \\ ${ }^{1}$ Institute of Food Biotechnology and Genomics, National Academy of Sciences of Ukraine, Osipovskogo St., 2a, 04123, Kyiv, Ukraine; ${ }^{2}$ Centre of the Region \\ Haná for Biotechnological and Agricultural Research, Department of Molecular Biology, Šlechtitelu 27, 783 71, Olomouc, Czech Republic; ${ }^{3}$ Department of \\ Herpetology, Zoological Institute of Russian Academy of Sciences, Saint Petersburg, Russian Federation (j_krasylenko@ukr.net)
}

Juniper dwarf mistletoe (Arceuthobium oxycedri (DC.) M. Bieb; Viscaceae) is a semi-parasitic species parazitizing at the Crimean Peninsula Juniperus deltoides as a principal host, and $J$. excelsa and Platycladus orientalis as secondary ones. Basing on the detailed surveys on A. oxycedri range in 20132018 it was found that heterogenously distributed populations of hemi-parasite are confined predominantly to the Southern and South-East Coast, as well as to the South-Western Foothills, generally coinciding with the range of $J$. deltoides. According to Maxent modelling, A. oxycedri range is limited by such climatic factors as average temperature of the most humid and the driest seasons, precipitation of the driest month, and annual amplitude of temperatures (Krasylenko et al., 2017; Kukushkin et al., 2017). It is noteworthy that host infection pattern is patchy, since the heavily infested trees neighbour the completelely unaffected ones even within one mountain slope. Moreover, the sole $J$. deltoides trees parazitized by $A$. oxycedri were found at a distance of circa $0.5-1 \mathrm{~km}$ from the infected localities, probably, due to ornithochory. Exclusively negative impact of $A$. oxycedri on host at the Crimea is doubtful, since both components of hostparasite system are related to Quaternary refugia of thermophyllic plants and to this extent are relics. Currently, $A$. oxycedri dissemination rate is lower than the host one, its distribution is limited, and junipers lifespan in natural biotopes is compromized by multiple (a)biotic stress factors. Therefore, $A$. oxycedri "behaves more like a hyena, then a wolf", and is hardly a key factor of host decline.

\title{
Effects of gap harvest on ectomycorrhizal fungal biodiversity and pine seedling growth
}

Lill Eilertsen ${ }^{1}$, Anders Dahlberg'ㄹ, Lina Nilsson ${ }^{1}$, Johanna Urzua ${ }^{1}$, Nicklas Samils ${ }^{3}$, Judith Felten ${ }^{1}$

${ }^{1}$ Swedish University of Agricultural Sciences, Umeå, Sweden; ${ }^{2}$ Swedish University of Agricultural Sciences, Uppsala, Sweden; ${ }^{3} B e r g v i k$ Skog AB, Falun, Sweden (lill.eilertsen@slu.se; anders.dahlberg@slu.se; lina.nilsson@slu.se; johanna.urzua@slu.se; nicklas.samils@bergvikskog.se; judith.felten@slu.se)

The majority of temperate and boreal forest trees live in symbioses with ectomycorrhizal fungi (EMF). Considering the significance of EMF for forest soils, tree growth and health, their conservation is ecologically important. Clear-cutting, that is the predominant forest harvest practice in Sweden, strongly affects the presence and composition of EMF communities in soils. How fungi are affected by alternative harvesting and forest management strategies is debated. Here we focus on gap-harvest as an alternative harvesting practice using DNA amplicon sequencing, currently the most accurate technique to identify fungi in soil. We compare the effect of gap-size $(35,50,70 \mathrm{~m} / \varnothing)$ on seedling growth and EMF biodiversity in humus and mineral soil at an experimental site installed by Bergvik Skog AB in Middle Sweden. To provide both the forest industry as well as conservationists and scientific research with a more rapid and inexpensive method for fungal identification in soil samples, we are also developing a method using hand-held spectroscopic devices. To validate this method, results on sensitivity and specificity of fungal identification in soil samples, will be compared to data from DNA-amplicon sequencing. This has the potential to allow vast data acquisition on effects of forest management and harvesting practices on EMF biodiversity, as well as to enable routine measurements for matching EMF inoculum for nurseries to the EMF composition at sites of out-planting. The long-term aim of this project is to provide novel tools and research-based guidelines for more sustainable forestry where EMF and their potential benefits are taken into account.

\section{Radial and axial variation on the wood structure of some 'giant' mistletoes: three species of Loranthaceae}

Victor Sibinelli ${ }^{1}$, Luiza Teixeira-Costa ${ }^{1}$, Gregório Ceccantini ${ }^{1}$

'Universidade de São Paulo, São Paulo, Brasil (sibinelli95@gmail.com; luiza.teixeirac@gmail.com; gregorio@usp.br)

Mistletoes, from a hydraulic perspective, show one of the most interesting examples of xylem structure. These plants can develop a "chimeric sap transport system", which comprises both host and parasite woods. At the connection site there is a complex structure generally called haustorium, that connects cells of host and parasite. Additionally, these parasites may cause an overload for the transport capacity, since they usually bear stomata in both leaf faces, which low gas exchange control. Therefore, the capacity to regulate and adjust the transport system is a key factor in determining the probability of survival of a parasitic plant. This work investigated whether and how the wood structure of some mistletoes varies within the stem topology. Three Loranthaceae species with variation in size and form, but all with relatively large dimensions were studied either radially or axially. Psittacanthus robustus is a woodrose-forming shrub with thick branches up to $3 \mathrm{~m}$ long and $4 \mathrm{~cm}$ in diameter; Tripodanthus acutifolius, a lianescent/tree species that reaches several meters; and Struthanthus flexicaulis, a decurrent shrub with very flexible and long stems. Our data suggest that, at least the thickest calibre species (P. robustus and T. acutifolius) indeed reached a state of wood maturity. In the case of Struthanthus flexicaulis, our data suggest that one of two things might be occurring: i) there is a reduction on the mean vessel diameter, lowering the risk of cavitation; ii) there is an increase in the total vessel density, increasing the redundancy of the system

\section{Ectomycorrhizal community composition changes along to silver fir (Abies alba Mill.) phenological stages in Slovenia}

Tina Unuk ${ }^{1}$, Domen Finžgar ${ }^{1}$, Rok Damjanic ${ }^{1}$, Tine Grebenc ${ }^{1}$, Hojka Kraigher ${ }^{1}$

'Slovenian Forestry Institute, Ljubljana, Slovenia (tina.unuk@gozdis.si; domen.finzgar@gozdis.si; rok.damjanic@gozdis.si; tine.grebenc@gozdis.si; hojka.kraigher@gozdis.si)

The timing of leaf phenology is one of the most important characteristics for tree growth and survival. In most forest tree roots form symbiotic associations with mycorrhizal fungi, however till date still little is known about effects of mycorrhizal fungi on tree phenology and vice versa. The aim of this study was to analyze ectomycorrhizal fungal community of silver fir and changes in abundance linked to phenology. The phenological stages of silver fir trees were followed weekly for two years, and along these, 5 soil cores per individual observed silver fir tree were analyzed for ectomycorrhizal symbionts, which were further identified using Sanger sequencing of an individual ectomycorrhizal morphotype. Analyzes of beta diversity between phenological stages revealed significant differences in the overall ectomycorrhizal community between dormancy and bud bursting, whereas there is an overlap between ectomycorrhizal community in dormancy and full needle expansion as well as between bud bursting and full needle expansion. Abundance analyzes of ectomycorrhizal species between phenological stages revealed higher abundances of Russula ochroleuca, Tomentella stuposa, Tomentella sublilacina and Tylospora fibrillosa during bud bursting, which are ectomycorrhizal species for which the presence of manganese peroxidase and/or laccase has already been suggested or confirmed. Our results indicate a need for more detailed analyzes of possible presence of mentioned enzymes, as well as any hormonal regulation among ectomycorrhizal species associated with bud burst and silver fir trees. The presentation contributes to the aims and means of the project LIFEGENMON (LIFE13 ENV/SI/000148). 
Effects of the parasitism of the mistletoe Struthanthus martianus (Loranthaceae) on the reduction of increment in Tipuana tipu (Leguminosae): evidence of a systemic effects by one single parasitized branch

Evelyn Pereira Camargo ${ }^{1}$,Eduardo Mineo Iegawa ${ }^{1}$, Luiza Teixeira-Costa ${ }^{1}$, Gregorio Ceccantini ${ }^{1}$

IUniversidade de São Paulo,São Paulo,Brasil (camargoevelyn@usp.br; eduardoiegawa@usp.br; luiza.teixeirac@gmail.com; gregorio@usp.br)

The mistletoe species Struthanthus martianus (Loranthaceae) is a generalist hemiparasite native to Brazil. Among its many host species, it is frequently observed to infest an urban tree species named Tipuana tipu (Leguminosae), originally endemic species to Northern Argentina Given to the clearly marked semi-porous growth rings, $T$. tipu is widely used in dendrochronological analyses. In the present study, we have analyzed the influence of the parasite $S$. martianus on the annual growth rates of T. tipu. From infested trees, both parasitized (PB) and non-parasitized branches (NPB) were sampled. Branches from non-infested trees (NIT) were also sampled and analyzed. Our results show that, despite the overall decrease in growth rates for all analyzed samples, during the five most recent rings, both PB and NPB a faster decrease in growth rates was detected, which was indicated by the slope of the adjusted growth curve. This recent decrease could correspond to the moment in time when the presence of the parasite starts affecting host branch growth. Also, this is evidence of a systemic effect, since branches without a parasite also respond in growth decrease. However, phenological observations of other host-parasite pairs in the same area show no increase in death rates of neither host branches, nor the trees themselves. This suggests a mild effect of $S$. martianus when compared to other mistletoe species, such as Arceuthobium spp. and Phoradendron spp. Further whole-tree dendrochronological analyses could improve our understanding of the growth dynamics of parasitized trees, especially in tropical and/or urban areas.

\section{'Large' mistletoe parasitism in a conifer host: anatomy of the interface between Psittacanthus cf schiedeanus and Pinus hatwegii}

Mariana Oliveira-da-Silva ${ }^{\prime}$, Luiza Teixeira-Costa ${ }^{I}$, Gregório Ceccantini ${ }^{\perp}$

${ }^{1}$ University of São Paulo, Institute of Biosciences, Department of Botany, Rua do Matão 277, 05508-090, São Paulo, Brazil (mariana.oliveira.silva@usp.br; luiza.teixeirac@gmail.com; gregorio@usp.br)

Mistletoes of the genus Psittacanthus (Loranthaceae) are large-sized hemiparasites that infest a wide range of hosts, including conifers. However, similar to what has been observed for other Loranthaceae species, the relationship between Psittacanthus spp. and conifers are rare, thus not often analyzed. As part of a larger effort to understand how angiosperm parasitic plants are able to establish vascular connections with conifer hosts, this work aimed at analyzing the anatomy of the host-parasite interface between Psittacanthus cf schiedeanus and Pinus hartwegii. Light, confocal and electron microscopy were used in conjunction with x-ray computed tomography. Our results showed that the general morphology and the three-dimensional structure of the host-parasite connection were similar to what has been reported for Psittacanthus and another angiosperm-host associations. Detailed anatomical analyses revealed that the mistletoe attaches the host xylem conduits via parenchyma cells, bridging the parasite vessel elements and the tracheids of the host. This pattern contrasts with the direct xylary (from one tracheal element to another) reported for Psittacanthus sp.-angiosperm host associations, as well as for Arceuthobium sp.-conifer host associations. Being composed of tracheids, the vascular system of $P$. hartwegii offer higher resistance to sap flux, which probably would require the parasite to reach a lower-thanusual water potential in order diverge sap flux towards itself. By establishing vascular connections with the host via parenchyma cells, which normally contain various solutes, this might lower cell water potential even more than the usual, allowing $P$. cf schiedeanus. to be able to successfully infest $P$. hartwegii.

\section{Effects of the parasitism of the mistletoe Phoradendron bathyoryctum (Santalaceae) on the increment of tree rings in urban trees of Cedrela fissilis (Meliaceae)}

Eduardo Mineo Iegawa ${ }^{I}$, Evelyn Pereira Camargo ${ }^{I}$, Gregório Ceccantini ${ }^{I}$, Luiza Teixeira-Costa ${ }^{1}$

IUniversity of Sao Paulo, Sao Paulo,Brazil (eduardoiegawa@usp.br; camargoevelyn@usp.br; gregorio@usp.br; luiza.teixeirac@gmail.com)

Dendrochronology is the study of tree-rings and their use for estimating information on the growth of the analyzed plants and also the environment in which it happened. In the present work we have analyzed the increment rate (growth-ring width) of branches of the host tree Cedrela fissilis (Meliaceae) parasitized by the mistletoe Phoradendron bathyoryctum (Santalaceae). Based on previous analyses of $C$. fissilis trees, showing no significant effect of this parasitism on the main trunk, this time we have chosen to analyze parasitized branches (PB), non-parasitized branches of otherwise parasitized trees (NPB), and branches from healthy, non-parasitized trees (NPH). Despite the relatively young age of the analyzed branches, we observed that during the period (2009 - 2011) in which NPH individuals grew less, both PB and NPB individuals grew more. This inverse growth pattern could indicate a short-term positive effect of the parasite not only on the infested branch but also on other branches of the same tree. However, highly infested trees were still observed to die, probably due to long-term effects of the parasite $P$. bathyoryctum. Probably those effects could overcome punctual positive ones on host branch growth, such as continuous and prolonged high hydric stress for the branch and the whole plant since it's known that a parasite can demand as much water as a host.

\section{Undetected endophytic fungi as a quarantine risk to commercial Eucalyptus plantations in Colombia}

Ginna Marcela Granados ${ }^{1}$, Alistair R. McTaggart ${ }^{2}$, Carlos Alberto Rodas ${ }^{3}$, Jolanda Roux ${ }^{4}$, Michael J. Wingfield ${ }^{1}$ ${ }^{1}$ Forestry and Agricultural Biotechnology Institute (FABI), University of Pretoria, Pretoria, South Africa; ${ }^{2}$ Queensland Alliance for Agriculture and Food Innovation, University of Queensland, Queensland, Australia; ${ }^{3}$ Smurfitkappa Colombia, Yumbo, Colombia; ${ }^{4}$ Sappi, Hilton, South Africa (ginna.granados@fabi.up.ac.za; a.mctaggart@uq.edu.au; carlos.rodas@smurfitkappa.com.co; jolanda.roux@sappi.com; mike.wingfield@up.ac.za)

Healthy plant tissues pose a cryptic quarantine threat to global forests and forestry because undetected endophytic fungi can be moved with them. Host shifts between Melastomataceae and Myrtaceae by different species of Cryphonectriaceae has increased the host range of a number of important stem canker pathogens. For example, species of Chrysoporthe, which cause serious canker diseases on commercially planted Eucalyptus, also occur as asymptomatic endophytes in native Myrtaceae. The aim of this study was to identify possible species of Cryphonectriaceae that occur as endophytes in four native hosts from Colombia and two that have been introduced from Brazil. Healthy branches of each Melastomataceae host were collected from five provinces in Colombia, and then incubated between 2 to 4 weeks to stimulate production of Cryphonectriaceae fruiting bodies. Isolates were identified based on DNA sequence data for two gene regions. The results revealed three species of Cryphonectriaceae namely Aurapex penicillata, Chrysoporthe inopina and C. cubensis. Host specificity was not observed for species of Cryphonectriaceae on Melastomataceae. Aurapex penicillata is now known as an endophyte in four species, and $C$. inopina and $C$. cubensis were endophytic in three hosts each. Chrysoporthe cubensis was also found in symptomatic lesions on native M. rubiginosa. Native and introduced tree species in the Melastomataceae that occur naturally alongside Eucalyptus plantations could thus act as a reservoir of potential pathogens to commercial plantations. This has important implications on quarantine programs regarding the movement of latent, endophytic pathogens in apparentlhy healthy plant material. 


\author{
Phytophthora-damage in deciduous forests of Southern Sweden: from genes to landscape \\ Johanna Witzell ${ }^{\text {ID, Michelle Cleary }}{ }^{\text {(D) }}$ \\ 'Swedish University of Agricultural Sciences, Southern Swedish Forest Research Centre, Alnarp, Sweden (johanna.witzell@slu.se; michelle.cleary@slu.se)
}

Phytophthora-pathogens have recently emerged as a challenging forest health problem in southern Sweden, reducing the vitality of trees and leading to instability and premature mortality. The invasive behavior of these pathogens, and their ability to adapt to different conditions result in a forest disease problem that has a potential to profoundly worsen the conditions for forest production and conservation. Starting in 2010-2011, extensive Phytophthora-damages were registered on European beech (Fagus sylvatica) in urban settings and national parks in southern Sweden. Using field site surveys of symptomatic trees, classical isolation techniques and sequencing of soil and tissue samples we mapped Phytophthora-damage on beech and identified the causal agents. Oomycete diversity was determined by sequencing ITS environmental DNA (eDNA) from stem tissues and soil (multiplex-sequenced using 454- and Illumina MiSeq), while isolates were identified via Sanger sequencing. Results revealed the presence of $P$. plurivora, $P$. cactorum, P. syringae, $P$. cambivora, and $P$. gonapodyides. This was the first time $P$. gonapodyides has been associated with stem damages on beech in Sweden. Alarmingly, there are now indications that the disease front for Phytophthora spp. is advancing in the landscape, and Phytophthora-pathogens are increasingly affecting also other tree species than beech. The spreading pathways and consequences of Phytophthora, as well as management options in urban and production forest settings are discussed.

\title{
First report of cottonwood leaf beetle Chrysomela scripta (Coleoptera: Chrysomelidae) in South America
}

Carlos Wilcken ${ }^{1}$, Amanda de Souza ${ }^{1}$, Carolina Jorge ${ }^{2}$

${ }^{1}$ Universidade Estadual Paulista “Júlio de Mesquita Filho”, Botucatu, Brasil; ' ${ }^{2}$ nniversidad de La Republica (UDELAR), Tacuarembó, Uruguay (carlos. wilcken@unesp.br; agroamandarodrigues@yahoo.com.br; carolina.jorge@cut.edu.uy)

The insect pest invasions in forest plantations were significantly increased in the latest decades. The forestry genera most planted for commercial purposes in the world are Eucalyptus, Pinus, Populus, Acacia, Toona, among others. In South America species of Populus and Salix are secondary in importance to industry but are commonly used as urban trees. The leaf beetles of the Chrysomelidae family are the main insect pest affecting poplar plantations in North America, especially of the genus Chrysomela, where Chrysomela scripta is consider the most harmful species. C. scripta is endemic of North America, being more abundant in poplars plantations in the United States. The aim of this work was report for the first time the presence of C. scripta in Brazil. In July, 2016 some beetles unidentified were observed feeding in trees of Salix nigra and Populus deltoides in an urban area of Botucatu municipality in São Paulo State, Brazil, causing complete defoliation. In June 2017 were observed in Piracicaba. Adults, larvae, pupae and eggs were collected and reared in laboratory. These specimens were identified as the exotic species Chrysomela scripta (Coleoptera: Chrysomelidae). This is the first detection of this exotic pest outside their natural range is important for the development of the sanitary surveillance strategies to prevent the expansion of this species and evaluate their impact in Salix humboldtiana, a native species. Studies to determine the bioecology and distribution of C. scripta in Brazil are ongoing.

\section{Improving diagnostics for Xylella fastidiosa, a potential threat to UK's trees}

\author{
Sundeep Kaur ${ }^{1}$, Alex Lewis ${ }^{1}$, Caroline Gorton ${ }^{1}$, Ruth Chitty ${ }^{1}$, Ana Pérez-Sierra', Sietse van der Linde ${ }^{1}$ \\ ${ }^{1}$ Forest Research, Alice Holt Lodge, Farnham, Surrey GU ${ }^{10}{ }^{4} \mathrm{LH}$, United Kingdom \\ (sundeep.kaur@forestresearch.gov.uk; alex.lewis@forestresearch.gov.uk; caroline.gorton@forestresearch.gov.uk; ruth.chitty@forestresearch.gov.uk; \\ ana.perezsierra@forestresearch.gov.uk; sietse.vanderlinde@forestresearch.gov.uk)
}

The bacterium Xylella fastidiosa has a large host range including over 500 plant species. Broadleaf tree hosts such as oak (Quercus), plane (Platanus) and elm (Ulmus) have already been identified in Xylella affected regions in North America. Some trees can be infected with low-level or asymptomatic symptom expression and could potentially act as reservoirs of the pathogen in the wider environment, possibly asymptomatically. Current diagnostics rely on $X$. fastidiosa-specific real-time PCR assays for detection (EPPO PM7/24(3)). The diagnostic process relies on DNA extraction from potentially infected plant tissue and sample processing is labour intensive and time-consuming. In real-time PCR detection trials with various tissue types and different potential host trees, it was found that the sensitivity of the molecular detection varied markedly between tissue type and tree host. This is most likely due to varying amounts of secondary metabolites in foliage of some of the key tree hosts which inhibit detection assays and affect sensitivity. Positive Xylella detection is followed by multilocus sequence typing for subspecies identification. Subspecies of $X$. fastidiosa show a varying degree of host-specificity and subspecies identification is therefore important in case of a new outbreak. The aim of this study is to make adjustments to current DNA extraction protocols and real-time assays to reduce sample processing time and improve overall detection sensitivity and efficiency on trees. These improvements can be applied to newly developed diagnostic technologies which will aid tree health inspectors during an outbreak situation.

\section{A project for a Eucalyptus sentinel garden in the Mediterranean island of Sardinia (Italy)}

Giuseppe Brundu ${ }^{1}$, Arturo Cocco ${ }^{1}$, Vanessa Lozano ${ }^{1}$, Roberto Mannu ${ }^{1}$, Ignazio Floris ${ }^{1}$

IDepartment of Agriculture, University of Sassari, Sassari, Italy(gbrundu@tin.it; acocco@uniss.it; vlozano@uniss.it; rmannu@uniss.it; ifloris@uniss.it)

Sentinel plants and sentinel gardens are commonly located close to high risk areas in order to timely detect signs and symptoms of novel pest attacks. They are an important part of the post-border surveillance toolbox and can be carried out for early detection of recently-introduced, non-native species, therefore increasing chances of eradication and control. Occasionally, sentinel plants and sentinel gardens may also help in identifying new associations between pests and planted trees. Many non-native trees used in planted forest are successful because they have been separated from their natural enemies. However, when plantation trees are reunited with their coevolved pests, which might be introduced accidentally, or when they face novel pests to which they have no resistance, substantial damages can be observed. Among non-native trees, eucalypts play a very important role in the economies of many countries, including the Mediterranean and Europe, but there might be also environmental, economic and social concerns associated with their widespread use, namely on biodiversity, water and soil resources. Plantations of eucalypts have increased during the last 50-70 years and have experienced a steady increase of pest problems as well. Fairly large numbers of native pests and pathogens have also adapted to feed on or infect eucalypts in the non-native range. Considering the importance of this group of species for the southern Italian region, the Sardinian Regional Authority, Environmental Directorate supported the establishment of a Eucalyptus sentinel garden in the Mediterranean island of Sardinia (Italy). We here describe its preliminary planning and establishment phases. 
Ecological restoration and protection of ant fauna in an Andean forest (Bello, Colombia) / Restauración ecológica y protección de la mirmecofauna en un bosque andino (Bello, Colombia)

David Felipe Bulla Guaqueta ${ }^{\prime}$, Jaime Polanía ${ }^{1}$ Carolina Serna ${ }^{1}$

'Universidad Nacional de Colombia, Medellin, Colombia(dfbullag@unal.edu.co;jhpolaniav@unal.edu.co; csernac@unal.edu.co)

En el corregimiento San Félix (Bello, Colombia), a $2510 \mathrm{msnm}$, con $17^{\circ} \mathrm{C}$ promedio, se desarrollan ganadería y agricultura. Los campesinos atacan las "plagas", especialmente hormigas, con productos organofosforados ('Lorsban'), su uso excesivo ha reducido drásticamente la diversidad local. Este estudio se enfocó en la diversidad de hormigas en un terreno en proceso de restauración (mediante estacas y núcleos que, desde 2015, han generado un bosque secundario + de 1 ha), cuyas áreas circundantes siguen siendo fumigadas regularmente. El muestreo consistió en 14 trampas de caída: siete en el costado sur y el resto en el norte del terreno; se dispusieron también dos trampas Winkler, una por cada costado. Las trampas fueron recogidas 48 horas después. Se colocaron 14 cebos de proteína por 90 minutos. Las muestras fueron conservadas en alcohol al 70\% y llevadas al laboratorio de Ecología y Manejo de Vida Silvestre de la Universidad Nacional de Colombia Sede Medellín, donde fueron identificados representantes de las subfamilias Myrmicinae y Dolichoderinae (mayoritariamente del género Linepithema). Los géneros de Dolichoderinae presentan hábitos arborícolas y sus especies suelen dominar incluso hasta 4.000 msnm, mientras las de Myrmicinae muestran variedad de adaptaciones ecológicas. Ambas logran coexistir, ya que sus hábitos de forrajeo y formas de nidificación son diferentes. También se encontró abundancia de representantes de órdenes Dermaptera y Collembola, y de los filos Annelida y Mollusca. Esta fauna puede presentarse porque: (i) el bosque secundario actúa como barrera para el insecticida y protege el ecosistema, y (ii) hay mayor disponibilidad de materia orgánica.

\section{Effects of environmental pollution on the physiological and biochemical responses of Roadside Trees}

Hana You ${ }^{1}$, Myeongja Kwak², Suyoung Woo², Jongkyu Lee

${ }^{1}$ University of California, Davis, California, USA; '2University of Seoul, Seoul, Republic of Korea(hnyou@ucdavis.edu; 016na8349@hanmail.net; wsy@uos.ac.kr;gpl90@naver.com)

Environmental pollution is an important issue in metropolitan areas. Roadside trees are directly affected by various source of pollution, to which they show numerous responses. This experiment was conducted to identify the responses of Ginkgo biloba and Platanus occidentalis grown in three different environmental conditions and to assess the possibility of using plant physiological and biochemical parameters as a bio-monitoring factor in urban areas. Ginkgo biloba and Platanus occidentalis are the most abundant roadside tree species in Seoul, the capital city of Korea. The physiological, biochemical and morphological parameters of the roadside tress in High pollution (RH), Low pollution (RL) and Green space (RG) were investigated. RH showed the lowest photosynthetic rate, nitrogen use efficiency, and photo pigment content of the three, and water use efficiency, leaf temperature, ion leakage, and malondialdehyde contents were highest in high polluted condition. The stomatal size, density and closure of the trees did not differ significantly among the RH, RL, and RG. In this study, photosynthetic rate showed a positive correlation with chlorophyll and carotenoid content, whereas it showed a negative correlation with relative ion leakage and leaf temperature. This study was carried out with the support of Development of urban forest management and management technology to reduce air pollutants - Focusing on particulate matter - (Grant No. FE0000-2018-01-2018) from National Institute of Forest Science (NIFoS), Republic of Korea.

\section{Invasion of West Africa sahelian rangelands by the plant Senna obtusifolia: ecological dynamics and local resilient strategies in Burkina Faso \\ Oumarou Ouédraogo ${ }^{1,2}$, Alhassane Zaré $^{3}$, Karim Ouédraogo $^{4}$, Anja Linstädter ${ }^{2}$, Gabin Korbéogo ${ }^{4}$, Adjima Thiombiano \\ ${ }^{1}$ Laboratory of Plant Biology and Ecology-University Joseph Ki Zerbo, Ouagadougou, Burkina Faso; ${ }^{2}$ Range Ecology and Range Management Group Botanical Institute, University of Cologne, Cologne, Germany; ${ }^{3}$ Laboratory of Plant Biology and Ecology-University Joseph Ki-Zerbo, Ouagadougou, Burkina Faso; ${ }^{4}$ Group of research on local initiatives - University Joseph Ki-Zerbo, Ouagadougou, Burkina Faso (ouedraogooumar@yahoo.fr; rezareza093@gmail.com; ouedraogo.karim85@yahoo.com; anja.linstaedter@uni-koeln.de; kgabin1@hotmail.com; adjima_thiombiano@yahoo.fr)}

Rangelands in Sahelian countries are continuously over-grazed decreasing forage resources and causing rapid environmental changes. The invasion of rangelands by a less palatable plant species, Senna obtusifolia could be an indicator of land degradation. This research aims to explore the drivers of invasiveness and evaluate consequences of Senna obtusifolia invasion on Sahelian rangelands systems and on rural population's livelihood. Data were collected through an interdisciplinary approach integrating ecological and socio-anthropological methods in three different climate conditions and two land use systems. The relative dominance of $S$. obtusifolia was significantly $(\mathrm{p}<0.001)$ influenced by topography, climate conditions, land use patterns and the mix-effect of these environmental factors. The level of land invasion by $S$. obtusifolia affected negatively both the above ground biomass production ( $\mathrm{p}=0.002$ ) and the plant richness $(\mathrm{p}<0.05)$ of rangelands. However, the ecological results about the drivers of performance of $S$. obtusifolia were in accordance with the perceptions of local populations. With the scarcity of plant natural resources especially in the Sahel zone, this invasive plant is used for multiple purposes such as food, forage and handicraft. Indeed local populations had in general a positive perception on S. obtusifolia in their environment. With its multiple benefits, the surveyed people hide the negative impacts of this species on the production systems of rangelands. The endogenous uses $S$. obtusifolia offer opportunities for the development of innovations and technologies to control its expansion for a sustainable management of sahelian rangelands and help rural populations to be more resilient from land degradation and climate change.

Urban forestry species most likely to fall in Belo Horizonte, Minas Gerais, Brazil / Análise das espécies da arborização urbana com maior frequência de queda em Belo Horizonte, $M G$

Agnus Bittencourt ${ }^{1}$, Marina Souza ${ }^{2}$, Angeline Martini ${ }^{3}$

${ }^{1}$ Prefeitura Municipal de Belo Horizonte, Nova Lima, Brasil; ${ }^{2}$ Cemig, Belo Horizonte, Brasil; ${ }^{3}$ Universidade Federal de Viçosa, Viçosa, Brasil (agnus@pbh.gov.br; mourasouzam@gmail.com; martini.angeline@gmail.com)

O correto planejamento e manejo da arborização urbana permite a otimização dos benefícios proporcionados pelas árvores, bem como a diminuição de problemas. Esta pesquisa teve como objetivo identificar as espécies arbóreas com maior ocorrência de queda no município de Belo Horizonte. Para isso, os dados foram coletados por meio de amostragem aleatória após a ocorrência das quedas, entre os anos de 2015 e 2018 . Um pesquisador se deslocou ao local, sempre após o registro da queda para realizar a identificação botânica. A análise, realizada em 69 exemplares arbóreos indicou a queda de 24 espécies pertencentes a 10 famílias botânicas. A família que apresentou o maior número de queda dos indivíduos foi Fabaceae, correspondente a 46,3\% do total. Sete espécies foram responsáveis por aproximadamente $60 \%$ das quedas registradas, destas, destacaram-se as espécies Pachira aquatica e Libidibia ferrea var. leiostachya responsáveis por 10,1\% das ocorrências cada uma e Poincianella pluviosa $(8,7 \%)$. Constatou-se um número significativo de quedas caracterizada por indivíduos de espécies nativas do 
Brasil (57,6\%), sendo 36,4\% de espécies nativas da região de Belo Horizonte, 21,2\% das demais regiões do Brasil e 42,4\% de exóticas. Conclui-se, portanto, que os resultados apontados podem contribuir para a melhoria do planejamento e manejo da arborização na cidade, uma vez que fornece informações sobre as espécies com maior frequência de queda e que por consequência necessitam de maior atenção. Recomenda-se que estudos como este se intensifiquem nas cidades brasileiras para garantir o correto desempenho da arborização, auxiliando na diminuição dos problemas ocasionados pelas árvores urbanas.

\title{
D7s: FUNGAL PATHOGENS, CONSERVATION OF FUNGI, AND INSECT CHEMICAL CONTROL
}

\author{
A high resolution phylogeny from the genome data of Teratosphaeria leaf and stem pathogens \\ Janneke Aylward ${ }^{1}$, Francois Roets ${ }^{2}$, Leanne Dreyer ${ }^{3}$, Michael J. Wingfield ${ }^{1}$, Brenda D. Wingfield ${ }^{1}$ \\ ${ }^{1}$ Forestry and Agricultural Biotechnology Institute (FABI), University of Pretoria, Pretoria, South Africa; ${ }^{2}$ Department of Conservation Ecology and \\ Entomology, Stellenbosch University, Stellenbosch, South Africa; ${ }^{3}$ Department of Botany and Zoology, Stellenbosch University, Stellenbosch, South Africa \\ (janneke.aylward@fabi.up.ac.za; fr@sun.ac.za; ld@sun.ac.za; mike.wingfield@up.ac.za; brenda.wingfield@up.ac.za)
}

Teratosphaeria (Dothideomycetes: Capnodiales) is a genus of fungi primarily associated with the leaves of Eucalyptus hosts. Whereas the majority of species appear not to be important, some Teratosphaeria species have emerged as aggressive pathogens causing substantial economic losses in areas where Eucalyptus spp. are grown as exotics in plantations. Two of these are unusual in being stem canker pathogens rather than infecting leaves and shoots. The taxonomic relationships for this diverse group are generally poorly resolved, especially at the deeper branches of phylogenetic trees. The aim of this study was to construct a robust phylogenomic tree to resolve the relationships among Teratosphaeria species for which whole genome sequences are available. We incorporated seven Teratosphaeria species into the phylogenomic tree, using a total of 11 genomes that have been sequenced by our research group. Single-copy, orthologous core genes, shared by all isolates, were identified using the Ascomycota dataset in BUSCO (Benchmarking Universal Single-Copy Orthologs). More than 1000 orthologous genes were used to construct a Maximum Likelihood phylogeny with RaXML. The resultant phylogenomic tree provided strong support for internal branches that were poorly supported in single-gene trees.

\section{Life cycle and field epidemiology of the rust pathogen Uromycladium acaciae on Acacia mearnsii}

Stuart Fraser ${ }^{1,2}$, Alistair McTaggart ${ }^{1,3}$, Jolanda Roux ${ }^{1}$, Michael J. Wingfield ${ }^{1}$

${ }^{1}$ Department of Plant and Soil Sciences, Tree Protection Co-operative Programme (TPCP), Forestry and Agricultural Biotechnology Institute (FABI), University of Pretoria, Pretoria, South Africa; ${ }^{2}$ Scion, Rotorua, New Zealand; ${ }^{3}$ Queensland Alliance for Agriculture and Food Innovation, The University of Queensland,Brisbane,Australia (stuart.fraser@scionresearch.com; a.mctaggart@uq.edu.au; jolanda.roux@gmail.com; mike.wingfield@fabi.up.ac.za)

Uromycladium acaciae causes a rust disease that threatens black wattle (Acacia mearnsii) forestry in South Africa. Little is known regarding the life cycle or field epidemiology of the pathogen. Knowledge on these aspects is required in order to develop an integrated pest management programme for this disease. Disease monitoring and spore trapping were undertaken at three infected plantations of $A$. mearnsii in Mpumalanga. These studies considered the following hypotheses based on observations from prior controlled experiments: (i) uredinia and telia of $U$. acaciae are not conspecific; (ii) teliospores of $U$. acaciae are the main dispersal agents (rather than basidiospores) and spread mainly under wet conditions, (iii) conditions during the summer wet season (October - March) will be optimal for dispersal of teliospores and infection by basidiospores. Observations supported all three hypotheses. Spermogonia and telia co-occurred regularly on both developing and fully developed plant tissues, whereas uredinia were observed only on fully expanded leaves. Spermogonia and uredinia were not observed co-occurring without telia. Furthermore, single nucleotide polymorphisms and indels of rDNA in uredinia were not present in next-generation sequences from telia. Teliospores were observed abundantly on spore traps. There was a positive relationship between relative humidity and abundance of teliospores. There was a polynomial relationship between rainfall and abundance of teliospores, with a predicted peak in abundance of teliospores at c; 9 mm rain day-1. Although teliospores were observed on traps at all trapping periods, the greatest abundance of teliospores were observed towards the end of the wet season in February-March 2017.

\section{Fusarium circinatum on non-pine hosts enhance the global threat of pine pitch canker}

Darryl Herron ${ }^{l, 2}$, Emma Steenkamp ${ }^{l, 2}$, Brenda Wingfield ${ }^{1,2}$, Michael J Wingfield ${ }^{1,2}$

${ }^{1}$ FABI, Pretoria, South Africa; ${ }^{2}$ University of Pretoria, Pretoria, South Africa (darryl.herron@fabi.up.ac.za; emma.steenkamp@up.ac.za; brenda.wingfield@up.ac.za; mike.wingfield@fabi.up.ac.za)

Since the original discovery of the pitch canker fungus, Fusarium circinatum, in the United States of America in 1945, the pathogen has spread to almost every continent on the planet. Originally a pathogen of Pinus species and Pseudotsuga menziesii, we now know that it can also colonise non-coniferous plants, including different grass and herbaceous plant species, as an endophyte. In South Africa, we investigated this endophytic association by identifying the Fusarium species inhabiting sixteen species of grass occurring in the understory of pitch canker-affected Pinus patula trees in a commercially managed plantation. Isolates were identified using their morphological characteristics as well as by phylogenetic inference based on DNA sequences for the beta-tubulin and translation elongation factor-1-alpha gene regions. A number of important Fusarium species were recovered from these grasses, including $F$. circinatum, which was found on five of the sixteen grass species examined. The cryptic occurrence of $F$. circinatum in non-coniferous plants highlights a need to consider the role that other plant species might play in its biology and distribution. It also raises a quarantine threat that has not been fully considered in the past. This is amplified by the fact that new and highly virulent genotypes of the pathogen could easily be introduced into countries where $F$. circinatum is known to occur. Such introductions of novel and virulent genotypes would set back already established breeding programmes that have focused on limiting the damage caused by genotypes already in a country. 


\section{Volatile organic compounds to identify root and butt rot pathogen Armillaria spp.}

Nicola La Porta ${ }^{1,2}$, Claudia M.O. Longa ${ }^{1}$,Andrea Corinzia ${ }^{3}$, Luca Cappellin ${ }^{1}$, José Sanchez del Pulgar ${ }^{1}$, Franco Biasioli ${ }^{1}$

${ }^{1}$ IASMA Research and Innovation Centre, Fondazione Edmund Mach, Trento, Italy; ${ }^{2}$ The EFI Project Centre on Mountain Forests (MOUNTFOR), Trento, Italy; ${ }^{3}$ University of Catania, Catania, Italy (nicola.laporta@fmach.it; claudia.longa@fmach.it; andrea.corinzia89@gmail.com; luca.cappellin@fmach.it; jose.sanchez@fmach.it; franco.biasioli@fmach.it)

PTRMS-TOF analysis of Armillaria volatomic profile was used as molecolar tools for the taxonomic identification of six European species of genus Armillaria: A. borealis , A. cepistipes, A. gallica, A. mellea, A. ostoyae and A. tabescens. This mycete is known as honey mushroom and it is one of the main opportunistic pathogenic fungus found in many forest and ornamental trees where it causes white root rot. It is also a saprotroph who allows the wood degradation and the easy transfer, by wood trade, the other more than 40 esotic species present in the other continents. Volatile Organic Compounds (VOC) pattern was analyzed for 77 strains of Armillaria by PTR- MS-TOF technique in order to discriminate the species. Armillaria strain were previously identified by DNA amplification by PCR. Samples were analyzed after 30 days of incubation to allow the mycelial growth on MEA substrate added with silver fir sawdust. Data analysis was performed using univariate and multivariate statistical tools. The analysis of variance (ANOVA) discriminated $A$. borealis by using acetylene concentration and $A$. cepistipes by using hexanal concentration. The distribution of specific masses concentration, as a function of species by boxplots, allows to discriminate A. tabescens, A. borealis, A. cepistipes and A. mellea. Principal component analysis allows discriminate the A. borealis and A. tabescens clusters. The future improvement of this approach is to identify some VOC which can discriminate invasive Armillaria species to develop a rapid and accurate identification diagnostic method based on gas chromatographic separation of these VOCs.

\section{A wide host range and high levels of genetic diversity characterise Cryphonectriaceae stem canker pathogens on Myrtales in Southern China}

Wen Wang ${ }^{1}$, Michael J. Wingfield ${ }^{2}$, ShuaiFei Chen ${ }^{1}$

${ }^{1}$ China Eucalypt Research Centre (CERC), Chinese Academy of Forestry (CAF), ZhanJiang, China; ${ }^{2}$ Forestry and Agricultural Biotechnology Institute

(FABI),University of Pretoria, Pretoria, South Africa (wangwencerc@126.com; mike.wingfield@fabi.up.ac.za; cerccsf@126.com)

Plantation-grown Eucalyptus (Myrtaceae) and other trees residing in the Myrtales have been widely planted in Southern China. These fungal pathogens include fungi of Cryphonectriaceae that are well-known to cause stem and branch canker disease on Myrtales trees. During recent disease surveys in southern China, fruiting structures with typical characteristics of the Cryphonectriaceae were observed on the surfaces of cankers on stems and branches of Myrtales trees. In this study, a total of 206 Cryphonectriaceae isolates were identified based on comparisons of DNA sequence of the partial LSU gene, ITS region of the nuclear ribosomal DNA gene, two regions of the $\beta$-tubulin $(B T 2 / B T 1)$ gene and the translation elongation factor 1-alpha (TEF-1a) gene region, as well as their morphological characteristics. The results showed that eight species reside in four genera of Cryphonectriaceae occurring on five genera of Myrtales. These included Celoporthe cerciana from a Eucalyptus grandis hybrid clone, C. eucalypti from Syzygium jambos (Myrtaceae), C. guangdongensis from S. jambos, C. syzygii from E. grandis hybrid clones, Psidium guajava (Myrtaceae), S. hancei, S. jambos and S. samarangense. The notorious pathogen Chrysoporthe deuterocubensis was identified from E. grandis hybrid clones, Melastoma candidum (Melastomataceae), M. sanguineum, P. guajava, S. jambos and S. samarangense. A novel species of Aurifilum was isolated from Terminalia neotaliala (Combretaeeae) and an undescribed genus including two species of Cryphonectriaceae were identified from E. grandis hybrid clones. This study revealed an unexpected and surprising level of Cryphonectriaceae diversity on a wide-range of Myrtales hosts in southern China.

\section{Designing chemical control measures against fungus gnats in log yards}

Guilherme Schnell Schühli ${ }^{1}$, Wilson Reis Filho ${ }^{2}$, Susete do Rocio ChiarelloPenteado ${ }^{1}$

${ }^{1}$ Embrapa Colombo, Colombo, Brasil; '2Epagri, Florianópolis, Brasil (guilherme.schuhli@embrapa.br; wilson.reis@colaborador.embrapa.br;

susete.penteado@embrapa.br)

For the production of wood panels, it is important to keep the continuous supply of logs to the plant. Therefore, the factories usually maintain log yards (Pinus elliiottii and P. taeda) where these logs are arranged in piles. The environmental conditions provided by these piles predispose the boom of large populations of fungus gnats (Sciaridae) (as Bradysia matogrossensis, Euricrium varians and E. edwardsi). These insects cause discomfort to the workers, disturbing the operation of the plant and impacting the surrounding urban areas. Based on the observation of the chemical treatments adopted by the companies and a small scale experiment, we present here a strategy for the control. We recommend the use of Carbamate (80\%) and Pyrethroid (40\%) in alternate applications (in order to manage the effects of biological resistance). Alpha-cypermethrin (12\%) and Fipronil (18\%) may also be an alternatives tools to reach individuals that may acquire resistance due to chemical selection. The chemicals may be applied with a manual knapsack sprayer, nonetheless, mist blower or agricultural cannon sprayer will perform better. These chemicals can also be applied at a cargo disinfection arch, treating the load on the trucks at the entrance to the yard. This would minimize the colonization of the piles and increase the treated surface area. We advise against the use of organophosphates since there is cross-resistance with the pyrethroid and also due to its greater toxicity to vertebrates.

\section{Threats and mitigation to macrofungi (Mushroom) conservation in the Mount Cameroon Region, Central Africa}

Tonjock Rosemary-Kinge ${ }^{1}$, Afui Mathias Mih ${ }^{2}$

${ }^{1}$ Department of Biological Sciences, Faculty of Science, The University of Bamenda, Bamenda, Cameroon; '2Department of Botany and Plant Physiology, Faculty of Science, University of Buea, Buea, Cameroon (rosemary32us@yahoo.com; mathias.afui@ubuea.cm)

Mount Cameroon is found in the South West Region of Cameroon and is diverse with macrofungi species which have socio-economic functions as food and medicine, and also play essential roles in ecosystem functioning such as in decomposition and forming mycorrhizae association. Inhabitants of this region depend on the forest for their livelihood. This study was carried out for 2 years to assess the threats to macrofungi conservation in the mount Cameroon Region and provide solutions to the communities for mitigation. Interviews, questionnaires and focus group discussions were carried out in ten communities living around the Mount Cameroon forest reserves. The major reasons accounted for threats to macrofungi were habitat degradation due to landslides and volcanic eruptions, climate change, over harvesting of some edible and medicinal mushrooms, deforestation for farmlands by the locals and oil palm cultivation by multinational companies, settlement expansion due to urbanization and fire outbreaks by the local communities around Mount Cameroon region. It was found that, though there are laws and policies on biodiversity conservation in Cameroon, these laws are not being implemented with regards to fungi conservation and this can expose fungi to the risk of extinction. Solutions proposed and carried out for mitigation were implementation of in situ conservation methods, cultivation of the over harvested species on local substrates with the communities and planting of fast growing leguminous trees for multipurpose usage to limit deforestation. The government was encouraged to enact and implement laws regarding the conservation of fungi. 


\section{Phytogeographical and sociolinguistical patterns of the diversity, distribution and uses, of wild mushrooms in Côte d'Ivoire,} West Africa

$N^{\prime g o l o}$ Abdoulaye Kone ${ }^{1,2}$ D, Bakary Soro ${ }^{1}$, Linda Patricia Louyounan Vanié-Léabo ${ }^{3}$, Souleymane Konate ${ }^{1}$

${ }^{1}$ Nangui Abrogoua University, Abidjan, Côte d'Ivoire; ${ }^{2}$ Comoe Research Station, Bouna, Côte d'Ivoire; ${ }^{3}$ Felix Houphouet Boigny University, Abidjan, Côte d'Ivoire(ngolo197804@yahoo.fr; s.y.bakary.1@gmail.com; lindaleabo@hotmail.fr; konatesoul.sn@univ-na.ci)

Many fungal species in tropical Africa are useful, with high added value and play essential roles in the structure and dynamic of ecosystems. However, the diversity, distribution and use by local populations of these Non-Timber Forest Products and their respective habitats are still very poorly understood in subSaharan Africa in general and more specifically in Côte d'Ivoire. This study aims at inventorying the wild useful mushrooms of Côte d'Ivoire within its major protected areas and their respective surrounding sociolinguistic groups according to climatic and phytogeographical gradients Field and ethnomycological surveys were conducted. Sixty eight useful wild fungal species, belonging to 17 families and 23 genera, were listed and collected. Four categories of usage were reported by the rural people, with a dominance of food and medicinal uses. Fifty six species were reported to be used as food and 16 species as medicinal fungi. These uses varied not only from one sociolinguistical group to another but also from a visited village to another. These mushrooms were either saprotrophic or symbiotic. Auricularia sp3, Psathyrella tuberculata and Termitomyces spp. were found as the most commonly used mushrooms. Mushrooms are relatively well known and used by the Ivorian people within the main phytogeographic zone of the country. These people also have an interest in all the functional groups with an important phytogeographic zone-fungal specific used species. However, protected areas seem to represent the last sanctuaries of these organisms due to high rate of loss of natural habitats.

\section{D7t: FOREST HEALTH}

\section{Ceratocystidaceae on trees in China and their potential threat to plantation tree health}

FeiFei Liu ${ }^{1,2}$, Irene Barnes ${ }^{1}$, Michael J. Wingfield ${ }^{1}$, ShuaiFei Chen ${ }^{2}$

${ }^{1}$ Department of Biochemistry, Genetics and Microbiology, Forestry and Agricultural Biotechnology Institute (FABI), University of Pretoria, Pretoria, South Africa; ${ }^{2}$ China Eucalypt Research Centre (CERC), Chinese Academy of Forestry (CAF), ZhanJiang, China (feifei.liu@fabi.up.ac.za; irene.barnes@fabi. up.ac.za; mike.wingfield@fabi.up.ac.za; shuaifei.chen@gmail.com)

Species in the genus Ceratocystis occurs on a wide range of hosts and a global distribution, and they include important tree pathogens. However, little is known regarding the species, their diversity, origin or impact of these fungi in China. Recently, large numbers of Ceratocystis isolates and those in the closely related genus Huntiella (Ceratocystidaceae) have been collected from different hosts in five provinces of China. In this study, we identified these species and considered their relative pathogenicity. More than 500 Ceratocystis and Huntiella isolates were obtained from different tree hosts, including freshly cut stumps and wounds of Acacia species, Cunninghamia lanceolata and Eucalyptus species, as well as from some rotten corms of Colocasia esculenta (taro). Morphological and DNA sequence comparisons revealed three novel species of Ceratocystis, including $C$. cercfabiensis from Eucalyptus species, $C$. collisensis from $C u$. lanceolata and $C$. changhui from Co. esculenta, as well as nine novel species of Huntiella, including $H$. confusa from Acacia species, H. ani, H. bellula, H. eucalypti, $H$. fabiensis, H. fecunda, H. glaber, H. inaequabilis and H. meiensis from Eucalyptus. Pathogenicity tests showed that C. cercfabiensis is pathogenic to Eucalyptus, C. changhui can cause black rot on taro corms, and nine Huntiella species produce lesions on Eucalyptus seedlings although they are not considered aggressive pathogens. The results of the study substantially advances our understanding of the host range and distribution of these important genera in China.

Identifying and mapping termites of the genus Nasutitermes Dudley (Termitidae: Nasutitermitinae) in an urban forest fragment in Manaus, Brazil / Mapeamento e identificação de cupins do gênero Nasutitermes Dudley (Termitidae: Nasutitermitinae) em árvores de um fragmento florestal urbano em Manaus

Luiz Neto ${ }^{1}$, Norma Bustamante ${ }^{1}$, Rayssal Vasconcelos ${ }^{1}$, Diulio de Souza ${ }^{1}$

'Universidade Federaldo Amazonas, Manaus, Brasil(luizmouraneto@yahoo.com.br; ncbustamante@gmail.com; rayssagomes85@gmail.com; diulio51@gmail.com)

Espécies de Nasutitermes estão entre as mais abundantes que podem se alimentar de madeiras, devido a existência de bactérias capazes de promover a hidrólise de celulose e xilema no intestino. No entanto, o desequilíbrio ambiental, contribui para que estas demostrem características de nocividade. Por meio do presente estudo, objetivou-se mapear espécies de cupins deste gênero, a fim de obter informações de distribuição e possível preferência por espécies arbóreas específicas. Foram selecionadas 3 áreas no Campus-UFAM: Faculdade de Educação Física e Fisioterapia (T1), Prefeitura (T2) e Bloco U (T3). Árvores com cupinzeiros encontradas nestas áreas, foram identificadas e georreferenciadas. Amostras de cupins foram acondicionadas em frascos contendo álcool $70 \%$, para posterior identificação mediante comparação com chaves ilustradas, nos Laboratórios de Preservação da Madeira (UFAM) e de Entomologia (INPA). No T1 foram identificadas 4 árvores com cupins arborícolas: castanha-do-brasil (Bertholletia excelsa), mangueira (Mangifera indica), buxixu (Licania poeppigii) e buxixu-anil (Miconia regelii). No T2, 2 mangueiras (M. indica) e um tachi-branco (Tachigali vulgaris) e no T3, 4 mangueiras. Quanto às espécies de cupim, a mais frequente foi Nasutitermes surinamenses, sendo encontrada em todas as árvores no T2 e T3. No T1, a mesma espécie ocorreu na castanha-do-brasil e no buxixu, enquanto que na mangueira e no buxixi-anil, foram encontradas Nasutitermes corniger e Cornitermes acignathus, respectivamente. As mangueiras demonstraram maior susceptibilidade ao ataque de cupins, sugerindo que o formato do tronco e dos ramos, as tornam mais atrativas aos cupins por oferecer maior quantidade de alimento e condições para que os ninhos sejam instalados.

\section{Comparison of genomes in closely related Ceratocystis pathogens of trees}

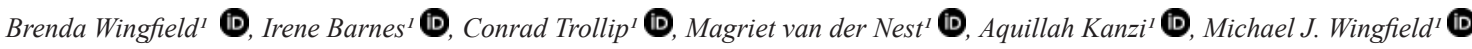

'University of Pretoria,Pretoria, South Africa (brenda.wingfield@fabi.up.ac.za; irene.barnes@fabi.up.ac.za; conrad.trollip@fabi.up.ac.za; magriet.vandernest@fabi.up.ac.za; aquillah.kanzi@fabi.up.ac.za; mike.wingfield@fabi.up.za)

The taxonomic history of Ceratocystis (Ceratocystidaceae), a genus that includes important pathogens of trees is complex and remains a topic of active debate. This is largely because many of the commonly used species recognition concepts (morphological, biological) are inconclusive or violated in this genus. Species delineation in Ceratocystis has relied predominantly on genealogical concordance phylogenetic species recognition (GCPSR) using multiple markers, including the Internal Transcribed Spacer (ITS) region, $\beta$-tubulin and translation elongation factor 1- $\alpha$. Recent research has, however, provided evidence of intragenomic variation in the ITS region and genealogical discordance in the placement of isolates belonging to what has been referred to as the Latin-American clade (LAC). 
This phylogenetic incongruence is not limited to the LAC and increasing numbers of new Ceratocystis species are revealing similar problems. In this study, we examined the level of phylogenetic incongruence in Ceratocystis using a phylogenomics approach, and explored the potential role of hybridization as the source of the incongruent signal. The results once again showed that incongruence is common in Ceratocystis, particularly for species of the LAC, which was typified by three equally represented topologies. The role of hybridization as the possible source of discordance requires further research. This is because, the results of this study could also be explained by high levels of shared ancestral polymorphism in this recently diverged lineage. This study is the first to apply a phylogenomics approach to resolve species boundary questions in Ceratocystis and the results will contribute to our understanding of important pathogens which cause tree diseases.

\title{
QTLs and the genes linked to growth rate differences in Fusarium circinatum, the pine pitch canker pathogen

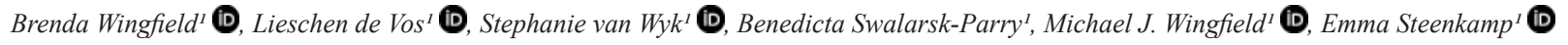 ${ }^{1}$ University of Pretoria, Pretoria, South Africa (brenda.wingfield@fabi.up.ac.za; lieschen.devos@fabi.up.ac.za; stephanie.vanwyk@fabi.up.ac.za; benny.swalarsk@fabi.up.ac.za; mike.wingfield@fabi.up.ac.za; emma.steenkamp@fabi.up.ac.za)
}

More than a 100 genome sequences are now available for Fusarium and in some cases numerous isolates of a single species have been sequenced. Understanding the functions of the proteins coded by the genes in the genome sequences, especially in non-model species, is becoming an increasingly important aspect of disease management and this will clearly be more so in the future. Using a combination of whole genome sequences and a genetic linkage map for a hybrid cross between the pine pitch canker pathogen Fusarium circinatum and F. temperatum, we have identified some key genes involved in growth rate differences in these two species. Genome sequence data were used to map two Quantitative Trait Loci (QTLs) for growth in culture. One QTL allowed for the identification of a five gene indel specific to F. circinatum. The second QTL involves an indel of two genes only in some $F$. circinatum isolates. Further investigations of these QTLs will enable a better understanding of fungal growth in F. circinatum and potentially, also regarding the basis of pathogenicity in F. circinatum and F. temperatum.

\section{Ophelimus eucalypti (Gahan) (Hymenoptera: Eulophidae) insect associated with gall on the Eucalyptus sp. (Myrtaceae) plantation in North Sumatra, Indonesia}

\author{
Mutiara Harapan ${ }^{1}$, Omar Syaref $^{2}$, Alvaro Jorge Duran Sandoval ${ }^{3}$, Adventris Lestarina Hutagaol ${ }^{1}$, Marthin Tarigan ${ }^{3}$, Wagner Souza Tavares ${ }^{3}$, \\ Jupiter Muro Abad \\ ${ }^{1}$ Toba Pulp Lestari, Kerenci, Indonesia; ${ }^{2}$ Toba Pulp Lestari, Porsea, Indonesia; ${ }^{3}$ April Asia, Kerinci, Indonesia (irfan_pasaribu@tobapulp.com; \\ omar_syaref@tobapulp.com; alvaro_duran@aprilasia.com; adventris_hutagaol@tobapulp.com; marthin_tarigan@aprilasia.com; \\ wagner_tavares@aprilasia.com; jupiter_abad@tobapulp.com)
}

Many species of Eucalyptus is attacked for different pest. The gall wasp is one of those that can be very aggressive and with big damage for plantations. The Ophelimus eucalypti is one wasp that attack Eucalyptus and produce a gall as reaction of plant tissue. Biology is actually known for a relatively small number of species as reported in Eucalyptus botryoides Sm. and E. saligna Sm. in New Zealand since 1924. The damage of this insect in commercial plantation can be direct in the susceptible plants, due the high infestation. For the other side, for those clones resistant, can occur a reaction in the plants and abnormal stress that affect growth a new shoots emission. In this research, we found the gall from eucalypts hybrid, which has E. urophylla with other species $E$. grandis and E. pellita. The preferences for oviposition and gall development were determined on young leaves and various age growing on eucalypts plant. Mostly the female oviposited randomly in the margin of leaf. Totally, $O$. eucalypti takes around 35- 40 days for fix the stage from egg until adult. After ovoposition, around 3 to 5 day the wasp emerge as larvae. Some insects are associated with gall, it's emerged from gall which collected from some locations, like Pteromalidae, Torymidae, Eulophidae and Eurytomidae. These insects identified by morphological characters and some are reported in literature as a parasitoid of gall wasp. The knowledge of this life cycle important to direct the different studies and screening of resistant Eucalyptus.

\section{Dry weight and fat content of spruce bark beetles Ips typographus, L., (Coleoptera) during different stages of dispersal Frank Bohlander ${ }^{1}$ \\ ${ }^{1}$ University of Applied Sciences, Erfurt, Germany (frank.bohlander@fh-erfurt.de)}

Dry weight and fat content in male and female spruce bark beetles (1) freshly emerged from a lap rearing, caught inside forest with (2) pheromone slot traps, (3) avoiding pheromone traps and caught with accompanying passive flight traps (4) landing on trap trees, and (5) walking on trap trees for an unknown time, were analysed. Male and female beetles from (1) the lap rearing had a dry weight of 5,2 $\mathrm{mg}(+/-0,23)$ and 4,8mg $+/-0,24)$. Males and females from (2) pheromone slot traps $4,5 \mathrm{mg}(+/-0,8)$ and 4,2 (+/-0,8), respectively. In case of (3) passive flight traps, males weight 4,7 $\mathrm{mg}(+/-0,6)$ and females $4,1 \mathrm{mg}(+/-0,8)$. Males landing on trap trees $4,7 \mathrm{mg}(+/-0,9)$ females $4,5 \mathrm{mg}(+-/ 0,9)$ and (5) 4,2 $\mathrm{mg}(+/-0,8)$ and 4,6 $\mathrm{mg}(+/-) 0,6)$, respectively. The content of lipids in the bark beetles was measured in acyl ester equivalents (nmol/mg dry weight) The males and females of the five groups (1-5) showed noteworthy differences. (1) $976 / 886$ nmol/mg; (2) 369/365; (3) 624/539; (4) 452/445); (5) 460/361. Moreover, the amount of acyl ester equivalents within the 4 groups from the forest showed high variances. Due to the different energetic status beetles could be differentiated. Beetles caught with pheromone traps seemed to be strongly exhausted, whereas beetles caught by passive traps had the highest average reserves. In accordance with other findings Ips typographus seems to be more susceptible to pheromone signals when his energetic reserves decrease.

\section{Genetic analyses reveal signatures of host specialization and recent host shifts in the Ceratocystis manginecans complex}

FeiFei Liu ${ }^{1,2}$, Tuan A. Duong ${ }^{1}$, Irene Barnes ${ }^{1}$, Michael J. Wingfield ${ }^{1}$, ShuaiFei Chen ${ }^{2}$

${ }^{1}$ Department of Biochemistry, Genetics and Microbiology, Forestry and Agricultural Biotechnology Institute (FABI), University of Pretoria, Pretoria, South Africa; ${ }^{2}$ China Eucalypt Research Centre (CERC), Chinese Academy of Forestry (CAF), ZhanJiang, China (feifei.liu@fabi.up.ac.za; tuan.duong@fabi.up.ac. za; irene.barnes@fabi.up.ac.za; mike.wingfield@fabi.up.ac.za; shuaifei.chen@gmail.com)

Large-scale population structure analyses of pathogens can shed light on their diversity, migration patterns and evolutionary history. This could be particularly important for fungal pathogens such as Ceratocystis manginecans and C. eucalypticola (C. manginecans complex), that are known to occur on different continents and are able to spread to new regions and plant hosts relatively easily. In this study, ten microsatellite markers were used to determine the genotypes of 500 isolates residing in the C. manginecans complex from Acacia spp., Eucalyptus spp., Mangifera indica and Punica granatum across a wide geographic range in nine countries. Principal coordinate analysis, Bayesian clustering analysis and Bruvo's distance analysis revealed two major genetic clusters among the isolates considered. One of these clusters consisted of isolates associated with Eucalyptus and Punica and the other cluster was made up of isolates associated with 
Acacia and Mangifera hosts. We used approximate Bayesian computation (ABC) to compare different competing scenarios describing ancestral relationships among the four host-associated populations. The results suggested that the Eucalyptus-associated population is the most likely source of established populations on other hosts. The results also highlighted the fact that the Mangifera-infecting population probably originated via a recent host jump from populations on Acacia, and that the Punica-infecting population could have originated from populations on Eucalyptus.

\section{D8c: THE ROLE OF TREE RELATED MICROHABITATS IN FOREST ECOSYSTEMS}

\section{Tree-related microhabitat spatial patterns in European beech-dominated forests}

Laurent Larrieu ${ }^{1,2}$, Benoit Courbaud ${ }^{3}$, Michel Goulard ${ }^{1}$, Wilfried Heinz ${ }^{1}$, Daniel Kraus ${ }^{4}$, Thibault Lachat ${ }^{5}$, Sylvie Ladet ${ }^{1}$, Fabien Laroche ${ }^{6}$, Jörg Müller ${ }^{7,8}$, Yoan Paillet $^{6}$, Andreas Schuck ${ }^{9}$, Jonas Stillhard ${ }^{10}$, Miroslav Svoboda ${ }^{11}$

${ }^{1}$ DYNAFOR, Université de Toulouse, INRA, Toulouse, France; ${ }^{2}$ CRPF Occitanie, Tarbes, France; ${ }^{3}$ University Grenoble Alpes, Irstea, LESSEM, Grenoble, France; ${ }^{4}$ Chair of Silviculture, Freiburg University, Freiburg, Germany; ${ }^{5}$ Bern University of Applied Sciences, School of Agricultural, Forest and Food Sciences HAFL, Bern, Switzerland; ${ }^{6}$ Irstea, UR EFNO, Nogent sur Vernisson, France; ${ }^{7}$ Bavarian Forest National Park, Grafenau, Germany; ${ }^{8}$ University of Würzburg, Würzburg, Germany; ${ }^{9}$ European Forest Institute, Bonn, Germany; ${ }^{10}$ Swiss Federal Research Institute WSL, Birmensdorf, Switzerland; ${ }^{11}$ Czech University of Life Sciences (CULS), Praha, Czech Republic (laurent.larrieu@inra.fr; benoit.courbaud@irstea.fr; michel.goulard@inra.fr; wilfried.heinz@inra.fr; pauldaniel.kraus@fstsw.bayern.de; thibault.lachat@bfh.ch;sylvie.ladet@inra.fr;fabien.laroche@irstea.fr; joerg.mueller@npv-bw.bayern.de; yoan.paillet@irstea.fr; andreas.schuck@efi.int; jonas.stillhard@wsl.ch; svobodam@fld.czu.cz)

A Tree related Microhabitat (TreM) is a distinct, well-delineated morphological singularity occurring on living or standing dead trees. It constitutes a crucial substrate or life site for species. TreMs are widely recognized as key features for biodiversity. Since TreMs are not to be found on every tree, their spatial distribution within a forest may affect TreM associated communities related to dispersal capacities of some taxa. However, these spatial patterns are not well known, either in old-growth or in managed forests. We assessed the spatial distribution of eleven TreM groups in European beech-dominated forests both in forests that have not been harvested for at least 100 years and in forests still ongoing management today. We made the assumptions that (i) we can detect spatial patterns in unmanaged forests, (ii) tree-dbh (diameter at breast height) spatial distribution is the main driver of TreM spatial distribution and (iii) management affects these patterns. We did not highlight any consistent spatial pattern, neither in managed nor in old-growth forests. The effect of dbh on TreM occurrence depended on both TreM and forest status. Plot features matters for explaining the occurrence of most of the TreMs. Considering the 10,000 ha natural forest of Uholka (Ukraina) as a case study, we highlighted a significant spatial aggregation for crown deadwood within the whole forest, but we did not find aggregation for the other TreMs.

\section{Modelling the occurrence of tree-related microhabitats in managed uneven-aged forest stands over time}

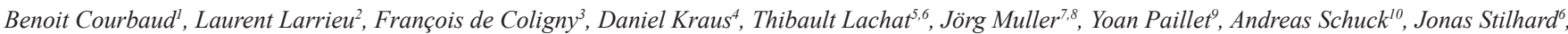
Miroslav Svoboda ${ }^{11}$

${ }^{1}$ Univ. Grenoble Alpes, Irstea, LESSEM, Grenoble, France; ${ }^{2} I N R A$, UMR DYNAFOR \& CRPFOcc, Toulouse, France; ${ }^{3}$ AMAP, INRA, CIRAD, CNRS, IRD, Univ Montpellier, Montpellier, France; ${ }^{4}$ Integrate Foundation, Bonn, Germany; ${ }^{5}$ Bern University of Applied Sciences, School of Agricultural, Forest and Food Sciences HAFL, Bern, Switzerland; ${ }^{6}$ Swiss Federal Research Institute WSL, Birmensdorf, Switzerland; ' Bavarian Forest National Park, Grafenau, Germany; ${ }^{8}$ University of Würzburg, Würzburg, Germany; ${ }^{9}$ Irstea, UR EFNO, Nogent sur Vernisson, France; ${ }^{10}$ European Forest Institute, Bonn, Germany; ${ }^{11}$ Czech University of Life Sciences, Prague, Czech Republic (benoit.courbaud@irstea.fr; laurent.larrieu@inra.fr; francois.decoligny@inra.fr; d.kraus@integrate-foundation.org; thibault.lachat@bfh.ch;joerg.mueller@npv-bw.bayern.de; yoan.paillet@irstea.fr; andreas.schuck@efi.int; jonas.stillhard@wsl.ch; svobodam@fld.czu.cz)

A Tree related Microhabitat (TreM) is a distinct, well-delineated morphological singularity occurring on living or standing dead trees, that constitutes a particular and crucial substrate or life site for species. TreMs are essential to support forest biodiversity. The retention of some trees bearing TreMs is increasingly prescribed in sustainable forest management guidelines. However, this may not be sufficient to ensure an appropriate density and diversity of TreMs to support TreM-dwelling taxa over time. Indeed, trees that are harvested often either display TreMs or have the potential to develop them over time (future habitat trees). Moreover, little is known about the dynamic process of TreM's formation at the tree level. Most of the TreM data currently available are cross-sectional data (trees are observed only once) making it more difficult to estimate TreM formation rates. In this presentation we show how to estimate the probability of a new TreM being formed during tree growth by adapting statistical survival analysis approaches. Using a harmonized European TreM database, we analyze variations in the probability of formation of a new TreM on a tree of a given DBH for 11 different groups of TreMs and different groups of tree species. Then, using Samsara, a spatially-explicit individual-based forest stand model, we show how thinning regimes influence the TreM profile of uneven-aged mixed stands of spruce, fir and beech over time.

\section{Structural complexity in managed and unmanaged mountain forests after management cessation: effects on the habitat suitability for indicator bird species}

Veronika Braunisch ${ }^{1,2}$, Stefanie Roder ${ }^{2}$, Joy Coppes ${ }^{1}$, Kurt Bollmann ${ }^{3}$

${ }^{1}$ Forest Research Institute of Baden-Wuerttemberg, Freiburg, Germany; ${ }^{2}$ University of Bern, Bern, Switzerland; ${ }^{3}$ Swiss Federal Institute for Forest, Snow and Landscape ResearchWSL, Birmensdorf, Switzerland (veronika.braunisch@iee.unibe.ch; steroder@hotmail.com; joy.coppes@forst.bwl.de; kurt.bollmann@wsl.ch)

Increasing the proportion of unmanaged forests in multi-functional forest landscapes is a primary goal of national and international conservation strategies. However, the development of structural features and associated habitat suitability for forest species after management cessation is unknown. We evaluated these effects on key habitat characteristics of four mountain forest bird species indicative of different structural components: Capercaillie (Tetrao urogallus), Hazel grouse (Bonasa bonasia), Three-toed woodpecker (Picoides tridactylus) and Pygmy owl (Glaucidium passerinum) across four mountain regions in Central Europe. Habitat suitability was modelled based on 300 forest sites selected independently of their management status, and predicted to an independent dataset of 42 strictly protected forests.We compared forest reserves to managed forests with species presence or absence with regard to habitat suitability and key habitat structures and related both to the time since reserve designation. For all species, except Pygmy owl, habitat suitability in reserves was significantly higher than in managed forests with species' absence, but not different from managed forests with species presence. For the species associated with open forest structures (Capercaillie, Hazel grouse, Pygmy owl) habitat suitability decreased significantly in the first three decades after reserve designation, when the relatively young forests grew dense, and increased afterwards. No such correlation was found for the Three-toed woodpecker associated with deadwood and 
barkbeetle infestations following temporally unpredictable disturbance events. Structural characteristics varied greatly in abundance and distribution, but only open structures were related to the "reserve age". We therefore recommend focusing on mature, near-natural and structurally diverse forests when designating new reserves.

\section{Effects of clumped versus dispersed retention of potential habitat trees}

Thomas Asbeck ${ }^{1}$, Jürgen Bauhus ${ }^{1}$, Christian Messier ${ }^{2}$

${ }^{1}$ University of Freiburg, Freiburg, Germany; ${ }^{2}$ University of Quebec, Quebec, Canada (thomas.asbeck@waldbau.uni-freiburg.de; juergen.bauhus@waldbau.uni-freiburg.de; ch.messier@gmail.com)

The question whether it is more advantageous for biodiversity conservation to retain live habitat trees in clumped or dispersed distribution has occupied forest ecologists and managers alike. To identify the most valuable live retention trees, a common approach is to quantify tree-related microhabitats (TreMs). In this paper, we asked whether a) abundance and richness of TreMs differs between live potential habitat trees in either clumped or dispersed distribution, and b) whether the abundance of fifteen groups of TreMs is related to the type of distribution of potential habitat trees (clumped or dispersed). The fifteen groups of TreMs are based on varying creation processes and include for instance woodpecker cavities, rot holes or crown deadwood. For few TreMs such as rot holes, twig tangles, nests and burrs and cankers weak relationships to different degrees of clumping were identified. Overall abundance, richness and the abundance of TreMs in four groups increase with slope, altitude and DBH. These results show that it is more important to select the right retention trees in the appropriate numbers rather than focusing on grouping them within 1 ha stands.

\section{Water and the conservation of wide-ranging Forest Red-tailed Black-Cockatoos in a drying climate}

Michael Craig ${ }^{1,2}$, Tony Kirkby ${ }^{3}$, Vicki Stokes ${ }^{4}$, Michael Renton $^{1}$, Ron Johnstone ${ }^{3}$, Geoff Barrett ${ }^{5}$, Richard Hobbs ${ }^{1}$

${ }^{1}$ University of Western Australia, Nedlands, Australia; ${ }^{2}$ Murdoch University, Murdoch, Australia; ${ }^{3}$ Western Australian Museum, Welshpool, Australia; ${ }^{4}$ Birdlife Australia, Floreat, Australia; ${ }^{5}$ Department of Biodiversity, Conservation and Attractions, Crawley, Australia (michael.craig@uwa.edu.au; akirkby@vtown.com.au; vicki.stokes@birdlife.org.au; michael.renton@uwa.edu.au; ron.johnstone@museum.wa.gov.au; geoff.barrett@dbca.wa.gov.au; richard.hobbs@uwa.edu.au)

Spatio-temporal reductions in water availability, due to climate change, are likely to have significant effects on forest fauna, particularly for species that need to drink regularly. We investigated how water availability influenced forest fauna by examining the nesting ecology of the threatened Forest Red-tailed BlackCockatoo (Calyptorhynchus banksii naso) in the northern jarrah forest of southwestern Australia, a region that has experienced a $25 \%$ decline in rainfall in recent decades. We located 156 cockatoo nests across three jarrah forest landscapes and related their spatial location to variables at the hollow, tree, site and landscape scales and compared them to similar hollow-bearing trees containing no nests. At the landscape scale, we found nests were no closer to granite outcrops, roads or watercourses than unused trees but were significantly closer to both ephemeral and permanent drink sites, suggesting cockatoos locate nests to increase access to water during their nesting cycle. These results suggest numbers of suitable nesting hollows may decline in the future as reduced water availability renders potentially suitable hollows unsuitable. We conducted additional work investigating the potential of water as a management tool to offset reductions in water availability by placing artificial water points at various sites in the northern jarrah forest. We found that artificial water points are utilised by cockatoos, which suggests providing water appears to be an effective management tool to offset reductions in water availability. It should be considered more widely as a forest management tool to better conserve forest fauna under a drying climate.

\section{Does forest biodiversity respond to pulses of saproxylic microhabitats induced by tree dieback: a case study in mountain French silver fir forests}

Christophe Bouget ${ }^{1}$,Laurent Larrieu², Laurent Burnel ${ }^{2}$, Lopez-Vaamonde Carlos ${ }^{3}$, Moliard Carl ${ }^{1}$, Jerome Molina ${ }^{2}$, Guillem Parmain ${ }^{1}$, Grégory Sajdak ${ }^{4}$, Lucas Sire ${ }^{5}$, Jerome Willm²

${ }^{1}$ Irstea, Nogent-sur-Vernisson, France; ${ }^{2} I N R A$, Toulouse, France; ${ }^{3} I N R A$, Orleans, France; ${ }^{4} C R P F$, Toulouse, France; ${ }^{5}$ IRBI, Tours, France (christophe. bouget@irstea.fr; laurent.larrieu@inra.fr; laurent.burnel@inra.fr; carlos.lopezvaamonde@inra.fr; carl.moliard@irstea.fr; jerome.molina@inra.fr; guilhem.parmain@irstea.fr; gregory.sajdak@crpf.fr; lucas.sire.17@gmail.com; jerome.willm@inra.fr)

Forest diebacks are likely to increase in response to climate change, with increased frequency and intensity of droughts. In line with climate change scenarios, ecoclimatic modelling predicts a decrease in the range of silver fir, a drought-sensitive species, in its southern limit in the French Pyrenees. Diebacks are expected to induce a pulse of resources potentially favorable to certain forest species, e.g. tree-related microhabitats (TreM) for saproxylic species. The impact of forest dieback on biodiversity has nonetheless been poorly studied. As part of the international Climtree project, we set up a balanced sampling design of 56 plots crossing the intensity of local silver fir dieback and the salvage logging of weakened or dead trees. Detailed stand structure metrics and insect communities sampled by Malaise traps (insect MOTUs) or flight-interception traps (saproxylic beetles) have been measured. The structure of fir stands was affected by the level of decline, and to a lesser extent by salvage logging. We indeed observed a slight increase in CWD and in some TreM-bearing trees (crown deadwood, annual polypores , trunk rot holes) with dieback intensity, and a slight decrease in some TreM-bearing trees (crown deadwood, annual polypores) in salvaged compared with unharvested plots. However, these stand changes did not strongly affect local insect assemblages. Guilds of TreM-associated insects did not increase in abundance or richness with dieback-induced increase in resources. In conclusion, forest changes through dieback result in habitat and resource changes with still hard-to-predict impacts at the stand scale on a major reservoir of biodiversity.

\section{Water-filled tree holes as model system to study management effects on insect communities and related functions in temperate forests}


Martin Gossner', Mykola Jaremchuk', Vasyl Chumak², Thibault Lachat ${ }^{1}$, Jana Petermann ${ }^{3}$

${ }^{1}$ Swiss Federal Research Institute WSL, Birmensdorf, Switzerland; ${ }^{2}$ Uzhgorod National University, Uzhgorod, Ukraine; ${ }^{3}$ University of Salzburg, Salzburg, Austria(martin.gossner@wsl.ch; kolya.yaremchuk.1995@mail.ru; chumak.vasyl@yahoo.com; thibault.lachat@bfh.ch; jana.petermann@sbg.ac.at)

Forest ecosystems are strongly affected by management. Predicting the consequences of management for biodiversity and ecosystem functions is, however, challenging due to the complexity of these ecosystems. Here, we used water-filled tree holes, which are abundant tree microhabitats in temperate forest ecosystems, as model system to study the effects of forest management on entire insect communities and the functions they provide. The food-webs in these aquatic microcosms comprise many trophic levels of specialized larval insect species, which are simple enough to allow studying the whole system, but sufficiently complex to derive results that can be transferred to larger ecosystems. We found that management strongly affected insect communities in these microcosms by altering resource and habitat availability at different spatial scales as well as habitat diversity. Moreover our results suggest that functions, i.e. decomposition, measured by artificial tree holes, and predation by terrestrial predators, measured by fake larvae, might also be altered by forest management. We conclude that aquatic micro-ecosystems are both, interesting and important habitats in themselves and useful model systems for studying effects of forest management on entire communities.

\author{
Substrate specific restoration promotes saproxylic beetle diversity in boreal forest set-aside \\ Joakim Hjältén ${ }^{1}$, Ruaridh Hägglund ${ }^{1}$ \\ 'Department of Wildlife, Fish and Environmental Studies, Swedish University of Agricultural Sciences, Umeå, Sweden (joakim.hjalten@slu.se; \\ ruaridh.hagglund@sweco.se)
}

In many parts of the boreal biome intensive forest management has resulted in profound changes in forest structure, tree species composition and dead wood availability, and by so negatively effecting forest biodiversity. Restoration of degraded forest habitats is therefore of high priority. Consequently, it is of uttermost importance to develop cost-efficient restoration methods. We have therefore initiated ecological restoration experiment aimed at increasing the variety and volume of dead wood in voluntary set-asides (FSC certification requirements) by mimicking the two natural disturbances, forest fire and small scale gap dynamics. We studied how tree species and substrate type, i.e. the way in which a tree was killed (cut, girdled, tipped over or cut to produce a high stump), affect species composition, abundance and species richness of saproxylic beetles. We found that species composition differed between tree species in burned as well as gap-cut stands, and that tree posture, i.e. standing or downed trees, also affected species composition in gap-cut stands. In addition, abundance and species richness differed between tree species in gap-cut stands, generally being higher in spruce than in pine and birch. Based on our results we recommend a wider practice of dead wood creation involving a multitude of tree species and tree postures, through mimicking natural disturbances in the management of boreal forests. Furthermore, we suggest that voluntary set-asides provide an excellent opportunity for restoration as they are already available and restoration cost can therefore be kept at a minimum or totally avoided as in this study.

\title{
How to deal with tree microhabitats in daily forest management? Different tools to implement conservation aspects related to microhabitats into forestry
}

Frank Krumm ${ }^{1}$, Rita Bütler ${ }^{2}$, Laurent Larrieu ${ }^{3}$, Thibault Lachat ${ }^{4}$

${ }^{1}$ Swiss Federal Institute for Forest, Snow and Landscape Research WSL, Birmensdorf, Switzerland; ${ }^{2}$ Swiss Federal Institute for Forest, Snow and Landscape Research WSL, Lausanne, Switzerland; ${ }^{3} I N R A$, Toulouse, France; ${ }^{4}$ Bern University of applied sciences, Zollikofen, Switzerland (frank.krumm@wsl.ch; rita.buetler@epfl.ch; laurent.larrieu@inra.fr; thibault.lachat@bfh.ch)

The need to address biodiversity protection measures into forest management is widely accepted among foresters and society as the loss of species and habitat structures is still ongoing on a big scale. Management practices and education have been focusing for a long time on timber production. Consequently, knowledge and awareness about processes related to tree microhabitats are not sufficiently present. Various initiatives across Europe are aiming to enhance information for a broad variety of target groups including forest practitioners, decision makers and scientists from different sectors, students as well as other potentially interested/relevant communities and other stakeholders. Marteloscopes, delineated, rectangular plots in forests where all trees are numbered, mapped and recorded, have been further developed as a training tools for virtual tree selections with a focus on biodiversity conservation. All recorded trees are economically and ecologically assessed and have a price tag and an ecological value. This so called ecovalue is evaluated based on a tree microhabitat catalogue based on a widely accepted typology. Different projects have taken this further and software tools are released or under development. Publications, especially tailored for practicioners are distributed among foresters and increase the awareness for tree microhabitats and biodiversity relevant structures. The presented tools aim for supporting improved decision making capabilities addressing the integration of biodiversity aspects into forest management. Practical implementation can be altered by many factors and the introduced tools cover mostly the lowest level of implementation, the selection of trees during thinning (including habitat trees)

\section{Predictors of Microhabitat Frequency and Diversity in Mixed Mountain Forests in South-Western Germany}

Grossmann Josef, , Juliane Schultze ${ }^{1}$, Jürgen Bauhus ${ }^{2}$, Patrick Pyttel ${ }^{2}$

${ }^{1}$ Forest Research Institute Baden-Wuerttemberg, Freiburg, Germany; ${ }^{2}$ Albert-Ludwigs-Universität, Freiburg, Germany

(josef.grossmann@waldbau.uni-freiburg.de; juliane.schultze@forst.bwl.de; juergen.bauhus@waldbau.uni-freiburg.de; patrick.pyttel@waldbau.uni-freiburg.de)

Tree-related microhabitats are an important determinant of forest biodiversity. Habitat trees, which typically provide many microhabitats such as hollows, crown dead wood, etc., are therefore selected to maintain those structural attributes within managed forests. To what extent the occurrence of microhabitats on potential habitat trees may be predicted from common tree attributes is a question of high practical relevance. Until now, most studies have attempted to predict the quantity of microhabitats at the tree or forest stand level. In our study, we aimed at explaining microhabitat occurrence from a qualitative perspective by considering their diversity. Tree diameter at breast height (dbh), tree species, and canopy class were useful predictors of microhabitat diversity. Microhabitat diversity on broadleaved trees was on average higher than in conifers of the same diameter. In contrast to microhabitat quantity, microhabitat diversity saturated towards higher dbh levels. Microhabitat diversity in beech trees of lower tree canopy classes was found to be surprisingly high. Habitat trees support not only more, but also more diverse, microhabitats in comparison to crop trees. Considering these findings on microhabitat distribution, the selection of habitat trees within Central European mixed mountain forests can be significantly improved. 


\title{
FRA 2020 Remote Sensing Survey - participatory approach for generation of global and regional forest area statistics
}

Anssi Pekkarinen ${ }^{1}$, Adolfo Kindgard ${ }^{1}$, Valeria Contessa ${ }^{1}$, Lars Gunnar Marklund ${ }^{2}$

${ }^{1}$ Food and Agriculture Organization of the United Nations, Rome, Italy; ${ }^{2}$ Swedish University of Agricultural Sciences, Umeå, Sweden

(anssi.pekkarinen@fao.org; adolfo.kindgard@fao.org; valeria.contessa@fao.org; marklundlg@gmail.com)

FAO has been monitoring the world's forests at 5 to 10 year intervals since 1946. The Global Forest Resources Assessments (FRA) are now produced every five years to provide a comprehensive analysis on world's forests and their changes. These assessments are based on Country Reports prepared by officially nominated National Correspondents. Since 1990, FRA has complemented the information collected through the country reporting process with global and regional analyses of the world's forest resources using remote sensing. With better access to a growing archives of satellite imagery, and increasing availability of new tools that facilitate image processing and interpretation, remote sensing can now allow more efficient assessments of status and changes in tree cover and land use than ever before. First FRA remote sensing assessments were done in a centralized manner. Later, in FRA 2010, a more participatory model was introduced and the national experts were invited to validate the pre-classified results. The FRA 2020 Remote Sensing Survey takes this participatory process to the next level. A global sample of roughly 430,000 sampling units, allocated using a stratified sampling scheme based on tree cover change and Global Ecological Zones, will be visually interpreted by the national experts through a series of interpretation workshops, using an innovative tool developed by FAO and NASA with the support of USAID and Google. This paper will present the methodology, approach and current status of the FRA 2020 Remote Sensing Survey as well as share some of its implementation experiences and preliminary findings.

\section{Overview of the assessment framework: the GuidosToolbox Workbench (GWB)}

Peter Vogt ${ }^{1}$

${ }^{1}$ European Commission, Ispra, Italy (peter.vogt@ec.europa.eu)

The GuidosToolbox Workbench (GWB) is a collection of popular image analysis routines packaged as command-line tools for Linux server applications. The ten routines provide feature mapping and quantitative summary assessments of digital land cover data for a variety of topics, locating and measuring morphological pattern, fragmentation, accounting, distance, contagion and landscape mosaic. The conceptual ideas are summarized, followed by a sample application showing a continental assessment of forest fragmentation selected by Forest Europe as a key indicator to assess the state of forests and measuring the progress toward sustainable forest management at regional and national level. Forest Europe aims at a close collaboration with FAO's Global Forest Resource Assessment, through harmonizing data collection and assessment tools to accurately reflect temporal evolutions and evaluate achievements towards the 2020 targets of sustainable forest management of European forests.

\section{Interpreting fragmentation, morphological pattern, and landscape mosaic in national and global forest assessments}

Kurt Riitters ${ }^{I}$

IUSDA Forest Service, Research Triangle Park, USA (kriitters@fs.fed.us)

High-resolution maps of forest and land cover support harmonized, detailed mapping and assessment of landscape patterns at global scale. The conceptual models and implementations of three aspects of pattern are summarized, followed by illustrations and interpretations of results produced by the popular Guidos Toolbox and Workbench software in national and global assessments. The USA country report for the Montréal Process interprets fragmentation using the multi-scale FAD (forest area density) analysis, while the USA RPA (Resources Planning Act) national assessment additionally considers MSPA (morphological pattern) and LM (landscape mosaic). Global results are illustrated for fragmentation using 30-m forest maps, and for landscape mosaic using 300-m global land cover maps.

\section{Integrating maps of forest fragmentation and landscape mosaics with national forest inventory plot data}

\author{
Jennifer Costanza ${ }^{1}$, Kurt Riitters ${ }^{2}$, Peter Vogt ${ }^{3}$ \\ ${ }^{1}$ North Carolina State University, Research Triangle Park, NC, USA; ${ }^{2}$ USDA Forest Service, Research Triangle Park, NC, USA; ${ }^{3}$ European Commission Joint \\ ResearchCentre, Ispra, Italy(jkcostan@ncsu.edu; kriitters@usda.gov; peter.vogt@ec.europa.eu)
}

Changing land use and fragmentation of forest ecosystems threaten the ability of forests to provide ecosystem services. Tools and software such as GuidosToolbox Workbench (GWB) provide metrics with which to examine patterns of land-use and forest fragmentation. However, assessment of the impacts of those patterns on forests depends on the integration of those tools with in-situ data. We demonstrate how metrics and maps from GWB can be used in conjunction with forest inventory data. We used data from over 100,000 forest plots in the USDA Forest Service's Forest Inventory and Analysis (FIA) database to examine the landscape context of forest ecosystems across the conterminous U.S. For spatial neighborhoods surrounding each FIA plot, we extracted information from maps of forest fragmentation and landscape mosaics from GWB. We examined the degree to which those GWB metrics varied by forest type and ownership. We found that forest types in the eastern U.S. and those owned by families, rather than industry or government, were more likely to exist within fragmented landscapes, suggesting both threats and opportunities for those forests and their associated ecosystem services. Our results demonstrate that integrating in-situ inventory data with maps of spatial patterns can lead to critical information regarding the effects of landscape spatial patterns on forest ecosystems and the services they provide. It is our hope that this national case study will prompt similar assessments in other countries where forest inventory or other plot data exist, thus expanding the integration of $i n-$ situ data with maps of spatial patterns.

\section{Priorizatization analysis of riparian forest corridors in the Brazilian National Forest Inventory}

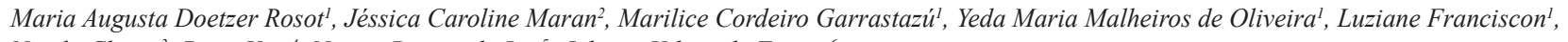
Nicola Clerici ${ }^{3}$, Peter Vogt ${ }^{4}$, Naissa Batista da Luz ${ }^{5}$, Joberto Veloso de Freitas ${ }^{6}$ 


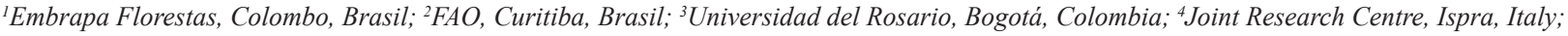
${ }^{5}$ Universidadey Federal de Uberlandia, Uberlandia, Brasil; ' ${ }^{6}$ Serviço Florestal Brasileiro, Brasilia, Brasil (augusta.rosot@embrapa.br; jess.maran@gmail.com; marilice.garrastazu@embrapa.br; yeda.oliveira@embrapa.br; luziane.franciscon@embrapa.br; nicola.clerici@urosario.edu.co; peter.vogt@ec.europa.eu; naissa@gmail.com; joberto.freitas@florestal.gov.br)

The landscape component in the Brazilian National Forest Inventory (NFI-BR) evaluates habitat quality and spatial structure in national Landscape Sample Units (LSUs), established in a grid of $40 \mathrm{x} 40 \mathrm{~km}$. The analysis includes indices for riparian environments as a measure of their structural connectivity as forest corridors, the degree of human pressure acting on them and the extension of protected areas within those zones. LULC maps of twenty LSUs in Southern Brazil were used as pilot samples to conduct a Morphological Spatial Pattern Analysis (MSPA) and derive the following indices: Structural Corridors Index (SCc), showing the proportion of core and bridge MSPA categories within the riparian zone; the Structural Corridors under Pressure Index (CPc), to identify areas where structural corridors are subject to anthropogenic influences; and the Structural Corridors under Pressure Protection Index (UCPc), identifying corridor areas under anthropogenic pressure but with little or no legal protection. These indices were converted into ranking scores to prioritize riparian areas for conservation and landscape restoration. Three of the 20 pilot LSUs exhibited standardized values of UCPc, close to 1, thus indicating a critical conservation status for these areas.

\section{Forest disturbances in the Brazilian Amazon: large-scale monitoring based on cloud-computed remote sensing analysis}

René Beuchle ${ }^{1}$, Yosio Edemir Shimabukuro ${ }^{2}$, Andreas Johannes Langner ${ }^{1}$, Peter Vogt ${ }^{1}$, Silvia Carboni ${ }^{3}$, Klara Janouskova ${ }^{4}$, Thais Almeida Lima ${ }^{5}$, Frédéric Achard ${ }^{1}$

${ }^{1}$ European Commission, Joint Research Centre (JRC), Ispra, Italy; ${ }^{2}$ Brazilian National Institute for Space Research (INPE), São José dos Campos (SP), Brazil; ; ${ }^{3}$ GFT ITALIA Srl., Milan, Italy; ${ }^{4}$ ARHS Developments S.A., Luxembourg, Luxembourg; ${ }^{5}$ University of British Columbia, Forest Sciences Centre, Vancouver,Canada(rene.beuchle@ec.europa.eu; yosio.shimabukuro@inpe.br; andreas-johannes.langner@ec.europa.eu; peter.vogt@ec.europa.eu; silvia.carboni@ext.ec.europa.eu; klara.janouskova@ext.ec.europa.eu; tha.almeida.lima@gmail.com; frederic.achard@ec.europa.eu)

The disturbances of forest cover by processes like selective logging and forest fires are very common in tropical forest. These disturbances heavily affect forest functionalities, lead to a decrease of forest biomass and contribute to greenhouse gas emissions. However, the quantification of the disturbance extend remains a challenging task because disturbed forest areas do not consist in a long-term conversion to another land use, but often undergo fast regrowth and thus are easily detectable only for a limited amount of time. We have applied a novel approach based on the $\Delta \mathrm{rNBR}$ index, which maps the loss of forest canopy on a yearly basis by a multi-image analysis with cloud computing on Google Earth Engine. We have analysed 12 years of forest disturbances (2000-2011) over large area of interest (ca; 414,000 $\mathrm{km}^{2}$ ), defined by the intersection of the Mato Grosso State border and the Brazilian Amazon biome. We assessed the logging and fire intensity by applying a grid of $300 \mathrm{~m} \times 300 \mathrm{~m}$ spatial resolution over the mapped disturbance pixels. In 2016, more than 220,000 km² (53,3\%) were covered by forest within the area of interest, thereof more than $38,000 \mathrm{~km}^{2}(17,3 \%)$ were disturbed by selective logging within the 12 years analysed, ranging from 1,819 $\mathrm{km}^{2}$ (2009) to $6,984 \mathrm{~km}^{2}$ (2005). The burned forest added up to $18,711 \mathrm{~km}^{2}(8,4 \%)$ during this period, the smallest forest area burned in $2001\left(68 \mathrm{~km}^{2}\right)$ the larges area in $2007\left(10,258 \mathrm{~km}^{2}\right)$.

\section{Five decades of boreal forest disturbance in Ontario, Canada}

Tarmo Remmel ${ }^{1}$, Marc Ouellette ${ }^{2}$

${ }^{1}$ York University, Toronto, Canada; ${ }^{2}$ Ontario Forest Research Institute, Sault Ste. Marie, Canada

(remmelt@yorku.ca; marc.ouellette@ontario.ca)

The boreal forest biome in Ontario encompasses approximately $76 \mathrm{M}$ ha across seven eco-regions that are defined by geo-climatic variability and gradients within the province. Located within this biome is the Area of Undertaking (AOU), a zone of highly regulated and monitored extractive forest activities that delineates our area of interest. There exits great concern over the state of the forests within the AOU, with a desire to understand the disturbances affecting them, their recovery, and any resultant dynamic patterns in space and time given the integrated ecological, financial, and physical processes involved. Just the sheer area involved has enormous implications on the economy, environmental quality, carbon sequestration, and recreation; these underscore the need to consistently collect and summarize information in the context of improving management activities and decision making surrounding this resource. We have produced a consistently processed dataset, at $120 \mathrm{~m}$ spatial resolution (1.44 ha), of annual disturbances (harvesting and fire) for the entire AOU from 1972-2018 and developed a workflow for annually updating this database. All base data comes from Landsat imagery (MSS, TM, ETM+, OLI) and are cross-referenced with supporting documentation and datasets to produce confidence attributes for each mapped location. Our spatio-temporal dataset provides a consistent means for assessing spatial patterns, fragmentation rates, impacts of management decisions, climate change trends, and various ecological states and implications through nearly 5 decades.

\section{Forests and trees in national adaptation plans (NAPs)}

Alexandre Meybeck ${ }^{1}$, Vincent Gitz ${ }^{1}$, Julia Wolf ${ }^{2}$

${ }^{1}$ CIFOR, Bogor, Indonesia; ${ }^{2} F A O$, Rome, Italy(a.meybeck@cgiar.org; v.gitz@cgiar.org; julia.wolf@fao.org)

The national adaptation plan (NAP) process was established under the UNFCCC in 2010. Least developed and other developing countries prepare (NAPs) that identify and address medium- and long-term adaptation needs. Some developed countries have prepared similar documents. The objective of this presentation is to give some preliminary insights on how forests and trees are considered in the NAPs. It will successively consider the way forests and trees are integrated in the process, the measures aimed at the adaptation of forests and trees and how they are used for the adaptation of other sectors. Most NAPs are organized by sectors, with forests and trees being often included in the biodiversity sector, with significant exceptions like for Chile where planted forests are part of the sylvoagropastoral sector. The main risks identified for forests and trees in the NAPs are increased climate variability, increased heat and drought, increased risk of extreme events, salinity in coastal areas, forest fires, pests and invasive species. The main measures promoted are sustainable forest management, biodiversity conservation, monitoring and risk management systems, conservation and sustainable management of genetic resources and to anticipate future changes. In almost all sectors figure measures that promote forests and trees as an adaptation mean, for a great variety of purposes that can be gathered in three main groups: natural resources management, agriculture, and protection of cities; however often omitting the consequences for forestry and the necessary enabling environment. This analysis leads to some important conclusions, with consequences for both research and policy making. 


\title{
Multisource and multiscale earth observation of biodiversity in Boreal Forests
}

Petteri Vihervaara ${ }^{1}$, Timo Kumpula², Arto Viinikka ${ }^{1}$, Sonja Kivinen², Topi Tanhuanpä̈̈2, Anton Kuzmin ${ }^{2}$, Sarita Keski-Saari², Peter Kullberg', Pekka Hurskainen ${ }^{1}$, Laura Mononen ${ }^{2}$, Aleksi Ritakallio², Pasi Korpelainen ${ }^{2}$

${ }^{1}$ Finnish Environment Institute (SYKE), Helsinki, Finland; '2University of Eastern Finland, Joensuu, Finland (petteri.vihervaara@ymparisto.fi; timo.kumpula@uef.fi; arto.viinikka@ymparisto.fi; sonja.kivinen@uef.fi; topi.tanhuanpaa@helsinki.fi; anton.kuzmin@uef.fi; sarita.keski-saari@uef.fi; peter.kullberg@ymparisto.fi; pekka.hurskainen@ymparisto.fi; laura.mononen@uef.fi; aleksi.ritakallio@gmail.com; pasi.korpelainen@uef.fi)

Earth observation techniques to estimate biodiversity in boreal forests are improving rapidly. The aims and selected findings presented here are to: (i) collect cutting-edge EO data at various spatial and temporal; (ii) develop and produce novel remotely sensed indicators of BD variables and variables for C-sequestration. Different variables describing biodiversity and ecosystem properties are produced using a multi-sensor approach. We will utilize 1) optical satellite images (e.g. Sentinel, Landsat), 2) airborne laser scanning and hyperspectral data, and 3) unmanned aircraft systems (UAS). Optical remote sensing covers large geographical areas at 10-30 m spatial resolution and temporal span of several decades. Laser scanning is a superb method to capture the 3D structure of forested ecosystems with sub-meter accuracy and has been used in growing numbers to study wildlife habitats and BD. Hyperspectral data (HySpex) is used to characterize tree species recognition and identification, and to collect information from spectral traits. Integrating multisource and multiscale remote sensing (RS) data and methods allows studying forest BD and C-sequestration related questions in great detail. Novel UAS methods contribute for bridging the gap in EO between field and airborne measurements and providing ultra-high spatial and temporal resolution imagery for detailed assessment of different ecosystems properties. Field data (e.g. species diversity, canopy foliar traits) has been collected from the airborne and UAS sites. Deriving spectral traits from various RS data can provide detailed valuable information for BD research. In addition, the use of lidar data allows studying traits related to forest and vegetation structure in 3D.

\section{Essential biodiversity variables informed by earth observation technologies}

Ruben Valbuena ${ }^{1,2,3}$, Brian O'Connor ${ }^{2}$,Florian Zellweger ${ }^{3}$, Felix Morsdorf', Petteri Vihervaara ${ }^{5}$,Will Simonson', Matti Maltamo ${ }^{6}$, Fiona Danks ${ }^{2}$, Gherardo Chirici, Nicholas Coops ${ }^{8}$, David Coomes ${ }^{3}$

${ }^{1}$ Bangor University, Bangor, United Kingdom; ${ }^{2}$ UN Environment World Conservation Monitoring Centre (UNEP-WCMC), Cambridge, United Kingdom; ${ }^{3}$ University of Cambridge, Cambridge, United Kingdom; ${ }^{4}$ University of Zurich, Zurich, Switzerland; ${ }^{5}$ Finnish Environment Institute (SYKE), Helsinki,

Finland; ${ }^{6}$ University of Eastern Finland, Joensuu, Finland; ${ }^{7}$ Università degli Studi di Firenze, Florence, Italy; ${ }^{8}$ University of British Columbia, Vancouver, Canada(r.valbuena@bangor.ac.uk; brian.o'connor@unep-wcmc.org; flo.zellweger@gmail.com; felix.morsdorf@geo.uzh.ch;

petteri.vihervaara@ymparisto.fi; will.simonson@unep-wcmc.org; matti.maltamo@uef.fi; fiona.danks@unep-wcmc.org; gherardo.chirici@unifi.it; nicholas. coops@ubc.ca;dac18@cam.ac.uk)

Observations of biodiversity and ecosystem status are relevant to evaluating progress towards many of the targets set by the three Rio Conventions and the UN Agenda 2030. However, the multi dimensionality of biodiversity is difficult to measure and a suite of indicators are necessary to track changes in all aspects of biodiversity for monitoring and evaluating progress towards these targets. A set of Essential Biodiversity Variables (EBVs) has therefore been proposed to standardise how biodiversty is measured, some of which can be observed with Earth Observation (EO). Here we investigated the potential of LiDAR to retrieve EBVs on vegetation structure and draw some general conclusion about the use of EO for EBVs. Firstly, almost any type of global observation will be geographically biased, with significant gaps in tropical areas and plentiful observations for North America, Europe and Australia. Secondly, there is no single type of observation with global coverage at a suitable temporal recurrence. As a result, the retrieval of EBVs in practice will require the combination of different datasets. Thus, we advocate for a system architecture that can accommodate disparate observations as inputs to EBVs, which should allow for evaluation of uncertainties and bias in EBV estimations, as these will vary spatially. A standardized framework for observing terrestrial ecosystem morphological traits for incorporating disparate types of LIDAR data from any platform is proposed, with applications for Sustainable Development Goal 15, in particular indicators 15.1.1 (forest area as a proportion of total land area) or 15.2.1 (sustainable forest management).

\author{
The added value of multi-temporal Sentinel-2 data detailed forest monitoring in the Wienerwald Biosphere Reserve \\ Markus Immitzer I Debastian Böck', Francesco Vuolo ${ }^{1}$, Harald Brenner ${ }^{2}$, Clement Atzberger ${ }^{1}$ \\ ${ }^{1}$ University of Natural Resources and Life Sciences, Vienna (BOKU), Institute of Surveying, Remote Sensing and Land Information (IVFL), Vienna, Austria; \\ ²BiosphärenparkWienerwald Management GmbH,Tullnerbach,Austria (markus.immitzer@boku.ac.at; sebastian.boeck@boku.ac.at; \\ francesco.vuolo@boku.ac.at; hb@bpww.at; clement.atzberger@boku.ac.at)
}

Detailed knowledge about tree species composition is of great importance for forest management. The European Sentinel-2 (S2) satellites provide data with unprecedented spectral, spatial and temporal resolution. Here, we investigate the potential benefits of using high temporal resolution data for classification of five coniferous and seven broadleaved tree species in a diverse Central European Forest. To run the classification, 18 cloud-free S2 acquisitions were analyzed in a 2-step approach. The available scenes were first used to partition the study area into six broad land-cover classes. Subsequently, additional classification models were created separately for the coniferous and the broadleaved class, taking into account all 262,143 possible permutations of the 18 S2 scenes. Each model includes a stepwise recursive feature reduction. Individual mono-temporal tree species accuracies range from 48.1\% (January 2017) to 78.6\% (June 2017). Compared to the best mono-temporal result, the multi-temporal analysis approach improves the out-of-bag overall accuracy by 11 and 12 percentage points for the coniferous and the broadleaved tree species, respectively. Remarkably, a combination of 6-7 scenes achieves a model quality equally high as the model based on all data; images from April until August proved most important. The classes European Beech and European Larch attain the highest user's accuracies of $96.3 \%$ and $95.9 \%$, respectively. The most important spectral variables to distinguish between tree species are located in the red (coniferous) and SWIR bands (broadleaved), respectively. Overall, the study highlights the potential of multi-temporal S2 data for species-level classifications in middle European forests.

Airborne Laser Scanning to detect Tree-related Microhabitats in order to support the conservation of biodiversity 
Giovanni Santopuoli ${ }^{1}$, Marco Marchetti ${ }^{1}$, Mirko Di Febbraro', Bruno Lasserre ${ }^{2}$

${ }^{1}$ Università degli Studi del Molise, Campobasso, Italy; ${ }^{2}$ Università degli Studi del Molise, Pesche, Italy (giovanni.santopuoli@unimol.it; marchettimarco@unimol.it; mirkodifebbraro@gmail.it; lasserre@unimol.it)

Maintain and enhance the conservation of biodiversity is one of the most important aims of the Sustainable Forest Management, among the multiple goods and services that forest ecosystems provide to human wellbeing. However, monitoring forest biodiversity is a challenging task due to field inventory activities are strongly expensive and time consuming. In addition, inventory data often appear inadequate to assess the biodiversity value of forests and it is necessary to develop new approaches and methods to promote the conservation of biodiversity and at the same time to ensure the provision of other ecosystem services. This study aims to demonstrate how Airborne Laser Scanning data can contribute to assess forest biodiversity through the detection of Habitat Trees. We describe an experimental approach to detect the abundance of Tree-related Microhabitats using LiDAR could points and correlated them with ALS metrics. The frequency and abundance of these particular niches, such as cavities, dead branches, injuries and woods, allow to identify Habitat Trees, which play a significant role for the conservation of biodiversity. Four statistical models were implemented to assess and map the biodiversity value in a mixed and multi-layered forest in Central Apennine, Italy. Results show that the RMSE and R2 values for Habitat Trees ranging between 3.37 - 4.51 and 0.6 - 0.8 respectively, while for Treerelated Microhabitats ranging between 5.8 - 6.9 and 0.6- 0.8 respectively. This study was supported by the project "FRESh LIFE-Demonstrating Remote Sensing integration in sustainable forest management" (LIFE14 ENV/IT/000414).

\section{Biodiversity assessment in a tropical deciduous forest in Mundumulai National Park in India using AVIRIS-NG data}

Margarita Huesca ${ }^{1}$, Maria J. Santos ${ }^{2}$, Raman Sukumar ${ }^{3}$, Susan L. Ustin ${ }^{1}$

${ }^{1}$ Center for Spatial Technologies And Remote Sensing (CSTARS), University of California Davis, USA, Davis, USA; ' ${ }^{2}$ niversity Research Priority Program in Global Change and Biodiversity and Department of Geography, University of Zurich, Zurich, Switzerland; ${ }^{3}$ Centre for Ecological Sciences, Indian Institute of Science in India, Bangalore,India (mhuescamartinez@ucdavis.edu; maria.j.santos@geo.uzh.ch; rsuku@iisc.ac.in; slustin@ucdavis.edu)

Global biodiversity loss is one of the major threats to ecosystems, their functions and services across the world. There is an urgent need to develop effective tools to estimating biodiversity. Recent studies have explored the potential of remote sensing to estimate biodiversity, as spectral variability is expected to correlate with biodiversity. Most studies used multispectral data to estimate species richness and diversity, finding significant correlations with poor or low predictive power. Few studies used image spectroscopy data, achieving stronger relationships and predictive power. Here we build on the later approach to estimate diversity across a moisture gradient, from moist tropical deciduous forests to dry deciduous forests in Mudumalai National Park in India. The Park has 7 long-term plots and one 50-ha plot which we used to validate the results. We propose a new method using AVIRIS-NG imagery. Then we use both a K-means unsupervised classification and a random forest classification to assign each pixel to a spectral class and calculate the agreement between the two methods. The procedure is then repeated for several numbers of classes and plot sizes to determine optimum mapping unit to estimate $\alpha$-diversity. We find that the optimum mapping unit is close to 1 ha. $\beta$-diversity was estimated with Bray-Curtis dissimilarity index. $\alpha$ and $\beta$-diversity achieved highest accuracies in dry and wet deciduous forests while being underestimated in degraded moist deciduous forests. The greatest advantage of this method over previous methods is that our procedure determines the maximum species richness without knowing the area a priori.

\section{Assessing aboveground carbon sequestration potential of trees in agroforestry systems in Southern Africa using 3D data \\ Rafael Bohn Reckziegel (D, Anton Kunneke ${ }^{2}$, Christopher Morhart ${ }^{\text {(D), Jonathan P. Sheppard }}$ (D, Hans-Peter Kahle ${ }^{1}$ (D) \\ ${ }^{1}$ Chair of Forest Growth, University of Freiburg, Freiburg im Breisgau, Germany; ${ }^{2}$ Department of Forest and Wood Science, Stellenbosch University, Stellenbosch, South Africa(rafael.bohn.reckziegel@iww.uni-freiburg.de; ak3@sun.ac.za; christopher.morhart@iww.uni-freiburg.de; jonathan.sheppard@iww.uni-freiburg.de; hans-peter.kahle@iww.uni-freiburg.de)}

Due to its location and socio-economic context, Southern Africa is especially vulnerable to the impacts of climate change and is expected to face severe economic, social and environmental challenges in the approaching decades. Agroforestry systems (AFS) are expected to be part of the solution as innovative, sustainable and flexible land use systems capable of adapting to a changing climate, positively influencing agricultural production and food security, facilitate carbon capture and storage while moderating negative climatic influences on rural livelihoods. An important attribute of promoting AFS in African landscapes is the carbon sequestration potential of the tree component. We describe an approach using Terrestrial Laser Scanning (TLS) to estimate the aboveground carbon sequestration potential of tree species growing in African AFS. This innovative non-destructive methodology uses 3D point cloud data derived from single trees collected with a TLS device, which has been proven to be an effective and precise procedure for the assessment of biomass. For that purpose the tree volume data are used as basis for calculating the biomass together with species specific wood densities. Validation is undertaken utilising a destructive approach, sample trees are felled and accurately weighed to generate precise ground truth data. The TLS derived biomass models for single trees will be used to model the aboveground carbon sequestration potential of different AFS management scenarios in the Southern Africa region.

\section{Biodiversity assessment based on unmanned aerial vehicle approach in boreal forests}

Anton Kuzmin ${ }^{1}$, Pasi Korpelainen ${ }^{1}$, Petteri Vihervaara ${ }^{2}$, Arto Viinikka ${ }^{2}$, Sonja Kivinen ${ }^{1}$, Topi Tanhuanpää ${ }^{1}$, Sarita Keski-Saari ${ }^{1}$, Peter Kullberg ${ }^{2}$, Laura Poikolainen ${ }^{1}$, Aleksi Ritakallio', Timo Kumpula ${ }^{1}$

${ }^{1}$ University of Eastern Finland, Joensuu, Finland; ${ }^{2}$ Finnish Environment Institute (SYKE), Helsinki, Finland (anton.kuzmin@uef.fi; pasi.korpelainen@uef.fi; petteri.vihervaara@ymparisto.fi; arto.viinikka@ymparisto.fi; sonja.kivinen@uef.fi; topi.tanhuanpaa@helsinki.fi; sarita.keski-saari@uef.fi; peter.kullberg@ymparisto.fi; laura.poikolainen@uef.fi; aleksi.ritakallio@gmail.com; timo.kumpula@uef.fi)

European aspen (Populus tremula) is a keystone species for boreal forests biodiversity, where large-sized trees are most valuable for maintaining a diverse group of other species and may host hundreds of animal and plant species, many of which are threatened in Fennoscandia. Due to a low economic value and sparse and scattered occurrence of aspen species in boreal forests, there is a lack of information on the spatial and temporal distribution from national forest inventories, which hamper efficient planning and implementing sustainable forest management practices and conservation efforts. Nowadays airborne remote sensing techniques are commonly used for biodiversity assessment over the large areas, however, operational costs of data acquisition are still relatively high and there is strong dependence on the availability and quality of field data. New unmanned aerial vehicle (UAV) based remote sensing proved to be very efficient in providing ultra-high spatial and temporal resolution imagery for detailed forest properties assessment at reasonable costs and serve as a supplement or even able to replace part of the currently required field work to support biodiversity assessments. In this study, the main objective was to recognize individual European aspen trees in old-growth boreal forests in conservation area and estimate its structural properties based on the combination of spectral bands and structural features extracted from UAV data. The results were compared with the airborne laser scanning and hyperspectral data-based methods. 


\section{A Land Surface Phenology monitoring system for forest conservation using a non-parametric approach and open access data and software}

Roberto O. Chávez ${ }^{1}$, Sergio A. Estay², Matías Olea ${ }^{1}$,José Lastra ${ }^{1}$, Ignacio Díaz-Hormazábal ${ }^{3}$, Diego Valencia ${ }^{3}$

${ }^{1}$ Pontificia Universidad Católica de Valparaíso, Valparaiso, Chile; ${ }^{2}$ Universidad Austral de Chile, Valdivia, Chile; ${ }^{3}$ Corporación Nacional Forestal, Santiago, Chile(roberto.chavez@pucv.cl; sergio.estay@uach.cl; matias.olea@pucv.cl; jose.lastra@pucv.cl; ignacio.diaz@conaf.cl; diego.valencia@conaf.cl)

Land surface phenology (LSP), or the recurring seasonal 'greening' and 'browning' cycle of the vegetated surface, has been defined as one of the Essential Biodiversity Variables in the framework of the Convention on Biological Conservation. Monitoring LSP is one of the simplest and most efficient ways to detect and geographically spatialize the effects of climate change on forests. Currently, satellite imagery make possible cost-efficient monitoring of LSP at different spatial and temporal scales, but available parametric methods are limited to describe all possible annual cycles of different forest types and also lack of reliability measures. Here, we introduce a non-parametric Forest LSP monitoring system for conservation purposes based on (a) the ' $n p p h e n$ 'R-package for LSP reconstruction and anomaly detection and (b) the 'shiny' R-package for web mapping implementation. Advantages of 'npphen' are: its flexibility to describe any LSP pattern (suitable for any forest type), it handles time series or raster stacks with and without gaps, and it provides confidence interval for the expected LSP at yearly basis, useful to judge the anomaly magnitude. The web platform was implemented to research the conservation status of Mediterranean forests from the La Campana National Park in Central Chile. Significant anomalies from the natural LSP in the last 18 years occurred mainly outside the National Park, which is an indication of a good conservation status. Our method constitutes a valuable alternative for a cost-efficient near-real-time monitoring system for the National Network of Protected Areas in Chile or for other conservation areas in the world.

\section{Investigating impacts of forest cover change on biodiversity using time-series remote sensing data}

Elizabeth Green ${ }^{1}$, William Simonson ${ }^{1}$, Valerie Kapos ${ }^{1}$, Mike Harfoot ${ }^{1}$, Samantha Hill ${ }^{1}$, Robin Freeman ${ }^{2}$, Louise McRae $^{2}$, Karen Mo $^{3}$, Pablo Pacheco $^{4}$, William Baldwin-Cantello 5

${ }^{1}$ UNEP-WCMC, Cambridge, United Kingdom; ${ }^{2}$ Institute of Zoology, Zoological Society of London, London, United Kingdom; ${ }^{3}$ WWF-US, Washington, DC, USA; ${ }^{4}$ WWF-International, Washington, DC, USA; ${ }^{5}$ WWF-UK,Woking,United Kingdom (elizabeth.green@unep-wcmc.org; will.simonson@unep-wcmc.org; val.kapos@unep-wcmc.org; mike.harfoot@unep-wcmc.org; samantha.hill@unep-wcmc.org;robin.freeman@ioz.ac.uk; louise.mcrae@ioz.ac.uk; karen.mo@wwfus.org; pablo.pacheco@wwf.org; wbaldwincantello@wwf.org.uk)

Remote sensing has greatly improved our ability to monitor forest cover change globally, but may mask below-canopy processes, such as defaunation, that can affect forest health and carbon storage. We investigated whether we could detect a relationship between remote-sensing derived tree cover data and forest vertebrate populations using time-series abundance data from the Living Planet Database. Using both a long-term low resolution tree cover data set (MEASURES VCF5KYR) and a shorter term high resolution dataset (Hansen), we assessed the relationship between forest vertebrate population change and tree cover change, matching the data in space and time. We also assessed the impacts of additional pressures such as human population density, road density and accessibility on forest populations, and repeated the analyses limiting the abundance data to forest specialists. We found little evidence of a consistent effect of tree cover change on forest populations when all populations were analysed together or when reducing the data to only include forest specialists. However, time-series analyses of individual forest specialist populations showed that some populations are closely aligned to tree cover change. Further, by reviewing the supporting literature associated with forest specialist populations, we identified several examples of additional drivers of population change that may have masked a relationship with tree cover change. While remote-sensing derived tree cover datasets are invaluable for assessing changes in forest cover, the importance of below-canopy forest biodiversity monitoring must not be overlooked when assessing forest health and integrity.

\section{Improving biodiversity monitoring using satellite remote sensing derived indicators}

\section{Sandra Luque (D)}

'Irstea UMR TETIS, Montpellier, France (sandra.luque@irstea.fr)

The increasing availability of open access satellite images provides enhanced possibilities with frequent revisit times, high/very high spatial resolution and multispectral information. We face new challenges to tackle, in terms of processing and software needs for biodiversity and conservation activities. Multitemporal Remote Sensing (RS) observations are particularly relevant to automatically quantify, habitat loss, degradation and fragmentation. They also help to optimize field data collection by focusing on relevant sites, with dramatically improved cost-effectiveness ratios. Ten candidate variables derived from spacebased remote sensing have been recently identified, known as remotely sensed EBVs (RS-EBVs) or now more commonly "RS-enabled EBVs" (Skidmore et al., 2015, Pettorelli et al., 2016, Luque et al 2018). We show here, the interest of taking advantage of multiple RS data sources offering complementary spatial resolutions and revisit capabilities to focus on a number of candidate EBVs. The idea is to provide examples of a generic method to derive indicators based on: i) ecosystem distribution, ii) land cover, iii) heterogeneity, iv) primary productivity and v) vegetation phenology. One major current challenge for an improved contribution of RS to conservation is to strengthen multiple collaborative frameworks among remote sensing scientists, conservation biologists and ecologists in order to increase the efficiency of methodological exchange and draw benefits for successful conservation planning strategies. The presentation will serve to conclude de session and provide a take home message to tackle challenges ahead in order to improve biodiversity monitoring and mitigation measures.

\section{D8f: INVASIVE SPECIES IN FOREST ECOSYSTEMS, CAUSES, CONSEQUENCES,} UTILIZATION AND MANAGEMENT OPTIONS

\section{Invasive plants of forest ecosystems: impacts and management options}

Daizy Rani Batish ${ }^{1}$, Shibu Jose ${ }^{2}$

${ }^{1}$ Panjab University, Chandigarh, India; ${ }^{2}$ University of Missouri,Missouri,USA (daizybatish@yahoo.com; joses@missouri.edu)

Invasive plants are fast proliferating within and around forests- one of the most important terrestrial ecosystems providing numerous ecosystem services to mankind. All types of forests, viz. tropical, sub-tropical, temperate and alpine, are threatened by the establishment of invasive species, mainly the woody perennials e.g. Acacia spp., Pinus spp., Prosopis spp., Robinia pseudoacacia, Broussonetia papyrifera, Leucaena leucocephala, and Lantana camara, etc. These invasive plants spread gregariously reducing the carrying capacity of the forests and altering their natural structure and composition. These also hamper forest productivity, reduce local biodiversity and have a profound effect on the ecosystem services; therefore, having serious ecological and economic implications. 
Their presence even hinders the restoration efforts and other conservation-related operations in the forest areas. Furthermore, disturbances posed by changing climate and increased anthropogenic activities have aggravated the spread of invasive alien species in forest ecosystems. The ecological implications of the invasive species, therefore, demand strong management strategies based on an integrated approach involving constant monitoring of alien species, large scale operations for the mechanical/chemical/biological removal of invasive plants and rehabilitation of the infested areas. This not only requires global attention and cooperation among developed and developing countries and strict legal framework but also the participation of the local people, NGO’s, multi-stakeholders, and forest authorities.

\section{The impact of Sirex noctilio in Canada}

Jeremy Allison ${ }^{1}$

${ }^{1}$ Natural Resources Canada, Sault Ste Marie, Canada (jeremy.allison@canada.ca)

The woodwasp Sirex noctilio was discovered in Canada over a decade ago. Permanent impact assessment plots in Ontario, CA suggest that to date it has not been a significant mortality agent in pine forests in Canada, a situation that differs from some pine forests in the southern hemisphere. Manipulative oviposition trials and life-table studies suggest that high levels of mortality occur in the egg and early larval stages in pine forests in Canada. Factorial exclusion caging trials suggest that exposure to the biotic community significantly reduces $S$. noctilio brood production in Ontario but not in South Africa where pines are introduced and have a limited biotic community associated with them. The results of these studies will be presented and discussed with respect to the variable impact $S$. noctilio has had in its invaded range.

\section{Effect of introduced species on forest regeneration: the case of Isla del Coco National Park, Costa Rica}

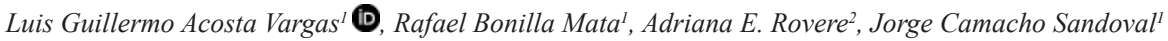

${ }^{1}$ Instituto Tecnológico de Costa Rica, Cartago, Costa Rica; ${ }^{2} I N I B I O M A$, CONICET-Universidad Nacional del Comahue. Centro Regional Universitario

Bariloche,Bariloche,Argentina (lacosta@itcr.ac.cr; rbonillam24@gmail.com; adrirovere@gmail.com; jorge.camacho.s@gmail.com)

Isla del Coco National Park is an oceanic island in the Eastern Pacific with tropical rain forest and high endemism. Deforestation and the introduction of flora and fauna species have impacted on the development and regeneration of its forest. We present the results of four exclosures established in a deforested area invaded by bushes and liana, where we applied treatments simulating gap dynamics for stimulating natural regeneration; and conducted an analysis of tree regeneration including data of forest permanent monitoring plots (PMP). We monitored regeneration within the exclosures; outside the exclosures herbivores consumed the regeneration after the first measure. Cecropia pittieri tree was the most successful reaching a density of 438 trees/ ha. The other tree species do not regenerate or reported a minimum amount, this indicated a depleted seed bank and lack of seed dispersion due to the lack of dispersers. The liana Entada gigas showed high invasion capacity, growing $1.6 \pm 0.2 \mathrm{~m} / \mathrm{month}$ from the edges of the remaining vegetation. The regeneration survey within PMP showed a low number of the canopy species: 166 seedlings/ha, 67 saplings/ha; instead, shrubs of Melastomataceae has the higher amount of regeneration 1478 seedlings/ha, 467 saplings/ ha, this replacement implies the loss of the composition and structure of the forest. Conserving the forest will require control of herbivores and invasive plants, and a program of reproduction and planting of tree species to overcome the poorly presented ecosystem services of the seed bank and seed dispersal.

\section{Invasive insect and disease threats to United States tree species and geographic patterns of their potential forest impacts \\ Kevin Potterl D, Maria Escanferla', Robert Jetton ${ }^{3}$ \\ ${ }^{1}$ Department of Forestry and Environmental Resources, North Carolina State University, Research Triangle Park, NC, USA; ${ }^{2}$ Department of Forestry and Environmental Resources, North Carolina State University, Raleigh, NC, USA, ${ }^{3}$ Camcore, North Carolina State University, Raleigh, NC, USA (kpotter@ncsu.edu; mescanf@ncsu.edu; rmjetton@ncsu.edu)}

Diseases and insects arguably pose the most destructive threat to North American forests. Recently, exotic invasive insects and diseases have wreaked extensive ecological damage and caused billions of dollars of economic impacts. As part of an effort to identify United States tree species and forests most vulnerable to such epidemics, we compiled a list of up to the five most serious insect and disease threats for 419 United States tree species and assigned a severity rating for each of the 1378 host and insect/disease combinations. We then combined this list with data from a spatially unbiased and nationally consistent forest inventory to assess potential ecological impacts of insect and disease infestations. Specifically, potential host species mortality for each host/agent combination was used to weight species importance values on 133,000 Forest Inventory and Analysis plots across the conterminous 48 United States which, when summed on each plot, represent an estimate of the proportion of existing importance value that could be lost on the plot. Plot estimates were then used to identify statistically significant geographic hotspots of potential forest impacts associated with insects and diseases in total. We found different patterns of potential impacts for insects than for diseases, and for exotic versus native insects. In particular, invasive insects, given their current geographic extents, should have the most impact in the Northeast, the Northwest, and along the Gulf Coast. Their impacts could increase greatly, however, if they infest the entirety of their hosts' distributions.

\section{A decision support system (DSS) for risk assessment and mitigation of forest invasive alien species (FIAS) in Canada \\ Valentine Lafond ${ }^{\prime}$, Gregory Paradis ${ }^{I}$, Vivek Srivastava ${ }^{I}$, Federico Lingua ${ }^{I}$, Stefanie Lumnitz ${ }^{I}$, Verena C. Griess ${ }^{I}$ \\ ${ }^{1}$ University of British Columbia, Faculty of Forestry, Department of Forest Resources Management, Vancouver, Canada(valentine.lafond@ubc.ca; gregory.paradis@ubc.ca; vivek.srivastava@ubc.ca; federico.lingua@ubc.ca; stefanie.lumnitz@ubc.ca; verena.griess@ubc.ca)}

With over 347 million hectares of forested area, Canada contains 9\% of the world's forests, 24\% of the world's boreal forests, and is one of the world's largest forest products exporters. Canada's forests and forest sector are vulnerable to forest invasive alien species (FIAS), with surveillance and mitigation efforts being particularly challenging given the large area of forest lands in the country. Decision Support Systems (DSS) can greatly facilitate invasion risk assessment and management. Hereby, the development and use of DSS is often limited by a lack of knowledge on FIAS ecology, especially regarding "invasiveness traits" (e.g. dispersal capacity). New opportunities arise from the use of genomics tools, which allow deriving such information from intercepted FIAS, thus allowing the integration of genomics informed data into DSS. We developed a model-based DSS framework for FIAS risk assessment and mitigation in Canada that allows to pipeline FIAS trait information derived from genomics and project potential impacts of FIAS invasions on forest ecosystem services (e.g. timber production, recreation). We illustrate its implementation and use for Asian Gypsy Moth (Lymantria dispar asiatica) invasions in British Columbia, using genomics-derived information on flight capacity from intercepted AGMs. The DSS provides stakeholders with essential information facilitating the identification and prioritization of areas at risk, estimation of potential socio-economic impacts of FIAS invasion, and comparison and selection of mitigation scenarios. 


\section{Reducing the invasibility of forests: Silvicultural strategies for integrating Black cherry}

Bart Nyssen 1 iD, Jan Den Ouden ${ }^{2}$, Kris Verheyen ${ }^{3}$, Erik Mathijs $^{4}$, Bart Muys ${ }^{4}$

${ }^{1}$ Bosgroep Zuid Nederland, Heeze, Netherlands; ${ }^{2}$ Wageningen University, Wageningen, Netherlands; ${ }^{3}$ University of Ghent, Ghent, Belgium; ${ }^{4}$ University of Leuven,Leuven,Belgium(b.nyssen@bosgroepen.nl; jan.denouden@wur.nl;kris.verheyen@ugent.be; erik.mathijs@kuleuven.be; bart.muys@kuleuven.be)

Forest managers are confronted with a seemingly endless flow of new species, the one more invasive than the other. The ease with which some of these species settle and prosper in particular forests, while other forests remain nearly immune to them, raises the question whether invasions are caused by the invasiveness of the new species or the invasibility of the receiving ecosystem. Understanding the link between traits making a tree species potentially invasive (invasiveness) and the ecosystem features leading to invasion (invasibility) offers tools to integrate potentially invasive tree species into forest ecosystem. We use the case of Black Cherry (Prunus serotina) to illustrate the role of silviculture in using the opportunities invasive tree species offer for integration into the forest ecosystem. This North American species became the foresters worst enemy in Europe 350 years after its introduction in 1623 . Two decennia of fiercely fighting the species proved in vain. Triggered by this observation, Dutch and Belgian foresters and researchers closely collaborated to develop approaches to restore forest ecosystems invaded by Black cherry. Production of Black cherry quality timber, followed by under-planting with more shade tolerant indigenous tree species as a transitional phase towards a more resilient mixed forest, was the basis for this integration strategy. This management strategy of utilizing an invasive species offers a perspective for other invasive tree species that are already widespread in the forest ecosystems and cannot be eliminated anymore.

\section{Technical, legal, and public responses to biological plant invasions in European temperate forests}

Katharina Lapin ${ }^{I}$, Magdalena Langmaier ${ }^{I}$, Janine Oettel ${ }^{I}$, Herfried Steiner ${ }^{I}$, Georg Frank ${ }^{1}$

${ }^{\prime}$ Federal Research and Training Centre for Forests, Natural Hazards and Landscape, Vienna, Austria (katharina.lapin@bfw.gv.at; magdalena.langmaier@bfw.gv.at; janine.oettel@bfw.gv.at; herfried.steiner@bfw.gv.at; georg.frank@bfw.gv.at)

The European temperate broad leaf and mixed forests (TF) cover large areas in 21 European countries. Unwanted naturalization of Invasive Alien Species (IAS) can entail risks to the biodiversity and ecosystem functions of TF. The aim of this study is to determine the current spread of IAS in TF and their impact on forest management, review existing technical measures, and discuss the prevailing legal and policy frameworks. The review of technical reports and publications shows that the plant species Solidago gigantea, Robinia pseudoacacia, Impatiens glandulifera, Fallopia sp., and Amorpha fruticosa are among the most-studied IAS in TF. Among the most-studied impacts are regeneration and changes to site conditions. The construction and use of forest roads as well as harvesting disturbances are considered to be the main pathways for the introduction of IAS into TF. Management measures include general considerations on preventing unintentional introduction and spread, early detection action plans followed by rapid eradication measures, mechanical removal, and the use of plant protection products (herbicides). Prevention measures are considered the most cost-efficient and effective measures. The effectiveness of control measures can be increased by way of integrated control strategies within a long-term management plan. Analysis of legal and policy frameworks shows overlapping responses in international conventions and agreements to address the risks. At the national level, policies and legal responses form a highly complex network of country-specific definitions and strategies. EU Regulation 1143/2014 stipulates an EU-wide ban of IAS of Union concern, including 8 plant species posing relevant risks for TF.

\section{Adaptive management of the invasive shrub Lonicera maackii and the herbivore Odocoileus virginianus for an endangered species in an old growth urban forest}

Robert Loeb ${ }^{1}$ iD, Will Peters ${ }^{2}$, Steve Ward ${ }^{2}$

${ }^{1}$ Pennsylvania State University,DuBois,PA,USA; ${ }^{2}$ RadnorLakeStateNaturalArea,Nashville,TN,USA(rxl5@psu.edu; will.peters@tn.gov; steve.ward@tn.gov)

The invasive shrub Amur honeysuckle (Lonicera maackii) became established in old growth urban forests of Radnor Lake State Natural Area, Nashville, Tennessee, USA in 1980. Also in 1980, the herbivore white-tailed deer (Odocoileus virginianus) returned to the Natural Area. The long-term change in all five forest communities found in the Natural Area was a decline in total tree stems from 1974 to 2008 and decimation of the seedling and sapling populations from 1994 to 2008. Amur honeysuckle has been the focus of intensive removal efforts since 2002. Comparison of areas with annual removals for seven years to areas with removal in only one year revealed greater effectiveness with annual treatments.Among the forests of the Natural Area are cedar glades, which contain both the endangered perennial herb wild dill (Perideridia americana) and Amur honeysuckle as well as transient white-tailed deer. Amur honeysuckle removals were performed in five cedar glades from 2014 through 2017 and the responses of wild dill and Amur honeysuckle were examined post-treatment in 2018 . In all five glades, the post-treatment Amur honeysuckle population was significantly smaller $(\mathrm{p}<0.001)$ as compared to pretreatment population. Wild dill increased from pretreatment to post-treatment in all five cedar glades, but the increase was not significant at one cedar glade. The effects of white-tailed deer trampling was demonstrated by declines in the population of wild dill from leaf out (mid-March) to flowering (early May) in 2018. Adaptive management changes considering the research outcomes will be presented.

\section{D8g: RESILIENCE OF TROPICAL FORESTS TO MULTIPLE DRIVERS OF CHANGE: CONTRIBUTING TO A MORE SUSTAINABLE FUTURE}

\section{Post fire regeneration of tree species in a Colombian tropical dry forest}

Anghy Gutiérrez-Rincón ${ }^{1,2}$, Angela Parrado-Rosselli, ${ }^{1,2}$

${ }^{1}$ Universidad Distrital Francisco José de Caldas, Bogota DC, Colombia; ${ }^{2}$ Use and Conservation of Forest Diversity Research Group, Bogota DC, Colombia (asgutierrezr@correo.udistrital.edu.co; aparrador@udistrital.edu.co)

Fire is a frequent and crucial disturbance in some tropical dry ecosystems such as savannas and tropical dry forest (TDF) in central-America. However, little is known about the capacity of inter-Andean dry forests to recover after a fire. Therefore, we compare the composition and structure of sexual regeneration between burned and unburned sites and evaluate the rates of mortality, recruitment, and growth of woody tree species after a fire in a tropical dry forest of the upper Magdalena river valley in Colombia. We install 75 plots of 2 x 2 m where we register and identify all woody individuals in burned and unburned sites. Every three months we recorded and measure the individuals found in 25 plots of burned sites. Results showed that species richness was lower in burned sites, but the number of individuals was significantly higher than in unburned areas. The mortality rate of the post-fire regenerated community was $0.91 \%$, while the recruitment rate was $1.93 \%$, which suggests a good post-fire establishment. In the burned sites, recruited species exhibited similar growth rates. Based on 
the natural regeneration index (TNR), species were classified as fire tolerant-species (e.g. Astronium graveolens, Eugenia procera and Swartzia trianae); firestimulated species (e.g. Casearia corymbosa, Cordia alliodora and Machaerium capote) and sensitive species (e.g. Posoqueria sp., Guarea guidonia, and Piptadenia sp.). Our results suggest that some inter-Andean TDF tree species can survive and regenerate after fire, and therefore they should be considered in restoration programs, in light of future and more frequent forest fires due to climate change.

\section{Miombo woodland regeneration dynamics after slash and burn agriculture and human settlement in Mozambique \\ Frédérique Montfort, Marie Nourtier, Clovis Grinand, Corentin Mercier \\ Nitidae, Montpellier,France (f.montfort@nitidae.org;m.nourtier@nitidae.org;c.grinand@nitidae.org;c.mercier@nitidae.org)}

Miombo woodland is the most extensive tropical dry forest formation in Africa, considered as a major biodiversity hotspot but is facing important threats including deforestation due to subsistence agriculture. To mitigate these impacts, passive or assisted forest regeneration is a key solution but little is known on the dynamics of this particular biome. The objective of this study was to analyze Miombo regeneration dynamics in the surroundings of the Gilé National Reserve in Mozambique. The landscape in the area is dominated by slash-and-burn agriculture with strong regeneration dynamics and some areas present long term forest regrowth due to past human migration in the 80's. We sampled 19 plots in mature Miombo forest and 63 regeneration plots from 1 to 40 years old, located over two distinct areas characterized by two dominant soil types. We observed that, changes in richness and species diversity are more linked to the age of the fallow and to anthropic pressure than to the edaphic conditions. Floristic differentiation begins after 10 years of growth, depending on the soil type. Miombo forest dominant trees species were observed as the dominant species of all the re-growing plots, whatever their age. Species richness, floristic composition and structure of the old fallows (30-40 year) are similar to those present in the mature forest, indicating a strong regeneration capacity in the absence of human pressure. This study provides new insights for the elaboration of passive forest restoration techniques adapted to Miombo woodland.

\section{Primary tropical forests, reduced impact logging, and resilience: implications for REDD+ and forest certification}

Peter Wood ${ }^{1}$, Solveig Firing Lunde ${ }^{2}$

${ }^{1}$ Rainforest Foundation Norway, Vancouver, Canada; 2Rainforest Foundation Norway, Oslo, Norway (peterjwood@gmail.com; solveig@rainforest.no)

In the past decade there has been much debate regarding whether primary tropical forests can be logged in a sustainable way, and whether such activities should qualify for support under REDD+ and certification programmes. While some advocate that reduced impact logging can lead to positive outcomes for the forest, others contest that primary forests should be excluded from these schemes. One of the main reasons cited for preventing further incursions into primary forests, in particular large intact forest areas, is that once access is introduced, it is difficult to prevent unregulated access, illegal logging, and conversion to other land uses. It has also been argued that logging in itself generates significant carbon emissions and creates vulnerability in terms of natural disturbances, most notably drought, fire, and pests. This paper examines the multiple stressors posed by logging in tropical forests and responses observed in different regions, and the ability of these ecosystems to maintain their biodiversity, structure and function. It examines what is known regarding the ability of these systems to maintain their resilience, thresholds and tipping points beyond which tropical forest is unlikely to return to its original condition, and the secondary consequences of introducing access, particularly in areas of poor governance. In light of these findings, recommendations are made as to what role REDD+ and forest certification could play in reversing the decline of tropical forests.

\section{Rethinking tropical forest management in the Anthropocene}

Jos Barlow

LLancaster University, Lancaster, United Kingdom (josbarlow@gmail.com)

Many of the guidelines regarding tropical forest management in sustainable-use or strictly-protected reserves focus on local issues within the area of interest itself, such as setting offtake limits for game or timber and defining the spatial configuration and extent of no-take zones. Yet tropical forests face a period of unprecedented environmental change. This talk will explore recent evidence highlighting the role of multiple interacting threats from climate change, climate shocks, and human land-uses outside of the forest itself - assessing their role in determining biodiversity loss, changing forest composition and limiting forest recovery. Finally, it will explore ways in which management strategies can be modified to more effectively integrate multiple stakeholders across the landscape, and outline ways in which the scientific and practitioner communities can work together to incorporate global environmental change into forest management.

\section{Policy alternatives to address tropical forest degradation}

Cecilia Viana ${ }^{1}$,Jos Barlow², Joice Ferreira ${ }^{3}$

${ }^{1}$ Rede Amazônia Sustentável, Ilhéus, Brasil; ${ }^{2}$ Lancaster Environment Centre, Lancaster, United Kingdom; ${ }^{3}$ Embrapa Amazônia Oriental, Belém, Brasil (cicaviana@gmail.com; jos.barlow@lancaster.ac.uk; joice.ferreira@embrapa.br)

In a rapidly changing environment, forests are exposed to multiple and interacting stressors that can lead to forest degradation. Within policy circles, forest degradation is often assumed to be the initial stage of the deforestation process, and thereby an implicit aspect of deforestation policies. Indeed, forests are often gradually degraded before they reach the final clear-cut state, which is usually the case in the Brazilian Amazon. Yet, there is growing evidence that degraded forests have both impacts and dynamics of their own, regardless if it reaches final stages of deforestation. Degraded forests are a source of greenhouse gas emissions, they are not able to secure biodiversity conservation and the provision of ecosystem services, and they may hinder the livelihoods of forest-dependent peoples. Importantly, degraded forests are more vulnerable to further degradation events. However, despite all evidences, forest degradation is overall neglected by policies. In this presentation, we will use Brazil as a case study to discuss policy alternatives to address the issue of tropical forest degradation. First, we will examine if and how environmental policies implemented in the Brazilian Amazon over the past decades address forest degradation. Second, we will depart from the Brazilian experience to discuss the challenges and opportunities of different alternatives for adequately addressing forest degradation. By examining environmental policies implemented in the Brazilian Amazon and considering scientific findings on forest degradation, we expect to contribute for a sustainable future for tropical forests by diminishing the gap between science and policy. 


\title{
The effects of increased temperature and drought on wildfires and adaptation needs in Daxing'anling, China \\ Fengjun Zhao ${ }^{1}$, Yongqiang Liu', Lifu Shu ${ }^{1}$ \\ ${ }^{1}$ Research Institute of Forest Ecology, Environment and Protection, Chinese Academy of Forestry, Beijing, China; ${ }^{2}$ USDA Forest Service, Athens, USA (zhaofengjun1219@163.com; yliu99@gmail.com; slfhxk@126.com)
}

Daxing'anling is a densely forested region in northeastern China. It contributes to about half of the burned areas in China. Climate is one of the major wildfire drivers and it has been changing. This study investigates the effects of the changing temperature and drought conditions on wildfires in Daxing'anling and the adaptation needs. Historical wildfire and climate data in the past half a century were used to analyze the temporal trends of wildfires and climate during fire seasons and calculate the correlations between wildfire properties and climate elements. The results indicate a remarkable change in fire season due to climate change. The fire season in this region was used to occur in bimodal peaking in spring and fall with minimal fires during summer. However, the number of fire occurrence decreased in both spring and fall in recent two decades, with larger magnitude in fall. In contrast, the number increased in summer. Most fires in summer were caused by lightning strike, which in turn was related to weather conditions. The changes in fires were mainly due to climate change featured by increased temperature and drought during summer. To adapt this summer fire increase, more fire management efforts in fire safety are needed because more complex and unstable weather in summer would make fire prevention and suppression more difficult and firefighters are expected to expose more to heat waves and elevated ozone conditions.

\section{D8h: TREES OUTSIDE FORESTS IN LANDSCAPE ANALYSIS: IMPORTANCE, DEFINITIONS} AND ASSESSMENT STRATEGIES

\author{
The role of trees in integrated agricultural-livestock-forestry systems / O papel das árvores nos sistemas de Integração Lavoura-Pecuária- \\ Floresta (ILPF) \\ Renato Rodrigues ${ }^{1}$, Fabiano Balieiro ${ }^{1}$, Natassia Armacolon', Júlia Silveira ${ }^{3}$, Jacqueline Jesus ${ }^{4}$ \\ ${ }^{1}$ Embrapa Solos, Rio de Janeiro, Brasil; ${ }^{2}$ Universidade Estadual de Londrina, Londrina, Brasil; ${ }^{3}$ Universidade Federal de Viçosa, Viçosa, Brasil; \\ ${ }^{4}$ Universidade Federal Fluminense, Niterói, Brasil (renato.rodrigues@embrapa.br; fabiano.balieiro@embrapa.br; nmarmacolo@gmail.com; \\ juliagrazielasilveira@gmail.com; jacqueufmt@gmail.com)
}

A Integração Lavoura-Pecuária-Floresta consiste em uma estratégia de produção agropecuária que integra sistemas produtivos (agrícolas, pecuários e florestais) dentro da mesma área, com cultivo simultâneo ou sequencial, de forma que haja interação entre os componentes, gerando benefícios mútuos. A configuração desses sistemas (iLP, iLF iPF ou iLPF) é compatível com as diferentes realidades do ambiente rural brasileiro e por isso esses sistemas se mostram tão promissores, apesar de desafios persistirem. Atualmente, menos de $20 \%$ da área com ILPF (o que corresponde a menos de 3 milhões de hectares) no Brasil possui o componente florestal e isso precisa mudar para que a paisagem e o produtor rural se beneficiem de bens e serviços a ele associados. É preciso discutir e apresentar aos produtores novas alternativas de sistemas, inserir novas espécies (incluindo nativas), testar novos arranjos de plantios, assim como aproximar mercados para produtos madeireiros e não-madeireiros oriundos desses sistemas. Intensificar a ciclagem de nutrientes, aumentar o sequestro de carbono, mitigar a erosão, amenizar o estresse calórico de animais e melhorar o fluxo gênico em paisagens degradadas são alguns serviços ecossistêmicos incrementados pela presença de árvores em agroecossistemas. O Brasil assumiu compromissos voluntários no âmbito do Acordo de Paris que visam o aumento da área de ILPF no país até 2030. Essa é uma excelente oportunidade para o desenvolvimento de políticas e financiamentos públicos e investimento privado na implantação de plantios de árvores em sistemas agrícolas e pastoris.

\section{Salvaging indigenous trees in Urban Areas: socio-cultural believes of remaining Iroko (Milicia excelsa) in Ibadan, Oyo State, Nigeria Folaranmi Dapo Babalola ${ }^{1,2}$ D, Paxie Chirwa ${ }^{2}$ \\ ${ }^{1}$ Forest Resources Management, University of Ilorin, Ilorin, Nigeria; ${ }^{2}$ Forest Science Postgraduate Programme, University of Pretoria, Pretoria, South Africa (babalola.fd@unilorin.edu.ng; paxie.chirwa@up.ac.za)}

Indigenous trees have been discovered to be disappearing from urban areas at alarming rates. Milicia excelsa is an indigenous trees species in tropical Africa and popularly known as Iroko. The tree is popular for its socio-cultural and economic importance. It has been classified as threatened and relics could only be found in a few locations. A survey of the trees in the city of Ibadan, the capital city of Oyo State in Nigeria, was therefore carried out to determine their distribution as well as the ecosystem services provided by the tree in the city. A total of 65 trees $\left(0.14\right.$ trees $\left./ \mathrm{km}^{2}\right)$ were sighted in the city. The trees provide environmental, medicinal, economic, spiritual and ecological services to the people. Topmost of the ecosystem services provided by the trees was provision "microclimatic environment' in the form of cooling effects $(95 \%)$ from the heat of the day. However, the people believe that the trees habour some "spirits" with evidences of sacrifices placed under them. Furthermore, snapping of branches of old trees and roosting by some birds on them cause damage to property hence the trees want them removed. Strategy for proper management of the trees in the city to prevent damage to property and to life is considered imperative. There is also a need for an appropriate policy that protects indiscriminate felling of indigenous trees in the city.

\section{Urban forest landscape metrics of Curitiba-Paraná-Brazil}

Mayssa Grise', Daniela Biondi', Hideo Araki ${ }^{1}$

${ }^{1}$ Universidade Federal do Paraná, Curitiba, Brasil (mayssamonteiro@gmail.com; dbiondi@ufpr.br; haraki@ufpr.br)

The urban landscape increasingly requires studies that brings a detailed analysis of its composition and configuration through its structural components - matrix, fragments and corridors that, when quantified and analyzed by the metrics calculation, can translate the landscape dynamics. The aimed of this research was to verify the utility of landscape metrics in urban forest spatial pattern characterization of the city of Curitiba-Paraná-Brazil. From the high spatial resolution image (Geoeye) classified, and the subsequent definition of the structural urban components matrix, vegetation fragments and corridors, 16 different landscape configuration metrics were calculated. The metrics that effectively contributed to the spatial analysisof the landscape were: Total Area (CA), Landscape Percentage (ZLAND) and Number of Polygons (Nump). The metrics that effectively contributed to the analysis of the landscape structurewere: Total Edge 
(TE), Edge Density (ED), Mean Patcht Tdge (MPE) and Shape Index (SI). The Patch Size Standard Deviation (PSSD) and Patch Size Coefficient Variation (PSCoV) translated the variety of structural components inherent to the urban landscape, wich is noted by the diversity of anthropic and natural elements that are responsible for the urban ecosystem functioning.

\section{Ensuring sustainable management of trees- on-farms in the off reserve landscape through tree registration and climate smart farming systems in Ghana}

Valerie Fumey Nassah', George Odame', alexander Asare ${ }^{1}$

${ }^{1}$ ForestryCommission, Kumasi, Ghana(valfn2003@yahoo.co.uk; grodame@gmail.com; abasare99@yahoo.com)

Ghana has a total land area of 238,540 $\mathrm{km}^{2}$ made up of two major vegetation zones. Approximately $18 \%$ of the country has been set aside as forest reserves and wildlife parks and the remaining $82 \%$ is owned by stools, skins and individuals across the country. All naturally occurring trees in off reserve landscapes are vested in the state but they occur in individual and community lands and farms. In the past farmers destroyed these trees because their cocoa farms were destroyed by felling of trees for timber and they could not get compensation or any support from the state. To achieve Ghana's Forest policy goals and objectives of the forest Plantation strategy, Ghana is implementing a programme to provide legal support for farmers, optimize the productivity and sustainability of smallholder farming systems by developing appropriate technologies that involve trees (incorporation of trees-on farm within 3.75 million hectares) and enhances connectivity and biodiversity between the agricultural and forest landscapes. A pilot programme to register all planted and naturally occurring trees at the district level has began with recent support from Climate Investment Fundthrough Ghana's Forest investment programme(GFIP) to provide options for tree tenure regimes, tree ownership and benefit sharing mechanisms for farmers to plant more trees. This paper highlights the importance of trees on farm for landscape restoration, legal framework and the procedures for tree registration, identified strengths and weaknesses and potential for carbon stock enhancement

\section{Historical tree cover percentage of trees outside forest: methods and challenges for urban tof when using landsat imagery}

Nils Nölke ${ }^{1}$, Marco Sendner ${ }^{1}$, Christoph Kleinn ${ }^{1}$

${ }^{1}$ University of Goettingen, Göttingen, Germany (nnoelke@gwdg.de; m.sendner@stud.uni-goettingen.de; ckleinn@gwdg.de)

Urban trees are a particular class of "trees outside forests" and they have particularly relevant functions in many urbanized regions and settlements. Accordingly, tree resources management increasingly demands relevant and updated information on urban trees, their cover, diversity, spatial configuration and functions. Even though remote-sensing satellite sensors have, in general, proven very useful for estimating forest and tree cover in many contexts, still many related methodological issues require a closer look, also when it comes to monitor changes in tree cover back in time. This study examines how spatial configuration and spectral reflectance of tree cover may affect the pixelwise tree cover estimation in an urban setting and in turn identifies methodological challenges for the estimation of historical tree cover when establishing time series. We give an example how a global tree cover product "struggles" when the focus is on urban tree cover. Our study area is the rural-urban gradient of the very fast-developing megacity, Bengaluru, India, where we cover a wide range of tree densities and tree spatial configurations. This study area is a perfect ground to shed lights on the issue when estimating continuous tree cover percentage from Landsat time series.

\section{Mapping Trees Outside Forest and their contribution to the above ground biomass}

Mostarin Ara ${ }^{1}$, Iris Van Duren ${ }^{2}$, Louise Van Leeuwen ${ }^{2}$

${ }^{1}$ Swedish University of Agricultural Science, Alnarp, Sweden; ${ }^{2}$ University of Twente, Enschede, Netherlands (mostaringem@gmail.com;

i.c.vanduren@utwente.nl; l.m.vanleeuwen@utwente.nl)

Trees in non forest setting are coined as Trees Outside Forest (TOF) which is considered as essential resource around the world. TOF provides different social, economic and ecosystem services including carbon and biomass storage. TOF shows unique property as it is part of another land class which makes it difficult in many places to access due to the ownership of private land. Moreover, it is also tedious and expensive to do inventory in a traditional plot based survey because of their spatial position in landscape level. But the method in combination of remote sensing and few ground data can be promising. In this study, we used remote sense based approach using very high resolution imagery to map TOF and their biomass potential in an agriculturally dominant landscape. Object based image analysis was used to delineate TOF cover from other land class and to model their biomass potential. The method shows feasibility for TOF and biomass mapping and it could be a potential supplement of ground inventory data.

\section{Other lands with trees at Brazilian Forest Inventory (NFI-BR)}

Marilice Cordeiro Garrastazúl (D), Jéssica Maran ${ }^{1,2,3}$, Maria Augusta Doetzer Rosot ${ }^{1}$ D. Yeda Maria Malheiros de Oliveira ${ }^{1}$ (D, Luziane Franciscon ${ }^{1}$, Naissa Luz ${ }^{4}$, Denise Cardoso ${ }^{1}$, Patricia Póvoa de Mattos ${ }^{1}$ iD, Joberto Freitas ${ }^{3}$

${ }^{1}$ Embrapa Florestas, Colombo, Brasil; ${ }^{2}$ FAO, Curitiba, Brasil; ${ }^{3}$ Serviço Florestal Brasileiro, Brasilia, Brasil; ${ }^{4}$ Univeridade Federal de Uberlandia, Uberlandia,Brasil (marilice.garrastazu@embrapa.br; jess.maran@gmail.com; augusta.rosot@embrapa.br; yeda.oliveira@embrapa.br; luziane.franciscon@embrapa.br;naissal@gmail.com; denise.cardoso@embrapa.br; patricia.mattos@embrapa.br;joberto.freitas@florestal.gov.br)

National Forest Inventory (NFI-BR) is under development in many Brazilian states, aiming at generating information on forest resources, from natural areas and forest plantations and based on a 5-year measurement cycle. Besides field data collection, the program includes an initiative that comprises remote sensing and landscape scale spatial analysis, which consider aspects such as land use/land cover (LULC). Those are called landscape sample units (LSUs) which are established at each $40 \times 40 \mathrm{~km}$. The LSUs are $100 \mathrm{~km}^{2}$ wide areas with RapidEye satellite imagery coverage. A methodology for image classification and landscape analysis was developed based on 20 LSU pilot sample units. Object-oriented classification using a process tree was adopted, through which the size of the segments between 1,000 and $500 \mathrm{~m}^{2}$ was defined, in order to detect the presence of small forest fragments. The classification of LULC was based on FAO protocols for Forest Resource Assessment (FRA) 2015: a) natural forests; b) planted forests; c) other wooded land; and d) other lands with trees, the only one that is located in non- forestlands, as agricultural or urban areas. This LULC class covers part of the so called "trees outside forests (TOF)" concept, as defined by FAO. Through the methodology and considering the sensor with spatial resolution of 5 meters, it was possible to detect that this class corresponds on average to 38 hectares of each pilot area, with an average frequency of 171 polygons per LSU. They can be also considered as stepping stones in the connectivity process of the forest landscape. 


\section{The carbon-water-energy-climate nexus and forest-water-people-climate systems}

David Ellison ${ }^{1}$

${ }^{1} S L U$, Umea, Sweden (ellisondl@gmail.com)

Rapid population growth, increasing agricultural production, mushrooming urban (and suburban) settlements and the continuous decline of forest cover bode ill for the delicate balance between carbon, water, energy and climate. People-forest-water-climate systems create ever more complex and potentially interactive feedbacks across the carbon-water-energy-climate nexus. Climate change can further exacerbate fundamental imbalances created by the anthropogenic modification of terrestrial landscapes. Globally warming temperatures and declining rainfall (in particular in the tropical and temperate regions), both compound and further aggravate an increasingly grim misuse of planetary resources. Where the forest-water debate is concerned, however, the scientific world remains divided into easily politicized camps, seemingly unable to observe and adequately understand what the other camp is up to. Despite this, as this presentation will demonstrate, many or most of the basic tools necessary for restoring at least a part of the delicate balance between the major ecosystem components of the carbon-water-energy-climate nexus are increasingly well understood and documented. Thus, an optimized ecosystem strategy could effectively use these tools to at least partially address the rapid advance of climate change and its increasingly threatening impacts on the availability of at-risk water resources, and on the million to billions of people and livelihoods who depend on them.

\section{How good could be forest restoration to streamflow at Atlantic forest ecosystem?}

Silvio Ferraz ${ }^{1}$, Aline Fransozi ${ }^{1}$, Carolina Rodrigues ${ }^{2}$, Lara Garcia $^{3}$, Katherine Vasquez ${ }^{1}$, Matheus Ogasawara $^{1}$

${ }^{1}$ Escola Superior de Agricultura "Luiz de Queiroz", Universidade de São Paulo, Piracicaba, Brasil; ${ }^{2}$ Pratica Socioambiental, Piracicaba, Brasil; 3Instituto de Pesquisas e Estudos Florestais,Piracicaba,Brasil (silvio.ferraz@usp.br; aline.fransozi@usp.br; cabreuva@gmail.com; lara@ipef.br; katherinevasquezvasquez1@gmail.com; matheus.ogasawara@usp.br)

Following Brazilian restoration goals, more than 1 million of hectares will be restored at Atlantic Forest biome. Many sectors of society have high expectation about benefits on water provision and regulation by forest restoration, since there an association between native forest cover and quantity of clean water. Considering this context, it is necessary to increase understanding the effects of forest restoration on hydrological processes and, consequently, on water resources in tropical region. We used field data obtained at restored sites and forest catchments covered by on growing native vegetation and forest plantations (Pinus and Eucalyptus) to understand effects of active forest restoration at Atlantic Forest region. Effects of conversion to forest on hydrological dynamics vary according to forest growing rate, relative position of forest on topographic position and site resilience. Forest structure establishment is not directly linked to its hydrological processes' recovery, and the time lag depends on ecological condition of new forest, historical land-use and local natural physical characteristics. Positive effects of forest restoration on hydrological regime is expected on long term, when stream flow regulation is achieved, compensating the short-term effect of stream flow reduction. Based on current knowledge, a framework of forest restoration effects on streamflow is proposed and discussed.

\section{Landscape characteristics and their implications to ecological restoration: observation and experience from Western China \\ Runsheng Yin ${ }^{1}$, Daojun Zhang ${ }^{2}$ \\ ${ }^{1}$ Michigan State University, East Lansing, USA; '2Northwest A\&F University, Yangling,China (yinr@msu.edu; cugzdj@gmail.com)}

So far, inadequate attention has been given to the design and implementation payments for ecosystem services and other ecological restoration programs in line with the characteristics of landscapes to be restored. Evidence from China's Sloping Land Conversion Program indicates that one family had only $1 / 3$ ha of retired cropland in Sichuan and one ha in Shaanxi. Studying a watershed of 543.5 ha in Wuqi county of Shaanxi further reveals that it includes 491 plots, with an average size of only 1.1 ha, ranging from less than 0.01 ha to 27.2 ha. Also, these plots belong to $>50$ households in three villages, with each household having 18 plots at the maximum and one at the minimum. Moreover, the slopes of these plots range from $3.7^{\circ}$ to $37.5^{\circ}$, averaging $19.1^{\circ}$. Given the fragmented and tiny amount of the retired cropland, it is impossible to execute a contract bidding process at the household level; local- or landscape-level projects must be structured and bidding by community groups or intermediary aggregators be sought in order to achieve the functionality of the restored landscape on the one hand and market-based voluntary participation on the other. This is in contrast to the situations in some other countries. For instance, the restoration contract size in the U.S. averaged 30.4 ha and the mean sign-up amount was 44.8 ha per farm. It is thus more appropriate to construe ES provision and bidding contracts at the farm level in the U.S.

\section{Recovering soil infiltration along a gradient of pasture to forest restoration in Atlantic Forest}

Aline Fransozi ${ }^{1}$, Marcia Sousa do Nascimento ${ }^{1}$, Sílvio Frosini de Barros Ferraz ${ }^{1}$

${ }^{1}$ Escola Superior de Agricultura “Luiz de Queiroz”, Universidade de São Paulo, Piracicaba, Brasil (aline.fransozi@usp.br; marcia.sousa36@gmail.com; silvio.ferraz@usp.br)

Forest transition describes a landscape transformation where a huge decline of forest induced by human activities is followed by a partial recovery in the extent of new forests. Atlantic Forest is following this trend and after deforestation, exploitation and intensive soil use on this biome, many goals are been established for restoration of forest on previous agriculture landscapes. Most of these efforts occurs in pasture areas, sometimes actively with high investment costs, or passively, where the abandonment of areas less productive allows natural regeneration and create small forests in secondary succession processes. In most of Atlantic Forest biome, it is expected that these new forests support essential ecosystem functions related to soil and water protection. We assessed infiltration rates on new forests originated by natural regeneration on a pasture matrix landscape in two soil types: one loam and other sandy soil. It was used Beerkan Estimation of Soil Parameters through Infiltration Experiments, referred as BEST, to get the soil satured hydraulic conductivity. After one decade, both soils at forest restoration sites presented infiltration rates around 10 times higher than pasture ones. Preliminary results from areas of active restoration coupled with management practices show that is possible to accelerate the recovery of infiltration rates on formerly pasture fields. A time framework to recovery soil infiltration capacity by forest restoration is discussed. FAPESP Process 2015/23719-6 
Estimating the effects of restoration practices on controlling soil and water losses in China's Wei River Basin based on longitudinal observations and integrated methods

\author{
Yifei Wang ${ }^{1}$, Runsheng Yin ${ }^{2}$ \\ ${ }^{1}$ Northwest A\&F University, Yangling, China; ${ }^{2}$ Michigan State University, East Lansing, USA (wangyifei1223@nwafu.edu.cn; yinr@msu.edu)
}

Understanding the soil and water processes and their interactions over time and space has attracted research and policy attention worldwide. But past studies have rarely adopted an interdisciplinary approach to integrating the primary natural and social forces in assessing the causes of soil and water loss or conservation. The purpose of this study is to evaluate the effects of restoring degraded cropland by means of reestablishing forest/vegetation covers and terracing on water and sediment control in the Wei River Basin, which was notorious for its high erosion rates but has witnessed tremendous improvement since the beginning of the new century. Based on a unique panel dataset covering 44 counties over 16 years (2000-2015), our simultaneous equations model was able to capture the structural linkages between water runoff, sediment concentration, and sediment transport. To highlight the crucial role of human interventions, a stepwise regression approach was undertaken. Our empirical results show that the reduction of sediment concentration has been driven largely by improved land cover, induced by implementing the Sloping Land Conversion Program, whereas terracing, as part of the Water and Soil Conservation Project, has played a positive role in mitigating runoff and sediment discharge.

\title{
Atlantic forest restoration and hydrological services: trade-off between water supply and protection services \\ Lara Gabrielle Garcial (D), Silvio Frosini de Barros Ferraz ${ }^{2}$ \\ ${ }^{1}$ Instituto de Pesquisas e Estudos Florestais, Piracicaba, Brasil, ${ }^{2}$ Escola Superior de Agricultura Luiz de Queiroz, Universidade de São Paulo, Piracicaba, Brasil(lara.garcia@usp.br; silvio.ferraz@usp.br)
}

Water supply is the one the main objectives of forest restoration at Atlantic Forest biome, especially in critical regions like São Paulo State. Once forest has a direct influence on hydrologic processes, the increase of forest can affect hydrological services, however, effects could be positive or negative. In this context, our aim was to assess how forest restoration can affect hydrological services. The study area was an agricultural catchment located at southeast Brazil and simulations of forest cover increase were conducted using the physically based distributed hydrological model MIKE-SHE, previously calibrated. The scenarios used were $0 \%$ forest cover (FC) to $100 \%$ FC (nine scenarios between $10 \%$ and $90 \%$ FC). Hydrological services were analyzed through three water supply indicators (Q - annual flow, Q95 - minimum flow, and BFI - base flow index) and one protection indicator (Q5 - maximum flow). The results allowed us to affirm that the increase of forest cover resulted in a decrease of Q and Q95 values, and an increase of Q5 values. Therefore, our results indicate a water supply decrease and a protection increase following forest cover gain at catchment, which put in evidence a trade-off between hydrological services. The $50 \% \mathrm{FC}$ scenario seems to be an important threshold for hydrological services since until this forest cover proportion simulations not show difference in water supply in relation to $0 \% \mathrm{FC}$, also this scenarios results in gain of water protection in relation to $40 \% \mathrm{FC}$. We discuss the tradeoff of hydrological services in relation to forest restoration strategies.

\section{Modelling forest restoration to evaluate hydrology ecosystem services in the Cantareira System water supply context}

Claudia Moster ${ }^{1}$, Marcos Vinícius Folegatti ${ }^{2}$, Jorge Eduardo Leon Sarmiento 3

${ }^{1}$ Universidade Federal Rural do Rio de Janeiro, Seropédica, Brazil; ${ }^{2}$ Universidade de São Paulo, Piracicaba, Brazil; ${ }^{3}$ The Nature Conservancy, Bogotá, Colombia(claudiamoster@usp.br;mvfolega@usp.br;jleon@tnc.org)

The modeling of hydrological ecosystem services is an auxiliary tool in decision making for financial investment in land use practices and in forest restoration projects. Due to the need for improvement in the provision of these services at the lowest investment cost, this work aimed to evaluate scenarios for diferent methods of forest restauration in riparian areas and the transition of land use to hydrology ecosystem services. The study area comprises the Jaguari watershed, located in the head of water suplly Cantareira System, which has the purpose of supplying water to the metropolitan region of São Paulo, Brazil. This study identified priority areas to transitions land use and land cover in RIOS model and evaluated export sediment and base flow production using the InVEST tool, to forest restoration assisted and unassisted in riparian areas and the transition to silvopasture in grassland. These scenarios were evaluated for the reduction of sediment exports in relation to the transition in the total drainage area, with unlimited financial resources initially, and the generation of base flow in second step. The priority area to transition resulted in $37.56 \%$ of Jaguari watershed, considering the agroforestry in the pasture land and restauration of riparian areas, could to reduce about $72 \%$ of sediment export and $9 \%$ of baseflow. The assisted restauration of riparian forest could improve the sediment retention but the reduction of baseflow would be significant. The modelling was effective to identify priority areas and simulate the effects of transition land use and cover to water supply.

Efficient water use in two forest species used for ecological restoration in a dry tropical forest in colombia. Municipio del Agrado (Huila) / Uso eficiente del agua en dos especies forestales usadas para restauración ecológica en un bosque seco tropical de Colombia. Municipio del Agrado (Huila)

Miguel Eugenio Cadena Romero ${ }^{1}$, Jaime Harley Gonzalez Cárdenas ${ }^{2}$, Yaneth Sierra Carantón ${ }^{1}$

${ }^{1}$ Universidad Distrital Francisco José de Caldas, Bogota, Colombia; ${ }^{2}$ Universidad Distrital Francisco josé de caldas, Bogota, Colombia (cademielro@hotmail.com; harforest@gmail.com; ysierrac@gmail.com)

Este estudio se realizó en el departamento del Huila, municipio El Agrado; Sobre el área de compensación de la central hidroeléctrica del Quimbo en bosque seco tropical. El objetivo del estudio fue evaluar el uso eficiente del agua (WUE) de las especies, Albizia guachapele (Kunth) Dugand y Enterolobium cyclocarpum (Jacq.) Griseb. a la edad de un año y en tres estrategias de restauración ecológica (Nucleación, Nodrizas y Multinodrizas). Se caracterizaron física química y taxonomicamente los suelos, tomando registro micro climático del área y realizando análisis geoestadístico de las variables regionalizadas del suelo. Algunas propiedades físicas de los suelos varían de acuerdo al tipo de estrategia. Existe similitud en las propiedades químicas. El registro climático muestra que diciembre es más seca que abril y que esta condición influye significativamente en el WUE. El uso eficiente del agua analizado mediante el diseño experimental de bloques completos al azar en arreglo factorial 2 x 3 con submuestreo y en series de experimentos, empleando la prueba de comparaciones múltiples de Bonferroni determinó con una confiabilidad del 78\% ( $\operatorname{Pr}>0.22)$ que la especie $A$. guachapele perteneciente al arreglo florístico de Nucleación y medido en época seca (interacción de segundo grado) registró el mayor WUE con un valor de $0.89 \mathrm{mmol} \mathrm{CO}_{2} \mathrm{~mol}^{-1} \mathrm{H}_{2} \mathrm{O}$. En el análisis geoestadístico se evidencia que el mayor uso eficiente del agua instantáneo (WUE0) lo presentó la especie E. cyclocarpum con un índice de 3.3 mmol $\mathrm{CO}_{2}$ mol $^{-1} \mathrm{H}_{2} \mathrm{O}$, en la estrategia Nodrizas y en época húmeda. 
Variable areas of affluence as priority areas for implementing ecosystem service programs: a proposal for application via river basin plans / Áreas Variáveis de Afluência como áreas prioritárias para implementação de programas de serviços ecossistêmicos: uma proposta de aplicação via planos de bacias hidrográficas

François Lopes Alves ${ }^{1}$

${ }^{1}$ Forestis Brasilis, Rio de Janeiro, Brazil (francois.eng@live.com)

A Política Nacional de Recursos Hídricos, instituída pela Lei federal nº 9433 de 1997, almeja a sustentabilidade e segurança hídrica através do gerenciamento eficaz das bacias hidrográficas brasileiras. Para tal estabelece que os planos de bacias hidrográficas são instrumentos que atuam como planos diretores de gerenciamento dos recursos hídricos. Um dos itens que devem conter nos planos de bacias são os programas voltados à proteção e conservação dos corpos hídricos e a definição de áreas sujeitas à restrição de uso, com vistas à proteção dos recursos hídricos através de áreas florestadas. Observando a realidade brasileira os planos de bacia visam em geral para a recuperação florestal às áreas previstas no Código Florestal, o que não significa proteger e conversar os recursos hídricos de maneira efetiva. O diploma legal não consegue garantir a conservação e preservação da zona ripária em sua totalidade, pois a delimitação da área variável de afluência de uma microbacia não está transcrita no texto jurídico, o que reflete diretamente na oferta hídrica e qualidade socioambiental da bacia hidrográfica. Partindo das bases de hidrologia florestal e com vistas a contribuir com o alcance de metas políticas à qualidade hídrica e ambiental o presente estudo propõe, fundamentado em uma sólida base bibliográfica, que as áreas variáveis de afluência sejam adotadas em conjuntos com as áreas de preservação permanente como áreas prioritárias para a execução de restauração florestal através de programas de serviços ecossistêmicos, como o pagamento de serviços ambientais, via plano de bacia hidrográfica.

\title{
D8k: FOREST MANAGEMENT AND BIODIVERSITY CONSERVATION
}

\author{
Genetic criteria and indicators for Brazilian Araucaria Forest conservation policies

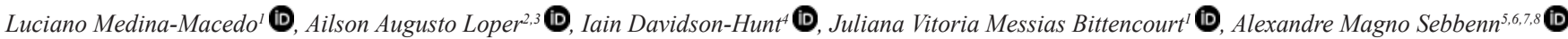 \\ ${ }^{1}$ Universidade Tecnológica Federal do Paraná, Ponta Grossa, Brasil; ; ${ }^{2}$ Associação Paranaense de Empresas de Base Florestal, Curitiba, Brasil; \\ ${ }^{3}$ Universidade Federal do Paraná, Curitiba, Brasil; ${ }^{4}$ UOM, Winnipeg, Canada; ${ }^{5}$ Instituto Florestal de São Paulo, Piracicaba, Brasil; ${ }^{6}$ Universidade Estadual \\ Paulista “Júlio de Mesquita Filho", Ilha Solteira Brasil, ${ }^{7}$ Escola Superior de Agricultura "Luiz de Queiroz", Universidade de São Paulo, Piracicaba, \\ Brazil; ${ }^{8}$ Thünem Institute,Braunschweig, Germany(medina.ppgebb@gmail.com; ailsonloper@apreflorestas.com.br; iain.davidson-hunt@ad.umanitoba.ca; \\ julianavitoria@utfpr.edu.br; alexandresebbenn@yahoo.com.br)
}

The objective of this study is to present how the genetic dataset from key-species can support conservation policies of endangered biomes. The Araucaria Forest is one of the most important subtropical biomes from Southern America covering near to $200.000 \mathrm{Km}^{2}$. However, the indiscriminate use leads in the 1990 s to a dramatic reduction of mature forest stands to less than $2 \%$ of its original area. To avoid extinction, rules for sustainable management were established in the 1990s, but in 2000 four Araucaria Forest tree species were classified as vulnerable by IUCN. In 2001 the log of endangered species was forbidden in Brazil, and in 2006 the government selected areas to compose new conservation units. In the other hands, since 1998 more than 35 genetic studies with the emblematic Araucaria angustifolia species have been carried, looking for support conservation policies to Araucaria Forest biome. The most important results verified by different authors point that very well conserved areas have a low density of individuals; gene-flow is possible up to $2 \mathrm{Km}$ distance; the pattern of seed dispersal leads to a significant spatial genetic structure, but genetic mechanisms avoid the mating among relatives; and in spite the diversity levels usually are relatively high anywhere, new alleles can be found at $5 \mathrm{Km}$ distance. This evidence allows the adoption of integrative conservation policies to the farmers' owners of significant forest remnants areas, ensuring the creation of biodiversity corridor zones, able to promote the functional and ecologic connection among expressive Araucaria Forest fragments.

\section{There are much more rare tree species in secondary subtropical Atlantic forests than it was thought: a tree rarity assessment using systematically gathered data}

Laio Zimermann Oliveira', André Luís de Gasper', Débora Vanessa Lingner', Lucia Sevegnani ${ }^{1}$, Alexander Christian Vibrans ${ }^{1}$

${ }^{1}$ Fundação Universidade Regional de Blumenau, Blumenau, Brasil (laiozoliveira@gmail.com; algasper@furb.br; deboravanessa.ef@gmail.com; luciasevegnani@gmail.com; acv@furb.br)

Biodiverse forests are usually composed of tree species with small abundance and/or narrow occurrence area. These rare species carry with them a sense of uniqueness and increased risk of extinction. Therefore, we sought to classify 646 tree species growing in three forest types within the Brazilian subtropical Atlantic Forest into seven rarity forms encompassing population size, habitat preference, and geographical distribution. In addition, we investigated the influence of sample size on the outcomes of rarity classification. We used data collected within 418 systematically distributed 0.4 ha plots. Among the 646 recorded species, $67.3 \%$ were classified into one of the seven rarity forms at least in one forest type; they represented less than $5 \%$ of the trees in each forest type. In turn, about $50 \%$ of the species observed in each forest type were rare. Myrtaceae was the family with the greatest number of rare species, followed by Fabaceae, Lauraceae, and Melastomataceae. Species with scarce populations ( $\leq 10$ trees)-i.e., forms 1, 3 and 7 -represented more than $40 \%$ of the total species richness recorded in each forest type. The sample plots located in old-growth stands, ecotone areas, or areas with particular environmental features (e.g., hydromorphic soils), often presented larger proportions of rare species. Quadratic plateau models suggested that the mean proportion of recorded rare species did not increase substantially in sample size classes greater than $70-80 \%$ of the reference sample. The rarity forms comprising scarce populations were particularly influenced by sample size if compared to other rarity forms.

\section{Early successional bird community based clear-cut size modelling}

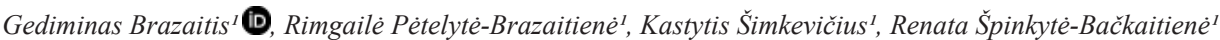

IInstitute of Forest Biology and Silviculture Vytautas Magnus university, Kaunas, Lithuania (gediminas.brazaitis@asu.lt; rimgaile@zoosodas.lt; ksimkevicius@gmail.com; renata_shpy@yahoo.com)

We analyzed how local breeding bird communities are influenced by clear-cut spatial characteristics in hemi-boreal forest south-west Lithuania $\left(54^{\circ} 24^{\prime}-\right.$ $\left.55^{\circ} 11^{\prime} \mathrm{N}, 23^{\circ} 17^{\prime}-24^{\circ} 35^{\prime} \mathrm{E}\right)$. Birds studied by mapping method, surveyed during breeding season from April 15th to June 15 th. Inventory covered 146 clear-cuts, totally 546 ha. New bird species colonized and local community density decreased significantly while clear-cut areas reached 2 ha. Bird communities were 
almost stable in larger clear-cuts. We registered 55 bird species totally; 43 of them were sensitive to the minimum clear-cut size as habitat area. The size of minimum area up to 0.5 ha were typical for 18 bird species as well as $0.5-1.0$ ha -6 species; $1.1-2.0$ ha -9 species; 2.1-4.0 ha -10 species. Increasing felled area proportion on landscape level affected positively the number of breeding bird species in clear-cut area. The highest density of bird communities was in landscapes of 11-35\% felled area. Optimal shape coefficient of clear-cuts was 3.0-4.0 (for 1 ha area-530-640 m of edge). For modeling optimal clear-cut size on landscape level we used real information on local bird communities. We compared bird community data from 100 ha clear-cut areas (clear-cuts of 0.5 ha v.s; 5.0 ha) and totally calculated: 18 vs; 43 inhabiting bird species and 950 vs; 650 bird pairs. Optimal clear-cut size distribution model must include various size clear-cuts in suggested proportions of (I) the number and/or (II) size. Forest types with dominating small-scale disturbance events can be based on equal size proportions as well as large-scale disturbance (e.g. fire) equal quantity of clear-cut proportions.

\title{
Does forest policy properly consider forest ecosystem services in decision making? An assessment from the Bangladesh Forest Inventory
}

Nikhil Chakma ${ }^{1}$, Rajib Mahamud ${ }^{1}$, Md. Akhter Hossain ${ }^{1,2}$ (D), Rashed Jalal ${ }^{1}$, Purnata Chakma ${ }^{1}$, Mondal Falgoonee Kumar ${ }^{1}$, Kristofer Johnson $^{1}$, Matieu Henry $^{1}$ ${ }^{1}$ Food and Agriculture Organization of the United Nations, Dhaka, Bangladesh; ${ }^{2}$ Institute of Forestry and Environmental Sciences, University of Chittagong, Chittagong,Bangladesh(nikhil.chakma@fao.org; rajib.mahamud@fao.org; akhter.hossain@cu.ac.bd; rashed.jalal@fao.org;purnata.chakma@fao.org; mondal.falgooneekumar@fao.org; kristofer.johnson@fao.org; matieu.henry@fao.org)

Trees and forests provide numerous benefits to the humans in terms of income, foods, energy, environmental sustainability, mitigating climate change, water purification, soil protection and many more. While the role of forests to our society's welfare and provisioning ecosystem services are recognized in the national economy but other forest ecosystem services are neglected in that comparison. This paper aims to draw attention of policymakers to take into consideration for assessing the contribution of other forests ecosystem services for decision making in forestry and natural resources. National socioeconomic survey data conducted by Bangladesh Forest Department were considered to analyze the contribution of tree and forests to humans' activities and economic valuation of these services. From the survey data, the economic value of tree and forest products and net income were analyzed using specific mathematical formula at national level. The results showed that economic value of the collected products higher in non-forest (NF) areas than forests. Similarly, the annual net income of households from NF is also higher than forests. The economic value and net income increased at NF may be government policy restriction on collection of forests products from forests. However, the economic value of forest ecosystems would be higher than NF if cultural (tourism), regulating (i.e., pollution control) and supporting (i.e., nutrient cycling) services are considered in the survey assessment for economic valuation. Policies need to reflect the importance of forest ecosystem services in the economic assessment for effective decision making and investment in national resources management and improve livelihood.

\begin{abstract}
Abundance and diversity of coleoptera beetles in areas of anthropized forests and forest remnants in the Southern sector of the Federal University of Amazonas / Abundância e diversidade de coleópteros em áreas de floresta antropizada e remanescente florestal no setor sul da Universidade Federal do Amazonas

Jekiston Silva ${ }^{1}$, Norma Bustamante ${ }^{1}$

'Universidade Federal do Amazonas, Manaus, Brazil (jekistonandrade@gmail.com; ncbustamante@gmail.com)

A Ordem Coleóptera destaca-se devido sua enorme diversidade taxonômica e funcional. Estes insetos desempenham papel fundamental para o funcionamento dos ecossistemas e o entendimento da relação do ambiente alterado pela ação humana pode trazer dados relevantes, como bioindicadores ambientais. Com isso, este estudo teve por objetivo realizar um levantamento das famílias de Coleóptera para avaliação de sua diversidade e abundância em dois tipos de fragmentos florestais localizados no Campus da Manaus - AM. Os besouros foram coletados em dois períodos (chuvoso e seco) e em dois fragmentos (antropizado e remanescente florestal). Os besouros coletados foram transportados para o Laboratório de Preservação da Madeira - UFAM onde foram alfinetados, etiquetados e separados por fragmento e período coletado. Foi realizado a identificação em nível de família e a partir disto, análise estatística de dados para avaliar abundância, diversidade e similaridade. Foram coletados 308 indivíduos, representando 13 famílias nos dois fragmentos, sendo que as mais abundantes foram Scarabaeidae, Chrysomelidae e Cerambycidae. Para abundância, percebeu-se que no remanescente florestal foram coletados 191 indivíduos e no fragmento antropizado, 117 indivíduos da coleta total $(\mathrm{T}=2,01 ; \mathrm{p}<0,05)$. Os valores de diversidade pelo índice de Shannon variaram entre 1,32 no fragmento antropizada/ período seco e 2,13 no remanescente florestal/período chuvoso. Correlacionando a diversidade dos dois fragmentos estudados pode-se observar diferença significativa $(\mathrm{T}=1.19 ; \mathrm{p}<0,001)$. Os resultados indicaram que os fragmentos revelam diferenças de abundância e diversidade para coleópteros, mostrando que a perturbação antrópica pode explicar o número reduzido de famílias amostradas em ambientes antropizados se comparado com ambientes remanescentes.
\end{abstract}

\section{Springtails (Collembola spp) as soil bioindicators in remnants of native forests in the Colombian Orinoco region / Estudio de colémbolos} como bioindicadores del suelo presentes en relictos de bosque natural en la Orinoquia colombiana

\author{
Dayssy Anyely Duarte Nuñez ${ }^{1}$ Olga Patricia Pinzón Florián ${ }^{\prime}$, Walter García Suabita ${ }^{1}$ \\ 'Universidad Distrital Francisco Jose de Caldas, Bogotá, Colombia (daduarten@correo.udistrital.edu.co; opatriciap@udistrital.edu.co, \\ walter.suabita@gmail.com)
}

Los colémbolos (Hexapoda) contribuyen al ciclaje de nutrientes y a la estabilidad del suelo, de allí la gran importancia ecológica que representan en la productividad primaria de los bosques. Debido a su alta sensibilidad frente a cambios provocados en el ambiente, los colémbolos se consideran como bioindicadores frente a modificaciones relacionadas con cobertura vegetal y características físicas y químicas del suelo. Con el objeto de estimar la diversidad de colémbolos en relictos de bosque natural, se hicieron muestreos con trampas Pitfall instaladas en Villanueva (Casanare, Colombia) durante la época seca y húmeda en el año 2015. Se identificó la diversidad mediante el método de número efectivo y se explicó la composición de colémbolos mediante un análisis de redundancia integrando variables dasométricas y de suelos. La colembofauna estuvo compuesta por un total de 208 individuos clasificados en 17 géneros representados en las familias Entomobryomorpha (7), Poduromorpha (5) y Symphypleona (5). Se evidenció mayor presencia de colémbolos durante la época húmeda (133) que durante la época seca (75). No obstante, el registro de géneros indicadores para ambas épocas coincidió, destacando Ptenothrix, Sphyrotheca e Isotoma. La composición de especies se analizó teniendo en cuenta 14 variables ambientales evaluadas, de las cuales hubo mayor significancia en la variable de suelo Nitrógeno $(\mathrm{N})$. Este trabajo resalta la importancia de relictos de bosques natural en la Orinoquia colombiana para la conservación de especies clave en los ecosistemas, y a su vez el gran valor que representa la diversidad de colémbolos para la provisión de servicios ecosistémicos. 
Structure and composition vegetation in Pinus caribaea Morelet forests and their implication for the diversity of associated bird species / Estructura y composición de la vegetación de dos pinares de Pinus caribaea Morelet y su relación con la diversidad de las aves asociadas

Meiely Arteaga Nuñez ${ }^{1}$

${ }^{I} I N A F$, Pinar del Rio, Cuba (disney.martinez96@nauta.cu)

La presente investigación se realizó en la Estación Experimental Agroforestal Viñales, con el objetivo de determinar la relación entre la diversidad de aves asociadas a dos áreas de pinar,con la composición y estructura de la vegetación. Para este fin se escogió un área natural de Pinus caribaea y una plantación de la misma especie con la finalidad de comparar ambas, se establecieron 4 parcelas circulares en cada una,con un radio fijo de $15 \mathrm{~m}$. Se inventariaron las especies vegetales presentes en cada parcela y se midió la altura y el diámetro a los árboles, así como se inventariaron las aves presentes en cada parcela en los meses de enero y febrero 2018. Tanto para la vegetación como para las aves se determinó la diversidad alfa, la estratificación vertical. Se realizó la prueba de comparación de medias Kruskal-Wallis, para determinar si existían diferencias entre los valores de riqueza y abundancia de las aves detectadas, entre los estratos y los meses muestreados. Se realizó una matriz de correlación de Spearman para determinar la relación entre las aves y las variables de la vegetación medidas. Se identificaron un total de 18 especies de aves, las cuales se agruparon en 5 órdenes, 11 familias y 16 géneros. La mayoría de las especies fueron las residentes permanentes, no existiendo diferencias significativas en relación a la riqueza y abundancia de especies entre los meses y las parcelas, existiendo entre el estrato alto con el estrato medio y bajo. Existiendo poca relación entre las variables de la vegetación medidas y las especies de aves detectadas.

Fragmentation and changes in land use in the Del Valle del Magdalena Medio dry tropical forest in Tolima, Colombia / Fragmentación y cambio de uso del suelo en un bosque seco tropical del Valle del Magdalena Medio, Tolima Colombia

Fabian Hernandez ${ }^{1}$, Angie Montañez ${ }^{1}$

'Universidad Distrital Francisco José de Caldas, Bogota, Colombia (faahernandezr@correo.udistrital.edu.co; avmontanezs@correo.udistrital.edu.co)

Implementando tecnologías GIS y elementos de la ecología del paisaje, se estudiaron los patrones espaciales y factores determinantes en el cambio del paisaje de un bosque seco tropical ubicado en el valle del Magdalena en los municipios de Falán, Armero, Honda y Mariquita. Tomando datos de imágenes satelitales de los años 1988, 2003, 2014 y 2018, se utilizaron diferentes índices de composición y configuración de paisaje asociados a la cobertura de la tierra para analizar las características de pérdida de masa boscosa en esta zona. Los resultados muestran una disminución aproximada de 2600 hectáreas para la cobertura de bosque, evidenciando un cambio hacia una matriz de paisaje compuesta en su mayoría por mosaicos de pastos junto con cultivos de maíz y algodón. Se presentó una reducción de los parches de bosque seco en términos de tamaño, área núcleo y aumentó del efecto borde, lo que está generando alteraciones en las condiciones microclimáticas del bosque, la funcionalidad ecosistémica y servicios ecosistémicos. La pérdida de cobertura boscosa responde a las dinámicas naturales, económicas y sociales presentes en la zona de estudio, siendo la expansión de la frontera agrícola y el establecimiento de ganado los principales factores que han modificado la matriz original del paisaje y afectando la biodiversidad.

\section{D8p: FOREST ENVIRONMENT}

Aquatic macroinvertebrates: indicators of conservation and ecological restoration processes in a disturbed Andean watershed in Zapatoca, Colombia / Macroinvertebrados acuáticos: indicadores de procesos de conservación y restauración ecológica en una cuenca andina perturbada en Zapatoca (Colombia)

Vanesa Jaramillo Rodríguez ${ }^{1}$ Jaime Polanía ${ }^{1}$, Carolina Serna ${ }^{2}$

${ }^{1}$ Universidad Nacional de Colombia, Medellín, Colombia; ${ }^{2}$ Universidad Nacional de Colombia sede Medellín, Medellín, Colombia (vjaramillor@unal.edu.co; jhpolaniav@unal.edu.co; csernac@unal.edu.co)

La restauración ecológica brinda servicios ecosistémicos, que incluyen la provisión de agua para consumo humano. Los macroinvertebrados acuáticos, sensibles a perturbaciones y contaminación antrópica, pueden revelar el estado de tal recurso; además, su presencia/ausencia y su consecuente abundancia y/o comportamiento reflejan diversos tensores sobre su hábitat. En Zapatoca (Santander) varios cauces han sufrido durante décadas el impacto de la producción agrícola y ganadera. La cuenca El Poleo se ha integrado a la Reserva Natural de la Sociedad Civil "La Montaña Mágica-El Poleo", se encuentra desde hace más de un lustro en un proceso de restauración, por lo cual se propuso evaluar el grado perturbación de dos afluentes mediante transectos de 100 m. Allí se midieron parámetros fisicoquímicos e hidrológicos y, con una red Surber, se tomaron muestras biológicas. El transecto en restauración mostró representantes de Progomphus (Odonata), Phylloicus y Farrodes (Ephemeroptera), y Anacroneuria (Plecoptera), así como la calidad de bosque de ribera (QBR=75) y diversidad de hábitats fluviales $(\mathrm{IHF}=67)$, representaron una calidad biológica aceptable. En contraste, el transecto del sitio perturbado mostró una vegetación de ribera disminuida $(\mathrm{QBR}=45)$, con presencia de familias del orden Diptera: Chironomidae, Tipulidae y Simuliidae, las cuales son tolerantes a la contaminación y típicas de zonas alteradas. Las actividades agrícolas persistentes impactan negativamente la diversidad y las interacciones bióticas de las comunidades bentónicas. El hábitat circundante determina la calidad biológica e hídrica de estas quebradas andinas, por lo cual acciones de restauración resultan importantes para alcanzar óptimos ecológicos.

\section{Structure and sucessional dynamics in atlantic rainforest fragments with different disturbance histories in the South Central region of São Paulo State, Brazil}

Deicy Carolina Lozano Sivisaca ${ }^{1}$, Celso Anibal Yaguana Puglla ${ }^{1}$, Felipe Góes de Moraes ${ }^{1}$, Renata Cristina Batista Fonseca ${ }^{\prime}$, Iraê Amaral Guerrini ${ }^{1}$ ${ }^{1}$ Escola Superior de Agricultura Luiz de Queiroz, Universidade de São Paulo, Botucatu, Brasil (caroladeicylo@hotmail.com; anibalya@hotmail.com; felipe.goes.de.moraes@gmail.com;rfonseca@fca.unesp.br;irae.guerrini@unesp.br)

The Atlantic Rainforest is one of the world hotspots and is under pressure from deforestation and fragmentation. The aim of the study was to characterize vegetation structure and natural regeneration in Atlantic Rainforest fragments with different disturbance histories. The sampling areas were: $a r e a A, B, E$, $G$, selective logging of wood; area $C$, tree fall and landslides; area $D$, conserved and, area $F$, pasture until the 80 s. In each area were allocated plots ( $5 \mathrm{x} 5 \mathrm{~m}$ ) to tree layer (DBH $<5 \mathrm{~cm}$ ) and the regenerating layer $(5 \times 1 \mathrm{~m})$, totaling 90 plots in all seven areas. Phytosociological parameters, successional stage, dispersion syndromes and the Shannon-Wiener (H') diversity indexes, Jaccard similarity (Cj), and Pielou (J) fairness were calculated. The seven sampled areas are similar in relation to floristic composition of the tree and regenerating layer. There is greater similarity between areas $D, E$, $G$ and $A$. The differences found were in the 
forest structure (density and dominance). The families with the highest diversity were Fabaceae, Euphorbiaceae and Ochnaceae. The highest H' occurred in area $A$ and $C$. Area $D$ (lower degree of disturbance) showed low H', indicating a higher equilibrium. Although area $F$ has been pasture in the past, it is noticeable that it presented good recovery capacity when compared to area D. Area A presented the largest ecological group of species, such as Trichilia elegans and Trichilia claussenii. Zoocoria was the predominant dispersion syndrome for the species studied. This information can be used in planning programmes of conservation.

Integrated management of watersheds and ecosystem services: synergistic focuses of forest adaptation to climate change / Gestión integrada de cuencas hidrográficas y servicios eco-sistémicos: enfoques sinérgicos de adaptación forestal al cambio climático

Samuel Francke

${ }^{1}$ Corporación Nacional Forestal Conaf, Santiago, Chile (samuel.francke@conaf.cl)

La gestión integrada cuencas hidrográficas representa un enfoque viable y sostenible, que contempla en lo central la potenciación de los servicios eco-sistémicos y servicios del bienestar humano, mediante medidas tipo buffer de amortiguación de impactos, medidas facilitadoras de la restauración de ecosistemas/cuencas hidrográficas y medidas complementarias adaptativas institucionales e instrumentales de tipo legal, reglamentarias y normativas. Las opciones de adaptación con medidas "buffering" (amortiguación) en cuencas hidrográficas y ecosistemas alterados medidas para "facilitadoras" (restauradoras de ecosistemas y cuencas hidrográficas) para re-direccionar la evolución de ecosistemas y cuencas hidrográficas hacia nuevos estadios y adaptables a las condiciones dinámicas cambiantes. Se necesitan enfoques flexibles y diversificados en función de la incertidumbre. El Modelo "ABE" de adaptación basada en ecosistemas implica el Manejo Sostenible de Recursos Naturales, la Gestión Integrada de Cuencas Hidrográficas, el manejo forestal sostenible, la Conservación en Áreas Silvestres, la Restauración de Ecosistemas, el Ordenamiento Territorial Sostenible, la Reducción de Riesgos de desastres y el mejoramiento del bienestar humano, entre otros aspectos. La implementación de los instrumentos del Ministerio de Agricultura (MINAGRI) por un monto de inversión anual del orden de US\$150 millones y su focalización debieran reorientarse en suelos y cuencas hidrográficas prioritarias, críticas y vulnerables conjuntamente con la aplicación de principios rectores como: la multisectorialidad, la integralidad, la transversalidad, la mancomunidad y participación de los actores, lo que permitirá enfrentar sosteniblemente los desafíos de la adaptación y mitigación frente a escenarios variables de cambio climático.

Planting trees in a rural area of the Cerrado: the impact on evapotranspiration / Influência do plantio de árvores em área rural do Cerrado sobre a evapotranspiração

Bruno Adorno ${ }^{1}$ D, Sybelle Barreira', Manuel Ferreira ${ }^{1}$, Gabriel Veloso ${ }^{1}$

'Universidade Federal de Goiás, Goiânia, Brazil (brunoadornoflorestal@gmail.com; sybelle.barreira@gmail.com; mferreira.geo@gmail.com; gabrielveloso.geo@gmail.com)

O presente estudo buscou avaliar a influência do plantio de árvores em áreas rurais no Cerrado sobre a evapotranspiração, considerando seu papel como serviço ecossistêmico dentro do ciclo hidrológico. Definiu-se como área de estudos a fazenda Entre Rios, integrante do projeto Biomas no Distrito Federal, e sua vizinhança em dois períodos: antes e depois do plantio de árvores para fins comerciais ou de restauração. Utilizaram-se imagens Landsat dos dias 04/11/2008 e 21/09/2015 para o mapeamento da cobertura do solo da própria área da fazenda e de sua vizinhança. A partir disso regiões onde se detectaram mudanças de cobertura e uso do solo, ao se compararem os resultados para os dois períodos, foram selecionadas e avaliadas quanto o comportamento da evapotranspiração, calculada a partir do algoritmo SEBAL aplicado no sensoriamento remoto das imagens. Observou-se que áreas de agricultura e solo exposto convertidas em florestas plantadas sofreram aumento na evapotranspiração total. O contrário aconteceu em: áreas de florestas perenifólias ou semidecíduas convertidas em pastagens; áreas de savanas ou outras fitofisionomias de Cerrado convertidas em pastagens; e em qualquer tipo de cobertura do solo recém queimado. Na fazenda, os diversos plantios de árvores com apenas 2,5 anos de idade, onde antes se praticava agricultura, promoveram uma tendência no aumento da evapotranspiração. Confirmou-se, assim, a influência do plantio de árvores para o aumento da evapotranspiração local durante a estação seca e sugere-se mais estudos sobre até que ponto isso é benéfico ou não, considerando áreas originárias de diferentes fitofisionomias do bioma Cerrado.

Ecological analysis of bird fauna in the Pedro Antonio Pineda Tropical Forest Center in the lower Calima River Watershed in Buenaventura, Colombia / Análisis ecológico de la avifauna del Centro Forestal Tropical "Pedro Antonio Pineda", en la cuenca baja del río Calima (Buenaventura, Colombia)

Stefany Patiño Forero ${ }^{\text {(D) Camila Martínez Páez }}{ }^{1}$ (D), Miguel Ángel Quimbayo Cardona ${ }^{\prime}$ (D)

'Universidad del Tolima, Ibagué, Colombia (spatinof@ut.edu.co; aquinadie23@gmail.com; miguelq@ut.edu.co)

El Centro Forestal Tropical (CFT) "Pedro Antonio Pineda" localizado en el municipio de Buenaventura (Valle del Cauca, Colombia), se caracteriza por la realización de estudios con participación directa de comunidades afrodescendientes orientadas al manejo sostenible del bosque secundario desde la Facultad de Ingeniería Forestal de la Universidad del Tolima desde hace más de 40 años. Entre los años 2013 y 2017 se realizaron observaciones de la avifauna, en los meses de abril y septiembre, durante ocho días. Se registró un total de 562 individuos, pertenecientes a 166 especies, 20 órdenes y 40 familias taxonómicas. Los órdenes más abundantes fueron Passeriformes (62.6\%) y Apodiformes (8.3\%). Las familias más abundantes fueron Thraupidae (17.3\%), Tyrannidae (8.9\%), Trochillidae (7.1\%) y Thamnophilidae (6.5\%). El 45\% de las especies son insectívoras, 30\% frugívoras y 8\% granívoras y nectarívoras. El estrato de forrajeo más utilizado fue sotobosque (49\%), seguido por dosel (26\%); $89 \%$ presentan anidamiento individual y $11 \%$ presentaron apoyo entre individuos de la misma especie; $47 \%$ de las especies anduvo en bandadas ( $26 \%$ mixta y $21 \%$ monoespecífica), $42 \%$ comportamiento solitario, y $10 \%$ comportamiento de congregación. El 82\% residentes y el 18\% en estatus migratorio. Una especie está en LC, una especie en VU y tres especies en NT. El total de especies equivale al 8.6\% de las aves de Colombia y $21.3 \%$ de las aves del Chocó biogeográfico. A pesar del bosque encontrarse en estado sucesión natural, actúa como hábitat para 22 especies casi endémicas y para especies que requieren de cavidades de árboles para anidación.

Accuracy of digital elevation models applied to mapping permanent preservation areas / Precisão de modelos digitais de elevação aplicados ao mapeamento de áreas de preservação permanente

Edézio Miranda ${ }^{1}$ Bruno Mendonça ${ }^{1}$

${ }^{1}$ Universidade Federal Rural do Rio de Janeiro, Seropédica, Brazil (edezio.florestal@gmail.com; brunoafmendonca@gmail.com)

O uso de modelos digitais de elevação (MDE) de bases de dados de domínio público disponíveis não apresentam informações precisas para a delimitação de Áreas de Preservação Permanente (APP) em encostas, sendo necessário valida-los para serem utilizados no mapeamento de áreas com alta declividade. Deste modo, o objetivo desse trabalho foi criar uma estratégia de diferentes rotinas de pré-processamento para o mapeamento de APP maiores que $45^{\circ}$ utilizando MDEs 
disponíveis gratuitamente (IBGE, ASTER GDEM, SRTM e TOPODATA), validados com referência dos dados LIDAR. A área do estudo está localizada no assentamento São Pedro, município de Japeri - Rio de Janeiro sendo utilizado o softwares Notepad++ e Fusion para o processamento dos dados LIDAR e o ArcGIS 10.2 para as demais etapas. Foram reduzidos os tamanhos das células da resolução padrão dos modelos para 10 e 5 metros e comparado as áreas encontradas com a declividade de $45^{\circ}$ e $30^{\circ}$ para APP de encosta. Os resultados mostram uma área de 438 ha de APP considerada verdade de campo encontrada pelos dados de referência, seguida da redução da resolução dos pixels com a declividade do dados testados, sendo determinantes para representar a declividade do terreno. A validação dos dados ASTER GDEM apresentou o melhor resultado dentre as demais bases avaliadas, tendo sido encontrando uma área de 412,24ha com resolução de $10 \mathrm{~m}$ e $30^{\circ}$ de declividade, representando $94 \%$ da área encontrada pela base de referência. Os dados IBGE apresentaram valores significativos encontrando 387,32 ha, dados SRTM e TOPODATA não apresentaram valores confiáveis.

\author{
Assessing the dynamics of flora composition in a forest fragment after fire in Viçosa, Minas Gerais, Brazil / Avaliação da dinâmica da \\ composição florística em um fragmento florestal após ocorrência do fogo em Viçosa, MG (Brasil) \\ Fábia Maria dos Santos Souza , Cintia Virginia Mieko Souza Sekiya ${ }^{I}$, Aldo Teixeira Lopes ${ }^{I}$, Danusia Amorim Souto ${ }^{I}$, Fillipe Tamiozzo Pereira Torres ${ }^{I}$, \\ Lydiane Lucia de Sousa Bastos ${ }^{1}$ \\ 'Universidade Federal de Viçosa, Viçosa,Brazil (fabiasantos93@hotmail.com; cintiasekiya@hotmail.com; aldo_ufv@hotmail.com; \\ danusiasouto@gmail.com; torresftp2@gmail.com;lbastos@ufv.br)
}

A ocorrência do fogo pode influenciar na estrutura, composição da floresta e sucessão vegetal, tornando fundamental entender como as comunidades naturais se regeneram após sofrer esse tipo de perturbação. Esse estudo objetivou analisar as mudanças ocorridas em nível de composição florística e estrutura da comunidade vegetal de um fragmento de Floresta Estacional Semidecidual após quatro anos da ocorrência do fogo de baixa intensidade. Foi realizado o censo florestal de todos os indivíduos com Circunferência Altura do Peito $\geq 15 \mathrm{~cm}$ em uma área de 0,6 hectares, sendo 0,3 ha na área queimada (T1) e 0,3 ha na área não queimada (T2). A diversidade florística nas duas áreas foi considerada alta, revelada pelos índices de Shannon (1,00 T1 e 1,19 T2) e de concentração de Simpson (0,166 T1 e 0,129 T2). Além disso, o índice de Pielou (0,29 T1 e 0,31 T2) e de Jaccard (0,37) revelou alta uniformidade e similaridade nas duas áreas. A diversidade florística da regeneração natural nas duas áreas foi considerada média, revelada pelos índices de Shannon, $(0,85$ T1 e 0,65 T2) e de concentração de Simpson (0,33 T1 e 0,46 T2). O índice de Pielou (0,25 T1 e 0,21 T2) revelou que a uniformidade e equitabilidade nas duas áreas podem ter sido alteradas pelo fogo. O índice de Jaccard $(0,20)$ indicou baixa similaridade. Portanto, a ocorrência do fogo de baixa intensidade não alterou a composição florística dos indivíduos adultos, porém a regeneração está acontecendo com importantes mudanças na sucessão.

The impact of fire on the soil seed bank in a fragment of semideciduous forest in Viçosa, Minas Gerais, Brazil / Impacto dos incêndios florestais sobre o banco de sementes do solo em um fragmento de Floresta Estacional Semidecidual em Viçosa, MG

Fábia Maria dos Santos Souza ${ }^{1}$, Danusia Amorim Souto ${ }^{1}$, Aldo Teixeira Lope's, Cintia Virginia Mieko Souza Sekiya ${ }^{1}$, Fillipe Tamiozzo Pereira Torres ${ }^{1}$, Lydiane Lucia de Sousa Bastos

'Universidade Federal de Viçosa,Viçosa,_Brazil (fabiasantos93@hotmail.com; danusiasouto@gmail.com; aldo_ufv@hotmail.com; cintiasekiya@hotmail.com; torresftp2@gmail.com; lbastos@ufv.br)

O banco de sementes do solo é um importante reservatório de sementes de espécies nativas, matéria orgânica, insetos, mesofauna e microfauna do solo, microrganismos e nutrientes. Em decorrência dos intensos impactos que vêm sofrendo os ecossistemas, aumentou-se o interesse em conhecer o papel do banco de sementes do solo na determinação da composição florística de áreas alteradas. Na área de estudo em que a presente pesquisa foi desenvolvida houve um incêndio de baixa intensidade, mesmo assim houve evidências de significativas diferenças na composição florística da comunidade de espécies lenhosas, com alta predominância de Cecropia sp. na área queimada em comparação com área não queimada. O objetivo deste trabalho foi verificar a influência do fogo sobre a estrutura do banco de sementes em um Fragmento Estacional Semidecidual Viçosa, MG. A germinação do banco do solo da área queimada há quatro anos não foi comprometida pelo incêndio de baixa intensidade, com número de sementes germinadas igual à da área não queimada.

D8q: FOREST ENVIRONMENT

\title{
Forest fires and resin tapping: anthropogenic factors affecting subtropical pine forests
}

Peter Fule ${ }^{1}$, Satish Garkoti ${ }^{2}$, Rajeev Semwal ${ }^{2}$

${ }^{1}$ Northern Arizona University, Flagstaff, USA; 2Jawaharlal Nehru University, New Delhi, India (pete.fule@nau.edu; sgarkoti@yahoo.com; rajeevsem@gmail.com)

Tropical and subtropical coniferous forests provide critical ecosystem services but the effects of anthropogenic disturbance factors have not received sufficient scientific attention. We studied forest disturbance using tree-ring methods in a chir pine (Pinus roxburghii) forest of Uttarakhand, India. We developed a multicentury tree-ring chronology and crossdated fire scars from trees at three sites near rural villages. Fires were highly frequent but of low severity, so most mature trees of this thick-barked species survived numerous burns. However, intensive resin tapping interacted with surface fire by allowing fire to burn into the wood of tapped trees, damage the cambium, and weaken the structural integrity to the point of breakage and mortality. The effects of anthropogenic fire and resintapping merit further investigation at landscape to regional scales. We suggest developing a research network in Himalayan to East Asian coniferous forests to track interacting disturbances and their ecological and social implications.

\section{Tree-related microhabitat co-occurrences: towards easier monitoring?}

Laurent Larrieu ${ }^{l, 2}$, Alain Cabanettes ${ }^{1}$, Benoit Courbaud ${ }^{3}$, Michel Goulard ${ }^{1}$, Daniel Kraus ${ }^{4}$, Thibault Lachat ${ }^{5}$, Jörg Müller $^{6,7}$, Yoan Paillet ${ }^{8}$, Andreas Schuck ${ }^{9}$ Jonas Stillhard ${ }^{10}$, Miroslav Svoboda ${ }^{11}$

${ }^{1}$ DYNAFOR, Université de Toulouse, INRA, Toulouse, France; ${ }^{2}$ CRPF Occitanie, Tarbes, France, ${ }^{3}$ University Grenoble Alpes, Irstea, LESSEM, Grenoble, France; ${ }^{4}$ Chair of Silviculture, Freiburg University, Freiburg, Germany; ${ }^{5}$ Bern University of Applied Sciences, School of Agricultural, Forest and Food Sciences HAFL, Bern, Switzerland; ${ }^{6}$ Bavarian Forest National Park, Grafenau, Germany; ${ }^{7}$ University of Würzburg, Würzburg, Germany; ${ }^{8}$ Irstea, UR EFNO, Nogent sur Vernisson, France; ${ }^{9}$ European Forest Institute, Bonn, Germany; ${ }^{10}$ Swiss Federal Research Institute WSL, Birmensdorf, Switzerland; ${ }^{11}$ Czech University of Life Sciences,Praha,Czech Republic laurent.larrieu@inra.fr; alain.cabanettes@inra.fr; benoit.courbaud@irstea.fr. michel.goulard@inra.fr; pauldaniel.kraus@fstsw.bayern.de; thibault.lachat@bfh.ch;joerg.mueller@npv-bw.bayern.de; yoan.paillet@irstea.fr; andreas.schuck@efi.int; jonas.stillhard@wsl.ch; svobodam@fld.czu.cz)

Pesq. flor. bras., Colombo, v. 39, e201902043, Special issue, p. 1-768, 2019 
A Tree related Microhabitat (TreM) is a distinct, well-delineated morphological singularity occurring on living or standing dead trees, that constitutes a crucial substrate or life site for species. TreMs are widely recognized as key features for biodiversity. The current TreM typology identifies 47 TreM types according to both to their morphology and associated taxa. These TreMs have been pooled into 15 groups then seven forms, in order to provide a range of accuracy and speed of use for different typology users. Thus, forest managers may use the form level during tree marking to ensure a TreM diversity at the stand scale while researchers should use the type level for recording TreMs in biodiversity assessment. Another approach to simplifying TreM recording in routine management job may be to use co-occurrence pattern to reduce the number of TreMs to be observed. From a large international TreM database, we evaluated both the significance and the magnitude of TreM co-occurrence on living trees for 11 TreM groups. We highlighted 33 non-random and positive co-occurrences for broadleaves while only nine for conifers. Bark loss, Rot-hole, Crack and Polypore showed the highest number of positive co-occurrences with the other TreMs for broadleaves $(\mathrm{N}=8)$ while bark loss $(\mathrm{N}=4)$ did for conifers. We found negative co-occurrences only for conifers: Exposed Heartwood with Dendrotelm and Sap run. Among a set of three variables tested for their positive contribution to significant co-occurrences, dbh was the most consistent.

\section{The influence of riparian forests on surface water: a case in Southern Atlantic Forest biome, Parana, Brazil}

Elenice Fritzsons ${ }^{1}$, Luiz Eduardo Mantovani ${ }^{2}$

${ }^{1}$ Embrapa Florestas, Colombo, Brasil; ${ }^{2}$ Universidade Federal do Paraná, Curitiba, Brasil (elenice.fritzsons@embrapa.br; lem@ufpr.br)

The stream water quality depends on the presence of riparian forest which acts as a filter to protect surface waters in watersheds. We have worked with 1,300 water samples and according with the following parameters: turbidity, color, $\mathrm{pH}$, conductivity, dissolved solids, alkalinity, nitrate, chloride. Samples were collected in 33 field experiments over six contiguous hydrographic basins. These basins are located in the Southern Atlantic Forest biome, Humid Subtropical Climate of Altitude, ecosystem of Mixed Ombrophilous Forest, Parana, Brazil. The land use map and stream conflict map were drawn. The stream conflict map was drawn taking into account the fluvial PPAs (permanent preservation areas). This study has found 5 main land use typologies: natural forest, forestry, buildings, agriculture and pasture. Conflicts of PPAs were defined when natural riparian forest was absent and replaced by another typology, considering a 5-meter strip along the stream's banks, in compliance with the Brazilian law applied to this local situation. Multiple correlation analyses were performed taking into account water quality parameters, conflict over fluvial disputes, and land use. Our conclusion is that amount all streams studied, 51\% of them, contain with the Brazilian law concerning fluvial PPAs. The water quality changes according to different seasons and also with the conflicts of fluvial PPAs in some typologies (agriculture, buildings and pasture). However, changes in water quality have not being found when taking to account different land uses, as well as precipitation events. This work confirms the close connection between occupation of riparian areas and surface water quality.

\section{An assessment of the anthropic activities effects on canopy layer attributes in subtropical Atlantic Rainforest}

Débora Lingner ${ }^{1}$, Arthur Rodrigues ${ }^{2}$, Laio Oliveira ${ }^{1}$, André de Gasper ${ }^{1}$, Alexander Christian Vibrans ${ }^{1}$

${ }^{1}$ Fundação Universidade Regional de Blumenau, Blumenau, Brasil; ${ }^{2}$ Universidade Federal do Rio Grande do Sul (UFRGS), Porto Alegre, Brasil

(deboravanessa.ef@gmail.com; rodrigues.arthurv@gmail.com; laiozoliveira@gmail.com; algasper@furb.br; acv@furb.br)

Subtropical forests are predominantly composed of second-growth remnants as a result of degradation processes caused by human-driven disturbances. We aimed to investigate the effects of anthropic disturbances on forest attributes of the canopy layer (DBH $\geq 10 \mathrm{~cm})$, namely: aboveground biomass, rarefied species richness, and proportion of individuals of pioneer and threatened species. The study was carried out in the Brazilian subtropical Evergreen Rainforest and data from 186 systematically distributed 0.4 ha sample plots were used. The effects of anthropic disturbances on the forest attributes were modeled through ordinary least squares (OLS) and geographically weighted regression (GWR) models. Yet, a path analysis was applied to investigate if topographic heterogeneity (TH; standard deviation of altitude) influences indirectly the forest attributes via anthropic disturbances. The GWR models outperformed the OLS models in predicting the proportion of individuals of pioneer and threatened species. We showed that anthropic disturbances at different spatial scales - landscape, forest patch, and sample plot - may affect the forest attributes. Agriculture area was related to stands with greater biomass in landscapes with large forest remnants, while pasture area was related to stands with lesser species diversity and more exposed to proliferation of pioneer species. We identified stands with great proportion of threatened species exposed to risk factors, such as long road networks and selective logging. TH showed to limit the expansion of pasture areas over the landscape, affecting indirectly the species richness. Evidences were found regarding biotic homogenization and variation in forest productivity resulting from forest fragmentation and edge effects.

\section{Human-induced edge influence on vegetation in boreonemoral forests}

\section{Lìga Liepa ${ }^{1}$, Inga Straupe ${ }^{1}$}

${ }^{1}$ Latvian University of Life Sciences and Technology, Jelgava, Latvia(liga.liepa@llu.lv; inga.straupe@llu.lv)

During the last centuries European forest landscape has changed from mostly natural conditions of forest growth to the dominance of production forests. For forest management, it is important to understand the predictable influences on set-asides adjacent to post-harvesting areas. We studied temporal response on vegetation in black alder (Alnus glutinosa) swamp woods in boreonemoral forests in terms of the influence of edge after post-harvesting in adjacent forest stands. Forest edges have been well studied in nemoral and tropical forests, but less is known about the vegetation response toward human-induced edges in boreonemoral and boreal forests. We surveyed data on forest vegetation at black alder swamp woods adjacent to edges in a different age chronosequence $(<10$, $20-40$ and $\geq 41$ years post harvesting) was used to test how dynamics of edge effects changes during the time. We tested this by setting permanent sample plots from forest stand edge to interior, then vegetation survey at set distances from stand edge. The main results showed that even more than 41 years after harvesting the magnitude of edge influence persists on the herbaceous layer and rare epiphytic lichen species. This result highlights the need to consider edge effects in sustainable forest principles for set-asides where nature conservation has been prioritized.

\section{A Belize forest landscape and its management}

Nicholas Brokaw ${ }^{1}$, Sheila Ward ${ }^{2}$

${ }^{1}$ University of Puerto Rico, San Juan, Puerto Rico; ${ }^{2}$ Mahogany for the Future, Inc., San Juan, Puerto Rico (nvbrokaw@ites.upr.edu; sheila.emily.ward@gmail.com)

Permanent forest sample plots provide information on landscape patterns in space and time of tree composition, growth, and population and community dynamics. We present a 25-year study of trees $\geq 10 \mathrm{~cm} \mathrm{DBH}$ in four 1-ha plots in old-growth, subtropical moist forest in Northwest Belize (Rio Bravo Conservation and Management Area, managed by Programme for Belize). The four plots are in upland mesic forest, upland dry forest, palm/hardwood forest, 
and riparian forest, respectively, and are within $12 \mathrm{~km}$ of each other. At the first census (1991) the number of stems ranged from 374 to 700 among the four plots, the number of species from 45 to 59 . In each plot five to six species accounted for $50 \%$ of stems, while 15 to 19 species were represented by only one stem. Thirty-three species, of 118 total over all four plots, were represented by just one stem over all plots. Only 13 species were found in all plots. Growth and stem turnover were relatively high in riparian and palm/hardwood forests and low in upland forests. Parts of the upland forests were exceptionally slow growing and stable. This forest landscape is a mosaic of forest types differing in both composition and dynamics. Based on our results, and using a landscape perspective, we suggest actions for use and protection of this forest reserve.

\section{D8r: FOREST BIODIVERSITY IN THE FRAMEWORK OF GLOBAL CHANGE AND THE ROLE OF} LANDSCAPE

\section{Saracá-Taquera National Forest: a case study of native terrestrial mammals in Pará, Brazil}

Fabiano Melo ${ }^{1,2}$, Analice Calaça ${ }^{2}$, Michel Faria ${ }^{3}$, Diego Silva ${ }^{2}$

${ }^{1}$ Universidade Federal de Viçosa, Viçosa, MG, Brasil; ${ }^{2}$ Universidade Federal de Goiás, Jatai, GO, Brasil; ${ }^{3}$ Universidade do Estadao de Minas Gerais, Carangola, MG, Brasil (frmelo@ufv.br; analicecalaca@gmail.com; mchel.faria@uemg.br; diegoafonsosilva@gmail.com)

One of the most diverse mammal assemblage inhabits the Amazonian rainforest, not found anywhere around the World, therefore this species richness is still poorly understood. Many studies including inventories or monitoring are important for the comprehension of the ecology of many species and still provide basic data for conservation actions. During two decades of sampling in the Saracá-Taquera National Forest, we recorded at least 72 species of small - nonvolant, medium, and large mammals, considering 30 families in 10 orders. We also found 29 endemic species to the Amazon forest, some of them were classified as endangered. In summary, we found one of the most mammal species richness recorded in the Amazonian basin, probably greater than that already found in other sites elsewhere, indicating high levels of diversity in a biogeographic narrow scale. Our findings indicate the importance of this national forest for the maintenance of the mammalian fauna and highlight how important is the sustainable use of the forest, especially when we have to conciliate the rational exploitation and the protection of the biodiversity.

Changes in natural resources and the effect on landscapes in important tourist areas in Southern Chile / Alteración de los recursos naturales y su efecto en el paisaje en zonas de interés turístico al sur de Chile

Gastón Vergara ${ }^{1}$, Miguel Ángel Herrera ${ }^{2}$

${ }^{1}$ Universidad Austral de Chile, Valdivia, Chile; ${ }^{2}$ Universidad de Córdoba, Córdoba, Spain (gastonvergara@uach.cl; mc1hemam@uco.es)

El plan de acción propuesto al sur de Chile en el territorio de Panguipulli, Región de los Ríos, tiene como objetivo promover la actividad turística en la zona, diversificación de la economía local, generación de empleo y la valorización de los recursos naturales, a través de estrategias competitivas de tipo pública y privada, siguiendo las tendencias del mercado nacional e internacional. Sin embargo es necesario establecer que la intervención humana genera entropía que influye en el cambio climático y el calentamiento global, acciones que repercuten directamente en las características del territorio, generando transformación, alteración del paisaje y desaparición de recursos naturales indispensables para el desarrollo turístico. El objetivo de la presente investigación es revelar y cuantificar las transformaciones de los recursos naturales que ha sufrido la zona de interés turístico (ZOIT) de Panguipulli. Para el análisis de los cambios de uso del suelo en la zona, se utilizaron imágenes satelitales LANDSAT y técnicas geoestadísticas. Determinando alteraciones importantes en el cambio uso del suelo, principalmente el aumento de plantaciones forestales industriales, disminución de las praderas y del bosque nativo, de gran valor endémico que alberga sistemas de alta biodiversidad.

\section{Exploring indicator species for evaluating forest degradation in Andean forests in Peru}

Kazuki Miyamoto ${ }^{1}$,Edgar Alexs Arana Olivos ${ }^{2}$, Gabriel Clostre Orellana $^{2}$, Christian Marcel Rohner Stornaiuolo ${ }^{3}$, Tamotsu Sato $^{4}$

${ }^{1}$ Forestry and Forest Products Research Institute (FFPRI), Tsukuba, Japan; ${ }^{2}$ Servicio Nacional Forestal y de Fauna Silvestre (SERFOR), Lima, Peru;

${ }^{3}$ Administraciones Técnicas Forestal y de Fauna Silvestre (ATFFS) Cusco, SERFOR, Cusco, Peru; ${ }^{4}$ Forestry and Forest Products Research Institute, Tsukuba, Japan (mkazuki@affrc.go.jp; earana@serfor.gob.pe; gclostre@serfor.gob.pe; crohner@serfor.gob.pe; satoo@affrc.go.jp)

It has been recognized that as well as deforestation, forest degradation has a great impact on forest ecosystems at global scale. However, the methodological approach is still not fully developed to appropriately evaluate the impact of forest degradation on forest structure and function. Utilizing indicator species has a potential to represent levels of forest degradation. We aimed to explore indicator species for forest degradation in relation to forest types (primary forest or secondary forest), forest structure and species composition. We conducted field survey to collect ground-based forest inventory data in Cusco region, Peru. Our study area covers upland tropical forest connecting to Amazon forest and Andean montane forest (ranged from $600 \mathrm{~m}$ to $3500 \mathrm{~m}$ a.s.l.). Using indicator species analysis, we found 12 tree species at low elevation sites (600 to $1000 \mathrm{~m}$ ), four tree species at mid elevation sites (1000 to $2400 \mathrm{~m})$ and one tree species at high elevation sites $(>2400 \mathrm{~m})$. Not all, but some of the detected indicator species corresponded to primary/secondary forest classification of the stands based on field observation. Our results suggest that indicator species has a potential to evaluate current condition of forest degradation on a regional scale in the Andean region, but its availability might vary with elevation zone.

\section{Tree strata strucutre in an ecotone among Amazon Forest types: a comparative study \\ Aline Canetti ${ }^{1}$ (D), EvaldoMuñoz Braz ${ }^{2}$ D, Patrícia Póvoa de Mattos ${ }^{2}$ (D), Afonso Figueiredo Filho ${ }^{3}$ ${ }^{1}$ Universidade Federal do Paraná, Curitiba, Brasil; ${ }^{2}$ Embrapa Florestas, Colombo, Brasil; ${ }^{3}$ Universidade Estadual do Centro-Oeste do Paraná, Irati, Brasil (alinecanetti@gmail.com; evaldo.braz@embrapa.br; patricia.mattos@embrapa.br;afigfilho@gmail.com)}

As it is an ecotone composed by two forest types, high composition complexity is expected in the Transitional Amazonian Forest. Thus, we aimed to describe the structural dynamics of the Transitional Amazonian Forest in Mato Grosso State, Brazil, and to evaluate whether the most abundant tree species present a structural pattern. Forest analysis occurred with six $100 \%$ inventories data considering all trees with $1.30 \mathrm{~m}$ diameter above the ground $\geq 40 \mathrm{~cm}$, totalizing up to 5 thousand ha. The study areas were compared in terms of tree density, number of species and importance value of the most abundant species. The Morisita index and the cluster analysis tested the forests similarity. We also evaluated importance value of species in the upper and middle strata. Differences between study areas were detected regarding tree density and number of species. However, the forests presented more than $75 \%$ similarity and were grouped in 3 
structural clusters. Some species showed alternations of dominance in the middle and upper strata. Although it is an ecotone, the trees had a structural pattern, where the same species dominate large areas, allowing us to apply results in a huge scale of approach.

\title{
Conservation of biodiversity in Boreonemoral Forests
}

Līga Liepa ${ }^{1}$, Inga Straupe ${ }^{1}$, Olga Miezìte ${ }^{1}$, Aris Jansons ${ }^{2}$,Edgars Dubrovskis ${ }^{1}$

${ }^{1}$ Latvia University of Life Sciences and Technologies, Department of Silviculture, Jelgava, Latvia; ${ }^{2}$ Latvian State Forest Research Institute "Silava",

Salaspils,Latvia(liga.liepa@llu.lv; inga.straupe@llu.lv; olga.miezite@llu.lv; aris.jansons@silava.lv; edgars.dubrovskis@llu.lv)

Boreonemoral forests have distinct floral and faunal communities and they provide multiple ecosystem services. Extensive tracts of boreonemoral forests are actively managed for timber production, but actions aimed at increasing timber yields may also affect other forest functions and services. An essential component of forest certification schemes (e.g. FSC) is that landowners should voluntarily set aside forest stands for biodiversity; maintain ecological quality in EU protected habitats and leave retention trees. It is now unclear how functional are all these conservation tools in the context of ecological quality and its linkage with land-use intensity. The aim of this study is to evaluate how existing forest conservation tools contribute to the conservation of biological diversity and the provision of ecosystem services. In order to investigate the relative roles of different types of conservation tools for sustainable forest management, field data were collected on ecological quality of 40 study areas in Latvia (including vegetation assessment, diversity of structural features and presence of rare species). The results allow developing cost-efficient tools, used in the sustainable management of forests in the boreonemoral biome. These preferences can be important knowledge to sustainable forest management complexity and policies balancing economic, ecological and social interests in the production forest landscape. Acknowledgments: This study was financially supported by the ERDF Post-doctoral Research Support Program (project nr.1.1.1.2/16///001) Research application "Balancing ecological interests with increasing demands for natural resources in production forests" (nr.1.1.1.2./VIAA/2/18/294).

Analysis of fragments of the Atlantic Forest biome in municipalities within the Recife micro-region: a focus on environmental management / Análise de fragmentos florestais do Bioma Mata Atlântica em municípios situados na Microrregião do Recife: um enfoque na gestão ambiental

Marília Regina Costa Castro Lyra ${ }^{1}$, Felipe Pinto Guimarães ${ }^{2,1}$, Jurandir Barbosa Cavalcanti Junior ${ }^{3,1}$, José Antônio Aleixo da Silva ${ }^{4}$ ${ }^{1}$ Instituto Florestal de Pernambuco, Recife, Brasil; ${ }^{2}$ Embrapa Solos, Recife, Brasil; ${ }^{3}$ Adagro, Recife, Brasil; ${ }^{4}$ Universidade Federal Rural de Pernambuco, Recife,Brasil (mariliarcastro@uol.com.br; lipegui@yahoo.com.br; jbcengenharia@gmail.com; jaaleixo@uol.com.br)

A fragmentação da Mata Atlântica, motivada por um intenso processo de transformação da paisagem, tem tornado mais difícil a tarefa de preservar o bioma. Neste contexto, os instrumentos de gestão ambiental surgem como alternativa para viabilizar a conservação ambiental de fragmentos florestais em ambientes cujo uso antrópico predomina. A análise da paisagem apoiada com recursos do sistema de informações geográficas (SIG) é de suma importância na caracterização dos fragmentos florestais e respectivo planejamento ambiental. O trabalho baseou-se na análise de fragmentos florestais situados na Microrregião do Recife, para o ano de 2011 e de 2016. As métricas de ecologia utilizadas para caracterizar os fragmentos florestais e a verificação da significância estatística das diferenças observadas para as duas épocas propostas permitiu constatar que houve efetiva diminuição no tamanho dos fragmentos sem, contudo causar alteração expressiva mancha de vegetação geral. Sob o enfoque da gestão ambiental, os fragmentos florestais remanescentes mais expressivos estavam submetido a proteção legal. Fragmentos de supressão observados demandam ações de gestão ambiental orientada de acordo com a situação político-organizacional do município e o contexto socioeconômico do local. Fragmentos ligados a recomposição da vegetação indicaram práticas de gestão ambiental focadas na minimização do potencial degradador dos impactos antrópicos.socioeconômico do local. Fragmentos ligados a recomposição da vegetação indicaram práticas de gestão ambiental focadas na minimização do potencial degradador dos impactos antrópicos.

\section{Reflections on managing land for conservation / Reflexões sobre a gestão do território para a conservação}

\author{
Mariana Beauclair ${ }^{1}$, Paulo Fevrier ${ }^{1}$, Marie Ikemoto ${ }^{1}$, Barbara Schmidt ${ }^{1,2}$, Vitória Araujo ${ }^{1,2}$, Graziela Genovez ${ }^{1,3}$ \\ ${ }^{1}$ Instituto Estadual do Ambiente do Rio de Janeiro, Rio de Janeiro, Brazil; ${ }^{2}$ Universidade Federal Fluminense, Niterói, Brasil; ${ }^{3}$ Universidade Federal \\ Ruraldo Rio de Janeiro, Seropédica,Brasil (maribo.inea@gmail.com; paulofevrier@gmail.com; ikemoto.inea@gmail.com; batrouche4@gmail.com; \\ vitoriaaraujo@id.uff.br; grazielamartinsamoufrrj@gmail.com)
}

O planejamento para a conservação em geral se baseia em dados geobiofísicos e tem como objetivo o subsídio a ações predominantemente no espectro do comando e controle, como a criação de unidades de conservação ou outros instrumentos de ordenamento territorial. O custo (político, social e econômico) de implementação dessas ações é alto, o que limita sua adoção e dificulta o alcance dos objetivos pretendidos. A inclusão dos fatores políticos e sociais no planejamento - conjuntamente com os geobiofísicos - pode possibilitar o desenvolvimento de projetos, programas e ações cooperativos e de suporte, que conjuguem o atendimento a demandas coletivas (globais, nacionais ou regionais) com as demandas locais ou até individuais. Embora essas ações possam ter um custo semelhante ou até maior do que as de comando e controle no início, tem um potencial maior de se sustentarem ao longo do tempo e se difundirem no território sem a ação direta do Estado. A transição para esse novo paradigma - que não necessariamente substitui o existente, mas o complementa - ainda necessita de maior sustentação política, normativa e institucional para ser amplamente adotado como política de Estado. Essa questão será discutida com base na experiência do Projeto Conexão Mata Atlântica no Rio de Janeiro.

\section{Deforestation and wildlife management: are elephants attracted by recently deforested areas?}

Hugo Valls-Fox ${ }^{1}$, Alessandro Fusari ${ }^{2}$, Paola-Catalina Amaya-Corredor ${ }^{3}$, Marie Nourtier ${ }^{3}$, Frédérique Montfort ${ }^{3}$, Telina Randrianary ${ }^{4}$, Emmanuelle Richard ${ }^{5}$, Thomas Prin 5 , Philipe Chardonnet ${ }^{5}$

${ }^{1}$ Centre de coopération internationale en recherche agronomique pour le développement (CIRAD), Montpellier, France; ${ }^{2}$ Fondation François SOMMER - Fondation Internationale pour la Gestion de la Faune, Maputo, Mozambique; ${ }^{3}$ Nitidae, Montpellier, France; ${ }^{4}$ Nitidae, Antananarivo, Madagascar;

${ }^{5}$ Fondation François SOMMER - Fondation Internationale pour la Gestion de la Faune,Paris, France (hugo.valls-fox@cirad.fr; alessandrofusari@yahoo.it; paola-catalina.amaya-corredor@etu.umontpellierfr; m.nourtier@nitidae.org;f.montfort@nitidae.org; t.randrianary@nitidae.org; e.richard@chassenature.org, thomas.prin@chassenature.org; igf@fondation-igf.fr)

Deforestation is a major cause of wildlife decline in tropical ecosystems. The conversion of mature forest to fields by shifting cultivation leaves behind fallow lands with secondary vegetation. Paradoxically, secondary forest regrowth that provides abundant forage in comparison with mature forests can benefit some species as the African elephant (Loxodonta africana) but they are also attracted towards human communities and cultivations raising conservation issues. The 
study was conducted in Gile National Reserve, Mozambique, an unfenced protected area composed of Miombo woodland. Among 60 elephants remaining in the Reserve, 5 individuals were equipped with GPS collars in 2014 in 2016. Deforestation was monitored by remote sensing from 1990 to 2016 and a map of forest productivity was built. To test our hypothesis, we modelled resource selection functions using the GPS data. Elephants spend about half of their time in the core area and half in the buffer zone where most of the deforestation occurs. Elephants neither prefer nor avoid pristine forest habitats and cleared between 1990 and 2005. They prefer areas cleared since 2005 where forest regrowth occurred since 2009. The areas the most selected were cleared between 2010 and 2013 and were in cultivation during the study. Shifting agriculture leads to the displacement elephants toward cultivated fields and regenerating forest vegetation thus increasing Human/Elephant conflicts. This resource selection strategy also raises conservation questions related to the Reserve management aiming at reducing deforestation. Diversity of habitats should be maintained and resource selection linked to vegetation dynamics should be further understood.

\section{D8s: INVASIVE SPECIES IN FOREST ECOSYSTEMS, CAUSES, CONSEQUENCES,} UTILIZATION AND MANAGEMENT OPTIONS

Leafcutter ants: impacts on herbaceous vegetation in South America's native temperate forests / Hormigas cortadoras de hojas: impactos sobre la vegetacicón herbácea en bosques nativos templados de Sudamérica

Julian Alberto Sabattini ${ }^{1}$

${ }^{1}$ Universidad Nacional de Entre Ríos,E3100AXD,Argentina (juliansabattini@hotmail.com)

Las hormigas cortadoras de hojas son consideradas consumidores dominantes de América en diferentes ambientes naturales. El objetivo fue cuantificar y evaluar la herbivoría anual de Atta vollenwederi sobre la vegetación en bosques nativos del Espinal Argentino. El trabajo se realizó en dos regiones de la provincia de Entre Ríos, Argentina. En ambos sitios, se seleccionaron 5 nidos, recolectándose material vegetal entre Mayo 2015 a Octubre 2017. actividad forrajera se determinó recolectando fragmentos vegetales de hormigas cargadas en cada nido durante cinco minutos registrados cada dos horas. En laboratorio se identificaron cuatro fragmentos de material vegetal: a) monocotiledóneas graminiformes y ciperáceas, b) dicotiledóneas herbáceas y arbustivas, c) dicotiledóneas arbóreas y, d) material de desecho senescente. La biomasa total forrajeada promedio por nido de Atta vollenweideri fue de $312 \mathrm{~kg} \mathrm{MS.nido}^{-1}$.año-1. No se obtuvieron diferencias significativas entre sitios, registrando $282 \mathrm{~kg}$ MS.nido-1.año-1 en el Sitio I, mientras que en el Sitio II se obtuvo un total de $342 \mathrm{~kg}$ MS.nido ${ }^{-1}$.año ${ }^{-1}$. Los resultados globales indicaron que la tasa de forrajeo estaba conformada mayoritariamente por especies monocotiledóneas graminiformes y ciperáceas. Las colonias de Atta vollenweideri cosecha anualmente un 9,5\% de la productividad primaria de un pastizal natural en bosques nativos del Espinal Argentino. Estacionalmente se observó una combinación de estrategias en el forrajeo para conformar su dieta mostrando gran plasticidad, que permite afirmar un comportamiento estrictamente selectivo sobre especies monocotiledóneas herbáceas graminiformes y ciperáceas cuando la abundancia relativa es alta, de lo contrario expresa un oportunismo muy marcado cortando otras especies vegetales.

\section{Allelopathic effects of paper mulberry (Broussonetia papyrifera (L.) L'Hér. ex Vent.) extracts to the morpho-physiological characteristics of supa (Sindora supa merr.) seedlings}

Marilyn Combalicer', Mark Bryan Carayugan ${ }^{I}$, Ma. Fatima Critica ${ }^{1}$

${ }^{1}$ Department of Forest Biological Sciences, College of Forestry and Natural Resource, University of the Philippines Los Baños, Los Baños, Philippines (mscombalicer@up.edu.ph;macarayugan@up.edu.ph;micritica@up.edu.ph)

The study investigated the allelopathic potential of leaves, stem and root aqueous extract of Broussonetia papyrifera using Sindora supa as a test plant for morpho-physiological implication. Parameters (height increment, root collar diameter increment, sturdiness quotient, leaf number increment, leaf area, chlorophyll content, net photosynthesis, transpiration, stomatal conductance, and water use efficiency (WUE), were tested at B. papyrifera extract concentration of $10 \%, 15 \%, 20 \%$ and $30 \%$. Results indicated that stem and root extracts of B. papyrifera deterred the height of the test plant at $20 \%$ and $30 \%$, respectively. Stem extract stimulated the root collar diameter growth of $S$. supa at $15 \%$ concentration. A stimulatory response is observed at low concentration levels, while deterrence transpires along increasing concentrations. This is similar to parameters of leaf area, chlorophyll count, net photosynthesis and WUE (stem extract). Transpiration, stomatal conductance and WUE (root extract) incurred variable response along increasing concentration levels. Seeds are more vulnerable to allelochemicals as compared to the 4-month old seedlings of $S$. supa (leaf extract). Therefore, increasing levels of $B$. papyrifera root and shoot extracts inhibit the growth of $S$. supa, indicating B. papyrifera's allelophatic effect and dominance. Hence, this has implications in an effort to conserve native species and prevent the proliferation of invasive exotic species in the area. Further research on the allelopathic potential of the flowers and fruits of $B$. papyrifera is recommended, coupled with chemical characterization, to determine its full detrimental effect on natural forest areas, and to recognize the interplay of different chemicals affecting morpho-physiological dynamics of the affected plant.

\section{Native plants recommended for cover of roadway slopes / Plantas nativas indicadas para o recobrimento de taludes rodoviários}

Ana Cláudia Nogueira da Silva ${ }^{1}$, Angeline Martini ${ }^{1}$, Sebastião Venâncio Martins ${ }^{1}$

${ }^{1}$ Universidade Federal de Viçosa, Viçosa,Brasil (anasilvanogueira@yahoo.com.br; martini@ufv.br; venancio@ufv.br)

Um dos principais impactos provocados pela construção de estradas é a criação de taludes, estes sofrem ação direta das intempéries possuindo alta taxa de erosão hídrica. A inserção de espécies vegetais é uma das técnicas mais recomendadas para a conservação de taludes. Espécies alóctones são as mais recomendadas devido à capacidade de recobrirem a área mais rapidamente e por possuírem maior resistência às condições climáticas. Contudo existem espécies autóctones que possuem comportamento semelhante às alóctones, porém não são comumente encontradas no mercado. Nessa premissa este estudo realizou um levantamento de plantas herbáceas e arbustivas nativas indicadas para a cobertura vegetal e/ou recuperação de taludes rodoviários. Espécies nativas com potencial ornamental foram priorizadas, uma vez que estas espécies são mais facilmente comercializadas. Foram listadas 62 espécies, sendo 48 de potencial ornamental. Poaceae foi a família com maior representatividade (9 espécies), seguida da Fabaceae (8 espécies). A Mata Atlântica foi o bioma com maior número de espécies (49), seguida do Cerrado (48), o Pampa foi o bioma que apresentou menor quantidade de espécies (16). Andropogon bicornis, Andropogon leucostachyus, Axonopus siccus, Dolichandra unguis-cati, Ipomoea alba, Ipomoea cárnea, Sphagneticola trilobata, Stachytarpheta cayennensis, Stylosanthes guianensis são espécies que podem ser utilizadas em todos os biomas brasileiros. Esta pesquisa corrobora com a Estratégia Nacional para Espécies Exóticas Invasoras enfatizando a importância da utilização de plantas nativas, diminuindo assim a introdução, dispersão de exóticas invasoras e selecionando espécies mais apropriadas para cada região, como também espécies adaptadas ao tipo de solo, clima e bem inseridas na paisagem. 


\section{Advancing understanding of invasion ecology with Pines}

Susan Nuske ${ }^{1}$, Paul Kardol ${ }^{1}$, David Wardle ${ }^{2}$, Marie-Charlotte Nilsson Hegethorn ${ }^{1}$, Jane Smith ${ }^{3}$, Anibal Pauchard ${ }^{4}$, Alex Fajardo ${ }^{5}$, Duane Peltzer ${ }^{6}$, Martin Nuñez ${ }^{7}$ Michael Gundale ${ }^{1}$

${ }^{1}$ Swedish University of Agricultural Sciences, Umeå, Sweden; ${ }^{2}$ Nanyong Technological University, Singapore, Singapore; ${ }^{3}$ US Forestry Service, Corvallis, USA; ${ }^{4}$ Universidad de Concepción, Concepción, Chile; ${ }^{5}$ Centro de Investigación en Ecosistemas de la Patagonia, Coyhaique, Chile; ${ }^{6}$ Landcare Reseach, Lincoln, New Zealand; 'National University of Comahue, Neuquén, Argentina (susan.nuske@slu.se; paul.kardol@slu.se; david.wardle@ntu.edu.sg; marie-charlotte.nilsson@slu.se; jsmith01@fs.fed.us; pauchard@udec.cl; fajardo.alex@gmail.com; peltzerd@landcareresearch.co.nz; nunezm@gmail.com; michael.gundale@slu.se)

Pine species have been introduced around the world for timber, soil stabilization and wind breaks. Selection for highly productive species and provenances has led to productive forestry but also to species that can readily spread and become invasive in otherwise productive pasture land, or biodiverse native grassor shrub-land. Our research uses Pinus contorta as a model species to investigate mechanisms that underpin invasion ecology. Our international network of field sites enables us to compare native (USA and Canada), introduced and invaded ranges (New Zealand, Chile and Argentina). In order to disentangle the relative effects of genetics, abiotic nutrients and microbial community on seedling growth we performed an experiment that combined sterilization treatments, provenances and measurements of soil nutrients and fungal communities of soil and roots while keeping environmental conditions stable in a growth chamber 'home-versus-away' design. Our research allows us to compare multiple hypotheses at once, advancing understanding of invasion ecology.

\section{So similar so different: evaluating the invasive potential of Lymantria dispar along the temperate South American}

Stella Januario ${ }^{1}$, Carmen Paz Silva², Sergio Estay ${ }^{2}$

${ }^{1}$ Universidad San Sebastian, Valdivia, Chile; ${ }^{2}$ Universidad Austral de Chile, Valdivia,Chile (stella.mjs@gmail.com; carmenpazsilva@gmail.com; sergio.estay@gmail.com)

One of the most important species of the genus Lymantria is Lymantria dispar, commonly known as "gypsy moth". Highly polyphagous, the species feed on more than 500 species of trees and forest, fruit and ornamental shrubs. The gypsy moth is native to a wide region that ranges from Europe to Asia, currently distinguishing 3 subspecies: Lymantria dispar dispar; Lymantria dispar asiática, Lymantria dispar japonica. This genus of moths is not present in Chile, however in 2012 some egg masses were intercepted from the port of San Antonio, corroborating the effective risk of entry of the species into the country and damage to plant resources. Here, we used occurrences from multiple invaded regions, statistical and GIS tools to model and validate the environmental conditions that might allow the 3 subspecies to persist and spread in Chile. Our results highlight that, by using portions of the habitat that are apparently distinguishable, the subspecies seem to be not only genetically distinct, but ecologically distinct as well. Understanding the relation of the distinct species with the surrounding environment provided valuable insights about probable routes of dispersion in Chile, especially into those areas considered suitable for the forest industry. We discuss the implications of our findings as a useful tool to anticipate the invasion of such harmful invasive species with regard to the most relevant environmental variables.

\section{Effects of a native invasive species, Magnolia kobus, on the persistence of a rare species, $M$. stellata}

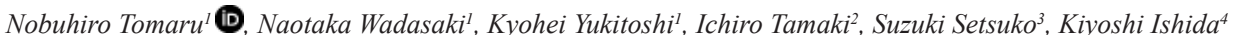

${ }^{1}$ Nagoya University, Nagoya, Japan; ${ }^{2}$ Gifu Academy of Forest Science and Culture, Mino, Japan; ${ }^{3}$ Forestry and Forest Products Research Institute, Tsukuba, Japan; ${ }^{4}$ Hirosaki University, Hirosaki,Japan(tomaru@agr.nagoya-u.ac.jp; www.wk.nk@gmail.com; kkkyohe1@yahoo.co.jp; ichiro@forest.ac.jp;

setsukos@affrc.go.jp; ishidak@hirosaki-u.ac.jp)

Invasive species poses a serious threat to the native species genetically related to the invasive species through interspecific hybridization. $M$. stellata is a rare tree species, distributed only in Tokai region, Japan. In contrast, $M$. kobus is a common tree species, widely distributed mainly in Japan, but it is not distributed in the range of $M$. stellata. However, because $M$. kobus trees is well planted, the escaped trees that are their offspring are occasionally growing near the habitat of $M$. stellate and interspecific hybridization may occur. In this study, we evaluated the effects of a native invasive species, $M$. kobus, on the persistence of a rare species, M. stellate. First, we examined the genealogical classes of adult trees in two areas using nuclear and chloroplast microsatellite markers. We identified F1, F2 hybrids and backcrosses to M. stellata and M. kobus, indicating that the interspecific hybridization and the subsequent introgression can occur. Second, we conducted hand-pollination experiments. Interspecific crosses succeeded like intraspecies crosses. We also carried out pollination with mixed pollen from both species and determined pollen parents using paternity analysis with microsatellite markers, suggesting that reproductive interference between the two species can occur. Third, we examined the differences in survival and growth of adults and saplings (including seedlings) for four and two years, respectively, among the two species and hybrids. No significant differences appeared among them. Based on these findings, we discuss the effects of $M$. kobus on the persistence of $M$. stellata.

\section{Influence of reproductive biology on the invasive capacity of Hymenoptera}

Joséphine Queffelec ${ }^{1}$, Jeremy Allison ${ }^{2,3}$, Jaco Greeff ${ }^{4}$, Bernard Slippers ${ }^{1}$

${ }^{1}$ University of Pretoria, Department of Biochemistry, Genetics and Microbiology, Forestry and Agricultural Biotechnology Institute, Pretoria, South Africa; ${ }^{2}$ University of Pretoria, Department of Zoology and Entomology, Forestry and Agricultural Biotechnology Institute, Pretoria, South Africa; ${ }^{3}$ Natural Resources Canada-Canadian Forest Service, Great Lakes Forestry Centre, Sault Ste. Marie, Canada; ${ }^{4}$ University of Pretoria, Department of Biochemistry, Genetics and Microbiology,Pretoria, South Africa (josephine.queffelec@fabi.up.ac.za; jeremy.allison@canada.ca; jaco.greeff@up.ac.za; bernard.slippers@fabi.up.ac.za)

Introduced species face numerous ecological barriers before they can establish in a new environment. Understanding how they overcome these barriers is crucial for the development of effective risk assessment, regulation and control strategies. Reproductive biology is known to influence invasive success in plants and is widely used for risk assessment. In the case of insects, this biological field should receive more attention as insects display a wide range of reproductive traits and have a great impact on the global economy and environment. Among insects, the order Hymenoptera is of interest for its diversity, both in terms of reproductive traits and introduction history, as invasive species and biological control agents. We review the main reproductive strategies of Hymenoptera and evaluate their effect on invasive potential. Thelytoky could decrease the strength of Allee effects while Arrhenotoky could increase adaptive potential. A species with complementary sex determination could be more affected by inbreeding than other species, while paternal genome elimination could lead to high levels of homozygosity. Finally, some reproductive behaviours could increase inbreeding, impede mate location or facilitate adaptation by encouraging admixture. The 
invasive European Woodwasp, Sirex noctilio, is a pest of pine species causing losses for the industrial forestry of the southern hemisphere and is now threatening the forests of North America and China. This species serves as a case study to illustrate the influence of reproductive traits on the capacity of invasive species to establish in a new area, and their relevance to management.

\title{
D8t: FOREST ENVIRONMENT
}

The quality of forests located in springs in the Cascavel Sub-Plain area of the Paraná III Basin, Paraná, Brazil / A qualidade das florestas em nascentes do subplanalto de Cascavel, Bacia Hidrográfica Paraná III, Paraná, Brasil

Annete Bonnet ${ }^{1}$, Gustavo Ribas Curcio ${ }^{1}$, João Henrique Caviglione ${ }^{2}$

${ }^{1}$ Embrapa Florestas, Colombo, Brasil; ${ }^{2}$ Instituto Agronômico do Paraná, Londrina, Brasil (annete.bonnet@embrapa.br; gustavo.curcio@embrapa.br; jhcaviglione@gmaii.com)

As nascentes, como locais de descarga hídrica da paisagem, devem ser protegidas para garantir suas funcionalidades. São ambientes únicos que, no meio rural, compartilham espaço com os sistemas de produção. A vegetação que circunda as nascentes é protegida pela Lei 12.651/12, Código Florestal, em um raio de 50 m, denominada Área de Preservação Permanente. Como parte do projeto PronaSolos Paraná, estão sendo realizados levantamentos sistemáticos da vegetação em áreas de nascentes e de margens de rios, relacionando-se geomorfologia e solos. Os resultados demonstram que, de modo geral, a maioria dessas florestas se encontra simplificada em diversidade e estrutura e reduzida em tamanho de área ocupada, o que pode ser relacionado com a devastação causada pela colonização na região, que é recente (década de 30) e com a excelente aptidão dos solos para a agricultura. Pode-se citar como espécies arbóreas comuns branquilho (Gymnanthes klotzschiana Müll.Arg.), angico vermelho (Parapiptadenia rigida (Benth.) Brenan), vacum (Allophylus edulis (A.St.-Hil. et al.) Hieron. ex Niederl.), tapiá (Alchornea triplinervia (Spreng.) Müll.Arg.) e açoita-cavalo (Luehea divaricata Mart. \& Zucc.). As espécies nativas ocorrem em baixa diversidade e com pequenas dimensões, denotando frequentemente estágios sucessionais iniciais de regeneração. Corroborando o quadro, registraramse também várias espécies exóticas, como nêspera (Eriobotrya japônica (Thunb.) Lindl.), uva-do-Japão (Hovenia dulcis Thunb.), alfeneiro (Ligustrum lucidum W.T.Aiton), eucalipto (Eucalyptus spp.) e leucena (Leucaena leucocephala (Lam.) de Wit), por vezes, perfazendo a floresta que circunda a nascente. Finalmente, destaca-se a baixa ocorrência de epífitos vasculares e abundância de cipós cobrindo as árvores e prejudicando seu desenvolvimento.

Division of functional groups in Cerrado dry forest and seasonal semi-deciduous forests / Divisão de grupos funcionais em cerrado sentido restrito e floresta estacional semidecidual

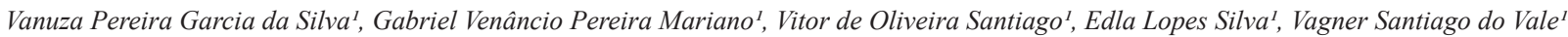

IUniversidade Estadual de Goiás, Ipameri,_Brasil (garciavp@outlook.com; gabrielvenancio_@outlook.com; vitoroliveiras@gmail.com; silvaedla2@gmail.com; vsvale@hotmail.com)

Grupos funcionais (GF) são agrupamentos de espécies vegetais com características semelhantes que desenvolvem o mesmo papel para a manutenção do ecossistema. O objetivo deste trabalho foi verificar se existem diferentes grupos funcionais entre as fitofisionomias cerrado sentido restrito e floresta estacional semidecidual e assim, analisar a influência das variáveis para o bom funcionamento do ecossistema. Foram amostradas 18 espécies consideradas entre as mais importantes de cada fitofisionomia. Foi elaborada uma matriz contendo as espécies e os atributos funcionais para grupos sucessionais, tolerância à luz e dessecação da semente, síndrome de dispersão e polinização, deciduidade, número de sementes por quilo, fenologia de floração e frutificação e cor da flor, e realizado um o dendrograma de similaridade utilizando o método de agrupamento UPGMA e o método de Gower como medida de distância. Foram definidos 5 grupos funcionais. O grupo 1 foi formado por espécies de cerrado e de florestas cujas principais características foram a demanda de luz, dispersão por mamíferos e polinização por pequenos insetos; o grupo 2 foi formado por espécies de cerrado, demandantes de luz com dispersão anemocórica e polinização principal por abelhas; os grupos 3, 4 e 5 foram formados por espécies típicas das florestas, dispersas por aves ou mamíferos e polinizadas por insetos. Foi possível observar que a fitofissionomia inferiu diretamente na divisão e apenas o grupo 1 foi formado por semelhante número de espécies de ambas as fitofisionomias. Houve mais grupos formados por espécies florestais do que de cerrado, refletindo a maior complexidade destes ambientes.

\author{
Edge effects on tree communities in semi-deciduous seasonal forests / Efeito de borda em comunidades arbóreas de florestas estacionais \\ semideciduais \\ Gabriel Venâncio Pereira Mariano ${ }^{1}$, Vanuza Pereira Garcia da Silva ${ }^{1}$, Lilian Cristina da Silva Santos ${ }^{1}$, Joao Paulo Costa ${ }^{1}$, Ana Carolina Ribeiro Vaz ${ }^{1}$, \\ Vagner Santiago do Vale ${ }^{1}$ \\ 'Universidade Estadual de Goiás, Ipameri, Brazil (gabrielvenancio_@outlook.com; garciavp@outlook.com; liliancristina_2011@hotmail.com; \\ joaopaulo_mc@hotmail.com; anavazuegflorestal@gmail.com; vsvale@hotmail.com)
}

A borda é a região de contato entre a paisagem e o fragmento de comunidade arbórea natural. Efeito de borda são modificações nas estruturas e composição da vegetação marginal em uma floresta. O objetivo foi mensurar a distância abrangida pelo efeito de borda em dois fragmentos de Floresta Estacional Semidecídual. Em cada área foram alocadas três transectos com 10 parcelas de 10 x 10 m, da borda em direção ao interior da floresta, amostrando indivíduos com circunferência a 1,30 $\mathrm{m} \geq 15 \mathrm{~cm}$. Foi elaborada a curva espécie-área, baseada na distância em relação a borda. Para cada área foram gerados dois dendrograma de similaridade, baseados na presença/ausência das espécies por parcela (índice de SØrensen) e no número de indivíduos por parcela (índice de Bray-Curtis). Em A1, a curva espécie-área demonstrou aumento expressivo de espécies a partir dos $40 \mathrm{~m}$ houve e na Área 2, a partir dos 70 m. Nos dendrogramas houve a divisão de grupos em ambos os índices e áreas analisados. Na Área 1 formaram-se grupos de parcelas mais próximas a borda (0 a 30 m) e interioranas (40 a 100 m) e na Área 2 os grupos foram de 0 a $60 \mathrm{~m}$ e 70 a $100 \mathrm{~m}$. O efeito de borda na primeira área atingiu $30 \mathrm{~m}$, já na segunda área, $70 \mathrm{~m}$, ambos em direção ao interior da floresta. Assim, diferentes florestas podem ter diferentes tamanhos de borda, influenciadas de maneiras diferentes pelo efeito de borda e novos estudos devem demonstrar as razões destas distinções. 
Spatial distribution of jatobá (Hymenaea courbaril L) / Distribuição espacial de jatobá (Hymenaea courbaril L)

Álef Solon Galdino ${ }^{1}$, Hallefy Junio de Souza ${ }^{1}$, Francieudes Pereira do Nascimento ${ }^{1}$, Sybelle Barreira ${ }^{2}$

${ }^{1}$ Universidade Federal de Goiás, Goiânia, Brasil; ${ }^{2}$ Universidade Federal de Goiás, Porangatu, Brasil (alefsolongaldinogomes10@gmail.com;

hallefyj.souza@gmail.com; framurilo@gmail.com; sybelle.barreira@gmail.com)

O estudo da distribuição espacial de indivíduos arbóreos é uma importante ferramenta para se entender a estrutura populacional das espécies, pois determina como as espécies se encontram na floresta que nos ajuda com informação para manejo e aproveitamento da espécie. O objetivo deste trabalho foi avaliar a distribuição espacial de Jatobá (Hymenea Courbaril L). A amostragem foi feita de forma aleatória com parcelas 20 x 20 m $\left(400 \mathrm{~m}^{2}\right)$ sorteadas ao a caso no software arcgis, foram alocadas 25 parcelas, considerando-se todas as espécies arbóreas com DAP (diâmetro a altura do peito superior a 10 cm, foram coletados os seguintes dados: identificação da espécies vegetal (em campo), CAP (circunferência a altura do peito) e altura coletada com o auxílio de um clinômetro. Para tanto foi calculado o índice de Morisita para a espécie e o valor encontrado foi de 1,67, o que classifica a espécie como intermediária o por sua vez nos diz que a espécie possui uma distribuição aleatória dentro do espaço amostral. A distribuição aleatória dessa espécie é relacionada com as suas síndromes de dispersão, que são descritas como barocórica, devido a ocupação da espécie no extrato superior(porte superior a 20 m), e zoocórica, pois fruto é bastante atrativo para animais, essas sementes necessitam que ocorra sua facilitação para sua germinação, e essa interação entre as sementes e o trato digestivo desses animais, auxilia na sua germinação devido a quebra de dormência. A interação com esses animais justifica a dispersão dessas espécies por toda área e justifica sua distribuição aleatória da espécie.

CO2 emissions patterns in a small municipality in Paraná, Brazil / Padrão de emissão de CO2 em um município de pequeno porte do estado do Paraná, Brasil

Dianafaz Eloiza Canan ${ }^{I}$, Natália Maria Venciguerra Aires ${ }^{I}$, Felipe Spina Vieira ${ }^{1}$, Ana Letícia de Campos ${ }^{1}$, Jaqueline de Morais ${ }^{1}$, Cristian Medrado Canonico ${ }^{1}$, Flávia Gizele König Brun ${ }^{1}$, Eleandro José Brun ${ }^{1}$

'Universidade Tecnológica Federal do Paraná, Dois Vizinhos, Brazil (dianafaz_eloiza@hotmail.com; natalia.maria.venciguerra@hotmail.com; felipespina@outlook.com; analeticiacampos95@hotmail.com; jaquemoraesinha@gmail.com; cristianc@alunos.utfpr.edu.br; flaviag@utfpr.edu.br; eleandrobrun@utfpr.edu.br)

O Painel Intergovernamental de Mudanças Climáticas cita que 95\% das mudanças climáticas sejam devido aos gases antrópicos do efeito estufa. O CO ${ }_{2}$ é um dos principais gases atmosféricos causadores do efeito estufa em 2018 segundo a Organização Meteorológica Mundial com valores de 403,3 ppm, ultrapassando o nível proposto pelo Acordo de Paris 2015 (400ppm). Estudou-se, em Dois Vizinhos/Paraná/Brasil, em 2018, em três setores: industrial (sem arborização), residencial (arborizado em um lado da via) e centro (sem arborização) por três dias nos horários das 09:00; 15:00 e 18:00h. Os locais e horários avaliados apresentaram diferença significativa ao nível 5,0\% (Teste Duncan) entre locais e horários, sendo os níveis de poluentes mais elevados no centro (436,67 ppm), área residencial (421,13 ppm) e industrial (416,49 ppm), o que se deve a fatores econômicos/culturais como presença de veículos automotores por habitante (0,7 veículos/hab. (Jornal de Beltrão 2018)), sistema deficitário de transporte público e baixo estímulo a outras formas de mobilidade, falta de fiscalização de emissões locais (frota veicular, setor industrial e emissões domésticas), baixa arborização. Os valores obtidos estão acima dos estabelecidos em acordos nacionais e globais. Assim, recomenda-se que as políticas nacionais de redução de emissões (Lei 12.187/2009)) devem ser trabalhadas não somente em grandes centros urbanos, mas também em cidades pequenas, para que estas consigam se adequar e contribuir para o alcance das metas previstas para 2020, que visa $36,1 \%$ de redução de emissões de $\mathrm{CO}_{2}$.

Forest dynamics and detecting permanent preservation and legal reserve areas in municipalities in São Paulo, Brazil / Dinâmica florestal e detecção de áreas de preservação permanente e reserva legal em municipios paulistas

Carlos Ronquim ${ }^{I}$, Ivan Alvarez ${ }^{I}$, Cristina Rodrigues ${ }^{I}$, Marcelo Fonseca ${ }^{1}$, Edlene Garçon ${ }^{I}$

'Embrapa Territorial,Campinas,Brazil (carlos.ronquim@embrapa.br; ivan.alvarez@embrapa.br; cristina.rodrigues@embrapa.br; marcelo.fonseca@embrapa.br; edlene.garçon@embrapa.br)

Por meio do uso de geotecnologias avaliou-se a dinâmica florestal e a adequação ambiental de dois municípios delimitando-se as Áreas de Preservação Permanente (APPs) e estimando as áreas de Reserva Legal (RL). A área das florestas nativas de São Carlos em 2016 representou $28,4 \%$ do território ante 19,4\% em 1988, crescendo de 22,1 mil para 32,5 mil ha, ou 9,0\%. A área total de APP é de 6,4 mil ha estando 3,5 mil ha preservados o que dá um total 64,9\% regularizados. A área de RL em função da área cultivável é de 19,9 mil ha sendo que há um total de mata nativa em 27,0 mil ha. Há uma área florestal vegetada maior que a determinada por lei, porém essa área não está distribuída perfeitamente pelas propriedades. Em Ribeirão Preto houve diminuição de $0,7 \%$ das florestas nativas que perderam 481,2 ha passando de 8,1 mil para 7,7 mil ha. A área total de APP cobertas por mata é de 913 ha, ou seja, apenas 37,7\% das APPs estão regularizadas. Os $20 \%$ de área florestal nativa fora das APPs foi de 4,1 mil ha, havendo um passivo ambiental de RL de 2.972,2 ha. Seriam necessários trabalhos de campo para verificar o local exato das nascentes e um levantamento detalhado dos corpos d'água segundo sua situação (naturais ou artificiais) para determinação com exatidão das APPs, além da verificação dos limites das propriedades por meio do Cadastro Ambiental Rural (CAR) para determinação exata dos passivos de RL em cada propriedade.

Water quality in a reservoir located in a small municipality in the State of Paraná, Brazil / Qualidade de águas em reservatório de um parque municipal em município de pequeno porte no Paraná, Brasil

Natália Maria venciguerra Aires', Dianafaz Eloiza Canan', Gabriel Mancini Antunes ${ }^{1}$, Nathielly Alice Luiz Carvalho', Paulo Afonso Vieira Pastori ${ }^{1}$, Gabriela Lovison', Flavia Gizele König Brun ${ }^{1}$

'Universidade Tecnológica Federal do Paraná, Dois Vizinhos, Brazil (natalia.maria.venciguerra@hotmail.com; dianafaz_eloiza@hotmail.com; twilight.mancini@hotmail.com; nathiellycarvalhoo@outlook.com; pauloavp2@yahoo.com.br; gabrielalovison@gmail.com; flaviagbrun@gmail.com)

A análise da qualidade hídrica é essencial, os compostos químicos estão presentes na água contaminada por resíduos podem fazer mal ao organismo humano. Portanto, objetivou-se analisar a qualidade hídrica de um reservatório para o consumo e banho. O lago está localizado no município de Dois Vizinhos, situado na região Sudoeste do estado do Paraná, Brasil. Possui 40.234 habitantes e contém 8 áreas verdes, sendo 2 parques municipais e 6 praças. Para determinação da qualidade da água foram realizadas análises in loco com o uso do termômetro digital e Phmetro. Os resultados obtidos mostraram que o pH da água encontrado variam de 6.5 a 9, sendo parâmetros recomendados pela portaria 2914/2011 do Ministério da Saúde, para que a água adquira características de potabilidade de consumo e banho, apesar das condições visuais apresentar grande quantidade de gordura na superfície, turvamento da água, causando a redução de oxigênio na 
água, causado pela destruição da mata ciliar ao entorno. As temperaturas máximas e mínimas tiveram valores elevados a $29^{\circ} \mathrm{C}$, pelo pouco sombreamento no lago, resultando numa água básica e bastante contaminada por poluentes provenientes de empresas e dos dejetos humanos. A educação ambiental, a fiscalização e a revitalização do lago, são medidas fundamentais para a resolução de tal problemática, além da desintoxicação da água tanto para consumo, quanto para banho, isso seria um fator que atuaria principalmente para redução da fila do SUS, pois as pessoas poderiam usufruir desse recurso hídrico sem ter medo de contaminação .

Associations of tree species within a miombo woodland ecosystem in Quirimbas National Park, Mozambique, and implications for their conservation / Associações de espécies arbóreas em um ecossistema de Miombo no Parque Nacional das Quirimbas (PNQ), Moçambique e implicações para a sua conservação

Nocy Bilal, ${ }^{1,2}$ Roman Carlos Rios ${ }^{1}$, Alessandro Camargo Angelo ${ }^{1}$, Salomao Olinda Bandeira ${ }^{2}$

${ }^{1}$ Universidade Federal do Paraná, Setor de Cencias Agrarias - CIFLOMA, Curitiba, Brasil; ${ }^{2}$ Universidade Eduardo Mondlane, Maputo, Mozambique (nocybila@gmail.com; rioselvas@gmail.com; alessandrocangelo@gmail.com; salomao.bandeira4@gmail.com)

Decorreu um estudo fitossociologico no PNQ com 1358 indivíduos arbóreos (331 em áreas de baixa altitude (0 - 200 m), 728 em áreas de média altitude (200 - 400 m) e 299 em áreas declivosas e longo dos Inselbegs (400 - 700 m). Identificou-se 116 espécies, 68 gêneros e 32 famílias. Fabaceae-Caesalpinoideae (15), Mimosoideae (12), Papilionoideae (10), Combretaceae (8), Anacardiaceae (7), Sterculiaceae (6), Bignoniaceae (5) e Burseraceae (5 espécies). Entre 200 - 400 $\mathrm{m}$, os indivíduos são mais diversificados, melhor distribuídos e estruturalmente mais conservados. As principais essências florestais Brenaniodedron carvalhoi, Millettia stuhlmannii, Pteleopsis myrtifolia, Brackystegia allenii e Terminalia sericea. Existem 154 aldeias, estas populações vivem dentro e entorno do PNQ e dependem dos recursos (florestais e faunísticos). As actividades humanas constituem formas de pressão sobre os recursos, sendo queimadas descontroladas usadas para limpeza de áreas agrícolas, caça e corte ilegal de madeira valiosa; geradores de grandes conflitos entre autoridades do PNQ, populações e empresas privadas madeireira. A exploração madeireira ilegal reduziu consideravelmente devido incursões do Governo e entidades do PNQ, no entanto, existem algumas dificuldades para controlar esta situação na Zona Tampão devido à sua vastidão e existência de vários pontos de acesso. As populações locais necessitam de pequenas quantidades de madeira para construir habitações tradicionais e carpintaria, embora estas actividades não representem grande problema para a conservação. Foi desenvolvido um projecto de Gestao e Conservação produzido no Plano de Maneio do PNQ (2012-2021), que regulamenta a exploração com base em licenças simples para comunidades locais em áreas apropriadas no PNQ.

\section{D8u: FOREST ENVIRONMENT}

\section{Ecosystem decay: influence of 'edge effect' on forest structure, tree species diversity and above-ground carbon stock in fragmented forest patches of Taita Hills, Kenya}

Chemuku Wekesa ${ }^{1}$, Bernard Kirui ${ }^{2}$, Elias Maranga ${ }^{2}$, Gabriel Muturi ${ }^{3}$

${ }^{1}$ Kenya Forestry Research Institute, Wundanyi, Kenya; ${ }^{2}$ Egerton University, Nakuru, Kenya; ${ }^{3}$ Kenya Forestry Research Institute, Nairobi, Kenya (chemukukefri@gmail.com; bkkirui@egerton.ac.ke; ekmaranga@yahoo.com;gabrielmukuria2012@gmail.com)

Comparative studies were undertaken in five forest fragments of varying sizes to determine the effects of forest edge on the forest structure, species diversity and richness and above-ground carbon stock along forest edge-interior gradient, and the relationship between pioneer and late successional tree species. Belt transects proportional to the forest area were established for data collection. Within each belt transect, plots of $10.0 \times 10.0$ m were systematically established and replicated three times in a stratum at an interval of between 10.0 and $50.0 \mathrm{~m}$ along forest edge-interior gradient depending on the size of the forest fragment. Results showed that there was no significant edge effect on tree species diversity in Chawia ( $p=0.564)$, Fururu $(p=0.689)$, Mbololo $(p=0.369)$, Ngangao $(p=0.576)$ and Vuria $(p=0.338)$, although species diversity was higher in the forest interior than in the intermediate forest and on the forest edge. Similarly, there was no significant edge effect on species richness in Chawia $(p=0.490)$, Fururu $(p=0.507)$, Mbololo $(p=0.303)$, Ngangao $(p=0.886)$ and Vuria $(p=0.090)$. Aboveground carbon stocks were not significantly affected by edge effect in Chawia $(p=0.704)$, Fururu $(p=0.908)$, Mbololo $(p=0.544)$, Ngangao $(p=0.991)$ and Vuria $(p=0.590)$. Tabernaemontana stapfiana and $M$. lanceolata co-existed with $45.5 \%$ and $18.2 \%$ of the late successional tree species respectively while $9.1 \%$ of the late successional tree species co-existed with each of the following pioneer tree species: A. gummifera, M. conglomerata, S. guineense and X. monospora. These results could be used to develop conservation strategies that may minimize forest degradation, and biodiversity erosion and loss in fragmented forest ecosystems.

\section{Effects of seed size and leaf litter depth on early settlement in Major Korean Trees}

EuiJoo Kim ${ }^{1}$, SooIn Lee 2 , YoungHo Jung' ${ }^{2}$, SeungYeon Lee ${ }^{1}$, YongSik Hong ${ }^{1}$, EungPill Lee ${ }^{1}$, JiEun Kim ${ }^{1}$, MinJoo Kim ${ }^{1}$, YoungHan You ${ }^{1}$ ${ }^{1}$ Kongju National University, Gongju-si, Korea, Republic of; ' ${ }^{2}$ Baekdudaegan National Arboreum, Bonghwa-gun, Korea, Republic of (euijoo@kongju.ac.kr; ecolove093@kongju.ac.kr; jyh5250@kongju.ac.kr; ecolee21@kongju.ac.kr; hongfin@smail.kongju.ac.kr; lyp2279@kongju.ac.kr; jekim64@kongju.ac.kr; minjoo1164@naver.com; youeco21@kongju.ac.kr)

The forests in Korea are getting thicker and the litter layers are getting higher. Also, It is now progressing succession from pine forests to oak ones. In this study, we investigated the difference of response of tree seeds to the leaf litter in order to verify autogenic influential factor that causes the forest succession in Korea. Seeds used in the experiment were six species such as succession early species (Pinus densiflora), and the later species (P. koraiensis, Abies holophylla) and oak's three species. The seed of these trees were sown at the above and below in litter depth of $5 \mathrm{~cm}$ and $10 \mathrm{~cm}$ or on the bare ground, and germination rate was measured and initial survival rate was counted. To determine the effect of drying, the survival rate was surveyed after stopping the water supply. As a result, germination rate of oaks were higher on the bare ground. And regardless of the depth of litter, germination rate of the pines were higher than oaks. Under the litter, germination rate of Oaks were $100 \%$. Germination rate was highest $Q$. acutissima among the oak trees and $P$. densiflora among the pine trees. And $Q$. acutissima than $P$. densiflora was highest the survival rate relation to the drying stress. Therefore, $Q$. acutissima in Korea will be advantageous for early settlement. This work was supported by the National Research Foundation of Korea(NRF) grant funded by the Korea government(MSIT)(No. NRF2018R1A2B5A01021358) 


\title{
Interaction network of Quercus humboldtii honeydew: possible ecological dynamics of an NTFP in Colombia
}

Hugo Alexander Benjumea Ochoa ${ }^{1}$, Jaime Polanía ${ }^{1}$, Carolina Serna ${ }^{1}$

'Universidad Nacional de Colombia, Medellin, Colombia (habenjumeao@unal.edu.co; jhpolaniav@unal.edu.co; csernac@unal.edu.co)

Honeydew is a sugary solution coming from the anal projection of Stigmacoccus asper (Hemiptera: Stigmacoccidae) in interaction with oak forests (Quercus humboldtii, a 'vulnerable' species, whose use is legally restricted) and a sooty mold, growing over the tree's bark. Honeydew is used by hummingbirds (Trochilidae), Meliponin bees and Apis mellifera (Hymenoptera: Apidae). The latters take it to produce honey of international quality. Here, we deepen in the understanding of, and we differentiated between interaction types (e.g., parasitism or commensalism) in oak forests of the Colombian Cordillera Oriental (municipality of Zapatoca, Santander). Furthermore, we determine the infestation degree on oak specimens in the Natural Reserve of the Civilian Society "El Páramo-La Floresta". In 2015, four permanent $400 \mathrm{~m}^{2}$ plots were set up inside the oak forest, at 2,500 masl, and two years later DAPs were measured again. The infestation was estimated at $\sim 80 \%$ of the trunks. Using R and a Kruskal test, significant differences were found for DBH growth compared to a neighboring oak grove lacking the hemiptera. However, the mean growth was higher in the infested oak forest. Here we suggest guidelines for assessing the sustainability of honeydew as a potential NTFP for neighboring communities, and as food for hummingbirds. This study emphasizes the articulating role of Colombian oak in the ecology of mountain forests. In addition, we show the set of chain reactions that can be generated around a parasitism, and speculate about the possible effects that oak groves will have in the light of continuous monitoring.

\section{Forest landscape characteristics of Prionailurus bengalensis's habitat in Rural area, South of Korea}

\author{
HoSeung Choi ${ }^{1}$, EuiJoo Kim ${ }^{1}$, JeongGeun Yun ${ }^{1}$, DaeHee Kim ${ }^{1}$, HaeIn Yu ${ }^{1}$, SeungJun Lee ${ }^{1}$, KiHwan Lim ${ }^{1}$, YongSik Hong ${ }^{1}$, EungPill Lee ${ }^{1}$, SeungYeon Lee ${ }^{1}$, \\ YoungHan You ${ }^{1}$ \\ ${ }^{1}$ Kongju National University, Gongju-si, Republic of Korea (rhrorchl@hanmail.net; euijoo@kongju.ac.kr; yunterry26@naver.com; \\ daehee1999@naver.com; feline27@daum.net; gudwp98@hanmail.net;feverfew79@kongju.ac.kr; hongfin@smail.kongju.ac.kr; lyp2279@kongju.ac.kr; \\ ecolee21@kongju.ac.kr; youeco21@kongju.ac.kr)
}

In order to find out about the characteristics of the preferred habitat in the forest area of Prionailurus bengalensis, authors analyzed the relationship between the area where Prionailurus bengalensis appeared from August 2016 to May 2017 and the environment factors such as forest landscape element, elevation element, slope element, Age-class element, DBH-class element, density, etc. using ArcGis, AutoCad, Photoshop, etc. As a result, the share of environmental factors in the research area and the share of distribution areas by environmental factors in the research area were relatively high, with the appearance of Prionailurus bengalensis in areas with a slope ranging from $15-20^{\circ}$ to $35-40^{\circ}$. These results indicate that the research area is feeding in grassland areas, the area extending to the north is used as a transportation route, and that the slope is slower than the slope of the slopes of the forest or the valley. This research was supported by Basic Science Research Program through the National Research Foundation of Korea (NRF) funded by the Ministry of Education(NRF-2018R1D1A1B07050269)

Estimating the density and productive potential of Brazil nuts (Bertholletia excelsa H.B.K.) based on environmental variables in Madre de Dios / Estimación de densidad y el potencial productivo de castaña (Bertholletia excelsa H.B.K.) en base a variables ambientales - Madre de Dios

Jheyson Jerzel Valdivia Gómez, ${ }^{2}$

${ }^{1}$ Universidad Nacional Amazónica de Madre de Dios, Puerto Maldonado, Peru. ${ }^{2}$ Universidade Estadual Paulista "Júlio de Mesquita Filho", Botucatu, Brazil (jheyson540@gmail.com)

El objetivo de este proyecto fue, estimar la densidad y el potencial productivo de la castaña (Bertholletia excelsa H.B.K.), en base a variables ambientales en más de 400 concesiones ubicadas en el departamento de Madre de Dios, con un total de 135528 individuos, así como entrevistas realizadas a 32 concesionarios. Además, se realizó un inventario del 10\% de la población dentro de éstas concesiones, para corroborar los datos obtenidos entre el primer y segundo quinquenio. Los resultados demuestran que, a mayores temperaturas, la producción es menor, mientras que con las precipitaciones sucede lo contrario; se encontró una productividad mayor a la misma, antes de la estación seca (mayo-septiembre). También se observó mayor productividad en suelos con $\mathrm{pH}<5$, y con mayor contenido de arcilla, limo y carbono (lo inverso al contenido de arena). Las altitudes entre 250-350 m.s.n.m., favorecen la densidad y productividad, con pendientes no mayores de $10^{\circ}$. B. excelsa, tiene una alta densidad y productividad a medida que se aleja de los cuerpos de agua, distinto con respecto a los caminos, ya que cercano a ellos se obtuvo una alta densidad y productividad. Así mismo, se evidenció que la productividad también depende de las condiciones fitosanitarias y estructurales de esta especie. Se lograron hallar valores de mayor productividad en individuos con presencia de termitas y menor en aquellos con presencia de lianas, exudación, ramas rotas y huecos en la estructura del árbol. La presencia de tumores y la presencia de árboles cercanos no tienen influencia en la productividad.

Alpha diversity indexes for woody species in the departments of Glass and Alberdi, Santiago del Estero, Argentina / Índices de diversidad alfa de especies leñosas en los departamentos Copo y Alberdi, Santiago del Estero, Argentina

Constanza Josefina Garnica1, Maria de los Angeles Basualdo ${ }^{1}$, Franco Diaz ${ }^{2}$, Walter Cassino ${ }^{3}$

${ }^{1}$ Facultad de Ciencias Forestales, Universidad Nacional de Santiago del Estero, Santiago del Estero, Argentina; ${ }^{2}$ Dirección General de Bosque y Fauna, Ministerio de Produccion, Santiago del Estero, Argentina; ${ }^{3}$ Nodo Regional Parque Chaqueño, Santiago del Estero, Argentina (garnicaconstanza@gmail. com;mbasualdo@agro.uba.ar;francodiaz.sgo@gmail.com; walter.cassino@gmail.com)

Los inventarios forestales proporcionan información valiosa para el conocimiento cuali y cuantitativo del recurso bosque; además de la determinación del volumen de madera y su crecimiento podemos estimar biodiversidad. El objetivo del trabajo es generar información sobre diversidad local y regional de especies leñosas de los bosques de Copo y Alberdi pertenecientes a la Región Chaqueña Semiárida. Se trabajó con datos provenientes del muestreo piloto del Segundo Inventario Forestal de Bosques Nativos (MAyDS, 2015- 2016). El diseño de muestreo fue sistemático, se relevaron 169 unidades muestrales, cada una conformada por un conglomerado de 3 parcelas circulares de $1000 \mathrm{~m}^{2}$ (tamaño de la UM $3000 \mathrm{~m}^{2}$ ). La estimación de diversidad regional se realizó a través de Riqueza (R), la diversidad local a partir de los índices Shannon-Wiener (H) y Simpson (D). Los resultados muestran para Copo un índice H de 1,49 y un índice D de 0,30; para Alberdi de 1,44 y 0,32 respectivamente. El valor R promedio para Copo y Alberdi es 39. Concluimos que los resultados obtenidos se asemejan a los reportados por otros autores para la región. Valores de H varían generalmente entre 1,5 y 3,5 (Magurran, 1988). Valores de 1-D varían entre 0,80 y 0,93 (Gimenez et al, 2008). En un bosque primario del Parque Nacional Copo se encontró un R de 31 especies (Torrela et all, 2011). Debido a las altas tasas de deforestación destacamos la importancia de promover el conocimiento y valoración de la region chaqueña; considerada una de las ecorregiones con alta prioridad de conservación según la SAyD. 
Conservation and use of Gossypium mustelinum in restoration of degraded areas / Conservação e uso do Gossypium mustelinum na restauração de áreas degradadas

Rafaela Gonçalves da Silva ${ }^{1,2}$, Lucia Vieira Hoffmann'2, Amanda Moreira Siqueira ${ }^{1}$, Alessandra da Cunha Moraes ${ }^{3}$

${ }^{1}$ Universidade Federal de Goiás, Goiânia, Brasil; ${ }^{2}$ Embrapa Algodão, Goiânia, Brasil; ${ }^{3}$ Embrapa Arroz e Feijão, Goiânia, Brasil (rafaelags05@gmail.com; lucia.hoffmann@embrapa.br; amandamoreira-s@hotmail.com; alessandra.moraes@embrapa.br)

Gossypium mustelinum é uma espécie de algodão nativo do Brasil. A espécie arbórea ocorre naturalmente nos estados da Bahia, Pernambuco e Paraíba e Rio Grande do Norte, mais frequentemente próxima a leitos de rios que não são perenes e, quando na mata, parece ter preferência por clareiras. O uso do Gossypium mustelinum poderia ser uma opção de espécie utilizada na restauração de áreas degradadas, seja em áreas de preservação permanente (APP) ou reserva legal, como uma espécie que não seja para fins lucrativos, ainda que possua características favoráveis para tal finalidade, o objetivo é restaurar a forma e a funcionalidade do local. A Embrapa promove a conservação em banco de germoplasma. Ainda são poucos indivíduos de G. mustelinum encontrados no país, alguns foram encontrados em Áreas de Proteção Ambiental como a APA Santa Cruz, e poucas sementes já foram coletadas, para a restauração é necessário plantar as sementes existentes, e assim formar uma área de coleta de sementes-ACS e/ou área de produção de semente-APS, o ambiente tem que ser semelhante aos locais de plantio, por isso sugere-se parcerias com prefeituras para implantação das mesmas. Neste sentido, sugere-se alternativas para aumentar a população de indivíduos de Gossypium mustelinum nas regiões de ocorrência. Contudo, a conscientização da comunidade local é essencial, sendo esta realizada por diversos meios de comunicação, como Jornais e a ação de guardiões, pois a principal ameaça é a interferência humana, garantindo que o desenvolvimento socioambiental se faça com a conservação de seu patrimônio natural, histórico e cultural.

Challenges of forest governance related to paying for environmental services, directed at subsistence farms in Costa Rica / Desafios de la gobernanza forestal para atender la nueva modalidad de PSA dirigido a fincas de subsistencia en Costa Rica

Victor Meza ${ }^{1}$, Monserrat Romero ${ }^{1}$, Kevin Alfaro ${ }^{1}$

${ }^{1} U N A$, Heredia, CostaRica (victor.meza.picado@una.cr; mariamonse01@gmail.com; kevin15aj@gmail.com)

Se crea en el año 2018 una nueva modalidad de PSA que busca reconocer los servicios ambientales que se generan en fincas de menos de 10 ha. Con la intención de evaluar la efectividad de la nueva modalidad se trabajó en tres proyectos pilotos en diferentes regiones del país. Uno de estos ha sido desarrollado por la UNA en un asentamiento llamado Asarias María ubicado en la Región Huetar Norte, con un promedio de tamaño de finca de tres hectáreas. La finalidad principal es contribuir al mejoramiento de la economía de pequeños productores mediante el cultivo de clones superiores de caoba (Swietenia macrophylla) en sistemas agroforestales (SAF); apoyado con el PSA. Se observó que los productores están dispuestos a plantar en promedio un $30 \%$ más de árboles en sus fincas con tal de acceder al PSA. No obstante, se ha dado una baja respuesta de las instituciones encargadas en certificar requisitos de los productores que son solicitados por el FONAFIFO. Las organizaciones no muestran interés por fomentar esta nueva modalidad debido al bajo ingreso que les significa. Se mantuvieron requisitos que se presentan en los otros esquemas de PSA que son más rentables para implementar por las organizaciones, por tal motivo le resta competitividad al nuevo esquema de PSA. En consecuencia, existe un gran desafío para que las actuales instituciones cambien sus estructuras rígidas hacia estructuras más adaptativas que puedan promover la implementación del nuevo esquema reconociendo las particularidades de los pequeños productores.

\section{D9a: CONSERVATION ECONOMICS: PROSPECTS AND CHALLENGES}

\section{Prevented degradation of payments for forest conservation: an empirical analysis of the Socio Bosque Program}

Francisco Aguilar (D, Philip Mohebalian ${ }^{2}$

${ }^{1}$ Swedish University of Agricultural Sciences, Umea, Sweden; ${ }^{2}$ US Census, Washington,USA (francisco.aguilar@slu.se; phillip.m.mohebalian@census.gov)

Payments for forest conservation programs financially compensate forest owners to maintain and increase the provision of ecosystem services. We examined the additionality of the Socio Bosque Program (SPB) in prevented deforestation based on the establishment of field-level plots within the Ecuadorian Amazon basin region. Forest inventories were complemented with face-to-face landowner surveys to elicit preferences for various conservation contractual arrangements. Inventory data suggest that forests within SPB-enrolled areas exhibited less evidence of degradation. The likelihood of finding a tree species at risk of extinction within forests enrolled in the SBP was 1.8 times that of non-enrolled forests. An experiment conducted with 200 forest owners suggests that opportunities for greater conservation impacts remain if participants were allowed to harvest timber under a strict management plan. Moreover, contracts managed by local municipalities or international NGOs showed stronger preferences over those managed by centralized institutions. Taking risk of deforestation into consideration and based on stated landowner preferences, greater conservation benefits might be attainable if sustainable timber harvesting is allowed along with long-term conservation agreements.

\section{A cost-effective way to increase revenue and reduce illegal deforestation in Amazon forestlands}

Vivian Ribeiro ${ }^{1}$, Paulo Moutinho ${ }^{1}$, Claudia Azevedo-Ramos ${ }^{2}$, Ane Alencar $^{1}$, Raissa Guerra ${ }^{1}$, Isabel Castro ${ }^{1}$, Daniel Silva ${ }^{1}$, Marcelo de Castro Chaves Stabile ${ }^{1}$, André Loubet Guimarães ${ }^{1}$

${ }^{1}$ Amazon Environmental Research Institute, Brasilia, Brazil; ${ }^{2}$ Center for Higher Amazonian Studies. Federal University of Para, Belém, Brazil (vivian.ribeiro.bio@gmail.com; moutinho@ipam.org.br; claudia.azevedoramos@gmail.com; ane@ipam.org.br; raissa.guerra@ipam.org.br; isabelcastro@ipam.org.br; daniel.silva@ipam.org.br; marcelo.stabile@ipam.org.br;a.guimaraes@ipam.org.br)

The Brazilian Amazon has over 60 million ha of public forests not allocated for any specific use. These areas have been register by the Brazilian National Cadaster of Public Forest. However, the lack of allocation of these public forest under some protect area category threatens their integrity. The weak enforcement and governance associated with the availability of these undesignated forest leads to land grabbing and illegal deforestation. The deforestation in these areas represents around $25 \%$ of the total annual deforestation in the region. Since these areas are key to maintaining ecosystem services and carbon stock, contributing to climate change mitigation, we applied a prioritization methodology considering environmental, social and economic variables, to identify which of these areas should be allocated as integral protection or sustainable use conservation units. Furthermore, we also estimated the cumulative costs over a 12 year period to allocate all of the public forests to conservation units as been BRL 4.49 billion (approximately USD 1.28 billion). On the other hand, this investment may have a financial return of BRL 5.85 billion (approximately USD 1.67 billion) as result of tourism and harvesting of timber and non-timber products. Additionally it can preserve a carbon stock of $0.4 \mathrm{Gt} \mathrm{CO}_{2}$, which would be at risk during the period. By allocating these areas as Conservation Units, we could reduce potential deforestation by $88 \%$ in the allocated area. 


\author{
Assessment of the World's largest afforestation program “Three North Protective Forest Program": success, failure and future

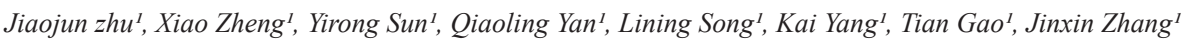 \\ ${ }^{I}$ CAS Key Laboratory of Forest Ecology and Management, Qingyuan Forest CERN, Institute of Applied Ecology, Chinese Academy of Sciences, Shenyang, \\ China(jiaojunzhu@iae.ac.cn; xiaozheng@iae.ac.cn; yirongsun@iae.ac.cn; qlyan@iae.ac.cn; liningsong@iae.ac.cn; kyang@iae.ac.cn; tiangao@iae.ac.cn; \\ zhangjinxin@iae.ac.cn)
}

Large-scale afforestation programs have been attempted worldwide to help improve environmental conditions. Most of these attempts have been unsuccessful for social-political, technical, and/or ecological reasons. However, China's Three-North Protective Forest Program, the World's Largest Afforestation Program (TNAP), is still ongoing (1978 to 2050). TNAP was designed to improve environmental conditions over an area of $\approx 4 \mathrm{million}^{\mathrm{km}}{ }^{2}$ (42\% of China). Although US $\$ 35.2$ billion were invested in TNAP during its first 40 years (1978 2017), its rationale and success are still being debated among scientists and in the media. To provide an objective evaluation of TNAP, we systematically conducted a range-wide assessment of it based on remote sensing, field surveys, and statistics. TNAP has produced significant ecological and socio-economic benefits: $71.5 \%$ increase in forest coverage, $1.4 \%$ improvement incrop yield,61.0\% and $14.9 \%$ reduction in areas ofsoil erosionand desertification, respectively between 1978 and 2017. TNAP helped 15 million persons out of poverty, provided the jobs for 300 million people, and enhanced the people's awareness of ecological protection. Challenges for TNAP include limited success in desertification control (the $14.9 \%$ total reduction almost exclusively limited to light desertification areas), and low coverage of shelterbelts (the ratio of shelterbelt area to farmland area was only $2.4 \%$ ). Overcoming these challenges during the next 32 years will further enhance the contribution of TNAP, and profoundly influence the policy and practice of environmental protection and improvement in China and worldwide.

\title{
Promoting socio-economic development and cultural wellbeing in protected Atlantic forest areas: the potential and limitations of ecological fiscal transfers
}

\section{Gracie Verde Selva ${ }^{1}$ (D) Milena Kiatkoski Kim² (DD}

${ }^{1}$ Instituto Brasileiro de Desenvolvimento e Sustentabilidade, Brasilia, Brasil; ${ }^{2}$ The University of Western Australia, Perth, Australia (gracieselva@gmail.com; milena.kim@uwa.edu.au)

Protected areas are an important component of Brazilian environmental policy to preserve forests. Protected areas require community support in order to achieve optimal outcomes, which can be facilitated through a number of policy approaches. Pioneered in Paraná in the early 1990s and then adopted by other states, the Ecological ICMS (ICMS-E) is an example of an ecological fiscal transfer (EFT) policy which attempts to address the trade-offs and opportunity costs associated with protected area regulation. In this presentation we examine versions of the ICMS-E from two states; Paraná and São Paulo. In both cases the ICMS-E provides monetary compensation to local governments that host protected areas within their municipal area of jurisdiction, whilst in Paraná the ICMS-E also promotes and rewards local conservation initiatives. We interviewed 51 state and local stakeholders from Brazilian municipalities located within relatively intact areas of Atlantic rainforest. We show the opportunities and obstacles municipalities have encountered in using the ICMS-E to (1) support local economic development that is aligned with environmental restrictions and (2) promote the cultural wellbeing of traditional communities. The results highlight the importance of the institutional arrangement underpinning the implementation of EFTs, and the necessity to engage with local institutions and communities in order for social, economic and environmental benefits to be realised. As the ICMS-E is now being widely adopted within Brazil and EFTs are being implemented elsewhere, the lessons learned in this case study have wider relevance for policy makers internationally.

\section{Economics of wildlife conservation: the case of Chitwan National Park in Nepal}

Ram Pandit ${ }^{1}$

'University of Western Australia, Perth, Australia (ram.pandit@uwa.edu.au)

Wildlife conservation involves various direct and indirect benefits and costs. The benefits of conservation are often shared by both local and global communities, while most of the direct costs are often borne by local communities. Conservation policies and economic instruments intend to balance such benefits and costs to achieve optimal conservation outcomes. Considering the conservation policies used over-time, this paper aims to examine an array of benefits and costs of conserving wildlife at Nepal's Chitwan National Park. The paper further draws on aspects of policy evolution and conservation status of targeted species in enhancing conservation benefits while minimising conservation costs. It also highlights the prospects and challenges associated with species conservation where private costs and public benefits are involved.

\section{Real Options theory to value a forest restoration project in Legal Reserve}

Rafaele Almeida Munis $^{1}$ (D, Maria Jose Brito Zakia ${ }^{1}$ (D), Silvana Ribeiro Nobre ${ }^{2}$ (D), Mariana Aparecida Carvalhaes ${ }^{3}$ (D), Danilo Simões ${ }^{1}$ (D) ${ }^{1}$ São Paulo State University (Unesp), School of Agriculture, Botucatu, Botucatu, Brazil; ${ }^{2}$ Universidad Politécnica de Madrid (UPM), Madri, Spain; ${ }^{3}$ Embrapa Produtose Mercado,Campinas,Brazil(rafaele.munis@gmail.com; zeze.zakia@uol.com.br; silvana.rnobre@gmail.com; mariana.carvalhaes@embrapa.br; danilo.simoes@unesp.br

The obligation of an area located in a property is called Legal Reserve (LR) and in Brazil is given by the Law 12.651 / 2012 which provides for the protection of native vegetation to landowners holding areas greater than four fiscal modules. The main purposes of Legal Reserve are the conservation and restoration of the native flora, in addition the sustainable forest management. In this sense, the objective of this study was to value a forest restoration project destined to LR, with phytoecology of Seasonal Semideciduous Forest, through the approach of pricing of discrete time multiplicative binomial options. The forest assets investment project, located in Botucatu city, State of São Paulo, Brazil, included species of native occurrence that generated income from timber and non-timber products. The cash flow planning horizon was 20 years, time required for RL recovery, discounted by CAPM. Due to uncertain commercial prospects, the forest producer may wait two years to realize the investment. Furthermore, if the investment is executed in the fifteenth year, the forest producer may expand the restored area by $30 \%$. The results show that the probability of the investments being executed after two years was $100 \%$. Moreover, the expansion at the end of the fifteenth year has a $7 \%$ probability of being exercised. Considering the options jointly exercised, the project added $90.04 \%$ of value to the forest producer, resulting in an expanded net present value of USD4,004.95, corroborating the economic feasibility of the restoration of native flora. 


\title{
Framing woodland key habitats: how has the debate in media evolved over time?
}

Isabella Hallberg-Sramek ${ }^{1}$, Therese Bjärstig ${ }^{2}$, Annika Nordin ${ }^{1}$

${ }^{1}$ Swedish University of Agricultural Sciences (SLU), Department of Forest Genetics and Plant Physiology, Umeå, Sweden; ${ }^{2}$ Umeå University, Department of Political Science,Umeå,Sweden (isabella.hallberg.sramek@slu.se; therese.bjarstig@umu.se; annika.nordin@slu.se)

Woodland key habitats (WKHs), is a well-used concept in northern Europe, denoting sites in the forest landscape with particularly high nature conservation values. In Sweden WKHs on private forestland have been inventoried by the governmental Forest Agency since the early 1990ies in order to inform forest owners of valuable biotopes. Recently, various actors have started to question the WKH concept and its policy implications. To investigate how framing of the WKH concept has changed over time we conducted an media analysis based on collective action frames-theories, which states that actors who wants to promote a change often points out (1) who/what is causing a problem?, (2) who/what is solving a problem?, and (3) who/what is suffering from a problem?. In total, the analysis covered the period 1991-2018 and 294 articles in daily newspaper media framing WKHs. Our results showed that over time WKHs have mostly been framed by governmental agencies and by newspaper journalists as suffering from various forestry practices. However, during the most recent period, WKHs have also been framed as causing problems to private forest owners. This indicates a more polarized debate than previously between actors supporting forests' biodiversity vs economic values. We conclude that the WKH concept has changed from being a tool informing forest owners of their forest's biodiversity values to a highly politicized concept frequently debated in media. To fully understand the rationale behind this development, further studies are necessary.

From constrain to opportunity: win-win public-private partnership for financing sustainable poplar plantations and biodiversity conservation in Lombardy (Northern Italy)

${\text { Alex } \text { Pra }^{1,2} \text {, Alessandro Leonardi }}^{2}$, Giulia Amato ${ }^{2}$, Mauro Masiero $^{1}$, Paola Gatto $^{3}$

${ }^{1}$ TESAF Dept. University of Padova, Padova, Italy; ${ }^{2}$ ETIFOR, Padova, Italy; ${ }^{3}$ TESAF Dept. University of Padova, Padova, Italy (alex.pra@etifor.com,

alessandro.leonardi@etifor.com; giulia.amato@etifor.com; mauro.masiero@unipd.it; paola.gatto@unipd.it)

Financing the creation and maintenance of biodiversity conservation areas is a major challenge in times of constraints in public spending. In this context, Payment for Ecosystem Services are considered innovative and effective market approaches to conservation finance. We analyzed the objectives, the contents of the negotiated agreement, and the main outcomes of a Payment for Biodiversity Conservation Scheme (ECOPAY Connect) in the Lombardy Region in northern Italy, which brings together Regional Park authorities, timber industry, and private poplar growers as partners involved in complying with the requirements connected to an FSC $®$ (Forest Stewardship Council) certification initiative. This scheme represents a win-win solution and transforms a certification compliance requirement, i.e. the set-aside of the $10 \%$ of the productive area for ecological restoration, into an opportunity, where a public-private partnership led to reduction of costs for both partners, and more functional restoration interventions within the park. The scheme now runs by its own, making ECOPAY Connect one of the few functioning PES schemes in Italy and in EU. The scheme was launched with a grant from the Bank Foundation and this partnership is now used as a best practice in many EU projects such as Gestire 2020, an integrated LIFE project by Lombardy Region, and Sincere, a Horizon 2020 project.

Social and spatial approach in constructing biodiversity indicators / Abordagem social e espacial na construção de indicadores de biodiversidade

Maria Luiza Almeida Luz ${ }^{1}$

'Universidade de Brasília,Brasília,Brazil (marialuizaluz@gmail.com)

A conservação da biodiversidade necessita ser ampliada sem prejudicar a economia e o seu crescimento. Isso poderá ser realizado pelos economistas se eles incorporarem indicadores de biodiversidade apropriados em seus modelos. Adicionalmente, os países devem assegurar que tais indicadores sejam metodologicamente robustos, que as necessidades dos diferentes grupos sociais estejam representadas e que os indicadores sejam os instrumentos ideais para avaliar a política à qual estão atrelados. Este trabalho propôs que a construção de indicadores de diversidade biológica incorpore os aspectos social (stakeholders) e espacial (escala). Foram analisados qualitativamente as metas e indicadores brasileiros de biodiversidade apresentados nos relatórios nacionais para a Convenção sobre Diversidade Biológica (anos 2011 e 2015), e o conjunto nacional de indicadores do PainelBio (2016). Os resultados apontam que o Brasil não adotou uma boa metodologia para as metas de 2011, com mais da metade das 51 metas não cumpridas, mas vem tentando incorporar as metodologias recomendadas pela CDB a partir do relatório de 2015 e do PainelBio. O avanço é frágil e o país ainda pauta o acompanhamento das metas de maneira qualitativa, carecendo de uma abordagem quantitativa. Outro gargalo identificado foi quanto à rastreabilidade das informações apresentadas nos documentos oficiais. Dessa forma, é preciso avançar para que o processo metodológico de elaboração dessas metas e indicadores seja registrado, compartilhado e disponibilizado de maneira mais transparente e acessível para toda a comunidade, para garantir que a metodologia empregada corresponda às expectativas científicas que se desejam alcançar com os instrumentos de avaliação da biodiversidade.

D9b: INTEGRATED APPROACHES TO SUPPORT EFFECTIVE IMPLEMENTATION OF FOREST LANDSCAPE RESTORATION

\section{Who are stakeholders in forest landscape restoration?}

\author{
Stephanie Mansourian ${ }^{1}$ \\ ${ }^{1}$ Mansourian.org, Gingins, Switzerland. University of Geneva, Geneva, Switzerland (smansourian@infomaniak.ch)
}

Understanding the diversity of stakeholders involved in large scale forest restoration is essential to success as they are at the core of any forest restoration effort. Stakeholders may be categorised in many different ways, recognising that categories hide unique differences. The purpose of this contribution is to better understand why it is important to identify stakeholders, present ways of categorising stakeholders in forest landscape restoration (FLR) and understanding what motivates them to engage in restoration. When dealing with landscapes or large scales, stakeholders can be found at many different spatial scales, and those involved in the restoration action may not necessarily be the ones benefitting or losing the most from restoration. Over time stakeholders evolve and change. Power dynamics are also an essential component in decision-making related to large scale forest restoration. Integrating different stakeholder characteristics, needs and values in FLR helps to secure long term buy in and success. Exploring some of the specificities of FLR also helps to better understand the full range of issues associated with stakeholders. I outline the diversity of stakeholders, at different scales, and highlight some of the reasons different stakeholders engage in restoration. 
Integration for restoration: reflecting on lessons learned from the silos of the past

Rachel Carmenta ${ }^{I}$, Bhaskar Vira ${ }^{1}$

'University of Cambridge, Cambridge, United Kingdom(rc730@cam.ac.uk; bv101@cam.ac.uk)

Momentum for forest and landscape restoration (FLR) is building and holds the potential to make a positive contribution to local livelihoods, wellbeing and the ecological integrity of forest landscapes. Yet FLR is operating amid multiple and competing demands for land and resources, which are too often acting in parallel rather than in unison. Silo-style approaches in which ecologists produce narrow restoration guidelines, foresters plant trees for production, companies invest in tree planting for carbon credits, and so on must be exchanged for new models of governance, management and knowledge production. This talk will draw on evidence that elaborates the shortfalls of approaching sustainable forest management through sectoral approaches. We focus in particular on the challenges that impact the management and governance of FLR interventions and those which confound and constrain the knowledge creation and the intellectual back-drop informing interventions and their implementation. These two issues are relevant to the fundamental questions that surround all forms of FLR: notably, FLR for what, pursued where and measured how. We focus on the tropics, drawing on the literature and specific case studies which illustrate how a lack of integration can undermine initiatives. We stress, in particular, the previous pot-holes on the road to forest restoration in order to highlight the need to incorporate these lessons in the current and emergent FLR agenda. We argue that without such reflection, the FLR momentum risks adopting an ahistorical and apolitical technocratic approach to the challenges of forest and land management.

\title{
Integration of traditional and western knowledge in forest landscape restoration
}

\author{
John Parrotta ${ }^{1}$,Frank K. Lake ${ }^{2}$, Christian P. Giardina ${ }^{3}$, Iain Davidson-Hunt ${ }^{4}$, Yadav Uprety ${ }^{5}$ \\ ${ }^{1}$ USDA Forest Service, Research \& Development, Washington, DC, USA; ${ }^{2}$ USDA Forest Service, Research \& Development, Arcata, CA, USA; ${ }^{3}$ USDA Forest \\ Service, Research \& Development, Hilo, HI, USA; ${ }^{4}$ University of Manitoba, Winnipeg, Canada; ${ }^{5}$ Tribhuvan University, Kathmandu, Nepal \\ (jparrotta@fs.fed.us; franklake@fs.fed.us; cgiardina@fs.fed.us;iain.davidson-hunt@umanitoba.ca; yadavuprety@gmail.com)
}

The diversity of environmental, historical, social, economic and cultural contexts in which forest landscapes (and their degradation) occur requires that restoration efforts effectively engage and mobilize the social and cultural capital that exists within these socio-ecological systems. In many parts of the world, the importance of incorporating local and indigenous knowledge, into land management decision-making is increasingly recognized, particularly to better align management with the varied needs and place-based objectives of diverse stakeholders and the historical ecological realities of forest landscapes, In this presentation, we explore the process of integrating multiple knowledge systems in FLR, with a primary focus on experiences in North America. We will first examine the values and world views underlying Western and Traditional knowledge systems, as well as specific efforts to integrate knowledge systems in restoration and management at landscape scales in a variety of ecological and socio-cultural contexts. We consider the challenges - and opportunities - involved with integrating Traditional and Western knowledge systems at various stages of the FLR planning and implementation process, and how these challenges have been met, through case studies in Canada and the US.

\section{Reconciling biodiversity conservation with livelihoods of vulnerable value chain actors through land degradation neutrality: shaping an enabling environment for sustainable and inclusive resource and market access in Brazil}

\author{
Marcelo Inacio da Cunha \\ ${ }^{1}$ United Nations Convention to Combat Desertification, Bonn, Germany (mcunha@unccd.int)
}

This study analyses value chains of non-wood forest products (NWFP) - which occur in areas of high biodiversity and low human development indices - such as the Brazil nut chain in the Amazon. Such food chain actors are embedded in landscapes characterised by the lack of an enabling environment for achieving land degradation neutrality (LDN). Yet, ensuring no net loss of land-based natural capital depends on an enabling environment - particularly inclusive governance structures - for balancing socioeconomic and environmental trade-offs. Qualitative and quantitative data were collected from 2012-2015 to understand how institutions affect the resource and market access by vulnerable rural dwellers in Brazil. Household interviews ( $N=185)$ and key informant interviews, as well as problem-centered and narrative interviews $(\mathrm{N}=89)$ were conducted from community to national level - inter alia with the Brazilian Ministry of Environment. Results demonstrate that $15.5 \%$ of overall household income comes from forests, including $13.1 \%$ from Brazil nut gathering and marketing in the Lower Amazon basin. Environmentally sound resource and market access as well as inclusive sustainable development of the Brazil nut value chain is found to mainly depend on local democratic participation in decision-making by transforming the governance structures of councils for managing inhabited protected areas from consultative to deliberative ones. Results illustrate the importance of NWFP and the relevance of inclusive governance for reconciling environmental conservation and local livelihoods, while avoiding unsustainable land uses. Evidence is offered for shaping an enabling institutional and policy environment towards inclusive governance for sustainable integrated landscape planning.

\section{Forest stewardship for restoration: integrating grassroots initiatives into landscape approaches}

\author{
Andre Eduardo Biscaia de Lacerda ${ }^{1}$, Maria Izabel Radomski ${ }^{\dagger}$, , Julio R C Tymus ${ }^{2}$ \\ ${ }^{1}$ Embrapa Florestas, Colombo, Brasil; ${ }^{\dagger}$ in memoriam; ${ }^{2} T N C$ do Brasil, Curitiba, Brazil (andre.biscaia@embrapa.br; maria.radomski@embrapa.br; \\ jtymus@tnc.org)
}

In Southern Brazil, we have been developing and testing models of forest restoration that are economically viable and enable farmers to move away from monocultures, reduce their use of pesticides, and maintain the forest cover that is critical for local and regional ecosystem services. These models have been developed in collaboration with small-scale erva-mate (Ilex paraguariensis) producers and based on traditional knowledge of the forest. Forest products are key aspects of these models, including trees for wood production, erva-mate and other native fruit tree species; but they must adhere to Brazil's restrictive Forest Code. Avenues of agricultural innovation are needed to ensure that restoration approaches value the knowledge and important role farmers play in forest stewardship. The rational of our restoration model is to rapidly establish a forest cover using fast-growing native pioneer species, especially Mimosa scabrella (bracatinga), which provides an appropriate shaded environment for erva-mate to thrive and direct economic return. After a forested environment is established ( $\sim 3$ years), natural regeneration is managed for species and product diversification while maintaining erva-mate production for a period of $>30$ years. Additionally, we seek to value and document the voices and knowledge of traditional erva-mate producers not only to ensure that their products and culture is valued by society, but also that their important role in rural and urban ecological well-being is recognized and appreciated. 


\section{Forest Landscape Restoration (FLR) in Chile: how far are we?}

Rodrigo Mujica ${ }^{1}$, Andrés Meza², Daniel Alvarez ${ }^{3}$, Constanza Troppa ${ }^{2}$

${ }^{1}$ Instituto Forestal (INFOR), Ministry of Agriculture, Valdivia, Chile; ${ }^{2}$ Corporación Nacional Forestal (CONAF), Ministry of Agriculture, Santiago, Chile; ${ }^{3}$ División de Recursos Naturales y Biodiversidad, Ministry of Environment, Santiago, Chile (rmujica@infor.cl; andres.meza@conaf.cl; dalvarezl@mma.gob.cl; constanza.troppa@conaf.cl)

In the last decades, Chile has made significant efforts to stop deforestation, recover soils through exotic forest plantations and conserve native forest ecosystems in protected areas. Likewise, in recent years sustainable management of native forests has been promoted through new regulations with the purpose of reversing their degradation. Although these processes are well valued by sector actors, they are increasingly criticized for their excessive centralism, which does not adequately account for the ecosystem and socio-cultural diversity of the territories in Chile. This aspect is one of the main motivations to promote the elaboration of the National Forest Landscape Restoration Plan, initiated in 2018 jointly by the Ministries of Agriculture and Environment. There is consensus in recognizing that the deterioration of ecosystems and their impact on the provision of ecosystem services diminish the current and potential future economy of the country and the well-being of the population. Likewise, it is recognized that Forest Landscape Restoration allows the search of common objectives by the different actors in the territories, which facilitates directing more effectively the public-private efforts to advance towards a socio-ecological development in balance with the local economies. In Chile, this process is considered a national strategic challenge of high relevance, which should specify and modify aspects of governance, financing, associativity, innovation, market, among others. A first version of the National Forest Landscape Restoration Plan will be presented at the next United Nations Climate Change conference, COP25, in Chile.

Systematizing experiences and analysis related to the processes of landscape degradation and restoration in Puriscal, Costa Rica / Sistematización de experiencias y análisis del proceso de degradación y restauración del paisaje en el Cantón de Puriscal, Costa Rica

Lizbeth Perea ${ }^{1}$, Róger Villalobos ${ }^{2}$

${ }^{1}$ CATIE, ustin Metzquititlán, Mexico; ${ }^{2}$ CATIE, Turrialba, Costa Rica (lizp.badillo@gmail.com; rvillalo@catie.ac.cr)

Puriscal es el cuarto cantón de la provincia de San José. Tiene una extensión de 55366 ha y se encuentra ubicado en el Pacífico Central de Costa Rica, se caracteriza por poseer una gran biodiversidad, se destaca la presencia de especies endémicas; sin embargo, una gran área presenta altos niveles de degradación, por lo que en la zona se han implementado diversas acciones para detener este proceso, mejorar la productividad de las tierras, y con ello, mejorar la calidad de vida de la población. Esto ha sido posible por medio de proyectos locales, nacionales o internacionales. Los procesos de degradación y restauración en el cantón de Puriscal se han dado como respuesta de la sociedad ante las pautas establecidas por los convenios internacionales a través de financiamiento y acompañamiento técnico, las tendencias políticas, principalmente las relacionadas con el sector agropecuario y ambiental y las demandas del mercado nacional e internacional. La identificación de los factores sociales, ecológicos, económicos que impulsaron la degradación y la restauración en parte del paisaje del cantón de Puriscal, dejan ver la influencia que han tenido las políticas de desarrollo económico y las demandas de los mercados de productos agropecuarios principalmente a nivel internacional o nacional y como la suma de todos estos factores ha moldeado el paisaje de esté territorio, sin dejar de señalar que existe entre la población un sentimiento de apego al territorio y una ya formada conciencia ambiental que va favoreciendo a los cambios.

\section{THEME E: FORESTS, SOIL AND WATER INTERACTIONS}

E1a: AN INTEGRATED APPROACH FOR AFRICAN FOREST LANDSCAPE MANAGEMENT: WATER, ENERGY AND FOOD (WEF) NEXUS

\section{Tropical montane forests are a critical resource for water and food security in East Africa}

Mariana Rufino ${ }^{1}$, Paolo Cerutti2 ${ }^{2}$, Jan Gräf ${ }^{3}$, Suzanne Jacobs ${ }^{3}$, Naomi Karimi Njue ${ }^{4}$, Christopher Martius ${ }^{5}$, Anne Marie Ran ${ }^{6}$, John Quinton ${ }^{1}$, Jaqueline Stenfert-Kroese', Lutz Breuer ${ }^{3}$

${ }^{1}$ Lancaster University, Lancaster, United Kingdom; ${ }^{2}$ CIFOR, Nairobi, Kenya; ${ }^{3}$ Justus Liebig University, Giessen, Germany; ${ }^{4}$ Kabianga University, Kabianga, Kenya; ${ }^{5}$ CIFOR, Bogor, Indonesia; ${ }^{6}$ GIZ, Nairobi, Kenya; ${ }^{7}$ Lancaster University, Lancaster, Kenya (m.rufinol@lancaster.ac.uk; p.cerutti@cgiar.org; jan.graef@umwelt.uni-giessen.de; suzanne.rjacobs@zeu.uni-giessen.de; kariminaomi@gmail.com; c.martius@cgiar.org; annemarie.ran@giz.de; j.quinton@lancaster.ac.uk; j.stenfertkroese@lancaster.ac.uk; lutz.breuer@umwelt.uni-giessen.de)

Tropical forests are critical for the water cycle and for water provisioning. In East Africa, increasing human population, rising incomes and competing demands on the land have led to massive forest loss. In Kenya, the forests of the 'water towers' are the headwaters of rivers delivering drinking water to most towns in the country. These forests are hotspots for biodiversity, and important carbon sinks, facing increasing pressure of human encroachment. Since 2014, we quantify the importance for water provisioning of the Mau forest, the largest montane forest in Kenya. Water is a critical currency for most people: it can be a blessing and a curse evidenced by the impacts of drought and floods. Excess water can cause crop and infrastructure damage and soil loss leading to community conflicts. Understanding of the dynamics of water flows, water quality and land use is required to improve land management. Our research shows that the largest concerns related to forest cover loss are the large amount of sediments in rivers and streams. The loss of fertile top-soil has direct impacts on food security with consequences for future generations, reducing the amount of crop harvests and their quality. Lack of forest cover undermines water and food security and therefore supporting communities to monitor their water resources is critical to create awareness and empower local decision-making. Our research used a citizen-science approach and demonstrated that communities can monitor their resources and use this information to implement sound management plans for forests, water and landscapes.

\section{Anthropogenic influence on the floristic composition and water quality of a watershed ecosystem in three ecological zones of Nigeria: a need for integrated watershed management}

Samuel Olajuyigbe ${ }^{1}$, Israel Asinwa ${ }^{2}$, Adebola Adegeye

${ }^{1}$ University of Ibadan, Ibadan, Nigeria; ${ }^{2}$ Forestry Research Institute of Nigeria, Ibadan, Nigeria (lekito2001@yahoo.com; israelasinwa@gmail.com; badegeye2005@yahoo.com)

Watershed forests protect rivers that provide water for agriculture, domestic and industrial uses, while ensuring biodiversity conservation and ecosystem sustenance. Thus, understanding the influence of land use change on the floristic composition and water quality are pertinent. Ogun River meanders through a 
riparian ecosystem in three ecological zones in Nigeria. Using a stratified sampling technique, plant community diversity indices, water quality and soil physicochemical characteristics were evaluated in the three land use types (primary-forest, degraded-forest and farmland) of the savanna, rainforest and swamp-forest ecosystems. Land use significantly influenced the vegetation cover, species diversity, soil properties and water quality. For instance, ground flora increased with land disturbance $266.55 \pm 20.2 / \mathrm{m}^{2}$ to $972.4 \pm 51.3 / \mathrm{m}^{2}$ with invasive herb species (Chromolaena odorata and Petiveria alliacea) dominating the disturbed ecosystems. Tree population and canopy cover increased with reduced disturbance of the ecosystem with 145 plant species (56 families) identified. Species diversity indices were inversely proportional to the degree of degradation and indicator species dominated each ecological zone e.g. Daniella oliveri (19.4\%), Adansonia digitata (20.7\%), Parkia biglobosa (41.1\%). Soil physical and chemical properties improved with reduced disturbance of the land use types. For example, nitrogen and organic matter ranged from $0.88 \pm 0.01 \mathrm{~g} / \mathrm{kg}-4.79 \pm 0.05 \mathrm{~g} / \mathrm{kg}$ and $1.48 \pm 0.01 \mathrm{~g} / \mathrm{kg}-13.12 \pm 0.21 \mathrm{~g} / \mathrm{kg}$, respectively. Undisturbed forest had the richest forest structure and diversity with a corresponding increase in the water quality of the river, irrespective of the ecological zone. There is need for an integrated approach to watershed management and restoration of the forest cover.

\title{
Forests and freshwater fish consumption in Nigeria
}

Amy Ickowitz', Michaela Lo ${ }^{1}$, Sari Narulita ${ }^{1}$, Terry Sunderland ${ }^{1}$

${ }^{1}$ Center for International Forestry Research (CIFOR),Bogor, Indonesia (a.ickowitz@cgiarorg; m.lo@cgiar.org; s.narulita@cgiar.org)

Nigerians depend on fish for maintaining diverse and healthy diets. Fish are a key source of protein and micronutrients, both of which are important for healthy diets. Some research has shown that forests provide important ecosystem functions that support the productive capacity and sustainability of inland fisheries. Our study aims to empirically assess the relationship between forest cover around rivers and fish consumption. We use data from the Living Standards Measurement Survey (LSMS) and spatially merge household and village data with forest cover and river maps. We estimate the relationship between forest cover around rivers and average village fresh fish consumption, whilst also accounting for other socio-economic and geographical determinants. We find that that the density of forest cover around rivers is positively and significantly correlated with village consumption of fresh fish. Our results suggest that forests influence the consumption of fresh fish by improving the productivity of inland fisheries and increasing the availability of fish. Thus clearing forests for agriculture in order to produce more agricultural crops, might have the unintended consequence of reducing another important food source.

\section{The conservation of the forest of Acacia etbaica located in Tigray region, Northern Ethiopia for the sustainable utilization}

\author{
Masazumi Kayama1, Koichi Takenaka², Kazuhisa Koda², Toru Sakai ${ }^{2}$, Shunji Oniki', Masahiro Hirata ${ }^{3}$, Ryunosuke Ogawa ${ }^{3}$, Buruh Abebe ${ }^{4}$, \\ Gebreyohannes Girmay ${ }^{4}$, Melaku Berhe ${ }^{4}$, Birhane Gebreanenia ${ }^{4}$,Emiru Birhane ${ }^{4}$ \\ ${ }^{1}$ Forestry and Forest Products Research Institute, Tsukuba, Japan; ${ }^{2} J a p a n$ International Research Institute for Agricultural Sciences, Tsukuba, Japan; \\ ${ }^{3}$ Obihiro University of Agriculture and Veterinary Medicine, Obihiro, Japan; ${ }^{4}$ Mekelle University, Mekelle, Ethiopia (kayama@affrc.go.jp; \\ koichitk@affrc.go.jp; kodakazu@affrc.go.jp; torus@affrc.go.jp; oniki.shunji@affrc.go.jp; masa@obihiro.ac.jp; ryunosuke0225@gmail.com; \\ buruhtetemke@gmail.com; gebreyohannes.girmay@gmail.com; melakuberhe@gmail.com; birhane.gebre12@gmail.com; emiru.birhane@mu.edu.et)
}

Acacia etbaica is a main woody species in the highland of Tigray region located in Northern Ethiopia. In this forest, deforestation due to expanding farmland and harvesting of fuelwood has been continuing. Longstanding deforestation causes soil erosion in rainy season. To conserve forest vegetation, we started up the integrated project in 2016. The contents of our project were divided into forest-ecology and socio-ecology. To estimate basic productivity of $A$. etbaica, we measured the biomass and growth. We also investigated the actual situation on the utilization of timber of $A$. etbaica by the residents. The annual productivity of A. etbaica in the research site was $63.6 \mathrm{~kg} \mathrm{ha}^{-1}$. Meanwhile, residents at the research site collect branches of $A$. etbaica for the fuelwood, and their consumption were markedly exceeded by their production. Therefore, forest of $A$. etbaica could not conserve because of large consumption of timbers. We should promote to plant the seedlings of $A$. etbaica for the sustainable utilization of fuelwood. However, seedling is easy to die by the long period of dry season. Biochar have a role to increase survival and growth of seedlings, and use of biochar produced by $A$. etbaica can contribute sustainable utilization by circulation of resource. We conducted the experiment to examine the effects of biochar. We planted the seedlings of A. etbaica adding $1 \mathrm{~kg}$ of biochar of $A$. etbaica in July 2017. After 14 months, we confirmed that addition of biochar increased leaf biomass of $A$. etbaica.

\section{Determining Leaf Area Index threshold for obtaining an expected water yield for Pinus radiata plantations}

\author{
Carlos Gonzalez-Benecke $e^{1}$, M. Paulina Fernandez ${ }^{2}$,Horacio Bown ${ }^{3}$, Oscar Mardones ${ }^{4}$ \\ ${ }^{1}$ Oregon State University, Corvallis, USA; ${ }^{2}$ Pontificia Universidad Catolica de Chile, Santiago, Chile; ${ }^{3}$ Universidad de Chile, Santiago, Chile; ${ }^{4}$ Forestal \\ Mininco,LosAngeles,Chile (carlos.gonzalez@oregonstate.edu; pfernan@uc.cl; hbown@uchile.cl; oscar.mardones@cmpc.cl)
}

Intensive forest management of Pinus radiata plantations in Chile has been focused on increasing stem volume production and maximizing revenue. Nevertheless, increasing drought, in addition to emerging conflicts with neighbor communities regarding water use in the watersheds, have opened the discussion about the sustainability of pine plantations, with emphasis in the general water balance. Base on that, in this study we explored the inclusion of critical Leaf Area Index (LAI) needed to attain a desirable water yield (WY) as an alternative decision variable for managing planted $P$. radiata. The 3-PG model was parameterized and validated for $P$. radiata plantations using the approach proposed by Gonzalez-Benecke et al. (2014 and 2015), including a new module that allows for thinning based on threshold upper and residual LAI. We tested the use of LAI in terms of WY and volume production. Thirty site conditions were selected, including different soils and climate across the distribution of planted forests in Chile. Using the newly parameterized 3-PG model, yearly LAI, WY and stem volume yield were computed for each site. Then, a range of critical or desired values of water yield were tested, and the mean LAI that can support this WY were obtained for each site. We determined the relationship between mean annual LAI and WY on sites with different water deficit. We also determined the trade-off between WY and stand volume yield at age 22 years. We demonstrated that LAI and water yield can be considered in future management for $P$. radiata plantations.

\section{Modelling the impacts of Wattle (Acacia mearnsii) plantations on Ecosystem Services in South Africa \\ Dennis Junior Choruma ${ }^{1,2}$, Stephan A. Pietsch ${ }^{3}$ \\ ${ }^{1}$ Institute for Water Research, Rhodes University, Grahamstown, South Africa; ${ }^{2}$ Southern African Systems Analysis Centre, Stellenbosch, South Africa; ${ }^{3} I I A S A$ - International Institute of Applied Systems Analysis, Laxenburg, Austria (denychor@gmail.com; pietsch@iiasa.ac.at)}

Commercial forestry in South Africa is based on plantations of fast growing alien timber species like Pine, Eucalyptus and Acacia (Wattle). Besides the potential problem of species invasion towards sites outside of plantations, these exotic species exert a strong impact on ecosystem services delivery at the local, catchment level and regional scale. Among the best studied areas in South Africa, the case of the two streams catchment area is exceptionally rich in data collected over the last two decades. Data collected include tree growth, stand transpiration, above canopy eddy covariance fluxes, stream flow and soil water profiles. As such the 
two streams catchment area is an ideal test case for the application of biogeochemical (BGC) vegetation models to complement ongoing soil water atmosphere transport (SWAT) modeling. Within this research we will assess the possible benefits of detailed process based vegetation modelling using field data from wattle plantations within the Two-Streams catchment area, BioGeoChemical ecosystem modelling to assess best options in terms of timber yield, catchment hydrology and their respective temporal dynamics.

\section{E1b: SILVICULTURAL CHALLENGES UNDER ABIOTIC AND BIOTIC STRESSES AND} ADAPTATIONS TO CLIMATIC ABNORMALITIES

\section{Silvicultural production under climatic conditions of high-water deficit}

Ben du Toit ${ }^{1}$, Keith M Little ${ }^{2}$, Dean da Costa ${ }^{1,3}$, Paul W M Viero ${ }^{3}$, Jonathan Sheppard ${ }^{4}$, Anton Kunneke ${ }^{1}$, Hugo A Lambrechts ${ }^{1}$, Werner Mbongo ${ }^{1}$, Gideon F Malherbe ${ }^{1}$

${ }^{1}$ Stellenbosch University, Stellenbosch, South Africa; ${ }^{2}$ Nelson Mandela University, George, South Africa $;{ }^{3}$ Mondi Limited, Hilton, South Africa; ${ }^{4}$ AlbertLudwigs-University, Freiburg, Germany (ben@sun.ac.za; keith.little@mandela.ac.za; dean.dacosta@mondigroup.com; paul.viero@mondigroup.com; jonathan.sheppard@iww.unifreiburg.de)

Several forested regions of the world experience high water deficits for protracted time periods. This limits productivity and poses significant environmental and economic risks to sustainability. We draw most examples from African landscapes where planted forest systems have been established to supplement production from (usually sparse and slow growing) natural forest enclaves. Under high water stress conditions, adaptations to conventional silvicultural systems may increase ecosystem resilience and profitability, and these adaptations apply at three different scales: (1) At the landscape scale, it is necessary to match the chosen silvicultural system(s) with a strategic risk management plan, to cater for stream flow impacts, fire and biotic risks. Case studies where tree planting is confined to specific terrain positions in the landscape (in combination with risk-averse silvicultural systems) are evaluated. We discuss landscape-scale wildfire buffer zones combined with intensified fuel management. Silvicultural systems in semi-arid zones may need multiple or enhanced income sources (such as nontimber forest products for high-end markets, combined with ecosystem benefits) to remain economically viable. (2) At the farm level, selection of silvicultural regimes that match site capability with viable wood product and market options are essential for system resilience. This may involve changes to conventional silvicultural regimes with respect to the species composition, stand density, thinning operations and rotation length. (3) Adaptation of operations at the forest compartment level (e.g. enhanced site preparation and residue management, intensive establishment and vegetation management techniques, as well as robust, vigorous transplant material) may increase survival and early tree growth.

\section{Drought effect on root architecture and non-structural carbohydrate of Cunninghamia lanceolata}

Zhenya Yang ${ }^{I}$, Benzhi Zhou ${ }^{1}$, Xiaogai Ge ${ }^{1}$, Yonghui Cao ${ }^{1}$

${ }^{1}$ Rsearch Institute of Subtropical Forestry Chinese Academy of Forestry, Hangzhou, China (yangzhenya1234@163.com; benzhi_zhou@126.com; gexiaogai2006@163.com; fjcyh77@sina.com)

The drought is a main abiotic stressor, which significantly impacts the eco-physiological processes of forest plants. Plant root is the first receiver of the soil drought, therefore, its response and adaptability is of great significance to forest silviculture under the climate change scenario. In this study, the root architecture and total non-structural carbohydrate (TNC) composition were investigated of one-year-old potted seedlings of Cunninghamia lanceolata, one of the most important timber tree species in subtropical area in China, under medium-level (50-55\% maximum field capacity, MFC) and severe-level (30-35\% MFC) drought stress. The dry weight, length, surface area and volume of root were all significantly lower under drought treatments than those under CK, and the differences significantly increased as the drought duration expanded. The drought significantly decreased the root fractal dimension, root tip number and root branching angle, turning the root systems more simplifiedly-constructed and developing downward into the deeper soil. The content of soluble sugar and TNC under medium-level drought was significantly higher than that under CK at the 30th day of this experiment, and declined over time, with no significant difference at the 60th day, and a significant decrease at the 90th day. C. lanceolata tends to invest more carbon to root system at the early stage of drought, and as the stress proceeds, it could simplifies its root architecture at limited cost, and reduced root branching angle to facilitate the water absorption form deeper soil.

\section{Water availability effects on growth and phenology of 11 poplar cultivars growing in semiarid areas in Turkey}

Akkin Semerci ${ }^{1}$, Claudio Guevara ${ }^{2}$, Carlos Gonzalez-Benecke ${ }^{2}$

${ }^{1}$ Gaziosmanpaşa University, Tokat, Turkey; '2Oregon State University, Corvallis, USA (aksemerci@gmail.com; guevarac@oregonstate.edu; carlos.gonzalez@oregonstate.edu)

In Turkey, current wood production does not meet the demand of wood-products, and that gap is expected to be larger in the near future. It is necessary to increase the productivity and growth efficiency of current forests and to expand the extension of forest plantations, including areas where drought is the main climatic constraint. Fast-growing species, such as poplars, are an effective way to obtain large volume yield. Even tough Turkish researches have been working in hybridization programs to improve the quality and productivity of poplars cultivars, there are still large gaps in the understanding of the effects of drought on the performance and physiology of these cultivars. In this study, we analyzed the effects of water stress on growth and phenology of eight cultivars of black poplar (Populus nigra), two cultivars of Canadian poplar (the hybrid P. x canadiensis), and one cultivar of eastern cottonwood (P. deltoides). The objective was to identify the cultivars better adapted to dry conditions in semiarid areas of Turkey. Seedlings of the eleven cultivars were grown under two contrasting watering regimes (well-watered and water stress). Seedling height, ground line diameter, and biomass were registered along with phenological traits such as bud break, leaf loss, and infection by Cytospora chrysosperma, a common fungal disease in Turkey. Significant interactions in the response of cultivars to water availability were observed for most of the traits assessed. Results obtained from this study provide valuable information for forest managers for selecting better adapted poplar cultivars for semiarid conditions. 


\title{
A potential approach to restore inland salinity with Eucalyptus hybrids in Thailand
}

\author{
Nisa Leksungnoen ${ }^{1}$ \\ 'Kasetsart University, Chatuchak, Thailand (ffornsl@ku.ac.th)
}

Salinity is an ongoing abiotic stress problem, in the northeastern part of Thailand, due to the presence of salt in the parent rock material together with salt mining and deforestation. It leads to the reduction in the agricultural and plantation area, especially of the Eucalyptus plantation. Salinity varies with soil depth and seasons, ranging from 3 to $120 \mathrm{dS} / \mathrm{m}$ from the surface to a depth of $100 \mathrm{~cm}$. During the dry season, the highest salinity is found in the top soil, while it is evenly distributed throughout the soil profile during the rainy season. Therefore, in the field, planting Eucalyptus seedlings, at a spacing of $3.5 \mathrm{~m} \times 3.5 \mathrm{~m}$, at a depth of $30-50 \mathrm{~cm}$ soil during the rainy season, is suggested to ensure survival at high salinity levels. Apart from the technique, the selection of high salt tolerant Eucalyptus species is equally important. Due to a similar drought and salt response, a Eucalyptus hybrid between E. camaldulensis $\times$ E. urophylla (H4), identified as drought tolerant, was selected to test for its salt tolerance and found that it could tolerate a salinity of up to $16 \mathrm{dS} / \mathrm{m}$. Therefore, exogenous chemicals were applied to improve the salt tolerance. Selenium can enhance salt tolerance in the Eucalyptus seedlings at levels up to $40 \mathrm{dS} / \mathrm{m}$ with a $60 \%$ survival rate and a lower cell damage when compared to salicylic acid and proline. We recommend to treat Eucalyptus seedlings with selenium before planting with the suggested technique to improve the survival in the field.

\section{Closing the forest hydrology loop: surface water and groundwater interaction within a South African Pine plantation and indigenous afrotemperate forest}

Tatenda Mapeto ${ }^{1}$, Mark Gush ${ }^{2}$, Richard Bugan', Nangamso Tuswa ${ }^{3}$, Josua Louw ${ }^{1}$

${ }^{1}$ Nelson Mandela University George Campus, George, South Africa; ${ }^{2}$ Council for Scientific and Industrial Research, Stellenbosch, South Africa; ${ }^{3}$ University of Western Cape, Cape Town, South Africa (tatendamapeto@gmail.com; mgush@csiro.co.za; rbugan@csir.co.za; 3137233@myuwc.ac.za;

josua.louw@mandela.ac.za)

In water scarce South Africa, natural forests are limited in extent and the country is reliant on plantations of introduced tree species for its fibre and timber requirements. These highly productive tree systems replaced lower leaf area vegetation such as grassland and scrub, causing increases in evapotranspiration with resultant changes in hydrological dynamics of afforested catchments. Paired catchment experiments and later process measurements, combined with modelling have allowed for quantification and regulation of stream flow reductions associated with tree plantations. However, aligning plantation hydrological impacts with only stream flow reduction represents a "black box" approach to understanding groundwater and surface water interaction. In this study, the hydrological processes in a catchment characterised by a mosaic of two Pine species plantations and indigenous afrotemperate forest, and generally a fractured rock aquifer environment were monitored over four years. The catchment is located in the southern Cape region of South Africa. A novel combination of sap flow, eddy covariance, groundwater, weather, and soil water monitoring, was combined with modelling. The mean annual precipitation over the monitoring period was $835 \mathrm{~mm}$, including a dry 2016/17 total of $639.6 \mathrm{~mm}$. Annual transpiration totals for the Pinus radiata and Pinus elliotii stands were $640 \mathrm{~mm}$ and $575 \mathrm{~mm}$ respectively in 2016/17, while mean evapotranspiration totals for the two stands over the entire monitoring period were $712 \mathrm{~mm}$ and $868 \mathrm{~mm}$ respectively. Modelling indicated significantly higher potential groundwater recharge in the indigenous forest compared to the Pine plantation stands.

Effect of planting density and irrigation in growth and $\mathrm{CO}_{2}$ uptake of Gmelina arborea in Colombian dry tropical forests / Efecto de la densidad de plantación y la irrigación en el crecimiento y la captura de $\mathrm{CO}_{2}$ de Gmelina arborea en el bosque seco tropical colombiano

Omar Melo ${ }^{I}$, Carolina Betancourt ${ }^{1}$

${ }^{1}$ Universidad del Tolima, Ibagué, Colombia (omelo@ut.edu.co; acbetancourtoro@ut.edu.co)

La investigación se realizó en áreas de bosque seco tropical del valle geográfico del río Cauca, en la región central colombiana (precipitación promedio=1266 mm.año-1., temperatura media anual de $25,5^{\circ} \mathrm{C}$. altitud $\left.=595 \mathrm{~m}\right)$. Se estableció un experimento con seis densidades de plantación $(3000,2000,1300,900,600$ y 400 árboles.ha-1) y dos condiciones de agua en el suelo (irrigación y no irrigación). Se evaluó el cociente de forma base (QB), el volumen del fuste, la biomasa total y la actividad fotosintética. Las evaluaciones se realizaron durante 4 años. Árboles establecidos en alta densidad (3000, 2000 árboles.ha-1), presentaron volúmenes entre 0,05 a $0,07 \mathrm{~m}^{3}$. La forma del fuste fue cilíndrica $(\mathrm{QB}=0,72)$ y con ramas delgadas $(18,4 \mathrm{a} 22,3 \mathrm{~mm})$. El factor de expansión de biomasa fue de 1,12 . La dominancia apical del fuste se mantuvo en mas del $90 \%$ de los individuos. Los árboles establecidos en baja densidad de plantación (600 y 400 árboles.ha-1), alcanzaron volúmenes de 0,28 y $0,42 \mathrm{~m}^{3}$. La forma del fuste fue ahusada $(\mathrm{QB}=0,43)$ y con ramas gruesas $(75,5$ a $82,5 \mathrm{~mm})$. El factor de expansión de biomasa fue de 1,94. La dominancia apical fue menor al 54\%. La irrigación impidió la defoliación de los árboles en el periodo de sequía y la productividad se incrementó en más del $57 \%$ en comparación con el tratamiento de no irrigación. La asimilación neta con irrigación fue $28,9 \mu$ mol.m $\mathrm{m}^{-2} . \mathrm{s}^{-1}, \mathrm{y}$ de $17,5 \mu \mathrm{mol} . \mathrm{m}^{-2} . \mathrm{s}^{-1}$, sin irrigación. Estos resultados permiten entender el efecto de los factores limitantes y la competencia.

\section{Modeling the effects of competing vegetation on soil moisture dynamics and planted conifer seedling water stress, growth and mortality in the U.S. Pacific Northwest}

Claudio Guevara', Carlos Gonzalez-Benecke', Maxwell Wightman ${ }^{1}$

'Oregon State University, Corvallis, USA (guevarac@oregonstate.edu; carlos.gonzalez@oregonstate.edu; maxwell.wightman@oregonstate.edu)

Competition between newly established seedlings and competing vegetation can restrict seedling growth resulting in significant growth reductions. Forest vegetation management (FVM) reduces the cover of non-desired vegetation allowing seedlings to more effectively capture site resources and has been shown to increase the survival and growth of numerous conifer species, including Douglas-fir and western hemlock. However, there are still large gaps in the understanding of competition dynamics and resources usage, which could be addressed by studying the ecophysiology of these species. The Competition and Site Interactions Experiment (CoSInE) being conducted by the Vegetation Management Research Cooperative (VMRC) at Oregon State University is investigating the influence of a common set of FVM treatments on planted conifer seedling survival, growth and ecophysiological responses across a range of climatic and soil conditions in the Pacific Northwest. The VMRC currently has 2 intensively measured CoSInE research sites, one for western hemlock and one for Douglas-fir. Measurements being conducted at these sites include: soil moisture and weather dynamics, seedling growth, seedling predawn and midday water potential, and understory vegetation growth dynamics (cover, height and biomass). The data being collected at these study sites is being used to develop a process-based model to predict planted seedling growth and survival using site-specific weather, soils, and vegetation community information. This presentation will provide an overview of the CoSInE project and share preliminary results on the water use of competing vegetation and the impact of competing vegetation on seedling drought stress and mortality. 


\section{Measurements of leaf water potential for three Eucalyptus species in Brazil}

Amanda de Castro Segtowich ${ }^{1}$, José Leonardo de Moraes Gonçalves ${ }^{1}$, Alexandre de Vicente Ferraz ${ }^{2}$

${ }^{1}$ Escola Superior de Agricultura "Luiz de Queiroz", Universidade de São Paulo, Piracicaba, Brasil; "2Instituto de Pesquisas e Estudos Florestais, Piracicaba, Brasil(amandasegtowich@usp.br;jlmgonca@usp.br; alexandre@ipef.br)

Leaf water potential (LWP) is an important physiological attribute of the plant water status. In this study, LWP was measured monthly during pre-dawn and midday in three Eucalyptus species (E. grandis, E. urophylla and E. camaldulensis). The experiment was carried out at the Experimental Station of Forest Sciences in Itatinga/SP, Brazil. Measurements were performed using the Scholander pressure chamber during a six-month period. Sixteen leaves per species (four per tree) were used in each campaign. The leaves were collected from the upper third of the canopy. E. urophylla had the lowest mean value of LWP throughout the whole period of study, both during pre-dawn and midday, reaching its lowest (-1.98 MPa) in the driest month (July 2018), when the gross rainfall was of $14.3 \mathrm{~mm}$. E. grandis had the highest mean value of LWP in most of the measurements. Although E. camaldulensis is considered a tolerant species to water deficit, this species had a similar behavior to E. grandis, which showed lower water stress during most of the study period, including the driest month (July 2018) during midday. The results obtained for E. urophylla in this site suggest that this species has another type of mechanism in relation to water stress, one that shows it can grow under lower water potentials without having its growth and vital processes being affected. The high values of LWP measured during pre-dawn, however, suggest that there are hardly any water-related issues in the study site.

Production of carbohydrates, lignin, and flavonoids in Eucalyptus urophylla plants with B, Cu, and Zn deficiency / Produção de carboidratos, lignina e flavonoides em plantas de Eucalyptus urophylla sob carência de B, Cu e Zn

Liamara Masullo ${ }^{1}$, José Leonardo de Moraes Gonçalves ${ }^{1}$, Alexandre de Vicente Ferraz ${ }^{2}$, Gislene Roberta Manarim ${ }^{1}$, Patrícia Andressa de Ávila ${ }^{1}$ ${ }^{1}$ Escola Superior de Agricultura “Luiz de Queiroz”, Universidade de São Paulo Piracicaba, Brasil; '2Instituto de Pesquisas e Estudos Florestais, Piracicaba, Brasil(liamaramasullo@usp.br;jlmgonca@usp.br; alexandre@ipef.br; gislene.manarim@usp.br; andressapa@yahoo.com.br)

Os micronutrientes são necessários em diversas rotas metabólicas que atuam na defesa das plantas contra o ataque de pragas e patógenos, tais como a produção de lignina, fenóis e fitoalexinas. Neste estudo, avaliou-se os impactos da deficiência de boro (B), cobre (Cu) e zinco (Zn) sobre a produção de carboidratos, lignina e flavonoides em folhas de Eucalyptus urophylla. O experimento foi conduzido em casa de vegetação. Mudas clonais de Eucalyptus urophylla com seis meses de idade foram cultivadas em vasos com solução nutritiva por 120 dias. Foram avaliados os tratamentos: fertilização completa (FC) e omissões de B, Cu e Zn na solução nutritiva de cultivo. A carência de Cu e Zn elevou a concentração de carboidratos nas folhas em cerca de $10 \%$ (774 para 834 mg g-1). A omissão de $\mathrm{Cu}$ desfavoreceu em $10 \%$ o processo de lignificação quando comparado à fertilização completa. A produção de flavonoides foi de 8,05 mgRE $\mathrm{g}^{-1}$ nas plantas com fertilização completa, entre 45 e $75 \%$ maior do que nas plantas que ficaram sob omissões de $\mathrm{B}$, Cu e $\mathrm{Zn}$. O aumento do teor de carboidratos e as reduções dos teores de lignina e flavonoides nas folhas podem tornar as plantas de E. urophylla mais susceptíveis ao ataque de pragas e patógenos, além de reduzir sua resiliência (ex. cicatrização dos tecidos danificados).

\section{E1p: SILVICULTURE AND HEALTH IN PLANTATION FORESTS}

\section{Adaptive capacity of different Norway spruce populations to lethal drought}

Andreas Bolte ${ }^{1}$, Tomasz Czajkowski ${ }^{1}$, Tamalika Chakraborty ${ }^{\prime}$,Tanja Sanders ${ }^{1}$, Marco Natkhin ${ }^{1}$

'Thünen Institute of Forest Ecosystems, Eberswalde, Germany(andreas.bolte@thuenen.de; tomasz.czajkowski@thuenen.de; tamalika.chakraborty@thuenen. de; tanja.sanders@thuenen.de;marco.natkhin@thuenen.de)

Climate change is affecting forest ecosystems in particular by more frequent and severe extreme weather events like heat waves and droughts. This possess a specific risk for the drought sensitive Norway spruce (Picea abies), one of the most important commercial tree species in Europe. Thus it is assumed that maintaining a forest structures with spruce will increase the risk of forest damage. Here different populations of Norway spruce from its European range were studied in their response to extreme drought. In a greenhouse pot experiment lethal drought was simulated on spruce seedlings of eight provenances. Drought was applied until plants' death; during the experiment soil water availability (SWA, percentage proportion of available water AW), gas exchange, plant water status (pre-dawn water potential), and survival rate for each provenance were recorded. Based on survival rates, survival functions for the different populations were fitted. Results show varying responses of the provenances to drought, with the critical mortality rate of 50\% (LD50) reached at a remaining soil water availability (SWA) ranging from 7\% for a lowland population with low yearly precipitation to 8,3\% for a mountainous population with considerably higher yearly precipitation. These outcomes demonstrate the general possibility to increase drought resistance of Norway spruce regeneration by using more droughttolerant spruce provenances. Based on the results for spruce and those found in previous experiments with European beech (Fagus sylavtica) we will discuss the options and limitations of the use of rear-edge provenances of native species to improve forests' adaptive capacity in Central Europe.

\section{Nutritional diagnosis of clonal Eucalyptus plantations in different climate zones in Brazil}

Alvaro Andres Ramirez Palacio ${ }^{1}$, José Leonardo de Moraes Gonçalves ${ }^{1}$, Alexandre de Vicente Ferraz ${ }^{2}$ ${ }^{1}$ Universidade de São Paulo. Escola Superior de Agricultura Luiz de Queiroz., Piracicaba, Brasil; ${ }^{2}$ Instituto de Pesquisas e Estudos Florestais, Piracicaba, Brasil(aramirez@usp.br;jlmgonca@usp.br; alexandre@ipef.br)

To maintain a high and sustainable productivity in forest plantations it is necessary to monitor the nutritional status of trees based on foliar analysis. The accuracy of the nutritional diagnosis of plants depends on the leaf concentrations that are used as reference values. For Brazilian conditions, with a large climatic gradient, establishing specific nutritional reference values for climate zones would contribute to a more accurate nutritional diagnosis, improving fertilizer recommendations as well as avoiding productivity losses. Considering the lack of specific nutrient reference values for different regions and genotypes, in this study we determined the nutritional sufficiency ranges in three different climate zones for the most planted Eucalyptus urophylla clone in Brazil. We used data of foliar nutrient content and tree growth from 454 sites (10,100 ha) with 1 to 2 years old stands of I144 clone, located in regions with different Köppen's climate types: Cfa (Paraná), Cwa (São Paulo) and Aw (Minas Gerais). There were differences in sufficiency ranges and in the nutrient limitation order among the climate zones. The differences were associated with water availability and soil attributes, mainly clay and soil organic matter levels. We conclude that the use of specific sufficiency ranges by climate zones could contribute to improve the accuracy of the nutritional diagnosis, providing a greater optimization of fertilizer use in forestry. 
Fine-root distribution in Eucalyptus pellita F. Muell plantations in response to fertilizing with dolomitic lime, $\mathbf{P}_{2} \mathbf{O}_{5}$, and $\mathrm{K}_{2} \mathrm{O}$, in Puerto López, Colombian Orinoco region / Distribución de raíces finas, en plantación de Eucalyptus pellita F. Muell, en respuesta a fertilización con Cal dolomita, $\mathrm{P}_{2} \mathrm{O}_{5}$ y $\mathrm{K}_{2} \mathrm{O}$, en Puerto López, Orinoquía colombiana

Sandra Milena Díaz-López ${ }^{1,2}$, Cristian Alexander Vega Marin ${ }^{3}$, Miguel Eugenio Cadena Romero ${ }^{2}$

${ }^{1}$ Instituto de Proyección Regional y Educación a Distancia. Universidad Industrial de Santander, Málaga, Colombia; ${ }^{2}$ Universidad Distrital Francisco José de Caldas, Bogotá, Colombia; ${ }^{3}$ Corporación Colombiana de Investigación Agropecuaria-AGROSAVIA, Rionegro, Colombia (smdiazl09@gmail.com; cavcid@gmail.com; cademielro@hotmail.com)

En plantación de Eucalyptus pellita F. Muell, sometida a fertilización, con Cal dolomita (t/ha), $\mathrm{P}_{2} \mathrm{O}_{5}(\mathrm{Kg} / \mathrm{ha})$ y $\mathrm{K}{ }_{2} \mathrm{O}(\mathrm{Kg} / \mathrm{ha})$, localizada en la Orinoquía colombiana, zona de clima tropical, con distribución de precipitación monomodal, suelos muy pobres en nutrientes y alta acidez. Se instalaron cilindros de crecimiento interno a profundidad de 0 a $15 \mathrm{~cm}$, en 4 distancias definidas desde el árbol, en diseño de bloques completos al azar $3 \times 3 \times 3$ en la modalidad de serie de experimentos con diferente sitio e igual época, para conocer la incidencia de la fertilización en la distribución de raíces. Las muestras se recolectaron cada tres meses durante un año. Se obtuvo diámetro, área y longitud de raíz, analizadas junto con propiedades físicas y químicas del suelo. La interacción de los tres fertilizantes es preponderante y afecta la resistencia tangencial al corte; los tratamientos con mayor desarrollo radicular se encuentran en zonas de baja y media resistencia a la penetración, entre 18 - $25 \mathrm{kpa} / \mathrm{cm}$ y dosis medias y altas de P2O5 (75 y $120 \mathrm{Kg} / \mathrm{ha}$ ). Para la longitud (m) en las localizaciones desde el árbol, la interacción en segundo grado fue significativa para los cilindros más cercanos $(37.5 \mathrm{~cm})$ y más alejados del árbol $(150 \mathrm{~cm})$. La forma de aplicación de los fertilizantes afecta la distribución de las raíces. Se confirma mayor concentración radicular con las dosis altas de $\mathrm{P}_{2} \mathrm{O}_{5}$ y la tendencia de las especies que crecen en suelo con texturas gruesas de tener más raíces laterales que buscan explorar mayores volúmenes de suelo.

Quality of Eucalyptus clonal seedlings produced in Ellepot and tube systems / Qualidade de mudas clonais de eucalyptus produzidas nos sistemas Ellepot e tubetes

Renan Santos ${ }^{1}$, Adalberto Novaes ${ }^{1}$, Nilton Sousa ${ }^{2}$

${ }^{1}$ Universidade Estadual do Sudoeste da Bahia, Vitória da Conquista, Brazil; ${ }^{2}$ Universidade Federal do Paraná, Curitiba, Brasil

(renanalves93@hotmail.com; adalberto.brito@globo.com; nilton.ufpr@gmail.com)

Esta pesquisa foi desenvolvida no sul da Bahia, Brasil e analisou a viabilidade do uso de uma nova metodologia para a produção de mudas clonais de Eucalyptus spp., comparando a eficiência de recipientes biodegradáveis (Ellepot $\left.{ }^{\circledR}\right)$, por meio de parâmetros morfo-fisiológicos, com mudas produzidas no sistema de tubetes. O experimento foi instalado em esquema fatorial 3x3, sendo três recipientes (Ellepot ${ }^{\circledR} 76,9 \mathrm{~cm}^{3}$ e Ellepot ${ }^{\circledR} 115,5 \mathrm{~cm}^{3}$ ); tubetes plásticos $\left(55,0 \mathrm{~cm}^{3}\right)$; e três clones de Eucalyptus: VCC-865, CO-1407 e AEC-144). No viveiro e casa de vegetação avaliou-se os parâmetros morfo-fisiológicos: a) altura da parte aérea (H); b) diâmetro de colo (D); c) relação H/D; d) biomassas fresca e seca aérea, radicial e total; e e) potencial de regeneração de raízesP.R.R. No campo avaliou-se: a) sobrevivência; b) altura da parte aérea; c) diâmetro ao nível do solo; d) comprimento e profundidade da raiz principal; e e) deformações radiciais. A análise estatística constou de análises de variância, teste de médias (Tukey 95\%) e análise de regressão. O sistema de produção de mudas em recipientes biodegradáveis (Ellepot $\left.{ }^{\circledR}\right)$, com adequada formação e distribuição de raízes, foi superior em todas as fases de avaliação no viveiro e campo, quando comparado ao sistema convencional em tubetes $\left(55 \mathrm{~cm}^{3}\right)$. O P.R.R. foi considerado um parâmetro fisiológico confiável na determinação da qualidade das mudas e na predição de seu desempenho no campo. O clone VCC-865 apresentou a maior taxa de crescimento em altura e diâmetro no campo, 120 dias após o plantio.

\section{Dynamics of growth of Eucalyptus clonal stands under wide edaphoclimatic and nutritional variations}

Andréa V. A. Wenzel', José Leonardo de Moraes Gonçalves ${ }^{1}$, Eduardo A. S. C. Melo², José Henrique T. Rocha ${ }^{3}$, Clayton Alcarde Alvares ${ }^{4}$, José Carlos Arthur Junior ${ }^{5}$, Rodrigo E. Hakamada ${ }^{6}$, Cristiane C. Z. Lemos ${ }^{7}$, Jarbas S. Borges ${ }^{8}$, Rogério R. Malheiros ${ }^{9}$

${ }^{1}$ Escola Superior de Agricultura "Luiz de Queiroz", Universidade de São Paulo, Departamento de Ciências Florestais, Piracicaba, Brasil; ${ }^{2}$ Sinarmas Forestry, Perawang, Indonesia; ${ }^{3}$ Faculdade de Ensino Superior e Formação Integral, Agriculture and Forest Engineering College, Garça, Brasil; ${ }^{4}$ Instituto de Pesquisas e Estudos Florestais, Piracicaba, Brasil; ' ${ }^{5}$ niversidade Federal Rural do Rio de Janeiro, Departamento de Silvicultura, Seropédica, Brasil; ${ }^{6}$ Universidade Federal Rural de Pernambuco, Departamento de Ciências Florestais, Recife, Brasil; ' International Paper do Brasil, Mogi Guaçu, Brasil; ${ }^{8}$ Duratex, Agudos, Brasil; ${ }^{9}$ Ramires Reflortec, Ribas do Rio Pardo, Brasil (andreaw.esalq@gmail.com;jlmgonca@usp.br; eascmelo@yahoo.com.br; rocha.jht@gmail.com; caalvares@yahoo.com.br; josecarlosarthurjunior@gmail.com; rodrigo_hakamada@yahoo.com.br; cristiane.lemos@ipaper.com; jarbas.borges@duratex.com.br; rogerio@ramires.com.br)

Despite the adaptation of the genus Eucalyptus to the edaphoclimatic conditions of Brazil, reaching high productivity, the rhythm of increment in sectional area of the trunk and leaf area are influenced by abiotic agents, being soil fertility and water availability the most limiting for growth. Since the majority of soils destined for these plantations are highly weathered and with low nutritional content, the objective of this study was to evaluate over the course of 12 months the growth patterns of clonal stands between 48 and 60 months of age, established under omission of fertilization with N, P, K, complete omission and complete fertilization. This study was conducted in 4 forest sites, 3 in the State of São Paulo and 1 in Mato Grosso do Sul, differing as genetic material (E. grandis $x$ urophylla and E. urophylla $x$ globulus hibrids), soil class and climatic classifications (Aw and Cwa). The experiment consisted of 5 treatments, being the increase in the trunk of the trees evaluated by means of permanent dendrometers measures and, the canopy, by hemispheric photographs. It can be verified that the atypical climate of 2014 significantly influenced tree growth, being the water restriction the most limiting factor, between 18 and $40 \%$. The dynamics of growth (gain and contraction of the trunk) varied between forest sites and class of trees, which can be explained by up to 66\% by the rainfall, mean temperature and thermal amplitude. The treatments with the lowest accumulated increment were the omission of $\mathrm{K}$ and complete fertilization.

\section{Potentially toxic elements in tropical soil under long-term effect of sewage sludge applied in Eucalyptus plantation \\ Antonio Leite Florentino (D), José L.M. Gonçalves ${ }^{1}$, Alexandre de Vicente Ferraz², Cassio Hamilton Abreu-Junior ${ }^{3}$ (D) \\ ${ }^{1}$ Escola Superior de Agricultura "Luiz de Queiroz", Universidade de São Paulo, Departamento de Ciências Florestais, Piracicaba, Brasil; ${ }^{2}$ Instituto de Pesquisas e Estudos Florestais, Piracicaba, Brasil; ${ }^{3}$ Centro de Energia Nuclear na Agricultura, Universidade de São Paulo, Piracicaba, Brasil (antonio. florentino@usp.br; jlmgonca@usp.br; alexandre@ipef.br; cahabreu@cena.usp.br)}

Studies about long-term effects of sewage sludge (SS) application are still scarce, especially in tropical areas under forestry management. Normally, the SS application in forestry plantations increase soil fertility, plant growth and nutrient cycling. However, there is a risk of contamination by potentially toxic 
elements (PTE). We aimed to evaluate the long-term effects of SS application in tropical soil in terms of PTE (As, $\mathrm{Ba}, \mathrm{Cd}, \mathrm{Co}, \mathrm{Cr}, \mathrm{Cu}, \mathrm{Mo}, \mathrm{Ni}, \mathrm{Pb}, \mathrm{Se}$ and $\mathrm{Zn}$ ) concentration in soil and their stock in Eucalyptus plantations. The measurements were after 12.2 years of the SS application on the soil, in Eucalyptus plantation with 45 months old, in Brazil. The long-term effect of SS increased PTE levels in soil and plants. There was a positive relationship between dose of sludge and concentration PTE in soil, mainly in superficial layers $(0-20 \mathrm{~cm})$. Notwithstanding, the PTE concentrations in soil were generally lower than the prevention values according the Environmental Company of São Paulo State (CETESB). In the same time, the aerial biomass production was favored by SS doses at 12.2 years ago, compared with control treatment. Consequently, we observed higher PTE stock in the steam, bark, branch and leaf compartments, respectively. The concentrations of As, $\mathrm{Ba}, \mathrm{Cd}, \mathrm{Co}, \mathrm{Cr}, \mathrm{Cu}, \mathrm{Mo}, \mathrm{Ni}, \mathrm{Pb}, \mathrm{Se}$ and $\mathrm{Zn}$ in soil didn't cause soil contamination or plant toxicity. Studies on long-term $\mathrm{SS}$ effects should be done to monitoring the pedoenvironment and serve for guidelines to ensure best practices when applying SS in forest plantings.

Forest performance of Eucalyptus grandis $\mathbf{x}$ E. camaldulensis hybrids in different planting spacing arrangements in the Chapada do Araripe, Araripina, Pernambuco, Brazil / Desempenho silvicultural do hibrido de Eucalyptus grandis $x$ E. camaldulensis, sob diferentes espaçamentos de plantio na Chapada do Araripe, Araripina-PE

Marcos Drumond ${ }^{1}$, Viseldo Oliveira ${ }^{1}$, José Gomes Chaves ${ }^{2}$, Jorge Ribaski ${ }^{3}$

${ }^{1}$ Embrapa Semiárido, Petrolina, Brasil; ${ }^{2}$ Universidade Federal de Alagoas, Maceió, Brasil; ${ }^{3}$ Embrapa Florestas, Colombo, Brasil (marcos.drumond@embrapa.br; viseldo.oliveira@embrapa.br;jgomeschaves@hotmail.com; jorge.ribaski@embrapa.br)

O presente trabalho teve por objetivo avaliar efeitos de diferentes espaçamentos de plantio no desempenho silvicultural do híbrido Eucalyptus grandis x E. camaldulensis, na Chapada do Araripe. O ensaio foi instalado na Estação Experimental do IPA no município de Araripina-PE, (Latitude: 7²7’50”S, Longitude: $40^{\circ} 24^{\prime} 38^{\prime}$ W, Altitude de $828 \mathrm{~m}$ ), com temperatura média anual de $24^{\circ} \mathrm{C}$. A precipitação média anual é de $750 \mathrm{~mm}$ concentrados entre os meses de fevereiro e abril. O delineamento experimental adotado foi blocos ao acaso com cinco espaçamentos: 3,0 x 2,0 m; 3,0 x 2,5 m; 3,0 x 3,0 m; 3,0 x 3,5m e 3,0 x 4,0m, e quatro repetições. Cada parcela foi constituída de 64 plantas, com áreas úteis variáveis de 216 a $432 \mathrm{~m}^{2}$, totalizando $11.520 \mathrm{~m}^{2}$ de ensaio. Para efeito de análise foram consideradas apenas as 36 plantas centrais de cada parcela. O plantio foi feito no início do período chuvoso, após a aplicação de 2 toneladas por hectares de calcário dolomítico. Aos três anos de idade o híbrido Eucalyptus grandis x E. camaldulensis apresentou a menor sobrevivência (94\%) para o espaçamento mais amplo, diferindo estatisticamente, dos demais, sendo $100 \%$ para os espaçamentos 3,0 x 2,0 m e 3,0 x 3,0 m. A altura variou de 12,5 a 13,2 m sem diferença significativa. Os dois espaçamentos mais amplos, apresentaram diâmetros superiores a $11,0 \mathrm{~cm}$, diferindo dos demais. Quanto ao volume, o espaçamento de 3,0 x 2,0 m foi de 45,5 $\mathrm{m}^{-3} \mathrm{ha}^{-1}$, sendo superior aos demais, porém, sem diferença significativa do valor apresentado no espaçamento de $3,0 \times 3,5 \mathrm{~m},\left(38,4 \mathrm{~m}^{-3} \mathrm{ha} \mathrm{a}^{-1}\right)$.

Effects of different spacing arrangements on forest performance of Eucalyptus urophylla $\mathrm{x}$ E. brassiana hybrids in the Chapada do Araripe, Araripina, Pernambuco, Brazil / Efeitos de diferentes espaçamentos de plantio sob o desempenho silvicultural do híbrido de Eucalyptus brassiana $x$ E. urophylla, na Chapada do Araripe, Araripina-PE

Marcos Drumond ${ }^{1}$, Viseldo Oliveira ${ }^{1}$, João Calixto Junior ${ }^{2}$, Jorge Ribaski ${ }^{3}$

${ }^{1}$ Embrapa Semiárido, Petrolina, Brasil; ${ }^{2}$ Universidade Regional do Cariri, Juazeiro do Norte, Brasil; ${ }^{3}$ Embrapa Florestas, Colomo, Brasil

(marcos.drumond@embrapa.br; viseldo.oliveira@embrapa.br;joaojrbio@gmail.com; jorge.ribaski@embrapa.br)

O trabalho teve por objetivo avaliar desempenho silvicultural do híbrido Eucalyptus brassiana x E. urophylla submetido a diferentes espaçamentos de plantio, na Chapada do Araripe. O ensaio foi instalado na Estação Experimental do IPA no município de Araripina-PE, (Latitude: 7²7'50"'S, Longitude: 40²4'38”W, Altitude de $828 \mathrm{~m}$ ), com temperatura média anual de $24^{\circ} \mathrm{C}$. A precipitação média anual é de $750 \mathrm{~mm}$ concentrados entre os meses de fevereiro e abril. O delineamento experimental foi blocos ao acaso com cinco espaçamentos: 3,0 x 2,0 m; 3,0 x 2,5 m; 3,0 x 3,0 m; 3,0 x 3,5 m e 3,0 x 4,0 m, com quatro repetições. Cada parcela foi constituída de 64 plantas, com áreas úteis variáveis de 216 a $432 \mathrm{~m}^{2}$, totalizando $11.520 \mathrm{~m}^{2}$. Para efeito de análise foram consideradas apenas as 36 plantas centrais de cada parcela. O plantio foi feito no início do período chuvoso, após a aplicação de 2 toneladas por hectares de calcário dolomítico. Aos três anos de idade, observou-se a sobrevivência do híbrido Eucalyptus brassiana x E. urophylla diferiu estatisticamente entre os diferentes espaçamentos, sendo inferior (83,3\%) para o menor espaçamento (3,0 x 2,0 m), e superior (97,7\%) para o espaçamento de 3,0 x 3,5 m. Para as demais variáveis os espaçamentos não influenciaram significativamente entre si, entretanto o espaçamento de $3,0 \times 2,0 \mathrm{~m}$ em valores absolutos apresentou a maior produção volumétrica de madeira $\left(49,0 \mathrm{~m}^{-3} \mathrm{ha}^{-1}\right)$ enquanto que no espaçamento de $3,0 \times 3,0 \mathrm{~m}$ a menor produção volumétrica foi de $30,0 \mathrm{~m}^{-3} \mathrm{ha}^{-1}$, evidenciando não existir competição entre as plantas nesta fase de desenvolvimento.

E4b: MANAGING INDUSTRIAL PLANTATION FORESTS FOR MULTIPLE OBJECTIVES

\section{Review: productivity, economics and environmental impacts of short-rotation forest plantations in Northern Europe}

Hardi Tullus ${ }^{1}$, Reimo Lutter ${ }^{1}$, Tea Tullus ${ }^{1}$, Heiki Hepner ${ }^{1}$, Arvo Tullus ${ }^{2}$

${ }^{1}$ Estonian University of Life Sciences, Tartu,Estonia; ${ }^{2}$ University of Tartu, Tartu, Estonia (hardi.tullus@emu.ee; reimo.lutter@emu.ee; tea.tullus@emu.ee; heiki.hepner@kohila.ee; arvo.tullus@ut.ee)

Short-rotation forest (SFR) plantations have steadily expanded from southern regions to Northern Europe (NE). Poplars, aspens, birches are regarded as potentially suitable species for SRF in the region. SRF plantations could satisfy an increasing demand for renewable energy resources, reduce harvest pressure in natural forests, mitigate climate change and support biodiversity conservation. Hereby, we review the recent research progress concerning SRF in NE during the last decade and point out the future research needs. Research conducted during the last decade has proven that SRF plantations have a very high production potential compared to traditional long-rotation forestry. Besides that, the depletion of soil nutrient reserves is negligible and the need for additional fertilisation has not occurred, at least in short term. However, long-term understanding about nutrient dynamics is still needed. The testing of new plant material from breeding programmes is showing promising results; however, more attention should be paid to the adaptation with climate change. The studies about SRF plantations carbon $(\mathrm{C})$ balance are reporting $\mathrm{C}$ sequestration effect but dynamics of soil $\mathrm{C}$ pools needs a longer observation time. The nature conservation studies are showing that SRF plantations can improve biodiversity in the landscape and offer a temporal habitat for forest species. SRF is probably an inevitable reality in NE in order to satisfy the increasing demand for wood-based products and mitigate climate change. The larger expansion of SRF plantations is currently mainly restricted by political boundaries such as lack of stable subsidies and uncertainties about certification. 


\title{
A framework for assessing ecosystem goods and services from planted forests
}

\author{
Himlal Baral, Manuel Guariguata ${ }^{1}$, Rodney John Keenan ${ }^{2}$ \\ ${ }^{1}$ Center for International Forestry Research, Bogor, Indonesia; ${ }^{2}$ The University of Melbourne, Melbourne, Australia (h.baral@cgiar.org; \\ m.guariguata@cgiar.org; rjkeenan@unimelb.edu.au)
}

Recent research highlights the essential role of planted forests in providing multiple ecosystem goods and services (EGS) to human society. However, there has been little assessment of these EGS due to the lack of an appropriate framework, and knowledge of the tools to make EGS assessments. Researchers, policymakers and society at large have shown considerable enthusiasm and called appropriate approaches, classification and tools to be developed for assessment of EGS from planted forests. Drawing on lessons derived from EGS assessments around the world and consultations with a variety of stakeholders, we propose an easy-to-apply framework to assess EGS from planted forests that will be useful for various plantations types around the world. We recognise that the diverse characteristics of planted forests such as location, purpose, choice of species, rotation, management intensity, local demand and supply situation can influence the provision of EGS from planted forests. We anticipate this framework will be tested in various settings and will provide an important avenue to assess EGS from planted forests.

\section{From acacia to eucalypt: productivity and fertility implications of plantations species shift in Indonesia}

Johannes Pirker ${ }^{1,2}$, Stephan A. Pietsch ${ }^{1}$, Dmitry Schepaschenko ${ }^{1}$, Sidiq Pambudi ${ }^{3}$, Subekti Rahayu ${ }^{3}$, Florian Kraxner ${ }^{1}$ ${ }^{1}$ International Institute for Applied Systems Analysis (IIASA), Laxenburg, Austria; ${ }^{2}$ KU Leuven - Catholic University Leuven, Leuven, Belgium; ${ }^{3}$ World AgroforestryCenter(ICRAF),Bogor,Indonesia (pirker@iiasa.ac.at; pietsch@iiasa.ac.at; schepd@iiasa.ac.at; s.pambudi@cgiar.org; s.rahayu@cgiar.org, kraxner@iiasa.ac.at)

The plantation forestry sector in Indonesia has seen a change in species from Acacia mangium to Eucalyptus pellita. This change, forced by diseases spreads, has affected more than $90 \%$ of the plantation area in Indonesia and it is unprecedented in its scale in the history of plantation forestry (Nambiar et al., 2018). It is also a change of tree species with very different eco-physiological patterns: Acacias - in contrast to eucalypts - are leguminous trees and therefore self-sufficient in nitrogen supply and capable of building significant stocks of nitrogen and carbon in the soil, two main determinants of plantation productivity. The large-scale species shift therefore raises questions about the sustainability of the pulp and paper sector in Indonesia in the coming decades as well as the role of past land use and site quality in Indonesia's forest restoration pledge. The proposed contribution therefore aims at analyzing the sustainability in terms of productivity of the Indonesian plantation forestry sector under the new eucalypts regime. To that end, we will deploy the BioGeoChemistry Management Model (BGC-MAN; Pietsch, 2014) which is capable of representing the carbon, water and nitrogen cycles in great detail. Expected results will include a reconstruction of the rise and fall of A. mangium and shift to E. pellita as well as forecasts of plantation productivity and soil fertility over the next decades; it will notably answer the question for how long soil N-stock accumulated by acacias will be able to feed eucalypts.

\section{Discussion on sustainable management strategy of Eucalyptus plantation in China}

\section{Yaojian Xie}

${ }^{1}$ China Eucalypt Research Centre, Chinese Academy of Forestry, Zhanjiang, China (cercxieyj@163.com)

Eucalyptus was introduced to China as early as 1890s. After successfully development of some larger plantations in western Guangdong and southern Guangxi in 1950s, Eucalyptus gradually came to be recognized as one of key plantation tree species in southern China. Since the beginning of 1990s Eucalyptus plantations have developed particularly rapidly, and their plantation area reached 4.5 million $\mathrm{m}^{2}$ in 2015 . The annual production of wood from this Eucalyptus plantation resource have reached over 30.0 million $\mathrm{m}^{3}$, accounting for $26.9 \%$ of China's entire domestic timber production and making significant contributions to the security of the country's wood and fibre supply. China's Eucalyptus industry now comprises a complete industrial chain that includes nurseries and seedling production, fertilizers, saw-timber, pulp and papermaking, artificial board, biomass and forest by-products with a total annual outputs of around RMB $¥ 300$ billion. The key to future successful development of Eucalyptus plantations is scientifically sustainable management. Firstly, the government should have a good planning for Eucalyptus development. Secondary, we must revise industry's concept of management from that purely for timber production to management that combines timber production with environment protection. At the same time, following technical measures of sustainable management need to be achieved: (1) Planting tree species and varieties properly matched with sides; (2) establishing mixed species plantations; (3) Scientific management of all vegetation; (4) improving site preparation and planting techniques; and, (5) scientific management of plant diseases and pests.

Precision forestry in zoning the productive potential of Pinus taeda L. in Midwestern Santa Catarina, Brazil / Silvicultura de precisão no zoneamento do potencial produtivo de Pinus taeda L. na região Centro-Oeste do Estado de Santa Catarina, Brasil

Edison Rogério Perrando ${ }^{1}$, Sérgio Luiz Bostelmann ${ }^{2}$, Vlademir Martarello ${ }^{2}$, Bruno Conte $^{2}$, Juliana Tramontina ${ }^{2,3}$, Rudinei De Marco ${ }^{4}$, Maio Boff Burgin ${ }^{5}$ ${ }^{1}$ Universidade Federal de Santa Maria, Frederico Westphalen, Brazil; ${ }^{2}$ Adami S/A Madeiras, Caçador, Brazil; ${ }^{3}$ Universidade Federal do Rio Grande do Sul, Porto Alegre, Brazil; ${ }^{4}$ Universidade Federal de Pelotas, Pelotas, Brazil; ${ }^{5}$ Klabin, Telêmaco Borba, Brazil (edison.perrando@ufsm.br; sergio.bostelmann@adami.com.br; vlademir.martarello@adami.com.br; bruno.conte@adami.com.br; tramontina.ju@gmail.com; rudineidemarco@hotmail.com; marioboffburgin@hotmail.com)

As florestas plantadas ocupam 7,84 milhões de hectares e são responsáveis por mais de $90 \%$ de toda a madeira utilizada para fins produtivos. A perspectiva para os próximos anos aponta um desequilíbrio entre oferta e demanda de madeira, com risco de déficit no fornecimento. O planejamento e a gestão florestal possuem o desafio e a responsabilidade de tomar ações que preconizam a otimização dos recursos e atividades, garantindo aumento de produtividade e maximização dos lucros. A silvicultura de precisão, no âmbito das geotecnologias, é uma ferramenta útil à decisão e implementação de intervenções eficazes e economicamente sustentáveis no manejo dos povoamentos. O presente estudo objetivou mapear a variabilidade espacial da capacidade produtiva em povoamentos de Pinus taeda L., bem como avaliar e identificar os principais fatores limitantes de sua produtividade florestal. A abrangência do estudo foi equivalente a 17.200 hectares, na área de manejo florestal da empresa Adami S/A, localizada na região Centro Oeste de Santa Catarina, e contou com o apoio da Universidade Federal de Santa Maria Campus Frederico Westphalen. Uma base de dados com 2.308 pontos de coleta de campo permitiu, em ambiente SIG (Sistema de Informações Geográficas), a caracterização fisiográfica do meio e dos atributos físico/químicos do solo. A análise integrada de mapas temáticos de produtividade em relação aos atributos do meio físico, assim como uma análise hierárquica "multicritérios" (AHP) possibilitou identificar as variáveis condicionantes à produtividade de Pinus taeda e, por conseguinte, embasar a tomada de decisão em nível de Unidades de Manejo Florestal. 


\section{Effects of site preparation and fertilization on early growth of Gmelina arborea growing under environmental conditions of the tropical dry forest in Colombia}

Ana M. López ${ }^{1}$, Alonso Barrios ${ }^{1}$, Alvaro Davila

'Universidad del Tolima, Ibagué, Colombia (amlopeza@ut.edu.co; abarriost@ut.edu.co; aadavilag@ut.edu.co)

Site preparation and fertilization applied in the first years of development of a forest plantation allow the maximization of economic benefits of the crop with increased yield in volume. Quantifying the response to these intensive silvicultural practices is essential to develop environmentally sustainable and costeffective systems. Gmelina arborea is one of the main species used in reforestation programs in Colombia because of its adaptability to different site conditions and its growth rates. The aim of the study is to evaluate the effect of site preparation and fertilization on the early growth of $G$. arborea growing under edaphic and climatic conditions of the upper Magdalena river basin, Colombia. The experimental design used is a randomized complete block design with arrangement in split plots. The treatment arrangement has two factors: site preparation (two levels) and fertilization (eight levels) and three replications. The evaluated response variables are growth in diameter, height, basal area and volume. After 20 months of evaluation it was found that site preparation and fertilization had a significant effect on growth in height, diameter, basal area and volume. The mechanized site preparation showed increases of up to $34 \%$ compared to the manual site preparation. The combination of fertilization with $\mathrm{N}+\mathrm{P}+\mathrm{K}$ and subsoiling showed to be the best combination of treatments reaching mean annual increments of up to $54 \mathrm{~m}^{3} / \mathrm{ha} /$ year. These results allow to identify practices that contribute to increase yields and decrease rotation times for the species.

Strengthening forest productivity through diffusion and transfer of alternative forest species, promoting innovation and competitiveness among forest owners and companies in Chile / Fortalecimiento de la productividad forestal a través de la difusión y transferencia de especies forestales alternativas, promoviendo la innovación y competitividad de propietarios forestales y empresas en Chile

Juan Carlos Pinilla Suárez', Karina Luengo Vergara', Mauricio Navarrete Torres ${ }^{1}$

Instituto Forestal de Chile, San Pedro de la Paz, Concepción, Chile (jpinilla@infor.cl; kluengo@infor.cl; mnavarre@infor.c)

El Instituto Forestal de Chile desarrolla programas de investigación sobre especies forestales, con el propósito de ofrecer al sector nuevas opciones productivas, generando información acerca de ellas y sus mejores técnicas de establecimiento y manejo de plantaciones, en estrecha colaboración con empresas forestales, servicios públicos y asociaciones de medianos y pequeños propietarios. El artículo se enfoca en el potencial de desarrollo y aporte de bosques con especies de Acacia a la comunidad rural y sector productivo, el cual a través de la difusión de los resultados y el trabajo directo con los propietarios, ha permitido la adopción de adecuadas herramientas de gestión forestal, con mejoras en la productividad de bienes económicos y sociales proporcionados por este tipo de bosques, lo que se asocia a mejoras en las condiciones de habitabilidad de las comunidades rurales y emprendimientos locales, con un incremento de la calidad de vida, además de externalidades positivas referidas a la protección de los suelos, su aporte a la mitigación de los efectos de los gases de efecto invernadero y del cambio climático. Las especies del Género Acacia en Chile, presentan crecimientos y productividad que permiten alcanzar retornos económicos a temprana edad, asociado a adecuadas propiedades de la madera, permitiendo optar a opciones de negocio a propietarios y productores. Se presenta el proyecto y sus resultados, centrado en fomentar la utilización eficiente de especies de Acacia en procesos de producción, industria de la madera y energía, apoyando a productores locales y el bienestar de los habitantes rurales y urbanos.

\section{E4c: TROPICAL WETLANDS, CLIMATE, AND LAND-USE CHANGE: CHALLENGES AND} OPPORTUNITIES

\section{The Sustainable Wetlands Adaptation and Mitigation Program (SWAMP) as a model program for integrating science with international development}

Randy Kolka ${ }^{1}$

${ }^{1}$ USDA Forest Service Northern Research Station, Grand Rapids, MN, USA (kolka003@umn.edu)

Carbon-rich tropical wetlands (mangroves and peatlands) are important in climate change adaptation and mitigation strategies and provide numerous ecosystem services such as storm protection, nursery areas for fish, habitat for rare species, long-term storage of carbon, and food, fiber, and fuel for humans. Because of their importance we developed the Sustainable Wetlands Adaptation and Mitigation Program (SWAMP) to assist countries with their accounting and conservation of tropical wetlands. SWAMP is a collaborative effort between the Center for International Forestry Research and the USDA Forest Service through support from the US Agency for International Development. The goal of SWAMP is to provide policy makers and natural resource professionals with credible information and training to make sound decisions regarding the role of tropical wetlands in climate change adaptation and mitigation. The SWAMP objectives are to: (1) Quantify greenhouse gas emissions from intact and disturbed wetlands; (2) Quantify carbon stocks of representative tropical wetlands; (3) Develop carbon modeling tools and scaling approaches using remote sensing; (4) Define roles for tropical wetlands in climate change adaptation strategies; and (5) Promote capacity building and outreach as integral parts of all activities. Through integrating research, outreach and policy, SWAMP has led to many leveraged efforts both within and across participating countries leading to more accurate tropical wetland greenhouse gas accounting and governmental responses to changing climate.

\section{Carbon burial in mangrove forests: implications for mangrove restoration}

Richard MacKenzie ${ }^{1}$,Sahadev Sharma ${ }^{2}$, Sigit Sasmito ${ }^{3,4}$, Daniel Murdiyarso ${ }^{4}$, Joko Purbospito ${ }^{5}$, Alan Castillo ${ }^{6}$

${ }^{1}$ US Forest Service, Hilo, USA; ${ }^{2}$ University of Malaya, Kuala Lumpur, Malaysia; ${ }^{3}$ Charles Darwin University, Darwin, Australia; ${ }^{4}$ Center for International Forestry, Bogor, Indonesia; ${ }^{5}$ Sam Ratulangi University, Manado, Indonesia; ${ }^{6}$ Department. of Environment and Natural Resources, Los Banos, Philippines (rmackenzie@fs.fed.us; sahadev.isro@gmail.com; sigitdeni.sasmito@cdu.edu.au; d.murdiyarso@cgiar.org;jpurbop@gmail.com; allan536@yahoo.com)

Mangrove forests remove and store massive amounts of $\mathrm{C}$ from the atmosphere. This occurs through $\mathrm{C}$ burial in waterlogged and anoxic sediments that preserve C stocks, increasing mangroves importance in climate change mitigation and adaptation strategies. Despite their importance, mangroves continue to be cleared for charcoal, salt pannes, aquaculture ponds, and rice fields. This has resulted in an average loss of $516 \mathrm{Mg} \mathrm{C} / \mathrm{ha}$, most of which has come from mangrove sediments. Despite recent mangrove restoration efforts to offset $\mathrm{C}$ losses, it has been suggested that it could take $\sim 300$ years to restore mangrove $\mathrm{C}$ stocks that have been lost. This estimate is based off of a global average $\mathrm{C}$ burial rate of $1.74 \mathrm{Mg} \mathrm{C} \mathrm{ha}^{-1} \mathrm{yr}^{-1}$. More recent studies comparing $\mathrm{C}$ stocks across different aged restored sites have found that $\mathrm{C}$ stocks of restored mangrove can approach baseline levels of intact systems in as little as 30 -70 years. This is likely due to higher 
C burial rates in younger forests through greater root production. Using the naturally occurring radionuclide $210 \mathrm{~Pb}$ and the Constant Rate of Supply model, we tested this idea by quantifying $\mathrm{C}$ burial rates from sediment cores collected across different aged restored mangrove sites in Southeast Asia. Preliminary results revealed that $\mathrm{C}$ burial in restored sites can range from 2.85-14.25 $\mathrm{Mg} \mathrm{C} \mathrm{ha-1}^{-1} \mathrm{yr}^{-1}$, much greater than the global average. This suggests that $\mathrm{C}$ stocks of younger restored sites may approach $\mathrm{C}$ stocks of intact forests much faster than previously suggested.

\section{Evaluation of large-scale mangrove plantations in the Philippines and its policy and management implications}

John Benrich Zuniga ${ }^{1,2}$, Carmelita Villamor ${ }^{1}$, Alvin Gestiada ${ }^{1}$, Diana Riza Africa ${ }^{1}$

${ }^{1}$ Ecosystems Research and Development Bureau, Los Banos, Laguna, Philippines; ${ }^{2}$ University of the Philippines, Los Banos, Laguna, Philippines

(johnbenrichzuniga@gmail.com; villamor321@gmail.com; alvingestiada@yahoo.com.ph; diane.africa@gmail.com)

In the Philippines, ecosystem damages from strong typhoons has prompted the government to rehabilitate mangroves to increase coastal resiliency. However, various environmental and management factors affect mangrove plantation success. The study evaluated the survival rate of 30 selected large-scale plantations across the Philippines as affected by different environmental parameters. The average survival rates were found to be highly variable across the sites which ranges from 24\%-84\% and an average of 56\% to 48\% in 2016 and 2017 respectively. Survival rate was found to be related to distance from shoreline/mangrove forest edge $(\mathrm{p}=0.002)$, planting of correct species $(\mathrm{p}=0.025)$, land-use type $(\mathrm{p}=0.025)$ and negatively correlated with average wind speed $(\mathrm{p}=0.029)$. Multiple Regression Analysis $(\mathrm{R} 2=0.56, \mathrm{p}<0.001)$ was done to determine the corresponding regression weights of significant factors. Results further show that mortality were attributed to climatic phenomenon such as frequency and strength of storms in combination with species-site mismatch. In response, there have been several initiatives by the Philippine government to improve mangrove rehabilitation initiatives which includes nationwide capacity building and technical assistance on mangrove conservation and rehabilitation projects. It is further recommended to strengthen science-based mangrove planting and interagency convergence particularly in rehabilitating former mangrove areas such as abandoned brackish water fishponds which was also shown to have higher survival rate compared to other habitat types. Science-based policy recommendations from this study may be applied to improve the effectiveness of future mangrove rehabilitation projects for coastal protection in the Philippines.

\section{Opportunities and challenges for effective, efficient and equitable mangroves management: lessons learnt Vietnam}

Thuy Pham Thu ${ }^{1}$, Phuong Vu Tan ${ }^{2}$, Chien Pham Duc ${ }^{2}$, Truong Nguyen Van ${ }^{2}$, Trang Dao Le Huyen ${ }^{2}$, Hoa Hoang Nguyen Viet ${ }^{2}$, Long Hoang Tuan ${ }^{1}$, Chi Dao Thi Linh', Tien Nguyen Dinh ${ }^{1}$

${ }^{1}$ Center for International Forestry Research (CIFOR), Hanoi, Vietnam; ${ }^{2}$ Vietnamese Academy of Forest Sciences (VAFS), Hanoi, Vietnam (t.pham@cgiar.org;phuong.vt@vafs.gov.vn; p.d.chien@vafs.gov.vn; truong.nv@vafs.gov.vn; huyentrang0804@gmail.com; hoa.hnv@vafs.gov.vn; bberviet@gmail.com; chi.daolinh161194@gmail.com; ndtien.up@gmail.com)

The area of mangrove loss in Vietnam has been increased for the last 20 years. This study aims to analyses both opportunities and constraints for mangrove protection and management in Vietnam and draws out lessons learnt for more effective, efficient and equitable policies. We collected data from focus group discussion, household survey, semi-structure interviews and consultation workshops with more than 1000 people. We found that a large number of policies and projects in place to promote mangrove conservation activities has helped to enhance stakeholders capacity, provide additional funding for mangrove protection, raise local awareness of the role and importance of maintaining mangrove. However, drivers of mangrove deforestation and degradation are complex, and often associated with national economic development strategies. Current mangrove protection policies and projects are impeded by insecure tenure, land grabbing, elite capture, and inequitable benefit-sharing mechanism. Institution setting for mangrove protection is also constrained by overlapping and unclear responsibilities amongst government agencies and weak monitoring and evaluation system. The current policies and projects gave a strong emphasis and create incentives to replant mangrove forests but not to maintain and conserve existing mangrove. Incentives are also designed to compensate local labor costs to reforest mangrove or carry out patrolling activities rather than addressing direct drivers of mangrove loss. Protecting existing mangrove area requires a policy shift in land use planning to address drivers of mangrove deforestation and degradations, accountable and transparent benefit sharing mechanism, inclusive decision-making process and a combination of both in-kind and in-cash payments

\section{Enhancing NDC ambitions of countries with carbon-rich peatlands in the tropics: a preliminary account}

Daniel Murdiyarso', Christopher Martius ${ }^{1}$, Kristell Hergoualc ' $h^{2}$, Stephen Leonard ${ }^{1}$

${ }^{1}$ Center for International Forestry Research, Bogor, Indonesia; ${ }^{2}$ Center for International Forestry Research, Lima, Peru (d.murdiyarso@cgiar.org; c.martius@cgiar.org; k.hergoualch@cgiar.org; s.leonard@cgiar.org)

The recent IPCC report confirmed that an average global temperature increase of $2{ }^{\circ} \mathrm{C}$ above pre-industrial levels poses greater risks than previously believed. Limiting warming to $1.5^{\circ} \mathrm{C}$ can substantially lower these risks - but requires dramatic emission reductions by 2030 and carbon neutrality by around 2050. The Paris Agreement requires Parties to the United Nations Framework Convention on Climate Change to contribute their emission reduction target through Nationally Determined Contributions (NDCs). Southeast Asia and the Amazon are among the regions with great opportunities to transform their NDC ambitions through peatlands. Indonesia's first NDC with emission reduction target of $29 \%$ would bring the emission level to 2,034 $\mathrm{Mt} \mathrm{CO}_{2}$-e in $2030 \mathrm{from} 1,334$ $\mathrm{Mt} \mathrm{CO}_{2}$-e in the base year of 2010. Meanwhile, Peru's first NDC with emission reduction target of $20 \%$ would bring down its emission level to $298 \mathrm{Mt} \mathrm{CO}_{2}$-e in 2030 from $171 \mathrm{Mt} \mathrm{CO}_{2}$-e in the base year of 2010. Provided the current strong policy on peatland conservation and restoration is sustained, Indonesia could further lower its emissions by 11 to $110 \mathrm{Mt} \mathrm{CO}_{2}$-e annually depending on how peatland fires prevention can be imposed. Since Peru has no peatland-related policy in place, the opportunity from emission avoidance of around 30\% due to drainage might be missed. The only factor that sustain Peruvian peatlands is their remoteness and lack of road network.

\section{Tropical peatland degradation and restoration of Indonesia: inclusive evidence-based diagnostics and planning}

Sonya Dewi ${ }^{1}$, Andree Ekadinata ${ }^{1}$, Arga Pandiwijaya ${ }^{1}$, Ping Yowargana ${ }^{2}$

${ }^{1}$ ICRAF, Bogor, Indonesia; IIASA, Laxenburg, Austria (s.dewi@cgiar.org; a.ekadinata@cgiar.org; a.pandiwijaya@cgiar.org; yowargan@iiasa.ac.at)

Land use changes have been imposing major pressures to peatland ecosystems of Indonesia, being the largest in the tropics, and causing extensive and severe degradation. Climate changes, through extreme weather, especially droughts, exacerbate the impacts of peat draining on fire and GHG emissions. The government have made commitments to restore peat ecosystems. Planning, implementation and impact monitoring have been initiated, supported by policies and fiscal instruments. In supporting this aspiration, we conduct the analysis of land use/cover changes on peat ecosystems throughout Indonesia over the past 
25 years, teasing apart the large-scale plantation-driven and smallholder-driven conversion of land and forest across various designated functions, including production and protection forest land and agricultural land. We then delve deeper in South Sumatra province, which in 2015 had experiences the worst fire incidence throughout Indonesia. The paper describes the process and discuss the results of the technical analysis that serve as diagnosis of driver-pressure-stateimpacts of peat degradation, followed by the strategy development to restore the degraded peat ecosystems. We conclude that the interaction between large-scale operations, namely oil palm and pulp forest plantations, with the smallholder agricultural practices have been the primary activities that causes unprecedented rate and extent of peat degradation in the relatively recent years. In restoring peat ecosystems, system-wide diagnosis, broad solution space, coherent policies and strong partnerships need to be in place. Economic-based scenario modelling at the national level combined with spatially explicit modelling at the local level are instrumental to support the evidence-based planning of peat restoration.

\section{Carbon dioxide and methane budgets of a palm swamp peatland in Iquitos, Peru}

Timothy Griffis ${ }^{1}$, Daniel Roman ${ }^{2}$, Lizardo Fachín Malaverri ${ }^{3}$, Randall Kolka ${ }^{2}$, Jhon Rengifo Marin ${ }^{3}$, Dennis del Castillo Torres ${ }^{3}$, Erik Lilleskov ${ }^{4}$, Rodney Chimner ${ }^{5}$, Craig Wayson ${ }^{6}$

${ }^{1}$ University of Minnesota, Saint Paul, USA; ${ }^{2}$ USDA Forest Service, Grand Rapids, USA; ${ }^{3}$ Instituto de Investigaciones de la Amazonia Peruana, Iquitos, Peru; ${ }^{4}$ USDA Forest Service, Houghton, USA; ${ }^{5}$ USDA Forest Service, Washington D.C., USA; ${ }^{6}$ International Programs, Washington D.C., USA (timgriffis@umn.edu; danielroman@fs.fed.us; lfachin@iiap.org.pe; rkolka@fs.fed.us; jhevrema@gmail.com; ddelcastillo@iiap.org.pe; elilleskov@fs.fed.us; rchimner@mtu.edu; cwayson.silvacarbon@gmail.com)

Tropical peatlands have been identified as a major biophysical feedback factor on the atmospheric greenhouse effect. The largest expanses of tropical peatlands are located in lowland areas of Southeast Asia and the Amazon basin. The Loreto Province of Amazonian Peru is comprised of $\sim 36,000 \mathrm{~km}^{2}$ of peatlands. However, little is known about these peatlands and their carbon dioxide and methane budgets and their response to hydrometeorological forcing. To address these knowledge gaps we established an eddy covariance flux tower in a palm swamp peatland in Iquitos, Peru. Here, we report on energy balance, carbon dioxide, and methane flux observations over the period January 2017 to present. The seasonal variation in hydrometeorology had a strong control on evaporation and carbon dioxide fluxes. Evaporation was most pronounced in November through December, while the net ecosystem carbon dioxide exchange revealed large uptake from November through April. The cumulative net ecosystem carbon dioxide exchange for 2018 indicated that the peatland was a significant carbon sink of $330 \mathrm{~g} \mathrm{C} \mathrm{m}^{-2} \mathrm{y}^{-1}$ and was substantially larger than that reported for other tropical peatlands. The annual methane emissions were on the order of $20 \mathrm{~g} \mathrm{C} \mathrm{m}^{-2} \mathrm{y}^{-1}$ and were comparable with other tropical and temperate peatlands. Thus, the annual carbon budget of this tropical palm swamp peatland appears to be a major carbon sink given the current hydrometeorological conditions. Our ongoing research is assessing the major controls on these fluxes including satellite-based sun-induced fluorescence measurements to help verify the large photosynthetic uptake of carbon dioxide.

\section{Degradation of palm swamp peatlands in the Peruvian Amazon severely raises emissions of greenhouse gases}

Kristell Hergoualc' ' ${ }^{1}$, Jeffrey van Lent ${ }^{1}$, Rupesh K Bhomia ${ }^{1}$, Nelda Dezzeo ${ }^{1}$, Julio Grandez ${ }^{1}$, Mariela Lopez ${ }^{1}$, Louis Vincent Verchot ${ }^{2}$ ${ }^{1}$ CIFOR, Lima,Peru; ${ }^{2}$ CIAT, Cali, Colombia (k.hergoualch@cgiar.org; vanlent.jeffrey@gmail.com; r.bhomia@cgiar.org; ndezzeo@gmail.com; jmgr_19@hotmail.com; m.lopez@cgiar.org;.verchot@cgiar.org)

Palm swamp peatlands of the Amazonia have barely been the subject of biogeochemical investigation despite their large extent and potential to mitigate climate change. In Peru, these ecosystems are suffering recurrent degradation due to slashing of palms for harvesting their fruits. We conducted long-term research to evaluate how this practice affects carbon and nitrogen dynamics across a gradient of degradation that comprised an intact site, a moderately and a heavily degraded site. Site properties and fluxes of above and below-ground litter, soil heterotrophic respiration, and $\mathrm{CH}_{4}$ and $\mathrm{N}_{2} \mathrm{O}$ were monitored monthly for $1-4$ years. Degradation altered the hummock-hollow micro-topography of the forest floor, the structure and composition of the vegetation and properties of the soil. Inputs of organic matter to the peat decreased by twofold while outputs increased by $40 \%$ as a result of heavy degradation. The net $\mathrm{CO}_{2}$ balance indicated that the peat at the intact and moderately degraded sites was neutral $\left(0.5 \pm 5.3\right.$ and $\left.2.8 \pm 3.6 \mathrm{Mg} \mathrm{CO}_{2} \mathrm{ha}^{-1} \mathrm{y}^{-1}\right)$ but it was a source at the heavily degraded site (25.9 $\left.\pm 3.4 \mathrm{Mg} \mathrm{CO}_{2} \mathrm{ha}^{-1} \mathrm{y}^{-1}\right)$. Soil $\mathrm{CH}_{4}$ emissions were high $\left(200 \mathrm{~kg} \mathrm{C}^{-1} \mathrm{yr}^{-1}\right)$ and not affected by degradation. Small site-differences in $\mathrm{N}_{2} \mathrm{O}$ emissions seemed driven by spatial heterogeneity of soil water-filled pore space. Palm swamp peatlands in their natural state constitute a net source of greenhouse gas $(27 \pm 8 \mathrm{Mg}$ $\mathrm{CO}_{2}$-equivalent ha-1 $\mathrm{y}$-1). Their degradation leads to increased emission rate by $70 \%$ highlighting the urgency to develop sustainable management practices.

\section{Quantifying carbon sink and source activities in Amazonian peatlands under a changing climate}

Qianlai Zhuang ${ }^{1}$, Sirui Wang ${ }^{1}$, Outi Lähteenoja ${ }^{2}$,Frederick Draper ${ }^{2}$, Hinsby Cadillo-Quiroz ${ }^{2}$

${ }^{1}$ Purdue University,West Lafayette, USA; 2Arizona State University,Tempe, USA (qzhuang@purdue.edu; wang2381@purdue.edu; outituulikki.lahteenoja@asu.edu; freddie.draper@gmail.com; hinsby@asu.edu)

Amazonian peatlands store a large amount of soil organic carbon (SOC) and its fate under a future changing climate is unknown. Here we use a process-based peatland biogeochemistry model to quantify the carbon accumulation for peatland and non-peatland ecosystems in the Pastaza-Marañon foreland basin (PMFB) in the Peruvian Amazon from 12,000 years before present to 2100 AD. Model simulations indicate that warming accelerates peat SOC loss while increasing precipitation accelerates peat SOC accumulation at millennial time scales. The uncertain parameters and spatial variation of climate are significant sources of uncertainty to modeled peat carbon accumulation. Under warmer and wetter conditions over the $21^{\text {st }}$ century, SOC accumulation rate in the PMFB slows down to 7.9 from the current rate of 16.1 and the region may turn into a carbon source to the atmosphere at -53.3 (negative values indicate a source), depending on the level of warming. Peatlands show higher sensitivity than flooded forests. Peatland and non-peatland soils in the PMFB may lose up to 0.4 Pg C by 2100 $\mathrm{AD}$ with the largest loss from palm swamp. The carbon-dense Amazonian peatland area may switch from a current carbon sink into a source in the $21^{\text {st }}$ century. 


\author{
The effects of post-mountain pine beetle infestation vegetation recovery on carbon and water interactions at the watershed scale \\ Krysta Giles-Hansen ${ }^{1}$, Xiaohua (Adam) Wei ${ }^{1}$ \\ ${ }^{1}$ University of British Columbia, Kelowna, Canada (krysta.gh@gmail.com; adam.wei@ubc.ca)
}

Mountain pine beetle (MPB) infestation and associated salvage logging mainly occurred 10 years ago had caused destructive impacts on carbon and many other ecological functions over a very large scale of forested landscapes in western Canada. For example, it was found that forests in British Columbia was switched from carbon sinks to carbon sources as a result of the MPB infestation. A big question now is: what would happen to forest carbon and water after 10 year or long-term vegetation recovery. This presentation will provide a critical assessment on the long-term effects of post-MPB infestation recovery on forest carbon and water interactions at the watershed scale using the modelling approach (CBM-CFS3 for forest carbon). Our analysis demonstrated that forest recovery mainly through understory vegetation has rapidly increased forest carbon sequestration. However, the increase of total forest carbon storage is not as much as we expected due to high respiration from dead materials. Annual water yields are greatly decreased due to ET increasing as a result of rapid recovery of understory vegetation and natural regeneration of lodgepole pine trees. Clearly, there are trade-offs between forest carbon storage and annual water yield. The dynamic interactions between forest carbon and water yields during the recovery period and their management implications are discussed.

\title{
Effect of adaptive forest management on the soil carbon pool in Central Europe
}

\author{
Robert Jandl', Georg Kindermann ${ }^{1}$ \\ ${ }^{1}$ Bundesforschungszentrum für Wald, Vienna, Austria (robert.jandl@bfw.gv.at; georg.kindermann@bfw.gv.at)
}

Adaptive forest management is required in order to cope with climate change effects. Emerging problems with current forests call for the investigation of alternatives. The management of forest stands has immediate and lasting effects on the soil carbon pool because the quantity and chemical quality of the aboveground and belowground litterfall is altered. In a simulation exercise we used the data of the Austrian Forest Inventory as starting point and ran scenarios for (i) business as usual forest management, (ii) replacement of conifer stands with deciduous stands, (iii) shorter rotation periods of conifer stands, and (iv) nonmanagement. The chosen scenarios are currently discussed as potential remedies. We used 150-years climate scenarios (RCP 4.5, RCP 8.5), a climate sensitive forest growth model (Caldis vatis), and the soil carbon model YASSO15. Preliminary results show a slight decrease in the soil carbon pool in the business-asusual scenario. A climate-change effect is likely, but the signal over-ridden by tmanagement effects. A shorter rotation period from previously approx 100 years to 70 years leads to a decline in the soil carbon pool. The analysis of the change to deciduous-tree dominated forests is in progress. We put the management effects on the soil carbon pool in perspective with the change in carbon in the aboveground biomass and the carbon that is retained in harvested wood products.

\section{Forest management practices for maintaining and increasing soil organic carbon}

Cindy Prescott ${ }^{11}$

${ }^{1}$ University of British Columbia, Vancouver, Canada (cindy.prescott@ubc.ca)

Globally, more than $40 \%$ of the total organic C in terrestrial ecosystems is stored in forest soil. Sustaining or increasing stocks of soil organic carbon has many benefits in addition to $\mathrm{C}$ sequestration, such as increased soil fertility and water-holding capacity, increasing potential site productivity, and fostering belowground biodiversity. As the manner in which forests are managed can influence SOC stocks, there is potential to consider this factor when planning management activities. Recognizing the need for action toward preserving and enhancing stocks of SOC, the FAO requested syntheses of current scientific evidence. In this talk I present ten forest management practices that could be employed to sustain or increase C stocks in forest soils.

\section{Manage temperate forest for soil carbon: lessons from natural forests}

Junwei Luan ${ }^{1}$, Shirong Liu ${ }^{2}$

${ }^{1}$ International Centre for bamboo and Rattan, Beijing, China; ${ }^{2}$ Institute of Forest Ecology, Environment and Protection, Chinese Academy of Forestry, Beijing,China (junweiluan@icbr.ac.cn; liusr@caf.ac.cn)

Temperate forests have large potential in sequestering carbon (C), especially to soil, and reasonable management practices can reduce the release of $\mathrm{C}$ from soils. Here we are synthesizing around ten years study on temperate forests of middle China, focusing particularly on soil $\mathrm{C}$ stability and soil $\mathrm{CO}_{2}$ fluxes, in order to feed insights in managing temperate forests for soil $\mathrm{C}$ sequestration, and cope with climate change such as warming and drought. We evaluated the effect of 1) natural succession; 2) restoration strategies (natural versus artificial regeneration); 3) tree species (broad-leaved versus coniferous) and diversity; and 4) manipulated warming and drought on soil organic $\mathrm{C}$ quality, stability and $\mathrm{CO}_{2}$ fluxes. Our results illustrated the mechanisms of higher soil $\mathrm{C}$ stability of natural regeneration versus artificial regeneration, and long-term forest succession in soil $\mathrm{C}$ sequestration; Also, we reveal that higher tree species diversity will benefit the soil $\mathrm{C}$ stability but different mechanisms may prevail the underling mechanisms between broadleaf mixed and broadleaf and coniferous mixed. We point out the vulnerability of soil $\mathrm{C}$ to climate change such as warming and drought in temperate forests, and future study should focus on mechanisms of plant soil feedbacks, in clarifying relationships between tree species diversity, soil biota functional diversity, and soil C sequestration, especially under the threat of climate change, to feed insights of management strategies of soil C sequestration in temperate forests.

\section{Response of $\mathbf{N}$ losses from the boreal forest soil to logging residue piles of different tree species}

Tiina Törmänen ${ }^{1}$,Veikko Kitunen ${ }^{2}$, Antti-Jussi Lindroos ${ }^{1}$, Juha Heikkinen ${ }^{1}$, Aino Smolander ${ }^{1}$

${ }^{1}$ Natural Resources Institute Finland, Helsinki, Finland; ${ }^{2}$ Natural Resources Institute Finland, Espoo, Finland (tiina.tormanen@luke.fi;

veikko.kitunen@luke.fi; antii.lindroos@luke.fi; juha.heikkinen@luke.fi; aino.smolander@luke.fi)

With current harvesting practices piles of logging residues are left on the forest floor. As a result on clear cut area under the piles, soil nitrogen ( $\mathrm{N}$ ) cycling processes can be accelerated, especially net nitrification. When $\mathrm{N}$ is transformed to more mobile form, the risk for $\mathrm{N}$ losses via leaching or nitrous oxide $\left(\mathrm{N}_{2} \mathrm{O}\right)$ emissions from the forest floor may increase. The aim of this study was to understand how logging residues of Norway spruce (Picea abies), Scots pine (Pinus sylvestris) and silver birch (Betula pendula) affect N losses in forest soil after clear-cutting. A spruce-dominated stand was clear-cut. Plots with fresh 
logging residue piles of different tree species, and control plots without logging residues, were subsequently established. Effects of logging residue piles were monitored; leaching as $\mathrm{N}$ concentrations in soil percolating water, and $\mathrm{N}_{2} \mathrm{O}$ emissions with closed chamber technic over two growing season. Soil denitrification activity and the contribution of nitrification and denitrification to $\mathrm{N}_{2} \mathrm{O}$ production were determined in laboratory experiment, as well as nitrogenase activity in the logging residues. Logging residue piles increased nitrate $\left(\mathrm{NO}_{3}-\mathrm{N}\right)$ concentrations in soil percolation water. In addition logging residues piles tended to stimulate $\mathrm{N}_{2} \mathrm{O}$ fluxes although in general the fluxes were low. Logging residues showed some nitrogenase activity. Currently we study the effects of large logging residue storage piles on $\mathrm{N}$ mobilization and losses.

\title{
Nitrogen addition to nitrogen rich forests: effects on soil nitrogen content
}

Lars Högbom ${ }^{1}$, Ulf Sikström ${ }^{2}$

${ }^{1}$ The Forestry Research Institute of Sweden, Uppsala, Sweden; ${ }^{2}$ The Forestry Research Institute of Sweden, Uppsala, Sweden (lars.hogbom@skogforsk.se; ulf.sikstrom@skogforsk.se)

Human activities have altered the pools and fluxes of nitrogen $(\mathrm{N})$ in the forest soil. In southern Sweden, a substantial deposition of air-borne $\mathrm{N}$ pollution has been going on for several decades. During the most recent decades up to $15-25 \mathrm{~kg} \mathrm{ha}^{-1} \mathrm{yr}^{-1}$ of $\mathrm{N}$ has been deposited in forested areas. At present the major part of deposited $\mathrm{N}$ is retained in the soil. However, there are concerns that the input of $\mathrm{N}$ into forest ecosystems will lead to so called N-saturation. Generally, the $\mathrm{N}$ cycle in Swedish forests is closed and the small amount of leaching that occurs is mainly of organic N. However, quite high leaching of inorganic $\mathrm{N}$ has occasionally been observed in some areas, especially in southwestern Sweden. In order to simulate effects of an elevated N deposition a series of experiments was established in forest in the southern part of Sweden including annual addition of low N doses $\left(20 \mathrm{~kg} \mathrm{ha}^{-1} \mathrm{yr}^{-1}\right)$. The experiments were established in stands of two different site productivity classes within two regions with differences in $\mathrm{N}$ deposition. The main aim of the project is to study effects on several forest ecosystem properties of low $\mathrm{N}$ dose addition as well as of conventional practical forest $\mathrm{N}$ fertilization. Here we report on changes in soil $\mathrm{N}$ content in the upper soil layer following addition of low-dose $\mathrm{N}$ application by a series of soil samplings, in order to estimate how much of the added $\mathrm{N}$ is retained there.

\section{Is there a niche complementarity for nitrate uptake among savannah shrub and tree species in a very deep Brazilian soil?}

Rafael Pinheiro ${ }^{1}$, Jean-Paul Laclau ${ }^{2,3}$, Iraê Guerrini $^{2}$, Livia Aló $^{2}$, Jean-Pierre Bouillet ${ }^{3,4}$

${ }^{1}$ Faculdade de Ciências Agronômicas de Botucatu/UNESP, Montpellier, Brasil; ; ${ }^{2}$ Faculdade de Ciências Agronômicas de Botucatu/UNESP, Botucatu, Brasil, ${ }^{3}$ UMR Eco\&Sols - CIRAD, Montpellier, France; ${ }^{4}$ Escola Superior de Agricultura "Luiz de Queiroz", Universidade de São Paulo, Piracicaba, Brasil (rafamic_10@hotmail.com; laclau@cirad.fr; iguerrini@fca.unesp.br; livialanzi@yahoo.com.br; jpbouillet@cirad.fr)

Belowground niche complementarity between deep-rooted and shallow-rooted species in mixed forests may result in a more complete exploitation of soil resources than in monocultures. Our study aimed to assess 1) the maximum distance (horizontally and vertically) where the fine roots from common Cerrado species take up mobile nutrients in deep Ferralsols, and 2) whether there is a niche complementarity in nitrate uptake between some Cerrado species. Our study was carried out in a closed-canopy forest with dense woody understory (cerradão) at Bauru (Sao Paulo State); $15 \mathrm{~N}_{-} \mathrm{NO}_{3}$ - was injected at the onset of dry and rainy seasons at 6 depths $(0.1,1.5,3,6,9$ and $12 \mathrm{~m})$ with 3 plots per depth and a distance $>50 \mathrm{~m}$ between each injection depth. Leaves were sampled 4 months after tracer injection in 3 frequent species in each plot located at 4 intervals of distance from the tracer injection point $(0-2 \mathrm{~m} ; 3-6 \mathrm{~m} ; 7-10 \mathrm{~m} ; \geq 12 \mathrm{~m})$ and $15 \mathrm{~N}$ atom $\%$ was determined. Great differences in $15 \mathrm{~N}$ tracer uptake between the studied species showed a niche complementarity in this native savannah. Xylopia aromatica exhibited a strong $15 \mathrm{~N}$ uptake at $6 \mathrm{~m}$ of depth, irrespective of the season. This species seems to exploit a much larger soil volume than the others, both vertically and horizontally (15N taken up at $5 \mathrm{~m}$ from the injection point). Miconia albicans and Coussarea hydrangeifolia showed similar behaviours, with a strong $15 \mathrm{~N}$ uptake in the topsoil and down to $1.5 \mathrm{~m}$ depth, within $2 \mathrm{~m}$ from the injection point.

\section{Litterfall production and litter decomposition at several forests considering climate and litter quality in South Korea}

\author{
Byung Bae Park ${ }^{1,2}$, Si Ho Han ${ }^{1}$, Afroja Rahman ${ }^{1}$, Huong Thi Thuy Dao ${ }^{1}$, Jeong Min Seo ${ }^{1}$, Woo Bin Youn ${ }^{1}$, Aung Aung ${ }^{1}$, Ji Young An ${ }^{3,1}$, Hwa Ja Hyun ${ }^{4}$, \\ Hyung-Soon Choi ${ }^{5}$ \\ ${ }^{1}$ Chungnam National University, Daejeon, Korea, Republic of; ${ }^{2}$ Korean Society of Forest Sicence, Seoul, Republic of Korea; ${ }^{3}$ Kyoto University, Kyoto, Japan; \\ ${ }^{4}$ Warm Temperate and Subtropical Forest Research Center, Seogwipo, Republic of Korea; ${ }^{5}$ Forest Conservation Department, Seoul, Republic of Korea \\ (bbpark@cnu.ac.kr; bupleurumhan@cnu.ac.kr; afroja.r10@gmail.com; thuyhuong.150495@gmail.com;jmseo3@naver.com;dbsdnqls95@naver.com; \\ baganaung777@gmail.com; an.jiyoung.2e@kyoto-u.ac.jp; viola1974@korea.kr; forgene@korea.kr)
}

We investigated litterfall production and litter decomposition, which are the major pathway for carbon and nutrients in forest ecosystem, at a couple of different forests considering climate and litter quality. Litterfall production has been observed at several deciduous or evergreen forests for about ten years across temperate and sub-tropical region in Korea. Leaf litter translocation experiments have been carried out covering $14^{\circ} \mathrm{C}-17^{\circ} \mathrm{C}$ range of mean annual temperature and 1,200 $\mathrm{mm}-1,400 \mathrm{~mm}$ range of mean annual precipitation. The results showed that total litterfall was much higher at evergreen broadleaf forest $\left(903 \mathrm{gm}^{-2} \mathrm{yr}^{-1}\right)$ than others $\left(698 \mathrm{gm}^{-2} \mathrm{yr}^{-1}\right)$, but was annually fluctuated. Litterfall production in evergreen forest was the highest at spring season, but for deciduous forest fall season was the maximum. Litter decomposition follows the similar decomposition trend, but decomposition was much faster in forests which has higher temperature during winter season. Litter decomposition was diverse by litter quality and average temperature during winter season. Although the effect of forest type, climate, and litter quality on litter production and litter decomposition is complex, this experiment will give an overview how these factors influence on carbon and nutrient cycling by modifying litterfall production and litter decomposition.

\section{Post-logging management and soil type can affect litter layers in Amazon tropical forest?}

Fernando Cesário (D), Fabiano Balieiro², Lucas Mazzei ${ }^{3}$

${ }^{1}$ Universidade Federal Fluminense, Rio de Janeiro, Brasil; ${ }^{2}$ Embrapa Solos, Rio de Janeiro, Brasi; ${ }^{3}$ Embrapa Amazônia Ocidental, Pará, Brasil (fernandovieiracesario@gmail.com; fabiano.balieiro@embrapa.br; lucas.mazzei@embrapa.br)

Litter is one of the main carbon and nutrient pools in the terrestrial ecosystem. However, the litter structural organization and the characteristics of its horizons, especially in humus forms perspective, that enables us to understand the topsoil processes of tropical forest ecosystem functioning are not well understood. We hypothesize that the soil class affects the soil macro and microbial activity and fertility, and thus the humus forms horizons. Likewise, the logging practices and the producer-decomposer forest processes altering the decomposition rates and litter input was evaluated. We used morpho-functional approach (Zanella et al., 2017) to describe the humus forms horizons on two different soil types (Ferralsols and Gleysols), under two post-logging practices of management (with 
and without crown removal). The fine roots, the Ai horizon, the presence of fungi and the aggregates were variables most important to the separation of soil types and post-logging management. While the presence of fungi suggests interference of the post-logging on the humus forms horizons, the root thickness was related to soil type indicating two different strategies for nutrient retention. The presence of fungi seems to be related to the presence of more recalcitrant material associated with loamy soils and to the development of the Ai thickness. Soils with superficial sandy layer and restricted drainage (as Gleysols) favored the formation of superficial root mantle; nevertheless, they inhibited the formation of the Ai horizon.

\section{Phloem sap analysis: a novel diagnostic tool to determine forest growth performance}

Nirmol Kumar Halder ${ }^{1,2}$, David Fuentes ${ }^{1}$, Malcolm Possell ${ }^{1}$, Benjamin Bradshaw ${ }^{3}$, Andrew Merchant ${ }^{1}$

${ }^{1}$ Center for Carbon, Water and Food, Faculty of Science, The University of Sydney, Camden, Australia; ${ }^{2}$ Ministry of Planning, Government of Bangladesh, Dhaka, Bangladesh; ${ }^{3}$ Australian Blue Gum Plantations, Victoria,Australia(nhal6573@uni.sydney.edu.au; david.fuentes@sydney.edu.au; malcolm.possell@sydney.edu.au; ben.bradshaw@austgum.com.au; andrew.merchant@sydney.edu.au)

Improving the efficiency of fertiliser application is paramount to both sustainability and profitability in forest plantations. Developing reliable, cost-effective tools to assess tree nutritional status is therefore of great interest. This investigation sought to assess the use of phloem sap derived metabolites as an indicator of nutritional status on a background of seasonal (hence water) availability of E. globulus trees grown under field conditions. Phloem derived amino acids were found to vary in accordance with $\mathrm{N}$ supply, however, this response was lost in the concurrent addition of P. Significant seasonal variation in all measured parameters was also detected highlighting the need for caution in making quantitative relationships with growth. Broader implications of the interactive effects of both water supply and multi-nutrient additions and relationships with growth are discussed.

\section{Nitrogen transfer from Acacia mangium to Eucalyptus appears to controls the decomposition of Eucalyptus litter under mixed plantation \\ Fabiano Balieiro ${ }^{1}$, Caio Rachid ${ }^{2}$, Guilherme Chaer ${ }^{3}$,Etelvino Novotny ${ }^{1}$, Felipe Santos $^{4}$, Raquel Peixoto $^{2}$, Alexandre Rosado ${ }^{2}$ \\ ${ }^{1}$ Embrapa Solos, Rio de Janeiro, Brasil; ${ }^{2}$ Universidade Federal do Rio de Janeiro, Rio de Janeiro, Brasil; ${ }^{3}$ Embrapa Agrobiologia, Seropédica, Brasil; \\ ${ }^{4}$ Universidade Federal Rural do Rio de Janeiro, Seropédica, Brasil (fabiano.balieiro@embrapa.br; caiorachid@micro.ufrj.br; \\ guilherme.chaer@embrapa.br; etelvino.novotny@embrapa.br; martinisantos@gmail.com; raquelpeixoto@micro.ufrj.br; asrosado@micro.ufrj.br)}

Litter decomposition is a key process for the sustainability of planted forest since it determines the magnitude of organic matter transformations and nutrient cycling. Although $\mathrm{N}$ deposition is high in Acacia mangium (acacia) plantations, the high internal cycling of $\mathrm{P}$, provides reduced inputs of $\mathrm{P}$ to soil. The litter decomposition of Eucalyptus urograndis (eucalyptus) and acacia under tropical climate in Brazil was studied was studied from the perspective of the Domestic Advantage Theory. To test this hypothesis, we used the mass loss of reciprocal translocated litterbags, the changes in fungi communities structure (pyrosequencing) using litter samples with different ages and structural alterations in litter composition using spectroscopy and factor analysis. Was observed a distinct HFA for decomposition litter from acacia and eucalyptus, with acacia decomposing in home stand faster than under eucalyptus stand and in contrast, litter from eucalyptus decomposed faster under acacia stands. Additionally, litter of each material showed a very distinct fungal and change very little in function of time, besides the local of incubation did not influence the microbial community. Higher diversity and lower dominance of fungi were observed in litter from acacia and mixed plantations during the decomposition period (180d), independently of the local that they decompose. Eucalyptus litter during the decomposition under acacia stand be more proteinaceous than the initial residue. Migration of $\mathrm{N}$ to eucalyptus litter is speculated. In contrast, the acacia litter did not change in terms of chemical composition during the incubation. Our results demonstrate the importance of biological $\mathrm{N}$ fixed to the eucalyptus litter decomposition.

\section{E8b: HYDROLOGICAL AND BIOLOGICAL RESPONSES OF AQUATIC ECOSYSTEMS TO} CONTEMPORARY FOREST PRACTICES AROUND THE WORLD

\section{Saturation excess overland flow generation in a catchment covered by forest plantation of Pinus spp.}

Carla Riovane Chiles ${ }^{1}$, Mariane Bueno de Camargo ${ }^{2}$, Fábio Vale Scarpare ${ }^{3}$, Quirijn de Jong van Lier ${ }^{3}$, Silvio Frosini de Barros Ferraz ${ }^{1}$

${ }^{1}$ Escola Superior de Agricultura "Luiz de Queiroz", Universidade de São Paulo, Piracicaba, Brazil; ${ }^{2}$ Klabin, Telêmaco Borba, Brazil; ${ }^{3}$ Universidade de São Paulo, Centro de Energia Nuclearna Agricultura,Piracicaba, Brazil (carla.chiles@usp.br; maricamargo@klabin.com.br; fabioscarpare@hotmail.com; qdjvlier@usp.br; silvio.ferraz@usp.br)

Native forest plays important role in regulation and provision of water, however, land-use change can affect the original hydrological functions, such as the overland flow mechanism. The saturation excess overland flow occurs at Variable Source Area (VSA), which have high probability of saturation during a storm event, varying over time according to lateral flow and water table. Thereby, since VSA has different hydrological characteristics than other areas along hillslope gradient, its mapping is essential to guide management practices and to preserve its ecosystem functions.The objective of this study was to use a method to delineation the VSA in a catchment covered by forest plantation of Pinus spp. The VSA delimitation was done using a modified wetness index calculated from a high-resolution Digital Elevation Model $(1 \mathrm{~m})$ and the validation was made by data collected of soil water potential in a transect along topographic gradient. The soil with topographic index (>7) remained saturated more than $30 \%$ of the time in the two catchments, contributing with overland flow generation. The VSA occur in $18,5 \%$ of the catchment area, which $86 \%$ of the VSA are in areas covered by forest plantation of Pinus spp., $12,7 \%$ are in areas with native forest, and $1,3 \%$ are in roads. The VSA mapping identified sensitive areas that are not restricted to areas with native forest, so this demonstrate the importance of identification and mapping to be used in the forest management and roads, reducing risks of soil loss, stream contaminations and modify streamflow regulation. 
Infiltration capacity of dense woods, a key to hydraulic sustainability in watersheds / Capacidad de infiltración bajo bosques, una clave para la sostenibilidad hidrica de cuencas

Carlos Francisco Garcia Olmos ${ }^{1}$, Diana Constanza Garcia Rincón ${ }^{2}$

${ }^{1}$ Universidad Distrital Francisco José de Caldas, Bogota D.C., Colombia; ${ }^{2}$ Universidad de Sao Paulo, Sao Paulo, Brazil (cfgarciao@gmail.com; dianinat4@gmail.com)

Se estudió la capacidad de infiltración bajo bosques maduros de Cupressus lusitanica, Eucalytus globulus y bosque natural en la cuenca del río San Cristóbal al sureste de Bogotá. Se hizo la caracterización de los bosques y se escogieron al azar tres áreas circulares de nueve metros de diámetro y con centro en cada una de ellas se realizaron mediciones de capacidad de infiltración según diseño de ensayos. Con las curvas de la capacidad de infiltración obtenidas se obtuvieron las curvas características de la capacidad de infiltración según los modelos de Horton, Philip, Kostiakow y Kostiakow modificado. Las curvas más representativas fueron las de Horton. Se pudo establecer que el bosque de Cupresssus lusitanica presenta las curvas características con los mayores valores de la capacidad de infiltración, y luego el de Eucalytus globulus, ambos por sus sistemas radiculares más robustos y profundos. Estos resultados fueron validados estadísticamente, y se estableció que las diferencias halladas son significativas. Este estudio permite conocer las bondades de estos bosques maduros en la recarga de las aguas subterráneas, y son una guía sobre los criterios a establecer en la selección de especies arbóreas que fomenten la capacidad de regulación y la sostenibilidad hídrica de las cuencas.

Comparative analysis of international legislation on buffer zones, with an emphasis on Latin America / Análisis comparado de la legislación internacional de zonas buffer con énfasis en América Latina

Samuel Francke ${ }^{I}$, Celso Carnieletto ${ }^{1}$

${ }^{1}$ Corporación Nacional Forestal Conaf, Santiago, Chile (samuel.francke@conaf.cl; celso.carnieletto@conaf.cl)

Las zonas amortiguación vegetacionales (buffer) resultan fundamentales para la protección contra la erosión, la sedimentación, contaminación y eutroficación de los cauces y cuerpos de agua en función de factores edáficos, vegetacionales, hidrológicos, topográficos, climáticos y paisajísticos. Se presentan diversos esquemas de protección vegetacional para cursos hídricos según legislación: Sistemas Buffer, EE.UU. Forest Service, Se establecen recomendaciones técnicas que varían desde $16,5 \mathrm{~m}$ a $50 \mathrm{~m}$ y se incrementa $1,5 \mathrm{~m}$ en función de cada $1 \%$ de pendiente, para anchos medios que varían de 25 m a 50 m ; Matas Ciliares Brasil (1965); En el Código Forestal de Brasil establece fajas de protección vegetacional de cursos hídricos que aumentan con el ancho y que varían de 30m a 500m de cada margen de ríos, lagos, embalses, represas o nacientes, respecto del espejo de agua. Fajas Hidroreguladoras, Cuba (1988); En la legislación forestal de Cuba, se establece el concepto de "Fajas Hidroreguladoras" para la protección de ríos y embalses. En relación al orden de los ríos varían de 10m. a 20m. ; Legislación comparada en Chile en relación a fajas de protección vegetacional cursos hídricos y cuerpos de agua Ley de Bosques 1931,ey de Bosque Nativo 2007, Protocolo de plantaciones forestales. Se establecen anchos mínimos como zonas de protección en función de la pendiente. Se incluyen medidas de protección en humedales, manantiales, cuerpos de agua y microcuencas abastecedoras de agua potable. El presente trabajo analiza y compara la normativa legal para mejorar y garantizar los servicios eco sistémicos a nivel de cuencas hidrográficas.

\section{Effects of Eucalyptus forest plantation on stream water quality: what we know in Brazil?}

Lara Gabrielle Garcia ${ }^{1}$, Carolina Bozetti Rodrigues ${ }^{1}$, Arthur Vrechi ${ }^{1}$, Silvio Frosini de Barros Ferraz ${ }^{2}$

${ }^{1}$ Forestry Science and Research Institute, Piracicaba,Brazil; ${ }^{2}$ Luiz de Queiroz College of Agriculture, Piracicaba, Brazil (lara@ipef.br; cabreuva@gmail.com; arthur@geplant.com.br; silvio.frosini@usp.br)

Forest plantations in Brazil are reaching about 7.8 million of hectares, more than 5 million are occupied by Eucalyptus, which is characterized as a fast-growing forest (6 to 8 years rotation). These characteristics require forest intensive management operations (e.g. clearcutting and application of fertilizers) that could affect water quality. The aim of this study was to assess stream water quality from Eucalyptus forest plantation in relation to the concentration of nitrate $\left(\mathrm{NO}_{3}\right)$ and total suspended solids (TSS). The catchments are monitored by Program of experimental catchments monitoring and modeling (PROMAB) in different regions of Brazil. PROMAB was created with the objective of understanding forest management effects on hydrological resources and it is based on continuous monitoring of discharge and water quality at the catchment scale. We analyzed a data set of water sample collected at nine catchments mainly covered by Eucalyptus forest (namely Eucalyptus total - ET). Furthermore, we assessed differences in $\mathrm{NO}_{3}$ and TSS concentrations among catchments. The median concentration of NO3 $(n=2878)$ was $0.6 \mathrm{mg} \mathrm{L}^{-1}$ and the median concentration of TSS $(n=3011)$ was $6.0 \mathrm{mg} \mathrm{L}^{-1}$ in the ET data set. Our results showed that the most part of the nine catchments present differences in both parameters analyzed, thus the same land cover results in distinct water quality. Therefore, others catchments features (e.g. soil type, etc.) have impacted on $\mathrm{NO}_{3}$ and TSS concentration and could influence water quality at catchment scale. We discuss the contribution of local physical variables and management on observed differences on water quality.

\section{Effect of deforestation of different genesis on seasonal changes in water chemistry in the Carpathians: a Beskid Śląski and Western Tatra case study}

Amanda Kosmowska1, Mirosław Żelazny ${ }^{1}$, Stanisław Małek ${ }^{2}$, Tomasz Stańczyk ${ }^{3}$, Mateusz Żelazny ${ }^{4}$

${ }^{1}$ Department of Hydrology, Institute of Geography and Spatial Management, Jagiellonian University in Kraków, Gronostajowa 7, 30-387 Krakow, Poland, Krakow, Poland; ${ }^{2}$ Department of Forest Ecology and Reclamation, Institute of Ecology and Silviculture, Forest Faculty, University of Agriculture in Kraków, al; 29-go Listopada 46, 31-425 Krakow, Poland, Krakow, Poland; ${ }^{3}$ Department of Environmental Improvement, Faculty of Civil and Environmental Engineering, Warsaw University of Life Sciences - SGGW, Nowoursynowska 166, 02-787 Warsaw, Poland, Warsaw, Poland; ${ }^{4}$ Faculty of Mining Surveying and Environmental EngineeringAGH UST, Mickiewicza 30,30-059 Krakow, Poland, Krakow, Poland (amanda.kosmowska@doctoral.uj.edu.pl; miroslaw.zelazny@uj.edu.pl; rlmalek@urk.edu.pl; tomasz_stanczyk@sggw.pl; miroslaw.zelazny@gmail.com)

The purpose of the study was to determine the effects of deforestation caused by a set of different factors on water chemistry. The study occurred in catchments of the Skrzyczne Massif in the Beskid Śląski Range (anthropogenic impact) and in the Kościeliska Valley in Tatras (windfall, bark beetle degradation). Changes in chemistry water were assessed using 180 water samples collected in the field on a monthly basis in 15 catchments deforested to a varying degree. Ion chromatograph was used to determine the presence of ions: $\mathrm{Ca}^{2+}, \mathrm{Mg}^{2+}, \mathrm{Na}^{+}, \mathrm{K}+, \mathrm{NH}_{4}^{+}, \mathrm{Li}^{+}, \mathrm{HCO}_{3}^{-}, \mathrm{SO}_{4}^{2-}, \mathrm{Cl}^{-}, \mathrm{NO}^{-}, \mathrm{NO}_{3}^{-}$, $\mathrm{PO}_{4}^{3-}, \mathrm{Br}^{-}, \mathrm{F}^{-}$. The research showed the variable effect of different types of deforestation on water chemistry. Hillslope deforestation caused changes in water chemistry, especially in relationships between anions. An increase of several hundred percent in the $\mathrm{NO}_{3}^{-}$concentration and increase in its share of the total anion content $\left(4,3 \%\right.$ mval $\left.\cdot \mathrm{dm}^{-3}\right)$ were observed in the Tatras in catchments affected by wind-driven deforestation. A significant increase in the $\mathrm{SO}_{4}^{2-}$ content $\left(31,6 \%\right.$ mval $\left.\cdot \mathrm{dm}^{-3}\right)$ was observed along 
with a marked decrease in $\mathrm{HCO}_{3}^{-}\left(5,2 \% \mathrm{mval} \cdot \mathrm{dm}^{-3}\right)$ in total anion content in water in catchments deforested due to air pollution in the Beskid Śląski. Sulfate ions play a dominating role in the water chemistry of deforested catchments. Research has shown the key role of forests covering mountain slopes in the hydrochemistry of a catchment. The spatial context includes an atypical phenomenon known as hydrochemical mosaics, as manifested in the occurrence of different relationships between bicarbonate, sulfate, nitrate.

\section{Do contemporary forest harvesting practices return sediment fluxes to pre-settlement levels in oregon forests?}

Jeff Hatten

'Oregon State University, Corvallis, USA (jeff.hatten@oregonstate.edu)

Forest harvesting practices can expose mineral soils, decrease infiltration capacities of soils, disturb the stream bank and channel, and increase erosion and fine sediment supply to stream channels. To reduce nonpoint source sediment pollution associated with forest management activities and to maintain the high water quality typically provided from forests, contemporary harvesting practices employed forestry regulations and best management practices (BMPs), which were developed and implemented in the 1970s in the Oregon Coast Range. We examined the impact that these improved management practices had in 2 studies 1) a 10-year long study in the Alsea Paired Watershed Study and 2) a 1500-year long sediment core from an Oregon Coast Range Lake. In both cases, we found that contemporary harvesting practices were associated with lower sediment concentrations/fluxes and sedimentation rates, respectively. While we found that annual sedimentation rates appear to have returned to pre-settlement levels, sedimentation rates during rare, large events with low frequency still appear to be elevated. We will discuss recent research that attempts to pin the source of this elevated event associated sedimentation to hill-slope processes (e.g. harvesting) or in-channel processes (e.g. ditches and channel alterations) and the implications for forest management.

\section{Changes in water quality and primary producers after forest harvest in the Trask Watershed, Oregon, USA}

Alba Argerich', Sherri L. Johnson' ${ }^{2}$ Linda Ashkenas ${ }^{3}$

${ }^{1}$ University of Missouri, Columbia, MO, USA; ${ }^{2}$ US Forest Service Pacific Northwest Research StationS Forest Service, Corvallis, OR, USA; ${ }^{3}$ Oregon State University,Corvallis,OR,USA (argericha@missouri.edu; sherrijohnson@fs.fed.us; linda.ashkenas@oregonstate.edu)

Forest harvest and its associated land changes have the potential to increase nutrient delivery to streams, alter water temperature, and affect the physiology and distribution of benthic algae. Although the impacts of forest harvest to streams have been significantly reduced because of Best Management Practices (BMPs), there is still concern about their potential effects on water quality and the aquatic organisms. Here we present results from the Trask Watershed Study, a multidisciplinary research project located in the Coastal Range of Oregon, designed to evaluate the effectiveness of BMPs in protecting aquatic ecosystems during forest management in headwater basins. We have examined algae and water quality parameters during eight years (four before and four after forest harvest) in eleven headwater basins subjected to different treatments (existence of a riparian buffer/ no buffer/ no harvest). Water chemical composition changed after harvest, with a 6 to 40 -fold increase in nitrate concentration in relation to pre-harvest levels. However, the increased availability in nitrogen did not reflect on the amount of algal biomass, which remained relatively constant throughout the study.

\section{E8c: NEXUS: FOREST, WATER AND CLIMATE}

\section{The forest-water nexus: an international perspective}

Elaine Springgay ${ }^{\prime}$

${ }^{1}$ FAO, Rome, Italy (elaine.springgay@fao.org)

Water security is one of the greatest challenges we face to ensure a sustainable future. Trees and forests are imperative for quality water supply. Integrating natural solutions in land-water management, including the strategic management of forests and landscapes with water considerations, will be crucial for a resilient water supply in the future. The MEA (2005) estimates that 75 percent of available freshwater resources comes from forested watersheds. Despite the importance of forests for water, only 25 percent of forests globally are managed with water considerations (FAO, 2015). An international perspective on forests and water will be presented, taking a closer look at the status of forest management for water, and the extent to which the forest-water nexus is considered in climate change based on a review of the (Intended) National Determined Contributions ((I)NDCs). The objective is to identify and discuss the gaps and opportunities where the forest-water-climate nexus can be addressed globally, regionally and nationally; in particular, where science and practice could support and shape the political agenda.

\section{On the concept of hydrologic space}

David Ellison ${ }^{1}$

${ }^{I} S L U$, Umea, Sweden (ellisondl@gmail.com)

Forests provide many important water-related, ecosystem services including water purification and flood mitigation. We illustrate that the forest role in precipitation recycling and the regulation of the hydrologic cycle must also be clearly recognized as an ecosystem service. Deforestation leads to more local runoff and reduced precipitation. However, the importance of reforestation in supporting the flow of atmospheric moisture and promoting precipitation recycling is underappreciated. Since the evapotranspiration from forests falls again as precipitation, the terrestrial, forest-based production of atmospheric moisture has important consequences, both for local and downwind precipitation and water availability. We emphasize the importance of atmospheric inter-basin connectivity. This spatial interconnectedness is rarely reflected in the study of land-atmosphere interactions and their contribution to the hydrologic regime. Focusing on the supply-side characteristics of rainfall, we define and formalize the concept of hydrologic space and apply the concept to the derivation of the catchment basin water balance. Conventional approaches to the c-basin water balance typically fail to consider the import and export of atmospheric moisture as a principal determinant of locally and regionally available water supply. Land use modification has important implications for the production of atmospheric moisture and downwind precipitation, as well as for the re-export of local moisture and the availability of runoff: the total amount of water available for productive and consumptive purposes. These consequences are not adequately reflected in most policy efforts at multiple levels and scales of governance. 


\section{A spatial pattern of water and carbon tradeoff among China's natural forests and planted forests}

Shirong Liu ${ }^{1}$, Zhen Yü, Jingxin Wang ${ }^{3}$

${ }^{1}$ Institute of Forest Ecology, Environment and Protection, Chinese Academy of Forestry, Beijing, China; ${ }^{2}$ Department of Ecology, Evolution, and Organismal Biology, Iowa State University, Ames, USA; ㄱivision of Forestry and Natural Resources, West Virginia University, Morgantown, USA (liusr@caf.ac.cn; zyu@iastate.edu; jingxin.wang@mail.wvu.edu)

The area of planted forests in China has been expanding rapidly and ranked first of the world. However, the benefits of large-scale afforestation in carbon sequestration in relation to water consumption is unclear. We know little about carbon sequestration and water consumption among natural forests and planted forests across different climate zones. How does climate change affect this spatial pattern? We compare carbon sequestration and water consumption in plantation forest (PF) and natural forest (NF) across China using combination of remote sensing and field inventory. We foundNF consumed $6.8 \%$ (37.5 mm per growing season) less water but sequestered $1.1 \%$ (12.5 $\mathrm{g} \mathrm{C} \mathrm{m}^{-2}$ growing season-1) more carbon than PF in the period of 2000-2012. While there was no significant difference in water consumption in energy-limited areas (dryness index $[\mathrm{DI}]<1$ ), water consumption was significantly $(\mathrm{p}<0.001)$ higher in PF than that in NF in water-limited regions (DI > 1). Moreover, a distinct and larger shift of water yield was identified in PF than in NF from the 1980s to the 2000s, indicating that PF were more sensitive to climate change, leading to a higher water consumption when compared with NF. Our results suggest NF should be properly valued in terms of maximizing the benefits of carbon sequestration and water yield. Future forest plantation projects should be planned with caution, particularly in water-limited regions where they might have less positive effect on carbon sequestration but lead to significant water yield reduction.

\section{Ecological restoration and conservation of soil and water towards water resources, forestry and climate change policies in Brazil}

Marcos Airton De Sousa Freitas ${ }^{1}$, Sandra Regina Afonso ${ }^{2}$

${ }^{1}$ National Water Agency, Brasilia, Brazil; ${ }^{2}$ Serviço Florestal Brasileiro, Brasília, Brazil (masfreitas@ana.gov.br; sandra.afonso@florestal.gov.br)

The article deals with the discussion of ecological restoration and conservation of soil and water in relation to the integration and implementation of three important Public Policies in Brazil: National Policy of Water Resources, National Policy on Climate Change and Forest Policies. National Water Resources Policy, created by Law 9.433/1997, has been implemented through its instruments: grants, charges, watershed plans. National Policy on Climate Change (Law 12.187/2009) has tools, such as the National Plan and the National Fund on Climate Change. The main policy that regulates Brazilian forests is the Forest Code (Law 12.651 /2012), which presents several instruments, such as: Environmental Rural Registry (ERR), Environmental Regularization Program (ERP) and Environmental Reserve Quota (ERQ) and Program of Support and Incentive to the Preservation and Recovery of the Environment. This last program presents as a line of action the payment or incentive to environmental services as monetary retribution to the activities of conservation and improvement of ecosystems. This scope includes the Water Producer Program, implemented by the National Water Agency and partners. In analyzing the implementation of the various instruments and programs established in these three policies, there is a need for greater integration between them in order to ensure the participation of society in decision-making processes. In addition, these policies need to ensure ecological restoration and soil and water conservation, as well as mitigate the adverse effects of climate change.

\section{Forest and water relations in a changing environment, increased human activities and complex watershed conditions}

Zhiqiang Zhang

${ }^{1}$ Beijing Forestry University, Beijing, China (zhqzhang@bjfu.edu.cn)

Understanding forest water relations is becoming a more challenging issue under the changing environment, increased human activities and complex watershed conditions. Here we present an evolving framework shifted from traditional forest water studies to the current forest eco-hydrological studies and beyond. Our recent studies from tree and stand water use to watershed stream-flow responses to land use/ human activities and climate variability will be presented to illustrate the critical needs for understanding forest water relations in the future. In doing this, a couple of methods were used including sap-flow measurement and eddy covariance system at ecosystem scale while elasticity differential analysis and physically-based MIKESHE model at watershed scale. We concluded that to identify forest water relations in future will heavily dependent on the novel and robust methodological innovations to excluding many factors influencing eco-hydrological processes at multiple spatial and temporal scales.

\section{Forest disturbance thresholds on hydrology: concept, quantification and variation}

Xiaohua (Adam) Wei

${ }^{1}$ University of British Columbia, Kelowna, Canada (adam.wei@ubc.ca)

Forest disturbance including both human and natural disturbance can significantly affect various ecological processes. However, forest disturbance is often cumulative over space and time, particularly for any large landscapes or watersheds. Forest disturbance thresholds are commonly defined as levels of disturbance at or above which ecological processes are significantly altered. Thus, determination of forest disturbance thresholds can be useful and important to guide forest planning and management. In terms of hydrological changes caused by forest disturbance, 20-30\% disturbance thresholds in a given watershed are commonly used. However, those are unlikely accurate as they do not address variability in climate and watershed property, which are also key drivers for hydrological responses. In addition, they are likely varied with choice of hydrological variables. This presentation will describe the concepts of forest disturbance thresholds, and provide in-depth discussion on quantification methods using some examples, and highlight possible uncertainties or variations.

\section{Forests for water security in a changing climate}

Juliana Baladelli Ribeiro ${ }^{1}$,Fabio Scarano ${ }^{2}$, Aliny Pires ${ }^{3}$, Rafael Barbieri ${ }^{4}$

${ }^{1}$ Boticario Group Foundation, Curitiba, Brazil; ${ }^{2}$ Intergovernmental Science-Policy Platform on Biodiversity and Ecosystem Services (IPBES), Rio de Janeiro, Brazil; ${ }^{3}$ Intergovernmental Science-Policy Platform on Biodiversity and Ecosystem Services, Rio de Janeiro, Brazil; ${ }^{4}$ The World Resources Institute, São Paulo,Brazil(ribeiroj@grupoboticario.com.br;fscarano@gmail.com; alinypfpires@gmail.com; rafael.barbieri@wri.org)

The Boticario Group Foundation, the World Resources Institute (WRI), the Brazilian Foundation for Sustainable Development (FBDS) and the Intergovernmental Science-Policy Platform on Biodiversity and Ecosystem Services (IPBES) have been working on assessments to understand the best strategies for improving Return on Investment in natural areas (for both restoration and protection) and compliance with environmental laws, such as the Native Vegetation Protection Act (NVPL). Natural infrastructure investment opportunities have been evaluated to reduce sediment management costs and ensuring water flows, considering 
climate change. Cases conducted in 4 Brazilian Metropolitan Regions (Cantareira-Sao Paulo, Guandu-Rio de Janeiro, Jucu-Vitoria and São Bento do Sul, Santa Catarina), showed that forest restoration could boost sedimentation avoidance, provide cleaner water, and reduce turbidity levels. Regional benefits such as avoided costs of flood damages and global benefits (carbon sequestration) were also evaluated. Law enforcement also has the potential to improve several water-related ecosystem services provided by forests, but such effect can depend on the land use and climate context. The NVPL aims for the Atlantic Forest the restoration of 10 million ha of riparian vegetation, which will contribute to the achievement of the Brazilian NDC. In Cerrado, the restoration of riparian areas near reservoirs returns the investment in less than 5 years. These results show that it is worth it to invest in natural infrastructure and to consider restoration and nature conservation as part of the solution.

\section{Forest cover, windspeed and precipitation recycling}

Emory Ellis ${ }^{1}$, Robin Sears ${ }^{2}$, David Ellison ${ }^{3}$

${ }^{1}$ Hampshire College,Amherst, USA; ${ }^{2}$ Harvard Forest, Petersham, USA; ${ }^{3}$ SLU, Umea, Sweden (ece16@hampshire.edu; robin.sears@aya.yale.edu; ellisondl@gmail.com)

Within the broader scope of forest-water interactions, there is a clear gap in our comprehension of how forest cover potentially alters and sustains regional precipitation cycles across continental scales. We analyze high resolution data on forest cover, annual average wind speed and total annual precipitation amounts in order to better understand how forest cover and forest density impact windspeed, and how the forest impact on windspeed can influence the transport and potential re-deposition of atmospheric moisture as downwind rainfall. Our global analysis of these interactions indicates that forests slow wind speeds, providing more opportunity for the accumulation and aggregation of incoming atmospheric moisture and local evapotranspiration, thereby contributing to its potential re-deposition as rainfall. Our findings suggest that greater forest cover intensifies the hydrologic cycle by providing more opportunities for atmospheric moisture and evapotranspiration to condense, precipitate, re-evaporate and re-transpire back to the atmosphere, thereby optimizing terrestrial rainfall and water availability across continental surfaces. With an improved understanding of how forest, wind, and water interact, the scientific community will be able to develop a more rigorous approach to hydrological preservation through forest landscape restoration.

\section{Projecting the climate change and its impact on the hydrology of a watershed in Northern China}

Wenxu Cao', Zhiqiang Zhang ${ }^{1}$

${ }^{1}$ Beijing Forestry University, Beijing, China (caocaowenxv@163.com; zhqzhang@bjfu.edu.cn)

Climate change, especially global warming and uneven precipitation distribution, is expected to intensify the earth's hydrological cycle and increase flood/ drought risks. This study aims to project the impact of climate change under different scenarios on streamflow. The Regional Hydro-Ecological Simulation System (RHESSys) and Statistical Downscaling Method were coupled to investigate future streamflow variation and extreme events over the 21st century in the Chaohe watershed, northern China, based on climate change scenarios generated by three GCMs. The results indicated that future temperature over the Chaohe watershed will continually increase: annual maximum temperature Tmax and minimum temperature Tmin are forecast to increase by 1.51 to $2.39{ }^{\circ} \mathrm{C}$ and 0.44 to $1.21^{\circ} \mathrm{C}$ under RCP2.6, 1.91 to $3.64{ }^{\circ} \mathrm{C}$ and 0.62 to $2.14^{\circ} \mathrm{C}$ under RCP4.5, 2.19 to $7.12{ }^{\circ} \mathrm{C}$ and 1.15 to $3.87{ }^{\circ} \mathrm{C}$ under RCP8.5, respectively. Increasing trends in annual precipitation were projected by different GCMs under different RCP scenarios with different rates and fluctuations. Consistent with future precipitation, streamflow is forecast to increase in general in the 21st century. It was worth noting that streamflow predicted by CanESM2 and CNRM-CM5 showed an increase in monthly dispersion coefficient in July and August, indicating that future streamflow could be expected to be highly unstable in those months. Moreover, most GCMs indicated that high-streamflow (95th percentile) would increase over the 21st century with the potential for intensifying flood hazard. Similarly, influenced by increased precipitation, low-streamflow (5th percentile) will increase in the future, suggesting that drought risk will alleviate in the $21^{\text {st }}$ century.

\section{Effects of climate change on water yield and water quality of forested watersheds in Southeastern Brazil}

Matheus Ogasawara ${ }^{1}$, Marina Otto ${ }^{1}$, Eduardo Mattos $^{2}$, Humberto Rocha $^{3}$, Ricardo Figueiredo ${ }^{3}$, Silvio Ferraz ${ }^{1}$

${ }^{1}$ Universidade de São Paulo, Piracicaba, Brasil; ${ }^{2}$ Geplant Tecnologia Florestal, Piracicaba, Brasil; ${ }^{3}$ Embrapa Meio Ambiente, Jaguariúna, Brasil

(matheus.ogasawara@usp.br;msgentil@usp.br;eduardo@geplant.com.br;humberto.rocha@iag.usp.br;ricardo.figueiredo@embrapa.br;silvio.ferraz@usp.br)

Climate change effects on water resources are one of the most concerns of public authorities, and such impacts can be predicted through hydrological simulation, considering climate change scenarios and models calibrated using a historical climatic data from a given region. We considered that watersheds have different responsiveness to climate change due to their physical characteristics. Therefore, effects of these changes will cause different levels of impact on water flow and quality, depending on the region in which the basin is located. The objective of this study is use the hydrological model of Fu adapted, calibrated and validated for a series of climatic data from 29 watersheds in the Southeastern region of Brazil. Model was used to simulate and predict the climate change effects and identify critical factors for the stability of water yield and water quality in watershed. At studied watersheds, forest cover varied from $5 \%$ to $80 \%$, mean annual precipitation ranged from 1200 to $1800 \mathrm{~mm}$ and the annual runoff represented $20 \%$ to $50 \%$ of the annual precipitation across all sites. The model proposed was able to capture the differences among watersheds, enabling simulations under climate change scenarios. Simulations showed high variation on sensitiveness to climate change. Regional mapping of sensitiveness was created, critical areas for stability of water yield and water quality were identified in the watersheds. Results provide subsidies to guide the planning of public policies and propose ways of managing and conserving forest on watersheds.

Planted forests: an alternative for natural maintenance of flying rivers and ecological corridors, mitigation of climate change, and prevention of natural disasters related to extreme rainfall / Florestas plantadas: uma alternativa para a manutençâo natural dos rios voadores e corredores ecológicos e mitigação das mudanças climáticas e medida de prevenção de desastres naturais relacionados às precipitações extremas

Vania Santos ${ }^{1}$

${ }^{1}$ Viveiro Florestal de Taubaté, Instituto Florestal, Secretaria do Meio Ambiente, Taubaté, Brasil (vas.vania1@gmail.com)

Nos últimos anos o Brasil sofre com desastres naturais relacionados às precipitações extremas, ao mesmo tempo em que vivencia uma crise hídrica generalizada. Longas secas no campo acarretam perdas econômicas, contribuem para a migração rural-urbana e colocam em risco a segurança alimentar. Eventos climatológicos, hidrológicos, geofísicos e meteorológicos como estiagem e chuvas de granizo; alagamentos e enchentes; movimentação de massa e deslizamentos; tornados e vendavais decorrentes das mudanças climáticas acarretam perda de vidas, proliferação de doenças e danos econômicos. A diminuição da cobertura florestal 
impacta diretamente no clima e na sobrevivência de espécies que ficam isoladas em pequenas áreas, como acontece na mata Atlântica, correndo o risco de extinção. A Floresta amazônica, por exemplo, além de manter a umidade do ar para si mesma também exporta rios aéreos de vapor, conhecidos como rios voadores que possibilitam as chuvas fartas por todo o hemisfério, sua diminuição dá causa as estiagens vivenciadas no sudeste brasileiro. A floresta é recicladora de umidade e o desmatamento impede que o fluxo de umidade transcurse do norte ao sul do país, acarretando escassez hídrica. A recomposição florestal possibilita reverter o uso do solo de extensas áreas ocupadas e por meio da transpiração, restabelecer dentro de 10 a 15 anos as funções exercidas pelas matas e os rios voadores. Como medida preventiva de desastres naturais vinculados a precipitações extremas, a pesquisa propõe reflorestar terras desmatadas ao longo do curso dos "rios voadores" e a criação de um novo modal de Unidades de Conservação específico de Florestas Plantadas.

\section{Converting native deciduous hardwoods to evergreen conifers reduces water yield in the Southeastern United States}

Ge Sun ${ }^{1}$, Johnny Boggs ${ }^{1}$, Steven McNulty ${ }^{1}$

${ }^{1}$ Southern Research Station, USDA Forest Service, Research Triangle Park,USA (gesunmail@gmail.com; jboggs@fs.fed.us; smcnulty@fs.fed.us)

The compositions of forests in the southeastern United States are changing as result of changes in forest management objectives, climate patterns, fire regimes, and urbanization. Consequently, there are concerns about how these biophysical changes in forests may impact watershed hydrology and water availability through altered evapotranspiration processes in forests. The paper reports a long-term paired watershed study that aims at understanding the hydrological effects of converting naturally-generated hardwoods to pines. The study used two paired mixed-pine hardwood watersheds located in two distinct geological regions (i.e., Carolina Slate Belt, (CSB) and Triassic Basin, (TB)) that have different soil characteristics. In 2010, loblolly pines (Pinus taeda) were planted in the CSB watershed and shortleaf pine (Pinus echinata) were planted in the TB. Water yield increased by 263\% in the CSB and 248\% in the TB one year after the clearcut. Yield decreased in subsequent years following a rapid regrowth of planted pines and vegetation. By 2017, the TB watershed annual water yield was $5.5 \%$ less than what yield would have been if the hardwood trees were not cut (i.e., $171 \mathrm{~mm}$ vs $181 \mathrm{~mm}$ ). Flow from the CSB watershed was lower than precut levels by the end of 2018. This study links basal area changes and water yield and soil conditions to expand our ability to effectively sustain forest and water resources using innovative silvicultural practices. Results are being integrated to modeling tools to predict hydrological changes in vegetation on water supply in the southeastern U.S. and beyond.

\section{E8d: PLANT: SOIL INTERACTIONS IN FORESTS}

Factors affecting rhizospheric soil carbon stability in nitrogen-fixing plants and non-nitrogen-fixing plants in rainforests of southern China

Huai Yang ${ }^{1}$, Shirong Liu ${ }^{2}$

${ }^{1}$ International Center for Bamboo and Rattan, Beijing, China; ${ }^{2}$ chinese Academy of Forestry, Beijing, China (yanghuai@icbr.ac.cn; liusr@caf.ac.cn)

In this study, we examined the influence factors of the rhizosphere soil $\mathrm{C}$ stability such as selected functional traits of leaf, root and soil nutrient characteristics for both N-fixing and non-N-fixing plants in southern China. The results show that: (1) N-fixing plants have significantly lower specific leaf areas, and higher leaf carbon, leaf nitrogen, and leaf phosphorus content relative to non-N-fixing plants; (2) N-fixing plants have significantly lower rhizosphere soil nitrogen, soil phosphorus, and higher light fraction carbon and heavy fraction carbon relative to non-N-fixing plants; (3) The diameters of $\mathrm{N}$-fixing plants are relatively large and the specific root length (SRL) values of these roots are low relative to non-N-fixing plants; (4) The influence patterns of regulating rhizosphere soils C stability was contrary between $\mathrm{N}$-fixing and non-N-fixing plants; (5) The spatial distribution of rhizosphere soil C stability demonstrated different environmental influence factors among different $\mathrm{N}$-fixing types and different orders roots.

Tree species effects on stocks and vertical distribution of soil carbon: links to mycorrhizal association, soil fauna and soil microbial characteristics

Lars Vesterdal ${ }^{1}$, Yan Peng ${ }^{1}$, Christina Steffens ${ }^{2}$, Haifeng Zheng ${ }^{1}$, Petr Hedenec ${ }^{1}$, Luciana Bachega ${ }^{1,3}$, Bingru Wang ${ }^{1}$, Inger K. Schmidt ${ }^{1}$, Cindy E. Prescott ${ }^{1}$ University of Copenhagen, Frederiksberg C, Denmark; ${ }^{2}$ University of Hamburg, Hamburg, Germany; ${ }^{3}$ Federal University of São Carlos, São Paulo, Brazil; ${ }^{4}$ University of British Columbia, Vancouver,Canada (lv@ign.ku.dk; yape@ign.ku.dk; christina.steffens@uni-hamburg.de; hazh@ign.ku.dk; peh@ign.ku.dk; bachegalr@gmail.com; biw@ign.ku.dk; iks@ign.ku.dk; cindy.prescott@ubc.ca)

Tree species with leaf litter traits driving slow rates of leaf litter decomposition have traditionally been associated with accumulation of higher SOC stocks than tree species with fast litter decomposition rates. This hypothesis has mainly been based on observations of thick C-rich forest floors under tree species associated with ectomycorrhizae (ECM). However, a recent hypothesis suggested that tree species with foliar litter traits conducive to fast decomposition will lead to more pronounced microbial transformation and stabilization of litter C. The latter tree species are often associated with arbuscular mycorrhizae (AM) and may enhance deeper incorporation of C by more active soil fauna communities and by higher belowground rates of litter input. The Danish common garden tree species experiments include ECM and AM tree species that differ widely in traits such as foliar litter chemistry. Six common European tree species formed distinct groups that largely reflected their mycorrhizal association. Forest floor $\mathrm{C}$ stocks were consistent with the traditional perception of slowly decomposing ECM species being conducive to high SOC stocks, but an intriguing pattern of more $\mathrm{C}$ in the mineral soil in AM tree species supported the recent microbial stabilization hypothesis and suggested deeper incorporation of $\mathrm{C}$ in more stable forms. Based on new results on microbial, macro- and mesofauna communities, fine root dynamics and repeated soil sampling, this talk will revisit Danish common garden tree species experiments for a synthesis of processes and patterns in organic matter formation that may explain observed patterns in SOC stocks and vertical SOC distribution.

\section{Regulation mechanism of vegetation on slope runoff, sediment yield and soil water infiltration}

Xiao Li $^{1}$, Zhiqiang Zhang ${ }^{1}$

${ }^{1}$ College of Soil and Water Conservation, Beijing Forestry University, Beijing, China (lxsdau@yeah.net; zhqzhang@bjfu.edu.cn)

Vegetation is the main component of ecosystem and plays an important role in controlling soil erosion. The relationships between precipitation, vegetation and erosion are important yet unresolved issues in the field of earth surface processes. Through indoor simulated rainfall experiments, we analyzed the characteristics, regulation of, and correlation among the slope rainfall-infiltration-runoff, erosion and sediment under different vegetation conditions, and the process mechanism of soil and water loss on slopes was revealed from the viewpoint of hydrodynamics and physical mechanics. The results showed that vegetation had a strong role in regulating runoff and sediment, and its spatial structure (canopy, root, etc.) can effectively reduce runoff and flow velocity and 
increase infiltration, then achieved water storage and sediment reduction. Vegetation reduced the velocity of slope flow by increasing the slope roughness, affected the hydraulic parameters of slope shallow open channel flows, and effectively increased slope resistance coefficient and soil anti-scourability. At the same time, vegetation had a significant role in enhancing soil shear strength. Under different conditions, soil cohesion had a significant negative correlation with runoff and sediment yield. The change characteristics of soil cohesion and internal friction angle were affected by both cover conditions and water content of vegetation slope. Based on this, vegetation had a good role in soil and water conservation. The research results would help us to quantitatively evaluate the effects of water storage and erosion reduction of vegetation and deepen the understanding of soil erosion mechanics process.

\section{Do Norway spruce, Douglas fir and European larch stands differ in litter decomposition and belowground carbon storage?}

Lisa Bischofer ${ }^{1}$, Torsten W. Berger ${ }^{1}$, Douglas L. Godbold ${ }^{1}$, Mathias Mayer ${ }^{1}$

'University of Life Sciences and Natural Resources, Institute of Forest Ecology,Vienna, Austria (bischofer.l@gmail.com; torsten.berger@boku.ac.at; douglas.godbold@boku.ac.at; mathias.mayer@boku.ac.at)

An increase in droughts and insect infestations threatens Norway spruce (Picea abies) stands across European forests. With a higher drought tolerance, Douglas fir (Pseudotsuga menziesii) and European larch (Larix decidua) became a suitable non-native and a native silvicultural alternative to Norway spruce. How tree species selection affects litter decomposition and belowground carbon (C) storage is, however, still not fully understood. Here, we want to 1) answer if Norway spruce, Douglas fir and European larch differ with regard to litter mass loss partitioning into leaching of dissolved organic $\mathrm{C}(\mathrm{DOC})$ and $\mathrm{CO}_{2}$ efflux during decomposition, 2) to link mass loss partitioning to litter biochemical properties and 3) to relate mass loss partitioning to belowground C stocks. It is hypothesized that tree species with a higher partitioning into leaching of DOC have higher belowground C stocks. The study took place in Austria and measurements were conducted over the course of one year. Litter $\mathrm{CO}_{2}$ efflux and leaching of dissolved organic $\mathrm{C}$ was measured in situ by means of respiration chambers and lysimeters. Litter bags were used to study mass loss and biochemical litter processes/properties. The results of this study will help to improve our understanding of tree species effects on the forest belowground $\mathrm{C}$ cycle. In order to lower the uncertainties of $\mathrm{C}$ sequestration estimates for the forestry sector, this information is very important. Furthermore, new insights into the complex process of litter break down will be provided. First results of the study will be presented at the conference.

Use of arbuscular mycorrhizal fungi (AMF) in ecological restoration projects for the Atlantic Forest /Uso de fungos micorrizicos arbusculares (FMA) em projetos de restauração ecológica da Mata Atlântica

Girlei Cunha ${ }^{1,2}$, Susane Rasera ${ }^{3,2}$, Frederico Miranda ${ }^{1,2}$, Eduardo Gusson $^{1,2}$, Flávio Mendes $^{3}$, Alexandre Astorino $^{4}$

${ }^{1}$ Biodendro Consultoria Florestal, Piracicaba, Brazil; ${ }^{2}$ Instituto de Pesquisas e Estudos Florestais, Piracicaba, Brazil; ${ }^{3}$ Escola Superior de Agricultura

"Luiz de Queiroz", Universidade de São Paulo, Piracicaba, Brazil; ‘ AES TIETÊ, Bauru, Brazil (girlei.cunha@gmail.com; susanerasera@yahoo.com;

fredtsmiranda@gmail.com; eduardogusson@gmail.com; fgandara@usp.br; alexandre.astorino@aes.com)

A maioria das plantas superiores associa-se a fungos micorrízicos arbusculares (FMA). A simbiose promove efeitos positivos para a nutrição e sobrevivência das plantas. A pesquisa está inserida no P\&D da ANEEL realizado pela AES-Tietê e IPEF. O experimento de campo está na Estação Experimental de Genética de Anhumas, ESALQ/USP, em Piracicaba, SP. As espécies avaliadas foram: Mabea fistulifera, Lafoensia pacari, Psidium myrtoides, Esenbeckia leiocarpa, Gallesia integrifolia e Maclura tinctoria. Os FMA foram: Glomus intraradices e G. etunicatum. Delineamento experimental de blocos ao acaso, com cinco tratamentos: 1) Mudas não inoculadas em viveiro (MNIV), recebendo fertilizantes na quantidade recomendada por análise de solo (FR); 2) Mudas inoculadas em viveiro (MIV) e FR; 3) MIV, com fertilização recomendada para N e K e redução de P para 1/3 do indicado (P1/3); 4) MNIV e FR, com adição de FMA na cova (MIC); 5) MIV, P1/3 e MIC. Aos 24 meses foi realizado inventário com medição das plantas. E. leiocarpa apresentou alta mortalidade em todas as situações; $M$. fistulifera apresentou maior sobrevivência nos tratamentos com FMA; L. pacari, P myrtoides, G. integrifolia e M. tinctoria apresentaram alta sobrevivência em todos os tratamentos. A redução de P em plantas com FMA não afetou o crescimento, exceto $G$. integrifolia que apresentou altura significativamente superior quando inoculado com FMA no viveiro ou no campo e recebendo fertilização da quantidade recomendada. O efeito da adição de FMA variou conforme a espécie mas, de uma maneira geral, pode ser considerado vantajoso na restauração ecológica da Mata Atlântica.

\section{Plant responses to belowground variations along elevational gradients in temperate and tropical climates}

Monique Weemstra ${ }^{1,2}$, Alexia Stokes ${ }^{1}$, Leonore Jimenez ${ }^{3}$, Nereyda Cruz ${ }^{4}$, Fabien Anthelme ${ }^{5}$, Luis Merino-Martin ${ }^{2,1}$, Manon Bounous ${ }^{1}$, Beatriz Marin-Castro ${ }^{6}$, Hervé Rey ${ }^{7}$, Awaz Mohamed ${ }^{8}$, Zhun Mao ${ }^{1}$, Stephane Fourtier ${ }^{1}$, Marco Morales-Martinez ${ }^{9}$, Grégoire Freschet ${ }^{2}$, Katrin Sieron ${ }^{9}$, Guillermo Angeles ${ }^{3}$, Catherine Roumet ${ }^{2}$

${ }^{1} I N R A$, Montpellier, France; ${ }^{2}$ CNRS, Montpellier, France; ${ }^{3} I N E C O L$, Xalapa, Mexico; ${ }^{4}$ University of Montpellier, Montpellier, France; ${ }^{5}$ IRD, Montpellier, France; ${ }^{6}$ UNAM, Mexico City, Mexico; ${ }^{7}$ CIRAD, Montpellier, France; ${ }^{8}$ University of Angers, Angers, France; ${ }^{9}$ University of Veracruz, Xalapa, Mexico(monique.weemstra@cefe.cnrs.fr; alexia.stokes@cirad.fr; leonorjimenez2004@gmail.com; nerecruz@gmail.com; fabien.anthelme@ird.fr; luismerinomartin@gmail.com; manon.bounous@supagro.fr; beatriz.marin@gmail.com; herve.rey@cirad.fr; awazmsm@yahoo.com; maozhun04@gmail. com; stephane.fourtier@cirad.fr; marcomm1@gmail.com; gregoire.freschet@cefe.cnrs.fr; ksieron@gmail.com; angelesguillermo@gmail.com; catherine. roumet@cefe.cnrs.fr)

Soil is a hyper-heterogeneous environment, and how plants respond to changes in belowground variations in soil properties and microclimate is poorly understood. Environmental gradients are useful for examining how root traits mediate plant responses to soil heterogeneity. We measured soil/air temperature, soil water potential and physical/chemical properties in 30 plots along elevational gradients located in France and Mexico, both above- and below the treeline. High elevations were colder than lower elevations at both sites, but in Mexico, precipitation decreased at high elevations, whereas in France, higher elevations were wetter than lower altitudes. Soil properties were more idiosyncratic along both gradients. We selected 11 (France) and 14 (Mexico) woody and herbaceous species based on their abundance along the gradients. A range of root and leaf functional traits were measured. Data showed that trends in root traits along gradients were often masked by the hyper-heterogeneous belowground environment, whereas patterns in leaf traits were more evident. Results will be discussed with regard to the effect of elevation as an environmental filter on plant traits. 
Epiedaphic springtails (Collembola) in commercial forests and savanna regions of the Colombian Orinoco region / Colémbolos epiedáficos en forestaciones comerciales y sabanas en la orinoquia Colombiana

Adriana Ramos Diaz², José G. Palacios Vargas², Olga Patricia Pinzón Florián ${ }^{3}$

${ }^{1}$ Universidad Distrital Francisco José de Caldas, Bogotá, Colombia; ${ }^{2}$ Departamento de Ecología y Recursos Naturales, Facultad de Ciencias, Universidad Nacional Autónoma de México, 04510, México D.F., Mexico, ${ }^{3}$ Laboratorio de Sanidad Forestal, Universidad Distrital Francisco José de Caldas., Bogotá,

Colombia(adriramdi@gmail.com; troglolaphysa@hotmail.com; opatriciap@udistrital.edu.co)

Los colémbolos desempeñan un rol ecológico clave en la descomposición de la materia orgánica y ciclaje de nutrientes y son considerados indicadores del cambio de uso del suelo. Con el fin de estimar cambios en la diversidad de colémbolos luego del establecimiento de plantaciones de Acacia mangium en sabanas, se muestrearon plantaciones de tres edades y áreas de sabana en el municipio de Puerto Gaitán (Meta, Colombia) durante un periodo húmedo y seco. Para estimar y comparar la diversidad efectiva de colémbolos epiedáficos (diversidad $q 0, q 1, q 2$ ), se realizó un muestreo utilizando trampas de caída. Con el objeto de explicar el ensamblaje de los colémbolos, se midieron variables fisicoquímicas del suelo y estructurales de las plantaciones que se correlacionaron con la diversidad mediante un análisis de redundancia (RDA). Las plantaciones favorecieron la diversidad y abundancia de los colémbolos epiedáficos en los primeros 5 años desde el establecimiento de la plantación. La época seca tuvo un efecto más limitante en la abundancia y diversidad de colémbolos en los suelos de sabana, que el mismo establecimiento de las plantaciones. La temperatura y contenido de humedad del suelo, desarrollo de la plantación (altura), contenido de arcilla, carbono orgánico y compactación están relacionados con la abundancia y/o riqueza de colémbolos en las áreas estudiadas. Se concluye que estados tempranos de la forestación de sabanas con A. mangium favorecen la diversidad de colémbolos pero se requieren más estudios para entender los efectos en el suelo, a largo plazo de este tipo de actividad.

\section{Mycorrhizal association in Plathymenia reticulata and Dalbergia nigra plantations in Southeast of Brazil}

David Pessanha Siqueira ${ }^{1}$, Andréia Francisca Riter Netto ${ }^{1}$, Juliana Müller Freire ${ }^{2}$, Deborah Guerra Barroso ${ }^{1}$

${ }^{1}$ Universidade Estadual do Norte Fluminense Darcy Ribeiro, Campos dos Goytacazes, Brazil; ${ }^{2 E m b r a p r a A g r o b i o l o g i a, ~ S e r o p e ́ d i c a, ~ B r a z i l ~(d p s @ p q . u e n f . b r ; ~}$ afrancis@uenf.br; juliana.muller@embrapa.br;deborah@uenf.br)

The brazilian forestry species plantations are alternatives to reduce the deforestation as well to degraded areas recovery. In this context, the association with arbuscular mycorrhizal fungi can enhance the host plant growth, improving nutrients absorption. Our work aimed to verify mycorrhizal colonization in $P$. reticulata and $D$. nigra homogeneous plantations, five years after planting. Soil sampling were collected nearby the trees and fine roots were selected. To determine the mycorrhizal colonization, the fine roots were washed and clared in $10 \% \mathrm{KOH}$ at $85^{\circ} \mathrm{C}$ for 10 minutes and after in $\mathrm{H}_{2} \mathrm{O}_{2}$ for 1 hour. $\mathrm{Next}$, the roots were placed in $5 \% \mathrm{HCl}$ for 5 minutes and then in $0.05 \%$ trypan blue for 15 minutes at $90^{\circ} \mathrm{C}$. After coloring, root segments were distributed on slides, under a coverslip and carried out to a microscope to observe fungi structures. Spore counting were assessed by wet sieving and centrifugation and sucrose flotation techniques. The spore quantification was performed on acrylic plates with concentric rings under a microscope (50x). Both in $P$. reticulata or D. nigra roots we found fungal structures (vesicles and hyphae) that confirm the mycorrhyzal colonization. In $50 \mathrm{~cm}^{3}$ of soil under younger stands we found 4,913 and 8,123 spores in P. reticulata and D. nigra plantations, respectively. Have been identified Glomus macrocarpum and Ambispora leptoticha, in soil under $P$. reticulata and G. macrocarpum; G. agregatum, and Claroideoglomus etunicatum in soil under D. nigra, suggesting that there are different fungi colonizing the roots in both studied species.

E8f: CURRENT UNDERSTANDING AND FUTURE CHALLENGES FOR FOREST RESEARCH AFTER THE TWO NUCLEAR ACCIDENTS OF CHERNOBYLAND FUKUSHIMA - I

\section{Radioactivity in forests: research, importance and risk}

Brenda J Howard ${ }^{1}$

'University of Nottingham, Nottingham, United Kingdom (bjho@ceh.ac.uk)

Widespread contamination of forests by radionuclides occurred due to the atmospheric releases from two major nuclear accidents, at Chernobyl in the Ukraine in 1986 and Fukushima Daiichi in Japan in 2011. In both countries, large areas of forests were contaminated by long-lived radionuclides, notably isotopes of radiocaesium, strontium and plutonium. The impact of contamination was diverse and lasted for many years after deposition of fallout occurred. In both the USSR and Japan, the utilisation of the forest for forestry, extensive animal production, harvesting of wild plants and mushrooms and hunting of wild animals was severely curtailed. Extensive research studies were conducted on the dynamic behaviour of radionuclides in different types of forest, the effects of exposure to radiation on biota, the transfer of radionuclides to edible products and the vertical and lateral movement of radionuclides. The outcome of these studies has been recently summarised in the International Atomic Energy Agency's MODARIA II programme and will be briefly summarised. The importance of such studies for our understanding of the ecological behaviour of contaminants in forests and the diversity encountered between different types of forests, landscapes and climate will be outlined. The consequent impact in terms of both external and internal routes of exposure to radiation for both humans and wildlife, and the impact of remediation activities on communities, will also be considered. Lessons learned from the research response needs to be made readily available to other countries to ensure appropriate responses to future similar events.

\section{Introduction to radiation session of forests - current understanding and future challenges for forest research after the two nuclear accidents of Chernobyl and Fukushima}

\section{Satoru Miura ${ }^{1}$ D}

${ }^{1}$ Forestry and Forest Products Research Institute, Tsukuba, Japan (miura@ffpri.affrc.go.jp)

Technical session about radioactive contamination of forests was first held in IUFRO World Conference 2014. Now, in 2019, 33 years from Chernobyl accident and 8 years from Fukushima Daiichi accident, this session aims to review current knowledge of the environmental behavior of radioactive substances in various forest areas after the both accidents. Exchange idea between experiences in Chernobyl and in Fukushima must be meanigful for deepening understanding radiation contamination. It consists of a short keynote and seven overview/synthesis papers (E8f) combined with technical oral (E8h) and poster (E8fp) presentations. The scope covers the distribution of radioactive contamination in components of forest ecosystems, the changes with time that have occurred and may occur in the future, the technological or management-based remediation options that were applied and developed and the long-term social consequences 
for the affected communities. Challenging studies of the biogeochemical behavior of both radio- and stable- cesium in forest vegetation are also addressed. And, through this session, I would like to lay the foundation for a gradual international network of radiation protection and radiation ecology over forests. Countries with nuclear power plants and countries adjacent to them could be learned from experiences in Chernobyl and Fukushima and should be prepared for the worst possible accidents. Forests are ecosystems located on land and very close to human society and strongly utilized. However, we should be aware that once a severe accident occurs at a nuclear power plant, radioactive contamination of the forest will last for a very long time.

\section{Iodine and uranium isotopes in forest soils around Chernobyl, 30 years after deposition}

George Shaw ${ }^{1}$, Liz Bailey ${ }^{1}$, Neil Crout ${ }^{1}$, Maria Izquierdo ${ }^{2}$, Scott Young ${ }^{1}$

${ }^{1}$ University of Nottingham, Nottingham, United Kingdom; 'Institute of Environmental Assessment and Water Research, Barcelona, Spain (george.shaw@, nottingham.ac.uk; liz.bailey@nottingham.ac.uk;neil.crout@nottingham.ac.uk; maria.izquierdo@idaea.csic.es; scott.young@nottingham.ac.uk)

At the time of the Chernobyl accident in 1986, 40-50\% of the area surrounding the power plant was covered by forest. Since then, forests have expanded and encroached on highly contaminated land which has now been abandoned for over 30 years. The forest soils within the 30 km Chernobyl Exclusion Zone (CEZ) contain a complex mixture of radionuclides, some of which are so long-lived that the area will probably never be rehabilitated for public access. The CEZ now provides a unique natural laboratory for the long-term measurement of radionuclides such as I-129, U-238 and U-235, which have been relatively poorly studied compared to the shorter-lived radionuclides Cs-137 and Sr-90. Of particular interest is the rate and degree to which I-129 and uranium isotopes equilibrate with the natural biogeochemical cycles within the forest soils. Measurements of soil samples taken from the CEZ almost 30 years after the Chernobyl accident show that neither I-129 nor the two uranium isotopes, U-238 and U-235, have reached equilibrium with native I-127 or naturally-occurring uranium isotopes, respectively. This is important information when considering the long-term impacts of severe nuclear accidents and radioactive waste disposal on forest ecosystems. In both cases, safety assessments must account for the fate of radionuclides including I-129 and uranium isotopes, for which a reliable understanding of their biogeochemical fate is needed, based as much as possible on 'real world' measurements.

\section{Radiological situation in forests of Ukraine on late phase of the Chernobyl disaster}

Dmytrii Holiaka ${ }^{1}$, Valerii Kashparov ${ }^{1}$, Svjatoslav Levchuk ${ }^{1}$, Sergiy Zibtsev ${ }^{2}$

${ }^{1}$ Ukrainian Institute of Agriculture Radiology, National University of Life and Environmental Sciences of Ukraine, Kyiv, Ukraine; ${ }^{2}$ National University of Life and Environmental Sciences of Ukraine, Institute of Forestry and Landscape-Park Management, Kyiv,Ukraine (george.shaw@nottingham.ac.uk; liz.bailey@, nottingham.ac.uk;neil.crout@nottingham.ac.uk; maria.izquierdo@idaea.csic.es; scott.young@nottingham.ac.uk)

Chernobyl accident (1986) led to contamination with 137Cs of more than 1 million hectares of forests in Ukraine (density $>40 \mathrm{kBq} \times \mathrm{m}^{-2}$ ). During first two decades, milk and meat were major source for internal doses of population. Currently, more than half of cases of excess of permissible levels (PL) (137Cs) derived from forest products - wild mushrooms, berries, meat. Activity concentration of 137Cs in dried mushrooms outside the Chernobyl Exclusion Zone (ChEZ) can be two-three orders of magnitude (up to $3 \mathrm{MBq} \cdot \mathrm{kg}-1)$ higher than PL $\left(2.5 \mathrm{kBq} \cdot \mathrm{kg}^{-1}\right)$. ChEZ and its vicinity contaminated with $90 \mathrm{Sr}$ with a density of more than $5.5 \mathrm{kBq} \cdot \mathrm{m}-2$, where $90 \mathrm{Sr}$ activity concentration in fuelwood may exceed PL $\left(60 \mathrm{~Bq} \cdot \mathrm{kg}^{-1}\right)$. The radiological threat of wildfires in ChEZ for firefighters and population has been evaluated. Distribution, depots and fluxes of $90 \mathrm{Sr}$ and $137 \mathrm{Cs}$ in forest ecosystems were studied. Currently, up to $10 \%$ of $137 \mathrm{Cs}$ located in biomass of pine forests and up to $40 \%$ in litter. Due to high mobility of 90Sr in sandy soils, its content in 20-cm root layer of pine forests has decreased up to $20 \%$ of total amount in ecosystem because of intensive root uptake ( $>50 \%$ ) and vertical migration in soil ( $>20 \%)$ so TF of $90 \mathrm{Sr}$ increased of more than order of magnitude over the last 20-30 years. Radionuclides have lower bioavailability in deciduous forests compared to coniferous. The data on the non-uniform distribution of 90Sr and 137Cs in wood of pine and birch trees for typical forest stands presented.

\section{Forests in Fukushima: radiocesium dynamics and their ecological and social impacts}

Shoji Hashimoto ${ }^{1,2}$, Masabumi Komatsu $^{1}$, Shinta Ohashi ${ }^{1}$, Naohiro Imamura ${ }^{1}$, Toshiya Matsuura ${ }^{1}$, Satoru Miura ${ }^{1}$ ${ }^{1}$ Forestry and Forest Products Research Institute, Tsukuba, Japan; ${ }^{2}$ The University of Tokyo, Tokyo, Japan (shojih@ffpri.affrc.go.jp; kopine@ffpri.affrc.go.jp; shinta0084@ffpri.affrc.go.jp; nimamura@ffpri.affrc.go.jp; matsuu50@ffpri.affrc.go.jp; miura@ffpri.affrc.go.jp)

The majority of the land contaminated by the Fukushima Daiichi Nuclear Power Plant accident is forested (approx; 70 \%). Since the accident, many scientists have been devoted to researching the resulting contamination and tracking radionuclides in Fukushima forest ecosystems. Studies of the Chernobyl accident revealed that trees efficiently captured radioactive deposition and the deposited radionuclides migrated within forests; similar dynamics have been observed in Fukushima forests. Furthermore, after the Chernobyl accident, radioactive contamination damaged the economy, communities, and livelihoods of local people. The Japanese government has taken several measures to mitigate damage from the contamination; however, effective countermeasures for forest ecosystems are limited, and the forests remain contaminated. Some parts of contaminated forests have been established as exclusion zones, but people still worry about the contaminated forests and their products. In this presentation, we compiled research on Fukushima forests and report 1) the uncovered and predicted dynamics of radiocesium, the major radionuclide, in contaminated Japanese forests, 2) how radioactive contamination has affected the livelihoods of local people, and 3 ) what countermeasures have been taken in Fukushima.

\section{Decline and future recovery of wild plant/mushroom gathering in rural communities in Fukushima}

Toshiya Matsuura ${ }^{1}$, Ken Sugimura ${ }^{2}$

${ }^{1}$ Forestry and Forest Products Research Institute, Tsukuba, Japan; ${ }^{2}$ Nagasaki University, Nagasaki, Japan (matsuu50@affrc.go.jp; k-sugimura@nagasaki-u.ac.jp)

Radioactive contamination due to the Fukushima Dai-ichi Nuclear Power Plant accident had deteriorated provisioning and cultural ecosystem services in eastern Japan. Wild plant/mushroom gathering is one of such services for rural residents as their food culture and outdoor recreation. In this study, we elucidated a drastic decline in the gathering frequency after the accident using household questionnaire surveys in rural communities in Fukushima. We then delineated former potential gathering areas of common edible wild plants/mushrooms with specific environmental conditions, e.g., vegetation, topography, and proximity to roads, using multicriteria evaluation and geographic information system. We also estimated external radiation dose using different scenarios of frequency, species, and areas of gathering, under the physical decay trend of radiocesium. By overlaying maps of potential gathering areas and external radiation dose, we estimated the future recovery of gathering under different scenarios. We found that it was difficult to recover the former gathering sites due to high external radiation dose, particularly in highly contaminated areas. However, we also saw some possibility of recovery by reducing the gathering frequency or by 
gathering only within areas with less contamination since radiocesium deposition is spatially heterogeneous even in a community or a municipality. Selection of gathering species is also useful for further reduction of internal radiation dose because radiocesium absorption differs widely among species.

\section{How knowledge on $\mathrm{K}$ and ${ }^{133} \mathrm{Cs}$ biocycling can be used to estimate ${ }^{137} \mathrm{Cs}$ root uptake in Japanese cedar stands contaminated by the Fukushima fallouts}

Pierre Hurtevent ${ }^{1}$, Frederic Coppin ${ }^{1}$, Marc-André Gonze ${ }^{1}$, Philippe Calmon ${ }^{1}$, Kenji Nanba $^{2}$, Yuichi Onda ${ }^{3}$, Yves Thiry ${ }^{4}$

${ }^{1} I R S N$, Saint-Paul-Lez-Durance, France; ${ }^{2} I E R / F u k u s h i m a$ University, Fukushima, Japan; ${ }^{3}$ CRIED/University of Tsukuba, Tsukuba, Japan; ${ }^{4}$ ANDRA,

Chatenay-Malabry,France (pierre.hurtevent@irsn.fr; frederic.coppin@irsn.fr; marc-andre.gonze@irsn.fr; philippe.calmon@irsn.fr;

nanba@sss.fukushima-u.ac.jp; onda@geoenv.tsukuba.ac.jp; yves.thiry@andra.fr)

The radiocesium (rCs) deposited onto forests of the Fukushima region was incorporated into the biogeochemical cycle of elements leading to its persistence within these ecosystems. To date, rCs partitioning has not reached an apparent steady state and its root uptake flux must still be accurately determined for long-term predictions of rCs behavior. Using its stable analogs ( $\mathrm{K}$ and ${ }^{133} \mathrm{Cs}$ ) is a relevant approach to quantify this flux. Data were obtained from monitored even-aged Japanese cedar stands sampled in November 2013, 2014 and 2016. A mass balance approach was used for the determination of rCs, K and ${ }^{133} \mathrm{Cs}$ annual recycling fluxes. Part of the results obtained in this study was used for parameterizing a dynamic rCs transfer model (cf. Gonze et al, IUFRO 2019). As expected, $\mathrm{K}$ and ${ }^{133} \mathrm{Cs}$ concentrations remained constant over the 4-year period in all tree compartments. By contrast, rCs concentrations slowly decreased in all tree compartments over the same period. The measured $[133 \mathrm{Cs}] /[\mathrm{K}]$ ratios significantly varied between the biomass compartments, the discrimination between those elements being especially pronounced between living and corresponding senescing organs (e.g. outer and inner bark). It was also demonstrated that the root uptake fluxes of $\mathrm{K}$ and ${ }^{133} \mathrm{Cs}$ were higher than internal translocation fluxes in both stands. We estimated the root uptake of ${ }^{133} \mathrm{Cs}$ by applying the observed discrimination factors to each $\mathrm{K}$ apparent flux. This approach allows the use of $\mathrm{K}$ instead of ${ }^{133} \mathrm{Cs}$ measurements that are poorly available for the calculation of rCs root uptake. Its efficiency will be discussed.

\section{Process-based modelling of the short and long-term dynamics of radiocesium in Fukushima coniferous forests}

Marc-André Gonze ${ }^{I}$, Philippe Calmon ${ }^{1}$, Pierre Hurtevent ${ }^{1}$, Frédéric Coppin ${ }^{1}$, Valérie Nicoulaud ${ }^{1}$

IIRSN, Saint-Paullez Durance,France (marc-andre.gonze@irsn.fr; philippe.calmon@irsn.fr; pierre.hurtevent@irsn.fr; frederic.coppin@irsn.fr; valérie.nicoulaud@irsn.fr)

Since Fukushima accident, numerous surveys have been conducted by Japanese researchers in a variety of forest stands contaminated by atmospheric radiocesium (rCs) fallouts. The thousands of observations acquired offer a genuine opportunity to improve models for predicting rCs transfers in the soil-vegetation system, eventhough there are still relatively few studies on this subject (Hashimoto et al; 2013, Calmon et al; 2015, Nishina and Hayashi 2015, Ota et al; 2016, Nishina et al; 2018). To benefit from this new knowledge, significant improvements have been made to a simple model developed after Chernobyl (in RODOS project). Major efforts were invested in: the refinement of the conceptual approach, the quantification of the hydrological/eco-physiological functioning of the forest stand and the parameterization of tree transfer processes based on K/biomass cycling. This process-based dynamic model (TREE4) was tested against a comprehensive set of time observations over 2011-2017 in Japanese cedar \& cypress stands. This dataset was established by extending the meta-analysis by Gonze et al (2017) to field studies conducted throughout Japan after 2013. While most of the model parameters could be estimated from the literature, including their ranges of variability, a few of them could not be otherwise than by calibrating outputs (with a Bayesian technique). We then conducted SA/UA to evaluate the predictive accuracy of the model over this 7-year period, quantify the respective contributions of root/foliar pathways and evaluate sensitivity of the outputs to forest specificities and atmospheric deposition conditions. Further, prognostic simulations until 2041 will be discussed.

\section{E8g: PLANT: SOIL INTERACTIONS IN FORESTS - II}

\section{Forest conversion to conifers induces a regime shift in acidic soils that affects soil carbon stability}

Ellen Desie ${ }^{1}$, Karen Vancampenhout ${ }^{2}$, Kathleen Heyens ${ }^{2}$, Jakub Hlava $^{3}$, Kris Verheyen ${ }^{4}$, Bart Muys ${ }^{1}$

${ }^{1}$ KU Leuven, Leuven, Belgium; ${ }^{2} \mathrm{KU}$ Leuven Campus Geel, Geel, Belgium; ${ }^{3}$ Czech University of Life Sciences, Prague, Czech Republic; ${ }^{4}$ Ghent University, Ghent,Belgium(ellen.desie@kuleuven.be; karen.vancampenhout@kuleuven.be; kathleen.heyens@kuleuven.be; hlava@af.czu.cz; kris.verheyen@ugent.be; bart.muys@kuleuven.be)

A substantial part of forests worldwide is located on acidic soils. In such soils, processes are typically characterized by non-linear responses to external drivers. Acid buffer ranges and thresholds in soils are widely acknowledged, yet these non-linearities are rarely incorporated into our understanding of soil carbon dynamics. We studied the effect of conversion of broadleaved mixed forest to Norway spruce monocultures on different functional compartments of the belowground carbon cycle, i.e. litter layers, soil fauna and soil micro-organisms. We have examined how they affect soil biochemical characteristics and ultimately, soil carbon stability. By studying these effects along a soil buffering gradient we were able to evaluate the relative significance of forest management and edaphic constraints on soil carbon processing. Our findings show that effects of conversion are more dramatic for forests that shifted from one buffering domain to another upon conversion. This indicates that changes in forest composition can, depending on the initial acid buffering capacity, cascade through different compartments of the soil carbon cycle and eventually alter the way carbon is stored. Although increased carbon concentrations were observed in stands converted to conifers, this carbon is stored in less protected pools. In these pools, carbon is not occluded in aggregates or bound to soil minerals and thus more vulnerable to disturbance. As the vast majority of the worlds' forest soils are acidic, considering non-linearities in the belowground ecosystem is crucial to optimize carbon sequestration and climate smart forest management.

\section{Soil and tree regeneration relationships in an old growth urban forest, Philadelphia, Pennsylvania Robert Loeb ${ }^{1}$ (D) \\ 'Pennsylvania State University, DuBois, Pennsylvania, USA (rxl5@psu.edu)}

One focus of urban foresters is to increase the urban forest by planting trees in the streets and parks of cities. A valuable alternative to plantings in urban parks is enabling natural tree regeneration to become reestablished which is particularly important for the long-term survival of natural old growth urban forests. A key limiting factor for tree regeneration is depauperate forest soils in urban parks. Understanding which nutrients are needed to reestablish natural regeneration of 
existing canopy trees is key to ensuring the long-term survival of old growth urban forests. Haddington Woods in Cobbs Creek Park, Philadelphia, Pennsylvania, USA contains a 2.2 ha natural old growth urban forest. The canopy dominants Carya glabra, Liriodendron tulipifera, Prunus serotina, Quercus alba, and Quercus rubra are the typical canopy species found in natural old growth urban forests in the eastern United States. The atypical aspect is that parts of the forest contain extensive populations of seedlings and saplings of the canopy dominants, which is in sharp contrast to the dearth of natural regeneration in other natural old growth urban forests in the eastern United States. The natural regeneration occurs despite the presence of white-tailed deer which over browse other urban forests and open public access permitting trampling that kills seedlings. This presentation will provide the statistical analysis of relationships between forest regeneration and measures of soil fertility including $\mathrm{pH}$, phosphate, potash, magnesium, calcium, exchangeable cation capacity, organic matter, soluble salts, nitrogen, and aluminum stress to examine the limiting factors for natural tree regeneration.

\section{Comparison of soil fertility in artificial and natural stands of Persian oak (Quercus brantii)}

Mehrdad Zarafshar ${ }^{1,2}$, Mohammad Matinizadeh', Yahya Kooch ${ }^{3}$, Kokab Enayati $^{1}$, Alireza Abbasi ${ }^{1}$, Mohammad Reza Negahdarsaber ${ }^{1}$, Mohammad Javad Rousta ${ }^{1}$, Sayed Kazem Bordbar ${ }^{1}$

${ }^{1}$ Fars Agricultural and Natural Resources Research and Education Center, AREEO, Shiraz, Islamic Republic of Iran; ${ }^{2}$ Research institute of forests and rangelands, Iran, Tehran, Islamic Republic of Iran; ${ }^{3}$ Tarbiat Modare University, Tehran, Islamic Republic of Iran (mehrdadzarafshar@gmail.com; yahya.kooch@yahoo.com; enayatik@yahoo.com; a.abasi@areeo.ac.ir; sabersiamak@gmail.com; m.roosta@areeo.ac.ir; sbordbar86@gmail.com)

In Zagros forest, Persian oak is an important species that grows along southern parts of forests. This current research was aimed to study the effect of Persian oak plantation on the soil chemical and biological parameters to compare the obtained results with a natural stand of the species. We tested the hypothesis that afforestation with Persian oak can improve soil fertility in the long-term when compare with natural forests of the species. For this purpose, three afforested oak plots $(11 \times 11 \mathrm{~m})$ with 50 years old, beside a natural forest, were selected and soil samples were taken from two depths $(0-10$ and 10-20 cm) and their physicochemical, biological, and enzymatic properties were assessed. The obtained data demonstrated that artificial stands could considerably improve of the soil fertility. The higher values of soil moisture, organic carbon and magnesium and potassium concentrations were observed at natural stand while higher concentration of phosphorous was belong to the planted stand. $\mathrm{pH}, \mathrm{EC}, \mathrm{N}, \mathrm{C} / \mathrm{N}, \mathrm{Na}, \mathrm{Fe}, \mathrm{Mg}+\mathrm{Ca}, \mathrm{Zn}$ and $\mathrm{N}$ and $\mathrm{C}$ stock did not show any considerable difference between the stands. activity of Acid and Alkaline phosphates and Dehydrogenase and Urease were slightly higher in planted plots. On the other hand, soil microbial parameters including soil microbial respiration and microbial biomass of $\mathrm{N}$ and $\mathrm{C}$ were at the same level for both the stands. Our finding clearly show that plantation with Persian oak could be considered to rehabilitate degraded natural forests of the species along Zagros region through improving soil quality.

\section{Trees, soil chemistry and microbiota interactions: driving forces and feedback processes in a Mediterranean remediated ecosystem}

Teodoro Marañón ${ }^{1}$, Marta Gil-Martínez ${ }^{1}$,Cristina Aponte ${ }^{2}$, Álvaro López-García ${ }^{3}$,Paula Madejón ${ }^{1}$, Carmen M. Navarro-Fernández ${ }^{1}$, María T. Domínguez ${ }^{4}$ ${ }^{1} I R N A S$, CSIC, Seville, Spain; ${ }^{2}$ University of Melbourne, Melbourne, Australia; ${ }^{3}$ EEZ, CSIC, Granada, Spain; ${ }^{4}$ University of Seville, Seville, Spain (teodoro@irnase.csic.eshttps://orcid.org/0000-0002-7751-9316; marta-gil@irnas.csic.es; caponte@unimelb.edu.au; lopez.garcia.alvaro@gmail.com; pmadejon@irnase.csic.es;nfcarmen@gmail.com; mdominguez23@us.es)

Trees are ecosystem engineers able to generate effects on soil properties and microbiota that could lead to a feedback effect (Aponte et al; 2013). We present here several evidences of interactions between different tree species with soil chemistry and microbiota, in the Guadiamar Green Corridor (SW Spain); 1) We have analysed the potential of seven tree species for phytoremediation of soils contaminated by trace elements. Some of the studied tree species showed a positive effect on soil phytoremediation: increase soil $\mathrm{pH}$ underneath the trees and high phytostabilisation of trace elements in the rhizosphere (Madejón et al; 2018); 2) Tree species identity was a driving factor for the activities of four soil enzymes involved in $\mathrm{C}, \mathrm{N}$ and $\mathrm{P}$ cycles. For example, beta-glucosidase activity tended to be higher in soils under white poplar (Populus alba) trees (Gil-Martínez et al., unpublished); 3) Composition of soil fungal communities, determined by next generation sequencing (NGS) techniques, differed in relation to the tree species (Gil-Martínez et al., unpublished); 4) Ectomycorrhizal fungal communities and their functional traits affected holm oak (Quercus ilex) performance in contrasted soil conditions. For example, As, Mn and Zn translocation from soil to roots was best explained by the composition of mycorrhizal fungal communities rather than by toxic elements concentrations (Gil-Martínez et al; 2018). A synthesis of tree-soil-microbiota interactions in a Mediterranean remediated ecosystem is presented.

Effect of uniformity and fertilizing on wood production in one clone of Pinus taeda in Paraná, Brazil / Efeito da uniformidade e fertilização na produção de madeira de um clone de Pinus taeda no Paraná

Isabel Deliberali ${ }^{1}$, Mauro Valdir Schumacher ${ }^{2}$, Marco Aurélio Figura $^{3}$, James Stahl ${ }^{3}$, Monique Pimentel Lagemann ${ }^{2}$, Rodrigo Toledo Coutinho ${ }^{4}$, Reinaldo Hoinacki da Costa ${ }^{5}$

${ }^{1} I P E F$ - Forestry Science and Research Institute, Piracicaba, Brazil; ${ }^{2}$ Universidade Federal de Santa Maria, Santa Maria, Brazil; ${ }^{3}$ Klabin S.A., Telêmaco

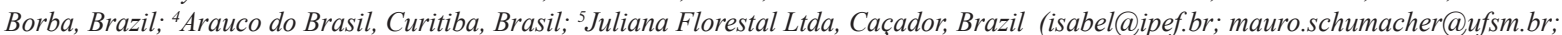

mafigura@klabin.com.br; jstahl@klabin.com.br; moniquelagemann@gmail.com; rcoutinho@arauco.com.br; reinaldo@frameport.com.br)

A uniformidade do povoamento é afetada pelo material genético e pelo manejo silvicultural utilizado, principalmente no estabelecimento do plantio. Estudos mostram que povoamentos com estrutura mais uniforme resultam em maiores produtividades devido ao aumento na captura e eficiência de uso dos recursos. Deste modo, este trabalho busca avaliar o comportamento da uniformidade e da fertilização na produção de madeira de um clone de Pinus taeda em Telêmaco Borba - PR. O delineamento experimental utilizado foi fatorial com 2 níveis de nutrição (com e sem fertilização) e 2 níveis de uniformidade (uniforme e heterogêneo - replantio tardio), com 3 repetições. O estoque de biomassa de tronco aos 11 anos foi significativamente maior no tratamento uniforme (ganho de $8 \%$ ) e no tratamento fertilizado (ganho de $44 \%$ ), não havendo interação entre estes fatores. O índice de área foliar $\left(\mathrm{m}^{2} \mathrm{~m}^{-2}\right.$ ) não apresentou diferenças significativas entre os tratamentos, porém foi $2 \%$ superior nos uniformes e $9 \%$ no fertilizado. As diferenças de produtividade nas parcelas fertilizadas podem ser explicadas em parte por apresentarem o dobro da eficiência de uso da luz $\left(0,41 \mathrm{~g} \mathrm{MJ}^{-1}\right)$ do que as parcelas sem fertilização $\left(0,16 \mathrm{~g} \mathrm{MJ} \mathrm{MJ}^{-1}\right)$, sendo que para o fator uniformidade não houve diferença. Também se deve considerar os padrões de alocação de carbono, fator não avaliado. Portanto, estes resultados mostram que a qualidade das atividades silviculturais realizadas no estabelecimento da floresta são de grande importância para o resultado final da produtividade, pois o fato das árvores serem geneticamente idênticas não garante elevadas taxas de crescimento. 


\section{Climate and fire influence fine root traits of tropical forests across Ghana}

Shalom Addo-Danso ${ }^{1}$, Lucy Amissah ${ }^{1}$, Mark Appiah ${ }^{1}$, Ernest Foli ${ }^{1}$ Daniel Ofori ${ }^{1}$, George Ametsitsi ${ }^{1}$, Reginald Guuroh ${ }^{1}$, Gloria Djagbletey ${ }^{1}$, Stephen Adu-Bredu ${ }^{I}$

${ }^{1}$ CSIR-Forestry Research Institute of Ghana, Kumasi, Ghana (sadanso@csir-forig.org.gh; lamissah@csir-forig.org.gh; mappiah@csir-forig.org.gh; efoli@csir-forig.org.gh; dofori@csir-forig.org.gh; gametsitsi@csir-forig.org.gh; rtguuroh@csir-forig.org.gh; gddjagbletey@csir-forig.org.gh; sabredu@csir-forig.org.gh)

Fine root traits offer insights into root exploitation strategies, and how ecosystems respond to environmental changes. However, our knowledge of fine-root trait distribution, and the driving factors in the tropical forest biome is limited by the lack of data, particularly from Africa. Here, we assessed fine ( $<0.6$ mm in diameter) root architectural (branching intensity and biomass) and morphological (root diameter, specific root length and root tissue density) traits in forest ecosystems ranging from dry through moist to wet evergreen across Ghana. We further correlated root trait estimates with mean annual precipitation (MAP) mean annual temperature (MAT). Overall, specific root length and branching intensity were highest in forests in dry sites compared to those in moist and wet sites. On the other hand, root diameter and root biomass were highest in wet sites, and correlated with MAP and MAT. Specifically, root biomass correlated strongly and positively with MAP, but was negatively correlated with MAT. Root diameter correlated negatively with MAT. Additionally, when the data were separated into fire-prone and non-fire dominated forests, fine-root biomass was significantly lower in the fire-prone forests. Our study suggests that there is diversity of belowground strategies in these tropical forests, depending on climatic conditions and fire disturbances. Hence, future changes in climate, and resultant influence on wildfires could modify root traits, with consequences for resource acquisition and biogeochemical cycling in tropical forests.

Influence of vegetation in hydraulic conductivity in three types of forests in the San Cristóbal River Watershed in Bogotá, Colombia I Influencia de la vegetación en la conductividad hidráulica en tres tipos de bosque en la cuenca del Río San Cristóbal, Bogotá, Colombia

Tatiana Bermejo ${ }^{1}$, Angela Bibiana García ${ }^{1}$, Luis Fernando Soler ${ }^{\prime}$

'Universidad Distrital Francisco José de Caldas, Bogotá, Colombia (ltbermejoc@correo.udistrital.edu.co; abgarciah@correo.udistrital.edu.co; lfsoleru@correo.udistrital.edu.co)

La conductividad hidráulica saturada (Ks) es la propiedad que determina el movimiento del agua en el suelo en condiciones de saturación, su estudio resulta fundamental para entender dinámicas que confluyen en el ciclo hidrológico y la compleja interacción entre suelo-vegetación, por tanto permite evidenciar la incidencia de las alteraciones que han sufrido los ecosistemas, para este caso de carácter estratégico en la regulación hídrica producto de cambio de coberturas vegetales y la ausencia de éstas. El objeto de investigación fue evaluar la incidencia de la cobertura vegetal en la (Ks) en tres bosques: Bosque-natural (BN) dominado por Weinmannia tomentosa L.f., Bosque Hesperocyparis lusitanica (Mill.) Bartel (C) y Bosque Eucalyptus globulus Labill (E), ubicados en la cuenca del Río San Cristóbal (Bogotá-Colombia) a partir de factores como la densidad, cobertura de la vegetación arbórea y de sotobosque además de características físicas del suelo determinadas para el área de estudio. Los valores de (Ks) en cada uno de los bosques evaluados presentó diferencias en las tasas de infiltración: 4,21 a $0,89 \mathrm{~mm} / \mathrm{h} ; 8,06$ a 1,50 mm/h y 1,84 a 0,72 mm/h, respectivamente. En relación, se encontró que no hay diferencias significativas de la vegetación arbórea que incida en la (Ks), sin embargo sí las hay en el sotobosque en cuanto al porcentaje de cobertura y densidad presentando una correlación positiva con la (Ks) en $\mathrm{C}$ y BN, no obsta resaltar las propiedades del suelo evaluadas obteniendo relación entre la (Ks), el grado de compactación y la cantidad de materia orgánica.

\section{Does hydrochar-amended nursery substrate improve growth of pine seedlings? \\ Samieh Eskandari ${ }^{1}$ iD, Ali Mohammadi ${ }^{1}$ iD, Maria Sandberg ${ }^{1}$, Karin Granström ${ }^{1}$ \\ 'Karlstad University, Karlstad,Sweden (samieh.eskandari@kau.se; ali.mohammadi@kau.se; maria.sandberg@kau.se; karin.granstrom@kau.se)}

Sweden is the world's second largest exporter of pulp, paper and wood products. There is about 28 million hectares of forest land in Sweden where pine trees constitute $40 \%$ of the total standing volume. The forest land is annually restocked with container-grown tree seedlings dominantly produced in peat and peatbased growing media. Nutrient-rich growing media alternatives, especially biochar, have become an interest area for researchers as growing global demand for wood will end in further degradation of forest soils in a near future. Biochar and hydrochar have been proposed as novel materials for providing soilless growth media. However, research to date has not yet determined the potential benefits of hydrochar for producing pine seedlings at nurseries. Hydrcohar is characterised by numerous good properties to be used as a soil amendment, however, properties of hydrochar depend on the feedstock and the production procedure. Treatment plant sludge and ash are rich in nutrients and cations such as $\mathrm{K}$, Ca and Mg and therefore can be a great feedstock for hydrochar. This study aimed to investigate whether adding enriched hydrochar (mixed with wood ash) from biosludge, in either forms of powder or pellets, improves the growth of pine seedlings. Therefore, we amended raw peat with $10 \%$ and $20 \%$ hydrochar-ash composites with no added fertilizers, and fertilizers added in $50 \%$ and $100 \%$ of recommended rates for pine seedlings. This study reports for the first time the effects of hydrcohar-ash powder and pellets, when used as a growing media component, on pine seedling growth.

\section{E8h: CURRENT UNDERSTANDING AND FUTURE CHALLENGES FOR FOREST RESEARCH} AFTER THE TWO NUCLEAR ACCIDENTS OF CHERNOB YL AND FUKUSHIMA - II

\section{${ }^{137}$ Cs circulation in plants of forest ecosystems on the territory of the Chernobyl exclusion zone \\ Nataliia Zarubina ${ }^{1}$ \\ Institute for Nuclear Research of NAS of Ukraine, Kiev, Ukraine (nataliia.zarubina@gmail.com)}

Research was carried out on the territory of two sampling areas in Chernobyl exclusion zone. We investigated changes of ${ }^{137} \mathrm{Cs}$ specific activity levels in plants of the forest ecosystems throughout the year. Sampling of one- and two-year-old needles and branches, and wood of Pinus sylvestris L. (the main forest-forming species) was carry out from 25 model trees with a frequency of one time per two weeks during 2013-2015. The content of ${ }^{137}$ Cs in the researched organs of $P$. sylvestris was defined by method of gamma spectrometry. The specific activity levels of $137 \mathrm{Cs}$ change in the needles, branches and wood during the year. The maximum of ${ }^{137} \mathrm{Cs}$ content in the needles and branches is noted in summer. The opposite effect is observed in wood - the maximum concentration of ${ }^{137} \mathrm{Cs}$ is fixed in the middle of winter. The presence of a correlation $(0.67137 \mathrm{Cs}$ specific activity in one-year needles, one-year branches and two-year branches indicates the similarity of the processes of radiocaesium intake and elimination in this organs of $P$. sylvestris. The correlation between the content of ${ }^{137}$ Cs in wood and other organs is practically absent $(\mathrm{r}<|0.24|)$. This evidences about distinction of the redistribution mechanisms of ${ }^{137} \mathrm{Cs}$ in organs of $P$. sylvestris with different 
physiological activities. Periodic changes in the content of ${ }^{137} \mathrm{Cs}$ in investigated organs of $P$. sylvestris evidence that the radionuclide fallen after the accident in forest ecosystems is in a constant circulation; ${ }^{137} \mathrm{Cs}$ intakes to the plants and it eliminates from plants during a year.

\section{Tracing radiocesium in stem wood after the FDNPP accident}

\section{Shinta Ohashi ${ }^{1}$,Katsushi Kuroda ${ }^{1}$,Takeshi Fujiwara ${ }^{2}$, Tsutomu Takano}

${ }^{1}$ Forestry and Forest Products Research Institute, Tsukuba, Japan; ${ }^{2}$ Forest Bio-Research Center, Forestry and Forest Products Research Institute, Hitachi, Japan (shinta0084@ffpri.affrc.go.jp; kurodak@affrc.go.jp; fujiwara@ffpri.affrc.go.jp; ttakano@ffpri.affrc.go.jp)

To understand situations of radioactive cesium $\left({ }^{137} \mathrm{Cs}\right)$ contamination in tree stem wood after the Fukushima Nuclear Power Plant accident, ${ }^{137} \mathrm{Cs}$ concentration distributions in the radial and vertical directions of the stem were investigated. In addition, to clarify whether the ${ }^{137} \mathrm{Cs}$ distributions differ from distributions of stable isotope cesium $\left({ }^{133} \mathrm{Cs}\right)$, which has been transferred into the tree stem only by root uptake since before the accident, ${ }^{133} \mathrm{Cs}$ concentration distributions of some samples were also analyzed. About 3 years after the accident, 6 cedars (Cryptomeria japonica), 3 cypresses (Chamaecyparis obtusa) and 2 larches (Larix kaempferi) (around 50 years old) were cut down and disks were collected from different heights of the tree stem. The disk was divided every $2 \mathrm{~cm}$ in the radial direction, and the ${ }^{137} \mathrm{Cs}$ concentration was determined using a Ge detector and the ${ }^{133} \mathrm{Cs}$ concentration using ICP-MS. In many individuals, both ${ }^{137} \mathrm{Cs}$ and ${ }^{133} \mathrm{Cs}$ concentrations in the heartwood tended to be higher at the upper part of the stem. In the cedar and cypress, the ${ }^{137} \mathrm{Cs}$ concentration was typically higher in heartwood than in sapwood; however, depending on the individual and stem height, there was also a case that the ${ }^{137} \mathrm{Cs}$ concentration was higher in sapwood than in heartwood. In the larch, the higher ${ }^{137} \mathrm{Cs}$ concentration in sapwood than in heartwood was found in all individuals and stem heights. The radial distribution of ${ }^{137} \mathrm{Cs} /{ }^{133} \mathrm{Cs}$ concentration ratio differed among the individuals and species, indicating a variety of ${ }^{137} \mathrm{Cs}$ transfer processes into the tree stems.

\section{Reduction of radio cesium uptake by Japanese cypress seedlings with potassium fertilization}

Keizo Hirai ${ }^{1}$, Masabumi Komatsu ${ }^{1}$, Junko Nagakura ${ }^{1}$, Kyotaro Noguchi ${ }^{2}$

${ }^{1}$ Forestry and Forest Products Research Institute, Tsukuba, Japan; ${ }^{2}$ Tohoku Research Center, Forestry and Forest Products Research Institute, Morioka, Japan(hirai@ffpri.affrc.go.jp; kopine@ffpri.affrc.go.jp; kurya@ffpri.affrc.go.jp; kyotaro@ffpri.affrc.go.jp)

We investigated effects of potassium (K) fertilization on root uptake of radio cesium $\left({ }^{137} \mathrm{Cs}\right)$ by hinoki cypress (Chamaecyparis obtusa) seedlings from soils contaminated after the Fukushima accident. During June-July 2014, three-year-old seedlings without contamination were planted in a clear-cut forest and potassium chloride fertilizer (83 $\mathrm{kg} \mathrm{K} \mathrm{ha}^{-1}$ ) was applied three times (August 2014, April 2015 and 2016); ${ }^{137} \mathrm{Cs}$ concentrations in the needles in the fertilized plots were one-fifth of those in the unfertilized plots at the end of the third growing season (November 2016). Our results clearly indicated that K fertilization reduced radio cesium transfer from soil to planted cypress seedlings. A linear mixed model analysis revealed that ${ }^{137} \mathrm{Cs}$ concentrations in the needles were significantly affected by ${ }^{137} \mathrm{Cs}$ inventory in the soil $\left(\mathrm{Bq} \mathrm{m}^{-2}\right)$, exchangeable $\mathrm{K}$ in surface mineral soils $(0-5 \mathrm{~cm})$ and fertilization. These results suggested that the levels of exchangeable $\mathrm{K}$ in the soil would increase by fertilization during the growing season, and radio cesium uptake by tree roots was suppressed.

\section{Six-year trends in exchangeable and organic matter-bound radiocesium in Fukushima forest soils}

\section{Takuya Manaka ${ }^{1}$, Naohiro Imamura ${ }^{1}$, Shinji Kaneko², Satoru Miura ${ }^{3}$, Hitomi Furusawa ${ }^{1}$, Tsutomu Kanasashi ${ }^{1}$}

${ }^{1}$ Department of Forest Soils, Forestry and Forest Products Research Institute, Tsukuba, Ibaraki, Japan; ${ }^{2}$ Kansai Research Center, Forestry and Forest Products Research Institute, Fushimi, Kyoto, Japan; ${ }^{3}$ Center for Forest Restoration and Radioecology, Forestry and Forest Products Research Institute, Tsukuba,Ibaraki,Japan (manaka@affrc.go.jp; nimamura@ffpri.affrc.go.jp; kanekos@ffpri.affrc.go.jp; miura@ffpri.affrc.go.jp; ful103@ffpri.affrc.go.jp; tkanasashi00@ffpri.affrc.go.jp)

A large amount of cesium-137 $\left({ }^{137} \mathrm{Cs}\right)$ was released into the atmosphere after the Fukushima Dai-ichi Nuclear Power Plant (FDNPP) accident and deposited in forests in Fukushima prefecture. We investigated the changes of exchangeable ${ }^{137} \mathrm{Cs}$ in soils of contaminated forest ecosystems until 6 years after the Fukushima radioactive atmospheric deposits; to do so we performed chemical extractions of ${ }^{137} \mathrm{Cs}$ by using ammonium acetate, from both organic and mineral soil layer sampled in two forest stands, one Japanese cedar and one broadleaf deciduous, located $26-27 \mathrm{~km}$ southwest from FDNPP. The exchangeable ${ }^{137} \mathrm{Cs}$ as a proportion of the total ${ }^{137} \mathrm{Cs}$ inventory was only $10 \%$ in the organic layer and $6.1 \%$ in the mineral soil layer about 5 months after the accident. We observed an exponential decrease in the exchangeable 137Cs proportion in both organic and mineral soil layer samples over the 6-years observation period at both sites. The pronounced decrease within 2-4 years after the accident is attributed to (1) the decreasing transfers of ${ }^{137} \mathrm{Cs}$ from the canopy to the organic layer and from the organic layer to the mineral soil layer, and (2) the rapid fixation of ${ }^{137} \mathrm{Cs}$ by frayed edge sites of clay minerals. The exchangeable ${ }^{137} \mathrm{Cs}$ was almost constant after that. Those results support the interpretation that contaminated forests have entered in a steady-state phase of the ${ }^{137} \mathrm{Cs}$ cycling. We will also report the changes of ${ }^{137} \mathrm{Cs}$ which was bound to various contents of organic matters, such as acid-insoluble lignin, in the organic layer samples.

\section{Uptake of radio- or stable-cesium and potassium by hardwood forests \\ Satoru Miura ${ }^{\text {D. Tsutomu Kanasashi }}{ }^{1}$, HIroki Itô ${ }^{2}$, Junko Nagakura ${ }^{1}$, Keizo Hirai ${ }^{1}$ \\ ${ }^{1}$ Forestry and Forest Products Research Institute, Tsukuba, Japan; ${ }^{2}$ Forestry and Forest Products Research Institute, Hokkaido, Sapporo, Japan (miura@ffpri.affrc.go.jp; tkanasashi00@ffpri.affrc.go.jp; hiroki@ffpri.affrc.go.jp; kurya@ffpri.affrc.go.jp; hirai@ffpri.affrc.go.jp)}

Reducing incorporation of radio-cesium by hardwood coppice forests is one of the most concerns for local forestry people in Fukushima after nuclear accident in March, 2011. Because Abukuma Mountains was a famous major production area of mushroom logs, for which the allowable radiation limit was determined to $50 \mathrm{~Bq} / \mathrm{kg}$ by Forestry Agency of Japan. We investigated the relationship of ${ }^{137} \mathrm{Cs},{ }^{133} \mathrm{Cs}$ and $\mathrm{K}$ concentrations in current shoots of major hardwood species for mushroom logs and exchangeable those elements in soils at 40 hardwood forests in Miyakoji, Tamura, Fukushima. We detected clear nonlinear inverse correlation between ${ }^{137} \mathrm{Cs}$ in current shoots and mass of $\mathrm{K}^{+}$in $0-5 \mathrm{~cm}$ soils. We observed a hundred folds increase of ${ }^{137} \mathrm{Cs}$ in current shoots against a ten folds decrease of $\mathrm{K}^{+}(100$ to $10 \mathrm{~kg} / \mathrm{ha})$ in the soils. This relationship was by far stronger than that of ${ }^{137} \mathrm{Cs}$ in current shoots and ${ }^{137} \mathrm{Cs}$ inventory in soils. We also found almost the similar relationship about ${ }^{133} \mathrm{Cs}$ in current shoots and ${ }^{133} \mathrm{Cs}^{+}$in the soils for the same dataset. However, K concentrations in current shoots were almost constant irrespective of variable $\mathrm{K}^{+}$in the soils. We led two suggestions from these findings. One is that incorporation of ${ }^{137} \mathrm{Cs}$ is controlled by incorporation property of ${ }^{133} \mathrm{Cs}$ because of 4-6 orders larger atomic ratio of ${ }^{133} \mathrm{Cs}^{+}$to ${ }^{137} \mathrm{Cs}^{+}$. The other one is that the observation of Cs incorporation by current hardwood trees in forest ecosystems may reflect competition between $\mathrm{K}^{+}$and $\mathrm{Cs}^{+}$for ion influx to root cells. 


\title{
Radiocesium concentrations in edible wild mushrooms in eastern Japan
}

Masabumi Komatsu ${ }^{\text {I }}$

${ }^{1}$ Forestry and Forest Products Research Institute, Tsukuba, Ibaraki, Japan (kopine@ffpri.affrc.go.jp)

Wild mushrooms tend to absorb large amounts of radioactive cesium. The commercial shipping of wild mushrooms has been restricted across eastern Japan (spanning across more than one hundred municipalities) as a result of the Fukushima Daiichi Nuclear Power Plant accident. The concentrations of radioactive cesium in wild mushroom species after the Chernobyl accident have been shown to vary greatly, depending on the species. Detailed information on these concentrations could be very important when considering the criteria for safe collection. However, the absorption concentrations for each species in Japan have not been investigated thoroughly. Therefore, we analyzed the data from radioactivity monitoring of wild edible mushrooms that were collected by the local governments in eastern Japan. In the analysis, the radioactivity deposition data from aircraft monitoring was used to standardize the mushroom radiocesium concentrations with the contamination levels of the sampled area. Our results showed that there was a large difference of up to 100 times within each species. As in previous studies, the concentration of mycorrhizal species tended to have higher concentrations of radiocesium. Some saprophytic species also had high concentrations. For the mushroom species that were also evaluated in the post-Chernobyl studies, we found that the same species had similar levels of absorption and a positive correlation was found. Moreover, the estimation of radiocesium concentration was much improved by the use of information from the municipalities of mushroom collection. We observed regional bias from the municipality effect.

\section{Temporal changes in spatial distributions of radiocesium in forest floors in Fukushima, Japan}

Naohiro Imamura ${ }^{1}$, Toshiya Matsuura ${ }^{1}$, Akio Akama1, Yoshiki Shinomiya ${ }^{1}$, Masahiro Kobayashi ${ }^{1}$, Satoru Miura ${ }^{1}$, Shinji Kaneko ${ }^{2}$ ${ }^{1}$ Forestry and Forest Products Research Institute, Tsukuba, Japan; ${ }^{2}$ Forestry and Forest Products Research Institute, Kyoto, Japan (nimamura@ffpri.affrc.go.jp; matsuu50@affrc.go.jp; akama@affrc.go.jp; shinomiya@ffpri.affrc.go.jp; kbmasa@affrc.go.jp; miura@affrc.go.jp; kanekos@affrc.go.jp)

Due to the Fukushima Dai-ichi Nuclear Power Plant accident, the majority of areas of East Japan forests were contaminated by radiocesium. Estimation of the spatial distributions of radiocesium within the forest would help in devising strategies both for reducing exposure for forest workers and for decontamination in the forest. In this study, the spatial distribution of radiocesium and its temporal change were estimated at both observed plot ( $2 \mathrm{~m} \times 2 \mathrm{~m})$ and forest $(0.12-0.24$ ha) scales. Radiocesium inventories of the litter and mineral soil layers $(0-5 \mathrm{~cm})$ were collected in 12 observed plots in each of four forest with various topographies in Fukushima Prefecture. The ambient dose rate at a height of $10 \mathrm{~cm}$ was measured in 20-36 points in the same forests. These observations were conducted in summer from 2012 to 2016. Results showed temporal change in the radiocesium inventories accumulated in the litter and mineral soil layers collected at the observed plot scale. However, the distribution pattern of the ambient dose rate did not change significantly over time at the forest scale. These findings suggested that the spatial variation at the observed plot scale could be affected by the initial distribution or local migration of radiocesium in the litter and mineral soil layers. However, there was no significant migration of radiocesium that could affect the ambient dose rate in the forest. This study also indicated that topographic characteristics had no effect on the spatial distributions of the ambient dose rate.

\section{A rechargeable increment borer for radiocesium monitoring}

\author{
Akira Kagawa', Takeshi Fujiwara', Shinta Ohashi ${ }^{1}$ \\ ${ }^{1}$ Forestry and Forest Products Research Institute, Tsukuba, Japan (akagawa@ffpri.affrc.go.jp; fujiwara@ffpri.affrc.go.jp; shinta0084@ffpri.affrc.go.jp)
}

Radioactive cesium analysis requires large amount of wood (Kagawa et al; 2002, Journal of Environmental Quality 31(6):2001-2007). Initially, in our Fukushima project, we have felled trees to obtain stem disks for the analysis. In recent years, we have explored the possibility of using increment cores (12-mm diameter) for radio-cesium analysis as a substitute of wood disks. Increment core sampling has advantages over disk sampling because it does not kill the trees and therefore enables continual monitoring of radio-cesium levels within an individual tree over many years. Disk sampling may cause significant disturbance that may affect dynamics of radio-cesium movement within a forest ecosystem. We developed an automated increment-core sampling device, "Smartborer", to increase the sample throughput (Kagawa and Fujiwara 2018, Journal of Wood Science 64(1):52-58; www.smartborer.com). The lightweight, portable device employs a battery-powered electric wrench and the complete system to drive the boring operation weighs less than $10 \mathrm{~kg}$. It is capable of taking both 5 - and 12-mm diameter cores of more than 800-mm length, even from hardwood. Compared to equipment used in previously published articles, Smartborer enables more rapid sampling and demonstrates a superior torque output/total weight ratio. Overall, averaged radio-cesium concentrations over the two increment cores sampled from two opposing directions of a stem showed a good match to the values obtained from the stem disk. However, the radio-cesium concentrations of heartwood based on increment-core measurement showed a little less accuracy than those based on disk measurement.

\section{E8p: FOREST MANAGEMENT PRACTICES AND THE RESPONSES OF SOIL CARBON, WATER, NUTRIENTS AND THEIR INTERACTIONS}

\section{Dendrometric aspects of the biochar application in Eucalyptus urograndis}

Ricardo Trippia dos Guimarães Peixoto ${ }^{1}$, Claudia Maria Branco de Freitas Maia ${ }^{1}$, Leticia Machado dos Santos ${ }^{2}$, Lucilia Maria Parron ${ }^{1}$

${ }^{1}$ Embrapa Florestas, Colombo, Brasil; ${ }^{2}$ Pontificia Universidade Católica do Paraná, Curitiba, Brasil

(ricardo.trippia@embrapa.br; claudia.maia@embrapa.br; leticia.agronomiapucpr@gmail.com; lucilia.parron@embrapa.br)

Biochar application aims to improve the soil properties and increase its carbon stable reservoir. The aim was to evaluate the effect of the use of biochar in soils with Eucalyptus urograndis, under different fertilization rates in tree growth. The experiment is in São Jerônimo da Serra (Paraná, Brazil), in a Red-Yellow Latosol, as a factorial in 4 randomized blocks with subdivided plots, with and without biochar in plots, and 3 fertilization rates in subplots. The treatments were: T1 - without biochar and without fertilizer; T2 - without biochar and fertilizer rate reduced by $20 \%$; T3 - without biochar and commercial fertilizer rate; T4 - with biochar and without fertilizer; T5 - with biochar and fertilizer rate reduced by 20\%; and T6 - with biochar and commercial fertilizer rate. Each plot comprised of 36 trees spaced of $3 \mathrm{~m} \times 3 \mathrm{~m}$. It was applied $9 \mathrm{~kg}$ of biochar $\left(1 \mathrm{~kg} /\right.$ tree or $\left.3.21 \mathrm{t} \mathrm{ha} \mathrm{H}^{-1}\right)$ in strip with $1 \mathrm{~m}$ of width and incorporated $15 \mathrm{~cm}$ with a grid. The commercial fertilization (NPK at planting 4:42:6 and second dose 15:05:30) were of 166 g/tree. The tree height (AP) and stem basal diameter (DC) were measured in 20 trees/plot at the 3, 6, 9, 12 and 18 months age. The AP and DC at each age varied between treatments with and without fertilization. However, there were no effect reducing the fertilizer rate neither with the biochar application until 18 months old. The effect of biochar on soil quality attributes and carbon storage are being evaluated. 


\section{A broadleaf species alters and evenly distributes soil organic carbon chemical composition in a Pinus massoniana planted forest in southern China}

Hui Wang ${ }^{1}$, Shirong Liu ${ }^{1}$, Jingxin Wang ${ }^{2}$, Zuomin Shi ${ }^{1}$, Daoxiong Cai ${ }^{3}$, Lihua Lü ${ }^{3}$, Angang Ming

${ }^{1}$ Institute of Forest Ecology, Environment and Protection, Chinese Academy of Forestry, Beijing, China; ${ }^{2}$ Division of Forestry and Natural Resources, West Virginia University, Morgantown, USA; ${ }^{3}$ Experimental Center of Tropical Forestry, Chinese Academy of Forestry, Pingxiang, China (wanghui@caf.ac.cn; liusr@caf.ac.cn; jxwang@wvu.edu; shizm@caf.ac.cn; rlzxcdx@126.com; kjc8526136@163.com; mingangang0111@163.com)

There are potential effects of planted forest type conversions from conifer to broadleaf or mixed-species on the soil organic carbon (SOC) chemical composition, and the evenness of its distribution remains uncertain. An afforestation experiment with different tree species (Pinus massoniana, Erythrophleum fordii, and mixed P. massoniana and E. fordii) was conducted in a clear-cutting site of $P$. massoniana planted forests in a subtropical region. Topsoil organic C quality and microbial diversity were assessed after eight years of afforestation. The proportions of alkyl C and carbonyl C in SOC, as well as alkyl C/O-alkyl C ratios and the evenness of the SOC chemical composition distributions were higher in monospecific $E$. fordii and mixed-species planted forests than the monospecific $P$. massoniana planted forest. The positive relationship of SOC chemical composition distribution with litter as well as fine root C quality was observed. Microbial biomass $\mathrm{C}$ was positively correlated with the labile SOC. Fine root C had a closer correlation with the chemical composition of SOC than litter. The present results are not consistent with our previous findings in a 25-year afforestation site, in which soil microbial community composition rather than litter quality was linked with SOC chemical composition, suggesting plant $\mathrm{C}$ chemical composition would better predict belowground $\mathrm{C}$ sequestration functioning in the early afforestation system. These results highlight that mixing native $\mathrm{N}$ fixing broadleaf species into conifer forests probably enhance the SOC chemical stability and resistance to climate change by increasing the recalcitrant $\mathrm{C}$ components and the evenness of SOC distribution.

\section{Allometric models to estimate biomass aboveground in forest recovery areas \\ Anani Morilha Zanini ${ }^{1}$, Rafaella Mayrinck ${ }^{2}$, Bruna Santos Lopes ${ }^{1}$, Simone Aparecida Vieira ${ }^{3}$, Ricardo Ribeiro Rodrigues ${ }^{1}$ \\ ${ }^{1}$ Escola Superior de Agricultura Luiz de Queiroz, Universidade de São Paulo, Piracicaba, Brazil; ; ${ }^{2}$ niversity of Saskatchewan, Saskatoon, Canada; ${ }^{3}$ Universidade Estadual de Campinas, Campinas,Brazil (ananizanini@hotmail.com; rafamk@hotmail.com; bruna.santos.lopes@usp.br; savieira08@gmail. com; rrresalq@usp.br)}

Quantify carbon stock on forest restauration areas is a global interest, since this area provide the important environmental service of mitigating climate change. It is crucial have more studies on allometry to help on predicting biomass and carbon stocking for those areas. Thus, the objective of this study was to quantify forest biomass and carbon content to a 5-year-old region under restoration process, so models could be fitted to the area and also used to similar sites. Three sites nearby Itu city, SP, Brazil, were studied, 5 years after the restoration process was implemented. In each site, three $900 \mathrm{~m}^{2}$-plots were installed, and a forest inventory was done, measuring tree height and circumference at breast height. Sub-plots $\left(25 \mathrm{~m}^{2}\right)$ were randomly selected in each $900 \mathrm{~m}^{2}$-plots and all trees inside it were cut and had its volume measured, stratified into foliage, roots and stem pools. Carbon content was determined on the Isotopic Ecology Laboratory for each species and pool. This data was used to fit models to estimate biomass. The best model was selected using the adjusted coefficient of determination ( $\mathrm{R}^{2}$ ), residual charts and Akaike's information criterion (AIC). Mean biomass for the area was $20.19 \pm 0.146 \mathrm{Mg} \mathrm{ha}^{-1}$, mean Carbon stock was $9.73 \mathrm{Mg} \mathrm{C}^{-1}$, and average carbon content was $45.3 \%$.

\section{$\mathrm{N}_{2}$ fixing trees (Acacia mangium) introduce in eucalypt plantations modify rapidly the pools of organic $\mathbf{P}$ and low-molecular-weight organic acids (LMWOAs) in tropical soils contrasted for their C/P stoichiometry \\ Kittima Waithaisong ${ }^{1,2}$, Agnès Robin ${ }^{3,4}$, Louis Mareschal $^{3}$, Jean-Pierre Bouillet ${ }^{3}$, Jean-Paul Laclau ${ }^{3}$, José Léonardo de Moraes Gonçalves ${ }^{4}$, Manon Villeneuve ${ }^{5}$, Philippe Deleporte ${ }^{3}$, Claude Plassard ${ }^{1}$ \\ ${ }^{1}$ INRA/ UMR Eco\&Sols, Montpellier, France; ${ }^{2}$ Department of Microbiology, Faculty of Science Silpakorn University-Sanam Chandra Palace Campus, Nakhon Pathom, Thailand; ${ }^{3}$ CIRAD, UMR Eco\&Sols, Montpellier, France; ${ }^{4}$ Escola Superior de Agricultura Luiz de Queiroz, Universidade de São Paulo, Piracicaba,Brasil; ${ }^{5} I R D$, UMR Eco\&Sols, Montpellier, France (kittima2214@gmail.com; agnes.robin@cirad.fr; louis.mareschal@cirad.fr; jean-pierre. bouillet@cirad.fr; laclau@cirad.fr; jlmgonca@usp.br; manon.villeneuve@ird.fr; philippe.deleporte@cirad.fr; plassard@supagro.inra.fr)}

In this study, soil organic $\mathrm{P}(\mathrm{Po})$ and low-molecular-weight organic acids (LMWOAs) were quantified under different land uses in order to investigate the effect of $\mathrm{N}_{2}$ fixing tree introduction on phosphorus cycle. Soils were collected from plantations of pure acacia (Ac), pure eucalyptus (Euc) or both species (50/50) and original savannahs (S) that were located in Brazil (low P, high N and high $\mathrm{C}$ soil) and in Congo (high P, low N and low C soil). Po and LMWOAs were identified in sodium hydroxide soil extracts with ion chromatography (IC). Phosphate monoesters as AMP and glucose-6-phosphate (G6P) were the main Po forms in both sites. Phytate, ATP and fructose-bisphosphate (FrucbisP) were also present as well as the mineral form of pyrophosphate (PrP). Malate, oxalate and malonate were the major components of LMWOA fraction in the two soils. Citrate was also present at low concentrations. Interresingly, phytate concentrations were always decreased under acacia plantations. This could result from a better mineralisation or lower inputs into these soils. In mixed stands, the effect of acacia introduction on Po and LMWOAs composition is more pronounced in high $\mathrm{P}$ than in low P soil, due to a much better $\mathrm{N}_{2}$ fixation. Our results highlight that the introduction of a legume tree is able to strongly modify the composition of Po and LMWOAs in soil even after a first short-time rotation, especially when the rate of $\mathrm{N}_{2}$ fixation is high.

\section{Microbial enzymatic activities and community-level physiological profiles (CLPP) in subsoil layers are altered by harvest residue management practices in a tropical Eucalyptus grandis plantation}

François Maillard ${ }^{1}$, Valentin Leduc ${ }^{1}$, Cyrille Bach ${ }^{1}$, José Léonardo de Moraes Gonçalves ${ }^{2}$,Fernando Dini Andreote ${ }^{2}$, Laurent Saint-André3, Jean-Paul Laclau, Marc Buée ${ }^{1}$, Agnès Robin ${ }^{3,4}$

${ }^{1}$ Université de Lorraine, INRA, IAM, Nancy, France; ${ }^{2}$ Escola Superior de Agricultura Luiz de Queiroz, Universidade de São Paulo, Piracicaba, Brasil; ${ }^{3}$ INRA UR 1138 Biogéochimie des Ecosystèmes Forestiers, Nancy, France; ${ }^{4}$ CIRAD, UMR Eco\&Sols, Montpellier, France (francois.maillard@inra.fr; valentinleduc@hotmail.fr; cyrille.bach@inra.fr; jlmgonca@usp.br; fdandreo@gmail.com; laurent.saint-andre@inra.fr; laclau@cirad.fr; marc.buee@inra. fr; agnes.robin@cirad.fr)

Harvest residue management is a key issue for the sustainability of Eucalyptus plantations established on poor soils. Soil microbial communities contribute to soil fertility by the decomposition of the organic matter $(\mathrm{OM})$, but little is known about the effect of whole-tree harvesting (WTH) in comparison to stem only harvesting $(\mathrm{SOH})$ on soil microbial functional diversity in Eucalyptus plantations. We studied the effects of harvest residue management (branches, leaves, bark) of Eucalyptus grandis trees on soil enzymatic activities and community-level physiological profiles in a Brazilian plantation. We measured soil microbial 
enzymatic activities involved in OM decomposition and we compared the community level physiological profiles (CLPP) of the soil microbes in WTH and SOH plots. WTH decreased enzyme activities and catabolic potential of the soil microbial community. Furthermore, these negative effects on soil functional diversity were mainly observed below the 0-5 cm layer (5-10 and 10-20 cm), suggesting that WTH can be harmful to the soil health in these plantations.

\section{Carbon sequestration and soil fertility in dryland Acacia senegal plantations of varying age in Sudan}

Wafa Abaker ${ }^{1}$, Frank Berninger ${ }^{2}$, Gustavo Saiz ${ }^{3}$, Mike Starr $^{4}$

${ }^{1}$ University of Khartoum, Khartoum, Sudan; ${ }^{2}$ University of Eastern Finland, Kuopio, Finland; ${ }^{3}$ Imperial College London, Ascot, United Kingdom; ${ }^{4}$ University of Helsinki,Helsinki,Finland(wafaadam59@yahoo.com; frank.berninger@uef.fi; g.saiz@imperial.ac.uk; mike.starr@helsinki.fi)

African drylands are extensively degraded as indicated by reduced soil organic carbon (SOC) contents. Restoration through management practices that increase tree cover can be expected to increase SOC contents and soil fertility. We investigated the potential of Acacia senegal trees for increasing SOC and improving soil fertility at two sites in Sudan. Biomass C and SOC stocks, contribution of trees and herbs to SOC, soil nutrient (N, P, available P, K, exchangeable K) contents and potential $\mathrm{N}_{2}$ fixation by $A$. senegal in plantations of varying age (7 to 24 years) and in adjacent grasslands were determined. Total biomass $\mathrm{C}$ stocks increased with plantation age. While most of this increase was due to the trees, the ground vegetation $\mathrm{C}$ stock also increased (facilitation effect). SOC stocks $(0-50 \mathrm{~cm})$ increased with plantation age and were greater than in the grasslands. $\delta 13 \mathrm{C}$ partitioning values indicated that the age-related increase in SOC stocks was derived not only from the acacia trees but also from an increase in ground vegetation biomass. While soil concentrations of the studied nutrients were relatively low, they were positively correlated to SOC concentrations, highest in the topsoil $(0-10 \mathrm{~cm})$ and increased with plantation age - all indicating the importance of SOC to soil fertility. High acacia foliage $\delta 15 \mathrm{~N}$ values indicated that $\mathrm{N}_{2}$ fixation was not an important contributor to soil N. Our findings showed that increasing tree cover in African drylands can increase SOC stocks and thereby improve soil fertility for the benefit of local communities besides sequestering atmospheric $\mathrm{CO}_{2}$.

\section{Role of nitrogen availability on enhancing soil carbon sequestration in typical subtropical planted forests in Southern China}

Shirong Liu', Hui Wang ${ }^{2}$

${ }^{1}$ Chinese Academy of Forestry, Beijing, China; ${ }^{2}$ Institute of Forest Ecology, Environment and Protection, Chinese Academy of Forestry, Beijing, China

(liusr@caf.ac.cn; wanghui@caf.ac.cn)

Planted forest ecosystem is becoming a key component of the China's forest resources and timber storage and plays a key role in the context of potential carbon (C) sequestration and sustainable forest management. Information on the effects of tree species composition and diversity on soil nitrogen (N) availability and organic carbon (C) sequestration remains limited. The investigation and long-term manipulation experiment were carried out in typical subtropical planted forests. Soil under Eucalyptus mixed with $\mathrm{N}_{2}$-fixer accumulated more soil organic $\mathrm{C}$ and $\mathrm{N}$, and had lower $\mathrm{CO}_{2}$ emission than in pure stands by increasing total organic $\mathrm{C}$ and microbial biomass $\mathrm{C}$, as well as through increased soil microbial community diversity and abundance. SOC and N stocks in the Pinus massoniana and Castanopsis hystrix mixed plantation were higher than in $P$. massoniana monospecific plantation. The admixing with the higher-quality $C$. hystrix litter hastened mass loss for recalcitrant $\mathrm{C}$ chemical compositions and nutrient return of conifer litter. Our results also showed that tree species mixture significantly altered the soil bacterial community composition and structure, compared with single-species plantations. The C/N ratios of soil and litterfall, TOC, NH4-N, litterfall mass and NO3-N were key factors affecting the soil microbial community. There was a negative relationship between SOC mineralization rates and the abundance of K strategists and a positive relationship for $\mathrm{r}$-strategists. These results indicated that $\mathrm{N}$ availability plays an important role on enhancing SOC sequestration through changing soil microbial community composition in subtropical plantations.

\section{Forest management strategies to safeguard water supply in karst regions under climate change}

Klaus Katzensteiner ${ }^{1}$

${ }^{1}$ Institute of Forest Ecology, University of Natural Resources and Life Sciences, Vienna (BOKU), Vienna, Austria (klaus.katzensteiner@boku.ac.at)

Worldwide, karst aquifers developed on calcareous bedrock are important sources of drinking water. Large karst areas of the montane and subalpine vegetation belts in the Calcareous Alps are dominated by forests. The increasing frequencies and intensities of disturbances, partly a consequence of climate change, may alter the water storage, filtering and buffering capacity of forest ecosystems, thereby threatening the continuous provision of pristine water. Safeguarding water supply from karst regions therefore requires the adaptation of forest management strategies. In the presentation, forest management and disturbance effects upon soil condition and water quality in karst regions are discussed based on case studies from the Alps. Stability- and vulnerability- indicators of karst systems and its subsystems, from tree species, the vadose zone, in particular soils, to karst water, are incorporated in a conceptual framework for adaptive forest management strategies in view of water protection.

\section{E8q: EFFECTS OF FOREST MANAGEMENT PRACTICES ON SOIL PROPERTIES AND} ECOSYSTEM PROCESSES

\section{Teor de carbono e nitrogênio no solo em função da adubação em um sistema de integração Lavoura-Pecuária-Floresta e Plantio} Direto

Luciane Cristina Lazzarin ${ }^{1}$, Juliano Coruli Corulli Corrêa ${ }^{2}$, Iraê Amaral Guerrini ${ }^{1}$, Paulo Hentz ${ }^{3}$

${ }^{1}$ Unesp, Botucatu, Brazil; '2Embrapa Suínos e Aves, Concórdia,Brazil; ${ }^{3} I F C$, Concórdia, Brazil (lucianelazzarin@unc.br; juliano.correa@embrapa.br; iguerrini@fca.unesp.br; paulo.hentz@ifc.edu.br)

A prática de adubação, quando necessário, promove ganho de produtividade até três vezes maior em comparação a sua não adoção. O uso de fertilizantes orgânicos pode resultar em ganhos econômicos e ambientais, potencializando a diversidade do sistema. Este trabalho objetivou avaliar o teor de carbono e nitrogênio no solo no sistema de produção integração lavoura-pecuária-floresta (iLPF) e plantio direto (PD) após 3 anos com fertilizantes orgânicos ou minerais. O experimento foi conduzido no município de Concórdia-SC, onde o delineamento experimental foi blocos casualizados, com 3 repetições, em fatorial 2 x 4 , sendo dois tipos de sistemas de produção (ILPF e PD) em interação com três tipos de fertilizantes (dejeto de suínos, cama de aves e mineral) e o controle (sem adubação). As amostras de solo foram coletas até $100 \mathrm{~cm}$, e analisadas através do analisador elementar (CNHOS). Não houve efeito da adubação sob o teor de carbono nas diferentes camadas para o sistema ILPF, enquanto que para o PD houve diferença para a adubação cama de aves e mineral nas camadas superficiais. 


\section{Soil net $\mathbf{N}$ mineralization in responses to forest type conversion in a subalpine region of the Eastern Qinghai-Tibetan Plateau}

Zuomin Shi ${ }^{1}$

'Institute of Forest Ecology, Environment and Protection, CAF, Beijing, China (shizm@caf.ac.cn)

Soil Soil nitrogen $(\mathrm{N})$ availability and cycling are crucial in regulating the dynamics of ecosystem functions. Subalpine areas of the Eastern Qinghai-Tibetan Plateau have experienced different forest re-establishment methods after primary forest clear-cutting. We investigated soil net $\mathrm{N}$ mineralization and microbial community compositions in four forest types, i.e. Abies faxoniana primary forest (AF), Picea asperata broadleaved mixed forest (natural regeneration after artificial planting, MF) composed of planted P. asperata and naturally regenerated native broadleaved species, natural secondary forest (natural without assisted regeneration, NF) and Picea asperata plantation (artificial planting, PF) from June to November. Forest type had a significant effect on soil net ammonification rate, but not on net nitrification rate. The cumulative ammonified $\mathrm{N}$ value was significantly higher in $\mathrm{NF}(11.40 \mathrm{~g} \mathrm{~kg}-1)$ and lower in PF (4.79 $\left.\mathrm{g} \mathrm{kg}^{-1}\right)$, and the cumulative nitrified $\mathrm{N}$ value ranged from 17.75 (in AF) to $27.98 \mathrm{~g} \mathrm{~kg}^{-1}$ (in MF) with no significant difference among forest types. However, average net $\mathrm{N}$ mineralization varied smoothly among the four forest types with generally negative values of net ammonification rate for MF and NF. These results indicate that $\mathrm{NF}$ might consume larger ammonium $\mathrm{N}$ by plant uptake and microbial immobilization relative to other forests. The net ammonification and nitrification rates exhibited different monthly patterns with the higher values at the end and the middle of the period, respectively. The net $\mathrm{N}$ mineralization rates could be well described by soil properties and the ratio of fungal to bacterial PLFAs.

\section{Why fine-root decomposition rates of 13 tree species differ between mixed- and monospecific forest stands: a search for mechanisms across European forests \\ Janna Wambsganss ${ }^{1}$, Friderike Beyer ${ }^{1}$, Gregoire Freschet ${ }^{2}$, Jürgen Bauhus ${ }^{1}$, Michael Scherer-Lorenzen ${ }^{3}$ ${ }^{1}$ Chair of Silviculture, University of Freiburg, Freiburg, Germany; ${ }^{2}$ Centre d'Ecologie Fonctionnelle et Evolutive, Montpellier, France; ${ }^{3}$ Institute of Geobotany, University of Freiburg, Freiburg, Germany (janna.wambsganss@waldbau.uni-freiburg.de; friderike.beyer@waldbau.uni-freiburg.de; gregoire. freschet@cefe.cnrs.fr; juergen.bauhus@waldbau.uni-freiburg.de;michael.scherer@biologie.uni-freiburg.de)}

Decomposition is one of the key processes determining carbon and nutrient cycling and thereby crucial for overall ecosystem functioning. To which extent the management for mixed-species forests affects litter decomposition has mainly been investigated for above-ground plant organs, despite the fact that fine roots contribute substantially to the soil organic matter pool. The objective of this study was therefore to determine fine-root decomposition rates in relation to tree species diversity, fine-root traits and environmental conditions. We hypothesized that decomposition rates (1) are higher for mixed-species stands than for monospecific stands; (2) are related to morphological, architectural and chemical traits as well as microbial associations; (3) are largely explained by fine-root traits, more than climate or tree species diversity. Fine-root litter bags containing absorptive fine roots of 13 different tree species were incubated for 12 months in the field in mixed-forest stands consisting of three tree species and in the corresponding monospecific stands in the frame of a large-scale pan-European project. The four study sites represented major European forest types along an environmental gradient across Europe ranging from boreal to thermophilous forests. Fine-roots of the 13 species were analyzed for morphological, architectural and chemical traits as well as microbial associations. The results of this study will provide new insights in the dynamics and controls of fine-root decomposition of 13 significant European tree species and thereby could eventually be used for forest management recommendations.

\section{Microbe-mediated attenuation of soil respiration in response to soil warming in a temperate oak forest \\ Yi Wang ${ }^{1}$, Junwei Luan ${ }^{1}$, Shirong Liu ${ }^{l, 2}$ \\ ${ }^{1}$ Institute for Resources and Environment, ICBR, Beijing, China; ${ }^{2}$ Institute of Forest Ecology, Environment and Protection, CAF, Beijing, China (wangyi@icbr.ac.cn; junweiluan@icbr.ac.cn; liusr@caf.ac.cn)}

Soil respiration (Rs) in response to climate warming received wide concerns thank to its role in terrestrial ecosystem carbon (C) cycling. But the warming induced effects of soil microbes on soil respiration are still less understood, especially over time. Our study aims to understand the long-term warming induced effects of soil microbes on Rs. A field soil warming experiment was conducted in a naturally regenerated oak forest (Quercus aliena) in central China from 2011 to 2015. Our results showed that soil temperature was a main factor in regulating Rs in a temperate oak forest, but soil water content only determined Rs in natural dry year. The positive effect of soil warming on Rs that was observed with the significant increase (i.e; 37.5 to $42.0 \%$ in the first two years) gradually diminished in the following three years (i.e., $0.9-15.4 \%$ in the last three years). Significant positive warming effect on temperature sensitivity of Rs (Q10) only occurred in the second year. Continuous soil warming caused the decline in nitrogen $(\mathrm{N})$ availability, but with the significant increase in microbial biomassspecific enzyme activities for $\mathrm{N}$-acquiring. The attenuation of microbial biomass increment and the deceased ratio of enzymatic C:N acquisition contributed to the diminished warming effect on Rs over time. Our study suggests that microbe-mediated attenuation of Rs accompanied by the concomitant decline in soil $\mathrm{N}$ availability in response to warming should be taken into consideration in global C cycle modeling.

\section{Effects of different natural secondary Quercus mongolica forest management models on leaf functional traits and soil physical and chemical properties}

Youjun He ${ }^{1}$,Gao Yue', Chaofan Chen', Qin Lin ${ }^{1}$

${ }^{1}$ Chinese Academy Of Forestry, Beijing, China (hyjun163@163.com; ziguang_yue@163.com; 494634999@qq.com; nilniq@163.com)

Plant functional traits is a bridge between plants and environment. In this paper, effects of natural secondary forest of Quercus mongolica under three management modeson the leaf functional traits and soil physical and chemical properties was studied at Danqinghe forest farm in Harbin, Heilongjiang province, China. The results showed that: (1) in addition to the total soil potassium, available potassium and organic carbon content, there were no significant difference in soil physical and chemical properties between different management modes. (2) the functional traits of natural secondary Quercus mongolica forest under different management modes were obviously different, the individual leafarea of target tree management modelwas significantly higher than ecosystem management model and no interference $(P<0.01)$, and the leaf organic carbon content and leaf nitrogen content of target tree management model were significantly lower than ecosystem management model and no interference $(P<0.01)$; there were significant negative correlation between leaf area, leaf nitrogen content and leaf organic carbon content $(P<0.01)$. (3)soil organic carbon had significant influence on the individual leafarea, leaf nitrogen content, leaf phosphorus content and leaf organic carbon content. Soil organic carbon was the main factor affecting the variation of leaf functional traits. The natural secondary Quercus mongolica forest communities adapted to the environment through the coupling or combination of functional traits. The response of plant functional traits on soil physicochemical properties is a long process, we need to strengthen the long-term monitoring and study more. 


\section{The influence of different nutrients solutions at Eucalyptus benthamii adventitious rooting}

Leticia Miranda ${ }^{I}$, Regiane Abjaud Estopa ${ }^{I}$, Marco Aurélio Figura ${ }^{I}$

'KlabinS/A, Telêmaco Borba, Brazil (lemiranda@klabin.com.br; restopa@klabin.com.br; mafigura@klabin.com.br)

The clonal propagation of Eucalyptus by mini-garden system is a technique already elucidated in the Brazilian forest sector. However, subtropical Eucalyptus species, such as Eucalyptus benthamii, are recalcitrant to adventitious rooting, which causes a reduction in the rooting rate of the mini-cuttings produced in this system. The nutrition of mini-stumps is one of the most important factors in clonal mini-gardens, and affects the mini-cuttings production as well as their rooting. In this context, this work evaluated the influence of five mini-garden nutrient solutions in the production of shoots and rooting of mini-cuttings of two E. benthamii clones. The treatment solutions had different concentrations of nitrogen $(\mathrm{N})$, iron $(\mathrm{Fe})$ and zinc $(\mathrm{Zn})$. The reference solution was denominated T1, and the other treatments had the following differences: $45 \%$ of $\mathrm{N}$ reduction in T2 and T3 treatments, and $27 \%$ of N reduction in T4 and T5; Fe increase of $2.5 \mathrm{x}$ in T2 and T3 and of 1.9x in T4 and T5; Zn increase of 20x on T2 and T4, and of 40x on T3 and T5. Different formulations of nutrient solutions influenced the rooting rates of the two clones at 1\% statistical significance. Clone K1100 solutions T2 and T3 had the highest rooting rates and did not have differences between them. For clone K1101, only the T3 solution had the rooting rates higher than the other treatments. These findings make T3 solutions the most recommended for these clones, and potential ones for this specie.

Initial decomposition of forest litter in different levels of coverage in a forest of Nothofagus obliqua within a silvopasture management system / Descomposición inicial de hojarasca en diferentes niveles de cobertura en bosque de Nothofagus obliqua bajo manejo silvopastoril

Marianela Alfaro ${ }^{1}$, Francis Dube ${ }^{2}$, Erick Zagal ${ }^{2}$

${ }^{1}$ UniversidaddeCostaRica,SanJosé,CostaRica; ${ }^{2}$ UniversidaddeConcepción,Concepción,Chile(marianela.alfaro@ucr.ac.cr;fdube@udec.cl; ezagal@udec.cl)

La hojarasca constituye la vía de entrada principal de los nutrientes en el suelo y es uno de los puntos clave del reciclado de la materia orgánica y de los nutrientes. Se realizaron experimentos de descomposición de hojarasca en un sistema silvopastoril con pradera mejorada en un bosque de Nothofagus obliqua, bajo tres diferentes niveles de cobertura arbórea: abierta, parcialmente abierta, y parcialmente cerrada. Se utilizó la técnica de "bolsas de litera", y se evaluó las pérdidas de peso de hojarasca y liberación de nutrientes inicial a los 6 meses de descomposición. La combinación de cobertura arbórea abierta y el sistema silvopastoril con pradera mejorada presentó una pérdida de peso por descomposición de hojarasca significativamente más elevada. Las coberturas parcialmente abierta y parcialmente cerrada no presentaron diferencias. Se registraron pérdidas de peso de 29,67; 23,12; y 24,43\% para las coberturas abierta, parcialmente abierta y parcialmente cerrada, respectivamente. Las constantes de descomposición k asociadas a esas pérdidas de peso fueron 0,71; 0,53; y 0,56; respectivamente. Los contenidos de carbono, potasio, magnesio, hierro, manganeso, se establecieron como los primeros elementos en ser liberados en las etapas iniciales de descomposición de la hojarasca en las tres coberturas arbóreas evaluadas. El crecimiento de pastos pudo influenciar en el comportamiento de las temperaturas sobre y del suelo y su contenido de humedad en las diferentes coberturas arbóreas, y la adición de nitrógeno con la implementación del sistema silvopastoril pudo influenciar aumentando las tasas iniciales de descomposición de la hojarasca.

\section{Fertilizer distribution and its influence on initial growth and uniformity of Eucalyptus plantations}

Ana Rosaria Sclifo Zucon ${ }^{1}$, Guilherme Batistuzzo ${ }^{2}$, José Henrique Bazani ${ }^{3}$, José Leonardo de Moraes Gonçalves ${ }^{3}$, Rodrigo Eiji Hakamada ${ }^{4}$, Cristiane Lemos ${ }^{2}$, Brandon Hawkes ${ }^{5}$, Clayton Alcarde Alvares ${ }^{6}$, Guilherme Rodrigues de Pontes ${ }^{2}$, Thiago Ubiratan de Freitas ${ }^{2}$, José Carlos Arthur Junior ${ }^{7}$

${ }^{1}$ Universidade Federal do Paraná, Departamento de Solos e Engenharia Agrícola, Curitiba, Brasil; ' ${ }^{2}$ nternational Paper do Brasil, Mogi Guaçu, Brasil; ${ }^{3}$ Escola Superior de Agricultura "Luiz de Queiroz", Universidade de São Paulo, Departamento de Ciências Florestais, Piracicaba, Brasil; ${ }^{4}$ Universidade Federal Rural de Pernambuco, Departamento de Ciências Florestais, Recife, Brasil; ${ }^{5}$ North Carolina State University, Raleigh, USA; 'Instituto de Pesquisas

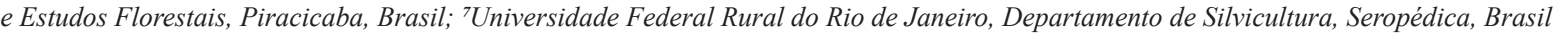
(zuconana@gmail.com; guilherme.batistuzzo@ipaper.com; bazani.jh@gmail.com; jlmgonca@usp.br; rodrigo_hakamada@yahoo.com.br; cristiane.lemos@ipaper.com; bahawkes@ncsu.edu; caalvares@yahoo.com.br; guilherme.pontes@ipaper.com; thiago.freitas@ipaper.com; josecarlosarthurjunior@gmail.com)

Eucalyptus clonal plantations commonly present variations on tree growth within stands, being often related to quality of forest operations. In order to improve efficiency and precision of it, the precision silviculture concept has been adopted among forest companies. It consists on a technology frequently used on forest fertilization operation which enables uniform application of fertilizers. However, the quality of application should be verified as well as its effects on plants initial growth uniformity. Thus, the objectives of this study were to validate this technology and to verify the relation between quality of fertilizer distribution and initial growth uniformity of Eucalyptus in stands in the countryside of São Paulo. The validation of this technology was based on observed and estimated data (at the dosage of $220 \mathrm{~kg} \cdot \mathrm{ha}^{-1}$ ) provided by the application system. The initial growth of the trees was quantified using measures of plant crown area from images taken from an Unmanned Aerial Vehicle and fieldwork. The Pvar50 was used as uniformity index for crown areas. The relationship between variation of fertilizer dosage applied by the system and the initial plant growth uniformity measures was checked. The application system was validated presenting $82 \%$ of the data within $10 \%$ of recommended dosage tolerance. The stand presented high fail index ( $10 \%$ in average), which may indicate lapses in forest operations or due to the hydric deficit occurred after planting in 2014. The $10 \%$ variation of recommended dosage did not explain the variation found in the uniformity of Eucalyptus crown area of this study.

E8r: FOREST MANAGEMENT PRACTICES, WATER SUPPLY, WATER QUALITY AND SOIL EROSION 
Impacts of reducing permanent preservation areas (APP) in urban areas on water quality: the case of the Irurá Watershed in Santarém, Pará, Brazil / Influência da diminuição das áreas de preservação permanente-APP em áreas urbanas, sobre a qualidade da água: Estudo de Caso Microbacia do Irurá, em Santarém-PA

Thiago Nascimento ${ }^{l}$ D. Christiane Monte ${ }^{1}$, Edinelson Saldanha ${ }^{1}$

${ }^{1}$ Universidade Federal do Oestedo Pará, Santarém, Brasil (shinaigger@gmail.com; christiane.monte@yahoo.com.br; edinelson_saldanha@hotmail.com)

As ações antrópicas provocam uma diversidade de impactos ambientais, entre estas, sobre os recursos hídricos, nas últimas décadas vem sofrendo alterações significativas, como no caso do córrego do Irurá, localizado em Santarém-Pará, região Amazônica. Sobre o contexto em que o poder público, não consegue sanar necessidades básicas, como esgotos, habitação, drenagem, ou seja, componentes mínimos para o saneamento, o que traria mitigação dos danos sobre as florestas e nos recursos hídricos. Mesmo considerando a capacidade de autodepuração do corpo córrego do Irurá, a conservação da mata ciliar é um fator importante sobre a qualidade da água. Desta forma este tem como objetivo monitorar a qualidade da água do córrego que o igarapé, as relacionando com a diminuição da área das matas ciliares. Para isso foram realizadas coletas de 2015 á 2018 no períodos sazonais, em cinco pontos da nascente até sua foz, realizando análises físicas, químicas e bacteriológicas, os quais foram utilizados no cálculo do índice de qualidade de água(IQA), para se conhecer os impactos que vem sofrendo no decorrer dos últimos anos, para a definição da área de drenagem, foi realizada com uso do modelo digital de elevação(MDE), uma classificação supervisionada de imagens spots definirão o monitoramento das APP, no período do estudo. Desta forma pode-se observa que a expansão urbana desordenada, provocou diminuição das APP, isso refletiu sobre a qualidade das águas ao longo dos três anos de monitoramento, embora ainda tenham se mantido dentro dos valores limitantes pelo CONAMA 357, para rios de classe II.

\section{Suspended sediments discharge before and after thinning related to construction of spur roads}

Yoshiki Shinomiya ${ }^{1}$, Masahiro Kobayashi ${ }^{1}$,Tatsuya Tsurita ${ }^{1}$, Yoshio Tsuboyama ${ }^{1}$, Shinji Sawano ${ }^{1}$, Yuko Itoh ${ }^{1}$, Yasuhiro Ohnuki ${ }^{2}$, Koji Shichi $^{3}$ ${ }^{1}$ FFPRI, Tsukuba, Japan; ${ }^{2}$ FFPRI,Tohoku, Morioka, Japan; ${ }^{3}$ FFPRI,Shikoku, Kochi, Japan (sinomiya@affrc.go.jp; kbmasa@affrc.go.jp; tatuya@affrc.go.jp; tsubo@affrc.go.jp; ssawano@affrc.go.jp; yuko106@affrc.go.jp; bchankan@affrc.go.jp; shichi@affrc.go.jp)

We investigated suspended sediment (SS) discharges before and after line thinning in a forested watershed located in a national forest in Ibaraki Prefecture, Japan. Line thinning was conducted at a thinning rate of 35\% across 17\% of the watershed area in 2012 and at same rate for the rest of the watershed in 2013. Spur roads were constructed along all streams. The lower slopes of the watershed were covered with conifer plantations of Japanese cedar, whereas the upper slopes were covered with deciduous trees. Line thinning has not conducted in the upper slopes. Stream water samples of about 1 -2 L were collected hourly using an automatic water sampler and filtered through glass fiber filters $(0.5 \mu \mathrm{m})$ to measure SS concentrations. Comparison between the same ranges of runoff showed higher SS concentrations in flood flow after thinning (October 2013-December 2014) than before thinning (June 2010-August 2012). Higher SS concentrations were not found in the second and third years after implementation of thinning, compared with levels observed before thinning. Although SS increased once, it tended to decrease because bared areas (mainly spur road) were covered with litterfall and vegetation regrowth within a few years after thinning. Results indicated that SS discharges in stream water increased after thinning, but that it eventually returned to the initial condition.

Hydraulic status and carbon buildup in ecological restoration systems depend on functional diversity, not taxonomic diversity / O status hídrico e acúmulo de carbono de sistemas de restauração ecológica dependem da diversidade funcional e não da diversidade taxonômica

Angelo Bertholdi, Vera Engel, Luiz Fernando Almeida

'UNESP, Botucatu,Brazil (angelobertholdi@gmail.com; vera.lex@unesp.br; luiz.rolim@unesp.br)

Espera-se que sistemas de restauração com alta diversidade de espécies alcancem melhor performance e estabilidade. Por exemplo, a combinação de espécies de crescimento rápido e lento possibilita uma rápida estratificação vertical, maior sombreamento e estabilidade do microclima no interior dos plantios. Entretanto, não se sabe se essas combinações seriam mais eficientes quanto ao uso da água e sequestro de carbono dos sistemas, questões relevantes num contexto de mudanças climáticas. Nosso objetivo foi avaliar se a capacidade de perda e recarga hídrica e acúmulo de carbono de espécies com ritmos de crescimento contrastantes favorecem as trajetórias de sistemas de restauração, e se a estrutura e diversidade dos mesmos afetam a performance das espécies. Avaliamos variáveis relacionadas à disponibilidade de água no solo e ambiente, relações hídricas e acúmulo de carbono em 6 espécies, com crescimento rápido e lento, em três sistemas de plantio: alta diversidade (40 espécies), sistema agroflorestal (20 espécies) e consórcio de espécies comerciais para madeira e lenha (25 espécies), em dois solos com fertilidade contrastante. As espécies de crescimento rápido mostraram melhor quanto ao status hídrico e acúmulo de carbono, principalmente no sistema agroflorestal e consórcio madeira e lenha, implantados com menor riqueza de espécies. Além disso, estes sistemas, embora com menor riqueza taxonômica e complexidade, apresentaram maior diversidade funcional. A eficiência fisiológica de determinados sistemas de restauração dependeu da diversidade funcional e não da diversidade taxonômica. Os resultados são importantes para orientar a escolha de espécies e de sistemas mais resilientes, num contexto de mudanças climáticas.

\section{Effects of natural disasters (wind damage, beetle damage) on nitrate concentrations in water in high mountain areas (Southern Poland, Tatras)}

Mirostaw Żelazny ${ }^{1}$, Monika Sajdak', Agnieszka Rutkowska², Marta Pufelska ${ }^{1}$, Tomasz Zwijacz-Kozica ${ }^{3}$

${ }^{1}$ Institute of Geography and Spatial Management, Jagiellonian University in Kraków, Kraków, Poland; ${ }^{2}$ Department of Applied Mathematics, University of Agriculture in Kraków,, Kraków, Poland; ${ }^{3}$ Tatra National Park, Zakopane, Poland (miroslaw.zelazny@uj.edu.pl; monika.sajdak@doctoral.uj.edu.pl; rmrutkow@cyfkr.edu.pl; marta.pufelska@doctoral.uj.edu.pl; tzwijacz@tpn.pl)

Tree stand decline has been observed in recent years due to beetle damage and wind damage in the high mountain areas of the Tatra Mountains in Poland. The aim of the study was to identify spatial and temporal differences in the concentration of nitrate in spring and stream water in the woodland zone of the Tatras (Poland). The Polish Tatras (area: $211.6 \mathrm{~km}^{2}$, woodland: 70\%) are located in Central Europe and are characterized by the presence of climate and vegetation zones. The mountain range is an environmentally unique area and remains protected by law in the form of a national park and an International Biosphere Reserve (UNESCO). Two hydrologic and chemical surveys were conducted for a total of 1,397 spring and stream water samples including 529 samples in 2007 and 868 samples in 2017. Water chemistry was determined at IGIGIP in Kraków using ion chromatography (DIONEX 2000) for the following ions: $\mathrm{Ca}^{2+}, \mathrm{Mg}^{2+}, \mathrm{Na}^{+}, \mathrm{K}^{+}$, $\mathrm{NH}_{4}^{+}, \mathrm{Li}^{+}, \mathrm{HCO}_{3}^{-}, \mathrm{SO}_{4}^{2-}, \mathrm{Cl}-, \mathrm{NO}_{3}^{-}, \mathrm{NO}_{2}^{-}, \mathrm{PO}_{4}^{3-}$. The concentration of nitrate in water has increased rapidly due to tree stand decline caused by beetle damage and wind damage from $2.37 \mathrm{mg} / \mathrm{L}$ in 2007 to $3.27 \mathrm{mg} / \mathrm{L}$ in 2017 or a $42 \%$ increase. The maximum concentration in 2007 was $7.91 \mathrm{mg} / \mathrm{L}$, while in 2018 it was 
$21.3 \mathrm{mg} / \mathrm{L}$ or roughly a $260 \%$ increase. The increase in the concentration of nitrate is observable also at the D90 level, which has risen roughly $160 \%$ (2007 $\left.\mathrm{D}_{90}=3.84 \mathrm{mg} / \mathrm{L}, 2018 \mathrm{D}_{90}=6.16 \mathrm{mg} / \mathrm{L}\right)$.

Superficial runoff in initial remediation after bauxite mining / Escoamento superficial na reabilitação inicial após mineração de bauxita Aline Gonçalves Spletozer ${ }^{1}$, Lucas Jesus Silveira ${ }^{1}$, Herly Carlos Teixeira Dias ${ }^{1}$ 'Universidade Federal de Viçosa, Viçosa, Brazil (alinespletozer_afmt@hotmail.com; ljsfloresta@hotmail.com; herly@ufv.br)

A mineração de superfície altera os processos hidrológicos e as características do solo e o escoamento superficial é um parâmetro que pode ser utilizado para monitorar a eficiência da reabilitação após a mineração. Neste trabalho, comparamos o escoamento superficial gerado na reabilitação inicial, após a mineração de bauxita, com o escoamento de antes da mineração. Sete parcelas, em área de mina de bauxita em Minas Gerais, Brasil, foram alocadas para coleta de escoamento superficial e monitoradas antes da mineração (janeiro a maio de 2017) e durante a reabilitação inicial (janeiro a maio de 2018). Os fatores físicoambientais que interferem no escoamento superficial foram caracterizados nos dois períodos e submetidos à análise de componentes principais (ACP). O escoamento superficial diminuiu de 0,76 para $0,30 \%$ da precipitação na reabilitação inicial em relação à área de referência. A inclinação do terreno e rugosidade da superfície foram os fatores determinantes na ACP, pois restringem a velocidade e o volume das perdas de água. A cobertura de vegetação nas parcelas antes e na reabilitação inicial foi de 100 e $64 \%$, respectivamente. A densidade e o teor de silte do solo aumentaram e a porosidade total, macroporosidade e matéria orgânica diminuíram na reabilitação inicial. As taxas de infiltração foram iguais nos períodos, provavelmente devido a presença de fissuras e fendas no substrato da reabilitação inicial que se assemelha aos caminhos biológicos de antes da mineração. A reabilitação após a mineração reduziu o escoamento superficial, sendo a inclinação e rugosidade da superfície os fatores determinantes.

\section{Comparative analysis of maintenance models to improve efficiency and sustainability in forest operations in Parana, Brazil}

Carlos Diniz', Claudio Guevara ${ }^{2}$,Eduardo Lopes ${ }^{3}$, Gabriel Miranda ${ }^{3}$,Henrique Koehler ${ }^{4}$

${ }^{1}$ Universidade Federal do Paraná, Curitiba, Brasil; ${ }^{2}$ Oregon State University, Corvallis, USA; ${ }^{3}$ Universidade Estadual do Centro-Oeste, Irati, Brasil; ㄴuniversidade Federaldo Paraná, Corvallis,Brasil(carlos.diniz@ufpr.br; guevarac@oregonstate.edu; eslopes@unicentro.br; gmiranda@unicentro.br; koehler@ufpr.br)

Most Brazilian forestry companies are using modern and high technology machines in performing wood harvesting operations. This situation requires constant precaution and new maintenance management models. The mechanical maintenance of wood harvesting machines is of great importance within the forest production process, as it is able to represent from 50 to $60 \%$ of the machine's total operational cost. Therefore, it is necessary to increase the mechanical availability of the machines and the reliability of the operations, since these factors are fundamental to increase the yield and to reduce costs in the production processes. Among the main maintenance programs, World Class Maintenance (WCM) stands out as a basis for preventive maintenance. In this sense, WCM promotes a culture change in respect to the reactive maintenance methods commonly employed by many industry segments. The objective of this research is to perform a comparative analysis between models of mechanical maintenance with a grapple skidder and to reduce operational costs. The comparative analysis included the Traditional Maintenance and the World Class Maintenance models, through determining mechanical availability, hydraulic oil consumption, and maintenance costs. The results showed an $8.2 \%$ increase in mechanical availability, a $1.1 \%$ decrease in maintenance costs, and a $77.8 \%$ reduction in hydraulic oil consumption using the WCM maintenance model. This would have a big impact preventing soil contamination by oil during harvesting operations, along with improving the efficiency and sustainability of forest operations. WCM models have the potential to enhance machine maintenance, operational safety, production capacity, and prolong machinery life.

\section{Eucalyptus forest plantation management's effect on watershed's water quality in the atlantic rainforest: Sao Paulo, Brazil}

Bianca Oliveira Fernandez ${ }^{1}$, Yugo Matsuda ${ }^{2}$, Isis Westphal de Oliveira ${ }^{2}$, Kelly Cristina Tonello ${ }^{1}$

${ }^{1}$ UFSCar, Sorocaba, Brazil; ${ }^{2}$ Suzano Papele Celulose, Itapetininga, Brazil (bih.fernandez@hotmail.com; yugoma@gmail.com; isis.westphal@hotmail.com; kellytonello@yahoo.com)

A watershed soil management can alter water quality at its basin. Agricultural activities are one of the main sources of water pollution and quality change on rural areas. In this scenario, the management of Eucalyptus planted forests have the potential to influence watershed's water quality where its situated or at its downstream. The aim of this study was to verify the influence of Eucalyptus forest management for pulp production and the rainfall regime in watershed's water quality monitored in São Paulo state. The parameters evaluated were turbidity, pH, total nitrogen, phosphorous, potassium, dissolved oxygen (DO) and biochemical oxygen demand (BOD) at four watersheds in the Atlantic rainforest, being Eucalyptus forest plantations common to all of them. The data analysis, comprised up to 84 months, demonstrated that the Eucalyptus forest management did not modify the water quality parameters monitored. Phosphorus concentrations were above from the naturally found in Brazilian rivers references. However, it wasn't possible to correlate statistically phosphorous concentrations to the forest management. This conclusion motivates the necessity to study and understand specifically phosphorus behavior face to other influences (e.g.: soil characteristics and other natural resilient process). The rainfall regime influenced parameters such as turbidity, total nitrogen and potassium. The results indicate that basins containing forest areas may benefit from them to buffer effects of agricultural uses with intensive soil management.

\section{E8s: NEXUS: FOREST, WATER AND CLIMATE}

\section{Tools for strategic decision making on water resources management under climate variability and drought conditions on the Caatinga's Biome of Northeast Brazil}

Marcos Airton de Sousa Freitas ${ }^{1}$

${ }^{1}$ National Water Agency - Brazil, Brasilia, Brazil (masfreitas@ana.gov.br)

Drought impacts in Northeast Brazil, which tend to intensify due to climate change and overexploitation of the caatinga biome, have repeatedly brought famine, mass migration and social conflicts in this region. Drought prediction and monitoring, however, remain a central research theme. In water resources management in semiarid regions such as the Northeast of Brazil, it is fundamental to have tools to aid decision making. This work presents three components of the so-called SIGES (Drought Management System), the items related to drought prediction and monitoring, as well as many reservoir operation methodologies for water scarcity situations. Statistical models and artificial neural networks were used for drought prediction. In order to perform precipitation monitoring, several indexes were adapted and incorporated into a drought basic characteristic monitoring system (duration, severity and intensity), so that different mitigating 
actions could be implemented in accordance with the values reached by these parameters. The following indexes have been used for this purpose: Rainfall Anomaly Index (RAI); Bhalme \& Mooley Drought Index (BMDI); Lamb Rainfall Departure Index (LRDI). Finally, new adaptive reservoir operation strategies for water scarcity situations are presented and discussed. The described components were applied to all federal States of Northeast of Brazil.

\author{
A stand evapotranspiration model coupling the effects of environment and stand structure of larch plantation \\ Zebin Liu ${ }^{1}$, Yanhui Wang ${ }^{1}$, Ao Tian ${ }^{1}$, Pengtao Yu ${ }^{1}$, Yarui Wang ${ }^{1}$, Lihong X ${ }^{1}$ \\ ${ }^{1}$ Research Institute of Forest Ecology, Environment and Protection, Chinese Academy of Forestry, Beijing, China (binarystar1989@163.com; \\ wangyh@caf.ac.cn; tianao640249@126.com; yupt@caf.ac.cn; wangyaruio@163.com; xulh@caf.ac.cn)
}

Evapotranspiration (ET) is an essential component of the forest stand water budget. Both the quantitative expression and accurate prediction of ET require the models describing the ET response to changing environment and stand structure. For an easy application, a relatively simple but mechanism-based forest stand ET model coupling the effects of the potential ET (ETref), relative extractable soil water (REW) of 0-60 cm, and forest canopy leaf area index (LAI) was developed, based on the field data of a larch (Larix principis-rupprechtii) plantation obtained in the non-rainfall days of the growing season (May. -Sep.) of 2015-2016 in northwest China. Results showed that: (1) with rising ETref, the weather-dependent potential ET (ETmax) increases initially quickly and then slowly following a binomial equation; (2) Daily ET increases with rising REW firstly quickly, then gradually slowly till to a certain threshold, and thereafter tends to be stable. The ET response to LAI is similar to REW. The response can be described by a saturated exponential growth function; (3) The daily stand ET model coupling these response functions to individual factors was determined as: ET $=E T \max (\mathrm{ETref}) \cdot f(\mathrm{REW}) \cdot f(\mathrm{LAI})=(-0.0992 \mathrm{ETref} 2+1.3253 \mathrm{ET}$ ref-0.1041) $\times(1-\mathrm{EXP}(-15.729 \mathrm{REW})) \times(0.900-0.262 /(1+\mathrm{EXP}((\mathrm{LAI}-1.381) / 3.294)))$, which showed a good performance in both calibration $\left(R^{2}=0.85\right.$, NashSutcliffe efficiency coefficient $(\mathrm{NSE})=0.85)$ and validation $(R 2=0.73$, NSE $=0.70)$. This indicated that the stand ET model coupling the effects of ETref, REW, and LAI can provide a way to accurately predict the daily ET.

\title{
Evidence on the relationship between landscape pattern and water quality
}

Ligia M. B. Campanhão' Victor E. L. Ranieri ${ }^{1}$

${ }^{1}$ Universidade de São Paulo (USP), São Carlos,Brazil (ligiambc@hotmail.com; vranieri@sc.usp.br)

Strategies aiming at conserving and restoring natural forests can help mitigate the negative impacts of land use and land cover change on the provision of environmental services (ES). However, little is known about the relationship between landscape pattern and the provision of ES, particularly watershed services. We provide a review of the literature on the relationship between the pattern of natural forests in the landscape and water quality. The landscape pattern at multiple scales, i.e., watershed and riparian buffer, can influence water quality. There is strong evidence indicating that higher proportions of forest cover in both scales are related to better water quality. While landscape composition has a prominent effect on water quality, the importance of landscape configuration is less evident. A major role of landscape configuration has been observed in both landscapes with intermediary values of forest cover and landscapes with very low forest cover. There is evidence that habitat fragmentation affects water quality both positively and negatively. The positive effect would occur by the reduction of landscape homogeneity with forest patches that act as physical barriers to nutrient and sediment transport. Other factors; e.g., slope, soil erodibility, and nutrient input; can play a crucial role and override the effect of landscape pattern on water quality. These results indicate that the influence of landscape pattern on water quality, particularly landscape configuration, needs clarification. To further explain this issue, studies addressing different landscapes, scales, and covariates, are needed.

\author{
Sustainability and vulnerability of the Moju River Basin in eastern Amazonia in Pará, Brazil / Sustentabilidade e vulnerabilidade da \\ bacia do Rio Moju, PA - Amazônia Oriental \\ Susane Ferreira ${ }^{I}$ iD, Aline Lima ${ }^{\prime}$, José Augusto Corrêa ${ }^{I}$ \\ ${ }^{1}$ Universidade Federal do Pará, Belém,Brasil (susane_cristini@hotmail.com; alinemeiguins@gmail.com;jamc@ufpa.br)
}

A água é um dos recursos naturais mais afetados pelo modelo de desenvolvimento adotado no Brasil. Fato relacionado ao sentimento generalizado de abundância de água no país que não ajuda a engajar plenamente todos os níveis de governo, como também obscurece os verdadeiros problemas de poluição, demanda, disponibilidade e conflitos da água. Este estudo visa fortalecer a gestão das águas e contribuir com a avaliação do processo de desenvolvimento da região nordeste do estado do Pará, utilizando Índices de Sustentabilidade de Bacias Hidrográficas, que considerem a situação hidrológica, a cobertura florestal, social e de gestão da bacia do rio Moju. Os resultados indicaram níveis moderados de sustentabilidade e governança. A Bacia possui 37,1\% de seu território com cobertura florestal, correspondendo a uma área de $5803,7 \mathrm{~km}^{2}$, entretanto sofre pressão devido ao seu potencial econômico, contemplando importantes atividades produtivas do Estado, que já ocupam 30\% de sua área, dentre elas a dendeicultura. De forma geral, falta uma maior informação de demanda e disponibilidade hídrica, com a ampliação do número de empreendimentos regularizados quanto às vazões de captação e de diluição. O quadro de governança das águas é marcado por uma organização associada à gestão ambiental e hídrica pouco consolidada, comum da maioria dos municípios amazônicos. Desta forma, a bacia do rio Moju reproduz o perfil da gestão das águas na bacia Amazônica associada à necessidade de implementar as políticas de recursos hídricos e de meio ambiente existentes, para a redução dos conflitos que vinculam uso da terra e das águas.

\footnotetext{
The impact of leaf litter on runoff in a fragment of Atlantic Forest / Influência da serapilheira no escoamento superficial de um fragmento florestal na Mata Atlântica

Aline Gonçalves Spletozer ${ }^{1}$, Sérgio Guedes Barbosa ${ }^{1}$, Herly Carlos Teixeira Dias ${ }^{1}$, Rodolfo Alves Barbosa ${ }^{1}$

${ }^{1}$ Universidade Federal de Viçosa, Viçosa, Brazil (alinespletozer_afmt@hotmail.com; sergioflora@hotmail.com; herly@ufv.br; rodolfo.ufv@gmail.com)

A função da serapilheira no escoamento superficial ainda não está esclarecida devido as características hidrofóbicas da matéria orgânica, portanto novos estudos principalmente de campo são necessários para esclarecer esse tema. O objetivo foi comparar o escoamento superficial em parcelas com e sem serapilheira em um fragmento florestal em estágio inicial de regeneração na Mata Atlântica. Seis parcelas foram construídas com bordas metálicas para a coleta do escoamento superficial, sendo três com serapilheira e três sem serapilheira. O escoamento superficial e a precipitação em aberto foram medidos após 28 eventos de chuva. A precipitação total foi de 1013,47 mm e os valores de escoamento corresponderam a 1,79\% e 2,54\% da precipitação para as parcelas com e sem serapilheira, respectivamente. O escoamento superficial das parcelas com serapilheira foi menor que as parcelas sem serapilheira, inferindo a isso a função dos resíduos vegetais na redução da velocidade do escoamento. A presença de serapilheira reduziu o escoamento superficial no fragmento florestal em estágio inicial de regeneração na Mata Atlântica.
} 


\section{Effects of composition and seasonality on transpiration of forest species in riparian zone}

Bruna Santos Lopes ${ }^{1}$, Pietro Fernandes ${ }^{1}$, Marina Otto ${ }^{1}$, Silvio Ferraz ${ }^{1}$, Robert Hubbard ${ }^{2}$

${ }^{1}$ Universidade de São Paulo, Piracicaba,Brazil; ${ }^{2}$ USDA Forest Service, Fort Collins, USA (bruna.santos.lopes@usp.br; pietro.fernandes@usp.br; groesalq@yahoo.com.br; silvio.ferraz@usp.br;r.m.hubbard@comcast.net)

Inadequate land use causes damage to the ecosystem, degrades the soil and waterways. Interventions for forest restoration seek the conservation of soils, as well as the recovery of ecosystem services. Although the beneficial effect of the tree vegetation around streams is known, little is known about the effect of forest restoration on the water regime of streams and the consumption of trees of different species and sizes. The aim of this study is to analyze how access to water by different native species influences their behavior in relation to water use. Sap flow measurements are being collected in three repetitions of four species of different successional stages. The variation in sap flow is measured by the Garnier method (1985), using heat dissipation probes. Preliminary results have shown differences in sap flow density and transpiration among different species. Faster growing tree species have consumed more water compared to slower growth species. It was observed that the trees present small differences in the transpiration rates between the rainy and dry periods, indicating that this may be due to the easier access to water in the riparian zone. From the results, it is hoped that this study can support the planning of the restoration areas aiming at maintaining the water available for consumption.

\section{E8t: PLANT: SOIL INTERACTIONS IN FORESTS}

\section{Soil surveys in the Cascavel Sub-Plain area: PronaSolos, PR / Levantamento de solos no Subplanalto de Cascavel - PronaSolos, PR}

Gustavo Ribas Curcio', Annete Bonnet ${ }^{1}$, João Henrique Caviglione ${ }^{2}$

${ }^{1}$ Embrapa Florestas, Colombo, Brasil; '2Instituto Agronômico do Paraná, Londrina, Brasil (gustavo.curcio@embrapa.br; annete.bonnet@embrapa.br; jhcaviglione@gmaii.com)

O PronaSolos Paraná tem como objetivo executar, concomitantemente, levantamento de solos e vegetação protetiva de rios e nascentes, respectivamente, nas escalas 1:50.000 e 1:10.000 na Bacia Hidrográfica Paraná III, a qual possui extensão territorial de $11.450 \mathrm{~km}^{2}$. A metodologia de amostragem de solos é pedossequencial, partindo dos topos das paisagens, sendo concluída nas margens de rios e nascentes. O subplanalto de Cascavel se caracteriza por paisagens pouco declivosas (menores que 20\%), com predomínio de paisagens constituídas por rampas de conformação convexa-divergente e côncavo-convergente. As rampas convexas-divergentes possuem os maiores comprimentos, frequentemente acima de 1,5 a $2 \mathrm{~km}$ ou mais de extensão, constituídas dominantemente por solos de alto potencial de uso - Latossolos Vermelhos Distroférricos típicos de textura muito argilosa, chegando praticamente até a beirada dos rios. As rampas côncavo-convergentes, em geral de menores dimensões, onde maciçamente se encontram nascentes, também são constituídas por Latossolos, tendo-se em alguns casos a presença dos Nitossolos Vermelhos mais próximos das nascentes. Chama a atenção a dicotomia ambiental no que se refere a estabilidade destas duas formas de rampa, pois nas rampas côncavo-convergentes há grande tendência de fortes concentrações de enxurradas. Este fato é preocupante devido as ocupações e manejos instituídos em passado recente, pois ao final destas rampas se identifica, com muita frequência, os Organossolos Háplicos Térricos sápricos, solos com importantes funções ecológicas. Grande parte destes encontram-se degradados ou em fase de degradação, incorrendo em perdas funcionais, tanto no que se refere a sua flora específica como nas funções relacionadas às questões hidrológicas.

Quantifying above-ground biomass and nutrients in monoculture plantations of Parapiptadenia rigida in the Pampa biome / Quantificação da biomassa e nutrientes acima do solo de Parapiptadenia rigida em plantio monoespecifico no Bioma Pampa

Hamilton Luiz Munari Vogel ${ }^{1}$, Monique Pimentel Lagemann ${ }^{2}$, Frederico Costa Beber Vieira ${ }^{1}$, Mirla Andrade Weber ${ }^{1}$, Mauro Valdir Schumacher ${ }^{2}$ ${ }^{1}$ UNIPAMPA, São Gabriel, Brazil; 2UFSM, Santa Maria, Brazil (hamiltonvogel@yahoo.com.br; moniquelagemann@gmail.com; fredericocbv@gmail.com; weber.mirla@gmail.com; mvschumacher@gmail.com)

O objetivo principal do estudo foi quantificar a biomassa, teores e estoques de nutrientes (N, P e K), de plantios de Parapiptadenia rigida (Benth.) Brenan, com presença e ausência de adubação NPK. O estudo foi realizado na área experimental da FEPAGRO Forrageiras, São Gabriel, RS. O solo da área é classificado como Argissolo Vermelho distrófico latossólico, com clima predominante Cfa (Köppen). O plantio do Angico-vermelho foi realizado com diferentes espaçamento (4x2, 6x2 e 10x2 m) em pastagem nativa nas entrelinhas, em três blocos com parcelas subdivididas com e sem adubação (15x36 m). Foram aplicados anualmente $50 \mathrm{~kg} \mathrm{ha}^{-1}$ de N, $40 \mathrm{~kg} \mathrm{ha}^{-1}$ de $\mathrm{P}_{2} \mathrm{O}_{5}$, e $70 \mathrm{~kg} \mathrm{ha}^{-1}$ de $\mathrm{K}_{2} \mathrm{O}$ (recomendação para pastagens). A biomassa foi coletada em maio de 2017, quando as árvores tinham 4,5 anos. Foram cortadas três árvores médias por subparcela, e, fracionadas em madeira, casca, galhos e folhas, pesadas com balança de gancho no campo. Após procedeu-se com a metodologia de digestão sulfúrica, para determinação dos teores de N, P e K. Foi usado o software RStudio para análise estatística. Para todos os espaçamentos, o crescimento das árvores foi significativamente superior nas subparcelas adubadas; a produção de biomassa foi quatro vezes superior quando aplicou-se adubação, principalmente de galhos e madeira. Em todos os tratamentos, os maiores estoques de N, P e K estão nas folhas e galhos, com os maiores teores de N, P e K encontrados nas folhas, indicando a grande importância da deposição de matéria orgânica e nutrientes para o solo destes componentes.

Soil-plant interaction and its relationship to dominant height in stands of Prosopis alba / Interacción suelo-planta y su relación con la altura dominante en rodales de Prosopis alba

Maria Gracia Senilliani ${ }^{l}$ (D), Miguel Brassiolo ${ }^{1}$

${ }^{1}$ Universidad Nacional de Santiago del Estero Facultad de Cs forestales - INSIMA, Santiago del Estero, Argentina (senilliani@yahoo.com.ar; mikyb@unse.edu.ar)

Prosopis alba es la especie nativa de mayor importancia en el Chaco semiárido para la forestación con múltiples objetivos. La actividad es incipiente en la región, gran parte de la superficie forestada se ha establecido en áreas muy diversas en función de la calidad del sitio, con comportamientos heterogéneos en el crecimiento de las plantaciones. Este estudio tiene como objetivo determinar factores edáficos que favorecen y limitan el desarrollo de la especie, información que será de utilidad para predecir la calidad de determinados sitios donde aún no hay plantaciones pero sí se conocen las condiciones edáficas. Los parámetros utilizados: Altura dominante (Hd), Edad (E) y área basal (AB), en relación a propiedades químicas como PH, Contenido de sales solubles (CE), Cationes solubles (Ca, Mg, Na), presencia de carbonatos, RAS y entre las propiedades físicas, humedad (hdad), Drenaje(D), Permeabilidad (P) y Textura (Text). Se realizó la primera evaluación de la correlación entre variables de crecimiento y variables edáficas mediante análisis de componentes principales en relación a 3 clases de calidad de sitio. Se determinó un modelo de proyección de HD en función de variables de mayor correlación, estimado a partir del análisis de 
regresión lineal múltiple que explica mas del 50\% de la variación en Hd de los rodales implantados. Resultados preliminares reportan que el crecimiento está condicionado principalmente por propiedades químicas de los suelos, entre las cuales la presencia de sales (CE y cationes solubles) explicaría en mayor medida el impacto en el crecimiento.

Quantifying the leaf litter and nutrients in a native forest in the central region of Rio Grande do Sul, Brazil / Quantificação da serapilheira e nutrientes em uma floresta nativa na Região Central do RS, Brasil

Hamilton Luiz Munari Vogel ${ }^{1}$, Monique Pimentel Lagemann², Mauro Valdir Schumacher ${ }^{2}$

${ }^{1}$ UNIPAMPA, Santa Maria, Brazil; ${ }^{2} U F S M$, Santa Maria, Brazil (hamiltonvogel@yahoo.com.br; moniquelagemann@gmail.com; mvschumacher@gmail.com)

Os estudos com deposição de serapilheira são considerados um importante indicador da qualidade ambiental dos ecossistemas florestais, constituindo a principal via de entradas de matéria orgânica e nutrientes para as florestas. O presente estudo teve como objetivo, quantificar a produção anual de serapilheira, sua sazonalidade, e a deposição de N, P e K pelas folhas, em um fragmento de floresta nativa do tipo Estacional Semidecidual, na região da Depressão Central, município de São Sepé, RS. No interior desta floresta, com condições homogêneas de sítio, foram alocadas sistematicamente cinco parcelas de $20 \mathrm{~m}$ x $15 \mathrm{~m}$, onde foram distribuídos cinco coletores de serapilheira por parcela (0,1963 $\mathrm{m}^{2}$ por coletor), envoltos por uma tela com $2 \mathrm{~mm}$, a um metro a partir do solo. As coletas foram realizadas mensalmente por um período de dois anos (maio/2015 a abril/2017). No laboratório, as amostras foram separadas nas frações folhas, galhos finos (diâmetro $<0,5 \mathrm{~cm}$ ) e miscelânea (cascas, sementes, flores e detritos não identificáveis). Após foi determinado os teores de $\mathrm{N}$, $\mathrm{P}$ e K nas folhas. Verificou-se maior deposição de serapilheira na primavera, com os maiores picos de devolução principalmente no mês de outubro, indicando um comportamento sazonal de deposição. A deposição média de serapilheira foi de 6,87 Mg ha-1 ano-1; deste total as folhas foram responsáveis por 67,67\%, seguido da miscelânea com $17,59 \%$ e dos galhos finos com $14,74 \%$. As folhas foram responsáveis pela deposição média para o solo de 97,$4 ; 4,2$ e $25,5 \mathrm{~kg}^{2} \mathrm{a}^{-1}$ ano-1 de N, P e K respectivamente.

Assessing heavy metals using energy-dispersive X-ray spectroscopy in two conifers at the Chapingo Autonomous University I Determinación de metales pesados mediante espectrometría de dispersión de energía por rayos $x$ en dos coniferas de la Universidad Autónoma Chapingo

Andrea Janet Granados Mendoza1, Edgar Fernando Vázquez Soto ${ }^{2}$

${ }^{1}$ Universidad Juárez del Estado de Durango, Durango, Mexico; ${ }^{2}$ Universidad Autónoma Chapingo, Texcoco, Mexico (andiimendozza@gmail.com; edgarvzz18@gmail.com)

Los metales pesados se encuentran en aire, agua y principalmente en el suelo, concentrándose esencialmente en raíces, mientras que, secundariamente estos elementos tóxicos se almacenan en tallos y hojas, causando graves problemas en estos, e inclusive ocasionando la muerte de la planta completa. Por lo tanto, los objetivos de este estudio son evaluar la presencia de metales pesados, así como la cuantificación de ellos en dos coníferas Pinus pseudostrobus Lind. y Pinus maximartinezii Rzed de la Universidad Autónoma Chapingo. Para identificar y cuantificar los agentes nocivos acumulados en dichas especies, se tomaron muestras de estas, a una altura de 1.30 metros, con la ayuda de un taladro de Pressler, donde posteriormente las virutas fueron divididas en parte inicial, intermedia y final, para después ser sometidas a técnicas de Microscopia Electrónica de Barrido (MEB) y Espectrometría de Rayos X (EDX). Los datos obtenidos indicaron que el elemento con mayor acumulación en las muestras de Pinus fue el Arsénico (As) con un valor máximo de $75.10 \%$ ubicado en la parte media y un valor mínimo de 31.19 \%, mientras que el elemento con menor incidencia fue el Plomo (Pb) con un valor máximo de 5.94 \% y con un valor mínimo de $1.02 \%$ respecto de las muestras. Este estudio concluye que para asegurar que los pinos de la Universidad Autónoma Chapingo continúen proporcionando servicios ambientales claves, es necesario implementar programas enfocados en técnicas de biorremediación para la remoción de los metales pesados presentes en la zona de estudio.

Soil fertility and growth in a Pinus taeda plantation considering the residual effect of 30 years of accumulated detritus in Rio Negrinho, Santa Catarina, Brazil / Fertilidade do solo e crescimento de um plantio de Pinus taeda dado o efeito residual de 30 anos do acúmulo de necromassa no municipio de Rio Negrinho - SC

Ana Rosaria Sclifo Zucon ${ }^{1}$, Antonio Carlos Vargas Motta ${ }^{1}$, Shizuo Maeda 2 , Cleiton Frigo ${ }^{1}$,Edvaldo Renner da Costa Cardoso ${ }^{1}$, Lenir Fátima Gotz ${ }^{1}$

${ }^{1}$ Universidade Federal do Paraná, Curitiba, Brasil; ${ }^{2}$ Embrapa Florestas, Colombo,Brasil (zuconana@gmail.com; mottaacv@ufpr.br;

shizuo.maeda@embrapa.br; cleiton.frigo@hotmail.com; edvaldorcardoso@hotmail.com; lenir_gotz@hotmail.com)

Durante a expansão da implantação de povoamentos florestais comerciais, áreas de vegetação primária foram convertidas, e os resíduos resultantes do desmate enleirados ou acúmulo de necromassa. Nesse contexto, inserem-se os plantios comerciais de Pinus da empresa Companhia Volta Grande, localizada no município de Rio Negrinho, SC, com talhões com leiras acumuladas há mais de 30 anos, atualmente ocupados por plantio de Pinus taeda com 12 meses de idade. Esse trabalho teve como objetivo a avaliação dos efeitos do acúmulo de material lenhoso (leiras) na fertilidade do solo e crescimento do povoamento de Pinus. O experimento foi instalado em um talhão da empresa, utilizando-se uma adaptação da metodologia de linha transectal, demarcando-se um transecto de $300 \mathrm{~m}$ de comprimento ao longo do talhão de forma transversal às leiras. Coletaram-se dados de altura das plantas e amostras de solo (0 a 20 e 20 a 40 $\mathrm{cm}$ de profundidade). Verificaram-se alturas médias dos indivíduos de 2,24 e 1,79 m para locais das leiras e sem acúmulo, respectivamente. Solo da leira comparativamente a fora da leira, apresentava menor $\mathrm{pH}$ para ambas profundidades avaliadas e maior valor para K, P, Mn, Fe e Zn disponível e menor valor de Cu disponível, na camada de 0-20 cm. Para a profundidade de 20-40 cm, verificaram-se maiores valores para K, P, Cu e Fe e diminuição de Mn para as áreas da leira. O acúmulo de resíduo afeta a fertilidade do solo e por consequência o crescimento da planta a longo prazo.

Fragility index of forest soils within the Chilean Forest Plantation Protocol / Índice de fragilidad de suelos forestales en el marco del protocolo de plantaciones forestales Chile

Samuel Francke', Celso Carnieletto ${ }^{1}$

'Corporacion Nacional Forestal, Santiago, Chile(samuel.francke@conaf.cl; celso.carnieletto@conaf.cl)

Los principales impactos ambientales a nivel nacional de operaciones forestales se expresan en la generación de procesos erosión, sedimentación y turbidez 
de las aguas que contribuyen a disturbar el funcionamiento de las cuencas hidrográficas del país. En la actualidad, los sistemas de cosecha a tala rasa pueden extenderse hasta una superficie de 500 ha y se cosechan anualmente una superficie del orden 80.000 ha. Si bien la cosecha forestal debe estar acompañada de procesos de reforestación y mitigar los impactos en el suelo y aguas, provenientes de las operaciones forestales en el marco de los lineamientos FSC, resulta posible la adopción voluntaria del Protocolo de Plantaciones Forestales y la normativa vigente del plan de manejo "corta, explotación y reforestación", que se presenta a Conaf. El presente trabajo, integrado a una guía respectiva para los actores del sector forestal, contempla lo siguiente: Los conceptos y definiciones técnico-legales, Los elementos metodológicos en la construcción de Î́ndices de fragilidad de suelos forestales, Los factores a considerar edafo-climáticos, hidrológicos y topográficos, El Índice, clases de fragilidad y compendio de suelos forestales. a principal lección aprendida para el sector forestal se refiere a lograr armonizar una producción forestal sostenible con una conservación forestal sustentable a nivel de cuencas hidrográficas, de tal forma, que la fertilidad del suelo, la productividad sitio forestal y la conservación de los signos vitales de salud de la cuencas hidrográficas y recursos hídricos, resulten sostenible a través de sucesivas rotaciones forestales.

Soil attributes and yields from Pinus taeda in forests in southern Brazil / Atributos do solo e produtividade do Pinus taeda em florestas no sul do Brasil

Renato Marques ${ }^{1}$, Carolina Benghi Pinto ${ }^{1}$, Isabel Deliberali ${ }^{2}$, Mauro Valdir Schumacher ${ }^{3}$

${ }^{1}$ Universidade Federal do Paraná, Curitiba, Brasil; ${ }^{2}$ Instituto de Pesquisas e Estudos Florestais, Piracicaba, Brasil; ${ }^{3}$ Universidade Federal de Santa Maria, SantaMaria,Brasil(rmarques@ufpr.br; carolinabenghi@gmail.com; isabel@ipef.br;mauro.schumacher@ufsm.br)

$\mathrm{O}$ conhecimento das relações entre os atributos edáficos e a produtividade das árvores pode servir como base para a orientação das práticas de manejo em plantações florestais. Este trabalho de pesquisa é fruto do Programa Cooperativo sobre Produtividade Potencial do Pinus no Brasil (PPPIB) desenvolvido pelo Instituto de Pesquisas e Estudos Florestais (IPEF) em plantações localizadas nos estados do Paraná e Santa Catarina. Teve por objetivo identificar os atributos edáficos relacionados com a produtividade do Pinus taeda. Dezesseis perfis de solos sob reflorestamentos foram descritos e amostras de solos foram coletadas para a realização das análises físicas e químicas, sendo a classificação realizada até o quarto nível categórico conforme o Sistema Brasileiro de Classificação de Solos. Os dados de produtividade como índice de sítio (IS), volume (V) e incremento médio anual (IMA) foram obtidos dos inventários anuais realizados pelas empresas florestais. Foram identificados 2 grandes grupos de produtividade por meio de análise de agrupamento. Os atributos do solo que mais se relacionaram com a produtividade florestal, nestas plantações de Pinus no Sul do Brasil, foram o teor de argila no perfil do solo e a profundidade do horizonte A, associada ao carbono do solo.

E8u: PLANT: SOIL INTERACTIONS IN FORESTS

\section{Soil fertility and earthworm activity are affected by dead trees in old-growth temperate forests of Northern Iran}

Mehrasa Zare ${ }^{\prime}$, Yahya Kooch ${ }^{1}$

${ }^{1}$ Tarbait Modare University, Noor, Islamic Republic of Iran (mehrasazr@gmail.com; yahya.kooch@yahoo.com)

Dead tree is an important ecological factor for changing of soil features that attracts different livings. Due to investigation the decay degree effects of downed tree on soil properties and earthworms ecological groups, the Sardabrood forest (Mazandaran, Iran) was choosed. For this purpose, 306.2 ha areas considered at $700-1300 \mathrm{~m}$ altitude range and twenty seven downed trees of beech and hornbeam species were found. Decay degree of downed tree classified in four classes (DC1, DC2, DC3 and DC4). Whole of dead trees selected as the center of sample plots and mixed soil samples were taken from theirs besides and along at 0 - 10, 10 - 20 and 20 - $30 \mathrm{~cm}$ depth. Soil pH, water content, organic carbon (C), total nitrogen (N) and C/N ratio measured at the laboratory. The earthworms were collected simultaneously with the soil sampling by hand sorting. The maximum of soil $\mathrm{pH}$ and water content considered under DC4 of dead trees and significant differences were found. But, soil depth had no significant differences for these characters. Also, the most amounts of soil C and N found in DC4 of dead trees and upper layers of soil. DC1 of dead trees and soil lower depths devoted the maximum of C/N ratio. Principal component analysis (PCA) showed that the most assemblage of earthworms were around of dead trees with high decay degree (DC4). Density and biomass of earthworms group in dead trees positions indicating endogeics are due to creating significant statistical differences between beech and hornbeam downed trees.

\section{Stomatal density of Eucalyptus and Corymbia species with different levels of drought tolerance}

Patricia Andressa de Avila ${ }^{1}$, Alexandre de Vicente Ferraz ${ }^{2}$, Liamara Santos Masullo ${ }^{1}$, José Renato Drago ${ }^{3}$, José Leonardo Moraes Gonçalves ${ }^{1}$ ${ }^{1}$ ESALQ/USP, Piracicaba, Brazil; ${ }^{2} I P E F$, Piracicaba, Brazil; ${ }^{3}$ Bahia Specialty Cellulose/Copener Florestal, Alagoinhas, Brazil (avilapa@usp.br; alexandre@ipef.br; liamaramasullo@usp.br;jose_drago@bahiaspeccell.com; jlmgonca@usp.br)

Many leaf morphological characteristics (e.g., stomatal density) are closely related to the level of drought tolerance (DT) in eucalyptus. Considering the expansion of Eucalyptus plantations in Brazil into areas with lower water availability (Northeast and West-central), it was studied stomatal density of $E$. grandis e E. urophylla (low DT), E. cloeziana e C. citriodora (intermediate DT), E. camaldulensis e E. brassiana (high DT). The study is located in the municipality of Itatinga-SP, Brazil, in a completely randomized design. At 11 months post-planting, 10 leaves of crown upper third of four tree were collected, totalizing 40 healthy and totally expanded leaves of each specie. Epidermal impressions of middle abaxial portion of leaf surface were made using colorless adhesive. So, epidermal impressions were placed onto a microscope slide and photographed three times (20x objective). The stomatal number by mm ${ }^{2}$ was evaluated by ImageJ software. The E. cloeziana had higher stomatal density (600 stomatos.mm-2), followed by E. urophylla and E. grandis (450 stomatos.mm-2). More tolerant species to drought (eg., C. citriodora, E. camaldulensis and E. brassiana) showed lower stomatal density (300 stomatos.mm-2). Normally, plants with lower stomatal density values have lower leaf transpiration rate, resulting in a higher tolerance to water and thermal stress.

\section{Woodland resilience to climate change: assessing tree-soil-water relations under elevated atmospheric $\mathrm{CO}_{2}$}

Susan Quick ${ }^{1}$,Stefan Krause ${ }^{1}$, Giulio Curioni ${ }^{1}$, Neil Loader $^{2}$, Alan Jones $^{3}$, Phillip Blaen $^{1,4}$, Carolina Mayoral ${ }^{1}$, A.Rob MacKenzie $^{1}$ ${ }^{1}$ Birmingham Institute of Forest Research, University of Birmingham, Birmingham, United Kingdom; ${ }^{2}$ Geography Department, University of Swansea, Swansea, United Kingdom; ${ }^{3}$ Earthwatch Institute, Oxford, United Kingdom; ${ }^{4}$ Yorkshire Water (currently), Leeds, United Kingdom (seq616@student.bham.ac.uk; s.krause@bham.ac.uk;g.curioni@bham.ac.uk;n.j.loader@swansea.ac.uk; ajones@earthwatch.org.uk; 
p.j.blaen@bham.ac.uk; c.mayoral@bham.ac.uk;a.rmackenzie@bham.ac.uk)

Birmingham Institute of Forest Research (BIFoR) has a second generation Free Air $\mathrm{CO}_{2}$ Enrichment FACE experiment set in mature UK broadleaf temperate forest dominated by 160-year-old and $25 \mathrm{~m}$ tall oak (Quercus robur) trees interspersed with sycamore (Acer pseudoplatanus), hazel (Corylus avellana), hawthorn (Crataegus monogyna), and holly (Ilex aquifolium). The basic FACE treatment consists of +150 ppmv above ambient applied in daylight hours throughout the growing season ( A April-November, depending on phenology). There are three $\mathrm{eCO}_{2}$ treatment patches, three full-infrastructure control patches, three no-infrastructure control patches, and up to two years of pre-treatment baseline data. Elements of Tree-Soil-Water relations at BIFoR FACE, including total precipitation, throughfall, soil moisture, and xylem sapflow, were measured relating to the dominant species pedunculate oak ( $Q$. robur). Preliminary baseline pre-treatment datasets (to April 2017) are compared, using seasonal and species specific approaches, with initial response datasets for enriched carbon dioxide $\left(\mathrm{eCO}_{2}\right)$ during the 2017-2019 seasons. Variability in response to $\mathrm{eCO}_{2}$ is assessed and related to measurements of tree physiology, canopy structure, and meteorology (including incident radiation levels and air/soil temperature profiles).

\section{Benchmarking edaphic properties of Arabuko Sokoke forest for long-term biodiversity monitoring}

Mwadalu Riziki', Muturi Gabriel2, Gathara Mary²

${ }^{1}$ Kenya Forestry Research Institute, Malindi, Kenya; ${ }^{2}$ Kenya Forestry Research Institute, Nairobi, Kenya (zikiemwa@gmail.com;

gabrielmukuria2012@gmail.com; mwgathara@gmail.com)

Biodiversity monitoring is an essential aspect of effective forest resource conservation and sustainable management. Monitoring edaphic properties of a forest is a useful tool in forest biodiversity assessments due to the role played by different soil properties in forest regeneration. Spatial and temporal monitoring of soil functions and dynamics provides vital information on response of forest soil to changes in climate, pollution and forest management practices. In light of this, a study was initiated at Arabuko Sokoke forest to monitor changes in biodiversity indicators over a period of time. The experiment was set as a completely randomized design with three treatments (Brachystegia spiciformis zone, Cynometra webberi zone and mixed forest zone). A total of 27 permanent sample plots measuring $50 \mathrm{~m}$ x $30 \mathrm{~m}$ each were established. Baseline soil samples were collected for soil physical and chemical analysis using standard procedures. Baseline results indicate that Soil Organic Matter, Total Nitrogen and Carbon were significantly different across the different vegetation zones $(\mathrm{p}<0.05)$. The Brachystegia and Cynometra zones recorded higher P concentration of $3.4 \mathrm{ppm}$ and $3.35 \mathrm{ppm}$ respectively, while the mixed forest zone which is dominated by white sand had a P concentration of $2.7 \mathrm{ppm}$. The $\mathrm{pH}$ was significantly different across the vegetation zones $(\mathrm{p}<0.001)$. Bulk density of the forest soil was $1.34 \mathrm{~g} / \mathrm{cm}^{3} \mathrm{dominated}$ by sandy and sandy loam soils. The baseline soil data is crucial for providing information necessary for developing rehabilitation frameworks and supporting biodiversity related decision making in forest policy and management.

\section{Soil diversity as influenced by different forest ecosystems in the Southern Western Ghats, India}

Sujatha MPP', Thomas $T P^{1}$, Kavitha $C^{1}$, Sandeep $S^{1}$

'Kerala Forest Research Institute, Thrissur,India (sujatha@kfri.org; thomas@kfri.org; kavien2007@gmail.com; sandeep@kfri.res.in)

Soil, the key source of life in this planet is very dynamic and heterogeneous natural resource. The Southern Western Ghats of India, which occupy mostly in the State of Kerala is endowed with different types of natural vegetations and soils, owing to the wide variation in topography, litho sequence, rainfall and temperature. The major forest types of this region include wet ever green, semi evergreen, deciduous, shola grassland systems, natural bamboo etc. The diversity in soils with respect to morphological, physical and chemical properties as influenced by different forest covers is explored in this study. The study revealed that the occurrence of natural forest ecosystems in this region is mainly governed by the climatic and altitudinal variations, and each vegetation exerted significant influence on the soils supporting them. Among the ecosystems, shola forest was very unique in its soil characteristics with its higher stock of organic carbon (631.2 $\mathrm{Mg} \mathrm{C} \mathrm{ha-1}^{-1}$ ) even up to $1.5 \mathrm{~m}$ along with higher content of exchangeable Al. But the same pattern with respect to carbon stock and Al was not seen in grasslands, which was adjacent to shola forest. The disturbance to natural forests showed a strong impact on weathering and laterisation processes while clay minerological make up was found associated with peculiar forest ecosystems.

Influence of forest structure on soil respiration in different sites in Central Amazonia / Influência da estrutura da floresta na respiração do solo em diferentes sítios na Amazônia Central

Marcelo Teles ${ }^{1}$, Roberval Lima², Celso Paulo de Azevedoº, Jörg Matschullat ${ }^{3}$

${ }^{1}$ Universidade Federal do Amazonas, Manaus, Brazil; ; ${ }^{2}$ mbrapa Amazônia Ocidental, Manaus, Brazil; ${ }^{3}$ Technishe Universität Bergakademie Freiberg,

Freiberg,Germany (renanteles@yahoo.com.br; roberval.lima@embrapa.br; celso.azevedo@embrapa.br; matschul@tu-freiberg.de)

O papel das florestas tropicais nas mudanças globais vem sendo estudado em função da sua dimensão e inter-relação com os gases de efeito estufa que influenciam no aquecimento global. O objetivo deste estudo é investigar a influência da estrutura da floresta na respiração do solo em diferentes sítios na Amazônia Central, abrangendo 5 municípios do estado do Amazonas. As variáveis dependentes selecionadas para as análises foram o efluxo de $\mathrm{CO}_{2}, \mathrm{CH}_{4} \mathrm{e} \mathrm{N}_{2} \mathrm{O}$, que apresentaram médias de $6,23 \mu \mathrm{mol} \mathrm{CO}_{2} \mathrm{~m}^{-2} \mathrm{~s}^{-1} ;-4,86 \mu \mathrm{mol} \mathrm{CH}_{4} \mathrm{~m}^{-2} \mathrm{~h}^{-1} \mathrm{e} 1,33 \mu \mathrm{mol} \mathrm{N} \mathrm{O} \mathrm{m}^{-2} \mathrm{~h}^{-1}$, respectivamente. Foram realizadas análises de correlação para avaliar as relações entre as variáveis das florestas, onde área basal, DAP máximo e índice de Shannon apresentaram sinais de correlação com a respiração do solo; por sua vez as variáveis edafoclimáticas umidade do ar e do solo e temperatura do ar também apresentaram correlações com os fluxos de gases. Foram ajustados modelos de predição com as variáveis da estrutura da floresta e as edafoclimáticas. As médias dos parâmetros da estrutura floresta mostraram diferenças significativas entre os sítios estudados. O efluxo de gases a partir do solo, nos sítios sob cobertura de florestas não apresentaram diferenças relacionadas ao $\mathrm{CO}_{2}$, entretanto apresentaram diferenças significativas entre alguns sítios para efluxos de $\mathrm{CH}_{4}$ e $\mathrm{N}_{2} \mathrm{O}$. Detectou-se diferenças nos efluxos de gases entre os sítios sob florestas e aqueles em que ocorreram mudanças no uso da terra.

E8v: PLANT: SOIL INTERACTIONS IN FORESTS

\section{Stands of norway spruce and scotch pine on postagrogenic soils of the Boreal Zone of the North-West of Europe}

Dmitriy Danilov ${ }^{1,2}$, Natalia Beliaeva ${ }^{2}$

Pesq. flor. bras., Colombo, v. 39, e201902043, Special issue, p. 1-768, 2019 
${ }^{1}$ Leningrad Research Institute For Applied Agricultural Science «Belogorka», Leningrad region, Gatchina District, Russian Federation; ${ }^{2}$ St. Petersburg State Forest Engineering University named after S. M. Kirov».,St. Petersburg, Russian Federation (stown200@mail.ru; galbel06@mail.ru)

To date, there is a significant amount of coniferous forests have arisen on lands previously used in agriculture. For the conditions of the boreal zone of Europe, the formation of stands of pine and spruce on post-agrogenic lands has its own characteristics different from similar stands growing on forest soils. In contrast to forest lands, the presence of a more powerful root profile on arable soils makes it possible to form more productive coniferous plantations. The structure of mixed stands of pine and spruce on the representation of trees of different classes of diameters differs from natural forest plantations. In mixed stands on postagrogenic lands, the distribution rows of spruce pine trees have a greater number of classes of trunk diameter. Depending on the share of participation in the composition of pine and spruce plantations formed with different reserves to the age of mature stands. The stock of pine and spruce stands on former arable lands at the age of 80 years is equal to the stock of forest stands on forest soils at the age of 100-120 years. It is necessary to develop a regime of farming in coniferous stands on postagrogenic soils of the boreal zone.

\section{Phytoremediation strategies using various cover plants for Mined-Out Areas in Bagacay Western Samar, Philippines}

Angelito Exconde ${ }^{I}$, Albert Piñon ${ }^{I}$, Analyn Pasagdan ${ }^{I}$, Allan Castillo ${ }^{I}$, Maria Theresa De Alday ${ }^{I}$

${ }^{1}$ Ecosystems Research and Development Bureau, Department of Environment and Natural Resources, Los Baños, Laguna, Philippines

(erdb.excondelito@gmail.com; alpinon@yahoo.com; arpasagdan@gmail.com; alan.castillo@usq.edu.au; mtvdealday@gmail.com)

Increasing mining activities brought by industrial progress causes heavy metal sedimentation that pollutes the surrounding landscapes. Since this condition is affecting the environment and the people living within the site adversely, it requires immediate rehabilitation. Fortunately, the trees" "phytoremediation" ability offers the best option as they are cheap and locally available. However, with the extreme micro-climate condition, looking for the best cover crop and soil amelioration to ensure the trees growth and survival is a challenge. Hence, this study sought to conduct soil amelioration, identify suitable cover plants, and ascertain the effect of mulching materials to plant's growth and survival in mined-out areas. Using nine soil amelioration treatments and various farm wastes as mulch, the experiment used a split-plot in Randomized Complete Block Design with three replicates and arranged in 5 x 10 meter individuals per plot to test the four species of cover plants such as Saccharum spontaneum L., Wedellia trilobata (L.) A.S. Hitchc., Arachis pintoi Krapov. \& Greg., Vetiveria zizanioides (L.) Nash. After a year, all cover plants planted in soil media with a combination of forest soil + chicken manure + lime were found to have better growth and percent survival compared to control treatment (forest soil). $V$. zizanioides outperformed the other species in terms of growth and percent survival. Aside from protective cover, farm waste materials as mulch serves as nutrient-source of the cover crop's root systems.

\section{Flora and vegetation characteristics of desertification restoration area for reduction of yellow sand}

EungPill Lee ${ }^{1}$, SeungHyuk Lee ${ }^{2}$, SungBae Joo ${ }^{3}$, EunJoo Lee ${ }^{4}$, YongSik Hong ${ }^{1}$, SeungYeon Lee ${ }^{1}$, EuiJoo Kim ${ }^{1}$, YoungHan You ${ }^{1}$ Kongju National University/Life science, Gongjusi, Republic of Korea; ${ }^{2}$ Baekdudaegan national arboretum, Bonghwagun, Republic of Korea; ${ }^{3}$ National Institute of Ecology, Seochungun, Republic of Korea; ${ }^{4}$ Seoul National University, Seoulsi, Korea, Republic of(lyp2279@kongju.ac.kr; sensus@bdna.or.kr; doctorjoo@nie.re.kr;.lyp2279@kongju.ac.kr; hongfin@smail.kongju.ac.kr; ecolee21@kongju.ac.kr; euijoo@kongju.ac.kr;youeco21@kongju.ac.kr)

Dust from dry and semi-arid areas is emerging as an environmental issue. In order to reduce the damage of desertification and dust caused by land degradation, restoration of vegetation was carried out in the Huronbeyar region of China. In order to understand the changes of plant diversity and the structure and characteristics of ecosystem, this study was conducted to investigate flora and vegetation, chlorophyll content, chlorophyll fluorescence and soil respiration in each year from 2014. As a result of the flora investigation of the Ganjiru restoration area, the main dominant species were the Caragana koreana and Astragalus membranaceus which appeared in all regions, and there was a difference in the plant classification which was found by restoration year. As a result of PCA and cluster analysis based on vegetation survey, it was found that plant communities were distinguished over time of restoration, and R-2008 and R-2011 were mixed a little so that plant composition had many common points. The chlorophyll content was much different from that of 2014, and the chlorophyll fluorescence was not significantly different but it seems to be under some stress. Soil respiration rate showed a tendency according to the restoration. This work was supported by the National Research Foundation of Korea(NRF) grant funded by the Korea government(MSIT) (No. NRF- 2018R1A2B5A01021358) and Joint Research on Dust and sandstorm among Korea, China, Japan in 2018.

\section{Rhizosphere ecoenzymatic stoichiometry of over- and under-stories in subtropical plantation}

Xiaoqin Dai', Yuqiu Gao', Huimin Wang ${ }^{1}$

${ }^{I}$ Qianyanzhou Ecological Research Station, Key Laboratory of Ecosystem Network Observation and Modeling, Institute of Geographic Sciences and Natural Resources Research, Chinese Academy of Sciences, Beijing, China (daixq@igsnrrac.cn; gao_yuqiu@qq.com; wanghm@igsnrr.ac.cn)

Identifying the nutrient status of root-soil interface of coexisting species is important for plantation ecosystem management. Soil extracellular enzyme activities and their stoichiometries, reflecting the relative microbial energy and nutrient limitations, are important indicators of soil nutrient status. Seven hydrolytic enzyme (C-, N- and P-acquiring enzyme) activities of rhizosphere soil of overstory trees, understory shrubs (Loropetalum chinense, Adinandra millettii and Eurya muricata) and herbs (Woodwardia japonica, Dryopteris atrata and Dicranopteris dichotoma) were measured in plant early growth stage (April) and plant vigorous growth stage (July) in Cunninghamia lanceolata, Pinus massoniana and Pinus elliottii pure plantations at Taihe, Jiangxi. C-acquiring enzyme was represented by $\beta$-1,4-glucosidase, $\alpha$-1,4-glucosidase, $\beta$-xylosidase and $\beta$-d-cellobiosidase, $\mathrm{N}$-acquiring enzyme was represented by $\beta$-1,4-Nacetylglucosaminidase and leucine aminopeptidase, and P-acquiring enzyme was represented by acid phosphatase. The C- and N-acquiring enzyme activities of rhizosphere soil of $L$. chinense in April were significantly higher than those of $P$. massoniana and $P$. elliottii. In July, three enzyme activities of rhizosphere soils of overstory trees and $L$. chinense were significantly higher than those of E. muricata, except for P-acquiring enzyme in $C$. lanceolata forest. The ratios of C-, N-, and P-acquiring enzymes averaged to 1:0.88:1.25 in April and 1:1:1.25 in July. More microbial investment in C-acquiring enzyme was found compared to $\mathrm{N}$-acquiring enzyme in April. Higher P-acquiring enzyme was obtained compared to C- and N-acquiring enzymes whatever in April and in July. Considering forest stand types, understory species and sampling seasons is helpful for the understory vegetation management of subtropical plantation ecosystem.

\section{Change in soil properties and plant growth at reclaimed land due to application of torrefied wood chip and vermicompost}

Byung Bae Park ${ }^{l, 2}$, Aung Aung ${ }^{1}$, Si Ho Han', Jeong Min Seo ${ }^{1}$, Woo Bin Youn ${ }^{1}$, Huong Thi Thuy Dao ${ }^{1}$

${ }^{1}$ Department of Environment and Forest Resources, Chungnam National University, Daejeon, Korea, Republic of; ${ }^{2}$ Korean Society of Forest Science, Seoul, Korea,Republic of (bbpark@cnu.ac.kr; baganaung777@gmail.com; bupleurumhan@gmail.com; jmseo3@naver.com; dbsdnqls95@naver.com; 
thuyhuong.150495@gmail.com)

Soil salinity change in reclaimed land is one of major constraints for food production. However, soil properties in this land can vary by time as attempts for desalinization process accelerate. There are several soil-amendment methods to remediate reclaimed land. A field study was conducted for three years at Saemangeum reclaimed land to investigate effects of certain organic amendments to its soil. Three levels $\left(0,2.5\right.$ and $\left.5.0 \mathrm{Mg}^{-1}\right)$ of torrefied wood chip (TWC), and two levels ( 0 and $\left.2.7 \mathrm{Mg} \mathrm{ha}^{-1}\right)$ of vermicompost (VC) were applied in split-plot design $(\mathrm{n}=3)$. Populus euramericana was used as crop tree. To observe soil properties, soil samples were collected twice at 2016 and 2017 in three depths $(0 \sim 15,15 \sim 30$ and 30 45 cm), and analyzed its properties. We measurec growth parameters of poplar, and biomass and nutrient analysis of weed to know the nutrient uptake across treatments. TWC, VC and soil depths did not show interaction for all soil elements. Similarly, TWC and VC did not have interaction on all soil properties, poplar growth, and weed nutrient uptake. However, higher TWC application showed removal of $\mathrm{Na}^{+}$, especially at $0 \sim 15 \mathrm{~cm}$ soil depth. For tree growth, VC showed significant positive response to height and diameter. VC application significantly affected on weed biomass and nutrient uptake of weeds too. These results suggested that TWC could be used in higher application rate to leach out $\mathrm{Na}+$ concentration in salt-affected soil, whereas VC can be applied as an organic fertilizer to reclaimed soil.

\section{Changes of physical properties of a soil reforested with Tectona grandis L. F. in the region of Urutaí, GO}

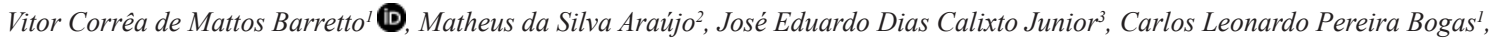
Teresa Cristina Tarlé Pissarra ${ }^{4}$, Allan de Marcos Lapaz ${ }^{1}$

${ }^{1}$ São Paulo State University (UNESP/FCAT), Dracena, Brazil; ${ }^{2}$ University of São Paulo (USP), Piracicaba, Brazil; ${ }^{3}$ University of Brasília (UnB), Brasília, Brazil; ${ }^{4}$ São Paulo State University (UNESP/FCAV), Jaboticabal,Brazil (vitor.barretto@unesp.br; araujomatheus@usp.br; junplant@hotmail.com; carlospereirabogas@gmail.com; teresa.pissarra@unesp.br; allanlapaz60@gmail.com)

The changes of soil physical properties occur in several ways, influencing the development of plants. However, is not very well known the changes of soil physical properties in populations of teak (Tectona grandis L. F.). The teak is an arboreal specie that has been cultivated in Mato Grosso, and presents potential for planting in Goiás, Maranhão, Bahia and Minas Gerais, whose purpose is to obtain wood for the sawmill industry. To this end, the aim of this study was to evaluate changes of soil physical properties of Red-Yellow Latossol reforested with teak with 4 years of age. For that, chose a population of teak with 6 hectares, 3 x 2 meters spaced, PU farm in Urutaí-GO (220 km from Goiânia-Goiás). It was determined the particle size, the density of the soil, macroporosity, microporosity, total porosity, resistance to root penetration and gravimetric moisture. The soil sampling was carried out in 2 depths $(0-0.20$ and $0.20-0.40 \mathrm{~m})$, 34 simple samples being collected for each depth. It was used a complete randomized design with 34 replications. The averages were compared by the Tukey test at $5 \%$ of significance, through the SISVAR program. There have been changes in porosity, soil density and resistance to penetration in depths. The highest values of total porosity was $0.56 \mathrm{~m}^{3} \mathrm{~m}^{-3}$, soil density was $1.48 \mathrm{~g} \mathrm{~cm}^{-3}$ and the resistance to penetration of $3.1 \mathrm{MPa}$ in $0.20-0.40 \mathrm{~m}$, due to the adoption of minimum tillage system in planting, no soil plowing and maintenance of litter on the surface.

\section{Density of ammonificators and nitrifiers bacteria in soils cultivated with pine and native forest in the South of Brazil}

Kauanna Brok Ferreira Pepe ${ }^{1}$, Rafael Hennel Tulio ${ }^{1}$, Krisle Silva², Josiléia Acordi Zanatta', Marcos Fernando Gluck Rachwal ${ }^{2}$

${ }^{1}$ Pontifícia Universidade Católica do Paraná, Curitiba, Brazil; '2Embrapa Florestas, Colombo, Brazil (kauanna.pepe@hotmail.com; rafael.tulio@outlook.com; krisle.silva@embrapa.br; josileia.zanatta@embrapa.br;marcos.rachwal@embrapa.br)

This work aimed to evaluate the density of soil bacteria involved in the process of $\mathrm{N}$ mineralization and nitrification in soils cultived with pine and native forest in the south of Brazil. Soils samples were collected at 0-10 cm depth in two areas: Rio Negrinho - Santa Catarina in a soil cultived with pine (Pinus taeda) for 6 years and in a native Mixed Ombrophilous Forest and Telêmaco Borba - Paraná in an area cultivated with pine (P. taeda) for 4 years and a native seasonal Semideciduous Forest. Bacterial density was evaluated by the most probable number method utilizing media for ammonificators (N mineralization) and nitrite oxidizers (nitrification). The soil $\mathrm{pH}$ was also evaluated. The mean values of ammonificators ranged from 5.61 to $6.15 \mathrm{log}$ cells g-1 soil and there was no significant difference between pine and native forest in both areas. In the media for nitrite oxidizers significant differences were observed, with higher density values in soils with pine compared to native forest in the two areas. In Rio Negrinho/SC the mean values obtained were 7.29 (pine) and 6.24 (forest) log cells $\mathrm{g}^{-1}$ soil and Telêmaco Borba/PR 7.65 (pine) and 6.85 (forest) $\log$ cells g ${ }^{-1}$ soil. Also, a positive correlation between soil pH and density of nitrite oxidizers was observed. Thus, there were differences in the density of nitrite oxidizers in pine compared to native forest, which could be inferring in different rates of nitrification in these soils.

\section{E8w: CURRENT UNDERSTANDING AND FUTURE CHALLENGES FOR FOREST RESEARCH AFTER THE TWO NUCLEAR ACCIDENTS OF CHERNOBYL AND FUKUSHIMA \\ Movement of radiocesium as litterfall in deciduous broad leaved forests with special reference to litter origin compost production \\ Tatsuhiro Ohkubo', Mineaki Aizawa', Kazuya Iizuka ${ }^{1}$ \\ ${ }^{1}$ Utsunomiya University, Utsunomiya,Japan(ohkubo@cc.utsunomiya-u.ac.jp; aizawam@cc.utsunomiya-u.ac.jp; kiizuka@cc.utsunomiya-u.ac.jp)}

Litterfall is important agent in the process of radiocesium (RCs) movement from tree canopy to forest floor in forest ecosystems, and for litter origin compost production, however, the information on the relationships between them is limited. We clarified the process of radiocesium movement in Konara oak (Quercus serrata) coppice forest after the Fukushima Dai-ichi Nuclear Power Plant (FDNPP) accident for seven years in three studied sites with different RCs deposition level, and also predicted the time of resume of leaf litter collection for leaf litter origin compost production. RCs concentration of foliar litter is getting lower according to the level of RCs initial deposition, and also lower than that of A0 layer in three sites. The level of RCs deposition to the canopy depends on that of initial deposition, and also the initial deposition before flushing in March 2011 cause the difference of RCs concentration between foliar litter and A0 layer. Seasonal concentration of RCs in living leaf and branches in the canopy in 2015 showed the highest value in April and May, and the values are getting a decrease in living leaves and a increase in living branches in defoliation period. This suggested the transfer of RCs from flushing to defoliation is limited within the part of the branch. RCs concentration of A0 layer on the forest floor is fitted by negative exponential decay curve, and the availability of foliar litter for litter origin compost production after the FDNPP accident is predicted by the level of initial RCs deposition. 


\author{
Effect of $\mathrm{NH}_{4}^{+}$and $\mathrm{NO}_{3}{ }^{-}$, i.e. nitrification, on uptake of radioactive Cs in Japanese cedar \\ Hitoshi Sekimoto', Keiko Sekiguchi', Yuri Shinohara', Kei Hirata', Kazuya IIzuka ${ }^{1}$ \\ IUtsunomiyaUniv.,Utsunomiya, Japan (hitoshis@cc.utsunomiya-u.ac.jp; sekiguchi.keiko.0511@gmail.com; friend-61m.beckoning-cat@yahoo.ne.jp; \\ hiratak@cc.utsunomiya-u.ac.jp; kiizuka@cc.utsunomiya-u.ac.jp)
}

It is well known that the uptake of ${ }^{137} \mathrm{Cs}$ in plants is suppressed by $\mathrm{K}$, the homologous element, which is the same monovalent cation as Cs. It is expected that $\mathrm{NH} 4+$, the same monovalent cation, will also affect the uptake of ${ }^{137} \mathrm{Cs}$ in plants. Therefore, the influence of $\mathrm{NH}_{4}^{+}$and $\mathrm{NO}_{3}{ }^{-}$on ${ }^{137} \mathrm{Cs}$ uptake in $\mathrm{Japanese}$ cedar seedlings was compared. Humus containing ${ }^{137} \mathrm{Cs}$ was mixed with a granular volcanic ash soil, and Japanese cedar seedlings were planted and cultivated while giving $0.7 \mathrm{mmol} / \mathrm{L}$ of $\mathrm{NH}_{4}^{+}$and $\mathrm{NO}_{3}{ }^{-}$solution once a week for 20 weeks, and analyzed ${ }^{137} \mathrm{Cs}$ of Japanese cedar seedlings; ${ }^{137} \mathrm{Cs}$ of $\mathrm{NH}_{4}{ }^{+}$seedlings was obviously lower than that of $\mathrm{NO}_{3}^{-}$. Also, in the $\mathrm{RI}$ experiment of water culture, the uptake of ${ }^{137} \mathrm{Cs}$ was suppressed as the $\mathrm{NH}_{4}^{+}$ratio increased. It was found that $\mathrm{NH}_{4}^{+}$suppresses uptake of ${ }^{137} \mathrm{Cs}$ similarly to $\mathrm{K}$, however the effect of $\mathrm{NH} 4+$ will decay with progress of nitrification from $\mathrm{NH}_{4}^{+}$to $\mathrm{NO}_{3}^{-}$.

\title{
Role of arbuscular mycorrhiza in uptake of radiocesium by Chengiopanax sciadophylloides
}

Chisato Takenaka ${ }^{1}$, Akihisa Fukushi ${ }^{1}$, Yosuke Matsuda ${ }^{2}$

${ }^{1}$ Nagoya University, Nagoya, Japan; ${ }^{2}$ Mie University, Tsu, Japan (chisato@agr.nagoya-u.ac.jp;pantera.meshuggah.terror2000@gmail.com; m-yosuke@bio.mie-u.ac.jp)

The accident of Fukushima Daiichi Nuclear Power Plant in 2011 caused a serious radionuclide contamination problem in Japan. Cesium-137 (radiocesium) has been the most concerned radionuclide due to its deposited amount and long half-life. Especially, the contamination in forest area has been an unsolved problem. Phytoremediation, through which radiocesium is accumulated in the specific plant and removed from the contaminated area, might be a useful decontamination method. Chengiopanax sciadophylloides is a hopeful candidate tree plant for phytoremediation of radiocesium. It has been known that this tree plant has arbuscular mycorrhiza (AM) in roots. Therefore, the purpose of this study is to clarify the role of AM fungi in uptake of radiocesium. Pot experiment was conducted using seedlings of $C$. sciadophylloides collected from the uncontaminated forest area in Aichi prefecture. Double structure pot, in which a small pot with nylon mesh $(50 \mathrm{~mm})$ in bottom filled with uncontaminated soil was put in a large pot filled with contaminated soil, was used. In order to understand the effect of $\mathrm{K}$, three kinds of treatment with and without $\mathrm{K}$ application were performed. After 22 months growth in a greenhouse, radiocesium concentration in the seedlings and soils were analyzed. As a result, we confirmed that radiocesium concentrations in seedlings significantly increased, indicating that AM fungi contribute to the uptake of radiocesium by $C$. sciadophylloides. In addition, the application of K into the rhizosphere increased the uptake of radiocesium, as the contrary to the usual knowledge that K application depresses the radiocesium uptake by plants.

\section{Suppression of cesium uptake in Konara oak using potassium: for a revival of mushroom production in Fukushima}

Riona Kobayashi ${ }^{1}$, Natsuko Kobayashi ${ }^{1}$, Masaya Masumori ${ }^{1}$, Keitaro Tanoi $^{1}$, Takeshi Tange $^{1}$, Kensuke Fukuda ${ }^{2}$, Satoru Miura ${ }^{3}$

${ }^{1}$ The University of Tokyo, Tokyo, Japan; ${ }^{2}$ Ibaraki Prefectural Forestry Research Institute, Ibaraki, Japan; ${ }^{3}$ Forestry and Forest Products Research Institute,

Ibaraki,Japan(rkoba@fra.u-tokyo.ac.jp; anikoba@g.ecc.u-tokyo.ac.jp; masumori@fra.u-tokyo.ac.jp;uktanoi@g.ecc.u-tokyo.ac.jp;

tange@fr.a.u-tokyo.ac.jp; ke.fukuda@pref.ibaraki.lg.jp; miura@ffpri.affrc.go.jp)

Radiocesium contamination of forests has been a severe problem after the Fukushima Daiichi Nuclear Power Plant accident in 2011. Bed logs of Konara oak (Quercus serrata), used for mushroom cultivation, were an economically important product from the forests prior to their contamination, and it is necessary to reduce radiocesium concentration in oak for a revival of the log production. We cultivated Konara oak seedlings through hydroponics with various rhizospheric potassium concentrations and investigated an effect of potassium to suppress cesium uptake in the seedlings. Cesium contents in seedlings under potassiumsufficient condition were $1 / 2$ to $1 / 12$ those in seedlings under potassium-deficient condition. This result suggests potassium suppressed cesium uptake in the seedlings, though an additional experiment focusing on potassium transporters implied differences of suppression mechanisms between Konara oak and other plants previously reported. We also investigated the effect of potassium through a pot experiment and an analysis of natural-growing seedlings. In the pot experiment, we cultivated seedlings in soils with different contents of exchangeable potassium by adding potassium fertilizer. Cesium contents in the seedlings were lower in fertilized soils than in non-fertilized soil, showing the suppression effect of exchangeable potassium on cesium uptake. On the other hand, results of the analysis of the natural-growing seedlings and soils collected at 106 sites showed no general relationship between exchangeable potassium contents in the soils and cesium contents in the seedlings. Mineral composition and organic matter of the soil may influence the effectiveness of potassium on cesium uptake suppression.

\section{Differences in radiocesium concentrations among crown positions in several tree species in Fukushima, Japan}

Tanaka Kenzo ${ }^{1}$, Satoshi Saito², Takuya Kajimoto ${ }^{3}$

${ }^{1}$ Forestry and Forest Products Research Institute, Tsukuba, Japan; ${ }^{2}$ Kansai Research Center, Forestry and Forest Products Research Institute, Kyoto, Japan; ${ }^{3}$ Tohoku Research Center, Forestry and Forest Products Research Institute, Morioka, Japan (mona@affrc.go.jp; stetsu@affrc.go.jp; tkaji@ffpri.affrc.go.jp)

To evaluate distribution in radiocesium among crown positions after accident of Fukushima Dai-ichi Nuclear Power Plant, we collected leaf and branch from upper to lower crown position in four tree species (Chamaecyparis obtusa (Co), Cryptomeria japonica (Cj), Pinus densiflora (Pd), Quercus serrata (Qs)) in 2014, 2015 and 2016 in Fukushima, Japan. We divided those samples into current-year and more than one-year-old (expressed as old leaf and old branch), which sometimes include direct contamination part. Radiocesium $\left({ }^{137} \mathrm{Cs}\right)$ concentration was measured for ground samples of leaf and branch by using a germanium semiconductor detector. There were complex differences in ${ }^{137} \mathrm{Cs}$ concentration among species and organ types such as current leaf and old branch between crown positions. In the case of 2016 samples, ${ }^{137} \mathrm{Cs}$ concentration in old branches in Pd and Qs tended to be higher in the lower crown position, but not significant difference was found in current branches and leaves among crown positions. The concentration in branches of $\mathrm{Cj}$ were higher in the lower and middle crown positions, but the differences in current leaf concentration were unclear; ${ }^{137}$ Cs concentration in current leaves in Co were higher in upper crown position, while the concentration in branch and old leaves were lower in the position. Although factors on those differences on interspecific and crown position are unclear, there is a possibility that presence or absence on direct contamination by the accident, and interspecies traits in ${ }^{137} \mathrm{Cs}$ translocation and/or absorption from soil may cause the differences.

\section{Seasonal changes in radiocesium and potassium concentrations in current year shoots in three tree saplings in Fukushima, Japan}


Tanaka Kenzo ${ }^{1}$, Satoshi Saito ${ }^{2}$, Satoru Miura ${ }^{1}$, Takuya Kajimoto ${ }^{3}$, Natsuko I. Kobayashi ${ }^{4}$, Keitaro Tanoi ${ }^{4}$

${ }^{1}$ Forestry and Forest Products Research Institute, Tsukuba, Japan; ${ }^{2}$ Kansai Research Center, Forestry and Forest Products Research Institute, Kyoto, Japan; ${ }^{3}$ Tohoku Research Center, Forestry and Forest Products Research Institute, Morioka, Japan; ${ }^{4}$ The University of Tokyo, Tokyo, Japan (mona@affrc.go.jp; stetsu@affrc.go.jp; miura@ffpri.affrc.go.jp; tkaji@ffpri.affrc.go.jp; anikoba@g.ecc.u-tokyo.ac.jp; uktanoi@g.ecc.u-tokyo.ac.jp)

We studied the seasonal change in radiocesium $\left({ }^{137} \mathrm{Cs}\right)$ and potassium $(\mathrm{K})$ concentrations in current leaves and branches in Pinus densiflora (naturally regenerated saplings), Cryptomeria japonica (planted saplings) and Quercus serrata (planted and sprouted saplings) in Tamura, Fukushima, Japan. Current year shoots were collected from June 2016 to December 2017 at intervals of one to four months. For deciduous species of $Q$. serrata, we also collected dead leaves that still attached on branches in December. All collected shoots were divided into leaves and branches and the samples were grounded. The concentration of ${ }^{137} \mathrm{Cs}$ was measured by a germanium semiconductor detector. K concentration was quantified by ICP-AES method. Regardless of tree species, there were seasonal changes in ${ }^{137} \mathrm{Cs}$ concentration, and those concentrations were higher in young leaves and branches at May or June, while the concentrations decreased thereafter and the change was relatively small from August to winter. Decreasing of ${ }^{137} \mathrm{Cs}$ concentration in dead leaves in $Q$. serrata also observed in several individuals in December. This reduction may indicate reabsorption of ${ }^{137} \mathrm{Cs}$ in leaves before shedding. K concentration was also higher in the younger leaves compared with the mature leaves. A positive relation between ${ }^{137} \mathrm{Cs}$ and $\mathrm{K}$ concentration in leaves was observed in $P$. densiflora, C. japonica, and sprouted $Q$. serrata. From these results, ${ }^{137} \mathrm{Cs}$ was thought to be high at relatively younger organs with higher K concentration in those three species.

\section{Potassium content in the wood and bark of 38 tree species}

Hisashi Abe ${ }^{1}$, Yooko Tsuchiya ${ }^{2}$, Akira Kagawa ${ }^{1}$

${ }^{1}$ FFPRI, Tsukuba, Japan; 2CRIEPI, Abiko,Japan (abeq@affrc.go.jp; yooko@criepi.denken.or.jp; akagawa@ffpri.affrc.go.jp)

After the Fukushima Daiichi Nuclear Power Plant accident, fallen radionuclides, especially radiocesium, have contaminated a vast area of Japanese forest. Potassium, which is an essential nutrient for plants, is believed to influence the behavior of radiocesium in the plant body. To understand the behavior of radiocesium in tree trunks, potassium contents in the wood and bark were measured for 27 native Japanese species (12 softwood and 17 hardwood), and 9 foreign species frequently used in Japan, by means of inductively coupled plasma emission mass spectrometry. The potassium content showed a wide range of values, from 70 to $20,000 \mathrm{mg} / \mathrm{kg}$, and very different values in each sample. For most of the species, the potassium content was higher in the bark than in the wood, except for the cases of Chamaecyparis obtusa, Picea jezoensis, and, P. jezoensis var. hondoensis. In a Gingko biloba sample, the potassium content in the bark was $20,000 \mathrm{mg} / \mathrm{kg}$, which was the highest value among all the samples. In the heartwood of the Cinnamomum camphora sample, the potassium content was $5,300 \mathrm{mg} / \mathrm{kg}$, which was the highest value among all the wood samples. As for the wood, potassium contents were higher in the heartwood than in the sapwood, except for the cases of Magnolia obovata, Pinus densiflora, Larix kaempferi, Cerasus sergentii, and Betula platyphylla var. japonica. The potassium contents in the wood of tropical species belonging to the family Dipterocarpaceae (Dipterocarpus, Dryobalanops, and, Shorea) were relatively lower than in other species.

\section{Mobile radiocesium in felled logs of Sugi cedar}

Masaya Masumori ${ }^{1}$ D. Tetsuro Sakai ${ }^{1}$, Takeshi Tange ${ }^{1}$, Norio Nogawa ${ }^{1}$

'The University of Tokyo,Tokyo,Japan (masumori@fr.a.u-tokyo.ac.jp; t.sakai@fr.a.u-tokyo.ac.jp; tange@fr.a.u-tokyo.ac.jp; nogawa@ric.u-tokyo.ac.jp)

The accident of Fukushima Dai-ichi Nuclear Power Plant polluted vast areas of forest including plantations of Sugi cedar (Cryptomeria japonica), a major evergreen timber tree in Japan. The persistent radioactivity by radiocesium taken into the wood still impedes the resumption of timber production, local economy and consequently the restoration of local community of the affected area in wooded western Fukushima, Japan. Distributions of radiocesium within trunk of Sugi cedar were analyzed by radiographic imaging with storage phosphor screens. The most of radiocesium was found in the surface of bark even 6 years or more after the deposition, while some radiocesium was also detected in xylem, particularly in heartwood. When the cut log was dried by exposing to the air or experimentally using a drying oven, the radiocesium content in the cut end of log became much higher. If the cut end was sealed up with silicone caulk or plastic wrap, the radiocesium accumulated at another surface where was exposed to the air. These results mean that some portion of the radiocesium in xylem is soluble in water and can move along with apoplastic water movement during the wood drying after felling.

\section{Aerologically reconstruction of spatial variation in global radiocesium fallout across Japan}

Eriko Ito ${ }^{1}$, Satoru Miura ${ }^{2}$, Michio Aoyama ${ }^{3}$, Koji Shichi ${ }^{4}$

${ }^{1}$ FFPRI, Sapporo, Japan; ${ }^{2}$ FFPRI, Tsukuba, Japan; ${ }^{3}$ University of Tsukuba, Tsukuba, Japan; ${ }^{4}$ FFPRI, Kochi, Japan

(iter@affrc.go.jp; miura@ffpri.affrc.go.jp; michio.aoyama@ied.tsukuba.ac.jp; shichi@ffpri.affrc.go.jp)

Radioactive contaminations in forests were caused by ${ }^{137} \mathrm{Cs}$ discharged from the Fukushima Dai-ichi Nuclear Power Plant (FDNPP) accident. To provide scientific guidance on long-term forest management, insights on how ${ }^{137} \mathrm{Cs}$ will be redistributed across few decades are needed. Although it is often the case that ${ }^{137} \mathrm{Cs}$ would remain on forest surface soil for decades, it is unclear whether this holds true also in Japan, where topography is usually steep and precipitation is high. Nuclear weapon tests in the 1950s and 1960s have discharged global fallout ${ }^{137} \mathrm{Cs}\left({ }^{137} \mathrm{Cs}-\mathrm{GFO}\right)$. It has previously been reported that ${ }^{137} \mathrm{Cs}-\mathrm{GFO}$ has remarkably high variation in spatial distribution across Japan, with high accumulation in the north-western area along the Sea of Japan. More recently, similar spatial patterns were found in ${ }^{137} \mathrm{Cs}-\mathrm{GFO}$ inventories of forest soil (0-30 $\mathrm{cm}$ in depth), which were collected across Japan right before the FDNPP accident. One of the most clear differences between Japan and other countries is that this spatial variation in ${ }^{137} \mathrm{Cs}$-GFO cannot been explained by spatial variation in the amount of precipitation. This inconsistency between ${ }^{137} \mathrm{Cs}$-GFO and precipitation peculiar to Japan was likely related to the spatial and seasonal differences in ${ }^{137} \mathrm{Cs}$-GFO concentration in the waterfall. To answer how much ${ }^{137} \mathrm{Cs}$-GFO still remain in forest surface soil, this study aimed to re-construct the spatial distribution of initial ${ }^{137} \mathrm{Cs}$-GFO based on polynomial calculation $p f(x)$ of an element $p$ as monthly precipitation using an argument $x$ of atmospheric turbulence indexed by multiple tropopause structure.

\section{Vertical distributions of ${ }^{137} \mathrm{Cs}$ in Japanese forest soils post Fukushima Dai-ichi Nuclear Power Plant accident: a meta-analysis}

Naohiro Imamura ${ }^{1}$, Masabumi Komatsu ${ }^{1}$, Shoji Hashimoto ${ }^{1,2}$, Hiroaki Kato ${ }^{3}$, Kazuya Nishina ${ }^{4}$, Kazumichi Fujii $^{1}$

${ }^{1}$ Forestry and Forest Products Research Institute, Tsukuba, Japan; ${ }^{2}$ The University of Tokyo, Bunkyo, Japan; ${ }^{3}$ University of Tsukuba, Tsukuba, Japan; 
${ }^{4}$ National Institute for Environmental Studies, Tsukuba, Japan (nimamura@ffpri.affrc.go.jp; kopine@ffpri.affrc.go.jp; shojih@ffpri.affrc.go.jp; kato.hiroaki. ka@u.tsukuba.ac.jp; nishina.kazuya@nies.go.jp;fkazumichi@affrc.go.jp)

After the Fukushima Dai-ichi Nuclear Power Plant (FDNPP) accident, there has been a translocation of radiocesium at the litter and mineral soil layers over time. Parameterizing the vertical distribution of radiocesium within the soil compartment is useful for predicting its fate and estimating the ambient dose rate in the forests. We collected 99 radiocesium inventory data at the litter and mineral soil layers from six journal papers published after the FDNPP accident. The fraction related in the litter (F-lit: the ratio between litter and litter + mineral soil inventories), the half depth ( $X$ : the soil depth above which $50 \%$ of the total activity is present), and the relaxation depth ( $\alpha$ : the necessary distance at which surface depth decreases to $1 / \mathrm{e} \approx 1 / 2.7)$ were calculated using these data as the parameters of vertical distribution of radiocesium at the litter and mineral soil layers. A decrease in F-lit over time was observed, indicating that radiocesium moved from the litter layer to the mineral soil layer after the FDNPP accident. In contrast, the half depth and relaxation depth did not show changes. This finding supports the retention of radiocesium in the surface mineral soil layers.

\section{Vertical radiocesium transfer process in soil via roots}

Wataru Sakashita ${ }^{1}$,Satoru Miura ${ }^{1}$, Akio Akama ${ }^{1}$,Shinta Ohashi ${ }^{1}$, Shigeto Ikeda ${ }^{1}$, Tomoyuki Saitoh ${ }^{2}$, Masabumi Komatsu ${ }^{1}$, Yoshiki Shinomiya ${ }^{1}$, Shinji Kaneko ${ }^{3}$ ${ }^{1}$ Forestry and Forest Products Research Institute, Tsukuba, Ibaraki, Japan; ${ }^{2}$ Tohoku Research Center, Forestry and Forest Products Research Institute, Morioka, Iwate, Japan; ${ }^{3}$ Kansai Research Center, Forestry and Forest Products Research Institute, Fushimi, Kyoto, Japan (sakashita@affrc.go.jp; miura@ffpri.affrc.go.jp; akama@affrc.go.jp; shinta0084@ffpri.affrc.go.jp; ikedas@ffpri.affrc.go.jp; tsaitoh@ffpri.affrc.go.jp; kopine@ffpri.affrc.go.jp; sinomiya@affrc.go.jp; kanekos@ffpri.affrc.go.jp)

Radiocesium $\left({ }^{137} \mathrm{Cs}\right.$ and $\left.134 \mathrm{Cs}\right)$ dynamics has been investigated in Japanese forests after the Fukushima Dai-ichi nuclear power plant (FDNPP) accident, but there are few reports about radiocesium transfer process in soil via roots. In this study, we report radiocesium concentrations of root and soil in Japanese cedar plantations, which obtained from four soil layers (0-5, 5-10, 10-15 and 15-20 cm) in two sites (Mitsuishi and Kanayama, Kawauchi Village, Fukushima Prefecture, Japan) in August, 2013. Comparisons between root and soil in Mitsuishi (26 km from FDNPP) showed that radiocesium concentrations of root at 15-20 cm layer were three times higher than those of soil, whereas root radiocesium concentrations at $0-5 \mathrm{~cm}$ layer were clearly lower than those of soil. Similar trends were also found in Kanayama site (28 km from FDNPP), and the difference between root and soil at 15-20 cm layer was larger than Mitsuishi site. Considering the turnover of roots in Japanese cedar forests, radiocesium transport following root dynamics (e.g., downward elongation and mortality) may play an important role in vertical migration of radiocesium in the soil.

\section{Discharge of suspended sediments and radiocesium before and after thinning}

Yoshiki Shinomiya ${ }^{1}$, Masahiro Kobayashi ${ }^{1}$,Tatsuya Tsurita ${ }^{1}$, Yoshio Tsuboyama ${ }^{1}$, Shinji Sawano ${ }^{1}$, Yuko Itoh ${ }^{1}$, Yasuhiro Ohnuki ${ }^{2}$, Koji Shichi $^{3}$ ${ }^{1}$ FFPRI, Tsukuba, Japan; ${ }^{2}$ FFPRI, Tohoku, Morioka, Japan; ${ }^{3}$ FFPRI, Shikoku, Kochi, Japan (sinomiya@affrc.go.jp; kbmasa@affrc.go.jp; tatuya@affrc.go.jp; tsubo@affrc.go.jp; ssawano@affrc.go.jp; yuko106@affrc.go.jp; bchankan@affrc.go.jp; shichi@affrc.go.jp)

After the accident of the Fukushima Daiichi Nuclear Power Station (FDNPS) accident in March 2011, radiocesium was deposited in forests in East Japan. Understanding the relationship between forest operations and radiocesium dynamics is important to promote the resumption of forestry in Fukushima. In this work, the discharge of suspended sediments (SS) and radiocesium before and after line thinning in a forested watershed (located about 120 km southwest of the FDNPS) was investigated. Line thinning was conducted at a thinning rate of $35 \%$ across $17 \%$ of the watershed area in 2012 and at same rate for the rest of the watershed in 2013. Spur roads were constructed along all streams. The concentration of SS was decreasing with passing of time. High Cs-137 concentrations of SS were not observed during or after thinning. When the sampling period included heavy rainfall (>100 mm total rainfall), Cs-137 concentration of SS became low. SS concentration and SS load increased immediately after thinning. Although SS increased, it tended to decrease within a few years because bared areas were covered with litterfall and vegetation regrowth. From these results, SS load increased immediately after thinning but Cs-137 exports from the forested watershed did not increase sharply. This is caused by the suppressing of Cs-137 exports (e.g., declines in the Cs-137 concentration of SS in heavy rainfall, reductions in bared areas).

E8x: FOREST ENVIRONMENT

\section{Effect of impounding of the Three Gorges Reservoir on seven kinds of soil metals contents in its abandoned farmland of hydro- fluctuation belt, China}

Ruimei Cheng ${ }^{1}$

${ }^{1}$ Institute of Forest Ecology,Environment and Protection, Chieses Academy of Forestry, Beijing, China (chengrm9533@sina.com)

In order to provide a theoretical reference for soil ecological restoration in the Three Gorges Reservoir area, China, the impact of water level fluctuating on metals contents were explored, and typical abandoned farmland in hydro-fluctuation belt was selected in this study area. Then the contents distribution characteristics of heavy metals $(\mathrm{Cu}, \mathrm{Fe}, \mathrm{Zn}, \mathrm{Mn})$ and alkaline metal (Ca, Mg, Na) in different altitudes $(145-155,155-165$, and 165-175 m) and soil layers $(0-5$, $5-10$, and 10-20 cm) of the abandoned farmland were examined in 2009 and 2013. The results showed that the contents of 4 heavy metals were highest at $10-$ $20 \mathrm{~cm}$ soil layer at 145-165 m in 2009, while those at 0-5 cm layer were highest in 2013, while contents of Ca were the highest at $10-20 \mathrm{~cm}$ soil layer both in 2009 and 2013. Compared with 2009, the contents of Cu, Fe, Zn and Mn (0.065, 59.37, 0.068 and $\left.0.069 \mathrm{~g} \cdot \mathrm{kg}^{-1}\right)$ were increased by 50.75\%, 18.84\%, 27.46\% and $27.44 \%$ respectively at $165-175 \mathrm{~m}$ in 2013. Meanwhile, water level fluctuating resulted in more Ca and Mn contents while less Na content. So, water level fluctuating can lead to distribution characteristics difference of soil mental contents in different year, but also result in accumulation of $\mathrm{Cu}, \mathrm{Fe}, \mathrm{Zn}, \mathrm{Mn}, \mathrm{Ca}$ and Mg contents and lost of Na content.

An experimental class on water-holding capacity in forestry using a handmade sprinkling instrument by vocational high school students

Takashi Higashihara ${ }^{1}$, Koichiro Kuraji $^{2}$, Mariko Inoue ${ }^{3}$,Tadashi Ohtani ${ }^{4}$, Yuji Araki ${ }^{5}$, Yuji Ikami ${ }^{6}$,Eiji Watanabe ${ }^{7}$ 
${ }^{1}$ Joetsu University of Education, Joetsu, Japan; ${ }^{2}$ The University of Tokyo, Tokyo, Japan; ${ }^{3}$ Forestry and Forest Products Research Institute, Hachioji, Japan; ${ }^{4}$ Tokyo Gakugei University, Koganei, Japan; ${ }^{5}$ Saitama University, Saitama, Japan; ${ }^{6}$ Forestry and Forest Products Research Institute, Tsukuba, Japan;

${ }^{7}$ Kimitsuaobahighschool, Kimitsu, Japan (htakashi@juen.ac.jp; kuraji_koichiro@uf.a.u-tokyo.ac.jp; imariko@ffpri.affrc.go.jp; t-ohtani@u-gakugei.ac.jp; arakiy@mail.saitama-u.ac.jp; ikami@ffpri.affrc.go.jp; e.wtnb16@chiba-c.ed.jp)

This study reports on an experimental class on water holding capacity in forestry, involving the use of a handmade and low-cost sprinkling instrument by vocational high school students to detect Hortonian overland flow, as proposed by Tanaka and Kuraji (2016). The low-cost sprinkling instrument consists of three plastic garden stakes, an iron flower-pot holder, a two-liter plastic bottle with a hole in the bottom, and a shower nozzle attached to the plastic bottle-goods can be bought at "100-yen shops" (a dollar store). Using the proposed instrument, students examined thrice whether Hortonian overland flow occurred at the forest plantations at school. These experimental classes were conducted in 2017 and 2018 in Kimitsu City, Japan. No flow or a few flows were observed during the first experiment. A leaf lodged against the shower nozzle restricted the water flow at the time of the second experiment; as a result, the drop of water was big, and Hortonian flow was observed in the ground. No leaves affected the water flow from the shower nozzle in the third experiment; as a result, the drop of water was small, and the flow was low in the ground. Thus, the students could consider the relationship between water-holding capacity and rainfall in a forest plantation.

\section{Conductividad hidráulica bajo bosques, una clave para el manejo hídrico de cuencas}

Carlos Francisco Garcia Olmos ${ }^{1}$

'Universidad Distrital Francisco José de Caldas, Bogota D.C., Colombia (cfgarciao@gmail.com)

La conductividad hidráulica bajo el suelo de los bosques se relaciona con los flujos sub superficiales. Se buscó conocer estos comportamientos y sus diferencias, con enfoque al manejo hídrico de cuencas. Se caracterizaron áreas experimentales en bosques de Cupressus lusitanica, Eucalytus globulus y bosque natural en la cuenca del río San Cristóbal, Bogotá, y se realizaron ensayos de pozo barrenado invertido. Se determinaron las curvas características de la velocidad de infiltración y según ellas se obtuvieron las curvas de conductividad hidráulica. Se verificó que no se presentaron diferencias significativas en la conductividad hidráulica saturada. Se desprende de esta investigación que los sistemas radiculares sub superficiales de las especies del sotobosque pueden llegar a disminuir la conductividad hidráulica en el sub suelo por el efecto del atrapamiento de aire que impide la saturación total de los poros del suelo, hecho que podría influir sobre el flujo de las aguas subterráneas y los procesos de erosión entre otros.

Linking deep soil water reliance to plant distribution and resource economy strategy among coexisting woody shrub species in a subtropical ecosystem

Peipei Jiang ${ }^{1}$, Xiaoli $\mathrm{Fu}^{1}$, Huimin Wang ${ }^{l}$

IInstitute of Geographic Sciences and Natural Resources Research Chinese Academy of Sciences, Beijing, China (peipei769049728@126.com;

fuxl@igsnrr.ac.cn; wanghm@igsnrr.ac.cn)

Strategy of deep soil water acquisition is critical to plant's adaption to drought stress. However, it is unknown how the deep soil water acquisition determines species' distribution and resource economy strategy in an experimental context. With data from 13 woody shrub species of subtropical coniferous forests, we investigated the associations of deep water acquisition patterns (ability of deep water use and plasticity of deep water use between season), plant hydraulic traits (leaf water potential, water use efficiency), species distribution (relative occurrence frequency and importance), and economic traits across organs (first-order root diameter of shallow soil, wood density, specific leaf area, and leaf nitrogen concentration). Higher ability of deep resource utility acted synergistically with higher intrinsic water use efficiency to promote plants' adaption to seasonal drought, but was not a necessary trait possessed by the common species. Species with higher plasticity of deep water use (rather than higher ability of deep water use) had lower wood density, but not smaller first-order root diameter, indicating species being fast in deep soil resource acquisition not necessarily being fast in shallow fine root resource acquisition. Our result provide new insight in the mechanisms through which deep soil resource acquisition trait interacted with shallow soil and aboveground resource acquisition traits to integrate the whole-plant economic spectrum and thus community assembly process.

\section{Contrasting root foraging strategies of native and exotic pine forests under an increased diversity of understory species}

Han Yan', Liang Kou' ${ }^{1}$,Huimin Wang ${ }^{1}$

${ }^{1}$ Qianyanzhou Ecological Research Station, Key Laboratory of Ecosystem Network Observation and Modeling, Institute of Geographic Sciences and Natural Resources Research, Chinese Academy of Sciences, Beijing, China (419501806@qq.com; koul@igsnrr.ac.cn; wanghm@igsnrr.ac.cn)

Studies on the aboveground growth and traits of plants suggest that plants exhibit faster growth, with greater plasticity in leaf traits, to adapt to changing environments. However, our knowledge of belowground growth and trait responses, and associated root foraging strategies, under competition remains limited. Using an understory species-addition experiment, we investigated the responses of function-based root (absorptive fine roots [AFRs] vs. transport fine roots [TFRs]) growth, mycorrhizal association, and order-based root traits (morphological, architectural, and chemical traits) of Pinus massoniana (native species) and Pinus elliottii (exotic species), which are the dominant coniferous tree species in subtropical China. Higher understory-species diversity increased the biomass of AFRs, but not TFRs and total fine roots of both species. Higher diversity increased the biomass ratio of the AFRs and TFRs of $P$. elliottii, indicating a tradeoff in plant carbon investment between the two functional root modules for $P$. elliottii. Increased species diversity decreased the ectomycorrhizal colonization rate of $P$. massoniana, but increased that of $P$. elliottii. Increased species diversity altered the branching-related traits (increased branching ratio and intensity), but did not affect the morphological or chemical traits across the root orders of either species. Our findings indicate that $P$. elliottii employed dual root foraging strategies (growth and mycorrhizal strategies) and had a cost-benefit tradeoff between AFR and TFR construction. In comparison, P. massoniana only accelerated root growth under competition. These results facilitate a better understanding of the root foraging strategies of plants and the rapid adaptation of exotic species in novel environments.

\section{Competition and coordination between understory vegetation and canopy trees in subtropical plantations}

Huimin Wang ${ }^{l}$, Xiaoli $\mathrm{Fu}^{l}$, Xiaoqin Dai ${ }^{1}$, Liang $\mathrm{Kou}^{l}$ 
${ }^{1}$ Institute of Geographic Sciences and Natural Resources Research, Chinese Academy of Sciences, Beijing, China (wanghm@igsnrr.ac.cn; fuxl@igsnrr.ac.cn; daixq@igsnrr.ac.cn;koul@igsnrr.ac.cn)

Understory vegetation removal is an important management practice for plantations in China. However, the limitation of this management practice is still under debate. We conducted a serial of field investigations and site experiments in subtropical plantations of China to study the interspecific interactions between understory and trees to explore suitable understory management practice. We found that understory plants exploited the advantage of occupying topsoil by filling the readily occupied soil macropores and being less affected by nearby stems. Understory plants may also increase their efficiency of topsoil-resource uptake by allocating a greater proportion of their absorptive roots to transport roots than trees in the topsoil. Because of the intensive competition for topsoilresource between trees and understory plants, a substantial portion of the increase of the aboveground biomass of the understory was at the expense of the tree aboveground biomass. On the other hand, however, understory vegetation also had important ecological functions, e.g. increasing soil organic carbon content, alleviating soil acidification, and enhancing the functional traits of soil microbial communities. Therefore, a rational understory density around $113 \mathrm{~g}$ $\mathrm{m}-2$ for plantations in subtropical China was suggested based on our case study. Moreover, we found that the aboveground biomass of understory was more important than understory diversity in improving the ecological functions of plantations. Therefore, we advocated for optimizing the community structure of the understory vegetation based on the niche complementarity theory and controlling the understory density in subtropical plantations in China.

\section{Changes in the floating meadows of Keibul Lamjao National Park, India and their implications for the conservation of globally threatened Eld's deer}

Syed Ainul Hussain ${ }^{1}$, Chongpi Tuboi ${ }^{1}$, Ruchi Badola ${ }^{1}$

'Wildlife Institute of India, Dehradun, India(hussain@wii.gov.in; chongpituboi@gmail.com; ruchi@wii.gov.in)

Keibul Lamjao National Park, India is the last remaining home of the endangered Eld's deer or Sangai (Rucervus eldii). The characteristic feature of the park, the floating meadows locally known as phumdis, are important for the conservation of the Sangai. The thickness of the meadows is changing due to change in water regime and anthropogenic pressures. To understand these changes, the park was divided into northern and southern zones. Transects ( $\mathrm{N}=138$ ) of $500 \mathrm{~m}$ were laid and meadow thickness was measured at $50 \mathrm{~m}$ intervals at 1659 points during 2005-2010. The mean thickness in the northern and southern zone ranged between $91.75 \pm 12.43 \mathrm{~cm}$ and $129.73 \pm 17.2 \mathrm{~cm}$, and between $87.58 \pm 13.65 \mathrm{~cm}$ and $171.48 \pm 26.55 \mathrm{~cm}$, respectively. The overall thickness declined by factors of 0.01958 and 0.019/annum during 2005-2007 and 2008-2010 respectively. There was a decline by a factor of 0.1305/ annum during 2005-2007 in the north zone, but a slight increase by a factor of 0.0352/ annum during 2008-2010. The southern zone had declines by factors of 0.2516 and $0.0736 /$ annum during 2005-2007 and 2008-2010, respectively. Out of the total area of $22.3 \mathrm{~km}^{2}$ where Sangai presence was observed, meadow thickness was $>120 \mathrm{~cm}$ in 8.64 km², $60-120 \mathrm{~cm}$ in $7.32 \mathrm{~km}^{2}$ and $<60 \mathrm{~cm}$ in $6.33 \mathrm{~km}^{2}$. Allowing a major portion of the floating meadows to settle during lean seasons by reducing the water level through a consultative process involving multiple stakeholders, could help reduce the rate of decline.

\section{Effect of deforestation on stream water chemistry changes during rainfall events in small Carpathian catchments (Tatra Mts., Poland)}

Joanna Siwek ${ }^{1}$, Monika Sajdak ${ }^{1}$, Mirosław Żelazny ${ }^{1}$

${ }^{1}$ Institute of Geography and Spatial Management, Jagiellonian University in Kraków, Kraków, Poland (joanna.siwek@uj.edu.pl;

monika.sajdak@doctoral.uj.edu.pl;miroslaw.zelazny@uj.edu.pl)

The aim of the study was to recognize the role of deforestation on stream water chemistry changes during rainfall events in small catchments in the Tatra Mountains (Poland). Substantial damage in spruce and fir stands in the northern part of the Polish Tatra Mountains is result of hurricane-force winds that occurred on 25-26 December 2013. Since then, the decline of forests accelerated due to the bark beetles invasion and fungus expansion. Three small, adjacent catchments with a different degree of deforestation, 97.0, 66.1, and 19.9\% were selected for the study. Fieldwork was conducted in 2017 and 2018 . Stream water samples were collected during 24 rainfall events. Water level (discharge) and electrical conductivity (EC) of stream water were measured continuously in the

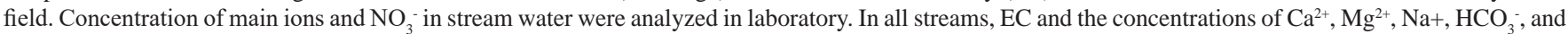
$\mathrm{SO}_{4}{ }^{2-}$ decreased with increasing discharge while the concentrations of $\mathrm{K}^{+}$and $\mathrm{NO}_{3}^{-}$increased with increasing discharge. In the forested catchment stream water $\mathrm{Cl}^{-}$concentration decreased with increasing discharge while in the deforested catchments it increased with increasing discharge. Relationships between stream water chemistry and discharge took the form of a hysteresis. In the forested catchment, the concentration of $\mathrm{Cl}_{-}, \mathrm{K}^{+}$, and $\mathrm{NO}_{3}^{-}{ }^{-}$was higher during the falling limb than during the rising limb of hydrographs (counterclockwise hysteresis). In the deforested catchment higher concentrations of $\mathrm{Cl}^{-}$, $\mathrm{K}^{+}$, and $\mathrm{NO}_{3}^{-}{ }^{-}$were noted during the rising limb than during the falling limb (clockwise hysteresis).

\section{E8y: FOREST POLICY AND ECONOMICS - IV}

\section{The effects of deforestation on the water balance of watershed using hydrological modeling (on the example of the Ukrainian and Slovak Carpathians)}

Tomáš Hlásny ${ }^{1}$, Martin Maretta ${ }^{1}, Z u z a n a$ Sitková ${ }^{1}$, Taras Parpan², Dušan Kočický1, Ivan Barka

${ }^{1}$ Forest Ressearch Institute, National Forest Centre, Zvolen, Slovakia; ${ }^{2}$ Ukrainian Research Institute for Mountain Forestry, Ivano-Frankivsk, Ukraine (hlasny@nlcsk.org;maretta@nlcsk.org; sitkova@nlcsk.org; tarasparpan@gmail.com; kocicky@nlcsk.org; barka@nlcsk.org)

The relationship between the forest cover and the degree of flood hazard in the Bodrog River basin on both sides of the Slovak-Ukrainian border was investigated. A hydrological modeling was carried out using the newly created hydrological model ISSOP using a theoretical example of large-scale deforestation. The results confirmed the importance of the forest cover influence on the hydrological regime in highly wooded watersheds of Eastern Slovakia and the Transcarpathian region of Ukraine. Continuous deforestation, that is, a theoretical replacement of forests occupying $4 / 5$ of the basin with a grass cover can increase the total water flow by as much as $20.4 \%$. This effect was particularly noticeable during the climax of water discharge, when the regulatory action of forests is particularly important. An assessment of the hydrological response of the catchment to simulated extreme precipitation showed that the forest significantly changes the parameters of the surface and flow path of the water and affects the time during which the simulated flood wave reached the final catchment. The research results are to some extent a response to the growing interest in multifunctional forest management due to their hydrological functions. They can be used for assessing flood potential, analyzing the causes of the current state and anti-flood measures, in integrated decision support systems, and can also contribute to conflicts of 
interest in the provision of various ecosystem services by forest stands.

\author{
Multifunctional forests for revitalizing rural landscapes / Florestas multifuncionais para a revitalização da paisagem rural \\ Jozrael Henriques Rezende ${ }^{1}$ D, José Carlos Toledo Veniziani Junior ${ }^{1}$, Brian Craig Campbell ${ }^{1}$ \\ 'FatecJahu, Jaú, Brazil (jozrael.rezende@fatec.sp.gov.br; jose.veniziani@fatec.sp.gov.br; briancampbell@outlook.com)
}

Este trabalho teve como objetivo identificar em Jaú/SP, cujo território é de 68.744,52 ha, áreas para a implementação de sistemas florestais multifuncionais. Por intermédio do QGis e com as informações do Sistema de Cadastro Ambiental Rural do Estado de São Paulo, foram caracterizadas a declividade, a vegetação remanescente, as áreas de preservação permanente e a estrutura fundiária do município. O índice de vegetação remanescente encontrado foi de 4.354,26 ha $(6,3 \%)$. A área potencial para florestas multifuncionais, sem considerar as áreas de preservação permanente, foi estimada em $4.823,24$ ha, considerando o passivo de reserva legal e as áreas com declividades superiores a 12\%, por serem inapropriadas a colheita mecanizada da cana-de-açúcar, matriz da paisagem na região permanente. O maior obstáculo para a recuperação da vegetação nesse contexto são os custos da restauração ecológica. É fundamental transformar estes custos em oportunidades, harmonizando conservação com produção. Nesse sentido, as florestas multifuncionais são uma alternativa promissora, pois elas permitem as atividades madeireira e não madeireira concomitantemente a prestação dos serviços ecossistêmicos. Estas florestas heterogêneas viabilizam a produção, conservam água e biodiversidade, possibilitam a regularização ambiental das propriedades e incrementam a geração de renda e a oferta de trabalho no âmbito regional por meio da diversificação das atividades rurais. O sucesso da implementação das florestas multifuncionais, entretanto, depende do planejamento sistêmico no âmbito da paisagem e da existência de conhecimento, modelos, métodos e assistência técnica que assegurem a viabilidade econômica e o uso sustentável dos recursos naturais, garantindo assim a reabilitação dos processos ecológicos.

\author{
Improving ecosystem services of fast-wood plantation landscapes in Brazil \\ Silvio Ferraz ${ }^{1}$, Carolina Rodrigues ${ }^{2}$, Carla Cassiano ${ }^{3}$, Lara Garcia ${ }^{4}$ \\ ${ }^{1}$ Escola Superior de Agricultura "Luiz de Queiroz", Universidade de São Paulo Piracicaba, Brasil; ${ }^{2}$ Pratica Sócioambiental, Piracicaba, Brasil; \\ ${ }^{3}$ Universidade Federal do Mato Grossso, Cuiabá, Brasil; ${ }^{4}$ Instituto de Pesquisas e Estudos Florestais, Piracicaba, Brasil (silvio.ferraz@usp.br; \\ cabreuva@gmail.com; carla_cassiano@hotmail.com; larajangada@gmail.com)
}

Fast-wood plantations in Brazil are increasing in last years reaching about 6 million of hectares in 2016, due to increasing demand for fiber and wood. Forest management plans are usually focused on keeping wood productivity, however, guided by crescent restrictions enforced by Brazilian government, environmental certification and society pressure, it seems to be necessary increasing their ecosystem services provision. Based on long-term stream monitoring data of several experimental catchments installed on forest plantation and native areas along Brazil and Uruguay, field data collection regarding biodiversity and pest damage, we tested effects of landscape composition and structure on ecosystem services related to provision (wood and water), support (terrestrial and aquatic biodiversity) and regulation (water, soils and pest control). Water use has been a major concern, and we propose a framework for water availability risk assessment based on aridity and seasonality indices. At local scale, it was considered the inherent risk offered by natural climatic constraints combined with local physical attributes, resulting into a natural resilience. Results show that natural condition could be enhanced by forest management in order to build resilience to forest plantation, increasing the provision of ecosystem services. Finally, we found evidences of forest management alternatives related to water provision and regulation, erosion control, insect damage control, and support avian biodiversity that could contribute to balance ecosystem services provision and productivity in forest plantation landscapes towards the Sustainable Development Goals.

\title{
Forestry and the carbon-water policy nexus
}

Gregory Valatin, Thomas Nisbet, James Morison

${ }^{1}$ Forest Research, Farnham, United Kingdom (gregory.valatin@forestresearch.gov.uk; tom.nisbet@forestry.gov.uk; james.morison@forestry.gov.uk)

Forestry is widely recognised as having an important role to play in helping reach goals of both climate change mitigation and water protection, whether through carbon sequestration and storage, enhancing the hydrological cycle, water quality improvement, or reducing flood risk. The available evidence also points to forestry measures offering cost-effective options to help address associated policy goals. However, the multiple (e.g. carbon- and water-related) benefits that forests provide are often not accounted for in decision making, limiting forestry's role. Programmes at Forest Research cover a spectrum of research on carbon and water policy-relevant issues, including on the cost-effectiveness of UK woodland creation for climate change mitigation and water protection, carbon savings associated with harvested wood products and incorporating forest flood regulating services in natural capital accounts. Ongoing work within the PESFOR-W EU COST Action on developing a common approach to estimating the cost-effectiveness of woodland measures for reducing diffuse pollution is considering how to take wider benefits into account, and also potential for linking incentive (payment for ecosystem services) schemes for carbon- and waterrelated benefits more closely. An overview of work on these topics is provided, noting a number of existing evidence gaps and research opportunities, and highlighting ways to better capture forestry's potential in pursuing the goals of the carbon-water policy nexus.

\section{The afforestation in Bulgaria: practice and research}

Alexander Alexandrov ${ }^{1}$, Ivan Iliev², Zdravko Bakalov ${ }^{1}$

${ }^{1}$ Forest Research Institute, Sofia, Bulgaria; ${ }^{2}$ Universityof Forestry, Sofia,Bulgaria (alexandrov_38@abv.bg; ivilievltu@yahoo.com; zdravko_bakalov@abv.bg)

The civilizations of Roman, Byzantine and Ottoman empires caused degradation and fragmentation of the Mediterranean and the Balkan forests. The forest territories of Bulgaria are 3,877,626 ha (woodiness - 34.4\%), including primary forests - 15.9\%, naturally regenerated forests - $62.2 \%$ and planted forests $21.9 \%$. The share of afforestation in Bulgaria is the highest compared with the other Southeast European countries (at average for the region $8.5 \%$ ) while it is 9\% for Europe. Three periods of afforestation activities are distinguished in this country: First - from 1878 (the Liberation) to 1944, second - from 1945 to 1989, third - since 1990. The afforestation types applied in Bulgaria are as follows: on torrential lands and dam basins, on forests destroyed by fires, on lands degraded by industry, on unregenerate forests after felling, for field-protecting shelter belts, with exotic and forest-fruit tree species. Due to afforestation programs to a great extent the growing stock has increased from 220 million $\mathrm{m}^{3}$ (1944) to 400 million $\mathrm{m}^{3}$ (1989), to 680 million $\mathrm{m}^{3}$ (2017). The triple enlargement of wood biomass and corresponding sequestration of $\mathrm{CO}_{2}$ are some other results of afforestation apart from environmental benefits. The afforestation methods used in Bulgaria are applicable in other countries at appropriate latitude and altitude.

Origins Brasil @: operation and environmental impacts of added value and transparency in producing and marketing socio-biodiversity 


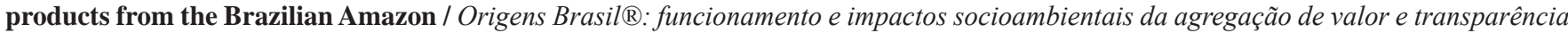
na produção e comercialização de produtos da sociobiodiversidade da Amazônia brasileira

Carlos Eduardo Marinelli, ${ }^{1,2}$, Ana Patrícia Gomes ${ }^{3}$, Helga Yamaki ${ }^{3}$, Mariana Finotti ${ }^{3}$, Roberto Palmieri ${ }^{4,3}$

${ }^{1}$ Grupo Natureza, Sociedade e Conservação (NSC), Brasília, Brasil; ${ }^{2}$ Instituto Nacional de Pesquisas da Amazônia, Manaus, Brasil; ${ }^{3}$ Instituto de Manejo e Certificação Florestal e Agrícola (Imaflora),Piracicaba,Brasil; ${ }^{4}$ Universidade de Campinas, Campinas, Brasil (caenscgrupo@gmail.com; patricia@) imaflora.org; helga@imaflora.org; mariana.finotti@imaflora.org;palmieri@imaflora.org)

Por meio da identificação da origem, rastreabilidade e de relações comerciais éticas de produtos da sociobiodiversidade originários de áreas protegidas da Amazônia brasileira, o Origens Brasil ${ }^{\circledR}$ contribui para manter e valorizar o patrimônio e a diversidade socioambiental de territórios. Para avaliar os impactos do Origens Brasil ${ }^{\circledR}$ foi desenvolvido um sistema de monitoramento baseado em um conjunto de indicadores socioambientais. O objetivo deste trabalho é apresentar como funciona o Origens Brasil ${ }^{\circledR}$ e os principais resultados dos dois primeiros anos do seu sistema de monitoramento de impactos. Alguns indicadores são monitorados anual e outros bienalmente junto à três públicos diferentes: consumidores e interessados nos produtos; organizações não-governamentais envolvidas no Origens Brasil@; e produtores, jovens e lideranças das comunidades atendidas. Os dados produzidos são enviados automaticamente para a Plataforma do Origens Brasil ${ }^{\circledR}$ para análise e geração de saídas gráficas. No início de 2019, o Origens Brasil ${ }^{\circledR}$ envolve 33 produtos, 1279 produtores, 14 empresas e 39 organizações não-governamentais, cobrindo 36 áreas protegidas que totalizam 28 milhões de hectares e uma movimentação financeira de cerca de R\$1,5milhão. Foram avaliados 22 indicadores sobre 10 temas diferentes e que representam 8 impactos (diretos e indiretos) sobre as dimensões econômica, socioambiental e de governança. Os resultados são observados em um painel de indicadores e subsidiam debates e decisões sobre o funcionamento do Origens Brasil@, permitem identificar alertas de resultados indesejados e propor aprimoramentos, além de possibilitar às empresas, produtores, organizações envolvidas, consumidores e demais interessados conhecerem e comunicarem os impactos alcançados.

\section{Sustainable development of South Korea from an environmental perspective}

Sea Jin Kim, Mina Hong, Cholho Song, Woo-Kyun Lee

'Korea University, Seoul, Republic of Korea (bluegulcy@gmail.com; alsdk920902@naver.com; cholhosong@gmail.com;leewk@korea.ac.kr)

We all aim that our countries develop sustainably and the Sustainable Development Goals (SDGs) set by the United Nations cover social, economic and environmental development issues, which is virtually every aspect of our lives. Environmental development is both affected by and affects social and economic developments and is critical to achieving sustainable development. South Korea is often cited as one of the best practice cases of environmental development, especially on forest restoration and rehabilitation, having gone through a quantum shift over the last half century. After the Korean War, the land has been devastated and the people had to start from scratch to rebuild the shattered post-war environment. This study introduces the environmental development of South Korea in which the development paradigm can be identified within 50 years after the Korea War despite some limitations. This study aims to analyse the Korean development with relevant indicators in a narrative structure. As a result, the environmental development of South Korea can be considered as a model. To translate the theory into practice, some of the Mid-Latitude countries are sorted out to estimate the phase of environmental development in the perspective of Korean case. The results show the comparison among the countries based on the model and indicate Mid-Latitude countries has room for sustainable development for a better future. This work was supported by the National Research Foundation of Korea (NRF) grant funded by the Korea government (MSIT) (No; 2018R1A2B6005682).

Considerations in constructing a national policy on ecosystem services / Considerações na construção de uma política nacional sobre serviços ecossistêmicos

Michele Benetti Leite ${ }^{1}$, Pablo Martinez de Anguita ${ }^{2,3}$

${ }^{1}$ LandsCare, Santa Maria, Brasil; ${ }^{2}$ Universidade Rey Juan Carlos, Madri, Spain; ${ }^{3}$ LandsCare, Madri, Spain (micheleleit@gmail.com;

pablo.martinezdeanguita@gmail.com)

Apesar do enorme potencial do Brasil em ofertar os serviços ecossistêmicos, ainda não possuímos uma política específica sobre a gestão destes na esfera nacional, mesmo com um número considerável de projetos em funcionamento no país e com alguns estados e municípios já possuindo legislação específica. Dado que o Estado é o responsável da tutela dos recursos, o estabelecimento desta, regulamentada por lei, parece auxiliar para que as promessas sejam cumpridas, independente da administração. Após analisar as principais leis, decretos e projetos de leis relacionados aos serviços ecossistêmicos, mudanças climáticas e REDD+ existentes no Brasil, e algumas leis de outros países, nossa pesquisa recopilou diversos aspectos, que, em nossa opinião, devem ser trabalhados para a construção de uma política nacional e dividimos em temas: Econômicos, Legais, Financeiros, Ecológicos e Sociais. O planejamento de tal futura política afronta grandes desafios como o de ser um mecanismo flexível, eficiente e não vulnerável à corrupção, alinhando diversos setores do governo. Para que sua construção seja bem representativa é fundamental o envolvimento dos diversos setores da sociedade organizada, como as empresas, os governos e organizações não governamentais. Em geral falta boa vontade dos entes públicos para concretizar esquemas de compensação para a preservação no Brasil. É imprescindível mais integração das iniciativas federais, estaduais e locais, públicas e privadas, pois numerosos programas, projetos e atividades são realizados em diferentes etapas e escalas, de maneira desconectada. A falta de regulação favorece aos contratos especulativos, que podem ser prejudiciais para o nosso patrimônio natural, especialmente das comunidades tradicionais.

E9a: FORESTS FOR WATER PAYMENTS FOR ECOSYSTEM SERVICES: EVIDENCE \&

Pesq. flor. bras., Colombo, v. 39, e201902043, Special issue, p. 1-768, 2019 


\title{
Assessing the environmental effectiveness, design and governance, and cost-effectiveness of Woodlands for Water Payments for Ecosystem Services schemes: activities, findings and ambitions of the PESFOR-W COST Action
}

\author{
Gregory Valatin ${ }^{1}$, Thomas Nisbet ${ }^{1}$,Zuzana Sarvasova ${ }^{2}$, Lars Högbom ${ }^{3}$, Rik De Vreese ${ }^{4}$, Paula Gatto $^{5}$, Yiying Cao ${ }^{6}$ \\ ${ }^{1}$ Forest Research, Farnham, United Kingdom; ${ }^{2}$ Department of Forest Policy, Economics and Forest Management, National Forest Centre - Forest Research \\ Institute Zvolen, Zvolen, Slovakia, ${ }^{3}$ Forestry Research Institute of Sweden - Skogforsk, Uppsala, Sweden; ${ }^{4}$ independent researcher, Ghent, Belgium; \\ ${ }^{5}$ Department TESAF - Land, Environment, Agriculture and Forestry, University of Padova, Padova, Italy; ${ }^{6}$ RSK ADAS, Helsby, United Kingdom \\ (gregory.valatin@forestresearch.gov.uk; tom.nisbet@forestry.gov.uk; sarvasova@nlcsk.org;lars.hogbom@skogforsk.se; rik.devreese+pesfor@gmail.com; \\ paola.gatto@unipd.it; yiying.cao@adas.co.uk)
}

The PESFOR-W EU COST Action (15206) is a network of researchers and practitioners from 40 countries interested in the effectiveness of woodland measures in reducing agricultural diffuse pollution to watercourses, and the design and governance and cost-effectiveness of woodlands for water payments for ecosystem services (PES) schemes. Diffuse pollution from agriculture is a significant pressure affecting over $40 \%$ of Europe's river and coastal water bodies. Accumulating evidence indicates that the EU Water Framework Directive's objective that each water body reaches "Good Ecological Status" by 2027 in many cases will only be achieved by targeted land use change. Small-scale forest planting ("Woodlands-for-water") is a potential solution to this problem. To help underpin future development of woodlands for water projects, PESFOR-W is creating 'look-up' tables on the effectiveness of woodland creation for reducing a number of key diffuse pollutants. An initial evidence review found that woodlands buffers reduce nitrate concentrations by over $70 \%$ on average in both oceanic and Continental climates, with the strength of effect strongly related to buffer width. PESFOR-W is developing a common protocol for assessing the cost-effectiveness of woodlands for water PES, creating a spatial repository of case studies, and will develop guidance on development of new schemes. It is exploring the potential for creating a Woodland Water Code along similar lines to the Woodland Carbon Code developed for the carbon benefits of woodland creation projects in the UK, and for linking with existing schemes covering other woodland benefits to help achieve wider goals of the carbon-water policy nexus.

\section{Assesing of payments for forest ecosystem services: Slovak examples related to water \\ Martina Sterbova ${ }^{1,2}$, Zuzana Sarvasova ${ }^{1}$, Zuzana Dobsinska ${ }^{2}$, Klara Balikova², Jaroslav Salka ${ }^{2}$ \\ ${ }^{1}$ National Forest Centre Zvolen, 96092, Slovakia; ${ }^{2}$ Technical University in Zvolen, 96053, Slovakia (sterbova@nlcsk.org; sarvasova@nlcsk.org; \\ dobsinska@tuzvo.sk; xbalikova@gmail.com;salka@tuzvo.sk)}

The aim of the paper is to analyse main approaches and types of payments for forest ecosystem services (PFES) mechanisms or financial arrangements related to water with the emphasis on three basic schemes: (i) public or government-financed PFES, (ii) private or user-financed PFES, and (iii) public-private schemes. The main classification of PFES schemes was based on Wunder's (2005) 5 criteria. The empirical part was based on the review of PFES schemes implemented in different Forest Europe signatory countries. The personal interviews with actors presented as ES providers were used to describe the main features of PFES schemes on chosen examples from Slovakia. The results pointed out, that only a few "core" PES schemes are applied in Europe that usually have a mixed public-private character. In Slovakia three types of public PFES schemes were identified: 1) forest land tax relief for protective and special purposes forests, 2) refunds for the restriction of ownership rights and 3) Forestry Support for non-productive forest functions, which are public schemes. Private PFES scheme related to the provision of drinking water for local use has been identified so far. In this case the "Piggy-backing" principle is applied where a single service generated from the water managing authority (Military Forests and Estates of the Slovak Republic, that provides water management in accordance with area needs and environmental regulations) is sold to one specific buyer (local water management and supply company, that manages and maintains forest land and is responsible for land improvements and stream dikes).

\section{Incorporating agroforestry into water quality trading: evaluating economic-environmental tradeoffs \\ Samuel Scott ${ }^{1}$, Kelly Cobourn ${ }^{1}$, John Munsell ${ }^{1}$, Kurt Stephenson ${ }^{1}$, Brian Strahm ${ }^{l}$ \\ 'Virginia Tech, Blacksburg,USA (samuels6@vt.edu; kellyc13@vt.edu; jfmunsell@vt.edu; kurts@vt.edu; bstrahm@vt.edu)}

Water quality trading (WQT) holds promise as a flexible policy approach to reduce agricultural nutrient pollution by encouraging the adoption of best management practices (BMPs). WQT can theoretically achieve water quality improvements at least cost, but its ability to do so in practice depends on how tradable credits are awarded. Ideally, crediting should reflect heterogeneity in water quality improvements under alternative management practices. However, because it is challenging to quantify the environmental outcomes associated with different BMPs, WQT programs often award uniform credit allocations to practices that deliver different water quality improvements. In the Chesapeake Bay Watershed of Virginia, USA, we estimate the water quality benefits and economic costs of a suite of alternative BMPs, including land retirement, forestry, and agroforestry practices (e.g., multi-zone riparian buffers and alley cropping). We implement a biophysical mass-balance model to quantify the marginal environmental benefits of each BMP in terms of reduced nutrient runoff. We couple this biophysical model with an economic model of the marginal costs associated with each practice to examine the tradeoffs between economic and environmental outcomes. We present evidence of significant heterogeneity in water quality benefits across BMPs and demonstrate that efficiency gains are possible with differentiated water quality crediting. Moreover, we find that the status quo uniform approach to crediting undervalues the water quality benefits of agroforestry practices, dampening farmers' incentives to adopt these systems. The economic-environmental approach presented here offers a practical approach to designing WQT policies that are both economically sound and biophysically grounded.

\section{Evaluating willingness to pay for watershed protection in thika dam, murang'a county: case of nature based solution to water challenges in Kenya}

Joram Kagombe ${ }^{1}$, James Kungu ${ }^{2}$, Daniel Mugendi ${ }^{3}$

${ }^{1}$ Kenya Forestry Research Institute, Nairobi, Kenya; ${ }^{2}$ Kenyatta Univeristy, Nairobi, Kenya; ${ }^{3}$ Embu University, Nairobi, Kenya (jokagombe@gmail.com; kungu.james@ku.ac.ke;dmugendi@yahoo.com)

Payment for Environmental Services is an incentive based approach in natural resource management aimed at linking the suppliers and consumers of goods and services from a natural resource in a way that both parties contribute to improved delivery. Nairobi City has experienced serious water shortages in the past due to water levels in Thika dam subsiding to low levels and resulting in water rationing. The dam supplies $80 \%$ of water to Nairobi city but few of the residents are able to link availability of clean water in their pipes to conservation of water catchments areas. The objective of the study was to find out whether users of 
water from Thika dam could participate in watershed protection scheme through Payment for Water Services. The study identified factors that could influence willingness of water users to pay for the environment services. Primary and secondary data were collected based on baseline survey and qualitative research approaches, interview schedules, questionnaires and, focus group discussions. Results showed that $83 \%$ of farmers are willing to participate in scheme aimed at improving conservation. There was significant relationship between farmer's source of water and amount of money they could give but attached condition of clean and regular water. Rewards in kind were more preferred. There was no framework in which consumers willing to pay could use to provide incentives to the providers of environment services. The government could make use of the findings of the study to develop a nature-based payment model for Nairobi residents.

\section{Consequences of Mexico's Payment for Hydrological Services program for ecosystem service and economic trade-offs: an integrated field and modeling approach}

Heidi Asbjornsen ${ }^{1}$, Carter Berry ${ }^{2}$, Kelly Jones ${ }^{3}$, Randall Kolka ${ }^{4}$, Nate Looker ${ }^{5}$, Sergio Lopez-Ramirez ${ }^{6}$, Robert Manson ${ }^{7}$, Alex Mayer $^{6}$, Mariana Quetzalli $^{7}$, Jacob Salcone ${ }^{8}$, Guadalupe Williams-Linera ${ }^{7}$

${ }^{1}$ University of New Hampshire, Durham, USA; ${ }^{2}$ Chapman University, Orange, USA; ${ }^{3}$ Colorado State University, Fort Collins, USA; ${ }^{4}$ US Forest Service, Grand Rapids, USA; ${ }^{5}$ University of Minnesota, Minneapolis, USA; ${ }^{6}$ Michigan Technological University, Houghton, USA; ${ }^{7 n}$ stituto de Ecologia, Xalapa, Mexico; ${ }^{8}$ Colorado State University, Fort Collins, USA (heidi.asbjornsen@unh.edu; zcberry@gmail.com; jones.kelly.west@gmail.com; rkolka@fs.fed.us; ntlooker@gmail.com; sergiomiguel009@gmail.com; robert.manson@inecol.mx; asmayer@mtu.edu; marianaquetzalli@gmail.com; jsalcone@gmail.com; guadalupe.williams@gmail.com)

Payment for Watershed Hydrological programs (PHS) are increasingly used worldwide as a policy tool to provide incentives for upstream landowners to adopt land use activities favoring sustainable provision of high quality water to downstream areas. Because PHS operate at the interface between human and biophysical systems, complex and often unexpected interactions often occur, yet knowledge about how these interactions affect ecosystem services and economic outcomes is currently lacking. We assessed the ecosystem service and economic tradeoffs of Mexico's PHS program in two watersheds in Veracruz, Mexico. We found strong consistencies between provisioning of different ecosystem services (i.e., water quality and quantity, carbon storage, and biodiversity) across land uses, such that provisioning for one service allowed for greater provisioning of another. Further, we found that conversion of primary forests to other land uses (i.e., coffee, sugarcane, pasture) would result in net decreases in ecosystem service provisioning, with the exception of young forests. All forest land uses had much greater ecosystem service benefits than other land uses but the specific provisioning of each land use to ecosystem services varied in unexpected ways. Additionally, many PHS participants (30\%) indicated that PHS did not provide significant income benefits, and a majority highlighted that their motivations for participation included not only financial benefits, but also other factors such as environmental stewardship and community benefits. Current efforts focus on integrating these data into a modeling framework to assess the consequences of different PHS policy and land use change scenarios for watershed sustainability.

\section{Transaction and implementation costs and the environmental effectiveness of the Water Producer Programme (Brazil)}

Leidimari Neves do Prado ${ }^{1}$, David Shanafelt ${ }^{2}$

${ }^{1}$ INRA, Nancy, France; ${ }^{2}$ BETA, Nancy, France (leidimari.neves-do-prado@inra.fr; david.shanafelt@inra.fr)

This paper studies the economic impacts and the environmental effectiveness of a large-scale public investment in the Water Producer Program (WPP) in the Pipiripau River Basin in Brasília, Brazil. The WPP is a voluntary payment for ecosystem services (PES) program aimed to improve the quality and quantity of water via three types of actions: (i) soil conservation, (ii) restoration or conservation of areas under permanent protection and/or legal reserves, and (iii) conservation of native vegetation remnants. All three actions are required for landowners to be eligible for payment. However, contract signatories bear no costs of implementation - all works and services are offered free of charge to landowners. This incentive scheme deviates largely from the willingness-to-pay approaches predominant in the literature. Created in January 2012, the WPP is still in its implementation phase and there are questions as to its attractiveness and effectiveness. In this paper we develop a model of a PES program in which landowners are given traditional incentive schemes to enroll in the program, as well as subsidized implementation costs. We evaluate the effectiveness of the incentive scheme for enrollment and expected returns from ecosystem services. We complement the model with an empirical analysis of the WPP. We find that since the implementation of the WPP in 2012, over 350,000 seedlings of native trees were replanted in participating properties and over 200 ha of additional land are undergoing restoration. We find evidence of reductions in the cost of water treatment over the course of the study.

\section{The Stick and the Carrot: explaining the decision to participate in the Water Producer Programme (Brazil)}

Leidimari Neves do Prado ${ }^{1}$, Serge Garcia ${ }^{2}$, Pablo Andrés-Domenech ${ }^{3}$

${ }^{1}$ INRA, Nancy, France; ${ }^{2}$ BETA, Nancy, France; ${ }^{3}$ AgroParisTech, Nancy, France (leidimari.neves-do-prado@inra.fr; serge.garcia@inra.fr; pablo.andresdomenech@agroparistech.fr)

In 2012 the Brazilian Government set up the Water Producer Programme (WPP) in the Pipiripau River Basin (Federal District). WPP is a voluntary membership programme focused in stimulating the protection of water resources and reducing damages from soil erosion through a policy of Payment for Environmental Services (PES). Since the creation of WPP roughly half of the landowners in the basin have joined the Programme. A non-negligible number of owners, however, have decided not to join. We interviewed landowners in the area covered by WPP to find out more about their motivation to join the programme. We conducted econometric analyses based on (i) observed participation to WPP and (ii) their compliance with the Brazilian Forest Code (BFC). A non-spatial probit model and both spatial binary probit models spatial auto-regressive (SAR) and spatial error (SEM) were used to explain the decision of landowners to participate. We found that programme's benefits (carrot-like incentives) alone were not strong enough to attract owners to join WPP as owners already complying with BFC have a much low participation rate. On the contrary, carrot-like incentives together with stick-like incentives greatly improved participation. This last result shows how important it is for landowners to sign the contract for fear to be punished by the BFC and in order to avoid regularisation costs, rather than for the programme's objectives and their own pro-environment values

“Water-solidarity” in management of planted forests / Manejo hidrossolidário de florestas plantadas 
Yasmin Rocini ${ }^{1}$,Felipe Faria ${ }^{1}$, Marciano Silva ${ }^{1}$, Arnaldo Gunzi ${ }^{2}$, Maria José Zakia ${ }^{2}$, Andreia Pimentel ${ }^{1}$, Mariane Bueno de Camargo ${ }^{1}$

${ }^{1}$ Klabin S/A, Telêmaco Borba, Brazil,; ${ }^{2}$ Klabin S/A, São Paulo, Brazil (yasminrocini@gmail.com; ffaria@klabin.com.br; marciano.silva@klabin.com.br; asgunzi@klabin.com.br; zeze.zakia@gmail.com; anpimentel@klabin.com.br; maricamargo@klabin.com.br)

Todas as organizações têm procedimentos e rotinas que são necessárias para que os objetivos estabelecidos sejam alcançados, no entanto, esses padrões podem se tornar obstáculos para chegada de novas ideias. Estas devem ser embasadas em parâmetros técnicos e critérios relevantes para incorporação no manejo florestal, aperfeiçoando aspectos no âmbito econômico, ambiental e social. A operação de colheita é tida como item de destaque no processo produtivo, sendo determinada pela sequência de corte de talhões com bom rendimento operacional, que está diretamente ligado ao tamanho dos blocos e dispersão dos talhões, contribuindo para redução dos custos operacionais e deslocamento das frentes de trabalho. Para isso, diversos fatores devem ser considerados no momento do sequenciamento de corte, como produtividade das florestas, gênero plantado e distribuição espacial dos talhões. A mudança conceitual realizada foi a inserção do conceito de hidrossolidariedade no planejamento florestal, guiando a tomada de decisão das operações. Entende-se que o tamanho dos blocos de colheita pode acarretar prejuízos aos processos hidrológicos e à conservação da biodiversidade. Para compatibilizar os interesses foram avaliadas todas as microbacias de terceira ordem sob a influência das áreas plantadas e estabeleceu-se uma regra que propõem que pelo menos $40 \%$ da cobertura vegetal da microbacia seja mantida enquanto os outros $60 \%$ sejam manejados.

\section{The forest based industry and SDGs most linked to water resources}

Nathalia Granato Loures ${ }^{1}$

'Ibá, São Paulo, Brazil (n.granato@iba.org)

Water is an essential resource for any productive chain and its availability in terms of quality and volume has been significantly affected by a set of issues including climate change, increasing population and demand of resources and products, besides land use management amounts others. This session aims to show the ecosystem services related do water resources, including services on regulation, provision, support and culture. Additionally, the session aims to show the contribution of forest based industry in Agenda 2030 (Sustainable Development Goals) considering primarily the role of forestry and the forest-based industry on water resources. It seeks to present challenges that should be better addressed by private sector, academy, policy makers and civil society towards a better water resource management; and to propose solutions to promote and scale up good water management as an environmental service adding value to large scale producers, but particularly smallholders.

THEME F: COMMUNICATING, EDUCATING, NETWORKING \& PUBLISHING

\section{F1a: TEACHING AND TRAINING IN SILVICULTURE, SILVICS AND SILVOLOGY}

\section{Teaching and training in silviculture: contemporary challenges and future prospects}

Jens Peter Skovsgaard (D)

${ }^{1}$ Swedish University of Agricultural Sciences, Alnarp, Sweden (jps@slu.se)

There are three main challenges for the classical approach to teaching in silviculture: (a) the economic basis for running a course, (b) the increasing diversity of students, and (c) the staff reductions in operational forestry. The economic basis is a major problem because silviculture courses generally are allocated similar budgets as other, purely classroom-based courses. For silviculture courses this is due mainly to transportation costs and severely challenges field tours as an integral part of the teaching. The increasing diversity of students is a pedagogic challenge. Many forestry curricula are based on optional subjects rather than following an essentially fixed progression of courses with a gradually increasing complexity. Moreover, students from other professions may wish to attend silviculture courses. Consequently, due to the lack of basic skills among some students, this generally lowers the entry-level requirements, demands more basic knowledge to be included in the course and prevents the course from reaching into advanced level silviculture. The staff reductions in operational forestry has a major impact on teaching options simply because the remaining potential hosts for field tours have less time available for apprentice training, supervision and teaching. This makes it increasingly difficult for forestry staff to plan and conduct field tours and to host students, and many decline to do so due to other competing and sometimes urgent work. Remote-distance teaching, virtual reality facilities and electronic media may help alleviate some of these problems in the future, but also pose challenges for the indispensable hands-on training in silviculture courses.

\section{The cross-border further training for close to nature silviculture (CTN): best practice}

Milan Sarvaš ${ }^{1}$, Peter Balogh ${ }^{1}$

${ }^{\prime}$ National Forest Centre - Institute for Forestry Consultancy and Education, Zvolen, Slovakia (sarvas@nlcsk.org; balogh@nlcsk.org)

Logging and wood-processing industry is the main source of income in many areas of the Carpathians, especially in Slovakia-Ukrainian border region. The forest exploitation was very intense in the 19th and early 20th century, when many native forest stands were clear-cut. To improve sustainable forest management in border region the education project focused on close to nature silviculture (CTN) was implemented. The overall objective of the project was to develop conditions for further learning of forestry practitioners of the border regions of Ukraine and Slovakia. In additional the next objective was to change the paradigm of forest management among forestry practitioners thus changing the system of forest management towards multifunctional and sustainable close to nature management. The project was divided into four phases. During first phase analysis and concept development the assessment of the current situation was done. In the second phase-capacity building the training program and the practical manual was developed. During the third phase training activities the training of trainers was done. The fourth phase was focused on consolidation and dissemination. The projects outcomes: 4 sample plot areas were established and serve regularly as demonstration and training sites; 14 trainers, 160 forest practitioners, 20 engineer specialists and managers of forest administrations and 10 members of forest owner associations were trained; the new training manual was published and disseminated; four joint practical training events organized with participation of 80 forestry practitioners were carried out; cross-border web-platform (www.foresterslearning.eu) for further training and knowledge exchange was developed.

\section{Bsc Forestry curriculum in University of Eldoret: teaching silviculture and its challenges}


Jane Kiragu ${ }^{1}$

'University of Eldoret, Eldoret, Kenya (wambuikirash@gmail.com)

Silviculture is and will remain a core subject in forestry training. It deals with all aspects of forestry and its sustainability. Traditional forestry is changing due to changes in forest land size, climate change, population size and status, forest type i.e. changing from Natural forestry to plantation forestry, rain forest to dryland forest, gazetted forest to farm forestry etc, which leads to changes in species type, uses and management methods. This calls for the change in the teaching of Silviculture. For the Foresters to be able to cope with these changes, the curriculum needs revision, which is also a challenge due to the cost involved. Challenges encountered in teaching Silviculture in the University is mainly lack of recent book publications leading to relying on very old text books, research in forestry aspects especially, Silviculture, takes too long to get results, making the research expensive, lack of information on the proper propagation methods, tending and management of most indigenous and exotic species for the tropics, lack of enough land where these research can be undertaken and insufficient funds. The teaching is mainly theory which makes in even more challenging. There is therefore need for government intervention so as to allocate more funds for research and training in order to improve the teaching of the subject.

\section{A network of university forests in Asia for long-term monitoring of forest ecosystems}

Naoto Kamata ${ }^{1}$, Toshiaki Owari ${ }^{2}$, Koichiro Kuraji ${ }^{3}$

${ }^{1}$ The University of Tokyo, Furano, Japan; ${ }^{2}$ The University of Tokyo, Kamogawa, Japan; ${ }^{3}$ The University of Tokyo, Tokyo, Japan (kamatan@uf.a.u-tokyo. ac.jp; owari@uf.a.u-tokyo.ac.jp; kuraji_koichiro@uf.a.u-tokyo.ac.jp)

Under changing environments, long-term monitoring and inventory data are important to detect temporal changes in environments and ecosystems. There have been so many attempts that aimed long-term research or monitoring. However, many of them have stopped due to the retirement of responsible researchers. On the other hand, university forests own various kinds of long-term data because they can obtain data as organizations, which is useful for forest research and education. The most typical one is meteorological data. Meteorological Agency in each country has been accumulated meteorological data for long. However, their observatory stations are normally located in urban areas so that data obtained by them need to be corrections before applying to forest research. On the other hand, university forests are normally located in remote areas so that climate data that have been obtained by university forests can be used for forest researches. The University of Tokyo Forests (UTF) consists of seven regional forests. The seven forests have accumulated basic long-term data that are available for researches and education: LTER plots, other stand plots, meteorological and hydrological data, bird community, plant and vertebrate inventory, and others. Since 2016, we teamed up with other university forests in Asian countries and started to share data and knowledge that have been accumulated in each university. We would also introduce activities of the network.

Forest science field education at the university of helsinki: a case study analysing learning diaries

Mika Rekola ${ }^{1}$

${ }^{1}$ University of Helsinki, Helsinki, Finland (mika.rekola@helsinki.fi)

A Helsinki University field course "Forest and peatland ecology", organised in June 2017, was studied using qualitative text analysis of students' learning diaries as a main source of data. Students' self-regulative knowledge was explored and found rather limited which is in line with some earlier literature. Teaching methods during the course were evaluated very positively by students. One of the main results was that the more activating teaching methods were perceived more positively. Learning diaries included a few negative evaluations and these can be seen as a valuable source of feedback. It is concluded that the field course is an extremely relevant method in order to achieve professional knowledge in forest sciences. The recommendations for future teaching planning are that more emphasis should be put on communicating learning aims, modern learning technology, and finally, critical self-regulation knowledge.

\section{Silviculture: Our way of beating the odds}

Biing Guan ${ }^{1}$

${ }^{1}$ National Taiwan University, Taipei, Taiwan (btguan@ntu.edu.tw)

Silviculture is considered to be a core course in classical forestry education program. However, many undergraduate students in Taiwan, perhaps around many parts of the world as well, nowadays challenge the idea with the question and argument: "Why we need to learn silviculture? It is a waste of time because nature will regenerate trees for us." From a probabilistic perspective, the likelihood of any single seed can survive and become a regenerating adult is next to zero. Nature uses hundreds of years, by continuously outputting seeds, to even the odds, but the outcomes are unpredictable. In this presentation, I will argue that silviculture is our way of beating the odds and obtaining more predictable outcomes. An example based on a restoration project in Taiwan will be offered to strengthen the arguments.

“Field cycle I:" a strategic educational model in professional education based on competencies among forest engineering students at FCF-UNALM in Lima, Peru / "Ciclo de campo I": Modelo educativo estratégico en la formación profesional basada en competencias de los estudiantes de Ingeniería Forestal de la FCF-UNALM Lima-Perú

Ethel Rubin de Celis Llanos, Carlos Fernando Bulnes Soriano, Wilfredo Ojeda Ojeda

IUniversidad Nacional Agraria La Molina,Lima, Peru (erubin@lamolina.edu.pe; cfbulnes@lamolina.edu.pe; wojeda@lamolina.edu.pe)

La realización el Ciclo de Campo I mediante un análisis descriptivo, el objetivo es evaluar el papel que tiene el Ciclo de Campo I en la formación de los egresados forestales mediante su malla curricular. Este Ciclo de Campo I se inició en el 1995 a la fecha en la Facultad de Ciencias Forestales de la Universidad Nacional Agraria La Molina, se inició con un plan curricular compuesto por conocimientos teóricos y prácticos que son articulados directamente en el campo forestal y en la actualidad se encuentra migrando al curriculo basado en competencias. En este ciclo se logra que estudiantes sean protagonistas de su aprendizaje, produce mejoras significativas como la motivación, integración de saberes mediante el conocimiento directo del recurso forestal, aumento en la colaboración entre estudianes, mejor desempeño académico, conocimiento de la realidad peruana, expectativa de aplicar sus conocimientos en el quehacer forestal, así como en la formación integra y humanista del egresado. Los resultados obtenidos muestran que el Ciclo de Campo I es un momento adecuado para la evaluación de competencias del perfil del egresado forestal buscando satisfacer al mercado laboral y el manejo sostenible del recurso. 
Intersection of arts and science: a conceptualization of motives, approaches and practices

Teppo Hujala ${ }^{1}$

'University of Eastern Finland, Joensuu, Finland (teppo.hujala@uef.fi)

Combining arts with science is not a new idea, but it seems to attract growing attention in different arenas, including bioeconomy and forest conservation. Reasons behind that trend may be several, but it is likely that the complex nature of today's scientific and societal problems calls for using diverse knowledge and communication domains. However, science may be linked with arts in various ways and for different purposes. This contribution proposes a conceptual framework for understanding, evaluating, and designing arts and science mixes. The framework is multidisciplinary, because it contains concepts adopted from philosophy, cognitive and social psychology, communication sciences, futures studies, and behavioral economics. The suggested dimensions of the framework are: ethical commitments; contributor balance; expected impact logic; performative nature; collaboration; and mode of creativity. As an illustrative example, a recent arts and science blending process from Finland is described and decomposed according to the framework's dimensions. The example, "Encounter on the Top" was an innovation workshop organized in collaboration between Human Security Finland, Greenpeace, and Eastern Finnish culture festivals in June 2017 at Koli Hill, Finland's national scenery. The event incorporated tens of artists as well as environmental and forest scientists, to collaboratively design a performance, an event, or a piece of art that communicates recent scientific research on climate change to relevant audiences in a fresh and impactful way. After analyzing the example, the potential value of the proposed conceptual framework will be summarized, and amendments and refinements will be queried from the audience.

The confluence of art, music and science fosters scientific discovery and conservation at long-term ecological research stations in the United States

Lindsey Rustad ${ }^{1}$, Mary Martin $^{2}$, Xavier Cortada ${ }^{3}$, Marty Quinn ${ }^{4}$, Sarah Garlick ${ }^{5}$, Sarah Thorne ${ }^{5}$, Michael Casey ${ }^{6}$

${ }^{1}$ USDA Forest Service, Durham, NH, USA; ${ }^{2}$ University of New Hampshire, Durham, NH, USA; ${ }^{3}$ University of Miami, Miami, FL, USA; ${ }^{4}$ Design Rythmics, Lee, NH, USA; ${ }^{5}$ Hubbard Brook Research Foundation, Woodstock, VT, USA; ${ }^{6}$ Dartmouth College, Hanover, NH, USA (lindsey.rustad@usda.gov; mary. martin@unh.edu; xcortada@gmail.com; martyq92@gmail.com; sarahgarlick@hubbardbrookfoundation.org; sarahthorne@hubbardbrookfoundation.org; michael.a.casey@darmouth.edu)

Human societies in the $21^{\text {st }}$ century are faced with increasingly broad, complex and connected social and environmental conservation challenges. An example is the competing need to provide a growing world population with food, water, and fiber, while at the same time maintaining the health, vitality and cultural values of the natural ecosystems that provide these very services. The integration of science, which provides knowledge on how humans impact the natural world, with the arts (writ large), which imbue scientific knowledge with empathy, provides a powerful unified approach to solving the inter-related ecological and social issues of the 21 st century. Here we describe a program of research which integrates art, music and science to foster new scientific discoveries while simultaneously promoting education, conservation and shared stewardship of natural resources at long term ecological research stations in the United States. Focused on "Water in a Changing World," this program: (1) uses real-time environmental sensor data to create artistically-inspired data visualizations and musical sonifications of the water cycle (available online at https://waterviz.org), (2) employs neurobiological tools and theory to provide a mechanistic understanding for why the integration of arts and science can increase understanding of pattern and process in ecological data; and (3) uses the data visualizations and sonifications as an innovative and inviting approach to educating and connecting the public with water science and environmental literacy. Taken together, the program offers a model for the integration of art, science and education to address pressing contemporary socio-ecological and conservation issues.

Potential contribution of socio-environmental educational and communicative activities to Sustainable Development Goal 15, Life on Earth / Perspectivas de contribuição das práticas educomunicativas socioambientais para o objetivo do desenvolvimento sustentável, ODS-15 Vida na terra

Vania Beatriz Oliveira ${ }^{1}$, Michelliny Bentes ${ }^{2}$, Carla Fernandes ${ }^{3}$

${ }^{1}$ Embrapa Rondônia, Porto Velho, Brazil; '2Embrapa Amazonia Oriental, Belém, Brazil; ${ }^{3} U F B A$, Salvador, Brazil (vania.beatriz@embrapa.br; michelliny.bentes@embrapa.br; carla.visi@uol.com.br)

Integrar ciências, artes e culturas não é iniciativa recente. Cientistas renomados estabeleceram conexão entre a ciência e a arte, ao desenvolver suas pesquisas e comunicar os resultados, seja para a disseminação cientifica ou a popularização da ciência. Em âmbito mundial, a Agenda 2030, em seu ODS 15-Vida Terrestre, objetiva "Proteger, recuperar e promover o uso sustentável dos ecossistemas terrestres, gerir de forma sustentável as florestas [...] e deter a perda de biodiversidade". Uma mobilização planetária que requer a participação social. Originalmente, a produção coletiva de narrativas audiovisuais e videoclipes ambientais em oficinas é uma prática educomunicativa socioambiental, desenvolvida e aplicada a partir de 2007, em projetos do Núcleo de Pesquisa Florestal da Embrapa Rondônia, como estratégia para produção coletiva de informação a partir da interação entre diversos atores sociais. Consiste no uso do discurso de músicas de artistas da Amazônia para a sensibilização ambiental, sendo a oficina o espaço de interação e de diálogo entre comunicadores, pesquisadores, artistas autores da música e a sociedade representada pelos participantes das Oficinas. A metodologia baseia-se na concepção de linguagem (Bakhtin) na qual a interação caracteriza-se pelo diálogo, entre a arte (discurso literário da música) e o cotidiano dos cidadãos. Foram realizadas oficinas com diversas temáticas e contextos, cujo resultado é a elaboração coletiva de um novo discurso. Atualmente a prática faz parte da proposta de capacitação de técnicos da extensão, professores e alunos de escolas rurais, no Projeto Manejo Florestal e Extrativismo (Fundo Amazônia), com enfoque na valorização de produtos da biodiversidade amazônica.

Scouting in Bolivia through forest planning, the scouting method of learning by doing: consolidating the restoration and recovery of 
soils and the landscape in the field school at Arani, Cochabamba, Bolivia / El escultismo en Bolivia a través de la planificación forestal, el método scout aprender haciendo; consolida la restauración, recuperación de suelos y paisaje del campo escuela, en Arani, Cochabamba Bolivia

Huascar Camacho

${ }^{1}$ Asociación de Scouts de Bolivia, Cochabamba, Plurinational State of Bolivia (huascachoo@hotmail.com)

La asociación de scout de Bolivia (ASB)a través del método scout, desarrolló en coordinación, con profesionales forestales, biólogos, agrónomos, voluntarios scouts, un programa de restauración, recuperación de suelos y paisaje, en un espacio físico de 12 has. de tierras desertificadas por la erosión eólica, en el municipio de Arani, departamento de Cochabamba Bolivia. Se estableció un plan de acción en el que participaron scouts de la ASB y de varios países miembros de La Organización Mundial del Movimiento Scout (OMMS) con los objetivos de: recuperación de áreas degradadas y la creación de un bosque de biodiversidad para convertirse en un centro de educación ambiental y para la vida, que permita reconectar a los scouts en sus diferentes ramas, con el cuidado, la conservación y el manejo de la biodiversidad; en un espacio propio que facilita desarrollar sus métodos educativos y actividades en contacto directo con la naturaleza y la biodiversidad.; a través del programa scout mundial de medio ambiente y aplicar los objetivos de desarrollo sostenible. Transcurridos más de 10 años de constante trabajo de voluntariado, la aplicación de técnicas forestales y el trabajo en equipo del método scout, aprender haciendo, hicieron posible consolidar el campo escuela en el que se desarrollan actividades permanentes de educación ambiental y para la vida, con la participación de grupos conformados desde 30 personas hasta 2000 en eventos departamentales, nacionales e internacionales.

\section{Education regarding culture-forming value of the forest implemented in a Polish State Forests Holding: the forest culture centre in Gołuchów: case study}

Alicja Antonowicz, Benedykt Roźmiarek

IThe Forest Culture Centre in Goluchów, Goluchów, Poland (alicja.antonowicz@okl.lasy.gov.pl; benedykt.rozmiarek@okl.lasy.gov.pl)

Non-productive functions of the forest have been gaining on significance and appreciation in a sustainable social and economic development of the society. Throughout stimulating the sense of wonder about the forest ecosystems, emphasizing the beauty of wooden artifacts, environmental inspirations in painting, literature or sculpture, one may directly develop the better understanding of the forest potential. The effectiveness of environmental protection depends on the level of the society's awareness, which can be increased by taking particular actions. The Forest Culture Centre in Gołuchów holds special place in the forest culture in Poland, as well as fulfills educational functions of the Polish State Forests. It enables participation of the wide public in active and passive educational forms. Since 1986 the FCC has been making available six permanent exhibitions, an extensive exhibition on culture-forming function of the forest among them. Since 1988, the Center organizes National Exhibition of the Art Achievements of Foresters. Other periodic didactic events organized by the Centre include: International Open-air Painting Event Forest Inspirations and National Competition Storytellers from the Forest Glade. The Centre also serves as a place, where projects propagating artistic creation of children and youth are held. It cooperates on a permanent basis with institutions and associations propagating culture and publishes books, albums and catalogues that popularize forest in human creativity.The work of the FCC has a profound impact on the public throughout promoting the interest in the forest and encouraging reflection on the individual's attitude towards the natural environment.

\section{Illustrated videos: bringing art to science communication}

Jennifer Hayes, Nehalem Clark

${ }^{1}$ USDA Forest Service - Rocky Mountain Research Station,Fort Collins, USA (jennifer.hayes@usda.gov; ncclark@fs.fed.us)

Art is a powerful tool for communicating complex science. Visual images paired with narration improve information uptake as different parts of the brain are engaged as opposed to written or oral information alone. Further, artistic videos (animated videos in our case) excite viewers because of the motion related to drawing. At the USDA Forest Service Rocky Mountain Research Station, we worked with an artist to create illustrated videos to help communicate complex social science concepts related to wildland fire. For example: How can communities use risk management principals to guide pre-season suppression readiness? Our creative team included scientists, skilled communicators and an artist. Together we identified the science concepts we wanted to convey and then created a story around those concepts. The artist took that story and illustrated the concepts using hand-drawn and painted images. The artist video'd her illustration process and we paired this with our scientists narrating the story - creating a set of visually appealing illustrated videos for various audiences. We use these videos to communicate with the general public, managers and decision makers. The final illustrations were framed and will be part of a new art exhibit at our Station headquarters that also features a loop of these videos and photography submitted by our researchers. During this presentation we will showcase several of our short videos ( 2 minutes). We will share how we balanced needing to convey challenging ideas with simple messages and how for each video we worked with the artist to bring these to life.

\section{Poetic Science: artistic-scientific approximations of El Yunque (an arts and science collaboration in Puerto Rico)}

Grizelle Gonzálezid

${ }^{1} U S D A$ FS - IITF, San Juan, Puerto Rico (ggonzalez@fs.fed.us)

POETIC SCIENCE: Artistic-Scientific Approximations about E1 Yunque is an interdisciplinary project created by the Museo de Arte Contemporáneo de Puerto Rico (MACPR) in alliance with the USDA Forest Service-International Institute of Tropical Forestry (IITF). The project unites art and science for the purpose of celebrating Earth and its resources, and the resources protected under the Wilderness Act enacted in 1964 in order to establish the National Wilderness Preservation System. The project commenced in March 2013, with an artistic residence in El Yunque National Forest (EYNF), organized by IITF together with the Aldo Leopold Wilderness Research Institute and the Colorado Art Ranch. Said residence was the first of a series of collaborations that took place in six different ecosystems in the United States throughout 2013. This presentation will focus on the benefits of the residence that took place in Puerto Rico which resulted in an innovative project that creatively depicts the value and ecosystem of EYNF and the collaboration that took place between the invited artists and scientists from IITF. Poetic Science presents the artistic and scientific projects born from that collaboration. The projects were exhibited at the MACPR in 2014 with great success, making the institution a recipient of the 2014 Best Collective Art Exhibit Award granted by the Puerto Rico Chapter of the International Association of Art Critics (AICA). 


\section{Green jobs in the forest sector}

Alicja Kacprzak ${ }^{1}$

${ }^{1} U N E C E / F A O$ Forestry and Timber Section, Genève, Switzerland (alicja.kacprzak@un.org)

Until recently, forest jobs were associated with traditional activities related to silviculture and timber harvesting. Today, the potential for the creation of new job opportunities is enhancing all forest ecosystem functions. The green economy is creating job opportunities in the forest sector in a variety of areas, such as recreation, leisure and sports, ecotherapy, urban forestry, and the control of pests, fire and disease. The further development of green jobs in the forest sector will strongly depend on the revision of existing curricula aimed at addressing existing skill gaps and adapting to new career paths. This can improve the public perception of the forest sector as an innovative sector that attracts qualified workers and offers modern careers in a green economy. This paper focuses on understanding the potential of green jobs in the forest sector and provides guidance on how to carry out the identification of current and anticipated skill needs for green jobs. Examples of green jobs presented in the study, along with emerging tasks, depict new employment opportunities in the forest sector, which can facilitate the integration into the labor market of vulnerable groups, such as young people, women or rural populations. The publication identifies "green" skills needed for the careers of the future. New, environmentally-driven competencies will feature the application of new technologies and business management models. New careers will stem from enhanced awareness of environmental and social consequences of economic activities in the forests and from the willingness to apply sustainable development values at the workplace.

\section{Contents of specialized education on forest and forestry in high schools and universities in Japan}

Mariko Inoue ${ }^{1}$, Yasuhiko Oishi ${ }^{1}$, Natsuko Joko $^{2}$, Katsuaki Sugiura ${ }^{2}$

${ }^{1}$ Forest and Forest Products Research Institute, Hachioji, Japan; ${ }^{2}$ Nihon University, Fujisawa, Japan (imariko@ffpri.affrc.go.jp; oishi@ffpri.affrc.go.jp; brna15081@g.nihon-u.ac.jp; sugiura.katsuaki@nihon-u.ac.jp)

Specialized education on forest and forestry is provided at 28 universities and colleges and 72 vocational high schools that have forest related courses in Japan. Education on forest and forestry has changed as a result of educational reforms, and so there are various curriculum which differ at each school. In this study, we tried to grasp an overview of the contents of education on forest and forestry in high schools and universities. The high schools were following the Ministry's official guidelines for school teaching, which have been published nine times since 1947, so we analyzed the contents based on them. In the universities, we analyzed based on school subjects include in the curriculum in two universities that have forestry departments.As the result, 15 items of education in high school were extracted and 9 items in universities. Six items were included in both: forest policy with timber processing, forest management with forest mensuration, forest engineering and forest utilization, silviculture with ecology, forest disaster prevention and hydrology, and forest products and wood research. Forest animals and insects were taught only at university, whereas the relationship with society and forest functions was emphasized in high school. We grasped an overview of the contents of education on forests and forestry, including both compulsory and optional subjects. In addition, forest education should be updated to include essential contents in line with social demands.

\section{Educating without colonizing?: graduate education in forestry for international students at Northern Arizona University}

Yeon-Su Kim, Peter Fule, Kristen Waring

${ }^{1}$ Northern Arizona University, Flagstaff, USA (ysk@nau.edu; pete.fule@nau.edu; kristen.waring@nau.edu)

Educating for global engagement is becoming more urgent for training all future forest professionals in the face of worsening global challenges, such as climate change and loss of biodiversity. The National Science Foundation estimates that more than a quarter of graduate students in agricultural and biological science in the US are international students. Providing effective education to those students is not only important to the future of the countries of their origin, but also vital to global engagement of the US students and faculty who benefit from the presence of international students on campus. The School of Forestry at Northern Arizona University has experience in educating ethnic minority students, especially Native Americans, though personal attention, small class size, and a structured curriculum on research methods, philosophy of science, statistics, and effective science communication. The recent influx of international graduate students, especially from Indonesia through the USAID/CIFOR fellowship program, provided an opportunity for us to re-evaluate our program and the factors promoting student success in graduate education. We will present our ongoing efforts to improve the existing program through development of innovative curriculum and strategies for personal mentoring. We will also encourage participants to share their own experiences and facilitate a discussion on global forestry education.

\section{Generational differences in the wood products industry}

Michelle Maller ${ }^{1}$, Ashley Plagmann ${ }^{1}$,Eric Hansen ${ }^{1}$

'Oregon State University, Corvallis, USA (michelle.maller@oregonstate.edu; plagmana@oregonstate.edu; eric.hansen@oregonstate.edu)

In the next 10 years, we will see an incredible turnover of the leadership in the North American wood products industry. To maintain the successes industry is accustomed to, we must address the transition and inform the current leadership in the best ways to relate to, train, and support the younger generations. Focusing more on the backgrounds, values, and workplace motivators of each generation will help to create an understanding that will affect both generations. In short, the end goal is to ensure that the leadership change is smooth and does not disrupt the current status of economic and financial success the industry is currently experiencing. Based on information gleaned from a national survey, this presentation will highlight the differences and similarities between each generation and how the workplace culture can change to ensure the successful transition of generational leadership.

TRANSatlantic FORestry Master (TRANSFOR-M)An award-winning program for developing the next generation of globally- 


\section{minded forest and environmental managers and scientists}

Heinrich Spiecker ${ }^{1}$,Jorma Neuvonen ${ }^{2}$, Brigitte Leblon ${ }^{3}$, Marjoriitta Möttönen $^{4}$, Sopan Patil ${ }^{5}$, Raffaele Cavalli ${ }^{6}$, Andreas Hamann ${ }^{7}$, Georg Gratzer ${ }^{8}$ ${ }^{1}$ Institute for Forest Sciences/Chair of Forest Growth Albert-Ludwigs-Universität Freiburg, Freiburg, Germany; ${ }^{2}$ Faculty of Forestry, University of British Columbia, Vancouver, Canada; ${ }^{3}$ University of New Brunswick Faculty of Forestry and Environmental Management, Fredericton, Canada; ${ }^{4}$ University of Eastern Finland, Faculty of Science and Forestry School of Forest Sciences, Joensuu, Finland; ${ }^{5}$ Bangor University School of Natural Sciences, Bangor, United Kingdom; ${ }^{6}$ Università degli Studi di Padova, Padova, Italy; ${ }^{7}$ University of Alberta Department of Renewable Resources, Alberta, Canada; ${ }^{8}$ BOKU Vienna Department of Forest- and Soil Sciences, Institute of Forest Ecology, Vienna, Austria (instww@uni-freiburg.de; jorma.neuvonen@ubc.ca; bleblon@unb.ca; marjoriitta.mottonen@uef.fi; s.d.patil@bangor.ac.uk; raffaele.cavalli@unipd.it; andreas.hamann@ualberta.ca; georg.gratzer@boku.ac.at)

The sustainable management of forests is crucial in addressing the growing global challenges of this century. Forest ecosystems need to be stable yet adaptive to changes, and multifunctional providing protection, recreation, sustainable production, and use of valuable goods. Management must be responsive to not only the changing site and forest conditions but especially the increasing complexities of evolving economic and social circumstances. Tackling these complex challenges requires talented people who are educated in a combination of disciplines including the natural, technical, and social sciences. They need to have social skills, the ability to identify and solve problems, to work in teams, and to understand different point of views. They have to learn from global experience and adapt the knowledge to meet local needs of both today and the future while meeting environmental and social standards. They have to manage complex projects involving various disciplines in a multicultural environment. TRANSatlantic FORestry Master (TRANSFOR-M) is a dual-degree Master's program in forest and environmental management, which is aiming to educate the next generation of globally minded forest and environmental managers and scientists on the cultural differences, diverse historical contexts, and differing economic drivers that exist in Canadian and European natural resource management approaches. As detailed in Leblon et al. (2013), TRANSFOR-M draws from the expertise and opportunities of graduate programs across eight institutions through a blended practical and theoretical approach. TRANSFOR-M won an international award in 2014 for the most innovative graduate program across Northeastern US, Ontario, Québec, and Atlantic Canada.

\section{Quality assurance of MSc in European forestry}

Marjoriitta Möttönen ${ }^{1}$, Harald Vacik ${ }^{2}$, Heinrich Spiecker ${ }^{3}$, Mériem Fourier ${ }^{4}$, Cristina Vega Garcia ${ }^{5}$, Lucian Curtu ${ }^{6}$, Timo Tokola ${ }^{1}$ ${ }^{1}$ University of Eastern Finland, Joensuu, Finland; ${ }^{2}$ BOKU, Vienna, Austria; ${ }^{3}$ University of Freiburg, Freiburg, Germany; ${ }^{4}$ AgroParisTech, Nancy, France; ${ }^{5}$ Univeristy of Lleida, Lleida, Spain; ${ }^{6}$ Transilvanian University of Brasov,Brasov, Romania (marjoriitta.mottonen@uef.fi; harald.vacik@boku.ac.at; instww@uni-freiburg.de; meriem.fournier@agroparistech.fr; cvega@eagrof.udl.cat; lucian.curtu@unitbv.ro; timo.tokola@uef.fi)

Forest based bio-economy is a global business and requires wide competences and the use of different methods for different temporal and spatial scales ranging from regional differences in practices and cultures. The Master of Science in European Forestry (MSc EF) is a two-year programme that provides academic education in the field of sustainable resource management with special emphasis of bio-economy. Six European top-class forestry universities collaborate intensively to offer interdisciplinary courses of global relevance in a multicultural environment. Based on the specific competences of the partners thematic profiles have been developed. In addition, Associate Partner Universities in Brazil, Canada and China and Associate Industrial and Scientific Partners contribute to the programme delivery by providing challenging internships. The programme has been financed by the European Commission (2004-2014, 2016-2019). Since 2004 over 186 students, representing 72 countries, have graduated under the programme. The process of quality assurance is very important for the Consortium and detailed feedback is evaluated annually. Questionnaires are also sent to graduated students to get suggestions on how to make the study programme better fitted to the professional requirements. An external Quality Review Board is the authority responsible of external quality assurance. Currently, consortium is carrying out an accreditation process of "European Approach for Quality Assurance of Joint Programmes" based on Standards in the European Higher Education Area (ESG). This contribution will demonstrate the key findings of the feedback analysis and how they have contributed to the overall improvement of the course program through the years.

From the university into the field: connecting the next generation of forest professionals through the international society of tropical foresters

\section{Ruth Metzel $^{1}$}

IInternational Society of Tropical Foresters/Fundación Pro Eco Azuero, Los Santos, Panama (ruth@proecoazuero.org)

Multidisciplinary programs in academic institutions related to forest fields are incredibly important, but what happens when these budding foresters go out into the world, often with little support network and in disparate rural locations, to work within the landscape? The International Society of Tropical Foresters (ISTF) is an institution that over the decades has worked to connect and support forest-related professionals as they navigate this transition and the challenges and opportunities that come with working in tropical forests worldwide. The movement to strengthen the Global International Society of Tropical Foresters has grown rapidly since the 2018 Yale ISTF conference, with the passage of global bylaws and chapter establishment guidelines, over 1000 members, $50+$ chapter formation requests, and the nomination of a new Board of Directors. Come to this session to discover and discuss ISTF's approach to connecting forest practitioners navigating real life resource management problems and help shape the way forward for this rapidly growing global movement.

\section{Global Outlook on Forest Education: university curricula meet competence needs in current working life, results from Behavioral Event Interviews (BEI) and gap analysis}

Mika Rekola ${ }^{1}$, Terry Sharik ${ }^{2}$,Tara Bal ${ }^{2}$, Dalia Abbas ${ }^{3}$, Sandra Rodríguez ${ }^{4}$

${ }^{1}$ University of Helsinki, Helsinki, Finland; ${ }^{2}$ Michigan Technological University, Houghton, USA; ${ }^{3}$ American University, Washington, USA; ${ }^{4}$ Universidad Autónomade Chihuahua,Chihuahua,Mexico (mika.rekola@helsinki.fi; tlsharik@mtu.edu; tlbal@mtu.edu;daliaabbas@yahoo.com; sandra_osu@yahoo.com)

The Global Outlook on Forest Education (GOFE) study focuses on the working-life competence needs and forestry education on the university level. These working-life competence needs were analyzed using Behavioral Event Interviews (BEI) of recent forestry and natural resources graduates in more than 10 countries in 5 continents. After conducting the work-competence needs of forestry graduate students in the work place, a gap analyses compared these needs based on BEIs and the content of forestry education university curricula. The BEI method is based on McClelland's proposal to use deep interviews about success and failure stories of working life for revealing the most evident lacking competencies (threshold) and highly beneficial ones (differentiating) that make an employee superior among peers. Results have shown that the most frequently observed threshold and also differentiating competencies were related to generic skills such as leadership and management, human interactions, and communication. The subject-specific competencies were not so frequently observed 
in BEIs indicating that graduates have presumably been satisfactorily prepared in these skills for success in their working life. Gap analysis results are reflecting threshold competences. Finally, based on the results of this study, there are recommendations made to review existing university curricula.

F6c: HOW TO TEACH FOREST SCIENCES IN THE FUTURE - CHALLENGES

AND OPPORTUNITIES OF CHANGING ECOLOGICAL, SOCIO-ECONOMIC, AND

TECHNOLOGICAL CIRCUMSTANCES.

\section{Challenges and solutions to the development of MOOC for forestry higher education}

Youqing Luo ${ }^{1}$, Yu Lin', Yong Liu

'Beijing Forestry University, Beijing, China (youqingluo@126.com;duke_lin@163.com; lyong@bjfu.edu.cn)

It is a consensus for Chinese educational authorities that information technology will bring revolutionary influences to modern education, and the deep integration with information technology will overwhelmingly increase the quality of education and teaching. Having held 5 international conferences on MOOC in the past 5 years, China has become a big country of MOOC, with over 5000 online courses and more than 70 million users. Non-governmental capital has also attached great significance to the development of MOOC. Yidan Prize, for example, was launched in 2016 with a donation of \$ 320 million by Hong Kong high-tech entrepreneur, Mr. Chen Yidan. As one of the most influential educational prizes in the world, Yidan Prize is awarded to 2 winners every year ( \$ 3.8 million to each winner), and one of the 2018 winners was exactly the CEO of edX, Anant Agarwal. This presentation analyzes the logics and hierarchical relations of key elements in modern educational information technologies, investigates the advantages and limits of MOOC which is not almighty in all circumstances, and illustrates the adaptation of MOOC in different course types. Meanwhile, the development and application of MOOC have been going through four phases, namely general consensus, joint development, wide sharing and extensive recognition. Based on the status quo of China's education, this presentation hence elaborates on the key elements in each phases and particularly focuses on the challenges and solutions to wide sharing and extensive recognition, especially for forestry higher education.

\section{Innovative education in sustainable forest management}

Guangyu Wang ${ }^{1,2}$, Min Qian (Michelle) Zeng ${ }^{1,2}$

${ }^{1}$ The University of British Columbia, Vancouver, Canada; ${ }^{2}$ Asia Pacific Forestry Education Coordination Mechanism, Vancouver, Canada (guangyu.wang@ubc.ca; michelle.zeng@ubc.ca)

Challenges such as climate change and deforestation have created a high demand for sustainable forest management (SFM), and access to relevant education is important for improving forest management and helping to create a balance between environmental, economic, and social values in the Asia-Pacific Region. To improve capacity building, a joint educational program entitled Innovative Sustainable Forest Management Education in the AP region has been established by a group of international renowned forestry universities including UBC, Beijing Forestry University, University of Melbourne, University Putra Malaysia, and University of the Philippines Los Baños. This program has developed a series of online courses by using an innovative pedagogical method to convey SFM knowledge. As the open educational resources (OER), this program has attracted over 9000 global learners. The program won the CNIE-RCIE Award and the IUFRO Best Practices in Forest Education. This study will present technology, curriculum, pedagogy used in the course development, discuss strategies and methodology in creating courses, share lessons learned from the program development and introduce new initiatives of new courses in tropical forest and potential SFM online program. In addition, we will demonstrate our current practices. It will display good examples in delivering SFM knowledge using available quality OER to global audiences from various cultural backgrounds, meanwhile creating an effective learning community to promote learning and experience sharing in forestry practices in the Asia Pacific region. We believe this study will provide useful experience and information to benefit online education in the field of natural resources worldwide.

\section{The future of employment in the global forest sector: reviewing trends with a focus on "green jobs"}

Juliet Owuor ${ }^{1}$, Lisa Prior ${ }^{1}$, Georg Winkel ${ }^{1,2}$

${ }^{1}$ European Forest Institute, Bonn, Germany; ${ }^{2}$ University of Freiburg, Freiburg, Germany (juliet.achieng@efi.int; lisa.prior@efi.int; georg.winkel@efi.int)

The overall goal of this study is to evaluate global employment trends and competence needs in the forest sector with a special focus on the recently much debated field of "green jobs". The forest sector is currently facing significant changes, including globalization, digitalization, changing societal demands, and climate change. These developments have caused the nature of employment in the sector to shift, partly, away from traditional occupations in forest services or companies. More emphasis is being placed on jobs that promote the general well-being of people while at the same time promoting sustainable development. Yet, at the same time, significant regional differences prevail. This study based on literature review and expert interviews, will give an overview on the available knowledge in scholarly and grey literature relating to the topic. In this way the paper analyses how employment in the forest sector is changing globally, and the dynamics that drive such changes in different regions. Skills and competencies needed for future employment will also be explored. The paper will conclude with elaborating knowledge gaps and possible points of departure for further research.

\section{The health of tomorrow's forests depend on the actions of young forest scientists today}

Darryl Herron

${ }^{1}$ FABI, Pretoria, South Africa. University of Pretoria, Pretoria, South Africa (darryl.herron@fabi.up.ac.za)

The human race depends deeply on forests; natural forests as well planted forests. Yet these vital resources are deeply threatened by invasive insect pests and pathogens. Global organizations, such as IUFRO, have made considerable contributions to bring forest scientists together to protect forests and provide communities and governments with evidence-based knowledge to inform policies aimed at protecting the world's forests. But much remains to be done. The fight against pests and diseases rests strongly on the shoulders of young professionals who must commit to this cause. Pests and diseases know no borders and do not discriminate between countries. Young forest professionals should break down the barriers - in what ever form - that divide us and sieze the opportunities offered by digital connectivity, i.e. digital conferences, skype meetings, social media, etc., to more effectively tackle the scourge of pests that threaten our forests. My call is for young forest professionals to become ambassadors for their countries, institutions, companies, etc. and to use these opportunities to engage broadly and regularly, outside of IUFRO meetings and conferences. As ambassadors of our forests and for their protection, we not only have 
opportunities to communicate with each other but we can also provide lines of contact between IUFRO and the institutions where we reside and where we have influence. In this way, we will establish meaningful networks that are built on a foundation of understanding to drive real change across the different divisions of IUFRO and to ensure sustainable forest protection.

\section{Fostering the transformative potential of roleplays in forestry education: learning for an uncertain future}

Ida Wallin ${ }^{1}$, Vilis Brukas ${ }^{2}$

${ }^{1}$ University of Freiburg, Freiburg, Germany; ${ }^{2}$ Swedish Universityof Agricultural Sciences, Alnarp,Sweden (ida.wallin@ifp.uni-freiburg.de; vilis.brukas@slu.se)

Higher-education study programs mainly equip forestry students with subject-specific knowledge such as biology, ecology, wood technology and forest economics. Typically lacking in the study programs are skills related to social relationships and communication. This is problematic since dialogue and collaboration with the public and stakeholders in various participatory processes is an increasingly important feature in everyday forestry practices. Forestry professionals often have to handle complex decision-making situations including conflicting interests and high levels of uncertainty regarding future states of forests, climate and market conditions. Coupled with an increased uncertainty in general society, this means that we can no longer rely on specific or generic skills alone to give us adequate tools to understand and deal with reality in all its forms. We describe how forestry education can adapt to this changing reality through engaging students on a deeper level and facilitate their personal development. Transformative learning aims to raise students' self-awareness and selfreflection, and help the individual to better understand his/her own and others perceptions and norms. These are necessary skills for effective collaborative problem-posing and -solving in any modern democracy. Such learning conditions are accomplished by introducing unpredictable elements in the teaching and encouraging the students to take own standpoints. Roleplaying plausible real-life forest management situations in the classroom allow for experimentation under safe conditions and can foster transformative learning. The presentation will critically examine practical findings from a roleplay and transformative learning intervention, and convey challenges and opportunities to integrating such elements in regular curricula.

Cross-hemispheric international academic exchange: lessons from more than $\mathbf{5 0}$ years of cooperation between the forest faculties at University of Paraná, Curitiba, Brazil, and University of Freiburg, Germany

Hans-Peter Kahle ${ }^{1}$ D, Christel Lingnau ${ }^{2}$

${ }^{1}$ Chair of Forest Growth, Institute of Forest Sciences, Albert-Ludwigs-University Freiburg, Freiburg, Germany; ${ }^{2}$ Departamento de Ciências Florestais, Universidade Federal do Paraná, Curitiba, Brazil (hans-peter.kahle@iww.uni-freiburg.de; lingnau@ufpr.br)

Although it possesses one of the world's greatest forest resources, Brazil had no academic forestry school until 1960. On May 30, 1960 the first university-based course in forestry engineering was created under the name 'National School of Forestry' and started to function at the then Federal University of Minas Gerais, now Federal University of Viçosa; 3 1⁄2 years later, on November 14, 1963 the school was transferred to Curitiba and incorporated to the Federal University of Paraná (UFPR). From 1961 to 1969 the academic development was promoted through an agreement with the Food and Agriculture Organization of the United Nations (FAO). The cooperation program between the forest faculties at UFPR and at Albert-Ludwigs-University Freiburg, Germany, which existed in two phases from 1972 to 1991 paved the way for the development of postgraduate curricula in forest sciences and forestry at UFPR, which was later complemented by a doctoral program. In the following years until today, the cooperation continued with several joint research and student exchange programs between the two faculties.In this presentation, we analyse the challenges that evolved during this more than ${ }^{50}$ years lasting cross-hemispheric international academic exchange and conclude with lessons learnt for the development of effective multicultural and multidisciplinary educational strategies for the new generations of forest professionals to come.

Assessing graduates of a forest engineering course over the past decade: the case of two traditional teaching institutions / Diagnóstico dos egressos do curso de engenharia florestal na última década: estudo de caso em duas instituições tradicionais de ensino

Rodrigo Hakamada1, Silvio Ferraz', Italo Cegatta ${ }^{3}$ Rafael Braz

${ }^{1}$ Federal Rural University of Pernambuco, Recife, Brazil; ${ }^{2}$ University of Sao Paulo, Piracicaba, Brazil; ${ }^{3}$ Forestry Science and Research Institute, Piracicaba, Brazil(rodrigo.hakamada@ufrpe.br; silvio.ferraz@usp.br; italo.cegatta@usp.br; rafael.braz@ufrpe.br)

Apesar da larga abrangência de atuação e da sua importância socioambiental e econômica para o país, não é do nosso conhecimento um estudo que identifique as áreas de atuação dos engenheiros florestais no Brasil. Visando cobrir parte dessa lacuna, o objetivo deste trabalho foi identificar, através de questionário e contato direto, quais as áreas de atuação dos profissionais graduados entre 2008 e 2017 da Escola Superior de Agricultura "Luiz de Queiroz" (ESALQ) e da Universidade Federal Rural de Pernambuco (UFRPE). De 40 e 68 ingressantes por ano, respectivamente, 20 e 66\% desistiram do curso ao longo da graduação e 15 e 22\% se formaram e atuam fora da área, em áreas correlatas ou estão em busca de oportunidades. Assim, 65 e 12\% dos ingressantes da ESALQ e UFRPE ( 80 e $35 \%$ dos egressos) atuam em atividades diretamente ligadas às ciências florestais. Dentre aqueles formados pelas duas instituições e que trabalham na área, 47 e $21 \%$ desenvolvem atividades ligadas à silvicultura e manejo florestal e 41 e $62 \%$ à conservação de recursos naturais e ecologia, evidenciando diferentes perfis de atuação. Detectou-se ainda que $40 \%$ daqueles que atuam na área desenvolvem atividades de administração e gestão. Outra característica distinta entre as instituições é a permanência na região em que estão inseridas: 67 e 84\%. Esse diagnóstico não procura esgotar o tema, mas fornecer subsídios para o aprimoramento dos cursos de engenharia florestal em escalas regional e nacional.

The need to teach digital technologies in forestry education: new perspectives in forest inventories / A necessidade do ensino de tecnologias digitais na educação florestal: novas perspectivas em inventários florestais

Esthevan Augusto Goes Gasparoto ${ }^{1}$, Mateus Yamamoto $^{1}$, Marcos Isaac Junior ${ }^{1}$, Maycow Berbert ${ }^{1}$, Emily Shinzato ${ }^{1}$, Marcel Mello ${ }^{1}$

${ }^{1}$ Treevia Forest Technologies, São Josédos Campos, Brazil (esthevan@treevia.com.br; mateus.yamamoto@treevia.com.br; isaac.junior@treevia.com.br; maycow.berbert@treevia.com.br; emily@treevia.com.br;marcel.mello@treevia.com.br)

A quarta revolução industrial já é realidade em diversos setores da economia. Essa revolução está associada principalmente à utilização de tecnologias viabilizadoras, também conhecidas como tecnologias exponenciais como a Internet das Coisas, a Computação em Nuvem e a Inteligência Artificial. Tais tecnologias, há menos de uma década atrás, apresentavam restrições técnicas que inviabilizavam o uso operacional em grande parte das aplicações. Entretanto, devido ao seu caráter exponencial, atualmente é possível fazer uso do benefício de tais tecnologias diariamente em smartphones, por exemplo. No setor florestal, o uso de sensores IoT, para o monitoramento do crescimento florestal já é aplicado operacionalmente. Sensores sem-fio podem ser instalados nas árvores permitindo o acompanhamento remoto do crescimento da floresta e as suas interrelações com as variáveis climáticas, em tempo real e com 
precisão submilimetrica. A alta resolução temporal na coleta de dados associada a grande variedade de parâmetros coletados automaticamente, permite a aplicação de abordagens matemáticas inéditas no setor. O ensino florestal nas universidades deve acompanhar também a velocidade das mudanças tecnológicas vivenciadas no setor, cenário necessário para a formação do profissional florestal já imerso no meio das tecnologias digitais na sua ementa curricular. O mercado florestal demandará dos novos profissionais, além do conhecimento florestal, conhecimentos típicos da ciência da computação e estatística, bem como a proficiência em linguagens de programação e algoritmos. Sendo assim, uma instrução com mais pluralidade de um acadêmico na área florestal, isto é, combinando sua formação com tecnologias modernas, traz poderosas ferramentas para toda a ciência florestal.

\title{
F6p: COMMUNICATING, EDUCATING, NETWORKING \& PUBLISHING
}

\author{
Digital onboarding for natural resource extension professionals- pilot “Seeds Success” for next generation professionals \\ Mark Megalos ${ }^{1}$, Leslie Boby ${ }^{2,3}$, William Hubbard ${ }^{4}$, Janean Creighton ${ }^{5}$, James Johnson ${ }^{5}$, Karen Bennett ${ }^{6}$, Jeff Stringer \\ ${ }^{1}$ NC STATE University, Raleigh, NC, USA; ${ }^{2}$ University of Georgia, Athens, USA; ${ }^{3}$ Sou. Regional Forestry Extension, Athens, USA; ${ }^{4}$ University of Maryland, \\ College Park, USA; ${ }^{5}$ Oregon State University, Corvallis, USA; ${ }^{6}$ University of New Hampshire, Durham, USA; ${ }^{7}$ University of Kentucky, Lexington, USA \\ (mamegalo@ncsu.edu; lboby@uga.edu; whubbard@uga.edu; janean.creighton@oregonstate.edu; jim.johnson@oregonstate.edu; karen.bennett@unh.edu; \\ stringer@kyu.edu)
}

A USDA grant offered an opportunity to stand up a synchronous webinar series to onboard next generation extension professionals via a national platform. After 9 months of planning, a comprehensive needs assessment, 33 expert videos and a pre-course survey, the principals refined and delivered 8 module synchronous webinar course during the autumn of 2018. Pre-course survey of 88 likely participants showed a moderate level of understanding of extension philosophy, networking, mentoring, needs assessments, program delivery, and evaluation. Those same respondents expressed below average level grasp of scholarship, financing program enhancement and negotiating external partnerships. The typical student (mode) was female, forestry or natural resource agent with state-wide responsibility, less than 5 years on the job, with a completed master's degree and located in an off-campus location. A social media page allowed for interactive questions, additional reading or video clips and tips for newly-hired professionals. A course website complete with readings, video and recorded lectures was built during the course and allowed current and future participants to conduct self-paced work by topic or the entire course as desired by the professional. A post-course survey is under way and results will be shared during the presentation at the XXV World Congress.

\section{Discourse analysis on sustainability in forest-based engineering / Análise do discurso em sustentabilidade nas Engenharias de Base Florestal \\ Marcelo Langer ${ }^{1}$, Dimas Agostinho da Silva ${ }^{1}$, Alexandre Behling ${ }^{1}$, Julio Eduardo Arce ${ }^{1}$, Silvana Heidemann Rocha ${ }^{2}$ \\ ${ }^{1}$ Universidade Federal do Paraná, Curitiba, Brazil;; ${ }^{2}$ Universidade Tecnológica Federal do Paraná, Curitiba, Brazil (marcelolanger@ufpr.br; dimas. agostinho.silva@gmail.com; alexandre.behling@yahoo.com.br; jarce@ufpr.br; silvanaheidemann.utfpr@gmail.com)}

O termo "sustentabilidade" é livre e amplamente empregado em todas as áreas de conhecimento; nos diferentes setores econômicos; e, nas amplas esferas governamentais. Desde o final dos anos 70 vem se tornando componente de análise e orientação para as ações e decisões públicas e privadas, entretanto, as divergências sobre seu conceito, definição e aplicação ainda estão longe de uma unanimidade. O conceito de sustentabilidade nas engenharias de base florestal apresenta diferentes compreensões, sua aplicação surgiu nos modelos matemáticos para produção e gestão dos recursos florestais e atualmente busca integrar os aspectos sociais, ambientais e econômico em toda a cadeia de valor dos produtos florestais madeireiros e não-madeireiros. Programas mundiais promovem a sustentabilidade e o desenvolvimento sustentável das atividades antrópicas, como: normas de padronização, mudanças climáticas e os objetivos de desenvolvimento sustentável. Estes programas buscam orientar as decisões de empresas, governo e academia no desenvolvimento dos princípios da sustentabilidade. Outros programas como certificações voluntárias, índices de sustentabilidade ou desenvolvimento sustentável, avaliação do ciclo de vida de produtos servem para a avaliar os desempenhos das atividades econômicas e governamentais. Esta pesquisa teve como objetivo analisar como os aspectos de sustentabilidade são empregados nos discursos dos atores das engenharias de base florestal, quais são suas percepções intermultidisciplinares e como definem suas ações pessoais e profissionais. Foi aplicada a técnica de "análise de discurso" por meio da pesquisa Survey a profissionais e representantes das instituições de ensino e pesquisa brasileira. Foram obtidas 517 respostas e tratadas por meio de análise fatorial de correlação.

\section{The perceptions of young people on urban trees: construction of a questionnaire}

Liz Farleidy Villarraga Flórez ${ }^{1}$, Diana Patricia Morales Espinosa ${ }^{1}$, Sandra Rodriguez-Pineros ${ }^{2}$

${ }^{1}$ Universidad Distrital Francisco José de Caldas, Bogotá, Colombia; ${ }^{2}$ Universidad Autónoma de Chihuahua, Chihuahua, Mexico (lizv@udistrital.edu.co; dianamoralesespinosa@hotmail.com; sandra_osu@yahoo.com)

Forest education in Colombia has always been addressed at the University level, leaving a gap in the basic educational level where most of the attitudes and values of the citizens are developed. This study aimed to build a questionnaire that helps to inquiry about perceptions of the secondary students towards urban forests. Using the photovoice technique students were asked to build the ideal city. Two hundred and thirty-four students were divided in 36 groups to build their ideal city based on pictures of their favorite places in the city of Bogota, Colombia. Students were asked to explain the importance of each place; $97 \%$ of the students included green areas in their ideal cities stating that trees are important to produce oxygen, reduce the pollution, preserve species of fauna and flora, regulate the temperature of the city, and provide places for recreation. The results of this academic project served as the basis to design a questionnaire to assess perceptions of urban forests. The resulting questionnaire is composed of 38 statements that contained the three categories of the ecosystems services, regulation, provision, and cultural. The questionnaire was applied to 64 students for validation. Results showed a Cronbach's alpha of 0.852 and non-negative correlations indicating that questionnaire is unidimensional and it can be applied in further studies.

The Forestry Practices Group at the Federal Rural University of Pernambuco: a case study in applying problem-based learning 
methodology in forest engineering / Grupo de Práticas Florestais da Universidade Federal Rural de Pernambuco: um estudo de caso de aplicação do método de aprendizagem baseada em problemas na engenharia florestal

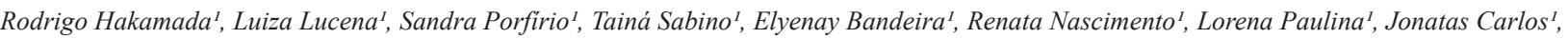
Ana Santana ${ }^{1}$

'Federal Rural University of Pernambuco,Recife,Brazil (rodrigo.hakamada@ufrpe.br; luizaalmeidalucena@hotmail.com; sandraborbap@gmail.com; coelhos.taina@outlook.com; naaybandeira@gmail.com; renata_nascimento02@outlook.com; lorena_aht2011@hotmail.com; jonatascarlos00@gmail.com; anaclarasantana_12@outlook.com)

A vivência prática associada à multidisciplinaridade resulta na consolidação do conhecimento teórico adquirido em sala de aula. Uma das maneiras de explorar estes conceitos ocorre pelo método de Aprendizagem Baseada em Problemas, que consiste em atribuir aos estudantes a busca pela resolução de problemas atuais relacionados à área e estimula os alunos no desenvolvimento da criatividade e do empreendedorismo, habilidades indispensáveis para atuação no mercado de trabalho. Como forma de unir estas temáticas dentro de um curso tradicional de engenharia florestal no Brasil, relataremos a formação e funcionamento do Grupo de Práticas Florestais (GPFlor) da Universidade Federal Rural de Pernambuco. O grupo é formado por alunos de todos os anos do curso, que trabalham de maneira voluntária em atividades divididas na forma de projetos. Os principais projetos são: "Mudas Florestais" que visa produzir mudas para plantios de florestas de uso múltiplo e restauração de áreas degradadas; "Reflorestar Rural", que objetiva restaurar áreas degradadas no entorno da universidade; "Vem da Floresta", com o objetivo de transformar árvores em produtos madeireiros e não-madeireiros e o projeto "Agroflorestar" que maneja dentro da universidade uma área de integração agrossilvicultural. Com cerca de um ano de existência, o grupo já proporcionou a vivência prática e a busca por resolução de problemas florestais a cerca de 40 estudantes ( $25 \%$ do total de estudantes matriculados). No total, cerca de 10.000 horas de atividades práticas já foram realizadas. Esperase que ações como esta possam no longo prazo serem convertidas em benefícios à sociedade através de engenheiros melhores capacitados.

\section{Role of nature education camps in creating nature awareness among school children in Haryana State of India}

Subhash Chander ${ }^{1}$, Vivek Saxena ${ }^{1}$, Dasharathi Hembram ${ }^{2}$

${ }^{1}$ Haryana Forest Development Corporation, Gurugram, India; ${ }^{2}$ Haryana Forest Development Corporation, Panchkula, India (syadavhfs02@gmail.com; viveksax1@gmail.com; dhembram@gmail.com)

Haryana Forest Department has developed some of nature camps at different sites of the state during recent past. The main objective of establishing these nature camps is to provide nature education and creating awareness among school children by involving them in various on site learning by doing activities like plantation, nursery raising, forest trailing, film shows, camping at site etc. The initiative keeps the children from routine classroom and will help in inculcating and sensitisation them towards nature. This initiative wil future generations in conservation of forests and other natural resources. The initiatives taken by State Forest Department will be presented in the Congress.

\section{Introduction of the Japan committee of the International Union of Forestry Research Organization (IUFRO)}

Sumire Kawamoto ${ }^{1}$, Alexander Buck ${ }^{2}$

${ }^{1}$ Forestry and Forest Products Research Institute, Tsukuba, Japan; ${ }^{2}$ IUFRO, Vienna, Austria (sumirekw@gmail.com; buck@iufro.org)

The IUFRO-Japan (IUFRO-J) Committee is an organization launched by the Forestry and Forest Products Research Institute (FFPRI) to promote global and domestic partnerships in forest-related research in cooperation with IUFRO. FFPRI originally established in 1905 as a forest experiment center of the Forestry Service, Ministry of Agriculture and Commerce, Government of Japan, has contributed to science, technology, policies, and promoting international partnerships through research that uses the rich and diverse forests in an environmentally sound way. FFPRI has been cooperating with IUFRO since its establishment. The activity with IUFRO Headquarters led to the formal establishment of the IUFRO-J Committee in 1976 and since then FFPRI has maintained the secretariat of IUFRO-J. The 600 IUFRO-J members represent 35 Japanese organizations and individuals who wish to further global contributions to the role of research in sustaining forests and people. In order to give IUFRO-J members up-to-date information regarding international forest issues, the IUFRO-J secretariat has published IUFRO-J NEWS three times a year since 1977. IUFRO-J Committee and IUFRO-J News can serve as an effective model also for other countries and institutions for promoting research collaboration and partnership with IUFRO.

Raising voices together to communicate about the forests of Latin America and the Caribbean / Levantando la voz juntos para comunicar sobre los bosques en América Latina y el Caribe

Marianella Argüello L ${ }^{1}$, Cristina Miranda Beas ${ }^{2}$, Raúl Pérez Albrecht ${ }^{3}$

${ }^{1}$ CATIE, Turrialba, Costa Rica; ${ }^{2}$ PUCP, Lima, Peru; ${ }^{3}$ (cristinamirandabeas@gmail.com; marguello@catie.ac.cr)

Comunicar es más que la simple transferencia de información. Comunicar sobre ciencia forestal y ambiental representa la construcción y sostenibilidad de espacios de diálogo e interacción, capaces de influir y orientar percepciones acerca de los bosques de América Latina y el Caribe, su manejo sostenible y el papel que juegan las plantaciones forestales en el desarrollo de los países, entre otros. En ese sentido, es indiscutible la relevancia y la imperativa necesidad de articular esfuerzos entre tomadores de decisión, técnicos, investigadores y usuarios, para fortalecer la comunicación de ciencia forestal, generando nuevos sentidos en los imaginarios de ciudadanos de los países de la región acerca de temas clave relacionados con bosques, sus usos y servicios ambientales. Por ello, comunicadores de Latinoamérica y el Caribe trabajan juntos para levantar la voz, impulsar y visibilizar el tema forestal y ambiental que caracteriza a la región, por medio de la Red de Comunicadores Forestales y Ambientales de América Latina y el Caribe (Recofalc). Por lo tanto, con el objetivo de crear espacios de información y reflexión dentro del contexto social y cultural latinoamericano, la Recofalc realiza campañas y utiliza sus diferentes canales para contribuir positiva y estratégicamente a través de la comunicación.

F6q: FORESTRY EDUCATION 


\title{
Education of forestry professionals in Slovakia
}

Peter Balogh ${ }^{1}$, Milan Sarvaš ${ }^{1}$

'National Forest Centre, Zvolen, Slovakia (balogh@nlcsk.org; sarvas@nlcsk.org)

Further forestry education in Slovakia is offered by the National Forest Centre - Institute for Forest Consulting and Education Zvolen (NFC - IFCE Zvolen) and by the Further Education Centre of the Technical University in Zvolen. NFC - IFCE Zvolen is one of four institutes forming National Forest Centre (NFC), state contributory directly managed organization with countrywide occupation. The NFC was founded to provide a modern national platform for the integration of forest research, planning, consulting and further education into one coherent unit able to better respond to challenges facing forestry in the 21st century. Consultancy, further education, and public relation activities in the NFC are being ensured by NFC - IFCE Zvolen. Composition of its educational activities reflects the needs of forestry practice with emphasis on sustainable forest management. It includes mainly short term courses, workshops, fieldtrips, etc. The institute carries out activities assigned by Ministry of Agriculture and Rural Development of the Slovak Republic, especially examinations and life-long learning of certified forest managers, forest management planners and experts for work with forest reproduction material. To increase quality of these education activities, new didactical approaches have been implemented. It means mainly blended learning approach, combining distance and presence learning. Mentioned life-long learning of certified forest managers and further development of consulting services are vital for sustainable development of small-scale forest properties as well as whole forestry sector. It is important to ensure continual support of the Government and effective use of available financial instruments of the EU.

\section{The Forest of Experiments - promoting forestry science in Slovenia}

Urša Vilhar ${ }^{1}$, Boris Rantaša ${ }^{2}$ Špela Planinšek ${ }^{1}$, Marjana Westergren ${ }^{1}$

${ }^{1}$ Slovenian Forestry Institute, Ljubljana, Slovenia; ${ }^{2}$ Slovenian Forestry Service, Ljubljana, Slovenia (ursa.vilhar@gozdis.si; boris.rantasa@zgs.si; spela. planinsek@gozdis.si; marjana.westergren@gozdis.si)

Slovenian Forestry Institute prepared a "Handbook for learning and play in the forest" for everyone who wants inspiration or starting point for creating new, interesting activities that will bring people in nature to gain knowledge and experience. With interesting and fun content Slovenian forest researchers, joined under brand Forest of Experiments, wants to bring an incomprehensible scientist into the world of popular science, where both children and adults will listen and learn with curiosity. The Handbook contains inovative activities for learning through play that will bring people of different ages (children and teachers) closer to the forest science. Activities are divided into four chapters: Trees, Forest animals, Water and Genetic diversity. Slovenian researchers have designed the activities according to the principle of "flow learning", with a certain sequence of steps: the excitement of enthusiasm, the focus of attention, the direct experience and the sharing of inspiration. Content is adjusted to follow the learning program of kindergartens and schools. The Forest of Experiments is designed with the help of passionate young researchers, working on different research, demonstration or applied projects in Forestry institute. Our opinion is that it is the utmost duty of any scientist, expert or person with knowledge to spread this knowledge in an ethical way and for the betterment of human society. As people gather new experience, they connect, upgrade and expand their interests while developing a positive attitude towards nature in future - just try it!

Goods and services from the forest: environmental education in the Cazumbá-Icarema extractivist reserve directed at high school students in Rio Branco / Bens e serviços da floresta: prática de educação ambiental na Resex Cazumbá-Iracema aos alunos de Ensino médio de Rio Branco

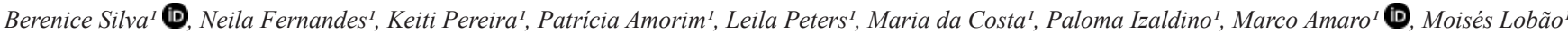 \\ ${ }^{1}$ Universidade Federal do Acre, Rio Branco,Brazil (bereniceka@gmail.com; neila.fernandes@hotmail.com; keiti.roseane@hotmail.com; \\ patriciagomesribeiro@gmail.com; leilappeters@gmail.com; natureza.2@hotmail.com; hizaldinopaloma@hotmail.com; marcoantonioamaro@hotmail.com; \\ moiseslobao.6@gmail.com)
}

Apesar da educação ambiental fazer parte das propostas curriculares de ensino, a mesma esbarra na dificuldade dos professores em implantar projetos desta natureza em suas programações letivas. Portanto, o principal objetivo desse projeto foi auxiliar os professores das escolas de ensino médio, a trabalhar valores e atitudes ecológicas valorizando os múltiplos produtos e serviços ambientais oferecidos por nossa floresta amazônica, seguindo-se a concepção do manejo sustentável defendido pela comunidade tradicional ali existente. Para tal, alunos de graduação da Universidade Federal do Acre (UFAC) após realizarem um estágio de vivência na Reserva Extrativista Cazumbá-Iracema montaram conjuntamente com os professores, estratégias de ensino sobre a preservação ambiental e o uso sustentável das florestas. Foram realizadas palestras em três escolas de Ensino Médio de Rio Branco, logo após houve visita às trilhas do Parque Zoobotânico da UFAC para visualização das espécies que fornecem produtos madeireiros e não madeireiros, além dos serviços ambientais proporcionados pela floresta. Após as visitas foram realizadas oficinas: de confecção de quadros artísticos utilizando-se produtos coletados na floresta, de pequenos objetos de madeira e bambu e de papel reciclável. Ao final do projeto, as atividades foram avaliadas pelos alunos das escolas participantes para mencionar os pontos que necessitam ser melhorados para continuidade das atividades. Como produto final foi confeccionado um e-book a partir das entrevistas sobre a vida e experiências dos extrativistas da Reserva Cazumbá-Iracema que servirá de apoio aos professores para a continuidade do ensino de Educação Ambiental nas Escolas participantes.

\section{Professional forest science education and employers preference between the University of Yaounde I and University of Dschang Cameroon}

Atebeh Lekah ${ }^{1}$ D, William Mala ${ }^{1}$

IUniversity of Yaounde I, Yaounde, Cameroon (rein.bcyui@gmail.com; williammala@yahoo.fr)

Marketplace demand for professional skills and competencies of forest science graduates is evolving very quickly and forestry schools need to continuously track these changes and adapt their institutions to respond appropriately. Professional master's degree in Forest science was created by the Minister of higher education in the University of Yaounde I and University of Dschang to meet up with this growing trend. This study seeks to highlight employers' and graduates perception of the strength and weakness of the two institutions providing professional forestry training. Questionnaires captured information on the forest science specialties highly demanded in the job market, which university is believed to be stronger in terms of content delivery, field trip and enrollment; ${ }^{60}$ graduates making sure that ${ }^{50 \%}$ of this number came from each university and ${ }^{25}$ employers were interviewed; ${ }^{70}$ percent of graduates from the University of Dschang were recruited by government organizations as opposed to ${ }^{25 \%}$ graduates from the University of Yaounde I. Employers prefer graduates from the University of Dschang. Most of the students that easily found employment were those specialized in Forest certification, biodiversity and protected 
area management. Graduate were satisfied with their training but University of Yaounde I graduates were not comfortable with the administrative disorder surrounding the program which may be the reason of the dwindling enrollment number. Harmonization of forest science curriculum should be considered when designing policies to improve forest education to provide graduate with equal opportunities in the job market.

Necessary competencies in forest soils for superior education in forestry: a new perspective for future generations / Competencias requeridas en suelos forestales para la educación forestal superior desde una nueva perspectiva para futuras generaciones

Samuel Francke

${ }^{1}$ Conaf, Saantiago, Chile (samuel.francke@conaf.cl)

En el marco de los objetivos de desarrollo sostenible , los objetivos de la convención de lucha contra la desertificación, sequia y de cambio climatico la educación forestal superior debiera incorporar las siguientes funciones asociadas a suelos de acuerdo a páradigmas: i) funciones de protección, preservación y conservación de suelos y aguas en áreas protegidas y bsoque naturlales ii )las funciones de recuperación y recuperación de suelos devastados por el flagelo de la erosión y la desertificación iii) las funciones de fomento a la forestación y recuperación de suelos degradados, procesos de con técnicas de conservación de suelos y aguas, iv) Las funciones de ordenamiento territorial de cuencas hidrográficas, de sitios y suelos forestales. Se recomienda incluir en curriculum academico la formación de las competencias que se indican: a)cartografía, inventarios ,catastros, clasificación y pedo- genética de suelos, sistemas de información de suelos b)nutrición, fertilidad ,manejo de nutrientes, permacultura, agricultura biodinámica y orgánica, biofiltros, zonas buffer, eutroficación c)conservación de suelos y aguas, control de erosión, recuperación, rehabilitación y restauración ,manejo integral de suelos y cuencas hidrográficas d)descontaminación de suelos, bioremediación, desalinización, manejo de relaves, pasivos ambientales ,oasificación, enmiendas, estandares de eco-calidad de suelos y certificación ambiental e)suelos y ecosistemas naturales ,ciclos y balances, asociaciones e interrelaciones suelo-sitio-agua- bosque-vegetación - biodiversidad /cuencas hidrográficas en áreas silvestres f)legislación y ordenamiento territorial en suelos urbanos, rurales ,cuencas hidrográficas pre- cordilleras y cordilleranas, borde costero g)suelos y cambio climático, captura de carbono, servicios ambientales, manejo adaptativo y mitigación.

\section{Modernization of the study at the Czech University of Life Sciences Prague with an emphasis on forestry and environmental fields of study}

Jiři Remeš ${ }^{1}$

${ }^{\prime}$ Czech University of Life Sciences Prague, Czech Republic Prague (remes@fld.czu.cz)

The aim of the contribution is to inform about the project, which is focused on the modernization of study and increasing the quality of study programmes on the Czech University of Life Sciences Prague (CULS). Currently the university has more than 19000 students (15\% are international students), 6 Faculties (including Faculty of Forestry and Wood Sciences and Faculty of Environmental Sciences) and 1 Institute. CULS offers over 170 accredited study programmes at BSc, MSc and PhD levels. The modernization of studies and study programs is a response to the developments and changes such as globalization of the economy, climate change and new technologies. Significant socio-economic changes that have taken place during the past years in the Czech Republic also have a major impact on the demands that society places on education. The new education strategy is based on the development of teaching facilities (teaching laboratories equipped with the most modern technology) together with new educational methods (requiring an increase in the competencies of academic staff) and study programme innovation (including preparation of new study programs). A key role is played by a new way of university accreditation which was adopted in the Czech Republic in 2016. With the acquisition of institutional accreditation, the possibility of creating multidisciplinary and international study programs was opened for the CULS.

Recognizing traditional knowledge and forest practices in the Cochabamba Valley, Bolivia / Reconocimiento de saberes y practicas forestales tradicionales en el Valle de Cochabamba, Bolivia

Juan Carlos Medrano Vargas ${ }^{1}$

${ }^{1}$ Colegio de Profesionales Forestales de Cochabamba, Cochabamba, Plurinational State of Bolivia (jcarlosmedrano@hotmail.com)

La Constitución Política del Estado Plurinacional de Bolivia, declara que los bosques naturales y los suelos forestales son de carácter estratégico para el desarrollo del estado, y se plantea como política la promoción del manejo sustentable e integral de los bosques con participación de las comunidades, que acepte la complejidad y diversidad de los sistemas boscosos y el reconocimiento de los saberes y prácticas tradicionales. La Universidad Mayor de San Simón, han implementado programas académicos desconcentrados, que responden a las demandas de formación, las necesidades y potencialidades locales, siendo una de ellas el Programa de Técnicos Básicos Forestales. Se ha desarrollado el programa, dirigido a personas de instituciones públicas (Gobernación y Municipios de Cochabamba, Bolivia); que se dedican al sector forestal, a la producción de plantines y al manejo de plantaciones forestales; la mayoría eran personas que no han tenido formación formal pero si han desarrollado capacidades de forma empírica, sus edades oscilan los 20 a 60 años. Producto de cada curso, se observaba el intercambio de información y conocimiento que se daba entre los docentes y los alumnos; reconociendo los saberes y prácticas que tradicionalmente habían aprendido y por otro lado adquirir conocimientos científicos de los docentes. Cada estudiante realizo una investigación, sobre acciones que realizan cotidianamente pero ajustadas al método científico, siendo sorprendente los resultados obtenidos y que fueron plasmados en documentos técnicos, se otorgó un título de Técnico Básico Forestal como reconocimiento a los saberes y prácticas forestales tradicionales de personas que promueven el sector forestal.

A tunnel to virtual reality: an immersive experience with knowledge on integrated crop-livestock-forest systems / Túnel de realidade virtual : uma experiência de imersão e conhecimento sobre a ILPF

José Heitor Vasconcellos ${ }^{1}$, Gabriel Faria ${ }^{2}$

${ }^{1}$ Embrapa Milho e Sorgo, Sete Lagoas, Brasil; 2EmbrapaAgrossilvipastoril, Sinop, Brasil (jose.heitor@embrapa.br; gabriel.faria@embrapa.br)

Como forma de atrair a atenção do público e de proporcionar uma experiência imersiva e de conhecimento, em 2018 trabalhou-se na adaptação do conteúdo do aplicativo "Maquete Virtual de ILPF em Realidade Aumentada" para um formato de realidade virtual (RV). Pensando-se na participação da Associação Rede ILPF no Congresso Mundial de Ciência do Solo, realizado no Rio de Janeiro, criou-se um túnel por onde os visitantes passavam por dezesseis painéis utilizando óculos de RV. Em cada painel uma cena mostrava uma etapa de um sistema ILPF ou abordava algum aspecto do sistema, como comportamento de raízes, infiltração de água, ciclagem de nutrientes, ciclo de gases de efeito estufa, etc. Um áudio, em português ou inglês, explica cada imagem. Além da experiência imersiva da RV, foram utilizadas também experiências sensoriais, como iluminação diferenciada, vento simulando o conforto térmico da sombra e uso de essência de eucalipto e folhas espalhadas pelo chão nas cenas com o componente arbóreo. No Congresso de Solos, 370 pessoas, de 30 países passaram 
pelo túnel. A experiência levou a várias requisições para sua instalação em eventos do setor agropecuário e em exposições voltadas para público urbano. Uma grande vantagem dessa ferramenta é a facilidade de ser replicada. Basta imprimir os 16 targets e montá-los num caminho sequencial. Também é necessário ter um smartphone com o aplicativo baixado, fone de ouvido e óculos de RV. Modelos simples, vendidos por R\$25 na internet, são suficientes. Tanto o aplicativo quanto os targets estão disponíveis para download gratuito em www.ilpf.com.br.

\section{F8b: WOOD AND FOREST CULTURE: ADDRESSING A SUSTAINABLE FUTURE}

\section{Immortal Wood Traditions in India and there contemporary relevance}

Sangeeta Gupta ${ }^{1}$

${ }^{\prime}$ Forest Research Institute, Dehradun, India (sangeeta.fri@gmail.com)

Wood has been part of Indian culture since time immemorial. Most religious and domestic architecture in India, from its very inception, was wood-based. In the year 1918 a detail account was published on Indian timbers mentioning the usage of over 1400 tree species. This knowledge became the basis for furthering scientific studies on wood identification, their properties and efficient utilization. Indian Standards were formulated to list wood species recommended for various purposes like Railway sleepers, Defense tools, construction, cooling towers, sports goods etc. The presentation shall draw a chronology of wood traditions in India through pre-historic period and would throw light on how this knowledge has been utilized in recent time. An account shall be given on woods used traditionally for construction, dockyard, mortars, coffins, charcoal, sculptures, wicker work, toys, musical instruments, agriculture implements, incense etc. utilizing various properties of wood like strength, durability, shock absorbance, self lubricating, weight, calorific value etc. It shall also throw light on how this already prevailing age old knowledge has been presently useful in efficient utilization of the wood. Wood species used in temples, shipbuilding, furniture, musical instruments, toys etc. suggest well-developed and immortal wood traditions in India that still holds relevance today. The tradition of usage of various medicinal woods is still in practice today, the account of which dates back to several centuries. The wood explorations have also led in throwing light on broad distribution of trees and thus provide useful information for their rehabilitation. .

\section{Schwarzenberg Floating Canal: An unwanted forest cultural heritage?}

Jiři Woitsch ${ }^{1}$

${ }^{1}$ Czech Academy of Sciences, Institute of Ethnology, Praha, Czech Republic (jiri.woitsch@post.cz)

The aim of presentatiton is to describe and analyse history and current status, including ongoing conflicts and future prospects, of perception and protection of Schwarzenberg Floating Canal as an important cultural monument and heritage object of forestry, timber and wood utilisation in the Central Europe. The paper is based on study of historical sources, analysis of current conservation and heritage policies in the Czech Republic, public and media coverage of the topic and field anthropological research. The Canal - one of the most remarkable water structures of its times - was built in two phases from 1789 to 1822 to transport firewood and timber from the Šumava (Böhmerwald) mountains to Vienna, thus enabling utilization of formerly inaccessible parts of the Šumava forests. Total length of the waterway was $89,7 \mathrm{~km}$ and was complemented with hundreds of bridges, sluices, water moats and gates. Construction of the Canal intensified logging in the South-Western Šumava, provoked the colonisation of area and led to gradual transformation of the Šumava forests in the course of 19th Century. However only a shorter part of the Canal was used in the 20th Century and after the 2nd WW the waterway was abandoned and heavily damaged. On the other hand it has been listed as a cultural monument since 1963 and partly renovated from 1980s to 2001. After the establishment of Šumava national park in 1991, however, the Canal became an unwanted heritage: it clearly shows that forests in Šumava are much more of a biocultural heritage than untouched nature.

\section{Wood culture programs: paving the way for responsible wood usage and a sustainable future}

Charlotte Chia Hua Lee ${ }^{1}$, Howard Rosen ${ }^{2,1}$

${ }^{1}$ IWCS, Newport Beach, USA; ${ }^{2}$ US Forest Service, Silver Spring, USA (chiahua.lee@iwcs.com; howard.rosen@verizon.net)

Wood culture can be defined as "The value and the way we use wood in our society." The International Wood Culture Society (IWCS) was established over a decade ago to raise public awareness of wood as an eco-friendly biomaterial and encourage academic research and responsible wood usage for a sustainable wood future. The Society established World Wood Day (WWD) on March 21st each year to celebrate the human use of and activities with wood, as well as attitudes toward wood, wood products and wood-related environments. To manage these celebrations, the World Wood Day Foundation (WWDF) was established in 2013. The Foundation also manages funds and grants for World Wood Day and the global research, education and promotion of wood culture. The first World Wood Day (WWD) celebration was held in Dar Es Salam, Tanzania in 2013; followed by a new country each year. Activities at each celebration include wood carving, wood turning, a technical symposium, tree planting, a wooden instrument musical festival, furniture making, wooden folk art, a children's program, wood design, and a collaborative project. These programs continue our wood heritage and traditions with creative new ideas for our daily development and provide a greater appreciation for the interplay between wood, nature, and the people who work with and use wood. This talk will give examples of how these goals are accomplished.

\section{Characterization of municipalities in the timber production chain in the north of Mato Grosso, Brazil}

Vinicius do Prado Capanema ${ }^{1}$, Maria Isabel Escada ${ }^{1}$

IInstituto Nacional de Pesquisas Espaciais, São Josédos Campos, Brasil (livia_cipriano@hotmail.com; edulongui@gmail.com; lech.muszynski@oregonstate.edu; awballarin@fca.unesp.br)

Selective logging have been occured for more than three centuries in the Amazon and, in the past, it was made for subsistence in lowland forests and, therefore, it was very low impact. The intensification of logging occurred in the 1970 s, mainly due to the construction of roads, depletion of southern and southeastern stocks, and uncontrolled exploitation. These factors led the Amazon to the position of the world's second largest producer of tropical timber, in which Pará and Mato Grosso the main producing states. At Mato Grosso state, timber sector plays an important economic role, contributing strongly to the state's revenues and generating jobs. In this context, the present study aimed to characterize the municipalities in the north of the state of Mato Grosso considering their participation in the wood production chain, according to a typology of municipalities' influence patterns in the state's timber sector, and the profile socioeconomic context in which they are inserted. The results showed that there are five different patterns: 1) municipalities with highly developed industry, 2) municipalities with primary industries with high wood processing capacity, 3) municipalities with industries with low processing capacity and high lumber stock, 4) few lumber and small 
timber industries, and 5) municipalities with virtually no logging and poor-quality stock. Regarding the socioeconomic characterization, the results showed that the municipalities with high industrialization have the highest indicators analyzed.

\section{Comparative environmental impact assessment between natural and plastic Christmas tree: a case study}

Andrea Laschi ${ }^{1}$, Azzini Lapo ${ }^{1}$, Francesco Nicese ${ }^{1}$,Francesco Del Pero ${ }^{2}$,Enrico Marchi ${ }^{1}$, Massimo Delogu ${ }^{2}$, Giacomo Goli ${ }^{1}$ ${ }^{1}$ DAGRI - Dipartimento Scienze e Tecnologie Agrarie, Alimentari, Ambientali e Forestali - Università di Firenze, Firenze, Italy; ${ }^{2} D I E F-D i p a r t i m e n t o ~ d i$ Ingegneria Industriale - Università di Firenze, Firenze, Italy (andrea.laschi@unifi.it; lapo.azzini@stud.unif.it; francesco.nicese@unifi.it; francesco.delpero@unifi.it; enrico.marchi@unifi.it; massimo.delogu@unifi.it; giacomo.goli@unifi.it)

The production of natural Christmas trees is a niche between forest and agriculture sectors. In Italy, Christmas tree cultivation is a traditional activity, typical in upper hills and mountains, which was very common and remunerative in some areas. Since a long time, the market of natural tree underwent the competition of the plastic one, which is often considered by customers as more practical, durable and efficient in terms of environmental sustainability. The aim of this study was to answer to the question: "is it better the natural or the plastic Christmas tree?". To answer, under an environmentally point of view, a Life Cycle Assessment (LCA) was applied to compare the two different kinds of product. The study has been divided in four phases: - Analysis of customer preferences about Christmas tree; - Data collection on the production of both natural and artificial trees, considering the most common products available on the market in central Italy (local production chain for natural trees and industrial production in China for plastic ones). - Identification of system boundaries; the analysis is a cradle to grave LCA, being all the phases of life cycle included in the analysis, from raw material production to disposal of the product at the end of its life. Life cycle impact assessment (LCIA) and comparison of results with Gabi software. In this contribution, the best environmental profile and the hotspot in $\mathrm{CO}_{2}$ eq emission, which is a parameter used as indicator for Greenhouse Gas (GhG) impact category, will be presented.

\section{Linking the tradition and modern technology: how the Japanese traditional tea culture using bamboo and solid wood being adopted} into the modern society?

Sumire Kawamoto ${ }^{1}$, Takako Nikaidou ${ }^{2}$, Mariko Inoue ${ }^{1}$

${ }^{1}$ Forestry and Forest Products Research Institute, Tsukuba, Japan; ${ }^{2}$ Food and Agricultural Materials Inspection Center, Saitama, Japan

(sumirekw@gmail.com; takako_nikaidou@nm.famic.go.jp; imariko@ffpri.affrc.go.jp)

The art of Tea as it exists in Japan today is the legacy of Sen Rikyu, a 16th century Tea Master who lived when war prevailed among the provinces in Japan. After his death, his philosophy that focused on simplicity has lived in the art of Tea. Various kinds of utensils made from bamboo and solid wood that can be returned to the soil have been representing an important philosophy in old Japanese culture. It comes from a background that Japanese people tend to consider that beauty exists in humble simplicity, a gradual deterioration caused by the service life, and some fragility of biological materials. This paper includes introduction of traditional tea culture and craft items, which has survived for long years in Japan. It might give us some insight on how we can keep linkage between the tradition and the modern society.

\section{F9b: DELIVERING AND COMMUNICATING FOREST SCIENCE FOR PEOPLE AND A} GREENER FUTURE

\section{A link between Foresters and the general public: forest and wood in 100 questions}

Jean-Luc Peyron ${ }^{1,2}$, Yves Birot ${ }^{2}$, Bernard Roman-Amat ${ }^{2}$

${ }^{1}$ GIP Ecofor, Paris, France; '2Académie D'agriculture de France, Paris, France (jean-luc.peyron@gip-ecofor.org; yves.birot@numericable.fr; bernard.roman-amat@wanodoo.fr)

Communication on forest issues with the general public is more often the work of environmental non-governmental organisations than forest professionals and scientists. Naturalistic films and best-selling books on man-to-nature relations have a large audience. They usually focus on ecological or sociocultural aspects, using frequently over-simplistic arguments. They rarely, if ever, deal with sustainable forest management. Foresters are ill-equipped to meet the challenge of communication: they often have little affinity and time for communication activities and their task is difficult: how to communicate on how to seek the right compromise, for each place considered both now and for the future, between ecological, economic and socio-cultural aspects? One of the ten sections of the French Academy of Agriculture deals with the forest-based sector. Under the coordination of Yves Birot, this section took the initiative of developing a digital book: "Forest and wood in 100 questions". Based on up-to-date scientific and technical knowledge, it is intended to support the dialogue between science and society. Answers to a hundred questions, organized in ten chapters, are given in the form of articles of four pages each. The set is available free of charge on the website of the "Académie d'agriculture de France". The majority of these forest and wood-related questions are general in scope. The answers are aimed preferentially at the French public but most of the articles could easily be adapted to other contexts. This contribution aims to present this initiative, the main lines of its realization and some comments on its interest.

\section{Communicating about forest issues with schoolchildren}

Débora Lingner ${ }^{1}$, Alexander Christian Vibrans ${ }^{1}$, André de Gasper ${ }^{1}$, Laio Oliveira ${ }^{1}$, Manoela de Aguiar ${ }^{I}$ Fundação Universidade Regional de Blumenau (FURB),Blumenau,Brasil (deboravanessa.ef@gmail.com; acv@furb.br; algasper@furb.br; laiozoliveira@gmail.com; manooaguiar@gmail.com)

Involving young people is a well known strategy to provoke awareness of environmental issues and changes in behaviour of the present and future generations. We created a virtual forester named "Pedro Carvalho" who guides kids through the universe of Santa Catarina State Forests (Southern Brazil), object of a long-term systematic inventory and studies on species composition, structure, ecology and dynamics. The inventory team members desired to improve the communication with rural populations through schoolchildren and decided to engage efforts on this goal. Our approach is simple and threefold: we published a booklet with specially designed illustrations, for free distribution at primary schools. Additionally, we created an itinerant exhibition with banners, panels and showcases, which was also made virtually available on the project's homepage (www.iff.sc.gov.br). We visited more than a hundred of primary schools in rural regions of Santa Catarina State. An adequate language, focusing on local known practices, on multiple uses of a large range of forest species, on environmental problems like floods and droughts, and cartoon like illustrations facilitated the interaction with young audiences, catching their attention and raising their 
curiosity. The joint effort together with the local teachers, using booklets, exhibition and class-room activities stimulated vivid discussions on ecosystem services, sustainable uses of forests, the importance of forests for survival as for local populations as at global scale, and their role in the context of climate change. We hope to achieve long-term gains in consciousness and responsible acting into a greener future of our target group.

\section{Rethinking forest landowner outreach: applying targeted marketing principles to promote prescribed burning on private lands}

Jennifer Fawcett ${ }^{1}$, Laurel Kays ${ }^{1}$

${ }^{1}$ North Carolina State University, Raleigh,USA(jlevans3@ncsu.edu; lekays@ncsu.edu)

Forest research is most meaningful when it gets into the hands of those who can apply it to the land, including private landowners. In the Southern United States, private landowners hold 86 percent of the forest area. These landowners are a diverse mix of people, from farmers to environmentalists and a host of other groups, who have many and varied reasons for owning land. It is important to be able to translate and disseminate research findings to these various types of landowners through outreach programs. However, unsurprisingly, each of these groups are motivated by different messages and emotions, often making outreach efforts difficult. The Tools for Engaging Landowners Effectively (TELE) program assists practitioners in designing outreach programs to bring about a specific behavior change in a selected group of people, rather than using a broad-brush approach that tries to appeal to everyone. This approach has been shown to be an effective and efficient way to change behaviors and norms in a variety of fields. We used the TELE methodology to promote the use of prescribed fire by applying targeted marketing principles to reach specific landowner audiences. Using this method allowed us to design fliers and other outreach materials using effective messaging that aligned with their needs and values, thus ultimately allowing us to better deliver and communicate fire science. Lessons learned from the approach of using targeted marketing to promote increased prescribed fire use on private lands will be shared as a case study during this presentation.

\section{Voice lessons for scientists: what to say and how to say it}

Nehalem Clark ${ }^{1}$, Jessie Golding ${ }^{2}$

${ }^{1}$ USDA Forest Service, Fort Collins, USA; 2USDA Forest Service, Missoula, USA (ncclark@fs.fed.us; jessie.golding@usda.gov)

Communicating just the right information in the right tone often does not come naturally. Just ask parents of young children. Like parents, scientists are unlikely to have received training in effective communication for diverse audiences. Different approaches are required for scientists sharing information outside of their network of science colleagues. For science to be integrated into realms such as decision-making and land management applications, understanding the needs of users and packaging the information in accessible and appealing formats is paramount. The U.S. Forest Service is a large agency where effective science communication is essential at every level. From the technician setting up the remote camera in the field, to the leadership teams creating national strategies, science needs reach every part of the organization. Science communication training today has illuminated the need for better storytelling. Further, we suggest that science communication and the teaching of it needs a different message. To set the tone for successful communication, be flexible and responsive to user needs. We share a variety of case studies from our experiences at multiple levels of science communication within the U.S. Forest Service to illustrate our main lessons learned: start with the end in mind, tell a story that resonates with your audience, keep your equations to yourself, leave them wanting to know more, brief is better, and do not be afraid of novelty. As in parenting, these approaches take practice and continual adaptation.

\section{Inspiring climate action through role play and interactive computer simulation: world climate simulation experiences in Kenya}

Sheila Shefo Mbiru ${ }^{1}$

${ }^{1}$ The Low Emission and Climate Resilient Development (LECRD) Project, Nairobi, Kenya. World Climate Ambassador, Nairobi, Kenya (sheilambiru@gmail.com)

Climate change is difficult to communicate by its very nature and should be communicated in such a way that it is easily understood and relevant to the audience. There are various climate change communication tools that bring complex climate change issues to public attention, understanding and action. One such tool is World Climate. World Climate, an interactive climate negotiation role playing simulation enables learning through scientifically grounded and socially engaging experiences. Participants play the role of negotiators for different nations and blocs of nations and work together to limit global warming to well below 20 Celsius in line with the Paris Agreement. Using C-ROADS simulation software, participants find out, in real-time how their proposed policies impact the global climate system. In Kenya, World Climate has been used in various settings including with policy makers, media practioners and youth in high school and church. Results were extremely positive with most participants indicating they now have a deeper understanding of climate change, its impacts and the need for urgent action at all levels; global, national, sub national, community and most importantly individual level.

\section{Rooting forest science through knowledge co-creation and the arts and the transition to a biosociety}

Nina Tokola, Irmeli Mustalahti

${ }^{1}$ University of Eastern Finland, Joensuu, Finland (nina.tokola@uef.fi; irmeli.mustalahti@uef.fi)

We argue that acceptability is a key issue in the transition towards forest bioeconomy. Young citizens are the decision-makers of the future decades and thus a focal audience for forest science communication. We study the visions of Finnish youth regarding a green transition and sustainable well-being in the multidisciplinary research project All youth want to rule their world. We explore the capabilities of youth (aged 16-30) and the obstacles that hinder their engagement with society and environment. Our key ideas for sustainable well-being are responsive governance and transition towards a biosociety, based on a circular- and bioeconomy. We see communication and delivering as two-way processes and as genuine interaction between scientists, youth, project partners, decision-makers, and the public. Thus, we chose action research as research strategy, allowing us to study the activities of various forest bioeconomy and youth sector actors. Our goal is to root "living knowledge" through knowledge co-creation and to develop trajectories that our partners consider relevant. We further aim to translate the co-created results into a language of the arts. The following methods of communication are applied: i) citizen science: young people as co-researchers of sustainable well-being, ii) co-development of a mentoring model for boosting youth employment in the bioeconomy sector, iii) art meets science in an art-inspired dialog series, iv) co-production of policy recommendations: youth voices included in the National Forest Strategy 2025. We propose participatory and deliberative ways of knowledge creation that enable the communicating forest science more effectively to target audiences.

\section{Using RIU-Model to assess impact of big research projects in the practice: example of ALTERFOR}


Mirjana Stevanov ${ }^{1,2}$, Max Krott ${ }^{1}$, Nataly Juerges ${ }^{1}$

${ }^{1}$ University of Goettingen, Faculty of forest sciences and forest ecology, Chair of forest and nature conservation policy, Goettingen, Germany; ${ }^{2}$ University of NoviSad, Institute of lowland forestry and environment, NoviSad,Serbia (mzavodj@gwdg.de; mkrott@gwdg.de; nataly.juerges@uni-goettingen.de)

ALTERFOR (Alternative models and robust decision-making for future forest management) is a joint European Horizon 2020 project examining existing forest management models (FMMs) in the light of different alternative scenarios over 100-years period in ten case studies: Germany, Italy, Ireland, Lithuania, the Netherlands, Portugal, Slovakia, Sweden, and Turkey. The project develops robust FMM alternatives for delivering ecosystem services and reducing vulnerabilities at stand to landscape level and aims to provide based on the innovative results policy support in practice. The knowledge transfer activities are oriented toward the RIU-model which claims to bridge science and practice. The RIU-model assumes Research and Utilization of scientific results (which comprises politics) as independent phases which follow their own rational: science is looking for new theoretical and empirical based knowledge whereas utilization by practice and politics is an interest and power driven process. Nevertheless, the both different areas can be bridged by "Integration". Integration builds a link by fully respecting the autonomy of science but selecting specific results and research questions which fits into the interests of actors. These actors will become allies for scientific knowledge transfer who put their power behind specific science-based solutions forcing other actors to follow them.In all cases ALTERFOR analyzed existing networks of forest-related actors, organized workshops with targeted actors and critically analyzed experiences with such Integration activities. They show that a big project like ALTEROF creates promising linkages into practice but lacks resources to implement the RIU-model on a high level and trigger major impact that way.

\section{Storytelling for science communication and media engagement}

Ewa Hermanowicz ${ }^{1}$, Michele Bozzano ${ }^{1}$

${ }^{1}$ European Forest Institute, Bonn, Germany (ewa.hermanowicz@efi.int; michele.bozzano@efi.int)

Storytelling is one of the most effective and natural mechanisms to supply new knowledge to the human brain. Using a storytelling approach in communications enables audiences of different professional and social backgrounds to learn about forest research projects. It also increases the likelihood of engaging media, thus increasing the visibility of the work. The session will focus on digital storytelling and filmmaking, which can be used effectively in a broad range of projects to drive change. I will outline the building blocks of an effective story and explain how these translate into film production. An essential building block is a character to whom viewers can relate, who conveys the key messages through un-scripted interview as an authentic voice. The session will include a screening of a successful film to illustrate the proposed ideas and will analyze the steps necessary for pre-production, production and promotion.

\section{Explaining my PhD through cartoons}

Alex Giurca ${ }^{1}$

${ }^{1}$ University of Freiburg, Freiburg, Germany (alex.giurca@ifp.uni-freiburg.de)

During my PhD studies, I rediscovered my love for art, and learned that science and arts are not necessarily mutually exclusive. My thesis dealt with the emerging bioeconomy paradigm, the actors and political coalitions that shape the bioeconomy discourse in Europe. Political science is complex, the general stereotype being that it heavily relies on large amounts of dense, ambiguous text and scientific jargon. This preconception is not necessarily wrong. Indeed, communicating and simplifying the main points of ones research into small digestible bits of "take-home" or "key messages" is not always easy. Dealing with the bioeconomy issue from a political science perspective, made the task of communicating my research results even more daunting. An old saying goes, a picture can tell a thousand words. So I started experimenting with illustrations/cartoons that would explain my main findings in a fun and engaging way. I started creating digital art for my scientific papers and posting them on my personal blog. Later I experimented with explainer-animated videos in PowerPoint. So far the response has been nothing but positive.In this presentation, I aim to share my approach and the lessons I’ve learned from my attempts to communicate science with the help of cartoons.

\section{Forestry and natural resources webinars: success, challenges, and implications based on 10 years of experience \\ Robert Bardon ${ }^{1}$ (D), William Hubbard ${ }^{2}$ (D) \\ ${ }^{1}$ North Carolina State University, Raleigh, USA; '2University of Maryland, College Park, USA (rebardon@ncsu.edu; whubbard@umd.edu)}

To help forestry professionals, landowners, and others increase their forestry and natural resource management knowledge, Universities have turned to using learning management systems for online education. The Webinar Portal for Forestry and Natural Resources is a learning management system designed to transfer research-based information from scientists and educators to practitioners, landowners and others, through live and on-demand webinars. The portal was developed through a partnership of university extension programs, government agencies and others to provide an effective platform for delivering webinars. Post webinar evaluations of approximately 3,700 participants utilizing the portal in 2018 indicate webinars are an effective tool for increasing participant knowledge and aspiration; two factors known to lead to adoption and implementation. Based on post evaluations 34\% of the participants indicated an increase in knowledge and 65\% aspire to further investigate the topic. These changes in knowledge and aspiration have resulted in 55\%, $24 \%$ and $54 \%$ of the participants indicating they will improve their land management skills, business practices, and ability to respond to client questions respectively. By training online in 2018, verses on site, participants achieved over $\$ 11$ million dollars in costs savings due to elimination of travel expenses. The portal is an effective tool for scientists and educators to disseminate knowledge to forestry professionals, landowners and others. Within the scope of this presentation, the authors will discuss lessons learned from delivering approximately 200 webinars, focusing on challenges faced in developing and delivering the webinars, and how webinars may increase the effectiveness and efficiency of technology transfer.

Use of an augmented reality app to disseminate integrated crop-livestock-forest systems / Uso de aplicativo de realidade aumentada para a divulgação dos sistemas de integração lavoura-pecuária-floresta (ILPF)

Gabriel Faria ${ }^{1}$, Jose Heitor Vasconcellos ${ }^{2}$

${ }^{1}$ Embrapa Agrossilvipastoril, Sinop, Brasil; ²Embrapa Milho e Sorgo, Sete Lagoas, Brasil (gabriel.faria@embrapa.br; jose.heitor@embrapa.br)

A necessidade de expandir o entendimento de diferentes públicos sobre a complexidade dos sistemas de integração lavoura-pecuária-floresta (ILPF) levou à busca por novas ferramentas de comunicação que pudessem ser facilmente utilizadas por qualquer pessoa, em qualquer local, a qualquer momento. A tecnologia da realidade aumentada (RA) mostrou-se com grande potencial, tanto pela expansão do número de smartphones no país como pela sua praticidade 
e interatividade. Desenvolveu-se, então, o aplicativo Maquete Virtual de ILPF em RA, que mostra a evolução de um sistema ILPF desde sua implantação, passando por todas as combinações possíveis entre lavoura, pecuária e floresta. O usuário pode acompanhar as diferentes etapas não só no que ocorre sobre a terra, mas também abaixo dela, como a mudança no perfil do solo, o ciclo de nutrientes e de carbono, a infiltração de água e o comportamento de raízes. O aplicativo foi disponibilizado nas versões Android e IOS, em português e inglês, e pode ser baixado gratuitamente nas lojas online. Para usá-lo é preciso imprimir uma imagem (target), para onde se aponta a câmera do celular ou tablet. Este aplicativo pode ser usado em palestras por pesquisadores, extensionistas e professores, sendo didaticamente adaptável aos seus diversos públicos. Além disso, esse app pode ser usado para divulgar a ILPF em feiras, exposições, congressos, entre outros eventos.

\section{F9c: FOREST SCIENCE EDITING IN THE CONTEXT OF OPEN SCIENCE: WHAT CHANGES} ARE AHEAD FOR US?

\section{Global, regional, local: What kind of peer-reviewed forestry journals are being published?}

Maja Peteh ${ }^{1,2}$, Alan Pottinger ${ }^{3}$

${ }^{1}$ Slovenian Forestry Institute, Ljubljana, Slovenia; ${ }^{2}$ Biotechnical Faculty, University of Ljubljana, Ljubljana, Slovenia; ${ }^{3}$ International Forestry Review, Shropshire,United Kingdom (maja.peteh@gozdis.si https://orcid.org/0000-0002-9636-1155; alan.pottinger@cfa-international.org)

Bibliometric analysis of scholarly journals in forestry shows us high publishing in journals primary covering other disciplines (eg. Chirici, 2012), mostly due to low impact (eg. Bojovic et al., 2014). A key objective of IUFRO WP 9.01.06 (Forest Science Publishing) is to clarify the range of forestry journals within an overall goal of assisting both authors and readers to further our knowledge of forestry. In this study we expanded this list of forestry journals prepared by Vanclay (2008) using the ISSN database, journals indexed and cited in Web of Science and listed in Scopus, journal indexed in the Forest Science Database (or CAB s), and other sources. Each title was recorded with the ISSN, publisher, language of publication, web page, and geographical coverage (i.e. local, regional, national or international). It is hoped that the list will be published and regularly updated on the IUFRO website and therefor thereby available to forestry students, researchers, and practitioners.:

\section{What level of publication transparency should we request in forest sciences?}

Pekka Nygren ${ }^{1}$

${ }^{1}$ Finnish Society of Forest Science, Helsinki, Finland (pekka.nygren@metsatiede.org)

Publication transparency is an important dimension of open science. Naturally, transparent publication with adequate opening of data, methods, and code is needed for fully understanding how a research was done and avoiding serious misunderstanding. Second, transparency is needed for evaluating the quality of the research even when good scientific practice is followed. Third, transparency is needed for reproducing new research findings or verifying results of inherently non-reproducible work, e.g. long-term ecological research. Fourth, reuse of research data in new studies or meta analyses requires full understanding on the study environment and methods. Fifth, transparency is needed for detecting questionable research practices. While serious scientific misconduct is quite rare, lighter deviations from good research practice, or sloppy science, are quite common: A recent survey indicated that up to $60 \%$ of ecology researchers have sometimes used questionable research methods. A peer-reviewer or an editor can detect them only if publication transparency is required. Both general and discipline-specific transparency guidelines have been published and major publishers have created their own versions of them yet the policies require stronger enforcement. Journals are in the frontline for bringing transparent practices to the main steam of research. Without a signal from journals, scientists' expectations for publication transparency are not likely to shift en masse towards open data, methods, and codes. Forest science journals should develop common guidelines on publication transparency because the typical characteristics of forest research, especially the large spatial and temporal scales, call for specific applications of common or publishers' standards.

\section{The opportunities offered by open science to forest and wood science journal editors \\ Erwin Dreyer ${ }^{1}$ (D), Aurore Coince ${ }^{1}$, Odile Hologne ${ }^{2}$ \\ ${ }^{1}$ Inra, Champenoux, France; ${ }^{2}$ Inra, Versailles, France (erwin.dreyer@inra.fr; annforsci@inra.fr; odile.hologne@inra.fr)}

The movement towards open science has gained strong momentum across the world, which is good news for the editors of forest and wood science journals who favour the broadest possible dissemination of research results. The current trend is towards open data, open access to published papers, open review of submitted manuscripts, posting of pre-print manuscripts in open repositories. The number of submitted manuscripts increases readily and peer review is made difficult given the overload of work it induces. In parallel, the number of journals and outlets increases continuously. There is a strong competition between publishers and between journals, all aiming to attract the best and potentially most cited paper. This context, opposing the ideal of open science and the reality of competing interests of publishers may lead to the end of the traditional model of science editing/publishing and our good old journals. In the contrary, we believe that our journals still have a bright future ahead if they adapt to this new context and serve forest and wood sciences requiring long lasting time series, large data bases and tight cooperation across disciplines and countries. In this presentation, we will address following questions: (i) how can our journals adapt to this context and develop innovative and open editorial processes; (ii) how can they enhance their cooperation to develop the innovative editorial processes required by open science. Our final aim is in all cases to support the development of forest and wood sciences while their contribution is absolutely required.

\section{Developing a sustainable solution to funding open access publishing}

Michael Donaldson ${ }^{1}$, Philip Burton ${ }^{2,3}$, Suzanne Kettley ${ }^{1}$

${ }^{1}$ Canadian Science Publishing, Ottawa, Canada; ${ }^{2}$ University of Northern British Columbia, Terrace, Canada; ${ }^{3}$ Co-Editor in Chief, Canadian Journal of Forest Research,Canada (michael.donaldson@cdnsciencepub.com; phil.burton@unbc.ca; suzanne.kettley@cdnsciencepub.com)

Despite a widespread desire for Open Access (OA) publications from the research community and its stakeholders, one of the major stumbling blocks to OA remains the cost of publishing research. Publication costs are often covered by authors themselves, through an Article Processing Charge (APC), despite limited research budgets to do so. With funding agencies and institutions more commonly requiring published research to be made OA, there is a pressing need to identify alternative models for funding OA publishing. To tackle this issue, Canadian Science Publishing, a not-for-profit scholarly publisher, hosted a national summit with various Canadian stakeholders, including researchers, research administrators, librarians, publishers, and research funders. The purpose of the 
summit was to propose and refine various funding models with the goal of moving away from the author-paid APC. Following the summit, we are convening a working group to take a solutions-based approach to alternative funding models. The purpose of the working group is to further develop the models and take an experimental approach to test and refine them by applying them in practice to one or more existing journal(s). This presentation will discuss our progress to date including a critical analysis of the strengths and limitations of our new models and ideas for improving them. The ultimate goal of this work is to develop a model that could be applied broadly to other journals in order to move to a sustainable model for OA publishing.

\section{Results vs. discussions in journal articles: lessons for authors}

Warren Moser ${ }^{1}$

${ }^{1}$ USDA Forest Service, Flagstaff, AZ, USA (warren.k.moser@usda.gov)

The function of a scientific journal article is to present a hypothesis, evaluation of data and the results of a study or analysis. Readers can better evaluate the results and implications of a study if they understand the place that the article occupies in the overall constellation of work in a particular discipline. Authors all too often enter into a study inspired by an idea but do not place the study and its results in the context of other work or important issues. This failure to provide context most frequently occurs in two places in a manuscript: the objectives of the study and the relevant literature review, and the discussion of the results and the implications thereof. Authors often present the results as if the implications are self-evident and pay limited attention to the "so what?" of their results. This paper will present the authors' view of what constitutes a discussion of study results and how it differs from the results section. Examples of successful and less successful result-discussion combinations will illustrate this distinction. This paper is intended both for both more experienced authors and for newer authors. The suggestions can help authors with a longer publication record to sharpen their skills at sharing their findings with land managers and other practitioners in a way that is practical and applicable to users of this research. New authors will find clear guidance as they publish their own work.

The influence of European Framework Programmes on researcher's publishing activity: bibliometric case study of Slovenian research groups in the filed of forestry

Maja Peteh ${ }^{1,2}$ D, Primož Južničc

${ }^{1}$ Slovenian Forestry Institute, Ljubljana, Slovenia; ${ }^{2}$ Biotechnical Faculty, University of Ljubljana, Ljubljana, Slovenia; ${ }^{3}$ Faculty of Arts, Department of library and information science and book studies, Ljubljana, Slovenia (maja.peteh@gozdis.si; primoz.juznic@ff.uni-lj.si)

To develop a researcher's career, it is important to participate in international and domestic research projects. With bibliometric approach we investigated the influence of selected EU Framework Programmes on researcher's publishing activity of Slovenian research groups in the filed of forestry. Additionally, we tested fulfillment of double requirements: the requirement on open access mandate for publications (via OpenAIRE) and acknowledgment of co-financing (via Web of Science). The presentation contributes to the aims and means of the project LIFEGENMON (LIFE13 ENV/SI/000148) LIFE For European Forest Genetic Monitoring System which is in line with goals of EUFORGEN (European Programme for Forest Genetic Resources).

\section{In-Sylva-France a new research infrastructure for forest adaptation and silvicultural innovations}

Christian Pichot ${ }^{1}$,Laurent Saint-André ${ }^{2}$,Alain Bouvet ${ }^{3}$, Christine Deleuze ${ }^{4}$, François Ehrenmann $^{5}$, Christian Ginisty ${ }^{6}$, Céline Meredieu ${ }^{5}$, Eric Paillassa $^{7}$, Christophe Plomion ${ }^{5}$, Sonia Said ${ }^{8}$, Lucile Savagner ${ }^{3}$, Plinio Sist ${ }^{9}$

${ }^{1}$ Institut National de la Recherche Agronomique, Avignon, France; ${ }^{2}$ Institut National de la Recherche Agronomique, Nancy, France; ${ }^{3}$ Institut Technologique Forêt Cellulose Bois-construction Ameublement (FCBA), Champs-sur-Marne, France; ${ }^{4}$ Office National des Forêts (ONF), Paris, France; ${ }^{5}$ Institut National de la Recherche Agronomique, Bordeaux, France; ${ }^{6}$ Institut national de recherche en sciences et technologies pour l'environnement et l'agriculture (IRSTEA), Nogent-sur-Vernisson, France; ${ }^{7}$ Centre National de la Propriété Forestière (CNPF), Bordeaux, France; ${ }^{8}$ Office National de la Chasse et de la Faune Sauvage (ONCFS), Birieux, France; ${ }^{9}$ Centre de coopération internationale en recherche agronomique pour le développement (CIRAD), Montpellier, France (christian.pichot@inra.fr; laurent.saint-andre@inra.fr; alain.bouvet@fcba.fr; christine.deleuze@onf.fr; francois.ehrenmann@inra.fr; christian.ginisty@irstea.fr; celine.meredieu@inra.fr; rrich.paillassa@cnpf.fr; christophe.plomion@inra.fr; sonia.said@oncfs.gouv.fr; lucile.savagner@inra.fr; sist@cirad.fr)

Forests have to cope with three interlinked transitions: climatic transition, energetic transition and economic transition with an up-rising demand on wood such as new needs to feed up the emerging bioeconomy. Meanwhile, forests are part of a world-wide, nature-based solution for climate warming mitigation, although forests are at the center of territorial conflicts. Thus, it is urgent to foster the development of innovative forest management practices taking into account the quadruple interaction 'which forest resources $\mathrm{x}$ in which biogeoclimatic zones $\mathrm{x}$ with which forest managements $\mathrm{x}$ for which purposes'. By doing so we expect to provide decision tools for forest managers and policy makers. The French national infrastructure IN-SYLVA federates in a common organization tropical and tempered in situ experimentation networks managed by the public and private sectors (5,000 experimental trials covering 4,000ha) as well as in lab facilities (functional ecology, wood properties and genomics) and in silico resources (data bases and models). In such a way IN-SYLVA deals jointly with forest management, biogeochemical features, genetics and economy. IN-SYVA will guide public policies by scientific or technical enlightening and will be the link to the academic and professional sphere. Within the Open Science framework IN-SYVA data policy and practices will contribute to the sharing of data and knowledge. Our first practical goal is to set up an information system federating the distributed resources and providing through the IN-SYLVA data portal the necessary metadata for discovery and access to the data collected by the experimental networks. 
F9p: DELIVERING AND COMMUNICATING FOREST SCIENCE FOR PEOPLE AND A GREENER FUTURE

\author{
Social perception of forestry in the Northern region of Uruguay: beyond the economic impact \\ Virginia Morales Olmos ${ }^{I}$, Isabel Bortagaray ${ }^{1}$, Diego Passarella ${ }^{I}$, Cecilia Marrero ${ }^{I}$, Aylen Paiz ${ }^{1}$ \\ ${ }^{1}$ Universidad de la República, Tacuarembó,Uruguay(vmolmos@gmail.com; isabelbortagaray@gmail.com; diego.passarella@cut.edu.uy; \\ ceciliamarrero3@gmail.com; aylenpaiz@gmail.com)
}

The measurement of the impact of a new economic activity on a territory beyond the economic impact is a topic of special interest for different sectors of a society, especially for activities involving the use of natural resources. In Uruguay, forestry has been increasing its relevance on the national economy over the last decades. As a consequence, the adoption of a comprehensive assessment of its impact is of common interest for the population. The changes in forest sector the Northern region lead to raising questioning of the sustainability of the forest-related investments and their long-term impact on the territory. A multidisciplinary approach was used to elucidate the perception of the forestry sector and to learn on the society's perceptions. The project consisted on: a review of different approaches of sustainability assessment; a collaborative construction of the sustainability assessment of the forestry sector on the northern region of Uruguay; and a collaborative definition of the communication strategy of the assessment parameters previously obtained. The local peculiarities of the forestry sector were investigated through interviews to a set of experts and workshops with targeted audiences. A web-based consulting platform have been launched in order to elucidate and construct the society perception to assess the forestry sector and its sustainability. Preliminary results indicate that the perception of the population on the sector and its impact varies by sub-regions. It confirms the existence of some "myths" about the sector, as well as the demand for available and reliable information for the population.

\title{
Creative and didactic communication through infographics / Comunicação criativa e didática por meio de infográficos
}

Cindy Correa, Milena Serro

IIbá, São Paulo,Brazil (cindy.correa@iba.org; milena.serro@iba.org)

A Indústria Brasileira de Árvores (Ibá) é a entidade responsável pela representação institucional da cadeia produtiva de árvores plantadas em nível nacional, do campo à indústria, com ênfase em celulose, papel, painéis de madeira e pisos laminados. Nosso principal desafio de comunicação é apresentar aos stakeholders a importância dessa agroindústria para o meio ambiente, a economia e as pessoas. Além de fornecer produtos essenciais para o uso diário da população, as plantações de árvores também desempenham papel fundamental na prestação de serviços ambientais, como a conservação de florestas naturais e da biodiversidade, a regulação do clima e da água, entre outros. Apesar do compromisso desta indústria com esses serviços ecossistêmicos, ainda há pouco conhecimento por parte do público em geral sobre os benefícios gerados por uma plantação florestal e o manejo das paisagens pelas quais estes indústrias são responsáveis. Muitas vezes, a indústria de árvores plantadas ainda é alvo de críticas e de antigos mitos sobre sua atuação. Para combater esses mitos, a Ibá adotou como estratégia de comunicação a construção de uma nova narrativa sobre a atuação sustentável deste setor, por meio da criação de infográficos que demonstram, de forma ilustrativa e didática, como se faz gestão da paisagem, a gestão de recursos hídricos e a conservação da biodiversidade, entre outros. Os infográficos também são compostos de textos que contextualizam tudo o que é representado graficamente por meio das ilustrações. Os textos trazem, em linguagem amigável, informações técnicas baseadas em estudos e pesquisas de fontes renomadas - nacionais e internacionais.

\section{"Science and the media:" the importance of forestry research for communicators / "Ciência e mídia": a importância da pesquisa florestal para comunicadores \\ Ana Laura Lima ${ }^{1}$, Priscila Viúdes ${ }^{2}$, Adriano Venturieri ${ }^{1}$, Sabrina Gaspar ${ }^{1}$, Dulcivânia Freitas ${ }^{3}$ \\ ${ }^{1}$ Embrapa Amazônia Oriental, Belém, Brazil; ${ }^{2}$ Embrapa Acre, Rio Branco, Brazil; ${ }^{3}$ Embrapa Amapá, Amapá, Brazil (analaura.lima@embrapa.br; priscila.viudes@embrapa.br; adriano.venturieri@embrapa.br; sabrina.gaspar@embrapa.br;dulcivania.freitas@embrapa.br)}

Os comunicadores são importantes influenciadores e formadores da opinião pública. Além disso são mediadores do debate entre a sociedade e instituições. Para aproximar desse público o debate sobre as questões ambientais na Amazônia, a Embrapa - Empresa Brasileira de Pesquisa Agropecuária - realizou ao longo de dois anos encontros denominados "Ciência e Mídia", em nove cidades dos sete estados da Região Norte e no Maranhão. Este pôster apresenta a experiência de realização dos cursos e o impacto no público-alvo. O público participante totalizou 250 pessoas, entre profissionais da imprensa, lideranças comunitárias e estudantes de Comunicação. As temáticas abordadas foram: "Clima, mudança no uso da terra e o papel da floresta", "Sistemas sustentáveis de produção na Amazônia", "Jornalismo de Dados: um novo olhar sobre a Amazônia - acesso e uso do Prodes" e "Uso e cobertura da terra na Amazônia". Com base nas avaliações dos cursos, $66 \%$ do público considerou o evento ótimo e $33 \%$ excelente. Ficou evidente que eventos dessa natureza são importantes para ampliar o debate sobre o papel da floresta e as questões ambientais globais, e qualificar a cobertura jornalística sobre esses temas. Além disso é uma boa oportunidade para aproximar as instituições de pesquisa dos formadores de opinião. Os especialistas nas temáticas ambientais ainda apresentam dificuldade em se comunicar com o público por diversos motivos, em especial a linguagem. A análise apontou também que é necessário buscar outros formatos de apresentação, utilizar exemplos da pesquisa com a realidade, inferir sobre o impacto dos resultados no cotidiano, direta ou indiretamente.

\section{Communication as a strategy for awareness among the urban public on forestry issues / Comunicação como estratégia para sensibilização} do público urbano para as questões florestais

Katia Regina Pichelli ${ }^{1}$, Luciane Cristine Jaques ${ }^{\prime}$, Paula Geron Saiz ${ }^{1}$

'Embrapa Florestas, Curitiba, Brazil (katia.pichelli@embrapa.br; luciane.jaques@embrapa.br; paula.saiz@embrapa.br)

A presença das florestas no dia a dia das pessoas ainda é desconhecida pela maioria dos brasileiros. Percebe-se isso quando a frase "não imprima, assim você evita o corte de árvores" ainda é vista em diversas assinaturas de e-mail, ou quando o conceito "não use as florestas" permeia fortemente discussões equivocadas em mídias sociais. Diante disso, a Embrapa Florestas tem procurado trabalhar com o público urbano para desmistificar estes conceitos. Para isso, tem produzido materiais voltados a este público, em especial vídeos, animações, página web, mídias sociais e materiais impressos. São estratégias usuais de comunicação, mas que pretendem atingir um público diferenciado, que não está habituado à ciência e à temática florestal, levando a informação científica de forma acessível, criando sentido e despertando interesse. A mensagem principal destes materiais é "a floresta está presente em seu dia a dia". Alguns materiais: 1) animações: "Florestas no dia a dia", "Florestas nas propriedades rurais", "Plantios florestais para geração de energia"; 2) vídeos: "Pesquisas com araucárias", "Estradas com Araucárias", "Sistema silvipastoril"; 3) Páginas web: "Araucária", com infográficos; 4) Cartões postais (belas imagens com impressão diferenciada 
estimulando que as pessoas guardem como decoração/recordação - no verso, QRCodes levam ao portal da Embrapa com links sobre o tema): pesquisa florestal, Integração Lavoura-Pecuária-Floresta, Araucária, erva-mate, pragas florestais, pupunha; 5) impressos: quebra-cabeça e desenho de propriedade rural com florestas para crianças colorirem; folderes diversos com linguagem acessível ao público leigo. Estes materiais são utilizados em palestras, feiras/exposições e, em paralelo, divulgações em mídias sociais.

Narrowing the distance between public research and the Brazilian population: the climate change impacts in the Atlantic Forest study Jennifer Viezzer ${ }^{1,2}$, Mariana Egler ${ }^{1}$, Marco Follador $^{3}$, Martin Becher ${ }^{4}$, Armin Deitenbach $^{5}$, Melina Amoni Silveira Alves ${ }^{6}$, Virgílio de Almeida Pereira ${ }^{6}$, Felipe $^{2}$ Bittencourt ${ }^{6}$, Henrique de Almeida Pereira ${ }^{6}$, Priscila Lopes Soares da Costa ${ }^{1}$

${ }^{1}$ Ministério do Meio Ambiente (MMA), Brasília, Brazil; ${ }^{2}$ Universidade Federal do Paraná (UFPR), Curitiba, Brazil; ${ }^{3}$ European Comission - Joint Research Centre (JRC), Ispra, Italy; ${ }^{4}$ NIRAS - IP Consult GmbH, Berlin, Germany; ${ }^{5}$ Deutsche Gesellschaft für Internationale Zusammenarbeit (GIZ), Brasilia, Brazil; ${ }^{6}$ Waycarbon,Belo Horizonte,Brazil (jen.viezzer@gmail.com; mariana.egler@mma.gov.br;marco.follador@ec.europa.eu; martin.beche@niras-ip.de; armin.deitenbach@giz.de; melina.amoni@waycarbon.com; virgiliobio@gmail.com; felipe.bittencourt@waycarbon.com; hpereira@waycarbon.com; priscila.costa@mma.gov.br)

The Brazilian Ministry of Environment (MMA) developed an integrated modeling tool to assess the potential climate change impacts in the Atlantic Forest, aiming at supporting the definition of local adaptation measures in instruments such as protected areas' management plans, and municipal land use plans. This study resulted in hundreds of georeferenced maps and a technical report, available on the MMA's website, even though an effective subnational communication strategy did not take place. Consequently, the research outcomes were hardly accessible and usable by non-experts, such as local decision-makers and practitioners, which are supposed to be the end users of this study. Identifying, filtering and sharing available scientific evidence about climate change impacts to support territorial planning at the local level are necessary activities to guarantee the best selection of adaptation measures and allocation of available resources for each context. To address this issue and improve the dissemination of the study outcomes the MMA decided to: i) elaborate a summary for decision-makers, highlighting the most significant and impending results; ii) make a substantial effort to format, organize and visualize the 812 georeferenced maps, through the MMA's geoprocessing platform; and iii) organize and participate in webinars, workshops, and courses with different stakeholders from both the public and private sectors, civil society and academy. However, further communication efforts - through different formats and platforms - must be implemented by MMA. Making sense of scientific data, information and knowledge is an imperative goal of every project and must be correctly planned from its very beginning.

Embrapa Mais Amazônia: a communication network for agricultural and forest research in the Brazilian Amazon / Embrapa Mais Amazônia: comunicação em rede para a pesquisa agropecuária e florestal no Brasil amazônico

Ana Laura Lima ${ }^{1}$, Priscila Viúdes², Vinicius Kuromoto ${ }^{3}$, Dulcivânia Freitas ${ }^{4}$

${ }^{1}$ Embrapa Amazônia Oriental, Belém, Brazil; ; ${ }^{2}$ mbrapa Acre, Rio Branco, Brazil; ${ }^{3}$ Embrapa Informática Agropecuária, Campinas, Brazil; ${ }^{4}$ Embrapa Amapá, Macapá,Brazil (analaura.lima@embrapa.br; priscila.viudes@embrapa.br; vinicius.kuromoto@embrapa.br; dulcivania.freitas@embrapa.br)

"Embrapa Mais Amazônia" é um projeto de comunicação executado em rede pelos profissionais das nove Unidades da Empresa Brasileira de Pesquisa Agropecuária (Embrapa) na Amazônia Legal. O objetivo é divulgar resultados da pesquisa e estimular junto à sociedade o debate em torno da floresta, uso sustentável dos recursos naturais e questões ambientais na região. O projeto atua em três vertentes: desenvolvimento de produtos de comunicação; ampliação dos fluxos de informação e canais de diálogo; e capacitação de cientistas das áreas florestal e agropecuária e de profissionais de comunicação. Entre os principais resultados estão: cursos para comunicadores sobre temáticas florestais; cursos de fotografia para pesquisadores; media trainings para pesquisadores; e desenvolvimento de folders e aplicativo sobre as principais fontes de informação técnico-científicas sobre as temáticas florestais e agropecuárias trabalhadas pela Embrapa na região. Ao final do projeto foi realizada pesquisa de imagem para aferir o impacto das ações a respeito da ampliação do debate sobre as questões ambientais na região, bem como as referências (instituições) dos jornalistas quando o assunto é pesquisa florestal e agropecuária na Amazônia. Verificou-se que as temáticas ambientais na Amazônia ganham amplitude junto à imprensa quando são realizadas as conferências internacionais sobre clima e mudanças climáticas e/ou grandes eventos no tema. Entre as instituições citadas como referência na temática "mudanças climáticas", ONGs aparecem em primeiro lugar, seguidas de perto pelas universidades; na temática "pesquisa florestal" e "pesquisa agropecuária", Embrapa ocupa a primeira posição; e na temática "uso sustentável dos recursos naturais", instituições de ensino aparecem primeiro."

Illustrations and infographics in scientific journalism: the experience of Embrapa Eastern Amazonia / Ilustração e infografia no jornalismo científico: a experiência da Embrapa Amazônia Oriental

Sabrina Maria Morais Gaspar ${ }^{1}$, Ana Laura Silva de Lima Costa ${ }^{1}$, Vinicius Milleo Kuromoto ${ }^{2}$, Joice Nunes Ferreira

${ }^{1}$ Embrapa Amazônia Oriental, Belém, Brazil; ${ }^{2}$ Embrapa Informática Agropecuária, Campinas, Brazil (sabrina.gaspar@embrapa.br; analaura.lima@embrapa.br; vinicius.kuromoto@embrapa.br;joice.ferreira@embrapa.br)

A infografia traduz temas complexos em linguagem de fácil entendimento. No Jornalismo esse recurso contribui na construção de narrativas. Em materiais produzidos pela Embrapa - Empresa Brasileira de Pesquisa Agropecuária - o seu uso é comum em cartilhas e manuais que apresentam práticas agropecuárias, mas na comunicação institucional ainda é pequeno. Apresentamos a experiência de construção e uso de ilustrações e infografia em uma série de quatro reportagens sobre a relação da floresta e o uso da terra, resultantes de artigos científicos elaborados no âmbito da Rede Amazônia Sustentável e publicados em revistas internacionais. As reportagens foram publicadas na Agência Embrapa de Notícias, focando no conteúdo científico sobre o impacto do uso da terra nos estoques de carbono e biodiversidade em florestas primárias, secundárias e com exploração madeireira e queima. Com dados complexos gerados pela pesquisa foi necessário o tratamento para publicação em formato visual e jornalístico, onde o conteúdo pudesse ser compreendido pelo público. O analytics do portal Embrapa indicou que as quatro reportagens tiveram 2.712 acessos únicos com tempo médio de quatro minutos de leitura cada. Na rede social Facebook a reportagem com infográfico na chamada obteve 192 compartilhamentos, $80 \%$ a mais que aquela sem o recurso na chamada. As duas postagens alcançaram 29.458 pessoas. Os dados são relevantes também quando analisamos a replicação das reportagens em outros portais sobre temáticas florestais. Isso mostra a importância do uso de recursos visuais e gráficos para comunicar informações complexas, contribuindo para o debate sobre conservação e uso sustentável das florestas. 


\title{
Aspects of communication in rural communities / Aspectos comunicacionais em comunidades rurais
}

Mauricilia Pereira da Silva1, Priscila Viudes ${ }^{1}$, Marcio Muniz Albano Bayma ${ }^{1}$, Selma Lucia Lira Beltrãoº , Antônio Luiz Oliveira Herbele $\hat{e}^{3}$ ${ }^{1}$ Embrapa Acre, Rio Branco, Brazil; '2Embrapa Sede, Brasilia, Brazil; ${ }^{3}$ Embrapa Café, Brasília, Brazil (mauricilia.silva@embrapa.br; priscila.viudes@embrapa.br;marcio.bayma@embrapa.br; selma.beltrao@embrapa.br; antonio.herbele@embrapa.br)

Conhecer os principais fluxos de comunicação existentes nos territórios da cidadania do Vale do Juruá, de Capixaba e do Alto Acre, no estado do Acre, Brasil, foi o objetivo da pesquisa realizada em dezembro de 2018, no âmbito do projeto "Interação, intercâmbio e construção do conhecimento e comunicação nos projetos do Fundo Amazônia - Amazocom", que busca articular ações com foco nas estratégicas de comunicação, transferência de tecnologia, intercâmbio e construção de conhecimentos para atendimento de ações de outros projetos Integrados da Amazônia. Mesmo com as facilidades de comunicação oferecidas pelas tecnologias digitais que proporcionam amplo acesso à informação, é fundamental investigar como ocorre a troca de informações, conhecimentos e tecnologias na interação entre agricultores e extrativistas da região Amazônica e profissionais de diversas instituições que atuam no universo da extensão rural, ensino e pesquisa. O resultado das 39 entrevistas com informantes de sete municípios do Acre revelou uma diversidade de aspectos comunicacionais nesses territórios amazônicos. Há quem viva em total isolamento, distante dos centros urbanos, e o rádio ainda é o protagonista. Em outras localidades, há moradores que possuem televisão e utilizam dispositivos móveis com frequência para estabelecer a comunicação. A pesquisa também revelou grande potencial de jovens agricultores e extrativistas no processo de comunicação. Eles dominam a tecnologia móvel no espaço da família, mesmo em localidades onde o uso do equipamento é restrito devido à falta de acesso à internet, como, por exemplo, em boa parte das comunidades que vivem na floresta amazônica.

INNOVATION AND EXCELLENCE IN EMERGING RESEARCH: IUFRO STUDENT AWARDS

S1a INNOVATION AND EXCELLENCE IN EMERGING RESEARCH: IUFRO STUDENT AWARDS

\section{Recovery of a tropical rain forest over 30 years following silvicultural interventions}

\author{
Angela Luciana de Avila ${ }^{1}$, Ademir Roberto Ruschel ${ }^{1}$, José Natalino Macedo Silva ${ }^{1}$, Lucas Mazzei ${ }^{1}$, João Olegário Pereira de Carvalho ${ }^{1}$, Jürgen Bauhus ${ }^{1}$ \\ (angela.avila@forst.bwl.de)
}

Tropical rain forests are highly biodiverse and provide globally important ecosystem services. In the face of increasing dominance of human-modified landscapes in tropical regions, managing these forests sustainably may contribute to maintain ecosystem integrity while fulfilling society's demand for forest goods. Nonetheless, little knowledge is available regarding tropical forest responses to silvicultural interventions, especially in the medium to long-term. Here, we investigated how silvicultural intervention intensity and type (harvesting and thinning) influenced the recovery of important forest attributes and functions related to biodiversity conservation, carbon sequestration and timber provision. Furthermore, the effect of post-logging (remaining) biological legacies (basal area and species diversity) on above ground biomass recovery was also investigated. We analysed data from a unique long-term experiment located in the Tapajós National Forest, Pará, Brazil, where trees $\geq 5 \mathrm{~cm}$ DBH were measured on 8 occasions in 41 permanent sample plots including unlogged forest. Management intensities comprised logging (1982) with associated damage and follow-up thinning (1993-1994). Tree species diversity was not impaired by silvicultural interventions, but basal area reduction above $20 \%$ impaired recovery of composition, biomass and timber stocks over 30 years after initial logging. Additionally, stand-level aboveground biomass recovery rates were largely determined by basal area remaining and less by post-disturbance composition. These results indicate that the resilience of these forests of the Eastern Amazon depends primarily on harvesting and thinning intensity and, therefore, silvicultural interventions must be carefully controlled for the ecosystem to be able to recover rapidly.

\section{International forest policy by International and Transnational Organizations: case studies of the World Bank and forest certification organizations in Argentina and Armenia}

Sarah Lilian Burns ${ }^{1}$

${ }^{1}$ Facultad de Ciencias Agrarias y Forestales, Universidad Nacional de la Plata, Buenos Aires, Argentina (angela.avila@forst.bwl.de)

In recent decades, globalization and internationalization led to an increase in the number of international regimes attempting to influence national behaviour over many different issues. By using the case of the international forest regime the thesis sought to answer how do international and transnational organizations influence domestic forest policies? The cases of Argentina and Armenia were selected as examples of developing countries open to international influences with weak forest sectors that went through an administrative restructuring. The results show that: First, which issues from the International Forest Regime become relevant in different countries depends on the domestic actors and their interests. Second, by means of funding and capacity building, the World Bank, as an international organization, assisted the coalition of agricultural bureaucracies and landowner associations that emerged after the economic crisis in Argentina at the beginning of the 1990s. Third, the influence of the World Bank in Argentina and Armenia through direct access pushed the forest sector towards deregulation. Fourth, state bureaucracies play an important role in the implementation of transnational regimes at the national level. In forest certification processes international actors seek coalitions with different state bureaucracies. However, in situations where new promising venues for political influence open, private actors prefer ad hoc coalitions with weaker bureaucracies with less technical knowledge. Fifth, the political system of federal countries provides multiple institutional access points for policy change that international and transnational regimes try to use in order to influence the domestic level, consequently changing the power balance of domestic networks.

\section{Influence of pruning on development of even-aged Pinus radiata D. Don and Pinus pinaster Aiton stands in SW Europe}

Andrea Hevia Cabal ${ }^{1,2}$, Juan Gabriel Álvarez González ${ }^{3}$, Juan Majada Guijo ${ }^{2}$

${ }^{1}$ Dept. de Ciencias Agroforestales, Escuela Técnica Superior de Ingeniería, Universidad de Huelva, Huelva, Spain; ${ }^{2}$ Forest and Wood Technology Research Centre (CETEMAS), Siero, Spain; ${ }^{3}$ Department of Agroforestry Engineering, Unit of Sustainable Forest Management (UXFS), School of Engineering, University of Santiago de Compostela,Lugo,Spain (aheviacabal@gmail.com; juangabriel.alvarez@usc.es; jmajada@cetemas.es)

Demand for wood products is one of the main drivers of investment in forest management. Additionally, a major challenge being faced by forest managers is related to wood quality, particularly on timber species where forests productivity is higher. Silvicultural treatments allow to obtain higher quality of wood and increase the value of forests. However, optimal interventions and better understanding of the variation of wood quality in response to silviculture is still unclear in the main timber species. The influence of silviculture on fuel management and wildfire mitigation is also a key research question. The objective of this study is 
to evaluate the effect of silviculture on wood quality and to ensure a sustainable forest management under forecasting forest risks. A network of permanent plots was established in two of the most important timber species, Pinus radiata D. Don and Pinus pinaster Ait., in SW European Atlantic forests. Forest inventory (before and after silvicultural treatments) together with modelling approaches of forest growth, wood quality and fire risk have proved of importance for guiding forest policy in the Atlantic region. Models were based on tree-growth, productivity, dominance, pruning variables -central knotty-core, diameter over stubs, epicormic sprouting, pruning wounds occlusion-, stem taper and form, above-ground biomass -total and by-heights, nutrients and carbon, and also vertical profile of canopy fuel. Moreover, the established network of silvicultural experiments is, nowadays, the study site in several national and european projects, and provide unique long-term datasets in forest research.

\section{Characterization of variability, growth and production of Stone pine (Pinus pinea L.) in Chile according to climate and some silvicultural practices}

Verónica Loewe-Muñoz ${ }^{1}$

Instituto Forestal, Santiago, Chile (vloewe@infor.cl)

Stone pine (Pinus pinea L.) is one of the most economically important species in the world due to its pine nuts, the most expensive nuts. Advances in semiintensive and intensive management for its cultivation as a fruit tree have been limited, with cones being harvested mostly from natural forests. In this PhD thesis, a comprehensive study was conducted including: 1) assessment of growth and cone production along a climatic gradient; 2) description of the species variability through morphometric and chemical variables comparing pine nuts harvested in Chile, Argentina, Italy, Spain, Turkey, and Israel; 3) the use of Near Infrared Spectroscopy (NIRS) for identifying pine nut geographical origin; 4) molecular analyses -proteomic-, to differentiate populations growing in Chile; 5) evaluation of adaptation of European provenances to Chile by assessing growth and cone production; 6) effects of two intensive silvicultural practices, fertilization and irrigation, on cone production and growth. Three macrozones showing marked growth differences were defined. Climatic and biometeorological variables, defined based on 11 physio-phenological reproductive phases, were related to cone production traits. Stone pine was found to be well adapted to soil and climate of Chile within a wide range of conditions, and to have a production capacity that allows predicting productive levels similar to or even higher than those in its native distribution. These results show that the species cultivation is a productive alternative for Chile and for other countries with similar environmental conditions. This thesis makes a valuable scientific contribution to the advance of stone pine domestication.

\section{Entropy or inequality?: indicators of tree size heterogeneity and other adaptations of Lorenz curves to forest science.}

Ruben Valbuena ${ }^{1}$

${ }^{1}$ School of Natural Sciences, Bangor University, Bangor, LL57 2UW, United Kingdom (rvalbuena@bangor.ac.uk)

On the outset of national programmes covering entire countries with lidar surveys, I envisaged that these datasets could be employed to derive trans-national indicators and classifications of habitat structure, and secured a scholarship for "Obtaining Pan-European Indicators of Forest Structural Diversity by means of Airborne Laser Scanning" at the European Forest Institute. The starting point was a range of indicators available in the literature for describing the structural complexity of forests, most typically the Shannon index of tree size classes or foliage height diversity. However, taking a deeper insight in the mathematical foundations of diversity and equitability ordering and elaborating diversity profiles instead of observing single indices, I concluded that indices based on theory of information were unsuited for such purposes. This made it clear that Lorenz curves were the fundamental basis for describing heterogeneity in tree sizes, and thus I further focused in adaptations of Lorenz ordering to forest science. These included proving that Gini Coefficient $=0.5$ is a beacon for maximum entropy which serves as a boundary between even-sized and uneven-sized forests. Also, the inflexion point of the Lorenz curve signals the quadratic mean diameter, and it is key in describing asymmetry and competitive conditions in forest assemblages, because it yields the proportion of basal area larger than mean (BALM), a population-level indicator similar to those commonly used at tree level in growth models involving competition (BAL). After learning how to read them, Lorenz plots become a powerful tool to diagnose forest structure and competition conditions promptly.

\section{Forest management and governance in Sweden: a phronetic analysis of social practices}

\section{Ida Wallin ${ }^{1}$}

${ }^{1}$ Chair of Forest and Environmental Policy, University of Freiburg, Freiburg, Germany (ida.wallin@ifp.uni-freiburg.de)

The transition to a sustainable society requires improved knowledge about what determines forest management and the relationship to governance and policies. My doctoral thesis constitutes a phronetic analysis of social practices in forest management in Sweden and of how social practices materialize and influence forest governance and ultimately, forest management more broadly. The research applied a case study approach where interviews and foresight workshops were carried out together with forest owners and other stakeholders on local and national level. Social practices found relevant for forest management were related to local social context, family circumstances, conflicting logics of practice, social values and personal, trusting relations to different actors. Especially, trusted advisors were a major factor determining forest management and policy outcomes. A tendency of social practices to streamline rather than to diversify forest management actions was observed. From a policy-making perspective, trying to balance the different services from the forest requires diversification of outreach strategies and fostering of trustful relationships between responsible authorities and stakeholders. Digitalization of communication provides both opportunities and challenges in this regard. I conclude that participatory and collaborative forest governance efforts could build on and strengthen the strong social capital and willingness to cooperate found at the local level. Power structures embedded between governance levels and among local stakeholders should not be underestimated and more research into the pre-conditions for collaboration is needed. Social practices as the object of study provides a promising path for future studies in order to find effective policy solutions.

\section{Forest ecosystem services assessments via evaluation of biophysical responses}

\section{Zhen $\mathrm{Yu}^{1}$}

${ }^{1}$ School of Applied Meteorology, Nanjing University of Information Science and Technology, Nanjing Jiangsu, China (zyu@mix.wvu.edu)

Terrestrial ecosystems are likely to be affected by climate change, as climate change-induced shift of water and heat stresses patterns will have significant impacts on species composition, habitat distribution, and ecosystem functions, and thereby weaken the terrestrial carbon (C) sink and threaten global food security and biofuel production. This dissertation focuses on forest ecosystem services assessments via evaluation of biophysical responses (NDVI, LAI, and phenology) and biochemical responses (e.g. water flux, carbon dioxide exchange such as NPP, GPP, NEE) to climate change and human management. Specifically, using field measurements, spatial modeling, and remote sensing technique, the doctoral research revealed that 1) temperate vegetation phenology (green-up) is dependent 
on both seasonal air temperature and soil thermal conditions regulated by snowfall and snow depth; 2) winter ecosystem respiration in the Northern forested area significantly decreased in responses to decreasing snow cover depth, which accounts for approximately $25 \%$ of the simulated annual carbon sink trend in non-permafrost region of Northern forest area from 1982 to 2009; 3) the impacts of drought extremes on ecosystem GPP, evapotranspiration ET, and water use efficiency varies between biomes; and 4) planted forest has been more sensitive and consumed more water than natural forest in dry regions of China.

\title{
Economic optimization of forest biomass collection, processing and transportation for aviation fuel production
}

${ }^{1}$ Rene Zamora Cristales

${ }^{1}$ Food, Forest and Water / World Resources Institute, USA (rzamora@wri.org)

In 2018 more than 355 billion liters of aviation fuel were consumed by commercial airlines. There is substantial interest by the aviation industry in reducing the dependence on fossil fuels and promote the use of alternative renewable energy sources. The production of liquid fuels from forest residues are particularly relevant for the industry given the characteristics of the commercial aircraft technology that cannot use at scale other renewable sources such as electricity, nuclear power or wind turbines. However, Aviation fuels derived from forest biomass must compete with traditional fossil fuel supply chains to become a successful alternative. My doctoral research focuses on the Economic optimization of forest biomass processing and transport for aviation biofuel. The production of energy from forest harvest residues constitute an opportunity to develop a supply chain for producing heat, electricity and liquid fuels from renewable materials. This research is path-breaking in that it combines operational and tactical planning methods, as well as simulation, in a decision support system. A mixed integer programming/simulation solution procedure was developed to provide support to biomass processing and transportation decisions at the operational level, taking into account operational factors not considered in previous models; such as residue pile location, road characteristics, turnaround and turn-out location, processing, and transportation equipment available, and truck-machine interactions. I also developed an innovative costing model for the standing cost of equipment. All the methodologies proposed have been validated with real-world operations which confirmed the accuracy of his simulation and optimization models.

\section{Connecting nature to people: ecosystem services in adaptation to a changing climatean insight from the Panchase Mountain Ecological} Region of Western Nepal

Shankar Adhikari ${ }^{I}$

'Ministry of Forests and Environment, Kathmandu, Nepal (adhikarishankar@gmail.com)

Ecosystem services (ES) are considered critical for facilitating adaptation to climate change and improving human well-being, particularly in developing countries. Various anthropogenic and natural drivers however pose a myriad of environmental challenges to the sustainable supply of ES. Improved understanding of the interactions between ES and drivers of change is required to help people adapt; however, many relationships between drivers of change and ES are largely unknown and are likely to be context specific. To determine the role of ES in adaptation to a changing climate and how they can enhance human well-being, this study applies the Intergovernmental platform for biodiversity and ecosystem services (IPBES) conceptual framework. The study uses a catchment of the Panchase Mountain Ecological Region (PMER) in Western Nepal as a case study. Major natural drivers of change were identified as climate change, drought, and invasive species, whereas anthropogenic drivers included agriculture land abandonment, planting of new species, and change in population demography. All drivers were found to have an impact on the availability of ES and the livelihoods of the people reliant on them. Current anthropogenic assets and institutional mechanisms were found to be effective in managing some of the challenges. Proper governance and adequate financial and technical support are likely to be essential for addressing environmental challenges that influence the sustained flow of ES and help people adapt to a changing climate in the region.

\section{Impacts of environmental change and forest management on mountain forest ecosystem services}

\author{
Katharina Albrich ${ }^{1}$, Werner Rammer ${ }^{1}$, Dominik Thom ${ }^{1,2}$, Rupert Seidl ${ }^{1}$ \\ ${ }^{1}$ Institute of Silviculture, University of Natural Resources and Life Sciences (BOKU), Vienna, Austria; ${ }^{2}$ Rubenstein School of Environment and Natural \\ Resources, University of Vermont, Burlington, USA (katharina.albrich@boku.ac.at)
}

Mountain forest ecosystems provide important ecosystem services (ES) such as timber production, protection from natural hazards and carbon storage. Climate change and accompanying changes in disturbance regimes are putting increasing stress on forests and on their ability to provide ES. Forest managers therefore may need to find approaches which ensure stable ecosystem services provisioning in a highly uncertain future In this study, we used the simulation model iLand to investigate the ecosystem services supply on an 8100 ha landscape in the Northern Front Range of the Alps. We imposed four different forest management strategies on the landscape, ranging from a management approach which tries to maximize timber harvest to a strategy trying to adapt the forest to future climate conditions. In addition to differences between the management strategies, the analysis focused on ES provisioning both under past and future climate and disturbance regimes. We also paid special attention to the trade-off between level and temporal stability of ES provisioning under future climate. While traditional, conifer-focused strategies performed well under past climate and disturbance regimes for several ES, they showed clearly reduced provisioning under future climate. The two future-adapted strategies faced a smaller reduction in performance under climate change and were less susceptible to disturbance impacts. They also had a smaller trade-off between level and stability of ES provisioning. This emphasizes that forest managers will have to adapt their silvicultural approaches in order to ensure ecosystem services provisioning even under future climate and disturbance regimes.

\section{Effects of mixed plantations of Acacia auriculiformis with Swietenia macrophylla and Gmelina arborea on growth, biomass and soil Fertility}

Shourav Dutta ${ }^{1,2,3}$, Mohammed Kamal Hossain ${ }^{3}$

${ }^{1}$ Faculty of Environment and Natural Resources, Albert-Ludwigs-Universität, Freiburg, Germany; ${ }^{2}$ Faculty of Science and Forestry, University of Eastern

Finland, Joensuu, Finland; ${ }^{3}$ Institute of Forestry and Environmental Sciences, University of Chittagong, Chittagong, Bangladesh

(shouravforestry@gmail.com; mkhossain2009@gmail.com)

The replacement of pure plantations by mixed stands with suitable nitrogen-fixing species is a possible way to maintain soil fertility together with highest growth and biomass. The study was conducted to assess the effect of mixed plantings of Acacia auriculiformis (A) with Swietenia macrophylla (S) and Gmelina arborea $(\mathrm{G})$ on growth, biomass and soil fertility in 16 month old tropical plantations of Bangladesh. The plantations consist of three pure planting plots (100\%A, 100\%G, 100\%S) and eleven mixed planting plots (1A:1S, 1A:1G, 1A: 1G: 1S, 1A:2S, 1A:2G, 1A:3S, 1A:3G, 2A:1S, 2A:1G, 3A:1S and 3A:1G) 
of three common plantation trees of Bangladesh. The methods consist of measurement of growth performance of plants, soil pH, soil organic carbon, nutrient contents and finally statistical analysis. It was found that Swietenia was significantly tallest when planted with nitrogen-fixing Acacia in a proportion of $1 \mathrm{~A}$ : 3S. Gmelina attained maximum height and diameter in a mixture of 1A:1S:1G, whereas Acacia was tallest in the pure 100\%A plantation. The study showed that in comparison with the pure plots of Swietenia and Gmelina, mixed plantings have positive relationships with increasing soil $\mathrm{pH}$, organic carbon, $\mathrm{N}$, $\mathrm{P}$, and available K. Results from the periodic measurement of growth parameters of plants revealed that there was a significant difference in height and diameter increment due to the variation of nutrient uptake by the individuals. The research findings suggested that in comparison to mono-plantation plots, species mixture has significantly $(p<0.05)$ better growth and biomass in addition to increasing positive effects on soil fertility.

\title{
Climate change threat to protected areas in Madagascar
}

Ange Raharivololoniaina ${ }^{1}$

'Biogeography Department, Bayreuth Center of Ecology and Environmental Research, University of Bayreuth, Germany (ainaange@gmail.com)

Madagascar figures among the most extraordinary biodiversity hotspots and is identified in the same time as an important conservation priority in terms of vulnerability and irreplaceability. Protected areas is one of the most efficient way to conserve biodiversity and to halt deforestation but anthropogenic climate change is now a growing threat to protected areas. In the present study, I quantify the exposure of climate change effect on protected areas network in Madagascar. Using climate similarity classification rules, I computed and mapped novel climates within protected areas in Madagascar under two future time periods (2050 and 2070), two climate scenarios (RCP 4.5 and RCP 8.5), four different global circulation models and compared two different conceptual approaches. The overall result of my research showed that at least eight percent of the entire protected areas network in Madagascar is under threat of novel climates in the future. To my knowledge, this is the first quantitative analysis of the potential impact of climate change on protected areas in Madagascar. Results of this study can help guide conservationist with management planning in the era of anthropogenic climate change.

\section{Indigenous federations in the Peruvian Amazon: perspectives from the Ashéninka and Yine-Yami peoples}

\author{
Andrea $M$ Vásquez Fernández ${ }^{1}$ \\ ${ }^{1}$ Faculty of Forestry, University of British Columbia, Vancouver, Canada (andrea.vasquezfernandez@alumni.ubc.ca)
}

The emergence of a globalized model of development in Peru, based on extraction of natural resources, has led to the rise of Indigenous movements. One of the strategies to address the negative impacts of public policies generated to support this model is through the creation of Indigenous federations. Indigenous federations have emerged as a strategy of Indigenous Peoples to make their voices heard and to determine their own futures. Scholars, Indigenous community members, and federation representatives themselves have identified the strengthened relationships between representatives and community members as a major challenge for Indigenous movements. In alliance with six Ashéninka and Yine-Yami communities and their local Indigenous federations, we conducted a collaborative research. The question that frames this research is: How could Ashéninka and Yine-Yami Peoples improve Indigenous federations’ representational work from their own ontologies (ways of being), epistemologies (ways of knowing), axiologies (values), and methodologies (ways of doing)? Through culturally sensitive methods of co-creating knowledge using Indigenous theories and decolonizing methodologies, this study addresses two objectives: (1) to identify factors that contribute to Indigenous federations' representatives ability to effectively achieve communities' objectives; and (2) to articulate recommendations to improve Indigenous federations. Results show that the principal factors that explain representatives' sources of capacity to address member communities' objectives are primarily to establish close interpersonal relationships and to cultivate spiritual, ethical, and moral behaviours between representatives and community members. Five recommendations are identified by Ashéninka and Yine-Yami Peoples to enhance their institutions: (1) to define the jurisdiction of the federations; (2) to formalize the federations; (3) to improve the processes of interaction; (4) to strengthen their self-determined Indigenous economies; and (5) to increase political participation. The results inform current Indigenous politics that aim to have a larger influence on the regional and even national formulation of public policies that impact the Peruvian Amazon. The recognition and practice of a pluri-national state and the need to establish more meaningful indicators of endo-development are important in the formulation of the factors influencing a positive change and a way to address current and future conflicts around use of natural resources.

\section{Sustainable forest management and soil quality: an enhanced virtual educational experience}

\author{
Khalil Walji ${ }^{1}$, Maja Krzic ${ }^{1}$, Ben du Toit ${ }^{1}$, Saeed Dyanatkar ${ }^{1}$, Chris Crowley ${ }^{1}$, Michael Sider ${ }^{1}$ \\ ${ }^{1}$ International Forestry Students Association, IFSA, Freiburg im Breisgau, Germany (khalilwalji@gmail.com)
}

Soils play a crucial role in food and fiber production, carbon and nutrient cycling and many other environmental processes. Effective responses to these issues require not just scientists but also citizens with a sound understanding of sustainable soil management. Hence, post secondary institutions need to provide students with a strong foundation and core knowledge applicable to the context of current global issues and should focus on creating more innovative curricula in the process. This project aimed to develop an open access web based learning resource, combining problem based learning (PBL) with virtual tours and other multimedia to illustrate soil quality changes brought by various forestry practices used in the Western Cape of South Africa. Two PBL study cases were developed, highlighting the importance of sustainable forestry and impacts to the surrounding ecosystem, focusing on soil preparation treatments and their impacts on soil water dynamics, nutrient supply and their influence on tree growth and health. The incorporation of media with PBL cases enriched student learning, allowing them to gain international perspectives by transcending boundaries and experiencing forests across the globe. The project also facilitated better understanding of dynamic and varied ecosystem functions in new and novel environments as well as the opportunity for students to reflect on how these specific contexts equate or differ from forest ecosystems in their own geographical region. Overall, the project aimed to enhance student engagement with course material and comprehension of a complex material.

\section{Forensic timber identification: the authenticity diagnostics of species using DNA barcode}

\author{
Lichao Jiao ${ }^{1}$ \\ ${ }^{1}$ Wood Anatomy and Utilization Department, Research Institute of Wood Industry, Chinese Academy of Forestry, Beijing, China. Wood Collections \\ (WOODPEDIA), Chinese Academy of Forestry,Beijing, China (jiaolc@caf.ac.cn)
}

Deforestation represents a massive threat to global biodiversity with illegal logging and the associated trade in illegally sourced wood products. Timber identification of tree species is crucial and essential for monitoring and control of illegal activities in timber production and thus enforcement of species trade regulations around the world. Currently, timber identification based on the anatomical features of wood is a well-established science in botany. To improve the 
resolution of wood recognition, we have developed the technical system combined traditional wood anatomy technology with DNA barcode methods together; that is, the identification of wood on the genus level (or to a specific classification under genus) is the first step according to wood anatomical structure; when species identification could not be achieved successfully using wood anatomy method, DNA barcoding will be carried out to make it. In recent less than 10 years, we have demonstrated the application of DNA barcoding method for species discrimination of endangered and precious commercial timber, such as Aquilaria, Dalbergia, Pterocarpus and Santalum. The work is now ready for monitoring of the trade of these valuable resources, and provides an effective approach for wood species identification and product authentication.

\title{
S4a: STUDENT INCUBATOR - 1
}

\author{
Nature conservation challenges in peri-urban landscapes: the case of a protected area in Bengaluru Metropolitan Region, India \\ Harini $K S^{1,2}$, Dhanya $B^{2}$ \\ ${ }^{1}$ The University of Trans-Disciplinary Health Sciences and Technology, Bengaluru, India; ${ }^{2}$ Azim Premji University, Bengaluru, India (harini.pg2@tdu.edu.in; \\ dhanya.b@apu.edu.in)
}

Conservation strategies in India often overlook the complex social- ecological interactions that have historically shaped ecosystems. This study highlights the livelihood and conservation impacts of a recently initiated conservation project in the periphery of India's fastest growing metropolis: Bengaluru. We focus on how the change in legal status of the protected area (PA) from a reserve forest to wildlife sanctuary for conserving endangered vultures, along with urbanization pressures have reconfigured nature- society interactions around the area.We use ecosystem services (ESS) framework to understand the transformations in societal preferences for the PA. Exploratory interactions, participatory mapping and ranking of ESS were conducted in six villages in ecosensitve zone (ESZ) of the PA. Land use changes in ESZ were temporally traced during 2004-2018 using open source data in QGIS platform. The study reveals a shift in use of ESS owing to change in governance status and urbanisation. Provisioning services including forest produce collection and grazing of livestock have declined, while cultural services such as tourism are actively promoted. Local livelihood dependency has shifted from forest based to urbanisation induced opportunities like construction work. Landuse change analysis shows significant changes in rainfed farming to horticulture plantations to cater to urban demand. Land acquisition by government for developmental projects and increasing land values triggered landuse changes. Such changes are impacting the PA in terms of decline of nesting trees and food (animal carcasses) for vultures. The study highlights the necessity of evolving participatory governance paradigms recognising socialecological interactions and feedbacks.

\section{Restoration and indigenous stewardship of (post)fire landscapes: towards co-management and (re)connection to place in Secwépemecul'ecw, Canada}

Sarah Dickson-Hoyle ${ }^{1}$, Secwepemcul'ecw Restoration and Stewardship Society ${ }^{2}$

${ }^{1}$ University of British Columbia, Vancouver, Canada; ${ }^{2}$ Secwepemcul'ecw Restoration and Stewardship Society, British Columbia, Canada (sarahedh@mail. ubc.ca; ceo@srsssociety.com)

Worldwide, recent decades have seen increasing socio-economic and ecological impacts resulting from high severity wildfires. In British Columbia (BC), Canada, 20th century practices of fire suppression and exclusion, coupled with climate change, have resulted in longer and more severe fire seasons. The 2017 and 2018 wildfire seasons burned a record-breaking 2.5 million hectares across the province and disproportionately affected First Nations communities. These impacts catalyzed many communities into action, and the 2018 Provincial Flood and Fire Review recommended establishing equal partnerships with First Nations governments, and incorporating Indigenous knowledge, across all stages of fire management and planning. Along with Canada's current emphasis on advancing reconciliation with Indigenous peoples, this points to a clear need to advance Indigenous-led collaborative approaches to landscape-scale forest restoration and adaptation. Drawing on my developing research with the Secwépemc Nation, I will present the case study of the 2018 Elephant Hill Initiative Agreement as an example of successful government to government collaboration and Indigenous forest stewardship. I will highlight the processes of collaborative decisionmaking between the BC government and the eight Secwépemc communities directly impacted by the 2017 192,000 hectare 'Elephant Hill' wildfire, which have informed principles for post-fire salvage harvesting, reforestation and understory vegetation management. Finally, I will explore how proposed co-management initiatives that have emerged from this collaborative agreement seek to support Secwépemc people in implementing traditional stewardship systems, adaptive management, and forest restoration across Secwépemcul'ecw (the Secwepemc traditional territory), while advancing reconciliation and wildfire resilience.

\section{Management and conservation strategies for Nothofagus forests: landscape scales and factors that determine variations in the assemblage of vascular plants}

Alejandro Huertas Herreral (D), Vanessa Lencinas ${ }^{1}$, Guillermo Martinez Pastur ${ }^{1}$, Juan Manuel Cellini ${ }^{2}$

${ }^{1}$ CADIC-CONICET, Ushuaia, Argentina; ${ }^{2} U N L P$, La Plata, Argentina (alejandrohuertasherrera@gmail.com; mvlencinas@gmail.com;

cadicforestal@gmail.com; cellini@gmail.com)

This work analyses the factors related to environment and human that influence over the assemblage of vascular plant species in timber forests of Nothofagus pumilio and their associated environments of Tierra del Fuego. Analyses used a multi-scale approach that integrated regional, landscape and stand spatial levels. The main results indicated that: (i) At a regional level, although the distinct ecosystems share plant species, the assemblages were significantly different from each other in almost all studied areas, where the influence of climate explained these variations beyond human impacts (e.g. cattle grazing). (ii) At a landscape level, differences observed among environmental gradients (e.g. aspect) and human impacts (harvesting > cattle grazing) were found, and not only the geographical area determines the diversity and plant assemblages, but also the intrinsic properties of the forest environments and associated open environments (forest vs open-lands). (iii) At the stand level, different harvesting schemes (e.g. different levels and types of retention) influenced over the conservation of the understory plants, where vascular plant assemblages remained more similar to primary forests in aggregate retention than in dispersed ones. It was concluded that the exclusion of environments for forestry or cattle use does not guarantee the conservation of all species. The retention approach in each environment must be implemented at spatial scales, e.g. at the stand scale by private or public landowners, or at larger scales by the government through medium-scale reserves or the design of a new network of protected areas. 


\section{LULC dynamics in Mesopotamia: trends and driving factors to validate priority areas for socioecological restoration.}

Victoria E. Espinoza-Mendoza

IDECA - Universidad Maimonides, Buenos Aires, Argentina. CONICET, Buenos Aires, Argentina (espinoza.victoria@maimonides.edu)

Mesopotamia region covering around 20 Mha in Argentina and includes four provinces Buenos Aires, Entre Rios, Corrientes and Misiones. The landscape is dominated by a significant eco-regional gradient from temperate, subtropical forest to wetlands and is composed by seven ecoregions. The aim of the PhD thesis is analyzing and determine multitemporal dynamics related to land use and land change (LULC) for a period of 30 years: (1) deepening on identify proximate and underlying drivers of LULC, (2) establishing trends through the generation of projected regional scenarios by 2050 and (3) propose public - private policy focus on validate priority areas for socioecological restoration. The methodology contains: (1) exhaustive scientific and historic review with data around 500 years to understand the landscape and their historic process of change, (2) supervised classification and interpretation of LANDSAT images for period 1985 - 2015, (3) development and application of a cross-tabulation matrix to calculate transitions in terms of gains or losses and (4) participatory workshops and extensive interviews with stakeholders. Is considered highly relevant the use of spatial tools at all levels to develop the work.

\section{Understanding beneficiaries' needs to improve ecosystem service delivery}

Vasja Leban ${ }^{1}$, Lidija Zadnik Stirn', Špela Pezdevšek Malovrh ${ }^{1}$

'University of Ljubljana, Biotechnical faculty, Department of forestry and renewable forest resources, Ljubljana, Slovenia (vasja.leban@bf.uni-lj.si; lidija.zadnik@bf.uni-lj.si; spela.pezdevsekmalovrh@bf.uni-lj.si)

Current misunderstanding regarding different land and ecosystem service (ES) uses originates also from inadequate consideration of people's actual needs, historical flows of ESs, ecosystem potential to provide relevant ESs and impacts of external drivers on ES allocation. As a consequence, beneficiaries do not experience all potential benefits, natural resources are being under- or over-used and the region's biodiversity is jeopardized. From a theoretical perspective, the solution lies in allocating ESs in an efficient way, where the ecosystems' condition and benefits provided to the ESs beneficiaries are balanced. In this study, we take the position that the current allocation of ESs on a landscape level is primarily subject to interactions between ESs beneficiaries and other land users, historical experiences and related traditional ecological knowledge. Direct users and ESs beneficiaries perceive the ESs and potential benefits differently than regional stakeholders (e.g. regional planners, public service employees), despite their minor role in regional planning. We argue that in a setting with small and heterogeneous land uses, ecosystems are more vital and ESs allocation is more efficient when policy regulations are less restrictive and obligatory. This insight is decisive to design better regional policies, secure sustainable management practices and enhance biodiversity.

\section{Divergence of evapotranspiration after replacement of Eucalyptus regnans with Acacia dealbata in response to climate change and fire}

W.A. Shyanika Lakmali ${ }^{1}$, Richard G. Benyon ${ }^{1}$, Patrick N J Lane ${ }^{1}$, Gary Sheridan ${ }^{1}$

${ }^{1}$ The University of Melbourne, Melbourne,Australia (swasalamuni@student.unimelb.edu.au; rbenyon@unimelb.edu.au; patrickl@unimelb.edu.au; sheridan@unimelb.edu.au)

Climate, fire and vegetation have the potential to produce complex sets of feedbacks. Changes in climate may influence the structure and function of forest ecosystems. A significant intensive cumulative effect of climate change may result in species replacement and vegetation shift. Persistence of Eucalyptus regnans forest in South East Australia is highly vulnerable under increasing climate change. High intensity, multiple interactive fires cause regeneration failures in E. regnans forests, which then allows fast-growing common understorey species (e.g. Acacia dealbata) to dominate over E. regnans. This is a significant species replacement in natural forests in response to changes in climate-driven fire regimes. These forests are water supply catchments; any change in species mix may have significant implications for catchment water yield. However, it is largely unknown what eco-hydrological responses are associated with this climate-related vegetation shift. This study used field measurements of annual evapotranspiration (ET) in sample plots of $E$. regnans and $A$. dealbata aged 10 , 20,35 and 80 years to understand the ecohydrological implications of species replacement. Both species had similar ET during the first 10 years of their life but ET began to diverge by age 20 (lower in acacia), with maximum divergence by age 80 . This difference between species is attributed to differences in sap velocity and sapwood area. Therefore, species replacement in these forests has significant implications for catchment water yield.

\section{Spatio-temporal effects of climate change on southern pine beetle}

Holly L. Munro', Cristian R. Montes ${ }^{1}$, Kamal J. K. Gandhi ${ }^{1}$

IUniversity of Georgia, Athens,USA(hmunro@uga.edu; crmontes@uga.edu; kgandhi@warnell.uga.edu)

Southern pine beetle (Dendroctonus frontalis Zimmerman) (SPB) is an economically and ecologically important bark beetle pest of forest ecosystems. Historically, the range of SPB has been confined to the southeastern United States (U.S.), likely due to temperature constraints. Researchers have expressed concern about future warmer temperatures facilitating the species niche expansion into the northeast U.S. and eastern Canadian Provinces, and this new distribution range may devastate naïve pines lacking defenses against SPB. The objective of this study was to evaluate the effect of temperature on the occurrence of SPB using dynamic models, to allow for further evaluation under future climatic scenarios. The model was built using SPB trap catch data for 2014-2017 and average monthly temperatures for each of the preceding 12 months. Temperature data used in the model were obtained from DAYMET (NASA Earth Data), and future data used for forecasting were obtained from WorldClim. Analyses were performed using a two-step regression approach relying on Akaike Information Criteria for model selection. Our study found 7oC as the February minimum critical temperature needed to support SPB. Thus, temperatures were unlikely to support SPB populations in the lower northeast U.S. until early-1900s. When combined with future temperature scenarios, we hypothesize that all the northeast U.S. and the lower eastern Canadian Provinces will have adequate temperatures to support SPB populations by 2050. Our information may allow forest managers to design management regimes tailored to reduce future outbreaks proactively and provide critical pest management technology for maintaining healthy pine forests. 


\section{Prediction of Eucalyptus grandis chemical compounds in a climate change context using hyperspectral imaging}

Mariana Pires Franco ${ }^{1,2}$, Gilles Chaix ${ }^{2}$, Mario Tomazello-Filho ${ }^{1}$, Cristiane Vidal ${ }^{3}$, Celio Pasquini ${ }^{3}$, Nathalie Gorretta ${ }^{4}$, Jean-Michel Roger ${ }^{4}$ ${ }^{1}$ USP/ESALQ, Piracicaba, Brazil; ${ }^{2}$ Cirad, Montpellier, France; ${ }^{3}$ Unicamp, Campinas, Brazil; ${ }^{4}$ Irstea, Montpellier, France (ma.pires@hotmail.com; gilles. chaix@cirad.fr; mtomazel@usp.br; cristiane.vidal@iqm.unicamp.br; pasquini@iqm.unicamp.br; nathalie.gorretta@irstea.fr;jean-michel.roger@irstea.fr)

The study of wood chemistry to explain the response of trees to climate variation is efficient for retrospective analysis of changes induced in wood during the process of adaptation to seasonal variations. Hyperspectral imaging (HSI) in near infrared could be useful for prediction of several wood chemical components. The objective is understand how water constraints influence wood formation. Wood disks of E. grandis clone from six treatments (100\% and 65\% of rainfall crossed with potassium and sodium fertilizations) were sampled. HSI were obtained on transversal section of the disks using a line scan hyperspectral camera from 1000-2500 nm with a pixel size of 625 x $625 \mu \mathrm{m}$. For calibration, were selected 60 wood solid samples from an Eucalyptus collection, which were measured the total extractive values. HSI of these samples were acquired from transversal section with the same camera. We regressed the mean spectra for each sample with extractives values by Partial Least Square Regression. Due to the model, the total extractives for each pixel to produce an image for the wooden disks were predicted. Based on them, the total extractive distribution according to growth conditions were compared, revealing that trees under stress conditions show a higher heterogeneous chemical profile from the pith to bark. Eucalyptus demonstrates sensitive precipitation variations, with rapid growth and considerable increase in DBH during rainy seasons and the reverse in drought. Consequently, is possible to discriminate different patterns of chemical compound distribution according to the growth conditions.

\section{Alternatives for soil nitrous oxide emission reduction associated to nitrogen fertilization in eucalyptus \\ Mariana $\operatorname{Ibarr}^{1}$ \\ 'Universidade Federal do Paraná, Curitiba, Brazil (marianaibarr@gmail.com)}

The aim was to select nitrogen sources with potential for reduce soil nitrous oxide $\left(\mathrm{N}_{2} \mathrm{O}\right)$ emission under eucalyptus in controlled environment conditions, and from this selection, to evaluate its emission reduction potential under field conditions. Eight nitrogen sources were evaluated in greenhouse over six months Urea and ammonium sulphate sources with nitrification inhibitor dicyandiamide (U-DCD and AS-DCD, respectively) significantly reduced $\mathrm{N}_{2} \mathrm{O}$ emission in relation to conventional source most used in Brazilian forest sector (urea). The same pattern occurred when these sources were evaluated in the field, where U-DCD and AS-DCD had similar cumulative $\mathrm{N}_{2} \mathrm{O}$ emission to soil without nitrogen fertilization $\left(2.55 \mathrm{~kg} \mathrm{~N}^{-\mathrm{N}_{2} \mathrm{O} \text { ha }}{ }^{-1}\right.$ year $\left.{ }^{-1}\right)$, although $\mathrm{U}_{-} \mathrm{DCD}$ had emitted $4.1 \mathrm{~kg} \mathrm{~N}-\mathrm{N}_{2} \mathrm{O}$ ha $^{-1}$ year-1. Besides that, U-DCD and AS-DCD treatments presented emissions two and three times lower than those without inhibitor, urea and ammonium sulfate, respectively. In this sense, it is concluded that urea and ammonium sulfate sources associated with nitrification inhibitor dicyandiamide have potential for reduce soil $\mathrm{N}_{2} \mathrm{O}$ emission from eucalyptus nitrogen fertilization.

\section{Efficiency of biostimulants in promoting Eucalyptus sp. growth under water stress}

Vitor Augusto Cordeiro Milagres ${ }^{1}$, Bruna Sampaio Crivilin ${ }^{2}$, Luiza Belfort ${ }^{3}$

${ }^{1}$ Gerdau Aços Longos, Três Marias, Brazil; ${ }^{2}$ Universidade Federal de Lavras, Lavras, Brazil; ${ }^{3}$ Universidade Federal dos Vales do Jequitinhonha e Mucuri,

Diamantina,Brazil(vitor.milagres@gerdau.com.br; brunacrivilin@gmail.com; luiza.belfort@gerdau.com.br)

Despite the adaptability of Eucalyptus in the diverse Brazilian edaphoclimatic situations, water limitations can affect its development. In periods of drought, the irrigation in more than one application becomes essential in the implantation of a stand, providing the development of the seedlings. However, this operation considerably increases operating costs. Biostimulants have been an alternative in promoting rooting and improving productivity. In this sense, the objective of this work was to compare different biostimulants and irrigation management in the growth of a planting of Eucalyptus sp. The study located in Três Marias, Minas Gerais, under a dystrophic Red-Yellow Latosol, medium sandy texture, was installed in May, the beginning of the dry season. The treatments were two and three irrigations, two irrigations + Fertiactyl Sweet ${ }^{\circledR}(\mathrm{FW})$, two irrigations + KSC PHYT Actyl $1{ }^{\circledR}(\mathrm{KP})$ and two irrigations + Fertiactyl Sweet ${ }^{\circledR}+$ KSC PHYT Actyl 1® (FWKP). Three parameters were evaluated: Height (m), uniformity index PV50 (\%) and distribution of fine roots at 365 days. FWKP obtained the highest growth in height differing statistically from the others. This was the only one that presented a PV50 above the optimal index of uniformity. In all treatments, the highest root density was observed in the $36 \mathrm{~cm}$ layer of the soil, concentration region of at least $47 \%$ of the total roots. It was observed that the higher the tree height, the higher the number of roots in the profile. It is concluded that the use of biostimulants promotes the development of Eucalyptus seedlings on water stress.

\section{Value of physiological assessments for monitoring initial development of Pinus radiata D. Don young plantations under water stress \\ Thiago Wendling Gonçalves de Oliveira1 ${ }^{1}$ Rafael Rubilar ${ }^{2}$, Alex Mauricio Medina ${ }^{3}$ \\ ${ }^{1}$ Universidade Federal do Paraná, Curitiba, Brazil; ${ }^{2}$ Universidad de Concepción, Concepción, Chile; ${ }^{3}$ Florestal Mininco, Los Angeles, Chile \\ (thiago.wgdeoliveira@gmail.com; rafaelrubilar@udec.cl; alex.medina@cmpc.cl)}

This study compares gas exchange response of six Pinus radiata genotypes during a progressive drought period. Experiment was planted in volcanic sands soils in central South Chile. Climate is Mediterranean (Csb) with a mean annual temperature of $14^{\circ} \mathrm{C}$ and $1300 \mathrm{~mm}$ of rainfall. One year old seedlings were submitted to drought by stopping irrigation during maximum atmospheric demand conditions. Weekly gas exchange assessments considering stomatal conductance ( $\mathrm{g}_{\mathrm{s}}$ ), photosynthesis (A), predawn water potential $\left(\Psi_{\mathrm{pd}}\right)$ and leaf area index (LAI) were measured during a month after drought. Statistical analyses showed significant differences in $g_{s}, A$ and LAI, and time was only significant for $\Psi_{\mathrm{pd}}$, which was the best variable monitoring increasing water stress. Nonlinear modeling for $g_{\mathrm{s}}$ $\mathrm{x} \Psi_{\mathrm{pd}}$ showed significant differences by genotype. Our results suggest that specific genotypes decrease $\mathrm{g}_{\mathrm{s}}$ in order to avoid water losses. Modeling for A x $\Psi_{\text {pd }}$ showed that genotypes maintain A rate even when $g_{s}$ is decreasing. Nonlinear modeling between $g_{s}$ and A with LAI showed that genotypes with largest LAI maintain higher values $\mathrm{g}_{\mathrm{s}}$ and A. Physiological responses are an effective way to monitor genotypes stress. Use of this information may help on assessing strategies for early management of forest plantations on critical sites. 


\section{"Flopal" model plantation: creating sustainable values trough qualification of the productive process}

Samara Lazarotto ${ }^{1}$, Rafaelo Balbinot ${ }^{1}$

'Universidade Federal de Santa Maria Campus Frederico Westphalen, Frederico Westphalen, Brasil (samara.fk@hotmail.com; rafaelo.balbinot@gmail.com)

Forestry of the genus Pine is considered as a threat to the Pampa Biome, especially on the southern coast of Rio Grande do Sul. This concept disregards its productive potential, its social and economic importance, and its effective environmental services. The study area is located in the city of Santa Vitória do Palmar - RS and has a total area of 17.000 ha of which 6.727 ha is effective planting of Pinus elliottii Engelm. Thus, the objective of this work is to link production values with conservation values and to develop a qualified production model. The environment studies began in 2015 by means of initiatives like the invasion control of its natural regeneration; experiments with pine hybrids; analysis of soil physical and chemical attributes; forest inventories and analysis of the social impacts of the resin. There are three main phases. First, understanding and characterizing the process of resin production: how it began in Brazil and the state of the art today. Second, diagnosing and identifying the social and economic interactions seeking information directly with the workers. Finally integrate this historical and social information to develop a grid of values that assign production function to the areas of conservation and conservation function for the production areas, within the methodology of the triple bottom line. Achieving this goals, the previous conflict between tree monoculture and environmental conservation can be mitigated. Highlighting the role of good forestry practices to created positive impacts to forest products for a greener future.

\section{Mill dynamics: exploring mill entry and exit patterns in the Southern U.S.}

Nidia Panti ${ }^{1}$, Donald Hodges ${ }^{1}$, Consuelo Brandeis ${ }^{2}$

${ }^{1}$ University of Tennessee, Knoxville, USA; ${ }^{2}$ U.S. Forest Service, Knoxville,USA (npanti@vols.utk.edu; dhodges2@utk.edu; consuelo.brandeis@usda.gov)

Timber is the most valuable commercial commodity taken from most forests. The US South produces approximately 60\% of the Nation's timber products, where the majority is obtained from private forests. U.S. mills were studied using information from the US Forest Service, Forest Inventory and Analysis (FIA) Timber Products Output (TPO) program survey of primary wood-using mills. Surveys were conducted biennially from 2005 to 2017 in 12 southern states and participants included all primary mills varying from sawmills, veneer mills, poles and post production mills. This historical TPO mill information was analyzed using a time to event analysis (survival analysis), controlling for size and other internal and external factors likely affecting its survival. Variables included plant size, plant structure (single-firm or multi-firm), mill consumption capacity, county demographics, etc. In terms of size and structure, studies have shown that larger plants are less likely to close while multi-firm plants are more likely to close. Competition is also another factor which has shown a positive influence on plant closure. We also studied how the changes in mill numbers and distribution affect wood procurement patterns. Studies indicate that plants aim to minimize the transportation costs for inputs which in turn determines the optimal location of the mills. Other studies also suggest that there is an increasing trend of industrial concentration regardless of economic influences.

\section{How policies and market incentives have affected the expansion of planted forests in Brazil?}

Manuela Czinar

IImperial College London,London,United Kingdom (m.czinar@imperial.ac.uk)

The objective of this study was to identify the main policies and market incentives that have affected the expansion of planted forests in Brazil. The methods used included literature review and the interview of nineteen stakeholders during field work in 2017. It was possible to identify four distinctive phases in the evolution of planted forests in the country. The first phase of 'policy-driven expansion' occurred between the 1960s and 1980s, when the Brazilian government has imposed to the steel industry to move away from charcoal from natural forests and has given tax rebates for reforestation projects. The second phase was the 'policy-driven collapse' when tax rebates were abolished and planted area fell as a consequence. The market-driven phase started in the early $2000 \mathrm{~s}$ when commodities prices faced a strong upside following the strong Chinese demand. On the other hand, similar reasons resulted in the 'market-driven collapse' of the late 2000s, when the planted forest area stagnated and even reduced in some regions because of the strong reduction in prices caused by the global economic crisis, the Brazilian political turmoil and the increase of the steel production capacity in China. Based on the historical experience, this study argues that the next expansion phase should be both market and policy driven, otherwise Brazil risks to repeat the same mistakes of the past.

\section{Determining the potential contribution of utilising forest biomass resources for bioenergy production and climate change mitigation in Queensland, Australia}

Sam Van Holsbeeck ${ }^{1}$

${ }^{1}$ University of the Sunshine Coast, Maroochydore, Australia (svanhols@usc.edu.au)

By 2020 the Australian government anticipates 23.5\% of its total energy will be derived from renewable energy sources. Forest biomass has proven its potential as climate change mitigating renewable in other continents and are identified as a large potential contributor of biomass for renewable energy to replace fossil fuels in Australia. However, the share of forest biomass contributing to the total bioenergy production in Australia remains unknown. With the help of the Australian Renewable Energy Mapping Infrastructure (AREMI), this research will determine the potential contribution of utilising forest biomass for bioenergy production and climate change mitigation in Queensland, Australia. The study aims to (1) provide information on the available energy in forests in Queensland, (2) optimise the location of power plants, and (3) simulate the cost and emission balance of using forest biomass resources for bioenergy and impacts on climate. And exclusion and suitability analysis in GIS identified 13.5 million hectares of harvestable forest with a theoretical forest biomass potential over 1 million dry metric tonnes per year. A GIS decision support system was developed to define strategic and tactical locations for power plant and to evaluate existing plant-locations based on biomass availability, capacity, transport distance and plant quantity. A total of 138 tactical location are then used to simulate supply chain costs and related emissions using mixed integer programming in Python. The developed GIS-Python decision support tool will help Australian industry, investors and governments in the design and implementation of forest biomass for bioenergy supply chains. 
Wood use in traditional toy-making in Channapatna: resource conservation and livelihood implications

Samudyatha Ramananda ${ }^{1,2}$, Dhanya Bhaskar ${ }^{2}$

${ }^{1}$ The University of Trans-Disciplinary Health Sciences and Technology, Bengaluru, India; ${ }^{2}$ Azim Premji University, Bengaluru, India

(samudyatha1096@gmail.com; dhanya.b@apu.edu.in)

The famous wooden toy crafts of Channapatna in Karnataka employing over 5000 artisans is heavily dependent on Wrightia tinctoria (ivory wood), a common native tree species in farmlands. Our study focuses on the sustainability of wood resource use in the handicrafts industry. The industry had faced stiff competition from cheaper imported toys, but was revived recently by a Geographical Indication tag. In the context of recent boom and bust phases of the industry, we investigated the trends in use and status of ivory wood. We used diverse methodological approaches including Focus Group Discussions and Semi-Structured interviews with artisans, tree-growing farmers and saw mill owners supported by ecological assessment of ivory word populations in farmlands. Our analysis indicated more than $90 \%$ dependency of artisans on ivory wood followed by Tectona grandis (60\%), Ficus amplissima (40\%) and Dalbergia latifolia (35\%) as alternative wood sources. Substitution though possible, comes at a huge social cost of depriving poor sections of the resource. Farm assessments shows few trees in mature size (above $20 \mathrm{~cm}$ ) and age classes (above 10), and low tree to sapling ratio indicating intensive extraction and unsustainable harvesting. Higher tree density was found closer to protected forests, indicating the critical role of the Forest Department in maintaining healthy populations of Wrightia in forests to promote tree growth in farmlands. The study further provides recommendations to promote sustainable use of this lowcost resource to sustain artisanal livelihoods.

\section{Physiochemical properties of bio-oil from the pyrolysis of Pinus caribaea (Morelet) Needles in Southwest, Nigeria \\ Popoola Ayodeleola ${ }^{1}$ \\ ${ }^{1}$ University of Ibadan, Oyo, Nigeria (ayodeleolapopoola@gmail.com)}

The objective was to investigate the physical and chemical properties of Bio-oil from the pyrolysis of Pinus caribaea Needles obtained from an urban environment in Southwest, Nigeria. Pine Needles were collected from a felled tree and it was ground to $6 \mathrm{~mm}$ particles. Approximately $4.92 \mathrm{~kg}$ of pine needles was oven dried at $103^{\circ} \mathrm{C}$ until constant weight was obtained to determine the moisture content; $820 \mathrm{~g}$ of shredded pine needles was loaded into the vacuum pyrolysis chamber reactor at $600{ }^{\circ} \mathrm{C}$ and $700^{\circ} \mathrm{C}$ in triplicates. Physico-chemical analyses of the Bio-oil were achieved through carbon-hydrogen-nitrogen-sulfur (CHNS) studies, Calorific Values, Fourier transform-infrared (FT-IR) spectroscopy and Gas chromatography-mass spectrometry (GC-MS) through standard procedures such as American standard for Testing and Materials (ASTM). The physical properties such as density, pour point, fire point and flash point agreed with the typical values of conventional fuels and the result from the GC-MS spectrum indicates mostly aromatic hydrocarbons (phenolic in nature) and some aliphatic compounds also. From FT-IR analyses, it can be deduced that there is a larger amount of saturated compounds. The knowledge of chemical composition will aid its use as fuel and as raw material in chemical industries. The results also showed promising indication that Bio-oil from Pinus caribaea needles has high potentials for fossil fuel substitution.

\section{Perspectives of productive conservation: situational status of agrobiodiversity in the Mariño Micro-Basin, Apurimac, Peru \\ Marianella Crispin Cunya ${ }^{1}$ \\ ${ }^{1}$ Universidad Nacional Agraria la Molina-Unalm, Lima, Peru (20161595@lamolina.edu.pe)}

The conservation of local cultivated biodiversity is an issue that is becoming increasingly important among decision makers, academy, civil society and mainly those directly involved in conservation. The approach involves an adequate analysis of the image of the territory where a socio-agricultural profile is adequately developed, identifying characteristics of the study area, which allows the construction of an agricultural identity, identifying the variety of existing native species, analyzing the role of women and of family members in the conservation of cultivated biodiversity. It is worth noting, not to forget that climate change exists and therefore the impacts are escalating more and more, where the first affected are the main actors in productive conservation. It is important to mention that if you do not act on time, not only run the risk of losing native species but also their genetic content as national heritage and affecting food security mainly of directly related producers and Peruvian population. This research shows how an image of territory could be constructed from an adequate schematization of productive conservation and identifying the own variables of the study area, which can be considered as a model and starting point for the formulation of conservation policies in different territories where agrobiodiversity or cultivated biodiversity are developed.

\section{Zoning of green infrastructures to reduce the runoff volume and mitigate the vulnerability to flood in Páez river basin, Cartago, Costa Rica}

Kevin Alfaro-Jiménez ${ }^{1}$

'Instituto de Investigación y Servicios Forestales (INISEFOR), Heredia, Costa Rica (kevin15aj@gmail.com)

The change of more than a third of the terrestrial ecosystems has unbalanced the regulatory and stabilizing capacity of the environment, increasing the vulnerability to flooding in urban and peri-urban environments. Forest management has advanced in silvicultural practices that take advantage of the water regulation capacity of vegetative structures. The green infrastructure (GI) is an approach to restoring urban and peri-urban areas, which integrates the multifunctionality of the landscape and takes advantage of the properties of the vegetation, to improve the retention capacity of the river basin. The study was in the Páez River sub-basin and presents a new methodology for the determination of the development zones of GI, in order to reduce the volume of runoff and mitigate the floods. The effect of GI on the surface runoff of the landscape was verified through a hydrological modeling. The scene of GI proposed, reduced the runoff between $14 \%$ and $5 \%$ at the sub-basin scale, and up to $44 \%$ at the micro-basin scale, consequently, it generates less vulnerability to flooding.

The state of the art in research and development of agroforestry systems in Colombia / Evaluación del estado del arte de la investigación y desarrollo sobre sistemas agroforestales en Colombia

Maria Riaño, Paula Alejandra Alba Martínez

'Universidad Distrital Francisco José de Caldas, Bogota D.C., Colombia (mfrianop@gmail.com; pau.alba.m@gmail.com)

El propósito de la investigación es identificar hasta donde se ha avanzado en las temáticas agroforestales del país por medio de la crítica y el uso de publicaciones de manera ordenada, precisa y analitica. El conocimiento del estado del arte, la seriedad en términos de publicación, justificación con datos de respaldo, aceptación, entre otros; y la rigurosidad de la investigación en los sistemas agroforestales no lo hacemos únicamente con la finalidad de hacer investigación. 
La importancia de esta revisión resulta en brindar una herramienta básica para avanzar en la práctica; abre las puertas a la inspiración y difusión de nuevas ideas, poniendo sobre la mesa las contradicciones en los conocimientos actuales. Este proyecto posibilita la evaluación de las prácticas vigentes y formulación de recomendaciones. Por medio de una recolección de documentos se hará la organización inicial de los mismos de categorías conceptuales con el fin de determinar la saturacion teórica en el tiempo, una codificación axial y selectiva de la información y finalmente, estará la generación de una matriz condicionada para delimitar la teoría que ponga en evidencia el vacío de información en el campo de investigación de los sistemas agroforestales con base en un grupo de conceptos de alta abstracción. =

\section{Volatile monoterpene 'fingerprints' of resinous Protium tree species in the Amazon Rainforest}

Luani Rosa de Oliveira Piva1, Kolby Jardine ${ }^{2,3}$, Bruno Oliva Gimenez ${ }^{2}$, Ricardo de O. Perdiz ${ }^{2}$, Leticia O. Cobello ${ }^{2}$, Carlos Roberto Sanquetta ${ }^{1}$, Niro Higuchi ${ }^{2}$, Jeffrey Chambers ${ }^{2,3}$

${ }^{1}$ Federal University of Paraná, Curitiba, Brazil; ${ }^{2}$ National Institute for Amazon Research, Manaus, Brazil;; ${ }^{3}$ Lawrence Berkeley National Laboratory, Berkeley,USA lluanipiva@yahoo.com.br; kjjardine@lbl.gov; bruno.oliva.gimenez@gmail.com; ricoperdiz@gmail.com; cobelloleticia@gmail.com; carlossanquetta@gmail.com; higuchi.niro@gmail.com; jchambers@lbl.gov)

Volatile terpenoid resins represent a diverse group of plant defense chemicals involved in defense against herbivory, abiotic stress, and communication. However, their composition in tropical forests remains poorly characterized. As a part of tree identification, the 'smell' of damaged trunks is widely used, but is highly subjective. Here, we analyzed trunk volatile monoterpene emissions from 15 species of the genus Protium in the central Amazon. By normalizing the abundances of 28 monoterpenes, 9 monoterpene 'fingerprint' patterns emerged, characterized by a distinct dominant monoterpene. While 4 of the 'fingerprint' patterns were composed of multiple species, 5 were composed of a single species. Moreover, among individuals of the same species, 6 species had a single 'fingerprint' pattern, while 9 species had two or more 'fingerprint' patterns among individuals. A comparison of 'fingerprints' between 2015 and 2017 from 15 individuals generally showed excellent agreement, demonstrating a strong dependence on species identity, but not time of collection. The results are consistent with a previous study that found multiple divergent copies of monoterpene synthase enzymes in Protium. We conclude that the monoterpene 'fingerprint' database has important implications for constraining Protium species identification, phylogenetic relationships and enhancing understanding of physiological and ecological functions of resins and their potential commercial applications.

\section{Class Insecta as bioindicators of ecological restoration in the Brazilian Ombrophilous Dense Montana forest}

Taise Cristina Plattau Arenhardt ${ }^{1}$, Marcelo Diniz Vitorino², Sebastião Venâncio Martins

${ }^{1}$ Universidade Federal de Viçosa, Viçosa, Brazil; ${ }^{2}$ Universidade Regional de Blumenau, Blumenau, Brazil (taise.arenhardt@hotmail.com;

dinizvitorino@gmail.com; venancioufv@gmail.com)

Insects are not a common bioindicators to evaluate ecological restoration in Brazil. However, these organisms have many advantages as bioindicators, and can be used in the characterization of different successional stages during the ecological restoration process. In this study, we investigated leaf litter insect fauna in different degraded areas by pastures submitted to ecological restoration from different techniques. We compared the litter fauna from a preserved forest and a natural regeneration area with our restorations sites to identify insect diversity during this process. Fauna was sampled with pitfall traps in the period of April/2017 until December/2018. The study area is located in Serra do Itajaí National Park in the Santa Catarina state, southern Brazil. To compare the areas, parameters of richness, abundance, diversity, equability, similarity, univariate and multivariate analyzes, species indicators indices and correlations with microclimatic variables and plant community were used. Analysis of taxonomic sufficiency was also performed (Insecta families and Formicidae species). From the results, we conclude that less specific taxonomic levels (family) allow us to observe and interpret the differences resulting from changes in ecological succession during the restoration process. The structure of the insect community was influenced by vegetation structure and microclimate. We identified indicative families and species of the different restoration process stages (for example, Ptiliidae, Staphylinidae and Leiodidae for advanced stages and Cicadellidae and Delphacidae for initial stages). In this context, they are organisms that can be used in the monitoring of the ecological restoration stages and basis for decisions making regarding restoration strategies.

\section{Mixed forests of Nothofagus pumilio and $N$. betuloides: are they stable? Approximation based on the study of the first stages of natural regeneration cycle}

Mónica Toro Manriquez, Rosina Soler ${ }^{1}$ (D), María Vanessa Lencinas, Guillermo Martínez Pastur

${ }^{1}$ Centro Austral de Investigaciones Cientificas CADIC-CONICET, Ushuaia,Argentina (monicatm@cadic-conicet.gob.ar; rosisoler@yahoo.com.ar;

mvlencinas@gmail.com; cadicforestal@gmail.com)

Flowering, seeding, seedling are a paramount process for tree regeneration, forest conservation and management. In mixed forests, the impact of limiting (biotic and abiotic) factors on tree reproductive success regulate the maintenance of species in balanced proportions or the conversion towards monospecific forests. Tree reproductive phenology were studied in three forest type (pure deciduous Nothofagus pumilio, pure evergreen Nothofagus betuloides and mixed forests) considering two location (coast and mountain), during three years in Tierra del Fuego, Argentina. The incidence of different loss factors (e.g., premature abortion, fruit, seed predation) was evaluated. Flowering and seeding varied interannually for both species for forest type. Both species showed advantages in pure forests than in mixed forests. A strong effect of location on seeding and in losses factors were detected. The main limiting factor in flowering results in empty seeds due to the pollen self-incompatibility. Premature abortion was associated with extreme climatic events (e.g., late frosts). $N$. pumilio presented in general higher losses associated with seed foraging and stratification losses in $N$. betuloides. Finish for each cycle, the seedling proportion was higher for $N$. pumilio in the mountains and coast than for $N$. betuloides. $N$. pumilio presents a better probability of transition than $N$. betuloides in the mixed forest. Therefore, in mixed forests the tendency would be to be non-stable forests. This study contributes to an understanding of the possible roles of reproductive phenology for detecting shifts in forest communities between pure and mixed forests under natural dynamics and the current climate change.

\section{Leaf wax abundance and distribution in vegetation and soils from a South American Temperate Forest}

Carol Cerda-Peña ${ }^{1}$, Sergio Contreras ${ }^{1,2}$, Eduardo Tejos ${ }^{1}$

${ }^{1}$ Universidad Católica de la Santísima Concepción, Concepción, Chile; ${ }^{2}$ University of Pittsburgh, Pittsburgh, USA (carolpecer@gmail.com; scontreras@ucsc.cl; edutejos@gmail.com)

Leaf wax compound classes (i.e long chain alkanoic acids and alkanes) from plants are naturally deposited in soils and sediments, where abundance and 
distribution have been used as a vegetation and terrestrial biomarkers. This study compares the leaf wax from dominant plant temperate forest community ( $\mathrm{n}=178$ individuals) and soils collected in 9 sites at the Andean part of the South-Central American temperate forest. The leaf wax fingerprint of the plant community is heterogeneous, with significant differences in alkanes abundance and distribution and only in abundance for alkanoic acids between sites ( $\mathrm{p}<0.05$ ). The plant community of the forest has a major abundance of alkanoic acids than alkanes with significant differences $(\mathrm{p}<0.001)$ between the compound classes, with the same pattern observed in the soil. Considering the abundance and distribution of both leaf waxes and all sampled sites only alkanoic acid abundance is not significantly different between plant community and soil. The mean distribution of alkanoic acids from the plant community and soils in each site are similar, with higher values in plant than soils. However, alkane distribution showed different results, with higher values in soils than in the plant community, observing some sites with almost two units of difference. These results provide valuable information of leaf wax composition from temperate forest in South America. Moreover, the observed patterns suggest that alkanoic acid abundance and distribution in modern leaves from the temperate forest community are reflected in soils and therefore are useful as a vegetation biomarker in the area. 


\section{AUTHOR INDEX}

\begin{tabular}{|c|c|c|}
\hline Aaltonen, H., 231 & Addo-Danso, S., 656 & Akama, A., 658, 674 \\
\hline Aarne, M., 63 & Adeagbo, A. A., 226 & Akashi, N., 496, 529, 544 \\
\hline Abad, J., 589 & Adegeye, A., 632 & Akay, A. E., 53, 350 \\
\hline Abad, J. M., 305, 598 & Adenesky Filho, E., 162 & Akinyele, A., 309, 311, 424, 518 \\
\hline Abaker, W., 111, 660 & Adeyemi, O., 140 & Akpagana, K., 432 \\
\hline Abanto-Rodriguez, C., 276, 278, 279, 291, 292 & Adeyiga, G. K., 171 & Akpalu, S., 31 \\
\hline Abarzúa, A., 238 & Adhikari, S., 104, 703 & Akpona, H., 465 \\
\hline Abasse, T., 502 & Adi, D. S., 346 & Akurugoda, I., 125, 142 \\
\hline Abbas, D., 23, 52, 53, 350, 364, 417, 686 & Adnan, S., 205 & Alba, E., 235, 236 \\
\hline Abbasi, A., 655 & Adolt, R., 62 & Albaugh, T., 337, 366, 368 \\
\hline Abdo, M. T. V., 498 & Adorno, B., 617 & Alberdi, I., 62 \\
\hline Abdo, Z., 565 & Adu-Bredu, S., 656 & Albernaz, W., 419 \\
\hline Abdollahi, K., 69, 460 & Aeschlimann, C., 288, 388 & Albiero-Júnior, A., 238 \\
\hline Abe, H., 431, 673 & Affleck, D., 534 & Albrecht, A., 570 \\
\hline Abebe, B., 633 & Afonso, C., 316 & Albrecht, R. P., 690 \\
\hline Abekah, R. B., 39 & Afonso, R., 469 & Albrectsen, B., 567 \\
\hline Abel, E. L. da, 32, 164 & Afonso, S., 463 & Albrich, K., 703 \\
\hline Abelleyra, D. de, 523 & Afonso, S. R., 421, 465, 648 & Albuquerque, F. S., 397 \\
\hline Abib, T. H., 214 & Africa, D. R., 641 & Albuquerque, R., 60 \\
\hline Abibu, A., 91 & Aga, V., 284 & Albuquerque, R. P., 178 \\
\hline Abiyu, A., 237 & Agarwal, S., 130 & Albuquerque, S. V. de, 46 \\
\hline Abreu, A. H. M. de, 32, 164 & Agathokleous, E., 569 & Alcantara, M. A. M., 511, 512, 513 \\
\hline Abreu, G. C. F., 278 & Ager, A., 341 & Alday, M. T. de, 168, 670 \\
\hline Abreu, I., 186 & Aggarwal, S., 94, 144 & Alechandre, A., 136, 260, 527 \\
\hline Abreu, J. C. de, 534, 536 & Agostinelli, M., 567 & Alecio, P., 176 \\
\hline Abreu, M. L. de, 160 & Aguiar, A., 316 & Aleinikovas, M., 425, 472 \\
\hline Abreu-Junior, C. H., 181, 637 & Aguiar, A. L. da, 161 & Aleixo, C., 551 \\
\hline Abt, K., 445 & Aguiar, A. V. de, 47, 48, 51, 174, 179, 269, 270, & Aleksandrowicz-Trzcińska, M., 589 \\
\hline Abt, K. L., 385 & & Alekseev, A., 203, 400 \\
\hline Abt, R. C., 385 & Aguiar, D. L., 420 & Alem, B. B., 491 \\
\hline Acevedo, M., 166, 488 & Aguiar, M. de, 694 & Alén, R., 417 \\
\hline Aceves, T. T., 448 & Aguiar, N. V., 555 & Alencar, A., 523, 525, 628 \\
\hline Achard, F., 603 & Aguiar, O. J. de, 289, 313 & Alessi, N., 158 \\
\hline Acheampong, E., 131 & Aguilar, F., 445, 628 & Alexander, S., 462, 530 \\
\hline Achim, A., 238, 419 & Aguilar, I., 173 & Alexandrov, A., 677 \\
\hline Acho, C., 260 & Aguilar, L. A. O., 65 & Alfaro, K., 628 \\
\hline Acil, N., 194 & Aguilar, M., 146, 335 & Alfaro, M., 662 \\
\hline Acker, J. V., 296, 345, 460, 471 & Aguilar-Palma, N., 33 & Alfaro-Jiménez, K., 709 \\
\hline Ackerman, P., 364 & Aguilera, I., 243 & Alfenas, A., 579 \\
\hline Acosta, M., 202 & Aguilon, D. J., 519 & Alfonso, M., 507 \\
\hline Acuna, M., 333, 364, 417, 423 & Aguirre, P., 173 & Ali, F., 511 \\
\hline Acuña, B., 40 & Ahlström, M., 217 & Alia, R., 18, 507 \\
\hline Acuña, M., 362 & Ahtikoski, A., 394, 469 & Alía, R., 511 \\
\hline Adaja, A., 454 & Ahumada, R., 577 & Alice, F., 193 \\
\hline Adams, C., 59 & Aires, N. M. V., 625 & Alivernini, A., 181 \\
\hline Adams, M. B., 464 & Aitken, S., 16, 19, 444 & Alizoti, P., 159, 504 \\
\hline Adamson, K., 443 & Aizawa, M., 671 & Allen, C., 193 \\
\hline
\end{tabular}


Allen, L., 337

Allison, J., 607, 623

Allmanova, Z., 191

Alloysius, D., 155, 447

Almado, R., 316

Almado, R. de, 449

Almario, N. P., 271, 272, 422

Almeida, C., 212, 317, 324, 532

Almeida, C. C. F., 420

Almeida, C. de, 393

Almeida, D., 490, 526

Almeida, E., 136, 324

Almeida, J. G. de, 415

Almeida, J. R. da, 235

Almeida, J. S., 313

Almeida, L., 121

Almeida, L. F., 663

Almeida, M., 315, 321

Almeida, M. H., 216

Almeida, M. P. de, 108, 136

Almeida, R., 43, 294, 298, 300, 309, 421

Almeida, R. G. de, 289

Almeida, S. A. de, 415

Almeida, T., 207

Almqvist, C., 443

Aló, L., 644

Aló, L. L., 389

Alonso, C. O., 300

Alonso, J. M., 32, 164

Alonso, R., 252

Altamirano, R. A., 467

Altoé, T., 361

Alvarado, L. F., 28

Alvares, C., 337

Alvares, C. A., 181, 315, 316, 321, 323, 368, 637, 662

Alvares, V., 526

Alvarez, A., 69

Alvarez, D., 632

Alvarez, I., 625

Alvarez, J., 54

Álvarez, J., 27

Alvarez Aquino, C., 312

Álvarez González, J. G., 701

Alvarez Romero, J., 33

Alvarez-Dávila, E., 217

Alves, A., 575, 577, 579

Alves, F., 294, 298, 300, 309
Alves, F. L., 614

Alves, F. V., 289

Alves, G. F., 289

Alves, H., 313

Alves, J. U., 438

Alves, M., 55

Alves, M. A. S., 700

Alves, M. de, 41

Alves, P. F., 511, 512

Alves, R., 494

Alves, R. C., 46, 57

Alves, T. C. V., 161

Amacher, G., 57

Amanzi, N., 71, 132

Amaral, A., 532

Amaral, C., 213, 234

Amaral, C. H. do, 219, 348, 399

Amaral, J., 577, 579

Amaral, P. N. C. do, 289

Amaral, R., 68

Amaral, W., 103

Amaral Neto, M., 81, 103, 106

Amare, D., 35

Amarilla, S. M., 147

Amarillo, G., 294

Amaro, M., 261, 272, 397, 691

Amato, G., 630

Amatya, S., 433

Amaya-Corredor, P., 621

Amazonas, N., 490, 560

Ametsitsi, G., 656

Amissah, L., 656

Amm, A., 151

Ammer, C., 217

Amorim, L., 501

Amorim, P., 437, 691

An, J. Y., 197, 644

Anarna, J. A., 499

Anatol'evich, T. V., 185

Anav, A., 172, 181, 254

Anderbrant, O., 556

Andersen, H., 189

Anderson, L. O., 528

Anderson, N., 52, 122, 341, 347

Anderson-Teixeira, K., 217

Andersson, E., 85, 138

Andianto, A., 346

Andini, S., 418
Andrada, R. I., 125

Andrade, A., 76

Andrade, D. F. C. de, 230

Andrade, E., 576

Andrade, F. B. de, 513

Andrade, G., 41

Andrade, G. de, 297, 563

Andrade, H., 321

Andrade, I., 361

Andrade, J. A., 512

Andrade, M., 213

Andrade, M. M., 363, 403

Andrade, P., 246

Andrade, R. A. de, 73, 478

Andrade, V., 165, 183

André, A. C., 161, 162

André, F., 250

André, T., 207

Andreae, H., 200

Andreote, F. D., 659

Andres, K., 409

Andrés-Domenech, P., 301, 680

Angeles, G., 651

Angelis, M. de, 418

Angelo, D. H., 70

Angelo, H., 57

Ângelo, A. C., 46, 626

Angelstam, P., 143

Angst, F. A., 557

Anguita, P. M. de, 38, 678

Anguruwa, G. T., 424

Anholetto Junior, C. R., 80, 82, 160, 242

Anhuf, D., 178

Anjos, R., 578

Anna, B., 127

Annisa, C. N., 94

Anthelme, F., 651

Antkowiak, P., 199

Antoniazzi, L., 470

Antonio, G. L., 564, 565

Antonowicz, A., 684

Antunes, D., 545

Antunes, G. M., 625

Aoyama, M., 673

Aparício, P. da, 534

Aponte, A. E. C., 144, 384

Aponte, C., 204, 655

Apostol, E., 208, 250 
Apostol, E. N., 510, 522

Appiah, M., 656

Appiah-Kubi, E., 427

Applegate, G., 467, 468

Apud, E., 340, 343

Ara, M., 337, 611

Aracil, S. G., 536

Aragão, L., 380

Aragão, L. E., 212, 528

Aragón, S., 207

Arai, E., 390, 394, 528

Araki, H., 71, 403, 610

Araki, Y., 675

Araldi, E. P., 50

Araminiene, V., 569

Arango, F. B., 372

Araujo, E., 316

Araujo, M., 71

Araujo, R. D. de, 434, 435, 436

Araujo, V., 621

Araújo, A. C. C., 275

Araújo, E., 110

Araújo, J. B. C. N., 286

Araújo, M. da, 671

Araújo, M. I., 51, 160

AraÚjo, R. da, 272

Araujo-Murakami, A., 217

Aravanopoulos, F., 173, 504

Aravanopoulos, F. A., 157, 505

Arcalá, L. F., 386

Arcangeli, C., 400

Arce, J. E., 689

Arco-Verde, M. F., 29, 31, 329

Arenhardt, T. C. P., 162, 710

Arevalo, H. G., 278, 292

Arevalo, W. F. G., 278, 292

Arévalo, W. F. G., 276, 279, 291

Arévalo-Gardini, E., 276, 291

Arevalos, F., 523

Arfaoui, M., 463

Argerich, A., 647

Arguedas, M., 579

Arguelle, W. T., 68

Ariffin, A. K., 310

Arih, A., 143

Armacolo, N., 610

Armacolo, N. M., 226, 300

Armston, J., 189, 382
Arndt, S., 575

Arndt, T., 481

Arnold, R. J., 277

Aronson, M., 550

Arora, G., 227

Arora-Jonsson, S., 130, 131, 132

Arriagada, R., 79

Arrivabeni, B., 358

Arroyo, L., 217

Arroyo-Vargas, P., 489

Arruda, N. L. F. V., 412

Arruda, V., 523

Artati, Y., 418

Arteaga Nuñez, M., 616

Arthur Junior, J. C., 637, 662

Arthur Neto, , 361

Arts, B., 132

Aruga, K., 382, 445

Arvola, A., 135

Asadi, F., 267

Asante, B., 418

Asare, A., 317, 611

Asare, R., 131

Asbeck, T., 600

Asbjornsen, H., 262, 680

Ascorra, C., 260

Asfa, R., 586, 587

Ashkenas, L., 647

Asi, E., 200

Asiegbu, F., 565

Asinwa, I., 632

Assad, L. T., 119

Assal, T., 238

Assede, E. S. P., 90

Assédé, S. P. E., 91

Astorino, A., 290, 651

Astrid, M., 549

Asubonteng, K., 133

Ata, J., 443, 489, 519

Ata, J. P., 467

Atakpama, W., 432

Atar, D., 538

Atero, N., 587

Atkinson, B., 200

Atkinson, M., 33

Atmadja, S., 129, 244

Attia, A., 255

Atyi, R. E., 447
Atzberger, C., 604

Auer, C. G., 563

Augustaitis, A., 170, 368

Augusti, J. C., 481

Augustin, F., 464

Augustynczik, A., 19

Augustynczik, A. L. D., 486

Aulló-Maestro, I., 360

Aung, A., 40, 295, 644, 671

Aussenac, R., 379, 402

Autio, M., 474

Avanzado, M., 229

Avelino, L. T., 339, 351, 352

Avila, A. L. de, 153, 701

Avila, P. A. de, 668

Ávila, M. L. de, 167

Ávila, P. A. de, 636

Avitabile, V., 62

Avramidou, E., 173, 504

Awono, A., 120, 447

Axelsson, P., 155, 217

Ayala, G. T., 45

Ayala, L., 64

Aylward, J., 595

Aymerich, J. P. M., 449

Ayodeleola, P., 709

Azeez, I., 91

Azevedo, C. P. de, 160, 161, 229, 669

Azevedo, G. B. de, 460

Azevedo, G. T. de, 460

Azevedo, T., 522, 524, 525

Azevedo-Ramos, C., 57, 92, 103, 114, 135, 137, 140, 436, 628

Azihou, A. F., 409

Azihou, F. A., 90

Azizi, R., 211

B, D., 705

Babalola, F. D., 72, 89, 95, 140, 610

Baber, K., 472

Babili, I., 340

Babst, F., 236

Bach, C., 659

Bachega, L., 650

Back, S., 182

Badan, P., 424

Badea, O., 171, 181, 204, 208, 250, 254, 510

Bader, M., 197

Badola, R., 538, 676 
Bae, P. B., 310

Baetens, J., 471

Baez, M. A. M., 458

Baggio, G., 109

Baggio, T., 42

Bagley, J., 187

Bagnoli, F., 511

Bahamodez, C., 38

Bahamondez, C., 60, 61, 228, 332, 496

Bahia, M. A. M., 219

Bahn, M., 208

Bahýl', J., 115, 288

Baidhani, M., 574

Bailey, L., 653

Bailey, T. G., 156

Baillie, B., 457

Baird, A., 263

Baison, J., 172

Bajc, M., 157, 504, 505

Bakalov, Z., 677

Baker, P., 154, 199, 232, 377, 488

Baker, T., 24, 28

Baker, T. R., 217

Bal, T., 686

Bala, P., 45

Balabasciuc, M., 177

Balasso, M., 411

Balatibat, J. B., 467

Balbinot, C. F., 67

Balbinot, R., 77, 708

Balboni, B. M., 420

Baldi, P., 503

Baldin, E. L., 451

Baldoni, A. B., 328

Baldwin-Cantello, W., 606

Bałęczny, W., 420

Balieiro, C., 60

Balieiro, F., 610, 644, 645

Balikova, K., 679

Balkovic, J., 117

Ballarin, A., 417

Ballian, D., 326, 505, 506

Balmelli, G., 173, 548, 584

Baloch, F. S., 511

Balogh, P., 681, 691

Baloh, T., 144

Balsi, M., 378

Balzani, C., 523
Balzarini, M., 158, 302, 398

Banchero, S., 523

Bandara, K. M. A., 277

Bandeira, E., 690

Bandeira, J., 76

Bandeira, L. F., 328

Bandeira, S. O., 626

Bandiera, S., 537

Bannister, J. R., 166, 488

Banos, V., 488

Baptista, M., 65

Baptiste, B., 28

Baral, H., 37, 418, 446, 493, 639

Baranchikov, Y., 25

Barbas, E., 504

Barbati, A., 282, 300, 378

Barbeito, I., 337

Barber, P., 574

Barbieri, R., 648

Barbosa, A. C. O. F., 328

Barbosa, L., 441

Barbosa, L. R., 449, 452, 582

Barbosa, M. de, 539

Barbosa, R. A., 665

Barbosa, R. C., 102

Barbosa, S. G., 348, 665

Barbour, J., 75, 348

Barbrook, J., 573

Barcena, A., 507

Barcza, Z., 375

Bardon, R., 696

Baréa, A. R., 460

Barigah, T. S., 175

Barka, I., 676

Barletti, J. P. S., 115

Barlow, J., 609

Barlow, R., 530

Barnard, T., 369

Barnes, G., 15

Barnes, I., 442, 454, 515, 581, 597, 598

Barnett, T., 102

Barona, C. O., 65

Barotto, A. J., 175

Barraza, G. Q., 299, 534

Barraza, V., 60

Barré, J., 402

Barreira, A. P., 545

Barreira, S., 219, 289, 306, 393, 410, 431, 514,
617, 625

Barreiro, S., 200, 409, 446, 468, 583

Barrera, F. L., 448

Barrero Medel, H., 87, 278, 309

Barreto, T., 560

Barrett, G., 600

Barrette, J., 464

Barretto, V. C. de, 671

Barrientos, M., 156

Barrios, A., 325, 393, 398, 640

Barrios, M. F., 398

Barros, C. F., 178, 355

Barros, F. A. S., 354

Barros, F. A. S. de, 346

Barros, L. R. F. de, 318

Barros, S., 324

Barroso, D., 167

Barroso, D. G., 426, 652

Barry, J., 129

Bartel, E., 177

Bartelt, P., 199

Bartlett, M., 581

Bartlett, R., 252, 263

Basílio, J., 321

Basnet, D., 125

Basnet, S., 381

Basnett, B. S., 132

Bassa, G., 316

Basso, L., 528

Basso, L. S., 528

Bassolé, I. H. N., 42

Bastos, A., 169, 535

Bastos, L. L. de S., 162, 497, 618

Basualdo, M. de, 627

Batawila, K., 432

Bathgate, S., 370

Batish, D. R., 422, 606

Batista, A., 281

Batista, A. C., 67, 68, 356

Batista, D. C., 436

Batista, G. de, 289

Batista, J. L. F., 303, 374, 383, 535, 536

Batistela, G. C., 183, 339, 352

Batistella, M., 92

Batistuzzo, G., 662

Batkhuu, N., 310

Baud, I., 133

Bauer, N., 84 
Bauerhansl, C., 62

Bauhus, J., 149, 150, 153, 168, 169, 280, 281, 489, 600, 601, 661, 701

Baumeister, C., 84

Baumflek, M., 28

Bava, J., 60

Bayma, M. M. A., 701

Bayne, K., 97, 104, 556

Baynes, J., 105, 467, 468

Bazan, G., 555

Bazani, J. H., 401, 403, 662

Bazurto, C. C., 271, 272

Beas, C. M., 690

Beauclair, M., 621

Beaudoin, D., 419

Beaudoin, J., 98

Bebi, P., 199

Becchi, L., 441, 451

Becchi, L. K., 449, 451, 452

Becher, M., 700

Becker, D., 348

Becker, E., 151

Becker, G., 287

Bedranova, D., 266

Beeckman, H., 296, 345

Beenken, L., 444

Beer, W. de, 584

Beguin, J., 464

Beguš, J., 77, 500

Behling, A., 352, 533, 534, 536, 689

Behling, M., 226, 299, 300, 495

Bekele, T., 154, 293

Bekhta, P., 428

Belavenutti, P., 369

Belenkii, I., 203

Belfort, L., 707

Beliaeva, N., 542, 670

Bell, S., 554

Bellamy, C., 33

Belleville, B., 414

Bellman, C., 377

Bello, A., 156

Belloncle, C., 433, 435, 436

Bellote, A. F. J., 297, 563

Beltrão, S. L. L., 701

Bembenek, M., 353

Benali, A., 200

Benavides, R., 157

\begin{tabular}{|c|c|}
\hline Benavides-Meza, H. M., 64 & Betancourt, C., 197, 635 \\
\hline Bender, S., 62 & Bethmann, S., 344 \\
\hline Benedetti, V., 317, 324, 420 & Bettini, B. A., 498 \\
\hline Benedito, D., 329 & Bettini, P., 566 \\
\hline Benedum, M., 348 & Beuchle, R., 388, 603 \\
\hline Benham, S., 200, 201 & Beudez, N., 250 \\
\hline Benitez, M., 567 & Bevilacqua Junior, V. G., 541 \\
\hline Bennadji, Z., 462, 507 & Bewg, W. P., 515 \\
\hline Bennet, A., 79 & Beyer, F., 280, 281, 661 \\
\hline Bennett, K., 689 & Bezos, D., 578 \\
\hline Bennett, L., 199, 204 & Bezuidenhout, C., 97 \\
\hline Bentacur, O., 284 & Bhagwat, S., 131 \\
\hline Bentes, M., 136, 683 & Bhaskar, D., 709 \\
\hline Bento, M., 136 & Bhomia, R. K., 642 \\
\hline Bento, M. de, 430 & Bi, Q., 318 \\
\hline Bentrup, G., 23 & Biaou, S. S., 90 \\
\hline Bentsen, N. S., 273, 445 & Biaou, S. S. H., 91 \\
\hline Benyon, R. G., 706 & Biasioli, F., 596 \\
\hline Berbert, M., 384, 688 & Bibeiro, F. de, 328 \\
\hline Berg, L. V. D., 284 & Biber, P., 386, 530 \\
\hline Berger, H., 566 & Bicca, S., 109 \\
\hline Berger, R., 410 & Bichel, A., 105 \\
\hline Berger, T. W., 651 & Bidartondo, M., 200 \\
\hline Bergeron, Y., 497 & Biernaski, F. A., 298, 412, 458 \\
\hline Berghäll, S., 474 & Bigler, C., 222 \\
\hline Bergmark, P., 26 & Bila, N., 626 \\
\hline Bergo, M. C. J., 346 & Bilek, T., 52 \\
\hline Bergstedt, J., 230 & Bílek, L., 387 \\
\hline Bergsten, U., 367 & Bilici, E., 53, 350 \\
\hline Bergstén, S., 85 & Biligt, B., 382, 445 \\
\hline Berhe, M., 633 & Bilodeau, G., 574, 582 \\
\hline Berlin, M., 172 & Bilous, A., 271 \\
\hline Bermejo, T., 656 & Bilyk, A., 361, 388 \\
\hline Bermejo, V., 252 & Bim, O., 329 \\
\hline Bernardi, A. C. de, 285 & Binfield, L., 429 \\
\hline Bernardinis, G. B., 249 & Bing, Y., 216 \\
\hline Bernardino, L., 359 & Binkley, D., 316, 325, 368 \\
\hline Bernardo, J., 38 & Binoti, D. H. B., 485 \\
\hline Berninger, F., 111, 198, 231, 660 & Biondi, D., 67, 68, 70, 71, 610 \\
\hline Bernö, H., 473 & Biondo, L., 137, 527 \\
\hline Berredo, A. C. de, 359 & Birhane, E., 633 \\
\hline Berry, C., 262, 680 & Birot, Y., 694 \\
\hline Berry, N. J., 243 & Bischofer, L., 651 \\
\hline Bertholdi, A., 663 & Bisewski, V. M., 546, 555 \\
\hline Bertoldo, C., 412, 425 & Bisht, D., 177 \\
\hline Bertolini, I. C., 286 & Bisht, V., 144 \\
\hline Bérubé, J., 574 & Bista, R., 113 \\
\hline Bespalhok Filho, J. C., 322 & Bittencourt, A., 570, 594 \\
\hline
\end{tabular}




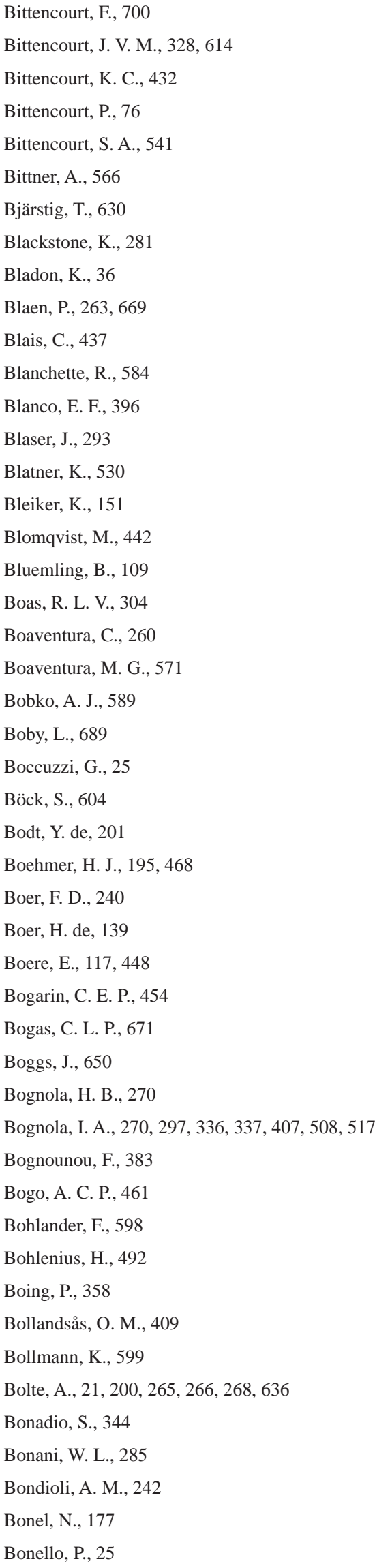

Bonello, P. (., 515, 567

Bonete, I., 339

Bongers, F., 217

Bongiolo, E., 81, 160

Bonifácio, L., 590

Bonnefond, J., 314

Bonnet, A., 624, 666

Bonomi, A., 274

Bonora, F. S., 580, 586

Bontemps, J., 209

Bordbar, S. K., 655

Bordron, B., 229, 280

Borges, J., 323, 531

Borges, J. G., 386

Borges, J. S., 637

Borja, M., 524

Borrass, L., 45

Bortagaray, I., 699

Bortoletto Junior, G., 317, 420

Bortolucci, J., 255

Borycka, K., 201

Bos, A., 244

Boscana, M., 284

Bosch, M. V. D., 131

Boschetti, L., 206

Boscolo, M., 55

Bose, A. K., 150, 194

Bose, P., 15, 35, 98

Bosela, M., 62

Bošel'a, M., 115, 288

Bostelmann, S. L., 639

Bosu, P., 492

Botache, L. A. L., 111, 522

Botequim, B., 386

Botin, A. A., 328

Botosso, P. C., 241, 435

Bottaro, M. V. e, 513

Böttcher, F., 338

Botter-Kuisch, H., 471

Bottero, A., 149, 150, 194

Bouget, C., 600

Bouhtoury, F. C. E., 418

Bouillet, J. D., 280, 299, 303, 314, 644, 659

Bouillon, P., 97

Bouissou, C., 266

Boulanger, Y., 199

Bounous, M., 651

Bourgeau-Chavez, L., 27
Bourguiba, N., 239

Bouriaud, O., 62

Bourland, N., 296

Bouvet, A., 698

Bouzon, P., 361

Bovi, R. C., 241, 242

Bown, H., 633

Bozzano, M., 696

Brabec, M., 409, 410

Bradshaw, B., 645

Bradshaw, R., 442, 507

Braeuning, A., 237

Braga, E., 481

Braga, J. W., 354

Braga, J. W. B., 346, 355

Bragança, H., 576, 578, 590

Braitmayer, H., 476

Brañas, M. M., 28

Brancalion, P., 490

Branchi, B., 70

Branco, M., 60, 441, 569, 583

Branco, R. da, 181

Brand, M. A., 425

Brandani, C. B., 303

Brandão, S. E., 25

Brandao Junior, A., 133

Brandão Junior, A., 525

Brandeis, C., 708

Brandes, A. F. D. N., 355

Brandes, A. F. N., 178

Brändli, U., 209

Brando, P., 272

Brandt, L., 151

Brännström, H., 417

Branquinho, C., 251, 551

Branthomme, A., 62

Brasier, C., 582

Brasil, A., 76

Brasileiro, B., 432, 433

Brassiolo, M., 666

Braun, M., 179, 245, 269, 476

Braunisch, V., 112, 599

Bravo, F., 282

Bravo-Oviedo, A., 279

Brawner, J., 305

Braz, E. M., 154, 155, 293, 329, 375, 392, 455, 620

Braz, R., 688 
Brazaitis, G., 282, 302, 326, 614

Brazill-Boast, J., 145

Bréda, N., 301

Bremer, M., 387

Brena, D., 61

Brena, D. A., 196, 538

Brenner, H., 604

Brèteau-Amores, S., 301, 487

Breuer, L., 632

Breunig, F., 402

Breva, L., 229, 230

Breznikar, A., 144, 500

Brienen, R. J. W., 217

Briggs, L., 112

Brighenti, A., 286

Bringezu, S., 96

Brink, M., 22

Brinkhoff, R., 298

Brito, A. F. A., 172

Brito, C., 196, 533

Brito, C. N., 533

Brito, G. G. S., 290

Brito, K., 163

Britto, P., 338, 352

Brockerhoff, E., 559

Brockhaus, M., 114, 128, 135

Brodde, L., 443

Brodrechtova, Y., 115, 116, 288

Brokaw, N., 619

Bronner, G., 190, 387, 400

Brotto, L., 468, 538

Brown, F., 136, 259, 260

Brown, G. G., 493

Brown, H., 317

Brown, I., 260

Brown, M., 417

Brown, R. O., 359

Bruffaerts, N., 201

Bruggisser, M., 387

Brukas, V., 116, 117, 368, 688

Brum, F. T., 249

Brum, S. S., 420

Brun, E. J., 49, 50, 105, 294, 424, 482, 625

Brun, F., 224

Brun, F. G. K., 552, 625

Brundu, G., 559, 593

Brunette, M., 486

Brunner, A., 282

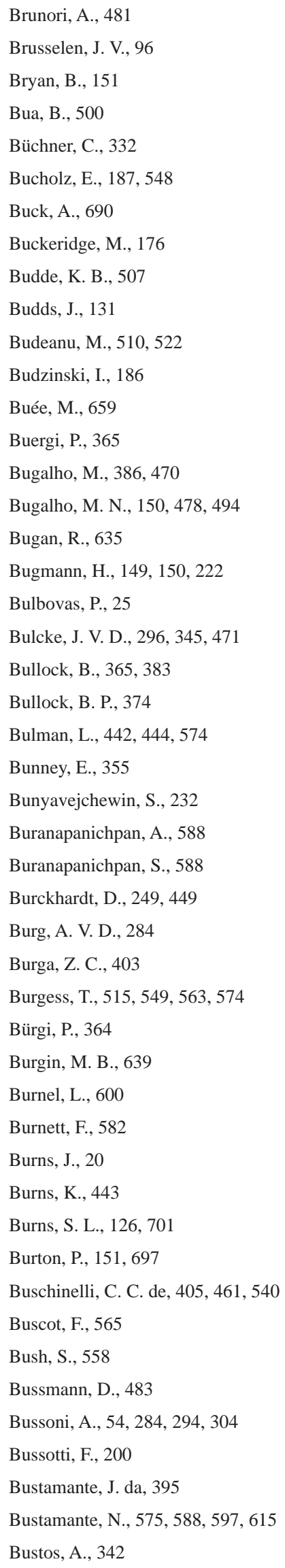

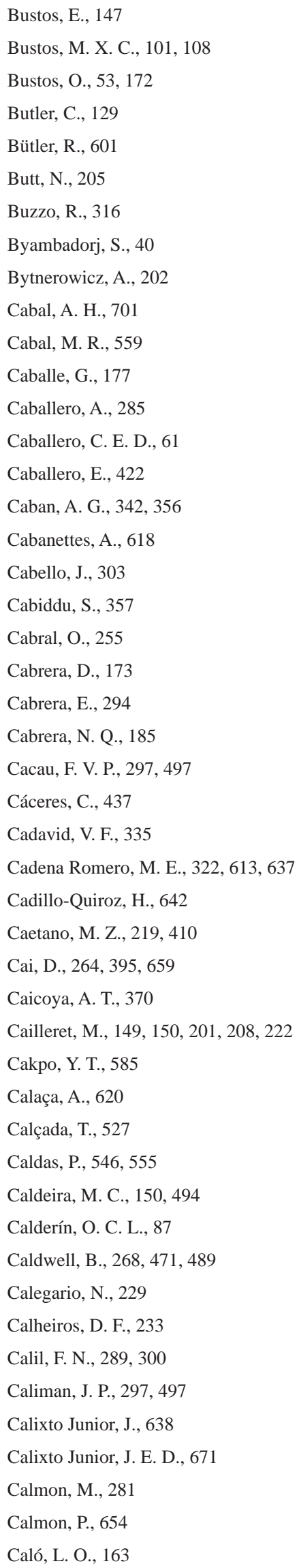




\begin{tabular}{|c|c|c|}
\hline Calota, C., 483 & Cao, Z., 187 & Carriazo, F., 550 \\
\hline Calvert, J., 170 & Capador, H., 557 & Carrilho, C., 274 \\
\hline Calvo, J., 541 & Capanema, V. do, 391, 693 & Carroll, C., 200 \\
\hline Camacho, C. A. F., 422 & Capo, L. F. M. C., 514 & Carstensen, K., 479, 481 \\
\hline Camacho, H., 39, 684 & Cappellin, L., 596 & Cartaxo, C., 526 \\
\hline Camacho, R. e, 372 & Capretti, P., 575 & Cartaxo, C. B. da, 527 \\
\hline Camacho, R. L., 398 & Carandang, W., 206 & Carter, D., 366, 368 \\
\hline Câmara, G., 246 & Carantón, Y. S., 613 & Carter, S., 217 \\
\hline Camargo, A., 508 & Carayugan, M. B., 622 & Cartes, E., 488 \\
\hline Camargo, D., 226, 299, 300, 495 & Carboni, S., 603 & Carvajal, C., 522 \\
\hline Camargo, D. A., 339, 351, 352 & Cardellini, G., 270 & Carvalhaes, M., 55 \\
\hline Camargo, E. P., 592 & Cárdenas, J. H. G., 613 & Carvalhaes, M. A., 629 \\
\hline Camargo, J. L. C., 238 & Cardona, A. M. A., 276, 308 & Carvalhais, L. C., 170 \\
\hline Camargo, J. R., 358 & Cardona, M. A. Q., 111, 388, 522, 617 & Carvalho, A., 246, 500 \\
\hline Camargo, L. R. M. B., 38 & Cardoso, C., 524 & Carvalho, C., 136 \\
\hline Camargo, M. B. de, 321, 645, 681 & Cardoso, D. J., 47, 493, 611 & Carvalho, C. A. de, 118 \\
\hline Camarretta, N., 156 & Cardoso, E. R. da, 667 & Carvalho, E. F. de, 395 \\
\hline Cambi, M., 349, 350 & Cardoso, H. M., 552 & Carvalho, G., 167 \\
\hline Cambuim, J., 324, 511, 512, 513, 514 & Cardoso, L. R., 82 & Carvalho, G. de, 495 \\
\hline Camelo, A. P., 404 & Cardoso, M. N. L., 241 & Carvalho, H., 176 \\
\hline Cameron, I. R., 367 & Cardoso, P., 308 & Carvalho, J., 486 \\
\hline Camia, A., 62 & Cardoso, P. H. S., 181 & Carvalho, J. O. P. de, 153, 154, 701 \\
\hline Campanha, M., 419 & Cardoso-Gustavson, P., 25 & Carvalho, M. L. de, 261 \\
\hline Campanhão, L. M. B., 665 & Cardoso-Leite, E., 69, 234 & Carvalho, N. A. L., 625 \\
\hline Campbell, B. C., 677 & Carl, M., 600 & Carvalho, S. M., 555 \\
\hline Campbell, J. L., 262 & Carle, J., 471 & Carvalho, T. de, 108, 136, 348, 552 \\
\hline Campbell, R., 52 & Carlos, J., 690 & Carvalho, V. R. de, 451, 453, 455 \\
\hline \multirow{2}{*}{$\begin{array}{l}\text { Campoe, O., 255, 256, 314, 315, 316, 320, 321, } \\
\text { 322, 323, 325, 366, } 368\end{array}$} & Carlos, L., 600 & Casagrande, N. B., 425 \\
\hline & Carlos Romero, , 246 & Casapia, X. T., 28 \\
\hline \multirow[t]{2}{*}{ Campos, A. L. de, 625} & Carlucci, M. B., 249 & CasaubÓn, E., 327 \\
\hline & Carmenta, R., 631 & Cascarejo, I. P., 195 \\
\hline Campos, S., 361 & Carmo, G., 313 & Casella, E., 263 \\
\hline Campos, T. de, 506 & Carmo, M., 260 & Casero, J. J. D., 577 \\
\hline Campos Filho, E., 313 & Carnegie, A., 579, 580 & Casey, M., 683 \\
\hline Camprubi, G. E., 343 & Carneiro, M. G., 506 & Cassiano, C., 677 \\
\hline Canales, E. T., 511 & Carneiro, R., 314, 315, 316, 320, 321, 322, 325 & Cassino, W., 627 \\
\hline Canan, D. E., 625 & Carnieletto, C., 152, 646, 668 & Cassol, H. L., 528 \\
\hline Cancharis, L. C., 390 & Carpanezzi, A. A., 430 & Castagneri, D., 175 \\
\hline Cândido, N. R., 438 & Carr, S., 45 & Castagneyrol, B., 282, 570, 572 \\
\hline Cañellas, I., 62, 360 & Carrari, E., 171, 180, 181, 254, 498, 569 & Castanho, F. P., 412 \\
\hline Canetti, A., 154, 375, 620 & Carrasco, L., 152 & Castellini, R., 353 \\
\hline Cannas, A., 357 & Carrasquinho, I., 371 & Castilho, B., 329 \\
\hline Cannon, C., 458 & Carreira, A., 473, 474 & Castillejo, M. A., 577 \\
\hline \multirow[t]{2}{*}{ Cannon, P., 567, 579} & Carrer, H., 516 & Castillo, A., 168, 173, 640, 670 \\
\hline & Carrer, M., 175 & Castillo, D., 269 \\
\hline \multirow{2}{*}{$\begin{array}{l}\text { Cao, W., } 649 \\
\text { Сao, X., } 210\end{array}$} & Carrera, F., 55, 73, 95, 101, 108, 115, 147, 380, & Castro, A., 185 \\
\hline & & Castro, B. C. de, 357 \\
\hline Cao, Y., 46, 171, 268, 493, 532, 634, 679 & Carrette, T., 379 & Castro, D. C. V., 303 \\
\hline
\end{tabular}


Castro, E., 163

Castro, G. S. A., 118, 139

Castro, I., 628

Castro, K., 527

Castro, M. M. F. de, 341

Castro, M. R. C., 298, 399, 502

Castro, N. L., 348

Castro, N. L. M., 485

Castro, N. L. M. de, 219

Castro, P. C. de, 41

Castro, R., 419

Castro Junior, A. A., 403

Castro-Díez, P., 469

Casula, A., 357

Casula, F., 357

Caurla, S., 215, 477

Cavalcante, R. B. L., 219

Cavalcanti, N., 425

Cavalcanti Junior, J. B., 621

Cavalett, O., 274

Cavalli, R., 36, 686

Caviglione, J. H., 624, 666

Cayuela, L., 572, 583

Cazani, A. C., 351

Ceccantini, G., 176, 178, 561, 562, 591, 592

Ceccerini, G., 362

Cegatta, I., 688

Celentano, D., 146

Celer, E., 323

Celhay, J. A., 156

Cellini, J. M., 705

Cerchiari, A. M. F., 420

Cerda-Peña, C., 711

Cerignoni, F., 92

Cerrillo, T., 327, 471

Certini, G., 498

Cerutti, P., 632

Cervantes-Arango, S., 157

Cerveny, L., 124

Cesário, F., 644

Cesoniene, L., 487

Ceulemans, R., 202

Cezar, R., 329

Cezare, C., 219, 399

Cha, S., 353, 384, 405, 408

Chacon, M., 380, 438

Chacón, C. B., 346

Chaer, G., 277, 645

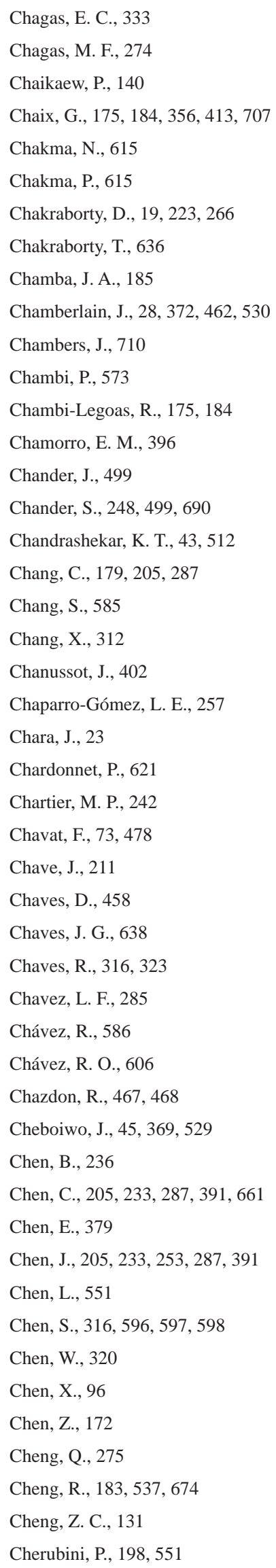

Chessa, M., 357

Chestnykh, O., 259

Chettri, P., 442

Chhin, S., 373

Chiara, J. P., 304

Chiarello, L. M., 424

Chichinye, A., 90

Chifarelli, V., 177

Chiles, C. R., 645

Chiles, J., 421

Chimner, R., 27, 642

Chinchero, M., 64

Chirici, G., 189, 313, 378, 604

Chirteș, A., 284

Chirteș, E., 284

Chirwa, P., 45, 140, 610

Chirwa, P. W., 30, 72, 90

Chitty, R., 593

Chiu, C., 287

Chivulescu, S., 181, 208, 250

Chizhov, M., 548

Cho, K., 145

Choi, B., 490

Choi, H., 627, 644

Choi, H. T., 385

Choi, J., 393

Choi, S., 333

Choinski, N., 483

Chong, J. M., 556

Choruma, D. J., 633

Chourmouzis, C., 19

Christie, M., 133

Christina, M., 314

Christophe, K., 31

Chudomelová, M., 288

Chumak, V., 601

Chung, G., 511

Chung, H., 414

Chung, S. H., 296

Chung, W., 21, 36, 369

Chuter, A., 27, 369

Cialdella, N., 466

Cian, J. C., 225

Ciancie, R. C. R., 438

Ciceu, A., 250, 522

Cid, N. M. C., 56

Ciriani, M., 181

Cissé, G., 129 
Ciuvat, C. G., 522

Claire, M., 583

Clamer, G. de, 308

Clark, B., 573

Clark, D., 566

Clark, N., 684, 695

Clarke, N., 201

Clasing, G., 303

Claudino, C., 308

Cleary, M., 25, 442, 547, 567, 568, 593

Clegg, P. A., 305

Clerici, N., 603

Climo, C. A., 202

Clopeau, A., 465

Cobbinah, J., 491

Cobello, L. O., 710

Coble, A., 262

Cobos, A. H., 110, 158

Cobourn, K., 679

Cocco, A., 593

Cock, P., 573

Cocozza, C., 551

Coe, M., 272

Coelho, A. S. G., 328

Coelho, K., 329

Coelho, M., 317, 324, 420

Coelho, R., 81

Coelho, S. T., 446

Coffin, A., 530

Cohen, W., 189

Cohn, A., 525

Coince, A., 697

Colangelo, G., 182, 544

Colella, E., 548

Colfer, C. J. P., 17, 129, 130, 132

Coligny, F. de, 250, 599

Colin, F., 413

Colmanetti, M. A. A., 255

Colwell, R., 467, 468

Combalicer, M., 489, 519, 622

Commandré, J., 240

Comnick, J., 538

Conceição, F. G., 179

Conceição, S. C., 316

Connett, M., 389

Conserva, A. S., 466

Conte, A., 181

Conte, B., 639
Contessa, V., 602

Contin, D. R., 182

Conto, T., 347

Contreras, C. W. R., 30

Contreras, S., 711

Cook, M., 561

Cook, R., 337, 366, 368

Cook-Patton, S., 217

Cooke, A., 538

Cooke, D., 573

Cools, N., 200, 201

Coomes, D., 604

Coomes, D. A., 205

Cooper, L., 94, 170

Cooper, M., 242

Cooper, N., 81

Coops, N., 604

Coppes, J., 599

Coppin, F., 654

Coradin, V., 354

Coradin, V. T. R., 346, 355

Coral, M. F. C., 430

Cordeiro Junior, P. S., 498

Cordeiro-Beduschi, L. E., 59

Corinzia, A., 596

Corley, J., 25, 442

Corley, J. C., 583

Cornacini, M. R., 185, 511, 512, 513

Cornacini, M. R. C., 513

Cornejo, I., 59

Cornejo, V., 188

Cornelissen, T., 571

Cornut, I., 256

Corona, P., 189, 202, 409

Coronado, E. H., 28

Coronado, E. N. H., 217

Coronel, J., 64, 342

Corradini, G., 39

Correa, C., 699

Correa, D. S. S., 82

Correa, J. C., 308

Corrêa, A. J. M., 512, 519

Corrêa, C. M. C., 546, 555

Corrêa, J. A., 665

Corrêa, J. C. C., 660

Correia, A. H., 216

Correia, B., 577

Correia, C., 528
Correia, C. de, 98

Correia, C. S., 528

Correia, M. F., 521

Cortada, X., 683

Corte, A., 169

Corte, A. P. D., 291, 403, 535

Cortés-Palacio, L., 33

Corti, D., 156, 303

Cosio, E., 573

Cosmo, N. L., 358

Cosovic, M., 386

Costa, A. C. L. A., 412

Costa, A. L. S. de, 700

Costa, B., 484

Costa, B. M. R., 405

Costa, C., 426

Costa, D. da, 342, 634

Costa, D. P., 523, 524

Costa, E. A., 363

Costa, G. F. da, 289

Costa, J., 60

Costa, J. A., 434

Costa, J. P., 624

Costa, J. R. da, 136

Costa, J. S., 543

Costa, L., 313

Costa, L. S. da, 357

Costa, M., 55

Costa, M. da, 691

Costa, M. R. da, 439

Costa, N. S. L., 154

Costa, P., 44

Costa, P. da, 241, 506

Costa, P. L. S. da, 700

Costa, R., 316, 321

Costa, R. H. da, 252, 655

Costa, T., 419, 531

Costa, V., 449

Costa, W., 246, 524

Costa, W. da, 399

Costa Filho, E. J., 351

Costanti, E., 98

Costanza, J., 602

Cotrozzi, L., 254, 281

Courbaud, B., 599, 618

Coutinho, J. C., 67

Coutinho, M., 336

Coutinho, R., 316 
Coutinho, R. T., 252, 655

Coutts, J., 369

Couture, J., 281

Cox, F., 200

Cox, M., 442

Crabbe, S., 61, 159, 228

Craig, M., 600

Crane, B., 503

Cranston, B., 264

Creighton, J., 689

Cremonese, J., 329

Crespo, I., 502

Crisóstomo, M. C., 433

Crispim, S., 528

Crispim, S. P., 528

Cristales, R. Z., 140, 145, 703

Cristofolini, F., 201

Cristofori, A., 158

Critica, M. F., 622

Crivilin, B. S., 707

Cronkleton, P., 119

Cropper, W., 160

Cross, C., 131

Cross, J., 538

Crous, K., 263

Crout, N., 653

Crow, P., 547

Crowley, C., 704

Crowley, L., 263

Cruickshank, M., 151

Crusciol, C. A. C., 229

Cruz, D. C., 271, 272

Cruz, E. J., 522

Cruz, I. de, 434

Cruz, J. C. C., 517

Cruz, L. S., 522

Cruz, N., 651

Cruz, O. A. M., 111

Cruz, P., 360

Cruz, R. V., 277

Cruz-Burga, Z., 89

Cu, N., 439

Cuadra, S. V., 255

Cuadros, M. de, 403

Cubbage, F., 54, 121, 365

Cubbage, F. W., 385

Cuccu, G., 357

Cudlín, P., 202, 265

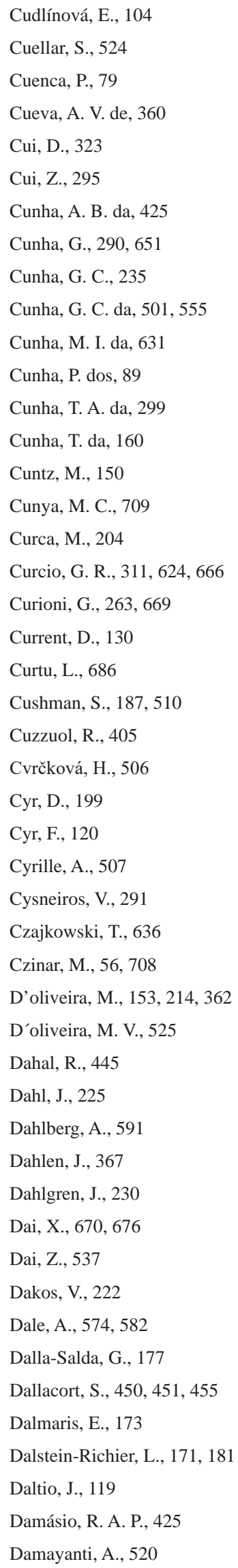

Damayanti, E. K., 243

Damayanti, R., 346, 414

Damjanic, R., 157, 223, 505, 591

Damjanić, R., 505

Dancer, H., 544

Dănescu, A., 149

Daniel, J., 389

Danieli, M. A., 109

Danilov, D., 542, 670

Danks, F., 604

Dantas, A. R., 326, 328

Dantas, B. F., 157, 255, 518

Dantas, C. A. F., 421

Danusevicius, D., 157

Danusevičius, D., 326

Danylo, O., 362, 548

Dao, H. T. T., 40, 295, 644, 671

Dařenová, E., 202

Darr, D., 29, 35, 44, 422, 461, 542

Dassan, M. A. A., 403

Daubaras, R., 487

David, T. S., 150

Davidson, N., 156

Davidson-Hunt, I., 614, 631

Davies, M., 166

Davies, S. J., 211

Davila, A., 640

Davis, A., 312

Davydenko, K., 577

Dawson, L., 83, 266

Daza, J. F. C., 473

De Marco, A. , 172

De Marco, A. de, 171, 180, 254, 569

De-Carvalho, P., 219

Deakin, G., 566

Deal, R., 75, 143, 281, 539

Dean, T., 366

Deboni Neto, A., 181

Dees, M., 245

Degenhardt-Goldbach, J., 322

Deitenbach, A., 700

Deklerck, V., 345

Delard, C., 158, 302

Deleporte, P., 659

Deleuze, C., 698

Delfin, A. R., 279

Delgado, D., 147, 148, 380, 438

Delgado, J. M., 271, 272 
Deliberali, I., 252, 655, 668

Delogu, M., 694

Delpierre, N., 256

Demóstenes, F. da, 65

Deng, X., 196

Denman, S., 566

Dennis, P., 170

Derka, C. A., 343

Derks, J., 84, 541

Derrien, M., 124

Derroire, G., 153

Desene, N., 329

Desie, E., 284, 301, 654

Desprez-Loustau, M., 507

Deuffic, P., 488

Deusdará, R., 527

Deutscher, J., 210, 378

Devisscher, T., 65, 131, 551

Dewantoro, A., 322

Dewi, L. M., 346, 414

Dewi, S., 31, 641

Dey, D., 282, 283

Dezzeo, N., 642

Di Toro, A. P. , 69, 234

Dias, A., 192

Dias, H. C. T., 664, 665

Dias, R., 337, 359

Dias, S., 316

Dias, S. C. M., 589

Diaz, A., 146

Diaz, A. R., 652

Diaz, F., 627

Díaz, J. A. P., 276, 277, 308, 309

Diaz-Balteiro, L., 246, 369, 386

Diaz-Baltero, L., 246

Diaz-Chavez, R. A., 56

Díaz-Hormazábal, I., 606

Díaz-López, S. M., 637

Díaz-Maroto, I. J., 287, 293

Diaz-Pines, E., 208, 263

Díaz-Timoté, J., 146, 348

Diazdiaz, J., 144

Dibdiakova, J., 330

Dick, G., 255, 256

Dickson-Hoyle, S., 705

Dieckow, J., 225

Dieta, V., 327

Dieter, M., 364, 365, 476
Dieterle, G., 334

Dietrich, H., 200, 201

Diez, J., 576, 577, 578, 579

Diez, J. J., 568, 575, 578, 579

Diez, J. P., 177, 559

Dimarco, R., 559

Diminić, D., 454

Ding, C., 323

Ding, Y., 166, 323

Dinger, E., 312

Dinh, T. N., 114, 641

Diniz, C., 664

Diniz, J., 421, 463, 466

Diogo, E., 576, 590

Dirnberger, G., 280

Dirnböck, T., 200, 208

Dittrich-Schröder, G., 585, 558

Divakara, B. N., 65, 413, 439

Diviakova, A., 39

Djagbletey, G., 656

Djagoun, C., 112, 432, 465, 585

Djurdjevic, V., 241

do, T. T. H., 449

Dobbs, C., 65

Dobeš, C., 179

Dobor, L., 198, 223

Dobrovolsky, A., 473

Dobsinska, Z., 679

Dobšinská, Z., 116

Dodan, M., 222, 326

Dogmus, T., 575

Doimo, I., 39

Dolenc, G. S., 161, 162, 459, 501

Domingos, M., 25

Domingues, L., 528

Domingues, L. G., 528

Domingues, M. M., 449, 450, 451

Domingues, T., 71

Domínguez, M. T., 655

Domisch, T., 170

Domke, G., 381

Donald-Amaechi, U., 311

Donaldson, M., 697

Dong, A., 320

Donoso, P. J., 166

Dopazzo, V. M., 225

Dormontt, E., 355

Doty, S., 471
Douglas, A., 576

Dovč, N., 505

Downes, C. M., 530

Doyon, F., 233

Drago, J. R., 668

Draper, F., 642

Drazo, A., 85

Drenkhan, R., 443

Drenth, A., 170, 581

Drew, D., 418

Dreyer, E., 697

Dreyer, L., 595

Drigo, I., 118, 486

Driscoll, C., 262

Drobyshev, I., 347

Drumond, M., 638

Drumond, M. A., 465

Duan, A., 237, 373

Duan, W., 551

Duarte, G. de, 458

Duarte, J. R. de, 521

Duarte, L. F. C., 307

Duarte, T., 336

Duarte, V., 390, 394

Duarte Nuñez, D. A., 615

Dubayah, R., 189

Dube, F., 148, 662

Dubrovskis, E., 621

Duc, C. P., 641

Duchateau, E., 496

Duchelle, A., 244, 245

Duchelle, A. E., 118, 244

Dudik, R., 225

Dudík, R., 138

Dudley, R., 132

Dueñas, M., 568

Duinen, G. V., 284

Dumarcay, S., 413

Dumitru, M., 483

Duncanson, L., 189

Duncanson, L. I., 382

Dunn, M., 543, 568, 573

Dunning, G., 470

Dunningham, A., 369

Duong, T. A., 598

Dupont, P., 442, 507

Dupont-Leduc, L., 496

Dupuy, G. E. G., 188, 292 
Dura, H., 98

Duran, A., 586, 587

Duran, L., 115

Duran, O., 173

Durán, A., 563, 586, 589

Durán, E., 123

Durán, L., 73

Durán, N. M., 494

Duren, I. V., 611

Durigan, G., 218, 219

Durrieu, S., 379

Dušek, J., 202

Dutech, C., 507

Duthweiler, S., 570

Dutra, A. C., 390, 394

Dutta, S., 703

Duverger, S., 523

Dwiputra, A., 117

Dyanatkar, S., 704

Dyson, R., 263

Dzindzik, W. M. R., 49

Echeverría, C., 79

Eckert, A., 18, 187, 510

Eckhardt, L. G., 563

Eduarte, G., 125

Edwards, D., 33

Edwards, P., 87, 95, 97, 104, 369

Efhamisisi, D., 239

Egenolf, V., 96

Egler, M., 700

Egnell, G., 463

Egorov, A., 587

Eguiguren, P., 159

Ehrenmann, F., 698

Eichhorn, J., 200

Eid, T. H., 409

Eigenbrod, F., 33

Eilertsen, L., 591

Ekadinata, A., 117, 448, 548, 641

Ekström, M., 382

Elbakidze, M., 83, 138, 266, 480

Elena, H., 523

Eleotério, J. R., 164, 435

Elfving, B., 337

Elham, P., 431

Elia, M., 544

Elias, R., 370

Elizalde, M. C. M., 231, 232

\begin{tabular}{|c|c|}
\hline Elkin, C., 152 & Espinoza-Mendoza, V. E., 78, 79, 706 \\
\hline Elli, E. F., 315 & Esposito, M. P., 25 \\
\hline Ellias, N. F., 455 & Essien, C., 427 \\
\hline Ellis, E., 19, 649 & Estay, S., 586, 588, 623 \\
\hline Ellis, P., 19 & Estay, S. A., 590, 606 \\
\hline Ellis, P. W., 159 & Estevam, L. S., 167 \\
\hline Ellison, D., 612, 647, 649 & Estopa, R., 174 \\
\hline Ellrichshausen, A. S. M. V., 559 & Estopa, R. A., 321, 412, 535, 662 \\
\hline Ellsworth, D., 263 & Etiir, C., 510 \\
\hline Elsasser, P., 54, 265 & Etzold, S., 194 \\
\hline Elvira, S., 252 & Eu, S., 349 \\
\hline Elvira-Recuenco, M., 575 & Eufrade-Junior, H., 196, 417 \\
\hline Emanikor, F., 510 & Eufrade-Junior, H. de, 460 \\
\hline Emellek, J. E., 546 & Euler, A. M., 15, 80 \\
\hline Emery, M., 462, 530 & Euler, A. M. C., 102 \\
\hline Emeyriat, R., 353 & Evangelista, J. S., 112, 521 \\
\hline Emídio, K., 160, 396 & Everhart, S., 582 \\
\hline Emilia-Adela, S., 428 & Evison, D., 192 \\
\hline Enayati, K., 655 & Ewert, M., 29, 31 \\
\hline Endalamaw, T. B., 422, 542 & Ewing, C., 567 \\
\hline Endo, T., 431 & Exconde, A., 168, 670 \\
\hline Ene, L. T., 389 & Ezzati, S., 423 \\
\hline Engel, V., 663 & Fabiano, F., 349 \\
\hline Engel, V. L., 499 & Faccoli, M., 569 \\
\hline Engela, M. R., 25 & Fadini, R., 207 \\
\hline Englert, H., 364 & Fady, B., 511 \\
\hline Englisch, M., 208, 385 & Faedda, R., 577 \\
\hline Englund, M., 332 & Fahey, R., 262 \\
\hline Engman, M., 312 & Fahey, T., 262 \\
\hline Enyang, G., 510 & Fahlvik, N., 302 \\
\hline Epinosa, D. P. M., 545 & Fahy, O., 239 \\
\hline Erasmus, J., 418 & Faias, S., 371 \\
\hline Erickson, A., 402 & Fajardo, A., 623 \\
\hline Erlandsson, E., 349 & Falade, O. F., 192, 226 \\
\hline Ermisch, N., 364 & Falck, J., 155, 447 \\
\hline Ernest, S., 340 & Falcon, Y. L., 411 \\
\hline Escada, M. I., 693 & Falkowski, M., 381 \\
\hline Escada, M. I. S., 79, 391 & Fallgatter, J., 495 \\
\hline Escandón, M., 577 & Famelli, S., 211 \\
\hline Escanferla, M., 503, 607 & Fan, Z., 563 \\
\hline Escobedo, F., 65 & Fang, C., 416 \\
\hline Escobedo, F. J., 550 & Fang, G., 411 \\
\hline Escribano, M. C., 371 & Fang, R., 360 \\
\hline Eskandari, S., 0, 656 & Fantini, A. C., 164, 338, 352, 391, 435 \\
\hline Espada, A. L. V., 76, 81, 99, 100, 101, 525 & Fardin, A., 316 \\
\hline Espinosa, D. P. M., 689 & Fares, S., 171, 181, 202 \\
\hline Espinoza, D. C., 276 & Faria, A. B. C., 498 \\
\hline Espinoza, E., 345 & Faria, A. B. de, 135, 179 \\
\hline
\end{tabular}




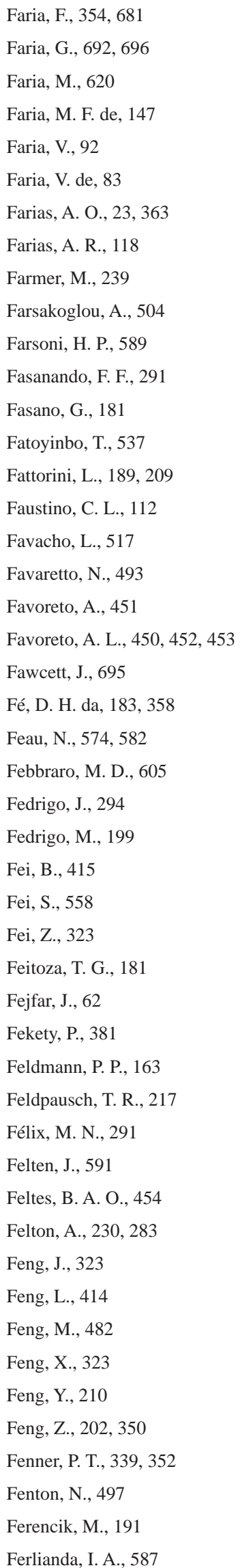

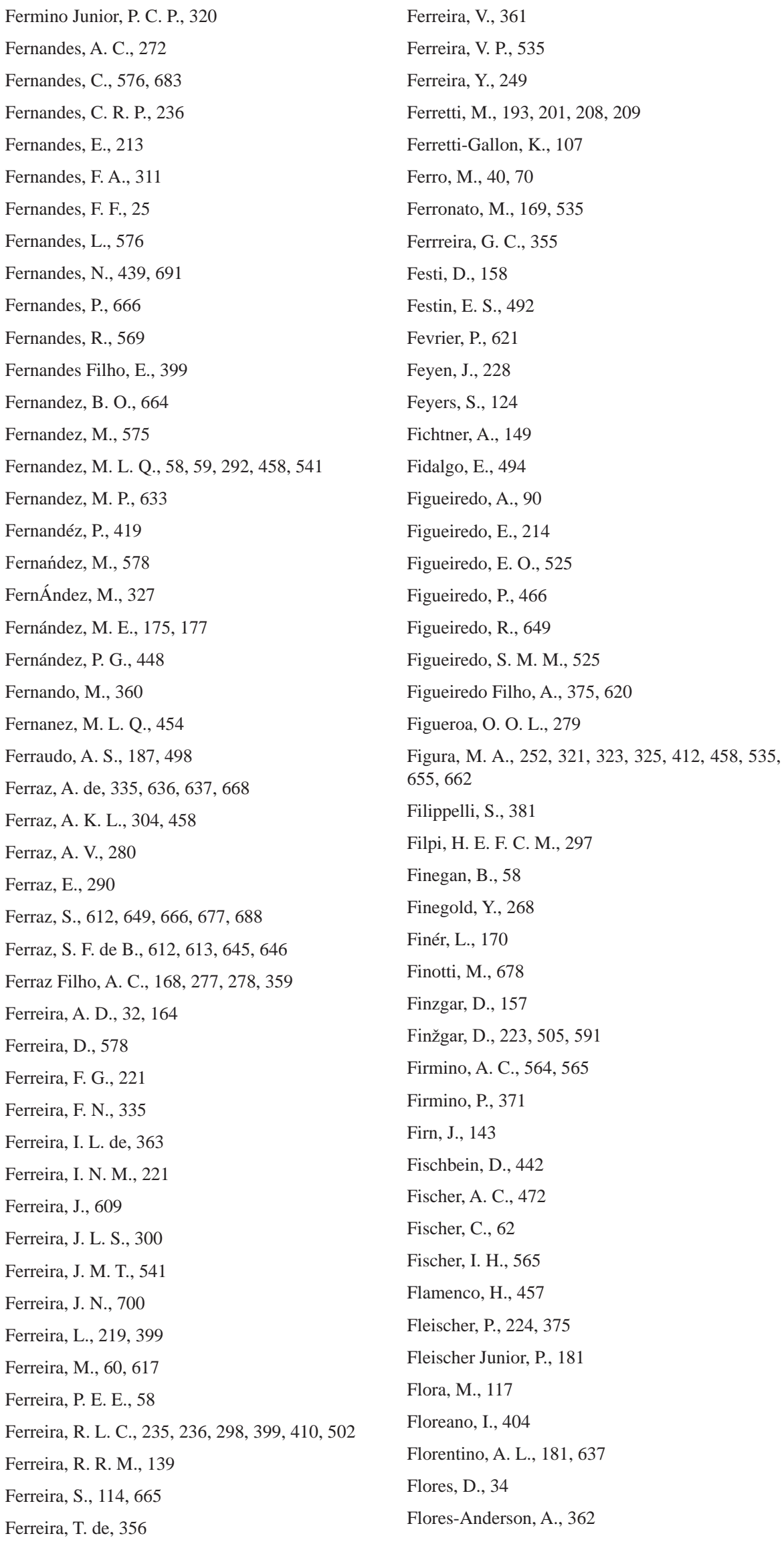

Ferreira, V., 361

Ferreira, V. P., 535

Ferreira, Y., 249

Ferretti, M., 193, 201, 208, 209

Ferretti-Gallon, K., 107

Ferro, M., 40, 70

Ferronato, M., 169, 535

Ferrreira, G. C., 355

Festi, D., 158

Festin, E. S., 492

Fevrier, P., 621

Feyen, J., 228

Feyers, S., 124

Fichtner, A., 149

Fidalgo, E., 494

Figueiredo, A., 90

Figueiredo, E., 214

Figueiredo, E. O., 525

Figueiredo, P., 466

Figueiredo, R., 649

Figueiredo, S. M. M., 525

Figueiredo Filho, A., 375, 620

Figueroa, O. O. L., 279

Figura, M. A., 252, 321, 323, 325, 412, 458, 535, 655, 662

Filippelli, S., 381

Filpi, H. E. F. C. M., 297

Finegan, B., 58

Finegold, Y., 268

Finér, L., 170

Finotti, M., 678

Finzgar, D., 157

Finžgar, D., 223, 505, 591

Firmino, A. C., 564, 565

Firmino, P., 371

Firn, J., 143

Fischbein, D., 442

Fischer, A. C., 472

Fischer, C., 62

Fischer, I. H., 565

Flamenco, H., 457

Fleischer, P., 224, 375

Fleischer Junior, P., 181

Flora, M., 117

Floreano, I., 404

Florentino, A. L., 181, 637

Flores, D., 34

Flores-Anderson, A., 362 
Flores-López, C., 257

Flores-Renteria, L., 187

Flores-Rentería, L., 510

Flórez, L. F. V., 689

Florián, O. P. P., 615, 652

Floris, A., 62

Floris, I., 593

Florsheim, S. B., 355

Foderi, C., 349, 440

Fogaça, C. P., 451

Folegatti, M. V., 613

Foli, E., 154, 216, 491, 656

Foli, E. G., 491

Follador, M., 700

Folmann, W. T., 58, 59, 292, 454, 458, 541

Foltynová, L., 202

Fonseca, D., 298, 300

Fonseca, F., 526

Fonseca, F. L. da, 521, 527

Fonseca, M., 625

Fonseca, P. H. T. da, 307

Fonseca, R., 357, 539, 575

Fonseca, R. C. B., 229, 616

Fonseca, S. R. P. da, 106, 340

Fonseca, T. de, 195, 341

Fontana, C., 241

Fonturbel, F., 560

Ford, R., 243, 396

Forero, S. P., 617

Formayer, H., 385, 557

Formolo Junior, M. R., 461

Forrester, D., 296, 490

Forrester, D. I., 150, 314

Forsell, N., 259

Forster, J., 543, 568

Fortier, J., 100

Fortin, M., 301, 372, 487

Foster, M., 16

Fourie, A., 442

Fourier, M., 686

Fournier, M., 240

Fourtier, S., 651

Fowler, J. A. P., 187, 337

Fox, T., 366, 463, 468

Fraga Filho, C., 401

Fragiskakis, N., 144

França, L., 419

França, L. H. V., 419

\author{
Franceschi, S., 189 \\ Franceschini, T., 496 \\ Franciscon, L., 603, 611 \\ Francke, S., 148, 152, 617, 646, 668, 692 \\ Franco, C., 80 \\ Franco, G., 220 \\ Franco, J., 185 \\ Franco, M. P., 175, 413, 707 \\ Frank, G., 608 \\ Frank, S., 571 \\ Franklin, O., 543 \\ Fransozi, A., 612 \\ Franzim Junior, J., 109 \\ Franzin, J. P., 119 \\ Franzini, F., 474 \\ Franzol, S., 413 \\ Fraser, S., 444, 574, 581, 595 \\ Frederickson-Matika, D., 573 \\ Fredman, P., 123 \\ Fredriksson, E., 198, 200 \\ Freeman, R., 606 \\ Freer-Smith, P., 470 \\ Freire, J. M., 652 \\ Freire, R., 146 \\ Freire, R. M., 31, 41, 102 \\ Freitas, C. H. de, 315 \\ Freitas, D., 699, 700 \\ Freitas, F. C. de, 229 \\ Freitas, J., 61, 63, 611 \\ Freitas, J. M., 196 \\ Freitas, J. V. de, 196, 221, 538, 603 \\ Freitas, M., 512 \\ Freitas, M. A. de, 648, 664 \\ Freitas, M. L. M. de, 47, 269, 516, 519 \\ Freitas, N. de, 289 \\ Freitas, R. A. de, 424 \\ Freitas, T. U. de, 662 \\ Freitas Junior, G. de, 41 \\ Frelich, L., 495 \\ Freschet, G., 280, 651, 661 \\ Freschet, G. T., 281 \\ Fretes, C. B. A., 103 \\ Freudenschuss, A., 62 \\ Frey, G., 121, 372, 530 \\ Fricke, A., 570 \\ Fridman, J., 62 \\ Friederichs, G., 316 \\ Frigeri, J. V., 363, 403
}

Frigerio, J., 294

Frigo, C., 667

Fritz, D., 245

Fritz, S., 362, 548

Fritze, H., 253

Fritzsons, E., 179, 270, 508, 517, 519, 619

Froufe, L. C. M., 329, 337

Frybort, S., 409, 410

Fu, J., 429

Fu, L., 377

Fu, X., 675, 676

Fuentes, D., 645

Fuentes, H., 259

Fuentes-Ramírez, A., 166

Fujii, K., 674

Fujiwara, T., 431, 657, 658

Fukuda, K., 672

Fukushi, A., 672

Fukuzawa, K., 327, 464

Fule, P., 618, 685

Fulvio, F. D., 52, 117, 259, 364, 365

Fulwider, W., 29

Funk, R., 45

Furlan, C. M., 25

Furlani, F., 440

Furtado, E. L., 397, 565, 589

Furusawa, H., 657

Furuya, N., 379

Fusari, A., 621

Fuss, S., 96, 227

Fussi, B., 157, 504, 505

Gabay, M., 131

Gabirro, T., 68

Gabriel, M., 669

Gacitúa, S., 88

Gadda, T., 67

Gaiad, S., 311

Gaire, D., 381

Gairola, S., 267

Gaitan, J. J., 523

Galaz-Segura, S., 26

Galdino, A. S., 625

Galdos, M., 255

Galeano, E., 516

Galindo, N., 488

Galizia, L. F. de, 357

Gallay, I., 39

Gallayova, Z., 39 
Gallego, L. E. C., 308, 309

Gallego, M. G., 197

Gallotti, G. J. M., 410

Galloway, G., 17, 129

Galvão, F., 67, 555

Galvão, L., 212

Galvin, S., 195

Gama, J. R. V., 230

Gama, N. C., 106, 340

Gamba-Trimino, C., 82

Gamborg, C., 544

Gan, J., 365

Gandara, F., 220, 290

Gandhi, K. J. K., 706

Ganem, K. A., 523

Gangga, A., 93

Ganley, B., 567, 569, 580, 581, 590

Gann, C., 457

Ganopoulos, I., 504

Gao, J., 319

Gao, R., 497

Gao, T., 629

Gao, Y., 670

Gao, Z., 319

Gaol, P. D., 563

Gárate, L. D., 163

Garbacea, G. F., 483

Garbelotto, M., 547, 573

Garcete, R. A. B., 59

Garcia, C., 174

Garcia, C. V., 686

Garcia, E., 31, 102

Garcia, G., 412, 425

Garcia, J. N., 420, 472, 473

Garcia, J. R., 432, 493

Garcia, L., 612, 677

Garcia, L. G., 613, 646

Garcia, M. M., 34

Garcia, M. N. B., 559

Garcia, M. U., 499

Garcia, S., 680

García, A. B., 656

García, L. A. M., 367

García, M. de, 398

García-Abril, A., 205

Garcia-Alvarez-coque, J. M., 392

Garcia-Drigo, I., 155, 479

García-Gil, M. R., 172
García-Gómez, H., 252

Garcia-Gonzalo, J., 531

García-Hernández, M. de, 264

García-Méijome, A., 396

García-Rangel, S., 246

Garçon, E., 625

Gardi, O., 293

Gardiner, B., 232

Gardiner, E., 283, 471

Gardner, A., 253, 263, 369

Gariba, V., 38

Garibaldi, L., 572, 588

Garivait, H., 251

Garkoti, S., 618

Garlet, C., 255, 256

Garlick, S., 683

Garms, C., 187, 376

Garnett, S., 145

Garnica, C. J., 627

Garrard, G., 556

Garrastazu, M. C., 155, 249, 611

Garrastazú, M. C., 47, 603

Garrido, J., 269

Garrido, M., 412

Garzon, A. M., 244

Garzuglia, M., 62

Gaspar, C., 392

Gaspar, M. J., 578

Gaspar, R. de, 272

Gaspar, S., 699

Gaspar, S. M. M., 700

Gaspar', R. de, 421

Gasparini, P., 62

Gasparoto, E. A. G., 384, 688

Gasparri, P., 173

Gasper, A. de, 619, 694

Gasper, A. L. de, 195, 614

Gathogo, M., 584

Gattas, J., 472

Gatti, L., 528

Gatti, L. V., 528

Gatto, P., 39, 538, 630, 679

Gatziolis, D., 360, 402

Gaviria, J., 19, 266

Gawlak, M., 577

Gaytan, S. A. V., 61

Gazda, A., 469

Gbadamosi, A. E., 169
Ge, X., 171, 634

Gebauer, R., 214, 250

Gebreanenia, B., 633

Gebrekirstos, A., 193, 237

Gehrmann, J., 200

Geldenhuys, C. J., 90, 91, 128

Gelhaye, E., 239

Gélinas, N., 419

Genouw, G., 201

Genovez, G., 621

George, J., 19, 266

Gérardin, P., 413

Gerber, T. R., 307, 311

Gerhardt, I., 322

Germano, A. D., 363

Geronasso, G., 174

Gerritzen, T., 331

Gerstenberg, T., 84

Gervaz, M., 363

Gessler, A., 150, 209, 222

Gestiada, A., 641

Gevana, D. T., 467

Gevers, C., 558

Gezahgne, A., 492

Gezan, S., 197, 457

Ghelardini, L., 575

Ghersovic, D., 240

Ghorbani, H., 302

Giacomelli Sobrinho, V., 104

Giacomin, L. L., 207

Giacon, V. P., 69

Giannetti, F., 189, 300, 313, 378

Giannico, V., 544

Giardina, C. P., 631

Gibb, H., 497

Gibbs, H., 133

Gibe, R., 507

Giblin, F., 580

Gichora, M., 224, 492

Gielen, B., 203

Giertliová, B., 473

Giessen, L., 126, 127, 133

Gil, A., 502

Gil, M. R. G., 18

Gil-Martínez, M., 655

Giles-Hansen, K., 643

Gillerot, L., 150

Gimenez, A., 177 
Gimenez, B. O., 710

Ginisty, C., 698

Ginzler, C., 62

Giorello, F., 173

Giovannelli, A., 181

Giovannelli, G., 511

Gipoulou, T., 243

Giraldo, C., 23

Girão, V., 60

Girard, A., 19

Girardi, M., 158

Girling, C., 440

Girmay, G., 633

Giroux, M., 383

Gislason, M., 129

Gitz, V., 14, 104, 440, 603

Giuliarelli, D., 378

Giurca, A., 473, 696

Glatzel, S., 208

Glehn, H. C. V., 137

Glehn, H. V., 55

Glen, M., 579

Glenn, E., 142

Glir, L. G., 163

Gloor, M., 528

Gnoumou, A., 271

Gobakken, T., 531

Godbold, D. L., 491, 566, 651

Godoy-Veiga, M., 176, 178

Godsey, L., 530

Goedecke, A., 344

Goes, F., 446

Goib, B., 548

Gold, M., 530

Goldammer, J. G., 341

Golding, J., 695

Goldmann, K., 565

Goldsmith, A., 342

Goli, G., 694

Gollob, C., 205

Goltz, E. P., 358

Gomes, A. P., 678

Gomes, F., 163, 316

Gomes, G. C., 270

Gomes, G. S. L., 485

Gomes, J. B. V., 270, 297, 407, 508, 517, 563

Gomes, J. F. B., 83

Gomes, J. K. da, 521

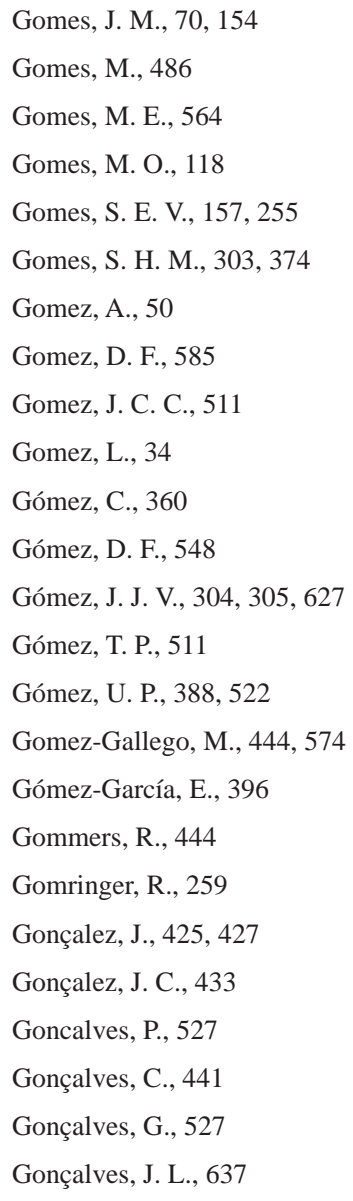

Gonze, M., 654

Goodman, R., 19

Goosse, H., 250

Gopalakrishna, T., 19

Gordillo, F., 54

Gordula, R. D., 467

Gorenstein, M., 290, 498

Gorfer, M., 566

Gorgens, E., 213

Gorgens, E. B., 213

Gorretta, N., 175, 707

Gorte, E. P., 446

Gorton, C., 593

Gossner, M., 601

Gossner, M. M., 469

Gosweiler, B., 411

Götmark, F., 230

Gottardini, E., 201

Gottlieb, A., 508

Gotz, L. F., 667

Goude, M., 190

Goudie, J. W., 367

Goulard, M., 599, 618

Goulart, I. C. G. dos Reis, 433

Goulart, L. M. L., 147

Goulart, schuhli, 432

Gouveia, F. N., 452

Gouveia, V. M., 83, 133, 136

Gouwakinnou, G. N., 409

Govina, J., 427

Govindarajan, V., 0

Grabner, M., 385

Grabowsky, W., 259

Graca, R., 579

Gracia Neto, T., 106

Gräf, J., 632

Graff, P., 329

Grafström, A., 191

Granados, G., 581

Granados, G. M., 592

Grande, J., 327

Grandez, J., 642

Grandpre, L. de, 199

Granström, K., 0, 656

Grant, J., 449

Grant-Smith, D., 87

Grattapaglia, D., 48, 174, 188, 313

Gratzer, G., 686 


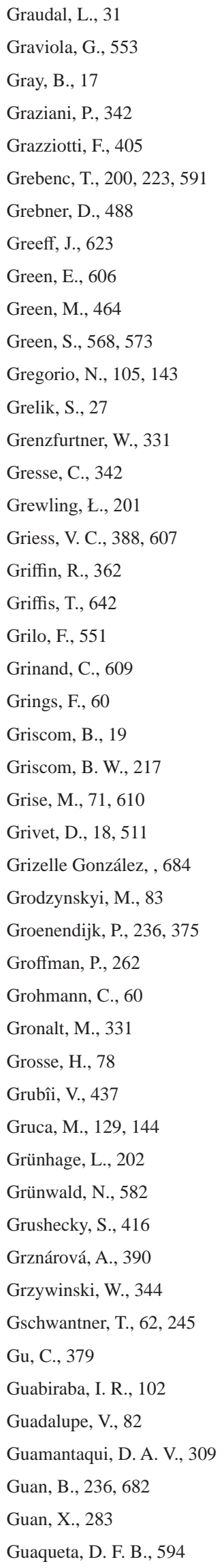

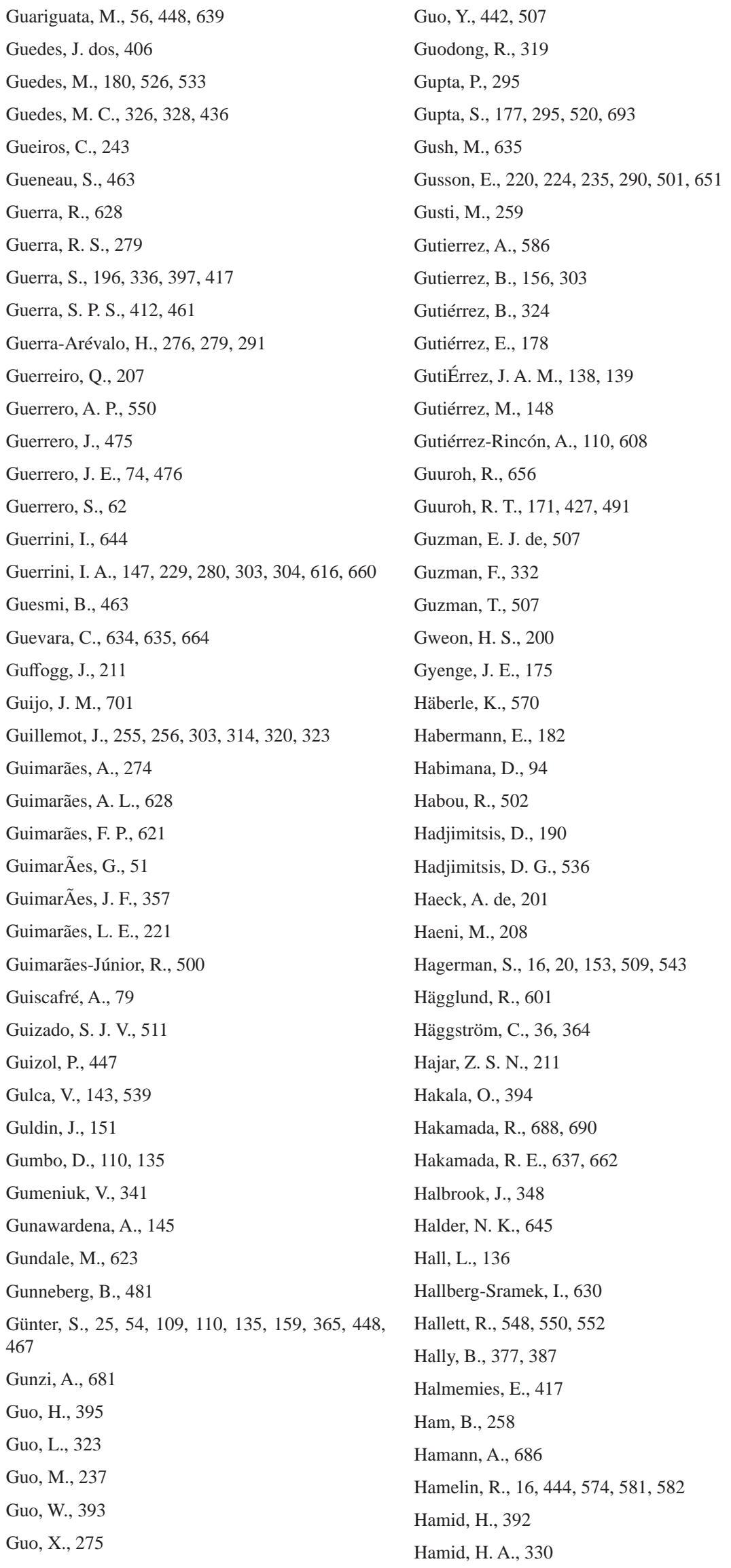

Guo, Y., 442, 507

Guodong, R., 319

Gupta, P., 295

Gupta, S., 177, 295, 520, 693

Gush, M., 635

Gusson, E., 220, 224, 235, 290, 501, 651

Gusti, M., 259

Gutierrez, A., 586

Gutierrez, B., 156, 303

Gutiérrez, B., 324

Gutiérrez, E., 178

GutiÉrrez, J. A. M., 138, 139

Gutiérrez, M., 148

Gutiérrez-Rincón, A., 110, 608

Guuroh, R., 656

Guuroh, R. T., 171, 427, 491

Guzman, E. J. de, 507

Guzman, F., 332

Guzman, T., 507

Gweon, H. S., 200

Gyenge, J. E., 175

Häberle, K., 570

Habermann, E., 182

Habimana, D., 94

Habou, R., 502

Hadjimitsis, D., 190

Hadjimitsis, D. G., 536

Haeck, A. de, 201

Haeni, M., 208

Hagerman, S., 16, 20, 153, 509, 543

Hägglund, R., 601

Häggström, C., 36, 364

Hajar, Z. S. N., 211

Hakala, O., 394

Hakamada, R., 688, 690

Hakamada, R. E., 637, 662

Halbrook, J., 348

Halder, N. K., 645

Hall, L., 136

Hallberg-Sramek, I., 630

Hallett, R., 548, 550, 552

Hally, B., 377, 387

Halmemies, E., 417

Ham, B., 258

Hamann, A., 686

Hamelin, R., 16, 444, 574, 581, 582

Hamid, H., 392

Hamid, H. A., 330 
Hamilton, E., 263

Hamilton, L., 252

Hamunen, K., 86

Hamzah, M. Z. B., 392

Han, A., 37

Han, D., 551

Han, H., 52, 348

Han, S., 53

Han, S. H., 40, 197, 295, 644, 671

Han, W., 497

Han, Z., 482, 554

Hancock, S., 189

Handel, S., 550

Hanewinkel, M., 149, 150, 199, 486, 487

Häni, M., 201

Hanisch, A. L., 285, 410

Hanna, J., 565, 579

Hansen, E., 74, 102, 475, 476, 685

Hansen, K., 200, 201

Hansen, O. K., 267

Hanson, P., 264

Hantula, J., 575

Harada, K., 89, 95, 103, 104

Harapan, M., 598

Hardiman, B., 281

Harding, S., 515

Hardy, G., 563, 574

Harfoot, M., 606

Hargrove, W., 503

Harini, K. S., 705

Härkönen, S., 215

Harman, M., 19

Harper, A., 263

Harris, N., 217

Harrison, J., 481

Harrison, L., 561

Harrison, P. A., 156

Hart, K., 263

Hartley, I., 252, 263

Hartmann, H., 193

Hartmann, P., 150

Hartsell, J., 187

Harvey, W., 37

Hasenauer, H., 24, 156, 191, 469, 470, 491

Hashimoto, S., 384, 653, 674

Hassani, M., 302

Hassegawa, M., 20, 238, 270, 419

Hassler, S. K., 45

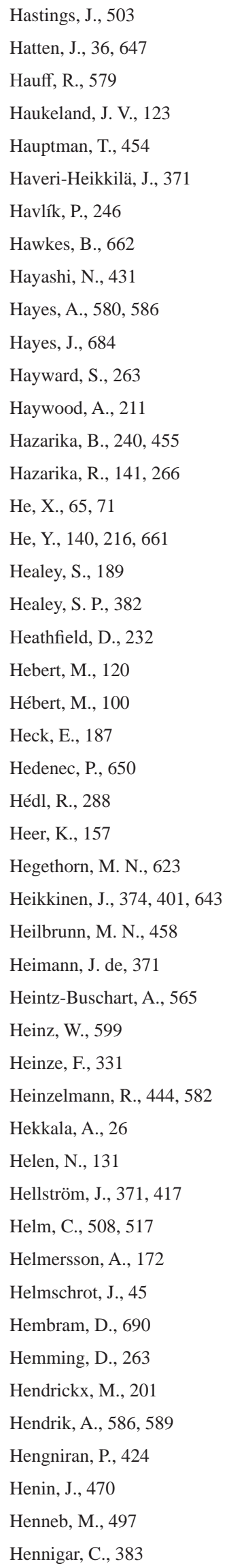

Henning, L., 19, 223, 266

Hennon, P., 281

Henrique, R. L. P., 564

Henry, M., 222, 615

Henttonen, H. M., 374, 464

Hentz, P., 308, 660

Hepner, H., 638

Hera, P. L., 332, 338, 350

Heräjärvi, H., 477

Herault, B., 153

Hérault, B., 217

Herbelê, A. L. O., 701

Herbert, C. M., 473

Herbohn, J., 105, 143, 467, 468

Herder, M. D., 96

Hergoualc'h, K., 27, 641

Hergoualc’h, K., 642

Hermanowicz, E., 696

Hernadez, S. O., 294

Hernán, E., 523

Hernandez, F., 616

Hernandez, J., 88, 377, 489

Hernández, M. G., 87

Hernández, P., 508

Hernández, R., 437, 471

Hernández-Agüero, J. A., 572

Hernández-Aguilar, J. A., 123

Hernández-Ramos, A., 257

Herndon, K., 362

Hernea, C., 287

Herold, M., 217

Herrera, A. H., 705

Herrera, C., 148

Herrera, D., 244

Herrera, M. A., 620

Herrera, X., 64

Herron, D., 595, 687

Hess, A. F., 48

Hess, Y. C., 124

Hesser, F., 179, 245

Heuertz, M., 18

Heyens, K., 654

Hidy, D., 375

Higa, A. R., 328

Higa, R. C. V., 229, 328

Higachi, H. Y., 67, 555

Higashihara, T., 675

Higashikawa, E. M., 160 


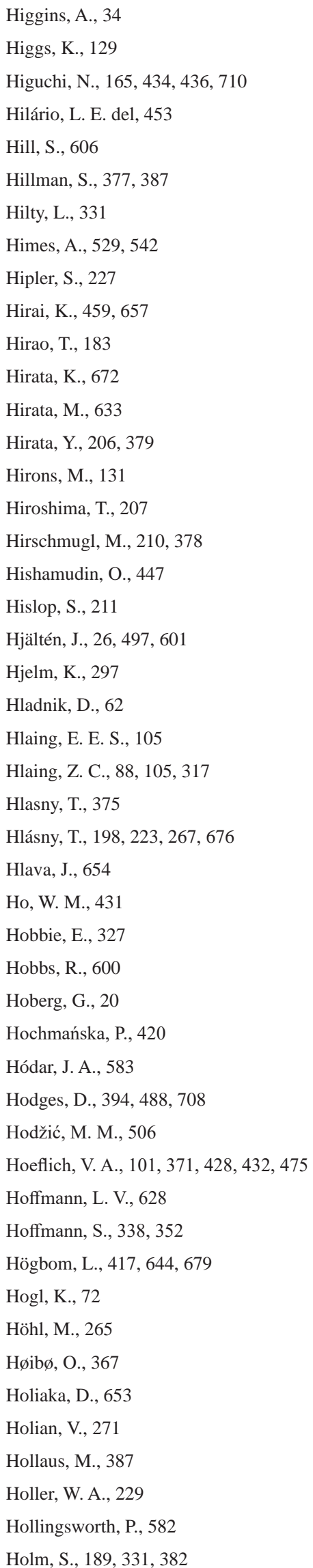

\begin{tabular}{|c|c|}
\hline Holmes, T., 356 & Hubau, W., 296 \\
\hline Holmgren, J., 389, 524 & Hubbard, R., 325, 666 \\
\hline Holmgren, S., 473 & Hubbard, W., 689, 696 \\
\hline Holmström, E., 190, 302 & Hudak, A., 206, 381 \\
\hline Hologne, O., 697 & Huesca, M., 605 \\
\hline Holopainen, M., 190, 206 & Huff, E., 94 \\
\hline Holsbeeck, S. V., 423, 708 & Hujala, T., 86, 477, 483, 683 \\
\hline Holt, L., 369 & Huka, M. A., 331 \\
\hline Hong, M., 353, 408, 537, 678 & Hulbert, J., 547, 549 \\
\hline Hong, Y., 49, 145, 553, 626, 627, 670 & Hulcr, J., 585 \\
\hline Hong, Y. S., 296 & Hull, J., 548 \\
\hline Honghao, G., 520 & Humphreys, D., 131 \\
\hline Honorio, E., 153 & Humphris, S., 582 \\
\hline Hood, I., 444, 574 & Hunt, M., 24, 156, 298, 411 \\
\hline Hoogerheide, E. S. S., 506 & Hunziker, L., 442 \\
\hline Hoppen, M., 331 & Hurel, A., 18, 158, 507 \\
\hline Horn, H., 330 & Hurley, B., 441, 558 \\
\hline Hornink, B., 242 & Hurley, B. P., 585 \\
\hline Horta, J., 196 & Hurmekoski, E., 270, 477 \\
\hline Horwitz, P., 129 & Hurskainen, P., 604 \\
\hline Hoshika, Y., 171, 180, 181, 249, 254, 350, 569 & Hurtado, F., 516 \\
\hline Hosokawa, R. T., 48 & Hurtevent, P., 654 \\
\hline Hossain, M. A., 222, 615 & Hussain, S. A., 538, 676 \\
\hline Hossain, M. K., 703 & Hussin, Y., 212, 361 \\
\hline Hotte, N., 99 & Husson, H., 353, 541 \\
\hline Hou, R., 408 & Hutagaol, A., 305 \\
\hline Hovenden, M., 298 & Hutagaol, A. L., 598 \\
\hline Hovis, M., 121 & Hutchinson, S., 260 \\
\hline Howard, B. J., 652 & Huth, N., 315 \\
\hline Hrenko, M., 505 & Huuskonen, S., 394 \\
\hline Hrib, M., 117 & Huyen, T. D. L., 641 \\
\hline Hribljan, J., 27 & Hynynen, J., 394 \\
\hline Hrideek, T. K., 317 & Hyun, H. J., 644 \\
\hline Hrunyk, N., 504 & Нyyррӓ, J., 190, 206 \\
\hline Hsu, Y., 189, 361, 376, 419 & Iacob, N., 287 \\
\hline Нu, J., 467, 468 & Iacoban, C., 204 \\
\hline Hu, P., 521 & Ianniruberto, M., 501 \\
\hline Hu, S., 46 & Ibañez, C., 240 \\
\hline Huaman, A. A. C., 438 & Ibarluzea, N., 281 \\
\hline Huaman, V., 573 & Ibarr, M., 225, 707 \\
\hline Huamaní, W., 27 & Ibrahim, W. A., 431 \\
\hline Huang, G., 318 & Iciar, A., 409 \\
\hline Huang, M., 391 & Ickowitz, A., 633 \\
\hline Huang, P., 327, 393, 509, 521 & Idjigbérou, S. E., 91 \\
\hline Huang, Q., 323 & Iegawa, E. M., 592 \\
\hline Huang, S., 391 & Ifejika-Speranza, C., 152 \\
\hline Huang, X., 497 & Iglesias, J., 64 \\
\hline Huang, Y., 233 & Iii, J. C., 558 \\
\hline
\end{tabular}

Holmes, T., 356

Holmgren, J., 389, 524

Holmgren, S., 473

Holopainen, M., 190, 206

Hong, M., 353, 408, 537, 678

Hong, Y. S., 296

Honghao, G., 520

rio, E., 153

Hoogerheide, E. S. S., 506

Hoppen, M., 331

Horta, J., 196

Horwitz, P., 129

Hosokawa, R. T., 48

Hossain, M. A., 222, 615

Hotte, N., 99

Hou, R., 408

Hovenden, M., 298

Howard, B. J., 652

Hribljan, J., 27

Hrideek, T. K., 317

Hrunyk, N., 504

Hsu, Y., 189, 361, 376, 419

u, J., 467, 468

Hu, S., 46

Huaman, A. A. C., 438

Huang, G., 318

Huang, M., 391

Huang, P., 327,

Huang, Y., 233
Hubau, W., 296

Hubbard, R., 325, 666

Hudak, A., 206, 381

uesca, M., 605

Huff, E., 94

Huka, M. A., 331

作, J., 547, 549

Hull, J., 548

Hunt, M., 24, 156, 298, 411

Hunziker, L., 442

Hurel, A., 18, 158, 507

Hurmekoski, E., 270, 477

Hurskainen, P., 604

Hussain, S. A., 538, 676

Hussin, Y., 212, 361

Husson, H., 353, 54

utagaol, A., 305

aol, A. L., 598

Hutchinson, S., 260

Huth, N., 315

Hynynen, J., 394

Hyun, H. J., 644

Нyyppä, J., 190, 206

ob, N., 287

Ianniruberto, M., 501

Ibañez, C., 240

Ibarluzea, N., 281

Iciar, A., 409

Ickowitz, A., 633 
Iizuka, K., 671, 672

Ikami, Y., 675

Ikeda, S., 674

Ikeda, T., 431

Ikemoto, M., 621

Iliev, I., 677

Ilstedt, U., 155, 447, 463

Im, S., 349

Imamura, N., 653, 657, 658, 674

Immitzer, M., 604

Inagaki, M., 459

Inagaki, Y., 327

Ingram, V., 120

Iñiguez, C. I. E., 109

Inomata, Y., 251

Inoue, M., 675, 685, 694

Ioniță, M., 284

Ioos, R., 575

Ipeaiyeda, A., 439

Ipinza, R., 156, 188, 303, 324

Iponga, D. M., 120

Irauschek, F., 215

Irle, M., 435

Isaac Junior, M., 384, 688

Isaacs, P., 146

Isabel, C., 409

Ishibashi, S., 207

Ishida, K., 623

Isienyi, N., 439

Isikhuemen, E. M., 490, 560

Islam, M. W., 125, 246, 247

Ismail, M. H., 212

Ismenyah, M., 448

Isnaeni, I., 346

Issaoui, H., 418

Ito, E., 673

Ito, T., 93, 113

Itô, H., 657

Itoh, Y., 663, 674

Ivan, R., 522

Ivanauskas, N., 220, 466

Ivanov, A., 269

Iwaizumi, M. G., 183

Iwakiri, S., 435, 436

Izaldino, P., 691

Izquierdo, M., 653

Jabardo, P., 68

Jackson, W., 556

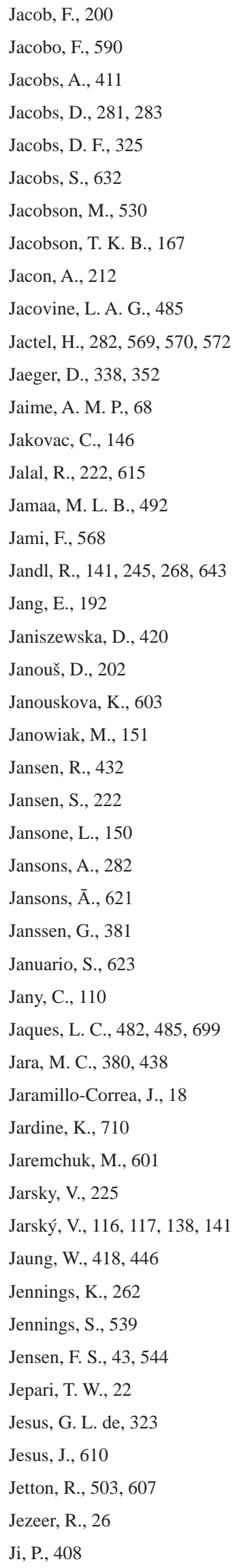

\author{
Jia, N., 320 \\ Jia, W., 493 \\ Jiang, L., 334 \\ Jiang, P., 675 \\ Jiang, Y., 240 \\ Jiang, Z., 415, 428, 429, 571 \\ Jianmei, Y., 125 \\ Jianmin, C., 520 \\ Jiao, C., 323 \\ Jiao, L., 344, 345, 704 \\ Jimenez, L., 651 \\ Jiménez, D., 64 \\ Jiménez, V., 434 \\ Jimu, L., 88 \\ Jingu, S., 93, 113 \\ Jirle, E. V., 556 \\ Jo, H., 66, 384, 405 \\ Joaquim, M. S., 286 \\ Jocher, G., 202 \\ Joelsson, K., 497 \\ Joey, Z., 159 \\ Jogiste, K., 495 \\ Jõgiste, K., 227 \\ Johann, E., 28 \\ Johannsen, V. K., 43, 273 \\ Johansson, M., 349 \\ Johansson, U., 337 \\ John, A., 240, 455 \\ Johnsen, F. M., 445 \\ Johnson, J., 187, 200, 689 \\ Johnson, K., 222, 615 \\ Johnson, S. L., 647 \\ Johnston, I., 263 \\ Johnstone, R., 600 \\ Jokela, E., 197, 457 \\ Joko, N., 685 \\ Jonard, M., 250 \\ Jones, A., 263, 669 \\ Jones, K., 680 \\ Jones, N., 576 \\ Jones, S., 211, 377, 387 \\ Jong, W. de, 17, 122, 129, 131 \\ Jonikavicius, D., 380 \\ Jonoobi, M., 239 \\ Jonsson, R., 332 \\ Joo, S., 670 \\ Jordan, C., 452, 453 \\ Jorge, C., 451, 452, 455, 593
}


Jose, S., 606

Josef, G., 601

Joshi, N., 362, 548

Jossefa, C., 311

Joung, D., 553

Joy, C., 112

Juerges, N., 696

Juliao, H., 311

Juma, K., 416

Jung, H., 49

Jung, J. B., 37

Jung, K., 333

Jung, Y., 553, 626

Juniwaty, K., 418

Junqueira, A. M., 30

Junqueira, L. R., 441, 450, 452, 582

Junqueira, R., 146, 313

Junqueira, R. A. S. A., 322, 536

Junttila, S., 206

Juodkiene, V., 380

Jurc, D., 454

Jusko, V., 191

Juutinen, A., 124

Juvenal, T. L., 55, 97, 334

Južnič, P., 698

Jyske, T., 417

Kaakkurivaara, N., 364

Kabwe, G., 135

Kachaka, C., 129

Kacprzak, A., 97, 685

Kadir, W. R., 310, 431

Kadiri, Y., 570

Kadooka, C., 579

Kagawa, A., 237, 658, 673

Kagombe, J., 108, 679

Kagosi, P., 340

Kahle, H., 45, 218, 605, 688

Kaimre, P., 116

Kainer, K., 80, 81, 160

Kainer, K. A., 112

Kaitera, J., 557

Kajimoto, T., 672, 673

Kakinuma, K., 248

Kalaba, F., 44, 120, 491

Kalil Filho, A. N., 329, 337, 406, 509, 518

Kallio, A. M. I., 477

Kallio, M., 94, 135

Kaltenbrunner, M., 331
Kamakura, M., 480

Kamata, N., 588, 682

Kanasashi, T., 657

Kanashiro, M., 106, 153, 335

Kane, V., 381

Kaneko, S., 657, 658, 674

Kang, M., 404

Kang, Y., 320

Kangas, A. S., 63, 401

Kangur, A., 235, 495

Kanieski, B., 365

Kankare, V., 190

Kanninen, M., 94

Kanowski, P., 126, 130, 470

Kant, P., 20, 270

Kant, S., 75, 84, 134

Kanzi, A., 597

Kanzian, M., 266

Kapos, V., 246, 606

Kapron, J., 61

Karaszewski, Z., 353

Kardol, P., 623

Karel, W., 387

Karhunen, A., 394, 404

Karimidoost, A., 267, 302

Kärkkäinen, L., 63

Karlsson, B., 172

Karmann, M., 143, 344

Karna, Y., 204, 357

Karnasuta, N., 395

Karnat, M., 439

Karpuk, A., 258

Karttunen, K., 394, 404

Karunaratne, M., 125, 142

Kasel, S., 154

Kashparov, V., 653

Kaspar, J., 395, 487

Kasprzyk, I., 201

Kasubova, M., 121

Kasurien, V., 231

Katel, O., 103

Katila, P., 17, 129

Kato, H., 674

Katsumata, K., 431

Katsuyama, M., 464

Katzensteiner, K., 37, 385, 566, 660

Kaulfuss, S., 344

Kaur, A., 248
Kaur, S., 593

Kaushal, R., 227

Kavaliauskas, D., 504, 505

Kavitha, C., 669

Kawamoto, S., 690, 694

Kayama, M., 633

Kays, L., 695

Kazama, D. C. da, 29

Kazungu, M., 110, 135

Kc, R., 394

Kebbi-Benkeder, Z., 413

Keenan, R., 21, 243

Keenan, R. J., 639

Keene, S., 130

Kellner, J., 189

Kellner, J. R., 382

Kemboi, J., 510

Kennedy, R., 381

Kenzo, T., 672, 673

Kerfriden, B., 209

Kerr, I., 223

Kershaw, J., 189, 361, 376, 419

Kershaw, J. A., 378, 402

Keski-Saari, S., 604, 605

Keskitalo, C., 85

Kettley, S., 697

Khabarov, N., 258

Khai, T. C., 390

Khalumba, M., 108

Khan, M. F. A., 133

Khan, Y., 478

Khasa, D., 508, 512

Khasa, D. P., 129

Khatun, K., 131

Khedhri, I., 383

Kiasari, S. M., 267

Kieran, F., 543

Kietvuttinon, B., 251

Kigomo, J., 492

Kiill, L. H. P., 518

Killick, S., 564

Kilpeläinen, J., 170

Kilpeläinen, P., 417

Kim, D., 385, 627

Kim, E., 49, 145, 553, 626, 627, 670

Kim, H., 53, 182, 184, 254, 255, 414

Kim, H. D., 182

Kim, H. J., 37 
Kim, H. S., 385

Kim, J., 66, 254, 408, 490, 626

Kim, J. E., 182

Kim, M., 333, 384, 405, 408, 565, 579, 626

Kim, M. K., 33, 629

Kim, S., 29, 537

Kim, S. B., 40

Kim, S. J., 408, 537, 678

Kim, T. H., 119, 500

Kim, Y., 52, 685

Kimberly, M., 580

Kimura, R. K., 318, 506

Kimwemwe, J., 416

Kindelán, O. H., 68

Kindermann, G., 245, 643

Kindgard, A., 602

King, B., 369

King, J., 202

Kinnunen, J., 394

Kiourtsis, F., 144, 504

Kiprop, J., 369, 529

Kipsat, J., 169

Kiragu, J., 15, 682

Kirchner, T., 208

Kirkby, T., 600

Kirui, B., 626

Kisiwa, A., 45

Kitahara, F., 408

Kitheka, E., 416

Kitunen, V., 643

Kitzberger, T., 572

Kitzler, B., 208, 269

Kivinen, S., 604, 605

Kiviste, A., 227

Kjartansson, B. T., 62

Kkadan, S., 586, 589

Kkadan, S. K., 586, 587

Klebinder, K., 385

Klein, B. C., 274

Klein, T., 194

Kleine, M., 20, 265

Kleinn, C., 65, 611

Kleinschmit, D., 126, 128, 473

Kleist, K. V., 105

Klemann Junior, L., 363

Klisz, M., 19, 266

Klitzke, A., 373

Klitzke, A. R., 164, 391, 435
Klizentyte, K., 124

Kloosterman, H., 361

Kloosternam, H., 212

Klopfenstein, N., 565, 579

Klosterhuber, R., 385

Klunk, G. A., 162

Knight, O., 33

Knoke, T., 531

Ko, Y., 258, 353

Koba, K., 327

Kobayashi, M., 658, 663, 674

Kobayashi, N., 672

Kobayashi, N. I., 673

Kobayashi, R., 672

Kocaeli, G. M., 538

Koch, A., 27

Koch, M. B., 425

Koch, N., 96, 551

Kočický, D., 676

Koda, K., 633

Koehler, H., 352, 534, 664

Kohler, M., 150, 169

Kohn, I., 62

Kohnle, U., 150

Kohsaka, R., 248

Koirala, A., 374, 381

Kojola, S., 394

Kojwang, H., 492

Kolka, R., 264, 640, 642, 680

Koller, T., 179

Koloszl, L., 62

Komalasari, M., 244

Komatsu, M., 653, 657, 658, 674

Konate, S., 597

Konczal, A., 541

Kone, N. A., 597

Konijnendijk, C., 131, 439, 440, 546

Koning, J. de, 541

Konnert, M., 469

Konoshima, M., 480

Kons, K., 332

Kooch, Y., 655, 668

Kopfmüller, J., 570

Korb, J., 585

Korbéogo, G., 594

Koreň, M., 360

Korhonen, J., 474

Korhonen, K. T., 63
Korosuo, A., 259

Korpelainen, P., 604, 605

Korpinen, R., 417

Kosinov, D., 269

Kosmowska, A., 646

Kostecki, J., 343

Köster, E., 198

Köster, K., 198, 231

Košulič, O., 288

Koter, R. B., 392

Köthke, M., 467

Kotlarewski, N., 411

Kottusch, C., 257

Kou, L., 675, 676

Kourmouli, A., 252, 263

Koury, C. G., 124

Kouyaté, A. M., 42

Kovac, M., 62

Kovalčík, M., 273

Kovalsyki, B., 271, 356

Kowalczyk, J., 19, 266

Kowalska, A., 201

Kowalska, N., 202

Kozak, R., 16, 99, 131, 153, 509, 543

Kozlov, M. V., 571, 572, 587

Kozovits, A., 202

Kraigher, H., 144, 157, 159, 223, 326, 504, 505, 506, 591

Kraskovska, A., 97

Krasovskii, A., 155, 258, 448, 543

Krasylenko, Y., 591

Kraus, D., 599, 618

Kraus, S., 96

Krause, A., 418

Krause, S., 263, 669

Kravets, P., 478

Kraxner, F., 117, 180, 191, 227, 246, 257, 258, 362, 448, 543, 548, 639

Krč, J., 354

Kreczkiuski, D., 50, 294

Krejčí, P., 409, 410

Kremer, K., 489

Kresoja, M., 241

Kristell, H., 494

Kristianova, K., 554

Kristöfel, F., 200

Krokene, P., 267

Krott, M., 395, 696

Krottenthaler, S., 178 
Kruchelski, S., 42, 499

Krüger, I., 208, 251

Krumm, F., 601

Krupová, D., 209

Krzic, M., 704

Kubík, P., 409, 410

Kubo, S., 431

Kucera, M., 62

Kujala, S., 394

Kukushkin, O., 591

Kulbokas, G., 62, 302, 368

Kuliesis, A., 62

Kullberg, P., 604, 605

Kumar, A., 240, 455

Kumar, M. F., 222, 615

Kumar, R., 64

Kumela, H., 86

Kumpula, T., 604, 605

Kungu, J., 679

Kunneke, A., 605, 634

Kunttu, J., 96, 477

Kunz, J., 150, 169

Kuraji, K., 675, 682

Kurian, P., 130

Kuribayashi, T., 431

Kurjak, D., 375

Kuroda, K., 657

Kuromoto, V., 700

Kuromoto, V. M., 700

Kurt, B., 538

Kurttila, M., 124, 371, 395

Kurz, W., 257, 381

Kuželka, K., 387

Kuzmin, A., 604, 605

Kuzovkina, J., 471, 503

Kvist, V., 62

Kwafo, J. O., 102

Kwak, M., 182, 184, 254, 255, 594

Kweon, H., 333

Kwon, O., 414

Kyaw, C. N., 105

Kylkilahti, E., 474

Kyselova, I., 202

Laas, M., 443

Labidi, J., 418

Lacerda, A. E. B. de, 47, 631

Lachat, T., 599, 601, 618

Laclau, J-P., 255, 256, 303, 314, 323, 644, 659
Ladet, S., 599

Lafond, V., 607

Lafortezza, R., 544

Lagemann, M., 256

Lagemann, M. P., 255, 655, 666, 667

Lagomasino, D., 537

Lähdesmäki, M., 138

Lähteenoja, O., 642

Lahtinen, M., 417

Lähtinen, K., 474, 475

Laihanen, M., 394, 404

Lake, F., 28

Lake, F. K., 631

Lakhchaura, P., 64

Lakmali, W. S., 706

Lakyda, I., 258, 271, 478

Lakyda, M., 258

Lakyda, P., 258

Lalande, B., 565

Lam, T. Y., 378

Lämås, T., 531

Lamb, D., 467, 468

Lambrecht, F. R., 534

Lambrechts, H. A., 634

Lamonica, L., 274

Lamparelli, R. A. C., 255

Lancaster, C., 335, 345

Landburg, G., 228

Landguth, E., 187

Landry, S., 383

Lane, P. N. J., 706

Lang, F., 45

Langat, D., 510, 529

Langer, M., 38, 359, 446, 472, 541, 689

Langmaier, M., 608

Langner, A. J., 603

Lankia, T., 32

Lantschner, M. V., 25, 583

Lantschner, V., 442

Lanz, A., 62, 209

Lapaz, A. de, 671

Lapin, K., 179, 608

Lapo, A., 694

Lara, A., 560

Lara, R. A. C., 61

Larasatie, P., 102, 475

Larcher, R., 253

Laroche, F., 599
Larocque, G., 361, 388

Laroque, C., 221

Larrieu, L., 599, 600, 601, 618

Larsen, S., 445

Larson, A., 15, 16, 115, 130, 243

Larson, A. M., 89

Larue, E., 281

Larwanou, M., 246

Laschi, A., 22, 349, 353, 694

Laserre, B., 378

Lasko, R., 341

Lasserre, B., 605

Lastra, J., 606

Latałowa, M., 201

Latif, Z. A., 361

Launiainen, S., 170

Laura, V., 294, 298, 300, 309

Laura, V. A., 289

Laurén, A., 460

Lauri, P., 117, 259

Laverde, M. C., 415

Lavnyy, V., 504

Lawlor, K., 129

Lawson, I., 28

Lazarotto, S., 77, 103, 708

Lazo, R., 524

Lazzara, M., 181

Lazzarin, L. C., 304, 308, 660

Lazzarotto, M., 406

Leal, I., 151

Leal, L., 358, 359

Leal-Saenz, A., 187, 510

Leao, R., 63, 196, 538

Leavitt, S. M., 217

Leban, J., 209

Leban, V., 354, 706

Leblon, B., 686

Leca, S., 181, 204, 208, 250, 510, 522

Lech, P., 200

Leckie, A., 556

Lecomte, X., 150, 494

Ledermann, T., 245

Ledezma, M., 411

Leduc, S., 227, 543

Leduc, V., 659

Lee, B., 29, 537

Lee, C., 537,562

Lee, C. C. H., 693 
Lee, D., 393, 453, 562, 580, 586, 590

Lee, D. K., 295

Lee, E., 49, 145, 349, 553, 626, 627, 670

Lee, H., 258, 500

Lee, J., 29, 53, 182, 184, 254, 255, 333, 594

Lee, J. H., 453

Lee, J. K., 182, 453

Lee, S., 29, 49, 145, 353, 405, 500, 553, 562, 590, 626, 627, 670

Lee, S. J., 537

Lee, S. K., 453, 537, 562, 590

Lee, S. M., 418

Lee, S. T., 296

Lee, W., 258, 353, 384, 405, 408, 537, 678

Lee, Y. K., 296

Leeuwen, L. V., 611

Legese, M. T., 154

Leggett, M., 93

Legoas, R. C., 175, 413

Lehto, T., 170

Lehtonen, P., 334

Lei, L., 196

Lei, X., 153, 395

Leidinger, D., 557

Leigh, A., 561

Leitão, P., 370

Leitch, M., 336

Leite, E., 30

Leite, F., 316, 323

Leite, H., 234, 398

Leite, H. G., 32, 390, 484, 485

Leite, M. B., 38, 678

Leite, P. L., 316

Leite, R., 234, 398

Leite, R. V., 219, 230, 348, 390, 399

Leitner, S., 263

Lekah, A., 691

Leksungnoen, N., 66, 635

Leles, P. S. dos, 164

Lella, S. D., 253

Lemes, P. G., 479

Lemoine, G., 362

Lemos, C., 662

Lemos, C. C. Z., 637

Lemos, D. C., 269

Lencinas, M. V., 710

Lencinas, V., 705

Leng, C., 206
Lenhart, J., 131

Lent, J. V., 642

Lenti, F., 523, 525

Lentini, M., 76, 83, 155

Leonard, S., 641

Leonardi, A., 630

Leonello, E. C., 412

Leshchinsky, B., 36

Leskinen, P., 20, 96, 270, 477

Leslie, G., 244

Lestianska, A., 181

Letelier, L., 383

Leuzinger, S., 197

Levanič, T., 241

Levchuk, S., 653

Lévesque, M., 150

Levy, P. B., 111

Lewark, S., 344

Lewin, K., 263

Lewis, A., 593

Lewis, S. L., 211, 217

Lexer, M. J., 199, 215, 557

Leyva, A., 34

Li, B., 521

Li, C., 221

Li, D., 323

Li, H., 327

Li, J., 109

Li, L., 122, 319

Li, M., 377

Li, Q., 171, 349

Li, S., 377, 585

Li, W., 320, 334

Li, X., 231, 319, 347, 650

Li, Y., 60, 334, 408, 409, 462, 482

Li, Z., 323, 377, 378, 379, 416, 429

Liang, X., 190

Liberato, M. da, 195

Liblikas, I., 556

Lichy, J., 121

Lidestav, G., 117, 138

Lidman, F., 302

Liebhold, A., 267, 558, 559

Liebhold, A. M., 583

Liebsch, D., 113, 407

Liepa, L., 619, 621

Lier, M., 63, 97

Lier, Q. de, 645
Liesebach, M., 471

Liesenberg, V., 257, 363, 377, 403, 543

Ligt, R. de, 381

Liimatainen, J., 417

Likoski, J. K., 373, 391

Lilja, A., 475

Lilleskov, E., 27, 642

Lim, C., 258

Lim, K., 627

Lim, Y., 182, 184, 254, 255

Lim, Y. J., 182

Lima, A., 165, 207, 210, 329, 665

Lima, A. C. B. de, 436

Lima, A. L., 699, 700

Lima, B., 174

Lima, C. A. T. de, 106

Lima, D., 361

Lima, E., 57, 261, 262

Lima, F. F. de, 358

Lima, G. S., 108, 136, 162, 348

Lima, J. T., 471

Lima, M. da, 434

Lima, M. de, 76, 421, 425

Lima, N., 329

Lima, R., 68, 220, 669

Lima, R. B. de, 534

Lima, R. Y. M., 57

Lima, T. A., 388, 603

Lima Filho, N. P. de, 108

Lima Junior, M. de, 186

Lima Neto, J. T., 167

Lin, F., 393

Lin, L., 129

Lin, Q., 661

Lin, Y., 687

Lind, B., 19

Lindberg, E., 524

Lindberg, K., 123

Linde, S. V. D., 200, 593

Lindenkamp, T. C. M., 92, 124

Lindenmayer, D., 528

Lindeskog, M., 194

Lindgren, A., 86

Lindgren, N., 191

Lindhe, A., 82

Lindroos, A., 643

Lindroos, O., 332, 349

Lindroth, R., 202 
Lindström, N., 330

Lingachar, M., 43, 512

Lingnau, C., 688

Lingner, D., 619, 694

Lingner, D. V., 195, 614

Lingua, F., 607

Linh, C. D. T., 114, 641

Linhales, S., 465

Linkevičius, E., 472

Linn, W. W., 231, 557

Linnakoski, R., 206, 371

Linser, S., 97

Linstädter, A., 594

Lintunen, J., 214

Lippe, M., 467

Lira, D. F. de, 63, 196, 538

Lira-Guedes, A. C., 102, 326, 328, 466

Lisi, C. S., 178, 346

Lister, T., 64

Little, C., 146, 496, 560

Little, K. M., 634

Liu, F., 597, 598

Liu, H., 428

Liu, J., 134, 275, 571

Liu, K., 415

Liu, N., 379

Liu, Q., 231, 347, 377

Liu, S., 231, 264, 347, 379, 585, 643, 648, 650, 659, 660, 661

Liu, X., 46, 153, 295, 318, 395, 414, 426, 429, 493, 497, 532

Liu, Y., 312, 340, 509, 610, 687

Liu, Z., 415, 665

Livramento, D. E., 438

Lizardo, R. S., 99

Liziniewicz, M., 172

Llampazo, G. F., 28

Llanos, A., 524

Llanos, E., 284

Llanos, E. R., 403

Llanos, E. R. de, 390, 682

Llanos, L. F., 325

Llavallol, C. I., 73

Lo, M., 633

Loader, N., 263, 669

Loaiza, H., 522

Lobão, D. E., 542

Lobão, J. S. B., 524

Lobão, M., 183, 437, 439, 691
Lobianco, A., 215

Lobo-Do-vale, R., 150

Lobos, D., 560

Locatelli, B., 20

Locatelli, T., 232

Locci, A., 336

Locosselli, G., 176, 178

Lodge, J., 579

Loeb, R., 69, 608, 654

Loewe-Muñoz, V., 158, 302, 702

Löf, M., 21, 230, 282, 283, 295, 312, 490

Löfroth, T., 198, 200, 497

Löfstedt, C., 556

Logato, E., 465

Loguercio, G., 60

Lohr, L., 530

Lombardi, F., 222, 253, 296

Lombo, D. F., 285, 294, 503

Long, H., 134

Longa, C. M., 596

Longauer, R., 266

Longhi, S. J., 179

Longhi-Santos, T., 241, 435

Loo, M. V., 156

Looker, N., 680

Loomis, J., 356

Looney, C., 151

Loos, R. A., 323

Loper, A. A., 614

Lopes, A. T., 618

Lopes, B. S., 659, 666

Lopes, E., 136, 260, 339, 352, 527, 664

Lopes, F., 370

Lopes, M. I., 25

Lopes, M. T. G., 186

Lopes, P. R. de, 564

Lopez, M., 642

López, A. M., 325, 393, 398, 640

López, D., 588, 590

López, J. L., 307

López, L. A. A., 276, 279

López, M. M., 307

López-Barrera, F., 264

López-García, A., 655

Lopez-Ramirez, S., 680

López-Ramirez, M., 579

Lorensani, R. G. M., 413

Lorenzo, M. J. R., 396
Lorenzon, A. S., 219, 348, 485

Lorida, R., 519

Loshakov, S., 269

Louman, B., 55

Louppe, D., 296

Lourdes González, , 147

Lourenço, H., 316, 321

Loures, L., 545

Loures, N. G., 274, 480, 681

Lousada, J., 321

Loustau, D., 203

Louw, J., 635

Loval, S., 327

Lovatel, Q. C., 311

Lovison, G., 625

Lowe, A., 355

Lowell, E., 348

Lozano, D., 218, 219

Lozano, V., 593

Lozantos, E. J. R., 59

Lstibůrek, M., 266

Lu, L., 264, 373, 659

Lu, M., 444

Lu, Y., 153, 395

Luan, J., 585, 643, 661

Lubowski, R., 244

Lucca, C. M. D., 426

Lucena, L., 690

Lucero, A., 40

Luchi, N., 575

Lucia, M., 534

Lucieer, A., 156, 377, 387

Ludvig, A., 72, 74, 245

Luiz Neto, , 588, 597

Lukman, K. M., 248

Lula, M., 483

Lumnitz, S., 607

Lumsden, L., 199

Luna, A., 519

Luna, A. G. S., 411

Luna, Q., 260

Lundbäck, M., 36, 364

Lunde, S. F., 609

Lundmark, T., 225, 302

Lundqvist, L., 217

Lundqvist, S., 172

Lundström, H., 332

Lunnan, A., 227 
Luo, Y., 687

Lupek, M., 121

Luque, S., 606

Luque, V. J., 111

Lusiana, B., 117, 448

Lussetti, D., 155

Lustosa, S. B. C., 286

Lutrell, C., 128

Lutter, R., 638

Luz, A., 551

Luz, M. L. A., 107, 630

Luz, N., 611

Luz, N. B. da, 603

Luzuriaga, P., 46

Lwasa, S., 131

Lwila, A. S., 217

Lykke, A. M., 42

Lyra, M. R. C. C., 621

Lysak, F., 265

Lyytikäinen-Saarenmaa, P., 206

Ma, J., 414, 429

Ma, K., 572

Ma, X., 429

Maas, G., 192

Macaya-Sanz, D., 567

Macedo, F., 501

Macedo, J., 542

Macedo, M., 272

Macedo, R., 234, 532

Macedo, R. P., 399

Macêdo, N., 260

Macfarlane, D., 170

Machado, C., 358

Machado, P., 579, 581, 582

Machado, S. do A., 455

Macharia, E., 492

Macharia, J., 374

Máchová, P., 506

Maciel, J. L. M., 304, 305

Macinnis-Ng, C., 264, 564

Mackenzie, A. R., 265, 669

Mackenzie, R., 253, 263, 640

Macri, G., 296

Madejón, P., 655

Madsen, P., 20, 21, 235, 267, 495

Maduro, R. O., 575

Maeda, C., 30

Maeda, S., 297, 311, 337, 407, 667
Maelicke, M., 45

Maffia, V. P., 163

Magalhães, I. P., 564, 565

Magalhães, W. L. E., 186, 424

Magallon, F., 335

Magari, L., 357

Magazniece, Z., 456

Maggi, V., 158

Maghsudloo, K., 267, 302

Magistrali, P., 407

Magliano, M., 57

Magni, C., 303

Magnusson, W., 207

Maguire, D., 367

Maguire, D. A., 366

Mahamane, L., 180

Mahamud, R., 222, 615

Mahmud, M. A. A., 65

Maia, C. M. B. de, 493, 658

Maier, C., 366

Maier, R., 45

Maier, T. F., 31, 41, 102

Maillard, F., 659

Mainwaring, D. B., 366, 367

Maire, G. L., 255, 256, 303, 314, 320, 323

Majewsky, M., 64

Mäkelä, A., 215

Mäkinen, H., 374, 464

Mäkipää, R., 253

Makovskis, K., 62

Makrickiene, E., 116, 326, 368

Mala, W., 691

Malabrigo, P. J., 507

Malaverri, L. F., 642

Maldia, L., 519

Małek, S., 646

Malewski, T., 577

Malheiros, R. R., 637

Malherbe, G. F., 634

Malhi, Y., 205

Malkamäki, A., 474

Malkamäki, A. J., 473

Malkiewicz, M., 201

Maller, M., 685

Malliarou, E., 144, 504

Malovrh, Š. P., 706

Maltamo, M., 205, 604

Maltoni, A., 313, 325
Man, G., 503

Manaka, T., 657

Manalo, M. M. Q., 467

Manarim, G. R., 636

Manavella, C., 76, 427

Mandasari, T., 22

Mandu, T. da, 181

Mangialardo, R., 196

Mangora, M., 537

Manh, T. L., 114

Maniesi, V., 535

Manka, F., 464

Manley, B., 192

Mann, C., 74

Mann, D., 52

Manner, J., 332

Manninger, M., 200, 201

Mannu, R., 593

Manoel, R. de, 511, 512

Manríquez, C., 489

Manríquez, M. T., 710

Manso, F. da, 341

Manso, R., 400, 413

Manson, R., 680

Mansor, P. B., 392

Mansourian, S., 20, 265, 630

Mansur, H., 60

Mansuy, N., 266, 349

Mantau, U., 105, 418

Manton, M., 552

Mantovani, A., 377

Mantovani, L. E., 619

Mäntymaa, E., 124

Manzanera, J. A., 205

Manzano, I., 224

Mao, Z., 651

Mapaura, A., 88

Mapeto, T., 635

Marais, Z., 24

Maran, J., 611

Maran, J. C., 603

Maranga, E., 626

Marangon, C., 480

Marangoni, O., 82

Marani, L., 528

Marañón, T., 655

Marcato Junior, J., 403

Marcatti, G., 526 
Marcatti, G. E., 219, 390, 485

Marchão, R., 500

Marchesini, A., 158

Marchetti, M., 373, 546, 605

Marchetti, S., 443

Marchi, E., 22, 23, 52, 349, 350, 694

Marco, A. de, 181, 202

Marco, R. de, 639

Marcondes, N. J. S., 167

Marcos, V. da, 80

Marcos-Martinez, R., 233

Mardones, O., 633

Marek, M., 265

Marek, M. V., 202

Mareschal, L., 256, 659

Maretta, M., 676

Marianella, A. L., 690

Mariano, G. V. P., 624

Marielle, B., 583

Mariki, S. B., 90

Marimom, B. S., 217

Marin, A., 50

Marin, C. A. V., 637

Marin, G., 62, 483

Marin, J. R., 642

Marin, W., 146

Marin-Castro, B., 651

Marinelli, C. E., 678

Marino, C. L., 511, 512, 513, 589

Mariotti, B., 313, 325, 350

Marjanom, G., 228

Marjanovic, H., 375

Markewitz, D., 457

Marklund, L. G., 602

Markovskaja, S., 443

Marlene González, , 88

Marnila, P., 371

Marozas, V., 170

Marques, I., 375

Marques, J. A. de, 328

Marques, J. G., 249

Marques, M., 110, 336

Marques, R., 668

Márquez, E. J., 277

Marra, E., 349, 350, 353

Marrero, C., 699

Marshall, A., 467, 468

Marta González, , 488
Martarello, V., 639

Marusak, R., 395, 487

Martin, J., 200

Martin, M., 60, 61, 228, 332, 683

Martin, T., 197, 457

Martín, J. A., 567

Martín, R. S., 568

Martin Nuñez, , 559, 623

Martin-García, J., 578

Martín-García, J., 575, 576, 577, 578, 579

Martin-Stpaul, N., 177

Martinez, C. A., 182

Martinez, M. A., 87

Martinez, M. T., 34

Martínez, A., 442

Martínez, A. N., 312

Martínez, G., 442, 451, 548

Martínez, O. A., 45

Martínez, P. A. A., 292, 709

Martínez, P. L. de, 418

Martínez, R. O. G., 398

Martinez-Alvarez, P., 575

Martínez-Alvarez, P., 577, 578, 579

Martinez-Gomez, V., 392

Martínez-Meier, A., 175, 177

Martínez-Salazar, I., 312

Martínez-Viilalta, J., 222

Martini, A., 67, 68, 70, 108, 136, 552, 570, 594, 622

Martini, D. R. D., 403

Martini, E., 31

Martini, S., 313, 325

Martinovič, T., 223

Martins, A. C. G., 389

Martins, C., 286

Martins, J. C., 339, 351

Martins, K., 318, 506, 509, 516, 519

Martins, L. A., 499

Martins, L. M. F., 68, 578

Martins, M., 146

Martins, M. H., 498

Martins, S. V., 622, 710

Martins, T. G. V., 297, 497

Martius, C., 217, 632, 641

Martorano, L., 533, 553

Martorano, L. G., 506

Martorano, P., 533, 553

Martorello, A. Q., 175

Marus, M., 479, 481
Marušák, R., 409

Mary, G., 669

Marzano, M., 543, 568

Marziliano, P. A., 222, 296

Masaki, T., 528

Maschetti, S., 397

Maseyk, K., 263

Masiero, M., 39, 468, 473, 538, 630

Masiero, M. A., 49

Masolel, R., 361

Mason, B., 470

Massaoudou, M., 180, 502

Masson, M., 316

Mastelaro, A., 298, 300

Mastelaro, A. P., 289

Mastrolonardo, G., 353, 498

Masullo, L., 636

Masullo, L. S., 668

Masumori, M., 672, 673

Mata, R. B., 607

Matavelli, C. J., 141

Matei, C., 284

Mateo, L. H., 62

Materassi, A., 181

Mateus, C. M. D., 304

Mathijs, E., 584, 608

Matias, H. de, 534

Matias, J. R., 255

Matilainen, A., 138

Matinizadeh, M., 655

Matos, A. M. S., 564

Matos, E. J. S. de, 454

Matos, J. C., 51

Matos, J. L. M., 475

Matos, M. de, 270

Matos, P., 551

Matovic, B., 241

Matricardi, E., 404

Matschullat, J., 669

Matsubara, E. T., 403

Matsuda, K., 251

Matsuda, Y., 664, 672

Matsumoto, Y., 431

Matsuoka, Y., 382, 445

Matsushita, K., 482

Matsuura, T., 384, 528, 653, 658

Mattalia, G., 38, 87 
Matte, O., 234

Matthews, B., 566

Matthews, R., 400

Matthies, B., 530

Mattila, P., 371

Mattos, E., 649

Mattos, E. M. de, 368, 401, 403

Mattos, L., 421

Mattos, P. de, 508, 517

Mattos, P. P. de, 48, 154, 155, 270, 293, 375, 392, 455, 535, 611, 620

Matula, R., 214, 250

Matule, B., 567

Matusick, G., 563

Matyssek, R., 202

Matzarakis, A., 570

Maunder, C., 539

Mauri, E., 223, 549

May, J. de, 411

May, M., 481

May, P. H., 118

May, R., 263

Mayer, A., 680

Mayer, M., 566, 651

Mayes, R., 87

Mayol, M., 511

Mayoral, C., 263, 265, 669

Mayrinck, R., 221, 659

Mažětis, R., 302

Mazon, J., 50

Mazon, J. A., 48

Mazurechen, M., 85

Mazzei, L., 153, 163, 644, 701

Mbairamadji, J., 144

Mbiru, S. S., 695

Mbonayem, L., 447

Mbongo, W., 634

Mbuvi, M. T. E., 134

Mcavoy, D., 53

McCallum, I., 362, 548

McCartan, S., 444

McCarthy, M., 556

McDermott, C., 131, 132, 480

McDougal, R., 442, 507, 574

McElligott, K., 457

McEwan, A., 22

McFarlane, R., 129

McFarlane, R. A., 132

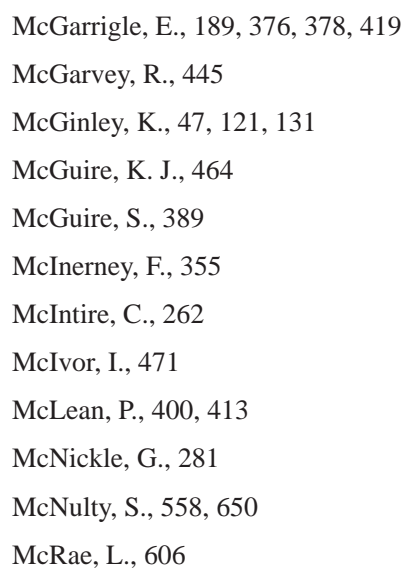

Melo, S., 465

Melvani, K., 35, 494

Memišević, M., 326

Mena, C., 53, 172

Mendes, A. M., 119

Mendes, C., 174

Mendes, F., 651

Mendes, F. B. G., 235, 501

Mendes, F. H., 67

Mendes, G., 571

Mendes, J. E., 449

Mendes, L., 527

Mendes, R., 137, 527

Mendez, M., 573

Méndez-Gamboa, J., 54

Mendez-Paiz, B., 49

Mendonça, B., 617

Mendonça, G. V., 163

Mendoza, A. C., 291

Mendoza, A. J. G., 667

Mendoza, A. M., 217

Mendoza, E., 259

Mendoza, K. Y., 285

Mendoza, L. E. S., 164

Mendoza-Trejo, O., 332, 350

Menegol, O., 336

Menezes, G. I., 311

Menezes, M. A. de, 160

Menezes, M. C. de, 106, 340

Menezes, N. A., 346

Menezzi, C. H. S. del, 433

Menǵele-Stillere, L., 121

Mengich, E., 374

Menon, M., 187, 510

Mensah, A. A., 190

Mensah, C., 202

Mensah, J. K., 563

Menton, M., 131

Mercado, L., 263

Mercer, D. E., 530

Merchan, D. C. B., 300

Merchant, A., 645

Mercier, C., 609

Meredieu, C., 698

Merganic, J., 191, 375

Merganič, J., 224, 390

Merganicova, K., 181, 191, 375

Merganičová, K., 224 
Merilä, P., 200, 201

Merino-Martin, L., 651

Merlo, E., 175

Merry, F., 57

Mesa, V. C., 276, 277

Mesarich, C., 507

Mesquita, A. G. G., 430

Mesquita, C., 163

Messaoudi, D., 239

Messier, C., 600

Metslai, M., 235

Metslaid, M., 227, 495

Metzel, R., 686

Metzger, M. J., 370

Meulman, R., 455

Meusburger, K., 201

Mexia, T., 551

Meybeck, A., 104, 440, 603

Meyer, F., 340, 342, 343, 350

Meyer-Soylu, S., 570

Meza, A., 632

Meza, V., 628

Meza-Picado, V., 54

Mfuni, T., 110

Mialhe, R., 359

Miccolis, A., 55

Michalichen, G., 50, 294

Michaud, F., 435, 436

Michel, A., 208, 251

Michel, K., 269

Miezīte, O., 621

Migliorini, D., 559, 575

Miguel, M. de, 18, 507

Mih, A. M., 596

Mihelič, M., 354

Miilumäki, N., 474

Miina, J., 371

Mijailoff, J. D., 126

Mikalajunas, M., 368

Mikami, E. E., 76

Mikich, S., 113, 407

Mikkelsen, T., 202

Mikkonen, K., 417

Mikolo, C. Y., 120

Milagres, V. A. C., 707

Milan, M., 303

Milaneto Junior, C., 426

Milani, J. E. de, 271
Milberg, P., 230

Miles, P., 61

Mileski, J., 354

Miller, A., 124

Miller, D., 469

Miller, E., 581

Miller, J. B., 528

Miller, S., 336

Mills, H., 472

Miltiadou, M., 190, 536

Minaverry, C., 40, 70

Ming, A., 264, 659

Mingoti, R., 233, 389

Minini, D., 291

Minn, S. T., 390

Miranda, A. L. T., 448

Miranda, B. P., 435

Miranda, C., 99, 300

Miranda, E., 617

Miranda, E. E. de, 139

Miranda, F., 147, 290, 501, 651

Miranda, F. T. de, 224, 235, 555

Miranda, G., 664

Miranda, J. R., 119

Miranda, K., 81, 103, 106

Miranda, L., 298, 412, 662

Miranda, S., 219, 399

Miranda Filho, R. J. de, 167

Mireski, M. C., 325

Mirzaee, A., 445

Missia, J. G., 291

Mitchell, M., 551

Mitloehner, R., 374

Mitrică, C., 284

Mitsuda, Y., 528

Miura, S., 652, 653, 657, 658, 672, 673, 674

Miyajima, R. H., 183, 339, 352

Miyamoto, K., 620

Mize, C. W., 312

Mizoue, N., 390

Mo, K., 19, 606

Moad, A., 345

Mochiutti, S., 80, 517, 532

Modena, E., 180

Moelinono, M., 128

Moeliono, M., 114

Moglia, J., 177

Mohamad, F., 548
Mohamed, A., 651

Mohamed, J., 330

Mohammadi, A., 0, 656

Mohammed, M., 560

Mohan, S., 489

Mohebalian, P., 628

Mohren, F., 191, 193, 469, 470

Möhring, B., 338, 364, 376

Moiseyev, A., 215, 477

Mojica, J. E., 294, 503

Mokria, M., 237

Mokros, M., 191, 375

Mokroš, M., 360, 390

Moldaschl, E., 269

Moler, E., 187, 548

Molin, J., 337, 359

Molin, P. G., 224, 555

Molina, E., 199, 332

Molina, F. I., 58

Molina, J., 600

Molina, M. P., 156, 188, 303, 324

Molina, P., 185

Molina-Murillo, S., 56

Mollick, A. S., 247

Mologni, O., 36

Momo, A., 245

Mondin, M., 318

Monges, C., 103, 248

Monges, E., 248

Moniz, A., 370

Monnet, J., 379, 402

Mononen, L., 604

Monserrat Romero, , 628

Montagne-Huck, C., 267

Montague, M., 281

Montañez, A., 616

Montaño, A. A., 356

Montaño, V., 393

Monte, C., 663

Monteiro, A. M. V., 391

Monteiro, C. H., 403

Monteiro Junior, J. J., 235, 236

Montenegro, J., 88

Monteoliva, S., 175, 327

Monterroso, I., 89, 93, 130

Montes, C., 315, 321, 337, 365, 383, 536

Montes, C. R., 374, 381, 706

Montfort, F., 609, 621 
Montoya, J., 79, 245

Moorthy, I., 362, 548

Mora, H. E. G., 430

Mora, M. R., 83

Moraes, A. da, 628

Moraes, A. de, 42, 499

Moraes, A. J., 136

Moraes, D., 426

Moraes, F. G. de, 229, 616

Moraes, I. S., 92, 135

Moraes, K. N. O., 430

Moraes, L., 404

Moraes, L. F. D. de, 178

Moraes, M., 146, 512

Moraes, M. A. de, 182, 512, 513

Moraes, M. L. T. de, 182, 185, 187, 324, 511, 512, 513, 514, 519

Moraes, M. T. de, 269

Moraes Neto, S., 500

Morais, J. de, 625

Morales, C., 64

Morales, D. O., 332, 350

Morales, M. F. B., 111

Morales-Freese, N., 550

Morales-Hidalgo, D., 62

Morales-Martinez, M., 651

Moravčík, M., 273

Moreaux, V., 203

Morecroft, M., 205

Moreira, A., 421

Moreira, A. C. de, 421

Moreira, A. de, 306

Moreira, C., 46

Moreira, F., 370

Moreira, F. T. A., 502

Moreira, G., 316, 321, 323, 325

Moreira, G. G., 401

Moreira, J. G. dos, 436

Moreira, J. M. M. A. P., 113, 407, 461, 540

Moreira, R. M. e, 252, 383

Moreno, A., 191

Moreno, P. L. T., 137

Moreno, R., 577, 579

Moreno-Fernandez, D., 409

Moretti, V., 181

Morhart, C., 45, 605

Morin, P., 550

Morin, R., 558

\author{
Morin, X., 282 \\ Morison, J., 677 \\ Moritz, T., 186 \\ Mörk, A., 332 \\ Morland, C., 476 \\ Mörling, T., 217 \\ Morneau, F., 62 \\ Morohashi, M., 206, 251 \\ Morris, A., 576 \\ Morris, J., 547 \\ Morrissette, B., 36 \\ Morsdorf, F., 604 \\ Morsello, C., 89, 274 \\ Mortati, A., 207 \\ Moser, W., 382, 698 \\ Mosnier, A., 117, 180, 245, 246 \\ Mosquera, L., 522 \\ Moster, C., 532, 613 \\ Mota, P. H. S., 399, 485 \\ Mota, T. A., 451 \\ Mota, T. A. da, 450, 455 \\ Motta, A. C. V., 667 \\ Motta, A. Z. V., 213 \\ Möttönen, M., 686 \\ Moulaert, F., 584 \\ Moulin, L. B., 436 \\ Moura, A. C. de, 333 \\ Moura, M., 370 \\ Moura, R., 329 \\ Moutinho, P., 140, 628 \\ Mowo, J., 31 \\ Mozgeris, G., 116, 368, 380 \\ Mp, S., 318, 669 \\ Msadala, C. C., 44 \\ Mtui, Y., 212 \\ Mubareka, S., 62 \\ Muchena, R., 211 \\ Mugendi, D., 679 \\ Mugo, N., 329 \\ Muita, R., 224 \\ Mujica, R., 632 \\ Mujuru, L., 88, 246 \\ Mukul, S., 467 \\ Muller, J., 599 \\ Müller, B., 174 \\ Müller, J., 267, 599, 618 \\ Müller, M., 286 \\ Müller, M. V. Y., 163
}

Muller-Using, S., 156

Müller-Using, S., 38, 60

Mullett, M., 444

Munaretti, A., 526

Mund, M., 217

Munger, J., 133

Munis, R. A., 183, 351, 352, 629

Munka, C., 304

Munks, S., 27, 52

Muñoz, A., 238, 243

Muñoz, J., 218, 219, 577, 579

MuÑoz, R., 88

Muñoz-Adalia, E. J., 579

Munro, H. L., 706

Munsell, J., 372, 679

Munthali, C., 44

Muntoni, G., 357

Muo, K., 224

Mura, M. D., 402

Muraca, B., 542

Muralidharan, e, 520

Muralidharan, E., 415

Murara Junior, M., 174

Murdiyarso, D., 640, 641

Mureva, A., 88

Murgueitio, E., 23

Musta, E., 548

Mustalahti, I., 695

Muturi, G., 374, 510, 626

Muvengwi, J., 88

Muys, B., 148, 284, 301, 385, 584, 608, 654

My, L. N. T., 44, 184

Myllyviita, T., 477

Myrholm, C., 443

Myroniuk, V., 341

N'dja, J. K., 217

N'guessan, A. E., 217

Nabade, K. J. P., 432

Nabuurs, G., 446

Nacif, M., 572, 588

Nadeau, S., 86

Nadeem, M. A., 511

Nadel, R. L., 563

Nader, G., 68

Næss, J. K., 269

Nagakura, J., 459, 657

Nagel, L., 151, 152

Nagy, L., 266 
Nagy4, L., 19

Nahama, E. T., 134

Nahrung, H., 580, 586

Nakajima, N. Y., 48

Nakamura, A. P. D., 420, 422, 433

Nakata, M., 251

Nakazato, R. K., 25

Nalesso, P. H. P., 147

Namba, S., 579

Nana, T., 245

Nanba, K., 654

Nanko, K., 384

Nardi, M., 82

Nardin, T., 253

Nario, A., 173

Naro, R. I., 438

Narulita, S., 633

Nascimento, B., 306

Nascimento, C. C. do, 434, 435, 436

Nascimento, C. S. do, 434, 435, 436

Nascimento, D. A., 450

Nascimento, D. A. do, 450

Nascimento, E. A. do, 82

Nascimento, F. P. do, 514, 625

Nascimento, H. C. do, 518

Nascimento, J., 313, 407

Nascimento, L. B. do, 355

Nascimento, M. S. do, 612

Nascimento, R., 690

Nascimento, S. S. de F., 272

Nascimento, T., 663

Naseri, B., 267

Nassah, V. F., 317, 611

Natkhin, M., 636

Natta, A. K., 91

Navarro, C., 303

Navarro, G., 58

Navarro, J. A., 360

Navarro, M. N., 65

Navarro-Fernández, C. M., 655

Navegantes-Alves, L., 41

Naves, R. P., 322, 383, 536

Navrátilová, L., 473

Navroski, M. C., 306, 307, 311

Nawaqalevu, A., 556

Nawaz, M. F., 575

Nazareno, L. S. Q., 168

Nazario, P., 101
Nazário, P., 387

Ndalilo, L., 86, 87, 134

Ndlovu, N. P., 45

Ndung'u, S., 329, 492

Neagu, S., 483

Neary, D., 457, 464

Nechita, C., 510

Nedel, T., 461

Negahdarsaber, M., 234

Negahdarsaber, M. R., 655

Negash, M., 226

Negrelle, R. R., 285

Negreros-Castillo, P., 312

Neirynck, J., 201

Nelson, E., 34

Nelson, K., 124

Nelson, T., 281

Neophytou, C., 156

Neri, F., 349, 353

Nervo, G., 471

Nesbitt, L., 131, 440, 546

Nest, A. V. D., 442, 515

Nest, M. V. D., 597

Netto, A. F. R., 652

Netto, S. P., 533, 534

Neumann, M., 191, 201

Neuvonen, J., 686

Neuvonen, M., 32

Neves, A. P. A., 195

Neves, L., 590

Neves, L. G., 328

Neves, R., 528

Neves, R. A., 528

Nguinguiri, J., 94

Ngulube, E., 22

Nguyen, D., 567

Nguyen, G. H., 129

Nguyen, H., 449

Nguyen, T., 211

Nicese, F., 694

Nicholls, D., 348

Nichols, J. D., 449

Nicola, A., 284

Nicolas, M., 200, 201, 208

Nicolau, A. P., 362

Nicolescu, V., 284, 287, 470

Nicoletti, M. F., 425

Nicolleti, A. L., 373
Nicoulaud, V., 654

Nie, S., 415

Nieminen, M., 460

Nieminen, T. M., 460

Nieto, V. M., 398

Niiyama, K., 211

Nijnik, M., 116

Nikaidou, T., 694

Nikhitha, C. U., 65, 413

Niklasson, M., 347

Nilsson, L., 591

Nilsson, O., 297

Nilsson, U., 297, 337, 483

Nimmo, E., 34

Nina, A., 573

Ning, Z. H., 69, 460

Nisbet, T., 677, 679

Nishina, K., 674

Nitami, T., 333

Nitesh, K. C., 512

Nitschke, C., 154, 199, 377, 488, 575

Nitta, N., 496

Nitu, M., 483

Njue, N. K., 632

Nk, N., 283

Nobre, S., 55, 137, 386

Nobre, S. R., 629

Nóbrega, C., 523

Nock, C., 149, 281, 296

Nogawa, N., 673

Noguchi, K., 657

Nogue, S., 37

Nogueira, A. C., 325

Nogueira, J., 98

Nogueira, V., 316

Nöjd, P., 374, 464

Nojiri, M., 431

Nolan, G., 411

Nolet, P., 233

Nölke, N., 65, 611

Nölte, A., 317

Nopp-Mayr, U., 112

Nord-Larsen, T., 43, 62, 284

Nordén, B., 295

Nordfjell, T., 22, 36, 349, 364

Nordin, A., 630

Noronha, E. F., 452

Notarangelo, M., 62 
Nothdurf, A., 282

Nothdurft, A., 204, 205

Notivol, E., 157, 158

Nourtier, M., 609, 621

Nouvellon, Y., 255, 256, 314, 323

Novaes, A., 329, 637

Novaes, D. da, 290, 552

Novoa, C. P., 584

Novotny, E., 645

Novotný, R., 209

Nowak, D., 64, 196

Numazawa, C. T. D., 155

Nunan, F., 131

Nunes, L., 62

Nunes, M. T. A., 292, 485

Nunes, P., 569

Nunes, S., 146

Nurmi, J., 417

Nurminen, J., 474

Nurtjahya, E., 22

Nuruddin, A., 447, 448

Nuruddin, A. A., 330, 455

Nuske, S., 623

Nussbaumer, A., 201

Nwogwugwu, J., 439

Nyakudya, I., 88

Nyam-Osor, B., 256

Nyamai, N., 416

Nyambati, R., 45

Nygren, P., 697

Nyoka, B. I., 45

Nyrud, A. Q., 269

Nyssen, B., 284, 301, 584, 608

Nyström, K., 191

Nyström, M., 191

Nziavake, S., 85

O’brien, L., 84, 554

O'grady, A., 24

O’sullivan, J., 129

O’connor, B., 604

O’reilly-Wapstra, J., 411

Obersteiner, M., 246

Obolari, A. de, 292, 485

Ocampo, G., 561

Ocampo-Zuleta, K., 498

Ochoa, H. A. B., 627

Ochoa, V., 146

Oda, T., 464

\begin{tabular}{|c|c|}
\hline Odame, G., 611 & 555 \\
\hline Odén, P., 492 & Oliveira, F., 352, 553 \\
\hline Oduor, N., 416 & Oliveira, F. C. de, 67, 555 \\
\hline Oeba, V., 246 & Oliveira, F. L. de, 328 \\
\hline Oeggl, K., 158 & Oliveira, F. N. L. de, 430 \\
\hline Oettel, J., 608 & Oliveira, G., 137, 527 \\
\hline Ofoegbu, C., 152 & Oliveira, G. H. de, 85 \\
\hline Ofori, D., 656 & Oliveira, G. M. de, 157 \\
\hline Ofori, D. A., 31, 491 & Oliveira, I. R. de, 280, 299, 303 \\
\hline Ogana, F. N., 227 & Oliveira, I. W. de, 664 \\
\hline Ogana, T. E., 227 & Oliveira, J. C. de, 185 \\
\hline Ogasa, M. Y., 459 & Oliveira, J. J. de, 308 \\
\hline Ogasawara, M., 612, 649 & Oliveira, J. M., 241 \\
\hline Ogawa, R., 633 & Oliveira, J. M. de, 301 \\
\hline Ogura, K., 431 & Oliveira, J. R. V. de, 452 \\
\hline Oguri, G., 336, 397, 461 & Oliveira, L., 274, 362, 563, 619, 694 \\
\hline Ohashi, S., 210, 653, 657, 658, 674 & Oliveira, L. M. de, 311 \\
\hline Ohizumi, T., 206, 251 & Oliveira, L. R. dos S., 453 \\
\hline Ohkubo, T., 671 & Oliveira, L. Z., 164, 195, 391, 614 \\
\hline Ohler, C., 127 & Oliveira, M., 44, 155, 427 \\
\hline Öhman, K., 386 & Oliveira, M. A., 251 \\
\hline Ohno, Y., 496 & Oliveira, M. D., 233 \\
\hline Ohnuki, Y., 663, 674 & Oliveira, M. G. de, 181 \\
\hline Ohtani, T., 675 & Oliveira, M. S., 498 \\
\hline Ohte, N., 464 & Oliveira, P., 516 \\
\hline Oishi, Y., 685 & Oliveira, P. P. A. de, 285 \\
\hline Ojeda, G. O. M., 372 & Oliveira, P. S., 578 \\
\hline Ojeda, W. O., 682 & Oliveira, P. S. S. de, 560 \\
\hline Okahisa, Y., 431 & Oliveira, R., 291, 433, 490 \\
\hline Okoth, S., 45 & Oliveira, R. S., 446 \\
\hline Okumu, J., 45 & Oliveira, T. W. G. de, 707 \\
\hline Olajuyigbe, S., 454, 632 & Oliveira, U., 316 \\
\hline Olchowik, J., 589 & Oliveira, V., 638 \\
\hline Oldenburger, J., 62 & Oliveira, V. B., 683 \\
\hline Olea, M., 606 & Oliveira, Y. M. M. de, 47, 603, 611 \\
\hline Olembong, O., 223 & Oliveira Junior, J. O. J., 514 \\
\hline Olguin, M., 381 & Oliveira Neto, M., 41 \\
\hline Oliet, J., 325 & Oliveira Neto, S. N. de, 32, 292, 484 \\
\hline Olisaemeka, U. O., 560 & Oliveira-Da-silva, M., 592 \\
\hline Oliva, J., 117, 138, 443 & Oliveira-Júnior, J., 512 \\
\hline Oliveira, A., 220 & Oliver, C. D., 538 \\
\hline Oliveira, A. J. S. de, 80 & Olivera, A., 364 \\
\hline Oliveira, A. L. de, 410 & Olivos, E. A. A., 620 \\
\hline Oliveira, A. X. de, 163, 483 & Ollerova, H., 39 \\
\hline Oliveira, B., 234 & Olmos, C. F. G., 646, 675 \\
\hline Oliveira, B. de, 219, 348, 485 & Olmos, V. M., 54, 699 \\
\hline Oliveira, D. C. B. de, 424 & Olsen, S. L., 26 \\
\hline Oliveira, E. B. de, 49, 67, 113, 174, 285, 286, 407, & Olson, Å., 557 \\
\hline
\end{tabular}




\begin{tabular}{|c|c|}
\hline Olsson, H., 191, 524 & Ota, T., 390 \\
\hline Olsson, S., 511 & Otani, T., 210 \\
\hline Oluwadare, A. O., 424 & Otarola, M., 55 \\
\hline Omar, F. A. U., 225 & Othman, N. F., 431 \\
\hline Ometto, J., 212 & Ott, A. F., 522 \\
\hline Ometto, J. P., 249 & Otto, M., 649, 666 \\
\hline Omondi, S. F., 508 & Ouden, J. D., 284, 608 \\
\hline Onaindia, A., 468 & Ouédraogo, A., 42 \\
\hline Oñate, E., 343 & Ouédraogo, K., 594 \\
\hline Onda, Y., 654 & Ouédraogo, O., 594 \\
\hline Ong, C. L., 447 & Ouellette, M., 603 \\
\hline Ongaratto, L. L., 311 & Ouertani, E., 463 \\
\hline Ongugo, P. O., 134 & Ovalle, J. F., 166 \\
\hline Ongugo, R., 72, 169 & Oviedo, F. B., 300 \\
\hline Oni, P., 550 & Owari, T., 24, 207, 379, 682 \\
\hline Oniki, S., 633 & Owino, J., 510 \\
\hline Oo, T. N., 105 & Owiny, A. A., 310, 521 \\
\hline Opgenoorth, L., 157 & Owuor, B., 72 \\
\hline Oporto, O., 411 & Owuor, J., 687 \\
\hline Orazio, C., 203, 216, 223, 232, 409, 465, 469, 549, & Ozaki, K., 529 \\
\hline & Ozbagdatli, N., 538 \\
\hline Orcherton, D., 165 & Ozkal, K., 538 \\
\hline Orellana, G. C., 620 & Özparpucu, M., 472 \\
\hline Oreti, L., 300 & Ozturk, I. K., 442 \\
\hline Orfanidou, C., 96 & Paap, T., 563, 569, 574, 584 \\
\hline Orjuela, O., 272 & Pablo Nuñez, , 507 \\
\hline Orlikowska, E., 281 & Pacatuba, B., 76 \\
\hline Orlovic, S., 241 & Paccard, P., 379 \\
\hline Orme, D., 200 & Pach, M., 282 \\
\hline Ormond, S., 442 & Pacheco, E. V., 73 \\
\hline Ormsby, M., 569, 582 & Pacheco, N., 396 \\
\hline Orozco, J. M., 59 & Pacheco, P., 16, 17, 18, 118, 129, 486, 606 \\
\hline Orrandre, G., 468 & Pacheco, R., 136 \\
\hline Orshoven, J. V., 385 & Pachinsky, O. J., 343 \\
\hline Ortega, M., 515 & Packalen, T., 63 \\
\hline Ortiz, S. A. R., 422 & Padilla, G. P., 411 \\
\hline Ortolan, C., 354 & Padonou, E. A., 42 \\
\hline Osano, P., 224 & Padovani, C. R., 233 \\
\hline Osawa, A., 197 & Páez, C. M., 617 \\
\hline Oshiro, O. T., 118 & Page, G., 187 \\
\hline Ospina, P. E. M., 367 & Page-Dumroese, D., 565 \\
\hline Ospina, S., 271, 285 & Pagnussat, M., 339 \\
\hline Oste, L. S., 413 & Pagoto-Lopes, M. B., 564 \\
\hline Oswalt, C., 558 & Paillassa, E., 698 \\
\hline Oswalt, S., 61 & Paillet, Y., 599, 618 \\
\hline Oszako, T., 577 & Paim, F. A. de, 118, 119 \\
\hline Ota, I., 30, 480 & Paim, R., 316 \\
\hline Ota, L., 105, 143, 467, 468 & Paiva, D., 576 \\
\hline
\end{tabular}

Paiva, H. N. de, 32, 484

Paiva, P. M., 47

Paiva, S. N. de, 85, 161, 162, 459

Paiva, U., 85, 108, 109

Paiz, A., 699

Pajewski, F., 271

Pajtík, J., 224

Pakparvar, M., 234

Palacio, A. A. R., 636

Palahí, M., 20

Palátová, P., 138

Palma, J., 43, 419

Palma, S., 426

Palma, V. H., 29, 31

Palmieri, R., 92, 678

Palomino, W., 259

Paludzyszyn Filho, E., 186

Paluš, H., 273

Palviainen, M., 231

Pambudi, S., 448, 639

Pampolina, N. M., 467, 499

Pan, E., 434

Panagopoulos, T., 545, 554

Panasolo, A., 67, 555

Panda, P., 507

Pandit, R., 145, 629

Pandiwijaya, A., 641

Panduro, M. P., 0

Pang, Y., 378

Pannell, D., 33, 145

Pant, N., 509

Panthi, S., 251

Panti, N., 708

Pantoja, N., 214

Panzacchi, P., 202

Paoletti, E., 171, 172, 180, 181, 202, 249, 254, 350, 569

Papa, D., 214, 527

Papale, D., 203

Pappas, M. de C. R., 318, 506

Pappas Junior, G., 318

Paquette, A., 570

Parada, C., 189

Paradis, G., 607

Pardo, A. C. F., 513

Paré, D., 464

Paredes-Villanueva, K., 345

Pareira, J., 93 
Pareyn, F., 109, 110

Pareyn, F. G. C., 524

Parhizkar, P., 302

Pari, G., 414

Parisi, I. L., 0

Parisotto, D. C., 328

Paritsis, J., 559

Park, B., 553

Park, B. B., 40, 197, 295, 644, 671

Park, E., 258, 405

Park, H., 66

Park, J., 365, 553, 562, 590

Park, M. S., 119, 123, 500, 545, 554

Park, P. S., 24, 37, 184

Park, R., 580

Park, S., 122, 182, 184, 254, 255, 537

Park, S. H., 182

Park, S. W., 453

Park, Y., 414

Parker, L., 575

Parkery-Forney, M., 345

Parkins, J., 86

Parmain, G., 600

Parmeggiani, R. P., 77, 248

Parobek, J., 273

Parodi, O., 570

Parpan, T., 676

Parrado-Rosselli, A., 110, 111, 158, 348, 498, 608

Parrish, C., 376

Parron, L. M., 493, 658

Parrotta, J., 631

Pasa, A., 143

Pasagdan, A., 168, 670

Pasaribu, I., 586

Pascual, D. A., 231, 232

Pasquel, J. del, 28

Pasquini, C., 175, 707

Passarella, D., 699

Passaretti, R. A., 235

Passos, J. R., 450

Passos, J. R. de, 389

Passos, V. T. da, 299

Pastana, D., 180

Pastore, F., 422

Pastore, T. C. M., 346, 355

Pastore, T. M., 354

Pastori, P. A. V., 625

Pastur, G. M., 705, 710

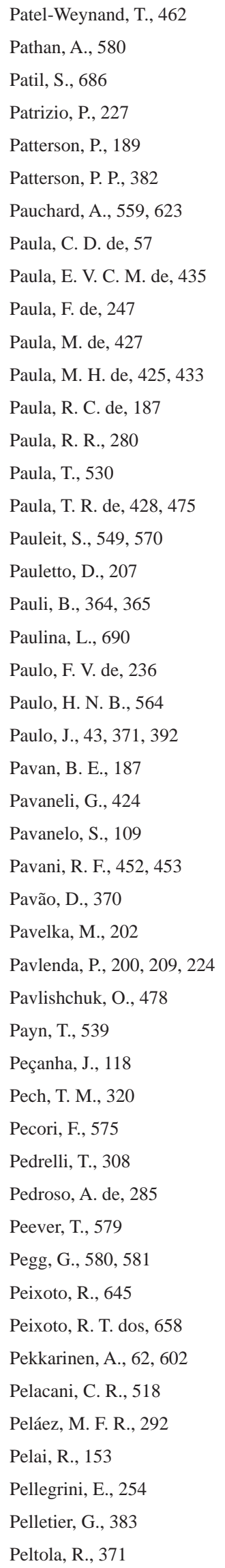

Peltoniemi, K., 253

Peltoniemi, M., 253

Peltzer, D., 623

Peluffo, L., 357

Pena, J., 553

Pena, M., 246

Pena, R. F., 292

Peña-Claros, M., 153

Peng, G., 428

Peng, P., 287

Peng, Y., 588, 650

Penha, A., 466

Penman, T., 204

Penteado, S. do R. C., 563, 596

Penteado Júnior, J. F., 432, 433

Peñuela-Mora, M. C., 397

Penuelas, J., 179

Peñuelas, J., 200

Pepe, K. B. F., 671

Pepori, A., 566

Peque, D., 143

Perales, M., 260

Perdiz, R. de, 710

Perdomo, C., 23, 363

Perea, L., 632

Pereira, A. M., 478

Pereira, A. P., 533

Pereira, B., 255

Pereira, C., 571

Pereira, D. do, 420

Pereira, F., 212

Pereira, F. A., 424, 482

Pereira, H. de, 700

Pereira, J. A., 70

Pereira, J. F., 335

Pereira, K., 691

Pereira, L. C., 555

Pereira, M. A., 25

Pereira, M. C., 299

Pereira, M. de, 306, 307, 311

Pereira, R. de, 41, 522

Pereira, S., 298, 300, 309

Pereira, V., 246, 412

Pereira, V. de, 700

Pereki, H., 432

Perez, C., 584

Perez, M., 523

Pérez, C., 579 


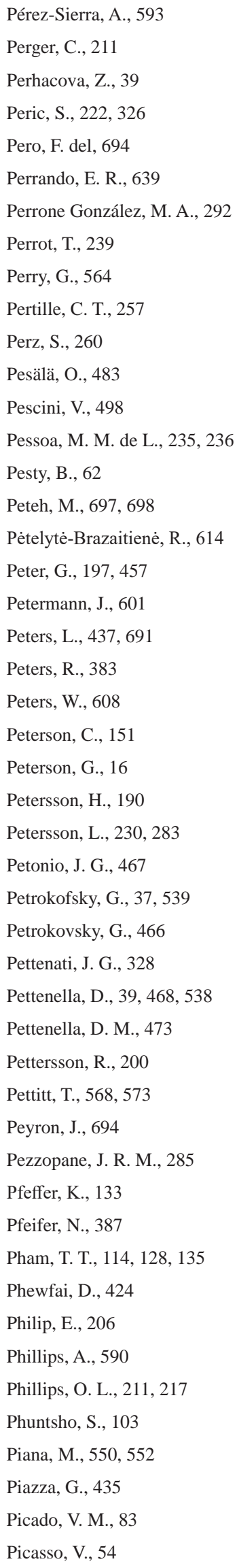

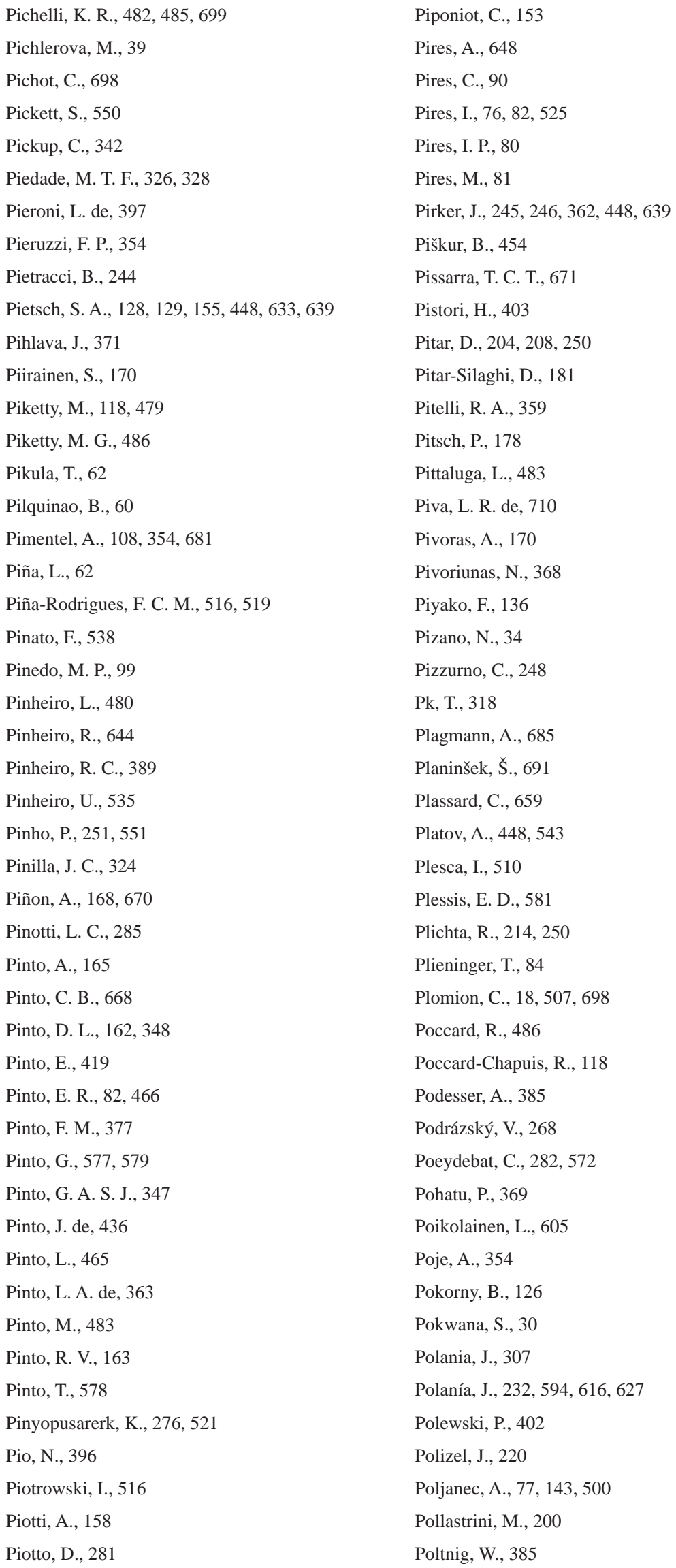

Pires, A., 648

Pires, C., 90

Pires, I., 76, 82, 525

Pires, I. P., 80

Pires, M., 81

Pirker, J., 245, 246, 362, 448, 639

Piškur, B., 454

Pissarra, T. C. T., 671

Pistori, H., 403

Pitar, D., 204, 208, 250

Pitar-Silaghi, D., 181

Pitelli, R. A., 359

Pitsch, P., 178

Pittaluga, L., 483

Piva, L. R. de, 710

Pivoras, A., 170

Pivoriunas, N., 368

Piyako, F., 136

Pizano, N., 34

Pizzurno, C., 248

Pk, T., 318

Plagmann, A., 685

Planinšek, Š., 691

Plassard, C., 659

Platov, A., 448, 543

Plesca, I., 510

Plessis, E. D., 581

Plichta, R., 214, 250

Plieninger, T., 84

Plomion, C., 18, 507, 698

Poccard, R., 486

Poccard-Chapuis, R., 118

Podesser, A., 385

Podrázský, V., 268

Poeydebat, C., 282, 572

Pohatu, P., 369

Poikolainen, L., 605

Poje, A., 354

Pokorny, B., 126

Pokwana, S., 30

Polania, J., 307

Polanía, J., 232, 594, 616, 627

Polewski, P., 402

Polizel, J., 220

Poljanec, A., 77, 143, 500

Pollastrini, M., 200

Poltnig, W., 385 
Pölz, W., 245

Ponce, Y. R., 61, 228

Ponchart, J., 574

Ponette, Q., 250, 282

Pontes, G. R. de, 662

Poorter, L., 217

Popa, I., 171, 177, 181, 208, 250

Pope, F., 263

Popescu, F., 510

Popoff, F. M. B., 103

Porfírio, S., 690

Porfirio-Da-silva, V., 493

Porfírio-Da-silva, V., 499

Porta, N. L., 253, 265, 503, 596

Porteiro, J., 370

Porter-Bolland, L., 448

Porto, J., 207

Portugal, A., 576

Portugal, T. B., 499

Posadas, H. M. de, 299, 534

Poschenrieder, W., 530

Pose, R. B., 502

Possell, M., 645

Postolache, D., 510

Potter, K., 503, 607

Potthast, A., 424

Pottinger, A., 697

Potts, B. M., 156

Potvin, C., 149

Pötzelsberger, E., 156, 469, 470, 491

Poudyal, M., 131

Pouliot, M., 462

Poulter, B., 194

Poupon, V., 19, 266

Pourhasemi, M., 109

Pouta, E., 32

Poynter, A., 263

Pra, A., 468, 538, 630

Prado, L. N. do, 122, 680

Prakasa, E., 346

Prata, G., 347

Pregitzer, C., 552

Pregitzer, K., 202

Prentice, I. C., 263

Prescher, A., 200, 208, 251

Prescott, C., 268, 643

Prescott, C. E., 650

Prestes, M., 163, 483

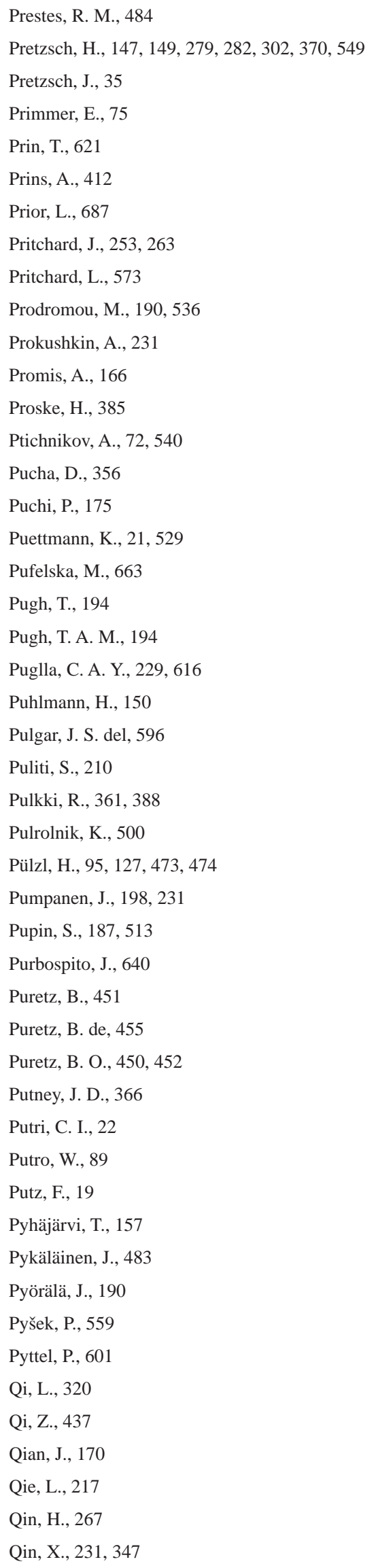

Prestes, R. M., 484

Pretzsch, H., 147, 149, 279, 282, 302, 370, 549

Pretzsch, J., 35

Prins, A., 412

Prior, L., 687

Pritchard, J., 253, 263

hard, L., 573

Prokushkin, A., 231

Ptichnikov, A., 72, 540

Pucha, D., 356

Puchi, P., 175

Pugh, T., 194

Pugh, T. A. M., 194

Puglla, C. A. Y., 229, 616

Puliti, S., 210

Pulkki, R., 361, 388

Pupin, S., 187, 513

Purbospito, J., 640

tz, B. de, 455

Putney, J. D., 366

C. I., 22

Putz, F., 19

Pyhäjärvi, T., 157

Pykäläinen, J., 483

yörälä, J., 190

X., 231, 347
Quadros, T. M. C., 516

Quang, P., 467

Queffelec, J., 623

Queiroz, C. S., 358

Queiroz, D. A. H. de, 555

Queiroz, D. L. de, 249, 449

Queiroz, J., 532

Queiroz, M., 437

Queiroz, T., 321

Quesada, T., 197, 457

Quetzalli, M., 680

Quevedo, J. M. D., 248

Quezada, M., 173

Quezada, N., 218, 219

Quick, S., 263, 669

Quimado, M., 519

Quine, C., 547, 582

Quinn, M., 683

Quintero, C., 559, 588

Quinton, J., 632

Quinton-Tulloch, M., 518

Quispe, J. S. G., 164, 178

Quispe-Herrera, R., 164

Rabaglia, R., 585

Rábago, I., 252

Rabelo, S., 107

Rachetti, M., 304

Rachid, C., 645

Rachwal, M. F. G., 225, 229, 671

Raddi, S., 313, 325

Radics, R., 97, 556

Radomski, M. I., 631

Radzali, S. F., 310

Rafael, G. C., 479

Raffa, K., 267

Rahanjam, S., 504

Raharivololoniaina, A., 704

Rahayu, S., 31, 448, 639

Rahman, A., 644

Rahman, M., 549

Rahman, M. A., 549

Rahman, S., 42, 493

Rahman, S. A., 446

Rahmayanti, D., 520

Raimundo, F., 578

Rainha, M., 441

Raitelaitytè, K., 443, 577

Rajão, R., 136 


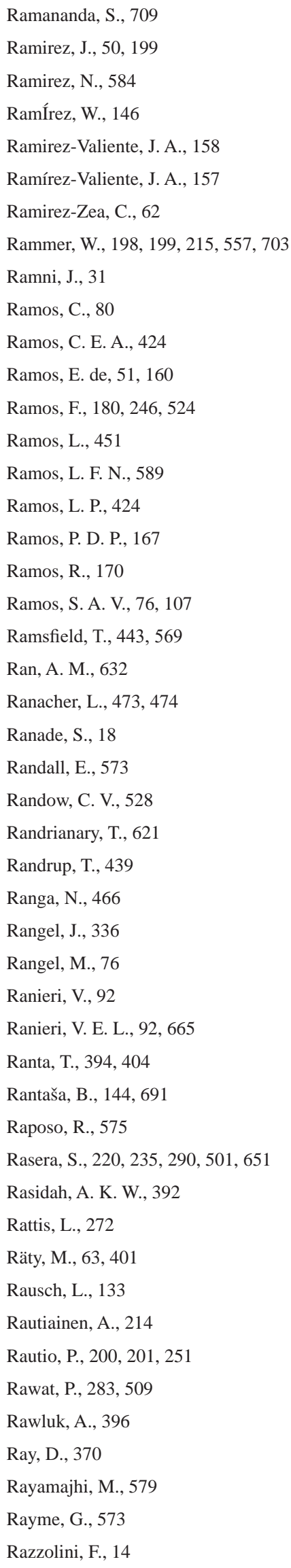

Razzolini, F., 14

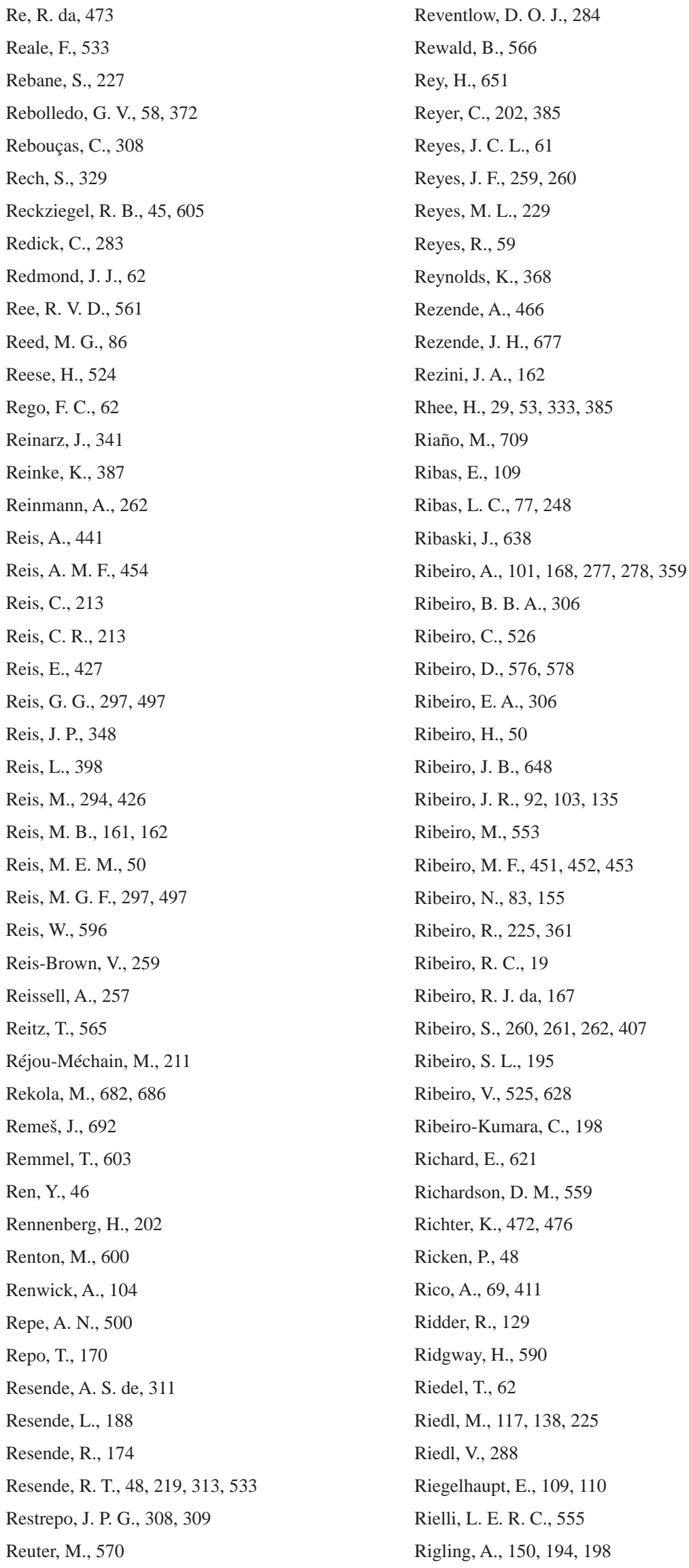

Re, R. da, 473

Reale, F., 533

Rebane, S., 227

Rebolledo, G. V., 58, 372

Rebouças, C., 308

Rech, S., 329

Reckziegel, R. B., 45, 605

Redick, C., 283

Redmond, J. J., 62

Ree, R. V. D., 561

Reed, M. G., 86

Reese, H., 524

Rego, F. C., 62

Reinarz, J., 341

Reinke, K., 387

Reinmann, A., 262

Reis, A., 441

Reis, A. M. F., 454

Reis, C., 213

Reis, C. R., 213

Reis, E., 427

Reis, G. G., 297, 497

Reis, J. P., 348

Reis, L., 398

Reis, M., 294, 426

Reis, M. B., 161, 162

Reis, M. E. M., 50

Reis, M. G. F., 297, 497

Reis, W., 596

Reis-Brown, V., 259

Reissell, A., 257

Reitz, T., 565

Réjou-Méchain, M., 211

Rekola, M., 682, 686

Remeš, J., 692

Remmel, T., 603

Ren, Y., 46

Rennenberg, H., 202

Renton, M., 600

Renwick, A., 104

Repe, A. N., 500

Repo, T., 170

Resende, A. S. de, 311

Resende, L., 188

Resende, R., 174

Resende, R. T., 48, 219, 313, 533

Restrepo, J. P. G., 308, 309

Reuter, M., 570

Reventlow, D. O. J., 284

Rewald, B., 566

Rey, H., 651

Reyer, C., 202, 385

Reyes, J. C. L., 61

Reyes, J. F., 259, 260

Reyes, M. L., 229

Reyes, R., 59

Reynolds, K., 368

Rezende, A., 466

Rezende, J. H., 677

Rezini, J. A., 162

Rhee, H., 29, 53, 333, 385

Riaño, M., 709

Ribas, E., 109

Ribas, L. C., 77, 248

Ribaski, J., 638

Ribeiro, A., 101, 168, 277, 278, 359

Ribeiro, B. B. A., 306

Ribeiro, C., 526

Ribeiro, D., 576, 578

Ribeiro, E. A., 306

Ribeiro, H., 50

Ribeiro, J. B., 648

Ribeiro, J. R., 92, 103, 135

Ribeiro, M., 553

Ribeiro, M. F., 451, 452, 453

Ribeiro, N., 83, 155

Ribeiro, R., 225, 361

Ribeiro, R. C., 19

Ribeiro, R. J. da, 167

Ribeiro, S., 260, 261, 262, 407

Ribeiro, S. L., 195

Ribeiro, V., 525, 628

Ribeiro-Kumara, C., 198

Richard, E., 621

Richardson, D. M., 559

Richter, K., 472, 476

Ricken, P., 48

Rico, A., 69, 411

Ridder, R., 129

Ridgway, H., 590

Riedel, T., 62

Riedl, M., 117, 138, 225

Riedl, V., 288

Riegelhaupt, E., 109, 110

Rielli, L. E. R. C., 555

Rigling, A., 150, 194, 198 
Riitters, K., 602

Rinaldi, M. C., 25

Rincon, D., 307

RincÓn, D. C. G., 646

Ringenbach, A., 199

Rinne-Garmston, K., 253

Rio, M. del, 302

Río, M. del, 149, 279, 282

Río, R. del, 158, 302

Rioja-Ballivián, G., 260

Riond, C., 379

Rios, E. M., 271, 272

Rios, R., 517

Rios, R. C., 626

Rios, S., 524

Ríos, L., 188

Riquelme, C., 588, 590

Riquelme, J., 195

Riquelme, L., 303

Risse, M., 476

Risyda, A., 22

Ritakallio, A., 604, 605

Ritter, T., 204, 205, 280

Riva, L., 512

Riva, L. C., 512

Riva, L. C. R., 514

Rivas, J. J. C., 299

Rivero, E. G., 61

Rivière, M., 477

Riyanto, Y., 346

Rizek, M. B., 16, 118

Riziki, M., 669

Rizo, V., 478

Rizzo, M., 62

Roa, S. C., 503

Robalino, J., 79

Roberge, J., 497

Robert, E., 222

Robert, R., 338, 352

Robert, R. C. G., 339, 359

Roberto, T., 253

Robiglio, V., 118

Robin, A., 280, 659

Robinson, A., 199

Robledo-Arnuncio, J. J., 157, 158

Robson, J., 86

Rocco, R., 586

Rocha, B., 551

\begin{tabular}{|c|c|}
\hline Rocha, E., 260 & Rodriguez, F., 78 \\
\hline Rocha, E. L. F. da, 285 & Rodriguez, L., 347 \\
\hline Rocha, H., 649 & Rodriguez, L. C., 213, 386 \\
\hline Rocha, J., 137, 527 & Rodriguez, L. C. E., 213, 214, 360, 419 \\
\hline Rocha, J. H. T., 637 & Rodríguez, L., 78 \\
\hline Rocha, K. da, 235 & Rodríguez, S., 686 \\
\hline Rocha, M. do, 358 & Rodríguez, V. J., 616 \\
\hline Rocha, M. P. da, 38 & Rodriguez-Pineros, S., 33, 689 \\
\hline Rocha, R. T., 318 & Rodríguez-Quilón, I., 18, 507 \\
\hline Rocha, S., 315, 321, 398 & Roets, F., 549, 595 \\
\hline Rocha, S. H., 689 & Rogal, L., 546, 555 \\
\hline Rocha, S. J. S. S. da, 230, 536 & Roger, J., 175, 707 \\
\hline Rocha, S. M., 291 & Roger, V., 392 \\
\hline Rocha, W. F., 523, 524 & Rogers, L., 538 \\
\hline Rocini, Y., 354, 681 & Rohner, B., 194 \\
\hline Roda, J., 447, 448 & Roig, F. A., 238, 242 \\
\hline Roda, J. M., 447 & Rois, M., 96 \\
\hline Rodas, A., 93, 95 & Roitberg, E., 60 \\
\hline Rodas, C. A., 592 & Roitman, I., 167, 221 \\
\hline Roder, S., 599 & Roitman, L., 427 \\
\hline Roderjan, C. V., 435 & Roitto, M., 170 \\
\hline Rodney, K., 153 & Rojas, C., 115, 332 \\
\hline Rodon, T., 98 & Rojas, C. A. L., 458 \\
\hline Rodrigues, A., 619 & Rojas, G., 368 \\
\hline Rodrigues, C., 612, 625, 677 & Rojas, J. A. A., 294, 503 \\
\hline Rodrigues, C. B., 85, 646 & Rojas, M. R., 294, 503 \\
\hline Rodrigues, C. G. de, 92 & Rojas, P., 156, 173, 303, 324, 422 \\
\hline Rodrigues, D., 532 & Rojas, Y., 332 \\
\hline Rodrigues, D. A., 79 & Rolando, C., 444 \\
\hline Rodrigues, F., 101 & Rolim, S., 281 \\
\hline Rodrigues, G., 509, 518, 519 & Roman, D., 642 \\
\hline Rodrigues, G. H. S., 518 & Roman, T. M. Y., 292 \\
\hline Rodrigues, J. D., 458 & Roman-Amat, B., 694 \\
\hline Rodrigues, J. R. da, 269 & Roman-Cuesta, R. M., 27 \\
\hline Rodrigues, J. S., 346 & Romanelli, T., 303 \\
\hline Rodrigues, L. M., 92 & Romeralo, C., 577, 578, 579 \\
\hline Rodrigues, M., 357 & Romero-Duque, L. P., 111, 550 \\
\hline Rodrigues, M. I., 286 & Romero-Herrada, R. J., 587 \\
\hline Rodrigues, P. J. F. P., 355 & Romeu, L., 437 \\
\hline Rodrigues, R., 220, 466, 490, 610 & Rönnberg, J., 442, 456 \\
\hline Rodrigues, R. de, 226, 300 & Ronquim, C., 625 \\
\hline Rodrigues, R. R., 228, 659 & Roopsind, A., 19, 159 \\
\hline Rodrigues, S., 437 & Roos, U., 113 \\
\hline Rodrigues, S. A., 304 & Roque, V., 221 \\
\hline Rodrigues, Y., 183 & Roques, A., 569 \\
\hline Rodrigues Junior, R. A., 333 & Rørstad, P. K., 295 \\
\hline Rodrigues Neto, C., 89 & Ros-Tonen, M., 132, 133 \\
\hline Rodriguez, D. R. O., 176, 242 & Rosa, C., 63, 567 \\
\hline
\end{tabular}

Rocha, E., 260

Rocha, J., 137, 527

Rocha, J. H. T, 637

Rocha, K. da, 235

Rocha, M. do, 358

Rocha, S., 315, 321, 398

Rocha, S. H., 689

Rocha, S. J. S. S. da, 230, 536

Rocha, W. F., 523, 524

Rocini, Y., 354, 681

Rodas, A., 93, 95

Rodas, C. A., 592

Roder, S., 599

Roderjan, C. V., 435

ey, K., 153

Rodrigues, A., 619

Rodrigues, C., 612, 625, 677

Rodrigues, C. B., 85, 646

Rodrigues, D., 532

Rodrigues, D. A., 79

Rodrigues, F., 101

Rodrigues, G., 509, 518, 519

Rodrigues, J. D., 458

Rodrigues, J. R. da, 269

drigues, J. S., 346

Rodrigues, M., 357

Rodrigues, M. I., 286

Rodrigues, P. J. F. P., 355

Rodrigues, R., 220, 466, 490, 610
Rodriguez, F., 78

Rodriguez, L., 347

Rodríguez, L., 78

Rodríguez, S., 686

Rodríguez, V. J., 616

Rodriguez-Pineros, S., 33, 689

Roets, F., 549, 595

Rogal, L., 546, 555

Rogers, L., 538

Rohner, B., 194

Roig, F. A., 238, 242

Roitman, I., 167, 221

Roitman, L., 427

115,332

Rojas, G., 368

Rojas, J. A. A., 294, 503

Rojas, Y., 332

Rolando, C., 444

Rolim, S., 281

Roman-Amat, B., 694

Roman-Cuesta, R. M., 27

Rosa, C., 63, 567 
Rosa, C. M. M., 196, 538

Rosa, H., 71

Rosa, M., 523

Rosa, M. R., 524

Rosa, T. S., 433

Rosa, T. S. da, 434, 436

Rosa Junior, J. A., 498

Rosado, A., 645

Rosado, L. R., 275, 278

Rosado, S. C. da S. , 275, 278, 306

Rösch, C., 33, 570

Rosemary-Kinge, T., 596

Rosen, H., 693

Rosenberg, O., 556

Rosenkranz, L., 364, 365

Roskams, P., 201

Rosot, M. A. D., 47, 406, 603, 611

Rosot, N., 155

Rosot, N. C., 403

Ross-Davis, A., 312, 579

Rosse, L., 174

Rossi, L. M., 229

Rossi, P., 329

Rossi, R., 427

Rossi, S., 175

Rossini, B. C., 513

Rossmann, J., 331

Rotella, A., 577

Rother, D., 220

Rötzer, T., 549, 570

Roucoux, K., 28

Rouhier, M., 239

Roumet, C., 651

Rousseu, F., 347

Rousta, M. J., 655

Routa, J., 417

Roux, J., 592, 595

Rovere, A. E., 607

Rozenberg, P., 177

Rozendaal, D. M., 217

Roźmiarek, B., 684

Rua, J., 200, 446, 583

Rubilar, R., 365, 366, 368, 707

Ruehr, N., 193, 194

Rufino, M., 632

Ruggiero, J., 76, 83

Rugman-Jones, P., 585

Ruivo, H., 246
Ruiz, A. M. M., 397

Ruiz-Checa, R., 252

Ruiz-Guevara, N., 163, 380, 438

Ruiz-Tapiador, I., 572

Ruschel, A. R., 153, 154, 230, 701

Russo, D., 296

Russo, T., 389

Rustad, L., 262, 683

Rutishauser, E., 217

Rutkowska, A., 663

Rutzinger, M., 387

Ruy, M., 413, 426

Sá, A. C. S., 306

Sá, L. A., 441

Sá, L. A. de, 449

Sá, L. A. N. de, 452, 582

Sá, M. de, 437

Saarela, S., 189, 190, 382

Saarinen, N., 190

Saarto, A., 201

Sabaté, S., 179

Sabatini, F., 181

Sabattini, I. A., 225

Sabattini, J. A., 225, 622

Sabattini, R. A., 225

Sabine, M., 228

Sabino, L. A., 467

Sabino, T., 690

Sabogal, C., 55

Sadath, M. N., 125, 246, 247

Sadiković, D., 454

Sadler, J. P., 194

Sadowska, K., 577

Sagardia, R., 61, 228, 332

Sagheb-Talebi, K., 24, 504

Sagüí, N., 58

Saha, S., 33, 570

Sahu, S., 129

Said, S., 698

Saint-André, L., 659, 698

Sainte-Marie, J., 150

Sais, I. C. R., 233

Saito, D., 281

Saito, H., 206

Saito, O., 88

Saito, S., 672, 673

Saito, T., 206, 251

Saitoh, T., 674
Saiz, G., 660

Saiz, P. G., 485, 699

Sajdak, G., 600

Sajdak, M., 663, 676

Saji, S., 317

Sakai, T., 633, 673

Sakashita, W., 674

Sakata, K., 113

Sakata, Y., 89, 95, 104

Sakaue, D., 379

Sakila, L., 22

Salami, G., 235, 236

Salamuni, R., 85

Salas-Eljatib, C., 195

Salbitano, F., 131, 440, 546

Salcedo, L. D. P., 565

Salcone, J., 680

Salda, G. D., 175

Saldanha, E., 663

Sales, A., 32, 484

Sales, F. M. da, 273

Salgado, M. R., 61

Salinas, A. V. M., 398

Salinas, J., 40, 430

Salinas, N., 573

Salis, S. M., 535

Salk, C., 230, 492

Salka, J., 679

Šálka, J., 116, 138

Salles, P., 527

Sallustio, L., 373, 546

Salminen, H., 394

Salomão, R. de, 531

Salvalaggio, A., 473

Salvati, L., 181

Salvia, M., 60

Samame, N. M., 390

Sambaraju, K., 444

Sambou, A., 305, 531

Samils, B., 557

Samils, N., 591

Sampaio, C., 481

Sampaio, R. C. N., 499

Sanches, K., 404

Sanchez, J. J., 34, 233, 342, 356

Sanchez, S., 364

Sánchez-Basualdo, R., 33

Sánchez-González, M., 360 
Sanchez-Lopez, N., 206

Sanchotene, C., 38, 472

Sandberg, M., 0, 656

Sandeep, S., 669

Sandén, H., 566

Sanders, A., 243

Sanders, T., 193, 251, 636

Sanders, T. G., 200

Sandhu, K., 580

Sandoval, A. J. D., 598

Sandoval, J. C., 607

Sanesi, G., 182, 544

Sangama, M. S., 99

Sanguansub, S., 588

Sankar, V. R., 520

Sanquetta, C. R., 169, 192, 291, 329, 535, 536, 710

Sanquetta, F., 192

Sanquetta, M., 169, 291, 401, 536

Sanquetta, M. I., 535

Sant'anna, G., 358

Santaclara, O., 177

Santana, A., 690

Santana, C. S. F., 346

Santana, F., 213

Santana, G. M., 221

Santana, P., 109

Santana, T. R. de, 83, 133

Santi, S., 143

Santiago, V. de, 624

Santibañez, F., 156

Santillan, J. A. V., 511

Santin, D., 432, 433

Santini, A., 559, 566, 569, 575

Santini, L., 176

Santini, P., 363

Santini-Junior, L., 241

Santini-Júnior, L., 355

Santopuoli, G., 546, 605

Santoro, G. B., 555

Santos, A., 261, 262, 407, 530

Santos, A. F. dos, 563

Santos, A. T. dos, 392, 455

Santos, C. A. dos, 513

Santos, C. A. F., 518

Santos, D. C. dos, 518

Santos, D. D., 25

Santos, E. K., 525

Santos, E. S. dos, 436
Santos, F., 645

Santos, F. A. dos, 450, 451

Santos, F. M., 277

Santos, G., 260

Santos, G. dos, 439

Santos, G. V. de, 391

Santos, G. X. L. dos, 498

Santos, I. N. L. dos, 186

Santos, J., 165, 439

Santos, J. dos, 435, 436

Santos, J. E. G., 351

Santos, J. E. G. dos, 351

Santos, J. F. L. dos, 356

Santos, J. P. M. S., 235

Santos, L. C. da, 624

Santos, L. M. dos, 658

Santos, M., 403

Santos, M. E. da, 49

Santos, M. J., 26, 139, 605

Santos, P. E. T. dos, 186, 297

Santos, R., 402, 637

Santos, R. B. N. dos, 103

Santos, R. L. dos, 458

Santos, S., 41, 183

Santos, T. L. dos, 452

Santos, V., 294, 649

Santos, W., 509

Santos, W. dos, 269

Sanz, J., 252

Sanz-Ros, A., 578

Sanzetenea, E., 69

Saowaphak, T., 588

Sapsford, S., 563

Saputri, L. D., 22

Sar, S., 206

Saraiva, S., 433

Saranpää, P., 22

Sarasola, M., 559

Saravia, C., 304

Sardans, J., 200

Sardemann, G., 570

Sarjala, T., 371

Sarker, P. K., 126

Sarkki, S., 116

Sarkkola, S., 460

Sarmento, T., 422

Sarmiento, J. E. L., 613

Sarmiento, J. P., 16
Sarmiento, L. G., 164

Sarmiento, M. A., 248

Sarvani, X., 144

Sarvaš, M., 116, 681, 691

Sarvasova, Z., 679

Sarvašová, Z., 116, 117

Sasal, Y., 559

Sase, H., 206, 251

Sasmito, S., 640

Sassi, C. de, 244

Sathre, R., 270

Sato, L., 212, 512

Sato, L. M., 512

Sato, L. M. S., 514

Sato, S., 529

Sato, T., 211, 384, 620

Satyal, P., 131

Saul, F., 512

Saul, F. A. C., 324, 512, 513, 514

Saul, R. A. de, 513

Sauter, U. H., 344

Savagner, L., 698

Savolainen, O., 157

Sawano, S., 663, 674

Saxena, V., 248, 690

Sayama, K., 529

Sayer, M. A. S., 563

Sbardella, M., 320

Scanlon, T. M., 464

Scarabello, M., 180, 246, 524

Scarano, F., 648

Scarante, A. G., 270

Scarascia-Mugnozza, G., 202

Scarazatti, B., 119

Scarlett, K., 566

Scarpare, F. V., 645

Schaberg, P., 262

Schadauer, K., 61, 62, 245

Schaitza, E. G., 563

Schardt, M., 190, 210, 378

Schaub, M., 200, 201, 208

Schelhaas, M., 267, 446

Schepaschenko, D., 117, 155, 191, 211, 227, 257, 258, 448, 543, 639

Scheraiber, C., 108

Scheraiber, C. F., 459

Scherer-Lorenzen, M., 280, 281, 296, 661

Schettini, B. L. S., 230, 292 
Schicora, L., 307

Schiehser, S., 424

Schier, F., 476

Schimalski, M. B., 257, 363, 377, 403

Schimleck, L., 367

Schindlbacher, A., 264, 269

Schjolden, A., 98

Schlegel, B., 146, 496

Schlenzig, A., 573

Schluse, M., 331

Schmid, C., 245

Schmidt, B., 621

Schmidt, F., 260, 273

Schmidt, G., 418

Schmidt, I. K., 650

Schmidt, L., 291, 401, 536

Schmidt, M., 52

Schmit, L., 548

Schmitt, M., 201

Schmitz, A., 200, 208, 251

Schmitz, R., 293

Schnabel, F., 149, 169

Schneider, R., 263, 372, 400, 496

Schnell, S., 62

Schoenbeck, L., 208

Schoenig, D., 166

Schoerghuber, S., 266

Schons, S., 57

Schraml, U., 84

Schröck, H., 200

Schröder, M., 558

Schroeder, J. M., 110

Schuck, A., 599, 618

Schueler, S., 19, 179, 223

Schuerkman, A., 538

Schühli, G. S. e, 596

Schuldt, B., 193

Schüler, S., 201, 266

Schultze, J., 601

Schumacher, M. V., 252, 255, 256, 655, 666, 667, 668

Schwab, P., 288

Schwaiger, F., 530

Schwarz, J., 149, 150, 168, 169

Schwarzbauer, P., 179, 245, 476

Scipal, K., 211

Scipioni, M., 531

Scoles, R., 506
Scolforo, H., 315, 337, 359, 374, 401, 536

Scolforo, J., 361

Scolforo, J. R., 374, 401

Scott, P., 197, 581

Scott, S., 679

Scotti-Saintagne, C., 511

Sears, R., 649

Sebbenn, A., 47, 48

Sebbenn, A. M., 269, 614

Šebek, F., 409, 410

Seben, V., 62

Sebestyen, S. D., 464

Secco, L., 473

Sedmák, R., 115, 116, 288

See, L., 227, 362, 548

Seebacher, A., 570

Segah, H., 418

Segtowich, A. de, 636

Segura, D., 64, 342

Segura, L. C., 111

Seidl, R., 194, 198, 267, 703

Seidling, W., 200

Seidu, H., 427

Seifert, T., 45

Seintsch, B., 365

Sekiguchi, K., 672

Sekimoto, H., 672

Sekiya, C. V. M. S., 618

Sekot, W., 364, 365

Selaya, G., 260

Selin, S., 124

Selter, A., 75

Selva, G. V., 119, 629

Selviana, V., 244

Semeniuc, A., 177

Semerci, A., 634

Semwal, R., 618

Senda, T., 482

Sendner, M., 611

Senf, C., 194

Senilliani, M., 177

Senilliani, M. G., 666

Senra, J., 554

Sens, T. M. Z. G., 286

Sentelhas, P. C., 315

Seo, J. M., 40, 197, 295, 644, 671

Seo, S., 453, 562, 590

Seo, Y., 393
Seoane, C. E. S., 329

Sepp, K., 487

Seppälä, J., 270, 477

Septanil, M. P. B., 92

Ser-Oddamba, B., 310

Serejo, E., 99, 525

Serengİl, Y., 534

Sergent, A., 177, 379, 473, 474

Serna, C., 232, 307, 594, 616, 627

Serrano, H. C., 251

Serrano-León, H., 203, 216, 296, 469

Serro, M., 699

Sessions, J., 36

Sethy, A. K., 413

Setsuko, S., 623

Setyowati, A., 131

Sevegnani, L., 614

Shahi, C., 361, 388

Shamsudeen, S. M., 231

Shanafelt, D., 680

Shang, L., 414, 429

Shao, C., 415

Shaoliang, Y., 125

Sharifat, M., 239

Sharik, T., 686

Sharma, S., 640

Sharma-Wallace, L., 369, 556

Shaw, D., 562

Shaw, G., 653

Shaw, J., 187

Shen, H., 50, 166, 551

Shengqing, S., 520

Shenkin, A., 153

Sheppard, J., 634

Sheppard, J. P., 45, 605

Sheppard, S., 440

Sheridan, G., 706

Sherwood, P., 25

Shi, W., 312

Shi, Z., 183, 196, 252, 263, 264, 659, 661

Shichi, K., 663, 673, 674

Shimabukuro, Y. E., 390, 394, 603

Shimbo, J., 523, 525

Shimizu, J. Y., 47, 174

Shimizu, M., 431

Shin, S., 500

Shindo, J., 206

Shinohara, Y., 672 
Shinomiya, Y., 658, 663, 674

Shinzato, E., 384, 688

Shirasawa, H., 382, 445

Shiraz, B. K., 267

Shirk, A., 187

Shivas, R., 170

Shono, K., 268

Shortis, M., 377

Showalter, D., 25

Shrestha, R., 457

Shrestha, S. S., 433

Shu, L., 610

Shuey, L., 580, 581

Shuirong, W., 227

Shukor, N. A., 392

Shurpali, N., 231

Shvidenko, A., 191, 227, 257, 258

Šibanc, N., 223, 504

Sibinelli, V., 561, 562, 591

Sibold, J., 238

Sicard, P., 171, 180, 181, 202, 254, 569

Sider, M., 704

Sidor, C., 510

Siebra, M., 439

Siegrist, D., 123

Sieron, K., 651

Sierra, A. M., 148

Sievänen, T., 32

Šigut, L., 202

Sikanwe, A. N., 110

Sikström, U., 644

Silinskas, B., 425

Sills, E., 129, 244, 530

Silva, A., 234, 290

Silva, A. B. da, 67

Silva, A. C. N. da, 162, 552, 622

Silva, A. C. O. da, 101

Silva, A. J. R., 328

Silva, A. M. da, 513, 514

Silva, A. P., 68

Silva, A. P. de, 446

Silva, A. S. da, 356

Silva, A. S. V. S. da, 452

Silva, B., 183, 329, 691

Silva, B. K. da, 385, 419

Silva, C., 316, 490

Silva, C. A. da, 241, 356, 413

Silva, C. C., 297

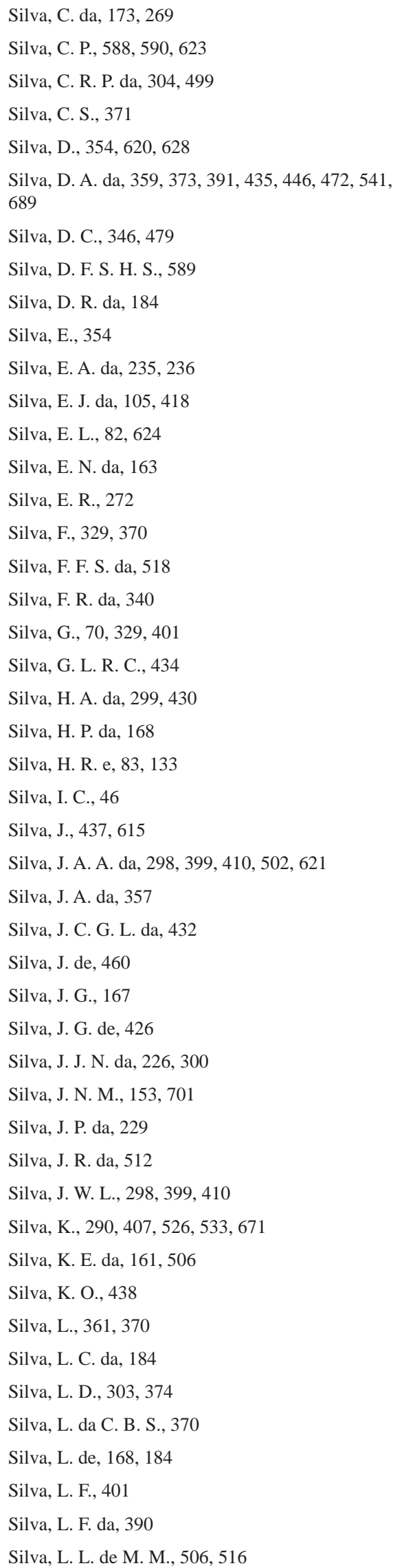

Silva, L. N., 273, 470, 478

Silva, L. T. de, 297

Silva, M., 103, 316, 681

Silva, M. A., 260, 261

Silva, M. da, 27, 324, 513

Silva, M. F. da, 216

Silva, M. J., 207

Silva, M. L. da, 484, 485

Silva, M. M. da, 100

Silva, M. P. da, 701

Silva, M. R. da, 304, 305, 358, 458

Silva, M. S. da, 373

Silva, M. S. de, 108

Silva, P. H. M. da, 185, 324

Silva, R., 50, 109, 260, 261, 262, 483

Silva, R. A. L. da, 339

Silva, R. A. R., 48

Silva, R. B., 147

Silva, R. B. G. da, 458

Silva, R. G. da, 628

Silva, R. M. L. da, 450

Silva, S., 259, 292

Silva, T., 41

Silva, T. N., 363

Silva, V., 323

Silva, V. P. G. da, 624

Silva, W. B. da, 67

Silva, Z. A. G. P. da, 290

Silva, Z. D., 80

Silva Junior, F., 317, 324

Silva-Junior, O., 174, 188

Silva-Junior, O. B., 48, 313

Silvan, N., 371

Silveira, A. da, 161

Silveira, J., 610

Silveira, J. G. da, 226, 300, 485

Silveira, L. J., 664

Silveira, M. F. da, 452

Sim, A., 442

Simalti, A., 509

Simanungkalit, J. P., 305

Simard, M., 537

Simard, S., 14

Simard, T., 263

Simeto, S., 173, 548, 579, 584

Simioni, F. J., 461, 540

Šimkevičius, K., 614

Simões, D., 183, 339, 351, 352, 358, 484, 629 
Simões, M., 337

Simões, R., 246

Simon, A., 358

Simon, M., 121, 405

Simonson, W., 246, 604, 606

Simpson, C., 376

Simpson, D., 208

Sims, L., 573

Simson, A., 440, 545

Sinclair, A. J., 86

Sing, L., 370

Singer, B., 131

Singh, A., 154

Singh, R., 114

Singh, T., 240, 423

Sinsin, B., 90, 432, 465, 585

Šipoš, J., 288

Siqueira, A. M., 628

Siqueira, D., 167

Siqueira, D. P., 426, 652

Siqueira, H., 403

Sire, L., 600

Siregar, U. J., 322, 520

Sirois, L., 496

Sisak, L., 225

Šišák, L., 117

Sist, P., 153, 207, 211, 217, 698

Sitch, S., 263

Sitko, R., 39, 224

Sitkova, Z., 375

Sitková, Z., 224, 676

Sittichaya, W., 585

Siviero, M. A., 32, 484

Sivisaca, D. C. L., 229, 616

Siwe, R., 245

Siwek, J., 676

Siziba, V. I., 515

Skarpaas, O., 26

Skelton, J., 585

Skema, M., 425

Skorupa, L., 136

Skovsgaard, J. P., 24, 284, 409, 681

Skudnik, M., 62

Slavík, M., 387

Slippers, B., 441, 516, 558, 568, 585, 623

Slot, J., 567

Sloup, R., 225

Small, C., 372
Smets, P., 19

Smith, B., 61

Smith, J., 623

Smith, N., 539

Smith, R., 131

Smith-Hall, C., 462

Smith-Ramírez, C., 166

Smolander, A., 643

Smyth, C., 257, 270

Snäll, T., 370

Snel, F. A., 355

Sniezko, R., 187

Snorrason, A., 62

Soares, A. A. V., 314

Soares, A. C., 450

Soares, A. C. D., 83, 133

Soares, C. P. B., 390

Soares, G., 215

Soares, K. L., 303, 374

Soares, L. F., 346

Soares, L. G., 461

Soares, M., 519

Soares, M. B. B., 498

Soares, M. T. S., 179, 270, 311, 508, 517

Soares, P., 409

Soares, S., 482

Sobe, C., 210

Sobral, L., 83, 155

Socha, J., 353, 409

Society, S. R. A. S., 705

Söderberg, J., 389

Soe, K. T., 500

Soewarto, J., 580, 581, 590

Sogbohossou, E. A., 432

Sokolova, I., 587

Solano, A. A. V., 30

Solatre, J., 507

Solberg, B., 215, 477

Solberg, S., 210

Soldal, E., 445

Solé, A., 157, 158

Soledade, A. S., 575

Soler, L. F., 656

Soler, L. S., 249

Soler, R., 710

Soler, R. R., 461

Soler, S. H., 172

Solomon, A., 309
Soltovski, P., 108

Somashekar, P. V., 512

Sombrio, F., 311

Somchit, C., 581

Somo, R., 412

Song, A., 61

Song, C., 258, 353, 384, 408, 678

Song, K., 490

Song, L., 629

Song, X., 312

Songwathana, K., 129

Sonké, B., 217

Sonnenschein, K., 144

Sonnhoff, M., 75

Sonwa, D., 120

Sopanen, J. O., 473

Sorge, S., 74

Sorgi, T., 181

Soriano, C. F. B., 682

Sormani, R., 239

Soro, B., 597

Sosa, M. H., 346

Sosa, V., 264

Soshenskyi, O., 341

Soterroni, A., 180, 246, 524

Sotirov, M., 126

Soto, C., 422

Soto, E. F. V., 667

Soto, H., 156

Soto, L. de, 222

Soto, R. V., 108

Soto-Berelov, M., 211

Sotomayor, A., 40

Soukand, R., 87

Sõukand, R., 38

Sousa, F. G. de, 289

Sousa, H., 68

Sousa, J., 437

Sousa, L. de, 508, 517

Sousa, L. P. de, 270

Sousa, M. V. C., 359

Sousa, N., 637

Sousa, R., 81

Sousa, R. V., 543

Sousa, S. G. A. de, 51, 160

Sousa, V. A. de, 47, 48, 51, 174, 179, 188, 270, 508, 517, 518, 519

Sousa, V. de, 90 
Sousa Neto, J. de, 498

Sousa-Silva, R., 148, 233

Souto, D. A., 618

Souza, A. de, 344, 593

Souza, A. L. de, 495

Souza, A. M. de, 301

Souza, A. N. de, 76, 286, 425

Souza, A. R., 449

Souza, A. R. de, 391

Souza, B., 286

Souza, C., 247

Souza, C. D. de, 450, 451, 452

Souza, C. R. de, 161, 229

Souza, C. S., 167

Souza, D. de, 588, 597

Souza, D. O. de, 108

Souza, D. T., 524

Souza, D. T. de, 139

Souza, F. M. dos, 618

Souza, H. J. de, 625

Souza, K. de, 500

Souza, L. da S., 564

Souza, L. H. C. de, 226, 300

Souza, L. J. B. de, 357

Souza, L. K. V. dos S., 242

Souza, M., 570, 594

Souza, N. R. D. de, 274

Souza, O. M., 82

Souza, P. A. de, 286

Souza, R. M. de, 168

Souza, R. T., 363

Souza, S. R. de, 184

Souza, V., 220

Souza, V. A. de, 269

Spake, R., 33

Spano, G., 544

Spathelf, P., 21, 265, 268

Speranza, P., 294, 508

Sperlich, D., 149, 179

Spiecker, H., 227, 409, 469, 470, 495, 686

Spiering, B., 328

Spinelli, R., 364, 416

Spinilli, R., 52

Špinkytè-Bačkaitienè, R., 614

Spletozer, A. G., 348, 664, 665

Spokas, K., 227

Sprengel, L., 227

Spring, A., 35
Springgay, E., 647

Sr., P. F., 181

Sraku-Lartey, M., 216

Šrámek, V., 200, 209

Srivastava, A., 385

Srivastava, L., 233

Srivastava, V., 607

St-Laurent, G. P., 20, 509, 543

Stabile, M. de, 628

Stahl, J., 252, 298, 316, 321, 323, 354, 458, 535, 655

Ståhl, G., 189, 191, 382

Stähler, B., 570

Stainbok, A., 284

Stakenas, V., 487

Stamati, S., 544

Stańczyk, T., 646

Stansell, N., 37

Stanturf, J., 20, 227, 235, 265, 495

Stape, J., 256, 314, 315, 316

Stape, J. L., 181, 323, 368

Starr, M., 111, 660

Statland, C. B., 367

Staudhammer, C. L., 80, 112, 160

Steel, A., 193

Steele, K. A., 518

Steenkamp, E., 568, 576, 595, 598

Steffen, T., 405

Steffens, C., 650

Stehling, E. de, 275, 278, 306

Stein, S., 23

Stein, T., 124

Steinbrenner, M. K., 80

Steindlegger, G., 257

Steiner, H., 608

Steininger, S., 585

Steinman, B., 37

Stejskal, J., 266

Stelzer, C., 473

Stelzer, V., 570

Stenfert-Kroese, J., 632

Stenger-Letheux, A., 531

Stenlid, J., 443

Stephenson, K., 679

Sterba, H., 280

Sterbova, M., 679

Sterjovska, M., 288

Stern, O., 331
Stétz, C. C., 459

Stevanov, M., 142, 241, 395, 696

Stewart, J., 443, 565, 579

Stewart, L., 567

Stilhard, J., 599

Still, C., 187

Stillhard, J., 599, 618

Stinson, G., 61

Stirn, L. Z., 394, 488, 706

Stocchero, A., 556

Stoenica, L., 76

Stöger, W., 62

Stoian, D., 93, 94, 130

Stojanovic, D., 241

Stojnic, S., 241

Stokes, A., 651

Stokes, V., 600

Stolle, L., 297, 336

Stolpe, N., 148

Storms, I., 385

Stornaiuolo, C. M. R., 620

Stouthamer, R., 585

Stoyanov, N., 62

Strahm, B., 457, 679

Straigyte, L., 552, 554

Strang, S., 539

Stratopoulos, L., 570

Straupe, I., 554, 619, 621

Stravinskas, H., 380

Strelcova, K., 181, 375

Striamets, S., 236

Strigul, N., 402

Strimbu, B., 360, 376

Stringer, J., 689

Stritar, C., 309

Stryamets, N., 38, 87, 138, 236

Studnicki, M., 589

Stuhldreher, A., 54

Stupak, I., 445

Štupar, B., 504

Sturm, C., 527

Sturn, T., 548

Sturrock, R., 151

Su, X., 323

Suabita, W. G., 615

Suarez, D. R., 217

Suarez, E., 27

Suárez, J. C. P., 423, 640 
Subedi, P., 457

Suchant, R., 112

Sudekum, H., 445

Sudharto, D., 346

Sugiarto, B., 346

Sugimura, K., 653

Sugiura, K., 685

Sugiyanto, K., 346

Suing, H. C., 185

Sukumar, R., 605

Sulek, R., 121

Suliyanti, M. M., 346

Sullivan, M. J., 217

Sun, G., 231, 558, 650

Sun, P., 379

Sun, X., 323

Sun, Y., 629

Sunderland, T., 129, 132, 633

Sung, J. H., 296

Sunthornhao, P., 395

Suomala, T., 474

Suota, M. J. B., 424

Surova, D., 83

Surovy, P., 387

Sutherland, R., 580, 581, 590

Sutter, L., 457

Suvanto, S., 374

Suwa, R., 210

Suz, L. M., 200

Suzuki, H., 431

Suzuki, S. N., 207

Suzuki, Y., 36, 431

Svátek, M., 214, 250

Svensson, G. P., 556

Svensson, J., 26

Sverdrup-Thygeson, A., 26

Svoboda, M., 267, 599, 618

Swalarsk-Parry, B., 598

Swanston, C., 151

Swenson, J., 187, 548

Święta-Musznicka, J., 201

Sy, V. de, 217

Syampungani, S., 45, 110, 492

Syaref, O., 598

Tabaco, E. L., 467

Taber, A., 94, 144

Tabima, J., 582

Taghouti, I., 392, 463
Tahvanainen, V., 483

Takahashi, E., 174

Takahashi, M., 183, 206, 251, 384

Takano, T., 657

Takarada, L. M., 275

Takayama, N., 384

Takenaka, C., 672

Takenaka, K., 633

Talarczyk, A., 62

Talebi, K. S., 267, 302

Tamaki, I., 623

Tamutis, V., 487

Tan, B., 174

Tan, P. V., 641

Tan, X., 60, 408, 409

Tanaka, N., 141

Tanaka, R., 431

Tanase, M., 204

Tang, S., 287

Tang, W., 537

Tang, X., 327

Tang, Y., 320

Tange, T., 672, 673

Tanguay, P., 444

Tanhuanpää, T., 604, 605

Tani, A., 313, 325

Tanno, P., 48, 188

Tanoi, K., 672, 673

Tapia, C. P., 189, 472, 473

Tardin, A. B. B., 506

Tardin, F. D., 328

Tarigan, M., 586, 587, 589, 598

Taromian, A., 239

Taş, I.., 53, 350

Tassinari, R., 174

Tateno, R., 327

Taura, T. A., 518

Tausz, M., 263, 265

Tavani, R., 62

Tavares, L., 407

Tavares, S. F., 472

Tavares, W., 586, 587, 589

Tavares, W. S., 598

Tavares Junior, I. da, 230, 536

Tawi, C. A., 239

Tchetan, T. B., 409

Tebera, A., 380

Tedesco, F. G., 451, 452
Teitelbaum, S., 480

Teixeira, D., 76, 85, 427

Teixeira, D. E., 76, 415, 420, 425

Teixeira, F. P., 458

Teixeira, S., 361

Teixeira-Costa, L., 561, 562, 591, 592

Tejada, G., 528

Tejos, E., 711

Tekle, Y., 96

Teles, M., 669

Teles, T. A. S., 306

Teles, T. S., 306

Telfer, E., 556

Telles, L. A. de A., 219, 234, 348, 390, 399, 485

Tellnes, L. G. F., 269, 445

Tello, M., 397

Templer, P., 262

Temporário, V., 557

Teng, F., 312

Tennanet, P., 579

Terkenli, T., 554

Terra, G., 277

Tesfaye, M., 226

Tesfaye, M. A., 293

Tesón, N., 175

Tetila, E. C., 403

Tetto, A. F., 57, 271, 356

Tewari, V. P., 64, 65, 267

Than, W. W., 557

Thapliyal, M., 283, 509

Thees, O., 331

Theodoro, S., 215, 501

Thevenon, M., 239

Thevenon, M. F., 240

Thiec, D. L., 202

Thiersch, C. R., 389

Thiersch, M. F. B. M., 389

Thiffault, N., 497

Thimonier, A., 200, 201

Thiombiano, A., 271, 594

Thiry, Y., 654

Thom, D., 703

Thomas, C., 290

Thomas, E., 327, 506

Thomas, J., 151

Thomas, R., 263

Thompson, M., 341, 347

Thompson, S., 525 
Thomsen, I. M., 200, 201

Thorne, S., 683

Thorpe, P., 573

Thu, T. B. T., 44

Thu, T. P., 114, 641

Thulasidas, P. K., 317, 415

Thürig, E., 209

Tian, A., 665

Tian, G., 414, 429

Tian, P., 71

Tian, X., 379

Tienne, L., 405

Tigabu, M., 492

Tikkanen, J., 86

Timko, J., 131

Timmermann, V., 201

Timo, L., 213

Timofeiczyk Junior, R., 432

Tingson, K. N., 467

Tinio, C., 519

Tippner, J., 409, 410

Tirocke, J., 565

Titeux, H., 200, 201

Tito, M., 146

Titus, B., 464

Toda, K., 384

Togawa, E., 431

Tognetti, R., 202, 222, 551

Toïgo, M., 572

Toit, B. D., 45, 342, 634, 704

Toivonen, R., 96, 474, 475

Tokola, N., 695

Tokola, T., 686

Toledo-Aceves, T., 264, 448

Tomaru, N., 623

Tomás, A., 43

Tomaselli, M. F., 131

Tomášková, I., 266

Tomaštík, J., 390

Tomazello-Filho, M., 175, 176, 184, 238, 241 , 242, 355, 356, 375, 413, 707

Tomé, M., 43

TomÉ, M., 192

Tomé, M., 200, 371, 373, 409, 446, 468, 583

Tomić-Petrović, N., 142

Tomicevic, J., 554

Tomigian, D., 518

Tomigian, D. S., 51
Tomm, B., 443

Tommasiello, M., 189

Tomson, P., 487

Tomter, S., 62

Tonello, K. C., 664

Tong, L., 431

Toniato, M. T., 466

Tonouéwa, J. F. M. F., 91

Too, D., 374

Toppinen, A., 96, 431, 474, 475

Törmä, H., 394

Törmänen, T., 643

Torre, L. A. L. de, 430

Torre-Cuadros, M. de, 89

Torres, C., 213, 398

Torres, C. E., 348

Torres, C. M. M. E., 154, 230, 399, 534, 536

Torres, D. del, 28, 292, 642

Torres, E., 577, 579

Torres, F. T. P., 348, 618

Torres, G., 142

Torres, G. P., 278

Torres, J., 259

Torres, M., 260

Torres, M. N., 423, 640

Torres, Y. B., 292

Torres-Dini, D., 187, 269

Toscani, P., 364, 365

Toskovic, O., 554

Toth, I., 582

Tourne, D., 533

Tourvas, N., 504

Tovar, C. L. M., 61

Tovar, J. G., 15

Toyama, K., 134, 207

Tp, T., 669

Traag, D., 228

Tracey, C., 370

Tramontina, J., 639

Travaglini, D., 378

Travieso, G., 488

Trčková, O., 506

Trenks, H., 570

Tres, A., 271, 356

Trettin, C., 537

Treue, T., 462

Trevisan, E., 165

Trianoski, R., 433, 435, 436
Triches, G. P., 499

Trincado, G., 383, 398

Trinh, B., 449

Tripathi, H., 64

Trollip, C., 597

Trompczynski, R. D., 546, 555

Troppa, C., 632

Trouet, V., 236

Trouve, R., 199, 488

Trovão, B., 137, 527

Trubins, R., 483

Tsai, C., 515

Tsedensodnom, E., 256

Tshidzumba, R. P., 30, 72

Tsuboyama, Y., 663, 674

Tsuchiya, Y., 673

Tsuda, Y., 183

Tsukamoto Filho, A. de, 226, 300

Tsumura, Y., 183

Tsurita, T., 663, 674

Tsushima, T., 529

Tuan, L. H., 114, 641

Tuan, N. T., 50

Tubby, K., 444

Tuboi, C., 538, 676

Tuček, J., 288

Tuček, J. J., 115

Tudoroiu, M., 522

Tulio, R. H., 671

Tullus, A., 638

Tullus, H., 638

Tullus, T., 638

Tumushime, I., 457

Tuomasjukka, D., 96

Tuovinen, J., 202

Turner, D., 377, 387

Turner, R., 559

Tusa-Jumbo, E., 402

Tuswa, N., 635

Tyler, B., 582

Tymus, J. R. C., 631

Tyrväinen, L., 84, 123, 124

Tysiachniouk, M., 480

Ubaekwe, R. E., 192

Uchida, J., 579

Uchiyama, Y., 248

Uetela, A., 311

Ugalde-Alfaro, S., 54 
Ugawa, S., 327

Ugolini, F., 325

Ugulino, B., 471

Uhl, E., 370

Ukonmaanaho, L., 201, 460

Ukrainetz, N., 444

Ullah, C., 515

Ullah, S., 263

Uller, H. F., 164, 373, 391, 435

Ulloa, F. N., 423

Umbelino, M. T., 229

Umlandt, M., 434

Umunay, P., 19

Unno, A., 529

Unrau, A., 287

Unuk, T., 223, 591

Uprety, Y., 631

Urakawa, R., 464

Urban, A., 589

Urban, J., 250

Urbinati, C., 440

Uribe, J. C. S., 300

Urregomesa, J. B., 406

Urzua, J., 591

Usai, L., 357

Usenia, V., 341

Ustin, S. L., 605

Ușurelu, B., 284, 287

Uva, J., 446

Uzêda, M., 494

Vacik, H., 265, 385, 395, 487, 531, 686

Vadeboncoeur, M., 262

Vadeboncoueur, M., 262

Vaes, A., 530

Vahlström, I., 200

Vaidelys, T., 552

Vaidya, A., 423

Vainio, E., 575

Vaio, M., 508

Valatin, G., 677, 679

Valbuena, R., 205, 604, 702

Valdes, J., 38

Valdez, Y., 573

Valdivia, C. I. G., 61

Vale, F. do, 483

Vale, H. M. M. do, 452

Vale, V. S. do, 624

Valencia, D., 606
Valencia-Manzo, S., 257

Valente, C., 441, 590

Valente, M. S. F., 186

Valente, R., 234

Valenzuela, C., 148

Valenzuela, R. B., 123

Valeri, S. V., 498

Valeria, O., 199, 497

Valeriano, C., 178

Valin, H., 117, 180, 246

Valinger, E., 217

Valle, J. I. del, 50

Valledor, L., 577

Vallet, P., 379

Valls-Fox, H., 621

Valsta, L., 474, 530

Valsta, L. T., 473

Van, T. N., 641

Vancampenhout, K., 284, 301, 654

Vance, J., 416

Vanclay, J., 279, 449, 467, 468

Vanguelova, E., 200, 201, 566

Vanhanen, H., 371

Vanié-Léabo, L. P. L., 597

Vaninni, A., 575

Vansconcelos, R. F., 167

Vantroba, A. P., 286

Varela, C., 88

Varela, F., 284

Varela, S. A., 177

Vargas, A. F., 322

Vargas, J. C. M., 692

Vargas, J. G. P., 652

Vargas, L. G. A., 607

Vargas, L. N., 472

Vargas, N. J. C., 430

Vargas González, J. A., 111

Vargas-Gaete, R., 166, 489

Vasconcellos, J. H., 692, 696

Vasconcellos Sobrinho, M., 101

Vasconcelos, M., 575

Vasconcelos, M. C., 454

Vasconcelos, R., 523, 524, 526, 588, 597

Vasconcelos, T., 336

Vasconcelos, W., 219, 399

Vasic, V., 575

Vasquez, K., 612

Vasquez, L. P., 388
Vásquez Fernández, A. M. , 99, 704

Vásquez Vela, A. L. M. , 276, 279, 291

Vastaranta, M., 190, 206

Vasylyshyn, R., 258, 271

Vatanparast, M., 267

Vaz, A. C. R., 624

Veiga, A., 261

Veiga, N. S., 413

Velarde, S. J., 369, 556

Velasco, R. F., 467

Velasquez, E., 173

Velasquez, R., 156

Velez, L. F. O., 300

Velezescobar, F., 93, 406

Velho, M. I. A., 77

Velosa, W. K. L., 393

Veloso, G., 617

Velozo, S. G. M., 449

Vendrami, J., 220

Vendramin, G., 18

Vendramin, G. G., 158, 511

Venegas-González, A., 238, 243

Veniziani Junior, J. C. T., 677

Ventura, A., 370

Venturieri, A., 699

Venturoli, F., 221, 533

Veras, I., 76

Verbisky, R., 73, 101

Verbist, B., 385

Verchot, L., 27

Verchot, L. V., 642

Vergara, G., 496, 620

Vergara, K. L., 423, 640

Vergara-Asenjo, G., 146

Vergarechea, M., 149

Verhegghen, A., 388

Verheyen, K., 148, 608, 654

Verkerk, H., 20, 96, 270

Vernesi, C., 158

Verón, S., 523

Verstraeten, A., 200, 201

Vertinsky, I., 84

Verweij, P., 26

Vesela, P., 515

Veste, M., 45

Vesterdal, L., 200, 201, 650

Vestøl, G. I., 367

Veteli, P., 371 


\begin{tabular}{|c|c|c|}
\hline Vettraino, A. M., 575 & Villanova, P. H., 230 & Wallace, L., 377, 387 \\
\hline Viana, A., 213 & Villanueva, Y., 307 & Wallgren, M., 198 \\
\hline Viana, C., 609 & Villarraga, L., 30, 545 & Wallin, I., 127, 473, 688, 702 \\
\hline \multirow{2}{*}{$\begin{array}{l}\text { Vibrans, A. C., 164, 195, 338, 352, 373, 391, 435, } \\
\text { 531, 614, 619, } 694\end{array}$} & Villarroel, A., 40 & Walter, M., 144 \\
\hline & Villegas, D., 173 & Walzer, C., 143 \\
\hline Vicente, J., 469 & Villeneuve, M., 659 & Wambsganss, J., 280, 661 \\
\hline Vicente, W., 426 & Vincke, C., 250 & Wan, F., 312 \\
\hline Vicentini, J., 214 & Violato, A., 82 & Wan, Z., 532 \\
\hline Victor, A., 524 & Vira, B., 631 & Wandelli, E. V., 51 \\
\hline Vidakovic, D., 19, 444 & Vismara, E., 220, 290 & Wang, A., 170 \\
\hline Vidal, C., 175, 707 & Vismara, E. de, 224 & Wang, B., 650 \\
\hline Vidal, E., 83, 155, 356, 375 & Vitali, V., 169 & Wang, C., 437 \\
\hline Vidaña, D. L. S., 73 & Vitorino, M. D., 162, 710 & Wang, D., 140, 387, 426 \\
\hline Vidaurre, G., 291, 315, 321 & Viudes, P., 701 & Wang, G., 107, 687 \\
\hline Videla, M. E., 398 & Viúdes, P., 699, 700 & \multirow{2}{*}{$\begin{array}{l}\text { Wang, H., 264, 361, 373, 556, 659, 660, 670, 675, } \\
676\end{array}$} \\
\hline Vieira, A. C., 99, 100, 525 & Vlckova, M., 191 & \\
\hline Vieira, C. C., 354 & Vliet, N. V., 85 & Wang, J., 40, 264, 379, 416, 496, 585, 648, 659 \\
\hline Vieira, E., 325 & Vodlan, V., 144 & Wang, L., 318, 431 \\
\hline Vieira, F., 76 & Vogel, H. L. M., 666, 667 & Wang, M., 240, 377 \\
\hline Vieira, F. C. B., 666 & Vogel, J., 197, 457 & Wang, M. M., 217 \\
\hline Vieira, F. S., 625 & Vogt, P., 388, 602, 603 & Wang, Q., 40, 571 \\
\hline Vieira, J., 551 & Voitka, D., 577 & Wang, S., 319, 642 \\
\hline Vieira, J. L., 110 & Volante, J., 523 & Wang, W., 65, 71, 596 \\
\hline Vieira, S. A., 228, 659 & Vomero, P. A. de, 450 & Wang, X., 318, 330, 395 \\
\hline Vieira, S. B., 32, 484 & Vos, B. de, 200, 201 & Wang, Y., 190, 323, 404, 585, 613, 661, 665 \\
\hline Vieira, T., 526 & Vos, L. de, 598 & Wang, Z., 437 \\
\hline Viero, P., 342 & Vrechi, A., 401, 403, 646 & Wapstra, M., 369 \\
\hline Viero, P. W. M., 634 & Vreese, R. de, 679 & Ward, S., 46, 47, 466, 558, 608, 619 \\
\hline Viet, H. H. N., 641 & Vries, W. de, 200 & Wardle, D., 623 \\
\hline Viezzer, J., 67, 68, 70, 700 & Vuaden, E., 290, 498 & Wardoyo, R., 346 \\
\hline Vihemäki, H., 96, 474, 475 & Vuolo, F., 604 & Waring, K., 152, 187, 510, 548, 685 \\
\hline Vihervaara, P., 604, 605 & Výbošt'ok, J., 390 & Warmenhoven, T., 369 \\
\hline Viinikka, A., 604, 605 & Vymazalová, P., 288 & Wartalska, P., 577 \\
\hline Viiri, H., 267 & Wabasa, M., 85 & Warwell, M., 565 \\
\hline Vilanova, E., 217 & Wachira, J., 510 & Wästlund, A., 386, 524 \\
\hline Vílchez, S., 58 & Wadasaki, N., 623 & Watanabe, A., 183 \\
\hline Vild, O., 288 & Wadt, L. H. de O., 80, 81, 112, 160, 318, 506, 518, & Watanabe, E., 675 \\
\hline Vilela, A. de, 438 & $521,526,527,533$ & Waterworth, R., 381 \\
\hline Vilela, E. S., 275, 306 & Wagner, B., 377 & Watson, D., 561, 562 \\
\hline Vilela, G. F., 118, 119 & Wagner, F., 281 & Watts, K., 33 \\
\hline Vilela, L., 500 & Wai, Y. S., 447 & Watzlawick, L., 392 \\
\hline Vilhar, U., 691 & Waipara, N., 564, 581 & Watzlawick, L. F., 48, 50, 286, 293 \\
\hline Villacide, J., 442 & Waithaisong, K., 659 & Waweru, S., 510 \\
\hline Villacide, J. M., 25 & Waitz, C., 570 & Wayson, C., 642 \\
\hline Villalba, J., 147 & Waldner, P., 200, 201 & Weber, M. A., 666 \\
\hline Villalobos, A., 312 & Waldron, T., 146 & Weber, V., 290, 498 \\
\hline Villalobos, R., 73, 115, 147, 148, 163, 632 & Walji, K., 704 & Weber, V. P., 290 \\
\hline Villamor, C., 641 & Wallace, K., 33 & Weemstra, M., 651 \\
\hline
\end{tabular}


Wehenkel, C., 152, 187, 510

Wei, Q., 323

Wei, X. (., 643, 648

Weih, M., 471

Weijters, M., 284

Weimar, H., 476

Weinbrenner, H., 344

Weisberg, P., 149

Weiskittel, A., 195

Weiskittel, A. R., 378

Weiss, E. C., 49

Weiss, G., 72, 74, 117, 245

Weiss, P., 245

Wekesa, A., 192

Wekesa, C., 87, 626

Wells, L., 21

Wellstein, C., 158

Wen, Z., 109

Wen-Qiang, G., 176

Wendling, I., 50, 406, 432

Wenming, L., 143, 540

Wenzel, A. V. A., 637

Wergifosse, L. de, 250

Werner, C., 150

Wessels, B., 412, 418

West, P. W., 218

Westergren, M., 144, 157, 159, 504, 505, 691

Weston, C., 312

Weyandt, A. J., 481

Wezen, J., 588

Whalen, J., 585

Wheeler, D., 442

Whipple, A., 187, 548

Whitby, C., 566

Wicaksono, D., 563

Wieser, G., 202

Wieser, M., 387, 400

Wiezikova, A., 39

Wightman, M., 312, 457, 458, 635

Wijk, S., 200

Wilcken, C., 441, 593

Wilcken, C. F., 441, 449, 450, 451, 452, 453, 455, 582

Wild, J., 141

Wildberg, J., 376

Wilhelmsson, P., 386

Wilhelmy, M., 385

Willén, E., 389
Williams, D., 17, 142

Williams, K., 396

Williams, N., 197, 444, 507, 574

Williams-Linera, G., 680

Willis, K., 37

Willm, J., 600

Wilmer, J., 494

Wilpert, K. V., 150

Wilson, B., 389

Wimmer, P., 76, 427

Win, J., 507

Windeisen, E., 472

Wing, M., 187, 376

Wingate, L., 238

Wingfield, B., 578, 595, 597, 598

Wingfield, B. D., 595

Wingfield, M. J., 316, 454, 515, 549, 568, 581, 584, 585, 592, 595, 596, 597, 598

Winkel, G., 17, 18, 127, 129, 687

Winkler, G., 385

Wip, G., 228

Wirtz, Z., 546

Wiset, K., 105

Wit, F. de, 259

Witzell, J., 547, 567, 593

Wohlgemuth, T., 469

Woitsch, J., 693

Wolf, J., 603

Wondafrash, M., 558

Wong, A. H., 239

Wong, B., 444

Wong, G., 114, 128

Woo, S., 182, 184, 254, 255, 594

Woo, S. Y., 182

Wood, P., 609

Woodward, S., 559, 568, 575

Work, T., 497

Worrall, J., 443

Wortel, V., 153, 228

Wrage-Mönnig, N., 112

Wreford, A., 104

Wrege, M. S., 179, 249, 270, 311, 508, 517, 519

Wroblewski, C. A., 67, 555

Wu, C., 276

Wu, H., 172

Wu, J., 429

Wu, R., 320

Wu, S., 495
Wu, T., 411, 493

Wu, Z., 187

Wulandari, W. S., 346

Wunder, S., 74, 244, 245

Wurpillot, S., 62

Wyatt, S., 99, 100, 120, 130

Wyborn, C., 17, 142

Wyk, S. V., 598

Wynn, P., 263

Xanthopoulou, A., 173

Xia, E., 428

Xiang, E., 414

Xiang, H., 415

Xiang-Dong, L., 176

Xiao, L., 65

Xiao, W., 196, 537

Xiaoxia, L., 319

Xie, H., 140

Xie, Y., 153, 395, 639

Xu, C., 393

Xu, D., 295, 426

Xu, H., 319

$\mathrm{Xu}, \mathrm{L} ., 665$

Xu, X., 40, 566

Xue, H., 121

Yagihashi, T., 211

Yaguana, C., 218, 219

Yahya, A. F., 243

Yakouchenkova, I. M. A., 33, 570

Yakusu, E. K., 296

Yamada, T., 459

Yamada, Y., 338, 344, 384, 528

Yamaguchi, K., 482

Yamaki, H., 678

Yamamoto, M., 688

Yamamoto, T., 382, 445

Yamanaka, S., 529

Yamashita, N., 206, 251

Yamaura, Y., 384, 528, 529

Yamoto, M., 384

Yan, H., 675

Yan, M., 379

Yan, Q., 496, 629

Yang, G., 318

Yang, H., 650

Yang, K., 629

Yang, L., 166

Yang, P., 29 
Yang, S., 414, 429

Yang, T., 60, 189, 361, 376, 378, 402, 408, 409, 419

Yang, W., 509

Yang, X., 327

Yang, Z., 189, 634

Yangayobo, S., 85

Yanti, N., 322

Yanuariadi, T., 316

Yao, D., 130

Yao, R., 539, 556

Yap, S. L. C., 90, 120

Yarnvudhi, A., 66

Yawanawa, E., 136

Yeaman, S., 19, 444

Yeboah, R., 39

Yeo, H., 414

Yeo-Chang, Y., 122, 123, 192, 554

Yin, R., 612, 613

Yin, X., 393

Yin, Y., 344, 345

Yli-Viikari, A., 63

Yoga, S., 223, 232, 549

Yojo, T., 68

Yong, J. H., 453

Yoon, S., 254

Yoshida, S., 390

Yoshida, Y., 482

Yoshimura, T., 36

Yoshioka, M. H., 101

You, H., 594

You, Y., 49, 145, 553, 626, 627, 670

You, Y. H., 296

Youn, W. B., 40, 197, 295, 644, 671

Young, S., 653

Yousefpour, R., 19, 149, 199, 317, 486, 487

Yousepfour, R., 150

Yovi, E. Y., 338, 344

Yowargana, P., 117, 227, 448, 548, 641

Yu, H., 318, 353, 405, 627

Yu, P., 665

Yu, Z., 379, 648, 702

Yuan, H., 320

Yuan, J., 86

Yuan, S., 275

Yue, C., 218

Yue, G., 661

Yuexian, W., 520
Yukitoshi, K, 623

Yun, J., 627

Yung, L., 17, 142

Yusypovych, Y., 504

Yuwono, B., 227

Zabala, J. F. G., 354

Zaccaron, S., 424

Zacharova, A., 39

Zagal, E., 662

Zakia, M. J., 137

Zakia, M. J. B., 55, 85, 108, 629, 681

Žalkauskas, R., 302

Zalman, J., 19, 228

Zambrano, J. R., 294

Zamolodchikov, D., 259, 269

Zamora, J., 58

Zamora, J. C., 149, 150, 179

Zamora, P., 568

Zamora-Ballesteros, C., 576, 578

Zanatta, J. A., 225, 229, 671

Zander, K., 145

Zanella, L., 322

Zang, R., 166

Zanini, A., 221

Zanini, A. M., 228, 659

Zanlorenzi, E., 412

Zanuncio, J., 441

Zanuncio, J. C., 348, 449, 452, 479, 582

Zanzarini, F., 121

Zarafshar, M., 234, 655

Zare, M., 668

Zaré, A., 594

Zarubina, N., 656

Zaruma, D. G., 185, 511, 513

Zaruma, D. U. G., 324

Zasada, M., 409

Zavala, F. H., 430

Zechmeister-Boltenstern, S., 208, 263

Zeferino, S. L., 106, 340

Żelazny, M., 646, 663, 676

Zeleke, B. G., 210

Zeller, L., 370

Zellweger, F., 604

Žemaitis, P., 472

Zeng, L., 196

Zeng, M. Q., 687

Zeng, Y., 320, 465

Zerbe, S., 158
Zevallos-Pollito, P., 164

Zhan, Y., 287

Zhang, C., 323, 570

Zhang, D., 134, 471, 612

Zhang, H., 60, 408, 409

Zhang, J., 237, 373, 496, 629

Zhang, L., 254, 275, 379

Zhang, P., 123

Zhang, S., 572

Zhang, T., 415

Zhang, W., 283, 323

Zhang, X., 237, 373

Zhang, Y., 75, 134, 200, 237, 320, 521, 572

Zhang, Z., 497, 648, 649, 650

Zhao, D., 299, 365, 534

Zhao, F., 340, 610

Zhao, H., 187

Zhao, J., 123

Zhao, M., 404

Zhao, X., 122

Zhao, Y., 318

Zheng, B., 320

Zheng, H., 650

Zheng, X., 629

Zheng, Y., 393, 509, 521

Zhong, C., 276, 521

Zhou, B., 171, 268, 634

Zhou, D., 493

Zhou, H., 437

Zhou, L., 172

Zhou, X., 231

Zhou, Y., 330

Zhou, Z., 318

Zhu, A., 237

Zhu, H., 46, 482, 493

Zhu, J., 496, 629

Zhu, X., 320

Zhu, Y., 465

Zhuang, Q., 642

Zhunusova, E., 135

Ziantoni, V., 44

Zibtsev, S., 341, 653

Ziegler, C., 263

Ziemińska, K., 194

Zilli, M., 180, 246

Zimbalatti, G., 296

Zimmer, H., 449

Zimmer, Y., 365 
Zimny, M., 201

Zimová, S., 198

Zingg, A., 194

Zivojinovic, I., 72, 74, 116, 117, 554

Žlindra, D., 200

Zoljargal, S., 310

Zong, Y., 393, 509

Zopollatto, M., 289
Zoveda, F., 268

Zucon, A. R. S., 662, 667

Zuidema, P. A., 236

Zuleta, G. A., 78, 79

Zulian, D., 512

Zulian, D. F., 185, 324

Zulian, D. F. Z., 513, 514

Zulkarnain, M. T., 548
Zuniga, J. B., 641

Zúñiga-Méndez, C., 54

Zverev, V., 587

Zvereva, E., 587

Zvereva, E. L., 571

Zwiener, V. P., 249

Zwijacz-Kozica, T., 663

Zych, M., 487 




Impressão e acabamento

\section{Gráfica Monalisa}




\section{Embrapa}

Florestas

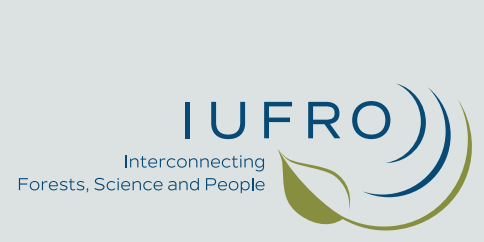

Support

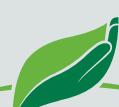

BRAZILIAN FOREST SERVICE

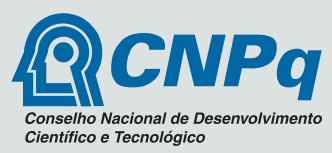

